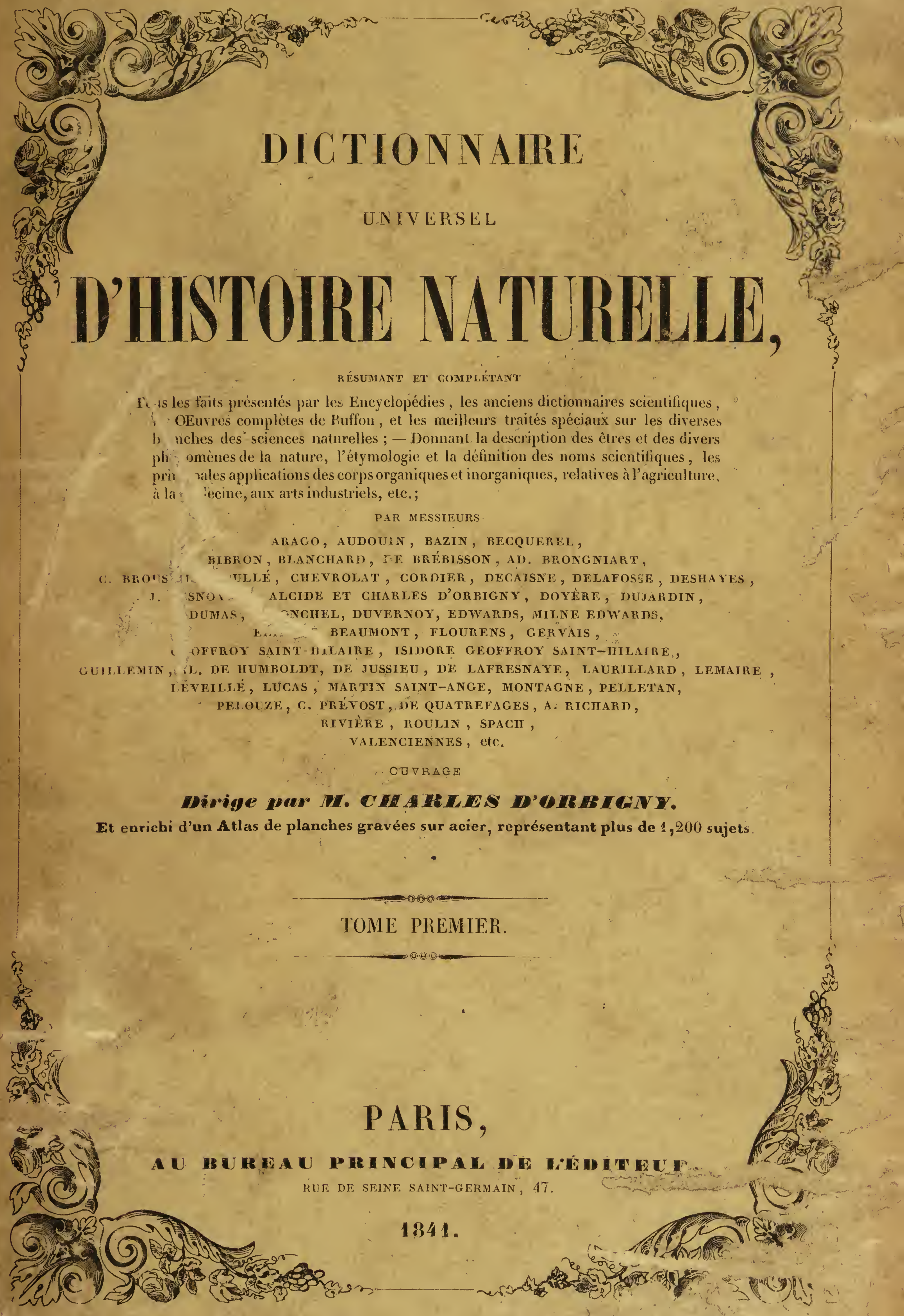



$x_{2}^{5}||^{5}=$ 
Digitized by the Internet Archive in 2019 with funding from Wellcome Library 


\title{
DICTIONNAIRE
}

\author{
UNIVERSEL
}

\section{D'HISTOIRE NATURELLE.}

TOME PREMIER. 


\section{LISTE DES AUTEURS PAR ORDRE DE MATIERES.}

Avec l'indication des lettres iniliales dont leurs rerlicles sont signés.

\section{Zoologie gènerale, Anatomie, Physiologie, Tératogie et Anthropologie.}

MII.

CASIMIR BROUSSAIS, D.-M., professeur à i'hôpital militaire du Val-de-Grâce.

DUPONCHEL fils, médecin de l'École Polytechnique.

[C. B. $]$

[A. D.]

DUVERNOY, D.M. professeur d'Histoire naturelle au Collège royal de France, etc.

EDWARLS, (W. E), D.-M., inembre de l'Iustitut, etc.

[Duv.

[E.]

FLOURENS, D.-II., secrétaire perpétuel de l'Acad. royale des Sciences: membre de l'Aeadémie francaise, professeur-adninis trateur au Muséum d'llistoire naturelle.

GEOFFROY SAINT'HILAIRE, membre de l'Instilut.

[FL. S.]

[G. S,H.
MM.

ISIDORE GEOFFROY SAINT.HILAIRE, D.M., membre de l'Institut. inspecteur de l'Académie de Yaris, administraicur a Muséum d'Hist. naturelle.

[I. G. S.-II.]

DE IIUMBOLDT (le baron Alexandre, membre de I'Institut, de l'Academie royale de Berlin, de la Suriéte royale de Londres, ele. BAZIN, D.-M., membre de plus. sociétés savantes, professeur de zoologie à la facultè des sciences de Bordeaux. [Baz.]

MARTIN SAINT-ANGE, D--M., membre de plusieurs sociélés savantes.

[M.S.A.

\section{Mammi fères et Diseaux.}

ISIDORE GEOFFROY SAINT.HILAIRE, D.-M, membre de LAURILLARD, membre de la Société philomatique, etc. (IIam-

I'Institul, etc. [I.G.S.-II.]
[I.

DE LAliRENAYE (le baron,) meinbre de plusieurs sociélés savantes.

\section{Reptiles et Porissoms.}

BIBF.ON, professeur d'Histoire naturelle, aide-naturaliste au IIu- | VALENCIENNES, professeur-administrateur au IIuséum d'Histoir $\begin{array}{ll}\text { séum d'Histoire naturelle. } & \text { [G. B.] naturelle. }\end{array}$

Mollusques.

ALCIDE D'ORBIGNY, auteur du Voyage dans l'Amèrique mé- | DESIIAYES, membre de la Soc. philomatique, etc. ridionale, membre de la Soc. philomatique, ete. [A. D'O.] VALENCIENNES, prof.-adn. au Musı d'Hist. nat.

\section{Articulés.}

(Insectes, Myriapodes, Arachnides, Crustacés, Cirrhopodes, Annélides, Helminthides, Systolides.) AUDOUIN, D.M., membre de I'Institut, professeur administra. DUJARDIN, cocteur ès-scienees, doyen de la Facultè des sciences teur au Mluseum d Histoire naturelle.
[AvD.] BLANCIIARD, membre de la Soc. entomologique de France. [B. BRULLÉ, professeur à la Faculı́ des sciences de Dijon. CHEVROLAT, membrc de plusieurs sociẻtés savantes. GERVAIS, membre de la Sociélé plitomalique.

$[$ P. G. DOYERE, prof. d'Hist. nat. au coll. r. de IIenri IV. [L.D. y. r.] MILNE LDWARDS, D.・M., mcinbıe de l'Institut.

\section{Roophytes ou reayonthés.}

(Échinodermes, Acalèphes, Foraminifères, Polypes, Spongiaires et Infusoires.) ALCIDE D'ORBIGNY, menbre de la Sociétć fhilomalique, DUJARDIN, membre de la Socièté philomalique, etc ecr. [A. b'O. $]$ MLNE EDWARDS, D. -MI., membre de l'Instirut.

\section{Botamidue.}

DE BRÉBISSON, membre de plusieurs soc. savantes. BRONGMIART, D.-M., membre de l'Institut, professeur-administrateur au Muséum d'Histoire nallurelle. [AD. B.] membre de la Sociéte philomatique[J. D.]
UILLEMIN, D. M., aide de botanique au Muséum d'Ilistoire naturelle, unembre de la Société phIomatique.

DE JUSSIEU, D. MI membre de l'Institut, professeur.adminis-

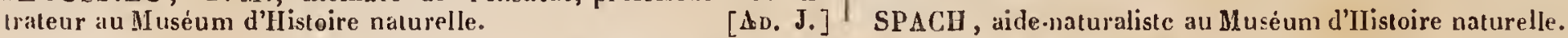

LEIIAIRE , ancien professeur de I'Universilé, membre de plusieur sociètis saranen LÉVEILLÉ, D.-HI., membre de la Société philomalique et de plusieurs autres sociétés savalles.
[LET.

MONTAGNE, D.MI, inembre de la Société philonatique el de plusieurs autres sociètés savantes
[l. MI.] RICIIARD, D..M., membre de l'Institut, professeur à la Faculté de médecinte.
[A. R.]

\section{Géologie, Mimeralogie.}

CORDIER, membre de l'Institut, professeur-administrateur au Muséum d'Ilistoire nalurelle, pair de France, inspecteur général des mines, conseillel d'État.
[L. C.]

DELAFOSSE, professeur de minéralogie à la Faculté des sciences, etc. [DEL.]
[Dions

DESNOYERS, bibliothéraire au Muséun d'Ilist. nat. (Questions
géologiques sous lo point de vue historiquej.
[J. Desv.] géologiques sous lo point de vue historiquej.

ÉLTE DE BEAUMONT, inembre de I'Institut, professeur au Collège royal de France, ingénieur en chef des mines, etc. CHARLES D'ORBIGNY, mombre de plusieurs sociétés savantes, [C. D'O.] CONSTANT PRÉVOST, professeur de gèologie à la Faculté des sciences, etc.

[C.P.]

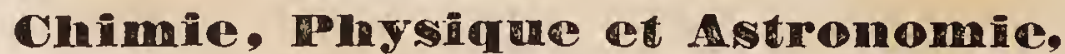

ARAGO, secrélaire perpétuel de l'Académie des sciences, député, | PELLETAN, D.-MI., professeur de physique à la Faculté de mé. ctc.
[An.] HECQUEREL, nembre de l'Institut, professcur administrateur au Muséun d'Ilistoire naturelle. [BecQ. ]

UMLAS, membre de l'Institut, professcur de chimie à la Faculte de médecine et à la Faculté dessciences, etc.

ELLETAN, D.-II., professeur de pliysique à la Faculté de me-
dceine, etc. PELOUZE, membre de l'llustitut, professeur de chimie au Col lége royal de Frauce et à l'École Polytchnique, etc. [DEL. RIVIĖRE, professeur de sciences physiques de l'Unircisitć royale] 


\section{DICTIONNAIRE}

UNIVERSEI,

\section{I'HISTOIRE NATURELLE}

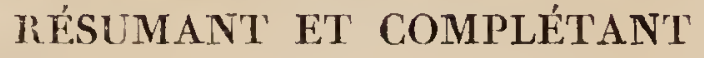

Tous les faits présentés par les Encyclopédies, les anciens dictionnaires scientifiques, et les meilleur's traités spéciaux sur les diverses branches des sciences naturelles;Donıant la description des ètres et des divers phénomènes de la nature, l'étymologie et la définition des noms scientifiques, les principales applications des corps organiques et inorganiques, relatives à l'agriculture, à la médecine, aux arts industriels, etc.;

\section{PAR MESSIEURS}

ARAGO, AUDOUIN, BAZIN, BECQUEREL,

BIBRON, BLANCHARD, DE BRÉBISSON, AD. BRONGNIART,

C. BROUSSAIS, BRULIÉ, CIEVROLAT, CORDIFR, DECAISNE, DELAFOSSE, DESHAYES,

J. DESNOYERS, ALCIDE ET CHARIES D'ORBIGNY, DOYERE, DUJARDIN,

DUMAS, DUPONCHFL, DUVFRNOY, EDWARDS, MILNE EDWARDS,

ÉLIE DF REAUMONT, FLOURENS, GFRVAIS,

GEOFFROY SAINT-IILAIRE, ISIDORE GEOFFROY SAINT-HILAIRE,

GUILLFMIN, AL. DE HUMBOLDT, DE JUSSIEU, DE LAFRESNAYE, LAURILLARD, LFMAIRF, LÉVEILLÉ, IUCAS, MARTIN SAINT-ANGE, MONTAGNE, PELLETAN,

PFLOUZE, C. PRÉVOST, DE QUATREFAGES, A. RICHARD, RIVIERF, ROULIN, SPACH, VAIENCIENNES, ete.

$O U \nabla R . A G E$

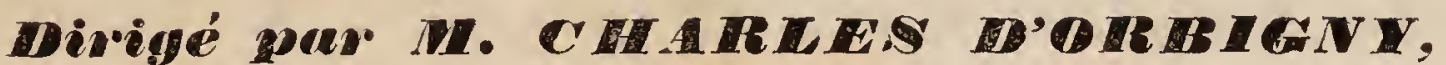

Et enrichi d'un Atlas de planches gravées sur acier, représentant plus de 1,200 sujets.

TOME PREMIER.

\section{PARIS,}

A U BUREAU PRINCIPAL DE LEDITEUR,

RUE DE SEINE SAIN'T-GERMAIN, 47.

1811. - 
9 


\section{AVER'TISSEMEN'T.}

Depuis un demi-siècle, les Sciences naturelles ayant fait des progrès immenses, leurs éléments, jusqu'alors dispersés, ont été groupés dans un ordre logique. On a établi des nomenclatures nouvelles, redressé d'anciennes erreurs; et, plus sûrs de leur point de départ, les savants se sont élancés avec confiance vers de nouvelles découvertes dont l'ensemble a dù finir par amener une véritable révolution scientifique.

Pour apprécier la valeur de cette révolution, dont les conséquences se font chaque jour sentir davantage, il suffit de comparer aux connaissances modernes celles de la fin du siècle dernier. L'imperfection de l'analyse rendait alors toute synthèse impraticable. Privée des principes immuables qui pouvaient seuls en assurer la marche, l'étude errait à l'aventure, sans rien coordonner, jetant çà et là, en lẻs isolant, des idées qui devaient former, de nos jours, les anneaux d'une mème chaîne. Des faits, mal interprétés, étaient enregistrés sans ordre, et souvent à côté des hypothèses les plus insoutenables. Les écrivains même les plus distingués n'étaient point à l'abri de ces erreurs; et, comme aucune loi n'était posée, si la science avait ses adeptes, elle comptait aussi beaucoup d'incrédules. Le scepticisme, en effet, ne s'était point arrêté à la subversion des idées morales et politiques; il avait aussi envahi les sciences. Toutes les vérités reconnues étaient remises en question. Que l'on me fasse un grain de blé, s'écriait Voltaire, et je croirai à la chimie! - Buffon, à la même époque, dictait des écrits éblouissants des pompes du style, et qui, déjà souvent critiqués pour le fond, ne doivent plus guère qu'à leur mérite littéraire le rang qu'ils conservent encore dans l'estime publique. 
Cependant (quelque incompréhensible que cela puisse paraître dans l'état actuel des sciences), beaucoup d'hommes, désireux ,d'acquérir des connaissances scientifiques, en sont encore à les puiser dans les oeuvres des naturalistes de cette époque. Ce seul fait incontestable suffirait pour démontrer l'urgence d'une publication résumant les connaissances acquises jusqu'à ce jour sur les Sciences naturelles. Jamais la tendance des esprits vers l'étude sérieuse de la nature n'a démontré plus évidemment l'opportunité d'un semblable travail. Partout, une réaction se manifeste en faveur de la Science. Génie multjple et puissant, elle vient sourire à tous, se mettre à la portẻe de tous, dispenser à tous les innombrables trésors dont elle fut si long-temps la gardienne avare et jalouse. Jamais l'Histoire naturelle ne fut aussi florissante; jamais elle n'offrit à l'observateur d'aussi nombreux, d'aussi intéressants résultats.

Cet ouvrage ne pouvait donc paraitre sous des auspices plus favorables; car, indépendamment de son mérite intrinsèque, qu'il ne nous appartient pas d'apprécier, nous pouvons affirmer qu'il aura du moins le mérite assez rare et non moins précieux de l'à-propos.

Pour être d'un usage facile aux érudits, comme aux simples amis de la Science, ce vaste panorama des Sciences naturelles devait être à la fois court et complet. Nos lecteurs comprendront sans peine les difficultés que présentait, dans la rédaction d'un Dictionnaire de ce genre, la solution de ce double problème; et pour les leur faire mieux sentir, ils nous permettront de leụr soumettre la méthode que nous avons suivie.

Voulant créer un ouvrage vraiment utile, nous nous sommes efforcés de le rendre aussi exact que possible; et à cet effet nous avons réclamé le concours des premières notabilités scientifiques. Chaque article scra traité d'une manière neuve et pris au point de vue le plus devé. Nous sommes à cet égard dispensés de toute explication : la pureté des doctrines, la justesse des aperçus, pour le fond; la précision, 
la netteté du style, pour la forme, y sont assez garantis par les noms des savants qui doivent signer les diverses parties de cet ouvrage.

Un simple coup d'œil jeté sur quelques articles pris isolément, convaincra bientòt le lecteur que, grâce à la précision des termes, à l'exclusion rigoureuse de toute superfluité, à la combinaison réfléchie des moyens typographiques, nous sommes parvenus, sans nuire à la clarté des sujets traités, à dire beaucoup en peu de mots, à faire entrer en une colonne ce qui eût ailleurs exigé plusieurs pages.

Une innovation importante, et dont nous espérons qu'on nous saura gré, a été de donner, autant que possible, l'étymologie de tous les noms de genres, ainsi que celle des principaux termes scientifiques qu'on chercherait en vain dans les précédents Dictionnaires.

Notre travail à cet égard a été parfois pénible, en raison même des erreurs commises dans la combinaison de ces mots. Nous n'avons néanmoins négligé, parmi les étymologies, que celles dont les lois de l'analogie ne nous ont pas permis de constater directement l'origine, et qu'il ne faut chercher souvent que dans l'imagination bizarre de leurs auteurs.

Les soins apportés à l'exécution des planches de notre Atlas le mettront de beaucoup au-dessus de tous ceux qui ont été publiés dans le même genre. Plusieurs de nos savants collaborateurs ont bien voulu se charger d'en exécuter diverses parties; ainsi M. Decaisne dessinera la plus grande partie des planches de botanique relatives aux familles dont il donnera les caractères avec la précision et l'exactitude consciencieuse qui distinguent ses observations; M. A. Richard fera tous les dessins de l'anatomie et de la physiologie végétales, et les traitera avec sa supériorité accoutumée; enfin les animaux des classes inférieures seront presque tous dessinés par M. Dujardin, qui joint au mérite de bien observer celui de représenter avec une rare habileté les objets d'Histoire naturelle; qualité précieuse surtout chez les naturalistes appelés, comme lui, à enrichir la Science de nombreuses découvertes faites à l'aide du microscope. 
Parmi les artistes auxquels nous avons confié les autres séries iconographiques, il suffira de nommer MM. Meunier, Prêtre, Traviès, Werner, etc., dont la supériorité comme peintres d'Histoire naturelle est bien reconnue. La gravure sur acier de ces dessins, et leur coloriage, seront exécutés par les premiers artistes en ce genre, dont la signature répondra au public du degré de perfection apportée à cette partie de notre publication.

Quoique nous nous soyons fait une loi de rédiger cet ouvrage avec une extrême concision, les articles généraux, auxquels se rapporteront particulièrement les planches, recevront tous les développements qu'exige l'état actuel de la Science. Le lecteur trouvera d'ailleurs, à la fin de chacun de ces articles, une liste des meilleurs ouvrages spéciaux sur le même sujet. Nous nous sommes surtout efforcés de coordonner l'ensemble d'une aussi vaste entreprise, de manière à ce qu'une harmonie parfaite en liât toutes les parties. Nous sommes heureux d'ajouter que nos collaborateurs entrent, à cet égard, avec empressement dans nos vues, et nous aimons à penser que la réunion de tant d'efforts dotera la Science d'un livre utile à tous, résumant exactement l'état actuel de nos connaissances sur la nature, et susceptible, en raison de son peu de volumes, de devenir le vade mecum du savant comme celui de l'homme du monde. 


\title{
LISTE DES ABRÉVIATIONS
}

\author{
EMPLOYẼES DANS CE DICTIONNAIRE.
}

Abd. .....Abdomen.

Acal. ..... Acalèphes.

Adj. ...... Adjectif.

Afriq...... Afrique.

Amér. mérid. . . Amérique méridionale.

Amér. sept.... Amérique septentrionale.

Amph. ..... Amphibiens.

Anat...... Anatomiè.

Anim...... Animal.

Ann. ..... Annales.

Annél. ..... Annélides.

Ant....... Antennes.

Antér..... Antérieur.

Anth...... Anthère.

Arach. ..... Arachnides.

Art........Article.

Astr. .....Astronomie.

Bot. . . . . Botanique.

Bot.cr. .... Botanique cryptogamique.

Bot.ph..... Botaniq. phanérogamique.

Bull. ..... Bulletin.

C.-à-d..... C'est-à-dire.

Cal....... Calice.

C. B.-E.... Câp de Bonne-Espérance.

Can....... Canine.

Capit...... Capitule.

Caps. ...... Capsule.

Car., caract. . . Caractère.

Carn...... Carnassière.

Catal. ..... Catalogue.

Chim...... Chimie.

Cirrh...... Cirrhopodes.

Cl. ...... Classe.

Classif..... Classification.

Col........ Coléoptères.

Cor........ Corolle.

Cors...... Corselet.

Cotyl...... Cotylédon.

Crust...... Crustacés.

Crypt...... Cryptogame ou cryptogamie Dicotyl. . . . . Dicotylédones.

Dict. class. . . Dictionnaire classique.

Dict. sc. nat. . - - des sciences naturelles.

Dim. ..... Diminutif.

\author{
Dipt. .... Diptères. \\ Div...... Division. \\ Échin..... Échinodermes. \\ Édit. . . . Édition. \\ Élyt. . . . E. Élytres. \\ Esp......Espéce. \\ Étam..... Étamines. \\ Etym...... Étymologie. \\ $E x$...... Exemple. \\ Extér......Extérieur. \\ Fam..... Famille. \\ Fem. ..... Féminin. \\ Fig....... Figure. \\ F. mol. . . . Fausse molaire. \\ Foram..... Foraminifẻres. \\ Foss. ...... Fossile. \\ G. ou g. ... Genre. \\ Géol. .... Géologie. \\ Haut. . . . Hauteur. \\ Helm. . . . . Helminthides. \\ Hémipt. . . . . Hémiptères. \\ Hétérom ..... Hétéromères. \\ Hétéropt. ... Hétéroptères. \\ Hist. . . . . Histoire. \\ Hist. nat. . . Histoire naturelle. \\ Hyménopt. . . Hyménoptères. \\ Incert...... Incertain. \\ Incis. ...... Incisive. \\ Indét...... Indéterminé. \\ Inf. ...... Infusoires. \\ Infér. ..... Inférieur. \\ Infloresc. .... Inflorescence. \\ Ins. . . .... Insectes. \\ Intér. ..... Intérieur. \\ Invol. ..... Involucre. \\ Journ . . . J Journal. \\ Lég...... Légume. \\ Légumin. . . . Légumineuses. \\ Lépidopt. ....Lépidoptères. \\ Long. . . . . Longueur. \\ Mach ..... Mâchelière. \\ Mandib .... Mandibule. \\ Mam...... Mammilères. \\ M. ou masc. . Masculin.
}




\section{LISTE DES ABREVIATIONS.}

Méditerr... Méditerranée.

Mém..... Mémoirc.

Mérid. ... Méridional.

Météor. . . Météorologie.

Min . . . Minéralogie ou minéralogique.

Mol ..... Molaire.

Moll. .... Mollusque.

Monocotyl. Monocotylédones.

Monog. ... Monographic.

Mus. ....Muséum.

Myriap.. . Myriapodes.

Myth.Mythol.Mythologie, Mythologique.

Nat . . . Naturelle.

N.-Hull. . Nouvelle-Hollande.

Névropt . . Névroptères.

Ois...... Oiseaux.

Ord..... Ordre.

Orthopt.... Orthoptères.

Pédonc. . . Pédoncule.

Pentam.... Pentamères.

Ph. ou Phan. Phanérogame ou Phanérogamie.

Phys..... Physique.

Physiol.... Physiologie ou Physiologique.

Pist..... Pistil.

Pl.....Planche.

Poiss.... Poissons.

Pol..... Polypes.

Postér.... Postérieur.

Récept... Réceptacle.

Rept. . . . Reptiles.

S. ou subst. . Substantif.

Sc.nat.... Sciences naturelles.

S. $C l$..... Sous-classe.

S.-Div. ... Sous-division.

Sect..... Section.

S.-G..... Sous-genre.

S.-Ord. . . Sous-ordre.

Spécif.... Spécifique.

Spong..... Spongiaires.

Stigm..... Stigmate.

S. $-T r . .$. Sous-tribu.

Supér..... Supérieure.

S'uppl..... Su pplément.

Syn...... Synonyme.

Systol..... Systolides.

Térat.... Tératologie.

Tétram.... Tétramères.

Thor..... Thorax.

Tr..... Tribu.

$V \ldots \ldots$ Voyez.

Var..... Variété.

Vég...... Végétal.

Voy...... Voyage.

Vulg....Vulgaire.

Zool .....Zoologie, ou zoologiste.

Zooph.....Zoophytes.

1..... Uni.

2. ..... Bi.

3. .... Tri.

4...... Quatri, ou tétra.

5. ..... Quinque, ou penta.

$6 . . .$. Sex, ou hexa, etc. 


\section{LISTE ABREVIATIVE \\ DES AUTEURS IEE PLUS FRĖQUEMMENT CITĖS \\ DANS CET OUVRAGE.}

A la fin de l'un des premiers volumes, on donnera une liste romplète de tuns les auteurs dont les noms sont abrégés.

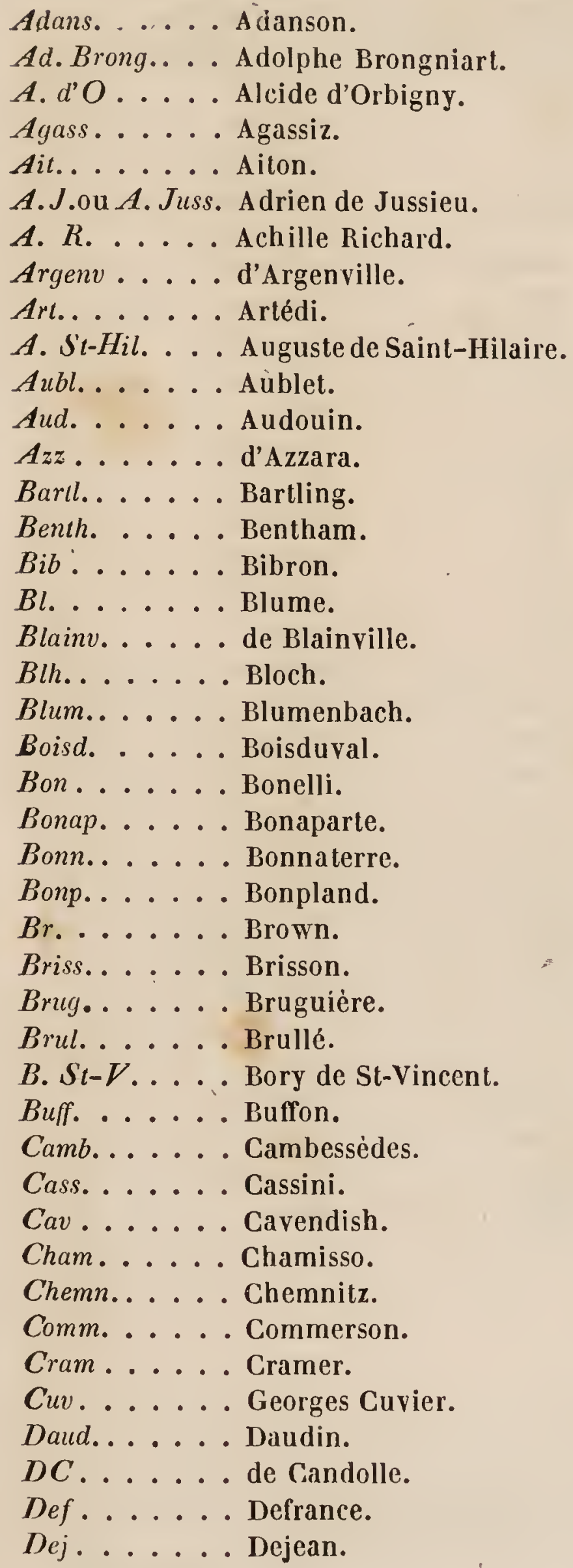

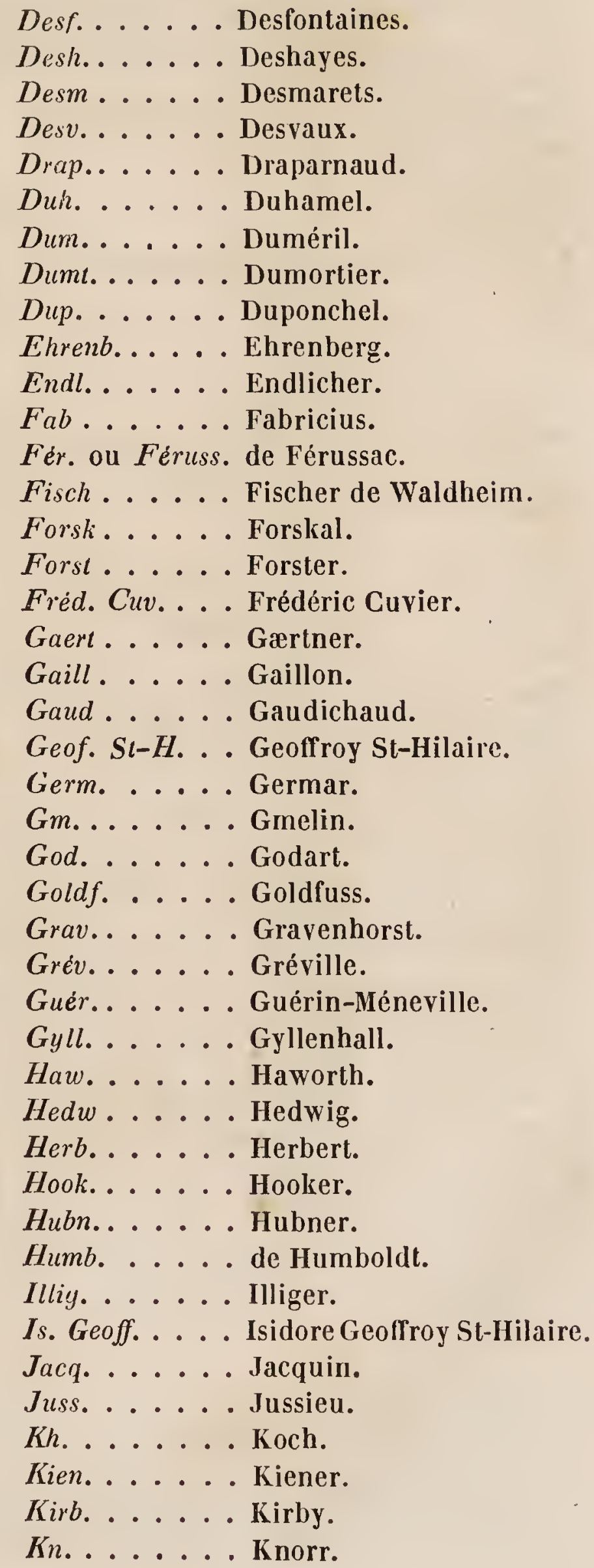




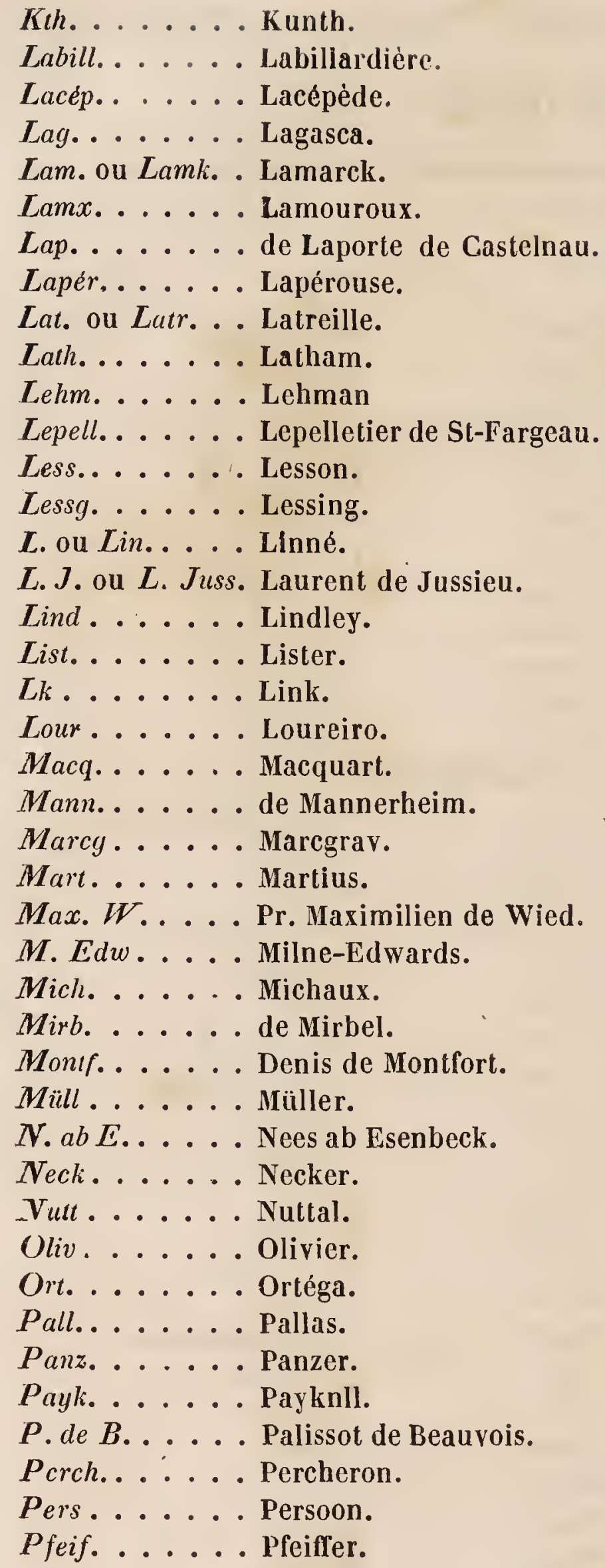

Plum...... Plumier.

P.Th. .... Dupetit-Thouars.

Pœpp..... Pœppigg.

Raf....... Rafinesque.

R.Br...... Robert Brown.

Réaum. .... Réaumur.

Reich..... Reichenbach.

Robin...... Robineau-Desvoidy.

Rossm . ... Rossmaessler.

R. et P. . . . Ruiz et Pavon.

Rupp..... Ruppel.

Sav....... Savigny.

Schl...... Schlotheim.

Schn. .... Sehneider.

Schocn..... Schœnherr.

Schrad..... Schrader.

Schreb...... Schreber.

Scop...... Scopoli.

Serv....... Serville.

Sm. ...... Smith.

Sold...... Soldany.

Sow....... Sowerby.

Spin...... Spinola.

Spr....... Sprengel.

Slep....... Stephens.

Swt....... Sweet.

Swz...... Swartz.

Tur....... Turton.

Temm..... Temminck.

Thunb.... Thunberg.

Tourn.... Tournefort.

Vaill..... Vaillant.

Wag. .....Wagner.

Walck..... Walckenaer.

Val. ..... Valenciennes.

Fent...... Ventenat.

Vied...... Viedemann.

Vieill. . . . . Vieillot

Westw. ..... Westwood.

Wild...... Wildenow.

Zet.......Zetterstedt.

Ziet......ZZieten. 


\section{DISCOURS PRÉLINIINAIRE.}

\section{PRÉA M B ULE ?}

L

Historre naturelle remonte à la plus haute antiquité : l'homme en effet, dès les temps les plus reculés, dut être frappé de la majesté de la nature; assemblage inconnu de causes et d'effets dont il ne peut, il est vrai, qu'imparfaitement saisir l'ensemble et le but, mais qui, contemplé dans ses moindres détails comme dans ses manifestations les plus puissantes, le remplit d'admiration par sa merveilleuse harmonie.

Lève-t-il les yeux vers les régions célestes? il y voit des myriades de globes lumineux, régis dans leurs mouvements éternels par des lois immuables. L'atmosphère au milieu de laquelle il respire lui offre à chaque instant de nouveaux phénomènes qui, dans leur irrégularité même, sembleraient résulter d'un ordre mystérieux. L'eau, réduite en vapeur, tantôt s'élève dans les airs, s'y forme en nuages, puis retombe en pluie, pour arroser et fertiliser la terre; tantôt, suspendue dans les régions

x Grâce au concours éclairé de MM. Delafosse, A. Duponchel, Duvernoy, Isidore Geoffroy-Saint-Hilaire, Gérard, Gervais, Guillemin, etc., qui ont bien voulu ajouter des notes précieuses aux matériaux que nous avions réunis pour ce travail, nous donnerons, sur l'état actuel des sciences, un ensemble de renseignements que n'aurait pu nous fournir aucun corps d'ourrage. 
inférieures, elle vient, bienfaisante rosée, se condenser sur le sol; renduc solide par le froid, elle couvre la terre de flocons de neige, ou, durcie en grêlons, elle frappe et brise les végétaux. L'agitation de l'atmosphère, due à tant de causes diverses, tempère parfois par sa douceur les ardeurs du soleil, parfois devient un ouragan terrible qui renverse tout sur son passage. La foudre alors gronde dans les airs; elle déchire la nue, sillonne l'espace, sème l'effroi sur la terre, consume ou pulvérise tout ce qu'elle frappe ; mais bientôt le calme se rétablit, les nuages se dissipent, et sur un léger rideau de vapeurs se dessinent les teintes brillantes de l'arc-en-ciel.

L'homme jetle-i-il ses regards autour de lui? il ne peut s'empêcher de remarquer la variété des productions et la multiplicité des êtres vivanıs qui l'environnent: l'air, les eaux, la terre en sont peuplés; s'il fouille le sol, il retrouve les innombrables débris d'animaux et de végétaux contemporains d’âges depuis longtemps écoulés, et ensevelis au milieu de masses minérales dont les variétés ne sont pas moins nombreuses.

La vie remplit l'espace; le rocher, dont la masse a bravé les tempêtes, cède à la puissance incessamment vivifiante de la nature. Les lichens, les mousses, s'attachent à ses flancs robustes, les minent, et préparent ainsi le berceau oì se développen des végélaux plus complexes; et quelquefois même l'arbre s'élève là où naguère la plus humble plante ne pouvail végéter.

Voyez le chène, ce roi des forêts, qui annonce une si grande puissance vitale; il est en butte aux attaques de myriades de parasites dont beaucoup ne doivent leur existence qu’à la sienne. Sous son écorce, des scolytes dessinent mille figures; à sa surface, des kermès se fixent; dans le parenchyme de ses feuilles s'insinuent des cynips qui y déterminent les excroissances appelées noix de galles; des lichens tapissent son écorce, et des mousses s'établissent à sa base. Si sa vie s'épuise, il est bientôt assailli par une foule d'autres insectes et de végétaux qui s'en emparent comme le ver s'empare du cadavre. Chaque animal, chaque plante, devient ainsi la proie de nombreux ennemis, et particulièrement de certaines espèces qui semblent nées avec eux. Le cossus dévore l'orme ; l'hépiale détruil les houblonnières ; la pyrale, le rhynchite et l'eumolpe, la vigne; la saperde, les lamies, les cérambyx, rongent le peuplier, le bouleau et généralement les arbres de haute futaie. Les animaux nourrissent dans leurs tissus les plus intimes des helminthes qui parfois causent leur mort. Les insectes eux-mêmes, tout 
petits qu'ils sont, ne peuvent se soustraire à cette loi commune : le géotrupe est couvert de mites; le ver à soie, dans nos magnaneries, périt de la muscardine; les chenilles et d'autres larves reçoivent à leur insu les œufs des ichneumons, et les vers qui en sortent les dévorent.

A peine une goutte d'ean est-elle tombée du ciel qu'elle devient un monde organisé; car la vie existe partout el se manifeste sous toutes les formes; mais chaque règne ou chacune des classes qui le composent ne se renferme pas dans un cercle limité de formes et de phénomènes. Tous les êtres, au contraire, se fondent et se mêlent à l'infini sans qu'il soit possible d'assigner les bornes oì une série finit et où une autre commence. Ainsi les chéiroptères ont des ailes, et l'air est leur élément comme il est celui de l'oiseau; le polatouche et le phalanger volant, quoique dépourvus d'ailes véritables, franchissent, en déployant leurs membranes, un espace que ne saurait franchir aucun animal sauteur. L'ornithorhynque se rapproche des oiseaux par son bec, et des reptiles par plusieurs caractères anatomiques particuliers à certains animaux de cette classe. Les phoques, les cétacés, ont une vie analogue à celle des poissons; doués d'une agilité extrème dans l'eau, ils rampent lentement sur le sol. Privés des poils que présentent la plupart des autres mammifères, les pangolins sont couverts d'écailles; les tatous, d'une sorte de cuirasse; les hérissons et les porcs-épics, d'épines qui ne sont que des faisceaux de poils.

Parmi les oiseaux, quelques-uns, comme le casoar et l'autruche, marchent, courent, mais ne volent pas; d'autres, comme le cygne, le canard, et, en général, les palmipèdes, vivent à la surface des taux. Tels poissons, comme les exocets et les dactyloptères, abandonnent la surface des ondes et se soutiennent quelques instants dans l'air au moyen de leurs vastes nageoires pectorales. Les batraciens ont un double mode d'existence; poissons dans le premier âge, ils respirent comme les animaux de cette classe au moyen de branchies, que des poumons viennent remplacer après leur métamorphose; et quelques-uns, comme la sirène et le protée, restent à demi-poissons pendant toute leur vie.

Parmi les invertébrés et les végétaux, même variété pour les milieux dans lesquels ils vivent, même incertitude sur leur enchaînement. On a vainement essayé de tracer une classification graduelle des êtres organisés, en marquant le pasșage des uns aux autres. Quelques naturalistes les ont rangés sur une ligne verticale et dans un ordre ascendant; d'autres les out placés sur deux ou sur plusieurs lignes parallèles, ou bien ont 
tracé des lignes convergentes formant des cônes emboîtés les uns dans les autres, tous créant, tous plaçant et déplaçant tour-à-tour des familles et des genres plus ou moins naturels et qui s'associent plus ou moins bien avec les groupes voisins; mais aucune de ces tentatives de classement qui ne convient qu'à telle ou telle théorie, n'a paru pleinement satisfaisante, car la science humaine n'est point encore assez avancée pour avoir pu embrasser l'ensemble de tous les faits. On a voulu placer les êtres dans l'ordre de leur prétendue perfection ; mais les mots perféction et imperfection ont donné lieu à de sérieuses controverses; qui peut dire, en effet, d'une manière absolue ce qui est parfait et imparfait? Dans le sens philosophique du mot, l'être le plus parfait serait celui dont la structure est la plus simple, et dans lequel se font, avec le moins d'organes possibles, les fonctions complexes de la nutrition, de la respiration, de la génération, de la locomotion, des sensations et des perceptions. Dans ce cas, le polype l'emporterail sur l'homme; la plante cryptogame la plus simple, sur les phanérogames. Tant que nous ne connaîtrons pas les lois qui président à la vie, disons que chaque animal, étant organisé pour le milieu dans lequel il doit vivre, possède le degré de perfection nécessaire pour que les phénomènes qui constituent son existence s'accomplissent aves ordre et régularité. Ainsi, les quadrupèdes, que leur organisation attache à la terre, ont une large base de sustentation; les uns, destinés à se nourrir de proie vivante, sont souples et légers; les autres, se nourrissant d'herbes, sont moins agiles. Dans l'oiseau, tout concourt à rendre son vol plus facile: ses os creux et celluleux, sa poitrine spacieuse, ses membres inférieurs admirablement disposés pour leur usage. Les poissons, par leur forme comprimée et allongée, par la queue très développée et flexible qui leur sert de gouvernail et par des nageoires remplissant l'office de rames, ont également les mouvements souples et faciles; ils divisent le fluide en offrant le moins possible de surface résistante. Leur corps est le plus souvent protégé par des écailles sur lesquelles glissent ou s'amortissent tous les chocs. Les insectes répandus partout, présentent une organisation des mieux appropriée à leur genre de vie : ceux dont les larves vivent sur le tronc des végétaux ligneux sont armés d'unetarière pour percer le bois; les insectes broyeurs ont deux mandibules et deux mâchoires horizontales agissant comme des ciseaux; ceux qui se nourrissent du sang des autres animaux ou dusuc des fleurs ont une bouche en forme de sucoir, propre à entamer les peaux les plus dures, ou une trompe déliée qui s’insinue 
jusqu'au fond des corolles. Les coléoptères, dont les ailes sont de fragiles membranes qu'un souffle pourrait détruire, sont munis d'étuis cornés qui lès recouvrent; les papillons, destinés à une existence éphémère, ont des ailes qui doivent peu durer. Les mollusques, dont le corps dépourvu d'un soutien osseux serait exposé à toutes les causes de destruction, sont, pour la plupart, protégés par.une coquille calcaire d'une extrême solidité. Enfin, dans les derniers degrés de l'échelle animale, les polypes, qui semblent braver la mort et se multiplient à mesure qu'on les divise, et les infusoires, vivant par milliers au sein d'une goutle d'eau qui pour eux est un monde, sont autant de preuves de l'admirable diversité des moyens que la nature emploie pour arriver au même résultat, la vie.

Si notre esprit s'attriste à la vue des scènes de destruction dont la nature vivante est le théâtre, rappelons-nous que la vie n'est qu'à ce prix, et que la mort ne fait rentrer tous les êtres dans le sein de la matière que pour qu'ils en sortent de nouveau après d'innombrables métamorphoses. La vie est à la fois but et moyen; aussi les êtres organisés sont-ils nés pour se servir mutuellement de pâture : le végétal pousse plus vigoureusement lorsque ses racines sont plongées dans un sol fertilisé par des débris animaux. L'animal à son tour vil soil de végétaux, soit de chair. L'homme même, tout puissant qu'il est, l'homme qui met à contribution pour sa nourriture el pour ses autres besoins toute la nature organique, devient l'objet de terribles représailles; mais chaque fois qu'un ètre est exposé à beaucoup de chances fatales, il se multiplie avec plus de rapidité. Les portées des petits quadrupèdes sont plus fréquentes et plus nombreuses que celles des grands; certains oiseaux pondent une assez grande quantité d'œufs. On comnaît l'étonnante fécondité des poissons et des insectes; mais on ne peut encore la comparer à celle des plantes, qui, chaque année, produisent d'innombrables graines qu'emportent au loin les eaux, les vents et les animaux.

La nature ne se préoccupe pas des individus; sa sollicitude s'arrête à la conservation de l'espèce; on pourrail mème dire, avec quelque raison, qu'elle ne s'en irquiète que faiblement; pourvu que la vie se multiplie, se répande, peu lui importent les transformations, les destructions; elle ne connaîl d'autre privilége que celui de la force et n'a de prédilection particulière pour aucun type d'espèce. Mais, comme un lien intime unit l'individu à l'espèce, elle a domné à chaque classe d'êtres les moyens de conserver sa vie; une course prompte comme la flcche 
ou des ruses nombreuses à ceux qui n'ont pas d'armes défensives; aux autres, des dents tranchantes; des ongles aigus, un cuir impénéurable, de solides écailles, des appareils électriques, des glandes venimeuses, etc.

Le caractère essentiel de la nature est d'être une, immuable, quoique multiple dans ses manifestations. Sa loi, c'est la variété de l'unité; la matière organique est comme une cire molle qu'elle pétrit ou combine de mille façons, en produisant toujours des êtres nouveaux, qui ne ressemblent à leurs devanciers que par l'identité de leurs condilions physiologiques d'existence. Nous ne pouvons faire un pas sans découvrir une de ces créations, ancienne sans doute, mais qui nous était restée inconnue. Quel vaste champ ouvert à l'observation! quel aliment pour l'insatiable curiosité de l'homme! Voir, voir encore, el découvrir toujours ; ne soulever que peu-à-peu le voile dont la nature a convert ses trésors, c'est une de ces joies qu'il n'est donné qu'au naturaliste de connaître.

Les sciences naturelles ne sont pas arrivées à leur état actuel de perfection sans avoir subi l'épuration des siècles. Il a fallu bien des tàtonnements, bien des théories hasardées, reçues longtemps comme des vérités, puis rejetées avec dédain comme autant d'erreurs grossières, pour réunir le petit nombre de faits authentiques sur lesquels repose la science moderne. Ce n'est que de loin en loin, qu'ont apparu ces naturalistes philosophes qui, devançant l'expérience par la haute portée de leur génie, ont indiqué avec assurance la marche à suivre pour arriver à la vérilé.

Quand l'homme, nu, faible, exposé à mille causes d'anéantissement, eut une idée moins confuse des objets qui l'entouraient, il dut examiner avec attention chacun de ces objets afin d'en reconnaître, par rapport à lui, les qualités utiles ou nuisibles. Tous les fruits n'avaient pas la même saveur et n'étaient pas également propres à servir d'aliments ; les animaux dont il fit plus tard sa nourriture et qu'il tua pour se couvrir de leurs fourures, n'étaient pas des viclimes résignées recevant la mort sans résistance. Ceux-ci lui échappaient par la fuite ou la ruse ; ceux-là, carnassiers comme lui, ne cédaient qu'à la supériorité de la force ou de l'intelligence. Il les observa donc d'abord isolément, comme de simples individus, avant de remarquer entre eux des rapports plus ou moins éloignés.

Les premières observations comparatives furent les commencenents 
de la science; clles ne remontent, sans doute, qu'à l'époque où une vic sociale moins agitée permit à la pensée de prendre me direction spéculative.

Les peuples chasseurs, plus rapprochés que les autres de la vie sauvage, étudièrent seulement l'instinct propre aux animaux de proie. Épier un animal avec une patience infatigable, lutter avec lui de ruse et d'agilité, telle fut leur occupation journalière. Celte vie turbulente s'opposait au développement de la pensée.

Les peuples pasteurs, au contraire, déjà descendus dans les plaines et sur le bord des eaux, groupés par tribus nombreuses, menant une existence plus douce et plus régulière, furent portés par lerur position même à la contemplation el à f'observation. Ils durent choisir pour eux des lieux d'habitation salubres, et des pâturages abondants pour leurs troupeaux ; veiller à la mulliplication de ces derniers, les soigner dans leurs maladies; assister à toutes les phases de la vie animale, éloigner de leurs tentes les animaux nuisibles; toutes ces occupations étaient autant d'aliments pour l'intelligence. Ainsi, par exemple, les bergers de la Chaldée, condamnés à l'oisiveté des gardiens de troupeaux, cherchèrent dans l'étude des astres une diversion à la monotonie de leur existence: aussi culıivèrent-ils très anciennement l'astronomie.

Les peuples agriculteurs, en combinant l'exploitation du sol avec l'éducation des troupeaux, ajoutèrent de nouvelles observations sur la zoologie et la botanique à celles déjà faites par les peuples pasteurs. Les villes, bâlies pour servir d'abri contre les incursions des tribus voisines, virent naître dans leur sein des hommes qui consacraient leur vie aux travaux de l'intelligence; et les sciences, dépouillées de leur grossière et rude enveloppe, prirent la forme dogmatique. L'écriture, remplaçant la tradition, fixa les faits empiriquement acquis et assit la science sur une base inébranlable; mais la superstition, les mauvaises mœurs, les institutions vicieuses, qui se reflètent nécessairement sur les connaissances humaines, faussèrent bien des idées et engendrèrent bien des croyances erronées.

On concoit que sur un tel canevas il dut être brodé beaucoup de fables, que d'une telle source il dut découler beaucoup d'erreurs. Les anciens naturalistes, nés au milieu de peuples amis du merveilleux, ont rempli leurs ouvrages de rêves souvent aussi poétiques que leur mythologie. Tantôt ils disent qu'un petit poisson (le rémora), malgré sa faihlesse, arrête méchamment la marche des navires, tandis que le rémora 
n'est en réalité qu'un paresseux, qui, pour s'épargner la peine de nager, s'attache aux corps flottants, aux gros poissons même, par le moyen d'une sorte de rentouse dont sa tête est armée ; tantôt des lamantins, aux formes lourdes et grossières, sont métamorphosés, par l'imagination bril lante des Grecs, 'en vigoureux tritons ou en gracieuses sirènes. N'accusons pas ces hommes des erreurs auxquelles ils se sont laissé prendre; l'expérience ne s'acquiert qu'avec le temps; et, pour voir les faits tels qu'ils sont, dépouillés de tout prestige, il faut s'affranchir des préjugés qui obscurcissent la raison et des hypothèses qui l'égarent. Notre époque même n'en est pas exempte, et bien des fictions sont données pour des réalités; ainsi l'on a vu une reine dans la femelle féconde d'une ruche, et I'on a cru y trouver un emblème de la monarchie; ainsi l'on a fait des pucerons, dont les fourmis sucent la liqueur sucrée qui transsude de leurs tubes abdominaux, les chèvres et les vaches de ces insectes.

L'histoire des progrès des sciences naturelles est celle de l'esprit humain et de la civilisation. Les sciences, mystérieuses d'abord, enveloppées du même voile que la religion, furent exploitées par les prêtres seuls au profit d'un petit nombre d'adeptes; elles furent ensuite professées par les philosophes sous les formes obscurément ambitieuses de l'antiquité. Le peuple demeurait étranger à leur développement, et l'on ne lui livrait que des fictions propres à perpétuer son ignorance. Le mouvement des esprits, cette tendance continuelle de l'humanité vers le perfectionnement de l'intelligence, a vaincu les préjugés. Longtemps voilées par le charlatanisme, l'orgueil et la mauvaise foi, les lumières ont peu-à-peu éclairé les nations et agrandi la sphère de la pensée. A chaque réforme, à chaque grand mouvement social, les sciences naturelles ont vu s'accroître leur domaine, et l'on a compris que leur propagation intéressait tous les hommes qui, vivant au milieu de la nature, puisent dans l'étude des lois qui président à la vie et au développement des êtres, de nouveaux moyens de satisfaire leurs besoins et d'augmenter leurs jouissances.

L'agriculture, le premier des arts, emprunte aux sciences naturelles ses connaissances et ses améliorations les plus précieuses. La botanique lui fournit des renseignements exacts non-seulement sur les végétaux cultivés à raison de leur utilité pour l'homme, mais aussi sur ceux que leurs propriétés nuisibles doivent faire soigneusement extirper. C'est la physiologie végétale qui le guide dans ses opérations principales, telles que les labours, les assolements, les engrais; c'est encore d'elle que dé- 
rivent tous les perfectionnements de la culture des forêts et des jardins. La zoologie lui indique les races propres au labourage, ou celles dont l'éducation lui est avantageuse; elle lui dit comment on obtient, par le croisement, des sujets plus forts dont la chair est plus savoureuse, ou dont les enveloppes sont d'une plus grande valeur. Elle lui fait connaître ses ennemis, leur's ruses, leurs moyens de multiplication, les animaux qu'on peut dresser pour les détruire. Elle lui fait voir que les oiseaux qui vivent d’insectes doivent être épargnés, parce qu'ils lui rendent d'immenses services; tandis que ceux qui dévorent les grains sont des pillards qu'il faut éloigner des champs ensemencés el des récoltes. L'étude de la géologie, qui conduit à la découverte des trésors que le globe recèle, lui fournit les connaissances nécessaires pour déterminer la nature des terrains et les mélanges qui peuvent les améliorer'; elle facilite le forage des puits artésiens et les diverses exploitations, soit des pierres qui servent à élever nos édifices, soit des métaux dont l'emploi est si général. La météorologie enseigne l'immense influence que les saisons et leurs variations exercent sur la culture, et le rôle que jouent dans la végétation les phénomènes atmosphériques.

II n'est pas une branche d'industrie qui ne tire le même parti de l'étude de la nature. Les ouvriers qui travaillent le bois doivent connaître les lois de l'accroissement des végétaux ligneux, l'action des climats et des terrains sur leur dureté, la finesse de leur grain, la richesse de leurs veines. Les ouvriers en métaux puisent dans la minéralogie des notions précieuses; elle leur révèle les gisements des divers minerais, leurs propriétés, leur mode d'épuration, l'influence des diverses agrégations métalliques sur leur valeur industrielle, leur abondance ou leur rarelé. Les ouvriers qui travaillent la pierre tirent de la même science el de la géologie la juste appréciation des matériaux qu'ils mettent en œuvre. C'est à ces données pratiques que les anciens durent le choix judicieux et la merveilleuse variété des matériaux qu'ils employaient à la construction et à la décoration de leurs édifices. Les arts industriels, le commerce, enfin tout ce qui concourt à accrôitre la prospérité des nations, trouve donc, dans l'étude de la nature, des enseignements profitables.

Nous ne parlerons pas du médecin, pour qui la nature ne doil pas avoir de mystères, s'il veut remplir avec conscience ses devoirs envers l'humanité. Les sciences spéculatives elles-mêmes ne peuvent trouvel de base solide et rationnelle que dans l'observation des faits. Long- 
temps égarés par les vagues rêveries d'une métaphysique obscure, les philosophes ont enfin abandonné les régions de l'hypothèse pour se livrer à l'observation. Leur main s'est armée du scalpel, leur oeil du microscope ; ils ont interrogé tous les êtres, scruté toutes les décou: vertes; et, après avoir vu, comparé, jugé, ils ont rejeté comme autant d'erreurs tout ce que leur doigt ne pouvait toucher, tout ce que leur ceil ne pouvait voir, tout ce que leur esprit ne pouvait comprendre: chaque fois que la nature leur a fermé son livre, ils ont su attendre patiemment qu'elle le rouvrît. C'est ainsi que l'industriel et le savant puisent dans les sciences naturelles des lumières qui multiplient leurs moyens d'application ou contribuent au perfectionnement de leur esprit ; c'est ainsi que l'homme du monde y trouve une source d'inépuisables jouissances qui embellissent la vie, sans laisser après elle de repentir ou de satiété. Elles ont sur toutes les autres connaissances l'avantage d'être toujours neuves, toujours attrayantes.

Les anciens comprenaient toutes les sciences sous le nom de Philosophie, et l'histoire naturelle n'en était qu'une branche sans importance, qui disparaissait dans les sciences purement spéculatives. A celte époque, encore si rapprochée du berceau de la civilisation, les faits étaient peu nombreux et l'esprit pouvait sans peine en embrasser l'universalité. Les temps ont bien changé. Chaque partie de la science est devenue si riche, que l'intelligence de son ensemble et de ses détails demande de longues et sérieuses études. Le plus mince ouvrage élémentaire de notre époque contient plus de faits que n'en connaissait l'homme le plus érudit de l'antiquité; ainsi l'on trouve dans le traité de botanique de Théophraste l'énumération de quatre cents plantes seulement, tandis que nous comptons aujourd'hui plus de cent mille végétaux. On connaît quatre mille espèces d'oiseaux; deux fois autant de poissons; la seule classe des insectes comprend, d'après les calculs de M. Burmeister, quatre-vingt mille espèces, et les collections en renferment encore une grande quantité d'inédites. Les crustacés, les myriapodes, les arachnideś, quoique moins abondants, sont aussi très multipliés, et les mollusques, réunis aux zoophytes, ne le cèdent pas en nombre aux insectes. Cependant on est bien loin encore de pouvoir énumérer tous les êtres qui peuplent le globe, et chaque jour ajoute une déconverte nouvelle. aux découvertes antérieures.

Aujourd'hui que les progrès des sciences ont contraint de les diviser', on ne trouve plus de ces têtes encyclopédiques capables d'en embrassel' 
l'ensemble, et chacun doil se borner aux généralités ou spécialiser ses études. M. Isidore Geoflroy Saint-Hilaire a calculé que, pour se laire une idée seulement superficielle de tous les animaux, il faudrait quarante années d'étude, en y employant dix heures par jour; et la vie de plusieurs hommes y suffirail à peine. Il a donc fallu diviser les sciences en coupes nombreuses, fondées sur leurs affinilés.

Les sciences naturelles proprement dites comprennent l'étude des ètres organisés et des corps inorganiques, considérés, les uns sous le rapport de leur structure externe et interne, de leurs conditions d'existence, de leur mode de reproduction, de leurs métamorphoses, de leurs moeurs, des analogies qui les rapprochent ou des dissemblances qui les séparent; les autres, sous le rapport de leur formation, de leur forme, de leur structure cristalline, de leur mode d'agrégation et de leurs applications. Autour de ces sciences se groupent l'Astronomie, complètement soumise aux mathématiques; la Physique, qui s'occupe de l'action que les corps exercent les uns sur les autres, sans que leur composition en soil altérée, el la Chimie, dont l'objet est l'étude des actions inlimes qui ont lieu entre ces mêmes corps. Ces trois sciences constituent les sciences physiques; leur manière de procéder dans leur's recherches les distingue des sciences naturelles, qui ne considèrent que les phénomènes révélés par l'observation immédiate, appliquée à des êtres spéciaux et déterminés, ou, par la généralisation, à des choses identiques; cependant leurs principes généraux doivent être connus du naturaliste, qui sans elles ne pourrait s'expliquer un grand nombre de faits.

Une énumération rapide des principales divisions des sciences naturelles fera comprendre combien leur étude présente de points de vue différents, el comment on a pu voir dans chacune d'elles une science à part.

En tête de ces sciences se trouvent celles qui se rapportent aux êtres organisés, dont le mode d'accroissement a lieu par intus-susception, soil au moyen d'un tube digestif absorbant les parties assimilables des aliments ingérés, soit au moyen de racines qui pompent les sucs nourriciers contenus dans le sol, ou par des feuilles absorbant les gaz qui entrent dans la composition de l'àtmosphère.

La Zoologie cmbrasse la généralité des animaux, les compare entre eux, les divise, les groupe, établit les méthodes de classification, et réunit, dans son domaine, toutes les branches de la scicnce qui se rapportent à ces ètres organisés. L'Anatomie, soil spéciale, soit comparée, 
étudie leurs parlies, cherche à en connaitre la structure intime et les. relations réciproques. La Physiologie conduit à surprendre les mystères de la vie et à en expliquer les phénomènes; elle étudie le jeu et les fonclions des organes. La Tératologie, sorte d'anatomie comparée, observe les diverses anomalies organiques, et en recherche les lois. Après ces sciences, qui embrassent l'universalité des êtres vivants, en viennent d'autres plus spéciales qui ne considèrent qu'une partie du règne animal ; ainsi l'Anthropologie prend l'homme pour but particulier de ses méditations: elle constate l'influence des climats, des sexes, de l'âge, des moeurs, du mode d'alimentation, de la civilisation et de l'état sauvage sur les diverses races humaines. La Mammalogie s'occupe des Mammifères considérés indépendamment des autres classes. L'Ornithologie en fait autant pour les Oiseaux. L'Erpétologie a pour objet la série des Reptiles, comprenant les Serpents, les Lézards, les Tortues et les Batraciens. L'Ichthyologie traite de tous les autres vertébrés qui peuplent les eaux, et ont des branchies au lieu de poumons pour organes respiratoires; ce sont les Poissons qui viennent clore la classe des vertébrés. On a placé les animaux à vertèbres à la tête des ètres organisés, comme étant ceux chez lesquels les fonctions sont les plus distinctes et l'intelligence la plus développée.

Viennent ensuite les Invertébrés, tous privés d'un support osseux interne, et dont beaucoup n'ont que des masses ganglionnaires et pas de centre commun d'innervation. Ils ont été classés suivant l'ordre de perfection de leur système nerveux.

La Conchyliologie ou Malacologie est la science qui traite des Mollusques à coquille ou sans coquille. L'Entomologie étudie les insectes et plus généralement les animaux articulés, parmi lesquels on comprend, outre les véritables insectes ou hexapodes, les Myriapodes, les Arachnides, les Crustacés, les Cirrhopodes et les Annélides.

Enfin, une dernière branche, l'Actinologie, embrasse une série d'ètres dont l'organisation est excessivement simple, doués de la faculté locomotive ou fixés au sol, et présentant certains caraclères spéciaux; ce sont les Zoophytes ou Animaux Rayonnés, qu'on a dû partager en plusieurs classes, comprenant les Échinodermes, les Acalèphes, les Polypes, les Spongiaires, les Infusoires homogènes el les Oscillariées, qui, sans organes musculaires et nerveux, jouissent de la propriété d'exercer des mouvements oscillatoires, et ont été considérés comme établissant le passage du règne animal au règne végétal. 
On a désigné sous le nom de Botanique ou de Phytologie la science qui traite des végétaux, êtres organisés el vivants, mais privés de mouvement volontaire et de sensibilité apparente. Elle a, comme la zoologie, son anatomie, sa physiologie, sa tératologie et sa nosologie. Si l'on ne considère que la botanique proprement dite ou la connaissanice des végétaux indépendamment de toute application, c'est encore, une vaste science qui peu se subdiviser en autant de sections qu'il y a de classes ou de grands groupes de végétaux. Ainsi les Acotylédones comprennent tous les végétaux dépourvus de feuilles séminales ou cotylédons; les organes sexuels n'y sont pas apparents ou du moins ne ressemblent pas à ceux des plantes plus élevées dans l'échelle de l'organisation; d'où le nom de Cryptogames, appliqué aussi à cette classe, à laquelle appartiennent les familles si étendues el si polymorphes des algues, des champignons, des lichens, des mousses, des fougères, etc. Les plantes pourvues de cotylédons forment deux divisions principales, les Monocotylédones et les Dicotylédones. Leurs orgánes sexuels sont si apparents qu'on a pu en déterminer les fonclions avec une certitude presque absolue; ce qui a valu le nom de Phanérogames à l'ensemble des plantes qui composent ces grandes classes. Elles renferment les grands végétaux qui peuplent nos forêts et nos vergers, les fleurs qui décorent nos parterres, la plupart des plantes d'où nous tirons notre nourriture, nos vêtements, et de celles qui nous guérissent ou nous soulagent dans nos maladies.

Ici finit la nature vivante el commence la nature morte, inerte, à laquelle appartiennent les corps qui croissent par juxta-position. A la lête de cette nouvelle branche des sciences naturelles se place la Géologie, qui a pour objet l'histoire du globe; elle en fait connaître la forme extérieure, la nature, la structure, et cherche à découvrir les révolutions qu'il a éprouvées depuis son origine. A la Géologie se rattache la $P a-$ léontologie, ou la science des êtres organisés conservés à l'état fossile: ils offrent de précieux caractères pour distinguer les terrains des différents àges. La Minéralogie vient fermer l'étude de l'histoire naturelle; elle s'occupe des corps inorganiques, non pas sous le rapport de leur gisement, mais sous celui de leur composition et de l'agrégation de leurs molécules; elle indique el détermine, sous le nom de Cristallographie, la figure géométrique des cristaux et recherche leur forme primitive. On ne peut faire un pas de plus sans entrer dans les sciences physiques.

On voil que l'étendue des sciences naturelles, la mulliplicité des ob- 
jets qu'elles renferment et leurs progrès journaliers, rendent indis-pensable la publication d'annales nouvelles, qui enregistrent soigneusement les faits récemment acquis et viennent remplir les lacunes dès anciennes, devenues insuffisantes. L'introduction tout à la fois la plus instructive et la plus intéressante pour nos lecteurs, comme la plus propre à les initier aux progrès des sciences naturelles et de la partie des sciences physiques qui s'y rattachent, serait donc un tableau qui présenterait le développement successif de ces sciences dans l'ordre et suivant le cours des siècles, tableau mouvant, dont nous allons ten-ter de crayonner l'esquisse, et que son caractère même nous fera nattrellement diviser en trois parties : l'état de l'histoire naturelle dans l'antiquite', au moyen âge, et dans les temps modernes.

\title{
PREMIÈnE PARTIE.
}

\author{
A N T I QUITE.
}

Des temps historiques jusqu'au vir siècle de l'ère vulgaire.

Les générations ne disparaissent pas de la terre sans y laisser des traces de leur passage. Dans tous les lieux où les hommes ont formé des établissements, on retrouve le souvenir et les leçons d'une civi-lisation plus ou moins parfaite, suivant la durée de leur existence en corps de nation.

L'homme l'emporte sur tous les autres êtres organisés par le développement de son intelligence et par la rapidité de ses moyens de manifestation; aussi existe-t-il chez l'espèce humaine, depuis la formation des premières sociétés, un mouvement continu et progressif, ralenti quelquefois par des guerres désastreuses, par des invasions perturbatrices; mais elle n'en a pas moins grandi en science, en sagesse, et tout, jusqu'aux fautes du passé, a profité aux générations successives.

On peut donc dire que Jes sciences naturelles remontent aux pre- 
mières sociétés, et que les faits recueillis un à un, réunis sans ordre et sans choix par les premiers observateurs, se sont progressivement classés et ont formé les fondements de la science moderne, fécondée par la généralisation, la plus belle et la plus précieuse des facultés de l'intelligence.

Il existe bien des systèmes sur l'origine des nations qui, les premières, habitèrent les terres de l'ancien continent. Quelques auteurs veulent qu'il y ait eu dans chaque pays une population autocthone, c'est-à-dire née sur le sol qu'elle habitait; mais l'opinion la plus généralement admise, quoiqu'elle manque de preuves positives et que l'existence des races distinctes, aujourd'hui reconnue par les savants, semble la contredire, c'est qu'il y a eu, dans la haute Asie, un point central, berceau de l'espèce humaine, d'où elle se répandit sur la surface du globe. Sans connaître ni l'ordre ni l'époque de ces migrations, on admet que les premières tribus qui s'éloignèrent du sol natal descendirent du plateau thibétain et s'établirent au pied de ses hauteurs, sur les terrasses où le Gange prend sa source; ou bien que, franchissant la chaîne orientale de l'Himâlayâ, elles jetèrent les fondements du vaste empire de la Chine. Celles qui avaient peuplé l'Indoustan se répandirent sur toute la surface de l'Asie occidentale; deux courants, l'un méridional et l'autre septentrional, s'écoulèrent en Afrique et en Europe. Les populations commencèrent alors à se mêler et à se confondre; elles passèrent et repassèrent sur les mêmes traces, de sorte que, faute de lumières, on est obligé de se contenter de l'hypothèse la plus généralement adoptée. Quoi qu'il en soit, il est incontestable que l'Asie a été le berceau de la civilisation du monde; les monuments qui nous restent de l'état de ces sociétés primitives semblent du moins le démontrer. 


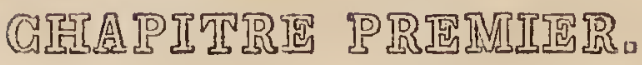

\begin{abstract}
Etat des sciences uaturelles en Orient, chez les Chinois, les Indiens, les Assyriens et les Babyloniens, les IRèdes et les Perses, les Égptiens, les Hébreux, les Phéniciens.
\end{abstract}

Les peuples dont la nationalité est puissante et vivace, et dont le caractère, fortement tranché, se perpétue par leurs institutions, sont ceux chez lesquels l'observation scientifique se développe sous la forme la plus originale; mais il faut y joindre, comme condition essentielle du progrès, le contact de peuple à peuple, la liberté absolue de la pensée, l'affranchissement de toute entrave politique ou religieuse; c'est le seul moyen d'arriver à la connaissance de la vérité ; aussi l'Orient, enchaîné par ses préjugés religieux et par ses formes gouvernementales, est-il resté stationnaire, et n'a-t-il pas joué dans la civilisation du monde le rôle auquel il semblait appelé.

Les Chinois sont de tous les peuples, sinon le plus ancien, du moins celui dont les annales ont le cara ctère le plus authentique, et dont la civilisation remonte le plus haut. Cette nation, froide et positive, qui ne s'est jamais plongée, comme l'Indou, dans une stérile contemplation, s'attacha, depuis plus de quatre mille ans, à perfectionner ses institulions, sans tenir compte de celles de ses voisins; et si quelquesunes des bonnes et saines pensées de l'Europe eussent été fécondées par ce rameau persévérant de la race jaune, la Chine aujourd'hui pourrait se voir à la tête des nations.

Les Chinois possèdent, comme monuments écrits d'une haute antiquité, les King, où sont déposés les secrets de leur civilisation. D'après ces livres, c'esı à Chin-Noung ( laboureur divin), qui succéda à Fou-Hi (3218 ans avant J.-C.), que remontent les premières inventions utiles à l'homme; il enseigna à ses peuples l'usage de la charrue, leur apprit à cultiver les champs, à se nourrir de blé, et à extraire du sel de l'eau de la mer. On lui attribue l'invention de la médecine et la distinction de toutes les plantes avec la connaissance de 
leurs propriétés. Il mesura le premier la figure de la terre et lui trouva $900,000 l i$ de l'est à l'ouest et 850,000 du nord au sud. Le rapport de ces deux nombres, dont on peut déduire l'aplatissement des pôles, est fort remarquable, et ce fait scientifique paraît avoir été très anciennement connu chez les Chinois.

On trouve dans leur's Annales des détails pleins d'intérêt sur leurs relations avec les peuples voisins. Sous Hoang-Ti ( 2785 ans avant notre ère), il vint du sud un étranger voyageant sur un cerf blauc, qui offril comme tribut une coupe et des peaux. Les Youé-Yéou, dont les cheveux étaient courts et le corps tatoué, apportèrent de l'est des caisses de peaux de poissons, des épées courtes et des boucliers; et du sud des perles, des écailles de tortues, des dents d'éléphants, des plumes de paons, des oiseaux et de pelits chiens. Hoang-Ti fut, disent les anciens livres, l'inventeur d'un char qui, de quelque côlé qu'on le tournàt, indiquait toujours le nord, allusion évidente à la boussole. Ce prince, qui établit dans ses états le système décimal pour les divisions territoriales et les mesures linéaires, forma le premier collége d'astronomie chargé d'observer les astres et les phénomènes célestes; on lui attribue encore la découverte de la période enseignée plus tard aux Grecs par Méton. On dressa, sous son règne, d'après des calculs exacts, le calendrier qui servail à réglel l'ordre des travaux agricoles. On s'occupait alors beaucoup de l'observation des éclipses, et l'on mesurait le temps avec des clepsydres. Ce fut en 2155 , dans la troisième année du règne de Tchoung-Kang, qu'arriva l'éclipse de soleil dont il est fait mention dans le Chou-King.

Yao (2357 ans avant J.-C.) s'occupa aussi beaucoup d'astronomie. On voil avec étonnement que, sous son règne (Chou-King, chap. YaoTien), les savants chinois avaient une connaissance exacte du cycle que l'Occident a postérieurement nommé période julienne.

Yu, qui régnait 2200 ans avant notre ère, enseigna au peuple à cultiver les nouvelles terres, c'est-à-dire les terres conquises sur le déser'; et le Chi-King parle de la culture générale qui consistail en blé, riz, panis, mil noir (sans doute le sorgho), chanvre, pois, fèves el coton. Déjà, chez ce peuple, l'agriculture n'était pas, comme chez nous, livrée au caprice du cultivateur: le gouvernement réglait et surveillail la production. Chun, associé à l'empire par Yao, nomma HeouTsi directeur de l'agriculture; et, en l'investissant de ces fonctions (Chou-King, chap. Chun-Tien) il lui dit : “Vous connaissez les besoins 
du peuple; apprenez-lui à cultiver les cent espèces de grains suivant les saisons. " Ce mème Heou-T'si introduisit de nouvelles cultures et perfectionna les méthodes.

Il est souvent question, dans les anciens ouvrages d'astronomie chinoise, de la sphère de Chun, qui est conforme au système de Plolémée.

Il existe en Chine un herbier attribué à Chin-Noung, et un ouvrage d'Histoire naturelle, le Chan-Hä̈-King, attribué à Yu. Quand bien même cet ouvrage ne remonterait pas à une si haute antiquité, il est toujours de beaucoup antérieur à tout ce que nous avons en Europe. Le style en est aussi simple que celui des King, et il comprend, en deux cent soixante volumes, la description, souvent fort exacte, toujours pittoresque, mais quelquefois mêlée de fables, de presque toutes ies productions des trois règnes.

Les connaissances anatomiques des Chinois paraissent remonter à la plus haute antiquilé. On en peut juger par leur' système médical qu'ils appellent la médecine moderue et qui date de plus de 200 ans avant notre ère. Leurs anciens livres d'anatomie, tout en renfermant de graves erreurs, portent le caractère d'un esprit d'observation fort minulieux ; et le gouvernement, qui est intervenu à toutes les époques dans la marche des sciences, s'est beaucoup intéressé à ce qui concerne les études médicales. Plusieurs siècles avant notre ère, un gouverneur de province ayant fait saisir quarante brigands qui avaient ouvert le ventre à des femmes et à des enfants, les condamna au mème genre de mort ; mais, pour que leur supplice fût utile à la science, il chargea des peintres de représenter leurs viscères, el ordonua à des médecins de guider le fer du bourreau.

La circulation du sang était connue des Chinois dans l'antiquité. Ils ont calculé depuis bien longlemps la rapidité de la progression du sang dans les artères à chaque pulsation, et les variations qu’il éprouve suivant les saisons, l’àge, le sexe, le tempérament, le genre de vie, etc.; le tout mêlé à du merveilleux. Ils possèdent de nombreux traités sur le pouls qu'ils ont de tout temps considéré comme le signe diagnostique le plus sûr dans les maladies.

Le Tchatchin, introduit en Europe sous te nom d'acupuncure, est un des moyens curatifs le plus anciennement employés en Chine; il en est question dans le livre des ĺcheou, plusicurs siècles avant l'incendic des King.

Les lirres d'anatomie, de physiologic el de médecine ayant été 
exceptés de la proscription prononcée par Tsing-chi-hoang-li, qui (221 ans avant J.-C.) fit brùler les livres el persécuta les lettrés, les observations qui y sont consignées remontent à plus de vingl siècles.

Nous ne savons pas à quelle époque la culture du thé a commencé en Chine; mais elle doit y être fort ancienne; car, an vil ${ }^{e}$ siècle de notre ère, l'usage eu étail devenu si commun que l'empereur Té-tsong le frappa d'un droit dont le produit f́ut consacré à l'entretien des greniers publies et des gens de gucre.

Les vers à soie ne furent connus en Occident qu'au temps de Pline le naturaliste. Il est historiquement démontré que l'art d'en tirer parli est connu en Chine depuis plus de 4,000 ans. On en allribue la découverte à Si-ling, l'une des femmes de l'empereur Hoang-ti. Les vers à soie sauvages qui vivent sur l'arbre que les missionnaires appellen fagara ou poivrier de Chine, sur le frêne et le chêne, ont été louğlemps les seuls connus, parce qu'ils sont moins délicats. On ne sait ì quelle époque le bombyx mori a élé élevé artificiellement; on trouve seulement en 1456 de notre ère une ordonnance qui fixe la quantité de soie que chaque canton doit fournir.

La méthode scientifique des Chinois est positive; ils s'arrêtent derant ce qui leur semble impossible; et leurs théories, quoique mêlées ì les préjugés, ont toujours un còté posilif : ainsi les annales qui fom mention du déluge arrivé sous Yao regardent ce phénomène comme une inondation partielle et non comme un calaclysme universel, dont ils ne paraissent pas avoir eu l'idée.

Lat philosophie chinoise, essentiellement panthéiste, est renferméc lout entière dans l'Y-king ou le livre de l'Unité, dont Kong-fu-Tsí (550 ans avant J.-C.) est le plus moderne commentateur. File considère la monade combince arec elle-mème pour produire la diade et la urade, comme la cause génératrice de tous les phénomènes qui frappent notre vuc. C'est un jeu numéral dont les combinaisons infinies roulent sur deux principes: Yang, lumière ou mouvement; et Yu, obscurité et repos; le tout dominć par Tao ou la raison, qui rap-pellerail l'ahsolu des philosophes modernes.

Lorsque Leibuitz inventa ses monades, il ne savair fas que l'Y-King, qui lui est antérieur de 2,500 ans, contient une partic de son système.

A l'occident de l'empire céleste, nous trouvons, dès les premicrs temps de l'histoire, les Hindous, qui sont peut-être antéricurs aux Chinois ; mais te silence de leurs monuments laisse la priorito a ces derniers. La 
division des Hindous en castes étrangères les unes aux autres a saus doute empêché leur développement scientifique d'être aussi complet que chez leurs voisins; el les formes mystiques de leur religion, en les enievant à la vie positive pour les plonger dans les rêveries contemplatives, ont absorbé l'activité de leur esprit, et donné naissance à des compositions où l'obscurité de la pensée le dispute an vague de l'expression.

Les richesses littéraires de l'Hindoustan nous sont peu connues; car à peine y a-t-il quarante années que l'étude des langues indiennes s'est r'épandue en Europe. Au milieu de la confusion inséparable des premiers travaux, et par suite de l'obscurité des textes sanscrits, on a jusqu'à présent tiré peu de parti de ces découvertes. Nous savons seulement aujourd'hui que les Hindous n'étaient pas étrangers aux sciences d'observation, et qu'ils possédaient des traités didactiques, don la perte mérite des regrets. Le recueil encyclopédique connu sous le nom général de $V e ́ d a s, q u i$ remonte à quatorze siècles avant notre ère, contenait les quatre Oupavédas ou Sous-Védas, dont il n’existe plus que des fragments. Le deuxième, Ayouch, comprenait la médecine, la chirurgie, la botanique, la minéralogie et l'histoire des animaux. Le quatrième, Sthâpâtyâ, trailait des arts mécaniques, au

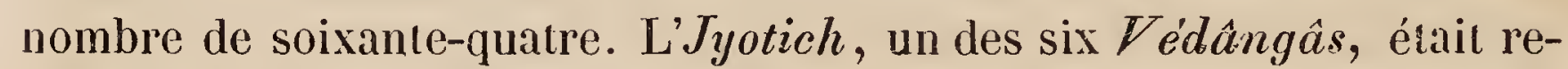
latif à l'astronomie. La théorie des atomes, reprise quelques siècles plus lard par les Grecs, apparlient à l'école physique nommée Kanadas.

C'est aux Hindous que nous devons les signes numériques appelés improprement chiffres arabes. On sait qu'ils se sont de cout temps occupés avec succès de la science du calcul, que les Arabes leur ont emprunté l'algèbre, et qu'ils passent généralement pour avoir inventé le jeu des échecs.

Leur ancienne philosopliie, selon l'école Brahma-Mimansa, est panthéiste et prouve une observation attentive de l'évolution des êtres et des phénomènes naturels. Dans ce système, la vie et la mort ne sont qu'une émanation el une absorption. Tous les phénomènes s'accomplissent dans le sein de l'ètre infini ; et lesmondes, emportés pour l'éternité dans un courant circulaire, naissent et s'éteignent sans que ces manifestations multiples épuisent la fécondité de la force créatrice. Manou dit, en parlant de l'action de Brahma dans les phénomènes cosmologiques : "Echangeant tour-à-tour le sommeil cé la veille, constamment il fait naître à la vie iout ce qui a le mouvement et tout co qui ne l'a pas, puis il l'anéantit et remeure immobile... Il y a des 
mondes qui se développent sans fin, des créations et des destructions ; Brahma fait tout cela presque en se jouant, lui, le plus grand créateur. »)

Nous ne savons pas comment la science périt chez les Hindous ni quelles furent leurs relations avec les peuples voisins; car nous ne pouvons les suivre à travers les temps, et l'histoire primitive des Assyriens et des Babyloniens est trop remplie d'obscurité pour qu'on y trouve la lumière; nous voyons seulement, comme trait de ressemblance entre eux, l'autorité religieuse toute puissante et dépositaire des secrets de la science et la nation divisée en castes; ce qui semblerait indiquer le contacl des Hindous.

Chez ces peuples, la science paraît avoir eu la même physionomie, et leur histoire se résume dans celle des Babyloniens qui étaient parvenus au plus haut degré de la civilisation.

L'astronomie était cultivée chez eux par les Chaldéens, qui paraissent y avoir joué le même rôle que les prêtres en Égypte. On auribue à ces savants la détermination exacte de l'année solaire. Aristote reçut d'Alexandre un registre d'observations astronomiques non interrompues, qui remontaient à 1903 années. Cette assertion est exagérée sans doute ; mais il est certain que, 700 ans avant notre ère, ils observèrent des éclipses de lune qui ont été constatées par des calculs récents. Chez eux , l'astronomie faisait partie de la religion, et se confondait, comme chez les Perses, avec l'astrologie.

Leur médecine élail toute empirique. Exposés sur la voie publique, les malades demandaient aux passants s'ils n'avaient pas été atteints d'un mal semblable, et par quel moyen ils s'étaient guéris. S'ils revenaient à la santé, ils plaçaient dans le temple du dieu de la médecine un tableau indicatif des remèdes dont ils s'étaient servis. Hippocrate fit copier ces observations qui lui fournirent d'excellentes nolions thérapeutiques.

Nous trouvons chez ces peuples une agriculture étendue et variée, un vaste système d'éducation du bétail, tant pour leur nourriture el leur service que pour le commerce. Ils avaient des villes populeuses et inagnifiques, et entre autres Babylone avec ses splendides monuments, ses tours gigantesques, ses vastes canaux, ses jardins suspendus; tout cela atteste des connaissances déjà précises dans les sciences physiques et naturelles; mais ce qui prédominait chez eux, c'était le commerce ; la position de Babylone la rendait maîtresse de tout celui qui se faisait avec les pays limitrophes de la Mésopolamie. Les marchands venaient de 
tous les points de l'Asie acheter à Babylone les objets qu'on y fabriquait avec une rare perfection. Saint Jean dit, dans ses Révélations, qu'ils consistaient en objets d'or et d'argent, en pierres précieuses, perles, crêpes, pourpre, soie, écarlate, bois odoriférants; vases d'ivoire, de bois précieux, d'airain, de fer et de marbre; encens, parfums, vin, huile, blé, farine, brebis, chevaux, chariots et esclaves. Il ajoute au sujet de la chute de cette superbe cité : « Babylone la grande est tombée... Les marchands de la terre plemreront et seront en grand deuil à cause d'elle... Hélas! diront-ils, elle est tombée, la grande cité qui était vêtue de lin, de pourpre, d'écarlate; qui élait parée d'or, de pierres précieuses et de perles...»

Nous ignorons ce que devinrent les arts que Babylone avait poussés si loin et quels furent les héritiers de celte grande renommée; car nous ne possédons aucun ouvrage qui expose l'état des sciences à cette époque et chez ce peuple; nous voyons seulement que les progrès de l'humanité ne s'étaient pas ralentis, mais que chez les Babyloniens comme chez tous ceux que le besoin du moment captive et qui appliquent les efforts de leur intelligence à produire pour le présent sans s'occuper de l'avenir, il ne s'est rien manifesté de durable comme généralisation d'une grande pensée. Ces nations ont vécu sans rien laisser qu'un peu de poussière et quelques souvenirs vagues et incomplets.

A côté des Babyloniens, et vers le même temps, nous trouvons les Mèdes et les Perses dont l'histoire nous fournit à peine quelques renseignements sur l'étal des sciences chez ces peuples au temps de leur grandeur. La doctrine des mages, qui remonte à l'an 1500 arant J. - C., n'eut pas son siége dans la Perse proprenent dite, mais dans les pays qu'arrosent l'Euphrate et le Tigre. Le Parsisme, d'abord transmis par la voie orale, fut plus lard fixé par l'écrilure, et l'on y retrouve des idées de philosophie numérale. L'Avesta, plus conmu sous le nom de Zend-Avesta (parole Zend), est, comme les livres indiens, une encyclopédie où domine la pensée religieuse; car on a vu qu'à ces époques théocratiques la science n'était pas séparée de la ruligion. On remarque parmi les 21 Naskas (nombre formé des chilfres 7 el (qui jonent un grand rôle chez les Parsis ou Guèbres), le 6 , Nader, comprenant tout ce qui se rapporte à l'astronomie, à la médecine e à l'inThence des planètes sur les événements humains; le $7^{\circ}$, Pardjem, rehir aux quadrupèdes qu'il est permis de manger; le 13", Sephand, qui uratr" de l'homme et de l'humanité, et le 18 Davarsoudjed, qui contient le tableau des infirmités anxquelles sont sujets les hommes et les animar. 
Quelques autres lives se rattachent plus ou moins directement aux sciences d'observalion, le tout mêlé à des pratiques superstitieuses el aux spéculations d'une grossière cosmogonie. Nous trouvons néanmoins daus Zoroastre quelques idées sur la formation des montagnes par soulèvement. Il dit, dans le Boun-Dehesch : « Ormusd fit d'abord le mont Albordj..., et les autres montagnes se multiplièrent comme étant sorties de sa racine. Elles sortirent de la terre et parurent dessus comme un arbre dont la racine croît tantôt en haut, tantôt en bas. ) Malheureusement l'Avesta que nous possédons n'est qu'une altération de l'œurre primilive, et nous n'y trouvons aucun des livres qui avaient trait aux sciences; cependant les ruines si brillantes encore des anciennes villes perses, qui altestent un grand talent architectural, semblent prouver que les nations orientales, ayant puisé leur civilisation à un fonds commun, en ont toutes joui à un degré presque égal, et que leurs institutions civiles et religieuses, les agitations politiques qui les ont fait disparaître de la surface du globe, les ont seules privées de sciences formulées et de monuments scientifiques.

Les doctrines de l'Inde paraissent avoir profondément empreint les institutions des peuples qui dès les premiers temps s'étaient répandus sur la terre el nous en retrouvons des traces chez les Égypliens, descendus, d'une colonie venue de la Haute-Éthiopie, ou subjugués par des Éthiopiens qui introduisirent dans le pays conquis le gouvernement théocratique. Les enseignements scientifiques mystérieusement confinés dans les temples, la division du peuple en cinq classes qui ne s'alliaient jamais, l'obligation imposée aux hommes des castes laborieuses de suivre l'état de leur père, toul enfin contribuait à rendre chez eux, comme chez les Hindous, la science étrangère à la majorité de la nation, en en faisant l'apanage d'une minorité intéressée à ne pas la répandre; mais, quand on considère les vastes travaux publics exécutés par ce peuple, sous la direction de ses chefs, les monuments gigantesques qu'il a élevés depuis tant de siècles et qui néanmoins sont encore debout, on y reconnaît une civilisation avancée et des études sérieuses. L'art de l'embaumement, qu'il a poussé si loin, exigeaiı des études d'anatomie générale sinon étendues, du moins précises, et ces pratiques iniliaient nécessairement les hommes qui en étaient chargés, à la connaissance de la splanchnologie, de la myologie et de l'ostéologie. Ce qui cependant s'opposait au progrès de la science de l'organisation, c'est que les médecins égyptiens ne pouvaient prescrire que les remèdes reconnus par la loi, ne devaient s'occuper que d'un seul organe, afin de mieux 
connaitre les maladies qu'ils traitaient; ils devaient enfin n'employer, dans leur traitement, qu'un seul remède, et si le traitement étant changé le malade venait à mourir, on punissait le médecin dı dernier supplice. Quelques-unes de leurs hérésies scientifiques sont assez étranges pour mériter d'ètre citées : ils croyaient qu'il part du cœur un nerf se rendant au petit doigt el soumis à l'influence de ce viscère; c'est sans doute par suite de cette relation sympathique qu'ils portaient leur anneau nuptial à ce doigt; et ils expliquaient la cause pour laquelle la vie humaine ne va pas au-delà d'un siècle, par une diminution régulière et constante du coeur, dont il résulte qu'à cent ans, cet organe, complètement atrophié, ne peut plus entretenir la vie. Ils avaient cependant fait assez de progrès en anatomie pour avoir construit un squelelte de bronze que Galien alla visiter.

Le plus ancien médecin égyptien dont l'histoire ait conservé le souvenir est Sésostris, roi de Memphis. Athotès fut aussi, dit-on, un médecin célèbre, et composa quelques livres d'anatomie. On assure également que, parmi les livrè hermaïques ou attribués à Hermès Trismégiste, il y en avait six qui traitaient de la médecine el de l'anatomie.

Le culte des animaux et des plantes, le choix qu'ils en faisaient comme emblèmes ou comme objets d'adoration ou de mépris, dénote un certain esprit d'observation. Parmi les hiéroglyphes gravés sur leurs monuments, on trouve des figures d'animaux représentés avec exactitude, tels par exemple que l'antilope, la girafe, l'épervier, le vautour, l'ibis, des silures, des cyprins, etc. Notre célèbre entomologiste Latreille y a reconnu des insectes, et surtout le scarabœus sacer, dont les caractères étaient indiqués avec une scrupuleuse fidélité.

La nécessité de rétablir la délimitation de leurs champs après la retraite des eaux du Nil, le partage des terres exécuté par Sésostris, les conduisirent à l'étude de la géométrie; ils se livrèrent avec une application extraordinaire à l'astronomie, qui finit par dégénérer chez eux en astrologie judiciaire ; ils connurent l'année solaire 1325 ans avant l'ère chrélienne.

Leurs lumières sur la géologie, la minéralogie, la métallurgie, découlant de leur position même, se retrouvent dans leurs monuments et leurs procédés industriels. Nous ignorons quelles étaient leurs connaissances en chimie générale, car les traités d'alchimie, attribués à Hermès, ne sont rien moins qu'authentiques, et semblent être le fruit des élucubrations des savants alexandrins. Cependant on y trouve une cer- 
taine forme philosophique, dont sans doute l'idée-mère remontait traditionnellement à une haute antiquité; mais nous savons qu'ils étaient fort avancés dans les applications industrielles de la chimie empirique; ils fabriquaient, comme nous, des émaux, des fäences, et savaient compo ser des couleurs à la fois solides et brillantes. Il paraît que leurs procédés se perdirent avec eux, car les arts chimiques ne furent jamais aussi perfectionnés chez les Grecs.

Les Égyptiens, subjugués par les Perses, ne recommencèrent à s'occuper' sérieusement de science que lor'sque des relations șuivies furent élablies entre eux et les Grecs; mais, à celte époque, ils avaient perdu leur caractère primitif', et les sciences qu'ils cultivaient étaient des importations européennes.

La civilisation, fin dernière des sociétés humaines, ne se propage que par le contact: la guerre, la conquète, la servitude, ces fléaux de l'humanité, sont souvent des moyens de diffusion des lumières; aussi royons-nous les Israélites, dont les ancêtres habitaient la Mésopotamie et n'étaient que des pasteurs d'une civilisation douteuse, recevoir de l'Égypte, où ils gémirent en esclavage, les connaissances que nous trouvons répandues dans la Bible; mais les institutions, en se transplantant, perdent de leur caractère primitif, et celles de l'Égypte ne furent pas conservées par Moïse, qui, élevé par les prêtres égyptiens, était le seul d'entre les Israélites qui connût leur's sciences et le sens caché de leurs doctrines philosophiques. Les autres chefs du peuple d'Israël, associés à l'entreprise du grand législateur, n’étaient iniliés qu'aux sciences pratiques connues du vulgaire, et ne secondèrent Moïse que parce qu’ils avaient la conscience de sa supériorité.

Les livres sacrés des Hébreux portent les marques d'une connaissance aussi parfaite de la nature qu'on pouvait l'avoir alors. Les théories géogréniques qu'ils renferment prouvent que l'Orient avait des idées asse\% justes sur le soulèvement des montagnes et la présence des eaux sur les continents.

Le Pentateuque est la partie des textes hébraïques dans laquelle se trouve le plus grand nombre d'observations, el qui fait le mieux connaître l'état des lumières chez les IIébreux primilifs. Quoique Moïse ait avancé des faits erronés dans son classement des animaux en purs et impurs, on y reconnaît une étude attentive de la nature; ses nombreux exemples sont tirés de la mammalogie, de l'ornithologie, de l'ichthyologic el de l'entomologie, le tout appuyé sur des considérations hygiéniques 
d'une assez haute portée. La Bible contient l'énumération de soixantedix espèces de plantes qu'on a pu rapporter à des cspèces connues.

Les rois d'Égypte étaient communément les plus savants de leur royaume, et les rois juifs eurent la même réputation. Le troisième livre des hois dit que Salomon connaissait tous les végétaux et tous les animaux de la terre, les oiseaux, les reptiles et les poissons; les alchimistes lui attribuent de profondes connaissances dans les sciences occultes et dans l'art de transmuer les métaux : c'est ainsi même qu'ils veulent expliquer la prodigieuse quantité d'or qui se trouvait répandue dans les temples et les édifices publics.

La culture chez les Israélites consistait en blé, orge, légumes de diverses sortes, lin, vin, dattes, olives, grenades, figues; et ils nourrissaient de nombreux troupeaux d'ànes, de bœufs, de chameaux et de brebis. Leur commerce avec Tyr, en parfums et en plantes tinctoriales, et le cas qu'ils faisaient de l'art dı teinturier, indiquent des procédés d'application et, un commencement d'industrie. L'art métallurgique devait aussi leur être familier dans ses procédés les plus simples, car les livres juifs parlent d'armures de fer, de chariots garnis de fer, etc. : or, la mise en œuvre de ce métal suppose des connaissances spéciales appuyées sur une longue pratique.

Tout chez ce peuple démontre qu'il était attentif aux beautés de la nature: Job décrit, avec un talent d'observation très remarquable et un coloris aussi brillant que celui de Buffon, le cheval dont il peint la noble fierté, le rhinocéros au caractère stupidement farouche, et l'insouciante autruche qui confie ses œufs aux sables brûlants du désert. Les images dont se servent les poètes hébreux sont presque toujours empruntées aux objets naturels. Les noms donnés aux saisons ne sont pas même arbitraires: ils sontrelatifs au temps des semailles et des récoltes, et aux modifications de la température.

Les vicissitudes politiques de ce peuple, ses longues et successives captivités, puis, en dernier lieu, l'occupation de son territoire par toutes les nations guerrières qui mettaient le pied en Syrie, ont sans doute empêché qu'il ne donnât à ses connaissances scientifiques une forme arrêtée, occupé qu’il était à défendre son indépendance et sa vie.

Nous ne savons par quel lien rat tacher à l'histoire générale des peuples celle des Phéniciens, que nous trouvons déjà puissants avant d'avoir pu les suivre en remontant à leur origine. Leur position sur le bord de la Méditerranée les avait portés à devenir commerçants, et ils ne restèrent sans 
doute pas étranger's au mouvement des esprits. Comme ils étaient for't habiles dans l'art de la navigation et réputés les marchands les plus expérimentés, ils ont dû approfondir les sciences dans leurs moyens d'application; mais l'histoire se tait à leur égard sous le rapport scientifique, et il ne nous reste d'eux aucun monument qui nous fasse connaître quelle part ils ont prise aux progrès de l'humanité. On ne peut citer parmi leurs philosophes que Cadmus, qui passe généralement pour l'inventeur de l'écriture, mais dont l'histoire est enveloppée de merveilleux; et Sanchoniathou, hiérophante de Tyr, des œuvres duquel nous ne connaissons que quelques fragments conservés par Philon de Biblos, quoiqu'un savant allemand ait prétendu les avoir retrouvées. Les écrits de Sanchoniathon sont loin d'avoir un caractère positif; il mêle des fables grossières à tous ses récits, et le fragment de chronologie qui nous reste sous son nom n'est rien moins qu'authentique.

Ici s'arrête l'histoire des sciences chez les anciens peuples de l'Asie et de l'Égypte; esquisse incomplète, où manque souvent la lumière, mais qui n'est pas sans intérêt quand on songe que c'est chez ces peuples primitifs, au milieu de ces sociétés naissantes, que les sciences eurent leur berceau, et que c'est de là qu'elles ont été importées dans l'Europe barbare. Si l'on en excepte les Chinois qui seuls peuvent lier leur présent à leur passé, tous ces peuples, jadis si pleins de vie, sont inconnus à leurs descendants ou à leurs successeurs, et les grands monuments qu'ils ont laissés, incompris de ceux qui errent dans leurs ruines, sont des feuillets épars de l'histoire de l'humanité.

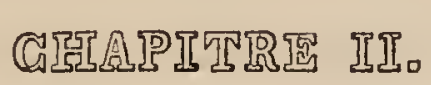

Etat des sciences naturelles chez les Grecs et chez les Romains.

Il est impossible de dire à quel peuple les Grecs doivent leur origine, ot à quelle époque précise ils s'établirent en Europe. Leurs historiens n'ayant écrit que long temps après que la civilisation orientale eut pénétré dans leur pays, et lorsque la tradition de l'origine de leur nation était déjà perdue, sont restés muets sur cette question. Les premiers temps de la Grèce, tels que les peint Thucydide, nous montrent une agglomération de 
peuplades barbares, sans établissements fixes, sans agriculture, sans industrie, vivant en état d'hostilité perpétuelle, et ne reconnaissant d'autre loi que la force. Les Pélasges, qui les avaient précédés dans le Péloponèse, nous sont encore moins connus. Aujourd'hui que l'étude de l'anlique langue des Brahmes a remplacé l'hébreu dans les spéculations philologiques, on croit retrouver en eux un peuple Hindou. Sans rechercher ce que cette hypothèse a de plausible, nous pouvons affirmer, d'après le témoignage d'Hérodote, qu'ils avaient une origine différente, parlaient une autre langue que les Grecs, et paraissaient être venus à une époque antérieure. Les premières lumières de la civilisation précédèrent sans doute l'époque historique ; car on a quelques fragments informes sur les Pélasges et sur les premiers chefs de nations qui gouvernèrent ces petites tribus sauvages. Nous ne répéterons aucune de ces fables; nous citerons seulement un nom auquel se rattache un grand événement; c'esı celui d'Ogygès, sous le règne duquel eut lieu l'inondation de la Béotie et d'une partie de l'Attique, qui ( 1832 ans avant J.-C.) fit périr la nation presque entière des Hectènes. On attribue cet événement à l'état d'abandon dans lequel étaient restés les canaux creusés par les Pélasges, au travers du mont Ptoüs, à l'effet de donner une issue aux eaux du lac Copaïs.

Sans nous arrêter aux différents systèmes, plus ou moins spécieux, inventés par les historiens pour expliquer la présence des Grecs en Europe, nous nous bornerons à dire que c'est à Cécrops, l'Égyptien, le premier chef dont il soit fail mention dans les marbres de Paros (1643 ans avant l'ère chétienne), et qui vint apporter la civilisation dans l'Attique; à Deucalion, venu de la Haute-Asie en Thessalie, quelques années après Cécrops ; à Danaüs, qui quitta l'Égypte (1572 ans avant J.-C.) pour venir s'établir dans l'Argolide, et aux Orientaux enfin qui affluèrent de toutes parts en Grèce, que les Hellènes furent redevables des premières connaissances auxquelles, plus tard, ils durent leur supériorité sur les autres nations.

Les chefs égyptiens ne semblent pas avoir importé en Grèce la domination de la caste sacerdotale, et être restés en possession des mystères religieux et des arcanes de la science; ou, s’il en fut ainsi, cette institution dura peu, puisque nous voyons dans l'Iliade, dix siècles avant notre ère, Agamemnon, Nestor, et tous les autres chefs de tribus, immoler de leurs propres mains les victimes des sacrifices. La liberté de la pensée permit aux sciences de se développer sans entraves; et la religion publique ayant revĉtu les dieux des altributs extérieurs de l'humanité, el cessé 
d'ètre un mythe inaccessible au vulgaire, l'émancipation de l'intelligence fut plus complète qu'elle ne l'avait été chez aucun autre peuple.

Les premier's hommes de science dont parlent les poèmes grecs sont Esculape, Orphée et Chiron le Thessalien, qui passent pour avoir connu les propriétés médicinales des plantes; mais on ne sait si ces lıommes ont réellement existé, ou s'ils ne sont que des personnifications de déconvertes utiles à l'luunanité. Machaon et Podalyre recueillirent ces premiers préceptes de niédecine et les mirent en pratique : le premier étudia surtout la chirurgie, le second s'appliqua à comnaître les causes internes des maladies; ils furent attachés à l'expédition contre Troie. Leurs successeurs furent Nicomaque et Gorgasus.

Les relations qui, par la force des choses, s'établirent entre les Griecs, les peuples de la Colchide et ceux des côtes de l'Asie, initièrent rapidement les premiers aux mystères des sciences de l'Orient. Du temps d'Homère, les connaissances en liistoire naturelle étaient déjà assez répandues pour qu'on trouve dans ce poète des descriptions de végétaux et d'animaux, des détails anatomiquès, agricoles et industriels, fruits d'une observation positive et non de l'imagination.

Hésiode, qu'on croit postérieur à Homère, donne, dans sa Théogonie, une explication symbolique de la création du monde, où l'on retrouve les idées orientales; dans son poème des travaux et des jours, il décrit les principales opérations de l'agriculture, les divers procédés de l'économie rurale, et il énumère un certain nombre de plantes dont il indique les propriétés.

Pendant plus de trois siècles, la Grèce fut le théâtre de troubles sanglants causés par l'ambition des Héraclides, qui voulaient étendre leur domination sur tout le Péloponèse. Ces guerres eurent pour résultat l'émigration des Doriens, des Éoliens et des Ioniens en Asie-Mineure. Des colonies grecques s'établirent aussi dans la grande Grèce, et la civilisation répandit partout sa lumière. Pendant cette longue tourmente, la science sommeilla, et ne dut son réveil qu'à l'émigration des prêtres égyptiens fuyant les persécutions de Cambyse, et aux Grecs d'Asie, tels que Thalès, Pythagore, Démocrite, Anaxagore, et un grand nombre d'autres qui avaient visité l'Égypte et pénétré dans les temples; lorsque Psamméticus ouvrit aux étrangers les portes de son royaume.

Les théories mystiques de l'Orient, en s'établissant sur le sol européen, ne conservèrent pas leur caractère primitif, peut-être parce qu'a tor's les prêtres égyptiens en avaient cux-mêmes peidu le sens. Sous l'in- 
fluence de la liberté de la pensée, qui renverse tous les obstacles, elles subirent de grandes modifications; mais, avant de s'élever à la liateur de sciences positives, elles flottèrent pendant plusieurs siècles, sans presque enfanter autre chose que des fictions poétiques.

Thalès, le fondateur de l'école ionique, et le premier qui enseigna la philosophie en Grèce, professait des idées systématiques el purement orientales sur l'origine du monde par les eaux; il démontra la sphéricité de la terre, expliqua les éclipses, et fixa l'année à 365 jours. Il connaissait les propriétés attractives du snccin et de l'aimant. Anaximandre, son disciple, qui introduisit à Sparte l'usage des cadrans solaires, et dressa le premier avec Anaxagore des cartes géographiques, voulait que les hommes eussent d'abord été poissons, puis successivement reptiles el mammifères. Héraclite, au contraire, prétendait que le monde n'est l'ouvrage ni des dieux ni des hommes, que c'est un feu qui s'allume et s'éteint suivant un certain ordre, et que notre globe est un astre refroidi. Il s'occupait d'observations posilives; et, pour éviter les perséculions de l'ignorance, il errait dans les cimetières afin d'y étudier sur la nature morte les mystères de l'organisation humaine.

Pythagore, qui avait vécu 22 années en Égyple et y avait été admis aux enseignements des prêtres, vint à Crotone, dans la grande Grèce, fonder l'école italique. Sa métaphysique, toute empreinte des formes égyptiennes, se rapproche par son caractère numéral de l'Y-King des Chinois. Il professe une sorte de panthéisme spiritualiste, allié à des idées de transmigration des âmes avec souvenir de l'existence antérieure. On luiattribue un ouvrage sur les végétaux, dans lequel il parle de la culture dı chou, de la moutarde et de l'anis. Il connaissait le double mouvement de la terre sur elle-même et autour du soleil, et savait fort bien qu'elle est sphérique. Suivant les philosophes de cette école, non-seulement les planètes, mais les comètes même sont de véritables astres en mouvement autour du soleil. Ils avaient des notions assez précises sur la théorie de la réfraction et sur la production des conleurs.

Alcméon de Crotone, disciple de Pythagore (520 ans avant J.-C.), fil des dissections d'animaux pour arriver par analogie à la connaissance de la structure de l'homme. Il professail des idées assez exactes en physiologie, et avait reconnu que chez les animaux la tête est la partie qui se développe la première. On lui attribue, sans preuves, la découverte de la irompe d'Eustache.

Empédocle fut un des observateurs les plus exacts de l'école italique. 
Il écrivit sur les plantes médicinales, leur attribua un sexe et du sentiment, reconnut l'analogie qui existe entre la semence des plantes et l'œuf des animaux, découvrit l'amnios, paraît avoir entrevu le limaçon de l'oreille, el composa un poème de la nature, connu de Lucrèce, qui en parle avec admiration. Cet ouvrage ne nous est pas parvenu.

L'école éléatique, fondée par Xénophane, à peu près vers la même époque que l'école italique, compta beaucoup de disciples qui s'appliquèrent surtout à la philosophie spéculative. Ainsi que presque tous les philosuphes de son temps, Xénophane avait son système géogénique; et, ayant observé les débris de mollusques fossiles qui couvrent le sol de la Sicile, il en conclut que toutes les terres avaient originairement été couvertes par les eaux. Parménide professait le système de la non-existence des corps; d'après ce philosophe, les manifestations matérielles émanent de l'intelligence et sont le résultat unique de l'illusion, doctrine qui se rapproche de la théorie indienne, dont Maïa est la déesse.

Anaxagore, le maître de Socrate, appartenait à cette école. Il paraît avoir possédé des notions anatomiques assez étendues; il a exposé, sous le nom d'homœoméries, des idées saines sur les molécules constituantes des corps; il prétendait, comme le croient plusieurs savants modernes, que la lune et les planètes sont habitées.

Leucippe, de l'école d'Élée, est le créateur de l'école atomistique ; il croyait l'univer's composé d'atomes, dont le mode d'agrégation suffit pour constituer les différents corps de la nature. Il eut pour disciple le célèbre Démocrite, qui étudia avec soin l'organisation d'un grand nombre d'animaux, découvrit les conduits biliaires et le rôle que joue la bile dans la digestion; mais, abandonné à l'empirisme comme tous les savants de son époque, il n'eut que des idées très bornées en physique générale. Ses conjectures en astronomie offrent plus d'intérêt; car il disait que la voie lactée est formée par la réunion d'une multitude d'étoiles, et que les taches de la lune sont produites par l'ombre de ses montagnes. Il s'occupa également de botanique, et traita de plusieurs parties de cette science.

Ces quatre écoles eurent la gloire de jeter les fondements des études scientifiques en Grèce; mais on y découvre, malgré l'unité de but, deux principes opposés. Les Leucippe et les Atomistes, tout en faisant de la science à priori, rejetaient la métaphysique et cherchaient à expliquer tous les phénomènes parl'action réciproque des agents sensibles ; Pythagore et les Éléates, au contraire, étaient des idéalistes purs, qui 
allaient chercher dans le monde immatériel la base de leurs théories. Ces systèmes, fondés sur des hypothèses et non sur l'observation réfléchie des faits, avaient accoutumé les Grecs aux créations fantastiques de l'esprit, entravé les progrès de l'observation, et les sophistes étaient les continuateurs de ces études stériles. Socrate ( 470 ans avant notre ère) mit fin à leurs vaines déclamations. Bien qu'on ne lui doive aucun travail sur les sciences naturelles, il leur rendit un service immense, en attaquant toutes les théories qui ne s'appuient pas sur des données posiuves. On peut le regarder, sous ce rapport, comme le créateur de la méthode expérimentale.

Quoique philosophe et historien plutôt que naturaliste, Xénophon, l'un de ses disciples, s'est beaucoup occupé de sciences naturelles. Sous le titre de Cyrégétiques, il a composé sur la chasse un ouvrage qui traite de l'éducation des chiens et des ruses des animaux. Il nous apprend que jadis la Macédoine et le nord de la Grèce renfermaient des lions, des panthères, et quelques autres mammifères qui ont cessé d'exister en Europe, et ne se trouvent plus qu'en Afrique et en Asie.

Platon (430 ans avant J.-C.) fut le fondateur de l'école académique. Ce philosophe n'était pas né pour les sciences d'observation. Une imagination ardente et poélique, un penchant irrésistible à l'idéalisme, le détouruèrent de la méthode expérimentale; aussi ses œuvres fourmillentelles de paradoxes que le charme de l'exposition ne lui fait pas toujour's pardonner. Son Timée, le seul de ses écrits qui ait un caractère scienlifique, est un mélange confus d'idées bizarres bien au-dessous des connaissances de son époque; cependant il résulta de cet essai encore informe de classification méthodique des sciences une impulsion dont nous trouvons les résultats dans Aristote. Son Atlantide, qu'on a sérieusement cherchée de nos jours, n'est peut-être qu'une fiction de poète. On peut considérer Platon comme le créateur de cette philosophie purement spéculative qui, ne.tenant aucun compte des faits, se crée un monde idéal où viennent trop souvent s'égarer les meilleurs esprits.

A côté de ces écoles philosophiques grandissait la famille des Asclépiades, descendant d'Esculape, investie des fonctions médicales comme d'un sacerdoce. On y trouve une observation plus attentive, un jugement plus froid, plus de pratique que de spéculation, plus de faits que de théories; les membres de cette caste sont donc de véritables naturalistes. L'école de Cos a complé parmi ses plus illusires disciples plusieurs médecins du nom d'Hippocrate, de sorte que nous ne savons amquel atribuer 
les écrits qui nons restent sous ce nom; quelques autèurs pensent qu'on les doit au second, contemporain de Socrate, de Platon et d'Aristote. En thérapeutique et en lyggiène, Hippocrate est un homme d'une supériorité incontestable; mais n'ayant pas visité l'Égypte, où l'anatomie était très avancée, tandis qu'en Grèce les préjugés religieux en arrêtaient les progrès, il est d'une profonde ignorance sur cette science et sur la physiologie. Il prend le cerveau pour une masse spongieuse destinée à absorber l'humidité du corps; il ne connaît pas les nerfs, surtout ceux qui naissent de l'encéphale, et ne donne ce nom qu'aux tendons et aux ligaments. Son angéiologie et sa physiologie ne sont nullement fondées sur l'observation : ce sont des théories bizarres. Il mentionne dans ses ouvrages environ cent cinquante plantes employées en médecine ou comme aliments ; et le premier parmi les anciens il nous a donné l'état des connaissances botaniques à son époque.

Ctésias, attaché en qualité de médecin à l'expédition des Dix mille, et qui fut fait prisonnier à la bataille de Cunaxa, a écrit un ouvrage sur l'Inde, dont il ne nous reste qu'un fragment. On y trouve des descriptions de plantes et d'animaux quelquefois très exactes; mais cet écrivain admet aussi des fables ridicules qui montrent un homme crédule ou un observateur fort inattentif.

Les sciences, confuses, et dénuées de méthode, ne sortent du chaos dans lequel elles étaient plongées qu'à l'apparition d'Aristote (384 ans avant notre ère). Ce grand lomme, à qui ses prodigieux travaux ont valu l'immortalité, appliqua le premier à l'histoire naturelle la méthode expérimentale créée par Socrate. Il fit cesser l'anarchie qui régnait dans les sciences, en les classant avec un ordre admirable, assignant à chacune d'elles les limites rigoureuses de ses attributions, et en en faisant l'objei d'études spéciales, sans méconnaître jamais le lien étroit qui les nnit.

Tous ses renseignements sont fondés sur l'observation; jamais il n'établit de théorie à priori; il généralise les faits qu’il a lui-même observés, et l'on trouve rarement dans ses écrits une déduction hasardée.

Ses travaux sur toutes les brunches des connaissances humaines sont immenses; peu de savants ont plus vu et plus produit que lui. Si ses ouvrages nous offrent quelques parties qui nous semblent faibles aujourd'hui, il faut attribuer cette faiblesse à l'impossibilité où il se trouvait de faire les expériences que nous facilite la supériorité de nos moyens d'observation; mais son histoire des animaux restera comme un des monuments de la puissance du génie. 
It ne faut pas chercher dans Aristote une véritable classification méthodique des êtres organisés; mais on ne peut trop admirer la haute portée de son esprit, qui lui avait fait entrevoir les caractères fondamentaux sur lesquels repose la méthode naturelle. Il divise les animaux en deux classes : ceux qui ont du sang (हैvau...) et ceux qui n'en ont pas

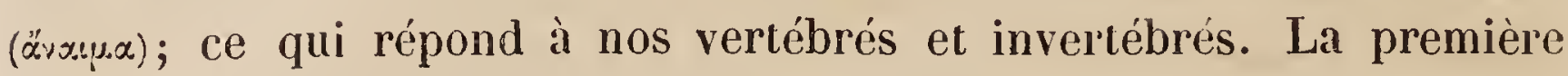
comprend les quadrupèdes, les oiseaux, les reptiles, les amphibies et les poissons. Il avait fort bien reconnu que les cétacés forment une classe distincie de celle des poissons; sa sagacité est en défaut quand il place parmi les quadrupèdes des animaux de la classe des reptiles; mais comme ils sont ovipares, il fait remarquer leur analogie avec ces derniers.

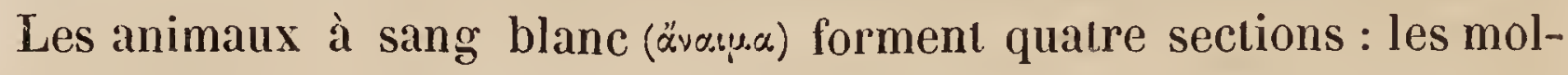

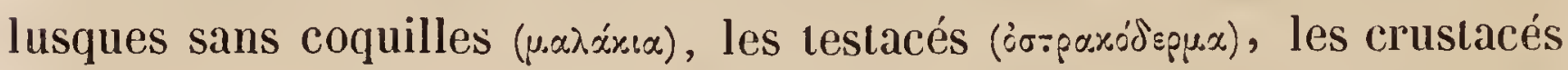

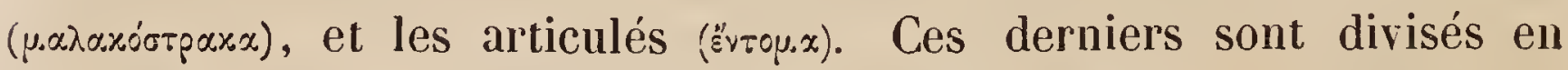
ailés et en aptères, et les ailés appartiennent à des ordres différents, suivant qu'ils ont deux ou quatre ailes, que ces ailes sont membraneuses ou recouvertes d'élytres. Il semble aussi avoir entrevu leur distinction en broyeurs et en suceurs.

L'anatomie d'Aristote est moins avancée; tontefois on trouve, dans cette partie de ses ouvres, une bonne description du cerveau. Ses connaissances en névrologie sont plus étendues que celles de ses prédécesseurs, et l'on reconnaît qu'il a étudié avec soin le trajet des veines et dfs artères. C'est lui qui le premier, pour faciliter l'intelligence des descriptions anatomiques, accompagna son texte de figures avec renvois.

Ses monographies, malheureusement trop rares, sont pour la plupart remarquables par leur précision; et sa description de l'éléphant l'emporte sur celle de Bufion, qui s'est presque toujours trompé en le contredisant.

Sa classification des oiseaux est celle qu'ont adoptée les ornithologistes modernes, surtout Brisson; il avait remarqué avec sa sagacité ordinaire que les ailes sont les analogues des membres antérieurs des quadrupèdes.

Ses connaissances en ichthyologie sont en général presque aussi complètes que celles que nous possédons; car il s'étend beaucoup sur les migrations des poissons, sur leurs maladies, et donne sur leurs moeurs des détails qu'on a longtemps crus erronés, mais dont quelques observations récentes ont démontré l'exactitude.

Son traité d'anatomie comparée, qui fut, avec celui de Galien, le seul jusqu'au xve siècle, prouve combien il avait fait d'observations di- 
rectes. Il décrivit l'oeil de la taupe, qu'après lui encore on a cru longtemps privée de la vue, et il constata l'existence de la faculté auditive chez les poissons et chez les insectes.

Dans son traité de la voix, il distingue fort bien le son résultant de l'expulsion de l'air à travers le larynx, et le bruit produit chez les insectes soit par le frottement des pattes sur les élytres, soit par un appareil vibrant, comme chez la cigale.

Il traite en maitte de l'hibernation et de la génération des animaux, du sommeil des poissons, des métamorphoses des insectes. II avait soigneusement observé les mœurs des abeilles et des guêpes, et les phases de l'évolution du poulet dans l'œuf. II fait naître tous les insectes par la voie de la génération spontanée, n’en exceptant que les araignées, les criquets et les cigales; opinion que nous retrouvons dans toute l'anliqquité.

Les notes qu'il avait recueillies étaient rangées par ordre alphabétique, et formaient comme une espèce de dictionnaire; malheureusement cette partie si intéressante de ses ouvres ne nous est pas parvenue.

Aristote essaya le premier de ranger avec ordre les corps bruts; il en forma deux grandes classes, les fossiles et les métalliques; les premiers étaient considérés par lui comme d'origine terrestre et les seconds comme d'origine aqueuse, parce qu'ils se liquéfient par la fusion.

En géogénie, Aristote est neptunien, c'est-à-dire qu'il attribue à l'eau la formation du globe. Ayant vu que la mer a laissé çà et là des coquilles, et que les alluvions des flenves s'accroissent avec rapidité, il en conclut que les terres ont été alternativement découvertes ou enva-hies par les eaux. Cette opinion fut celle de la plupart des naturalistes anciens; le système contraire ou vulcanien, qui attribue au feu l'origine de tout ce qui existe, ne comptait chez eux que peu de partisans. Aristote admet, avec les autres philosophes grecs, quatre éléments, auxquels il en joint un cinquième, qui est l'éther.

II avait écrit deux livres sur les végétaux, mais ils out péri arce la plus grande partie de ses ouvrages, et ceux qui sont arrivés jusqu’à nous ont été altérés par de fréquentes interpolations, qui en dénallir'ent le sens primitif.

Cette rapide esquisse des travaux les plus remarquables de ce philosophe sur les sciences naturelles a pour but de pronver que l'admiratlion dont il a ćté l'objet n'est pas fondée sur min frivole cngouemem, 
mais sur un mérite réel. Peut-être faut-il ajouter que sans Alexandre, qui envoyait à son maître les productions les plus rares des pays qu'il parcourait en vainqueur, et qui consacra plusieurs millions à faciliter ses recherches, Aristote n'aurait jamais pu leur donner autant de développement. Comme le jeune conquérant avait puisé dans les leçons du philosophe le goût des sciences naturelles, il voulut contribuer à leurs progrès en les enrichissant de nouvelles découvertes. Il fit faire, dans ce but, par l'amiral Néarque, sous la direction d'Onésicrite, homme d'un profond savoir, une exploration des côtes de la Perse, qui procura la connaissance de plantes et d'animaux jusqu'alors inconnus, el entre autres du cotonnier et du tigre rayé. Il introduisit en Europe les paons, qu'on n'y avait jamais vus, et une espèce de perruche verte, à collier rouge, qui a reçu le nom de Psittacus Alexandri.

Les contemporains les plus célèbres d'Aristote furent Démocrite d'Abdère, Hipporrate, Xénophon et Platon. Quand on lil les œeuvres de ces grands hommes, on s'étonne de voir combien étaient rares leur commerce scientifique et la lecture de leurs écrits; car chacun deux a des opinions indépendantes de celles de ses contemporains, et l'expérience acquise par l'un est complètement perdue pour les autres.

On attribue à Dioclès, à Epicure, à Épiménide, à Métrodore et à Cratoevus, des traités de botanique descriptive ; mais ces ouvrages ont péri comme la plupart des chefs-d'œuvre de l'antiquité; on dit que le dernier avail joint à ses descriptions des figures coloriées.

Théophraste (320 ans avant J.-C.), d'abord disciple de Platon, puis d'Aristote, et chef du Lycée. ò̀ il réunit plus de deux mille élèves, fit pour la botanique et la minéralogie ce que le philosophe de Stagyre avait fait pour la zoologie. Il écrivit sur les plantes deux traités que nous possédons tout entiers. L'un, sous le titre d'Histoire des plantes, commence par l'exposé de ses idées sur l'organographie végétale; idées fort incomplètes à cause de l'absence d'instruments d'observation; et inexactes parce qu'il était beaucoup trop enclin à voir dans les végétaux, comme dans les animaux, des fibres et des veines. II dispose ensuite les plantes non pas avec cette méthode savante et philosophique qui fait la gloire de son maître, c'est-à-dire d'après une profonde étude des analogies, mais en les divisant suivant leur grandeur en arbres, arbrisseaux, sousarbrisseaux etherbes. Ce système, tout faux qu'il est, fut cependant le seul adopté jusqu'à la renaissance des lettres. Il traite ensuite de leur inflorescence, de leur mode de reproduction; parle, entre autres, de la fé- 
condation artificielle du dattier; el quoiqu'il n'ait qu'une idéc vague du sexe des plantes, il en désigne quelques-unes sous le nom de mâles et de femelles; mais quelquefois il appelle mâles celles qui portent des fruits. Il mêle à ses observations sur la fécondité des végétaux, sur la durée de leur vie et sur leurs maladies, des descriptions qui, bien que placées sans ordre el souvent hors de propos, ne manquent pas d'intérêt. Il parle de la sensibilité de certains mimosas, différents de notre sensitive; décrit le citronnier, le figuier des pagodes, le bananier, le cotonnier, le lotus, etc. Il énumère toutes les plantes connues de son temps; et dans la partie de son ouvrage oì il traite des arbres forestiers, il cite quelques-uns des insectes qui les dévorent, ce qui prouve qu'il avail beaucoup observé.

Son autre ouvrage, intitulé des Causes des plantes, est plus philosophique. C'est une sorte de traité de physiologie végétale, dont on ne peut nier l'intérêt; mais l'auteur s'étant souvent écarté des voies expérimentales s'est égaré dans le champ des hypothèses.

On a encore de ce philosophe un grand nombre de traités séparés sur la zoologie, relatifs surtout aux productions de l'Inde.

Après ses écrits sur la botanique, son livre sur les pierres est d'une haute importance, en ce qu'il est le premier que nous connaissions sur cette matière. Il y suit la méthode d'Aristote; seulement il divise les minéraux en pierres et en terres, et les groupe d'après leur densité et la manière dont ils se comportent au feu. Il connaissait les propriétés attractives de l'aimant et de l'ambre jaune, et comme il les attribuait à une même cause, il les rangeait dans la même classe. La partie relative aux pierres précieuses renferme des détails fort intéressants. On y trouve aussi l'indication de débris paléontologiques tirés du sein de la terre.

Théophraste n'était pas étranger à la technologie; il s'occupe de l'emploi des substances minérales, de la fabrication du verre, de l'usage en peinture des oxydes métalliques, et de celui du plâtre dans le moulage.

L'élégance et la pureté du style sont le principal mérite de cet écrivain, car il est loin de s'élever à la hauteur d'Aristote : son esprit it moins de profondeur; c'est un observateur exact, attentif, mais manquant souvent de pénétration. Il réunit dans un même emplacement des plantes indigènes et cxotiques, qu’à sa mort il légua à la république, méritant ainsi d'être signalé conme l'inventeur des jardins botaniques.

Les troubles qui déchirèrent la Grèce, par suite desrivalités des succes- 
seur's d'Alexandre, for'cèrent les savants, amis de la paix, à quitter un pays livré à tant de sanglantes discordes. Ils se retirèrent en Égypte (300 ans avant notre ère), où ils furent accueillis par Ptolémée Lagus, élève d'Aristote. Ce prince, fondateur de la célèbre bibliothèque d'Alexandrie, oǹ l'on comptait quatre cent mille volumes, favorisa de tout son pouvoir l'étude des sciences et attira dans sa capitale des savants de divers pays, auxquels il assura une existence honorable, pour qu'ils pussent se consacrer entièrement à des travaux scientifiques. Cette institution, qui prit le nom de Musée, aurait dû contribuer puissamment aux progrès des études sérieuses; mais, malgré les efforts de Ptolémée, les sciences d'observation, étudiées en Grèce avec tant de succès, grâce à la méthode expérimentale, perdirent de leur éclat après leur translation à Alexandrie. Les théories remplacèrent de nouveau l'observation et la lecture des livres fut souvent substituée aux travaux directs: aussi cette école ne produisitelle pas un seul naturaliste distingué; de toutes les sciences naturelles, la médecine et la partie de la botanique qui concerne les propriétés médicinales des végétaux y furent seules cultivées.

Ptolémée Philadelphe se livra à l'étude des sciences naturelles sous la direction de Straton, disciple d'Aristote. On lui attribue un ouvrage de critique sur les animaux vrais et fabuleux; la perte de ce livre est regrettable pour la science qui lui eût emprunté des documents précieux. Il établit le premier une ménagerie, dans laquelle il réunit à grrands l'rais un nombre prodigieux d'animaux de tous les pays.

L'anatomie, si sévèrement proscrite en Grèce, où le respect dú aux cadavres était sous la sauvegarde des magistrats, prit de l'essor dès que l'Égypte fut visitée par les médecins grecs, avides de connaissances qu'ils ne pouvaient acquérir dans leur patrie. Proxagoras, qu'on prétend avoir été disciple d'Aristote, alla le premier y étudier celte science. Ce fuı lui qui donna le nom d'artèreș aux vaisseaux partant de l'aorte, et qui découvrit qu'ils sont le siége du pouls. Il les distingua fort bien des veines et constata leur vacuité après la mort.

Hérophile de Chalcédoine, disciple de Proxagoras, ayan! longtemps étudié en Égypte, poussa plus loin que son maître les découvertes en anatomie. Il distingua les nerfs des ligaments, avec lesquels on les avait jusqu'alor's confondus, et découvrit qu'ils président à la volition et à la sensation. Il a laissé une bonne description du cerveau, et l'on a conscrvẻ le nom de pressoir d'Hérophile au confluent des sinus de la duremère. Il décrivit les tuniques internes de l'oeil, l'os hyoïde et la veine 
pulmonaire; il donna le nom de duodenum à l'intestin qui suit l'estomar: et aboutit au pylore. Il découvrit l'isochronisme des battements du cœu' etde la pulsation des artères; mais sans se rendre compte de la cause de ce phénomène.

Erasistrate de Céos, petit-fils d'Aristote et disciple de Théoplıraste, est généralement connu par la sagacité avec laquelle il découvril qu'Antiochus, fils de Séleucus Nicanor, élait malade d'amour pour sa bellemère Stratonice; mais il a d'autres titres au souvenir des hommes : c'est à lui qu'on doit la découverte de la communication médiate et immédiate des nerfs avec le cerveau, dont il fit le siége de la pensée et du sentiment; on lui doit encore celle des vaisseaux lactés, retrouvés seulement au xvı ${ }^{\mathrm{e}}$ siècle par Aselius. Il fit un pas de plus qu'Hérophile dans la connaissance de la structure du cour; car il reconnut le mouvement de systole et de diastole, mais sans s'être douté de la circulation du sang; il pensail, au contraire, que l'air inspiré par les poumons se rend dans le cour.

Aucun des ouvrages de ces célèbres médecins ne nous est parvenu; nous ne connaissons leurs travaux que par les ouvrages de Galien, qui parle aussi de leur grande instruction en botanique.

A la même époque eut lieu le voyage de Mégasthes, qui enrichit l'histoire naturelle de nouvelles découvertes.

Si les sciences naturelles ne brillèrent pas d'un grand éclat après leur translation à Alexandrie, il n'en fut pas de même des sciences physiques. Timocharis et Aristillus étudièrent le mouvement des planètes et jetèrent les fondements du système de Ptolémée ; Aristarque de Samos enseigna le double mouvement de la terre; Ératosthènes essaya de calculer la grandeur du degré terrestre, et observa, ainsi que Pithéas de Marseille, l'obliquité de l'écliptique. Hipparque (200 ans avant J.-C.) estima l'année solaire à 365 jours 5 heures 35 minutes 12 secondes, découvrit la précession des équinoxes, observa plusieurs éclipses, dressa des tables du soleil et de la lune, et entreprit une nomenclature des étoiles fixes. Héron, le plus célèbre physicien de l'antiquité, à qui l'on doit l'appareil hydraulique qui porte son nom, et Ctésibius, l'inventeur des pompes, appartiennent à la mème époque. Depuis lor's, jusqu'au milieu du I' siècle de l'ère chrétienne, nous ne connaissons plus aucun savant alexandrin digne d'être cité.

Nous trouvons, en dehors des savants de l'école d'Alexandrie, dans le $111^{e}$ siècle avant notre ère, Archimède de Syracuse, qui s'occupa arec un 
prodigieux succès de la mécanique et de l'hydrostatique, dont il eśt le véritable créateur. On lui doit la vis qui porte son nom, et qui sert à faire monter l'eau; les mouffles, les roues dentées et peut-être le miroir ardent.

Les rois d'Égypte s'occupaient avec un zèle infatigable de l'accroissement de leur biblio thèque; Ptolémée Évergète en fonda même une seconde dans le temple de Sérapis. Jaloux de voir les Auale de Pergame rivaliser d'ardeur avec lui pour augmenter leurs richesses littéraires, il défendit l'exportation du papyrus, que l'Égyple seule produisait. Cette prohibition fit inventer le parchemin (charta pergamena). C'est donc à cette rivalité et à la découverte précieuse qui s'ensuivit que nous devons la conservation de tant de trésor's de l'antiquité, qui, confiés aux fragiles et périssables membranes du papyrus, eussent été perdus pour nous. Privés de ce secours, la plupart des autres peuples faisaient usage de tablettes de métal ou de bois enduites de cire et sur lesquelles on traçait des caractères avec un style de fer; mais l'imperfection de ces moyens était un obstacle aux progrès des sciences.

Sous le règne de six princes successifs, elles jouirent d'une proteclion éclairée; mais Physcon, quoique versé lui-même dans la connaissance de la nature, puisqu'il avait écrit un ouvrage sur les poissons de l'Afrique, persécuta les savants avec un tel acharnement que la plupart d'entre eux retournèrent en Grèce, à laquelle ils rendirent momentanément sa prépondérance scientifique.

Lathyre, encore plus impitoyable que son prédécesseur, chassa d'Égypte le petit nombre de savants qui ne l'avaient pas quiltée; un seul, Agatharchides, échappa à la proscription. Ce philosophe a composé un ouvrage ethnographique sur les peuples qui habitaient les bords de la mer Rouge, et a laissé des descriptions zoologiques assez exactes, quoique souvent mêlées à des créations fabuleuses.

Nous devons à Nicandre (100 ans avant J.-C.), médecin a'Attale III, deux poèmes relatifs à l'histoire naturelle. Le premier, Theriaca, traite des animaux venimeux, et donne des descriptions d'ophidiens, de crustacés et d'aranéides, assez précises pour que plusieurs espèces soient faciles à reconnaître. Dans son Alexipharmaca, il étudie l'action des poisons ingérés et surtout des poisons végétaux. Il fait mention de quelques plantes dont ne parle pas Théophraste, ce qui prouve qu'à cette époque la botanique avait fait des progrès; mais ce dernier ouvrage renferme beaucoup d'erreurs. C'est Nicandrc qui a donné le nom de phalène aux papillons de nuit. 
Atule 11 l et Mithridate, le célèbre roi du Pont, peuvent être comptés parmi les botanistes; ce dernier s'était beaucoup occupé de toxicologie. On lui doit une drogue composée qui porte encore son nom.

Ici finit le règne des sciences en Grèce et en Égypte. L'anarchie qui aéchirait les petites républiques grecques et leurs colonies, la dépravation toujours croissante des mœur's qui avait étouffé les vertus guerrières, les mirent hors d'étal de résister aux armes romaines.

Nous allons maintenant parler de Rome, cette reine des cités, qui eut des commencements si humbles, et grandit au point de ne connaître d'autres bornes à sa puissance que les limites du monde.

Les Romains descendent d'une tribu gallo-grecque (750 ans avant J.-C.), chez laquelle l'élément grec finit par dominer. Les Étrusques, qui sont peut-être des Pélasges émigrés de l'ancienne presqu'île du Péloponèse, paraissent avoir occupé la Péninsule italique à une époque très reculée, et s’être plus tard confondus avec les Grecs, dont de nombreuses colonies s'étaient établies dans la partie méridionale de l'Italie; aussi y avail-il au sud des Érusques et des Grecs, landis que le centre et le nord élaient habilés par des Celtes. Denis d'Halicarnasse nous apprend que les Sabins, ennemis de Rome naissante, étaient descendus des Ombriens, dont l'origine celtique n'est pas douteuse; de là cette lutte entre des peuplades de race différente. Numa, qui était Sabin, favorisa les usages et la religion des Celtes; mais les rois qui lui succédèrent et la famille des Tarquins, qui était corinthienne, firent pencher la balance en faveur de la civilisation grecque. Il résulta, du mélange de ces peuples, des institutions et des coutumes qui participèrent de leur double origine; et nous savons aujourd'hui que la langue romaine n'est qu'un mélange de grec et de celte dans lequel dominent les formes plus harmonieuses du premier idiome.

Ce n'est sans doute pas aux Gaulois transalpins que les Romains durent leur première civilisation; car le peu que nous savons des institulions druidiques nous montre des prêtres sans instruction investis des fonctions les plus importantes de l'état. Médecins, philosophes, législateurs, ils tenaient leurs disciples dans une dure dépendance, exigeaient d'eux des études orales de vingt années; et, pour prévenir la diffusion des connaissances dont ils étaient dépositaires, ils en avaient défendu la propagation par l'écriture. Il ne nous est resté aucun monument caractéristique de leurs arts, si ce n'est leurs Dolmen et leurs Menhir. On peut donc avancer arec cerlitude que les barbares guerriers de Rome furent 
redevables de leurs premiers progrès aux. Érusques, dont les vastes travaux architectoniques et les ouvages ficliles attestent lè génie créateur ; mais ils empruntèrent aux Grecs leurs connaissances scientifiques, et encore ne fut-ce que fort tard; car la constitution romaine, dont le but exclusif était l'agrandissement par la conquête, et qui bannissait le luxe, les arts, le commerce, comme pouvant distraire l'esprit des citoyens des occupations guerrières, s'opposa long-lemps à la culture des sciences.

Caton le censeur (130 ans avant J.-C.) est le premier écrivain latin qui se soit occupé des sciences naturelles, mais seulernent comme agriculteur. Son ouvrage, de re rustica, est un petit traité d'agriculture pratique, d'économie rurale et de médecine vétérinaire; essai bien informe pour un homme qui avait été en contact avec les Grecs. Rome cependant commençait à perdre de sa rudesse et à devenir sensible aux richesses intellectuelles des vaincus; car, après la prise de Carthage, le sénat fit traduire en latin un traité de Magon sur l'agriculture. Cet ouvrage et le périple d'Hannon, qu'on trouve dans le recueil des petits géographes grecs, et dont l'authenticité longtemps contestée paraît aujourd'hui hors de doute, sont les seuls monuments scientifiques qui nous restent de cette puissante rivale de Rome.

Varron (116 ans avant J.-C.), qui avait étudié à Athènes, a écrit, sous le titre de l'ouvrage de Caton, un traité qui l'emporte de beaucoup, quant au style et à la méthode, sur celui de cet écrivain. Il doit sa supériorité aux relations fréquentes qui s'étaient établies avec Athènes, depuis la conquête de la Grèce par les Romains.

Lorsque Pompée eut vaincu Mithridate, il trouva, dans les trésors de ce prince, des livres de médecine écrits en plusieurs langues et qu'il fit traduire. Les doctrines d'Hippocrate, généralement admirées, eurent à Rome un succès prodigieux; mais elles y rencontrèrent un vigoureux antagoniste dans la personne d'Asclépiades l'épicurien, qui enseignait, contrairement à l'opinion d'Hippocrate, l'inaltérabilité de la matière, et admettait dans l'organisme le jeu incessant des atomes.

Jules César, guerrier plutôt que naturaliste, mais observateur attentif et écrivain judicieux, nous a laissé, dans ses Commentaires, des renseignements très curieux sur les animaux de la Germanie; il nous apprend. que certaines espèces, exilées par la civilisation, ont disparu en même temps que la race humaine s'est accrue. A l'époque où il pénétra dans ses forêts séculaires, elles étaient peuplées d'aurochs, d'élans et de rennes, qui de nos jours ne se trouvent plus que dans les pays septen- 
trionaux; encore l'aurochs n'luabite-t-il que les forêts de la Lithuarie.

Lucrèce, contemporain de César, et représentant à Rome des doctrines d'Épicure, a exposé, dans son poème de rerum natura, un système complet de philosophie naturelle. Il forme la terre, les mers et l'atmosphère, de la réunion d'atomes élémentaires, mus par les lois de l'affinité; et, quoiqu'il n'eût aucune connaissance positive en paléontologie, il dit qu'avant que les hommes et les choses actuelles existassent, la terre avait nourri des ètres d'une forme extraordinaire et des végétaux monstrueux; mais à des doctrines générales pleines de sens et de logique, et dénotant un esprit aussi profond que judicieux, se mêlent les plus graves erreur's. La physique de Lucrèce n'est pas moins arriérée que celle de tous ses contemporains; il cherche ses explications dans les théories faites à priori et non dans l'observation des faits.

A mesure que nous approchons de l'époque où le gouvernement subit à Rome une nouvelle métamorphose, la philosophie et l'étude des sciences disparaissent. Les Romains dégénérés ne sont plus qu'un peuple voué au culte des sens; et c'est désormais dans les parcs, les volières, les viviers, et jusque dans les traités culinaires, qu'il faudra chercher la science antique pour en retrouver quelques traces.

Ces maîtres de la terre, longlemps les premiers du monde par leur sage tempérance, ne se contentèrent plus des mets simples el salubres qui avaient entretenu chez leurs ancêtres la force du corps et la puissance de l'esprit. Leur imagination dépravée, leur sensualité blasée par l'excès des jouissances, durent mettre la terre entière à contribution pour satisfaire leurs caprices: Les paons, les faisans, les gangas, les grues, les cigognes et les autruches, étaient élevés dans des volières, pour concourir au faste des banquets. Des viviers d'eau douce ou salée construits à grands frais, et amenant le poisson jusque dans les salles de festin, étaient remplis de truites, de dorades, de soles, de mullets, dont trois individus furent payés, sous Tibère, une somme égale à $6000 \mathrm{fr}$. de notre monnaie; et Pollion nourrissait des murènes de la chair de ses esclaves. On portait si loin cetle coupable folie que la mort d'un de ces poissons fit prendre le deuil à un certain Crassus.

Le luxe des parures, des ameublements et des constructions égalait celui de la table. On tirait des pays étrangers des tissus précieux; des pierres fines, des parfums et des bois recherchés pour satisfaire les fantaisies les plus puériles.

Depuis longues années (216 ans arant J.-C.), les Romains avaient 
adopté l'usage d'introduire dans le cirque des animaux qu'ils tuèrent d'abord à coups de flèches, et qu'ensuite ils firent combattre ensemble ou même avec des hommes. Les premiers qu'on y lança furent des éléphants pris sur Pyrrhus, et qui ne furent exposés à la vue des citoyens que pour les accoutumer à affronter ces animaux; plus tard, on y introduisit des lions et des panthères; mais le goût de ces sanglants spectacles s'étant répandu avec la facilité de le satisfaire, il s'accrut jusqu'à la démence, et c'était à qui ferait paraître à-la-fois, dons le cirque, un plus grand nombre d'animaux. A cette joie féroce, se mêlait aussi la curiosité, et l'on attachait un grand prix à l'apparition d'animaux nouveaux. Quintus Sextus fit, le premier, descendre dans le cirque, des hommes qui combattirent contre quarante lions, Emilius Scaurus, pour flatter cette passion populaire, y montra, pendant son édilité, des hippopotames et des crocodiles; sous Pompée, on y réunit des rhinocéros et un nombre considérable de lions, d'éléphants, de panthères. Sous les empereurs, époque d'exagération en toutes choses, on alla plus loin encore. Auguste y fit, en un seul jour, périr 3,500 animaux sauvages; et, après les victoires de Trajan sur les Partles, on mit à mort en vingt-trois jours de fête, 11,000 animaux domestiques. On vit successivement figurer dans les jeux, des girafes, des hyènes, des strepsicères, des ibis et des autruches. Ces fètes barbares continuèrent sous les empereurs chrétiens; mais, au milieu de ces fréquentes apparitions d'animaux curieux, avec des occasions si répétées d'étudier leurs møurs, leur structure, les variétés des races suivant les pays de provenance, on ne voit paraître aucun observateur, on ne trouve aucune description exacte.

Parmi les rares auteur's qui écrivirent sur les sciences naturelles, nous pouvons considérer comme des naturalistes Musa, médecin d'Auguste, savant botanịste, à qui l'on a dédié le bananier (Musa sapientium), et Apuleius Celsus qui écrivit un traité sur les plantes, leurs noms et leurs propriétés. L'empereur Auguste lui-même n'était pas étranger à la science; il avait fait recueillir dans l'île de Caprée, des restes de mastodontes, regardés comme des ossements de géants.

Virgile cite, dans ses Géorgiques, un grand nombre de plantes et d'animaux; mais il en parle plutôt en poète qu'en naturaliste; cependant quelques-unes de ses descriptions sont pleines d'exactitude.

Ovide présente encor'e plus d'intérêt comme descripteur. Dans son poème sur la pèche, Halieuticon, dont il ne nous reste que cent tręte- 
quatre vers, on trouve cinquante-trois poissons décrits avec assez de précision pour qu'on puisse les reconnaître. Il parle du physis (gobius niger) qui se construit un nid comme les oiseaux. Ce fail, déjà mentionné par Aristote, et qu'on avait toujours regardé comme une fable, a été confirmé, il y a environ dix ans, par un naturaliste italien.

Diodore, de Sicile, a laissé dans ses écrits quelques descriptions d'animaux, de plantes et de minéraux. Il a le premier parlé du riz.

Strabon, né en Cappadoce, cinquante ans avant notre ère, s'est acquis ıne juste célébrité par sa géographie, ouvrage fort étendu, disposé avec uıe méthode remarquable. Il joint à la description de chaque pays une esquisse de leurs productions naturelles. Ainsi, il cite le-muge, en parlant de la Gaule-Narbonnaise, et l'élan en parlant des Alpes. En décrivant les monts Taygètes, il rappelle les carrières de marbre qui servaient à décorer les édifices romains; et, à propos de Byzance, il parle de la route que suivaient les bancs de poissons qui venaient tomber dans les filets des pêcheurs byzantins. Il a décrit le premier la canne à sucre, et fait mention de la soie, qu'il regardait comme le produit d'un arbre. Cet auteur a donné une description assez exacte des poissons du Nil pour que, lors de l'expédition des Français en Égypte, la plupart aient été retrouvés. Tous les faits consignés dans ses écrits et qui ne sont pas le résultat d'observations personnelles, sont des compilations faites avec un choix judicieux.

Diodore et Strabon devraient se raltacher à la littérature grecque, puisqu'ils ont écrit dans cette langue; mais, comme ils ont vécu longtemps à Rome et qu'ils appartiennent à la civilisation romaine, nous n'avons pas cru devoir les séparer' des naturalistes latins.

Un ouvrage précieux pour l'histoire naturelle, quoique d'un caractère bien différent, est le traité de l'art culinaire d'Apicius, ce célèbre gastronome du siècle d'Auguste, qui se donna la mort quand ses prodigalités eurent épuisé sa fortune. Il y décrit minutieusement tous les mets en usage chez les Romains. C'est un bon catalogue à consulter pour in naturaliste.

Columelle a écrit un ouvrage d'agriculture sur le même plan que ceux de Caton et de Varron ; il y donne des détails fort intéressants sur la construction des viviers, et des instructions étendues sur la direction des ruches. En général, ses descriptions sont beaucoup plus complètes que celles de Varron.

Sénègue pourrail prendere place parmi les naturalistes anciens, si, dans 
son livre sur les questious naturelles, où il traite de physique générale, il II'avait fait trop souvent preuve d'une profonde ignorance de la matière.

On doit à Arétée, de Cappadoce, qui vivait sous Néron, de bonnes descriptions anatomiques, entre autres celles de la veine cave et de la veine porte; mais, par une erreur singulière, il fait partir toutes les veines du foie, quoique Aristote ait dit expressément qu'elles partent du coeur.

Dioscoride, médecin des armées romaines sous Néron (75 ans de J.-C.), fut un botaniste célèbre. Il a décrit environ six cents plantes, mais avec une telle inexactitude qu'on a pu à peine en reconnaître le quart; suivant la coutume de cette époque, il attribue aux plantes des propriétés imaginaires, erreur que l'autorité des auteurs anciens a perpétuée presque jusqu'à nos jours. Ce botaniste a joui jusqu'au xv siècle d'une célébrité pourtant bien contestable; mais il était le seul dont les écrits nous fussent parvenus par des traductions illustrées, et les Arabes n'ont eu long-temps aucun autre traité de botanique. Il s'occupa aussi de minéralogie, et divisa les corps bruts d'après leur nature en terrestres et en marins. On l'accuse d'avoir emprunté cette classification à Sextus Niger.

La plupart des empereurs romains, depuis Auguste jusqu'à Vespasien, favorisèrent peu les sciences; mais ce dernier institua des écoles destinées à répandre le goût des études, et rétribua les professeurs sur le trésor public. C'est sous son règne que vécut Pline, dont le nom est aussi répandu que celui d'Aristote.

Ce naturaliste est un des hommes les plus laborieux qui aient existé. Quoique mort dans un âge peu avancé, puisqu'il périt à 56 ans, lors de l'éruption du Vésuve qui détruisit Pompéïa et Herculanum, il a laissé sur différentes matières cent soixante gros volumes extraits des écrivains qu'il avait lus. Son ouvrage sur l'histoire naturelle est la compilation de plus de deux mille ouvrages, et il cite un grand nombre d'auteurs dont sans lui les travaux auraient été perdus pour nous : c'est un titre à la reconnaissance de la postérité. Mais il n'est pas scrupuleux sur le choix des matériaux; chaque fois qu'il compulse un observateur judicieux ses descriptions sont exactes; quand, au contraire, il a entre les mains un auteur fabuleux, il consigne les faits qu'il lui emprunte sans lia moindre critique, et mêle ainsi sans cesse la vérité à l'erreur. Les écrits de Pline, dont le but est évidemment d'amuser plutôt que d'instruire, offrent une lecture très agréable; mais il n'y faut pas chercher de la science sérieuse; il a copić dans Aristote toul ce qu'il renferme de bon.

Son septième livre, qui est le commencement de sa zoologie, est 
zne espèce d'anthropologie informe et remplie de fables. Il y fitit menlion d'lommes à pieds d'autruche, sans bouche, à oreilles gigantesques, elc. Ses délails ethnographiques et son esquisse de l'histoire des inventions et des arts présentent un intérêt plus réel.

Sa classification des êtres organisés n'est pas fondée sur leur's caractères anatomiques, mais sur leur mode d'existence. Il divise les animaux en terrestres, aquatiques et aériens; et de cette classification arbiIraire naît uue confusion facile à comprendre.

Le nenvième livre renferme de précieux détails sur les céracés de la mer du uord el de la Méditerranée. Nous y voyous que de son temps ces animaux venaient jusque dans notre golfe de Gascogne. Il parle aussi d'un boa qui fut tué par Régulus, près du fleuve Bagrada, non loin de Carthage.

Son ornithologie est faible; mais elle contient des choses fort curieuses. Il donne du plénix une description assez exacte pour qu'on y puisse reconnaître le faisan doré, et fait mention du tragopan, oiseau cornu, long-temps regardé comme fabuleux.

Dans son entomologie, il décrit longuement les moeurs des abeilles que, d'après un préjugé commun à l'antiquité, il croyait pouvoir être spontanément engendrées par la putréfaction du ventre d'un boeuf. Il parle aussi de la soie qui venait, dit-il, d'un pays fort éloigné, et que produisaient des insecles différents du bombyx mori.

Si la zoologie de Pline est confuse, sa bolanique l'est plus encore. Sa classification est arbitraire et ses descriptions sont trop inexactes pour que les plantes qu'il cite puissent être reconnues. Il a cependant le mérite de cette ingénieuse remarque qu'il serait possible, par l'époque de la floraison des végélaux, de reconnaître les mois de l'année; Linné pourrait bien y avoir pris l'idée de son calendrier de Flore.

La thérapeutique de Pline est pleine d'erreurs. Il multiplie à l'infini les remèdes qu'on peut tirer des plantes et des animaux; selon lui, la tortue seule en fournit soixante-six.

Sa minéralogie est intéressante sous le rapport technique et comme histoire des beaux-arts ; car il a sauvé de l'oubli les noms d'un grand nombre de sculpteurs, de peintres et de graveurs, en donnant la description d'édifices, de statues el de pierres gravées qui n'existent plus pour nous. Il nous fait connaître le mode d'extraction des métaux, l'emploi de l'amalgame du mercure pour l'exploitation des mines d'or ef d'argent, la fabrication du laiton, de l'acier, du bronze, de l'arain de 
Corinthe; celle du blanc de céruse et du minium. II parle des propriétés de l'aimant, de celles de la pierre de touche, du soufre, du cinabre, de la litharge, etc.

On trouve dans ses ouvrages une foule d'observations sur les aérolithes, les auror'es boréales, et sur d'autres phénomènes météoriques.

Plutarque a consigné, dans ses Propos de table et dans son ouvrage sur P'Industrie des animaux et sur la raison dont ils sont doués, certains faits d'histoire naturelle qui ne sont pas dépourvus d'intérêt; mais il traite toutes ces questions plutôt en philosophe qu'en naturaliste. II a laissé deux traités de physique générale, sous le titre de Questions naturelles et de Recherches sur le froid, el un petit écril fort curieux, à caluse de certaines observations très justes concernant la nature du globe lunaire, et qui est intitulé : De la face qui paraît dans la lune.

A cette époque, oì l'empire romain touchail à la grande crise qui devait se terminer par sa dissolution, la plus déplorable anarchie régnait dans les esprits, et Alexandrie était le principal théâtre de celte confusion. Les Juifs, dont l'établissement dans cette ville remontait au règne de Physcon, y avaient apporté le goût des études de pure spéculation. Plus tard, sous le règne de Trajan el d'Adrien, la philosophie indienne devenue, sans doute, plus incompréhensible à mesure qu'elle s'éloignair de sa source, et le néo-platonisme qui, de son côté, se livrait aux conceptions les plus insaisissables, vinrent ajouter au verlige qui poussait les esprits vers ces études sans nom qu'on a tenté de nos jours de rajeunir. De ce conflit d'idées toujours vagues et rarement profondes naquit la philosophie cabalistique, cette déplorable aberration de la raison humaine dont le règne fut si long et qui n'occupe plus aujourd'hui que quelques cerveaux vides. Ces stériles études, mortelles pour l'intelligence, firent oublier les sciences d'observation, qui tombèrent bientôt dans l'oubli.

Au II siècle de l'ère chrétienne, nous ne trouvons que trois écrivains, Athénée, Élien et Oppien, dont les ouvrages intéressent directement les naturalistes; mais, lorsqu'ils parurent, la langue latine avait, comme langue scientifique, fait place à la langue grecque.

L'ouvrage d'Athénée, le Banquet des sages, n'est autre chose qu'une compilation indigeste et confuse; mais il renferme beaucoup de détails précieux. L'auteur fail raconter à chacun des convives tout ce qu'il sait sur les mets qui paraissent sur la table, et de là des détails souvent fort piquants. C'est ainsi qu'il nous dome la description de quatre-vingt-dix 
poissons et d'un grand nombre d'oiseaux, le tout mêlé d'anecdotes qui varient agréablement son récil.

Élien n'est, comme Athénée, qu'un simple compilateur. Pour rendre son livre plus original, il a eu la malencontreuse idée de mêler toutes les malières sans ordı'e ni méthode. Il cite soixante-dix espèces de mammifères, entre autres le bœuf sans cornes, l'yak, le babiroussa et la souris épineuse. Sur les cent neuf espèces d'oiseaux dont il fait menlion, quelques-unes n'ont été constatées que dans les temps modernes : tels sont ceux qu'il appelle les paons de mer, et dans lesquels on a reconnu les combattants. Il donne la description de cinquante espèces de reptiles qui n’ont pas tous été retrouvés, et il n'y a guère que dix années qu'on a découvert aux Indes son crocodile à muscau cornu. Il décrit cent trente poissons; quelques-uns le sont pour la première fois, tels que le diodon, le citharodon et l'anchois. Les détails qu'il présente sur les animaux de cette classe sont d'autant plus importants que les Grecs étaient presque aussi avancés que nous en ichhyologie.

Oppien, né en Cilicie, vers la fin du règne de Marc-Aurèle, a écrit les Cynégétiques, les Halieutiques et les Ixeutiques, poèmes tous trois précieux pour les sciences naturelles; mais dont le dernier est perdu.

Les Cynégétiques rous font connaître les races de chevaux et de chiens dont on se servait alors pour la chasse, et le nom des animaux qui étaicnt l'objet de ce délassement. L'auteur y citc entre autres le bison et le mouflon, qui vivaient alors en Italie. Les Halieutiques contiennent des détails d'un plus grand intérêt. Le poète y décrit le lieu d'habitation des poissons et de certains mollusques, leur mode de reproduction et leurs mœurs; ainsi, il rappelle les propriétés électriques de la torpille, la ruse si connue de la baudroie pour attirer les petits poissons, celle de la sèche qui teint l'eau de son encre, afin d'échapper à ses ennemis, et le dangereux aiguillon dont la pastenade est armée. Les développements dans lesquels il entre sur la manière de pêcher les diverses espèces de poissons et sur leurs migrations sont fort intéressants pour la science. L'ouvrage d'Oppien contient la description de cent soixante poissons; et il est à remarquer que, parmi tant de détails, on ne trouve que peu de fables; cependant certains faits deman. dent à être vérifiés.

Ce jeune poète est l'un des derniers naturalistes distingués de l'antiquité ; nous ne trouvons plus après lui que Galien de Pergame, savant médecin de Marc-Aurèle el de Lucius Vérus. 
Galien sc fixa à Rome après avoir successivement visité, pour s'instruire, Corinthe, la Lycie, la Palestine et l'Égypte. A l'époque où il étudia l'anatomie à Alexandrie, cette science y était en décadence; mais par son seul génie il la soutint et lui fit fảre d'étonnants progrès. Il a considérablement écril, en suivant toujours dans ses travaux un ordre méthodique : il commence par l'anatomie; viennent ensuite la physiologie, l'hygiène, la pathologie, la séméiotique et la thérapeutique.

Ses aaministrations anatomiques, dont nous n'avons qu'une partie, sont pleines de faits qui annoncent une merveilleuse sagacité et une persévérance opiniâtre. Les difficultés qui entouraient l'étude étaient cependant alors fort grandes. On ne pouvait disséquer des adultes, et l'on était réduit à ouvrir les cadavres des enfants morts dans les lieux où on les avait exposés, on bien ceux des ennemis restés sur le champ de bataille; toutes ces ressources étant insuffisantes, Galien conseilla d'étudier l'organisation des animaux qui se rapprochent le plus de l'homme, surtout les singes de l'espèce appelée magot. Il en résulte que, dans ses descriptions myologiques et ostéologiques, il rapporte souvent à l'homme des détails organiques qui ne sont vrais que pour le singe. Son livre de la Digestion contient des indications fort précises sur l'anatomie comparée; il fait remarquer, après Aristote, que tous les animaux qui n'ont pas d'incisives à la mâchoire supérieure ont plusieurs estomacs. II soutient aussi, contre l'opinion généralement admise de son temps, que les éléphants ont une vésicule biliaire. Ses travaux relatifs à la respiration donnent une haute opinion de son habileté. Il avait fait de nombreuses expériences sur la production de la voix, et coupé, chez des porcs, les deux branches du nerf pneumo-gastrique qui montent le long du larynx, pour démontrer leur influence dans la formation du son. Nous n'avons qu'une partie de sa description du cerveau ; mais elle est assez remarquable pour nous faire regretter la perte de ce qui ne nous est pas parvenu.

Galien fait preuve d'une grande pénétration dans son ouvrage intiulé : De l'usage des parties du corps humain. II a signalé le premier la perforation du cœur dans le foetus. Toutes ses erreurs sur la structure el les fonctions de cel organe et de ses dépendances viennent de ce qu'il n'expérimentait que sur des animaux, et n'avait aucune idée de la circulation du sang; aussi ne peut-il expliquer le mouvement d'élévation et d'abaissement du cerveau, qu'il attribue à l'afflux de l'air. Il a aussi le premier parlé des nerfs optiques, et 
décril avec exactitude les conches optiques. Il maite ensuite de l'usage des parties de la tète, des dents, de la moelle épinière, des nerfs auxquels celle-ci doune naissance, des organes de la reproduction, de la différence qui existe entre le foetus et l'adulte, de la distribution générale des nerfs, des artères et des veines. Chacun de ces sujets particuliers prouve le même talent d'observation et la même puissance de déduction. Dans son écrit sur les opinions d'Hippocrate, il fail de la lète le siége de toutes les facultés, contrairement à la théorie des stö̈ciens, qui le plaçaient dans le cœur.

Son traité, relatif aux propriétés des aliments, renferme une foule de détails intéressants sur les substances nutritives tirées des deux règnes.

Ce grand homme, qui eût peut-être égalé Aristote, si, au lieu de spécialiser ses études, il les avait généralisées, dut au hasard d'un songe survenu à son père d'avoir étudié la médecine. Il est du petit nombre de ceux qui ont perșonnellement joui de leur gloire et dont le nom est le plus long-temps demeuré populaire. Admiré pendant sa vie, il fut jusqu'au $\mathrm{xvi}^{\mathrm{e}}$ siècle une autorité toute-puissante; et jusqu'à nos jours les Arabes n'eurent pas d'autre guide. Galien est le dernier savant qui se soil occupé des sciences naturelles avec distinction; à sa mort, elles tombèrent dans la barbarie, pour ne se relever qu'au $x I^{\mathbf{e}}$ siècle : aussi n'entrerons-nous pas dans de grands détails sur les hommes qui lui succédèrent.

Justin, écrivain du II ${ }^{\mathrm{e}}$ siècle, à qui nous devons la conservation de plusieurs passages fort curieux de l'historien Trogue-Pompée, semble adopter son opinion sur l'origine ignée de notre planète, et pense que le refroidissement du globe ayant d'abord eu lieu aux pôles, les Scythes doivent avoir été les premiers habitants de la terre.

Au II $^{\mathrm{c}}$ siècle, nous trouvons fort peu d'écrivains remarquables; ce qu'il faut attribuer à la lutte qui s'engagea entre les chrétiens et les seclateur's du paganisme. Cependant quelques hommes se montrèrent encore sensibles aux attraits de la sience: Philostrate de Lemnos, philosophe pythagoricien, qui vivait à Rome sous l'empereur Sévère, a consigné, dans la vie d'Apollonius de Thyanes, de fort bonnes observations sur les productions naturelles de l'Inde, qu'Apollonius avait visitée en compagnie de quelques philosophes. Tout ce qu'il rapporte sur les mœurs des éléphants est très exact. Il décrit avec précision plusieurs des poissons de l'Indus, et donne quelques détails curieux sur les mœurs des singes; mais ces vérités sont mêlées aux fables si communes 
à cette époque. Nemesianus le Carthaginois a écrit un poème sur la chasse aux mammifères et un autre sur l'aviceptologie, dont il ne nous reste que quelques vers. Titus Calpurnius, élève de Nemesianus, a composé des élégies, dont la septième renferme des détails sur les lièvres blancs et sur le babiroussa ; il y cite un bœuf à bosse et à crinière, qu'on suppose ètre le bison.

A cette époque, la chimie, dont il n'a pas encore été question, occupait beaucoup les savants d'Égypte, et avait puissamment contribué aux progrès de la métallurgie. Déjà, sous le nom d'art hermélique, converti plus tard en celui d'alchimie, elle rêvait la transmutation des métaux; et Dioclétien fut tellement effrayé de ses progrès, qu'apiès la prise d'Alexandrie, il fil brûler tous les livres qui en traitaient.

Les plus anciens ouvrages d'alchimie, échappés à la proscription, et qu'on attribue faussement à Hermès, mais qui appartiennent évidemment à l'école d'Alexandrie, sont le Pimandre, le Traité des sept chapitres, et la fameuse Table d'éméraude tant de fois commentée sans avoir été comprise. Tous ces ouvrages sont empreints du panthéisme primitif particulier à l'Orient, et l'on aurait peine à reconnaître, sous leur forme apocalyptique, les premiers àges de la chimie moderne; mais nous suivrons pas à pas cette science, et nous montrerons comment la vérité sans cesse mêlée à l'erreur finit par triompher.

Après quinze siècles d'une gloire toujour's croissante, l'empire romain succombait sous le poids de sa propre grandeur. Travaillé au dedans par des factions politiques et des querelles religieuses auxquelles venait se joindre, comme une cause inévitable de dissolution, la profonde corruption de la société paienne; harcelé par les invasions de plus en plus menaçantes des barbares, il touchait à sa ruine. Depuis le commencement de notre ère, les populations teuto-cimbriques, qui s'étendaient du Danube jusqu'à l'Elbe, s'étaient incessamment précipitées sur l'Italie; leur nombre et leur audace allaient toujours croissant. $A u I^{e}$ et au $\mathbf{v}^{\mathbf{e}}$ siècle, les Ostrogoths et les Hérules, les Vandales, les Alains, les Suèves, les Visigoths et les Francs, inondèrent l'Ttalie, les Gaules, l'Afrique, l'Espagne; et Attila (Etzel) vint à son tour, comme un torrent dévastateur, sillonner le sol de la péninsule italique. Pour l'éloigner, les Romains, qui ne pouvaient plus supporter le poids d'un glaive, le gorgèrent de riches présents. Genserich et Odoacre vinrent enfin s'asseoir sur le trône des Césars, mais ne prirent des vaincus que la foi chrétienne. 
Cependant vers le milieu du rv siècle, Constantinople avait recueilli les débris de la civilisation romaine; et l'Occident, en proie aux guerres acharnées des tribus germaniques qui se disputaient la possession du sol, tomba pour huit siècles dans la plus affreuse barbarie. La lutte engagée entre les chrétiens et les païens absorbait l'attention de tous les hommes d'intelligence, et ne laissait aux esprits aucun loisir pour s'occuper de science. Toutefois, Eustathius, archevêque d'Antioche, composa, sous le titre de Commentaire de l'Hexameron, un traité d'histoire naturelle, où les êtres sont rangés suivant l'ordre de leur création et dont tous les détails sont empruntés aux naturalistes anciens. Saint Ambroise (370) publia un ouvrage semblable, mais dans un but exclusivement théologique. Vegèce et Gargilius écrivirent sur l'art vétérinaire deux trailés d'une grande médiocrité, et Palladius a laissé un ouvrage intitulé : De re rustic $\hat{a}$, qui mérite à peine une mention. Ausone, précepteur de l'empereur Gratien, est l'auteur d'un poème sur la Moselle, dans lequel il décrit quatorze espèces nouvelles de poissons, entre autres la truite commune, la truite saumonée et le barbeau. Oribase, médecin de l'empereur Julien, fut un des hommes les plus remarquables de ce siècle; il réunit en un seul corps divers trailés de médecine, qui sans lui ne fussent pas parvenus jusqu'à nous.

Saint Augustin, l'illustre évêque d'Hippone et l'un des plus célèbres pères de l'Église, a décrit quelques poissons, et mentionne la découverte faite en Afrique de débris de mastodontes qu'il croit être des ossements de géants. On a de lui un traité sur la génération. Macrobe a écrit deux ouvrages sur les sciences: le premier, sous le titre de Commentaire du songe de Scipion, contient un exposé des opinions des anciens sur l'astronomie; le second, intitulé Saturnales, rédigé sur le même plan que celui d'Athénée, fait connaître certaines opinions scientifiques, que sans lui nous aurions toujours ignorées. Sidoine Apollinaire a laissé des détails topographiques sur l'Auvergne. Orose, de Tarragone, n'est intéressant que par une assertion qui justifie le calife Omar de l'incendie de la bibliothèque d'Alexandrie; car il déclare que, dans son voyage en Égypte, il visita cette bibliothèque et la trouva vide, les, Arabes l'ayant dévastée depuis deux siècles. Martianus Capella a écrit, à la fin du $\mathbf{v}^{\mathrm{e}}$ siècle, un poème intitulé : Noces de la philologie avec Mercure. On y trouve une division des connaissances humaines en sept branches appelées les sept arts libéraux, division adoptée par les universités dans tout le cours du moyen âge; 
et Saint Cyrille a laissé un petit traité sur les plantes et les animaux.

Les efforts des empereurs n'avaient pu empêcher les Gaules de tomber sous la domination des Francs ni soustraire l'Italie au joug des barbares. Cependant les chefs des conquérants n'étaient pas tous insensibles aux avantages de la civilisation. Sous le règne de Théodoric, roi des Ostrogoths, le calme se rétablit un peu; et ce sage prince, non content de favoriser dans ses états les progrès des lumières, s'efforça de les faire pénétrer chez ses voisins; mais les querelles suscitées par l'arianisme occupaient l'attention des esprits el les détournaient de l'étude. Aux dissensions causées par ce schisme se mêlèrent de plus graves préoccupations: les institutions politiques cherchaient à se régulariser'; la féodalité s'organisait sur toute la face de l'Europe, et tandis qu'en Occident une arisiocratie puissante renfermait le pouvoir royal dans les bornes les plus étroites, le despotisme régnait à Constantinople.

Le fameux commentaire de la Misnah, le Talmud, code civil et canonique des Juifs, remonte à cette époque, et eut une très grande influence sur la direction des idées philosophiques de l'Europe. C'était un mélange informe de la philosophie néo-platonicienne, avec les idées superstitieuses des Juifs, qui attribuaient aux caractères alphabétiques, à leur combinaison, à certains mots barbares, une puissance refusée à l'homme, et mettaient à son service les êtres supérieurs. Les études théologiques, fondées sur la lecture des gloses de la Bible et sur celle des livres juifs, entretenaient cette déplorable erreur. Il en naquit la cabale que le xvir ${ }^{\mathrm{e}}$ siècle seul vit s'éteindre, et qui fascina certains esprits faibles au point de les faire croire à leur propre supériorité. De là les astrologues, les magiciens et les sorciers qui souvent expièrent dans les flammes leur coupable crédulité.

La littérature ecclésiastique, qui avait eu pour brillants interprètes les pères de l'Église, commençait à décliner. Dans les premiers temps dı vi ${ }^{\mathbf{e}}$ siècle, on ne comptait d'hommes célèbres que Cassiodore et Boëce, qui firent de vains efforts pour tirer les letres de la barbarie; et vers la fin brilla le savant saint Grégoire, dont le palais était devenu l'asile des sciences. Nous ne trouvons aussi à cette époque que deux médecins célèbres, Aétius d'Amède et Alexandre de Tralles. La corruption toujours croissante des mours fut suivie d'un abrutissement général. Les écoles, abandonnant les études sérieuses, s'étaient laissé envahir par les dispules théologiques, el une fausse dialectique rendail les discussions verbeuses et sans profondeur. 
Les disciples de saint Benoît, dégoùtés diun monde d'où la vertu était bannie, se retirèrent, en 543, sur le mont Cassin et se consacrèrent à l'éducation de la jeunesse el à l'étude; ils rendirent d'immenses services à la civilisation, en multipliant les manuscrits, précieux monuments de l'antiquité.

Ce siècle fut pourtant signalé par une importation d'un grand intérêt pour les arts. Deux moines, envoyés à Ceylan, en rapportèrent à Constantinople les vers à soie, se livrèrent à leur éducation et fabriquèrent les premiers tissus. Le commerce, abandonné aux Syriens dont l'influence était alors considérable, consistait en aloès, épices, ivoire, pierres préeieuses, etc.; mais bientôt toute relation avec l'Orient cessa.

Le règne des sciences chez les anciens finit lors de la translation du siége de l'empire à Constantinople. Une ère nouvelle va commencer, empreinte du caractère de mysticité sauvage émanant de son origine. Sa lutte contre les ténèbres et le besoin d'asseoir ses institutions l'absorbent tout entière, et elle semble un pont jeté entre deux âges pour les réunir.

\section{SEGONDE PARTIE.}

M OYEN AGE.

\footnotetext{
Histoire des sciences naturelles, depuis le $v \mathrm{Ir}^{\mathrm{e}}$ jusqu'au $\mathrm{xvI}^{\mathrm{e}}$ siècle de l'ère vulgaire.
}

Le moyen âge, cette époque si peu, si mal connue, et pendant si longtemps jugée avec une injuste prévention, est cependant digne, comme époque de transition, de fixer nos regards. II nous présente, d'un côté, la lente et laborieuse élaboration de la civilisation au sein d'une société qu'aucun fil ne guide à traver's des routes inconnues; de l'autre, la lutte acharnée de l'intelligence contre l'abrutissement qui, sous toutes les formes, vient s'opposer à sa marche progressive. Nous commencerons l'histoire de cette longue période par celle des Orientaux, qui devinrent de nouveau, pour quelques siècles, les maîtres ou plutôt les conservateurs de la science. Les peuples de l'Occident n'occupant que la seconde place, ne viendront qu'après eux. 
Au milieu des révolutions, les peuples antiques de l'Orient avaient perdu le goût des études scientifiques. La barbarie étouffait lentement les lumières que tant de siècles avaient si péniblement fait éclore, et l'Europe était devenue l'héritière de ces trésors ; mais lorsque les hordes dévastatrices vomies par le Nord, se jetant comme une troupe de vautours sur Rome agonisante, l'eurent mise en lambeaux, l'Europe, à son tour, occupée des luttes de ses maîtres et de la constitution d'une société nouvelle, demeura pendant plusieurs siècles étrangère aux travaux de l'esprit, et la science retourna à son berceau. Les Arabes alors la recueillirent, la cultivèrent avec succès, et peuvent en être regardés comme les fidèles dépositaires pendant la nouvelle enfance de l'Europe. Les travaux des Grecs leur servirent de guide, et ils embrassèrent dans leurs études toutes les sciences d'observation; mais ils n'avaient pas l'esprit positif et indépendant des peuples óccidentaux. Leur imagination brûlante suppléa souvent à l'observation ; les erreurs de l'astrologie et de l'alchimie, qui commençaient à dominer à l'époque de la chute de l'empire, furent accueillies et développées par eux avec un enthousiasme extraordinaire, el arrêtèrent les progrès des études positives. Le viI ${ }^{\mathrm{e}}$ siècle compte parmi les savants Arabes, Persans et Juifs, Ahmed-ben-Ibrahim, Ibn-Sirin, Ibn-el-Mocaffa, Dchafer, médecins, botanistes et alchimistes, Ahron, auteur des pandectes de médecine, Jeanle-Grammairien, traducteur des œuvres de Galien, El-Kinâni, professeur de médecine à Alexandrie, Dchâbir (Géber), qui réforma la chimie et dont les opérations sont d'une exactitude remarquable. On lui attribue la découverte de l'acide sulfurique et la connaissance empirique de l'augmentation du poids des métaux par la calcination. Livré aux chimères de la transmutation, il a écrit sur cette matière avec une netteté et une précision qui feraient croire à des opérations sérieuses. Il fut aussi fort habile en astronomie, corrigea plusieurs erreurs de l'almageste de Ptolémée, et donna une exposition du système de cet astronome. 
L'un des événements les plus importants de ce siècle est la fondation de l'islamisme par Mahomet. Ce législateur, qui révolutionna l'Orient tant par la force de son bras que par la puissance de sa parole, acheva de détruire les anciennes constitutions religieuses et politiques de ces contrées. Longtemps occupé de la tâche laborieuse d'asseoir le nouvel empire des Arabes, incessamment menacé par Héraclius, et de propager sa religion, il livra le pays à des luttes qui étouffèrent toute manifestation scientifique. Son Coran, qui défendait les représentations d'hommes ct d'animaux, priva pour longtemps l'histoire naturelle du dessin, l'un de ses plus puissants auxiliaires. Les Égyptiens ne soumirent à son jougg que six cent mille têtes, débris d'une population imménse; ils vireint s'éteindre à jamais leurs institutions théocratiques successivement modifiées par les Grecs et les Romains, et devinrent les esclaves d'un peuple pour lequel les sciences positives avaient peu d'attrait.

Pendant les vır et $\mathrm{Ix}^{\mathrm{e}}$ siècles, on trouve peu de savants parmi les sectateurs de Mahomet; la plupart sont chrétiens. Au milieu d'une foule de médecins, pleins de savoir, se distingue la famille des Bachtichoua, qui pendant trois siècles fit la gloire de la Perse. Les plus célèbres sont Dehordchis Ben Bachtichona, Dchabril Ben Bachtichoua, médecin d'Haroun-el-Rachid, et Dchabril Ben Obeidallah, médecin de Ben Buneih. Sous le calife El Mamoun (815), plusieurs savants traduisent les ouvragres d'Euclide, d'Hippocrate, d'Aristote, et l'almageste de Ptolomée. Un observatoire est élevé à Ragdad.

En dehors de la famille des Bachtichoua se trouvent des Indiens, des Juifs et des Arabes. Un de ces derniers, El Kindi, fut l'un des plus féconds ; il a écrit au moins deux cents ouvrages sur la médecine, la toxicologie, la pharmacologie, la météorologie et la physiologie, tant humaine que générale. Ben Mésué, élève de Dchabril Ben Bachtichoua, a laissé plusieurs traités de médecine et d'anatomie comparće. Abou Othman Amr, plus connu sous le nom d'EI Dchâdidh, était si célèbre par l'étendue et la variété de ses connaissances, que le calife El Mottakkil voulut lui confier l'éducation de son fils; mais son excessive laideur l'em* pêcha d'obtenir cet emploi. Ses ouvrages contiennent un grand nombre de faits scientifiques; le plus estimé est une histoire des animaux. Abou Zeid Honein, d'El Hira, est aussi savant qu'El Dchâdidlı ; on a de lui plusieurs traités spéciaux sur divers points de médecine; et, comme il était bon helléniste, il traduisit Hippocrate et Galien. Ben Corra ( 836$)$, d'Harran en Mésopotamie, le chef d'une famille connue sous le nom de 
Sabéens d'Harran, parce qu’il était altaché à celte secte, est un auteur d'une fécondité prodigieuse; on lui doit un ouvrage sur l'anatomie des oiseaux. Abou Hanifa a écril sur l'agriculure, l'hippiatrique et la botanique; Ibn Wahchijd, sur la zoologie générale et sur la magie. On compte parmi les nombreux astronomes de celte époque le cólèbre $\mathrm{El}$ Baten, qui détermina l'aphélie; et dans le même temps d'autres savants calculaient l'inclinaison de l'écliptique, composaient des tables astronomiques, faisaient des observations sur les étoiles fixes et sur les clipses.

On doil d'autant plus s'étonner de trouver en Orient un si grand nombre de savants du premier ordre, que les califes, accoutumés à une domination despotique, traitaient avec une barbarie révoltante ceux d'entre eux qui encouraient leur disgrâce en s'exprimant avec trop de liberté. Et Dchâdidh fut emprisonné sur un simple soupçon. Sä̀d Ben Naufel, médecin de l'émir Ben Touloun, lui ayant reproché un écart de régime qui s'opposait à sa guérison, fut condamné à recevoir deux cents coups de fouet, et mourut pendant l'exécution. Isaac Ben Amran, que ses contemporains nommaient le refuge de son siècle, ayant eu le malheur de déplaire au prince dont il était le médecin, fut condamné à être saigné aux quatre veines; et son cadavre, attaché à une croix, devint la pâture des vautours.

Au commencement du $\mathrm{x}^{\bullet}$ siècle, les mahométans se livrent pour la première fois à l'étude des sciences. El Razi (Rhazès), le Galien de son époque, leur ouvre la voie. Le nombre de ses ouvrages excède deux cents. On a de lui d'excellentes monographies anatomiques, et une foule d'autres travaux sur les diverses branches de l'art de guérir, renfermés dans un corps d'ouvrage qui forme un cours complet de médecine. Il a écrit sur la médecine talismanique, et sa crédulité lui fut bien funeste : le calife El Manzour lui ayant demandé de répéter une des expériences indiquées dans son livre, et Rhazès n'ayant pas réussi, le calife le frappa si rudement sur la tête, qu'une cécité complète fut la suite de cette brutalité.

El Fàrâbi (950) a écrit sur l'alchimie, et sur un grand nombre d'autres sujets. On a de lui un ouvrage fort curieux relatif à la classification des sciences. Ibn Abul Achath (970) a laissé un traité de zoologie générale. El Madchriti (975), de Madrid, fut le premier mathématicien et le plus célèbre astronome de l'Espagne ; il est l'auteur d'un livre concernant la génération des animaux, l'alchimie et les pierres précieuses. Le célèbre 
Ferdrousi, a qui l'on doit un traité sur l'origine de la terre, a soutenu l'opinion du soulèvement des montagnes.

L'activité des Arabes embrassait toutes les parties des connaissances humaines, et ils s'occupaient de l'agriculture avec un soin particulier. Le-code agricole des Arabes d'Espagne est un modèle de perfection; on y trouve une comparaison judicieuse entre les théories des divers peuples, calculées d'après les climats et la nature du sol. La fermentation causée par les croisades n'interrompit pas leurs travaux; pendant que l'Europe occidentale courait aux armes pour renger la cause du Christ, l'Orient poursuivait ses progrès scientifiques. Depuis 1006 jusqu'à 1210, les Arabes de Syrie, de Perse, d'Égyple et d'Espagne sont à la tête des sciences.

Le plus célèbre médecin de cette époque est Mésué le jeune, ou Ibn Sina (Avicenne), de Bokhara daus le Turkestan. Son principal ouvrage, intitulé Canon, eut une réputation prodigieuse dans toute l'Asie, et sa doctrine fut longtemps la seule qu'on enseignât dans les écoles de médecine. Sa physiologie est cependant fausse et erronée, et ses divisions se multiplient sans nécessité. On reconnâ̂t que Galien lui a servi de guide dans les explications qu'il donne des causes des maladies. Ibn Sina a laissé de plus trois traités sur l'alchimie. El Biruni, astrologue cl alchimiste plutôt que médecin, a écrit un traité sur les propriétés des métaux, des minéraux et des plantes. Ibn Dchezla (1074) a laissé une lisie alphabétique des plantes officinales.

La plus grande partie des savants de ce temps appartient à l'Espagne, dont les écoles étaient fréquentées par tous les Européens avides de connaissances : ce sont surtout des médecins praticiens qui ont tous laissé des travaux généraux sur l'anatomie et la médecine.

La célèbre famille des Ibn Zohr (Avenzoar), dont le chef s'établit en Espagne au commencement du $\mathrm{x}^{\mathrm{e}}$ siècle, a produit un grand nombre de médecins. Avenzoar (1140), un des plus zélés partisans de Galien, est plus original que les autres médecins arabes; il s'est occupé à la fois de médecine, de chirurgie et de pharmacie, quoique ce ne füt pas la coutume d'alors. Les préjugés s'opposaient déjà chez. eux aux progrès de la science; car ils regardaient comme infâmes certaines opérations, entre autres celle de la pierre. Ibn el Awwam, de Séville, fut un des naturalistes célèbres du xur siècle; il a écrit sur l'agriculture. Ibn Matran, médecin du sultan Salah-ed-din (1189 à 1201), a ecrit sur les plantes médicinales. Ibn Roschel (Arerrhoës) (1195), de 
Cordoue, a laissé un Compendium de médecine et une foule d'autres traités; il s'esı livré à l'étude de la philosophie. Son anatomie est calquée sur celle de Galien, qu'il a augmentée ; il s'est aussi beaucoup occupé de médecine spéculative. Il comptait parmi ses disciples les plus distingués le célèbre Ben Maïmon (Maïmonidès).

Fahr-ed-din el Razi (1149), de Rai dans le Taberistan, est un médecin d'une fécondité remarquable. Il s'est occupé de philosophie et de science générale. La réputation de sa famille était telle que, lorsque Dchingiz. kan eut battu Chowarcyn Schah, il excepta la postérité de Fahr-ed-din du massacre général des habitans de Hérat. Il figurait parmi les plus célèbres alchimistes de son temps.

Pendant le $\mathrm{xII}^{\mathrm{e}}$ siècle, nous trouvons chez les Arabes peu de travaux originaux sur les sciences naturelles; nous en excepterons cependant ceux de Kazwyny (1283), descendant d'Ana Ben Malest, compagnon de Mahomet, el que sa vaste érudition a fait surnommer le Pline des Orientaux. Il a composé un grand nombre d'ouvrages, dont le plus estimé est son grand traité d'histoire naturelle, qui comprend l'astronomie, la météorologie et l'histoire des trois règnes. Nous citerons encore Muwafficed-din qui a écrit l'histoire de tous les médecins arabes, syriens, persans et indiens jusqu'au xur siècle, avec un coup-d'œil sur l'origine de la médecine et sur l'état de la science à Alexandrie : il cite quatre cent deux médecins.

Au xıv ${ }^{\mathrm{e}}$ siècle, les sciences tombèrent en décadence chez les Arabes; le joug des Osmanlis devint mortel aux travaux de l'intelligence; cependant les derniers efforts des savants brillèrent encore d'un vif éclat. Ibn el Doreihim publia à Mossoul, sous le titre de l'Utilité des Animaux, une histoire des mammifères, des oiseaux, des poissons et des insectes. Ibn el Wardi a laissé un ouvrage scientifique fort remarquable intitulé : Unio rerum mirabilium, et un extrait des ouvrages d'Abul Féda, célèbre géographe syrien. El Demiri de Cahira, le plus célèbre naturaliste arabe, a composé un dictionnaire d'histoire naturelle, qui comprend la description de neuf cent trente-un animaux. Bochart s'en est beaucoup servi pour la rédaction de son Hierozoicon.

Les Arabes d'Espagne furent les derniers et les plus brillants représentants de la science orientale au moyen âge; mais, lorsque les chrétiens eurent détruit leur empire, la plupart n'emportèrent pas dans leur exil le goût des études, et depuis le $\mathrm{xv}^{\mathrm{e}}$ siècle, jusqu'à la fin du $\mathbf{x v I}^{\mathrm{e}}$, nous ne trouvons à citer que quatre naturalistes : El Calcachendi (1418), qui a 
écrit une histoire des animaux ; El Schebi, dont nous avons un supplément à l'histoire naturelle d'El Demiri; El Sojuti (1445), auteur du Codex animalium, extrait d'El Demiri, avec un supplément et des indications sur l'utilité des animaux; et enfin, El Antaki, surnommé l'Aveugle (1596), célèbre médecin de Misr, qui a écrit un traité général de médecine. A partirde celte époque jusqu'à nos jours, les Arabes, plongés dans la plus profonde ignorance furent obligés de venir emprunter à l'Europe, leur ancienne ćlève, le peu de connaissances répandues parmi eux; et ce n'est qu'en 1841 que les descendants d'Othman, sentant la nécessité de s'appuyer sur la civilisation européenne, ont permis les dissections.

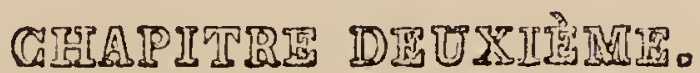

Etat des sciences chez les peuples occidentaux et septentrionaux.

Le vir ${ }^{\mathrm{e}}$ siècle est complètement mort pour la science; nous n’y royons partout que luttes sanglantes et acharnées qui troublent dans leurs projets civilisateurs les apôtres de l'évangile; et, au commencement du vir ${ }^{\mathrm{e}}$ siècle, l'Europe centrale, déjà déchirée par ses querelles intestines, est obligée de repousser l'invasion des Sarrasins que Charles-Martel défait dans les plaines de l'Aquitaine.

Les sciences avaient vainement cherché un refuge à Constantinople; elles y furent persécutées par Léon l'Isaurien, qui fit brûler dans la grande bibliothèque les livres et les savants. On ne connaît à cette époque d'autre ouvrage sur les sciences naturelles qu'un mauvais poème de George Pisidès, qui traite de la création.

Le milieu de ce siècle (768) vit paraître Charlemagne, ardent propagatcur des lumières et des croyances religieuses. Sous son règne, les lettres commencèrent à renaître; il établit une règle des études, et poussa si loin l'amour des sciences, qu'il changea son palais d'Aix-la-Chapelle en une académie, dans laquelle il réunit des savants de tous les pays; il fit recopier les manuscrits précicux sous la direction d'Alcuin, moine anglais, son maître et son ami; et ses filles elles-mêmes prirent part à ces travaux. La tendance générale des esprits est néanmoins toute religieuse; et si les 
études philosophiques sont quelque peu cultivées, c'est pour lutter sans désavantage contre les théologiens grecs, avec lesquels était engagée une polémique active. L'érudition la plus vaste de cette époque embrassait le trivium, qui renfermait la grammaire, la rhétorique, la dialectique; et le quadrivium, qui comprenait la musique, l'arithmétique, la géométrie, l'astronomie. Il n'y avait qu'un petit nombre d'élèves qui terminassent le trivium. Quant au quadrivium, regardé comme le nec plus ultrà de la science humaine, peu d'élèves osaient s'élever à cette hauteur; encore n'avait-on aucun livre pour ces études, et les maîtres manquaient partout.

A cette époque, la médecine était tombée dans la barbarie, même en Grèce; ses doctrines, privées de l'appui des sciences d'observation, n'étaient plus qu'une réunion d'erreurs et de pratiques superstitieuses. Charlemagne, frappé de ce vice, fonda la célèbre école de médecine de Salèrne, où il appela les Grecs qui cultivaient les sciences médicales. Ses efforts furent tous impuissants, malgré la protection dont il entoura les études; l’intelligence humaine semblait frappée de stérilité. La métallurgie seule avait conservé quelques-uns de ses secrets; mais des créalions grossières remplaçaient l'art si délicat des Grecs.

L'agriculture était aussi retombée dans l'enfance. De vastes et sombres forêts qui descendaient des montagnes jusqu'au fond des plaines, et des marais infects conrraient la face de l'Europe, et en abaissant la température s'opposaient aux progrès des sciences agricoles. Les fleuves et les l'ivières, dont aucune digue n'arrêtait les eaux, débordaient à la moindre crue et inondaient les terres basses. Le défrichement avait lieu, comme aujourd'hui encore dans le Nouveau-Monde, par l'incendie des arbres qui couvraient le sol, et cette terre vierge, qui aurait dû tant produire, si elle avait été cultivéc par des mains habiles, fournissait à peine à la subsistance de l'homme; il n'en sortait que des miasmes putrides, sources de maladies mortelles. L'art d'élever les troupeaux était le plus répandu; mais on multipliait seulement les produits sans améliorer les races.

La division des terres, en rendant indispensable l'étude de la géométrie, avait sauvé cette science d'un entier oubli; mais on négligeait les autres parties des mathématiques, et l'astronomie n'était cultivée dans les cloîtres que pour celle de ses parties qui servait à la supputation du retour périodique des fêtes religieuses. Sous l'influence des idées astrologiques, on n'observait plus les mouvements des corps célestes pour en 
éludier les lois, mais dans le but d'en découvrir l'influence sur les deslinées humaines. L'apparition des comètes passait pour un événement funeste; et Charlemagne, malgré son génie, prononça une sentence contre une aurore boréale, regardée par les théologiens du temps comme un malćfice du duc de Bénévent, destiné à ensorceler la France.

Sous les faibles successeurs de Charlemagne, le mouvement des esprits vers le progrès s'arrête, et les sciences retombent dans l'obscurité. Des dérangements survenus dans les saisons causent des famines qu'accompagne la peste; et le commerce, privé d'appui, reste impuissant contre ces maux.

Les seigneurs, étranger’s aux occupations de l'esprit, consacraient à la chasse les moments qu'ils pouvaient enlever aux travaux guerriers; ils dressaient pour cet exercice le faucon, l'épervier, l'émérillon et même le vautour.

Les damoiselles cependant s'occupaient de l'art de soigner les blessures, et étudiaient, d'après des données empiriques, les propriétés des végétaux. Les mires ou médecins, méprisables charlataus, étrangers aux sciences d'observation, allaient criant leurs remèdes par les rues, suivis de femmes qui faisaient métier d'accoucher et de saigner. L'anatomie était complètement négligée, parce que retombant, sous ce rapport, dans les préjugés de l'antiquité grecque, on regardait comme un sacrilége l'étude sur le cadavre.

La géographie était dans le même état de délaissement, et l'on croyait fermement à l'existence de quaire parties dụ monde, par le motif que ce nombre correspondait aux divisions de la croix.

D'un autre côté, la guerre avait embrasé toute l'Europe. Les Anglais repoussaient les invasions des Danois, les Français combattaient les Normands, les Espagnols luttaient contre les Musulmans, et les rois chrétiens s'armaient les uns contre les autres sous les plus frivoles prétextes.

Les savants des $\mathrm{Ix}^{\mathbf{e}}$ et $\mathrm{x}^{\mathrm{e}}$ siècles sont Raban Maur, archevêque de Mayence; Agobard, archevêque de Lyon; Méthodius; Scott Erigène, et saint Hérié, moine d'Auxerre, que sa méthode philosophique, pour arriver à la découverte de la vérité, a fait comparer à Descartes.

Constantinople, quoique riche encore en débris de la science antique, semblait frappée de la même torpeur; mais cette ville sortit de son engourdissement sous Constantin Porphyrogénète. Ce prince y rassembla les manuscrits les plus précieux, en fit faire des copies, et s'entoura d'hommes qui consacraient leur vie à l'étude. Eutychius, patriarche 
d'Alexandrie, qui cultiva avec succès la physique et la philosophie, appartient a cette époque. Photius, patriarche de Constantinople en 857, a laissé sous le titre de Bibliothèque un ouvrage remarquable par l'érudition qu'il y déploie. Il cite cent soixante-sept auteurs, dont la moitić nous sont inconnus. Nous lui devons la conservation de quelques fragments de Ctésias et d'Agatharchides. Constantin fit composer par Cassianus Bassus un traité d'agriculture, qui n'est qu'une compilation des ouvrages antérieurs au sien. Cassianus fait connaître les noms de plus de trente auteurs anciens qui ont écrit sur cet art.

Quittons un instant l'Occident, pour nous occuper de ces fiers enfants du Nord qui, pendant plusieurs siècles, ravagèrent le littoral de l'Océan. Un voile épais couvre l'origine des peuplades septentrionales; leurs sagas nous apprennènt seulement que les Ases, dont la tradition fit plus tard des divinités, élaient une tribu asiatique, qui, sous la conduite d'Odin, quitta les bords du Tanaïs, et vint apporter aux populations encore sauvages de l'Europe septentrionale une religion et des lois. Leur cosmogonie, éminemment originale, diffère de toutes les autres, et indique que ces peuples appartenaient à une civilisation exceptionnelle. Les premières strophes de la Voluspa présentent un caractère solennel : « Faites silence, dit-elle, divines créatures, enfants d'Heimdall, je vais vous apprendre les secrets de Valfödur; je connais les mystères des premiers temps....

“ Au commencement, lorsque vivait Ymir, il n'y avait ni sable, ni mer, ni vent. En bas, pas de terre; en haut, pas de ciel : partout levide; de verdure nulle part...

“Ymir, le géant, est formé au sein du chaos, du froid et de la chaleur, l'un venu de Niflheim, l'autre de Muspelheim, et qui se rencontrent dans le Ginumgagap, l'abîme, le vide. Ymir est la matière dont fut composé le monde. Son sang forma les mers, les lacs et les fleuves; ses os les montagnes; ses dents les minéraux, les pierres, les rochers; son crâne la voûte céleste; son cerveau les nuages, et ses sourcils le Midgard, derrière lequel sont réfugiés les Ases, pour se mettre à l'abri des attaques des géants. " Toute leur cosmogonie est dans ce goût mythique ; mais ótez-lui sa forme mythique, et vous n'y verrez plus, comme chez les autres peuples, qu'une personnification des agents naturels. Les Scandinaves, guerriers intrépides, accoutumés à regarder comme un déshonneur de mourir dans leur lit, furent longtemps livrés à une vie vagabonde, et s'occupèrent peu de sciences. 
Cependant, lor'sque la tyrannic d'Harald aux beaux cheveux ( $\mathrm{x}^{\mathrm{e}}$ siècle) eut forcé les populations norwégiennes à fuir la terre natale, elles commencèrent à former, dans l'Europe occidentale et dans les îles de l'océan glacial, des établissements fixes; et leurs guerriers parcoururent les mers. Ce fut sans doute dans ces longues excursions qu'ils apprirent. à connaître le lion et le serpent, qui figurent souvent sur leurs monuments; ce dernierjoue un grand rôle dans leurs sagas, surtout le lingorm, serpent monstrueux, sous lequel croissait l’or à mesure qu'il ̧̧randissait, et qu'on retrouve en bagues, en anneaux, en bracelets, sur les haches de pierre, sur la poignée des épées.

Jusqu'au $\mathrm{xI}^{\mathrm{e}}$ siècle, époque de ces grandes migrations, leurs sagas toutes mythiques, ou tout au plus semi-historiques, ne nous apprennent rien sur l'état des sciences chez ces peuples. Nous y voyons une agriculture paurre et improductive, une éducation des troupeaux assez peu étendue, mais une pêche déjà réglée, où figure la baleine, qu’ils osent,sur leurs frêles embarcations, attaquer corps à corps, et. la chasse, destinée à garantir les troupcaux de la dent des loups et des ours; ce qui exige certaines connaissances pratiques. Navigateurs audacieux, ils courent les mers d'abord en forbans, puis en marchands, enfin en pélerins et en curieux. Ils vont former des colonies au Groënland, et leur humeur aventureuse les porte jusque dans l'Amérique du nord.

Leurs sagas contiennent quelques noms d'animaux ou de plantes, mais les traités spéciaux leur manquent ; cependant les Islandais, qui poussèrent leurs institutions au plus haut degré de perfection, étaient des observateurs assez attentifs pour qu'on ait trouvé chez eux l'indication nominale de toutes les plantes et de tous les animaux de leur ile, sous une forme qui prouve que certaines analogies ne leur avaient pas échappé. Un peuple aussi belliqueux, dont la vie n'était au dehors qu'un long combat, au dedans qu'un duel continu, devait avoir étudié la partie de la science médicale qui touche à la guérison des blessures. On trouve dans l'Havamal, doctrine morale d'Odin, une indication de l'emploi du chêne dans les dysuries. Le Rafn Svenn bioernsens saga nous apprend que Rafn était renommé pour la guérison des blessures et des maladies. Il guérit par l'application d'un fer rouge sur la poitrine, sur la tête et entre les épaules, un homme atteint d'une enflure générale, et par une saignée surle dos de la main, une femme dont les mamelles étaient engorgées. Le fait le plus remarquable consigné dans cette saga est l'opération de la pierre par la taille périnéale 
avec un simple couteau. Il parait que, dans beaucoup de cas, les maladies étaient traitées par les sorcières (spákona), qui connaissaient les runes (formules) propres à les guérir. Les fonctions n'étant pas distincles chez ces peuples, le même homme se trouvait à-la-fois agriculteur, pêcheur, navigateur, guerrier, poète, savant; d'où il suit que les études araient un caractère trop vague pour constituer une science véritable. La vie du Scandinave se passait à acquérir quelques connaissances élémentaires, et rien de plus.

Comme dans les combats qu'ils livraient aux peuples chez lesquels ils faisaient des descentes ils se vengeaient cruellement de ceux qui tombaient entre leurs mains, ils avaient trouvé le moyen de prolonger les souffrances du prisonnier avec sa vie, et certains hommes se livraient à cette barbare pratique ; ainsi, l'on voit dans Ragnar Lodbroks saga, que le roi Elli, qui avait fait mourir Ragnar, en le jetant dans une fosse pleine de vipères, fut condamné par les fils du pirate à un supplice qu'ils appelaient tailler un aigle de sang. Cette opération consistait à faire séparer, par un homme habile dans cet art, les côtes de la colonne vertébrale et à les déployer ensuite, pour figurer les ailes d'un oiseau.

Nous avons dit que les Islandais élaient grands amateurs de voyages; aussi méprisaient-ils ceux qui ne quittaient pas leur pays, et ils les appelaient injurieusement Heimsker (casaniers). Dans le Miroir du roi (Kongs skuggsio), il est expressément recommandé à tous les voyageurs d'étudier les mouvements des corps célestes, la diversité des climats, la configyuration des côtes, l'époque des marées, les phases lunaires, les vents dominants, les productions des pays qu'ils visitent, les mours ainsi que la langue deshabitants, et d'en faire un minutieux rapport à leur retour, afin de servir aux navigateurs qui viendront après eux.

Comme il n'a été traduit qu'un très petit nombre de sagas, qu'il y en a même encore beaucoup d'inédites, et que toutes celles qui ont été commentées ne l'ont été que sous le rapport philologique, il reste à faire un travail spécial sur l'état des connaissances scientifiques chez les peuples du Nord. Plus tard, les Scandinaves ayant adopté les mœurs de l'Europe occidentale, leurs institutions perdirent leur caractère primitif; ils entrèrent dans la grande famille européenne et prirent les occidentaux pour guides dans leurs études.

Un grave événement qui eut en Europe un retentissement universel, et favorisa le développement des pensées d'émancipation qui fermentaient parmi le peuple, cut lieu à l'instant où l'on s'y attendait le moins, et mit 
fin aux querelles intestines. Les chrétiens d'Orient, opprimés par les sectateurs de Mahomet, poussèrent un long cri de détresse qui retentit dans tout l'Occident. L'esprit actif et aventureux des Francs fut le premier à céder aux prédications de l'ermite Pierre. Hauts barons, vassaux, serfs attachés à la glèbe, tous prirent les armes pour la défense du christianisme; cette longue et sanglante guerre, qui dura plusieurs siècles et dévora, dit-on, près de deux millions d'hommes, eut pourtant pour effet de rattacher l'une à l'autre ces deux parties de l'ancien monde, longtemps demeurées étrangères, de lier le présent au passé, et de perfectionner les intelligences, en étendant les relations des peuples.

Les sciences, cultivées par les Arabes avec tant d'éclat, ne furent pas perdues pour l'Occident. On allait puiser dans les écoles de Séville et de Cordoue, regardées comme le foyer des lumières, une éducation supérieure à celle de l'Europe occidentale. Les ouvrages des savants arabes, versions souvent infidèles de ceux des Grecs, étaient traduits en latin, se répandaient en Italie, en France, en Allemagne, en Angleterre, et y propageaient le goût des études sérieuses; aussi les hommes remarquables sont-ils moins rares au $x^{\circ}{ }^{\circ}$ siècle qu'aux époques précédentes. L'activité règne dans les cloîtres, où les moines écrivent des chroniques en se liviant à des travaux d'érudition; et tout ce qu'il y a de science humaine est l'apanage du clergé. Au premier rang brillent Fulbert, évêque de Chartres; Guy d'Arezzo, l'inventeur de l'échelle musicale; Thieddas, qu'on regarde comme un médecin distingué; l'alchimiste Hortulanus, qui alla étudier en Espagne, et à son retour écrivit un commentaire sur la table d'Émeraude; Constantin l'Africain, qui, banni de sa patrie par la jalousie de ses concitoyens, se réfugia en Sicile, où il devint l'ornement de l'école de Salerne, fut un des plus célèbres compilateurs en médecine, et passe pour avoir introduit en Italie la médecine greeque arabe; Gerbert (Silvestre II) enfin, élève de l'école de Cordoue, qui importa en France les horloges à rouage, les chiffres et la numération empruntés aux Indiens. C'est sans doute à l'épo'que où l'Europe alla puiser dans les écoles arabes la science qui lui manquait que la langue s'enrichit des termes scientifiques qui y sont restés, tels qu'almanach, algèbre, azimuth, nadir, alcool, etc. Au dehors des cloîtres, on ne trouve guère que des hommes d'armes et des serfs, les uns abrutis par l'habitude d'une domination tyrannique; les autres, jar celle de l'obéissance passive.

Un autre service rendu à la civilisation par les Arabes, et qui con- 
tribua à la diffusion des lumières, fut l'invention du papier de coton, et plus tard celle du papier de lin. Ce fut encore l'Espagne qui jouit la première de ce bienfait; car l'Europe barbare, après s'être longtemps servie de papyrus, avait été obligée, par suite de la disette de cette substance, d'employer à la copie des missels et des psautiers les manuscrits grecs et latins, ce qui hâta la décadence des lettres.

Une des causes qui s'opposait à la propagation de la science était l'instabilité des formes du langage. La langue latine, défigurée par les barbares, avait perdu sa pureté primitive ; et celle des Francs, longtemps mêlés à des populations d'origine différente, n'avait pu encore atteindre une parfaite unité. Tant que dura cette incertitude dans les moyens de manifestation, les sciences restèrent brutes, et le peuple, chez qui se trouvent ces nobles intelligences, auxquelles il ne manque que les occasions pour s'élever aux plus hautes conceptions du génie, languissait dans l'ignorance la plus profonde.

Vers la fin de ce siècle (1094), une horrible maladie, le mal des ardents, espèce d'anthrax contagieux, préparé sans doute par plusieurs siècles de misère, dépeupla l'Europe, et cette fois encore la médecine fut impuissante; on ne trouva d'autre digue à opposer à ce fléau que des prières publiques qui, en augmentant les contacts, propagèrent l'épidémie avec une effrayante rapidité.

Au xur siècle, la philosophie s'est répandue partout sous la forme péripatéticienne. Elle a pénétré au sein desécoles; et les théologiens, la métamorphosant au gré de leur caprice, en forment la doctrine scolastique, doctrine étroite et inféconde, qui étreignit longtemps la pensée, mais ne fut pourtant pas aussi funeste au progrès qu'on l'a voulu faire croire.

Pendant cette période les études conservent le même caractère d'incertitude, et tous les savants sont divisés par les querelles des réalistes et des nominaux. Les hommes les plus remarquables sont Anselme, Guillaume de Champeaux, saint Bernard de Clairvaux, et le célèbre Abeilard, homme d'une trop grande indépendance d'esprit pour' ne pas s'attirer les persécutions des partisans de la philosophie étroite et mesquine qui s'agitait sur les bancs de l'école. Nous trouvons cependant aussi quelques auteurs qui ont écrit sur l'histoire naturelle : ce sont l'abbesse Hildegarde de Pinguia, qui vivait en 1180, et a laissé, sous le titre de Physica S. Hildegardis, un traité complet d'histoire naturelle; Alexandre Neckam de Hartford, qui écrivit sur la nature des choses 
un ouvrage mêlé de prose et de vers; Alfred, qui commenta la physique d'Aristote et publia un livre sur le mouvement du cour, et Robert CapiIon, versé dans toutes les sciences de son temps, ce qui le fit accuser de magie. A la mème époque, le juif Benjamin de Tudèle publia une relalion de ce qu'il avait vu de curieux dans son voyage en Syrie, en Égypte et anx Indes.

Le xmr $^{\mathrm{e}}$ siècle fut signalé par quelques nouveaux progrès; les sciences commencèrent à se répandre, et l'on vit naître à Paris l'Université, qui jouit de toute la faveur de Philippe-Auguste, et devint l'école la plus célèbre.

Sous le règne de ce prince, Gioja Flavio d'Amalfi découvrit ou perfectionna la boussole. Cet instrument en facilitant la navigation, favorisa les progrès des sciences géographiques, si puissantes auxiliaires des sciences naturelles; mais la prise de Constantinople par les Croisés fut encore fatale. aux études, en ce que la soldatesque latine détruisit un grand nombre de bibliothèques. Toutefois les lettres, quoique languissantes, n'y périrent pas entièrement, et Byzance continua d'être jusqu'au $\mathbf{x v}^{\mathbf{0}}$ siècle, le foyer d'où sortirent les lumières pour se répandre sur l'Europe. Le dernier des auteurs byzantins de cette époque est Manuel Phylis d'Éphèse, qui a donné un abrégé d'Élien, sous le titre De la Nature des Animaux.

Dans l'Espagne chrétienne, Alphonse le Sage se livra à l'étude des sciences, surtout de l'astronomie. Il fit établir de nouvelles tables astronomiques, qui furent appelées tables alphonsines, et il fonda huit chaires à l'Université de Salamanque.

A la tête des hommes illustres de ce siècle se place Roger Bâcon, qui tint longtemps le sceptre de la philosophie hermétique, et mérite en partie sa brillante réputation. Ses ouvrages, quoique empreints quelquefois d'une crédulité sans égale et de toutes les erreurs de l'alchimie, frappent par l'universalité du savoir qu'il y déploie. Son Opus majus contient un chapitre remarquable sur l'art d'expérimenter. On y trouve aussi l'idée de découvertes qui n'ont eu lieu que bien longtemps après. "L'art, dit-il, peut fournir aux hommes des moyens de naviguer plus promptement et sans le secours des bras; il y a telle construction de char's à l'aide desquels il est possible de se passer d'animaux; on peut traverser les airs en volant comme les oiseaux. Il y a des verres qui approchent les objets, les éloignent, les agrandissent, les diminuent ou les multiplient à volonté.”On pourrait voir dans ces prophélies la vapeur, les acrostats et tous nos instruments d'optique. On lui 
attribue le secret de la composition de la poudre à canon dont l'indication se trouve, dit-on, dans ses OEuvres décrites de l'art et de la nature et de la nullité de la magie. Il tenait sans doute ce procédé des Arabes, dont les ouvrages lui étaient familiers. On lui prête aussi linvention de la chambre obscure et du télescope; mais ce qui est positif c'est qu'il ramena les sciences dans la voie de l'observation, et, sous ce rapport, il peut être considéré comme le précurseur de son immortel homonyme. Ses connaissances en astronomie étaient très étendues; il signala l'erreur qui existait dans le calcul de l'année solaire depuis la réforme du calendrier par Jules César, el ce fut seutement trois siècles plus tard qu'eut lieu la rectification qu'il avait indiquée.

Un contemporain de Roger Bâcon non moins célèbre que lui, est Arnauld de Villeneuve, médecin de Montpellier (1246), qui a laissé sur la médecine de nombreux ouvrages remplis d'observations pleines d'inlérêt et un traité de pharmacologie qui prouve de vastes lumières en chimie. Ses écrits sont difficiles à lire à cause de l'obscurité de son style. On y trouve la recette de la pierre philosophale et le mode de transmutation des métaux. Il y parle de l'émétique et du sublimé corrosif, et on lui attribue la découverte de l'alcool.

Son plus brillant disciple, le type de l'alchimiste, l'inventeur du fourneau nommé athanor et de la médecine universelle, est Raymond Lulle de Barcelone, qui, pendant cinquante années, parcourut l'Europe pour obtenir l’assistance des princes dans son projet de convertir les Algériens à la foi chrètienne et d'abolir l'esclavagè, et qui fut enfin lapidé par le peuple de Bougie. Malgré cette existence aventureuse et vagabonde, il trouva le moyen d'écrire sur la médecine, la physique, la chimie, la théologie; et, en dégageant ses écrits des rêveries alchimiques qu'ils renferment, on est surpris de l'érudition et de la méthode qui y règnent. Il rendit de grands services à la chimie en employant la voie humide dans la recherche de la pierre philosophale, procédé qui attira l'attention des alchimistes sur les produits que fournissent les corps par la distillation.

Albert le grand, évêque de Ratisbonne, fut encore un des auteurs les plus remarquables de ce siècle. Il quitta la chaire épiscopale pour se livrerà l'étude des sciences, dont il a embrassé toutes les branches; et il écrivit plusieurs livres sur l'alchimie. Son ouvrage sur les minéraux est composé avec plus de sagesse qu'on n'en pouvail attendre de cette époque. Il partage, il est vrai, l'opinion de Gcber sur la nature des mélaux; mais 
ses observations sont souvent fort judicieuses et indiquent un homme versé dans les procédés métallurgiques employés de son temps. Ses traités sur les plantes, les animaux, le sommeil et la veille, les principes du mouvement progressif chez les animaux, les aliments et l'alimentation, suffisent pour le disculper de l'accusation de magie portée contre lui. On voit qu'Albert était un homme d'une science profonde, et que toutes les erreurs répandues sous son nom, et qui le rabaissent au rôle de charlatan, sont autant d'injures faites à sa mémoire. Ses disciples les plus célèbres furent Thomas de Chantepré, Ambrosius Senensis, Albert de Saxe, qui fit paraître un traité sur les plantes, les pierres et les minéraux et qui commenta Aristote, Thomas d'Aquin, qu'on suppose avoir été pénétré des doctrines de son maître. On attribue à ce dernier, sur l'autorité de Pic de la Mirandole, un ouvrage d'alchimie, intitulé De re metallicâ, ce travail, s'il en était l'auteur, ferait plus d'honneur à son jugement que sa fameuse Somme théologique. Parmi ses plus illustres contemporains, se trouvent Vincent de Beauvais, dont le Miroir doctrinal renferme l'idée d'une classification méthodique des sciences, sur lesquelles il donne de précieux détails; Pierre d'Abano, philosophe et médecin, et Conrad d'Halberstadt qui écrivit sur l'ensemble des sciences naturelles avec beaucoup de succès. On cite encore un frère prêcheur, nommé Théodoric, qui expliqua la cause des arcs-en-ciel aussi bien que le fit plus tard Antoine Dominis.

A la fin de ce siècle brillent les Trouvères dont les chants annoncent le réveil de l'intelligence, et favorisent les progrès des lumières en donnant aux langues de l'Europe une forme plus arrêtée.

Les républiques italiennes, Gênes et Venise surtout, contribuèrentpar l'étendue de leur commerce à la diffusion des lumières et aux progrès de la géographie. Quelques voyageurs visitèrent l'Asie. Guillaume Ruysbroek ou Rubruquis, moine franciscain, fut envoyé en 1258, par le roi Louis IX, au Khan des Tartares, qui voulait, disait-on, se convertir à la foi chrétienne, et la relation qu'il publia de son voyage fit connaître l'Orient. Marco Polo visita le Japon el quelques provinces de la Chine, oi personne n'avait pénétré avant lui. Ce voyage est d'un grand intérêt pour Ia science; car Marco Polo était un homme d'un profond savoir, et ses observations sur les productions naturelles des pays qu'il a parcourus sont d'une exactitude remarquable.

Frédéric II, le puissant empereur d'Allemagne (1250), fut un des plus ardents protecteurs de la science. Il établit plusieurs écoles en 
Sicile, augmenta l'éclat de celles de Salerne et du Mont-Cassin et fonda à Palerme une académie poétique, dans laquelle il sollicita la faveur d'être admis avec ses fils. Il composa sur la chasse à l'oiseau un ouvrage qui iraite des oiseaux de terre, d'eau et de passage, de leur structure, de leur vol et de leurs mœurs.

Sous le règne de ce prince, les mines d'Allemagne furent exploitées avec une grande activité. Il favorisa beaucoup la médecine, recommanda l'étude d'Hippocrate et défendit de pratiquer à ceux qui ignoraient l'anatomie humaine. Il ordonna le premier des dissections dans les écoles de l'empire; mais, pour obtenir l'autorisation d'en faire une seule par an, il fallait une bulle du pape, ce qui dura jusqu'à la fin du $\mathbf{x} v^{e}$ siècle. Comme il ne pouvait retrouver le texte grec de l'almageste de Ptolémée, il en fit traduire en latin la traduction arabe.

$\mathrm{Au} \mathbf{X I V}^{\mathrm{e}}$ siècle appartiennent un grand nombre d'alchimistes, parmi lesquels nous citerons Nicolas Flamel, maître écrivain de Paris, qui fut en outre peintre, architecte, poète, philosophe et mathématicien. Il raconte, dans son livre des hiéroglyphes, qu'en faisant des inventaires pour gagner sa vie, il lui tomba sous la main un ouvrage d'alchimie ayant appartenu à des Juifs et contenant le secret de la pierre philosophale. Ne comprenant pas les caractères mystérieux dont ce livre était rempli, il fit le voyage d'Espagne et alla trouver un rabbin qui lui apprit que ce livre était du célèbre Abraham le Juif, et lui en expliqua le sens. A partir de cette époque, Flamel acquit de grandes richesses que l'ignorance publique attribua à l'alchimie, mais dont l'origine est inconnue. On croit qu'il fut chargé par les Juifs encore exilés de France du recouvrement de leurs créances; et, si ce fait est exact, les causes de sa fortune seraient moins douteuses.

Nous mentionnerons aussi un certain Riplée, qui donne dans ses œuvres la recette de la pierre philosophale, recette que nous citerons en entier comme un des monuments les plus curieux de la science du moyen âge. "Pour faire, dit-il, l'élixir des sages, la pierre philosophale, il faut prendre, mon fils, le mercure des philosophes (plomb), et le calciner jusqu'à ce qu'il soit transformé en lion vert (massicot). Après qu'il aura subi cette transformation, tu le calcineras davantage et il se changera en lion rouge (minium). Fais digérer au bain de sable ce lion rouge avec l'esprit aigre des raisins (vinaigre), évapore ce produit, et le mercure se prendra cn une espèce de gomme qui se coupe au couteau (acétate de plomb). Mets cette matière gommeuse dan's une cucurbite latée, et con- 
duis la distillation avec lenteur. Recueille séparément les liqueurs qui te paraîtront de diverses natures. Tu obtiendras d'abord un flegme insipide, puis de l'esprit, puis des gouttes rouges. Les ombres cymériennes couvriront la cucurbite de leur voile sombre, et tu trouveras dans l'intérieur un véritable dragon; car il mange sa queue. Prends ce dragon noir, broie-le sur une pierre, touche-le ensuite avec un charbon rouge, il s'enflammera, et prenant bientôt une couleur citrine glorieuse, il reproduira le lion vert. Fais qu'il avale sa queue et distille de nouveau le produit; enfin, mon fils, rectifie soigneusement, et tu verras paraître l'eau ardente et le sang humain (acide pyroacétique brut). " On voit que le langage mystique des alchimistes, la singularité des transformations qu'ils ne pouvaient comprendre, ont dû longtemps exciter la curiosité et l'admiration des ignorants.

En 1345, les navigateurs génois et catalans retrouvèrent les îles des Canaries, bien connues des Phéniciens et dess Carthaginois. Cette découverte donna une nouvelle activité au commerce, et favorisa les progrès des études en multipliant les relations des peuples.

Ce siècle vit paraître un traité d'anatomie, resté classique jusqu'en 1500 ; c'est celui de Mundinus, de Bologne, qui avait emprunté ses connaissances à la science informe des Arabes. Il y avait cependant ajouté quelques observations directes; mais elles devaient être bien peu nombreuses, puisque, dans le cours de onze années, il ne disséqua que trois corps. Nous trouvons aussi, parmi les botanistes de cette époque, Giacopo di Dondis, médecin de Padoue, qui inventa une horloge indiquant les jours, les mois, les fêtes de l'année, le cours du soleil et les phases lunaires. Il fit paraître, sous le titre d'Herbier vulgaire, un traité de botanique descriptive qui n'est qu'une compilation, à laquelle sont ajoutées, pour les plantes naturelles de l'Italie, des descriptions plus exactes que celles qui avaient été faites avant lui.

Le $\mathbf{x v}^{\mathrm{e}}$ siècle fut un des plus féconds en événements propres à influer sur les progrès de l'esprit humain. En 1431, Guttenberg découvre l'imprimerie, et vient ainsi en aide aux esprits qui, de toutes parts, se montraient plus que jamais avides de lumières. Les chefs-d'œuvre antiques, écrits sur du papyrus ou du parchemin, et reproduits en petit nombre par des copistes inexacts ou ignorants, avaient presque entièrement disparu dans les commotions du moyen-âge; l'art typographique, en en facilitant la reproduction, les garantit d'une ruine complète, et mit les trésors de la science à la portée de tous les hommes. 
Bientôt ce ne furent plus seulement les rois et les seigneurs qui purent avoir des livres; le peuple commença à jouir des bienfaits de l'instruction, et les belles intelligences, restées stériles faute de culture, vinrent puiser à celte nouvelle source de précieuses connaissances qu'elles accrurent à leur tour.

Le Bas-Empire, sans cesse menacé par les Ottomans et livré au scandale de la plus honteuse dépravation, finit par succomber. En 1453, Constantinople tomba sous le joug de Mahomet II; et les savants grees, chassés de leur patrie par le vainqueur, cherchèrent un refuge en Europe, où ils répandirent les sciences de l'antiquité et firent mieux connaître la langue d'Aristote. Au xmr siècle, un concile avait anathématisé les écrits du philosophe de Stagyre, en en défendant la lecture sous peine d'excommunication; mais, trente ans à peine après la proscription de ses curres, une réaction s'était opérée en sa faveur dans la partie éclairée du clergé; il devint l'idole du xve, l'oracle de la philosophie; et le pape Nicolas $\mathrm{V}$ ordonna de traduire ses ouvrages en latin. Quand on songe aux discussions puériles, ạx conceptions étroites, aux querelles intolérantes dont le nom d'Aristote était devenu l'occasion ou le prétexte, on s'étonne de voir l'émancipateur de la pensée devenu, après deux mille ans, un obstacle à l'affranchissement de l'esprit.

L'Amérique, connue des anciens Scandinaves depuis plus de quatre siècles, sans que le souvenir de sa découverte eût été conservé par l'Europe, est retrouvée, en 1492, par Christophe Colomb qui cherchait un passage pour aller aux Indes. Le nouveau continent, en ajoutant un monde à celui que connaissaient les anciens, fut pour les sciences physiques une nouvelle cause de progrès, pour l'histoire naturelle une mine féconde par la nouveauté de ses productions, et un heureux stimulant pour les esprits. La cupidité des Portugais, enflammée par le succès des navigateurs espagnols, leur fit braver les dangers d'une traversée longue et périlleuse, afin de découvrir des pays inconnus. La fortune sourit à ces audacieux aventuriers. Vasco de Gama osa le premier parcourir l'immense étendue des còtes de l'Afrique, doubla le cap de Bonne-Espérance; et, après des faligues sans nombre, fit connaître à l'Europe la route des Indes. Ces nouvelles voies ouvertes à l'humanité ne furent d'abord réquentées que par des hommes avides de richesses; mais ceux-ci firent bientôt place à des observateurs, qui les parcoururent en tous sens, au grand avantage de la science.

Les ourres des naturalistes anciens, regardées alors comme infail- 
libles el dispensant de toute observation, furent en partie traduites dans le cours de ce siècle et trouvèrent de nombreux commentateurs, dont les plus célèbres sont: Théodore Gaza, qui traduisit en latin l'histoire des animaux d'Aristote, celle des plantes de Théophraste, el les aphorismes d'Hippocrate; George Valla, médecin de Venise, célèbre par son livre De expetendis et fugiendis rebus; Hermolaüs Barbaro, patriarche d'Aquilée, qui a laissé une traduction de Dioscoride, des pará phrases sur Aristote et une édition de Pline le naturaliste, dans laquelle il corrigea cinq mille passages, en substituant cependant quelques erreur's à celles qu'il faisait disparaitre. Jean de Cuba publia, sous le litre de Jardin de la santé, un traité de botanique médicale, qu'il accompagua de figures sur bois.

La chimie, que nous avons vue naître à Constantinople, puis cultivée par les Arabes d'Espagne qui la transmirent à l'Europe, se répandit au commencement du $\mathrm{xv}^{\mathrm{e}}$ siècle en Italie et en Allemagne, où ses applications métallurgiques la firent accueillir favorablement; elle y arriva mêlée à de grossières superstitions; mais ce furent ces erreurs même qui la firent adopter par les amis du merveilleux. La transmutation des mélaux, la recherche de la pierre philosophale et de la panacée universelle devinrent pour celte science autant de causes de progrès. Les peiples ignorants s'inclinèrent avec respect devant l'appareil mystérieux et imposant dont s'entouraient les alchimistes, et les princes se déclarèrent les protecteur's d'une science qui leur promettait de faciles richesses.

La véritable science naît cependant de ces creuses rêveries; et les ouvrages de Basile Valentin, qu'on suppose avoir été un bénédictin d'Erfurt, ont fait connaitre les propriétés pharmaceutiques de l'antimoine ainsi que certaines préparations médicinales encore en usage de nos jours, et dont le nom vulgaire s'est même conservé. Sa théorie chimique n'est qu'une reproduction de celle des trois principes, adoptée par les Arabes d'Espagne, et les manipulations chimiques qu'il avait décrites, conservèrent la même forme jusqu'au xvı I siècle.

Les astronomes les plus célèbres de ce temps furent George van Purbach el Jean Müller, son disciple, plus connu sous le nom de Régiomontanus; ils préparèrent la grande réforme que Copernic devait accomplir. Ce furent aussi d'habiles physiciens; ils laissèrent des ouvrages estimés sur les poids el mesures, la conduite des eaux, les miroirs ardents, etc.; et Walther, un de leurs contemporains, étudia les eflets de la réfraction. Ce fut à celte époque (1456) que parut la fameuse comète 
dont la périodicité a été constatée, et qui a reparu en 1835. Son apparition répandit dans toute l'Europe la plus profonde consternation, et fut considérée comme le présage de grandes calanités publiques.

Ici finit le moyen âge et commence l'époque moderne. Nous y verrons la science se créer lentement, sans secousses, sans perturbạtions violentes; et, après de nombreuses transformations, de longues et pénibles études, devenir ce qu'elle est aujourd'hui; c'est-à-dire riche en faits, riche en expérience, et non plus fondée sur des hypothèses.

\section{TROISIEME PARTIE.}

TEMPS MO DER N ES.

Histoire des sciences naturelles depuis le XVI ${ }^{\mathrm{e}}$ siècle jusqu'à nos jours.

Les temps modernes dont les premier's âges se lient d'une manière presque immédiate à l'antiquité, où ils cherchent à puiser de nouvelles connaissances, succédèrent à une longue et ténébreuse époque qui n'avait guère laissé dans la science que de vagues souvenirs, des réminiscences incomplètes et des erreurs sans nombre. Par l'effet d'une sorte de prédestination qui semble être le résultat de la tendance de l'homme au progrès, les études, enchainnées l'une à l'autre par des liens étroits, se développent dans l'ordre nécessaire de leur importance ou en raison inverse des entraves qui les ont comprimées. Chaque siècle est dominé par une série d'études qui absorbent toutes les autres, jusqu'à ce qu'au milieu de commotions politiques, religieuses ou sociales qui sont autant d'excitations nouvelles, les sciences qui composent le savoir humain, ayant acquis un égal degré de développement et se servant mutuellement d'auxiliaires, finissent par former un réseau tellement étroil qu'on ne peut se renfermer dans une spécialité sans devenir incomplet.

Lhistoire des siècles précédents a un caractère scientifique négatif, et 
se trouve mêlée à des faits qui intéressent le perfectionnement général de l'humanité; mais dans l'histoire des trois derniers siècles nous n'aurons pas besoin de beaucoup de digressions pour lier entre elles les diverses époques, la science seule suffira pour opérer cette liaison et nous ne mentionnerons les grands événements extérieurs qu'autant qu'ils pourront nous en expliquer les progrès.

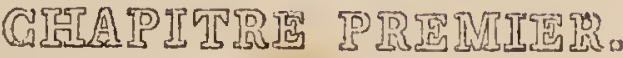

Ėtat des sciences naturelles au xvie siècle.

Le $\mathrm{xvI}^{\mathrm{e}}$ siècle riche des découveries $d \mathbf{u} \mathrm{xv}^{\mathrm{e}}$, stimulé par les conquêtes transocéaniennes de l'Europe et violemment agité par les ardentes querelles de la réformation, ne resta pas oisif au milieu des trésors qui l'environnaient de toutes parts et sollicitaient son activité; mais son émancipation était de trop fraîche date pour qu'il pût se délivrer de toutes ses entraves; aussi fut-il longtemps soumis à l'autorité des anciens dont les travaux incomplets servaient de texte à mille commentaires, et soulevaient d'àcres controverses. Peu-à-peu cependant l'autorité s'ébranla; les hommes de science ne se contentèrent plus de croire sur parole des auteurs dont les œuvres avaient été mutilées par les copistes ou qui s'étaient trompés eux-mêmes; les défenseurs de l'antiquilé furent obligés de s'avouer vaincus et de reconnaître qu'en fait de science il n'y a pas de révélation, et que l'expérience est l'unique source du savoir.

L'astronomie, cultivée avec éclat par les Arabes d'Espagne, passá en Europe sous la forme dont ils l'avaient revêtue, et jusqu'au xvi ${ }^{\mathrm{e}}$ siècle on suivit Ptolémée, sans songer à le réformer.

Copernic, qui appartient plus an xvi siècle qu'au $\mathrm{xv}^{\mathrm{e}}$, fut choqué de Ia contradiction que le système de Ptolémée présentait avec les lois physiques, en faisant tourner les planètes autour de la terre. Il renouvela te système des pythagoriciens, plaça le soleil immobile au centre du monde, et fit de la terre une planète, qui se meut comme les autres autour de l'astre central. Il détermina les dimensions des orbes décrils par' 
les corps planétaires, et réduisit la révolution diurne du ciel à une simple illusion d'optique.

Ce système, si simple et si logique, rencontra cependant des contradicteurs. Tycho-Brahé, auquel la science doil de grandes découvertes, telles que la variation de la lune, le mouvement de ses nœuds, l'inclinaison de son orbite, etc., ne l'adopta pas. Tout en avouant les vices de celui de Ptolémée, il ne voulut pas reconnaître au soleil sa place au centre du monde. Il y mit la terre, autour de laquelle il fit tourner le soleil, entraînant avec lui les planètes dans sa révolution aunuelle. Ce système, contraire aux lois de la saine physique, mais qui ne change pas l'apparence des phénomènes, fut soutenu avec chaleur par Longomontanus, Morin et Riccioli.

En 1519, le voyage autour du monde, commencé par Magellan et terminé par son lieutenant, mit hors de doute la sphéricité de la terre; et à la fin du xvı siècle, sous le pontificat de Grégoire XIII, eut lieu la réforme du calendrier, réclamée depuis longtemps avec instance par les astronomes. En 1582 , on était de dix jours en retard sur les phénomènes qui règlent le retour des saisons. Pour rentrer dans l'ordre normal, on supprima dix jours au mois d'octobre; et l'Europe entière, à l'exception des Grecs et des Russes, adopta cette réforme.

Les grands travaux en physique ne sont pas nombreux à cette époque; les connaissances des anciens forment encore le fond de la science, et il n'y fut ajouté que peu de choses. Cependant nous y trouvons l'importante découverte de la déclinaison de l'aiguille aimantée, observée par Sébastien Cabot dans un voyage au nord de l'Amérique, pour chercher un passage qui pùt conduire en Chine. Frascator découvrit le principe de la décomposition du mouvement; Stévin trouva le véritable rapport qui existe entre la puissance et le poids dans le plan incliné. En 1560, le Napolitain Porta, qui s'occupait de magie et de sciences occultes, perfectionna la chambre obscure et forma le plan d'une encyclopédie. Maurolico de Messine publia, sur le mécanisme de la vision, une théorie fort avancée qui lui fit découvrir les moyens de remédier aux défauts de la vue, en employant des verres concaves pour les myopes et convexes pour les presbytes. A la fin de ce siècle, Gilbert de Colchester fit paraître un traité sur le magnétisme et l'électricité, et Dominis, évêque de Spalatro, donna une bonne théorie de la formation de l'ar'c-cn-ciel intérieur.

L'alchimie, fondée sur une idée peut-être mal définie plutò qu'erronéc, mais sérieusement occupée d'études sur l'analyse et la synthèse des corps, 
Ćail devenue un moyen d'acquéril des richesses aux dépens des hommes crédules; à Basile Valentin, véritable chimiste, araient succédé d'indignes charlatans. Les attaques d'Érasme de Rotterdam et de Ben Johnson contre les alchimistes jetèrent sur leurs recherches un tel ridicule, que l'arl de faire de l'or tomba bientôt dans le discrédit. Il n'en fut pas de même de la préparation du remède universel qui occupait toutes les têtes.

Au commencement du $\mathrm{XvI}^{\mathrm{e}}$ siècle, les hosecroix parurent en Allemagne. Cette mystérieuse société, bravant le ridicule, s'occupa activement d'alchimie, d'astrologie et de cabale; et, quoiqu'elle ait poussé cette manie jusqu’à une exaltation maladive, elle rendit quelques services à la science.

Cardan, habile mathématicien, dont les découvertes indiquent un vaste génie, se jeta à corps perdu dans les sciences occultes, ct y entraîna uII grand nombre de savants, surtout parmi les médecins, qui cherchaient alor's de bonne foi la panacée universelle et s'évertuaient à préparer des remèdes secrets.

C'est à l'influence de ces idées qu'on dut Paracelse, un des plus célèbres médecins-alchimistes de cette époque. Plutôt aventurier que savant, il courait par les chemins, hantant les cabarets et les bouges, demandant aux vieilles femmes si elles connaissaient des secrets, el travaillant sérieusement au grand cuvre. A travers les absurdités cabalistiques répandues dans ses ouvrages, on trouve de bonnes et saines idées de chimie, noyées dans un langage ridicule. On doit cependant à Paracelse une heureuse innovation, celle des cours publics en langue vulgaire; ce qui contribua à populariser les études scientifiques.

Il introduisit l'un des premiers dans la thérapeutique des substances préparées chimiquement; mais un des plus fâcheux résultats de la médecine alchimique fut de faire croire à l'inutilité des études pathologiques. On se contentait de préparer des remèdes secrets; et, comme les malades sont toujours portés à ajouter foi aux promesses des charlatans, la nouvelle médecine eut un succès prodigieux.

A la renaissance des lettres, l'Italie, qui avait été si longtemps à la tète des nations, reprit son antique renommée; ce fut dans ce pays que les sciences naturelles, et surtout l'anatomie, furent cultivées avec le plus de succès.

Zerbis et Achillini (1500 à 1512) se contentèrent de commenter Mundinus; mais Bérenger de Carpi fit des études sérieuses, et porta par ses travaux un coup terrible à l'autorité de Galien, encore toutc 
puissante. A cette époque, les grands artistes italiens étudiaient l'anatomie avec enthousiasme.

Vésale, disciple de Sylvius, fut un des anatomistes les plus célèbres du xvi ${ }^{e}$ siècle. Il s'attacha à relever les erreurs de Galien, et détruisit pour toujours son influence sur les études. Il publia, en 1543, sa grande anatomie, remarquable par les planches magnifiques dont elle est ornée. Ses nombreuses observations apportèrent dans la science d'importantes rectifications; mais l'acharnement qu'il mit à attaquer Galien, afin de prouver que les descriptions de ce médecin se rapportent, pour la plupart, à des animaux et non à l'homme, lui valurent de cruelles perséculions. La fin de Vésale, dont la vie avait été une longue polémique, fut déplorable : ayant ouvert le corps d'un gentilhomme espagnol dont on vit palpiter le cœur sous le scalpel,il fut accusé de l'avoir disséqué vivant et se vit condamner à faire un pélerinage à la Terre-Sainte. A son retour, il mourut de faim dans l'île de Zante, où l'avait jeté la tempête.

Après Vésale, dont les travaux régénérèrent la science, tous les anatomistes le prirent pour guide; deux de ses contemporains, Fallope et Eustache, acquirent une juste célébrité. Le premier, successeur de Vésale à l'école de Padoue, a laissé d'excellents travaux sur l'ostéologie du foetus et sur la structure de l'oreille interne. Un des mérites de cet anatomiste est d'avoir discuté avec une modération et une bonne foi inconnues à cette époque. On trouve dans ses écrits que le grand-duc de Toscane livrail aux anatomistes des criminels, pour qu'ils les missent à mort comme ils le jugeraient convenable et en fissent le sujet d'observations. Princeps jubet, dit-il, ut nobis dent hominem quem nostro modo interficimus et illum anatomisamus.

Eustache se livra à des travaux spéciaux sur diverses parties de l'organisme; et, quoique ses recherches sur l'organe de l'ouie laissent encore dans le doute sur certaines découvertes qu'on lui attribue, on a donné le nom de trompe d'Eustache au canal qui va de l'oreille interne à l'arrière-bouche. Il s'occupa avec beaucoup de succès d'anatomie comparée, et il est certain qu'il avait découvert et décrit le canal thoracique du cheval, retrouvé chez l'homme par Pecquet, et qui porte le nom de cet anatomiste. Par suite d'une fatalité qui nuisit à la science et à la gloire de ce grand homme, son traité d'anatomie est resté inédit jusqu'au commencement du xvıI ${ }^{\mathrm{e}}$ siècle; de sorte que, pendant un siècle et demi, il perdit le droit de priorité pour ses propres découvertes. Eustache eut le défaut de discuter avec aigreur, et montra, dans la polémique qu'il 
soutint contre Vésale, un acharnement indigne d'un homme supérieur.

Fabrizio d'Aquapendente s'occupa avec succès d'anatomie comparée, et n'isola pas, comme l'avaient fait Vésale et Sylvius, l'homme des autres mammifères. Il étudia avec soin la structure des veines, sans découvrir le phénomènc de la circulation ; mais il facilita beaucoup cette découverte, et ce furent ses.travaux qui mirent Harvey sur la voie. Il a laissé un beau travail, accompagné de planches, sur le développement du poulet, et il avait dessiné trois cents planches d'anatomie comparée, qui ont été perdues après sa mort. Casserius et Spiegel furent les derniers professeurs de l'école de Padoue qui, après eux, tomba en décadence.

Ingrassias de Palerme fut célèbre par ses connaissances générales en anatomie, et particulièrement par ses descriptions ostéologiques ; on lui doit l'institution des lazarets. Botal d'Asti décrivit le premier avec exactitude la perforation du cceur dans le foetus, déjà connue de Galien; et l'on a, par reconnaissance, donné le nom de trou de Botal à cette disposition organique. Varole, professeur de Bologne, a laissé, dans son livre de Resolutione corporis humani, une méthode nouvelle de disséquer le cerveau : au lieu de le couper, comme les anatomistes de son temps, en tranches horizontales, en commençant par la partie supérieure, il le prend par la base, part de la moelle allongée, et suit les fibres à travers la protubérance annulaire jusqu'aux couches optiques où elle paraît s'épanouir. Colombo et Césalpin se distinguèrent aussi par leurs travaux; fous deux décrivirent la petite circulation, et entrevirent vaguement la grande.

La France peut opposer à ces savants Italiens, Ambroise Paré, le père de la chirurgie, le premier qui se soit occupé d'ostéologie comparée, et qui ait prouvé que dans le squelette de l'oiseau il y a des parties analogues à ceiles des mammifères.

Servet, un des plus habiles élèves de l'Allemand Günther, qui vint à Paris, en 1530, professer l'anatomie, et eut pour élèves les plus célèbres anatomistes du xvi ${ }^{\circ}$ siècle, a décrit fort nettement la circulation pulmonaire; il eût fait faire un grand pas à la science si, poursuivi par l'implacable Calvin, comme anti-trinitaire, il n'eût été brûlé à Genève, en 1553. Il faut noter encore parmi les hommes distingués de l'école de Günther, Charles Étienne, parent des célèbres imprimeurs de ce nom; Dubois d'Amiens, plus connu sous le nom de Sylvius, et cité pour l'éclat de son talent, la brutalité de ses manières et l'âcreté de ses controm 
verses; Dulaurens, médecin d'Henri IV, dont les ouvrages brillent plus par la forme que par le fond, et le célèbre botaniste G. Bauhin, dont on a une excellente description du cerveau.

L'Allemagne est représentée dans les études anatomiques par Leonhard de Tubingue, Plater de Bâle et Coiter de Groningue, qui s'est livré à de grands travaux d'ostéologie comparée.

L'Espagne compte parmi ses anatomistes Collado, qui s'attribua la découverte de l'étrier de l'oreille, et. André de Laguna de Sćgovie, commentateur d'Hippocrate, d'Aristote, de Galien, et traducteur de Dioscoride. On voil dans son Anatomica methodus qu'il s'était approché de bien près de la découverte de la circulation.

A côté des anatomistes viennent se placer les physiologistes qui cherchent à expliquer par des théories les causes de la vie et le jeu des organes. Argentier introduisit dans cette science la méthode salutaire de soumettre les idées théoriques à la discussion la plus libre, sans recon* nâtre d'autre autorité que celle de la raison. Il démontra l'absurdité du principe de la pluralité des esprits animaux, et prouva guu'une seule force vitale explique d'une manière satisfaisante l'action des organes.

Paracelse fonda sa physiologie sur les idées cabalistiques. Il dédaigna l'étude, dans la pensée que la contemplation suffit pour acquérir toutes les connaissances. Cette doctrine inintelligente, mais flatteuse pour les esprits paresseux, fit école et trouva beaucoup d'adeptes.

Quoique l'anatomie ait plus spécialement occupé le $\mathrm{xvi}^{\mathrm{e}}$ siècle, la zoologie eut sa part dans les études générales; et c'est encore en Italie qu'on en publia les premiers travaux. En 1524, Paul Jove, de Côme, donna une description des poissons qui se trouvent sur les marchés d'Italie; mais son ouvrage n'offre d'intérêt que comme nomenclature. Dans le même temps, Massaria, médecin vénitien, écrivait un commentaire sur le $9^{\mathrm{e}}$ livre de Pline; et Pierre Gilles, d'Alby, voyageur instruit et intelligent, à qui l'on doit quelques travaux monogrảphiques, mettait Élien en ordre.

Ces premiers essais servirent de guide à l'Anglais Édouard Wotton, qui écrivit un traité de zoologie particulière et comparée, dans lequel il prit Aristote pour guide.

Bientôt parurent des ouvrages plus importants. Pierre Belon, du Mans, écrivit une histoire naturelle des poissons marins, dont les figures furent empruntées à Daniel Barbaro, ambassadeur de Venise à la cour d'Angle- 
terre et patriarche d'Aquilée, qui avait fait peindre trois cents poissons de l'Adriatique. Belon inséra dans les relations de ses voyages en Orient et en Grèce de nombreuses descriptions d'animaux, et publia, en 1555, une histoire naturelle des oiseaux, dédiée à Henri II, avec un traité de la chasse à l'oiseau de proie, alors fort en vogue. Il s'occupait de la traduction de Théophraste et de Dioscoride, lorsqu'il fut assassiné en 1566, sur la route du bois de Boulogne, où il habitait le château de Madrid. Belon est un écrivain d'une naïvelé remarquable; ses travaux portent toutefois le cachet d'une critique fort saine, pour l'époque ò̀ il écrivait. Il peut être regardé comme ayant le premier ouvert la voie aux anatomistes philosophes par ses observations comparatives sur les olganes des animaux.

Salviani, de Rome, écrivit aussi sur l'ichthyologie, et accompagna son ouvrage de planches assez bonnes comme exécution, mais d'une extrème faiblesse sous le rapport de la précision des caractères.

Rondelet, de Montpellier, contemporain de ces deux naturalistes, fut un des hommes les plus érudits de son temps. Il publia, en même temps que Belon et Salviani, un ouvrage d'ichthyologie, accompagné de plan ches d'une grande perfection sous le rapport des caractères. Son texte est savant, et ses descriptions sont très exactes, surtout pour les poissons de la Méditerranée. On trouve dans Rondelet, qui avait des connaissances anatomiques assez étendues, une ébauche de méthode naturelle : il avait élabli ses coupes sur les rapports existant entre les espèces. Son ouvrage, classique jusqu'à la moilié du svill ${ }^{e}$ siècle, peut encore être consulté avec avantage.

A la même époque, Longolius, d'Utrecht, et Turner', de Morpeth, écrivirent de petits traités d'ornithologie, dénués d'importance.

Le flambeau du xv I ${ }^{\mathrm{e}}$ siècle est Conrad Gessner, de Zurich, homme d'une érudition profonde. Après avoir passé sa jeunesse dans une misère qui le força de recourir à la charité des chanoines de Zurich et d'un Bernois, son ami, il s'occupa d'études médicales, d'histoire naturelle, de bibliographie, de philologie et de géographie descriptive; il traduisit du grec et de l'arabe des ouvrages de botanique et de médecine; mais son ocuvre capitale est son histoire des animaux, en 5 volumes in-folio. C'est un traité de zoologie générale comprenant la synonymie, des descriplions, des détails physiologiques, anatomiques, nosologiques el elhnographiques qui supposent des recherches immenses. On n'a de lui que des rapplochements et pas de classification; mais il indique avec précision les rapports 
sur lesquels elle peut être établie. Gessner brille par la justesse de son esprit. C'est un compilateur habile, un critique pleir de finesse et de sagacité; aussi son ouvrage doit-il être souvent consulté.

Aldrovande, d'une famille patricienne de Bologne, fut contemporain de Gessner. Il publia une longue série de travaux sur les sciences naturelles. Ses écrits indiquent une grande facilité, mais il n'a pas la sagacité de Gessner, et il a moins observé par lui-même. Uterverius, de Delft, successeur d'Aldrovande; Barthélemy Ambrosinus et Thomas Dunster, professeur de Bologne, publièrent, après sa mori, aux frais de la ville, les dix volumes in-folio qui forment le complément des quatre qu'il avait fait paraitre pendant sa vie, et dans lesquels leurs travaux sont mêlés aux siens. On ne voit pas de traces de méthode dans Aldrovande; il suit l'ordre adoplé par Aristote, et n'a fait un essai de classification que pour les insectes; encore a-t-il pris ce philosophe pour guide.

L'apparition de ces deux célèbres zoologistes contribua beaucoup aux progrès des études zoologiques, dont ils furent les plus intelligents promoteurs.

Olaüs Magnus a donné, dans son histoire des nations septentrionales, des détails fort curieux sur la zoologie du Nord. On trouve cependant encore dans son livre des préjugés empruntés aux anciens. Il parle, entre autres animaux fabuleux, du Kraken, poulpe gigantesque qui de ses longs bras enlace les navires et les entraîne dans l'abîme. Cet écrivain n'est pas très scrupuleux; car il donne comme résultat d'observations personnelles des faits empruntés à Gessner et à Aldrovande.

Clusius (DelÉcluse), d'Arras, quoique n'ayant jamais quitté son cabinet, a écrit, sous le titre d'Exoticorum librix, quibus animalium historice describuntur, un ouvrage fort intéressant sur toutes les branches dessciences naturelles. On y trouve un grand nombre de faits nouveaux. Il a décrit le premier la roussette, espèce de chauve-souris à ailes gigantesques.

Nous comptons au nombre des naturalistes les voyageur's que l'Amérique appelait dans ses vastes déserts, et nous citerons, parmi ceux qui ont laissé une relation de leurs observations, Gonzalès, d’Oviédo, d'Acosta et Hernandez. Nous y joindrons Bernard de Breidenbach, Guilandinus et Rauwolf qui ont visité le Levant, et ont consigné dans la relation de leurs voyages des détails fort curieux sur l'histoire naturelle de ces contrées. Ce dernier a laissé un herbier très précieux des plantes recueillies par lui dans ses excursions; cet herbier se voit encore aujour- 
d'hui à Leyde. Prosper Alpin a donné une histoire naturelle de l'Égypte. L'Europe septentrionale, où se répandait la civilisation, ayant assez adouci ses mœurs pour qu'on pût la visiter, Herberstein et Possevin parcoururent la Moscovie et les pays du nord, et en firent les premiers connaitre les productions naturelles.

A cette époque si voisine encore de la découverte du Nouveau-Monde et de celle de la route des Indes orientales, la manie des colonisations s'était emparée de tous les esprits. Elle ne tarda pas à gagner les Français. En 1555, l'amiral Coligny favorisa l'émigration au Brésil de quelques familles protestantes. Cet établissement, qui n'eut qu'une courte durée, produisit deux ouvrages d'histoire naturelle, ceux de Thevet et de Jean de Léry.

Ici s'arrêtent les travaux zoologiques de ce siècle. Nous passerons rapidement en revue les botanistes qui sont plus nombreux, la phytologie descriptive étant d'une observation beaucoup plus facile, parce que les plantes peuvent être transportées dans des jardins où elles s'acclimatent et que leur dépouille se conserve sans autant d'altération.

L'Italie, qui avait produit les premiers anatomistes, eut la gloire de fournir aussi les premiers botanistes. Leonicenus, Monardus et Brasavola, plus connu sous le nom d'Antonius Musa, sont de simples commentateurs des auteurs anciens. Ce dernier posséda le premier, depuis Théophraste, un jardin botanique.

Matthiole, de Sienne (1550), célèbre commentateur de Dioscoride, a publié un nombre considérable de figures ombrées assez exactes; mais on n'avait pas encore songé à faire connaître les caractères botaniques des plantes; on ne les représentait que sous leur aspect général. Dodoens Rembert, professeur à Leyde, est encore un commentateur de Dioscoride. Ruel, qui vivait au commencement $d u \mathrm{xvI}^{\mathrm{e}}$ siècle, publia une compilation des botanistes anciens, et il confondit souvent les plantes décrites par ces auteurs avec celles qui croissent en France. Son traité De naturâ stirpium est l'un des plus volumineux ouvrages de botanique publiés à cette époque.

L'Allemagne comptait alors plusieurs botanistes distingués : Brunfels, auteur d'une iconographie végétale; Tragus, les deux Cordus et Fuchs, qui joignirent à leurs commentaires sur les anciens des descriptions résultant de leurs observations, et accompagnèrent leurs ouvrages de figures au trait gravées avec beaucoup de soin.

L'exploration des Indes orientales par les Portugais donna naissance 
à des travaux botaniques d'un grand intérêt. Garcias publia à Goa, en 1563, une histoire des plantes médicinales des Indes. Acosta en fit autant et y joignit une bonne description de la sensitive.

Oviédo et Monardès, de Séville, firent connaître la Flore des Indes occidentales; ce dernier retraça l'histoire du tabac, plante dont les jongleurs indiens usaient souvent pour se procurer une ivresse prophétique; on trouve aussi dans son ouvrage la description du haricot, inconnu des anciens.

Clusius fit connaître plusieurs plantes d'Amérique et donna le premier la figure de la pomme de terre. Nous ferons remarquer à cette occasion que cette plante, dont on a attribué l'importation à Raleigh, en 1585 , était déjà très répandue en Italie en 1586 , et qu'elle y servait à la nourriture des hommes et des animaux. Il est évident que ce sont les Espagnols qui l'ont apportée en Italie. Gomara, écrivain espagnol, nous apprend que ce précieux tubercule était employé comme plante alimentaire chez les habitants du Pérou septentrional.

Au xvi ${ }^{e}$ siècle, des jardins botaniques s'établirent en Europe et le goût de l'horticulture commença à s'y répandre. Il se forma des jardins en Italie, en Allemagne et en France. Jusqu'à cette époque, ce n'avaient été que des établissements particuliers; mais le grand-duc Côme ${ }^{{ }^{\mathrm{er}}}$ en créa un public, à Pise, en 1543, d'après les conseils de Luc Ghini. Padoue, Ferrare, Florence et Bologne eurent bientôt les leurs. La ville de Leyde suivit cet exemple; en 1597 seulement, l'université de Montpellier en eut un qui tomba bientôt faute de protection.

Dès que ces établissements eurent été créés, on délaissa les ouvrages si obscurs et si incoinplets des anciens, pour étudier les plantes sur la nature. Conrad Gessner, déjà célèbre par ses travaux en zoologie, fut le premier à poser en principe que c'est dans les organes de la fructification, les seuls vraiment caractéristiques, qu'on doit chercher la base de la méthode de classification des végétaux. Ce principe si fécond en applications utiles ne fut cependant pas adopté. On continua à classer les plantes d'après certaines méthodes artificielles qui les groupaient en raison de leur ressemblance extérieure. Les figures des plantes que ce botaniste avait fait graver suivant son système furent publiées par Camerarius, savant directeur du jardin botanique d'Altorf, qui les mit dans un abrégé de Matthiole, qu'il édita en 1586.

Lobel, médecin du prince d'Orange, puis botaniste de Jacques I ${ }^{\text {er }}$, publia, en 1581, un ouvrage dans lequel on reconnait, pour la premic̀re 
fois, quelques familles naturelles, tclles que les graminées, les mousses, les orchidées, les labiées, les ombellifères, etc. Il a séparé d'une manière nettement tranchée les monocotylédones des dicotylédones. Zaluzianski entrevit le premier les organes sexuels des végétaux.

Césalpin, d'Arezzo (1583), suivit la méthode expérimentale d'Aristote et fut le créateur d'un système de botanique complet, avec des divisions vicieuses encore, mais qui cependant furent un acheminement vers la méthode naturelle. On doit d'autant plus s'étonner que Césalpin ait pu établir un tel système, qu’il n'avait, pour faciliter ses études, qu'un faible herbier de quinze cents plantes, dont sept à huit cents avaient été recueillies par lui-même.

Dalechamps, Desmoulins son continuateur, et Tabernæmontanus sont des botanistes routiniers, serviles imitateurs de l'ancienne méthode. Jean Bauhin donna, dans son histoire générale des plantes, un travail de synonymie encore utile à consulter; mais Gaspard Bauhin, son frère, rendit à la science phytologique un plus grand service en publiant son Pinax theatri botanici, composé sur le même plan que l'ouvrage de Jean, et qui lui avait coûté plus de quarante ans de travail. On ne trouve pas, il est vrai, dans Bauhin un système complet de classification, mais il contient un essai de classement par genres qui ne manque pas d'intérêt. Ce botaniste a le mérite d'avoir essayé de fixer par un travail d'une critique judicieuse, la synonymie, déjà si multipliée, et il mit au dessous du nom de chaque espèce une petite phrase caractéristique ré digée avec soin. Son ouvrage, qui contient la description de près de six mille espèces de plantes, fit oublier tous ceux qui l'avaient précédé ; et, jusqu'à Linné il servit de guide aux botanistes.

Nous citerons, à la suite des botanistes, l'agronome Olivier de Serres, à qui l'on doit la propagation du mûrier et des vers à soie.

C'est encore en Italie que la science des minéraux prit naissance ; mais elle n'y fut qu'ébauchée. En 1502, Leonardi, de Pesarro, écrivit un ouvrage sur les minéraux; imbu des préjugés de l'époque, il a rempli son livre d'erreurs et de fables sur les pierres gravées, ainsi que sur leurs vertus. Scudalupi et Stella suivirent ses traces.

L'Allemagne, si riche en gisements métallifères, dont les trésors excitaient la cupidité des princes, fut bientôt à la tête de la science et lui fit faire de grands progrès.

Le premier qui s'occupa avec succès de minéralogie fut Bauer, plus connu sous le nom d'Agricola. Son ouvrage De re metallicâ (1546) 
resta longlemps classique sans être exempt de bien des erreurs; il consacre un long chapitre à la baguette divinatoire, au moyen de laquelle on découvre les eaux et les trésors cachés. Cette croyance a été longtemps répandue, et nous trouvons encore dans nos campagnes des ignorants qui y ajoutent foi. Cet ouvrage est plutôt un traité de métallurgie que de minéralogie; mais il n'en est pas de même de son livre sur la nature des fossiles, mot par lequel il désigne tous les minéraux; c'est un véritable traité systématique de minéralogie, et la méthode qu'il y suit domina la science jusqu'à l'époque où les substances minérales furent classées d'après leurs propriétés chimiques.

L'ouvrage d'Encelius (1557), De re metallicâ, est mêlé à des idées d'alchimie sur la composition des minéraux; mais on y rencontre des vues de classification générale fort judicieuses.

Nous retrouvons le célèbre Gessner parmi les minéralogistes; il peut être regardé comme le premier qui ait écrit sur la cristallographie. A cette époque, on croyait généralement que les fossiles se forment naturellement au sein des masses minérales. Gessner n'avait pas adopté l'opinion vulgaire; il admettait comme possible que ces dépouilles eussent appartenu à des êtres vivants.

La France a eu la gloire de donner le jour au célèbre Bernard Palissy, créateur de la géologie, mais plus connu comme auteur de ces charmantes faïences à figures en relief encore recherchées de nos jours. Palissy, dont le nom doit être cher aux sciences, n'était qu'un pauvre artisan sans études qui s'était formé seul; aussi ne le voyons-nous pas entiché des préjugés dominants parmi les savants de son époque. Chez lui la science a toujours un côté pratique; il est avant tout applicateur, et ses ouvrages sont exempts de ces formes ambitieuses qui hérissent l'étude de difficultés inutiles.

Nous trouvons Palissy, dans sa jeunesse, forcé de faire pour vivre divers métiers, et parcourant la France, tantôt comme arpenteur, tantôt comme dessinateur et peintre d'images. Dans ses longues excursions, il avait recueilli un grand nombre de pétrifications. En 1575, il fit à Paris un cours de minéralogie, et combattit l'idée que les fossiles fussent de simples jeux de la nature. Il soutint que les coquilles qui se trouvent au sommet des montagnes sont des restes d'animaux marins, et que les mers ont jadis couvert les continents, vérité dès ce moment acquise à la science, mais dont l'établissement rencontra de grands obstacles dans les préjugés existants. C'est à lui que l'agriculture doit l'emploi de la marne comme 
amendement. Ses ouvrages renferment beaucoup de choses restées longtemps inconnues, et leur lecture excite encore l'intérêt.

Césalpin, le botaniste, et Schwenckfeld, de Silésie, ont publié des essais de classification minéralogique assez satisfaisants pour une époque où la chimie était fort peu avancée.

On voit que le $\mathrm{xvr}^{\mathrm{e}}$ siècle, si rapproché des temps d'ignorance profonde, a produit, dans presque toutes les branches des sciences, des travaux d'une haute importance et que déjà les naturalistes de l'antiquité avaient été laissés en arrière sous beaucoup de rapports ; aussi n'auronsnous plus que des progrès à signaler, et les siècles suivants ne feront souvent que confirmer les savantes prévisions des hommes de génie qui ont ouvert à l'humanité les portes de la science.

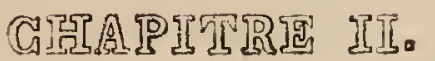

État des sciences naturelles au $\mathbf{X V I r}^{\mathrm{e}}$ siècle.

Le xvie siècle, absorbé tout entier dans des travaux d'analyse, occupé de sa lutte contre l'autorité despotique des anciens, n'a créé aucune théorie. Si l'on en excepte l'astronomie, qui était plus avancée que les autres sciences, on ne trouve nulle part de synthèse. Cependant l'impulsion était donnée: sur tous les points les études renaissaient et trouvaient dans les souverains un salutaire appui. Il restait néanmoins à combattre une ennemie redoutable dont l'existence était un obstacle au progrès: nous voulons parler de l'autorité dont la philosophie scolastique était la représentante. Renfermée dans le cercle étroit d'un dogmatisme sans portée, étouffée par les formes verbeuses et décolorées de sa méthode syllogistique, elle s'opposait à toute pensée qui ne rentrait pas dans le cadre de ses théories. Argentier l'avait bien attaquée en refusant de reconnaître d'autre autorité que celle de la raison; mais sa voix n'était pas assez puissante pour donner le signal de la réforme; il fallait pour cela un homme d'un génie supérieur; et, comme dans l'humanité il n'est pas un cri qui ne soit entendu, Bảcon, le réformateur des sciénces, le créateur de la physique et de la philosophie, vint porter 
les premiers coups à la scolaslique. Il publia dans ce but, en 1606 et 1620 , les deux parties d'un même ouvrage composé sous le titre général d'Instauratio magna; la première, De dignitate et augmentis scientiarum, est une classification méthodique des sciences, destinée à montrer qu'elles découlent les unes des autres et ont entre elles une connexion intime; la deuxième, Novum organum scientiarum, est la méthode philosophique à employer pour arriver à la vérité. Bâcon procède par induction, c'est-à-dire qu'il n'arrive à la généralisation qu'après avoir rassemblé des faits assez nombreux pour qu'il soit permis d'en tirer des conséquences. Sa méthode est toute expérimentale; el l'on remarque dans ses écrits une foule d'aperçus profonds ou ingénieux qui l'ont fait regarder comme le prophète des vérités démontrées par Newton. Cependant il n'a pas toujours été heureux en application; ses ouvrages sur les vents, et sur la vie et la mort, sont pleins d'erreurs. Sans s'en apercevoir, il s'est appuyé sur l'autorité qu'il avait si victorieusement combattue; car il y a reproduit sans choix l'opinion d'autres auteurs, et non le résultat de ses propres observations.

Sa Nova Atlantis est la description d'un établissement consacré au perfectionnement des sciences naturelles, et son Sylva sylvarum sive Historia naturalis, un recueil d'observations et d'expériences dont les unes lui sont personnelles et les autres étrangères. Cet ouvrage a élé publié après sa mort.

René Descartes, né en 1596, est encore un des principaux insligateurs de la grande révolution du xvir ${ }^{\mathrm{e}}$ siècle; ce fut un habile mathématicien, un philosophe d'une haute intelligence; il rendit aux sciences de grands services, en achevant de secouer le joug de l'autorité scolastiq!ı, et en conseillant, dans sa méthode pour arriver à la connaissance de la vérité, de prendre le doute pour point de départ. Cependant il semblerait avoir cessé de reconnaître la vérité dès qu'elle ne revêlit plus les formes absolues et infaillibles du calcul. Lui, à qui l'on doit l'admirable simplicité du langage algébrique, et qui enrichit l'application de l'algèbre à la géométrie de si heureuses découvertes; lui, le créateur d'une méthode philosophique où l'erreur est impossible, il ne fit pourtant, faute de s'être appuyé sur l'expérience, qu'imprimer aux esprits un mouvement salutaire. Ses travaux en physiologie, entachés des plus graves erreurs, ne lui ont pas survécu, non plus que la théorie qu'il inventa pour expliquer le secret du mécanisme planétaire. On peut lui repro- 
cher l'entêtement qui l'empeêcha de rendre justice à Galilée, et le porta à répandre le faux système de Tycho-Brahé. Substituant des hypothèses à celles qu'il avait contribué à détruire, il introduisit dans la science des erreurs nouvelles. On lui doit néanmoins la découverte de la force centrifuge, l'explication de la réfraction de la lumière, un excellent traité de dioptrique et une bonne explication de l'arc-en-ciel intérieur, mal décrit par Dominis. C'est en modifiant la théorie de Descartes sur la production de la lumière, qu'Huyghens créa celle des vibrations aujourd'hui adoptée. Descartes fit école, et sa doctrine, longtemps répandue sous le nom de cartésianisme, compta de nombreux disciples.

Pendant tout le cours du $\mathbf{x v i r}^{\mathrm{e}}$ siècle, la physique et l'astronomie furent cultivées avec ardeur.

Galilée, de Pise, contemporain de Bàcon, fut comme lui l'un des plus redoutables adversaires de la philosophie scolastique, et l'un des plus habiles astronomes de cette époque. Il étudia, avec la profondeur d'un homme de génie, la mécanique céleste; et la découverte qu'il fit du mouvement accéléré, des satellites de Jupiter, de l'anneau de Saturne, des phases de Vénus, et des mouvements de cette planète, lui firent adopter le système de Copernic. Ses fameux dialogues dans lesquels il développe ce système furent publiés à Florence en 1617, malgré l'improbation des théologiens. Il l'enseigna depuis à ses élèves et en devint un des plus ardents propagateurs. Il se vit, à soixante-dix ans, obligé de faire amende honorable pour avoir osé démontrer le mouvement de la terre, que les livres saints regardaient comme immobile au centre du monde, et fut contraint d'abjurer sả doctrine taxée d'hérésie. Il fit connaîre les taches du soleil, les inégalités de la lune, sa ressemblance avec la terre, etc. Ses découvertes en physique sont également importantes; on lui doit la connaissance des propriétés du pendule, la balance hydrostatique et le perfectionnement du télescope.

Képler, élève de Tycho-Brahé, physicien d'une haute intelligence, dont les recherches portent sur les points élevés de la science, s'occupa avec succès d'optique et d'astronomie; il détermina la véritable nature de la courbe que les planètes décrivent, découvrit les lois générales auxquelles leur's mouvements sont soumis, et démontra que les orbites planétaires sont des ellipses dont le soleil occupe l'un des foyers. La théorie des planètes, contenue dans les trois propositions qui portent le nom de lois de Képler, expliquait déjà une partie des phénomènes célestes; il ne restait plus quà découvrir le principe des lois qui régissent le mou- 
vement des corps planétaires; et il le fit presque en attribuant au soleil une force motrice qui les anime tous et une puissance qui les retient dans leurs orbites. Il expliquait les irrégularités de la lune par les actions combinées du soleil et de la terre, et les marées par l'attraction lunaire; hypothèses dont une seule eût suffi à la gloire d'un physicien. Les découvertes de Képler ruinèrent le système de Tycho-Brahé et répandirent les idées de Copernic.

Stévin, de Bruges, se livra à des travaux importants sur l'hydrostatique et découvrit l'égale pression des fluides dans tous les sens. En 1621, Drebbel inventa le premier thermomètre, construit, non pas comme les nôtres, avec de l'alcool ou du mercure; mais consistant simplement en un tube plongé dans l'eau, et contenant de l'air dans sa partie supérieure. On attribue à Zacharie Jan et à Jean Lapprey, opticiens de Middelbourg, la découverte du microscope et celle du télescope.

Salomon, de Caus, mort à Bicètre, jeta les premières idées de l'emploi de la vapeu' comme force mécanique, dans son ouvrage intilulé : Raison des forces mouvantes. En 1629, le physicien italien Branca donna la description d'un éolipyle, dont le jet de vapeur faisait mouvoir une roue horizontale. En 1663, le marquis de Worcester décrivit un appareil regardé par les Anglais comme la première machine à vapeur, mais dont on suppose que l'idée a été empruntée à Salomon de Caus; et, en 1690 , le Français Papin inventa la première machine à vapeur fonctionnant avec un piston.

Toricelli, disciple de Galilée, en démontrant la pesanteur de l'air, détruisit l'idée absurde de l'horreur du vide, encore professée dans les écoles. Il donna aussi la théorie du baromètre dont Pascal devait faire une heureuse application à la mesure des hauteurs, et posa les bases de la théorie du mouvement des fluides.

L'académie del Cimento confirma quelques années après, par de nouvelles expériences, les découvertes de Toricelli.

Gassendi, qui fit école comme Descartes, s'occupa de l'étude de la lumière et expliqua avec bonheur quelques-uns des phénomènes qu'elle présente. Il contribua aussi aux progrès de l'acoustique.

Otto de Guerike, que son désintéressement place au nombre des savants les plus honorables du xvir siècle, s'occupa d'hydrostatique, d'électricité et de magnétisme. Tous ses travaux indiquent une sagacité prodigieuse. Sa découverte de la machine pneumatique et ses expériences sur l'électricité, pour la production de laquelle il se servit d'un globe 
de soufre, avancèrent beaucoup la physique. La première de ces inventions devint pour Boyle, qui la perfectionna, la source d'une foule d'expériences ingénieuses.

Le jésuite Kircher s'occupa avec succès de catoptrique, inventa la lanterne magique et plusieurs autres machines ayant un même principe. Il établit d'une manière incontestable la possibilité de faire des miroirs ardents, substitua au porte voix un miroir parabolique qui renvoie les sons à une grande distance, et fit faire quelques progrès à cette partie si obscure de la science concernant la déclinaison de l'aiguille aimantée.

Huyghens appliqua le pendule aux horloges, calcula les lois de la force centrifuge, inventa le micromètre, perfectionna le baromètre, et confirma la découverte faite par Galilée de l'anneau de Saturne et des satellites de Jupiter. On lui doit l'ingénieuse théorie des vibrations de la lumière, dont l'idée est due à Descartes.

Hook de Freshwater perfectionna le microscope, inventa le baromètre à cadran et le ressort en spirale qui sert à régler les montres ; il découvrit les taches de Jupiter et de Mars, et soupçonna le mouvement de rotation de ces planètes. Wall s'occupa d’électricité et proposa, comme un moyen facile de développer ce fluide, les morceaux de drap et les peaux d'animaux.

Cassini, conquis à la France, comme Huyghens, par la munificence de Louis XIV, fit faire de grands progrès à toutes les branches de l'astronomie; il établit la théorie du mouvement des satellites de Jupiter, compléta la découverte de ceux de Saturne, et calcula la vitesse du temps que la lumière met à parvenir du soleil jusqu'à nous. Il construisit la célèbre méridienne de Bologne.

Mariotte, physicien d'une haute sagacité, détermina dans quelles proportions l'air peut se dilater et se condenser' il fit voir, à l'aide de la machine pneumatique, que la pesanteur de l'air retarde l'ébullition de l'eau, et s'occupa de la loi des vitesses dans l'écoulement des fluides. Römer. de Copenhague, découvrit le mode de propagation de la lumière. Picard mesura un degré terrestre, qu'il trouva équivalent à 25 lieues, et en conclut que le diamètre de la terre est de 2,864 lieues.

Newton fit une révolution dans Ja science par ses admirables découvertes sur la gravitation et la lumière. On sait qu'en 1665, la peste ayant éclaté à Londres, Newton, alors âgé de 24 ans, se retira à Woolstrop, et que ce fut là qu'une pomme lui étant tombée sur le visage, il se demanda pourquoi la puissance d'attraction qui déterminait celte chute ne s'éten- 
drait pas aux corps planétaires, et si la loi de la pesanteur qui les attire vers le soleil, ne suffisait pas pour les retenir dans leurs orbites. De cette idée, il fut conduit à la théorie de la tendance des molécules à se rapprocher, ou de la gravitation moléculaire. Il découvrit la cause de l'élasticité de l'air atmosphérique, donna à l'étude de la lumière une étendue et une précision nouvelles, et démontra, au moyen du spectre solaire, que chaque rayon lumineux est composé d'un faisceau de rayons diversement colorés et réfrangibles à un degré différent; il expliqua les phénomènes de la réfraction, ceux de la réflexion et créa la théorie de l'émission, opposée à celle des ondulations, qu'elle balança longtemps. Ses travaux sur la théorie des interférences datent de 1674. Les opinions de Newton rencontrèrent des contradicteurs, et ne furent admises qu'au milieu du xvirI ${ }^{\mathrm{e}}$ siècle. Laméthode donı il se servit est empreinte d'une profonde sagesse; il découvre la loi de la pesanteur, qui, combinée avec la force de projection des corps célestes, leur fait décrire une courbe elliptique; mais il ne connait pas la cause de cette pesanteur, non plus que l'origine de la projection des corps planétaires; et, comme il ne veut pas devancer l'expérience, il ne cherche point à expliquer ces phénomènes par des hypothèses.

Leibnitz, contemporain de Newton, fut la gloire de l'Allemagne. A vingt-deux ans il publia un traité complet de physique générale qui dénote une perspicacité admirable, mais qui est rempli de subtilités métaphysiques pour lesquelles l'auteur avait un penchant décidé.

Vers le même temps, plusieurs physiciens s'occupèrent d'hygrométrie, et c'est au père Mersenne qu'on doit les hygromètres en corde à boyau. Flamsteed augmenta considérablement la liste des étoiles visibles connues et détermina leur position.

Hauksbée perfectionna la pompe de Boyle et la machine de Papin, et acheva de détruire le préjugé de l'horreur du vide qui existait encore dans quelques esprits. Il s'occupa avec succès d'électricité, et substitua au globe de soufre d'Otto de Guerike d'abord un tube, puis un globe de verre. Ce fut lui qui vit jaillir la première étincelle électrique, et en ressentit la commotion. Il découvrit aussi la phosphorescence électrique.

Appliquant la méthode de Newton à la détermination des orbites paraboliques des comètes, Halley prédit le retour, en 1758 ou 1759, de la comète observée en 1531, en 1607 et en 1682. Clairaut en fixa l'apparition pour le mois d'avril; mais il commit une erreur de calcul et la comète ne parut que dans les premiers jours de mai. Bernouilli observa 
aussi la marche des comètes, et annonça le retour de celle de 1680 pour 1719. Il développa les principes de Leibnitz sur le calcul différentiel, et présenta les premiers exemples de calcul intégral. Son frère Jean contribua au perfectionnement des découvertes de Leibnitz. Amontons composa un traité sur la théorie des frottements, et donna les premières idées sur la construction du télégraphe.

Paracelse, en enseignant publiquement la chimie, avait répandu le goût de cette science et en avait assuré les progrès. Les luttes ouvertes auxquelles elle donnait lieu devenaient pour elle une cause de durée. A mesure qu'elle se dépouillait de sa forme mystique, les préjugés disparaissaient; cependant l'idée de la transmutation des métaux resta dans quelques esprits, mais sous une forme scientifique. Cette idée subsiste encore de nos jours, et peut-être n'est-ce pas sans raison, car on ne peut dire absolument que les corps considérés comme simples soient véritablement élémentaires; et qui sait si ces corps indécomposables ne sont pas seulement des corps indécomposés?

Van Helmont, grand partisan de Paracelse, est encore un alchimiste, ou plutôt, comme ce dernier, un médecin-chimiste, travaillant à la recherche de la panacée universelle. Cet homme, qui possédait une vaste érudition, rendit de grands services à la chimie; il créa le mot de gaz, resté dans la science, et qu'il appliqua d'abord à la vapeur d'eau ; mais ensuite il donna le même nom à l'acide carbonique qu'il appelait $g a z$ sylvestre et au gaz hydrogène. Plusieurs des grandes vérités de la chimie moderne lui étaient connues, mais confusément; de sorte qu’il n'a pu les développer.

En Allemagne les Rosecroix continuaient à travailler avec persévérance à la recherche de la pierre philosophale; et en 1614, ils annoncèrent qu'ils devaient régénérer le monde en s'emparant de l'esprit des princes, au moyen des trésors que leur procurerait cette découverte. Oughtred parle dans ses ouvrages de la préparation de la terrevierge destinée à faire la pierre philosophale, par l'évaporation de l'eau pure. A côté d'eux, nous trouvons des hommes qui cherchent véritablement à s'éclairer, et ne considèrent plus le secret de la transmutation comme le but de leurs efforts; tels sont : Cassius, Libavius et Glauber dont le sulfate de soude a conservé le nom; Crollius, Rivère, Barner et Bohnius, déjà les représentants de la science expérimentale; Kunckel qui, en cherchant encore la pierre philosophale, retrouva le phosphore dont Brand avait emporté le secret dans la tombe, et publia 
un ouvrage fort estimé sur l'art de faire le verre; Becher qui, toujours un des zélés partisans de la doctrine de Paracelse, jeta, par la publication qu'il fit en 1669 de sa Physica subterranea, les premiers fondements de la science; Bötticher enfin, qui, sur le bruit qu'il connaissait le secret du grand-ouvre, fut renfermé par l'électeur de Saxe jusqu'à ce qu'il eût transmué des métaux; en découvrant la porcelaine, il dota la Saxe d'une industrie plus précieuse que l'art de faire de l'or. La plupart de ces chimistes connaissaient Boyle, et l'on doit s'étonner qu'aucun d'eux n'ait abandonné les doctrines alchimiques pour adopter une théorie plus conforme à la vérité.

Le paracelsisme fut sinon introduit, du moins répandu en France par Joseph Duchêne, médecin de Henri IV, et y trouva un grand nombre de partisans. Riolan, qui s'était déclaré l'antagoniste de toutes les idées nouvelles, ne manqua pas d'attaquer la thérapeutique de Paracelse. Il combattit, avec son emportement ordinaire, l'emploi des préparations pharmaceutiques empruntées au règne minéral; et son influence était si grande qu'il fit interdire par la faculté un médecin paracelsiste, nommé Mayerne, et obtint du parlement la déclaration que, dans tous les cas, l'antimoine est un poison.

Les paracelsistes n'étaient cependant pas tous exclusifs; il y avait parmi eux beaucoup d'hommes vraiment instruits, et la France peut revendiquer l'honneur d'avoir vu naitre ou d'avoir accueilli dans son sein Béguin, Davidson, Lefèvre, dont les ouvrages jouirent d'un succès mérité; Sylvius, Digby, Glazer et Lemery, son élève. Ce dernier chimiste, quoique fondant ses explications sur le paracelsisme et sur le cartésianisme, fut longtemps classique; et Homberg, tout en suivant la même voie, fut plus savant que ses prédécesseurs.

Jean Rey, médecin du Périgord, écrivit, en 1630, une petite brochure, dans laquelle il expliqua, par une théorie semblable à celle de Lavoisier, la cause de l'augmentation du poids des métaux par la calcination; aussi lorsque ce dernier publia sa découverte, lui opposa-t-on la théorie de Rey.

En Angleterre, nous trouvons à la tête de la science Boyle, qui appliqua à la chimie la méthode expérimentale de Bâcon , c'est-à-dire qu'il commença par de nombreuses expériences pcur en tirer des déductions. II s'occupa de l'influence de l'air dans la respiration et la combustion, et fit servir à ses expériences la cuve pneumato-chimique; il reconnut l'augmentation du poids des métaux par la calcination, sans se rendre uII 
compte exact de ce phénomènc, qu’il attribuait à la fixation du feu et de la flamme rendus pondérables; mais ses travaux firent à peine sensation à l'époque où ils parurent; et la chimie suivit son ancienne routiue. Cependant l'école anglaise était dans la meilleure voie; et si tous les chimistes en eussent suivi les traces avec persévérance, il en fùt résulté une régénération complète de la science.

Mayow, enlevé aux sciences à la fleur de son âge, a laissé dans ses écrits la relation d'expériences fort intéressantes sur le rôle de l'air dans la combustion et la respiration, phénomènes qu'il attribuait à un principe appelé par lui sel nitro-aérien, correspondant à l'oxygène, et qu'il considérait comme la cause de la formation des acides, de la combustion et de la motilité animale.

Dans le cours du xvi ${ }^{\mathbf{e}}$ siècle, l'anatomie descriptive avait fait de rapides progrès. Affranchie des erreurs du galénismè, cette science avait marché à pas de géant dans la voie des découvertés; mais le xvin préluda par une conquête qui forme dans la science une ère nouvelle : nous voulons parler de la circulation du sang.

L'Angleterre, qui n'avait joué jusqu'alor's qu'un rôle secondaire dans les révolutions scientifiques de l'Europe, se trouva tout-à-coup illustrée par la grande découverte d'Harvey. Ce célèbre anatomiste, élève de Fabrizio d'Aquapendente, avait assisté son maître dans ses recherches sur les valvules des veines; il fut frappé de la direction constante de ces valvules vers le cœur, et en conclut qu'elles servaient à diriger le sang vers cet organe. Le premier pas fait, la seule inspection des valvules qui garnissent les artères à leur départ du cœur lui prouva que le sang est porté de celui-ci dans les vaisseaux artériels. Le principe de la circulation démontré par Harvey avait déjà été entrevu par l'infortuné Servet, par Colombo, par Césalpin; mais ces auteurs n'en avaient qu'une idée vague, confuse, qu'il eut la gloire de développer. L’envie se déchaîna contre lui, plusieurs anatomistes cherchèrent à lui enlever le mérite de ses observations. Ses contradicteurs luttèrent en vain; ils ne tardèrent pas à se voir condamnés au silence, et sa découverte fut unanimement adoptée.

Harvey compléta les travaux de Fabrizio sur le développement du poulet dans l'œuf; il avait écrit sur l'embryologie un traité plein d’idées neuves qui eût suffi à son illustration. On trouve dans ses écrits les premières lueurs de la théorie des inégalités de développement. Il avait composé un ouvrage sur la génération des insectes; mais cet ouvrage 
fut perdu dans le pillage de sa maison, à la chute de Charles $I^{e x}$, dont il était devenu le médecin, et qui l'avait beaucoup favorisé. Harvey, trop âgé pour recommencer ses travaux, ne put réparer cette perte.

La France comptait alors parmi ses anatomistes le célèbre Riolan qui passa toute sa vie à lutter contre les modernes, en faveur des anciens, et contredit, non par ignorance mais par envie, la découverte d'Harvey. Ne pouvant contester un fait admis par tous les savants, il nia qu'il y eût une circulation dans les vaisseaux capillaires; question qui, du reste, n’est pas encore résolue.

Jacques Primerose, élève de Riolan, fut un des antagonistes les plus acharnés de Harvey. Les défenseurs de la circulation, Georges Ent et Willis, contribuèrent beaucoup à faire adopter les doctrines de l'anatomiste anglais.

Les autres découvertes de ce siècle ne sont pas moins importantes: $\Lambda$ selius retrouva dans l'homme les vaisseaux lactés, dont le souvenir s'était perdu depuis Érasistrate; Wirsung fit connaître le canal pancréatique. En 1650, Pecquet rectifia les fausses idées de son époque en démontrant que le sang ne se forme pas dans le foie, et que le chyle est conduit aux veines par le canal thoracique, réunion de tous les vaisseaux lactés, pour être de là conduit par la veine sous-clavière au cour et non al foie, ainsi qu'on le croyait alors. Riolan ătaqua encore la découverte de Pecquet; mais les expériences de Van Horn la confirmèrent.

Olaüs Rudbeck et Th. Bartholin, tous deux médecins suédois, se disputèrent la découverte des vaisseaux lymphatiques du foie, du thorax, des lombes et du réservoir du chyle, ainsi que celle de la circulation de la lymphe dans l'économie animale. On croit devoir rendre à Rudbeck l'honneur de cette découverte, et l'on suppose que Bartholin en avait eu connaissance par un de ses élèves.

Sténon, disciple de Th. Bartholin, continua d'étendre la découverte des vaisseaux lymphatiques, et essaya le premier de calculer les forces mécaniques des muscles. Il fit connaître les ossements fossiles qui se trouvent en abondance dans le val d'Arno.

Le système nerveux, à peine connu des anciens, étudié d'une manière superficielle par les anatomistes du moyen-âge et du $x^{2} I^{\mathrm{e}}$ siècle, le fut plus sérieusement vers le milieu du xvir ${ }^{\mathrm{e}}$. Wepfer et Schneider (de 1658 à 1668) rectifièrent les idées des anciens sur la prétendue communication du cerveau avec la cavité nasale, sur la nature du nerf olfactif, el 
sur l'usage des ventricules du cerveau qu'ils regardaient comme le siége de l'âme.

Willis étudia le cerveau avec beaucoup de soin, en perfectionnant la méthode de Varole. Ses idéns sur les fonctions de cet or'gane se rapprochent de celles de Gall ; non-seulement il le considère comme le siége de l'intelligence, mais encore il localise les facultés, met la mémoire dans les replis des hémisphères, l'imagination dans le corps calleux et la perception dans le corps strié. Il a donné une figure de l'appareil nerveux bien supérieure à celle de Vésale.

Vieussens, médecin de Montpellier, consigna ses découvertes. sur le système nerveux dans un ouvrage intitulé : Nevrographia universalis. Il avait une méthode de dissection préférable à celle de Willis. Cet anatomiste était partisan des idées physiologico-chimiques de Sylvius.

Malpighi, professeur à Bologne et à Pise, quoique attaché encore à l'école de Sylvius, fit faire un pas immense à la science enappliquant le microscope à l'étude de la structure intime des organes; mais, par suite d'une erreur difficile à comprendre, il croyait tous les tissus composés de petites glandes; et cette opinion domine tous ses écrits. Ses travaux sur les poumons, les systèmes nerveux et veineux, le tissu tégumentaire et les viscères, s'appliquent à divers animaux aussi bien qu'à l'homme. Il publia le premier une anatomie du ver à soie et de son insecte parfait; il fit connaître que, dans les animaux de cette classe, la respiration a lieu par des stigmates aboulissant à des vaisseaux contournés en spirale, appelés trachées, et que l'air, au lieu de se rendre dans un réservoir commun, est distribué dans toutes les parties du corps. II suivil avec une patience admirable ce même insecte dans ses métamolphoses, et fit l'anatomie des organes qui se développent successivement dans le papillon, pendant ses transformations. Il appliqua le microscope à l'observation du développement du poulet dans l'œuf, et en donna une représentation exacte.

Ruysch, professeur d'anatomie à Amsterdam en 1665, contribua aux progrès de la science par ses admirables injections dont il emporta le secret dans la tombe. On a de lui des travaux monographiques estimés sur des questions isolées d'anatomie. Il fit plusieurs découvertes sur la structure intime des organes, constata le premier que dans l'homme, destiné à se tenir debout, la distribution des vaisseaux sanguins est différente de celle des animaux dont la station est horizontale, et il découvrit, au moyen des injections, que la substance corticale du cerveau 
est un lacis de vaisseaux et non une masse glanduleuse, ainsi que le prétendait Malpighi ; aussi fut-il un des plus ardents antagonistes du système de cet auteur, qu'il attaqua dans toutes les occasions. On peut le considérer comme une des illustrations du xvir ${ }^{\mathrm{e}}$ siècle.

Leuwenhoek, né à Delft en 1638, était un homme de peu d'instruction, mais doué d'une patience qui lui permit de faire les observations les plus minutieuses, au moyen de lentilles qu'il polissait avec une perfection admirable. Il fit connaitre la composition globuleuse des fluides animaux, révéla à la science les innombrables animalcules qui les peuplent, étudia la structure des poils, celle de la fibre musculaire, découvrit les pores de l'épiderme, observa la circulation dans les animaux transparents, et connut la multiplication de plusieurs générations de pucerons par une seule fécondation et celle des polypes par bourgeons.

Toutes ses observations indiquent une patience infatigable; mais il s'est plusieurs fois laissé entraîner par son imagination; ce qui arrive trop souvent aux micrographes.

Redi, d'Arezzo, publia, en 1664, de belles recherches sui le venin des vipères; mais son travail capital a pour objet le développement spontané des insectes dans les substances putréfiées et des helminthes dans le corps des animaux. Il se prononça pour la négative, et son opinion fut adoptée par la plupart des savants, quoique la grave question des généralions équivoques soit encore un mystère pour tous les hommes qui recherchent la vérité sans se laisser égarer par des hypolhèses. Tous les travaux de Redi sur les questions d'anatomie et de physiologie indiquent un esprit judicieux et un bon observateur. Grew est un anatomiste comparateur, dont les travaux ont servi de base aux diverses théories proposées de son temps sur la digestion.

Needham, Nuck, Warton, Graaf, Drelincourt et Bidloo, sont encore des anatomistes de cette époque. L'ouvrage de ce dernier est accompagné de belles planches dessinées par Guillaume de Lairesse. Perrault, le célèbre architecte à qui l'on doit la colonnade du Louvre, a publié quelques travaux anatomiques qui font voir qu'il était animiste, et considérait le jeu des organes sous le point de vue physique et mécanique. Lorenzini de Florence, Caldesi, médecin toscan, Tyson, de Londres, Muralto, de Zurich, et Schellhammer, de Helmstadt, se sont occupés de monographies anatomiques. C'est alors seulement qu'a commencé l'étude sérieuse des animaux invertébrés. Martin Lister, médecin de la reine Anne, a laissé, sous le titre d'Fxercitatio anatomica, des re- 
cherches anatomiques sur certaines espèces de mollusques nus ou à coquille.

Swammerdam est un des plus habiles observateurs du xvir ${ }^{\mathrm{e}}$ siècle. Il a écrit une histoire générale des insectes, pleine de recherches intéressantes sur la structure intime de ces animaux, dont il a suivi les métamorphoses avec une étonnante sagacité. On a de lui une anatomie du pou, du limacon, que de son temps on comptait encore parmi les insectes, du scarabée nasicorne, de l'abeille, du taon, etc. Les travaux de Swammerdam sur la chenille et le papillon sont admirables. En suivant les métamorphoses des insectes, il a, le premier, démontré que la chrysalide existe toute formée dans la chenille, à l'époque où doit s'opérer sa métamorphose, et que le papillon existe dans la chrysalide avec les organes qui lui sont propres. Cette observation eut une grande influence sur les idées relatives à la génération, et jeta les fondements du système de l'évolution. On a aussi de lui quelques traités séparés d'anatomie humaine.

A ces travaux d'observations, presque toujours dominés par les théories de l'époque, s'unissent des travaux spéciaux dans un but philosophique.

Sylvius Leboë, professeur de médecine à Leyde en 1658, fut le créateur d'une application à la physiologie de la chimie, étudiée d'après les principes de Descartes. Il réduit tous les phénomènes à de la chimie pure; et ne voil dans les fonctions des viscères que des opérations semblables à celles qui ont lieu dans un laboratoire. Son système fut longtemps à la mode; et, en le simplifiant, Otto Tackenius, un de ses élèves, perpétua ses erreurs dans les écoles de médecine, jusqu'à la moitié du xvin ${ }^{\mathrm{e}}$ siècle.

Glisson, médecin anglais, rejeta la théorie purement physique du mouvement des muscles, et leur reconnut la propriété qu'il appela irritabilité, nom qui a été conservé à ce phénomène. Il étudia avec soin les contractions musculaires tant extérieures qu'intérieures.

Borelli de Florence publia, en 1681, un ouvrage sur les fonclions physiques des muscles, travail remarquable, en ce qu'il s'applique aux animaux de toutes les classes. Il reconnaît que, parsuite de la position désavantageuse des muscles, il faut, pour exécuter le moindre mouvement et soulever un poids léger, une dépense de force bien supérieure à la résistance à vaincre; mais il montre en même temps que la nature n'a pu procéder autrement. Chaque fois que Borelli sort de la thćorie du levier, ses explications perdent de leur justesse, el il avance parfois des 
idées étranges; il dit, entre autres choses, que par l'effet de la volonté et de l'habitude nous pourrions maitriser les mouvements physiques du cœur. Sa théorie de la contraction des muscles n'est pas aussi satisfaisante que la partie purement mathématique de ses travaux.

Laurent Bellini, disciple de Borelli, et Pitcairne, médecin d'Edimbourg et professeur à Leyde, furent aussi des iatro-mathématiciens, mais d'une moindre portée que Borelli; et leurs expériences ne sont nullement concluantes; ils ne tenaient aucun compte des forces vives des muscles, et les comparaient aux forces mortes. Pitcairne pensait que la chaleur animale est le résultat d'un simple frottement, et que la force vitale n'est autre que celle du cœur. Toutes ces théories pèchent par leur caractère absolu, et les explications qui en découlent sont presque toujours absurdes.

Jusqu'au commencement du dix-septième siècle, les savants avaient travaillé isolément, et ne devaient souvent leur position qu’à la faveur d'un souverain ou d'un prince. Les avantages qui devaient résulter pour la science, d'une simultanéité d'efforts, les déterminèrent alors à se réunir' en sociétés nommées académies. Nous trouvons en Italie l'académie des Lyncées, établie en 1603. Vers 1648, au milieu de la révolution qui précipita Charles Ir du trône, se constitua la Société-Royale de Londres, qui, interrompue pendant le paroxisme de la fièvre révolution naire, reprit ses travaux à la restauration de Charles II. Un des élèves de Galilée établit à Florence, en 1651, l'académie del Cimento, ou de l'Expérience. En 1652, un médecin de Schweinfurt, nommé Bausch, fonda l'académie impériale des Curieux de la Nature, qui siège aujour d'hui à Bonn. L'Académie des Sciences de Paris ne fut régulièrement constituée qu'en 1666, mais elle remonte plus haut. Dans ces sociétés, les travaux sont régularisés, et les efforts réunis des savants ont le double avantage de prévenir l'extinction des lumières et d'en amener la diffusion. Comme complément nécessaire de ces créations utiles se présente l'établissement de musées destinés à favoriser les travaux des savants auxquels est refusée la facilité de voyager.

Partout on s'occupe de science, et les terres du Nouveau-Monde, sillonnées pendant un demi-siècle par d'avides conquérants ou d'audacieux aventuriers, deviennent aussi le théâtre d'observations scientifiques.

La colonie formée par les Hollandais dans la province de Pernambouc, au Brésil, produisit un travail d'une haute importance, celui de Marggraf, qui parut en 1648, sous le titre d'Histoire naturelle du Brésil. Pi- 
son, médecin de l'expédition, a publié sur le même sujet un ouvrage peu méthodique. On eut alors pour la première fois la description avec figures de l'ananas, du cactus, de la grenadille, du manioc, végétaux d'un grand intérêt à cause de leur nouveanté; l'on joignit aux mammifères connus le fourmilier, le tapir, dont la lèvre supérieure, prolongée en une sorte de petite trompe, rappelle l'éléphant, le coëndou, le lama, le cabiai et le jaguar; aux oiseaux, le kamichi, dont les ailes sont armées d'éperons, le toucan, au bec monstrueux, etc. L'erpétologie, l'ichthyologie et l'entomologie s'enrichirent également d'un grand nombre d'espèces nouvelles.

Le prince de Nassau, gouverneur de la colonie, envoya au gouvernement deux recueils de figures, peintes avec soin, qui servirent à illustrer les ouvrages de Marggraf et de Pison.

Un défaut capital dans ces publications, et qui peut avoir de graves inconvénients pour l'étude, c'est que Marggraf, Pison et Laëı ont souvent fait servir les mêmes planches pour représenter des objets n'ayant que de la similitude. Laët était directeur de la Compagnie des Indes, et a écrit, avant Marggraf et Pison, un ouvṛage sur le même sujet, et digne d'estime quoique moins important.

Bontius (1631) a laissé sur les Indes Orientales un travail qui fait connaître le tigre royal, le babiroussa aux défenses retroussées, le casoar à crins au lieu de plumes, le rhinocéros de Java, le dronte, oiseau lourd et massif qu'on croil avoir complétement disparu, et l'orang-outang. On lui doit, en botanique, la description du cannellier, de la noix muscade et du monstrueux coco des Maldives. Son ouvrage, quoique plus faiblement écrit que celui de Marggraf, n'en est pas moins d'un grand intérêt. Bernier, médecin d'Aureng-Zeb, a consigné dans la relation si intéressante de son séjour en Asie, des descriptions de plantes et d'aninimaux qui peuvent encore être consultées avec avantage.

Gaspard Schwenkfeld décrivit les animaux de la Silésie; Merrett, les productions naturelles de la Grande-Bretagne; Wagner, celles de Ia Suisse. Sibbald écrivit une histoire naturelle de l'Écosse et un livre très curieux sur les cétacés qui de son temps échouaient fréquemment sur les côtes. Neuhof nous a fait connaître l'histoire naturelle des Indes orientales, et Dutertre, celle des Antilles.

En 1649, Jonston, naturaliste polonais, publia un grand ouvrage où il résume, en les récapitulant, tons les travaux qui ont paru jusqu'au milieu du xvir siècle. C'est un compilateur laborieux, mais d'une 
critique peu sévère; il fait souvent mention d'animaux fabuleux et semble même s'être complu à rassembler des faits extraordinaires.

Nieremberg, jésuite espagnol, a, comme Clusius et Jonsıon, écrit un ouvrage dans lequel il résume les connaissances de son époque; mais on Iui doit de plus la description de plantes et d'animaux nouveaux.

Après lui paraît Fabius Colonna, devenu raturaliste et médecin, par suite de l'idée qu'il se guérirait d'une épilepsie qui le tourmentait beaucoup, s'il retrouvait la plante que les anciens considéraient comme un spécifique contre cette maladie. Il commença par étudier la botanique, puis la zoologie, et il a laissé sur les mollusques un travail très remarquable pour son temps. Les planches qui accompagnent son texte sont fort belles, comme toutes celles de cette époque.

Olina était un ornithologiste d'un grand mérite, dont l'ouvrage est fort estimé sous le rapport graphique. Un médecin anglais, Th. Moufet, s'est occupé avec succès d'entomologie. On a de lui le Theatrum insectorum, qui ne fut publié qu'après sa mort. Sa classification est judicieuse; mais la science était trop neuve encore pour qu'on pût espérer un travail parfail; cependant on trouve dans Moufet d'excellents renseignements.

La fin du xviı ${ }^{e}$ siècle ne nous offre comme naturalistes classificateurs d'une haute portée que Jean Ray et François Willughby, qui ont toujours travaillé en commun.

Jean Ray esı le premier naturaliste qui ait modifié la classification d'Aristote, et sa méthode a servi de modèle à tous les classificateurs venus après lui. Il partil du même point que le Stagyrite, en adoptant pour caractéristique d'une partie des mammifères la forme des pieds; mais il y joignit les caractères tirés des dents. Sa distribution des quadrupèdes ovipares est encore suivie aujourd'hui; seulement il réunit les salamandres aux lézards au lieu de les rapporter aux grenouilles.

Willughby, dont les ouvrages ont été publiés par Ray qui y avait appliqué sa méthode, fit pour les oiseaux ce que son ami avait fait pour les mammifères; mais on trouve dans cet ouvrage peu d'observations qui appartiennent à l'auteur. Il jeta les bases d'une classification fondée sur la forme du bec et des ongles pour les oiseaux terrestres, et sur celle des jambes et des pieds pour les oiseaux aquatiques. Linné n'y apporta que quelques modifications insignifiantes; et, jusqu’à ce jour, les Anglais ont conservé la méthode de Ray. 
Willughby s'occupa aussi d'ichthyologie; et, en 1686, la Société royale de Londres publia son Historia piscium dont la mise en ordre appartient. à Ray. Cet ourrage est bien au-dessus de son ornithologie, en ce qu'il a beaucoup observé par lui-même. Il joignit aux figures empruntées aux ichthyologistes anciens, tels que Rondelet, Aldrovande, Belon et Marcgrav, $n$ grand nombre de planches qui lui appartiennent. Sa classification, la seule suivie jusqu'à ce jour, n'a subi d'autres modifications qu'un simple changement dans les noms : ses cartilagineux sont les chondroptérygiens; ses osseux sont divisés d'après leur forme: les ronds sont les anguilliformes, et les plats avec une nageoire ventrale sont les malacoptérygiens ou à rayons mous, et les acanthoptérygiens ou à rayous épineux. Willughby avait seulement, suivant la coutume, rapproché les cétacés des poissons. Son ichthyologie a été compilée, jusqu’à Cuvier, par tous ceux qui ont écrit sur cette matière.

Nous avons parlé avec éloge de Swammerdam comme anatomiste; mais, comme classificateur, il est fort incomplet, et l'on ne trouve de méthode générale de classification des insectes que dans Ray, dont le travail fut publié en 1710. Sa méthode entomologique porte le même caractère de précision que ses autres travaux, et a servi de base à notre classificalion actuelle.

Nous voyons que les sciences abandonnent peu à peu l'Italie pour se répandre en Europe, et que la France et l'Angleterre, malgré les guerres qu'elles eurent à soutenir, prennent une large part aux travaux généraux de l'époque. L'Allemagne, déchirée par des guerres intestines, ne paraît qu'à de rares intervalles sur la scène scientifique. Quant à l'Espagne et au Portugal, courbés sous le joug du despotisme inquisitorial et de la superstition, ils restent étrangers au mouvement des esprits.

La botanique, qui, dans le cours du xvi ${ }^{e}$ siècle, comptait beaucoup de descripteurs, n'avait fait que peu de progrès sous le rapport de la connaissance de la structure intime des plantes. L'anatomie végétale attendait, pour sortir du néant, l'invention du microscope. En 1661, Henshaw, de la Société royale de Londres, découvrit les trachées des végétaux à l'aide de cet instrument perfectionné par Hook; mais les essais de cet observateur ne furent que le prélude de découvertes importantes, dues surtout à Grew et à Malpighi.

En 1682, Grew publia un traité de l'anatomie des plantes, dans lequel il indiqua le tissu végétal comme composé de cellules qui en forment le fond. Il reconnut les vaisseaux et les fibres qui le traversent, 
ainsi que les vaisseaux propres où s'élaborent les sucs nécessaircs à la vie de la plante; il confirma l'existence des trachées, et découvrit les pores corticaux. Malpighi étudia avec succès la structure intime des végétaux el surtout la germination; il connut fort bien le mode d'accroissement du tissu lignèux; mais, entraîné par la similitude des trachées des plantes avec celles des insectes, il les prit pour des organes de respiration. Ses opinions erronées en physiologie végétale viennent de ce qu'il cherchait un rapprochement entre la structure des végétaux et celle des animaux.

Une découverte d'un plus grand intérêt encore fut celle du sexe des plantes, entrevu par Zaluzianski dans le cours du siècle précédent, mais dont les premières idées formelles appartiennent aux Anglais. Millington, professeur à Oxford, l'avait déjà indiqué; Gr'ew avait défendu l'importance des anthères comme organes fécondateurs; Bobart l'avait mise hors de doute par des expériences sur le Lychnis dioica. En 1685, Ray appuya de l'autorité de son nom la théorie du sexe des plantes. Depuis que cette vérité eut pénétré dans la science, les botanistes de tous les pays s'occupèrent d'expériences tendant à la confirmer. En 1694, Camerarius, professeur à Tubingue, en parla dans une thèse, et vérifia la nouvelle découverte par de nombreuses expériences sur la fécondation du chanvre. En 1697, Boccone, naturaliste sicilien, en fit autant pour le palmier. Tournefort et Malpighi repoussèrent cependant cette doctrine; ce dernier considérait les étamines et les anthères comme de simples organes excrétoires. Malgré son erreur, le naturaliste de Bologne n'en est pas moins l'un des plus savants phytologistes de la fin de ce siècle.

On doit à Leuwenhoek d'excellents travaux micrographiques su' l'anatomie végétale. Il avait aperçu, mais mal formulé, la distinction, aujourd'hui fondamentale en botanique, des végétaux à fibres longitudinales et éparses qui correspondent à nos monocotylédones, et à fibres rangées par cercles concentriques qui sont nos colylédones. Sa théorie de l'évolution des plantes ne fut point adoptée, faute de développements convenables. Un grand tort de Leuwenhoek est de n'avoir pas coordonné ses observations, qu'il faut chercher éparses dans ses lettres à la Société royale de Londres.

Claude Perrault confirma l'existence de la sève descendante. Dodart chercha sans succès la loi en vertu de laquelle le végétal dirige toujours ses tiges vers le ciel et ses racines vers le centre de la terre; 
il essaya d'analyser les végétaux par le feu; mais Mariotte mil fin ì ces essais inutiles, en démontrant aux botanistes que cette méthode ne pouvait les conduire à aucun résultat.

Woodward répéta les expériences de Van Helmont, qui tendaient à prouver que les végétaux subsistent avec de l'air et de l'eau senlement; ou, en d'autres termes, que la plante décompose l'eau et l'acide carbonique, pour en extraire le carbone et l'hydrogène.

Nous avons vu, dans la partie de ce travail relative à la zoologie, que Kay avait établi une méthode sur tous les embranchements des sciences naturelles. Il vint tirer la science taxonomique du chaos dans lequel elle était plongée, et il se place encore à la tête des classificateurs du xvıI ${ }^{\mathrm{e}}$ siècle; car nous ne trouvons, après l'essai de Bauhin, d'autres systèmes botaniques que ceux encore bien arbitraires de Johnston et de Morison. On reconnaît dans sa méthode le prineipe dicholomique; il prend pour base de ses divisions le nombre et la forme des pétales, la quantité des semences, la nature du péricarpe, etc.; mais, entraîné par la routine, il sépare encore les végétaux ligneux des plantes lierbacées.

Magnol développa avec sagacité, dans son Prodrome d'une histoire générale des plantes, les principes sur lesquels doit être établie une méthode naturelle; mais, dans l'application, il s'en écarta sans cesse, et longtemps après il publia un système tout artificiel.

Malgré l'imperfection de son système, Rivin fut le seul botaniste de son temps qui ne séparât pas les végétaux ligneux des plantes herbacées; ce qui était déjà un grand progrès. La simplicité de sa méthode la fit adopter par un grand nombre d'auteurs, surtout en Allemagne.

Pitton de Tournefort publia, en 1694, ses Institutiones rei herbaria, dans lesquelles il donna un système entièrement fondé sur l'absence ou la présence de la corolle, sa configuration, le nombre de ses divisions et son mode d'inflorescence; on y trouve un certain nombre de familles naturelles. Malheureusement, il ne donna aucune importance aux affinités qui unissent les plantes herbacées aux végétaux ligneux, et il en forma deux groupes distincts. Le petit nombre de plantes qu'il connaissaill'empêcha de perfectionner son système, dans lequel ne peuvent entrer la plupart de celles qui ont été récemment découvertes. La forme attrayante des ouvrages de Tournefort el la lucidité de ses démonstrations lui vatlurent une réputation qu'éclipsèrent à peine les admirables travaux des phytologistes du xvm ${ }^{e}$ siècle; car la phupart des botanistes adoptèrent 
ses idées, et jusqu'en 1740, l'Académie les suivit dans ses Mémoires. Tournefort eut, en outre, le mérite d'avoir le premier fixé l'idée des genres en botanique et d'en avoir donné d'excellents modèles dans ses Institutiones rei herbaria.

La botanique s'enrichit, dans le cours de ce siècle, des découvertes faites par les voyageurs. Hermann décrivit les plantes du Cap de Bonne. Espérance et de Ceylan; Kæmpfer rassembla dans ses Amceritates exo ticce le résultat de ses observations faites au Japon et en Asie. Tournefort et Shérard parcoururent, surtout en botanistes, la Grèce et l'Asie-Mineure; Banister visita l'Amérique; Van Rheede décrivit les plantes des Moluques et celles du Malabar, et Rumph celles d'Amboine. Plumier fit connaître les végétaux des Antilles. Sloane parcourut la Jamaïque, et en rapporta une nombreuse collection de plantes; on vit paraître des fiores générales et particulières de toutes les parties de l'Europe. Barrelier publia une flore du midi de l'Europe, contenant environ 1400 végétaux, et Loesel, une flore de Prusse. Ce fut lui qui employa le premier le nom de flore.

Les jardins botaniques, ces puissants auxiliaires de la science, étaient nombreux en Italie et en Hollande. Montpellier avait eu le sien; mais Paris en manquait; ce ne fut qu'en 16 4, après huil années d'instances, que Guy de la Brosse y en établit un, qui, par des agrandissements successifs, est devenu notre célèbre Jardin des Plantes. L'Allemagne en fonda aussi quelques-uns, ainsi que l'Espagne et le Portugal.

Vers la fin du $\mathrm{xvir}^{\mathrm{e}}$ siècle, nous avons peu de progrès à signaler en minéralogie et en géologie.

Scilla, peintre napoỉitain, défendit en 1670, dans un ouvrage fort remarquable, l'opinion de Bernard Palissy sur les coquilles fossiles, el trouva pour contradicteurs le célèbre conchyliologiste Martin Lister, el Edouard Lhuyde.

Cesius, Georgius de Stockholm et Aldrovande ont écrit sur la minéralogie en classificateurs. Ils divisent les minéraux en terres, sucs concrets, pierres et métaux; leurs idées souvent raisonnables sont mèlées aux erreurs de l'alchimie et de la cabale.

Ce siècle, qui avait si bien commencé à seconer le joug qui écrasait la pensée, s'était peu à peu assez émancipé pour laisser un libre cours à son imagination; et, quoique la minéralogie fùt daus l'enfance, que la géologie n'existât pour ainsi dire pas, nous trouvons plusieurs théories sur l'origine de la terre. Thomas Burnet et Jean Ray publient deux theories 
génésiaques, dans lesquelles ils cherchent à expliquer le déluge et la conflagration du globe à la fin des siècles.

Leibnitz, partant de l'opinion de Descartes, qui faisait de notse planète un soleil éteint, admit dans son Protogea que la terre, enveloppée d'une croûte épaisse dont la chaleur centrale ne pouvait empêcher le refroidissement, avait vu les eaux se former à sa surface par suite de la condensation des vapeurs qui l'entouraient à l'époque de son incandescence; il suppose qu'attaquant les diverses parties du noyau vitrifiable, elles changèrent successivement de nature, et déposèrent les montagnes secondaires. Suivant cet auteur, c'est dans les profondeurs des mers qu'auraient vécu les animaux dont nous trouvons les restes dans les dépôts de seconde formation.

A Leibnitz succéda Whiston, qui publia aussi, en 1698, une théorie de la terre. Quoiqu'il se renferme dans le même cercle d’idées que Burnet, il se montre plus rationnel. D’après lụi, la terre, née de l'atmosphère d'une comète, ne vit les êtres organisés s'établir à sa surface qu'après avoir été retenue dans une orbite qui en égalisa les saisons. Les matières qui constituent le globe et son atmosphère sortirent alor's du chaos et se rangèrent dans l'ordre de leur pesanteur. Il donne pour cause au déluge la rencontre de la terre avec la queue d'une comète qui noya tous les êtres vivants, et il explique la disparition des eaux par delarges ouvertures qui se formèrent dans la croùte terrestre et les absorbèrent.

Woodward fut le dernier géologue de ce siècle. Son hypothèse, toute génésiaque, est insoutenable; mais il a le mérite d'avoir développé mieux que ses prédécesseurs l'histoire des conches de la terre.

On n'a pas rendu au xvi e siècle la justice qui lui est due, et l'on attribue au xvır une influence sur le développement de la pensée qui ne fut que le résultat des travaux du siècle antérieur. C'est dans le cours de ce siècle encore absorbé par les travaux d'analyse, mais qui a déjà ouvert les portes de la synthèse, que les théories scientifiques, fécondées par les plus heureuses découvertes, prennent une forme plus positive, et que se préparent tous les travaux qui font la gloire du siècle présent. 


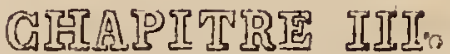

\section{tat des sciences naturelles depuis le commencement du xvirı siècle jusqu'en 1789.}

Plus nous approchons de l'époque contemporaine, plus l'analyse des travaux en histoire naturelle devient difficile. Non seulement toutes les branches de la science se perfectionnent, mais encore le champ s'en agrandit, et l'on en voit se développer dont nous avons à peine entrevu le germe. Le xviri siècle est pour les sciences une des époques les plus lécondes. Une activilé fébrile s'est emparée de tous les esprits : dans le silence du cabinet, dans les académies, dans les laboratoires, dans les champs, dans les forêts, au sein des mines, sur les eaux, des hommes laborieux travaillent avec un accord admirable au grand-ceuvre, à l'union des peuples par la science. D'intrépides voyageurs parcourent toutes les parties du globe : les uns gravissent les sommets glacés des monlagnes pour en mesurer les hauteurs; les autres s'égarent dans les forêts vierges, dans les savanes du Nouveau-Monde, ou dans les steppes inhospitalières de la Tartarie; d'autres encore bravent les climats brûlants et meurtriers des tropiques, les âpres frimas du nord, ou les dangers d'une longue navigation dans des parages inconnus; tous veulent enrichir la science de leur's découvertes.

Anson, Wallis, Carieret, Vancouver, Cook, Bougainville, Lapeyrouse, parcourent les mers et découvrent des terres et des productions nouvelles. Pallas, Gmelin, Messerschmidt, Steller, explorent la Russie et la Sibérie; Gulden, le Caucase; G. Shaw, la Nouvelle-Hollande; le père Labat, les Antilles; Osbeck, la Chine; Olivier et Chardin, la Perse; Sonnerat, la Nouvelle-Guinée et les Indes-Orientales; Hasselquist, Forskal, l'Arabie et la Syrie ; Levaillant, Sparrmann, l'Afrique méridionale; Adanson, le Sénégal; Olafsen, I'Islande; Thunberg, le Japon; Bruce, l'Abyssinie, etc.

Les collections s'augmentent et se multiplient; les musées, les ménageries s'établissent; on crée de nouveaux jardins botaniques, et partout les corps savants s'organisent.

Les souverains eux-mêmes prennent part à l'aclivité générale. 
Louis XIV et ses strccesseurs se déclarent protecteurs des sciences, et leur exemple est suivi par les autres princes de l'Europe. En Angleterre, Charles II encourage la Société de Londres, établie pendant les troubles de la révolution. George III ordonne des circumnavigations, el crée l'un des plus beaux jardins botaniques de l'Europe. En Suède, Christine accueille les savants, encourage leurs efforts, et la science récompense généreusement son hospitalité. En Danemark, Frédéric V fait exécuter des voyages de découvertes. La Russie, elle-même, apparaît pour la première fois sur la scène, et se mèle avec intelligence aux travaux scientifiques de cette époque. Pierre $\mathrm{I}^{\text {er }}$ établit à Saint-Pétersbourg une académie; et, comme il ne trouve pas parmi son peuple d'hommes capables d'y siéger, il y appelle des étrangers. L'impératrice Anne et Catherine II continuent à encourager les sciences; et c'est d'après leurs ordres que Gmelin et Pallas font connaître au monde savant les productions naturelles de la Sibérie. En Prusse, Frédéric I ${ }^{\text {er }}$ élablit l'académie de Berlin qui, sous Frédéric II, obtient de grands encouragements. En Autriche, François $I^{\text {er }}$ et Marie-Thérèse favorisent les prògrès des sciences, et la Hollande met à leur service ses plus grands artistes.

Le caractère le plus frappant du xvir ${ }^{\mathrm{e}}$ siècle, héritier des travaux du siècle précédent, est son allure libre et dégagée. Il accepte avec empressement l'émancipation que lui a léguée son devancier; et, sans se laisser arrêter par une autorité dont il ne connaît plus la voix, il pénètre au fond de toutes les questions et sonde tous les mystères; aussi le voyons-nous, dès ses premiers pas, reviser la cosmogonie génésiaque, faiblement défendue par les hommes de science, el que les orthodoxes eux-mêmes cherchent à faire concorder avec les connaissances de leur époque. Des cosmogonies, auxquelles la tradilion n'a nulle part, surgissent de tous côtés; l'homme cherche à pénétrer le mystère de son origine, en interrogeant les monuments du passé. Les physiologistes, élevés à l'école du doute, ne se contentent plus des vaines hypothèses par lesquelles on a cru, jusqu'à ce moment, expliquer le phénomène de la vie ; ils ont pénétré dans les profondeurs de l'organisation; et, sous le nom d'animistes, ils attribuent à une force particulière le phénomène des mouvements involontaires non perçus par l'intelligence ou, sous celui de sulidistes, ils en cherchent la cause dans la contractilité musculaire. Petr-à-peu le doute se formule et s'élève à l'état de doctrine : son expression la plus élevée est l'encyclopédie, qui paraît vers le milieu du 
xvrut $^{\mathrm{e}}$ siècle et fut le triomphe des penseurs. De profonds philosophes la dirigent et lui impriment un grand caractère d'unité. Ces vastes travaux portent bientôt des fruits : Locke et son école, qui enfanta le sensualisme en France, dissèquent la pensée et n'y voient qu'un jeu des organes; Mably, dans un autre ordre d'idées, est encore le champion de la pensée émancipée. Rousseau jette à la foule ses brillants paradoxes voilés sous la magie de son style. Enfin tous les travaux viennent se résumer dans une vaste et puissante synthèse qui domine toute la science.

L'abondance des matériaux ne nous permet pas de donner une esquisse étendue des travaux de ce siècle. Nous nous contenterons donc de tracer à grands traits les progrès des sciences, et nous ne nous arrêterons qu'à leurs plus brillants interprètes.

Astronomie. - L'astronomie, à laquelle les découvertes de Newton avaient imprimé une impulsion nouvelle, s'enrichit d'observations qui en augmentent l'exactitude. Keil, émule de Locke, professe pubiiquement, en 1704, la physique de Newton, et popularise ainsi les vérités répandues dans les ouvrages de ce grand homme, mais combattues par les ignorants et les envieux. Cette doctrine eut bientôt dans toute l'Europe le plus grand retentissement; cependant jusqu'au milieu du $\mathbf{x v m}^{\mathrm{e}}$ siècle, le cartésianisme en paralysa l'influence.

Halley découvre 350 étoiles australes; il constate le passage de Mercure sur le soleil, et développe la théorie de Newton sur les comètes. Bradley fait connaitre, en 1727, la cause de l'aberration de la lumière; et, quelques années plus tard, il explique le phénomène de la nutation de l'axe terrestre. Moskelin calcule la densité de la terre et trouve qu'elle n'est supérieure à celle de l'ean que de quatre fois et demie. Euler et Bernouilli, tous deux géomètres habiles, portent la lumière dans plusieurs parties obscures de la science. En 1736, La Condamine et Bouguer mesurent un degré du méridien sous l'équateur; Maupertuis, Clairaut, Camus et Lemonnier font le même travail au pôle arctique. D'Alembert publie ses recherches sur la précession des équinoxes.

Fontenelle, quoique n'étant ni physicien, ni astronome, fait pour les sciences physiques ce que Buffon fit pour les sciences naturelles; il en fait disparaître l'aridité et sait les populariser en les rendant aimables.

De 1750 à 1754, Lacaille fait un voyage au cap de Bonne-Espérance, et détermine la position de 9,800 étoiles situées autour du pôle austral. 
En 1780, Herschell calcule, d'après les observations faites avec son immense télescope, la hauteur des montagnes de la lune. Un an après, il découvre la planète Uranus, el aperçoit, en 1785, deux nouveaux saltellites de Saturne. Il étudie les étoiles, surtout celles qu'on nommedoubles et nébuleuses, la nature du soleil, la formation des corps célestes, etc.

Les découvertes que Newton avait léguées à ses successeurs étaient immenses : il leur avail laissé le soin de déduire les conséquences de la loi de gravitation; de rendre compte de toutes les inégalités des mouvements des planètes et de ceux de la lune, de trouver une démonstration de la stabilité et de la permanence de notre système, au milieu des influences qu'exercent sur lui les perturbations auxquelles il est sujet. Ce travail et la gloire qui s'y rattachait étaient réservés ill xvm ${ }^{\circ}$ siècle et furent successivennent partagés par Clairaut, d'Alembert, Euler, Lagrange, Herschell, Laplace, etc. Les recherches de Laplace et celles de Lagrange ont, entre autres, mis hors de doutc que la distance moyenne de chaque planète au soleil et par conséquent la durée moyenne de ses révolutions périodiques sont absolument invariables. Par la suite, nous mentionnerons d'autres découvertes faites

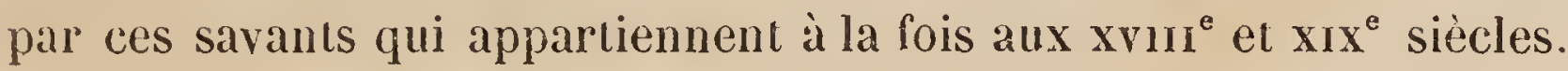

Météorologie. - La météorologie se lie intimement aux études de physique générale; mais les travaux spéciaux sur cette branche des sciences d'observations ont, pendant longtemps, été peu nombreux. Cependant, vers le milieu du xvı1 ${ }^{e}$ siècle, nous voyons les expériences se régulariser et la météorologie prendre place dans la science en se séparant de la physique. Demaison étudia les phénomènes de la congélation, et expliqua, d'une manière satisfaisante, l'augmentation de volume de l'eau solidifiée. Saussure se livra à des travaux intéressants sur la pluie les nuages et la formation des vapeurs. Franklin et Mairan observ rent les aurores boréales. Le premier découvrit l'identité de la foudre et de l'électricité. Il soutira aux nuages des étincelles électriques au moyen d'un cerf-volant, à la queue duquel était un fil de fer terminé en pointe. Il répéta les expériences faites avant lui, par Dalibard et Romas, sur le pouvoir des barreaux de fer pointus pour soutirer l'élec tricité des nuages orageux; mais c'est à lui qu'on doit la précieuse application de cette propriété à la préservation de nos édifices. Volta étudia la formation de la grêle; Dufay celle de la rosée; et Kraaf la vitesse des vents, et Halley, les effets du mouvement de la terre sur les 
vents. Pugh et Kirwan publièrent des travaux sur la température, et le dernier donna un essai sur les variations de l'atmosphère. Toaldo, Van Swinden, Réaumur, Mairan, Gautier, de Lalande, Mercier, Dampier, etc., s'occupèrent d'observations météorologiques. Duhamel du Monceau publia ses observations botanico-météorologiques; Malouin s'occupa de travaux médico-météorologiques; le P. Cotte fit de nombreux mémoires sur celte science, et se distingua par la précision de sa méthode. En France et en Angleterre, des registres soigneusement tenus apportèrent de la régularité dans les observations; enfin il s'établit sur plusieurs points des Sociétés de méléorologie.

Physique. - Les progrès de la physique furent rapides dans le xviı ${ }^{*}$ siècle; mais, de toutes les branches de celte science, l'électricité el le magnétisme furent celles qui se perfectionnèrent le plus. En 1729, Gray fit connaître un plus grand nombre de corps électrisables par le frottcment; il découvril les bons et les mauvais conducteurs de ce fluide, ainsi que le moyen de le développer dans les corps organiques. Wheeler partagea ses travaux. Desaguliers donna le premier le nom de conducteurs aux corps qui s'électrisent par communicaiion, et Dufây reconnut deux sortes d'électricités; il appela l'une viirée, parce qu'elle correspond à l'état électrique du verre, et l'autre résineuse, parce qu'elle se dégage de la résine. En 1746, Cuneus découvrit la bouteille de Leyde, et répéta ses expériences avec Musschenbroek; ce dernier alors compara la commotion produite par cette bouteille aux secousses vives que produisent la torpille, le gymnote et divers autres poissons; bientôt cet instrument fut perfectionné par Wilson; Watson et Bevis furent les premiers qui le garnirent à sa surface d'une feuille métallique, et qui imaginèrent les jarres électriques.

Boze, professeur à Wittemberg, perfectionna la machine électrique, en substituant un globe de verre au tube employé par Hawkesbee, et en y adaptant un conducteur métallique. Klingstierna et Stroema y ajoutèrent des frottoir's.

Nollet, expérimentateur intelligent, qui popularisa la physique générale, répéta le premier en France l'expérience de la bouteille de Leyde sur cent quatre-vingts personnes qui se donnaient la main. Il fit voir que le fluide électrique, auquel on avait reconnu la propriété d'accélérer le mouvement des fluides jaillissants et d'activer la végétation, augmentait anssi la transpiration culanéc; il inventa un électromètre, 
perfectionné d'abord par Waitz, puis laissé en arrière par celui de Coulomb. Watson essaya de calculer la rapidité de la marche de l'étincelle électrique; mais ne put constater que son instantanéité.

Cependant, malgré leś perfectionnements de cette science dans sa partie expérimentale, la partie théorique était restée stationnaire; et, jusqu'à Franklin, on n'eut que des idées vagues sur la nature de l'èlectricité. Le philosophe de Philadelphie, frappé des phénomènes de la bouteille de Leyde, fit de l'électricité l'objet spécial de ses études. II admit qu'un fluide électrique existe partout; que tous les corps en sont plus ou moins chargés; qu'aussitôt qu'on les frotte, l'équilibre électrique est rompu; que de celte quantité en plus ou en moins il résulte deux états électriques différents : l'un, qu'il appelle éltectricité négative, et l'autre qu'il nomme électricité positive; ce qui répond aux électricités vitrée et résineuse de Dufay.

OEpinus, physicien russe, fít des expériences sur l'électricité, et expliqua, par une hypothèse ingénieuse, le phénomène de répulsion qué présentent deux corps doués d'électricité de même nature.

Jusqu'à Symmer, les physiciens admettaient qu'il n'existe qu'un seul fluide électrique susceptible de changer d'état; il admit le premier' l'existence de deux fluides, et son hypothèse a obtenu la préférence. Beccaria, Richman, Canton, Ammersin s'occupèrent encore d'électricité, et Ramsden construisit sur un plan nouveau la machine à plateau de glace en usage aujourd'hui.

L'existence du fluide galvanique, indiquée, en 1767, par Sulzer, et, en 1786, par Cotugno, fut confirmée par Galvani, qui crut y voir un fluide particulier; mais Volta, professeur de Pavie, renversa bientôt la théorie de Galvani, en rétablissant l’identité du galvanisme avec le fluide électrique.

Le magnétisme, qui avait peu occupé les physiciens dans le siècle précédent, devint l'objet d'études suivies. Halley observa, à Sainte-Hélène, les variations de l'aiguille aimantée; Taylor détermina, de concert avec Hawkesbee, la décroissance de l'intensité de la force magnétique en raison des distances; Musschenbroek se livra aux mèmes recherches et inventa le tribomètre.

En 1746, Knight perfectionna les aimants artificiels et tint son procédé secret, ce qui n'empêcha pas Duhamel et Antheaume, en France, de composer des barreaux magnétiques. Michell, en Angleterre, arriva au même résultat et calcula le décroisscment de la force magnétique. 
OEpinus apporta des perfectionnements à la méthode de Michell pour l'aimantation des barreaux d'acier.

Jusqu'à Coulomb, on avait cru que le fer seul étrit attirable à l'aimant. Ce physicien écrivit que tous les corps terrestres sont doués de la même propriété, mais à des degrés inégaux. Il perfectionna la méthode d'aimantation, et admit que le phénomène magnétique est dû à un fluide analogue à celui de l'électricité. Ce fut lui qui indiqua d'une manière précise les dimensions que doit avoir l'aiguille aimantée pour recevoir avec la plus grande intensité possible la vertu magnétique.

Au milieu du xvir siècle, François de Lana et, plus tard, le père Galiani avaient admis la possibilité de former des corps plus légers que l'air. Cavendish et Black, ayant reconnu la légèreté de l'air inflammable, supposèrent qu'en en remplissant une vessie elle s'éleverait en l'air. En 1782, les frères Montgolfier d'Annonay, auxquels on doil le bélier hydraulique, enlevèrent les premiers un ballon de papier contenant de l'air raréfié. Pilastre Desrosiers et d'Arlande osèrent monter dans cet appareil. Peu de temps après, Charles substitua avantageusement le gaz hydrogène à l'air raréfié.

En 1769, Watt perfectionna la machine à vapeur de Newcomen et de Savery, et imaģina le condensateur isolé. De 1775 à 1781 divers essais eurent lieu en France pour appliquer la vapeur à la navigation; essais qui ne furent répétés que plus tard aux Etats-Unis, mais avec plus de succès.

Réaumur et Hales construisirent des thermomètres à alcool, et Fahrenheit inventa, en 1724, le thermomètre à mercure; il donna à cet instrument deux termes fixes à l'aide d'une solution d'hydrochlorate d'ammoniaque et d'eau bouillante. Delisle en construisit un n'ayant qu'un terme fixe, celui de l'eau bouillante. Malgré leur imperfeclion, ces instruments sont encore de pratique usuelle. Pour apprécier les hautes températures, Musschenbroek construisit un pyromètre qui fut pendant longtemps le seul. Wedgwood en donna un d'argile, bien supérieur à celui de Musschenbroek, et Guyton-Morveau en fit un de platine, plus sensible encore que celui de Wedgwood.

Stahl, Crawford, Wilkes et Black démontrèrent l'existence du calorique latent. Hawkesbee étudia le poids spécifique des corps et reconmut les différents degrés de dilatation que la chaleur fait éprouver à l'air atmosphérique.

Amontons, auquel appartient la première idée du télégraphe, construisit un hygromètre de corne, qui fut bientôt abandonné; l'hygro- 
métrie doit surtout ses progrès à Saussure, observateur attentif, qui construisit le premier un hygromètre à cheveu, et étudia tous les phénomènes que présentent les vapeurs en se répandant dans l'atmosphère.

Halley et Hawkesbee étudièrent la réfraction des rayons lumineux à leur passage du vide dans l'atmosphère. Euler, physicien habile et plein de sagacité, partant des idées et des travaux de Descartes et d'Huyghens, chercha à substituer à la théorie de Newton sur l'origine de la lumière une autre théorie, fondée sur l'analogie du mode de transmission des sons et du fluide lumineux; mais elle eut peu de succès. Il construisit, à force de soins et d'expériences, des lunelles achromatiques; mais il ne réussit pas entièrement. Son invention fut perfectionnée par Dollond, qui obtint un achromatisme complet, en combinant ensemble des lentilles de flintglass et de crownglass. Rochon et Herschell analysèrent les propriétés des rayons lumineux. Ce dernier confirma l'opinion de Newton, que tous les rayons ne chauffent pas avec la même intensité; que les jaunes possèdent la plus haute puissance calorifique; que quelques-uns donnent de la chaleur et d'autres seulement de la lumière.

Buffon fut, avec le cardinal de Polignac, Sigorgue et Maupertuis, le propagateur de la philosophic de Newton; il construisit des miroirs ardents et fit des expériences intéressantes sur les ombres coloriées.

Vossius, Borelli, Hawkesbee, Carré et Clairaut cherchèrent sans succès à expliquer le phénomène de la capillarité. Weibrecht en donna une explication plus simple et plus satisfaisante, fondée sur l'attraction moléculaire de l'eau sur elle-même et par le verre. A la fin de ce siècle, Laplace fit, sur le mème phénomène, des observations dont il conclut que tout liquide renfermé dans un tube a de l'action sur lui-même, et que la capillarité est due à celte cause et non à l'attraction des molécules dı liquide par le verre.

L'Académie des sciences entreprit des expériences d'acoustique. Taylor, à qui l'on doit des travaux sur le magnétisme, appliqua l'analyse au mouvement vibratoire des corps sonores el créa la théorie des sons. Sauveur découvrit les nœuds de vibration. Tartini et Bernouilli ont aussi rendu de grands services à l'acoustigue.

Chimie.-Pendant le xvin ${ }^{\mathrm{e}}$ siècle, la chimie fit de rapides progrès; mais ce fut surtout vers sa fin gu'elle subit une métamorphose complète. L'empirisme en fut banni, les théories anciennes furent repoussées, et les nouvelles furent assises sur des découvertes confirmées par tous Jes 
chimistes. Dépouillée de ses vieux préjugés, la science put alors marcher à grands pas. La méthode de Bâcon, la scule capable de conduire à la vérité, devint générale. On cessa de compter les écoles; il n'y en eut plus qu'une, celle de l'expérience. La France, l'Allemagne, l'Angleterre oubliaient leurs rivalités quand il s'agissait de science; et il y avait, pour ainsi dire, solidarité entre tous les savants de l'Europe. Malgré ses doctrines erronées, nous mettrons en tête des hommes qui imprimèrent un grand mouvement à la chimie Stahl, le commentateur de Becher, le créateur d'une philosophie chimique, et de la théorie du phlogistique, vaste généralisation qui embrassait la science entière. Par malheur pour les progrès de la chimie, Stahl, dont les ouvrages indiquent une grande sagacité, partit d'une base fausse en considérant les oxydes comme des corps simples et les métaux comme des corps composés. De là toutes ses erreurs. D'après sa théorie, les métaux sont formés de l'union du phlogistique avec les terres et les oxydes, et la combustion n'est autre chose que le dégagement du phlogistique; il s'en dégage d'autant plus que le corps est plus inflammable. Le phénomène de l'oxydation n'était alors, suivant Stahl, que l'effet d'un métal qui se déphlogistiquait. Ce renversement de toutes les idées rationnelles entrava les progrès de la science, en substituant une fausse explication à la théorie véritable, qui avait pour base les faits observés; et, pendant tout le xvirr siècle, la théorie du phlogistique compta de nombreux partisans. Le célèbre Boerhaave, de Leyde, marcha sur les pas de Stahl; malgré ses erreurs, il contribua à la création de la chimie philosophique. Ses expériences, quoique neuves et habilement conduites, restèrent presque sans résultat par suite de ses fausses idées sur le calorique, sur la constitution de l'ail atmosphérique et de son ignorance complète de la diversité des gaz.

Hales, inventeur d'appareils ingénieux, est faussement considéré comme le créateur de la chimie pneumatique; car il ne connaissait point la constitution des gaz, qu'il regardait comme de simples modifications de l'air atmosphérique. Hales et Venel n'avaient d'abord vu que de l'air dans les fluides élastiques dégagés par la distillation. Malgré cette lenteur dans la marche des études, les idées se rectifiaient peu à peu, et l'on était à la veille d'une réforme, dont les premiers essais sont dus à Black, l'illustre professeur d'Édimbourg, qui, loin de chercher à voiler la science sous une phraséologie ambitieuse, s'efforça, au contraire, de la populariser par la clarté de sa méthode d'expo- 
sition, et sut la rendre attrayante par le charme dont il l'entotu'a. Il découvrit, après Van Helmont, le gaz acide carbonique, auquel il donna le nom d'air fixe, en le distinguant de l'air atmosphérique où néanmoins il le retrouvait comme partie constituante; il fit de nombreuses et savantes expériences sur les gaz; il découvrit aussi le calorique latent (1762), qui fait passer les corps solides à l'état de fluidité $\boldsymbol{e l}$ vice versâ, sans que leur température en soit sensiblement changée.

En 1764, Mac-Bride généralisa les propriétés de l'air fixe, et en fit une ingénieuse application à la médecine. Meyer d'Osnabrück, cher'chant à expliquer le principe de la chaux et des alcalis, fit de l'air fixe de Black un être de raison qu'il appela causticum ou acidum pingue. Cette prétendue découverte causa un schisme parmi les chimistes; mais les expériences successives de Jacquin, de Venel et de Cavendish firent triomplier la doctrine de Black. Cavendish alla plus loin que le chimiste. d'Édimbour'g. En 1766, il présenta à la Société royale un mémoire dans. lequel il disait positivement « que l'air n'est pas un élément et qu'il existe plusieurs espèces d'airs. ) II reconnut que l'air fixe est plus. pesant que l'air atmosphérique el qu'il est dégagé par la combustion du charbon. Il ajouta à cette découverte celle du gaz acide hydrochlorique, fit connaître le premier les propriétés de l'air inflammable (hydrogène), ainsi que la composition de l'acide nitrique. Dans ses $E x$ périences sur l'air, présentées à la Société royale, en 1784, il annonça qu'il avait brûlé par l'étincelle électrique de l'air inflammable en vase clos, en le mêlant avec de l'air respirable, et qưil avait vu le tou se résaudre en une quantité d'eau égale au poids des airs absorbés.

Cette expérience, dont le résultat eut un grand retentissement porta les chimistes à s'occuper de la décomposition de l'eau, et les mit sur la voie des transformations des corps organisés et inorganiques.

Un contemporain de Cavendish, non moins célèbre que lui, est le modeste Schèele, l'habile et patient expérimentateur, qui résolvait les problèmes les plus obscurs de la chimie et de la physique, avec les instruments les plus simples. Son Traité de l'air et $d u$ feu (1780) con tient des idées d'une grande profondeur sur la composition de l'air et sur la théorie de la chaleur. On peut cependant lui opposer l'étrangeté de ses conclusions qui font ombre à ses admirables talents comme observateur. Il fit la découverte d'un grand nombre d'acides organiques et de quelques corps simples.

Priestley fut encore un chimiste profond. Il ćludia les gaz avec une 
grande habileté, et découvrit, en 1774, l'oxygène qu'il nomma air déphlogistiqué, l'acide sulfúreux, l'azote, le protoxyde et le bioxyde d'azote et le gaz oxyde de carbone; mais, malgré ses grandes découvertes, on le trouve, à cause de son attachement à la théorie chimique de Stahl, incertain dans ses principes et cheichant partout le phlogistique.

Bergmann, le généreux protecteur de Schèele, celui qui reconnut un grand chimiste dans l'obscur préparateur d'un pharmacien, démontra que l'air fixe est un acide, et l'appela acide aérien. Il découvrit l'acide oxalique et plusieurs acides végétaux et métalliques; il fit de nombreuses expériences sur la chaleur el la lumière. La théorie qu'il essaya de substituer à celle de Stahl n'eut ancun succès à cause de sa bizarrerie.

A ces savants, on doit joindre Smith, qui essaya de classer les différentes espèces d'air qu'il nomma gaz, à l'exemple de Van Helmont; Woolfe, qui perfectionna les opérations de la chimie, en améliorant les appareils; Rouelle, savant chimiste et habile praticien. le maître de Lavoisier, qui s'occupa de recherches sur les gaz el les sels, et auquel il ne manqua, pour tirer plus de parti de ses expériences, que de les avoir faites la balance à la main; Bayen (1774), qui avait obtenu l'oxygène sans en avoir reconnu les propriétés, et qui attaqua la théorie de Stahi, en démontrant l'inutilité du phlogistique dảns la réduction des chaux métalliques, et Wenzel, qui publia, à Dresde, en 1777, une théorie sur l'affinité des corps, dans laquelle il expliqua l'action réciproque des sels neutres. Ce fut Wenzel qui le premier se servil de balances dans ses analyses; il se distingua, parmi les chimistes de son temps, par la précision des résultats numériques de ses expériences. Le tableau des affinités chimiques, publié par Geoffroy, en 1778, est encore un des ouvrages qui ont fail époque dans la science.

Le plus illustre chimiste dı xvın siècle fut Lavoisier, l'élève de Rouelle, et dont la vie, malheureusement trop courte, fut une suite de découvertes. Il renversa la doctrine chimique de Stahl, en déclarant que le phlogistique n'existe pas, que l'air déphlogistiqué est un corps simple; que cet air se combine avec les métaux dans la calcination, qu'il convertit en acide le soufre, le phosphore et le charbon, qu'il entretient la combustion et la vie, qu'il forme les parties essentielles de la croûte du globe, de l'eau, des plantes et des animaux. Il répéta les expériences de Black sur les gaz, démontra la combustibilité du diamant et les produits qui en résultent, el fit connaître la nature de l'acide carbonique; il étudia les phénomènes de la respiration et de la combustion, analysa 
l'eau et la recomposa. Les chimistes, attachés aux anciennes idées, ne les abandonnèrent pas sans combattre le hardi novateur, et Lavoisier eut à soutenir une rude polémique; mais, malgré l'opposition que la doctrine pneumatique rencontra surtout en Allemagne et en Angleterre, elle se répandit dans toute l'Europe.

Berthollet, l'habile applicateur de la science à l'industrie, abandonna le premier la doctrine du phlogistique pour embrasser celle de Lavoisier.

Fourcroy, dont la carrière scientifique appartient plus au xvint ${ }^{\mathrm{e}}$ siècle qu'au xrx ${ }^{\mathrm{e}}$, fut un digne émule de Lavoisier; la science lui doit de nombreuses expériences sur les combinaisons salines, sur la combustion de l'air inflammable; et aussi de vastes essais de chimie animale; ce fut en 1792, qu'associé à Vauquelin et à Séguin, il obtint de l'eau composée de toutes pièces.

La science était devenue assez riche en découvertes; mais sa langue, empreinte des formes de l'alchimie, manquait encore de précision; c'était un mélange incohérent de noms bizarres, n'indiquant jamais les relations des corps constituants. Nous citerons entre autres la laine philosophique (oxyde de zinc), et la lune cornée (chlorhydrure d'argent).

Sur un travail et d'après les idées de Guyton-Morveau, Lavoisier, Berthollet et Fourcroy changèrent la nomenclature chimique. Les noms se simplifièrent et eurent une signification arrêtée. Un petit nombre de terminaisons unies aux radicaux suffirent pour faire connaître la composition des substances. Il y eut une même terminaison pour les acides; on appela oxydes les corps combinés avec l'oxygène sans acidité ; les alcalis et les corps terreux eurent des noms féminins et les métaux des noms masculins. On désigna par des noms du même genre les substances de nature semblable. Il en résulta pour l'étude un avantage immense; aussi tous les savants s'empressèrent-ils d'adopter la nouvelle nomenclature; mais, plus tard, cette langue, qu'on avait cru pouvoir toujours suffire aux besoins de la science, subit d'importantes modifications, et de nos jours elle en exige beaucoup encore.

Les dernières années du ${\mathrm{xv} ı{ }^{\circledR}}^{\circledR}$ siècle virent là chimie se perfectionner surtout en ce qui concerne son application aux arts et à l'industrie. La minéralogie et la géologie ne pouvaient marcher sans elle; la science des êtres organisés y puisait des connaissances précieuses; enfin, on reconnut qu'elle sert de lien à toutes les sciences naturelles; aussi lui assigna-l-on la première place parmi les autres sciences, of 
les progrès du xix* siècle ont, à cet égard, confirmé le jugement du xvili ${ }^{\mathrm{e}}$.

Anatomie. -- Dans le cours du xvir ${ }^{\mathrm{e}}$ siècle, les anatomistes furent urès nombreux. Nous ne citerons que les plus éminents. Le premier dans l'ordre chronologique est Heister, le professeur d'Altorf, qui publia un Compendium analomicum. Après lui vient le célèbre Winslow, qui doil sa gloire à la France, et qui fit paraître, en 1732, son Exposition ana tomique de la structure du corps humain. Dans cet ouvrage, traduit en plusieurs langues, il laissa derrière lui tous les anatomistes qui l'avaient précédé, sous le rapport de la perfection de ses travaux en ostéologie, en angéiologie, en névrologie et en splanchnologie. Il n’a été surpassé en myologie que par Albinus.

Ce dernier (dont le véritable nom est Weiss), professeur à Leyde en 1719 , où il occupa la chaire d'anatomie pendant cinquante années contribua aux progrès de la science non seulement par ses études personnelles, car on lui doit entre autres travaux un recueil de planches de myologie et d'ostéologie d'une perfection admirable, mais encore en publiant les travaux des anatomistes du siècle antérieur, et en publiant aussi, de concert avec Boerhaave, de belles éditions de Vésale, d'Harvey et de Fabrizio d'Aquapendente.

Haller, de Berne, disciple de Boerhaave et d'Albinus, un des hommes les plus distingués du xvıı ${ }^{\mathrm{e}}$ siècle, est celui dont les connaissances étaient à la fois le plus variées et le plus profondes. Il commença, en 1729, par commenter les institules de Boerhaave; et, pour s'aider dans son travail, il fit de nombreuses dissections de cadavres d'hommes et d'animaux. On a de lui des travaux étendus sur toutes les parties de la science de l'organisation; il ne se contenta pas d'observer il criliqua, scruta, pesa toutes les découvertes, et son jugement fut constamment celui d'un homme supérieur.

En 1753, il abandonna l'université de Goettingue, et se retira à Berne, oì, faute de cadavres humains, il fit des expériences sur les animaux vivants. Il recueillit des observations importantes sur les mouvements du coeur et la respiralion, sur la circulation dans les animaux invertébrés, sur la formation du poulet, et sur celle des os dans les mammifères.

Il avait des idées particulières sur l'irritabilité, qu'il distinguait expressément de la sensibilité; ainsi il niait l'irritabilité des nerfs, qu'il regardait seulement comme sensibles, et ne reconnaissait d'irritables 
que la fibre musculaire, el surtout le coeur. Il soutint, à l'occasion de sa doctrine, une polémique très vive contre les Stahliens. Il comballit aussi, daus un grand ouvrage sur le développement du foutus, le systèmc de Buffon sur la génération; et, s’il ne le détruisit pas, il l'ébranla fortement.

Santorini, médecin de la république de Venise, fut un des anatomistes dont les travaux en myologie ont le plus de délicatesse. Morgagni (1740) s'occupa également avec talent de la dissection des parties,les plus ténues de l'organisme, el réhabilita l'anatomie. Nous devons citer encore comme anatomistes d'une grande distinction Lieutaud et Sabatier.

Monro, Bertin, Hmuald, se sont occupés d'ostéologie;-Douglas, Parsons, Dupetil, Josué, de myologie; Porterfield et Hovius ont écrit sur l'œil; Cassebohm, sur l'oreille interne. Valsalva, professeur de Bologne, a publié, sur l'ouie humaine, un traité qui lui coùta seize années de travail et la dissection de mille têtes. Vieussens décrivit le cerveau avec un talent remarquable; Sénac fit connaître l'anatomie el la pliysiologie du coeur; Dodart el Ferrein ont publié chacun un système sur le mécanisme de la voix; Pecquet et Astruc ont étudié la digestion, et Lieberkühn a observé la structure des organes servant à cette fonction

Anatomie comparée. - Pendant les deux tiers du xvıı siècle, l'anatomie descriptive fut la seule cultivée; et, ver's sa fin, on recommença à cultiver l'anatomie comparée, que Boerhaave avail atlaquée comme toutà-fait inutile. Jusqu'alors elle n'avait pas eu un caractère bieu arrèté; les anatomistes se livraient à des travaux comparatifs, mais trop incomplets pour que cette science pût se régulariser. Cependant le xviı ${ }^{\mathrm{e}}$ siècle compta un assez grand nombre d'anatomistes comparateurs.

Duverney, professeur d'anatomie au Jardin du roi depuis 1679 jusqu'en 1730, se livra à des travaux considérables sur l'anatomie comparée. II publia d'abord l'anatomie des animaux de la ménagerie de Versailles, fit connaître la structure des organes de la respiration chez les poissons, et surtout chez la carpe, où son étonnante complication est une merveille. Il compara différentes parties du corps humain aux parties correspondantes chez les animaux. Pour expliquer les phénomènes de la circulation du foetus, dans lequel elle a lieu d'une manière analogue à celle des reptiles, il fit la dissection d'une tortue et d'un crocodile. Sia théorie l'exposa à de vives altaques de la part de Méry, qui s'occupait du mème sujet. Douglas et Garengeot composèrent une myographic 
dans laquelle le chien est comparé à l'homme. Pourfour-Dupelit publia un mémoire comparatif sur l'organe visuel de tous les vertébrés, et un travail sur le cerveau; Cheselden est l'auteur d'une ostéographie qui contient les squelettes de différents animaux; Haller, à qui l'on doit tant de travaux comparatifs, s'occupa de recherches sur l'appareil visuel et l'encéphale des poissons, en essayant de déterminer les rapports qui existent entre leur cerveau et le nôtre. Scarpa, Comparetti, publièrent de beaux travaux sur l'ouie; Ebel fit paraître des observations de névrologie comparée d'un grand intérêt. Monro père et Valentini essayèrent de petits traités d'anatomie comparée. On doit à Monro fils trois ouvrages capitaux, sur le système nerveux, sur l'anatomie, sur la physiologie des poissons comparés aux autres vertébrés, et sur l'organe de l'ouie dans les animaux supérieurs. William Hunter s'occupa avec succès de travaux anatomiques, et éludia la structure des dents chez différentes classes d'animaux. Blair donna une ostéologie de l'éléphant; Sarrasin, l'anatomie du castor et du porc-épic; Bertin Bourgelat, celle du cheval. Cavolini étudia la génération des poissons et des crustacés. On doit à Morgagni l’anatomie du lombric; Abildgaard et Neergaard se livrèrent à de sérieuses études sur lès intestins des mammifères et des oiseaux; Réaumur observa les phénomènes de la digestion chez les granivores et les propriétés électriques de la torpille; Albert de Brême fit connaître la strueture anatomique du phoque; Townson étudia la respiration des reptiles; Hachetı, la structure des os et des coquilles; Broussonnet, celle des écailles de poissons, le mode de respiration de ces animaux et leur reproduction. Richer, Watsh, Allamand et Patterson s'occupèrent des poissons électriques. Pierre Camper, élève d'Albinus, laissa d'admirables travaux sur l'organisation des animaux. On a de lui une anatomie de l'éléphant, de

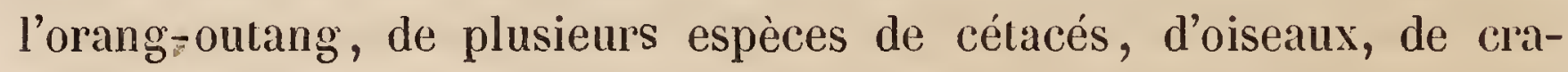
pauds, etc. On lui doil aussi des observations sur l'angle facial qui a servi de base à une classification des races humaines.

Daubenton, l'un des illustres collaborateurs de Buffon, est l'auteur de tous les travaux d'anatomie comparée qui accompagnent les œuvres du grand naturaliste, et il contribua ainsi à leur donner plus d'importance. Pallas, qui s'occupa avec tant de succès de toutes les branches de l'histoire naturelle, concourut également aux progrès de l'anatomie comparée, en démontrant son utilité pour la partie caractéristique. Vicq d'Azyr, écrivain aussi disert qu'habile anatomiste, l'aurait sans doute élevée a la hauteur qu'elle alteignit au commencement du siècle suivant, si 
une mor't prématurée ne l'eût enlevé aux sciences avant qu'il eût pu réaliser le projet de donner une anatomie et une physiologie complètes. On lui doit un excellent mémoire sur l'analogie qui existe entre les membres inférieurs et supérieur's chez l'homme el les animaux, de même qu'un travail complet sur l'anatomie du cerveau, science dont il peut être considéré comme le créateur; il fit aussi plusieurs découvertes sur la structure des poissons et sur celle des oiseaux. Sa classification des mammifères, tout artificielle et non fondée sur l'organisation, n'est pas digne de lui.

Physiologie. - Nous avons vu qu'à la fin du xvir siècle, les médecins mathématiciens avaient cherché à appliquer le calcul à la physiologie ; mais cette école ne tarda pas à tomber dans le discrédit; car, tandis que Borelli portait à cent trente-cing mille livres la puissance du cœur, Keill, professeur d'anatomie à Oxford, ne l'évaluait qu'à cinq onces. A côté de ce calcul, qui atténue si singulièrement celui de Borelli, Keill estimait à cinq mille deux cent trente-trois pieds par minute la vitesse du sang dans l'aorte. Ces contradictions résultant de ce qu'il manquait aux calculs des bases suffisantes, et de ce que les assertions devançaient l'expérience, causèrent la ruine de l'école iatro-mathématique.

Baglivi, sans appartenir positivement à cette école, s'en rapproche cependant en ce qu'il admet, comme une vérité absolue, l'action impulsive des solides dans les phénomènes vitaux; ce qui donna lieu à une secte médic ale nommée solidiste. Il est tombé dans de graves erreurs en faisant de la dure-mère un centre de mouvement antagoniste dı coeur.

Boerhave, un des plus célèbres médecins de celle époque, se rattacha encore à l'école mathématique et chercha à expliquer certains phénomènes morbides par des actions mécaniques. Il avait peu disséqué par lui-même; mais il suivait, pour ses études personnelles, les travaux anatomiques de Ruysch. Cependant il adopta les opinions de Malpighi. Bernouilli, Michelotti, Hales, sont encore des iatro-mathématiciens; mais moins célèbres.

Stahl, que nous avons vu en chimie crécl le phlogistique, est l'auteur d'une théorie psychique qui a beaucoup occupé les physiologistes: il substitua aux esprits animaux de Descartes une àme présidant à la formation du corps et à tous les actes vilaux, et se. servant comme agent de la tonicité qui en émane. 
Parmi les disciples de Stahl, il faut distinguer Gohl, Juncker el Alberti, qui adoptèrent sans examen la doctrine de leur inaître; Shell, qui plaça l'àme à l'origine dı système nerveux, auquel elle transmet sa volonté, et enfin François Nichols, le plus extravagant de tous, qui personnifia l'âme et lui donna des volontés entièrement indépendagntes de l'action des organes.

Porterfield et Robert White adoptèrent ces idées avec plus de réserve; et ce dernier s'en écarta sous plusieurs rapports. La théorie de Stahl ue pénétra pas en France dans sa forme primitive. Vers le milieu du xvın ${ }^{\mathrm{e}}$ siècle, le célèbre Sauvages, professeur à Montpellier, adopta les principes de White sur l'aclion de l'âme dans les mouvcments involontaires, et modifia le système de Stahl, en admettant l'intermédiaire des nerfs dans les mouvements physiologiques.

Bordeu, stahlien comme Sauvages, répandit, dans ses ouvrages, l'idée que chaque organe est doué d'une sensibilité spéciale, el que du concours de ces sensibilités particulières et des volontés propres à chaque organe, émane la volonté physiologique qui est sans relation avec le centre nerveux.

Lacaze, médecin de Louis XV, ajouta à la théorie de Bordeu l'idée d'un centre nerveux particulier pour les mouvements involontaires; il choisit le diaphragme, en faveur duquel il dépouilla le cerveau de ses prérogatives. Lecat, fondateur de l'académie des sciences de Rouen, attribua les mouvements involontaires aux ganglions, qu'il se représentait comme autant de petits cerveaux agissant sans la participation de l'encéphale, en vertu d'une espèce de spontanéité qui leur est propre.

Le dernier stahlien est Barthez (1773), clıancelier de la faculté de médecine de Montpellier; il admit un principe vital différent de l'âme, et exécutant les mouvements involontaires.

On voit que ces théories sont fondées sur l'idée que les mouvements physiologiques, n'étant pas perçus par le cerveau, n'en peuvent émaner. Cet embarras vient évidemment des difficultés que présentait, à une époque peu avancée de la science, l'accord des idées psychoJogiques avec les phénomènes vitaux.

A côté de l'école de Stahl il en existait une autre qui, pendant tout le xvıI' siècle, a fail beaucoup de bruil sous le nom d'irritabiliste; elle altribuait les phénomènes physiologiques à une âme sensitive dont l'agent était le fluide nerveux. Cette école eut pour créateur Glisson, pour promoteur Hoffmann, el pour disciples, Gorter, Gaubius, Kaau, Hart- 
ley, et Haller, qui l'éclaira en considérant l'irritabilité comme une propriété de la fibre musculaire, entretenue par les nerfs et différant de leur action.

A la physiologie se rattachent les divers systèmes sur la génération. Vallisnieri voulail que le foeus préexistât dans l'ouf; Hartsoeker et Leuwenhoek admirent la préexistence des germes dans le sperme, par suite de la découverte des animalcules qu'il contient, et ils représentent la théorie de l'emboîtement des germes, comme Maupertuis et Buffon représentent celle de l'épigénèse ou de la formation des corps par juxta-position. Plus tard, le système des germes fut reproduit par Haller, Bonnet et Spallanzani, dernier auteur auquel on doil des expériences pleines d'intérêt.

Ces théories générales, qui ne sont pour les savants qu'un délassement de l'esprit, et indiquent l'insatiable tendance de l'humanité vers le perfectionnement de son intelligence, n'entravèrent pas les travaux de l'anatomie d'observation, bien que Stahl et tous les physiologistes affectassent de la mépriser. Le $\mathrm{xvIl}^{\mathrm{e}}$ siècle avait glorieusement acquis à la science des vérités incontestables; il ne restait au xvmr ${ }^{\mathrm{e}}$, possesseur d'instruments plus parfaits, qu’à terminer ce qui avait été commencé.

Zoologie générale. - Nous mettrons à la lête des zoologistes du xvıri siècle, Linné et Buffon, qui en furent le plus bel ornement; ils donnèrent tous deux aux études de cette époque le caractère qui leur est propre. Le premier, homme d'analyse, plein de patience et de sagacité, étudiales faits avec une méthode lente mais sûre, les coordonna sans précipitation, sans illusion, et ne se permil pas, comme son rival, de brillantes hypothèses; il éleva sans bruit, avec une simplicilé et une modération admirables, l'édifice de la science dont il embrassait l'ensemble. Son Systema naturœ, qui, pendant sa vie, eut douze éditions, exerça une grande influence sur l'étude des êtres organisés. Il substitua au désordre des méthodes une classification fondée sur les véritables caractères, et qui a servi de base à celles qui ont été créées depuis.

Un autre mérite de Linné est d'avoir réformé la nomenclature, et substitué à ces longues phrases descriplives, difficiles à conserver' dans la mémoire, un double nom, l'un générique, exprimant les caractères généraux qui lient les êtres entre eux, el l'autre spécifique, énonçant les qualités par lesquelles ils diffèrent les uns des autres.

Le Systema nalure, qui apportail dans la science une véritable ré- 
forme, fut critiqué, lors de sa publication, avec une aigreur sans égale. Buffon et Haller, les deux plus célèbres contemporains de Linné, le traitèrent avec injustice; mais son triomphe, fondé sur la raison, ne se fit pas attendre, et condamna au silence tous ses détracteurs.

Buffon, l'émule de Linné, encore regardé comme l'oracle de la nature, fut un généralisateur hardi et brillant, doué d'une pénétration prodigieuse. Dédaignant les méthodes et l'aridité des descriptions scientifiques, il ne s'arrêta pas à la froide observation de chaque objet: il contempla la nature dans son ensemble, s'éleva, avec l'audace du génie, à des conceptions sublimes et devina souvent ce qu'il n'avait pas vu. Sa Théorie de la terre et ses Époques de la nature, qui datent de la moitié dı xvın ${ }^{\mathrm{e}}$ siècle, eurent un succès prodigieux; son histoire de l'homme et celle des mammifères et des oiseaux sont des chefs-d'œuvre de style, pleins d'observations, où il fait briller sa sagacité et son érudition. Ses travaux eurent pour résultat de réconcilier avec les sciences naturelles les hommes du monde, que l'aridité des écrivains antérieurs en avait détournés, et ses écrits resteront comme des modèles de description.

Après ces deux grands hommes vient Bonnet, qui contribua, par ses découveries, aux progrès de la science. Son ouvrage le plus remarquable sur la philosophie des sciences naturelles est sa Contemplation de la nature, dans lequel il présenta sa célèbre hypothèse de l'emboîtement des germes, théorie plus ingénieuse que vraie de la reproduction des êtres. Ce même écrivain, pénétré de la pensée que, dans ses créations, la nature procède régulièrement, avait établi une échelle de dégradation naturelle des animaux, destinée à représenter l'ordre dans lequel ils s'enchaînent entre eux.

Hermann publia une Table des affinite's des animaux. Il prétend, dans cet ouvrage, que chaque espèce se rapproche, par quelques détails organiques, d'espèces quelquefois for! éloignées. On a de lui de nombreux mémoires; mais il s'est surtout occupé de mammalogie. Darwiı fit connaître, dans sa Zoonomie, les lois de la nature organique.

Aux zoologistes généraux appartiennent Réaumur, qui embrassa dans ses minutieuses observations des animaux de toutes les classes; Needham, dont les travaux, quoique moins étendus, sont aussi variés, et Sarrasin, qui a publié quelques observations sur les animaux d'Amérique.

De 1751 à 1756, Klein et Brisson publièrent chacun un système du 
règne animal diffẻrent de celui de Linné. Brisson sépara le premier les cétacés des poissons, et les mit à la suite des quadrupèdes vivipares. En 1777, Erxleben compléta la synonymie, en citant l'histoire de chaque animal.

Mammalogie. - Le premier auteur de ce siècle qui ail écrit sur la mammalogie est Séba, dont l'ouvrage indigeste a néanmoins le mérite de renfermer de bonnes figures. Tous les travaux antérieurs furent éclipsés par la publication du Systema naturce, qui fixait les véritables rapports réciproques des mammifères. A ce traité succéda la magnifique histoire de Buffon qui, par le charme et la poésie de ses descriptions, vint compléter l'œuvre de Linné.

Storr établit ensuite un système fondé sur les organes de sustentation. Boddaert modifia sans avantage le système de Linné; Gmelin en publia aussi une édition avec de bonnes additions; Blumenbach fit paraître un traité d'histoire naturelle qui eut un immense succès : il sépara le premier, sous le nom de bimane, l'homme du singe, en se fondant sur la disposition du pouce du pied, opposable chez l'un, tandis que chez l'autre il n'a que le mouvement commun des doigts. Il décrivit pour la première fois l'ornithorhynque, ce singulier quadrupède à bec de canard. Zimmermann essaya de présenter un tableau de la distribution géographique des mammifères ; première tentative encore imparfaite, mais qui fut le point de départ d'une série de travaux d'une haute importance sur la même matière.

Ornithologie. - Les progrès de l'ornithologie furent plus rapides que ceux de la mammalogie. En 1707, Sloane décrivit des oiseaux américains inconnus jusqu’à lui; Marsigli donna, en 1728, une monographie des oiseaux du Danube; Catesby fit paraittre, en 1731, une ornithologie de l'Amérique septentrionale.

Albin publia, vers la même époque, une histoire des oiseaux classés d'après le système de Willughby; mais il ne reclifia pas les erreurs de son modèle.

En 173̊4, Frisch, naturaliste allemand, observateur philosophe, commença la publication d'une histoire naturelle des oiseaux de l'Europe centrale, qui ne fut terminée que trente années après. La méthode suivie par le naturaliste de Berlin est inférieure à celle de Ray.

Séba prend place parmi les ornithologistes, mais sculement à cause 
de la beauté des figures qui ornent son ouvrage, car son texte est en général d'ửne grande inexactitude.

Barrère publia, en 1745, à l'époque où le nom de Linné étail tout puissant dans la science, un essai de classification ornithologique exclusivement fondée sur la structure des pieds. Son système, mis cn tête de son Histoire naturelle de la France équinoxiale, ne fut pas adopté.

L'histoire des oiseaux d'Edwards, publiée à Londres, contient la description et la figure de beaucoup d'espèces nouvelles.

Les systèmes donnés, en 1750 et 1752, par Klein et par Mochring, ont le défaut d'être purement artificiels et de faire reculer la science de plus d'un siècle. Il n'en est pas de même de la méthode de Brisson publiée, en 1760, dans son ornithologie; elle est fondée sur la forme du bec et des pieds, sur le nombre des doigts et leur mode d'union. L'ouvrage de Brisson, qui a devancé notre époque en établissant beaucoup de coupes génériques admises aujourd'hui, est encore fort estimé pour l'exactitude des descriptions.

Le système ornithologique de Linné, dans lequel les caractères sont établis avec précision, quoiqu'il s'appuie également, comme signes caractéristiques de première importance, sur la forme du bec et sur celle des pieds, éclipsa tous ceux qui l'avaient précédé ou qui étaient contemporains de son Systema naturce. Les vrais principes de classification naturelle se retrouvent dans ce système, qui, encore aujourd'hui, est le plus suivi sous le rapport des divisions principales.

Schaffer essaya une méthode incertaine, fondée sur la forme des paltes. Scopoli (1777) ne prit pour base de sa distribution systématique des oiseaux que les écailles qui leur couvrent les pieds. Ce système, fort incomplet et d'une étude peu facile, n'eut aucun succès.

Le Synopsis général de Latham est une description systématique à peine différente de celle de Linné, et à laquelle ont été ajoutés quelques genres nouveaux. Il publia plus tard son Index ornithologicus, qui est une judicieuse épuration du premier ouvrage.

Mauduit, chargé de la rédaction de la partie ornithologique de l'Encyclopédie, adopta un système de classification imaginé par Bonnaterre, mais bien infërieur à celui de Brisson.

Ces divers travaux ne sont pas de stériles nomenclatures, fondées sur un déplacement arbitraipe et plus ou moins heureux des oiseaux; cesont toujours des travaux d'enisemble, généralement enrichis de nouveaux 
そrenres, et que les méthodistes ont cherché à classer de manière à éviter les fautes dans lesquelles sont tombés les auteurs précédents.

Buffon, en se servant des observations de ses devanciers et de ses con-temporains, peignit, avec son magique pinceau, les couleurs brillantes (les oiseaux, leurs moeurs, tous les phénomènes, jusqu'alors imparfaitement connus, de leur existence, et initia les hommes du monde à cette partie si intéressante de l'histoire de la ตature ; mais il procéda pour eux comme pour les mammifères ; aussi n'exerça-t-il aucune influence sur le cours des études systématologiques. Il fut assisté dans ses travaux par Guéneau de Montbéliard qui, dans ses descriptions, emprunta quelquefois le pinceau de son maître.

Erpétologie. - L'erpétologie, informe au temps de Ray, nè reçut point de Linné une impulsion nouvelle. Son système de classification est fautif, et la dernière édition du Systema natura, publiée par Gmelin, tout en y ayant apporté de grandes modifications, par suite des progrès toujours croissants de la science erpétologique, renferme encore un grand nombre d'erreurs. Le premier auteur méthodiste auquel l'erpétologie doit ses véritables progrès est Laurenti, naturaliste autrichien, qui, par la publication de son Systema reptilium emendatum, apporta, dans la méthode encore imparfaite de Linné, des modifications qui ont servi de base à tous les travaux postérieurs. Il ne désigna plus les animaux de cette classe sous le nom d'amphibies, mais sous celui de reptiles; il omit néanmoins dans son système le genre tortue. Scopoli essaya, en 1777, une classification qui ne mérite aucune attention.

Nous ne trowvons guère d'autres travaux généraux sur les reptiles; mais de bonnes observations sur des genres et des familles appartenant à celte classe ; ainsi Vallisnieri publia un excellent mémoire sur le caméléon; Dufay, un ouvrage remarquable sur les salamandres. On doit à Catesby de très bonnes figures de divers ordres de reptiles, insérées dans son histoire naturelie de la Caroline; Levin Vincent a décrit le pipa et son singulier mode de propagation; Scheuchzer, dans sa $P h y$ sica sacra, a douné de bonnes figures d'ophidiens.

Rœesel, l'un des observateur's les plus attentifs de cette époque, publia un travail monographique sur les grenouilles d'Europe, et Schneider, une monographie des tortues. Daubenton, quoiqu'on puisse lui reprocher de manquer souvent de coup d'ocil, s'acquitta avec sa précision oruinaire de la rédaction de la partie erpétologique de l'Encyclopédie. 
Ichthyologie. - Nous avons vu, dans le xvire siècle, Willughby s'occuper avec succès d'ichthyologie, tant descriptive que systématique, el ouvrir la voie à ses successeurs. L'écrivain le plus distingué du xvıı ${ }^{\mathrm{e}}$ siècle, sur l'ichthyologie, est P. Artedi, l'ami de Linné, qui commença à poser les principes qu'on suit encore dans l'étude de cette science. Il indiqua les véritables caractères d'après lesquels les groupes doivent être élablis. Il avait seulement confondu, parmi les poissons, sous le nom de plagiures ou poissons à queue plate, les grands mammifères aquatiques.

Artedi ayant été enlevé à la science avant d'avoir pu terminer son ouvrage, ce fut Linné qui publia sa Bibliotheca ichthyologica, histoire complète de l'ichthyologie, el sa Philosophia ichthyologica, qui établit les bases sur lesquelles elle est fondée.

Linné, dans les premières éditions de son Systema naturce, avait adopté la classification d'Artedi ; mais, dans la dixième (1758), il changea complètement de système, et créa une méthode ichthyologique nouvelle; il abandonna les divisions établies par son prédécesseur, sous les noms d'acanthoptérygiens, de malacoptérygiens, de chondroptérygiens et de branchiostéges. Il tira les caractères d'après lesquels il forma ses divisions, de la présence ou de l'absence des nageoires ventrales, et de leur position relativement à celle des pectorales. Il fit la faute de transporter dans la classe des reptiles, sous le nom d'amphibies nageurs, plusieurs genres qui ne peuvent être séparés des poissons.

Gmelin apporta au système de Linné des modifications importantes, en rétablissant les branchiostèges et les chondroptérygiens; Klein (1750), l'adversaire de Linné, Gronow et Brünnich (1752) proposèrent des classifications qui eurent peu de succès ou de durée. En 1770, Gouan publia un système dans lequel il combina les caractères d'Artedi et ceux de Linné. Son travail l'emporte sur celui de ses devanciers. Scopoli (1777) prit pour base de son système la position de l'anus; il tira les caractères secondaires de Gouan et les tertiaires de Linné.

Après ces ichthyologisies méthodistes, les auteurs qui, dans ce siècle, se sont occupés d'ichthyologie sont très nombreux. Nous citerons, parmi les plus célèbres, Bloch, qui a publié, sur l'histoire générale et particulière des poissons, douze volumes in-folio, contenant des descriptions exactes et des figures dessinées avec soin. C'est encore un des auteurs les plus recherchés; il a suivi le système de Linné. Le troisième volume du Thesaurus nature de Séba est consacré à l'iconographie d'un 
grand nombre de poissons des Indes. Louis Renard a publié, en 1754, une iconographie ichthyologique des Indes orientales; Cornide, une histoire des poissons de la côte de Galice; Parra, un travail sur l'ichthyologie du golfe du Mexique. Les faunes ichthyologiques de Wulf, Fischer ,Birkholz, Seetzen pour l'Allemagne; d'Ascanius pour le Danemark ; deBrünnich pour la Méditerranée ; de Meidinger pour l'Autriche ; de Garden, de Schœpf et de Forster pour l'Amérique du Nord; de Pennant pour tout le nord du globe, méritent d'être citées en raison de leur exactitude.

Conchyliologie. - Dans le cours du siècle précédent, Columna, Lister, Welles et Swammerdam s'étaient occupés de conchyliologie; mais n'avaient laissé que des descriptions isolées et pas de travail d'ensemble. Au commencement du xvm ${ }^{\mathrm{e}}$ siècle, Petiver, Sloane et Rumph donnèrent de bonnes observations, et les naturalistes sentirent le besoin de systématiser la conchyliologie. On vit alors (1742) Gualtieri appliquer aux coquilles la méthode de Tournefort, en prenant le test pour base de son système. D'Argenville, Klein, Martini, Chemnitz, Born, Walch et Knorr, Schroter, Spengler, etc., suivirent cet exemple. On n'avait pas encore compris la nécessité d'établir la classification des coquilles sur la structure de l'animal; mais bientôt des essais furent faits dans cette voie : en 1743, Daubenton lut à l'Académie des sciences un mémoire sur la nécessité d'étudier les animaux pour former un système complet de conchyliologie; mais il ne présenta pas de classification. En 1756, Guettard mit ce principe en pratique, et établit certains genres sur le double caractère de la coquille et de l'animal. Réaumur, Adanson, Geoffroy, Müller et Pallas appuyèrent ces idées de réformation qui ne furent adoptées qu'à la fin du xviñ siècle; car la classification artificielle de Linné, fondée sur la coquille, fut indistinctement admise par tous les conchyliologistes jusqu'à Bruguière, qui, le premier, essaya pourtant d'apporter une réforme dans les genres établis par Linné.

Nous comptons, parmi les trayaux particuliers, ceux de Rumph, sur les coquilles de la mer des Indes; de Breynius, sur les coquilles chambrées; de Deslandes, de Roussel et de Sellius, sur les tarets; le travail de Moehring, sur l'animal des moules; les expériences de Duhamel du Monceau sur la pourpre; les observations d'Admann, sur les huîtres; les travaux importants de Planchs et de Soldani, sur les coquilles microscopiques; de Ginnani, sur les coquilles marines de l'A- 
driatique, et sur les coquilles terrestres et fluviatiles des environs de Ravenne; de Bohadsch, sur certains mollusques dont il décrit les animaux; de Geoffroy, sur les coquilles dès environs de Paris; de Forskal, sur les mollusques des mers d'Orient; de Fabricius, sur ceux du Groënland, et d'Adanson sur les coquilles du Sénégal.

Entomologie. - L'entomologie, qui, sous le rapport de l'étude microscopique, avait fait des progrès sensibles pendant le xvrr siècle, prit, dans le xviri ${ }^{\mathrm{e}}$, un essor extraordinaire, et compta dans toutès ses parties des hommes remarquables. Cette période nous offre des observateurs minutieux qui passent leur vie à étudier les mours de quelques genres; et, à côté d'eux, des descripteurs et des méthodistes. on peut donc dire que cette branche de la science lui appartient tout entière. Vallisnieri, Petiver, Hans-Sloane et Albin sont les premiers entomologistes du xvmi siècle. On leur doit des observations et des rócueils iconographiques; mais leurs travaux ne firent point époque. Avec Linné s'ouvre une nouvelle ère pour l'entomologie; les insectes sont par lui divisés en ordres qui, presque tous, subsistent encore aujourd'hui. Il désigne et caractérise, pour la première fois, d'une manière claire et rigoureuse, les groupes, les genres, les espèces.

Réaumur fut un des observateurs les plus sagaces et celui qui contribua le plus à populariser le goût de l'entomologie. Personne ne le surpassa pour la patience avec laquelle il préparait et suivait ses expériences; mais on peut souvent lui reprocher sa prolixité et son profond dédain de toute méthode; ce qui a rendu plusieurs parties de ses travaux inutiles; car on ne sait pas toujours à quelles espèces d'insectes les rapporter. On lui doit une foule d'observations curieuses sur les mours des insectes, sur leur structure el sur leur industrie, consignées dans ses Mémoires pour servir à l'histoire des insectes.

Un de ses contemporains, comme lui contempteur des méthodes, est le célèbre Bonnet, de Genève. Observateur aussi minutieux, mais penseur plus profond, il a consigné dans ses nombreux écrits le résultat de ses longues études. On lui doit la découverte de la fécondation des pucerons sans accouplement pour plusieurs générations. Son Traile d'insectologie est d'un grand intérêt; mais il est dans les détails d'unc prolixité souvent fatigante.

Nous mettrons sur la même ligne que ces deux observateurs Lyonnet, qui a laissé, comme l'un des monuments les plus admirables de la saga- 
cité humaine, son anatomie de la chenille du saule (1760), de beaucoup supérieure aux meilleurs travaux de Swammerdam, surtout pour la myologie qui était à créer. Tontefois, Lyonnel ayant borné ses études ì une seule espèce, son travail n'a pas fait beaucoup avancer la science. Cet auteur avait laissé, sur les métamorphoses des insectes, un grant nombre de notes manuscrites qui ont été publiées, il y a peu d'années, par les soins de M. de Haan, dans les mémoires du Muséum.

Roesel a donné des observations intéressantes sur les insectes, mais sans aucune méthode. Son ouvrage est accompagné de planches admirablement exécutées pour le temps.

De Geer, entomologiste suédois, l'emporte sur les observateurs que nous venons de citer par son esprit méthodique. On a de lui une classification des insectes, inférieure à celle de Linné, à cause de leur enchaînement peu naturel et de l'attention trop minutieuse qu'il apporte aux modifications de leurs ailes; mais on lui doit d'avoir séparé les hémiptères des orthoptères, avec lesquels Linné les avail confondus, et d'avoir le premier fait usage des caractères pris de la forme des parties de la bouche, dont il n'a toutefois tiré qu'un parti médiocre.

En 1762, Geoffroy publia la Faune entomologique des environs de Paris, avec un essai de classification, qui n'est qu'une modification peu importante du système de Linné. Il classa le premier les coléoplères par le nombre des articles des tarses. Ce moyen, plus artificiel que naturel, n'a été adopté en France que parce que Latreille l'a employé dans ses ouvrages; mais il n'est guère en usage ailleurs. Cependant l'entomologie en a liré un grand parti, et la méthode tarsienne, quoique peu naturelle, est encore loin d'être abandonnée.

A ces hommes succéda Fabricius, qui introduisit dans la science une classification fondée sur les caractères de la bouche. Pendant toute sa vie, il poursuivit cette idée, dont l'inconvénient est d'apporter une grande hétérogénéité dans les insectes qui composent la plupart des groupes, par suite de l'unité absolue de caractère, prise pour base du système; mais il n'en a pas moins rendu de grands services à l'entomologie, en faisant connaître tout le parti qu'on en peut tirer.

Fabricius joignit à ces travaux systématiques des traités séparés sur chacun des ordres qu'il avait créés, et décrivit un nombre considérable d'espèces nouvelles. Ses descriptions, habilement imilées de Limné, pèchent cependant par un excès de concision. Il est le seul jusqu’à nos jours qui ait présenté des species généraux des divers ordres 
d'insectes; et, quoique aujourd'hui ses ouvrages ne soient plus au niveau des connaissances, ils n'en sont pas moins la base de tout travail descriptif. Ses principaux ouvrages datent des dernières années du xvin ${ }^{\mathrm{e}}$ siècle et des premières du $\mathbf{x I x}^{\mathrm{e}}$.

A ces hommes distingués soit comme classificateurs, soit comme descripteurs, s'en joignent d'autres qui traitèrent de la science en général, ou publièrent des descriptions et des monographies. Mlle Sybille de Mérian est l'auteur d'une iconographie des insectes de Surinam; Frisch a décrit ceux de l'Allemagne; Wilkes a écrit sur les lépidoptères de l'Angleterre; Clerck a traité le même sujet dans un ouvrage fort rare aujourd'hui ; Sepp a laissé une faune des insectes de la Hollande; Ladmiral est l'auteur d'un recueil d'observations 'curieuses sur les métamorphoses des insectes; Scopoli a publié l'entomologie de la Carniole; Schæffer, celle de Ratisbonne; Schrank, celle de Bavière; Pallas, l'entomologie de la Russie et de la Sibérie; Laicharting a fait connaître les insectes du Tyrol; Paykull, les coléoptères de Suède; Illiger, ceux de Prusse; et, de plus, cet auteur a cherché à combiner le système de Fabricius avec celui de Linné. Denis et Schiffermüller, en publiant leur catalogue systématique des lépidoptères des environs de Vienne, ont fait faire de grands progrès à l'histoire des papillons.

De toutes parts on publia des faunes entomologiques; chaque pays eut bientôt la sienne; et si la science n'était pas faite à cette époque, tout du moins annonçait qu'elle était près de l'être.

Actinologie. - L'actinologie resta dans l'enfance jusqu'au xvin ${ }^{e}$ siècle. Tous les botanistes réclamaient les polypiers comme appartenant au règne végétai. Marsigli décrivit la prétendue inflorescence des coraux ; Tournefort publia, en 1700, un mémoire ayant pour objet d'établir les différences qui existent entre les plantes marines et les plantes maritimes, et il y expliquait la manière dont il supposait que croissent les madrépores. Cependant quelques auteurs commencèrent à entrevoir celte erreur : Rumph démontra, le premier, la nature animale des coraux; mais ce ne fut qu'en 1727 que Réaumur fit connaître à l'Académie des sciences la découverte faite, par Peysonnel, de l'animalité des lithophytes, en assurant que les prétendues fleurs du corail, figurées par Marsigli, sont des animaux agrégés, et que les madrépores, les millépores et tous les lithophytes sont des tests agglomérés, qui semblent servir d'habitation à ces animaux. Toutefois Réaumur n'adopta pas cette opinion, et 
publia un mémoire sur la manière dont peurent végéler les coranx. Limné hésita longtemps à l'adopter, el Shaw décrivit la croissance du madrépore rameux ; mais la découverte des polypes d'eau donce, publiće par Trembley, en 1740, triompha des répugnances des naturalistes, ct l'on reconnut que ces polypes sont le type nu des animaux des coraux. En 1742, Bernard de Jussieu constata l'animalité de divers êtres rangés jusqu'alor's parmi les fucus, et il adopta le nom de polype pour désigner ces pelits animaux. Réaumur finit par se rendıe à l'évidence; il r'econnu l'exactitude de la découverte de Peysonnel, el créa le nom de polypier, adopté depuis pour désigner la partie solide des zoophytes. Dès ce moment, les polypes furent rapportés à la classe des animaux. Linné suivit l'exemple général ; dans la sixième édition de son Systema naturae, il comprit les coraux dans le règne animal; mais il rompil les rappor's naturels qui unissent les divers genres des zoophytes, en les séparant par son ordre des vermes testacei.

Le premier auteur systématique est Hill, bien que son travail soit très diffus. Dans les éditions du Systema natura, qui suivirent la sixième, Linné fit peu de changements à sa classification première, el laissa les zoophytes parmi les vers. Pallas publia, sur le même sujet, un ouvrage aussi remarquable que tous ceux qu'on doit à cet homme célèbre; ses genres sont bien établis; mais il les a rangés entre eux presque au hasard, et il a laissé les corallines parmi les végétaux. Roques de Maumont, dans son mémoire sur les polypiers de mer, a exposé d'une manière convenable le système de Pallas. Othon Müller a également beaucoup contribué aux progrès de la zoophytologie, surtout sous le rapport de l'étude micrographique de ces animaux; et son ouvrage, quoique contenant un grand nombre d'erreurs, est encore regardé comme classique. Scopoli fil quelques heureuses modifications au système de Linné, sans néanmoins rien ajouter à la science. Blumenbach et Batch firent un essai semblable, quoique moins heureux.

Les auteurs les plus célèbres en actinologie sont : Ellis, dont l'ouvrage, terminé plus tard par Solander, offre de bonnes descriptions et d'excellentes figures de polypiers; Forskal, qui a donné, dans son voyage en Orient, des détails intéressants sur les zoophytes, et qui a fait connaître plusieur's genres nouveaux ; Vitali et Donati, qui décrivirent un grand nombre de polypiers; Cavolini, auquel on doil un bon mémoire sur les polypes, travail remarquable sur les madrépores, les coraux, les lithophytes, distribués d'après l'étude des animaux. Esper, Link, 
Bianchi, Klein, Bohadsch, les voyageurs Sloane, Brown et Loeffling contribuèrent aussi par leurs travaux, tant descriptifs qu'iconographi ques, aux progrès de cette science qui, nce dans la première moitié dı xvmI siècle, avait, cinquante ans après, une forme arrêtée.

Botanique. - Si, dans le cours du xvin ${ }^{\mathrm{e}}$ siècle, la zoologie fit des progrès dans toutes ses parties, la botanique, toujours plus avancée, ne s'arrêta pas, et ses plus grands perfectionnements datent de cette époque.

La physiologie végétale, qui devait son premier essor aux travaux micrographiques de Grew, de Malpighi et de Leuwenhoek, avait encore beaucoup à faire pour éclairer certains points de la vie des végétaux. Le xvIII $^{\mathrm{e}}$ siècle ne manqua pas d'observateurs attentifs qui se livrèrent exclusivement à l'étude des phénomènes organiques propres aux végétaux. Woodward constata que les plantes absorbent l'eau; Wolff vit que les fibres se composent de cellules, reconnut la circulation ascendante ct descendante de la sève, et fit voir par des expériences, au moyen de la pompe pneumatique, que les trachées contiennent de l'air.

Hales publia à Londres, e» 1727, sa Satique des végétaux, qui valut à son auteur une réputation justement méritée, par la précision de ses expériences sur la nutrition des plantes, sur les phénomènes de la transpiration et de l'exhalaison, et sur la puissance ascensionnelle de la sève. Les expériences de ce physiologiste ont toujours été fort estimées ; tous les auteurs qui lui ont succédé les ont mentionnées avec éloge.

En'173̊3, Sarba, plus connu sous le pseudonyme de La Baisse, démontra que la sève monte par le corps ligneux, et non par la moelle et par l'écorce. Duhamel, dans sa physique des arbres (1758), répéta avec succès les expériences de La Baisse. Guettard, en reproduisant de son côié celles de Hales, reconnut l’influence de la lumière solaire sur la production du phénornène de la transpiration. Ses travaux sur les organes excrétoires ont un grand intérêt. Seligmann suivit la marche de la sève dans les feuilles; Bohmer étudia le tissu cellulaire; Bonnet fit de nombreuses expériences sur l'exhalaison des feuilles et sur leur mode d'absorption. H. de Saussure (1762) multiplia les observations sur l'usage de l'épiderme des feuilles et des pétales; il enrichit la science d'un fait important, en démontrant que l'exhalaison a lieu par des pores nommés stomates. Martin van Marum (1773) étudia le mouvement des fluides dans les végétaux, et le compara avec ceux des animaux. Corli (1775) observa la circulation dans les plantes 
aquatiques. A la mème époque, Koelreuter éclaircit, par de nombrenses expériences, la théorie de l'hybridité chez les végétaux. En 1780, Priestley découvrit que les parties vertes des plantes versent dans l'air du gaz oxyģène, sous l'influence de l'action solaire. Mustel publia, en 1781, un traité théorique de la végétation; Gleichen et Ludwig observèrent le pollen; Sennebier, expérimentateur précis et intelligent, fit connaitre le résultat de ses observations relativement à l'action de la lumière sur les végélaux. Hedwig, un des plus célèbres botanistes de la fin du xvm ${ }^{e}$ siècle, a emrichi la science de ses immortels travanx smr l'anatomie des cryptogames; mais il s'est peu occupé des phanérogames.

L'étude de la structure des organes des végétaux el de leurs fonctions, malgré son importance, n’occupait cependant pas aussi généralement les phytologistes que la botanique descriptive et la méthodologie. Nous avons vu qu'à la fin du xvir siècle, Tournefort avait établi un système de classification fondé sur certains rapports naturels, el que les défauts de sa méthode viennent de ce qu'il a omis des caractères d'une véritable importance pour leur en substituer qui en ont une beaucoup moindre. Sa réputation fut éclipsée par Linné, qui, non moins célèbre en botanique qu'en histoire natırelle générale, changea la face de cette science. Les uns exaltèrent ses travaux, et cherchèrent jusque dans ses fautes un sujet d'admiration; les autres furent à son égard d'injustes détracteurs. Sa méthode de classification, fondée sur le nombre des organes sexuels, sur les l'apports réciproques de ces organes el leur réunion dans un même individı, ou leur séparation sur deux individus différents, est entièrement artificielle; elle a l'inconvénient de séparer des plantes liées entre elles par les plus étroites affinités, de présenter des anomalies dans le nombre des organes pris pour caractère unique, et de comprendre dans une même classe un nombre trop considérable de végétaux. Ce système est pourtánt le plus commode, ct celui dont l'étude permet à l'élève de rapporter le plus facilement les plantes à des classes déterminées. II appliqua aux végétaux le même mode de nomenclature binaire qu'aux animaux, joignail au nom de chaque plante une phrase concise, qui en contient la descriplion succincte.

Quoique Linné ait attaché une grande importance à la propagation de son système artificiel, il regardait la méthode naturelle comme le dernier mot de la science; il en publiail des fragments, l'enseignail à ses plus chers élèves, el professail l'admiration la plus profonde pour Bernard de Jussieu. 
Haller, aussi habile botaniste qu'anatomiste profond, n'adopta pas le système de Linné, qu'il attaqua avec aigreur; et, comme la méthode naturelle, qui n'était encore qu'ébauchée, ne présentait pas un ensemble satisfaisant, il proposa dans ses ouvrages une méthode particulière, mais dont l'insignifiance est telle qu'elle ne mérite aucun développement.

En 1753, époque du plus grand triomphe de Linné, Adanson établit ses familles naturelles et chercha à délivrer la botanique des classifications arbitraires, pour ne suivre que les indications de la nature. II divisa les végétaux en cinquante-huit groupes ou familles, subdivisées en seize cent quinze genres qu'il s'efforca de ranger dans un ordre tel que ceux qui commençaient une famille fussent liés par l'analogie à ceux qui terminaient la famille précédente. Ce système, qui semble, au premier coup d'osil, remplir toutes les conditions d'exactitude, a le grave inconvénien de ne tenir aucun compte de la subordination des caractères, en donnant une égale importance à tous les organes, tandis qu'il s'en faut de beaucoup qu'il en soit ainsi. Adanson réforma la nomenclature, mais d'une manière trop arbitraire pour être adoptée. Son ouvrage est conç sur un plan large et empreint d'une profonde philosophie; cependant il ne put lutter contre la méthode artificielle de Linné; et il n'eut qu'un médiocre succès, quoiqu'il puisse toujours être consulté avec fruit.

Le savant et modeste Bernard de Jussieu, qui s'occupait dans la retraite du perfectionnement du système naturel existant déjà en germe dans les bons esprits, et qui le répandait parmi ses élèves, n'eût jamais osé le présenter au public, s’il n'avait été chargé par Louis XV, en 1759, de disposer à Trianon un jardin botanique, qui n'eut qu'une existence éphémère. Cet essai eut peu de retentissement, et la véritable divulgation de la méthode naturelle est due à Antoine-Laurent de Jussieu. Ce dernier rangea, d'après cette méthode, le Jardin des plantes de Paris; il fit paraître, en 1789 , le Genera plantarum, immortel ouvrage, qui, suivant le témoignage de Cuvier, a eu la mème influence sur les sciences naturelles que les travaux de Lavoisier sur les sciences physiques. Il comprend cent ordres naturels, divisés en quinze classes, et présentant un ensemble de dix-sept cents genres. On a rejeté à la fin, comme incertue sedis, un certain nombre de genres qui n'ont pu trouver place dans les ordres. Ce travail était un résumé complet, quoique succinct, de tout ce qu'on connaissait sur les végétaux à cette époque.

Ludwig contribua puissamment à la réforme de la phytologie. Après la philosophie botanique de Linné, les Institutiones historia physi- 
cee regni vegetabilis de Ludwig sont un des ouvrages les plus profonds sur cette science.

J.-J. Rousseau a consacré quelques pages éloquentes à la botanique. Il a voulu ainsi venger cette science aimable du reproche qu'on lui faisait de n'ètre qu'une nomenclature aride.

Lamarck publia, en 1778, un système dichotomique, au moyen duquel on arrive à la connaissance du nom de la plante, par une série de questions et sans aucune opération complexe de l'intelligence. Ce système fut modifié et simplifié quelques années plus tard par Lestiboudois.

Gærtner publia, en 1789, sa Carpologie, dans laquelle il examina et décrivit avec une patience admirable la structure de la graine et du fruil. Son ouvrage fut d'un intérêt tout particulier pour la méthode naturelle qui tire ses caractères principaux de la structure de la graine, et il jouit encore de toute l'estime des botanistes modernes.

Lamarck et Jacquin s'occupèrent avec succès de botanique descriptive. Le premier rédigea la partie botanique de l'Encyclopédie; et Jacquin fit paraître un grand nombre de figures de plantes, dessinées avec un talent remarquable. L'Héritier, Willdenow, Cavanilles, Duchesne, etc., publièrent des recueils de descriptions d'une grande exactitude. Michéli, Dillwin, Hedwig, Gmelin, Bulliard étudièrent les cryptogames.

A ces travaux, qui embrassent l'ensemble et les détails de la science, se joignent les flores, plus nombreuses pendant ce siècle qu'à toutes les époques précédentes. Pontedera décrivil les plantes d'Italie; Gleditsch, celles des environs de Leipzig; OEder, celles du Danemark; Jacquin, celles d'Autriche; Allioni, celles du Piémont; Smith, celles d'Angleterre; Lamarck et De Candolle firent paraittre leur Flore française.

Géologic. - La direction que les études antérieures avaient donnée à la pensée eut une influence bien prononcée sur les travaux du xvır siècle. On s'y occupa beaucoup de géogénie, et la manie des théories cosmogoniques y fut poussée si loin que chaque savant se crut obligé d'en inventer une. Loin d'arrêter cette tendance, les progrès de la géologie, en jetant quelques lumières sur l'histoire primitive du globe, furent, pour les géologues, la cause d'hypothèses nouvelles.

Vallisnieri, qui donna l'un des premiers (1721) une esquisse générale des dépôts marins de l'Italie, fut tellement frappé de la continuité de ces terrains, dans toute cette presqu'île, qu'il arriva à conclure que l'Océan avait primitivement recouvert la terre tout entière pendant un très 
long espace de temps, et que son niveau s'était ensuite graduellement abaissé.

De Maillet publia, en 1735, sous le titre de Telliamed, ses idées su' les révolutions de notre planète. Il partit du principe que le globe a été originairement couvert par des eaux marines qui, par leur diminution progressive, formèrent les terrains d'alluvion, et abandonnèrent sur les hautes montagnes les coquilles qu'on y rencontre. Étranger aux idées de soulèvement, ne voyant, dans tous les phénomènes géogéniques, que le résultat de l'action des eaux, il veut que les reliefs du globe aient été lentement accumulés au fond de la mer par des courants chargés de limon, et il ne voit pas d'autres révolutions. Ces explications forcées le conduisirent à des résultats plus extraordinaires encore pour expliquer la présence des plantes et des animaux. Comme il donne une origine aquatique à tout ce qui existe, il voit les végétaux marins, mis à découvert par la retraite des eaux, devenir des végétaux terrestres. Il en esi de même des animaux qui, d'après lui, se modifièrent à mesure que changea le milieu dans lequel ils vivaient; ainsi, les poissons, restés à sec sur des roseaux, se métamorphosèrent en oiseaux; leur's nageoires devinrent des ailes et leurs écailles des plumes; tandis que ceux qui étaient restés sur les hauts fonds prirent la forme d'animaux terrestres. Pour appuyer son système, De Maillet ne recule pas devant les exagérations les plus grossières; il accueille toutes les fables, se complaît dans des détails absurdes, et raconte avec une étonnante naïveté les aventures d'hommes marins ou devenus tels par accident; aventures qui occupèrent les esprits crédules du xvır siècle et amusèrent encore notre enfance.

Cet auteur n'est guère, au reste, que le reproducteur du systènı d'Anaxagore, qui ne voyait dans tous les animaux que des poissons transformés; et ses idées sur le rôle des eaux dans les révolutions du globe sont celles qui ont dominé de tout temps. Scheuchzer, l'un des plus ardents défenseur's des idées diluviennes, chercha à soutenir cette théorie par des suppositions prises en dehors de la science. Il rendit cependant de grands services à la géologie, en publiant un calaloguc raisonné des fossiles qu'il avait déterminés, quoique souvent d'une manière erronée; car on y trouve l'homo diluvii testis, reconnu depuis, par Cuvier, pour les restes d'une salamandre gigantesque.

L'habile minéralogiste Henckel essaya, dans sa Pyrilologi (1723), d'expliquer les faits consigués dans la Genese; mais sa théoric est vide 
et fausse ; seulement, en sa qualité de minéralogiste, il a domné de bons renseignements sur la direction des filons métalliques.

Lazaro Morro (1740) est l'auteur d'une théorie géogénique fort ingénieuse. Il admet le soulèvement de montagnes primitives el secondaires par l'action des feux souterrains; les premières, avant l'existence des êtres organisés ; les secondes, après leur apparition, ce qui explique leur présence sur le sommet de ces dernières montagnes.

Fontenelle reproduisit en partie l'opinion de Leibnitz dont nous avons parlé plus haut.

Linné, tout positif qu'il était, fit aussi sa cosmogonie; mais son système géogénique porte la trace de l'imperfection de ses études primitives, bornées à l'observation des phénomènes géologiquies naturels qui se manifestent en Suède. Il ne connaissait pas suffisamment la disposition des roches et ne pouvait demander de lumières à la minéralogie pour en déterminer la nature. Il admettait l'inondation primitive dı globe et la formation des continents par la retraite successive des eaux.

Linné déclare que, malgré toutes ses recherches, il n'a pu découvril de trace du déluge. Suivant cet auteur, les roches quartzeuses, quelquefois les gneiss, déposées par les eaux, forment l'assise la plus profonde dı globe; puis viennent les schistes, devant leur origine à la destruction des plantes marines accumulées au fond des eaux; la troisième assise, composée de substances calcaires et de matières animales fossiles, est formée par les mollusques, les zoophytes et les animaux marins; la quatrième est encore de nature schisteuse ; la cinquième est formée de roches dures, composées de parties hétérogènes, réunies par un ciment; la sixième et la seplième, de nature siliceuse ou argileuse, ont recouvert les débris animaux et constitué les vastes plages marines sur lesquelles s'accumulent les fucus, dont la destruction forme la terre, quand ils sont pulvérulents, et les roches quand ils sont réunis par un ciment. Ses idées théoriques ont beaucoup influé sur sa classification des minéraux. On reconnaît dans ce système, en le comparant à celui de Buffon, la différence de méthode qui séparait ces deux grands hommes, Linné toujours analyste, Buffon synthétiste audacieux.

Ce dernier, chez lequel la fécondité de l'imagination s'unissait à une grande puissance de déduclion, ne put résister au désir de créer une théorie géogénique, et il écrivit ses Époques de la nature; conception hardie, souvent juste, et nonument précieux de littérature. Il admet que notre planète, détachée dı soleil dans un état d'incandescence, 
s'aplatit sur les pôles, pendant sa période de fluidité, et que, s’étant peu à peu refroidie, elle se couvrit d'eau par suite de la condensation des vapeurs que finirent par absorber les cavités intérieures. Après quarante-trois mille années de refroidissement qui n'éteignirent pas le feu central, mais qui recouvrirent le globe d'une croûte possédant une chaleur tempérée, les végétaux et les animaux se produisirent à sa surface. Vinrent ensuite les formations secondaires. Pendant cette longue période eurent lieu de nouvelles révolutions et les reliefs du globe se formèrent. Les courants, les éruptions volcaniques et d'autres phénomènes déterminèrent les montagnes, creusèrent les vallées et donnèrent lieu aux différents mouvements de terrain. Buffon n'a point admis la théorie de la formation des montagnes par soulèvement; il pensait que toutes les causes modificatrices de la surface du globe se produisaient au sein des mers, dont le déplacement laissait à la nature organique le moyen de se développer. Un des principaux mérites de Buffon, comme géologue, est d'avoir inspiré le goût de cette science par le charme répandu dans ses écrits.

Vallerius, compatriote et contemporain de Linné, admet que les inégalités de la surface dı głobe sont dues à l'action du déluge et à la puissance érosive des eaux.

Guettard dressa le premier, en 1746, des cartes géologiques, destinées à représenter la nature des terrains. Il divisa la terre en trois bandes : la bande schisteuse, correspondant aux formations primitives et intermédiaires ; la bande marneuse comprenant nos terrains secondaires; et la bande sablonneuse ou formation tertiaire. On lui doit les premières études attentives du bassin parisien.

Needham (1769) admet la formation, par soulèvement, des montagnes dont les couches étaient originairement horizontales, et il trouve une preuve de leur origine neptunienne dans la présence des corps organisés qui s'y rencontrent.

Sulzer altribue les diverses modifications de la surface du globe à des cataclysmes successifs dont l'un, qui eut lieu à l'époque où la nature était organisée, est le déluge universel.

Rouelle, dont les opinions géogéniques nous ont été transmises par Desmarest, son disciple, a divisé l'écorce du globe en deux groupes, qu'il appelle l'ancienne et la nouvelle terre, séparées par un massif intermédiaire composé des masses argileuses et schisteuses, au sein desquelles il place les houillères. Dans le premier se trouvent le gra- 
nite, le gneiss, etc.; dans le second, il place les divers dépôts calcaires marneux, argileux, quartzeux, etc., divisés depuis en terrains sccondaires et tertiaires. Cet habile chimiste possédait des connaissances paléontologiques assez cxactes; il avait remarqué que la plupart des empreintes des végétaux qui se trouvent dans les houillères n'ont leurs analogues que dans des climats éloignés. Voyant qu'il en étail de même pour les débris d'éléphants et d'une multitude d'autres mammifères qu'on trouve dans les terrains diluviens, il crut pouvoir en conclure lę déplacement graduel de l'axe de notre planète.

La théorie de Lehmann (1759) est à peu près celle de Rouelle; mais une errcur de ce géologue est d'avoir cru que, de l'étude géognostique des montagnes du Harz et de la chaine de l'Erzgebirge, il pouvait déduire la structure de toute l'écorce du globe.

Michell, Whitehurst et Kier firent des études géologiques attentives. sur les diverses formations des Iles Britanniques. On doit aux deux dernier's des travaux intéressants sur les calcaires carbonifères.

Robiquel (1761), dépourvu de connaissances scientifiques, tenta d'ex pliquer la formation de l'homme comme fin dernière de la nature; il cmprunta une partie de ses idées à De Maillet, et les accompagna des extravagances les plus puériles.

En 1772, Bergmann; neptunien comme presque tous les géologues de son époque, exposa avec une grande justesse d'observation, dans sa géographie physique, les changements successifs que la terre a éprouvés depuis sa solidification. Il connaissait un grand nombre de faits relatifs à l'histoire paléontologique du globe.

La Théorie de la terre, publiće par Hutton, en 1785, eut une grande influence sur la géologie. Cet auteur repoussa une partie des hypothèses qui attribuaient à l'eau l'origine de certaines roches; il cxpliqua par l'action du feu central, non seulement la formation d'une foule de roches: et de minéraux, mais aussi celle de nos continents, qu'il considère comme soulevés du fond des eaux. Les raisonnements de Hulton on souvent une grande solidité; mais quclquefois aussi ce géologue se perd dans les hypothèses; ce qui détruit l'impression favorable produite par ses assertions sérieuses. Il fut le chef de l'école des vulcanistes.

A ces géologues succéda Werner, dont le système éclipsa ceux qui l'avaient précédé. En 1787, il publia sa théoric qui, jusqu'én 1796, recut de grands perfectionnements. Il distingua, comme Lehmamn, les terrains en plusicurs époques: il appela primilifis ou à filons, les terrains 
graniliques; secondaires ou à couches, les terrains stratifićs d'origine plus récente et présentant des restes organiques. Plus tard, il désigna, sous le nom de terrains intermédiaires ou de transition, des dépôts intercalés entre les terrains primitifs et secondaires, et présentant certains caractères particuliers. Il eut, comme Lehmann, le tort de croire que les montagnes du IIarz offrent le type de toutes celles de la terre, et il tomba dans l'erreur opposée à celle d'Hutton, en attribuant toutes les formations au fluide aqueux; d'où le nom de neptunistes donné à ses disciples.

Werner dut son influence à la forme arrêtée de son système, et surtout au talent avec lequel il enseigna à déterminer la composition minéralogique des roches; mais, comme tous les hommes à conceptions élevées, il inspira à ses disciples, non pas cette vénération indépendante qui doit caractériser les vrais savants, mais l'admiration fanatique qui préconise jusqu'aux plus grossières erreurs. Ce servilisme scientifiqne nuisit beaucoup aux progrès de la géologie.

De Saussure et Pallas, dont l'un explora les Alpes et l'autre les monts Ourals et la Sibérie, contribuèrent aux progrès de la science par leurs nombreuses observations. Ils s'accordèrent à reconnaître la formation des montagnes par l'action du feu ou des autres fluides élastiques, qui, renfermés dans l'intérieur du globe, en soulevèrent la masse.

On voit, malgré la diversité des théories géogéniques de celte époque, qu'à mesure que nous approchons du $\mathrm{xrx}^{\mathrm{e}}$ siècle, les systèmes acquic̀rent quelques degrés de cerlitude de plus, et que les théoriciens, même les plus hardis, ne se croient pas dispensés de l'observation; aussi les progrès de la géologie se trouvèrent-ils préparés par la nombreuse collection de faits que nos pères avaient amassés.

Minéralogie. - La minéralogic, celle compagne inséparable de la géologie, existait à peine au commencement du xvın ${ }^{\mathrm{e}}$ siècle. Son caractère purement descriptif, favorisant peu les hypothèses, n'avait aucun attrait pour les créateurs de systèmes; mais on reconnut bientôt les étroites relations qui l'unissent à l'étude des masses inorganiques, et les recherches, dirigées dans cète voie, amenèrent d'heureuses découvertes. Ce fut alors que partrent les premiers essais tentés pour systématiser celte science; essais qui allèrent toujours en se perfectionnant.

Bromel (en 1730) fut le premier des auteur's méthodiques qui divisa les minćranx d’après leurs caractères pyrognosliques, combinés arce 
leurs caractères extéricurs. ¿Qnelqnes années après, Linné, qui porta le mème esprit d'investigation sur toutes les branches des sciences naturelles, introduisit, dans la classification des minéraux, l'importante considération de la forme cristalline. Malggré l'imperfection de son système, qui tient à la nature de ses idées cristallogéniques, il peut être considéré comme l'un des fondateurs de l'école géométrique, qui a pris un développement si marqué vers la fin du xvmi siècle. Déjà, cependant, Sténon et Capeller avaient émis, sur les cristaux, des idées dignes de fixer l'attention des physiciens.

Le mode de division proposé par Bromel fut adopté, à quelques modifications près, par Cramer, Waltersdorff, Geller', Cartheuser et Wallerius. L'ouvrage de ce dernier alteste un véritable progrès, sous le double rapport du choix des caractères et de la précision de la nomenclature.

L'élan était donné, et la minéralogie allait enfin sortir de l'enfance. En 1758 commença pour celte seience une nouvelle période: Cronstedt eut recours à un principe de classification inconnu jusqu'alors, auquel il subordonna tous les caractères; le premier, il prit en considération la composition élémentaire des minéraux; il fut suivi dans celte voie par Bergmann, de Born et Karsten. Après lui, Kirwan, Wenzel et Richter firent sentir la nécessité de déterminer avec soin les proportions des ćléments. Buffon (1755), qui répandait tant de charmes sur les sujets les plus arides, s'occupa aussi de minéralogie; mais l'étal peu avancé de la science ne lui permit pas de s'élever à la mème lauteur que pour les autres branches de l'histoire naturelle.

En 1774, Werner, le célèbre fondateur de l'école de Freyberg, entrcpril de ramener à des principes réguliers la détermination empirique des espèces minérales, et il en définit les caractères extérieurs avec une précision inconnue avant lui.

Vers le même remps, Romé de Lille publia son Essai de cristallographie, dans lequel il établit le principe de la constance des angles dans les cristaux, et celui de la dépendance mutuclle des formes cristallines dans la même espèce. En 1779 et 1780, Monnet el Fourcroy établirent chacun une classification des minéraux, fondée sur leur composition chimique. Daubenton (1784) essaya un système de cristallisation qui fut bientôt oublié. Haüy, son élève, le véritable créateur de la cristallographie, fut plus heureux; il fit concourir à la distinction des substances minérales les caractères géométriques, physiques et chimiques; il donna to premier une défmition rignureuse de lespèce mï. 
nérale; et la science eut des lois pour diriger sa marche, des règles fixes, des principes solides et incontestables.

Les études sérieuses auxquelles se livrèrent les minéralogistes, guidés dans leurs recherches par les lumières de la chimie, firent chaque jour découvrir de nouvelles substances; ainsi, en 1723, Brandt avait fait connaître l'arsenic, et Wood, le platine; en 1730, Delnyard découvrit le tungstène; Grégor, le titane; Müller, le tellure; Hielm, le molybdène; Bergmann, la magnésie et la baryte; Richter essaya de déterminer la saturation des acides el des bases.

On voit, par ce rapide exposé des vastes travaux du xvIII $^{\mathrm{e}}$ siècle, que l'esprit humain, se dégageant peu à peu de ses entraves, n'était plus enchaîné, comme dạns les siècles précédents, par l'autorité des maîtres de la science; que la parole des Haller, des Linné, des Buffon, quelque puissante et quelque respectée qu'elle fût, ne pouvait plus arrêler le progrès, et que chaque jour une découverte, une révision nouvelles, apportaient, dans les systèmes les plus goûtés, des modifications tantôt heureuses, tantôt simplement hardies, ou les renversaient sans pitié. Le xvin ${ }^{e}$ siècle a donc ouvert aux sciences la voie de la vérilé, et le :Ix ${ }^{\oplus}$ n’a pas déserté les. larges routes qui lui étaient frayées.

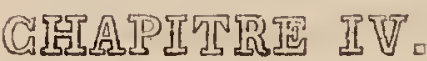

量tat des sciences naturelles depuis 1789 jusquà nos jours.

Les doctrines philosophiques du xvı ${ }^{e}$ siècle, l'indépendance née de l'esprit d'observation, affranchi du joug de toute autorité que n'avouait pas la raison, avaient répandu partout une vague inquiétude, avantcourrière d'une crise prochaine. Les études générales n'absorbaient plus l'attention des esprits méditatifs; chacun prenait part aux agitations de la politique, comme, dans le siècle précédent, les savants avaient mêlé à leurs travaux de vastes questions sociales. Cette sourde fermentation devenail sans cesse plus active. D'un côté, mouvement, agitation; de l'autre, compression, résistance. De ce choc d'intérêts et d'opinions résulta la plus grande commolion politique qui ail ćbranlé le 
monde. La révolution française portail dans son sein le germe de la guturre, et bientòt toute l'Europe fut embrasée. Pendant près de vingt-cinq ans, il y eut dans les sciences une perturbalion violente. Le commerce entre les savants fut interrompu, les communications des peuples perdirent tont caractère pacifique, les souverains n'eurent plus le loisir de s'occuper de science, et tous les esprits parurent agités du souffle révolutionnaire, qui se mêlait même à la vie intime. Les savants étrangyers se trouvèrent d'abord dans une position plus favorable que les savants français; mais bientôt la science, plus puissante chez nous que tous les obstacles, anima de son esprit des hommes dignes d'elle.

Au milieu de la tourmente, à l'époque où l'Europe entière armée contre nous semblait avoir concentré l'énergie nationale dans le sentiment exclusif de la défense, les sciences trouvèrent encore des représentants que n'effrayèrent ni le tumulte des armes, ni la vie des camps, ni les hasards d'une lutte acharnée. Nous voyons notre glorieuse expédition d'Orient devenir une nouvelle occasion d'études. Des géographes, des astronomes, des naturalistes, se pressent à l'envi sur les pas de nos guerriers. Savigny, Geoffroy Saint-Hilaire, Cordier, Delille, dressent l'inventaire des richesses naturelles de l'Égypte. Des expéditions lointaines ont lieu dans le même but : d'Entrecasteaux vole à la recherche de l'infortuné La Pérouse, et La Billardière rapporte de ce voyage des plantes et des animaux nouveaux; Baudin visite les Ancilles, la NouvelleHollande et l'archipel indien; et, grace au zèle infatigable de Péron et de Lesueur, ce voyage ne reste point stérile pour la science; Bosc visite l'Amérique; Bernardin de Saint-Pierre, l'Ile-de-France; Olivier, le Levant; Palisot de Beauvois, la Guinée et Saint-Domingue; Poiteau et Turpin explorent aussi celte dernière colonie; Desfontaines et Poiret parcourent la Barbarie; Levaillant et Delalande, l'Afrique et le Cap; La Billardière, la Syrie; Michaux, Cayenne et l'Ile-de-France; Sonnerat, Commerson et Dombey enrichissent nos musées du fruit de leurs pénibles recherches. Les étrangers ne nous le cèdent pas en activité : les Porlugais Loureiro et Vellozo visitent, l'un la Cochinchine, l'autre le Brésil; les Espagnols Ruiz et Pavon, le Chili et le Pérou; Mocéran, le Mexique. Les Anglais, mettant à profit leur puissance, visitent leurs vastes colonies dans un intérêt scientifique; Roxburgh parcourt l'Inde; Masson, le Cap; Smith et Shaw, la Nouvelle-Hollande, si riche en animaux inconnus.

Les résulats obtenus par les divers voyages antérieurs, l'accumula- 
tion des trésor's dont nos musées sont le vaste dépôt, le goût toujour's croissant des sciences naturelles, excitent le zèle des voyageurs. Différentes contrées sont plus soigneusement explorées. L'Amérique septentrionale est successivement parcourue par le prince Paul de Würtemberg; par les Français Milbert, Lesueur, Michaux, de la Pylaie, Charles Bonaparte; par les Anglais Lyon, Franklin, Richardson, Sabine; par les Américains Mitchill, Lewis, Clarke, Harlan, Bertram, Say el Wilson, qui s'avancent jusque dans les parties les plus reculées de ce continent.

Rengger visite le Paraguay, que la jalouse défiance du docteur Francia ferme aux voyageurs; Bertero et Jurieu explorent le Chili ; Aug. Saint-Hilaire, Spix, Martius, Pohl, le prince de Neuwied, le Brésil; de Humboldt, Bompland, Boussingault, Roulin, Alcide d'Orbigny, Lacordaire, Pœppig, parcourent les nouvelles républiques de l'Amérique méridionale; Descourtilz, Moreau de Jonnès, Lachesnaye, Pley, Ricord el Poey nous font connaître les richesses naturelles des Antilies.

Russel, Buchanan, Raffles, Leschenault, Diard, Duvaucel, Jacquemont, Dussumier, Ad. Delesserı, visitent les Indes, Sumatra, les îles de la Sonde; Blumhof et Siébold, le Japon; Reinwardt, Blum, Kuhl, Van Hasselt, affrontent le climat mortel de Java. Ehrenberg, Hemprich, Rüppel et Schimper choisissent l'Égypte, la Nubie, l'Abyssinie, la Syrie, l'Arabie, pour théàtre de leurs explorations scientifiques; Mungo-Park, Denham, Clapperton, Caillé, pénètrent dans l'intérieur de l'Afrique; Webb et Berthelot visitent les Canaries; Durville et Gauthier, les côtes de la mer Noire. Le vaste empire de Russie est parcouru par Klaproth, Parrot, Fischer et Vrangel. Ehrenberg et Rose explorent, en compagnie de de Humboldt, les régions de l'Oural el de l'Altaï.

A chaque expédition s'attachent des naturalistes. Des explorations scientifiques sont même organisées par les gouvernements. Krusenstern et Kotzebue font les premiers voyages de circumnavigation entrepris par la Russie, et sont accompagnés par Tilesius et Chamisso; Parry, Ross, Back, visitent les mers arctiques; Freycinet, Duperrey, Dumont d'Urville, Laplace, accompagnés des naturalistes Quoy, Gaimard, Gaudichaud, Garnot, Lesson, Eydoux, nous font successivement connaître, avec plus de détails, les îles de l'Océanie, découvrent de nouvelles terres et rapportent de précieuses collections d'histoire naturelle.

En 1829, une commission scientifique parcourt la Morée. Quelques années plus lard, le voyage de circumnavigation de la Bonite fournit à 
Eydoux, Souley, Gaudichaud et Chevalier, l'occasion de recueillir dimportantes observations sur les trois règnes et de rapporter de nombreuses collections. Nos nouvelles conquêtes d'Afrique, explorées en premier lieu par le capitaine Rozet et, plus tard, par Maurice Wagner, sont visitées en ce moment par une commission scientifique. Dumont d'Urville et Dupetit-Thouars reviennent riches d'abondantes récoltes de leur dernier voyage au pôle austral; et à peine deux ans se sont écoulés depuis qu'une expédition a visité, sous la direction de Gaimard, l'Islande, le Groënland, les îles Féroë et la Scandinavie.

Parmi ces nombreux voyageurs, à qui nous devons de si précieuses découvertes, on compte un grand nombre de martyrs. Delalande meurt à Madagascar ; Godefroy, à Manille; Noël de La Morinière, en Norwége; Bowdich, sur la Gambie; Mungo-Park sur le Niger; les cendres de Kuhl et de Van Hasselt reposent dans l'île de Java; Duvaucel, Jacquemont et Roux sont dévorés par le climat brûlant de l'Inde; Pley, Leschenault, Eydoux et d'autres encore périssent victimes de leur zèle. Honneur à leur mémoire! Leurs noms ne périront pas; ils figureront glorieusement dans le martyrologe de la science.

L'analyse des travaux de ce siècle, quelque rapide qu'elle soit, nous forcera d'entrer dans des détails que nous avons dû négliger en parlant des époques antérieures. Nous parlerons moins des hommes qui, depuis quarante années, enrichissent la science du fruit de leurs laborieuses recherches, que de l'état des connaissances actuelles, afin qu'on puisse mieux apprécier les résultats obtenus par quatre siècles d'éludes sérieuses.

Astronomie. - Les progrès de l'astronomie ne dépendent plus aujourd'hui, comme ceux des autres sciences, de nombreuses et fréquentes découvertes, appuyées sur des théories se renouvelant sans cesse. Ses bases ont été irrévocablement posées; ct toutes les recherches, toutes les observations, ne sauraient plus tendre qu'à les confirmer ; aussi l'éłude des phénomènes restés sans explication, celle des mouvements anomaux des corps célestes est-elle l'objet spécial et presque exclusif de tous les efforts. Le système de Copernic, vérifié par les travaux de Galilée, de Képler, de Newton, d'Euler, etc., avait atteint, au commencement du $\mathrm{x}_{\mathrm{x}}{ }^{\mathrm{e}}$ siècle, un degré de certitude qui ne laissait de place à aucun doute; l'astronomic mathématique se perfectionnait chaque jour. En 1789, Liplace publia sa mécanique céleste; et, en 1800, son svstème du 
monde. En 1801, Piazzi découvrit Cérès; Olbers, en 1503, aperçu Pallas; en 1807, Vesta; en 1811, Harding signala Junon. Ces découvertes, paraissent avoir complété le système des planètes qui gravitent autour du soleil.

Les différents arcs du méridien, mesurés en France, en Angleterre, au Pérou, au cap de Bonne-Espérance, aux Indes-Orientales et en Pensylvanie; les perpendiculaires à la méridienne, imaginées pour arriver au même but, l'observation des irrégularités du mouvement de la lune, la comparaison des variations locales de la longueur du pendule, on fait connaitre que la figure de la terre se rapproche d'un ellipsoïde de révolution autour de l'axe qui passe par les pôles; l'un des avantages pratiques de ces travaux est d'avoir fourni la base du système métrique.

Les comètes que Newton et Halley avaient ramenées aux conditions générales du système planétaire ont été étudiées de nouveau par Laplace. Olbers a dorné un catalogue complet de celles dont on a pu calculer la marche, et qui sont aujourd'hui fort nombreuses, par suite des découvertes récentes. Néanmoins il n'y en a que trois, celles de Halley, d'Enke et de Gambart, dont on puisse prédire le retour avec certitude. On doit à M. Lambert, géomètre prussien, ct à M. Cournot, des recherches curieuses sur la distribution des comètes dans l'espace. M. Valz a reconnu que le diamètre de la comète à courte période allait en diminuant à mesure qu'elle s'approchait du soleil; M. Arago, dont les études ont embrassé toutes les parties de la science, a composé sur les comètes une notice pleine d'intérêt.

Plusieurs astronomes ont dressé des catalogues d'étoiles bien supérieurs à ceux des anciens; mais, jusqu'à ce jour, on a vainement essayé d'en déterminer la parallaxe. Leur mouvement, déconvert par Halley, avait d'abord été considéré par MM. Herschel et Prévost comme dénué de réalité; mais ce point de la science a été mis hors de doute par MM. Piazi, Bessel-Struve, Argelunder et par tous les observateurs modernes. Les travaux importants de Bradley sur les étoiles ont servi à M. Bessel de Kœnigsberg à élablir un des meilleurs catalogues que nous possédions. MM. Piazzi, Herschel, Struve et South ont étudié avec succès les étoiles composées, et réuni sur ces astres une longue série d'observations. Le catalogue d'Herschel, continué par son fils, contient l'énumération de 2500 nébuleuses. M. Arago a présenté, il y a un an, une théorie fort ingénieuse pour expliquer la scintillation des étoiles. MM. Arago, Mathieu et Bessel ont calculé la distance de 
l'étoile du Cygne à la terre; et ils ont trouvé que sa lumière not dix ans pour arriver jusqu'à nous.

Le globe lunaire a été l'objet d'observations pleines d'intérêt. Lagrange a découvert la cause physique qui fait que la lune nous présente toujours la même face; MM. Olbers, Brandes, Rode, Lamarck, ont éludié son influence sur notre planète; M. Schrœeter a mesuré la hauteur de ses montagnes, que M. Élie de Beaumont a essayé de classer comme i! l'a fait pour celles de la terre; MM. Riccioli et Gruithuisen ont observé la configuration de cel astre avec une patience infatigable, et $\mathbf{M}$. Beer en a donné une des meilleures cartes.

M. Schrœeter a étudié Vénus, dont la surlace est hérissée de montagnes élevées. Mercure l'a été avec le même soin. Les astronomes romains ont cru remarquer plusieurs anneaux autour de Saturne. Il reste à vérifier si ce fait est réel ou si ceš anneaux multiples ne sont effectivement que des zones noires placées sur la masse de l'anneau.

Les étoiles filantes occupent depuis quelques années l'attention de nos astronomes. On a remarqué que ces phénomènes sont plus fréquents à certaines époques, surtout au 10 août et du 10 au 13 novembre. M. Erman, de Berlin, explique les étoiles filantes par la présence d'une mullitude de petits bolides circulant autour du soleil, et ne devenant visibles qu'au moment où ils s'enflamment, en pénétrant dans notre atmosphère. Cette théorie n'est pas généralement admise, et l'on y fait plusieurs objections auxquelles il est difficile de répondre.

Il reste à l'astronomie à nous appl'endre, comme fait d'observation directe, si Uranus est la limite de notre système planétaire, s’il n’existe rien au-delà; et, comme résultat d'études plus profondes, si les théories d'Herschel sont confirmées par l'observation, et si la force qui enchaine les globes dans l'espace est le résultat d'une impulsion première ou d'un fluide universellement répandu; mais, arrivée à ce point, c'est à la physique que l'astronomie doit avoir recours pour trouver l'explication de ces derniers phénomènes.

Météorologie. - La météorologie est la branche des sciences physiques qui laisse le plus à désirer, et celle dans laquelle les lacunes sont les plus nombreuses. L'étude des phénomènes atmosphériques a, de tout temps, été pour l'homme d'un haut intérêt; et, quoique les premières observations remontent à une époque fort reculée, il règne encore dans plusieurs parties une obscurité profonde; certains mótéores ne 
sont même pas mieux connus que du temps d'Aristote. Les faibles progrès de cette science ne proviennent pas de l'indifférence qu'elle inspire, mais des difficultés qui l'entourent, et, le plus souvent même, de l'impuissance des moyens d'exploration.

Toutes les parties de la météorologie ne présentent pas les mêmes difficultés; ainsi les observations barométriques, thermométriques, et celles du magnétisme terrestre, se font avec succès; mais la mesure précise des vapeurs contenues dans l'atmosphère attend encore un instrument exact, et les météores ignés n'ont été que très imparfaitement étudiés. Dans ces derniers temps, on a institué en Europe des observations réglées; des correspondances se sont établies entre les observateurs; on peut donc espérer que la météorologie, sortant enfin de l'en. fance, pourra diminuer le mal que causent les intempéries des saisons et les désastres qu'entraînent avec eux les̉ ouragans et les tempêtes.

MM. Leslie, Fourier, Brewster, Arago, Cordier, de Humboldt, Prévost, Six, Legrand et Walferdin, ont recherché les lois de la température dans les diverses régions, à différentes hauteurs, et jusque dans les profondeurs de la croûte terrestre et des bassins des mers.

Depuis Bâcon jusqu'à Horsburg, Ia théorie des vents réguliers a été bien étudiée et biẻn établie. D'Alembert, Ramond, Dunbar, MM. de Humboldt, Bouvard, Morin, Capper, etc., se sont occupés de cet intéressant sujet; mais il n'en est pas de même des bourrasques et des rafales qu'on a voulu à tort expliquer par des changements de température, qui ne produisent que les vents réglés, les brises et les moussons. Une telle cause ne peut convenir à ces coups de vent, dont la brusque énergyie est précédée et suivie d'un calme presque complet, pour reparaître soudainement, après quelques instants de repos ; elle ne peut produire ces grains blanes dévastateurs, dont la subite apparition ne laisse pas même le temps de carguer les voiles d'un navire. M. Peltier a commencé à publier sur ce sujet une suite d'observations el d'expériences, au moyen desquelles il rattache la cause de ces actions brusques et capricienses à la puissante tension électrique des masses de vapeurs opaques ou diaphanes qui nagent dans l'espace:

Les météores aqueux ont élé observés par MM. Daltọ el Gay-Lussac, qui ont déterminé les lois des vapeurs. M. Daniel, en étudiant les lois de l'évaporation dans l'air, a cherché à appliquer les résultats de ses observations à l'horticulture.

MM. Howard, Th. Forster et divers autres ont classé les nuages 
d'après certaines formes qu'ils revêtent. MM. Leslie, Dalton, et surtont H. Davy, ont donné une bonne théorie des brouillards. MM. Dalton et Bouvard se sont occupés des quantités d'eau pluviale qui tombent sur différents points, et M. Koenitz a rassemblé les résultats de ces observations dans sa Méléorologie.

De toutes les théories de la grèle, c'est celle de Volta qui résista le plus au temps, quoiqu'elle ne pût répondre d'une manière satisfaisante ni à la cause du froid, ni à la formation des épines ou des crêtes des ģrêlons, ni au bruit qui précède leur chute. M. Peltier ayant rempli ces lacunes, cette théorie rend comple maintenant de toutes les parties du phénomène.

Malgré les expériences contradictoires de de Saussure, de Guthrie el d'Erman, on persistait à considérer l'air comme le réceptacle d'une quantité prodigieuse d'électricité, lorsque M. Peltier est venu démontrer que, sous un ciel serein, on n'obtenait qu'une électricité d'influence transitoire et non permanente, daus laquelle la terre jouait le rôle d'un corps chargé d'une puissante électricité négative. Depuis Volta, Laplace et Lavoisier, on avait pensé que l'électricité des nuages provenait d'une évaporation spontanée à la surface du globe; cette hypothèse régnait sans contrôle, malgré l'observation judicieuse de Guthrie; mais M. Peltier a fait voir que la vapeur produite par une température au-dessous de 110 degrés, ne s'échappe pas assez promptement pou' conserver de l'électricité libre, ę que celle qu'on tronve dans les nuages est emportée par les vapeur's, lorsqu'elles se forment sous l'influence de l'électricité positive de l'espace, et de l'électricité négative du globe terrestre.

C'est le $\mathrm{D}^{\mathrm{r}}$ Wells qui a donné la véritable théorie de la rosée, fondée sur les lois du rayonnement de la chaleur.

M. Arago a jeté beaucoup de jour sur un grand nombre de ces questions, et le magnétisme terrestre lui devia une partie de ses progrès, ainsi qu’à MM. Hansteen, Biol, Duperrey et Gauss. Les expériences de ce dernier ont constaté que le fluide magnélique est dans un état constant et iucessant d'agitation, ce qui en rend l'étude difficile.

Les halos, les parhélies, les couronnes, ont été étudiés par MM. Leslie, Young, Wollaston, Frauenhoefer, Babinet, Arago; les phénomènes du mirage ont été complètement éclaircis par les observations de Monge, dans la campagne d'Égypte. M. Chladni a fait de fort beaux travaux su: les aérolithes, et M. Moreau de Jonnès, de nombreuses recherches sur les 
ouragans, les tremblements de terre, et sur le résultat des déboisements. Les ouragans sont, dans ce moment, un grand sujet de discussions entre MM. Bache, Redfield, Espy, Pellier, etc.; mais ce sujet présente de telles difficultés, qu'on ne peut encore entrevoir l'époque de sa solution.

Physique. - La physique, suivant l'impulsion que lui avail imprimée le $x_{n}{ }^{e}$ siècle, n’est point demeurée stationnaire. Quelques géniẹ privilégiés ont pu seuls, il est vrai, en embrasser le vaste ensemble; mais la plupart des savants, en en étudiant les diverses parties, ont recueilli dè nombreuses observations et reculé les limites de la science.

L'étude des propriétés générales des corps a fait de grands progrès; les lois en sont mieux connues et les théories établies sur des bases plus solides. Depuis le commencement de ce siècle, d'immenses recherches ont été faites pour trouver l'explication des phénomènes qui se reproduisent à chaque instant sous nos yeux. Nous voyons Laplace éludier la physique générale; après lui, MM. Lehot, Dubuat, Bossut, Prony, se livrent à l'étude de l'écoulement des fluides; Coulomb explique les propriétés des corps, appelées élasticité, ressort, vibration, ébranlement; M. Brunacci publie un travail sur la théorie des tubes capillaires; M. Girard calcule la résistance des cylindres creux métalliques, et recherche la loi de l'écoulement uniforme de l'air atmosphérique et de l'hydrogène, dans des tuyaux de conduite. M. Navier donne un mémoire sur la flexion des lames élastiques, théorie d'une application si importante dans les arts; plus tard, il fait connaître le résultat de ses recherches sur la résistance de diverses substances à la rupture causée par une tension longitudinale. M. Vicat publie ses observations sur la rupture des corps; et aux deux résistances admises par les physiciens, il en ajoute une troisième, qu'il appelle résistance ransverse. Poisson se live à des recherches sur l'équilibre et le mouvement des corps élastiques; M. Morin étudie le frottement et le choc des corps. MM. Savary, Cauchy et Ampère nous donnent des idées nouvelles sur leur constitution intime; MM. Poncelet et Piobert font de nombreuses expériences sur la mécanique.

L'acoustique, créée par Bàcon de Vérulam, qui découvrit la propagation et la réflexion du son, sans en connaitre la loi, a reçu d'Euler sa forme actuelle. MM. Cagniard-Latour, Chladni, Paradisi, OErsted, Delaroche, Biot et Savart, s'en sont beaucoup occupés; mais c'est principalement ce dernier qui l'a enrichic d'une foule de recher- 
ches qui rectifient les théories, et établissent sur des bases mieux constatées cette branche encore si neuve de la physique.

L'optique, quoique moins connue, a fait d'immenses progrès. La théorie des ondulations, créée par Huyghens, perfectionnée par Herschel, Laplace, MM. Young et Fresnel, confirmée par les expériences des plus lrabiles pliysiciens, l'a emporté sur celle de l'émission, à laquelle la théorie des interférences el celle des équivalents optiques, établic par M. Arago, a porté le dernier coup. La coloration des corps, opposée comme une objection au système des vibrations, paraît expliquée d'une manière satisfaisante par M. Young, qui l'attribue à l'inégalité de propagation des ondes dans les corps imparfaitement élastiques.

Les physiciens qui ont succédé à Newton ont donné une grande attention à la décomposition de la lumière blanche par le prisme, et ont bien déterminé le rapport de la longueur des ondulations dans chaque couleur. M. Wollaston a étudié les propriétés chimiques des rayons lumineux, et M. Frauenhœeer les lignes transversales qui les coupent. MM. Herschel et Leslie ont pensé que les rayons calorifiques correspondaient au rayon rouge et les rayons chimiques, au rayon violet; màis les beaux travaux de M. Melloni ont fait voir que le maximum de chaleur varie avec la source et la substance dı prisme.

C'est à la puissance des rayons chimiques qu'on doit la photographie (fixation des images par la lumière, au moyen du daguerréotype), découverte si favorablement accueillie par les savants, et qui n'est sans doute qu'un premier pas vers des applications plus parfaites.

La diffraction de la lumière, déconverte par Grimaldi, que Newton chercha vainement à expliquer, et qui donna lieu seulement à quelques hypothèses de S'Gravesand, de Marat, de Brougham et de Mairan, avait reçu une nouvelle impulsion des études de MM. Flaugergues, Biol, Pouillet et Parrot; mais il était réservé à MM. Young et Fresnel de meltre fin à ces hésitations, en proclamant le principe des interférences, qui montre que deux rayons lumineux émanant d'une même source, sous une faible obliquité, ont pour résultat de s'entredétruire lorsque le mouvement des ondes a lieu en sens contraire, ou de produire unc: clarté plus intense lorsqu'il a lieu dans le même sens. Les expériences les plus concluantes des physiciens modernes ont confirmé cette théorie, et c'est dans ce phénomène que M. Arago a cherché l'explication de la scintillation des étoiles.

Newton avait reconnu que la plupart des corps combustibles jouis- 
sent d'une grande réfrangibilité; par suite de cette observation, il soupconna la combustibilité du diamant, et l'existence, dans l'eau, d'un principe combustible. Des études plus profondes sur la loi de la réfraction ont fait reconnaître que le pouvoir réfringent des différents corps est très variable; qu'il n'est en raison de la densité que dans un milieu homogène; mais que néanmoins il est en rapport avec les proportions des parties constituantes; d'où il résulte que, par cette voie, on peut se faire une idée de la composition des corps.

La double réfraction dont la loi, découverte par Huyghens, ful rejetée par tous les physiciens, jusqu’à ce que Malus et Wollaston en eussent démontré l'exactitude, a été confirmée par les travaux de MM. Biot, Arago, Brewster et Fresnel. Les modifications qu'éprouve la lumière dans la double réfraction et dans la réflexion sous certains angles, phénomènes inconnus avant Malus, qui leur donna le nom de polarisation, ont pris, dans ces derniers temps, de grands développements. Les plus savants physiciens en ont, en partie, déterminé les lois par des expériences multipliées. M. Biot a donné d'excellents travaux sur la polarisation des liquides et des cristanx; il a continué les recherches de M. Fresnel sur l'analyse chimique, au moyen de la polarisation de la lumière.

Ces nombreuses études, si fertiles en découvertes, ont déterminé, dans la construction des instruments d'optique, d'importantes améliorations qui, à leur tour, ont donné lieu à de nouveaux progrès. Les plus habiles physiciens n'ont pas dédaigné de s'occuper de l'application de l'optique aux besoins usuels ou à la confection d'instruments de pur agrément. M. Fresnel a appliqué la loi des réfractions à la construction des phares. Les microscopes simples ou composés ont pu ètre perfectionnés, grâce aux verres achromatiques dus à Dollond. Les télescopes ont également été modifiés; celui d'Herschel, avec lequel ce savant astronome a fait les plus belles découvertes, possède un pouvoir amplifiant de six cents fois. La camera lucida, plus commode que la chambre noire, a été inventée par Wollaston.

La chaleur est un phénomène d'un trop haut intérêt pour qu'on n'ait pas recherché les lois de sa propagation, ainsi que les modifications qu'elle éprouve et fail éprouver aux corps qu'elle pénètre ou abandonne. La nature n'en est pas encore connue avec certitude, bien que ce problème ait exercé la sagacité de la plıpart des physiciens. Herschel, Lamarck et Thompson n'y ont vu qu'une simple modification de la lumière, conformément à la théorie des ondulations; Rumford et Scherer, 
au contraire, l'ont considérée comme un mouvement intérieur déterminant le rapprochement on l'éloignement des molécules des corps. Rumford et Davy ont étudié la production du calorique par le frottement. MM. Dulong et Pelit ont cherché à en élablir l’analogie avec les phénomènes galvaniques ou électriques; et M. Peltier a démontré le rapport existant entre un courant et la température qu'il produit. On sait aujourd'hui que les rayons solaires et la combustion ne sont plus les uniques sources de chaleur; que le frottement, la percussion et les combinaisons chimiques sont accompagnés d'émission de calorique. M. Herschel a également constaté que les rayons du calorique sont susceptibles de réfraction, et, comme les rayons lumineux, inégalement réfrangibles ; M. Bérard a cru reconnaître qu'ils peuvent aussi se polariser; mais ce fait important n'a encore été démontré que par M. Melloni et presque en même temps par M. Forbes: Ainsi, le calorique reproduisant les mêmes phénomènes que la lumière, ayant ses corps opaques et ses corps diaphanes, se polarisant, se diffractant et se dispersant comme elle, on en a conclu qu'il n'a pas plus qu'elle de substance spéciale, et qu'il n'est qu'une des modifications que peut subir la substance impondérée qui remplit les espaces et qu'on nomme éther.

Les lois de la distribution du calorique et ses divers modes de transmission ont été étudiés avec soin par MM. Leslie, Bérard, Arago, et réduits par M. Prévost en une théorie satisfaisante qu'il a nommée Doctrine des échanges. Suivant son opinion, généralement admise, le rayonnement du calorique est soumis aux mêmes lois que la lumière; cette observation a servi au docteur Wells à établir la théorie de la rosée et de la gelée blanche, et à M. Arago, à expliquer certains phénomènes météorologiques. Il est aujourd'hui bien démontré que, contrairement à la théorie de Newton, le refroidissernent ne s'opère pas en proportion géométrique décroissante.

MM. Despretz, Fourier et Poisson ont étudié la transmission du calorique à travers les corps non élastiques; MM. Nicholson, Pictet et Murray ont établi par des expériences réitérées la propriété conductrice des liquides.

La capacité des corps pour le calorique, établie par Black, développée jar Wilkes, a été savamment calculée par Dulong et M. Pelit. M. Dalton a prouvé que cette propriété augmente avec la température.

La détermination de la chaleur latente et spécifique a occupé beancoup de physiciens. MM. Leslie, Delaroche, Bérard, Bussy, Dulong 
et Petit l'ont étudiée avec soin, sans être arrivés à des résultats bien décisifs; tout récemment, M. Regnault a publié un beau travail sur le calorique spécifique des corps. La chaleur spécifique des gaz a occupé MM. Marcet, de La Rive, et Bérard, dont les travaux ont été perfectionnés par MM. Gay-Lussac, Dulong, Petit, Clément Desormes et Haycraft. M. Gay-Lussac a également étudié les phénomènes que présente le calorique dans le vide.

On doit à M. Melloni, de Parme, et à M. Forbes, d'Edimbourg, la connaissance des lois du calorique rayonnant; ces importantes découvertes sur les propriétés calorifiques des rayons solaires et des autres sources de chaleur ont été faites au moyen de la pile thermo-électrique inventée par Nobili. Le premier a également fait des recherches pleines d'intérêt sur les corps diathermaux et athermaux.

Le phénomène de la dilatabilité des corps a été l'objet de nombreux travaux: Ramsden, Dulong et M. Petit, s'en sont occupés avec succès. Ces deux derniers ont employé, pour déterminer cette propriété, une méthode fondée sur l'observation de la durée du temps nécessaire au refroidissement des corps. En combinant leurs recherches avec la théorie chimique, ils sont arrivés à plus de précision qu'aucun de leurs devancicrs. La construction des pyromètres repose sur ce principe.

Le phénomène de la caléfaction, en vertu duquel une goutte d'eau, projetée sur une plaque métallique chaude, conserve longtemps sa forme globuleuse avant de s'évaporer, et sans mouiller la plaque, a été étudié par divers savants, surtout par M. Boutigny; mais la cause de ce phénomène est encore inconnue.

L'étude de l'expansion des gaz et des liquides a conduit au perfectionnement du thermomètre. MM. Leslie, Rumford, Howard, ont construic avec l'air, la vapeur d'eau, l'alcool ou l'éther, un thermomètre différentiel et le thermoscope. M. Gay-Lussac est l'inventeur des thermomètres à minimâ et à maximấ; MM. Rietsen, Houriel et Bréguet ont construit. des thermomètres métalliques. Dans ces derniers temps, MM. Roth et Walferdin ont apporté dans la construction du thermomètre centigrade une précision extraordinaire; ce dernier a construit un thermomètre à déversoir très utile pour l’appréciation de la température des profondeurs, et il a commencé une série d'expériences tendant à substituer le thermomètre au baromètre, dans la mesure des hauteurs.

Deluc, à qui l'on doit le perfectionnement de plusieurs instruments, substitua la baleine au cheven dans la construction de l'hygromètre; 
MM. Wilson, Leslie et Babin, ont cherché à rendre cet instrument moins irrégulier dans ses effets.

MM. Dalton et Gay-Lussac ont trouvé la loi de la dilatation des gaz, sur laquelle repose le principe des aérostats.

Les tensions des vapeurs, sous des pressions différentes, ont été déterminées avec soin par MM. OErsted et Perkins, Dulong, Arago, de Humboldt, etc. On connaît l'application de cette étude à l'art du chauffage en général, à la mise en mouvement des machines, des voitures, à la navigation, el même à l'émission des projectiles.

Les études du xvur ${ }^{\mathrm{C}}$ siècle avaient fait faire de grands progrès à la science de l'électricité; toutes les expériences, toutes les découvertes étaient un pas de plus vers la connaissance des innombrables effets de ce fluide si subtil et si puissant à la fois. Franklin, en découvrant l'idenlité de l'étincelle électrique et de la foudre, inventa le paratonnerre, essayé pour la première fois en France par Dalibard. Romas et Richmann répétèrent les expériences du philosophe américain sur l'électricité des nuages; le dernier même périt victime de son ardeur pour la science. La théorie de Dufay sur l'existence de deux fluides distincts, systématisée par Symmer, fut d'abord accueillie peu favorablement par les savants; mais bientôt elle remplaça en France celle de Franklin. Les appareils destinés à produire l'électricité furent perfectionnés. La machine électrique reçut différentes modifications de MM. Nicholson, Adams, Wildt, Kohlreif, Ramsden et Van Marum. MM. Henley, Bohnenberger et Brooke, apportèrent à la bouteille de Leyde d'heureux perfectionnements. Wilkes découvrit l'électrophore; Bergmann constata la natu'e électrique de la tourmaline; Henley inventa l'électromètre; Volta, le condensateur; Coulomb, la balance de torsion; Bennet, l'électromètre condensateur statique; Cavallo, le multiplicateur et le doubleur, que perfectionnèrent MM. Nicholson et Bohnenberger.

Volta, qui, comme Galvani, n'avail vu d'abord dans le galvanisme qu'une électricité animale, en reconnut bientôt l'identité avec le fluide électrique, et ne trouva de différence que dans le mode d'excitalion ; il construisit l'appareil nommé, d'après son inventeur, pile de Volta, ap. pareil qui a si puissamment contribué aux progrès de la science.

Cruikshanks, voulant remédier aux vices de la pile à colonne, inventa la pile à auge. Plus tard, Wollaston en doubla l'effet, en entourant l'élément positif par l'élément négatif. Après la découverte vinrent les applications: Banks et Nicholson constatèrent que la pile 
de Volta possède la propriété de décomposer l'eau; Cruikshanks obtint le mème résultat poul les sels. MM. Tromsdorf, Van Marum, Pfaff, Children, Erman, etc., s'en servirent pour brûler des métaux. Les chimistes Davy, Berzelius, Gay-Lussac, Thenard, et beaucoup d'autres encore, ont changé la face de la chimie par la découverte des métaux alcalins el terreux, ainsi qu'on le verra en parlant des progrès de cette science. Bichat, Nysten, Legallois, MM. Nobili, Prévost, Dumas, Breschet, Magendie, Donné, ont expérimenté les effeis physiologiques de la pile. M. Becquerel, un des physiciens français qui s'occupent le plus spécialement d'électricité, a cherché les lois qui président au développement de l'électricité par la pression, en a étudié le développement et l'effet dans les actions chimiques, a appliqué la théorie électro-chimique aux phénomènes de combinaison des corps, et a cherché le rôle que joue ce fluide dans les grandes combinaisons naturelles. Comme toutes les piles humides ont l'inconvénient de se détruire promptement, Désormes et Hachette imaginèrent les premiers une pile sèche; Deluc en construisit une d'une autre sorte, qu'il appela colonne électrique; Zamboni répéta avec succès ces expériences, et Bohnenberger se servit de cet appareil pour construire un électroscope.

La connaissance de l'identité du magnétisme et de l'électricité ne remonte qu'à l'époque de la découverte de l'électro-magnétisme; mais depuis, cette science a fait de si rapides progrès, que les travaux dont elle a été l'objet sont innombrables; aussi ne citerons-nous que les principaux. L'action des courants électriques n'avait pas été assez étudiée pour qu'on ait pu sortir du cercle des faits connus : les travaux de Flinders, de Sabine, de Barlow, de Coulomb, avaient été sans succès; MM. OEpinus, Prévost, Eschenmayer, Hansteen, avaient vainement essayé de jeter du jour sur les points obscurs de la science; aussi la nature du fluide magnétique était-elle toujours un mystère, lorsque M. OErsted, qui étudiait depuis vingt années les questions de haute physique, et qui avait annoncé, en 1807, qu’il voulait vérifier si l'électricité, daus son état le plus latent, n'a pas une action sur l'aiguille aimantée, découvrit, en 1819, que le courant qui se dégage de l'appareil voltaïque exerce sur elle une influence sensible, et que la déclinaison dépend de la position du fil conducteur relativement à l'aiguille. La découverte du savant danois fut, sur tous les points de l'Europe, le sigual de nombreux travaux. Ampère, qui avait étudié avec une infatigable persévérance les phénomènes électro-dynamiques, et à qui cette science est redevable 
d'une partie de ses progrès, reconnut que les courants électriques agissent les uns sur les autres comme des aimants; qu'ils s'attirent ou se repoussent, suivant qu'ils ont lieu dans le même sens ou en sens opposé. M. Berzelius vérifia la découverte d'OErsted et d'Ampère; MM. de La Rive, Ferré et Faraday, se livrèrent à l'étude de ces phénomènes; dès ce moment, une nouvelle période scientifique commença. M. Schweigger inventa le multiplicateur au moyen duquel M. Becquerel constata qu'il y a production de courants électriques dans toutes les aecions chimiques. La brillante découverte de M. OErsted fut suivie de celle du magnétisme de rotation par M. Arago, qui parvint à aimanter des barreaux d'acier, en les soumettant soit aux courants d'un conducteur en spirale, soit aux décharges successives de la bouteille de Leyde. Ces ex périences démontrèrent complètement l'identité de l'électricité et du magnétisme. Seebeck, en reconnaissant qu'on peut établir un courant électrique dans les métaux par la seule action de la chaleur, donna une nouvelle preuve de l'identité de l'électricité, du calorique et de la lumière. M. Kupffer, professeur à l'Université de Casan, s'est occupé de la détermination de l'influence que la chaleur exerce sur la distribution dü magnétisme libre des aiguilles; en 1828, il a été construit pour la première fois des aimants électro-dynamiques. MM. Moll, Lardner, Webster, Hare, Henri et Ten-Eyck, se sont aussi occupés de cette question.

Jusqu'ici la science de l'électricité porte les marques de son enfance; elle s'appuie encore sur un ou deux fluides spéciaux ; mais tout fait espérer qu'il en sera de l'électricité comme de la lumière el de la chaleur; que sa cause sera ramenée à une modification particulière de l'Ether. Déjà nous savons produire les phénomènes de lumière et de chaleur, et nous croyons qu'on arrivera aussi à simplifier cette dernière partie de la science; c'est du moins ce que les travaux actuels de M. Peltier laissent entrevoir, lorsqu'il produit à volonté du froid ou de la chaleur avec le mème courant, el qu’il démontre que toute perturbation moléculaire, de quelque nature qu’elle soit, fait naître un phénomène électrique.

Les applications usuelles du fluide électrique sont encore pen nombreuses; cependant M. Jacobi s'en est servi comme d'une force motrice, qu'on a déjà appliquée à des machines d'une certaine puissance. Le même savant est le créateur de la galvano-plastique, au moyen de laquelle on obtient des reliefs en cuivre d'une pureté admirable. Ce procédé, en se perfectionnant, a produit des applications utiles; car on s'en est serv pour faire des caractères d'imprimerie, et M. de La Rive en a fait usage 
dans la dorure des métaux, que l'emploi du mercure rend si funeste aux ouvriers. On a même fait plusieurs essais fort ingénieux sur les télégraphes électriques.

La physique n'est pas, sans doute, encore arrivée au plus haut point de perfection : il lui reste beaucoup à faire pour découvrir les vérités les plus importantes de la science; mais, si les travaux de la fin de ce siècle répondent à ceux de ses quarante premières années, nous touchons de bien près à la solution de questions d'une grande importance en philosophie naturelle,

Chimie. - La chimie pneumatique, qui avait renversé le phlogistique de Stahl, contribua à de nouveaux progrès; mais, comme elle se montrait absolue, exclusive, en faisant de l'oxygène l'unique cause de l'acidification et de la combustion, elle fut fortement ébranlée par les découvertes nouvelles. Nous savons maintenant que ce n'est pas l'oxygène seul qui produit de la chaleur et des acides en se combinant avec un corps, mais que tous les corps dégagent de la chaleur et quelquefois mème de la lumière, en se combinant entre eux, et qu'en outre un grand nombre de ces corps peuvent former des acides. Après la découverte de la pile de Volta, on avait soupçonné que l'électricité joue un rôle dans la combinaison des corps. Nicholson et Carlisle avaient décomposé l'eau par la pile voltaïque; Cruikshanks, après eux, décomposa les hydrochlorates de magnésie, de soude, etc. MM. Hisinger et Berzelius découvrirent que les solutions alcalines neutres sont décomposées par l'électricité; mais ce fut Davy, qui, depuis 1800 , poursuivant ces expériences, embrassa le premier l'ensemble des phénomènes de décomposition des corps par la pile voltaïque, et établit la connexion intime qui existe entre les effets électriques et les changements chimiques qui ont lieu par la pile. On avail vu que l'eau, soumise à l'action d'une pile électrique, se décompose; que l'hydrogène est attiré au pôle négatif et l'oxygène au pôle positif. Par suite de ses travaux, Davy reconnut que tous les corps composés se comportent de la même manière ; il parvint à isoler les mélaux de la potasse et de la soude, qu'on avait jusque-là considérées comme des corps simples, et il indiqua ainsi la voie d'une série de découvertes intéressantes. D'autres savants reconnurent que l'acidité n'est pas une qualité absolue, mais relative, et qu'il existe des substances qui, combinées avec certains corps, jouent le rôle d'acide, et, avec d'autres, celui de base. Les admirables résultats, dus à l'introduction de 
l'usage de la pile voltaïque dans la science, y déterminèrent une révolulion complète; M. Berzelius, qui n'avait pas interrompu ses travaux sur cette importante matière, posa, en 1813, les bases de la théorie électrochimique, à l'infaillibilité de laquelle on crut pendant quelque temps; mais qui cependant ne devait avoir qu'une existence éphémère.

Depuis que les études chimiques se sont étendues, on a découvert des lois qui ne sont encore, il est vrai, que les premiers pas de la science vers des vérités nouvelles, mais qui n’en constituent pas moins des découvertes d'une haute importance. Ce sont: l'isomérisme, loi encore vague et assez douteuse, en vertu de laquelle des corps ayant une mème constitution moléculaire et un même poids atomique, ont des propriétés physiques différentes; l'isomorphisme, si important en chimie, en géologie et en minéralogie, et dont il résulte qu'un nombre égal d'atomes, se combinant de la même manière, peuvenı donner naissance à des formes cristallines semblables, bien que les éléments constituants soient de nature différente; la loi des équivalents, d'après laquelle les corps se combinent entre eux en des quantités constantes et invariables, et qui tend, depuis quelques années, à remplacer la théorie atomique, dont les bases avaient d'abord été posées par Wenzel et Bergmann; plus tard, cette théorie fut confirmée par les expériences de Berthollet et de Proust; mais elle ne pénétra dans le domaine de la science, qu'après que M. Dalton l'eût formulée; enfin, la loi des substitutions, appelée à tort peut-être théorie des substitutions, qui fait voir que les éléments constituants se substituent les uns aux autres, sans qu'il en résulte de changement dans la nature du composé. Cette loi, découverte par M. Dumas, et qui n'est peut-être qu'un cas particulier de la loi des équivalents, a porté un coup mortel a la théorie électro-chimique de M. Berzelius, en ce qu'on voit des corps électro-positifs se subsîtuer à des corps électro-négatifs el vice versâ. Une autre cause de ruine pour cette dernière théorie, c'est qu'on a reconnu qu'il est impossible de dégager de l'électricité en mettant. deux corps en contact, et que c'est à leur combinaison avec les corps ambiants qu'il faut attribuer les phénomènes électriques qui se manifestent dans la plupart des cas. Les expériences de Zamboni sur la pile sèche ont constaté cette vérité; de sorte qu'aujourd'hui l'on en revient à l'affinité, loi en vertu de laquelle des atômes différents s'unissent avec émission de chaleur, de lumière et d'électricité, l'électricité n'étaut alor's que l'effel et non la cause de la combinaison. 
Pour simplifier leur langage, les chimistes ont adopté des formules, espèce d'algèbre chimique, qui, comme formule empirique, indiquent la quantité des éléments qui entrent dans un composé; ou, comme formuie rationnelle, cherchent en même temps à rendre raison de la manière dont a eu lieu la combinaison des éléments.

Les méthodes de classification suivies par les chimistes ayant été reconnues fausses, on a, depuis quelques années, sérieusement songé à adopter une méthode naturelle. MM. Ampère et Despretz, pénétrés de cette vérité, ont essayé de donner une meilleure classification des corps chimiques. M. Hoefer, dans les éléments de chimie minérale qui viennent de paraître, a présenté une classification naturelle, fondéc sur l'isomorphisme et les propriétés chimiques des corps. Tous les travaux des chimistes les plus distingués d'Allemagne et d'Angleterre tendent vers ce but.

Par suite de ces nombreux efforts, la chimie s'est enrichie de nouveaux corps élémentaires. En 1787, nous ne connaissions que dix-sept corps simples; en 1S02, nous en comptions vingt-huit, et âjourd'hư nous en avons cinquante-cinq. Il n'est pas certain cependant que le dernier corps annoncé par M. Mosander soit réellement simple. Toutefois, on peut dire qu'un grand nombre de corps réputés simples ne sont que des corps composés, qui jusqu'à présent ont résisté à nos moyens d'analyse, mais que des instruments plus parfaits, des réactifs plus puissants, mettront probablement à découvert.

Les découvertes en chimie minérale se sont multipliées à un tel point qu'il serait impossible d'en faire l'énumération: nous ne citerons donc. que les plus importantes. Fourcroy et Vauquelin trouvèrent le moyen de distinguer et d'obtenir à l'état de pureté la baryte et la strontiane, et firent d'immenses recherches sur les combinaisons salines. Vauquelin découvrit la glucne et le chrôme; le zirconium, le titane, l'urane. (décomposé récemment, par $M$. Peligot, en oxygène et uranium), le tellure, sont découverts par MM. Klaproth, Berzelius et Grégor ; Tennant et Wollaston isolent du platine quatre corps nouveaux dont un seul, le palladium, possède les propriétés d'un métal ductile el malléable; Del Rio découvre l'érythronium, retrouvé en 1830 par Selfstrom, qui l'appelle vanadium. En 1804, le chlorure de soufre est décril pour la première fois par Thompson; le cérium est découvert, au moyen de la pile, par M. Hisinger, dans le cours de ses expériences avec M. Berzelius. En 1805, MM. de Humbold el Gay-Lussac donnent l'analyse de l'air' 
ils démontrent que l'hydrogène et l'oxygène se combinent dans le rappor't de deux volumes à un. M. Gay-Lussac fait connaître sa belle loi sur la combinaison des gaz en rapports simples. En 1807, Davy obtient, par l'emploi de la pile, les élémeuts des alcalis et des terres, et le potassium, le sodium, le barium, le strontium et le calcium, entrent daus la nomenclature des corps simples. En 1808, MM. Gay-Lussac et Thenard démontrent que le chlore est un corps simple; ces mêmes chimistes isolent, les premier's, le bore de l'acide borique; M. GayLussac découvre de plus le cyanogène et $M$. Thenard l'eau oxygénée; M. Th. de Saussure donne l'analyse du gaz oléfiant; et, en 1812, il examine la propriélé que possède le charbon d'absorber les gaz. En 181 a, M. Gay-Lussac fait de beaux travaux sur l'iode découvert par Courtois; l'année suivante, ces travaux sont complétés par ceux de MM. Sérullas, Colin et Gaultier de Claubry. Davy publie le résultat de ses expériences sur les fluorures.

En 1816, M. Berzelius découvre le sélénium; M. Stromeyer, en même temps que MM. Roloff et Hermann, le cadmium, dont il fait connaître les propriétés. M. Robiquet éludie l'acide borique. M. Arfwedson annonce la découverte du lithium; MM. Dulong et Berzelius déterminent, avec plus de précision, la composition de l'eau. En 1824, MM. Liebig et Gay-Lussac obtiennent l'acide fulminique. M. Berzelius continue ses recherches sur l'acide fluorique. En 1826, M. Balard découvre le bròme. En 1827, M. Mitscherlich fait connaître l'acide sélénique. M. Wochler opère la réduclion de l'alumine et de la glucyne, et M. Bussy celle de la magnésie. Depuis cette époque, M. Dumas fait des recherches sur les sels de phosphore; M. Pelouze démontre l'existence d'un seul oxyde de phosphore; M. Thilorier liquéfie et solidifie l'acide carbonique; M. Kullman compose de l'acide azotique au moyen d'ammoniaque soumis à l'aclion de l'éponge de platine et vice versâ. M. Gaudin étudie la cristallisation de certaines pierres précieuses ; il observe l'action lumineuse d'un courant de gaz oxygène et d'hydrogène sur un globule de chaux vive; il découvre la lumière sidérale et trouve le moyen de filer le quartz. Enfin nous devons citer encore, comme ayant contribué aux progrès de la chimie, MM. Thenard, Orfila, Berthier, Régnault, Baudrimont, Laurent, Faraday, Person, etc., elc.

La chimie organique, qui n'était, il y a quelques années, qu'une branche peu importante de la chimie générale, a tout récemment acquis de grands perfectionnements ; néanmoins elle attend encore un système qui unisse 
entre elles les lois isolées que nous connaissons. La plupart des chimistes du commencement de ce siècle s'étaient occupés de la dćcomposition empirique des corps organisés, et, jusqu'en 1835, on avait suivi les mêmes errements que les premiers observateurs. M. Raspail publia alors une nouvelle théorie de la chimie organique, dans laquelle il rectifia beaucoup d'erreurs, et qui fit faire un grand pas à cette science. M. Liebig a publié, l'année dernière, une chimie organique fondée sur un certain nombre de radicaux composés encore hypothétiques; mais tous les sam vants ont pris pour bases de la chimie organique les formules rationnelles qui conduisent à la connaissance des radicaux composés, et ils ont joint, à la méthode ordinaire d'analyse, le microscope, qui fail connaître la structure intime des corps.

Les travaux en chimie organique remontent, pour cette dernière période, à Fourcroy, qui étudia, avec une merveilleuse sagacité, les substances organiques, isola la gélatine, l'albumine et l'urée, et associa à ses travaux le célèbre Vauquelin. En 1812, M. Boullay découvre la picrotoxine; Vauquelin et Parmentier font connaître leurs expériences sur le sucre de betterave; M. Lecoq analyse l'orseille, et M. Robiquet le kermès. M. Berzelius fail connaître, en 1813, ses travaux sur les fluides animaux; MM. Pelletier, Robiquet et Séguin font de nombreuses expériences sur l'opium et le quinquina. En 1815, M. Chevreul commence ses travaux sur les corps gras et découvre la stéarine, la margarine, l'oléine et les acides gras produits par la saponification, dont il explique la théorie, et il donne le nom de glycérine au corps appelé par Schéele, principe doux des huiles; plus tard, il reconnait en mème temps trois acides volatils dans le beurre, un dans la graisse de marsouin, etc. En 1817, M. Sertuerner trouve dans l'opium l'alcali végétal qu'il appelle morphine; en 1819, MM. Pelletier et Caventou réussissent à extraire de nouveaux alcalis végétaux de la noix vomique et du quinquina. Vauquelin, pendant sa longue carrière, fait d'importantes expériences sur les corps organiques, et une foule de combinaisons nouvelles enrichissent la science. En 1826, MM. Robiquet ef Colin publient leurs observations sur la garance dont ils extraient l'alizarine; M. Pelouze distingue pour la première fois les périodes successives dans l'action de la chaleur sur les corps organiques; il découvre les acides pyrogènes et établit les lois de leur production. De 1820 à 1830, MM. Pelletier et Caventou, OErsted et Robiquet, découvrent de nouveaux alcalis végétaux, tels que la vératrine, la pipérine, 
la caféine, etc. En 1833, MM. Biot, Person et Payen font d'intéressants travaux sur la dextrine et la diastase. La science doil aussi à M. Dumas une foule d'observations et de découvertes importantes en chimie organique.

Malgré tous ces travaux, nous n'avons encore aucune idée de la manière dont la nature opère ses diver'ses transformations. Nous connaissons la vie, mais rien de plus, et nous ignorons comment, par suite de la divergence des espèces, il existe des végétaux ou des animaux qui, croissant et vivant dans des conditions semblables, présentent des différences tranchées dans leur nature, leur forme et leurs propriétés. Nous avons bien pu former artificiellement quelques produits semblables à ceux de l'organisme, tels, par exemple, que l'urée, l'acide prussique, etc., qu'on peut produire en partant de leurs principes constituants auxquels on fait subir diverses transformations successives; mais la synthèse de la chimie vivante nous est impossible : aussi cette science, qui touche aux plus hautes questions, est-elle encore dans un état d'impuissance qui appelle de nouveaux efforts.

Depuis un demi-siècle, la chimie a marché plus vite que toutes les autres sciences ensemble, sous le rapport de ses applications aux arts et aux besoins sociaux; elle doit une parlie de ces résultats aux guerres de la république et à la séquestration à laquelle nous avait réduits le blocus continental.

A l'époque où les armées républicaines se portaient aux frontières pour repousser les coalisés, la poudre manquait, faute de salpêtre. La Convention ordonna la démolition des vieux édifices, l'enlèvement des terres des caves et des écuries, et leur lixiviation en fournit d'énormes quantités. Les canons étaient rares, et Ies cloches des églises, devenues inutiles par suite de l'abolition du culte, contenaient trop d'étain pour être employées à la fabrication des pièces d'artillerie: on découvrit des procédés propres à séparer l'étain du cuivre, et nos pares se remontèrent. La plupart de nos soldats n'avaient pas de chaussures, et l'ancien procédé exigeait plus d'une année pour la préparation du cuir, Séguin trouva le moyen de le tanner en un mois.

Plus tard, lorsque la marine anglaise nous eut fermé le chemin de nos colonies, on vint à manquer de sucre, substance devenue de première nécessité. Parmentier fit de nombreux essais pour obtenir du sucre de fruits; Proust obtint le sucre de raisins; et le sucre de betterave, découvert par Marcgraf, fut bientôt fabriqué. On perfectionna les procédés de 
fabrication du for el de l'acier. On découvrit le moyen de se procurer la soude artificielle, les matières tinctoriales, etc. Quand le retour de la paix eut rétabli les relations avec les pays qui nous avaient été si longtemps fermés, on conserva la plupart des procédés dont la nécessité avait doté notre industrie. Ils sont encore en usage maintenant; et les hommes éminents dans la science font toujours de leur perfectionnement l'objet de leur's recherches.

Toutes les applications de la science à l'industrie datent de cette époque. M. Chevreul perfectionne les procédés de saponification ; Vauquelin introduit le jaune de chrôme dans la teinture; Chaptal, Davy , Boussingault, Payen, etc., appliquent la chimie à l'agriculture; Mollerat purifie les vinaigres provenant de la distillation du bois; Lampadius, Bréant, Berthier, Karsten, Fournet, etc., perfectionnent les procédés métallurgiques. On parvient à affiner la fonte avec les gaz perdus qui s'échappent des gueulards des hauts fourneaux ; le platine est rendu malléable et laminé comme les autres métaux. On découvre un grand nombre d'alliages; Deyeux, Pelletier, Hagen, s'appliquent à la préparation des substances pharmaceutiques, etc.

Ajoutez à ces services éminents l'application à l'éclairage des vílles du gaz hydrogène tiré de la houille, de l'huile, de la résine, des bitumes, des malières animales, de l'eau, etc.; la préparation des couleurs propres à la teinture des tissus; l'extraction de l'indigo du polygonum tinotorium; l'admirable découverte de Senefelder, la lithographie, devenue le signal d'une ère nouvelle pour les arts graphiques; la substitution des amorces fulminantes au silex, dans les armes à feu; l'emploi du chlore comme moyen de désinfection et de blanchîment; l'invention et le perfectionnement de la lampe de Davy, pour empêcher l'explosion de l'lydrogène carboné dans nos houillères; la saccharification de la fécule et l'emploi de ce produit à la fabrication de la bière; la substitution de la soude à la potasse, dans la fabrication du verre; la conversion des substances organiques en engrais inodores; la préparation de l'acide stéarique, qui sert à la confection de bougies aussi belles que la cire; l'emploi du caoutchouc, si longtemps resté inutile, pour la préparation de tissus imperméables; la fabrication des alliages; l'emploi de réactifs pour reconnaitre la sophistication des substances alimentaires; l'emploi du galvanisme pour préserver le fer de l'oxydation, et la nouvelle déconverte de M. Boucherie pour rendre les bois inaltérables, etc.

Nous avons, à côté de ces applications générales, une science toute 
nouvelle, la chimie légale, dont les résultats sont trop incertains encore pour que nous fassions autre chose que la mentionner.

Nous ne saurions dire quelles découvertes le temps réserve à la chimie; mais elle a déjà rendu d'assez grands services, et éclairé assez de questions obscures, pour qu'il soit permis de la proclamer la première des sciences.

Minéralogìe. - L'école géométrique, créée par Haüy, avait fait connaître d'une manière plus parfaite la structure cristallographique des minéraux; elle complétait ainsi tous les éléments des méthodes jusque-la fondées sur les caractères extérieurs et la composition chimique; mais la science avait un pas de plus à faire. Les progrès de la chimie, en facilitant les analyses, avaient procuré la connaissance de nouveaux corps. Au commencement du $\mathrm{xIx}^{\mathrm{e}}$ siècle, Vauquelin avait découvert le chrôme; Hatchett, le colombium; Wollaston, le palladium et le rhodium; Descotils, l'iridium; Tennant, l'osmium. Peu après, M. Berzelius fit connaître le cerium, le selenium et le thorium; Courtois, l'iode; M. Arfwedson, le lithium ; M. Stromeyer, le cadmium ; M. Balard, le brôme ; M. Selfstrœem, le vanadium. En même temps que le nombre des éléments chimiques augmentait, celui des espèces minérales s'accroissait, et la minéralogie subissait une révolution complète dans ses principes de classification.

Dayy, qui avail compris l'importance de la pile comme moyen de dé. composition des minéraux, obtint les éléments des alcalis et des terres ; le potassium, le sodium, le calcium, etc., entrèrent dans la science comme éléments nouveaux. M. Berzelius reconnut les lois de la combinaison mutuelle des terres; et, dès ce moment, la silice, ce principe si commun dans les composés naturels, prit rang parmi les acides. En même temps, l'analyse chimique se perfectionnait par les nombreux travaux de Klaprohl, de Vauquelin, de Laugier, de M. Berzelius et de plusieurs autres chimistes encore vivants. Les simples essais de minéraux par la voie sèche ou par la voie humide acquéraient une merveilleuse précísion entre les mains de Wollaston el celles du célèbre chimiste suédois.

Bientôt, s'appuyant sur les idées de Dalton, et sur la doctrine des proportions définies, M. Berzelius développa les principes de la théorie atomique, et introduisit dans la science l'usage des formules pour représenter, d'une manière simple et rigoureuse, la composition des corps. En 1819, il proposa une nouvelle classification des minéraux, fondée sur les propriétés électro-chimiques des corps. M. Mitscherlich, de son 
eôté, faisait faire un pas immense à la science, en publiant sa belle loi de l'isomorphisme (1820), qui amena bientôt une réforme dans les méthodes minéralogiques. M. Berzelius avait choisi pour base du genre, dans sa classification, l'élément électro-positif ; M. Beudant, s'appuyant sur les travaux de MM. Mitscherlich, Rose, Bonsdorff, Wachtmeister, etc., comprit qu'il y avait plus d'avantage à adopter l'élément électronégatif, et M. Berzelius ne tarda pas à se rendre à cette opinion. Peu de temps après, ce chimiste enrichit la science d'un nouveau principe important, celui de l'isomérisme, et M. Mitscherlich signala de nombreux exemples d'un autre fait, déjà connu, le dimorphisme, qui n'est peutêtre qu'une manière d'être particulière de l'isomérisme.

Pendant que s'opérait cette grande révolution dans les principes de la science et dans la marche des méthodes, la cristallographie et la physique des minéraux ne demeuraient pas stalionnaires. Wollaston avait doté les cristallographes d'un instrument précieux, le goniomètre, qui porte son nom. M. Weiss avait fait valoir l'importance de la considération des axes dans les cristaux, en étallissant sur cette considération la distinction et la classification des systèmes cristallins; il avait publié une théorie des zones, propre à faciliter le développement des formes composées, et qui a servi de base à certaines représentations gra* phiques des cristaux, proposées par deux de ses élèves, MM. Neumann et Quenstedt. M. Mohs, de son côté, donna un nouvel exposé des principes de la cristallographie, et publia une classificalion remarquable des minéraux, fondée uniquement sur leurs caractères physiques et extépieurs. Il fut suivi dans cette voie par MM. Breithaupt, Haidinger et Zippe. M. Neumann proposa une nouvelle notation des formes cristallines, beaucoup plus simple que celles de Weiss et de Mohs; publia, en 1830, un traité de cristallographie, l'ouvrage le plus savant et le plus complet qu'on ait sur cette matière.

Les faits si importants de la polarisation et de la double réfraction de la lumière ont été reconnus par Malus, Wollaston, ainsi que par MM. Biot et Brewster, qui ont donné les moyens de reconnaître le nombre et les caractères particuliers des axes de réfraction; le dernier a signalé la dépendance mutuelle qui existe entre les propriétés optiques et les formes cristallines. M. Mitscherlich a déterminé l'influence de la chaleur sur les variations de la forme des cristaux; MM. Frankenheim et Savart ont éludié, l'un les modifications de la dureté dans le même cristal, l'autre celles de l'élasticité. Plusieurs au- 
tres savants ont enrichi la science d'observations neuves et importantes; et la minéralogie, qui a dû tant de progrès à MM. Brongniart, Dufrénoy, Delafosse, Haidinger, Kupfer, G. Rose, etc., attend encore d'eux de nouveaux perfectionnements.

Anatomie. - Le xvmi $^{\mathrm{e}}$ siècle n'avait pas cessé de mettre à profit les travaux des siècles précédents déjà riches en découvertes, et ses efforts avaient été couronnés de succès; car la connaissance de la structure particulière des organes était arrivée à un haut degré de perfection; mais, jusque-là tous les travaux n'avaient eu pour but que l'anatomie descriptive, et l'on peut dire que l'anatomie générale n'existait pas, bien que quelques points de cette science eussent été entrevus par les anciens. Bichat, élève de Pinel, qui, dans sa nosographie philosophique, avait classé les maladies d'après l'analogie des tissus, développa l'idée de son maître et eut la gloire de donner aux études anatomiques une direction nouvelle. Après avoir étudié isolément les divers tissus, il les compara entre eux et les groupa suivant leur affinité ; il comptait jusqu'à vingt-et-un tissus élémentaires, quoique la plupart paraissent dériver du tissu cellulaire. La mort l'empêcha de mettre la dernière main à celte puissante création; mais ses travaux ne furent pas stériles, et les routes qu'il ouvrit à la science sont les seules aujourd'hui suivies.

L'étude de la structure intime des organes avait beaucoup plus de progrès à accomplir que l'anatomie générale, et notre siècle n’a poin manqué d'hommes capables de descendre jusque dans les particularités de l'organisation. Sans faire précisément des découvertes nouvelles, ils ont beaucoup contribué au perfectionnement de la science de l'organisme. Nous citerons, parmi ceux qui se sont le plus occupés d'anatonnie générale el descriplive, MM. Chaussier, Boyer, Marjolin, J. et H. Cloquet, Meckel, Serres, Lauth, Tiedemann, Magendie, Bourgery, Jacob, Gerdy, Treviranus, Arnol, etc. A ces noms peuvent se joindre ceux des savants qui se sont occupés de zootomie, et qui ont répandu, sur les connaissances d'anatomie générale, un intérêt qui ne pouvait naître que d'un vaste point de vue comparateur. Nous passerons légèrement sur l'anatomie des régions, créée par Béclard, qu'une fin prématurée empêcha de réaliser complètement son idée, et qui eut pour interprètes MM. Velpeau et Blandin. Nous ne mentionnerons pas ici les travaux des hommes distingués qui se sont occupés et s'occupent encore d'anatomie pathologique, parce que celte science, malgré son intérêt 
et la réputation justement méritée de Morgagni, Mascagnin, Lieutaud, Scarpa, Corvisart, Laënnec, Broussais, de MM. Andral, Cruveilhier, elc., n'entre point dans le cadre de notre travail.

Anatomie comparée. - Dans le xvıII siècle, l'anatomie comparée, alor's à ses premiers essais, avait trouvé pour défenseurs les naturalistes les plus célèbres qui l'avaient sauvée du dédain el de l'oubli. Vicq-d'Azyr, le savant et brillant anatomiste, avait conçu le plan d'une anatomie comparée qui devail embrasser tous les faits relatifs à l'organisation des êtres. Ce projet, ajourné par la mort de son auteur, fut réalisé par G.Cuvier qui, en 1795, fut adjoint à la chaire d'anatomie comparée du Muséum national. Dès ses premières leçons on comprit ce qu'il y avait, entre ses mains, d'avenir pour cette science. Employant tour à tour l'analyse et la synthèse, il arrivait à la classification des animaux par l'étude de leurs organes, et à la division de leurs fonctions par l'étude des actes qu'ils accomplissent; il rangeait ces fonctions dans l'ordre de leur succession naturelle; car l'animal a deux grandes fins à remplir, sa conservation propre et celle de son espèce; c'est ainsi qu'un lien de perpétuité rattache les générations les unes aux autres. Guidé par ces hautes considérations, il disposa les faits dans un ordre tel que de leur simple rapprochement sortirent ces lois admirables qui donnèrent à l'anatomie comparée une certitude presque mathématique. En 1800 et 1805, ses leçons, publiées par les soins et la collaboration de MM. Duméril et Duvernoy, furent pour la science une époque non seulement de régénération, mais encore de création, puisqu'elles l'embrassèrent dans toutes ses parties, el que les principes qui y étaient renfermés devinrent les régulateurs de toutes les études qui ont pour objet la connaissance des êtres organisés. Ce précieux monument scientifique n'a pas perdu de sa valeur' car, depuis 1835, M. Duvernoy surtout s'occupe de mettre à la hauteur de la science les lccons d'anatomie comparée de Cuvier, dont le $1^{\text {cr }}$ volume avail été revu par lui-même. M. Laurillard a coopéré pour une part importante à cette nouvelle édition.

L'anatomie comparée a pris une telle importance, qu'elle fornte aujourd'hui la base des études de tous les hommes qui s'occupent de la science des êtres. Dans tous les pays il en a été entrepris des traités complets : Blumenbach, MM. de Blainville, Meckel, Carus, Treviranus, Jacobi, Home, Waguer, Wilbrand, Grant, ont publié, sur son ensemble; des traités généraux plus ou moins satisfaisants; mais tous ces travaux 
n’ont pas été terminés, et nous devons regretter surtout celui que la mort de Meckel laisse incomplet. Les mêmes auteurs, auxquels nous joindrons MM. Duméril, Rudolphi, Albers, Oken, Kubl, Delle Chiaje, ont publié des mélanges d'anatomie el de physiologie comparées qui sont pour la science autant de conquêtes nouvelles.

Pour des travaux plus spéciaux encore, se groupent une foule d'auteurs. MM. Rudolphi, Ilome, Duméril, Lherminier, Girou de Buzareingues, Spix, Mayer, Oken, Meckel, Nilzsch, etc., se sont occupés d'ostéologie générale et comparée. La structure et le développement des os ont été l'objet des études de MM. Béclard, Serres, Bailly, Steinmüllen, etc. L'application de l'ostéologie comparée à la paléontologie, déjà entrevile par P. Camper et si bien démontrée par les beaux travaux de G. Cuvier, a été reprise, dans ces dernier's temps, par M. de Blainville. MM. Schreger et Ilg ont étudié la syndesmologie; nous trouvons en myologie, MM. Hauch et Müller.

La névrologie, qui met sur la voie des mystères de la sensibilité et de l'intelligence, a occupé un grand nombre d'anatomistes. Nous citerons, parmi les plus célèbres, MM. G. Cuvier, Gall et Spurzheim, Bell, Desmoulins, Rolando, Bailly, Magendie, Treviranus, Roth, etc.

MM. E. Geoffroy Saint-Hilaire, Foville, Serres, Vimont, Flourens, Tiedemann, Burdach, Rolando, Bellingieri, ont fait une étude spéciale du cerveau et de ses dépendances.

La structure et la distribution des nerfs ont occupé MM. Raspail et Breschet, Prost, Girard, Jacobson, Kilian, Lobstein, Hirzel, Weber, Canaveri, etc. Nous citerons, en parlant de chaque branche de la zoologie, les travaux qui se rapportent spécialement à chaque classe d'êtres.

L'anthropologie ou la connaissance des races humaines est une science due tout entière aux travaux de ce siècle, et trop jeune encore pour mériter une longue mention. En effet, soit résultat de l'influence des milieux, soit dissemblance originelle dans les races, il existe entre les peuples qui couvrent la surface du globe une diversité sur laquelle devait se porter l'attention des savants; il en est résulté plusieurs systèmes de classification qui, sans satisfaire pleinement la raison, servent, comme toules les méthodes, à ne pas s'égarer dans le dédale de la science. Les principaux auteurs qui se sont occupés d'anthropologie sont: MM. Rudolphi, Virey, Edwards, Bory de Saint-Vincenl, Lesson, 
Desmoulins, Prichard, Alcide d'Orbigny, d'Omalius d'Halloy, Knor, Roussel, Gruithuisen, etc.

Anatomie philosophique. - Porté naturellement à la généralisation, notre siècle a vu naître une science belle, attrayante, heureux résultat de l'union de l'étude des faits et de la philosophie; nous voulons parler de l'anatomie et de la zoologie philosophiques, dont les éléments, entrevus de siècle en siècle par divers naturalistes, n'ont été réunis en corps de doctrine que dans le nôtre. Aristote avait vaguement pressenti l'unité de composition organique; en 1555, Belon compara l'homme à l'oiseau; en 1704, Newton, frappé de l'uniformilé des lois qui régissent les masses du système planétaire, avait pensé que le même mode d'uniformité devait régner chez les animaux; en 1756 , Buffon formula, le premier, avec netteté, le principe de l'unité de composition; Herder, le grand philosophe, était persuadé que, dans tous les êtres, il domine une conformité d'organisation qui, formant un type exemplaire, se modifie à l'infini. En 1786, Vicq-d'Azyr proclama la même loi, et reconnut dans la nature un modèle primitif et général qu'on retrouve partout. Camper, un morceau de craie à la main, métamorphosait un chien en cheval, un cheval en homme, eic.; mais le grand développement de cette idée est dù, en zoologie, à M. Geoffroy Saint-Hilaire, et, en botanique, à Goëthe.

M. Geoffroy Saint-Hilaire, collaborateur de G. Cuvier, avait publié avec lui la classification des mammifères. Frappé, dans le cours de ce rravail, de l'arbitraire qui régnait dans la division des groupes, il abandonna, dès lors, toutes les études de nomenclature pour se livrer à celles du rapport des êtres entre eux. Une fois dans cette route, il repassa dans son esprit ses impressions antérieures; il fit des observations nouvelles, et vit que des animaux, considérés comme différents, ne se distinguent que par des modifications dans la forme, la proportion, la disposition, et, d'une manière générale, dans le degré de développement de parties qui, au fond, restent les mêmes. Ainsi ont lieu des variations infinies dans l'arrangement, et par conséquent dans le jeu des organes, sans que les rapports essentiels soient changés; de là l'idée de l'unité de composition dans les êtres organisés. Partant de ce principe, il reconnut que les os élémentaires des membres antérieurs se retrouvent dans les nageoires pectorales des poissons, que la tête des vertébrés est formée chez tous de parties analogues, et que, chez les poissons, l'opercule 
de l'ouie n'est que la série des osselets de cet organe, poussćs au dehors pour servir à d'autres usages. Une découverte fort remarquable, ct qu'il avait en partie prévue depuis longtemps, est celle qu'il fit, en 1821, d'un véritable système dentaire chez les jeunes oiseaux. Par suite d'études faites dans une direction semblable, il fut constaté que, dans toutes les classes des vertébrés (mammifères, oiseaux, reptiles ou poissons), il y a un type de formation primilive pour les membres antérieurs: ainsi, chez. les mammifères terrestres, ce sont des organes de préhension ou de locomotion ; ensevelis dans l'intérieur des chairs, comme chez les mammifères aquatiques, il n'en sort que la main pour fendre l'eau; chez les oiseaux, ce sont des leviers destinés à frapper l'air; chez les poissons, des nageoires ayant pour fonction de faciliter les mouvements de progression. Cette identité est si rigoureuse, que, chez les mammifères, dont le pied est enveloppé d'une corne, on reconnaît les os dư métatarse et ceux des doigts réunis dans le sabot. Il en est de même de la colonne vertébrale qu'on retrouve toujours, avec des modifications corrélatives, suivant les différentes classes d'animaux et la diversité de leurs conditions d'existence, et dont le développement résulte de la prépondérance plus ou moins grande du système sanguin ou du système cérébro-spinal.

La même loi s'applique cncore aux articulés: l'insecte, le crustacé, vivent au dedans de leur colonne vertébrale, dont les pièces différentes sont représentées par leurs divers anneaux. Nous trouvons dans les tortues, parmi les vertébrés, un exemple de cette singularité de structure; et l'on peut comparer les segments articulés du homard et de la scolopendre à une série de vertèbres constituant une colonne vertébrale, dont les pattes figurent les côtes; mais, pour continuer l'analogie et la trouver jusque dans les organes intérieurs, il faut renverser ces animaux sur le dos, si l'on veut placer dans le même ordre les systèmes nerveux et sanguin; car, chez eux, le système viscćral est en dessus, et c'est sous le ventre que se trouvent les ganglions qui remplacent la moelle épinière et le cerveau. Chez eux comme chez les vertébrés, ces ganglions donnent naissance aux nerfs sensitifs; ct, ce qui rend plus frappante l'idée d'unité de plan, c'est que les vertébrés, encore dans l'œuf, sont fixés par le ventre au vitellus, tandis que les insectes le sont par le dos.

Après cette grande découverte de l'unité de plan du système osseux vient, comme complément indispensable, celle du balancement de's organes, canse inépuisable de diversitć dans les êtres. Parmi tant de 
faits d'une si admirable fécondité pour l'explication des données philosophiques, nous citerons seulement celui de l'évolution du foetus, qui, avant d'arriver à l'état que lui assigne son origine, passe, pour ainsi dire, par la forme des animaux des classes inférieures. L’idée du plan unique remonte à 1796 ; en 1807 , elle avait une forme plus arrêtée; depuis, son auteur n'a pas cessé d'en poursuivre la démonstration avec une patience infatigable. Il a recherché les analogies non seulement dans la comparaison des organes, mais encore dans leurs éléments, ne négligeant pas plus ceux qui restent à l'état rudimentaire que ceux qui acquièrent le plus grand développement.

Pendant que cette science se créait en France, l'illustre Goëthe préludait, en 1792, à une semblable découverte, par son ouvrage sur les mélamorphoses des plantes, écrit dans la même pensée. Bientôt après, il démontra la nécessité de fondre ensemble l'anatomie humaine et l'anatomie comparée; et, pour donner à la science une base plus certaine, d'établir, d'après les fonctions, un type anatomique, un modèle universel, qui pût servir de guide dans l'étude des animaux. Les travaux de ce grand philosophe, mal compris de ceux à qui il les avait soumis, ne parurent qu'en 1820, quoiqu'ils eussent été terminés en 1796.

En 1807 et 1808, M. Oken en Allemagne et M. Duméril en France, urent conduits, par des considérations différentes, à l'idée de la composition vertébrale de la tête, que Goëthe avait entrevue, plusieurs années auparavant, d'après le témoignage de quelques auteurs allemands. Cette théorie est aujourd'hui généralement admise en principe; et les auteurs les plus opposés à l'anatomie philosophique reconnaissent que la tête est composée, sinon de vertèbres agrandies, au moins de ceintures osseuses, comparables à des vertèbres. MM. de Blainville, Geoffroy Saint-Hilaire, Spix, Carus et Meckel, ont contribué an développement de la première idée, mais ils n'ont pas encore pu s'entendre sur le nombre des vertèbres crâniennes. Une autre question, moins importante, il est vrai, mais à la solution de laquelle Goëthe fit faire un grand pas, est la démonstration de l'existence de l'os intermaxillaire chez l'homme. Cette découverte a fait disparaître la différence établie par Blumenbach entre l'homme et le singe. A la même époque, Vicqd'Azyr constata le même fait.

A peine cette voie fut-elle ouverte, qu'un grand nombre de savants dirigèrent leurs recherches dans le but de pousser plus loin les découvertes récentes; dans l'article Mammifères du Dictionnaire de Déterville, 
M. de Blainville posa les bases d'une morphologie rationnelle des animaux supérieurs; M. Serres contribua aux progrès de cette science par ses ouvrages sur les Lois de l'ostéogénie, et sur l'Anatomie comparative du cerveau dans les quatre classes d'animaux vertébrés. Le point de vue de $\mathbf{M}$. Serres est le développement centripète de l'organisme, d'après lequel on voit tout tendre de la circonférence au centre. Partant de cette base, l'auteur poursuit, à travers lá modification infinie des formes, la concordance des parties analogues; mais l'Allemagne, dont les esprits sont si propres aux spéculations, a fourni les conceptions les plus hardies. En 1821, M. Oken publia, sous le titre de Système d'anatomie, de physiologie et d'histoire naturelle, un exposé de ses vues d'unité, dans lequel la nature entière est l'objet de ses méditations. Il prend pour point de départ les quatre éléments des anciens, l'air, le feu, l'eau et la terre, dont il explique toutefois la nature; il trouve quatre classes correspondantes pour le règne minéral, trois pour le règne végétal, quatre pour le règne animal. Dans les animaux, les parlies organiques élémentaires sont les intestins, les veines, les trachées ou poumons, et les organes de la vic de relation, qui sont eux-mêmes des répétitions des éléments typiques, et passent à travers cette répétition de parties organiques. Il montro ensuite, comme conséquence de ce principe, que le règne animal s'est développé dans le même ordre que les organes dans le corps des animaux. Ce sont, d'après lui, ces organes qui caractérisent les classes, et il y a autant de classes d'animaux qu'il y a d'organes; en conséquence ses trois grandes divisions sont: les animaux à viscères qui forment les invertébrés ; les anımaux à chair ou les poissons, les reptiles et les oiseaux; enfin les animaux à sens ou les mammifères. Ces mêmes caractères se retrouvent dans les différentes classes. Ce système, dont les idées paraissent étranges au premier abord, est d'une grande profondeur philosophique.

M. Carus prend l'ouf ou la sphère creuse, figure des êtres les plus élémentaires, comme la base de tout le développement de l'organisme. D’après ses idées, la partic molle de la sphère tend à conserver sa forme, tandis que la partie solide ou l'axe, susceptible de déplacement, tend à produire des figures terminées par des lignes droites qui modifient la forme de la sphère.

M. Spix a suivi une voie semblable, c'est-à-dire qu'il s'est lancé dans Ic champ des abstractions; aussi son système est-il peu en harmonic avec 
nos idées positives. La marche de l'anatomie philosophique française est toute différente : elle déduit plus froidement, et remonte des faits à la généralisation, au lieu de prendre l'inconnu pour point de départ.

Cette grande et puissante création, à laquelle il ne reste qu'à se développer par l'observation, n'a pas trouvé partout des partisans; ell effet, elle a encore à répondre à des objections puissantes. G. Cuvier se montra l'un de ses antagonistes les plus sévères; il admettait que les êtres organisés, loin de former une ligne continue, sans interruptions, en forment plusieurs marchant parallèlement; qu'alors un seul plan ne suffit plus, et qu'il en faut plusieurs, puisqu'il y a plusieurs gradations parallèles. Il disail que les zoologistes philosophes cherchaient en vain l'unité dans les organes; qu'elle réside dans les fonctions générales et essentielles, qui sont les conditions absolues de l'animalité. La divergence qui sépare les deux écoles existe encore, et ce n'est pas à nous de décider la question : nous dirons seulement de l'anatomie philosophique que si, comme les théories générales, elle a procédé d'une manière peut-être trop absolue, elle renferme assez de vérités pour qu'on ne puisse la repousser sans examen.

Physiologie.- Nous avons vu, dans les siècles précédents, la physiologie soumise aux hypothèses des sectes chimiques et mécaniques, ou allant puiser, dans des théories plus ou moins spécieuses, l'explication des phénomènes de la vie. Les progrès des sciences ne lui ont pas encore, il est vrai, permis d'asseoir ses explications sur des démonstrations toujours rigoureuses; mais elle a cessé d'être l'esclave des systèmes dominants en philosophie et dans les sciences physiques, et elle domine toutes celles qui ont pour but la connaissance de l'être et de ses fonctions : aussi la métaphysique et la philosophie transcendante, qui s'épuisent en vains efforts pour trouver, dans des hypothèses, l'explication des faits de l'ordre le plus élevé, sont-elles obligées de venir demander à la physiologie les lumières qui leur manquent. Cette science intéresse donc profondément tous ceux qui voient dans l'étude de la nature l'unique base de la certitude humaine; et la société civile elle-mème peụt en attendre des modifications importantes dans sa constitution organique.

A la tête des hommes du siècle qui ont rendu le plus de services à la physiologie, se place náturellement Bichat. Observateur judicieux, sachant tirer des inductions profondes de simples rapprochements ou 
de simples analogies, il rapporte tous les phénomènes de la vie à des propriélés dont les unes résident dans les organes, tandis que les autres sont répandues dans le reste de l'économie vivante. Les dislinctions qu'il fait entre les tissus et leur rôle dans l'état normal et pathologique sont devenues la source des révolutions qui, depuis le commencement de ce siècle, ont régénéré la médecine.

La physiologie touche de si près aux phénomènes appelés psychologiques, que presque tous les physiologistes ont abordé cette grande question. L'un des plus célèbres sous ce rapport, Cabanis, fit principalement servir ses vastes connaissances à l'explication des phénomènes de l'intelligence; dans son éloquent ouvrage sur le rapport du physique et du moral de l'homme, il remplit la lacune laissée par les philosophes sensualistes dans l'explication du mécanisme mystérieux de la pensée. De Laméthrie, Priestley et Darwin, ne virent dans les phénomènes de l'économie vivante que des propriétés de la matière organique. Baumes, Ackermann, suivant la même voie, rentrèrent dans les théories des physiologistes chimistes et mécaniciens, tandis que d'autres y cherchaient des explications prises en dehors de la science. Nous ne sommes pas tout à fait affranchis de ces idées exclusives; chacun explique encore par une théorie, résultat de ses études, de ses croyances ou de ses préjugés, les phénomènes de la vie; mais il n'en résulte pas moins des travaux de ce siècle que chacun contribue, par ses recherches laborieuses, à enrichir la science de faits nouveaux, abstraction faite de toute théorie.

MM. Buisson, Grimaud, Magendie, Richerand, Adelon, Dumas, Broussais, Breschet, Bourdon, Sprengel, Burdach, de Blainville, Dugès, Müller, ont écrit des traités généraux qui se rapportent aussi bien aux animaux qu'à l'homme, et embrassant l'ensemble de la science; mais ces grands travaux n'ont pas empêché les études spéciales, et les fonctions particulières des organes ont été observées avec soin. MM. Leroy, Dhéré, Duncan, Edwards, etc., ont étudié les phénomènes de la nutrition en général; MM. Chaussier, Montègre, Magendie, Tiedemann, Gmelin, Schwann, ceux de la digestion; MM. Barry, Legallois, Davy, Allen, Edwards, Martin Saint-Ange, Goodwyn, Pépys, ont fait de nombreuses recherches sur la respiration et la circulation; M. Poiseuille a calculé la force impulsive du cœur sur le fluide sanguin; MM. Legallois, Prévost, Dumas, Donné, Schultz, Kaltenbrumner, Wilson, Müller, Andral, etc., ont réuni un grand nombre d'observations sur le 
sang; Bichat, MM. Magendie, Fohmann, Tiedemann, Gmelin, Lippi, Panizza, Antomarchi, Bell, Parsons, Configliachi, ont traité des sécré-lions et des excrétions dans des ouvrages généraux ou des mémoires particuliers; MM. Despretz, Coutanceau, Brodie et Chossat, se sont occupés de la chaleur animale; MM. Breschet et Becquerel ont déterminé, par des expériences délicates, la température des tissus animaux; MM. Dutrochet, Fodera, Home, Tiedemann, Carlisle, Lauth, Meckel, Blainville, Tilesius, Séguin, etc., ont fait de nombreuses recherches sur l'absorption; MM. Scarpa, Gaillardi, Flourens et Serres, sur la formation des os; M. Flourens s'est livré à des expériences pleines d'intérêt sur la coloration des os par la garance; MM. Dumas, Prévost, Prochaska, Carlisle, ont étudié le mouvement musculaire; MM. Gautier, de Blainville, Delle Chiaje, Mojon, Breschet, Roussel de Vauzème et Flourens, ont donné des travaux intéressants sur la structure de la peau; MM. Pinel, Gall, Spurzheim, Broussais, Legallois, Jacobson, Rolando, Bell, Béclard, Desmoulins, Flourens, Burdach, Bouillaud, Adelon, Bailli, Breschet, ont fait une profonde étude du système nerveux. Gall est le créateur de la phrénologie, science nouvelle, entrevue, il est vrai, par plusieurs physiologistes anciens, mais qui s'est, de nos jours, établie comme doctrine philosophique au milieu des théories existantes, et qui attend de ses laborieux sectateurs la confirmation des premières vérités dont elle a posé les bases. MM. Cuvier, de Blainville, Duméril, Home, Froriep, Lehmann, Knox, Houston, Broussais, Breschet, Flourens, Cloquet, Dugès, Müller, etc., ont étudié spécialement les organes des sens.

Les fonctions si complexes de la génération ont occupé un grand nombre de physiologistes; mais les premiers travaux entrepris dans cette direction se sont bornés à des recherches plus ou moins spéciales. Nous citerons, parmi les hommes qui s'y sont livrés, MM. Pander, Baër, Meckel, Rathke, Tiedemann, Bojanus, Purkinje, Huschke, Cuvier, Dutrochet, Serres, Weber, Breschet, Prévost, Dumas, Velpeau, Flourens, Martin Saint-Ange, etc. D'autres physiologistes ont étendu leurs études à toute la série animale, et des traités spéciaux ont été publiés sur cette matière par MM. Burdach, Müller, Valentin, etc., en France, M. Coste a fait de l'embryogénie et de l'ovologie comparée l'objet d'un enseignement dans la chaire d'anatomie comparée de M. de Blainville, au Jardin du Roi. Un brillant avenir est promis à celte parlie de la science. 
Il est une autre branche de la science physiologique qui, de nos jours, vient se heurter contre un scepticisme bien naturel, mais poussé trop loin, sans doute: c'est le somnambulisme magnélique, qui a occupé MM. Deleuze, Bertrand, Puységur, Frappart, Teste, Ricard, etc., et qui compte encore un grand nombre d'adeptes. Depuis les mystifications de Mesmer, l'Académie des sciences et celle de médecine sont intervenues, par intervalle, dans cette question, chaque fois qu'il s'est présenté des magnétiseurs annonçant de nouveaux prodiges; jusqu'à ce jour, le problème n'est pas résolu; ce qui vient peut-être de ce qu'on cherche dans un phénomène réel des effets imaginaires.

Tératologie. - Une nouvelle branche de la science, d'un puissant intérêt et destinée à révéler les mystères de l'évolution des êtres, est la tératologie, qui repose sur le principe dont il a été question en traitant de l'anatomie philosophique, c'est-à-dire que les embryons passent, dans le cours de leur développement, par la forme des animaux des classes inférieures. Il résulte de ce principe que, s’il survient un temps d'arrêt, il naît un être incomplet dans son espèce.

Les anciens tératologistes ( si l'on peut donner ce nom à des hommes qui n'ont recueilli que des faits mal vérifiés, au lieu d'aller chercher dans un principe sûr les causes de ces anomalies) voyaient, dans tous ces monstres, les fruits de l'œuvre du démon ou d'unions antinaturelles : Montaigne et Bâcon, doués d'une raison plus froide, ne virent dans les êtres anomaux que les résultats de lois différentes de celles qui sont communes à l'espèce. Au xvin ${ }^{\mathrm{e}}$ siècle, la tératologie prit une marche plus rationnelle; mais avant Haller, le régénérateur de cette importante partie de la science, on ne trouve qu'à glaner parmi des absurdités; ou, si quelques faits vraisemblables se présentent, on flotte entre l'affirmation des uns et la négation des autres. Ce fut ce savant anatomiste qui démontra l'utilité de l'étude des anomalies organiques pour le progrès de la physiologie.

Les anatomistes philosophes ont cherché dans les inégalités de développement de l'embryon l'explication des phénomènes tératologiques. MM. Meckel, Geoffroy Saint-Hilaire, Serres et Isidore Geoffroy, ont démontré, à l'aide d'un grand nombre de faits, que les anomalies résultent presque toujours d'un arrêt survenu dans le développement d'un certain nombre d'organes, ayant conservé juscqu'à la naissance les caractères qui cessent ordinairement d'exister pendant les premiè- 
res périodes foetales ou même embryonnaires. Il suit de là que la monstruosité n'est pas un aveugle désordre; mais un ordre régulier, soumis à des lois précises, à des règles constantes. Toute loi tératologique a sa loi correspondante dans l'ordre normal, et les monstres peuvent être classés d'après le principe des méthodes linnéennes; il existe donc un rapprochement forcé entre les divers degrés de monstruosité et ceux de l'échelle animale. Cette idée de classification, due à M. Geoffroy Saint-IIilaire, a été développée et complétée par M. Isidore Geoffroy. En l'étendant à tous les groupes, et en les échelonnant suivant le principe de la subordination des caractères, il a rendu la classification tératologique plus régulière que la classification zoologique.

Il existe à notre époque de nombreux travaux tératologiques: MM. Geoffroy Saint-Hilaire père et fils, Meckel, Serres et Otto, ont écrit des traités généraux. MM. Delle Chiaje, Meckel, Otto, Antomarchi, Burkard, Herold, ont étudié les monstres doubles et simples.

L'hermaphrodisme et l'hémitérie ont occupé MM. Jacobi, Martin Saint-Ange, Weese, Stampini, Nicati, etc. MM. Breschet et Geoffroy, Orth et Himly, ont recherché les lois des monstruosités par inclusion.

Zoologie générale. - La zoologie, cultivée avec un succès toujours croissant depuis la renaissance des lettres, ne prit un véritable caractère de stabilité qu'après que le génie de Linné eut jeté les bases de la méthode naturelle; mais les travaux de l'illustre Suédois et les perfectionnements successifs qu'il avait apportés à sa classification dans les

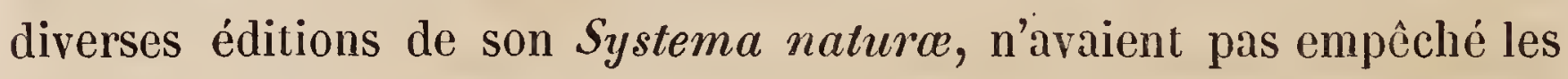
essais d'autres méthodistes. G. Cuvier qui, pendant longtemps, résuma toute la science française, ou, pour mieux dire, fut la plus haute expression scientifique du commencement de ce siècle, commença par réviser, en 1795, de concert avec M. Geoffroy Saint-Hilaire, la classification des mammifères, puis il fit des études semblables sur les êtres de la série animale, et partout il apporta une réforme depuis longtemps désirée. Linné avait formé sans choix sa classe des vers de tous les animaux qui n'avaient pu trouver place dans les classes précédentes; cette classification vicieuse réclamait d'importantes modifications. Cuvier, qu'un séjour sur les côtes de Normandie mit à portée d'étudier les animaux marins, prépara, de 1790 à 1795, pour la classe des vers, un nouveau mode de classification, qui, dès sa publication (1795), obtint l'adhésion 
de tous les naturalistes. Ce grand et beau travail remplit toutes les conditions d'une méthode naturelle, quelle que soit la disposition des groupes intermédiaires; mais il a déjà subi d'inévitables perfectionnements, par suite des progrès qu'ont amenés des études de plus en plus profondes sur les êtres des diverses classes. En 1797, Cuvier publia son tableau élémentaire de l'histoire naturelle des animaux; il présenta, en 1817 et en 1830, dans la $2^{\mathrm{e}}$ édition du Règne animal, ouvrage aussi capital dans la science que le Systema naturce de Linné, une classification complète de tous les animaux, fondée sur leur organisation, d'après le principe des affinités naturelles.

Le système de Cuvier est fondé sur l'ordre descendant, c'est-à-dire qu'on y trouve le type le plus complexe an sommet et le plus simple à la base; il a été adopté par la plupart des naturalistes, comme le mieux approprié aux besoins de l'étude, en ce qu'il va du connu à l'inconnu. Cependant tous les zoologistes n'ont pas accepté ce système; ils ont fait des efforts constants pour arriver à une classification plus parfaite et plus philosophique encore; et, si leurs tentatives n'ont pas toujours été accompagnées de succès, du moins ont-elles contribué au progrès de la science, en variant les points de vue. Lamarck, porté par sa nature à l'abstraction, a adopté l'ordre inverse de Cuvier; il a établi un système général de classification des animaux, en suivant l'ordre ascendant, comme celui qui répondait le mieux à la théorie de la génération successive des êtres.

Toutefois, ce renversement de l'ordre de classification générale n'a pas exercé une bien grande influence sur les divisions des groupes fondamentaux, et la méthode naturelle a triomphé de tontes les tentatives faites en dehors de ses principes. Différentes modifications y ont été apportées par plusieurs auteurs, sans l'altérer profondément; mais M. de Blainville est venu, avec l'autorité de son profond savoir, proposer de nouvelles bases de classification, en opposition avec celles de Cuvier. Selon cet auteur, le règne animal doit être partagé en troı̀s groupes primordiaux seulement, fondés sur les formes générales des animaux et sur leur relation avec la disposition du système nervenx. Plusieurs des hommes éminents dans la science inclinent vers l'opinion de M. de Blainville, el quoique son système n'ait pas obtenu une adhésion générale, la plupart des naturalistes flotlent entre les deux systèmes qui se disputent la prééminence.

Il est une autre manière d'envisager la connexion des êtres vivants: 
c'est celle de MM. Oken et Mac-Leay. Nous avons fait connaître les idées du premier, en parlant de l'anatomie philosophique; il nous reste à exposer la méthode de Mac-Leay : cet auteur base son système sur ce principe déduit des affinités naturelles des êtres, que tous les groupes organiques affectent la forme circulaire; d'après son arrangement, chacun de ces cercles contient cinq autres groupes formant un nouveau cercle; aux points où ces cercles se touchent par leur circonférence, se trouvent des groupes intermédiaires qui les lient entre eux. Ainsi, il y a affinité entre les êtres d'un même cercle, et analogie seulement entre ceux de deux cercles différents. D'après ce système, tous les êtres organisés sont divisés en deux grands cercles comprenant l'un le règne végétal, l'autre le règne animal, et chacun d'eux est ensuile partagé en groupes secondaires. Ce mode de classification, appelé système quinaire et exposé dans les Horæentomologicœ, publiées de 1819 à 1821 , a été étendu et appliqué à tout le règne animal par plusieurs naturalistes anglais, et entre autres par M. Swainson.

Après les ouvrages systématiques, résultats des efforts des maîtres de la science, viennent ceux des naturalistes qui, sans créer de systèmes, acceptent les méthodes généralement admises, ou se contentent de modifications de peu d'importance. Nous citerons les éléments de zoologie générale de MM. Latreille, Duméril, Milne Edwards, Pouchet, Van-der Hoeven, Grant, Hollard, Memprich, Kaup, Munck, Reichenbach; mais il manque un Systema animalium, contenant l'indication de tous les animaux décrits ou renfermés dans les collections et les traités séparés.

Mammalogie. - Le nombre toujours croissant des animaux dont se sont enrichis les collections a nécessité la division de la zoologie en plusieurs branches. En tête, se trouve la mammalogie. Cette science, perfectionnée sous le rapport de la méthode par les classificateurs généraux, a vu le système de G. Cuvier modifié par MM. Desmarest, Duméril, Duvernoy: Latreille, Ranzani, Desmoulins, Fréd. Cuvier et Van-der Hoeven, qui tous sont partis d'un point de vue commun, fondé sur les principes de la méthode naturelle; mais, comme la science n'arrive pas d'un seul coup à un degré de certitude tel que toute contradiction soit impossible, d'autres essais ont eu lieu pour donner une classification plus parfaite des mammifères. En 1811, Illiger publia son Prodromus systematis mammalium, qui contenait une nouvelle méthode, fondée sur les organes de préhension et de sustentation; ce travail, quoique 
remarquable sous plusieurs rapports, a le défaut d'ètre empreint d'un néologisme qui ajoute à l'étude des difficultés nouvelles. M. de Blainville a publié, en 1816, une classification différente de celle de Cuvier, et basée sur l'unité ou la dualité de l'utérus, ainsi que sur une appréciation rigoureuse de la valeur des principaux caractères mammalogiques. M. Desmoulins a cherché, en 1825, à concilier le système de Cuvier et celui de M. de Blainville, sans que celte modification ait été adoptée. M. Isidore Geoffroy a divisé les mammifères en trois séries parallèles, commençant, cliacune, par les êtres les plus complets et descendant jusqu'aux plus simples. Le prince Charles Bonaparte a également établi une classification naturelle dans laquelle on retrouve la plupart des ordres de Linné, mais qui est divisée en deux séries fondées sur le mode de reproduction des mammifères. Dans son état actuel, la méthode mammalogique doit subir les perfectionnements depuis longtemps proposés par les zoologistes, et qui tendent à séparer ou à unir certains ordres ou certaines familles dont la structure et les détails d'organisation sont aujourd'hui mieux connus. Les travaux généraux sur les mammifères sont fort nombreux. Les ouvrages de Buffon, malgré leur charme, sont aujourd'hui surannés et ne sont plus en harmonie avec la forme sérieuse qui, à notre époque, domine toutes les études. Les ouvrages généraux renferment tous l'histoire des mammifères; mais il y a aussi quelques traités spéciaux : tels que ceux de Desmarest, de MM. Lesson et Schinz; la grande histoire naturelle des mammifères pał M. Geoffroy Saint-Hilaire et F. Cuvier, un des plus précieux monuments de la science mammalogique, el le Systema mammalium de M. Fischer, encore incomplet, peut-être, à cause des progrès rapides de la science, mais qui peut donner une idée des espèces connues. On doit compter parmi les travaux qui ont contribué le plus puissamment à faire avancer la mammalogie, les monographies et les faunes, parmi lesquelles nous citerons celles de MM. d'Audebert, Geoffroy père et fils, Temminck, Lichtenstein, de Blainville, Desmarest, I. Cuvier, Duvernoy, Bennetl, Gray, Rengger, le prince Maximilien de Neuwied, Roulin, Savi, Spix, Bowdich, Ritgen, Waterhouse, etc.

On a, de tout temps, attaché une grande importance à l'étude de là structure des mammifères; mais, de nos jours plus que jamais, des recherches spéciales ont été failes pour arriver à une connaissance plus intime de l'organisation des grands vertébrés. M. Meckel a publić une monographic anatomique de l'ornithorhynque et de l'ć- 
chidné ; MM. E. Home, Georges Cuvier, de Blainville, ont traité le même sujel. F. Cuvier a composé, sur les dents des mammifères, considérées comme caractère zoologique, un ouvrage destiné à faire apprécier l'importance du système dentaire dans les diverses familles du règne annimal; M. Rousseau en a fait connaître le développement dans les différents âges chez plusieurs espèces. MM. Reızius, de Stockholm, Owen et Dujardin, en ont étudié la structure intime. G. Cuvier a rédigé un grand nombre de mémoires sur des parlicularités organiques propres à certains ordres ou à certains genres, entre autres sur l'oreille interne des cétacés, sur les narines des mêmes animaux, sur la rate des marsouins, sur l'ostéologie des hippopotames, des paresseux, et sur celle des mammifères en général. M. Fischer a donné une anatomie des makis; MM. Pander et Dalton ont publié un traité d'ostéologie des mammifères; M. Weber a contribué, par ses travaux, à la connaissance de leur charpente osseuse. M. Wolf a étudié la production de la voix dans les animaux de cette classe; M. Gurtl a donné une anatomie des animaux domestiques, ainsi qu'un beau travail sur les glandes des canaux sudorifères, sur les glandes sébacées de la peau dans les animaux domestiques, et sur la structure des ongles et des cornes. M. Walch a traité de l'organisme animal dans les mammifères. M M. Lobstein et Duvernoy ont publié des détails fort intéressants sur l'anatomie des phoques, et M. Rapp, sur celle des cétacés. M. Otto a étudié la dis-position particulière des artères encéphaliques dans les animaux hibernants; il a découvert, dans une espèce de singe, une disposition particulière de l'estomac, que les travaux de MM. Owen et Duvernoy ont démontré caractériser les semnopithèques. Le premier a découvert le sphincter osophagien du diaphragme dans les mammifères grimpeurs. MM. Breschet et Roussel de Vauzème on tétudié l'appareil tégumentaire des manmifères. MM. Meckel, Lauth, Savart, Gerdy, Bennati, Cagniard-Latour et surtont J. Müller, le savant professeur de Berlin, ont avancé, par leurs travaux, la théorie de la voix dans l'homme et dans les autres vertébrés à mammelles. MM. Flourens, Henle, Bischof et Turpin, ont étudié les membranes muqueuses; MM. E. Geoffroy Saint-Hilaire, de Blainville, Owen et plusieurs autres ont fail des recherches sur le mode de génération des marsupiaux et des monotrêmes. 'M. Martin SaintAnge a fait des villosités du chorion des mammifères le sujel d'un grand mémoire. MM. Coste, Eschricht, Gluge, se sont occupés du même sujet. MM. Baër et Rathke ont recueilli des obscrvations sur l'embryogénic 
des mammifères. MM. Dujardin et Verger ont entrepris des recherches sur la structure intime du foie de ces animaux. MM. Rathke, Baër, Weber et J. Müller, se sont servis du microscope pour étudier la structure des organes des sécrétions. MM. Ehrenberg, Th. Schwann, Valentin, Burdach et Mandl, ont exercé leur sagacité sur l'anatomie microscopique des nerfs.

M. Roulin, continuant les observations d'Azara sur les moeurs des animaux de l'ancien monde, transportés en Amérique, s'est occupé des changements qu'ont produits sur les espèces les nouvelles circonstances dans lesquelles elles se sont trouvées.

L'histoire des mœeurs des mammifères est la partie la moins étudiée et par conséquent celle sur laquelle il règne le plus d'obscurité. Nous trouvons bien, dans les relations des voyageurs, des détails épars sur certaines particularités concernant la manière de vivre des animaux qu'ils ont observés; mais nous ne connaissons d'ouvrage complet, sous ce rapport, que l'histoire naturelle des mammifères dont il a été question plus haut, et pour laquelle F. Cuvier a observé à l'état vivant la plupart des animaux qu'il a décrits. M. Flourens a publié un résumé plein d'intérêt des nombreux travaux de F. Cuvier sur le moral des animaux et sur leurs caratères zoologiques. MM. d'Obsonville, Leroy, Virey et Pougens, se sont aussi occupés de l'instinct des animaux. MM. Dureau de La Malle et Isidore Geoffroy Saint-Hilaire ont traité, après Buffon et F. Cuvier, de leur domestication.

L'appréciation des phénomènes intellectuels, entreprise d'abord par Buffon, a occupé l'attention de Dupoṇt de Nemours et plus récemment de F. Cuvier. Depuis, les phrénologistes ont essayé de vérifier leur doctrine, en cherchant, dans la structure du crâne des mammifères, l'indication de leurs penchants et de leurs facultés.

Ornithologie.-L'ornithologie n'est pas moins cultivée que les autres branches de l'histoire naturelle. Quoique les hommes spéciaux dans cette science soient généralement peu nombreux, les travaux systématologiques ont occupé plusieurs savants qui, presque tous, ont pris pour base la classification linnéenne, la plus naturelle de toutes. En 1790, Latham fit paraître son Index ornithologicus, remarquable par sa clarté et sa précision. Cuvier vint ensuite et fit, pour la classification des oiseaux, ce qu'il avait fait pour toutes les autres classes du règne animal, c'est-à-dire qu'il commença par ébaucher un système appelé, 
comme ses autres travaux, à faire époque dans la science; il le perfectionna plus tard, en mettant à profit ses propres observations ef les études des autres ornithologistes. Lacépède, Illiger, M. Duméril, ont attaché aussi à leurs travaux ornithologiques une méthode de classification particulière, fondée, comme toutes celles de l'époque, sur les caractères tirés du bec et des pattes. En 1812, M. de Blainville parla, pour la première fois, de l'avantage de l'étude de l'appareil sternal dans la distribution systématique des oiseaux. Cette idée fut mise à profit par le docteur Lherminier, qui la prit pour base d'un système ornithologique. M. Merrem est arrivé en même temps que M. de Blainville à un résultat semblable dans son Tentamen systematis naturalis avium. Les deux classes fondamentales de sa méthode sont basées sur la présence ou l'absence du bréchet. M. Ranzani dè Bologne a également eu égard aux caractères résultant de la forme de l'appareil sternal, dans la classification des oiseaux faisant partie de ses éléments de zoologie. Vieillor, Latreille, MM. Kuhl, Horsfield, Vigors, Swainson, Ch. Bonaparte, Temminck, Isidore Geoffroy Saint-Hilaire et Wagler, ont aussi joint à leurs descriptions une classificalion systématique; nous pouvons citer, parmi les ornithologistes qui contribuent par leurs études au perfectionnement de la méthode naturelle, M. de Lafresnaye, qui a publié, dans le Magasin zoologique, un grand nombre d'articles d'ornithologie et plusieurs mémoires fort estimés.

Les travaux descriptifs généraux d'ornithologie sont moins abondants que les monographies ou les faunes ornithologiques. Buffon, dont les nombreuses éditions se sont chaque fois enrichies des nouvelles découvertes de la science, a toujours été un ouvrage fondamental en ornithologie. Les méthodologistes ont aussi pour la plupart donné un tableau raccourci, mais aussi complet que possible, du nombre des oiseaux connus. Divers manuels d'ornithologie ont été publiés, et les dictionnaires des sciences naturelles sont devenus des répertoires complets.

Les monographies ornithologiques sont d'un haut intérêt, et presque toutes, surtout de nos jours, sont accompagnées de figures d'une grande beauté et d'une parfaite exactitude. Levaillant avait publié, en 1799, une monographie des perroquets; depuis cette époque jusqu'en 1807, on a eu de lui l'histoire des oiseaux de paradis, des rolliers, des toucans, des couroucous, des promerops, des guêpiers, etc.; Desmarets a fait paraître la monographie des tangaras, des manakins et des todiers; Daudin, celle des tangaras, des moucherolles, etc.; Vicillot, celle des oiseaux 
chanteurs de la zone torride; Temminck a donné l'histoire des pigeons; M. Lesson, celle des oiseaux-mouches; M. Gould a publié, dans ces dernières années, la monographie des ramphastidés, des couroucous et de plusieurs autres genres ou familles; MM. Wagler, Lea et Bourjot SaintHilaire, celle des perroquets; M. Swainson, celle des tyrans d'Amérique. M. Ménétrier est l'auteur d'une monographie des fourmiliers.

Les auteurs de faunes ornithologiques sont très nombreux : Levaillant a donné l'histoire des oiseaux d'Afrique; Savigny nous a fait connaître ceux de l'Égypte et de la Syrie; Shaw, ceux de la NouvelleHollande; M. Grould a publié une centurie des oiseaux de l'Himalaya ainsi que la faune des oiseaux de la Nouvelle-Hollande; M. Alcide d'Orbigny a publié une partie de l'ornithologie des Antilles; il a commencé et il continue la description des oiseaux de l'Amérique méridionale. MM. Rüppel, Smith, Ehrenberg, ont étudié les oiseaux de l'Afrique; MM. Vicillot, Wilson, Audubon, Ch. Bonaparte, ceux de l'Amérique du Nord; le prince de Neuwied et M. Spix, ceux du Brésil; M. Siebold, ceux du Japon; M. Sykes, ceux du pays des Mahrattes; Sonnerat, ceux des Indes et de la Chine; MM. Temminck, Brehm, Gould, etc., ont publié l'histoire naturelle des oiseaux d'Europe; MM. Gérardin, Vieillol, Polydore Roux, Crespon et Degland, la faune ornithologique de la France; MM. Brehm, Schilling, Borkhausen, Spalowsky, Naumann, Meyer et Wolf, celle de l'Allemagne; MM. Lewin, Lord, Bewick, Selby, Pennant, elc., celle de l'Angleterre; MM. Nuccavi, Bonelli, Ch. Bonaparte et Savi, l'ornithologie de l'Italie; M. Schinz a décrit les oiseaux de la Suisse; M. Meyer, ceux de la Livonie et de l'Esthonie; M. Besecke, ceux de la Courlande. M. Nilson est l'auteur d'une ornithologie suédo.se; MM. Rafles, Kuhl et Horsfield ont donné des descriptions d'oiseaux de Java; M. Faber a publié un prodrome des oiseaux de l'Islande et une faune des oiseaux du Nord; M. Kittlitz a fait connaître quelques oiseaux du Chili. La plupart des voyageurs, tels que MM. Quoy, Gaimard, Lesson, Bellanger, Garnot, et en général tous les circumnavigateurs, ont consacré, dans leurs relations, une place importante à la description des oiseaux.

Nous ne connaissons que fort peu de savants qui se soient spécialement occupés d'ornithotomie. Nous ne trouvons guère que M. Tiedemann qui en ait fait l'objet d'études particulières; nous ajouterons seulement que les plus célèbres anatomistes comparateurs se sont occupés de la structure des oiseaux. G. Cuvier a fait connaître leur 
larynx inférieur, et a publié un mémoire sur l'ossification du sternum dans les animaux de cette classe; M. Geoffroy Saint-Hilaire s'est livré à de nombreux travaux sur leur squelette et sur leurs organes reproducteurs; M. Breschet a étudié chez eux l'organe de l'ouïe; M. Brandt, de Saint-Pétersbourg, a publié un grand travail, avec iconographie, sur leur ostéologie. MM. Lauth, Mäller et Duvernoy ont découvert les tissus élastiques qui, dans l'aile des oiseaux en général et dans la poche sous-mandibulaire du pélican en particulier., remplissent la même fonction que les' ligaments dénués de force vive. Le dernier de ces anatomistes a décrit les nombreuses modifications osseuses et musculaires que présente la langue des oiseaux. MM. Cuvier, Dutrochet, Flourens et Coste, ont cherché les analogies qui existent entre l'œuf de l'ovipare el celui du mammifère; M. Richard Owen a donné l'anatomie zoologique de plusieurs espèces; M. Nitzsch a étudié les pennes des oiseaux; M. Thienemann a fait l'histoire de la reproduction des oiseaux d'Europe; M. Schinz est l'auteur d'un travail sur leurs nids et leurs oeufs, etc., etc.

Une partie bien importante et encore peu connue de l'ornithologie, est la partie ethnographique. On peut dire que, sous ce rapport, la science ornithologique présente une grande lacune que le temps seul pourra remplir. Les migrations des oiseaux ont bien été l'objet des études de quelques observateurs; mais nos connaissances à ce sujet sont encore fort incertaines.

Erpétologie. - Nous avons vu la science erpétologique naître au xvıI siècle sous l'inspiration de Laurenti; depuis elle a grandi, et le xIx $^{e}$ siècle est riche en observations de toutes sortes. Nous passerons rapidement en revue les méthodologistes qui sont très nombreux. Lacépède, le premier dans l'ordre chronologique, a donné, dans sa continualion des œuvres de Buffon, une histoire naturelle des quadrupèdes ovipares et des serpents; il a fondé sa classification, pour les premiers, sur la présence ou l'absence de la queue, pour les autres sur la présence ou l'absence des pieds. Ln 1799, M. Brongniart a publié un arrangement systématique des reptiles, fondé sur les caractères anatomiques, affranchissant ainsi la science des entraves d'une étroite routine: Latreille n'a donné qu'une modification du système de Lacépède; Daudin a fait paraitre, en 1802 et 1803 , une histoire générale des reptiles, où il a suivi la méthode de $\mathbf{M}$. Brongniart. Il est à regretter que ce travail, fait avec rapidité, soil quelquefois inexact. G. Cuvier a 
publić, en 1798, dans son Tableau élémentaire de l'histoire naturelle des animaux, une classification qui se rapproche de celle de Lacépède. II adopta, plus tard, celle de M. Brongniart; et, vingt annćes après, il publia un nouvel arrangement des reptiles fondé sur la subordination des caractères. M. Duméril, qui a succédé à Lacépède, et qui, depuis près de quarante années, occupe la chaire d'erpélologie, a successivement perfectionné la méthode naturelle qu'il a suivie dans les nouvelles suites à Buffon, publiées en 1834, conjointement avec M. Bibron. Oppel, naturaliste bavarois, a fait paraître, en 1811, un travail systématique sur les reptiles. M. Merrem a donné, en 1820,'son Tentamen systematis amphibiorum; cet ouvrage, peu au courant de la science, n'est que la reproduction d'un autre qui lui est antérieur; le système qu'il a suivi est presque celui d'Oppel. M. de Blainville a apporté, dans sa classification, la science et la sagacité qui le distinguent. M. Gray a publié plusieurs essais de classification qui n'ont pas été adoptés. Le docteur Harlan est l'auteur d'une faune erpétologique de l'Amérique du Nord, dans laquelle il propose un système de classification fondé sur les organes respiratoires. On distingue surtout dans son travail la partie relative aux genres grenouille, rainette et crapaud. M. Haworth a proposé un système dichotomique de la classe des reptiles, emprunté en partie à Merrem. M. Fitzinger, auteur doué d'une saine critique, a proposé un nouvel arrangement systématique, dans son catalogue des reptiles que renferme le musée zoologique de Vienne. M. Ritgen est l'auteur d'une méthode inadmissible, par suite des nombreuses particularilés qu'il y a introduites. Il nous reste à citer avec éloge le travail de M. Wagler sur la classification des reptiles, comme étant conforme aux vrais principes de la méthode naturelle. On voit que les travaux systématiques relatifs aux animaux de cette classe ont beaucoup exercé la sagacité des naturalistes, à cause des modificalions nombreuses que présente leur organisation. Chacun des auteurs que nous venons de citer ne s'est point contenté d'un simple travail de nomenclature; mais il y a joint des descriptions augmentées, chaque fois, des genres nouveaux dont la science s'était enrichie. L'erpétologie compte aussi, au nombre de ses historiens, MM. Meyer, Kaup, Reuss, en Allemagne ; Lichtentein, Gravenhorst et Wiegmann, en Prusse; Schlegel, Boié, en Hollande; Bell, en Angleterre; Rusconi et Ch. Bonaparte, en Italie; Cocteau, en France, etc.

Les travaux d'anatomie relatifs aux reptiles sont nombreux, et ont. puissamment contribué au perfectionnement des méthodes. En $1794 \mathrm{cl}$ 
1795, Townson a public des observations physiologiques sur la respiralion de ces animaux. M. Geoffroy Saint-Hilaire père, dans sa philosophie anatomique, a décrit leurs organes respiratoires; il a fait aussi une étude comparative des organes de l'ouie chez les reptiles, chez l'homme et chez les poissons. M. Windischmann a fait paraître, en 1831, un traité sur la structure de l'oreille dans les amphibies. En 1832, M. Breschet a publié un travail semblable. M. Jacobson a donné des recherches sur un système veineux particulier aux reptiles. Nous devons à M. Martin Saint-Ange un travail comparatif sur la. circulation des quatre classes des animaux vertébrés. M. Panizza, de Pavie, a éudié leur système lymphatique. MMI. Schoepf, Schneider et Bojanus, ont publié l'anatomie des tortues; MM. Jules Cloquet et Meckel, celle des glandes lacrymales et venimeuses des serpents. En 1832, le professeur Müller, de Bonn, a donné, sur les ordres des batraciens et des serpents, un excellent travail anatomique et descriptif. M. Meyer a découvert, dans plusieurs espèces de ces ordres, des rudiments de membres postérieurs; M. Serres a publié une anatomie du cerveau des reptiles, comparé à celui des autres classes des vertébrés. Un travail semblable esı dû̀ à M. Trevirañus. Dumoulin et M. Bischopf ont fait connaître le système nerveux de ces animaux. Les mémoires de l'Académie des sciences de Naples contiennent un travail de Cavolini sur la génération des amphibies. On doit à M. Dutrochet des observations très intéressantes sur l'œuf des reptiles et sur les enveloppes du foelus dans les êtres de cette classe. M. Fricket nous en a fait connaître l'organe de la vue. M. Dugès est l'auteur d'un travail sur leur mode de déglutition; M. Schlegel, de Leyde, a publić le résultat de ses recherches sur les glandes salivaires des serpents venimeux el non venimeux; M. Duvernoy a composé un mémoire sur les caractères anatomiques qui distinguent les premiers de ces animaux des seconds. M. Rusconi a éludié le développement de l'œuf des grenouilles. M. Sébastien a donné une anatomie du lézard, appelé dragon par Linné. MM. Siebold, Funck et Rusconi, ont publié des mémoires pleins d'intérêt sur l'organisation des salamandres. MM. Isidore Geoffroy Saint-Hilaire et Martin Saint-Ange ont découvert, dans le crocodile, les canaux péritonéaux, déjà observés par M. Duvernoy dans les tortues. MM. Emmert, Weber, Tiedemann et Gravenhorst, ont contribué, par leurs travaux, à la connaissance de l'organisation des reptiles.

Nous possédons aujourd'hui un grand nombre de faunes erpélologiques, intéressantes sous le double rapport de l'histoire naturelle des 
reptiles et de leur distribution géographique. Kuhl, Van Hasselt et Boié, morts à Java, ont laissé, sur l'erpétologie de cette île, des manuscrits dont on a publié plusieurs extraits dans divers journaux allemands et particulièrement dans l'Isis. M. Russel a enrichi l'iconograplie de magnifiques gravures représentant plus de vingt espèces de serpents du Bengale. On doit au $\mathrm{D}^{\mathrm{r}}$ Green la description de beaucoup d'espèces de reptiles de l'Amérique du Nord. M. Lesson a publié la partie erpétologique du voyage de Bélanger aux Indes orientales; il a donné la description des reptiles apportés des Indes et de l'Afrique par M. Lamare-Piquot, et rédigé l'erpétologie du voyage de la $C_{0}$ quille. M. Lindaker est l'auteur d'une faune erpétologique de la Bohême; M. Risso a publié celle des environs de Nice; M. Van Hayden, celle du nord de l'Afrique. MM. Spix de Munich, Roddi de Pise, nous ont fait connaître diverses espèces nouvelles de tortues et de grenouilles propres au Brésil. Le prince Maximilien de Neuwied a aussi doté la science de nombreuses découvertes faites par lui-même dans celte partie de l'Amérique méridionale. Nous ne parlerons pas ici des relations de voyages, renfermant des descriptions de zoologie générale, et dans lesquelles la classe des reptiles se trouve naturellement comprise.

Ichthyologie.-A l'époque où les études d'anatomie comparée vinrent apporter à la science les lumières dont elle était privée, l'ichthyologie était sèche et aride, el l'histoire naturelle générale des poissons se bornail presque à leur classification. Néanmoins, dans le cours du xvın $^{\mathrm{e}}$ siècle, surtout ver's sa fin, il avail paru des ouvrages d'une haute importance; et les anatomistes comparateurs avaient réuni, sur les particularités de la structure des poissons, des observations assez nombreuses, pour que les progrès de notre siècle fussent faciles à prévoir. Lacépède comprit qu'il était possible de rendre la science plus attrayante, sans lui rien ôter de sa précision; dans l'ichthyologie qui fait suite aux oeuvres de Buffon, il décrivit la structure, les moeurs et les migrations des poissons dans un style souvent aussi riche que celui de son modèle. Malheureusement la méthode qu'il a suivie, quoique simple, régulière, et permettant de classer sans peine tous les genres nouveaux, est purement artificielle, et son travail présente au moins deux cents doubles emplois, ce qui vient du trop de confiance qu'il avait eue en ses devanciers; mais cette histoire, malgré ses imperfections, a servi de base à tous les travaux qui, jusqu'ì ce jour, ont été fitis sur celle science. 
Sonnini de Manoncourt a publié, dans son édition de Buffon, la partie relative aux poissons, qui n'est qu'une copie de Lacépède. On peut encore considérer comme conçus sous son influence, la partie ichthyologique de la zoologie générale de Shaw et les ouvrages élémentaires de M. Duméril, dans lesquels le système de Lacépède est cependant présenté avec plus d'ordre, et qui sont enrichis de toutes les acquisitions successives de la science. Beaucoup de nomenclateurs ont encore suivi ce système ; M. Raffinesque a successivement fait paraître, en 1810 et 1815, un catalogue des poissons de la Sicile, dans lequel la méthode qu'il a adoptée, tout en s'écartant de celle de Lacépède, est fondée sur les mêmes principes.

G. Cuvier a publié une classification qui reçut son perfectionnement en 1817, et qui se distingue, comme tous les travaux de ce naturaliste, par la supériorité de sa méthode, basée sur la subordination des caractères. Schneider a donné, en 1820, sous le titre de Systema ichthyologice Blochii, un essai de classification trop bizarre pour qu'on. ait pu l'adopter. Le système de M. de Blainville, publié en 1816, se rapproche beaucoup de celui de Gmelin, sous le rapport des caractères généraux des grandes classes, et de celui de Linné, pour le reste des subdivisions. MM. Goldfuss et Risso ont également pris pour modèle de classification, dans des ouvrages récents, le système de Gmelin, auquel ils ont fait quelques modifications peu importantes. M. Oken, dont nous avons exposé les principes en parlant de l'anatomie philosophique, a appliqué son système général à la classification des poissons; il a publié, en 1822, sa quatrième distribution ichthyologique, plus essentiellement fondée sur les principes qu'il suppose dominer dans les êtres des diverses classes; en 1837, le prince Charles Bonaparte a lu à la Société linnéenne de Londres, man travail systématique comprenant les quatre classes de vertébrés. Dans sa classification des poissons, il a pris pour base de ses trois grandes divisions la structure des branchies, et il a apporté quelques modifications dans l'ordre des genres entre eux.

L'anatomie et la physiologie des poissons ont, de tout temps, été l'objet des études des naturalistes: nous trouvons le xviri ${ }^{\theta}$ siècle déjà riche en observations; cependant, la zoologie de cette classe existait à peine au commencement du $\mathrm{xux}^{\mathrm{e}}$ siècle; les plus grands travaux sur ce sujet sont dus à la fois aux anatomistes comparateurs et philosophes. En 1800, M. Autenrieth donna une anatomie de la plie; en 1807, M. Geoffroy Saint-lfilaire publia des travaux comparatifs sur l'ana- 
logie des as qui portent la nageoire pectorale avec ceux qui, dans les autres vertébrés, souliennent lès membres antérieurs. De 1811 à 1818 , cet anatomiste arriva au même résultat que M. Spix, sur la correspondance des pièces operculaires avec les osselets de l'oreille, et sur l'analogie de l'appareil des branchies avec le sternum, l'os hyoïde, le larynx, la trachée et les bronches. En 1824 et 1825, après de nouvelles observations, M. Geoffroy reproduisit son travail sur les opercules, en y joignant sa théorie générale sur la composition de la vertèbre. De 1811 à 1822, M. Rosenthal a publié de beaux travaux sur l'ostéologie des poissons; de 1812 à 1817, G. Cuvier, qui s'était beaucoup occupé de ce sujet (il avait déjà rassemblé plus de trois cents squelettes de poissons), publia ses idées sur l'ostéologie de la tête. Au commencement du xıx ${ }^{e}$ siècle, M. Duméril découvrit les rapports dı crâne avec les vertèbres. Les anatomistes philosophes s'étant emparés de cette donnée nouvelle pour l'appliquer à la structure de la tète des animaux, M. Spix la développa dans sa Céphalogénésie, publiée à Munich, en 1815; il avança le premier l'opinion, adoptée depuis, sur la signification des pièces operculaires. MM. Bojanus, Fenner, Carus, Weber, Van der Hoeven, Bakker et Meckel, ont fait aussi de grands travaux sur l'ostéologie ichthyologique. Nous ne trouvons que G. Cuvier et M. Carus pour la myologie des poissons; mais leur névrologie a été l'objet d'études plus nombreuses. MM. Weber, Kuhl, Fenner, Sœmmering, Apostole-Arsaki, Desmoulins, Duméril, Serres, Magendie, s'en sont occupés avec succès; MM. d'Alton et Schlemme ont fait un beau travail, accompagné de planches, sur le système nerveux du saumon. Les descriptions particulières, relatives aux autres détails anatomiques des poissons, ne manquent pas non plus. MM. Home et de Blainville se sont occupés de la splanchnologie de cette classe; MM. Duméril et Rathke ont donné celle des lamproies. M. Rathke a publié, en 1824 et 1825, des travaux du plus haut intérêt sur le système circulatoire et digeslif, et sur les organes génitaux des poissons. M. Breschet a composé un mémoire sur l'organe de l'audition dans ces animaux; MM. Tiedemann et Doellinger ont particulièrement étudié leur cœur, et M. Fohmann a fait une étude spéciale de leurs vaisseaux lymphatiques; M. Rosenthal a fait des recherches sur la structure de leurs branchies, et M. Flourens sur le mécanisme de leur respiration.

Les autres particularités relatives aux animaux de cette classe n'ont pas été moins observées. Bailly a fait connaitre le mécanisme des filets 
de la baudroie. MM. Geoffroy, de Humboldt, Rudolphi et Valenciennes, ont étudié les organes qui, chez les poissons électriques, développent de l'électricité. MM. Biot, Treviranus, G. Cuvier, ont réuni de nombreuses observations sur la vessie natatoire des poissons ; l'air qu'elle renferme a été l'objet d'expériences particulières. MM. Kunzmann et Agassiz ont publié le résultat de leurs recherches sur les différences de forme et de structure que présentent leurs écailles. Quelques expériences ont eu lieu sur la composition chimique des divers organes de ces animaux.

Les faunes et les travaux descriptifs sont nombreux : De la Roche a publié, en 1809, l'ichthyologie des Baléares; M. Risso, celle de Nice; M. Yarrell, celle d'Augleterre; M. Thompson, celle d'Irlande; M. Nilson,celle de la Suède; MM. Fries et Eskstroem, celle de la Norwège; M. Raffinesque-Schmaltz, un catalogue d'ichthyologie sicilienne. MM. Otto, Bonelli, Ranzani, Giorna, etc., ont contribué à faire connaître les poissons de la Méditerranée; MM. Naccari et Nardo ont décrit ceux de l'Adriatique. On doit à M. Low une faune des Orcades et la description de quelques poissons de la mer du Nord; M. Montagu a décrit plusieurs espèces rares des côtes méridionales de la Grande-Bretagne; MM. Geoffroy Saint-Hilaire, Ehrenberg et Rüppell, nous ont fait connaîire les poissons du Nil et de la mer Rouge; M. Tilesius, ceux de la mer du Kamschatka. M. Mitchill a donné une histoire des poissons qui se pêchent aux environs de New-York. Lesueur et Raffinesque ont publié de nouveaux détails sur l'ichthyologie des États-Unis. M. Buchanan nous a fait connaître les poissons du Gange; M. Russel ceux du Bengale; M. John M'Clelland, les cyprins de l'Inde, et M. Heckel les poissons de Kaslımir; M. Bailli a exploré la Grèce sous le rapport ichthyologique. Les diverses expéditions autour du monde et les explorations des voyageurs ont également enrichi nos colleetions de genres nouveaux ou incomplètement counus. Un assez grand nombre d'amateurs d'ichtllyologie ont réuni les poissons de leurs côtes ou de leurs localités, pour contribuer à compléter cette partie si intéressante de J'histoire des animaux. Les Dictionnaires d'histoire naturelle qui ont paru depuis le commencement du siècle, contiennent tous, à mesure qu'ils se rapprochent de notre époque, des descriptions plus fidèles, des figures plus exactes, ainsi que des indications de genres nouveaux; mais le travail le plus grand et le plus bean qui ait paru sur cette science, ot qui en renferme à-la-fois l'ensemble et les détails, est l'histoire naturelle des poissons, commenece par G. Cuvier, conjointement avea 
M. Valenciennes, qui l'a contimuée, après la mort de son illustre collaborateur.

Une partie, moins connue et récente encore, est l'ichthyologie fossile, dont M. Agassiz s'est occupé avec beaucoup de succès, el à laquelle il faut joindre les essais de MM. de Blainville, Buckland, Sedgwick, Murchison, Valenciennes, Bronn, etc.

Conchyliologie. - A la fin du xvm ${ }^{\mathrm{e}}$ sic̀cle, la conchyliologic sortait à peine du chaos. Les coquilles, assez bien connues, étaicnt considérées, par la plupart des auteurs, comme offrant les seuls cáactères propres à élablir la classification; mais quelques savants de premier ordre, aussi bons observateurs que philosophes profonds, avaicnt reconnu que les vérilables caractères sur lesquels doit être fondée la classification naturelle des mollusques, ne se trouvent pas dans le test, mais dans les animaux. Cependant, tous les auteurs ne crurent pas devoir abandonner le système linnéen, et la modification qu'y avait apportée Bruğuière, fut encore adoplée par Bosc dans, les suppléments à Buffon.

L'histoire des testacés des Deux-Siciles par Poli, publiée en 1791, donna une impulsion nouvelle à la conchyliologie. Les trois groupes établis par lui, sur la considération de l'animal, abstraction faite de la coquille, ont été admis par tous les naturalistes, quoique, dans ce syslème, il y ail des rapprochements peu naturcls. En 1798, G. Cuvier s'occupa de la classification des mollusques. Ce nouveau système, dans lequel le grand naturaliste avait mis à profit les travaux des conchyliologistes antérieurs, fut pour la science un progrès de plus; mais, comme tous les hommes supérieurs, et par suite de ce sage point de vue scienlifique qui fonde sur l'expérience le perfeclionnement ultérieur des méthodes, il ne cessa de travailler à la classification dont il avait jeté les premières bases. Profitant des divers travaux des hommes qui s'occupaient de conchyliologie, il arriva à établir une méthode dont les naturalistes classificateurs ne se sont que peu écartés. Vers la même époque que lui, mais se fondant toujours sur les principes immuables de la méthode naturelle, Denys de Montfort, Lamarck, Péron, Daudebard de Férussac père et fils, Latreille, MM. de Roissy, Duméril, de Blainville, Alcide d'Orb́igny, Deshayes, établirent des systèmes de malacologic, qui sont pour la plupart des modifications du système primilif; enfin les travaux particuliers de tous les savants ont mieux fait connaître certains ordres, certains genres, placés d'abord au hasard, 
faute d'études suffisantes. Ces travaux ont servi à établir les classifications généralement adoptées aujourd'hui.

L'Allemagne vit paraître, en 1810, le travail de M. Oken, qui n'introduisit dans la classification aucun point de vue neuf, et qui ne fit qu'augmenter ou diminuer les genres établis. La classification de M. Raffinesque-Schmaltz est peu précise el difficile à comprendre. MM. Schweigger et Goldfuss sont encore des compilateurs qui ont plus ou moins heureusement modifié le système de Lamarck et celui de Cuvier. M. Say, en Amérique, le docteur Leach et M. Gray, en Angleterre, ont proposé des modifications dans les genres ou des dénominations nouvelles de peu d'influence sur la classification, mais qui ont néanmoins contribué à perfectionner la science.

Parmi les iravaux généraux, nous citerons l'histoire naturelle des animaux sans vertèbres de Lamarck, dont MM. Deshayes et Milne Edwards ont donné une nouvelle édition; la conchyliologie générale de Wood; celle des coquilles terrestres et fluviatiles de l'Europe par Rossmassler; l'histoire des mollusques terrestres de Férussac; la monographie des hélicines, des porcelaines, etc., de M. Gray; celle des bulimes et d'une foule d'autres genres exoliques de M. Sowerby; la conchyliologie appliquée à la géognosie que publie M. Deshayes; le beau species général des coquilles marines vivantes entrepris par M. Kiener, etc.

Les conchyliologistes anatomistes ou descripteurs n'ont pas travaillé avec moins d'ardeur. On trouve naturellement à leur tête tous les savants que nous avons cités plus haut; nous y joindrons ceux qui, sans avoir fait des travaux de méthodologie, ont publié, soit des traités généraux, soit des observations particulières. Draparnaud modifia, en 1803 , dans son grand travail sur les mollusques terrestres et fluviatiles de la France, le mode de description des coquilles, et abandonna le système vicieux suivi par Linné et ses disciples. Cuvier publia successivement, dans les Annales du Muséum, depuis 1802 jusqu'en 1810, des travaux très nombreux sur l'anatomie de différents genres de mollusques. En 1813, M. Meckel jeta du jour sur la structure des pleurobranches et des ptérupodes. En 1814, M. Home inséra, dans ses Mémoires d'anatomie comparée, des observations relatives aux mollusques; M. Erman a publié un mémoire sur leur sang; MM. Lesueur et Desmarest ont donné des détails anatomiques sur la botrylle étoilée; M. Stiebel est l'auteur d'un travail sur la lymnée des étangs. M. de Blainville a le premier donné une juste appréciation des organes respiratoires des 
malacozoaires; il a publić, dans le Diclionnaire des Sciences naturelles, des délails précieux sur l'anatomie et la physiologie de ces animaux; M. Ratzani a fait un mémoire très intéressant sur les mollusques arliculés el les acéphales; M. de Haan a étudié les ammonites et les gonialites; Alcide d'Orbigny el de Férussac ont donné un travail très étendu sur les céphalopodes. Péron el Lesueur, vcyagem's infatigables, firent paraître d'importants travaux sur divers genres de mollusques recueillis ou observés par eux. Péron, le premier, et, après lui, Desmarest et M. Savigny, ont fuit connaîte les mollusques agrégés, sur la structure et la classification desquels M. Milne Edwards a donné tout récemment un travail considérable. MM. Olfers et Leach ont publić des travaux spéciaux sur les genres balane et anatife; M. Martin Saint-Ange s'est occupé de l'anatomie de ces animaux, et MM. Thompson el Burmeister ont fait conuâtre les métamorphoses qu'ils subissent dans leur jeune âge. MM. Quoy el Gaimard ont éludié, dans leurs longs voyages, les mollusques de plusieurs points du globe. MM. Delle Chiaje, A. d'Orbigny, Richard Owen, Deshayes, Valencicnnes, Rang, Milne Edwards, Audouin, Van Beneden, Lesson, Graleloup, Charles Desmoulins, etc., ont contribué, par leurs laborieuses recherches, au progrès de la conchyliologie; et, depuis que l'étude de l'animal est devenue la partie la plus importante de la science des mollusques, la plupart des conchyliologistes ont étudié avec soin l'anatomie de ces animaux, dont certaines particularités ont été découvertes par MM. Néry et Bojanus, qui en ont éludié l'appareil générateur, ainsi que par MM. Van Beneden, Siebold, clc.

On compte un grand nombre de faunes conchyliologiques. Geoffroy; le inédecin, a réuni, dans un ouvrage, les mollusques de la France, et surtout ceux des environs de Paris. M. Michaud a continué le travail de Draparnaud sur les coquilles fluviatiles et terrestres de la France; MM. Desmoulins, Bouillet, Goupil, Millet, de Gerville, Collard des Chères, Payraudeau, Brard, Pouret, Bouchard, Chantereaux, d'Orbigny père, Hécart, Dillwyn, etc., ont rédigé des catalogues départementaux ou laissé de bons travaux sur les mollusques de diverses contrées. M. Nilson a publié une histoire des mollusques terrestres et fluviatiles de la Suède; MM. Pfeiffer, Kleb, Muhlfield, Alter, Grertner, en ont fait autant pour l'Allemagne; M. Müller a décrit les espèces de Danemark; M. Hartmann, celles de la Suisse; Bowdich, celles de PorloSanto; MM. Poli, Costa et Philippi, celles de la Sicile; MM. Montagu, 
da Costa, Pennant, Donovan, etc., celles de la Grande-Bretagne; M. Deshayes, celles de Morée. MM. Spix, Wagner et Moricand, ont décrit et figuré quelques mollusques terrestres qui habitent le Brésil; M. Lowe, ceux de Madère; M. Rang a fait connaître les mollusques terrestres nouveaux propres à la côte d'Afrique. MM. Say, Isaac Lea, Raffinesque, ont publié une faune malacologique des Érats-Unis. M. Alcide d'Orbigny a décrit tous les mollusques qu'il a trouvés dans l'Amérique méridionale, et publié des faunes malacologiques des Antilles el des Canaries; MM. Ehrenberg, Botta, Rüppel, ont recueilli les mollusques de la mer Rouge, etc.

Entomologie. - L'entomologie, si jenne encore au xviri ${ }^{\mathrm{e}}$ siècle, malgré ses brillantes découvertes, et alors si fort dédaignée que Réaumur croyait devoir se justifier de l'entrainement irrésistible qui l'atlirait vers cette science, a fait de rapides progrès depuis 1789. Fabricius, quí, pendant vingt annćes, avait dominé la science, fut détrôné par Latreille. Dans son Précis des caractères génériques des inseckes, publié en 1796, ce dernicr appliqua, pour la première fois, aux animaux articulés, les principes de la méthode naturelle. Céi essai, qui s'écartail du système artificiel de Fabricius, révéla dans son auteur un sentiment profond des affnités; mais il ne fut perfectionné qu'en 1806, quand Cuvier eut indiqué la séparation nécessaire entre les insectes et les crustacés, et que Lamarck l'eut réalisée. Pendant toute sa vie, et jusqu'en 1832 , Latreille remania son système, et y introduisit successivement la classe des arachnides, créée par Lamarck, et celle des myriapodes, établie par Leach. Le Genera crustaceorum et insectorum, son véritable titre de gloire, est admirable pour la mitnière dont les diver's genres s'enchaînent dans chaque ordre, et dont les caractères sont présentés. Dans le Règne animal de Cuvier et notamment dans la seconde édition, dont la partie entomologique a été écrite par Latreille, ce dernier a encore perfectionné sa méthode, qui ne pèche guère que par les points où toute idée systématique n'a pas complètement disparı. Bien que Latreille fût exclusivement méthodiste et qu'il ne prît aucune part aux travaux des anatomistes et des physiologistes, il sut habilement tirer parti de leurs observations. M. Duméril a donné aussi, dans sa Zoologie analytique (1806), un système de classificalion des insectes qui ressemble beaucoup à celui de Linné. D'accord avec plusienrs naturalistes, il assigne aux insectes la première place dans la série des invertébrés. 
Leach publia, en 1817, un système dans lequel il prit la mélamorphose pour point de dépar' ; mais les imperfections de cette classification la firent bientôt tomber dans l'oubli. Celle de MM. Kirby et Spence n'est pas fondée, non plus, sur les véritables rapports naturels. Dans ces derniers temps, MM. Burmeister et Westwood ont donné, l'un dans son Manuel d'Entomologie, l'autre dans sa Classification des insectes, 1 u arrangement qu'ils croient devoir se rapprocher le plus de la méthode naturelle. M. Burmeister parı comme Leach, de la métamorphose incomplète ou complète des insectes, en comprenant, dans la première classe, les espèces qu'on regarde comme n'en subissant ancune; il en résulı deux séries parallèles entièrement indépendantes l'une de l'autre. L'auteur donue, comme un grand pas ver's la classification philosophicue, la disposition de ses séries, en tête desquelles il met les ordres les moins parfaits sous le rapport de l'organisation, ce qui avait été fait avant hi par Lamarck; on voil du reste dominer chez cet auteur certaines idées systématiques, qui empècheront sans doute sa méthode d'ètre généralement adoptée.

L'école philosophique est représentée, en entomologie spéculative, par MM. Oken et Mac-Leay. Le premier, fidèle au sysième que nous avons développé eu parlant de sa classificalion générale des êtres orgatuisés, a disposé les insectes en trois ordres, en tête desquels sont les insectes-germes ou à métamorphose imparfaite; les insectes-sexes, à métamorphose complète et à ailes égales, et les insectes-poumons ou à métamorphose complète et à ailes et élytres.

M. Mac-Leay, dout nous avons exposé la théorie en parlant des méthodologistes, a appliqué, dans ses Horæe entomologica, le système circulaire à la classification des insectes; sa méthode, qui contient des aperçus souvent profonds, a fait peu de sensation sur le continent; mais elle a obtenu beaucoup de succès en Angleterre:

L'anatomie et la physiologie des insectes, que les travaux de Lyonnet étaient venus clore au xvın ${ }^{\mathrm{e}}$ siècle, furent reprises par Cuvier dans son mémoire sur la nutritiou des arliculés, oì il montra que cette fonction ne peut avoir lieu que par imbibition. Dans son traité d'anatomie comparée, il présenta le résumé des conmaissances de son époque sur l'organisation des hexapodes.

A la mème époque, Lehmann publia deux dissertations sur l'usage des antennes dans les animaux de cette classe; M. Posselt fit connaître quelques particulariés de leur structure; MM. Haussmann el Sorg 
étudièrent leur mode de respiration; M. Treviranus s'occupa de leur anatomie, et publia un mémoire sur leurs organes de succion et d'olfaction. M. Marcel de Serres composa une série de mémoires sur les yeux lisses et composés des insectes, sur les usages du vaisseau dorsal, sur les organes de l'odorat et le tube intestinal dans les hexapodes. Ramdhor s'est occupé de leur anatomie et de leur système digestif, el M. Strauss a publié un fort beau travail sur l'anatomie du hanneton; mais c'est à M. Léon Dufour qu'appartiennent les travaux les plus complets sur cette matière. Il avait déjà fait connaître la struclure des coléoptères et des hémiptères, et il vient de publier tout récemment l'anatomie des orthoptères, des névroptères et des hyménoptères.

Des naturalistes philosophes, tels que MM. Geoffroy Saint-Hilaire et Robineau-Desvoidy, n'ont pris part aux travaux des entomologistes que pour rechercher l'unité de plan dans tout le règne animal, tandis que d'autres l'ont cherchée dans la classe des insectes seulement; ainsi M. Savigny s'est livré dans ce but à des études sur la bouche des hexapodes; MM. Audouin et Mac-Leay en ont fait sur le thorax de ces animaux; Latreille sur leurs pattes et leurs ailes, et Newman sur leur ostéologie. C'est au commencement du xix ${ }^{\mathrm{e}}$ siècle qu'on a le mieux étudié la structure des ailes, et qu'on s'en est servi comme moyen de classer certains groupes; Jurine est le naturaliste qui a donné le plus grand développement à cette étude, bien qu'il l'ait bornée à l'ordre des hyménoptères.

Nous devrions ajouter à ce qui précède la longue série de travaux spéciaux sur les insectes, ainsi que les faunes entomologiques, etc.; nous nous bornerons à citer parmi les faunes : l'entomologie helvétique de Calairville; celle des lépidoptères de Géorgie, par Smilh-Abbot; la description des insectes de la Chine, de l'Inde et de la Nouvelle-Hollande, par Donovan, qui avait précédemment publić la faune entomologique de l'Angleterre; la faune d'Ingrie par Cederhielm; celle de Prusse par Illiger et Kugellan; celle d'Autriche par Duftschmidt et Schrank; de l'Italie supérieure par Rosși ; des coléoptères de Suède par Paykull, et surtout par Gyllenhall, qui a donné le meilleur ouvrage parmi les faunes; la faune d'Allemagne par Panzer, continuée par. MM. Germar et Herrich-Sehoeffer; la description des insectes de la Russie et de la Sibérie par M. Fischer; de ceux d'Angleterre par MM. Spence et Curtis; de Laponie par M. Zetterstedt; de Danemark par M. Schiodte; du Brandcbourg par M. Erichson; de la Morée par M. Brullé; de l'A- 
mérique boréale par M. Say ; la description, publiée par M. GuérinMéneville, des animaux articulés de l'Australasie et des Iles de la mer du Sud, recueillis pendant le voyage de la Coquille autour du monde; celle des articulés de l'Amérique méridionale, fạisant partie du voyage de Spix et Martius, par M. Perty; la partie entomologique du voyage de M. Alcide d'Orbigny, par MM. Blanchard et Biullé. Parmi les travaux spéciaux sur les divers ordres, nous citerons l'entomologie d'Olivier dont l'ouvrage a été, après les travaux de Fabricius, l'un des plus utiles pour la connaissance des espèces de l'ordre des coléoptères ; les intéressantes observations de M. Duméril sur les insectes; ceux des deux Huber sur les abeilles et les fourmis; la synonymie des insectes par Schoenherr; la magnifique collection iconographique des papillons indigènes et exotiques par Hubner' l'histoire des papillons d'Europe, commencée par Godart et continuée par M. Duponchel; celle de Treitschke; le catalogue méthodique des papillons d'Europe par M. Boisduval; le species et l'iconographie des coléoptères par M. Dejean, continués par M. Aubé; l'ouvrage de Stoll sur les orthoptères et les hémiptères; ceux de M. Serville sur le premier de ces ordres; de MM. Lepelletier de Saint-Fargeau et Kirby, sur les hyménoptères; de Hahn, sur les hémiptères; de MM. Fallen, Meigen, Wiedemann, Macquart, sur les diptères; de M. Pictet, sur les névroptères; le Manuel d'entomologie et le Genera de M. Burmeister; I'histoire des insectes de M. Brullé; celle des animaux articulés de MM. Laporte, de Castelnau, Brullé, Lucas et Blanchard, présentant un Genera complet pour tous les ordres; plusieurs grands travaux entomologiques de M. Guérin-Méneville; l'iconographie des coléoptères, par MM. Laporte et Gory. Nous devons mentionner aussi l'introduction à l'entomologie de M. Lacordaire, qui, dans cet ouvrage, a présenté, avec beaucoup d'habileté, un ensemble de considérations générales sur toute la classe des insectes.

Il importe encore d'ajouter que c'est à notre époque qu'appartiennent les applications de l'entomologie à l'agriculture ; déjà les plus brillants succès ont été obtenus par MM. Audouin, Ratzebourg, etc.

Arachnides. - L'histoire des animaux articulés compris sous le nom d'arachnides, de crustacés et d'annélides, avait toujours élé confondue dans celle des insectes et des vers de Linné, jusqu'au moment où les travaux de Müller, de Fabricius et de Pallas commencèrent à faire com- 
prendre que, par suite de leurs rapports naturels, ces animaux devaient former une classe distincte dans le règne animal. Jusqu'à Cuvier et Lamarck, on continua de suivre les errements de Linné; ces animaux se trouvaient donc dispersés dans trois divisions de la classe des ver's. Lamarck a le premier séparé les arachnides des insectes, pour en former une classe à part; mais c'est à M. Walckenaër que nous devons les progrès de cette branche de la science. Son tableau des aranéides fut le premier ouvrage important sur cette matière, et son histoire des aplères, faisant partie des suites à Buffon et presque entièrement publiée, est un travail complet sur les araignées. Latreille, dans ses ouvrages, a généralement adopté la méthode de $\mathbf{M}$. Walckenaër, avec peu de modifications. Nous sommes redevables à Hermann père et fils, à Savigny et à Dugès, de travaux importants sur les arachnides inférieures; à M. Ehrenberg, de bonnes études sur les scorpions; à M. Koch, de la description el de la représentation des arachnides indigènes; à M. Savigny, de l'iconographie de celles d'Égypte, etc. G. Cuvier, Vincent Amoreux, A. Lepelletier, Treviranus, Lyonnet, MM. Marcel de Serres, Léon Dufour, Brandt et Ratzebourg, ont aussi contribué, par leurs recherches anatomiques, à la connaissance de la structure intérieure de ces animaux.

Crustacés. - Linné avait le premier tiré la carcinologie du néant, en indiquant les caractères distinctifs des crustacés; mais sa méthode était défectueuse. Fabricius vint après lui établir les divisions encore en usage aujourd'hui ; mais on doit à G. Cuvier d'avoir assigné à ces animaux le rang qu'ils occupent dans l'ordre naturel des êtres. Lamarck, Latreille el Leach, ont ensuite établi des divisions génériques et contribué à faire connaître ces animaux. Desmarest est l'auteur de considérations générales sur les crustacés, avec la description des espèces qui habitent le littoral de la France. Herbst a publié, sur les animaux articulés de cette classe, un ouvrage iconographique encore précieux à consulter, malgré ses nombreuses erreurs. M. Jurine a décrit et étudié les mœurs de plusieurs espèces microscopiques, telles que les monocles d'eau douce; M. Strauss a étudié le développement et l'organisation de quelques crustacés; $M$. Risso a fail connaître les espèces de la mer de Nice. M. Savigny a fait représenter les espèces d'Égypte, dont les déterminations sont dues à M. Audouin; M. Milne Edwards a publié les détails relatifs à leur organisajion 
MM. Audouin, Milne Edwards et Duvernoy, ont étudié plusicurs points importants de l'organisation des crustacés. On leur doit la connaissance du véritable mode de circulation chez ces animaux. M. Milne Edwards vient de donner, dans les suites à Buffon, une histoire complète des crustacés, dans laquelle il a établi une classification qui paraît reposer sur des bases beaucoup plus naturelles que celles présentées par ses devanciers. Enfin, nous devons ciler encore les travaux de M. Bell, qui a représenté et décrit des espèces remarquables, et ceux de M. Hahn, qui a donné Ĩa description de celles du Japon.

Annélides. - Lamarck a le premier donné le nom d'annélides à ces animaux, que G. Cuvier arait d'abord désignés sous le nom de vers à sang rouge. Depuis la réforme introduite par G. Cuvier, dans la manière de les envisager, et après qu'il en eut formé une classe distincte, plusieurs naturalistes s'en sont occupés avec succès. M. Montègre, dans ses observations sur les lombrics, MM. de Blainville, Carena, Delle Chiaje, Moquin-Tandon et Thomas, par leurs travaux sur les hirudinées, en ont mieux fait connaître la structure. Leach, MM. de Blainville, Audouin, Milne Edwards, ont contribué à en perfectionner la connaissance; mais c'est principalement M. Savigny qui, dans son système général des annélides, faisant partie du grand ouvrage sur l'Égypte, en a assuré les progrès; car non-seulement il a augmenté le nombre des espèces, mais il en a décrit avec détail l'organisation extérieure. Les travaux les plus récents sur l'anatomie de ces animaux sont dus à Dugès, à M. Milne Edwards, et surtout à M. Grube.

Zoophytes. - La connaissance des zoophytes, née des sérieuses éludes du xvıI ${ }^{\mathrm{e}}$ siècle, a reçu, dans le cours du $\mathbf{x I x}^{\mathrm{e}}$, une partie de la perfection à laquelle elle pouvait atteindre. Non-seulement elle s'est enrichie de faits nouveaux, mais encore elle a fait des progrès dans sa partie philosophique; il en résulte que le lien qui unit entre eux les êtres de cette vaste catégorie a été mieux connu.

En 1789, quand Gmelin publia sa nouvelle édition du Systema naturce, il profita peu des travaux antérieurs; Bruguière eut le même tort; nous ne trouvons donc, au commencement de celle dernière époque, parmi les zoophytologistes distingués, qu'Olivi, à qui l'on doit beaucoup d'observations nouvelles; il a éclairci l'histoire de plusieurs genres, et a compris que les lithophytes et les zoophytes ne doivent for- 
mer qu'un seul groupe. Il avait déjà été produit divers travaux sur cette matière, lorsque Gr. Cuvier publia son Règne animal, dans lequel on trouve, pour la première fois, les zoophytes classés d'après leur organisation, avec un coup-d'œil remarquable; aussi, depuis l'apparition de ce travail, la classification n'a-t-elle eu de changements à subir que dans les divisions secondaires; car Lamarck, en y introduisant des modifications qui portaient sur les groupes fondamentaux, a détruit en partie la précision de la classification de Cuvier. Les nouvelles richesses apportées par Péron et Lesueur le portèrent plus tard à réformer son système; mais il ajouta aux inconvénients de sa première publication au lieu d'y remédier. M. Duméril se borna, dans sa zoologie analytique, à adopter la méthode de Lamarck.

Plusieurs mémoires, parmi lesquels nous distinguerons ceux de MM. Savigny et Meckel, ayant pour objel des genres spéciaux, vinrent ensuite contribuer aux progrès de la science; ils eurent pour ré. sultat, en 1812, le grand travail de Lamouroux, qui, par malheur, est basé sur une méthode tout artificielle. En Allemagne, M. Oken, dont nous avons déjà eu l'occasion de parler, fit un essai de classification naturelle des zoophytes; mais, dominé par sa théorie, il a présenté des coupes forcées; toutefois il s'éloigne peu de Lamarck, dont il adopte jusqu'aux erreurs.

Il parut, presque en même temps, une classification de M. de Blainville, fondée sur la considération des animaux, et repoussant de la classe des 7.0ophytes les corallines, comme étant des végétaux et non des animaux. La distribution systématique de Cuvier, dans le dernier volume de son Règne animal qui traile des animaux rayonnés, se rapproche davantage de celle de Lamarck, et est jugée moins naturelle que son premier essai. Le travail de Schweigger, publié en 1819 , et fondé sur le mode d'agrégation de ces animaux, contient quelques familles peu naturelles. Il en esı de même de celui de Mi. Goldfuss : cet auteur, malgré son éclectisme, n'a pas établi un système propre à contribuer au perfectionnement des méthodes. On pourrait même dire que, loin d'avoir fail avancer la science, il a augmenté l'incertitude qui y régnait. Latreille est dans le même cas; il y a jeté la confusion, en introduisant des mollusques dans la classe des zoophytes. A côté de ces essais systématiques, nous trouvons des études spéciales et attentives sur certaines familles ou sur certains genres. M. Delle Chiaje a donné un travail plein d'intérêt sur les actinies, les oursins, les astéries et les 
holothuries, qu’il a puissamment contribué à faire connaître. M. Gaillon a étudié au microscope les thalassiophytes; M. Bory de Saint-Vincent, les infusoires, auxquels il a donné le nom de psychodiaires; il a, en outre, créé un grand nombre de genres nouveaux. M. Nitzsch a jetó du jour sur quelques points obscurs de la science. D'autres genres ont été étudiés par MM. Dutrochet, Leclerc, Losana, etc. M. Miller a fait un travail intéressant sur les encrines dont M. A. d'Orbigny a commencé la monographie complète des espèces vivantes et fossiles; M. Grant s'est livré à des recherches importantes sur les zoophytes du nord de l'Angleterre. En 1828, MM. Audouin et Milne Edwards ont fait connaître l'existence de deux orifices digestifs chez certains polypes, et publié un premier essai de classification naturelle de ces animaux, fondée sur leur structure intérieure. M. Rapp a publié, en 1829, une classification des polypes et des aclinies, où il a surtout pris pour caractère li forme des animaux des polypiers. La même année, M. Eschscholtz a donné une classification des êtres réunis par Cuvier sous le nom d'acalèphes. Aujourd'hui que l'organisation des zoophytes est mieux connue, la méthode de distribution de Cuvier est insuffisante; et ceux qui la suivent encore y ont apporté des modifications que les progrès de la science rendaient indispensables. En 1854, M. de Blainville a fait paraître son traité d'actinologie, qui, tout en paraissant n'être qu'une nouvelle édition de l'arlicle zoophyte du Diclionnaire des sciences naturelles, est un ouvrage complet sur cette matière. M. Milne Edwards a donné ure nouvelle édition de la partie zoophytologique des animaux sans vertèbres de Lamarck.

Les ouvrages généraux d'actinologie sont peu nombreux; nous ne citerons que ceux de MM. Esper, Lamarck, Lamouroux, de Blainville et Johnston. Les monographies au contraire sont en grand nombre. Lesueur et Péron ont les premiers abordé avec succès l'étude des méduses et autres animaux pélagiens observés aujourd'hui avec soin par les naturalistes. MM. de Blainville, Desmoulins, Agassiz, ont écrit sur les oursins; M. Brandt, sur les holothuries; MM. Agassiz, Müller, Troschel et Gray, sur les astéries; MM. Ehrenberg et Dujardin, sur les infusoires rolateurs; MM. Rndolphi, Nordmann, Siebold, Diesing et Bremser, sur les entozoaires; MM. Quoy et Ehrenberg, sur les polypiers coralligènes. Il faut noter, de plus, les travaux faits sur les polypiers marins, par MM. Milne Edwards, Lister, elc.; sur les bryozoaires d'cau douce, par MM. Gervais, 'Nordmann, etc. M. Grant a donné sur les 
éponges un lort beau travail relatif à la physiologie des espèces marines; la seule éponge d'eau douce a occupé plus de quinze observateurs qui n'en ont pas encore épuisé l'histoire.

En général, malgré tous ces travaux, l'obscurité règne encore sur les phénomènes physiologiques de l'existence des zoophytes. L'histoire de leurs moeurs, quoique nécessairement très bornée, vu la simplicité de leur structure, est fort peu avancée. Cependant l'étude de ces êtres dont l'existence même a été si longtemps douteuse et qui jouent néanmoins un rôle si important dans la modification de la surface de la terre, est digne de l'attention du philosophe. On sait que les coraux, les madrépores et les millépores, forment des bancs calcaires d'une puissance considérable, des écueils, des îles, et que leur exploitation sert à la construction de villes entières.

Les infusoires ont de nos jours dorné naissance au grand ouvrage de M. Ehrenberg. La partie la plus intéressante de ce travail est la découverte de la formation de terrains d'une étendue considérable par le dépôt d’infusoires à carapaces siliceuses, au fond des eaux tranquilles. La plupart des tripolis, et des silex, n'ont pas d'autre origine; el l'auteur dit avoir reconnu qu'ils sont le résultat de l'agrégation des tests de ces animaux, dont la petitesse est iclle que, dans un millimètre cube, on en trouve près de trois millions. On voit se former encore aujourd'hui de semblables dépôts, car ceux qui sont connus sous le nom de farine de montagne, sont dus, d'après M. Relzius, à l'accumulation de cadavres d'infusoires. Néanmoins, dans l'échantillon de farine fossile chinoise adressé à l'Académie des sciences par M. Stanislas Julien, M. Peltier a déclaré n'y en avoir trouvé aucune trace. L'histoire de ces êtres insaisissables a également occupé d'autres naturalistes : M. Dujardin a fait un travail fort intéressant sur les animaux microscopiques; MM. Dujardin et Ehrenberg ont étudié quelques divisions des coquilles foraminifères, que leur structure singulière a fait rapprocher des infusoires homogènes. M. Alcide d'Orbigny, qui a publié sur cette matière plusieurs ouvrages généraux, ainsi que les faunes locales des Antilles, des Canaries, de l'Amérique méridionale, et de la craic blanche du bassin parisien, a reconnu que ces petites coquilles sont si abondantes à l'état fossile, qu'elles forment seules des chaînes de collines et des bancs immenses de pierres à bâtir.

Arrivé à un certain degré de l'échelle animale, l'incertitude commen- 
ce; aussi a-t-on mis à la fin des zoophytes, les pseudozoaires, tels que les corallines el les nématophytes, que MM. Bory de Saint-Vincent el Gaillon ont regardés, l'un, comme appartenant à un règne intermédiaire servant de passage aux végétaux, l'autre, comme des animalcules simples, libres, doués de vie, s'agglutinant de manière à former des filaments sans que pour cela leur animalité cesse; mais les divers travaux faits depuis par MM. de Blainville, Marquis, Rennie, Chamisso, Eysenhardı, Leuckart, Ruppell, Raspail, Fries et Turpin, les ont décidément fai ranger parmi Jes végétaux.

En dernier lieu se présentent les zoospermes, dont l'histoire se lie intimement à celle de la génération, el qui ont élé éludiés avec une attention toute particulière par Spallanzani et par Gleichen. Depuis, MM. Prévost et Dumas, dont l'opinion est partagée par M. Raspail, ont considéré les zoospermes comme les rudiments du système nerveux s'unissant au système viscéral contenu dans l'œuf de la femelle, ce qui détruisait leur animalité, el ils s'en sont servis pour reconnaître les sexes dans les mollusques acéphales. MM. Dutrochet el de Blainville avaient d'abord cru à la non-animalité des zoospermes; mais des expériences plus récentes ont porté ces deux observateurs à modifier leur opínion, et à les considérer comme le dernier degré de petitesse auquel puissent se montrer les êtres organisés. En 1832, M. Czermack a annoncé qu'il regardait les zoospermes comme un élément aussi essentiel à la semence que les globules le sont au sang; cette opinion est aussi celle de M. Treviranus, qui pense que ces animalcules sont aux ètres organisés ce que le pollen est aux plantes; M. Burdach, au contraire, n'y voit que des parasites accidentels de la semence, et il diffère en cela de la plupart des physiologistes, qui ne regardent plus les zoospermes comme des animaux, mais comme des machines destinćes à transporter dans l'ovule le germe fécondant du mâle. M. Duvernoy a même, depuis plusieur's années, changé le nom de zoospermes en celui de spermazoïdes. Dans ces dernier's temps, M.M. Wagner, Siebold, Milne Edwards, Peters, etc., ont étudié les zoospermes dans les animaux inférieur's, et ils ont découvert le sexe mâle dans des zoophytes que jusque-là on en avait cru privés. M. Lallemand vient de publier sur ce sujet un travail d'une haute importance; il considère l'intervention du mâle dans la génération comme ayant lieu par les zoospermes, et celle de la femelle par les ovules. Il a cherché la confirmation de son assertion dans les générations anomales; et, si sa théorie se vérifie, on verra disparaître en 
partic l'obscurité qui règne sur le rôle des zoospermes dans la repro-: duction des êtres.

Botanique. - L'étude de la botanique, à laquelle la méthode de Tournefort, celle de Linné, et l'ouvrage fondamental de Jussieu, si fécond en heureux résultats, avaient donné de l'éclat, poursuit sa marrche progressive dans le $\mathrm{x}_{\mathrm{x}}{ }^{\mathrm{e}}$ siècle.

La botanique descriptive, favorisée par les explorations des voyageurs dans toutes les parties du globe, fait d'abord plus de progrès que les études d'organographie et de physiologie végétales, ce qui s'explique par les difficultés d'étude que présentent à la fois la ténuité des organes intérieurs des plantes, l'emploi dı microscope, et la possession si rare d'un bon instrument; toutefois, celte partie de la science ne reste pas stérile. Priestley, Senebier, Ingenhouz, Th. de Saussure, qui appartiennent en grande partie au xix $x^{\mathrm{e}}$ siècle, guidés par les lumières de la chimie pneumatique, nous font voir que toutes les parties des végélaux sont formées d'oxygène, d'hydrogène el de carbone, et quelquefois aussi d'une petite quantité d'azote; que les parties rertes exhalent, pendant la nuit, de l'oxygène et du carbone, sous l'influence de la lumière; que les plantes décomposent l'acide carbonique contenu dans le milieu ambiant, et que leurs racines s'emparent de celui que le sol récèle; enfin, que le tissu ligneux doit sa force à l'assimilation du carbone. On avait reconnu que l'électricité, la lumière et la chaleur, jouent un rôle important dans la vie dı végétal; les admirables travaux du siècle précédent sur cette matière sont continués par $\mathbf{M}$. De Candolle. M. de Mirbel, dont la vie tout entière a été consacrée à l'étude de la structure interne des plantes el de leurs conditions d'existence, fait de belles et nombreuses découvertes. Ses premiers travaux donnent lieu à des controverses qui tournent au profit de la science. Daubenton, et principalement Desfontaines, découvrent les différences de structure de la tige des monocotylédones et des dicotylédones. Rudolphi, MM. Link et Treviranus, étudient l'organisation des plantes dans toutes ses parties, et enrichissent l'anatomic et la physiologie de découvertes nouvelles; mais ils sont souvent en désaccord avec M. de Mirbel, qui leur répond, en 1809, par l'exposition de sa théorie de l'organisation végétale. A la même époque, paraissent les observalions d'Aubert Dupetil-Thouars, de Palisot de Beanvois, de Kieser et Moldenhawer, qui publient difféfents travaux sur la structure des végétaux. En 1812, la Société Tey- 
lírienne de IIarlem propose un prix pour le mémoire qui rectifierait les erreurs que renferme l'anatomie végétale; car la polémique engagée entre les phytotomistes français et allemands durait toujours; le prix est décerné au mémoire de Kieser. En 1814, M. Nees d'Esenbeck fait connaître la structure des algues d'eau douce; en 1817, il publie son grand travail sur les champignons. En Angleterre, Smith domne un traité de physiologie végétale; en Allemagne, Kurt Sprengel, Treviranus et Martius, font paraître des traités généraux et spéciaux sur la structure des plantes.

Vers 1815 , l'anatomie végétale subil une révolution par suite de l’emploi général du microscope qui permit de pénétrer plus profondément dans la structure intime des végétaux, et de rectifier beaucoup de fausses idée's. Il est vrai que l'emploi de cet instrument est devenu aussi la cause d'erreurs nouvelles; mais les services qu'il a rendus sont incalculables. En 1818, M. Amici de Modène publie, au moyen du microscope perfectionné, un mémoire sur la circulation du chara, ainsi que diverses observations sur les végétaux; mais ces travaux physiologiques sont éclipsés par ceux de M. Treviranus, qui fait paraître divers mémoires sur le mouvement de la matière verte dans les végétaux, sur l'épiderme des plantes, sur leurs sucs propres et sur la structure des organes de reproduction. M. Meyen publie ses recherches sur la métamorphose des raisseaux spiraux, et M. Schultz fail connaître, dans un mémoire couronné par l'académie des sciences de Paris, ses observations sur la circulation du latex. M. Eschweiler publie, en 1824, son mémoire sur les lichens; M. Guillemin, ses recherches microscopiques sur le pollen; plus tard, MM. R. Brown, Brongniart, Fritzsche, Mohl et Purkinje, approfondissent et éclaircissent complètement le même sujet. MM. R. Brown, Treviranus, Mirbel et Brongniart, publient des vues nouvelles sur le développement et la structure de l'ovule. M. Dutrochet fait connaître ses ingénieuses théories sur la structure interne des végétaux et sur l'agent immédial de leur vie, ainsi que ses recherches anatomiques sur la structure intime des animaux et des végétaux el sur leur motilité. M. Raspail publie son mémoire sur le développement de la fécule dans les organes de fructification des céréales, ses analyses microscopiques de cette substance, et ses recherches chimiques et physiologiques sur la structure et le développement des tissus végétaux. M. Decaisne fait connaître, dans un mémoire couronné par l'académie de Bruxelles, le développement des lissus et du principe colorant de la gamance. M. De Can- 
dolle, à qui la science phylologique doil de si précieux travaux, fait paraître, en 1827, son organographie végétale, et, quelques années plus tard, sa physiologie; M. Brongniart, son mémoire sur la génération et le développement de l'embryon dans les végétaux phanérogames. M. Agardh, botaniste suédois, dote la science de son travail sur l'anatomie des plantes. En 1834, Turpin l'enrichit de son ormanographie végétale. En 1836, M. Meneghini fait paraître un travail très remarquable sur la lige des monocotylédones. En 1837, M. Gaudichaud publie, sous le titre de Recherches surl'organographie, la physiologie et l'organogénie des végétaux, un ouvrage dans lequel il développe el agrandit le système de Dupetit-Thouars sur l'influence du bourgeon dans la production du corps ligneux. A la même époque, MM. de Jussieu et Decaisne fixent l'altention sur la structure anomale de quelques tiges grimpantes, appartenant à des végétaux dicotylédones. M. Raspail publie un nouveau système de physiologie végétale, dans lequel il attribue la formation successive de toutes les parties du végétal à une vésicule primordiale, en vertu de l'évolution moléculaire, et explique la modificalion des organes par transformation. M. Boussingault se livre à des études expérimentales, qui ont déjà jeté beaucoup de lumières sur certains points obscurs de la science. Dans une leçon pleine d'intérêt, M. Dumas a récamment résumé le rôle important que joue l'atmosphère dans la végétation. M. Auguste de Saint-Hilaire vient de publier mne morphologie végétale. M. Moquin-Tandon, appliquant aux végétaux les idées de MM. Geoffroy Saint-Hilaire, Serres et Isidore Geoffroy, dont il a emprunté la classificalion et la nomenclature, a donné depuis peu, après M. De Candolle, des éléments de tératologie végétale. On peut prédire, sans crainte de se tromper, que la tératologie animale et végétale tendent à se confondre en une seule el même science, la tératologie comparée.

Des considérations nouvelles sur la disposition spirale des feuilles et des autres organes appendiculaires ont, dans ces derniers temps, exercé la sagacité des savants les plus recommandables. C'esı à MM. Schimper et A. Braun qu'on doil les premiers fondements de ces éludes, poursuivies avec succès par nos compatriotes, MM. Marlins el Bravais, el d'une autre part, soumises à une ingénieuse crilique par M. Steinheil. Des travaux du plus haut intérêt sur l'inflorescence sont dus à MM. R. Brown et lioper.

Pour terminer ce qui a rapport à l'examen de la plante en général, nous parlerons en peu de mots des théories philosophiques qui cher- 
chent à expliquer les phénomènes de l'érolution du végétal. Grethe, MM.De Candolle, Brown, Cassini, Turpin, Auguste de Saint-Hilaire, ont adopté la théorie de la métamorphose, entrevue par Linné, qui avait dit dans sa philosophie botanique: Principium florum et foliom idem est; elle est aujourd'hui admise par la plupart des botanistes, après soixante ans d'incrédulité. D’après cette théorie, tous les organes appendiculaires des végétaux ne sont que la transformation de la feuille.

La théorie de la fécondation, qu'on croyait définitivement établie, et dans laquelle l'étamine joue le rôle de mâle el le pistil le rôle de femelle, n’a pas été à l'abri de la critique. D'après M. Schleiden, c'esı le pollen qui contient l'embryon, et l'ovule est l'utérus dans lequel il se développe. Cette théorie qui, sans détruire celle des sexes, change cependant les fonctions des organes, a été combattue par MM. Meyen, Brongniart et Mirbel. MM. Griffith et Decaisne publient des recherches sur la structure anomale de l'ovule des Santalacées et Loranthacées. M. Ad. de Jussieu suit, avec le soin qui caractérise chacun de ses travaux, le développement et la structure des embryons des végétaux monocolylédones.

M. Dutrochet avait remarqué, dans une série d'expériences, que, toutes les fois que deux liquides de densité différente sont séparés par une membrane organique, il s'établit entre eux un courant qui fait que le moins dense, attiré par celui qui l'est le plus, traverse la membrane, el que le mélange a lieu. Ce courant se manifeste de dedans en dehors et de dehors en dedans, suivant que l'un ou l'autre des deux liquides est contenu dans la membrane; dans le premier cas, il a reçu le nom d'endosmose, dans le second celui d'exosmose. C'est sur ces deux faits, qui paraissent être le résultat d'une action électrique, que l'auteur a établi ses principes sur la statique des végétaux; selon lui, l'ascension de la sève est le résultat de l'endosmose. C'est une hypothèse nouvelle à ajouter à toutes celles qui ont déjà été émises sur ce sujet; mais elle ne paraît pas pouvoir expliquer, seule, tous les phénomènes de ce mouvement. Les expériences récentes de M. Boucherie, sur les injections des bois, sont appelées à éclaircir la question encore si obscure et si complexe de la circulation de la sève daus les végélaux.

Les travaux de classification, fondés sur une étude de plus en plus profonde des organes caractéristiques, avaient successivement produit les sysı̀̀mes de Tournefort, d'Adanson, de Jussieu. Malgré les nombreuses découvertes de la botanique, qui en ont incessamment 
agrandi le domaine, la méthodologie n'a éprouvé de changements remarquables, ni dans ses principes ni dans sa direclion. A part quelques essais de classificalion artificielle destinés à faciliter l'étude, le système de Jussieu, ou la méthode rationnelle, qui doit être l'objet de tous les efforts des botanistes, a prévalu et a servi de but à des modifications sans nombre. Le célèbre $R$. Brown, dans ses remarques générales et sa Flore de la Nouvelle-Hollande, a non-seulement fail connaître les plantes de cette contrée, mais il a contribué, par une foule d'observations intéressantes, à fixer les limites des familles el à déterminer les affinités des plantes en général. Nous citerons encore parmi les botanistes qui ont le plus contribué au perfectionnement de la méthode naturelle, MM. De Candolle, A. Richard, Lindley, Bartling, Kunth, Endicher el Meissner. Par suite de ces travaux, qui sont autant de pas faits vers une méthode plus parfaite, de nombreuses transpositions on eu lieu dans les familles, ainsi que dans les genres et dans les espèces. Le nombre des familles s'est élevé successivement de cent à plus de deux cents. Ces travaux sont résumés dans deux ouvrages immenses récemment publiés, le Prodromus de M. De Candolle, et le Genera plantarum de M. Endlicher. Nous devons mentionner d'autres ouvrages qui, quoique moins élendus, n'en ont pas moins un mérite incontestable. Ainsi nous citerons le travail de M. Spach sur les phanérogames, faisant partie des suites à Buffon, et les ouvrages élémentaires de MM. A. Richard, Bernhardi, Treviranus, Agardh, Meyen, Lindley, Bischoff, A. St.-Hilaire.

Pour mettre un telme à l'instabilité des méthodes, les botanistes font des éludes complètes sur les diverses familles du règne végétal, afin de mieux établir les rapports qui existent entre elles. M. De Candolle a publié diverses monographies, particulièrement cellés des Légumineuses, des Crucifères, des Ombellifères, des Combrélacées et d'un grand nombre d'autres; son fils, M. Alph. De Candolle, celle des Campanulacées; M. Dunal a étudié les Solanées et les Anonacées; M. Adrien de Jussieu, les Rutacées, les Méliacées et les Euphorbiacées ; Cassini et M. Lessing, les Composées; MM. Martius, Mohl, Blume, les Palmiers; M. Nees d'Esenbeck, les Laurinées; M. A. Richard, les Rubiacées et les Éléagnées; M. E. Chavannes, les Antirrhinées; M. A. de Sainl-Hilaire, les Résédacées, les Sapotées, les Passiflorées el les Cucurbitacées; MM. de Saint-Hilaire et Moquin-Tandon, les Polygalées; MM. Richard et Liıdley, les Orchidées; M. Brongniart, les Rham- 
nées; MM. Miquel et Kunth ont fait connaître les Pipéracées ; M. Moquin-Tandon, les Chénopodées; M. Decaisne, les Lardizabalées; M. Gay, les Byttnériacées vraies; MM. Palisot de Beauvois, Raspail, Kunth et Trinius, les Graminées; M. Kunth, les Mimosées; M.L.-C. Richard, les Conifères; M. Lemaire, les Caclées; Lamouroux, MM. Agardh, Meyen, Greville, Decaisne, les Algues; Persoon, Paulet, Bulliard, MM. Brongniart, Corda, Léveillé, les Champignons ; M.M. Montagne, Schwagrichen, Bruch et Schimper, les Mousses; MM. Acharius, Fries, Fée, les Lichens; Gaudichaud, Presl, Kunze, Schkuhr, Kaulfuss, Hooker el Greville, les Fougères; MM. de Brébisson, Morren, Meneghini, les Algues microscopiques; Lindenberg, Lehmann, Bischoff, les Hépatiques. D'autres ont étudié de simples genres; M. Lambert a publié un travail monographique sur les genres Pinus el Cinchona; M. Bonafous, sur le Maïs; M. Bonpland, sur les Mélastomes et les Rhexia; Salm-Dyck sur les Ficoüdes; M. Jacquin, sur les Oxalis, etc., etc.

La botanique fossile, science nouvelle encore, se fonde sur les études et les découvertes de MM. Ad. Brongniart, Sternberg, comme elle s'enrichit des travaux de MM. Hutton, Lindley, Schlotheim, Schimper, Gœppert, etc.

Les voyageur's et les botanistes sédentaires ont composé des flores, des herbiers, qui rendent l'étude plus facile, et l'iconographie végétale a, dans ces derniers temps, fait de rapides progrès, réclamés par l'état avancé de la science. MM. Walhenberg et Fries ont publié la flore de Suède; M. Ledebour, celle des monts Altaï et de la Russie; Sibthorp et Smith, celle de la Grèce; MM. Schrader, Sturm, Mertens, Koch, Reichenbach, celle d'Allemagne; MM. Lamarck, De Candolle, Loiseleur-Deslonchamps, celle de France; MM. Lestiboudois, Lejeune et Courtois, celle de Belgique; MM. Koch, Suter et Gaudin, celle de Suisse; Smith, Hooker, celle d'Angleterre; MM. Tenore et Bertoloni, celle d'Italie; Presl et Gussone, celle de Sicile; MM. Delile, Desfontaines, R. Brown, Perrottet, Guillemin, Palisot de Beauvois, Harvey, nous ont fait connaître les plautes de l'Afrique; MM. Bojer et Bouton, celles de Madagascar, de Bourbon et de Maurice; MM. Webb et Berthelot, celles des Canaries; M. Low, celles de Madère; MM. Wallich, Wight et Arnott, Royle et Jacquemont, celles de l'Inde-Orientale; M. Bennett et surtout M. Blume, celles des îles de l'Archipel indien; M. Decaisne, celles de Timor; MM. de Humboldt, Bonpland, Kunth, de Jussieu, A. 
de Saint-Iilaire et Martius, celles de l'Amérique équinoxiale; MM. Nut1al, Torrey, Michaux et Asa-Grey, celles des États-Unis ; le docteur Hooker, celles de l'Amérique arclique; Descourtilz ol Swartz, celles des Antilles; MM. Gay et Bertero, celles de Juan-Fernandez; M. d'Urville a composé la flore des îles Malonines; M. Meyer, celle du Labrador; MM. Labillardière, Brown, celle d'Australie; M. Endlicher, celle de l'île Norfolk; M. Guillemin, celle de Taiti, ou îles des Amis; MM. Siebold et Zaccharini, celle du Japon; M. Ach. Richard a donné l'essai d'une flore de la Nouvelle-Zélande.

La géographie botanique, qui concourt si bien à la connaissance physique du globe, doit ses premiers fondements à Tournefort el à Linné. Depuis, MM. de Irumboldı, De Candolle, Brown, de Mirbel, Walhenherg, de Buch, Link, Schouw et Meyer, ont donné à celte science une importance qui s'accrôit chaque jour.

Géologie. - Nous avons vu, pendant tout le xvin ${ }^{\mathrm{e}}$ siècle, la géologie, encore si près de son berceau, revêtir la forme de théories géogéniques auxquelles l'expérience n'avait nulle part. Cependant; vers la fin de cette période, les diverses formations commencèrent à être mieux connues, et les descriptions de géologie locale remplacèrent les théories générales. Les systèmes ne cessèrent pas pour cela, tant l'homme est porté à substituer à la vérité les rêves de son imagination, tant il lui répugne d'avouer son ignorance; mais ils prirent un caractère plus positif, et l'on ne voit plus se renouveler les ridicules théories dont De Maillet et Robiquet nous ont laissé des exemples.

De Lamétherie, regardant les faits acquis comme suffisants et assez bien constatés, crut pouvoir essaye l'histoire des révolutions de notre planète, et publia une Théorie de la terre (1791) qui ressemble à la plupart de celles de cette époque.

En 1792, Dolomieu consigna, dans le Journal de physique, ses opinions sur la formation de notre globe. Il admit la dissolution de tous les éléments qui en composaient l'écorce, dans un liquide où ils s'agglomérèrent par suite d'une cristallisation confuse. Les montagnes el les vallées primilives furent le résultat de mouvements d'élévation et de déchirement dans l'écorce terrestre, et les vallées secondaires furent creusées par d'immenses courants. Il ne croyait pas au séjour de la mer sur nos continents; mais il pensait que le dépôt des couches marines que nous y remarqúons élail dû à des marées d'une hauteur prodigieuse. 
Delue est plus original : il suppose l'état complet de congélation du globe à son origine. De la fonte successive des glaces par le soleil devenu lumineux, résulta la dissolution des terres et autres substances, qui, en se cristallisant, formèrent les terrains primitifs; puis les ètres organisés parurent, ęl leurs dépouilles vinrent se mêler aux terrains secondaires, qui se déposèrent au fond des eaux. Les glaces continuant à fondre dans la croùte du globe, il se forma d'immenses cavernes dont l'affaissement successif fut l'origine des montagues et des vallées.

De Saussure, dont nous avons déjà parlé au xvm siècle, termina, en 1796, son immortel ouvrage, intiulé : Voyage dans les Alpes; mais dans lequel il traite, en outre, de toutes les parties de la science géologique. Il y donne l'exemple d'une précision remarquable dans sa description de la structure el de la composition des terrains.

Faujas de Saint-Fond, dont les travaux sont encore bons à consulter, avança le premier que beaucoup de coquilles fossiles ont leurs analogues vivants dans les mers; mais ses idées sur la formation des couches de l'écorcedu globe et sur celle des inégalités de sa surface sont le résultat d'une théorie que démentent tous les faits. Ses travaux les plus importants, ceux qui ont été le plus profitables à la science, sont ses observalions sur les volcans.

Spallanzani, qui s'est attaché à étudier les volcans et les laves qui en jaillissent, a le premier reconnu la présence de l'acide hydrochlorique dans les productions volcaniques. Nous ne devons pas oublier Albert Fortis, qui, sans avoir traité les hautes questions de la géologie, a rendu de grands services à la science, par ses travaux sur la constitution géo logique du Vicentin et de plusieurs parties de l'Italie.

Scipion Breislak, de Rome, publia, en 1811, sous Je titre d'Introduction à la géologie, le premier traité régulier qui ait paru sur celtc science. Dans son ouvrage Sur la structure extérieure du globe, il ne se prononce pas exclusivement pour la formation par le feu ou par l'eau; mais il admet d'abord la fluidité ignée primitive du globe, comme cause de sa forme sphérö̈dale, puis le concours des eaux dans les phénomènes dont sa surface a été le théâtre. Il commence par développer la série des phénomènes résultant de la fluidité ignée, tels que les soulèvements de montagnes, etc.; ensuite il examine ceux qui sont dus à l'action de l'eau. Ce système est celui qui a prévalu. Les hommes les plus éminents dans la seience ont dirigé leurs études vers la confirmation de celte théorie, qui śappuic déjà sur tant de faits. 
Pour faire comnaître l'élat de la synthèse géologique, nous donnerons une esquisse rapide de la théorie généralement admise aujourd'hui.

La terre fut dans le principe une masse incandescente de matière liquéfiée, qui prit, sous la double puissance de l'attraction centrale et de la force centrifuge, la forme d'un sphéroïde aplati vers les pôles et renflé vers l'équateur. Pendant cetle période d'incandescence, que démontrent les traces d’ignition des roches primitives et l'élévation successive de la température à mesure qu'on pénètre dans les entrailles de la terre, l'atmosphère exerçait sur le globe une pression cinquante fois plus grande environ, et occupait un espace beaucoup plus considérable qu'aujourd'hui. Elle tenait en suspension, ainsi que la masse ignée, les diverses substances élémentaires des roches et des minéraux. Cette atmosphère était dense, impropre à la vie, et nul rayon lumineux ne pouvait la pénétrer. Un commencement de refroidissement s'étant manifesté, il se forma, autour de la masse en fusion, et de haut en bas, une couche solide, composée de gnciss, granites, etc. (roches primordiales). La température continuant à s'abaisser, les vapeurs aqueuses contenues dans l'atmosphère se condensèrent, et les premières eaux tombèrent; elles furent mises en ébullition par l'état encore incandescent de la croûte du globe; de là résultèrent des combinaisons chimiques, semblables à celles qui ont lieu par la voie humide, et qui donnèrent lieu, au point de contact et de bas en haut, à des dépôts ou couches plus ou moins puissantes. C'est ainsi que se formèrent les premières roches sédimentaires. Des fentes et des crevasses, formées dans la croùte du globe par suite des contractions qu'il éprouvaiten se refroidissant, jaillirent des masses minérales liquides qui donnèrent naissance à des roches pyrogènes, telles que les granites, les syénites, les porphyres, elc. A ces influences dynamiques furent dus les soulèvements des montagnes qui eurent lieu, non par un mouvement lent et continu, mais par suite de secousses brusques et rapides. Ces phénomènes paraissent avoir augmenté de plus en plus d'intensité, de telle sorte que les chaines les plus élevées sont, en général, les plus récentes. De ces soulèvements, il résulta des changements dans la configuration du sol, et dans le niveau des eaux des modifications qui durent causer des inondations partielles, d'où résultèrent des courants dont lat puissance érosive vint modifier puissamment le relief du sol.

Beaucoup de filons métalliques et pierreux ont dù être formés, comme ceux des roches ignées, par une éruption de bas en haut, qui remplissait 
les fissures du globe de vapeurs el de gaz résultant de la sublimation de métaux qui se cristallisaient en se refroidissant.

Tant que la chaleur de la surface du globe fut considérable (et l'on eslime à 265 degrés, sous une pression de 50 atmosphères, celle qui a précédé la formation des dépôts calcaires), il ne se forma aucun être organisé; mais, quand la pression atmosphérique fut, par une condensation successive des vapeurs, descendue à peu près à l'état actuel, et que la température des eaux ne dépassa pas 90 degrés, la vie se manifesta. La terre se couvrit alors de végétaux appartenant aux espèces inférieures. Les eaux se peuplèrent de nombreux animaux sans vertèbres, zoophytes, mollusques, etc., au milieu desquels on remarque une seule famille d'articulés, les trilobites. Vers la fin de cette période, parurent les premier's animaux vertébrés : ce sont les sauroïdes, poissons aux formes de lézard, tels que les ichthyodorulites. La végétation prit alors un nouveau caractère; des fougères, des équisétacées, elc., commencèrent à déployer leurs formes gigantesques.

A celte période succéda la formation des terrains anthraxifères, comprenant le terrain houiller si riche en végétaux d'une dimension souvent considérable mêlés à des débris d'animaux.

Une aussi puissante végétation enlève successivement à l'atmosphère une énorme quantité de gaz acide carbonique; des êtres plus complexes peuvent désormais y respirer ; c'est alors qu'apparaît, dans toute sa variété et dans toute sa force, le grand type des reptiles d'espèces perdues: l'ichthyosaure à la tête de lézard, au corps de poisson, et vivant dans l'eau; le plésiosaure à la tête grêle, portée sur un col flexueux comme le corps d'un serpent; le ptérodactyle, sorte de lézard volant, au museau allongé, aux dents aiguës, aux ongles crochus; puis d'énormes crocodiliens, le mégalosaure, le géosaure, le mosasaure; des tortues géantes, appartenant aux genres Emys et Chelonia, le monstrueux iguanodon, etc. Les mers sont habitées par des clupes, des anguilles, des brochets, des chétodons, et par la puissante famille aes squales.

Quelques rares oiseaux de l'ordre des échassiers, et un seul mammifère appartenant aux didelphes paraissent à la fin de cette époque, c'est-ìdire quand l'atmosphère est devenue plus propre encore à la vie; quelques végétaux dicotylédones, de la famille des conifères, viennent aussi rompre l'uniformité de la végétation. Déjà de violents soulèvements avaient élevé de nouveaux continents aut-dessus des mers et couvert la terre de nombreuses aspérités; des sources thermales coulaient de toutes parts. 
L'époque arrive enfin où l'atmosphère, suffisamment purifiée, peut entretenir la vie d'animaux plus parfaits. Cette période tertiaire voit naître les grands mammifères aquatiques el terrestres. Les lamantins, les dauphins, les phoques, partagent le domaine des eaux avec les poissons devenus plus nombreux. De lourds pachydermes, auxquels se mèlent des carnassiers, des rongeurs, des marsupiaux, habitent la terre, que couvre une riche végétation de dicotylédones. C'est alors que vivent tous ces animaux dont les genres, maintenant perdus, ont été recréés par les admirables travaux de Cuvier: tels sont les paloevthères, les anoplothères, les lophiodons, les anthracothères, les mastodontes, etc.; d'autres appartiennent à des genres existants encore, mais leurs espèces n'existent plus; ce sont des tapirs, des éléphants, des rhinocéros, des ours, des hyènes, et des singes, dont les restes ont été récemment découverts dans le midi de la France, ete.

Puis enfin, quand le globe se trouva dans des conditions atmosphériques, qui permirent aux êtres organisés de se développer.librement, et qu'ils eurent épuisé toutes les transformations auxquelles était appelée l'animalité, I'homme parut. Bientôt, soumettant la nature à la puissance de l'esprit, il établit son empire sur tout ce qui existe, el chaque jour encore il lutte contre elle pour lui arracher ses secrets.

Les savantes recherches de MM. Fourier, W. Fox, Arago et Cordier, sur la chaleur centrale, et surtout le grand travaii de ce dernier, ont donné à cette opinion un tel degré de certitude, que la théorie de l'incandescence du noyau du globe; adoptée aujourd'hui par presque tous les savants, est devenue le principe fondamental de la géologie moderne. En elfet, comme il est suffisamment démontré que la température s'accroìt à mesure qu'on pénètre plus profondément daus le sol, on est porté à admettre que le noyau du globe doil avoir conservé sa fluidité primilive. Indépendamment des nombreuses observations thermométriques sur lesquelles s'appuie cette théorie, les volcans, les tremblements de terre, les puits artésiens, les eaux thermales, confirment l'existence d'une immense chaleur dans l'intérieur du globe. Suivant M. Cordier, l'accroissement de cette chaleur serait d'un degré centigrade par 27 mètres ; d'où il résulterait qu'à 2,700 mètres de profondeur (un peu plus d'une demi-lieue), la températture de la terre serait celle de l'eau bouillante, et qu'à 6,500 mètres (une lieue et demie), le plomb serait constamment en fusion. L'écorce terrestre continue à se consolider et acquiert une épaisscur d'autant plus grande que le re- 
froidisscment augmente davantage; mais, comme cette épaisseur, qu'on suppose avoir environ vingt lieues métriques, n'est pas la même par10ut, il en résulte une différence dans la température des climats, et dans l'écorce minérale, une plus ou moins grande flexibilité qui aide à expliquer les volcans, ainsi que le soulèvement de certaines parties des continents et l'abaissement de certaines autres. Nous en avons pour exemples récents la formation des îles de Santorin, le soulèvement de la Scandinavie, l'abaissement du Groënland, etc.

Ia belle théorie des soulèvements, appuyée sur les travaux de MM. de Buch et Élie de Beaumont, a pris place dans la science comme une vérité démontrée; les anciennes théories ont donc disparu pour faire place à celle que toutes les observations concourent à confirmer. M. Élie de Beaumont, qui a fait de nombreuses études sur cet important sujet, est parvenu à calculer et assigner facilement l'âge relatif du soulèvement de la plupart des chaînes de montagnes.

La théorie, dont on peut, à juste titre, considérer Hutton comme le père, celle du métamorphisme, ou transformation de roches stratifiées, d'origine neptunienne, en roches stratiformes cristallines, d'apparence plutonienne, occupe beaucoup les géologues depuis quelques années. Plusieurs d'entre eux se livrent à des recherches tendant à établir la vérité de cette théorie, qui chaque jour prend plus de consistance. Parmi les travaux qui ont été publiés sur ce sujet, nous citerons ceux de MMl. de Buch, Lyell, Élie de Beaumont, Dufrénoy, Virlet, Boblaye, Studer, Gras, Coquand, etc.

La transformation des calcaires en gypse et en dolomie occupe aussi beaucoup les géologues, depuis la publication du travail de M. de Buch. Cette question a été récemment l'objet de plusieurs mémoires de MM. Élie de Beaumont, Gucymard, Coquand, etc.

A côté des grands travaux généraux qui embrassent dans leur domaine l'histoire entière du globe, il y en a d'autres très nombreux qui se rapportent aux détails de la science.

La plupart des géologues ont étudié la structure des montagnes, en ont mesuré la hauteur, et les ont classées d'après leurs.directions. L'origine des vallées a occupé MM. d'Omalius d'IIalloy, Conybeare, Lyell et Murchison : les deltas, les alluvions, ont eu des explications rationnelles. MM. Iugi, Venetz, de Charpentier, Agassiz et Rendu, ont éludié les glaciers; les eaux qui coulent à la surface du globe, comme fleuves, rivic̀ces ou ruisseaux, ou qui y séjournent, comme mers, lacs, eaux 
stagnantes, ont été le sujet d'observations pleines d'intérêt de MM. Dick, Sander, Knight, Merian, Arago, Strelke, Silliman, Horner, Everest, Taylor, Stevenson, Lyell, etc.

On a reconnu que toutes les mers ne sont pas au même niveau et qu'à diverses époques, elles sont revenues couvrir les mêmes pays; leur température a été mesurée. Les sources minérales ont aussi donné naissance à de nombreux ouvrages de MM. Alibert, Osann, Stifft, Sigwart et Leipprand, Gardner, Anglada, Boussingault, etc.

Les tremblements de terre ont été observés et leurs causes recherchées par MM. Lambert, Kries, de Hoff. Les volcans, phénomènes mystérieux, qui, dans leurs jours d'effervescence, glacent d'épouvante tous les êtres vivants, ont été l'objet d'études fort nombreuses. MM. Cordier, Élie de Beaumont, Davy, Brongniart, Gay-Lussac, de Humboldt, Ampère, Huot, Poulett Scrope, Melograni, Maravigna, Marcel de Serres, etc., ont observé les phénomènes qu'ils produisent, étudié les lois auxquelles ils doivent leur origine, cherché à déterminer leur âge et essayé des théories pour en expliquer la cause.

Les blocs erratiques ont été le sujet de mémoires de MM. Brochant, Sedgwick, De La Bèche, Brongniart, Kloden, Bernhardi, Buckland, etc.

Les cavernes à ossements ont de nos jours été explorées dans toutes leurs parties et ont donné lieu à des travaux spéciaux de MM. Buckland, Marcel de Serres, de Christol, Tessier, Buchet, Laurens, Schmerling, Rosenmüller, Scina, Hoffmann, Coulibine, Claussen.

La connaissance des roches est devenue l'un des plus puissants auxiliaires de la géognosie. Leur classification et leur description ont été l'objet de travaux importants de MM. Jameson, Haüy, de Buch, Brochant, de Leonhard, Boué, Huot, Rivière, etc., et surtout de IMM: Cordier, Al. Brongniart et d'Omalius d'Halloy. Leur structure, leur composition, tous les accidents qu'elles présentent et les modifications qu'elles subissent, ont été égaiement l'objet des travaux de MM. Hall, Peghoux, Fleuriau de Bellevue, Koch, Haussmann, Conybeare, Miller, Haldat, Brocchi, Gaudin, Mitscherlich, etc.

Les principales difficultés de ce genre de recherches ont d'ailleurs été levées par un travail spécial, d'une très grande importance, dû à M. Cordier. En combinant les procédés d'une analyse mécanique toute nouvelle avec l'emploi du microscope sous certaines conditions, ce géologue a donné lè moyen de déterminer avec certitude la nature de la plupart des masses compactes qui, sur beaucoup de points, jouent 
un si grand rôle dans la constitution des terrains, surtout dans celle des terrains pyrogènes. Ces masses, jusque-là problématiques, sont devenues des roches hétérogènes, à parties individuelles microscopiques; elles ont cessé d'appartenir à la minéralogie où elles avaient longtemps constitué de fausses espèces. On est ainsi arrivé à la théorie de la consolidation, de la composition et de la contexture des couches et des amas volcaniques de tous les âges. Les divers produits de ce genre se sont trouvés réunis par des liens communs, et la solution des questions depuis longtemps controversées entre les nepłunistes et les vulcanistes est devenue dès lors simple et facile.

Tous les terrains ont été aussi mieux étudiés, mieux divisés et mieux groupés. Les terrains inférieurs aux terrains houillers ont été examinés d'une manière spéciale par MM. Sedgwich, Murchison, Dumont, Boué, d'Omalius d'Halloy, Dufrénoy, Rivière, Boblaye, de Verneuil, etc.

Les topographies géognostiques se sont multipliées dans ces dernier's temps : nous citerons parmi les plus importantes, pour la France, celles de MM. Élie de Beaumont, Dufrénoy, Al. Brongniart, d'Omalius d'Halloy, Constant Prévost, Desnoyers, Passy, de Bonnard, Graves, Dujardin , Boué, Thirria, de Caumont, Lecoq, Bouillet, Rozet, Puillon Boblaye, d'Archiac, Triger, Leymerie, Fournet, Manès, Rivière, Bertrand-Geslin, Voltz, etc.; pour les Pyrénées, celle de M. Charpentier ; pour les Alpes et la Suisse, celles de MM. de Saussure, Studer, Thurmann ; pour l'Allemagne, celles de MM. Boué, Keferstein, Steininger, Klœeden, de Buch, de Bonnard, Beudant; pour l'Italie et les îles adjacentes, celles de MM. de Buch, Sismonda, Hoffmann, Reynaud; pour l'Angleterre, celles de MM. Phillips, Murchison, Mantell, De La Bèche, Fitton, Sedgwick, Greenough, Boué; pour la Belgique, celles de MM. Dumont, Davreux, Galeotti; pour la Scandinavie, celles de MM. Esmark, de Buch, Hisinger; pour la Russie, celles de MM. Pusch, de Verneuil, Huot; pour la Turquie et la Grèce, celles de MM. Virlet, Boblaye et Boué ; pour l'Espagne, celles de M. Leplay; pour l'Inde, celles de MM. Fraser, Hardie et Jacquemont ; pour le Groënland et l'Islande, celles de MM. Giesecke, Robert; pour les États-Unis, celles de MM. Maclure, Rogers, Troost; pour le Mexique et l'Amérique du Sud, celles de MM. de Humboldt, Alcide d'Orbigny, Darwin; pour l'Afrique, celles de MM. Rozet, de Buch, Berthelot, Boblaye, Smith; et sur l'Australasie, celles de MM. Fitton et de Buch.

Enfin l'étude de la géologie a été facilitce par des carles géologiques, 
exécutées, pour la France entière ou quelques-unes de ses parties, par MM. Boué, d'Omalius d'Halloy, Élie de Beaumont, Dufrénoy, Brongniart, d'Archiac, Triger, de Caumont, Lecocq, Rivière, Raulin, Desmarets, de Charpentier; pour diverses parties de l'Europe, par MM. William Smith, Greenough, Murchison, Dumont, de Buch, Hoffmann, Naumann, Partsch, Beudant, Virlet, Keilhau, Hisinger; pour les États-Unis, par Maclure, etc.

La paléontologie est aujourd'hui une partie essentielle de la géologie; elle a jeté un grand jour sur les questions relatives à l'âge des terrains, à leurs divisions, à la température de la surface du globe, pendant les diverses époques géologiques, etc. Nous parlerons de ses progrès à l'article qui lui est spécialement consacré.

La géologie, dont la haute importance ne peut être niée, a successivement absorbé des sciences qui jadis en étaient distinctes. Elle embrasse aujourd'hui la géographie physique, la géographie mathématique, la. géologie spéculative, l’oryctognosie, la géognosie, la géogénie, etc.; en un mot, elle s'occupe de tous les faits et de toutes les hypothèses relatifs à l'histoire du globe. La forme de la terre, sa densité, sa température extérieure et intérieure, les phénomènes magnétiques dont elle est le théâtre, les mouvements oscillatoires de son écorce, le relief de sa surface, les phénomènes volcaniques, l'atmosphérologie, la répartition des eaux, rentrent dans le domaine de cette science.

Paléontologie. - La paléontologie, cette science si neuve encore et qui n'avait pas même été systématisée à la fin du xvıı siècle, a grandi avec la géologie, dont elle est devenue le plus puissant auxiliaire. Elle soulèvera sans aucun doute le voile mystérieux dont sont encore couverts les premiers âges de l'histoire dı monde. Ici encore nous nommerons G. Cuvier. Cet illustre naturaliste, faisant de l'anatomie comparée l'application la plus neuve et la plus brillante, tire des mondes entiers de leurs ruines, de leurs débris, et devient ainsi le créateur de la paléontologie positive, dont personne jusqu'à lui n'avait compris toute l'importance. En 1796, il publia son premier mémoire sur les éléphants fossiles, et il est à remarquer que ce travail, qui ouvrait la carrière aux plus grandes découvertes, fut lu le jour même où l'Institut tenait sa première séance publique. Deux ans après, il commençait la publication de ses beanx ra vaux sur les ossements des platrières des environs de Paris. Depuis cente époque, Cuvier ne cessa de s'occuper de la recherche des osse- 
ments fossiles; ses différents mémoires, qu'il publia d'abo rd daus les Annales du Muséum, ont été réimprimés par lui de 1821 à 1824, el forment un grand ouvrage en cinq volumes in- $4^{\circ}$.

L'impulsion donnée par le naturaliste français à la paléontologie s'étendit rapidement ; un grand nombre de savants, tant français qu'étrangers, s'occupèrent de cette branche importante de la zoologie. MM. Meyer, Bojanus, Goldfuss, de Humboldt, Sœmmering, Schlolheim, Jreger, Buckland, l'abbé Croizet, Jobert, Kaup, etc., ont publié, sur les vertébrés fossiles, des renseignements d'un grand intérèt. L'ornithologie fossile est encore peu avancée; et l'on ne connait, dans les terrains secondaires, qu'un petit nombre de débris d'oiseaux appartenant à l'ordre des palmipèdes, comme ceux du calcaire de Pappenheim ; à celui des échassiers, enfouis dans les terrains de l'Angleterre; à ceux dés rapaces, des passereaux et des gallinacés, trouvés dans les gypses de Paris, el Auvergne, en Provence et en Italie. Sir Everard Home, MM. Buckland, De La Bèche, Conybeare, ont étudié les reptiles et les sauriens; MM. Agassiz, de Münster, Buckland, Sedgwick, Murchison, de Blainville, etc., se sont occupés des poissons; MM. Desmarets, Alexandre Brongniart, Green, ont étudié les crustacés. Les invertébrés fossiles de l'embranchement des mollusques ont été l'objet d'études attentives de la part de MM. Lamarck, Sowerby, Parkinson, de Schlotheim, Des-hayes, d'Orbigny père et fils, de Basterot, Voltz, Dujardin, d'Archiac, Phillipi, de Buch, de Münster, Rœmer, Zieten, Goldfuss, Pander, Brocchi, Filippi, etc. Les échinodermes ont été étudiés par MM. Goldfuss, Agassiz, Charles Desmoulins, Grateloup, etc.; les crinoïdes, par Miller et M. Alcide d'Orbigny. Les zoophytes sont le bul de travaux spéciaux de la part de MM. Goldfuss, de Blainville, Michelin, etc. M.M. Agardh, Ad. Broñgniart, Sternberg et Goppert, ont surtout éludié les végétaux fossiles. Enfin, depuis ces dernières années, tous les êtres organisés fossiles ont été observés avec un soin particulier.

Les collections paléontologiques se sont formées partout, et des recherches habilement dirigées sur tous les points habités par des savants laborieux, ou que parcourent des voyageurs intelligents, ont déjà jeté les fondements d'une faune paléontologique. Lorsqu'elle sera complète, nous pourrons sans doute pénétrer plus avant dans l'histoire primitive de notre planète. Les fossiles d'Europe commencent à être passablement connus. MM. Gaillardot, Darlu, l'abbé Croizet, Lartet, de Blainville, Dechen, Constant Prévost, Brongniart, de Christol, 
Boué, Lamouroux, Grateloup, de Basterot, Dujardin, Marcel de Serres, de Laizer, d'Orbigny père, etc., ont fait pour quelques-uns de nos départements et pour certains terrains, ce qu'a fait Cuvier pour les ossements du bassin de Paris. M. de Blainville a commencé l'histoire de tous les vertébrés fossiles; M. Alcide d'Orbigny entreprend celle de tous les animaux mollusques et rayonnés fossiles de France; M. Deshayes en a fait autant pour les coquilles fossiles tertiaires des environs de Paris; MM. Drapiez, Bory de Saint-Vincent, Delaunay, Morren, Schmerling, Knitz et de Koninck, pour plusieurs points de la Belgique; MM. Ritter, Sommering, Hermann de Meyer, Razoumowski, Keferstein, Germar, Siedemann, de Schlotheim, Rosenmüller, Rœemer, le comte de Münster, pour l'Allemagne; M. Kaup, pour les environs de Darmstadt; MM. Zieten et Hehl, pour le Wurtemberg; MM. Buckland, Owen, Conybeare, Phillips, De La Bèche, Parkinson, Sowerby, Murchison, Fitton et Mantell, pour l'Angleterre; M. Iugi, le docteur Lavater et M. Burdet, pour la Suisse; MM. Nilson, Hisinger et Walhenberg, pour la Suède; MM. Brocchi, Philippi, A. Fortis, Spinola, Cortesi, Michelotti, etc., pour l'Italie; MM. Nesti, Pander, Eichwald, Gotthelf, de Fischer, Bojanus, Adams, pour la Russie d'Europe el la Russie d'Asie. L'Afrique n'a jusqu'ici donné que peu de fossiles; mais l'Asie et surtout l'Inde ont fourni de riches collections, et ses gisements ne le cèdent en rien aux nôtres. MM. Falconer, Cautley, Baker, Durand, etc., nous en ont fait connaître les intéressantes productions, et y ont découvert des animaux inconnus aux savants. L'Amérique du Nord, cette sœur de l'ancien monde sous le rapport de la civilisation, n'est point restée en arrière de nous dans la connaissance des ossements fossiles qu'elle renferme dans son sein. En 1797, Jefferson, président des États-Uṇis, fit le premier connaître les débris du mégalonyx. Depuis cette époque, le sol des Citats-Unis, où les fossiles se trouvent généralement à une moindre profondeurque chez nous, a été fouillé sur plusieurs points; les cavernes ont été visitées, les alluvions des fleuves et des marais sondées; on y a trouvé un nombre considérable d'animaux antérieurs aux temps historiques. Les plus laborieux paléontologistes américains sont : MM. Harlan, Fink, Peale, Hitchcock, Cooper, Barton, etc. ; la connaissance des débris paléontologiques que r'enferme l'Amérique méridionale est due principalement à MM. de Humboldt, Darwin, Owen, Laraga, Lund, Claussen, etc.; ce dernier a découvert récemment, dans les cavcrnes du Brésil, plus de cent espèces de mammifères.

Nous n'entrepons ici dans autun détail sur l'existence des hommes 
fossiles, malgré l'intérêt que présente cette question ; nous dirons seulement, sans chercher à en pénétrer la cause, qu'aujourd'hui les hommes faisant autorité dans la science sont à ce sujet d'opinion diamétralement. upposée.

Distribution géographaque des animaux. - Les animaux sont répandus sur la surface du sol conformément à des lois toujours ell harmonie avec les conditions de leur existence; il est certaines limites que beaucoup d'entre eux ne peuvent franchir, malgré leur longévité et le puissant développement de leurs forces musculaires. Quant à l'homme, il couvre le globe entier; et, sauf quelques dissemblances dans les races, il vit sous toutes les latitudes, dans les climats glacés des pôles, au milieu des neiges éternelles, aussi bien que dans les pays brûlants des tropiques. Les animaux qu'il a attachés à son sort par la domestication, le suivent presque tous dans ses migrations et s’identifient, comme lui, avec la diversité des températures; mais, pour ceux qu'il n'a pas réduits en esclavage et qui vivent libres au sein de la nature, une inflexible loi les retient dans certains climats; partout ailleurs, ils languissent ou meurent. La connaissance de la distribution géographique des animaux est une science qui intéresse le naturaliste, et dont on peut regarder Buffon comme le créateur, bien qu'il ait souvent exagéré l'influence des milieux sur le développement de l'organisme. Depuis Buffon, tous les voyageurs qui ont exploré les diverses contrées du globe ont concouru aux progrès de cette science. La distribution géographique des mammifères est généralement bien connue, leur nombre étant assez borné, et leurs conditions d'existence les mettant constamment en rapport avec l'homme ; MM. Bory de Saint-Vincent, Minding, Lesson, Desmoulins, Fischer, Desmarets, Lyell, ont publié des travaux spéciaux sur ce sujet. Les oiseaux, moins sédentaires, vivant plus loin de l'homme, sont moins bien connus; Illiger, MM. Lesson, Alcide d'Orbigny, Quoy et Gaimard, se sont occupés de leur distribution sur le globe. Les deux derniers ont étudié la distribution des reptiles, et M. Wiegmann a publié un mémoire fort intéressant sur celle des sauriens. Les poissons sont bien, comme les autres êtres, soumis à des lois constantes d'habiation, quoique certaines espèces émigrent; mais, malgré les travaux de MM. Nouel, Macculloch, Forbes, de Humboldt, et Valenciennes, leur répartition dans les eaux du globe n'est encore qu’incomplètement connue. A me- 
sure que nous descendons dans l'échelle animale, l'incerlitude devient plus grande; cependant, les travaux sur cette matière ne manquent pas entièrement, mais ils sont encore incomplets. Fabricius et Latreille , ont donné les premiers une géographie des insectes, poussée plus loin par MM. Kirby, Spence, Mac-Leay et Lacordaire. Dans ces derniers temps, elle a été l'objet de nouveaux travaux de MM. Milne Edwards et Blanchard ; MM. Quoy et Gaimard en ont fait autant pour les crustacés. MM. Broderip, de Férussac, de Blainville, A. d'Orbigny, etc., ont donné la géographie des mollusques; MM. Quoy et Gaimard, celle des polypiers, ei M. Ehrenberg, celle des infusoires.

Il reste à résoudre un problème qui, à toutes les époques, a beaucoup occupé les hommes de science, et qu'enveloppe la plus grande obscurité; nous voulons parlér de la distribution primitive des êtres sur la terre; c'est de la paléontologie que nous attendons la connaissance de ces faits primordiaux de l'histoire de notre globe. Quand nous saurons ce qu'a été l'animalité à sa naissance, peut-être, en comparant son état primitif à son état présent, pourrons-nous pressentir ses destinées futures ; mais jusqu'à ce moment les hypothèses qui ont été hasardées manquent absolument de certitude.

Conclusion. - Arrivés au terme de notre tâche, il nous reste à reconnaître quel but s'est proposé la science et quel parti l'humanité a tiré de ses longs travaux. Déjà bien des progrès se sont accomplis, depuis que nous ne la voyons plus, renfermée dans les cabinets, devenir, sous l'inspiration de quelques hommes, un arcane inaccessible à l'intelligence de tous, et un monopole profitable seulement à la vanité des maîtres et des disciples. Elle est descendue des hauteurs des théories philosophiques pour devenir pratique, el elle a abordé jusqu'aux détails les plus humbles de la vie; car elle a compris qu'entre la vie scientifique et la vie civile, il existe une étroite solidarité. Le savant est donc devenu tour à tour agriculteur, mineur, distillateur, chaufournier, tanneur, teinturier, etc. Tous les arts, toutes les industries, sont venus lui demander des lumières, et il a répondu à tous. L'économie politique, quoique paraissant fondée sur des besoins d'un autre ordre, s'appuie également sur la science, qui en est le principal levier, et toutes les institutions reposent sur ses progrès. Depuis qu'elle est entrée dans cette large et noble voie, les intelligences se sont agrandies, les préjugés ont, sinon complètement disparu, du moins diminué, et la civilisition à 
marché à grands pas. L'admiration n'est plus fondée sur un fol engouement : la célébrité du savant est proportionnée au degré d'utilité de ses travaux; les hommes les plus populaires sont ceux qui ont fait contribuer la science au bien-être de tous, et qui ont compris qu'elle n'est pas seulement un but, mais qu'elle doit être aussi un moyen. L'homme ne veut plus être livré à l'empirisme, depuis qu'il a reconnu que l'expérience et l'observation, en vivifiant l'intelligence, le préservent du malheur d'errer à l'aventure; aussi les peuples civilisés se sont-ils jetés à l'envi dans les voies que leur ouvrait la science, et se sont-ils empressés de réunir tout ce qui pouvait contribuer à ses progrès. Les bibliothèques s'enrichissent chaque année de tous les trésors de l'esprit; les musées accumulent, conservent et classent les produits des trois règnes, et offrent le tableau de plus en plus complet de la variété de la nature. Chaque ville de quelque importance a son cabinet d'histoire naturelle, son jardin botanique, sa bibliothèque, son académie. Des chaires d'enseignement sont confiées aux hommes les plus éclairés et les plus dévoués aux progrès de la science; des voyageurs rétribués par les gouvernements, récompensés par les Sociétés savantes, parcourent le monde et rapportent le fruit de leurs longues et périlleuses recherches; de nombreux recueils, dans lesquels sont consignées les découvertes nouvelles, sont publiés dans toutes les parties du globe; des ouvrages didactiques vont chaque année porter à une multitude de lecteurs les connaissances les plus propres à développer leur intelligence. Dans l'éducation même la plus humble, l'étude de la nature a sa part. Tous les arts se sont mis au service de la science : la gravure et la peinture enrichissent les collections, de précieuses iconographies; l'art plastique, imitant la nature, multiplie les préparations anatomiques qui facilitent l'étude, en en éloignant le dégoût et le danger; enfin le règne de la science est établi; son domaine s'est agrandi, et nul n'oserait plus lui disputer son empire.

Nous sommes loin de l'époque oì les travaux scientifiques, regardés comme le fruit d'une révélation, laissaient l'esprit errer dans le vide. Après avoir laborieusement passé plusieurs siècles dans les secs et arides travaux d'analyses que venaient çà et là égayer quelques théories, nous en sommes arrivés à posséder une telle collection de faits que nous avons cru la généralisation permise; aussi notre époque est-elle devenue synthétique, trop synthétique peut-être. Nous avons voulu, devançant le temps, prévoir ce qu'il n'est donné qu'à nos neveux de connaître: 
dans notre ignorance sur le principe el l'essence des choses, nous avons énoncé l'existence d'une unité absolue, dont nous n'avons aucune idée. Le physicien, en admettant la molécule qu'il ne connaît ni ne comprend, cède à cette tendance vers l'unité; le chimiste prend, pour un type d'unité, l'atome quïn'existe, sous une forme arrêtée, que dans son esprit ; le naturaliste, soit qu'il s'occupe de la nature inerte, soit qu'il étudie la nature vivante, cherche sans cesse à remonter des unités individuelles aux unités collectives, pour arriver systématiquement à une sorte d'unité phénoménale; mais ces essais, si louables par la bonne foi de ceux qui les hasardent, et tout infructueux qu'ils puissent être, sont une preuve de progrès.

Voici quatre mille ans que la science s'organise; et, depuis près de quatre siècles, notre Europe marche à la tête de la civilisation. La science a dévoré bien des générations; elle ne compte même plus aujourd'hui ses martyrs; cependant, après tant de sacrifices, pouvons-nous dire que nous soyons arrivés à la certitude scientifique? N'errons-nous pas encore dans un dédale de nomenclatures diffuses, de synonymies nombreuses, de langues imparfaites qui augmentent les difficultés de l'étude, de théories contradictoires, de préjugés qui voilent la raison et retardent le progrès? Mais à côté du mal, suite inévitable de l'isolement des premiers peuples et de l'imperfection des moyens de manifestation, nous avons, pour remèdes, les causes qui ont amené l'émancipation de la pensée, les causes qui cimentent et garantissent l'union des peuples. Depuis ce moment, les conquêtes de l'esprit humain ne sont plus livrées au bon vouloir d'un aréopage scientifique et à l'existence incertaine d'une nation. Tous les peuples en sont solidairement les dépositaires; et quand les rivalités qui les séparent et les arment les uns contre les autres auront à jamais cessé; quand tous les hommes, jouissant des bienfaits des lumières, marcheront d'un pas égal dans- les voies de la science, alors seulement on connaîtra les limites de la puissance de l'esprit humain. La science, quelque incomplète qu'elle nous paraisse aujourd'hui, n'en est pas moins l'ancre de salut de l'humanité : dans la science pratique, expérimentale, repose la vérité, tandis qu'en dehors il ne peut y avoir qu'incertitude, erreur ou mensonge.

Charles d'Orbigny. 


\title{
DICTIONNAIRE
}

\author{
U N I VERSEL
}

\section{D'HISTOIRE NA'TURELLE.}

MAL. вот. PI. (1).-Nom donné par Rumphius à deux arbres de l'Inde, qu'il a décrits très incomplétement, et qu'on suppose appartenir à la famille des Térébinthacées.

(C. D'O.)

* AAL. poiss. - Nom allemand de l'angruille, d'où dérivent ceux d'Aalquappe ou de Aalquabbe, pour la Lotte (Gadus lolla L.), et de Aal formigen platt leib, cité par Lacćpède, pour le Plotose anguillé (Plotosus anguillaris Bloch).

(VAL.)

ABACA. BoT. pn. - Selon Sonnerat, ce nom, aux îles Philippines, est donné á une espèce de Bananier (Musa textilis). (C. D’O.)

*ABACATUR A TACAPA. P01ss.-On distingue sous ce nom, suivant le prince Maurice de Nassau, le poisson que Cuvier a nommé Vomer de Brown ( $V$. Brownii), et qu'on a confondu avec l'Argyréiose vomer. (VAL.)

* ABACHTUS (ábaxńs, taciturne).ıNs.G. de Coléoptères pentamères, famille des Carabiques, tribu des Féroniens, établi par M. Dejean, ét dont voici les caract. : les 3 premiers articles des tarses antérieurs dilalés dans les mâles, moins longs que larges et fortement triangulaires ou cordiformes. Dernier article des palpes allongé, presque cylindrique et tronqué à l'extrémité. Antennes filiformes, assez allongées etlégèrementcomprimées; lèvre supérieure en carré moins long que large. Mandibules peu avancées, légèrement arquées et assez aiguës; menton trilobé; lobe intermédiaire arrondi. Cors. trapézoïde, presque aussi large à sa base que les élytres. Élyt. peu allongées, se rétrécis-

(1) Les abréviations en petites capitales, placées au commenrement de chaque artiele, indiquent la grande classe à laquelle il appartient.

* Les astérisques qui prérèdent un trés grand nombre d’articles, désignent ceux qui n’avaient pas eneore figuré dans les Dictionuaires d'flistoire naturelle deja jublics cu France.

T. I. sant un peu vers l'extrémilé et arrondies postérieurement.-Ce g., auquel M. Dejean ne rapporle que 4 espèces, a pour type l' $A$. Gagates Dej., qui se trouve en Guinée et au Sénégal. Il est d'un noir brillant en dessus, et ressemble un peu, pour la forme et la taille, à la Feronia abaxoüdes.

ABAJOUES. Mam. - Poches que certains g. de Mammiféres portent aux 2 còtés de la bouche. Presque tous les Singes de l'ancien continent, quelques Rongeurs américains appelés Diplostomes ou animaux à double bouche, enfin les Nyctères, parmi les Chauves-souris, sont pourvus d'Abajoues qui diffèrent, dans les divers genres, par leur forme, leur capacité, et les fonctions physiologiques qu'elles remplissent. Elles servent à la plupart de ces animaux comme de gardemanger pour la conservation et le transport momentané des aliments dont ils se nourrissent.

(C. D'O.)

ABALON, Adans. BoT. Pr. - Synonyme d'HELONIAS.

(C. D'O.)

ABAMA. Bo'T. pn.-Ce g. de Plantes, créé par Adanson pour l'Anthericum ossifragum L., a été adopté par M. De Candolle (Flore française); mais avant Adanson, Mohring (Ephem.natur. Curios.) en avait déjà fait son g. Narthecium qui paraît aujourd'hui généralement adopté. $V$. Nartieciun. (C. L.)

ATAPUS, Adans. Bot. PH. - Syn. de gETHYLLIS.

(C. $\left.D^{\prime} \mathrm{O}.\right)$

* ABARIDI. Abaris (á5aprís, léger). ins. - Genre de Coléoptères pentamères, famille des Carabiques, tribu des Féroniers, établi par M. Dejean et qui a pour caract. : Les 3 premiers articles des tarses antériewrs dilatés dans les mâles, triangulaires, et aussi longs que larges; dernier article des palpes presque cylind'ique et tronqué à l'extrémité. 
Ant. assez courtes, légèrement comprimées et presuque filiformes. Lève supér. en carré moins long que large, et coupée presque carrément dans sa partie antér. Mandib. peu avancées, légèrement arquées et assez aiguës; une dent simple et presque obtuse au milicu de l'échancrure du menton. Tête triangulairc. Yeux assez gros et lévres saillantes. Corselet carré. Élyt. en ovale peu allongé. - Ce g. se rapproche un peu par le pacies du g. Pogonus ; mais il en difrére beaucoup par les caract. génériques. Il a pour type et unique espéce, l'A. cenea Dej., trouvé dans les environs de Carthagène, en Amérique, par M. Lebas.

* ABASICARTON, Andrz. (á priv.; 6 ́́-

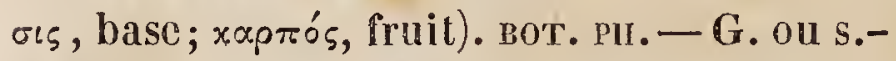
g. de la famille des Crucifères, très voisin de l'Arabis et de l'Arabilizum, dont il paraît ne différer que par sa silique subcylindrique ou peu compriméc. Il est composé de 6 ou 7 espèces détachécs du g. Arabis. (SF.)

* A ASOLOA. bot. pir.-G. de Plantes appartenant à la famille des Composées, mais sur l'organisation duquel on ne possède encore que des données trés vagues. M. de Candolle le caractérise de la manière suivante : Capitule radié. Fleurs du rayon femelles, capillaires, bi-tri-sériées; celles du disque hermaphrodites, tubuleuses, à 4 dents. Involucre á écailles bi-sériées. Réceptacle plan, couvert de paillettes linéaires, aiguës, denticulées, cilićes à leurs bords. Akènes tétragones, rhomboïdaux et terminés supérieurement par un disque ombiliqué. - L' $A b a-$ soloa est une plante a feuilles opposées linéaires, légèrement scabres, présentant des dents de distance en distance; les capitules sont solitaires, longuement pédonculés; les fleurs du disque et du rayon sont blanches. On n'en connaît qu'une espèce, originaire du Mexique.

(J. D.)

A ATIA, Ruiz et Pav. вut. PH.—Gr.sur la classification duquel les auteurs ne sont pas d'accord; les uns le placent dans les Tiliacées; les autres dans les Bixacées; M. Don pense qu'il apparticntaux Lythracées. Suivant M. Kunth , ce g. offre les caract. essenticls suivants : Cal. 4-parti, coloré en dessus ; estivation valvaire. Pétales nuls. Ctam. trés nombreuses, insérées au fond du calice : les cxtéricures stériles (ananthères), cordiformes. Auth. ovales, dithéques. Ovaire inad- hérent, monostyle. Style filiforme. Stigm. simple. Capsule 1-locuhaire, 2-valve, polysperme, à 2 placen taires pariélaux, linéaires. Graines oblongues, striécs.-Ce g. ne renferme que 2 esp. de l'Amér. équatoriale. (Sp.)

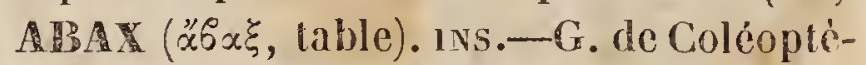
res pentamères, ćtabli par Bonelli dans la famille des Carabiques, mais non adopté par Latreille qui ne l'a pas trouvé assez caractérisé pour le séparer de son grand g. Féronie, où il ne forme qu'une division. M. Dejean a suivi cet exemple dans son Species el dans la dern. édit. de son Catalogue. V. les mots Fúronie et Féroniens. (D.)

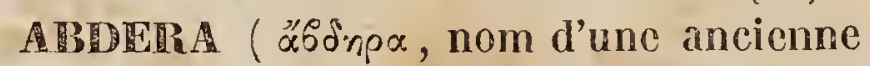
ville de Thrace). INS. - - G. de l'ordre des Coléoptères, section des Hétéroméres, établi par Stéphens et adopté par Westwood. II ne reniferme que quelques esp. indigènes, dont le type est l'A. bifasciata (Mordella bifasciata Marsh.), que M. Curtis considèro comme appartenant au g. Hypalus de Paykull. $V$. ce mot.

(BL.)

ABDITOARUES. Abditolarvo (Abditus, caché; larva, larve). ins. - Nom donné par M. Duméril (Zool. analy tique) à une famille d'Hyménoptères dont les larves naissent dans le tissu de certains végélaux, où elles ont été primilivement déposćcs à l'état d'œufs. Cette famille correspond aux 3 dernières tribus de la famille des Pupivores de Latrcilic : les Gallicoles, Chalcidites et Oxyures. (B.)

ABDDONEN ou VENTRE (abdomen; d'abdo,

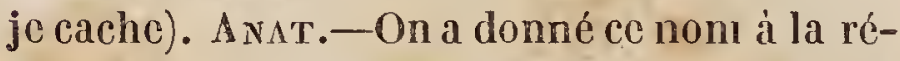
gion du corps des animaux qui, plus ou moins distincte, suivant les espéces, offre une cavité d'une étenảuc très différente, destinée àloger constamment une portion du canal digestif, et le plus souvent d'autres organes importants. En général, dans la súrie animale, l'abdomen fait suite au thorax; mais là où ce dernier manque, comme par exemple dans la classe des Annélides, il est difficile d'assigner des limites au ventre proprement dit; alors les naturalistes emploient le mot corps pour désigner l'animal tout entier.

Ce que l'on nomme improprement queue chez tous les Crustacés, n'est autre chose que l'abdomen. Elle fait suite en effet au thorax, et contient une portion du canal intestinal. On peut donc réserver le nom de queue à des appendices articulés ou non, mobiles ou immobiles, et qui ne renferment 
jamais aucune portion du canal intestinal. Ie celle manière, Ie motabdomen aura plus l'extension, et le mot queue se trouvera jlus rigoureusement défini.

Sous le point de vue physiologique, on peut dire que, dans l'abdomen, la solidité est en général sacrifiée à la souplesse. Du reste, comme dans la série animale, il est impossible d'assigner à une même région du corps des limites bien tranchées, et que ces mêmes limites ne renferment pas tonjours le nombre ni la disposition de certains appareils organiques, il est indispensable, pour se faire une idée générale et précise de l'abdomen, de l'étudier dans les diverses classes d'animaux. Comme il sera parlé des organes digestifs et de l'abdomen aux articles Marnmiferes, Oiseuux, Reptiles, Poissons, Articulés, Mollusqucs et Zoophytes, nous y renvoyons le lecteur. On trouvera aussi au mot T'ératologie, tout ce qui a rapport aux vices de conformation el au développement du ventre.

(M. S. A.)

ABDOMINAL ou ABDOMEISUX. Abdominales (abdomen, ventre; d'abdo, je cache). polss.-Linné comprenait sous ce nom, dans le $4^{\mathrm{e}}$ Ord. de sa classification ichthyologique les Poissons pourvus d'une membranc branchiostège, ayant les nageoires ventrales insćrées en arrière des pectorales. Les g. qu'il réunissait dans cet Ordre $12^{\circ}$ édition du Systema $\mathbb{N}$ atura) sont les suivants : Cobilis, Amia, Silurus, Teuthis, Loricaria, Salmo, Fistularia, Esox, Elops, Argentina, Alherina, Murjil, Mormyrus, Exococus, Polynemus, Clupea, Cyprinus. Mais, dans la classification qu'ils imaginèrent, les successeurs de Linné ont tous employé cette expression en lui donnant une autre valeur. Ainsi Bloch, auteur d'une méthode artificielle pour la distribution des I'oissons, fondée uniquement sur le nombre de nageoires, a employé l'épithète d'Abdominal pour désigner les divisions de quelques uns des 11 Ordres que cetie méthode lui fournissail. Dans le $11^{\mathrm{e}}$ Ordre des Decapterygii, la $3^{\text {e }}$ famille comprend comme Ablominaux le g. Polynemus. Dans le $4^{\mathrm{e}}$ Ordre, des Oclopterygii, les Abdominaux renferment les g. suivants : Culaphractus, Sphyrana', Atherina, Centriscus, Fistularia, Murjil, Gasterosteus, Loricaria, Squalus. Le 5e Ordre des Ilepcupterygii a aussi sa famille des Abdominaux, composee desg. Acipenser, Chimara,
Pristis, Rhina, Rhinobatus, Raia, Platystacus, Silurus, Anableps, Acanchonotus, Esox, Synodus, Salmo, Clupea, Exocoetus, Chauliodus, Elops, Albula, Cobitis, Cyprinus, Amia, Pocilia, Pegasus, Mommyrus, Polyodon. Argentina. Il n'y a pas de Poissons à ventrales sous l'abdomen dans les autres Ordres.

Lacépède, combinant la méthode de Pennant, qui subdivise les poissons en osseux et en cartilagineux, avec celle de Linné fondée sur la position des nageoires paires inférieures, a donné aussi une autre valeur au mot abdominal. Il comprend sous ce nom les esp. qui font partie du $4^{\mathrm{e}}$ ordre de chacune des divisions de chaque sous-classe, dans lesquelles sa méthode range les Poissons. Dans les Cartilagineux, Ies Abdominaux de sa $1^{\text {re }}$ div. sont : Ies Raies, les Squales et les Aodon; ceux de la $2^{m e}$ sont les Chimères; ceux de la $3^{\mathrm{e}}$ : Ies Polyodons et les Esturgeons; enfin dans sa $4^{\mathrm{e}}$ divis., il range sous le nom d'Abdominaux, les Macrorhynques, les $P$ Bgases et les Centrisques. La sous-classe des poissons osseux a aussi ses Abdominaux extrêmement nombreux dans la $1^{\text {re }}$ division ; car cet ordre, le $20^{\mathrm{me}}$ de sa méthode, se compose des genres : Cirrhite, Chéilodactyle, Cobite, Misyurne, Anableps, Fondule, Colubrine, Amie, Butyrin, Triptéronote, Ompock, S'ilure, Macropléronote, Malapière, Pimélode, Doras, Pogonathe, Caluphracle, Plolose, Aljénéiose, Macroramphose, Centranodon, Loricaire, Hypostome, Corydoras, Tachysure, Salmone, Osmère, Corrégone, Characin, Serrasalme, Ellope, Mégalope, Notacanthe, Esoce, Synode, Sphyrène, Lépisostée, Polyptère, Scombrésoee, Fistulaire, Aulostome, Solénostome, Argentine, Athérine, Hydrargyre, S'loléphore, Muge, Mugiloüde, Chanos, Mugilomore, Exocel, Polynème, Polydactyle, Biuro, Clupée, Myste, Clupanodon, 's'erpe, Méné, Dorsuaire, Xysière, Cyprinadon, Cyprin. Enfin le g: Mormyre appartient seul au $4^{c}$ ordre de la $3^{\mathrm{c}} \mathrm{div}$. des osseux, ou le $28^{\mathrm{e}}$ de la mélhode générale.

M. Duméril, dans ses ouvrages généraux sur l'Histoire naturelle, et surtout dans sa Zoologie analytique, a rendu la méthode do Lacépède plus facile à retenir, par la précision qu'il a donnée aux différentes subdivisions, on aux divers ordres. Il a conserve le mol Abdominaux pour le $4^{\text {me }}$ sous-ordre des Holobranches. Ces Abdominaux sont isi 
subdivisés en 8 familles, qui comprennent les g. énumérés plus haut pour représenter l'ordre du nuême nom de la $3^{\text {me }}$ subdivision de la s.-classe des Osseux de Lacépéde. Les fam. de M. Duméril sont : les Siphonostomes, $\mathrm{Cy}$ lindrosomes, Oplophores, Dimérèdes, Lépidopomes, Gymnopomes, Dermoptèresel Siagonotes.

Ce n'est pas le licu de parler des auteurs postérieurs á ceux-ci, dont les méthodes ne sont que des complications qui ne servirent nullement les sciences naturelles, tant que l'observation de la nature ne vint pas éclairer, par une critique saine ef savante, des méthodes imaginées précédemment. Mais J'arrive de suite à Cuvier, qui a fondé sa méthode ichthyologique sur les grandes divisions adoptèes par Artédi, el qui, par conséquent, ne pouvait donner au mot Abdominal la même extension que y altachait Linné.

C'est le $1^{\text {cr }}$ ordre de ses Malacopiérygiens; il retranche, par conséquent, de l'ordre de Linné, les Teuthis, Fistulaires, Argentines, Alhérines, Mluges et Polynèmes, qui sont pour lui des Aeanthoptéryyiens à nageoires ventrales abdominales, mais appartenant a différentes fam. de cette grande di vision. Les Malacoptérygiens abdominaux sont divisés en 5 tribus qui correspondent aux g. Salmo, Clupea, Esox, Cyprinus et Silurus de Linné. Ces familles sont elles-mêmes divisées en $\mathrm{g}$., subdivisés en s.-g, et ces derniers en groupes auxquels, dans sa méthode, il n'a plus donne de noms distincts. Il faut avouer que ces s.-g. de s.-g. sont un très grand défaut de nomenclature. Je mèsuis toujours étonné que Cuvier, d'un esprit si juste, si sévère, ait ainsi altéré la nomenclature binaire, ce qui a souvent empêché de bien comprendre son cuvre immortelle du liègne animal.

Ainsi, la $1^{\text {re }}$ famille, celle des Salmones, se partage dans les $2 \mathrm{~g}$. Saumon et Stcrnopiyx. Or, le g. des Saumons se divise dans les s.g. Saumons proprement dits (dont les Truites sont une s.-div.), les Eperlans, Ombres, Aryentines, Charaeins, subdivisés eux-mêmes en C'urinates, Anostomes', Serrasalmes, Piabuques, Tétragonopières, Raies, Iydrocyns, Cytharines, Saurus, Sicopèles, Aulopes et Serpes.

La $2^{\circ}$ lamille, celle des Clupes, se compose des g. Hareng, Filope, Chirocentre, Eryihrin, Amie, Vastres, Lépisostéc, Polyptère;

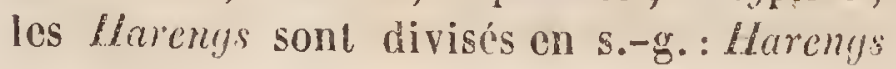

propres, Méralopes, Anchois, Thrisses, Odontognathes, Pristigastres, Notopières.

La 3 e famille, celle des Esoces, ne comprend que $3 \mathrm{~g}$., les Brochets, les Exocels, les Mormyres; mais les Brochets se composent des s.-g.: Brochets propres, Calaxies, Mierostomes, S'lomias, Chauliodes, Salanx, Orphies, Seombrésoces, Demi-becs.

La farnille des Cyprins se compose des $2 \mathrm{~g}$. Carpes et Loehes; le 1er subdivisé en : Carpes propres, Barbeaux, Goujons, Tanches, Cirrhines, Brèmes, Labcons, Ables et Gonorhynques. Celui des Loehes comprend les s.-g. : Anableps, Paeilie, Lebias, Cyprinodon. Enfin, suus le vom de siluroüdes, dans li dernière famille, il a réuni les g. Silure, Malaptérure, Asprède et Lorieaire. Le g. Silure a pour s.-g. les Silures propres, divisés euxmêmes en Silures spécialement dits et en Schilbés; le 2e s.-g., celui des Machoirans, est subdivisé en Pimélodes, Agénioses et $D_{0-}$ ras; mais ces Pimélodes sont encore scindés en Shals, Pimélodes propres et Pagres; le $3^{\mathrm{e}}$ s.-g., celui des Hétérobranches, se subdivise aussi en Maeroptéronotes et en Hétérobranehes propres. Viennent ensuite les s.g. Plotose et Callichte. Enfin les Lorieaires ont pour s.-g. les Hypostomes et les Loricaires propres.

On voif donc par cet examen que le mot $a b$ dominal, employé par Linné dans sa méthode arlificielle, avait une première signification précise, dont tous les auteurs ont altéré plus ou moins lc sens, parce que ces derniers, essayant de réunir les Poissons suivant les principes de la méthode naturelle, se sont servi d'un caractère artificiel. Celte position abdominale des nageoires ventrales est on effet peu importante dans l'organisation des Poissons, et la preuve la plus directe en est dans l'absence si fréquente de ces nageoires, ou quand elles existent, dans la variation de leur position. On doit done, selon moi, ne plus se servir désormais du mot abdominal, que comme d'un adjectif commode dans une description ichthyologique, sans y altacher l'idée d'une grande division naturelle de la classe des Poissons. (Vhlenciennes.)

ABDOMTNAUX. Abdominales (abdomen, ventre; d'abdo, je cache). Ins. - Section établie par Latreille, dans la famille des Cilrabiques, adoptée par Eichwall, et qui correspond aux Simplicimanes de Bonelli, ainsi qu'aux Simplicipedes de M. Dejean. Tous les 
Coléoptères de celle section ont l'abdomen tres grand relativement au prothorax. (D.)

ABEILLE. Apis(Pline). INs. - Ce genre, qui dans le système de Linné réunissail un grand nombre d'Insectes, cst aujourd'hui restrcint aux sculs Hyménoptères, ofrarit pour caract. : $1^{\circ}$, Antennes filiformes et brisées, c'est-d-dire faisant un coude; $2^{\circ}$, Mandibules en forme de cuiller chez les individus ncutres ou ouvriers, et au contraire bidentées dans les mâles el les femclles; $3^{\circ}$, enfin lc $1^{\text {er }}$ article des tarses des jambes postéricures très développé et quadrilatíre dans les individus neutres, où il présente intéricurement une sorte de brosse formée de poils régulièrement rangés en bandes transversales. Ces caract. et plusieurs autres permettent de distinguer les Abeilles proprement dites, des Insectes qui les avoisinent et qui apparticnnent aujourd'hui ì des g. différents. L'espèce qui sert de type aug. Abeille, est l'Abeille commune, Apis mellifica des auleurs. Nous allons donner brièvement l'histoire de ses mours; mais avant d'entrer dans ces détails, nous devons jeter un roup d'xil sur l'organisation de ces Inscetes, ne fùt-ce que pourfaire conmaître les instruments à l'aide desquels ils exécutent leurs merveilleux ouvrages.

Et d'abord, tout le monde sait qu'outre les mâles et les femelles, il existe parmi les Abeilles une autre sorte d'individus qu'on distingue sous le nom d'Uuvrières; cclies-ci composent la très grande majorilé des habitants d'une ruche. Ces trois sortes d'individus, savoir: les wales, qu'on nomme aussi Bourdons, les Femelles, appelées vulgairement les Reines, et enfin les Ouvrières, IVeutres ou Mulets, se distinguent facilement cntre cux par divers traits de leur organisation. Passons rapidement en revue ceux qui les caractérisent davantage.

Les Males, généralement plus gros que les Ouvrières, ont la têle arrondie, ce qui est dù surtout au développement des yeux presque contigus sur le vertex. Toujours ils manquent d'aiguillon; le thorax est tres velu; le ventre plus convexe que dans les femelles; enfin le premier article les tarses postérieur a une forme allongée et non quadrilatere comme dans les onvrieres.

Les Femelles ont les ailes proportionnellement plus courtes que celles des males et des ouvrieres; leur tête est triangulaire et non arrondic; leurs ycux sontécartes sur le vertex; leur ventre, prolonge en pointe, est armé d'un aiguillon; le premicr article des tarses postéricurs manque de la brosec dont sont pourvues les ouvrières.

Les Ouvrieres ou Neures se reconnaissent à une taille moindre; elles ont un aiguillon ayec lequel elles produisent une piqûre trés doulourease; nais ce qui les distingue surtout des femelles el des mâles, c'est la conformation de lcur dernière paire de paltes. Le premier article du tarse offre une structure curicuse que nous avons déja signalée, mais qui mérite d'être décrite aree détail, à cause du rôle important qu'il joue dans les divers acles que l'abeille onvrièc cxécute. Ce premier arlicle, qui a resu ic noin spécial de pièce carrée, est en efiet de forme quadrilatere. Supéricurement il s'articule par son angle antérieur avec la jambc, de manióre a exéculer sur elle un mouvement de ginglyme, ḋ la maniere d'une lame de couteau qu'on fermerail et ouvrirait alternativement. L'angle opposé, ou postéricur, est libre et prolongé en une petitc pointe légèrement recourbéc. Ces deux parties, la jimbe et le premier arlicle du tarse, forment ainsi une sorte de pince, dont nous indiquerons l'usage en parlant de la construction des gâteaux de circ. Ce même article, si différent des quatre suivants, présente une autre particularilé très curieuse : lisse extéricuremeni, il est gami, sur sa face interne, de plusieurs rangées transversales de poils raides el paralleles qui ont valu à celte face le nom de brosse; la jambe elle-rnême, à cause de la forme qu'elle affecte, a ctés appelée palente triangulaire, et comme elle présente à sa surface cxterne un léger creux, ce petit enfoncement a reçu le nom de corbeille.

C'est au moyen de ces instruments bien simples, n'existant que dans la caste ouvière, que se fail la récolte d'une poussière particulière nommée pollen. Ce pollen, fourni par l'anthère des étamines d'un grand nombre de plantes, s'altache d'abord nalurellement aux poils qui recouvrent le corps de l'Abcille; il est ensuitc balayé au moyen des tarses des jambes, el surtont far ta brosse qu'on distingue à la troisicme paire. L'insecte parvient à réumir colle poussiere en petits globules, deposés successi- 
vement par la 2 maire de paltes dans la corbeille, jusqu'à ce que celle-ci en soit bien garnic. C'est aussi le même apparcil qui sert à la récolte d'unc autre substance résineuse, odorante, nomméc propolis, que les Abeilles emploient principalement pour clore leur demeure. Le tarse, outre la pièce carrée, est encore formé par 4 autres articles beaucoup moins développés, et se termine par 2 crochels bidentés que sépare une pelote charnue.

Tels sont les caractères extéricurs les plus saillants des 3 sortes d'Abeilles qu'on rencontre dans une-ruche. Jetons maintenant un coup d'oil sur les orgares de ces insectes, dont les fonctions se lient davantage aux merveilleux phénomènes que présente leur industrie.

Le systeme nerveux des Abeilles se compose, suivant Swammerdam, d'un cerveau formé de 8 parties rangées par paires, el d'une portion moyenne qui est l'origine de la moelle épinièrc. La moelle épinière présente 7 ganglions. Du cerveau et des ganglions naissent les principaux nerfs qui se distribuent aux divers organes.

Huber a tenté sur les organes des sens quelques expéricnces qui lni ont fait penser que la cavité de la bouche était le siége de l'odorat, et les antennes celui du toncher. Il n'a pu recomnaître l'organe de l'ouie, et cependant tout porte à croire que les Abeilles entendent, à moins de n'admettre aucun but dans les sons qu'elles produisent. Cetle sorte de voix n'est autre chose qu'un bourdonnement très nuancé; tantôt c'est la Rcine seule qui le fait entendre, et alors elle prend une attitude particulière qui Irappe les Abeilles d'immobilité; tantôt ce sont les jeunes Reines qui, retenues captives dans les cellules, produisent un son très singulier; d'autres fois, c'est un bruit général qui a lieu, dans certaines circonstances, i l'intérieur de la ruche; souvent enfin, e'est le bourdonnement d'une ou de plusieurs ouvrières, qui font part d'un danger. Quoi qu'il en soit, cette faculté, chez ces animanx, est toujours cn rapport avec leur instinct; car le bruit du connerre, d'une arme à feu, et même la vibralion de divers corps métalliques, ne paraissent pas les affecter.

Un sens, sur le sioge duquel il n'est plus permis d'élever aucun donte, est celui de la vue. On sait que les Abeilles apergoivent de très loin leur habitation, qu'clles distinguent leur ruche entre toules les autres, ef qu'elles y arrivent en ligne droite et avec rapidité.

Le siége de l'organe du goût, placé par Swammerdam dans la trompe, n’est pas , à beaucoup près, aussi bien déterminé que celui de la vue. On se rend mème difficilement raison de l'existence d'un tel sens, lorsque, jugcant d'après ses propres sensations, on considère que l'abeille, pour se désaltérer, préfère une cau croupie à une cau limpide, et qu'elle se nourrit indistinctement du suc d'un grand nombre de plantes ayant des propriétés très ditrérentes : de lá aussi les nombreuses variétés de miel que l'on ubserve dans des ruches placées les unes auprés des autres. Les Abeilles, en effel, se nourrissent de liquides végétanx, el principalcment de liquears sucrées; c'est du nectaire des plantes qu'elles retirent, au moyen de leur trompe, un suc qui sera bientôt converti en miel.

La trompe n'est pas exclusivement formée, comme celles des Papillons, par le prolongement des mâchoires, mais surtout par celui de la lévre inféricure. Au reste, la bouche est formée des mêmes parties que celle des autres Insectes. On y trouve : une lèvre supérieure, une paire de mandibules bidentées à leur sommet dans les mâles et dans les femelles, mais qui, chez les ouvrières, ont une terminaison très différente; en effet, celles-ci les ont tranchantes par leur bord el creusćes intérieurement d'unc fosselte divisce en 2 porlions par une arête longitudinale. Les mandibuies viennentelles à se rapprocher, l'une de ces portions, l'antéricure, s'applique exactement contre celle qui correspond à la mandibule opposée, et forme avec elle une pince tranchante. Au contraire, l'autre portion ou postérieure, ne se rapprochant pas également bien de celle qui lui fail face, constitue une sorte d'intervalle ou de goutlière.

C'est au moyen de celle conformation de leurs mandibules, que les ouvrières construisent avec tant d'art les cellules qui garnissent l'intéricur d'unc ruche. Nous reviendrons plus loin sur la manièe dont elles metlent on jeu ces instruments. Les 
màchoires (qu'on voil en arrière des mandibules sont réduiles it des lamelles enveloppail et prolégeant la trompe beaucoup plus hongue qu'elles. Celle-ci, qui est l'analogue re la lève inférienre des autres insectes, présente les mêmes pièces, mais à des degrés divers de léveloppement. L’Abeille sait, a l'aide de cette trompe, extraire le suc des neurs et le porter dans la cavité buccale, siluće plus en arrière. Swammerdam s'élail mépris sur les fonctions de ces parties. Réaunur en a mieux observé le jeu, et nous a appris que la trompe proprement dite élait une sorte de langue qui, en léchant ou lapant, se chargeait de la liqueur miellée ; que celte liqueur passait cntre elle el les étuis extéricurs ou les mâchoires, el qu'elle gagnait ainsi une ouverture qui avait échappé à Swammerdam. Cette ouverture, placée au-dessus et a la base de la trompe, est recouverte par une sorte de langue charnue et doit être considérée comme l'entrée pharyngienne ou le pharynx lui-même; c'est par elle que s'ćchappe ordinairement une gouttelette de miel, lorsqu'on presse une Abeille entre les doigts.

Le canal intestinal consiste en un osophage aboutissant à un jabot renfé, ordinairement plein d'une liqueur jaune, limpide, ayant loutes les proprićtés du micl. Après ce premier renflement, en vient un second que Swammerdam nommait colon, et qui a beaucoup plus de longueur et de capacilé que le précédent : c’est l'estomac proprement dit; il se continue arec l'intestin grêle, et vers le point de leur réunion on remarque un grand nombre de yaisseaux biliaires. Le canal intestinal est terminé par lơntesiin grêle, le cœecum et le rectum.

La respiration a lieu, comme dians les autres Hyménoplères, an moyen de trachées naissant des stigmates que l'on observe sur les côtés du thorax et sur les parties latérales de l'abdomen; elles aboulissent à quelques vésicules aériennes très développées, et à un grand nombre d'autres plus petites.

A cette fonction se rattachent quelques phénomènes très curieux, qui nous ont élé transmis par Huber. Cel observateur, ayant remarqué qu'une ouverture d'un assez grand diametre, pratiquée dans une boîte on une cloclıe de même capacilć qu'une ruche ordiraire, étail lout-á-fait inutile pour le renouvellement de l'air, ayant appris aussi, par plusieurs expériences, que les $\Lambda$ beilles ne pouvaient continuer de vivre dans un espace où l'air ne se renouvelait pas, et sachant, en outre, que dans une ruche peuplée quelquefois de 25,000 habilants, ce fluide est, à peu de chose prés, toujours aussi pur à l'intéricur qu'à l'extéricur, parvint à expliquer ce phénoméne par la rentilation que les ouvrières produisent presque continuellement, en agilant leurs ailes à la partic inféricure de la ruche. Sans pénétrer dans cette demeure, on peut, à l'époque des chaleurs, surprendre en dehors et près des portes de la ruche quelques Abeilles dans cetle singulière action. Ce mouvement, quelquefois général, suffit, suivant Huber, pour établir, entre l'air cxtérieur et l'air intérieur, des courants au moyen desquels cclui-ci est sans cesse renouvelé. Ce phénomène, qui n'a encore élé observé que dans les Abeilles et dans quelques Bourdons, était un fait digne d'être noté. Il est une conséquence immédiate de la respiration, ainsi que la chaleur des ruches, qu'il ne faut plus maintenant attribuer à la fermentation du miel. Si le système respiraloire est remarquable par son développement et ses fonctions, celui de la circulation se réduit, de même que dans tous les Insectes hexapodes, à un simple vaisseau dorsal n'offrant rien de particulier.

Aux différentes fonctions que nous avons jusquu'ici fait connaìtre, il faut en ajouter une très importante, celle des sécrétions. Nous ayons dit que les gâteaux sont formés de cire. On a pensé, pendant long-temps , que l'ingrédient principal de cette cire étai le pollen, dont les ouvrières se nourrissent quelquefois, et qu'elles mettent le plus souvent en magasin dans certaines cellules. Ce pollen, disait-on, était élaboré dans leur estomac, et dégorgé ensuile par la bouche sous la forme d'une bouillie blanchâtre, qui était dela véritable cire. Telle futl'opinion de tous les savants, jusqu'à ce qu'un cultivateur de Jusace, el par suite John Hunter, eussent découvert des lamelles de cire engagées entre les arceaux inféricurs de l'abdomen. Cetle observation fixa l'attention de IIu- 
ber, qui confirma celte importante decouverte en l'étayant de nouvelles preuves.

Non content d'avoir connu dans tous ses détails cet apprareil singulicr, des expériences ingénieuses lui apprirent que les Abcilles, nourries uniquement de pollen, ne sécrétaicnt jamais de cire, et que celles, au contraire, auxquelles on donnait une liqueur sucrée, en fournissaient en grande abordance. Une prenve d'un autre genre vint a l'appui des observations de Huber : il vit que l'ouvrière qui rentrait à la ruche l'estomac plein de micl ef avec l'intention de construire, se gardait bien de dégorger le produit de sa récolte dans les magasins, comme si elle n'ignorait vas qu'en agissant autrement elle ne pourrait produire des matériaux de construction.

C'est arec cette cire, dont l'origine n'est plus maintenant douteuse, que les ouvrières bâtissent les cellules, dont le principal usage est de contenir les aufs pondus par la femclle, quelque ternps aprés son accouplement avec le mâle. Les mâles, dont nous avons déjả fait comnaîte les caractères extérieurs, se distinguent principalement des femelles par leurs organes génilaux. Swammerdam, Réaumur et Huber les ont étudiés avec beaucoup de soin. Les organes femelles se composent de deux ovaires subdivisés en plusieurs oviductes et réunis en un canal commun; ils contiennent un nombre prodigieux d'oufs. Une fernelle, qui en avait déjả pondu plus de 28,000 , offrit à Réaumur son abdomen encore plein de plusieurs milliers d'autres. A ces organes se joignent un sac sphérique et deux vaisscaux aveugles s'ouvrant dans le canal commun des oviductes, et que Swammerdam suppose renfermer une liqueur visqueuse propre à enduire les oemis. Huber ne partage pas cette opinion, et quelques recherches que j'ai faites sur cet organe, ne me permettent pas non plus de lui attribuer cet usare.

Il sufit d'avoir jeté un coup d'œil sur les organes mâles et femelles pour penser que de tels appareils sont faits dans un but déterminé. Swammerdam et Réaumur n’ont pu être speclateurs de la jonction des sexes; mais Huber, plus heureux sans doute, reconnut que cette union avait toujours licu hor's de la ruche; il en eut des preuves certaines, quand, ayant tenu captives des femelles, soit isolées, soit arec des mâles, elles restèrent toujours stóriles; quand, au contraire, leur ayant laissé toute liberté, elles prirent leur essor, s'envolèrent au loin et revinrent fécondées; quand, enfin, il retrouva, dans la vulve des mêmes fernelles, l'organe copulateur du mâle, qui y adhérait encore.

Si les mâles sont inutiles à la ruche, parce que, n'étant pas pourvus des instrumients de travail, ils ne récoltent ni micl, ni pollen, et se nourrissent au contraire des provisions amassées par les ouvrières : si, dis-je, ils sont inutiles sous ce rapport, ils ne le sont pas sous celui de la propagation de l'espéce. Aussi voit-on les ouvrières, i une certaine époque, donner un soin particulier à leurs larves. Je dis a une certaine époque; car il arrive un autre moment oú elles percent de leur aiguillon tous les mâles et détruisent même ceux qui ćtaient près d'ćclore. C'est ordinairement dans les mois de juin, de juillet et d'aont que se fait au fond de la ruche ce grand carnagc. Après cette époque, on ne trouve plus de mâles dans les ruches, et ce n'est qu'en avril et en mai suivants que, de nouveaux cufs ayant été pondus, on en voit reparaîlue, d'abord en petit nombre, et ensuite en grande quantité. Ils ćclosent dans les ruches avant les Reines : celles-ci sont aussi impropres que les mâles a toute espèce de travail; leur seule fonction est de perpétuer l'espèce; aussi ne restent-clles que très peu de temps dans l'état de virginité. Cet état peut être prolongé par certaines circonstances; mais ordinairement, cing ou six jours après leur naissance, ct un jour après qu'elles se sont établies dans une nouvelle demeure, à la tête d'une colonie (ce qui a lien vers le mois de mai, juin et juilled), on les voir sortir pour aller à la recherche d'un mâle. Elles reviennent à la ruche ordinairement fécondées, et la perte de leur virginité n'est pas équivoque. Elles recoivent alors, de la part des ouvrières, des lommages et des soins empressés qu'on ne leur avait pas encore rendus. C'est généralement 46 heures après l'acte de la copulation que la ponte a licu; elle se continue jusqu'au printemps suivant, sans que la femelle ait été fécondée de nouveau; car nous avons dit qu'à dater du mois d'aoùt on ne 
rencontrai plus de mâles. La ponte peut donc avoir lieu 11 mois après l'accouplement; et ee terme n'est pas le plus éloigné, car Huber nous apprend qu'un seul aecouplement peut rendre une femelle féeonde pendant 2 ans.

Si la fcmelle est fécondée dans les 15 premiers jours de sa vie, elle ne pond guère, jusqu'au printemps, que des aufs d'ouvriéres. A celte époque, elle fait une eopieuse ponte de mâles, et, immédiatement après, a lieu eelle des Reines; mais à un jour d'intervalle, afin que ees Reines, conductrices des eolonies qui doivent sortir de la ruche, ne naissent pas toutes en même temps. Si, au contraire, la fécondation de la Reine est

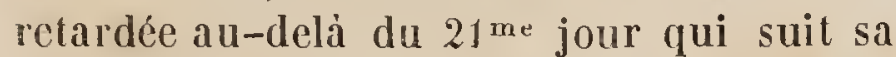
naissanee, ou bien si la ponte éprouve quelque retard à eause de la température trop peu élevée, elle ne produit plus que des œufs de mâles, et les dépose indistinetement dans toutes les eellules, mais avant de parler de la ponte et des phénomènes qui l'aceompagnent, nous devons jeler un eoup d'œil dans la ruche et faire eonnaître les eellules des gâteaux, dans lesquels sont déposés les aufs.

Nous avons déjả parlé, sous plusicurs rapports, des 3 sortes d'individus qui s'observent dans une ruehe, e'est-à-dire des mâles, des femelles ou Reines, et des ouvrières. Ces dernières ne différent des Reines que par un moindre développement des organes génitaux. Leurs fonetions principales sont d'aller à la récolte $\mathrm{du}$ miel et du pollen, de bâtir les eellules, de soigner les larves, de faire la police extérieure de la ruehe, et de la défendre eontre ses ennemis. Réaumur avait remarqué qu'elles n'étaient pas toutes de même grosseur, ce qu'il attribuait à une plus ou moíns grande quantité de matière eontenue dans leurs intestins; mais Huber donna plus de valeur á eette différenee, quand il découvrit qu'elle constituait deux variétés, plus distinctes eneore par les fonctions qu'elles étaient appelées à remplir. Leș unes, dont l'abdomen est habituellement dilaté et qu'il nomme Cirières, s'occupent uniquement de la construction des gâteaux ; les autres, dont l'abdomen a moins de volume, et qu'il aprelle les Nourrices, ont pour emploi de soigner le produit de la conception jusqu'à son entier aeeroissement.

Les alvéoles ou cellules, lorsqu'elles sont T. I. réunies, portent, ainsi que lout le monde le sait, le nom de gateaux. Chacune d'elles constitue ordinairement un petit godet hexagone, ouvert d'un eóté et fermé de l'autre par un fond ou calotte pyramidale, résultant de la réunion de 3 rhombes, qui auraient chaeun de leurs angles obtus au centre de ce fond pyramidal, et seraient réunis entre eux par les côtés qui renferment cet angle. Le contour de la base de cette pyramide présenterait alors six angles rentrants et saillants alternativement, qui, se joignant à la cireonférence d'un tuyau hexagonal formé par six trapézes, et auquel on remarque ies mêmes angles, l'emiboîteraient et seraient à leur tour emboîtés par lui.

Ces gâteaux présentent deux faces semblables, e'est-à-dire, qu'ils résultent de l'adossement de deux couehes ou séries de eellules. Les Abeilles, dans leur eonstruction, sont surteut étonnantes par l'éeonomie qu'elles savent faire de la matière et de l'espaee; à cet effet les fonds des eellules de l'une des eouehes constituent les fonds des cellules de l'autre; par eela même la base de chaque eellule est formée par la réunion de 3 eellules opposées. Ceei peut être rendu palpable et très intelligible, au moyen d'une expérienee fort simple : introduisez 3 longues épingles dans l'intérieur d'une cellule et percez-en le fond au eentre des trois rhombes qui le constituent, ehaeune d'elles aboutira alors à une cellule distinete du côté opposé.

Ces ouvrages admirables ont ordinairement une très grande régularité; et ả la régularité du travail se joignent dans l'exécution un fini et une délieatesse qu'on a peine a concevoir. L'admiration n'est pas moindre quand on observe la simplicité des instruments de eonstruetion; les ayant précédemment décrils avee assez de détail, nous n'aurons plus qu'à considérer iei leur aetion.

Lorsque l'Abeille reut construire, elle prend suecessivement les plaques de eire sécrétèes et tenues en réserve entre les anneaux inférieurs de son ventre, les porte entre ses dents pour les mâeher et leur faire subir une eertaine préparalion; mais son ventre étant éloigné de sa bouehe, eelle-ci ne saurait atteindre les lamelles de eire. La nature a pourvu à ectle diffieulté, cn conformant la dernière paire de pattes, 
de telle sorte qu'elle devient un instrument commode, à l'aide duquel l'Abeille saisit ces lamelles. Nous avons dit que le $1^{\mathrm{cr}}$ article du tarse élait très allongé, mobile sur la jambe, de manière a former avec elle ane sorte de pince; l'Abeille insinue cette pince entre les anneaux de son ventre, s'empare d'une plaque de cire, la porte aussitot a sa bouche, et la rompt avec lc bord tranchant de ses mandibules. Lorsque la lamelle de cire a passé et repassé entre ses dents, clle en sort de nouveau sous forme d'un filament mou que l'insecic, s'il commence à construire, applique contre la voûte de la ruche, oü bien qu'il ajoute aux lamelles déjá posées. Plusicurs Abeilles agissent de concert à la même place, et la matière qu'elles y déposent ne tarde pas à former une masse dans laquelle clles commencent à creuser les cellules du premicr rang. Celies-ci n'ont plus les formes que nous avons décrites, et celte sorte d'anomalie a pour but de foumir une base plus solide a la masse qui va bicntot se montrer; en effet, les ouvrières ajoutent successivement au travail que l'une d'elles a commencé; d'antres posent les fondements de nouvelles constructions à des distances égales; et tous ces gâteaux, ordinairement parallèles entre eux et perpendiculaires au fond de la ruche, s'agrandissent en très peu de temps. Réaumur nous apprend qu'un gàteav de huit à neuf pouces de diamètre est quelquefois l'ouvrage d'une seule journée. Nos archilcetes toutefois ne mettent pas de suite la derniere main à l'œuvre : lorsque tont nous paraît achevé, on voit d'autres Abeilles cirières entrer dans chaquc alvéole pour en raboter et polir, en quelque sorte, les parois. Elles s'occupent aussi à encadrer les pans des cellules et leur orifice de propolis gu'elles recucillent sur certains végétanx, et entre autres sur les bourgeons du peuplier sauvage. Elles se servent aussi de cetle gomme résine pour boucher toutes les ouvertures de leur ruche, et, à une certaine époque, elles l'emploient pour consolider la base des gâleaux.

Si, comme il convient de le faire, nous distinguons les cellules on petites, moyennes et grandes, nous devrons observer, que ce qui viont d'être dit de leur construction et de leur forme s'appligue uniguement aux deux premières. En effet, les grandes cellules, qu'on nomme aussi cellules royales, outre qu'on n'en comptc jamais plus de 27 (ieur nombre étant ordinairement de 16 a 20), diffèrent des autres sous plusicurs rapports. Elles sont en général oblongues, piriformes et très amples. Rien n'est épargnés pour leur solidité, et, dans leur construction, on ne se montre avare ni d'espace, ni de matic̀re; à tcl point que le poids d'une loge royale équivaut au moins à celui de cent cellules ordinaires. Leur position ensuite est bien différente : au lieu d'être placées horizontalement comme les alvéoles des ouvrières et des mâles, elles le sont vericalement. Quelquefois elles ressemblent à une stalactite, et paraissent détachées du gâlcau.

L'observation a appris que la plupart des alvéoles, tant petites que moyennes, recoivent les oufs. La pontc a lieu pendant toute l'année, mais principalement au printemps et dès le mois de mars, lorsque la température est un peu élevée. La reine parcourt alors les gâteaux, regarde et palpe avec ses antennes les cellules sur lesquelles clle passe, y enfonce profondément son abdomen, et lorsqu'elie les trouve vides, elle y dépose un nuf qu'clle colle par l'un de ses bouts au fond de l'alvéole. Elle pond d'abord dans les petites cellules des œufs d'ouvrières ; cnsuite, dans les collules moyennes, des ceuîs de mâles; et, en dernier lieu, des oufs de femelles dans les cellules royales.

Il n'est personne qui n'ait entendu parler des hommages rendus au Roi par ses sujets frdèles. Ce Roi ou plutôt cette Reine, car l'individu auquel ils s'adressent est toujours une femelle, en reçoit en effet de la part des ouvriceses, surtout au moment de la ponte. Il est curieur de voir les soins assidus que rendent a leur femelle les Abcilles du cortége, pendant cette importante opération ; elles la nettoient, la frottent avec leur trompe, et lui présentent de temps en temps du miel qu'elles dégorgent. S’il arrive que la femelle soit trés féconde, et qu'au contraire les ciriéres soient en trop petil nombre pour bâtir une quantilé de cellules égale à celle des ouis, la femelle, pressée de pondre, cn dépose 2, 3 et mème 4 dans les mêmes alvéoles. Les ouvrieres, qui s'en apercoivent, 
ne tardent pas à enlever tous les oufs surnunićraires et à les détruire.

Les oufs sont oblongs, un peu courbes et d'un blanc bleuâtre. Une fois pondus, ils sont abandonnés aux soins de celle varićlé d'ouvrières qu'on appelle nourrices; cellesci ne commencent leurs fonclions que lorsque les vers sont íclos, c'est-i-dire 3 jours après qu'ils ont élé pondus. Alors, selon Swanmerdam, elles apportent à plusieurs heures du jour une sorte de bouillie, différente suivant l'àge de la larve. D'abord insipide et blanchâtre, puis légèrement sucrée et transparente, d'une couleur jaune verdâtre, elle devient ensuite très sucrée; la quantilé de celle bouillie est proporlionnée d'une manière si exacle aux besoins du ver, que, selon Huber, il la consomme toujours en enlier. Le même anteur a observé que le pollen des étamines des plantes était la vérilable nourriture des larves; les nourrices en remplissent leur estomac et le dégorgent, sans doute après l'avoir mêlé avec une cerlaine quantité de miel.

La nourriture varie non seulement suivant les àges, mais encore suivant les sexes. Celle des mâles et des ouvrières paraît analogue; mais celle des larves de Reines est une bouillie toute particulière, dont l'infuence sur le développement de l'individu est telle qu'elle rend fécondes les ouvrières qui en ont été nourries à l'étal de larves. Il n'est plus permis de douter de ce fail, depuis que Huber a confirmé les expériences de Riem et de Schirach. Ce dernier avail observé que, lorsqu'une ruche se trouve privée de Reine, les Abeilles agrandissent, aux depens des cellules voisines, les alvéoles de quelques ouvrières, dans lesquelles se trouve une jeune larve, et qu'elles lui apportent en outre, avec abondance, une bouillie semblable à celle dont elles nourrissent les vers royaux; qu'enfin il naît bientòt de ces larves des Reines ou Abeilles femelles. Si, pendant que les ouvrières sont occupées á réparer une perle qui entrainerait celle de la colonie tout entière, on introduit une Reine dans la ruche, aussitól ces travaux cessent, comme si elles sentaient que leur précaution est devenue desormais inulile. Riem avait remarqué un fait non moins extraordinaire : il rit plusieurs ouvrières, absolument semblables aux autres, pondre dans les al- véoles. Huber observa le même fait, mais il remarqua que ces ouvrières ne pondaient jamais que des oufs de mâles, et supposa que celte fécondilé était due à une petito portion de bonillie royale, tombce commo par accident dans leurs élroiles demeures, toujours situées dans le voisinage des cellules roy ales. Ces Abeilles ouvrières ne deviennent fécondes que dans les ruches privées de Reines; car celles-ci ont grand soin de détruire ces chólives rivales. Les Abeilles ouvrières sont donc réellement des femelles dont les organes génitaux et quelques autres parties n'ont pas atteint tout leur accroissement.

La larve ou le ver, objet de tant de soirs, et qui nous présente des faits si remarquables, est blanchâtre, apode, composé de 14 anneaux, y compris la lête : celle-ci est munie, selon Réaumur, de deux mandibules rudimentaires, d'une lèvre supéricure et d'une lèvre inféricure trifide.

Ce ver, contenu dans l'alvéole, après avoir changé plusicurs fois de peau, arrive vers le

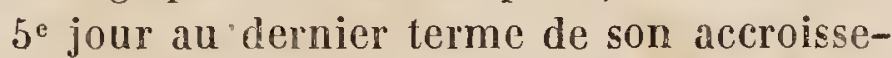
ment. Pendant ce temps il s'est approché petit à pelit de l'ouverture de sa loge, et n'en est plus qu'à deux lignes; à cette époque, les ouvrières bouchent l'alvéole au moyen d'un pelil couvercle de cire, plus bombé pour les cellules de mâles que pour celles d'ouvrières; alors le ver lui-même file en trente-six heures une coque de soie, complète, Iorsqu'il appartient à une ouvrière ou à un mâle, et incomplète, s'il doit donner une Reine. Trois jours après seulement il se métamorphose en nymphe. La nymphe est le passage de la larve à l'insecte parfait; il dure 7 jours et demi; ce temps écoulé, on voit paraître l'insecte parfait 20 jours après que l'œuf qui l'a produit a été pondu. $A u$ contraire, les femelles ne mellent que 16 jours a prendre tout leur accroissement. L'insecte, pour arriver à son état parfait, doit, sans auxiliaire, se débarrasser de son enveloppe, percer sa coque soyeuse ainsi que le couvercle de cire qui fermait son alvéole. A peine est-il né, que les autres Abeilleslui prodiguent mille soins, l'essuient ou le léchent, et lui offrent du miel. 11 ne tarde pas lui-même, s'il appartient à la caste ouvrière, à se mettre à l'ouvrage, el 
n'a pas besoin de leçons pour remplir ses devoirs : soninstinct est son maitre.

Un grand nombre d'Abeilles sont nées, l'habitation ne peut plus contenir tous les habitants; le nombre en est prodigieux; car, selon Réaurnur, une ruche peut contenir alors plus de 26,426 Abeilles ouvrières, 700 mâles et une seule femelle. Une émigration devient nécessaire; elle ne peut toutefois s'effectuer que lorsqu'une nouvelle Reine, qui remplacera celle qui va partir en tête de la colonie, est sur le point d'éclore. Quelles que soient les incommodités résultant de cette nombreuse réunion, le départ est toujours retardé jusqu'à cetle époque. A peine cel événement attendu est-il arrivé, qu'un grand nombre a'Abeilles, ayant à leur tête la vieille Reine, abandonnent l'habitation. Cette colonie errante porte le nom d'Essaim; les insectes qui la composent ne tardent pas à s'arrêter dans un endroit quelconque, souvent sur une branche d'arbre; là , ils forment une sorte de grappe ou de cône en se cramponnant les uns aux autres au moyen de leurs pattes. Au moment oú ce groupe se fixe, la femelle reste ordinairement dans le voisinage, et ne se réunit à la masse que quelque temps après. C'est le inoment que doit choisir le cultivateur, pour s'emparer de l'essaim et lé placer dans une demeure convenable.

Le départ est précédé de phénomènes assez singuliers, et s'annonce par des signes non équivoques. Les mâles, qui viennent de naître, paraissent alors en grand nombre; plusieurs milliers d'habitants, ne trouvant plus de place dans la ruche, se groupent par tas au dehors. Un bourdonnement particulier se fait souvent entendre le soir et la nuit dans lintérieur de l'habitation, ou bien on y remarque un calme qui n'est pas ordinaire; enfin, dès le matin du jour où la colonie doit s'expatrier, le calme est encore plus parfait, et le repos succéde à l'activité générale qu'on remarquait la veille.

Les Abeilles qui doivent émigrer semblent ainsi prévoir l'heure du départ, qui a ordinairement lieu vers le milieu du jour, par un temps chaud et un cicl pur. Il paraîtrait aussi qu'clles jugent inutile d'entreprendre ou d'achever des travaux dont elles ne doivent pas jouir. La même inaction a lieu, lorsqu'un essaim, après s'être établi dans une demeure et y aroir commencé quelques travaux, se décide à l'abandonner. Une ruche donne grdinairement, pendant le printemps, trois ou quatre essaims; quelquefois aussi elle n'en fournit aucun, lorsque les habitants sont en trop petit nombre. Dans le premier cas, les vieilles femelles se mettent toujours à la tête de la $1^{\text {re }}$ colonie; les autres essaims se forment, quand de nouvelles ouvrières et une nouvelle Reine étant nées, la ville est de nouveau trop petite pour contenir la population. Ces émigrations se succedent par conséquent dans des intervalles plus ou moins longs, mais qui ne dépassent pas 9 jours, et il est curieu. de remarquer que les ouvrières savent retarder la naissance des Reineś, jusqu'à ce qu'il soit éclos un assez grand nombre d'ouvrières pour former une nouvelle colonie: elles les constituent prisonniéres dans leurs propres cellules, en renforçant le couvercle qui bouche les alvéoles, el ne leur permettent d'en sortir que successivement, à quelques jours de distance les unes des autres. En vain les femelles se débattent-elles dans leurs cellules, en vain font-elles entendre un son particulier, les ouvrières ne les délivrent que lorsque le besoin le réclame, etne laissent pas, pendant cette captivité, de leur prodiguer les soins indispensables à leur existence : un trou pratiqué dans le couvercle de l'avéole permet à la Reine d'y passer l'extrémité de sa trompe; les ouvrières, qui s'en aperçoivent, dégorgent du miel et en répandent sur cet organe.

Nous avons rendu compte des phénomènes qui précédent la sortie d'un essaim, et de quelques unes des causes auxquelles semble due cetle émigration. La cause prochaine et en quelque sorte déterminante de départ, est l'antipathic ou plutòt la haine que les femelles se portent réciproquement, et l'inquiétude qui en résulte pour les ouvrièrcs qui font la garde. Ces sentinelles vigilantes harcellent de toutes parts la femelle qui doit émigrer, la poursuivent avec opiniâtreté; ne sachant plus où se retirer, elle parcourt avec vitesse les gâleaux, et met en mouvement toutes les Abeilles qu'clle rencontre sur son passage. L'agitation est bientòt générale; plusieurs individus se précipitent vers l'entrée de la ruche; la Reine cédant á cotte impulsion, sort, s'envole, et est aussi- 
tot suivie par un grand nombre d'ouvrières.

La chaleur qui résulte de l'agitation dont nous venons de parler, semble aussi contribuer beaucoup à la sortie des essaims. Le thermométre de Réaumur, qui, dans une ruche habitée, est ordinairement, l'été, de 27 à 29 degrés, s'ćlève dans ces circonstances jusqu'à 32 .

On serait dans l'erreur si l'on pensait que le nombre des femelles est toujours exactement proportionné à celui des colonies; il n'est pas rare d'en trouver 2 et même 3 dans un seul essaim. Si un essaim de ce genre est mis dans une ruche, on remarque bientòt que les Reines, toutes les fois qu'elles se rencontrent, se livrent des combats à mort. Les circonstances qui accompagnent ces combats, les ruses qu'emploient les 2 champions, le ròle qu'y jouent les ouvrières, qui en sont spectatrices, mériteraient des descriptions détaillées qu'il nous est impossible de donner ici. Nous nous bornerons à ajouter, que lorsqu'une ruche est réduite à une seule Ricine, si l'on enlevait celle-ci, au moment oủ les travaux sont déjà en pleine ac. livité, et à une époque où les oufs n'ont pas encore été pondus, on verrait l'oisiveté succéder au travail, l'espoir de perpétuer l'espéce serait détruit, la langueur atteindrait les ouvrières laborieuses; elles ne construiraient plus d'alvéoles, ne feraient plus de provisions, vivraient au jour le jour, et ne tarderaient pas a mourir. Leur rend-on unc femelle dans une telle circonstance, ou, ce qui revient au même, leur présente-t-on des gâteaux contenant des cellules royales ou de jeunes larves, capables d'être converlies en femelles, à la manière déjá indiquée, tout aussitôt les travaux reprennent leur activité, et ce peuple découragé recouvre son énergie. Les ouvrières ne sont donc pas seulement instruites par la présence d'une femelle, qu'elles doivent compter sur une postérité; mais cet espoir se réveille encore par la présence des ouf́s ou des larves contenues dans les alvéoles.

L'histoire des Abeilles, comme on voit, présente trop d'intérêt, pour qu'il soit nécessaire de l'embellir de suppositions idéales et merveilleuses. Ce peuple industrieux, si remarquable par l'union et l'ensemble qui règnent'dans ehaque habitation, ne l'est pas moins, lorsqu'il s'agit de defendre sa pro- priété contre les ruses des ennemis nomhreux qu'il doit combattre. Suivant quelques observaleurs, une Abeille ne vit jas plus de 5 ans. Il est probable que lorsqu'elle meurt, les ollvrières adoptent une jeune Reine, qui ne quitte pas la ruche. Si l'insecte, comme quelques uns l'ont prétendu, était une simple machine, et privé de toute faculté intellectuelle, serait-il susceptible de modifier ses actes, saurait-il prévoir, ealculer l'événement, le juger lorsqu'il se présente, proportionner les moyens de défense à ceux de l'attaque, et substituer mille stratagèmes à la force, quand l'infériorité du nombre ne lui permet pas de triompher avec ses armes? C'est pourtant lả ce qui arrive, lorsque des Frelons, des Guêpes, des Souris, des Teignes, des Sphinx Tête-de-Mort, etc., cherchent à s'introduire dans sa demeure. Tous les moyens sont alors mis en usage pour s'opposer à leur entrée; tous les efrorts sont dirigés vers ce but; ear, une fois que ces redoutables ennemis ont pénćtré dans la ruche, il est bien difficile aux Abeilles de s'opposer à leurs dégâts; elles n'ont plus d'autre parti à prendre que de fuir, et de transporter ailleurs leur industrie. Les ouvrières, comme on le pense bien, sonl les seuls combattants; elles veillent sans cesse à la ruche, et font une reconnaissance seru-puleuse de tous les individus qui y entrent, en les touchant de leurs antennes.

Réaumur et Hubert ont étė les historiens de leurs victoires et de leurs défaites, et nous ont donné des détails curieux sur leurs combats. Nous engageons de nouveau à recourir à leurs intéressants ouvrages.

Tout ce que nous avons dit des Abcilles s'applique à celle de notre pays, c'est-àdire à l'Abeille mellifique, Apis mellifica Linn.Fab. ( $V$. Pl. 14, fig. 1, le mâle; fig. 2, la femelle; fig. 3 , wne ouvric̀re on neutre.) Parmi les autres espćces d'abeilles qu'on a distinguées jusqu'à présent de la précédente, les plus remarquables sont :

l'A Berlle ligurienne, Apis ligustica Spin., cultivée dans loutc l'Italie, el qui habitc peut-être aussi la Morće, l'Arehipel, elc.

L'A Beilie unicolore, Apis unicolor Lat., qui habite les îles dic France, de Madagascar et de Bourbon, ef qui fournit un miel vert très estimé.

l'abeulle indenne, Apis indica Fab., 
que l'on rencontre au Bengale ot is Pondichéry.

L'ABEllLe TASClée, Apis fasciata laal., domestique en Égpte, el qu'on faisait voyager sur le Nil, de la basse Egypte dans la haute, pour obtenir une double récolte de iniel.

L'ABElele D'AD $A$ NSON, Apis Adansonii Lat., lrouvée au Sénégal.

l'Abeille de péron, Apis Peronii Lat., qui se trouve à Timòr, d'où clle a été rapportée par Péron.

(V. Audouin.)

* ABRER (Dédié au doct. Abel Clarke). вот. PI.-G. de la famille des Caprifoliacées, tribu des Lonicérées, élabli par R. Brown, qui en donne les caractères essentiels suivants : Cal. à tube linéaire, oblong, adhérent, un peu comprimé, urcéolé au sommet; limbe 5-parti, persistant, à segments foliacés. Cor. infundibuliforme, subrégulière; limbe à 5 divisions ovales, étalées. Ttam.4, subdidynames, incluses ou à peine saillantes, insérées au tube de la corolle. Oraire 3-loculaire; 2 des loges pluriovulées; la $3^{\mathrm{e}}$ uniovulée et seule séminifére; ovules axiles : ceux des 2 loges pluriovulées, 1-sériés; les infér. suspendus, le supér. ascendant; l'ovule de la loge séminiféresuspendu, anatrope. Style court; stigm. disciforme. Baie coriace, 3-loculaire, couronnée par le limbo calicinal; deux des loges aspermes par ayortement; la $3^{\text {me }}$ plus grande, monosperme. Graine suspendue, anatrope, subcylindrique. - Arbrisseaux à feuilles opposées, pétiolées, crénelées. Pédoncules, soî axillaires et trichotomes ou trifides; soit terminaux et indivisés. Fleur's accompagnées d'un invol. polyphylle. On connaît 3 espèces d'Abelia : une indigène en Chine, les 2 autres dans l'Himâlâyầ.

(Sp.)

ABPRCEA (corruption d' $\alpha \pi \varepsilon \lambda \iota x \varepsilon \varepsilon^{\prime} \alpha$, Théoph.; arbre indét.). вот. PI.-Wonorius Belli (Clus. Hist.Plant.) a donné ce nom à un arbre qu'il trouva dans le Péloponése, où il croît dans les endroils les plus escarpés des montagnes. Smith le rapporte à l' Ulmus nemoralis d'Ailon; Pallas à son Rhamnus carpinifolia, elc. Les botanistes modernes le réunissent au g. Planera de Gmelin, dans lequel ils en font un s.-g. sousle nom d'Abelicea. (C. L.) AD-RE-HOSGH. Abelmoschus, Medili. Bamia, R. Br. (En arabe, père du musc, à cause de l'odeur de ses graines). boT. PH.-G. de la famille des Malvacées, tribu des Mibiscees, Reich. Il ne différe essentiellement des $\mathrm{Hi}_{\text {- }}$ biscus ou Ketmia que par son calice coniquecylindracé, légèrement 5-denté, se fendant irrégulièrement d'un côté, vers l'époque de l'épanouissement de la corolle. Graines glabres.-Ce g., propre aux régions équatoriales, renferme environ 40 esp., la plupart imparfaitement connues. Les graines de l' $\boldsymbol{A}$. moschatus Moench, sont employées en parfumerie sous le nom d'Ambrelle. (SP.)

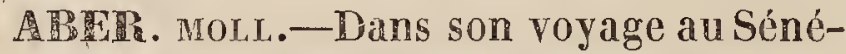
gal, Adanson donne ce nom à une petite esp. de moule, le Irytilus puniceus (Gmelin, Dilwyn), qui, peut-être, est la même que le Mytilus senegalensis de Lamarck. (Desu.)

ABERAS, Gesner. вот. PH.-Syn. d'ANANAS.

(C. D'O.)

ABPTEROA, Aubl. (nom Galibi).вот.PH. - Syn. du g. Gualleria.

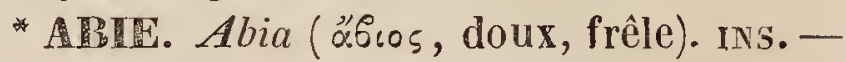
G. d'Insectes Hyménoptères, famille des Tenthrédines, établi par Leach (zool. miscell.) aux dépens du g. Cimbex, sur des espèces qui ont la massue des antennes formée de 5 articles. $V$. Cimbex.

ABHES. вот. РH. - $V$. S $\Lambda$ PIN. $\left(\mathrm{AD}_{\mathbf{Q}} \mathrm{B.}\right)$

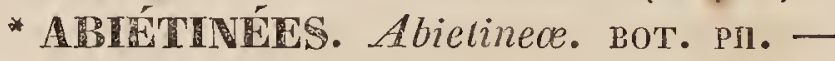
Nom d'une des tribus élablies par L. C. Richard dans la famille des Conifères. (AD. B.)

ABILDGART (Abildgaard, naturaliste danois). Poiss. - Nom donné par Bloch à un poisson d'Amérique, qu'il a représenté pl. 259, et que Lacépéde a reproduit sous le même nom (Sparns Abildgaardii). C'est un poisson d'une loul autre famille el du g. Scare. Il revient en double emploi dans Lacépède, comme espèce nominale, sous le nom de Spare ronge or (III, xxx111, 3). C'est auss: le Scarus coccineus de Bloch Schn., établi d'après Parra (xхуıI, fig. 2). (VAL.)

APRDGAMDIE. Abildgaardia (dédié a Abildgaard, savant danois). вот. PII.-G. de la famille des Cypéracées, établi par Vahl et adoplé par tous les bolanisles. Il est très voisin du g. Fimbristylis, dont il diffère par les caract. suivants : Epis multiflores, composés d'écailles distiques, mais devenant presque trisériés, par suite de la torsion $\mathrm{du}$ rachis ou axe de l'épi; écailles carénèes, caduques; mais leur base, persistant de chaque côté, arait fait dire á Vahl que l'axe offrait des fossettes membraneuses sur les 
bords; les plus inféricures sont seutes vides et stériles. Les fleurs manquent de soies ou d'écailles hypogynes. Élam. au nombre de 1 i 3. Style trifide, renflé a sa base, et comme triangulairc, caduc et arliculé avec l'ovaire. Fruit piriforme ou triangulaire. - Les espèces de ce g., au nombre de 12 environ, ont leur chaume rarement aphylle et plus souvent pourvu de feuilles à sa basc. Les épis sont solitaires ou géminés, ternés, ou entin réunis soit en capitule, soit en une ombelle simple ou décomposée. Toutes ces especes sont exotiques et habilent pour la plupart les régions tropicales.

ABIMLE. GÉol. $V$. ABYMe.

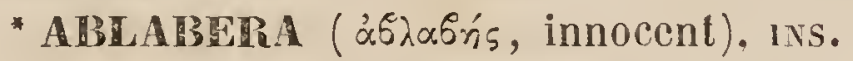
— G. de Colćoptéres pentaméres, famille des Lamellicorues, établi par M. Dejean dans la dernière ćdition de son Catalogue, mais dont il n'a pas publić les caractères. Il ne renferme que des espèces du Cap de BonneEspérance, à l'exception d'une seule ( $\mathcal{A}$. myrmidon) qui est du Sénćgal.

AREANA, Aubl.; Trichocarpus, Schrcb. (Ablani, nom Galibi de cette plante dans les Guyanes). вот. Ріг. - G. incomplètement connu, rapporté avec doute, par la plupart des auteurs, à la famille des Tiliacées, mais qui peut-être est plus voisin des Bixacées. Suivant la description d'Aublet, ses caractères sont les suivants : Cal. 4- ou 5-parti, persistant. Corolle nulle. Etam. nombreuses, hypogynes; filcts libres, capillaires; anth. petiles, suborbiculaires. Ovaire ovale; styles 2 , bifides. Capsule 1-loculairc, 4-valve, polysperme, hérissée de sétules caduques; placenta central, libre. Graines recouvertes d'une membrane (arille?) muqueuse. - Ce g. n'est fondé que sur une scule espéce, indigène à la Guyane. C'est un arbre atteignant environ 50 pieds de hautcur, remarquable par son bois de couleur rouge, tandis que l'aubier en est blanc. Les feuilles sont grandes, alternes, indivisées; les fleurs disposées en panicules axillaires. (Se.)

ABLAOUT: Moll. - Nom vulgairc de la soie que fournit le byssus des Pinnes marines.

(DESH.)

ABRE (albus, blanc). Porss.-Ce nom a été employé par Bonnaterre comme épithète du Salmo albula I. dont Lacépède a fait son Corrégone able. La même espèce est reproduitc par Bloch, sous le nom de Salmo Murcenu- la, qui est le Corrégone Murémule le Iackpéde. Ce nom est encore employé, dans Bonnaterre et dans lacépède, comme épithèle du Cyprin Able, plus connu sous le nom d'Abletle. Enfin, Cuvier s'est servi de ce mot Able, corruption d'Albus, pour un g.de Poissons de la famille des Cyprins, conmus des pêcheurs de nos rivières sous la dénomination de Poissons blanes, et que Klein avait déjà mal indiqués sous le nom de Lcuciscus. Ceg. comprenait, dans le Rènne animal, tous les Cyprins i dorsale et à anale courtes, manquant d'épines et de barbillons, et ì lèvres simples. Cuvier établissail plusieurs subdivisions dans lesquclles étaient rangées un grand nombre d'esp. europécnnes ou étrangères connues.

Depuis, M. Agassiz a donné des noms à quelques unes des subdiv. de Cuvier, et en a lui-même établi de nouvelles; d'oú il suit que le g. Able se divise aujourd'hui en: Chondrostoma (Cyprinus $N a z u s$ Bl.), en $\mathscr{A} s$ pius (Cyprinus aspius L.), en Phoxinus (Cyp. phoxinus L.), en Peloeus (Cyp. cultratus L.) ( $V$. ces mots); ct que les Ables (Lenciscus) no comprennent plus maintenant que les $C y$ prinus dobula L., aryenteus Agass. (C. Leuciscus Auctor.), orfus L., Jeses $\mathbb{L}_{\text {. }}$, erythrophthalmus L., et un grand nombre d'autres espèces curopécnnes ou étrangères. La chair de tous ces poiæsons est en général peu estiméc.

M. Agassiz cite une quinzaine d'esp.; mais j'en ferai connaître un bien plus grand nombre dans l'Histoire naturelle des Poissons. II décrit plusicurs espèces d'Ables fossiles : Les Leuciscus aningensis, $\boldsymbol{L}$. papillus et $\boldsymbol{L}$. heterurus, viennent d'OEningen; le Leuciscus papyraccus des lignites tertiaires, les Leuciscus leptus du Habichtswald; enfin les Lcuciscus gracilis et $\mathbb{L}$. Harmannii viennent de Stcinheim.

(VAL.)

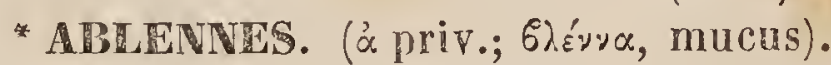
poIss. - On trouve ce nom dans Lacépède comme l'un des synonymes de l'Orphic (Esox belone L.). . (VAL.)

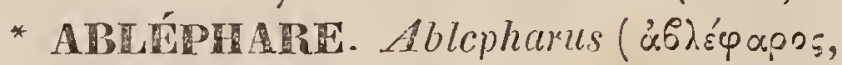
sans paupières). REPT. - C'est le nom d'un g. appartenant á la $1^{\text {re }}$ division de la famille des Scincoüdiens, celle des Ophioph thalmes. Il a pour caract.: 4 pattes terminées chacune par 5 doigts inégaux, simples, cylindriques. Le muscau conique; l'oreille distincte exté- 
rieurement, etla langue squameuse.-Ce g., établi par Fitzinger dans le recueil des travaux de la Société des naturalistes de Berlin (Verhand. der Gesel, natur. Freunde in Berlin, in-4, etc.), ne se compose que de 3 espèces: l’A. de Kilä̈bel, l'A. de Péron, et l'A. de Leschenault, dont il existe d'excellentes figures dans les études sur les Scincoïdes par Th. Cocteau (Paris, 1836). Les 2 premiers méritent particulièrement d'être cités comme les seuls reptiles connus dont l'espèce soit répandue en des contrées ou toutes les autres productions naturelles présentent, au contraire, les plus grandes difrérences; ainsi, l'Abléphare de Kitaïbel se trouve en Hongrie, en Morée, à la N.-Hollande; et l'A. de Péron, outre ces 2 derniers pays, habite encore l'ile de France, Java, et presque toute l'Océanie. - Ce sont de fort petits sauriens tout-à-fait innocents, qui vivent à la manière de nos lézards communs. $V$. Ophiolitimalmes.

* ABLPRTARIS. REPT. - Cucteau a employé ce nom au lieu d'Ablepharus pour désigner le g. précédent, dont une des principales particularités se trouve peut-être par là moins bien exprimée, attendu que $\beta \lambda \varepsilon-$ yxpis, en grec, signifie seulement les cils, tandis que $\beta \lambda \varepsilon \varphi$ ' xpov veut dire la paupière, et $\alpha 5 \lambda \varepsilon \varphi \propto \propto \rho \circ$ celui qui en est privé. (G. B.)

ABELT ou ABLETTE (Dim. d'Able, albus). Porss. - Poisson connu par Linné sous le nom de Cyprinus Alburnus, et par Lacépède sous celui de Cyprin able. Cuvier le rangeait dans les Ábles, et M. Agassiz le place aujourd'hui parmi ses Aspius. Il est long de 5 à 8 pouces, très commun dans toutes les eaux douces de l'Europe; á corps comprimé, à ligne latérale très arquée et très infléchie vers le ventre; vert jaunâtre sur le haut du dos, brillant du plus bel éclat d'argent sur tout le corps ainsi que sur tout le péritoine. Cette matière, recueillie au moyen de l'Ammoniaque, produit l'essence d'Orient, employée pour la fabrication des perles fausses. On prend l'Ablette à la ligne, ou souvent avec des filets en nappe ou dans des nasses. Elle se réunit quelquefois en grandes troupes.

11 parait que sous ce nom d'Ablette on désigne aussi quelquefois l'Épinoche, Gasterosteus aculeaus de Bloch.

(VAL.)
ABLETTE DE MER. poiss.-Nom spécif. dans Bonnaterre du Perca alburraus L., figuré par Catesby sous le nom d'Alburnus americanus; e'est le Centropome Alburne Lacép. Nous avons démontré, dans l'Hist. nat. des Poiss. que cette espèce est du g. Ombrine et de la famille des Sciénoïdes, et non de celle des Percoïdes.

(VAL.)

ABOE ou ABOE-BRTINA. PoISS. - Mols de la langue malaise, dont l'un, Aboe, veut dire gris ou plus spécialement cendré, et $B e-$ tina, femelle. Lacépède les a trouvés extraits par Bloch, qui les avait fort mal copiés dans Valentyn, en les tirant d'une petite phrase malaise citée par le Naturaliste Holiandais : Ikan Batoe jang Aboe betina, femelle d'un poisson de roche gris.

Ces noms des Malais d'Amboine ou de Java, et point du tout des Hindous, se rapportent à une figure de Valentyn qui représente 2 fois, dans son ouvrage, le Choetodon Meyeri de Bloch, et non l'holacanthe annulaire, auquel cet auteur el Lacépède son copiste l'ont mal à propos rapportée. Lacépède a commis d'ailleurs une autre erreur sur ce poisson; car, ne connaissant pas le système de Bloch, édité par Schneider, il a regardé ce Choetodon Meyeri comme une espèce non décrite, et l'a placée dans le g. Holacanthe, dont il n'a aucun des caractères, sous le nom d'H. jaune et noir, dénomination impropre, puisque Valentyn nous apprend que le fond de la couleur est gris. C'est aussi le Douwing-Marquis de Renard.

(VAL.)

ABOHEWENT. Lalralio. MAn. - L'aboiement est moins le cri naturel qu'une sorte de langage particulier au chien, et plus ou moins parfait suivant l'intelligence des races. La preuve de cette assertion, c'est que les chiens qui naissent chez les nations sauvages n'aboient point, et que, promptement dégénérés, les chiens d'Europe, perdus dans les îles de l'Océan Pacifique, cessent d'abover, ne proférant plus qu'un long hurlement plaintif, qui rappelle celui des nòtres, lorsqu'on les bat ou qu'on les renferme.

(C. D'O.)

МBOL , Adans. вот. PII. - Synon. de CINNA.

ABOLBODA (Nom indien?). вот. PH. G. de la famille des Xyridacées, créé par Humboldt et Bonpland (Pl. requiu. $11, t .114$. 
qui le placaient parmi les Restiacées, avec lesquelles il oflre beaucoup d'affinités; mais Agardh (Aphor.) et Desvaux (Ann. Sic. nat. 1823) l'en ont séparé, parce qu'entre autres caract. différentiels, son ovaire triloculaire pluriovulé, le développement plus parfait de ses enveloppes florales, et la structure de ses graines, l'en éloignent suffisamment. En voici les caract. constitutifs : Glume du périgone externe adverse, roulée sur elle-même et caduque; les latérales plus petites, naviculaires, persistantes. Périgone interne corollacé, hypocratériforme, pourvu d'un tube filiforme asse $z$ allongé, à limbe trilobé, étalé, dont les lobes sont nus ou crêtés-barbus. Étam. 3, oppositives, insérées au tube du périgone interne. Ovaire triloculaire, surmonté d'un style trifide, que terminent des stigm. simples, 2 ou 3-lobés, contenant plusieurs ovules dressés, sessiles, nichés dans l'angle infér. de chaque logette. Caps. triquêtre, triloculaire, á columelle séminifère, devenant libre par déhiscence loculicide; graines anguleuses et en petit nombre. - Les Abolboda sont des plantes herbacées, vivaces, à feuilles radicales graminéennes, distiques, à hampe nue ou bi-bractéolée au milieu, et terminée par un capilule solitaire dont les fleurs sont bleues. On en connaît 2 ou 3 espèces qui se plaisent dans les marais montagneux de l'A mérique tropicale. Link rapporte à ce g. le Chlocrum de Willdenow.

(C. L.)

*ABOPFGENE. Aborigenes (ab, de; origo, origine).-On nomme ainsi les hommes, les animaux, et même les plantes qu'on suppose originaires de la contrée qu'ils habitent.

(C. D'O.)

* ABORTir. Abortivus.-Un corps organisé, un organe quelconque sont abortifs, lorsqu'ils n'ont point reçu leur entier développement, et qu'il leur manque certaines conditions indispensables à leur perfection.

(C. D'O.)

ABOU-BURS ou Abu-burs (en arabe, père de la lèpre). REPT. - C'est le nom que les habitants du Kaire donnent au Ptyodactyle d'Hasselquist, parce qu'on prétend que l'usage de quelques aliments sur lesquels il aurait passé, suffit pour produire la lèpre.

ABOU-HANNES. Ors.-Nom égyptien de l'Ibis sacré. (C. D'O.)
ABorduR ou Aboyense (Abbaubo, j'aboie; b. La!.). ors.-Echassiers. Nom d'une espéce du g. Chevalier (Totanus, Cuv.) dont le cri a quelque rapport avec l'aboiement du chien. C'est le Totanus glotiis de Beclistein, la Barge aboyeuse de Buffon, le Chevalier aux pieds verts de plusieurs auteurs modernes. Cette esp. est très commune en Europe, sur les bords des rivières, surtout lorqu'elles sont débordées. On la trouve aussi dans l'Inde. (F.P.)

* ABPa. moll. - G. proposé par Risso (IIis!.nat. des principales productions de l'Europe méridionale), pour 2 espéces de très pelites corquilles bivalves de la Méditerranée. D'après les caractères qui leur sont assignés et dont nous n'avons pu vérifier l'exactilude sur nature, ces coquilles rentreraient assez bien dans le g. Erycina de Lamarck.

(DESH.)

* ABRAMIS (áboquís, nom chez les anciens d'un poisson indéterminable). Porss.Genre de la famille des Cyprins, proposé par Cuvier. C'est aussi le nom grec d'un poisson du Nil, cité par Athénce et par Oppien, et que la plupart des modernes, trompés par la ressemblance de nom, ont cru correspondre à notre Brême, qui est un poisson d'eau douce, vivant solitaire, tandis que l'ubpauss vivait en troupe dans la mer et entrait dans les rivières. Quelques passages, et entre autres celui d'un auteur arabe de la Renaissance, pourraient faire croire que les Grecs désignaient sous ce nom certaines espèces de Muges.

(VAL.)

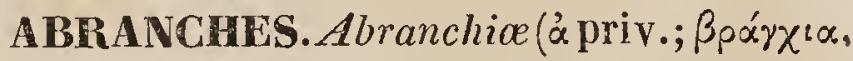
branchies). ANvÉL. - L'absence des branchies a paru à Cuvier un motif suffisant pour réunir sous ce nom, en un seul ordre, d'une part, les Lombrics et les $\mathbb{N a}$ äs, constituant sa famille des Abranches sétigères, et de l'autre les Sangsues et les Gordius composant la famille des Abranches sans soies. Considérée sous le rapport de sa séparation d'avec les autres Annélides, cette division serait excellente; mais il n'en est pas de même du rapprochement des divers genres qui la constituent. M. Milne Edwards, dans ses fíléments de zoologie, a formé avec ces deux familles deux ordres distincts, sous le nom d'Annélides terricoles et d'Annélides suceurs, en excluant toutefois deces derniers les Gordius, qu'il renvoie parmi les Hel- 
minthes. $V$. Anvétides (leur classification), lombrics, NAïs, Hirudinées, gordius, et l'article VERS.

$$
\text { (L. D.Y.R.) }
$$

* ABRAXas (Nom d'une divinité de la secte des Basilidiens). INs.-G. de l'ordre des L pirloptères, famille des Nocturnes, tribu des Phalénites, établi par Leach, et correspondant en particau g. Zérènede Treitschke, et que nous avons adopté, avec modifications, dans notre Hist. nat. des Lépidoptères de France.

* ABRAZITE. min.-Syn. du Gismondine. (C. D'O.)

*ABRÉE. Abrceus (爻ôpós, élégant, etc. Il faudrait écrire Abroeus par H, ici, et dans

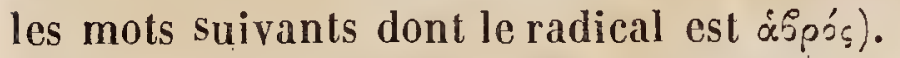
Ins.-G. de Coléoptères pentamères, famille des Clavicornes, tribu des Hystérides, établi par Leach aux dépens du g. Hyster (Escarbot) des auteurs, et adopté par M. Dejean (dernière édition de son Catal.). Il a pour type l'Hyster globosus Payk., qui se trouve aux environs de Paris. Les caract. de ce g. sont: Mandib. retirées. Antennes à massue ovale un peu comprimée; fossetles placées au milieu du thorax pour recevoir les antennes. Prosternum court, large, tronqué antérieurement. Pieds assez longs; tibias postérieurs cylindriques; les antér. comprimés. Extrémité de l'abdomen courbée. Corps menu, arrondi.

ABRICOTIER. BoT. PI.-Nom vulgaire du Prumus armeniaca L.

* ABROBAPTE. Abrobapta (¿́śpós, magnifique ; $\zeta_{\alpha \pi \tau o ́}$, teint, coloré).-INs. G. de Coléoptères pentamères, famille des Sternoxes, tribu des Buprestides, établi par M. Dejean dans la dern. édit. de son Catal., mais dont il n'a pas publié les caractères. Ce g. a pour type le Buprestis chrysoptera Lat., espèce de la Nouvelle-Hollande. (D.)

* ABRoComa (ábós, mou; xóun, fourrure). Man. - IVaterhouse (Proceed. Zool. Soc. Lond. 1837) a formé sous ce nom un g. de Mammi fères qui lui paraît très voisin, d'un còté del'Octodon, du Ctenomys et du Prephagomys, et de l'autre des Chinchillidés; mais son organisation dentaire l'éloigne suflisamment des uns et des autres.

Il diffère du Ctenomys el du Paphagomys par la grandeur de ses oreilles, la délicatesse de ses ongles er la petitesse de ses incisives; de l' Uctodon par la longuevr uniforme des poils de sa queue. 'Toutefois il se rapproche de ce demier genre par la conformation de ses patles qui sont nues, et dont le dessous est couvert de petits tubercules ronds et cliarnus; mais le genre Octodon présente sous l'orteil des incisions transverses qui manquent dans l'Abrocoma. Chez celui-ci le dessous des orteils, ainsi que le reste du dessous de la patte, est couvert de tubercules.

L'extrême finesse de la fourrure des deux esp. (A. Bennetii, et $A$. Cuvieri, du Chili) qui composent ce nouveau $g$ a suggéré à l'auteur le nom spécif. qu'il lui a donné. Cette fourrure est composée de deux sortes de poils, dont les plus longs sont tellement déliés que l'on peut presque les assimiler aux fils d'une toile d'araignée. $\quad$ (C. D'O.)

ABTPOMA ( $\alpha$ priv.; $\beta p \tilde{\omega} \mu \alpha$, nourriture; plante non alimentaire, par antithèse à Theobromaj. вoT. PII. - G. de la famille des Byttnériącées, tribu des Byttnériées, établi par Limé fils, et dont les caract. essentiels sont les suivants : Cal. 5-parti. Pétales 5 , à onglets sacciformes. Androphore urcéolaire, fendu au sommet en 10 lanières alternativement stériles (pétaloides) et 3 -anthérifères. Styles 5. Caps. pentaptère, tronquée au sommet, mucronée, 5-loculaire, polysperme; placenta barbu. Graines ovalesglobuleuses, arillées, périspermées; cotylédons foliacés, transversalement plissés. Arbrisseaux à feuilles grandes, lobées. Pédonc. oppositifoliés et terminaux, uniflores ou pluriflores. Ce g. renferme 3 esp. indigènes dans les régions intertropicales de l'ancien continent. L'écorce de ces végétaux est filandreuse, et sert dans l'Inde à faire tes cordages.

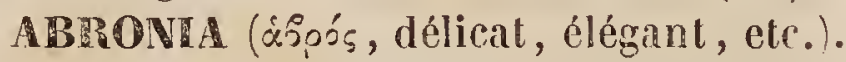
вот. Рн.-G. de la famille des Nyclaginées, fondé par Jussieu (Gen.el Am. Mus. 1. 11) et adopté par les auteurs postérieurs, qui le préférèrent au g. Tricralus, que L'Hérilier a établi sur le mème type. Voici ses caract. essentiels : Invol. persistant, pentaphylle, multiflore. Cor. longuement tubulée, renflée à sa base, à limbe hypocratériforme, étalé, 5-lobé, à div. obovales, décidues. Étam.5, hypogynes, incluses, connées à la base en une gaine courle soudée avec le tube de la corolle. Anthères oblongues. Ovaire uniloculaire, surmonté d'un style simple, que lop- 
mine un stigmate en massue, et contenant un ovule unique, dressé, à micropyle infére. I. fruil est un akene libre dans la base pentaptère de la corolle. Graine unique, dressée, a test couné avec l'endocarpe. Embryon à cotyl. condupliqués, enveloppant un albumen amylacé, à radicule infére et saillante. - Les Abronia sont des plantes herbacécs, vivaces, indigènes dans la Californie; leurs fruilles sont opposées, pétiolées, très entières; leurs fleurs remarquables, longuement pédonculées, et disposées en bouquets terminaux. On n'en counait bien qu'une seule espèce que la beanté de ses fleurs fait rechercher dans les jardins : c'est l' $A$. umbellata Juss.

(C. L.)

* ABIBOSTOLE. Abrostola (\&́5oós, élé-

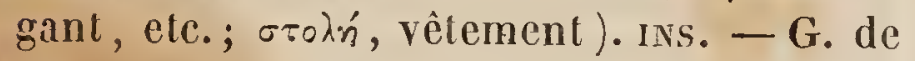
l'ordre des Lépidoptères, famille des Nocturnes, tribu des Plusides, établi par Ochsenheimer aux dépens des Plusies, dont il se rapproche beaucoup à l'état parfait, mais dont il s'éloigne par ses chenilles qui ont 16 pattes, tandis que celles des Plusies n'en ont que 12. Il a pour type la Noctua triplasia L. et Fabr., qui se trouve aux environs de Paris, et dont la chenille vit sur la grande ortie. M. Treitschke rapporte à ce g. le Bombyx celsia L., lépidoptère très remarquable du nord de l'Europe, que pen de collections possédent. M. Guénée, qui a adopté ce genre dans sa nouvelle classification des Nocturnes d'Europe (Annal. de la Soc. entom. de France), lui assigne les caract. suivants : Chenilles rases, très atténuées inférieurement, à incisions profondes, ayant le $11^{\mathrm{e}}$ anneau trés élevé , munies de 5 paires de pattes membraneuses, mais ne s'appuyant au repos que sur les 2 ou 3 dernières paires, tenant la partie antérieure du corps très arquée et globuleuse; la tête petite. Elles vivent à découvert sur les plantes basses. Chrysalides luisantes, déprimées par places, incolores, ayant la partie postérieure trés conique, et l'antérieure terminée par une gaîne ventrale, un peu renflée. Elles sont renfermées dans des eoques molles, composées de soie et de corps étrangers, et placées entre les mousses ou les écorces. Insectes parfaits: Ant. filiformes dans les deux sexes. Palpes dépassant la têle, très ascendants, mais point ou médiocrement recourbés; leur dernier article très long. Thorax peu robuste, subcarré, à collier arrondi, un peu relevé, et ofrant, entre les ptérigodes, 2 crêtes de poils trés saillantes. Abdomen déprimé, crêté, velu latéralement dans les mâles. $\Lambda \mathrm{i}$ les supérieures, aigües au sommet, un peu luisantes, mais sans taches métalliques; au repos, elles couvrent les inférieures et sont disposées en toit très déclive.

* ABROTANELA (dim. d'abrotanum; ¿́pórovor, aurone; espéce de plante). вот. PI. - Cassini a établi ce g. sur une petite plante de la famille des Composées, originaire des îles Malouines. Elle présente, par ses petites toufles, l'aspect des Bryum qui couvrent nos toits humides; elle a pour earactères : Capit. à 5 fleurs ; les 3 plus externes femelles, les 2 internes mâles par avortement; les unes et les autres tubuleuses. L'invol. à 5 folioles quinconciales. Réceptacle nu. Cor. des fleurs femelles 3-dentée, celle des fleurs mâles 4 ou 5-fide. Étam. obtuses, dépourvues de prolongement basilaire. Styles, dans les fleurs femelles, dépassant la corolle et bifides au sommet; ceux des fleurs mâles, évasés en forme d'entonnoir. Akènes comprimés et nus. Une seule espèce. (J. D.)

ABROTANUM, Tourn. (ábórovov, aurone; espèce de plante). вот. ріл. - Syn. d'Artemisia.

(C. L.)

* ABROTHRIX (ábós, mou, etc.; spí́, poil). mam.-Waterhouse a proposé de former sous ce nom, dans le grand g. Mus, un s.-g. dont il cite comme type le $\boldsymbol{M}$. longipilis, et auquel il réunit 8 espéces. Voici les caractères différentiels qu'il lui assigne: Plis de l'émail pénétrant profondément dans les côtés des molaires; $1^{\text {res }}$ molaires de la mâchoire inférieure ayant 3 plis d'émail a leur côté interne, et 2 a l'externe; la $2^{\text {me }}$ molaire en ayant 2 au côté interne et 1 à l'externe, et la dernière un de chaque côté. Fourrure longue et douce. Queue courte, bien fournie de poils. Pouce ayant l'ongle arrondi. Oreilles touffues. (Proceed. Soc. Zuol.Lond., 1837.) （C. 1'O.)

ABHOYCAYN. ors.-Ancien nom sous lequel Gesner a désigné l'Hirondelle de rivage (Hirundo riparia L.). (C. n’O.)

* ABRUPTI-PENNÉ. Abrupti-pennatus. вот. Pfr.-Cette épithète s'emploie pour désigner les feuilles pennées terminées par une paire de folioles opposées, et non par une foliole unique. C'est dans le même sens 
qu'on dit feuille pari-pennée. Ex.: le Caroubier.

(A. R.)

ABRUS, L. (á5pós, élégant, etc.) вот. PII. - G. de la famille des Légumineuses, s.-ordre des Papilionacées, tribu des Phaséolées. Wight et Arnott (Prodr. Flor. Penins Ind.) assignent à ce $g$. les caract. suivants : Cal. campanulé, à 4 lobes peu marqués; le lobe supér. plus large ou 2-fide. Étendard ovale. Étam. 9, monadelphes (gaîne fendue, le $10^{\text {me }}$ filet manquant), adnées par la base à l'onglet de l'étendard. Style court; stigm. capitellé. Légume oblong, comprimé , 4-6sperme, septulé transversalement entre les graines. Graines subglobuleuses.-A rbustes volubiles ou diffus; feuilles abrupti-pennćes, multifoliolées; fleurs rouges, disposées en grappes axillaires.

Ce g. est propre à la zône équatoriale. On en connaît aujourd'hui 5 espéces. Leurs racines ont une saveur douceâtre et les mêmes propriétés que les racines de Réglisse; aussi l'espéce la plus commune ( $A$. precatorius L.) est-elle connue aux Antilles sous le nom de Liane à réglisse. Les graines des Abrus servent à faire des colliers, des chapelets, etc.; elles sont du volume d'un gros pois, luisantes, et en général d'un beau rouge de corail, avec une grande tache noire a l'une des extrémités. En Égypte et dans l'Inde, ces graines se mangent en guise d'autres légumes secs, quoiqu'elles soient bien inférieures sous ce rapport aux haricots.

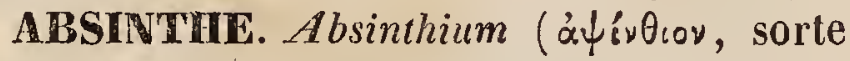
d'herbe amére, dans Dioscoride). вот. PH.G. de plantes établi par Tournefort, et que les Botanistes modernes ont réuni au grand g. Artemisia L.

ABSINTHION, Adans. вот. PH.-Synon. d'Absinthe.

(C. D’O.)

ABEOTPTION (absorptio; ab-sorbeo, j'avale). PIYsioL.-Action par laquelle certains corps se pévètrent et s'empreignent de fluides ou de solides très divisés. L'absorption est le phénomène le plus général dans tous les êtres vivants; en effet, sans la fonction d'aspirer ou de faire pénétrer dans son intérieur les matériaux du monde extérieur, sans la faculté de rejeter simultanément les substances á éliminer, comment concevoir l'accroissement et l'entretien des animaux et des végétaux? Une foule d'expériences indiquent comment s'effectue cet accroissement, et de quelle manière se comportent les fluides absorbés. Nous ne citerons qu'un exemple : si l'on mêle pendant quelque temps de la racine de garance aux aliments d'un animal, on voit bientôt ses os prendre une coloration rose, qui devient de plus en plus intense, pour diminuer ensuite successivement, dès qu'on cesse l'usage de cette racine. Il est bien évident que, dans cette expérience, les molécules nutritives ont été charriées dans toutes les paríies du corps; qu'elles s'y sont fixées pour en devenir parties intégrantes, jusqu'à ce que, expulsées et remplacées par de nouvelles, elles aient été rejetées au dehors. Cela prouve non seulement l'absorption des molécules nutritives par les organes digestifs, mais aussi la reprise ou l'expulsion des matériaux anciens, qui doivent cesser a leur tour de faire partie des organes. On a donné à cetle dernière sorte d'absorution le nom d'interstitiel'e, récomposante, organique, par opposition à la première, appelée absorption alimentaire. Il nous reste maintenant á indiquer les conditions physiques ou vitales sons l'influence desquelles la substance, mise en contact avec les organes, pénétre les tissus au point de parvenir jusqu'aux systèmes vasculaires. D'a près M. Magendie, tontes les fois qu'une substance liquide est en contact avec un point quelconque des tissus, elle s'introduit dans les porosités physiques qui s'y trouvent. En un mot, l'absorption est, suivant le physiologiste cité, un simple phénomène d'imbibition, d'où il résulte que tous les vaisseaux peuvent s'imbiber, les lymphatiques comme les veines; ce qui explique comment les observateurs ont vu les matières absorbées dans l'un et l'autre ordre de vaisseaux; et que tous les tissus entin sont doués de la propriété d'absorber. Ces faits ont amené les physiologistes, qui, jusqu'à ce jour, avaient considéré tous les actes d'absorption comme le résultat d'une propriété vitale particulière, à modifier celte opinion exclusive dans sa généralité.

(M. S. A.)

ABU-BURS. REPT. $V$. ABOU-BURS.

ABUMON (étym. incert.). в0T. PI.-Adanson donnait ce nom au Crinum africanum $\mathbf{L}$. Plus tard, Lhéritier fit de cette même

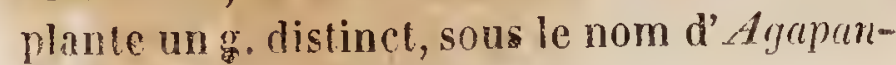


thus, adopté depuis par tous les Botanistes. (V. ce mot.)

(C. L.)

* ABUSSEAU. PoIss. - Nom vulgaire d'une espéce particulière d'Athérine (Atherina presbyter Nob.), commune sur les côtes de La Rochelle et dans les ìles du golfe de Gascogne. Ce mot, qui vient probablement de celui d'Abbé, rappellerait la dénomination de Prestre, sous laquelle on désigne les Athérines et autres petits Poissons à raies argentées sur les flancs, que les pêcheurs ont comparées à l'étole d'un prêtre. L'Abusseau de La Rochelle est estimé sur cette còte et sur celles de Bretagne. A Lorient on la compare à l'Éperlan pour le goût. Elle paraît en mars, époque de son frai, et s'éloigne de la côte en octobre ou en novembre. On la prend sur tous les fonds, par 4 brasses de profondeur et à une lieue de la côte. Elle se nourrit de vers, de petits crustacés, etc. C'est le Roseret ou le Roseré des côtes de Normandie. Il parait que. les Anglais de Southampton, la comparent aussi à l'Éperlan, car ils la désignent sous le nom de Smell. comme ce poisson.

( $\mathrm{VAL}$.)

ABUTA, Aubl. (Abutua, nom de cette plante chez les Indiens de la Guyane). вот. Pr. - G. de la famille des Ménispermacées, lequel, suivant M. Aug. de St.-Hilaire, doit être réuni au Cocculus dont il ne diffère que par l'absence de pétales.

ABUTILON, Tourn., Gærtn. вот. PI.G. de la famille des Malvacées, tribu des Sidées. Il diffère des Sida par son ovaire à loges pluriovulées, ainsi que par son péricarpe, dont les coques s'ouvrent par la suture dorsale, sans se désunir latéralement. La plupart des Abutilon croissent dans la Zône équatoriale; on en connaî́ environ 60 espéces. Plusieurs se cultivent comme plantes d'ornement. Leur écorce est en général filandreuse et peut servir à des usages. économiques.

* ABYLE. Abyla. (Nom d'une des colonnes d'Hercule, près desquelles on a trouvé ces animaux.) ACaL. - G. de Diphydes, établi par MM. Quoy et Gaymard, pour un animal marin observé par eux dans le détroit de Gibraltar. Les Abyles se distinguent des Calpés parce que, des deux corps distincts dont ils se composent, celui qui emboîte l'autre est en forme de cloche et un peu plus petit que l'emboité. Le filament ou la production cirrhigère et ovigère est très long. Eschscholtz réunit les $2 \mathrm{~g}$. en un seul sous le nom d'Abyla, qu'il place dans la famille des Dyphides, la $3^{\text {e }}$ de l'ordre des Siphonophores. Il lui donne les caract. suivants : Conduit nourricier ou suçoir, entouré de plusieurs tubes en manière de branchies; partie du corps servant a la nutrition, munie d'une petite cavité natatoire intérieure et s'ouvrant au dehors. - II n'y comprend que les espèces décrites par MM. Quoy et Gaymard (Ann. sc. nat., t. x. 1827). $V$. eschsciroltz, Syst. der Akalephen. 1829. p. 130 .

(1)UJ.)

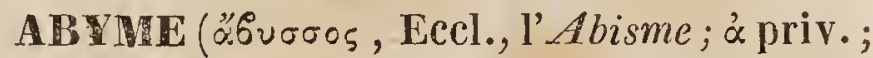

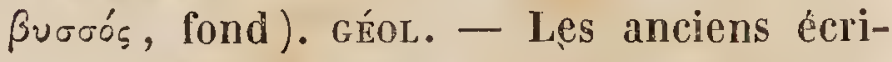
vains, et notamment les historiens sacrés, ont appelé abyme la masse des eaux formée en même temps que la terre, ou bien le réservoir immense qu'ils supposaient exister sous celle-ci ou dans son intérieur, celui qui, suivant la Genèse, s'ouvrit pour produire en partie le Déluge mosaïque.

Un abyme est aujourd'hui, pour les naturalistes et pour les géologues, úne cavité généralement verticale, une sorte de puits naturel, dont l'ouverture est à la surface du sol, et dont le fond n'est pas connu. L'abyme est à sec ou, soit en tout, soit en partie, rempli d'eau. C'est quelquefois un lac tranquille, d'autres fois un gouffre où vont se perdre les eaux qui ont coulé à la suŕface du sol; c'est aussi une bonche de laquelle sortent continuellement ou d'une manière intermittente des torrents d'eau froide ou d'eau bouillante, pure ou chargée de substances minérales.

Il est difficile de fixer une limite entre ce qu'il faut appeler abyme et les autres anfractuosités du sol, depuis les immenses et profondes dépressions qui servent de bassin aux mers et aux lacs, jusqu'aux cavernes, aux puits naturels, aux fondrières. $-V$. ces mots, et anfractuosilés du sol, où seront indiquées les causes auxquelles on peut attribuer les diverses cavités qu'il présente.

$$
\text { (C. P.) }
$$

* ABVSSIOUES ou Terrains isémiens abyssiques (äbvoбos, sans fond). GÉOL. - Dénomination employée par M. Alex. Brongniart, pour désigner les dépôts qui auraient été formés, par la voie aqueuse, dans le sein de la fre mer ou l'abyme. Ce sont les for- 
mations aqueuses des terrains inférieurs ou primaires. Le même auteur appelle Terrains isémiens pélagiques, les terrains secondaires, et Terrains isémiens thalassiques, les terrains tertiaires.

ACACA , Neck. (Acacia, Pline ; arbre épi-

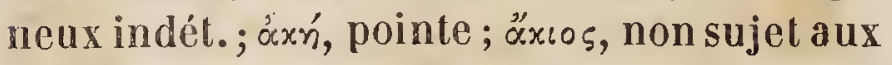
vers). вот. Рн.-G. de la famille des Légumineuses, s.-ordre des Mimosées.Linné et beaucoup d'auteurs plus modernes le confondent avec les Mimosa. M. Kunth. ( Nov. Gen. et Spec.) Iui assigne les caract. suivants : Cal. turbiné ou urcéolé, ou campanulé, 5-denté (moins souvent 2 ou 4-denté). Cor. infundibuliforme, on turbinée ou subcampanulée, réguliẻre, plus longue que le calice, à limbe 5 -fide ou moins souvent 4-fide. Etam. en nombre indéfini (de 8 à 200), insérées soit au stipe de l'ovaire, soit au réceptacle, so $t$ au fond de la corolle; filets libres, ou moins souvent monadelphes par la base, capillaires, saillants. Ovaire (abortif dans les fleurs unisexuelles) unistyle, en général stipité. Stigmate simple. Légume inarticulé, continu, sec, uniloculaire, 2-valve. Graines en nombre indéfini. - Arbres ou arbrisseaux inermes ou armés d'aiguillons; feuilles simples ou composées ou décomposées, stipulées; péliole el rachis souvent glanduleux; stipules souvent spinescentes. Inflorescence axillaire ou terminale très variée; fleurs sessiles ou rarement pédicellées, bractéolées, jaunes, blanches, rouges ou verdâtres.

La plupart des Acacia croissent, soit dans la zône équatoriale, soit dans les contrées extra-tropicales de la N.-Hollande. On en a énuméré près de 300 espéces, dont la plupart, toutefois, ne sont que très superficiellement connues et pourront fournir des $\mathrm{g}$. nouveaux. Une foule d'espéces se cultivent comme plantes d'ornement de serre ou d'orangerie. Beaucoup sont remarquables par la dureté de leur bois, ou par les produits immédials qu'ils fournissent à la thérapeutique. La gomme arabique provient, suivant MM. Guillemin et Perrottet, de plusieurs esp. d'Acacia.

(Sp.)

* ACATA ( «ँxáva, pointe). Ins. - Nom donné par MM.Treitschke à ung. de Lépidoptères Nocturnes, tribu des Phalénites, que Leach avait nommé précédemment Ourapevix. $V$. ce mot.

(D.)

ACAN L. (áxaiva, nointe). Бот. PH, -
G. de la famille des Rosacées, tribu des Sanguisorbées, DC. Ses caract. essentiels sont les suivants: Calice tubuleux, inadhérent, indivisé, hérissé d'une multitude de spịnelles oncinées. Pétales 4 ou 5 , soudés en corolle rotacée, insérée à la gorge du calice. Étam. au nombre de 2 à 10 . Ovaires solitaires ou géminés, distincts; stigmates pénicilliformes. Akènes 1 ou 2, monospermes, inadhérents, inclus. - Herbes vivaces, ou sous-arbrisseaux. Feuilles imparipennées, à folioles dentelées. Fleurs petites, hermaphrodites, disposées en épis, en capitules ou en grappes. - Ce g., propre à l'Amérique, renferme environ 10 espéces. Ies caractères exposés ci-dessus ne s'appliquent point aux Ancistres, que plusieurs auteurs y ont réunis.

(Sp.)

ACANITES ( $\not ै x \alpha \iota v a$, pointe). INS. Synon. d'AcENITUS.

* ACENITUS ( $\ddot{\alpha} \times a$ alv $\alpha$, pointe). INs.--G. de la famille des Ichneumoniens, de l'ordre des Hyménoptères, établi par Latreille, qui le distingue des g. voisins par la tête ne présentant point en avant de saillie en forme de bec, et par les antennes droites et filiformes. - Le type de ce genre est l' $A$. $d u$ bitor (Cryplus dubitator Fab.), répandu dans la plus grande partie de l'Europe.

(BL.)

ACAJOU ou Pommier d'acajou. вот. Рн. - Noms vulgaires de l'Anacardier. (Sp.)

* ACAJUBA, Gartn. вот. PI. - Syn. du g. Anacardier.

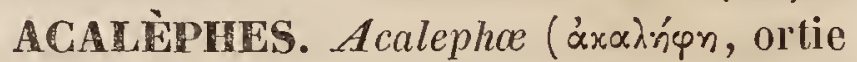
de mer). zool. - Classe d'animaux sans vertèbres, comprenant plusieurs ordres, qui n'ont guère d'autre lien commun que des caractéres négatifs par rapport aux autres animaux rayonnés, aux Polypes et aux Mollusques; de sorte qu'on pourrait notamment considérer comme des classes distinctes les ordres des Médusides, des Béroüdes et des Physograties ou Acalèphes hydrostatiques.

Le nom d'Acalèphes'fut donné par Aristole aux Actinies, puis appliqué par extension aux animaux que nous considérons ici. Cuvier dans la $1^{\text {re }}$ édit. de son Règne animal, faisait des Actinies un $1^{\mathrm{er}}$ ordre de cette classe, sous le nom d' $A$. fixes; mais plus tard, dans sa 2 édit., à l'exemple d'Eisenhard t et de Chamisso, il reporta les Actinies dans la classe des Polynes, el ne divisa plus les Acaléphes 
qu'en 2 ordres, savoir : les $A$. simples, comprenant les Médluses, les Béroés, les Porpitos, les Vélelles; et les $\mathcal{A}$. hydrostatiques, comprenant les Physales et les Diphyes.

Lamarck, dès 1816 (Hist. des Anim. saus vert:), avail établi, sous le nom de Radiaives mollasses, une division corresundant assez exactement à la classe dos Acalèphes. Une $1^{\text {re }}$ sect. ( $R$. anormales) comprenait les Béroés, les Physales, les Vélelles, et en outre la Lucernaire, qui peut-être devrait rester dans le voisinage des Méduses, quoiqu'elle soit toujours fixée aux corps marins. Une ¿̨e section était formée des $R$. médusaires. M. de Blainville, dans le Dict. des sc. Nal., et plus tard, en 1834, dans son Man. d'Aciin., sépara formellement du type des Zoophytes, pour les rapprocher des Mollusques, les Béroïdes, dont il fait l'ordre des Ciliogrades; les Physalides, qui forment son ordre des Physogrades, et enfin les Diphyes. Il ne laissa parmi les Zoophytes que les Méduses et les Vélelles, formant la classe des Arachnodermaires.

Cependant, en 1829, Eschscholtz avait publié á Berlin, sous le titre de System der Alalephen, un ouvrage méthodique d'autant plus précieux, que, dans son voyage de circumnavigation, ce naturaliste avait pu observer lui-même la plus grande partie de ces animaux. Son travail peut être considéré comme une base solide pour des recherches ultérieures. Tout en les rectifiant, surtout quant á la disposition el à la caractéristique des familles, les Naturalistes, qui ont écrit depuis sur ce sujet, ont adopté la mêrne marche et les mêmes idées générales.

Brandt, dans ses mémoires récents qui font partie du Recueil de l'Acad. de St. Pétersbourg, a notamment conservé pour les Médusides les familles établies par Eschscholtz, en les disposant dans un ordre qui se rapproche de celui adopté par Cuvier.

Eschscholtz définit ainsi les Acalèphes, dont il forme une classe intermédiaire à celles des Zoophytes el des Echinodermes : Animaux rayonnés, pourvus d'organes digestifs, distincts dans la masse du corps, et d'organes locomoteurs qui leur permettent de se mouvoir librement dans la mer.-D'ailleurs les animaux compris sous celte dénomination commune doivent former des groupes distingures par les caractéres les plus différents.
Ainsi le mème auteur les partage en 3 grandes divisions, qu'à tort sans doute il nomme des ordres.

Ce sont : $1^{\circ}$, les Clénophores, qui sont symétriques, pourvus d'une grande cavité digestive centrale, et qui ont pour organes locomoteurs des rangées de lamelles vibratiles ì la surface extérieure; ils comprennent les 3 familles des Callianirides, des Mnémiides et des Béroïdes, et seraient mieux désignés comme classe par cette dernière dénomination.

$2^{0}$, Les Discophores, qui sont circulaires, rayonnés, avec une grande cavité digestive centrale, et n'ont pour organes locomoteurs que le disque gélatineux en forme de champignon ou de cloche, qui constitue la masse principale de leur corps. Ils comprennent toutes les Méduses, et devraient former une classe sous la dénomination de Médusides.

$3^{0}$, Les Siphonophores, dont la forme est plus ou moins irrégulière et anormale, qui n'ont pour organes digestifs que des snçoirs séparés, sans cavité centrale commune, ct pour organes locomoteurs qu'une cavilé particulière contractile, ou des vessies remplies d'air. Ils comprennent 3 familles ayant si jeu de rapports entre elles, qu'on en devrait faire au moins des ordres, savoir : les Diphyides, dont le corps mou est contenu dans une sorte de caisse polyédrique, cartilagineuse, et possède une $2^{2}$ partie ressemblant à un $2^{e}$ corps engagé dans le $1^{\mathrm{er}}$; de sorte qu'on les a prises pour les assemblages de deux animaux; les Physophorides ou Physalides, dont le corps mou est pourvu à l'extrémité antérieure d'une vessie natatoire remplie d'air; les Vélellides, dont le corps contient une pièce cartilagineuse ou calcaire, creusée à l'intérieur de cellules remplies d'air.

(DU.)

* ACALICAL. Acaliralis (à priv.; xá̀u calice). вот. - L'insertion des étamines est acalicale, lorsque ces organes partent di réceptacle, sans contracter d'adhérence avec le calice.
(C. 1’O.)

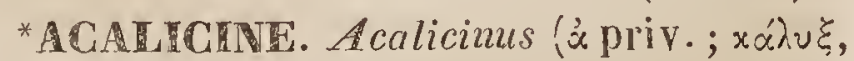
calice). вот. - Se dit d'une plante dépourvue de calice. (C. I'O.)

* ACALICULÉ. Acalirulatus (à priv.; xś̀ par ofposition à celui de caliculé, pour ex- 
primer un genre ou unc fleur en général dépourvue de calicule, comme certains g. de la famille des Malvacées, comparés à ceux dans lesquels le calicale environne la fleur.

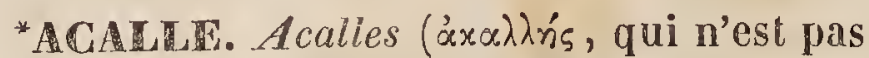
beau). ıns.-G. de Coléoptẻres tétram., fam. des Curculionides, établi par Schoenherr dans sa div. des Cryptorhynchides, et dont voici les caract. : Ant. médiocres, assez minces; leur funicule composé de 7 art.; les 2 premiers allongés, obconiques, les autres courts, presque ronds, peu séparés; massue subovale. Rostre assez long, robuste, presque cylindrique, s'aplatissant insensiblement vers la pointe, légèrement arqué. Yeux placés latéralement, ovales, un peu déprimés. Prothorax un peu court ou presque oblong, tronqué à la base, légèrement arrondi sur les côtés, un peu saillant au milieu antéricurement; lobé plus ou moins distinctement derrière les yeux. Écusson nul ou tellement petit qu'on peut à peine l'apercevoir. Élyt. presque ovales, conjointes, convexe en dessus. Pattes médiocres, presque d'égale longueur, robustes; cuisses un peu épaisses, et quelquefois denticulées. - M. Dejean a adopté ce g. dans la dernière édit. de son Catal.; mais la majeure partie des espéces qu'il y rapporte, au nombre de 17, sont difiérentes de celles qui composent ce même g. dans l'ouvrage de Schocnherr, et même il place parmi les Tylodes, 2 esp. ( $T$.obesus Dej., et $T$.apicalis Dej.), qui sont des Acalles pour l'auteur suédois. Au reste, celle qui a servi de type à ce dernier pour établir le g. dont il s'agit, est le Curculio camelus Fab., qui se trouve en Styrie. (D.)

*ACALLOPISTUS ( $\propto x a \lambda \lambda \omega^{\prime} \pi \iota \sigma \tau \varsigma$, sans parure). Ins.-G. de l'ordie des Coléoptères tétramères, famille des Curculionides, div. des Érirhinides, établi par Schoenherr. Ce g. a pour type l' $A$. vellicosus Gyll., esp. des Indes orientales. M. Dejean, qui l'adopte, en mentionne une autre du Sénégal, qu'il nomme $A$. senegalensis. Les caract. assignés à ce g. par Schoenherr sont: Ant. de longueur médiocre, peu fortes, insérées vers le milieu du rostre; leur funicule composé de 7 art.; les 2 premiers peu longs, subconiques, le suivant un peu épais, les autres transverses, presque perfoliés, serrés, s'épaississant graduellement jusqu'i la massuc, qui est subova- laire. Rostre assez long, robuste, linéaire, un peu courbe. Yeux écartés, presque ronds, point proéminents. Prothorax un peu plus court que sa largeur postér., bisinué à sa base, légèrement arrondi sur les côtés, beaucoup plus étroit antérieurement. Élyt. un peu plus larges que le thorax a sa base, oblongues, presque carrées, arrondies à leur extrémité, avec les angles huméraux obtus. Cuisses antér. offrant en dessous une dent dans leur milieu, et serratiformes après cette dent ; tibias antérieurs courbés en dedans.

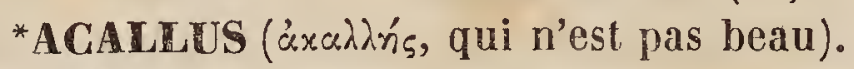
INs.-M. Dejean avait d'abord appelé ainsi un g. de Coléoptères de la famille des Lamellicornes; mais attendu la trop grande ressemblance de ce nom avec celui d'Acalles, donné antérieurement à un g. de la famille des Curculionides, il lui a susbtitué celui d'Atimus.

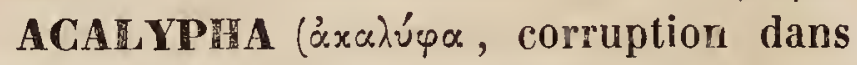
Théophraste d'áxin'sipn, ortie de mer, ou plante épineuse indét.).вот.PI.-C'est le nom grec de l'ortie, que Linné a transporté à un g. de la famille des Euphorbiacées, et type de la tribu des Acalyphées, dont quelques espéces présentent une ressemblance extérieure avec l'ortie commune sans que lcurs poils aient la même propriété. Ce même g. porte en français le nom de Ricinelle. Ses caract. sont : Fleurs monoïques ou dioïques; dans les mâles : un cal. 4-parti ; de 8 à 16 étam., dont les filets se soudent entre eux par leurs bases épaissies ct dont les anth. offrent, suspendues sur les deux côtés d'un connectif qui termine le filet, 2 loges distinctes, libres, allongées, flexueuses et en forme de vers; dans les femelles : un cal. 3-parti ; un ovaire à 3 loges 1-ovulées, surmonté de 3 styles qui se découpent en une foule de lanières fines, inégales, irrégulières, le plus souvent rouges; il devient une capsule à 3 coques. Les espèces, dont on connaît un grand nombre (plus de 60), pour la plupart originaires de l'Amérique et surtout des régions tropicales, sont arborescentes, frutescentes et plus souvent encore herbacées, et rappellent par leur aspect l'ortie, ainsi que nous l'avons dit, ou souvent encore les Amarantes. Leurs feuilles, accompagnées de stipules, sont alternes, le plus souvent dentées, glabres ou velues; leurs fleurs disposces en épis axil- 
laires ou terminaux, amentiformes; cpis dans lesquels les fleurs mâles extrêmement petites se groupent en petits pelotons sessiles à l'aisselle de courtes bractées, tandis que les femelles sont solitaires, environnées chacune d'une bractée plus longue qu'elles, persisIante, ordinairement dentée ou lobće. Lorsque le même épi porte des fleurs des deux sexes, ce sont les femelles qui sont inférieures.

(AD. J.)

* ACAL YPIUÉES. Acalyphece, вот. PI, $V$. achiypira et euphorbacées. (AD.J.)

*ACAL IPTÉRES. Acalyptera (áxádurtos nu; $\pi \tau \varepsilon$ póv, aile). Ins. - Section établie par M. Macquart dans la tribu des Muscides (Diptéres), et renfermant elle-même $17 \mathrm{~s}$-tribus dont les noms suivent: Dolichocères, Loxocérides, Cordylurides, Scatomysides, Psilomydes, Ortalidées, Téphritides, Sepsidées, Leplopodites, Thyréophorides, Ulidiens, Lauxanides, Hyaromysides, Prophiiides, Sphorocérides, Héléromysides et Hypocères. Cette section comprend le plus grand nombre des Muscides; les autres sont réparties dans celles des Créophiles et des Anthomyzides. Outre les caract. généraux de la tribu a laquelle ils appartiennent, les Acalyptères présentent les caract. particuliers suivants : Style des ant. composé de 1 ou 2 articles distincts ; front large; cuillerons nuls ou rudimentaires; $1^{\text {re }}$ cellule postérieure des ailes ouverte.'L'absence des cuillerons a donné licu au nom appliqué à cetle section.

Le grand nombre de divisions qu'on a été obligé d'établir parmi les Acalyptères prouve combien leurs formes sont variées. Pour ne pas nous répéter à cet égard, nous renvoyons à chacun de leurs g. et de leurs sous-tribus, nous bornant à parler ici de leurs habitudes qui se ressentent généralement, suivant M. Macquart, dé l'infériorité de leur organisation et de la délicatesse de leur complexion. Ils vivent le plus souvent sous l'ombrage des bois, l'épaisseur des gazons el dans les plantes aquatiques. On en rencontre peu sur les fleurs. Ils s'exposent rarement aux rayons du soleil, dont l'éclat et la chaleur semblent trop vifs pour leurs faibles organes. Leur vol est énervé, et ne s'étend qu'à de courtes distances: jamais on ne les voit, comme beaucoup d'autres Diptères, s'ćlancer à la poursuite d'une proie fugitive. Lanature, en les eondamnant à une vic obseure, en a cependani varié la destination. On peut les séplarer en 2 grandes div. sous le rapport de leur manière do vivre: les uns se nourrissent de substances animales et végétales en décomposition, les autres de substances végétales seulement, mais vivantes. Les premiers cherchent leur nourriture et placent le berceau de leurs larves, tantôt sur les cadavres, comme les Thyréophores, ou sur les excréments, comme les Scalophages; tantòt sur les détritus des plantes, sur les champignons en déliquescence, comme les Sapromyzes. Les liqueurs spiritueuses nourrissent les larves, des Drosophiles, et les laitages fermentés celles des Piophiles. Les Acalyptères de l'autre div. déposent leurs œufs sur les Plantes. Les larves des Ortalidées et des Téphrilides se développent dans les organes de la fructification et y déterminent souvent des excroissances galliformes; celles des Hydromysides et d'une partie des Hétéromysides pénètrent dans l'intérieur des tiges et en dévorent la substance médullaire. Ainsi les Chlorops dévastent quelquefois les céréales et particulièrement l'orge dans les plaines de la Suède. Un grand nombre de ces Diptères, tels que les Dolichocères, vivent sur les plantes aquatiques. Les larves des Doricères ont été observées sur les lentilles des étangs. Les Calobates semblent pourvus de la faculté de marcher sur les eaux. Frifin les Actores sont propres aux plages maritimes; elles habitent les fucus, et marchent même sur l'écume des flots.

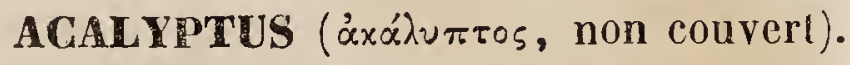
Ixs..-G. de l'ordre des Coléoptères tétramères,famill. des Curculionides, div. des Erirhinides, établi par Schoenherr et adopté par M. Dejean. Il a pour type le Rhynchoenus Carpini Gyll. espèce de la Suède. M. Dejean en mentionne 2 autres dans son Catal., l'une qu'il nomme $A$. canescens, et l'autre appelée $A$. rufipenuis par Schoenherr. Toutes deux sont du midi de la France. Voici les caract. assignés à ce g. par l'auteur suédois: Ant. médiocres, assez minces; leur funicule composé de 7 art.; les 2 basilailes allongés, obconiques, dont le premier plus long et plus épais; les autres courts, tronqués au sommel, resserrés, s'élargissant insensiblement; massue ovale. Rostre allongé, un peu mince, linéaire, arqué. Yeux placés latéralement, arrondis, peu convexes. Prothorax légèrement bisinué à la 
base, plus étroit par devant, un peu arrondi sur les côtés, tronqué au sommet. Élyt.carrément ovales, légèrement convexes, arrondies à leur extrémité et ne couvrant point l'anus.

ACABMRCIIIS (nom myth. d'une fille de l'Océan). polyp. - Lamouroux a établi sous ce nom une div. générique, comprenant les Cellariées à polypiers dichotomes dont les cellules unies, alternes et terminées par 1 ou 2 pentes latérales, portent une vésicule à leur ouverture, comme cela se voit dans le Cellaria neretina, figuré par Ellis (Corall. pl. 19). Mais ce g. ne me paraît pas devoir être adopté; car le seul caract. qui le distingue est la vésicule qui surmonte l'ouverture des cellules, et cette vésicule n'est évidemment autre chose qu'un recept. gemmifère analogue à ceux qui se développent chez les Escharres, etc. Si l'on en faisait abstraction, ces Polypiaires ne dirrèreraient en rien de diverses Cellariées, rangées à tort par Lamouroux dans son g. Crisie, etdésignées par M. de Blainville sous le nom de Bicellaires. Ainsi, suiṿant toute probabilité, ce sont les mêmes polypes, dont on a formé $2 \mathrm{~g}$., suivant qu'on les observa avant ou après le développement de la vésicule ovarienne.

(M. E.)

*ACAmatUS (áxćucs, infatigable). INs. - Schonherr fait précéder sa Monographie des Curculionides d'une table synoptique des g. dont il la compose, et y fait mention du g. Acamatus, créé par lui, et auquel il donne pour type le Monomus scutellaris de Say; mais, soit oubli, soit qu'il ait jugé à propos de le supprimer ensuite, il n'en est plus question dans la partie descriptive de ces mémes genres.

ACAMP. Acamas. moll.-Dans sa Conchyliologie systématique, Montfort a proposé ce genre, dont on a reconnu depuis l'inutilité, pour une espèce de Bélemnite ayant naturellement, ou peut-être accidentellement, un pore au sommet.

(DESH.)

* aGANa Gí⿴囗s. Acunaceo, Césalpin. botr. PII.-Syn. de Chicoracées. (C. D'O.)

* ACANDES. poiss.-Nom maí écrit par Bonnaterre, etqui a été ainsi copié par tous ses successeurs. $V$. alcinandes. (VAL.)

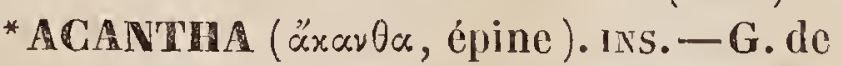
l'ordre des Coléoptères pentamères, fam. des Stenoxes, tribu des Buprestides, établi par
MM. Gory et de Laporte, qui lui assignent les caract. suivants : Palpes maxillaires assez longs, grêles, formés de 3 art. visibles; le basilaire très long, cylindrique et grêle; le $2^{\mathrm{e}}$ conique; le $3^{\mathrm{e}}$ en ovale allongé. Palpes labiaux de 3 art.; le $1^{\mathrm{er}}$ a peine visible, le $2^{\mathrm{c}}$ cylindrique, le $3^{\text {me }}$ ovalaire. Labre en carré transversal, trés échancré en avant. Menton large, transversal. Lèvre pointue et ciliće. Mâchoires formées de 2 lobes, dont l'externe très grand, arqué; l'interne petit et pointu. Mandib. fortes, arquées, armées intérieurement à l'extrémité de 3 fortes dents. Antennes de 11 articles : le $1^{\text {er }}$ gros; le $2^{\text {me }}$ assez petit, allongé; les $3^{\text {me }}$ et $4^{\text {me }}$ égaux, longs et coniques; les autres transversaux, dilatés intérieurement. Tarses à $1^{\mathrm{er}}$ art. allongé; les a suivants échancrès, triangulaires. - Ce g., qui ne figure pas dans le Catal. de M. Dejean, ne renferme qu'une seule espèce, celle de Cayenne, que les auteurs appellent $A$. octopunctata, et que M. Dejean rapporte à son $g$. Prionophora sous le nom spécifique de $P$. calachlora.

AGANTIIICEES. Acanthacece. вот. PII. - Famille de plantes dicotylédones, à corolle monopétale hypogyne, ofrant les caract. suivants : Cal. à 4 ou 5 div., souvent complètement distinctes et ordinairement imbriquées, quelquefois multifides; d'autres fois, mais rarement, entier et réduit à un petit anneau, persistant. Cor. tubuleuse, à limbe quelquefois personné, plus souvent bilabié, ofrrant plus rarement ou une seule lèvre, ou des div.presque égales. Étam.4, didynames, la paire antér. plus courte, quelquefois dépourvue d'anthères, d'autres fois manquant toút-à-fait. Anthères à 2 loges symétriques ou non, ou à une seule, s'ouvrant par une fente longitudinale. Ovaire surmonté d'un style simple que termine un stigmate 2-lobé ou plus rarement indivis, environné d'un disque à sa base, à 2 loges contenant chacune 2 ou plusieurs ovules. Fruit capsulaire, biloculaire, s'ouvrant en 2 valves opposées à la cloison, qui se sépare elle-même, suivant son axe, en 2 moitiés restant chacune attachées à la valve correspondante, ou d'autres fois s'en séparant avec élasticité. Graines atlachées à l'axe, el, après la déhiscence , por-tées sur le bord intér. de chaque demi-cloison, au moyen d'appendices qui en partent, et qui ofrent le plus souvent la forme d'un 
crochet sous-tendant la giaine, plus rarement celle d'une cupule ou d'un simple mamelon, et qu'on a distingués par le nom de rétinacles. Ces graines, recouvertes d'un test làche, sont dépourvues de périsperme, à embryon droit ou courbe, dont les cotylédons sont droits et arrondis; la radicule droite ou courbe elle-même est dirigée en bas.

Les esp. de cette famille sont des plantes herbacées ou frutescentes, à feuilles opposées, simples, indivises, entières ou dentées, rarement sinueuses ou tendant à se partager en lobes, souvent obliques ȧ leur base et inégales dans chaque paire par une alternation régulière, qui les fait quelquefois paraître distiques; à infloresc. axillaire ou terminale, quelquefois uniflore, plus souvent disposée en panicules, faisccaux, grappes ou épis, dans lesquels les fieurs, ordinairement opposées, sont accompagnées de 1 ou 3 bractées, quelquefois trés développées, foliformes, et venant suppléer le calice alors diminué. - Elles habitent, pour la plupart, les régions tropicales, quoiqu'un petit nombre vienne se montrer en Europe, jusque sur les bords du bassin méditerranéen, et en Amérique jusqu'en Pensylvanie. Leurs propriétés n'offrent rien de remarquable ni de général.

Le travail le plus complet et le plus rècent dont elles aient été l'objet, est celui de Nees d'Esenbeck, qui, en décrivant les nombreuses esp. de l'Inde, dans l'ouvrage de Wallich ( $P l$.asiat.rarior.), a donné de la famille une monographie à laquelle nous empruntons les div. ultérieures et le catalngue des g., tel qu'il a ceté présenté avec additions par Lindley. Il partage les Acanthacées en 3 tribus, dont le principal caract. distinctif est $\mathrm{em}-$ prunté à la forme des rétinacles, qui est un crochet sous-tendant la graine dans les $\boldsymbol{E} c$ matacanthées, un petit mamelon la portant suspenduc dans les $I$ Velsoniees, une cupule cornée la soutenant dans les Thunbergiées. La $3^{\mathrm{me}}$ tr., qui renferme la plus grande partie des g., a été subdivisée elle-même en 7 sect., d'aprés des considérations tirées des combinaisons diverses qu'ofren i la forme du calice et surtout de la corolle, le nombre des étamines, fertiles ou stériles, la hauteur à laquelle leurs filets s'insèrent sur la corolle, le nombre, la forme et la direction relative des loges de l'anthère, la proportion et la situa- tion des graines, ainsi que d'après quelques modifications secondaires des rétinacles et de l'inflorescence.

$$
\text { GENRES. }
$$

1re tribn. TIUNBERGIÉS. - Thmbergia, L.; Meyenia, Nees.; Hexacentris, Nees.; Mendoza, R. et P.; Clistax, Mart.

$2^{\text {me }}$ trib. NELSONIEES.-Elytraria, Vahl.; Nelsonia, R, Br.; Adenosma, R.Br.; Ebermaycra, Nees.; Erythracanthus, Nees.; Gymnacanthus, Nees.

$3^{\text {me }}$ trib. RCMATACANTHEES.-1. HYGRoPHILÉes. Hemiadelphis, Nees.; Hygrophila, R.Br.; Geissomeria, Lindl.;-2. RuElliÉES。 Dyschoriste, Nees.; Chatacanthus, Nees.; Dipteracanthus, Nees.; Aphragmia, Nees.; Petalidium, Nees. ; Stephanophysum, Pohl.; Haberlea, Friw.; Calophanes, Don.; Ruellia, L.; Phlebophyllum, Necs.; Buteraa, Nees.; Adenacanthus, Nees; Stenosiphonium, Nees.; Strobilanthes, Bl.; Stenandrium, Nees.; Actimanthera, Nees.; Goldfussia, Nees; Asystasia, Nees.; Echinacanthus, Nees.; Leptacanthus, Nees. - 3. Barlériées. Asteracantha, Nees.; Barleria, L.; Lophostachys, Pohl.; Nomaphila, BI.; Nheliema, R. Br.; Lepidagathis, W.; Aphelandra, R. Br.; Neuracanthus, Nees.; Corythacanthus, Nees. - 4. ACANTHÉEs. Blepharis, J.; Blepharacanthus, Nees.; Acanthus, L.; Acanthodium, Del.; Dilivaria, J. - 5. Justiciées. * Ruelliö̈des : Crossandra, Sal.; Endopogon, Nees.; Loxanthus, Nees.; Phlogacanthus, Nees.; Cryptophragmium, Necs. ${ }^{*}$ Gendarussiées : Rostellaria, Nees.; Hemichoriste, Nees.; Graptophyllnm, Nees.; Beloperone, Nees.; Adhatoda, Nees.; Gendarussa, Nees.; Rhytiglossa, Nees.; Leptostachya, Nees.; Gymnostachyum, Nees. *** Eranthémées: Eranthemum, R. Br.; Chameranthemum, Nees.; Justicia, L.; Khinacanthus, Nees. - 6. DICLIPTÉRÉes. Blechum, J.今 Rungia, Nees.; Dicliplera, J. ; Amphiscopia, Nees.;Peristrophe, Nees.; Sautiera, Decaisne.; Hypoestes, Sol.; Rhaphidospora, Nees.-7. Аనdrographúées. Erianthera, Nees.; Haplanthus, Nees.; Andrographis, Wall.

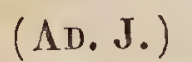

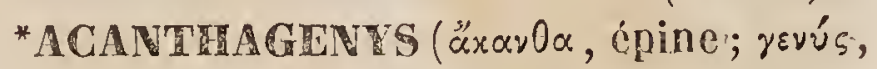
mâchoire). ors. - Nouveau g., établi par Gould (Proceedings 1937), sur une esp. du g. Philedon de Cuvier et dont les caract. sont : Bec de la longucur de la tête, comprimć, aigu, légèrement arquć; narines basales; 
mandib. supér. échancrée vers son exlrémilé et finement denliculée en scie; une partic sous-oculaire, nue, en forme de bandeletie depuis la base du bec; les joues garnies de pointes rigides au dessous de cette nudité. Pieds robustes; pouce fort, plus grand que le doigt médian. Ailes courtes, obtuses.Queue médiocre, égale à son extrémité.-Ce g., voisin de l'Arthochara de vigors, ayant pour type le Merops carunculatus ou pie à pendeloques, en diffire par sa queue égale, sa nudité sous-oculaire et ses joues épineuses. L'esp. type est l' $A$. rufo-gularis Gould, de la N.-Galle du Sud (S'ynops. ois. de l'Aust.).

(LAFr.)

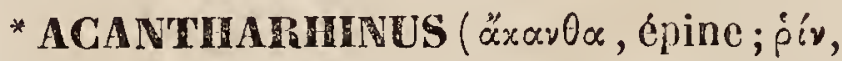
bec, nez). ins.-G. de l'ordre des Coléoptères "tétramères, famille des Curculionides, établi par Schœnnerr, qui lui donne les caract. suivants : Ant. de médiocre longueur, peu fortes; le $1^{\mathrm{er}}$ article de leur funicule turbiné, les autres transverses, un peu tronqués et serrés au sommet, s'épaississant graduellement en dehors; massue presque sécuriforme. Rostre assez court, robuste, se courbant subitement vers la pointe, presque gibbeux, bidenté au dessous de l'insertion des antennes. Prothorax oblong, légèrement bisinué à la base, plus étroit dans sa moilić antéricure, un peu convexe en dessus; écusson assez graind, triangulaire. Elyt. ovales-oblongues, arrondies à leur extrémité, légèrement convexes en dessus. Pattes robustes, presque d'égale longueur; le pénultième article des tarses presque rond. - Ce g., qui ne figure pas dans le Catal. de M. Dejean, a pour type une esp. unique du Cap de B.-E., nommée $A$. Dregei par Schœenherr.

ACANTIIL. Acanthus, Juss. (äxav日os, nom de cette plante chez les Grecs). Bor. Pr. G. de la famille des Acanthacées, dont il est le type. Voici comment Nees d'Esenbeck ( $P l$. asiat. rarior., t. 3 ) en circonscrit les caract. : Cal. 4-fide; la div. supér. et l'infér. beaucoup plus grandes, cette dernière 2 -fide au sommet. Cor. 1-labiée ; lèvre 3-fide ou 3lobce, quelquefois auriculée à la base, à bord supérieur trés entier. Étam. 4, subdidynames, à filaments infères, infléchis au sommet; Antb. 1-loculaires, cilićes, les supér. dressées, les infér. transverses, à l'extrémité du filament en crochet. Capsule ovale, 2-10- culaire, comprimée, 4-sperme, loculicidebivalve; cloison lignease, 1 -sulquée, dilatée au sommet, obliquement tronquée, s'écartant des valves. Graines ovales, comprimées, tuberculées, sous-tendues par des tinacles épais, obtus, un peu dressés. Inflorescence en épi terminal, aphylle; fleurs 3-bractéifères; une bractée commune, ciliée-soyeuse. - Les Acanthes sont des plantes herbacées, vivaces ou sufrutescentes, remarquables par la beauté de leur port. On en connaît environ une douzaine d'esp., presque toutes particulières aux régions tropicales. Deux d'entre elles, les $A$. mollis et spinosus', croissent nalurellement dans le midi de l'Surope et de la France. Ces espèces portent le nom vulgaire de Branc-ursine, à cause, dit-on, d'une prétendue ressemblance avec une patte d'ours. Vitruve a rendu la $1^{\text {re }}$ célébre par l'historiette qu'il raconte à son sujet, et d'où il résulte que le sculpteur Callimaque, d'aprés une feuille de cette Acanthe roulée par accident en volute, aurait imaginé le modèle du beau chapiteau corinthien. Dans nos officines, elles sont aujourd'hui peu employées comme plantes médicinales.

(C. L.)

*ACANTIÉES. Acanthece. not. PH.-Une des sect. de la tribu des Ecmatacanthées, dans la famille des Acanthacées. (AD. J.)

- ACANTHÉPHIPPIE. Acanthephippium

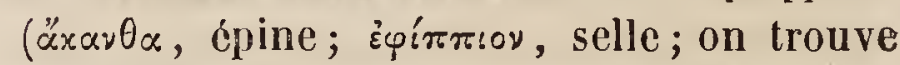
souvent écrit par erreur acanthophippium). вот. Pн.-Ce g., de la famille des Orchidées, tribu des Vandées, a été ćtabli par Blume, dans sa Flore de Java, pour une plante non parasite, dépourvue de tige, croissant dans les forêts montueusés de Java, et à laquelle ce botanis te donne les caract. génériques suivants : Cal. globuleux et renflé, à div. extér. soudées; les 2 latérales attachées à la base du gynostème; la supér., réunic aux 2 intér. et latérales qui sont spatulées, forme une sorte de voûte. Labelle unguiculé, attaché à la base très prolongée du gynostème; limbe à 3 lobes. Anth. charnue, a 2 loges, contenant $S$ masses polliniques inégales et sessiles. - L'espèce la 1re connue est l' $A$.

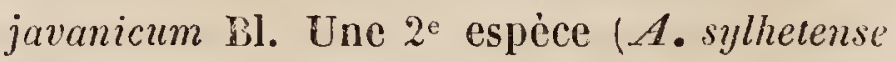
Lindl.), a été trouvé dans le Sylhet par Wallich.

(A. R.)

ACANTILAS ( $\left.\alpha^{\prime} \alpha \alpha \theta^{\prime} \alpha^{\prime} \alpha\right)$. polss. - Nom grec employé par Aristole ( $L i b$. vi, cap.x. 
comme épithète, d'un de ses $y x \lambda \lambda_{\varepsilon} \sigma_{5}$, et que Gaza explique ainsi : Spinaces vero Musteli, sic à spina quam habent, muncupati. Rondelet a appliquécette expression au Squale que nous désignons actuellement sous le nom d'Aiguillat (Squal'ss acanthias I.). Il me semble cependant que Rondelet et ses successeurs auraient pu tout aussi bien l'attribuer au Squale Humantin (Squalus centrina Lin.), qu'il a regardé comme le Kevтpín d'Athénée. En adoptant, avec tous les Ichthyologistes, l'application actuelle du mot Acanthias, je ferai remarquer qu'on ne peut, dans aucun cas, le traduire, comme l'ont fait tant de Glossaires, par le mot de $R e$ quin; le poisson désigné sous ce nom, et si connu des navigateurs et des naturalistes, n'ayant aucune épine.

Gmelin s'est aussi servi du mot Acanthias comme épithète de sa dernière esp. de Gastérostée ; mais ce Gasterosteus acanthias, dont Lacépède a fait un Centronote sous le même nom, n'est autre que l'Épinoche commune (Gusterosteus aculeatus L.)

(VAL.)

AGANTHIE. Acanthia ( $\alpha_{x} \alpha \nu \theta \alpha$, épine). Ins. - G. de l'ordre des Hémiptères, établi par Latreille, appartenant à la famille des Leptopodiens de Brullé ou Riparii de Burmeister, et ayant pour caract. propres à le distinguer de ses congénères : la forme de son bec long et dépourvu d'épines, et les cuisses des pattes antérieures qui sont inermes. - On ne connaìt de ce g., dont le type est l' $A$. saltatoria L., que 7 ou $S$ esp. européennes, qui sont de petite taille; elles vivent dans le voisinage des eaux douces ou salées, courent trés vite el sautent avec beaucoup d'agilité. Acanthie est a ussi le nom d'un g. créé par Fabricius pour la punaise des lits. Panzer, de son côté, l'applique aux Tingis et Syrtis de Fabricius et au Piesma de l'Encyclopédie.

(BL.)

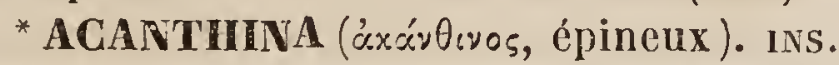
- G. de l'ordre des Diptères, div. des Brachocères, famille des Notacanthes, tribu des Stratiomy des, établi par Wiedemann et adopté par Mr. Macquart, qui le caractérise ainsi : $3^{\text {me }}$ article des ant: cylindrique, à 5 div., dont la $1^{\text {re }}$ allongée; les 3 suivantes plus courtes, et la $5^{\text {e }}$ conique, dirigée obliquement. Thorax allongé, assez étroit; écusson a 4 pointes. Abdomen assez large, ovalaire.
Ailes a 4 cellules postéricures. Les a pointes de l'écusson et la forme allongée du thorax rendent ce g. très remarquable. II a pour type l' $A$. elongata Wied., qu'on trouve dans l' $\Lambda$ mérique méridionale.

ACANTHINION ( $\alpha x_{\alpha} \alpha \nu \alpha$, épine; iviov, occipul). porss. - Nom donné par Lacépède à un g. de Poissons, qu'il croyait voisin des Chétodons, parce que Bloch avait placé parmi les Chétodons les 2 esp. sur lesquelles le naturaliste français établissait cette coupe. Ce g., quant à ces 2 esp. (1'A. Rhomboüde, et l'A. bleu), n'est qu'un double emploi de 2 autres qu'il établissait sous les noms de Traclinote et de Casiomore; quant à la $3^{\text {me }}$ esp. (l'A. orbiculaire), elle est du g. des Platax, de la famille des Squamipennes; ce qui a engagé Cuvier à ne point conserver le g. Acanthinion dans la classif. des poissons da Règne animal. (VAL.)

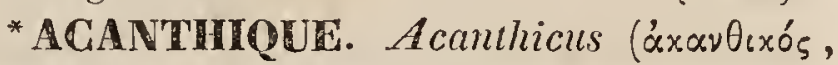
épineux). ıns.-G. de l'ordre des Hémiptères, section des Homoptères, famille des Cicadelles, dont l'établissement est dû à M. de Laporte, qui en a tiré les principaux caract. de la formedes antennes (composées de 3 art., dont les 2 premiers tris courts, et le $3^{\text {me }}$ ayant l'apparence d'une soie), et de celle du corselet, surmonté d'un prolongement dirigé en avant et bifide à l'extrémité. Ce g. se rapproche beaucoup des Centrotus; les esp. en sont peu nombreuses et propres à l'Améririque méridionale. Il a pour type l' $A$. Stollii Lap., figuré dans l'ouvrage de Stoll (Icon. cim.).

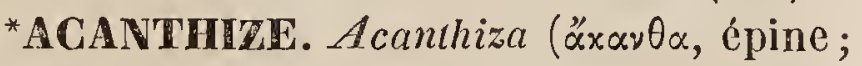
$\widetilde{\xi} \omega$, je place). ors. - G. de Vigors et Horsfield, faisant partie des Becs-fins de Cuvier, et ayant pour caract. : Bec court, grêle, droit, déprimé à la base, comprimé vers la pointe; mandib. supér. á peine échancrée; narines linéaires recouvertes d'une membrane, en partie cachées par les petites plumes et les soies de la base du bec ; ailes médiocres ou longues, arrondies; $1^{\text {res }}$ rémiges élagées, la $2^{\text {me }}$ plus courte que les 4 suivantes dont les 3,4 , et $5^{\text {me }}$ sont les plus longues et à peu près égales; queue médiocre, légèrement échancrée ou arrondie ; l'extrémité des rectrices et des rémiges finissant quelquefois en une petite pointe courte; plumes du front et du vertex souvent arrondies en forme de petites écailles; pieds de 
longueur moyenne; doigts et ongles annonsant assez de force de préhension. Ce pelit groupe australien semble élablir le passage les Roitelets aux Mérions et se compose aujourd'hui de 11 esp., dont \& sont figurées dans le Synop. des ois. de l'Austr. de Grould, qui a retiré du g. l'A. frontalis de vigors pour en former le type de son nouv. g. Serricornis (même ouvr. part.4). (LAFR.)

* ACANTISOBOTRTA, Eckl. et Zeyh.

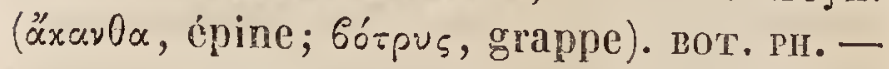
G. de la famille des Légumineuses, s.-ordre des Papilionacées, tribu des Lotées, s.-tribu des Génistées. Suivant Ecklon et Zejher (Plam Cap. 1, p.192), ce g., dont ils décrivent 6 esp., est voisin des Cebeckia, et offre les caract. suivants: Cal. à 5 dents presque égales. Corolle (glabre) a élendard suborbiculaire, onguiculé; ailes courtes ; carène dicéphale, subrectiligne. Etam. monadclphes, à gaîne fendue antérieurement. Ovaire 6-8ovulé; style filiforme, glabre; stigm. capitellé. Légume presque membraneux, stipité, linéaire-oblong, comprimé, apiculé, subacinaciforme. Graines réniformes, déprimées.-Arbrisseaux : Feuilles non stipulées, trifoliolées. Fleurs jaunes, disposées en grappes. Pédicelles dibractéolés vers leur milieu.

* CANTHOCÉPRAL. Acanthocephala

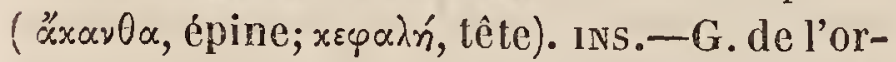
dre des Hémiptéres, sect. des Héléroptères, famille des Coréens, établi par M. de Laporte (Essai sur la classif. des Ilémipt. hétéropt.), qui le place dans sa famille des Anisoscélites. Ce g., qui renferme 25 à 30 esp., diffère à peine des Anisoscelis; le seul caract. propre à l'en faire distinguer existe dans les pattes postérieures, dont les cuisses sont armées d'épines, et les jambes dilatées dans toute leur longneur.-Le type de ce g. est l'A. compressipes (Ligceus comp. Fab.). Cette esp., ainsi que ses congénères, se trouvent dans l'Amérique méridionale.

ACANTIOCEPIIALS. Acanthocephala ( $\check{x} x \alpha \nu 0 \alpha$, épine; $x \varepsilon \varphi \alpha \lambda \dot{n}$, tête). HELM.-Rudolphi avait réuni sous ce nom les 2 g. Echinorynchus et Tetrarhynchus; plus tard il sentit que ce rapprochement n'était point naturel, et il reporta ce dernier g. parmi les Cestö̈des. Cuvier lui avait assigné, parmi les Tonioüdes, une place qui yarait lui convenir mieux. Par suite de ce changement, la div. des Acan- thocéphales, adoptée maintenant par tous les auteurs, reste composée du seul grand g. Echinorhynchus Rud., comprenant les 2 g. Heruque Gm. et Échinorizmque proprement dit. Rudolphi en faisait son $2^{e}$ ord. des Entozoaires. Dans la classif. adoptée par Cuvier. Ils constituent la $1^{\text {re }}$ des 4 familles de l'ordre des Parenchymateux, ê, dans celle de M. de Blainville, le $2^{e}$ ord. de la classe des Subannélidaires ou Gastrorhyzaires. Voici comment ce dernier auteur les caractérise : Corps plus ou moins sacciforme, peu ou point articulé, obtus aux 2 extrémités ; l'anlérieure avec une sorte de renflement céphalique ou de trompe céphaloïde, garnie d'aiguillons recourbés, et percée d'un pore médian extrêmement petit; la postérieure percée d'un orifice médian, également terminal, souvent très petit. Canal intestinal? Sexes séparés?

(L. D.x.R.)

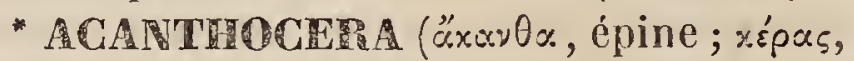
corne).1ns.-G. de l'ordre des Diptères, div. des Brachocères, famille des Tabaniens, établi par M. Macquart aux dépens du g. Hcematopoda Wied., et qu'il caractérise ainsi : Face à callosité de chaque côté ; front à callosité antér. et une autre postér. Antennes de la longueur du thorax $; 1^{\text {er }}$ article un peu plus étroit à sa base $2^{\text {me }}$ article subcyathiforme, une pointe longue et courbée à la base des 2 premiers; le $3^{\text {e }}$ fusiforme, à 6 div.; point d'ocelles. Abd. cylindrique; $1^{\text {re }}$ cellule sousmarginale, appendiculée.-Ce g. présente le facies des Chrysops, et a pour type une esp. du Brésil, nommée $A$. longicomis Maca. (Tabanus longicornis Fabr.).

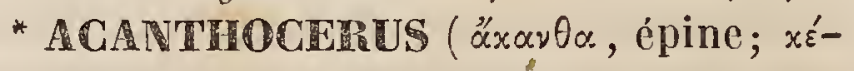
pas, corne). - G. de l'ordre des Hémiptères, sect. des Hétéroptères, famille des Coréens, créé par Palissot de Beauvois, et adopté par M. de Laporte. Ce g., fondé sur la forme des antennes dont le dernier art. est dilaté et le premier muni d'une dent, répond en partie au g. IVIictis de Leach, ou Crinocerus de Burmeister.

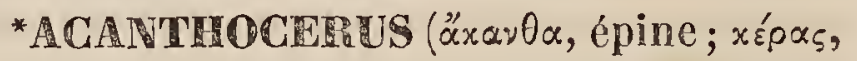
corne). INs. - G. de l'ordre des Coléoptères pentamères, famille des Lamellicornes, tribu des Scarabéides, établi par Mac-Leay, et adopté par M. Dejean. Il correspond au g. Sphceromorphus, Germ. Les Acanthocères se rapprochent beaucoup, par le facies, des Trox de Fabricius ; cependant, d'aprés Mac- 
Leay, ils en diffèrent par une foule de caractères ( $\boldsymbol{V}$. Hor a cutomologica). Il nous a paru qu'une dés principales différences résidait dans les antennes, dont le $\mathrm{f}^{\text {er }}$ article est chez eux, nu, épais, triangulaire, et dont un des angles se prolonge en pointe aiguë, tandis qu'il est grêle et velu chez les Trox. - Mac-Leay donne pour type de ce g. l'A. Eneus, de l'Amér. septentrionale, et lui associe le Trox spinicornis Fab. M. Dejean y rapporte 9 esp. de différentes parties de l'Arnérique, dont nous ne citerons qu'unc seule, rapportée de Cayenne par M. Lacordaire, l' $\Lambda$. Dejeanii.

"ACANTHOCHITE. Acanthochites (“’xay$\theta \alpha$, épine; $\chi \iota \tau i o \nu, ~ t u n i q u e)$. MoLL.-M. Risso propose de former sous ce nom un g. particulier pour les Oscabrions qui ont de chaque còlé du corps des fascicules de poils. Ce g. ne peut être adopté.

(Desh.)

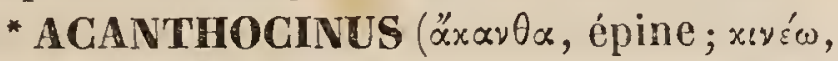
je meus; allusion à la mobilité de l'épine du corselet). INs.-G. de Coléoptères tétramères, établi par Mégerle dans la grande famille des Longicornes, et supprimé par M. Serville, qui l'a remplacé par le g. Acanthoderus. $V$. ce mot.

- ACANTHODACTYLE. Acanthodacty-

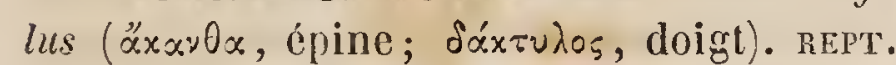
- Nom donné par Fitzinger à un g. de la sous-famille des Lacertiens Coelodontes. Ses caract. sont: Dents intermaxillaires, coniques, simples; dents maxillaires et mandibulaires comprimées, 3-cuspides; palais lisse ; langue plate, en fer de flèche, échancrée à sa pointe, couverte de papilles squamiformes, imbriquées. Narines percées, chacune cntre 3 plaques, une naso-rostrale, une naso-frénale et la $1^{\text {re }}$ labiale. Des paupières; oreille ouverte extérieurement; cinq doigts à chaque patte, carénés en dessous et dentclés latéralement; des pores fémoraux. Ils ofrrent un ensemble de formes semblables à celles de nos lézards ordinaires. Parmi les plaques qui revêtent leur crâne, on ne remarque pas d'occipitale; celles qu'on nomme palpébrales sont au nombre de 2 senlement, et forment un disque subcirculairc qu'un cordon granuleux environne plus ou moins complétement; la frontale, toujours rétrécic en arrière, est ordinairement canaliculée dans sa longueur et arrondic en avant. Les lamelles squameu- ses qui protègent le ventre de ces petits sauriens sont moins grandes et plus nombreuses que chez les lézards proprement dits; mais elles sont de mème quadrilatères et disposées en quinconce. L'écaillure dorsale se compose de petites pieces rhomboüdales, imbriquées, avec ou sans carène. Il existe, sous lc cou, un repli de la pean garni de squamelles, formant une espéce de demicollier, qui tantòt s'étend simplement en travers, tantôt se brise en angles plus ou moins obtus.-Les Acanthodactyles fréquentent de préférence les lieux secs, arides, sablonneux. On en connaît 4 esp., dont 3 sont d'Égypte; la $4^{\text {me }}$ se trouve en Espagne, en Italie et dans le midi de la Erance. C'est l'A. commun, Dum. et Bib. (Erpét. gén., t. v.) $V$. Pristidactyles. (G. B.)

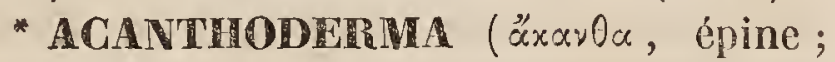
$\delta \delta^{\prime} p u \alpha$, peau ). poiss. Foss. - G. de Poissons fossiles établi par M. Agassiz pour un Ichthyolithe de Glaris que l'auteur range dans la famille des Sclérodermes de Cuvier. On n'en cite qu'une espèce, l'A. spinosim, dans le Catal. des Poissons fossiles de Lord Cole et de Sir Philip Grey Egerton. (VAL.)

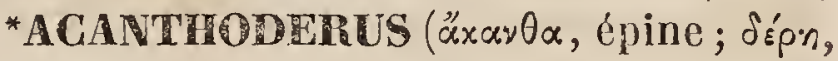
cou). Ins. - G. de l'ordre des Orthoptères, famille des $\boldsymbol{S}$ pectres, établi par Gray, et ayant pour principal caract. la présence de nombreuses épines situées sur le corselet. Ce g., dont toutes les espèces connues sont dépourvues des organes du vol, pourrait bien, comme le pense M. Brullé, ne renfermer que des larves d'esp. appartenant au g. Cyphocrane. Burmeister (Handb. der Entom. t. 11) adopte le g. Acanthodère de Gray, en y réunissant le g. Eurycantha Boisd. (Br.)

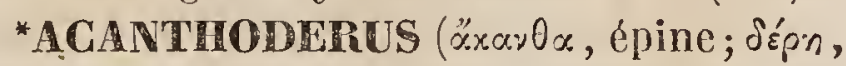
cou). Ins. - G. de Coléoptères tétramères, famille des Longicornes, tribu des Lamiaires, établi par M. Serville (IMonog. des Longicornes) et adopté par M. Dejean, dans la dernièrc édition de son Ca talogue. Ses caract. sont : Corps déprimé; corselet presque aussi long que large, uni-épineux latéralement; son disque inégal ou tuberculé. Ant.glabres, sétacées, distantes à leur base de la longueur du corps dans les femelles, plus longues que lui dans le mâle; de 11 art. : le $1^{\text {er }}$ grand, renflé; le $2^{\text {me }}$ court, cylindrique, ainsi que les suivants; le $3^{\text {me }}$ le plus long de tous. Palpes maxillaires assez courts ; leurs 2 der- 
niers articles i peu près igaux. Mandib. assez courtes, aiguës. Abd. sans tarière saillante. Élyt. déprimées, plus ou moins rétrécies vers leur extrémité ; écusson sémicirculaire. Pattes de longueur moyenne, les anter., dans les mâles, un peu plus grandes que les autres; cuisses en massue; tarses antér. très houppeax dans les mâles. - Ce g. , auquel M. Dejean rapporte 27 esp. toutes exotiques, a l'excepi. de l' $A$. varius qui est d'Europe, a pour type le Ceramby $x$ Daviesii (Oliv. Entom.; t. IV, fig. $42, a, b$.$) de Cayenne. (D.)$

* ACANTHODES ( $\alpha x \alpha \nu \theta \omega \dot{\delta} \hat{n} s$, épineux). porss. Foss. - Genre établi par M. Agassiz dans le groupe des Hétérocerques de la famille des Lépidoïdes, la $1^{\text {ere }}$ de l'ordre des Ganoïdes. Ils ont la gueule très fendue, la mâchoire inférieure plus longue que la supérieure, les dents en brosse, les écailles très petiles, la dorsale opposće à l'anale, ou même en arrière de cette nageoire sur le tronçon de la queue; les ventrales très petites, attachées un peu au-dessus du milieu de l'abdomen, et au tiers de l'espace compris entre l'anale et l'insertion des pectorales. Le $1^{\mathrm{er}}$ rayon de la dorsale, de l'anale, des pectorales, est osseux, épais, fort ; celui des ventrales, quoique osseux, est très petit; ceux de la caudale sont très fins et à peine distants. Les écailles sont trés petites; ce sont des plaques rhomboïdales et presque carrées, disposées par rangées obliques du dos vers l'abdomen, et formant aiusi des ceintures transverses dirigées d'avant en arrière. M. Agassiz cite 2 esp. dans ce genre. L'une est son $A$. Bromii (Poiss. foss., t. xl), qui a les écailles lisses, et qui vient des mines houillères des environs de Saarbruck. L'autre, A. \$ulcatus (ibid.), a les écailles striées. Elle a été découverte par M. Greennock dans les géodes de New-Haven.

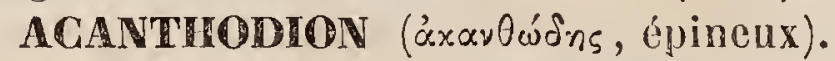
BoT. PII. - G. de la famille des Acanthacées, ćtabli par M. Delille, dans sa Flore d'Egypte, sur une seule esp. (A.spicalum), trouvée par lui dans une plaine déserts près de Soueys, et dont il donne la description suivante : Plante presque ligneuse à la base, a épis terminaux, beaucoup plus longs que la tige. Cal. 4-parti, persistant, à div. concaves : les 2 latérales intér. plus petites, les 2 extér. plus grandes, unguiformes, dont la supér. plus longue, acuminée; 3 bractées, dont les
2 latérales sétacées, la $3^{\text {mo }}$ intermédiaire foliacéc, dentée, épincuse. Cor. unilabiée, à tube court, rétréci à l'ouverture, velu, échancré supérieurement, à lévre dilatée, 3-lobée au sommet. Étam. 4, à anth. barbues, conniventes; les 2 filaments infér. acinaciformes et se prolongeant au-delà de l'anthère en une dent aigüe. Capsule ovale, aiguë, biloculaire, bivalve; valvules élastiquement déhiscentes par le sommet. Graine unique dans chaque logette, ovale, compriméc, insérée sur un rétinacle en crochet et couverte de poils couchés; radicule placée vers le point d'attache de la graine.- Ce g. diffẻre principalement de l'Acanthus, dont il a le port et les formes générales, par la structure des graines, leur nombre dans chaque cloison et la position de la radicule. C'est une plante suffrutescente, à feuilles opposées, ovales, dentées-épineuses, à inflorescence en épis quadrifariés, munis de bractées foliacées et de bractéoles sétacées. (C. L.)

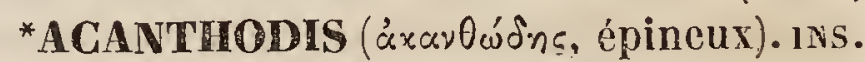
- G. de la famille des Locustaires de l'ordre des Orthoptères, créé par M. Serville (Rev. méthod. des Orthopt.) aux dépens du grand g. Locusta, Lat. Ses principaux caract. sont tirés de la forme, $1^{0}$ des palpes dont le dernier art.des maxillaires est une fois plus long que celui des labiaux; 20 des élytres, qui sont fort étroites; $3^{0}$ des pattes, toujours armées d'épines robustes. - Le g. Acanthodis renferme une douzaine d'especes répandues dans toutes les parties du monde. L'espéce type est l' $A$. aquilina (Teligonia aquilina L.;), provenant de Surinam).

* ACANTHODON ("̋x $\alpha \nu \theta \alpha$, épine; ojoús, óóovos, dent). АRACH.-G. de la famille des Aranéides, tribu des Théraphoses, section des Acutilabres, créé par M. Guérin (Revue Zool.). et dont voici les caract. : Yeux au nombre de 8 , dont 2 trés rapprochés sur le bord antér. du céphalothorax, et 6 beaucoup plus en arrière, formant un triangle transverse très étroit. Palpes presque aussi longs que les pattes, insérés à l'extrémité supér. des mâchoires, ayant les 2 derniers articles aplatis et armés en dessous d'épines fortes et courtes, en forme de râteau. Mandib. saillantes, avec leurs erochets repliés en dessons, le long de leur tranche inférieure. Pattes robustes, offrant entre elles ces rapports de longueur: $4,1,3,2$; armées en dessous, comme 
les palpes, d'une sorte de râteau gue présentent seulement les deux dernicrs articles des $1^{\text {res }}$ et $2^{\text {mes }}$ pattes. - On n'en connaît encorc qu'une scule espéce ( $A$. Petitii Guér.), du Brésil.

(H. L.)

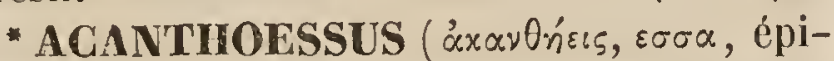
neux). Poiss. ross. - Nom donné par M. Agas-

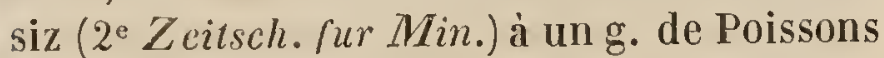
découvert dans les géodes de fer hydraté des houillères de Saarbrück, et qu'il a changé en celui d'Acanthodes.

(VAL.)

* ACANTHOGLOSSE. Acanthoglossum ( $\alpha_{\alpha} \alpha \nu \theta \alpha$, épine; $\gamma \lambda \widetilde{\omega} \sigma \sigma \alpha$, langue ). вот. ріI. -G. de la famille des Orchidées, établi par Blume, dans sa Flore de Java, et adopté par Lindley, dans son travail sur les Orchidées. Il ne se compose que d'une seule $\operatorname{esp}$. ( $A$. nervosum Bl.). C'est une plante parasite croissant sur les arbres des forêts les plus élevées de l'ìle de Java. Ses caract. sont: Calice étalé; les 2 div. intér. et latérales plus étroites que les extérieures. Labelle ventru á sa base, à limbe réfléchi, à 2 lobes, à 2 callosités intérieures. Gynostème libre supérieurement, prolongé en 2 ailes latérales et courtes. Anth. bi-loculairc, appliquée sur un rostellum échancré. Masses polliniques au nombre de 4, obovoïdes, avec une glande recourbéc en hamecon. - Ce g. appartient à la grande tribu des Vandées.

(A. R.)

* ACANTHOLEPIS ( $\varkappa_{x} \times \alpha \nu \theta \alpha$, épine; $\lambda \varepsilon-$ тís, écaille). вот. Рн. - Plante annuelle, grèle, laineuse, à feuilles terminées par une petite épine. Ce g., appartenant à la famille des Composées, tribu des Cynarées, a pour caract. génériques : Capit. uniflores, réunis en glomérules au sommet de la plante, ct entourés de feuilles épineuses en leurs bords. Involucre comprimé, composé de plusieurs séries d'écailles frangécs ou plumeuses sur les côtés, et terminées en pointe. Corolle 5fide. Anthères terminées à la base par des appendices courts et ciliés. Style presque entier. Akène oblong et couvert de poils, terminé par une aigrette uni-sériée, très courte, composée de paillettes elliptiques et fimbriées. - La seule espéce connue cst originaire de la Perse et de l'Arménie.

(J. D.)

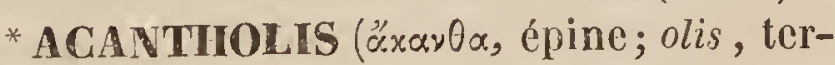
minaison d'Anolis; nom défectueux). REFT. - G. établi par Cocteau pour une petite espéce de Saurien de l'île de Cuba ( $A$. LoyT. 1 . siana), qui, selon nous, ne doit pas être distraite du groupe des Anolis. Ce g. n'est effectivement fondé que sur un seul caract. : celui d'avoir le dos semé de petits tubercules pointus parmi les petites écailles qui le revêtent.

* ACANTHOLOpHUS ( $\alpha x_{\alpha} \alpha \theta_{\alpha}$, épinc ;

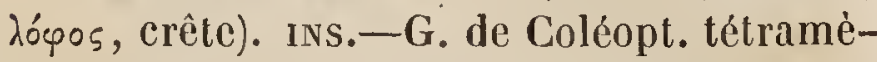
res, de la fam. des Curculionides, établi par M. Mac-Lcay et adopté par M. Dejean. Ce g., dont les caract. ne nous sont pas connus, ne renferme que des espéces de la N.-Hollande, dont nous ne citerons qu'unc seule, l' $\boldsymbol{A}$. echinatus, rapportée par M. d'Urville. (D.)

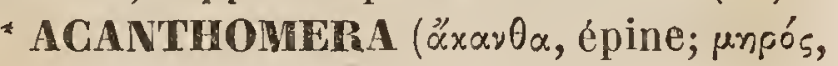
cuisse). ıns.-G. de l'ordre des Diptères, div. des Brachocères, subdiv. des Hexachœtes, famille des Tabaniens. Ce g., établi par Wicdemann, et adopté par M. Macquart, a pour type et unique esp. l' $A$. picta, qu'on rencontrc au Brésil. Ses caract. sont : Trompe entićrement retirée dans la bouche. Palpes de 4 articles, les 2 premiers velus; le $1^{\text {er }}$ très court, le $2^{\mathrm{e}}$ assez long; et le $3^{\mathrm{e}}$ le plus long de tous. Face à tubercule conique, raboteuse á sa partie inférieure, avec un sillon de chaque côté; $3^{\mathrm{e}}$ article des antennes long, conique, un peu comprimé, à 8 div., dont la dernière est la pluslongue. Des ocelles. Abdomen large, déprimé, les 3 derniers segments petits, formant l'oviducte. Pieds grêles; cuisses postér. allongécs, un peu en massue, velues en dessous; jambes intermédiaires garnies de 2 petites épines à leur extrémité ; cuisses postérieures munics d'une épinc en dessous dans les mâles; $4^{\mathrm{c}}$ cellule postérieurc des ailes fermée.

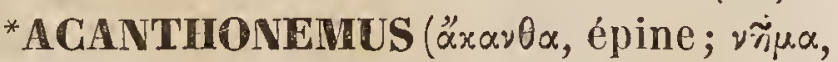
fil, tissu). PoIss.-Nom donné par M. Agassiz á un g. de Poissons fossiles du Monte-Bolca, et dont on trouve la figure de plusieurs individus dans l'Ichthyologie véronaise de Gazzola. Le plus grand el le miéux conservé est figuré sous le nom de Zeus gallus $\mathbf{L}$., et un plus petit sous le nom de Choetodon aureus Gm. M. Agassiz a rapporté avec doute á ce genre les Chotodon orbis, macrolepidotus, rosiratus. Ces 3 derniers individus sont très incomplets, eton ne peutémettre à lcur sujet qu'une opinion douteuse. Quant au rapprochement des deux premiers entre cux, et des deux dernicrs, il avait été déjá établi. M. de Blainville avait en effet recon- 
nu l'identité spécifique des deux individus figurés sous les noms de Zeus gallus el de Choetodon aureus, et cet ichthyolithe est devenu, dans son travail sur les poissons fossiles, son Choelodon subaureus. Il a de même rapproché, mais avec hésilation, le Chotodon rostratus (p. 50, n0 76) du prétendu Choetodon macrolepidotus qui est devenu son Choetodon ignotus ( $\mathrm{p} .50, \mathrm{n}^{0} 72$ ); mais cel auteur ne me paraìt pas avoir saisi les vrais rapports de cet ichthyolithe; car les dents ne sont pas semblables à celles des Chétodons, ni, comme l'avance H. Agassiz, à celle des Equula qui les ont en velours ou en brosse très fine et serrées comme les Chélodons. Celles de l'Acanthonème sont fortes, un peu crochues, et sur un seul rang. La crête impaire du crâne n'est pas à beaucoup près aussi élevée que celle des Zeus et des Equula; les apophyses épineuses des vertèbres sont différentes, celles de l'Equula étant dilatées par une créte placée sur le haut de l'apophyse, tandis que cette crête est vers le bas dans l'Acanthonème. Si je suis de l'avis de M. Agassiz en regardant ce dernier $g$. comme distinct, je le considère comme devant appartenir à la famille des Teuthies, comme très voisin des Amphacanthes, et je ne le placerais ni près des Chétodons, avec lesquels il n'a aucun rapport, ni avec les Scombéroüdes, voisins des Vomers et des Olistes. La longueur des coracoüdiens arrondis, courbés et dirigés en arrière vers la pointe avancée des premiers interépineux de l'anale, établit la ressemblance, qui est corroborée par la forme du crâne, par les granulations et par les ciselures de ces os, par la conformation des mâchoires, la disposition des dents qui les garnissent, la briéveté des côtes, la largeur des crêtes des apophyses épineuses des vertèbres dilatées vers le bas, et tout-à-fait semblables à celles des Acanthures. Je crois même voir sur le petit individu figuré ( $\iota a b .51, \mathrm{n}^{0} 3$ ), de l'Ichthyologie véronaise, prétendu Chætodon aureus, que la ventrale avait 2 rayons épineux, un externe et un interne. Ce dernier caract. complèterait la ressemblance, et le g. Acanthonème ne diffèrerait des Amphacanthes que par la forme des dents sur 1 seul rang, coniques, en pointes recourbées, mais simples, et sans bord dentelé ou festonné comme l'ont celles des Amphacanthes. Toutefois, si je présente avec quelque hésitation l'existence du caract. des 2 rayons épineux à la ventrale, les autres caract. que j'ai signalés sont đ'une telle évidence, qu'ils ne peuvent laisser aucun doute dans l'esprit de l'Ichthyologiste.

M. Agassiz cite une $2^{\text {e }}$ esp. de ce g., l' $A$. Bertrandi, trouvée dans un calcaire terliaire bleuâtre, très siliceux, près de Schio, dansle Vicentin ; mais cette espèce n'a été détermi née que par l'inspection du dessin. (VAL.)

ACANTHONOTE. Poiss.-Syn. de Notacanthe.

(VAL.)

* ACANTHONOTUS ( $\alpha_{x} \alpha \nu \theta \alpha$, épine;,$\widetilde{\omega}-$

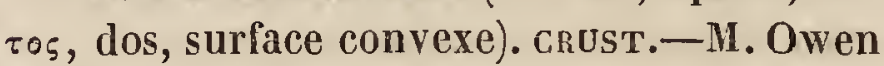
a établi sous ce nom un petit g. de Crustacés de l'ordre des Amphipodes, famille des Crevettines, très voisin des Talitres; il n'en diffère guère que par la longueur des antennes supér.; mais il se rapproche encore davantage des Lysianasses. On n'en connait bien qu'une espèce trouvée à Igloolik.

(M. E.)

*ACANTHONYCHAA, DC. $(\not ̋ x \alpha \nu \theta \alpha$, épine; oขúxเov, onglet). вот. Рн. - $V$. реNTACIENA.

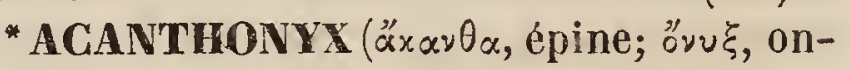
gle). CRUSt. - G. de Crustacés décapodes brachyures, de la famille des Oxyrhynques et de la tribu des Maïens, établi par Latreille et caractérisé par : Des yeux non rétractiles, logés dans des orbites circulaires qu'ils dépassent à peine; des antennes extér. dont l'article basilaire, soudé avec les parties voisines de la carapace, est étroit en avant, et dont la tige mobile s'insére en dehors du niveau du bord du rostre, de façon à n'être pas recouvert par ce prolongement; la forme élargie du pénultième art. des pattes des 4 dernières paires, article qui est tronqué en dessous près du haut et porte un tubercule ou dent, vestige d'un doigt immobile contre lequel le tarse vient se replier. - Par leur forme générale, ces Crustacés se rapprochent beaucoup des Pises; on en connaît 3 esp. qui sont toutes de très petite taille; l'une habite la Méditerranée, la $2^{\text {me }}$ les còtes de l'Amérique, et la $3^{\text {me }}$ le Cap de B.-E. (M.E.)

*ACANTHOPE. Acanthops ( «ँx $\alpha \theta \alpha$, épine; ॐै $\psi$, øil). INs. - G. de l'ordre des Orthoptères, famille des Mantides , créé par M. Serville, et ayant pour caract. essentiels : La forme des yeux avancés en pointe et terminés par une petite épine ; les ćlytres larges avec leur côte 
sinueuse, et labdomen dilaté latéralement. -Ce g. ne renferme que 3 esp. propres à l'Amér. méridionale, et dont le type est l' $A$. fuscifolius (Mantis fuscifolia) Oviv.). (BL.)

ACANTHOPIIS ("ü $\alpha \nu 0 \alpha$, épine ; "̋̋ $\varphi$ ts, selpent). REPT.-Daudin a établi sous ce nom un g. d'Ophidiens de la famille des Vipères, dont un des principaux caract. est de porter une forte épine à l'extrémité de la queue. Il se distingue d'ailleurs par : Un corps court, épais, revêtu d'écailles carénées ; par des lamelles sous-caudales non divisées; par des narines simples, ouvertes latéralernent chacune dans une seule plaque; par l'existence de scutelles sur la région antérieure de la tète; par des yeux à pupille verticale et entourés d'un cercle de petites plaques, parmi lesquelles il en est une, la surcillaire, qui forme comme une sorte d'auvent au-dessus du globe de l'œil. - La seule espéce qui appartienne encore à ce genre, l' $A$. cerastimus Daud., habite la N.-Hollande. On en trouve des figures dans plusieurs ouvrages ; la meilleure est celle de l'Icon. du Règne animal de M. Guérin. (G. B.)

ACANTHOPHORA ( $\alpha x \alpha \nu \theta \alpha$, épine ; yopós porteur). вот. CR. - G. de l'ordre des Floridées, famille des Phycées, établi par Lamouroux (Thalass. non art., Paris, 1813), négligé par Agardh qui en fail la $4^{\mathrm{me}}$ tribu de son g. Chondria; puis récemment repris et admis comme distinct par Gréville qui, dans le Synopsis qu'il a placé en tête de ses $A$ lg. brilannicae, le caractérise ainsi : Fronde continue, cylindracée, cartilagineuse, garnie de petites épines. Fructification immergée ou placée à la base des épines, et consistant, soit en capsules ou conceptacles, soit en granules ternés, c'est-à-dire disposés 3 par 3 le long de la fronde. Deux ou trois esp. composent ce genre. Comme il n'existe point de différence notable entre la fructification des Acanthophora et celle des Chondria, et que d'ailleurs l'organisation des frondes est absolument la même dans les uns et dans les autres, nous ne saurions adopter le g. de Lamouroux, uniquement fondé sur la forme et le port de ces mêmes frondes, et, à l'exemple d'Agardh, Martius et Endlicher, nous n'en faisons qu'une section ou tribu du genre Chondria. (C. M.)

*ACANTHOPHORUS ( $\alpha x_{x} \alpha, \theta \alpha$, épine; $\varphi$ opós, porteur). ıns. - G. de Coléoptères tétramè- res, famille des Longicornes, tribu des Prioniens, établi par M. Serville et adopté par M. Dejean. Il a pour type le Prionus serraticornis Oliv., espéce des Indes orientales. Les principaux caractères de ce g., suivant M. Serville, sont : Cors. tri-épineux latéralement. Mandib. allongées, plus ou moins arquées, multidentées intérieurement. Antennes de 3 à 10 articles prolongés en épines, au côté interne. Dernier art. des tarses de la longueur des 3 autres réunis.

* ACANTHOPHYLLUM (ä $\alpha \alpha_{\nu} \theta \alpha$, épine;

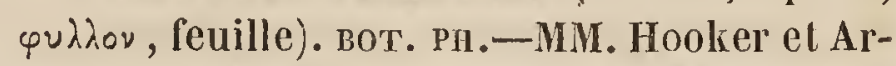
nott (Bot. Mag. comp. t. 1) ont proposé d'établir sous ce nom ung. de plantes de la fam. des Composées, qui ne contiendrait qu'une espèce re l'Amérique méridionale ( $A$. axillare); mais avant eux, Meyen avait déjà employé cette dénomination pour un g. qu'il plaçait parmi les Silénées. Endlicher (Gen. $P l$.), bien qu'adoptant l'Acanthophyllum, le rapporte comme simple section au Triptilion de Ruiz et Pavon. M. de Candolle (Prod. t. vil) a élevé cette section au rang de g., sous le nom de Strongyloma. (C. L.)

* ACANTHOPHYTON ( $\alpha x_{x} \alpha \nu \theta \alpha$, épine ;

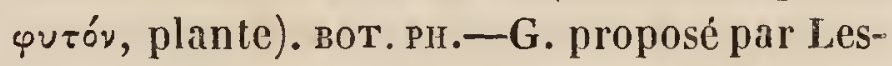
sing (Synops.) pour une plante de la famille des Composées, qui a été réunie au Cichorium $\mathbf{L}$. dans le Prodrome de M. J)e Candolle. Cependant MM. Lindley et Endlicher ont adopté depuis ce genre comme tout-à-fait distinct. Voici les caract. que lui assigne le second (Gen. Pl.).: Capit. homocarpe, d'environ 6 fleurs. Involucre cylindracé, imbriqué; squames presque égales. Récept. planiuscule, épaléacé; cor. ligulée. Akènes uniformes, érostres, turbinés, un peu rugueux transversalement; aigrette uniforme, très courte, multipaléacée, ceinte à la base d'un rebord prolongé de l'akène; paillettes elliptiques, obtuses, assez distantes. - L'A. spinosum, seule esp. du g., est une plante herbacée bisannuelle, appartenant au bassin méditerranćen.

ACANTHOPODE. Acanthopodus ( $\alpha x \times \nu 0 \circ \varsigma$ épireux ; $\pi \otimes \tilde{v} s, \pi 0 \delta^{\circ} \varsigma$, pied). PoIss. - Lacépède a établi sous ce nom un g. dans lequel il réunissait 2 espèces déjà méntionnées dans son ouvrage sous d'autres dénominations et dans des g. différents. L'une, l' $\mathcal{A}$. argenteus (Chcetodon argenteus L.), est la même que le Monodactyle falciforme; c'est le Psetus 
Commersoni de notre Ichthyologie (t. VII). La $2^{\text {me }}$ espéce, l' $A$. Boddaerti, est d'un tout antre g. que la $1^{\text {re }}$ : c'est l'Holacanthe Duc de Lacépède. Ce g., ainsi formé de 2 espèces nominales d'ailleurs dissemblables, n'a pu être conservé.

$(\mathrm{V} \Lambda \mathrm{L}$.

ACANTHOPOMES.Acanthopoma (äx $\alpha \nu \theta \alpha$, épine; $\pi \tilde{\omega} \mu \alpha$, opercule). Poiss. - Nom de la $11^{\text {me }}$ famille du s.-ordre des Thoraciques, la $14^{\mathrm{me}}$ de l'ordre des Holobranches, et la $21^{\mathrm{me}}$ de la classe des Osseux, dans la méthode de M. Duméril. Elle comprend les g. de Poissons de ces groupes à opercules épineux ou dentelés. Voici les noms des g. que l'auteur y rapportait: Holocentre, Persèque, Tonianote, Bodian, Microptère, Sciene, Lutjan et Centropome, tous pris de Lacépéde et adoptés sans aucune critique. (VAL.)

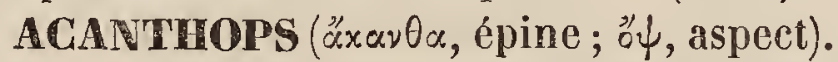
PoIss. - Nom spécifique imaginé par Lacépède pour une esp. de ses Holocentres. (VAL.)

* ACANTHOPS ( $\alpha x_{\alpha} \alpha \theta \alpha$, épine ; $\partial ै \psi$, oil). INS. - $V$. ACANTHOPE.

* ACANTHOPSIDES. Acanthopsido (äxay-

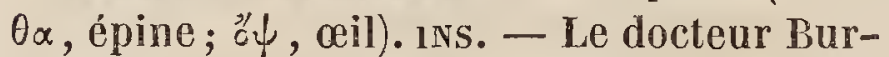
meister donne ce nom à un petit groupe de la famille des Mantides (ordre des Orthoptères), dont le caract. est d'avoir les yeux terminés en pointe. Ce groupe renferme les g. Acanthops et Schizocephalus.

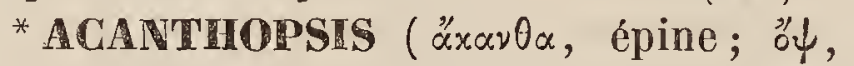
neil). polss. - G. démembré des Cobitis par M. Agassiz, et qui comprend les espèces de Loches à sous-orbitaires épineux. Le corps est comprimé et glissant ; la bouche est entourée de petits barbillons; les dents pharyngiennes sont très pointues et sur une seule rangée.-La Loche de nos rivières $(A$. toenia Agass. (Cobitis toenia L.) est répandue dans toute l'Europe. C'est un petit poisson qui vit sur les fonds sablonneux. Plusieurs esp. de ce g. vivent dans les eaux douces de l'Inde, et ont été décrites par Buchanan. On n'en connaît pas de marines. M. Agassiz en cite une esp. fossile d'OEningen , $A$. Angusuns (Poiss. foss., vol. V).

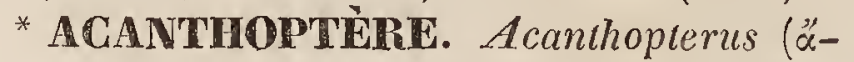
$x \alpha \nu \theta \alpha$, épine; $\pi \tau \varepsilon p o ́ v$, aile). - INS. G. de l'ordre des Coléoptères tétraméres, famille des Longicornes, établi par M. Gory, mais non adopté par M. Dejean, qui l'a réuni au g. Purpuricenus. (Dup.)

ACANTWOPTER YGIENS. Acanthopte-

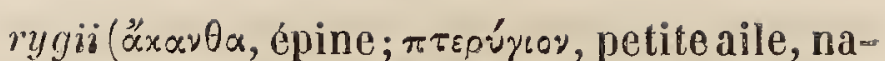
geoire). Polss. - Norn donné par Artédi à l'un de ses ordres de Poiss., pour exprimer que les rayons des nageoires sont durs et piquants, tandis qu'ils sont mous et flexibles chez d'autres Poissons. Pour bien comprendre la valeur de ce mot qui désigne encore, dans l'état actuel de la science, le groupe le plus naturel que l'on puisse établir dans la classe des Poissons, il faut faire attention à l'observation si juste d'Artédi, que les rayons, soutiens des nageoires, sont toujours de deux natures dans ces animaux; tantôt, et c'est même le cas le plus général, ils sont composés de petits ossicules deubles, plus ou moins quadrilatères et articulés par synchondrose à la suite les uns des autres, de façon que ces articulations n'ont aucune mobilité, mais que, le plus souvent, il résulte du peu d'épaisseur des rayons, et même de la longueur des piéces articulées, une sorte de flexibilité qui a fait donner à ces rayons l'épithète de mous ou de flexibles. On leur a substitué aussi la dénomination de rayons articulés, qui est certainement meilleure, car elle donne une idée juste de la nature et de la composition du rayon quelle que soit sa rigidité. En effet, on conçoit qu'un rayon très épais, c'est-à dire composé d'articulations à pièces très larges et de très petite épaisseur, forme un rayon dur et poignant, tels que ceux des Barbeaux (Cyprinus barbus L.); quelques Silures en offrent l'exemple.

Mais il est aussi des Poissons dont les rayons sont simples, inarticulés et composés de fibres osseuses plus ou moins paralléles à leur axe. Ces rayons, qui ne sont jamais divisés à leur extrémité, sont tantôt de véritables épines, par leur rigidité, tantôt de simples filets, grèles, mous, flexibles, etbeaucoup moins rigides que les rayons articulés de plusieurs espéces, désignées sous le nom de Poissons á rayons mous. Cependant, la rigidité de l'épine pouvant être opposée, dans le plus grand nombre de cas, à la flexibilité et à la mollesse du rayon articulé, Artédi donna avec raison au $2^{\text {me }}$ ordre de ses Poissons osseux l'épithète d'Acanthoptérygiens, ordre qui, dans sa méthode, comprenait les g. Blennie, Gobie, Xiphias, Scombre, Mugil, Labre, Spare, Sciène, Perche, Vive, Trigle, Scorpène, Cotte, Zée, Chétodon et Gastérostée. Limné 
ayant cessé d'établir la classlfication des poissons sur les caractères tirés de la nature des rayons, le néologisme d'Artedi fut oublié dans le Systema Naturce; mais nous le retrouvons dans la méthode suivie par Gronovius (Museum ichthyologicum). Ses Acanthoptérygiens comprennent les genres d'Artédi, sauf les Gobies; il y ajoute cependant les g. Polynemus, Mystus et Holocentrus. Depuis cet auteur jusqu'à Cuvier, les Ich thyologistes ne se sont pas servis du caractère tiré de la nature des rayons pour classer les Poissons ; mais, dans sa classification, l'auteur du Règne animal a fait, sous le nom d'Acanthoptérygiens, le $3^{\text {me }}$ ordre des Poissons osseux. Il lui a donné la même valeur qu'Artédi, et en a fait comme lui un ordre tellement naturel, qu'on ne peut le diviser que très difficilement en familles. Néanmoins je crois que celles établies dans nołre Hist. nat. des $P_{\text {oiss. }}$ seront généralenıent admises par les Naturalistes.Cuvier compte dans cet ordre 15 familles, dont nous donnerons les principaux caractères en traitant dans cet ouvrage de chacune de ces familles. La plupart ont pour type les g. établis et rangés par Artédi dans le groupe du même nom, et auxquels nous en avons ajouté quelques uns, en groupant dans une même famille plusieurs des g. de cet auteur, tels que les Scombres et les Xiphias, qui appartiennent à nos Scombéroïdes.

Depuis Cuvier, M. Risso a fait usage du mot Acanthoptérygien, mais en s'en servant pour désigner une subdiv. des différentes familles qu'il a établies, en ayant égard à la position des ventrales, d'oú il est résulté qu'il y a des Poissons jugulaires acanthoptérygiens, placés à côté des jugulaires malacoptérygiens, etc. (VAL.)

* ACANTHOPUS ( $\alpha_{\alpha} \times \alpha \nu \theta \alpha$, épine; $\pi \circ \tilde{v}_{5}$, pied.) ıns. - G. de l'ordre des Coléoptères hétéromères, fam. des Mélasomes, établi par Megerle et adopté par M. Dejean. Il ne renferme qu'une seule esp. qui se trouve en Dalmatie el en Italie; c'est le Blaps caraboïdes Germ. on l'Helops dentipes Panz.

ACANTHORHINE. Acanthorinus ("œx $\alpha, \nu-$ Oa, épine; ṕìn, ange, nom d'un poisson de mer). rolss. - M. de Blainville a établi sous ce nom une coupe générique que $\mathrm{Cu}$ vier a subdivisée en Acanthias, Centrina et Scymnium (Journ.phys. LXxxı1, 1816). (VAL.)
* ACANTHORIIYNCUS (ax $x_{\alpha} \alpha \theta \alpha$, épine; púyxos, bec). ols. - Nouveau genre formé par Gould (Proceedings, 1837), dans la famille des Melliphages ou Philcédons de Cuvier et synon. du g. Phylidonyre de Lesson ( Tr. d'Orn.). Ce dernier nom nous parait devoir être préféré comme antérieur et comme exprimant le rapport intime de ces oiseaux avec 2 g. connus. $V$. Pilylidonyre. (LAFr.)

* ACANTHOSCELIS ( $\alpha^{\prime} \times \alpha^{\prime} \theta \alpha$, épine ;

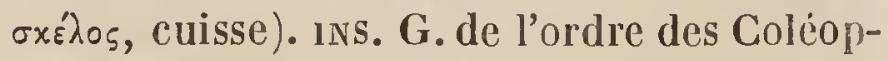
tères pentamères, établi par Latreille dans sa famille des Carnassiers (Carabiques de M. Dejean), tribu des Scaritides. Latreille n'a fail qu'indiquer ce g. dans ses familles nalurelles; il est fondé sur une seule espéce du Cap de B.-Esp., le Scarites ruficornis Fab. M. Dejean, en l'adoptant, lui donne les caracl. suivants : Menton articulé, presque plane el fortement bi-lobé; lèvre supér. très courte et bidentée. Mandib. grandes, avancées, fortement dentées intérieurement; dernier art. des palpes labiaux presque cylindrique. Antennes moniliformes; le $1^{\text {er }}$ art. très grand, les autres beaucoup plus petits et grossissant insensiblement vers l'extrémité. Corps court et convexe. Cors. bombé, transversal et presque carré. Élyt. courtes et très convexes. Jambes antérieures très fortement palmées; les postérieures courtes, larges, arquées et couvertes d'épines; trochanters presque aussi grands que les cuisses postérieures. (D.)

* ACA NTHOSOMA ( $\alpha_{x} \alpha \nu \theta \alpha$, épine; $\sigma \tilde{\omega} \mu \alpha$, corps). Ins. - G. de la famille des Scutellaires, de l'ordre des Irémiptères, établi par Curtis, adopté par MM. de Laporte et Burmeister. Ce g. détaché des Pentatoma Latr., ne s'en distingue que par la présence d'une pointe, située à la base de l'abdomen et se prolongeant sur lesternum. - On y rapporte une douzaine d'esp. répandues dans toules les parties du monde. Le type en est l' $A$. hoemorroïdale (Cimex hoemorroüdalis Fab.), qui se rencontre dans la plus grande parlie de l'Europe.

(BL.)

* ACANTHOSOME. Acanthosoma (äxav$\theta \alpha$, épine; $\sigma \widetilde{\omega} \mu \alpha$, corps). crust. - Petit g. de l'ordre des Amphipodes, famille dès Crevettines, établi par M. Owen, et ne différant guère des Amphiloés, que parce que le front est orné d'un rostre assez saillant, que les pattes des deux premières paires sont filiformes, et que la griffe de l'une de ces paires 
(la $1^{\text {re }}$ ) est ornée d'un petit ongle. Le type de cette dernière est l' $A$. Hystrix des mers polaires.

(M. E.)

* ACANTIOSPETIVA ( $\alpha x \alpha \nu \theta \alpha$, épine;

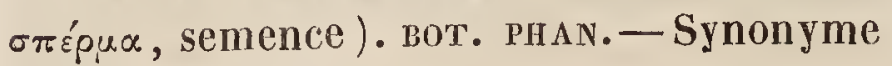
d'Acicarpha. $V$. ce mot.

* ACANThOSPORA ( $\alpha^{\prime} x \alpha \nu 0 \alpha$, épine; $\sigma \pi 0-$ pá, semence, graine). вот. Рн. - Sprengel (Anleit.t.1I) a proposé ce g. pour une plante dont Dietrich a forméson g. Misandra; mais Ruiz et Pavon avaient, avant ces auteurs, fondé sur le même type leur g. Bonapartea, aujourd'hui préféré par tous les Botanistes.

*ACANTHOTHEGA ( $\ddot{x}_{x} \alpha \nu \theta \alpha$, épine ; $\theta \dot{r} x$, boîte). вот. Pн. - Ce g. de la fam. des Composées, renferme plusieurs esp. particulières à l'A frique australe. M. De Candolle le caractérise de la manière suiv. : Capit. multiflore, radié; les fleurs du rayon 1 -sériées, ligulées; celles du disque stériles, tubuleuses, ả 5 den ts. Invol. 1-sérié , à écailles linéaires, dépassant les fleurs du disque. Récept. nu. Fleurs ligulées, ciliées-hispides à la base. Styles bifides, très glabres ; ceụx des fleurs du disque, simples, capités, légèrement hispides. Akènes du rayon, les seuls développés, 3-gones et armés, surtout aux angles, d'aiguillons épais et acérés. Fleurs jaunes; celles du rayon souvent marquées de brun à la base. - Ce g. est voisin du Steirodiscus, dont il diffère par les akènes du rayon, qui sont anguleux et épineux; il a aussi quelques affinités avec les Dimorphotheca et l'Osteospermum; mais la conformation de ses fruits l'en éloigne également.

* A ANTHOTHECA ( $\varkappa_{x} \alpha \nu \theta \alpha$, épine;

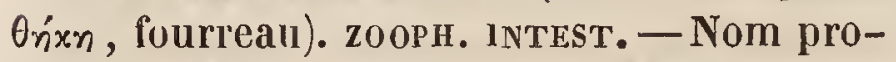
posé par M. Diesing dans sa Monog. dug. Pentastome, pour établir un ordre dans la classe des vers intestinaux, intermédiaires entre les Trémalodes et les $N$ émaloz̈des, et dans lequel il place le seul g. Pentastome.

(VAL.)

* AGANTHOTHORAX ( $\alpha x_{,} \alpha \nu \theta \alpha$, épine ; Swp $x_{\xi}$, tronc). Ixs. - G. de Coléoptères tétramères, famille des Curculionides, établi par Gacde, mais non adopté par M. Dejean. Ce g. répond au g. Mecocerus de Schoenherr. $V$. ce mot.

ACANTHURE. Acanthurus ( $\alpha_{x} \alpha \nu \theta \alpha$, épine; oupá, queue). polss. - G. de la famille des Teuthies, tenant des Scombéroïdes el un peu des Squamipennes. Ce nom, imaginé par Forskal, adopté par Bloch et Lacépède, et exprimant le caractẻre le plus saillant de ces poissons, est tiré de la forte épine mobile dont la queue est armée de chaque côté. Dans l'état de repos, elle est couchée dans une rainure qui la reçoit, et sa pointe postér. assez courte fait seule saillie. Mais quand le Poisson redresse son arme, la pointe, dirigée du côté de la tête, s'écarte du corps, et fait souvent une saillie de plusieurs millimètres. Ii est d'ailleurs assez difficile de concevoir l'usage de cet organe. Cet aiguillon tranchant, en forme de lancette, a fait donner aux espèces qui le portent le nom de Chirurgien, de Barbier ou de Porte-lancetle.

Ce genre, très naturel, comprend de nombreuses esp., originaires des mers des Tropiques et plus abondantes dans celles de l'Inde que sur les côtes de l'Océan Atlantique. Elles ont toutes le corps comprimé, la tête haute, l'œil élevé, la bouche petite, arrnée de dents le plus souvent crénelées sur le bord, tranchantes, et sur un seul rang. La membrane branchiostége est soutenue par 5 rayons. Une seule dorsale étendue sur tout le dos, et non écailleuse. - Linné plaçait les 2 ou 3 esp. qu'il en connaissait, parmi les Chélodons; rapprochement qu'il avait fait d'après la forme générale du corps, quoique les dents et l'organisation interne ne justifiassent ces rapports en aucune manière. Il avait aussi connaissance d'une belle espèce indienne, qu'il classait avec une espèce d'Amphacanthe dans un même g., sous le nom de Teuthis, qu'il plaçait dans l'ordre des Abdominaux. Il aura sans doute été trompé par une mauvaise interprétation de cette phrase de Gronovius : Pinnce ventrales in infimo abdomine medio inter regionem pinnarum branchiam et ani pinnam, mox ante anum siloe, etc. Les ventrales sont bien voisines de l'anus, mais elles n'en sont pas moins thoraciques, parce que l'anus de ces poissons est ouvert très en avant, á cause de l'enroulement en spirale de leur canal intestinal.

Ce g. devait donc être réformé; mais il l'a été peu habilement par Lacépède, puisqu'il a placé le Teuthis javus parmi ses Chétodons; quant au Teulhis hepalus, il l'a rangé dans ses Acanthures. C'est ainsi que le nom générique de Teuthis a été effacé de la no- 
menclature ichthyologique, et c'est avec raison ; car on sait que cette expression était appliquée, chez les anciens, à un mollusque (le Calmar). Il faut aussi remarquer ici que le g. Aspisure de Lacépède n'est qu'un double emploi de son g. Acanthure. On connaìt aujourd'hui 3 ou 4 espèces de ce g. dans l'Océan atlantique, et plus de 40 dans l'Océan Indien. On en a reconnu aussi parmi les poissons fossiles. L'Ichthyolithe du Monte - Bolca (Ichthyologie véronaise), que Volta avait déjà rapproché du Chatodon lineatus, est en effet un .4canthure que M. Agassiz nomme Acanthurus tenuis.

*AGANTHURUS ( $\alpha x_{\alpha} \alpha \nu \alpha$, épine; ờpó, quene). 1Ns. - Nom donné par Kirby à un g. de Coléoptères, famille des Lamellicornes, précédemment appelé Valgus par Scriba. (D.)

* AGANUS ( äxavos, crête épineuse de poissons ). polss. Foss. - G. de poissons fossiles de Glaris, établi par M. Agassiz, qui le range dans la famille des Percoïdes de $\mathrm{Cu}$ vier, et dont il reconnaît 3 espèces. L'une est son $A$. oblongus. Le nom spécif. de la $2^{\mathrm{e}}$ n'est pas encore cité dans le Catal. du cabinet de lord Cole et de sir Phillipp Egerton.

(VAL.)

ACARA. porss. - Nom en quelque sorte générique que l'on trouve dans Marcgrav, le plus souvent accompagné d'une èpithète, et qui désigne des Poissons de g. et d'espèces fort différents. Celui-ci se trouve seul et sans épithète dans Marcgrav pour un poisson d'eau douce du Brésil. que Bloch a nommé Perca bimaculata (Sparus Acara Lacép.), et qui à notre avis est un poisson du g. Chromis.

(VAL.)

AGARAUNA. poiss. - Esp. de Marcgrav qui appartient certainement à un Acanthure et que nous croyons être notre Acanthurus phlebotomus; mais, ce qu'il y a de sûr, c'est qu'il ne faut pas rapporter cette synonymie au Choetodon nigricans de B̈loch, et encore moins au Choetodon nigricans $\mathrm{L}$. qui est différent de celui de Bloch. ( ${ }^{r}$ a ce sujet Cuv. et Val. Ichth. X, p. 209.)

Sous ce même nom, M. Sebastianof a publié dans les Novaacta Petropolitana (t. xu1, p. 257, pl. xı), un g. de Poissons identique au g. établi par Lacépède, et adopté par tous les Ichthyologistes sous le nom de Gomphosc ( $V$. ce mot).
ACARDE. Acardo (’́ priv.; cardo, charnière; mot hybride). MoLL. - On a voulu désigner, par cette dénomination vicieuse, une coquille sans charnière. Bruguière paraît être le $1^{\text {er }}$ qui ait fait usage de ce mot. il l'appliqua à deux choses très distinctes que l'on confondit pendant quelque temps : l'une, que l'on croyait être les valves sans charnière et sans ligament d'un mollusque particulier, a été reconnue pour des épiphyses vertébrales de grands Cétacés; l'autre est le corps fossile dont Lamarck a fait depuis son g. Sphérulite. Dans le Système des animaux sans vertèbres, Lamarck adopta le g. Acarde, dont il avait élimniné les Sphérulites; mais il les remplaça par la coquille dont il fit par la suite son g. Ombrelle. Lamarck revint bientòt à des idées plus justes sur ces différents g., et celui d'Acarde disparut de ses autres ouvrages.

(DESH.)

ACARIDES. Acarida (Acayus, ״̈xapl, sorte de petits ins.; $\varepsilon \tilde{\imath} \delta \circ$, forme). ARach.-Cette famille que $M$. Walckenaër regarde comme le dernier ordre de la classe des Acères, a été établie par Latreille avec ces caract. : Palpes grêles, surnuméraires à la lèvre qui est échancrée. Mandibules en forme de pince. Yeux nuls. Hanches distantes. Pieds caronculés. - Les Arachnides qui composent cette famille sont microscopiques, parasites, et pullulent beaucoup. Quelques unes vivent sur des Insectes, notamment sur les Coléoptéres orduriers ou fouisseurs ; d'autres rongent les provisions de bouche, comme la farine, le vieux fromage, les viandes desséchées. Les collections d'Insectes, placées dans les lieux froids et humides, sont également exposées à leurs ravages. On attribue avec raison à quelques espèces la maladie de la gale, qui se manifeste chez l'Homme comme chez divers animaux domestiques. Certaines Acarides propres à quelques Mammifẻres peuvent aussi se multiplier sur l'Homme et l'incommoder extrêmement. D'autres esp. sont errantes et se trouvent sur les plantes, les écorces des arbres, dans la terre, sous les pierres, etc. Plusieurs naissent avec 6 pattes, les 2 autres se développent peu de temps après; leurs tarses se terminent souvent de diverses manières. Les g. que cette famille renferme sont au nombre de 9 .

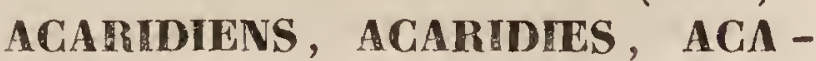


RIENS , ACARINS. ARACH. - Syn. d'ACARIDES.

(H. L.)

ACARNA (nom du chardon? dans Théophraste). вот. Pн. - Vaillant (Act. Acad., 1718) a fondé sous ce nom un $g$. de la famille des Composées, qui est le Picnomon de Lobel et d'Adanson, adopté depuis par tous les botanistes. Linné réunit l'Acarna au g. Cnicus, en l'y appliquant comme nom spécifique d'une espèce. Willdenow reprit cette dénomination pour désigner un nouveau g. qu'il forma aux dépens de l'Atracıylis de Linné, et que Lessing admit dans son Synopsis. Cassini, en adoptant ce g., le limita à une seule espèce, l' $A$. cancellata (Atractylis canc. L.). L'Acarna paraît avoir été définitivement réuni au g. Atractylis (DC., Prodr., vi).

ACARNE. Porss. - Nom tiré littéralement de Pline, qui lui-même l'avait pris des auteurs grecs, et que Rondelet a appliqué assez arbitrairement à un poisson de la Méditerranée, (le Pagellus acarne Cuv. et Val. Hist. Poiss. VI). Salviani a donné le nom d'Acarne à la Vive commune (Trachinus draco).

(VAL.)

ACARUS (axapi, sorte de petits insectes). A RACH.-G. de l'ordre des Acarides, créé par Linné, adopté par Degéer, Hermann et Latreille, et placé par ce dernier dans sa $4^{\mathrm{e}}$ famille, celle des Acarides. Les caractères distinctifs de ce g. sont ainsi exprimés : Labre et palpes cachés par les mandibules. Corps entre le $2^{\mathrm{e}}$ et le $3^{\mathrm{e}}$ pied, entouré par un sillon, mou, légèrement renflé, hanches ả peine distantes; $3^{\mathrm{e}}$ pied plus petit que le $4^{\mathrm{e}}$. Caroncules membraneuses, pointues. Larves très semblables à l'animal adulte. - Ce g. renferme 3 ou 4 espèces, dont une, l'acarus scabiei Fab., se trouve ordinairement dans la poussière du vieux fromage. On a regardé, à tort, cette dernière espèce comme l'Acarus de la gale. C'est ce qu'a pleinement démontré M. Raspail. $V$. S $\Lambda$ RCOPTE.

(H. L.)

ACASTE. Acasta (nom d'une nymphe de l'Océan mythol.). curnI. - Genre établi par le docteur Leach, appartenant á la classe des Cirrhopodes (ou Cirrhipédes), et dont voici les caractères essentiels : Coquille sessile, ovale, subconique, composée de pièces séparables. Còne formé de 6 valves latérales, inégales, réunies; ayant pour fond une lame orbiculaire, concave au côté interne, et res- semblant à une patelle ou à un gobelet. Opercule quadrivalve. - Ce genre, non admis par M. de Blainville, qui en fait une division des Balanes, est composé de 3 ou 4 espèces qui paraissent vivre toutes dans des éponges.

(M. S. $\Lambda$.)

ACAULE Acaulis (ó priv.; xaỳós, lige). вот. PII. - Cette expression s'applique aux Plantes qui paraissent dépourvues de tige, c'est-à-dire dont les feuilles et les fleurs semblent naître du collet de la racine, comme, par exemple, dans le pissenlit, la primevère des jardins, etc. Mais nous devons faire remarquer, que, même dans ces plantes, la tige existe constamment; seulement elle est réduite à de très petites proportions et cachée sous la terre, oú elle constitue une souche ou rhizome ( $V$. ces mots); car les feuilles et les supports de la fleur naissent toujours de la tige.

(A. R.)

ACAVE. Acavus. moll. - G. inutile proposé par Montfort, dans sa Conchyliologie systématique, pour les Hélices qui ont l'ouverture grande et la columelle très arquée, telles que les Helix hamastoma et as persa de Muller.

(DESir.)

ACGENTEUR. Accentor."ors.-G. établi par Bechstein sur le Pégot ou fauvette des Alpes (Buff. pl. enl. 668, fig. 2; Motacilla alpina Gm.), formant le $30^{\circ}$ de l'ordre des Insectivores de la méthode de Temminck, et l'un des s.-g. des Becs-fins (Motacilla, Lin.) de la famille des Dentirostres du Règne animal de Cuvier. Les caract. de ce g. sont : Bec droit, pointu; mandibule supérieure échancrée à l'extrémité, comprimée sur ses bords; narines nues; pieds assez robustes; doigt externe réuni à sa base à celui du milieu; ongle postérieur assez allongé et très arqué; les ailes, de moyenne grandeur, ont leur $1^{\text {re }}$ rémige très petite, la $3^{\text {e }}$ la plus longue de toutes; queue égale et de moyenne longueur. - Ce g. se'compose actuellement de 3 espèces : celle qui en est le type est l'Accenteur des Alpes ( $A$. alpinus Bechst.), les deux autres sont: l'A. mouchet ( $A$. modularis Cuv.) et l'A. montagnard ( $A$. montanellus Temm.). Quelques auteurs y ont ajouté la Fauvette Calliope (Molacilla Calliope Pall.); mais les caract. essentiels de cet oiseau, qui a toutes les proportions des $\boldsymbol{S}$ ylvia et leur système de coloration, ne nous permettent pas de l'admettre comme 
appartenant vérttablement au genre Accenleur.

Le plumage des Accenteurs, généralement terne, est d'un gris roussâtre, parsemé de taches brunes, noires ou blanches, dont la position, la forme et l'étendue varient suivant les espéces. Les femelles sont semblables aux mâles, et les jeunes n'ont pas de livrée. Les Accenteurs n'émigrent point et semblent ne pas craindre le froid. Néanmoins l'hiver amène dans leurs habitudes un changement remarquable : le Pégot et l'Accenteur montagnard, qui ne se trouvent que dans les montagnes du midi de l'Europe et de l'Asie, descendent alors dans les vallées, et le Mouchet, qui habite toutes les parties tempérées des mêmes pays, quitte seulement le sommet des arbres pour se réfugier dans l'épaisseur des taillis, ce qui lui a fait donner le nom vulgaire de traînebuissons.

Les Accenteurs se nourrissent de larves et de graines pendant l'hiver, d'insectes pendant l'été. Ils construisent leur nid avec de la mousse, dans les fentes des rochers, sous les toits des maisons et sur les plus hautes branches des arbres, principalement des arbres verts. Ils pondent 4 ou 5 œufs d'un bleu verdâtre.

(F. P.)

ACCIPITRES (Accipiler, épervier; accipitro, je déchire). ors. - Traduit du latin accipitres de Linné, adopté par Vieillot dans sa méthode, et répondant aux Oiseaux de proie de Cuvier et aux Rapaces de Temminck. $V$. RAPACES.

(LAFr.)

ACCIPITRINÉES. Accipitrince (Accipiter, épervier, oiseau de proic). ols.-Ce mot désigne pour nous, comme pour Willughby, le seul g. Epervier. C'est une s.-famille de la famille des Falconidées, répondant en parlie à la sect. des Autours de Cuvier et aux Autours de Temminck ( $P l$. col.). Cette s.-famille de Swainson que nous adoptons, mais avec des additions et des soustractions de g. nous paraît offrir les caract. suivants : Bec en général court et fortement crochu, courbé des la base. Mandib. supér. comprimée, non dentée, mais dilatée vers le milieu de ses bords en un simple feston plus ou moins prononcé ; mandib. infér. tronquée et retroussée à son extrémité; narines ovalaires, ou orbiculaires et tuberculées dans leur milieu. Pieds i tarses longs et grêles, ou de lon-

$$
\text { T. I. }
$$

gueur métiocre, écussonnés on réticulés, garnis en dessous de pelotes saillantes. Ongles des doigts antér. très inégaux; l'interne souvent de moitié plus gran que l'externe et presque aussi fort que celui du pouce. Tête généralement petite, mais grosse dans un des g., ornée quelquefois d'une huppe tombant postéricurement. Ailes longues, obtuses ou sub-obtuses, à primaires médiocres ou courtes, atteignant, dans le repos, la moitié de la queue, quelquefois le tiers seulement; queue longue ou médiocre arrondie ou étagée. La plupart des esp. qui composent ce groupe sont en général des Rapaces chasseurs et les plus courageux après les vrais faucons; ils poursuivent leur proie à tire d'ailes, la saisissent au vol, souvent même au milieu des bois et des endroits couverts. Nous regardons à l'exemple de Teinminck et d'Azara les Aigles-autours comme de véritables Autours ou grands Éperviers à tarses emplumés, courageux et entreprenants comme eux, d'après les observations d'Azara, de Le Vaillant et de d'Orbigny. Nous les réunissons donc dans ce groupe et y joignons encore le g. Harpye de Cuvier, qui n'ofre d'autre différence avec les $A i$ gles-autours que des tarses plus gros. Ie g. Macagua, malgré ses mours plus analogues à celles des Buses reptivores, nous paraìt d'après ses formes devoir aussi y être rangé. - Notre sous-famille des Accipitrinées se compose donc des g. Épervier, Autour, Aigle-autour, Harpye et Macagua. $V$. ces mots.

$$
\text { (LAFr.) }
$$

* ACCIPITRInS. ors. - C'est dans la méthode de Vicillot la $3^{\text {me }}$ famille de ses Accipitres ou Oiseaux de proie. (LAFr.)

* ACCLIMATEMENT ( $x \lambda^{\prime} \mu \alpha$, climat.). Prrysiol. - La nécessité et l'usage ont déjá consacré dans les sciences ce mot, dont l'Académie n'a point encore sanctionné l'emploi. On appelle Acclimatement, le conflit qui s'exerce à chaque transition entre les corps organisés et les climats. Ici se présentent à la fois une question médico-industrielle, omise dans les autres Dictionnaires de ce genre, el l'étude philosophique des rapports des formes organisées avec les milieux ambiants. Ce double titre commande l'attention des naturalistes.

Il suffit d'un regard jeté autour de nous, d'un simple coup d'ocil sur l'étendue di 
globe, pour voir chaque saison, chaque localité, chaque région varier ses produits. Les éléments de l'ai i', de la terre et des eaux, sont aussi les éléments de la vie; elle doit suivre l'inégalité de leurs conditions. La végétation, moins indépendante que l'être animé, incapable de se soustraire aux influences qui l'environnent, fournit de ces exemples qui frappent chaque jour nos yeux. Chaque plante subit l'alternative des lieux et des saisons; l'humidité fait prédominer l'absorption : la sécheresse, l'exhalation; l'eau, que pompent les racines, et qui sert de véhicule à l'aliment, emprunte plus ou moins les qualités du sol et fait varier ainsi les qualités des végétaux; ceux d'entre eux qui vivent dans les eaux chargées d'acide carbonique, contiennent beaucoup de carbone et sont plus durs; les champignons qui naissent snr le fumier et les détritus d'animaux sont essentielle-ment azotés; d'au tres absorbent des matières siliceuses; enfinceux qui a voisinent les mers contiennent du sel. On sait aussi que l'excès d'humidité donne un tissu aqueux et lâche; que son défaut nuit à la nutrition, et rend les plantes chétives et misérables. La constitution de l'air opère donc selon son degré de température ou son état hygrométrique; mais une des influences les plus marquées est celle de la lumière. Elle doit être regardée comme déterminant, en grande partie, l'absorption de la séve, si l'on considère que les plantes pompent peu d'humidité pendant la nuit et à l'obscurité, que l'exhalation aqueuse est aussi plus considerable de jour, et surtout aux rayons directs du soleil. C'est encore la lumière qui, dans les cas les plus connus, détermine, dans le parenchyme des parties vertes, la décomposition de l'acide carbonique, et, conséquemment, la fixation du carbone dans les végétaux. Elle détermine encore leur coloration, le degré de leur allongement et de leur consistance, l'intensité des proprićtés sensibles et la direction de plusieurs de leurs organes.

Ce que nors disons des localités, nous pourrions l'étendre aux zônes de la terre ¿oumises ì de plus vastes vicissitudes sidérales; mais les bornes de cet ouvrage nous arrêtent. II reste démontré, quant à présent, fu'une intime relation lie le sol à ses produits comme la cause i l'effet, et que cette étude approfondie doit fournir de précieuses inductions à celle des acclimatements. C'est pourquoi nous renvoyons au mot Climat, n'ayant à nous occuper ici que des effets qui résultent des translations.

Tout le monde sait qu'arrachée au lieu de sa naissance, une plante ne parvient á vivre ailleurs qu'après avoir vaincu les premiers effets de la souffrance, et qu'elle acquiert aussi un aspect et des propriétés en harmonie avec sa nouvelle habitation. Mille faits de culture appuieraient au besoin cette assertion; mais la nature elle-même nous offre encore des exemples de ces transformations. Que quelques feuilles, larges organes respiratoires, viennent à être submergées et privées du contact de l'air, leur tissu, désormais sans action, s'atrophic et prend la forme linéaire. L'Ulva compressa devient, suivant les circonstances, plante marine, d'cau douce, ou même terrestre; on la voit se dégrader selon la profondeur de sa situation marine; elle perd déja de sa taille, devient crépue et raccourcic vers les dernières lames liquides; jetée dans les terres par les hautes marées, elle vit dans quelques ruisseaux, dans les eaux saumâtres, et enfin dans les eaux douces, oú elle devient l'Ulva confervö̈dea; que l'eau disparaisse, elle se transforme en l'Ulva terrestris. Ceci suffira pour donnèr une idée de la puissance des milieux; les effets des changements de climats sur les végétaux sont d'ailleurs trop connus pour nous y arrèter davantage.

Les animaux ne subissent pas des effets moins marqués de ces sortes de translations, mais les observations de ce genre, loin d'ètre nombreuses et complètes, comme celles qu'on trouve dans les traités d'Agricuiture, sont, au contraire, d'une extrême rareté, et d'autant plus rares, qu'elles ont trait à des ètres plus inférieurs; aussi en viendronsnous de suite à quelques faits qui se rapportent aux animaux des ordres supérieurs, et sur l'authenticité desquels le caractère même des personnes qui ont bien voulu nous les communiquer ne nous permet pas d'élever le moindre doute. Ces faits sont trés concluants, bien qu'ils naissent sous l'influence assez peu différente de deux de nos provinces : les chevaux et les bêtes à cornes qu'on transporte de Bretagne en Normandie, ac- 
quièrent une tallle plus élevée et les caractères dela race normande; et réciproquement les animaux transférés de Normandie en Bretagne n'atteignent ordinairement qu'à une taille inférieure á celle qu'ils eussent acquise dans leur pays natal. Il y a quelques années, le département du Finistére donna à la Société d'Agriculture de Morlaix un taureau et une vache du Poitou, d'une taille très élevée. Ces animanx furent placés chez les cultivateurs qui pouvaient inspirer le plus de confiance pour les soins qu'exigeait l'introduction de cette nouvelle race. A la $3^{\text {me }}$ génération, les caractères distinctifs étaient entièrement effacés, et Ies descendants ne différaient plus des bêtes du pays, ni par la taille, ni par les formes. On peut ajouter, à cet égard, que l'abondance de nourriture, qui produit de grandes espéces animales dans les pays fertiles, n'est pas toujours la seule cause agissante, non plus que les autres soins qui forment nos variétés domestiques, puisque, dans les exemples que nous venons de rapporter, elle n'a pu prévenir la dégénérescence des races. II laut tenir compte, sans doute, d'autres circonstances dépendantes de l'action générale des climats. C'est ainsi que l'Amérique, qui ne manque pas de fécondité, présente néanmoins des races plus petites que celles de l'ancien continent, et qu'elle a même vu diminuer la taille des races importées.

Rien n'est plus curieux relativement à ces sortes de modifications des formes animales sous l'influence des climats, que les observations recueillies par M. Roulin sur les espèces transportées de l'ancien continent dans le Nouveau-Monde. Selon cet auteur, des poulets importés, depuis plusieurs siècles, à Cusco, oú ils se sont perpétués dans une température qui ne descend pas au-dessous de $20^{\circ}$ centig., n'offrent plus, en souvenir de leur vêtement originaire, qu'un léger duvet, qui tombe bientôt pour laisser l'animal entièrement nu, sauf les plumes de l'aile, qui croissent comne à l'ordinaire. Le chat a éprouvé peu de modifications, par son importation à la Nouvelle-Grenade depuis Colomb, si ce n'est qu'il n'a pas de saison marquée pour la reproduction, et qu'il ne miaule plus comme dans nos pays. Quant aux autres Mammifẻres, les observations a faire présentent quelques difficul- tés, à cause de l'influence qu'exéce l'homme. sur les animaux domestiques, en les protégeant contre l'action du climat. Néanmoins, on peut remarquer que dans les contrées chaudes del'Amérique, dans lesplaines du Méta, il est très difficile d'élever des agneaux, et que les brebis sont peu fécondes. Ici encore la nature opère rapidement, sous nos yeux, les effets ordinairement lents mais constants des climats sur le pelage de ces animaux, plus abondamment foumi de poils dans les pays froids, plus nu dans Ies pays chauds. Si la main de l'homme ne touche pas à leur toison, la laine s'épaissit, se feutre, et finit par se détacher en plaques qui laissent au-dessous d'elles, non une laine naissante, non une peau nue et dans un état maladif, mais un poil court, brillant, bien couché, très semblable à celui de la chèvre, sous ces mêmes climats. Dans les places où ce poil a paru, la laine ne renaît jamais.

Il résulte aussi des observations de M. Roulin, que Ies animaux domestiques, transportès en Amérique, lors de sa découverte, ont fini par s'y acclimater, et que Ieur fécondité devint même bientôt telle, qu'affranchis par cette surabondance, la plupart reprirent leur vie sauvage. De ce nouveau cas résultèrent de nouvelles modifications : les oreilles du porc se sont redressées, son crâne s'est élargi ; l'agilité du cheval s'est développée, le courage de l’âne a reparu, la vivacité de la chèvre a augmenté; enfin le pelage, perdant ses variélés dans chaque espèce, y est devenu uniforme. Remarquons à cette occasion que là se trouve la contreépreuve de la proposition avancée par M. Isidore Geoffroy-Saint-Hilaire : que les nombreuses variétés du bœuf, du cheval, du porc, de la chèvre, etc., ne sont que des produits de la domesticité.

Il reste évident que les formes organiques sont, d'une part, modifiées par les agents extérieurs chez les êtres qui ont acquis leur développement, et de l'autre, que la génération finit par transmettre ces mêmes modifications; mais le succés des acclimatements offre souvent des difficultés; $\mathrm{ct}$, bien que les éléments ambiants aient toujours une grande puissance, la vie résiste quelquefois, et succombe même au lieu de phlier. Il se développe dans ce conflit des réactions 
maladives qu'il importc de connaitre. Labat avait déjà observé la nécessité de n’opérer les translations en des climats difrérents, que graduellement et par stations intermédiaires, afin de prévenir les déchirements, produits par une iransition trop brusque. Ainsi, la viggne, importée directement de France dans nos colonies des Antilles, a eu bien de la peine á s'y naturaliser, tandis que le Muscat, venu de Madère et des Canaries, y mûrit parfaitement bien. Le même auteur fait aussi observer que le temps est quelquefois une condition indispensable pour compléter certains acclimatements. « J'ai expérimenté, dit-il, qu'ayant semé des pois qui venaient de France, ils rapportaient très peu; les seconds rapportaient davantage ; les troisièmes rapportaient d'une manière extraordinaire par le nombre et la grosseur. " Puis il ajonte: : Un habitant de ma paroisse, nommé Sellier, sema du froment qui était venu de France; il vint très bien en herbe; mais la plupart des épis étaient vides et les autres avaient très peu de grains; ceux-ci, nés dans le pays, étant semés, poussèrent à merveille, et produisirent les épis les plus beaux et les mieux fournis qu'on puisse imaginer. ")

Rien n'a été plus négligé que ces sortes d'observations appliquées aux animaux des classes inférieures. La plupart vivent dans l'eau, il est vrai ; mais les différentes eaux ne sont-elles pas pour eux autant de climats? On n'en a pas fait davantage pour les insectes qui appartiennent éminemment au domaine de l'air. Il ne sera pas sans intérêt, sans doute, de rappeler ici les expériences de M. Beudant sur les Mollusques. Quelques uns de ces animaux pris dans des eaux douces et placés immédiatement dans de l'eau salée au degré de celle de la mer, ne tardèrent pas à périr; mais si, au contraire, on n'opérait que par une transition graduée dans des eaux de plus en plus salćes, l'acclimatement avait lieu avec quelques difrérences relatives aux espèces soumises à l'expérience. Les mêmes effets ont eu lieu pour les Mollusques marins plongés dans l'eau douce, à la seule différence près que les espèces vivant sur des rochers couverts et découverts alternativement par la marée, souvent hors de l'eau, ont résisté plus long-temps a l'efret de l'immersion brusque. L'acclima- tement gradué, au contrafre, s'opéra fort bien : M. Beudant conserva 5 mois des Patelles, des Arches, des Huîtres, des Moules, des Balanes bien portantes, en compagnie de Planorbes el de Lymnées. L'Auteur a fait plus : il est parvenu à faire vivre, dans des eaux chargées de 0,31 de sel, des Mollusques marins, qui vivaient dans celles qui n'en contenaient que 0,04 . La formation des cristaux a été la dernière limite de l'acclimatement.

En ce qui touche les animaux supérieurs, on voit encore, dans le Mémoire de M. Roulin, que des Oies et des Paons apportés en Colombie éprouvèrent, dans les premiers temps, toutes les difficultés de l'acclima tement : les pontes étaient rares, composées d'un petit nombre d'œufs, dont un quart à peine venait á éclore, et plus de la moitié des jeunes oisons mourait dans le premier mois. Plus tard les générations s'améliorèrent; et, pour la fécondité, l'espèce aujourd'hui diffère peu de celle d'Europe. Les Poulets éprouvèrent les mêmes effets : à Cusco el dans toute la vallée, on fut plus de trente ans sans pouvoir en obtenir, tandis qu'aujourd'hui les races importées sont devenues fécondes. La race anglaise, amenée depuis peu d'années, n'en est pas à ce point; et, dans les commencements, on s'estimait heureux d'avoir deux ou trois Poulets sur toute une couvée. Il est enfin d'observation vulgaire que beaucoup de Mammifères étrangers s'acclimatent parfaitement chez nous, tandis que d'autres ne s'y reproduisent pas ou n'y vivent qu'environnés des plus grands soins. L'Homme lui-même, quoique appelé cosmopolite, n'a pas moins à souffrir de ces déplacements, et il n'échappe le plus souvent à la mort que par les précautions que son intelligence lui indique. Deux grandes fonctions sont principalement intéressées, selon qu'on passe sans intermédiaire d'un climat chaud dans un climat froid, ou de celui-ci dans un climat chaud : la respiration et la digestion. Dans le premier cas, le poumon éprouve un surcroît d'activité, soit parce que la vitalité de la peau étant diminuée, le sang reflue vers les organes intérieurs, soit parce que les animaux consomment plus d'air sous un môme volume à une basse température. Lorsqu'on passe, au contraire, dans un climat chaud, l'excitation du poumon 
diminue, celle de la peau augmente; elle devient le siége de la fluxion, el reste exposée á toute sorte d'exanthêmes. Les mouvements étant ainsi portés à la périphérie, la digestion perd de soll activité; e'est ce que nous observons même daus nos climats, par le seul eflet des changements de saisous. Si douc on ne diminue la quantité d'aliments, si l'on ne les choisit légers, ou si l'on se livre à quelques excès, cette fonction se trouble, les organes digestifs s'irritent, et il en résulte ces gastro-entérites et ces hépatites si communes dans les pays chauds. D'un autre côté, le poumon continue de produire une trop grande somme de chaleur, la circulation s'accélère, il se manifeste une pléthore générale et des symptômes de congestion au cerveau. Le régime végétal, les boissons tempérantes, les bains froids, etc., préviennent ordinairement ces accidents et favorisent l'acclimatement.

Tel est l'exposé succinct des principaux faits de l'acclimatement : partout des agents modifiıateurs, partout des êtres modifiés. Il n'en faut pas davantage, sans doute, pour faire sentir que nous ne posons pas ici une simple question d'économie industrielle; nous touchons au fond même de la science. La juissance des milieux ambiants, dans la modification des formes organiques, n'est qu'un fait secondaire, comparativement à la loi universelle de l'instabilité de toutes choses ; mais e'est un fait dont l'étude approfondie peut concourir à nous mettre sur la voie d'une immense genèse. Remarquons d'abord, que lorsqu'un être se développe dans un milieu favorable, c'est-à-dire dans celui qui a vu ses plus antiques générations, il parcourt sans efforts ses diverses périodes. Que ce milieu vienne à changer, aussitòt il souftre, et une luttes'engage entre lui et la circonstance nouvelle. Il semblerait, en n'y regardant pas de près, que l'organisme jouit d'une force propre, antagoniste de celle des milieux et de nature différente; mais l'observation prouve le contrairc. Que l'être acclimaté, et dont les générations ont subi l'empreinte du nouveau climat, soit replacé dans son milieu primitif, aussitôt même lutte, même résistance, même difficulté pour ce nouvel acclimatement; d'où il suit que la forme organisée ne tient l'ien d'elle-même, et que le nisus formativus n'est qu'un jeu des élé- ments. Que si les formes du ressort de la Botanique et de la Zoologle sont renfermées, de nos jours, dans une certaine limite de variations relatives a l'état actuel de notre planète, celte question de quantité ne touche au principe que pour le consacrer. L'admirable relation des formes et des milieux a fait demander quelquefois lequel des deux était fait pour l'autre. Il ne peut y avoir là qu'une question de priorité facile à résoudre : le monde physique ne suppose que luimême; l’organisation, au contraire, suppose le monde physique.

Une grande découverte ne naît pas dans les sciences sans ébranler au loin les principes déjá posés. Dès que l'unité de composition organique fut reconnue; dès qu'il fut établi que tous les êtres, quelque variés qu'ils soient, sont composés des mêmes éléments organiques, et que la nature n'a fait qu'en diversifier les proportions pour les approprier à différentes relations avec le monde extéricur, c'est à celui-ci qu'il fallut demander la raison des formes, et la création se présenta comme un vaste accli matement. La philosophic dans les sciences doit couronner l'œuvre des détails; espérons pour notre gloire que l'étude de la nature entre aujourd'hui dans cetle voic. (ANT.)

ACCORTE (Curtus, écourté). ıns. - Nom donné par Godard à une Chenille qui se nourrit des feuilles du Rosier d'hiver. (D.)

ACCOUCHEMENT. zoor. Expulsion naturelle ou extraction d'un foetus et de ses dépendances hors de la matrice. (A. T.)

ACCOUCHEUR. REPT. - C'est le nom spécif. d'un batracien anoure de notre pays, appartenant au g. Alytes. (G. B.)

ACCOUPLEMENT. Copulatio. pHYsion. Rapprochement du mâle et de la femelle pour accomplir l'acte de la génération. L'accouplement n'est point indispensable dans toutes les espèces; certains animaux sont pourvus des deux sexes à la fois et peuvent se féconder isolément. Comme il existe une différence très grande dans le mode que suit la Nature dans la reproduction des diverses espéces, les Naturalistes ont établi les divisions suivantes : $1^{\circ}$ accouplement simple, pour désigner l'union du mâle avec la femelle; $2^{\circ}$ réciproque, lorsque deux animaux hermaphrodites donnent et reçoivent à la fois ; $3^{\circ}$ composé, lorsque le même 
animal hermaphrodite se féconde sans le secours d'un autre individu. La durée de l'accouplement varie à l'infini en raison des espèces. Il est instantané dans beaucoup d'oiseaux, et dure trés long-temps dans le limaçon et dans un grand nombre d'insectes. Le mode de l'accouplement, et l'époque à laquelle il a lieu chez les animaux, sont subordonnés : dans le $1^{\text {er }}$ cas, à la conformation générale du corps, et particuliẻrement à celle des organes de la génération; dans le $2^{\mathrm{e}}$, aux saisons, à la température et à la domesticité. La plupart des animaux sauvages s'accouplent une fois l'an, à une époque fixe. Il en est qui s'unissent entre variétés d'une même espéce, ou entre espèces voisines; et dans ce cas on emploie ce moyen pour obtenir de plus beaux produits.

L’influence de l'accouplement sur la génération est très variable : tantôt un seul acte féconde un très grand nombre d'œu is; tantôt son action est limitée à une seule portée, tandis que pour certaines espèces un seul acte féconde plusieurs générations successives.

Les moyens qu'emploient les animaux, et particulièrement les Insectes, sont aussi intéressants que curieux à connaître dans tous les détails ; aussi renvoyons-nous aux articles qui traiteront des diverses classes d'animaux.

(M. S. A.)

ACGRESGENT. Accrescens. вот. рн. Cet adjectif est usité pour caractériser les parties ou organes qui continuent de s'accroître, quand les autres parties du même système organique s'arrêtent dans leur développement. Ainsi, le calice est accrescent dans l'Alkékenge, les Rumex; le style, dans les Clématites et les Pulsatilles, etc., parce que ces organes continuent à se développer postérieurement à la fécondation, c'est-à-dire au moment où les autres parties constituantes de la fleur s'arrêtent dans leur développement.

ACCROISSEMENT. Accretio, incremenıum. PIYsioc. - Augmentation de l'étendue d'un corps par le dépôt successif de nouvelles molécules constituantes. L'accroissement des corps organisés est soumis aux lois de l'absorption. Les molécules qui doivent servir à nourrir et à augmenter le volume des corps, entrent dans leur intérieur, y subissent une élaboration particulière, sont mises cn mouvement dans les canaux ou cellules dont ces corps sont composés, s'assimilent à eux, et en augmentent la masse de dedans en dehors. Si on compare entre eux les animaux et les végétaux, on voit que les uns et les autres reçoivent et élaborent à l'intérieur les matériaux de leur accroissement; mais que, dans les animaux, il est plus rigoureusement assujetti à des conditions fixes, tandis que la qualité du sol et la culture peuvent changer entièrement l'aspect, la taille et la nature des productions du végétal. La température et les climats ont aussi une influence remarquable sur l'accroissement des animaux et des végétaux ; toutefois, cette influence n'apporte que des modifications légères à la masse et à la forme de l'homme et des animaux, tandis qu'elle en a une très grande sur le développement des végétaux.

$$
\text { (M. S. A.) }
$$

ACCHOISSEMENT dans les végétaux. вот. - Les végétaux, comme tous les autres êtres organisés, s'accroissent dans tous les sens, c'est-à-dire que les différents organes qui les composent éprouvent une augmentation de volume plus ou moins considérable. Cet accroissement est, comme on sait, l'un des caract. communs à tous les corps naturels; seulement dans les Végétaux, comme dans les Animaux, il est contenu dans de certaines limites qu'il ne saurait dépasser. Cette augmentation se fait dans tous les organes des végétaux, et simultanément dans tous les sens. Ainsi, tandis que la tige et la racine, c'est-à-dire la partie centrale et axile du végétal, s'accroissent en hauteur, elles augmentent aussi en diamètre. Il en est de même des feuilles et de tous les autres organes foliacés et appendiculaires, où l'accroissement se fait également en tous sens.

C'est particuliẻrement dans la tige des Végétaux que cet accroissement est le plus remarquable, et c'est dans cet organe qu'il a été étudié avec le plus de soin; aussi est-ce decelui-là que nous allons nous occuper avec quelques détails. Nous l'étudierons successivement, $1^{\circ}$ dans les plantes Dicotylédones; $2^{\circ}$ dans les plantes Monocotylédones, où il offre des différences notables; et, dans chacune de ces grandes divisions du Règne végétal, nous parlerons successivement de l'accroissement eu diamctre, et de l'accroissement en hauteur. 
\$I. TIGR DES VÉGÉTAUX DICOTYLÉDON?. $1^{\circ}$ Accroissement en diamètre.

Pour faire bien connaître les phénoménes de l'accroissement dans la tige des Végétaux dicotylédonés, il est indispensable d'abord que nous exposions ici en peu de mots la structure anatomique de celte tige, et les différentes parties qui la composent, afin de mieux faire comprendre le mode de formation et le développement de chacune de ces parties.

Une tige ligneuse dicotylédonée, coupée transversalement, celle d'un chêne, par exemple, se compose des trois parties suivantes, immédiatement unies entre elles : $1^{\circ}$ à l'extérieur, l'écorce; $2^{\circ}$ le corps ligneux; $3^{\circ}$ le canal médullaire, qui en occupe le centre.

I. L'écorce, formée de feuillets minces, intimement soudés entre eux, est la partie la plus extérieure de la tige. En procédant de l'extérieur à l'intérieur, elle offre : $1^{\circ} l^{\prime} \dot{e}$ piderme, membrane celluleuse et incolore, souvent fendillée et se détachant par fragments: $2^{\circ}$ l'enveloppe herbacée, couche assez mince de tissu utriculaire, prenant quelquefois beaucoup de développement dans certains végétaux, comme l'orme, le chêneliége, et plusieurs autres, contenant, dans les jeunes individus, des granulations vertes qui finissent par disparaître avec l'âge ; $3^{\circ}$ les couches corticales, ou le liber, plus ou moins nombreuses, quelquefois formées de feuillets, qu'on sépare facilement les uns des autres, ou soudés en une masse peu distincte. Ces couches corticales se composent d'un réseau de fibres vasculaires, anastomosées entre elles, et formant des mailles remplies par du tissu utriculaire. Ces vaisseaux de l'écorce sont: $1^{\circ}$ des tubes ligneux, très allongés, très grêles, mais à parois épaisses, qui en constiluent la majeure partie; $2^{\circ}$ des lubes laticifères, ou vaisseaux du latey, épars dans le tissu utriculaire, ou au milieu des faisceaux ligneux corticaux; $3^{\circ} \mathrm{en-}$ fin des vaisseaux ou lacunes du suc propre, qui n'existent que dans un certain nombre de végétaux à suc propre. L'épiderme, l'enveloppe herbacée et les couches corlicales sont unis de manière à former un seul et même corps, dont les diverses parties ne sont distinctes que par la différence de leur organisation.
II. Le corps ligneux est toute la partie de la tige sítuée entre l'écorce et le canal médullaire. Il se compose de couches ou de zônes plus ou moins circulaires et concentriques, disposées autour du canal médullaire. Ces couches, dont l'épaisseur est variable et souvent inégale dans les différents points de leur circonférence, sont distinguées en deux parties : l'une, inlérieure, composée de couches plus denses et plus colorées, porte les noms de cour du bois, duramen ou bois proprement dit; l'autre, extérieure, appelée aubier, est formée des couches ligneuses les plus extérieures, dont la couleur est plus pâle et le tissu moins dense. Quelquefois cette différence de coloration et de dureté est très marquée entre le bois et l'aubier; c'est ce qu'on observe surtout dans les bois très durs, et particulièrement dans ceux dont la couleur est plus foncée. Dans les bois blancs et mous, au contraire, on n'observe presque aucune différence de coloration entre ces deux parties du corps ligneux. Du centre à la circonférence, les couches ligneuses sont coupées par des lignes, rayonnant et divergeant du canal médullaire vers l'écorce, et qu'on désigne sous le nom de rayons médlullaires. Ces rayons médullaires se prolongent jusque dans l'intérieur de l'écorce, où ils viennent se perdre, et servent à établir une communication directe entre la moelle et le tissu cellulaire de l'écorce. Ils sont eux-mêmes uniquement composés de tissu utriculaire, mais offrant une disposition fort remarquable : leurs utricules sont allongées transversalement et disposées en lignes parfaitement parallèles. Le bois se compose de deux éléments anatomiques : $1^{\circ}$ le tissu ligneux, proprement dit, ou les fibres ligneuses qui sont des tubes courts, à parois très épaisses, coupés obliquement en biseau à leurs deux extrémités, ou se terminant en pointe, mais unis entre eux bout à bout, de manière à former des fibres très longues et très résistantes; $2^{\circ}$ les vaisseaux aériens, épars au milieu du tissu ligneux, et généralement désignés sous le nom de fausses trachées ou vaisseaux poncutés. Ces deux éléments sont combinés entre eux sans intermédiaire d'aucun tissu utriculaire, le corps ligneux ne contenant ce dernier tissu que dans les rayons médullaires.

III. L'étui médullaire, c'est-à-dire les parois 
du canal ligneux dans lequel la moelle se trouve contenue, occupe, en général, le point á peu près central do la tige. Il est composé de faisceaux vasculaires généralement contigus entre eux latéralement, et qui, indépendamment des tubes ligneux et des fausses trachées, contiennent encore de véritables trachées; c'est même la seule partie de la tige oú l'on trouve ces derniers vaisseaux. La moelle n'est que du lissu utriculaire dans lequel existent quelquefois des fibres vasculaires. Telles sont les diverses parties dont se compose la tige dicotylédone ligneuse. Une tige dicotylédonée herbacée présentera les mêmes parties essentielles que la tige ligneuse, c'est-à-dire une écorce, une couche de tissu ligneux et un étui médullaire. Mais ces parties y sont moins distinctes, et surtout le canal médullaire y est proportionnellement beaucoup plus grand.

Chaque année, il se produit une nouvelie couche ligneuse à l'extérieur de celles qui existaient déjá dans la tige des arbres dicotylédonés. Cette couche se forme successivement, à mesure que les bourgeons se développent sous la forme de jeunes branches ou de scions, par l'addition de fibres nouvelles, qui tendent constamment à en augmenter l'épaisseur. Mais pour bien nous rendre compte des phénomènes de cet accroissement, étudions d'abord la manière dont se produisent et se montrent, dès la première année, les diverses parties dont se compose la jeune tige.

Si l'on examine une jeune tige dès le moment-de son apparition, ou, ce qui est la même chose, un jeune scion tout-à-fait à son extrémité, par exemple dans son dernier entre-nœud ou mérithalle, on y trouve l'organisation suivante: Le canal médullaire excessivement grand occupe, en général, la majeure partie de la tige. Ses parois sont formées de faisceaux ligneux, souvent peu nombreux, généralement très petits, distincts les uns des autres et séparés par du tissu utriculaire, qui d'un côté vient de celui qui remplit le canal médullaire, et s'écend jusque dans la couche celluleuse placée sous l'épiderme. Disposés sur une coupe transversale comme autant de coins on de figures ovales, dont la petite extrémité est tournée vers le centre de la tige, ces fais- ceaux sont à la fols l'origine, par leur partic intérieure, de l'étui médullaire, et par leur partie externe de la première couche ligneuse; mais ces 2 parties ne sont nullement distinctes; et dès lors, il est évident que le canal médullaire n'est pas originairement un organe à part des faisceaux ou compartiments ligneux, mais qu'il n'en est que la partie la plus intérieure. Déjà à cette première époque, où l'organisation de la tige n'est en quelque sorte qu'ébauchée, la partie la plus intér. des compartiments ligneux montre des trachées à l'état rudimentaire, ainsi que les autres vaisseaux aériens. En dehors de ces faisceaux ligneux, ảejà disposés circulairement et formant les rudiments de la première couche de bois, se voit une zône plus ou moins épaisse d'un autre tissu cellulaire rempli de granulations vertes. Quelquefois à cette première période, ce tissu forme à lui seul toute l'écorce. D'autres fois, à la partie intérieure de ce tissu cellulaire herbacé, on aperçoit des faisceaux fibreux disposés égaIement en une zône, plus souvent interrompue, rarement continue, qui constitue le premier liber. Cette couche fibreuse de l'écorce est toujours séparée de la zône des faisceaux ligneux par du tissu utriculaire dépourvu de granulations vertes, et à laquelle on peut donner le nom de zône génératrice, parce que c'est en effet en elle que se passent les phénomènes de la formation et de la multiplication des fibres ligneuses et corticales. Le liber, ou la partie fibreuse de l'écorce, a quelquefois une autre origine. Il provient de la partie la plus extérieure de chacun des faisceaux ligneux qui se séparent du tissu du bois par l'interposition d'une couche de tissu utriculaire sans granulations, qui représente la zône génératrice. C'est ce que nous avons observé dans plusieurs végétaux, comme la vigne, l'épine-vinette, etc. Ces faisceaux du liber se distinguent facilement des faisceaux ligneux, en ce qu'ils ne contiennent aucune trace des vaisseaux aćriens qui n'existent que dans les compartiments du bois.

Les faisceaux ligneux augmentent successivement de volume et de nombre. A leur côté externe, en effet, c'est-à-dire du côté qui regarde l'écorce, s'ajoutent successivement de nouvelles fibres ligneuses, au milieu desquelles se montrent des vaisseaux 
aćriens. Lorsqu'on examine, sur la coupe transversale d'une jeune branche, la disposition du bois et de l'écorce, on voit que ces deux organes sont parfaitement contigus l'un à l'au tre, sans que, par conséquent, l'œil puisse discerner entre eux aucune ligne de séparation. Ainsi, les faisceaux ligneux sont unis aux faisceaux corticaux par une couche plus ou moins épaissè d'un tissu utriculaire fin et comme à l'état rudimentaire, dont les utricules se continuent et se transforment en tubes ligneux, par le côté qui touche au bois, et en fibres corticales, par la partie tournée du côté de l'écorce. C'est cette couche de tissu utriculaire, véritable matrice oú se forment les fibres nouvelles, que nous avons désignée sous le nom de zône génératrice.

A mesure que les faisceaux ligneux s'accroissent par leur còté extéricur, le diamètre de la tige ou de la branche augmente proportionnellement. Cet accroissement en diamètre se poursuit, tant que la tige s'allonge, par le développement de son bourgeon terminal, et ne s'arrête que quand elle cesse de croître en hauteur. Un développement analogue a lieu simultanément dans la partie fibreuse et vasculaire de l'écorce, mais cependant avec une différence remarquable. Ainsi, toutes les fibres qui s'ajoutent à chacun des faisceaux ligneux primitifs se soudent et se confondent tellement avec eux, qu'elles ne forment, au, bout de l'année, qu'une seule et mème couche circulaire, dans laquelle il esi à peu près impossible de recounaitre les traces de cet accroissement successif. Quelquefois les choses se passent ainsi pour le liber, qui, lor'sque la première période d'accroissement est achevée, n’offre aussi qu'une seule couche de faisceaux fibreux. Il arrive aussi que dans le même temps oú il ne se forme qu'une seule couche ligneuse, il se développe plusieurs conches de liber, ou, pour mieux dire, plusieurs zônes de faisceaux corticaux. C'est un fait qui, à notre connaissance, n'avait pas encore été signalé et dont nous avons eu l'occasion d'observer de nombreux exemples. Ainsi, dans le laurier-rose, le nover commun, le peuplier noir et une foule d'autres arbres différents, nous avons remarqué qu'à la fin de la première année l'écorce se composait de plusieurs couches de faisceau x vasculaires.
Mais l'addition de nouvelles fibres à la partio externe de charque faisceau ligneux, ou à la partie interne de chaque faisceau de l'écorce, n'est pas la seule origine de l'accroissement en diamétre. Si, en effet, on observe attentivement ces faisceaux ligneux primitifs, on voit que leur nombre augmente peu à peu. Ce fait avait été déjả observé par M. de Mirbel pour les faisccaux ligneux des racines, et pour ceux de la tige par le professeur Link de Berlin. M. Du Trochet a, par de nouvelles observations, appelé l'attention sur ce point. Ce savant a remarqué que, dans la jeune tige de la clématite, il y avait d'abord six faisceaux ligneux disposés en un cercle autour du canal médullaire, faisceaux séparés les uns des autres par de larges rayons médullaires. Peu à peu, au milieu de chacun de ces espaces remplis de tissu utriculaire, se montre un nouveau faisceau de fibres longitudinales; de sorte qu'au bout d'un an la jeune tige offre 12 faisceaux. $A$ la fin de la $2^{\text {me }}$ année on en compte 30 : chacun des 6 faisceaux primitifs s'est partagé en 3 par la production de 2 rayons médullaires, et les 6 faisceaux secondaires se sont eux-mêmes partagés chacun en 2. Cet accroissement est aussi très visible dans la tige de la vigne. Dans une jeune branche de cet arbrisseau , les faisceaux vasculaires; dont le nombre est considérable, sont séparés les uns des autres par des rayons médullaires très marqués. Peu à peu, il se forme au milieu de chaque faisceau vasculaire une ligne de tissu utriculaire rempli de granulations vertes, et paralléle aux rayons médullaires. D'abord peu étendue dans l'intérieur du faisceau, elle gagne de proche en proche, et finit par le séparer en deux. A mesure que cette lame de tissu utriculaire s'accroît, ses granulations verles disparaissent insensiblement, de sorte qu'elle finit par se changer en un vérible rayon médullaire qui offre les caractères de tous les autres rayons médullaires déjà existants. Cet accroissement latéral, résultat de la multiplication des faisceaux ligneux, tend à diminuer i'épaisseur des espaces cellulaires qui séparent ces faisceaux, c'esi-à-dire les rayons médullaires. On concoit qu'il ne peut avoir lieu que tant que les faisceaux vasculaires sont encore tendres et à l'état récent, et qu'il s'arrête dès que eur tissu s'est lignifić. 
Ainsi, l'augmentation en volume d'une jeune lige est lc rósultal de deux accroissements s'exerçant en deux sens différents; $1^{\circ}$ un accroissement en épaisseur, qui a lieu par l'addition de nouvelles fibres vasculaires a la parlie externe de chaque faisceau ligneux, dans cette ligne circulaire el celluleuse que nous avons appeléc zône génératrice ; $2^{\circ}$ un accroissement latéral ou en largeur, qui résulte de l'augmentation du nombre des faisceaux vasculaires, soit par la division des faisceaux primitifs en 2 ou 3 faisceaux secondaires, soit par la formation de nouveaux faisceaux de fibres au milieu des espaces ou rayons médullaires. Ainsi une tige d'une année, quand les phénoménes 'de son accroissement sont terminés, se compose $: 1^{\circ}$ d'un nombre ordinairement très considérable de compartiments ligneux, séparés par des rayons médullaires minces et formant une couche dont l'épaisseur varie; $2^{\circ}$ d'unc écorce dont la partie interne présente des faisceanx de fibres anastomosées dans tous les sens et formant souvent, dès la première année, plusieurs couches minces ou feuillets, qu'on peut artificiellement séparer les uns des autres; de là le nom de liber donné á cette partie.

Si nous suivons l'accroissement de la lige pendant les années qui suivent la première, dont nous venons d'exposer les phénomènes, nous verrons que chaque année, il se forme une nouvelle couche ligneuse qui s'ajoute à celles qui existaient déjà. Cette nouvelle couche s'est développée dans la zône génératrice en dehors de celle qui l'a précédée, et n'en est séparée par aucun tissu interposé. Si, sur une jeune branche de l'année précédente, on examine, au premier printemps, la manière dont la nouvelle couche ligneuse va se former, on observe les phénomènes suivants. Le lissu cellulaire, in terposé entre la surface externe de la couche ligneuse et la partie interne de l'écorce, et qui sert de moyen d'union entre le bois et l'écorce, éprouve de notables modifications; ainsi sa porlion en contact avec la couche ligneuse, qui en est d'abord fort distincte, prend peu à peu des caractères qui l'assimilent au tissu ligneux. Ce tissu de nouvelle formation diffère sensiblement des tubes ligneux, dont plus tard il est destiné á prendre les caracteres. Ainsi, sur une conpe horizontale examinée au microscope, cette zône présente un tissu à mailles inégales, non sculement par leur grandeur, mais encore par leur irrégularité. Leurs parois sont minces et transparentes, et le diamètre de leur canal est assez grand. Si an contraire nous examinons le bois en contact avec ce tissu, nous verrons qu'il présente l'aire de tubes très serrés les uns contre les autres, à p̀arois excessi vement épa isses, ayant un canal d'une extrême ténuité. Ce qui n'est pas moins remarquable, c'est que les rayons médullaires du bois se continuent sans interruption dans cette nouvelle couche de tissu, qui commence à peine à s’ébaucher, et qu'ils la traversent de part en part pour aller se terminer dans la couche herbacée superficielle. Celte disposition est extrêmement remarquable dans un grand nombre de végétaux ligneux, et entre autres dans le faux platane (Acer Platanoüdes). Sur une jeune branche de l'année précédente, on voit, dès la fin de février, áu moment où les bourgeons commencent à se gonfler pour se développer, que les rayons médullaires sont encore remplis de matière verte, et qu'ils se continuent, sans aucune interruplion, à travers la nouvelle couche qui tend à se former et dans laquelle on les distingue, non seulement parce qu'ils forment autant de lignes vertes, mais encore par la régularité de lenr tissu, composé d'utricules régulières, allongées de dehors en dedans; en un mol, offrant les caractères du tissu des rayons médullaires déjà tout constitués.

Peu à peu ce tissu de nouvelle formation prend tous les caraclères des tubes ligneux, et cette transformation se fait par an mouvement excentrique, c'est-à-dire que c'est la portion la plus rapprochée de la surface de la couche ligneuse qui s'organise la première en bois. A mesure que le bourgeon terminal et les bourgeons latéraux de la jeune branche se développent, en donnant naissance a autant de scions, la nouvelle couche ligneuse gagne en épaisseur, et cet accroissement ne s'arrête que quand ces jeunes scions ont acquis tout leur développement. Au milieu de celte nouvelle couche ligneuse, qui, au premier abord, ne paraît composée que de tubes ligneux, on voit peu à peu se dessiner des vaisseaux aériens ( ce sont or- 
dinairement des valsseaux ponctués ) qui, sur une coupe transversale, se distinguent bientòt des tubes ligncux par la largeur de leur canal et le peu d'épaisseur de leurs parois.

De même que, la première année, il s'est formé une couche de liber en même temps qu'une couche lignense, de môme aussi, dans les années suivantes, il s'ajoute un ou plusieurs feuillets d'écorce à la face interne de ceux qui existaient déjà. En effet, ces deux parties constituantes dela tige, l'écorce et le corps ligneux, ont un accroissement simultané, qui ne peut avoir lieu dans une de ces deux parties sans se montrer également dans l'autre.

Les couches ligneuses récemment formées sont d'abord composées de tubes et de vaisseaux aériens plus ou moins mous, et qui conservent, pendant quelques années, les caractères d'un bois imparfait. En un mot, elles sont d'abord à l'état d'aubier; mais par les progrès de l'âge, elles finissent par acquérir plus de dureté, plus de ténacité, et par prendre une tcinte plus foncée. Ce n'est que quand elles ont acquis ces dernières qualités, que les couches ligneuses sont passées ả l'état de bois parfait ou de duramen. Ainsi, dans les premiéres années, la jeune tige n'est composće que d'aubier. Plus tard, la couche d'aubier la plus intéricure se convertil en vrai bois; et chaque année, en même temps qu'il se développe à l'extérieur une nonvelle couche d'aubicr, la couche la plus intérieure se convertit en une nouvelle couche de bois. Le nombre des couches ligneuses, dans une tige dicotylédonée, exprime donc le nombre des années de la tige, puisque tous les ans il s'en est formé une nouvelle.

Nous nous sommes contenté jusqu'à présent d'exposer les faits, c'cst-à-dire de donner la suite des phénomènes que présente la tige dans la formation successive de ses couches ligneuses. Les observations nombreuses auxquelles nous nous sommes livré pour éclairer ce point important de la physiologie des végétaux, nous ont permis de l'exposer peutêtre d'une manière assez précise pour avoir été bien compris de chacun. Mais si tous les physiologistes sont d'accord sur le fait de la formation, chaque année, d'une nouvelle couche lignense, la plus grande dissidence régne au contraire parmi ellx, quand il s'a- git d'expliquer ces phénomènes, d'en reconnaìtre la source et de les rapporter it nne théorie générale. Ici, en effet, Ies opinions sont assez différentes, et nous allons voir comment on a pu donner au même fait des causes presque opposées. Sans entrer dans des détails que ne comporte pas la nature de ce livre, nous allons brièvement exposer les principales théories proposées pour expliquer la formation des couches annuelles du bois.

On peut rapporter à trois chefs difrérents, les opinions diverses émises sur l'origine des couches ligneuses qui se forment chaque année. $1^{\circ}$ Selon Malpighi et Duhamel, le liber ou la partie la plus intérieure de l'écorce se change en bois. $2^{0}$ Selon Lahire et Dupetit-Thouars, Ies nouvelles couches ligneuses sont dues au développement des bourgeons, qui de leur base émettent des fibres glissant entre le corps ligneux et l'écorce. $3^{0}$ Enfin, Grew a émis l'opinion que le bois provenait de l'organisation du cambium, sorte de liquide organisé ou de tissu à l'état liquilde, qui, chaque année, donne à la fois naissance à une couche d'aubier et à une couche de liber.

$1^{\circ}$ Le liber se change en aubier.

Malpighi, comme nous venons de le dire, est le premier qui ait émis l'opinion que le liber ou la partie intérieure el vasculaire de l'écorce se transformait chaque année en bois, tandis qu'un nouveau liber se développait pour remplacer l'ancien. Mais cette théorie est généralement altribuée à Duhamel, qui l'a en effet développée en l'appuyant sur un nombre considérable d'expériences, qui font de sa Physique des arbres un des ouvrages les plus importants de physiologie végétale expérimentale. Quoique cette théorie de la formation des couches ligneuses ait élé pendant fort long-temps adoptée presque universellement par les physiologistes, un grand nombre d'observations plus précises ont prouvé qu'elle n'était pas fondée, ou plutôt qu'elle reposait sur une observation entachée d'erreur. Duhamel ayant fait passer des fils d'argent tres minces dans la partic extéricure de l'écorce, s'aperçut qu'au bout de quelques années ils étaient rejetés en delıors de l'écorce. En ayant engagé d'autres dans sa partie la plus intérieure, ou dans le liber, il les retrousa, 
au bout de quelques années, dans les couches lignenses les plus extérieures. Duhamel avait liré de cette observation les deux conséquences suivantes : $1^{\circ}$ la partie extérieure de l'ćcorce est douée d'un mouvement d'accroissement centrifuge qui tend à remplacer par de plus intérieures celles de ses parlies externes qui se détruisent; $2^{\circ}$ le liber, par les progrès de la végétation, se convertit chaque année en bois, et chaque année il se produit entre le bois nouvellement formé et l'écorce, un liquide organisé nommé cambium qui reproduit un nouveau liber. Cette théorie serait en effet à l'abri de toute attaque, si le fait sur lequel elle repose et dont elle semble une conséquence naturelle, était bien établi. Malheureusement l'expérience de Duhamel, au sujet des fils engagés dans le liber, a été répétée un grand nombre de fois; et, contrairement à ce qui avail été annoncé par le savant expérimentateur, on les a toujours retrouvés dans le liber, même après plusieurs années d'expérience, quand on s'était assuré qu'en effet ils avaient été placés dans cette partie. Ainsi le liber une fois formé n'éprouve plus de changement notable, et surtort ne se transforme pas en bois, puisque les fils que l'on $y$ passe y sont retrouvés au bout de plusieurs années. La théorie de Malpighi et de Duhamel ne repose donc pas sur un fondement solide. Duhamel, dans son expérience, n'avait pas fait assez d'attention à cette couche celIuleuse interposée entre le corps ligneux et la partie interne de l'écorce, couche que nous avons nommée zône génératrice. C'est en effet dans cette zòne, comme nous le verrons bientôt, que se passent les phénomènes de l'accroissement en diamètre, c'est-d-dire en dedans du liber. Dans l'expérience de Duhamel, les fils d'argent avaient été engagés, non dans la partie vasculaire de l'écorce qui constitue le liber proprement dit, mais dans cette zône génératrice où les fibres ligneuses se reproduisent; et c'est ainsi qu'au bout d'un certain nombre d'années ils avaient été retrouvés plongés au milieu des fibres ligneuses. Nous n'insisterons pas davantage sur cette théorie. Duhamel a fait, particulièrement sur le développement de l'écorce, un grand nombre d'autres expériences que nous ferons connaitre plus tard, quand nous parlerons spécialement de l'organisation de l'écorce. $2^{\circ}$ La formation des couches annuelles du bois est due au développement des bourgeons.

Cette ingénicuse théorie a d'abord été présentéc par Lahire dans les Mémoires de l'Académie des sciences (année 1719). Entièrement oubliée, Dupetit-Thouars la développe plus d'un siècle aprés comme tou t-à-fait nouvelle. Enfin, aprés des vicissitudes variées, tantôt combattue et sapée dans ses bases, elle vient d'être de nouveau soutenue par des observateurs du plus grand mérite, en Angleterre par Knight et Lindley, et en France surtout par M. Gaudichaud, qui néanmoins l'a sensiblement modifiée en quelques points. Exposons d'ahord brièvement les idées de Dupetit-Thouars.

Les bourgeons qui naissent sur les jeunes branches, à l'aisselie des feuilles, sont appliqués sur le parenchyme extérieur, et leurs fibres communiquent avec celles des jeunes scions qui les supportent.

Il existe un bourgeon à l'aisselle de toutes les feuilles; mais ce bourgeon n'est apparent que dans les plantes dicotylédonées, et parmi les monocotylédonées, dans la famille des Graminées seulement. Dans les autres plantes de ce dernier embranchement, ce bourgeon est latent, et ne consiste qu'en un point vital, susceptible, dans certaines circonstances, de se développer à la manière des bourgeons apparents des dicotylédons.

Par leur développement, ces bourgeons donnent naissance à des scions ou jeunes branches chargées de feuilles et souvent de fleurs. Chacun d'eux a une existence en quelque sorte indépendante de celle des autres. Dupetit-Thouars les regardait comme analogues, dans leur développement et leur structure, aux embryons renfermés dans l'intérieur des graines, qui par leur germination donnent naissance à une jeune tige que l'on peut comparer au scion produit par le développement d'un bourgeon. Aussi donne-t-il à ces derniers le nom d'embryons fixes ou adhérents, par opposition à celui d'embryons libres, conservé pour ceux que renferme l'intérieur de la graine.

Sur un jeune scion, ces bourgeons, examinés dans leur structure intérieure, communiquent directement avec le parenchyme intérieur ou la moclle. Or, celte moelle est d'abord verte, et ses cellules sont remplies de sues aqueux. C'est dans ces fluides aqueux 
que les bourgeons pulsent les premiers matériaux de leur développement. Ils se nourríssent donc aux dépens du parenchyme intérieur, et, en absorbant les fluides qu'il contient, ils le dessèchent et le font passer à l'état de moelle proprement dite, plus ou moins opaque et séche.

Dès que ces bourgeons se manifestent, ils obéissent à deux mouvements 'généraux, l'un montant ou aérien, l'autre descendant ou terrestre. C'est ici que Dupetit-Thouars rapproche la structure et les usages des bourgeons de ceux des embryons-graines. Il considère en quelque sorte les bourgeons comme des embryons germant. La couche de cambium, situce entre l'écorce et le bois, est, pour le bourgeon, analogue au sol sur lequel la graine commence à germer. Son évolution aérienne donne naissance à un scion ou jeune branche; tandis que de sa base, c'est-à-dire du point par lequel il adhère à la plante-mère, partent des fibres analogues à la radicule de l'embryon, qui, glissant dans la coucho humide du cambium, entre le liber et l'aubier, descendent jusqu'à la partie la plus inférieure dn végétal. Or, chemin faisant, ces fibres rencontrent celles qui descendent des autres bourgeons, s'y réunissent, s'anastomosent entre elles, et forment ainsi une couche plus ou moins épaisse, qui prend de la consistance, de la solidité, et constitue chaque année la nouvelle couche de bois. Quant au liber, une fois formé, il ne change plus de nature et n'éprouve aucune transformation.

D'après ce court exposé, on voit que ce sont les bourgeons qui jouent ici, par leur développement, le rôle essentiel dans la formation annuelle et successive des couches ligneuses. Les fibres qui partent de leur point de contact avec la jeune branche se convertissent donc en fibres ligneuses. Quand on fait une ligature circulaire à une tige dicotylédonée, il se forme, comme chacun le sait, un bourrelet au-dessus de cette ligature, et des couches ligneuses cessent de se former au-dessous du point embrassé. Dupetit-Thouars expliquait de la manière suivante ce phénoméne : Les fibres qui descendent de la base des bourgeons sont arrêtées par la ligature. Elles s'accumulent donc sur ce point et y forment un bourrelet, d'autant plus épais que l'arbre est plus vigoureux et plus en séve. La cessation de la formation des couches ligneuses au-dessous de la ligature, provient de ce que les fibres qui les forment ne peuvent franchir l'obstacle que leur oppose la ligature.

De nombreuses objections ont étè présentées contre cette théorie. Nous les reproduirons ici en peu de mots. $1^{\circ}$ Rien ne prouve que les fibres qui établissent la communication entre les bourgeons et les branches qui les supportent, descendent depuis la base de ces bourgeons jusque dans les racines. $2^{\circ}$ Les phénomènes du bourrelet circulaire formé à la suite de la ligature du tronc peuvent s'expliquer par l'interception de la sève descendante, et de son accumulation au-dessus de l'obstacle; de lá, la non-formation de nouvelles couches ligneuses au-dessous de la ligature. $3^{\circ}$ Il est presque impossible de concevoir comment des fibres aussi grêles et aussi molles au moment de leur formation, que celles qui unissent les bourgeons aux tiges, peuvent, dans un espace de temps aussi court que celui durant lequel la tige s'accroît en diamétre, descendre de leur propre poids, ou par une propriété inhérente en elles, du sommet d'un arbre de 80 pieds, par exemple, jusqu'à sa base. $4^{\circ}$ Si ce sont les fibres descendant de la base des bourgeons, qui constituent les couches ligneuses, lorsque dans la greffe en écusson on insère un bourgeon d'un arbre à bois coloré sur un individu à bois blanc, les fibres qui partent de ces bourgeons devraient conserver leur couleur, et les nouvelles couches ligneuses qu'elles forment en présenter une semblable; ce qui n'a pas lieu. $5^{\circ}$ Enfin si c'est le développement des bourgeons qui donne lieu à la formation du bois, comment la première couche ligneuse a-t-elle pu se former sur le jeune scion de l'année, puisque aucun des bourgeons qu'il porte ne s'est encore développó, ou bien dans la tige des plantes annuelles, oú les bourgeons sont à l'état latent?

Telles sont les principales objections faites à la théorie de Dupetit-Thouars. Il est vrai que cesavant avait répondu à chacune d'elles d'une manière qu'il croyait péremptoire, mais qui n'a pas paru telle à la plupart des physiologistes.

M. Gaudichaud, comme nous l'avons dit précédemment, a adopté l'opinion de Du- 
petit-Thouars, sur l'origine des couches liglleuses. Néanmoins les nombreuses observations que cet habile physiologiste a faites pendant le cours de ses lointains voyages dans les régions tropicales du globe, l'ont amenć à présenter quelques modifications a la théorie de Dupetit-Thouars, dont cependant il admet les bases générales. Pour bien faire connaître les opinions de M. Gaudichaud, nous allons transcrire ici l'aperçu suivant, qui résume leș idées de l'auteur, et qu'il a eu la bonté de nous communiquer, pour être inséré dans la $6^{\mathrm{me}}$ édition de nos Éléments de Botanique.

$1^{\circ}$ Tout dans les végétaux dicotylédonés et monocotylédonés se forme dans les embryons et les bourgeons.

$2^{\circ}$ Le végétal phanérogame le plus simple et le plus réduit (l'individu vasculaire), est représenté par une feuille cotylédonaire.

$3^{\circ}$ Ine feuille cotylédonaire se compose, outre ses autres tissus, d'un système vasculaire, qui peut être divisé en inférieur et en supérieur.

$4^{\circ}$ Le système supérieur se divise de plus en trois parties ou mérithalles, qui sont le mérithalle inférieur ou tigellaire, le mérithalle moyen ou pétiolaire, et le mérithalle supérieur ou limbaire.

$5^{\circ}$ Les lignes de démarcation de ces mérithalles sont, le mésophyte, qui sépare la tigelle du pétiole, et le mésophylle, qui sépare le pétiole du limbe.

$6^{\circ}$ Le système descendant des embryons ne se développe que dans l'acte de la germination, en sorte que jusqu'à ce moment l'embryon tout entier appartient au système ascendant. La ligne qui sépare le système ascendant du système descendant, est le mésocauléorhize.

$7^{\circ}$ Les vảisseaux des deux systèmes partent done du même point, et se développent en sens contraire. IIs sont alternes entre eux, ainsi que ceux des mérithalles qui changent de direction dans les mésophytes et les mésophylles.

Ils sont aussi diversement nombreux et réticulés suivant les groupes végétaux.

$8^{\circ}$ Dans quelques cas, la radicule et la tigelle avortent en totalité ou en partie; dans d'autres, ce sont le pétiole ou le limbe, ou tous les deux.

$9^{\circ}$ Dans un embryon monocotylédoné, il n'y a origlnairement qu'un système vaseulaire mérithallien enveloppant.

$10^{\circ}$ Il y en a 2 ou plusieurs dans les embryons dicotylédonés ou polycotylédonés.

$11^{\circ}$ Un système vasculaire est l'ensemble des vaisseaux primitifs d'une feuille quelconque, considérée comme plante distincte.

$12^{\circ}$ Les cotylédons s'associent dans les embryons dicotylédonés ou polycotylédonés; comme les sépales, dans les calices monosépales; comme les pétales, dans les corolles monopétales; comme les étamines, dans les plantes monadelphes, diadelphes ou polyadelphes; comme les carpelles, dans les ovaires composés; enfin comme les feuilles elles-mêmes, les stipules, les bractées.

Ces sortes de soudures ont lieu par les bords, comme par les deux surfaces.

$13^{\circ}$ Du nombre des cotylédons, puis des feuilles, de la disposition de leur tissu vasculaire, résultent les deux ordres principaux d'organisation des tiges phanérogames, et leurs modifications diverses.

$14^{\circ}$ Ce qu'on a dit de l'embryon s'applique surtout au bourgeon.

$15^{\circ}$ Indépendamment du bourgeon axifère, chaque nœud vita! (mésocaulév'hize, mésophyce, mésophylle) peut, dans les plantes vivaces, donner naissance à des bourgeons axillaires.

$16^{\circ}$ Il y en a normalement un dans les embryons monocotylédonés.

$17^{\circ}$ Il y en a deux ou plusieurs dans les embryons dicotylédonés, un pour chaque feuille.

$18^{\circ}$ Les bourgeons axillaires avortent souvent dans les deux grands ordres de végétaux, les monocotylédons et les dicotylédons, mais rarement à l'aisselle de leurs feuilles. Leur nombre peut s'aceroître par des causes accidentelles.

$19^{\circ}$ Les bourgeons axifères et axillaires représentent des scions ou rameaux à l'ćtat rudimentaire.

$20^{\circ}$ Ils sont composés d'un nombre déterminé de feuilles régulièrement disposées en spires ou verticilles.

$21^{\circ}$ Les feuilles, selon qu'elles croissent dans la terrc, dans les eaux ou dans l'air, oú elles éprouvent des modifications diverses, selon leur position ou leur état particulier de développement, peuvent être dites : feuil- 
les bulbeuses, tubéreuses, squamelleuses, primordiales, propres ou normales, terminales, écailleuses, stipulaires, bractéales, calicinales, nectarifẻres, discoïdes, torusiennes, pédaloïdes, staminales, carpellaires, ovulaires; et ces dernières se divisent en funiculaires ou arillaires, en priminaires, secondinaires, tercinaires ou nucléines, quartinaires, quintinaires, embryofères et cotylédonaires.

$22^{\circ}$ Elles ne sont que les divers états de modification d'un organe originel unique, l'individu vasculaire, ou phyton.

$23^{\circ}$ Elles se divisent, comme les cotylédons, en système supérieur et en système inférieur, et ce dernier en trois mérithalles.

Elles se développent de bas en haut à partir d'un point donné, et constituent le système ascendant des végétaux, système caractérisé par la présence de vaisseaux particuliers, au nombre desquels sont les trachées (les véritables trachées ne se rencontrent que dans le système ascendant).

$25^{\circ}$ L'accroissement des mérithalles est simultané et régulier rlans quelques cas, isolé et très irrégulier dans d'autres.

$26^{\circ}$ Toutes les parties de la feuille peuvent subir les modifications exprimées au $\$ 7$.

$27^{\circ}$ De la base du système ascendant ou aérien de chaque feuille part un système descendant ou terrestre qui se distingue par des vaisseaux tubulcux, tous plus ou moins déroulables naturellement ou par déchirement, mais qui ne sont pas de vraies trachées.

$28^{\circ}$ Chaque espéce de feuille a son système descendant propre, sa racine.

$29^{\circ}$ Ce système descendant, dont l'abondance ou la rareté dépendent des corps appendiculaires d'où il provient, glisse dans des voies particulières (par exemple entre l'écorce et le bois des végétaux déjà formés), et contribue, en grande parlie, à la formation des couches ligneuses du bois et fibreuses de l'écorce, ou autrement dit, à l'accroissement en épaisseur du tronc des végétaux dicotylédonés et de leurs racines.

$3^{\circ}$ D'après cela, une tige ligneuse dicolylédone est forméc de feuilles régulièrement ou irrégulièrement opposées et situées les unes ali-dessus des autres (d'où l'accroissement en hauteur) dont les mérithalles infé- rieurs ou tigellaires persistants et plus ou moins développés, sont successivement couverts par les tissus radiculaires ou descendants des feuilles de tous les verticilles supérieurs, soit de l'annéc, soit des années subséquentes, et par des couches également successives de tissu cellulaire (d'où l'accroissement en largeur des tiges êt en épaisseur des couches concentriques).

$31^{\circ}$ Les tiges ligneuses des monocotylédonés sont à peu de chose près comme celles des dicotylédonés, et s'accroissent de la même manière, c'est-à-dire par un système ascendant, par un système descendant, et par un développement utriculaire excentrique, improprement nommé rayonnemient medullaire.

$32^{\circ}$ Un embryon monocotylédoné n'a primitivement qu'un système vasculaire"cnveloppant, parce qu'alors il n'est formé que d'une seule feuille rudimentaire roulée. Au centre de cette $1^{\text {re }}$ feuille, centre uniquement formé de tissu cellulaire naissant, il s'en développe bientôt une $2^{\mathrm{e}}$, puis une $3^{\mathrm{e}}$, et enfin un nombre déterminé, normal pour chaque espèce végétale.

$33^{\circ}$ De la base de la $2^{\text {me }}$ feuille, base indiquée par le tissu cellulaire naissant par des points sphéroïdes transparents, fluides ou gélátineux, et qui sont en rapport avec les nervures de la feuille, partent obliquement du haut en bas et du centre à la circonférence, des sortes de tubes vermiculés, dichotomes d'abord, puis rameux, à rameaux généralement sinueux, anastomosés, qui vont sortír au-dessous du pétiole de la $1^{\text {re }}$ feuille, entre les vaisseaux de son mérithalle tigellaire, et descendent ainsi parallèlement et extérieurement à ces vaisseaux, jusqu'd la racine. Les vaisscaux descendants de la $3^{\text {me }}$ feuille s'agencent avec ceux de la $2^{\text {me }}$, comme ceux-ci l'ont fait avec les vaisseaux de la $1^{\text {re }}$, et ainsi de suite.

$34^{\circ}$ Les vaisseaux tubuleux ou radiculaires ne descendent pas toujours aussi réguliers jusqu'à la racine. Il arrive souvent, surtout dans les liges articulées creuses el à mérithalles ordinairement très développés, que, rencontrant sur certains points des voies plus humides ou plus convenablement préparées, ils se détournent de leur route naturelle pour se porter, en lout ou en partie, tantôt à la circonférence des tiges, pour 
former des faisceaux ligneux particuliers ou des racines, tantôt vers le centre pour former des articulations, des diaphragmes ou cloisons.

$35^{\circ}$ Comme dans les mónocotylédons, le mérithalle tigellaire ou inférieur de la feuille, est généralement très réduit ou manque totalement, les vaisseaux du système descendant ou radiculaire des feuilles supérieures se croisent immédiatement avec ceux du système ascendant des feuilles inférieures, d'où résultent ces lacis inextricables ofierts par presque toutes les tiges des grandes monocotylédonées ligneuses dans leur coupe verticale.

Telle est en résumé la théorie à l'aide de laquelle M. Gaudichaud explique les phénomènes de l'accroissement des tiges et la formation des couches ligneuses. Cette théorie, comme il est facile de le reconnaître, repose sur l'idée fondamentale de Lahire et de Dupetit-Thouars, l'émission des fibres ligneuses par la base des bourgeons. Mais cependant M. Gaudichaud a introduit une idée neuve dans cette théorie phylogénique; c'est la distinclion qu'il établit entre le système ascendant et le système descendant de la tige. En effet, selon ce savant physiologiste, le système ascendant se compose de trachées, de fausses trachées, et de tous les vaisseaux qui constituent le canal médullaire : c'est par son développement qu'a lieu l'accroissement en hauteur de la tige. Quant au système descendant, il se compose des vaisseaux rayés, ponctués, et des tubes ligneux qui partent et descendent de la base des bourgeons, et forment les couches ligneuses et les feuillets vasculaires de la partie intérieure de l'écorce.

Dans l'état actuel de la science, nous ne saurions avoir une opinion bien arrêtée sur les idées de M. Gaudichaud. Les objections soulevées contre la théorie de DupetitThouars, subsistent tout entières contre celle de M. Gaudichaud, qui n'en est qu'une modification. Le grand travail qui sert de base à cette théorie, et dans lequel l'auteur a consigné les faits nombreux et les expériences qui l'ont conduit à ses idées, n'a point encore été publié. Lés amis des sciences doivent désirer ardemment cette publication ; car ce n'est qu'alor's qu'il sera possible de porier un jugement sur une théorie ingénieuse, mais contre laquelle s'élèvent des objections qui n'ont point encore été détruites.

$3^{\circ}$ La formation annuelle des couches ligneuses est due au cambium qui, chaque année, fournit les matériaux d'une nouvelle couche d'aubier et d'une nouvelle couche de liber.

Cette opinion est celle qu'indiquent plusieurs passages des ouvrages de Grew, et que plus récemment ont adoptée MM. Kieser et de Mirbel.

Voici comment ces auteurs expliquent cette manière d'envisager les phénomènes de l'accroissement en diamètre. Dans une jeune branche en état de végétation on trouve, entre le liber et l'aubier, une couche d'un fluide d'abor'd clair et limpide, qui peu.á peu s'épaissit et prend de la consistance; ce fluide, nommé cambium, est formé par la sève descendante, mélangée à une partie des sucs propres des végétaux. Cette opinion sur la nature du cambium était celle admise généralement depuis Grew et Duhamel; mais, dès l'année 1816, M. de Mirbel en avait émis une autre. Pour ce savant, en effet, le cambium n'est pas un liquide s'épanchant entre le bois et l'écorce; c'est un véritable tissu qui naît à la fois de ces 2 parties de la tige. Il se forme, dit-il, entre le liber et le bois une couche qui est la continuation du liber et du bois. Cette couche régénératrice a reçu le nom de cambium. Le cambium n'est donc pas une liqueur qui vienne d'un endroit ou d'un autre : c'est un tissu très jeune qui continue le tissu plus ancien. Il se nourrit et sedéveloppe à 2 époques de l'année, au printemps et en automne. Son organisation paraît identique dans tous ses points; cependant la partie qui touche à l'aubier se change insensiblement en bois, et celle qui touche au liber se transforme peu a peu en liber. Cette transformation est perceptible à l'œil de l'observateur. Ainsi, en résumé, il se forme chaque année, dans le tronc des arbres dicotylédonés, une nouvelle couche ligneuse et une nouvelle couche d'aubier. Ces nouvelles couches sont une production de l'aubier et du liber qui s'organisent et se solidifient. L'aubier formé l'année précédente acquiert plus de densitó et se change en bois; mais le liber n'éprouve ancune transformation; seulement il se sépare et s'accroit par sa face interne, au moyen du 
cambium, et forme successivement de nouveaux feuillets.

Cette dernière opinion paraît être celle qui se rapproche le plus des faits observés; cependant nous croyons devoir la modifier en un point. Nous admettons, avons-nous dit dans la $6^{\text {me }}$ édit. de nos Éléments de Botanique (p.174), que les nouvelles couches qui se forinent soient une production, une sorte d'extension de la face externe de l'aubier et de la face interne du liber; mais nous ne saurions donner le nom de cambium à ce tissu de nouvelle formation. Pour nous, le cambium est toujours ce fluide nutritif, produit de la sève élaborée, qui s'épanche au printemps et en automne entre le bois et l'écorce. Mais nous n'admettons pas pour cela que le cambium se transforme, d'une part, en une nouvelle couche d'aubier, et d'autre part, en une nouvelle couche de liber. Le cambium est le fluide essentiellement nourricier du végétal, comme le sang est celui des animaux; mais, de mème que ce dernier fluide ne se transforme ni en muscles, ni en tissu cellulaire, ni en graisse, en un mot en aucun des tissus élémentaires des animaux, fournissant seulement à chacun de ces tissus les matériaux propres à leur développement, à leur entretien; de même aussi nous pensons que le cambium, dont on ne peut nier la similitude avecle sang des animaux, fournit à la fois à l'aubier et au liber, dont il baigne les surfaces, les principes nécessaires à leur développement. Il ne devient pas tissu cellulaire ni lissu vasculaire ; mais ces tissus déjà existants y puisent les principes au moyen desquels ils s'accroissent et se multiplient.

L'observation confirme d'ailleurs pleinement la nouvelle théorie que nous émettons ici. En effet, que l'on examine attentivement une jeune branche d'arbre, quand, au printemps, l'afllux du cambium en détermine l'accroissement en diamètre, on verra que la surface externe de l'aubier et la surface interne de l'écorce sont, en quelque sorte, dans un état de turgescence. Elles sont recouvertes l'une et l'autre d'une couche plus ou moins épaisse de tissu cellulaire à l'état naissant, abreuvée d'une grande quantité de sucs. Ce tissu de nouvelle formation, analogue à la couche de bourgeons charnus qui s'élèvent de la surface d'une plaie tendant à se cicatriser, est non seulement adhérent aux T. 1 . deux surfaces sur lesquelles on le volt, mais en est évidemment une production, une vếritable continuation.

C'est en effet le tissu de l'aubier ou du liber, qui, recevant alors une plus abondante nourriture, produit à sa surface ce nouveau tissu. Ce mode de multiplication du tissu cellulaire entre tout-á-fail dans le mode de développement auquel le professeur Mirbel a donné le nom de développement extrautriculaire.

Si c'était le suc épanché ou cambium qui s'organisât chaque année, au printemps, en nouvelles couches ligneuses et corticales, il devrait nécessairement former, entre le bois et l'écorce, une masse continue qui souderait ces deux parties de la branche; et c'est ce qui n'a pas lieu. A aucune époque de l'année, ainsi que tout le monde le sait, l'écorce ne se détache plus facilement de la surface du corps ligneux qu'au printemps et en automne, c'est-à-dire au moment où se forment les couches ligneuses et corticales. Loin d'ètre une masse continue, interposée entre ces deux parties de la branche, le nouveau tissu cellulaire forme 2 couches simplement contignës. Ainsi l'accroissement en épaisseur de la tige des arbres dicotylédonés provient de nouvelles couches que produisent la surface externe de l'aubier et la surface interne du liber, et dont le cambium fournit les matériaux.

Nous avons déjà parlé, au commencement de cet article, de l'accroissement latéral ou en largeur, quand nous a vons exposé le mode de formation des diverses parties qui composent la tige, la $1^{\text {re }}$ année de son existence. Nous ne reviendrons pas sur ce point, ce que nous avons dit de l'accroissement en largeur pour la $1^{\text {re }}$ couche ligneuse et jour la $1^{\text {re }}$ couche du liber s'appliquant également à toutes celles qui sont produites chaque année. L'accroissement en diamètre de la tige a donc sa source dans deux phénomènes : $1^{0}$ la formation de nouvelles fibres ligneuses venant s'ajouter à la surface de celles qui existaient déjà ; et 20 l'écartement latéral des fibres déja formées par la production de fibres nouvelles qui s'interposent entre elles.

\section{$2^{0}$ Accroissement en hauteur.}

L'accroissement en hauteur de la jeune lige a lieu par suite de l'élongation et du 
développement du bourgeon qui la termine, et qui, en s'allongeant, forme un scion dont la hauteur s'ajoute à celle de la tige primitive. Ce bourgeon terminal communique avec les diverses parties de la tige ou de la bramrhe qui le supporte, de sorte que, lorsqu'il se développe, les parties du jeune scion communiquent avec les parties correspondantes de la branche placée immédiatement au-dessous; mais à mesure que le jeune scion s'est allongé et qu'il s'est formé en lui une couche ligneuse et un liber, les parties de la tige placées au-dessous ont éprouvé leur accroíssement annuel en diamètre, e'esta-dire qu'une nouvelle couche ligneuse s'est ajoutée à celles qui existaient déjả, en s'arrêtant au point d'où le nouveau scion est parti. Chaque année, un nouveau bourgeon terminal, en se développant, donne naissance à un nouveau scion, qui augmente ainsi successivement la hauteur de la tige.

Si l'on se représente la forme allongée de chaque couche ligneuse plus large à sa partie inférieure, insensiblement amincie vers son sommet, on reconnaîtra que le tronc d'un arbre dicotylédoné est formé par une suite de cònes creux dont le sommet est en haut et qui sont emboîtés et superposés les uns aux autres; mais le sommet du cône le plus intérieur s'arrête à la base de la seconde pousse; celui de cette seconde pousse au commencement de la troisième, et ainsi successivement; en sorte que ce n'est qu'à la base du trone que le nombre des couches ligneuses représente exactement le nombre des années du végétal. Ainsi, par exemple, une tige de chêne ou de tout autre arbre de dix ans présentera dix couches ligneuses, quand on l'examine tout-à-fait à sa base ; elle n'en offrira que neuf à la hauteur de la seconde pousse, huit à la troisième, sept à la quatrième, et ainsi de suite, jusqu'au sommet,où elle n'en présentera qu'une seule. Cette disposition explique la forme conique du tronc des arbres dicotylédonés.

\section{SII. TIGE DES VÉGÉTAUX MONOCOTYLÉDONÉS.}

Nrus nous sommes livré, dans ces derniers temps, à des recherches persévérantes sur cè point important de la physiologie des végétaux, recherches que nous avons publiées en grande partie dans la $6^{\mathrm{e}}$ édition de nos Éléments de Botanique et de Physiologie végétale. Nous en extrairons ici les points les plus importants.

La tige d'un végétal monocotylédoné offre des différences très tranchées, quand on compare sa structure interne avec celle des dicotylédonés. En effet, le stipe ou tige ligneuse d'un palmier ou de tout autre arbre monocotylédoné, ne présente pas, sur une coupe transversale, cette succession de couches emboîtíes régulièrement les unes dans les autres, avec un canal médullaire au centre et à l'exiérieur une écorce composée de feuillets superposés. Toute la masse se compose d'un tissu utriculaire dans lequel les fibres ligneuses sont éparses sous la forme de faisceaux plus ou moins épais. Chacun de ces faisceaux, plus nombreux et plus serrés les uns contre les autres à la partie externe de la lige, contieist à la fois des fibres ligneuses, des vaisseaux aériens de différente nature, et des vaisseaux laticifères. Tout-à-fait à l'extérieur de la lige on trouve une véritable écorce, comme nous l'avons démontré et comme nous le prouverons, en traitant spécialement de l'organisation de la tige et de celle de l'écorce. $V$. Écorce.

Ainsi, en résumé, la tige des plantes monocotylédonées se compose de faisceaux vasculaires, épars au milieu d'un tissu utriculaire qui en forme la masse, sans apparence de couches emboîtées. L'écorce y existe également, quoique moins distincte que dans les dicotylédonés. Elle se compose d'un épiderme de tissu utriculaire, et enfin de faisceaux de tubes fibreux (qui manquent quelquefois), mais ne formant jamais de feuillets. Le corps ligneux est une masse de tissu utriculaire dans laquelle sont épars des faisceaux vasculaires Inngitudinaux et plus ou moins flexueux, distincts les uns des autres, plus nombreux, plus rapprochés et plus durs vers la partie externe de la tige. Chaque faisceau vasculaire se compose $: 1^{0}$ de faisceaux aériens; $2^{0}$ de tubes fibreux ; $3^{\circ}$ de vaisseaux laticifères ; $4^{\circ}$ de tissu utriculaire. Ces différents vaisseaux finissent par se lignifier avec le lemps.

Leur direction dans l'intérieur de la tige est partout à peu près la même. Ils forment, à partir de la base des feuilles auxquelles ils vont tous aboutir, des arcs très allongés, a convexité tournée vers le centre, de telle 
sorte que leurs deux extrémités sont dirigées vers la partie la plus extérieure de la lige. Dans toute leur longueur, ces faisceaux u'ont pas la même organisation. A leur extrémité inférieure, ils ne sont composés que de tubes fibreux; plus haut se montrent d'abord les laticifères, puis les vaisseaux aériens, d'abord les fausses trachées, et enfin les vraies trachées à spiricule déroulable.

Examinons maintenant l'accroissement de la tige monocotylédonée dans ses 2 directions, c'est-á-dire en hauteur et en épaisseur.

\section{Accroissement en hauteur.}

Nous avons démontré dans un ouvrage (Nouv. Élèm. de Bot.et de Phys. végét.,6ééd., p. 181) que pour les végétaux monocotylédonés, la plupart des physiologistes qui ont parlé de la formation et. de l'accroissement de la tige destinée à devenir ligneuse, sont partis d'une erreur. Tous, en effet, disent que la tige n'existe pas primitivement, et qu'elle se forme à la fin de la $1^{\text {re }}$ année qui suit la germination de la graine, par suite de la soudure de la base du petit nombre de feuilles qui résultent de l'évolution de la gemmule. D'après celte opinion, le stiped'un palmier ne seraì pas une véritable tige, mais, en quelque sorte, un organe accidentel, résultant de la base des pétioles confondus en une masse de tissu utriculaire et de vaisseaux. Dès lors l'accroissement en hauteur proviendrait, en quelque sorte aussi, d'une suite de disques ayant tous la même origine que celui de la $1^{\text {re }}$ année, placés. les uns sur les autres, et se réunissant de manière à constituer une tige plus ou moins allongée.

Les observations que nous avons faites nous ont amené à un tout autre résultat sur l'origine de la tige dans les monocotylédonés. Le palmier qui commence à se développer, a bien réellement une tige dès la $1^{\text {re }}$ année, et cette lige n'est pas formée par la soudure de la base des feuilles qui persisteraient pour former une sorte d'anneau, origine de tous ceux qui lui succéderont chaque année, et dont la réunion doit constituer le stipe..En étudiant la structure d'un jeune palmier pendant la première année de sa végétation, nous avons reconnu qu'il se composait de 3 parties bien distinctes : une tige, des fibres radicales et des feuilles.

La tige est d'abord excessivement peu dé- veloppéc. Elle se montre sous la forme d'un corps charnu, cylindracé, très court, arrondi et comme tronqué à son extrémité, quii est nne. Celte lige rudimentaire et déprimée porte, dans ses deux tiers supérieurs, de larges écailles redressées, terminées en pointe à l eur sommet, d'autant plus grandes et plus longues qu'elles sont plus supérieures, et de plus , 5 ou 6 feuilles longuement pétiolées, semi-amplexicaules a leur base, très rapprochées les unes des autres. En écartant ces feuilles, on voit qu'elles sont placées sur une partie de la lige en forme de còne très déprimé, el qu'au centre de leur réunion se trouve une sorte d'étui ou de gaîne tronquée obliquement à son sommet, d'où sortent deux feuilles; enfin, dans l'intérieur de cette gaine on distingue un petit bourgeon terminal très allongé, contenant des feuilles rudimentaires, et destiné à pourvoir au développement ascensionnel qui aura lieu l'année suivante. Le tiers inférieur de la tige donne naissance á un grand nombre de fibres radicales.

Il y a donc bien réellement, dans un jeune palmier d'un an, une tige primitive, parfaitement distincte des écailles et des feuilles. Seulement, cette tige est excessivement courte et déprimée, mais sa structure intérieıre est la même que celle de toutes les autres tiges monocotylédonées. Maintenant, l'année suivante, lébourgeon termina! dont nous avons signalé l'existence au centre de l'assemblage des feuilles provenant de l'évolution de la gemmule, se développe, donne naissance à un certain nombre de feuilles très rapprochées les unes des autres, par suite du peu d'élongaticn de l'axe qui les supporte. Les feuilles de la première année sont un peu rejetées en dehors par l'accroissement excentrique de la portion de tige qui les supporte, et dont celle qui vient de se former la seconde année n'est que la continuation. Il y a donc ici, comme dans toutes les autres tiges, développement simultané en épaisseur et en hauteur; mais, nous le répétons, l'accroissement en hauleur est dù à l'élongation d'un axe caulinaire déjà existant; et non pas aux disques formés par la partie inférieure des feuilles qui persisterait et se souderait.

Ce développernent est, elı conséquence, le même que celui que nous avons dejà oh- 
servé dans la tíge dicotylédonée qui s’accrồt en hauteur. C'est une suite d'axes verlicaux qui se continuent sans interruption les uns les autres, et dont l'ensemble constitue le stipe. Seulement, dans le plus grand nombre de cas, ces axes étant fort courts et s'allongeant peu, la tige croît lentement en hauteur, en sorte que les mérithalles resteni confondus les uns avec les autres. C'est pour cette raison que la tige ligneuse des monocotylédonés est recouverte extérievirement, dans toutes ses parties, de feuilles généralement persistantes. Cependant, à mesure que de nouvelles feuilles se développent, les plus anciennes, qui sont en même temps les plus inférieures, finissent par se détacher de la tige, en y laissant une cicatrice ou des vestiges dont les traces ne s'effacent jamais complètement; aussi la surface d'un stipe n'olfre-t-elle jamais cette nettelé et ce poli qu'on observe généralement dans le tronc des arbres dicolylédonés. Les feuilles qui recouvrent ainsi la tige monocotylédonée paraissent au premier abord dispersées sans ordre, parce qu'elles sont extrêmement rapprochées et serrées les unes contre les autres. Néanmoins elles ont ordinairemen $i$ une disposition spirale plus ou moins régulière, analogue à celle des feuilles des végétaux à 2 cotylédons, que l'on reconnaît très facilement dans quelques arbres, comme le Pandanus, par exemple, et que l'on retrouve également dans les cicatrices qu'elles laissent a la surface de la tige, quand elles viennent à s'er détacher.

La tige des palmiers et des autres monocotylédons ligneux est, comme on sait, généralement simple; cela provient de ce qu'il ne se développe pas de bourgeons á l'aisselle de leurs feuilles, ou du moins de ce que ces bourgeons restentál'état rudimentaire. C'est un des caractères qui distinguent le mieux la lige des monocotylédons de celle des dicotylédons, dans lesquels un ou plusieurs bourgeons, existant à l'aisselle de chaque feuille, s'allongent chaque année pour donmer naissance à des scions ou des branches. Cependant il y a certains cas ou certaines circonstances pariliculières oú quelques uns des bourgeons qui existent ả létat latent dans l'aisselle des feuilles de monocotylédons venant à se développer, la tige est alors rameuse. C'est ce qu'on observe constamment dans le Palmier doum de la Thébaide (Crucifera thebaïca Del.); vians quelques Draccena, Y rucca, Aloë, etc. Cette ramification de la tige peut également se montrer quand on vient à retrancher le bourgeon terminal d'un monocotylédon, et en particulier des Dracœena ou des Aletris. Un ou plusieurs des bourgeons latents, dont les rudiments existent à l'aisselle des feuilles, se développent et forment la base d'autant de nouvelles ramifications, qui continueront à s'accrô̂tre absolument de la riême manière que la tige principale.

$2^{0}$ Accroissement en diamètre.

Quant à l'accroissement en diamétre du stipe, il a lieu par la production de nouveaux faisceaux de fibres ou de vaisseaux dans la masse utriculaire qui forme la baso de la tige. On comprend qu'il ne peut avoir lieu que dans la portion de cette tige non encore entièrement solidifiée, et qu'il s'arrète dans celles qui sont devenues ligneuses. Les fibres nouvelles, se formant toujours vers la partie centrale de la tige, doivent tendre constamment à rejeter vers la périphérie les fibres plus anciennes, qui s'y accumulent et se pressent les unes sur les autres, de manière á constituer la partie la plus solide et la plus résistante de la tige. Aussi arrive-t-il fréquemment que, tandis qu'une tige ligneuse monocotylédonée offre à l'extérieur une zône plus ou moins épaisse de fibres dures, compactes et très serrées, sa partie intérieure est composée d'un tissu cellulaire lâche, présentant des fibres ligneuses éparses et sans liaison entre elles. Le contraire a lieu, comme on sait, dans la tige dicotylédonée, dont la partie ligneuse est d'autant plus solide qu'on l'observe plus près du centre.

Si l'accroissement en hauteur des Monocotylédons se fait par une cause semblable à celle qui détermine l'élongation de la tige des Dicotylédons, savoir : le développement d'un bourgeon terminal; il n'en est pas tou à-fait de même de l'accroissement en diamètre. Dans les premiers, en effet, les nouvelles fibres se forment toujours vers la partie centrale de la lige, seul point véritablement végétant de cet organe, tandis que dans les secondes, c'est à la partie externe, c'est-à-dire à la surface exlérieure du corps ligneux et à la surface intérieure de l'écorce, 
que se développent les nouvelles fibres, dont l'accumulation constitue les couches annuelles du bois et les feuillets de l'écorce. Ainsi, dans la tige monocotylédonée, il n'y a qu'un seul systène de développement, tandis qu'il en existe deux dans la tige des arbres dicotylédons.

Plusieurs points, simplement énoncés dans cet article, seront développés plus en détail aux mots: Tige, Stipe, Bourgeon, Bulbe, Monocolylédons, Dicotylérlous, etc.(A. Ricmand.)

ACCLOISSEMENT dans les minéraux. mix. - L'accroissement dans les minćraux , ou plus généralement dans les corps inorganiques, diffère sous deux rapports de l'accroissement dans les corps organisés. Chez ces derniers, le phénoméne est renfermé dans de certaines limites, et il s'opère par intussusception, c'est-à-dire par le dépôt de nouvelles molécules dans toutes les parties de l'être à la fois. Dans le corps inorganique, au contraire, l'accroissement n'a pas de limite, et il n'a lieu que par juxta-position, c'est-àdire seulement à l'extérieur; les molécules additionnelles ne faisant qu'envelopper de nouvelles couches la masse déjả formée, qui demeure invariable pendant toute la durée du phénomène. Ce n'est pas qu'il n'y ait quelquefois dans l'intérieur des minéraux des déplacements et des transports de molécules, occasionnés par les actions électrochimiques; mais alors le minéral éprouve une surcomposition ou une décomposition; c'est un changement de nature qui en résulte, et non plus un simple accroissement. $V$. Minéral et minéralogie.

(DEL.)

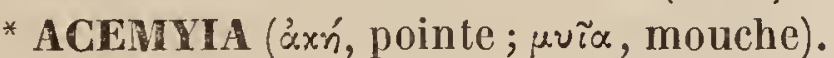
ıns. - G. de Diptères de la section des $T a$ chinarice, Rob. Jesv., correspondant au g. Tachina, Macq.

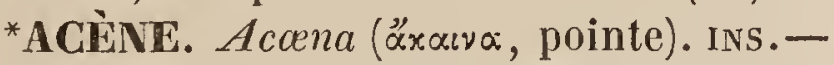
C'est le nom que donne Treitschke à un g. de Lépidoptères de la famille des Nocturnes, tribu des Phalénites, qui antérieurement avait été appelé Ourapleryx par Leach. (D.)

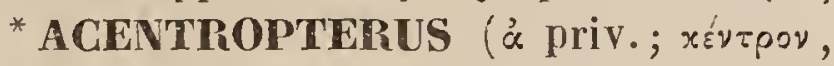
aiguillon ; $\pi \tau \varepsilon p^{\prime}$, aile). Ins. - G. de l'ordre des Coléoptères pentamères, famille des Chrysomélines, proposé par M. Chevrolat et adopté par M. Dejean. Il est fondé sur une seule esp. du Brésil nommée par M. Dejean $A$. Lacordairii, et regalis par M. Chevrolat. (D.)

* ACENTRUS (á priv.; x ́́vтpov, aiguillon).
INs. - G. de Coleoptères pentamères, famille des Curculionides, proposé par M. Chevrolat et adopté par M. Dejean. Il est fondé sur une seule esp. du midi de la France, l'A. histrio Schoënh.

ACÉPHALE. Acephalus ( $\alpha x \varepsilon^{\prime} \varphi \alpha \lambda \circ 5$, sans tête). тÉRAT. - On appliquait autrefois ce nom à tous les monstres dépourvius de tête, ou pourvus seulement d'une tête, soit incomplète, soit même complète, mais mal conformée. Il appartient aujourd'hui en propre à l'un des principaux g. de la famille des Acéphaliens. (I.-G. ST.-H.)

ACÉPIIALE (' $\alpha$ priv.; $x \varepsilon \varphi \alpha \lambda \lambda^{\prime}$, tête). BOT. Pll. - M. de Mirbel applique cette épithète à l'ovaire, quand il ne porte point immédiatement le style, comme on le remarque dans les I.abiées, les Ochnacées, etc. (C. L.)

"ACÉPHALÉNIE ('a priv.; $x \varepsilon \varphi \propto \alpha \lambda_{n}^{\prime}$, tête;

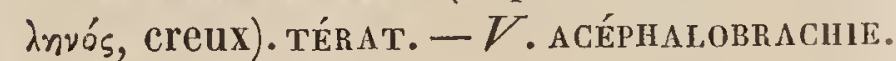

$$
\text { (I.-G. S.-H.) }
$$

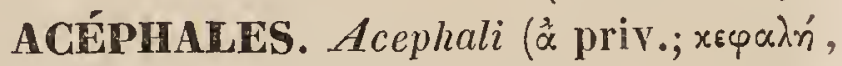
tête). molc. - Animaux sans tête, comme le sont, en effet, les Mollusques auxquels Cuvier (Tabl. élém. de l'hist.nat. des anim., 1798) a le premier imposé ce nom. Les Acéphales contiennent tous les Mollusques à coquilles bivalves, et constituent un des grands embranchements des Mollusques; c'est à ce mot que nous en traiterons. D'abord admis par Lamarck comme grande division de ces animaux, ce savant Naturaliste en fit plus tard une classe particuliẻre du règne animal, pour laquelle il proposa le nom de Conchifères. Nous exposerons, en traitant des généralités des Mollusques, les motifs qui ne nous permettent pas d'adopter la classe de Lamarck. (DesH.)

ACÉPHALES ( $\alpha$ priv.; $x \varepsilon \varphi \alpha \lambda n^{\prime}$, tête). ARACHN. - Nom donné par Latreille à un groupe d'Insectes, dont Lamarck a fait depuis l'ordre des Arachnides palpistes. C'est à la classe des Arachnides que répond aujourd'hui cette division. $V$. Aracunides. (H. L.)

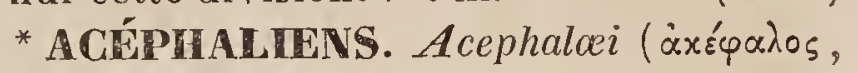
sans tête). TÉrat. - Famille de Monstres unitaires, appartenant au second ordre, celui des Omphalosites, et comprenant un très grand nombre d'êtres anomaux, dont l'organisation singulière a fixé également, mais sous des points de vue très différents, l'attention des Tératologues de tous les temps. Les $\Lambda$ céphaliens ne sont pas seulement ca- 
ractérisés, comme l'indique leur nom, par l'absence de la tête, dont il existe tout au plus quelques restiges appréciables seulement par l'analyse anatomique. A ce caractère premier et fondamental qui distingue nettement ces monstres des Paracépháliens, s'ajoutent généralement les anomalies suivantes, dont l'ensemble fait des Acéphaliens les plus imparfaits de tous les êtres tératologiques, après les Parasites et les Anidiens.

Le corps, plus ou moins imparfait, souvent très incomplet, est constamment de forme binaire; et c'est même ce qui distingue principalement les Acéphaliens des Anidiens. Mais, malgré les figures faites de fantaisie et les assertions fausses de quelques auteurs, cette forme binaire est toujours mal symétrique. Les régions droite et gauche présentent constamment des anomalies plus ou moins nombreuses de forme ou de proportions, qui ne se répètent pas ou se répètent mal d'un côté ou de l'autre. Il existe souvent, sur une grande partie de la surface du corps, et aussi des membres, des éminences irrégulières provenant de l'accumulation locale du tissu cellulaire, et sur d'autres points, des plis de la peau et des enfoncements dont la disposition est très variable. L'imperfection de la symétrie peut même être portée au point qu'il devienne presque nécessaire de recourir à l'analyse anatomique, pour distinguer les deux moitiés du corps, ou plus exactement, les deux parties homologues, mais dissemblables, en lesquelles il se divise. L'extrémité supérieure du corps est arrondie, recouverte de téguments, et quelquefois garnie de poils, qui sont de véritables cheveux; car, au-dessous d'eux, on trouve parfois quelques osselets en connexion avec l'extrémité cervicale du rachis, et dans lesquels il est impossible de méconnaître les rudiments du crâne.

Le nombre des membres varie de 4 à 1 . Lorsqu'il n'en existe qu'un, c'est toujours un membre abdominal. Les membres, quel qu'en soit le nombre, sont mal proportionnés, contournés, presque toujours pourvus de moins de 5 doigts, et surtout terminés par des pieds-bots. Le renversement du pied en dedans est le cas le plus commun; mais les autres genres de pieds-bots, et surtout le renversement en dehors, s'observent aussi chez les Acéphalfens. Nous avons vu quelquefois les deux pieds du mème sujet renversés en sens contraire, et les auteurs rapportent plusieurs exemples de cette disposition.

L'anus est le plus souvent perforé, malgré l'asserlion contraire de quelques auteurs, parmi lesquels on est étonné d'avoir à citer Elben, dont l'ouvrage sur les Acéphaliens est d'ailleurs fait avec tant de soin. Les organes externes de la génération existent presque toujours, mais si imparfaitement conformés dans beaucoup de cas, que la détermination du sexe est impossible sans dissection.

Avec ces anomalies extérienires coüncide constamment l'état imparfait de tous les viscères, soit de la région sous - ombilicale de l'abdomen, soit, et cette distinction esí très importante, de la région sus-ombilicale et du thorax. Les viscères de la région sous-ombilicale, l'intestin, les organes urinaires, les organes génitaux intérieurs, existent d'ordinaire; et l'intestin même constamment, au moins en ce qui concerne la plus grande partie du gros intestin et la fin de l'iléum. Au contraire, les viscères de la région sus-ombilicale de l'abdomen, la portion supérieure de l'intestin, l'estomac, la rate, le foie, le pancréas, et surtout les organes thoraciques, les poumons et le cour, sont, le plus souvent, non seuleinent mal conformés, incomplets, plus ou moins rudimentaires, mais même entièrement absents. Pendant long-temps même on a regardé tous les Acéphaliens comme totalement dépourvus de cour, et Elben a cru pouvoir présenter comme exactement équivalentes ces deux expressions : Monstres acéphales et Monstres privés de cœur; mais il est incontestable aujourd'hui qu'un cœur rudimentaire peut exister, aussi bien que des poumons rudimentaires, chez un véritable acéphalien.

Le développement de tous les autres appareils organiques est proportionnel à celui des viscères digestifs, respiratoires et circulatoires. Le squelette est toujours très incomplet, et le rachis lui-même peut manquer presque complétement. Un auteur assure même avoir constaté dans un cas l'absence complète de la colonne vertébrale, y compris le sacrum. La moelle épinière est 


\section{ACÉ}

ordinairement, comme le rachis, très incomplète, et parait aussi pouvoir manquer en entier. Les nerfs existent au contraire constamment, de même que le grand sympathique; mais ils sont imparfaits. Les museles, toujours peu distincts dans la plupart des régions du corps, sont souvent tout-àfait confondus, comme chez les jeunes embryons. Enfin le système vasculaire présente une multitude d'imperfections, comme on peut le prévoir par ce qui a été dit plus haut des divers viscéres, et spécialeınent du cour.

Les faits, dont nous venons d'offrir le résumé, démontrent la liaison intime qui existe, chez les Acéphaliens, entre les modifications cxtérieures de l'être et les anomalies de ses organes intérieurs. Tout monstre de cette famille, en même temps qu'il est à l'extéricur irrégulièrement conformé et imparfaitement symétrique, présente à l'intérieur une organisation très simple et très imparfaite, les viscères thoraciques manquant plus ou moins complètement, et les viscères abdominaux étant, les uns absents, les autres incomplets. Ce résultat est aussi général, aussi rigoureusement établi, que l'est en Zoologie la possibilité de ramener un animal à son type sur le seul examen de ses caractères extéricurs, et de déterminer immédiatement, avant tout examen anatomique, les principales modifications de son organisation interne.

Tous semblables entre cux, comme il résulte de cette remarque, par les conditions générales de leur organisation, les $\Lambda$ céphaliens le sont aussi, et d'une manière singulièrement frappante, par les circonslances de leur naissance, sur lesquelles Elben et surtont Geoffroy St.-Hilaire ont appelé l'attention des Tératologues. Ces monstres, qui presque toujours viennent au monde avant terme, naissent jumeaux, quelquefois même plus que bijumeaux, et en outre, comme on va le voir, dans des rapports constants avec leur jumeau. Celui-ci est bien conformé, et beaucoup plus volumineux que son frère. L'un et l'autre n'ont en commun qu'un seul placenta, et des deux c'est le jumeau bien conformé qui naìt le premier ; l'acéphalien le suit, soit immédiatement, soit après un intervalle de plusieurs minutes, ou même de plusicurs heures. Une autre circonstance extrêmement remarquabie par sa constance
ACE

est la similitude des sexes des deux jumeaux. En effet, dans les cas où les sexes sont indiqués par les auteurs, on trouve toujours que les jumeaux sont extérieurement, tous deux mâles, tous deux femelles, ou, comme l'a rapporté Katzky, tous deux hermaphrodites; et même, si un acéphalien sans sexe naît avec un jumcau, soit mâle, soit femelle, on peut être presque assuré, en soumettant l'acéphalien à une dissection exacte, de trouver au moins quelques parties d'un appareil générateur, mâle dans le premier cas, femelle dans le second. Quand un acéphalien naît avec 2 ou 3 frères, il ressemble pareillement par son sexe, soit à l'un d'eux, soit même à tous à la fois.

Le jumeau d'un acéphalien naît ordinairement plein de vic, et souvent même complétement viable. L'acéphalien, a contraire, dont l'organisation réalise à tant d'égards celle d'un jeune embryon, non seulement n'est pas viable, mais encore ne saurait prolonger sa vie au-delà du moment mème de sa naissance. Une fois hors des eaux de l'amnios, il meurt avec une extrême promptitude, et sans même avoir donné de signes de vie. Deux auteurs italiens parlent seuls de quelques mouvements qu'aurait exécutés un acéphalien en naissant; encore leur témoignage doit-il être révoqué en doute; car toutes les relations bien faites attestent que les Acéphaliens, comme les Paracéphaliens et Ies Anidiens, ne sauraient vivre un seul instant au milicu des conditions, pour eux inharmoniques, du monde extéricur.

Après avoir fait connaître les principaux faits relatifs a l'organisation et aux circonstances de la naissance des Acéphaliens considérés en général, il nous reste à indiquer les principaux caractères distinctifs sur lesquels repose la division en genres de cette famille, composée dẻs a présent d'un très grand nombre d'êtres anomaux. Les genres auxquels nous avons cru devoir les rapporter sont au nombre de trois, et sont dénommés et caractérisés comme il suit :

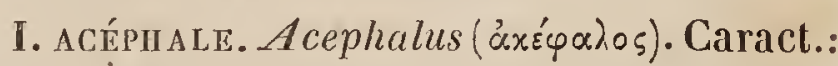
Corps imparfaitement symétrique, irrégulier, mais dont les diverses régions sont bien distinctes; thorax existant complétement ou presque complétement, et porlant les membres thoraciques ou au moins l'un d'eux. Ce g. comprend les Acéphaliens les moins éloi- 
gnés de l'état normal : ils sont privés seulement de la tête et des organes qui manquent généralement avec elle, et par conséquent sont encore aussi complets, aussi entiers que peuvent l'être des Acéphaliens. On connaît dès à présent un assez grand nombre d'Acéphales, tous nés dans l'espèce humaine.

II. PÉracéphale. Peracephalus ( $\pi \varepsilon^{\prime} \alpha$, au-

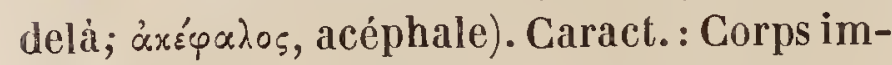
parfaitement symétrique, irrégulier, ayant ses diverses régions bien distinctes; point de membres thoraciques.

Ce genre, dont les conditions ont été déjả observées dans 50 individus, et qui est l'un des groupes tératologiques les plus nombreux, présente un degré de plus d'anomalie que le genre précédent. Ce n'est plus seulement ici la tète, mais aussi les membres supérieurs, et avec eux une partie souvent très considérable du tronc, qui manquent entièrement, ou dont la dissection fait retrouver tout au plus quelques vestiges. Dans quelques uns même l'anomalie est portée si loin, que le tronc semble réduit au tronçon pelvien du corps. Ce genre a été surtout observé chez l'homme; mais on en connaît aussi quelques exemples chez le mouton et le cerf.

III. MYLACÉPHALE. Mylacephalus (c'est-à-

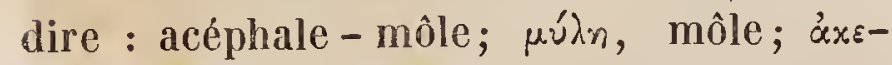

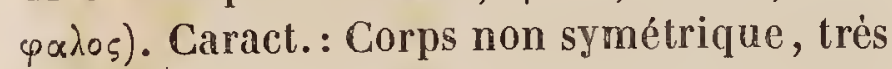
irrégulier, informe, ayant ses diverses régions peu ou point distinctes; membres très imparfaits, rudimentaires, ou même presque tous nuls. - Ce genre, par lequel la famille des Acéphaliens se lie avec celle, plus anomale encore, des Anidiens, ne se compose que d'un très petit nombre de cas, la plupart observés dans l'espèce humaine, un autre chez la chère.

Ainsi, des trois genres de monstruosités acéphaliques, l'un n'est connu que chez l'homme; et deux observés surtout dans cette même espèce, se sont présentés en outre chez quelques ruminants, tous unipares, plus rarement bipares, et par conséquent offrant avec l'espèce humaine une similitude rrès marquée dans l'une des conditions les plus importantes de leur reproduction.

Les auteurs principaux qui ont écrit sur les monstres Acéphaliens sont: MeckeL, Handbuch der path. Anat., t. I. - Tiedemann, Anat.derkopflosen Misgeb. (Landshut, 1813).
- Béclard, Mém. sur les Acéph. dans les Bull. de la fac. de Méd., ann. 1815 et 1817. - Elben, de Acephalis sive Monst. corde carent., Berlin . 1821; ouvrage spécial dans lequel sontrésumées toutes les connaissances acquises avant Elben.-Groff.S.-Hil., Phil. anat. t. II, et Note sur l'Acéph. dans la Revue méd., I, 1826. - Vernikre, sur les foutus acéph. dans le Répert. génér. d'Anat., t. III, - $V$. aussi notre Hist. génér. des Anomalies, t. II, p. 464-528. (Is.-G.S.-H.)

* A CÉPHAl OBRACHEE. Acephalobra-

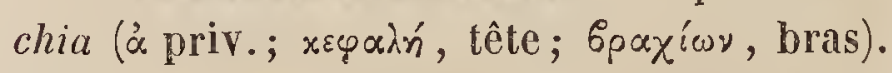
тÉrat. - Pair ce nom et ceux d'Acéphalénie, d'Acéphalochéirie et d'Acéphalénie, M. Breschet a proposé de désigner les monstruosités acéphaliques compliquées de divers états imparfaits des membres. $V$. ACÉPHALIENS.

(Is.-G. S.-H.)

ACÉP IALOCYSTES. Acephalocystis (åxé-

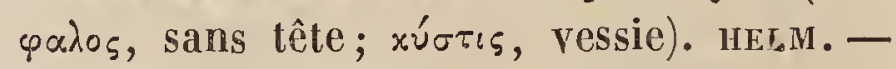
G. fondé par Laënnec pour renfermer certains ètres si simples, que l'on peut mettre en doute s'ils doivent réellement être placés au nombre des animaux. Ils consistent en une simple vessie plus ou moins transparente, sans fibres apparentes, sans corps ni tête, et sans aucun orifice naturel, conme remplie d'un liquide très limpide, et toujours renfermée dans un liyste fibreux ayant des communications vasculaires avec les organes qui la contiennent. Jamais on n'y a observé de mouvements spontanés, même dans l'acception la plus simple de ce mot; jamais on n'y a pu reconnaître aucun organe, ni rien qui ressemble à des fonctions digestives. Cette vessie constitue à elle seule l'organisme tout entier; elle est mince, fort délicate, et se laisse déchirer en tous sens avec une égale facilité, sans jamais offrir aucune apparence de structure fibreuse. On peut la diviser en lamelles ou feuillets, dont le nombre varie suivant le degré de développement des individus. Coupée transversalement, et examinée ainsi au microscope, on y reconnaît alors cette division en feuillets, ce qui prouve qu'elle n'est pas purement artificielle, comme le pensent certains auteurs.

Sont-ce là des organismes à part? et pouvons-nous donner le nom d'ánimaux à des êtres chez lesquels la vie ne se manifeste par aucune des fonctions propres à la vie animale? Beaucoup d'auteurs, en effet, n'y ont 
vu autre chose que des productions norbides. Rudolplii et Blumenbach sont de ce nombre; et, bien que cenx qui professent l'opinion colltraire soient en très forle majorité, nous devons reconnaìtre qu'elle ne s'appuie sur aucune preuve posilive; il nous semble même impossible de l'adopler sans restriction. On a cité ce fait, que le liquide interne est tout-à-fait limpide et fort différent de celui dans lequel la vessie est plongée à l'intérieur du kyste qui l'enveloppe; el Laënnec voil là une véritable assimilation. On a allégué aussi l'espéce de parenté intime qui semble unir ces êtres si singuliers avec les vessies des Floriceps, des Cœnures, des Cysticerques et des Echinocoques; enfin Kuhn, médecin à Niederbronn (Alsace), a fait voir qu'ils ont un mode de reproduction bien déterminé, et qui semblerait démontrer en effet que ce sont là des êtres complets, bien que réduits à une excessive simplicité. Cette reproduction se fait par des gemmes qui se développent entre les feuillets de la vésicule mère, et qui, une fois parvenus à un certain degré d'accroissement, se détachent, soit en dehors de cette même vésicule, soil dans l'intérieur de sa cavité, suivant qu'ils appartiennent à l'espèce que Kuhn a désignée sous le nom d'Endogène, et que l'on ne rencontre que chez l'homme; ou à celle que l'on trouve chez le bœuf et le mouton, et qui a reçu du même observateur le nom d'Exogène.

De ces 3 arguments, le $1^{\text {er }}$ nous semble peu concluant; le $2^{\text {me }}$ l'est peut-être davantage.

Les rapports intimes qui existent entre les êtres qui nous occupent et les vers que Laënnec a désignés sous le nom de $V$ ésiculaires, et qui portent colleclivemeut, dans une foule d'ouvrages, celui d'Hydatides, ces rapports, disons-nous, sont incontestables; or, nous avons vu nous-même, au microscope, et Leblond avait signalé avant nous, des mouvements propres dans l'espéce de vésicule albumineuse oủ les Floriceps sont enfermés ( $\boldsymbol{V}$. FLORICEPS). Quant au mode de reproduction signalé par Kuhn, il rappelle complétement celui des utricules du tissu cellulaire des plantes, tel que les Botanistes le conçoivent aujourd'hui.

Ce qui nous semble ressorlir de ces faits, c'est que les Acéphalocystes ont une existence propre et ristincte de celle des organes T. I. dans lesquels on les trouve eufermées; mais il nous paraît aussi que, pour arriver, du moins dans l'élat actuel de la question, $\dot{a}$ dire que ce sont des animaux, il laudrail dépouiller ce dernier terme de lout ce que sa définition renferme de précis. Ce sont des êtres équivoques, dont la science n'a probablement pas encore su saisir les véritables caractères, el qui nous paraissent rester en dehors de ces définitions des 3 règnes, dans lesquels, au premier coup d'œil, tous les êtres sembleraient devoir naturellement venir se grouper.

Les 2 esp. d'Acéphalocystes que nous a vons déjà mentionnées d'après $\mathbf{K} u h n$, se rencontrent dans les principaux viscères; mais surtout dans le foie, les poumons, la rate, les épiploons, etc. Elles y sont l'origine d'une maladie désignée, dans les bœufs, sous le nom de pommelière, on vulgairement sous celui de poches d'eau. En général, elles sont enkystées; on en a pourlant trouvé qui étaient complétement libres, dans la cavité des plévres ( $D^{r}$ Freleau), dans la vessie urinaire (Béclard), dans la cavité de l'arachnoïde (Rostan), dans les veines pulmonaires (Andral); mais la lecture que nous avons faite des mémoires où ces faits sont déposés ne nous a pas paru démontrer suffisamment, ou que ce fussent véritabiement des Acéphalocystes, ou qu'elles ne fussent pas tombées des poumons dans la cavité pleurale, des reins dans la vessie, elc.

Lorsque les Acéplaalocystes sont renfermées dans un kyste, on les y tronve isolées ou réunies au nombre de $2,3,4$, et même 6 ou 8 , dans un même kyste, suivant que celle qui la $1^{\text {re }}$ a occupé le kyste, a déjà été ou non récondée. On rencontre quelquefois les débris de l'Acéphalocyste mère, surtout lorsqu'elle appartient à l'espéce endogène qui se développe par l'emboîtement des gemmes. Kuhn a fail voir comment certains tubercules peuvent devoir leur existence à la présence el à la destruclion successive de ces produclions dans le parenchyme des organes.

M. H. Cloquet a le $1^{\text {er }}$ proposé de regarder comme des Acéphalocysles, les vésicules qui se développent dans l'alfection de l'utérus, désignée communément sous le nom de môle hydatique; elles constituent l'esp. qu'il a appelée $\mathrm{A}$. en grappe ( $A$. racemosa). La plupart des auteurs qui ont traité ce sijet 
depuis $M$. M. Cloquet, ont refusé d'admettre celte opinion, qui ne pourra être disculée a'une maniere définitive que lorsque de noureaux travaux auront mieux fait connaitre les caractères génériques des Acéphalocystes, et la nature des produrtions dont i) s'agit. Nous nous contenterons done, pour cette question, ainsi que pour plusieurs autres relatives au même sujet, de renvoyer aux ouvrages speciaux des auteurs suivants: Laënnec, Mém. sur les vers vésiculaires, in-4, p. 96 et 170 , arec planches. - H. Cloquet, Faune des médecins, art. Acéphalocystes. Cruveilhier, Anat. palh., art. Maladies du foie, de la rate el du grand épiploon; art. Acés phalocystes du Dict. de Médl et de Chir. prat.-Kuhn, Recherches sur les Acéphalocystes, ctc. dans les Mém. de la Soc. d'hist.nat. de $S$ trasbourg, $\imath$. I; art. reproduit en grande partie dans les Ann. de la Soc. d'Ilist. nat., t. XXIX, $1^{\text {re }}$ série. - Leblond, Atlas de l'ouvrage de Bremser, pl. 10 et 11 , et p. 17 et suiv., 29 et suiv. du texte explicatif, etc., ctc. - Nous reviendrons nous-même, à l'art. Hydatides, sur diverses questions qui nous semblent devoir gagner à être traitées d'une manière plus générale, et notamment sur celle du développement originaire de ces êtres singuliers au sein des organes.

(L. DOYÈRE.)

* ACÉPILACOGASTRIE. Acephalogas-

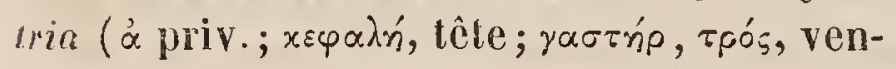
Ire). TÉRAT. - Nom proposé par M. Breschet pour les Monstruosités acéphaliques avec absence du thorax et de l'abdomen. $V$. ACÉPIIALiens. (I. G. S.-H.)

*ACER ALOMIE. Acephalomia (á priv.;

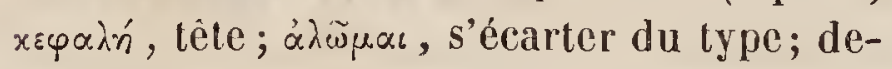
venir monstrueUX). TÉRAT. - V . aĆ́PHALOBRACHIE.

$$
\text { (I. G. S.-H.) }
$$

ACEPBLALOPHOPES. Acephalophori (á

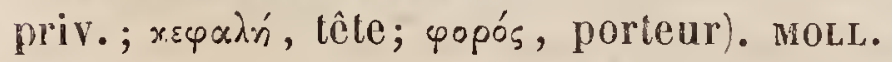
-M. de Blainville, dans son Manuel de Malacologie, a substitué à tort ce nom à celui d'Acéphales. Ce mot Acéphale convient très bien a des animaux dépourvus de tête, tandis qu'Acéphalophore signifierait, à la rigueur, animal portant une tête, et cependant sans tête. Nous pensons que M. de Blainville n'a créé ce mot défectueux que pour le meltre en consonnance avec celui de Céphalophores, qu'il propose pour les Mollusques qui ont veritablement une tête.

(DESH.)

\section{ACE}

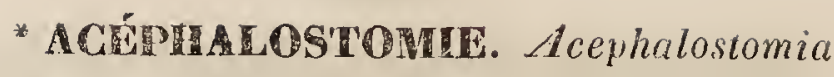

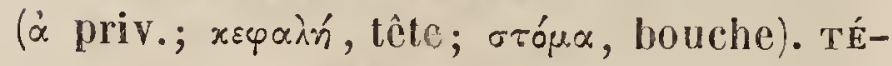
rAT. - Syn. de Monstruosité acéphalique, proposé par $\mathrm{M}$. Breschet, qui a voulu, par ce mot, rappeler spécialement l'absence de la bouche, nécessairement liée, chez tous les Acéphaliens, à l'absence de la tête. $V$. $\Lambda$ céPHALIENS.

(I. G. S.-H.)

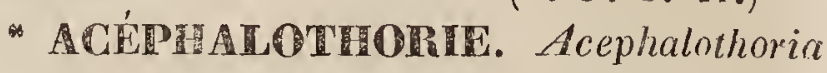
(å priv.; xespaińn, tête; Nés $\alpha \xi$, tronc). TÉRAT. - Nom proposé par M. Breschet pou ies Monstruosités acéphaliques avec absence du thorax. $V$. ACÉPIIALIENS.

(I. G. S.-H.)

ACER (Acer, vigoureux). вот. Рн. - Nom latin du g. Érable.

* ACERACÉRS. Aceracece. вот. PII. Lindley a substitué ce nom à celui d'Acérinées.

(AD. J.)

* ACERANTHUS (á priv.; xépas, corne; ¿̌v0os, fleur; sans cornets ou éperons). воT. PII. - Nous avons établi ce g. sur une plante de la famille des Berbéridées, voisine des Epimedium, dont elle difière par ses feuilles munies seulement de 2 folioles, et surtout par ses fleurs dépourvues de cornets et formées de 2 verticilles alternes, composés chacun de denx pétales blancs, étalés. Les autres caract. sont communs aux Epimedium.On n'en connaît gu'une esp. du Japon, introduite dans nos jardins par Siebold. (J.D.)

ACERAS (á priv.; x́́pas, corne). BoT. FH. - R. Brown a proposé d'établir, sous ce nom, dans la famille des Orchidées, un $g$. que plus tard 1. . C. Richard a décrit sous le nom de Loroylossum. Il se rapproche singulièrement des vrais Orchis, dont il diffère surtout : $1^{0}$ par son labelle dépourvu d'éperon, ou n'en ayant qu'un excessivement court; $2^{\circ}$ par ses deux masses polliniques venant se terminer sur une glande ou rétinacle unique (comme dans le g. Serapics), et non chacune sur une glande distincte, caract. des véritables esp. du g. Orchis. - A ce g. appartiennent le Satyrium hircinum L., l'Ophrys anthropophora Wild., et l'Ophrys anthropomorpha du même, qui n'en est peutêtre qu'une simple variété.

(A. R.)

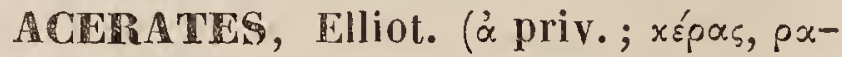
то5, cornej. вот. Pн. - G. de plantes de la famille des Asclépiadées, particulier aux provinces méridionales de l'Amérique septentrionale. Il difière des Asclepias par l'absence des petites pointes qu'on remarque à 
l'intérieur des cornets qui composent la couronne staminale dans ces derniers. - Le g. Acerates renferme aujourd'hui plusieurs espéces, la plupart inédites ou confondues avec celles du g. Asclepias. Il a pour synonyme l'Anantherix Nutt.

* ACERATIUM , DC. (a priv.; xepótioy, petile corne). вот. PII. - G. ou s.-g. de la famille des Éléocarpées, ne difiérant du g. Lilceocarpus que par des pétales à onglets velus et des an thères non sétifères au sommet. Wight et Arnott (Prodr. flor. penins. Ind., v, 1, p. 82) sont d'avis que les Areratium doiyent être réunis aux Eloeocarpus. M. De Candolle n'en signale qu'une espèce. (Sp.

* ACCRDESE (axepóńs, non profitable; c.-à-d. d'un mauvais emploi dans les arts). miN. - Même chose que Manganite ou Manganèse oxydé hydraté.

(DEL.)

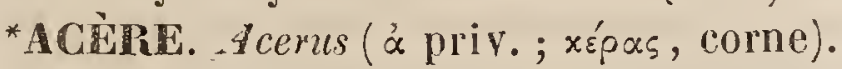
Ins. - G. de l'ordre des Coléoptères pentamères, famille des Lamellicornes, établi par M. Dejean ( $3^{\mathrm{e}}$ édit. de son Catal.), qui n'en a pas publié les caractéres. Il renferme 2 esp. du Brésil, normmées par lui, l'une $A$. davus, et l'autre $A$. monachus.

* ACERE. Akera et mieux Acera ("xixpos, sans cornes; animal sans tentacules!. MoLL. - L'absence des tentacules n'est pas propre seulement au g. Acera de Muller, mais encore à toute la famille des Bulléens de Lamarck. Muller donnait le nom d'Acére à 2 esp. fort distinctes, l'Acera bullosa, qui appartient aug. Pulla Lamk., et l' $A$. carnosa, qui est le g. Doridium, Mick. (Desn.)

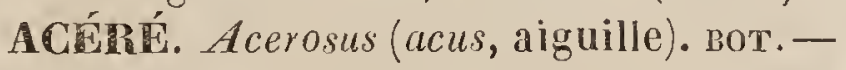
On appelle feulles acérées celles qui sont étroites, aigües, dures etpersistantes, comme celles de beaucoup de Pins et de Sapins.

\section{(A. R.)}

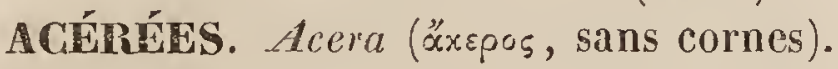
notr. - Tel est le nom que, dans ses familles naturelles du régne animal, Latreille a donné ả une famille qui correspond à celle des Bulléens de Lamarck.

(Desh.)

ACQRES. Acera ('a priv.; xépas, corne). $\Lambda$ RACHN. - M. Walckenaër (Hist. nat. des Aptères) désigne sous ce nom la $1^{\text {re }}$ classe des insectes aptères, ainsi caractérisée : Animaux ne subissant point de métamoryhoses, privés d'ailes et ayant un corselet réuni, en 'ntier ou en partic, á la tète, conformation qui a fait désigner retle partie sons le nom de céphalothorar. - Cette classe, qui correspond aux Arachnides, comprend: les Aranéides, Phrynéides, Scorpionides, Solpugides, Phalangides et Acarides. (H. L.)

ACÉRINA. poiss. - Nom spécif. d'une esp. de Percoïdes à une seule dorsale, à 7 rayons branchiaux, a dents en velours, et dont Cuvier a fait le nom générique latin d'un g. qui comprend aujourd'hui 3 esp., l'A. vulgaris, l'A. Schretzeri ct l'A. Rossice, celle-ci était le Perca acerina de Guldenstædt.

(VAL.)

ACW'DINE. Acerina. Crust.- - G. de l'ordre des Isopodes, établi par M. Rafinesque, qui n'en a pas indiqué les caractères.

(II. L.)

ACEDTWES. Acerinece. вот. PH. - La famille des Érables ou Acérées de Jussieu contenait deux sections ayant pour types, l'une l'Érable, l'autre le Marronnier. Chacune de ces sections est devenue plus tard une famille distincte, dont la $1^{\text {re }}$, qui a recu le nom d'Acérinées, présente les caract. suivants: Cal. divisé ordinairement en 5 , plus rarement en 4-9 parties, à préfloraison imbriquée. Pétales en nombre égal, insérés sur le pourtour d'un disque charnu, hypogynique, manquant quelquefois. Étam. insérées sur le même disque, en nombre toujours défini, quelquefois égal à celui des autres parties de la fleur, ordinairement plus grand, mais cependant non proportionnel, généralement celui de 8 . Ovaire à 2 lobes, entre lesquels s'élève le style, partagé à son sommet en 2 stigmates; chacun de ces lobes répolid à une loge contenant 2 ovules collatéraux, adnés par leurs faces internes à un large placenta. Le fruit se sépare en 2 samares mono ou dispermes. Graines attachées à l'angle interne de la loge, dressées, à tégument un peu charnu, dépourvues de périsperme, à 2 cotylédons foliacés, chifronnés, superposés et recourbés au-dessus de la radicule inférieure. - Les esp. de cette famille sont des arbres á feuilles opposées, simples, rarement pennées, dépourvues de stipules, à fleurs souvent polygames, quelquefois même complétement dioïques, disposées en corymbes ou grappes axillaires, dans lesquels les latérales sont le plus souvent réduites aux élamines avec un pistil avorté. Elles habitent les parties tempérécs de l'hémisphère septentrional. Grinkes: Acer, R.,; Negundium, Raf. (AD. X.) 
"ACERODOr (äxspos, sans cornes ou pointes; odoús, đóvros, dent). MaM.-M. Jourdan, de Lyon, appelle ainsi un g. ou plutô une section qu'il a proposé d'établir parmi les Roussettes pour une espèce de l'île Lucon, assez voisine par le port et la taille du Pteropus fuscus ou edulis, et qui est caractérisée surtout par la saillie des tubercules mousses de ses molaires. Cette espèce avait reçu de feu Eschscholtz le nom de Pteropus subulatus, et M. Meyer l'a nommée depuis Pt. pyrocephalus.

(C. NOO.)

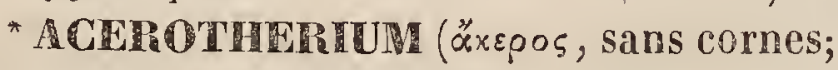
Enpior; animal). Marr. Foss. - Nom donné par M. Kaap à un animal dont les dents sont tout-à-fait semblables à celles des Rhinocéros, mais qui avail, comme les Tapirs, 4 doigts aux pieds de devant, 3 à ceux de derrière, et dont les os du nez, minces, étroits et recourbés en dehors, ne portaient vraisemblablement pas de cornes. L'espèce décrite, qui paraît êtré le Rhinoceros incisivus de Cuvier, porte le nom d' $A$. incisivum. M. Lartel a trouvé dans les environs d'Auch une espèce de rhinocéros à 4 doigts aux pieds de devant, qui est probablement du même g., sinon de la même espèce. $V$. rinnocéros FOSSILE.

(L. D.)

ACTTABULAIRE. BOT。 ИR. $-V$. ACÉTABULE.

ACETABULARIÉES (Acelabulum, petit vase). Boт. Cr. - Famille d'Algues marines, que nous proposons pour renfermer le seul g. Acétabule.

(Dus.)

ACÉT IBULE ou acétabulaire (Acelabulum, espèce de petil vase). вот. CR. - G. de Cryptogames marines (ALGUES), classé à tort parmi les Zoophytes, mais rapporté au règne végétal par M. Raffeneau-Delille, qui a pr l'étudier vivant, et par d'autres observa teurs plus récents. L'Acétabule, en acquérant son entier développement, s'encroûte de sels calcaires comme les Corallines etles Nullipores, ct, comme ces objets, elle avait dû être prise pour un Zoophyte par Lamarck, Lamouroux, Cuvier, etc., qui ne l'avaient vue que sèche dans les collections; mais, quand on l'observe encore jeune dans les eaux de la mer, on ne peut conserver de doute sur sa nature végétale. Alors, en effet, elle a le port et la forme d'un petit agaric vert, demiIransparent, composé d'un stipe creux, épais de $\frac{1}{9}$ a $\frac{5}{4}$ de millimetre, haut de 5 à 10 cen- timètres, et d'un disque en ombrelle un peu concave ou en soucoupe, formé de 60 à $9 ?$ rayons tubuleux en cônes allongés, terminés à la circonférence par une ex trémi té close, arrondie, et se mettant en communication avec le stipe, par leurs pointes réunies à un disque central de 1 à 2 millimètres. De ce disque partént des filaments confervoïdes, dichotomes, extrêmement fins, que diver's naturalistes ont pris pour les tentacules des polypes supposés. Dans les rayons tubuleux se forment des gongyles verts du même calibre que ces rayons, et destinés à reproduire le végétal. Quand ils sont devenus libres, par suite de la destruction des bor as du disque, ces gongyles se fixent sur des pierres ou sur des coquilles, et se développent sous la forme d'une tige simple d'abord, d'ou partent des filaments confervoïdes, et à l'extrémité de laquelle se forme successivement l'ombrelle qui se montre d'abord très étroite, turbinée, puis de plus en plus évasée.

On ne peut encore indiquer avec précision les affinités des Acétabules avec les autres Algues; on voit bien que, pal leur mode d'encroûtement, elles se rapprochent des Corallines, et que par la production de leurs gongyles ou corps reproducteurs, elles ont des affinités avec les Conjuguées; mais on ne pourrait, comme vient de le faire Moneghini, dans son ouvrage sur l'organographie et la physiologie des Algues, réunir dans une même famille, sous le nom de Siphonées, les Acétabules, les Vauchéries, les $V$ alonia, les Codium, les Halimeda et les Anadyomènes. Le mieux serail de constituer provisuirement pour ce seul genre une famille des Acélabulariées.

ACETARULTERES (Acetabulum, gobelet, coupe ; fero, je porte). MoLL. - Division des Céphalopodes, renfermant tous les animaux de cet ordre pourvus de cupules ou ventouses. Cette coupe correspond aux Cryptodibranches de M. de Blainville, et aux Dibranchiata de M. Owen. $V$. CÉPHALOPODES.

$$
\text { (A. D’O.) }
$$

ACETTCES (Acelas, d'Acetum, vinaigre). Cun. - On nomme ainsi les combinaisons de l'A cide acétique avec les diverses bases.Les Acétates sont tous très solubles dans l'eau, excepté celui d'argent et celui de protoxyde de mercure, qui le sont peu. L'Acide sulfurique en dégage une odeur de vinaigre, vive. agréa- 
ble et caractéristique. La chaleur les décompose tous. Ceux qui résistent le mieux à son influence sont les Acélates alcalins. L'Acélate d'argent est, au contrairc, un de ceux dont la décomposition est la plus facile. Parmi les produits de ces décompositions, on remarque particulièrement l'Acide acélique, l'Acétone, l'Acide carbonique et l'eau.

On croit que l'Acétate de potasse se rencontre en petite quantité dans la sève des végétaux. Tous les autres sont le produit de l'art.

Les principaux sont : $1^{\circ}$ l'Acétate d'alumine, fréquemment employé dans la fabrication des toiles peintes; $2^{\circ}$ l'Acétate de cuivre neutre, connu sous le nom de Verdet crislallisé, el que l'on prépare en traitant le vert-de-gris (sous-acétale de cuivre) par une dissolution bouillante de vinaigre distillé; $3^{\circ}$ l'Acétate de fer, ou pyrolignite de fer, dont on se sert beaucoup en teinture, et que l'on substilue avantageusement, dans beancoup de cas, au Sulfate de fer; $4^{\circ}$ enfin, les Acélates neulre el tri-basique de plomb, employés en médecine ou dans les arts, le premier sous le nom de sel ou de sucre de $\boldsymbol{S} a-$ turne, et le second sous le nom d'extrail de Saturne.

(PEL.)

* ACETES (nom mythol.! CRUst.-G. de la famille des Crustacés Décapodes Macroures et de la tribu des Salicoques, établi par nous, et remarquable par l'absence des 2 dernières paires de pattes thoraciques et le développement considérable des pattes-mâchoires externes, qui remplissent les fonctions des pattes ordinaires. - On n'en connaît qu'une seule esp., l' $A$. indicus, M. Edw. (Ann des sc.nat., t. xıx, pl. 11), qui habite l'embouchure du Gange.

(M. E, )

* ACETOSA (Acetum, vinaigre). вот. PII. - Tournefort a donné ce nom à une sousdiv. du g. Rumex, caractérisée par des fleurs dioïques.

ACHAUS, Leach. CRUS'.-Syn. latin d'ACIIÉE. $V$. ce mot.

(C. D'O.)

ACHANA, Sw. (áxayńs, qui ne s'ouvre pas; allusion à la corolle). вот. PIr. - Syn. du g. Mauvisque ou Malvaviscus Dill.

(Sp.)

ACHANTILLES. Achantilloc. Ins. - Latreille (Gen. Crust. el Insect.) donne ce nom à une sect. de sa famille des Cimicides, comprenant les g. Cimex, Punaise proprement dite, Macrorephalus, Phymata, Tingis, Aradus.

ACIIARIA (Acharius, naturaliste suédois). воT. PIr. - G. fondé par Thunber'r (Prodr.) et si incomplétencnt caractérisé, que l'on n'a pu, jusqu'ici, le rapporter à aucune des familles naturelles. (C. L.)

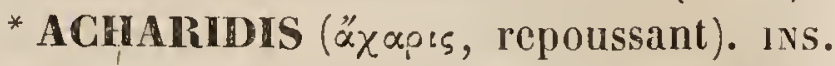
— G. de l'ordre des Coléoptères tétramères, famille des Longicornes, tribu des Lamiaires, établi par M. Dejean (Catul., $3^{\text {me }}$ édit.) qui n’en a pas publić les caract. - II est fondé sur une seule esp. (l'A. lunifera Ioj.) de l'Amér. septentrionale.

ACMARITLRIURI. вот. pH. - Ce g, a été réuni par M. De Candolle au Filago, et rentre comme synonyme dans l' Oglifa, Cass.

(J. D.)

ACHATE (nom myth.). Iss.-Nom d'une esp. de Lépidoptères diurnes du g. Papillon.

* ACHATIA (Achate, nom myth.). ins.G. de l'ordre des Lépidoptères, famille des Nocturnes, établi par Stephens dans la grande trinu des Noctućlites Lair., et qui correspond aux g. Trachea de M. Treitschke et Ilarus de M. Boisduval.

AGIE. Apium, Tourn. (Apion, eau ; mot celtique; allusion à l'habitation de ces plantes). вот. Pн. - G. de la famille des Ombelliferes, tribu des Amminécs. Koch (Deutsch. flora) a assigné à ce g. les caract. suivants : Bord calicinal inapparent. Pétales égaux, planes, arrondis, non échancrés, acuminés et enroulés au sommet.Disque presque planc, sinuolé au bord. Styles trés courts, recourbés. Péricarpe solide, subglobuleux, didyme; méricarpes subhémisphériques, à cinq còtes filiformes, un peu tranchantes ; les latérales marginales; périsperme très convexe; carpophore indivisé; vallécules en général à une seule bandelette. Fleurs blanches, très petites, en ombclles sessiles ou courtement pélonculées, de 6 à 12 rayons; collerette générale nulle ou réduite à 2 ou 3 folioles; point d'involucelles. Feuilles pennées, 3-7foliolées. - M. Koch ne comprend dans ce g. qu'une seule esp., connue sous te nom de Céleri.M. De Candolle (Prodr.v.4) en a ajouté 3 autres dont les caractères génériques yaraissent ne pas être les mêmes. (Sp.)

* ACIIÉE. Achous (nom cité par les Anciens, comme celui d'un Grec paresseux 
et stupide). maik. - T. Cuvier a proposé ce nom générique pour un groupe de Bradypiens, dont l'Ai est le type. Le nom de Bradypus appartiendrait ainsi en propre à l'Unau ; mais déjả Illiger avail divisé les Bradypiens en deux g. (Cholcepus et Bradypus), dont le dernier correspond précisément à l'Acheus de F. Cuvier.

(I. G. S.-H.)

* ACIIĹt. Achous (nom mythol.). CRUST. - G. de Crustacés Décapodes Brachyures de la famille des Oxyrhinques et de la tr. des Macropodiens, établi par Leach et ayant pour caract. principanx : Yeux non rétractiles. $3^{\text {me }}$ art. des pattes-mâchoires externes presque triangulaire, fortement tronqué en avant, á peine plus long que large, et portant l'article suivant ả son angle externe. Rostre médiocre et laissant à découvert de chaque côté le point d'insertion de la tige mobile des antennes externes. Pattes des 2 dernières paires terminées par un tarse presque falciforme. $\Lambda$ bdomen composé de 6 art. dans les 2 sexes. - On n'en connaît qu'une esp. de très petite taille, l'A. Cranchii (Leach, Malac., pl. 22, fig. C), qui habite la Manche. (M. E.)

ACUÉE. ANNéL. - Nom vulgaire des Lombrics, dans quelques parties de la France; d'où les pêcheurs ont appelé Achées ou Aches les vermisseaux, larves et insectes, dont ils font des appâts pour amorcer le poisson.

(C. D'O.)

ACIÉLOITE. Achelös (Acheloüs, nom my th. d'un fleuve). MoL. -G. de Céphalopodes siphonifères, établi par Montfort (Conchyliologie systématique), sur une figure de Knorr, pour une coquille fossile appartenant aux Orthocératites. $V$. ce mot. (A. d'O.)

* ACIIEIUUM (áxńv, pauvre). INs. - G. de Colćoptères pentamères, famille des IBrachélytres, établi par Leach, qui n'en a pas publié les caractères, et adopté par M. Dejean. Ce g. est composé de 4 esp., dont l' $A$. cordaum Dahl., qui se trouve aux environs de Paris.

(D.)

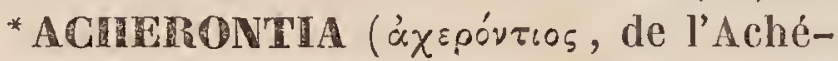
ron; myth.). ıns. - G. de l'ordire des Lépidoptères, famille des Crépusculaires, tribu des Sphingides, établi par Ochsenheimer el adopté par Latreille. Il a pour type le Sphinx atropos $L$. et Fabr., vulgairement appelé $P a-$ pillon à tête de mort, parce que la tache de son corselct en représente assez bien la figure. En adoptant ce g. dans notre Catal. métho- dique des Lepid. d'Europe, nous l'avons caractérisé ainsi : Chaperon large et très proéminent. Yeux gros et saillants. Ant. très courtes, droites, presque d'égale grosscur darts leur longueur, légèrement striées transversalement du côté interne et terminées en crochet. Palpes épais, séparés à leur extrémité et dépassantà peine le chaperon. Trompe courte et large. Ailes supérieures entières et lancéolées; angle anal des inférieures arrondi. Cors. ovale, peu convexe, a vec un double collier bien marqué et les épauleltes peu distinctes. Abdomen ovalaire et légèrement aplati. Paltes courles, épåisses, avec les crochets du bout des tarses très forís; cuisses grosses et garnies de poils longs et toufrus; ergots des 4 jambes postér. très courts. Chenilles lisses, rayées obliquement, avec la tête plate et ovalaire, et une corne rocailleuse, contournée en queue de chien sur le $11^{\text {me }}$ anneau. Elles se métamorphosent dans la terre sans former de coque. Chrysalide déprimée sur la poitrine, avec une pointe anale bifurquée. $V$. Aтropos.

ACHERUSIA (Achérusie, caverne. Mythol.) Ins. - G. de l'ordre des Coléoptères pentamères, famille des Sternoxes, tribu des Buprestides, établi par MM. Gory et Delaporte, qui lui assignent les caract. suivants: Palpes maxillaires de 4 articles; le 1 er à peine visible; le $2^{\text {me }}$ long, cylindrique, arqué; le $3^{\text {me }}$ court, triangulaire; le dernier assez grand, renflé, ovalaire; palpes labiaux de 3 articles ; les 2 premiers très courts, grêles, égaux; le dernier grand, renflé, ovalaire. Labre carré; à angles antér. arrondis; menton large, rétréci en avant, élargi en arrière, arrondi; lévre petite, un peu transversale; mâchoire bilobée, velue; lobe extérieur grand, l'intérieur petit, triangulaire. Mandib. fortes, arquées intérieurement, échancrées à l'extrémité. Ant. de 11 art. : le $1^{\text {er }}$ très grand; les 2 suivants courts, égaux et globuleux; les $4^{\text {me }}$ et $5^{\text {me }}$ grêles, cylindriques, d'égale longueur; les suivants triangulaires, transversaux, élargis extérieurement. 'Tarses assez petits, à articles presque cylindriques, le pénultième bilobé, ce dernier portant des crochets. Corps assez court, épais. - Ce g., qui ne figure pas dans le catalogue de M. Dejean, a pour type l' $A$. Childrenii, espèce unique, communiqué aux auteurs par Children, entomologiste de Loudres.

(D.) 


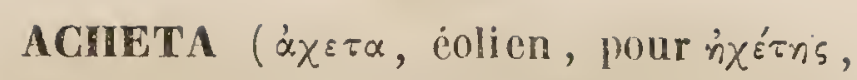
bruyant; épithèle donnée par les Grecs à plusieurs insectes qui produisent une stridulation, lels que les Cigales et les Sauterelles). 1Ns. - Cette dénomination est donnée par Fabricius (Eut. syst.) au g. Gryllus de Geoffroy. Burmeister (Handb. der Ent.) l'applique au g. Schizodactylus de M. Brullé. $V$.ces mots.

*ACIIETARIA (áexplétif; $\chi$ ń $\tau$, cavité ; allusion à l'échancrure dn pistil). вот. Pn. - G. de la famille des Scrophularinées, R. Br., tribu des Gratiolées, Benth., fondé par Chamisso (Limn. 11, 567), qui en limite ainsi les caract. : Cal. pentaphylle, bi-bractéolé. Cor. hypogyne, bi-labiée ; lèvre supér. dressée, plus courte, entière; l'infér. trilobée. Étam. 2, incluses, insérées antérieurement au tube de la corolle; filaments simples; parallèles aux loges des anthères. ('́tam. slériles, nulles). Ovaire bi-loculaire; placentas multi-ovulés, sondés de chaque côté à la cloison. Style simple; stigmate èchancré. Caps. bi-loculaire, septifrage, bi-valve; valves entières ou courlement bi-fides au sommet, parallèles à la cloison placentifère. Graines nombreuses, très petites.-Ce g. ne contient qu'une esp.; c'est une plante herbacée, un peu hirsutée, dont le port imite celui d'une mélisse; ses tiges sont tétragones, a feuilles opposées, courtement pétiolées, ovales-aigües, crénelées: les pédicelles axillaires, solitaires, uni-flores, opposés; les corolles pubescentes. Indigène au Brésil.

(C. L.)

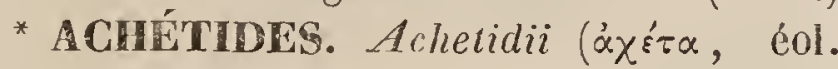

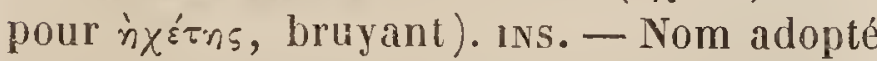
par quelques auteurs pour désigner la famille des Grylloniens de Latreille.

ACHEUS, Cur. man.- Syn. latin d'ACIÍE.

(C. D'O.)

ACHISS. INs. - G. de l'ordre des Diptères, établi par Bose et adopté par M. Hacquart, qui le place dans sa div. des Brachocères, subdiv. des Dichoètes, famille des Athéricères, tribn des Muscides. Ce g. se distingue principalement par une modification singulière de la tête, qui se dilate de chacque côté en un long pédoncule supportant l'ail. Cette forme hui est commune avec le g. Diopsis, dont il se distingue par l'insertion des antennes sur le front. Du reste, ses caract., suivant B. Macquart, sont: Trompe grande. Palpes filiformes, de la longueur de la trompe. Epistome saillant; front transversal, dont les côtés prolongés forment un pédoncule oculifère. Ant. distantes, n'atteignant pas l'épistome; $3^{\text {me }}$ art. allongé, cylindrique; style très courl, inséré à la base. - Ceg a pour type l' $A$. oculatus Fab., originaire de Java. Depuis cet auteur, 2 autres esp. du même g. ont été découvertes au Brésil, savoir: '' $A$. lobularis Wiedm., et l' $A$. dispar du même.

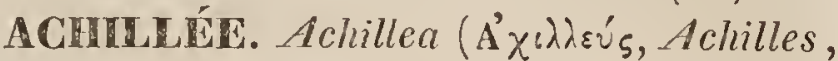
élève du centaure Chiron, qui lui enseigna la médecine; allusion aux vertus attribuées à l'A. Mille-feuille). вот. pI. - Les Achillea sont des herbes vivaces, communes aux 2 continents; mais la partie orientale de l'Europe australe est le point oú les esp. de ce g. se rencontrent en plus grande quantité. Elles ont pour caract. génériques : Capit. multiflores, hétérogames, disposées en corymbe; fleurs du rayon au nombre de quatre á six, ligulées, souvent très courtes, difformes, et même parfois complétement avortées; celles du disque tubuleuses, à 5 dents, à tube obcomprimé. Les lruits ou akènes sont oblongs, glabres, obcomprimés, dépourvus d'aigrette, munis de nervures marginales, qui cependant ne les rendent pas ailés.Récept.étroit,quelquefois presque plan, et même allongé en forme de rachis, portant des paillettes oblongues, hyalines, placées entre les fleurs. - Le g. Achillea, aux dépens duquel on a formé le g. Piarmica, etdont on a également retranché un grand nombre d'espèces pour les reporter principalement parmi les Pyrethrum, en renferme encore aujourd'hui plus de 50 . On emploie la Millefeuille comme médicament. (J. D.)

ACIILLEES. Achillex (Achilles, myth.). BOT. PH.-Nom donné par Jussieu à une tribu de la famille des Composées, dont le type étail le g. Achillée. Les Synzanthérographes ont fondu depuis cette tribu dans celle des $A n-$ thémidées, appartenant à la même famille (DC., Prod. vi; Endl. Gen.Pl. vu1). (C. L.) * ACDILILUM. 200pH. - Ce g., de la famille des Spongiaires, a été établi par Schweiggen pour recevoir les espèces dont le tissu est lacuneux et composé de fibres réticulaires, à surface recouverte d'une couche glutineuse continue, ou ne présentant que des pores très petits. L'Eponge commune est le type de cette division qui, du reste, 
n’a guère été adoptée que par Goldfuss, et qui, ell eflel, ne repose pas sur des caractères suffisants. Ce dernier auteur y rapporte plusieurs Spongiaires fossiles qui ne présentent ni tube, ni excavation centrale, et paraissent être des Éponges proprement dites.

(M. E.)

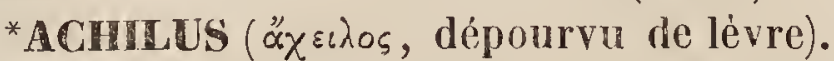
Iss. - G. de l'ordre des Hémiptères, section des Homoptères, famille des Fulgorelles, établi par Kirby (Cent. of Ins.) sur une seule espèce, provenant de la Nouv.-Hollande, et qui présente les mêmes caractères que les Cixia de Latreille. $V$. ce mot.

ACHIVENES (Étym. incert.). вот. Рн.Brown a créé sous ce nom un g. qu'il plaçait parmi les Scrophulaires de Jussieu, et que L'Héritier nomma ensuite Cyrilla. Scopoli le réunit au Buchnera, L., el Lamarck au Colımnea. D'un autre côté, Wildenow fonda sur le même type song. Trevirana, qui, malgré l'antériorité acquise au premier de ces auteurs, paraît être adopté de préférence. Vahl appliqua ensuite la dénomination d' $A$ chimenes à un nonveau g. dela même famille, tribu des Gratiolées, qui comprend quelques espèces du g. Columnea de Linné; il a pour synonymes le Diceros de Persoon (Encheir.), l'Arlanema de Don (ex Benth.). En voici les caract. essentiels : Cal. à 5 segments égaux. Cor. hypogyne, infundibuliforme ou campanulée, à limbe subquadrifide, subbilabié; division supér. plus large; tube pourvu intérieuremenc de 4 écailles. Etamines 4, fertiles, didynames, insérées au tube de la corolle; les infér. plus courtes, à filameuts simples; les supér. insérées á la base de la lèvre infér., à filaments allongés, pourvus à la base d'un appendice court et obtus. Anthères biloculaires, soudées par paires; loges conniventes, divariquées. Ovaire biloculaire; placentas multi-ovulés, insérés des deux còtés sur le milieu de la cloison. Style simple, à stigmate bilamellé. Capsule subglobuleuse, biloculaire, septifrage, bivalve ; valves membraneuses, entières, planes sur les bords, parallèles à la cloison qui devient libre. Graines nombreuses. - Les Achimènes sont des plantes herbacées, glabres, ay ant le port des Sésames; leurs feuilles sont opposées, denlées; leurs fleurs en grappes terminales opposées, courtement pétiolées. On les trouve dans l'Inde.

(C. L.)
* ACIIRITR. mir. - Nom emprunté de celui d'Achir Mahmed, qui a découvert ce minéral. $V$. DIOPTASE.

(DEL.)

ACHIRUS (’ priv.; $\chi$ síp, main). rorss. G. de la famille des Pleuronectes, établi par I.acépède, et adopté depuis par les Ichthyologistes. Semblables aux Soles, les Achirus en diffèrent par l'absence des pectorales. Ce sont des poissons des mers équatoriales; on en connaîl 4 ou 5 espèces.

(VAL.)

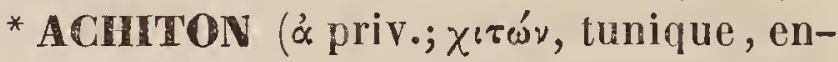
veloppe). вот. Gr.-G. de la famille des Hiépatiques, proposé par Corda, et qui ne peut être adopté, puisque Raddi l'avait plus anciennement désigné sous le nom de $R_{t} b o u l-$ lia. D'ailleurs, comme le remarque Bischoff, le nom de Corda, d'après son étymologie, serait inadmissible, la capsule du genre $\mathrm{he}$ boullia étant munie d'une calyptre. (C. M.)

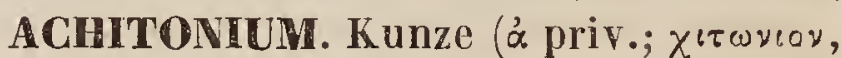
petite tunique). вот. св. - G. de Champignons dont les spores sont petites, globuleuses, vides, transparentes, d'une couleur blanche ou légèrement jaune, ou rouge. Elles n'ont a ucune enveloppe, el composent, par leur réunion, de petites masses d'une forme indéterminée, quelquefois sphéroïde, d'autres fois étalée. - Ce g., dont M. Nees d'Esenbeck avait indiqué l'existence dans son Systema der Pilze, et qui a été établi par G. Kunze (Flora oder Botanische Zeitung, n. 4, 28 janv. 1819), est encore problématique. L'auteur n'en a fait connaître qu'une seule espèce qui croît sur les feuilles du Pinus sylvestris, et qu'il a trouvée dans les environs de Leipzig.

(Lév.)

ACHLIS. MAm. - Nom sous lequel les anciens désignaient l'Élan (Cervus alces).

$$
\text { (C. D'O.). }
$$

* ACHLYA (áxiús, nom mythol. de la déesse de l'obscurité). вот. сr. - Ce g., de la famille des Phycées, établi par Nees d'Esenbeck (1 $1^{\mathrm{me}}$ vol. des Nov. act. nat. Cur.), diffère -t-il effectivement des Leptomitus d'Agardh? Comme il est conservé par Gréville dans Lindley, nous en donnerons une définition prise dans l'auteur lui-même : Filaments tubuleux, continus, simples ou devénant prolifères au sommet un peu renflé, contenant des spores qui, après leur sortie du tube, se réunissent en globules par un mouvement insensible.-L'auteur compare au Mycelium de certains champignons, l'unique espèce de 
ce genre qui habite l'eau douce. (C. M.) ACHLYS, DC. ('a $\chi \lambda^{2}{ }^{\prime} s$, obscurité). вот. PH. - G. fondé sur une seule esp. incomplètement connue; aussi M. De Candolle, tout en . le plaçant à la fin de ses Podophyllées, a-til voulu, par ce nom, faire allusion à l'incertitude de sa classification. Depuis, MM. Hoolier et Lindley ont considéré cette plante comme une Berbéridée, voisine des Leontice. Bernhardi, au contraire, pense qu'elle doit être r'egardée comme le type d'un nouveau groupe, tenant le milieu entre les Renonculacées et les Berbéridées. A notre avis, l'Achlys ne saurait être éloigné des Actoca; opinion déjà émise par Bartling. D’après la description donnée par M. Hooker (Flor. bor. Amer.), cette plante ofire les caract. suivants : Calice et cor. nuls. Étam. en nom. bre indéfini, hypogynes; filets filiformes, flexueux. Anth. subglobuleuses, didymes, introrses, dithèques, bivalves de bas en haut; bourses confluentes antérieurement; connectif étroit. Pistil à ovaire solitaire, 1-loculaire, 1-ovulé, couronné par un stigmate ovale, concave; ovule attaché au fond de la loge ; fruit et graines inconnus.-Herbe vivace, acaule; feuilles radicales, longuement pétiolées, 3-foliolées; folioles grandes, flabelliformes, sessiles, incisées-dentées; hampe nue, dressée, terminée en épi nu; fleurs petites, rapprochées. L'Achlys est indigène dans le N.-O. de l'Amérique. (Sp.)

ACHLria (Achlys, déesse de l'obscu-

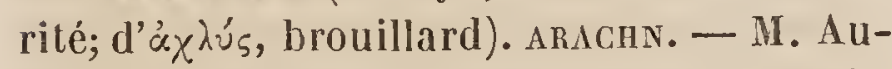
douin a désigné sous ce nom un g. d'Arachnides appartenant à l'ordre des Acarides; mais M. Dugès, dans les Mémoires qu'il a publiés sur cet ordre, a démontré que le g. Achlysian'était autre chose qu'un Hydrachne qui n'avait pas encore atteint son entier développement.

(H. L.)

ACHMITE, et mieux AKMITE ('axprí, pointe, à cause de la forme aiguë de ses cristaux). MıN.-Minéral découvert parStrom dans la commune d'Eger, en Norvége. Il est d'un brun noirâtre ou d'un vert sombre, en prismes obliques rhomboïdaux, très allongés, clivables parallèlement à leurs faces longitudinales. Ces prismes se terminent par des sommets très aigus, à 2 ou à 4 faces. L'inclinaison des faces latérales est de $86^{\circ} 56^{\prime}$, et celle de la base sur chacune d'elles est de $100^{\circ}$. Il est vitreux et assez dur pour rayer le verre. Sa pesanteur spécifique est de 3,24. Il fond aisément au chalumeau en un globule noir. Ce minéral est, d'après Berzélius, composé de silice 55,25 , d'oxyde de fer 31,25 , de soude 10,40, d'oxyde de manganèse 1,08 , et de chaux 0,72. - On le trouve engagé dans du quartz, au milieu de roches granitiques et syénitiques. Il est remarquable par l'analogie de sa forme avec celle du Pyroxène, malgré la différence de composition de ces 2 espèces.

(DEL.)

* ACHNANTHELLA. Dimin. d'Achnan-

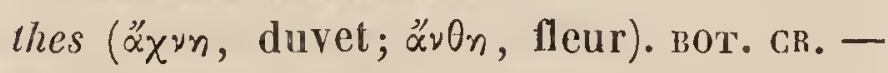
G. de la famille des Algues, proposé par Gaillon, et réuni au g. Achnanthes. (C. L.)

ACHNANTHES ( $\not \chi \chi \chi^{\nu} \cdot n$, paillette; $\propto^{\prime} \nu \theta_{n} n$, fleur). вот. CR - - G. établi par M. Bory-StVincent pour une Algue microscopique qui se jrésente sous la forme d'une petite lame rectangulaire, pédicellée latéralement et obliquement, de manière à former une sorte de petit étendard. La lame n'est point continue, mais composée de plusieurs petites bandes paralléles qui paraissent être autant d'articles composant la plante. - On en connaît $\delta$ ou 10 espèces, différant entre elles par la longueur du pédicule et par le nombre ou la courbure des pièces dont se compose leur lame rectangulaire. Les unes sont marines, les autres se trouvent fixées aux plantes marécageuses dans les eaux douces. M. Ehrenberg, qui les range parmi les Infusoires, ainsi que les autres Diatomées, leur suppose des estomacs non réunis par un intestin, et des prolongements charnus et variables servant de pieds.

(DU..)

ACHNATHERUM ( $\alpha^{2} \chi^{\nu \cdot n}$, duvet, etc.; $\theta \varepsilon \dot{p}$ os, été, etc.). вот. PII. - Le g. établi sous ce nom par Palissot de Beauvois dans son Agroslographie, et qui comprenait, entre autres esp. : les Agrostis calamagrostis L., miliacea, ou Arundo lanceolata Kol., n'a pas été généralement adopté. Les diverses esp. que Beauvois y avait réunies appartiennent en effet à des g. différents.

(A. R.)

ACHNERIA ( $\propto \chi \chi ข n$, duvet). вot. PII. - G. de la famille des Graminées, proposé par Palissot de Beauvois pour quelques esp. du g. Eriachne, auquel les auteurs le laissent réuni. (C. L.)

ACHNODONTON (äхขn, paillette; ن่doús, óvzos, dent). вот. PH. - G. de la famille des Graminées, ćtabli par Palissot de Beauvois 
pour quelques esp. de Phleum, mais qui n'a pas été gén éralement adopté.

(A. R.)

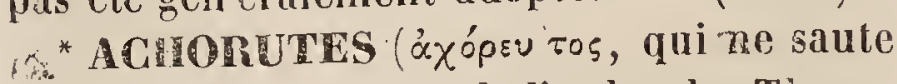
pas; triste). ins. - G. de l'ordre des Thysanoures, famille des Podurelles, établi par Templeton(Trans.Soc. Ent. Lond.), ct dont les caract. distinctifs sont: Ant. de 4 art., lus courtes que la tête. Queue obsolète. l'esp. type de ce g. est l'A. dubius Temp., trouvée sur l'eau, à Cranmore. (H.L.)

* ACIRAS. bot. ph. - Syn. latin de $S a-$ potillier.

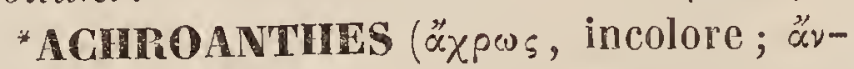
On, fleur). вот. Ріг. - G. de la famille des Orchidacées, Lindl., fondé par Rafinesque (New-York Med. Rep.), et réuni au g. Microstylis, Nutt. $V$. ce mot. (C. L.)

* ACHROLA (“xpora, pâleur). ins. - Dénomination appliquée par Curtis (Brit. Enıom.) à un g. de l'ordre des Lépidoptères, tribu des Tinéites, trop voisin des Galleria pour en être distingué, et dont le type est le G. alvearia Fab.

* ACHROMOL ENA (á priv.; $\chi$ pũ $\mu \alpha$, cou-

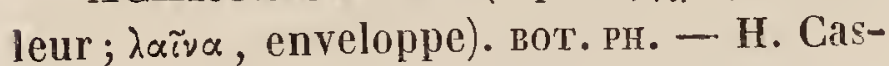
sini a donné ce nom à un g. de plantes de la famille des Composées, originaires de la Nouv.-Hollande; M. De Candolle le réunit comme section au g. Cassinia de R. Brown.

(J. D.)

* ACHRYSOy (ä xpusos, sans or). ins. G. de Coléoptères tétramères, famille des Longicornes, tribu des Cérambycins, établi par M. Serville dans sa monog. de celte famille. Ses caract. sont: Palpes 4, courts, égaux. Cors. cylindrique, mutique, point inćgal ni rugueux en dessous, allongé, évidemment plus long que la tête. Ant. velues, plus longues que le corps; dans les mâles (remelles inconnues) de 11 art.; le $3^{\text {me }}$ et le $11^{\mathrm{me}}$ assez longs. Pattes longues; cuisses point en massue, un peu élargies et comprimées. Élyt. terminées chacune par une épine médiane et non suturale, très distincte; elles ont leur angle huméral saillant et accompagné intérieurement d'une excavation arrondie, très prononcée ; écusson petit, triangulaire. Corps allongé. - Ce g. a pour type le Stenoconus cirćumflexus Fab. (Ceramby $x$ circumflexus Olliv.) de l'Amér. méridionale.(D.)

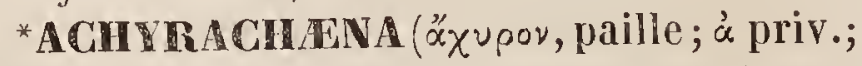
$\chi \alpha$ '́vw, j'ouvre.L'akène est indéhiscente). вот. pri_-Plante de la famille des Composées, ori- ginaire de la côte N.-O. de l'Amérique, ayant le port des Scorzonères, blanchâtre, à tige simple,monocéphale; voici ses caract.: Capit. multiflore; fleurs du rayon stériles, petites; celles du disque hermaphrodites. Anth. dépourvues d'appendices basilaires. Branches desstyles pubescentes, presque cylindriques. Akènes allongés, atténués à la base, striés longitudinalement; ceux du rayon dépourvus d'aigrettes; ceux du disque surmontés par une large aigrette 2-sériée, composée de 10 écailles membraneuses, obtuses ; les 5 extér. au moins de moitié plus courtes que les 5 intér. qui entourent le tube de la corolle. Piécept. plan, portant une rangéé d'écailles placées entre les fleurs du rayon et celles du disque; le reste de sa surface nu, marqué d'alvéoles bordées de fimbrilles très fines.

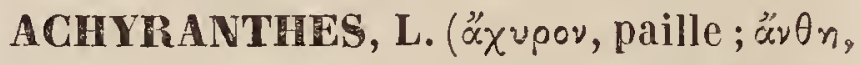
floraison). вот. PII. - G. de la familie des Amarantacées. Martius, dans sa monog. de cette famille, lui assigne les caract. suivants : Cal. 5-sépale, régulier, accompagné d'un calicule de 2 folioles en général spinescentes. Androphore cupuliforme ; 10 filets , alternativement anthérifères et stériles; ceux-ci dentés ou fimbriés; anth. dithèques.Style indivisé; stigmate capitellé. Péricarpe membraneux, indéhiscent, monosperme.- Herbes ou sous-arbrisseaux; feuilles opposées; fleurs scarieuses, disposées en épis aphylles. Dans ses limites actuelles, ce g. ne renferme qu'environ 12 esp., dont la plupart croissent dans la zòne équatoriale, et quelques unes dans la région méditerranéenne. ( $\mathrm{SP}$.)

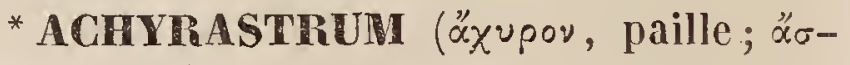
rpov, étoile). вот. PH. - Ce nom a été proposé par Necker pour quelques plantes du groupe des Chicoracées, qu'il séparait des Hyoseris et élevait au rang de genre; M. De Candolle, au contraire, le regarde comme synonyme. L'aigrette qui surmonte le fruit est formée alternativement par des écailles membraneuses, plus courtes les unes que les autres, et présentant, lorsqu'elles sont étalées, quelque ressemblance avec une étoile : disposition qui a servi à Necker pour caractériser ces plantes.

(J. D.)

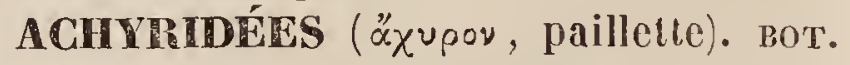
PH. - S.-division des Chrysocomées, appartenant à la tribu des Astéroidées, de la famille des Composées.

(J. U.) 
ACHYRITES. Min. - Syn. de Calcaire ooliticue,

(Dis.)

* AGHYROGLINE ("丷x vpov, paille; $x \lambda_{i} i n$, lil). вот. PII. - Le g., qui apparlient à la famille des Composées, diffère des Graphaïizm par les fleurs 1-sériées du rayon, des Helichrysum par ses fleurs femelles, plus nombreuses que les hermaphrodites, et de tous deux par un port particulier qui les rapproche presque des Stenocline. - Ce sont, en général, des végélaux de l'Amérique, à feuilles sessiles ou décurrentes, alternes, linéaires, presque toujours tomenteuses, à folioles de l'involucre jaunes ou rousses. (J.D.)

* ACHYRocoma (äxupov, paille; xóp.n, chevelure). вот. Pf. - G. de la section des Vernoniées-prototypes de Cassini, el que M. De Candolle réunit aux Vemonia. (J. D.)

ACHYRONIA, Wendl.(äxupov, paille). вот. PII. - G. de la famille des Légumineuses, s.-ord. des Papilionacées, tribu des Lotées, section des Génistées. Ce g. a été superficiellement constitué par Wendland, qui lui attribua les caract. suivants : Cal. 5 -denté; dent inférieure allongée, 2-fide. Élamines diadelphes (9 et 1). Légume comprimé, polysperme. - On n'en signale qu'une seule espèce ; c'est un arbrisseau indigène dans la N.-Hollande, á feuilles simples, à fleurs jaunes, axillaires, pédicellées.

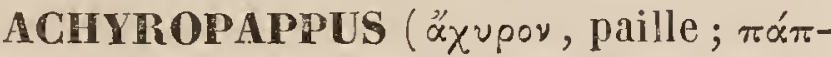
$\pi \circ \varsigma$, aígrette). вот. PII. - Ce g., de la famille des Composées, semble à peine différer du Schkuhria; il a pour caraci. : Invol. à 5 folioles très obtuses, quinconciales. Récept. nu, alvéolé. Fleurs du rayon, au nombre de 3 ou 5 , femelles; celles du disque dépassant à peine l'aigrette, qui est composée de 6-8 écailles membraneuses, obovées, mutiques. Branches des styles terminées par de courts appendices. Akènes noirs, linéaires, à 3-4 angles assez prononcés. - Les Achyropappus sont des herbes annuelles, originaires du Mexique.

(J. D.)

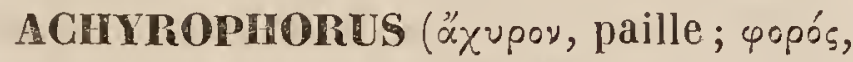
porleur). вот. Pн.-D’après M. De Candolle, ce g. diffère uniquement des Hypochoris par son aigrelle 1 -sériée, plumeuse el non dilatée, par son invol. hémisphérique ou campanulé. Il est intermédiaire entre ce dernier elle Seriola, avec lequel il a de l'affinité par son invol. 1-sérié. - Les 18 à 20 esp. qui composent ce g. sont pour la plupart des herbes vivaces, communes aux deus hérnisphères. (J. D.)

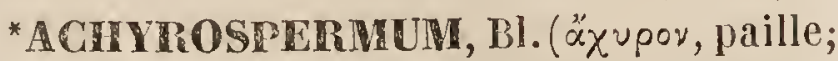
$\sigma \pi \varepsilon \dot{p} u \alpha$, graine). вот. PII. - G. de la famille des I abiées, tribu des Stachydées, s.-tr. des Ballotées. Suivant Bentham (Labiat., 643), les caract. de ce g. sont : Cal. ample, subbilabié ; lèvre supér. dressée, 3-fide; lèvre infér. un peu plus courte, horizontale, 2 -fide. Cor. plus longue que le calice; lèvre supér. courte, dressée, échancrée ; lèvre infér. semi-3-fide, concave, à lobe moyen plus grand. Étam. 4, subisomètres, ascendantes; filets nus; ant. à bourses confluentes. Style très légèrement 2-fide. Akènes garnis au sommet el au dos de paillelles membraneuses. Herbes ou sous-arbrisseaux à feuilles dentées, mollement pubescentes. Faux verticilles agrégés en épi terminal. Les espèces de ce g. habitent Java et Madagascar. (SP.)

* ACIA bot. Ph. - Syn. du g. Acioa Aubl. (Sp.)

ACIANTHE. Acianthus (äxís, pointe;

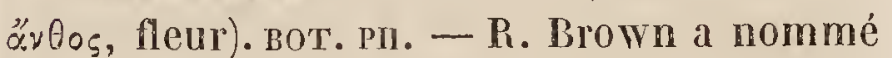
ainsi (Prodr. Florce IV.-Holl., t, i, p. 321) un $g$, de la famille des Orchidées, tribu des Malaxidées, qui se compose de 4 esp., toutes originaires de l'Australie. Ce sont de petites plantes grêles et dépourvues de poils, ayant des tubercules charnus, entiers el nus, une tige portant à sa base une seule feuille cordiforme, réliculée, brune en dessous, et des fleurs également brunes, tantôt solitaires, tantôt disposées en épis. Les 3 div. extér. du calice, longuement acuminées et libres, sont rapprochées; les 2 intér. trés petites, également acuminées; labelle libre, entier, offrant 2 callosités à sa base. Gynostème semi-cylindrique, un peu renflé dans sa partie supér., qui porte une anthère terminale et 2-loculaire. Stigm. ovoïde et transversal. Masses polliniques au nombre de 8 . (A. R.)

ACICARPIIA (áxn, pointe; xápyos, fétu de paille), вот. ри. - G. de la famille des Calycérées, élabli par Jussieu (Amn. Mus., 2, p. 347) et adopté par L. C. Richard (Mém. Cal.), qui en a donné les caract. suivants : Fleurs réunies en capitule; invol. de 4 à 5 folioles soudées par leur face interne avec les ovaires les plus extérieurs. Fleurs de la circonférence fertiles; les centrales beaucoup pius nombreuses et stériles; ovaires tous soudés ensemble. Divisions du calice terminées 
en pointe épineuse dans les fleurs fertiles. Cor. longuement lubuleuse, à 5 div. égales. Étam. soudées par leurs filets et la plus grande partie de leurs anthères, insérées vers la partie supér. du tube de la corolle.Ce g. se compose de 2 espèces herbacées, à feuilles alternes; l'une , $\mathcal{A}$. tribuloüdes Juss., croìt aux environs de Buénos-Ayres; l'autre, A. spathulata, est commune dans les lieux sablonneux aux environs de Rio-de-Janeiro.

On ne sait trop pourquoi Cassini a substitué le nom de Cryprocarpha à celui d'Acicarpha.

(A. R.)

* ACRCULAMES (Feuilles). Folia acicularia (c'est-à-dire en forme d'aiguille, acus). вот. Pн. - On appelle ainsi, en botanique, des feuilles étroites, linéaires, à peu près cylindriques, ayant une certaine rigidité, comme celles de plusieurs espéces de Pins. - Se dit aussi en minéralogie d'un cristal tirant son origine d'un prisme qui s'est aminci et allongé en forme d'aiguilles. (C.D'O.)

* ACICULE. Aciculatus (acus, aiguille; d'uxís, pointe). вот. PII. - Se dit quand la surface du tégument propre de la graine est marquée de lignes ou raies très fines et sans ordre, qui semblent avoir été tracées avec la pointe d'une aiguille.

(C. D’O.)

ACICULES. Aciculi (acus, aiguille; d'áxí, pointe). ANNÉL. - Les Acicules, ainsi nommés par Savigny, sont des soies subulées ou sans crochets qui se distinguent des soies proprement dites, parce qu'elles sont plus grosses, droites, coniques et d'une couleur plus foncée. Il en existe seulement 1 ou 2 à chaque pied; elles sont renfermées dans une gaîne particulière, et le plus souvent rentrées dans l'intérieur des mamelons sétigères, qui portent le nom de pieds chez les Annélides.

(L. D. Y. R.)

* ACIDAIIE. Acidalia (surnom de Vénus). rns. - G. de Lépidoptères nocturnes de la tribu des Phalénites de Latreille, qui correspond au grand g. des Phalènes-géomètres de Linné , établi par Treitschke et que nous avons adopté avec quelques modifications (Hist.nat. des Lépid. de France), en lui assignant les caract. suivants : Ant. ciliées dans les mâles et simples dans les femelles. Bords terminaux des ailes simples et entiers. Cors. étroil et squameux. Les 4 ailes traversées par des lignes parallèles, tantôt droites, tantòt ondulées ou sinuées, et dont le nombre varie de trois à cinq sur un fond uni; un point au milieu de chaque aile sur le plus grand nombre des espèces. Palpes très courts. Trompe longue. Chenille effilée, sans tubercules, à anneaux bien distincts et à tête arrondie. Chrysalide contenue ordinairement entre des feuilles retenues par quelques fils. La plupart des Acidalies se trouvent dans les clairières des bois, où croissent de haules herbes; quelques unes seulement volentdans les prairies ; toutes ne paraissent qu'une fois par an, et le plus grand nombre en juillet. Nous en avons fait connaître 19 esp. , parmi lesquelles nous citerons comme type : l' $\not$. pallidaria des auteurs, très commune en juin et juillet dans tous les bois.

(D.)

*AGIDALIE. Acidalia (surnom de Vénus). INs. - G. de Coléoptères tétramères, famille des Chrysomélines, proposé par M. Chevrolat et adopté par M. Dejean, mais dont les caractères n'ont pas été publiés. Il ne comprend qu'une esp., l'A. varians Sturm., originaire du Brésil. Si ce g. est conservé, le nom d'Acidalia devra être changé, attendu qu'il a été appliqué depuis long-temps à un g. de Lépidoptères.

* ACIDANDRA Mart. ('xxís, pointe; ávnip, ¿้vóós, homme, par extension étamine). вот. PH.- Syn., suivant Vogel, du g. Zollernia, Nees.

AGIDES cInm. et mis. - Dans l'état actuel de la Chimie, il n'est peut-être pas possible de définir rigoureusement ce que l'on entend par Acides; mais on applique généralement cette dénomination à des substances composées, douées d'une saveur aigre, rougissant la couleur du tournesol et celle de la violette, neutralisant d'une manière plus ou moins prononcée les propriétés des Oxydes métalliques et produisant avec eux des Sels, c'est-à-dire des combinaisons dont les Acides sont négatifs et les bases positives. Lorsque la solubilité manque dans un Acide, comme, par exemple, dans la Silice, la propriété de rougir les papiers-réactifs fait également défaut; mais celle de s'unir avec les bases n'en existe pas moins, et c'est là le caractère essentiel de l'acidité.

Les Acides sont très nombreux, et quelques uns occupent une place importante dans les applications de la chimie aux arts, à l'industrie et à la médecine. Tels sont les Acides sulfurique, nirique, hydrochlo- 
rique, acétique, oxalique, sydrocyaniqne, etc. Les uns sont produits exclusivement par la nature, les autres exclusivement par l'art. Quelques uns sont tout a la fois les produits de l'art et de la nature.

Les Acides que la nature nous présente et que les Chimistes ne sont pas encore parvenus à produire, appartiennent au règne organique; ce sont les Acides malique, pectique, butirique, caprique, caprö̈que, cévadique, hircique, phocénique, valérique, stéarique, maryarique, oléique, ricinique, palmique, esculique, tartrique, citrique, tannique, gallique, quinique, hippurique et urique. Ceux qui sont les seuls produits de l'art sont les Acides chloreux, chlorique, perchlorique, hyposulfurique, phosphoreux, hypophosphoreux, sélénieux, sélénique, bromique, iodique, périodique, nitreux, chromique, pyrogallique, oxalhydrique ou saccharique, subérique, carbazolique, indigotique, manganique, permanganique, mucique, osmique; enfin la plupart des Acides pyrogénés.

Les Acides qui sont tout à la fois les produits de la nature et de l'art sont les Acides sulfureux, sulfarique, phosphorique, carbonique, borique, chromique, acétique, allantoüque, arsénieux, arsénique, benzö̈que, succinique, oxalique, fumarique, aconitique et hydrocyanique.

Il n'est pas douteux que l'on ne puisse parvenil un jour ả préparer artificiellement, non seulement tous les Acides, mais encore toutes les matiéres organiques que l'on trouve dans la nature. C'est au moins ce que tendent à faire croire les découvertes qui se sont succédé depuis un demi-siècle.

La plupart des Acides contiennent de l'Oxygène au nombre de leurs éléments; et jusqu'à Berthollet, on avait même cru qu'ils en renfermaient tous; mais cet illustre chimiste a démontré que le Soufre, le Chlore et quelques autres corps, en s'unissant à l'Hydrogène, formaient des composés véritablement acides. On leur a donné le nom d'Hydracides, pour les distinguer des autres qu'on appelle Oxacides. Les principaux Hydracides sont les Acides hydrochlorique, hydrobromique, hydriodique, hydrofluorique et hydrosulfurique. Les 4 premiers sont fortement acides au goût, rougissent le papier de tournesol, et neutralisent complètement les propriétés des Alcalis, de la Polasse et de la Soude, par exemple.
Les opinions des Chimistes sont partagées sur la nature des combinaisons qui résultent du contact des Hydracides arec les Oxydes métalliques, quand la combinaison s'efiectue dans l'eau et que cette combinaison se dissout. Les uns admettent que l'Hydracide et l'Oxyde s'unissent purement et simplement, de telle sorte que l'Acide Hydrochlorique et la Soude, par exemple, forment de l'Hydrochlorate de Soude, tandis que les autres, et c'est le grand nombre, pensent que l'Hydrogène de l'Hydracide forme, avec l'Oxygène et l'Oxyde, de l'eau qui se sépare, tandis que le métal s'unit á l'autre élément de l'Hydracide; qu'ainsi, dans l'exemple précédent, l'Hydrogène de l'Acide hydrochlorique forme de l'eau avec l'Oxygène de la Soude (Oxyde de Sodium), et le Sodium avec le Chlore du Chlorure de Sodium. Nous aurons occasion de discuter plus tard ces denx théories. Nous verrons au mot SEL, que l'on a proposé de considérer tous les Acides aqueux comme de véritables Hydracides.

Parmi les Acides, il n'en est qu'un petit nombre que l'on soit parvenu à obtenir sans eau. Ils en contiennent presque toujours une certaine quantité qu'on ne peut leur enlever sans les détruire. C'est ainsi que l'Acide nitrique le plus concentré en renferme un atome. Il a pour formule $\mathrm{AZ}^{2} \mathrm{O}^{5}+\mathrm{H}^{2} \mathrm{O}$. Lorsqu'on la lui enlève par l'Acide sulfurique, ou par tout autre moyen, il se change aussitôt en Acide hyponitrique et en Oxygène; $\mathrm{AZ}^{2} \mathrm{O}^{5}$ devient $\mathrm{AZ}^{2} \mathrm{O}^{4}+\mathrm{O}$. L'A cide oxalique desséché dans le vide ou sublimé, a pour formule: $\mathrm{C}_{2} \mathrm{O}^{3}+\mathrm{H}^{2} \mathrm{O}$, c'est-à-dire qu'il renferme un atôme d'Acide réel, anhydre, et un atome d'eau. Quand on enlève cette dernière, $\mathrm{C}^{2} \mathrm{O}^{3}$ se change en $\mathrm{CO}$ et $\mathrm{CO}^{2}$, c'est-á-dire en Oxyde de Carbone et en Acide carbonique.

L'eau de cristallisation des Acides est toujours en proportion définie, et il y a constamment un rapport simple entre l'oxygène de cette eau et l'Oxygène de l'Acide même. Ordinairement pour un atome d'Acide, on rencontre un atome d'eau. Le même Acide ofrre quelquefois plusieurs degrés d'hydration, comme, par exemple, les Acides oxalique, borique, sulfurique; mais ces cas sont assez rares.

Il y a des Acides qu'on ne connaît que dans les sels; lorsqu'on cherche à les séparer des 
bases, ils se décomposent aussitôt par suite d'une réaction qui s'opère entre leurs éléments. L'Acide hyposulfureux est de ce nombre. Il a pour formule $\mathrm{S}^{2} \mathrm{O}_{2}$ dans les hyposulfites; aussitôt qu'on l'en retire, il se change en atomes égaux de soufre et d'Acide sulfureux.

Les Acides se combinent toujours avec une quantité déterminée de base (d'oxyde métallique), et cette quantité dépend constamment de celle de l'Oxygène contenue dans la base. Plus il y a d'Oxygène dans celle-ci pour la même quantité de métal, et plus il faut d'Acide pour la saturer; ainsi quand on sature de l'Acide nitrique, de l'Acide sulfurique ou tout antre Acide avec plusieurs bases différentes, un poids donné d'Acide se combine avec une quantité de ces bases, qui varie de l'une à l'autre, mais où la quantité contenue d'oxygène est la même pour toutes.

Si l'on cherche le poids des différentes ba. ses nécessaires pour neutraliser 501, 16 d'Acide sulfurique réel, on trouve qu'il en faut :

356,03 de Chaux.

258,35 de Magnésie.

390,90 de Soude.

589,92 de Potasse.

956,93 de Baryte.... etc., etc.

Si l'on cherche maintenant les quantités des difrérents $\Lambda$ cides nécessaires pour neutraliser 356,03 de Chaux, on voit qu'il en faut:

677,02 d'Acide nitrique.

401,16 d'Acide sulfureux.

902,32 d'Acide hyposulfurique.

276,43 d'Acide carbonique.

En outre,l'expérience prouve que ces quanlités d'Acide conviennent très exactement à ia saturation de l'une quelconque des bases du premier tableau.

D’où il suit que: "Les quantités pondérables de deux Acides nécessaires pour procurer un degré de saturation avec un alcali, conservenı le même rapport dans leur combinaison avec un alcali nouveau quelconque. "

Raisonnant d'une manière générale, j'ai deux Acides A et B, et une certaine quantité $M$ d'Alcali. Pour neutraliser $M$, il me faudra, par exemple, 2 kilog. de $\mathbf{A}$ et 6 kilog. de $\mathbf{B}$.

Si l'on me donne un poids $\mathrm{N}$ d'une nouvelle base, je dis que s'il fant 4 kilog. de
l'Acide A, il en Paudra necessairement le triple de $B$, c'est-à-dire 12 kilog.

Car $4: 12:: 2: 6$.

Une autre loi relative aux Acides est celleci : "Lorsqu'un Acide s'unit à une base salifiable en plusieurs proportions, c'est en un petit nombre, et ccs proportions toujours simples sont des multiples par $1 \frac{1}{2}, 2,3,4,5,6,7$, de la proportion d'Acide. " Pour plus de détails, $V$. les articles Sels, Oxydes, Alcalis. Acide acétique. - Tout le monde sait que le vin abandonné ả lui-même au contact de l'air, s'aigrit peu a peu et se change en $v i$ naigre. Celui-ci doit sa saveur et la plupart de ses autres propriélés à un Acide particulier, qu'on a appelé Acide acétique. IL vinaigre concentré par des distillations et des refroidissements successifs, représente de l'Acide acétique sensiblement pur.-C'est un liquide incolore, d'une saveur forte et caustique, d'une odeur pénétrante, agréable, soluble en toutes proportions dans l'eau et l'Alcool, susceptible de cristalliser en lames confuses par un froid de $16^{\circ}, 7$; lorsqu'il est pur, il a pour formule $\mathrm{C}^{4} \mathrm{H}_{6}^{6} \mathrm{O}^{3}+\mathrm{H}^{2}$ O. Sa densité est de 1,063. Elie ne diminue pas par son mélange avec l'eau en certaines proportions. Un mélange de parties égales d'Acide concentré et d'eau présente la même pesanteur spécifique que l'Acide pur; d'où il suit que l'Aréomètre ne peut être employé pour déterminer le degré de concentration de l'Acide acétique. Il bout à $119^{\circ}, 3$, et distille intégralement. A une température blanche, il est entièrement décomposé en eau, Acide carbonique et Oxyde de carbone. A une chaleur moins élevée, il se convertit en Acide carbonique et en Acétone (Esprit pyro-acétique).

L'Acide acétique concentré n'attaque la craie ni à chaud ni à froid. Étendu d'eau, il la décompose au contraire avec vivacité , ainsi que les autres carbonates. Toutefois les affinités changent, et l'Acide carbonique l'emporte á son tour, lorsque le milieu dans lequel on opère est l'Alcool; ainsi une dis solution alcoolique d'Acétate de potasse est décomposée par l'Acide carbonique qu’il déplace. - L'Acide acélique se produit dans une foule de réactions. La distillation du bois, celle de l'immense majorité des autres substances organiques, donnent naissance, entre autres produits, a des quantilés plus 
ou moins considérables d'Acide acétique. Extrail du bois, par la décomposition de celui-ci, car il n'y préexiste pas, il porte le nom d'Acide pyroligneux. - Préparé par la calcination de l'Acétate de cuivre, il porte celui de vinaigre radical; c'est de l'Acide acétique très concentré, mêlé d'un peu d'A. cétone. - Toutes les liqueurs fermentées donnent de l'Acide acétique par l'exposition à l'air. Il paraît que, dans ce cas, il contient quelqucfois une petite proportion d'Ether acétique. Quand il provient du vin ct qu'il n’a pas été distillé, il est mêlé nécessaỉrcment de toutcs les matières fixes renfermées dans le vin même. Telles sont particulièrement les matières colorantes, la Crème de tartre et le Tartrate de chaux.

Il paraîl que l'Acide acètique est l'un des produits constants de la décomposition des matières organiques sous l'influence de l'air et de l'humidité.

Lorsqu'on chautîe ces mêmes matières organiques avec un excès de Polasse ou de Soude caustique, on observe fréquemment la production d'une grande quantité d'Acide acétique.

Acide borique. - Il se présente en petites paillettes micacées, douces an toucher, inodores, à peine acides au goût, très peu solubles à froid, assez solubles à chaud, conterant 44 centièmes d'eau de cristallisation. Soumis à la chaleur, l'Acide borique perd d'abord son eau, puis entre en fusion au rouge, et présente, après le refroidissement, l'aspect du verre. Il csi d'ailleurs á peu près fixe et tout-á-fait indécomposable. Il existe en grande quantité dans les Lagoni ou sources thermales de la Toscane. C'est de là qu'on le retire pour les besoins de la Chimie ou pour préparer le Borax, en l'unissant avcc la Soude artificielle. On l'extrait aussi quelquefois par l'Acide sulfurique d'une dissolution chaude de Borax.

Acide carbonique. - Il a pour formule $\mathrm{CO}^{\prime}$, ou en d'autres termes il cst formé de 1 atome de carbone $=76,44$ et de 2 atomes d'oxygène.

C'est un gaz parfaitement incolore, d'une saveur et d'une odeur très légèrement piquantes, d'unc densité de 1,524. Un corps en combustion plongé dans le gaz acide carbonique, s'y éteint rapidement; un animal cesse d'y vivre au bout de quelyucs instants.
Le froid, quelque intense qu'il soit, ne change pas l'état aériforme de l'acide carbonique, mais une pression de 36 atmosphères suffit pour le liquéficr à la température ordinaire. M. Thilorier à imaginé, il y a peu de tcmps, un apparcil en fonte dans lequel on peut obtenir en quelques heures plusieurs litres d'acide carbonique liquide. On lc prépare en dćcomposant le bi-carbonate de soude par l'acide sulfurique. C'est le gaz qui produit lui-même, en s'accumulant de plus en plus dans l'appareil, la pression énorme qui détermine sa liquéfaction. L'acide carbonique liquéfié présente le fait étrange et unique d'un liquide 4 fois plus dilatable que le gaz. En efret, en passant de 0 à $30^{\circ}$, le volume de cc liquide devient de moitié plus considérable.

L'acide carbonique devient solide à unc tẹmpérature voisine du $100^{\mathrm{e}}$ degré au dessous de la glace fondante. Dans cet état, il ressemble à des flocons de neige, et sc maintient à l'air libre pendant assez long-temps sans qu'il soit besoin d'exercer sur lui aucune compression. Cet énorme refroidissement se produit par l'acide carbonique liquéfié, dans le passage subit et instantané de l'état liquide à l'état gazeux. Il suffit de diriger un jet d'acide carbonique dans l'intérieur d'une petite fiole de verre, pour que celle-ci se remplisse promptement d'acide solide.

L'eau absorbe une quantité de gaz acide carbonique, d'autant plus grande que la température est plus basse et la pression plus forte. A lá température et à la pression ordinaires, elle en dissout à peu près son volume. Dans le vide, l'eau perd sa faculté de dissoudre l'acide carbonique; elle la perd également à 100 degrés.

La nature présente, dans un assez grand nombre de localités, de l'eau plus ou moins chargée d'Acide carbonique. Lcs eaux minérales gazeuses, telle que l'eau de Seltz, doivent presque entièrement à la présence de l'acide carbonique les propriétés qui les font si souvent employer. On peut préparer artificiellement des eaux semblables à celles de la nature en foulant du gaz carbonique, sous des pressions diverses, soit dans l'eau pure, soit dans l'eau chargée de sels.

La solution de l'Acide carbonique dans l'eau est sans couleur, d'une saveur aigre- 
lette, agréable, d'une odeur piquante; elle communique à la couleur bleue du tournesol une teinte vineuse; l'ébullition ou le contact de l'air en dégagent l'acide carbonique. Le gaz carbonique se reconnaît facilement à la propriété qu'il possède de former dans l'eau de chaux un précipité blanc insoluble dans l'eau pure, soluble avec effervescence dans les acides, même dans l'Acide carbonique, si l'excès de ce dernier est considérable; les Alcalis l'absorbent sans résidu lorsqu'il est pur.

Le Potassium, à une température élevée, en absorbe l'Oxygène, et en sépare le charbon sous la forme d'une poussière noire facilement reconnaissable.

L'Acide carbonique est un des corps les plus abondanis et les plus répandus dans la nature; il n'est pour ainsi dire pas d'eau qui n'en renferme une petite quantité en dissolution. Combiné à la chaux, il constitue le Carbonate de chaux, dont les variétés sont si nombreuses et les masses quelquefois si prodigieuses. Il est également uni dans la nature avec une foule d'autres Oxydes. On le trouve accumulé dans les parties inférieures de beaucoup de cavités ou de grottes des pays volcanisés ou des terrains calcaires de sédiment.

L'air atmosphérique en renferme constamment une petite proportion qu'on peut évaluer a ux 4/1000 de son volume. Cet Acide carbonique atmosphérique joue un rôle extrêmement important dans les phénomènes de la végétation. C'est dans l'air que les plantes puisent la presque totalité du Carbone qu'elles renferment.

L'Acide carbonique se forme dans une multitude de circonstances; c'est un des produits de la respiration des animaux; de la combustion, de la décomposition spontanée des substances organiques, de la fermentation alcoolique, de la calcination des pierres à chaux, etc., etc.

On le prépare, soit en calcinant le Carbonate de chaux, soit en décomposant les Carbonates naturels par l'Acide sulfurique ou par l'Acide hydrochlorique.Pour le dépouiller complétement de la petite proportion de ces deax derniers acides qu'il pourrait entraîner, on le lave ordinairement dans un flacon rempli d'eau; il passe de ce flacon dans les vases où l'on veut le recueillir, soit comme gaz, soit en dissolution dans l'eau. La grande densité de i'Acide carbonique explique les accidents si fréquents qui arrivent dans les cuves à vendanges, et dans les caves oú fermentent le vin et en général les liqueurs sucrées. Ce gaz se mêle très lentement à l'aỉr atmosphérique, et l'on peut le faire passer d'un vase qu'on incline dans un autre vase, absolument comme si c'était un liquide. Dès lors on conçoit qu'il puisse descendre d'un lieu supérieur dans un autre moins élevé, dans une cave, par exemple, et y causer des accidents. Une ventilation ou une injection d'Ammoniaque dans l'air vicié par l'Acide carbonique l'assainit en peu d'instants.

Acide citrique. - Il existe dans beaucoup de fruits, particulièrement dans les citrons, d'où il tire son nom, dans les oranges, dans les groseilles, d'oú on l'extrait en saturant le suc de ces fruits avec de la craie et décomposant ensuite, par l'Acide sulfurique, le citrate de chaux préalablement lavé. On l'emploie pour les limonades et pour l'impression sur toile. Il avive certaines couleurs, telle que celle du Carthame, et, pour cet objet, il est préféré à tous les autres Acides.

Acide fluorique, aussi appelé Acide hydrofluorique.

Acide hydrofluorique.-Il est composé d'Hydrogène et de Fluor, corps simple non encore isolé. C'est un liquide incolore, très vénéneux, fumant à l'air, bouillant vers $30^{\circ}$, soluble en toutes proportions dans l'eau, et l'un des plus violents corrosifs que l'on connaisse. Il attaque avec facilité la silice, circonstance qui le fait employer avec succès pour graver sur le verre. On le prépare dans des vases de plomb, en décomposant à chaud le Spath-fluor par un excès d'Acide sulfurique concentré.

Acide hydrochlorique ou Acide muriatique. - L'Acide hydrochlorique pur est gazeux, mais ce qu'on désigne sous ce nom dans le commerce est un liquide saturé de ce gaz. Le gaz hydrochlorique est incolore, excessivement acide, d'une odeur piquante; il répand à l'air des fumées blanches très épaisses, et il est si soluble dans l'eau que ce liquide en prend quatre cents fois son volume. Cette dissolution est incolore, et jouit de toutes les propriétés du gaz luimême. Elle est caractérisée principalement 
far la propriété de former dans les sels d'argent, un précipilé blanc, caillebotté, insoluble dans l'eau et dans les Acides, très soluble au contraire daus l'ammoniaque, et se colorant en violet foncẻ par le contact de la lumière. Cet Acide, outre ses usages fréquents dans le laboratoire du clinniste, est employé à la prẻparation du clılore, à celle de la gélatine des os, etc., etc. On l'extrait particulièrement du sel marin, à l'aide de l'A $A$ cide sulfurique concentré.

Indëpendamment des compositions salines dont il fait partie, l'Acide hydrochlorique se reucontre assez fréquemment dans la nature. C'est lui, par exemple, qui, à l'état gazeux, constitue en grande partie les vapeurs épaisses et asphyxiantes qu'on voit s'échapper du cratère de certains volcans. Les sources chaudes qu'on rencontre du lac Cusco à Valladolid (Nouvelle-Espagne) le contiennent en dissolulion et à l'état libre, d'après Humboldt. Enfin on l'a également trouvé en Pologne, dars les fameuses mines de sel de Wieliczka.

Acide nitrique ou azolique; eau forte, esprit de nitre.-Liquide incolore, d'une odeur particulière, très acide, décomposé complétement parla chaleur et en partie par la lumière, en Acide hyponitrique et en Oxygéne. Concentré, il bout d'abord à $86^{\circ}$; mais son point d'ébullition s'éléve peu á peu à $122^{\circ}$; circonstance remarquable, qui tient à ce qu'une partie de cet Acide se détruit, tandis que l'autre forme avec la totalité de l'eau un Hydrate défini, plus stable. Cet Acide est caractérisé par sa propriété de détruire le sulfate bleu d'indigo ; de produire avec le cuiv'e des vapeurs rutilantes, avec l'Acide sulfurique et le Protosulfate de fer une couleur rose, ou, suivant les proportions, une couleur pourpre, et, avec les bases, des sels qui activent beaucoup la combustion du charbon ( $V$. Nitrate). On le prépare en décomposant le Nitrate de potasse par l'Acide sulfurique et condensant le produit de la distillation, qui est l'Acide nitrique même. Comme le Nitrate qu'on emploie contient presque toujours des Chlorures, l'Acide nitrique est mêlé d'Acide hydrocblorique, dont on le dépouille par un peu de Nitrate d'argent et par une seconde distillation.

Acide oxulique. - On l'emploie pour enlever les taches de rouille sur le linge, pour тกм. 1. doser la chaux, et comme réserve dans les fabriques de toiles peintes. Il existe daus uu très grand nombre de végétaux, mais plus particulièrement dans les ()xalis, dans les fruits du Sorbier, dans la Joubarbe, dans les Lichens. Il est tantòt libre, tantòt à l'état salin. On le prépare artificiellement de beaucoup de manières diverses, mais surtout en traitant certaines matières végétales, telles que le sucre, l'amidon, le ligneux, par l'Acide nitrique ou par la Potasse caustique.

Acide stéarique. - Cet acide est le produit de la saponification de la stéarine par les alcalis hydratés. On le prépare ordinairernent, dans les arts, en décomposant par l'acide sulfurique le savon quí résulte de l'action de la chaux sur le suif. Il en résulte une masse formée de 3 acides gras, qui sont le stéarique, le margarique et l'oléique. Cette masse est comprimée, d'abord à froid, puis à cliaud; ce qui la débarrasse de la plus grande partie de l'acide liquide , de l'acide oléique; on la fond avec de l'eau, on la clarifie, après l'avoir de nouveau lavée avec de l'eau aiguisée d'acide sulfurique. La masse stéarique refroidie est parfaitement blanche; on la fond au bain-marie, on la mêle avec 3 ou $47100^{\text {es }}$ de son poids de cire blauche, et on la coule, comme les cliaudelles, dans des moules préalablement chauffés à 50 ou $55^{\circ}$. Les mèches doivent être nattées et contenir une petite quantité d'acide borique et de bi-phosphate d'ammoniaque. C'est ainsi qu'on fabrique les bougies connues sous les noms de bougies de l'étoile, bougies stéariques, bougius margariques, etc., etc. Elles sont certainement destinées à remplacer les bougies de cire, donı elles présentent tous les avantages, leur prix étant d'ailleurs beaucoup moins élevé.

Acide sulfureux. - Gaz caractérisé particulièrement par son odeur piquante, sa résistance à la chaleur, la facilité avec laquelle on le líquéfie. Il sert au blanchíment de la laine et de la soie, et en médecine dans le traitement des maladies de la peau. On le prépare, soit en brùlant du soufre dans l'air, soit en désoxygénant partiellement l'Acide sulfurique par les métaux, ou certaines matières organiques, telles que le bois.

Acide sulfurique. - C'est le plus important de tous les Acides, et celui dont les arts consomment partout la plus grande quan- 
lité. II n'est, your ainsi dire, pas d'industric qui n'en emploie. On le désigne sonveut sous le nom d'huile de Vitriol. C'est un liquide incolore, inodore, d'une énorme causticiłé, d'une dersité de 1,945, bouillant à $320^{\circ}$, soluble dans l'eau en touies proportions, et a vec production d'une chaleur considérable. Une température élevée le décompose en Acide sulfureux et en Oxygène. Il attaque et dissout la plupart des métaux, détruit sans retour une foule de matières organiques et décompose la plupart des sels. Cet Acide, dans son étal de concentration, a pour formule : $\mathrm{SO}^{3} \mathrm{H}^{2} \mathrm{O}$, c'est-á-dire qu'il contient un atòme d'Acide sulfurique anhydre et un atôme d'eau. L'Acide anhydre $\mathrm{SO}^{3}$ a été isolé. Il se combine avec 2 et avec 3 atòmes d'eau, de sorte qu'il y a 3 Hydrates d'Acide sulfurique. L'Acide sulfurique se prépare en faisant rencontrer, daus de vastes chambres de plomb, de l'Acide sulfureux, de l'air, des vapeurs aqueuses et nitreuses. On le concentre dans des chaudières de platine. Il sert à la préparation de presque tous les autres Acides, de la Soude artificielle, de l'Alun. des Sulfates, des Éthers, du Phosphore, etc.

(Pelouze.)

ACDDTFERS (Acidum, acide ; fero, je porte). Haüy s'est servi de cetteépithète pour désigner une grande division des substances minérales, contenant un acide, soit libre, soit combiné avec un ou plusieurs autres corps. Ce nom a également été donné par Maraschini à un ordre de sa classification géognostique.

(C. D'O.)

* ACIDOnTIUV (áxıs, pointe; ỏdoús,

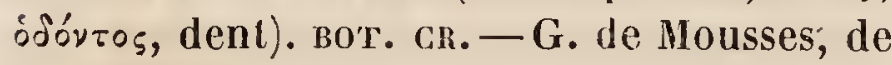
la div. des Acrocarpes, caractérisé ainsi qu’il suit par Schwrgrichen dans la $2^{\text {me }}$ partie de son second supplément au S'pecies Muscorum d'Hedwig; Péristome double; l'extér. composé de 16 dents obtuses, mucronées, infléchies; l'intér. consistant en une membrane réticulée, pliée en carène et fendue en 16 processus, entre chacun desquels se voit un cil, ou, ce qui est la même chose, ces processus sont inégalement divisés en 2 portions, dont la plus longue représente une dent, et la plus courte un cil. Epiphragme membraneux, hémisphérique. Coiffe cuculliforme ou en capuchon. Capsule égale, portée sur une apoph: se linéaire et munie d'un anneau. Feur's diö̈ques terminales. - La scule esp. connue de ce g. a le port d'un Bryum, g. auquel Hooker l'avait rapportée; ses feuilles sont larges, nervées, entières. La capsule est très longuement pédicellée, penchée horizontalement etmunie d'un opercule convexe, mucronulć. Elle croît sur la terre, dans la chaîne des Andes de l'Amérique méridionale, oú l'ont découverte MM. de Humboldt et Bonpland.

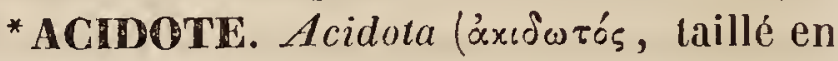
pointe). INs. - G. de Coléoptẻres pentamères, famille des Brachélytres ou Staphylliniens, établi par Kirby, adopté par M. Dejean, et qui a pour type le Staphylinus crcnatus Fab., qui se trouve aux environs de Paris.

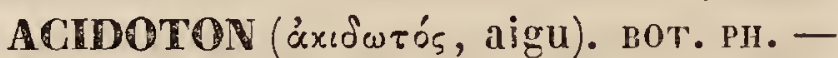
G. d'Euphorbiacées élabli par Swartz et ainsi caractérisé : Fleurs monoïques ou diö̈ques sans pétales. Dans les mâles: Cai. profondément 5-parti, réfléchi. Étam. nombreuses, dont les filets, insérés sur un réceptacle glanduleux, portent des anthères dressées. IDans les femelles : Cal. à 6 divisions profondes et étalées; style court, 3-fide, et 3 stigmates réfléchis, tomenteux ; capsule à ? coques monospermes et bivalves. - La seule espèce de ce g. est un arbuste de la Jamaïque, à feuilles stipulées, alternes, entières, glabres, à fleurs en grappe, ordinairenient terminales et unisexuées. Des poils forts et roides, dont la piqûre cause une sensation brûlante, hérissent les rameaux, les pétioles, les pédoncules et le bord des fenilles. Ce sont eux, sans doute, qui ont fourni l'étymologie du nom générique. (AD. J.)

ACIER (acies [áxń], tranchant). chim.-On donne ce nom à une matière métallique intermédiaire par sa composition entre les fontes et les fers du commerce. L'acier contient, terme moyen, 99 centièmes de fer et depuis 5 millièmes jusqu'à un centième de carbone. On peut regarder romme étrangères à la composition de l'Acier les autres matières qu'il renferme souvent, telles que le Phosphore, le Sonfre, l'Arsenic, l'Aluminium, le Culcium, etc.

Il y a dans le commerce beaucoup d'esp. d'Acier ; mais ces esp. peuvent être réduites á 4 principales, qui sont :

$1^{\circ}$ Acier de cémentation ou Acier poule. On le fabrique dans des caisses construites en terre très réfractaire, qu'on remplit arec 
des conches alternatives de fer de bonne qualité et de poussier de charbon. Le fer le plus propre à cet usage est celui de Suéde. Le charbon est quelquefois remplacé par du cément, mélange de substances très diverses, mais qui consistent ordiuairement en charbon, suie, sel et cendre. On élève peu à peu la température des caisses jusqu'au rouge vif, mais en ayant soin toutefois qu'elle soit insuffisante pour fondre l'acier. L'opération dure de 10 à 20 jours. Le carbone pénètre jusqu'au centre des barres de fer et les acière.

L'Acier ainsi obtenu est nécessairement carburé d'une manière inégale. Il offre à l'ril comme a l'analyse une masse hétérogène; et e'est à ce défaut d'homogénéité qu'on doit attribuer les qualités généralement mauvaises de cet Acier.

$2 \circ$ dcier fondu. - L'A cier de cémentation, étant fondu et brassé, se présente, après le refroidissement, sous la forme d'une masse homogène, à grain fin et serré. Il est devenu propre á la confection des objets les plus délicats. On le connaît sous le nom d'Acier fondu.

$3^{\circ}$ Acier naturel, confondu avec les Aciers de forge et defonte.-On le prépare par beaucoup de procédés différents, parmi lesquels on peut distinguer :

$1^{\circ}$ La réduction des minerais de fer riches et fusibles dans des foyers peu différents des forges catalanes.

: L'afinuage des fontes, particulièrement des fortes blanches et lamelleuses.

$3^{\circ}$. La fusion de la fonte avec du fer, de l'oxyde de fer, de la fonte grillée, ete., elc.

Souvent des objets en fonte moulés sont aciérés par cémentation avec du fer, de l'oxyde de fer ou de manganèse, et en général avec des corps susceptibles d'enlever à la fonte la quantité de carbone qu'elle contient, en sus de celle qui entre dans la composilion de l'Acier.

4. Acier Wootz, Acier indien ou damassé. - C'est avec cet acier que se font les lames de sabre si renommées, qu'on appelle $D a-$ mas, et qui présentent des dessins excessivement variés.

M. Bréant a le premier fait connaître à quelle circonstance est dù le moiré de l'Acier indien, et il a indiqué plusieurs procédés propres à la fabrication d'un Acier entièrement semblable à celui de Damas. D'il- prés cet habile observateur, l' Mrier damassé est un inélange d'Acier ordinaire et d'uil carbure de fer régulièrement cristallisé. L’Acier est-il poli? le carbone qu'il renferme est invisible. Le soumet-on dans cet état à l'action d'un Acide très affaibli? le carbone se trouve à découvert, et l'on voit des dessins grisâtres se détacher sur un fond clair.

M. Bréant a fait d'excellent Acier Wootz:

10 En fondant un mélange de 100 parties de fer doux de bonne qualité et de 2 parties de noir de fumée ou de coke.

$2^{\circ}$ En fondant 100 parties de fonte grise avec 100 jarties de mêrne fonte préalablement grillée.

3० En fondant un Acier du commerce, riche en carbone, et le laissant refroidir très lentement. Un refroidissement rapide laisserait le carbone uni ou disséminé dans Ia masse entière.

L'introduction de certains métaux, tels que le Platine, l'Argent, dans l'Acier ordinaire, lui communique la propriété de prendre le moiré.

Il y a dans les Aciers damassés, comme dans les autres Aciers, des qualités très difrentes, et le moiré ne doit en aucune manière être considéré comme le cachet d'une bonne qualité.

Propriétés de l'Acier. Sa couleur est plus blanche, plus éclatante que celle du fer. Son grain doit être fin, serré, brillant et hornogène. Il est plus malléable, mais moins ductile que le fer. II est aussi beaucoup moins tenace et moins oxydable. Sa densité varie de 7,7 a 7,9 . II entre en fusion vers $130^{\circ}$ pyrom. Avant la chaleur blanche, il devient cassant, se soude alors, moins bien toutefois que le fer. Soudé, soit avec d'autre Acier, soit avec du fer, il forme les éloffes. Mais de toutes les propriétés de l'Acier, la plus importante, sans contredit, est celle que lui fait acquérir l'opération de la trempe. L’Acier, s'il a été chauffé, puis refroidi lentement, n'est guère plus dur que le fer; mais s'il a élé, au contraire, refroidi subitement, il ac:quiert une dureté excessive, en même temps qu'il devient très cassant. C'est ce refroidissement rapide de l'Acier dans l'eau, l'eau salée, le mercure, etc., qu'on appelle trempe. Elle est d'autant plus forte, ou en d'autres termes, l'Acier est d'autant plus dur et plus cassant, que le refroidissement s'est effec- 
Lué plus promptement. La densité de l'Acier diminue par suite de cette opération. S’il est porté de nouveau au rouge vif et refroidi lentement, il est détrempé ; il ne l'est qu'imyarfaitement si la température n'a pas été trés élevée. Ordinairement on trempe trop l'Acier, puis on le recuit plus ou moins, suivant l'usage auquel on le destine. L'Acier prend plus facilement couleur que le fer, lorsqu'on le chaufie au contact de l'air. Pecuit a $220-230^{\circ}$, sa couleur devient d'un jaune paille; il a alors le degré de dureté qu'on recherche dans les rasoirs, les canifs, etc. A $300^{\circ}$, il devient d'un bleu trés clair; c'est la teinte des ressorts. Cette série de conleurs est due à l'absorption d'un peu d'oxygène par une couche très mince d'acier.

L'Acier fondu présente une propriété remarquable: ilse trempe très dur par la seule action de l'air ; mais on conçoit qu'alors il faut n'agir que sur des lames trés minces. Un autre fait bien connu et également curieux, consiste en ce qu'on peut, aves une feuille de fer doux (tôle), couper une barre de l'Acier le plus dur et le plus fortement trempé. A cet effet, on prend une barre d'Acier, on la fixe bien et l'on fait frotter contre elle, par un rhouvement de rotation, une fenille de tôle. Au bont de quelques instants, la barre d'Acier est coupée. Cela tient á ce que l'Acier frotté par la lame de tôle, s'échaufe, se détrempe, et s'adoucit, tandis que le disque, ofirant une large surface et d'ailleurs sans cesse en mouvement, s'échauffe peu, et présente conséquemment plus de dureté que l'Acier.

(PEL.)

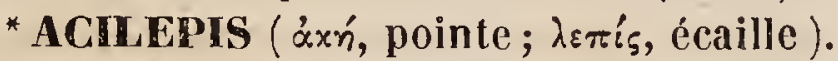
BoT. PII.-M. Don a formé ce g. aux dépens du Vernonia squarrosa L.; il a pour caract. d'avoir des capitules multiflores sessiles; les squames de l'involucre imbriquées, multisériées et pointues; le réceptacle alvéolé; les akènes velus et anguleux, surmontés d'une aigrette bisériée dont la série extér. très courte. - M. De Candolle réunit l'Acilepis aux $V$ ernonia pour en former la première section de ce vaste genre.

* ACILIE. Acilius (Mythol.; fleuve de Sicile '. Ins. - G. de Coléoptères pentamères, famille des Hydrocanthares, tribu des Dytiscides, élabli par Leach et adopté par M. Dejean ainsi que par M. Aubé, qui lui donne pour principaux caract.: Dernier art. des palpes maxillaires un peu plus long que les autres. Prosternuni droit, arrondi postérienrement. Pattes postér. terminées par deux crochets inégaux, dont le supér. fixe; tarses intermédiaires simples dans les deux sexes. - M. Aubé rapporte à ce g. 17 esp. qu'il parlage en deux divisions. Celles qui font partie de la $1^{\text {re }}$ ont les élytres sillonnées dans les femelles, tandis que celles de la $2^{8}$ les ont, dans le même sexe, couvertes à la base de petites impressions linéaires assez profondes ou entièrement lisses. Ces dernières sont toutes exotiques. Nous citerons comme type de la 1 re division : l' $A$. sulcatus Leach, qui se trouve dans toute l'Europe; et comme type de la $2^{\mathrm{me}}$, I' $A$. mediatus Say., de l'Amérique septentrionale.

ACINACEA ('axivx́xns, sabre). polss.G. de poissons établi par M. Bory de St-Vincent (Voyage aux îles des mers d'Afrique). Il se compose d'un seul poisson de l'Atlantique, a corps allongé en forme de lame de sabre et qui appartient à la famille des Scombéroïdes. L'auteur lui ayant trouvé des traits de ressemblance avec les Orphies et les Scombres, l'a nommé Acinacée batarde. Malheureusement la figure en est si incorrecte et la description si incomplète, qu'il est impossible de ríen dire de certain de ce poisson. J'ai cru d'abord pouvoir le rapprocher du g. Thyrsite, dont les espèces avancent dans l'Atlantique jusqu'aux Açores. Mais la différence dans le nombre des rayons est trop grande pour que je me décide à admettre aujourd'hui ce rapport. Ce nombre et la forme générale conviennent mieux aux Gempyles, et surtout aux Gempylus coluber, poissons de I'Atlantique. Cependant la manière dont les fausses pinnules sont rendues laisse bearicoup d'hésitation. Je crois néanmoins que cette $2^{\text {e }}$ supposition vaut mieux que celle que nous avons émise dans l'Hist. des Poissons, Cuv. et Val. (VAL.)

ANGINACHFORME. Acinariformis (Acinaces [áxıv'́xns], cimeterre; forma, forme). вот. PII.-Se dit des organes foliacés des végélaux, qui, comme les feuilles, les sépales, les styles, etc., approchent de la forme d'un sabre, c'est-à-dire sont comprimés, à 3 angles, à carène tranchante, et un peu redressés vers la partie supérieure. (A.R.)

* ACINetes ( axínntos, fixe). Inf. - G. 
ACI

établi par Ehrenberg, pour la Vorticella 11 berosa Müll., qui méritait bien, en effet, d'être considérée comme un type particulier, en raison de la fixité et de la quasi-immobilité de ses appendices ciliformes. Une $2^{\mathrm{e}}$ esp., A. Lingbyi, qui comme la $1^{\text {re }}$ se trouve sur les plantes marines et sur les sertulaires, a été décrite, en 1832, par le même auteur. Les caract. qu'il assignait alors aux Acinètes étaient d'être " des Infusoires polygastriques anentérés, épitriques, cuirassés, pourvus de soies roides, mais non de cils, et ayant une cuirasse de forme diverse, membraneuse, pédicellée. "Il les plaçait, quoiqu'ivec doute, dans la famille des Péridinćes; mais en 1838 (Hist. des Int.), il les plaça dans la famille des Bacillariées; puis enfin, dans le même ouvrage, dont l'impression s'était prolongée, il annonce par une note, p. 316, que la découverte d'une nouvelle forme, le Dendrosoma radians, l'a déterminé à séparer l'Acinète des Bacillaires, et les g. Podophrya et Trichodiscus des Enchélydées pour en former, a vec le nouveau g., une famille particulière sous le nom d'Acinétines, qui serait placéc entre les Bacillariées, et les Vorticellines, et serait caractérisée par la présence d'une seule ouverture, pour l'entrée et la sortie des aliments, sans orifice anal.

(Dus.)

* ACINÉTINes (áxíntos, immobile). INF. - Famille dont l'établissement a été proposé par Ehrenberg, pour plusieurs g. d'Infusoires à une seule ouverture et à cils allongés, roides, non vibratiles. (Dus.)

* ACINIA. 1ns. - G. de l'ordre des Diptères, div. des Brachocères, subdiv. des Dichœtes, famille des $\Lambda$ théricères, tribu des Muscides. Selon M. Macquart, ce g. formé aux désens des genres Musca, L., Tephriiis, Fabr., Typeta, Meig., et dans lequel se trouve fondu le genre Urellia, Rob. Desv., renferme 14 espèces, toutes europėennes, et vivant ordinairement sur des plantes de la famille des Synanthérées et des Ombellifẻres (Heracleum, etc.); ses caract. sont les suivants : Trompe à lévres épaisses; épistome non saillant. Ant. n'atteignant pas l'épistome, $3^{\mathrm{e}}$ article double du $2^{\mathrm{e}}$. Oviducte déprimé , large, court, peu velu; ailes réticulćes. Nous citerons pour type: l'Acinia conniculata Fab., no 11, ou l'A. Ja"eec Rob. Desv.

(1).)
ACINIER ( $\alpha \times \dot{n}$, pointe). Bo'T. PII. - Nom donné dans quelques cantons de la France à l'Aubépine (Cratoegus oxyacuntha L., Mespilus oxyacantha Gaert.).

(C. L.)

* ACINIPE (Nom d'une anc. ville d'Espagne). Ins. - G. de l'ordre des Orthoptères, famille des Acridiens, établi par M. Rambur (Faune de l'Andalousie) sur deux esp. du midi de l'Espagne, dont les caract. génériques sont tout-à-fait identiques avec ceux du g. Porthetis, Serv. ou Pamphagus, Brul. et Burm.

(BL.)

* ACINOCORIS ( $\alpha_{x} \times v_{0}$, thym sauvage, basilic; xópıs, punaise). ivs. - G. de la fa-s mille des Lygéens, de l'ordre des Hémiptères, établi par Hahn, et ayant pour caract. essentiels : La forme des yeux qui sont comme pédiculés, et la longueur du $1^{\text {er }}$ art. des antennes. Ce g. ne renferme que trois esp., qui habitent l'Amérique méridionale. Le type est l'A. calidus Hahn. C'est par erreur que quelques auteurs ont attribué à ce $\mathrm{g}$. pour caract. générique la présence d'ocelles.

ACINOPHORA ("x́xเvos, pepin; yópos, porteur). вот. Св.-G. de Champignons établi par Rafinesque Schmaltz, et appartenant à la famille des Lycoperdacées. Il est caractérisé par un péridium stipité d'abord globuleux, s'ouvrant ensuite en plusieurs valves. Il renferme, dans son intéricur et à la partie supérieure, des gongyles mous et aciniformes. L'Acinophora aurantiaća, qui croît dans les bois en Pensylvanie, a le pédicule cylindrique, légèrement réticulé; le péridium se divise en six parties; les spores sont arrondies et rouges.-M. Desvaux (Journ. de Bot. vol.6.) lui trouve de l'analogie avec le genre Tylostoma. M. Ad. Brongniart pense au contraire qu'il est plus voisin du g. Polysaccum. Les caract. exposés par Rafinesque ne sont pas suffisants pour établir des rapprochements certains. Ce g. serait fort remarquable, s'il était vrai qu'il eùt la fructification des $\boldsymbol{P}$ olysaccurri, et le mode de déhiscence des Geastrum.

(LÉv.)

ACINOPUS ( $\ddot{x} x$ เขอร, grain de fruit en grappe; $\pi \circ \tilde{v}_{5}$, pied ). 1xs. - G. de Coléoptères pentamères, famille des Carabiques, tribu des Harpaliens, établi par Ziegler aux dépens des Harpales de Bonelli, et adopté par M. Dejean, qui le caractérise ainsi (Specics., t. 4) :Les $41^{\text {ors }}$ art. des 4 tarses antér. 
Iriangulaires ou cordiformes et assez fortement dilatés dans les mâles seulement. Dernier art. des palpes assez allongé, très légèrement ovalaire, presque cylindrique et tronqué à l'extrémi té. Ant. filiformes et assez courtes. Lèvre supér. carrée ou trapézoïde, échancrée antérieurement. Mandib. fortes, asse $z$ avancées, asse $z$ arquées et assez aiguës; une dent simple, obtuse et plus ou moins marquée, au milieu de l'échancrure du menton. Corps convexe et épais. Tête grosse, presque carrée et comme renflée postérieurement. Cors. plus ou moins carré. Elyt. presque parallèles, plus ou moins allongées. - M. Dejean rapporte à ce g. 7 espèces, dont la plus connue est l' $A$. megacephalus d'Illiger ou le picipes d'Olivier, qui se trouve dans le midi de la France et quelquefois aux environs de Paris.

(D.)

ACINOS, Mœench ( $\not 2 x เ \nu \circ 5$, esp. de Thym, ou de Basilic). вот. PII. - G. de la famille des Labiées, tribu des Mélissées, Benth., offrant les caract. suivants (Møench, Benth.; Reich Flor. germ. excurs.) : Cal. tubuleux, gibbeux en dessous à sa base; lèvre supér. sinuée, tridentée; lèvre infér. bi-dentée; gorge poilue. Cor. à tube un peu renflé; lèvre supér. presque plane; lèvre infér. 3lobée. Branche infér. du stigm, recourbée, aplatie, embrassant par la base la branche supér., laquelle est très courte. Faux-verticilles axillaires. - Ce g. , propre à l'ancien continent, a été confondu par Linné avec les Thyms. Bentham, a tort selon nous, en fait dans sa Monog. des Labiées, un s.-g. des Mélisses.

(Sp.)

* AINULA (dimin.d'A cinum [üxivos] grain de fruit à grappe). вот. Pн.-Les Champignons de ce, g. sont globuleux, sessiles et sans racines. Leur intér. est formé d'un corps charnu plus ou moins coloré, persistant et enveloppé d'une couche de matière blanche composée de granules, quỉ se séparent facilement et tombent en dissolution avec l'âge. Comme le nom l'indique, ils donnent l'idée d'un pepin renfermé dans une pulpe.- On ne connaît encore qu'une espéce de ce g., l'A. candicans Fries, que Weinmann a trouvée cn Russie sur les feuilles pourries de l'Alnus incana. Elle est du volume d'une tête d'épingle. Les organes de la fruclification ne sont pas encore connus; c'est sans doute pour cette raison que M. Fries a rangé ce genre dans l'ordre des Sclérotiacées. (LÉv.)

* ACIOA, Aubi., Lcia, Willd.; Dulacia, Neck. (nom carä̈be). вот. PI. - G. de la famille des Chrysobalanacées. D'après la description d'Aublet (Flor. guyan.), ses caract. sont les suivants : Cal. turbiné, courbé, inégalement 5-lobé. Pétales 5, arrondis, inégaux. Disque charnu, unilatéral, situé entre les pétales les plus courts. Environ 12 étam. insérées au disque; filets subulés au sommet, soudés par leur moitié infér. en androphore liguliforme. Pistil latéral (situé du còté du disque); ovaire à stipe adhérent d'un côté; style filiforme, flexueux, courbé. Drupe coriace, monosperme, à noyau fragile. - Arbres à feuilles entières; stipules caduques; fleurs en cymes terminales, subtrichotomes; cal. bianchâtre; cor. petitẻ, violette; graine grosse, huileuse. L'unique esp. de ce genre est indigène dans les Guyanes. L'amande de ses graines est borne à manger.

(Sr.)

ACIONA. Moll. - Ce g. proposé par Leach (Miscell. zool. t. 11) ne pouvait être accepté ; Lamarck l'avait créé depuis longtemps sous le nom de Scalaire. (Desh.)

ACIOTIS, Don (dimin. d'axís, pointe). вот. Pr. - G. de la famille des Mélastomacées, tribu des Osbeckiées, DC. Don ( Mém. Wern. Soc.) assigne à ce g. les caract. suivants: Tube calicinal globuleux, charnu; limbe urcéolé, persistant, 4-denté. Pétales 4, obliquement aristés au sommet. Étam.8, comme articulées au milieu; anthères dressées, imberbes à la base. Baie charnue, 4loculaire; graines cymbiformes. - Herbe vivace à feuilles pétiolées, trinervées, rouges en dessous; fleurs petites, roses, disposées en grappes terminales. - L'unique esp. qui constitue ce g. est indigène aux Antilles. Ses baies sont acidules et mangeables. (SP.)

* ACHPHORÉES. Aciphorene (áxis, pointe; yopós, porteur). INs. DIPT. - Nom donné par M. Robineau Desvoidy à la s.-tribu des Tephritides de M. Macquart.

(D.)

*ACIS (áxis, pointe, dard). ors.-G. formé par M. Lesson pour quelques esp. de la fam. des Gobe-mouches de Cuvier, ayant pour syn. le g. Phonicomis de Swainson, plus généralement adopté, etexprimant bien un des caract. communs aux esp. du g. $V$. PHokNICORNIS. (LAFr.)

* ACIS (áxis, pointe). Ins. - G. de Co- 
lécoplères tétramères, famille des Chrysomélines, établi par M. Chevrolat et adopté par M. Dejean; mais dont les caract. n'ont pas été publiés. M. Dejean y rapporte 7 espèces dont nous ne cilerons qu'une seule, l' $A$. modesta (Eumolpus modestus Fabr.), des Indes orientales.

ACISANTHERA, Br. ( $\alpha$ xis, pointe; anthera, anthère, d'àvonoós, $\alpha$, de fleur). вот. Pur. - G. de la famille des Lythracées ou Lythraires, tribı des Salicariées, et dont les caract. sont: Cal. 5-fide, renflé à la base. Pétales 5, égaux, obovales. Étam. 10, saillantes, insérées (de même que les pétales) à la gorge du calice; anthéres sagittiformes, versatiles. Style court; stigm. pointu. Capsule subglobuleuse, biloculaire, recouverte par le calice; 2 placentaires polyspermes. - Herbe à feuilles opposées ; fleurs axillaires, alternes, rameaux 4-gones. Ce g. qui, malgré son calice inadhérent, serait probablement mieux placé parmi les Mélastomacées que parmi les Lythracées, n'est fondé que sur une seule espéce, qui croît à la Jamaïque, et que Linné comprenait dans le genre Rhexia.

(Sp.)

* ACISBA. ins. - G. de Coléoptères hétéromères, famille des Mélasomes, établi par Ziegler et adopté par M. Dejean. II répond aux g. Lophoma, Sol. et Pachychita, Esch., et a pour type l'Alis punctata Fab., espèce qu'on trouve à Tanger.

* ACISPERMUM (áxís, pointe; $\sigma \pi \varepsilon^{\prime} p \mu \alpha$, semence). вот. рн. - C'est un g. établi par Necker sur quelques pl. de l'Amér. du nord que M. De Candolle réunit au g. Coreopsis.

(J. D.)

* ACKAMA (nom nouveau-zélandais.) вот. Рн. - G. que Cunníngham (Prod. flor. Nov. Zeel. in Hook. Ann.) rapporte à la famille des Cunoniacées, et auqucl il assigne les caract. suivants : Cal. 5-parti, persistant; div. linéaires-spatulées. Pét. 5, indivisés, non persistants. Étam. 10, isomètres, insérées sur un disque hypogyne, cyathiforme, a 10 dents. Capsule septicide de haut en bas; loges polyspermes. Graines petites, ovoïdes, rostrées; test coriace, glabre. Arbre à feuilles imparipennées; fleurs en panicules terminales, rameuses, lâches, laineuses. Une seule esp., indigène dans l'île Ikanamawi, Nouv.-Zélande.

ACLADIUM ('́ prir.; $x \lambda_{\alpha} \dot{j} \circ \varsigma$, rameau). вот. Cr. - Ainsi que l'indique l'étymologie, ces Champignons bissoïdes sont composés de filaments simples, droits, transparents et cloisonnés, sur lesquels sont fixés çà et là des spores ovales et pellucides. Comme les spores ont à peu près la même grosseur que les filaments, il est probable qu'elles résultent de l'isolement spontané des cellules supérieures des filaments sur lesquels elles restent adhérentes en tombant. - On n'en connaît que 2 espèces qui ont été décrites par Link, et qui se trouvent sur le bois pourri. (LÉV.)

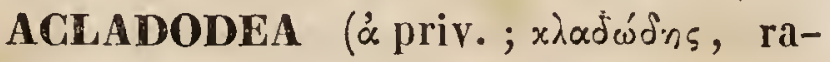
meux). вот. pir. - Ruiz el Pavon (Prodr. $F l$. Per.), ont décrit sous ce nom un genre de la famille des Sapindacées que l'on s'accorde aujourd'hui à réunir au g. Talisia d'Aublet. Toutefois, son fruit est encore inconnu; ce qui a fait penser à quelques Botanistes que cette plante est dioïque et que l'individu mâle a été seul observé. (C. L.)

* ACLÉE. Aclees (a’xisńs, obscur). Ins. - G. de Coléoptères tétramères, famille des Curculionites, div. des Érirhinides, établi par M. Schœnherr et adopté par M. Dejean. Ses caract. sont : Ant. médiocres, fortes; leur funicule composé de 7 articles : les 2 premiers assez courts, obconiques; les 5 suivants transverses, serrés; la massue oblongue, ovale, paraissant spongieuse, biarticulée. Rostre allongé, cylindrique, arqué et pourvu de chaque côté, dans la moitié de sa longueur, d'un sillon qui part du milieu de l'ocil. Prothorax long, subconique, bisinué à sa base et presque tronqué antérieurement; écusson arrondi au sommet, distinct. Élyt. oblongucs, subovalaires, légèremęnt convexes en dessus, calleuses vers leur extrémité ; les angles des épaules obtus. Pattes robustes; cuisses dentées; tibias onguiculés intérieurement à leur extrémité. - Ce g. est fondé sur une seule esp. rencontrée à Java, et nommée par M. Dejean $A$. cribrat'ıs. (D.)

* ACLEIA ( $\alpha \times \lambda \varepsilon^{\prime} \dot{\alpha} \alpha$, obscurité). BOT. PH. Ce g. a été formé avec le Senecio Belbeysius Del.; il a pour caract., d'après M. De Candolle : Des capitules multiflores, homogames, à fleurs lubuleuses; un invol. unisérié, cylindrique et globuleux, muni à sa base de 2 ou 3 écailles. Pour fruit, des akènes comr primés, étranglés au sommet, puis dilatés en une urcéole discoïde. L'aigrette, cadu- 
que, se compose de poils presque denticulés. - Cette plante, qui a le port du Seneçon d'Arabie, est glabre, rameuse, dressée, el porte inférieurement des feuilles pétiolées, crénelées, tandis que les supér. sont amplexicaules, incisées-dentées. (J. D.)

ACLÉIDIENS (á priv.; $x \lambda_{\varepsilon} i_{\zeta}$, dós, clavicule). mamm. - Expression abrégée de Mammiféres sains clavicules.

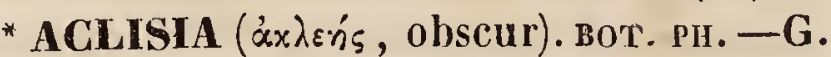
de la famille des Commélinacées, fondé par E. Meyer (Reliq. Haenk.2, 1. xxv), réuni avec doute par quelques auteurs au g. Pollia de Thunberg, et que Lindley considère comme distinct. $V$. POLLIA.

(C. L.)

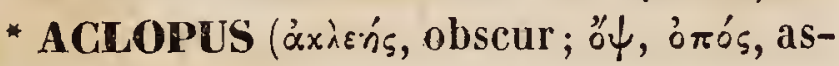
pect). ins. - G. de l'ordre des Coléoptères pentamères, famille des Lamellicornes, établi par Erichson, qui le place dans la tr. des Géotrupides de Mac-Leay. Il contient 2 esp., les A. viltalus et Brunneus. Ce g. ne figure pas dans le dernier Catal. de M. Dejean, et parmi ceux de cet auteur nous ne savons auquel le rapporter.

ACLYSIE. 1NS. $V$. ACIllysis. (C. D’O.)

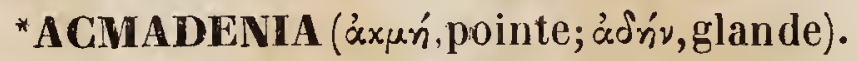
вот. Рн. - Sous celte dénomination, Bartling et Wendland, dans leur monographie des Diosmées, ont établi, dans celte famille, un g. qui doit son nom aux glandes pointues qui terminent les antlıères, et est ainsi caractérisé : Cal. 5-parti, adné par sa base à un disque dont le bord supér. est libre et entier. Pétales 5, dont les onglets larges présentent une touffe de poils en dedans. Filets 10, inclus ; 5 opposés aux pétales, stériles, courts ou presque riuls, insérés au bord du disque; 5 alternes, plus lougs, portant chacun une anthère ovale dont le connectif se prolonge en dessus en une glande conique. Style plus court que les filets, élargi à son sominet en un stigmate en tête, à 5 sillons peu marqués. Ovaires 5 , soudẻs ensemble, mais prolongés chacun à leur sommet en une masse ovoüde, libre, hispide, glabre du reste, et renfermant 2 ovules superposés. Fruit à 5 coques comprimées, dont le sommet s'allonge en dehors en une sorte de corne. - 5 esp. de ce g. se trouvent au C. de B.-E. Ce sont des arbrisseaux à fenilles décussées, imbriquées sur 4 rangs, courtes, épaisses, carénées, ponctuées en dessous, à fleurs blanches ou rouges, terminales, solitaires, presque sessiles, accompagnées de bractées imbriquées quil simulen! des sépales. (AD. J.)

*ACMEODERA (expaĩos, vigoureux; dépn, cou). ins. - G. de Coléoptères pentamères, famille des Sternoxes, tribu des Buprestides, élabli par Eschscholtz et adopté par M. Dejean ainsi que pir M. Solier, dans son Essai sur les Buprestides (Amual. Soc. ent. de Fr., t. $\left.2^{\text {m.e }}\right)$. Ce dernier auteur lui assigne pour principaux caract. : Menton subtriangulaire, avancé en pointe vers la languette. Dernier art. des palpes maxillaires, allongé, ovalaire, subsubulé. Cors. tronqué postérieurement; mésosternum non avancé en pointe antérieurement. - Ce g., d'après le Catal. de $M$. Dejean, renferme 44 esp. dont nous ne citerons que l'A. teniala (Buprestis toniala Fab.), qui a servi de type à M. Solier pour en élablir les caractères.

ACMELLA (áxu'́, pointe). вот. PII. -Syn. du g. SPilalthes.

(J. D.)

*ACMENA, DC. (nom mythol.). вот. нir. - G. de la famille des Myrtacées , tribu des Myrtées de M. De Candolle (Prodr. 3) qui lui assigne les caract. suivants : Tube calicinal turbiné; limbe tronqué, involuté en préfloraison. Pétales 5 (quelquefois moins par avortement), minimes, distants. Étam en nombre indéfini, libres. Style court, cylindrique; ovaire 3-loculaire. Baie subglobuleuse, monosperme par avortement. Graine grosse, subglobuleuse; cotylédons soudés. - Arbrisseaux à feuilles opposées, très entières. Infloresc. terminale, thyrsiforme, composée de cymules triflores. Fleurspetites, blanches. L'unique esp. de ce g. est indigène dans la N.-Hollande.

(Sp.)

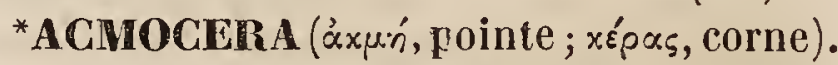
Ins. - G. de Coléoptères tétramères, famille des Longicornes, établi par M. Dejean, qui n'en a pas publié les caractères. Il est fondé sur une seule espèce, l' $A$. compressa Fab., qui se trouve en Guinée.

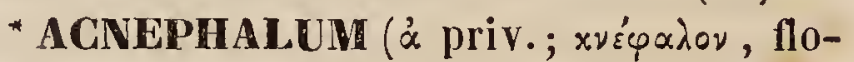
con de laine). ıss. - G. de Diptéres, division des Aplocères, subdivision des Tétrachætes, famille des Tanystomes, tribu des Asiliques, s. tribu des Dasypogonites, établi par M. Macquart (Dipt.exot. nouv. ou peuconnus). Ce g., formé aux dépens des Dasypogon, a pour caract. : Corps large. Tête basse. Moustache couvrant toute la face. Tubercule du front muni de longs poils. Article $1^{\text {er }}$ des antennes 
plus ou moins court; $2^{\text {me }}$ cyathiforme ; $3^{\text {me }}$ allongé, subulé; style un peu allongé et épais. Thorax assez élevé. Abd. large, déprimé et ponctué. Pieds velus; point de pelotes aux tarses. Cellule $2^{\text {me }}$ sous-marginale des ailes ordinairement appendiculée; 1 re postér. quelquefo is fermée, 4me ouverte ou fermée.-Le facies des Acnéphales leur donne une ressemblance singulière avec les Apiaires et surtout avec les Andrènes. Leur nom générique est tiré de l'absence de pelotes aux tarses: caract. qui les distingue de toute leur tribu, à l'exception des Gonypes. Parmi les 5 esp. décrites par l'auteur, nous ne citerons que celle qu'il appelle $A$. Olivieri, et qui a étè trouvée dans l'île de Paxos par Olivier.

ACNIDA, Mitch. L. '́a priv.; xvídn, ortie ; c.-á-d. sans aiguillon ; la plante ressemble à une ortic). вот. Pн. - G. de la famille des Chénopodées, tribu des Atriplicées, Meyer; M. Endlicher (Gen. Plant.) lui assigne les caract. suivants : Fleurs dioïques, non bractéolées; dans les mâles : Cal. à 5 sépales égaux, inappendiculés ; 5 étam. insérées au réceptacle; dans les femelles : Cal. persistant, à 3 sépales égaux. Ovaire 3 ou 5-gone, uniloculaire, uniovulé. Stigm. 3 ou 5 , linéaires, sessiles, révolutés. Akène 3 ou 5 -gone. Graine verticale, comprimée; test crustacé ; embryon périphérique, courbé en fer à cheval. - Herbes vivaces, à feuilles alternes très entières. Grappes axillaires : les fructifères nutantes. Ce genre appartient à l'Amérique septentrionale. On en connaît 2 espéces.

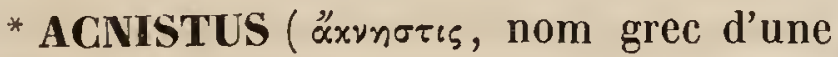
Pl. aujourd'hui indéterminée). вот. Рн. G. de la famille des Solanacées, Endl., proposé par Schott (Wien. Zeitschr. Iv, 1180, Lirncea, 1831), et dont voici les caract.: Cal. campanulé, 5-fide. Cor. hypogyne, infundibuliforme, à tube court, dilaté à la base, à limbe 5-parti, étalé ou réfléchi, à estivation imbricative. Étam. 5, exsertes, insérées au tube de la corolle, un peu au-dessus de sa base; filaments simples; anth. longitudinalement déhiscentes. Ovaire biloculaire; placentas subglobuleux, pluriovulés, adnés à la cloison. Style simple à stigmate capité, subconcave. Baie biloculaire, entourée du calice persistant. Graines peu nombreuses, réniformes, comprimées. - Le g. T. 1.
Acnislus, peu nombreux en esp., se compose d'arbustes appartenant à l'Amér. tropicale ; leurs feuilles sont alternes, trés entières; les fleurs fasciculées, axillaires, blanches, odorantes, les fruits rouges. (C. L.)

*ACOCEPHALUS ('axoń, oreille; $x \varepsilon \varphi \varphi \alpha \lambda n^{\prime}$ tête). ıns. - G. de l'ordre des Hémiptères do la section des Homoptères, famille des Cicadelles, établi par Germar ( $M a g$.$) , adopté par$ Burmeister (Handb. der Enı. 2), et ayant pour principaux caract. : $1^{\circ}$ le sommet de la tête triangulaire; $2^{\circ}$ des ocelles placées devant les yeux; $3^{\circ}$ les parties latérales $d u$ corps couvertes d'aspérités. - Ceg. renferme une quinzaine d'esp. tant européennes qu'américaines. Lesplus connues sont l' $A$. costatus (Cicada costata Panz., Faun. Germ.), et l'A'. striatus (Cercopis striata Fab., S'yn.Rh.), toutes deux répandues dans la plus grande partie de l'Europe. (BL.)

*ACOCHLIDES (á priv.; xo $\chi \lambda i_{s}$, coquille). MoLL. - Latreille a nommé ainsi une famille de Céphalopodes acétabulifères, dans laquelle il place ceux de ces animaux qui ont 8 pieds et qui sont dépourvus de coquilles. $V$. octopones. (A. D'O.)

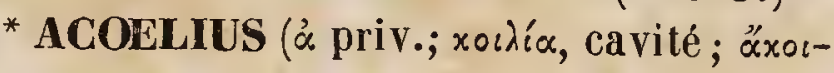
los, non creux). INs. - Syn. d'ADELIUS. (BL.)

*ACOETE. Acoëtes (áxoń, onie; allusion aux branchies). ANNÉLID. ERRANTES.-G. établi par MM. Audouin et Milne Edwards (Mérr. pour servir à l'Hist. nat. du litl. de la France, t.2,p. 99, pl. 2 A, fig. 7-14), et formant, avec leur g. Sigalion, la tribu des Aphrodisiens vermiformes. $V$. ApHrodisiens. Les caract. qu'ils lui assignent sont les suivants : Pieds pourvus d'élytres, mais n'ayant pas de cirres supérieurs, au nombre de 50 paires ou plus, alternant régulièrement avec des pieds sans élytres, mais garnis d'un cirre supérieur. Antennes 5; 4 mâchoires grandes et cornées. Des branchies tuberculeuses sur tous les segments du corps. - Ce g. a été adopté par Cuvier (Règ. anim., $2^{\text {me }}$ édit., t. 3, p. 207). On n'en connaît qu'une seule esp. qui se trouve aux Antilles; elle habite un long fourreau ayant l'aspect et la consistance $\mathrm{du}$ cuir ; c'est l'A. de Plée, A.Pleei. (L. D. y.r.)

*ACOLASTE ('́xódasтos, impudique; allusion au développement considérable de l'organe copulateur chez les mâles). Ins.-G. de l'ordre des Diptères, tribu des Muscides, établi par Meigen dans son $1^{\text {er }}$ ouvrage ( $\boldsymbol{E} s s$. 
d'une nouv. classif. des Dipt. europ., $\left.2^{\mathrm{me}} \mathrm{v}.\right)$, fondu depuis dans le g. Cordylura Fall., adopté par Macquart.

* ACOLEA ('́x priv.; xòrós, gaîne). BOT. CR. -G. d'Hépatiques établi par Dumortier aux dépens des Jongermanniées de Linné, et qu'il avait d'abord fait entrer lui-même dans son g. Schisma. La priorité étant acquise au Gymnomitrium de Corda, c'est à ce mot qu'il en faut chercher les caractères. (C. M.)

ACOLEA. BоT. CR. - S.-tribu des Jongermanniées, famille des Hépatiques, qui comprend, selon M. Dumortier, ses $3 \mathrm{~g}$. Mniopsis (Haplomitrium, N. ab. E.), Acolea et Schisma. Cette div. n'est point admise par M. Nees d'Esenbeck, dans son nouvel et important ouvrage sur les Hépatiques d'Europe (Europt. Leberm.)

* ACOLI. ors. - C'est le nom donné par Levaillant à une esp. d'oiseau de proie d'Afrique, figuré dans ses oiseaux d'Afrique, etqu'on croit appartenir au g.Busard.(LAFr.)

ACOLIUM (※. priv.; $x \tilde{\omega} \lambda \circ \%$, pied, support). Nom sous lequel Achar réunissait, dans son g. Calycium, famille des Lichens, toutes les espèces à apothécies sessiles. M. Fée a tenté d'élever ce s.-g. à la dignité de g., ce qui n'a pas été adopté.

(C. M.)

ACOMA, Adans.; Homalium Jacq.; Racoubea, Aubl. вот. PII. - G. considéré comme type de la famîlle des Homalinées. Ses caract. sont les suivants : Cal. tubuleux-turbinć, adhérent ; limbe 6 ou 7-parti, persistant. Pétales en même nombre que les sépales, persistants, insérés à la gorge du calice, uni-glanduleux à la base. Étam.insérées par faisceaux (de 3 à 6) devant les lobes calicinaux; filets filiformes; anth. suborbiculaires .Ovaire semi-infẻre, uniloculaire ; partie inadhérente conique : 3 styles filiformes; stigm. capitellès. Capsule seminifère, trivalve au sommet, uni-loculaire, 3 placentaires pariétaux, polyspermes. Graines petites, ovoïdes. - Arbrisseaux à feuilles dentelées; fleurs petites, disposées en grappes, soit terminales, soit axillaires et terminales. Ce g. appartient à la zône équatoriale; on en connaît 4 espèces.

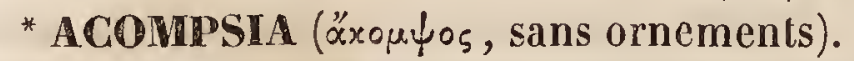
ıns. - G. de l'ordre des Lépidoptères, famille des Nocturnes, tribu des Tinéites, établi par nous aux dépens du g. Lita de Treitschke, et dont voici les caract. : Palpes infér. très minces, arqués êt relevès au-dessus de la tête; les deux $1^{\mathrm{ers}}$ art. à peine velus; le $3^{\text {me }}$ nu, subuliforme, plus long que les deux $1^{\text {ers }}$ réunis. Trompe longue et très visible. Ant. filiformes dans les deux sexes. Tête courte. Cors. arrondi. A bd. cylindrique, mince, terminé par une touffe de poils dans les mâles et en pointe dans les femelles. Pattes postér. longues et peu velues. Ailes supér. assez larges, à bord postér. presque droit et briévement frangé; ailes infér. plus larges et garnies également d'une frange étroite. Premiers états inconnus. - Ce g. renferme très peu d'esp., et a pour type la Teigne cendrée, Tinea cinerella $\mathbf{L}$., figurée par Hubner sous le nom d'Ardeliella. (D.)

*ACOMYS (áxń, pointe; $\mu \tilde{v} s$, rat). мамм. - G. de l'ordre des Rongeurs, famille des Muriens, établi par M. Isid. Geoffroy-SlHilaire. Ses caract. sont: Membres postér. un peu plus longs seulement que les antér., non palmés; queue arrondie; molaires au nombre de 3 à chaque mâchoịre de chaque côté; point d'abajoues ; corps revêtu, sur le dos et sur les côtés, de poils entremêlés d'èpines carénées. - Ces animaux diffèrent donc des véritables Rats par les piquants, des Hamsters par l'absence d'abajoues, et des Echimys par le nombre de dents.-L'Acomys du Caire , $A$. cahirinus, appelé aussi Rat du Caire, Souris du Caire, décrit par Geoffroy St-Hilaire, appartient à ce genre. Son pelage est gris cendré; sa taille de quatre pouces; sa queue de pareille longueur. - On connaît encore l'A comys perchal, le Rat perchal de Buffon; il est roussâtre en dessus, gris en dessous; sa taille est de 15 pouces non compris sa queue qui en a 9 . Il habite dans les maisons à Pondichéry. (A.)

*ACONIOPTERTS ('̊xóvเov, objet terminé en pointe; $\pi \tau \varepsilon$ pis , fougère; allusion à la forme des pinnules). воT. CR. - G. établi par Presl (Ptéridog.) dans la tribu des Acrostichacées, pour une fougère décrite par Hooker et Gréville, sous le nom d'Acrostichum subdiałhanım, qui croît à l'ìle SainteHélène et dans l'Inde; elle se distingue des Acrostichum proprement ${ }^{\circ}$ dits, tels que les définit Presl, par ses nervures pinnées, bifurquées et anastomosées seulement auprès du bord de la feuille; leurs anastomoses donnant naissance à une petite nervure extérieure, tuberculeuse. - Ce g. est ainsi in- 
Lermédiaire entre les Olfersia et les $A c r o-$ stichum de cet auteur. La seule esp. qu'il renferme est herbacée, à feuilles simples, lancéolées, coriaces et plus étroites lorsqu'elles sout chargées de fructification.

(AD. B.)

ACONIT. Aconilum, L. (áxovíros, aconil, d'áxóvn, rocher ). вот. PIr.-G. de la famille des Helléboracées, renfermant des végétaux en général trés vénéneux, remarquables tant par la beauté que par la singulière structure de leurs fleurs. Ses principaux caract. (Spach, Hist. des Pl.ph. Suites à Buffon, tom. 7.) sont: Sépales 5, non persistants (excepté dans l'Aconitum Anthora), bisériés ( 3 extérieurs et 2 intérieurs), subonguiculés, dissemblables, anisomètres : le supér. grand, ascendant, voùté en forme de casque comprimé ou naviculaire, très obtus, rostré ou acuminé antérieurement; les 2 latéraux (intérieurs) moins grands, un peu bombés, inéquilatéraux, presque égaux, horizontaux, connivents, recouvrant les organes sexuels; les 2 inférieurs petits, inégaux, déclinés, subnaviculaires. Pétales (staminodes ou nectaires de beaucoup d'auteurs ) 2 , libres, égaux, insérés devant le sépale supérieur (lequel les enveloppe complétement), longuement onguiculés , renversés, petits, cuculliformes, unilabiés antérieurement, éperonnés postérieurement; onglets filiformes, ascendants, plus ou moins arqués en avant ou inclinés au sommet. Étam. courtes, nombreuses, un peu déclinées, ascendantes pendant l'anthèse, puis défléchies: les extér. parfois ananthères; filets subulés, ailés jusque vers leur milieu; anth. elliptiques ou suborbiculaires, échancrées aux 2 bouts, comprimées, latéralement déhiscentes : connectif filiforme. Ovaires disjoints, pluriovulés, verticillés au nombre de 3 à 6 ; ovules horizontaux, bisériés. Styles subulés, subrectilignes, terminés chacun par un stigmate minime, bidenticulé. Péricarpe de 3 à 6 follicules verticillés, subcylindracés, obscurément trigones, non stipités, chartacés, réticulés, corniculés au sommet, univalves, polyspermes, persistant après la déhiscence. Graines subcylindriques ou trièdres, carénées ou ailées aux angles, lisses ou légèrement rugueuses, ou transversalement squamelleuses, horizontales, bisériées; embryon petit ou ponctiforme, à cotylédons plus ou moins divergents. Herbes vivaces à racines rhizomateuses ou tuberculeuses; tige feuillée; feuilles palmatifides, ou palmatiparties, ou pédatiparties (par exception indivisées) : les infér. longuement pétiolées; les autres courtement pétiolćes ou sessiles; grappes terminales ou axillaires et terminales, solitaires, tantôt feuillées, tantôt bractéolées ; pédicelles ascendants ou résupinés, dibractéolées tantôt vers leur milieu, tantôt plus haut ou plus bas, cupuliformes au sommet, plus ou moins inclinés au sommet durant la floraisun. Fleurs grandes, jaunâtres, ou blanchâtres, ou bleues, ou violettes, ou rougeâtres, ou panachées.

Nous n'avons pu reconnaître parmi les nombreuses esp. rapportées à ce g. que 8 ou 9 esp. distinctes, offrant chacune une foule de variétés.

* ACONITELLE. Aconitella, Sp. (dim. d'aconit). вот. Рн.-G. de la famille des Helléboracées, tenant exactement le milieu entre les Aconits et les Dauphinelles (Delphinium, Sp.); il diffère de ces derniers par le calice, conforme à celui des Aconits, et de ceux-ci par la corolle semblable à celle des Dauphinelles. Les graines sont transversalement squamelleuses; les fleurs, assez petites et de couleur rougeâtre, sont disposées en panicule divariquée, très lâche et aphylle. - La seule esp. qui constitue ce g. est indigène en Orient.

(SP.)

ACONITUM, Lin. вот. pH.-Syn. latin d'ACONIT.

* ACONOGONUM, Meisn. вот. PH.--G. ou s.-g. de la famille des Polygonées; ses caract. différentiels, suivant Meisner, sont les suivants: Périgone profondément 5-fide; div. planes, étalées. Étam. 8. Style trifide. Akène trièdre, recouvert à la base par le périgone. Cotylédons accombants, larges.-Herbes ou sous-arbrisseaux, à gaînes stipulaires cylindriques, nues; fleurs en grappes paniculées. - Ce g. est fondé sur le Polygonum alpinım L., et sur quelques esp. voisines. SP.)

* ACONTEA (Aconte, nom mythol.). Ins.-G. del'ordre des Lépidoptères Diurnes, tr. des Nymphalides, proposé par Horsfield (Lepid. of Java) et qui a pour type la $\mathcal{N}$. acontea des auteurs, qu'il désigne sous le nom de primaria. Ainsi, d'un nom spécifique, il a fait un nom générique. Cette 
marche, suivant nous, est vicieuse en ce qu'elle jette de la confusion dans la synonymie. Au reste, le g. Acontea est le même que celui d'Adolias, créé par M. Boisduval. $V$. ce mot.

* ACONTIA (áxov tias tenant du serpent; allusion a la rapidité des mouvements de l'insecte ). Ins. - G. de l'ordre des Lépidoptères, famille des Nocturnes, établi par Ochsenheimer et Treitschke (Hist. nat. des Lépid. d'Eur.) et adopté par M. Boisduval, qui le range dans sa tribu des Héliotides, mais sans en avoir fait connaître les caractères.Voici ceux qu'en donne M. Treitschke: Abd. court, mince chez les mâles ; épais et cylindrique chez les femelles. Ant. presque filiformes et finement crénelées. Ailes supér. étroites, les inférieures larges et arrondies. - Il ajoute que les Acontia sont blanches ou jaunes avec des taches noires ou brunes, en forme de bandes, et que leurs chenilles ne sont pas encore connues. Les Acontia sont des Noctuélides de petite taille, dont le blanc et le noir forment toute la parure, à l'exception d'une seule, l'A. Malvo, qui est jaune. On les voit voler en plein jour, avec la plus grande rapidité, dans les endroits arides et exposés au soleil. On en compte 7 ou 8 esp. dont les plus connues sont l' $A$. solaris et l'A. luctuosa, qui se trouvent aux environs de Paris.

ACONTIAS (áxovtias, sorte de serpent). веРт.-C'était, chez les Grecs, le nom d'un serpent qu'on disait s'élancer des arbres sur les passants. Aujourd'hui on l'emploie pour désigner un genre de la s.-famille des Scincoïdiens saurophthalmes, lequel a pour caract.: Corps dépourvu de pattes, allongé, cylindrique, à écailles lisses; queue courte, pointue; dents simples, coniques, obtuses, palais non denté; langue squameuse, à peine incisée à sa pointe; paupière supérieure rudimentaire; museau emboîté dans une très grande plaque percée de chaque côté par les narines, qui sont petites et en arriere desquelles est un sillon longitudinal. A l'intér. les Acontias n'offrent ni épaules, ni sternum, ni bassin; les còtes antér. sont réunies en dessous par des prolongements cartilagineux. L' $A$. pintade, espèce type de ce g. est très commune au cap. de B.-Espérance.

(G. B.)

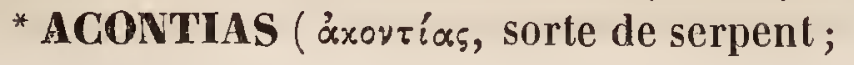

allusion aux taches des tiges). вот. PII. - G. de la familie des Aroüdées, Juss. (Aracées, Schott), tribu des Caladiées, fondé par cet auteur qui en établit ainsi les caract.: Spathe dressée, convolutée à la base. Spadice interrompu, androgyne ; les fleurs femelles occupant la partie infér. et les fleurs mâles, la partie supér. sans appendice stérile. Anth. nombreuses, bi-loculaires, distinctes, adnées en verticilles au moyen de connectif́s en cône tronqué, à logettes continues et déhiscentes au sommet par des fentes transversales. Ovaires nombreux, pressés, subtriloculaires, adhérents entre eux par des styles très épais, placentiformes. Ovules ascendants, insérés vers le milieu de l'axe et en grand nombre dans chaque loge. Stigm. exigu, orbiculaire, jaune-glutineux. Baie inconnue. - Ce g., dont le Caladium helleborifolium Jac. (Icon.rar.t.631) est le type, comprend quelques autres esp. du g. Caladium, Vent., appartenant au Brésil. Ce sont des plantes à Rhizomes tubéreux, à feuilles lobées-pédalées, partant toutes de la base, á pédoncules nus, et á spathe verte. (C. L.)

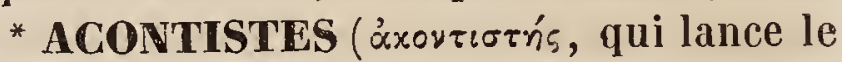
javelot). ors.-Nouveau g. créé par M. Sundeval, et indiqué par Bonaparte comme syn. de son g. Scolopacinus (Proceed. 1837 ) qui l'est lui-même du g. Ramphocène de Vieillot ( Nouv. Dict. et Gal.) $V$. ramproGÈne.

(LAFr.)

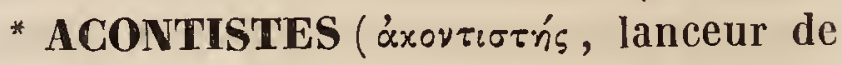
javelots). Ins.-Ce nom est donné par Burmeister à une div. qu'il a établie dans le g. Mantis. (BL.)

* ACORACÉES. Acoraceœ. вот. Рн. - $V$. ACOROÏDÉES.

(A. R.)

* Acorius (áxopńs, insatiable). Ins. G. de Coléoptères pentamères, famille des Carabiques, établi par Zirnmerman, qui le place dans sa tribu des Zabroïdes et le caractérise ainsi : Dent bifide au milieu du menton. Extrémité du tibia sans aucune dent. Les 3 premiers art. des tarses antér. dilatés dans le mâle, triangulaires, tronqués par devant. - Il ne rapporte à ce g. qu'une seule espèce trouvée en Égypte par Ehrenberg, l'A. metallescens. (D.)

* ACOROIDÉES. Acoroideœ. вот. PIr. $\Lambda$ gardh (Aphor. 133), et plus tard Schott et Endlicher (Meleth. 22), Link (Handb.1.144), ont proposé d'établir sous ce nom une famille 
distincte des Aroïdées, pour y placer le g. Acorus. Lindley ( $N a t$. syst. 365 ) adopte cette famille, qu'il nomme $A$ corace $\propto$, et lui donne, d'après Schott, les caract. suivants : Spathe en forme de feuille, non roulée. Fleurs hermaphrodites, formées d'écailles. Étam. complètes, opposées aux écailles, anth. biloculaires, introrses. Ovaires distincts. Fruit charnu. Graines ayant leur embryon placé au centre d'un endosperme charnu. - Indépendamment du g. Acorus, Lindley réunit dans cette familleles suivants: Gymnostachys, R. Br., Tupistra, Ker; Aspidistra, Ker. Les caract. précédents nous paraissent être ceux qu'on a attribués à la tribu des Orontiacées, famille des Aroïdées.

(A. R.)

ACORUS ( $\alpha$ priv.; xópn, prunelle; parce que, selon Dioscoride, cette plante était employée à la guérison des maux d'yeux). вот. Pн. - G. de plantes de la famille des Aroïdées, dont on a voulu récemment faire le type d'une famille distincte sous les noms d'Acoracées ou d'Acoroïdées ( $V$. acoroïdéEs). Voici les caract. du g. Acorus, tels que nous les avons observés sur les $A$ corus calamus et gramineus: Fleurs hermaphrodites, complétement sessiles et très rapprochées les unes des autres, disposées en une esp. de spadice simple et cylindrique. Cal. composé de 6 écailles dressées, inégales, dont 3 un peu plus grandes et un peu plus extér. Étam. 6 , hypogynes, à peine plus longues que les écailles, en face desquelles elles sont placées, et ayant les filets larges et planes; anth. introrses, à une ( $A$. gramineus) ou à 2 loges. Pist. unique, sessile au fond de la fleur, ordinairement 3 -angulaire. Ovaires à 3 loges, contenant chacune un certain nombre d'ovules renversés. Stigm. simple, comme tronqué, placé sur le sommet court et aminci de l'ovaire. Le fruit est charnu, et contient ordinairement 3 graines oll petits nucules, environnés de fibrilles. L'embryon est cylindrique, placé au centre d'un endosperme charnu. - Ce g. ne se compose que des 2 esp. déjà nommées, vivaces, à feuilles roides et rubanées, engaînantes à leur base, et à tige 3-angulaire, portant latéralement un seul spadice et se terminant par une feuille. L'une $A$. calamus L., originaire de l'Inde, croît également en Europe, dans les lieux inondés. Sa racine ou souche souterraine est très odorante et aromatique. On l'emploie en médecine comme excitante et sudorifique. L'A. gramineus vient de la Chine. (A. R.)

ACORYNUS ('á priv.; xopúyn, massue; allusion à la forme des antennes). INs. G. de l'ordre des Coléoptères tétramères, famille des Curculionites, div. des $\Lambda$ ntribides, établi par Schoenherr, qui lui donne les caract. suivants : Ant. peu longues, grêles, insérées dans une fossette profonde, oblongue, au milieu du rostre, et ayant les 3 derniers art. étroits, presque contigus, dont le pénultième très court. Rostre peu allongé , 3-caréné en dessus, avec le sommet presque tronqué. Yeux oblongs, convexes, un peu rapprochés. Prothorax presque conique, présentant, bien avant la base, un sillon élevé, transversal, courbé antérieurement des 2 côtés. Élyt. oblongues, presque ovales, 3-sinuées à la base, légèrement convexes en dessus. - Ce g., adopté par M. Dejean, a pour type l' $A$. sulcirostris du même auteur, espéce qui se trouve à Java. (D.)

* ACOSMÉTIE. Acosmetia (áxóбuntos, qui est sans ornement). Ins. - G. de l'ordre des Lépidoptères, famille des Nocturnes, établi par Stephens, dans sa tr. des Noctuides, aux dépens du g. Anthophile d'Ochsenheimer, et qui a pour type la $N$. caliginosa d'Hubner.

(D.)

* ACOSmIA. вот. pir. - G. indiqué par Lindley (Syst. of Bot., ed. II), comme fondé par Bentham et appartenant à la famille des Silénacées (Caryophyllées). Il ne paraît pas que les caractères en aient été publiés. (C. L.)

* ACOSMIUM, Schott.; Sweetia, Spreng.

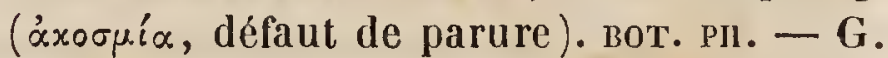
de la famille des Légumineuses, s.-ord. des Césalpiniées, R. Br.; Vogel (Linnoa, 1837) en donne les caract. suivants : Cal. cupulıforme, 5-denté. Pétales 5 , disposés comme ceux d'une corolle papilionacée, un peu divergents, insérés (de même que les étamines ) un peu au-dessus de la base du calice : les infér. obovales-oblongs, rétrécis à la base; les latéraux oblongs-linéaires, comme stipités, inéquilatéraux , un peu plus longs que les infér.; le supér., grand, arrondi, échancré, courtement onguiculé. Étam. 10 , toutes fertiles; filets filiformes; anthères arrondies. Ovaire courlement stipité, comprimé; style subcylindrique, onciné ; Stigm. simple. Fruit inconnu. Infloresc. terminale, ample, en grappes rameuses; pédonc. com- 
primés, eflilés. Fleurs petites. - L'unique esp. de ce genre croìt au Brésil. (Sp.)

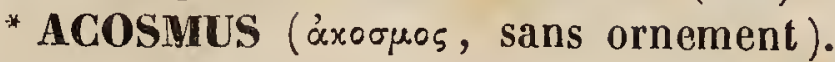
INS. - G. de Coléoptères hétéromères, famille des Trachélides, établi par M. Dejean, dans sun dernier Catalogue, mais dont il n'a pas publié les caractères. Ce g. est fondé sur une seule espèce du Cap de B.-Espérance qu'il nomme $A$. capensis.

* ACOSMUUS. bot. ph. $-V$. aspicarpa. (Ad. J.)

ACOSTA (nom d'homme). вот. PII. - G. de la famille des Chaillétiées, fondé par Ruiz et Pavon (Flor. Peruv.) et réuni définitivement au g. Moutabea, Aubl. - Nom donné par Loureiro à un arbre indéterminé de la Cochinchine, voisin du Vaccinium. - Adanson, et plus tard, Scopoli formèrent aussi sous cette dénomination, un g. de Composées, dont le type était le Centaurea spinosa L., et qui n'a point été adopté. - Enfin ce nom a été donné, par M. De Candolle, à un g. dont les caract. sont restés inédits et qu'on a réuni depuis au g. Spiracantha H. B. K., de la famille des Composées-Vernoniacées.

(C. L.)

ACOTYLÉDON ou Acotylédone ou Aco-

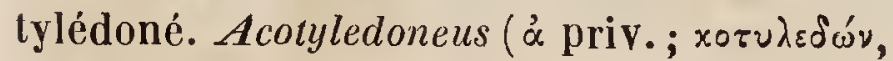
articulation creuse, et, ici par extension, sorte de petite feuille). вот. CR. - C'est-ádire embryon privé de cotylédons, la partie étant ainsi prise pour le tout; car les plantes privées de cotylédons sont, en effet, dépourvues d'embryon. Aussi quelques botanistes ont-ils substitué le nom d'Inembryonés à celui d'Acotylédons ou Acotylédonés, pour ce grand embranchement du règne végétal, qui comprend toutes les plantes que l'on a tour à tour désignées sous les noms de Cryptogames, Agames, etc.

(A. R.)

* ACOTylÉdoniE. Acotyledonia ( $\alpha$

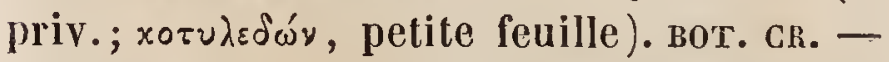
Nom de la $1^{\text {re }}$ classe du régne végétal, en suivant la série des familles naturelles, telle qu'elle a été établie par Jussieu, eł qui comprend toutes les familles de Plantes Acotylédones ou Inembryonées. (A. R.)

ACOUCHI. мnм. - Syn. du g. Agouti. (C. D'O.)

ACOUROA, Aubl. вот. Pн. - Syn. du g. Geoffroya.

* ACOURTia (Madame $\Lambda^{\prime}$ Court, zélée promotrice de la Bot.). вот. pur. - Le g.
Acourtia, établi par Don, fait partie de la tr. des Nassauviées, parmi les Composées, et comprend plusieurs sous-arbrisseaux du Mexique à feuilles épineuses, dentées, cordées ou amplexicaules. Ces pl. ont pour caract. : Capit. groupés en corymbes au nombre de 3-10; écailles de l'involucre couleur de sang, ciliées et souvent dilatées à la base, articulées avec le rachis dont elles se détachent. Cor. pourpres ou roses, hermaphrodites, bilabiées; lèvre externe à 3 dents, dont l'interne à lobes linéaires, obtus, révolutés. Anth. terminée supérieurement par un appendice lancéolé, cartilagineux, inférieurement par des soies simples, filiformes. Akènes allongés, légèrement anguleux et couverts de papilles.

* ACRACHNE, W. et W. Arn. ( äxpos, au sommet; $\propto \chi \chi \nu n$, duvet). вот. PII. - G. de la famille des Graminées, tribu des Chloridées, ainsi indiqué par Lindley ( $\$$ 'yst of Bot., ed. II), et dont les caract. n'ont probablement pas encore été publiés.

(C. L.)

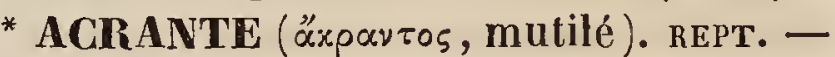
On désigne ainsi, d'après Wagler, un g. de Lacertiens, appartenant ḋ la sous-famille des Pléodontes, parce qu'il n'a en effet que 4 doigts, au lieu de 5 , aux pattes postér., caract. assez rare parmi les Sauriens. Ses autres marques distinctives sont : Dents inter-maxillaires coniques, simples; $11^{\text {res }}$ dents maxillaires et mandibulaires de mème forme; les suivantes élargies, bifides; palais denté; langue plate, en fer de flèche, non engaînée, à extrémité antér divisée en 2 filets, couverte de papilles squamiformes, imbriquées; narines latérales percées chacune dans une seule plaque, la naso-rostrale; des paupières; une ouverture externe de l'oreille, quelques plis non scutellés en travers de la région inférieure du cou ; ventre garni de plaques quadrilatères, lisses, en quinconce; des pores fémoraux; queue cyclo-tétragone. - Ce g. ne comprend qu'une seule esp., l'A. vert, ou Teyou vert d'Azara. Elle est représentée $p l .5$, Erpét. du Voyage d'A. d'Orbigny dans l'Amérique méridionale.

- ACRANTHERA ( äxpos, au sommet; an-

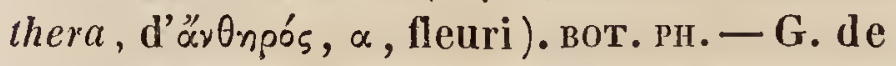
la famille des Rubiacées, établi par Arnoti (Hooker Ann. Nat. Hist.1839) qui en donne les caract. suivants : Cal. tubuleux, oblong- 
turbiné; limbe 5-fide, à div. linéaires. Cor. tubuleuse, glabre en dedans, très hérissée en dehors, profoudément 5-fide ; lobes dressés, spatulés, rétus. Étam. 5 , érigées, incluses, insérées au fond de la corolle; filets filiformes, papilleux; anth. innées, oblongues-linéaires, mucronées. Ovaire incomplétement 2-loculaire; cloisons opposées, chacune donnant attache à un placentaire 2-lamellé; ovules très nombreux. Style filiforme, porté sur un disque bulbiforme; stigm. claviforme, muriqué. Péricarpe hérissé, membraneux, indéhiscent, linéaireoblong, un peu comprimé, un peu pulpeux en dedans, incomplétement 2-loculaire, couronné par le limbe calicinal. Graines très nombreuses, petites, nidulantes, papilleuses. - Herbe basse, hérissée; feuilles opposées, pétiolées, très entières; stipules interpétiolaires, indivisées ; pédonc. courts, axillaires, pédicelles courts, subfastigiés, Cor. grande, bleue. Arnott dit que ce g. a de l'affinité avec les Mussœenda; il n'en signale qu'une esp., indigène à Ceylan. (Sp.)

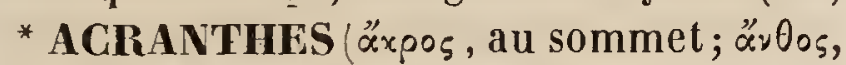
fleur).- Mème signification qu'Acrocarpes.

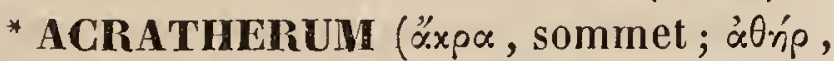
Épos, barbe d'épi). вот. Рн.-Link a nommé ainsi (Hort. Berol. I, p. 320) un g. de la famille des Graminées, qui se compose d'une seule esp. originaire du Népaul. Elle porte des chaumes hauts de 2 à 3 pieds; des fleurs disposées en panicule, ayant les épillets biflores; l'une des fleurs est hermaphrodite, garnie à sa base de 2 bouquets de poils; l'autre est stérile. Glume à 2 valves carénées; l'extér. aiguie, trinerve, scabre sur la nervure moyenne, plus courte que la fleur stérile; l'intér. lancéolée, aiguë, glabre, plus longue que la fleur fertile. Dans la fleur hermaphrodite, 2 écailles toutes couvertes de poils ; l'extér. allongée, obtuse et terminée à son somınet par une arête tordue à sa base, géniculée, brune, plus longue que la glume; l'interne plus courte, obtuse, un peu bifide. Squamules hypogynes, tronquées et denticulées. Étamines 3, a anth. longues et d'un rouge foncé. - La seule esp. de ce g. ( $A$. miliaceum Link, $l$. c.) est, comme nous l'avons dit, originaire du Népaul. Kunth, dans son Agrostographie, place ce g. parmi les incertains.

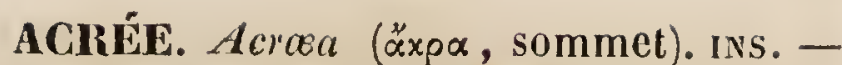
G. de l'ordre des Lépidoptères, famille des Diurnes, sect. des Tétrapodes, tribu des Héliconiens, établi par Fabricius et adopté par Latreille (Encyclopéd. méthod. 9), qui le caractérise de la manière suivante : Bord interne des ailes infér. n'embrassant pas le dessous de l'abdomen. Palpes infér. grêles et presque cylindriques. Ant. peu allongées et terminées brusquement en bouton. - Les Acrées ont au $1^{\text {er }}$ aspect quelque ressemblance avec les Héliconies qui ne se trouvent qu'en Amérique, tandis que les $1^{\text {res }}$ paraissent particulièrement propres á l'A frique. Cependant on en trouve aussi dans les Indes orientales, et Godart en décrit plusieurs comme originaires de l'Amér. méridionale ; mais il est à croire, relativement à ces dernières, qu'il aura été induit en erreur par les auteurs qui en ont parlé avant lui. Quoi qu'il en soit, ce sont des Lépidoptères aux ailes oblongues et arrondies, oú le fauve et le brun dominent; plusieurs ont le disque des ailes plus ou moins transparent. Godart en décrit 37, dont nous ne citerons que l' $A$. horıa Fab., figurée par Cramer (Pap. 25, p. 13, $p l .298$, fig. F.g.). Elle se trouve au C. de B.Esp. et dans d'autres parties de l'Afrique. (D.)

ACREMONIUM, Link (áxpśs $\omega_{\omega \nu}$, sommité). вот. cr. - G. de Bissoïdes, dont les filaments principaux sont étalés, rameux, cloisonnés et transparents. D'espace en espace, ils émettent des rameaux simples, courts et disposés en verticilles, au sommet de chacun desquels est fixée une spore ovale ou globuleuse. - On en connaît jusqu'à ce jour 6 esp. qui naissent sur les feuilles décomposées ou les bois pourris.

(LÉv.)

ACRIDIE. Acridium (àxpís, íos, sauterelle). ıns. - Ce nom, dans Fabricius (Ent. sysı.), répond à celui de Tetrix de Latreille. $V$. CRIQUET El TETRIX.

(BL.)

ACRIDIENS. Acridii ('axpís, ídos, sauterelle). ins. - Famille de l'ordre des Orthoptères établic par Latreille (Gen. Crust. et Ins.), ayant pour caract. : $1^{\circ}$ Antennes filiformes ou prismatiques, n'ayant jamais plus de longueur que la tête et le thorax réunis ; $2^{\circ}$ Tarses de 3 articles; $3^{\circ}$ Cuisses renflées et propres au saut; $4^{\circ}$ Abdomen ne présentant jamais de tarière apparente chez les femelles. - Cette famille renferme aujourd'hui un assez grand nombre de genres. Latreille ( $F$ am. 
nat. du Règne anim.) n'en avait distingué que 5 et aulant de s.-genres. M. Serville (Rev. méth. des Orthopt.) porta leur nombre à 23. M. Brullé (Hist. nat. des Ins.) le réduisit à 11; dans 2 ouvrages qui ont paru tout récemment (Burmeister, Hindb. der Entom.), l'on en compte 18; tandis que dans l'Hist. des Ins. Orthopt, suites à Buffon, nouvel ouvrage de $\boldsymbol{~} 1$. Serville, le nombre des g. ne s'élève pas à moins de 30 .

Les Acridiens sont répandus dans toutes les parties du monde, et dans presque toutes en très grand nombre. Plusieurs esp. se multiplient quelquefois en si prodigieuse quantité, qu'elles ravagent des champs entiers, et réduisent ainsi des campagnes à la dernière misère, surtout dans les parties méridionales du globe. Quelques insectes de cette famille, propres aux contrées équatoriales, ont de très grandes dimensions; mais les esp. qui se trouvent dans le nord de l'Europe sont presque toutes de taille moyenne.

Les Acridiens ne parviennent à leur état parfait que vers l'automne. Au printemps et pendant l'été, on les trouve à l'état de larve ou de nymphe, c'est-à-dire dépourvus d'ailes ou n'en ayant que des rudiments; mais à la fin de la belle saison, ils subissent leur dernière mue et deviennent aptes à la reproduction. Tous alors ont la faculté, au moins les mâles, de faire entendre un son aigu qui relentit au loin et sert à prévenir les femelles de leur présence.

Beaucoup d'insectes de l'ordre des Orthoptères produisent des sons ; mais ceux-ci ne sont pas tous produits par les mêmes organes. La plupart des Acridiens exécutent leur chant par le frottement des pattes postér. contre les élytres. Ces dernières présentent des nervures très saillantes et ' rès épaisses; les pattes au côté interne sont munies de dentelures et de carènes très rudes et très serrées, qui, venant á passer contre les élytres, produisent une stridulation plus ou moins pénétrante. Dans un g. de cette famille (Pneumora), on trouve des mâles qui ont également la faculté de faire entendre un chant; mais chez eux les élytres sont de très faible consistance et ne pourraient être soumises à aucun frottement; aussi un autre organe est-il disposé pour les remplacer avantageusement. L'abdomen est vésiculeux et offre entièrement l'aspect d'un tambour, ce qui fait retentir davanlage le son et le rend plus perçant. Ses côtés sont munis de petites plaques de stries élevées, contre lesquelles frottent les pattes que l'on peut comparer à l'archet d'un violon. Les insectes de ce dernier g. (Pneumora) sont tous exotiques; ceux que l'on trouve dans notre pays et que l'on entend dans les campagnes pendant les belles soirées d'automne, exécutent leur chant par le frottement de leurs pattes contre leurs élytres.

Ils altaquent de préférence les légumineuses, et font quelquefois beaucoup de tort aux luzernes.

Nous avons figuré dans notre Ailas (Ins. orthopt., pl. 6, fig. 2), pour représentant de la famille, l'Acridium mœsıum Serv., espèce nouvellement décrite et qui n'avait pas encore été figurée; les détails sont pris dans l'Acridium dux, l'une des plus grandes esp. et l'une des plus communes.

* ACRHDIOdea (áxpís, íos, sauterelle; Eidos, forme). Ins. - Cette dénomination, appliquée par Burmeister, répond à celle d'Acridiens de Latreille, ainsi que le nom d'Acridites de Serville. (BL.)

ACRIDIUM. ins. - Syn. latin d'ACridie.

* ACRIDOCARPUS (áxpís, ídoc, sauterelle; $x \propto \rho \pi o ́ \varsigma$, fruit). вот. PII. - G. de la famille des Malpighiacćes, établi par MM.Guillemin et Perrotel dans la Flore de Sénégambie (1. 123, t. 29), et le même que G. Don a nommé Anomalopteris. Ses caract. sont les suivants : Calice profondément 5-fide, offrant à la base d'une ou de deux de ses div. deux impressions glanduleuses. Pétales plus longs que le calice, onguiculés, presque entiers, inégaux. Étamines 10, toutes anthérifẻres, à filets courts, roides et libres; $\dot{a}$ anthères grandes, lancéolées en cœur, légèrement recourbées, glabres. Stigmates 2 , divergents, très longs, flexueux, filiformes et un peu aplatis, aigus au sommet, roulés en crosse dans la préfloraison; de plus, le rudiment d'un $3^{\text {me }}$. Style à peine visible; 3 ovaires amincis en ailes à leur sommet, velus, soudés entre eux par leurs faces internes. Fruit, par l'avortement de 1 ou 2 ovaires, réduit à 1 ou 2 samares qui sont surmontés d'une longue aile droite ou oblique, dont le bord supér. est épais. Dans le cas de 2 samarres à ailes obliques, le fruit ofre une sorte de ressemblance avec certains insectes, 
d'où l'oll a tiré son nom. - Ce g. comprend (i) esp., toutes originaires de I'Afrique tropicale, depuis la còte occidentale jusqu'à Madagascar. Ce sont des arbres ou des arbrisseaux quelquefois grimpants, à feuilles ordinairement alternes (caract. exceptionnel dans la famille), entières, obovales, glabres ou plus rarement velues, avec des impressions glanduleuses à la surface infér., portées sur de courts pétioles el dépourvues de stipules. Les fleurs jaunes sont disposées en grappes terminales ou latérales que I'avortement des dernières feuilles fait ordinairenıent paraître composées. Leur's pédicelles, plus ou moins grêles sont réfléchis au sommet, et offrent a la base une bractée cxtér. avec 2 bractéoles latérales plus intérieurement.

(AD. J.)

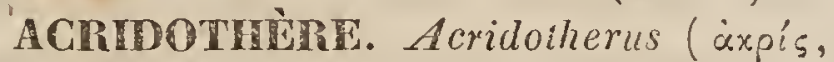

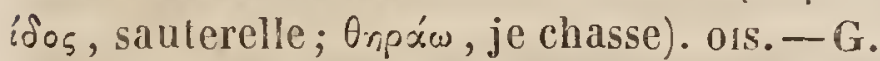
de Vieillot, synonyme du g. Gracula de Cuvier et du g. Pastor de Temmink. M. Swainson, dans sa nouvelle classification, l'á adopté et restreint aux seules esp. de Martins qui ont la tête nue et garnie de membranes charnues. $T$. MARTin. (LAFr.)

* ACRIOPSIDE. Acriopsis ("uxpís, sommet; ö $\psi$, เs, forme). вот. Pн. - G. de la famille des Orchidées, tribu des Vandées, établi par M. Blume (Bijdr. 376, $a b$. 71), et qui ne se compose encore que d'une seule esp. (l'A.Javanica Bl.), croissant en parasite sur les arbres, dans les forêts montueuses de Ia région occidentale de Java. - C'est une plante dont les feuilles naissent de faux bulbes. Elles sont linéaires lancéolées, obtuses; les fleurs forment une panicule naissant de la racine. Leur calice est étalé, à peu près égal; le labelle forme une sorte de tube avec la base du gynostème. Celui-ci est droit, terminé supérieurement par 2 cornes glanduleuses au sommet. L'anthère, à 2 loges, est cachée dans une excavation du clinandre. Elle contient 2 masses polliniques fusiformes, dont la caudicule se termine à une glande petite et arrondie.

(A. R.)

* ACRIPEZA (uxpís, sauterelle; $\pi \varepsilon^{\zeta} \zeta^{\circ} s$, piéton). Ins.- G. de la famille des Locustaires, de l’ordre des Orthoptères, créé par M. Guérin (Voyage de Duperr.), adopté par M. Brullé (His:. des Ins., t. ix), et qui offre la plus grande dissemblance dans les deux sexes. Les mâles ont une forme allongée et des ailes fort grandes comme dans les Locusta; le seul caractère générique propre à les distinguer des g. voisins, est tiré des pattes postér. cại ne sont pas renflées; lcurs jambes préselltent aussi une cavité fermée par une menbrane très mince. Les femelles, au contraire, offrent les plus grandes différences avec tous les antres g. de la même famille: leur corps est ramassé; les élytres, larges et courtes, sont cintrées de manière à envelopper l'abdomen; les ailes entièrement nulles; la tarière est si courte qu'on l'aperçoit difficilement. - La seule esp. connue est l' $\mathcal{A}$. reticulata Guêr. (Voyage Dup., et Brull., Hist. Ins., t. 1x, pl. 14, fig. 2 et 3), propre à la Nouvelle-Hollande.

*ACDITES. Acrila (äxpıเos, confus). zool. - Nom donné par Mac-Leay à une division du règne animal, comprenant les Infusoires, Ies Polypes, et une partic des intestinaux. (C. D'O.)

* ACROBRYA (äxpos, au sonmet; ßoúw, je bourgeonne). вот. Рн. - M. Mohl, dans la Flore du.Brésil de M. Martius, a créé ce nom, admis par M. Endlicher (Gen. Plant.) pour caractériser un groupe de végétaux dont l'accroissement a lieu uniquement par le sommet de la plante. Voici comment il le définit : Accroissement de la tige par son sommet; la partie infér. n’éprouvant que peu ou point de changement et n'etant chargée que de transmettre les sucs nourriciers; vaisseaux nuls parmi les plantes infér. de ce groupe, plus ou moins parfaits dans les supér.; fenilles à peine séparées et distinctes (discreta) ies tiges dans les plus infér. Organes de la propagation environnés de feuilles plus ou moins transformées, disposées en cercle ou soudées ensemble; les mâles susceptibles de répandre une humeur fécondante; nuls dans les plantes vasculaires du groupe en question. Spores dépourvues de test et d'embryon, renfermées dans des sporanges des cellules pariétales intér. desquelles elles proviennent, et s'allongeant par la germination, soit en filaments confervoïdes, soit en lames membraneuses.

Ce żroupe comprend : $1^{\circ}$ les Hépatiques et les Mousses : végétaux purement celluIaires, mais dont pourtant les organes mâles sont assez manifestes; $2^{\circ}$ les Equisétacées, remarquables tout à la fois par une organisation plus parfaite et par l'absence de l'un 
des sexes. M. Endlicher y réunit, sous forme d'appendice, les Cycadées, famille tout-dfait anomale, elles Rhizanthées, que leur végétalion terminale rattache bien à cetle section, mais que la structure plus compliquée des organes de la fructification place sur la limite d'ıne nouvelle période de la vie végétale, quoique, quant au mode d'accroissement et à lous les autres phénomènes vitaux, elles aient la plus grande analogie avec les TIALlophytes hystéropirtes.

Nous nous sommes chargé de cet article, qu'une plume plus habile et plus exercée traitera sans doute plus au long, quant à ce qui touche les acotylédonées vasculaires, parce que, nous étant spécialement engagé à faire connaître, dans ce Dictionnaire, les Mousses et les Hépatiques qui font partie du même groupe, nous ne devions pas omettre de nous en occuper un instant. (C. M.)

*ACROGAPPES ( $\alpha$ xpos, au sommel ; xap$\pi$ ós, fruit). BOT. CR. - Nom donné à une subdiv. de la famille des Mousses, dans laquelle le pédoncule qui supporte la capsule, ou celle-ci, quand elle est sessile, termine la tige ou les rameaux. C'est ce qu'on exprime encore par les mots capsule terminale. Il arrive quelquefois que de nouvelles pousses ou rejets, nés dans ou sous le bourgeon terminal, en imposent au point de faire penser que le fruit est latéral, tandis qu'il est réellement terminal. Dans če cas, on dit la capsule pseudolatérale. On évitera l'erreur en examinant bien le lieu précis d'où partent les rejets qui continuent la tige ou les ramęanx. $V$. pleurocínpes. (C. M.)

*ACROCENTRON (óxpos, qui est au som-

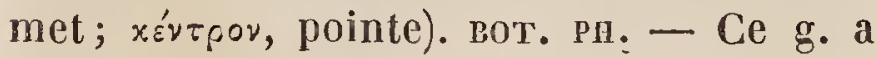
pour type, d'après Cassini qui l'a établi, le Centaurea collina, et diffère du Lopholoma du même auteur par le sommet des appendices des squames intermédiaires de l'involucre, formant une véritable épine bien manifeste et très différente des Ianières latérales. M. De Candolle le considère comme section du g. Centaurea, en y comprenant une trentaine d'espéces, parmi lesquelles nous citerons les $C$. collina, diffusa, centauroìdes, orientalis, que l'on cultive fréquemment dans les jardins de botanique. (J. D.)

* ACROCEPHALUS (äxpos, au sommet;

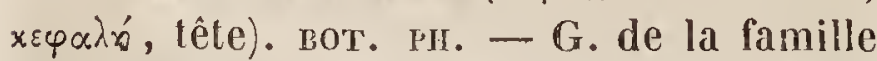
des Labiatées de Bentham, Iribu des Oci- moïdées, s.-tribu des Mochosmées du même, proposé par cet auteur pour quelques espèces du g. Ucimum de Linné, et dont il circonscrit ainsi les caract.: Cal. ovale après l'anthèse, allongé et tubuleux lors de li fructification, gibbeux à la base, bilabié ; lèvre supér. presque entière, plane; l'infér. entière ou quadridentée, à gorge nue intérieurement. Cor. aussi longue que le calice; limbe subilabié; lèvre supér. 4-dentée, à lobes égaux; l'infẻr. entière. Étam. 4, déclinćes; les infér. plus longues; filaments libres, non denticulés; anth. presque ovales-réniformes, à logettes subconfluentes. Style courtement bifide au sommet; lobe infẻr. subdilaté, presque plan; stigm. submarginaux. Akènes glabres et lisses. - Les Acrocéphales sont des plantes herbacées a tiges et à feuilles hérissées-velues ou presque glabres, à fleurs petites, serrées, imbriquées en capitules terminaux, subglobnleux. Elles appartiennent à l'Inde et àMadagascar.

ACROCWRE. Acrocera (äxpos, qui est au sommet $x_{\varepsilon} \alpha_{5}$, corne). INs. - G. de l'ordre des Diptères, div. des Brachocères, subdiv. des Tétrachotes, famille des Tanystomes, tribu des Vésiculeux. Ce g. établi par Meigen, aux dépens du g. Henops de Fabricius et Fallen, a été adopté par Latreille, ainsi que par M. Macquart qui lui assigne les caract. suivants : Point de trompe apparente. Ant. insérées sur le haut du front, de 2 articles distincts; le dernier fusiforme, terminé par un style. Yeux nus. Abd. sphérique et plus large que le thorax. Ordinairement point de cellule discoïdale aux ailes; 2 sous-marginales; 3 postér. imparfaites. - Le nom d'Acrocera fait allusion à l'insertion des antennes sur le sommet de la tête. Ces diptères sont petits et habitent les lieux aquatiques. M. Macquart en décrit 3 espèces, dont nous ne citerons qu'une, qui peut être considérée comme le type du genre : l' $A$. globulus Latr. (Syrphus globulus Panz., Faun. germ.)

* ACROCÉRIDES. Acroceridae (״̈xpos, au sommet; $x$ śpas, corne ; sidos, forme). INs. - Nom d'une famille établie par Leach dans l'ordre des Diptères, mais non adopté par M. Macquart. Elle ne comprend que les g. Henops, Illig., et Acrocera, Meigen. $V$. ces mots.

(D.) 
* ACROCHATA ( äxpos, au sommel ; $\chi$ x́t$\tau$, crin ). INs. - G. de l'ordre des Diptéres, div. des Brachocéres, subdiv. des Tétrachœtes, famille des Notacauthes, tribu des Stratyomides, établi par Wiedınann et adopté par M. Macquarl. II a pour type l'A. fasciata, qui se rencontre au Brésil. Ses caract. sont : Ant. longues; $1^{\text {er }}$ article allongé, cylindrique; $2^{\text {me }}$ peu allongé, conique; $3^{\text {me }}$ un peu plus long que le $1^{\text {èr }}$, renflé à la base et un peu à l'extrémité. Style terminal, assez épais, pubescent, subulé. Écusson mutique. Abd. rétréci à sa base.

ACROCHORDE. Acrochordus (áxpoxop$\delta \omega^{\prime} \nu$, verrue ). REPT. - G. d'Ophidiens non venimeux, dont toutes Ies parties du corps sont effectivement revètues d'écailles ayant tout-ì-fail l'apparence de verrues; ces écailles ou mieux ces tubercules squameux sont petils, nombreux, rhomboïdaux, juxtaposés et surmontés d'une petite corne ou seulement d'unc petite pointe plus ou moins aiguë. Voici les caract. essentiels du g. Acrochorde, le scul qu'on puisse encore rapporter aujourd'hui à la famille des Enhydrophides : Dents intermaxillaires nulles; dents maxillaires courtes, ćgales; narines tubuleuses, simples, libres, situćes fort près l'une de l'autre sur le dessus du bout du museau; yeux verticaux; pas de plaques sur la tête, sous le ventre, ni sous la queuc; pas de fossetles aux lévres; corps comprimé et caréné à sa partie inféricure. Queue pointue, préhensile, aplatic latéralement; pas de crochets à l'anus. - Les Acrochordes ont le corps fort gros au milieu, aminci aux deux bords; lc dos arrondi, le ventre tranchant et parcouru dans toute sa longueur par une carène denticulée; la tête petite, aplatie; le muscau court, large, arrondi; les yeux très petits, à pupille circulaire; la queue courle, assez fortement comprimée, carénée en dessus et enroulante en dessous, à la manière de celle des Boas. La bouche de ces Ophidiens est médiocrement fendue; les bords latéraux en sont droits. En avant, la lèvre supérieure offre, comme chez les autres serpents, une pelile gouttic̀re par laquelle ces reptiles poussent leur langue hors de la bouche, sans que celle-ci ait besoin d'être ouverte; mais ici, cetle pelite gouttière se trouve naturellement remplic par une protubérance corresjondante, mobile à la volonté de l'animal, laquelle existe à la partic médiane de l'extrémité antérieure de la mandibule; en sorte que, d'autre part, la lèvre infér. ayant son bord rentré en dedans, la bouche peut, pour ainsi dire, se fermer hermétiquement. Celle disposition, évidemment propre à empêcher l'eau de s'introduire dans la cavité buecale, est parfaitement en rapport avec plisieurs autres points de l'organisation des Acrochordes, qui sont toul-à-fait conformes pour vỉve dans les caux. Mais ce sont seulement les eaux douces qu'habitent ces reptiles enhydrophides, bien diflérents en cela des espèces de serpents énoliophides qui ont pour demeure la vaste étendue des mers. C'est à tort que quelques voyageurs ont signalé les Acrochordes comme des serpents dont la morsure pourrait occasionner la morl; car il est bien constaté aujourd'hui que parmi les dents de ces Ophidiens, il n'en est aucune venimeuse. La science n'est encore en possession que de 2 esp. d'Acrochordes; l'une, qu'on appelle l'A. de Java, habite les rivières de cette île; l'autre l'A. á bandes, y existe également; mais on l'a trouvée aussi dans des rivières et des étangs à Pondichéry, à la Nouvelle-Guinée, à Timor et à Sumatra.

(G. B.)

ACTRCDNE. Acrocinus (äxpov, pointe;

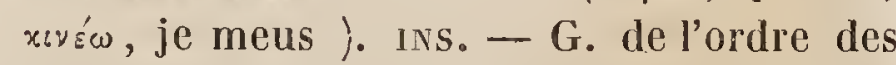
Coléoptères tétramères, établi par lliiger et adopté par M. Dejean (Catal. $3^{\mathrm{e}}$ édit.), ainsi que par M. Serville ( $N$ ouv. classif. des Longic.). Ce dernier le range dans sa tribu des Lamiaires, sous-tribu des Déprimés, el Iui donne pour caract. essenticls : Cors. armé d'une épine latérale posée sur un mamelon mobile (dans l'insecte vivant). Angles huméraux des ćlytres uni-épineux. - Ce g. ne renferme qu'une esp., le Cerambyx longimanus Fab.; Prionus longimanus Oliv.; $L_{a-}$ mia longimana Latr., vulgairement appelée le grand Arlequin de Cayenne. Cet insecte, de grande taille, est surtout remarquable par les couleurs agréablement bariolées de ses élytres et par la longucur de ses deux pattes antérieures. Voici ce qu'en dit M. Lacordaire, qui a eu occasion de l'observer sur les licux : Il se trouve toujours sur le tronc des arbres ou auprès d'eux, rarement sous les écorces; sa démarche est très lourde, et il se traîne plutôt qu'il ne marche. Son vol, qu'il prend quelquefois à l'entrée de la nuit, 
est bruyant, peu rapide, et l'insecte ne paraît pas toujours maître de le diriger à son gré, caril se beurte souvent contre les arbres, et tombe alors à terre. Le bruit qu'il produit avec le corselet s'enlend d'assez loin ; la mobilité des mamelons latéraux de celte partie est indépendante de la volonté de l'insecte et ne lui est d'aucun usage. J'ai observé cependant que, dans l'accouptement, le mâle appuie ses longues pattes antérieures sur ces organes, et peul-être est-ce un moyen que la nature lui a donné pour assujettir et exciter sa femelle. Chez celle-ci, en eflet, ces parties sont un peu plus mobiles que dans le màle. (Mérn. sur les habiudes des Coléopt. de l'Amér. mérid. Ann. des sciences natur. 1. $\mathrm{xx}$.)

* AROCONRA ('́xpov, sommet; xóun, chevelure ). BOT. PII. - Ce g. de Palmiers a été ainsi nommé par M. Martius ( $P$ alm.p. 66 t. 56 et 57 ) à cause de l'élégante masse de feuiles qui couronne sa tige; il ne comprend qu'une senle esp. qui croît depuis la Guyane jusqu’á Rio-Janeiro. Elle avait été désignée lar Aublet sous le nom de Pulnier mocaya, décrite par Jacquin sous celui de Cocos acuLeata et par Willdenow sous celui de Cocos fusiformis. Martius la nomme Acrocomia sclerocarpa. Ce g. appartient à la tribu des Cocoinnées et est ainsi caractérisé : Fleurs monö̈ques sur le même spadice, renfermées dans une spathe simple, dure et presque ligneuse; les mâles formant des épis serrés sur les parties supér. des rameaux du spadice. Cal. court, trisépale. Cor. cylinarique a 3 pétales oblongs-lancéolés. Étam. 6, incluses; flaments comprimés; anth. linéaires, oblongues, presque sagittées; un rudiment d'ovaire au centre. Les fleurs femelles sont sessiles, en petit nombre et assez espacées à la base des rameaux du spadice. Ce cal. a 3 sépales ovales-arrondies. La cor. à 3 pétales ovales-imbriqués; un disque annulaire, en forme de capsule à 6 denis, entoure l'ovaire, qui est velu, ovale, à 3 loges. Style courl; 3 stigmates lancéolés, recourbés. Le fruit est un drupe monosperme, á mésocarpe fihro-mucilagineux et dont le noyau épais, lenticulaire, est percé sur les côtés de 3 trous, dont un seul pénètre dans sa cavité. Le périsperme est uniforme et dur; l'embryon correspond au trou latéral. - Ce palmier croil dans les terrains secs et découverts, rarement dans les bois. Sa tige s'élève à 20 ou 30 pieds, sur 1 de diamètre; elle est souvent renflée vers son milieu. Ses feuilles nombreuses ont 1i) à 15 pieds de long, et sont garnies d'un grand nombre de folioles (70) à $S 0$ dé chaque côté) étroites, longues et flexueuses. Le pétiole et la base des folioles sont hérissés de longues épines noires. Les jeunes fenilles cuites de ce palmier passent pour foumir un des meilleurs choux-palmistes. On faic avec son péricarpe et avec l'amande une émulsion qui passe au Brésil pour avantageuse dans les affections catarrhales. (AD.B.)

ACTODACTYLA ( œxxpos, à l'extrémité;

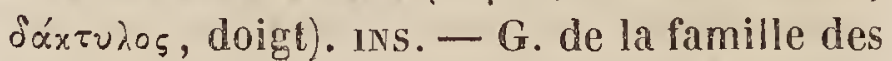
Ichneumoniens, de l'ordre des Hyménoptères, établi par Haliday pour 2 esp. indigènes dont l'une est l' $A$. degener Halid.

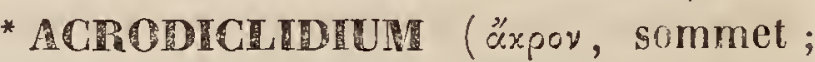
$\delta: x \lambda i s$, isos, porte a deux battants : allusion au mode d'ouverture des anthères ). - G. de la famille des Lauracées, fondé par Nees (Prog. 13, Laur. 266), qui lui assigne les caract. suivants : Fleurs hermaphrodites : cal. urcéolé, à limbe quinquéfide, infléchi, persistant. Étam. 9, très courtes, insérées au sommet du tube; 6 extér. stériles, pétaloüdes, églandulées; 3 intér. fertiles, pourvues, sur le dos et à la base, de glandules géminées, disposées presque carrément; anthères sessiles, tronquées, tétragones, conniventes au sommet en pores orbiculaires binès, et déhiscentes extérieurement, au moyen de valvules dressées. Ovaire unilocu . laire, uniovulé, entièrement couvert par le tube du calice; stigmate simple, aigu, Cariopse monosperme, enveloppé par le calice persistant et accru. - Ce g., dont le Laurus triandra de Swartz est le type, comprend quelques arbres de l'Amérique tropicale, à feuilles alternes, penninervées, à fleurs disposées en petits thyrses axillaires. (C.L.)

* ACRODON (äxpos, au sommet; ódov́s, óóvтos, dent) Ins. - G. de l'ordre des Coléoplères tétraméres, famille des Carabiques, tribu des Amaroïdes, établi par Zimmermann aux dépens du g. Amara de Bonelli et auquel il donne pour caract. essentiels : Dent simple au milieu du menton. Thorax dilaté et suborbiculaire. - II cst fondé sur une seule espèce, l'Harpalus brunneus Gyll. (Amara brunnea Dej.), qui est 
commune dans beaucoup de contrées. (D.)

* ACRODRYON ('́xpód́ovov, qui porte des fruits au sommet). - вот. pn. - G. fondé par Sprengel (Limn. S'yst. pl. 1\$25) et que la majorité des Botanistes réunit aujourd'hui au g. Cephalanthus. V. ce mot. (C. I.)

* ACRODUS (äxpos, all sommet; ódoús; dent). poiss. Foss.-G. dont M. Agassiz connaît aujourd'hui 5 espèces; l'une, l'Acrodus nobilis, est décrite et figurée dans les Transactions géologiques de Londres (2e sér. $1^{\text {er }}$ vol. $p l .4$, fig. 6). Elle vient du Lias de Bath et de Lyme-Regis. Une $2^{\text {e }}$ de la même époque géologique est son Acrodus gibberulus; ;ne $3^{\mathrm{e}} \mathrm{esp}$. , à laquelle il n'a pas encore donné de nom, vient du Lias inférieur d'Axmouth. Enfin il en signale deux autres de formations plus anciennes, l'Acrodus Bronnii, et l' $A$. Gaillardoti, du grès bigarré de Brunswick. Ce g. appartient à la famille des Cestraciontes, ordre des Placoïdes. (VAL.)

* aCROGaster ( $\alpha$ xpos, a u sommet;

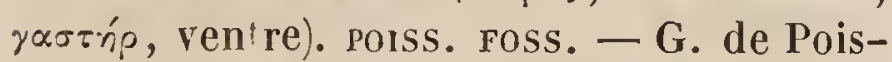
sons fossiles de la craie de Westphalie, établi par M. Agassiz (Jalcrb. 1834, p. 306), dans la grande famille des Percoïdes. Il appartient, selon M. Bronn, à la $4^{\mathrm{e}}$ période. Il est en effet cité par cet auteur, parmi les autres exemples donnés dans le Lothea, p. 563 et 747.

(VAc.)

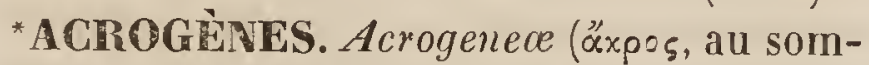

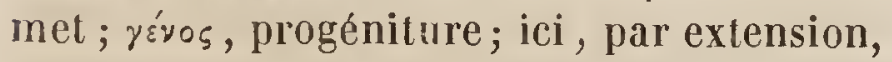
croissance). BOT. CR.-Expression introduite par Lindley, pour désigner la grande division des Acotylédones de Jussieu, par un mot analogue à ceux d'Endogènes et d'Exogènes, adoptés par M. De Candolle, pour les Monocotylédones et les Dicotylédones; mais ce mot, qui signifie croissant par le sommet, s'applique difficilement aux plantes purement celluleuses, telles que les Algues et les Champignons, qui croissent réellement dans tous les sens; elle est, au contraire, exacte lorsqu'on ne l'emploie que pour les Mousses, les Fougères, les Lycopodes, etc., dont la tige, en effet, ne 's'accroît que par l'allongement de son extrémité, sans éprouver aucun changement dans les parties déjá formées ; mais c'est spécialement à ces plantes que Mohl avait précédemment appliqué le nom d'Acrobrice; et l'ensemble de leur organisation est si différent de celui des plantes celloweuses, que presque tous les
Botanistes s'accordent à en former 2 grandes classes sous des noms différents. Ce sont encore les Acotyledonece et les Pseudocotyledonece d'Agardh; les Homonemexe et les Hcleroucmea de Fries; les Agancs et les Cryptogames, les Thallophyla et les Acrobrya d'Unger et d'Endlicher, etc. (AD. B.)

* ACROGLOCHIN, Schrad. (áxpos, au sommet; $\gamma \lambda \omega \chi i s$, pointe). BoT. PII.-Syn. du g. Lechyocarpus Nees.

* ACROGYlater ("xpos, au sommet; yupós, cercle). Bot. Gr. - Ce nom a été donné par Bernhardi à la tribu des Osmundacées, parmi les fougères.

(AD. B.)

*aCRolasia presl. (áxpos, au sommet;

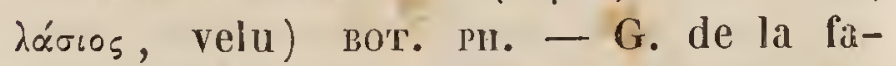
mille des Loasées, sous-tribu des Bartoninées, Spach; Presl (Rel. Honk. 2, p. 39) lui assigne les caract. suivants : Limbe calicinal 5-parti, persistant. Pétales 5, trés courtement onguiculés, planes, barbus au sommet. Étam. 10, toutes fertiles; les 5 extérieures plus longues, à anth. suborbiculaires. Filets filiformes, libres. Ovaire cylindracé. Style filiforme, trigone, non tordu, trifide à la base. Stigm. obtus. Caps. cylindracée, trivalve au sommet; oligosperme. Graines anguleuses, rugueuses. - Herbes annuelles, hérissées de poils scabres. Feuilles sessiles, oblongues, pennatifides. Fleurs terminales et latérales, non bractéolées, petites, solitaires. L'unique esp. qui constitue le g., habite le Chili.

* AGROLEPDE. Acrolepis ( «̈xpos, au sommet; $\lambda \varepsilon \pi i s$, écaille). вот. PII.-G. de la famille des Cypéracées, voisin des Dulichium et Gralınia, établi par Schrader (Annal. Cap. Cyp. 42. t. 2. f. 5.) pour une plante du Cap (A.trichodes), désignée successivement sous les noms de Hypophialium capillifolium et d'Hemichloena capillifolia. En voici les caract. génériques: Épillets 2-ou 3-flores; écailles imbriquées, distiques, la plus inférieure vide. Les fleurs manquent d'écailles ou de soies hypogynes. Étamines au nombre de 3 , style profondément 3-fide, caduc. Fruit dur, crustacé, 3-gone, entouré à sa base d'un disque persistant, 3-angulaire, à bord crénelé.

(A. R.)

* ACBOLEPIS ("丷xpos, au sommet; $\lambda \varepsilon \pi i \varsigma$, écaille). porss. Foss. - G. établi par M. Agassiz dans la famille des Sauroïdes, et voisin, dans la création actuelle, du Polypic- 
rus et du Lepisosteus. Ces polssons fossiles ont les éeailles surmontées d'une quille, et diffèrent des Pygoptères par une anale très courte. - On n'en connaît qu'une espèce, l'Acrolepis S'edgwichi, Ag. (Poiss. foss., vol. 1, tab.'D, fig. 1, et Trans. géol., $2^{\text {me }}$ série, vol. 3, pl. 18). Elle vient du Magnesian Limestone d'Angleterre, près East Thiekley.

(VAL.)

*ACROLOPHE. Acrolophus (öxpos, au sommet ; lóyos, aigrette). iNs. - G. de l'ordre des Lépidoptères, famille des Nocturnes, tribu des Tinéites, établi par M. Poey (Cenl. des Lépid. de Cuba), qui lui donne pour caraet. : Point de langue distincte. Ant. simples. Palpes très longs, eouehés sur le dos, avee tous les artieles barbus jusqu'à l'extrémité. Frange longue vers l'angle del'anus. - Ce g. a pour type une esp. que M. Poey n'a prise qu'une seule fois, et à laquelle il a donné le nom de $A$. vitellus, à eause de la position de sa tête qui ressemble à eelle d'un jeune taureau. Elle a les ailes d'un jaune brun, avee les supérieures eouvertes d'atômes bruns, plus distinets sur la côte. Cet auteur rattaehe au même g. la Teigne Hamiferella, Hubn. Zutr. 441. 2.

*ACROMION. Acromium (äxpos, au sommet ; et $\tilde{\omega} \mu o s$, épaule). arat. - Apophyse considérable qui termine l'épine de l'omoplate en haut et en dehors.

(A. T.)

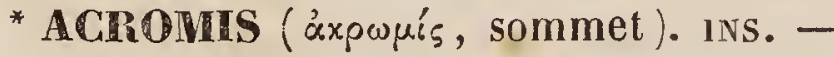
G. de l'ordre des Coléoptères tétramères, famille des Chrysomélines, proposé par M. Chevrolat et adopté par M. Dejean ( $C a-$ tal. $3^{\text {e }}$ edit.), mais dont les earact. ne sont pas eonnus. Il ne renferme qu'une esp., l' $A$. carnifex Fab., de Cayenne.

ACROMYIE. Acromyia (äxpos, élevé; $\mu \nu \tau \alpha$, mouche). Ivs. - G. de l'ordre des Diptères, établi par Bonelli, et correspondant au g. Hybos de Fabricius, adopté par M. Maequart. $V$. ee mot.

* ACRONIE. Acronia (æ̋xpor, pointe, sommet). вот. рн. - G. peu connu, rapporté avee doute à lá famille des Orehidaeées, fondé par Presl (Rel. Haenk. ı. 104; Symb. 2. 9. $t .57$ ), et ainsi earaetérisé : Sépales latéraux, étalés, allongés-acuminés, eonnés entre eux; le supér. adhérent aux intér. (pétales ). Labelle bifide jusqu'à la base, à segments linéaires, divergents. Gynostème court, un peu dressé, dilaté-arrondi au som-

\section{ACR}

met. Anth. sessile, déeidue. Masses polliniques 2, poudreuses. - L'auteur ne comprend dans ee g. qu'une seule esp.; e'est une plante herbacée péruvienne, qui paraît épigée, à seape solitaire, dressée, monophylle; feuille ample, ovale, nervée, amplexieaule ; infloreseence en épi terminal, lâehe; fleưis assez grandes, légèrement pourprées. (C. L.)

* ACRONODIA, Blum.; Acrozus, Spreng.

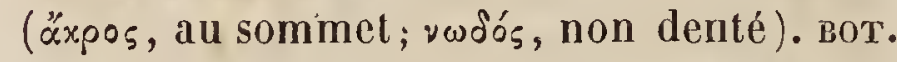
PII. - G. appartenant suivant M. Blume (Bijdr. 3, p. 123.), à la famille des Éléoearpées, et auquel ce botaniste assigne les earaet. suivants : Sépales 4. Pétales 4 , petits, linéaires, érosés au sommet. Étam. au nombre de 8 à 12 ; anthères linéaires, pubérules, mutiques au sommet. Fleurs dioïques; fleurs femelles et fruits inconnus. - Ce g. n'est fondé que sur une seule esp. qui eroît à Java.

* ACRONYGHIA. вот. PII. - M. Blume a changé en ee nom eelui du g. Cyminosma de Gartner.

(AD. J.)

*ACRONYCTE. Acronycta (áxpóvuそ̧, vux-

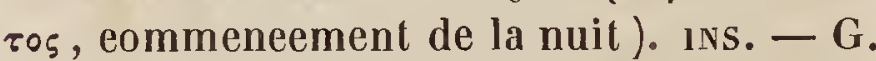
de l'ordre des Lépidoptères, famille des Nocturnes, tribu des Bombycoïdes, établi par Ochsenheimer et adopté par M. Boisduval (Index. méthod. des Lépidopt. d'Eur.), ainsi que par MM. Stephens et Curtis ( Catal. des Insectes de l'Anglet.); mais dont aueun de ces auteurs n'a publié les earaetères. Quant à eeux qu'en donne M. Treitsehke, continuateur de l'ouvrage d'Ochsenheimer, ils sont si vagues qu'il ne servirait à rien de les rapporter iei. Cependant il est vrai de dire que toutes les esp. qu'il y comprend ont la plus grande analogie entre elles, et forment, par conséquent, un groupe très naturel, mais seulement à l'état parfait; car leurs ehenilles présentent, au contraire, les plus grandes anomalies. Du reste les Aeronyetes ne peuvent être plaeées ailleurs que dans la grande tribu des Noetuélites, si on ne les eonsidère que sous forme de papillons; tandis qu'elles appartiendraient à eelle.des Bombyeites, si l'on n'avait égard qu'à la forme de leurs ehenilles et à leur manière de se transformer. Elles se filent toutes des eoques, dans la construetion desquelles quelques unes font entrer des pareelles d'écoree ou de bois pourri. Toutes les espèees que ee g. renferme sont figurées dans l'ouvrage d'Hubner, ainsi 
que dans l'Histoire naturelle des Lépidoptères dc France. Nous ne citerons que quelques unes des plus connues: l'A. leporina Fabr., vulgairement appelée le Flocon de laine, à cause de sa chenille qui est couverte de longs poils blanes; l' $A$. psi Fabr. , ainsi nommée parce que la lettre grecque $\psi$ est fidèlement représentée sur ses ailes supérieures; l' $A$. megacephala Fabr., tirant son nom de la tête de sa chenille, et enfin $l ' A$. Aceris ou Noctuelle de l'Érable, dont la chenille est très remarquable. Son corps est d'un beau jaune citron et marqué dans toute sa longueur d'une suite de taches dorsales blanches, bordées de noir, de chaque côté desquelles s'élèvent perpendiculairement, sans être implantés sur des tubercules, des faisceaux de poils trés longs en forme de cônes, d'un jaune citron et lavé de rose du côté interne. Presque toutes les esp. se trouvent aux environs de Paris.

(D.)

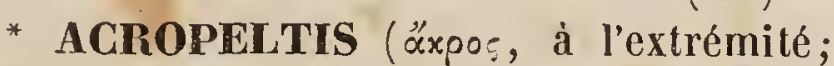
$\pi \varepsilon \lambda_{\tau} \eta$, petit bouclier). вот. CR.-Nous a vons imposé ce nom à un g. d'Algues appartenant à la sous-famille des Floridées, ordre des Phycées, et nous le caractérisons ainsi qu'il suit: Sporidies proportionnément assez grandes, piriformes, nichées dans des espèces de disques en forme de bouclier ou de raquette, placés à l'extrémité des frondes. Le point d'attache consiste en un épatement d'où s'élévent plusieurs frondes filiformes à leur naissance, puis planes, linéaires, dentées et presque ciliées en leurs bords, souvent tronquées au sommet et prolifères du milieu de la troncature, terminées par un évasement orbiculaire en forme de bouclier, dans lequel les séminules ou sporidies sont immergées. Celles-ci, en forme de poire ou de massue raccourcie, sont d'abord entièrement cachées dans le tissu de la fronde; mais bientôt elles dépassent l'une et l'autre face, qu'elles rendent raboteuses et inégales. Dans un état avancé de la plante, cette portion de la fronde se replie sur elle-même, comme une main qui se ferme. Une seule esp. a été trouvée dans la mer Pacifique, près de Coquimbo. Nous en avons donné une figure analytique dans la pl. vi. fig. 3. de la Bot. du voyage dans l'Amér. mérid. par M. Alc. d'Orbigny. La couleur normale de cette Algue doit être rose. - Ce g. tel que nous venons de le circonscrire, ne saurait rentrer dans aucun de ceux qui résultent du démembrement qu'a fait subir M. Gréville au g. Sphorococcus d'Agardh. Voisin des Délesseries, il s'en distingue aisément par sa fructification.

(C. Me.)

* ACRopkire. Acropera (äxpos, all sommet; $\pi \dot{n} \rho \alpha$, sac, poche ). вот. РI. - Lindley (Gen. et Sp. Orch. p. 172.) désigne sous ce nom un g. nouveau de la famille des Orchidées, tribu des Vandées, auquel il donne les caract. suivants : Divisions externes du calice étalées; la supér. creusée en forme de casque; les 2 latérales divariquées; les divisions intér. très petites, étalées, obliques et tronquées au sommet; labelle onguiculé, articulé avec la base du gynostème ; il est 3-lobé, et le lobe moyen est plus petit, concave et en forme de sac. Gynostème droit, mince sur les bords, et concave à sa base. Masses polliniques 2, linéaires, convolutées, terminées par une caudicule subulée, portant un très petit rétinacle externe. - La seule esp. qui compose ce genre ( $\mathcal{A}$. Loddigesii Lindl.) est une plante parasite assez semblable, pour le port, aux espèces du g. Maxillaria et qui croît aux environs de Xalapa, au Mexique.(A. R.)

* ACRophords ( «xpos, au sommet; yopós, qui porte). вот. Pr. - Presl a établi sous ce nom, dans sa Ptéridographie, un g. qu'il place dans la tribu des Aspléniacées, auprès du Cistopteris, et qui, ainsi que ce g., a peut-être plus de rapports avec le Dicksonia; il diffère du Cistopteris, en ce que les groupes de capsules sont placés près du bord de la foliole, à l'extrémité d'une des nervures. Ces groupes de capsules, disposés en rond, sont recouverts d'un tégument arrondi s'ouvrant en dehors, et fixé à sa base sur la nervure, comme dans le Cistopteris fragilis. - Ce g. est établi sur une plante de Java, décrite par Blume, sous le nom d'Aspidium nodosum; c'est une petite fougère ả fronde herbacée, très découpée.

(AD. B.)

* ACROPHYLLE. Acrophylla ( ̋̈xpov, ex-

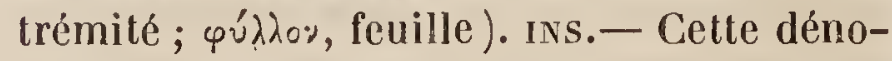
mination a été appliquée par Gray, comme nom générique, à quelques esp. de la famille des Spectres ou Phasmiens, qui ne peuvent être séparées des Cyphocranes, dont elles réunissent tous les caractères. 
MM. Brullé et Burmeister les ont réunies à ce dernier genre.

(BL.)

* ACROPODIUM, Desv. ( «̋xpos, au som-

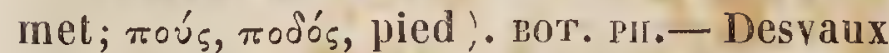
(Ann. des $S_{c}$. nat. 9, p. 408 ) a érigé sous cc nom, un g. fondé sur l'Aspalaus suffruticosa DC., et qui, d'après le caract. qu'il lui assigne, ne paraìtrait pourtant différer essentiellement des Aspalathus que par un stipe ovarien capillaire. - Reichenbach (Consp. Reyni Veget.) a admis ce g. en le plaçant à côté des Lotus.

(Sp.)

* ACROPTERIS (äxpos, au sommet;

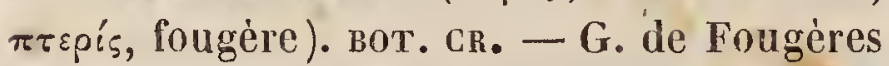
institué par Link, et dans lequel il place les Asplenium australe L., radiatum Kœn. et septentrionale L. Ce g. n'a pas été généralement adopté; suivant Presl, les deux $1^{\text {res }}$ esp. sont des Blechnum, et la dernière un véritable Asplenium.

(A. B.')

* ACROPTERON (axpos, au sommel; $\pi \tau \varepsilon \rho^{\prime}$, aile). 1Ns. - G. de l'ordre des Coléoptères tétrámères, famille des Hélopiens, établi par Perty, et correspondant au g. Phenosoma de M. Dejean. $V$. cc dernier mot.

* ACTOPTHLON (óxpov, sommet; $\pi \tau i-$ hov, plume). вот. PII. - C'est une plante vivace, rameuse, originaire de l'Europe orientale et qui, avantl'épanouissement des flcurs, a la plus grande ressemblance avec le $C e n-$ taurea Jacea. Elle a pour caract. de présenter des capitules homogames, dont les folioles infér. de l'involıcre sont fortement imbriquées, arrondies, mutiques, concaves, presque entièrement membraneuses et couvertes d'un duvet blanc; les moyennes sont lancéolées et les plusintér. linéaires-lancéolées, membraneuses sur les bords, ciliées et terminées par un appendice presque plumeux : caract. qui a contribué à séparer cette plante des Centaurea et Serratula, avec lesquels on l'avait placéc. Le réccp. est couvert de fimbrilles linéaires; la cor. est glabre, presque réguliẻre, à 5 divisions. Les étam. á filets glabres ou pourvus de quelques poils, supportent des anthères terminées supérieurement par des appendices obtus et inférieurement par de courts prolongements membraneux et entiers. Les branches du style se recourbent après l'épanouissement. Le fruit est obovale-oblong, comprimé, glabre; l'aigrette se compose de plusieurs rangées de poils blancs, inégaux; les extérieurs scabres, ceux de la rangée interne plus longs que les autres et presque plumeux au sommet. - L'Acroptilon (Centaurea Picris L.) se cultive au Muséum; Cassini en a décrit plusieurs esp. que M. De Candolle considère, peut-être à tort, comme de, simples variétés.

* ACrosanturie. Acrosanthes, Eckl. et Zeyh. (äxpos, au sommet; «ँ $\theta \cdot n$, fleur) вот. PH. - G. de la famillc des Ficoïdées, voisin des Atzoon. Ecklon ct Zeyher (Plant. Cap. 1, p. 328, 183\%.) lui assignent les caract. suivants : Cal. profondément quinquéfidc; segments dressés, acuminés, mucronés, pétaloïdes en dessus. Cor. nulle. Étam. 20 à 40 , polyadelphes, insérées au sommet du tube calicinal; filets capillaires. Ovaire uniloculaire, biovulé. Stigm. 2, filiformes, sessiles. Caps. globuleuse, un peu comprimée, uniloculaire, bivalve, recouverte par le calice; valves submembraneuses. Graines géminées ou solitaires par avortement, ascendantes, obliquement obovales, orbiculaires, tuberculeuses vers leur basc. -Sous-arbrisseaux dichotomes, diffus, très glabres. Feuilles opposées ou verticillées, quaternées, subconnées, un peu charnues. Pédoncules axillaires ou dichotoméaires, solitaires, uniflores. Ce g. est propre aux extrémités australes de l'Afrique; on en connaît 3 espèces.

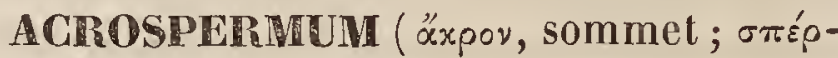
$\mu \alpha$, graine.) вот. CR. - Ce g., que Tode a caractérisé par la phrase suivante : Fungus simplicissimus suberectus apice extus fructificante, réunit différents individus que l'on doit séparer. Déjà M. Fries a rapporté au s.genre Coryne des Trémelles, l'Acrospermum unguinosum Tode; l'A. pyramidale Tode, et l'A. cornulum Fries, qui ne sont qu'une modification de l'Agaricus tuberosus arrêté dans son développement. L'A. lichenoiảes Tode, paraît être une monstruosité de quelque Lichen. L'A. compressum sert de type au g. Scleraglossum de Persoon, qui doit être conservé. II ne reste donc plus que 2 esp. qui ont été figurées par Persoon (planche $\times 1$, Iycolog. Europ.) l'A. sclerotioides Fries (Fig. 3 et 4 ), qui pourrait bien ètre un Pistillaria, et l' $A$. conicun Fries ( Fig. 6 et 7), qui seul présente les caract. génériques donnés par Tode. Cette dernière 
esp., qui est trés rare, se trouve sur les tiges sèches des plautes.

(LÉv.)

ACROSPORIUM (äxpos, au sommet; блора́, semence). вот. Cr. - G. de Byssö̈dées que le professeur Link a réuni peutêtre à tort au g. Oidium. Dans l'un et dans l'autre, les spores sont articulées et placées les unes à la suite des autres, comme les grains d'un chapelet; mais, dans l'Acroporium, la première, ou plutòt celle qui supporte les autres, est allongée; les autres sont ovales et d'autant plus grosses qu'elles approchent plus du sommet; tandis que dans l' Oidium, elles sont toutes égales. On ne connaît encore que l' $A$. monilioides Nees, qui croît sur les feuilles vivantes des graminées, qu'il finit par tuer. Dans cet état, les feuilles sont blanches et paraissent saupoudrées de sucre pulvérisé.

(Lív.)

ACROSTIC. Acrostichum (æ̋xpos, au som-

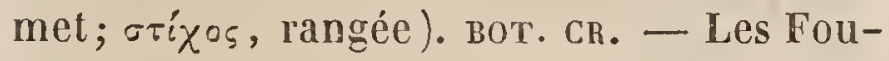
gères qui composent ce g. appartiennent á la div. des Polypodiacées à capsules nues; il fut établi par Linné pour toutes les plantes de cette division, dont les capsules couvraient toute la surface infér. des feuilles ou du moins la plus grande partic de leur étendue. Depuis lors, on en a séparé plusicurs esp. dont les capsules sont fixées le long des nervures comme dans les $\mathrm{He}$ mionitis, et le g. Acrostichum s'est trouvé réduit aux espèces dans lesquelles les capsules sont fixées sur toute la surface infér. des feuilles, surr les espaces mêmes qui séparent les nervures. On a encore séparé des Acrostics, les Polybotrya, Humb. et Bonpl., dans lesquels les divisions des feuilles fertiles sont beaucoup plus étroites que dans les feuilles stériles et tellement couvertes de capsules qu'elles forment presque de petits épis; les Ulfersia, Raddi, dans lesquels les capsules sont insérées sur les 2 faces des folioles fertiles et très étroites. Ce dernier g., qui renferme plusieurs esp. brésiliennes, paraît mériter d'être adopté; enfin Desvaux, sous le nom de Platycerium, et M. Gaudichaud, sous celui d'Alcicornium, ont distingué un groupe d'esp. très remarquables par leur forme et leurnervation; ce sontles $A$. alcicome, stemmaria et biforme. Les autres esp. très nombreuses constituaient jusque dans ces derniers temps le g. Acrostichum; mais la consilération de la distribution des nervures et l'introduction de ce caractére dans la définition des genres, a conduit M. Presl à créer dans sa Ptérillograplice, un grand nombre de g. aux dépens des Acrostics, et á reporter dans le g. Olfersia, défini autrement que ne l'avaient fait Raddi et Schott, la plupart des esp. d'Acrostichın des auteurs précédents ; ainsi, outre les g. Polybotrya, Olfersia et Platycerium, il a créé ou admis les g. Aconiopteris, Stenosemia, Campium, Pacilopteris, Eschw. (Bolbitis, Schott.) et Gymmopteris, Bernh. - $V$. ces mots.

Pour cet auteur, les vrais Acrostics se réduisent à un petit nombre d'esp. ( 10 environ), dont l'Acrostichum aureum peut être considéré comme le type. Leur fronde est simple ou plus souvent pinnée, coriace, à nervures secondaires réticulées, formant un réseau régulier et uniforme qui s'étend de la nervure moyenne jusqu'a u bord de la foliole; les feuilles fertiles ont tantòt toutes leurs folioles, tantôt une partie seulement, couvertes de capsules sur toute leur surface infér.; ces folioles fertiles sont quelquefois plus étroites que les stériles. Ces fougè res sont de belles esp. dont les feuilles, d'une assez grande dimension, naissent d'un Rhizôme rampant. Elles croissent entre les tropiques, ou peu au-delà, dans les 2 continents. - Le g. Pcecilopteris d'Eschweiler, ou Bolbitis de Schott, ne mérite peut-être pas d'en être séparé, quoiqu'il s'en distingue facilement par la texture herbacée de ses frondes.

(AD. B.)

* ACROSTICHACÉES. Acrostichacea

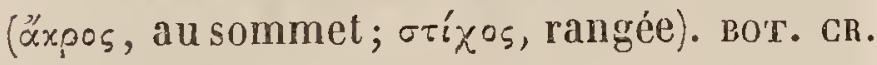
- Tribu de la famille des Fougères, section des Polypodiacées, établie par M. Gaudichaud, dans le Toyage de l'Uranie, et adoptée avec quelques changements dans ses limites par Presl, dans sa Pteridographia. Elle correspond à peu près au grand g. Linnéen Acrostichum; elle est caractérisée par l'insertion des capsules sur toute la face infér. des folioles ou des frondes fertiles, et par l'absence de téguments; elle comprend, d'après cet anteur, les g. Polybotrya, Olfersia, Aconiopteris, Stenosemia, Campium, Platycerium, Acrostichurn, Pacilopteris (Bolbitis, Schott.) Gymnopteris (Hymenolepis et Leptochilus, Kaulf.).

( $\triangle$ D. B.)

* ACROSTOMES. Acrostoma (äxpos, qui

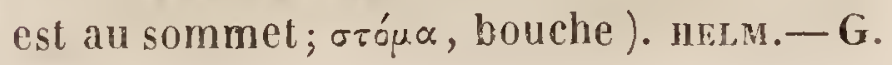


établi par M. Lesauvage (Ann. des sc. natır. xvılı, 433. pl. xı), qui le caractérise ainsi: Bouclie simple, terminale, plus ou moins irrégulièrement bilabiée; corps cylindrö̈de, légèrement cannelé, terminé par une et quelquefois deux vessies caudales. Voisin à beaucoup d'égards des Cysticerques, et n'offrant comme eux aucune apparence de viscères dans la vessie qui termine le corps, ni dans le corps lui-même, il en diffère en ce que ces deux parties sont beaucoup moins distinctes, en ce que son extrémité antér. est sans renflement, sans ventouses et sans crochets, en ce qu'au lieu d'être renfermé dans un kyste, il flotte dans l'intér. d'une cavité, à la paroi membraneuse de laquelle il est seulement fixé par la bouche, qui y exerce une succion assez forte pour y déterminer la formation d'un mamelon à vaisseaux capillaires très développés, et pénétrant souvent jusqu'à plus de la moitié de la longueur du corps, à l'intérieur duquel il se moule. Les lévres, arrondies dans leur pourtour, peuvent fermer la bouche, en s'appliquant l'une contre l'autre. On n'en a encore signalé qu'une seule espèce, l' $A$. amnii, qui se rencontre dans l'amnios des vaches; et c'est une raison suffisante pour que la caractéristique du g. ne puisse être admise que comme provisoire. $V$. CYsT1CERQUES Et HYDATIDES.

(L. D.Y.R.)

ACROTHAMNIUM, Nees (๕̋xpos, au sommet; souviov, arbrissean). вот. CR. - Ce g. , que je n'ai jamais eu l'occasion d'étudier, a les filaments couchés, rameux, opaques et faiblement entrelacés les uns dans les autres. L'A. violaceum, seule esp. qu'on en connaisse, a été trouvée en Allemagne, parmi les mousses, au pied des arbres. M. Fries considère ce g. comme une des nombreuses modifica tions qu'éprouve le Mycelium, avant de donner naissance à un champignon parfait. $V$. ce mot.

(LÉv.)

ACROTREMA, Jack ( œ̋pos, au sommet; $\tau \rho \hat{n n} \mu \alpha$, cavité ). вот. Рн.-G. rapporté à tort ou à raison à la famille des Dilléniacées. MM. Wight et Arnott (Prodr. Flor. Penins. Ind. Ir. p. 6.) lui assignent les caract. suivants: Sépales 5. Pétales 5. Étamines 5; filets filiformes, courts; anthères adnées, déhiscentes par 2 pores apicilaires. Ovaires 3 , bi-ovulés, distincts. Péricarpe de 3 follicules uni-loculaires. - Herbes acau- les; hampes nues, radicales. Fleurs en grappe. Ce g., dont on connaît 2 espèces, appartient à l'Inde.

ACROTRICHE ( «ँxpos, au sommet; $\theta$ p' $\xi$, трıхós, poil). вот. Рп.-G. de la famille des Épacridacées, tribu des Styphẻliées, fondé par R. Brown qui en circonscrit ainsi les caract: Cal. 5-fide, 2-bractéé. Cor. infundibuliforme, à segments terminés par des poils fasciculés, réfléchis. Disque périgyne, sublobé. Drupe charnue, bacciforme, à 5 loges celluleuses. - Ce g., créé aux dépens du g. Styphelia, Labill., renferme une dizaine d'espèces; ce sont de petits arbustes, originaires de la Nouv.-Hollande, trés rameux, à fleurs en épis courts, axillaires et latéraux, à fruits petits, globuleux, un peu déprimés.

(C. L.)

ACROZUS, Spreng. (äxpos, au sommet; "Һ̌s, rameau ). вот. Рн. - Syn. du g. Acronodia, Blume.

(Sp.)

* ACRYPHYLLUM. вот. PI. - Suivant Lindley ( Nat. Syst. of bot. ed 2), ce serait un g. créé par Loureiro, et syn. du Rhynchosia; mais Loureiro n'ayant point signalé de g. de ce nom, il est à présumer qu'au lieu d'Acryphyllum Lour., il faut lire $A r^{2} c y-$ phyllum, Elliot.

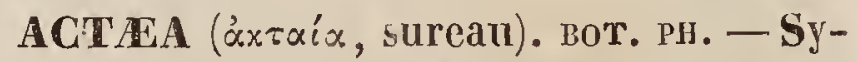
non. latin d'ActéE. - C'est aussi un g. de la famille des Dilléniacées, formé par Loureiro (Lindl. $N$. Syst. Ed. 2. App.) et qui n'a point été adopté, parce qu'il en existai un autre du même nom dans la famille des Helléboracées. C'est en outre un des nombreux synon. du genre Tetracera de Linné.

* ACTÉBHE. Actebia ( áxт́, rivage ; $\beta \iota \tilde{\omega}$, je vis). ıns - G. de l'ordre des Lépirloptères, famille des Nocturnes, établi par Stephens dans sa tribu des Noctuides, et qui a pour type la Noctua procox de Linné. C'est un démembrement du genre Trachea d'Ochsenheimer. $V$. ce mot.

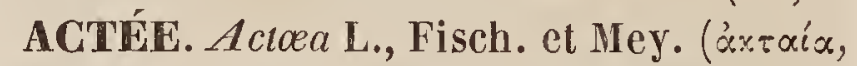
sureau). вот. Pп.-G. de la fam. des Helléboracées, tribu des Helléborées, $\mathrm{Sp}$., sous-tribu des Actéariées, Sp. Ce g., avec lequel on en a confondu plusieurs autres trés distincts ( $V$. Trautvelleria [Renonculacées], Actinospora, Botroplis et (imicifuga), offre les caract. suivants : Sépales 4 , pétaloïdes, caducs dès l'épanouissement. Pétales (accidentelle- 
ment nuls) 1 à 6 , petits, longuement onguiculés, planes, caducs en mêne temps que les étamines (plus tard que les sépales). Étam. en nombre indéfini (20 à 40), toutes fertiles; filets filiformes-spatulés; anthères suborbiculaires, obtuses, latéralement déhiscentes. Ovaire solitaire, oblique, ovoüde, 6-12 ovulé; ovules liorizontaux, opposés, bisériés. Stigm. gros, sessile, adné, transversalement oblong ou elliptique, oblique, subterminal, 1-sulqué. Péricarpe ovoïde ou ellipsoïde, non stipité, charnu, indéhiscent, 6-12-sperme, couronné par le stigmate. Graines anatropes, horizontales, opposées, bisériées, non squamelleuses, finement chagrinées, 3-gones, plus ou moins comprimées bi-latéralement, convexes au dos. Embryon minime, obcordiforme.

Les Actécs sont des herbes vivaces, à rhizôme souterrain, rampant, et à tige simple, oligophylle. Les feuilles sont décomposées ou surdécomposées, à pétiole en général d'abord trifurqué. Les fleurs, blanchâtres et de grandeur médiocre, sont disposées en grappe terminale. Ce g., propre aux régions, soit froides, soit tempérées, de l'hémisphère septentrional, ne renferme que 3 ou 4 espèces qu'il faudra peut-être réunir en une seule. Toutes les parties de ces végétaux sont vénéneuses, et aujourd'hui totalement négligées en thérapeutique.

* ACTEGETON, Blum. вот. PH. - G. rapporté par son auteur aux Rhamnées, et par Don aux Célastrinées. Ses caract. sont : Cal. infẻre, urcéolé, 4-denté. Cor. à 4 pétales. Étam. 4, submonadelphes par la base, alternes avec les pétales; anthères incombantes. Ovaire 1-loculaire, 4-ovulé. Stigm. 2, sessiles. Baie subglobuleuse, 1-3-sperme. Graines apérispermées; hile saillant, basilaire ; radicule infẻre. - Arbrisseau sarmenteux, armé d'aiguillons axillaires, géminés, horizontaux. Feuilles opposées, très entières, grappes axillaires et terminales; fleurs petiles, dioüques. On n'en connaît qu'une seule esp.'qui habite Java. (Blume, Bijd.)

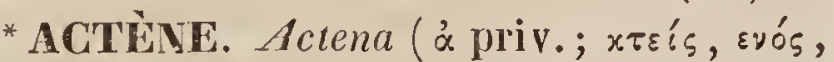
objet dentelé, peigne). ıss. - G. de l'ordre des Coléoptères pentamères, famille des Carabiques, tribu des Troncatipennes, établi par M. Dejean ( Catal., 3ime édil.), qui n'en a pas publié les caractères. Il est fondé sur une espéce unique de Java nommée par M. Lucien Buquel, A. atrata. Ce g. vient immédiatement après le g. Orthogonius.(D.)

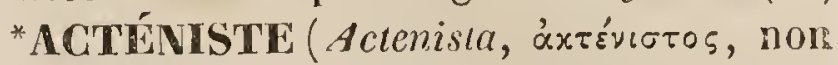
peigné). ıns. - G. de l'ordre des Coléoptères pentamères, famille des Malacodermes, établi par M. Dejean (Catal., $3^{\text {me }}$ édil); mais dont il n'a pas donné les caractères. Il y rapporte 7 esp., toutes nommées par lui, dont 2 de Cayenne et 5 du Brésil. Nous n'en citerons qu'une, l' $A$. melanoptera Dej., de Cayenne.

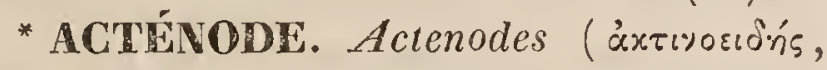
étoilé).ıns. - G. de l'ordre des Coléontères pentamères, famille des Buprestides, établi par M. Dejean (3me édiı. de son Cutal.), qui n’en a pas donné les caractères. II y rapporte 11 esp., toutes de l'Amérique, dont nous ne citerons qu'une seule, l'A. bellula Dej. (D.)

ACTÉN. Actoon (Mythol.). MoLt. L'animal que M. Ocken a pris pour type du g. auquel il donne ce nom a d'abord été décrit d'ure manićre incomplète par Montagu (Trans. Soc.Linn. de Londres, t. 8); il parait voisin des Aplysies. Malheureusement l'auteur anglais ne parle pas des branchies; il ne dit rien des organes de la génération, ni du rudiment testacé destiné à protéger l'appareil branchial. Sans avoir examiné de nouveau le Mollusque de Moritagu (Aplysia viridis), M. Ocken s'est cru autorisé à former pour lui un g. particulier qu'il place, on ne sail pourquoi, parmi les Gastéropodes pulmonés. Aucun Zoologiste n'a adopté l'opinion d'Ocken. Il paraît que M. Risso de Nice a découvert, dans la Méditerranée, un petit Mollusque qui, si l'on en juge par les figures, est très voisin de celui de Montagu; mais les caractères que lui assigne M. Risso sont si peu en harmonie avec ce qu'on connaît des Gastéropodes marins, qu'il est de toute nécessité de revoir et d'étudier avec soin ce Mollusque, dont il fait un g. Elysie. Comme on le voit, rien encore n'est certain sur le g. Actéon; aussi, tout en le rapprochant des Aplysies, M. Rang, dans sa bonne Monograplice des Aplysiens, a soin de ne l'admettre qu'avec doute.

(DesH.)

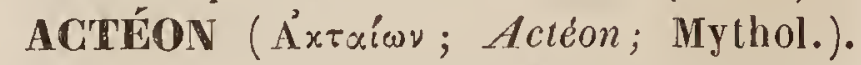
MoLL. - G. proposé par Montfort dans sa Conchyliologie systématique, pour des coquilles auxquelles Lamarck a donné le nom de Tornatelle. Ce dernier genre a été gé- 
néralement adopté. Voy. ce mot. (Drsn.)

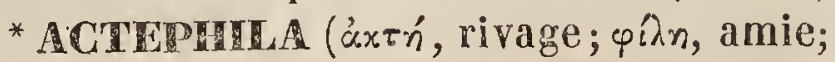
plante qui aime les rivages). вот. PI. - G. de la famille des Euphorbiacées, établi par M. Blume et caractérisé ainsi : Fleurs monoïques. Cal. divisé jusqu'en bas en 6 parties disposées sur 2 rangs. Pétales 6, plus courts, insérés autour d'un disque sinué qui porte dans les mâles, sur le pourtour, 6 étamines à filets subulés, à anthères, dont les loges arrondies s'ouvrent en dedans, et au centre trois rudiments pistillaires; dans les femelles : ovaire à 3 loges renfermant chacune 2 ovules, surmonté de 3 styles courts, divariqués, semi-bifides, et qui devient une capsule à 3 coques. La seule esp. connue est un arbrisseau de 15 pieds, trouvé sur le rivage d'une des îles dépendantes de Java, et nommé dans le pays Sikattang. Il a des fevilles alternes, bistipulées, elliptiquesoblongues, très entières, coriaces, glabres, veinées; des fleurs en pelotons axillaires, accompagnées de plusieurs bractées; les mâles à peu près sessiles; les femelles longuement pédonculées.

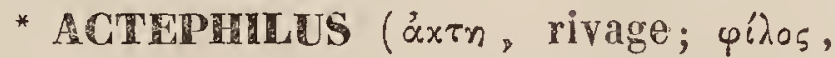
ami). Ins. - G. de Coléoptères pentamères, famille des Carabiques, tribu des Harpaliens, établi par Stephens aux dépens du g. Argutor de Megerle, et auquel il assigne les caract. suivants : Cors. transverse, à angles postér. arrondis. Jambes antérieures fortes. Antennes courles. Palpes avec le dernier article très long. - Ce g. a pour type le $\mathrm{Ca}$ rabus vernalis Fabr., qui appartient au g. Precilus, Bonelli et Feronia, Lat.

* ACTLA. ins. - G. de la section des Thryptoceratce, Rob. Desv., de l'ordre des Diptères, section correspondante au g. Thryptocera de Macquart. $V$. ces mots.

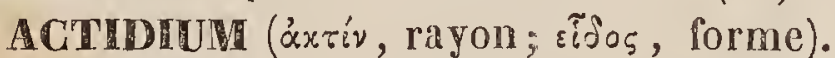
Bот. CR. - M. Fries décrit sous ce nom un g. de Champignons de l'ordre des Phacidiacés et de la tribu des Cliostomes, dont le périthécium est sessile, de forme arrondie, et qui s'ouvre en plusieurs fentes étendues du centre à la circonférence. Les organes de la fructification se composent d'utricules ou de théques dressées, très petites et cylindriques, qui renferment des spores globuleuses. - On n'en connaît encore que 2 espéces qui se trouvent sur les bois morts. Je n’ai pas eu loccasion d'analyser ce genre.

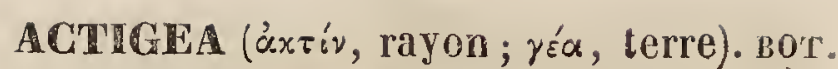
Cr. - Rafinesque Schmaltz a fait connaître sous ce nom un g. de Champignons, de la famille des Lycoperdacẻs, dont le péridium est sessile, sans volva, déprimé et étoilé. La fructification est pulvérulente et située dans le centre de la partie supérieure, qui se déchire pour la répandre. Cette description n'est pas suffisante pour établir un rapprochement avec aucun des g. de la même famille. L'auteur en décrit 2 espèces : l' $A$. multifida qui croît à New-Gersey, et l' $A$. sicula qu'il a rencontré à Palerme. (LÉv.)

* ACTLMERTS, Riafin. (contraction d'Actinomeris). BOT. PH. - $V$. ACTINUMERIS.

ACTINA ( $\alpha x^{\prime} \hat{\imath}^{\prime}$, rayon). 1Ns.-G. de Diptères établi par Meigen dans son $1^{\text {er }}$ ouvrage, et qu'ií a réuni depuis au g. Beris, formé antérieurement par Latreille. $V$. ce mot. (D.)

* ACTINANTHE. Actinanthas, Ehrenb.

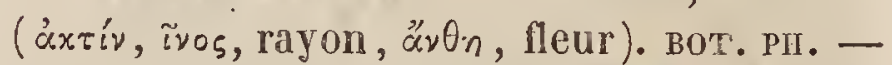
G. de la famille des Ombellières; M. Ehrenberg (Linncea, 1829, p. 398), lui assigne les caract. suivants : Fleurs monoïques, les femelles agrégées en capilules; les mâles en ombelles capitellées, à fleurs marginales abortives et spinescentes. Récept. sans paillettes. Cal. à dents persistantes. Pétales oblongs, condupliqués et cuspidés au sommet. Péricarpe comprimé des côtés; méricarpes à 5 côtes; les suturales plus grosses; vallécules à un seul canal résinifère; commissure plane, à 2 canaux résinifères. Carpophore adné. - Plante roide. Feuilles inférieures ternati-bipennées. Collerette générale nulle. Collerettes partielles polyphylles. Fleurs blanches. Ce g., très voisin des Echinophora, n'est fondé que sur une espèce qui croît en Syrie.

(Sp.)

ACTINEA ( $\alpha x \tau^{\prime}$ ', rayon).вот. Рн. - A.L. de Jussieu a proposé ce g. pour quelques plantes voisines de l'Hymenopappus. Elles se dislinguent par leur involucre court, polyphylle et unisérié; les fleurs du rayon sont ligulées, femelles et tri-dentées au sommet; celles du centre hermaphrodites à 5 -dents; les akènes, velus sur toutes leurs surfaces, sont couronnés par plusieurs paillettes subulées au sommet, élargies, et comme ailées à la base. Le réceptacle est nu. L'Actinea. décrite par A. L. de Jussiea, cst une herbe haute d'un demi-pied, à feuilles allemes, 
non décurrentes; elle a èté recueillie par Commerson aux environs de Buenos-Ayres. Ce g. fait anjourd'lıui parlie des Cephalophora dont il constitue une section.

* ACTINECTE. Actinecta (áx тív, rayon ;

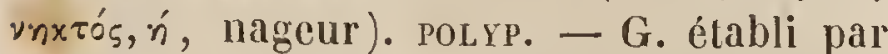
M. Lesueur pour les animaux que Cuvier avait placés, sous le nom de Minyas, parmi les Echinodermes. Les Actinectes, très voisins des Actinies, et qui sont, en quelque sorte des Actinies libres et flottantes comme l'indique leur nom, ont le corps court, plus ou moins globuleux, marqué de côtes saillantes, terminé en arrière par une vessie qui les soutient dans les eaux, et présentant en avant un disque couvert d'un grand nombre de tentacules courts, au milieu desquels est l'ouverture buccale. - M. Lesueur en a décrit 3 espèces ( $A$. olivacea, ultramarina, fluva), des côtes de l'Ámérique septentrionale. MM. Quoy et Gaimard en ont observé une $4^{\mathrm{e}}$ dans l'Océan Pacifique; mais en outre, ils en ont décrit une autre qui, en raison des suçoirs dont sa surface est pourvue, devra peut-être, suivant M. de Blainville, conserver le nom de Mimyas. $V$. ce mot. (Dus.)

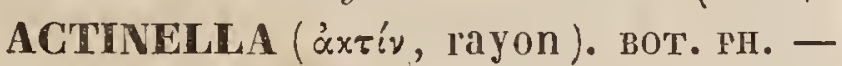
Synonyme d'Actinea. $V$. ce mot. (J. D.)

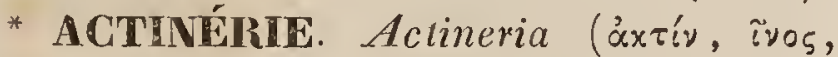
rayon). POLYP. - G. de la famille des Actiniens ou Zoanthaires mous, établi par M. de Blainville, pour recevoir l'Actinia villosa de MM. Quoy et Gaimard et caractérisé de la manière suivante: Corps cylindique, court, élargi aux deux extrémités et pourvu, dans tout son disque supérieur, de tentacules très petits, villeux, lanugineux, ramifiés et réunis en petites masses fusiformes et radiaires.

(II. E.)

ACTINIAIRES ou ACTININES ( $\alpha x<i v$, ivos, rayon). POLYP. - Famille de Polypes comprenant, avec les Actinies proprement dites, plusieurs g. qui en ont été démembrés et qui tous étaient appelés autrefois Anémones de mer. Les Actiniaires sont des animaux mous ou un peu coriaces, isolés, libres ou rampants, ou temporairement fixés aux corps marins, ovipares ou vivipares, rarement gemmipares, pourvus à l'intér. de lames rayonnantes, fibreuses, auxquelles sont fixés les ovaires, et présentant, autour de leur unique ouverture stomacale ou buccale, des tentacules nombreux. M. de Blainville place dans cette famille, qu'il nomme Zoanthaircs mous ou Actinics, les g.: $1^{\circ}$ Lucernaire; $2^{\circ}$ Moschate; $3^{\circ}$ Actinecte; $4^{\circ}$ Discosome; $5^{\circ}$ Actinodendron; $6^{\circ}$ Métridie ; ${ }^{\circ}$ Thalassianthe; $8^{\circ}$ Actinérie ; $9^{\circ}$ Actinolobe $; 10^{\circ} A c-$ tinie; $11^{\circ}$ Actinocère. M. Ehrenberg, qui n'admet pas tous ces genres, mais qui subdivise ses Actinies propres en plusieurs s.-g. , complète sa famille des Actinines avec les g. : $-1^{\circ} \mathrm{Me}$ tridium (auquel il réunit l' Actinérie Blainv.); $2 \circ$ Megalactis; $3^{\circ}$ Thalassianthus; $4^{\circ}$ Cribrina; lesquels, comme les Actinies propres, n'ont point de tubercules suceurs sur le disque, et dont le dernier seul (Cribrina) a des pores latéraux (pour la respiration, Ehr.). Ce dernier, ainsi que les Actinies, ont des tubercules simples, les autres les ont ramifiés ou pinnés. Les $4 \mathrm{~g}$. suivants : Actinodendron, Epicladia, Heterodactyla, Lucernaria, sont munis de tubes suceurs particuliers sur le disque.

(Duj.)

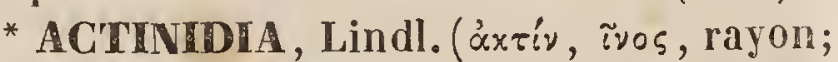
हiंos, forme ). вот. PH. - G. de la famille des Dilléniacées; M. Lindley ( Nat. S'yst. édit.2, p. 439) en donne les caract. suivants : Sépales 5. Pétales 5. Étam. en nombre indéfini ; anthères ciliées, extrorses. Ovaire à 22 loges pluri-ovulées; ovules bisériés; placentaire grand, central, fibreux cellulaire. Stigm. en même nombre que les loges, libres, claviformes, rayonnants. - Ce g., qui paraît a peine différer des Dillenia, n'est fondé que sur une seule esp., qui habite l'Inde.

(Sp.)

ACTINIE. Actinia (áx xív, rayon). polyp. — G. de la famille des Actiniaires, rangé par Lamarck dans les Radiaires Echinodermes, section des Fistulides, et par Cuvier, d'abord parmi les Acalèphes, mais plus tard (2 $2^{\text {me }}$ édit. du règne animal) parmi les Polypes charnus; ce qui est en effet la véritable place qu'il doit occuper. M. Ehrenberg le place en tête de sa division des Polypes Anthozoaires. M. de Blainville, de son côté, lui assigne le même rang dans sa classe des Zoanthaires. On ne peut, en effet, méconnaitre aujourd'hui les rapports des Actinies avec les Polypes des madrépores et des coraux. Les Actinies, nommés aussi Orties de mer ou Anémones de mer, à cause de leur contact brûlant et de leur aspect si semblable à celui d'une belle Anémone, se composent d'une masse 
charnue, contractile, plus ou moins coriace en dehors, et passant successivement de la forme d'un cylindre court à celle d'un conoïde aplati ou d'une demi-sphère, ou même devenant tout-à-fait globuleuse en se contractant. Cette masse se fixe temporairement par sa base sur les corps marins, et se termine supérieurement par des ten tacules nombreux, plus ou moins allongés, entourant une ouverture centrale qui est la bouche, ou mieux l'orifice unique de l'estomac, et servant à arrêter par leur simple contact les petits animaux marins qui viennent à les toucher en traversant les eaux. Le tégument, en se repliant a l'intérieur, forme la paroi de l'estomac qui ne se trouve fermé au fond que par la contraction de cette membrane, et peut, en temps convenable, livrer passage aux oufs ou aux jeunes polypes qui se sont développés entre le tégument extérieur et l'estomac. Dans cet intervalle se trouvent des lames ou cloisons imparfaites, partant du tégument externe pour converger vers le centre, et formées d'un tissu fibreux assez résistant. A ces cloisons sont fixés les organes reproducteurs, consistant en une sorte de fraise ou en un cordon parenchymateux, plats, repliés un grand nombre de fois, munis de cils vibratiles et dans lesquels se développent les ceufs. M. Wagner y a vu des tubes pelotonnés qu'il regarde comme les organes génitaux màles. Les Actinies se trouvent en grand nombre fixées aux rochers situés le long des côtes, à une faible profondeur. Les plus communes sont: l'Actinie rousse, $\mathcal{A}$. rufa Lamk, ou $A$. equina L., qui est large de 3 pouces environ; etl'Actinie coriace, $A$. senilis, qui est de même grandeur, mais dont la peau, au lieu d'être lisse et molle, est coriace et tuberculeuse. M. Ehrenberg l'a séparée des Actinies, ainsi que plusieurs espèces voisines, pour en faire le g. Cribrina ( $V$. ce mot). Il en a en outre divisé les vraies Actinies en 4 genres, suivant la longueur relative des tentacules, savoir : 1o les Isacmoea, qui ont les tentacules trés petits et trés nombreux; $2^{\circ}$ les Entamoea, qui ont les tentacules intérieurs très forts, et les marginaux peu à peu ou progressivement plus petits; $3^{0}$ les Mesacmoea, qui ont les tentacules moyens très forts, les internes et les externes plus petits; 40 enfin les Ectacmcea, qui ont les tentacules externes très forts, les moyens et les internes plus petits. A ce dernier groupe appartient une espèce que l'on mange en Provence et à Nice, et que M. Risso a nommée, pour cette raison, $A$. edulis; elle est très molle, verte avec des teintes brunes sur le corps, et l'extrémité des tentacules, qui sont très longs, est souvent teinte de rose.

(DuJ.)

* ACTINOCAMAX (áxนí, ivos, rayon ; $x x ́ \mu \alpha \xi$, bâton; allusion à la structure). MoLL. - G. proposé par Miller (Mém. de la Soc. Géolog. de Londres), pour les Bélemnites qui n'ont pas de cavité alvéolaire. Comme on passe par des nuances insensibles des espèces à cavité, profondes à celles qui n'en ont pas, la plupart des Zoologistes ont rejeté ce g. pour en faire une simple section des Bélem. nites. $V$. ce mot.

(DeSH.)

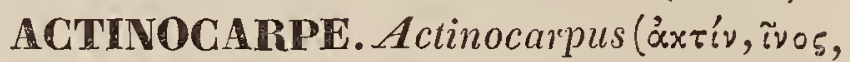
rayon; xaртós, fruit). вот. PII. - R. Brown (Prodr.Fl. Nov. Holl.1, p.442) appelle ainsi un g. de la famille des Alismacées qui a pour type l'Alisma Damasonium de Linné; mais ce g. avait déjá été étabii par Jussieu (Gen.Pl.46), sous le nom de Damasonium, qui nous paraît devoir être préféré. Il est vrai que Schreber a établi sous ce même nom un g. de la famille des Hydrocharidées qui a pour type le Stratiotes alismoides de Linné; mais ce dernier g. a été appelé $O_{t-}$ telia par le professeur L. C. Richard, dans son travail sur la famille des Hydrocharidées. Le nom de Damasonium nous paraît donc devoir être restitué à celui qui a pour type l'Alisma Damasonium L. $V$. DamasoNIUM.

(A. R.)

* ACTINOCENIA ( $\alpha x \tau i \nu$, ivos, rayon ; хєи'́, vide ). вот. Рн. - C'est une section du g. Cenia, Commers.

(J. D.)

*ACTINOCERE. Actinocera (axtí, זัขos, rayon; xnpós, cierge; allusion à la forme). POLYP. - Nom donné par M. de Blainville à une div. de la famille des Actiniens, caractérisée par un corps fixe, cylindrique, allongé, élargi aux deux extrémités, très contractile et pourvu, à la circonférence du disque buccal, d'un seul rang de tentacules plus ou moins pétaliformes. Ocken avait précédemment établi un groupe semblable sous le nom de Cereus.

* ACTInOCHLOA (áxזí, ivos, rayon ;

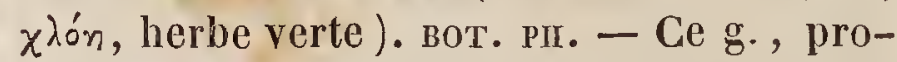
posé par Willdenow, dans la famille des 
Graminées, est le même que le Chondrosium de Desvaux. Voy. Cilondrosium.

(A. R.)

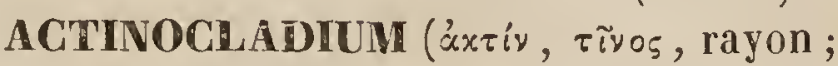
$x \lambda \alpha$ d̊ov, petite branche). вот. CR. - G. de Champignons appartenant aux Mucédinés, établi par M. Ehrenberg (Link.Lahrb.p.51) et caractérisé par des filaments épars, droits, roides et divisés en ombelles à leur extrémité. Les spores sont simples, se détachent promptement et se répandent çà et là. L'A. rhodospermum, qui lui a servi de type, est d'une couleur rose très agréable. M. Ehrenberg l'a trouvé à Berlin sur le tronc d'un charme Ce g., quoique parfaitement distinct, a besoin d'un nouvel examen, parce qu'on ne connaît pas le mode d'insertion des spores sur les rameaux. On n'en connaît encore que 3 esp. qui ont, quant á la forme, la plus grande analogie avec le $P_{e-}$ nicilium, dont les filaments sont cloisonnés, et les rayons formés de spores articulées.

(LÉv.)

ACTINOCRINITES ( $\alpha x \tau i x, \tau$ ¿ขos, rayon ; xpivor, lis). ECHin.-G. de Crinoïdes fossiles, établi par Miller pour des débris d'Encrinites des terrains de transition, dont les pièces principales montrent au centre de leur face externe des còtes saillantes en étoile. Les caractères indiqués d'après des morceaux plus ou moins complets sont les suivants : $\mathrm{Co}-$ lonne ou pédoncule cylindrique, traversé par un canal rond; bras auxiliaires épars; bassin à 3 articles; 6 pièces costales primaires, dont 5 sont hexagones et la $6^{\text {me }}$ pentagone; 11 piéces costales secondaires et intercostales; pièces scapulaires penta-hexagones; 10 bras bimanes. - L'ouvrage de Goldfuss sur les pétrifications du Musée de Bonn contient la description et la figure de quelques débris attribués à 9 espèces distinctes, dont 6 , nouvellement établies par l'auteur sur de simples fragments de la colonne, pourraient bien n'être que des variétés plus ou moins noueuses ou épineuses.

(Dus.)

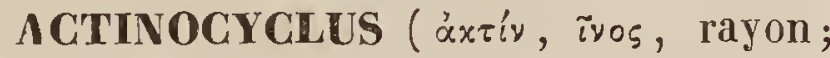
xúx>оร, cercle). вот. Foss.-G. de la fam. des Bacillariées, qui n'a été trouvé jusqu'à ce jour qu'à l'état fossile dans les tripolis d'Oran. Il est ainsi caractérisé par Ehrenberg, dans son grand ouvrage sur les Infusoires : A nimal de la famille des Bacillariées, libre, ayant une carapace simple, bivalve (siliceuse), de forme cylindrique (discoïde), divisée à l'intérieur par plusieurs cloisons rayonnantes, se multipliant par division spontanée, imparfaite, en forme de chaîne. - Ce g. ressemble aux articles détachés de plusieurs esp. de Gaillonella; mais il paraît toujours isolé et libre. Cependant, comme on ne le connaît qu'à l'état fossile, on peut douter si, dans l'état de vie, les disques nummuliformes qui le constituent n'ètaient pas empilés les uns sur les autres, comme dans les Gaillonelles, de manière à former un filament cylindrique se séparant en articles libres à une certaine époque de leur vie. Ehrenberg en décrit 2 esp.; l' $A$. senarius, d'environ $\frac{1}{60}$ à $\frac{1}{100}$ de ligne de diamètre, est divisée en six compartiments par les cloisons rayonnantes; l'autre, $A$. octonarius, est divisé en 8 compartiments par 8 cloisons rayonnantes, et atteint $\frac{1}{50}$ de ligne en diamètre.

(AD. B.)

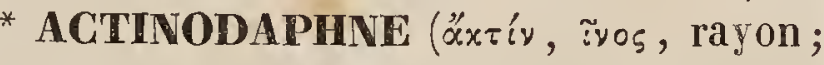

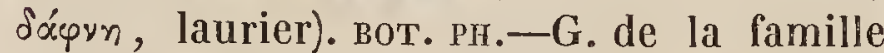
des Laurinées, tribu des Tétranthérées, fondé par Nees (in Wallich, $P l$. As. rar.), qui lui assigne les caract. suivants : Fleurs dioïques, naissant en nombre d'une gemme imbriquée. Cal. à 6 segments égaux, membraneux ou chartacés, persistants jusqu'au point de division, ou caducs jusqu'à la base. Dans les fleurs mâles : Étam. 9, bisériées; toutes fertiles ; 6 extérieures nues à la base; 3 intérieures pourvues á la base de glandules binées, sessiles ou stipitées ; anthères oblongues, introrses, quadrilocellées, déhiscentes par autant de valvules ascendantes, ovaire rudimentaire. Dans les flenrs femelles : Étam. stériles, spatulées, semi-sagittées ou pétalö̈des; ovaire uniloculaire, uniovulé; style un peu épais; stigm. discoïde, sinué; baie monosperme, enveloppée par le tube calicinal cyathiforme et muni d'appendices résultant des segments laciniés du limbe.-Ce g., auquel on a réuni le $g$. Jozoste du même auteur, comprend plusieurs espéces des g. Telranthera, Wall., et Litscea, Bl.; ce sont des arbres de l'Inde, à feuilles rarement alternes, plus souvent agrégées ou verlicillées par intervalles, penninervées, ou subtripli-multiplinervées, à fleurs paniculées, fasciculées ou en grappe. Lcs ombellules des faisceaux sont enveloppées avant 
l'anthèse par les squamules d'une gemme axillaire.

(C. L.)

* ACTINODE. Actinodium, Schauer ( $\alpha x-$

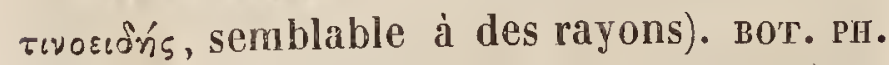
- G. de la famille des Myrtacées ; tribu des Chamélauciées, DC. L'auteur de ce g. en donne les caract. suivants (Lindley, $\mathbb{N a t}$. Syst. édit.2, p. 440) : Fleurs capitellées, accompagnées chacune d'une bractée basilaire; les bractées de la série la plus externe plus larges que les suivantes; les pédicelles qui naissent à leurs aisselles sont stériles, allongés, tri- ou pluri-bractéolés au sommet, et forment une sorte de rayon autour du capitule. Tube calicinal urcéolé, adhérent jusqu'au-delà du milieu, à 4 angles ailés; limbe à 4 lanières linéaires, très étroites, conniventes, persistantes. Pétales 4, ovales, connivents, membranacés, persistants. Étam. 8, toutes fertiles, rapprochées 2 à 2; filets subulés, plus courts que la corolle; anthères globuleuses, basifixes. Style saillant, capillaire, glabre. Stigmate ponctiforme. Fruit inconnu.-Arbuste nain, grêle, ayant le port du Diosma virgata. Feuilles imbriquées, lancéolées, mucronées, ponctuées. Ce g., que M. Schauer dit voisin du Genetyllis, appartient à la Nouv.-Hollande ; et n'est fondé que sur une seule espèce. (Sp.)

* ACTINODENDRE. Actinodendron ( $\alpha x-$

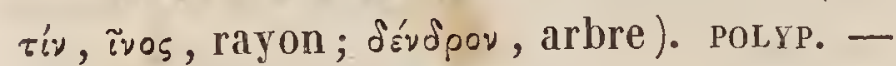
$V$. Syn. d'Actinodendon.

(M. E.)

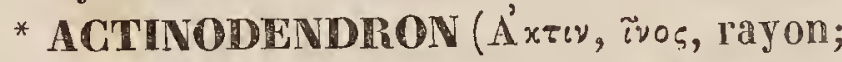
dévdpov, arbre).FolyP.-G. établi par MM. Quoy el Gaimard pour des Actinies dont les tentacules simples, très longs, sont munis de papilles vésiculeuses latérales qui les rendent branchus. Le disque est en outre muni de tubercules suceurs. On en connaît 2 esp., l'une ( $A$. alcyonoüdeum) des îles des Amis, l'autre ( $A$. arboreum) de la Nouv.-Guinée, qui sont remarquables par leur taille gigantesque, relativement aux autres Actinies, car elles ont souvent plus d'un pied de large.

(DUJ.)

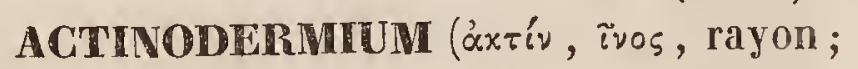

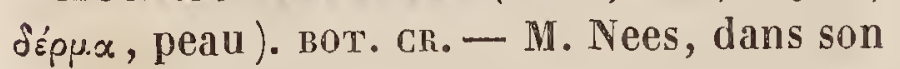
Systema der Pilze, a donné ce nom à une espèce de Geastrum, dont M. Link avait fait auparavant le g. Sterrebeckia, qui lui-même ne pouvait subsister, puisque Willdenow avait déjà décrit sous ce nom un g. des Phanérogames. $V$. Geastrum. (Lév.)
* ACTINODIUM, Schauer. вот. ри. - $V$. ACTINODE.

* ACTINODON ('́xтív rayon; ódov́s, dent). BotT. Cr. - G. de la famille des Mousses créé par Bridel (Musc.) et qui semble devoir être réuni au g. Actinodontium, Schwaegr. $V$.ce mot.

(C. L.)

* ACTINODONTHUM ( $\alpha x \tau i v$, rayon; o-

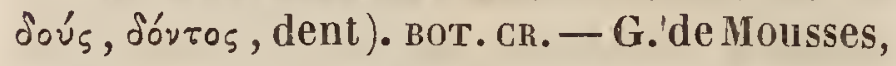
de la division des Pleurocarpes et voisin des Leskées, ainsi caractérisé par M. Schwagrichen (Supp. 2. Part. 2. p. 75. t. clxxiv. fig. $12,13,14,15,16)$ : Péristome double, composé, l'extérieur de 16 dents étalées, l'intérieur d'autant de cils aussi longs que les dents, dressés et partant d'une membrane très étroite qui leur sert de base. Coiffe mitriforme, laciniée en son bord. Capsule égale dépourvue d'anneau. Fleur hermaphrodite latérale. Anthères nombreuses. Pístils dont un seul fertile, moins nombreux, dépourvus de paraphyses. - Ces Mousses ont le port des Leskées; elles sont remarquables par leurs tiges courtes, couchées, rameuses, à rameaux légèrement comprimès. Les feuilles sont serrées, entièrement binervées. La capsule, longuement pédonculée, est étroite et dressée ; l'opercule, assez long, est aciculaire. - Elles vivent sur la terre dans l'Archipel indien. Une seule espèce, propre à l'île de Java, compose le g. Selon Bridel, ce g., voisin de l'Anacamplodon, en diffère par sa coilfe mitriforme, par les dents de son péristome interne, unies à la base, au moyen d'une membrane; enfin par ses fleurs hermaphrodites. (C. M.)

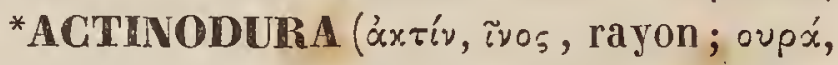
queue). o1s. - G. nouveau de Gould (Proceed. 1836), démembré du g. Turdus, et ayant pour caractères : Bec arqué, comprimé, à mandibule supérieure échancrée ; narines basales linéaires, recouvertes d'une large membrane; ailes courtes, concaves, à rémiges molles, la $1^{\text {re }}$ trés courte, les $4^{\mathrm{me}}$ et $5^{\text {me }}$ les plus longues; queue allongée, étagée, à rectrices molles; tarses longs; doigts grands, surtout le pouce et son ongle; plumage mollet et peu serré; les ailes et la queue sont barrées et les espèces-types sont huppées. L'auteur en décrit une seule espèce, du Népaul, sous le nom d' $A$. Egertoni. (LAFr.)

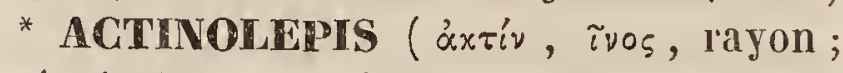

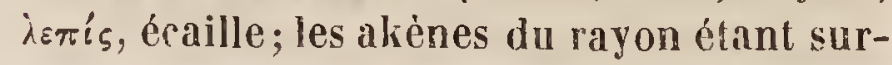


montés d'écailles aiguês). Bot. PII.-Ce g. a été élabli par M. De Candolle sur une petite plante originaire de la Californic, a tiges grèles, aranćcuses au sommet, il feuilles opposées, ovales, entières à la base, obtuses et 5-dentées au sommet. Les capitules, qui naissent à l'aisselle de ces feuilles, sont solitaires, ramassés, petits, et portent des fleurs jaunes. Ce g., encore imparfaitement connu, ne renferme qu'une espéce. M. De Candolle le caraclérise de la manière suivante : Capil. pluriflores; flẹrs du rayon 3-5-ligulées, femelles; celles du disque tubulcuses, à 5 dents, biscxućes; les fleurs mâles ont leur style avorté. Involucre ovale-oblong, entouré à la base de quelques bractées foliacécs, couvertes sur le dos d'un duvet tomenteux et mou. Réceptacle étroit, dépourvu d'écailles. Ligules larges, courtes, 2-3-dentées. Style bifide et cxsert. Les fleurs lubuleuses, cylindriques inféricurement, se dilatent au sommet, renferment des anthères blanches et un style presque nul ou simple, terminé par une petile têle. Fruits oblongs, légèrement anguleux ; ceux du rayon pubescents, toujours surmontés d'une aigrette forméc par environ 5 écailles scarieuses, aiguës, tandis que les fleurs du disque en sont dépourvues.

(J. D.)

* ACTINOLOBE. Actinoloba (áxzín, ivos,

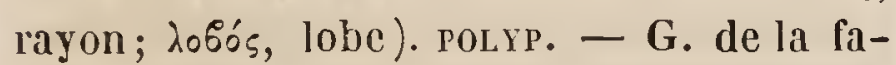
mille des Actiniens ou Zoanthaires, établi par M. de Blainville et caractérisé de la manière suivante : Corps déprimé, très ćlargi à sa base et plus ou moins lobé ả son disque buccal, couvert de tentacules très courts et presque tubcrculeux. Ce g. a pour type l'A. $\operatorname{aillet~(~} A$. Dianthus Ellis). (M. E.)

* ACTINOMERIS ('́xтì, iั้os, rayon;

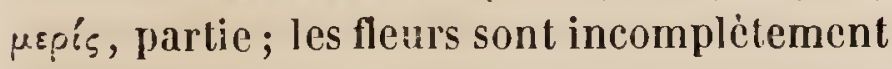
radiées). вот. PI. - C'est le nom donné par Nuttal à plusieurs plantes de la famille des Composées, originaires de l'Amér. septentrionale et ayant appartenu au g. Coreopsis, L. Elles ont pour caractéres : Capitules radićs, multiflores; ligules neutres, en petit nombre (4-8), allongécs et 1 -sériées. Fleurs du disque hermaphrodites, tubulcuses, à 5 dents. Involucre formé par 1-3 séries d'écailles foliacécs, aiguës, de grandeur inégale. Réceptacle petit, convexe, couvert d'écailles qui embrassent le bord des fruits. Rameaux des styles appendiculés. Alènes comprimés, T. 1. bordés par une aile étroite et surnontés par deux arêtes triangulaires, persistantes et presque lisses. - Le g. Actinomeris se compose aujourd'hui d'une dizaine d'espèces, particulières à l'A mérique septenírionale. Ce sont des herbes vivaces ou bisannuelles, a tiges dressées et à fenilles scabres et décurrentes, à capitules en corymbes, et ả fleurs jauncs.Ce g. diffère des Coreopsis par la forme des akènes, et des $V$ erbesina par ses rayons neutres. On cultive au jardin du Muséum de Paris, les $A$. alternifolia, tetraptera, clc. (J.D.)

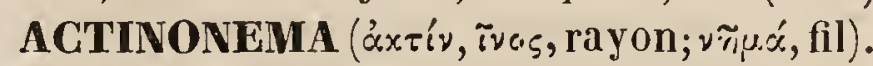
вот. Cr. - G. de Champignons bissoüdes, créé par Persoon (Mycolog. Europ.). Il se compose de fibres solides, rameuses, parsemées de tubercules, et s'étendant sous forme de rayons du centre à la circonférence. Ces fibres adhèrent très intimement à la surface sur laquelle elles se sont développées. On ne connaît pas encore les organes de la fructification; mais il est probable qu'ils existent dans les nombreux tubercules qu'on y observe, quoique Persoon n'y ait trouvé ni thèques, ni spores. I' $A$. Cratæegi se trouve très abondamment à la fin de l'automne sur les feuilles de l'Alisier, où il forme des taches noires assez étendues.L' $A$. caulicolum se rencontre sur les tiges des grandes Ombellifẻres; mais il est assez rarc. On pourrait, jusqu'à ce que la fructification des uns et des autres fût parfaitement connue, le réunir sans inconvénient aux genres Dothidea et $A$ steroma avec lesquels il a la plus parfaite analogie. (LÉv.) *ACTINOPE. Aclinopus (áxrí, ivos, rayon; rovs, pied). ARACIN. - G. de la famille des Aranéides, tribu des Théraphoses, établi par Perty avec ces caracières : Yeux au nombre de 8 , formant un groupe dilaté transversalement sur le devant du céphalothorax, entre les mandibules : 3 de chaque côté formant un triangle dont l'angle le plus aigu est dirigé en avant; les 2 autres situćs entre les latéraux antérieurs sur une ligne transverse. Lèvre allongće, étroite, s'avançant entre les mâchoires : ces dernières divergentes, allongées, fusiformes. Palpes très allongés, pédiformes, insérés laléralement à l'extrémité des mâchoires. Pattes grosses, courtes et renflécs. Les espéces, qui compcsent ce g., sont des Arachnides chasseuses qui courent après leur proie, et se creusent des souterrains qu'elles garnissent d'un suc 
de soie, dont la moitié sort du sol et dans lequel elles se renferment. Ce $\mathrm{g}$, comprend 6 espèces; celle qui en est le tỳje, est l' $A$. tarsalis Pert. (Delect. Anim. 2, 198, pl.39, fig. 6.) trouvé au Brésil.

(H. L.)

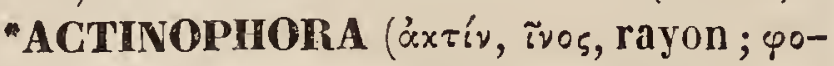
pós, porteur). EOT. PI.-G. désigné par Lindley (Syst. of bot., édit. II) comme fondé par Wallich, et appartenant à la famille des Sterculiacées, tribu des Byttnériées, DC. Toutefois il paraît que les caractères n'en ont pas encore été publiés.

(C. L.)

ACTINOPHORE. Actinophorus (áxtív, ¿vos, rayon; yopós, porteur). Ins. - G. de Coléoptères pentamères, famille des Lamellicornes, tribu des Scarabéides Coprophages, établi par Sturm et correspondant au g. Aleucus des anteurs. $V$. ce mot. (D.)

* ACTINOPHRYS (áxтiv, ivos, rayon; óppús, sourcil). ınfus. - G. établi par Ehrenberg pour le Trichoda sol de Müller, dont M. Bory de St-Vincent àvait déjà précédemment fait le g. Peritricha. Ce type, en effet, méritait bien d'être distingué; car les cils très fins el très longs, dont cet infusoire est entọuré, ne sont nullement vibratiles; ils sont cependant un peu mobiles et contractiles; mais les changements qu'ils éprouvent ne s'opèrent qu'avec une lenteur extrême. Ces cils, d'ailleurs, sont exactement de même nature que les prolongements filiformes des Rhizopodes, des Arcelles, des Trinema, ctc. A l'intérieur, ces infusoires ne présentent que des vacuoles sphériques irrégulièrement placées et des corpuscules étrangers, engagés dans la masse charnue. Ehrenberg cependant leur a assigné la même organisation qu'aux Enchélydes, dans la famille desquels il les plaçait. Il leur donne donc un intestin s'ouvrant au-dehors par une bouche et un anus opposés, et soutenant à l'intérieur une grappe d'estomacs. Il décrit dans son ouvrage (DieInfusions Thierschcn, 1838) 3 espèces d'Actinophrys : $\boldsymbol{A}$. sol, viridis, difformis; toutes 3 des eaux douces stagnantes. Nous pensons que leur vraie place dans la classification est auprès des Arcelles et des Amibes.

(Duj.)

ACTINOPHYLUUM, Ruiz et Pav. (áx-

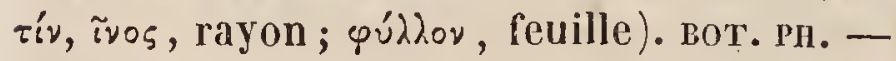
Syn., suivant M. De Candolle, du g. S ciadophyllum.

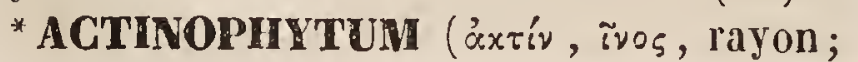

qvтév, plarte). BOT. PII. - Nom sous lequel Necker désignait les Composées ou plantes dont les fleurs sont disposées en rayons.

(J. D.)

- ACtinoptera (áxtí, ivos, rayon; $\pi \tau \varepsilon$ póv, aile). вот. PH. - Nom donné par M. De Candolle à une section du g. Wedelia; elle a pour caractères d'avoir les akènes du rayon entourés d'une aile élroite non membraneuse, tandis que ceux qui appartiennent aux fleurs du rayon en sont dépourvus; tous sont couronnés par une aigrette en forme de coupe membraneuse, oblique, dentée. Le $W$.helianthoüdes KLh. appartient.seul a cetle section.

(J. D.)

"ACTINORHYRE. Actinorhyza (áxrí, เัvos, rayon; $\dot{p}^{\prime} \zeta \alpha$, racine). POLYP. - Nom proposé par M. de Blainville pour remplacer celui de Zoanthe. $V$. ce mot.

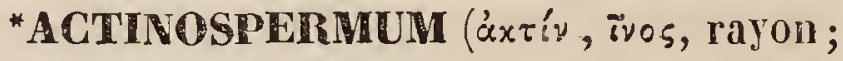
бле́qua, graine). вот. ВII. - C'est une section du g. Balduina, Nult., caractérisée par son aigrelte courte, formée de 12-14 paillettes obtuses, disposées en une sorte de coupe étalée ; l'involucre est bisérié. (J. D.)

*ACTINOSPORA, Fisch. el C. A. Mey. ( $\dot{\alpha} x$ -

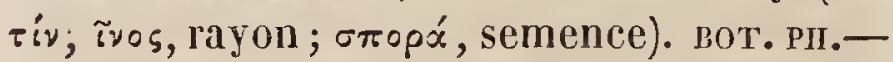
Syn. du g. Cimicaire ou Cimicifuga, L. (Sp.)

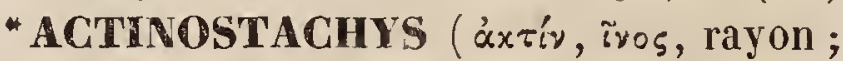

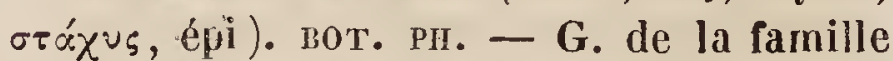
des Schizaacées, Mart. (Fougères), fondé par Wallich (Cat. 1.) et réuni depuis au g. S'chizoea de Smith. $V$.ce mol. (C. L.)

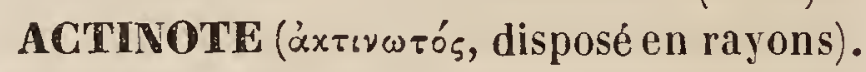

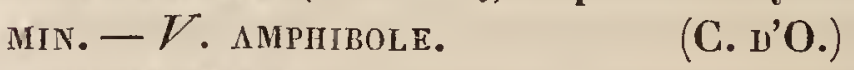

ACTINOTE. Actinotus, Labill.; Eriocalia,

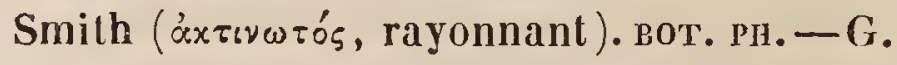
de la famille des Ombellifères, dans lesquelles M. De Candolle le classe en tête de sa tribu des Saniculées, en lui assignant les caract. suivants (Prodr. vol. 4, p. 83$)$ : Tube calicinal ovale, contracté au sommet; limbe à 5 lobes ovales-oblongs. Corolle nulle, Etamines 5 , insérées devant les lobes du calice. Ovaire uniovulé (dés la floraison). Styles 2, épaissis ef velus à la base, subulćs au sommet. Péricarpe ovoïde, couronné par le limbe calicinal, velu, quinquéstrié. Graine inconnue.-Herbes rameuses, dressées. Feuilles pennées, ou ternatisectées, alternes, pétiolées. Ombelles simples, multiflores, capituliformes, entourées d'une collerette rayonnante plus longue que les fleurs. 
Vleurs subsessiles. Ce g. est propre à la Nouvelle-Hollande. On n'en connaît que 2 esjèces; leur inflorescence ressemble á celle des Radiées.

(Sp.).

- ACTINOTHYRIUM (axtí, ivos, rayon; Suprós, bouclier). вот. PII. - G. de Champignons (Kunze, Myc.Hefı. 2, p. 81.), de l'ordre des Xylomacés, et parfailement distinct. Le périthécium en forme de bouclier est membraneux, inné, composé de fibres unies les unes aux autres, "et qui, sous le microscope, divergent du centre à la circonférence. A l’époque de la maturité et dans les temps humides, ce Périthécium se détache comme une écaille et laisse à découvert une couche composée de spores allongées, fusiformes et transparentes. - L'A. graminis, seule espéce connue, croît au printemps sur les graminées; son plus grand diamètre ne dépasse pas une demi-ligne.

(LÉv.)

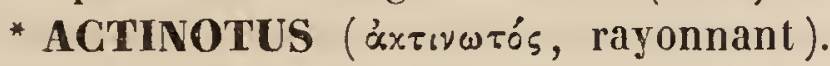
POLYP. - Gravenhorst a formé ce nouveau g. de Polypes à polypiers pour une esp. qu'il a trouvée sur les bords de la mer, aux environs de Trieste, et qu'il a nommée $A$. coccineus. Les caract. qu'il assigne à ce g. sont : Partie pierreuse cylindrique, fixe, bifourchue à l'extrémité ; orifice terminal des branches infundibulaires; strié en rayons.

$$
\text { (C. D'O.) }
$$

AGTINOTUS. BOT. PH. - V. ACTINOTE.

ACTINOzOAIRES. Actinozoa (áxтí, זัyos

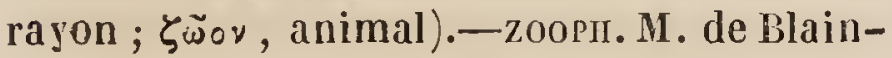
ville donne ce nom à l'embranchement ou type du régne animal, qui comprend tous les Radiaires proprement dits et se compose par conséquent des Echinodermes, des Acalèphes et des Polypes. $V$. le mot radiés.

(M. E.)

- ACTINURUS ( $\alpha$ xxíy, rayon, oúpó, queue). systol.-G. voisin des Rotifères, établi par Ehrenberg dans sa classe des Rotateurs, section des Rotateurs nus à double roue, famille des Philodinés. Il est caractérisé par sa queue divisée à l'extrémité en trois pointes égales; ce qui, avec les 2 autres pointes latérales qui se trouvent un peu en avant, forme une queue à 5 pointes. Les mâchoires sont d'ailleurs semblables à celles des Rotifẻres, et les yeux sont également placés en avant; de sorte que la seule différence paraît être dans la pointe médiane, qui répond à la ventouse terminale de la queue du Rotifère. Une seule espèce est décrite sous le nom d'Actinurus Neptuni. Sa longueur peut aller jusqu'à $\frac{s}{4}$ de millimé tre.

(DuJ.)

* ACTORE. Actora ('axiń, rivage; öpos, bord; qui liabite les bords de la mer. Ici et dans le mot suivant, il eùt fallı écrire $A c$ thore).ıvs.-G. de l'ordre des Diptëres, div. des Brachocères, subdiv. des Dichøtes, famille des Athéricères, tribu des Muscides, section des Acaliptẻres, s.-tribu des Ulidiens. Ce g., établi par Meigen, adoplé par Latreille et par M. Macquart, ne renferme qu'une seule esp. (l'A. cestuum), remarquable par l'ensemble de son organisation, et surtout par sa manière de vivre; car, jusqu'à présent, on ne l'a trouvée que sur les berds de la mer, et même sur l'écume des flots, dans le nord de l'Allemagne et en Angleterre. Le g. Actore a pour caract.: Corps allongé. Tête assez grande; trompe épaisse; palpes élargis ; face nue, un peu inclinée, allongée en dessous, présentant des fossettes antennaires et plusieurs petits sillons longitudinaux; épistome non saillant, et dépourvu de soies; front fort large, plat, obtus, avancé; quelques soies sur le veriex. Antennes avancées obliquement; $3^{\text {me }}$ article tentaculaire, un peu transversal. $\Lambda$ bdomen allongé, de 6 segments distincts; organo sexuel peu développé. Pieds velus, à l'exception des jambes intermédiaires; cuisses assez épaisses; pelotes des tarses élargies. Ailes grandes ; bord extérieur muni de soies le long de la tunique médiastine. (D.)

- ACTORE ('axiń, rivage; öpos, bord.)ıvs. - G. de la famille des Coréens, groupe des Anisoscélites, de l'ordre des Hémiptères, ayant pour caractères essenticls la forme linéaire du corps; la tête obtuse antérieurement; les antennes dont le $1^{\text {er }}$ article est plus court que la tête; le corselet cylindrique; les cuisses renflées et les jambes très grêles. On ne connaît qu'une seule espèce de ce genre, c'est l'A. Sossularum (Hydrometra fossularum Fab.) qui se trouve dans la France méridionale, oú il habite le bord des eaux.

ACULEATA (Aculeatus, qui est muni d'un aiguillon). Iss. - Section établie par Latreille dans l'ordre des Hyménoptères. $V$. Porte-Aigulllon.

* ACULÉIFORME. Aculeiformis (Acu- 
lelıs, aigullon ; forma, forme). Se dit $1^{0}$, en botanique des rameaux raides et aigus, des stipules persistantes, raides el pointues, etc., qui ressemblent à des aiguillons; tels sont les rameaux du prunellier, les stipules de l'épine-vinette et du groseiller à maquercau; $2^{0}$, en zoologie, des écailles de certains poissons qui out la forme de pointes recourbées, etc.

(A. R.)

ACUMINÉ. Acuminatus. вот. PI. - On appelle ainsi une feuille, un pétale ou tout autre organe végélal foliacé, qui so termine brusquement en pointe à son sommet, c'esta-dire dont les deux bords, après avoir insensiblement convergé l'un vers l'autre, se prolongent pendant quelque temps pour former une pointe plus ou moins allongée et distincte. Il est important de ne pas confondre une feuille acuminée (folium acuminatum) avec une feuille simplement aiguë (folium acutum). Dans cette dernière, les 2 bords convergent insensiblement l'un vers l'autre, jusqu'à ce qu'ils se rencontrent pour former une pointe; ainsi le Noiseticr a des feuilles acuminées et le Laurier rose des feuilles aiguës. - Se dit aussi en zoologie, des ailes des Insectes lorsqu'elles so terminent en pointe aiguë et prolongée.

(A. R.)

ACUNA ou ACUNNA ( $P$. d'Acuna, Espagnol, zélé promoteur de la botanique). вот. Pı.-Ce g., fondé par Ruiz el Pavon, dans leur Flore péruvienne, pour 2 plantes de la fami le des Ericacées, a été réuni depuis au g. Bejaria ou Befaria de Mutis. (C. L.)

*ACUPALPE. Acupalpus (acus, aiguille, pointe; palpo, je touche). INS. - G. de Coléoptères pentaméres, famille des Carabiques, tribu des Harpaliens, établi par Latreille dans ses derniers ouvrages et adopté par M. Dejean, qui, dans le $4^{\text {me }}$ volume de son Species, le caraclérise de la manière suivante : Les 4 premiers articles des 4 tarses antérieurs assez fortement dilatés dans les mâles, et triangulaires ou cordiformes. Dernier art. des palpes allongé, légèrement ovalaire et terminé en pointe. Antennes filiformes. Lèvre supérieure en carré moins long que large. Mandibules peu avancées, arquées et assez aiguës. Une dent simple au milieu de l'échancrure du menton. Corps oblong, plus ou moins allongé. Tête ordinairement triangulaire, quelquefois arrendie, rétrécie postérieurement. Corse- let plus ou moins carré, cordiforme ou arrondi. Élytres plus ou moins allongées et preșque parallćles.-Ce genre est très nombreux; M. Dejean y rapporle 49 especes dont la plupart étaient réparlies auparavant dans les genres Stenelophus et Trechus. Les Acupalpes sont ordiuairement de couleur brune, rarement noirâtre. On les trouve communément dans les endroits humides, sur le bord des rivages, dans le sable, sous les pierres et les débris des végétaux. Le plus grand nombre appartient au nord de l'Europe el de l'Amérique. Nous n'en citerons que 2: l'A. rufichorax Mannerheim, de la Finlande, et l' $A$. exiguus Dej., de la Sibérie.

ACURNIER. BoT. PI.-Ce mot, dans quelques parties du midi de la France, est synonyme de Cornouille. $V$. ce mot. (C. L.)

ACUSCHI. мим. - Syn. d'Acouchi dans les auteurs systématiques. (C. D'O.)

* ACUTANGULE. Acutangulatus (acutus, aigu; angulus, angle). вот. - Se dit de tout organe qui offre des angles aigus. Cette expression estl'inverse d'Obtusangulé.(A. R.)

*ACUTIFOLIÉ. Acutifolius (acutum, aigu; folium, feuille). вот. - Épithète peu usitée, qui qualifie les plantes dont les feuilles sont aiguës, c'est-à-dire terminées en pointe; c'est le plus grand nombre. (C. L.)

* ACUTLABBDS. Acutilabri. (acutum, pointu ; labrum, lévre). ARACII. - Epithète employée par M. Walckenaër pour désigner de petites divisions d'Aranéides dans les g. Sphodros et Drassus.

(H. L.)

"ACUTLOBßá. Acutilobatus (acutus, aigu, lobus, lobe, division). вот. - Adjectif peu usité, qui qualifie les feuilles dont les lobes sont aigus, comme celles des Passiflorées, de quelcues Renonculacées, Papavéracées, etc.

- ADA $(\tilde{\delta} \delta \alpha$, Dor. pour $\alpha \tilde{\delta} \cdot n$, morl; enfer; on aurait dû écrire Hada). oIs.-Wouveau g. formé par M. Lesson dans son Traité d'Ornithologie, pour quelques esp. de la famille des Gobe-Mouches, et synonyme du g. Bleciropus de Swainson (Monogr. des Gobe-mouches ou Flycatchers); ses caractères sont : Bec triangulaire en cône allongé, mais un peu déprimé, à arête supérieure arrondie ; narines arrondics, ouverles dans la substance cornée du bec, recouverles, ainsi que sa base, de soies assez épaisses et divergentes; ailes 
obtuses ou sub-obtuses, à rémiges primaires de longueur médiocre; queue arrondie; tarses et doigts assez développés, annonçant des esp. marcheuses. Quatre ou 5 esp., dont le Moucherolle à bec bleu de Vicillot, ou Suiriri noir à bec bleu de ciel d'Azara, composent ce petit groupe et se font remarquer par un plumage entièrement noir, sauf une tache d'un blanc pur sur les barbes internes de quelques rémiges, et qui n'est visible en dessus que lorsque l'aile est déployée. Les seuls renseignements de mœurs que nous ayons sur ces oiseaux, se bornent à ce qu'Azara nous a appris de son Suiriri noir à bec bleu qui, d'après lui, est un oiseau buissonnier, se tenant sur la lisière des bois, saisissant les insectes au vol et descendant quelquefois à terre pour les y prendre. Nous regardons ce petit groupe comme servant de transition entre les Gobe-mouches sylvains et les Gobe-mouches marcheurs; de plus nous partageons l'opinion de M. Swainson, qui en exclut le Traquet a lunettes ou le Clignot de Vieillot, malgré ses grands rapports de coloration. Ses tarses bien plus développés, sa queue plus courte et carrée, ses ailes surobtuses et surtout ses mœurs marécageuses l'en éloignent suffisamment. (LAFr.)

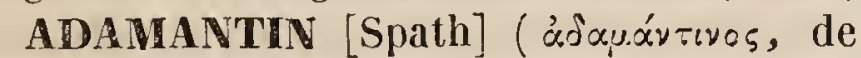
diamant; $\alpha$ priv.; $\delta \alpha \mu \alpha \xi_{\omega}$, je dompte). min. - Nom sous lequel on a désigné d'abord, en les considérant comme formant une espèce á part, les variétés de Corindon opaques et clivables en rhomboèdre, qui nous viennent de l'Inde et de la Chine. $V$. CORINDON.

(DEL.)

ADAMAS (ádápacs, diamant, plus ancien-

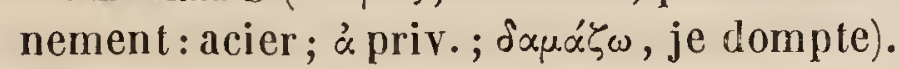
ur. - Nom du diamant chez les Grecs et les Pomains. Ce nom, qui veut dire invincible, fait allusion à la grande dureté de cette substance, laquelle surpasse celle de tous les autres minéraux.

(DEL.)

ADAMHBÉ ou ADAMBOÉ. Adambea, Lamk. вот. Prl. - G. ou s.-genre de la famille des Lythrarićes ou Lythracées; il diffẻre des Lagerstrcemia, auxquels le réunissent la plupart des auteurs, par un calice longiludinalement plissé et sillonné, ainsi que par des étamines isomètres.

(Sp.)

* AdAMra, Wallich. bot. Pn. - G. de la famille des Saxifragacées, Iribu des Hydrangées, DC. - Wallich ( Tent. Flor. Ne- pal. p. 4(i) lui assigne les caractères suivants : Calice adhérent, à 5 denticules séparées par des sinus obtus. Pétales 5 . Étamines 10. Ovaire semi-supère. Styles 5, terminés clıacun par un sligmate claviforme, subbilobé. Baie subquinquéloculaire, polysperme, couronnée par les dents calicinales. Graines petites, piriformes, striées. Arbrisseaux; feuilles opposées, pétiolées, non stipulées. Inflorescence terminale, corymbiforme, subtrichotome, multifiore. Fleurs non bractéolées, d'un bleu tirant sur le rose. Baie petite, globuleuse, de couleur bleue.-M. De Candolle (Prodr.vol.4, p. 16) présume que ce g. n'est pas suffisamment distinct du Cyanitis. On n'en connaì qu'une espèce, indigène au Népaul, et qui se cultive depuis quelques années en Angleterre, comme arbuste d'ornement.

* ADAMSIA, Willd. вот. pl..-Syn. du g. Puschkinia.

- ADAMSIA, Fisch. вот. Pा.-Section des Bénoites ou Geum.

ADANSONIA, L. (Dédié à Adanson, célèbre botaniste du $17^{\text {me }}$ siècle), vulgairement Baobab. вот. РI.-G. de la famille des Sterculiacées, tribu des Bombacées, Endl. (famille des Bombacées, Kunth; famille des Malvacées, tribu des Bombacées, Bartl.). Les caractères de ce $\mathrm{g}$. sont les suivants (Hooker, in Bot. Mag. sub. tab. 2791. Schott et Endl. Melet. Bot. 1, p. 36) : Calice coriace, cyathiforme, non persistant, profondément quinquéfide; lanières oblongues, révolutées. Pétales 5, ovales-arrondis. Éamines très nombreuses, monadelphes, révolutées, soudées jusque vers leur milieu. Androphore tubuleux, évasé au sommet; filets terminaux, grêles, étalés; anthères réniformes, mobiles. Style très long, ascendant. Stigmate pelté, multifide, rayonnant. Péricarpe gros, indéhiscent, ovoïde, ligneux, 10-14-loculaire; loges polyspermes, remplies d'une pulpe farineuse, qui se sépare, par la dessiccation, en quantité de polyèdres monospermes. Graines réniformes, très dures.-Arbre à tronc peu élcvé, mais acquérant avec l'âge une grosseur démesurée. Feuilles digitées, 3-7-foliolées; folioles pétiolulées, coriaces; pétiole long, cylindrique. Stipules petites, caduques. Pédoncules solitaires, axillaires, uniflores, pendants, bi- ou tri-bractéolés au somme!; 
bractées éparses, linéaires, caduques. Fleurs très grandes. Calice verdâtre à la surface interne. Corolle blanche ainsi que l'androphore. Filets des étamines rabattus en forme de parasol. Anthères rougeâtres.

Ce fameux colosse végétal constitue à lui seul le g. Adansonia. Cet arbre, d'abord observé par Adanson dans la Sénégambie, a été retrouvé depuis au Soudan, au Darfour et dans l'Abyssinie. Son tronc acquiert jusqu'à 25 pieds de diamètre, et, d'après les calculs d'Adanson, dont l'exactitude paraît d'ailleurs assez douteuse, des milliers d'années sont nécessaires pour que l'arbre parvienne à ce monstrueux développement. Ce tronc immense est couronné d'un grand nombre de branches étalées horizontalement, remarquables par leur grosseur, et plus encore par leur longueur, qui est de 50 à 60 pieds; d'oú il résulte que souvent leur propre poids en entraìne l'extrémité jusqu'à terre; aussi l'arbre, vu de loin, se présente-t-il sous la forme d'une masse hémisphérique assez régulière, de 60 à 70 pieds de hauteur, et dont le diamètre a le double. Quant aux racines, qui courent presque à fleur de terre, leur longueur est en harmonic avec celle des branches. Adanson estime qu'elles s'étendent jusqu'à la distance de 160 pieds.

L'écorce et les feuilles du Baobab possèdent des vertus émollientes qui les font fréquemment employer par les nègres du Sénégal. Le fruit, nommé vulgairement pain de singe, fournit aux Africains, dans la chair fongueuse qui enveloppe les graines, un aliment qu'ils estiment beaucoup. L'écorce ligneuse de ce fruit et le fruit lui-même, lorsqu'il est gâté, servent aux nègres à faire du savon, cn tirant la lessive de ses cendres, et en la faisant bouillir avec de l'huile de palmier. Enfin, les habitants du Sénégal ont coutume de déposer dans les troncs creux du Baobab, les cadavres de ceux qu'ils jugent indignes des honneurs de la sépulture. (Sp.)

ADAPIS. MaM. Foss.-Nom employé quelquefois pour le Daman et que Cuvier a appliqué à un Pachyderme fossile d'une taille un peu moindre que celle du Daman, et découvert par lui dans le plâtre des environs de Paris. Il avait à chaque mâchoire 4 incisives, 2 canines et 14 molaires en séries continues. Les collines pointues de ses dents le rapprochaient jusqu'à un certain point des Insectivores.

(L. D.)

ADDUCTEUR ( $A d$, vers; duclor, conducteur). AvaT. - Nom de plusieurs muscles qui rapprochent de l'axe du corps une partie qui en ayait élé écartée; ex. : adducteur de l'oil, adducteur de la cuisse, elc. (C. D'O.)

*ADDUCTORES (Adduco, j'amène). вот. LR.-Hedwig appelait ainsi les pistils avortés qu'on rencontre souvent le long ou au bas dela gaîne, d'oú part le pédoncule qui supporte la capsule dans les Mousses. C'est ce que M. Bischoff désigne sous le nom d' $A r$ chegones. $V$. ce mot.

(C. M.)

ADELE. Adela. ins. - G. de l'ordre des Lépidoptères, famille des Nocturnes, tribu des Tinéites, établi par Latreille et que nous caractérisons ainsi (Hist. natur. des Lépidoptères de France) : Palpes inférieurs grêles, cylindriques, de la longueur de: la tête et très garnis de poils. Trompe longue. Antennes très rapprochées à leur base, très longues, et se terminant en un fil imperceptible dans les mâles; dans les femelles, beaucoup plus courtes et garnies d'écailles qui les épaississent dans une grande partie de leur longueur. Tête petite, presque pyramidale avec les yeux gros et presque contigus dans les mâles. Corselet ovoüde. Abdomen cylindrique, court et tronqué dans les mâles, plus long et conique dans les femelles. Pattes postérieures longues et plus ou moins velues, suivant les espéces. Ailes supérieures, elliptiques; ailes inférieures plus courtes et ayant à peu près la même forme. Toutes les quatre garnies d'une frange courte.

Ce g. est un démembrement des Alucites de Fabricius, qui formaient un groupe assez incohérent; ce dont cet auteur s'est aperçu lui-même, en divisant depuis ses Alucites en $2 \mathrm{~g}$.: comme l'avait fait Latreille; mais, sans tenir compte du travail de ce dernier, il conserva le nom d'Alucile aux Adèles de l'entomologiste français, et imagina le nom d'Ypsolophe pour l'appliquer aux espéces auxquelles Latreille avait religieusement conservé celui d'Alucile. - Les Adèles sont des Lépidoptères très petits, ornés, la plupart, de couleurs métalliques très brillantes. Ils se reconnaissent au premier coup d'œil à la longueur démesurée de leurs antennes et à leur port de friganes. On les rencontre au printemps dans les bois, voltigeant 


\section{ADE}

en troupe autour des buissons. Leurs chenilles, encore peu connues, vivent dans des fourreaux portatifs, revêtus extérieurement de fragments de feuilles. - Un grand nombre d'Adéles sont figurées dans l'ouvrage d'Hubner, ainsi que dans l'Histoire naturelle des Lépidoplères de France. Nous n'en citerons que deux : $1^{\circ}$ la Coquille d'or de Geoffroy, qui est l'Alucita Degeerella de Fabricius ou l'Adèle Dégéerelle de Latreille; $2^{\circ}$ I'Adèle Réaumurelle, Adela Reaumurella de Latreille, qui est la Teigne noire bronzée de Geofroy, ou l'Alucita Reaumurella de Fahricius, laquelle sert de tspe au g. dont il s'agil.

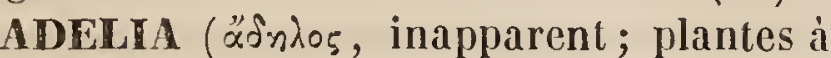
fleurs peu apparentes ). вот. PII. - Ce nom a élé donné, ainsi que celui de Bernardia, par P. Browne á ung. de la famille des Euphorbiacées, ainsi caractérisé : Fleurs dioïques; Calice 5-6-parti, à préfloraison valvaire; pas de corolle. Dans les mâles : Filets nombreux, dressés, soudés à leur base, terminés chacun par une anthère globuleuse. Dans les femelles : Ovaire porté sur un disque, a 3 loges uniovulées, surmonté de 3 courts stigmates déchiquetés; une capsule à 3 coques. - On compte dans ce g. 7 espèces, presque toutes américaines, mais la plupart mal connues. Ce sont des arbrisseaux dont les rameaux se terminent quelquefois en épines. Leurs feuilles sont alternes, entières ou légèrement dentelèes, tantôt glabres, tantôt courertes, ainsi que les pédoncules et les calices, d'un duvet tomenteux, formé de poils étoilés; les fleurs accompagnées de bractées, axillaires ou terminales, en épis ou en faisceaux, quelquefois même solitaires.

(AD. J.)

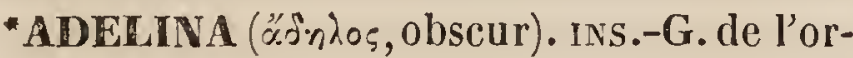
Ire des Coléoptères tétramères, famille des Xylophages, élabli par M. Chevrolat et adopté par M. Dejean (3me édit. de son Catal.). Ce g., dont les caractères n'ont pas été publiés, est un démembrement de celui auquel Fabricius a donné le nom de Cucujus. $(V$. ce mol.) M. Dejean y rapporte 4 espèces, toutes de l'Amérique; nous ne cilerons que l' $A$. plana, de Cayenne, qui est l'ancien Cucujus planus de Fabricius.

" ADELIUII (äsinior, obscur). INs. - G. de l'ordre des Colćoptères hétéromères, famille des Hélopiens, élabli par Kirby et
ADE

adopté par N. Dejean (3ine édit. de son $\mathrm{Ca}$ tal.). Ce g. ne renferme que des espèces de la Nouv. - Hollande, dont nous ne citerons que deux : $l \cdot A$. caraboïdes Kirby, qui est la même que le Calosoma porculatum de Fabricius, el $l$ ' $A$. virescens Latr. que M. Dejean avait placé ( $1^{\mathrm{er}}$ calalogue) dans le genre Helops. - Les caractères du g. Adelium, sont, d'après Kirby : Labre presque carré, un peu échancré. Lèvre bifide; mandibules courtes, conniventes au sommet, bidentées. Mâchoires découvertes à la base. Dernier article des palpes maxillaires très grand, presque triangulaire, un peu aplati. Palpes labiaux trés courts, filiformes; menton presque trapéziforme, inégal. Antennes filiformes avec leur dernier article oblong. Prothorax très court. Corps oblong, aptère. Ce g., ajoute Kirby, a peu d'affinités avec ceux de la même tribu; si l'on n'examinait pas attentivement les espèces qui le composent, on pourrait renouveler l'erreur commise par Fabricius, en les rapportant aux $\mathrm{g}$. Calosoma ou Carabus; cependant tous ces insectes sont hétéromères et apparliennent. suivant Kirby, aux Ténébrionides.

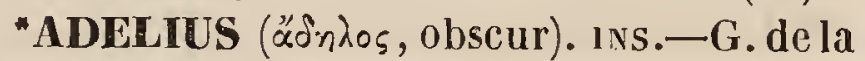
famille des Ichneumoniens, de l'ordre des Hyménoptères, établi par Haliday (Ent. Mag.) et adoplé par Wesmael (Mon. des Brac.), ne différant des Microgaster, Lat., que par un très petit nombre de caract.; ce sont : $1^{\circ}$ les ant. composées de 20 articles; $2^{\circ}$ Ia cellule radicale incomplète; $3^{\circ}$ l'abdomen plus large el plus arrondi. - On ne connait de ce g. qu'une seule espéce, $A$. subfasciatus Wesm. (Mon. des Br.p.6s, pl. 3, f. 7) trouvée en France, en Belgique et en Angleterre.

(BL.)

*ADELOBOTRYS, DC. (״'ंnios, obscur, Górpus, grappe). вот. PII. - G. de la famille des Mélastomacées, tribu des Rhexiées de M. De Candolle, qui (Prodr.vol. 3, p 127) en donne les caractères suivants : Cal. inadhérent, subcampanulé, à 5 dents courtes et obtuses. Pétales 5, elliptiques-oblongs. Étamines 10; anthères bifurquées à la base (bivalves au sommet). Pistil inconnu. Capsule quinquévalve; axe central finalement libre et terminé par 5 fibres originairement en communication avec le style. Graines inconnues. - Arbuste grimpant. Rameaux cylindriques. Feuilles cordiformes, quinquéner- 
vées, pétiolées, denticulées - spinelleuses. Fleurs blanches, disposées en cymes terminales. L'unique espéce sur laquelle se fonde ce g. croît dans la Guyane.

(SP.)

ADELOBRANGHES. Adelobranchia (ä’n-

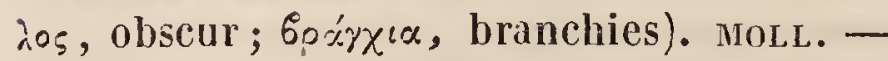
Ce nom, créé par M. Duméril dans son Traité d'Histoire Naturelle, aurait pu convenir à un petit groupe de Mollusques; mais M. Duméril ayant fait de ses Adélobranches un ordre dans lequel on rencontre des Mollusques pulmonés mélangés avec des Mollusques branchifères, on a abandonné l'ordre établi par M. Duméril et le nom qui servait à le désigner.

(DESII.)

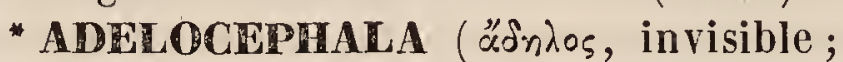

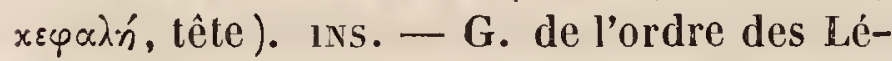
pidoptères, famille des Nocturnes, tribu des Bombycites, établi par M. Boisduval, aux dépens du g. Bombyx de Fabricius, ayant pour type le $B$. stygma du même auteur, de l'Amér. septentrionale, et qui a élé figuré par SmithAbbot. Ses caractères principaux sont : Tête cachée et rétractée sous le thorax ou corselet; chenilles pourvues de tentacules charnus.

* ADELOCERA ( ¿óninos, caché; ’x́pxs, corne ). ıxs. - G. de Coléoptères pentamères, famille des Sternoxes, tribu des Élatérides, établi par Latreille, mais sans indication de caract., et auquel il donne pour type une espèce de Java qu'il rapporte à l'Elater fuscus de Fabricius. Il comprend dans le même g. une autre espéce très voisine de l'E. marmoratus du même auteur, si ce n'est pas lui; et enfin une $3^{\text {ne }}$ espèce figurée par M. Guérin (Iconographie du Règne animal, Fasc. 4, pl.12, fig. 4.), sous le nom de Chabanii. Ce g. ne figure pas dans le derisier catalogue de M. Dejean. (D.)

*ADELOGENE. Adelogenus (ádiniós, caché ; révos, éléments). GEOL. - Ce nom est donné, par MM. Cordier et Brongniart, aux roches résultant d'un mélange de parties tellement fines, qu'elles semblent formées d'une seule substance, ne présentant point les caractères d'un minèral connu, et dont par conséquent la composition est non apparente à l'œil.

$$
\text { (C. D’O.) }
$$

* ADER OTNEUMONÉS. Adelopneumona

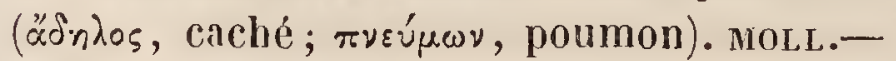
Tous les Mollusques qui respirent l'air en nature, et qui ont l'organe respiratoire dis- posé pour recevoir le contact de co fluide, ont été réunis depuis ìng-temps en un groupe auquel chacun des classificateurs a donné un nom particulier. Dans sa classification fondée sur la structure des Mollusques, M. Gray a proposé le nom qui fait le sujet de cet article, pour réunir tous les Mollusques pulmobranches. Il divise ces Mollusques en $3 \mathrm{~s}$. ordres, d'après les tentacules : $1^{\circ} \mathrm{Ceux}$ qui ont des tentacules rétractiles et qui sont terrestres; ils correspondent aux familles des Limaces et des Limaçons de Lamarck. $2^{\circ}$ Ceux qui ont les tentacules contractiles seulement et qui sont amphibies ; ce groupe correspond assez bien à celui des Auricules de Lamarck. $3^{\circ}$ Enfin ceux qui ont les tentacules comprimés et contractiles et qui sont aquatiques; ce dernier groupe représente la famille des Limnéens de Lamarck. A l'article mollusQues, auquel nous ren"voyons, nous discuterons la valeur du groupe principal et de ses subdivisions. (Desir.)

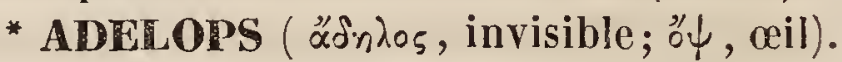
rns. - G. de l'ordre des Coléoptères pentamères, famille des Lamellicornes, tribu des Scarabéides, établi par M. Dejean ( $3^{\mathrm{me}}$ édit. de son Catal.) qui n'en a pas donné les caractères. Il est fondé sur une seule espèce originaile de Carthagène en Amérique, qu’il nomme $V$. carinatus.

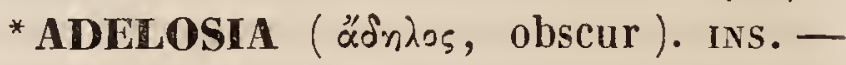
G. de Coléoptères pentaméres, famille des Carabiques, tribu des Féroniens, élabli par Stephens, aux dépens du g. Pterostichus Bonelli, et auquel il donne les caractères suivants : Corps très déprimé. Corselet très rétréci postérieurement. Antennes plutôt courtes que longues. Palpes très grêles. - Il a pour type le $P$. macer de Marsham, qui se trouve en Angleterre.

*ADELOSINE. Adelosina, A. d'Orb. For $\mathrm{M}$. -G. de Foraminifères, de l'ordre des Agathistèques, famille des Multiloculidées. Ce g., voisin dans l'âge adulte des Quinquéloculines, par le pelotonnement de ses loges sur 5 faces opposées, s'en distingue par sa coquille formée d'abord de grandes loges spirales, arrondies, comprimėes, pourvues d'un prolongement au bout duquel est une ouverture armée d'une dent. - Nous connaissons 4 espèces de ce g. dont 2 vivantes dans l'Adriatique el 2 fossiles des terrains tertiaires subapennins de l'Italie. (A. d'O.) 
* ADELOSTOMA ( žninos, ilvisible; orór $\alpha$, bouche ). INs. - G. de l'ordre des Coléoplères hétéromères, famille des Mélasomes, tribu des Adélostomites. Ce g., établi par moi dans un Mémoire inséré dans les Amn. de la Soc.Limn. de Paris, 1827, a élé adopté par Latreille et M. Dejean, ainsi que par M. Solier, qui en a développé et figuré les caraclères, tom. vi des Ann. de la Soc. Entomol. de France, $2^{\text {me }}$ trimestre, 1837. Il a pour type une esp. que j'ai appelée A. Sulcatum et que mon fils a trouvée dans les environs de Cadix en 1924. Demis M. 50lier y a réuni 4 autres especces, toules décrites par lui dans les Annales précitées, dont une d'Égyple, une du Sénégal, et les 2 autres dont il ignore la patrie. Ce qui caractérisc principalement le g. qui nous occupe, c'est la petilesse de ses palpes, de sa languelte et deses mâchoires, cachées presqu'en entier par le menton, de sorte que les insectes qui en font partie paraissent à la vue simple dépourvus de bouche. De là le nom générique d'Adelostoma que je leur ai donné.

* ADELOSTOMITTES ( œ'ंnìos, caché ; oróuc, bouche). ins. - Nom de la $s^{m e}$ tribu établie par M. Solier dans sa famille des Collaptérides, qui correspond en partie à celle des Mélasomes de Latreille. M. Solier partage cette tribu en 2 divisions: l'une composée des g. Eurychora et Pogonobasis, et l'autre ne comprenant que lc g. Adelosloma. La $1^{\mathrm{re}}$ a pour caractères : Tergum du prothorax fortement dilaté et notablement aminci latéralement, avec le bord antérieur profondément échancré pour recevoir la tête qui s'y enfonce jusqu'au-delà des yeux; palpes en parlie apparents. Les caractères de la seconde division sont : Prothorax caréné latéralement, mais non dilaté, et tronqué presque carrément dans la partie antéricure et à sa base : les angles antérieurs Cont cependant de chaque côté une petite saillie peu sensible.-Les Adélostomites ont en outre pour caractères communs: Antennes de 10 articles, dont le dernier notablement plus gros que le pénultième et tronquućcarrément ou en forme d'angle.

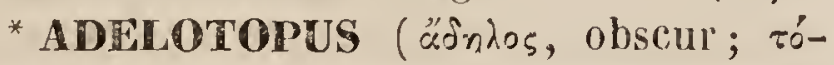
$\pi \circ 5$, lieu ). iss. - G. de Coléoptères pentamères, famille des Gyriniens, établi par M. Hope, qui lui donne pour caractères: AnT. I. tennes de 11 articles; le $1^{\text {er }}$ très grand; le second moindre, arrondi ; le $3^{\text {me }}$ petit; les antres formant une massue en ovale allongé, comprimé. Tête petite, enfoncće dans le prothorax jusqu'aux yeux. Labre transverse arec le bord antérieur presque droit ; mandibules robustes, cornées, convexes extérienrement, subaigües à l'extrémité, munies intérieurement de 2 dents obluses. Lobe interne des mâchoires aigu, falciforme, gami intérieurement de cils rigides; lobe interne palpiforme, de 2 articles. Palpes maxillaires courls, de 4 articles : les 3 promiers égaux; le demier ovale, tronqué. Nenton grand, corné, fortement échancré, avec une dent obtuse au milieu. Palpes labiaux de 3 articles : le $1^{\text {er }}$ puis le second, un peu plus grands, le $3^{\text {me }}$ très grand, tronqué. Corps petit, oblong, arrondi extérieurement et postérieurement. Prolliorax conique, fortement fléchi sur les côtés, brusquement tronqué antérieurement, la partie postérieure égalant la longueur des élytres. Prosternum aigu, prolongé entre les pieds postérieurs; pied scourts; cuisses renflées, recevant dans un sillon la base des tibias. Tarses simples, de 5 arlicles, qui égalent ensemble la longueur des tibias. Ongles droits. - Ce g. est fondé sur une espéce de la Nouv.-Inllande, nommée par l'auteur : $A$. Gyrinoides ef figurée dans le $1^{\mathrm{er}}$ vol. des Fransaciions de la Soc. entom. de Londres pour 1834, pl.1, fig. 1 .

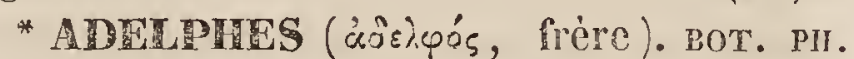
- Se dit des étamines réunies en certain nombre sur un ou plusieurs androphores; de là les épilhètes de monadelphes, diadelphes, triadelphes, etc., pour exprimer combien les étamines forment de faisceaux ou androphores divers. $V$. ces mots, et ADELPHIE, ANDROPUORE.

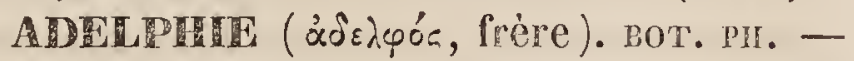
Réunion de plusieurs étamines sur un support commun, auquel M. de Mirbel a donné le nom d'Androphore. Lorsque ce support est unique, la réunion des étamines prena le nom de Ronadclphie; lorsqu'il est double, elle prend celui de Diadelphie; triple, celui de Triadelphie, etc. Cetle disposition des étamines a fourní à Linné 3 classes de son Système sexuel : MONADELPHIE, DIADELPIIE, POLYADELPIIE, etc.

* ADELPIUUS (åfiçós, frère). INs.$8^{*}$ 
G. de l'ordre des Coléoptères hétéromères, famille des Hélopiens, établi par M. De-

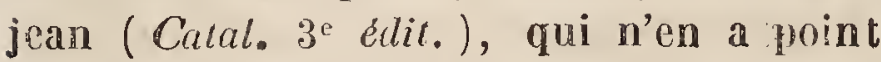
donné les caractères. Ce g., qu'il place immédiatement avant l'Helops, se compose de 10 espèces, dont 3 de l'Amérique boréale, une de la Guinée, 5 du Sénégal et 2 de Madagascar. Nous ne citerons qu'une de ces dernières, l'Adelp. Crosus de M. Dupont.

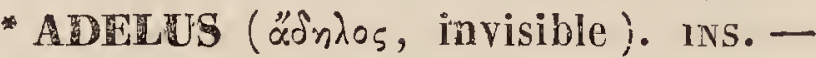
G. de l'ordre des Coléoptères tétramères, famille des Curculionites, tribu des Erirhinides, établi par Schœenherr, qui lui donne pour caractères : Antennes médiocres, minces, terminées en massue courbe; leur funicule de 6 articles : le $1^{\text {er }}$ épais ; le $2^{\text {me }}$ très brièvement obconique; les autres plus courts, perfoliés, resserrés, et s'élargissant graduellement; massue brièvement ovale. Rostre peu long, peu fort, cylindrique, arqué. Tête allongée postérieurement. Yeux ronds, pell saillants. Prothorax oblong, tronqué à la base et au sommet, légèrement arrondi sur les côtés, plus étroit antérieurement. Élytres oblongues-ovales, avec les angles huméraux obtus; extrémité ovale, nue, oblongue, arrondie - Ce g., non adopté par M. Dejean, est fondé sur une seule espèce que l'auteur nomme $A$. Cupreas el qui a un peu le facies d'un Apion.

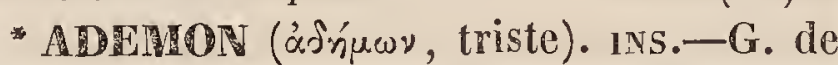
la fam. des Ichneumoniens, de l'ordre des $\mathrm{Hy}$ ménoptères, établi par Haliday, aux dépens du g. Rogas de Nees von Esenbeck et adopté par Westwood (Synops. of the gen. Br.Ins.); ses caract. principaux sont tirés de l'abdomen dont les $2^{\text {me }}$ et $3^{\text {me }}$ segments sont trayersés par un sillon, et des ailes, qui sont pourvwes de 3 cellules cubitales et d'une radiale incomplète. - On ne connaît de ce $g$. que quelques esp. européennes; celle que l'on en peut considérer comme le type, est $l$ 'A. decrescens Hal. Westw. (Rogas decrescens de Nees von Esenbeck Berl. Mag. เom. 5, tab. fig. 10).

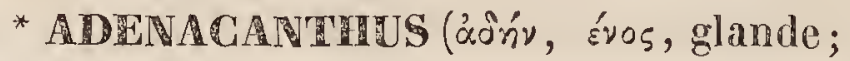

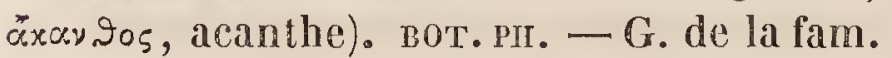
des Acanthacées, tribu des Echmatacanthées, Nees, s.-lribu des Ruelliées, DC, fondé par Nees ab Esenbeck (in Wall. Plant. Asiat. rar. 11.) qui lui assigne les caracteres suivants : Calice triparti, à segments postérieurs trifides. Corolle hypogyne, infondibuliforme, à limbe presque égal, quinquéfide, à divisions obtuses. Ltamines 4, incluses, didynames, insérées au tube de la corolle; anthères biloculaires, ovales, grandes, a logettes parallèles. Ovaire biloculaire, à loges biovulées; ovules comprimés. Style? - Ce g., encore peu connu, ne se compose que d'une seule plante herbacée, á tige dressée, noueuse, à rameaux opposés, grêles, portant des feuilles opposées, inégales, courtement pétiolées, oblongues-lancéolées, acuminées, sinuées-dentées, glabres, couvertes sur les 2 faces de points glanduleux. L'inflorescence de cette plante, trouvée dans l'empire Birman, est disposée en un épi terminal (long d'un pouce) muni de bractées herbacées, opposées, et de bractéoles à peu près semblables.

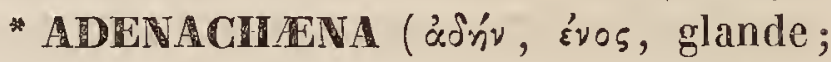

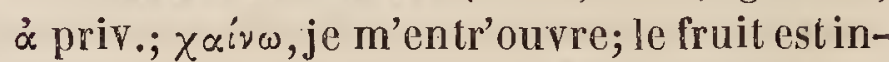
déhiscent). вот. Pн. - G. de la familie des composées-Sénécionidées, s.-tribu des Anthémidées, division des Chrysanthémées, fondé par M. De Candolle, qui lui assigne les caractères suivants (Prodr. vi, 49): Capitule multiflore hétérogame; fleurs $\mathrm{du}$ rayon unisériées, ligulées, femelles; celles $\mathrm{du}$ disque hermaphrodites. Involucre bitri-sérié; squames presque égales, linéaires-lancéolées, plus courtes que le disque ; les internes obtusiuscules. Réceptacle plan, convexe, légèrement papilleux, devenant quelquefois subglobuleux. Corolles du rayon ligulées; celles du disque tubuleuses; tube cylindracé; limbe 4-5-fide. Anthères écaudées. Sligmates exappendiculés. Akènes conformes, cylindriques, obtus, couverts de granules glanduleux. Aigrette nulle.-M. De Candolle (loc. cit.) divise ce g. en 2 sections, sous les noms de Leucanthémoïdes et d'Eitmorphoüdes, caractérisées principalement par le nombre des fleurs du disque ( 30 environ dansla $1^{\text {re }}$, et $12-15$ dans la $2^{\text {me }}$ ). Ce sont des plantes suffrutiqueuses, dressées, glabres, rameuses, à feuilles alternes, rigidules, trifides, munies de chaque còté d'une grande dent. Les capitules, à rayon blanc, réfléchi, rappellent ceux de la Matricaire. Ce g. est intermédiaire entre les g. Leucanthemum et Matricaria; il différe du premier par le tube cylindrique de la corolle, du second par ses akènes non anguleux, et de tous deux par 
ses fruits recouverts de papilles glanduleuses. Il renferme 3 ou 4 espèces, appartenant à l'Afrique centrale.

(C. L.)

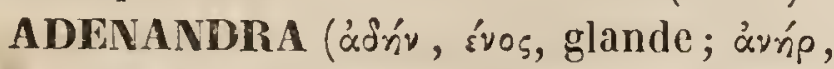
àvơós, mâle. Plante dont les organes mâles sont munis d'une glande). вот. Pн.-G. appartenant aux Diosmées du Ciap, le niême que le Glandulifolia de Wendland père, que l'Ockia et l'Okenia de Dietrich, et ainsi caractérisé : Calice 5-parti, ponclué, au fond duquel est accolé un disque dont le bord supérieur libre porte les élamines. Pétales 5 , plus longs que le calice, courtement onguiculés, ouverts; 10 filets velus : les 5 opposés aux pétales, stériles et portant à leur sommet, au lieu d'anthères, une glande globuleuse ou concave; les 5 autres alternes, plus courts, terminés chacun par une anthère grande et ovoïde que surmonte une glande pédicellée, d'abord dressée et plus tard réfléchie. Style plus court que le calice, élargi à son extrémité en un stigmate à 5 lobes. Ovaires 5 , soudés entre eux par leurs faces internes, couverts, surtout supérieurement, de glandes stipitées, contenant chacun 2 ovules collatéraux. Fruit à 5 coques.-Onze espèces, originaires du Cap de Bonne-Espérance, peuvent se distribuer en 2 sections caractérisées, l'une par des fleurs presque sessiles el par les glandes terminales des anthères, en forme de cuillère; l'autre par des pédoncules plus longs et par des glandes en forme de boule. Ce sont des arbrisscaux à feuilles éparses ou plus rarement opposécs, planes, coriaces, criblées de points glanduleux qui dessinent, sur leurs bords, comme de petiles crénelures, portées sur un court pétiole muni de 2 glandes à sa base. Les fleurs, de couleur blanche, de couleur de chair ou rougeâtre, sont assez grandes, solitaires à l'extrémité des rameaux qui se divisent quelquefois en manière d'ombelle, et souvent accompagnées de 2 bractées opposécs.

(AD. J.)

ADENANTHERA, L. (ádńv, ćvos, glande;

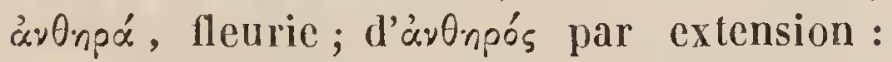
anthère). вот. PIl. - G. de la famille des Légumineuses, sous-ordre des Mimosées. M. Kunth lui assigne les caractères suivants (Nov. Gen. et Spee. vol. 6, p. 310.) : Calice cupuliforme, à 5 dents peu marquées. Pétales 5 , égaux, hypogynes. Étamines dont 5 (opposées aux pétales) plus courtes; filets libres; anthéres suborbiculaires, couronnées par une glandule stipitée. Ovaire non stipité, linéaire, pluri-uvulé. Style long. Stigmate simple. Légume très long, comprimé, membranacé, toruleux, uni-loculaire, bi-valve, \$-12-sperme. Graines éloignées, lenticulaires; tégument écarlate, dur, crustacé. Arbres inermes. Feuilles bi-pennées. Fleurs en épis axillaires ou terminaux. Les Adénantlières se cultivent, dans la zône équatoriale, comme arbres d'agrément; leurs graines, qui sont d'un beau rouge de corail, servent à faire des colliers et autres objets de parure. On en connaît 4 espéces.

ADENANTHOS ( $\alpha \dot{\delta} \dot{n} \nu$, glande; $\alpha ँ \nu \theta_{\circ}$, fleur ). вот. Рн. - G. de la famille des Protéacées, R. Br. (Protées, Juss.), s.-ordre des Nucamentacées, Endl., tribu des Protéinées,

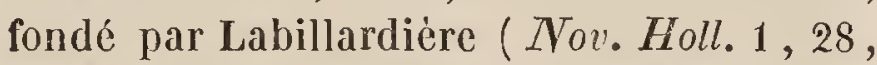
t. 36, 38), adopté par R. Brown (Linn. Trans. x, 151. et Prodr. 367, etc.) et ainsi caractérisé : Invol. 4-8-phylle, uniflore. Périgone quadrifide, circoncis à la base. Etamines 4 , insérées dans chaque cavité apicillaire des divisions périgonales. Squamules 4, hypogynes, adnées à la base persistante du périgone. Ovaire uníloculaire, uniovulé. Style filiforme, dépassant le périgone; Sligmate vertical. Noix renflée, sessile, monosperme.-Ceg.renferme 4 ou 5 arbrisseaux, trouvés dans la partie S.-O. de la Nouv.-Hollande, et distingués par des feuilles éparses, indivises ou trifides, par des fleurs rougedtres, renf crmćes dans des involucres axillaires, solitaires, ou plus rarement par des fleurs jaunâtres dans des involucres terminaux subagrégés. Le fruit est entouré à sa base de 4 glandes squaniformes. Labillardière (Loc. cit.) en a figuré 3 .

(C. L.)

* ADENAPIA, Kunth ('án'ń, évos, glande). вот. PH. - G. de la famille des Lythrariées, tribu des Salicariées, DC.-M. Kunth (Nov. Gen. el Spec. vol. 6, p. 185) en trace ainsi les caractéres: Tube calicinal turbiné - campanulé; limbe à 4 ou 5 lobes égaux. Pétales 4 ou 5 , égaux, onguiculés, insérés entre les lobes calicinaux. Étamines 8 ou 10, uni-sériées, saillantes, insérées un peu au-dessus de la base du calice. Filets libres. Anthères dorsifixes, latéralement déhiscentes, suborbiculaires. Ovaire stipité, biloculaire, multi-ovulé. Style terminal, inclus, persistant; stigmate bilobé. Péri- 
carpe (indéhiscent?) globuleus, en partie recouvert par le calice, mucroné, membraneux, polysperme. Graines cunéiformesobovécs, anguleuses, attachées à un placentaire central subglobuleux. - Arbres inermes. Feuilles opposées, très entières, parsemées en dessous (ainsi que le calice, la corolle et le pistil) de glandules ponctiformes. Fleurs blanches, disposées en ombelles; pédoncules axillaires, opposés. Ce g., dont on connaît aujourd'hui 4 espèces, appartient à l'Amér. équatoriale. (\$p.)

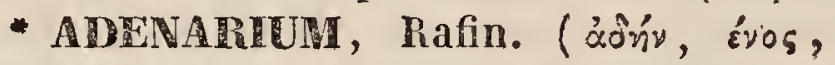
glande ). вот. рн. - Syn. du g. Honckenya, Ehrh. (non Willd.).

- ADENR ('óńn, glande; on aden, nom prétendu de cette plante chez les Arabes). вот. PH. - Dénomination imposée par Forslabl ( $F l$. Fgypt.), à un arbrisseau qu'il trouva en Arabie, el qu'il caractérisa a’une manière trop vague, pour qu'on puisse aujourd'hui le rapporter avec certitude à l'une des familles nalurelles, d'autant plus qu'il ne paraît pas avoir été retrouvé. Suivant cet auteur, les jeunes pousses de cet arbrisseau, réduites en poudre, sont très vénéneuses, et ont pour antidote cartain le Câprier épineux (Capparis spinosa L.). (C.L.).

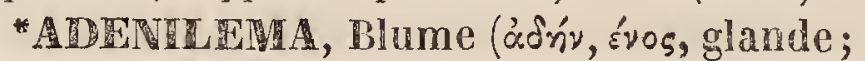
Arun, sécrétion). Bот. PH. - G. appartenant, soit à la famille des Rosacées, soit á celle des Cunoniacées. II a, dit M. Blume, le port des Rosacées; mais ses graines périspermées semblent le rapprocher davantage des Cunoniacées. M. Lindley le met parmi les g. non classés el incomplétement connus; M. Don (Gen. Syst. II, p. 522) pense qu'il diffère à peine des IVeillia (de la fam. des Rosacées-Spiréacées). Quoi qu’il en soit, voici les caract. que lui assigne M. Blume (Bijdr.xvil, p. 1120): Cal. campanulé, inadhérent, 5-fide, persistant, parsemé à la surface externe de poils glandulifères. Pétales 5 , petits, insérés à la gorge du calice. ilam. en nombre indéfini, ayant même insertion que les pétales. Ovaire 1-loculaire, piuri-ovulé. Style indivisé; stigm. pelté. Péricarpe folliculaire, 8-12-sperme, rostré par le style, latéralement déhiscent, recouvert par le calice. Graines bisériées, attachées à la suture, 1-costées, périspermées. - Arbrisseau sarmenteux, ayant le port des luubus. Fleurs en panicules termi- nales. Une seule espèce, indigène de Java.

* ADENUMR ( Liden, nom de cette plante chez les Arabes). BOT. PII. - G. de la famille des Apocynacées, Lindl., tribu des Apocynées vraies, s.-tribu des Échitées, proposé par Romer et Schultes ( $\boldsymbol{S} y$ st. Iv, p. 35 ), qui en circonscrivent ainsi les caractères : Calice quinqué-parti, à divisions lancéolées. Tube de la corolle rétréci à sa base, s'élargissant ensuite, pubescent, marqué intérieurement de 5 lignes longitudinales, velues; segments du limbe arrondis. Filaments des étamines très courts, insérés sur la partie rétrécie du tube. Anthères sagittées, cohérentes supórieurement avec le stigmate, et portant au sommet une soie hérissée, de la longueur de la corolle. Ovaires 2, globuleux. Style umique, de la longueur des anthères. Stigmate rapité, bidenté au sommet, quinquédenté latéralement. - Ce g. ne renferme encore qu'une seule esp., le 2 Verium obesum Forsk., qui avait déjả été indiquée par R. Brown comme ne devant plus faire partie du g. IVerium. C'est une plante indigène en Arabie, à souche molle, produisant un bulbe épigé de la grosscur d'une tête humaine, à rameaux ligneux, garnis de feuilles éparses, rapprochées au sommet des tiges, oblongues, resserrées à la base, mucronées, tomenteuses, velues en-dessous, munies de soies roides dans les aisselles; à inflorescence en corymbes terminaux, multiflores. Ce g. paraît devoir être adopté.(C. L.)

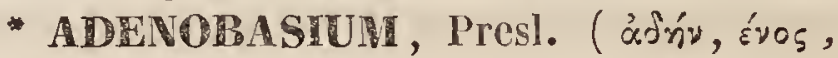
glande; 6x́бь, base). вот. Pн. - G. de la famille des Homalinées ou Homaliacées. M. Pres】 (Symb. Bot. vol. 1. p. 36) lui assigne les caractères suivants : Calice 4-parti; les 2 sépales intéricurs (pétales, en adoptant la manière de voir de M. Lindley) plus étroits. Etamines au nombre de 36, 4-sérićes, libres. Ovaire 4-loculaire, multiovulé, inséré sur un disque annulaire, de substance glanduleuse. Styles 4, subulés, étalés. Baic 4-loculaire, oligosperme.-Arbrisseaux à rameaux et à feuilles tantôt alternes, tantôt opposés, tantôt verticillés. Stipules sétacées, caduques. Fleurs axillaires, fasciculées.-L'auteur de ce g. n'en signale đu'une seule espèce, qui habite l'Amér. méridionale.

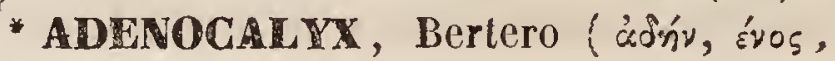


glande; $x x_{\lambda} \lambda \nu \xi$, bouton de fleur ). вот. Pн.Double emploi du g. Coulteria, Kuntl.

(Sp.)

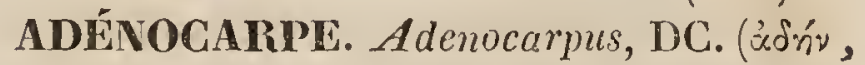
Éos, glande; харто́s, fruit). вот. PII.-G. de la fam. des Légumineuses, s.-ordre des Papilionaećes, tribu des Génistées, DC.-M.De Candolle (Flor. Frans. Suppl. p. 549, et Prodr. vol. 3, p. 158) assigne a ee g. les caraetères suivants : Caliee obconique, bilabié, souvent glanduleux; lèvre supérieure bipartie; lèvre inférieure plus longue, trifide. Carène obtuse, reeouvrant les organes sexuels. Étamines monadelplies. Légume oblong, eomprimé, couvert de glandules stipitées. - Arbrisseaux. Feuilles trifoliolées ; folioles souvent eondupliquées. Grappes terminales. Fleurs jaunes. Pédieelles bractéolés. - Ce g., extrêmement voisin des Cylises, renferme 7 ou $S$ espéees qui habitent la région méditerranéenne et les Canaries.

- ADENOCAUTON (árír, Évos, glande; xaùós, lige). вот. PII. - M. Lessing a donné ce nom à une plante originaire du Chiliet appartenant à la famille des Composées, tribu des Eupatoriées. Elle a pour caraetères de présenter des capilules pourvus de 9-10 fleurs tubuleuses de 2 sories, divisées supérieurement en 4-5 dents; celles du rayon, au nombre de 5 , sont femelles, tandis que les 4 ou 5 autres qui oceupent le centre du eapitule sont mâles. L'involuere est formé par un seul rang d'éeailles qui se réfléchissent à la maturilé. Le réeeptacle est nu; les fruits dépourvus d'aigretles sont oblongs-obovés et munis au sommel de glandes stipitées. - On eonnait 2 espèees du g. Adenocaulon, l'une du Chili, sur laquelle le g. a été établi; l'autre rapportée de la eôte N.-O. de l'Amér. septentrionale, des environs du fort Vaneouver, par le $52^{\circ} \mathrm{N}$.

(J. D.)

- ADENOCTEPIS ( áfinv, évos, glande; xprnís, base; fleur à réceptacle glanduleux). вот. pr. - M. Blume a établi ee $\mathrm{g}$. de la fam. des Euphorbiaećes, qu'il caraetérise ainsi : Fleurs dioïques; calice profondément quadriparli ; pas de eorolle. Ians les mâles : 6 filets libres, dressés, terminés par des anthères didymes et introrses, insérés sous un rudiment de pistil central et cyathiforme, alternant avee autant de glan- des. Dans les femelles : un ovaire globulcux à 2 loges biovulées; un stigmate simple et sessile, obtus, velu. Le fruil n'a pas été observé. - La seule espèee eonnue est un arbre de Java, haut de 40 pieds, à feuilles alterues, oblongues, obscurément erénelées, glabres, accompagnées de 2 pelites stipules caduques. Ses fleurs courtement pédicellées se rapprochent en général 3 par 3 sur des grappes axillaires. (AD. J.)

* ADENOCLCLS (ádńv, évos, glande; xúxdos, eercle ). вот. III. - Lessing a désigné sous ee nom un g. de plantes appartenant aux Composées, section des Vernonićes. II a pour earaetères, d'offrir des eapitules uniflores, des involucres assez petits, oblongs ou cylindraeés, formés d'éeailles fortementimbriquées, eoriaces, sèehes, paléacées, uninervées; eelles de l'intérieur presque linéaires. Le réceptaele ponctiforme. La corolle est régulière, a tube profondément divisé en 5 lobes, plus eourts eependant que la portion entière. Les filets des étamines sont lisses. Le fruit eourt, obconique, sillonné, glabre el dépourvu d'aigrette, est eouronné par un disque épigyne, eharnu el légérement ondulé sur le contour. - L'Adenocyclus est un arbrisseau originaire de l'île de la Trinité, dont les rameaux, munis de feuilles alternes, ovales-oblongues et aeuminćes, sont terminés par des eorymbes plusieurs fois diehotomes.

${ }^{*}$ ADENODUS, Loureir. ( $a \dot{\delta} \dot{n}^{\prime} \nu, \varepsilon^{\prime}$ 's, glande; ojo's, dent). вот. PII.-Suivant M. De Candolle, c'est un double emploi du g. Elceocarpus, $\mathbf{L}$.

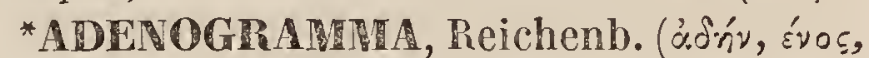
glande; yраниń, ligne). вот. Pr. - G. de la famille des Portulacaeées, tribu des Steudéliées, Reieh.; M. Reichenbaeh (Horl. Pol. sub tab. 109) en donne les earactères suivants: Cal. pétalö̈de, non-persistant, à 5 sépales striés. Corolle nulle. Étamines au nombre de 5 , alternes avec les sépales, insérées au fond du calice. Périearpe oblong, compri. mé, monosperme, indéhiscent, glanduleux aux bords, gibbeux de ehaque côté à la base. Embryon renversé, eurviligne.-Herbe annuelle, ayant le port des Pharnaceum. Feuilles verticillées. Fleurs petites. Ce g. n'est eonstilué que par une seule espèce. (SP.)

* ADENOLEPIS, Less. (¿dón'v, દ́vos, glande; $\lambda \varepsilon \pi i s$, écaille). вот. Pн. - G. de plantes de la 
fam. đes Composées, tribu des Génécionées et originaire des îles Sandwich. Ses caract. sont d'avoir des capitules pluriflores, hétérogames; les fleurs du rayon, au nombre de 4 environ, sont neutres, à ligules subelliptiques, échancrées; celles du disque tubuleuses, hermaphrodites, à limbe renflé à la base et divisé en 5 dents. Le réceptacle est plan, bractéolé. Les anthères dépassent la corolle; les fruits, tous semblables entre eux, sont presque triangulaires - obcomprimés, dépourvus d'ailes, légèrement atténués au sommet en forme de bec, et manquent d'aigrette; ceux du disque sont souvent linéaires par avortement. La seule espèce de ce g. a été rapportée d'O-Wahou par de Chamisso.

(J. D.)

- ADENOLINUN, Reichb. (ádín, ǵvos, glande; $\lambda$ ivov, lin). вот. PI. - M. Reichenbach (Syst. IVat.p. 307) donne ce nom à un g. qu'il fonde sur plısieurs espèces de Linum des auteurs ( $L$. austriacum, perenne et especes voisines); mais il n'en expose point les caractères.

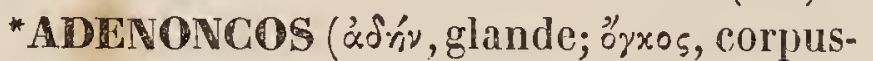
cule). вот. PII.-G. de la fam. des Orchidées, établi par M. Blume (Bijd., 381), adopté par M. Lindley et placé dans la tribu des Vandées. Il se compose d'une seule espèce ( $A$. virens BI.). C'est une plante parasite excessivement pelite qui croît dans les forêts de l'île de Java. Ses tiges simples portent des feuilles étroites, linéaires, aigües, distiques, creusées en gouttière en dessus; des pédoncules solitaires, opposés aux feuilles elterminés par un petit nombre de fleurs vertes et sessiles. Les divisions calicinales sont presque égales et dressées; le labelle concave, charnu, également dressé, glanduleux à sa face supérieure et entier. Le gynostème court se termine par une anthère presque bi-loculaire, contenant 4 masses polliniques globuleuses, un peu comprimées, avec une caudicule courte qui s’insère sur un rélinacle pelté.

(A. R.)

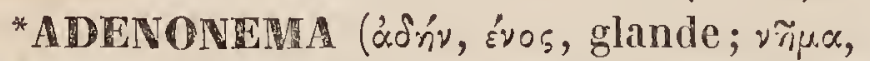
filament). вот. PI. - G. de la famille des Alsinacées, fondé par Bunge, indiqué par Lindley (New syst. of Bot.), et dont les caract. ne nous paraissent pas avoir été publiés.

(C. L.)

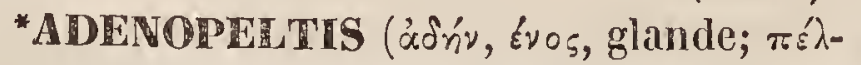
$\tau n$, bouclier; plante à bractées accompagnées de 2 glandes peltées). вот. РIr.-G. de la fam. des Euphorbiacées que distinguent les caract. suivants : Fleurs monoïques amentiformes; pas de calice. Les mâles consistent en 2 étamines dont les filets se soudent inférieurement en un seul articulé à sa base; les femelles en un ovaire à 3 loges biovulées, surmonté de 3 styles simples, réfléchis, et qui devient une capsule à 3 coques.-Ce g. a été formé d'après un arbrisseau connu au Chili sous le nom de Colliguay Macho. Les filets alternes sont bordés de dents glanduleuses. Les chatons présentent à leur base une ou 2 fleurs femelles, et sont couverts de mâles dans tout le reste de leur étenáue; toutes ces fleurs sont sessiles à l'aisselle d'une bractée écailleuse, accompagnéc intérieurement de 2 glandes pédicellées, et offrent un peu plus haut, au-dessous de l'articulation dans les mâles, 2 bractéoles sous forme de lanières filiformes.

(AD. J.)

" Aberophora (ádín, źvos, glande; yopós, porteur ). вот. Рн. - G. de la famille des Campanulacées, tribu des Campanulées, formé par Fisclier (Act. Acad. Mosq. vi. 165 , ayant pour synonyme le g. Floerkea de Sprengel (Aleit. 11, 523) et comprenant quelques espèces du g. Campanula, L. et Alior. En voici les caract. essentiels : Calice à tube ovale ou hémisphérique, conné avec lovaire, à limbe supère, quinquéfide. $\mathrm{CO}$ rolle insérée à l'extrémité supérieure du tube calicinal, campanulée ou infondibuliforme, quinquélobée au sommet. Étam. 5, insérées sur la corolle; fllaments étroitement connivents, à base dilatée, membraneuse, à sommet filiforme, à anthères libres. Ovaire infère, triloculaire; ovules anatropes, nombreux, portés sur des placentas dans l'angle central des logetles. Étui annuloire épigyne, cylindrique, nectarifère, engaìnant la base du style. Celui-ci souvent exsert, convert au sommet de 10 séries de poils rapprochés, et bientòl glabre; stigmates 3 , linéaires. Capsule ovoïde ou subsphérique, triloculaire, à loges déhiscentes auprès de la base par une valvule pariétale. Graines nombreuses, ovales, plus ou moins comprimées. Embryon or thotrope, dans l'axe d'un album charnu, à cotylédons très courts, obtus, à radicule centripète, rapprochée de l'ombilic. - Les Adénophores sont des lıerbes vivaces, ou quelquefois bisannuelles, 
ayant le port des Campanules, et habitant, á l'exception d'une seule espéce qui se trouve dans l'Europe orientale, le nord de la Sibérie, de la Daourie et de la Chine. Leurs racines sont souvent comestibles; leurs tiges dressées, garnies de feuilles alternes ou rarement verticillées; les radicales pétiolées, arrondies; les caulinaires souvent sessiles; les supérieures plus étroites, plus courtes. Leur inflorescence est en grappes ou en panicules terminales et axillaires; leurs fleurs pédicellées, nutantes.

* AdevophoruS (ásón, ćvos, glande; чорós, porteur). вот. сr. - Les plantes qui composent ce g. de la famille des Fongères diffèrent très peu par leurs caractères des Polypodes avec lesquels Kaulfuss et Presl les ont réunis; mais leur aspect est si particulier qu'on les distingue immédiatement de toutes les autres espèces de ce g. si nombreux, et qu'on est porté par là à donner de la valeur aux caractéres sur lesquels M. Gaudichaud l'a fondé. Ce sont de petites fougères croissant sur les troncs des arbres, à fronde découpée en lanières fines, ordinairement arrondies et spathulées, coriaces, traversées par une seule nervure renflée à son extrémité, et qui portent à cetle extrémité un seul groupe de capsules. En outre la surface de la fronde est couverte de poils vésiculeux, renflés et presque glanduleux qui ont motivé le nom donné à ce g. On connaît 3 espèces de ce g. ou de ce groupe de Polypodes, qui, toutes 3 , ont été déconvertes dans les îles Sandwich par M. Gaudichaud et figurées dans le Voyage de l'Uranie.

(AD. B.)

ADENOPHORUS ('́s'nv, $\varepsilon^{\prime} \vee \circ$, glande; $\varphi \circ-$ pós, porteur). вот. CR. - G. d'Algues, proposé par P. de Beauvois et non adopté par les Botanistes.

ADENOPHYLLUM ('śn'ń, évos, glande ;

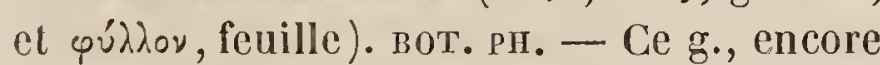
fort mal connu, est originaire du Mexique; ce sont des herbes ayant le port des Tagetes, munies de feuilles opposées dont les supéricures alternes sont découpées en segments ovales linéaires, terminés par une petite pointe que l'on retrouve également çà et là sur le rachis.Les pédoncules, renflés au sommet, portent un seul capitule radié, dont l'involucre se compose d'écailles linéaires, presque soudées entre elles et terminées au sommet en une arête subulée, glanduleuse à la base ; le capitule est muni inférieurement d'une rangée de braclées présentant des caractères semblables à ceux des folioles de l'involucre. Les fruits sont allongés, couronnés par une double aigrette dont les pailleltes extérieures sont courtes et tronquées; celles de la rangée intérieure sont ałlongées, à sommet aigu et trifide.

* ADENOPIS, DC. ( ás'ńv, śvos, glande ; "̋ $\psi$, ó $о$ '́s, aspect). вот. PII. - M. De Candolle (Prodr. 2, p. 446 ) donne ce nom á une section du genre Prosopis, L. (SP.)

* ADENORHOPIUM (ádín, évos, glande ;

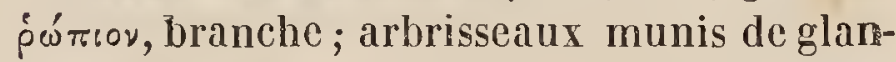
des sur leurs différentes parties). вот. РII. Ce g., établi par M. Pohl ( Pl. Bras. p. 12 , tab. 9), l'est aux dépens du Jatropha dont il prendrait la plupart des espéces. Les caractères qu'il lui assigne sont les suivants : Fleurs monoïques : Calice 5-parti, ordinairement muni de dents glanduleuses sur ses bords; 5 pétales. Dans les mâles : 8-10 étamines, dont les filets se soudent jusqu'à la moitié de la corolle en une colonne entourée à sa base de 5 glandes. Dans les femelles : 3 styles surmontés chacun d'un stigmate pelté, en cœur et ondulé. Capsule à 3 coques. - Les esp. de Jatropha qui présentent ces caractères, font partie de ce nouvean g. qui nous paraît distingué bien légèrement, par la forme de la corolle et un degré de plus d'élévation dans la soudure des filets. M. Pohl en compte 24 , la plupart nouvelles et brésiliennes. Ce sont des arbrisseaux originaires, à très peu d'exceptions près, des régions tropicales de l'Amérique. Leur suc est laiteux; leurs feuilles sont simples, lobées ou multiparties, garnies sur leurs bords de glandes visqueuses qu'on retrouve au sommet des stipules et au bord des calices; leurs fleurs en cymes axillaires, assez belles, rouges ou jaunâtres. $V$. JАTROPIL. (AD. J.)

* ADENosaCMEL, Wall. ( $\alpha \delta \delta^{\prime}$, évos,

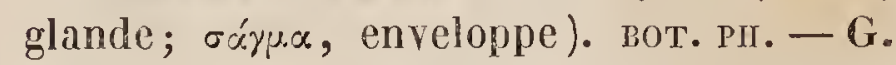
de la famille des Rubiacées, tribu des Hédyotidées. M. Endlicher (Gen. Plant. I, p. 552) en donne les caract! suivants : Tube calicinal ovoïde, adhérent; limbe supère, 5-fide, persistant; segments lancéolés, bordés de glandules globuleuses. Cor. infundibuliforme; tube cylindrique, pubérule à la surface externe, velu en dedans; gorge éva- 
sée, nue ; limbe 5-fide ; lobes étalés, pointus, valvaires en préfloraison. Étam. 5 , incluses, insérées á la base du tube de la corolle; filets très courts; anth. oblongues. Ovaire 2-loculaire; placentaires multi-ovulés, charnus, adnés à la cloison. Style filiforme. Stigm. bifide; lobes linćaires, dressés. Caps. ovoüde, 2-loculaire, polysperme, couronnée, s'ouvrant au sommet par une fente loculicide. Graines petites. - Arbrisseau. Feuilles opposées. Stipules bidentées à la base. Infloresc. dichotome, paniculée, lisse, garnie de braclées glanduleuses. Cor. grande, jamne. L'unique esp. sur laquelle se fonde ce g. croît au Népaul. (Sp.)

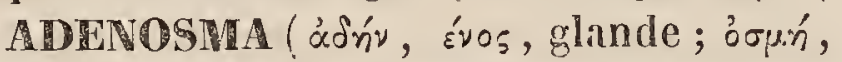
odeur; allusion à l'odeur qu'exhalent les fevilles). вот. риг. - G. de la famille des Acanthacées, tribu des Nelsoniées, Nees, fondé par R. Brown (Prod. 442), qui lui assigne les caractères suivants : Calice quinqué-parti, dont le segment postérieur plus grand ou égal. Corolle hypogyne, ringente, à lèvre supérieure indivise ; l'inférieure trilobée, égale. Étamines 4, didynames, incluses, insérées au tube de la corolle. Anthères rapprochées, bi-loculaires, à logetles parallèles. Ovaire bi-loculaire, à loges multi-ovulées.Style simple; stigm. bilabié, bilobé.Caps. étroite, rostrée, biloculaire, polysperme, loculicide-bivalve; valves septiferes au milieu. Graines privées de rétinacles. - Ce g., dont le Ruellia uliginosa L., est le type, renferme quelques espèces annuelles, indigènes en Asie et à la Nouvelle-Hollande tropicales; elles exhalent une odeur de menthe par les glandules dont elles sont parsemées. Leurs feuilles sont opposées, ovales ou oblongues, crénelées ou denticulées; leurs fleurs, sessiles dans l'aisselle des feuilles supérieures plus petites, sont solitaires ou ternées, opposées, et forment un épi feuillé; les calices en sont bibractéolés.

(C. L.)

* ADENOSOLRN (ádín, évos, glande; бwirv, tubel). вот. PII. - Ce g., créé par M. De Candolle, d'après un sous-arbrisseau originaire du Cap de Bonne - Espérance, a pour caractéres d'avoir: des capitules multilores d'une seule sorte; un involucre formé d'environ 3 rangées d'écailles imbriquées, un réceptacle convexe et nu; des corolles dont le tube est muni de glandes dilatées à la base par laquelle il adhère fortement au
Pruit; la gorge est dilatée-campanulée et le limbe 5-fide. Les anthères dépourvues d'appendices basilaires sont exsertes dans les fleurs stériles et presque incluses dans les 1leurs fertiles; le style qui dépasse les étamines se divise en 2 branches terminées chacune par une petite tête. Les fruits cylindriques manquent d'aigrettes. On ne connaît encore qu'une seule espèce de ce genre.

* ADPMOSTEGI (áón, Évos, glande;

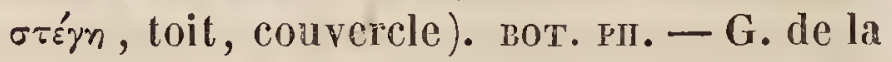
famille des Scrophularinées, tribu des Gérardiées de Bentham, créé par cet auteur ( in Lindl.. New Syst. Edit. 11), qui lui assigne les caractères suivants : Calice bifide, à segments aigus, entiers, cépassant un peu la corolle. Corolle hypogyne, bilabiée, à lèvres presque égales, dont la supéricure oblongue, galéiforme, dressée, courtement bifide. Etamines 4 , incluses, didynames, insérées sur le tube de la corolle. Anthères biloculaires, à logettes disjointes ; l'une médifixe, terminale; l'autre fixée en dessous au filament. Ovaire et style inconnus. Capsule biloculaire; loculicide-bivalve; à valves portant au milieu des cloisons placentifẻres. Graines inconnues. - Ce g., qui a besoin d'être mieux déterminé, ne se compose, selon l'auteur, que d'une seule espéce indigène dans la Nouvelle-Californic; c'est une plante roide et légèrement pubescente, à fcuilles étroitement linéaires, souvent trifides; ses fleurs sont rares, disposées en capitules au sommet des rameaux, accompagnées de bractées appliquées, trifides, glanduleuses, ciliées; les filaments et les anthères velus.

(C. L.)

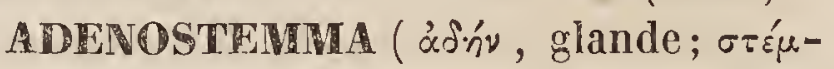
$\mu . x$, couronne). вот. Рі. — Ce g. se compose aujourd'hui d'une trentaine d'espèces assez difficiles á circonscrire et la plupart originaires de l'ancien continent; on le reconnaìt facilement à ses fruits surmontés de 3-5 arêtes terminées par une glande globuleuse ou claviforme, d'oú Forster a tiré son nom gériérique. Ses autres caractères sont d'ofrir des capitules multiflores d'une seule sorte; un involucre campanulé, formé d'écailles 1-sériées, foliacćes et oblongues, un peu plus courtes que les fleurs et se réfléchissant après l'anthèse. Les corolles sont tubuleuses, presque cylindriques et couver- 


\section{ADE}

tes de quelques poils dans la partic inférieure aux dents. Les branches du style, dilatées et colorées, dépassent de beaucoup la corolle. Les fruits sont obovés-oblongs, plus ou moins anguleux et surmontés par 3-5 pointes terminées par une glande globuleuse ou en forme de massue. Les $A d c-$ nostemma sont des herbes annuelles ou vivaces, couvertes de poils visqueux, munies de feuilles opposées, souvent rhomboïdales et trinerviées; les capitules, disposés en corymbe, renferment des fleurs blanches, comme la plupart des genres de la tribu des Eupatoriées, à laquelle ils appartiennent.

- ADENOSTEMUUR ( $\alpha \delta$ '́n, évos, glande,

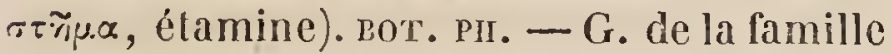
des Laurinées, formé par Persoon (Ench.1, 467) et réuni depuis au g. Cryptocarya de R. Brown. Lindley (Syst. of Bot. Edil., I. ) le cite à tort comme distinct de celui-ci. $V$. CRYPTOCARYA.

(C. L.)

* ADEvostoma, Hook. et Arn. (áfiń, ध́vos, glande; бтóuc, bouche; orifice). вот. PI. - G. de la famille des Posacées, tribu des Spiréacées. D’après la description de MM. Hooker et Arnott (Bol. of Bepchey's Toyage, p. 139), ce g. offre les caract. suivants : Cal. inadhérent, infondibuliforme, 5-fide, coriace, 5-gone ; lobes courts, arrondis, mucronulés; gorge couronnée de 5 glandes charnues. Pétales 5, suborbiculaires, à peine onguiculés, insérés à la gorge du calice. Élam. au nombre de 15 , ayant même insertion que les pétales. Ovaire obové, 1-loculaire, obliquement tronqué au sommet. Style latéral. Stigm. obtus. (Péricarpe inconnu.) - Arbrisseau. Feuilles fasciculées, linéaires-filiformes ; chaque fascicule accompagné d'une stipule bifide. Fleurs fasciculées; fascicules disposés en épis terminaux, aphylles. L'unique esp. sur laquelle est fondé ce g. croîl en Californie.

ADENOSTVEES. вот. PI. - C'est la

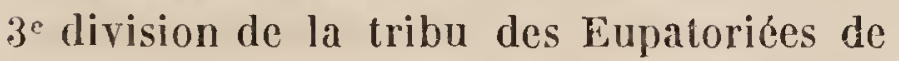
M. De Candolle ; elle correspond aux Lupatoriées de M. Lessing, aux Eupatoriées prototypes de Cassini qui désigna ces plantes sous le nom d'Adénostylées.

(J. D.)

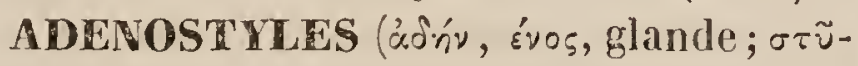
205, style). вот. PI. - Cassini a élabli ce g. sur plusieurs plantes d'Furope faisant partie des Tussilago de Linné. Il a pour caracléres d'a-
ADE

volr des capitules discoïdes, ne renfermant qu'un petit nombre de fleurs; un involucre cylindracé, formé par un pelit nombre d'écailles disposćes sur un rang. Les corolles de couleur blanche ou rose sont tubuleuses, à limbe campanulé, 5-denté; les branches des styles, qui dépassent de beaucoup ces corolles, sont semi - cylindriques el couvertes, sur toute leur surface, de papilles glanduliformes, qui ont servi a nommer et a caractériser ce g. - Les esp. qui en font parlie, telles que l'A. (Tussilago) glabra, Petasites, lcucophylla, etc., sont des plantes vivaces qui habilent les prairies tourbeuses des monlagnes.

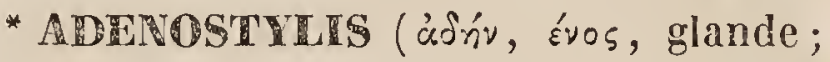

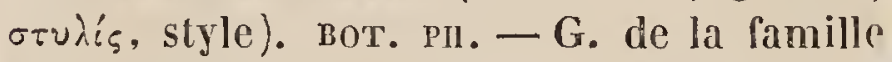
des Orchidacées, tribu des Néottiées, Lindl., fonde par Blume (Bijdr., 414, fij. 17) qui lui assigne les caractères suivants : Divisions périgonales conniventes; les externes latérales insérées sous le labelle; la supérieure voùtée, connivente avec les inférieures. Labelle ventru à la base, pubescent à l'intérieur, conné avec le gynostème. Limbe spatulé, indivis, étalé , épaissi. Gynostème court, échancré au sommel, glanduleux, renflé latéralement. Anthère dorsale, biloculaire, ovale. Pollinics 2, ovales, subbilobées; caudicule commune; glandule.

Il est singulier que l'auteur n'ait pas défini ce dernier organe, d'après lequel il a cependant caractérisé et nommé son g., qui ne contient encore qu'une plante herbacée de Java, à tige rhizomateuse à la base, á feuilles linéaires acuminées; ses fleurs sont sessiles, bractéées, blanches et disposées en épi spỉral. Selon Endlicher (Gener.pl. 1548), ce g. a pour synonyme le g. clonisaccus, Kuhl. et Hass. (Orch. edid. Breda, t. vıu.) $V$. ce mot.

- ADenotidchia (áśn, évos, glande; spı́, трıхо́s, poil). вот. Рн.-M. De Candolle a réuni ce g. au Senecio. On cultive dans les jardins de botanique les $A$. amplexicaulis et sinuatiloba. Ce sont des plantes annuelles, couvertes de poils entremêlés de glandes qui répandent une odeur assez agréable lorsque l'on en touche les tiges et les feuilles. (J. D.)

ADCONE. Adeona ( Adcona, nom mythologique). polyp. - G. de Polypes bryozoaires de la famille des Eschares, à polypier pierreux, étroit vers sa base, ou il s'en- 
croûte progressivement; frondescent ou flabelliforme à l'extrémilć supérieure, et composé de petites cellules serrées, sériales ou en quinconce, percées de pores irréguliers sur leur disque ventral à oscule rond, et disposées en 2 plan sadossés. La manière dont s'encroûtentles parlies inférieures du polypier est tout-i-fait analogue à ce qui arrive chez les Eschara fascialis, lichenoïdes, etc., et l'examen de quelques échantillons, ou cette parlie était extraordinairement allongée, avait fait croire à l'existence, chez ces polypiers, d'une tige pierreuse, articulée, et d'une structure particulière. En conséquence, Lamouroux plaça l'Adéone dans la famille des Isis, qui ont des polypiers corticifẻres. Lamarck, tout en assignant leur véritable place, contre les Eschares, indiqua mal à propos un rapport entre les Adéones et les Rétépores, rapport qui ne serait fondé que sur les perforations des lames d'Adéones, comparées aux mailles des Rétépores. On a rangé dans ce g. plusieurs especes: $A$. foliifera, cribriformis, elongata, qui pourraient bien appartenir à des g. diférents.

(DuJ.)

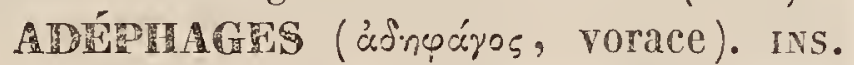
- Nom donné par Clairville et Eschswald à une famille de Coléoptères pentamères, la même que celle des Entomophages de Latreille. $T$. ce mot.

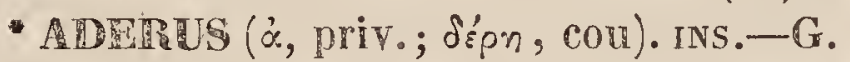
de Coléoptéres hétéromères, famille des Sténélytres, établi par M. Westwood, aux dépens du g: Xylophilus de Bonelli, et auquel il donne pour caractères : Corps ovoïde. Antennes médiocrement longues, de 11 articles, dont le $2^{\text {me }}$ et le $3^{\text {me }}$ minces ; yeux médiocres, entiers.-Ce g. a pour type la Lytta boleti Harsham, espéce propre il l'Angleterre. M.Stephens, qui l'adopte, le place dans sa tribu des Noloxides, et y rapporte 2 autres espèces qui nous sont inconnues. (D.)

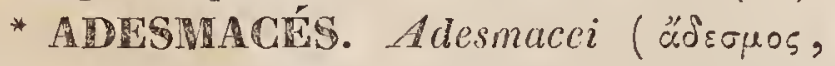
sans ligament). MoLt. - M. de Blainville a senti, l'un des premiers, que les familles des Pholadaires et des Tubicolés de Lamarck, n'étaient point naturelles. Il s'est apercu que les Tarets et les Térédines avaient beaucoup bus d'analogie avec les Pholades qu'avec les Fistulanes et les Arrosoirs. Voulant rassembler dans un même groupe tous les g. de Mollusques bivalves qui, comme les Pholades, n'ont point de ligament pour réunir les deux valves, il a donné á ce groupe un nom caractéristique qui exprime très bien son caractère principal. Nous faisions ces observations en même temps que M. de Blainville, et nous avons pu réformer, dans la famille des Adesmacés, un g. qu'il nomme Fistulane, et qui n'est qu'un double emploi du g. Taret lui-même, puisqu'il a été formé sur le Teredo nucivorus de Spengler. Nous anrions été un des premiers à adopter le nom proposé par M. de Blainville, si nous ne nous étions fait une loi de n'admeltre un nom dans la nomenclature qu'xutant qu'il ne s'y trouve rien d'équivalent. Lamarck ayant fait une famille des Pholadaires, il nous a paru plus convenable de la conserver en l'améliorant.

(Desir.)

* ADEgerer (ćśśrutos, qui n'est pas lié). INS.-G. de l'ord. des Colćoptères hétéromères, famille des Mélasomes, établi par Fischer

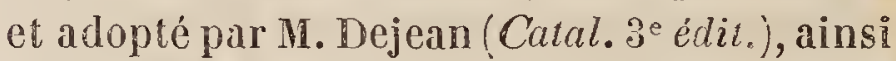
que par M. Solier qui le place dans sa tribu des Macropodites, et lui assigne pour caractères distinctis des autres g. de la même tribu savoir : Les mandibules sans sillon en dessus; le menton anguleux sur les côtés, et à échancrure profonde; le labre tronqué ou échancré, non recourbé à son extrémité. Ces caractères sont plus développés el représentés grossis par l'auteur dans le I. Iv des Ann. de la Soc. ent. de France, p. 522, pl. 15. M. Solier ne décrit que 24 espèces comme se rapportant à ce g.; mais M. Dejean en désigne 32. Nous n'en citerons qu'une qui parait avoir servi de type à M. Solier. c'est son Ad. dubia qui, d'après M. Dejean, est la Pimclia longipes Fabr.

(D.)

* ADSIIA, DC.; Patagonium, Schrank; Heteroloma, Desvaux. (ádśsuros, sans lien; parce que les étamines sont libres). Boт. prf. - G. de la famille des Légumineuses; s.ordre des Papilionacées, tribu des Hédysarées, sous-tribu des Euhédysarées, DC. M. De Candolle (Amn. des $S c$. IVat. Janv. 1325, et Prodr. v. 2, p. 318) assigne à ce g. les caract. suivants : Calice 5 -fide, lanières pointues, presque égales. Corolle papilionacée : ètendard enveloppant (avant l'épanonissement) les autres pétales; carène tronquée au sommet. Étamines libres, contiguës. Légume comprimé iransversalement, pluriarticulé : suture supérieure subrectiligne, épaissie; suture inféricure sinuée-lobée; 
articles monospermes, suborbiculatres, tialement désunis. Graines complrimées, réniformes-orbiculaires. - Herbes annuelles ou vivaces. Feuilles abrupté-pennées; péliole sétifére au sommet. Stipules lancéolées. Pédoncules uniflores, axillaires ou en grappe terminale. Fleurs pelites, jaunâtres. Ce g. appartient à l'Amér. méridionale. On en connaît environ 15 espéces.

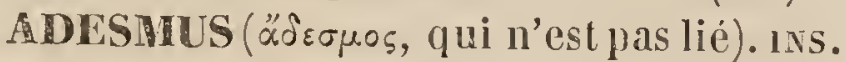
-M. Dejean avait désigné sous cenom (Catal. de 1821) un g de l'ordre des Coléoptères létramères, famille des Longicornes, fondé sur nne seule espèce du Brésil qu'il avait appelée $A d$. luctuosus; mais dans la $3^{\text {me }} e ́ d$. de son Catal., il a compris celle espèce dans son g. Amphionycha, et lui a restitué le nom d'Hesmipila, qui lui avait été donné précédemment par Germar.

* ADEXIUS ('ं $\delta^{\prime} \varepsilon^{\prime} \xi 05$, maladroit). INs.-G. de Coléoptères tétramères, famille des Curculionides, division des Molylides, établi par Schœnherr, qui lui donne les caract. suivants : Ant. médiocres; les 2 premiers art. du funicule assez longs, presque obconiques, les autres courts, presque turbinés, s'ćlargissant peu à peu ; massue presque ronde, à arlicles peu distincts. Rostre allongé, robuste, cylindrique, légèrement arqué. Yeux oblongs, déprimés. Prothorax transversal, presque tronqué à la base et au sommet, plus étroit par-devant, et un peu rétréci près de la base; écusson nul. Élytres grandes, ovoüdes, très convexes.-Ce g. est fondè sur une seule espèce que l'auteur nomme $A$. Scrobipennis, et qui lui a été communiquée par M. Schappel comme originaire des Alpes de Carinthie. Le g. Adexins ne figure pas dans la dernière édir. du Catal. de M. Dejean. (D.)

* AdHatoda. вot. ph. - Dénomination spécífique d'une espèce de Justicia ( $J$. Adhatoda L.) dont Tournefort avait fait un g. qui n’a pas été adopté. Selon Duchesne, ce mot signifie à Ceylan, expulsion du fous, d'après la vertu que les habitants altribuent à cette plante.

(C. L.)

* AdIantacécs. bot. cr.--Tribu de la famille des Fougères, diversement limitée par les divers botanistes qui se sont occupés de cette famille; M. Gaudichaud n'y comprend sous le nom d'Adiantées, que les g. Adiantum et Cheilanthes. Presl, au contraire, réunit sous ce nom, les Adiantées, une grande partie des Ptéridées, des Blechnées et des Notholænées de cet auteur, et les caractérise par leurs capsules en groupes marginaux, continus ou interrompus, recouverts d'un tégument formé par le bord replié de la feuille, et sur lequel les capsules sont le plus souvent insérées. Presl diviso cette tribu en 2 sections, les Adiantacées et les Lonchitidées. Les principaux g. de la $1^{\text {re }}$ sont : Lomaria, Pteris et ses subdivisions, Adiantum et Cheilanthes. $V$. FouGìres.

(AD. B.)

* ADIANTRTES. BoT. Foss. - M. Gappert a désigné sous ce nom un groupe nombreux de Fougères fossiles, qu'il considère comme assez analogues aux fougères vivantes du g. Adiantum, pour leur avoir appliqués ce nom. Quoiqu'il y ait pour plusieurs d'entre elles une assez grande probabilité, cependant la plupart ont trés peu de rapport par la forme deleurs frondes avecles Adiantam vivants; et la fructification n'étant inàiquée sur aucune de ces espèces, il nous paraît très douteux que la majorité d'entre elles puisse être rapprochée des Adiantum. La plupart de ces fougéres fossiles avaient été précédemment décrites dans mon Histoire des végétaux fossiles sous le nom de Cyclopteris. Quelques unes étaient placées dans le g. Sphenopteris. $V$. Fougines tossiles.

(AD. B.)

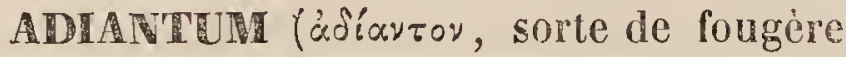
chez les Grees; d'ádíavто5, loujours sec). вот. cr.-Linné, qui a établi ce g., y plaçait un grand nombre de fougères, désignées par les anciens botanistes sous le nom de Capillaires et toutes remarquables par la finesse de leur pétiole et de ses divisions, ainsi que par la couleur ordinairement noire et par le brillant de ce péliole. Toutes ces plantes avaient en outre leurs capsules portées sur le bord de la fronde et séparées en groupes distincts; mais depuis lors, l'étude do l'insertion du tégument qui couvre ces capsules a conduil à diviser ce g. en plusieurs autres, dont les principaux sont les Cheilanthes et les Lindsea. Le g. Adiantum ainsi limité, est encore un des plus nombreux et des plus élégants de la famille des Fougères; il comprend, en efret, environ 70 espéces presque toutes des pays chauds ou de l'hémisphère austral ; très peu d'esper ces croissent dans les parties tempérées ou 
froides de l'hémisphère bonéal. De ce nombre, sont cependant l'Adianum Capillus Deneris, qui croît dans tout le bassin de la Méditerranée; l'Ad. pedalum du Canada, et PAd. boreale des îles Aléoutiennes. Toutes ces plantes ont des pélioles grêles, naissant d'une sonche rampante et se subdivisant en rameaux nombreux très fins, presque toujours glabres, lisses et d'un noir d'ébène, gui portent des folioles souvent cunéiformes a nervures flabelliformes dichotomes; ces rolioles sont presque toujours glabres, membraneuses, très minces, d'un vert tendre ; elles présentent, sur le bord de leur face inféricure, des groupes de capsules marginaux, arrondis et égaux, ou oblongs et inégaux, recouverts par un tégument membraneux brunâtre, oblong, arrondi ou lunnlé, s'ouvrant interieurement, faisant suite au bord de la feuille, et sur lequel sont insérées les capsules.-La finesse, le brillant et la couleurnoire des divisions du pétiole dans la plupart de ces plantes, les ont fait comparer à des cheveux, et leur ont fait donner le nom de Capillaires. Lc parfum léger qu'exhalentleurs feuilles, joint à leurs qualités mucilagineuses, les font employer en médecinc pour fabriquer des sirops ou des tisanes émollientes. Ce sont particulièrement: l'Adiantum Capillus Veneris du midi de l'Europe, ou Capillaire de Montpellier, et l'Adiantum pedalum ou Capillaire du Canada, qu'on emploie à cet usagc. Plusieurs espéces sont actuellement cultivées fréquemment dans les serres à cause de l'élégance de leurs frondes. L'une des plus jolies et des plus faciles à cultiver est l' $A d$. cunealum du Brésil, qui forme des touffes charmantes dans les serres chaudes.

(AD. B.)

* ADIE. Adia. ins. - G. de Diplères de la section des Anthomidoe herbicolce de M. Robineau Desvoidy, section qui répond au g. Chortophila, Macq. V. (:c mot. (D.)

ADIMONDE. Adimonia (áfinuovía, crainte). Ins. - G. de Coléoptères tétramères, famille des Chrysomélines, établi par Laicharting, et adopté par M. Dejean ( $\mathrm{Ca}$ ıal. $\left.3^{\text {me }} e ́ d i t.\right)$. Ce g., démembrement des Galléruques de Geofroy, a pour type la Galleruca Tanaceli de Fabricius. M. Dejean y rapporte 21 espéces, toutes d'Europe, à l'cxception de deux : l'A. ventricosa Klug, de Mexico, et l' $\mathcal{A}$. persica Falderm., de la Perse occidentale. M. Westwood, qui adopte également le g. Adimonia, dont il altribue mal à propos la création à Sehrank, le caractérise ainsi : Antennes ayant lc $2^{\text {nue }}$ et le $3^{\text {me }}$ article également courts; labre échancré.-Il lui donne pour type la Chrysomela Halensis $\mathbf{L}$.

* ADINA, Salisb. (áócvós, nombreux). вот. PH. - G. de la famille des Rubiacées, très voisin des $\mathbb{N}$ aurclea, auxquels le réunissent plusieurs autenrs. Salisbury (Parad. Lond. 115 ) le fonde sur ies caract. suivants : Tube calicinal oblong; limbe supère, campanulé, 5-parti, persistant, Cor. infundibuliforme, 5-lobce ; gorge nue; estivation valvaire. Anth. sessiles, insérées entre les lobes de la corolle. Style saillant. Stigm. capitellé.Caps. membranacée, obpyramidale, 2-loculaire, 4 -valve de haut en bas; l'axe central persistant avec le limbe du calice. Loges 2-4spermes. Graines marginées, suspendues au sommet des loges moyennant des funicules spongieux. - Sous-arbrisseaux glabres, inermes. Feuilles opposées. Stipules géminées, cohérentes par la basc. Pédoncules axillaires ou terminaux, solitaires. Fleurs sessiles, agrégécs cn capitule sur un réceptacle commun, poilu el dépourvu d'involucre. Capsules (de chaque capitule) non cohérentes. - Ce g. renferme 2 esp., indigènes en Chine, el cultivées comme arbustes d'ornement.

(Sp.)

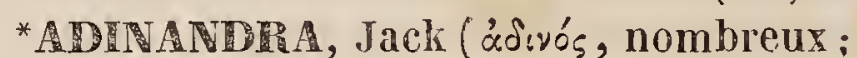
ávrip, àsjós, homme). вот. PII. - G. de la famille des Ternstrœmiacées, très voisin des Cleyera. Jack (Malay. Misc. in Hook. Comp.Bol. Mag. 1, p. 15) en donne lescaract. suivants : Cal. 5-parti, persistant, 2-bractéolé a la base; segments suborbiculaires , épais, imbriqués en préfloraison. Pétales 5, dressés, connivents, élargis à la basc. Étam. en nombre indéfini, pluri-sériées, subpolyadelphes; anthères dithèques, adnées, glabres, mucronées au sommet. Style indivisé, persistant, subulé; stigm. simple. Baic 5-10culaire, polysperme; placentaires axiles, septiformes, partageant chaque $\log \mathrm{c}$ en 2 compartiments presque complets. - Arbre. Feuilles allernes, non stipulées, à peine dentées. Pédoncules axillaires, subsolitaires, 1-flores.-Le g. n'est fondié que sur unc seule esp., indigène de Sumatra. (Sp.)

* ADNOLE ou mieux ADIRHOLE (ás:- 
vó; , compacte; ä̀os, entier). mix́-M. Beudant a décrit sous ce nom, comme espéce minérale, une substance compacte, homogène, á cassure aciéreuse, rouge, translucide sur les bords, que l'on trouve à Sahlberg, en Suède. J'après l'analyse que M. Berthier cn a faite, ce n'est qu'une Albite mêlée de quartz, et par conséquent une variété de la roche nommée Petrosilex. $V$. ce mot.

(DEL.)

ADIPEUX. Adiposi (Adeps, ipis, graisse). Porss.-On donne cette épithète á des Poissons qui ont les nageoires adipeuses, c'està-dire formées par un repli de la peau sans aucun rayon pour les soutenir. Toutes les espèces de Silures et de Saumons offrent des exemples de ces sortes de nageoires, plus ou moins étendues sur le tronçon dorsal de la quene.

ADPPOCRRE [Minéral]. (adeps, ipis, graisse; cera, cire). Mn.-Synonyme de Hatchétine.

(DEL.)

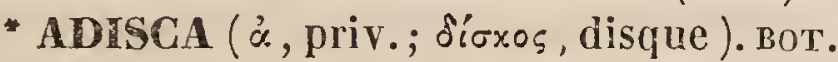
PII.-M. Blume décrit, sous ce nom générique, 5 espèces d'arbres ou arbrisseaux de Java, qu'il distingue des Rottlera, en ce que lenrs fleurs șont monoïques, el que les étamines des mâles ne s'insèrent pas sur un réceptacle ou disque. Du reste; les deux g. of Trent absolument les mêmes caractères. $V$. RotTLERA. (AD. J.)

* ADLERTA, Neck. вот. PII. - Double emploi du g. Parivoa, Aubl.

(Sp.)

ADLUMIR, Rafin. вот. pн. - G. de la famille des Fumariacées, tribu des Fumariées, Bernh.; S.-tribu des Diélytrinées, Reichb. Ses caractères essentiels sont les suivants (Spach, Hist. des Pl. ph. t. vil): Sépales 2 , denticulés, supra-basifixes. Corolle marcescente, ovale-oblongue, ringente au sommet, comprimée, composée de 4 pétales soudés presque jusqu'à leur sommet : les 2 pétales extérieurs gibbeux à la base; les 2 pétales intérieurs linéairesspatulés. Éamines 6 , diadelphes; filets soudés presque jusqu'au sommet en 2 androphores linéaires-lancéolés, ad̉nés inférieurement à la corolle, prolongés chacun postérieurement en glandule. Ovaire tétragone-ancipité, rétréci aux deux bouts; ovules campylotropes, renversés, uni-sériés sur chaque placentaire. Style grêle, tétraèdre-ancipité. Stigmate comprimé, cunéi- forme-rhomboïdal, échancré, 4-denticulé. Silique grêle, fusiforme, tétragone-ancipitée (comprimée bilatéralement), cuspidée, bivalve, 5-12-sperme; valves naviculaires, un peu carénées. Graines subréniformes, un peu comprincées, lisses, non strophiolées.-Pacine vivace; tiges sarmenteuses; feuilles bi-pennées ou tri-pennées, à ramifications pétiolaires souvent terminćes en vrille spiralce, tantòt simple, tantôt rameuse. Inflorescence corymbiforme ou paniculée, à évolution centrifuge. Pédicelles filiformes et pendants sur un pédoncule cornmun, court et plus ou moins incliné. Corolle assez grande et de couleur rose.- Ce g. ne renfermequ'une scule espèce, indigène dans l'Amér. septentrionale.

ADNE. Adnatus ou Adnexus. вот. pn.Un organe est adné á un autre, quand il y est collé ou soudé la téralement par sa superficie entière; ainsi, par exemple, le disque périgynique de la plupart des Posacées est adné au calice. On dit des 2 loges composant une anthère, qu'elles sont adnées au filet, quand elles sont soudées avec ce dernier dans toute leur longueur, comme dans la plupart des plantes de la famille des $R e-$ nonculacées.

ADOKIA. BоT. PH. - Nom brachmane, employé par Lamarck pour désigner un g. qu'il a fondé (Encycl.) sur 2 plantes figurées dans Rhéede (Hort. Mal. t. v. pl. 30 et 31) et dont les descriptions sont tellement vagues, qu'il est impossible de les rapporter à l'une des familles naturelles. Le nombre même de leurs étamines est inconnu. Lamarck leur trouve de l'affinité avec les Nerpruns.

(C. L.)

*ADOLIAS (á priv. dóncos, $\alpha$, rusé, e; non trompeur). INs.-Gr. de Lépidoptères, famille des Diurnes, section des Tétrapodes, tribu des Nymphalides, établi par M. Boisduval qui n'en a pas encore publié les caractères. Nous savons seulement qu'il correspond en parlie au g. Aconthea de Horsfield, dont il n'a pu conserver le nom, parceque c'est celui d'une espèce bien connue. Ce g. renferme un assez grand nombre de Lépidoptéres propres au continent et à l'archipel Indiens, ainsi qu'à la côte occidentale d'Afrique, parmi lesquels nous citerons seulement les Papilio Aconthea, Lubentina et Adonis de Cramer. 
* MDOLUS (ädòos, sincẻre). ins.-G. de l'ordre des Coléoptères pentamères, famille des Carabiques, tribu des Simplicipèdes, etabli par Eschscholtz et mon adopté par M. Dejean, qui (Catal. $3^{\text {me }}$ édit.) comprend l'espèce qui lui sert de type ( $A$. brunneus) dans le g. Leistus. $V$. ce dernier mot. (D.)

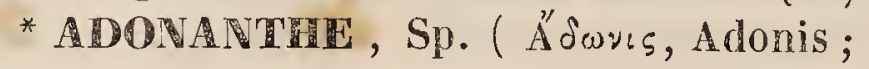
œ้ $\theta n$, fleur ). вот. Pп. - G. de la famille des Renonculacées, immédiatement voisin des Adonis. Ses caractères difrérentiels sont les suivants (Spach, Hi.t. des.Pl.ph.t. vir.): Sépales $5-8$, non prolongés au delà de leur base. Pétales 8-20. Etamines très nombreuses : filets filiformes, épaissis au sommet, toujours rectilignes; anthères non arquées après l'anthèse. Słyles recourbés après la floraison. Etairion ovoïde ou subglobuleux : nucules oncinées, un peu comprimées bilatéralement. - Les Adonanthes sont des herbes vivaces, âcres, vénéneuses, en général pluricaules, à feuilles bi-ou tri-pennatiparties, ou palmatiparties et multifides. Les flevrs sont grandes, jaunes, antéméridiennes, solitaires, terminales, subsessiles. Ce g. renferme 3 ou 4 espèces, dont l'une, A.vernalis Sp. (Adunis vernalis $\mathbf{L}$.), se cultive fréquemment dans les parterres. (Sp.)

ADONES, L.; Sp. (Ä'fwves, Adonis; Mythol.). вот. рп. - G. de la famille des Penonculacées, tribu des Renonculées, Sp., s.tribu des Adoninées, Sp.; ses caractères essentiels sont les suivants : Sépales 5 , subpétaloüdes, non persistants, un peu prolongés au delà de leur base. Pétales 5 à 9 (accidentellement moins de 5) : lame non fovéolée. Étamines en nombre indéfini, paucisépiées; filets subulés, infléchis au sommet pendant l'anthèse, puis réfléchis. Anthères elliptiques, très obtuses, latéralement déhiscentes, arquées après l'anthèse. Ovaires nombreux, ascendants, irrégulièrement téuragones, contenant chacun un ovule suspendu, attaché un peu au dessous du sommet de l'angle interne. Styles coniques-subulés ou pyramidaux, obliques, rectilignes, dressés or finclinés en avant après la floraison. Péricarpe spiciforme, composé de quantité de nucules coriaces, fovéolées, réticulées, subpyramidales, en général imbriquées, pluri-sériées. - Les Adonis sont des plantes âcres et vénéncuses, qu'on emploie parois en guise d'épispastiques. Leur rache est annuelle. Les feuilles inférieures sont bipennées ou tripennées, pétiolées; les feuilles supérieures digitées ou palmatiparties, subsessiles. Les fleurs, en général élégarites, sont solitaires el immédiatement terminales; leur corolle, de couleur jaune ou rouge, n'est épanouie qu'au soleil, à certaines heures de la matinée. Ce genre, selon nous, ne renferme que 4 ou 5 espèces.

ADOPRETS. uns.-G.de Coléoptères pentamères, famille des Lamellicornes, élabli par Eschscholtz, mais non adopté par M. Dejean qui (Catal. $3^{\mathrm{me}}$ édit.) le réunit à son g. Trigonostoma. $V$. ce dernier mot. (D.)

ADORIE. Adorium (Adorea, nom myth.). ins.-G. de l'ordre des Coléopt. tétram. fam. des Chrysomćlines, ćtabli par Weber, sous le nom d'Oüdes, auquel Fabricius a substitué celui d'Adorium qui a prévalu. Ses caractéres, suivant Latreille, sont: Antennes très rapprochées à leur base, insérées entre les yeux; pénultième article des palpes, surtout des maxillaires, dilaté; le dernier court, tronqué. Les antennes sont filiformes; le corps est presque orbiculaire ov ovoïde, avec les élytres larges et arquées, ou dilatées au bord extérieur. - Les Insectes de ce g. sont très voisins des Galléruques et tous exotiques. M. Dejean ( $\mathrm{Ca}^{\text {- }}$ tal. $3^{\text {me }}$ édit.) en désigne 6 espèces; nous ne citerons que celle qui a servi de type a l'élablissement du genre, l'Ad. bijunctatum Fabr., des Indes-Orientales. Latreille l'a figurée (Gen. Crust. el Ins., t. 11, tab.11, fig. 100.)

MDORPEUN. вот. Рн. - G. imparfaitement connu de la famille des Ombellifères, établi par Rafinesque (in Seringe, Bullet. de Bot. 1, p. 217) sur une plante de l'Amérique septentrionale, et appartenant peutêtre à quelque autre g. plus anciennement établi. Les caract. que lui assigne son auteur sont : Calice 5-denté. Pétales obcordiformes. Méricarpes ovoïdes, gibbeux, anguleux, glabres.

ADOXA, L.; Moschatellina, Tourn. ( $\propto$

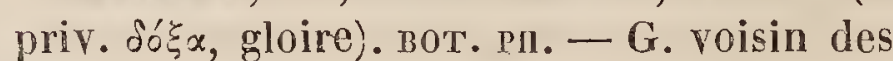
Viburnées, des Araliacées et des Saxifragées. Ses caract. sont les suivants (Spach, Obs. inéd.): Tube calicinal turbiné, adhérent; limbe accrescent, 2-ou 3-parti, périgyne. Corolle rotacée, profondément 4-ou 5-lobée, 
Ion persistante, insérée à la gorge du calice; lobes anisométres; estivation imbricative. Disque mince, annulaire, adné au tube de la corolle. Étamines $S$ ou 10 , insérées 2 à 2 devant les lobes de la corolle : filets très courts, filiformes; anthères minimes, peltées, transversalement elliptiques, monothèques, transversalement bivalves. Ovaire semi-supére, 3-5-loculaire; cloisons formées par les angles d'un gros placentaire central; ovules solitaires dans chaque loge, anatropes, suspendus au sommet de l'axe. Styles 3 , ou 4, ou 5, persistants, coniques-subulés, divergents, lerminés chacun par un petil stigmate capitellé. Baie charnue, 2 ou 3corne vers le milieu (par le limbe calicinal amplifié), finalement 1-loculaire, 3-bsperme. Graines comprimées, marginces, suspendues au sommet d'un axe central : tégument testacé; radicule supère.-Plante vivace, succulente. Racine rhizomateuse, rampante. Tiges basses, grêles, solitaires, diphylles. Feuilles trifoliolées : les radicales longuement pétiolées ; les caulinaires courtement pétiolées. Folioles flasques, Iuisantes, trifides. Fleurs petites, d'un jaune verdâtre, disposées (au nombre de 4 à 7 ) en capitule terminal; pédoncule nu, recourbé après la floraison. L'unique espèce, sur laquelle ce g. est fondé, est indigène et connue sous le nom vulgaire de Moscatelle: nom dù á ce que toute la plante exhale une légère odeur de musc. La racine élait jadis préconisée comme vulnéraire.

(Sp.)

ADRAGANT, ADTRAGANTE OU ADPRAGANTIE [gomme]. BOT. PII.-Matière gommeuse, qui découle naturellement de plusieurs esp. du g. Astragalé (fam. des Légumineuses) et particulièrement des Astragalus tragacantha L., creticus L., verus Oliv. Elle est en petits fragments opaques, rubanés, étroits ou cylindroïdes, de couleur blanche, se gonflant considérablement dans l'eau, s'y dissolvant en partie et lui communiquant une très grande viscosité. Autrefois employée dans les arts pour apprêter les étoffes, elle est encore usitée en médecine pour donner de la consistance aux pâtes pilulaires, ou, dans certaines potions, pour tenir en suspension des poudres, des huiles ou des résines. La gomme adragante nous est apporlèe de l'Asie mineure.

(A. R.)

ADPAGANTHINE. GHM. - M. Desvaux a donné ce nom au principe immédiat de la gomme $A$ dragante $(V$.ce mot), principe existant aussi dans la gomme qui exsude de la plupart de nos arbres fruitiers à noyaux.

(C. D'O.)

ADRASTEE. Adrastea, DC. (Adrastea, nom my thol.). BоT. PI. -G. de la fam. des Dilléniacées. M. De Candolle (Prodr. 1, p. 73) le caractérise ainsi : Élamines 10 , libres, égales; filets planes; bourses de l'anthère adnées latéralement. Ovaires 2 ; styles rectilignes, coniques, subulés. - L'unique espèce qui conslitue le g. a été observée dans la Nouvelle-Hollande extra-tropicale. (Sr.)

* ADThasTUS (nom d'un roi grec). ins. —G. de l'ordre des Coléoptères pentamères, famille des Sternoxes, tribu des Élatérides, établi par Eschscholtz el adopté par Latreille, dans sa Distribution méthodique des Serricornes, ouvrage posthume de ce célébre naturaliste, et inséré dans le t. un des Ann. de la Soc. ent. de France, $1^{\text {er }}$ trimestre, 1834 . Il a pour type l'Elater limbatus de Fabricius, et pour caractères principaux, suivant Latreille : Corps presque linéaire. Corselet cylindrique. Chaperon frontal presque de niveau avec le labre. Ant. simples, à articles obconiques allongés, le $2^{\text {me }}$ plus petit, le $3^{\text {me }}$ de la forme et presque de la grandeur des suivants. M.DCjean a adopté ceg. (Catal. $3^{\text {me }}$ édit.), auquel il rapporte 5 espéces, toutes d'Europe, et dont 2 se trouvent aux environs de Paris, l'A. limbatus, déjá cité, et $l^{\prime} A$. umbrinus de Germar.

* ADRIANA. воT. PH.- - G. d'Euphorbiacées, dédié par M. Gaudichaud à l'auteur d'un travail sur cette famille, et caractérisé de la manière suivante : Fleurs diö̈ques. Dans les mâles : Calice simple, profondément 5-parti, irrégulier, ả préfloraison valvaire; pas de pétales ni de glandes; Étamines nombreuses, dressées dans le bouton, à filets courts, libres, insérés sur un réceptacle conique, à anthères oblongues, dressées, biloculaires, dont le connectif se prolonge en languette au-delá des loges. Dans les femelles: Calice double; l'un et l'autre profondément 5-parti, à peu près régulier, persistant; pas de pétales; 3 styles profondément bipartis , velus; un ovaire à 3 loges 1-ovulées, devenant une capsule à 3 ' coques. - Les espèces connues de ce g. sont au nombre de \% Ce sont des arbrisseaux originaires de la 
Nouvelle-Hollande, à rameaux tomenteux, à poils fins étoilés, à feuilles alternes, portées sur un pétiole muni de deux glandes a sa base, entićres ou 3-5-lobées ; à fleurs en épis terminaux; les mâles sessiles, accompagnées de $3-5$ bractées imbriquées et inégales, les fernelles en plus petit nombre, courtement pédicellées.

(AD. J.)

* ADRTMUS ("ळopurs, non âcre; Adrimys, eût été plus correct). 1vs. - G. de Coléoptères pentaméres, famille des Carabiques, tribu des Féroniens, établi par M. Dejean (Catal. $3^{\text {me }}$ édit.); mais dont il n'a pas donné les caractères. Il y comprend 3 espèces, toutes de Cayenne, dont nous ne citerons que l' $A$. fugax de M. Lacordaire.

* ADSCIT AE. Ins.-Nom donné par Linné a la $4^{\text {me }}$ division de son grand g. Sphinx, laquelle comprend la tribu des Zigénides de Latreille. $V$. ce mot.

*ADSCITI (adscitus, d'adscisco; ajouter). Ivs. - Nees von Esenbeck applique cette dénomination au groupe ou sous-famille des Braconides, de l'ordre des Hyménoptères, et semble par ce nom les regarder comme une addition à la famille des Ichneumoniens.

ADULATPE (Mons Adula, le MontAdule, ou le St-Gothard). Miv. - Nom donné par le père Pini au Feldspath orthose transparent, blanc et nacré, dont on trouve de beaux cristaux au mont St-Gothard, en Suisse. $V$. FELDSPATII. (Der.)

* ADVENTIFS [Bourgeons] (advenitius, qui survient). BOT. PII.-Dupetit-Thouars a nommé ainsi les bourgeons qui se développent accidentellement sur certaines parties des végétaux, où on ne les apercevait pas d'abord, et sur lesquelles ils apparaissent par suite de causes excitatrices de nature variée. $V$. embryon et bourgeon. (A.R.)

ADYSETON, Scopol. вот. PH.-Double emploi du g. Alyssum.

* ECANTHUS. $V$. ofcantuus. (BL.)

* aCIMANTUIERA (aixuń, pointe ; àvinpณ́, d'à Onpós, fleuri; par extension, anthère). вот. PIr. - G. de la famille des Acanthacées, tribu des Ecmatacanthées, sous-tribu des Ruellices, fondé par Nees Von Esenhock, sur le Rucllia gossypina de Wallich ( $P l . A s$. rar. In, 87 ) et auquel it altribue les caractères suivants : Calice quin- quéparti, à segments égaux. Cor. hypogyne, infundibuliforme, quinquéfide, à divisions égales. Étamines 4, incluses, insérées au tube de la corolle; anthères biloculaires, mucronulées an sommet, à logettes parallèles. Ovaire biloculaire, à loges quadriovulées. Style simple; stigmate indivis, caréné sur le dos. Capsule tétragone, bilorulaire, octosperme, loculicide-bivalve; valves septifères par le milieu. Graines lenticulaires, lisses, sous-tendues par des rétinacles aigus. - La seule espéce connue est un s.-arbrisseau de l'Inde, à tige et à rameaux cotonneux, d'un blanc de neige, garnis de feuilles opposées, péliolćes, cordées, denié-crénelées, pubescentes, blanches. Ses fleurs sont disposées en capitules paniculés ou corymbiformes, terminaux, garnis de bractées et de bractéoles.

(C. I.)

ACHIME ( $\alpha_{i}^{\prime} \chi \mu^{\prime}$, pointe, piquant ; les graines et les bractées sont allongées en pointe ). воT. PII. - Ce g. de la famille des Broméliacées, tribu des Broméliées, $(V$. ce mol), a été institué par Ruiz el Pavon Prodr. 47, t. 8, et Fl. Peruv. 111, 27, t. 264), et adopté par tous les auteurs modernes. En voici les caractères essentiels, tels qu'ils ont été modifiés par Pœppig et Endlicher ( $\mathbb{N}$ ov. g. et $\$ p . P l$. Chil. 11, t. clix) : Bractées roulées en coupe sous les fleurs. Périgone (corolle et calice des auteurs) supère, sexfide. Divisions extér. calicinales, égales, roulées en spirale, mucronées ou aristées, dilatées obliquement d'un côté au sommet; les intér. pétaloïdes, plus longues, enroulées inférieurement, squameuses ou plus rarement nues intérieurement à leur point d'insertion. Étam. 6 , insérées à la base du périgone; 3 adnées à la base des divisions internes. Ovaire infère, triloculaire. Style filiforme. Stigm. 3, linéaires, contournés. Baie sèche, subglobuleusc, triloculaire, polysperme. Grairies suspendues par un funicule grêle à l'angle interne des loges, à test coriace. Embryon petit, dressé à la base d'un albumen farineux, à extrémité radiculaire supère, atteignant l'ombilic. - Ce g., borné encore à un très petit nombre d'espèces, renferme des plantes herbacées, vivant en faux parasites sur le tronc des arbres, plus rarement au pied, ou même dans les fentes des rochers ombrés. Les feuilles sont toutes radicales, ensiformes ou ligulées, coriaces, 
très entières ou plus souvent dentês en scie. Les fleurs, en général de peu d'apparence, sont disposées en épi terminal paniculé ou rameux. Elles ont toutes pour patrie l'Amérique tropicale.

* ECHMLA ( $\alpha i \chi \mu n^{\prime}$, pointe). Iss. - G. de I.épidoptères, famille des Nocturnes, tribu des Tinćites, établi par M. Treitschke, et que nous avons adopté (Hist.natur. des Lépidopt. de France), en le caractérisant ainsi : Palpes inférieurs courts, falqués, velus jusqu'au bout, el terminés en pointe obtuse. Trompe courte, mais visible. Antennes très longues et très fines. Tête aussi large que le corselet. Corselet mince. Abd. effilé et conico-cylindrique. Patles postéricures longues el pelt épaisses. Ailes supéricures allongées el dont le sommet se termine en lobe arrondi. Ailes inférieures très étroites, lancéolées et largement frangées, surtout au bord interne. Ceg. ne renferme qu'un petit nombre d'espèces, toutes remarquables par les lignes et les points d'argent dont leurs ailes sont ornces sur un fond bronzé très luisant. Nous cilerons pour type l'Achmia Thrasonella Scop., décrite par M. Treitschke, sous le nom d'Equicella, et figuré par Hubner sous celui d'Ayliella (tab. 64, fig.431). Elle se trouve en Saxe et en Bohême, ainsi que dans le nord de la France.

* ECIDINÉES et mieux OECIDINÉES (oixídor, maisonnette; par extension : loge, cellule). в0т. CR. - Petite famille de Champignons que j'ai forméc ( $A n n$. des sc. nat., janv. 1830) aux dépens de celle des Urédinées. Elle se compose de petits Champignons parasiles, qui se développent sur les feuilles, les tiges, et quelquefois sur les fleurs el sur les fruits. Leurs réceplacles, ordinairement très nombreux, sont coriaces, membraneux, arrondis ou tubuleux. Ils s'ouvrent de différentes manières, suivant le g., et laissent échapper leurs spores sous forme de poussière blanche, jaune ou orangéc. - Cette famille comprend les g. Raestelia, Rebent.; OEcidium, Pers.; Peridermium, Link; et l'Uredo sedi DC., dont j’ai fait le g. Endophyllım. (LÉv.)

AECIDIUM et mieux OECIDIUM (oixí-

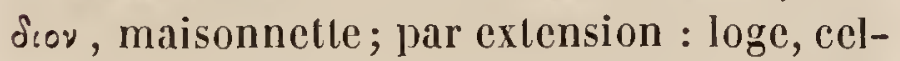
lule ). вот. Св. - Hill (History of plants) a le premier employé cette déllomination pour désigner un genre de ChampiT. 1. gnons auquel haller avait donné, quelques années auparavant, le nom de Sipheeria. Plus tard Persoon l'appliqua à un g. de la mêne famille, dont les individus, vivant parasites sur plusicurs espéces de plantes, avaieut été rangés avant lui parmi les Lycoperdon, parce qu'ils répandent, comme eux, leurs spores sous forme de poussière. Gmelin, dans la $13^{\text {me }}$ édition du Systema Naturæe de Linné, fil connaître plusieurs espèces nouvelles que Persoon lui a vait communiquées, et parmi lesquelles se trouvaient des Uredo et des Puccinia, que l'auteur du Synopsis Fungorum fit rentrer dans leur véritable $\mathrm{g}$. Ces distinclions paraissaient parfaitement établies, lorsque M. Link, considérant le péridium des OEcidium comme une altération accidentelle de l'épiderme, les réunit avec les Uredo sous le nom de Caoma. L'opinion du célébre professeur de Berlin, adoptée principalement par les auteurs allemands, a jeté de nouveau, parmi ces Champignons, une confusion que j'ai essayé de dissiper dans un mémoire sur le développement des Urédinćes (Ain. des $S c$. Nat. janv. 1839).

Le g. OEcidium appartient à la famille des OEcidinées et présente les caractères suivants : Réceptacles ou péridies isolés ou réunis, cylindriques, sessiles, membraneux et fragiles, s'ouvrant à leur sommel en plusieurs lanières qui se réfléchissent en dehors, et renfermant dans leur intérieur des spores libres, globuleuses ou ovales qui se répandent spontanément sous forme de poussière blanche, jaunc on orangée. - Dins toutes les espéces que j'ai étudiées, j'ai trouvé conslamment les spores globulcuses. M. Fries assure que l'OEcidium Podophylli de Schwein les a biloculaires comme les Puccinies. On ne trouve ces Champignons que sur les plantes vivantes. Ils se développent sur les feuilles, les pétioles, les tiges, quelquefois sur le calice, el même sur les fruits; ils sont tantôt épars, tantôt groupés en cercle, et cette disposition peut, micux que la couleur, servir à les diviser en 2 sections. Si l'on suit le développement d'un OEcidium, on voit sur les feuilles des surfaces pâles et décolorées. L'épiderme étant enlevé, on distingue à la loupe sur le parenchyme de petits filaments blancs qui, d'abord isolés, deviennent ensuite plus nom- 
breux et sanastomosent entre eux. A leur centre, il se forme un ou plusieurs tubercules qui s'allongent, percent l'épiderme par leur sommet qui se divise ensuite en un nombre plus ou moins considérable de dents ou de lanières, se réfléchissant en dehors comme le péristome des Rousses, et nermetlent de se répandre aux spores que les péridies renfermaient. C'est à tort que M. Link a considéré ce péridium comme une allération de l'épiderme; ces 2 parties sont parfaitement distinctes, n'ont aucune connexion entre elles, et penvent être isolées très facilement sur un grand nombre de plantes. Ces parasiles sont peu dangereux pour les végétaux sur lesquels ils vivent; on les voit cependant, quand ils sont nombreux, causer l'atrophie des feuilles et en empêcher le développement complet. L'Fuphorbia Cyparivias, que d'anciens auteurs ont appelé dans cette situation, Euphorbia degener, nous en ofre fréquemment un exemple. On observe pourtant quelquefois le contraire: les feuilles deviennent plus longues, plus larges et beaucoup plus ćpaisses qu'elles ne le sont ordinairement. J'ai remarqué la même bizarrerie sur le Thesium 'linophyllum. On a aussi accusé l'OEcidium Berberidis de causcr la ronille (Uredo mbiyo) des céréales; celte opinion, quoique erronée, puisque ces 2 champignons ne sont pas du même g., conserve encore des partisans; mais elle ne repose manifestement que sur le préjugé.

(LÉv.)

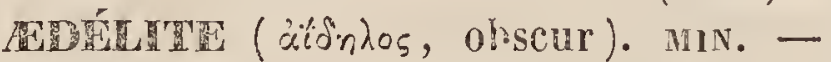
Kirwan a donné ce nom à une substance qu'on trouve à Edelfors, en Suède, où elle sert de support à l'Apophyllite; elle se présente cr petites masses tuberculenses a texture fibreuse ou striée, dont les couleurs varient entre le gris, le jaunâtre, le verdâtre et le rouge pâle. Bergmann, qui l'a analysée, en a fail une variété de Zéolithe, sous le nom de Zéolithe siliceuse. Elle est généraloment classée aujourd'hui parmi les Mésoiypes. $V$. ce mot.

(DEL.)

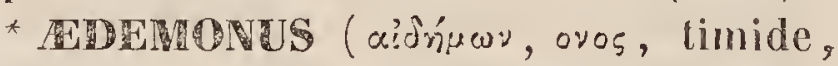
pudibond ). INs. - G. de l'ordre des Colćoptìres tétramères, famille des Curculionites, tribu des Apostasimérides, établi par Schnennerr, qui lui a donné les caractéres suivants: Autennes de médiocre longueur, un peu minces; leur funicule de 7 arlicles; les 5 premiers allongés, subobconiques, diminuant graduellement de longueur : les $6^{\text {me }}$ el $7^{\text {me }}$ courts, presque tronqués à leur sominet; massue en ovale, allongée, annincie. Rostre très long, assez robuste, presque cylindrique, arqué. Yeux très ćcartés, abaissés, subovales, déprimés. Prothorax légèrement bisinué à la base, un peu arrondi sur les còtés, se rétrécissant brusquement par devant, resserré, un peu allongé au sommet, lobé derrière les yeux. Élytres oblongues, ovales, convexes, déprimées sur lc dos avec les angles huméraux obtus.-Ce g., quine figure pas dans le dernier Catalogue de M. Dejean, est très voisin des Cryptorhynques, dont il est cependant facile de le distinguer par la forme des antennes, dont le funicule est organisé diféremment, ainsi que par les ycux qui sont très écarlés et surbaissés. Il a pour type une espèce de l'Afrique australe que l'anteur nomme Edemonus puniclatus.

FDES (ünóns, importun, désagréable). INs. - G. de l'ordre des Diptères, division des Némocères, famille des Culicides, établi par Hofrmansegg et adoplé par Meigen ainsi que par M. Macquart, qui lui donne pour caractères : Palpes à base épaisse, trés courts et pointus dans les 2 sexes. - Ces caractères suffisent pour distinguerles REles des Cousins, dont ils sont d'ailleurs très voisins, en ce que ces derniers, chez les mùles, ont toujours les palpes plus longs que la trompe. Ce g. ne renferme qu'une seule esp., qui habite le nord de l'Aliemagne, et que M. Iofrmansegg a nommće : $A$. cinereus. Elle est longue de 2 lignes et demie, d'un brun noirâtre, avec les cuisses jaunes et les ailes grisâtres.

* A Dida (ánoía, désagrément; par extension, tristesse). Ixs. - G. de l'ordre des Lépidoplères, famille des Noclurnes, tribu des Yponomeulides, établi par M. Stepliens aux dépens des Y ponomeutes de Latreille, sous le nom de Melanoleuca. En adoptant ce g. (Hist.nat. des Lépid. de France), nou's avons cru devoir en changer le nom, attendu sa trop grande ressemblance avec celui de Trelulenca, que porte une espéce de Nocluclle. Voici les caractères que nous lui assignons: Palpes grêles, très arqués, avec lo dernier article presque filiforme. Trompe assez développée. Corgelet robuste. Abdo- 
men cylindrique. Bord postérieur des $1^{\text {res }}$ ailes plus ou moins arrondi. - Les $\Lambda$ édies se distinguent au premier coup d'œil des Yponomeutes, en ce qu'clles sont largement lachetées et non finement poncluées de noir, comme celles-ci; elles en different plus essenticllement par la forme de leurs palpes, frar la coupe de leurs ailes, et en outre par les mours de leurs chenilles qui virent solitairement sur des plantes basses, tandis que celles des Yponomeutes virent en soriété sur des arbres ou des arbrisseaux. Des 4 espèces que nous rapportons à ce gr., nous ne citerons que l'Aédic de la Vipérine (Allcila bipunctella Fabr.), $A$. Echiella, dont la clienille vil entre les touffes des fleurs de la Vipérine (Echium vulgare). Celte espèce est figurée dans notre ouvrage précité (1. x, pl. 285, fig. 2).

* FDIRIS (Magistral chargé, chez les Romains, de la police de la ville et de la conservation des bâtiments publics). INs. G. de Colćoptères tétramères, famille des Longicornes, Iribu des Lamiaires, s.-tribu des Déprimés, établi par M. Serville et dont voici les principaux caractères : Tarières des femelles allongécs, toujours saillantes dans le repos, et dépassantl'abdomen. Antennes glabres, ordinairement trés grandes dans les mâles. Ejuine latérale du corselet occupant le milieu du bord. Toutes les palles d'égale longueur arec leurs tarses glabres. - Ce g. a pour type la Lamia Railis Fabr., ou Cerambix id. Oliv., dont M. Serville a converli le nom spécifique cn nom générique. M. Dejean en l'adoptant en a changé le nom en celui d'Astynomus ( $V$. ce mot). La Lamia dont il s'agit, habile plus souvent l'intéricur des maisons que les bois; et cela, parce que sa larve continue de croìtre et de se développer dans les poutres et les solives de sapin qui servent á construire les habitations dans les contrées du Nord et les pays de montagnes; de là, sans doate, le nom d'Edilis que lui a donné Fabricius.

* EDHANBR, Thunb. Bot. PIr.-Suivant M. De Candolle ( Protr. 2 p. 118), c'est un double emploi du g. Rafnia, Thunb. (Sp.)

ADOPE A. Ixs.- Nom générique de Coléoplères, mal orthographić dans le demier Calal. de Dejean. $V$. le mot osporeza. (I).)
RGA (Ega, nymplie, nourrice de Jupiter ; aijri, jeau de chèvre). crust. - Leach (Jim. Soe., trans. 1. Xi) désigne sous ce norn un g. de l'ordre des Isopodes, qui est ainsi caractérisé: Ies deux $1^{\text {ers }}$ articles des antemnes supéricures très larges et comprimés. Yeux grands, légèrement convexes, convergeaut antéricurement. Côtés des articles de l'abdomen imbriqués. Lame inléricure des appendices du ventre tronquée à son extrémité interne. - Ce g. renferme 3 espèces, dont une a été trourée dans les mers d'icosse; on ignore la patrie des denx autres. (H. I.)

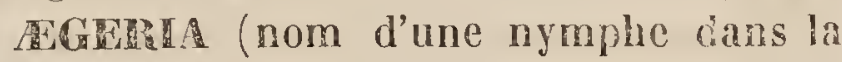
Myth.). Ixs.-G. del'ordre des Lépidoptères, établi par Fabricius ( $\$$ yst. Gloss.), aux dépens de son g. Sésie, el qui a pour lype le Sphinx apiformis de Linné. Ce g. parut trop peu caractérisé à Latrcille pour être adopté. Il n'aurail pu l'être d'ailleurs sans en changer le nom, déjà employé pour dćsiçner un g. de Diptères et une espéce de Papillons diurnes, et qui ne se distingue que par l'orthographe de celui d'Egeria, appliqué par Leach à un g. de Crustacés décapodes. $Y$. lo not Sésie.

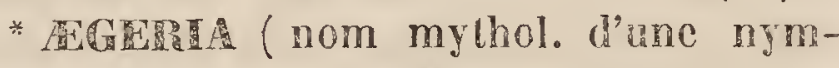
phe). 1ns. - G. de Diptères formé par M. Robineau-Desvoidy, aux dépens de quelques espéces du g. Hylemyia, Blacq., et qu'il a converi depuis en section sous le nom d'Hylemyice. ( $V$. ces 2 mols.) (D.)

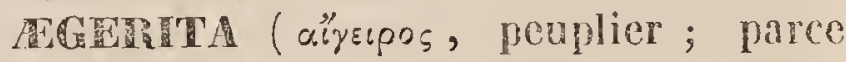
que, dit-on, la plante fut decouverte sur cet arbre; étym. obscure). BOT. Cr. - G. de Champignons, élabli par Pcrsoon, naissant sur les bois ou sur les écorces en décomposition, et se présentant sous la forme de corps très petils, arrondis, sessiles, nus ou garnis de soies. Leur centre est composé d'un tissa cellalaire, irrégulicr et condensé, dont la surface est couverte d'une couche de spores sphériques, inćgales, transparentes, qui se séparent et ressemblent a de la farine. On n'en connait que deux espéces. - Persoon m'a dit plusienrs fois qu'il ne fallait teuir aucun compte de l'Egerila ccesia; que c'était une espéce qu'il avait décrile sur un ćchantillon en mauvais ćtal, et fu'il n'avail jamais retrouvée, même dans l'endroil où il l'avait prise la première fois. La place que ce g. doit occuper daris la clas:ification mycologique est en- 
core incerlatne. M. Fries le range dans les Trichodermacés. Comme je n’ai jamais pu trouver dans les Egerita candida et setosa, le voile filamenteux qui est censé recouvrir la couche de spores, et former un péridium fugace, je pense qu'il serait mieux placé à còté des Tuberculaires, dont il diffère cependant par la forme des spores et par l'absence du pédicule composé de cellules allongées, rapprochées en faisceaux et parfaitement distinctes.

FEGIALE. Egialia ( $\alpha i \gamma \_\alpha \lambda^{\prime} s$, bord de la mer). ıns. - G. de l'ordre des Coléoptères pentamères, famille des Lamellicornes, tribu des Scarabéides, créé par Latreille, aux dépens de celui des Aphodies de Fabricius, et dont il s'éloigne par ses mandibules entièrement cornées, par son labre coriace et saillant, quoique très court; par ses mâchoires armées intérieurement d'un crochet robuste, terminé par 2 dents, et enfin par la forme de son chaperon. Par ses autres caractères, il se rapproche des Géotrupes; mais ceux-ci ont leurs antennes de 11 articles tandis qu'on n'en compteque 9 à celles des $\not E$ gialies.-Dans son dernier Calalogue, M.Dejean ne rapporte à ce g. que deux espéces, savoir: l' 2 . globosa lllig., qui se trouve dans le nord de la France, et l' $\mathbb{E}$. americana Dej., de l'Amérique du Nord. Ainsi que leur nom générique l'indique, ces Insectes se tiennent dans le sable, sur le bord de la mer. (D.)

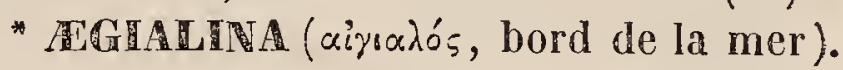
вот. Рн. - Schultes (Mant. 2, p. 222) avait proposé d'établir un g. sous ce nom, dans la famille des Graminées, pour une variété du Koeteric villosa de Persoon; mais ce g. n'a pas été adopté. $V$. KoELERI .

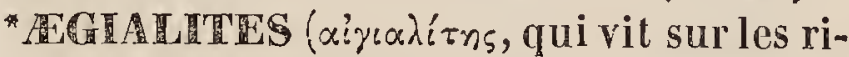
vages de la mer). ins. - G. de Coléoptères pentameres, famille des Térédiles, établi par Eschscholtz, sur une seule espéce, originaire de l'Amér. occidentale et qu'il nommo E. debilis. Ce g., dont les caractères ne nous sont pas connus, est placé par M. Dejean (Calal., $3^{\text {me }}$ édit.) entre le g. Gibbium, Scop., et le g. Mastigus, Hoffmansegg, et appartiendrait alors à la tribu des Ptiniores de Latreille.

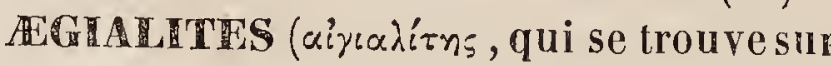
le bord de la mer). ois. - C'est, dans la Methode defivieillot, sa troisième famille de l'ordre des Chassiers, répondant en partie a celle des Pressirostres de Cuvier, ct renfermant les G. OEdicnème, Échasse, Huîtrier, Érole, Courevite, Pluvian, Sanderling et Pluvier.

(LAFr.)

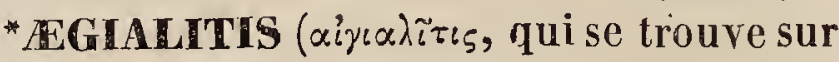
le bord de la mer). вот. PH.-Ce g., établi par Trinius (Agrost. fund. 127, t. 9), dans la famille des Graminées, pour le Koleria villosa Pers., n'a pas été adopté. (A. R.)

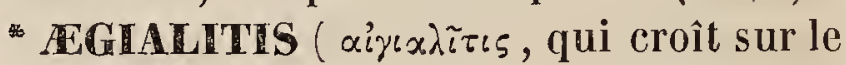
bord de la mer). вот. Pr. - G. de la famille des Plumbaginacées, Lindl. (Plumbaginées, Juss.), tribu des Staticées, fondé par R. Brown (Prod. 426), qui lui assigne les caractères suivants : Fleurs tribractéées, en épis paniculés. Calice tubuleux, quinquéfide, plissé-anguleux, coriace. Corolle hypogyne, pentapétale, à onglets cornés à la base. Etamines 5, insérées sur les onglets des pétales. Ovaire uniloculaire, uniovulé ; ovule anatrope, suspendu au sommet d'un placenta libre, assez épais. Cinq styles, distincts, terminaux; stigmates en tête. Utricule monosperme, coriace, exsert, subanguleux-cylindracé, se rompant au sommet, lors de la germination de la graine. Graine dépourvue d'albumen, germant dans le fruit; radicule supère; plumule diphylle, assez grande. - Ce g. ne se compose encore que d'une espèce : c'est un petit arbrisseau, très glabre, croissant avec les Rhizophores sur le bord de la mer, dans la partie tropicale de la Nouvelle-Hollande; ses rameaux sont cylindriques, fragiles, marqués, à l'entour, de cicatrices résultant de la chute des pétioles; ses feuilles sont alternes, planes, coriaces, ovales, très entières, sans stipules; leurs pétioles sont largement marginés, dilatés et engaînants á la base; les fleurs sont blanches, tribractéées, subimbriquées, alternes, et disposées en épis paniculés. (C. L.)

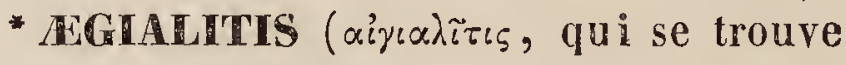
sur le bord de la mer). ors. - Nouveau g. formé par Gould et renfermant des espéces de Pluviers qui me paraissent conformés comme nos Pluviers à trois doigts, sans épines aux ailes et sans caroncules, telles que notre Pluvier à collier. Trois espèces de la Nouv.-Hollande sont décrites et figurées par Gould, dans son $\boldsymbol{S} y$ nopsis d'A ustralie(part.2). Une d'elles est l' Egialitis nigrifrons Gould,sy * nonyme du Charadrius nigrifrons Cuv. (Mus. de Paris et Tem. Col. 47, f. 1.) Char. me- 
lanops Vieillot, Dict. 27, p. 139. (Lafr.)

* EGICERAS ( $\alpha$ औ̌ , yós, chẻvre ; xépas, corne ). BoT. CR. - Nom imposé par Green au g. Ceratodon, Brid. ( $V$. ce nom), et qui s'appliquait surtout à une variété du Ceratodon purpureus, originaire de la province de Cornouailles, en Angleterre. Ne confondez pas ce g. avec son homonyme, établi par Gærtner.

(C. M.)

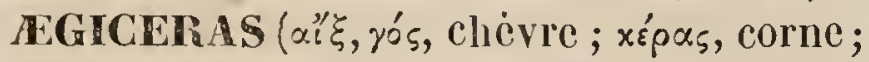
allusion à la forme du fruit). вот. PH. G. de la famille des Myrsinacées, Lindl. (Myrsinćes, R. Br.; Ardisiacées, Juss.), dont M. A. De Candolle (Rev. des Myrs.) a fait le type d'une tribu (AEgicérées) dans la même famille, et qui a été fondé par Gaertner (Sem.et Fruct. t. 46 ) aux dépens du Rhizophora corniculata L.En voici les caract. essentiels : Cal. pentasépale, coriace, persistant. Cor. infundibuliforme, quinquépartie. Étamines 5 , exseries, insérées à l'anneau basilaire du tube de la corolle; anth. oblongues, biloculaires, déhiscentes supérieurement; style persistant; stigm. simple. Follicule arqué, cylindrique, acuminé, monosperme. Funicule terminé en une arille calyptriforme. Cotylédons très petits, à radiculc très grande. - L'arbrisseau, type de ce g. E.majus (Rhiz. corniculata L.), croît parmi les mangliers, jusqu'au $34^{\circ}$ degré de latitude australe. Les fleurs en sont blanches et disposées en faisceaux axillaires. Gaertner rapporte au mêmeg., sous le nom d' $\mathscr{E}$. minus, l'Umbraculum maris de Rumph (Amb. 3, t. 82), dont le fruit est plus petit.

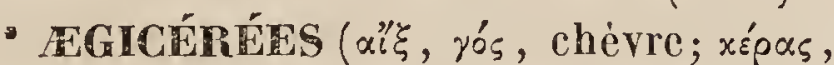
cornc). вот. PII.-Tribu formée par M. A. De Candolle dans la famille des Myrsinacées, Lindley (Ardisiacées, Juss.), et comprenant le seul g. Argiceras.

* TGDDIUN ( aijífov, chevreau ). Iss. G. de l'ordre des Coléoptères pentamères, famille des Lamellicornes, tribu des Scarabéides, établi par M. Dejean (Catal. $3^{\mathrm{me}}$ édit.) qui n'en a pas publié les caractères. Il y rapporte 2 espéces, l'une de la Guadeloupe, qu'il nomme F. Muticum, et l'autre du Brésil, qu'il appelle $A$. hodulus. Ce g. précède immédiatement le Phileurus de Latreille.

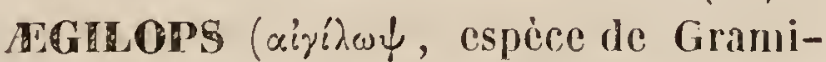
nées). вот. Рн.-G. de la fanille des Grami- nées, voisin du Triticum, élabli par Linné, et qui comprend 5 ou 6 espéces croissant en général dans les régions méridionales de l'Europe. Ce sont des plantes annuelles, peu ćlcvées, à feuilles planes, et á épi simple, composé d'épillets sessiles, solitaires, et en général distiques. Les épillets contiennent de 3 a 5 fleurs, dont la terminale est stérile. Lcs 2 écailles de la glume sont antéricures, collatérales, égales entre elles, concaves, coriaces, tronquées à lcur sommet, qui offre 3 ou 4 dents terminées par une arête. Les paillettes sont herbacćes; l'inférieure concave est tronquéc á son sommet qui est à 2 ou à 3 dents ordinairement aristées; la paillette supérieurc est bicarénée. Les stigmates sont sessiles, plumeux. La cariopse est allongée, nuc, marquée d'un sillon longitudinal. - Quatre espèces de ce g. croissent naturellement dans les provinces méridionales de la France : savoir : Egilops ovata L., triaristata Willd., triuncialis L. et squarrosa $\mathbf{L}$.

Nous ne discuterons pas ici l'opinion singulière émise par quelques personnes, et en. tre autres par le professeur Latapie de Bordeaux, qui pensent que notre blé ( Triticum sativum L.) n'est qu'une dégénérescence de l'Egilops ovala L., et qu'en cultivant celte dernière plante et semant plusicurs fois ses graines, on finit, au moyen de dégradations successives, par obtenir le Triticum sativum. De semblables opinions doivent paraître au moins paradoxales.

(A. R.)

* EGINA (nom mythol.). ac $\Lambda$. - G. de Méduses établi par Eschscholtz dans la famille des Equorides, la $3^{\text {me }}$ de sa division des Discophores cryptocarpes. Ses caractères sont: Appendices du ventriculc larges, sacciformes; Cirrhes alternes dans les intervalles des appendices. Il comprend 2 espèces de l'Océan pacifique septentrional. ( $V$. Eschs. Syst. der Acaleph.). (Dus.)

* EGINETIa Cavan. (Nom myth.). Bot. pIr. - Synon. du genre Bouvardia, Salisb.

$$
\text { (SP.) }
$$

* EGINOPSIS ( Egina, nom mythol.;

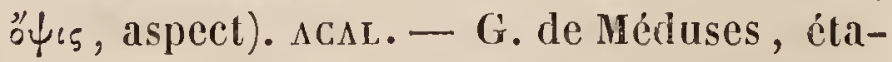
bli par Brandt pour une espèce ( $E$. Lauren(ii) observée par Mertens dans son Voyage autour du Monde. Il se rapproche beaucoup du g. Egina; mais il s'en distingue par la présence de 4 bras, dont celui-ci est dépourvu. 
(V. le Mém. desc, de Brandt, Recueil acad. Pétersb. 1838.)

(DU.s.)

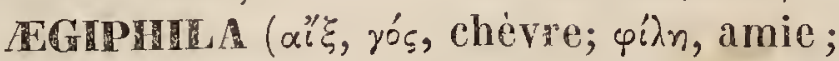
les chèvres en broutent les jeunes pousses de préférence). BoT. Pr. - G. de la famille des Verbénacées, type de la tr. des Egiphilées, Endl.(Vilicées, Bartl.), fondé par Jacquin (Am.elit.pict. t. 16), et ayant pour synonymes les g. Manabea, Aubl., et Omphalococca, Willd. Ses caract. sont ainsi circonscrits : Cal. campanulé ou turbiné, quadridenté. Corolle hypogyne, infundibuliforme ou hypocratérimorphe, à tube beaucoup plus long que le calice, à limbe quadriparti, égal. Quatre étam., exsertes, égales, insérées au lube de la corolle. Ovaire quadriloculaire, à logeltes uniovulées. Style bifide, terminal. Baiequadriloculaire ou biloculaire par avortement; graines solitaires dans chaque loge. - On connail environ une vingtaine de plantes de ce genre, toutes particulières à l'Amérique tropicale; ce sont des arbres ou des arbrisseaux à feuilles opposées, simples, à fleurs jaunes ou blanches, disposées en corymbes dichotomes, paniculés, axillaires el terminaux. Le nom vulgaire de quelques espèces dans les Antilles cst Bois-cabri.

* AGTre (aijis, écusson). Bot. Cr. G. de la tribu des Batrachospermées, famille des Phycées, créé par M. Fries (Pl. homon.) et dont les caractères sont ainsi exprimés : Thalle continu, entouré de mucus; filaments articulés, simples, naissant tout autour d'une couche médullaire centrale. - Ce g., fondé sur une seule espèce des mers du Nord, le Linckia Zosterce Lyngb. (Hydroph. t. 66.), nous semble devoir être rapportéau g. Mesogloia.

(ВRÉB.)

RGIPINE (AEgir, divinité scandinave). MiN. - Esmark a donnć ce nom à un minćral dont l'espece n'est pas encore déterminéc, et dont les cristaux ont de l'analogie avec ceux de l'amphibole hornblende. Il a été découvert dans une île, près de Skansfiord. Selon Berzélius, il contient de la silice, du manganèse, du fer et de l'acide phosphorique.

(DEL.)

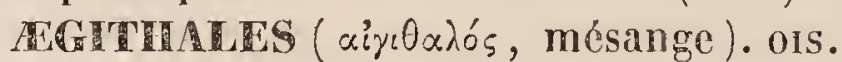
-C'est, dans la Mélhode de Vicillot, la $9^{\mathrm{me}}$ famille de l'ordre des Oiseaux sylvains.

$(\mathrm{I} \Lambda \mathrm{FR}$.)

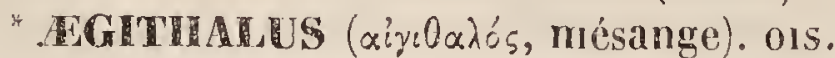

- G. formé par Vigors aux dépens du $P a-$ rus (Mésange), ayani pour type la $M \dot{e}-$ sange rémiz ou penduline de Buffon ( $P l$. Enl. 618 et 708), Parus Pendulinus L. Nous croyons, en adoptant ce g., devoir lui adjoindre la Mésange moustache (Parus biarmicus Lin.) quoiqu'elle en diffère par le bec et la queue; mais qui a de commun avec elle, la forme toute particulière des pattes et des ailes et la coloration du plumage. Toutes deux demeurent habitucllement dans les roseaux et les marais, où elles suspendent aux branches flexibles ou aux roseaux, leurs nids très artistement construits en forme de bourse ou de cornemuse, à entrée latérale.Ils sont composés du duvet des fleurs de saule et de diverses plantes aquatiques, et entrelacés de filaments. A l'excmple de Temminck, nous a vons rapproché ces 2 espéces sous le nom de Mésanges riveraines et renfermant notre g. Rgithale, dont les caractères sont alors: Ailes arrondies, subobtuses, à rémiges primaires couries; la $1^{\text {re }}$ très pelite, presque nulle. Pieds robustes à doigts anlérieurs presque égaux el arnés d'ongles longs et forts; le postérienr le plus fort de tous. Queue ou courte et légèrement échancrée, ou longue et fortement étagéc. Bec grêle, entier, comprimé ou très droit et en cône allongé, très aigu, ou arqué en dessus avec la mandibule supérieure plus longue que l'inférieure. Ce g., comme on le voit, répond aux 2 sections Rémiz et Mroustaches des Mésanges de Cuvier et à celle des Mésanges riveraines de Temminck.

On réunit ordinairement au Rémiz, le Parus capensis L., Sonnerat (2me $P$. $p l .112)$, on Petir deuil, Burp. Nous sommes étonné que le Figuier bec-fleurs de Vaillant ( $A f r .3,142, p l .134)$, qui, d'après ses formes génćrales et particulièrement celle de son bec, nous parait un véritable Agithale ou Rémiz, et probablement même ce Parus capcnsis des auteurs, n'ait cependant été signalé comme tel ou même comme Mésange par aucun auteur. Il est fort petit, moindre que notre Roitelet, d'un gris cendré terreux en dessus plus foncé sur la tète et avec les plumes du front noires et blanches arrondies, comme écailleuses et relevées. Il a le ventre d'un jaunâtre torne, mêlé de roussâtre. C'est encore, nous le pensons, l' Égithalus Smithii(Will. Jardine, pl. 113). Nous 
devons convenir cependant que dans ce que Vaillant nous apprend sur les mours de cet oiseau, qui vit habituellement en petites bandes, faisant entendre sans cesse un faible cri le rappel, el visitant toutes les fleurs pour y saisir les insectes qu'elles recèlent, nous retrouvons bien des mours analogues à celles de nos Mésanges, mais rien qui nous retrace l'habitant de nos espèces riveraines, quoiqu'il en ait tous les caractères extérieurs.

$\Lambda$ ces especes, M. Burton en ajoute une nouvelle : l'Egithalus flammiceps des monts Hymalaya, qu'il décrit dans les Proceed. Tond. Zool. Soc. 1835. Ie Parus melanocephalus de Gould (Cent. of birds from Hymalaya), d'après son bec grêle, mais légèrement arqué en dessus, nous paraìt une espéce de transition entre ce g. et le Parus.

$$
\text { (LAFr.) }
$$

AGriWINE. Egithina ( $\alpha^{\prime \prime} \gamma_{t} \theta_{0}$, nom de la Linotte chez les Grecs). ors. - G. de l'oldre des Oiseaux sylvains et de la famille des Chanteurs dans la méthode de Vieillot; offrant pour caractères : Bec en cône allongé, robuste, presque droit, à mandibules sujecrieures, légèrement ćchancrées. Ailes sur-obtuses à rémiges courtes; la $1^{\text {re }} n^{\prime}$ atteignant, comme chez les mésanges, que le tiers de la $5^{\text {me }}$. Queue courte, termince carrément. i'arses, ainsi que les doigts, peu allongés, mais robustes, terminés par des ongles forts, lrès arqués; celui du pouce, plus que les autres. Plumage lâche, allongé, très épais, surtout sur le dos et le croupion, comme chez les mésanges. - Ces caract. nous ont paru suffisants pour conserver le genre; mais nous le plaçons prés des Mésanges, avec lesquelles il a les plus grands rapports. Deux espèces seulement sont connues : l'A Eithina quadricolor Vieill. ( $N$. Dict. 1, 176, Vaill. Afre pl. 141.) et $l ' E$. atricapi!la Vieill. (lbid. et Vaill. Id. pl. 140. )

(LAFr.)

D:GLTIUUS ( $\alpha$ \% $\%$ : $\theta_{\circ 5}$, nom de la Linotte, chez les Grecs). ins. - G. de Coléoptères tétramères, famille des Clavipalpes, tribu des Erotylénes, établi par Fabricius. Dans ma Monograpbie des Erotyles, qui a paru en 1825, j'avais, d'après l'autorité d'Olivier et du célèbre Latreille, réuni à ces insectes les Egithus de Fabricius, comme ne présentant pas de caractères suffisants pour en être séyarés. En efret ils n'en diffèrent que parce que leur corps est plus hémisphérique, iıdépendamment d'une légère modification dans la forme de leurs palpes inféricurs. Cependant le nombre des esp. connues dans ces 2 g., ayant plus que doublé depuis la publication de ma monographie, on a senti la nécessité, pour s'y reconnaître, non seulement de rétablir le G. Azgithus, mais encore de créer de nouvelles coupes génériques parmi les Erotyles proprement dits; en sorte que les espéces que j'arais réunies en un seul g. se trouvent réparties aujourd'hui en 10, y compris celui des Egithes dont il est seulement ici question. D'après M. Dejean, ce dernier g.,qui se borne à 3 ou 4 espèces dans Fabricius, en confient aujourd'hui 17 , toutes de l'Amérique intertropicale. Nous citerons ici comme les plus connues: l' Egithus surinamensis Fabr., de Cayenne; l' $\mathbb{E} g$. guadalupensis Fabr., de la Guadeloupe. Ces 2 espéces sont figurées dans ma Monographie, pl. 7 , fig. 59 et 76 .

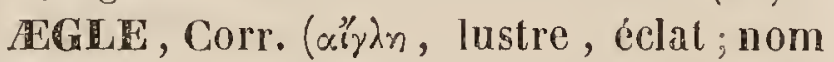
d'une nymphe de la Mythol. el de l'une des Hespérides). вот. PII. - G. de la famille des Aurantiacées. Corréa (Act. Soc. Linn. 5, p. 222) et Roxburgh (Corom.2, no 143; Flor. Iud. 2, $p .579)$, lui assignent les caractères suivants : Calice campanulé, 4 ou 5 -denté. Pétales 4 ou 5 . Étamines environ 40 ; filets courts, libres; anthères dressces, linća :res, mucronées. Ovaire 8-15-loculaire; loges multi-ovulées. Stigmate subsessile. Péricarpe coriace, indéhiscent, subglobileux, 8-15-loculaire; loges 6-10-spermes et remplies d'une palpe visqueuse. Graines oblongues, comprimées, laineuses; cotylédons à oreillettes trés courtes. - Arbre ordinairement armé d'épines axillaires, soil solitaires, soil géminées. Feuilles trifoliolées. Fleurs blanches, semblables à celles de l'Oranger, disposćes en courtes panicules terminales. - Le g. n'est fondé que sur une seule espèce; c'est un grand arbre indigène dans les montagnes de la côte de Coromandel. Son fruit est très estimé dans toule l'Inde, tant à cause de sa saveur délicieuse et de son arome, qu'à raison de ses propriétés relâchantes et dépuralives; ce fruit alteint le volume d'un petit melon. (Sp.)

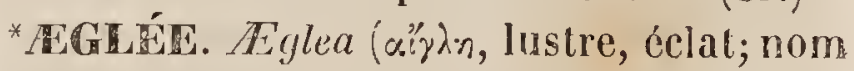
d'une nymphe de la Mythol. et de l'une des. Hespérides). crust. - G. de l'ordre des I) 
capodes, famille des Ptérygures, créé par Leach et ainsi caractérisé : Carapace déprimée, beaucoup plus longue que large, à régions branchiales fort dilatées. Front armé d'un rostre, avec une échancrure à sa base, représentant l'orbite. Pédoncules oculaires très courts, dirigés en avant. Antennes internes ayant leur tige très courte et s'insérant au-dessous des pédoricules oculaires; antenncs externes s'insérant sur la même ligne que les dernières ; mais ayant leurs pédoncules composés de 4 articles. Cadre buccal, plus large en avant qu'en arrière, non séparé de l'épistome. Pieds-mâchoires externes pédiformes. Plastron sternal triangulaire, très large à sa base, situé entre les pattes de la $4^{\mathrm{me}}$ paire. Pattes antérieures médiocres, renflées, dirigées en avant et se reployant en dessous; pattes des $3^{\text {mes }}$ paires suivantes grêles; les postérieures cylindriques, terminées par une pince rudimentaire. Abdomen moins long que la carapace, recourbé en dessous, composé de 7 segments, avec la nageoire qui le termine très large. Les 5 premiers segments dans"' le mâle sont dépourvus d'appendices, tandis que dans la femelle il existe 4 paires de fausses pattes ovifères. - On n'en connaît qu'une seule espéce, l' $E$. loevis Latr., qui se trouve sur les côtes du Chili.

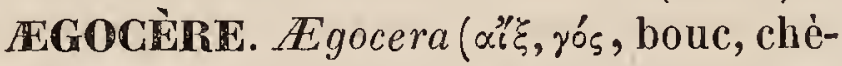
vre; xє́pas, corne). INs. - G. de l'ordre des Lépidoptères, famille des Crépusculaires, fondé par Latreille qui d'abord l'avait placé dans sa tribu des Zygénides, el qui l'en a retiré depuis pour le meltre avec doute, il est vrai, dans celle des Sésiades. Le fait est qu'elle n'a pas le moindre rapport avec les Sésies; aussi M. Boisduval, en l'adoptant, l'a-t-il comprise d'abord parmi les Zygénides et ensuite dans sa tribu des Agocérides. II lui donne pour caractères : Palpes dépassant le chaperon d'une manière remarquable; le $2^{\text {me }}$ article très velu, garni de poils fasciculés, réunis en une sorte de bec. Antennes fusiformes, en cornes de bélier, renflées au milieu. Ailes un peu en toit dans le repos; les supérieures triangulaỉres. Jambes recouvertes d'écailles allongées.-Ce ganre ne renferme qu'une seule espèce qui se trouve au Bengale, et que Cramer a figurée sous le nom de Bombyx Venulia. Elle est aussi fort bien représentée dans la Mono- graphic de M. Boisduval (pl 1; fig. 3). (D.)

* EGOCEIIDES. Egocerido ( $\alpha$ ‘̋ , yós, chèvre; xźpas, corne; sỉos, apparence). INS. - Tribu des Lépidoptères crépusculaires, établie par M. Boisduval, qui n'en a pas encore publié les caractères. Hlle se compose des g. Egocère, Amalhocère, Agrriste, Cathesia, et Eudrias. ( $V$. ces mots.)

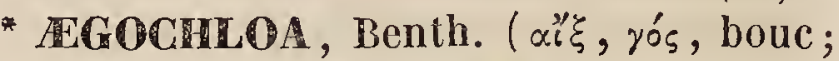
$\chi$ خón, herbe; parce que ces plantes ont en général une odeur fétide). вот. Рн. - G. de la famille des Polémoniacées; M. Bentham (Bot. Reg. sub. tab. 1622.) en donne les caractères suivants : Calice tubuleux, campanulé, membranacé à la base, quinquéfide au sommet : lanières indivisées ou pennatifides, roides, inégales, spinescentes. Corolle hypocratériforme: tube à peu près de la longueur du calice; limbe quinquéparti : lanières oblongues, entićres. Cinq étamines, insérées au dessous du sommet du tube de la corolle; anthères ovalesorbiculaires. Capsule à 3 loges polyspermes. - Herbes annuelles, en général visqueuses. Feuilles pennatipariies; lanières acérées, incisées. Fleurs capitellées, accompagnées de bractées spinescentes multifides. -Ce g., que M. Lindley confond très mal à propos avec le Navaretia, Ruiz et Pav., appartient aux côtes occidentales de l'Amérique septentrionale et au Chili. M. Bentham en a énuméré 6 espèces.

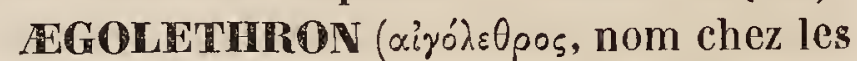
Grees d'une plante indéterminée; $\alpha . \xi$, yos, chèvre; ${ }^{\circ} \lambda \varepsilon \theta \rho \circ$ s, mort). вот. PII.-On trouve mentionnée sous ce nom, dans Pline, une plante qu'on a cherché en vain à rapporter avec certitude à des espéces fort différentes. On en a fait successivement une Renoncule, une Azalée, une Clandestine, elc. Le naturaliste latin dit qu'elle croissait aux environs d'Héraclée, qu'elle était dangereuse pour les chevaux, les chèvres, etc., et qu'elle communiquait au miel des qualités vénéneuses, quand les Abeilles en suçaient les fleurs.

$$
\text { (C. L.) }
$$

* EGOMARATHRUMI, Koch ( $\alpha$ ' $\xi$, yós, chèvre, bouc; $\mu \alpha ́ p \alpha \theta$ pov, nom grec du Fenouil). вот. PH.-S.-division du g. Cachrys.

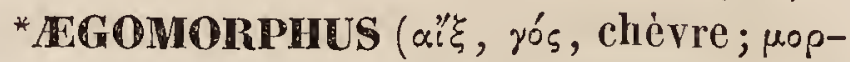
$\varphi$ ń, forme). Ins. - G. de Coléoptères tétra- 


\section{AEG}

mères, famille des Iongicornes, cré par M. Dejean, qui n'en a pas publié les caractéres. D'après la place qu'il occupe dans son dernicr catalogue, il paraîtrait appartenir à la tribu des Lamiaires de M. Serville. L'autcur y rapporte 7 esp., toutes nommées parlui, dont 4 du Brésil, 2 de Cayenne et une de l'Amér. septentrionale. Nous n'en citerons qu'une, l' $\mathscr{E}$. infuscatus, rapportèc de Cayenne par M. Lacordaire, qui l'avait appelée E. titillator.

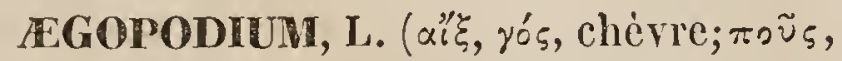
rodós, pied ; parce que les folioles sont fendues de manière à offrir quelque ressem-. blance avec un pied de chèvre). вот. Pн. G. de la famille des Ombellifères, tribu des Amminées, DC., et qui devrait probablement être réuni aux $C_{a r u m}$, dont il ne difrère que par l'absence des canaux résinifères du fruit. L'unique espéce ( Egopodium Podagraria L.) sur laquelle il se fonde, est commune en Europe, et connue sous le nom de Podayraive, parce que jadis on lui attribuait la propriété de guérir la goutte. Ses feuilles ont une saveur aromatique, analogue á cellc de l'Angélique; dans plusicur's contrées on en mange les jeunes pousses en salade.

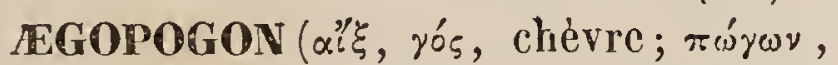
barbe). вот. рг.-G. de la famille des Graminées, établi sous ce nom par Willdenow, adopté par kiunth ( Nov. gen.1, p. 132) et faisant partie de la tribu des $A$ grostidées. Il se distingue par les caractères suivants : Épillets uniflores, géminés ou ternés; les latéraux ordinairement stériles et composés de fleurs mâles. Glumes presque égales, bifides au sommet, plus courtes que la flcur qui est un peu pédicellée, et tcrminée par unc arête; paillette inférieure trinervée, portant à son sommet 3 arêtes, dont la moyenne la plus longue; paillette supéricure bincrvéc et biaristéc. Étamines au nombre de 3. Squamules hypogynes, glabres et bilobées. Fruit nu et glabre. - Ce g. se composait d'abord de 2 espèces originaires de l'Amér. méridionale, d'où elles avaient été rapportées par MM. de Humboldt et Bonpland. Rœmer et Schultes en ont décrit quelques autres. Quant à Palissot de Beaurois, la plupart des espèces qu'ily a ajoutées appartiennent au g. Amphipogon de Brown. $V$. AmpiripoGON. (A. R.)

T. 1.
AEG

145

AGOPICICON. Bot. PH.- $\mathscr{V}$. Maprounea.

(AD. J.)

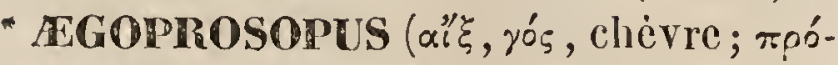
$\sigma \omega \pi \circ v$, face). Ins. - M. Dejean (Catal. $3^{\text {me }}$ édıt.), nomme ainsi un g. de Coléoptères tétramères, créé par M. Scrville dans la famille des Longicornes, sous le nom de Closterus qu'il n'a pas adopté, nous ignorons pour quelle raison.-Quoi qu'il en soit, $V$. le mot crostíre, oú nous faisons connaitre les caractères assignés à ce g. par M. Scrville, ainsi que l'espèce qui lui a servi de type pour l'établir.

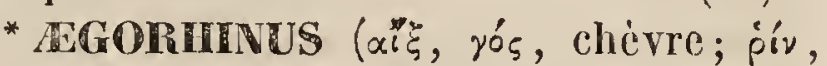
עós, nez). ixs. - G. de l'ordre des Coléoplères tétramères, famille des Longicornes, tribu des Cérambycins, établi par M. Dejean (Catal. $3^{\mathrm{me}}$ édit.), mais dont il n'a pas publié les caractères. Il le place entre le g. Oregostoma de M. Serville etle g. Rhizotragus de Germar. Il n'y rapporte qu'une seule espèce de la Nouvelle-Hollande qu'il nomme E. dimidiatus. Le nom d'Rgorhinus ayant été donné par Erichson à un g. de Curculionites dont il a publié les caractères, celui dont il est ici question devra recevoir un autre nom.

* RGORHINUS ( å vós, nez ). ıns. - G. de l'ordre des Coléoptères tétramères, famille des Curculionites, établi par M. Erichson, qui le caractérise ainsi: Antennes médiocres, insérées à la partie supéricure du rostre; article du funicule diminuant peu à peu de longucur jusqu'à la massuc, qui est petite et terminée en pointe. Rostre court, épais, caréné, avec les scrobicules antennales obsolètes. Yeux ronds, saillants. Prothorax oblong, tronqué à sa base, avancé au sommet, légèrement échancré en-dessous. Écusson poncliforme, immergé. Élytres allongées. - Cc g. est voisin des Aterpus de Schœnherr et appartiendrait par conséquent à sa division des Cléonides. Il est fondé sur une espéce du Chili, nommée par Erichson, $\mathscr{E}$. phalerulus, décrite et figuréc dans le $1^{\text {er }}$ supplément au $16^{\mathrm{me}}$ vol.

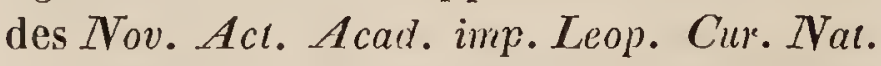
pag. 282, tab. 39, fig. 1.

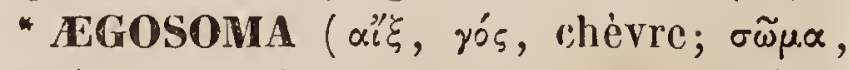
corps). ins. - G. de l'ordre des Coléoptères tétramères, famille des Longicornes, tribu des Prioniens, établi par M. Serville et adopté par M. Dejean (Catal. $3^{\text {me }} \dot{e} d i t$. ). Ce 
g. est un démembrement du g. Prionus de labricius, dont il diffère principalement par les antennes, qui sont filiformes et semblables dans les 2 sexes; par le corselet, qui est mulique, presque trapézoïdal, rétréci par devant; et par la tarière des femelles, longue, toujours saillante et dépassant de beaucoup l'anus. - Les Rgosomes ont d'ailleurs la forme allongée, et des pattes de longueur moyenne; ils ont le facies des Cérambycins. On n'en connaît encore que 2 espèces : l'A. scabricorne (Prionus scabricornis, Fabr.), ou Lepture rouillée de Geoffroy, qui se trouve dans la forêt de Fontainebleau, et l' $\mathbb{E}$. affine, originaire de Java.

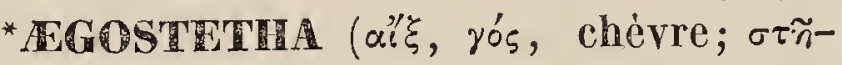
Oos, poitrine). Ins. - G. de l'ordre des Coléoptères pentamères, fam. des Lamellicornes, tribu des Scarabéides, section des Phyllophages, établi par M. Dejean (Catal. $3^{\text {me }}$ édit.), mais dont il n'a pas publié les caractères. Ce g. ne renferme que 3 espèces, toutes du Cap de Bonne-Espérance, savoir: A. maritima Burschell., distincta Dej. et longicomis Fabricius.

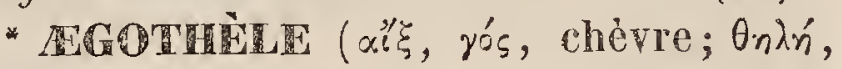
mamelle). ors. - G. formé par Vigors sur une espéce d'Engoulevent de la NouvelleHollande, le Cuprimulgus Novo-Hollandiae Lat., dont les caract. sont : Tarses et doigts grêles; ceux-ci allongés, l'externe surtout qui l'est presque autant que le médian; l'interne plus court; tous parfaitement libres et séparés dés leur base; le pouce également grêle et plus allongé que chez aucun autre g. de la fumille des Engoulevents ( nos $\mathrm{Ca}$ primulgida). Ongles assez courts, mais élevés. très comprimés, subitement arqués et très acérés, assez analogues à ceux des oiseaux réellement grimpeurs. Bec très élargi dans le genre de celui des Podarges, mais la partie cornée supérieure s'étendant moins vers le crâne et ses côtés. Vu d'en haut, ce bec décrit, un arc légèrement saillant, depuis l'ouverture jusqu'à la pointe, dont le prolongement forme en tombant, une espéce d'onglet cylindracé. La mandibule inférieure, plus large que la supérieure, posséde un rebord corné, peu élevé, que recouvre, dans toute sa longueur, celui de la mandibule supérieure dont la pointe s'appuie sur celle de dessous qui fléchit pour la recevoir. Les Lorum et tout l'espace suboculaire, garnis d'une rangée de très longs poils, munis de barbes décomposées à leur base; une parlie de ces poils retombant sur la mandibule inférieure, et l'autre se relevant a u-dessus des Lorum, en forme de crête frontale. Ailes obtuses, à rémiges courtes et arrondies, offrant peu de fermeté. Queue fortement étagée, à rectrices faibles et molles. - Ce g., fondé sur des caractères bien suffisamment importants, n'avait cependant été adopté et France ni par Cuvier, ni par Temminck et Iesson, lorsqu'en janvier 1837 nous publiâmes, dans le Magasin de Guérin, un mémoire détaillé sur la famille des Engoulevents, que nous partagions en 2 sections : les Humicoles et les Préhenseurs, et dans lequel nous faisions ressortir les caractères du g. Fgothèle, qui y faisait partie de la $2^{\text {whe }_{1}}$ section.

Une seule espèce compose, jusqu'à ce mo-

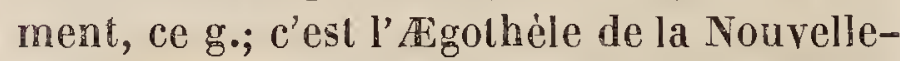
Hollande (Agotheles Nova-Hollandia Vigors et Hors. Lin. Trans. tome 15, page 197. Crested goatsucker Philipp. it. pl. et p. 170. Wile's Voyage to new South IV ales, pl. 29. L'Engoulevent à crête, Caprimul'gus $\mathbb{Z}$ ovocHollandice Vieillot, IV. Dict. 1. 10, p. 234, de Lair. Notice sur la famille des Engoulevents, Caprimulgidoe, Magaz. de Guérin, janvier 1837, pl. 82, 83). Cet oiseau est d'un quart environ plus petit que notre Engoulevent d'Europe. Son dos est d'un gris ardoisé, très finement vermiculé de gris-cendré ; un gris roussâtre couvre la tête et est interrompu par 3 bandes noires longitudinales, dont une médiane, et 2 partant de dessus les yeux, pour se réunir sur le sinciput. Ce noir est terminé sur la nuque par un demi collier roussâtre. Le dessons est d'un gris-roussâtre pâle, vermiculé de gris-ardoisé jusqu'à l'abdomen, dont le centre est blanc. La queue est noirâtre, traversée par un grand nombre de bandes grises. Les longs poils a barbules, qui forment la crête frontale ou retombent sur l'ouverture du bec, sont noirs et terminés de roussâtre au-dessous des yeux. Les pattes sont d'un jaune pâle et les ongles noirs. L'Agothèle se trouve à la Nouvelle-Hollande, aux environs du port Jackson.

(LAFR.)

* RGUS (a'k, yós, chèvre). INs.-G. de l'ordre des Coléoptères pentamères, famille 
des Lamellicornes, tribu des Lucanides, établi par Mac-Lcay, qui lui assigne les caracteres suivants : Massuc des antennes presque perfoliće, à peine quadrilamellée, a vec le dernier arlicle plus grand et semi-circulaire. Lèrre supérieure non distincte. Mandibules avancées, falquées, inermes. Mâchoires ayant leur saillie apicale cachèe sous le menton. Palpes maxillaires courts, avec lc dernier article dépassant seul le menton. Menton carré transversalcment, échancré antéricurement. Corps déprimć. Chaperon échancré ou plutôt bidenté. Écusson pctit. Jambes quadridentées. - M. Mac-Leay place ce g. entre les g. Dorcus et Lucamus, et y rapporte 4 cspèces, dont 3 de la Nouvclle-Hollande et une de Sumatra, qui est le Lucamus inermis de Fabricius. Le g. Egus ne figure pas dans le dernier Catalogue de M. Dejean.

RG IPIUS (aizurios, vautour). 01s. - G. formé par Savigny (Syst.des Ois. d'Égypte) sur le Vautour Arrian (Vulum cinereus Gmel.), et dont lcs caractères sont: Bcc gros, élevé, comprimé vers lc sommct, à dessus très convexc. Narines presque rondes ou ovalaires, placées en travers; lenr bord antérieur peu ou point étalé, el le milieu de leur ouverture pourvu d'une lame épaisse, cartilagineuse, qui s'élève du fond. Langue large saus aiguillon. Bouche très grande et fencue jusque sous les yeux. Tarses épais , complétement réticulés. Doigts forts, le médian allongé, les latéraux courts, presque égaux. Ongles antéricur et postéricur beaucoup plus grands que celui du milicu. Membrane interdigitale $\mathrm{cl}$ basale, du médian à l'externe, très développée; du médian à l'interne presque nulle. Ailes épaisses, très longues, obtuses, à rémiges primaircs de longueur médiocre, les secondaires grandes, voùtées, atteignant dans le repos le bout des primaires. Queue à 12 rectrices étagécs, à baguettes très fermes. Jabot garni d'un duvet à barbes roides, touffues el couchées sur la peau. Tête large et fort épaisse. Cou médiocrement allongé, couvert en partic de duvet ainsi que la têle, ou cn partie nu et coloré. Des plumes étroites, flottantes, formant au-dessus de la nuque un demi collier cervical. - Quoique ce g. de Savigny ne soil alopté par presque aucun Ornithologiste moderne, il nous paraît néanrnoins devoir l'être à plus d'un titre; car il difrère par des caractères nombreux, comme on vient de le voir, du g. Vautour proprement dit, ou Gryps, Savigny (ayant pour type le Vautour fauve); caractéres évidents dans la forme de la tête, du bec, des narines, et même de la langue, comme aussi dans ccllc de la queue et des ongles. Il ne faut que jeter un coup) d'œil sur un Vautour du g. Egypius, pour le distinguer au premier abord, à sa tête épaisse et largc, et à son bec très élevé, d'un autre sujet du g.Vautour, à têtc et bec cflilés.

L'cspèce prise pour type par Savigny est le Vautour arrian (Vultur arriames Picot de La Peyrouse, Encycl. méth.), nom spécif. sous lequel il devrait être désigné désormais pour ćviter la confusion des noms cinereus et niger de Linné, adoptès l'un et l'autre par différents auteurs; car c'est le Vultur cinereus de Cuvicr ( $/$. Règ. anim.), et de Temminck (Man.), le Vulur niger de Vieillot (Galerie, pl. 1), l'Agypius nïger de Savigny (Syst. des ois. d'Égyple, p. 74). Ce sera donc pour nous l'Egypius arrianus (Enl., 425) d'liurope, d'Af̂rique et d'Asie.

On doit ranger encore dans ce g. le Vautour Oricou d'Afrique (Vulue auricularis, Daud.); l'Oricou, Vaill. (Afr., pl.9), ou Vautour Agypius Tem. (Col. 407), non adulte, malgré l'indication de la planche, puisqu'il n'a point, sur les còtés du cou, de crête charnuc, longitudinale, et que sa tête et son cou sont encore duvcteux. Il est bien constant que le Vultur auricularis et le Vulur Egypius ne sont que cette seule et même cspèce, et nous sommes étonné que M. Temminck ( $P l$. col., et Index des espèces du g. Vautour) ait indiqué son $/$ ultur Egypius ou l'Oricou, comme synonyme de l' Egypius niger de Savigny, tandis que celui-ci cst l'Arrian, ainsi que l'indique Savigny; ce qu'il est facile encore de reconnaître dans la pl. 11 de ce grand ouvrage, ef comme l'indique M. Temminck lui-mêmo dans son Manuel (p.5) aux synonymes de son Vautour arrian.

Le Vautour royal ( Vuitur Pondicerianus Gmcl.;Tem.;Col.2; Sonncrat, $V$.Ind.pl. 104) en fait encore partie. Nous en avons reconnu les caractèrcs sur ccs trois cspèces, que nous possédons, et nous croyons, d'après l'inspection des planches de Temminck, que son Vautour à calotte ( $\boldsymbol{V}$ ulur galericularus, 
Col. 13) et son Vautour impérial ou Chincou ( Vultur monachus Gmel., Col.426; Vaill,, pl. 12) doivent aussi leur être réunis. Temminck (Man. $3^{\text {me }}$ partie), fait observer, à l'égard des Vautours d'Europe, qu'ils ne sont pas aussi lâches qu'on le dit; qu'attaqués, ils se défendent courageusement et se précipitent même sur l'homme, en se servant du bec et des serres; qu'ils enlèvent souvent de jeunes chèvres et des agneaux, et que les pâtres de la Dalmatie et des Iles de la Méditerranée les redoutent beaucoup comme dévastateurs de leurs troupeaux. L'Egypius arrianus est commun en Sardaigne, surtout en hiver; mais on ne connaît pas encore son mode de nidification, ni même le pays où elle a lieu. On croit cependant que c'est dans les contrées montueuses de l'Asie. (LAFr.)

FLHA. Ins. - G. de la Famille des Scutellériens, de l'ordre des Hémiptères, section des Hétéroptères, établi par Fabricius (Syst.Rhyng.), pour quelques espéces qui ont la partie antérieure de la tête trés prolongée en avant, et dont la plupart ont été réparties dans différents g. Celui d'Elia fut conservé pour le Cimex acuminatus L., et placé dans le groupe des Pentatomites par M. de Laporte (Ess. s. les Hemipt.) et par de Hahn (Wanzenartigen Ins.), réuni au g. Cimex, Fab., ou Pentatoma, Lat., par Burmeister (Handb. der Ent.); réuni encore au g. Scutellera par M. Brullé (Hist. des Ins.), et enfin regardé de nouveau comme g. distinct par nous (Hist. des Anim. art. t. Iv) qui le plaçons dans la famille des Scutellériens, groupe des Pentatomites. Ses principaux caractères sont tirés de la forme de la tête, qui est épaisse et prolongée en museau arqué; du rostre, dont l'extrémité atteint la base de la dernière paire de pattes; des antennes composées de 5 articles grossissant vers le bout, et enfin de l'écusson, qui est assez grand, mais qui ne recouvre pas entièrement les élytres. - Ce g. réunit du reste une partie des caractères des Pentatomes et des S'cutellères; ce qui l'a fait rapprocher, par différents auteurs tantôt de l'un, tantôt de l'autre de ces genres. Le type est I'Alia acuminata, Fab. (Cimex acuminatus, L.), espéce très commune dans toute l'Europe, le nord de l'Afrique et une grande partie de l'Asie.

* AELLO. nam - - G. de l'ordre des Chei- roptères, famille des Vampiriens, établi par Leach d'après les caractères suivan ts : 2 incisives, 2 canines et 4 molaires à chaque mâchoire ; une $4^{\text {me }}$ phalange au doigt alaire médius seulement; membrane interfémorale droite; oreilles rapprochées, courtes, très larges; point d'oreillons; queue ne dépassant pas la membrane, et formée de 5 vertèbres dans la partie visible. - L'établissement de ce g. ne repose d'ailleurs que sur une seule espèce très imparfaitement connue.

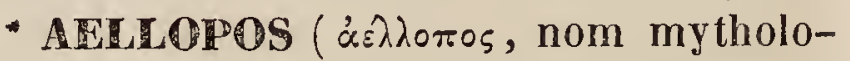
gique de l'une des Harpies). Porss.-Sous ce nom, M. Agassiz (Feuill.p.98), fera connaître un nouveau genre de Squale fossile, dont on doit la découverte au comte de Munster. Le squelette presque entier de cet Ichthyolithe provient des schistes de Kelheim.

(VAL.)

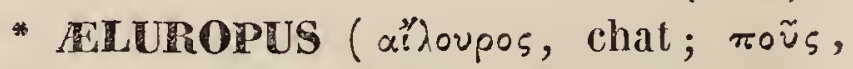
pied). вот. PI. - Trinius (Fund. Agrost., 143) a proposé d'établir sous ce nom, dans la famille des Graminées, un g. pour le Dactylis lagopodioüdes L. (Mant. 33), qui a été placé successivement dans les g. Kœleria et Poa. Ce g. n'a pas été adopté.

(A. R.)

* RMIDIUS (Emidus, gonflé ). Ins. Genre de Coléoptères pentamères, famille des Serricornes, Latr., ou Sternoxes, Dej., tribu des Élatérides, établi par Latreille qui lui donne pour caractères : Extrémité du chaperon manifestement plus élevée que le labre. Antennes simples (articles presque carrés, un peu plus larges supérieurement $;$, de la longueur au plus de $\mathrm{e}_{\mathrm{A}}^{\text {la }}$ tête et du corselet. Abdomen presque de la même longueur, arrondi et obtus au bout. - Ceg., qui ne figure pas dans le dernier Catal. de M. Dejean, a le port des Agriotes, suivant Latreille, et a pour type et unique espèce : l'Eucnemis yigas de Mannerheim.

* EOLANThUS, Mart.; Orolanthus, E.

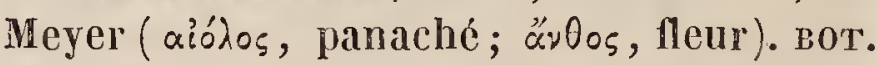
PH. - G. de la famille des Labiées, tribu des Ocymoïdées, s.-tribu des Plectranthées, Benth. Ses caractères sont les suivants (Martius, Amon. Monac. 4.; Bentham, Labiat., p. 61): Calice ovoïde-campanulé, à dents peu marquées, à gorge nue, close après la floraison; le fructifère se détachant de sa base par scission circulaire.Corolle bilabiée? 
tube saillant, décltné ; gorge rentlée; lèvre supérieure quadridentée; lévre inférieure indivisée, plus longue, concave. Étamines 4, déclinées : les 2 inférieures plus longues. Filets libres, non dentés. Anthères ovalesréniformes, à bourses confluentes. Style bifide au sommet: branches subulées. Stigmates petits, subterminaux. Akènes concaves au dos, carénés antérieurement.-Herbes annuelles, aromatiques, très finement pubescentes. Feuilles entières ou à peine dentées. Inflorescence cymeuse. Pédicelles unilatéraux. Fleurs petites, odorantes. - Ce g. , propre à l'Afrique australe, n'est fondé que sur une espéce.

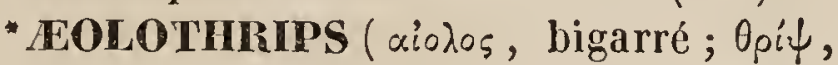
ver qui ronge le bois ). ıss. - Genre de notre famille des Thripsiens (Thysanoptera, Halid.), établi par Haliday (Ent. Mag.), adopté par Burmeister (Handb. der Ent.), et par nous (Hist. des anim. articul.). Il ne diffẻre des Thrips, que par les ant., qui sont composées de 9 articles, et par les ailes, pourvues de nervures transversales. Tous les anciens auteurs, Linné, De Géer, Fabricius, Geoffroy, confondaient les esp. de ce g. avec les Thrips. Elles sont peu nombreuses et toutes indigènes. Les principales sont l'A. fasciata, Hal., Burm., Bl. (Thrips fasciata, L.; D. G.; Fab.), qui se trouve sur les fleurs des Composées, et particulièrement sur les Résédas; et l' $E$. viltata Hal. Burm., Bl., que l'on rencontre aussi sur les fleurs de différentes plantes.

* LOLUS (aiólos, prompt, léger; de là Eolus, dieu des vents.) ixs.-G. de l'ordre des Coléoptères pentaméres, famille des Sternoxes, tribu des Élatérides, établi par Eschscholtz, qui lui donne pour caractères: Tarses dépourvus de pelotes; ongles simples. Front défléchi, le plus souvent plan ou concave. Bouche avancée ou infléchie. Carène frontale mince. Lames pectorales lancéolées, non subitement dilatées en dessous. Tarses poilus ou sétuleux, à $4^{\mathrm{me}}$ art. bilobé. Sternum plan. - M. Dejean ( $\mathrm{Ca}$ (al. $3^{\text {me }}$ édil.), qui a adopté ce genre, y comprend 15 espèces presque toutes exotiques; nous n'en citerons qu'une, l'Elater scriptus de Fabricius, que M. Dejean, par erreur, avait appelée amabilis dans son précédent catalogue. Elle esi du Brésil. (D.)

* NOREE. воT. PH.-Mot mal orthographié chez quelques auteurs. $-\boldsymbol{V}$. obonik. (C. L.)

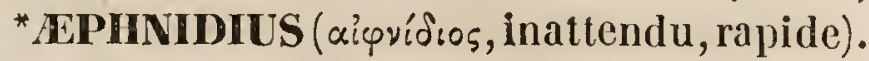
INs.-S.-g. de Coléoptères pentamères, fam. des Carabiques, tribu des Harpaliens, établi par Mac-Leay (Annul. Javan.), et auquel il assigne les caractères suivants : $\Lambda$ ntennes 2 fois aussi longues que la tête, plus épaisses à l'extrémité, pubescentes, moniliformes, avec le $2^{\text {me }}$ et le $3^{\text {me }}$ articles égaux. Labre carré transversalement, à peine échancré antérieurement. Mandibules larges, triangulaires, courbées extérieurement. Dernier article des palpes maxillaires allongé, plus mince que les précédents et presque subulé. Sinus du menton simple. Tête triangulaire, très petite, non bisillonnée entre les yeux. Prothorax bordé, 2 fois plus large que long, échancré antéricurement, presque sinué, lobé postérieurement, très légèrement canaliculé et à peine sillonné de chaque cóté postérieurement. Tout le corps faiblement déprimé, oblong, avec l'abdomen pédiculé. Élytres à peine bordées, striées, avec la $1^{\text {re }}$ strie qui a voisine l'écusson, courte et à peine distincte. Les 4 pattes postérieures spinuleuses.-Ce s.-g. est fondé sur une seule espèce, nommée par l'auteur $\mathbb{E}$. Adeliö̈des, et figurée dans son ouvrage $(p l .5$, fig. 2). Elle a été rapportée de Java par le $1 \mathrm{D}^{\mathrm{r}}$ Horsfield.

* AEPUS ( aĩ.05, élévation; étym. incert.). INs. - G. de Coléoptères pentamères, famille des Carabiques, tribu des Subulipalpes, Dej., et des Harpalides, Mac-Leay, établi par Leach sur une seule espèce, nommée par lui $\mathscr{E}$. fulvescens, et que M. Dejean, dans son Species, rapporte au g. Trechus de Clairville, après l'a voir d'abord placée dans le g. Blemus de Ziegler (Catal. de 1821), qu'il a supprimé, et dont il a réparti les espèces entre les g. Trechus ế Bembidium, dans son dernier Calal. de 1836. $V$. les mots bleMUS, trecilUs et BeMBIDIUM.

* RQUINOLETE. Min. - On a apporté sous ce nom, de l'Amérique en Europe, un minéral qui se rencontre dans les cavités de l'obsidienne du Mexique, et qui paraît avoir quelque analogie avec la substance appelée Sphérulite ou Sphérolite. $V$. ce dernier mot.

(DEL.)

* CQUOREA (aquor, la mer). ACaL.-G. de Méduses. $V$. Éọuorée.

(Dus.) 
* aQQUORTIDes (aquor, la mer). acal. - Famille de Méduses. $V$. equorides. (Duj.)

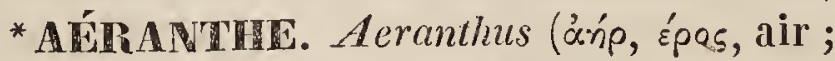

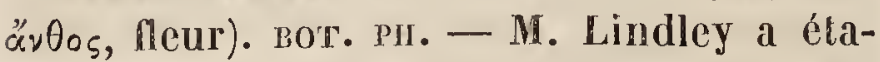
bli sous ce nom (Bol. Reg., t. 817), un g. de la fam. des Orchidées, tribu des Vandées, pour 2 plantes décrites et figurées par Dupetil-Thouars (Urch.d'Afriq.), sous le nom de Dendrobium Arachnitis, et Angracum sesquipedale. Leur caractère générique peut être défini de la manière suivante : Calice connivent; les 2 divisions latérales externes obliques à leur base, insćrćes au prolongement de la base du gynostème. Labelle creusé en forme de capuchon et entier, assez semblable aux divisions latérales internes, portant à sa partie inférieure un long éperon, arliculé ávec la base prolongée du gynostème. Celui-ci court, portant une anthère à 2 loges, contenant 2 masses polliniques globuleuses, perforées d'un côté el sessiles sur 2 rélinacles distinctes.Quand on considere le port des 2 plantes que M. Lindley réunit dans ce g., il est impossible de ne pas croire qu'elles appartiennent ¿ 2 g. bien différents. L'une (Dendrobium Arachnitis Dupetit-Th., i. 87) est dépourvue d'éperon, et se rapproche beaucoup des vrais Dendrobium; l'autre (Angroecum Sesquipedale Dupetil-Th., t. 66 et 69) a un éperon excessivement long, et donne peutêtre les fleurs les plus grandes de toute la famille. Malheureusement ces 2 espèces, qui croissent à Madagascar, sont fort rares et ne sont guère connues que par les figures de Dupetil-Thouars.

(A. R.)

* ERT (Eipnvaĩos, pacifique. Il aurait fallu écrire Irencea). Ins. - G. de l'ordre des Coléoptères pentamères, famille des Lamellicornes, élabli par M. Dejean (Catal. $3^{\text {me }}$ édition), qui n’en a pas publié les caractères. Ce g., qui appartient à la tribu des Lamiaires de M. Serville, ne renferme que des espéces du Brésil, au nombre de 4, et toules nommées par l'auteur, savoir : $\mathbb{E}$. incrassata, flavopunctata, ferrugata et ingrala.

* ARERICA ( Eionvexós, pacifique. Il aurait fallu écrire Irenica). INs. - G. de l'ordre des Coléoptères tétramères, famille des Longicornes, établi par M. Dejean (Catal. $3^{\text {me }}$ édit.), qui n'en a pas publić les caractires. Ce g., qui appartient à la tribu des Lamialres de M. Serville, ne renferme que 3 espèces, toutes au Brésil, et nommées par M. Dejean, savoir : $\mathbb{E}$. multipunctala, canescens et obliquata.

ATRIDES (áspis, habitante de l'air). BoT. PII. - G. de la famille des Orchidées, élablí par Loureiro ( $\boldsymbol{F l}$. Cochin, 525), et adopté par M. Lindley, qui y réunitle g. Dendrocolla de M. Blume. Voici les caract. du g. Aerides, tel que les définit le célèbre monographe des Orchidées: Calice étalé ou quelquefois dressé, ayant les sépales latéraux ordinairement obliques à leur base, et se soudant avec la base allongée du gynostéme. Labelle concave el quelquefois un peu éperonné, s'articulant avec le prolongement basilaire du gynostème, et offrant 3 lobes, dont les 2 latéraux très petits. Gynostème court, sans ailes, couché sur le sommet de l'ovaire. Masses polliniques 2, marquées d'un sillon dans leur face postéricure, se terminant par une caudicule qui s'attache sur un rélinacle arrondi et pelté. - Toutes les espéces de ce g., au nombre d'environ 26 , et originaires des Indes orientales, sont des plantes parasiles et épidendres, ay ant des tiges simples, des feuilles distiques et coriaces, et des fleurs en épis ou en grappes. (A. R.)

* AEROPION (áń, śpos, air; G:os, vie; qui vit dans l'air). вот. PH. - Le g. ainsi nommé par Sprengel (Syst. 3, p. 716), est le même què celui que Dupelit-Thouars appelle Angrocum, et qui a été maintenu sous ce dernier nom dans la famille des Orchidées. $V$. ANGREC.

(A. R.)

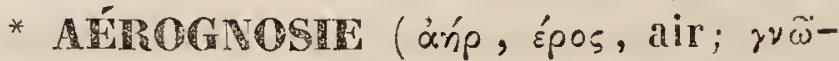

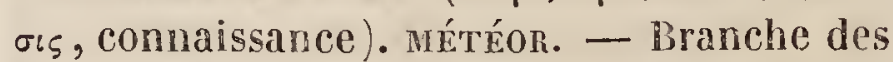
sciences naturelles, qui traite des propriétés de l'air, et du rôle qu'il joue dans la nature. (C. D'O.)

*AROLTTIER et non AEROLTTE (áńp,

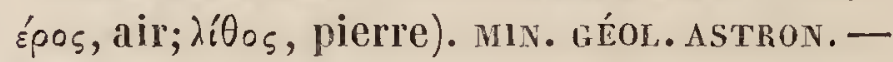
On comprend généralement sous cette dénomination, des massếs minérales plus ou moins grandes, qui, des régions élevées se précipitent à la surface de la terre, avec un ensemble assez constant de phénomènes lumineux et de détonation.

Celte définition est incomplète; car on confond souvent divers phénomènes plus ou moins analogues, que nous offrent les Aérolithes, les Bolides ou Météoriles, les Éloiles filantes, celles qui disparaissent ou s'étei- 
grient, et peut-être même d'autres phénomènes semblables aux feux follets, aux feux Saint-Elme, etc. Il est vrai que sous la mème expression on doit réunir plusienrs l'entre eux ; mais il y en a qui ne présentent aucune similitude, lorsquu'on y fait attention. C'est pourquoi nous devons, avant tout, définil exactement les principaux de ces phiénomènes, puis les décrire et parler ensuite de leur origine.

Nous trouvons d'abord 3 ordies de phénoménes bien trancliés : dans le $1{ }^{\text {er }}$ nous rangreous les Aérolithes, les Bolides, les Météorites, les Étoiles filantes; dans le $2^{\text {me }}$ nous ayons les feux Saint-Elme, les feux follets, etc.; dans le $3^{\text {me }}$ nous pouvons mettre les Étoiles qui disparaissent ou qui s'éteignent, etc. Quoi qu'il en soit, les mots Méléorite et Aćrolithe, ne donnant pas une idée exacte de l'origine des phénomènes du premier ordre, doivent être rejetés ; de plus relui d'étoile filante, outre cette inexactitude, en présente encore une autre : car il ne s'agit nullement d'étoiles, mais bien de petits corps ou astres qui nagent dans l'espace. La dénomination de Bolide doit donc seule subsister, pour désigner les phénomènes qui se rapportent à ceux du $1^{\text {er }}$ ordre. Au reste, nous allons dire un mot des principaux phénomènes mentionnés ci-dessus; ce qui éclaircira les réfiexions précédentes.

On donne le nom de feu Saint-Elme à des aigrettes lumineuses qui, dans les temps orageux, paraissent à l'extrémité d'objets élevés et terminés en pointe. Le pouvoir des pointes sur l'électricité atmosphérique étant connu, on expliquera aisément le phénomène.

Les feux follets sont des lumières semblables à des flammes qui voltigent dans l'air à une petite distance du sol. On les attribue a la combustion de certains gaz. Il est facile de concevoir que des combustions analogues peuvent aussi avoir liea dans les régions élevées de l'atmosphère et produire par conséquent des phénomènes semblables.

Quant aux étoiles qui disparaissent de la voûte des cieux, après y avoir brillé d'un ćclat plus ou moins vif, nous ne saurions expliquer le phénoméne, puisque nous sommes encore dans le vague sur le fait en luiIliême.
On appelle Bolides, des'corps qui semblent enllammés, qui se meuvent dans le ciel avec une extrême rapidité, el qui ont une grandeur apparente assez considérable pour ne point être confondus avec des étoiles. On croit avoir reconnu que les Bolides se montrent quelquefois à des distances beaucoup plus éloignées que les limites de l'atmosphère. Dans leurs mouvements, ils semblent lancer des étincelles et laissent quelquefois derrière eux une queue brillante, qui paraìt être de la flamme retenue par la résistance de l'air. Souvent le Bolide disparait sans que l'on ait remarqué d'autres phénomènes; mais quelquefois on entend une ou plusicurs fortes détonations pareilles à des coups de canon. Ces détonations suivies d'un roulement très fort, semblable ḋ celui de plusieurs voitures roulant sur un pavé, se prolongent pendant quelques minutes, en suivant la direction du Bolide. Enfin, si l'on est suffisamment rapproché du lieu oú se passe le phénomène, on entend des simlements et des bruits analogues à ceux que produit la chute de corps pesants, et l'on voit tomber des pierres en quantité variable.

Les Bolides possèdent, au moment de leur chute, une température très élevée et s'enfoncent plus ou moins dans le sol. Leur volume est extrêmement variable : il en est de très petits et de très grands; on en cite même un de 200 mètres de longueur. Leurs formes sont irrégulières et ne présentent aucun caractère particulier, sauf l'usure de leurs arêtes et de leurs angles. A l'extérieur, les Bolides sont généralement couverts d'une écorce noire, quelquefois terne, d'autres fois luisante comme un vernis; l'intéricur est toujours terne, d'un gris plus ou moins foncé, rarement uni, souvent veiné ou tacheté de différentes manières. Leur texture est ordinairement grenue; parfois les grains sont très adhérents et comme fondus l'un dans l'autre; d'autres fois ils sont très distincts et se séparent facilement. On reconnaît dans ces pierres le mélange de substances différentes, et l'on y apercoit trés souvent des parcelles de fer. On a cru aussi y voir de petits cristaux de pyroxène et de labradorite. La composilion chimique des aérolithes est très variable : leur élément le plus constant et le plus abondant est la silice qui 
forme ordinairement plus du tiers de leur poids. On peut ensuite citer le fer, qui constitue quelquefois près d'un autre tiers, et qui se présente tantôt à l'état métallique, tantôt à l'état d'oxide. On y trouve aussi de l'alumine, de la magnésie, de la chaux, de l'oxide de manganèse, du nickel souvent à l'état d'oxide, quelquefois à l'état métallique, du chrome ou de l'oxide de chrome, du soufre, de la soude, de la potasse, du cuivre, du carbone; mais ces principes n'y sont pas constants, et les derniers notamment ne s'y montrent que très rarement et en petite quantité.

On nomme étoiles filantes ou étoiles tombantes, des lumières qui se meuvent dans le ciel avec une extrême vitesse et qui présentent un point, un trait lumineux, d'un diamètre apparent assez petit pour être encore comparé aux étoiles. Dans ce dernier cas, ce corps laisse derrière lui, comme les Bolides, une traînéc lumineuse qui se dissipe plus lentement que la lumière principale. Ce phénoméne ne dure ordinairement que quelques secondes; mais on cite des cas oú il a duré plusieurs minutes. Il se passe, à ce qu'il paraît, à des distances très différentes.

Indépendamment des Bolides ordinaires, tels que nous venons de les décrire, et dont on a souvent observé la chute, on trouve, à la surface du sol ou à de très petites profondeurs, des blocs de fer plus ou moins volumineux, que l'on désigne souvent. sous le nom de fer météorique, parce qu'or leur suppose la même origine qu'aux Aérolithes. Cependant leur chute n'est pas constatée par des observations aussi positives; mais, outre les rapprochements tirés de leur nature et de leur position, il est à remarquer que beaucoup de relations historiques parlent de blocs de fer tombés du ciel.

L'origine des Bolides, encore loin d'être expliquée d'une manière irrècusable, a donné lieu néanmoins à plusieurs hypothèses ingénieuses. Entre autres, ces corps ont été attribués à des volcans terrestres; mais une pareille supposition ne paraît pas soutenable, lorsqu'on observe que les Bolides tombent dans des lieux extrêmement éloignés des contrées volcaniques, qu'ils diffèrent de tous les produits volcaniques connus, et qu'il est impossible de supposer que des objets aussi lourds parcourent horizontalement l'atmosphère par des temps calmes et clairs comme ceux qui règnent souvent quand on voit passer les Bolides. D'autres savants ont supposé que les Bolides étaient produits par les volcans de la lune, et ils ont calculé qu'un corps lancé de cette planéte avec une vitesse quintuple de celle d'un boulet de canon, pouvait parvenir à un point de l'espace où l'attraction de la terre serait prépondérante à celle de la lune; de sorte que ce corps, au lieu de retomber sur la lune, serait donc entraîné vers la terre et acquerrait dans sa chute une rapidité qui, combinée avec la résistance de l'air, développerait une chaleur suffisante pour produire l'état d'inflammation dans lequel se trouvent les Bolides lorsqu'ils approchent de la surface de la terre. Celte hypothèse n'a en sa faveur que la possibilité, et n'est fondée sur aucune observation qui la rende probable. On a également vu dans la formation des Bolides le résultat de la condensation de matières volatiles qui flottent dans l'atmosphère; or, si d'un côté, l'on conçoit difficilement la présence, dans ces régions, d'une telle quantité de matières aussi pesantes; d'un autre côté, la formation des grêlons nous prouve que la nature a des moyens de produire des condensations dont il est difficile de nous rendre compte. Enfin, d'après des recherches sur les nébuleuses, on pense que la matière éthérée a pu former les étoiles, le soIeil, les planètes, les comètes et les Bolides qui circulent dans l'espace ( $V$. les mots ÉTHER et cosmogonie). Ainsi la matière éthérée, d'abord répandue dans toute l'immensilé, aurait, par ses divers degrès de condensation, donné naissance aux nébuleuses, aux étoiles ou soleils, aux comètes, aux planètes, aux satellites, et à cette infinité de Bolides qui semblent errer dans l'univers, mais qui cependant nous apparaissent plus particulièrement à certaines époques, suivant des directions déterminćes, revenant même sur la route qu'ils ont parcourue, el parfois tombant à la surface de la terre. Telle est l'opinion la plus large et la plus rationnelle dans l'état présent des sciences cosmogoniques.

(R.)

ABROPL. Eropus (Erope, nom myth.), CRUST. - C'est un g. de l'ordre des Amphipodes, établi par Leach; mais qui n'a 
pas été caractérisé par cet auteur. (H. L.)

AÉROPHOBNES (úspóẹ wos, qui a une voix retentissante). ors. - C'est dans la Métliode de Vicillot la $s^{\text {me }}$ famille de l'ordre des tichassicrs, renfermant les genres Anthropoïde et Grue, répondant á la $1^{\text {re }}$ tribu de la famille des Cultrirostres du nême ordre de Cuvier, et faisantpartic de la $2^{\text {me }}$ famille des Gralles de Temminck.

(LAFR.)

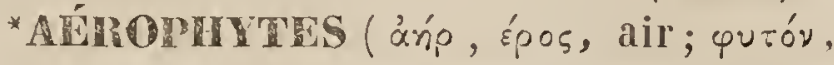
plante). вот. Pн. - Dénominalion appliquée par Lamouroux à toules les plantes qui rivent sur la terre, par opposition à eelle d'Hydrophytes, par laquelle il désignait les plantes aquatiques. Ces expressions, surtout la première, sont peu usitées. (C. L.)

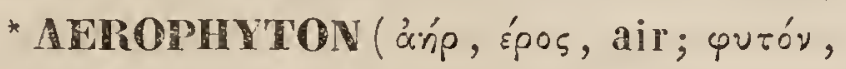
plante). вот. PI.-G. de Champignons, appartenant à l'ordre des Muećdinés, déerit par M. Eschweiler (Flora, 1823, et Syllog. Fl. Ratisb., 1, p. 163, tab. 1, fig. 1). Les filaments (Flocci) qui le composent sont très nombreux, transparents, cloisonnés, ramifiés sans ordre; leur sommet est renflé en forme de massue, et couvert de sporanges globuleux, remplis de spores extrêmement petites. L'A E. Principis, seule espéce de ce g. connue jusqu'à ce jour, se développe sur les feuilles du Cassellia brasiliensis. Ses filaments sont blancs, rameux, el très souvent stériles; les cloisons ont 2 ou 3 fois la longueur de leur diamètre ; on remarque parmi eux un très grand nombre d'autres filaments sans eloisons et beaucoup plus petits, que l'on peut considérer comme une modification des premiers, déterminée par quelque cause atmosphérique.

(LÉv.)

* AÉTOSTEE. Mu.-Nom donné par Selb à une variété d'argent rouge sombre, ou d'Argyrythrose. $V$. ce mot.

(DEL.)

AERU ou AERVA, Forsk. (nom donné par les Arabes à l'une des espèces du g.). вот. Рі. - G. de la famille des Amarantacées, tribu des Achyranthées, s. - tribu des Aervées, Endlieh. - M. Endlicher (Gen. Plant., I. p. 303 ) assigne à ce g. les caractères suivants : Fleurs hermaphrodites, tribracléolées. Périgone pentaphylle : folioles égales, laineuses. Élamines 10, monadelphes; androphore court, cupuliforme. Filets alternativement anthérifères et ananthères: les fertiles subulés, les autres planes, dentés. Anthères dithèques. Ovaire uniloTоบ. I. culaire, uniovulé. Style court. Stigmate bifide. Péricarpe membranacé, évalve, monosperme. Graines lenticulaires; test crustacé. Embryon périphérique, à radicule supere.- Herbes ou s.-arbrisseaux couverts d'un duvet laineux. Feuilles alternes. Fleurs pelites, disposées en épis denses, axillairez ou terminaux. - Ce g., dont M. de Martius ćnumère 6 espèces, est propre aux régions intertropicales ou subtropieales de l'ancien continent.

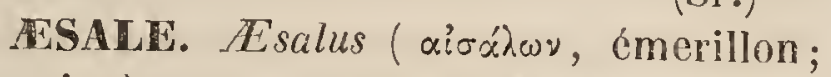
épervier ). Ins. - G. de l'ordre des Coléoptères pentaméres, famille des Lamellicornes, tribu des Lucanides, établi par Fabricius, et adopté par Latreille qui lui donne les caractères suivants : Labre apparent. Langue entière et très petite. Tête reçue dans une éehancrure du eorselet. Antennes courtes; le $1^{\mathrm{er}}$ article long el courbe (ce qui le distingue du g. Lamprima), formant à leur extrémité une massue denticulée. Mandibules avancées, différentes dans les 2 sexes. Màchoires présentant à leur extrémité libre un lobe court, arrondi et velu. Menton grand et earré. Prothorax plus large que long, à bords relevés. Corps ovoïde (ce qui l'éloigne des g. Platycère et Lucane, qui ont le leur déprimé). - Ce g. ne renferme qu'une seule espèee, l' Esalus Scaraboroides de Fabricius, qui se trouve prineipalement en Autriehe. C'est un petit Irsecte de 3 lignes au plus de long, très bombé, de couleur marron, avec les élytres finementpoinlillées. Panzer l'a figuré dans sa Faume germanique (Tab.xxvi, frg. 15 el 16). (D.)

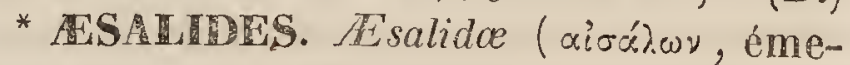
rillon; épervier, ziōos, forme). Ins.-Famille ou tribu de Coléoptères pentamères, établic par Mac-Leay dans sa division des Rectocères Thalérophages, poury plaeer le seulg. Esalc. Il lui donne pour caractères : Article basilaire des antennes courbé, comprimé. Labre distinct. Saillie apicale des mâchoires trés courte; l'interne nulle et non exserte. Levre entière, minime, glabre. Menton carré transversalement. Corps très conveze en dessus. $-V$. TSALE.

* AESCITRTES (aioxpótns, sale; laid). Ivs.-G. de l'ordre des Coléoptéres, famille des Lamellicornes, tribu des Searabéides Coprophages, établi par Mac-Leay, qui lui donne pour caractères distinctifs de $10^{*}$ 
ceux des Onites et des Oniticelles : Massue des antennes ayant ses 2 diamètres presque égaux. Bords latéraux du corselet fortement échancrés depuis leur milieu jusqu'à la partie postérieure. Élytres ayantleur dessus absolument plan, et leurs côtés rabattus subitement. - Ce g. a pour type l'Onitis planus de M. Dejean, que celui-ci (Catal. $3^{\text {me }}$ édit.) place dans le g. Eurystermus de Dalman. Cette espéce est de Cayenne. (D.)

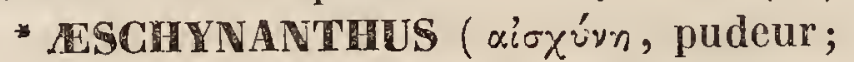
¿ैข०५, fleur ). вот. Рн. - G. de la famille des Cyrtandracées de Jack (Linn. Trans. 14, 23), Gesnéracées, Lindl., etc., fondé par Jack (l. c. 42, t. 2, f. 3 ), et auquel Endlicher (Gen.Pl.4134) rapporte ensyn. le g. Trichosporum de Don, et l'Incarvilloea parasitica lioxb. , qui en serait le type; il y ajoute encore, mais avec doute, les g. Orithya et Agalmijla de Blume. ( $V$. ces mots.) Voici les caract. constitutifs du g. Aschynanthus : Cal. tubuleux, 5-fide, égal. Cor. hypogyne; tube un peu tléchi; gorge dilatée; limbe bilabié, à lèvre supér. dressée, bilobée; l'inrér. trifide, à lobes presque égaux. Étam. insérées sur le tube de la cor., dont 4 didynames, exsertes ou incluses ; filaments filiformes; anth. basifixes, biloculaires, cohérentes par paires; $5^{\mathrm{e}}$ étam. incluse, ananthère. Ovaire faussement, 4-loculaire, ceint d'un disque annulaire, hypogyne, charnu; placentas 2, larges, pariétaux, stipités, contigus à l'axe, multiovulés le long de leurs bords révolutés. Style simple; stigm. en massue, bilamellé. Caps. stipitée par le calice, faussement 4-loculaire, en forme de silique, bivalve;placentas par la suite développés, séminifẻres sur leurs bords, et portés sur la partie moyenne des valves. Semences nombreuses, cylindriques, aristées de part et d'autre par un funicule filiforme et une chalaze renflée et ter. minée en un filet simple ou bifide. Embryon orthotrope dépourvu d'albumen, cotylédons courts, obtus; radicule cylindracée, atteignant l'ombilic. - Ce g. renferme un petit nombre d'espèces remarquables par la beauté de leurs fleurs, et appartenant à l'Asie tropicale. Ce sont des arbrisseaux volubiles ou grimpants, a articulations renflées, radicantes; leurs feuilles sont opposées, pétiolées, un peu charnues et coriaces, très entières; leurs fleurs sont orangé-coccinées, visqueuses, velues, disposées en ombelle, et les pédoncules axillaires, solitaires, biflores, rarement terminaux; les pédicelles bibractéolés.

* ESCHYNITE ET AISGHYNTTE ( $\alpha$ í $\sigma-$ $\chi^{u}$ y๘, je méprise). mon. - Nom donné par Berzélius à un minéral rapporté par Menge des Monts Iimen, prés de Miask, dans la chaine de l'Oural, et qui a été pris d'abord pour une variété de Gadolinite. Berzélius en a indiqué les caract. pyrognostiques dans son Truiı́ sur l'empioi du chalumeau, et une analyse approximative, faite dans son laboratoire parHartwall, a montré qu'il était composé d'acide titanique, de zircone, d'oxyde de cérium, de chaux et d'oxydule de fer. Cette analyse n'ayant ofiert aucune certitude relativement à la détermination quantitative, à raison de la difficulté de séparer complétement l'acide titanique de la zircone, Berzelius a tiré de cette circonstance le nom qu'il a imposé à ce minéral. Il est noir par réflexion, d'un jaune brunâtre par transparence ; celleci ne se manifeste que sur les bords; son éclat est résineux; sa cassure imparfaitement conclioïdale. Sa dureté est comprise entre celles de l'Apatite et du Feldspath. Pes. spécil. $=5,14$. Sur le charbon on sur la pince, il se gonfle et prend une couleur d'un jaune de rouille; il est infusible et se change seulement sur les bords les plus minces en une scorie noirâtre. Il cristallise dans le systeme rhombique, et se rencontre sous la forme d'un prisme de $127^{\circ}$, combiné avec les faces d'un octaèdre rhomboïdal. (DEL.)

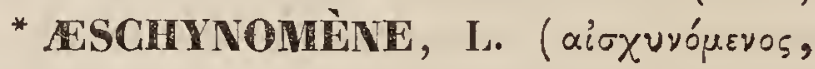
थn, pudibond; Pline a désigné par ce nom une certaine plante dont les feuilles sont sersitives). вот. Pr. - G. de la famille des Légumineuses, s.-ordre des Papilionacées, tribu des Hédysarées, s.-tribu des Euhédysarées. M. Vogel, dans son travail sur les Légumineuses du Brésil (Linnœa, v. 12, p. 81.1838), expose ainsi les caractères de ce genre: Calice courtement campanulé, quinquéfide-bilabié, dibractéolé. Corolle (papilionacée) à pétales subisomètres. Ailes ruğueuses, fovéolées. Étamines 10. Gaînc de l'androphore, en général, entière à sa base, fendue plus hant, soit postéricurement, soit postérieurement et antérieurement. Anthères conformes, oblongues. Ovaire stipité. Style filiforme, courbé. Stigmate presque entier. Légume stipité, com- 
primé, sallant, transversalement articulé , subsinué, onciné par le style<réfléchi en ar rière); articles déhiscents ou indéhisecnts , monospermes, finalement désunis. Graines lenticulaires. Périsperme très mince. Radicule à peine infléchic.-Herbes ou s.-arbrisseaux. Feuilles bistipulécs, subimparipennées. Grappes axillaires ou rarement terminales.-Ceg., propre à la région équatoriale, paraît être assez riche en espèces; les auleurs en ont énuméré 60 environ. Quelques unes offrent dans leurs feuilles des phénoménes d'irritabilité analogues à ceux qu'on observe dans les Mimoses sensitives.

* ESCULACÉES. вот. PII. - M. Lindlay a changć en ce nom celui de la famille des Hippocastanées.

(AD. J.)

* ESCULUS, L.; Spach (corruption d'Esculentus, comestible; les anciens donnaient le nom d'Esculus, ou par corruption Esculus, à un Chêne dont les glands sont mangeables. Il serait difficile de deviner par quelle raison Linné a jugé convenable de nommer ainsi le g. qui faille sujet decet article). вот. рп. - G. de la famille des Hippocastanées (ou Esculacées). A. Laurent de Jussicu l'avait, dans l'origine, compris dans sa famille des Erables. Ce g. offre les caractères suivants 'Spach, Suites à Buffon, v. 3, p 18 ; et Revis. Hippocastanearum, in Ann. des Sciences nat. 1834) : Calice campanulé, renflé, fendu presque jusqu'au milieu en 5 lobes inégaux et très obtus. Pćtales 4 ou 5 , courtement onguiculés, dissemblables: les 2 supérieurs redressés ou réfléchis, plus grands, elliptiques; les 2 ou 3 inféricurs déclinés, étalés, ovales-orbiculaires. Onglets concaves. Étamines 7, déclinėes, arquées en arriere. Capsule ordinairement spinclleuse. - Arbre. Feuilles digitées. Folioles septénées, doublement dentelées. Fleurs blanches, disposées en panicules thyrsiformes.Dans les limites que nous lui assignons, ce g. ne renferme que l' Esculus Hippocastanum L., végétal indigène dans l'Asic-Mineure, et connu de tout le monde sous le nom très impropre de Marronnier d'Inde. Ce fut l'Écluse qui le premier cultiva cet arbre en France; les graines lui en furent envoyées de Constantinople en 1550. Les autres espèces d' $E$ sculus des auteurs constituent les g. $P a-$ via et Macrothyrsus. $V$. ces mots.
ESHNA. Irs. - G. appartenant à la famille des Libelluliens, ordre des Névroptères, groupe des Libellulites, établi par Fabricius, adopté par Latreille et tous les Entomologistes modernes, confondu avec les Libellula par Linnè, Geofroy, De Géer, Olivier, etc., et dont les caractères sont tirés : De la position des ocelles, silués sur une simple élévation transversale, en forme de carène; de la forme du labre, dont le lobe intermédiairc est beaucoup plus grand que dans les Libellules, et de l'abdomen étroit, allongé et en forme de baguette presque cylindrique. - Les larves d'Eshna ont le corps plus court que celles des g. voisins; les palpes sont moins grands; la languette l'est beaucoup plus, et l'abdomen est terminé par 5 appendices, dont l'un est tronqué à l'extrémité. Elles vivent dans les marais, et se nourrissent de la même manière que les larves de Libellules. Ce g. renferme une très grande quantilé d'espèces réparties dans toutes les contrées du monde. On en connaît une vingtaine propres à notre pays, et dont la plus commune est l'ZEshna grandis Fab. (Libellula grandis L.), que l'on peut en considérer comme le type.

(BL.)

* ASSUS (áíow je m'élance). Ins.-Noms de g. cité en synonymic par M. Dejean (Spec. et Catal. $3^{\text {me }}$ édit.), au sujet d'un petit Carabique placé par lui dans le g. Trechus, et que Leach a nommé fulvescens; mais, d'après le catal. de Stephens, le nom génórique donné à cette espèce par Leach, serait Aëpus et non Aessus; ainsi ce dernier nom ne lui appartiendrait pas; peut-être est ce un mot altéré? $V$. le mot $\Lambda$ Eưs.

AETEE. Aetea (Nom myth.). rolyp. G. établi par Lamouroux pour un Polype à cellules solitaires, tubuleuses on cn massue arquée, à ouverture fort grande, ovale-oblique, naissant d'une lige cornée, et rampant sur les fucus. - Ce g., qui a pour type la Cellaria anguina L., a reçu de Lamarck le nom d'Anguinaria, qui doit être conservé. $V$. ce mot.

(Dur.)

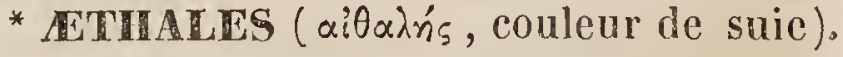
INS. - G. de l'ordre des Coléoptères hétéromères, famille des Mélasomes, tribu des Pimćliaires, établi par M. Dejean (Catal. $3^{\text {me }}$ édil.) aux dépens du g. Epitragus de Latreille, mais dont il n'a pas publié les ca- 
ractéres. II n'y rapporte que 2 espéces, l' tomentosus Dej. et l' $\mathbb{E}$. bunnicornis ou epitragus id. Latr., toutes deux de l'Amérique équinoxiale.

STIIILAR. INs.-Syn. d'Ethalion. (BL.)

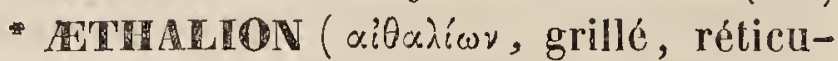
lé; allusion à la réticulation des élytres ?. ins. - G. de la famille des Cicadelliens, de l'ordre des Hémiptères, section des Homoplères, établi par Latreille ( $/$ oyage de Humb. eı Borpl.). Les caract. qui le distinguent de ses congénères sont tirés : dela forme dela tête, tronquée et inclinćc en avant; des antennes très petites, situées au-dessous des yeux ; des élytres plus larges que le corps, couvertes deccllules assez grandes, formées par les nervures. On n'en connaît que 2 espéces américaines, dont le type est l' $E$ thalion reticulatum (Cicada reticulata L.; Tettigonia reticulata Fab.), espèce propre au Brésil.

(Bu.)

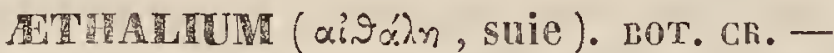
Dénomination que le professcur Link a proposé de substituer a celle de Fuligo, parce que cclle-ci signifie de la suie proprement dite. Le nom de Fuligo, imposé par Haller et généralement adopté, donne une idéc si parfaite de ce g.de Champignons, que je regarde ce changement comme inutile. $(V . F u-$ ligo.)

(LÉv.)

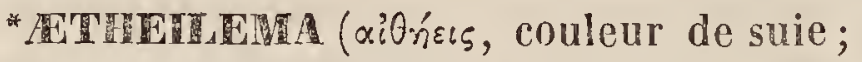
ińun, sécrétion). вот. PII.-G.de la famille des Acanthacées, tribu des Echmatacanthées, Nèes, s.tribu des Barlériées, fondé par Robert Brown (Prodr.478, in not.), adopté par Necs (WVall.Pl.asiat.rar.11, 94), ayant pour type le Ruellia imbricata Wahl, et ainsi caractérisé par l'auteur: Cal. 5-parti; la division postérieure très grande, bractéiforme. Corolle hypogyne, bilabiéc ou ringente; lèvre supér.bidentée ou bifide; l'inférieure trifide. Etam.4 incluses, didynames, rapprochées parpaire et insérées sur le tube de la corolle. Anth. biloculaires, à logettes parallèles, conliguës. Ovaire biloculaire, à loges biovulées. Style simple; stigm. aigu. Caps. mernbranacée, biloculaire, tétrasperme, loculicidcbivalve; segments cloisonnaires par la suite bipartibles spontanément. Graines comprimées, sous-tendues par des rélinacles.-Les Hitheilema sont des plantes herbacées, assez rares, indigenes dans l'Asic et l'A frique tropicales, à feuilles opposécs, à fleurs dis- posées en épis ou en petites grappes axillaires fenillées, munies dans l'aissclle des feuilles de bractées alternes, unilatérales, biquinqué-flores, veinćes, sans bractéoles.

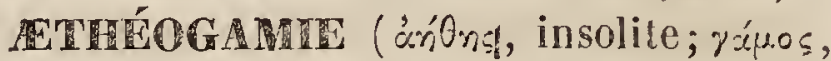
mariage). вот. cr. - Palissol de Beauyois a proposé ce nom pour remplacer celui de Cryptogamic; mais ce changement n'a pas été approuvé.

(A. R.)

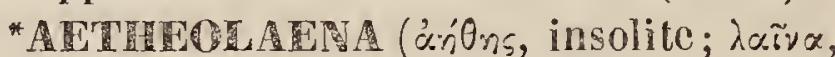
tunique). воT. PIt. - Cassini a formé ce g. aux dépens du Cacalia involucrata de Kunth. Plus tard, dans son Prodrome, M. De Candolle l'a réuni an S'enecio.

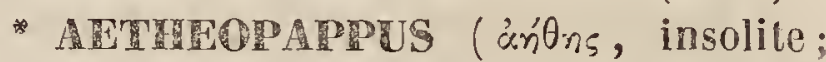
$\pi \propto ́ \pi \pi \circ 5$, aigrette ). BOT. PH. - Ce nom avait été donné par Cassini à un g. qu'il avait établi sur le Centaurea pulcherrima Willd. M. De Candolle en forme sa y.ue section du g. Centaurea, caractériséc par les folioles de l'involucre, qui sont scarieuses ct presque transparentes; par l'aigrette des fleurs du disque, qui est simple et formée de soies filiformes, distantes, barbelées à la basc, landis que les fruits, appartenant aux fleurs du rayon comme à celles du centre, en sont privés.

* A $\zeta \alpha$, racine ). Boт. Prl. - Le Leontodon bulbosum L. constituc senl le g. établi sous ce nom par Cassini; c'est une plante vivace, commune dans la région méditerranéenne, qui, d'un rhizome très court, ćmet des fcuilles ovales-oblongues, entre lesquelles s'élèvent des hampes dressécs, recouvertes au sommet de poils glandulcux accompagnant la base des folioles de l'involucre. Les capitules sont multifiores; l'involucre est double; l'cxtérieur caliculé, beaucoup plus court que l'intéricur, contre lequel il est appliqué. Le réceptacle est nu. Les fruits presque tétragones, atténués en bec, supportent une aigrettc composéc de plusicurs rangées de poils trés blancs. (J. D.)

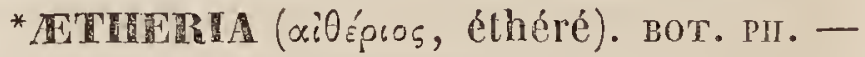
G. de la famille des Orchidacces, Lindl., tribu des Néottićes, Lindl., institué par Blume (Bydr. 409. fig. 14), qui lui assigne les caract. suivants : Périanthe (Cal. et Cor.) ringent; div. cxtér. (sépales) latérales plus larges, supposées au labelle; la supér. voùtée, conglutince avec les inter. Labelle ventru, 
allongé à la base, biglandulifère intérieurement; limbe indivis, un peu voûté, renflé sur les bords qui sont roulés et glanduleux. Gynostème court, très épais, semitrifide au soinmet, à lobe intermédiaire profondément échancré. Anth. dorsale, biloculaire. Pollinies 2, oblongues, subbilobées, fixées par une glande commune à l'échancrure intermédiaire du gynostème, à caudicules courtes.-Ce g., fort limité en espèces, renferme quelque plantes herbacées de Java, à liges radicantes inférieurement, gamies de feuilles alternes, nervées, membraneuses; à fleurs en épis, sonvent glanduleuses, pubescentes extérieurement.

(C. L.)

FTHONEMA, DC. ( án'ns, insolite;

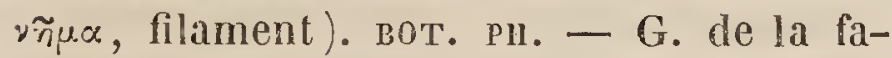
mille des Crucifères (Siliculeuses), très voisin des Thlaspi et des Iberis, dont il difière surtout par les filets des ćtamines paires, qui sont, ou cobérents, ou ailés du còté antéricur. La situation de la radicule a été employée à tort comme caractère distinctif; car elle est très variable dans plusieurs espèces, et peut-être dans toutes.-On en connait environ 12 espèces, la plupart indigènes en Orient. (Sp.)

* RTHOPIS, Benth. (Nom, dans Pline, d'une plante indéterminée). вот. Pr. II. Bentham nomme ainsi une s.-division g. Salvia.

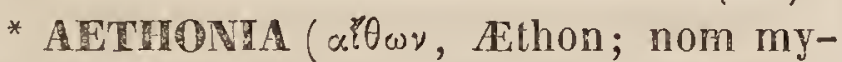
thol.) BoT. PH. - M. Don avait fondé ce g. aux dépens du Crepis filiformis Ait., que M. De Candolle fait rentrer dans la $2^{\text {me }}$ section du g. Tolpis, tel qu'il l'a établi dans son Prodrome.

(J. D.)

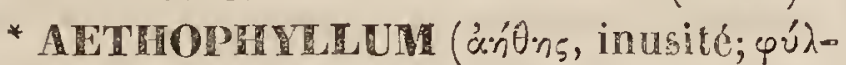
hov, feuille). Bot. Foss. - Ce nom a été donné dans mon Prodrome de l'Histoire des Végétaux fossiles à un g. de plantes fossiles du Grès bigarré, dont on ne connaît qu'un seul echantillon, remarquable par la disposition insolite de ses feuilles. Cette plante, malgré son état imparfait, semble devoir se rapporter, par ses feuilles alternes et rubanées, et par l'apparence de l'épi de fleurs qui termine sa tige, à une plante monocotylédone. Elle ressemblerait surtout méme à quelques orchidées; mais ses feuilles cont accompagnées á leur base de 2 phus petiles folioles, semblables par leur position à des stipules linéaires.--Cette plante, dont on n'a jamais trouvé qu'un seul échantillon, forme du reste un g. très douteux et dont il est fort à désirer qu'on retrouve des échantillons plus parfaits. Il est figuré dans les Amn. des Scienc.natur.t.xv pl .xvin. (Av. B.)

* FTHRE. Ethra (Fille de l'Océan et de Thétis). crust.-Leach désigne sous ce nom ung. de Crustacés qui appartient à l'ordre des Décapodes, famille des Brachyures et que M. Edwards place dans la tr. des Cancériens cryptopodes. Ce g. remarquable se distingue de tous ceux de la tribu des Cancériens par sa carapace ovalaire, horizontale, fortement bordée en dessus avec les bords la téraux dentés et courbés un peu en haut; ceux-ci el les postérieurs tellement prolongés qu'ils forment, au-dessus des 4 dernières paires de pattes, une voute assez prononcée pour cacher entièrement ces derniers organes. Yeux petits, avec le front saillant, les fosseties antérieures presque carrées et l'aríicle basilaire des antennes externes très grand. Pieds-mâchoires externes formant complétement le cadre buccal. Plastron sternal beaucoup plus long que large. Pattes aptér. ayant environ une fois et un quart la longueur de la portion post-frontale de la carapace. Abdomen composé de 7 articles dans la femelle et de 5 seulement dans le mâle.-La seule espèce connue, est l' Ethra scruposa L., qui habite l'Océan indien et les mers d'Afrique.

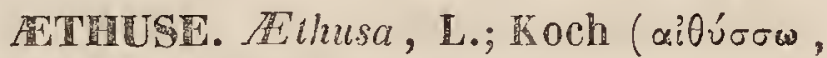
j'enflamme; allusion à l'âcreté du suc de cette plante; il aurait fallu écrire $\mathbb{E}(h y s a)$. вот. Ріг.-G. de la famille des Ombellifẻres, tribu des Sésélinées, DC.; M. Koch Deutsch. Flor. 2, p. 418; Umb., p. 95) en trace ainsi les caractères : Limbe calicinal inapparent. Pétales inégaux, obcordiformes, couronnés d'un appendice apicillaire infléchi. Disque convexe. Styles courts, finalement réfléchis. Péricarpe ovale-globuleux, solide. Méricarpes à 5 côles saillantes, grosses, presque contiguës, carénées; les latérales marginales, un peu plus larges que les médianes; vallécule à une seule bandelette; commissure plane, a 2 bandelettes. Carpophore finalcment libre, biparti.-Herbe tantôt annuelle, tantôt bisannuelle. Fenilles bi ou tripennées. Ombelles oppositifolićes, 10-20-radiées. planes; collerelte générale nulle; collerelles partielles dimidiées, triphylles, réfléchies. 
Fleurs blanches. - Dans ses limites actuelles, ce g. n'est constitué que par une seule espèce (triplée par quelques auteurs) qui est très vénéneuse, el connue sous le nom vulgaire de petite Ciguë. - Le nom d' $\mathbb{E}$ thusa était donné par les anciens à diverses Ombellifères vénéneuses.

(Sp.)

ALTIA, Adans. вот. Рі. - Synonyme du g. Combretum.

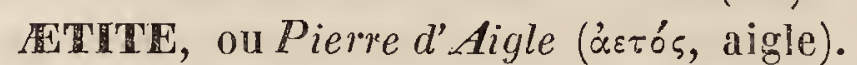
MIn. - Variété géodique de fer hydroxidé, renfermant un Noyau mobile, et ainsi nommé par les Anciens, parce qu'ils supposaient qu'on la trouvait fréquemment dans le nid des Aigles. Ils lui attribuaient beaucoup de vertus imaginaires, entre autres celle de faciliter l'accoucbement et la ponte. On en rencontre assez abondamment en France près de Trévoux et aux environs d'Alais. (DeL.)

AFFINAGE. métallurgie.-La fabrication du fer comprend deux opérations bien distinctes : $1^{\circ}$ la formation de la fonte; $2^{0}$ la conversion de la fonte en fer. ( $V$. les mots FER, FoŃtre et ACIER.) Néanmoins il existe une méthode particulière, nommée méthode catalane, au moyen de laquelle on obtient le fer doux et malléable en un seul feu, c’està-dire en une seule opération.

La conversion de la fonte ou gueuse en fer, qui a pour but, en brûlant son carbone, de la purger des matières vitrifiées, engagées dans ses pores, est l'opération qu'on nomme affinage. En général, pour pratiquer l'affinage, on se sert du procédé suivant, dont les détails varient selon les pays. On refond la fonte dans un bassin large et peu profond, en faisant arriver, sur la surface du bain, un courant d'air qui, par son oxigène, brûle le carbone et le silicium contenus dans la fonte. On réunit toutes les parties mélalliques en une seule masse ou loupe; ensuile, pour chasser les scories vitreuses, renfermées dans les pores de la fonte, on fait passer la loupe incandescente sous un martinet. Après quelques coups, on réchaufe la loupe, et enfin on façonne le fer en barres, en lames, elc.

MFFINTEE. Affinitas. cnim. - Autraction qui a lieu entre les parties des corps d'espèces difrérentes; c'est, en d'autres termes, la force inconnue qui sollicite les molécules d'espèces différentes à se porter les unes vers les autres. $V$. AтTRACTION.

(R.)
- AFFlCUREMTINT. gÉol-Portion apparente à la surface du sol, d'un banc, d'un amas ou d'un filon dont les autres ties sont plus ou moins profondément cachées sous d'autres masses minérales; l'affleurement d'une substance utile, ou des roches qui ordinairement lui servent de gangue et l'accompagnent, devient une indication précieuse pour les travaux de recherches et d'exploitation des mines.

(C. P.)

AOURMLLION. OIS. - Ce nom a été indiqué dans le Dictionnaire classique, comme synonyme de Grimpereau (Certhia familiaris L.) en plusieurs parties de la France.

(C. d'o.)

* ARPICALES. Africance. aracin. Nom donné par M. Walckenaër à une petife division du g. Altus, dans les Arachnides.

(H. L.)

ARROUSA. BOT. PII. - Nom vulgaire du Fraisier (Fragaria, L.), dans quelques parties de la France.

AFRLIA (Afzelius, Botaniste suédois). BOT. GR.-Ehrhart, dans ses plantes cryptogames publiées par Fascicules, avait tenté d'introduire ce nom pour désigner quelques espèces de Mousses, appartenant an g. Weissia ( $V$. ce mol); mais, outre que ce nom générique n’a pas pour lui la priorilé, il ne peut être admis, puisqu'il désigne déjà un g. parmi les plantes vasculaires. (C. M.)

AFZLER, Smilh.; Pancovia, Willd. (Dédié au $\mathrm{D}^{\mathrm{r}}$ Adam Afzelius, botaniste suédois). BoT. PII. - G. de la famille des Légumineuses, s.-ordre des Césalpiniées, R. Br., tribu des Cassiées, DC. Smith (Linn. Trans. 1798) donne à ce g. les caractères suivants : Calice tubuleux; limbe quadrifide, caduc. Pétales 4 , onguiculés : le supérieur plus court. Étamines 10, libres: les 2 supérieures stériles. Style subulé. Stigmate pointu. Légume transversalement pluriloculaire, ligneux. Graines recouvertes jusqu'à moitié par un arille cupuliforme; embryon (suivant M. De Candolle) rectiligne; radicule subincluse; cotylédons charnus. - L'anteur de ce g. en a signalé 2 espèces, indigènes dans l'Afrique équatoriale.

(Sp.)

AFEELIA, Gmel. (Afzelius, Botaniste suédois). вот. Pा.-Synonyme du g. Seymeria, Pursh.

AGABUS (Nom d'homme). ins. - G. de Coléoptéres pentamères, famille des Hydro- 
canthares, tribu des Dytiscides, établi par Leach et adopté par M. Aubé, qui, rlans son ouvrage faisant suite au Species général de M. Dejean, lui assigne Ies caractères suivants : Ecusson apparent; prosternum droit, fortement comprimé IaléraIement et formant la carène. Dernier article des palpes Iabiaux entier; derniers articles des palpes maxillaires à peine inégaux. Crochets des tarses postérieurs égatix ou presque égaux, mobiles. - Ce g. a été fondé par Leach sur une seule espéce dont les antennes sont dilatées dans, Ies mâles (Dytiscus serricornis Paykull); mais Erichson y a compris tous les anciens Colymbetes de Clairville, qui réunissent les caractères précités, de sorte qu'il se compose aujourd'hui de 60 espèces, dont plus de moitié appartiennent à I'Europe; les autres sont réparties dans l'Asie, l'Amérique et l'Afrique. Les Agabes ont la même manière de vivre que les Colymbetes et les Ilybius. Nous ne citerons que l'espèce Ia plus commune, qui se trouve dans toute l'Europe, l'Agabus oblongus Illiger, que M. Dejean (Catal. $3^{\text {me }}$ édit.) place dans le g. Leiopterus.

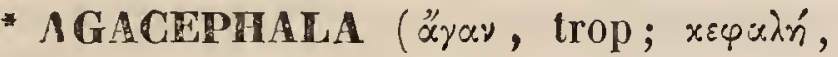
tête). Ins.-G. de Coléoutères pentamères, famille des Lamellicornes établi par le comte de Mannerheim, et adopté par M. Dejean (Catal., $3^{\text {me }} e ́ d i l_{\text {.) }}$, qui le place entre les Cyclocéphales et Ies Rutèles de Latreille; de sorte qu'il appartiendrait à la tribu des Scarabéides Xylophiles de ce dernier. Les caractères qui distinguent ce g. des Scarabées proprement dits sont d'avoir les mâchoires non dentelées intérieurement; Ies pattes antérieures (chez les mâles) sensiblement plus Iongues que Ies suivantes, et Ies élytres ne recouvrant pas entièrement l'abdomen. M. Dejean n'y rapporte que 2 espéces : $A$. Latreillei Dej., et $A$. cornigera Mannerh., toutes deux du 'Brésil. M. Delaporte (Ann. Soc. ent. de France, v. 1 ) en décrit 2 autres: l'une sous le nom de Duponti, et l'autre sous celui de Goryi, sans en indiquer Ia patrie.

AGALANCÉE OU AGALANCIÉ. вот. PH. - Nom vulgaire de l'Églantier (Rosa eglanteria L.), dans quelques cantons du midi de la France.

(C. L.)

AGALLOCHE OU AYALOUDJIN. вот. PH.-C'est ainsi ou à peu près que les Orien- taux appellent une substance balsamique qu'ils ont estimée, de temps immémorial, comme un parfum précieux, et à Iaquelle ils ont en outre attribué les vertus médicales les plus merveilleuses. Jadis, cette substance n'était pas moins préconisée en Europe, oú on la désignait par le nom très impropre de bois d'Aloès. D'ailleurs, jusqu'à une époque encore très récente, on a été dans le doute et dans l'erreur relativement à l'origine de ce parfum. Ia plupart des auteurs modernes avançaient, sans aucun fondement, que l'Agalloche provient de l'Excoecaria Agallocha, euphorbiacée indigène aux Moluques et remarquable seulement par ses propriétés délétères. Plus récemment Loureiro, trompé sans doute par de fausses informations, a décrit sous le nom d'Aloëxylon Agallocha, un arbre de la famille des Légumineuses, indigène dans les montagnes du nord de Ia $\mathrm{Co}_{-}$ chinchine, et qui, à l'en croire, serait le végétal en question. Il est hors de doute aujourd'hui que I'Agalloche est le produit d'une ou de plusieurs espèces d'Aquilaire.

(SP.)

AGALLOCHITES. воT. Foss. - On avait désigné, sous ce nom, dans d'anciens ouvrages, des bois fossiles auxquels on trouvait quelque ressemblance avec Ie Bois d'Aloës ou Agalloche; ressemblance qui n'a été nullement constatée.

(AD. B.)

* AGALMA ("̋ $\alpha \lambda \mu \alpha$, ornement). ACAL.-G. d'Acalèphes de la famille des Physophorides, établi par Eschscholtz ( $\$$ yst. der Acalephen, 1829), pour un animal qu'il observa en détail dans l'Océan pacifique septentrional, près des côtes du Kamtschatka. Le caractère de ce g. est d'avoir des tentacules pourvus de raméaux renflés en massue à l'extrémité et terminés par 2 pointes, avec des pièces cartilagineuses natatoires, dont les supérieures sont creuses, distiques, et les inférieures pleines, irrégulières et rapprochées sans ordre. A l'intérieur de chaque rameau des tentacules, on distingue un canal de-couleur foncée, tourné en hélice. Les pieces cartilagineuses creuses forment 2 séries à Ia partic supérieure, au nombre de 15 de chaque côlé et servent au mouvement de l'animal. Elles ont la forme d'une large massue aplatie, dont l'extrémité la plus épaisse se rétrécit et présente une ou- 
verture tubuleuse, tandis que le bord opposé est élargi el profondément ćchancré. Les 2 parties saillantes de ce bord tranchant s'adaptent à celles de la pièce correspondante de la rangée opposće, de telle sorte qu'elles forment ensemble une ouverfure centrale servant au passage du canal nutritif. La cavité de ces pièces est tapissée de vaisseaux qui font penser que ces organes tiennent lieu de branchies. Les plus antérieures de ces pièces diffèrent des moyennes, parce qu'elles sont plus courtes, plus épaisses, plus bombées, avec une cavitéplus grande, prolongée en 2 appendices latéranx. Après la série des pièces natatoires creuses, se trouve un grand nombre de pieces cartilagineuses, solides, plus petites et de diverses formes, tellement rapprochées qu'elles forment ensemble un tube servant au passage des suçoirs et des tentacules. C'est dans la disposition irrégulière de ces pièces solides que gìt la différence entre les Agalma et les Stephanomia.

L'espèce type, Agalma Okenii (Eschs.Acal. tab. 13. - Isis. 1825. tab. 5) a 3 pouces de longneur. Eschscholtz propose de rapporter à ce même g. : $1^{\circ}$ Le Stephanomia $A m-$ phitritis de Chamisso (N. Acta Naturce Curios.. . x., tab. 32, fig.5), dont les pièces natatoires séparées ont élé prises pour type du nouveau g. Cuneolaria, Eysenh.; $2^{\circ}$ les fragments qui ont servi à l'établissement du g. Pontocardia de M. Lesson.

(Dijo.)

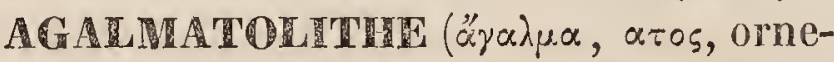
ment; $\lambda 0_{0}$, pierre). min. - Synon. de $\mathrm{Pa}-$ godile.

(DEL.)

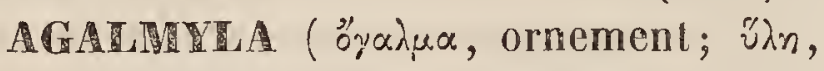
bois; agalmhyla!). Selon Endlicher (Gen. $p l .4,134$ ), ce g. est un double emploi du g. Eschynanthus de Jack ( $V$. ce mol). Lindley le cile néanmoins comme distinct et le place dans la famille des Cyrtandracées. Ce g. a donc besoin d'être mieux étudié pour permettre de juger la question. (C. L.)

AGATOUSSÉs. BoT. PII.-Selon M. Bory (Dicl.cl.). Cetle dénomination s'applique à divers arbrisseaux ou plantes épineuses, qui croissent en buisson ou en touffe, tels que le Houx (Mex aquifolium), la Bugrane (Ononis spinosa $\mathbb{L}_{\text {.) }}$, elc.

(C. L.)

AGATRE. REPT. - Ce nom ne vient pas, ainsi qu'on pourrait le supposer, du mot

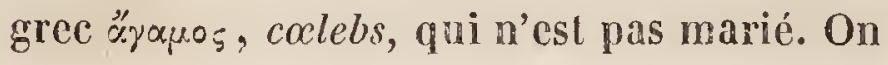

croil qu'il a été employé pour la 1 re fois par les colons de la Guyane, pour désigner une espèce de Lézard que Daudin a prétendu, mais à tort, être celle qu'il a appelée Agame des colons; car cet Agame des colons est une espèce africaine. Quoi qu'il en soit, elle a conservé ce nom et demeure le type du g. établi par Daudin sous le nom d'Agame. Ce g., qui, depuis sa création, a subi beaucoup de modifications, fait partie de la s.-famille des Iguaniens Acrodontes; en roici les caraclères essentiels : Langue fongueuse, rétrécie et échancrée en avant; narines simples, latérales; 2 à 5 incisives supéricures; membràne du tympan enfoncée dans le conduit audilif; 5 doigts inégaux à chaque patte; un pli en long sous la gorge , un autre souvent double en travers du cou; des pores anaux; point de pores fémoraux.Les 10 ou 12 espèces d'Agames que l'on connaît aujourd'hui, viennent des Indes orientales et d'Afrique. Elles sont nour la plupart revêtues de fortes écailles carénées, parmí lesquelles il en est qui forment des groupes d'épines sur les régions voisines de la nuque et des oreilles. Quelques espèces ont la queue simplement arrondie; toutes les autres l'ont plus ou moins comprimée et parfois surmontée d'une petite crète ou carène. Le g. Agame, lel que nous venons de le caractériser, comprend les Agames sans pores aux cuisses, de Cuvier, et les Changeants du même auteur. (G. B.)

* AGAIRES. Agama. ( äyouos, célibataire; par extension, sans organes sexuels). MoLL. - Dans les familles naturelles du Régne animal, Latreille a divisé les Moliusques en 2 grands embranchements et a donné au second le nom d'Agames. Ces Agames ne répondent á aucune des divisions précédemment établies par les auteurs; car Latreille place, à côté des Mollusques acéphalés ou conchifères de Lamarck, qui sont réellement Agames, ceux des Mollusques gastéropodes céphalés, qui sont également Agames ou réputés tels. Cette singulière agglomération contraint l'auteur a diviser ses Agames en 2 sections principales : ceux qui ont une tête et ceux qui n'en ont point. Cette création du célébre Entomologiste n'a point été adoptée; néanmoins elle peut être utile, en indiquant d'une manicre formelle les rapports de cer- 
tains Mollusques toucliant les phénoménes de la génération.

(DEsir.)

AGAMES (á priv., rár.os, noces; c'est-àdire plantes dépourvues d'organes sexuels). Bo'r.Cr. - Plusicurs Botanistes adoptant en principe général, à l'exemple de Necker, que les plantes désignées par Linné sous le nom de Cryplogames, et par Jussieu, sous celni d'Acotylédonées, sont entièrement dépourvues d'organes sexuels semblables à ceux des plantes phanérogames, ont proposé ce nom comme synonyme de Cryptogames; mais cette substitution n'a pas été généralement adoptée. Nous discuterons au mot cryptoGAllrs, lopinion sur laquelle elle est fondée.

(A. R.)

AGAML. Psophia ( $\psi \circ \varphi^{s} \omega$, faire du bruit). ols. - G. de l'orule des Echassiers, que Cuvier a placé en tête de sa tribu des Grues, et Temminck dans son $11^{\mathrm{me}}$ ordre des Alectorides et dans sa division des Alectorides campestres. Ses caractères sont : Bec court, voûté, conique, courbé, comprimé et élevé à la base, très fléchi à la pointe où la mandibule supérieure dépasse l'inférieure; fosse nasale large et très étendue; narines vers le milieu du bec, grandes, obliques, ouvertes en avant et fermées en arrière par une membrane nue; pieds longs, grêles; le doigt du milieu etl'exiérieur unis à la base par une membrane; l'interne séparé; pouce articulé intéricurement au-dessus des autres doigts ; ailes arrondies, concaves, surobtuses, à rémiges courtes, très étagées, les premières courbées en dedans en faucille; queue courte, à rectrices molles.-Ce g. est sans contredit tout-à-fait de transition, et par conséquent très embarrassant à clàsser méthodiquement; son bec, ses ailes et sa queue sont ceux d'un Gallinace; mais ses pieds, évidemment ceux d'un Échassier, ainsi que ses dernières rémiges très développées et à longues barbes décomposées, établissent entre lui et les Grues des rapports évidents qui n'avaient point échappé au savant coup d'œil de Cuvier, dont la classification des Échassiers nous paraît ce qu'on a fait de micux, quant à cet ordre. La place qu'il y a assignće à l'Agami, près des Grues, est bien encore la plus naturelle.

L'espéce la plus connue est l'Agawi trompette (Psophia crepitans L.; l'Agami, Bufr., Pl. Enl. 109 ; et Vieill., Gal. Pl. sans $n^{\circ}$ ), TOM. 1 . qui se troure à la Guyane. A l'état sauvage, cette espèce vit en troupes assez nombreuses dans les forêts les plus épaisses, sur les lieux élerés, et non dans les parties marécageuses. Elle se nourrit d'insectes et de fruits sauvages, court rapidement; mais son vol est lourd, de peu de durée, et elle ne se perche que sur les arbres de moyenne hauteur. Elle est d'un naturel très peu défiant, en sorte qu'elle fuit à peine devant le chasseur, qui parvient souvent à en abattre un grand nombre. Outre son cri ordinaire, elle a la faculté, sans ouvrir le bec, d'en émettre un autre intérieur, sourd et produit sans doute par une conformation particulière de sa trachée-artère; ce qui lui a valu, à Cayenne, le nom d'Oiseau trompette. Elle s'apprivoise avec la plus grande facilité, devient un des habitants les plus sociables de la basse-cour, reconnaît son maître et s'y attache, dit-on, au point de venir réclamer ses caresses. On assure qu'elle devient un guide et un protecteur courageux pour tous les autres oiseaux de la basse-cour, qu'elle défend avec intrépidité, même contre les chiens.

Dans la plupart des ouvrages d'Ornithologie, on ne cite que cette espèce dans le $\mathrm{g}$. Agami. Cependant Cuvier (Dernière édit. du R. anim.) en cile deux autres, le Psophia viridis Spix, pl. 83 , et le $P$ s. leucoptera id., pl. 84. M. A. d'Orbigny en a rapporté, de son voyage en Amérique, une $4^{\text {me }}$ qu'il publiera incessamment dans sa relation. Ce g. est particulier au Nouveau-Monde. (LAFR.)

* AGAMIE (á, priv., yóuos, noces; sans organes sexuels). воT. Gr. - Nom donné par le professeur L.-C. Richard à la $25^{\text {e }}$ et derniẻre classe du système sexuel de Linné réformé. Cette classe correspond exactement a la Cryptogamie de Linné. $V$. cry ptognmie et SYSTÈME SEXUEL.

(A. R.)

*AGAMHENS. REPT. - Cuvier désignait ainsi la $1^{\text {re }}$ des 2 sections qu'il avait établies parmi les Iguaniens, selon que ceux-ci étaient ou n'étaient pas armés de dents palatines. Les Agamiens comprenaient les g. à palais lisse, tels que les suivants : Cordyle, Stellion, Doryphore, Fonette-Queue, Agame, Tapaye, Changeant, Leiolepis, Tropidolepis, Lćposome, Galéote, Lophyre, Gonocéphale, Lyriocéphale, Brachylophe, Physignathe, Ystiure, Dragon, Sitane et 
Ptérodactyle; ce dernier est fossile. L'un de ces g., celui appẹlé Brachylophe, n'aurait pas dû être placé dans cette section, mais dans celle des Iguaniens proprement dits; car il a le plafond de la bouche denté de la même manière que les Iguanes. Le g. Gonocéphale était un double emploi de celui des Lophyres.

(G. B.)

*AGANAS (áyciós, gracieux). ivs.-G.de Lépidoptères, fam. des Nocturnes, établi par M. Boisduval aux dépens du g. Frèbe de Latreille, et qu'il caractérise ainsi : Tête médiocre. Yeux saillants. Antennes ordinairement un peu pectinées dans les mâles. Palpes longs, ascendants; leur dernier article très long, nu, grêle, comprimé latéralement. Trompe longue. Corselet velu, ponctué sur les épaulettes. Abdomen cylindrique, ponctué de noir, un peu plus long que les ailes inférieures. Ailes oblongues, les supérieures ponctuées à leur hase, soit en dessus, soit en dessous. Pattes longues. - Les espèces de ce g. habitent à la fois le Sénégal, Madagascar, l'lle Bourbon, la Chine, la Terre des Papous et la Nouvelle-Guinée. M. Boisduval en décrit et figure 4 dans la partic entomologique du Voyage de l'Astrolabe, el 2 dans la Fanne entomologique de Madagascar. Nous n'en citerons qu'une qui sert de type au g., l'A. du figuier (Noctua Carice Fabr.), qui se trouve dans une grande partie des pays précités.

AGANDDES. Aganides (áyavós, agréable). MouL.-Montfort a établi ce g. (Conchyl. syst., t. $1^{\text {er }}$ p. 30$)$ pour une coquille nautiloïde qu'il a recueillie dans les calcaires de transition des environs de Namur. Il est à présumer que cette coquille appartient au g. Goniatite de M. de Buch; mais la discription et la figure en sont peu propres à jeter quelque lumicre sur ce g. incertain. Montfort représente un siphon au centre des cloisons, et jusqu'à présent il est sans exemple que les coquilles multiloculaires, à cloisons sinueuses, aient le siphon placé de cette manière. Celles des coquilles à cloisons sinueuses, qui appartiemnent aux Ammonés, ont le siphon dorsal; celles qui dépendent des Nautilacés ont toujours le siphon ventral. $V$. Amonite el goniatite. (Desir.)

* AGANIPPEA (Nom Myth. d'une nymphe changée en fontaine). вот. PI. - Ce nom fait allusion au lieu où l'on a découvert la $1^{\text {ro }}$ espèce de ce g., qui se rencontre au bord des sources des environs de Mexico. Ce sont des herbes à feuilles opposées; de l'aisselle des supérieures s'élèvent des pédicelles nus, portant un seul capitule assez analogue à celui des Rellis. En voici les caract. : Capitules multiflores, radiés ; ligules 1-sériées, femelles; fleurs du disque tubuleuses, hermaphrodites, à 5 -dents; involucre composé d'une double série d'écailles ; l'extérieure formée d'environ 15 folioles lancéolées, presque soudées à la base; celles de la rangée intérieure, en nombre à peu près égal à celui des ligules, courtes, membraneuses, et ressemblant assez bien aux paillettes qui entourent les fruits. Réceptacle plan, couvert d'écailles membraneuses qui enveloppent les fruits : anthères dépourvues d'appendices basilaires; branches du style prolongées en une sorte de cône assez court ; fruits oblongs et dépourvus d'aigrette. - Ce g. ren$\begin{array}{ll}\text { ferme } 2 \text { espéces. } & \text { (J.D.) }\end{array}$

* AGANISTHOS. ins.-G. de l'ordre des Lépidoptères, famille des Diurnes, seclion des Tétrapodes, tribu des Nymphalides, créé par M. Boisduval, mais dont il n'a pas encore publié les caractères. Il est fondé sur une seule espèce, la $N$ ymphalis Orion God. (Papilio O ion Fabr.), figurée par Herbst, sous le nom de $P$. odius, et par Cramer sous celui de P. Danae (pl. 54 , fig. A. B.).Ce g., suivant M. Boisduval, doit être placé entre son g. Prepona et le g. Charaxes, Ochsenh.

AgANON ('ayxuós, agréable). MoLl. D'après Rondelet, dans le $1^{\text {ér }}$ livre des Poissons converts d'un test dur, ce nom aurait été employé vulgairement par les Grees modernes pour désigner le Concha imbricata, nommé aussi Tridacne par les Cénobites de l'Arabie. Ce dernier nom a été consacré dans la science, et appliqué au g. auquel nous renvoyons. $V$. Tridacne.

(Desir.)

* AGAON (Corruption d'áyzuór, admirable). ins. - G. de la famille des Chalcidiens, de l'ordre des Hyménoptères, établi par Dalmann (Annal entomol.), et adopté par Latreille ( $R e ̀ g$. anim.). Les caract. qu’il présente sont très nombreux et tirés de la structure de plusieurs partics qui affecient les formes les plus singulicres. On peut les résumer aiısi : Corps grêle et allongé. Tète très grande en forme de carré long, une fois 
Hus longue que large, ayant sa partie infér. couverte par 2 lamelles. Mandib. tridentées a u côté interne. Ant. un peu plus longues que la tête et le corselet réunis, et ayant leur $1^{\text {er }}$ article excessivement grand et en forme de palette triangulaire; les suivants extrêmement petits; les trois derniers fort grands, presque globuleux, couverls de poils et formant une massue allongée. Cors. muni de 2 épines latérales. Ailes antér. larges; les postér. très étroites et ciliéeś. Pattes très grêles avec les cuisses plus épaisses. Abd. très étroit, presque conique, ayant en dessous une épine dépassant un peu son extrémité. Tarière de la femelle en forme de soie, plus longue que le corps. Le g. Agaon est l'un des plus extraorainaires de tout l'ordre des Hyménoptères. Les formes que présentent ses diverses parties, sont presque toutes différentes de celles des genres voisins. La seule espéce que l'on en connaisse encore, est l'A. paradoxum Dalm. (Annal. ent.), Bl. (Hist. des Anim. art.), trouvé sur la côte occidentale d'Afrique.

(BL.)

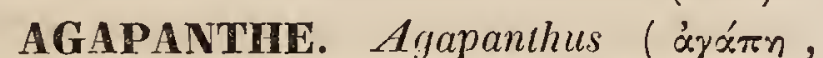
amour ; $\alpha^{\prime} \theta_{\circ}$, fleur. Fleur d'amour; allusion à la beauté de la fleur). вот. Рі. L'Héritier (Sertum Angl., t. xvini) a nommé ainsi un g. qu'il a établi pour le Crinum africanum de Linné, et qui fait partie de la tribu des Hémérocallidées, dans la grande famille des Liliacées. Ce g. diffère des vrais Crinum qui appartiennent à la famille des Amaryllidées, par son ovaire libre et non adhérent; son calice est tubuleux et infundibuliforme, pétaloïde, à 6 divisions à peu près égales; ses 6 étamines sont déclinées. L'A. umbellaus L'Hérit., l. c. (Crinum africanum L.) est une belle plante originaire du cap de Bonne-Espérance, très commune aujourd'hui dans nos jardins, et que l'on rentre dans l'orangerie, pour l'abriter contre les froids trop rigoureux de nos hivers. Ses fleurs, très nombreuses et de grandeur moyenne, sont d'un beau bleu d'azur, disposées en sertule au sommet d'une hampe de 2 pieds d'élévation. Il en existe une seconde espèce (Agapanthus procox Willd.) également du cap de BonneEspérance.

(A. R.)

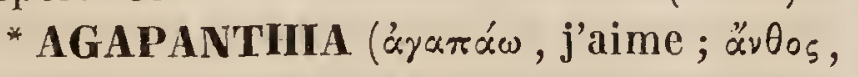
neur). INs.-G. de Coléoptères tétram., fam. des Longicornes, tribu des Lamiaires, s.-tribu des Convexes, établi par M. Serville, qui le caractérise ainsi : Corps convexe en dessus, ailé, cylindrique, pubescent. Antennes sétacées, frangées en dessous, de la longueur du corps dans les femelles, beaucoup plus longues que lui dans les mâles, et de $12 \mathrm{ar}^{\circ}$. ticles : le $1^{\mathrm{er}}$ allongé, peu en massue $;$ le $2^{\mathrm{me}}$ très petit, le $3^{\mathrm{me}}$ grand, les suivants cylindriques; le $12^{\text {me }}$ court dans les femelles, très long dans les mâles. Corselet mutique latéralement, presque cylindrique, souvent un peu rétréci vers sa partie antérieure; son disque uni. Palpes de longueur moyenne. Mandibules pointues. Élytres linéaires, arrondies et mutiques à leur extrémité. Pattes égales, de longueur moyenne; cuisses point en massue; tarses glabres. Mœurs et habitudes des Saperdes. - M. Dejean qui a adopté ce g. (Calal. $3^{\text {me }}$ édil.), y rapporte 16 espéces la plupart du midi de l'Europe et vivant toutes sur les fleurs. Nous nien citerons qu'une : l'A. Cardui (Saperda $i d$. Fab.), qui se trouve presque dans toute la France, et notamment aux environs de Paris sur les chardons, dans l'intérieur desquels vit sa larve.

*AGAPETES ( $\alpha \gamma \alpha \pi \cdot n \tau \tau^{\prime} \varsigma$, aimable). вот. PH. - G. de la famille des Ericacées, établi par Don (Syst. 111. 862), et qui n'a pas élé adopté. Les espèces qui le composaient ont été réparties entre les g. Thibaudia et Gaylussacia. $V$. ces mots.

* AGAPETUS ('́yarntós, aimable). Ins. - G. de Coléoptères hétéromères, famille des Hélopiens, établi par M. Dejean (Catal. $3^{\mathrm{me}}$ édil.), mais sans indication de caractéres. Il y rapporte 2 espéces nommécs par lui l'une, $A$. decoralus, de Java; et l'autre, $A$. hilaris, de l'île Bourbon.

(D.)

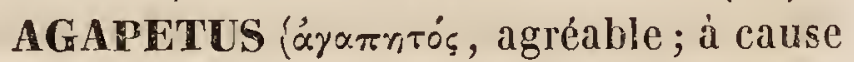
des formes gracieuses de ces insectes). ins. - G. de la famille des Phryganiens, de l'ordre des Névroptères, élabli par Curtis (Desc. of some list. nond." Bril. sp. in Lond. and Edinb. plitos. Mag.), qui lui assigne les caract. suivants : Ant. épaisses, bifides, moins longues que le corps. Abd. du mâle ayant une longue épine recourbée; celuide la femelle ayant son extrémité terminée en pointe. Ailes courtes et arrondies; les jambes intermédiaires, et postér. avec 2 paires de fortes épines. Il y rapporte 3 espèces d'An- 
gleterre. A. fuscipes Curt.; ochripes, Curt., et funereus? Oliv., Geofr. Les caract. que M. Curlis assigne à ce g., ainsi qu'à beaucoup d'autres de celte famille, ne sont pas appréciables, et ne sauraient offrir des différences bien tranchées d'un g. à l'autre.

(BL.)

* Agarhite. min. - Fischer, de Moscou, a ainsi nommé, en l'honneur de Démétrius Agaphi, une variété de la pierre bleue qu'on trouve désignée dans Pline soụs la dénomination de Calaïte, et qui porte dans le commerce de la joaillerie le nom de Turquoise orientale. $V$. TURQuolse. (DEL.)

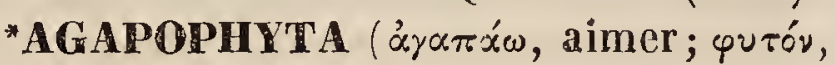
plante ). ins. - G. de la famille des Scutellériens, de l'ordre des Hémiptères, section des Hétéroptères, établi par M. Guérin (V́oyage de Dup.), adopté par M. de Laporte (Ess. sur les Hém.), Burmeister (Handb. der Em.), et nous (Hist.des Anim.art.), réuni au g. Tesseratoma par M. Brullé (Hist. des Ins.). Ses principaux caractères sont tirés e la forme de la tête, plus avancée que dans es g. voisins; des antennes composées de 4 aricles ; et du thorax, rétréci en avant, élargi postérieurement et déprimé, avec l'écusson triangulaire terminé en pointe bifide. - On n'en connaît qu'une seule esp., qui est l' $A$. bipunctata Guér., Burm., Bl., provenant des îles océaniques.

(BL.)

* AGAPORNIS ('áx́x $\pi n$, amabilité; öpves, oiseau). ors. - G. de l'ordre des Grimpeurs et de la famille des Perroquets, formé par Selby et adopté par Swainson (Class. of Birds). Ce g. fait partie de la s.-famille des Psillacince ou Perroquets à queue courte, et comprend ceux d'entre eux qui sont de petite taille et particuliers à l'Amérique du sud. Ses caractères sont : Mandibule inférieure très épaisse; ailes longues, mais plus courtes que la queue; les 3 premières rémiges égales et les plus longues; queue courte, arrondie; rectrices lancéolées et pointues. (LAFr.)

AGARDLIA (Agardh, Botaniste suédois). Bo'T. Cr.-Nom proposé par le chanoine Cabrera pour un g. de Thalassiophytes, de la tribu des Siphonées, famille des Phycées, mais qui avait déjá été désigné sous ceux de Codium par Stackhouse, de Lamarckia par Olivi, et de Spongodium par Lamónroux. $V$. conlum.

Meneghini, que nous royons arec plaisir partager et confirmer, par ses observations, notre opinion sur plusieurs productions marines considérées à tort comme des Polypiers, et qui ne sont en efret que des Algues encroûtées, a donné le nom d'Agardhia à un g. qu'il établit aux dépens de plusieurs Millépores de Lamarck et surtout de ses Nullipores. Voici comme il le définit (Cenmi sul. organ. et fisiol. delle Alghe) : Frondes indéfinies, ćpaisses, sinvieuses, "entortillées, encroûtées, composées de cellules allongées et disposécs en séries paralléles, percées de pores, et au fond desquelles se trouve la Pructification. Meneghini ne dit pas en quoi celle-ci consiste; il place cette production dans la tribu des Dictyotées, à côté du g. Haliseris. Le nom d'Agardhia, ayant déjà élé consacré par Sprengel à un g. de la Phanérogamie, ne saurait être conservé.

* AGDDHA, Spreng. (Agardh, Botaniste suédois). 'вот. Рн. - Touble emploi, suivant M. Sprengel lui-même (Gen. Plant. p. 8), du g. Amplizlochia, Mart.

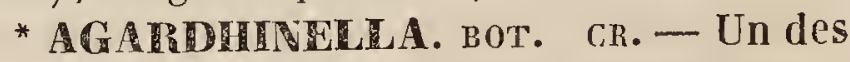
diminutifs proposés par Gaillon, et non adoptés. $V$. le g. AGARDHIA. (C. L.)

AGARTC. Agaricus (áx ypexóv). вот. CR. - L'étymologie de ce mot, employé par Dioscoride et par tous les auteurs jusqu'à nos jours, paraît assez obscure. On le fait dériver d'Agaria, contrée de la Sarmatie, dans laquelle croissait très abondamment le champignon auquel on avait donné primilivement ce nom. Le célèbre Scaliger a contesté cette étymologie, parce qu'il ignorait où était située Agaria; mais Saumaise a levé ces difficultés, et maintenant elle est généralement adoplée. Ce mot a servi pendant longtemps à désigner un champignon dont l'hymenium est poreux et dont on faisait un grand usage comme purgatif; c'cst le Bolet du Mélèze, Boleus purgans de Persoon ou Agaric des Pharmaciens ( $V$. ce $e^{7}$ mol). Plus tard il a élé donné à une autre esp. de Bolets, qui croît sur le chêne et sur d'autres arbres, et auquel on a accordé bien gratuitement la propriété d'arrêter les hémorrhagies. Persoon le désigne sous le nom de $P_{0-}$ lyporus igniarins. On le nomme encore Agaric des Chirurgiens $(V$. ce mot). Linné, sans que l'on puisse en deviner le motif, a jugé convenable d'appliquer ce nom à un autre g. 
de champignons, dont l'hymenium est composé de lames parallèles qui s'étendent du centre à la circonférence, comme les rayons d'une roue ou d'une ombrelle. Tous les auteurs ont, depuis celte époque, conservé Ie mot Agaric; Paulet seul a tenté de lui substituer celui d'Hypophyllum.

Ce g. est le plus nombreux en esp. que l'on connaisse. Les sections que l'on a établies, et les différents noms sous lesquels on les trouve indiquées dans les auteurs du $18^{\mathrm{me}}$ et du $19^{\mathrm{me}}$ siècle, comme Amanita, Petrona, Keuma, Gelona, Volva, Lactarius, Russula, etc., reposent sur des parties trop secondaires pour que l'on puisse les considérer comme genres, puisque dans toutes on trouvele même plan d'organisation. Persoon était tenté de diviser les Agarics en plusieurs g.; mais il a reculé devant cette innovation. Nous savons trop peu de close, disait-il, sur les organes de la reproduction, sur la structure et les fonctions des différentes parties, pour établir des g. véritables. Ce que Persoon n'avait osé, M. Fries vient de le faire dans un ouvrage extrêmement remarquable, publié à Upsal en 18361838, sous le titre d'Epicrisis Systematis $M y$ cologici.Je laisse aux savants, plus versés que moi dans la Mýcologie, Ie soin de décider si le célébre professeur en a rendu l'étude plus facile.

L'hymenium est la partie principale des agarics; celle sur laquelle repose le caractére du genre. Toutes les autres peuvent éprouver des modifications extrêmes, et c'est sur ces modifications, quand elles se présentent d'une manière normale et à peu près constante, que les subdivisions ont été établies. Il est donc nécessaire d'entrer dans quelques détails au sujet de ces parties. On peut considérer les Agaricus Cosareus, bulbosus, etc., comme les esp. qui présentent l'organisation la plus parfaite. On y distingue le mycelium, le pédicule, la volve, l'anneau et l'hymenium.

Le mycelium est une production blanche, filamenteuse, qui se développe dans la terre, sur le bois pourri, etc. Il se forme sur cet orgarie, à une cerlaine époque de l'année et sous l'influence de circonstances qui ne sont pas encore connues, des tubercules charnus qui, par l'évolution successive des différentes parties qui les composent; don- nent naissance à un Agaric ou à un autre champignon. On a considéré pendant longtemps le mycelium comme des racines; maintenant on le regarde généralement comme remplissant les fonctions d'une tige souterraine ou rhizome.

La volve, volva, bourse, voile général, enveloppe générale ou radicale est une membrane qui renferme toutes les parties du champignon, comme la coquille renferme tous les éléments de l'œuf. Il paraît qu'elle existe dans tous les champignons; mais elle est d'une texture si délicate dans le plus grand nombre, qu'elle disparait complètement pendant la $1^{\text {re }}$ évolution, sans que l'on puisse en trouver le moindre vestige. On n'y attache donc de l'importance que quand ses débris restent manifestes à la base du pédicule ou sur le chapeau. Le mot volve ou volva paraît dériver du verbe latin volvo, j'enveloppe. La volve est composée de cellules allongées et rameuses qui s'anastomosent entre elles. Elle est complète, quand elle se déchire pour laisser passer le chapeau et le pédicule, et qu'elle reste à la base de celui-ci; incomplète, quand elle ne recouvre pas Ie champignon en entier; elle est caduque ou persistante, épaisse ou mince; ample, quand elle représente un vase dont le bord est évasé; vaginée lorsqu'elle est assez étroite et longue, ế enfin ochrée ou en forme de guêtre, quand elle est exactement appliquée sur le pédicule. On ne connaît guère que l'Agaricus ochreatus qui soil dans ce cas. Dans les champignons comestibles on rejette toujours cette partie; mais elle est de la plus haute importance pour l'étude; aussi faut-il toujours enlever un champignon de terre avec précaution pour constater l'existence de cette membrane.

Le pédicule, stipe ou pied (stipes, caulis, petiolus, pediculus), est la partie qui supporte le chapeau et qui fixe le champignon au lieu oú il a pris naissance. Il est central, excentrique, latéral ou ascendant, quand il occupe le centre, un point plus ou moins éloigné du centre ou le côté du chapeau. Sa partie moyenne est nue ou munie d'un anneau ou d'une cortine. Il est court ou long, plein ou fistuleux; on le dit creux quand sa partie centrale vient à disparaître. Dans quelques esp., il est floconneux ou ir:versé dans toute sa longueur par un filament bys- 
soide. La forme du pédicule est très variable: il est simple, rameux, bulbeux, fusiforme, atténué à l'une ou à l'autre extrémité; gros, épais, long, court, filiforme, etc. Sa surface est lisse, rude, écailleuse, tomenteuse, villeuse, etc. Sa consistance est le plus ordinairement molle, spongieuse, cassante, quelquefois fibreuse, élastique, etc. Cette partie se dilate à sa partie supér. et forme le chapeau. Il arrive quelquefois que dans les endroits profonds et obscurs, comme les souterrains, elle s'allonge, se ramifie même et ne produit pas de chapeau. Dans cet état de monstruosité, les agarics ressemblent á des clavaires.

L'anneau, le collet, voile partiel (annulus, velum partialej, est cette partie membraneuse qui entoure le pédicule comme d'une manchette. Bulliard a dit que : "le collet paraît être au champignon, ce que le calice et les pétales sont aux fleurs. C'est un abri sûr pour les graines qui sont probablement fécondées avant que le collet se détache du chapeau.» - Rien ne prouve jusqu'à ce jour cette assertion, parce qu'il y a beaucoup plus d'agarics qui n'oni pas de collet que de ceux qui en ont; et dans ceux-ci, la fécondation, s'il en existe une, s'opére également bien. Si l'on étudie l'anneau dans les esp. qui l'ont parfaitement développé, comme les Amanites, l'Agaricus campestris : etc.; on voil que son extrémité supér. s'insère au sommel du pédicule, le recouvre dans une certaine étendue; puis ce même anneau s'en éloigne, s'élargil et se fixe à la marge du chapeau dont il se détache plus tard, et reste adhérent au pédicule, II est composé de cellules très allongées, presque toutes parallèles. Son épaisseur et sa consistance varient dans un grand nombre d'espéces. Il retient l'impression des lames, et il est persistant ou fugace; libre ou adhérent. Sa couleur est généralement blanche. Le collet présente de très bons caract. pour établir des sous-divisions dans le $\mathrm{g}$. Agaric.

La cortine, voile partiel, voile ou collet aranéeux ou arachnoïde (cortina, velum vartiale, velum araneosum), doit être regardée comme un anneau imparfail qui unit les bords du chapeau avec le pédicule, et qui se compose de filaments blancs ou colorés, restant adhérents sur le pédicule ou à la marge du chapeau, quand le champignon est développé. Persoon fait observer qu'on peut trouver une amanite qui ait en même temps une volve et un collet, mais jamais un agaric pourvu simultanément d'une cortine et d'un anneau. La cortine, organe généralement assez fugace, fournit pourtant de très bons caractères de sous-genres.

Le chapeau, chapiteau, table ( pileus, pileum, pileolus, pileolum, umbraculum, capitulum ou mieux hymenophorum du professeur Fries', considéré d'une manière générale, folme presque à lui seul ce que l'on nomme un champignon. C'est la partie qui frappe la vue, et celle que l'on mange. Ce chapeau est formé, comme je l'ai dit, par l'expansion de la partie supér. du pédicule. Il se compose d'une partie charnue et de l'hymenium. La forme $d u$ chapeau ou de l'hyménophore est arrondie, conique, campaniforme, convexe, plane, déprimée, infundibuliforme, mamelonnée, etc. La surface en est lisse, striée, villeuse, écailleuse, rugueuse, sèche ou visqueuse. L'épiderme qui la recouvre s'enlève dans quelques espèces, et fait, dans d'autres, corps avec la chair. Sa couleur et sa consistance sont extrêmement variables. Il est plus ou moins charnu, épais ou membraneux, se dessèche facilement, se pourrit, ou tombe en déliquescence. La marge de cette partie est très importante aussi à étudier dans ses formes, surtout quand elle est roulée en dedans, ou qu'elle est appliquée immédiatement sur le pédicule. M. Fries a, dans son Epicrisis, tiré un parti très avantageux de celte disposition, à laquelle aucun Mycologiste, jusqu’à ce jour, n'avait fait attention. La structure du chapeau est la même dans tous les Agarics. On n'y trouve que des cellules plus ou moins allongées; dans les uns, elles sont lâches, éloignées; dans les autres, au contraire, elles sont petites et très rapprochées. Elles renferment des liquides de différentes natures et très probablement de l'air ou des gaz.

Les lames ou feuillets (lamino, lamelloe sulci de Batarra), sont les prolongements membraneux el parallèles de la partie infér. du chapeau, qui se dirigent du centre à la circonférence. C'est sur cette disposition que reposent les caract. dı g. Agaric. Elles sont composées de 3 couches, une médiane ou 
trame formée de cellules qui se continuent avec eelles du chapeau, et 2 latérales formées par l'hymenium. Cette organisation existe dans tous les Agarics, et ne manque dans aucune espèce, malgré l'assertion du plus célébre Mycologiste de notre ćpoque. Si dans les Coprins, l'Agaricus contignus, Bull. , et quelques autres esp., les lames paraissent dépourvues de trame, e'est que les cellules qui la composent, sont moins abondantes, et qu'elles forment un tissu moins dense et moins résistant que celai de l'hymenium; ce qui permet de séparer quelquefois eette membrane du ehapeau. Dans aucune esp. d'Agarics, ni dans aucun des sous-genres établis, les 2 couches de l'hymenium ne sont ell contact immédiat. Elles sont toujours séparées par la trame, et tout earact. fondé sur l'absence de cetle partie est un prétendu caract. anatomique, qu'il faut soigneusement éliminer, dans la crainte que quelque botaniste ne soit tenté d'en faire usage pour former de nouveaux g. dans les Bolets, les Polypores, les Hydnes, etc. - On distingue dans une lame, deux bords : l'un, adhérent au ehapeau ou à la base; l'autre, libre, et que l'on appelle marge ou tranche; deux extrémitès : une interne qui répond au pédicule et que quelques auteurs regardent comme la base; l'autre, qui répond a la marge du chapeau; deux surfaces qui sont parallèles et qui forment les eôtés. L'Hỵmenium ou membrane sporulifère recouvre la trame des lames dans toute leur étendue. Son tissu est composé de cellules superposées en plus ou moins grand nombre et de formes qui varient suivant les espèces. Sur les surfaces examinées au microscope, dans les sous-genres Amanita, Lepiota, Gymnopus, Russula, etc., on remarque un nombre considérable de Basides, ou petites éminences qui se divisent en 4 pointes, à l'extrémité de ehacune desquelles est fixée une spore. Dans les Coprins, on trouve parmi les basides, des Cystides ou vésicules allongées transparentes, qui paraissent vides et dont la forme est tantôt celle d'un cylindre et tantôt celle d'une massie, etc. Ces organcs, sur lesquels j'ai donné ailleurs (Mém. sur l'Hymenium, Soc. Plitom., 12 mars 1837 , et Ann. des $S_{c}$. nut. décembre 1837.) des détails assez éten- dus, n'avaient pas échappé à la sagacité de Micheli; mais ce eélèbre Botaniste ne les avait vus et dessinés que d'une manière incomplete. Les observations de MM. Ascherson, Belierley et Corda, du moins pour l'Agaricus petasiformis, sont parfaitement conformes aux miennes. C'est maintenant un point d'organisation acquis à la science, il ne faut pas le considérer comme le caract. propre du g. Agaricus, mais bien eomme le caract. d'une grande famille à laquelle j'ai donné le nom de Basidiospores et qui eomprend Ies Agarics, Ies Bolets, les Polypores, les Hydnes, les Clavaires, etc., Les spores ou sporules (sporce, sporuloe), ou organes reproducteurs, sont d'une ténuité extrême et seulement visibles au microscope. Leur forme est constamment ronde ou ovale. Elles sont, eomme je l'ai dit, fixées aux divisions des basides, et dans quelques esp., à l'aide d'un fort grossissement, on en distingue le point d'insertion. La eouleur des spores a été pour le professeur Fries un moyen très ingénieux d'établir les earaet. des différents groupes du g. Agarie. Elles sont blanches, rosées, ochracées, ferrugineuses, noires ou d'un roux pourpre. Pour constater ees eouleurs, il suffit de mettre pendant quelques heures un Agaric sur une glace ou sur une feuille de papier, de maniẻre que les lames regardent en bas, les spores se détachent spontanément et forment une légère eouehe qui présente une des couleurs que je viens d'indiquer. Ces spores renferment quelquefois, dans leur intérieur, d'autres corps beaucoup plus petits que l'on nomme sporidioles; d'autres fois elles paraissent nébuleuses; mais le plus souvent elles sont transparentes. Telle est la strueture des lames des Agarics; mais ces parties, sous le rapport de leur proportion, de leur forme et de leur mode d'insertion avec le pédicule, présentent des caract. très précieux. On les dit simples ou égales, quand elles ont toutes la même longueur, et composées quand entre 2 lames qui s'étendent du pédicule à la marge du chapeau on en trouve un eertain nombre d'inégale longueur. Krombholtz, dans ee cas, les nomme didynamiques, tridynamiques, télradynamiques et polydynamiques, suivant que l'on trouve des lamelles ou portions de lames qui ont la moilié, le tiers ou le quart, ou moins d'une 
lame entière. Dans quelques esp. elles sont bifurquées à la base, et dans d'autres elles s'anastomosent à l'aide de divisions ou prolongements latéraux. Cette dernière disposition est rare, et doit être plutòt considérée comme un accident que comme un caract. particulier. Quand les lames sont écartées les unes des autres, on les dit rares ou peu nombreuses; dans le cas contraire elles sont nombreuses ou rapprochées. Suivant leur forme, elles sont minces ou épaisses, laryes ou étroites, aiguës, tronquées, arrondies ou obtuses à l'une ou à l'autre extrémité. Relativement aux rapports qu'elles ont avec le pédicule, on les dit décurrentes, quand leur extrémité interne se prolonge en pointe sur une ètendue plus ou moins grande du pédicule. Libres (remoto, distantes, discretoe), quand elles n'ont aucune connexion avec cette partie, et qu'elles en sont séparées par un certain intervalle. Quand elles adhèrent au pédicule par toute l'étendue de leur extrćmité interne, on les nomme adnées (adna$\iota x$ ) et adnexes (adnexo), quand l'insertion est incomplète, et enfin onguiculces, lorsqu'elles adhìrent au pédicule par le moyen d'un petit prolongement; la base, ou le bord supér. des lames ne présente pas de caract. Dans quelques esp. seulement, il est marqué de petites saillies ou veines qui se continuent avec le chapeau. Le bord libre ou tranche est régulier, denté, onduleux, droit. Dans un grand nombre d'esp., on remarque à sa partie interne une échancrure ou sinus ( lamellex sinuatoe). Persoon et M. Fries, dans plusieurs circonstances, se sont servis de ce caract. avec le plus grand avantage. La substance des lames est toujours la même que celle du chapeau, puisqu'elle n'en est que le prolongement; comme celui-ci, elles sont charnues, coriaces, fragilcs, succilentes, aqueuses, lactescentes, etc. Leur couleur est en général celle des spores; mais pourtant il ne faut pas juger la couleur des spores d'après celles des lames. On devra toujours recevoir ces organes sur une feuille de papier, afin de ne pas être induit en erreur.

M. Fries admet 6 couleurs dans les lames.

Le blanc, le rosé, le jaune, le rouillé, le brun pourpre, le noir et le noiratre. Quelquefois elles sont nébuleuses ou tachetées. On en rencontre aussi qui conservent la même couleur pendant toute leur durée (immuta- biles), et d'autres au contraire qui pâlissent ou qui en changent (decolorantes) comme dans les Cortinaires et les Pratelles. Enfin on dit que les lames sont persistantes (persistentes), quand elles durent autant que le chapeau, et fugaces (fugaces), dissolubles (diffuentes, liquescentes), quand elles disparaissent avant le chapeau ou qu'elles se liquéfient comme on le voit dans les Coprins.

Le g. Agaric, établi par Linné et adopté par tous les botanistes, présente les caract. que j’ai indiqués plus haut. Comme les esp. sont très nombreuses, tous les auteurs ont senti la nécessité de subdiviser ce g. pour en faciliter l'étude. Micheli, Gleditsch, Batarra, Haller, Schæffer, Batsch, Scopoli, Allioni, Gmelin, etc., n'ont guère consuitć que la couleur des différentes parties. Persoon le premier, dans son Synopsis fungorum, a saisi avec une admirable sagacité les affinités des différentes esp., et §n a formé 10 sous-genres. Malheureusement, comme les auteurs qui l'avaient précédé, il a plus attaché d'importance aux couleurs qu'à la disposition des lames qui présentent, comme je'l'ai dit, des caract. précieux. Ce célèbre botaniste a cru devoir séparer les Amanites du g. Agaric, par rapport à la volve dans laquelle le champignon est renfermé dans son jeune âge; mais comme cet organe finit presque par disparaître dans quelques esp., je pense, comme M. le professeur Fries, qu'il ne doit pas former un g. particulier. Le g. Agaric présentera donc 11 s.-genres.

1. Amanita. Agaric à volve. Chapeau charnu, le plus souvent verruqueux. Lames nombreuses, serrées, pédicule allongé, nu ou muni d'un anneau. Ex. $A$. vaginalus, Bull.; phalloüdes, Bull. etc.

2. Leprota: Pas de volve. Pédicule muni d'un anneau membraneux. Lames ni nébuleuses ni fuligineuses, dépourvues de sucs. Ex. A. procerus Scop., hocmatospermus Bull., cristatus Fries, etc.

3. Cortinaria. Cliapeau le plus souvent charnu. Lames émarginées ou sinuées à leur extrẻmité interne, unicolores et enfin couleur de cannelle. Pédicule souvent bulbeux entouré d'une cortine ou anneau arachnoïde. Ex.: A. violaccus Lin., hercynicus. Pers., collinitus, Sow., etc.

4. Gymnopus: Chapeau charnu entier et con- 
rexe. Lames unicolores, marcescentes. Pédicule sans anneau ni cortine. Ex.: A. Lencophyllus Pers.; gymnopodius Bull. sulplıreus Bull.; etc.

Mrcena : Chapeau le plus souvent membraneux, strié, presque transparent, convexe et persistant. Lames unicolores, se desséchant facilement. Pédicule allongé, fistuleux et nu. Ex.: A. alliaceus Pers.; polygrammus Bull.; citrinellus Pers.; etc.

Coprinus : Chapeau membrancux ou à peine charnu, fugace. Lames noires, se liquéfiant. Pédicule blanc, nu ou muni d'un anneau. Ex. : A. comatus Pers.; picaceus Bull.; ferruyincus Pers.; ete.

Pratella : Chapeau charnu ou presque membraneux, persistant. Lames nébuleuses et enfin noires. Pédicule nu ou muni d'un anneau. Ex.: A. campestris Linn.; ceruginosus Pers.; corrugis Pers.

LaC'TIFluUs : Chapeau charnu, le plus souvent déprimé au centre. Lames lactescentes. Ex. : A. torminosus, Pers.; theïogalus Bull.; plumbeus Bull.; etc.

Russula : Chapeau charnu, le plus souvent déprimé au centre. Lames dépourvues de suc et toutes de la même longueur. Pédicule nu. Ex. : A. vive us Pers.; alutaceus Pers.; furcalus Pers.; etc.

Onpiralia : Chapeau entier, charnu ou membraneux, infundibuliforme ou déprimé au centre. Lames d'inégale longueur, ni succulentes, ni lactescentes, le plus souvent décurrentes. Pédicule nu et central. : Ex. A. involutus Batsch. ; cupularis Bull. ; lentus Fries.

Pleuropus : Chapean charnu, déprimé, oblique, entier ou dimidié. Pédicule excentrique, latéral ou nul. Ex. A. ulmarius Bull.; ostreatus Curt.; applicatus Batsch.

Cette distribution des Agarics a été adoptée par tous les auteurs; et, en efret, malgré les imperfections qu'elle présente, celui qui l'adopte pour étudier les Champignons, rapporte avec la plus grande facilité les différentes esp. aux sections qui leur conviennent. Persoon l'a à peu près conservée dans son Traité des Champignons comestiblcs. II lui a fait subir quelques modifications dans son Mycologia europoea, mais comme cet important ouvrage n'a malheureusement pas été terminé, je crois inutile d'indiquer les corrections que cet auteur a été obligé d'y тон. I. faire, par suite de sa grande expérience ot des immenses progrès de la science. M. Frię, dans un ouvrage imprimé en 1821, sous le titre de Systema mycologicum, a présenté une nouvelle distribution du g. Agaricus, basée principalement sur la couleur des spores, et qui lui permet d'établir 5 grandes sections divisées en 36 sous-genres, à la suite desquels viennent les g. Coprinus et Gomphus. Je renvoie à l'ouvrage de $M$. Fries ceux qui désireraient connaître l'èlendue et la hardiesse de ce travail, dont une analyse ne pourrait que donner une idée très imparfaite. Plus tard, en 1825 , l'auteur, dans le Systema Orbis vegetabilis, ètablissant le g. Agaricus (sur les caract. suivants : Lamello simplices, inoquales, exsuccœ, persistentes, a pileo discretoe), en ćloigna les sous-genres Coprinus, Galorrheus, Russula, Lentinus, pour en former des g. distincts qui par leurs caractères particuliers semblaient rompre la continuité des séries formées dans les Agarics. Enfin M. Fries, dans l'Eicrisis $\$$ ystematis mycologici, a non seulement cunservé ces g., mais encore en a formé de nouveaux, comme Montagnites, Bolbitius, Paxillus, Gompliidius, Stylobates, Hygrophorus, etc., d'après des caract. que l'œil le plus exercé ne saisit pas toujours et que l'examen anatomique ne démontre pas constamment. Il en résulte, je ne dirai pas de la confusion, mais un bouleversement général dans cette partie de la Mycologie.

Voici la nouvelle disposition des Agarics, proposée par le professeurFries. Elle repose sur les lames, et principalement sur leur trame, c'est-á-dire sur la structure de la cloison qui sépare les 2 couches d'hymenium dont chaque lame est composée. Les sous-genres sont établis sur la couleur des spores, la forme et les rapports des lames avec les autres parties, sur la présence ou l'absence d'une volve, d'un anneau membraneux ou aranéeux et sur des états particuliers du chapeau et du pédicule.

AGARICI LEUCOSPORI (spores blanches). Amanita : Une volve. Pédicule nu ou muni d'un anneau. Hymćnophore séparé du pédicule. - A. cosarcus Scop.; rubescens Pers.; vaginatus Bull.; etc.

Lepıота: Voile général, uni avec l'épiderme du chapeau. Pas de volve. Pédicule mùni d'un anneau. Hyménophore éloi- 
gné du pédicule. Lames libres. - A. procerus Scop.; clypeolariıs, Bull.; granulosus Batsch.; etc.

Armularia : Pas de volve. Pédicule muni d'un arneau. Hyménophore contigu avec le pédicule. Lames décurrentes ou sinuées à leur extrémité interne. - A. ramentaceus Bull.; rhayadiosus Fries; A. millus Sow.; elc.

Tricioloms: Voile partiel, nul ou filamenteux, adhérent à la marge du chapeau. Pédicnle charnu. Hyménophore contigu avec le pédicule. Lames sinuées à leur extrémité interne. - A. equestris L.; frumentaccus Bull.; gambosus Fries; ctc.

Curtocybe : Ni volve ni anneau. Pédicule fibreux, élastique ; marge du chapeau roulée en dedans. Hyménophore contigu avec l'extrémité supérieure du pédicule qui est dilatce. Lames atténuées à leur extrémité interne, adnées ou décurrentes et jamais sinuées.- A. nebularis Batsch; molybdinus Bull.; gilvus Pers.; etc.

Collybia : Pédicule fistuleux, recouvert d'une couche corticale ferme et comme cartilagineuse.Chapeau peu charnu, convexe ou plan ; marge roulée en dedans. Lames membrancuses, molles, libres ou adnées. A. radicatus Bull.; collinus Scop. ; ocellatus Fries ; etc.

Mrcena : Pédicule fistuleux, cartilagineux. Chapeau presque membraneux, plus ou moins strié. Chapeau conique ou parabolique; marge droite, couchée sur le pédicule. Lames non décurrentes, mais adhérentes par le moyen d'un peiit onglet. A. purus Pers.; galericulatus Bull.; citrinellus Pers.; etc.

Omphalıa : Pédicule cartilagincux, dilaté à sa partie supér. Lamcs décurrentes. A. hydrogamus Bull.; hepaticus Batsch.;oniscus Fries; etc.

Pleurotus : Pédicule excentrique, latéral ou nul.-A. ulmarius Bull.; petaloz̈des Bull.; applicatus Batsch.; etc.

AGARICI HYPORRHODII (spores rosées).

Volvaris : Une volve. Hyménophore distant du pédicule. Lames libres.-Ce s.-genre ne diffère des Amanites que par la couleur des spores.-A.volvaceus Bull.; conicus Pico.; glojocephalus DC. ; etc.

Pluteus : Voile nul ou faisant corps avec l'épiderme du chapeau. Pédicule fibreux. IIyménophore isolé. Lames libres.-A. plu- teus Batsch.; umbrosus Pers.; phlebophorus Dittm.; etc.

Entolom : Voile nul. Pédicule charnu ou fibreux. Hyménophore contigu avec le pédicule. Lames sinuées à leur extrémité interne, rapprochées du pédicule et s'en éloignant ensuite. - A. sinuatus Bull.; placcnta Batsch.; rhodopolius Fries ; etc.

Clitopılus : Pédicule charnu ou fibreux, se dilatant en haut pour former le chapeau; marge roulée en dedans. Hyménophore colltigu avec le pédicule. Lames décurrentes, atténućes a leur extrémité interne. A. prunulus Scop.; orcellus Bull.; popinalis Fries; etc.

Leptonin : Pédicule cartilagineux, à surface lisse, brillante. Chapeau mince, ombiliqué, ou d'une coulenr plus intense sur le disque; marge roulée en dedans. Lames adhérentes ou rapprochées du pédicule et s'en séparant ensuite.-A. lampropus Fries; chalibous Pers.; nefreus Fries.; etc.

Nolınea : Pédicule fistuleux, cartilagineux. Chapeau presque membraneux, campanulé, strié, quelquefois lisse; marge droite. Lames rapprochées du pédicule et libres ensuite.-A. pascuıs Pers.; icterinus Fries; pleopodius Bull.; etc.

Ecciles : Pédicule cartilagineux, évasé à sa partie supérieure pour former le chapeau qui est presque membrancux; marge courbée en dedans. Lames atténuces à leur extrémité interne et décurrentes. - A. politus Pers.; atropunctatus Pers.; nigrellus Pers.; clc.

AGARICI DERMINI (spores ferrugineuses, rarement rousses ou brunes ).

Pholıta : Pédicule cylindrique, écailleux, muni d'un anneau membraneux ou floconneux. Chapeau convexe, puis plan. Lames inégales et changenut de couleur. - A. aureus Pers.; togularis Bull.; radicosus Bull.; etc.

Hebeloma : Voile filamenteux ou à peine visible. Pédicule charnu ou fibreux. Lames adhérentes et sinuées à leur extrémité interne. Leur marge est lc plus souvent blanche ou d'une coulcur différente de celle des surfaces. - A. lanuginosus Bull.; pyriodorus Pers.; rimosus Bull, ; etc.

Frammula : Voile filamenteux ou peu visible. Pédicule charnu, fibreux, furfuracé à sa partie supérieure. Chapeau charnu; marge roulée en dedans. Lames décurrentes 
non sinuées, leur tranclıe ćtant de la nême couleur que les surfaces. - A. gymnopodius Bull.; vinosus Bull.; pulverulentus Bull.; etc.

Naucoria : Voile nul ou fugace. Stipe cartilagineux, fistuleux ou spongieux en de dans. Chapeau plus ou moins charnu, convexe, puis plan ou conicue; marge roulée en dedans. - A. cucumis Pers.; melinoïdes Bull.; semi-orbicularis Bull.; etc.

Garfra : Voile nul ou fibrilleux. Pédicule cartilagineux, tubuleux. Chapeau plus ou moins membraneux, conique ou ovale,' strié. Marge droite appliquée sur le pédicule. A. campanulatus Bull.; pityreus Fries; pellıcidus Búll.; elc.

Crfpidotus : Voile nul. Chapeau excentrique, latéral ou résupiné.-A. olearius $\mathrm{DC}$.; mollis Schœfr.; variabilis Bull.; etc. Ce sousgenre ne diffère des Pleurotus que par la couleur des spores.

AGARICI PRATELLI (spores brunes ou d'un noir pourpre).

Psaliota : Pédicule charnu, ferme, muni d'un anneau. Chapeau plus ou moins charnu, convexe. Lames libres ou adhérentes. A. campestris L.; homatospernus Bull.; merdarius Fries; etc.

Hypholona : Voile aranéeux, adhérent à la marge du chapeau. Pédicule charnu ou fibreux. Chapeau plus ou moins charnu; marge roulée en dedans. Lames adnées ou émarginées. - A. silaceus Pers.; lacrymabundus Bull.; candolleanus Fries.; elc.

Psilocrbe : Voile nul. Pédicule presque cartilagineux, tubulenx, souvent prolongé en racine. Chapeau plus ou moins charnu, glabre; marge courbée en dedans.-A. planus Sow.; fœnisecii Pers.; coprophilus Bull.; etc.

Psathyra : Voile nul. Pédicule presque cartilagineux, tubuleux, poli, fragile. Chapeau conique ou campanulé, membraneux; marge droile, appliquée sur le pédicule. Lames pourpres ou brunes. $-A$. corrugis Pers.; obuusaus Pers.; gossypinus Bull.; etc.

AGARICI COPRINARII (spores et lames noires ).

Payoeorus.: Voile membraneux ou nul. Pédicule poli et ferme. Chapeau légèrement charnu, sans stries; marge saillante. Lames marbrées. - A. fimijuutris Bull.; campanulalus I.; prepilionaceus Bull.; elc.

PsatiYrella : Voile nul ou a peine visible. Chapeau membraneux, strié; marge ne dépassant pas les lames, qui sont d'une couleur noire fuligineuse uniforme. - - . hydropltorus Bull.; caudatus Fries; disseminalus Pers.

Les Agarics sont des Champignons très communs, croissant presque partoul. Comme beaucoup d'espéces servent à la nourriture de l'homme, on a cherché à les reproduire; mais on n'a réussi jusqu'a ce jour que pour un très petit nombre d'entre elles. Le champignon de couche (Agaricus edulis) est celui que l'on obtient le plus facilement. On fait pour cela un mélange de terreau, de fumier pourriet de crottin de cheval, et on en forme dans une cave des couches de 2 picds ou plus de haut, auxquelles on donne la forme d'un triangle dont on arrondil l'angle supérieur. On étend sur toute cette surface du blanc de Champignons, que l'on recouvreensuite d'une couche de terreau. Il faut avoir soin d'arroser de temps en temps pour entretenir la fermentation, la chaleur et l'humidité; trois circoristances essentielles au développement des Champignons. Dans un très court espace de temps, la couche se recouvre de filaments blancs et byssoides, sur lesquels naissent en nombre immense, de petits tubercules qui croissent et se succédent rapidement. Quelques personnes n'emploient pas le blanc de champignons, mais arrosent les couches avec de l'eau dans laquelle elles ont fait macérer les Champignons. Ce moyen réussit également; seulement, ces couches produisent peu, et cessent de produire peu de temps après leur préparation. Quand le nombre des champignons diminue, il faut songer á former une nouvelle couche, car c'est un signe de l'épuisement de l'ancienne, qu'on arroserait désormais en vain : les éléments de la fermentation n'existant plus, la chaleur n'est plus suffisante pour ce g. de végétation. On trouve quelquefois avec l'Ayaricus edulis différentes espèces de Coprins, l'Agaricus volvaceus Bull., le Fuligo vaporaria Pers. Dans ce cas il ne faut pas hésiter à détruire les couches et à en faire de nouvelles. Enfin on en rencontre quelques unes qui sont rempliesde Scolopendres, d'Iules, de Cloportes et de difiérentes autres esp. d'insectes. Il faut également en faire le sacrifice, neltoyer parfaitement l'endioil, l'enfumer, et même l'abandonner pendant quelque 
temps. On voit assez souvent les Champignons s'allonger, devenir difformes; leurs chapeaux se former avec peine; ou bien ils se recouvrent d'un duvet blanc plus ou moins épais. Ces accidents s'observent quand l'air n'est pas suffisamment renouvelé et que les couches sont trop humides. Comme celles-ci sont alors d'un mauvais rapport, il faut les placer dans un lieu mieux aéré, et les arroser moins abondamment. L'établissement de couches est un moyen trés avantageux pourse procurer des Champignons pendant toutel'année.On vend le blanc de Champignons comme les graines des plantes, et il peut se conserver pendant très long-temps sans perdre de ses propriétés. M. Tollard en a vu qui avait 20 ans de conservation, et qui produisit des champignons comme s'il eùt été récent. On peut encore, quand des Champignons croissent dans certaines localités, enlever la terre avec le mycelium qu'elle renferme, et la transporter dans des circonstances semblables. C'est un moyen qui m'a parfailement réussi pour me procurer abondamment et sans a voir la peine de le chercher, l'Agaricus albellus. Thore rapporte que, dans le département des Landes, on sème l'Agaricus palomet et.le Boletus edulis. Pour cela, on se contente d'arroser la terre d'un bosquet planté de chênes, avec de l'eau dans laquelle on a fait bouillir une grande quantité de ces deux Champignons. La culture n'exige d'autres soins que d'éloigner de ce lieu les chevaux, les porcs, et toute espèce de bêtes à cornes, qui sont très friandes de ces 2 plantes. Ce moyen ne manque jamais de réussir; mais nous laissons aux physiciens à nous expliquer pourquoi l'ébullition n'a pas fait mourir les germes de ces Agarics. ( $V$. Pers. Champ. com. p. 16). M. Tenore, dans une lettre à Persoon, indique le moyen que l'on emploie pour se procurer l'Agaricus neapolitanus, dont on fait une grande.consommation à Naples. Je ne puis m'empêcher de rapporter ce passage; quelques personnes seront peut-être tentées de répéter l'expérience. - "Le champignon que vous trouverez ci-joint, se développe sur le marc de café pourri et gardé dans un endroit humide, pendant 8 ou 10 mois. Ce n'est que depuis peu d'années que le hasard le fit découvrir. De jennes religieuses d'un couvent de Náples l'ont trouvé sur un tas de mare de café mis à l'écart dans un coin ombragé de leur jardin. Dés lors elles en ont répandu la nouvelle, et à présent on se le procure artificiellement; car ici, on a pris l'habitude de ramasser ce marc pendant quelque temps, en employant aussi celui des boutiques pour en faire une provision plus considérable. On le fait pourrir dans un pot de terre cuite, non vernissé, déposé à l'ombre, et on l'arrose pour y entretenir une humidité constante. Les Champignons paraissent au bout de 6 mois environ; ils sont bons à manger et d'un goût assez agréable. $(V$. Persoon, Myc. Europ. sect.tert.p. 74.)

Rumphius (Herb. amb.) nous fournit 2 exemples semblables. Une seule espèce d'Agarics, qu'il désigne sous le nom de Boletus moschocaryanus, croît à Amboine et dans les iles voisines, sur les brous de noix muscades que l'on entasse dans les forêts, lors de la récolte de ces fruits. A l'époque des pluies chaudes, la décomposition s'opère et il se développe sur ces matières des Champignons très délicats que l'on ramasse et qui se servent sur la table des riches. L'autre espèce d'Agarics ou Boletus saguarius se trouve également à Amboine et dans toutes les îles où croît le Sagus farinacea. Il naît sur les débris entassés et pourris qui proviennent de cet arbre quand on prépare le sagou. Il est moins délicat que le précédent, et les habitants le récolten t pour leur propre nourriture ou pour en engraisser les cochons et les poules. Les sangliers en sont très avides. Les personnes qui désirent cultiver cette esp., emportent dans leurs jardins des débris de sagou, les entassent, et, comme les Napolitains, obtiennent en tout temps un aliment agréable. J'ai cru devoir rapporter ces faits, parce qu'ils sont généralement peu connus, et qu'il serait possible que dans nos pays on rencontrât quuelque espèce qui offrît les mêmes avantages.

Les Agarics ne sont pas remarquables seulement par leur forme et leur mode de développement. Rumphius a le premier observé qu'une espèce, qu'il appelle Fungus igneus, est phosphorescente pendant la nuit. Ce phénomène, dont on ne possède pas encore une théorie satisfaisante, malgré les expériences de M. Becquerel, a été observé également par M. De Candolle sur I'Agaricus oleariuis, qui croît très communément 
dans le mild de la France el dans le Levant. Les lames seules sont phosphorescentes; mais la lueur qu'elles répandent n'est pas dúe à la décomposition du champignon ni au développement du Cladosporium umbrinum, comme M. Fries semble le soupconner; au contraire, plus l'Agaric est vigoureux, plus elle est brillante. M. Delille dit que cette phosphorescence se manifeste seulement pendant la nuit, et qu'elle n'est pas visible pendant le jour dans les souterrains les plus obscurs. Les expériences que j'ai faites a Smyrne ne me permettent pas de partager l'opinion du célèbre professeur de Montpellier', et mon ami Steinheil, qui vient d'être enlevé si malheureusement aux sciences, avait fait en Afrique les mêmes observations que moi.

Tous les jours on demande aux personnes qui s'occupent de l'étude des Champignons, comment on peut distinguer ceux qui sont vénéneux de ceux qui ne le sont pas. Cette question m'a mis bien des fois dans l'embarras, et j'avoue que je ne sais encore comment y répondre. On peut bien donner quelques caract. généraux; mais il est impossible, quand on ne connaît pas suffisamment ces végétaux, d'en faire une juste appli cation; car les caract. sont souvent si légers, qu'il faut en avoir une grande habitude pour les saisir. Mathiole dit que l'on doit considérer comme Champignons vénéneux, ceux qui croissent dans un endroit où il se trouve un clou rouillé, du drap moisi, auprès d'un trou de serpent ou au pied de quelque arbre à propriétés vénéneuses. Les auteurs modernes conseillent de repousser ceux que l'on trouve dans les lieux humides, ou à l'ombre dans les bois touffus; ceux qui au rontact de l'air changent de couleur quand on les brise; ceux qui ont les lames colorées en brun,'en jaune clair ou en bleu. Enfin, on doit regarder comme suspects ceux qui changent la couleur du papier de tournesol; ceux qui colorent en brun une cuiller d'étain ou d'argent; ceux enfin, qui donnent une couleur noire á l'ognon avec lequel on les fait cuire. La saveur ne fournit pas beaucoup de renseignements, car on mange plusieurs espèces de Galorrheus et de Riussula qui ont une saveur extrêriement âcre, mais qui disparaît par la cuisson. On conseille au contraire de manger les Cham- plgnons qui croissent dans les prés, sur le bord des forêts; ceux dont les lames sont blanches ou rosées, ou jaune citron; dont la saveur rappelle celle du champignon de couche. Il est évident que de semblables caractères ne peuvent être d'aucune utilité; il faut, pour manger des Champignons, suivre la routine du pays qu'on habite, ou les connaître par leurs caract. particuliers ; autrement on s'expose aux plus grands accidents. Pour les usages domestiques, on accommode les Champignons de différentes manières que je ne décrirai pas. M. Schwægrichen, dans une lettre à Persoon, dit, que dans un voyage qu'il fit en Allemagne, il remarqua dans les environs de Nuremberg, que les paysans mangeaient des Champignons crus avec leur pain noir assaisonné d'anis ou de carvi. Ce célèbre botaniste les imita, et loin d'en éprouver une influence nuisible, il sentit croître ses forces. J'ai observé, dit-il, que les Champignons, si l'on en use sobrement, sont très nourrissants; mais qu'ils perdent lenr bonne qualité par la préparation culinaire, qui, de plus, enlève leur goût naturel.

J'ai goûté bien souvent en effet des Champignons crus, et je leur ai trouvé un goût plus délicat et plus prononcé que quand ils étaient cuits ; mais on ne peut disconvenir qu'un grand nombre d'esp. détermineraient l'inflammation de la bouche et de l'estomac, si on ne détruisait par la coction le principe âcre et irritant qu'elles contiennent. Dans quelques pays, les Champignons sont d'une grande ressource comme aliment ou comme assaisonnement; aussi les conservet-or en les faisant sécher, ou en les mettant dans de l'huile, du vinaigre, ou de la saumure. On les boucane mème quelquefois. Par ces différents moyens on fait ses provisions pour toute l'année. Les Champignons secs forment même une branche de commerce assez étendue et qui mériterait un peu plus de surveillance de la part de l'autorité. On croit généralement que la dessiccation détruit leur principe vénéneux; c'est une erreur, et il est d'observation aujourd'hui, que les esp., qui à l'état frais sont dangereuses, le sontégalement après leur dessiccation.

On dit aussi que la cuisson détruit les propriétés vénéneuses des Cliampignons, ce qui est vrai; mais il faut alors les couper par 
morceaux, les faire bouillir, et jeter l'eau qui a servi à les faire cuire. C'est dans cet état, je pense, que l'on peut considérer tous ces végćtaux comme comestibles. Mais quelles peuvent être leurs qualités nutritives quand on les a dépouillés de tous leurs principes? On ne peut y avoir recours que dans les moments de nécessité. D’après Braconnot, on peut obtenir le même résultat en les faisant cuire dans de l'eau légèrement alcaline. Le principe actif n'est pas encore assez connu pour qu'on ail une confiance cntière dans ce moyen. Tous les auteurs conseillent aux amateurs de Champignons de les mettre dans du vinaigre élendu d'eau avant de les accommoder. C'est une précaution qu'il ne faut pas négliger, surtoul pour ceux que l'on ne connail pas; car aujourd'hui on a la certitude que le vinaigre dissout parfaitement bien le principe délétére de plusieurs espèces; et M. le professeur Kunth (Officin. Gewochse) dit qu'on les rend tous innocents en les faisant cuire dans cet acide.

On a observé que des Champignons que l'on mange tous les jours avaient été quelquefois pernicieux. Ceci peut tenir à des circonstances dont on n'a pas su se rendre compte. Ainsi ne doit-on jamais les récolter quand ils sont trop vieux, quand leurs coulenrs sont altérées, ou quand ils ont éprouvé un commencement de décomposition; mais bien quand ils sont jeunes, parce qu'alors ils sont plus tendres, plus parfumés et d'une digestion plus facile.

Les accidents qui arrivent tous les ans, et les expériences faites sur les animaux, nous apprennent seulement à connaître les dangers elles avantages qui peuvent résulter de ce genre d'aliment. Dans le premier cas, malheureusement pour la science, les esp. sont le plus souvent caractérisées d'une manière si vague qu'il est impossible de les reconnaìre. Les expériences sont précieuses pour la science el la pratique, quand elles ont élé failes par des hommes comme Schaffer, I'aulet, Bulliard, Mir. Schwogrichen, Orfila, Hertwig, Cordier, elc. L'analyse chimiqua nous a, jusqu'ici peu éclairés sur le principe vénéneux des Champignons. Les Uravaux de Bouillon-Lagrange, de Vauquelin et surtout de Braconnot, renfermés dans les tomes 79 et 87 des Annales de Physique et de Chimie, nons ont appris que ces végé- taux renferment wre grande quanlilé d'eau de végétation; de la fungine que l'on peut considérer comme un principe immédiat; un acide particulier ou fungique, le plus souvent uni à la polasse; "2 matières animales, l'une insoluble dans l'alcool et dont la nature est peu connue, l'autre, qui au contraire s'y dissout très facilement, et qui est l'Osmazome; de l'huile, de l'adipocire, de l'albumine, une espèce particulière de sucre, et enfin quelques autres substances, mais en très petite quantité. Le célèbre Schrader a trouvé dans l'Agaricus muscarius une substance rouge, âcre, soluble dans l'eau'et l'alcool et qu'il croit être la partie vénéneuse, puisque, administrée à de petits oiseaux, elle en a déterminé la mort. M. le docteur Letellier, dans sa dissertation inaugurale (Essai sur les propriétés chimiques et toxiques du poison des Agarics à volva) a trouvé un nouvel alcali végélal auquel il a donné le nom d'Amanitine et dans lequel, selon lui, réside la propriété vénéneuse. Les nombreuses expériences qu'il a faites ne laissent aucun doute à cel égard; mais l'alcalinité de ce principe n'est cependant pas encore parfaitement démontrée. Espérons que notre estimable confrère, qui consacre à la Mycologie, avec tant de zèle el de succès, les moments de loisir que lıi laisse le pénible exercice de la médecine, répétera ses expériences sur un plus grand nombre d'espèces.

Comme quelques personnes, passionnées pour les Champignons, ne craignent pas d'expérimenter sur elles-mêmes, je dois les prévenir que ces essais ne sont jamais sans danger. Le poison, en effel, n'agit pas immédiatement, mais constamment plusieurs heures après l'ingestion, et même quelquefois quand la digestion est terminée. Les vomitifs et les purgatifs sur lesquels on compte le plus pour en détruire les eflets, sont sans action, parce qu'alors le poison circule avec le sang. on doil donc agir avec la plus grande prudence, comparer l'odeur, le goût, et les caract. du champignon que l'on essaie, à ceux des espèces dont les propriétés sont parfaitement connues et avec lesquels il offre le plus d'aflinilés. Trattinnick, conseille de garder long-temps un morceau de champignon dans la bouche, et de le rejeter comme suspect, si la saveur en cst 
âcre ou repoussante. Il vaut mieux n'en manger qu'une pelite quantité et sans mélange d'autre aliment. Alors on observe les phénomènes qui ont lieu; et s'il survient le plus léger symptôme du côté du cerveau ou des voies digestives, il faut immédiatement recourir aux évacuants par le haut et par le bas; ne pas chercher à faciliter la digestion ni a en neutraliser les efrets par le thé, le café, l'huile, le lait, le vinaigre, etc. C'est en a'gissant ainsi que l'on parviendra à connaître les propriétés des Champignons. Les expériences failes sur des animaux, comme les chiens, les chats, donnent des résultats avantageux ; mais je n'oserais accorder la même confiance à celles que l'on tenterait sur des grenouilles, ou sur des animaux d'un ordre inférieur.

On croit que les maurais Champignons ne sont jamais attaqués par les limaces et les insectes : c'cst unc erreur; tous sont attaqués par des esp'. différentes. Si l'Agaricus muscarius tue les mouches, s'il a causé la torpeur ả un triton lacustre, comme on pourrait le penser d'après M. Ascherson, je puis assurer qu'il n'a aucune action sur la limace grise; car pendant huit jours j'en ai nourri une avec ce champignon, sans que sa santé et son appétit en aient été altérés. Il est donc impossible de tirer aucune conclusion formelle des faits de ce genre.

Presque tous les empoisonnements par les Champignons dont parlent les auteurs, et dont les journaux rapportent malheureusement chaque année un trop grand nombre d'exemples, sont produits par des individus du g. Agaric, que des personnes imprudentes ramassent et mangent ordinairement avec confiance en assez grande quantité, et souvent on n'observe que des symptômes d'indigestion, qui disparaissent après le vomissement; car beaucoup d'estomacs ne peuvent supporter les Champignons. Mais quand les esp. que l'on a mangées sont vénéneuses, les symptômes sont bien différents. "Les Champignons vénéneux, dil M. Orfila (Toxicol. t. 1, p. 409), ne manilestent leur pernicieuse action qu'un certain temps après qu'ils ont été mangés. Ce n'est le plus souvent que 5 ou 7 heures après. Il s'en écoule quelquefois 12,16 , plus rarement 24 , sans dqu'on ćprouve aucun symptôme. Les altérations graves de presque tous les viscères prouvent que ce venin, ayant acquis toute son énergie par le moyen de la digestion, se répand dans toute l'économie, y excite l'irritation la plus violente et une inflammation qui dégénère promptement en gangrène; ce qui a licu surtout avec plus d'intensité dans les voies digestives qui ont reçu le poison, el qui en conservent les restes dissous pendant plus long-temps. Les symptômes que l'on observe sont des nausécs, des envies de vomir, une salivation plus ou moins abondante, un malaise général, des sueurs tantôt chaudes, tantôt froides, une soif vive, des doulcurs dans le trajet de l'œsophage à l'estomac, ou dans tout le ventre; l'urine est rosée, quelquefois sanguinolente; les selles sont fréquentes, fétides, accompagnées de ténesme; le pouls est petit, fréquent, irrégulier. Quelquo temps après, agitation extrême, anxictó, refroidissement des membres, sueurs froides générales, altération des traits, coloration en violet du nez, des lévres et de la face, hoquets fréquents, aberration des sens, vertiges, délire, stupeur ; enfin, la mort termine cet afreux tableau, que l'on observe lc plus ordinairement sur plusieurs membres de la même famille."

Dans un rapport fait en juin 1809 à la Société de médecine à Bordeaux, l'auleur résume ainsi toutes les altérations pathologiques qui ont élé observées jusqu'à ce jour sur les cadavres des personnes empoisonnées par les Champignons. "Taches violettes très étendues et nombreuses sur les téguments; ventre très volumincux; conjonclive comme injectée; pupille contractée; estomac et intestins phlogosés et parsernés de taches gangréncuses; sphacéle dans quelques portions de ce viscère; contractions très fortes de l'estomac et des intestins, au point que dans ceux-ci, les membranes épaissics avaient entiérement oblitéré le canal; œsophage phlogosé et gangrené chez l'un des sujets; chez un antre, iléum invaginé de haut en bas, dans l'étendue de 3 pouces; un seul individu avait les intestins gorgés de matières fécales. On n'a trouvé chez aucun des vestiges de Champignons : ils avaient été complètement digérés ou évacués. Les poumons étaient enflammés el gorgés d'un sang noil. Le mêne engorgement avait lieu dans presque loutes les veines des viscéres abdo- 
minaux, dans le foie, dans la rate, dans le mésentère; taches d'inflammation et taches gangréneuses sur les membranes du cerveau, dans ses ventricules, sur la plèvre, les poumons, le diaphragme, la matrice el même sur le fotus d'une femme enceinte; le sang était très fluide chez cette femme; la flexibilité extrême des membres n'a pas été constante."

J'aurais pu passer sous silence ces détails qui se rapportent plus à la médecine qu'à l'histoire maturelle; mais on voit un si grand nombre de personnes manger des Champignous sans les connaître, qu'elles prendront peut-être quelques précautions, en voyant quelles peuvent être les suites de leur imprudence. Quand on est appelé auprès d'une personne qui a mangé quelque espèce vénéneuse, et qui éprouve des symptômes d'empoisonnement, il faut à l'instant même provoquer le vomissement par une potion émétisée, ou avec l'ipécacuanha; administrer un éméto-cathartique, afin d'évacuer les Champignons, s'il en restait encore dans l'estomac et les intestins. On fait ensuite boire assez abondamment au malade une infusion de thé, de café, ou du bouillon de poulet. On conseille également de donner de l'eau vinaigrée ou une potion éthérée. Comme on ne connaît encore ni la nature du principe délétère, ni son antidote, il faut combattre les symptônes les plus alarmants parles moyens que l'on jugera les plus convenables. Les anciens praticiens accordaient une grande confiance à l'ammoniaque liquide. Mirabelli la recommandait particulièrement, et, tout récemment, un médecin de Bordeaux, dont je regrette beaucoup de ne pouvoir citer le nom, en a obtenu des résultats si avantageux, qu'il n'hésite pas à regarder cette substance comme le contrepoison des Champignons vénéneux. Les expériences de Paulet et de M. Orfila ont prouvé que ce médicament était dangereux dans les premiers moments. On ne devra donc l'employer qu'après les émétiques et les purgatifs. M. Courhaut en a remarqué également les bons elfets dans les empoisonnements par le seigle ergoté. On le donne à la dose de 5 ou 6 gouttes dans un verre d'eau. sucrée ou de bouillon. Maintenant que quelques observations parlent en faveur de l'ammoniaque; un médecin aurait peut-être quelques reproches à se faire, s’il négligeait de l'employer dans ces tristes circonstances.

J'aurais desiré donner les caract. des espèces d'Agarics comestibles ou vénéneuses; mais la nature de cet ouvrage ne le permettant pas, je me contenterai de les indiquer en suivant les divisions qui ont été établies dans ce genre par Persoon.

Amanites : l'Agaricus aurantiacus Bull., et l'A. coesareus schoefr., que l'on connaît sous le nom d'oronges, ne diffèrent que par la couleur du chapeau, qui est rouge dans la $1^{\mathrm{re}}$, et jaune dans la $2^{\mathrm{me}}$. Les Romains en étaient très friands et les regardaient comme les meilleurs Champignons. Chacun sait que l'empereur Claude móurut après en avoir mangé : les historiens accusent Agrippine d'y avoir ajouté du poison; Paulet pense qu'on a pu servir à cet empereur un mets préparé avec l'Agaricus muscarius. C'est le champignon dont on fait la plus grande consommation après l'Agaric des couches.

A. ovoz̈des Bull. ou Oronge blanche, est une espèce aussi délicate et aussi recherchée que la véritable oronge, dont elle est peutêtre une variété.

A. solitarius Bull. J'ai rencontré quelquefois cette esp. dans les environs de Paris. Bulliard et M. De Candolle disent qu'elle est délicieuse. Dans quelques pays, cependant, on la regarde comme vénéneuse; peut-être la confond-on avec d'autres espèces.

A. rubescens Pers. ou $\Lambda$ garic verruqueux de Bulliard ; très commun dans les environs de Paris. Vittadini dit que l'on mange cette esp. en Italic. M. Cordier m'a dit en avoir mangé plusieurs fois, qu'elle est excellente et qu'il n'en avait jamais été incommodé. Krombhotz au contraire la regarde comme vénéneuse.

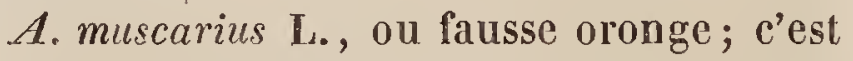
une esp. très dangereuse. On trouve dans les auteurs un grand nombre d'observations qui le prouvent. Loesel dit que 6 hommes perdirent la vie après en avoir mangé. Le docteur Vadrot, dans sa dissertation inaugurale, rapporte l'histoire de plusieurs soldats français qui eurent le même sort en Russie. Les expériences de M. ILetellier prouvent également que ce champignon est vénéneux. Nion confrère Cordier a vu celle année, dans 2 maisons différentes et le même jour, 10 personnes empoisonnées par ces 
Champignons, et un seul a suff pour causer des accidents alarmants chez 7 d'entre elles. Quelques auteurs disent que les Russes le mangent sans en éprouver aucun accident. Pallas dit au contraire très positivement : «On mange généralement en Russie toutes les esp. de Champignons et même ceux qui sont passés ou verreux. Le Champignon aux mouches, le Champignon puant du fumier et plusieurs autres petits entièrement dénués de chair, sont les seuls dont on ne fait point usage." Schceffer rapporte qu'une troupe de comédiens italiens achetèrent à Ratishonne l'Agaricus muscarius pour la véritable Oronge, et qu'ils n'éprouvèrent aucun accident après l'avoir mangé. Bulliard dit qu'il est agréable au goût et à l'odorat. Il n'a rien éprouvé après en avoir mangé 2 onces. D'après Murray, les brebis le mangent impunément. Hertwig, après en avoir fait prendre à des chiens et à des brebis, a seulement observé des nausées et des vomissements chez quelques uns de ces animaux. M. Mérat m'a dit avoir vu des gardes-du-corps en manger plusieurs fois et en abondance sans le moindre inconvénient. On ne sait véritablement quel parti prendre, en présence de résultats si différents, basés sur le témoignage d'hommes aussi respectables.

Mais ce qu'il y a de plus singulier dans l'histoire de ce champignon, c'est l'usage que l'on en fait au Kamtschatka. Krascheninnikow, dans sa description de ce pays, rapporte, et ces détails sont confirmés par Langsdorf, que les habitants coupent l' 1 manila muscaria en petits morceaux, qu'ils la font sécher pour la conserver, ou qu'ils en préparent avec le suc du $\sqrt[V]{\text { accinium uligino- }}$ sum, ou en le faisant infuser avec les feuilles d'une esp. d'Epilobium, une boisson dont ils se scrvent au lieu de vin. Quand ils ont bu de ces liqueurs, ou mangé le champignon sec, il se manifeste chez eux une ivresse particulière, dans laquelle les facultés intellectuelles sont anéanties; il survient des tremblements, des soubresauts dans les tendons, quelquefois des convulsions. Les uns sont gais, chantent ou sautent; les autres au contraire sont tristes et abattus. On les voit, les armes à la main, se précipiter les uns sur les autres, ou sc blesser cux-mêmes; ils ne connaissent plus aucun danger, et divulguent au premier venu lcurs plus intimes secrets. T. 1 .
Les forces musculaires paraissent considérablement augmentées. Langsdorf a vu un de ces individus qui dans l'état ordinaire ne pouvait porter un sac de 120 livres, le porter, après s'être enivré, à une distance de 15 werstes ( 5 lieues). Enfin les malades tombent, le sommeil s'en cmpare, calme cetle étrange exaltation, et bientôt ils se réveillent dans leur état naturel. On a observé qu'il survient quelquefois des vomissements, mais l'ivresse n'en est pas diminuée. L'urine de ceux qui se sont ainsi cnivrés jouit des mêmes propriétés que le champignon; aussi voit-on les indigents rechercher cclle des personnes riches afin d'y puiser cette ivresse; et quclques uns même prolongent ce triste état par des libations successives. Langsdorf fait observer que ceux qui s'adonnent habituellement à ce genre de crapule finissent par devenir fous. On a remarqué que la chair des rennes, tués quelque temps après avoir mangé de ce champignon, avait aussi la propriété d'enivrer. Enfin, l'Agaricus muscarius a été administrć avec succès dans l'épilepsie et dans quelques affections nerveuses. On l'a conseillé, réduit en poudre, pour combattre les ulcères de la cornée, les ulcères phagédéniques, les affections scrofuleuses. On a donné sa teinture contre la teigne, les affections cutanées, les catarrhes chroniques, elc. On doit donc, malgré quelques observations qui militent en sa faveur, s'abstenir de le manger, et le considérer comme dangereux.

Amanitavenenosa: Pcrsoon (Champ. com.) réunit sous cc nom 3 esp. que les auteurs reconnaissent comme distinctes: $1^{\circ} \mathscr{A}$. bulbosus vernus Bull., ou Oronge ciguë blanche de Paulet; $2^{\circ} A$. citrinus Schref., ou Oronge ciguë jaunâtre de Paulet; $3^{\circ} \mathcal{A}$. phalloz̈des Bull., ou Oronge ciguë verte de Paulet. Ces 3 esp. ou variétés sont vénéneuses au plus haut degré. Ce sont elles qui causent presque tous les empoisonnements dont on entend parler chaque année.

A. pantherinus Fries : Esp. assez rare dans les environs de Paris. J. Bauhin la regarde comme vénéneuse. Hertwig n'a obtenu aucun résultat en la donnantà des animaux, á la dose de dix gros.

A. crux melitensis, ou Agaric croix $d c$ Malıe Paul. : Je mentionne cette espèce qui 
n'a encure été trouvée que par Paulet, parce que, après en avoir mangé la moilić d'un individu, il ne tarda pas á éprouver une grañde faiblesse el à perdre connaissanee. L'émélique, pris une demi-heure après l'ingestion, lui fit rendre les morceaux du ehampignon; malgré cela, il eonserva pendant plusieurs jours de la faiblesse à l'estomae, des eoliques et du dévoiement.

A. excelsus Fries; Arr. amplu Pers. : II est vénéneux, quoique le goût cn soit assez agréable.

Toutes les espèees d'Amanites que je viens de eiter ont le pédicule entouré d'un anneau. Parmi celles qui n'en ont pas, et qui sont eomestibles, on distingue :

L'A. vaginatus' Bull. : La couleur du chapeau est jaune-orangée ou grise. Clusius regardait eette esp. et ses variétés commc dangereuses. On les mange en Allemagne, cn Italie et à Montpellier.

A. incarnatus Batseh : Se mange très fréquemment en Toscane.

A. lez̈ocephalus DC. : Esp. assez commune dans le midi de la Franec, et que l'on mange à Montpellier.

A. regius Fries : Commun dans l'Europe méridionale. On dit cette esp. délicieuse.

A. speciosus Fries : C'est une des plus bolles Amanites. Elle est comestible; mais M. Fries la regarde comme suspecte à eause de son odeur nauséabonde.

On peut considérer comme vénéneuses les esp. suivantes :

A. volvaceus Bull. qui croît très abondamment sur la tannée des serres chaudes; l'odeur de ce champignon est très désagrèable, et, conservé dans les appartements, il m'a causé plusieurs fois des maux de têle tres violents.

A. gloz̈ocephalus DC. : M. Letellier en a constaté plusieurs fois sur des lapins les propriétés vénéneuses.

A. insidiosus Letell.: Crôit solitaire dans les environs de Paris. Quelques grains de son extrait aqueux, injeetés dans le tissu eelIulaire d'une grenoville, l'ont fait périr dans les convulsions (Letel.).

A. maleficus Roques: Cclte esp. a étć trouvée dans les bois du département de la Girondc. L'auteur la cite comme ayant empoisonné cinq personnes, dont une mourut.

A. viperinus Fries; A. conicus Piceo. Cette esp. que je ne connais pas, et que Piceo $\left(M e^{e}\right.$ lethm. et Mim. de la Soc.roy. de Med.1780\$1.) regardc comme vénéneuse, a, suivant cet auteur, un pédiculc garni d'un anneau très fugaee. Les personnes empoisonnées par ce ehampignon se ressentaient encore, un an après, des maux qu'elles avaient soufferts.

LEPIOTA. Les esp. que l'on mange le plus eommunément dans cette. seetion sont les suivantes :

A. procerus Pers. Celte belle esp., qui croìt solitaire dans les bois, est une des plus grandes que l'on connaisse. Dans chaque pays, elle porte un nom difrérent; elle est généralement recherehée, quoique un peu eoriace. On ne la mange pas en Allemagne. La Gazette médicale (1939) rapporle un cas d'empoisonnement causé par ee champignon. C'est un des accidents les plus singuliers que je connaisse, et j'avoue que si le nom de M. Gréville ne eorroborait pas cette observation, je conserverais plus que des doutes sur la détermination de l'esp. cause de l'accident. Je rappellerai pourtant, dans cette circonstance, qu'en 1823 , dans le département de la Nièvre, j'ai garanii, peutêtre des plus graves accidents, une famille entière qui était sur le point de manger un plat préparè avec l'Agaricus clypeolarius Bull., qu'un développement considérable avait fait prendre pour l' $A$. procerus.

1. excorians Sehrff. : Celte espèce eroit en automne dans les bois, et quelquefois sur les pelouses. C'est un champignon plus tendre et plus délicat que le préećdent. Je l'ai mangé très souvent et en grande quantité, sans en avoir jamais éprouvé la plus légère incommodité.

A. caudicinus Pers. : Croîl dans les bois sur les vieux trones. C'est un des Champignons dont on fait la plus grande consommation en Allemagne.

A. polymyces Pers. : Celte csp. ressemble beaucoup à la précédente. Paulet, qui la nomme Tête de Méduse, dit qu'un chien à qui il en avait fait manger une certaine quantité, mourut 12 heures après. Persoon la considère aussi eomme délétère. Trattinniek, au contraire ( $\boldsymbol{E} s s b$. schwam.), dit que ce champignon est très agrèable i manger, qu'il a Je goût de la chair d'agneau, el que c'est lui que l'on trouve le plus abondam- 
ment et au plus bas prix sur le marché de Viennc. Mon confrère Cordier m'a dit en avoir mangé plusieurs fois cette année, et l'avoir trouvé très bon et parfaitement innocent.

A. squamosus Bull. : Beau champignon qui croît également par groupes sur les arbres. Bulliard dil qu’il a le goùt et l'odeur du champignon comestible. M. Cordier en a mangé, et l'a trouvé excellent.

A. altenucatus DC. : Croît en automne sur les trones de Saules. On le mange a Montpellier sous le nom de pivoulade, ainsi que l'A. cylindraceus DC., que je ne conmais pas.

A. albo-rufus Pers. (Champ. com.): Agaric paillet de Thore : croit dans les environs de Dax, au printemps et en automne, par groupes nombreux, au pied des Surcaux. Il est très recherché par quelques personnes.

Les esp. vénéneuses de cette section sont peu connues. On cite particulièrement l' $A$. Villadini Frics, qui croît dans les bois en Italie.

A. echinocephalıs Fries : Assez fréquent dans l'Europe méridionale.

1. clypeolarius Bull. : très commun dans les elldroits humides des bois. Son odeur pénétranle et vireuse le fait généralement regarder comme vénéneux; soupçon qui n'est du reste autorisé, jusqu’à cc jour, par aucune observation directe.

CorTinaria. Les auteurs ne ritent aucune esp. vénéneuse dans cette section et il n'y en a qu'un petit nombre de comestibles.

A. lurbinatus Bull. : Croît solitaire dans les bois. Il est surtout remarquable par le renflement de la base de son pédicule. Sa saveur est assez agréable.

A. castaneıs Bull. : Petite esp. très jolie, de couleur marron. Elle croît assez abondamment dans les bois. Persoon lui trouve une saveur très agréable et la croit comestible.

A. violacens Bull. : Micheli dit qu'on le mange en Italie.

A. violaceo-cinereus Pers. : Sc mange également en Italie.

Gympopus. Cette section fournit le plus grand nombre des champignons comestibles, et s'il y en a quelques uns vénéneux, ils ont été probablement mal déterminés.

A. fusipes Bull. : Très commun dans les bois. Allioni le regarde comme oomestible; il a le goût du champignou de couche; mais il est coriace.

A. russula Pers.: Comme son nom l'indique, ce champignon ressemble à un Russula, mais ses lames sont composées et sa saveur n'est ni àcre ni poivrée. On le mange en $\Lambda \mathrm{l}$ lemagne, surtout à Vienne.

$A$. graveolens Pers. : Assez rare en France, mais très commun en Allemagne oú on le mange communément.

A. albellıs DC.: C'est un des premiers Champignons qui croissent au printemps en France. On le nomme Mousseron. Il se fait remarquer par sa forme, sa blancheur et surtout son parfum. Les insectes en sont très friands. On le sèche trís facilement; et, comme dans cet état il conserve son odeur, on s'en sert pour les besoins de la cuisinc.

A. orcades Bat. : Petit champignon, que l'on nomme Mousseron godaille ou de Dieppe, et qui croît presque toute l'année sur les pelouses. Il se sèche et se conscrve comme le précédent. Son pédicule se tourne comme une corde en se desséchant; ce qui l'a fait. nommer A. iortilis, par M. De Candolle.

A. prunulus Scop. : Cette esp. est remarquable par l'épaisseur de sa chair, et par ses lames décurrentes, d'un rouge tendre. Son odeur rappelle celle de la farine. C'est un des meilleurs Champignons que l'on puisse manger.

A. orcella Bull. : Croît sur les pelouses. Il pourrait bien n'être qu'une varićté du précédent, ainsi que l'Agaricus auricula Dub., qui a les lames blanches, et que l'on mange dans les environs d'Orléans. Ces 3 Champignons, qui croissent à la même époque et dans les mêmes endroits, se ressemblent encore par le goût et l'odeur.

A. anisatus Pers. : Croît assez abondarnment parmi les feuilles en automne. Son odeur, qui est très agréable et rappelle celle de l'anis, disparait quand on le fait cuirc.

A. nebularis Batsch. : Ce champignon croît très abondamment dans les bois des environs de Paris. Bulliard dit qu'il est très agréable au goût, et qu'il a, quand il cstjcune, l'odeur du champignon comestible. Il est promptement attaqué par les insectes, et s'il était reconnu innocent, on pourrait en retirer les plus grands avantages. Malheureusement de nombreuses expériences faites récemment ont démontré à $M$. Cordier qu'il 
fallait s'en abstenir. Lui-même et plusieurs personnes après en avoir mangé ont éprowvé de violentes coliques, accompagnées de diarrhée abondante.

A. eburneus Bull. : Commun dans les bois en automne. M. De Candolle dit qu'on le mange en Italie sous le nom de gozzolo.

A. columbetta Fries : L'auteur donne cette esp. comme comestible. Son odeur et sa saveur sont peu prononcées.

A. imbricatus Fries: Commun en automne dans les forêts de Paris. On le mangeait autrefois.

A. carderella Frics: Cette esp., que Batarra a fait connaître, se mange fréquemment en Italie.

A. ilicinus DC. : Croît assez abondamment dans le midi de la France, et se mange a Montpellier sous le nom de pivoulade d'eousse. On rejelte le pédicule, parce qu'il est trop coriace.

A. pratensis Pers. : Très commun sur les pelouses. Son volume est extrêmement variable. Comme ce champignon a la même saveur que celui de couche, et qu'il croît dans les lieux exposés au soleil, Persoon pense qu'il est comestible.

A. palomet Thore, viridis Fries.: On le mange habitucllement dans le Béarn et dans les Landes, sous les noms de Palomet, $\mathrm{Pa}-$ lombette on Blavet.

A. alliatus Pers. : Très répandu dans toute l'Allemagne. Il croît au printemps et en automne. On s'en sert comme condiment à cause de son odeur.

On trouve dans les ouvrages de Micheli, de Batarra et d'autres auteurs, un grand nombre de Champignons de cette section regardés comme comestibles; mais nous ne les connaissons pas assez en France, pour les indiquer ici, sous leur véritable nom scientifique.

1. rimosus Bull. : Balbis rapporte que cette esp. a empoisonné toute une famille à Turin.

Mrcena. Cette section ne renferme que de petits Champignons dont le chapeau est presque membraneux. Ils ne pourraient être que d'une faible ressource pour ceux qui voudraient en manger.

A. esculentus Jacq. , ou Agaric clou : Très pelite esp. que l'on mange en Allemagne. 'Traliinnick dit que c'est le moins délicat des Champignons.
A. foniculaceus Fries : Cette esp. a beaucoup de rapporls a vec l' $A$. orcades, ct comme lui, elle sert d'assaisonnement dans quelques pays.

A. cepaceus Fries : Il a, comme quelques autres esp., une odeur d'ail qui fait qu'on le mange quelquefois; mais il n'est pas recherché.

A. urens Bull. : Cette esp. a une saveur âcre et brûlante; j’ai vu néaamoins, dans le département de la Nièvre, des charbonniers la faire cuire sur des charbons et la manger sans aucun inconvénient.

Coprinus. Tous ces Champignons sont repoussés, par rapport á leur ténuité et à la prompte décomposition qu'ils éprouvent. Les anciens les regardaient tous comme pernicieux.

A. comatus Schrff. : Paulet regarde cette esp. comme comestible dans le jeune âge; mais il conseille de s'en abstenir, si les lames sont rouges. Les expérierices de Hertwig sur des brebis et des chiens prouvent que ce champignon n'est pas vénéneux, lors même qu'il se fond en eau noire. Buxbaum dit que dans cet état on peut s'en servir au lieu d'encre. On hui a accordé, mais sans fondement, la propriété de guérir les ulcères de mauvaise nature.

A. atramentarius Bull. : Quand ce champignon est jeune, dit Bulliard, il n'est désagréable ni au goût ni à l'odorat. En vieillissant il prend une cdeur de pourri, se fond en une eau noire avec laquelle j'ai fait une très bonne encre pour le lavis; elle porte sa gomme avec elle; mais il faut la filtrer.

Pratella. Ce groupe ne renferme aucune esp. vénéneuse, et quelques unes sont comestibles.

A. campestris $\mathbf{L}$. : Ce champignon est le plus connu de tous, on l'appelle, suivant les pays, Paturon, Potiron, Champignon de couche, de pré, de fumier, etc. ; c'est aussi celui dont on fait la plus grande consommation. N'y a-t-il qu'une esp. de Pratelle à collier, dit M. De Candolle, comme je l'ai admis d'après Linné et Bulliard : y en a-t-il 2, comme le veut Persoon; 5 , comme le pense Paulet; 10 , comme le dit Micheli ? Peu nous importe, quant à la question actuelle; toutes sont mangeables et ne peuvent se confondre avec aucune esp. vénéneuse. Il existe cependant quelques observations qui promven: 
que l'Agaricus campestris peut causer les plus graves accidents. Dardana, dans une lettre a Pico (Melethemata), cite plusieurs personnes qui se seraient empoisonnées en en mangeant. Il rapporte en outre une observation de Crolla, médecin à Verceil, dans laquelle il est fait mention de 9 personnes chezlesquelles ce champignon aurait aussi produit des symptômes d'empoisonnement, et la mort de 2 d'entre elles. La description que l'auteur donne du champignon qui aurait causé ces accidents se rapporte trop bien à l'Agaricus campestris pour que l'on puisse avoir des doutes sur l'esp. dont il s'agissait. Willdenow (Prodrom. Fl. Berol.), dit aussi que, dans quelques circonstances, il peut être vénéneux.

LACTifuuus. Tous ces Champignons, quand on les brise, versent un suc plus ou moins abondant, âcre ou sans saveur. Ils sont vénéneux ou comestibles; et sur ce sujet il existe la plus grande confusion parmi les auteurs.

A. piperatus Pers., A. acris Bull. : Cette esp. , entièrement blanche, renferme un suc blanc, très âcre; malgré cela, on la mange en Allemagne, en Russie et même en France. On n'a jamais remarqué qu'elle ait causé d'accidents.

A. controversus Pers. : C'est un des plus gros champignons que l'on connaisse. Sor suc est si âcre, que dans quelques pays oú on le mange, on lui donne le nom de Lathyron.

A. deliciosus L.: Ainsi nommé probablement par les habitants du nord, parce qu'ils aiment les saveurs fortes; il croìt rarement dans les environs de Paris. Indépendamment des caract. propres qui lui appartiennent, les lames prennent une couleur verte très foncée quand on les brise. C'est une esp. très recherchée. Dufresnoy, médecin à Valenciennes (Caract. et trait. de quelq. mal.), dit avoir administré la poudre de cet Agaric à des malades affectés de phthisie tuberculeuse et en avoir obtenu les plus heureux résultats. L'esp. d'Agarics que l'auteur a employée avait le suc blanc, tandis que dans l' $A$. deliciosus, il est d'une couleur jaune safranée. Il y a donc ici des doutes sur l’identité de l'espèce.

A. lactifluus aureus Hofr., A. volemus Fries: On le mange très fréquemment en Allema- gne. Son suc est doux et si abondant qu'on lui donne le nom de vache.

A. flexuosus Pers, : Commun dans l'Europe méridionale. Il a une odeur très prononcée de cannelle. Bongard dil qu'il est comestible.

A. subdulcis Bull. : C'est l'esp. la plus commune. On dit qu'elle sert d'aliment dans quelques cantons (DC.).

A. torminosus Schæfr. : Très commun dans les bois. Schæffer, Paulet, regardent cette esp. comme très dangereuse. Bulliard, au contraire, dit qu'elle ne l'est pas; en efret, dans quelques pays on la mange aussi abondamment que possible et jamais elle ne cause d'accidents. M. Eries (Epic. syst. myc.) l'a vu manger en Suède au lieu de l'A. deliciosus, sans qu'il en soit résulté aucun accident. Dufrénoy l'a employée aussi dans le traitement de la phthisie tuberculeuse.

A. necator Bull. : Ce champignon, dont le nom seul épouvante, passe pour très dangereux. Il paraît pourtant qu'il n'en est pas ainsi, car M. Weinmann dit qu'on le mange en Russie; ce qui a engagé M. Fries à lui donner un autre nom ; mais je ne crois pas que celui de turpis le réhabilite beaucoup dans l'opinion publique.

A. the rogalus Bull.: Il est très commun dans nos bois en automne. On ne sait rien sur ses propriétés. Persoon dit qu'il peut être dangereux, tandis que M. Fries le regarde comme innocent.

A.pyrogalus Bull.: Comme son nom l'indique, le suc de ce Champignon a une saveur brulante. On le regarde généralement comme vénéneux.

A. campylus Fries : Cette esp. n'est pas très commune. Paulet la signale comme vénéneuse.

A. aspideus Fries : Petite esp. qui crôit dans les lieux humides. Suivant Pico (Mém. Soc.méd.Par., 1780, t. 12), elle aurait causé de graves accidents.

A. rufus Scop. : Ce champignon est très commun, et passe pour le plus dangereux des Lactaires.

Toutes les esp. qui composent cette section sont assez difficiles à distinguer ; de plus, les opinions sont ex trêmement divisées sur leurs propriétés. On ne saurait donc prendre trop de précautions quand on veut en faire usage, quoique. Krapf prétende que l'ébullition 
dans l'eau en détruise le principe vénéneux.

Russura. Les esp. de cette section sont aussi difficiles à distinguer que celles de la précédente. Parmi les auteurs, les uns veulent que celles qui ont les lames jaunes puissent être mangées sans inconvénient, et que celles qui les ont blanches soient vénéneuses; d'autres prétendent le contraire. On ne peut done tirer aucun avantage de ce caractére. Les uns sont sans saveur prononcéc, les autres en ont une extrêmement piquante, et doivent être rejetés.

A. lacteus Pers. : Ce champignon n'est pas très commun; il est tout blanc et sans saveur. On le mange en Allemagne.

A. esculentus Pers.: Cette espèce, dit Persoon, est d'une dimension assez grande et d'une consistance fragile. On la trouve fréquemment en Allemagne, où elle est d'un usage peu général.

A. aureus Pers. : Ce champignon est remarquable par la belle couleur jaune de son chapcau. On le dit excellent.

A. virescens Pers. : Assez rare; on le regarde comme comestible; mais il est peu recherché. M. le professeur Frics dit que l'on mange l' $A$. depallens Schref. ct l'A. heterophyllus que l'on peut regarder comme une variété rie l' $A$. furcalus.

A. emeticus Bull. : Cettc esp. cst très commune dans les environs de Paris; sa saveur est extrêmoment âcre.

A. roseus Bull. : Ressemble beaucoup au précédent, croît à la mème époque et dans les mêmes endroits. Les expériences de Paulet sur des animaux, et celles que Krapr a faites sur lui-même, et dont il a failli être victime, prouvent que ces deux esp. sont extrêmement dangereuses. Toutes les autres esp. sont suspectes.

Omprinu. On ne connaît dans cette seclion aucune esp. vénéneuse, et il n'y en a qu'un très petit nombre qui soient comestibles.

1. infundibuliformis Bull.: Très commun dans les bois, parmi les feuilles; sa saveur cst assez agréable.

A. viryineus Pers. : Il croît ássez abondamment dans les prés, sur les pelouses. Bulliard et $\mathbf{M}$. De Candolle disent qu'on le mange dans plusicurs contrées de la France, ou il porte le nom de petite oreille.
A. Garidelli Fries : Celte esp. est dite comestible par lauteur.

A. neapolitanus Pers. : Ce champignon est très recherelié á Naples, où on le cultive, comme je l'ai dit, sur du marc de café. M. Fries le regarde comme une variété de l'A. phyllophilus.

11 est probable que si l'on tentait quelques expériences, on augmenterait de beaucoup le nombre des esp. d'Omphalies comestibles, car dans aucune d'elles on ne trouve d'odeur ni de saveur désagréable.

Pieuropus. Cetle section fournit un assez grand nombre d'esp. comestibles; on n'en cile que deux qui soient vénéncuses.

A. ostreatus Jacq. : Croît sur les vicux arbres. Il est assez commun, et on le mange surtout en Allemagne.

A. glandulosus Bull.: 'Très belle ế très rare esp. Je ne l'ai trouvéc qu'une seule fois dans l'espace de vingt ans, sur un marronnier d'Inde, et j'ai pu constäter l'exaclitude de la figure qu'en a donnée Bulliard. Persoon pense qu'on peat la manger sans inconvénient.

A. umarius Bull. : On le trouve ordinairement sur le tronc des ormes, par groupes composés de 4 a 5 individus. Son chapeau est très grand, sa chair blanche et compacte; son odcur et sa saveur sont très agréables. On le mange très fréquemment dans le département de la Nièvre. Je l'ai mangé moimême plusieurs fois avec plaisir.

A. tessellatus Bull.: Assez rare; croit ordinairement sur les vieux pommiers. Persoon pense que l'on pourrail en faire usage sans avoir rien à craindre.

A. salignus Pers. : Assez commun. Comme il ressemble beancoup à l' $A$. ostreatus pour le gout el la saveur, Persoon le considére comme pouvant être mangé sans danger.

A. Eryngii DC., ou l'oreille de chardon de Paulet : Singulier champignon dont le pédicule est central ou excentrique, el qui croît sur les racines de l'Eryngium campestre. Il est fort rare dans les environs de $\mathbf{P a -}$ ris. Depuis long-temps on le cite comme un des meilleurs Champignons.

A. Aquifolii Paul. : Il croît sous le houx; c'est une esp. assez grande, que l'on dit délicieuse.

4. iranslucens DC.: Les pauvres le man- 
gent a Montpellier sous le nom de Pivoulade du saule.

$A$. petaloz̈des Bull. : Cette esp., assez rare, croìt en automne, à Saint-Cloud, près de la Lanterne de Diogène. Son odeur et sa saveur sont très ağl'éables. J'en ai mangé plusieurs fois des morceaux crus et assez considérables, sans en avoir ressenti aucun mal. Je ne serais pas ètonné qu'elle fùt annoncée un jour comme comestible.

A. olearius DC.: Champiggnon très commun dans l'Europe méridionale. Il croît par groupes nombreux sur les racines de l'olivier. Ses lames sont phosphorescentes pendant la nuit. M. De Candolle le regarde comme vénéncux. M. Orfila rapporte qu’à Florence un dessinateur et sa fermme, ayant mangé de ce champignon fricassé, èprouvèrent, 2 heures après, de vives coliques et furent très mal. On les traita avec succès par de l'huile et de la thériaque. A Smyrne, on m'a parlé de 3 personnes qui étaient mortes après en avoir mangé.

A. stypticus Bull. : Très petite esp. qui croît en automne et en hiver sur le tronc des chênes. Sa saveur styptique fait croire qu’elle est vénéneuse. Paulet, qui l'a fait prendre à des animaux, a remarqué qu'elle les purgeait, mais ne les tuait pas.

Je termine ici l'énumération des Agarics vénéneux et comestibles. Il m'eùt été facile d'en augmenter le nombre; mais la synonymie de beaucoup d'esp. est si obscure dans les auteurs, que j'aurais craint de faire quelques citations erronées. (LÉveILLÉ.)

AGARIG des pharmaciens (áyapixór, Agaric, dans Dioscoride ). BOT. Cr. et TIÉRAP. Depuis long-temps on donne en Médecine et en Pharmacie le nom d'Agaric à une esp. de Champignons qui croît sur les troncs du Larix Europeca. On le trouve abondamment dans les Alpes, sur les hautes inontagnes du Dauphiné. II est ausşi très commun dans le Levant, d'oú il nous arrivait autrefois par le commerce de Venise. On a cependant toujours attaché plus de prix à colui qui venait d'Agaria, contrée de Sarmatie, d'oú il a tiré son nom. Ce champignon est le premier que l'on ail connu sous le nom d'Agaric. Depuis que Linné a donné ce nom à un autre genre, on l'a rangé parmi les Bolets : e'est le Boletus Laricis de Jacquin, de Bulliard; le Boleus.s purgans de P'ersoon; le Polyporas officina- lis du professeur Fries. Il forme le plus ordinairement, surle tronc des Mélèzes, des masses charnues et irrégulières; mais quand i! est à l'état normal, il se présente sous forme de coussins semi-orbiculaires, très épais, convexes et fixés latéralement. Sa face supér. est glabre, d'un blanc jaunâtre, marçuée de zônes concentriques; la peau qui le couvre est dure, friable, et se laisse difficilement pénétrer par la pluie. Sa chair est blanche, épaisse, friable, et se réduit en poudre avec la plus grande facilité quand elle est sèche. La face infér. du chapesu est garnie de pores courts et pelits, quelquefois même à peine visibles, et qui ont une légère teinte jaune. Sa saveur, douce et farineuse d'abord, devient bientôt amère et désagréable. Quand on le livre au commerce, il est ordinairement dépouillé de ses pores, de la peau qui recouvre le chapeau, et assez souvent brisé en morceaux blancs et légers. Pour le réduire en poudre, il ne faut pas le contondre dans un mortier avec un pilon, mais le frotter fortement sur un tamis de crin. Braconnot en a donné l'analyse suivante en 1812 (Bullelin de Plactmacie, p. 304): Matière résincuse particulière 72 ; Extrait amer 2 ; malière fongueuse 26.

M. Bouillon-Lagrange (Ann. de Phys. et de Chim. vol. I.1, p. 75) l'a trouvé composé d'un Acide libre indéterminé, d'Acide benzoïque, de Sels ammoniacanx, d'Hydrochlorate de potasse, de différents sulfates, de matière animale, d'extractif, etc. Le grand nombre de produits que donne ce bolet, et qui ne sont pas exactement déterminés, laisse à désirer une nouvelle analyse. - C'est à la malière résineuse signalée par Braconnot, que le Bolet du Mélèze doit ses propriétés. C'est un drastique assez violent el qui dernande de la prudence dans son administration. Fréquemment arssi il cause des vomissements. IJans les pharmacies, on ne le garantit qu'avec la plus grande dificulté des atteintes des Insectes, mais il paraît, d'après un grand nombre d'observations, que ces sortes d'altérations ne lui ôtent rien de son activité. On faisait autrefois un grand usage de ce médicament comme vermifuge et comme purgatif: De Haën l'a préconisé comme ayant la propriété de modérer et d'empêcher les sueurs rhez les Phthisiques. Pour en corri- 
ger l'âcreté, les anciens l'unissaient aux aromatiques comme la Cannelle etle Gingembre. Lémery conseillel'hydrochlorate d'Ammonia que comme le meilleur correctif. La torréfaction que quelques auteurs ont indiquée pour obtenir le même effet, a l'inconvénient d'affaiblir ses propriétés en décomposant sa matière résineuse. On l'administre à la dose d'un demi-gros à un gros. La poudre du Bolet du Mélèze fait la base des Trochisques de Mésué; clle entre dans la composition de la Thériaque, etc. Ce médicament est depuis long-temps généralement abandonné. On trouve pourtant dans le Miscell. Taurin. vol. 3, p. 203, une observation très curieuse, oú son administration a déterminé la mort d'une sangsue qui avait été imprudemment avalée.

(LÉV.)

AGARIG des chirurgiens (áyxpexóv, agaric). вот. Cr. et тHÉR $\Lambda$ P. 一 On désigne sous ce nom, dans les Pharmacies, 'Amadou qui n'a pas été trempé dans une solution d'Azotate de potasse. On le prépare avec la chair du Bolents fomentarius L., qui est un Polyporus des auteurs modernes. On en retire de plusieurs autres esp., et particulièrement du Polyporus igniarius. Dans le commerce, il est impossible de les distinguer, quoique le dernier passe généralement pour être de mauvaise qualité. Le Polyporus fomentarius est un des Champignons qui prennent le plus grand développement; habituellement il pèse 12 ou 15 livres, et j'en ai vu un qui en pesait 25 ; mais ce poids est dù principalement à une grande quantité d'eau devégétation; car, quandil est sec, il diminue considérablement. On l'a nommé Agaric du chêne, parce qu'il croît sur cet arbre; on le rencontre aussi sur les saules, les peupliers, les marronniers, les poiriers; mais plus souvent sur les hêtres. Il est attaché par le côté, et forme un coussin trés épais, semicirculaire. Sa surface est d'un blanc gris et marquée de zònes plus prononcées vers le bord; la peau qui le recouvre est dure, cassante, très mince, et d'un brun noir très foncé dans sa tranche. La chair est épaisse, fibreuse, d'une couleur rousse, et formée de cellules allongées qui s'anastomosent entre elles. La marge du chapeau cst obtuse, arrondie, et la couche de pores qui recouvre la face inférieure du chapeau est, dans le jeune âge, d'un vert glauque; elle devient rousse quand on la froisse. Les tubes qui la composent sont courts et d'un diamètre extrêmement petit. Pour préparer cet amadou, on enlève la couche de pores et la peau dure du chapeau avec un instrument tranchant, et l'on ba! la chair avec un maillet de bois, aprés l'avoir fait séjourner dans l'eau, pour l'aplatir: On répèle cetle opération jusqu'à ce que l'on ait réduit cette substance en une lame plus ou moins épaisse, très molie et parfaitement souple. Puis on la fait sécher et on la concerve. On conseille de récolter le Boletus fomentarius en août ou cn septembre; mais je pense que cette époque est de peu d'importance. Les plus gros sont les meilleurs, pourvu qu'ils ne soient pas mangés par les insectes. L'Agaric de chêne a été regardé comme un des meilleurs moyens pour arrêter les hérnorrhagies, même celles qui sont la suite des anévrismes et des amputations. Vers le milieu du xvın siècle, Brossard, chirurgien de Chartres, le présenta comme un secret, Des expériences furent faites. Les résultats parurent avantageux, et Louis XV ordonna d'en faire l'acquisition. Ce moyen se répandit bientôt et les expériences se multiplièrent en France, en Angleterre, en Allemagne. Le résultat ne répondit pas toujours à l'attente des chirurgiens; il eut ses apologistes et ses détracteurs; ma is l'avantage est demeuré à ces derniers. Maintenant on ne l'emploie plus que comme un remède populaire pour arrêter le sang qui coule des piqûres de sangsues ou de légères coupures, concurremment avec la toile d'araignée, les chiffons à moitié brûlés et la colophane. On pensait qu'il agissait comme astringent, comme styptique, tandis qu'il n'agit que comme moyen mécanique, et encore sans effet, s’il n'est aidé de la compression. (LÉV.)

* Agarla minéral. (áyapcxóv, agaric). MıN. - Nom donné par les anciens minéralogistes à une variété de calcaire, blanche et spongieuse comme la chair d'un champignon. On la trouve ordinairement dans les fentes de certaines roches calcaires, d'où on la retire le plus souvent humide et molle; ce qui lui a valu aussi les noms de farine fossile, de lait de lune, de lait de montagne et de moelle de pierre.

(DEL.)

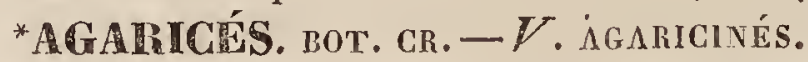

(LÉV.) 
AGARICLE. Agaricia (ày»próv, agaric; allusion à une sorte de ressemblance que présentent les polypes suivants avec ce g. de Champignons\}. PoLrP.-G. de Polypes an thozoaires, à polypier calcaire, lamellirère, fixé, composé d'expansions aplaties, lobées, subfoliacées, ayant une seule face garnie de sillons ou de rides, et parsemée d'étoiles lamelleuses, sériales, sessiles, souvent imparfaites et peu distinctes. Les Agaricies ne diffèrent des Pavonies qu'en ce qu'elles ont res étoiles sur une seule face, tandis que les Pavonies en ont sur les deux faces; cependant on trouve quelquefois des lames d'Agaricies adossées de manière à figurer une lame de Pavonie. Les principales esp. soní: 1''Agaricie contournée (Agaricia cucullata Lamk., figurée par Ellis et Solander, tab. 42, et par M. de Blainville, Man. d'Actin., pl. 56); $2^{\circ}$ L'Agaricie ondée, Agaricia undata Lamk. (Lamouroux, Exp. meth., pl. 40); $3^{\circ}$ L'Agaricie ridée, Agaricin rugosa Lamk. - On trouve six espèces a'Agaricies fossiles, décrites et figurées dans l'ouvrage de Goldfuss, sous les noms d'Agaricia lobata, boletiformis, swinder niana, granulata, rotata, crassa. M. Ehrenberg place les Agaricies dans sa douzième famille des Anthozoaires, les Dédalines, qui, avec les Ocellines, composent la tribu des Phytocoraux polyactiniés. Il sépare des esp. de Lamarck, l'Agaricia ampliata, pour en former son g. Merulina ( $V$. ce mot), et il doute, avec raison, que les esp. fossiles de Goldfuss appartiennent réellement au g. Agaricie. L'A. granulata lui semble devoir ĉtre reportée aug. Favia ou Explanaria; les autres pourraient être des Astrées; mais l'A. rotata pourrait aussi, suivant cet auteur, former le type d'un nouveau genre.

(Duj.)

* AGATHCINÉs, Agaricés, Agaricoïdes, Agarics. Agaricini, Agarici, Agaricoüdei. BOT. CR. - Les auteurs désignent sous ces différents noms, une tribu, un ordre ou un sous-ordre de la famille des Champignons. Cette tribu comprenail, dans leSynopsis Fungorum de Persoon, les g. Amanila, Ayaricus et Merulins. Plus tard, ce célébre mycologiste, dans son Mycologiu europoea, en sépara le g. Mernlius pour en former un ordre particulier, et composa les Agaricinés des g. Dcelalea, Schizonia el Agaricus. Cet imporT. 1. tant ouvrage était a ce point lorsque la mort enleva son anteur.

M. Fries, dans son S'ystema mycologicum, et les auteurs qui l'ont pris pour guide, ont formé des Agaricinés le premier ordre des $\mathrm{Hy}$ menomycetes. En 1825, le Systema Orbis vegetabilis présentait cet ordre sous un nouveau point de vue ; et enfin la réforme fut complète dans l'Epicrisis Syst. myc. publié de 1.836 à 1838. Dans cet ouvrage, les Champiguons sont divisés par familles, el les $\Lambda$ garicinés forment le premier ordre des Hymenomyceles, qui sont à la tête des Champignons. Cet ordre se compose des g. Agaricus, Montagnites, Coprinus, Bolbitius, Cortinarius, Paxillus, Gomphidius, Stylobates, Hygrophorus, Lactarius, Russula, Cantharellus, Nyctalis, Marasmius, Lentinus, Panus, Nerouls, Trogia, Schizophyllum et Lenzites ( $V$. ces mots). Dans la classification que je proposerai plus tard, les Agaricinés formeront également le premier ordre des Basidiospores, c'est-à-dire des Champignons dont les spores sont libres et supportées par des basides répandues sur la surface de l'hymenium. (LÉV.)

AGARICLTE. PoLYP. - Dénomination employée par d'anciens auteurs, pour désigner des Polypiers fossiles plus ou moins voisins des Agaricies. $V$. ce mot. (Dus.)

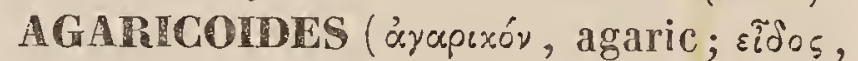
aspect). BOT. CR.-Ce mot devrait servir á désigner les Champignons qui ressembilent aux Agarics, comme les Merulius, les Cantharellus, etc. ; mais on l'emploie ordinairement comme syn. d'Agaricinés. $V$. ce mot.

(LÉv.)

AGARICON (áyapıxóv, agaric; d'Agaria, contrée de la Sarmatie ). $V$. AGARIC des pharmaciens.

(LÉv.)

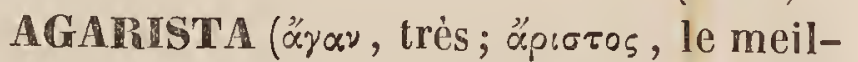
leur). INs.-G. de l'ordre des Lépidoptères, tribu des Hespéri-Sphingides, établi par Leach (Zool. Misc.xv) et adopté parLatreille (Enc. méth. Entom. t. 1x, p. 802), qui lui donne pour caract. : Palpes inférieurs longs, avec le $2^{\text {me }}$ article comprimé et barbu; Je $3^{\mathrm{mc}}$ subcylindrique et nu. - Il y rapporte 3 espèces, dont une du Brésil, une de la Nouv.-Hollande et une de l'Amérique septentrionale. Nous ne citerons que la $1^{\text {re }}, l^{\prime} A$. Leachii, dédiée au savant Naturaliste anglais Leach, par M. de Logsdorf. (D.)

* AGARTSTA (corrupt. d'áxúprotos, désa$12 *$ 
gréable). вот.PII.-D’après M. De Candolle, ce g. s'éloignede presque toutes les Hélianthées, par son aigrette formée d'écailles scarieuses, comme dans les Helenium, au lieu d'être aristées comme ceiles de la tribu à laquelle il rapporte son nouveau g. L'Agarisia est une herbe annuelle de la Californie, qui a le port des Calliopsis ou des Coreopsis, et dont voici les caractères : Tiges rameuses, portant des feuilles multifides; rameaux dépourvus de feuilles au sommet et terminés par un capitule multiflore, radié. Ligules 1-sériées, neutres, obovales-tronquées et parcourues par plusieurs nervures. Fleurs du disque hermaphrodites, tubuleuses, à 5 dents. Involucre campanulé, formé par une double rangée d'écailles aiguës; les extérieures cvoïdes, presque soudées à la base, les intéricures au nombre de 8 , ovales-oblongues, membraneuses, dépassant presque du double les extérieures. Écailles membraneuses, couvrant le réceptacle et s'en détachant avec les fruits qu'elles enveloppent sur un côté. Branches du style terminées par un còne. Fruits obcomprimés; ceux du rayon ovales, avortés, glabres et dépourvus d'aigrette; ceux du disque oblongs, glabres sur la partie recouverte par l'écaille, velues sur les bords et la face interne. Aigrette bi-squamellée; squamelles allongées, membraneuses, un peu plus courtes que la corolle et partant des angles du fruit.

(J. D.)

AGARON. Moll. - Dans son voyage au Sénégal (p. 64, pl. 4, f. 7), Adanson donne ce nom à une Olive que Lamarck a nommée Oliva hiatula. On trouve cette coquille fossile aux environs de Bordeaux, et, dans cet état, Lamarck l'a nommée Oliva plicaria. $V$. OLIVE.

(DEsH.)

AGARUM. вот. CR. - Rumphius nous apprend (Herb. Amboin. vi. 186. 2) que les Malais des îles de la Sonde, désignent par Te mot Agar toute espéce de fucus. C'est à ce qu'il paraît la véritable étymologie du mot. Link avait proposé ce nom pour un $\mathrm{g}$. de la s.-famille des Floridées, dont le Sphorococcus rubens Ag. est le type. Il le caractérisait de la manière suivante : Conceptacles situés sur les plus petits rameaux, presque sphériques et chargés à leur périphérie de cellules contenant des séminules. Ce g., qui forme aussi le type du g. Phyllophora, Grév., rentre dans une section des Sphcerococcus. $(V$. ce mot.) M. Bory a encore tenté d'établir sous le même nom un g. de la même famille, tribu des Laminariées, auquel il donne pour caractères : Lame ou fronde parcourue dans toute sa longueur par une ou plusieurs nervures très saillantes. Selon ce savant Algologue, allcun autre signe ne distinguerait les Agares des vraies Laminaires, ou du moins de celles auxquelles il conserve ce nom. Is même auteur étabilit encore 2 sous-genres pour y répartir les 6 ou 8 espèces qu'il place dans le g. Agarum; l'un est caractérisé par un stipe nu entre la racine et l'expansion de la lame; l'autre est remarquable par un stipe muni de pinnules en forme d'ailes. Ce g., quoiqu'il ait été admis et même subdivisé par M. Gréville ( $A$ ig . Brit.), ne nous paraît pas devoir être séparé des Laminaires. La nervure qui parcourt les frondes est en effet, selon nous, d'une valeur très secondaire quand la fructification n’offre pas de différence manifeste. Si nous admettions ainsi, comme distinctions génériques, toutes les modifications que subit la forme du thalle ou des frondes, ne rétrograderions-nous pas vers le temps où l'on fondait des gemres sur la grandeur relative des plantes, et ne devrions-nous pas craindre de voir bientôt autant de genres que d'espèces? Nous ne considérons donc le g. Agarum que comme une bonne section du g. LAMINAIRE. $V$. ce mot, et alaria et costaRlA.

(C. M.)

AGAS. вот. Pн. - Nom vulgaire de l'Érable champêtre (Acer campestris, L.) dans une partie du midi de la France. (C. L.)

* AGASSIzIA, Chav. (Agassiz, savant Zoologiste suisse). вот. PH. - Suivant M. Bentham, ce g. est le même que le Galvezia, Juss.

* AgASSIZIA, Spach. (Agassiz, savant Zoologiste suisse). вот. PIl. - Double emploi du g. Camissonia, Link.

AGASTACIYS (contraction d'o $\alpha \alpha_{5} 5^{\circ} \zeta$, admirable; $\sigma \tau \alpha^{\prime} \chi v_{\varsigma}$, еंpi). вот. Pн. - G. de la famille des Protéacées, tribu des Persoonićes, créé par R. Brown (Linn. Trans. x, 158, et Prodr. 371. Suppl. 11), qui le caractérise ainsi : Périgone (cal. et cor. des auteurs) simple, tétraphylle, régulier, à folioles cohérentes à la base. Étam.4, insérées ar milieu des folioles périgoniales; filaments dis- 
lincts. Glandules hypogynes nulles. Ovaire sessile, trigone, uni-loculaire, uni-o vulé. Style filiforme; stigmate bilobé. Fruit inconnu.Ce g., qui a besoin d'un plus mûr examen , a été formé pour un seul arbrisseau trouvé sur la terre de Diémen; il est très glabre, couvert de feuilles éparses, très entières, planes, munies de glandules sur la face inférienre. Ses fleurs sont jaumes, alternes, sessiles, unibracléées, disposées en épis nombreux, terminaux; style plus court que les étamines, à bractées persistantes, en forme de capuchon.

(C. L.)

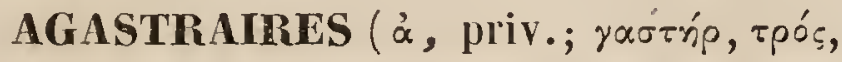
ventre). Infus. - Nom proposé en 1816 (Bull. Soc. philom.) par M. de Blainville, pour une classe de son sous-règne des Agastrozoaires, comprenant les Infusoires qui n'ont point de canal intestinal proprement dit. Ce nom n'est plus employé dans les derniers ouvrages de $M$. de Blainville. (DuJ.)

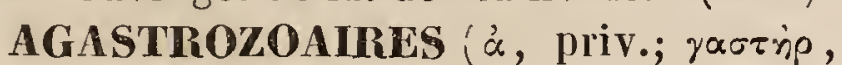

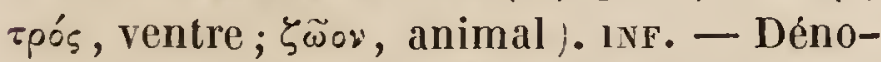
mination proposėe par M. de Blainville $\langle l$. suprac.) pour son $3^{\mathrm{e}}$ sous-règne, comprenant les animaux sans cavité digestive, et formé des deux classes des Spongiaires et des Agastraires. Cette dénominalion n'a pas été conservée.

(Dus.)

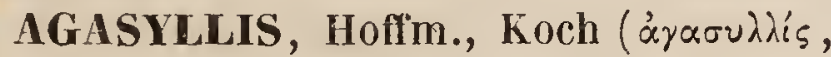
nom, chez les Grecs, d'un arbrisseau indét.). вот. PII.-G. de la famille des Ombellifères, très voisin du S'iler, dont il ne diffère essentiellement que par des méricarpes à côtes secoudaires, en partie oblitérées, et par un plus grand nombre de bandelettes. Au surplus, l'Agasyllis n'est fondé que sur une seule espèce.

* AGATE et non AGATHE (Corruption d'axátns, Agale). min. - C'est le nom que l'on donne à toutes les variétés de quartz, qui n'ont pas l'aspect vitreux, qui sont compactes, demi-transparentes, ont la cassure semblable à celle de la cire, et se distinguent des Silex ordinaires par la finesse de leur pâte, le brillant de leur poli, et la vivacité de leurs couleurs. Ce nom leur vient, si l'on en croit Théophraste et Pline, de celui du fleuve Achates en Sicile, aujourd'hui Drillo, sur les bords duquel les premières Agates auraient été tronvées. Ces pierres sont un peu inoins dures que le cristal de roche et le silcx; néanmoins elles font feu avec le bri- quet. Elles ne se présentent jamais dans la nature que sous la forme de rognons ovö̈des, de stalactiles, de masses mamelonnées, assez souvent eucroùtées extérieurenient d'une terre verte. Elles ont élé formées généralement par couches successives, qui se sont déposées dans les cavilés de certaius tufs volcaniques ou d'anciennes roches d'origine ignée, décomposées et remaniées par le travail des eaux.Un des gisements d'Agates les plus célèbres, est celui d'Oberstein sur les bords du Rhin, où se trouvent de grands ateliers pour la taille et le polissage de ces pierres. Etant susceptibles d'un beau poli, elles sont très recherchées pour l'ornement dans la bijouterie et pour la gravure sur pierre.

Les Agates prennent des noms différents, suivant les variations de couleur, de transparence et les jeux de lumière qu'elles présentent. Lorsqu'elles sont d'un blanc laiteux légèrement bleuâtre, on les nomme Calcécloines; on appelle Cornalines celles quil sont d'un beau rouge cerise; S'ardoines, celles qui sont d'un beau jaune fauve ou orange; on nomme Chrysoprases les Agates vertpomme, et Héliotropes celles d'un vert obscur, qui sont le plus souvent ponctuées de rouge. La coloration en rouge des cornalines et de certaines parties des héliotropes paraît due à une matière organique. La chrysoprase doit sa couleur à quelques centièmes d'oxyde de nikel; cette belle variélé se trouve à Kosemütz en Silésie, au milieu de roches magnésiennes. - Les Agates sont souvent composées de couches de différentes couleurs. Si elles ont été taillées de manière à offrir une série de bandes droites , ả bords nettement tranchés, on leur donne le nom d'Ag. rubanées; quand les bandes sont circulaires et concentriques, ce sont des Agates Onyx ; celles-ci étaient très recherchées par les anciens pour la gravure en camée. On a trouvé à Champigny, près Paris, sur les bords de la Marne, des $\Lambda \mathrm{g}$. rubanées et de véritables onyx à 3 couches, 2 brunes et l'autre bleuâtre; mais le gîte en est maintenanl épuisé. - Quelques Agates montrent dans l'intérieur de leur masse des dessins noirs ou rouges, qui simulent de petits arbrisseaux dépouillés de feuilles; se sont les Ag. arborisées. Ces arborisations sont dues à des particules métalliques, qui ont 
pénétrè dang' l'Agate à une époque oủ elle n'élait pas encore entièrement consolidée, et qui se sont disposées à la file les unes des autres, en se ramifiant en divers sens. Cette formation rappelle parfaitement ces cristallisations que Gorme l'humidité de l'air pendant l'hiver, en se congelant à la surface des vilres. Seulement, ces dernières arborisalions ne sont que superficielles, tandis que les premières s'étendent dans la profondeur de la pierre. On donne le nom d' $A g$. mousseuses à des Agates communément vertes ou jaunâtres qui, vues par transparence, montrent intérieurement des apparences de mousses, ou plutôt de conferves et autres plantes aquatiques, que quelques naturalistes prennent pour des réalités. Il est certaines Agates qui renferment des cavités en partie remplies d'eau; ce sont les Enhydres du Vicentin, qui ont ordinairement la forme de petites amandes. - On distinguailautrefois les Agates en orientales et occidentales, d'après la persuasion où l'on était que les plus belles ne se trouvaient que dans l'Inde; aujourd'hui ces épithètes ne servent plus qửà désigner dans le commerce les Agates de première et de seconde qualité; quels que soient les lieux d'où elles proviennent. Les Agates, en perdant de leur transparence, passent insensiblement à ces variétés de quartz plus grossières, qu'on nornme Silex et Jaspes. $V$. ces mots. (Det.)

AGATE d'Islande. Min: - Synon. d'Obsidienne.

(DEL.)

AGITE noire. Min. - Synon. de Jayet.

(DeL.)

AGATHIE. MIN. - $V$. AG $\Lambda$ TE. (DEL.)

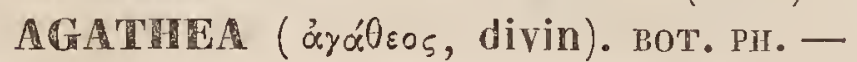
Cassini a formé ce g. arx dépens du Cinevaria amelloz̈des L., petit arbrisseau du Cap, que l'on cultive fréquemment comme plante d'ornement, à cause du nombre considérable de jolies fleurs bleues qu'il produit toute l'année. Ce g., qui fait parlie de la tribu des Astéroïdées parmi les Composées, a pour caractères: Capitules multiflores hétérogames. Fleurs du rayon ligulées, bleues et femelles; celles du disque tubuleuses, jaunes, à 5 dents, hermaphrodites, fertiles ou plus rarement stériles. Récept. nu, plan, ou à peine alvéolé. Involucre campanulé, composé d'1-2 séries d'écailles herbacées, assez roides, appliquées les unes contre les autres, et creusćes en goutlière à leur face interne. Fruits, lors de ia maturité, aplatis, comprimés et entourés d'une nervure proéminente. Aigrette 1-sériée, formée de soies scabres, rudes, caduques ou persistantes. Le g. Agathea renferme aujourd'hui environ 20 espèces, qui toutes sont originaires du Cap et portent des capitules ä fleurons bleus et à disque jaune.

(J. D.)

*AGATHELEPIS et non Agathelpis (àyaOós, ń, bon; $\lambda \varepsilon \pi \iota_{\varsigma}$, écaille). Bот. PI. - G. de la famille des Sélaginacées, créé par M. Choisy (Mém. Soc. H. nat. Genèv. 11, 95, t. I, f. 3, etc.), qui le caractérise ainsi : Cal. tubuleux, plissé, 5-denté, adhérent antérieurement à la bractée par son milieu. Cor. hypogyne; tube très long, cylindrique, courbé, à limbe hypocratérimorphe, 5-partí, égal. Étam. 2, incluses, insérées au sommet du tube de la corolle; filaments trés courts; anth.uni-loculaires.Ovaire bi-loculaire. Ovules solitaires, anatropes, suspendus au sommet des loges. Style terminal, simple; stigm. aigu. Akène unique par avortement, monosperme, sémicylindrique, subéreux, épais. Graine inverse. Embryon orthotrope, dans un albumen charnu, peu abondant; à cotyl. sémicylindriques, à radicule cylindrique, supére. - Ce g., formé aux dépens du g. Eranthemum L., renferme quelques s.-arbrisseaux du Cap, à feuilles alternes, linéaires-filiformes, à fleurs en épis terminaux, bractéés.

(C. L.)

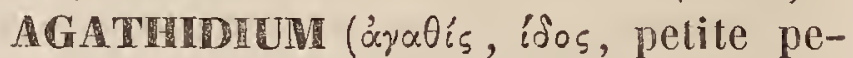
lotte). ins. - G. de Coléoptères tétramères, établi par Illiger aux dépens des Anisostomes de Fabricius et adopté par Latreille (Fam. natur.) qui le place dans celle des Clavipalpes, tribu des Érotylènes. Ses caractères sont: Antennes composées de 11 articles distincts, courtes et terminées par une massue perfoliée de 3 articles. Mâchoires bifides dont la division interne a la forme d'une dent. Palpes filiformes. Articles des tarses entiers. M. Duméril met ce g. dans sa famille des Fongivores ou Mycétobies, et le caractérise ainsi : Corps ovale, plat en dessous; élytres ne couvrant pas tout l'abdomen; masse des antennes de 3 articles seulement.-Mais c'est á tort qu'il le range parmi les Hétéromères; car il a le même nombre d'arlicles à tous les tarses. Les Agathidies sont de petits insectes de forme hémisphérique, qu'on trouve 
dans les bois, sous les écorces, et dans lés Chanpignons. Au moindre danger, ils courbent leur abdomen vers la poitrine, et contrefontles morts, en conservant une immobilité parfaile. M. Dejean (Catal. $3^{\text {me }}$ édit.) en mentionne 19 espéces, toutes du nord ou du centre de l'Europe, et dont 3 se trouvent aux environs de Paris. Nous cilerons parmi ces dernières : l'A. globus ou splecridium, id. Fabr.

AGATHIS ('́yatis, faisceau; disposition des anthères). вот. PI. - Créé par Salisburg (Liun. Trans.) et adopté par L. C. Ricliard dans son beau trav. sur les Conifères. Ce g. a pour type le Dammara alba de Rumphius; voici les caract. qu'on peut lui assigner : Fleurs dioïques; les mâles formant des chatons alternes, nus, extra-axillaires, composés d'écailles imbriquées, portant à leur base interne de 8 a 15 anth. disposées en double série, renversées et intimement soudées entre elles et avec l'écaille. Chaton femelle terminal, offrant des écailles imbriquées sans petite squamule intérieure, portant à leur face interne une seule fleur renversée. Cône ovoïde subglobuleux ; péricarpes coriaces et prolongés en une aile membraneuse et uni-latérale. - Une seule esp. compose ce g.; c'est l'Agatlis Dammara Rich. Conif. t. xix. Grand arbre originaire de l'Inde, portant des feuilles éparses, oblongues, lancéolées, épaisses, coriaces, très entières, à nervures longitudinales et parallèles.

Agathis ára $i_{i 5}$, peloton de fil; par allusion à la forme des antennes). INS. G. de la famille des Ichneumoniens, de l'ordre des Hyménoptères, dont l'établissement est dû à Latreille (Gen.Crust.et Ins.) qui en a tiré les principaux caract. : $1^{\circ}$ des ant. sétacées et roulées à leur extrémité; $2^{\circ}$ des mâchoires prolongées en avant en forme de bec; $3^{\circ}$ des ailes, qui n'ofirent qu'une seule cellule cubitale étroite, et 3 cellules radiales, dont la dernière incomplète. - Ce g. est confondu par certains auteurs avec les Bracons, et par d'autres avec les Ichneitmons. Le type est l'A. Malvacearum, Lat. (Hist. des $C_{r}$. et des Ins. t. xili ) Bracon purgator Fab., esp. répandue dans la plus grande partie de l'Europe.

(Bu.)

* agatimsanThes , Blume (áyatis,

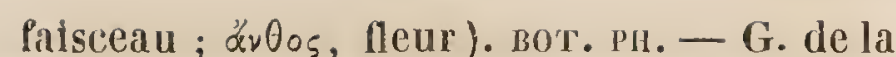
famille des Combrétacées, tribu des Terminaliées, De Cand.; M. Blume (Bijdr. p. 645) assigue a ce g. les caract. suivants : Fleurs diö̈ques, apétales; Mâles : Cal. 5-parti ; segments imbriqués, connivents. Étam. en général 10; filets très courts, insérés sur un disque plane; anth. didymes. Femelles : Limbe calicinal court, supère, 5-denté. Ovaire uni-ovulé, couronné par un disque plane. Style court, bifide. Drupe charnu, ombiliqué; noyau comprimé, monosperme. Embryon apérispermé, Padicule supère. Arbre très élevé. Feuilles oblongues, très entières, coriaces, agrégées vers l'extrémité des ramules. Fleurs disposées en capitules longuement pédonculés; pédoncules axillaires ou latéraux, solitaires ou géminés. Ce g., qui, suivant M. Blume, tient le milieu entre les g. Bucida et Ceratostachy: , n'est fondé que sur une seule esp. indigène à Java.

(SP.)

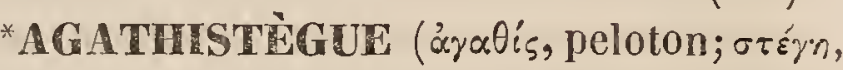
chambre). Foramin. - Nous avons donné ce nom à notre $6^{\text {me }}$ ordre des Foraminifères, comprenant toutes les coquilles dont les loges sont pelotonnées sur 2, 3,4 ou 5 faces et sur un axe commun; faisant chacune, dans leur enroulement, la longueur totale de la coquille, ou la moitié de sa circonférence. Par ce moyen, l'ouverture, presque toujours munie d'un appendice, se trouve alternativement à une extrémité ou à l'autre. ( $V$. notre ouvrage sur les Foraminifères de Cuba.)

Ainsi, toutes les esp. de cuquilles de cet ordre ont un mode d'accroissement tout-àfait particulier, mode qui est bien réellement un pelotonnement, et qui les distingue nettement de toutes les autres divisions. Ces esp. extrêmement nombreuses, et toutes microscopiques, peuvent être divisées en 2 familles. L'une sous le nom de Miliotidées, à coquille équilatérale, comprend nos g. : Uniloculina, Biloculina, Fabularia, Spiroloculina; l'autre, sous la dénomination de Multiloculidées, à coquille inéquilatérale, dont le pelotonnement a lieu sur 3,4 ou 5 faces, renferme les g. : Triloculina, Articulinc: Spheroüdina, Quinqueloculina, Adelosina. Nous avons observé 186 esp. de cet ordre, savoir : 130 vivantes et 56 à l'état fossile.

Les esp. vivantes sont ainsi riparlies: 
39 des Antilles, 18 de la Méditerranée, 16 de l'Inde, 14 de l'Adriatique, 11 des Canaries, 6 des côtes de l'Océan sur le littoral de la France, 6 de l'île de Ste-Hélène, 5 de la Patagonic, 5 de Rawack dans la mer du Sud, 4 de la mer Rouge, 4 du Pérou; les autres sont de lî̀le de France, du cap de Bonne-Espérance, de Madagascar et des îles Sandwich. Pour les espèces fossiles, elles sont loutes des terrains tertiaires, et aucune ne se voit dans les couches inférieures. Nous les avons trouvées ainsi réparties : 25 du bassin de Paris, 8 de Dax , 8 des terrains subapennins de l'Italie, dont le plus grand nombre ont leurs analogues encore vivantes, 5 des environs de Bordeaux, et 6 du Crag anglais de Suffolk.

C'est Plancus (en 1739), qui le premier figura une esp. de cet ordre, sous le nom de Conchula minima. Linné (12 $12^{\text {e }}$ édition Syst. nat.), en fit une Serpula, de même que Gmelin. Lamarck, sans parler de cette espèce, en décrivit 4 fossiles, et en forma le g. Miliola. Si, maintenant, on ajoute quelques figures données par Soldani, on aura tout ce qu'on connaissait sur ces coquilles, lorsqu'en 1825, nous présentâmes à l'Académie des sciences notre premier travail sur les Foraminilères. Nous créâmes alors, pour les différentes modifications, la famille des Agathistègues dont nous faisons aujourd'hui un ordre distinct, considérant les Foraminifères comme une classe séparée des Mollusques, et par conséquent des Céphalopodes, parmi lesquels nous les classions de même que Cuvier, Lamarck et M. de Blainville (A. D'O.)

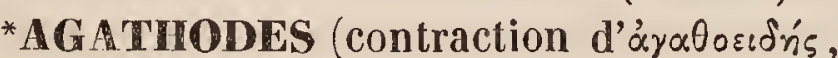
qui est bon en apparence). вот. Рі. — G. de la famille des Gentianacées, tribu des Chironices, fondé par Griesebach (Observ. 32), et dont voici les caract. : Cal. 4-parti. Cor. hypogyne, marcescente, rotacée, 4-fide; couronne nulle; divisions munies à la base d'une fossette glandulifère couverte d'une squamule frangée. Étam. 4, insérées à la gorge de la corolle; filaments égaux à la base; anthères immutées. Ovaire uni-loculaire. Ovules nombreux, a ttachés à des placentaires suturaux, spongieux. Stigm. terminal, sessile, bilobé. Capsule subconique, uni-loculaire, bi-valve. Graines nombreuses, très petites. - Une seule esp., le Swertia angusi- polia de Vallich. (Pl. asiat. rar., t. 204), compose ce g. C'est une plante herbacée de l'Inde, à tige 4-gone, à feuilles opposées, linéaires-lancéolées, tri-nervées, à fleurs paniculées.

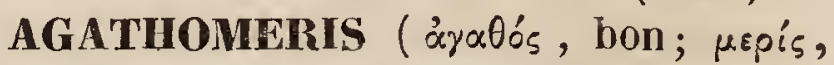
morceau). вот. PI.-G.de la famille des Cornposées, proposé par Delaune (Bon Jard., 1805 ), et qui, n’ayant pas été adopté, est réuni au g.Humea de Smith. $V$.ce mot. (C.L.)

*AGATHOPHOLIDOPHIDES ( $\alpha \gamma_{\alpha} \alpha \theta^{\prime} s$,

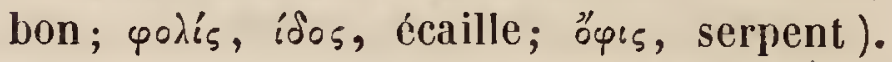
REPT. - Nom donné par J.-A. Ritgen à une famille de Reptiles Ophidiens, comprenant les Serpents écailleux qui n'ont pas de crochets à venin. (C. D'O.)

AGATHOPHYLLUM ( $a \gamma_{\alpha} \alpha \theta^{\prime} s$, bon ; $\left.\varphi v ́\right\rangle_{-}$ גov, feuille). вот. Pн. - G. de la famille des Lauracées, tribu des Cryptocaryées, Nees, créé par de Jussieu (Gen. Pl.431), adopté par Nees Von Esenbeck (Prog. 12. Laur. 231), et ainsi caractérisé : Fleurs hermaphrodites. Périgone (cal. et cor. des auteurs) infundibuliforme, resserré à la gorge, à limbe sex-fide, égal, persistant ou décidu. Étam. 12, quadrisériées; 9 extér. fertiles ; 3 intér. stériles; 3 des fertiles les plus internes, munies de chaque côté de glandes géminées, sessiles, subglobuleuses; anth. des deux $1^{\text {res }}$ séries introrses, ovales, membraneuses au sommet; celles de la $3^{\text {me }}$ extrorses, subulées au sommet; toutes biloculées, déhiscentes par autant de valvules ascendantes; les étam. stériles subsessiles, triangulaires, acuminées. Ovaire uni-loculaire, uni-ovulé. Style un peu épais ; stigm. capité. Caryopse monosperme, anguleuxlobé à la base, inclus dans le tube périgonial, qui est coriace, renflé, plissé 5 ou 6 fois intérieurement, et nu ou couronné de ses segments persistants. Cotyl. conformes, lobés à la base. - Ce g. ne renferme encore qu'un seul arbre ( $A$. aromaticum Lam.) d feuilles alternes, serrées; à bourgeons stipités, bivalves; à fleurs très petiles, disposées en panicules terminales, contractées. Il crồt à Madagascar, oú les naturels le nomment Ravensara, et se servent de ses feuilles comme condiment culinaire. Son fruit est aromatique, et renferme une amande d'une saveur âcre et caustique. C'est l'Evodia Ravensara de Gaertner', le Rav. aromatica de Sonnerat, etc.

(C. $L_{0}$ ) 
* AgATHOPHYTUM, Moq. Tand. ( $x y \alpha-$ Oós. bon; yutóv, plante). Sous ce nom M. Moquin-Tandon a élevé au rang de g. le Chenopodium bonus-Henricus, L.; esp. que nous considérons, à l'exemple de M. C.-A. Meyer (in Ledeb. Flor. Alı.) comme appartenant au g. Blitum.

(SP.)

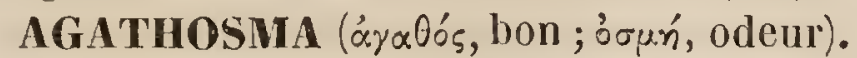
во'г. PI. - L'odeur forte et le plus ordinairement agréable qui a donuć son nomà ce g., est un attribut des Diosmées du Cap, parmi lesquelles il prend place. C'est aussi le Bucco de Wendland. Ses caractères sont: Calice 5-parti, au fond duquel est accollé un disque court et glanduleux. Pétales 5; à filets étroits, longs, souvent hispides, à limbe plus large, entier et ouvert. Filets 10; les 5 opposés aux pétales plus courts qu'eux; eux-mèmes pétaloïdes, spatulés et obscurément glanduleux à leur sommet; les 5 alternes à peu près cylindriques, saillants à des degrés souvent inégaux, terminés par des anthères presque globuleuses que surmonte une petite glande sphérique. Style s'élevant à la hauteur des étamines, glabre, aminci à son sommet en un petit stigmate 2 -3-lobé. Ovaires 2-3, soudés ensemble, prolongés à leur sommet et au-delà de l'insertion du style en une corne velue, glabre; du reste, renfermant chacun 2 ovules collatéraux. Fruit composé de 2-3 coques, terminées par une corne.-On a décrit plus de 30 espéces de ce g. , toutes originaires du Cap de Bonne-Espérance, et plusieurs d'entre elles sont cultivées dans nos orangeries. Ce sont des arbrisseaux à feuilles alternes, petites, courtes et d'antant plus étroites, que les bords de leur limbe, ordinairement roulés en dessous, diminuent leur largeur en augmentant leur épaisseur, d'autres fois planes, entières ou bordées de petites dents glanduleuses, le plus souvent criblées de points transparents. Les fleurs, de couleur rongeâtre, lilas ou plus souvent encore blanches, sont rapprochées en têtes ou en ombelles á l'extrémité des rameaux. Leurs pédoncules 1-flores sont accompagnés á la base de bractées écailleuses, et offrent souvent en outre vers leur milieu 2 bractéoles alternes, très petites, sétacées.

(AD. J.)

*AGATHYRSE. Agathyrsus (àrasós, bon; oúpoos, thyrse). вот. PH. - G. de la famille des Composées, proposé par Don (Edinb.
N. Phil. Journ. vi), adopté et réuni all g. Mulgedium de Cassini. $V$. ce mot.

(C. L. )

AGATHYRSE. Agathyrsus ( $\alpha \gamma_{\alpha} \theta_{o} o_{s}$, bon ; oúpoos, thyrse). MolL. - Montfort a placé a la fin de ses coquilles polythalames un Vermet fossile que presque tous les auteurs, a l'exemple de Lamarck, ont rangé parmi les serpules. On a cru que, selon son habitude, Montfort avait voulu en imposer aux naturalistes en disant que son Agathyrse est cloisonné; mais Montfort est dans le vrai cette fois, nous nous en sommes assuré sur plusieurs exemplaires de la même esjuece, qui se trouve rarement à Grignon. Si Montfort y eût fait attention, il aurait reconnu que les cloisons de son Agathyrse n'ont rien de semblable á celles des véritables coquilles cloisonnées. Cette coquille appartient évidemment au g. Vermet dont toutes les esp. présentent des cloisons semblables. $V$. verMET.

(DESH.)

*AGATI ou AGATY, Rheed., Adans.(Nom hindou, usité sur la côte de Malabar pour désigner l'une des esp. du g.). вот. PII.-G. de la famille des Légumineuses, s.-ordre des Papilionacées, tribu des Lotées, s.-tribu des Galégées, DC.-M. Desvaux (Journ. de Bot. 3, p. 120) en a tracé les caract. comme il suit : Cal. campanulé, tronqué, à 5 den ts séparées par des sinus obtus. Etendard ovale-oblong. Ailes oblongues, débordant l'étendard. Carène rectiligne, dicéphale. Étam. diadelphes (9 et 1), peu saillantes. Androphore bi-auriculé à la base. Style filiforme, rectiligne. Légume substipité, linéaire, comprimé, submoniliforme, transversalement septulé (mais inarticulé), bivalve, polysperme. Graines comprimées, ovales, solitaires dans chaque compartiment.-Arbres. Feuilles abrupti-pennées, multi-foliolées. Stipules lancéolées. Grappes pauciflores, subsessiles. Fleurs très grandes. Les 2 esp. qui constituent ce $g$. habitent l'Asie équatoriale. Parmi toutes les Papilionacées connues, il n'en existe aucune qui puisse rivaliser avec $\ell^{\prime}$ Agati grandiflora, quant à l'ampleur des fleurs; la cor. de cette esp. a 4 à 5 pouces de long, sur 2 à 3 pouces de large; blanche au moment de l'épanouissement, elle passe successivement du jaune au rose et au pourpre. La dimension de la gousse est proportionnée à celle de la fleur; quoique à peine large d'un demi pouce, elle 
alteint de un pied et demi à 2 pieds de long. Les fleurs de l'Agali coccinea, sont moins grandes que celles de son congénère, mais d'une écarlate brillante. Les graines de l'une et de l'autre esp. sont comestibles, et se rapprochent des haricots par leur saveur.

(Sp.)

AGATI. вот. pH. - Synon. du g. $\not E s c h y-$ nomene.

AGATINE et non Agathine. Achatina ( $\alpha-$ $\chi \propto$ х́ns, agate). moLt. - C'est à Lamarck que l'on doit la création dı g. Agatine; admis dans presque toutes les méthodes, il a été placé dans le voisinage des Bulimes. Ayant eu occasion de faire à son sujet un assez grand nombre d'observations, nous pensons à présent que ce g. peut être supprimé sans inconvénient et rentrer dans le $\mathrm{g}$. Bulime. Nous appuyons notre opinion, sur ce que les animaux des Bulimes et des Agatines sont identiquement semblables, non seulement à l'extérieur, mais encore dans toutes les parties de l'organisation. A ce fait important, nous en ajoutons un autre qui a aussi quelque valeur; c'est qu'il existe un passage lout-à-fait insensible entre les $2 \mathrm{~g}$; à ce point qu'un assez grand nombre d'espéces peut indifiéremment être rapporté à l'un et à l'autre g. Nous discuterons plus en détail le g. Agatine au g. Bullme.

AGATRPSE. moli. $V$. Agathirse.

* MGATOLDE. Min.-Épithète qu'on ajou te au nom de certaines pierres qui ont quelque ressemblance d'aspect avec l'Agate, quoiqu'elles en différent par leur nature chimique. Tel est entre autres l'Adinole ou Pétrosilex rouge de Sahlberg en Suède. (DEL.)

AGAVE. Agave (áyavós, magnifique). вот. PIl. - G. de la famille des Amaryllidèes, oú il forme une petite tribu établie par Herbert (App.to the Bot.mag. 1821) sous le nom d'Agavec. Ce g. offre les caract. suivants: Ovaire infẻre. Cal. coloré, pétaloüde, à 6 divisions, infundibuliforme, portant 6 étam. saillantes, attachées à la partie supér. du tube. Le fruit est une capsule obovoïde, oblongue, couronnée par le limbe calicinal, à 3 loges contenant chacune un grand nombre de graines planes, disposées sur 2 rangs. - Les esp. de ce g. au nombre d'environ 15 , sont toules originaires de l'Amérique méridiomale. Ce sont de grandes plantes vivaces, à racine fibreuse, ayant le port des esp. du g.
Aloẻs, c'est-à-dire présentant des feuilles allongées, aiguës, très épaisses et succulentes, réunies cn rosette, et généralement une tige extrêmement courte. C'est du centre de ces feuilles que part une hampe florifère et dépourvue de feuilles.

Parmi les esp. de ce g., nous citerons particulièrement l'Agave d'Amérique (Agave americana L.), originaire de l'A mérique méridionale, mais aujourd'hui naturalisée et devenue presque indigène dans toute la région méditerranéenne. Elle y croît sur les rochers maritimes dans les endroits exposés au midi. On la cultive aussi pour en faire des haies de clôture autour deschamps ou autour des vignes dans les régions méridionales de l'Europe, en Espagne, en Portugal, dans le royaume de Naples et surtout en Sicile. Ses larges feuilles épineuses sur les bords, poussant par touffes très serrées et ayant quelquefois 7 à 5 pieds de longueur, forment des clòtures presque impénétrables. C'est du milieu de ces groupes de feuilles qu'on voit s'élever avec une étonnante rapidité, une hampe gigantesque qui, dans l'espace quelquefois d'une quinzaine de jours, acquiert jusqu'à 20 ou 25 pieds d'élévation. Les fleurs trés nombreuses sont d'un jaune sale. La floraison épuise tellement la plante qu'elle périt toujours après avoir développé sa hampe. - On retire des feuilles de cette plante, que l'on connaît sous les noms vulgaires de Pille ou d'Aloës, des filaments soyeux très solides, avec lesquels on fabrique des cordes et des étoffes. - Une $2^{\text {me }}$ esp. de ce $g$. non moins intéressante, c'est le Maguey des Mexicains, Agave cubensis Jacq. (Am. p. 100), qui croît au Mexique et dans l'île de Cuba. Elle ressemble beaucoup à la précédente, quoique plus petite dans toutes ses parties. Ses fleurs, d'un blanc jaunâtre, sont disposées en une sorte de paniculẹ lâche, et répandent une odeur très suave. Ses feuilles fournissent aussi des fibres très résistantes avec lesquelles on fait des cordes et des tissus. Les Mexicains retirent de cette plante une liqueur sucrée, qui fermente facilement et dont la saveur rappelle un peu celle du cidre. Pour l'obtenir on enléve les feuilles in tér. de la touffe, et par la cicatrice qui en résulte, s'écoule un Iiquide transparent, d'une saveur douce, qui, abandonnée à elle-même, fermente; mais qui, réduite par l'action du 
feu, fournit une grande quantilé de suere.

$$
\text { (A. R.) }
$$

AGAVÉES. Agavece (àr ruós, ń, magnifique). - вот. PI. - Tribu de la famille des Amaryllidacées (anomales), renfermant les seuls g. Agave, L. el Fourcroya, Vent. (C. L.)

AGAVON. вот. PI. - M. Bory (Dicl. cl.) dit qu'on nomme ainsi, dans quelques cantons méridionaux de la France, l'Ononide Arrête-Bouf, ou Bugrane (Ononis spinosa $\mathbf{L}$.).

(C. L.)

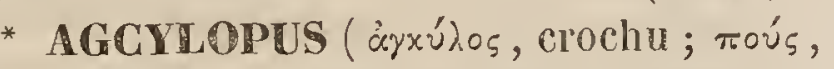
pied. Il aurait fallu écrire Ancylopus). INs. - G. de Coléoptères trimères, établi par M. Chevrolal el adoplé par M. Dejean , qui n'y rapporte qu'une espèce dans son dernier catalogue : l'Endomicus melanocephalus Oliv., de Sicile. Les caractères de ce g. n’ont pas encore été publiés.

AGDESTIS (Nom myth.), Moc. et Sess., DC. вот. PI. - G. incomplétenrent connu, que M. De Candolle rapporte, avec doute, à la famille des Ménispermées, et dont il donne les caract. suivants (Prodr. 1, p. 103): Fleurs hermaphrodiles, apétales. Sépales au nombre de 4. Etam. au nombre de 24. Anth. bifides aux 2 extrémités. Ovaire 4-sulqué, à 4 styles terminés chacun par un stigm. un peu réfléchi au sommel. - L'unique esp. sur laquelle se fonde ce g. est un arbuste indigène de la Nouvelle-Espagne, à fleurs roussâtres et semblables à celles de la $C l e ́-$ matite Flammule.

(Sp.)

AGE relatif des montagnes. GÉoL. $V$. MONTAGnes.

(C. D'O.)

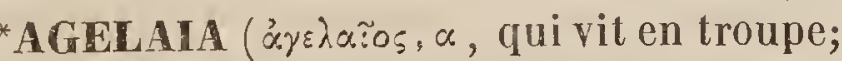
allusion à la manière de vivre de ces insectes ). 1ns. - G. de la famille des Polystides, St-Farg., ou Guêpiaires, Lat., de l'ordre des Hyménoptères, établi par M. Lepelletier de Saint-Fargeau (Hist. des Hym., Suites à Puff.), qui en a liré les principaux caractéres : $1^{\circ}$ Des ailes, dont la cellule radicale s'avance beaucoup plus près de l'extrémité que la $3^{\text {me }}$ cellule cubitale, dont la $2^{\text {me }}$ cellule cubitale est peu dilatée vers le disque, et la $3^{\text {me }}$ presque carrée; $2^{\circ}$ de l'abd. pédiculé. Ce pédicule est formé par le $1^{\text {er }}$ segment tout entier, qui est uni-tuberculé latéralement.On neconnaît encore de ce g. qu'une seule espèce (Agelaïa fuscicornis, Lep. St-Farg.) dont on ignore la patrie.

(BL.)

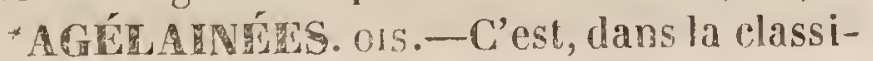
T. I. fication de Swainson, le nom d'une des s.familles de sa famille S'turnido. (L $\Lambda \mathrm{Fr}$.)

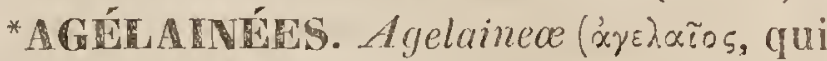
vit en troupe). o1s. - C'est une des s. familles de notre famille des Sturnidées. C'esi en grande parlie à M. Swainson que nous empruntons la formation de cetle s.-famille, que nous adoptons d'autant plus volontiers, qu'elle est fondée sur l'observation des mœurs el sur la forme des paltes. Tous les g. qui en font partic, sont essentiellement marcheurs, vivent en troupe et cherchent habiluellement, comme nos Étourneaux, leurnourriture à terre, sur les terrains découverts, souvent humides, tandis qu'une autre parlie de celte nombreuse famille, connue généralement sous les noms de Troupiales, Carouges, Cassiques, elc., ayant des pattes conformées différemment, présente des Oiseaux percheurs et sylvains, non marcheurs, ne vivant point habituellement en troupe. Ce nom d'Agélainées exprime donc un de ses principaux caractéres de mours, et n'est que l'application à une sous-famille, du nom générique Agelaius formé par Vieillot pour une partic des espéces qu'elle renferme. Ses caractères de forme sont : Becassez aliongé, épais à la base, entier, conique, quelquefois déprimé et arrondi à son extrémilé; l'arête supérieure assez mousse et aplatie à sa base; pieds longs, grêles et disposés pour la marche, les ongles étant longs, minces et peu courbés. - Celte s.famille renferme Jes g.: Stournelle, Vieill.; Troupiale, Vieill.; Dolichonyx, Swains.; Leïstes, Vig., et Molothrus, Swains. $V$. ces mots. (LAFr.)

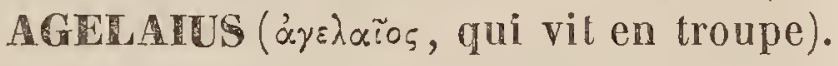
ors. - C'est, dans la Méthode de Vieillot, ung. appartenant à sa $15^{\mathrm{m} e}$ famille, celle des Tisserands, et répondant au g. Carouge (Xanthornus) de Cuvier. C'est pour nous le nom latin de notre g. Troupiale, faisant partie de notre s.-famille des Agélaünées. $V$. Trovpiale.

(LAFr.)

* AGELASTICA. (áyśliscrıxós, qui vit en troupe). Ins. - G. de Coléoptères tétramères, famille des Chrysomélines, établi par M. Chevrolat et adopté par M. Dejean (Catal. $3^{\mathrm{e}}$ édit.), qui y rapporte 3 espèces, dont une d'Europe (Galeruca Alni Fabr.), et 2 d'Amérique. Les caraclères de ce $g$. n'ont pas encore élé publiés.

(D.) 


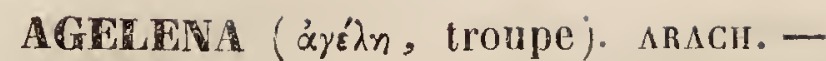
G. de l'ordre des Aranéides, établí par M. Walckenaer, et se distinguant des $T e-$ genaria par les caract. suivants : Yeux 8, presque égaux entre eux, occupant le devant du céphalo-thorax. Lévre grande, carrée, presque aussi large que haute. Mâchoires légèrement inclinées sur la lèvre, courtes et arrondies à leur extrémité. Pattes de longueur médiocre; la $4^{\text {me }}$ paire sensiblement plus longue que la $1^{\text {re }}$, laquelle surpasse la $2^{\text {me }}$; la $3^{\text {me }}$ est la plus courte. Ces A ranéides sont sédentaỉres; elles forment sur les buissons et les plantes, une toile grande, horizontale, à tissu serré, à la partie supér. de laquelle est un tube où elles se tiennent immobiles. Ceg. renferme 3 esp., dont la plus connue est l'. A . labyrinthica $\mathbf{L}$., gui se trouve assez communément aux environs de Paris.

* AGive. Agenes (á priv.; révos, race). те́в т т. - Syn. d'Agénosone. (I. G. ST-H.)

* AGENETENS. Agenii (á, priv.; $\gamma \varepsilon-$ vé́as, barbe). ols. - Ranzoni a donné ce nom à une famille de l'ordre des Oiseaux grimpeurs, comprenant ceux qui n'ont pas de soie à la base du bec. $\quad$ (C. D'O.)

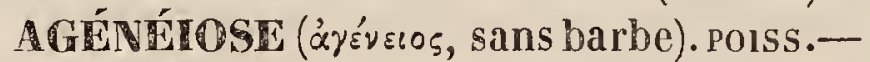
G. établi par Lacép., pour des Siluroïdes voisins des Pimélodes, qui n'ont pas de barbilions sous la mâchoire infér., et dont le maxillaire, suivant Bloch, ne se prolongerait pas en filet comme dans la plupart des Siluroïdes. Or, il faut remarquer que le filet maxillaire existe dans l'esp. que Bloch a désignée sous le nom de Silurus inermis (pl. 363); je l'ai vu moi-même sur l'individu conservé dans le cabinet de Berlin. Pour le Silurus militaris Bl. (pl. 362), le maxillaire denté se redresse en une sorte de corne sur la bouche, condition qui rentre dans celle des autres Siluroïdes. Ce g. a donc peu de valeur. Les deux esp. connues par Lacépède viennent des eaux douces d'Amérique. (VAL.)

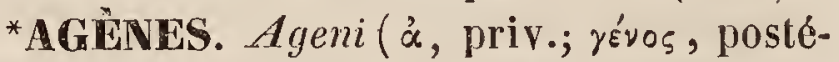
rité ). BOT. Cr. - Nom proposé par M. Lesliboudois pour désigner les végétaux cellulaires, à l'instar des épithètes d'Endogènes et d'Exogènes, créées par M. De Candolle pour remplacer celles de Monocotylédones et de Dycotylédones. Cette dénomination n'a pas été adoptée, parce qu'elle exprime une idée completement fausse; en effet, bien que l'acte de la récondation dans les végétaux cellulaires, soit encore un mystère pour les botanistes, il n'en est pas moins certain que ces végétaux émettent de véritables graines ( spores) capables de reproduire les mêmes individus.

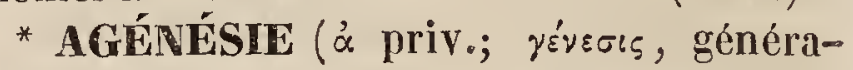
tion). TÉrat. - Synon. de Monstruosité par défaut.

(I. G. ST-H.)

*AGENIUM (áyร́vos, stérile). вот. PII. G. de la famille des Graminacées, tribu des Andropogonées, proposé par Nees von Esenbeck (Suppl. Fl. bras, ex Herb. Reg. Berl.) et qui n’a pas été adopté, parce qu'il ne diffère du g. Andropogon, L. (Sect. $A$. anatherum), auquel il est réuni, que par ses épillets subhomogames conformes. (C. L.)

* AGENIUS ('áśreıs, sans barbe). ins. - G. de Coléoptères pentamères, famille des Lamellicornes, tribu des Scarabéides, division des Mélitephiles, établi dans l'Encyclopédie par MM. I. Peletier de Saint-Fargeau et Serville, aux dépens du g. Trichius, Fabr., et dont les caractères sont: Mandibules membraneuses. Écusson en triangle curviligne, à peine plus long que large. Tarses postérieur's aussi longs que les jambes, ou guère plus longs qu'elles. Jambes antérieures tridentées au côté externe. Menton nu. Dernier article des palpes un peu dilaté extérieurement. - Ce g., le même que le g. Campulipus, Kirb., a pour type la Melolontha limbata Olỉv.; ou T'vichius limbatus Schoenh., auquel se réunissent 2 autres espèces, savoir : l'A. erythroptertis Dej., ou rufipennis Gory et Perch., et le flai ipenis de ces derniers auteurs, esp. que M. Dejean rapporte au g. Stripsifer. Ces 3 espèces sont du cap de Bonne-Espérance.

* AgÉNOR (Agénor, roi des Phéniciens; Myth.; árńves, vaillant). CRUST. - M. Audouin et moi, avons désigné sous ce nom un g. de Crustacés qui appartient à l'ordre des Décapodes, famille des Oxy rhinques, et dont les.caractères, encore inédits, doivent paraître incessamment dans l'ouvrage que publie M. Alcide d'Orbigny, sur les animaux qu'il a recweillis pendant son voyage dans l'Amérique méridionale. (H. L.)

* AGENORA (Agénor. Myth.; áníncos, brave, fier). вот. PII. - G. de la famille des 
Composées - Cíchoracées, proposé par Don (Edinb. phil. Jour. 1829), non adopté et réuni au g. Seriola, I. $V$. ce mot,

(C. L.)

*agenoria (Agenor. $V$. la Myth.; árńvws, fier, brave). вот. PIr. - Selon Lindley (Nat.Syst. Bot. Edit. 11, app.), ce g., de la famille des Asclépiadacées, proposé par M. De Candolle, doit être réuni au g. Apteranthes de Mikan ( N.A.N.C. xv11. 544, t. 41). A l'article Stapelia nous discuterons cette opinion. $Y$.ce mot.

(C. L.)

*AGTÓnOSOVE, Agenosoma (á priv.; $\gamma$ ś-

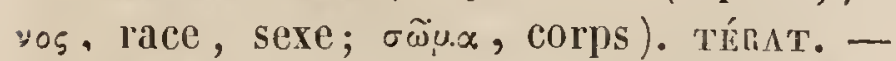
G. de Monstres unitaires, appartenant à la famille des Célosomiens. (I.-G. ST-II.)

* AGÉRATÉES (úgríporos, qui ne vieillit pas). вот. гн.- Une des divisions de la tribu des Eupatoriées, de la famille des Composées, caractérisée par des fruits surmontés d'une aigrette paléacée, formée de squamelles membraneuses ou rigides, distinctes, ou plus ou moins soudées entre elles. $V$. Ageratum.

$$
\text { (J. D.) }
$$

AGERATUM (áńparos, qui ne vieillit pas). воT.PI. - Ce nom, qui semble avoir été donné, dans le principe, par Dioscoride, à une esp. d'Immortelle, fut appliqué par Linné à des plantes originaires de l'Amérique, et appartenant à la tribu des Eupatoriées de la famille des Composées. Leurs caract. sont : Invol. formé de plusieurs folioles étroites, aigües, imbriquées. Réceptacle nu, portant des fleurs à 5 divisions. Branches du style terminées par des appendices cylindracés, obtus. Fruits à 5 angles légèrement atténués à la base, surmontés d'une aigrette paléacée, formée par 5-10 écailles libres, plus ou moins aiguës, quelque fois même atténuées en pointe. - On compte dans ce g. environ 10 esp., toutes d'origine américaine; l'une d'elles, l'A. conyzoüdes, se rencontre néanmoins dans presque toutes les parties équinoxiales des deux continents. On cultive depuis jeu d'années, comme plante annuelle d'ornement, l' $A$. coruleum ou mexicanum.

AGERIA, Adans. (áyńpws, qui ne vieillit pas). bot. Pll. - Synonyme du g. Prinos, L.; MI. De Candolle donne ce nom à une sect. des Prinos, caractérisée par des corolles 6-fides, et des feuilles non persistantes.

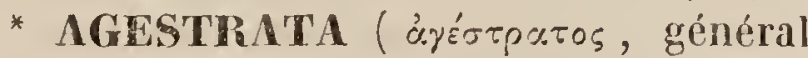
d'armée). ins. - G. de Colćoptéres pen- tamères, famille des Lamellicornes, tribu des Scarabéides mélitophiles, s.-tribu des Gymnétides, établi par Fschscholtz, et adopté par M. Dejean (Catal. $3^{\circ}$ édiı.), ainsi que par MM. Gory et Percheron ( Monogr. des Cét.), qui lui donnent pour principaux caractères : Chaperon carré. Mâchoire à lobe terminal bidenté. Antennes beaucoup plus longues que la tête. Corselet recouvrant presque tout l'écusson.-Ils en décrivent et figurent 3 espéces, dont 2 de Java el une de la Chine. Nous citerons seulement cette dernière, qui est la Celonia chinensis Oliv., ou nigrita Fabr.; elle est, comme les 2 autres, d'un vert cuivreux très brillant, mais avec les pattes et le chaperon d'un rouge cuivreux.

(D.).

AGGLOMÉRAT OU CONGLOMERRAT, Agglomeratio. Géor. - Expression générale qui sert à désigner toute roche visiblement composée de débris d'inégales dimensions et de diverses textures, accumulés sans ordre; les Poudingues, les Brèches, les Pépérino sont des Agglomérats. On peut également donner ce nomà beaucoup de Calcaires coquilliers grossiers, aux faluns solides, etc. Lorsque les débris de roches et de fossiles ont été finement triturés, et qu'ils ont été distribués en raison de leur volume, de manière à composer des masses homogènes plus ou moins terreuses et grenues, cellesci prennent les noms de Grès et de Sédiments proprement dits. $V$. ces mots et AGRÉGATION.

(C. P.)

\section{AGGRÉGÉS. ZOOL. - $V$. AgrégÉS.}

AGHIPLNES. polss. - M. Rafinesque a donné ce nom au $1^{\text {er }}$ ordre de sa $1^{\text {re }}$ sousclasse des Pommiodi. Il y place le seulg. Symphurus, établi par lui pour un Pleuronecte, nommé en Sicile Linguatidda, et qui est voisin de la Pégouse (Monochirus Pegusa, Risso ); mais qui en differe par la position des yeux. Ils sont á drcite lans la Pégouse, et M. Rafinesque les indique à gauche pour le Symphurus. $V$. ce mot. (VAL.)

AGLES. Agiles. мnм. - Nom donné par Illiger à la $9^{\text {me }}$ famille du $4^{\text {me }}$ ordre des Mammiféres. Cette famille élait composée de Rongeurs qui appartiennent aujourd'hui à 2 familles différentes, celle des Siciuriens et celle des Muriens. $V$. ces mots.

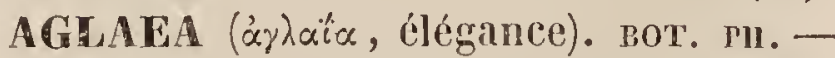
G. de la famille des Iridacées, fondé par 
Persoon (Ench., 1.46), el rémni par les auteurs an g. Diasia, DC. (V. ce mot. (C. L.)

* AGRA (áriaía, beaulé). ors. - G. formé par M. Swainson, aux dépens de celui de Tanagra (Tangara, Vieillot, Cuv.), et dont les caractéres sont: Taille petite; bec court, trigone à sa base, menu, échancré à sa pointe, garni à sa base de petites plumes frontales serrées, un peu lérissées, recouvrant plus ou moins les narines; ailes assez allongées, la $1^{\text {re }}$, et quelquefois les $21^{\text {res }}$ rémiges un peu plus conrtes que les suivantes; queue courte, terminée carrément; pieds en général petits; le doigt interne plus court que l'externe; ongles élevés et trés arqués. On reconnaît sans peine, a cette forme de pattes, des oiseaux sylvains, essentiellement percheurs; aussi les espèces qui composent ce g. particulier au Nouveau-Monde, se tiennent-elles habituellement dans ses forêts tropicales et sur la cime des arbres. Elles sont remarquables mar la vivacité et la variété des couleurs de leur plumage qui reflète souvent des teintes dorées el métalliques. Les espèces les plus connues sont les Aglaïa septicolor, uricolor, à tête bleue, etc.

Les Euphones; qui en ont toujours élé distinguées génériquement, s'y lient si étroitement par des espéces intermédiaires, qu'ils devraient peut-être n'en formerqu'une section. $V$. EUPHONES.

(LAFR.)

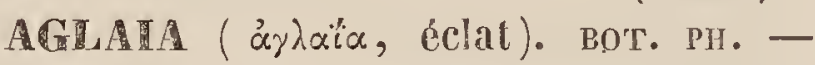
Nom de l'une des 3 Grâces, donné par loureiro a un arbre que son port élégant et ses fleurs parfumées font cultiver dans les jardins des riches de la Chine. On le retrouve dans Rumph, sous le nom de Camunium, mais confondu génériquement avec un arbre appartenant à une autre famille. Plus récemment, M. Blume a fait connaître 5 autres espèces d'Aglaz̈a, toutes de Java. Le g. ainsi composé, et classé parmi les Aurantiacées par M. De Candolle, se place mieux auprés des Méliacées, ei offre les caractères suivants : Calice 5-denté ou 5-parti. Pétales 5 , connivents, disposćs en quinconce. Étamines 5, dont les filets élargis se soudent en un urcéole entier ou 5-denté, dans lequel sont cachées les anthères. Stigmate presque sessile, obtus. Ovaire a mae seule loge, et à 2 ovules qui ne se développent pas dans beaconp de neurs mâ- les ainsipar avortement. Fruil charnu, presque sec. Graines dépourvues d'arille et de périsperme. Embryon à colylédons très épais.Les Aglä̈a sont des arbres, ou plus rarement des arbrisseaux à feuilles pennées, dans lesquelles les folioles sont opposées par paires avec une impaire terminale, á panicules axillaires. Soavent les rameaux, les feuilles et les inflorescences sont couvertes de petites écailles brillantes. Les pétales, ordinairement distincts, se soudent entre eux assez rarement. (AD. J.)

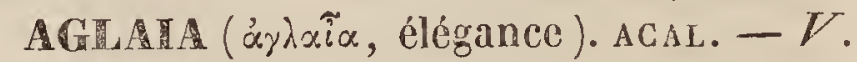
AGLAISMA .

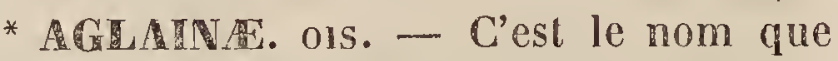
Swainson donne vers la fin du $2^{\text {me }}$ vol. de sa classif. à la s.-famille qu'il nomme au commencement $A$ gelaïnce. Nous ne nous rendons pas compte de ce changement que nous n'avons pas adopté.

(LAFR.)

* ATEAIS. (áyiciós, orné ). ins. - G. de Lépidoptères Diurnes, créé par Dalman, et qui a pour type la $V^{\top}$ anessa Urticce, vulgairement la Petite Tortue. $V$. vanesse. (D.)

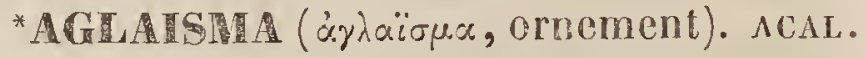
- G. de Diphyides, établi d'abord par Eschscholtz en 1825, sous le nom d'Aglaüa, puis en 1829, sous la dénomiuation actuelle pour éviter un double emploi. Ses caract. sont d'avoir: Un conduit nourricier ou suçoir unique, et une petite cavité natatoire dans l'intérieur de la partie du corps servant à la nutrition. Il ne contient qu'une esp., l'A. Baeri (Isis, 1825. - S'ystem. der Akal.1829, p. 129), trouvéc dans l'Océan atlantique entre les tropiques. (Duj.)

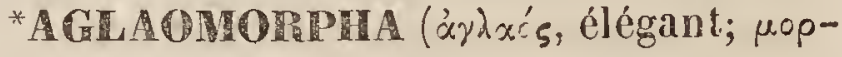
$\varphi$ ń, forme). вот. CR.-Division du g. Polypodium, proposée par Schott et caractérisée par des veines fourchues, à embranchements monosores, combinés au sommet. Ce g. n'a pas encore été adopté.

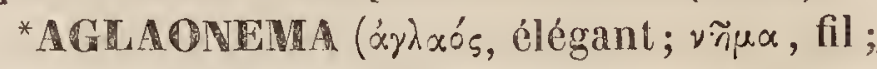
par extension étamine). Вот. PH.-G. de la famille des Aroïdées, tribu des Anaporécs Sch., s.-tr. des Richardiées, id., fondé par Schoti (IlIeleth.) sur l'Arum integrifolinm de Link (Ag.integ Sch.; Ag. simplex Bl.), et dont voici les caractères essentiels : Spathe entrouverte, se fermant ensuite. Spadice androgyne, sansinterruption. Etam. rudimentaires, mêlées aux ovaires; appendice stirile nul. Antheres nombreuses, libres, sessiles, 4-lo- 
culaires; logettes opposées par paires, déhiscentes par un pore situé au-dessous du sommet, immergées au moyen d'un connectif cunéiforme, dilaté supérieurement en un disque ondulé. Ovaires nombreux, libres, uni-loculaires. Ovule unique, basilaire, anatrope. Stigmate sessile, largement discoïde. Baies uni-loculaires, monospermes (graine inconnue). - Ce g. renferme 2 ou 3 espéces. Ce sont des plantes subligneuses, dressées, à feuilles oblongues, nervées, dont les pétioles sont vaginants jusque près du sommet; à pédoncules très courts, à spathe blanchâtre. On cultive au Muséum de Paris les A. simplex et marantcefolia, décrites et figurées dans la Rhumphia de M. Blume ( $p l$. 65-66). Elles habitent l'Archipel malais et les Moluques. (C. L.)

AGLAOPE (Nom d'une Sirène de l'Océan. Mythol.). CRust. - M. Rafinesque désigne sous ce nom un g. de Crustacés qui appartiendrait à l'ordre des Décapodes macroures, mais qui n'a pas été caractérisé d'une manière assez complète pour pouvoir prendre place dans une méthode naturelle. (H.L.)

AGLAOPE (Nom d'une sirène. Myth.). 1vs. - G. de l'ordre des Lépidoptères, famille des Crépusculaires, tribu des Zygénides, établi par Latreille aux dépens du g. Procris de Fabricius, et que nous avons adopté (Catal. méth. des Lépid. d'Europe), en lui donnant les caractères suivants : Tête plus étroite que le corselet. Yeux assez saillants. Palpes très petits, séparés et n'atteignant pas jusqu'au chaperon, ayant le dernier article plus grêle et presque nu. Trompe nulle. Antennes bi-pectinées dans les 2 sexes. Corselet avec' un collier très distinct, et les épaulettes très petites et peu adhérentes. Abdomen ne dépassant pas les ailes inférieures. Les 4 ailes à angles arrondis, presque d'égale grandeur, et beaucoup plus larges que dans les autres Zygénides.-Chenilles courtes, ramassées, garnies de petits bouquets de poils implantés sur des tubercules. Chrysalides renfermées dans une coque ovoïde d'un tissu très serré. Ce g. ne renferme qu'une espèce, l' $A$. infausta L., qui habite la partie centrale et méridionale de l'Europe. Elle parait en juin et juillet. Sa chenille est un fléau pour les Amandiers dans le midi de la France.

Dalman, dans son trayail sur les Lépidop- lères de la Snède, qui n'a paru qu'en 1816, a aussi créé un g. Aglaope qui répond au g. Procris de Fabricius.

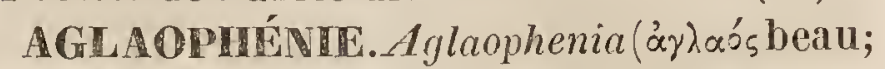
paiva, anémone). Polyp. - G. de la famille des Sertulariées, établi par Lamouroux pour des animaux analogues à ceux des Sertulaires, mais produisant un Polypier corné, dont les cellules axillaires sont toutes disposées d'un seul côté des rameaux; ce qui lui donne l'apparence d'une plume à barbes lâches, comme l'indique le nom de Plımularia, antérieurement donné par Lamarck à ce mème g., et qui doit être conservé. $V$. ce mot.

(Dus.)

AGLADE (Aglaure, Myth.; 'ajiavpós, á, beau ). ANNél. - G. établi par Savigny (Syst. des Annélid., in-folio, p. 54). 11 appartient à la famille des Euniciens, et à la tribu des Euniciens abranches (Aud. et Milne Edw., Rech. pour servir à l'hist. nat. du Litt. de la Fr., t. 11, p. 131). La tête cachée sous le fer anneau du corps, le nombre et la disposition des mâchoires distinguent les Aglaures des Lysidices et des Lombrinères , et l'existénce d'antennes ne permet pas de les confondre avec les OEnones. On peut les caractériser de la manière suivante: Tête cachée sous le $1^{\text {er }}$ segment du corns, qui est bilobé. Antennes presque rudimentaires. Bouche armée de mâchoires, 5 d'un côté, 4 de l'autre, et d'une esp. de lèvre sternale formée de 2 pièces cornées.-La seule esp. connue, l'A. fulgida (Voyage en Égypt., Annél. pl. v, fig. 2), longue de 10 pouces, a le corps formé de 253 anneaux. Elle a été trouvée à Suez. Cuvier, en aroptant cette désignation générique, en a complètement changé la signification; car il a réuni sous le nom d'Aglaure (Règ. an. $2^{\text {me }}$ édit., t. II, p. 201), les Aglaures et les OEnones de Savigny, avec quelques autres espèces. Il les définit de la manière suivante : Dorsibranches voisins des Eunices par leur trompe fortement armee, mais dont les branchies sont réduites à leurs cirrhes, et qui manquent de tentacules. (L. D.Y.R.)

AGLAURA (Aglaure, Myth.; áyiavpós, á, beau). AcAL. - G. établi par Oken, pour une espéce de Rataire ( $V$. ce mot), sous le nom d'Aglaura crista.

(Dus.)

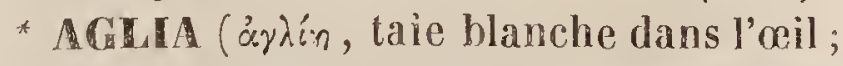
allusion a une tache blanche occupant lecen 
tre d'une autre plus grande, et en forme d'oil, qui existe sur chacune des 4 ailes de l'Insecte ). ıns. - G. de l'ordre des Lépidoptères, famille des Nocturnes, établi par Ochsenheimer et adopté par M. Boisduval, qui, dans son Index methodicus, le place dans sa tribu des Endromides; mais aucun de ces 2 auteurs n'en a donné les caractères. Il est fondé sur une seule espèce, le Bombyx Tau de Fabricius, qui se trouve dans une grande partie de l'Europe, et principalement dans les forêts plantées de Hêtres. Ce Bombyx est figuré dans l'Histoire naturelle des Lépidoptères de France, t. 1v, p. 73, pl. 6, fig. 1-3.

AGLOSSE. Aglossa ( $\ddot{\alpha} \gamma \lambda \omega \sigma \sigma \circ 5$, sans langue; par exlension, sans trompe ). Ins. G. de l'ordre des Lépidoptères, famille des Nocturnes, établi par Latreille aux dépens des Crambes de Fabricius, et que nous avons adopté en le plaçant dans notre tribu des Pyralites. Voici les caractères que nous lui assignons : Palpes inférieurs un peu plus longs que la tête; Jeur $2^{\text {me }}$ article presque aussi large que long, en forme de losange; le $3^{\text {me }}$ subuliforme. Trompe nulle, ou seulement rudimentaire. Antennes ciliées chez le mâle. Oviducte de la femelle térébriforme. Chenille a peau luisante et coriace. Chrysalide contenue dans un tissu de soie blanche, el recouvert de débris des substances environnantes. - Ce g. ne renferme que 2 espèces, dont les chenilles, par leur peau glabre et coriace, ressemblent à des larves de Coléoptères carnassiers; aussi se nourrissent-elles, comme celles-ci, de substances animales, au lieu de vivre de végétaux comme les autres chenilles. Degéer a donné une histoire détaillée de la $1^{\text {re }}$, qu'il a confondue mal à propos avec la $2^{\mathrm{me}}$, décrite par Réaumur. L'une est l'Aglosse de la graisse (Crombus pinguis Fabr.), dont la chenille se nourrit principalement de beurre et de lard, el qui, d'après Linné, pénètre quelquefois dans les inlestins de l'homme; l'autre est l'A. cuivrée (Pyr. cuprealis Hubn.), dont Ricaumur a décrit la chenille sous le nom de Fausse-Teigne des cuirs, parce que les premiers individus qu'il en trouva, s'étaient établis sur quelques livres qu'il avait oubliés à la campagne, en avaient rongé la couverture el s'étaient construit, comme les Fausses-Teignes de la cire (Galleria cerella), un long tuyau altaché à cette couverture, et composé presque en totalité de leurs excréments. Mais il trouva, depuis, des chenilles de la même espèce, logées également dans des tuyaux semblables, sous l'écorce de vieux ormes, où elles n'avaient pour se nourrir que des débris d'insectes morts. Ainsi, il paraît qu'elles vivent aux dépens de toutes les substances animales desséchées, tandis que celle de l' $A$. pinguinalis ne vit que de substances grasses, telles que le beurre, le lard, la graisse, etc. D'après leur manière de vivre, les Aglosses ne se trouvent guère que dans l'intérieur des cuisines et des offices tenus malproprement.

AGMAR. Porss. - M. Ruppel indique ce nom pour la dénomination vulgaire du Diacope coccinea à Djedda.(Ruppel, $A t l .75$.

(VAL.)

* AGMENELLUM (Agmen, bataillon). вот. CR. - G. de la tribu des Pleurococcoïdées, famille des Phycéées, que nous avions proposé en lui assignant les caractères suivants : Corpuscules globuleux ou ovoïdes, rapprochés dans un ordre quaternaire (16, 32, 64 et au-delà), formant une lame muqueuse; accroissement par duplication des corpuscules. - L'algue microscopique qui a donné lieu à ce g., (Agmenellum quadruplicaıum Bréb., seule espèce qui nous soit connue jusqu'à ce jour), se trouve dans les eaux douces de l'Europe, parmi les Conferves et les Diatomées; c'est le Gonium iranquillum d'Ehrenberg. Elle se rapproche effectivement beaucoup du g. Gonium; mais elle est toujours sans mouvement. M. Meneghini l'a réunie aux Trochiscia, et a, en même temps, décrit une seconde espèce qui n'est peutêtre que celle-ci, au moment de son accroissement, qui a lieu par division transversale (déduplication) des corpuscules présentant alors une forme hémisphérique ou demi-ovoïde.-Le mode d'accroissement des Pleurococcoïdées et la disposition de leurs corpuscules ne nous permettent pas de les réunir aux Desmidiées dont le g. Trochiscia fait partie. Il est probable que le g. Agmenellım devra être réuni au g. Gonidium, récemment proposé par M. Ehrenberg et qui renfermera alors 4 ou 5 espèces. (Вве́в.)

ACNATHES. Agnatha ( $\alpha$, priv.; yvá00s, mâchoire). ıns. - M. Duméril (Considér. 
génér. s. les Ins.) emploie cette dénomination comme nom de fam. pour désigner les Éphémères et les Phryganiens qui ont, en effet, les organes de la bouche rudimentaires.

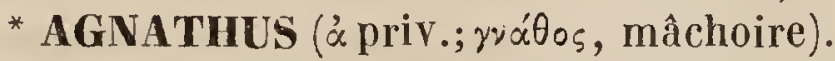
ıxs. - G. de Coléoptères hétéromères, famille des Trachélides, établi par Germar aux dépens du g. Notoxus Fabr., dans sa Faune des Ins. d'Europe; mais sans indication de caractères. Il le fonde sur une seule espéce , dont il donne la figure dans cette Faune (Fasc.12.tab. 4), et qu'il nomme $A$. decorauus. M. Dejean a adopté ce g. dans son dernier Catalogue.

* AGNE, Reichenb. (‘்yń, fém. d'àyrós, chaste; il aurait fallu écrire Hagne). вот. PH.-M. Reichenbach (Conspect. p. 157) désigne sous ce nom un g. (ou s.-g.) à créer aux dépens des Mimosa, dont il diffère par le légume comprimé et moniliforme. Ce g. correspond à la $1^{\text {re }}$ section (Eumimosa) des Mimosa de M. De Candolle (Prodr. 2, p.425), qui en signale 16 esp., toutes indigénes de l’Amérique équatoriale.

AGNEAU D'ISRAEL. MAM. - Nom sous lequel on a quelquefois désigné une esp. de Daman.

(C. D'O.)

agneaU. Agnus. mam. - Nom du petit de la brebis domestique et du bélier.

(C. D’O.)

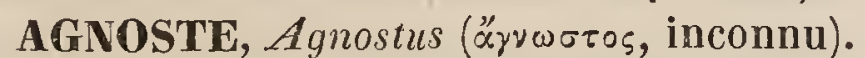
crust. - G. de l’ordre des Trilobites, créé par M. Al. Brongniart, et dont le seul caract. de l'espéce unique qui compose ce g. est la division trilobaire de son corps. L'espèce type de ce g. est I'Asaphus piriformis, Al. Brongn. Elle se trouve en très grande quantité à Heltris, en Suède, dans un calcaire sublamellaire, noirâtre et fétide. (H.L.)

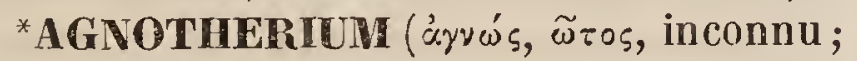
Snpiov, animal). MaM. Foss. - Nom donné par M. Kaup à un nouveau g. de Carnassiers fossiles, qui se rapproche du chien et qui pourrait être celui que M. Lartet a nommé Amphicyon. $V$. ce mot.

(L. D.)

AGON ou AGONE, des Italiens. porss. Nom vulgaire d'une espéce de Clupéoïdes, voisin de l'Alose, et que Lacépède a fait connaître sous le nom de Clupée finte. $V$. ce mot.

(VAL.)

AGONATES. Agonata (áyóvoros, non géniculé). crust. - C'est un nom qui a été employé par Fabricius, dans les premières éditions de ses ouvrages (Entom. Syst.édit. 1793), pour désigner une classe d'animaux articulés qui comprenait les g. : Crabe, $P_{a-}$ gure, Galathé, Hippe, Scyllare, Ecrevisse, Limule, Monocle, Cymothoë, Squille et Chevrelle. Depuis (Entom. Syst. supp.), il a distribué ces animaux en 3 ordres : les $P_{0-}$ lygonates, les Kleistagnathes et les Fxochnates. Ces 3 ordres répondent à peu près à la classe des Crustacés.

* AGONES. Agonce (’’ priv., yó rn, articulation, noud). ACEr. - Ce nom a été employé par Walckenaër pour désigner un petit groupe du g. Dysdera, lequel est ainsi caractérisé : Yeux de la ligne antérieure peu gros; lévre échancrée à son extrémité; mâchoires divergentes et pointues à leur extrémité ; mandib. divisées en avant. Ce groupe renferme 2 esp. qui habitent indistinctement l'Europe et l'Afrique. (H. L.)

*AGONhONEURUS (áyẃvios, sans angles; ขรืบpos, nervure. Allusion aux ailes de ces insectes qui n'ont qu'une seule nervure sans ramifications.) ins. - G. de la famille des Chalcidiens, de l'ordre des Hyménoptères, établi par M. Westwood (Lond. Mag.) sur une esp. d'Angleterre qui rentre parfaitement dans le g. Aphelinus de Dalmann. $V$. ce mot.

(BL.)

*AGONIS, DC. (sub-Leptospermo). вот PH. - G. de la famille des Myrtacées, voisin des Leplospermum, dont il diffère notamment par la disposition des fleurs, qui, au lieu d'être solitaires et éparses, sont agrégées en capitules; la capsule (4-5-loculaire dans les Leptospermum) est 3-loculaire. - Ce g., propre à la Nouvelle-Hollande, ne renferme que 3 espéces; on les cultive comme arbrisseaux d'ornement. (SP.)

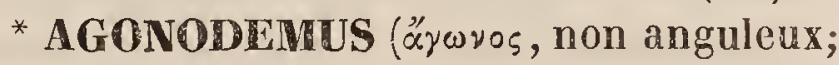
$\delta \varepsilon \dot{\varepsilon} \mu \alpha_{\zeta}$, corps ). Ins. - G. de l'ordre des Coléoptères pentamères, famille des Carabiques, tribu des Féroniens, établi par M. le baron de Chaudoir aux dépens du g. Feronia de Latreille, et auquel il donne les caractères suivants : $1^{\text {er }}$ article des antennes plus long que le $3^{\mathrm{me}}$. Pattes médiocres. Labre bien avancé. $4^{\text {me }}$ article des antennes presque cylindrique. - Il y comprend 2 espéces, le Platysma picimanum, Creutz., et le Graüum, Bonelli.

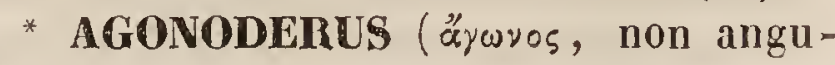


leux ; dépn, cou ). Ins. - G. de Coléoptères pentamères, famille des Carabiques, tribu des Harpaliens, établi par M. Dejean dans son Species général, et auquel il donne les caractères suivants: Les 4 premiers articles des 4 tarses antérieurs très légèrement dilatés dans les mâles, triangulaires et cordiformes. Dernier article des palpes très légèrement ovalaire, presque cylindrique et tronqué à l'extrémité. Antennes filiformes et assez courtes. Lèvre supérieure en carré moins long que large. Mandibules jeu avancées, assez arquées et peu aiguës; point de dent au milieu de l'échancrure du menton. Corps assez allongé et presque cylindrique. Tête presque triangulaire, non rétrécie postérieurement. Corselet ovalaire ou carré, dont les angles sont arrondis. Élytres assez allongées et presque parallèles. - Les Insectes qui composent ce g. ont presque la forme du Stenolophus vaporariorum; mais ils s'en éloignent beaucoup par les caractères génériques, qui les rapprochent plutôt des Daptus. M. Dejean (Catal., $3^{\text {me édit.) en }}$ mentionne 3 espèces, toutes de l'Amérique septentrionale. Nous ne citerons que l'A. lineola ou Carabus $i d$. Fabr., qui a servi de type au genre.

*AGONOSOMA (áywos, non anguleux; $\sigma \widetilde{\omega} \mu \alpha$, corps). ins. - M. Laporte applique cette dénomination à un s.-genre de la famille des Scutellériens (ordre des Hémiptères) dont le type est une espèce des Indes orientales, qu'il désigne sous le nom de Aflavo-lineaturn. Les caract. qu'il assigne à ce g. n'étant pas appréciables, il n'a été adopté par aucun Entomologiste. Le docteur Burmeister (Hand. der Ent.) le réunit au g. Trigonosona Burm. et nous (Hist. des Anim. artic.) au g. Tetyra, Fab. $V$. ces mots. (BL.)

* AGONOSTOMEL (" $/ \gamma \omega \%$ s, non anguleux;

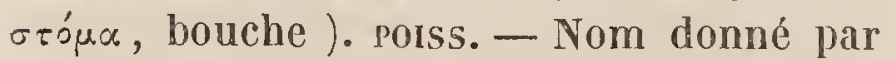
M. Bennett à un poisson que ce savant zoologiste a regardé comme voisin des Muges, et a vec lesquels il a les plus grandes affinités, mais dont le museau est un peu avancé, la bouche en dessous, et les deux mâchoires garnies de petites dents sur plusieurs rangées. M. Bennett en indique une seule esp., des eaux de l'ile de France, et qu'il a dédiée à sir Charles 'Telfair, président de la Société d'Histoire naturelle de l'lle de France, et donatcur de ce poisson au cabinel de la So- ciété zoologique de I.ondres. L'A. Telfairii est noirâtre en dessus et brunâtre à reflets argeníes ell dessous. ( $V$. Bennett, Proceed. of Zool. Soc. of London, $1^{\text {re }}$ part., p. 166.) Ce g. me paraît très voisin des $N$ estis; mais l'auteur, qui le caractérise trop brièvement, ne mentionne pas de dents au palais ni au vomer. Faute de ces renseignements, je n'ai pu en parler dans l'Histoire des Poissons.

(VAL.)

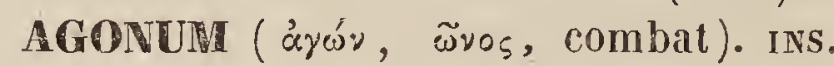
- G. de Coléoptéres pentamères, famille des Carabiques, établi par Bonelli et adopté par M. Dejean, qui, dans son Species général, le place dans la tribu des Féroniens, en lui assignant les caractères suivants : Les 3 premiers articles des tarses antérieurs di-latés dans les mâles, plus longs que larges, et légèrement triangulaires ou cordiformes. Dernier article des palpes allongé, cylindrique, plus ou moins ovalaire, et tronqué à l'extrémité. Antennes filiformes et assez allongées. Lèvre supérieure légèrement convexe, en carré moins long que large, et presque transversale. Mandibules peu avancées, légèrement arquées et assez aigües. Une dent simple au milieu de l'échancrure du menton. Corselet plus ou moins arrondi ; point d'angles postérieurs marqués. Élytres en ovale plus ou moins allongé. - Les Agones ont de si grands rapports avec les $A n-$ chomènes, que, d'après $\mathbf{M}$. Dejean, il serait peut-être convenable de les réunir. Tous ceux que l'on connaît sont des Insectes audessous de la taille moyenne. Leur démarche est assez agile, leur couleur est souvent métallique et très brillante, ou noire, et rarement brune ou variée. On les trouve ordinairement dans les endroits humides et aux bords des eaux, courant sur la vase, ou sous les picrres et les débris de végétaux. M. Dejean (Catal. $3^{\text {me }}$ édit.) en mentionne 61 espèces, dont le plus grand nombre est d'Europe; les autres sont de la Sibérie, de l'Amérique septentrionale et du nord de l'Afrique. Nous ne citerons que l' $A$. marginaum, Fabr., qui se trouve aux environs de Paris, et qui est figurẻ dans Olivier ainsi que dans l'Iconog. des Coléopt. d'Eur. (D.)

AGONUS ( «'wavos, non anguleux). polss. - Nom latin d'un g. de poisson foudé par Bloch en 1801, dans son Système posthume, pour des espèces rangées par Linné dans 
le g. des Cottes. Lacépède établissait de son còté le même g. sous le nom d'Aspidophore, que nous avons adopté comme dénomination française, dans notre Ichthyologie. $V$. ce mot.

(VAL.)

* AGORES. Agorce (arópalos, grossier). ARACI.-Walckenaër a employé ce nom pour désigner un petit groupe du g. Dysdera. Les caract. qu'il lui assigne sont : Yeux de la ligne antér. les plus gros; mâchoires arrondies à leur extrémité. Côtés intér. parallèles et non divergents; maridib. inclinées perpendiculairement. Les esp. que renferment ce groupe habitent l'Europe et l'Amérique.

(H. L.)

AGOSERIS (corruption d'Egoseris, a'

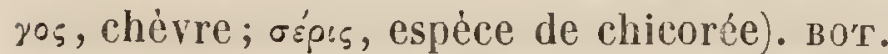
PIl. - Suivant M. De Candolle, ce g., établi par Rafinesque, serait synonyme du Troximon de Gaertner.

AgOUTI, Aguii ou Cavia, L. ; Dasyprocta, Ill. Mam. - G. de l'ordre des Rongeurs, famille des Caviens. Ces jolis animaux, de la taille et presque de la forme de nos Lapins, en diffẻrent par une tête plus arquée, plus comprimée; des conques auditives courtes, presque nues; un corps plus étroit vers les épaules, plus développé en arrière; ils sont aussi remarquables par leurs poils droits, roides et cassants, généralement de couleur noire à la base, jaune à la pointe, ce qui donne à quelques espèces un aspect verdâtre. Leurs caract. génériques sont : Brièveté des conques auditives; état rudimentaire de la queue; 3 doigts aux pieds postérieurs, de forme palmée; structure compliquée des dents molaires. L'émail exécute, en effet, dans la substance osseuse, des plissements nombreux et variés qui ne permettent pas de confondre les Agoutis avec les Cobayes et les Kérodons , qui partagent avec eux les autres caractères.

L'Amérique méridionale, les Antilles, et même le Mexique, sont la patrie des Agoutis. Ils représentent là nos lièvres et nos lapins, autant par leurs allures et leurs mours que par la qualité de leur chair, recherchée comme un excellent gibier. Ils vivent dans les hois, se nourrissent d'écorces et de fruits, et ne se creusent pas de terriers; ils se retirent dans des troncs d'arbres creux. On les élève facilement en captivité; ils vivent alors dans nos climats, mais ne perdent jamais complétement leur natırel craintif. Le Muséum d'hist. nat. de Paris en a possédé et en possède encore, qui s'accouplent souvent, mais ne se reproduisent que très rarement. L.e nombre de leurs pelits est ordinairement peu considérable: il est de deux seulement selon Buffon et Azara, de quatre à cinq s'il faut en croire Laborde. On assure que ces animaux se défendent bien, qu'ils mordent cruellement quand on les touche; il est certain qu'ils manifestent leur colère, soit en grognant, soit en hérissant leurspoils au point de les faire tomber, comme il arrive aux piquants du porc-épic. Les espèces de ce g. sont au nombre de trois : $1^{\circ}$ L'Agout proprement dit (Cavia Aguti des auteurs linnéens; Dasyprocta Acuti, Ill., Desm.; Buffon, t. vılı, pl. 50 ; Azara, t. II, p. 26 ); le jaune domine sur son pelage, et lui donne un aspect verdâtre. C'est ce qui avait fait donner à ce g. entier, par Fréd. Cuvier, le nom trop restreint de Chloromys (rat verdâtre). $2 \circ \mathrm{L}$ 'AKoucuI (Dasyprocta Acuschy, Desm.; Buft., S'uppl., t. Ill, pl. 36 ; Schreb, pl. 171, B), de couleur brune, tiquetée de fauve, les poils du dos formant un manteau plus foncé. La queue est un peu plus longue que celle du précédent. 3० L'Agout muppé (Dasyprocta cristata Geoff. St.-H., Ménag. du Muséum, pl. 3, 5e livraison), établi par M.Geofroy Saint-Hilaire ; de couleur très foncée ; dessus de la tête, col et pattes tout-à-fait noirs. Lorsqu'il.est irrité, il relève les poils de sa nuque et de son cou comme une sorte de crinière.

Le Cavia ruvestris, rapporté par quelques auteurs aux Agoutis, appartient au g. kéRODON, et l'Agouti patagonien au g. DOLIсноті. $V$.ces mots. (A. Antelme.)

*AGRA ( ärpa, proie ). ıns. - G. de Coléoptẻres pentamères, famille des Carabiques, établi par Fabricius et adopté par Latreille, ainsi que par M. Dejean qui le place dans sa tribu des Troncatipennes, en lui assignant les caractères suivants : Crochets des tarses dentelés en dessous. Dernier article des palpes labiaux très fortement sécuriforme. Les 3 premiers articles des tarses plus ou moins larges, triangulaires ou cordiformes; le pénultiène bilobé. Corps allongé et étroit. Tête ovale, très rétrécie postérieurement, et tenant au corselet par un col courl, dont elle est séparće par un 
étranglement très marqué. Corselet allongé, plus ou moins cylindrique et plus ou moins rétréci antérieurement.-Ce g. se distingue facilement de tous ceux de la même famille, parsa forme allongée, quilui donne une certaine ressemblance avec quelques espéces de Brentes. Il ne renferme que des espéces exotiques, toutes des régions intertropicales de l'Amérique. Le dernier Catalogue de M. Dejean en mentionne 13 seulement; mais Klug en a décrit 35. Nous ne citerons que l'A. cenea Fabr., qui se trouve à Cayenne. Celte esp. a été figurée par Olivier sous le nom de Carabus cayernensis, dans son ouvrage intilulé : Annales pour servir à la connaissance des Insectes, particulièrement de ceux du Musée de Berlin (pl. 12, no 1. tab.1, fig. 133).

AGTAM. вот. PH.-Selon M. Bory (Dict. $c l$.), ce mot est le synonyme vulgaire du Chiendent, dans quelques cantons de la France. $V$. ce mot.

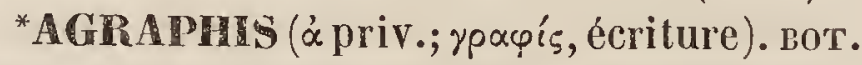
PH. - G. de la famille des Liliacées, tribu des Asphodélées, s.-tribu des Hyacinthées, Endl., fondé par Link (Handb. III, 166) aux dépens des g. Hyacinthus et S'cilla de Linné, et dont les caract. sont ainsi établis par l'auteur: Périgone corollacé, 6-parti, à divis. campanulé-conniventes, étalées et réfléchies au sommet. Étam.-6, insérées vers la partie moyenne des divisions périgoniales, à filaments adné-décurrents, les alternes subexserts, souvent plus longs. Ovaire triloculaire. Ovules nombreux, bi-sériés, horizontaux, anatropes. Style trigone, droit ; stigmate papilleux, obtusément trigone. Capsule à peu près trigone, membraneuse, 3-loculaire, loculicide-déhiscente par le sommet. Semences peu nombreuses, subglobuleuses, à test crustacé, noir, à ombilic nu. Embryon axile, à extrémité radiculaire atteignant l'ombilic. - Ce g. comprend un petit nombre de plantes bulbeuses, propres à l'Europe australe et au Cap de B.-Espérance, à fleurs penchées, disposées en un épi simple et terminal, dont les pédicules sont bibractéés.

(C. L.)

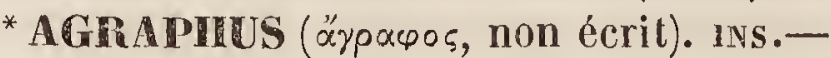
G. de l'ordre des Coléoptères tétramères, famille des Curculionides, division des Ottiorynchides, élabli par Schonherr, qui lui donne pour caractères : Antennes peu lon- gues, peu fortes; leur funicule composé de 6 articles subcylindriques, avec la massue briévement obovale, presque ronde, composée d'articles très étroitement unis. Rostre épais au sommet; fossette courte e! profonde. Yeux arrondis, saillants. Écusson petit, triangulaire. Elytres grandes, obovales, convexes. Tarses longs, étroits, soyeux, non spongieux en dessous. - Ce g., adopté par M. Dejean (Catal. $3^{\text {me }}$ édit.), ne comprend qu'une esp. nommée par lui $A$. leıcophous; elle est de l'Amérique boréale.

(D.)

AGRASSOL (grossulus, basse lat., petite figne). вот. PII. - On lit dans le Dict. classique, que telle est, dans quelques cantons du midi de la France, la dénomination vulgaire du Groseillier à maquereau. $V$. Ribes. (C. L.)

AGRAULE. Agraulus (äjpaviór, ruslique). вот. PI. - Palissot de Beauvois a proposé d'établir sous ce nom, un g. de la famille des Graminées pour les esp. du g. Agrostis, qui, ayant la valve supér. très courte ou presque nulle, ont la glume terminée par une arête. Telles sont entre autres les Agrostis canina et $A$. alpina; mais Trinius en a fait une simple section dans le grand g. Agrostis, et le professeur Kunth n'a même pas distingué ces esp. comme un groupe à part. $V$. AGRostide. (A. R.)

* AGRAULIS (áypaviós, qui vit dans les bois, les champs). INs. - G. de l'ordre des Lépidoptères, famille des Diurnes, section des Tétrapodes, créé par M. Boisduval aux dépens des Céthosies de Fabricius, et des Argynnes de Latreille, et qu'il place dans la tribu des Nymphalides. Ce g., dont il n'a pas encore publié les caractéres, comprend les Argynnes exotiques, à ailes oblongues, qui vivent sur les Passiflores, comme les Héliconies, et dont la forme rappelle celle des Acrées, qui du reste en sont très rapprochées, quoique d'une autre tribu. Telles sont les A. Vanillox, Dido, Julia et Pherusa, figurées dans Cramer.

AGRAULUS. bot. Ph. $-V$. Agraule. (C. L.)

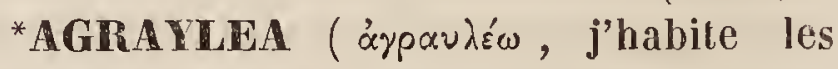
champs). ıns. - G. de la famille des Phryganiens, de l'ordre des Névroptères, détaché des Hydroptila de Dalmann par Curtis (Desc. some nond. Br. sp. of M. B. of an\%. 
extr. Lond. and Edinb. phil. Mag.). II ne diffère de ces derniers que par la présence d'une épine de plus aux jambes intermédiaires. Les esp. qu'il renferme sont peu nombreuses, loutes indigènes et de très petite taille; telles sont les $A$. tineoüdes (Hydroptila tineoüdes, Dalm.), sparsu, vectis, costalis, Curt., etc.

(BL.)

AGREFOUS ou AGRIROUS. вот. Рн.Synonyme vulgaire du Houx dans quelques cantons du midi de la France. Ce mot paraît être une corruption d'Agrifolium où d'Aquifolium, dénominations que les ancierı Botanistes appliquaient à cet arbre. Linné a imposé la dernière comme nom spécifique au Houx commun. $V$. ILEX et AQuifolium.

AGRÉGATION (Aggregatio, amas). GÉOL. - Juxta-position des particules minérales ou de fragments de corps organisés fossiles liés entre eux, par la cohésion ou au moyen d'un ciment plus ou moins apparent. Quelques géologues ne considèrent comme roche d'agrégation, que celles qui sont visiblement composées par voie mécanique de divers débris de masses minérales préexistantes, et ils désignent sous le nom de Roches de cristallisation les agrégations de cristaux simultanément formés. $\mathscr{V}$. RocHe et DÉSAGRÉCATION.

(C. P.)

AGRÉGATS (Aggregatio, amas). GÉoL. - Résultat de l'agrégation. $V$. ce mot et ROCHE.

(C. P.)

AGPÉGÉEs. Aggregato. - Se dit $1^{\circ} \mathrm{en}$ Géologie, des roches dont tous les individus composants sont formés sur place, par voie de cristallisation sans ciment intermédiaire (ex. le Granite); $2^{\circ}$ en botanique, de tous les organes (fleurs, fruits, feuilles, etc.) qui, naissant d'un même point, ou ayant une insertion très rapprochée, sont disposés par paquets ou capitules. Quelques anciens Botanistes donnaient aussi ce nom à la farnille des Synanthérées, etplus récemment M. Bartling (Ord. Nal.) imposa cette même dénomination à une classe qui renferme des plantes de cette catégorie; ex. : les Plantaginées, les Dipsacées, etc.

$$
\text { (C. D'O.) }
$$

AGRÉGÉS. Aggregati. zool. - Nom donné, $1^{\circ}$ par Illiger à un groupe d'oiseaux marcheurs, comprenant ceux qui vivent habituellement en troupes; $2^{\circ}$ par Cuvier à une famille de sa classe des Acéphales, composée de Mollusques réunis en une masse commune.

(C. D'O. $^{\prime} \mathrm{O}$

AGRENAS. вот. pH. - M. Bory rapporte (Dicl. cl.) que les Provencaux donnent ce nom au prunier sauvage, dont ils appellent aussi les fruits Agreno.

(C. L.)

AGRETA. вот. PH.-Telle est, selon M.Bory (Dict. cl.), la dénomination vulgaire du Rumex scutalus L., dans le midi de la France. Ce mot paraît être une corruplion d'Aigrelet. $V$. Oseille.

(C. L.)

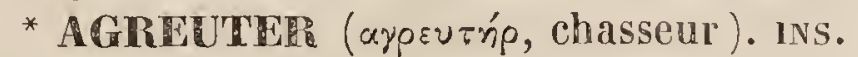
-G. de Coléoptères pentamères, famille des Carabiques,trib.des Patellimanes établi dans l'Eucyclopédie par MM. Lepelletier de StFargeau et Serville, aux dépens du g. Chlonius de Bonelli, dont il ne diffère que par le labre fortement échancré et les mandibules avancées, étroites et presque droites. Ce g., non adopté par M. Dejean, a pour type le Chloenius chlorodius de Mégerle.

AGRIA. INS. $V$. AgRiE.

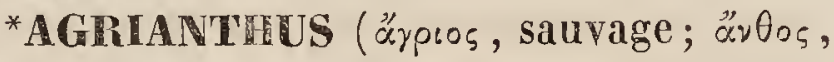
fleur). вот. PII.-M. Martius a donné ce nom à quelques plantes du Brésil, appartenant à la famille des Composées, tribu des Eupatoriées. M. De Candolle caractérise ce g. de la manière suivante : Capit. renfermant environ 20 fleurs; invo . composé de 1 ou 2 rangées d'écailles presque égales entre elles, linéaires, acuminées ; récept. nu ; corolles cylindracées à 5 dents; les branches des styles longues, arrondies, obtuses. I.es fruits à 5 angles aigus et scabres, présentent une aréole basilaire; ils sont couronnés par une aigrette plus courte que la corolle, et formée par une rangée de squamelles inégales, linéaireslancéolées, acuminées, rigides, fortement ciliées.-Le g. Agriandlius renferme 3 esp., originaires du Brésil. Ce sont des arbrisseaux rameux, glabres, couverts de feuilles alternes, presque imbriquées, roides, linéaireslancéolées ou acérées. Les capitules naissent sessiles à l'aisselle des feuilles supérieures, ou disposées en une sorte de corymbe assez dense. Ceg., suivant M. De Candolle, est intermédiaire entre les Agératées el les Adénostylées.

(J. D.)

AGRICOLA (qui habite les champs). вот. - PH. - G. de la famille des Verbénacées, tribu des Lantanées, fondé par Schrank (in Regensb. denksch.; 1808), et réuni depuis par 
les auteurs aug. Clerodendron de R. Brown. $V$. ce mot.

(C. I.)

* AGTIDEs. Agridoe (äypros, sauvage). INs. - Section établie par M. RobincauDesvoidy, et correspondant à une portion du g. Senomelopia, Macq., de l'ordre des Diptères. $V$. ce mot.

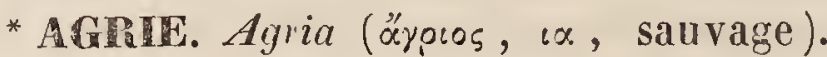
Ins. - G. de l'ordre des Diptères, division des Brachocères, subdivision des Dichætes, tribu des Muscides, section des Créophiles, s.-tribu des Sarcophagiens, formé par M. Macquart de quelques esp. du g. Sarcopluaga de Meigen, et présentant les caractères suivants : Front large chez les femelles. Antennes peu allongées; $3^{\text {me }}$ article large, style brièvement velu. Abdomen non déprimé chez la femelle. Point de soies distinctes au bord du $2^{\text {me }}$ segment. Ailes ordinairement assez courtes; nervure externomédiaire peu arquée après le coude. - Ce g., dont M. Robineau-Desvoidy a fait, sous le nom de Muscides foricola, une section de sa tribu des Muscides, et qui contient quelques espèces du g. Musca de Fallen, renferme une douzaine d'espèces, toutes européennes. Nous n'en citerons qu'une seule, l'A. affiris de Meigen, qui se trouve en France et en Suède.

AGRTEOUS. BOT. PII. - $V$. AgREFOUS.

* AGRILITES. Agrilitoe (dimin. d'Agrilus). 1xs. - MM. Delaporte et Gory, dans leur Iconographie des Coléoptères, désignent ainsi un groupe de Buprestides, qui se composent de $10 \mathrm{~g}$. dont les noms suivent : Castalia, Pocilonota, Zemina, Stenogaster, Eurybia, Agrilus, Pseudagrilus, Amorphosoma, Eumerus et Corobus. Ils assignent pour caract. commun à tous ces g., d'avoir les crochets des tarses avec une dent. (D.)

MGILOBHINUS (Rien dans la langue grecque ne répondant à ce mot, exprimant bec crochu, selon $\mathbb{M}$. Bonaparte; nous pensons quill y a eu méprise dans la manière dont on l'a orthographié el qu'il faudrait l'écrire $A n$ cylorinus, de áyxúlos, crochu et ṕí, เv०s, bec). o1s. - G. formé par M. C.-L. Bonaparte sur Ine petite espèce du Mexique, de l'ordre des Passereaux de Cuvier, et synonyme de notre g. Serrirostrum (Synops.desOis.d'Am. par d'Orb. et de Jafr., Mag. de Guérin, $1838)$. C'est au commencement de 1838 que nous publiàmes ce g., et c'est vers le milieu ou la fin de la même année que le prince de Musignano publia le sien, dans le.3me rasc. des Nouv. Annal. des Sc. natur. de Florence. Nous avons donc la priorité de la publication, et dés lors, nous ne pouvons renoncer au nom générique que nous lui avions imposé. Nous le formâmes sur 2 eșpéces rapportées cie Bolivie, par M. d'Orbigny; esp. que nous nommâmes Serrirostrum carbonarium et Silloides. M. Bonaparte a formé le sien sur une espèce du Mexique, qu'il nomme $A$. Sittaceus, et que nous avons publiée nous-même dans la Revue zoologique $\left(18.99, \mathrm{n}^{\circ} 4\right)$, sous le nom d'Uncirostrum Brelayi. N'ayant point alors connaissance de la publication de M. Bonaparte, et ayant cru devoir changer notre nom de Serrirostre en celui d'Uncirostre, comme exprimant mieux la forme tonte particulière du bec des espèces de ce g., lout en conservant notre nom générique, comme aniérieur, nous renonçons au nom spécifique de Brelayi pour l'esp. mexicaine, et adoptons celui de S'ittaceus, de M. Bonaparte, qui est antérieur au nôtre. Les caract. de ce g. tout-à-fait remarquable, sont: Bec assez haut, comprimé dans le genre de celui des Sittines; mand. supér. un peu concave à sa base, puis parfaitemeui rectiligne, et terminée par un crochet très long, très aigu, comme chez les Oiseaux de proie; ses bords munis de 3 petries dents immédiatement avant ce crochet; mand. in fér. beaucoup plus courte, ne s'étendant que jusqu'au point où commence la courbure de la supérieure, s'y trouvant en contact avec les petites dents, recourbée en haut, comme dans les Sittines, et très aigüe; langue bifide et soyeuse, comme chez les Guitguits, entre autres le Guitguil flaveola; ailes, queue et pieds conformés comme les leurs; le dessous du pouce épaté en forme de petite palette ovale. - M. Bonaparte, guidé sans doute par la forme du bec et surtout par la coloration du plumage, pense que ce g. nouveau appartient à la famille des Certhidées, et à la s.-famille des Sittinées, quoique se rapprochant beaucoup des Sylvicolinées, de la famille des Turdidées.

Quant à nous, la forme de la langue, que nous avons eu l'avantage de pouvoir obseryer, celle des différentes parties exté- 
rieures, et, bien plus encore, les communications que nous fit M. A. d'Orbigny sur les mœurs de ces oiseaux, lors de notre travail de collaboration, ne nous ont laissé aucun doute sur leur analogie avec les Guitguits d'Amérique, leurs compatriotes, el nous ont décidé à former du g. Guitguit ( $C_{0}-$ reba), une petite famille, sous le nom de Carébidées, se subdivisant en Caéébidées à bec arqué, el en Ccerébidées à bec en croc; c'est dans cette dernière section que nous plaçons notre g. Serrirostre, ou plutòt $U_{n-}$ cirostre, renfermant aujourd'hui à notre connaissance trois espèces, les Uncirostres charbonnier el Sittoüle (d'Orb. et de Lafr., Synopsis de Bolivie), et l'Uncirostre sittacé, Bonap., du Mexique. La forme des pieds, entièrement conformes à ceux des Guitguits, n'a point de rapport avec ceux des Siltines ou des Sitelles; ces oiseaux s'en servent comme les premiers, pour se cramponner aux fleurs des arbres, et en extraire le pollen ainsi que les petits insectes qu'elles recèlent, et dont ils se nourrissent.

L'intérêt que présente ce nouveau genre par la conformation lonte particulière de son bec, et le long délai qu’eût entrainé sa publication à la lettre $U$, dans ce Diclionnaire, nous a engagé à faire connaître nos observations sur ce sujet à l'article Agrilorhiuus, son synonyme.

(LAFr.)

* AGPILUS (äypıos, rustique) ins. - G. de Coléoptères pentamères, famille des Sternoxes, tribu des Buprestides, établi par Mégerle el adopté par M. Solier dans sa Nionographie de cette tribu, ainsi que par M. Dejean dans son dernier Catalogue. En voici les caractères d'après M. Lacordaire ( $F$ aune entom. des environs de Paris, t. I.) : $1^{\mathrm{er}}$ article des palpes maxillaires de grandeur variable; le $2^{\text {me }}$ court, obconique; le dernier ovalaire, plus long que le précédent. Labre étroit, presque carré, coupé carrément à sa partie antérieure. Mandibules très courtes, très épaisses, arquées el obtuses à leur extrémité. Menton plus ou moins avancé, triangulaire ou trapézoïdal, souvent caché par le prosternum. Yeux médiocres, peu convexes et très écartés sur le vertex. Antennes assez grêles, comprimées, moins longues-que le prothorax; les $31^{\mathrm{ers}}$ articles peu allongés, obconiques et de grandeur relative variab!e; les suivants subtriangulaires, courts, assez fortement dilatés à leur angle supérieuriuterne, diminuant graduellement de longueur. Front plus on moins canaliculé; épistome légèrement échancré à sa partie antérieure. Prothorax plus ou moins transversal, de la largeur des élytres el trilobé à sa base; prosternum, qui tantôt laisse le menton à découverl, tantôt le recouvre entièrement, aiusi que les palpes. Écusson triangulaire, transversal à sa base et acuminé postérieurement. Élytres très allongées, plus ou moins sinuées vers le milieu de leur longueur, dentées en scie ou simples à leur extrémilé. Patles médiocres, grêles; tarses courts et étroits; le $1^{\text {er }}$ article des postérieurs de la longueur des autres, ou seulement un peu plus long; une forte dent aux crochets des tarses près de leur extrémité. Pénultième segment abdominal entier dans les 2 sexes.Corps très allongé, trèsétroil, quelquefois arqué en dessus. - Ce g., ren'fermant un grand nombre d'espèces (M. Dejean [Catal. $3^{\text {me }} e ́ d i t$. $]$ en mentionne 106) a été divisé en 2 sections : La 1 re comprend celles dont le prosternum, tronqué antérieurement, laisse le menton á découvert; exemple: A. undatus (Elater id. Fabr.), qui se trouve quelquefois en août aux environs de Paris. La $2^{\text {me }}$ se compose des espèces dont le prosternum recouvre entièrement le menton, et se subdiv. en 2 autres, savoir : celles dont le prosternum est coupé carrément à sa partie antérieure; exemple: $A$. Guerini Dej.. qui se trouve vers le milieu de juin, sur le saule Marceau, mais rarement; celles dont le prosternum est échancré antérieurement, exemple : A. biguttatus Fabr., Richardà points blancs de Geofroy, qui se trouve en juin el juillet dans la forêt de Saint-Germain. Les Agrilus sont des insectes de moyenne taille, de forme allongée et plus ou moins cylindrique; la plupart d'un vert ou bleu métallique, ou couleur de bronze très brillant. Ils ne se montrent que lorsqu'il fait très chaud.

AGRTIMONA. BOT. PH. - $V$. AIGREMOINE. (Sp.)

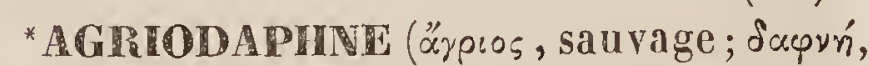
laurier). вот. pII. - G. de la famille des Laurinées, proposé par Nees (Laur., 304), et qui n'a pas été adopté. On ne le regarde que comme une div. du g. Oreodaphne du même anteur. $V$. ce mot. 
AGIBIODENDRON ( $\alpha_{\text {yp }} 0_{5}$, cruel, farou-

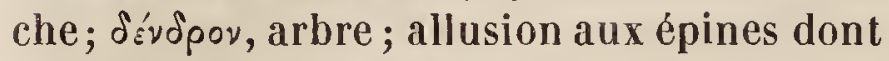
sont hérissées les feuilles). вот. Рн. - G. de la famille des Liliacées, tribu des Aloïnées, formé par Haworth de quelques espèces d'Aloës, et qui n'a pas été adopté. $V$. Rhipinodendron et Aloes.

AGRION (æxypıs, agreste, farouche). ins. -G. appartenant à l'ordre des Névroptères, fam. des Libelluliens ou Subulicornes, Lat., groupe des Libellulites, établi par Fabricius et adopté par Latreille et tous les entomologistes modernes, confondu avec les Libellula par Linné, Geofiroy, de Géer, Olivier, etc., séparć en plusieurs autres g. par MM. Leach et Brullé. Les caract. qui distinguent ce $g$. des Libeltula et des $\mathscr{E}$ shna sont faciles à saisir : Le corps est plus grêle, la tête est dépourvue de vésicule ou d'élévation transversale, et les ocelles sont disposés en triangle sur le vertex. Les ant. sont composées seulement de 4 articles; la lévre infér. est assez semblable à celle des $\not$ shna ; mais le lobe intermédiaire est divisé en deux jusqu'à sa base; les mâchoires ont leur côté intér. pourvu de 3 petites épines fort aigües; l'abd. est filiforme et toujours fort mince. Les larves et les nymphes d'Agrions vivent dans l'eau et sont au moins aussi carnassières qúe celles des Libellula et des $\mathbb{E}$ shna. Leur corps est plus grêle et plus allongé quie celui de ces derniers; leur masque est aplati ; leur languette est bifide, et leur abd. porte à son extrémité 3 feuillets minces en forme de nageoires. - Le g. Agrion renferme un grand nombre d'esp. réparties dans toutes les contrées du monde; mais la plupart des esp. exotiques sont encore inédites. On en connaît une vingtaine propres à notre pays, dont plusieurs ne le cèdent pas en beauté aux esp. exotiques. En général, les Agrions joignent à la plus grande agilité, aux formes les plus sveltes, les couleurs les plus belles et les plus éclatantes; ce qui Jeur a valu le nom vulgaire de Demoiselles, qu'ils partagent a vec les Libellules et les Eshnes. L'esp. que l'on doit considérer comme le type du g. est l'Ayrion virgo Fab. (Libellula virgo Linn.) répandu dans presque toute l'Europe, et qui se trouve pendant la belle saison dans les endroits marécageux.

* $\mathbf{G H}$ IOPE. Agriopus (áyptestós, qui a le regard farouche). poIss. - G. établi par
MM. Cuvier et Valenciennes (Ichihyol. génér.) pour des Poissons de l'hémisphère austral, dont une seule espèce, originaire du Cap, était connue depuis long-temps; mais avaitété placée très arbitrairement, par Walbaum, dans le g. des Blennies, quoique les ventrales soient soutenues par 6 rayons. Les Agriopes sont des poissons à bouche très petite, presque sans dents; à nuque relevée ; à tête rugueuse, surtout sur les sous-orbitaires; ả dorsale longue et élevée, étendue depuis le sommet de la tête jusqu'à la queue. On n'en connaît que 3 espèces, l'une du Cap, le Seepaard des Holiandais, Agriopus lorvus Cuv., et Val.; une $2^{\text {me }}$, rugueuse, des mêmes côres ; et la $3^{\mathrm{me}} \mathrm{du}$ Pérou.

(VAL.)

*AGPIOPHYLLE. Agriophyllum, Marsch.,

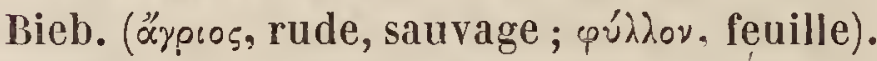
вот. Pн. - G. de la famille des Chénopodées, voisin des Corispermum, dont il diffère par des feuilles et des braclées spinescentes; par des fleurs disposćes en épis axillaires, et tout-a-fait dépourvues de périgone; par un péricarpe membranacé , déhiscent postérieurement, au moyen d'une ouverture basilaire orbiculaire; enfin par l'embryon, lequel, au lieu d'être complétement annulaire, ne décrit qu'un demicercle autour du périsperme. - Ce g. n'est fondé que sur une seule espéce (Corispermum squarrosum, L.), qui habite la Crimée et les landes voisines du Caucase.

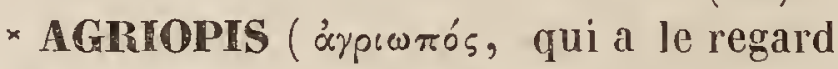
farouche). INs.-Gr. de Lépidoptères, famille des Nocturnes, tribu des Hadénides, établi par M. Boisduval aux dépens des Miselia d'Ochsenheimer, et qu'il caractérise ainsi (Genera el Index Lepidopt.): Antennes un peu épaisses, légèrement crénelées. Palpes de la largeur du front, à dernier article grêle. Corselet quadrangulaire, velu. Dos crêté dans les 2 sexes. Ailes robustes, variées de noir et de vert, à taches ordinaires bien écrites. - Ce g. est fondé sur la $N o c t$. aprilina de Linné, qu'on trouve aux environs de Paris.

*AGTIORNIS ("xpros, sauvage, farouche; opvis, oiseau). oIs. - G. de Gould que nous adoptons comme s.-g. de notre g. Pepoaza el répondant à notre sect. des Pepoaza rectirostris (d'Orb. et de Lafr. Synopsis; Mag. de 
Zool. 1837). C'est en 1839 que Gould a publié ce g. dans la relation intitulée The zool. of the voy. of H.S.M. Beagle under the conımand of captain Fitzory. Il cite entre autres espèces, son' $A$. guturalis d'après notre Pepoaza gutturalis, Synops. L.C. (Tyramus gutturalis Eyd. et Gerv., Favor. Ois. Pl. 11) et son $A$. leucurus, qu'il n'a pas reconnu être notre $P$. maritima, Synops. p. 65. $V$. Peponza.

(LAFR.)

* AGRIOTES (äpros, agreste). Ins. G. de l'ordre des Coléoptères pentamères, famille des Sternoxes, tribu des Élatérides, établi par Eschscholtz, et dont voici les caractéres : Dernier article des palpes maxillaires et labiaux légérement sécuriformes. Labre avancé, transversal, légèrement arrondi et coupé carrément. Antennes de grandeur variable, le plus souvent composées d'articles obconiques et toujours faiblement en scie, munies ordinairement d'un faux article peu distinct à leur extrémité; le $1^{\mathrm{er}}$ article renflé, le $2^{\text {me }}$ et souvent le $3^{\text {me }}$ obconiques. Tête inclinée, arrondie antérieurement, sans carène frontale, avec la bouche située plus ou moins en dessous. Prothorax plus ou moins trapézoïde, sans rainures pectorales. Élytres arrondies à leur extrémité. Pattes médiocres; les hanches postérieures assez fortement dilatées à leur côté interne, tantôt subitement, tantòt insensiblement; articles des tarses subcylindriques, presque glabres en dessous, tous entiers; leurs crochets simples. - Ce g. figure dans le dernier Catal. de M. Dejean, qui y rapporte 17 espéces, dont plus de moilié appartient à l'Europe, et les autres à l'Amérique. Toutes ces espèces sont, en général, de petite taille, rarement de moyenne grandeur. Nous cilerons d'abord comme type : l'Elater pilosus Fabr., et ensuite l'E. sputalor du même auteur, qui se trouve, comme le $1^{\mathrm{er}}$, aux environs de Paris; et, chose assez curieuse, il a été rapporté de la Perse occidentale par Faldermann, qui, le croyant nouveau, l'avait nommé $A$. lapicida.

*AGRIOTYPUS (Agrion, g. d'insectes:

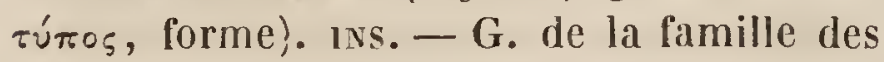
Ichneumoniens, de l'ordre des Hyménoptẻres, établi par Walker, qui en a tiré les principaux caractères de l'écusson présentant une large épine, et de l'abrl. épais et ovalaire, avec ses $2^{\text {me }}$ et $3^{\text {me }}$ segments réu- nis, et son pédoncule long, grêlé et reeourbé. Ce g. a été formé sur une seule esp., indigène, décrite par Walker sous le nom d'A. armatus.

(BL.)

AGRIPAUME. вот. PII. - $V$. LÉONURE, (Sp.)

AGRIPENNE ou Ortolan de riz, Buff.; (Emberiza oryzivora L.). oIs. - C'est l'espéce type du g. Dolichonyx Sw., que nous adoptons. $V$. Dolichonyx. (LAFr.)

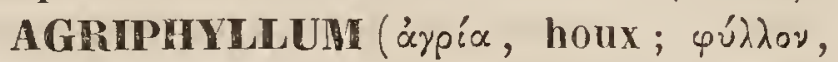
feuille). вот. PH. - A. L. de Jussieu a donné ce nom à un g. appartenant à la famille des Composées, considéré aujourd'hui comme une section du Berckheya. Celle-ci se distingue par son involucre à folioles à peine cohérentes à la base, denticulées sur les bords; les extérieures foliacées, les intérieures scarieuses. Ce sont des arbrisseaux on des herbes garnies' de feuilles dentées, èpineuses, assez semblables à celles du houx, quelquefois blanches en dessous; les fleurs sont jaunes. Tous sont originaires de l'Afrique australe. (J. D.)

AGRIPH YLLUM. BoT. PH. - Synon. du g. Rohria. $V$. ce mot.

(C. L.)

*AGROBa TRS (áypobátns, qui erre dans les champs). ors.-G. formé par Swainson, faisant partie de sa fam. des $\boldsymbol{S}$ ybliadoe et de sa s.-famille des Philomelince, et ayant pour type le Bec-fin Galactole (Temm. col. 251, 1). Pour Temminck, cet oiseau n'est qu'un Becfin de sa section des Becs - fins sylvains (Man., 3me part., p. 129), où il change son nom en celui de Bec-fin rubigineux. Les caraetères de forme, indiqués par Swaiuson, diffẻrent peu de ceux des grandes especes de Becs-fins sylvains, tels que le Rossignol et autres, et les derniers renseignements fournis par Temminck (Man., $3^{\text {me }}$ part.), se bornent à nous apprendre que cette espèce, commune en Andalousie, s'y tient dans les vallées montueuses, oú elle niche dans les buissons de Laurier-rose et dans les fentes des rochers. Aussi ne voyons-nous pas de motifs suffisants pour admettre ce nouveau g., qui supposerait à cet oiseau des habitudes toutes marcheuses, dont nous n'avons eneore aucune eonnaissance.

(LAFr.)

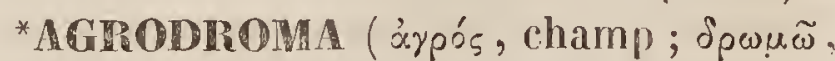
je cours). ols.-G. de M. Swainson, démembré de celni des Anthus (Pipit de Cuvier, 
Vieillot et autres), et dont les caractères sont: Bec mince, très comprimė; les 2 mandibules d'égale longueur; pointe de la supérieure non recourbée sur l'inférieure, et n'ayant qu'une petite échancrure à peine visible. Ailes longues; les 4 premières rémiges presque égales; les autres brusquement plus courtes et échancrées à leur sommel; les tertiaires allongées, pointues, de la longueur des autres rémiges. Queue moyenne, coupée carrément. Pattes longues, grêles, de couleur pâle; tarse plus long que le doigt médian; doigts latéraux égaux, mais l'ongle externe plus court que l'interne. Couleur du plumage analogue à celui des Alouettes. Ce g. es: cosmopolite. L'espéce type est, d'après Swainson, le Pipit rousseline de Temminck (Buff. enl.666, 1), à laquelle il ajoute l'Anthus australis, et son Agrodroma bistrigata. Sans vouloir prononcer sur le plus ou moins d'importance de ce nouveau g.; nous pensons que plus d'un Ornithologiste a sans doute remarqué, comme $M$. Swainson et comme nous-même, que le Pipit rousseline semblait, d'après son plumage, la force de son bec et ses formes générales, plus voisin des Alouettes que des Anthus; mais, comme nous croyons devoir rapprocher des Alouettes les Antlus, commes.-famille sous le nom d'Anthusinées, ce g. Agrodroma, qui en fait partie, devient pour nous un des g. de transilion de cette s.-famille à celle des $\Lambda \mathrm{LAU}$ -

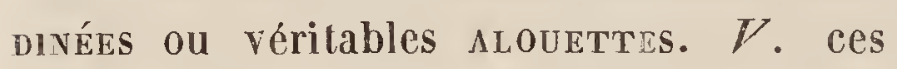
mots.

(LAFR.)

AGROECIA (ápós, champ:; oixć, demeure). ins. - G. de la famille de Locustaires, de l'ordre des Orthoptères, établi par M. Serville (Rev. méth. de l'ordre des Orth.), adopté par le docteur Burmeister (Handb. der Ent.), et réuni au g. Locusta par M. Brullé (Hist. des Ins.). Ses caract. principaux sont tirés : $1^{\circ}$ De la forme de la tête prolongée en pointe aigüe; $2^{\circ}$ des jambes antér. armées d'épines au côté interne; $3^{\circ} \mathrm{du}$ prosternum muni de 2 épines. - La seule esp. connue est l'A. punctala Serv. Burm., propre au Brésil.

(BL.)

*AGROMYZE. Agromyza (àyós, champ;

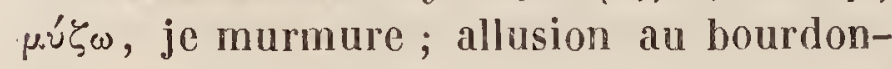
nement de ces insectes). ins. - G. de l'ordre des Diptères, division des Brachocères, subdivision des Dichoetes, famille des Athéricères, tribu des Muscides, section des
Acalyptères, s.-tribu des Hétéromyzides, existant dans les ouvrages de Fallen et de Meigen, el adopté par M. Macquart. Il présente les caract. suivants. Ouverture buccale petite; face descendant à peine plus bas que les yeux, munie de soies ainsi que le front. Antennes inclinées. Słyle nu ou pubescent. Abdomen oblong. Ailes à nervure nıédiastine double à la base, soudée à l'extrémité, et à nervures transversales rapprochées. - Ce g. ne diffère guère dug. Oscinis, que par les soies qui garnissent la face et le front. Il se compose de plus de 40 espéces, se trouvant toutes en France et en Allemagne, et vivant sur les lierbes des prairies et des bois. Nous n'en citerons qu'une qui est très commune, l' $A$ gromyza mobilis Meigen.

* AGROPHLL (áypós, champ ; pínos, ami ). 1Ns. - G. de Lépidoptères, famille des Nocturnes, tribu des Noctuo-Phalénides, établi par M. Boisduval (Genera et Index Lepidopt.), qui le caractérise ainsi : Antennes sétiformes dans les 2 sexes. Palpes très courts, velus, à articles non distincts. Trompe longue. Corselet petit, arrondi, assez robuste. Abdornen lisse. Chenilles demiarpenteuses, vivand de plantes basses. Chrysalide renfermée dans un cocon. Port des chenilles du g. Tortrix.-Ce g. a pour type la Pyralis sulphuralis de Linné. (D.)

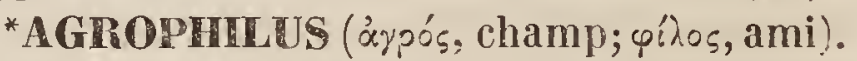
ols. - G. de M. Swainson, faisant partie de sa famille des Fringillida, el de sa s.-famille des Fringillince, ayant pour caract. : Bec semblable à celui des individus de son $g$. Chondestes, c'est-à-dire droit, conique, assez allongé, mais avec la mandib. supér. entière à son extrémité, et s'avançant à sa base assez loin au milieu des plumes frontales, à commissure sinueuse. Ailes un peu allongées; la $1^{\text {re }}$ rémige bâtarde, et n'étant pas de moitié aussi longue que la $2^{\text {me }}$; la $2^{\text {me }}$ et la $5^{\mathrm{me}}$, d'égale longueur, les $3^{\mathrm{me}}$ et $4^{\mathrm{me}}$, les plus longues. Queue moyenne, légèrement arrondie; pieds grands et forts; doigt médian un peu plus long que le tarse; doigts latéraux égaux, mais plus courts que le pouce; tous les ongles forts et arqués. - Le type de ce g. est le Ploceus superciliosus de Ruppel (Allas, pl. 15), décrit encore dans les Birds of western Africa de Swainson, vol. 1, p. 209. Nous possédons cet 
niseau africain dont Ruppel a fait un Tisserin ; comme il nous parait en avoir les caractères, et que le préparateur qui l'a monté nous a dit avoir remarqué qu'il avait la peau forte et épaisse des Tisserins, nous croyons devoir le grouper comme sous-g. à

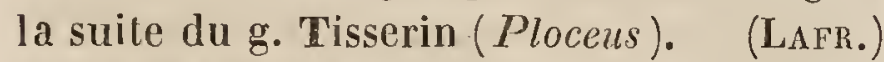

AGROPYRON (àyós, champ; $\pi$ voós, blé; blé sauvage). вот. PI.-G. établi par Gaertner dans la famille des Graminées pour quelques esp. de froment (Triticum), dont les glumes sont lancéolées ou linéaires-aiguës ou obtuses, les épillets multiflorès. Ce g. assez nombreux en esp. et qui renferme entre autres les Triticum repens $\mathbb{L}$., junceum L., etc., a été adopté par Trinius, Palissot de Beaurois, Romer et Schultes, etc. Mais le professeur Kunth a cru devoir le réunir de nouveau, comme une simple section, au g. Triticum. V. Fronent. (A. R.)

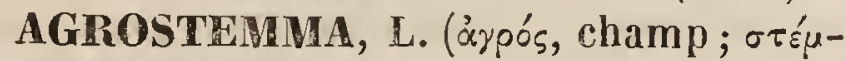
$\mu \alpha$, couronne). вот. Рн. - G. de la fámille des Silénées, à peine distinct des Lychnis, auxquels il a été réuni par plusieurs auteurs modernes. Suivant Linné, son caract. différentiel consisterait en un cal. coriace, au lieu d'ètre membraneux ; mais si l'on admettait cette différence comme caract. générique, la plupart des Lychnis des auteurs rentreraient dans le g. Agrostemma. ( $V$. Lychnis, Spach, Histoire des Plant.phan. v. 5, p. 164.)

* agrostera (áypurtríp, chasseur). rns. - G. de l'ordre des Lépidoptères, famille des Nocturnes, établi par Schranck, et qui correspond en partie au g. Asopia de Treitschke, que nous avons adopté. $V$.ce mot.

*AgROSTICULA (Dimin. d'Agrostis; äyp$\omega \sigma \tau เ s$, nom grec du chiendent). вот. PII. Sous le nom d'Agrosticula muralis, le professeur Raddi (Agrost. brasil., 33, t. I, f. 2) a décrit une petite plante de la famille des Graminées, très voisine des Agrostis, et que Link a réunie au g. Sporobolıs, sous le nom de $\boldsymbol{S}$. minutiflorus. Elle est vivace et origi naire du Brésil.

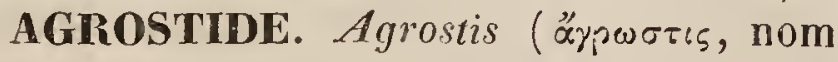
grec du chiendent). в0T. PH. - Grand g. de la famille des Graminées, qui se compose d'environ une centaine d'esp. éparses dans presque toutes les contrées du globe, et ayant des représentants sous les pôles comme dans TOM. I. les régions tropicales de l'un ei de l'autre hémisphère. Établi par Linné, ce g. a été adopté par tous les Bolanistes, qui en ont successivement retiré un certain nombre d'esp. devenues les types de g. distincts. Voici les caract. du g. Agrostis, tel qu'il a élé circonscrit par les auteurs modernes et en particulier par Trinius et Kunth dans leur Agrostographie : Fleurs disposées en panicule tantôt étalée, tantôt contractée. Épillets uniflores; glumes ả peu près égales entre elles, ordinairement plus longues que la fleur, carénées et mutiques, c'est-à-dire sans arête. Écailles au nombre de 2 ; l'infér. portant une arête dorsale, et rarement mutique; la supérieure bi-carénée, quelquefois très petite ou même complètement nulle. Ce dernier caractère se remarque dans les espéces dont on avait fait le g. Trichodium. On trouve quelquefois, mais rarement, un petit appendice subulé à la base de la fleur, et qui est l'indice d'une seconde fleur avoltée. Étam. 1 à 3. Ovaire glabre. Styles 2, extrêmement courts et plumeux. Écailles hypogynes, glabres et presque entières. Fruit glabre, libre et nu.-Ainsi que nous venons de le dire, ce g. est trés nombreux en espèces, et plusieurs g. ont été formés d'espèces qu'on y avait d'abord réunies. Nous mentionnerons ici quelques uns des plus remarquables : $1^{\circ} \mathrm{le} \mathrm{g}$. Trichodium, que nous venons de citer et dans. lequel on avait placé les esp. dont la paillette supér. est avortée. $2^{\circ}$ Tilfa d'Adanson ou Sporabolus de Brown, qui comprend les esp. dont les glumes sont plus courtes ou tout an plus de la même longueur que la fleur. Cette section renferme un grand nombre d'espéces. $3^{\circ}$ Mibora, qui comprend l'Agrostis minima L. $4^{\circ}$ Anemagrostis de Trinius ou Apera de Palissot de Beauvois, dans lequel on a rangé les Agrostis spica venti et interrupta L.. ( $V$. ces différents noms.) - Parmi les esp. d'Agrostis, il en est quelques unes qui sont excessivement communes dans presque toutes les contrées de l'Europe : telles sont les Agrostis vulgaris, alba, canina, spica venti, etc. Aucune des esp. de ce g. n'a d'utilité. Ce sont en général des graminées vivaces, qui croissent soit dans les bois, soit dans les champs ou les lieux incultes et sablonnenx. (A. R.)

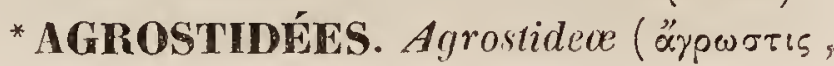


chienden(). вот. Pи. - Dans sa classification des Graminées, le professeur Kunth a nommé ainsi la $5^{\text {me }}$ des tribus qu'il a établies dans celte famille et qui comprend les g. Muchlenbergia, Lagurus, Coleanthus, Phippsia, Colpodium, Cinna, Epicampes, Sporobolus, Agrostis, Gastridium, Chototropis, Nowodworskya, Polypogon, Choelurus, Pereilema et OEgopogon. $V$. GramiNÉES.

(A. R.)

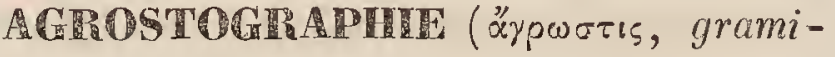

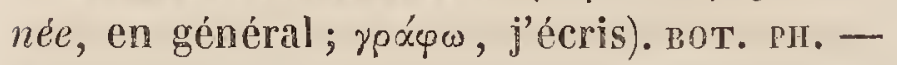
Ta famille des Graminées est tellement vaste, son organisation offre des particularités si remarquables, qu'on a donné un nom spécial, celui d'Agrostographie, á la partie de la botanique qui traite de ces végétaux; le même nom s'appliquant aussi aux ouvrages dans lesquels ils sont décrits. Peu de familles ont été l'objet d'autant d'ouvrages importants que les Graminées. Il nous suffira de rappeler, parmi les modernes, ceux de Host, Gaudin, Panzer, Koler, R. Brown, Palissot de Beauvois, Trinius, Presl, Kunth, Nees d'Esenbeck, etc. $V$. Graminées.

(A. P.)

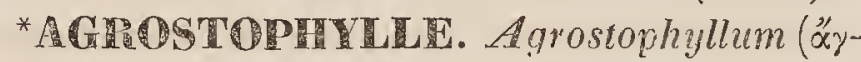

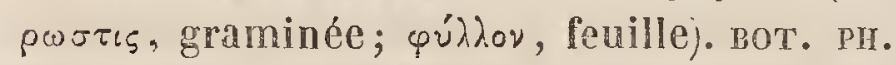
-G. de la famille des Orchidées, établi par M. Blume, dars sa Flore de Java, el que M. Lindley place dans sa tribu des Vandées, entre les g. Angracum et Calanthe. Une seule esp. ( 1 . javanicum Bl. Bijdr. 368, t.53) compose ce $\mathrm{g}$. Sa racine est fibreuse et épidendre; sa tige porte des fouilles linéaires, acuminées, et des fleurs terminales réunies en tête et entourécs de bractées paléacées. Leur calice est étalé; les sépales extér. sont égaux, larges; les intér. sont linéaires; le labelle concạve, étranglé dans son milieu, est entier et soudé avec la base du gynostème, qui est dressé et semi-cylindrique. L'anthẻre est à 2 loges subdivisćes chacune en 2 cavités. Elle contient 8 masses polliniques allongées, cunciformes et sessiles.Cette esp. croît dans les forêts montueuses de l'île de Java.

* AGPOTIS (áyó́trs, qui habile les champs ). Ins. - G. de l'ordre des leépidoptères, famille des Nocturnes, tribu des Noctuélides, établi par ochsenhe mer et Treitschke, son conlinuateur, aux dépens du g. Iocua de Fabricius, et adopté par M. Gué- née qui, dans son Essai pour servir à la classification des espèces de cette tribu ( $A n n$. Soc. entom. de France, t. vi), lui assigne les caractères suivants : Chenilles (à 16 pattes ) cylindriques, peu atténuées aux extrémités, à peau lisse, ayant les points ordinaires presque toujours subvariqueux et luisants, avec une plaque écailleuse bien distincte sur la nuque. Elles vivent de racines ou de feuilles de plantes basses, et se tiennent soigneusement cachées pendant le jour, tantôt sous les touffes de ces mêmes plantes ou sous les pierres, tantôt, et le plus souvent, dans des cavités qu'elles se pratiquent dans la terre. Leurs chrysalides sont luisantes,cylindrico-coniques, parfois garnies de petites pointes, ei enterrées plus ou moins profondément, sans coques sensibles, ou du moins dans des coques très peu solides. Ins. parfaits. Antennes plus ou moins ciliées ou seulement épaissies dans les mâles, filiformes dans les femelles. Pa!pes dépassant un peu la tête, droits ou très peu ascendants; le $2^{\text {me }}$ article large, velu, tronqué carrément au sommel; le $3^{\text {me }}$ nu, tronqué à l'extrémité. Toupet frontal serré, d'une seule toufre; mais offraní queiques dépressions. Spiritrompe de longueur moyenne. Thorax robuste, carré, à collier ordinairement relevé et bordé de noir. Abdomen un peu déprimé, non crêté, subconique. Paltes longues, à ergots prononcés. Ailes supérieures obtuses a l'angle apical, sombres, ayant les trois taches ordinaires plus ou moins distinctes. Ailes inférieures souvent luisantes, et comme irisées, avec les nervures bien marquées. Nous ajouterons à ces caractères que les ailes supérieures, lorsqu'elles sont fermées, sont placées sur le corps dans une position horizontale et croisées l'unesur l'autre à leur bord interne, ce qua donne á cette partie de l'insecte la forme d'un carré long. Les Agrotis, à l'étal parfait, volent rapidement au crépuscule du soir, et se tiennent cachées pendant le jour dans les broussailles et les hautes herbes, ou appliquées contre les arbres et les murs. Quelques unes cependant volent à l'ardeur du soleil, comme l' $A$. valligera, qui aime à se reposer sur les chardons. M. Guénée rapporte à ce g. une soixantaine d'espèces, parmi lesquelles nous ne citerons que l' $A$. exclamationis des auteurs, qui se lrouve 
partout. Elle est figurée dans l'llist. des Lépidopt. de France, t. v, pl. 67 , fig. 3 et 4.(1).)

AgROUELLES. crust. - Nom donné à la Crevette des ruisseaux (Gammarus Pulex Fabr.', par le vulgaire, persuadé que l'on gagne les écrouelles en avalant par liasard ce petit Crustacé.

* AGROUELLES. got. Pil. - Colruption d'Écrouclles. On donne, dans quelques cantons de la France, cette dénomination vulgaire à la Scrofulaire, que l'on croit à tort propre à guérir les maladies scrofuleuses, conmues anciennement sous le nom d'Ecrouelles. $V$. Scrofulaire.

AgRYPNia (àpurvia, veille, insomnie; parce que ces insectes voltigent la nuit). ins. - G. de la famille des Phryganiens, de l'ordre des Névroptères (Trichoptera, Kirb.) établi par Curtis. Les principaux caract. qu'il lui assigne sont: Tête et corps larges et déprimés; nervures des ailes semblables à celles des Anabolia ; jambes épineuses. On n'en connaît qu'une seule esp. décrite par M. Curtis sous le n:m d'A. pagetana, et qui est d'Angleterre.

(BL.)

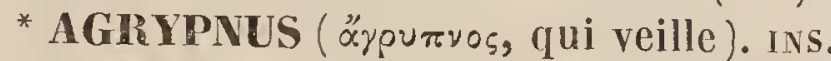
- G. de Coléoptères pentamères, famille des Sternoxes, tribu des Élatérides, établi par Eschscholtz, et dont voici les caractères : Dernier article des palpes maxillaires et labiaux légćrement sécuriforme. Labre transversal, coupé carrément à sa partic antérieure. Yeux grands, arrondis et saillants. Antennes un peu moins longues que le prothorax, se logeant au besoin dans des rainures des flancs de ce dernier, fortement en scie et comprimées, sans faux article à leur extrémité; leur $1^{\text {er }}$ article très gros, subquadrangulaire; lc $2^{\text {me }}$ et quelquefois le $3^{\text {me }}$ très courts, obconiques; les suivants triangulaires et égaux entre eux; le dernier ovoïde, plus ou moins allongé, a vec les angles postérieurs peu saillants. Prosternum avancé, fléchi et arrondi antérieurement. El tres allongćes, arrondies à leur extrémité. Pattes médiaires peu robustes ; hanches postérieures étroites; articles des tarses assez allongés, subcylindriques, légèrement comprimés, garnis de poils courts et serrés en dessous; le pénultième entier, presque de la grandeur des 2 précédents; crochets simples. Corps plus ou moins allongé, entièrement revêtu de poils très courts, imitant de petites écalles. - M. Dejean, qui adopte ce g. (Catal. $3^{\text {me }}$ édit.), y rapporte 43 esprees, dont 6 sculement sont d'Enrope; les autres sont exotiques. Nous citerons parmi les premières: l'Elater atomarius Fabr.,ou carbonarius Oliv., qui se trouve dans le midi de la France, ct l'Elal. murinus Fabr., très commun aux environs de Paris. Les Agrypnes sont des insectes de moyenne taille, qui se tiennent pour la plupart sous les écorces et dans les troncs des arbres cariés.

(D.)

AGUAPEAZOS. ols. - C'est dans l'histoire des oiseaux du Paraguay, par Azara, le nom que donnent les Guaranis aux Jacanas d'Amérique et qui vient du mol Ayuapé, par lequel ils désignent les Nénuphars et alltres plantes aquatiques, à larges feuilles, sur lesquelles ces oiseaux marchent avec légc̀reté, à cause de la conformation toute particulière et bien connue de leurs énormes pattes. $V$. JACANa.

(LAFR.)

* AGUASSIERE. Hydrobala. ols. - C'est le nom français générique employé par Vieillot pour le merle d'eau, et celui que porte cet oiseau dans les Pyrénées. $V$. Cinche. (Lafr.)

AGUSTITE (mothybride formé de á priv. et de gustu.s, goùt). mis. - Nom donné par 'Tromsdorff à une variété bleuâtre de phosphorite en cristaux péridodécaèdres, trouvée en Saxe, et dont on a fait pendant quelque temps une espèce particulière. On l'a désignée aussi sous le nom de Béryl de Saxe. On avait cru reconnaître dans ces cristaux l'existence d'une nouvelle terre, que l'on avait nommée Agustine, parce qu'clle ne communiquait aucun goût aux combinaisons salines dans lesquelles elle cntrait. Vauquelin s'est assuré que la substance de ces cristaux n'était autre chose que du phosphate de chaux. $V$. Phosphorite. (Dec.)

* A GLPMORA, Neck. (corruption liltér.

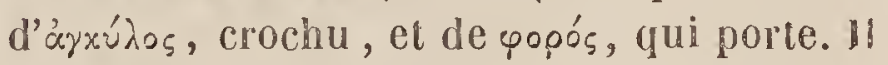
eût fallu écrirc Ancylophora). Bот. PII. Syn. du g. Uncaria, Schreb.

(Sp.)

* AGYNAIRE. Agynarius (à priv.; rúvn, fcrme; en bolanique, pistil). вот. PH.-Dénomination appliquée par M. De Candolle aux fleurs qu'il appelle permutées, c'est-á-dire dont les étamines sont, en tout ou en partie, transformées en péiales et où manou ue le style.

$$
\text { (C. L.) }
$$

AGYNEA (àpriv.; zúrn, femelle. Plante considérée ì tort comme dépourvue des or-m 
ganes femelles ). вот. PI. - G. de la famille des Euphorbiacées, qui présente les caractères suivants : Fleurs monoïques. Calice 6-parti. Dans les mâles, filets réunis en une colonne partant inférieurement d'un disque membraneux, 6-lobé, qui revèt en partie l'intérieur du calice, terminée supérieurement par 3 lobes, dont chacun porte adnée une anthère extrorse. Dans les femelles, un ovaire à 3 loges bi-ovulées, creusé au sommet d'une concavité d'où partent 3 styles, ou plutôt 3 stigmates courts et bifides (que Linné auteur du g. n'avait pas vus bien distinctement). Capsule se séparant de la base au sommet en 6 valves qui laissent à leur centre une colonne cannelée formée par le placentaire. - Les espèces d'Agyneia sont originaires de la Chine, de l'Inde, des îles de la Sonde. Ce sont des végétaux frutescents ou herbacés, à feuilles alternes ou presque opposées, stipulées, petites ; à fleurs disposées en faisceaux axillaires dans lesquels elles sont entremêlées de bractées en petit nombre; une ou deux femelles plus longuement pédonculées pour plusieurs mâles. (AD. J.)

*AG INIOUE. Agynicus (ả priv.; rúv:n, femme; en botanique, pistil). вот. рн. M. Lestiboudois dit (Botanog. élém. el aliō) l'insertion staminale agynique quand elle ne contracte pas d'adhérence avec l'ovaire.

(C. L.)

*AGYRIUM, Fries (á priv.; rũpos, cercle, circonvolution). воT. CR. - Petil g. de Champignons appartenant à l'ordre des Trémellinés, ainsi nommé parce qu'il n'offre pas de circonvolutions, comme les Trémelles. Il se présente sous la forme de petits corps plus ou moins globuleux, d'une structure homogẻne et d'une consistance gélatineuse; toute leur surface est recouverte par un bymenium de même nature. Or ne connaìt pas encore la disposition des spores. Ils se dessèchent avec la plus grande facilité, et reviennent à leur état naturel quand on les expose à l'humidité. Si, comme quelques auteurs le prétendent, l'Hymenium se résout en spores, ils auraient alors la plus grande analogie avec les $F$ gerita et les Tubercularia; mais ils s'en éloignent par leur structure intérieure. On doit donc les laisser parmi les Trémelles jusqu'à ce qu'une analyse rigonreuse leur assigne une autre place. On en coñnaît 5 esp., qui vivent sur les herbes et les bois morts. L: Agyrium coesium Fries (Egerilà cosia Pers.), qui croît abondamment sur le vieux bois des pins, est le type du genre.

(LÉv.)

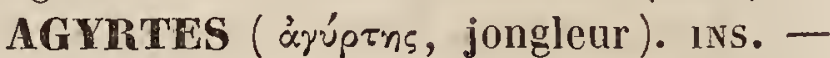
G. de l'ordre des Coléoptères pentamères, famille des Clavicornes, tribu des Peltoïdes, établi par Frolich aux dépens des Mycétophlages de Fabricius, dont il se distingue, ainsi que des autres g. voisins, par ses antennes en massue perfoliée, allongée, de 5 articles; par ses mandibules fortes, très crochues et sans dentelures; par ses palpes un peu plus gros à leur extrémité; par son corps ovale, convexe, dont le prothorax est en trapèze rebordé, et dont les pattes non contractiles ont les tibias épineux. Ce g. a pour type l'A. marron, Mycetophagus castaneus Fabr., figuré par Panzer (Faun. Insect. Germian. fascic. 24, tab. 20 ), et qui se trouve quelquefois aux environs de Paris. M. Dejean (Catal. $3^{\text {me e }}$ ét.) en désigne 3 autres, savoir: l' $A$. subniger de la Belgique, l'A. glaber Paik (tritoma) de la Laponie, et.l' $A$. latus Esch., de l'Amérique boréale occidentale.

AHETULA. Nom spécifique d'un Ophidien du g. DENDRopIIS.

(G. B.)

AHOVAI (nom indien). вот. Рн. - G. de la famille des Apocynacées, fondé par Tournefort (Inst., t. 434), et réuni depuis au g. Thevetia L. $V$. ce mot.

AIAUT. вот. PH - Nom vulgaire, dans quelques cantons de la France, du $I$ Vareissus pseudo-Narcissus.

*AIDEL. Aïdelus, Spreng. (äìnios, obscur). вот. PII. - Suivant M. Bentham, 气’est un double emploi du g. Veronica. (SP.)

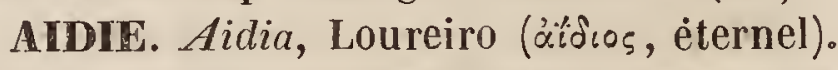
вот. PIr. - G. incomplétement connu, et sur la classification duquel on n'est pas d'accord. M. de Candolle le range, avec doute, à la suite des Caprifoliacées. Loureiro en a donné les caract. suivants (Flor. Cochinch. ed. Willd. 1, p. 177) : Tube calicinal adhérent; limbe 5-denté, dressé. Cor. supère, hypocratériforme; gorge laineuse; limbe 5parti ; lanières lancéolées. Anth. 5 , linéaires, insérées aux lanières de la corolle. Style de la longueur des étamines. Stigm. ovale-oblong. Baie ovale, ombiliquée , monosperme. - Grand arbre. Feuilles opposées, lancéolées, très entières. Fleurs blan- 
ches, disposées en courtes grappes axillaires. - L'unique esp. sur laquelle se fonde le g. est indigèrue en Cochinchine. Elle fournit un excellent bois de construction. (SP.)

AIEREBA ou $\Lambda$ jaroba. porss. - Nom cité par Marcgrave pour la dénomination vulgaiıe, au Brésil, d'une esp. de Pastenague.

AIGLE. Aquila. ors. - G. de l'ordre des Rapaces, de la famille des Falconidées et de la s.-famille des Aquilinées, dont les caract. sont : Bec fort, assez élevé, droit d'abord et ne cornmençant à se courber qu'à quelque distance de sa base garnie d'une cire poilue, assẻz long, comprimé, avec le dos un peu anguleux; mandibule supér. dilatée sur ses bords, non dentée, légérement sinueuse, très crochue, et se terminant en une pointe for tement acuminée to tombante, l'infér. plus courte, droite et obtuse; narines transverses, elliptiques; bouche très fendue. Tarses robustes, courts ou moyens, totalement emplumés jusqu'aux doigts ; dọigts forts, mais peu allongés, l'externe réuni à sa base au médian par une membrane; ongles puissants, très arqués, l'interne et le postér. surtout, qui sont plus forts que le médian ; l'extér. le plus court de tous; tous ces ongles canaliculés ou creusés en dessous en gouttière dont les bords forment des lames tranchantes; celui du milieu à double gouttière (une infér. et une latérale interne), et muni par conséquent de 3 lames, dont l'interne, souvent ébréchée irréguliẻrement, a fait dire à tort à Vieillot que cet ongle était pectiné sur le bord interne. Ailes longues, obtuses, à rémiges primaires allongées, atteignant à peu près dans le repos l'extrémité de la queue.

Cette conformation de pattes et d'ailes mérite une attention particulière, et suffit pour faire reconnaître que l'Aigle n'est point destiné, comme le faucon, le gerfault, à poursuivre dans les airs des oiseaux cherchant leur salut dans une fuite rapide, et ne doit pas nous offrir le type de ce courage entreprenant qu'on lui a si gratuitement accordé, tandis qu'il est le partage de ces derniers, qui ne s'adressent point comme lui à de jeunes animaux, mais qui poursuivent et attaquent intrépidement des mammifères et des oiseaux souvent beaucoup plus grands qu'eux. L'Aigle n'est point pourvu comme eux des deux facultes indis- pensables pour seconder cette sorte de témérité, la rapidité du vol et la facilité de la préhension, favorisée par la longueur des doigts, ce que nous retrouvons encore chez les Autours et Éperviers. Chez lui l'aile est obtuse, etles doigts, quoique forts, sont encore loin d'avnir une grosseur et surtout une longueur proportionnelle à ceux des faucons. Chez le faucon pèlerin femelle, par exemple, le doigt médian est tout aussi long que ce même doigt chez l'Aigle criard femelle, quoique celle-ci soit d'un volume de plus du double; ce qui indique suffisamment que ce dernier oiseau n'est point destiné, cornme le premier, à saisir habituellement au vol de gros oiseaux, qu'une patte á doigts allongés el nerveux pouvait seule arrêter facilement dans leur course rapide.

Si, dans la forme de ses doigts, l'Aigle n'a pas de grands moyens de préhension, il en trouve un puissant de destruction dans celle de ses ongles, dont le grand développement et les lames inférieures comprimées font de ses serres comme autant de poignards acérés, à plusieurs tranchants.

L'Aigle, destiné d'après son volume à se nourrir de mammifères assez gros, avait besoin plus que tout autre rapace, d'armes meurtrières pour hâter la mort de ses victimes, une fois qu'il s'en est emparé; mais, avouons-le, ces victimes ne sont la plupart du temps que de jeunes animaux, ofran bien peu de résistance, tels que chevreaux, agneaux, jeunes cerfs ou jeunes daims; il se rabat même, dans une grande disette de proie vivante, sur les cadivres, et l'Aigle criard, mange beaucoup de gros insectes pendant l'été.

Les Aigles et particulièrement les grandes esp. ont besoin, dit Temminck, de 5 à 6 années ou de 6 ou 7 mues pour se revêtir de la livrée parfaite et invariable qui les distingue. Les grandes pennes des ailes et de la quene sont les dernières parties du plumage qui changent de couleur; ces pennes portent souvent encore les teintes de l'âge moyen, tandis que le reste de la livrée est à l'état parfait.

Nous avons remarqué que, dans le cours de ces différentes mues, non seulement les conleurs du plumage varient incontestablement, mais que la longueur proportionnelle de la queue et même des ailes offre des différences tranchées. Ainsi il est bien cer- 
tain que chez l'adulte, la queue est beaucoup plus courte que chez le jeune, et que les ailes ofrrent aussi quelque changement dans les proportions des rémiges. Il n'est pas étonnant, d'après cela, que l'on ai fait autrefois plusieurs esp. sur des individus de la même en livrée diflérente.

Les véri tables Aigles ne se rencontrent guère que dans l'ancien continent. Cinq esp. habitent l'Europe, et une partie d'entre elles se rencontrent sur la chaîne des Alpes et des Pyrénées; ce sont: l'Aigle impérial, l'Aigle royal ou Aigle commun, l'Aigle criard, l'Aigle bonelli et l'Aigle botté. Une seule e£p. se rencontre à la Nouvelle-Hollande, et présente, dans la forme de sa queue, conique ou très étagée, une particularité qui se retrouve également chez les Pygargues du même continent; c'est l'Aigle à queue étagée de Cuvier, Falco fucosus Tem. col. 32. Une autre esp. des contrées adjacentes, l'Aigle malais (Tem. Col. 117), a l'ongle interne si allongé qu'il dépasse de beaucoup celui du doigt médian, d’oủ il résulte que les doigts semblent diminuer progressivement de longueur de l'interne à l'externe. Les Aigles, comme les Vautours, évitent les pays de plaines oú leur grand volume les ferait bientòt remarquer et détruire, et habitent particulièrement, comme ceux-ci, les grandes chaìnes de montagnes. C'est dans les forêts montagneuses ou dans les rochers les plus élevés de ces montagnes qu'ils se retirent et nichent de préférence.

(LAFr.)

AIGL du g. Myliobate, commune dans la Méditerranée. Lacépède a aussi employé ce nom comme épithète de son Chéilodiptère aigle, qui est un Sciénoïde de nos côtes de la Manche ainsi que de celles de la Méditerranée, et dont l'esp. est, suivant nous, du g. Sciène (Sciona anuila Cuv. VAL.). (VAL.)

AIGLT royal. MoLL. - Nom vulgaire du Bulimus bicarinatus de Bruguière, Achatina bicarinatc de Lamarck. Très rare autrefois, dans les collections, avant qu'on en connût la patrie, cette coquille est aujourd'hui très commune depuis que l'on sait qu'elle habite fréquemment l'Afrique équatoriale. (Desir.)

MGLES-AUTOURS. Morphnus, Cuv. (uop̣vós, sombre; nom d'une esp. d'oiseau de proie chez les Grecs). ols. - Ce g. répond à celui de Spizaëte de Vieillot; il fait partic de notre famille des Falconidées, é de notre sous-famille des Acci pitrinées. Ses caract. sont : Bec assez fort, droit d'abord, puis recourbé à quelque distance du front, garni d'une cire à sa base, mandibule supérieure comprimée, à arête assez anguleuse, fortement arquée et crochue, se terminant en une pointe acuminée, tombante, dilatée sur ses bords qui ne sont point dentés, mais légèrement sinueux; narines elliptiques. Tarses allongés, un peu grêles, emplumés dans toule leur longueur, comme chez les Aigles; doigts de grosseur médiocre, courts, mais le médian et le postér. allongés; l'externe et le médian unis à leur base par une membrane; ongles puissants, très arqués, le postér. et l'interne surtout, qui surpassent de beaucoup le médian; l'externe le moins long; le médian à double rigole, comme chez les Aigles; ailes sur-obtuses, á rémiges de longueur médiocre, les $4 \mathrm{me}$ et

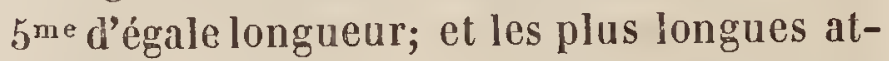
teignant dans le repos à peu près le tiers de la longueur de la queue qui est ordinairement fort longue et terminée carrément. La plupart des espèces sont ornées d'une huppe occipitale tombante. Ce nom d'AigleAutour convient d'autant mieux à ce groupe, qu'il offre des rapports évidents avec ces deux genres; à la forme du bec, aux tarses emplumés des Aigles, ils joignent la hauteur des pattes, la brièveté des rémiges et la longueur de queue des Autours, mais le tout porté à un degré plus éminent. Il paraît que dans leurs mœurs forestières, et leur maniẻre de poursuivre et saisir leur proie, les Aigles-Autours se rapprochent entièrement des vrais Autours et des Éperviers, et n'offrent plus de contact avec les Aigles; ce qui nous a décidé à les rapprocher des premiers dans notre classification.

Nous séparons des-vrais Aigles-Autours, ou Morphnus, à tarses toujours emplumés, une espèce à tarses nus, l'Urubitinga, non seulement à cause de cette différence, qui a paru suffisante pour séparer les Pygargues des Aigles, mais parce que, d'après ce que Azara, et après lui M. d'Orbigny, nous apprennent des mours de l'Urubitinga, cet oiseau est tout-à-fait inférieur en courage aux Aigles-Autours rapaces, courageux et entreprenants conme les $\Lambda$ utours.Suivant ces de $u x$ voyageurs, l'Urubitinga se tient constam- 
ment aux bords des marais, des lacs et des rivières, en embuscade sur quelque arbre mort, en attendant patiemment que quelque reptile aquatique, quelque petit mammifère, ou quelque oiseau mort se présente à sa vue, pour se laisser tomber dessus et s'en repaître; ne poursaivant jamais les oiseaux au vol, s'abattant souvent sur la fange des eaux stagnantes, probablement afin d'y saisir des reptiles, ce qui se reconnaît facilement à ses pattes souvent couvertes de cette vase. D'après ces indications c'est, sans nul doute, un rapace à mœurs de Buse, et qui ne peut rester avec d'autres à mœurs d'Autour; aussi Azara l'avait-il placé dans ses Buses mixtes, sous le nom de Buse mixte noire (l'adulte), et de Buse mixte à longues taches (le jeune), tandis qu'il range dans ses Éperviers, sous le nom d'Épervier patu, le bel Aigle-Autour Urutaurana, ou varié d'Amérique. Nous croyons donc devoir éloigner des AiglesAntours, l'Urubitinga, pour le grouper arec ces Buses d'Amérique reptilivores, désignées par Azara sous le nom de Buses des savanes noyées, à tarses presque aussi longs que les siens, el dont nous formons le genre Busarellus ou Buses des marais. Il y figurera comme s.-genre, à cause de ses ailes plus courtes, sous le nom d'Urubitinga, et nous laisserons le nom de Spizaëte, Vieill., qui a la même signification qu'Aigle-Autour, à ces autres espéces américaines confóndues avec l'Urubitinga dans les Morphnus ou Spizaëte à tarses nus, tels que l'Aigle-Autour Huppé de la Guyane (F. guyanensis Daud.), qui ne diffèrent réellement des vrais Morphmus que par l'absence de plumes aux tarses, et qui, par suite de leur grande conformité avec eux, en ont probablement aussi les mœurs.

Les Aigles - Autours habitent l'ancien comme le nouvea monde. L'Amérique nous en offre entre autres une espèce remarquable par la beauté de son plumage ('Urulaurana); l'Afrique une autre, qui semble s'éloigner un peu des espèces américaines par ses ailes plus longues, et sa queue beaucoup plus courte. C'est le Huppart de Isevaillant, Afr.pl.11, et de Bruce, Abyss., pl. 32, qui, d'aprés Levaillant, donne la chasse aux lièvres, perdrix et caniards sauvages. En espèces indiennes, nous citerons l'Autour mni- colore de Tem., Col.134, Falco limnatus Horsf. L'Europe et la Nouvelle-Hollande n'en possèdent point jusqu'à ce moment, à moins qu'on ne doive ranger parmi les $\mathrm{Ai}$ gles-Autours l'oiseau désigné par Vigors et par Horsfield comme un Pygargue, sous le nom de Halioctus calei, el que Gould en raison de la forme arrondie de ses ailes et de ses autres caractères rapproche plutôt des Autours.

(LAFR.)

AIGPEMOINE. Agrimonia, Tourn., I.

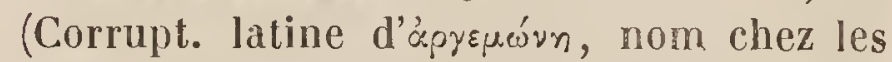
Grees d'une plante que les modernes rapportent à leur Argémone, et quí, selon Dio-

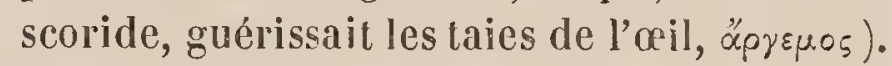
вот. Рп. - G. de la famille des Rosacées (Dryadées, Bartl.), tribu des Dryadées, Vent. (Potentillées, DC.; Fragariacées, Rich.; Roséées, Reichenb.). Ses caract. sont les suivants : Tube calicinal turbiné ou subcylindracé, accrescent, fovéolé à la surface exterre, hérissé vers son sommet de spinules glochidiées; limbe 5-parti, resserré après la floraison. Pétales 5, courtement onguiculés. Etam.10-20; filets subulés; anth. suborbiculaires, comprimées. Ovaires 2, inadhérents, insérés au fond du calice, inclus, terminés chacun par un style filiforme, saillant et couronné d'un stigm. capitellé. Péricarpe à 2 nucules (quelquefois, par avortement, une seule) chartacées, recouvertes par le cal. devenu osseux. Graine suspendue. Herbes vivaces. Feuilles interrupti-pennées. Fleurs en grappe terminale spiciforme. Pédicelles articulés au sommet, accompagnés chacun à sa base d'une bractée trifide, persistante. Cor. jaune ou blanchâtre. - Ce g., propre aux contrées extratropicales de l'hémisphère septentrional, se compose de 6 ou 7 espèces. L'esp. connue sous le nom vulgaire d'Aigremoine (Agrimonia Eupatoria L.), et qui est commune en Europe, était préconisée jadis comme remède lonique; mais, au fond, ses propriétés se réduisent à l'astringence si fréquente parmi les Rosacées en général. (SP.)

AIGEETTE. zooL. - Sorte d'ornement donné par la nature á certains oiseaux, tels que le Paon, les Ducs, quelques esp. de Hiboux, etc. L'existence de cet ornement, ou de quelque partie ayant de l'analogie avec lui, a motivé la désignation individuelle d'un assez grand nombre d'animaux de toutes les 
classes. C'est ainsi qu'on a appelé Aigretue une esp. de singe (Simia aygula) du g. Cercoabus de Geoffroy, plusieurs esp. de Hérons; un poisson du g. Coris; plusieurs esp. de coquilles, etc. - Enfin, les entomologistes désignent sous le nom d'Aigrette ( $P$ appus), les petits bouquets de poils, plus ou moins touffus, que l'on remarque sur le corps de différents insectes.

(A. T.)

AIGRETTE. Pappus ( $\pi \propto \pi \pi o ́ s$, duvet). вот. PI. - On appelle ainsi la réunion de poils ou d'appendices de formes si variées, qui couronnent le fruit dans la plupart des plantes de la famille des Synanthérées. L'ovaire étant infère ou adhérent dans toutes les plantes de cette famille, l'aigrette, quelle que soit la diversité de forme sous laquelle elle se présente, n'est en réalité que la partie supérieure ou le limbe du calice, dont le tube ou la partie inférieure est soudé avec l'ovaire. Les formes principales sous lesquelles l'aigrette peut se présenter sont les suivantes :

10 Aigretre membraneuse (Pappus membranaceus). Petite membrane entière, ou diversement lobée ou dentée, qui entoure le sommet du fruit, comme dans la Tanaisie, la Camomille, etc. On dit encore dans ce cas que l'aigrelte est marginale (Pappus marginalis).

$2^{0}$ Aigretre squameuse (Pappus squameus). Nous avons désigné sous ce nom les aigrettes formées d'écailles ou de petites folioles distinctes, qui sont évidemment les dents ou les divisions di limbe calicinal; ainsi, dans le g. Helianthus, l'aigrette se compose de 2 écailles aiguës; dans le g. Tagetes ou OEillet d'Inde, on en compte 5 , etc. Ces écailles, dont la forme varie beaucoup, sont quelquefois minces et membraneuses; d'autres fois plus épaisses ou roides et comme épineuses.

$3^{0}$ Aigrette soyeuse (Pappus setosus). C'est la forme la plus habituelle de l'aigrette qui se compose de poils ou soies très fines ordinairement blanches, nacrées et disposées sur plusieurs rangs. Quand on examine attentivement ces poils, on voit que les uns sont simples, tandis qu'il en est d'autres qui portent sur leur côté d'autres poils plus fins et plus courts. De là les 2 modifications qu'on a désignées sous les noms d'aigrette poilue et d'aigrette plumeuse.
Quelle que soit la nature des poils qui forment l'aigrettc soyeuse, on la dit sessile (Pappus sessilis), quand les poils naissent immédiatement du sommet du fruit, el stipitée, quand elle est portée par un prolongement filiforme du sommet du fruit, plus ou moins allongé et plus ou moins grêle.

L'aigrette, comme nous l'ayons déjà dit, n'est qu'une forme particulière que prend le limbe du calice. On l'observe spécialement dans les plantes de la famille des Synanthérées; mais quelques autres familles en présentent aussi des exemples, comme les Dipsacées et surtout les Valérianées. Quelques auteurs ont désigné sous le même nom d'Aigrette le bouquet de poils blancs et nacrés qui existent à la base de la graine dans un grand nombre de genres de la famille des Apocynées; mais c'est à tort, selon nous, ce nom devant être réservé pour une forme spéciale du limbe calicinal.

AKGRON. ois.-Synon. vulgaire de Cormoran et de Héron dans quelques parties de la France.

(C. D'O.)

AIGUE-MARINE (Aqua, eau; marina, marine ). MıN.-Nom que donnent les bijoutiers à certaines variétés d'émeraude commune ou de béryl, dont la couleur d'un vert bleuâtre rappelle celfe de l'eau de mer. Ces pierres font un assez joli effet, quand elles sont bien taillées et sans défauts; on en fait des colliers, des bagues, des épingles, des pendants d'oreilles; mais tous ces objets ont une faible valeur.Presque toutes les Aiguesmarines qu'on trouve dans le commerce viennent du Brésil et de la Russie. L'Aiguemarine orientale des lapidaires est une variété de Corindon-hyalin, dont la couleur est analogue à celle de l'Aigue-marine ordinaire. $V$. Eimeraude et Corindon. (Del.)

AIGUILCAT. Poiss. - Nom vulgaire du Squalus acanthias et des esp. voisines, qui ont été réunies sous la dénomination générique d'Acanthias. Ce g. appartient, dans la méthode de MM. Muller et Henle, à la $4^{\mathrm{e}}$ sect. de la famille des Squales. Ces auteurs y rapportent l' Acanthias vulgaris, l' $A$. Blainvillii et l'A. ayalus, toutes trois de nos mers.

$(\mathrm{V} \Lambda \mathrm{L}$. $)$

AIGULLE (corruption d'Acus, aiguille). PoIss. - Nom donné à plusieurs poissons de nos côtes, et particulièrement à un Syng- 
nathe (S'yng. acus Lin.) et a l'Orphie (Esox Belone Lin.).

(VAL.)

AIGULLC. Acus.zoor. et вот. - Dénomination vulgaire donnée à quelques Poissons el à divers animaux, que leur forme allongée et pointue a fait comparer à des aiguilles. On l'a aussi appliquée à divers végétaux dont les fruits affectent cette forme. Ex. : l'Aiguille de Vénus ou de Berger (Scandix pecten Veneris); l'Aiguille musquée (Geranium moschatum), etc. (C. D'O.)

ARGULLETTF. Moll. - Geoffroy, dans son traité des Coquilles des environs de Paris, a donné ce nom à une très petite esp. d'Agathine que l'on rencontre sous les mousses dans presque toute l'Europe: C'est l'Achatina acicula de Lamarck, le Buccimum acicula de Muller, et le Bulimus acicula de Bruguière. C'est réunie á re dernier g. que cette esp. doit rester, dans la sect. des Agathines.

(DESH.)

AIGULHON. Aculens. Porss. - Osselets formés d'une seule pièce et terminés par une pointe aigüe qui, chez certains Poissons tels que la Vive, remplacent les rayons des nageoires. - Les aiguillons ne font d'ailleurs pas indispensablement partie de l'appareil natatoire. C'est ainsi qu'on les voil rangés isolément sur les parties latérales qui avoisinent la queue des Acanthrres, et répandus sur toute la surface du corps des Paies et des Pleuronectes. Ils sont alors implantés sur un tubercule nommé Boncle.

(A. T.)

AKGUILLON (Aculeus). ins. - Dés les temps les plus reculés, cette dénomination a été appliquée à l'organe qui, chez ccrtains Uyménoptères et chez les Scorpions, est une arme défensive ou même quelquefois offensive, ayant la propriété d'opérer une piqûre et de donner passage à un liquide vénéneux. qui, s'épanchant dans la plaie, occasionne une douleur des plus vives. Considérée d'abord dans les Hyménoptères, cette partie se montre comme une dépendance des organes générateurs cxternes des femelles, et comme l'analogue de l'appareil qui, chez les autres insectes, est dlésigné sous les noms d'oviductus et de tarière; elle parait servir également á la copulation et a la ponte; mais la manière dont elle agit n'est pas parfaitement connue. D'apres une observation faite par MI. Audouin sur le Bombus lapidarins, et T. 1 . dont nous devons la communication a son obligeance, l'Aiguillon, pendant l'accouplement, est relevé sur le dos, et l'intromission de l'organe mâle parait avoir lieu à la base; mais l'on devra encore l'observer dans diverses circonstances avant de présenter des détails plus minutieux. Le principal caractère qui différencie l'Aignillon de la tarière consiste dans la faculté qui lui est propre d'émettre au-dekors un venin redoutable pour l'homme el pour les divers animaux, lorsqu'il se trouve introduit dans une piqüre ou dans un endroit quelconque dénudé d'épiderme. M. Audouin a fai ressortir une double analogie bien marquée de cet organe avec l'oviducte on oviscapte de plusieurs autres insectes, en établissant les rapports qui existent entre l'aiguillon des Abeilles, des Guêpes, etc., et la tarière d'autres $\mathrm{Hy}-$ ménoptères et même des Cigales, qui ont aussi la propriété d'opérer une blessure sur les végétaux à l'aide de cet organe, et de sécréter un liquide particulier qui occasionne une exubérance très nuisible an végétal qui en a été atteint. En effet, comme M. Lacordaire le fait remarquer, la transition est nulle ou presque inserisible de l'oviscapte des Cigales, et surtout des Cercopes, à l'aiguillon des Guêpes et des Abeilles; c'est donc à l'article TARière qu'il faut chercher de plus 'grands développements sur les formes qu'affecte cet organe, et sur les passages insensibles de ces formes, quand on considère cette même partie dans toutes les familles de la classe des Insectes. Ici nous nous bornons à décrire les diverses pièces qui constituent l'aiguillon et l'usage qu'en fait l'animal.

Les Hyménoptères qui en sont pourvus sont les Guêpes, les Frelons, les Abeilles, les Bourdons, etc.; mais seulement les femelles, puisque, comme nous l'avons dit, il constitue une partie essentielle de leurs organes générateurs; les neutres ou les ouvrières, qui ne sont que des femelles dont l'appareil reproducteur existe à l'état rudimentaire, en sont également munies; mais tout le monde sait que l'on peut toucher sans inconvénient les Abeilles et les Bourdons mâles, puisque jamais chez eux aucun organe ne se convertit en aiguillon. Les auteurs anciens avaient reconnu sa présence. Aristote prétendait que le roi des Abeilles, c’est-á-dire la reine ou la mère, 
en étail muni. Columelle assura qu'Arislore sétait trompé, et qu'il avait pris pour un aignillon un gros poíl que le roi a dans le ventre. Pline s'étonnait que les mâles en fussent privés ou qu'ils n'en fissent pas usage. Cette arme, que l'on désigne aussi vulgairement sous le nom de dard, est toujours renfermée dans l'intérieur du corps pendant l'inaction, et elle ne se montre au-dehors, par la contraction des muscles fixés as dernier segment de l'abdomen, qu'au moment où l'insecte veut en faire usage ou qu'on l'inquiète, tandis que, dans beaucoup d'autres insectes el particulièrement chez les Ichneamoniens qui ont une tarière quelquefois très longue, elle est toujours saillante.

Cel appareil a été assez bien décrit dans les Abeilles par Swammerdam et Réaumur. Ce dernier a donné de longs délails sur sa structure et sur les effets que produit le venin qu'il sécrète; mais c'est seulement dans l'Abeilie commune (Apis mellifica) qu'il a été étudié d'une manière assez complète pour faire connaître l'aiguillon, car dans les autres Hyménoptères qui en sont pourvus il n'en diffère que par de légères modifications dans la forme des pieces qui le constituent.

En effet, l'Aiguillon, qui, à la vue simple, paraît d'une si grande ténuité, est composé de plusieurs pièces qui ont reçu des noms différents. Les unes sont essentielles comme les Siylets; toutes les autres sont accessoires. Ainsi, au moment oú l'Abeille le fait sortir, on n'aperçoit que l'enveloppe ou l'étui de l'aiguillon. Les pièces que l'on distingue sont une base, un étıi et deux stylets, qui constituent un dard renfermé dans l'étui. La base est composée de plusieurs parties; Swammerdam en avait compté huil, et Réaumur a prétendu qu'il n'en existail que six; mais, d'après d'autres observations, il paraît évident que ce dernier a confondu en une seule 2 pićces que Swammerdam avait distinguées. Au reste, comme M. Audouin l'a fait observer, il existe plusieurs inexactitudes dans les figures représentées par ces deux auteurs, mais qui cependant sont suffisantes pour donner une idée assez exacte de l'aiguillon, lorsque l'on fait abstraction des détails. M. Duméril a fait connaître une nouvelle picece, dont l'existence n'avait pas en- core été signaléc, et que nous croyons avoir bien reconnue; clle est située sur la ligne médiane, ayant la forme d'un $\mathrm{V}$, dont les branches, dirigées en avant, s'articulent avec l'ètui, et sont très probablement destinées à le ramener en dedans. Les autres pièces, au nombre de quatre de chaque côté, sont jointes par une membrane solide, et forment par leur réunion, une sorte d'enveloppe qui entoure l'étui, et s'attache au dernier segment de l'abdomen. Quelques muscles s'insérent à celte enveloppe, dont les pièces en s'articulant entre les stylets, leur font exécuter ia plupart de leurs mouvements. Deux corps dépendant de la base se font encore remarquer par leur forme allongée et leur couleur blanchâtre; ils sont aussi membraneux, creusés en gouttière, et forment, par leur réunion, une sorte de gaîne incomplète, enveloppant la partie antérieure de l'étui. Réaumur pense qu'elle est destinée à garantir de tout contact les parties molles de l'abdomen et de l'élui, el Swammerdam croit qu'clles servent à faire mouvoir l'étui d'avant en arrière; depuis, l'usage n'en a pas été observé d'une manière plus satisfaisanle.

L'élui consiste en une tige cornée présentant à sa base un renflement que Réaumur désigne sous le nom de talon, et qui, diminuant sensiblement de grosseur, se termine en une pointe assez aiguë. Quand on eramine cette partie, on s'aperçoil qu'elle ne forme pas un cylindre parfait, mais qu'elle n'est qu'une sorte de gaîne dans laquelle est logé le dard; car il existe à sa partie infé-rieure une gouttière qui se prolonge dans toute sa longueur.

Le dard lui-même n'est pas simple, mais composé de deux stylets longs et cfrilés, qui rie remplissent pas complètement l'intérieur de l'élui, et s'appliquent l'un contre l'autre par leur face interne, qui est lisse, aplatie et parcourue dans sa longueur par un sillon; leur extrémité est très aigüe et munic extérieurement de petites dents dirigées vers la base. Ces deux stylets ne sont pas réunis dans toute leur longueur, ils s'écartent près du talon, et décrivent dans tout leur trajet une courbe très sensible. Swammerdam el divers autres observateurs pensaient qu'au moment oú les deux stylets s'étaient écartés, ils se trouvaient dégagés de 
l'étui et rejetés en dehors. Celte npinion devenait la conséquence nécessaire de la pensée que l'étui était un cylindre conique; mais d'autres observations faites plus attentive ment ou avec des iustrurnents plus parfaits, ont démontré qu'il n'en était pas ainsi, et que l'étui, au lieu de se terminer au talon, fournissait, comme les stylets, deux branehes presque aussi longues et eanaliculées l'une el l'autre, de manière à recevoir les deux stylets, comme cela a lieu dans le resie de leur étendue. Maintenant que la composition de l'aigui!lon est connue dans l'Abeille domestique, on peut la considérer comme également connue dans toutes les autres familles et genres de la section des Hyménoptères porte-aiguillon; car, après avoir comparé cet organe dans l'Abeille domesíique avec eelui des Abeilles perce-bois (Xylocopa violacea), des Guêpes, des Frelons (Vespa crabro, Vespa communis) el même de quelques autres genres, nous avons reeonnu une structure parfaitement analogue quant á ce qui est du nombre des parties consiituantes et de leurs connexions. Ce n'est que dans la forme que quelques différences peu prononcées se font remarquer, ainsi : dans l'Abeille perce-bois, l'aiguillon nous a paru plus petit et peut-être plus conique proportionnellement a la dimension des Insectes; dans les Guêpes, il est assez court et robuste, et les deux pièces constituantes die l'étui sont plus larges et plus fortement eilices sur les parties latérales. M. Westwood, dans son ouvrage intitule : Introduct. to the modern classif. of Insects, tome 2, pag. 174, fig. $79, \mathrm{n}^{\circ} 15$ à 20 , a représenté avec la plus grande exactitude les diverses parties de l'aiguilion dans cette même Gruêpe commune. On conçoit facilement que le grand nombre de pièces entrant dans la composition de cette arme si rile anx Insectes qui en sont pourvus, doit amener la plus grande mobilité. En effet, outre les deux principaux mouvements dont jouit eet organe, celui de protraction et de rétraction dus à la dilatation et á la contraciion des muscles insérés à la base, il existe difrérents mouvements indispensables à l'Insecte, car si l'aiguillon ne porvait que sortil de l'abdomen et y rentrer, l'animal qui en fait usage n'atteindrait que très dificilement les corps qu'il veut piquer; mais il est suscep- tible de directions dans tous les sens, de manière que l'Abeille ou la Guêpe peut le tourner également de tous les còtés, étant aidée encore par la grande mobilité de l'ahdomen.

Nous avons vu l'aiguillon consistant prineipalement en un dard formé par deux stylets ayant lout-á-fait l'apparence dela pointe d'une aiguille extrêmement fine, qui serait engagée dans un étui dont elle pourrait sortir à volonté; mais celte arme ne produil yas seulement l'effet que produit une aiguille. Deux vaisseaux analogues à des glandes se réunissent en un eanal comnun pour aboutir à une vésicule musculeuse, réservoir du venin, et éjaculant, par la contraction de ses parties latérales, le liquide vénéneux qui passe par un canal court et terminé à l'endroil oú les deux stylets se séparent, eoule dans le sillon qui existe a leur face interne, et s'épanche dans la piqûre pratiquée par le dard lui-même. Aussitôt que le poison a pénétré sous l'épiderme, il occasionne les douleurs les plus vives, et son action est suffisante pour paralyser, en quelque sorte, momentanément, l'endroil qui en a été atteint; il suffit pour tuer certains Insectes, ou pour les engourdir à tel point qu'il ne leur reste plus qu'une vie toute végélative. 'C'est ce que nous exposerons avec plus de développements à l'artiele Fouisszurs. Nous avons vu que dans toute la classe des Insectes, la tarière, ou mieux l'oviducte, n’é. tait eonverti en véritable aiguillon que dans l'ordre des Iyménoptères, et encore que ce n'étail seuiement que dans une section de cet ordre, dont il fournissait le principal caractère.

Que l'on examine donc maintenant si les Insectes qui en sont pourvus n'ont pas dans leurs habitudes quelque chose qui leur soi propre, et l'on verra que ce sont ceux-lá mêmes dont l'instinct est le plus développé , qui doivent prendre soin de leur progéniture, élever leurs pelits, les défendre ou !eur apporter leur nourriture. Le Sphex ou le Crabro ne verra jamais sortir la larve de ses œufs, car déjà il aura cessé de vivre. La petite larvene peut se nourrir que d'Inseetes; elle est privée d'organes de locomotion, elle ne peut aller chercher sa nourriture, et pérírait si le Sphex, qui lui a donné le jour, n'avait apporté autour d'elle des Insectes en quantité sulfisante pour sa subsistance 
pendant tout le temps qu'elle doil passer á l'état de larve; mais elle aurait eu beaucoup de peine á s'emparer de ceux qui devaient lui servir de pâture, si le Spher ne les eût percés de son aiguillon. Le venin les a plongés dans un engourdissement complet; ils vivent encore, mais ils sont incapables d'exécuter le moindre mouvement. Des observations'des plus curieuses ont été faites, par M. Audouin, sur ces habitudes dans plusieurs Hyménoptéres. La Guêpe, le Bourdon voient leurs peti ts éclore; ils vont chercher leur nourriture et la leur apportent; mais à combien d'attaques ces larves n'auraient-elles pas été exposées, si les femelles et les neutres n'avaient pu les défendre? Aussi ce sont les Insectes chez lesquels l'on remarque le plus d'instinct, dont la plupart vivent en sociétés nombreuses où tous les individus travaillent en commun aux soins de la progéniture.

L'aiguilion, en sécrétant le venin, a le pouvoir de tuer ou au moins d'engourdir complétement les Insectes qui en ont été piqués. Sur l'homme et sur les divers animaux vertébrés il peut aussi avoir des efrets assez fàchenx, car la piqûre d'un seul Hyménoptère suffit pour faire gonfler la partie blessée et y produire des donleurs très aigües; et même, dans certains cas, elle peut occasionner la fièvre. Plusieurs naturalistes et différentes personnes, pour se convaincre que la piquire de l'aiguillon n'était réellement vulnérante que par la présence de la liqueur venimeuse, ont introduit dans une piqûre faile avec une aiguille une pelite quantité de venin obtenu en pressant Ia vésicule qui le contient, et les effets qu'elles ont ressentis ont toujours été analogues à ceux qu'occasionne l'aiguillon même. La nature de ce liquide est encore inconnue. On sait seulement qu'il se coagule au contact de l'air, qu'il a une saveur styplique, enfin qu'il ne rougit pas la teinture de tourmesol et ne verdit pas le sirop de violetle ; mais ses effets irritants son t connus depuis bien des siècles. Plusieurs remèdes ont élé préconisés pour apaiser la douleur que produisent ces piqûres; mais il est évident qu'aucun ne donne de résultat satisfaisant ; l'huile, l'cau-de-vie, la salive, ont été employés, quelquefois, dil-on, avec succés; cependant il ne laut pas trop se fier à ces re- mèdes. L'ammoniagque produit de meilleurs résultats; mais un autre moyen qui réussit assez bien et que l'on concoit facilement, consiste á sucer la plaie avant que le venin ne se soit complétement épanché. Lorsque l'aiguillon est resté dans la plaie, il faut avoir soin de l'arracher, en évitant de presser la vésicule, car alors on ferait couler une plus grande quantité de liquide; du reste, il est rare que l'animal laisse ainsi son aiguillon. Cela arrive pourlant quelquefois, à cause des épines qui garnissent le dard au côté externe, et qui empêchent sa sortie du corps dans lequel il a pénétré. Dans ce cas, l'insecte périt bientòt à cause de la dechirure de son rectum et de son oviducte.

On rapporte généralement que la piqûre d'une Guêpe ou d'une Abeille est presque sans résultat fâcheux chez certaines personnes; će qu'il faut attribuer á une plus grande dureté de l'épiderme, qui dés lors empêcherait l'aiguililon de pénétrer autant. Il est presque inutile de dire qu'un Hyménoptère ayant piqué plusieurs fois de suite ne peut plus causer de douleur par de nouvelles piqûres, parce que le liquide s'épuise bientôt; mais il se reproduit au bout de trés peu de temps.

Chez les Scorpions, la structure de l'aiguillon est beaucoup plus simple : il est formé par le dernier segment de l'abdomen, qui se termine en une pointe perforée, donnant passage à un liquide très venimeux, dont les effets ne paraissent peut-être plus funestes qu'en raison de sa plus grande abondance. Nous ferons connaître sur ce sujet quelques particularités dignes d'intérèt en traitant de l'article Scorpion. (Émile Blanchard.)

AIGULLON, Aculeus.вот. PH.-On appelle ainsi les piquants qui existent sur certaines parties des végétaux, quand ils naissent simplement de l'écorce et qu'ils semblent n'être que des espèces de poils endurcis, comme, par exemple, dans les rosiers. Il ne faut pas confondre les aiguillons avec les épines, qui sont ordinairement des parties avortées, terminées en pointe roide et piquante á leur sommet, et qui se continuent intérieurement avec le corps ligneux de la lige. $V$. Épine.

(A. R.)

* IKINIA. BOT. PH. - Le g. ainsi nommé par Wallich (Pl. asiat. rarior. 3, p. 46, 1. 273), et qui fait partie de la famille des 
Graminées, avait été décrit et figuré par M. Kuntlı (Gram. 2, p. 486 , t. 158), sous le nom de Ratzeburgia. $V$. ce mot. (A.R.)

AIL. Allium. вот. pr.-Grand g. de la fam. naturelle des Asphodélées, caractérisé par des fleurs disposées en sertule ou en ombelle simple, enveloppée de spathes scarieuses. Le cal. est coloré, formé de 6 sépales égaux, étalés ou plus ou moins dressés. Les étam. au nombre de 6 , à peu près de la longueur des sépales, à la base interne desquels elles sont attachées, ont leurs filaments planes, assez souvent trifurqués au sommet; la pointe du milieu portant une anthère allongée et à 2 loges. Le fruit est une capsule à 3 côtes ou comme triangulaire, ordinairement enveloppée par le calice qui persiste, sans prendre d'accroissement, à 3 loges contenant chacune un certain nombre de graines ordinairement noires et anguleuses et s'ouvrant en 3 valves. Le bulbe est simple ou composé ; les feuilles planes ou cylindriques et creuses; la hampe nue ou feuillée. - Dans quelques espèces, les fleurs sont en partie remplacées par des sortes de bourgeons écailleux ou de petites bulbes qu’on nomme Bulbilles, et qui sont autant de moyens de propagation de la plante. On dit alors que ces esp. sont vivipares.

Le nombre des esp. de ce g. est très considérable; il dépasse 160. Elles sont répandues dans presque toutes les contrées dı globe, mais plus particulièrement dans l'Europe méridionale et l'Asie. Plusieurs sont cultivées dans nos jardins comme plantes potagères. Il nous suffira de citer ici les esp. suivantes, dont l'emploi et les propriétés sont connus de tout le monde.

\section{$\$$ I. Feuilles planes.}

1. L'sil commun (Allium sativum L.), qui paraît originaire des sables de la Sicile. Ses bulbes sont composés. On les emploie non seulement comme assaisonnement ou condiment, mais elles font aussi partie de plusieurs préparations médicamenteuses.

2. La Rocambole (Allium scorodoprasum L.), qui croît sauvage en Gréce, en Italie, en Portugal, etc., a également des bulbes comprosés; ses fleur's sont entremêlées de bulbilles.

3. Le Polreau (Allium porrum L.), dont la patrie parait être aussi le midi de l'Europe, et spécialement la Péninsule ibérique.
SII. Feuilles cylindriques eb creuses.

4. L'Ognon commun (Allimn cepa L.). C'est sans contredit l'esp. la plus importante et la plus utile dı g. par son emploi journalier daus nos préparations culinaires. On en cultive un grand nombre de variétés.

5. L'ÉCinate (Allium ascalonicum L.); on la croit originaire des montagnes de la Palestine.

6. La Ciboule (Allium fistulosum L.).

7. La Civetre ou Ciboulette (Allium Schcenoprasum L.).

Dans nos parterres d'ornement on cultive fréquemment une belle esp. nommée vulgairement Ail doré. C'est l'Allium Moly L. On la plante en bordure, et elle fleurit dès le premier printemps.

(A. R.)

ALANTUS. вот. pH. - Sous le nom d'Ailante ou arbre du ciel, les habitants des Moluques désignaient, à ce que nous apprend Rumph, le grand arbre si répandu maintenant dans nos promenades et nos parcs, et nommé vulgairement Vernis de la Chine. On l'avait pris lollg-temps pour un Sumac. Desfontaines, en l'en distinguant génériquement, lui donna le nom qu'il porte, grécisé mal à propos par l'addition d'un $h$; et, lorsque les familles naturelles furent établies, l'Ailante prit place auprès des Sumacs dans celle des Térébinthacées. Cette famille fut divisée plus tard, et plisieurs de ses g. durent quitter la classe des périgynes, pour prendre place parmi les hypogynes, où les appelait l'insertion de leurs étamines. L'Ailantus en fait partie et se classe maintenant á la suite des Zanthoxylées, ainsi que semblent l'indiquer les caract. suivants : Fleurs polygames; mâles : cal. 5-fide; 5 pétales plus longs, ouverts; étam. 10 ; 5 alternes avec les pétales, et les égalant en longueur; 5 opposées plus courtes. Disque central, portant en dehors les pétales et les étam., prolongés audessus de leur insertion en un rebord annulaire qui a 5 replis sinueux et cachant à l'intér. 5 petits rudiments d'ovaires. Fleurs hermaphrodites (ou femelles): cal., pétales et disque comme dans les mâles. Étamines en moindre nombre par avortement ; ovaires 4-5 distincts, comprimés, portant chacun inséré sur une échancrure de leur bord interme, un style que termine un stigm. réfléchi. Autant de samares oblongues, compriınées, membraneuses, diversement réticu- 
lées, renflées au milleu qụ correspond à une loge 1-sperme. Graines comprimẻes, suspendues, continuant sous un tégument membraneux, doublé d'une couche mince de périsperme, un embryon droit à radicule courte et supérieure, à cotylédons planes, fo-liacés.

Outre l'Ailantus glandulosa Desf. on Vernis de la Chine, on en connaît 3 autres esp. originaires de l'Inde et des Moluques, dont une est le Pongelion de Rheed. Ce sont de grands arbres, à feuilles composées de folioles disposées par paires avec ou sans impaire, inéquilatérales, entières ou dentées, sans points glanduleux. Leurs fleurs d'un blanc verdâtre ou jaunâtre forment de grandes panicules terminales.

(AD. J.)

ALE. Ala. Moll. - Nom vulgaire donné $1^{\circ}$ à la lèvre de certaines coquilles lorsqu'elle se développe d'une manière remarquable (ex. : l'Aile d'Aigle, syn. de Strombus gigas); $2^{\circ}$ à diverses coquilles, à cause des couleurs dont elles sont ornées (ex. : Aile de Papillon, syn. de Conus genuanus), ou de leur forme générale (ex.: Aile de corbeau, syn. de Pinna nigrina); 3о aux nageoíres, ou membranes latérales de quelques Céphalopodes et Pléropodes. Enfin, parmi les Zoophytes, on a nommé la Pennatule Aile de mer ou Aile marine, etc.

(C. D'O.)

MIL. Ala. вот. pн.-Toutes les fois qu'un organe présente des appendices foliacés ou membraneux, planes ou roides qui s'en élévent en formant des angles plus ou moins aigus, ces appendices sont appelés Ailes, et l'organe qui les porte est dit ailé. Ainsi la tige du bouillon blanc, de la consoude; le calice de quelques Begonia, le fruit des Érables, des Malpighiacées; les graines des Quinquinas et de plusieurs autres Rubiacées sont ailées.

(A. R.)

AIL DE PIGEON. вот. CR. - Nom vulgaire des Agaricus columbarius et argyraceus, esp. qui, sans être vénéneuses, ne sont néanmoins pas comestibles.

AILE SIVGULIERE. 015. - C'est dans Azara le nom d'une esp. de petit oiseau du Paraguay, qu'il décrit à la suite de ses Tachuris, espèces de petits gobe-mouches. Elle est remarquable. en effet, par ses ailes munies d'un grand nombre de pennes les plus pointues, les plus étroites et les plus faibles que cet auteur eut jamais vines, et par des tarses comprimés comme ceux d'un oiseau aquatique. Nous ue pensons pas que depuis l'individu cilé par Azara aucun autre de cette espèce ait été retrouvé ou indiqué par aucun naturaliste.

(LAFR.)

AILEES. Alato. NoLl. - Lamarch donne ce nom à une famille de Nollusques, dont les coquilles sont remarquables par la dilatation du bord droit. Cette famille renferme les g. : Rostellaire, Plërocère, et Strombe. $V$. ces mots. (Desil.)

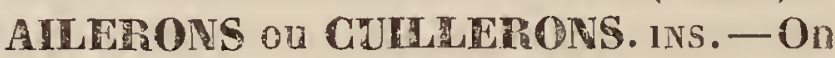
nomme ainsi 2 lamelles membraneuses, appliquées l'une sur l'autre en forme de valves et attaclıées de chaque côté du mésothorax à la base des ailes des Diprères. Ces lamelles varient pour la taille suivant les familles, et sont d'autant plus grandes que les balanciers au-dessus desquels elles sont placées sont plus petits et vice versa. Ainsi elles sont très développées dans les Muscides, dont les balanciers sont très courts, tandis qu'elles sont rudimentaires of même entièrement oblitérées dans les Culicides et les Tipulaires, dont les balanciers sont très longs; mais quelle que soit la taille des ailerons, leur lamelle infèr. est toujours plus grande que la supér. Du reste ces 2 lamelles sont ovales, convexes extérieurement et concaves intérieurement; elles sont plus ou moins transiucides, ciliées dans leur contour et attachées ensemble par leurs bords antérieurs, comme les 2 valves d'une coquille. Nous avons dit qu'elles étaient appliquées l'une sur l'autre, mais c'est dans l'inaction; car, lorsque l'insecte vole, elles s'ouvrent et se placent sur un même plan. - Plusieurs naturalistes ont pensé que les ailerons des Diptères remplaçaient pour eux les secondes ailes des Hyménoptéres; mais c'est une erreur ; car il faudrait pour cela qu'ils fussent insérés, comme elles, au métathorax ; or il est aisé de s'assurer, ainsi que l'a fait observer le premier M. Audouin, que non seulement ils tiennent au mésothorax, mais qu'ils font corps avec les ailes dont ils ont l'air d'être un organe distinct, n'en étant séparés que par une fissure plus ou moins profonde, qui disparaît même entièrement dans beaucoup d'espéces. Ce qui confirme encore la vérité de cette opinion, c'est la découverte faite par le même savant, ainsi que par Latreille, de l'existence des ailerons dans cer- 
taius Coléoptères; en effet, si l'ou soulève les élytres des grandes especes de Dystiques ct d'ilydrophiles, on apercerra facilement a leur base une meinbrane qui leur est adliérente, ayant la même forme et la mênie organisation que l'aileron des Diptères. A la vérité cette membrane est simple, mais elle l'est également dans les Taous, ce que nous avons oublié de dire au commencement de cet article.

Quant à l'usage des ailerons chez les Diptères, des expériences ont prouvé qu'ils ne contribuent en rien à leur bourdonnement, comme plusicurs naturalistes l'ont avancé. Tout porte à croire qu'ils ne servent qu'à diriger ou à modifier le vol: $V$. Balanciers.

ALES $(A l a)$. 200L.-Ce sont des membres modifiés, pour la locomotion aérienne.-Une analogie incompléte dans les fonctions a fait désigner sous le nom d'Ailes, des appendices auxquels ce nom doit être refusé, tels que les parachutes de certains mammifères et de quelques petites esp. de reptiles sauriens, les nageoires élargies des dactyloptères et des exocets. Les premiers ne sont pas des membres; et les uns comme les autres sont des organes de soutien, mais non de locomotion aérienne. La formule que nous proposons les rejette donc tous également, en même temps qu'elle nous parait embrasser toutes les formes organiques auxquuelles est dû véritablement le nom d'Ailes, á savoir, parmi les vertébrés, les membres antérieurs des Clıćiroptères, des Oiseaux et des Ptérodactyles, et deux paires de mernbres thoraciques chez les Insectes.

Le vol est de tous les rnodes de locomotion relui qui exige le déploiement de forces le plus considérable. Dans un miliez d'une derısité aussi faible que l'air, l'animal qui vole a d'abord a supporter par une action nusculaire tout le poids de son corps, comme celui qui marche à la surface de la terre; mais il n'a pas, comme ce dernier, uı point, un appui fixe. Il est perpétuellement placé dans la condition d'une masse qui tombe; et pour représenter la'somme des forces qu'il lui a fallu dépenser dans un temps donné, seulement pour se soutenir, il faudrait y faire entrer comme élément la quantité de mouvement qu'il aurait acquise, d'aprés les lois de la chute des corps, en tombant dans le vide pendant le même espace de temps. Cette dépense de forces musculaires qui peut êtré exigée d'un animal pour qu'il obtienne l'immobilité relative dans le milieu oú il se trouve plongé, est presque nulle chez les animaux aquatiques, qui ont à peu près le même poirls spécifique que l'eau dans laquelle ils vivent. Il en est de même dans plusieurs attitudes pour les animaux terrestres, et elle se réduit pour cux, dans les cas les plus défavorables, à l'effort musculaire nécessaire pour empêcher la flexion des pièces mobiles articulées dont se compose la charpente de leurs membres. Flle atteint son maximum chez les animaux aériens.

Aussi, est-ce à ces derniers que la plus grande puissance musculaire a été départic; et ne devons-nous pas nous étonner qu'ils appartiennent tous aux deux seuls embranchements qui aient été bien partagés sous le rapport de la solidité de la charpente et de la puissance des mécanismes, l'embranchement des vertébrés et celui des articulés. Si, au lieu de considérer l'ensemble des êtres, nous entrions dans les rétails, si nous examinions chaque être qui vole en particulier, en le comparant à ceux qui ne volent point, nous velrions que cette fonction si laborieuse est une sorte de centre vers lequel tend à se porter toute l'énergie musculaire, au détriment des autres fonctions qui ont pour principe l'action des muscles. Les Chéiroptères comme les Oiseaux, et ces derniers comme les Insectes qui volent bien, sont des animaux faibles partout ailleurs que dans leurs ailes, dans les muscles qui meuvent celles-ci, et dans les autres organes qui se rapportent à la fonction du vol. Lorsque dans un groupe créé en général pour le vol nous rencontrons des individus propres á quelque autre laborieuse fonction, ce sont des êtres détournés, en quelque sorte, de la destination générale ; car chez eux la locomotion aérienne est nulle ou réduite à de faibles proportions. Les Gallinacés, les Échassiers coureurs, les Palmipèdes plongeurs - parmi les Oiseaux; les Fourmis travailleuses, et les Insectes fouisseurs, nageurs, ou sauteurs, mettent dans toute son évidence ce fail, qui n'est qu'un cas particulier de la loi beaucoup plus vaste du balancement des organes, établie par M. Geofroy St-Hilaire. 
Nous n'avons pas á nous occuper ici de l'étude des ailes considérées dans chaque groupe d'êtres en particulier, ce qui nous entraînerait en des détails pour lesquels nous devons renvoyer aux différents articles spéciaux de ce Dictionnaire; nous nous contenterons d'envisager actuellement ces organes sous leur point de vue le plus général. Or, ils présentent á étudier un premier élément constant, leur charpente solide, qui n'est autre chose que celle diversement modifiée des membres mêmes qu'ils représentent, puis un second élément destiné à compléter le premier, et dont toutes les formes se rèduisent à deux.

Tantôt, en effet, cet élément est fourni par une portion de l'enveloppe générale du corps, par la peau étendue en une membrane à double feuillet, nue ou couverte d'appendices de nature diverse. Telles sont ou ont été les ailes des Chéiroptères, des Ptérodactyles, et de la presque totalité des Insectes. Le rapport des ailes de ce type avec les palmures qu'ofrent les pattes de la plupart des Vertébrés nageurs est fort remarquable.

Tantòt ce sont les appendices tégumentaìres qui sont appelés à fournir cet élément important. Les ailes des Oiseaux, et celles de certains petits lépidoptères qui portent le nom de Ptérophores, sont dans ce cas et ce secònd type nese montre pas moins fidélement représenté que le premier dans la conversion des membres en appareils spéciaux de locomotion aquatique; car l'agrandissement des membres en surface, pour la natation, par l'emploi des appendices tégumentaires, dont on trouve déjà des traces bien manifestes dans la classe des reptiles, est, avec l'élargissement des pièces squelettiques des articles eux-mêmes, le seul, que nous sachions, qui se manifeste chez les articulés proprement dits, ou artículés à membres articulés.

Mais jusqu'à quel point pouvons-nous dire, comme nous l'avons fait, que les ailes son! toujours des membres modifiés? C'est là ce qu'il importe que nous établissions, si nous voulons donner quelque valeur à la formule que nous avons proposée. Mais c'est là aussi, nous ne devons pas le taire, ce qu'il y a de plus diflicile dans l'histoire philosophique des Ailes, et nous n'espérons pas faire partager á lous nos lecteurs la conviction que nous avons acquise á cet égard; ce serair l'affaire d'un travail bien plus développé que ne peut l'être un article de la nature de celui-ci. Entre les ailes de ceux des vertébrés qui en possèdent et les membres antérieurs, il y a sans doute une analogie de nature à frapper les yeux les moins exercés; mais il n'en est plus de même des ailes des Insectes. Cependant, l'opinion qu'on doit les regarder comme des membres modifiés n'est pas à beaucoup près nouvelle dans la science. Déjà Jurine avait comparé les ailes des Hyménoptères aux ailes des Oiseaux; mais Latreille était allé beancouj plus loin, et en s'appuyant sur des analogies extérieures, dans un mémoire plein de cette sagacité d'observation extérieure qui n'appartenait guère qu'à lui, il avait réfuté l'opinion de M. de Blainville qui voulail que ce ne fussent que des trachées renversées, et il y avait fait ressortir une foule d'analogies frappantes qui existent entre certaines ailes et les membres de certains insectes; mais il s'en était tenu là. Bien plus, craignant d'avoir émis des doctrines trop audacieuses, il était revenu depuis sur ses premières assertions pour les abandonner en partie. M. Audouin, tout en faisan tressortir les nombreuses ressemblances qu'il y a entre ces deux ordres d'organes, combattit fortement l'idée quel'un fùt l'analogue de l'autre; mais on voit assez combien cette opinion avait d'attraits pour un esprit généralisateur comme le sien, car il va jusqu'à dire :

"Si nous ne partageons pas sur l'origine „ des ailes l'opinion de Latreille, c'est parce "que leur position sur le dos et sur un segn ment pourvu déjá d'une paire de pattes, " ne nous permettait pas de les considérer " comme les analogues de celles-ci; le fait " de la ressemblance sous tous les autres rap"ports n'en existait pas moins, etc. "

Une seule objection a donc arrêté M. Audouin, et l'a conduit à proposer une autre théorie des ailes des insectes. D’après lui, les ailes seraient des appendices bien distincts des pattes par tous leurs rapports analogiques, et appartenant en propre à l'arceau supérieur des $2^{\text {me }}$ et $3^{\text {me }}$ anneaux du thorax; chaque anneau devrait donc être considéré analogiquement comme possédant deux paires d'appendices.

Les nombreuses dissections d'insectes que 
nous avorns faites depuis quelques années, et qui avaient surtout pour but dobtenir de l'investigation du système nerveux de nouvelles données pour l'étude philosophique de ces animaux, nous ont conduit à une conviction différente, que nous nous contenterons de formuler ici, mais que nous désirons vivement pouvoir publier plus tard avec tous les développements nécessaires.

Le thorax des Insectes s'offre à notre esprit comme représentant 5 anneaux et non 3 seulement. - Le $1^{\mathrm{er}}$ est le prothorax, qui ne porte jamais d'appendices á son arceau supérieur, et dont M. Audou in a fait ressortir toute la simplicité de composition relativement aux autres.-Le $2^{\text {me }}$ serait l'anneau des $1^{\text {res }}$ ailes; celles-ci en seraient les membres.-Le $3^{\text {me }}$ serait l'anneau des $2^{\text {mes }}$ pattes. Ces deux anneaux, en se soudant intimement et en se portant, le $1^{\mathrm{er}}$ en haut, le $2^{\text {me }}$ en bas, pour obéir à des nécessités de fonction, constitueraient cet anneau si compliqué que M. Audouin a désigné sous le nom de mésothorax. - L'anneau des $2^{\text {mes }}$ ailes et celui des $3^{\text {mes }}$ pattes constitueraient, par une soudure toute pareille, le métathorax, et les ailes, d'après cette manière de voir, seraient les membres (les $2^{\mathrm{e}}$ et $4^{\mathrm{e}}$ anneaux du thorax. (L. D. Y.R.)

AILES. Ala. ols.-Bien qu'à l'article précédent on ait annoncé que le mot Aile, considéré dans ses rapports avec les différentes classes, ne serait traité qu'aux généralités de chacune d'elles, il acquiert tant d'importance dans l'étude comparée des familles diverses.des Oiseaux, que nous nous sommes décidé à présenter dès ce moment nos observations sur ce sujet.

Les Oiseaux ne pourraient se soutenir et se diriger dans le fluide aérien, si les rames qu'ils ont reçues de la nature n'avaient été douécs d'une étendue et d'une vigueur considérables. L'aile à forme allongée, mue par 12 muscles d'une incroyable énergie, arquée antérieurement et d'une légère coricavité, produit, à l'aide des pennes élastiques qui la terminent, un vol puissant, une force capable de résister aux vents les plus impétueux. Elic se compose, comme le bras de l'homme, et le membre antérieur des autres mammifères, de 3 parties analogues, à l'humérus ou bras ( $p l . C, f i g .1, a$.$) , à$ l'avant-bras, formé de $2 \mathrm{os}$, le radius $(b)$ et le cubitus $(c)$, ct à la main ou carpe $(d)$ réduite, Tow. 1. selon Cuvier a un seuł doigt et abx rudiments de 2 autres. Sur toute la longueur de ce membre, sont implantées de longues plunies, fermes, ćlastiques, qui, par leur rapprochement, forment ces rames au moyen desquelles l'oiseau frappe et fend l'air. Les plus extérieures de ces pennes se nomment primaires; elles sont au nombre de $10(e)$ et sont attachées à la main. Les suivantes, nommées secondaires $(f)$, varient en nombre et adhèrentá l'avant-bras; enfin les plus rapprochées du corps ou tertiaires sont fixées sur l'humérus. L'os qui représente le pouce, porte encore quelques pennes nommées bâtardes, petites, presque atrophiées, et que M. Swainson dit ĉtre au nombre de 10 comme les primaires $(g)$. Toutes ces pennes sont recouvertes a leur base par plusieurs rangées de plumes courtes et moyennes, désignées sous les noms de petites, moyennes et grandes couvertures. Celles-ci sont supérieures et inférieures aux pennes. Toutes les inféricures sont faibles, à tuyaux très déliés, et ne donnent à l'aile aucune fermeté. Parmi les supérieures, au contraire. les grandes, qui sont en nombre égal à celui des pennes, leur sont contiguës à leur base, dans une certaine élendue de leur tuyau, et semblent les doubler en dessus. Celles qui recouvrent les secondaires leur sont de beaucoup inférieures en grossenr; mais celles qui sont accolées aux primaires ont un tuyau singulièrement gros, vu leur peu de longueur, égalant presque celni de ces primaires, et leur sont tellement adhérentes à leur base ainsi qu'entre elles, qu'elles doivent doubler la fermeté et la force résistante de la main. La forme des pennes, leur plus ou moins de longueur et de fermeté, modifient à l'excés l'action du vol chez l'oiseau. On peut toutefois poser en principe que les ailes allongćes, pointues et étroites par suite de la décroissance rapide des primaires et de la brièveté des secondaires et des tertiaires, sont les plus favorables a u mécanisme d'un vol puissant et facile. Les Martinets, Hirondelles, Colibris, OiseauxMouches, les vrais Faucons, et, parmi les Palmipèdes, les Frégates, les Hirondelles de mer, les Albatros et les Pétrels, appuient cette assertion $(V \cdot f i g .2$, l'aile du Martinet; les primaires $(f)$, les secondaires (g). Par opposition, l'aile courte, arrondic et large, est l'in- 
dication d'un vol court et faible, comme celui du Troglodyte (fig. 3), ou d'un vol précipité et bruyant, mais de peu de durée, comme celui des Gallinacés (fig. 4, l'aile de la Pcrdrix). Dans ces 2 cas, les primaires sont courtes, presque égales entre elles, et d'une dimension voisine de celle des secondaires et des tertiaires. Ce caract. de brièveté se remarque particulièrement dans les Plongeurs ou Brachyptères de Cuvier, chez les Plongeons, les Pingouins ; il est porté au maximum chez les Manchots ( $/ \mathrm{ig} .5)$, chez les Autruches, et chez tous les Brévipennes de Cuvier, où l'aile osseuse est tellement réduite, qu'elle se trouve hors de toute proportion avec la dimension de l'oiseru. Entre ces 2 extrémités, les formes et les propriétés qui en dépendent sont moditiées à l'infini.

Chez un assez grand nombre d'Oiseaux, les primaires sont échancrées et rétrécies à quelque distance de leur sommet, comme chez les Pigeons et les Faucons ( $f(g .6)$. Il est présumable que ce rétrécissement des premières pennes vers la pointe rend ces oiseaux aptes à fendre l'air avec plus de puissance. Mais il en est d'autres chez lesquels quelques unes des $1^{\text {res }}$ pennes se rétrécissent tellement tout-à-coup, qu'elles en deviennent quelquefois filiformes à leur extrémité, comme chez les Coqs de roche ( $f g .7)$. Certains Cotingas, beaucoup de Tyrans, de Pepoazas et de $M o u-$ cherolles d'Amérique, sont dans le même cas. Quelquefois, la $2^{\mathrm{e}}$ ou même la $4^{\mathrm{e}}$ penne eprouvent seules celte modification comme chez les Bécardes, le Cotinga-onette (fig. 8). Cette particularité a-t-elle un but d'utilité, ou n'est-elle qu'un jeu de la nature, comine les huppes et autres ornements? c'est ce qu'on ignore entièrement.

En observant avec attention le squelette de l'aile, nous avons reconnu que des 3 parlies qui le composent, l'avant-bras est celle dont la longueur ou la brièveté influe le plus puissamment sur la qualité dı vol. En effet, quelles que soient les dimensions comparatives de l'humérus, le vol est facile ou même rapide si l'avant-bras est long, soit qu'il dépasse de beaucoup la longueur de cet humérus comme chez les Martinets, Hirondelles, Colibris; soit qu'il ne la dépasse que modérément comme chez les Oiseaux de proie diurnes, les Totipalmes, les Échassiers voyageurs; soit enfin qu’il lui soit égal comme chez les grands voiliers; mais dans ce dernier cas, ces 2 parties et même la $3^{\text {me }}$ sont d'une longueur prodigieuse. L'humérus, au contraire, qui fait levier dans le vol, peut, sans nuire à la rapidité ni à la puissance de celui-ci, être très court, réduit presque à ses apophyses d'articulations, comme chez les Martinets, Hirondelles, Colibris et les meilleurs voiliers. Alors, toutefois, ces apophyses ont un développement énorme, favorable à l'insertion des muscles moteurs. Quant aux os de la main, ils semblent avoir gagné en longueur et en largeur ce que l'humérus a perdu de ses proportions. Tous les Oiseaux, pourvus de ce genre d'aile osseuse, ont un vol très rapide ou très facile, comme nous l'avons déjả dit.

Chez les Oiseaux à vol précipilé et bruyant, mais de peu de durée (Galiinacés), l'avantbras est très court, et d'une longueur égale à l'humérus et au carpe; ces 2 parties sont par conséquent fort peu développées. Chez les Canards dont le vol, sans être très facile, est aussi à battements précipités, mais de plus longue durée que chez ces derniers, on retrouve dans ces 3 parties des proportions presque semblables aux leurs. Chez les Plongeuns et les Grèbes, elles ont plus de développement; mais chez les Guillemots et les Fingouins, l'humérus, dont la longueur est médiocre, st termine par un avant-bras plus ccurt enccre; aussi ces esp. volentelles très faiblement. L'avant-bras du grand Fingouin, qui ne vole pas du tout, est remarquablemnent court. Enfin, chez les Marnchots, entièrement privés de la faculté du vol et qui n'ont pas même vestige de plumes sur les ailes ( $f i y .5$ ), les 2 premières parties sont très courtes, el la $3^{\text {ne }}$ plus longue; mais toutes 3 sont élargies, comprimées et transformées en véritables nageoires, qui ne servent à ces oiseau $\mathrm{x}$ que pour la natation ou l'immersion.

Conduits par nos propres observations à donner à l' Aile, considérée sous le rapport des formes terminales, des qualifications différentes de celles dont se servent habituellement les ornithologistes, nous avons adopté les épithètes dont s'est servi M. Isidore-GeofrroySt-Hilaire dans la mème occurrence. Comme ces expressions sont encore peu connues, nous croyons devoir donner ici quelques explications à ce sujet. 
On est dans l'usage de désigner, assez improprement, par ailes courtes ou longues, celles dont les rémiges primaires, lorsque l'aile est plice, paraissent telles comparativement à la queue, sans égard à l'ensemble de leurs dimensions réelles. Cependant, l'aile se composant de 3 parties distinctes, reployées l'une sur l'autre dans l'état de repos, et qui sont l'humérus ou le bras, l'avant-bras et la main, il arrive souvent qu'en les déployant, on reconnait des ailes très longues, quoique les pennes primaires implantées sur la main soient assez courtes. Souvent aussi le contraire se présente, et une aile de longueur médiocre peut, lorsqu'elle est développée, se terminer par de longues rémiges. Chez les Albatros, par exemple, dont l'aile est démesurément longue, la dimension modérée des primaires, n'en laisserait point deviner l'étendue quand elle est pliée. L'aile des Éperviers, des Autours, classée jusqu'ici parmi les moins longues, courte, il est vrai, quant aux rémiges, présente, si on la déploie, une envergure proportionnellement aussi étendue que celle des Faucons, considérée d'ordinaire comme longue, attendu que ses primaires sont plus allongées que celles des Autours.

En comparant un squelette d'Épervier à celui d'un Faucon-cresserelle, on reconnaîtra facilement que chez le premier, la réunion de l'humérus, de l'avant-bras et du métacarpe, offre un plus grand développement que chez le second, expérience à laquelle on ne s'attend pas, d'après les définitions ordinaires des caractères extérieurs de ces Oiseaux.

Il nous a donc paru logique de ne désigner par longueur d'une aile, que celle de ce membre entièrement déployé; et par longueur des primaires, ce qu'on a appelé jusqu'ici la longueur des ailes et qui n’était réellement que celle de ces $1^{\text {res }}$ pennes.

En employant les termes d'aile aiguë ou obtuse, pour exprimer la manière dont se termine l'organe du vol chez les oiseaux, nous faisons un emprunt à M. Isidore-Geoffroy-St-Hilaire, qui s'est servi de ces expressions, dans son mémoire intitulé : Considérations sur les caract. employés en Ornithologie, etc., et dans son dernier Cours d'Ornithologie. Nous reconnaissons donc comme lui , 2 formes principales dans la terminaison de l'aile: $1^{\circ} l^{\prime}$ aile aiguë, dont la seconde rémige primaire est la plus longue, comme chez les vrais Faucons; se subdivisant cn aile sur-airguë, dont la $1^{\text {re }}$ rémige égale ou surpasse la $2^{\text {me }}$, comme chez les Langrayens, les Hirondelles, les Colibris, et en aile subriiguë, dont la $3^{\text {me }}$ égale la $2^{\text {me }}$, comme chez les Vautours et un grand nombre de Passereaux; $2^{\circ}$ en aile obtuse, dont la $4^{m \mathrm{c}}$ penne est la plus longue de toutes, comme chez les Aigles et la plupart des Gallinacés; se subdivisant en aile sub-obtuse, où la $3^{\text {me }}$ penne devient égale ou supér. à la 4 me (Brèves, vraisKakatoës, etc.), et en aile sur-obtuse, etc. Nous ajouterons avec le même auteur, et d'aprés nos propres observations, qu'en établissant ces 6 types dans l'ordre suivant : 10 Aile suraigzü ; $2^{\circ}$ aigü̈; $3^{\circ}$ sub-aiguë ; $4^{\circ}$ sub-obuse; 50 obtuse; $6^{\circ}$ sur-obtuse, chacun d'eux dilfère peu de celui qui le précède et de celni qui le suit immédiatement. Cette différence ne suffi t pas pour en produire une notable dans le vol, tandis qu'il en est tout autrement, si l'on compare entre elles deux de ces formes placées à quelque intervalle l'une de l'autre. 11 en résulte encore que 2 formes voisines peuvent se trouver réunies dans un même genre, tandis qu'il est très rare que dans un genre vraiment naturel on puisse remarquer des formes d'ailes assez différentes pour ne pas figurer immédiatement à la sui te l'une de l'autre. Ces six variétés de la forme de l'aile ne pouvant au premier abord se graver dans la mémoire, nous avons cru rendre service à nos lecteurs en les dessinant au bas de la planche (Oiseaux, Pl. C. fig. 9.) dans l'ordre indiqué ci-dessus. (LAFr.)

AILFER. вот. PH. - Dénomination vulgaire, appliquée dans le midi de la France à deux esp. d'Aulx (Allium sphorocephalum, carinatum).

(C. L.)

AILLAME. BơT. PII. - Nom vulgaire, dans quelques parties de la France, du Sorbier des Oiseaux (Sorbus aucuparia I.). (C. I..)

AlLURUS (alioupos, chat, belette). mam. - Syn. latin de Panda. $V$. ce mot.

$$
\text { (I. G.S. H.) }
$$

AIMANT. MIN. - On donne ce nom aux variétés du fer oxydé, qui jouissent de la double propriété de manilester des pôles magnétiques, lorsqu'ils sont en présence d'une aiguille aimantée, et de pouvoir communiquer la même vertu a des barres d'acier, a l'aide des procédés de l'aimantation 
artificielle. Les aimants naturels appartiennent tous à l'esp. de minerai de fer qui est le moins oxygéné, et c'est pour cela qu'on a a ppelé cette esp. fer oxydulé magnétique. Cependant les propriétés qui caractérisent les aimants ne se montrent pas dans toutes les variétés de l'espéce. Les variétés compactes et terreuses, celles qui offrent dans leur cassure une apparence lithoïde, les manifestent surtout au plus haut degré; d'où la dénomination vulgaire, mais assez impropre, de Pierves d'aimant, sous laquelle on désigne les aimants naturels, qui sont de véritables minerais ferrugincux. Quoique le mot aimant ne soit, comme on vient de le dire, qu'un nom de variété, Beudant a cru pouvoir l'étendre á toute l'espèce du fer oxydulé magnétique, qui, dans sa classification, porte le nom de Fer Aimant. $V$. le mot Fer.

(Dec.)

AIMANT. PIIYs: - On donne ce nom aux minerais de fer qui jouissent de la propriété d'exercer une action polaire sur l'aiguille aimantée ; c'est-á-dire de posséder 2 pòles magnétiques. Quant aux minerais qui exercent seulement une action attractive sur chacun des pôles de l'aiguille aimantée, ils ont reçu la dénomination de substances magnétiques. La puissance magnétique n'appartient pas seulement au fer et à quelques uns de ses minerais, mais encore au cobalt et au nickel à l'état métallique.

La plupart des substances qui renferment le fer à l'état métallique ou à l'état de protoxyde, sont magnétiques à des degrés dépendants de la quantité qu'elles en contiennent. Le peroxyde non hydraté, ou fer oligiste, est également magnétique.

L'aimant proprement dit, ou pierre d'aimant, est le fer oxydulé amorphe, taillé et entouré d'armures de fer doux, pour former les aimants artificiels qu'on trouve dans les cabinets de physique.

Les variétés de fer oxydulé possèdent également la propriété polaire. On distingue particulièrement le fer oxydulé cristallisé en octaèdres réguliers, que l'on trouve en abondance dans les terrains serpentineux; ces terrains possèdent eux-mêmes la propriété polaire, et peuvent en conséquence être considérés comme des aimants d'une grandeur :olossale. Yous citerons, entre autres, les exemples suivants :
Le Heidelberg, près de Zell, s'élève au milieu d'un vaste p'áteau, à la pente N.-O. du Fichtelgebirge. La montagne est dirigèe du S.-O. au N.-E. comme les Roches primitives et intermédiaires de ces contrées. Elle appartient au groupe des Serpentines enclavées dans les Schistes chloriteux et amphiboliques. Dans la chlorite, les parcelles de fer oxydulé sont visibles à l'œil nu, tandis que dans les autres roches on découvre le fer en pulvérisant la masse et en la remuant avec un barreau aimanté. Les strates de toutes ces roches sont parallèles à l'axe longitudinal de la montagne, qui agit à 20 pieds de distance.

On a cru observer que les roches du Heidelberg qui ont le plus de magnètisme polaire sont aussi celles dont la pesanteur spécifique est la plus grande.

Ce qu'il y a de remarquable dans Ic magnétisme de cette montagne, c'est la distribution et le parallélisme de ses axes magnétiques. M. de Humboldt a ubservé que les pòles nord sont tous situés à la pente S.-E., et les pôles sud a la pente N.-O.; de sorte queles pôles homonymes occupent une même pente. Le parallélisme des axes est constant à l'extrémité N.-E. et dans son centre; mais il est peu sensibie à l'extrémité S.-O., oủ les roches chloriteuses, amphiboliques et talqueuses passent i la vraie serpentine. Les points d'indifférence sont placés aux extrémités N.-E. et S.-O. de la montagne, c'est-àdire aux extrérnités de l'axe longitudinal du Heidelberg, ou selon la ligne qui détermine la direction des couches. Les axes magnétiques sont perpendiculaires à la direction de celles-ci.

M. Lichtenberg a supposé que ces axes peuvent bien être l'efiet de tremblements de terre, qui, dans les grandes catastrophes de notre planète, ont agi long-temps dans les mêmes directions. M. de Humboldt a cru voir effectivement changer, dans l'Amérique méridionale, l'inclinaison magnélique, à la suite d'un tremblement de terre, l'intensité des forces étant restée la même.

Il serait à désirer que l'on pût savoir si la direction de l'axe magnétique est constante, ou si elle change avec la direction du méridien inagnétiçue de la contrée voisine.

Le magnétisme polaire de ces roches, qui renferment des parcelles ou de petits cris- 
taux de fer oxydule, est souvent bien plus puissant que le magnétisme polaire de ces grandes masses de fer oxydulé, qui forment des couches dans les montagnes primitives, et qui ne sont point en contact avec l'atmosphire ou rapprochées de la surface du globe.

M. de Humboldt a trouvé prés de Voisaco, entre Almageur et Pasto, à 1045 toises de hauteur au-dessus de la mer, une roche de porphyre trachytique qui ofrail en petit presque les mêmes płénomènes que la monlagne magnétique de Franconie. Sur la pente orientale du Chimborazo, MM. de Humboldt et Bonpland ont trouvé aussi un groupe de porpliyre trachytique, en colonnes pentagones, dont le magnétisme polaire agit à 3 pieds de distance.

Enfin, pour dernier exemple, je citcrai le globe terrestre, qui est lui-mème un aimant, dont les pôles sont situés à peu de distance des pôles terrestres. (BeCnUEREI.)

* AImophila ( aî.os, buisson, haie ; ẹìos, n, ami ). ots.-C'est, dans la classification de Swainson, un s.-g. de son g. Pyjfrita, Cuv. (Moineau) et dont les caract. sont : Bec assez allongé, conique, comprimé; mandib. supér. élevée à sa base entre les plumes du front, légẻrement échancrée à la pointe et plus épaisse à sa base que l'infér.; commissure sinueuse; le dessus du bec légèrement courbé depuis la basc. Ailes arrondies, à rémiges courtes; les 2 premicres pennes étagées. Queue médiocre, arrondie; les rectrices assez étroites. Pieds forts, les doigts latéraux presque égaux; ongles légèrement courbés (chez les esp. d'A mérique seulement). L'auteur cite les $A$.rufescens et superciliosa, de la $5^{\text {me }}$ partie de sa classification, qui n'est pas encore publiće. Nous soupconnons fortement, que son $A$.rusescens est le mème oiseau que celui qu'i! avait déja décrit (Synops. of the Birds of Mexico) sous le nom de Pipilo rufescens, mais comme esp. de transition. (LAFr.)

* AINSLAFA (Whitclaw Ainslie, auteur d'un ouvrage sur la matière médic. de l'Inde.) BuT. PII.-M. De Candolle établit ce g. sur 2 plantes du Népaul, réunies antérieurement par M. Don aux Liatris. Il le caractérise ainsi : Capit. 3-flore, homogame; récept. 1u, étroit ; invol. cylindracé, à folioles imbriquées, lancéolées, acuminćes; les extér. courtes; les intér. allongées, cenendant moins longues que le disque. Les corolles sont tubulenses a la base, bilabices; la lévre extér. trifide, l'intér. 2-fide, et chacune de ces divisions, allongée, aiguë, souvent révolıtée. Les anthères, terminées par des appendices oblongs, obtus, présentent à leur base de longs appendices barbus. Le style, égal a li base, est terminé par 2 sligmates très courts, presque glabres, souvent inégaux par avortement, et même quelquefois totalement a vortés. Le fruit, cylindrique, ả peine atténué aux extrémités, couvert de poils, se trouve couronné par une aigrette 1-sériće: dont les soies sont plumeuses. - Ce g. renferme 2 esp. originaires des montagnes de l'finde. L'ine et l'autre sont vivaces, présentent lo port des Liatris ou des Lobelia, sont munics de feuilles radicales, longuement pétiolées, cordiformes cu ovales, et de hampes simples, terminées ordinairement par un seul capitule.

* AIOLOTHera (a'ólos, bigarré; tríxn, boîte, capsule). вот. PII. - M. De Candolle décrit sous ce nom générique, une herbe du Mexique qui présente le port du Parthenium incanum; il la caractérise de la manière suivante : Capit. monoïque, multiflore; fleurs du rayon au nombre de 5-6, ligulées, femelles; celles du disque, mâles, tubulcuses, it 5 dents. L'invol. bi-sérié, à $\$-10$ folioles extér. oblongues, dresscées, plus courtes que le disque; les intér. simulant des paillette. et embrassant à moitié les fruits des fleurs du rayon. Récept. petit et convexe, couvert d'écailles membraneuses, tronquées, dentėes ou aiguës au sommet, entourant les fruits. Ligules courtes, obtuses, 3-dentées. Les fruits du rayon velus, presque triangulaires, dépourvus d'aigreltes, mais surmontés de poils, sont renfermés entre les écailles intér. de l'involucre et les paillettes extér. du réceptacle; ceux du disque sont grêles, très glabres et dépourvus d'aigrettes.-Ce g., de la tribu des Sénécionidées, famille des Composées, ne renferme qu'une espèce. (J. D.

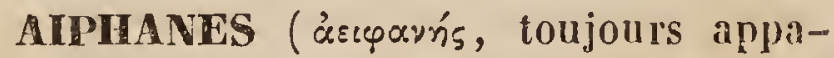
rent). Bо'T. PII. - Genre de la famille des Palmiers, établi par Willdenow (Mém. de l'Acad. de Berlin, 1801) pour une plante de l'Amérique mérid., qu'il a nommée $A$. aculeata. Kunth y a ajouté une $2^{\text {me }}$ esp. sous le nom d'A. prega. C'est un petit Palmier grêle, a fcuilles pinnces, des environs do Ciripe, 
dans l'état de Venezuela. Les auteurscités plus haut caractérisent ailsi ce g. : Fleurs hermaphrodites; cal. double; l'un et l'autre triparti. Etam.6,libres.Ovaire triloculaire.Style épais, trifide. Drupe globuleuse, charnue, monosperme. Fronde pinnée. Sparlice rameux; spathe monopliylle. - Ce g., dont il n'est plus question dans la partie déjá publicée de l'ouvrage de Martius sur les Palmiers, ni dans le Genera d'Endlicher, paraît à peine différer par ses caract. de l'Oreodoxa, auquel il doit peut-être se réunìr.

(Ad. B.)

AIPYSURE ( airús, haut, élevé; ơpó, queue). REPT. - Lacépède a proposé sous ce nom, l'établissement d'un g. d'Ophidiens, renfermant 2 esp. qu'on a réunies depuis aux Hydrophides de Daudin.

(G. B.)

AIR. Aer (áńp, air, atmosphère). pnys. et crilm.-L'air est invisible; mais cette propriété tient à sa transparence et a sa grande division; car il faut croire que l'air est bleu par réfraction, et qu'il donne lieu à la couleur bleue que nous présente le ciel, lorsqu'il n'y a pas de nuages ; tandis qu'il paraît rouge par réflexion, quand les astres sont dans le voisinage de l'horizon. L'air est extrêmement élastique; on peut, sans qu'il perde pour cela son élasticité ni sa forme de gaz, le comprimer a tel point que les instruments les plus forts n'aient plus la puissance de le retenir.

L'air est composé de gaz azote, de gaz oxygène, de gaz acide carbonique et de vapeur d'eau. Ces matières s'y trouvent, non dans un véritable état de combinaison, mais à l'état de simple mélange, et dans des proportions qui ne sont pas absolument fixes, du moins à l'égard de l'acide carbonique et de la vapeur d'eau. L'azote et l'oxyyène y existent loujours à peu près dans le rapport de 0,79 à 0,21 ou de 4 volumes d'azote et de 1 volume d'oxygène, proportions qu'on rencontre à, la surface de la terre aussi bien qu'aux élévations les plus considérables que l'homme ait atteintes, et dans les contrées les plus chaudes comme dans les plus froides. Néanmoins, l'oxygène de l'air étant absorbé par la combustion et la respiration, on sent que la proportion énoncée ci-dessus doit se trouver modiliée dans les lieux oú ces phénomènes se sont exercés sans que l'air ait eu le temps rle se renouveler; mais il faut qu'il y ait dans la nature une tendance à rétablir la composition normale de l'air' car, malgré cette absorption de l'oxygène, et malgré les émanations de gaz étrangers qui se répandent continuellement dans l'atmosphère, la proportion d'azote et d'oxygéne citée plus haut se rétablit toujours; ce qui annonce qu'on peut considérer ces 2 corps comme formant les éléments essentiels de l'air. D'un autre côté, les variations qu'éprouvent les proportions d'acide carbonique et de vapeur d'eau, indiquent que ces 2 matières doivent être regardées comme principes accidentels. Du reste, à la surface de la terre et à la température de $10^{\circ}$ centig., l'air est ordinairement composé en poids de 0,756 d'azote, de 0,233 d'oxygène, de 0,010 de vapeur d'eau et de 0,001 d'acide carbonique. La quantité de ce dernier corps est quelquefois plus considérable dans les lieux bas et resserrés, mais elle diminue promptement à mesure qu'on s'éléve dans l'atmosphère; enfin, elle parait être plus grande en été qu'en hiver.

L'air est également très raréfiable; et, a la température de $0^{\circ}$, il pèse 13 décigrammes pour chaque décimètre cube, c'est-àdire 770 fois moins que l'eau distillée. Or, sous nos latitudes moyennes, l'atmosphère, au niveau de la mer, faisant équilibre à une colonne de mercure de 762 millimètres, et l'ail pesant 10440 fois moins que le mercure, on pourrait en conclure que la hauteur de l'atmosphère serait de 7,955 mètres, si sa densité était toujours la mëme. Mais l'air étant un corps soumis, commeles autres, aux lois de la pesanteur, sa densité rliminue à mesure qu'on s'éloigne de la surface de la terre, en sorte que l'atmosphère s'étend a une hauteur bien plus grande. On n'a pas, jusqu'ả présent, de moyens pour caiculer d'une manière exacte l'étendue de l'atmosphère; cependant, l'étude des réfractions du soleil a fait connattre que cet astre devient visible le matin, ou qu'il cesse d'être visible le soir, lorsqu'il est à $18^{\circ}$ audessous de l'horizon, ce qui semblerait annoncer que la hauteur de l'atmosphére est de 7 à 9 myriamétres; d'autres consiclérations portent à admettre une épaisseur moins considérable. Quoi qu'il en soit, il paraît. que l'atmosphère, au lieu de finir insensiblement, s'arrête d'une manicre tranchée à sa partie supérieure. 
I.air jouit de la propriété d'entretenir la combustion et la respiration; mais seulement daus la proportion de l'oxygène qu'il renferme, ces propriétés cessant après l'absorption de celui-ci. Il paraît être insipide; néanmoins il est probable qu'il ne nous semble tel, que parce que nos organes y sont continuellement plongés; car les cris des nouveaux-nés et les douleurs occasionnées parles plaies ouvertes, semblent annoncer que l'air exerce une action trés vive sur les organes qui ne sont pas habitués à son contact. L'air manifeste surtout sa présence quand il est en mouvement, ou, lorsqu'étant en repos, c'est notre corps ou tout autre objet qui se meut avec vitesse; dans l'un et l'autre cas, l'air résiste, mais bien moins que les liquides ct les solides.

La quantité de vapeur. d'eau varie davantage et diffère selon la température, les saisons et la situation plus ou moins humide des lieux. Dans les zònes tempérées, elle est souvent de 0,055 à 0,017 en été; tandis que, en hiver, elle n'est habituellement que de 0,005 à $0,00 \%$. Dans la Zòne torride, elle forme fréquemment plus des 0,030 de l'air; elle diminue à mesure qu'on s'élève dans l'atmosphère.

L'air en mouvement évident porte en général le nom de vent. $V$. ce mot.

Non seulement l'air est indispensable à l'existence des êtres organisés, mais encore l'homme met à profit sa force impulsive pour faire mouvoir les machines, pour naviguer, pour griller les métaux, etc.

Pour quelques détails sur l'origine de l'air, $V$. les mots Atmosphère et GÉogénie; enfin nous renverrons aux mots Modfertes, GriSou: Oxygène, Acide carbonique, Hydrogìne, Azote, relativement aux mots $A$ ir déphlogistiqué, Air vital, Air fixe, Air méphilique, Air inflammable, Air phlogistiqué, Air vicié, etc.

AIRA ( $\alpha \hat{i} p x$, ivraie). вот. pH. - G. de la famille des Graminées, de la tribu des Avénacées, adopté par tous les Agrostographes, mais slont la circonscription et les caract. ont été successivement modifiés. Ainsi Palissot de Beauvois (Agrostog. p. 89, t. 18, f. 4) dit que ce $\mathrm{g}$. est un des moins naturels de toute la famille des Graminées. Il ne se distingue du g. Avena que par son arête insérée près de la base de la paillette. Aussi, le même auteur a-t-il réuni au g. Triselum, toutes les esp. d'Aira dont la paillette supér. se termine par 2 soies, et un grand nombre d'autres au $g$. Avena. Il a, de plus, proposé plusieurs g. nouveaux pour un certain nombre des esp. d'abord réunies dans ce g., et qui en diffèrent par des caract. assez tranchés. Ainsi, les Aira canescens et articulata forment le g. Corynephorus ( $V$.ce mot); les Aira caspitosa, juncea, etc., le g. Deschampsia ( $V$. ce mot). Trinius, dans son Ayrostographic, a a peu près adopté l'opinion du botaniste français; mais mon savant ami le professeur Kunth l'a modifiée, en caractérisant le g. Aira de la maniẻre suivante : Épillets à 2 fleurs presque égales, hermaphrodites et fertiles; glımes membraneuses, carénées, aussi grandes ou même plus grandes que les fleurs; paillettes herbacées; l'infér. bifide à son sommet, portant une arête dorsale et tordue à sa base, qui manque très rarement; paillelte supér. bicarénće. Étarn. au nombre de 3 ; ovaire glabre, surmonté de 2 stigm. plumeux, terminaux et presque sessiles. Glumelle composée de 2 paléoles aiguës et glabres. Caryopse glabre.

Les esp. de ce g. forment en général des touffes plus ou moins épaisses, à feuilles étroites et à bords souvent roulés en dessous, á panicule étalée ou quelquefois spiciforme. M. Kunth (S'ynops. 1, p. 289) rapporte à ce g. 32 esp.; mais 11 seulement avec certitude; les 21 autres avec doute. Ainsi caractérisé, ce g. diffère à peine du g. Trisetum, qui a ses épillets composés de 3 a 4 fleurs, et non biflores comme ceux de l'Aira.

Presque toutes les esp. qui font réellement partie du g. Aira sont originaires des diverses parties de l'Europe; telles sont les $A$ ira procox L. (Sp.97. Fl. dan., t. 383), Aira caryophyllea L. (Sp. 97), l'une des esp. les plus généralement répandues, puisqu'on la trouve en Europe, en Asie, au Chili, et aux îles Malouines; Aira flexuosa L. (Sp. 96. Host. gram., 2, t. 43), si commune dans tous nos bois, etc., et $\%$. Aucune de ces esp. n'offre d'utilité.

AITALN. CHIM. $V$. Bronze. (C. D’O.)

Allez. 0rs. - Nom que l'on donne aux nids des grandes espéces d'oiseaux de proie, telles que les Vautours, les Aigles, et autres, peut-être d'après leur forme aplatie et très 
large que l'on aura comparée à une aire de grange ou de plancher. Il serait difficile qu'un nid a bords relevés et formant la coupe ne s'afiaissât pas promptement sous le poids énorme de ces grandes espéces de Rapaces, qui emploient à la construction du leur, suivant leur force, des branches plus ou moins grosses et résistantes. Les Vautours, les Gypaëtes, les Aigles de mer, les placent sur des rochers, à une grande hauteur et au-dessus de précipices, soit entre 2 roches rapprochées, soit dans leurs crevasses; mais les Aigles proprement dits les construisent plus ordinairement sur les arbres élevés des forêts de montagnes. On voit par là que ce sont les espèces les plus marcheuses, et qui en cela offrent quelque analogie avec les Gallinacés, qui, comme eux aussi, construisent leurs nids à plat, soit sur des roches ou des buissons peu élevés, soit sur le sol nême, taudis que les espéces plus percheuses, comme les Aigles proprement dits, Ies Aigles-autours, les placent sur des arbres. Le même nid sert très long-temps au même couple qui, chaque annce, le restaure et l'augmente de volume. C'est ce qui explique la lorme singulićre et la grande hauteur de ce nid de Pygargue décrit et figuré dans l'atlas historique du voyage de Freycinet $(P l .13)$. M. Quoy y raconte que dans l'île de Dirckhatichs, baie des Chiens marins, à la Nouvelle-Hollande, "il aperçut sur un rocher isolé, peu élevé du côté de la terre, mais dominant la mer du côté opposé, de 150 à 200 pieds, un vaste nid en forme de tourelle, de 6 pieds de haut, construit en branches mortes de Mimosas entrelacćes régulićrement, plein jusqu'à sa partie supér., et dont l'aire était peu profonde. L'oiseau qui s'en échappa était, dit-il, un Aigle ou un Autour à ventre blanc et à dos gris. Une infinité de têtes de lianguroos-rats, des débris d'oiseaux, de serpents, de lézards, de crustacés, de poissons même couvraient le sol au bas de l'aire. Il est facile de reconnaître au genre de nourriture en partie marine de cet oiseau, qu'il devait être un Pygargue et non un Autour, et nous sommes ćtonné , que M. Quoy, l'ayant vu voler à plusieurs reprises au-dessus de sa tête, ait pu avoir à cet égard la moindre incertitude. Ce qu'il dit de la couleur de son plumage ne nous laisse d'ailleurs aucun doute que ce ne fùt l'Aigle océanique (Falco leu- cogaster Temm. Col. 49, le Blagre de Le Vaillanı) le seul de ce plumage à la Nouvelle-Hollande. Quant à l'élévation de ce nid, il cst facile de s'en rendre compte. Elle indique tout simplement, que jusqu'ầ l'époque où quelques personnes de l'expćdition Freycinet débarquèrent dans cette île, un couple d'Aigles océaniques avaient joui paisiblement et depuis longues années de cette demeure aćrienne, résultat de leurs premières amours. Pour qu'elle eût atteint cette hauteur de 6 pieds, elle avait dû être restaurée et augmentée successivement pendant bien des années, et fournissait sur cette petite île sauvage une preuve desplus étonnantes de la constance en amour de ce bel Aigle, au plumage moitié blanc moitté gris-satin. Cook, dans son premier voyage en 1770 , trouva aussi à la Nouvelle-Hollande, mais sur la còte opposée et orientale, sur une île basse et sablonneuse, un nid énorme, construit à terre avec des morceaux de bois ct n'ayaṇt pas moins, suivant ce célèbre voyageur, de 26 pieds de circonfërence sur 2 pieds 8 pouces de haut. Nous tenons de M. le capitaine Duperrey même, que pendant son séjour à la presqu'ìle Péron et dans le voisinage de la pointe des HautsFonds, il avait remarqué et dessiné un nid d'Aigle d'une énorme proportion, construit sur les rochcrs de la côte, dans une position presque inaccessible, et que d'après cela il avait donné à cette baie le nom de Baie de l'Aigle. Cook nomma également Eagle Islunu, ille de l'Aigle, celle où il avait trouvé cet énorme nid.

Ce rapprochement d'observations à peu près scmblables, par 3 célèbres navigateurs, n'est pas sans intérêt, et prouve que les nids d'Aigles, lorsqu'ils ne sont pas détruits et que leurs premiers constructeurs ne sont point inquiétés ni tués, finissent par acquérir une dimension vraiment étonnante. Parmi ces nids ou aires les plus remarquables, on peut encore citer celui du Messager ou Secrétaire, que cet oiseau construit en Afrique dans les vastes plaines et sur quelques buissons isolés et peu élevés; il est d'abord très plat, mais d'un diamétre énorme; il acquiert bientôt de l'épaisseur, car leSecrétaire y revient chaque année au moment de la reproduction, et l'augmente en hauteur, en rebâtissant toujours sur l'ancienne construc- 
tion. Si ces nids n'étaient pas détruits ou endommagés par les Hottentots et les voyageurs, ils présenteraient, sans nul doute, au bout d'un certain nombre d'années, la même singularité que ceux du Pygargue australien dont nous venons de parler. Nous tenons de M. J. Verreaux, qui a long-temps habité le Cap de Bonne-Espérance, que le Vautour Oricou est également daıs l'usage de pondre clıaque année dans le même nid,qu'il augmente successivement en hauteur par des couclies de branches nourelles. Ce voyageur en a trouvé dont les différentes couches, très distinctes, indiquaient bien une vingtaine d'années d'existence. (LAFR.)

AIRELLE. вот. PIr.-Dénomination vulgaire dı g. Vaccinium, et en particulier du $V$. Myrtillus L. $-V$. vaccinium. (C. L.)

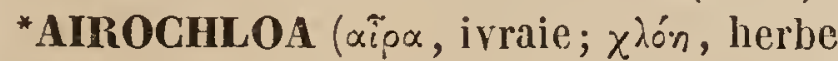
verte, verdure). вот. PII. - Le professeur Link (Horl. berol. s.p. 127) a nommé ainsi un g. de la famille des Graminées, qui a pour type l'Aira cristata L., et qui fait partie du g. Koeleria de Persoon, dans lequel il constitue une section à part, caractérisée surtout par l'absence de l'arête. $V$. KoEleria. (A.R.)

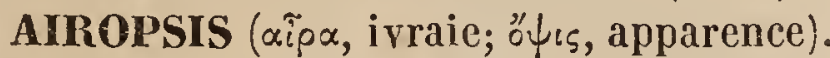
вот. Pн. - G. de la famille des Graminées, établi par Desvaux (Joum. bot. 1, p. 200) pour une petite plante décrite et figurée par Cavanilles (Icon. 3, p. 299 , t. 274, f. 1), sous le nom de Milium tenellum. Ce g., adopté par tous les agrostographes, peut être caractérisé de la manière suivante : Chaque épillet contient 2 fleurs fertiles; les glumes, membraneuses, mutiques et plus longues que les fleurs, sont égales et naviculaires. Les paillettes membraneuses et presque transparentes, à peu prés égales entre elles, sont privées d'arêtes; l'infér. est large, concave, velue et comme à 3 lobes; la supér. est plane et bicarénée. L'ovaire est glabre, piriforme, surmonté de 2 stigm. sessiles et plumeux. La caryopse est orbiculaire, convexe d'un côté, plane de l'autre, glabre et luisante. - L'espèce type de ce g., l' $A$.globosa Desv., est une trés petite plante annuelle, a feuilles su bulćes et roulées, et à panicule serrée. Flle croît dans le midi de la France et en Espagne. La $2^{\mathrm{e}}$ esp., l' $A$. agrostidea DC. (Suppl. $F l$. fr. p. 169) ou Poa agrostidea DC., Icon. t. 1) est vivace et croit dans les mares, en France, en Espagne et en Italie. Je suis le T. 1 . premier qui l'ai rencontrée aux environs de Paris, dans les mares de Franchart, dans la forèt de Fontainebleau. M. le professeur Nees d'Esenbeck (Linnoxa, 7, p. 317) a encore rapporté à ce g. 2 esp. originaires du Cap de Bonne-Espérance; mais il est fort douteux qu'elles lui appartiennent en effet. (A. R.)

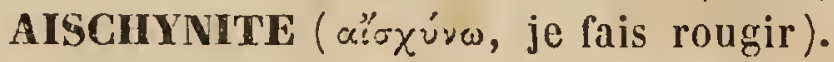
Min. - $V$. Escirynite.

(C. D'O.)

AISSELLE. Axilla. вот. pr. - C'est l'angle formé par la feuille, au moment oủ elle se sépare de la tige, angle plus ou moins aigu, plurs ou moins ouvert, suivant la direclion de la feuille. L'aisselle des feuilles contient ordinairement les bourgeons et très souvent les fleurs, qui sont alors dites axillaires.

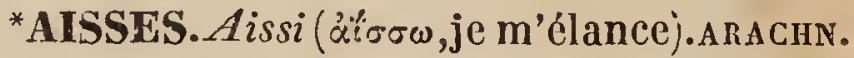
- C'est un petit groupe qui appartient au g. Penelops et qui a été créé parWalkenaër, avec ces caract. : Lèvre courte, semi-circulaire; mâchoires droites, peu resserrées à leur base; pattes : la $2^{\text {me }}$ paire la plus longue ; la $3^{\mathrm{me}}$ ensuite; la $4^{\mathrm{me}}$ est la plus courte. La seule esp. que ce groupe renferme, se trouve à la Martinique.

AITONIA, Linn. fils (Aiton, butaniste anglais). вот. Рн. - G. compris dans les Méliacées par A. L. deJussieu, mais que M. Adr. de Jussiell, sans se prononcer sur la place qu'il convient de lui assigner,énumère,dans sa monographie de cette famille, parmi les g. qui doivent en être exclus. M. De Candolle n'en fait pas mention parmi les Dicotylédones polypétales; M. Bartling le met parmi les Dicotylédones polypétales non classées. M. Lindley continue à le ranger à la suite des Méliacées. M. Adr. de Jussieu (Mém. du Mus., vol. 19, p. 187) expose les caract. de ce g. comme il suit : Cal.4-parti. Pétales 4, ovales, plus longs que le calice. Etam. 8 , plus longues que les pétales; filets presque planes, élargis inférieurement et soudés en un tube membraneux, plus court que la portion libre des filets. Anth. beaucoup plus larges que les filets, ovales, attachées par leur dos audessus de la base, dithéques, latéralement déhiscentes; pollen trigone. Ovaire inadhérent, hérissé , 4-loculaire, engaîné à sa base par un disque annulaire membraneux ; loges 2-ovulées; ovules collatéraux, ascendants, attachés à la base de l'angle interne. Style indivisé, un peu plus long que les étamines. 
Stigm. tronqué. Caps. vésiculeuse, profondément 4 ou 5-lobée, 4-loculaire, 4-valve (probablement loculicide); loges 2-spermes ( 2 ou 3 des loges souvent aspermes). Graines subréniformes; tégument assez épais, un peu charnu. Raphé nul. Embryon apérispermé, courbé ; cotylédons elliptiques-lancéolés, presque planes; radicule infère, 3 fois plus courte que les cotylédons. - Arbrisseau. Feuilles simples, alternes, en général comme fasciculées par l'avortement des ramules. Fleurs solitaires, axillaires, assez souvent 5-mères. Pétales convolutés en préfloraison. L'A. capensis constitue à lui seul ce genre.

* AITONIA (Aiton, jardinier royal à Kew). вот. Cr. - Ce nom, déjà consacré à un g. de plantes vasculaires, a été employé par Forster (Plant. all. ex. Ins. Madeira, etc. Comment. Soc. Reg. Gott. Ad. Ann. 1787 et 88 , vol. Ix.) pour désigner une Marchantiée long-temps douteuse. Découverte plus tard aux mêmes lieux, et dans un état de développement parfait, par Raddi, cet auteur la publia avec une figure, sous le nom de Reboullia mudeirensis (Mém. de la Soc. ital. de Modène, t. xx. tab. vil, fig. 7). Le g. Sedgwiclia, établi par Bowdich ( $E x-$ curs. in Madeira and Porto Santo, Lond. 1830 , in $-4^{\circ}$ p. 35.$)$, et auquel la Marchantiée en question fut rapportée à tort par M. Bischoff, n'est que la Lunularia vulgaris, dont les réceptacles femelles ne sont point encore développés. Elle a été déerite aussi sous le nom de Corsinia lamellosa par MM. Nees et Bischoff (Journ. de Bot. de Ratisb. 1830). M. Nees d'Esenbeck (Eur. Leberm. Iv, p. 41) l'a définitivement placée dans le g. Playiochamas $(\boldsymbol{V}$. ce mol). Cette plante est un exemple manifeste des erreurs grossières auxquelles on s'expose, lorsqu'on décrit comme nouvelle, une esp. que l'on n'a pas observée à toutes les époques de son existence. (C. M.)

* AIzOIDÉES. Aizoidece. вот. pll. M. Reichenbach (Syst. Nat. p. 238) donne ce nom à un groupe dans lequel il réunit, comme constituant une seule famille naturelle : $1^{\circ}$ les Oléracées, R. (Chénopodées, Amarantacées, et Phytolaccées); $2^{\circ}$ les $A i-$ zoüdées vraies $R$. (c'est-à-dire les Ficoüdées, les Neuradées, ainsi que les g. Giseckia et Poranthera); $3^{\circ}$ les Tamariscinées. (Sp.)

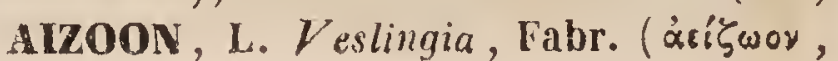

joubarbe). вот. 1н. - G. de la famille des Ficoïdées (Tétragoniacées, Lindl.), auquel on a assigné les caract. suivants : Cal. inadhérent, 5-parti, coloré en dessus. Cor. nulle, Etam. environ 20, insérées par faisceaux au fond du calice. Ovaire pentagone; stigm. 5 épais, sessiles. Caps. 'a 5 loges polyspermes, déhiscentes au sommet par 5 fentes rayonnantes. - Herbes quelquefois suffrutescentes; feuilles alternes ou opposées, charnues, très entières; fleurs axillaires ou dichotoméaires, sessiles ou rarement pédonculées. - On connaît environ 15 esp. de ce g.; la plupart habitent l'Afrique austraie; les autres croissent dans les contrées voisines de la Méditerrannée.

*AIZOONIA, Tausch:, Chondrosea, Haw. ( $\alpha \varepsilon i \zeta \zeta_{0 \%}$, joubarbe). вот. PII. - Genre ou s.-genre de la famille des Saxifragacées, établi sur plusieurs esp. du g. Saxirraga, L., telles que le s'axifraga Aizoon. Le caract. différentiel consiste en un calice dressé, persistant, adhérent presque jusqu'au sommet, légèrement lobé ou denté; les graines sont ovales-trièdres, rugueuses; les feuilles coriaces, sessiles, munies d'un rebord cartilagineux et fovéolé.

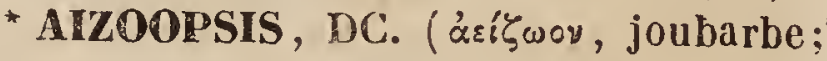
ö $\psi$ เs, apparence). вот. Рн. — S.-div. du g. Draba, L., caractérisée par des fleurs jaunes.

AJAR. MoLl.-Adanson ( $V$ oyage au Sénégal,p. 222, pl. 16, f. 2) donne ce nom à une jolie esp. du g. Cardite de Bruguière, à laquelle ce dernier auteur a conservé le nom de Cardita ajar. Bruguière regarde cette esp. du Sénégal, comme l'analogue vivant du Cardita imbricala, fossile des environs de Paris. Il a commis là une grave erreur : ces 2 esp. sont constamment très distinctes l'une de l'autre.

(i)ESI.)

AJONG. Ulex, L. вor. PH. - G. de la famille des Légumineuses, s.-ordre des Papilionacées, tribu des Lotées, s.-tribu des Génistées; il offre les caract. suivants : Cal. dibractéolé, profondément bilabié ; lèvre supér. bidentée; lèvre infér. tridentée. Étendard rccouvrant les ailes et la carène. Étam. monadelphes. Légume bouffi, oligosperme, à peine plus long que le calice. Les 3 esp. (ou plutòt variétés d'une seule esp.) qui constituent ce g. , habitent l'Europe occidentale et le nord de l'Afrique; ce sont des arbustes trés ra- 
meux, plus ou moins velus, aphylles, mais très épineux; fleurs jaunes, solitaires. Ces plantes sont excellentes pour former des haies; dans les localités oú elles abondent, on les emploie comme fourrage d'hiver. On les cultive aussi comme arbustes d'ornement.

AJOUVÉ. вот. pi., - Nom caraibe du g. Ajocea. $V$. ce mot.

(C. L.)

AJOVEA (Ajouvé, nom de cet arbre chez. les Caraïbes). вот. p1. - G. de la famille des Laurinćes, tribu des Oréodaphnées, fondé par Aublet (Gruyan., 1, 310, t. 20) sur un arbre de la Guyane, qui, à ce qu'il párait, n'a pas été retrouvé depuis. Les auteurs pensent qu'il est le mème que le Douglassia de Schreber, le Colomandra de Necker, l'Ehrhardia du même, enfin que le Laurus hexandra de Swart\%. Voici les caract. établis parAublet : Fleurs hermaphrodites. Périgone infundibuliforme, sexfide, a divisions égales, persistantes. Étam. 6 , bisériées, alternant avec les dir. périgoniales, à filaments filiformes, allongés; les 3 intér. munis à la base de glandes géminées, subglobuleuses, sessiles, velues; a anth. introrses, ovales, bilocellées, déhiscentes par autant de valvules ascendantes. Ovaire inconnu. Style un peu allongé; stigm. sexfide. Baie monosperme, ceinte à la base des divisions dressées du périgone immuté. - C'est un arbre à feuilles alternes, veinées, à panicules lâches, axillaires ou terminales, a bractées dénudées, promptement caduques. (C. L.)

* AJUGA, Linn. Bugula et Chamapilys, Tourn., Phleboanthe, Tausch. вот. PII.-G. de la famille des Labiées, tribu des Ajugoïdées de Bentham (Lubiat. 690), qui lui assigne les caract. suivants: Cal. ovoïdecampanulé, ou globuleux - campanulé, à 5 dents presque égales. Corolle à tube soit inclus, soit saillant, droit ou subspiralé; lèvre supèrieure courte ou presque nulle, échancrée; lèvre inféricure allongée, horizontale, trifide, à lanières latérales oblongues, à lanière médiane échancrée ou bifide, plus large. Étamines 4 , ascendantes, en général saillantes; les 2 inférieures plus longues; anthères à 2 bourses divergentes ou divariquées et finalement confluentes. Style bifide au sommet; branches presque égales ; stigmates petits. Nucules réticulées. - Herbes quelquefois suffrutescentes; cymules bi.- ou pluri-flores, denses, tantôt axillaires, tantòt rapprochées en épi bractéolé.

Bentham énumère 29 esp. de ce g.;ils croissent dans la Nouv. Hollande; les autres dans les contrées extra-tropicales de l'ancien continent. I'Ajuga reptans L., connu sous le nom vulgaire de Bugule ou Bugle, passe pour un excellent vulnéraire.

AJUGOIDÉES. Ajugoideœ. вот. PI. T'ribu de la famille des Labiées, indiquée parBentham (Labiat.) et dont le type est l' $A$ juga.

AKANTICONE. Akanticonite (d'ax $\alpha^{\prime} \theta^{\prime}{ }^{\prime}$ 's, serin, et xóvıs, poussière). MlN.-Nom donné par d'Andrada à l'épidote d'Arendal, en Norvége, dont la poussière est d'un jaune de serin ou jaune verdâtre. $V$. Frinote. (DEı.)

AKEBIA ́́nom japonais de la plante dont il s'agit). вor. PH. - Ce g. a été établi par M. Decaisne aux dépens des espèces de $R a-$ jania citees par M. Thunberg dans sa Flore. du Japon. L'Alkebia appartient à la famille des Lardibazalées, telle que l'a constituée le prernier de ces botanistes dans les Archives du Muséum. Les caract. du nouveau g. sont : Fleurs monoïques, en grappe ; les femclles placées à la base de l'inflorescence. Dans les deux sexes : Calice à 3 folioles, arrondies et concaves dans les femelles, lancéolées dans les mâles. Étam. 6-9, extrorses, à connectif épais et recourbé en arrière, à filets libres, au milieu desquels on trouve 3-6 ovaires, piriformes, avortés. Dans les femelles , 3-9 ovaires cylinuracés, couronnés par autant de stigmates peltés et pupilleux. Ces ovaires sont uniloculaires, et portent des ovules orthotropes sur toute la superficie de leur paroi interne, qui est lisse ou filamenteuse.-Les espèces qui composent ce g.sont au nombre de 3 ; ce sont des arbustes sarmenteux, à feuilles palmées, entières ou lobées, à l'aisselle desquelles se trouvent des grappes de fleurs roses ou lilas. Ils sont originaires du Japon, dont les habitants les cultivent pour l'ornement de leurs jardins, sous le nom de Kadsura-Akebi.

AKEESIA, Tussac (Akee, Nom donné par les nègres à ce végétal). BOT. PII. Synon. du g. Cupania, Plum.

AKÈNE ou ACHAINE. Akenium (á priv.;

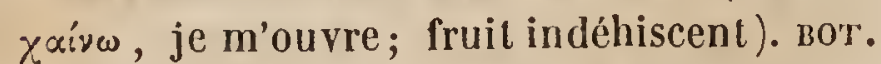
Pfr. - On nomme ainsi un g. de fruit dont les exemples sont très fréquents dans la na- 
ture et qui ofrre les caractéres suivants : Péricarpe sec, à une seule loge, contenant une seule graine, indéhiscent, distinct et non soudé avec la surface de la graine. C'est par ce dernier caractẻre que l'akẻne se distingue de la caryopse, qui en offre tous les caractères, mais dont le péricarpe esî intimernent soudé avec le tégument propre de la graine. A ce genre de fruit, appartient celui des Synanthérées, des Polygonées, etc.

L'akène peut provenir d'un ovaire libre ou d'un ovaire adhérent. Cette différence n'entraine aucun changement dans l'organisation de ce fruit. Cependant M. de Mirbel donne le nom de Cypsèle à l'akène provenant d'un ovaire infère qui peut être alors couronné soit par les dents du calice, soit par une aigrette; celui des Synanthérées est dans ce cas. $V$. Cypsète.

Le même fruit peut encore offrir quelques modifications dont on a fait des espèces distinctes; mais c'est à tort, selon nous, car l'organisation véritable de ce fruit reste la même dans ses parties essentielles; ainsi, M. Desvaux appelle Sphalérocarpe le fruit des g. Blitum, Basella, Hippophae, qui n'est qu'un véritable akẻne recouvert par un calice persistant et devenu charnu. Il en est de même du fruit nommé Śacellus par M. de Mirbel, Diclesium par M. Desvauy, et qui n'est encore qu'un véritable akène environné par un calice ou simplement une portion du calice devenu dur et résistant, comme par exemple dans la Belle-de-nuit, les Soudes, l’Épinard, eic.

(A. R.)

* Aricera (áxís, glaive, pointe; xépas, corne; allusion $\dot{a}$ la forme des antennes). Ins. -G.de la famille des Acridiens, de l'ordre des Orthoptères, établi par M. Serville (Revue Méth. de l'Ordre des Orth.) et regardé comme une simple division du g. Pamphayus de Thunberg, par M. Brullé (Hist. des Ins.), par nous (Hist. des Anim. artis.) et par Burmeister (Handb. der Entom.). L.es ant. fournissent le principal caract. de ce g., ou plutôt de cette division, par leurs articles très aplatis et dilatés. Les esp. qu'elle renferme sont peu nombreuses, et répandues dans les parties méridionales de l'Europe et en Afrique. Celle que l'on peut en considérer comme le type, est le Pamphagus griseus (A. grisea, Serv.) propre au Cap de BonneEspérance.

(BL.)
AKIS (axis, pointe). Ins. - G. de Colécptères hétéromères, créé par Herbst et adopté par tous les autres entomologistes. M. Duméril le place dans sa famille des Lucifuges; Latreille, dans celle des Mélasomes , tribu des Piméliaires; et M. Solier, qui dans ces derniers temps s'est occupé d'une manière spéciale des Hétéromères, le range dans sa famille des Collaptérides, tribu des Akisites, en lui assignant pour principaux caract. : Épistome échancré antérieurement; menton plan, rétréci à sa base et cordiforme; base du prothorax ne s'appliquant pas contre les élytres; jambes antér. minces ou peu épaisses; prothorax médiocrement transverse, à bords latéraux dilatés, relevés en dessus et à base tronquée, avec les angles postérieurs prolongés en arrière. M. Solier décrit 24 esp. d'Alis, qu'il partage en 2 div.; savoir : div. $A$. : Esp. à élytres sans côtes dorsales sensibles, ayant seulement quelquefois des rangées de tubercules; type A. punctala Thunb., commune dans le midi de la France. - Div. $B$ : Esp. ayant au moins une côte dorsale plus ou moins marquée, soit longue, soit courte et postérieure.-Subdiv $a$ : côte dorsale plus ou moins tuberculeuse ; type, $A$. algeriana Dupont, de Barbarie.-Subdiv. $b$ : côte dorsale entičre ou peu sensiblement tuberculeuse; type , $A$. nitida Sol., de Barbarie.

M. Dejean, dans son dernier Catalogue, ne mentionne que 17 espéces d'Akis, dont 7 sont différentes de celles de M. Solier, du moins nominativement.Ainsi le nombre total serait de 31 , dont une seule se trouve en France. Les autres appartiennent à l'Espagne, au Portugal, à la Sicile, à la Sardaigne, au nord de l'Afrique, á la Turquie asiatique, à la Perse occidentale et à la Russie méridionale.

Les espèces de ce g. semblent se plaire parmi les ruines et les décombres, et, comme la plupart de celles de la même famille, elles vivent de matiẹres en décomposition, soit végétales, soit animales, et même d'excréments. C'est ainsi que j'ai trouvé en quantité l'A. ilalica dans le Colysée de Rome et l' $A$. punctata dans les Arènes d'Arles.

* AKISITES ( axis, pointe). 1Ns. - Tribu de Coléoptères hétéromères, établie par M. Solier dans sa famille des Cọllaptérides, démembrement de celle des Mélasomes de I atreille. Il la compose de $6 \mathrm{~g}$. qu'il partage en 
2 divisions, $1^{n}$ : les g. Cacicus et Elenophorus, ayant le prothorax subglobuleux, tronqué ou subtronqué antérieurement et à la base, et l'épistome trilobé avec le lobe intermédiaire très large, rectangulaire, subtronqué; $2^{\circ}$ les g. Morica, Akis, Cyphogenia et Cryptoglossa, ayant le prothorax non globuleux : plus ou moins échancré antérieurcment pour recevoir la tête qui peut s'y enfoncer jusqu'au-delà rles yeux, et l'épistome échancré ou arrondi. Du reste les principaux caract. de cette tribu sont : Partic antérieure de la tête dilatée et couvrant, en grande partie, les mandibules qui sont bidentées; labre peu saillant et pouvant se retirer, dans quelques espèces, sousl'épistome qui est très développé. Ecusson formant une saillie assez prononcée, subtriangulaire, légèrement arrondie. Fattes longues, peu rugueuses et généralement minces. Les Akisites sont des Insectes très lents dans leurs mouvements. Ils fuient la lumière et habitent le plus souvent les ruines et les décombres. Ils se nourrissent de matières en décomposition et même d'excréments. La plupart des espéces connues sont du midi de l'Europe et du nord de l'Afrique.

AKODON. MAM. - Nouveau g. de Rongeurs, établi par Meyen dans la fam. des Muriens. L'esp. qui s'y rapporte (A.boliviense), a beaucoup d'analogie avec notre souris domestique; la formule dentaire est la mêrne; mais la disposilion des replis internes de l'émail est un peu différente, et les oreilles, très courtes, sont presque cachées sous les poils. Cette esp. est longue de 3 pouces, y compris la queue qui forme un peu plus du tiers; couverte de poils gris-jaunâtres, que dépassent d'autres poils noirs; la queue, revetue d'une peau écailleuse et annelée, est garnie de poils fins; les oreilles sont velues en dedans et la plante des pieds est noire. Cet animal habite le Haut-Pérou. (C. n’O.)

*AKYSTIQUES (á priv.; xú polss. - Nom donné par Latreille à la $2^{\mathrm{e}}$ section du Ge ordre des Poissons Acanthoptérygiens. Les g. de cette sect. devraient être composés d'esp.privées de vessie aćrienne; or, du propre aveu de l'habile entomologiste qui a occupé les derniers loisirs de sa vie à coordonner en familles trés peu naturelles tout le Règne animal, d'aprés l'ouvrage de Guvier, plusienrs g. de ce groupe des Akys- tiques ont une vessie natatoire. Latreille aurait dù remarquer que la sect. qu'il a nommée Kystophores, comprend un très grand nombre de Poissons qui n'ont point de vessie aćrienne. Cet organe, en efret, si considérable et si variable dans les Poissons, et celui sur lequel on devait le moins fonder de divisions, manque souvent dans les esp. les plus voisines.

(VAL.)

ALABANDINE et ALMANDINE (Alabanda, ville de l'Asie mineure). mun. Nom donné par les anciens à une pierre précieuse dure, d'un rouge forcé, qu'on tirait des mines d'Alabanda, et qui paraît être une variété de Grenat. - M. Beudant a aussi donné le nom d'Alabandine au Manganèse sulfuré. $V$. MANGanìse. (C. D’O.)

ALABASTRE. Alabastrite (d'à $\alpha \dot{b} a \sigma-$ гpov). Miv.-Les Grees nommaient Alabastron, une sorte de vase sans anse, que l'on avait souvent de la difficulté à saisir, quand ils étaient polis. Ils donnaient le nom d' $A$ labastrite aux pierres avec lesquelles on les fabriquait, et que nous connaissons sous les dénominations d'Albâtre culcaire et d' $A l$ bêtre gypseux.

(Der.)

ALABE ou ALABSS ('à $\alpha 6$ 'ńs, qu'on ne peut saisir). Porss. - Nom d'un poisson du Nil cité par Strabon (Lib.xvil, 823-1173), et que l'on trouve une seule fois dans Athénée, mais

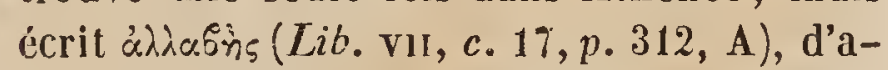
près Archestrate qui l'indique comme un poisson du Nil avec le Phragre, l'Oxyrhynque, le Silure, etc. Il est probable que Pline a fait du mot grec le nom d'Alabeta (Lib. v, cap. 10, 5), poisson qu'il place avec les $C_{0-}$ racins et les Silures dans un lac d'Éthiopie appelé $Z$ isides. Il est difficile de reconnaître dans ces deux seuls passages le Harmoulh ou Silurus anguillaris, comme l'a supposé M. Geoffroy, et comme on l'a répété après lui. Aussi, Cuvier, regardant ce nom comme un des mots indéterminables laissés par les anciens, l'a appliqué à un g. de Poissons de la famille des Anguilliformes, et voisin des Synbranches de Bloch. - Ce g. est caractérisé par une seule ouverture praliquée sous la gorge pour les 2 branchies, la présence de petites pectorales, un petit opercule, sous lequel on voit 3 rayons branchiostéges. On ne connaît encore qu'une seule esp). de ce g., rapportée par Péron, lors du voyage du capitaine Baudin aux terres australes. (VAI..) 
ALACAMITE, pour ATACAMITE. $V$. ce dernier mot.

(DEL.)

ALACTAGA. MAM. - Esp. du g. GERBoISE. $V$. ce mot.

ALAFIA ( $A l a f i$, nom de cet arbre chez les Madécasses). вот. Pн. - G. de la famille des Apocynacées, fondé par Du Petit--Thouars, sur un arbrissea peu commun, qu'il trouva à Madagascar et qu'il décrit comme débile, grimpant, à feuilles opposées, à fleurs pourprées, terminales, nombreuses. Voici les caractères que lui assigne cet auteur: Cal. petit, 5-lobé. Cor. tubuleuse, ventrue; à limbe 5-parti, contourné; à div. iantôt entières, tantôt plissées-sinuées. Etam. 5 , à filaments courts, attachés au pistil sous les anthères qui sont aiguës, distinctes, mais conniventes. Ovaires 2. Style filiforme, adné aux 5 filaments en appendices; stigm. edpité, acuminé, ne dépassant pas les anthères. Fructification inconnue.

(C. L.)

* ALAIRE ou ALARIE. Alaria. helMINT.-Proposé d'abord par Schranck, qui y renonça depuis en transportant dans le g. Festucaria, le Distoma alatum Rud. (Holostomum alatum Nitzch) pour lequel on l'avait créé, le g. Alaria avait été rétabli par M. de Blainville, pour quelques esp. de Distomes cylindriques pourvus d'une assez longue queue, et d'une expansion en forme d'aile de chaque côté dı corps; type Fasciola laciniata, du Maimon (Appendice à la traduction française de Bremser, p. 518, $p l .2$, fig. 5.1824). Mais peut-être M. de Blainville a-t-il lui-même renoncé ultérieurement à cette coupe générique; car, dans l'article Vers du Dict. des Sc. nat. (t. Lvil, p. 586,1828$)$, les Distomes dont il s'agit ne fignrent que comme une division du $\mathrm{g}$. Fasciole. $V$.Distome. $\quad$ (L. D.x.r.)

AraLITE (d'Ala, nom d'une vallée dans le Piémont). mis. - Variété de pyroxène Sahlite, d'un gris verdâtre, que l'on trouve dans le val d'Ala, et qui a été prise d'abord pour une nouvelle substance appelće Diopside par Haüy.

(DEL.)

ALA LONGA. - Dénomination donnée par les Italiens, et entre autres citće par Cetti, pour le Germon du golfe de Gascogne, ou le Thon aux longues pectorales. Gmelin en copiant Cetti a fait une faute d'impression, et a mis Alatunga ; ce qui a été copié par les compilateurs qui ont introduit ainsi un Scomber Alatunga. $V$. Germun. ( $V_{A L}$.

- Alamanie. Alamania. вот. PH.-C'est un g. de la famille des Orchidées, tribu des Vandées, proposé par MM. La Llave et Lexarzca ( Nov. veg. 31), pour une plante parasite originaire du Mexique, qu'ils nomment Alanania punicea, et à laquelle ils donnent les caract. suivants : Petite plante ayant des pseudobulbes oblongs, couverts d'écailles scarieuses, portant chacun 2 feuilles ovales-acuminées, épaisses ; une hampe terminale, de 2 pouces de longueur et colorée; des fleurs rouges et inodores. Le calice est étalé; les 2 divisions externes et latérales sont soudées a leur base, de manière à simuler une sorte d'éperon. Le labelle, semblable aux 2 autres divisions calicinales internes, est glanduleux ou tuberculeux à sa base. Le gynostème est charnu, a 3 pointes, et se prolonge à sa base en un éperon tubuleux. L'anthẻre, à 4 loges, contient 4 masses polliniques pédicellées. (A.R.)

* AlandiNA, Neck. вот. PH。 - Synon. du g. Moringa, Burm. (SP.)

* ALANGIÉES ou ALANGIAGÉES. вот. pir. - Un g. connu depuis long-temps, l' $A$ lanyium, L., Lam. , avait èté d'abord placé en tête de la famille des Myrtacées; mais avec quelques doutes qui résultaient de différences assez notables dans les caract. de sa végétation. Ils ont été pleinement confirmés par l'étude de sa graine; et, en conséquence, M. De Candolle a proposé d'en faire le type d'une petite famille nouvelle qui s'est depuis enrichie d'un second g., et qui, se rapprochant d'une part, des Myrtées par l'intermédiaire des Combrétacées, de l'autre, des Cornacées et des Hamamélidées, devrait peut-être venir se fondre dans ces derniéres. Ses caract. sont les suivants : Cal. adhérent, campanulé, 5-10-denté. Pétales en nombre égal, alternes, linéaires, à préfloraison valvaire, long-temps réunis ainsi, réfléchis plus tard. Étamines en nombre égal, double ou quintuple, à filets grêles, dilatés à leur base en une sorte d'écaille velue, et portant plus haut des anthères adnées, linéaires, biloculaires, internes, souvent vides de pollen. Disque charnu sur le sommet de l'ovaire et contenant l'inscrtion du style simple, que lermine un stigmate en tête. Une seule loge renfermant un seul ovule pendant de son sommet. Drupe ovoïde, relevée de côles peu 
saillantes, couronnée par le calice, contenant, sous une couche charnue, un noyau uniloculaire, percé, au sommet duquel pend une graine unique où l'on observe, dans le centre d'un périsperme charnu et faible, un embryon droit, à longue radicule supère, à cotylédons plancs et foliacés. Le petit nombre d'espèces, connues de cette famille, se compose de grands et beaux arbres originaires de l'Inde. Leurs fenilles sont alternes, sans stipules et sans points glanduleux, très entières, à nervures pennées; leurs fleurs disposées en faisceaux axillaires; les fruits de plusieurs sont bons à manger. (AD. J.)

ALANGIUM, Lamk., Angolam., Adans. (Alangi,Angolam, noms hindous du végétal). вот. PIl. - G. considéré par M. De Candolle comme type de la famille des Alangiées. Reichenbach (Syst. Nat.p. 247), à plus juste titre peut-être, le comprend dans les Combrétacées. Ses caract. différenticls sont les suivants : Cal. à 6 ou 7 dents; pét. 6 ou 7 ; ovaire adhérent, 1-loculaire, contenant un seul ovule suspendu au sommet de la loge (Roxburgh, Flor. Ind.). Drupe monosperme. Arbres à rameaux souvent spinescents; fleurs grandes, odorantes. - Ce g. appartient à l'Inde. M. De Candolle en signale 3 esp.; Roxburgh est d'avis qu'il n'y en a qu'une seule, offrant plusieurs variétés.

* Alaptus. ixs.-G. de l'ordre des $\mathrm{Hy}$ ménoptères appartenant à notre famille des Oxyuriens (Oxyures, Lat.; Proctotrupidee, Steph. et Westw.), établi par Haliday (Ent. Mag.) adopte par Westwood (Synop. of the Brit.Gen.) et par nous (Hist. des Anim.art.); il se distingue du g. Mymar avcc lequel il a beaucoup d'analogie, par des tarses de 5 articles et par des antennes filiformes, composées seulement de 10 articles dans les mâles et de 8 dans les femelles. - La seule esp. connue jusqu'à présent est l' $A$. minimus trouvé en Angleterre.

(BL.)

* ALARCONIA (Alarçon, qui aborda un des premiers en Californie, en 1540). вот. Pн. - G. de Composées, appartenant à la tribu des Sénécionidées, établi par M. De Candolle et ainsi caractérisé : Capitule multiflore, hétérogame; fleurs du rayon ligulées, femelles, unisériées; celles du disque tubuleuses, 5dentées, hermaphrodites. Involucre campanulé, formé par 1-2 rangées d'écailles làches, foliacées, égalant ou dépassant les fleurs du disque en longueur; les intérieures plus courtes, analogues aux paillettes. Réceptacle plane, couvert de paillettes à peu près de même longueur que les fleurs et les embrassant cn partie. Les ligules sont grandes, 3dentées; les fleurs du disque ont un tube court, coriace, terminé par des divisions légèremcnt velucs au sommet. Les rameaux des styles, appartenant aux flcurs femelles, sont courts et glabres, tandis que ceux des fleurs hermaphrodites sont au contraire aigus, très hispides et recourbés en dehors de la corolle. Les fruits sont prismatiques, allongés, épais, terminés par une aigrette en forme de calice. - Les Alarçonia sont des plantes herbacées, originaires de la Californie; elles ont le port de l'Aulnée et présentent des feuilles très entières, semi-amplexicaules, de grands capitules de fleurs jaunes. (J.D.)

ALARIA ( $A l a$, aîle). Bot. Cr.-G. de ia famille des Phycées, créé par M. Gréville aux dépens de la section Agarum ( $V$. ce mot) des Laminaires, et dont les caract. sont: Fronde membraneuse, parcourue dans toute sa longueur par une nervure cartilagineuse ; stipe muni de pinnules ; fructification consistant en séminules piriformes immergées dans lcs pinnules un peu renflées çà et là. Trois espèces, qu’on pourrait peut-être réduire d 2 , composent le g. Alarua dont le Fucus esculentus L. est le type. Nous avons exposé au mot Agarum les raisons pour lesquelles nous rejetons ces genres qui doivent tout au plus, dans l'état de la science, constituer des sect. du g. $L a-$ minaire. $V$. ce mot.

(C. M.)

ALARIE. helm. $V$. Alaire, (C. D'O.)

ALASMIDES. Alasmidia. Moll. - On trouve dans les Annales générales des sciences physiques de Bruxelles (t. vi, p. 287), un travail assez considérable de $M$. Raffinesque sur le g. Unio de Bruguière et de Lamarck. Il fait de ce g. très naturel, une grande famille qu'il partage en 5 s.-familles et en un très grand nombre de g. Toutes ces divisions n'étant fondćcs sur aucun caract. de quelque valeur, n'ont pas été adoptées. $V$. MuLETTE.

$$
\text { (DESH.) }
$$

ALASMIDONTES. Alasmidonta (ódóvs, óvos, dent). moll. - C'est à M. Say que l'on doit la création de ce g. On le trouve dans le Journal de l'Académie des sciences de la société de Philadelphie (1. 1, p. 459). 
Les caract. sur lesquels il est fondé, ont paru suffisants à quelques zoologistes qui l'ont adopté. Les coquilles de ce g. ne sont autre chose que des Mulettes qui manquent totalement de la dent cardinale postérieure. Si l'on ne voyait qu'un petit nombre d'esp. $d u$ g. Unio, on pourrail regarder comme fort important ce caract. du g. Alasmidonte. Mais parmi le grand nombre d'esp. aujourd'hui connues, on voit une série de modifications dans laquelle la dent postér. s'affaiblit peu à peu, el finit par disparaître complétement. Si à cette fusion des $2 \mathrm{~g}$., on ajoute la ressemblance parfaile des animaux dans tous leurs caract. zoologiques, on sera bientôt convaincu de l'inutilité du g. Alasmidonte, et on le joindra, comme nous le faisons depuis long-temps, aux Muletles proprement dites.

(DEsir.)

ALATA-IATA (Alatus, ailé ; latus, large). MoLL. - Klein est l'auteur de ce g. (Tent. Ostrac.p. 100). Il l'a établi pour quelques esp.de Strombes dont le bord droit est largement étalé. Ce g. n’a jamais été adoplé, à cause de l'insuffisance de ces caractères. $V$. Strombe.

(DESH.)

AlATERNE. Alaternus, Tourn.; Marcorella, Neck. (Alaternus, nom de cet arbrisseau dans Pline). вот. рн. - A l'exemple de Linné, la plupart des auteurs ont réuni ce g. aux Rhamnus, dont il ne diffère que par le nombre quinaire des organes floraux.

ALATITE. Alatites (alatus, ailé). mol.. - Dans son grand ouvrage sur les Pétrifications, Walch donne ce nom aux Rostellaires, aux Ptérocères et aux Strombes fossiles. $V$. ces mots.

(DesII.)

ALAUDA (nom donné par Pline, à un oiseau que les modernes rapportent à l'Alouette commune). 01s.-Nom latin de i'Aloueite. $V$. ce mot.

(LAFr.)

ALAUDIDÉES. Alaudida (d'Alauda, alouette). ors.-Famille de l'ordre des Passereaux et de la tribu des Conirostres de Cuvier. Nous la subdivisons en 2 s.-familles, celle des Alaudinées et celle des Anthusinées, renfermant les Anthus ou Pipis. Quoiqu'à la rigueur el en se renfermant dans les règles de la méthode, ce g. Anthus ne dùt pas figurer au milieu d'oiseaux conirostres, Jes rapports des esp. qui le composent avec celles du g. Alouette sont si nom. breux et si intimes, selon nous, qu'on ne pouvait les séparer, sans s'éloigner de l'ordre naturel, et qu'elles devaient au moins être groupées dans la même famille. Cet ancien nom d'Alouette de pré, donné à une des espéces les plus connues, est certainement la dénomination la plus naturelle et la plus vraie des Pipis; car en Jes comparant avec quelque détail, on est frappé de leur analogie avec les Alouettes.Parmi ces esp., il en est quelques unes, qui, telles que l'Alouetle sentinelle du Cap, l'Alouette jaune du Sénégal, si voisine de la première, notre Pipirousseline, forment évidemment, d'après leur bec plus fort ou la teinte de leur plumage, le chaînon entre les 2 g., et ont èté placées, par divers auteurs, tantôl avec les Alouettes, tantôt a vec les Pipis. Ces dernicres ont donc de commun avec les Aloueties, quant aux formes, les ongles antérieurs courts et peu arqués, le postérieur plus ou moins allongé, peu arqué ou presque droil; quelques unes des rémiges tertiaires pres qu'aussi longues que les primaires; un plumage sombre, généralement couvert de méches plus foncées, avec les pennes latérales de la queue en partie blanches; et quant aux mœurs, l'habitude de chanter en volant et en descendant les ailes étendues, de se tenir souvent à terre, d'y nicher, d'y pondre des nufs grisâtres, tout couverts de petites taches et de pelites lignes plus foncées, olivâtres ou roussâtres. Elles s'en éloignent toutefois, en ce que la plupart se perchenl et se tiennent dans les prairies, les vergers, et non dans les plaines, ce qu'exprime très bien leur ancien nom d'Alouetzes de pré. Les nombreux rapports que nous venons d'énumérer nous paraissant donc des rapports d'affinité bien plus que de simple analogie, nous nous sommes décidé, au risque de nous éloigner un peu des règles méthodiques, à rapprocher les $2 \mathrm{~g}$. dans la même famille, et comme s.-familles, sous le nom d'Alaudinées ou Alouetles arvicoles, et d'Anthusinées ou Aloueltes praticoles.

Les caract. de la famille sont : Un bec variant singulièrement dans sa forme, ou conique et non échancré, el alors, tantôt presque droit et un peu grêle, tantòt fort élevé et arqué en dessus, tantôt allongé, mince, et arqué dans toute sa longueur, ou mince en alène et chancré; des pattes organisées 
pour la marche, avec l'ongle postérieur toujours plus ou moins allongé, droit ou peu courbé, et les ongles antérieurs courts; ailes longues, moyennes ou courtes, à rémiges secondaires et tertiaires arrondies et échancrées à leur extrémité; quelques unes de ces dernières atteignant presque l'extrémité des primaires; plumage généralement sombre, roussâtre ou roux olivâtre, avec des méches plus foncées et les recirices latérales en partie blanches. Voyez les 2 s.-familles Alaudinées et Anthusinées.

(LAFr.)

* ALAUdinéEs, Alaudina. ors. - C'est, dans la classification de Swainson, une des s.-familles de sa famille Fringillidce. (LAFr.)

* ALAUdinÉES. Alaudina (Alauda, alouette). ors. - S.-famille faisant partie le la famille Alaudidées et ayant pour caract. : Tête assez grosse, arrondie et un peu déprimée; bec très variable dans sa forme, non échancré, à pointe mousse ou conique, presque droit et un peu grêle, ou gros, élevé, comprimé et arqué en dessus, ou très allongé, grêle et arqué dans toute sa longueur; narines en partie recouvertes par les petites plumes serrées et couchées de leur base; pattes d'oiseaux essentiellement marcheurs, à tarses de longueur moyenne, mais assez gros; doigts peu allongés, à articulations prononcées, totalement séparés dès leur base, les latériux courts et d'égale longueur; ongles presque droits, les antéricurs courts, les latéraux surtout qui sont égaux entre eux, le médian plus long, le postérieur souvent très allongé, droit ou presque droit; ailes aiguës ou sub-aiguës ou subobtuses, à premières rémiges souvent allongées et presque égales, ayant ou non la première penne bâtarde quelquefois de moyenne longueur; ou courtes, à rémiges tertiaires très allongées, atteignant presque l'extrémitè des primaires; queue un peu fourchue ou terminée carrément; plumage généralement teint de roux ou de roussâtre, couvert de mèches plus foncées, avec les rectrices latérales bordées de blanc ou de roux pâle.

Les Alaudinées sont répandues sur tout le globe. On a cru long-tenıps que dans le Nouveau-Monde,elles éíaient restreintes à l'A mérique du Nord, tandis que les Antbusinées étaient communes dans celle du Sud; mais nous avons reconnu, parmi les espèces rap. portées de ce continent par M. d'Orbigny et M. Gay, 2 esp. d'aloucttes du s.-g. Sirly, dont l'une est l'Alouelte mineuse de Azara, et l'autre est nouvelle.

Les esp. de cette s.-famille orrent, non seulement dans la forme de leur bec, mais encore dans celle de leurs ailes, tant de modifications graduées, qu'il nous paraît presque impossible d'y établir des g. basés sur de bons caractères. Les plus apparents sont ceux qui se tirent de la forme du bec et qui ont de tout temps donné lieu aux ornithologistes de signaler les 3 principales modifications dont nous avons parlé ci-dessus; clles ont étéindiquées par Vieillot, par Cuvier et par Lesson; mais la forme des ailes varie presque autant et arec autant de gradations que celle du bec chez la plupart des espèces, en sorte qu'en rapprochant les esp. à gros bec de notre Calandre, qui l'a effectivement tel, avec les rémiges fort longues, elles en diffèrent totalement par leurs ailes beaucoup plus courtes; et, chez l'Alouette bateleuse à bec moyen, nous trouvons des ailes singulièrement courtes et arrondies. Il en est de même des esp. à bec grèle, comme notre $A l$. arvensis, qui présentent également la plus grande disparité dans leurs ailes tantôt pourvues, tantôt dépourvues de première penne bâtarde, avec les premières rémiges ou très longues ou moyennes. N'osant donc adopter tous les g. de M. Swainson, nous nous contenterons d'abord des 3 qui répondent aux 3 modifications principales du bec el qui sont : Alouetle ( $A$. arvensis, type);Calandre (Calendula) Swains. ou Alouette à gros bec (type, l'Alouelle à gros bec de Levaillant, notre Calandre). M. Swainson place a la suite les s.-genres Mirafre (Mirafra), Horsf. et Braconyx,.Swainson; ce dernier s.-genre ayant pour type l' $A$ lonette bateleuse de Levaillant. Ces 2 s.genres diffèrent principalement de notre Calandre en ce qu'ils ont les rémiges très courtes et l'aile très obtuse. Il nous paraît indispensable d'y joindre, comme $3^{\mathrm{m}}$. s.-genre, le g. Megalotis ou Pyrrhulauda de Swains., ayant pour types le Gros bec croisé et le Gros bec oreillon blanc de Temminck. M. Swainson les range dans sa s.famille des Pyrrhulinc; mais ces oiseaux, $\mathbf{a}$ ongle du pouce droit, à tertiaires aussi lcn-. 
gues que les primaires, nous ont toujours paru, comme à Mr. Lichtenstein (Catal.), de véritables Alouettes, se rapprochant singulicrement, par leurs doigts et par leurs ongles fort courts, de l'Al. brachydactyla ou Calandrelle, et le colonel Sykis a fait connaître, dans les Proceed.1802, p. 94, que ce Fringilla crucigera de l'Inde a l'étrange habitude de se tenir à terre sur les routes élevées, et de ne s'envoler que lorsqu'on est près de marcher sur lui ; qu'il ne se perche jamais, et que ses mœur's l'éloignent du g. Fringilla; détails qui viennent encore à l'appui de notre selltiment.

Le $3^{\text {me }}$ g. est celui de Sirly, Lesson (Certhilauda, Swainson); type, l'A louette Sirly de Levaillant. M. Swainson, qui a fait de l' $A$ louette sentinelle, Vaill., son g. Macronyx, $\mathrm{el}$ du Pipi rousseline celui d'Agrodroma, les a retirés des Anthus où on les plaçait généralement, pour les mettre avec ses Alaudince. Tout en conservant ces $2 \mathrm{~g}$., il nous semble plus naturel de les laisser dans notre s.-famille des Anthusince, dont ils ont l'ensemble des caract.de forme etles mœurs, et dont ils ne diffèrent que par un bec plus fort et la couleur roussâtre de leur plumage. Nous les considérons positivement comme un petit groupe de transition qui lie les Anthusinées aux Alaudinées. $V$. les mots Alouelle, Calandre et S'irly.-Comme nous l'avons dit plus liaut, la forme des ailes varie beaucoup suivant les espèces. On peut cependant poser en these générale que, chez toutes nos esp. européennes, elles sont toujours longues, à rémiges primaires allongées, à penne bâtarde nulle ou très petite; les primaires dépassant toujours notablement les tertiaires à leur extrémité; tandis que, chez presque toutes les esp. africaines et indiennes, l'aile est sonvent arrondie, les primaires de longueur moyenne ou courtes, les tertiaires aussi longues ou presque aussi longues qu'elles à leur extrémité, et la penne bâtarde égalant souvent la moitié de celle qui la suit. (LAFr.)

*ALAUS. Alaus (á̀xós, aveugle). Ins. G. de l'ordre des Coléoptères pentamères, famille des Sternoxes, tribu des Ėlatérides, établi par Eschscholtz qui lui donne pour caract. : Tarses dépourvus de pelotes, fortement soyeux ou velus en dessous; ongles simples; front défléchi, le plus souvent lan ou concave; carène frontale très fine.
Lames pectorales lancéolées, non subitement dilatées en dessous; thorax entier en dessous, avec l'écusson oblong. Ce g. figure dans le dernier catal. de M. Dejean, qui y rapporte 11 esp.; 10 exotiques et 1 de la Russie méridionale; nous citerons seulement comme type, l'Elater oculalus de Fabricius. (D.)

*ALAUSTIEN. man.- $V$. Alunite. (Del.) ALPACOREA. polss.-Corruption du mot Albacoretta, sous lequel Pison a représenté un Thon (Thynnus balleatus, au vol. Poiss., vill, p. 136), et qui a été ensuite appliqué par les Anglais à plusieurs esp. de Scombéroïdes. On lit dans quelques anteur's $A l b i-$ corre au lieu d'Albacore; mais c'est évidemment une faute d'impression. (VAL.)

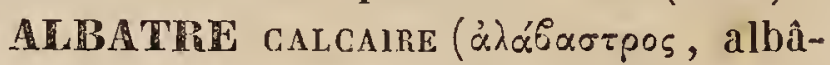
tre). min. - Ce que Pline dit de l'Alabastrite $(V$.ce mot) paraît se rapporter plus spécialement à la substance que l'on nomme aujourd'hui albatre calcaire ou albatre oriental. C'est une variélé de calcaire, d'une belle demi-transparence, et formée de couches successives, ondulées, qui se dessinent en veines à la surface. Sa cassure est imparfaitement cristalline et comme striée; sa couleur est le blanc-laiteux, un peu roux, ou jaune de miel. On le distingue de l'albâtregypseux, en ce qu'il est assez dur pour rayer le marbre blanc, et que, par l'action d'un acide puissant, il se décompose en faisant une vive effervescence, tandis que l'albâtre gypseux, beaucoup plus tendre, se laisse rayer par l'ongle el n'est point attaqué par les acides. On donne le nom d' $A$. oriental à l'albâtre calcaire dont les couleurs sont vives, la translucidité parfaite, et qui est susceptible d'un beau poli. Tel est celui que les anciens tiraient de l'Egypte, sous le nom de marbre onyx, et dont est faite la statue égyptienne que posséde le Musée royal de Paris. On a trouvé à Montmartre, prés de cette capitale, un albâtre d'un beau jaune de miel, tirant sur le brun, dont on a pu faire quelques coupes d'un assez bel effet; mais il y est rare, et toujours en masses peu volumineuses.

(DEL.)

ALBATRE GYPSEUX. MIN. - Cet albâtre appartieut à l'espéce minérale qu'on nomme Gypse (sulfate de chaux hydraté). Il perd promptement sa transparence, quand on le soumet au feu, et se change en plâtre. Il est beaucoup plus tendre que l'albâtre cal- 
caire; ce qui fait que le moindre frottement suffit pour lui enlever son poli et son éclat. Il offre souvent la blancheur la plus parfaite, quoique cette qualité ne lui soit point essentielle; et c'est à cette variété que se rapporie l'expression proverbiale blanc comme l'albatre. Celui que l'on trouve a Volterra, en Toscane, et que l'on travaille ả Florence, est remarquable par la finesse de son grain, son blanc de lait et sa douce translucidilé; on en fait des vases, des lampes, des pendules, et de petites statues. A Lagny-sur-Marne, près de Paris, sont des carrières d'un albâtre veiné, de couleur grise ou blanc-jaunâtre, qui s'exploitent avec avantage; on en fait des pendules, des socles et des revêtements de cheminée.

(DEL.).

ALBATROS. Diomoedea, L. (corruption d'albalus, vêtu de blanc). ors. - G. de l'ordre des Palmipèdes, de la famille des Longipennes ou Grands-Voiliers de Cuvier, et de celle des Siphorins de Vieillot. Ce g., réuni au genre Pétrel, nous parait former un groupe ou une s.-famille des plus naturelles, tant d'après la grande analogie de leurs formes et surtont de leur bec, que d'après la conformité de leurs mœurs. Nous donnerons donc à cette s.-famille le nom de Siphorinées (Siphorince. $V$. ce mot). Les caract. du g. sont : Bec très long, très robuste, suturé, assez élevé, droit, comprimé; mandibule supér. à arête arrondie, sillonnée de chaque côté dans presque toute sa longueur, néchie vers les deux liers, puis relevée, enfin fortement recourbée et crochue à la pointe; manảib. infér. droite, un peu dilatíe verticalement à son extrénité, et tronquée de manière à s'emboîter dans le crochet puissant de la supér.; leurs bords internes coupants, surtout vers l'extrémité, et s'emboîtant les uns dans les autres au moyen de rainures internes assez profondes; narines tubuleuses, en forme de rouleaux courts, couchées dans le sillon latéral du bec et couvertes en partie antérieurement à l'orifice de ces tubes, et en partie latéralement sous un repli qui leur est contigu, environ au quart de la distance du front à l'extrémité. Pieds courts; tarses réticulés; point de pouce; les 3 doigts antér. réunis par de larges membranes entières; les latéraux bordés d'un rudiment de peau en forme de bande; cette peau réticulée, ainsi que le dessus des doigts en majeure partie scutellés; d'ailleurs, ongles faibles et presque droits. Ailes sur-aiguës, très longues par suite du trẻs grand développement de l'humerus et de l'avant-bras, à rémiges primaires et secondaires courtes, ce qui les rend fort étroites. Queue courte, ne dépassant pas ou dépassant peu la pointe des ailes.

Les Albatros sont les géants des Palmipèdes. Malgré leurs énormes proportions, qui les ont fait nommer par les navigateurs Mottons du Cap, Vaisseaux de guerre, ils sont doués du vol le plus facile et le plus vigourenx en même temps. C'est ainsi qu'on les voit, tantòt se balancer avec grâce au-dessus des vagues, ou les effleurer en suivant leurs. ondulations pour y saisir les petits animaux qu'elles amèrent à leur surface, tantôt voler, dans les tempêtes, contre le vent le plus violent, sans effort et sans que leur vol en paraisse ralenti. Dans toutes ces circonstances, ils semblent ne faire que planer, et l'on ne s'aperçoit pas qu'ils impriment le moindre battement a leurs ailes. Ce sont de tous les Oiseaux pélagiens ceıx qui, saus nulle comparaison, s'éloignent le plus des côtes, et on les rencontre à des distances immenses de toute terre. Ils n'habitent que les vastes mers du l'òle austral, en dehors du Tropique du Capricorne, ou les mers de l'Océan pacifique septentrional, dans les parages de la Chine et du Japon.

Buffon et Vieillot d'aprćs lui, avaient annoncé que, malgré leur énorme taille, ces Palmipèdes ne se nourrissaient que de petits animaux marins et de Zonphytes mucilagineux. On a dit depuis qu'ils enlevaient une grande quantité de poissons, en rasant les llots, et qu'ils faisaient surtout une grande consommation de poissons volants, qu'ils saisissaient hors de l'eau; mais M. Gaimard a remarqué que, dans des parages oú le bâtiment qu'il montait était entouré de ces poissons, ainsi que de Méduses, de Biphores, de Physales et d'autres mollusques, on n'avait jamais trouvé dans l'estomac des Albatros qu'on y avait tués, aucuns débris de poissons ni de mollusques, mais bien de Céphalopodes, tels que des Sèches el des Calmars.

M. Tenıminck, dans son intéressant article sur les Albatros $(P l . c o l$.$) , cite les passages de$ plusieurs voyageurs qui les ont rencontrés mar bandes sur des cadarres de Cétacés, do 
Phoques et autres grands animaux marins, les dépeçant et se gorgeant de leur chair déjà corrompue. On pourrait conclure de ces divers récits, que les Albatros ne sont point piscivores; que les seuls animaux vivants qui font partie de leur nourriture sont des Céphalopodes, et qu'en général, le fond de leur nourriture est la chair déjà corrompue des grands animaux marins.

La forme de leurs ailes dont l'humérus et l'avant-bras sont si prolongés, celle de leur bec assez analogue à celui des Vautours, sur-tout des Cathartes et des Percnoptères, l'habitude de se gorger de nourriture, comme ces oiseaux, au point de ne pouvoir ni prendre leur essor ni fuir en nageant lorsqu'on les approche (et dans ce cas, leur seule ressource consiste à rejeter avec effort leurs aliments), tous ces rapports nous font envisager les Albatros et même les Pétrels comme de véritables Vautours de l'Océan, destinés à purger les mers des animaux morts et plus ou moins putréfiés qui flottent à leur surface. Par suite de l'immense faculté de vol qui leur permet de les parcourir dans tous les sens, et à des distances énormes de toute terre, ils rencontrent aisément ces cadavres flottants, qu'ils ont probablement la faculté de sentir de très loin. En effet, l'ouverture de leurs narines, que protègent un tube et un repli latéral, tendrait à faire croire que chez eux, le sens de l'odorat est doué d'une grande perfection, comme chez les Vautours, parmi lesquels les Cathartes nous ofrrent une ouverture de narines sous une arcade commune, un peu analogue à ce qu'on voit chez les Pétrels.

C'est surtout au-delà du Tropique du Capricorne, vers le $35^{\mathrm{me}}$ degré de latitude Sud que l'on commence à rencontrer les Albatros, et c'est vers le $40^{\text {me }}$ qu'ils sont le plus nombreux. Ils paraissent ne se rapprocher des terres qu'à l'époque de leur reproduction. L'île Tristan d'Acunha, située au $35^{\text {me }}$ degré, est un des points qu'ils choisissent de préférence, et où le voyageur Dougal-Carmichael a pu les observer à loisir. Il en reconnut 3 esp. distinctes, l'exulans, le chlororhynchos et le fuliginosa, couvant dans cette île. Cette dernière esp. s'y trouvait surtout en grand nombre; les nids, très rapprochés les uns des autres, ponvaient ctre évalués à plus de 100 dans un espace d'un acre environ. Ces nids étaient construits avec de la boue, et élevés de terre de 5 à 6 pouces seulement. Ceux du chlororliynchos, pyramidaux et plus élevés de 10 à 12 pouces environ, étaient plus isolés dans les ravins des montagnes. L'exulans ne se donne aucune peine pour construire le sien; ce n'est le plus souvent qu'un endroit sec, un peu concave pour que l'œuf n'y roule pas. Toutes ces esp. ne pondent jamais qu'un seul œuf, blanc, très gros, singulièrement oblong et d'égale grosseur aux 2 bouts. Les petits sont nourris très long-temps par la mère et se tiennent chacun sur leur petit monticule de la manière la plus grotesque, ne paraissant nullement effrayés de l'approche des hommes, retournant incontinent se poster sur leurs nids si on les en tire, et ne se défendant pas autrement qu'en lançant de leur estomac un déluge d'huile fétide. Dans l'usage de dégorger les aliments à leurs petits et dans l'obligation de courir l'espace de 20 a 30 toises avant de pouvoir prendre leur essor, ces oiseaux ont encore avec les Vulturidées, de nouveaux rapports qui nous confirment de plus en plus dans l'idée que notre s.-famille des Siphorineses est sur l'Océan le représentant de l'autre sur les continents, et constitue un groupe voisin seulement de celui des Larineses, mais bien distinct de tous les autres Palmipèdes. L'esp. la plus forte comme la plus généralement connue, est l'Albatros commun, Vieill. (Diomcedea exulans, L.), que M. Temminck propose de nommer Alb. mouıon, à cause de cette dénomination vulgaire de Mouton du Cap, adoptée depuis long-temps par les navigateurs, parce que ce n'est guère qu'à la latitude du Cap de Bonne-Espérance que l'on commence à l'apercevoir. Quatre autres esp. sont avec celleci tout ce qu'on en connaît jusqu'à ce jour, d'après Temminck qui les indique et en a figuré quelques unes ( $P l . c o l$.$) (LAFr.)$

ALBEN (Albus, blanc). min.-Nom donné par Petzl à un tuf calcaire incrustant et de formation récente, dont il existe des couches considérables près d'Erding, en $\mathrm{Ba}-$ vière.

(DEL.)

ALBERGAME DE MER. zoopir. - Nom donné par Rondelet à une production marine qu'on doit supposer être un Alcyon ou une Lobulaire.
(Dus.) 
ALBERGE. вот. PI. - Nom d'une variétė de l'A bricotier.

(Sp.)

- ALBERTA. Alberla, E. Meyer (Dédié à Albertus Magnus, ancien naturaliste). вот. PH. - G. de la famille des Rubiacées, tribu des Gardéniées. Suivant M. E. Meyer ( Linnaea, 1838 , vol. 12, p. 258), .ce g. a beaucoup de rapports avec les Musscenda, mais Il en diffère : $1^{\circ}$ par le cal., dont les 2 lanières latérales sont plus grandes que les trois autres; $2^{\circ}$ par une cor. a gorge nue, et à limbe court, dressé; $3^{\circ}$ par un péricarpe sec, couronné de toutes les lanières calicinales et ne renfermant que 4 a 6 graines. -Ce g. n'est fondé que sur une seule esp., découverte en Caffrerie par M. Drége. (Sp.)

- AlBERTIA (Nom propre....). syst. - G. de Systolides établi par nous, pour un ver parasite des Lombrics et des Limaces, et voisin des Rotifères. Il est vermiforme, contractile, nu, pourvu d'un appareil unandibulaire articulé, et présente en avant une pièce frontale, tantót saillante en forme de capuchon, tantôt rétractée et laissant voir la bouche ciliée. Il est aminci en arrière et terminé par une queu e courte, conique.-La seule esp. connue ( $A$. vermiculus) est longue d'un 1/2 millimètre environ; elle est vivipare et renferme ordinairement 2 ou 3 œufs ou fœtus, plus ou moins développés ( $V$. Ann. sc. nat. t. IX sept. I 838).

(DUJ.)

ALBERTINIA (nom d'homme). вот. PH. - Ce g., de la tribu des Vernoniées, de la iamille des Composées, a été établi par Sprengel, et a pour caract.: Des capitules composés d'1 ou de 3 fleurs; capitules qui sont réunis en glomérules globuleux, souvent entourés à la base d'un involucre commun, formé par un grand nombre de petites folioles soudées entre elles inférieurement. L'involucre partiel qui entoure les fleurs, est formé d'écailles droites, fortement pressées les unes contre les autres et quelquefois même soudées aussi entre elles dans une grande partie de leur longueur, de manière à constituer de petites alvéoles au centre desquelles se trouvent les fleurs ; celles-ci sont tubuleuses, régulières, à divisions souvent assez longues, réfléchies. L'aigrette qui surmonte le fruit est bi ou pluri-sériée, composée de poils filiformes, légèrement denticulés, prenant probablement par la dessiccation une couleur jaunâtre ou rougeâtre. - Les Albertinia sont des arbrisseaux brésiliens, munis de feuilles alternes, pétiolées, elliptiques, atténuées aux deux extrémités, glabres ou blanchâtres en dessous.

(J. D.)

ALBERTINIÉES. B0T. PH.-Sous-division de la tribu des Vernoniées, appartenant d la famille des Composées, et caractérisée par ses capitules pauciflores, réunis en glomérules arrondis. Linflorescence des Albertiniécs offre un caractère particulier ; celle des Composées a été considérée comme un épi déprimé oủ les pédicelles de chacune desfleurs, probablement disposés en corymbe tendant à l'épi ou à l'ombrelle dans certains cas, seraient intimement soudés, de manière à constituer un réceptacle plane, quand ils atteignent tous le même niveau (Reine-Marguerite, Soleil), un réceptacle convexe ou allongé, quand ceux du centre se prolongent au-delà de ceux du bord (Rudbeckia), et, ce qui est beaucoup plus rare, un réceptacle concave, quand le cas contraire se présente. Dans tous ces exemples, les fleurs s'épanouissent de la circonférence au centre; dans les Albertiniées, au contraire, cet ordre est en partie interverti ; on voit des fleurs s'épanouir en même temps au centre et à la circonférence. On a considéré ces cas anormaux comme une inflorescence en grappes, dans laquelle la soudure primitive des pédicelles serait à un moindre degré, et où chacun pourrait se développer dans un ordre moins dépendant de l'ensemble. Les Albertiniées présentent donc, pour inflorescence, de petites têtes globuleuses,formées elles-mêmes de plusieurs petits groupes secondaires, composés de une ou trois fleurs, qui toutes sont, en partie, indépendantes des groupes voisins.

(J. D.)

* ALBIKIA. bot. pr. - Le g. décrit sous ce nom par Presl (famille des Cypéracées), est le même que l'Hypoelytrum de Richard. $V$. Hypoflytrum.

(A. R.)

ALBIN ou ALBINE (Albus, blanc). min. - Variété d'Apophyllite, d'une belle couleur blanche, que l'on trouve à Marienberg, près d'Aussig, en Bohême, dans les cavités d'un phonolite, et qui a été prise d'abord pour une esp. particulière, puis pour une variété de mésotype. $V$. A pophyllite. (Dre.)

- ALBINIE. Albinia (Albin, naturaliste anglais ). ıss. - G. de l'ordre des Diptères, établi par M. Robineau-Desvoidy, dans si 
tribu des Entomobies, famille des Myodaires, et auquel il donne les caract. suivants : Ant. ne descendant pas tout-à-fait jusqu'à l'épistome; le $2^{\text {me }}$ art. un peu plus épais que le $3^{\mathrm{me}}$, qui est double en longueur et prismatique. Front carré; péristome développé; épistome saillant, en carré transverse; optiques ciligères. Corps cylindriforme, noir avec des nuances cendrées; cellule $\gamma$ C ouverte avant le sommet de l'aile. - Ce g. est fondé sur une seule esp. nommée par l'auteur $A$. buccalis, sans indication de patrie, et dédié à la mémoire de l'entomologiste anglais Albin.

ALBINISME (Albus, blanc). TẾRAT. M. Isid. Geoffroy-St-Hilaire divise les AnoInalies simples ou Hémitéries en cinq clasSes : $1^{\text {re }}$ chASSE : Anomalies relatives au volume des parties; $2^{m e}$, à la forme ; $3^{\text {me }}$, à la structure; $4^{\mathrm{me}}$, à la disposition $; 5^{\mathrm{me}}$, a u nombre et à l'existence. Dans la $3^{\mathrm{me}}$ classe, celle à laquelle se rapporte cet article, il établit deux sections : les Anomalies de couleur et celles de structure proprement dite; celle-là comprend trois ordres, dont le premier est relatif á la dimirution de la matière colorante : c'est l'Albinisme.

a L'Albinos.... est une espèce de singe, de couleur blafarde, qui a la taille du Lapon, la peau des lépreux et les yeux du hibou. Condamné, par la structure de son organe optique, à fuir la lumière, il regarde avec horreur le soleil et le spectacle de la nature, s'endort le jour, dispute la nuit quelques vils aliments aux bêtes féroces, qu'il n'égale ni en adresse ni en courage, el termine à 30 ans sa malheureuse carrière sans avoir vécu.

"Rien n'égale la stupidité de l'Albinos: tout ce qui n'est pas renfermé dans le cercle étroit de ses besoins, échappe à son intelligence; on n'a jamais pu lui faire expliquer de quelle couleur il voit les objets, ou seulement s'il a deux axes de vision. Le Nègre, que nous ne regardons qu'avec l'œil du dédain, est à l'égard de l'Albinos ce que serait à côté de luimmême un Newton ou un Montesquieu. "

Tels sont les termes dans lesquels l'un des philosophes du xv111 ine siècle, l'auteur du volumineux Recueil de la Philosophie de la Nature, traite de l'histoire de l'Albinos.

Nous avuns pris celte description presque au hasard; nous aurions pu choisir dans vingt autres fables non moins absurdes auxquelles l'anomalie qui nous occupe a donné lieu dans le siècle dernier.

Appelée à donner une description de l'Albinos, la science actuelle sera sans doute moins miraculeuse que la philosophie dont nous invoquions tout-á-l'heure les lumières ; mais en échange elle acquerra en précision et en exactitude autant qu'elle perdra en merveilleux.

L'Albinos, en efret, n'a presque aucun des traits étranges que des imaginations rivales de Telliamed se sont plu à lui prêter, et dont le grossier charlatanisme des foires et des places publiques perpétue le récit, parmi des espritsignorants et superstilieux. Il n'est aucun des traits de la description ou plutôt du tableau qui précède, qui ne puisse être réfuté, ou qui du moins n'ait besoin d'être profondément redressé. Dans ces êtres, dont l'amour du merveilleux se plut a faire des miracles ou des jeux de la nature, la science ne reconnaît que de légères modifications anatomiques, qui, quelle que soit d'ailleurs leur influence sur l'économie et le genre de vie de ceux qui les présentent, n'en sont pas moins fort simples en elles-mêmes et parfaitement appréciables.

Ainsi que l'indique la place que nous avons dit appartenir à l'Albinisme dans la série tératologique, les êtres qui présentent ce genre d'anomalies sont caractérisés par une structure particulière de la peau, consistant dans l'absence ou la diminution du pigmentum ou matière colorante.

Quelques mots pour bien faire comprendre ceci.

La peau est, comme on sait, formée de deux feuillets, l'un externe, l'épiderme; l'autre interne, formant presque toute son épaisseur, le derme. Sa trame est formée par des fibres lamineuses, très résistantes. Elle contient des vaisseaux artériels et veineux, exhalants el absorbants; des nerfs qui s'épanouissent à sa surface en forme de papilles, et dans lesquels réside sa sensibilité.

C'est à Malpighi que l'on doit la notion de la superposition et de la relation de ces différentes parties. Suivant ce grand anatomiste, le second feuillet de la peau, le derme, est formé de trois couches superposées; la plus interne, qui forme la partie la 


\section{ALB}

plus solide du derme, est constituée par des fibres denses, comme feutrées, criblies d'une infinité de trous qui livrent passage zux vaisseaux et aux nerfs. Celte premicre couche est le chorion.

Les vaisseaux et les nerfs qui traversent le chorion forment au-dessus de celui-ci, ən se réunissant en espèces de pinceaux au jein d'un tissu spongieux, érectile, une seconde couche à laquelle il donne le nom de corps papillaire.

Vient enfin, en troisième lieu, la couche externe du derme. C'est un mucus sécrété par les papilles que forme la couche précédente, une sorte de vernis gras et mou, destiné à abriter la seconde couche et à lui conserver sa souplesse; c'est le corps muqueux de Malpighi.

Nous devons dire que, sur l'organisation de cette troisième couche, il y a dissentiment parmi les anatomistes. Ce qui reste établi, c'est qu'elle est le siége de la matière colorante de la peau : matière diverse suivant les races, puisque c'est à elle que celles-ci doivent leur diversité de couleurs. - Bichat lui-même, qui n'a pas vu le mucus dont parle Malpighi, el pour lequel cette couche (corps muqueux) est un réseau de vaisseaux artériels, veineux, exhalants et absorbants, la regarde toutefois, comme étant, en mème temps que le siége de l'exhalation et de l'absorption, celui de la matière colorante, ou du pigmentum, suivant l'expression généralement adoptée par les anatomistes.

Ce pigmentum, sous-jacent à l'épiderme, est répandu partout; la peau, sans lui d'un blanc fade, mat et blafard, lui doit sa couleur; les poils et toutes les dépendances de la peau seraient sans lui d'un blanc de lait; il tapisse les membranes muqueuses, et la bouche el les lèvres, par exemple, lui doivent leur teinte rosée. Il recouvre également la face postéricure de l'iris el de la choroïde, et ce point a une grande valeur dans l'histoire de l'Albinisme.

L'œil, qui n'est autre cliose qu'un véritable instrument de dioptrique (el celte comparaison est presque triviale à force d'être vraie), l'œil, considéré sous ce rapport, se montre, comme on sail, formé de membranes qui en constituent la charpente, de parties faisant office de ce qu'on appelle en physique corps rérringents enfin d'un
ALB

diaphragme appeló iris, percé en son centre d'un trou qui est la pupille, destinée à livrer passage allx rayons lumineux, dont la direclion s'est déjà modifiée en traversant la cornée et l'humeur aqueuse. L'iris, tapissé a sa face postérieure par le pigmentum, remplissant dans toute son élendue l'office d'un corps opaque, refléchit les rayons qui viennent frapper sa grande circonférence, et ne laisse arriver jusqu'au cristallin, à travers lequel ils se réfractent, que les rayons qui ont traversé l'espace étroit que leur livre l'ouverture pupillaire. Si au contraire le pigmentum manque, alors l'iris, de corps opaque qu'il était, devient transparent; et passant de l'état de diaphragme aux conditions de corps réfringent, tel que la cornée, l'humeur aqueuse, le cristallin et l'humeur vitrée, admet dans la dernière chambre de l'œil, les rayons qu'il réfléchissail, el qui maintenant y arrivant comme à travers l'ouverture pupillaire, subissent seulement wne réfraction de plus, et blessent alors infailliblement, par leur nombre elleur intensité, les nerfs opliques qu'aucun corps opaquene protège plus.Supposons qu'il existe un tel être, et nous devons comprendre qu'en même temps que sa peau et toutes les parties qui en dépendent seront décolorées, sa vue sera d'une susceptibilité extrême; qu'une intensité de lumière, aisćment suportée par un être bien conformé le blessera; que le malaise qu'il éprouvera, imprimera à toute sa physionomie, lorsqu'il sera exposé à un trop vif éclat, des mouvements convulsifs; que, dès lors, il fuira la lumière, et qu'il ne jouira enfin de toutes ses facultés qu'à l'ombre ou dans l'obscurité. Or, telles sont les conditions de l'Albinos.

La valeur réelle de cette anomalie étant appréciée, quelle est maintenant la cause de la décoloration de la peau?

Le siècle dernier, qui a vu généralement dans les Albinos, une race ou nation à part. inférieure au nègre, n'a guère soulevé cette question. D'ailleurs Waffer assurail qu'au Darien l'Albinisme étail héréditaire (fai qui au reste serait en rapport avec la persistance des races blanches dans les espéces d'une autre couleur). Fontenelle donnait l'histoire d'un Albinos de Surinam, fils d'un négre blanc, et l'auteur de la Philos. de la 
Nal., disait tenir des officiers de la Compagnie française des Indes, qu'il existait au centre de Madagascar une grande peuplade d'Albinos qui, se regardant comme supérieurs au reste des habitants de l'ile, refusaient de contracter des alliances avec eux. Buffon lui-même, retraçant l'histoire des races bumaines, adopta cette idée erronée, sur la foi de Ribeiro, quand il en vint à parler des habitants de l'ile de Ceylan (dans son III ${ }^{\text {me }}$ vol.), et chercha à expliquer cette existance anomale d'une peuplade blanche, au milieu d'hommes basanés, ea supposant qu'ils provenaient originairemeut d'Européens qu'un naufrage avait jetés sur la còte. Ce n'est que long - temps après qu'il pencha à admettre (sans toutefois se décider positivement à ce sujet) que l'Albinisme pourrait bien n'être qu'une variété accidentelle. Quelques philosophes cependant, et, entre autres, l'auteur des Recherches philosophiques, le considérèrent comme une dégénérescence du Nègre; mais cette opinion parut insoutenable, lorsque Banks et Solander eurent vu des Albinos dans la mer du Sud, et en Amérique, au Darien. Maintenant, il n'est plus guère de contrée du globe oú on n'ait observé des Albinos.Suivant le relevé fait par M. Isidore-Geoffroy St-Hilaire, les voyageurs en ont rencontré à la Nouv.Guinée, aux îles des Amis et à celles de la Société, à l'isthme de Panama, aux Antilles, dans la Guyane, au Brésil, au Mexique, en Virginie et à la Louisiane, au Cap de Bonne-Espérance, au Congo, et dans différentes autres parties de l'Afrique, a Madagascar, à l'île de France, à Ceylan, à Amboine, à Manille, a Java, au Malabar, etc. Ia variété des noms qu'on leur a imposés (Bedas ou Bedos à Ceylan; Chacrelas, $\mathrm{Ka}$ krelas ou Kakerlaques à Java; Dondos en Afrique; Albinos dans l'isthme de Panama; sans parler des synonymes tels que Kalerlaquisme, Leucouthiopie, Leucopathie, Leucose, que plusieurs auteurs leur ont donnés), cette varièté, dis-je, témoigne suffisamment de leur peu de rareté. Maupertuis, de son côté, regarda l'Albinisme comme provenant d'une maladie héréditaire. Blumenbach, Winterbottom, Sprengel, Otto, etc., le considérent comıne le résultat d'une maladie particuliẻre. Hallé, Jefferson, Béclard, rejetant cette opinion, l'attribuent à une modification de la peau : sentiment qu'adopte Mansfeld, et auquel il donne une haute importance en l'expliquant par la théorie de l'arrêt de développement; application à laquelle Meckel avait déjà songé antérieurement.

Ainsi que le remarque l'auteur du Traité de Tératologie, le dissentiment de ces savants célèbres provient probablement de la différence des cas qu'il leur fut donné d'observer. Nul doute, en effet, que dans certaines circonstances, la peau et les cheveux ne soient susceptibles de perdre leur couleur, soit sous l'influence de causes morbides, soit par suite (et nous pouvons citer l'exemple historique et célèbre du comte de St-Vallier) d'une trop vive impression mo-. rale. Partant de ces vues, M. Isid. Geoffroy divise l'Albinisme, sous le rapport des causes qui le font naître, en deux sections: l'une dépendant d'une maladie, et c'est à celle-ci qu'il faut rapporter le résultat des expériences dans lesquelles il a pu produire 'Albinisme d'une laçon plus ou moins complète à l'aide de causes débilitantes; l'autre constituant une véritable anomalie, et qui s'explique par l'absence plus ou moins complète du pigmentum, c.-à-d. par l'arrêt du développement de celui-ci, explications que vient encore corroborer la persistance momentanée de la membrane pupillaire et l'existence permanente du duvet qui couvre le foetus pendant la seconde moitié de la vie intra-utérine et qu'on remarque fréquemment chez les Albinos, particulièrement chez ceux de l'isthme de Panama. Quant à la cause même de cet arrêt, c'est un point resté jusqu'à ce jour sans solution.

On le voit, réduit à n'être plus qu'un sim ple cas d'anatomie, l'Albinisme perd tout sor prestige, et n'a plus même, on peut le dire d'autre titre a l'attention du vulgaire que li singularité d'habitudes et d'aspect qu'il in prime nécessairement à ceux qui s'en trou vent atteints et qui leur a fait donner, er particulier par luzzi, le nom d'Héliophobes qui rappelle l'aversion que leur inspire ia lumière.

L'Albinisme ne constitue donc pas, comme on l'a cru long-temps, une race à part, mais une simple variété individuelle $\mathrm{c} \iota$ accidentelle. Alors tombent d'elles-mêmes toutes les théories que les philosophes, les 
naturalistes et les voyageurs du xvrn mo siècle avaient forgées sur les prétendues peuplades d'Albinos; alors s'écroulent ces opinions absurdes enfantées par des imaginations déréglées, comme celle qui, dans l'Encyclopédie, fait de l'Albinos un métis de l'Orang-outang et de la femme; celle de l'auteur des Recherches philosophiques, qui consacre un article entier à démontrer qu'il existe dans la semence des Africains un principe vénéneux qui, en agissant sur le fluide nerveux, altère l'organisation du fœtus; celle puisée par le voyageur WafTer, chez les Sauvages de Panama, qui lui assurèrent que les Albinos naissaient de feinmes qui, pendant leur grossesse, avaient regardé la pleine lune; et enfin cette autre opinion vraiment délirante, suivant laquelle la nature aurait posé dans l'Albinos une intelligence qui, long-temps latente, se fera jour à heure marquée, et lui assurera l'empire du monde, après la destruction préalable de tout le reste du genre humain, sur les ruines duquel il fondera enfin la meilleure des républiques.

Toutefois, l'opinion qui, dans l'absence des certitudes de la science et de données positives de la part des voyageurs, consistait à considérer les Albinos comme constituant une race à part, n'était pas absolument dépourvue de raison. On conçoit, en effet, que des malheureux, maltraités et proscrits par ieurs semblables, aient mis, en quelque sorte, leur iufortune en commun, et que la réunion deplusieurs d'entre eux sur un même point. ait pu induire les voyageurs en erreur. Mais il est remarquable que, par un singulier contraste, tandis que dans certaines régions de l'Afrique, les Albinos étaient, à ce qu'il paraît, méprisés et haïs, le roi de Bantam, si l'on en croit le voyageur Bruyn, en avait plusieurs en grand honneưr à sa cour, parmi ses femmes; qu'à Loango, ils avaient pour fonction spéciale de faire la prière en pré. sence du roi; et enfin que Montézuma en entretenait plusicurs dans son palais.

Loin de n'exister que dans l'espèce humaine, l'Albinisme s'observe, au contraire, et très fréquemment, chez un grand nombre d'animaux. Il n'est personne qui n'ait vu des lapins blancs; il n'est personne qui ne connaisse historiquement les célẻbres éléphants blancs si vénérés dans certaines contrées de

$$
\text { T. } 1 .
$$

l'Orient. Ce sont là de véritables variélés albines. Ajoulons qu'il est même plusieurs espéces chez lesquelles, comme chez le daim, la couleur blanche paraît remplacer constamment la couleur normale. On trouvera dans le Traité de Tératologie, l'énumération des espéces dans lesquelles l'Albinisme a éló observé.Nous citerons,toutefois, comme étant les plus remarquables: parmi les Mammiferes, la Taupe et la Barbastelle; parmi lcs Oiseaux, chez lesquels il se présente plus fréquemment encore, le Merle, etc., etc.

L'auteur de l'ouvrage cité, divise le genre d'anomalie qui nous occupe en :

$1^{\circ}$ Albinisme complet, caractérisé par la décoloration générale et complète de la peau. C'est à ce genre que se rapporte plus spécialement tout ce qui précède.

$2^{\circ}$ Albinisme partiel, ou certaines parties seulement de la peau sont décolorées; sec‘ion a laquelle doivent être rapportés les hommes ou enfants pies.

$3^{\circ}$ Albinisme imparfait, qui consiste simplement dans une diminution de la matière colorante.

On trouvera dans l'ouvrage déjả cité l'histoire de chacun de ces genres. Nous terminerons en mentionnant les cas suivants et nouveâux d'Albinisme, dont nous devons la communication ả l'obligeance de M. Isidore Geoffroy :

$1^{\circ}$ Une anguille frappée d'Albinisme imparfait sur tout le corps, sauf l'extrémité du nez et de la queue, qui étaient noirs. Tout le corps ćtait d'un jaune tirant sur le nankin. Ce cas est, comme on le voit, tout à la fois, un exemple d'Albinisme imparfait et d'Albinisme partiel. Ce poisson avait été pris aux environs de Paris, et envoyé vivant au Muséum d'histoire naturelle par mademoiselle 'Taglioni.

$2^{\circ}$ Une écrevisse, frappée également d'Albinisme imparfait. Elle était d'un beau bleu.

$3^{\circ}$ Enfin, plusieurs cas d'Albinisme complet, observés dans l'homme, et qui, extraits d'une lettre de M. Retzius á M. Isid. Geofrroy, ne présentent toutefois rien de bien remarquable. Deux d'entre eux étaient frères et nés à un an de distance. Un troisième, actuellement vivant, est un homme de 50 ans, et jouit d'une bonne santé. (V. Mevnifi.)

ALBINOS. téRAT. $-V$. AlbINISME. (C. d’O.) $16^{*}$ 
*ALBITE (Albidus, blanchâtre). Min.-Nom donné au Feldspath à base de soude, l'ancien Schorl blanc du Dauphiné, et dont les premières variétés connues étaient toutes d'un blanc mat ou laitcux; il en existe aujourd'hui de plusieurs couleurs. $V$. FridSPATH.

(DEL.)

ALBOUR ou AUBOUF. BOT. PH. - Noms vulgaires du Cytisus Laburnum L. (SP.)

ALBRAND ou HALEBRAND. 015. C'est, en terme de chasse, le nom des jeunes canards sauvages de l'annéc, qui n'ont pas encore quitté le plumage du nid. $V$. $\mathrm{CA}_{A}$ $\mathrm{N}: \mathrm{RD}$.

(LAFr.)

* albrandia (Nom d'homme). rot. pir. - Ce g. de la famille des Moréées, Endl. (Urticacécs, Lindl.), ćtabli par M. Gaudichaud (Voyage de l'Uranie), a été réuni par Endlicher à l'Epicarpurus de Blume. Lindley (Syst.), toutefois, l'adopte comme distinct, et le place dans la tribu des Broussonétiées. (C. L.)

ALBUCA (Albus, blanc). вот. pll. - G. de la fam. des Asphodélées, composé d'une vingtaine d'espèces, toutes originaires du Cap de Bonnc-Espér., une seule ( $A$.abyssinica Dryander) croissant en Ábyssinie. Ce sont des plantes à bulbe tuniqué et presque solide, donnant naissance à des feuilles, tantôt étroites, tantôt plus ou moins élargies. Lcur tige ou hampe est nue, d'une longueur très variable suivant les espèces. Les fleurs, très variées en couleur, sont tantòt disposées en épis simples, tantôt en grappes ou en panicules plus ou moins ramifiées. Calice pétaloïde, formé de 6 sépales plus ou moins profundément soudés entre eux; les 3 extér. révolutés dans leur partie supér., les 3 intér. dressés, rapprochés entre eux vers lcur sommet épaissi et concave. Étam. 6 , atta chées à la face interne des sépales; filets plus ou moins planes et élargis à leur base, tantôt tous anthériféres, tantôt 3 seulem ent portant une anthère allongée; ceux des filets fertiles, en général plus épais que ccux qui sont dépourvus d'anthère. Style triang ulaire, insensiblement épaissi vers sa partie supér. qui porte un stigm. triangulaire, glandulcux et velu; rarement il parait comme simplc. Le fruit est une capsule globulcuse ou à 3 angles, à 3 loges, s'ouvrant en 3 valves, et.contenant des graines planes et ailées. - Les Albuca ont de grands rapports avec les g. Ornithogalum et Anthericum. Ils different du $1^{\text {er }}$ par les divisions intér. de leur cal., qui sont dressécs, épaissies et concaves à leur sommet, ct par leur style triangulaire. Quant au g. Anthericum, sa racine fibreuse et non bulbifére le distingue suffisamment. On cultive dans les jardins d'amateurs, plusieurs esp. d'Albuca; telles sont les $A$. alba, lutea et minor. Elles doivent être placées en terre légère, dans des pots, et soigneusement garanties du froid pendant l'hiver.

(A. P.)

ALBULE (Albullı, tirant sur le blanc). PoIss. - Nom donné à plusieurs poissons à reflets argentés qui les font paraître tout blancs. C'est dans le même scns que les mots Albẻle, Albclen, Albulen et Alburne, ont été employés par divers auteurs. (VAL.)

ALBUIVEN (albumen, blanc d'œuf). вот. PI. - Plusieurs Botanistes désignent sous ce noin, cette partie de l'amande de certaines graines qui accompagne l'embryon et qu'ou appclle plus généralement Périsperme ou Endosperme. $V$. Endosperme. (A. R.)

ALBUMLINE (Albumen, blanc d'œuf). cir.u. - C'est, de toutes les substances azotées, la plus répandue dans l'économie animale; le blanc d'œuf et le sérum du sang la renferment en très grande quantité; il n'est peut-être pas de liquide sécrété par le corps humain qui n'en contienne plus ou moins. On la trouve dans la liqueur du péricarde, dans celle des hydropiques, des ventricules du cerveau, enfin, dans l'humeur des vésicatoires, de la brûlure, des hydatides, etc.

Elle sc présente sous trois états particuliers, et affecte des proprićtés différentes, suivant qu'elle est liquide, desséchée à unc donce chalcur, ou coagulée par le feu, ou par l'alcool.

L'Albumine liquide est transparente, inodore et insipide; ellc présente une rćaction alcaline duc à la présence d'un peu de carbonate de soude. Conservéc en vase clos, elle éprouve assez rapidement la décomposition putride, et répand une odeur d'acide sulfhydrique, qui paralt due à la présence d'une faible proportion de soufre.Les Acides, à l'exception toutefois des Acides phosphorique et acétique, troublent la dissolution d'Albumine. Elle forme avec certains scls métalliques, par excmple le bi-chlorurc 
de mercure, des composés insolubles; aussi l'a-t-on proposée comme contre-poison de ces substances.

La dissolucion d' Albumine évaporée spontanément se concentre et se prend peu à peu en une masse solide, jaune et transparente. Cette masse est soluble dans l'eau; sa dissolution jouit de toutes les propriétés de l'Albumine liquide. Elle possède, comme elle, la propriélé de se coaguler par l'acool, ou par le feu, à la température de 74 degrés centigrades.

$L$ 'Albumine coagulée est insoluble dans l'eau et ne peut, dans aucune circonstance, reprendre son premier état.

On a mis à profit, pour clarifier les sirops, la propriété qu'a l'Albumine liquide d'être coagulée par la chaleur; elle forme, en s'agglomérant ainsi, un réseau capable d'envelopper toutes les substances tenues en suspension dans le liquide. La clarification des vins repose sur un autre principe. L'opération se fait à froid; aussi l'Albumine n'est-elle pas coagulée; elle est précipitée par le tannin du vin; du reste le résultat est le même.

L'Albumine végétale présente toutes les propriétés de l'Albumine animale; elle est presque toujours accompagnée de substances étrangéres diverses, et particuliẻrement de gluten. On la rencontre en grande quantité dans les amandes et les graines qui, broyées avec l'eau, produisent des émulsions, ainsi que dans les sucs végétaux que la chaleur coagule.

M. Denys a fait l'observation que la fibrine, particulièrement celle qu'on extrait du sang, par l'agitation et le lavage à l'eau distillée, se dissout peu à peu dans l'eau nitrée, et qu'elle présente alors toutes les propriétés de l'Albumine. Ce physiologiste croil que, dans ce cas, la fibrine se transforme réellement en Albumine. (PEL.)

ALBUNÉE. Albunea (Nom mythol.). crust. - G. de l'ordre des Décapodes, famille des Macróures, tribu des Hippides, établi par Fabricius et adoplé par tous les Carcinologistes, avec ces caractères: Carapace droite d'avant en arrière, terminée antérieurement par un bord presque droil; ovalaire postéricurement el échancrée pour l'insertion de l'abdomen. Pédoncules oculaires larges et lamelleux; yeux extrême- ment petits, situés sur leur hord externe. Ant. interues très grandes, terminées par un seul filet multi-articulé; ant. externes larges, courtes, terminées par une tigelle composée de 7 à 8 articles. Pattes-mâchoires externes plus ou moins pédiformes. Pattes courtes; la $1^{\text {re }}$ paire terminée par une main subchéliforme; les suivantes de même forme, mais se terminant par un article falciforme. Abdomen composé de 7 articles dont le $1^{\mathrm{er}}$ est reçu dans une échancrure de la carapace, et le $7^{\text {me }}$ pourvu d'une paire de fausses pattes. On n'en connait encore que 2 esp.; la $1^{\text {re }}$, l'A. symnista Fabr., habile les mers d'Asie, et la $2^{\text {me }}$, dont on ne connaît pas la patrie, est l' $A$. scutellata Desm.

(H. L.)

* Alburnoides, DC. (Alburnum, ancien nom du Cylise aubours). вот. PI. MI. De Candolle (Prodr. 2, p. 153) donne ce nom à un s.-genre des Cylises, qu'il caractérise ainsi : Cal. campanulé; légume 1-t-sperme, à suture supér. non dilatée. Arbustes presque aphylles; rameaux inermes; fleurs blanches.

ALBURNUM. вот. pir. - Nom latin de l'aubier ou faux-bois. (A. R.)

AlGa. ois. - $V$. Pingouin. (C. D'O.)

* ALCADÉES (Alca, pingouin). ols. Famille de l'ordre des Nageurs ou Palmipè. des de Cuvier et faisant partie de sa famille des Brachyptères, qui devient alors pour nous une tribu; ses caract. sont : Bec comprimé, dont l'arête est plus ou moins élevée el tranchante, arquée et recourbée á son extrémité qui est quelquefois échancrée. Pieds implantés très en arrière, entiérement palmés, sans pouce; les ongles non déprimés, arqués et pointus. Ailes courtes, sur-aiguës, parfois impropres au vol, à premières rémiges de longueur moyenne, décroissant rapidement ; les secondaires fort courtes. Cette famille se compose des g. Pingouin, Guillemot, Mergule, Vieill., ou Cephus, Cuv., Macareux, Cérorhynque, Bonap. ou Chimerhina, Escholtz, et Starique, Tem. ( $V$. ces différents mots). Tous ces g. ainsi réunis forment un groupe des plus naturels, différant un peu par la forme du bec, mais ayant les ailes el les pattes entièrement conformées de même, tandis que les Plongeons, qu'on leur a quelquefois réunis, en différent par les pattes, et par d'autres caract. assez marquants, et ne 


\section{2}

Ald:

peuvent être séparés des Grèbes, a vec lesquels ils ont des rapports manifestes dans tout le squelette. On doit séparer, au contraire, de ces derniers les Héliornes et les Grébifoulques, qui ne peuvent être placés naturellement que près des Anhingas, avec lesquels Gmelin les avait classés. Ils sont le passage des Foulques aux Anhingas. Le grébifoulque d'Amérique est d'ailleurs bien positivement totipalmé.

ALCALIS. cmin. - On appelait autrefois Alcalis les oxydes du Potassium, du Sodium, du Lithium, et terres alcalines les oxydes de Barium, de Strontium, de Calcium et de Magnesium. Aujourd'hui, on a réuni sous le nom d'Alcalis, les Protoxydes des métaux de la $1^{\text {re }}$ section, savoir: le Potassium, le Sodium, le Lithium, le Barium, le Strontium et le Calcium, qui absorbent l'Oxygène à la température la plus élevée, et décomposent l'eau à la température ordinaire. Ces oxydes ont tous la propriété de ramener a u bleu le papier de tournesol rougi par un acide; de verdir le sirop de violettes et la teinture de choux rouges; enfin, de colorer en rouge-brun l'infusion jaune du Curcuma, du Pastel, du bois jaune, etc.

C'est cette propriété qu'on désigne sous le nom de réaction alcaline. Les Alcalis ne sont pas les sculs corps qui la possèdent. On la retrouve dans certains carbonates des métaux alcalins, et même dans les Sulfures et les Cyanures simples de ces mêmes métaux, ainsi que dans quclques autres oxydes métalliques.

On appelle Aleali volatil le Gaz Ammoniac, qui se rapproche des Alcalis par son alcalinité, et en diffère par son état. Toutes les autres propriétés communes des Alcalis sont partagées par loutes les bases salifiables. $(\boldsymbol{V}$. Ammoniague.) - Certaines substances végétales ont la propriété de neutraliser les Acides pour former des sels bien définis, et ramènent au blen la teinture de tournesol rougie par un Acide. On les a réunis sous les noms d'Alcalis végétaux, d'Ailcaloüdes.

Les Alcaloïdes sont éliminés de leurs sels par tous les Alcalis, et même par la Magnésie; mais ils se substituent à leur tour aux autres oxydes.

Les Alcaloïdes les plus importants sont: Cinchonine. Véralrine. Quinine. Narcéine.
ALC

$\begin{array}{ll}\text { Aricine. } & \text { Narcotine. } \\ \text { Sabadilline. } & \text { Atropine. } \\ \text { Delphine. } & \text { Solanine. } \\ \text { Strychnine. } & \text { Émétine. } \\ \text { Codéine. } & \text { Mélamine. } \\ \text { Brucine. } & \text { Amméline. }\end{array}$

Morphine.

Toutes ces substances sont formées d'Oxygène, d'Hydrogène, d'Azote et de Carbone, excepté la Mélamine, qui n'est pas oxygénée. Toutes sont peu solubles. Quelques uns de leurs sels se dissolvent facilement : tels sont les Sulfates, Azotates, Acétates; d'autres comme les 'Tartrates, Gallates, Oxalates neutres sont peu solubles. Toutes se décomposent par l'action de la chaleur et produisent de l'Ammoniaque; toutes en degagent sous l'influence de la chaux.-C'est en 1804 que fut découverte la Morphine, par M. Sertuerner d'une part el Séguin de l'autre. Ce futen 1816 seulement que M. Sertuerner vit qu'elle possédait toutes les propriétés des Alcalis, et en fit le type d'une nouvelle classe de corps. Les Alcalis se préparent tous au moyen de la décomposition d'un sel par un autre Alcali, plus énergique dans les circonstances de l'opération. C'est ainsi que tous les Alcaloïdes sont séparés de leur Acide par l'Ammoniaque. Les procédés de préparation des Alcalis inorganiques sont très divers. Ils seront décrits, dans les articles spéciaux sur chacune de ces substances. $(V$. Ammoña De, Chaux, Baryte, Strontiane, Potassi, Soude, Alumine et Magnésie. (PEL.)

AICALI VOLATIL. CHM. - $V$. AMMONIAOUE.

(C. D'O.)

ALCARON (Nom arabe). ARACHN. - Syn. du Scorpion africain, Buthus afer, L. (H.L.)

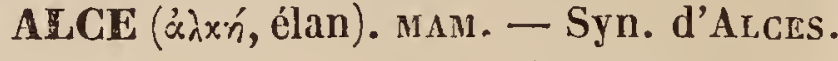

$$
\text { (I. G.-S.-H.) }
$$

ALCÉE. Alccea, L. ( $\alpha^{\alpha} \lambda x \varepsilon \alpha$, sorte de maure). вот. PII. - G. ou s.-genre de la famille des Malvacées, réuni par la plupart des auteurs aux Althoea, dont il ne diffère que par un péricarpe à coques marginées ; l'espèce qui le constitue est la plante d'ornement connue sous le nom de Rose-trémière.

*ALCÉDIDÉES. Alcedicioe (Alcedo, nom, chez les anciens, d'un oiseau que l'on disait nicher sur la mer; aujourd'hui le Mar(in-pécheur). ols. - Famille de l'ordre des Passereaux, faisant partie de celłe des Pelmatodes de Vieillot, ou des Alcyons de 
Temminck et des Syndactyles de Cuvier. Ses caract. sont: Bec fort, allongé, droit, presque quadrangulaire, ou très droit, comprimé, pointu, à commissure parfaitement droite, ou enfin conique, assez renflé et légèrement fléchi à la pointe avec la commissure plus ou moins sinueuse vers cette partie; bas de la jambe dégarni de plumes. Pieds à tarses très courts, complètement syndactyles, sans squamelles apparentes, ou revèlis, ainsi que les doigts, de squamelles très faibles et très petites; le doigt externe presque aussi long que le médian et soude avec lui jusqu'aux 2 tiers de sa longueur; l'interne beaucoup plus court et soudé seulement jusqu'à moitié ; pouce court, mais large à sa base; ce qui, joint à la soudure des doigts antérieurs, forme en dessous une sorte de plante prolongée; son ongle sensiblement plus petit que celui du doigt médian. Ailes de Jongueur moyenne, sub-aiguës ou sub-obtuses, à rémiges primaires ou courtes ou moyernes Queue courte en général ou de longueur moyenne et arrondie, rarement allongée et étagée, etc. - Cette famille comprend les g. Martin-pêcheur, Alcedo, L.; Ispida, Sw. ou Ceryle, Bonap.; Ceyx, Lacép.; Alcyone, Sw.; Dacelo, Leach; Halcyon, Sw.; Choucalcyon, Less; Syma, Less.; Todiramphus, Less.; Tanysiptera, Vig.; Melidora, Less.; $V$. ces mots.

(LAFR.)

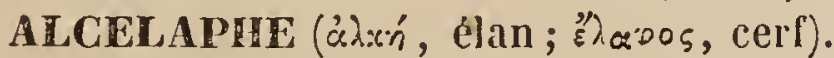
MaM. - Nom donné par M. de Blainville à une section du groupe des Antilores.

\section{(I. G.-S.-H.)}

- ALCÉMÉROPE. Alcemeropus (Alcedo, Martin-pêcheur; merops, g "êpier). ols.-G. formé par M. Is. Geoff.-St-Hilaire, aux dépens du g. Guêpier, répondant au IV yctiornis, Sw., et ayant pour type le Guêpier-ì-fraise, Merops amicus, Tem.(col. 310). Sescaract. sont: Bec allongé, courbé dans toute sa longueur, presque quadrangulaire, avec l'arête supér. légèrement et longitudinalement canaliculée. Pieds complétement syndactyles, à tarses très courts, à doigt externe presque aussi long que le médian et lui étant réuni jusqu'aux 2 tiers; l'interne beaucoup plus court et soudé seulement jusqu'à moilié; une sorte de plante allongée et épatée; l'ongle du pouce, le plus petit de tous. Ailes sub-obtuses, à rémiges primaires courtes, dépassant à peine l'cxtré- mité des secondaires. Queue allongée, coupée carrément à l'extrémité. - Ce g. est tellement voisill du g. Guepier par ses formes extér., que M. Temminck l'avait confondu avec lui. Ses caract. difrérentiels ne consistent effectivement que dans cette légère rainure super-rostrale, car celui tiré de la forme des ailes un peu plus courtes et un peu plus arrondies, nous paraît insigniliant, vu que, dans les vrais Guêpiers, nous trouvons 2 inodifications de ce g, bien prononcées et plus distinctes, aiguës ou même sur-aiguës, arec la $1^{\text {re }}$ rémige presque nulle dans les esp. a queue à filets, sub-obtuses dans celles à queue coupée carrément ou échancrée, d'où il résulte une différence d'ailes bien plus maiquée entre les $1^{\text {res }}$ et les secondes, qu'entre celles-ci et les Alcéméropes. Mais des habitudes nocturnes ou crépusculaires analogues à celles des Engoulevents et distinctes de celles des Guêpiers, autorisent, à plus juste titre, selon nous, la séparation générique des Alcémėropes. M. Swainson en a formé son g. Nyctiornis, mot qui exprime bien leur caract. de mours. A l'esp. type, le Guépiei-ci-fraise, vient s'en joindre une seconde, remarquable comme elle par la rainure super-rostrale et la fraise gulturale, mais qui en différe surtout par la couleur de cette fraise et par celle du front, qui sont d'un bleu glauque et non rouge vermillon et rose violacé comme chez la première. C'est le Merops Athertoni, Will. Jard. ou Nyctionis cornleus, Sw. (Ill. Orn. 2, pl. 58). Le 1er habite Sumatra, le second l'intér. du continent de l'Inde. (LAFr.)

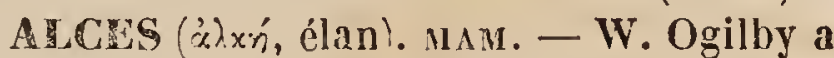
cru devoir faire de l'élan (Cervus Alces des auteurs) un g. particulier, qu'il place dans sa famille des Cervidées, ordre des Ruminants. Voici les caractères qu'il lui attribue (Proceed. Zool. Soc. Lond., 1836) : Cornes palmées, caduques, existant dans le mâle seul. Trompe nulle. Interdigitales grandes. Follicules inguinaux nuls. Mamelles 4.Le type de ce g. serait l'Alces machlis (Cervuls Alces). Le nom de Machlis, que Pline donne à l'Élan, n'est probablement qu'une altération latine de son nom celtique ELk. $V$. CERF. (C. D'O.

ALCHANDES. PoIss. - Mot probablement d'origine arabe, et que Bonneterre a écrit, par une faute de copie, Alcandes, or- 
thographe abusivement reproduile depuis dans tous les Dictionnaires. On le trouve dans Cuba (Hortus sanilatis, 98). Il est cité avec celui d'Abremon pour un poisson très soigneux de ses petits, qui s'attache aux navires et les rend immobiles. Ces deux dernières particularités ont fait rapporter cette dénomination à l'Echenë̈s, et quoique rien ne soit moins certain, les naturalistes ont suivi l'auteur de l'Encyclopédie. (VAL.)

ALCIIMIE (alchemia; étym. arabe, tirée de $\chi$ nusi $\alpha$, chimie).-Cette science, qui nous est venue par les Arabes, lesquels l'avaient eux-mêmes empruntée aux Grecs comme toutes leurs connaissances, comprenait d'abord l'ensemble de toutes les connaissanceschimiques et physiques; tandis qu'aujourd'hui ce nom ne s'applique plus qu'à une science qu'on regarde comme illusoire, et dont on ne peut s'occuper sans ridicule. Le but de notre article est de prouver que ce préjugé, comme tant d'autres, n'est fondé que sur l'ignorance.

Nous considérons l'Alchimie sous trois points de vue : 1. son histoire, 2. ses procédés, 3. l'opinion qu'on doit s'en former, et l'état actuel de la science.

1. Histoire. Chercher à fixer le lieu et l'époque oú l'Alchimie a pris naissance, serait un travail aussi fastidieux qu'inutile. Toutes les probabilités se réunissent pour indiquer l'Égypte comme le berceau de cette science et de beaucoup d'autres; et Hermès a reçu, dans ce pays, les lıonneurs divins, pour s'être présenté comme possédant la science qui donne la richesse et a santé, seuls éléments de bonheur pour la plupart des hommes.

Les livres attribués ȧ Hermès sont nombreux : St.-Clément d'Alexandrie (Sirom., l. 6) dit que de son temps on en connaissait encore 42. Si les deux ouvrages attribués à Hermès et qui sont parvenus jusqu'à nous (Pymandre et la Table d'Émeraude), ne sont pas textuellement de cet auteur, ils contiennent au moins la doctrine qui lui était attribuée en Égypte, au commencemeni de notre ére. Cinq cents ans avant cette époque, au rapport de Sénèque (lib. xıv, Épist. 19), Démocrite d'Abdère cultivait l'alchimie. Les prêtres égyptiens conservèrent long-temps le dépôt de ces connaissances ; mais Dioclétien, s’imaginant que les fréquentes révoltes de
l'Égypte ne se renouvelaient qu'á l'aide de l'argent que fabriquaient ces prêtres, ne trouva rien de mieux que de faire brûler les livres et détruire les colléges. $V$. Paul Diacre (in Vita Diocletiani), Orose (ch. xvı, l. 7), el Suidas (au mot Chemia).

Parmi le grand nombre de manuscrits que possède la Bibliothèque royale sur cette matière, on en trouve un de Synésius (évêque de Ptolémaïs en 410), qui contient une exposition de la doctrine et un commentaire, adressés à Dioscorus, prêtre de Sérapis. L'origine toute sacerdotale et sacrée de la philosophiehermétique, est démontrée par le serment qu'on exigeait des adeptes, de ne rien révéler au vulgaire, ainsi qu'on le voit dans les Épîtres de Synésius, et notamment dans la $142^{\text {me }}$, où il réprimande sévèrement Herculianus d'avoir parlé trop clairement des secrets de la philosophie qu'il lui avait révélés.

Tous les philosophes grecs, ei entre autres Zozime au $\mathrm{v}^{\text {me }}$ sièsle, continuèrent leurs travaux jusqu'à la prise d'Alexandrie par les $\Lambda$ rabes en 640 . Alors les arts et les sciences disparurent devant ces féroces envahisseurs ; et ce n'est que dans le $x^{\text {me }}$ siècle qu'on retrouve des traces de la science chez les Grecs et les Arabes eux-mêmes.

De tous les Alchimistes arabes, le plus ancien est incontestablement Geber ou Giaber; car tous les auteurs le citent et il n'en cite aucun. De ses nombreux ouvrages, trois seulement sont parvenus jusqu'à nous; un autre est resté en manuscrit à la Bibliothèque royale. Si ces livres ne révèlent pas le secret hermétique (ce qu'au demeurant aucun livre ne fait), au moins ils nous prouvent que la Chimie était très cultivée à cette époque. Dans son ouvrage intitulé : de Investigatione perfectionis metallarum, on trouve trente-trois préparations chimiques, dont le détail est fort intéressant. In autre de ses ouvrages, son Testament, contient dix-huit préparations de l'or et des métaux, pour les approprier à l'œuvre. Ces préparations différent peu de celles qu'on fait subir aujourd'hui à ce métal pour l'épurer ou l'oxyder. Il est l'auteur de la découverte de l'acidesulfurique, ou, comme on l'appelait, l'huile de vitriol.

Le $x^{\text {me }}$ siècle nous fournit Al-Faraby, savant lomme, dont les ouvrages manuscrits 
sont al la Bibliothèque de Leyde. Cent ans plus tard, parut $\Lambda$ vicennes, qui, dans son Traité de Congelatione el Conglutinatione Lapidum, parle du fer météorique, avec lequel on a fait des épées, et donne une théorie des soulèvements comme cause essentielle de la formation des montagnes (Theatr. chimic., lom. lv, p. 884).

Ce ne fut qu'au $\times 11^{\mathrm{me}}$ siécle, que la science hermélique pénétra dans l'Occident avec le retour des croisés. Vers cette époque, nous trouvons Roger Bacon en Angleterre, $A r$ nauld de Villeneuve, Christophe de Paris et Rupescissa en France; Albert-le-Grand en Allemagne; saint Thomas d'Aquin en Italie; et enfin en Espagne, le fameux Raymond Lulle qui vint en France pour étudier sous Arnauld $\mathrm{et}$ Roger Bacon. Le premier ouvrage que l'on trouve vers cette époque n'appartient cependant à aucun de ces philosophes : c'est le Traité d'Arthéphius, plus ancien que Roger Bacon, puisque celui-ci le cite, mais postérieur à Morien, qu'il cite à son tour. Nous n'ell parlons que parce qu'il est le seul entre tous les écrivains regardés comme adeptes, qui se soit prononcé sur la longévité que peut procurer la médecine hermétique. Il annonce qu'il écrit ayant plus de mille ans (sed cum per mille annos aul circiter, qui jam transierunt super me a nativitate mea, gratia solins Dei omnipotentis, el usu hujus mirabilis quintae essentioe). Tous les autres auteurs affirment que la médecine peut mener un homme jusqu'au terme le plus éloigné que sa constitution comporte en l'affranchissant de toutes les infirmités qui sont le cortége de la vieillesse; mais aucun ne suppose que ce terme puisse être dépassé, plusieurs même assurent le contraire; et Roger Bacon déclare très explicitement à ce sujet qu'il n'y a ni remède ni régime contre l'antique corruption de nos parents que nous apportons en naissant.

Ce même Bacon est un des Alchimistes les plus remarquables. Né en 1214 en Angleterre, il a fait plusieurs découvertes de la plus haute importance. Son Traité (de Speculis) fait connaître la nature des verres à surface courbe, à l'aide desquels il brûlait des matières a distance. Son travail sur la perspective prouve des connaissances en oplique. Il parle de la réfraction et de la réflexion de la lumière. et décrit la chambre obscure et la théoric des télescopes; mais si découverte la plus populaire est celle de la poudre à canon qu'il décrit ainsi : Sed $\iota$ men salis petrce LURU MOPE CAN UBRE el sulphuris; el sic facies tonitru et corruscationem, si scis artificium (Bacon, de S'ecretis operibus, cap. $\mathrm{x} 1$ ). Les mols : luru mope can ubre sont l'anagramme de carbonum pulvere.

Après les hommes dont nous venons de parler, parait en France le plus populaire de tous, Nicolas Flamel. En 1357, il était écrivain public. Un vieux livre d'Alchimie, qui avait appartenu à des juifs, lui tomba entre les mains. Il fit le voyage d'Espagne pour avoir l'explication de ce livre; et, de retour en France, il se mit à l'ouvrage, et fit sa première transmutation le 17 janvier 1382. C'est un des philosophes les plus naïs : il raconte que sa femme Pernelle l'aidait daus ses travaux. Les peintures qui, jusqu'à la fin du dernier siècle, décoraient les vitraux du charnier des Innocents, contenaient la description hiéroglyphique de l'œuvre. Flamel en a donné la description avec commentaire.

Le $\mathrm{xv}^{\text {me }}$ siècle fut cncore plus fécond que le $x ı v^{\text {me }}$ en philosophes hermétiques; les plus illustres sont Basile Valentin, Isaac Hollandais, Georges Ripley et Trévisan. Les artistes deviennent si nombreux dans les $\mathrm{xv}^{\text {me }}$ et $x v^{m e}$ siècles, qu'il est difficile de faire un choix. Il y en a cependant un qui les domine tous et dont nous devons parler : c'est Paracelse. Cet homme, né prés de Zurich, en 1493, se livra de bonne heure à la pratique de la médecine; on lui doit l'emploi de l'opium et du mercure, et en général des préparations chimiques.

Vers le milieu du xy I $^{\text {me }}$ siècle, l'Angleterre produisit l'homme que l'on peut regalder comme le dernier des adeptes de l'ancienne école; c'est lui qui ferme la longue série d'hommes étranges dont nous avons cité les principaux : nous voulons parler d'lrénée Philalèthe. Son nom, sa personne, sa vie, ses ouvrages, tout est chez lui une énigme indéchiffrable. On croit que c'était le même que Thomas Waughan, que Starkey avait connu en Amérique, ou Philalèthe avait été de bonne heure.

Beccher, le maìtre de Stahl, et Glauber, sont, parmi les Allemands, les deux derniers chimistes qui aient osé avouer publiquement leurs travaux sur l'Alchimie. Glauber 
a beaucoup écrit, et on lui doit un sel qui porte son nom : c'est le sulfate de soude, fort employé dans les arts et en médecine. A compter de ces deux hommes, la médecine et l'Alchimie se séparèrent. Condamnée à l'obscurité, cette dernière n'en a pas moins continué sa carrière, et, de temps en temps, quelques adeptes dévoués n'ont pas craint de se livrer au ridicule en venant proclamer l'existence perpétuée d'une science que l'on regarde généralement comme perdue avec tant d'autres. Le dernier de ces adeptes est le docteur James Price, membre de la Société royale de Londres et chimiste distingué, qui a publié, sous le titre de: Relation de plusieurs expériences faites sur le mercure, l'or et l'argent, à Cuilfort, en mai 1781, dans le laboratoire du docteur James Price, une sorte de procès-verbal,constatant, qu'en présence des magistrats et des personnes notables de la ville, entre autres de lord Palmerston, on a fait une série d'expériences dans lesquelles on a converti du mercure en or et en argent, selon la nature de la poudre que l'on employait. Dans une de ces expériences, 12 grains de poudre blanche ont produit 600 grains d'argent, et deux grains de poudre rouge ont produit 120 grains d'or. Cette relation est imprimíe tout au long dans le Mercure de France (ívrier 1783).

Nous n'irons pas plus loin dans l'exposition des faits; ce qui précède doit suffire pour prouver que tous les hommes dont nous venons de parler n'étaient pas des insensés ou des fourbes : ce sont simplement des hommes persévérants, opiniâtres , si l'on veut, qui, étant convaincus soit par les faits, soit par leurs lectures de la réalité de la science, ont consacré leur vie à son étude, dans l'espoir, souvent déçu il est vrai, d'arriver à la possession des deux plus grands biens : la richesse et la santé.

Mais quelles matières employèrent-ils? quelles préparations leur faisaient-ils subir? et le travail terminé, comment employaientils d'une manière utile le résultat obtenu? C'est ce que nous allons tâcher de faire comprendre dans le paragraphe suivant.

11. Des matières et des procédés de l'auvre.

Tous les philosophes s'accordent en ce point, que l'or et le mercure sonf les deux métaux sur lesquels ils doivent travailier. Quelques uns ajoutent une troisieme sub- stance, l'esprit universel; ce sont ceux qui suivent la voie humide, et qui généralement habitent les pays chauds. Ceux qui vivent dans le nord suivent plus particulièrement la voie sèche : on verra pourquoi. Mais on se tromperait grossièrement sil'on unissaitsimplement l'or au mercure pour en faire un amalgame: on le cuirait des années entières, comme a fait Rob. Boyle, qu'il n'en résulterait que de l'or et du mercure amalgamés. Les philosophes se hâtent d'ajouter : Nos métanx sont vifs, et les métaux vulgaires sont morts; l'or vulgaire, cependant, est la minière de notre or, comme le mercure vulgaire est la minière de notre mercure. Pour que ces métaux puissent nous servir, il faut les réduire à leur première matière;

Hoc opus, hic labor est,

et ce grand travail ne peut se faire qu'à l'aide de l'esprit aniversel, de l'âme générale du monde; c'est de l'air qu'il faut extraire l'aimant qui doit altirer cet esprit universel : Aer general magnetem, magnes vero generus vel apparere facit aerem nostrum. Est in aere occultus vitce cibus, etc., etc. Or, c'est cette humidité aérienne qu'il faut recucillir al moment de son apparition dans l'atmosphère, et avant qu'elle ne touche a aucune substance; car dès qu'elle est en contact avec une plante, elle a perdu son caractère d'universalité, et ne peut plus servir à l'œuvre. On devine qu'il s'agit de la rosée; mais ce n'est pas la rosée de nos climats froids : c'est la rosée des pays chauds, qui, par une évaporalion ménagée, laisse un résidu de 10 a 12 pour cent de sel; tandis que dans le nord on en obtient a peine 2 pour cent. Ce sel, qui est un nitrate de potasse ou un nitrate de soude sur les côtes de la mer, disparaît entièrement si l'on recueille la rosée sur des plantes. C'est ce sel qui, après avoir subi plusieurs préparations, dont quelques unes sont assez curieuses, sert à attirer l'esprit universel à certaines époques de l'annėe, ef dans des circonstances atmosphériques particulières. La purification de ces trois substances est ce que les adeptes appellent les travaux d'Hercule. Alors on ne compte plus les jours et les nuits; on ne quitte le laboratoire que quand une opération est termincee, et elle dure souvent plusieurs jours. Ces travaux préparatoires, auxquels un homme seul ne saurait suffire, se prolongent quel- 
quefois pendant un an, mais au moins jendant six mois.

Tout ce long travail doit donner en résultat un triple produit: $1^{\circ}$ un or exalté, réincrudé (ce sont les expressions consacrées), pulvérulent, et qui doit se dissoudre en totalité dans l'esprit de vin (comme preuve); 2० un mercure d'une limpidité et d'une lluidité sans exemple: c'est l'eau qui ne mouille pas les mains; $3^{\circ}$ une eau visqueuse, limpide, et d'une transparence parfaite : c'est le lait de la vierge, qui va nous servir á nourrir le nouveau-né.

Arrivés à ce point, le reste, disent-ils, n'est plus qu'un travail de femme et un jeu d'enfant. Enfin il ne s'agit plus que de réunir les matières, de faire le mariage. Il y a dans d'Espagnet le fameux canon 58 : Recipe virginem alatam, optimè lotam et mundatam, etc., que les philosophes regardent comme le vrai mode de faire la conjonction dont nous parlons. On prend un vase qui peut se boucher hermétiquement, et d'une capacité assez grande pour que les deux tiers restent vides; on y met, dans des proportions requises, les deux matières solides, savoir : le serviteur ronge et la dame blanche, le roi et la reine, Gabritius et Beya, etc., etc., mille noms divers, et on y ajoute assez d'humidité pour que l'aridité stérile ne se manifeste pas. Tout bien clos et scellé, on dépose le vase dans un lieu secret, assez éclairé pour que l'artiste puisse voir le travail intérieur à mesure qu'il se développe, sans que le soleil cependant puisse jamais le frapper.

Le vase ainsi déposé, et qu'on appelle l'œuf, parce qu'il en a la forme, reçoit une chaleur qui ne doit jamais dépasser $32 \circ \mathrm{R}$., ou la chaleur de l'incubation : tout serait perdu si la matière recevait de 40 à $50^{\circ}$.

Au bout de quarante jours de l'inhumation (quelques uns l'appellent ainsi), la matière devient noire, puis de plus en plus noire, nigrum nigrius nigro. C'est le règne de Saturne, qui dure aussi quarante jours. L'humide s'élève dans le vase et retombe en gouttes : il pleut sur la terre. Au noir succèdent des couleurs très variées : c'est la queue de paon, le règne de Jupiter et de Junon, dont la durée est presque égale à celle de leur père ; un cercle blanc commence à paraitre à la circonférence du vase, puis il aygmente, et la lotalité de la matière qui avait été noire T. !. devient blanche : e'est le régne de la Lune. Vient ensuite $V$ énus à la coulcur citrine, laquelle passe successivement à l'orangé, puis au rouge coquelicot, puis à la couleur de rubis. C'est le manteau de pourpre qui recouvre le nouveau roi plus vaillant que son père.

Quelques auteurs ne font mention que de trois couleurs principales : le noir, le blanc el le rouge: Tria pulcherrimorum florum in horto sapientium genera perquirenda, imo invenienda sunt: puniceæ violae, candens lilium et purpureus immortalisque amarantus (Arcan. Hernet. philos. canon., LiII). Un traité de chimie écrit dans ce style n'aurait pas aujourd'hui beaucoup de lecteurs ; à l'époque où celui-ci parut, en 1608, il fit l'admiration des amateurs de la science.

Le plus difficile est fait. On a alors la vraie matière de la pierre; et beaucoup d'auteurs, Artéphius entre autres, ne commencent leur livre qu'à l'ẻpoque où nous sommes arrivés, sans faire mention de tout ce qui a dû précéder. La pierre, dans cet état, ne peut servir encore ni pour la médecine ni pour la transmutation : afin de lui donner ces qualités, on recommence trois fois à l'humecter et à la cuire comme auparavant : coque et iterum coque, disent quelques auteurs; c'est là l'œuvre tout entier, en faisant allusion à cette dernière partie du travail. Au bout de ces trois réitérations ou rotations, comme on les appelle, on a la médecine, qui prend le nom d'élixir; lorsqu'on l'a fait dissoudre dans le même liquide et qu'on l'a tenue au feu pendant 40 jours, la couleur se fonce, et l'on a une liqueur couleur de grenat, dont quelques gouttes dans un véhicule quelconque, vin, bouillon, eau de plantes, suffisent, disent les auteurs, pour guérir les maladies les plus invétérées.

Lorsqu'il s'agit de la transmutation, on combine la poudre avec son poids d'or fin; on humecte et on remet cuire encore 40 jours ; et on a alors non seulement une poudre de projection très énergique, mais un levain des plus actifs. En résumé, on voit qu'il ne s'agit que de faire absorber par de l'or convenablement préparé une proportion considérable de cette eau céleste, recueillie avec tant de précautions et conservée à l'abri de la lumière. C'est au moyen de cette eau que l'or devient un levain, et qu'il est rendu vé- 
gétatif; de mort qu'il était on l'a rendu plus que parfait, vivant, afin qu'il pùt agir sur les métaux imparfaits et les rendre parfaits, ce qu'il ne pouvait faire s'il n'était seulement que parfait lui-même.

Nous disons un levain, car les auteurs considèrent la matière métallique comme identique, parfaite seulement dans l'or, imparfaite dans les autres métaux, et n'ayant besoin que d'un levain pour atteindre la perfection.

Voilá ce que l'on peut démêler de plus rationnel dans l'obscurité calculée qui règne dans les livres des philosophes hermétiques. Si les limites dans lesquelles nous sommes circonscrits nous l'eussent permis, nous aurions pu faire connaître quelques modifications importantes dans le travail général dont nous avons donné une courte esquisse. Nous terminerons par quelques lignes sur l'état actuel de la science tant en France qu'à l'étranger.

III. État actuel de la science. Opinion des savants. On ne se douterait pas que le pays de la terre oú la science hermétique est le plus généralement cultivée, est le royaume des Birmahs, d'après ce que nous assurent les Anglais qui ont visité ce pays, depuis la conquête. Mais, sans aller si loin, occuponsnous de ce qui se passe chez nous. Bon nombre d'amateurs travaillent encore à Paris; et en 1832 , il a paru chez Loquin une brochure sous le titre: Hermès dévoilé; mais l'auteur, en véritable adepte, est aussi obscur que les anciens. Nous sommes parvenu á découvrir cet adepte; il a fait une transmutation en notre présence; mais sa médecine n'étant pas arrivée á sa perfection, n'a pas pu l'empêcher de mourir l'année dernière, à l'âge de $\mathbf{7 0}$ ans. Sir Humphrey Davy pensait que les recherches hermétiques pouvaient avoir un résultat satisfaisant; mais $\mathrm{M}$. Dumas a été plus loin : voici ce qu'il dit dans ses Leçons de Philosophie chimique en parlant de l'Isomérie : "Serait-il permis d'ad" mettre des corps simples isomères? Cette "question, vous le voyez, touche de près à "la transmutation des métaux. Résolue affir" mativement, elle donnerait des chances de " succès à la recherche de la pierre philoso" phale....II faut donc consulter l'expérience, " et l'expérience, il faut le dire, n'est point " en opposition jusqu'ici avec la possibiliti
AIC

" de la transmutation des corps simples, ou " au moins de certains corps simples. "C'est ce dont on peut juger par le tableau qu'il présente, et dans lequel on trouve le même nombre pour l'or que pour l'osmium, pour le zinc et l'antimoine, etc., etc., et avec des différences si faibles, qu'il serait fort peu surprenant que la cause en résidât dans quelque erreur d'expérience. Ces rapprochements, continue M. Dumas, me semblent fort piquants, et s'il n'en sort aucune preuve de la possibilité d'opérer des transmutations dans les corps simples, du moins s'opposentils à ce qu'on repousse cette idèe comme une absurdité qui serait démontrée par l'état actuel de nos connaissances. (J. Gilbert.)

ALCHIMILLA, Tourn. (Mot arabe). Alchemilla et Aphanes, L. вот. PH. - G. de la familìe des Rosacées (Dryadées, Bartl.), tribu des Sanguisorbées (Rosées, Reichb.). Les caract. en sont les suivants : Cal. tubuleux, 4fide; lanières alternant avec 4 bractéoles adnées au tube. Cor. nulle. Etam. 1 à 4 . Ovaires 1 ou 2, libres, insérés au fond du calice, munis chacun d'un style latéral et carluc. Stigm. capitellés. Nucules 1 ou 2, monospermes, recouvertes par le tube calicinal; graine suspendue ; radicule supère. - Herbes annuelles ou vivaces; feuilles digitées ou palmées; fleurs petites, fasciculées, ou en corymbes ou en grappe. On connait environ 20 esp. de ce g.; elles sont réparties entre presque toutes les contrées du globe. L'Alchemilla vulgaris, L. , nommé vulgairement $P_{i e d}$ de lion, était jadis préconisé comme vulnéraire.

(Sp.)

ALGHIMINIER. вот. PH.-Ancienne dénomination vulgaire du NÉFLIER. (C. L.)

ALCHIMISTE. Ins. - Nom sous lequel Geoffroy désigne une esp. de Lépidoptères nocturnes (IVoctua Alchimista, Fabr.), appartenant au g. Catephia d'Ochsenheimer. $D$. ce mot.

ALCHORNEA (Nom d'homme). вот. pri. - Ce g. de la famille des Euphorbiacées, établi par Swartz, consacré par Solander au docteur anglais Alchorné, auteur de quelques travaux d'histoire naturelle, et auquel il faut réunir l'Hermesia de Bonpland, offre les caract. suiv. : Fleurs dioïques; Cal. 2-5-parti, réduit souvent a des dents dans les femelles; dans les mâles : 8 étam. dont les filets se soudent en un an- 
neau a leur base et dont les anthères sont introrses; dans les femelles : 1 ovaire didyme à 2 loges 1-ovulées, surmonté d'un style profondément biparti, dont les branches ont leur surface interne stigmatique; une caps. à péricarpe un peu charnu et à 2 coques; rarement il y en a 3 et autant de stigmates. On connait 5 esp. de ce g. , toutes originaires des régions tropicales; 3 de l'Amèrique et 2 de l'Afrique. Ce sont des arbres ou des arbustes, à feuilles alternes, presque entières ou dentées, glabres, cassantes, pourvues de nervures saillantes à leur face inférieure; à fleurs axillaires ou terminales, les mâles disposées sur des épis, le plus souvent rameux, par petits pelotons alternes et accompagnés de bractées; les femelles solitaires ou sur des épis simples. (AD. J.)

*ALCICORNIUMI (Alce, élan ; cornu, corne; forme des frondes). BOT. CR. - G. de la famille ou de l'ordre des Fougères (Polypodiacées) établi par M. Gaudichaud (Voyage de l'Uran.), aux dépens del'Acrostichum alcicorne, etc., et qui ne paraît pas avoir été adopté. Il reste réuni au g. Acrostichum, L., section des Neuroplatycérées. $V$. ces mots.

- ALCIDES (Surnom d'Hercule; Myth.). ivs. - G. de l'ordre des Coléoptères tétramères, famille des Curculionides, div. des Cholides, établi par Dalman et adopté par Schoenherr qui lui assigne les caract. suivants : Ant. fortes et assez courtes ; funicules de 6 articles, les 2 premiers assez longs, presque coniques, les autres plus courts, presque ronds; massue subovale, acuminée, composée de 5 articles, le $1^{\mathrm{er}}$ allongé, les autres courts, étroitement unis. Rostre médiocre, cylindrique, linéaire, presque droit ou un peu arqué. Yeux placés latéralcment, ovales, déprimés. Prothorax oblong, plus large postérieurement, trilobé et plus étroit antérieurement, resserré, présentant une éminence arrondic au milieu, lobé d'une maniére obtuse derrière les yeux et échancré profondément en dessous. Élytres ou allongées subcylindriques, ou en ovale oblong, bossues, fortement sinuées à la base, et remplissant exactement les échancrures du thorax. Pattes antér.de la plupart des esp. très longues; cuisses dentées en dessous; tihias comprimés, armés d'un fort ongle à 'extrémité, souvent dentés du côté interne.
- Ce g., suivant le Catal. de M. Dejear, renferme $22 \mathrm{esp}$. dont 7 d'Afrique, 2 de li Nouv.-Guinée, 7 de Java, 1 dont la patrie est inconnue, et les autres des Indes-Orientales. Schoenherr en décrit de son côté un grand nombre dont les noms ne figurent pas dans ce Catalogue. Parmi toutes ces esp., nous ne citerons que celle qui sert de type au g.: l' $A$. dentipes Rinchonus id. Fabr.; Oliv. ' $A$. dentipes (Rinchonus id. Fabr.; Oliv. Ins. 83, pl. 8, fig. 90).

* ALCIDION (dimin. d'á̀ $\lambda x^{\prime}$, élan). ins. - G. de Coléoptères tétramères, famille des Longicornes, établi par M. Dejean (Catal. $3^{\text {me }}$ édit.), mais dont il n'a pas publié les caract. D’après la place qu'il lui donne, ce g. appartiendrait à la tribu des Lamiaires de M. Serville. L'auteur y rapporte 13 esp., dont 10 du Brésil, 2 de Cayenne et 1 de l'Amérique du nord. Toutes ont été nommées par lui à l'exception d'une seule, appelée $A$. sublineatum par M. Lacordaire qui l'a rapportée de Cayenne.

ALCINE. вот.-Cassini a établi ce g. aux dépens d'une esp.de Melampodium, de la famille des Composées, et cultivée dans les jardins de botanique. M. De Candolle l'y réunit de nouveau pour en former seulement unc section a laquelle il donne pour caractères d'avoir les akènes du rayon embrassés par les écailles intérieures de l'involucre, qui sont ovales-oblongues, lisses, terminées au sommet par 2-4 petites glandes formant, par leur réunion, un très petit trou rond, entiérement rempli par le col ou disque épigyne de l'ovaire. - La seule espèce conservée par M. De Candolle dans la section du g. Melampodium, à laquelle il laisse le nom d'Alcina, est originaire du Mexique. (J. D.)

*ALCINOE (Nom mythol.). ACAL. - G. de la famille des Mnémièdes d'Eschscholtz, qui elle-même fait partie de l'ordre des Béroïdes ou Cténophores. Ce g. établi par M. Rang est caractérisé ainsi : Corps gélatineux,transparent verlical, cylindrique, avec 8 côtes saillantes, ciliées, terminées en pointe, et cachées en partie sous des lobes natatoires verticaux, libres à la base et sur les côtés seulement. Ouverture buccale pourvue de 4 appendices ciliés. - M. Rey a décril sous le nom. d'Alcinoe vermicularis (Mém. soc. hist. nat. de Paris, ı.ıv. pl. 19), l'esp. servant de type à ce g., M. Delle chiaje en fait connaî- 
tre une $2^{\text {me }}$, observée par lui à Naples : $A l-$ cinoe papillosa (Mern. sul. anim. senza vert. t. Iv. pl. 51).

*ALCIOPE (Nom mythol.). CRUST. M. Rafinesque désigne sous ce nom un petit g. de Crustacés, qui viendrait se placer dans la tribu des Pénéens, de l'ordre des Décapodes Brachyures; mais comme cet auteur n'a pas donné des détails suffisants sur la structure de ce nouveau g., il n'a pas été adopté.

*ALCIOPE (nom d'une nymphe, mère de Celmise). вот. PH.-M. De Candolle a formé ce genre aux dépens de deux espéces du g. Celmisia de Cass. ; il appartient à la tribu des Eupatoriées, de la famille des Composées. On le caractérise de la manière suivante : Capitule multiflore, fleurs du rayon 1-sériées, ligulées, femelles, mais pourvues de filaments presque avortés. Celles du rayon sont tubuleuses, à 5 dents, hermaphrodites. Le réceptacle large est dépourvu de paillettes. I.es squames de l'involucre sont disposées sur plusieurs rangs et pressées les unes contre les autres. Les branches du style sont courtes, obtuses, glabres, légèrement papilleuses et presque conformes dans les fleurs des deux sortes. Les fruits, oblongs-cylindracés, presque obcomprimés, sont surmontés d'une aigrette pluri-sériée, dont les poils scabres sont légérement soudés entre eux à la base. - Les Alciope sont des herbes sousfrutescentes, originaires du cap de BonneEspérance, à tiges couveries d'un duvet tomenteux blanc et épais. Les feuilles alternes pétiolées, entières et denticulées, glabres sur la face supérieure, sont couvertes, ainsi que les pétioles, d'un duvet sernblable à celui des tiges. Les capitules sont terminaux, laineux, et portent des fleurs jaunes. (J. D.)

* ARCIS (Nom mythol.) INs. - G. de Lépidoptères, de la famille des Nocturnes, tribu des Phalénites, établi par Curtis et adopté par Sléphens dans son Catal. des Ins. de l'Angleterre. Ce g. correspond en partie au g. Boarmia de Treitschke. $V$. ce mot.

* AlCITHOE (Nom mythologique). вот. PH. - C'est le nom donné par M. D. Don à une section du g. Trixis, appartenant à la famille des Composćes, section des Nassauviées. Ses caractères sont: Involucre à folioles unisérićes, entouré à la base de 5 gran- des bractées foliacées, disposćes en verticilles. - Toutes les espéces qui forment cette section sont originaires du Mexique. (J.D.)

ALCOOL. Chim.-C'est un liquide très volatil, qui se produit simultanement avec l'acide carbonique, par la fermentation du sucre. Tel qu'on le trouve dans le commerce, il n'est pas pur, et contient, avec beaucoup) d'eau, une petite quantité d'autres matières étrangères; on le connaît alors sous le nom d'eau-de-vie.

On obtient l'eau-de-vie par la distillation de diverses liqueurs fermentées. Les vios du midi produisent l'cau-de-vie de Cognac et de Montpellier; la mélasse brune donne le taffia; on prépare le rhum avec les sirops provenant du raffinage du sucre, le rack avec le rizet les fruits de l'Areca catechu, enfin le kirsch avec les cerises noires. On peut aussi retirer l'eau-de-vie des grains et de la pomme de terre; à cet effet on saccharifie la fécule, et l'on fait fermenter le sirop. La distillation s'opère dans un appareil particulier dù à Adam et perfectionné par Derosne; appareil qui a le précieux avantage de distiller d'une manière continue, et de fournir. des produits de la richesse alcoolique qu'on désire. Pour concentrer l'Alcool faible, on le distille sur différents corps très avides d'humidité; on préfère ordinairement la chaux vive. Sommering indique un procédè très curieux; suivant lui, l'eau-de-vie, conservèe dans une vessie de bœuf maintenue à 40 degrés environ, se concentre peu à peu : l'eau seule, à peine imprégnée d'Alcool, traverse la vessie. L'Alcool peut être amené, par ce procédé, à ne pas contenir plus que $3 \mathrm{p}$. cent de son poids d'eau. Seulement il est imprégnè de matières organiques enlevées à la vessie; pour l'en séparer, il faut le disliller. Pajol Descharmes a proposé de placer de l'Alcool aqueux contenu dans un vase plat, dans un espace parfaitement fermé, à còté d'un vase rempli de chlorure de calcium fondu. Le chlorure de calcium condense avec énergie les vapeurs aqueuses, et ne condense que très peu les vapeurs alcooliques.

L'Alcool concentrè par un moyen quelconque et entièrement privé d'eau, est connu sous le nom d'Alcool absolu; on le distingue de l'Alcool hydraté, en ce que la baryte s'y conserve sans se déliter. C'est un 


\section{Alí}

liquide d'une odeur vive, d'une saveur brûlante, due surtout à la propriété qu'il a d'absorber l'eau des tissus vivants; sa densité, a $15^{\circ}$ est de 0,7947 , celle de l'eau étant prise pour unilć. Il s'unit à l'eau avec dégagement de chaleur; le mélange se contracte sensiblement; sa combustion par l'oxygène de l'air ou par l'oxyde de cuivre, donne de l'eau et de l'acide carbonique. La potasse caustique hydratée le convertit en Acide acétique qui reste uni à l'alcali et en hydrogène qui se dégage; enfin sa combustion lente à l'air par un fil de platine rouge, donne naissance à un acide particulier. Lorsqu'on fait agir le noir de platine au contact de l'air sur l'Alcool, on convertit ce liquide en acide acétique; c'est une action du même genre qui se manifeste dans la fermentation acide; sculement elle se fait plus lentement. L'Alcool dissout le soufre en faible proportion; la dissolution est précipitéc par l'eau. Le phosphore est également soluble dans l'Alcool, et le rend lumineux dans l'obscurité, surtout lorsqu'on y ajoute de l'ean. Le chlore le transforme directement en chloral, indirectement en chloroforme. L'Alcool dissout les hydrates de potasse et de soude, et ne dissout point les sels que forment ces bases, aussi l'emploie-t-on pour la purification de ces Alcalis. Il dissout avec facilité les bases végétales ou leurs sels, et sert à leur préparation.

Les acides agissent différemment sur l'Alcool suivant leur nature et leur proportion. L'acide sulfurique peut déterminer la formation de 2 équivalents d'eau, aux dépens je tout l'oxygène et d'une quantité correspondante d'hydrogène, de l'Alcool absolu; on obtient alors de l'hydrogéne bicarboné.

C'est ce qui arrive lor'squ'on opère sur un mélange de 4 parties d'acide sulfurique, sur 1 d'Alcool. Lorsqu'on fait le mélange inverse, on détermine la sćparation d'un seul équivalent d'eau; il se produit dans ce cas de l'éther ordinaire, éther hydrique ou hydratique.

Les hydracides éliminent les éléments de 2 équivalents d'eau et produisent des éthers qu'on peut considérer comme formés de volumes égaux de gaz oléfiant et d'hydracide, ou bien, comme des combinaisons $d u$ radical de l'hydracide avec l'éther $=\mathrm{C}_{4} \mathrm{H}^{10}$.

Les acides végétaux éliminent 1 équivalent d'eau el s'unissent à l'éther hydrique (V. Étrien).

L'Alcool peut se combiner à divers sels, et remplacer quelquefois l'eau de combinaison.

L'Alcool dissout les essences; ces dissolıtions sont connues sous le nom d'alcoolats (eau de Cologne); et il est trés employé pou la confection des vernis, dits à l'esprit de vin, ainsi que pour la fabricalion des savons transparents. On en fait un fréquent usage dans les laboratoires, pour alimenter les lampes dites a Alcool, et pour opérer ces dissolutions qui ne se feraient point dans l'eau; enfin il sert à conserver les pièces d'anatomie et diverses substances organiques.

Les usages si multiplićs de l'cau-de-vie proprement dite, et de l'Alcool, en ont fait un objet de commerce considérable. Aussi est-il d'une grande importance de pouvoir reconnaìtre d'unc manière rapide et exacte la valeur de ces produits ou leur richesse en Alcool absolu.

M. Gay-Lussac a déterminé la densité de divers mélanges de l'eau avec l'Alcool. Au moyen de l'instrument qu'il a imaginé (instrument qui ne diffère du pése-liqueur quo par la graduation ) et des tables qui l'accompagnent, on connaît la quantité d'Alcool absolu que peut contenir un liquide, à une température donnée. La densité de l'Alcool croît a vec la quantité d'eau que l'on y ajoute, mais d'une manière irrégulière. Voici quelques rapports déterminés par M. Gay-Lussac à la temperature de 15 degrés centigrades : Dens. de la liqueur. Alcool. Eau.

$$
\begin{aligned}
& 0,7947 \ldots 100 \ldots 0 \\
& \text { 0,8379... } 75 . \ldots 25 \\
& 0,9348 \ldots 50 \ldots 50 \\
& 0,9656 \ldots 30 \ldots 70
\end{aligned}
$$

Le vin, le cidre, la bière, l'hydromel et toutes les liqueurs fermentées naturelles et artificielles, doivent leurs principales propriétés à la présence d'une certaine quantité d'Alcool.

(PEL.)

ALCVON. Alcyonium et Halcyonium (à-

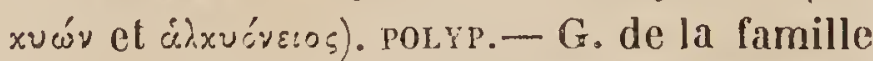
des Alcyoniens, nommé aussi Lobulaire par divers auteurs, mais devant conserver exclusivement le nom d'Alcyon, donné mal à propos á des Spongiaires, à des Algues et id d'autres productions marines. Il comprend 
des Polypiers charnus, en masse lobée ou irrégulièrement rameuse, fixée aux rochers ou aux plantes marines, par une tige courte et garnie, à la surface, de Polypes rétractiles, à 8 tentacules pectinés. Leur sac alimentaire s'ouvre en dehors par une seule ouverture entre la base des tentacules, et communique par son fond, qui se contracte plus ou moins, à une cavité commune ramifiée à l'intérieur. Ce sac alimentaire est fixé au milieu du corps de chaque Polype par 8 clcisons membraneuses, partant de la paroi externe, et faisant fonclions d'ovaires. La masse commune du Polypier est consolidée par des cristaux ou des concrétions calcaires irrégulières. M. Milne-Edwards, qui a récemment étudié avec soin ( $A n n$. $S c$. nat., ı. Iv, $2^{\text {me }}$ série) les Alcyons vivants, attribue a ces Polypiers un système de vaisseaux communs, servant à la circulation ou au transport d'un liquide nourricier. Il a observé chez ces mêmes Polypiers un mode de développement tout particulier et différent de celui des Alcyonides. C'est la masse commune elle-même qui pousse á l'extérieur un tubercule dans lequel on ne voit, en premier lieu, que les vaisseaux communs, sans aucune trace de Polypes; ces animaux ne s'y développent que plus tard et successivement, de manière à se montrer d'abord complètement renfermés dans la masse commune et sans communication avec l'extérieur, jusqu'à ce qu'une ouverture venant à se former, leur permette d'épanouir leurs tentacules au dehors, de se nourrir par eux-mêmes et d'acquérir ensuite leur enlier développement. Les Alcyons ont, en outre, des ouis qui prennent naissance dans les cloisons membraneuses prolongées au-delả de l'estomac, et qui, détachés à leur maturité, sortent de la cavité abdominale par le fond de l'estomac; puis, arrivés au-dehors, nagent librement dans les eaux de la mer au moyen des cils vibratiles dont ils sont revêtus, jusqu'au moment oú ils se fixent pour former un nouveau Polypier.

M. Edwards a décrit et figuré : 10 l'Alcyon palmé de la Méditerranée ( $\boldsymbol{A}$. palmatum; $\boldsymbol{A}$. exos Pallas, Lamouroux, Gmel., ou la Lobularia palmata de M. Deslongchamps et de M. Ehrenberg; Lobularia exos. Blainv.).2。 Il a décrit aussi une nouvelle esp. de l'Océan, l'Alcyon étoilé. A ce même g. appartien- nent : $3^{\circ}$ l'Alcyon aigité ( $A l$. exos Spix; $A l$. Lobatum Lamour.; Lobularia digilata Lamk., Blainv., Ehr., etc.); $4^{\circ}$ L'Alcyon conoïde (Al, cydonium Mull.; Lobularia Lamk.), si ce n'est, comme le pense M. Ehrenberg, le jeune âge de l'esp. précédente; $5^{\circ}$ l'Alcyon pauciflore (Lobularia Ehr.); 6० l'Alcyon arborescent ( $A$ l. arboreum Lamk., Lobularia Ehr.); $7^{\circ}$ l'Alcyon orangé ( $A$ l. aurantiacum Quoy et Gaim.), et peut-être les Cornularia multipennata et $C$. subviridis des mêmes auteurs; tandis qu'au contraire, leurs $\boldsymbol{A} l$ cyonium glaucum, flexibile, flavum, flabellum et viride, devront former un g. particulier de la même famille des Alcyoniens, si réellement leur cavité abdominale ne se prolonge pas en tube, comme chez les vrais Af cyons.

M. Ehrenberg, en conservant le g. Lobulaire, ne veut considérer comme appartenant au g. Alcyon que les esp. dont la masse commune est épaisse, charnue, gonflée, simple ou plissée et non découpée en lobes. M. de Blainville, qui attribue aux animaux de son g. Alcyon un cercle complet de tentacules simples, longs, filiformes, et qui dit que ces animaux sont contenus dans des cellules papilliformes, prend pour type l'Alcyon gélatineux (Halodactyle, Fare.), et rapporte au mème g. 3 esp. de Fleming, les $A$. hirsutum, echinatum et parasiticum, lesquels sont des Spongiaires.

Lamouroux a composé son g. Alcyon de diverses Spongiaires vivantes ou fossiles, et de l'Alcyon arborescent, qui seul mérite ce nom générique. Des 4 esp. décrites dans l'histoire des animaux sans vertèbres de Lamarck, une seule, l' $A$. arboreum, n' 28 , est un vrai Alcyon; un autre, l' $A$. bourse, no 38 , est une Algue (Spongodium bursa); une $3^{\mathrm{me}}, A$. orbiculé, $\mathrm{n}^{\circ} 33$, a été établie sur un débris de vertèbre de Cétacé; les autres sont des Spongiaires ou même en partie de vraies Éponges.

L'Alcyon fluviatile de Bruguière (Encycl. méth.) est l'Alcyonelle. (DuJ.)

*ALGYONAIRES. Alcyonaria ( ‘’ixuẃv). zoopIr. - Dénomination employée par M. de Blainville (Man. d'Actinologie) pour désigner la $4^{\text {me }}$ famille de ses Zoophytaires, qu'il nomme aussi Zoophytaires sarcinoïdes, et qui comprend les g. Briarée, Lobulaire, Ammothéc, Neptéc (Nephtée), Anthélie, 
Alcyon, Cydonie, Pulmonelle, Massaire et Clione. Il donne, à la vérité, pour caract. commun aux animaux de cette famille, d'être pourvus de 8 tentacules pinnés; mais ce caract.n'appartient réellement qu'aux cinq $1^{\text {ers }}$, et peut-être au g. Cydonie. La Clione est une vraic Spongiaire; la Pulmonelle est une Ascidie composée; l'Alcyon qui correspond a l'Alcyonidie de Lamouroux ou au g. Halodactylus, Farre, est un Bryozoaire, et la Massaire est une production fort douteuse ( $V$. ces mots).

ALGYONGELLE. Alcyoncellum. (Dim.

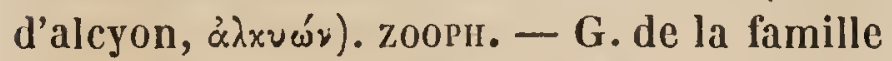
des Spongiaires, établipar MM.Quoy et Gaimard, pour un Zoophyte qu'ils ont rapporté des Moluques et décrit sous le nom d'Alcyoncelle spécieux (Voy. de l'Astrol. t. 4. p. 302. Zooph. pl.26). C'est un réseau délicat, contourné en forme de corbeille ou de panier profond et étroit, et dont les mailles nombreuses, arrondies, assez régulic̉res, sont soutenues par des spicules à 3 pointes. M. de Blainville (Man. d'Actin. p. 529. pl. 92), avait nommé cette même esp.,Alcyoncelle gélatineux, pour exprimer que, pendant la vic de ce Zoophyte, le réseau solide était revêtu d'une substance molle gélatineuse. ( Dus.)

*ALCYONE (Nom mythol.). ors. - G. formé par M. Swainson (Classif. of Birds), du Martin-pêcheur à 3 doigts, de la Nouv.: Hollande, connu sous le nom de Martinpêcheur à dos bleu (Alcedo tribrachys Shaw. et Vieill.), et placé jusqu'ici dans le g. Ceyx. sous le nom de Ceyx azurea Vig, et Hors. (Trans. Lin.1,15-208), à còté du Ceyx tridactyla de Sonnerat. M. Swainson l'en sépare en laissant le Ceyx tridactyla dans le g. Ceyx qu'il adopte également, mais comme faisant partie de la section des Martinschasseurs; tandis qu'il place son g. Alcyone dans celles des Martins-pêcheurs, se fondant sur ce que chacune des 2 espéces a le bec conformé comme celui de l'une ou de l'autre de ces 2 sections. Tout en reconnaissant, comme ce savant, que ces 2 esp. diffèrent effectivement un peu par la forme du bec, il nous semble qu'avant de les séparer génériquement, il serait bon de s'assurer s'il y a chez elles différence de mœurs comme de forme de bec, et si l'une a les habitudes des Martins-chasseurs et l'autre celles des Marlins-pêclieurs.

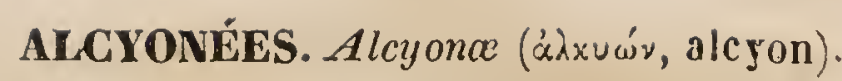
ZOOPH. POLY. - Dénomination employée par Lamouroux, pour désigner un ordre ou une famille de la division de ses Polypiers sarcoïdes, renfermant les g. Alcyon, Lobulaire, Ammothée, Xénie, Anthélie, Paly thoé, Alcyonidie, Alcyonelle et Hallirhoé. Cet ordre est fort mal caractérisé par l'auteur, qui lui attribue des animaux peu ou point connus, pourvus de 8 tentacules ou davantage, souvent pectinés, et presque toujours garnis de papilles de deux sortes. Si l'on en re"tranche les g. Alcyonidie et Alcyonclle, qui font partie de la division des Bryozoaires, et les g. Hallirhoé et Alcyon, qui sont des Spongiaires, cet ordre répond à la famille des Alcyoniens. ( $V$. ce mot.) (DUs.)

ALCYONELLE. Alcyonella (Dim. d'a' $\lambda-$ xućv). POLyp. - G. de la famille des Plumatelliens, Edw. ( ou Polypes Hippocrépiens, Gerv., faisant partie de l'ordre des Tuniciens tentaculés, Edw., ou Bryozoaires, Ehr.), établi par Lamarck pour un Polypier d'eau douce, que Bruguière avait nommé $A$ lcyon fluviatile. L'Alcyonelle a été l'objet d'un travail très détaillé de M. Raspail (Mém. Soc. d'hist. nat. ı. 4), qui considère comme devant lui être réunis, les Plumatelles, les Cristatelles, la Difflugie et la Leucophra heteroclita de Muller, laquelle n'est bien en effet qu'une Cristatelle jeune. M. Gervais, qui plus récemment (Ann.d'Anat. et de Physiol.), s'est occupć des Polypiers d'eau douce en général, conserve les g. Cristatelle et Plumatelle qui composent, avec le g. Alcyonelle, sa sous-classe des Polypes Hippocrépiens, c'est-á-dire ayant les tentacules ciliés, portés par un double appendice en fer-à-cheval, qui surmonte la bouche et l'entoure de chaque côté. Ils se multiplient par des œufs non ciliés, recouverls d'une enveloppe dure et entourés d'une sorte de bourrelet; mais, en même temps, M. Gervais avoue n'avoir pu trouver de différences génériques entre les Plumatelles et les Alcyonelles; celles-ci n'étant que des Plumatelles dont les tubes sont plus rapprochés et serrés les uns contre les autres, de manière à constituer une masse alvéolairc.

Les polypes des Alcyonelles et des Plumatelles ont un tube digestif complet, s'ouvrant au-dehors par une bouche au centre du fera-cheval, près du sommet, et par un anus 
situé également dans l'axe, au-dessous de la bouche. Les tentacules, a nombre de 42 a 44, forment une double crête épanouie sur les deux bords de l'appendice en fcr-à-cheval. Ils sont formés d'un tube membraneux, gonflé par les fluides intéricurs de l'animal, et garni sur 3 de ses faces d'une rangíe de lamclles vibratiles, dont l'agitation successive produit l'effet d'une rangée de perles ou d'une chaîne en mouvement, et sert à cxciter dans le liquide ambiant des tourbillons qui amènent à la bouche les corpuscules nottants dont l'animal se nourrit.

Les excréments de ces Polypes sont rejetés fréquemment sous la forme de globules ordinairement verdâtres, dans lesquels on reconnaît des débris d'Algues microscopiques et d'Infusoires cuirassés. La membrane cornée ou pergamentacée des tubes du Polypier n'est que la partic la plus ancienne et la plus consolidće du tégument externe de chaque Polype, dont la partie molle et active est complètement rétractile dans ce tube par l'action de fibres musculaires bien visibles. - L'esp. la plus commune d'Alcyonelle a recu le nom d'Alcyonella fluviatilis; les autres esp. doivent être reportées au g. $P a-$ ludicella, Gerv., ou au g. Plumatelle ( $V$. ce mot), auquel nous renvoyons pour de plus amples détails.

(Dus.)

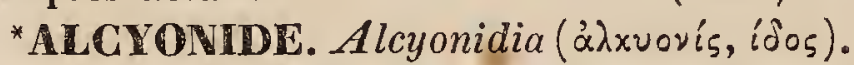
Polyp. - G. de la famille des Alcyoniens, établi par M. Milne - Edwards pour une esp. de Polypes réunis en une masse molle, cylindrique, brunâtre, simple ou rameuse, fixée par sa base à des fucus ou à d'autres corps marins. Ces Polypes, très petits, blancs, demi-transparcnts ainsi que l'extrémité des rameaux, sont cylindriques, terminés par un disque étoilé, composé de 8 gros tentacules pinnés, au milieu desquels on distingue l'ouverturc buccale. A la base de chaque tcntacule, on remarque quelques lignes saillantes disposées en pyramide ; et dans l'intéricur, on aperçoit un tube jaunâtre et opaque qui part de la bouche, pour arriver jusqu'à moitié de la longueur du corps cylindrique de chaque Polype; c'est le canal alimentaire, présentant $\&$ stries longitudinales intérieures avec une multitude de petits plis transversaux, ef communiquant par en bas, au moyen d'une large ouverture contractile, ayec la cavité générale et commune qui occupe l'intériem du Polypier. Ce canal intestinal est fixé à la paroi externe par 8 cloisons membraneuses, lc long desquelles se trourent des cordons flexueux, et dans l'épaisseur desquelles se développent les germes. Les polypes et l'extrémité molle des rameaux sont complètement rétractiles; la base du polypier est plus charnue, consistante, et contient de nombreuses spicules calcaires. C'cst la complète rétractilité de l'extrémité de l'Alcyonidc, qui distingue génériquement ce polypier des autres Alcyoniens. La seule esp. connuc, l'Alcyonidia elegans, vit dans la Mćditerranée, sur les côtes de l'Algérie.

(DUJ.)

ALCWONDIE. Alcyonidium (áixuovis, idos). Polyp. - G. établi par Lamouroux, pour divers corps marins à formes massires, lisses, lobées ou rameuses, ct auxqucls il attribuait des Polypes transparents, à corps infundibuliforme, armès de 12 tcntacules égaux, longs et filiformes. Une partie des Alcyonidies ont ćté reportées par Lamouroux lui-même parmi les Algues, dans le g. Dumontia. Plusieurs des esp. qu'il conscrve, comme les $A$. nostoch, $A$. bulle, sont au moins douteuses quant à leur nature. Pour ce qui est de son Alcyonidie gélatineuse, (Alcyonium gelatinosum de Pallas), qui avait été nommée d'aburd par lu i-même Alcyonidium diaphanum et rapportée aux Algues, elle a été étudiée récemment par M. Art. Farre, qui en a fait un g. des Ciliobrachiés ou Bryozoaires, sous le nom de Halodactyje. $V$. ce mot. Ainsi le nom d'Alcyonidie doit disparaître de la science. (DUJ.)

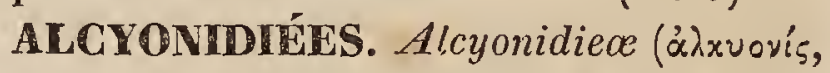
¿́os). POLYP. - Dénomination créée par Lamouroux pour un ordre d'Algues marines, parmi lesquelles il plaçait, sous le nom d'Alcyonidie, l'Alcyonium gelatinosum ou diaphanum.

(DuJ.)

ALCIONHDION (àxvovís, idcs). POLYP. Nom changé par Lamouroux en celui d'Alcyonidie, lequel est remplacé lui-même par celui de Fralodactyle. $V$. ce mot. (Dus.)

*ALGTONRENS. Alcyonia et Alcyonina ( $\alpha \lambda$ xvóviov). Polyp. - Famille de Polypes parenchymateux (Milne-Edwards) ou d'Enthozoaircs (Ehrenb.), dont la cavité diges tive, limitée par l'enveloppe parenchymateuse du corps et s'ouvrant au-dehors par une seule ouycrture, présente un tube asophagien 
frarfaitement distinct et a ses parois garnies de 8 ou 6 lames ovariennes. Les Alcyoniens ont aussi des tentacules pinnés, mais non ciliés, au nombre de 6 ou $S$.

Cette famille, pour M. Milne-Edwards, se divise en 5 tribus, savoir: $1^{\circ}$ les Alcyoniens pierreux, comprenant les g. Tubipore, Favosite, Caténipore, etc.; 2。 les Alcyoniens dendroïdes, tels que le Corail, l'Isis, les Gol'gones; $3^{\circ}$ les Alcyoniens libres, comme les Pennatules, les Vérélilles, les Rénilles; $4^{\circ}$ les Alcyoniens rampants, comme la Cornulaire; $5^{\circ}$ les Alcyoniens massifs, comprenant les Alcyons proprement dits ou Lobulaires, Jes Ammothées, les Nephtées et le nouveau g. Alcyonide.

M. Ehrenberg, qui donne le nom de familles à ces diverses tribus, les divise et les distribue d'une autre manière. Pour lui, les Isidées et les Gorgoniens, composent la $6^{\text {ne }}$ tribu de ses phytocoraux à $\&$ rayons; les Caténipores sont placés dans la famille des Madréporiens, et les Favosites dans la famille des Dædaliens, qui font partic des Phy tocoraux à 12 rayons. Il rapporte au contraire à la tribu des Zoocoraux à 8 rayons, les familles des Xéniens (Xenina), répondant en partie aux Alcyoniens rampants; des Pennatuliens (Alcyoniens libres, Edw.), des 'Tubiporiens, comprenant le seul g. Tubipore, et enfin des Alcyoniens (Halcyonina), comprenant les g. Halcyonium, Lobularia, Ammothea, Nephthya, Sympodium et Cliona; de sorte qu'à l'exception de ce dernier $g$. qui est véritablement une Spongiaire, cette famille de M. Ehrenberg répond aux Alcyoniens massifs de M. Edwards. (DuJ.)

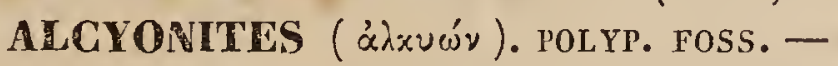
Dénomination vague, employée autrefois par les géologues, pour désigner des Zoophyles fossiles qui appartiennent réellement à la famille des Spongiaires et non à celle des Alcyonaires. Lamouroux a vait fait de ces prétendus Alcyonites les g. Hallirhoé, Chenendopoé, Hippalime, Lymnorée, etc. M. Goldfuss les a répartis dansles g. Siphonia, Cnemidium, Myrmecium et Tragos. Un des plus fréquemment observés parmi ces Alcyonites est la Siphonia piriformis, que sa forme avait fait nommer anciennement Figue pétrifiée ou ficoïte.

(Dus.)

ALCYONS. Alcyones (ảixwáv, alcyon). ors. - C'est dans la méthode de Temminck son $7^{\text {me }}$ ordre renfermant les g. Guêpier, Martin-pécheur et Martin-chasseur, répondant aux Pelmatodes de Vieillot. $V$. AlciDIDÉEs et MÉROPIDÉEs.

(Lifr.)

*ALDAMA, Lallav. вот. PII.-Synonyme du g. Gymnopsis de M. De Candolle. $V$. ce mot.

(C. L.)

ALDEA ou ALDETA. BOT. PII. - G. de la famille des Hydrophyllées, établi par Ruiz et Pavon ( $F l$. Per.), et rapporté en synonymie au g. Phacelia de Jussieu. $V$. ce mot.

(C. L.)

ALDINA. Adans. вот. PII. - Syll. du g. Brya, P. Br.

(Sp.)

* ALDINIA, Reichenb. (Aldini, savant physicien italien). вот. PH.-S.-genre fondé sur quelques esp. de Tacsonia; c'est le même que le Bracteogama, DC.

(Sp.)

ACDROVANDA, Mont. (Aldrovandi, naturaliste italien). вот. PH. - G. de la famille des Droséracées, offrant les caract. suivants : Cal. campanulé, 5-parti; sépales ovales, concaves; pétales 5 , courts, oblongs, connivents. Étam. 5. Ovaire 1-loculaire, à 5 styles courts, filiformes, terminés chacun par un stigm. obtus. Caps. globuleuse, 1-loculaire, 5-valve, 10-sperme ; graines pariétales. L'Aldrovanda vesiculosa, L., est la seule esp. qui constitue le g. Cette plante, remarquable par la structure de ses feuilles, croît dans les étangs et les lacs de la Toscane, ainsi que dans quelques localités du midi de la France. Attachée à la vase avant sa floraison, elle vient plus tard flotter librement à la surface de l'eau. Sa tige est simple ou peu rameuse. Ses feulles sont verticillées et se composent d'un pétiole cunéiforme, membrancux, semidiaphane, cilié au sommet, et couronné d'une vésicule du volume d'un gros pois; c'est à l'aide de ces vésicules remplies d'air, que la plante se maintient à la surface de l'eau.

(Sp.)

ALEBRENNE. REPT. - Nom que l'on donne à la Salamandre commune, dans certaines parties de la France. (G. B.)

*ALECTHÉLIE. Alecthelia (ả éxrwp, coq;

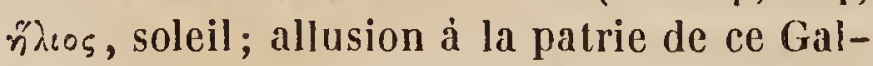
linacé, située immédiatement sous l'èquateur). ors. - S.-genre formé par M. Lesson, voisin de celui de $M \dot{e} g a p o d e$ et faisant partie de son s.-ordre des Passérigalles et de sa famille des Mégapodes. Une seule esp. de l'ile de Guébé a donné lieu à la formation 
de ce s.-gènre, dont les caract. sont, d'après cet auteur: Bec petit, droit, comprimé, pointu, à mandib. supér. plus longue que l'infér.; celle-ci renflée en dessous; fosses nasales placées à la base $\mathrm{du}$ bec, séparées par une arête étroite et bordées par les plumes avancées du front. Tour des yeux complètement emplumé. Ailes courtes, concaves. Tarses médiocres, robustes, scutellés, à doigts proportionnés comme ceux des Mégapodes. Queue à rectrices nulles; toutes les plumes décomposées. - L'oiseau type de ce s.-genre particulier aux Moluques orientales, l'Alecthélie de d'Urville, présente dans son ensemble de grands rapports avec les Mégapodes. Il est figuré dans le voyage de la Coquille ( $p l .37)$. M. Swainson dans sa classification, tout en adoptant ce sous-genre, le place à là suite du g. Gallinula dans sa famille des Rallidoe et non dans celle des $M e-$ gapodince. Nous iglıorons sur quoi il a basé cè changement, le seul individu connu étant venu à la suite d'un gros temps et à la hauteur de l'île de Guébé, se jeter épuisé de fatigue sur le bâtiment la Coquille; ce qui ferait supposer que cet oiseau, habitant des grèves, comme les Mégapodes, en aura été répoussé momentanément par une cause quelconque, qui lui aura fait prendre son vol au-dessus des flots, oú les vents l'auront emporté en pleine mer jusqu'au bâtiment.

(LAFR.)

* ALECTO (Nom, chez les Grecs, d'une des 3 Furies). ols. - G. formé par M. Lesson et ayant pour type le Tisserin, Alecto de Temminck (Col. 446). Ses caract. sont, d'après nous : Bec robuste, allongé, conique, comprimé, à mandib. supér. assez élevẻe vers le front et l'entamant angulairement, arqué dans toute sa longueur; narines basales, ovalaires, ouvertes et entièrement rues; commissure sinueuse; mandib. infér. beaucoup moins haute à sa base que la supér. Pieds robustes, à doigts latéraux d'égale longueur; ougles faibles et courts. Ailes subobtuses, à primaires courtes. Queue allongéc et arrondie. - Chez les individus adultes et probablement mâles, toute la base du bec devient enflée et comme boursouflée jusqu'à la moitié de sa longueur; elle perd son aspect corné pour en prendre un osseux et rugucux. La mandib. supér. offre alors 3 renflements : un frontal entre les narines et un depuis chaque narine jusqu'au bord latéral, de sorte que leur ouverture se trouve singulièrement rétrécic. La mandib. infér. en présente 2 : un sur chaque branche mandibulaire, à sa base latérale et infér. A cette singularité s'en joint une autre des plus remarquables chez cet oiseau: le mâle est muni d'une verge extérieure, longne de 4 à 6 lignes, très apparente dans la pluparı des peaux sèches; ce qui indique qu'il y a très probablement chez l'Alecto, plus qu'ur simple contact dans l'acte de la fécondation.

Malgré les grands rapports de forme existants entre cet oiseau et les Tisserins, les 2. anomalies qui lui sont particulières nous paraissent bien suffisantes pour en former le type d'un g. à part, et il serait d'un grand intérêt que quelque naturaliste pùt faire, au Sérićgal sa patrie, des observations précises sur son mode d'accouplement, sur l'époque du renflement du bec, et reconnaìtre si ces particularités sont particulières à l'un des sexes seulement ou à tous deux. M. Swainson, dans sa classification, a fait de cet oiseau son g. Dercroides, et sans ćgard pour son nom antérieur d'Alecto, il le nomme $D$. albirostris. Tout en citant la synonymie d'Alecto de Temminck (faute impardonnable, puisque l'on doit conserver les noms spécifiques antérieurs), il le retire de la famille des Tisserins, pour le mettre dans celle des Gros-Becs. Il est certain que la brièveté de ses ongles, très développés au contraire chez les Tisserins, la longueur de sa queue, toujours courte chez ces derniers, et ses ailes plus arrondies, semblent autoriser ce changement de famille, que nous scrions tout disposé à admettre; mais avant de prononcer, il nous semble indispensable d'attendre sur son mode de nidification, des renseignements qui nous fassent connaître si, comme les Tisserins, il construit son rid avec des tiges de Graminées, finement entrelacées, à ouverture latérale ou inférieure, d'où le nom de Tisserins; ou si, comme les Gros-Becs, il le fait en forme de coupe ouverte en dessus.

La seule esp. du g., connue jusqu'ici, est le Tisserin Alecto de Temminck. Il est de la grosseur d'un merle, tout noir, avec les bords externes des primaires et quelques taches irrégulières blanches sur les nancs, 
et la base du bec jaunatre. Il habite le Sénégal et les parties occidentales de l'Afrique.

$$
\text { (LAFr.) }
$$

- ALECTO. ins.-G. de Coléoptères pentamères, famille des Malacodermes, tribu des Lampyrides, établi par M. Delaporte, et dont cet auteur a donné les caract. dans le $2^{\mathrm{me}}$ vol. des Ann. de la Soc. Entom. de France, p. 135. Il est fondé sur une esp. unique, A. discoidalis rapportée de Cuba par M. Poey et qui fait partie de la collection de M. Chevrolat. Ce g. ne figure pas dans le dernier Catal. de M. Dejean.

* ALECTO (Nom mytliol.). échis.-Nom donné par Leach aug. Comalule. $V^{\prime}$. ce mot.

$$
\text { (DUJ.) }
$$

ALECTO (Nom mythol.). POLYP. - G. de Polypiers fossiles établi par Lamouroux qui le place dans l'ordre des Cellariées, parmi les Polypiers flexibles. M. De Blainville, en l'adoptant, l'a classé avec les Flustres, les Crisies et les Cellaires, dans la $2^{e}$ famille de ses Polypiaires membraneux, celle des Cellariées. M. Milne-Edwards enfin, le rapporte a la famille des Tubuliporiens, a vec les Crisies, les Hornères, etc.

Le polypier des Alecto se compose de cellules petites, allongées, tubuleuses, à orifice peu saillant, presque terminal, disposées à la suite les unes des autres de manière à former un réseau délicat à la surface de divers corps marins, sur lesquels elles sont couchées et adhérentes.

Lamouroux avait nommé Alecto dichotoma, l'esp. qu'il observa sur les Térébratules du lerrain jurassique; $\mathbf{M}$. De Blainville a donné le nom d' $A$. ramea à une esp. presque semblable de la craie; M. Milne-Edwards en a reconnu une $3^{\mathrm{e}} \mathrm{esp}, A$. gracilis, aussi de la craie, et une $4^{\mathrm{e}}, A$. granulata, du grès vert. M. Goldfuss avait cru devoir réunir les Alecto à son g. Aulopore. $V$. ce mot.

(Dus.)

* ALEGTON. Alecto (Nom mylhol.). ARACins. - Nom donné par M. Walkenaër, à une section du grand g. Mygale. (H. L.)

ALECTORIA. Alectoria. Bot. Cr.-Acharius a employé ce mot pour désigner un groupe de Lichens remarquables par un thalle filiforme, rameux, cylindrique, composé d'une substance filamenteuse, revêtue d'une écorce cartilagineuse ; par des apothécies orbiculaires, sessiles le long des rameaux, entiẻrement formées par le thalle, munies d'un disque plane ou convexe, concolore, et dépourvues de marge propre. Ce g., qui avait déjà fait partic des Parméliacées du mêıne auteur, que IIoffmann et M. De Candolle avaient, de leur côté, rangé parmi les Usnées, a subi de nouvelles vicissitudes depuis cetle époque. M. Fée, a près l'avoir adopté dans sa Mélhode lichénographique, et considéré comme appartenant à sa tribu des Corniculaires, l'a, plus tard (Suppl. à l'Essai, etc.), rejeté parmi les Ramalines. Quand ce g. a été créé, l'on avait peu étudié et l'on connaissait mal la physiologie des Lichens. La fructification, dont les caract. sont de première importance dans toute méth. naturelle, ne venait alors qu'après le thalle pour la classification. En conséquence, on élevait à la dignité d'esp. et même de g., des plantes que leur habitat avait complètement métamorphosées. Meyer et Wallroth nous ont fait connaître les causes de ces transformations, et nous en ont dévoilé le mode. Il est donc bien prouvé maintenant pour les botanistes, qui ont étudié les Lichens ailleurs que dans les herbiers, que les Alectoriées d'Acharius ne sont que des Évernies ou des Ramalines translormées et alypiques; aussi, Fries s'est-il servi du mot Alectoria pour désigner, parmi les g. Usnea, Evernia, Ramalina el Cetraria, la sect. de chacun d'eux, où viennent se ranger les esp. ou les formes a thalle filamenteux, capillacé, pendant. (C. M.)

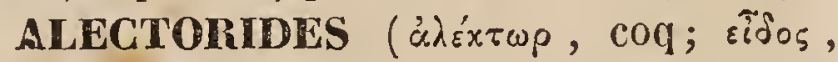
forme). ors. - C'est, dans la méthode de Ternminck, son $11^{\mathrm{me}}$ ordre, renfermant les Échassiers à bec court, tels que les g. $\Lambda$ gami, Cariama, Glaréole, Kamichi el Chavaria. (LAFR.)

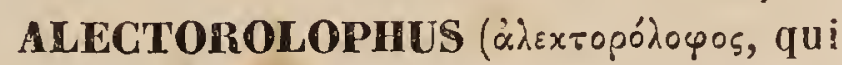
a une crête de coq). вот. rı. - Cette dénomination, après avoir été donnée par d'anciens botanistes a diverses plantes européennes, a été appliquée par Haller (Helv.) à un g. de la famille des Scrophularinées, tribu des Rhinantées, qui est ainsi caractérisé : Cal. membraneux, comprimé-ventru, de 4 dents inégales. Cor. hypogyne, ringente; lèvre supér. en casque, comprimée, bidentée au sommet; l'infér. trifide, presque égale. Étam. 4, insérées sur le tube de la corolle, didynames, cachées sous le casque; anth. horizontales, biloculaires, yelues, mutiques. 
Ovaire comprimé, biloculaire, pourvu d'une glande à la base; placentas linéaires, pauci-ovulés, attachés des deux côtés à la eloison. Style simple, subexsert; stigm. sub-capite. Caps. comprimée, loeulicide-bivalve ; valves septiféres au milieu. Graines rares, suborbiculaires, comprimées, pourvues d'un bord membraneux, appendues par l'ombilic marginé au sommet. - Ce g. a pour type le Rhinanthus crista-galli L. Il comprend un petit nombre de plantes herbacées annuelles, propres à l'Europe centrale et australe, ainsi qu'à l'Asie limitrophe; elles sont à feuilles opposées, sessiles, lancéolées, dentées, à fleurs axillaires, solitaires, sessiles, jaunes.

$$
\text { (C. L.) }
$$

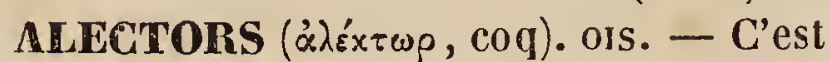
dans Merrem et dans Cuvier (Règ.anim.), la $1^{\text {re }}$ famille de l'ordre des Gallinacés, renfermant les Hoceos, les Pauxis, les Yacous, les Parraquas et l'Hoazin. C'est aussi dans Gmelin et Latham le nom du Hoceo de la Guyane.

(LAFr.)

*ALEGTRA. вот. PI._-G. établi par Thunberg (nov. Gen.) dans la famille des Scrophularinées, et qui ne paraît pas être généralement adopté. Endlicher (Gen. Pl.) le réunit au Glossostylis, Cham. et Sehlecht. $V$. ce mot.

ALECTIRIDES (contraction d' $\alpha \dot{\lambda} \varepsilon x \tau \rho \nu \omega \dot{\nu}$, coq ; عídos, lorme). ors. - C'est dans la méthode de Vieillot sa $30^{\text {e }}$ famille de l'ordre des Sylvains, composée du seul g. Yacou ou Pénélope.

(LAFr.)

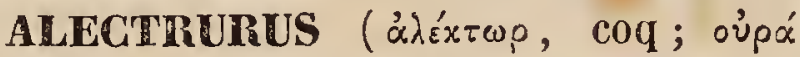
queue ). ols. - C'est le nom latinisé du g. Gallite de Vieillot, faisant partie de ses Myothères, $18^{\text {me }}$ famille de son ordre des Sylvains. ( $V$. GaLLITE).

(LAFR.)

ALECTRYON. Alectryon ( $\alpha \lambda \varepsilon x \tau p \nu \omega \dot{\nu}, \operatorname{coq})$. MoLL. - Démembrement inutile du g. Buccin, proposé par Montfort (Conchyl. systém., t. II, p. 566). Le type de ce g. est le Buccinum papillosum, dont les caract. s'aecordent très bicn avee ecux du g. $N$ asse de Lamarek. Les caraet. du g. de Montfort étant insuffisants, il a été depuis long-temps abandonné. ( $V$. Buccin.) (DesiI.)

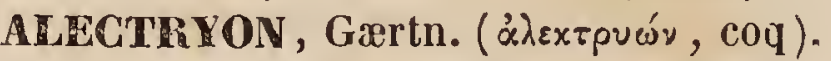
воT. PII.-G. de la famille des Sapindacées, tribu des Dodonéacées, Camb., dont les fleurs sont inconnues. Le fruit est une baic coriace, globuleuse, uniloculaire, monosperme; cou- ronnée d'une erête coriace, qui se prolonge d'un côté jusque vers le milieu; la graine est attachée au fond de la loge, et engaînée d'un arille basilaire. L'esp. sur laquelle se fonde ce g. est un arbre indigène dans la Nouv.Zélande.

(S.)

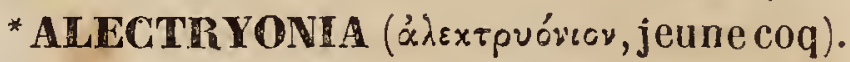
MoLL. - G. proposé par M. Fiseher (Bull. Soc. nat. Mosc.) pour quelques esp. d'Huîtres qui, telles que les Ostrea perrata et diiuviana, ont le bord des valves profondément dentelé. Ce g. ne peut supporter le moindre cxamen, et ne doit pas être adopté. ( $V$. Huitre.)

(DEsH.)

* ALECTURA et Alecturus. ols. - C'est dans la classif. de M. Swainson, un g. répondant à l'Alectrurus de Vieillot ( $V$. ce mot). Nous ignorons pourquoi cet auteur, adoptant ce g., a jugé convenable d'en altérer le nom : il écrit à la fois .Alectura et Alecturus. (LAfr.)

* AlEGRIA, Moç. el Sess. ex D. C. вgT. PH. - G. que M. De Candolle rapporte avec doute à la famille des Tiliacées, et dont il expose ainsi les caract. (Prodr. 1, p. 517): Involucelle de 12 folioles lancéolées, pointues, ćtalées. Sépales au nombre de 5 , valvaires en préfloraison, finalement révolutés au sommet. Pétales au nombre de 5 , planes, obovales. Étam. nombreuses, libres ou légèrement soudées par la base; les extér. ananthères; anth. suborbiculaires. Ovaire ovoïde, monostyle; stigm. au nombre de 5 , suborbienlaires, rapproehćs. Caps. 5-gone, 5-loculaire, loculicide, 5-valve. Graines ailées. Ce g. n'est fondé que sur une seule esp., indigène au Mexique; c'est un arbre à feuilles ovales, dentelées ; les fleurs, blanches et semblables à celles des Sparmannia, sont de la grandeur d'une rose. (Sp.)

*ALELODES. Ins. - Genre de l'ordre des Hynénoptères, appartenant à la famille des Ichneumoniens, groupe des Braconites, établi par M. Wesmael (Monographie des Bracon. de Belgique), qui le caraetérise prineipalement par une $2^{\text {me }}$ cellule cubitale, carrée ou reetangulaire aux ailes supérieures, et par un abdomen linéaire et non comprimé. Cet auteur en décrit 18 espèees indigènes, pour lesquelles $M$. Westwood $(S y)$. of Gen.) et nous (Hist. des An. art.) avous conservé le nom générique de Rogas, qui leur avait été đéjà appliqué pår $M$. Nees voll lisenbeck. ( $V$. ce mot.) (BL.) 
ALENE, polss.-Num vulg. d'une Raie d museau aigu. ( $V$. RAIE). (VAL.)

AH SNE. Subula. MoLt.-En examinant les coquilles du g. Terebra de Lamarck, M. de Blainville reconnut dans le nombre quelques esp). qui réellement n'appartiennent pas a ce g. et qui sont de véritables Buccins. Il aurait sans doute suffi de retirer ces esp. du g. Terebra, dont elles n'offrent pas les caract., pour les remettre parmi les Buccins. M. de Blainville, néanmoins, dans son traité de Malacologie, a cru devoir faire autrement; il a laissé aux 2 ou 3 esp. de Buccins le nom de Terebra, et il a établi un nouveau g., celui qui nous occupe, pour les vraisTerebra de Lamarck. Ces changements de nomenclature ne pouvaient être adoptés; aussi le g. Subula n’a-t-il été admis par personne. ( $V$. VIS.)

(Drsh.)

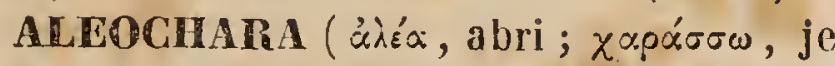
creuse). Ins. - G. de Coléoptères pentamères, établi par Gravenhorst et placé par Latreille dans la grande famille des BrachéIytres, tribu des Aplatis. Ses caract. sont: Ant. insérées à nu entre les yeux et près de leur bord intér.; les trois $1^{\text {ers }}$ articles sensiblement plus longs que les suivants; ceuxci perfoliés, le dernier allongé et conique. Palpes terminés en alène; les maxillaires avancées avec l'avant-dernier art. grand et le dernier très petit. Cors. presque ovale ou en carré arrondi aux angles. Ély t. trẻs courtes. Les Aléochares sont de petits Brachélytres très agiles, qu'on trouve ordinairement dans les Champignors ou bolets plus ou moins putréfiés; on en rencontre aussi sous les pierres et dans les débris de végétaux qui sont i terre, ainsi que dans les bouzes. M. Dejean dans' son dernier catal. en mentionne 23 esp., dont 5 d'Amérique et les autres d'Europe. Parmi ces dernières nous citerons les A. fuscipes, tristis, bipunctatu et nitida de Gravenhorst, quise trouvent toutes 4 aux environs de Paris.

(D.)

* AlÉOCharides (Aleochara, $V$. cidessus; ; हंos, forme). Ins.-Tribu de l'ordre des Coléoptères pentamères, famille des Brachélytres, établic par le comte Mannerheim et qui correspond à celle des Aplatis (Depressi) de Latreille. $V$. ce mot. Elle comprend $16 \mathrm{~g}$. dont voici les noms: Dinarda, Lomechusa, Cymnusa, Gyrophrena, Aleochara, Oxypoda, Sphenoma, Microura, Oligota, Trichophya,
Homalota, Culodera, Bolitochara, Drusilla, Falagria et Aulalia. Les deux premiers g. ont les angles du prothorax fortement prolongés, landis que les 14 autres les ont au contraire peu prolongés ou nuls. Du reste, cette tribu se compose d'esp. assez disparates, la tête étant clıez les unes non rétrécie postéricurement, tandis que chez les autres elle ofre un col aussi distinct que dans les Staphylinides. Les ant., souvent courtes, robustes et presque fusiformes, sont insérées tantôt dans des cavités latérales de la tête, au bord antér. des yeux, tantôt à nu, au même bord ou un peu plus avant sur le front; elles se trouvent alors situées presque au bord interne de ces organes. Cette tribu se distingue par ce caract. de cellè des Oxylélides; des Tachinides par les jambes, qui sont toujours mutiques, excepté chez les Gymmusa, et des Omalides, par la briẻveté des élytres, qui laissent la majeure partie de l'abdomen à découvert; celui-ci est constamment relevé, même pendant l'inaction, dans la plupart des esp., et quelques unes le raménent si complètement sur le dos qu'elles paraissent alors tout-à-fait globuleuses ou sphériques. Le corps des Aléocharicles est en général assez allongé, et presque parallèle dans la majorité des espéces. Ce sont des insectes de très petite taille, de couleur uniforme, brunâtre, noiràtre ou ferrugineuse et d'une détermination extrêmement difficile. (D.) *ALEPE. Alepas. Triton, L. (á priv.; is$\pi \dot{\alpha} \varsigma$, sorte de coquille). MolL. - G. de la classe des Cirrhipèdes, famille des Lépadiens, Blainv., formé par Rang (Man. d'hist. nat.des moll.) qui lui assigne les caract. suivants: Animal ovale, comprimé, fabiforme, arrondi près du pédicule; celui-ci médiocrement allongé; cirrhes un peu courts, se recourbant à peine à leur sommet, et composés d'environ 10 à 12 art. hispides à leur base. Coquille remplacée par une enveloppe d'une scule pic̉ee épaisse, subgélatincuse el un peu diaphane, sans autre ouverture que celle qui sert au passage des cirrhes, se colllinuant avec le pédicule et ne présentant aucune trace de pièces lestacées. - Ce g. ne se compose que d'une espèce, trouvè sur l'ombrelle d'une méduse; ce qui indique sufisamment qu'il est pélagien. (C. D'O.)

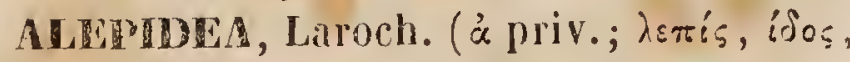
écaille). zот, pll, - G. de la famille des Om- 
belliféres, tribu des Saniculćes, de $M$. De Candolle, qui en donne les caract. suivanis (Prodr. 4, p. 87) : Tube calicinal légèrement tuberculeux. Pétales infléchis. Péricarpe ovoïde-cylindracé, tuberculeux ; méricarpe sans côtes ni bandelettes; carpophore adné. L'unique esp. sur laquelle se fonde le g. est une plante herbacée, du cap de BonneEspérance, dont les feuilles radicales sont pétiolées, oblongues, ciliées de soies spinescentes; les tiges presque nues, ombellifères au sommet; les ombelles semblables à celles des Astrantia.

ALÉPIDOTE ( $\alpha \lambda \varepsilon \pi i \delta \omega \tau \circ \varsigma$, non écailleux). Poiss. - Nom donné par Linné à un poisson qu'il classait parmi les Chétodons, et dont la peau est sans écailles. Lacépède a fait de ce Ch. Alepidotus L., un g. où il ne placait que cette seule esp., son Rhombe Alépidote. Depuis, nous en avons plusieurs autres qui viennent toutes, comme la première, des mers d'Amérique. (VAL.)

* ALEPISAURUS ( $\propto$ priv.; $\lambda \varepsilon \pi i ́ s$, écaille ; caũpos, g. de poissons ). posss. - Nom com* posé par le Révérend R.T. Lowe de Madère, pour exprimer un Saurus sans écailles, ou à peau nue. Ce nouveau g., découvert à Madére en 1833, décrit et figuré dans les Trans. de la Soc. Zool. de Londres, a le museau avancé, la gueule très ouverte, fendue audelả des yeux, ornée de dents très longues, rangées sur les mâchoires et sur le palais. Deux dorsales, l'une très haute; l'autre petite et adipeuse; de petites ventrales; une anale courle, pointue en avant; la caudale grande et fourchue. J'ajoute encore à ce caract. fourni par M. Lowe, l'observation faite sur le dessin que m'a communiqué feu mon ami M. Bennett, que les pectorales et les ventrales ont les rayons internes plus longs que les externes. Ce caract. est décisif, quoique paraissant artificiel, pour déterminer le rapport saisi par $M$. Lowe entre ce g. et les Saurus. Il a comme eux une adipeuse; des ventrales abdominales, forme de nageoires que je ne cormais jusqu'à présent que chez les Saurus, la gueule très fendue. Nous connaissons déjả un g.voisin des Saurus, qui a la peau nue et saus écailles. Ajoutez à cela que le canal intestinal est simple, sans inecum.

Je crois donc que c'est à la famille des Salmö̈des qu'appartient ce g., et non à celle des Tanioïdes, avec lesquelles cependant il a quelque analogie par la disposition des dents. On n'en connaît encore qu'une seule esp. nommée $A$. ferox; elle est argentèe avec des nageoires bleues; la dorsale est trés haute. Elle devient trës grande, on en a vu de 5 pieds de long.

(VAL.)

*ALÉPOCÉPHALE (á priv.; $\lambda \varepsilon^{\prime} \pi i s$, écaille;

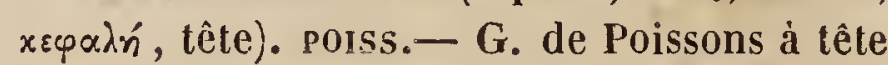
sans écailles, établi par M. Risso ( $M e ́ m$. de ' 'Acad. de Turin), qui le caractérise par: Un corps ovale, oblong, dont le tronc est couvert d'écailles ovales et caduques ; à gueule bien fendue; à mâchoires et palais garnis de dents fines et aiguës; à ouïes très larges; 8 rayons branchiostèges; la dorsale opposée à l'anale, et toutes deux réticulées sur le tronçon de la queue. - M. Risso a placé ce g. dans la famille des Clupéoïdes; mais il est facile de se convaincre, par le plus simple examen, que c'est dans le groupe des Ésoces, près des Microstomes, qu'il faut ranger ce g. curieux, dont on n'a décrit jusqu'à présent qu'une seule esp., l'A. rostré ( $A$. rostralus), d'un bleu violacé, à nageoires noires. Ce Poisson, selon M. Risso, sort des plus grandes profondeurs de la Méditerranée $(2,000$ pieds). Ses yeux sont très grands. La femelle pond des œufs brunâtres, et s'approche des rivages en juillet ou aoùt. (VAL.)

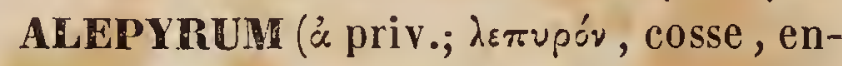
veloppe de fruit). вот. PI. - G. de la famille des Restiacées, établi par Rob. Brown ( $\boldsymbol{P}_{r}$ odr. Fl. Nov. Holl., 1, p. 25.3), voisin des g. Devauxia et Eriocaulon, dont il se distingue par les caract. suivants : Spathe bivalve, contenant une ou plusieurs fleurs. Glumes nulles, fleurs monandres, à anthère simple, de 6 à 18 pistils unilatéraux, attachés à un axe commun. Styles soudés par leur base, distincts dans leur partie supérieure. Fruits secs s'ouvrant par une suture longitudinale. - Les 3 esp. que M. Rob. Brown a décrites sont toutes originaires de la Nouvelle-Hollande. Ce sont de petites plantes grêles et touffues, très semblables aux esp. du g. Devauxia, dont elles diffẻrent surtout par l'absence des glumes et leur spathe généralement uniflore.

(A. R.)

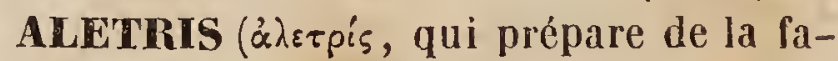
rine; allusion à l'une des espèces, dont les feuilles sont comme saupoudrées de farine). 
30т. Plı. - G. de la famille des Liliacées, qui peut être caractérisé de la manière suivante: Cal. pétalorde tubuleux, formé de 6 sépales égaux, soudés presque en totalité, rudes á l'extér. Étam. 6 , insérées au haut du tube calicinal et incluses; filets très courts, anth. sagittées. Ovaire semi-infère, aminci insensiblement à son sommet en un style triangulaire assez long, terminé par un stigmate obtus et a 3 angles. Le fruit est une capsule en partie adhérente au calice, qui est persistant et la recouvre; elle est pyramidale, à 3 angles, terminée en pointe á son sommet, à 3 loges, et s'ouvre en 3 valves adhérentes par leur partie inférieure. Les graines sont très petiles, nombreuses, oblongues, arquées et striées. - Linné, en établissant ce g., y avait rapporté 4 esp.: A. farinosa, capensis, hyacinthoides et fragrans. La $1^{\text {re }}$ seule en fait réellement partie;

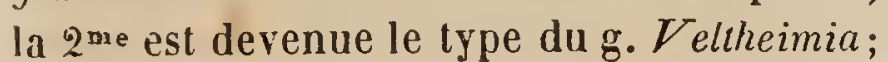
la $3^{\text {ne }}$ celui du g. S'anseviera; et enfin la derniẻre fait partie du g. Dracoena. A l'esp. primitive ( $A$. farinosa L.) on doit joindre l' $A$. aurea de Walter et de Michaux. Ces 2 esp.constitueri à elles seules le g. Elles sont originaires de l'Amérique septentrionale. Willdenow a substitué à tort le nom de Wurmbea à celui d'Aletris donné par Linné.

(A. R.)

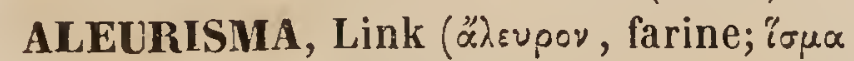
construction, par ext.amas; il faudrait écrire Aleurhisma). вот. Cr. - Petits Champignons qui ressemblent à des amas de farine. Ils ne diffèrent du g. Spcrotrichum, auquel on les rapporte maintenant, que par la finesse de leurs filaments et le grand nombre des pores qui les recouvrent. ( $V$.Nees d'Esenb., Syst. der Pilze, p. 25, ed. 1837.)

(LÉv.)

* ALEURITES (àisupítns, farineux ; plante couverte d'un duvet farineux). вот. Рн. Le g. de la famille des Euptorbiacées, ainsi nommé par Forster, a reçu aussi différents autres noms : celui de Camirium de Rumph, celui d'Ambinux de Commerson. Ses caract. sont : Fleurs monoïques, cal. 2-3-parti, à préfloraison valvaire; 5 pétales colorés, à préfloraison imbriquée; un disque à 5 lobes squamiformes. Dans les mâles, des filets nombreux, courts, soudés inférieurement en une seule masse corique, libres supéricurement, et terminés par des anthères adnées el introrses. Dans les femelles, un ovaile à 2 loges 1-ovulées, caclié dans une enveloppe distincte, tomenteuse, fendue supérieurement pour laisser passer 2 styles courts et bi-partis; fruit charnu, contenant à l'intéricur 2 noyaux percés d'une ouverture vers le haut de leur face interne, et finissant par se séparer chacun en 2 valves. On connaî̀ de ce g. 2 ou 3 esp. répandues dans les îles des mers tropicales, depuis Ceylan jusqu'à l'Océan Pacifique.Ce sont des arbresa feuilles alternes, entières ou lobées, longuement pétiolées et munies de 2 glandes à leur base. Les fleurs forment de grandes panicules composées, dans lesquelles les femelles, rares et portées sur des pédoncules épais, occupent le bas des panicules partielles; tandis que les mâles, très nombreuses, sont supérieures. Presque toutes les parties du végétal sont comme poudrées d'une farine dans láquelle la loupe fait reconnaître de très pelits poils en étoile. (AD. J.)

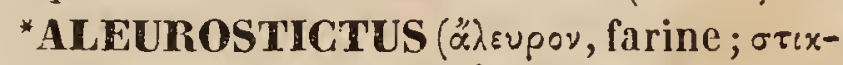

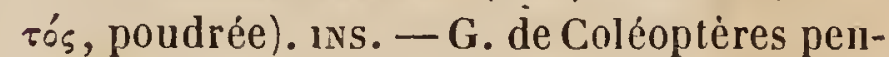
tamères, famille des Lamellicornes, tribu des Scarabéides mélitophiles, Latr., établi par Westwood (Syn. of the gen. of Brit.Ins.), et qui le caractérise ainsi : Corps glabre. Métasternum non avancé. Tibias antér. bidentés. Anus échancré. - Ce g., qui a pour type le Scaraboeus variabilis L., répond au g. Gnorimus de MM. Le Peletier et Serville, adopté par M. Dejean, dans son dernier Catalogue.

* ALEXIA (á $\alpha \lambda^{\prime} \xi \omega \omega$, je chasse, j'écarte). ins. - G. de Coléoptéres tétramères, famille des Agathidides de Westwood, et de celle des Anisotomides de Stéphens, établi par ce dernier auteuraux dépens du g. Tritoma, Fabr., et auquel il donne les caract. suivants: Corps très convexe. J)ernier art. des palpes épais, obtus. Massue des ant. de trois articles. Tète large, défléchie. Corselet court, sans rebords. Il a pour type le Tritoma pilifera de Germer.

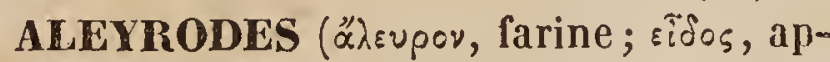
parence; allusion à la matière farineuse dont ces insectes sont couverts). ins. - G. de l'ordre des Hémiptères, section des Homoptères, appartenant à notre famille des Colriniens, aux Gallinsectes de Latreille, établi par ce dernier et adopté par tous les entomologistes modernes, confondu avec les Tinea par Linne, avec les Phalena par 
Geoffroy, et principalement caractérisé par : Des antennes filiformes, composées de six articles, des yeux échancrés, des ailes ovalaires, n'ayant qu'une seule nervure et les tarses formés de deux articles.

Les mâles et les femelles sont ailés; les larves sont très différentes des insectes parfaits, et les nymphes demeurent immobiles après s'être formé une couverture de leur peau de larve. - La seule esp. connue est l'Aleyrodes Chelidonii Latr., répandue dans toute l'Europe, où elle vit sur la GrandeEclaire (Chelidonium majus).

ALFONSIA (Alphonse d'Est, duc de Ferrare). вот. $\mathrm{PH.} \mathrm{-} \mathrm{G.} \mathrm{de} \mathrm{Palmiers,} \mathrm{établi} \mathrm{par}$ MM. Kunth et Humboldt dans les Nova Genera, 1, p. 307. Ce g. a été reconnu par M. Marlius comme identique avec l'Elä̈s de Jacquin et la seule esp. qu'il comprenait, l' $A l-$ fonsia oleifera Humb. et Kunth LC. ne paraît pas différer de l'Elaïs melanococca de Gartner. Il est connu sous le nom vulgaire de Corozo, et fournit une huile désignée dans les parties basses de la Colombie, oú il croît, sous le nom de Manteca del Corozo. $V$. ELAîs.

(AD. BR.)

ALELEDIA (nom d'homme). вот. PH. Nom donné par Cassini à un g. de Composées de la tribu des Cynarées. Ses caractères sont : Capitules homogames, multi et équaliflores ; involucre hémisphérique, composé d'écailles scarieuses, oblongues, appendiculées; les extérieures lacérées, spinescentes au somniet; les intérieures orbiculaires, concaves. Le réceptacle couvert de fibrilles libres. Corolles 5 -fides, presque régulières, à limbe du double plus long que le tube; filets des étamines libres, légèrement scabres; anthères terminées au sommet par un appendice long et aigu, à la base par des queues plumeuses. Les branches du style presque soudées et réunies au sommet. Les fruits obovés, comprimés, striés, couronné par une aigrette longue, bisériée, à soies extérieures plus courtes, barbellulées. L'Alfredia est une plante vivace, dressée, a feuilles blanches en dessous, épineuses sur les bords; les inférieures cordées, à pétiole légèrement ailé; les supérieures sessiles, semi-embrassantes. Capitules penchés, a corolles jaunâtres. Ia senle espèce connue est originaire de Sibérie.

*AL,GAROBRIA, DC. bot. pH.-M. De Can- dolle (Prodr. 11, p. 446) donne ce nom à une sect. du g. Prosopus, caractérisée par des anth. non glanduleuses.

ALGAZELLE (nom arabe de la Gazelle). мam. - Espéce du groupe des antilopes. $V$. ce mot.

(I.-G. S.-H.)

ALGÉRIENNE. MoLL. - On donne vulgairement ce nom à une grande esp. de Moule édule que l'on trouve particulièrement sur les côtes d'Alger, et qui probablement est une variété du Mytilus gallo-provincialis.

(DESII.)

ALGIRE. REPT. - Nom donné à tort par Cuvier à un g. de Lacertiens, dêjả établi sous celui de Tropidosaure. $V$. ce mot.

(G. B.)

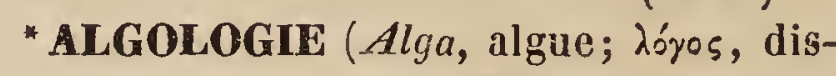
cours). вот. Cr. - Mot hybride qui ne doit pas plus être conservé que celui d'Algologue. $V$. Pircologie. (C. M.)

ALGUE, Algues. вот. скурт. - Les anciens n'étaient pas bien d'accord sur le sens à attacher au mot Alga. Ils comprenaient en effet sous ce nom, non seulement la plupart des végétaux qui croissent dans la mer, mais encore quelques Lichens, entre autres l'Orseille (Rocella), qu'ils nommaient $A$ lgn tinctoria; mais Pline, qui a introduit ce nom dans l'histoire naturelle, désignait les Ulves par le nom de ßpúov. Les modernes ne s'entendent guère mieux sur la signification précise de ce mot. Tournefort plaçait des Phanérogames et des Polypiers parmises Algues, qui forment une section de sa $17^{\mathrm{me}}$ classe. Linné vint ensuite, qui réunit sous le nom d'Algæe une foule d'êtres hétérogènes, tels que les Hépatiques, les Lichens, les Phycées, le Chara; les Trémelles el les Byssus.

Dans son immortel Genera, Jussieu a bien séparé de ce farrago, les Hépatiques, dont il a fait une famille, et le Chara; mais il a conservé parmi les Lichens, les Hypoxylées d'une part, et de l'autre les byssus, auxquels il assimile les Conferves, sans doute à cause de leur texture filamenteuse, rapprochement, au reste, pardonnable à cette époque, où l'on connaissait mal les uns et les autres. Depuis la science a fait d'immenses progrès. Quoique négligées dans beaucoup de pays, dédaignées même dans quelques uns, et regardées comme indignes d'occuper un instant l'esprit d'un homme raisonnable, les 
Cludes cryptogamiques n'ont heureusement pas élé partout frappées de la même rẻprobation. A l'exemple de Fries, nous considérons maintellant les Algues comme une sous-classe, qui se subdivise en 3 familles que nous examinerons en leur lieu. Ce sont les Plıycées ou Algues submergées, les Lichens ou Algues émergées, et les Byssacées ou Algues amphibies (qu'il ne faut pas confondre avec les Byssinées de la famille des Champignons), qui tiennent le milieu entre les $1^{\text {res, }}$, dont elles ont le thalle, ctles $2^{\text {es }}$, dont elles ont la fructification.

Les Algues sont donc pour nous des plantes agames, vivant dans l'air, au fond des eaux douces ou salćes ou à leur surface, le plus souvent vivaces, remarquables par une texture cellulaire ou filamenteuse dans laquelle il n'entre jamais de vaisseaux; en général libres, vivant isolément ou en société, nues ou enveloppécs dans une sorte de substance gélatiniforme; à végétation continue ou interrompue par intervalles, puisant dans l'humidité ou le liquide ambiant les matériaux propres à leur accroissement, et dans l'air et la lumière les principes de leur coloration, susceptibles enfin de se reproduire, soit par des gemmes prolifiques développées à leur surface (gonidia), soit par des sporules ou des séminules résultant, autant du moins que nous en pourons juger, du seul acte de la nutrition (germes non fécondés), soit enfin par des sporidies que contient un nucleus renfermé lui-même dans des réceptacles ou apothécies diversement conformés.

Cet ordre, tel que nous venons de le définir, est, indépendamment de l'habitus, fort distinct decelui des Fonginées qui comprend les vrais Champignons et les Hypoxylées. Le caractère essentiel el tranché sur lequel est fondée la distinction, consiste dans la présence d'organes gemmacés que Wallroth a nommés Gonidia ( $V$. ce mot) et qu'on ne rencontre dans aucun Champignon. Il y a encore d'autres différences qui dérivent de celle-là, comme de n'offrir jamais même un simulacre de vraies racines, de tiges ni de feuilles, etc., qu'il serait hors de propos d'exposer ici.

(C. M.)

AlGUES SUBDEFIRG Avec Correa de Serra et plusieurs botanistes modernes, nous comprenons sous ce nom T. I. toutes les plantes agames vivant dans l'eau douce ou salée, et nous lui donnons pour synonyme le mot Plycées, auquel nous renvoyons pour de plus amples détails. (C. M.)

*ALHAGI, Tourn. Manna, Desv. (Nom arabe de ces plantes). во'т. PI._-G. de la famille des Légumineuses, sous-ordre des Papilionacées, tribu des Hédysarées, D.C., s.-tribu des Alhagées, D.C. Ses caract. différentiels sont les suivants : Cal. a 5 dents courtes, presque égales. Pétales subisomètres; ćtendard obovale; carène obtuse. Étam. diadelphes. Ovaire pluri-ovulé; légume stipité, coriace, oligosperme, à plusieurs étranglements inarticulés. Herbes suffrutescentes ou sous-arbrisseaux; feuilles simples; stipules minimes; pédoncules axillaires, spinescents ; fleurs rouges, disposées en grappe. On ne connaît que 3 esp. de ce g.; elles croissent dans les déserts de l'Égypte et de l'Orient. L'Alhagi Maurorum, Tourn. (Hedysarum Alhagi L.) produit une substance gommeuse et sucrée qui suinte de l'écorce sous forme de petits grains jaunâtres, et qui, à ce qu'il paraît, estla manne dont se nourrissaient les Hébreux, pendant leur séjour dans les déserts de l'Arabie-Pétrée. (Sp.)

* ARIBERTIE, Alibertia. вот. PH.-Nous avons établi ce 'g. qui rappelle la mémoire du professeur Alibert, pour unc plante de la famille des Rubiacées, connuc à la Guyane française sous le nom de goyave noire. Ce g. qui a beaucoup de rapports avec les $\mathrm{Ge-}$ nipa, en diffère surtout par des fleurs unisexuées par avortement; par ses 5 stigmates et par son fruit à 5 loges. Il ne comprend qu'une esp. A. utilis A. Rich. (mém. Rub.p. $154, t$. II , f. 1), arbrisseau originaire de la Guyane, portant des feuilles opposées, oblongues, acuminćes, et des fleurs terminales solitaires ou réunies en petit nombre et presque sessiles. (A. R.)

* ALIBUM (anagramme de Liabum). вот. PII. - Ce g. diffère du Liabum par les fleurs du disque, dont l'aigrelle est bisériée, à rangées cxtéricures en forme de couronne dentée, l'intéricur garni de nombreuses denticules sélacées, tandis que les fleurs du rayon sont pourvues d'une aigrette 1 -sérice et dentée. L'Alibum est une herbe à rameaux trichotomes cylindriques, velus, garnis de feuilles opposées, presque connées el auriculées entipres ou pinnatifides, convertes en 
dessous d'un duvet blane tomenteux; les capitules sont solitaires et réféchis. La scule espéce connue appartient à l'Amérique Australe.

*ALECTERE. Alicteres, Neck. , Schott et Endl. (Le nom fait allusion à l'aflinité de ce g. avec les Hélictères). вот. Pн. - Gr. de la farnille des Sterculiacées, tribu des Hélictérées. - Endl. Schott et Endlicher (Melethem. bot.) lui assignent les caract. suivants : Cal. oblong-campanulé, renflé, irrégulièrement 5 -denté; pétales au nombre de 5 , liguliformes, à onglet nu ou appendiculé; androphore tubuleux; filets anthériféres très nombreux; filets stériles soudés en forme de cupule semi-5-fide, engaînant la base de l'ovaire. Ovaire longuement stipité. Styles 5 , allongés, soudés. Péricarpe de 5 follicules rectilignes, polyspermes, d'abord soudés, finalement disjoints. Ce g., propre à l'Amérique équatoriale, est fondé sur l'Helicteres carthaginensis $\mathbf{L}$. et quelques autres espèces.

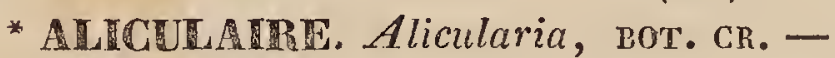
Cenre de la famille des Hépaliques, tribu des Jongermanniées, établi par M. Corda, (Sturm. Flor. germ. II. XIX et XX p. 32) et admis par M. Nees d'Esenbeck, qui le caractérise ainsi dans ses Europä̈scher Lebermoose, III. p. 448: Périanthe terminal inclus dans un involucre urcéolé, auquel il est adhérent par la basc. Orifice du périanthe régruliérement denticulé.Calyptre incluse membraneuse. Capsulc divisée jusqu'à la base en 4 valves. Élatères nues, dispires. Anthère comme dans le g.Jongcrmanne. Feuilles décombantes. Amphigastres simples, étalés, entiers. Tiges ascendantes, flexucuses, garnies de radicules et se ramifiant par innovations. Une seule esp. européenne, le Jungermannia scalaris Schrad. compose ce genre.

$$
\text { (C. M.) }
$$

* ALIME. Alima (̌́neuos, marin; il eùt èté mieux d'écrire : halima). CRUST. - G. de l'ordre des Stomapodes, famille des Unicuirassés, établi par Leach avec ces caract.: Carapace étroite; rostre droit, filiforme, avec les angles antér. et postér. constituant chacun 2 épines; anneaux ophthalmiques et antennulaires se voyant à découvert sous le ventre. Yeux dirigés en dehors, porlés sur des pédencules longs, cylindriques. Bouche située très loin du fron:, vers le tiers postér. de la face infér. de la carapace. Abd. étroí, allongé. Fausses pattes grandes, généralement dépourvues de branchies. - Ce g. renferme 3 esp., habitant les mers d'Afrique, des Indes et de la NouvelleHollande.

(H. L.)

ALIMENTS. Alimenta (alere, nourrir). PHYSIOL. - Les Aliments sont les substances qui, introduites dans l'appareil digestif, servent à l'entretien de la vie. Nous les considérerons sous le rapport : $1^{\circ}$ des éléments qui les constituent; $2^{\circ}$ des combinaisons les plus simples qui les composent, et que nous appellerons principes alimentaires; $3^{\circ}$ des principes comparés entre eux pour former les aliments que la nature nous présente, et que nous désignerons par le nom d'Aliments composés.

I. Élíments constitutifs. Considérés en général, les Aliments se résolvent dans les corps simples suivants: l'Oxygène, l'Hydrogène, le Carbone, l'Azote, le Phosphore, le Chlore, le Soufre, le Potassium, le Sodium, le Calcium, le Magnesium, I'Aluminium, le Silicium, le Fer, le Manganèse.

Aucun de ces dircrs principes, à l'état simple et élémentaire, ne sert à l'alimentation. Ils font partie des Aliments á l'état de combinaisons binaires; ternaires, quaternaires. Les combinaisons binaires sont bornées presque exclusivement à l'union avec loxygène, formant ainsi des oxydes et des acides. Il en résulte de l'eau, de la potasse, de la soude, de la chaux, de la magnésie, de l'alumine, de la silice, des oxydes de fer, de manganèse; les acides carbonique, phosphorique et sulfurique, etc.

Les combinaisons de ces corps binaires entre eux donnent naissance à des sels de composition ternaire et quaternaire, qui se trouvent également dans le règne minéral et dans le monde inorganique; mais en proportion incomparablement plus grande dans le premier que dans le second. Nous appelons cette classe les principes minéraux.

II. I.es autres éléments se réunissent pour former une seconde classe. Ils se distinguent des précédents, en ce qu'ils se trouvent dans les aliments en proportion incomparabicment plus grande, et qu'ils en forment ainsi la base; ils y présentent des combinaisons n'existant que dans le monde inorganique, qu'ils caractérisent sous le rapport 
de la composition démentaire ; éest pourquoi nous nommeroñs ces combinaisons principes organiques. Ces éléments sont le Carbone, l'Oxygène, l'Hydrogène et l'Azote. Parce qu'ils constituent des principes élémentaires organiques, il faut qu'ils forment des combinaisons ternaires ou quaternaires.

Les ternaires sont formées de Carbone, d'Oxygène et d'Hlydrogéne; les quaternaires, des mèmes éléments unis à l'Azote; airsi, les unes ne sont pas azotées, les autres le sont.

III. LeS PRINCIPES ORGANIQUES TERNAIRES forment plusicurs groupes que nous pouvons désigner de la façon suivante : $1^{\circ}$ les acides; $2^{\circ}$ les principes hydroyćnés; $3^{\circ}$ les substances neutres.

$1^{\circ}$ Les acides organiques sont: $1^{\circ}$ l'Oxalique; $2 \circ \mathrm{l}^{\prime} A$ cétiquc; $3^{\circ}$ le Citrique; 40 le Tartarique; $5^{\circ}$ le Malique; $6^{\circ}$ le Gallique; $7^{\circ}$ le Tanniquc; $8^{\circ}$ le Lactique; 9o le Butirique.

2. Les principes hydrogénés sont: $1^{\circ} \mathrm{l}^{\prime} \mathrm{Al}$ cool; $2^{\circ}$ les Huiles essentielles; $3^{\circ}$ les Résines; $4^{\circ}$ les Corps gras. Ils forment, par leur composition, un groupe qui se distingue du 1er, dans lequel les éléments qui prédominent sont l'Oxygène et le Carbone. Dans celui-ci, les éléments prépondérants sont l'Hydrogène et le Carbone.

$3^{\circ}$ Les principes neutres sont: le Sucre, la Gomme, la Fécule, le Ligneux, qu'on peut représenter exactement comme des combinaisons de Carbone et d'Eau.

IV. Principes Quaternaires. Les principes azotés se trouvant en abondance dans le règne animal, et en proportion bien inférieure dans le régne végétal, nous commencerons par les premiers.

I. Ceux du règne animal sont: $1^{\circ}$ la $\mathrm{Ma}$ tière colorante du sang; $2^{\circ}$ la Gélatine; $3^{\circ}$ le Caseum; 40 l'Albumen; $5^{\circ}$ la Fibrine.

11. Les principes azotés du règne végélal sont: 10 la Fungine; $2^{\circ}$ le Caseum végétal;

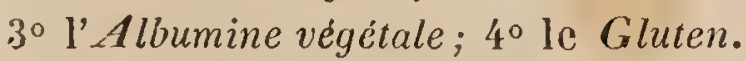

Les Aliments composés tirés du règne végétal consistent daus les différentes parties des plantes; car il n'est pas une de ces parties qui ne puisse en fournir á l'homme ou aux animaux; mais toutes ces parties ne sont pas également nutritives ; c'est pourquoi nous les diviserons en groupes, suivant les degrés de cette propriété; ainsi nous les rangerons en deux grandes classes, dont l'une conliendra :

$1^{\circ}$ Les parties hcrbacées, ou les feuilles et les tiges;

$2^{\circ}$ L'autre, les racines et les fruits.

V. Les parties hrrbacécs des plantes ont pour caractère d'être fort aqueuses, et de contenir une matière solide moins nutritive; car d'abord, il n'y a pas, en général, de fécule, qui est un des principes alimentaires les plus nutritifs; en second lieu, il y a presque toujours moins de sucre et de gomme. Il en résulte que les aliments de ce groupe sont moins nutritifs. Aussi l'homme n'est-il pas herbivore, dans le sens qu'il puisse faire des herbes sa nourriture unique. Pour qu'il en fût capable, il lui faudrait une organisation fort différente ( $V$. Hertivores).

$1^{\circ}$ Les parties herbacées des Phanérogames ont, indépendamment des formes, un caractère manifeste qui les distingue, au premier coup d'ail, des parties correspondantes $d u$ groupe des Cryptogames : c'est la couleur verte. Elle est due à un principe qu'on a désigné par le nom de matière vcrte, de Chlorophylle, etc. Elle a sans doute des qualités salutaires; car une longue expérience a fuit connaitre aux marins combien la privation des légumes frais dispose au scorbut, et combien leur usage est puissant pour les guérir de cette cruelle maladie.

Il y a une distinction à établir sous le rapport des vertus nutrilives des différentes parties herbacées. Les herbes et les feuilles sont bien moins nourrissantes que les tiges herbacées consistantes dans leurs parties décolorées : tels sont les épinards ct la chicorée comparés aux cardons et aux aspcrges, etc.

$2^{\circ}$ Les partics herbacées des Cryptoganes. Ici tout est herbacé, puisqu'ici il n'y a sensiblement ni racine ni fruit, et que ces végétaux alimentaires sont d'une consistance molle. Ici encore disparail la matière verte. Tout est, pour ainsi dire, tige ou feuille décolorée.

Ce sont: les Lichens, expansions foliacées, très répaudues et trés abondantes dans les pays où la nature prodnit á peine d'autres végétaux. Le Lichen d'Islande, qui sert à la nourriture de l'homme, dans les régions inhospitalières du pôle arctique, est 
naturellement très amer. Lorsqu'une partie de son amertunie est enlevée par un séjour prolongé dans l'eau et qu'il est réduit en farine, on en fait une bouillie avec le lait de Renne. Sans ce Lichen, ni le Lapon ni le renne n'existeraient.

Les Champignons, qu'on peut regarder comme des tiges, ont plus de consistance que les expansions foliacées. Ils la doivent à une substance qui a des rapports avec le ligneux, la fungine. Cependant c'est à cause de ce principe que les Champignons alimentaires ne sont pas d'une très facile digestion.

VI. Les Racines et Fruits. - Nous n'employons pas le mot racine dans le sens striclement botanique, mais dans une acception plus large, tel qu'il est usité dans le monde. Ainsi, nous désignons par là les racines proprement dites, et en même temps les bulbes et les tubercules.

Comme les racines et les fruits ont des principes communs, nous devons les réunir dans une seule classe, qu'on sous-divisera selon les qualités les plus saillantes. Ils forment plusieurs groupes, suivant que les uns ou les autres sont: $1^{\circ}$ piquants; $2^{\circ}$ acidules; $3^{\circ}$ huileux; $4^{\circ}$ doux (sans être farineux); $5^{\circ}$ farineux, quel que soit d'ailleurs le goủt accessoire.

10 Les racines piquantes doivent leur goût à la présence d'une huile essentielle, qui se trouve surtout dans les racines ou les bulbes des Crucifères et des Liliacées. Elles servent, à juste titre, de hors-d'œuvre ou d'assaisonnement; car l'huile essentielle âcre les rend trop excitants.

$2^{\circ}$ Les fruits acidulés réunissent trois principes qui les caractérisent : l'acide, le sucre et la gelée végétale. Sans le sucre, á cause de l'acide, ces fruits ne seraient pas alimentaires. On peut les distinguer en : $1^{\circ}$ fruits gélatineux, tels que les groseilles, les mûres, etc.; $2^{\circ}$ en fruits charnus, $\dot{a}$ consistance molle, tels que les cerises, pêches, etc.; et $3^{\circ}$ en fruits a chair ferme, tels que les pomines, les poires, les ananas, etc.

$3^{\circ}$ Fruits huileux. Ils se divisent naturellement en deux groupes, suivant que la partie comestible est fournie par l'enveloppe, comme les olives, ou par les graines, qui toutes soni des noix. Ils contiennent une huile douce, fort agréable, en proportion telle, qu'elle peut souvent en être tirée yar expression et fournir aux besoins du commèrce. Dans les climats fortunés voisins de l'équateur, il est de ces fruits qui, par leur grosseur, leur qualité et leur abondance, offrent à l'homme une nourriture qui suffit, en grande partie, à sa subsistance. Le fruit du Cocotier est celle des peuples dans l'enfance de la société, le lait des nations encore au berceau.

$4^{\circ}$ Racines et fruils doux (non farineux). $1^{\circ}$ Presque toutes les racines de cet ordre sont naturelles à nos climats tempérés; mais, dáns l'état de perfection oủ elles nous servent d'aliment, ce sont des produits de l'art. $2^{\circ}$ Les fruils doux sont tous d'origine étrangère, natifs de climats chauds et proviennent des Figuiers, des.Courges, des Dattiers, etc. La datte est le fruit des déserts brûlants; le dattier ombrage le puits soli taire, et ofire, dans ses fruits, au voyageur exténué, une nourriture suave et substantielle qui le ranime, lui, ses compagnons, ses esclaves, ses chevaux, ses chameaux; et soutient leurs forces, pendant qu'ils continuent á parcourir ces plaines arides.

$5^{\circ}$ Les $r$ acines et les fruits farineux. Les $r a-$ cines farineuses sont: l'igname, le manioc, la pomme de terre, etc., toutes natives des pays chauds. Les racines farineuses sont beaucoup plus productives que les graines de même ordre; mais la supériorité du produit est en masse et non en qualités nutritives.

Les fruits farineux proviennent d'arbres, ou sont les graines de plantes herbacées. Les premiers, comme les racines, sont plus aqueux, et par conséquent moins substantiels et nutritifs; ce sont : la banane, l'arbre à pain, le baquois (fruit du Pandanus odoratissima), la châtaigne, le gland doux, etc.

Les graines farineuses sont presque exclusivement tirées des Légumineuses et des Céréales. Les graines des Légumineuses diffèrent beaucoup de celles des Céréales, en ce qu'elles ont toutes une saveur prononcée; ce qui les rend moins nutritives que les $C \dot{E}-$ réales, qui sont très peu sapides. Les seules espèces susceptibles d'une bonne panification sont le S'eigle et le Froment, surtout ce dernier, qui est l'aliment par excellence de l'homme, mais qui, seul, ne sufirait pas toujours.

VII. Les A liments composés tirés du règne animal sont: 
1. Les chairs des animaux. Elles presentent plus de variétés et moins de différences essentielles que les aliments tirés du règne végétal. Les variétés y sont presque infinies, parce que les espèces qui peuvent servir a notre nourriture y sont, pour ainsi dire, innombrables; ainsi, à quelques exceptions près, les Mammifères, soit herbivores, soit carnivores, les Oiseaux de tout plumage, les Poissons de tous genres, les Crustacés, les Mollusques, et même quelques Zoophytes, peuvent assouvir notre faim et sustenter notre corps. La plus grande différence dans les chairs consiste principalement dans l'arôme. Nous donnons la préférence aux animaux domestiques; d'abord, parce que nous les avons sous la main; en second lieu, parce qu'ils sont réellement plus sains par leur arôme qui est d'une force moyenne, et par la tendreté moyenne de leur chair.

$2^{\circ}$ Le sang est inférieur aux chairs; d'abord, par la grande proportion d'eau qui s'y trouve; ensuite, parce qu'il y manque deux principes : en premier lieu, la graisse, qui y est presque en quantité insensible; en second lieu, la gélatine.

$3^{\circ}$ Le lait est également inferieur à la chair; d'abord, par la grande proportion d'eau, puis parce qu'il n'a qu'une seule substance azotée; aussi est-ce la nourriture des enfants et des petits des Mammifères, ainsi que des adultes dont les fonctions digestives sont très afraiblies.

L'homme peut se nourrir exclusivement des aliments composés tirés soit du règne végétal, soit du rẻgne animal; mais il est bien plus rare qu'il se nourrisse exclusivement des dernières. En général, un aliment en particulier est insuffisant pour sustenter l'homme; c'est l'ensemble des éléments formant son régime qui est capable de Je nourrir. $V$. Nutritiox.

(EDwards.)

ALISE. вот. Pll. - On nomme ainsi le fruit de l'Alisier (C'ratcegus), que l'on mange dans quelques parties de la France. (C. L.)

ALISÉs (Vents). Météorol. - Dans les mers ouvertes, et au large des côles, il existe des vents qui soufllent perpétuellement suivant la même direction, et que l'on nomme vents dlisés, d'un vieux mot français qui exprime l'uniformité et la constance. Ces courants d'air s'étendent des åeux côtés de l'équateur et jusqu'au trentième degré de latitude environ; à ce dernier point, leur direction est inclinée sur l'équateur, comme celle des moussons; mais, a mesure qu'on se rapproche de la ligne équatoriale, leur direction devient de plus en plus E. ou bien O. En général, la tendance des vents alisés est de l'E. à l'O., c'est-à-dire dans le même sens que le mouvement diurne du soleil. Malgré l'origine du mot alisé, il ne faudrait pas croire que ces vents soient réellement constants en force et en direction; car leur vitesse est plus ou moins accélérée, et leur marche a quelquefois lieu en sens contraire de la direction principale. Ainsi, dans l'Océan A tlantique, le vent souffle habituellement de la mer vers le continent; il est, par conséquent, $\mathbf{O}$. pour l'Europe et le Sénégal, S. O. pour le golfe de Guinée, et N.-E. pour le golfe du Mexique. Dans l'Océan Indien, compris entre l'Afrique, l'Asie, la Nouvelle-Hollande, nous trouvons un vent alisé qui ordinairement souffle du S.-E. Dans le Grand Océan, situé entre l'Asie el l'Amérique, on observe des vents dirigés du N.-E. vers les côtes orientales de l'Asie, et du S.-E. vers les côtes orientales de la NouvelleHollande. Ces vents, à leur point de rencontre sous l'équateur, prennent la direction de l'E. à l'O. Ils s'affaiblissent lorsqu'on laisse l'Asie, pour aller ver's l'Amérique; á une certaine distance de ce dernier continent on éprouve des calmes. Près des côtes occidentales du NouveauMonde, les vents sont dirigés d'une manière plus ou moins oblique vers l'intérieur des terres. Cette obliquité résulte probablement du voisinage de la Cordillière des Andes. Au reste, le vent est fréquemment parallèle à cette immense barrière que la nature oppose aux vents d'O., en les forçant à se replier, soit vers le N., soit vers le S. Enfin, dans la zône tempérée septentrionale, les vents soufflent habituellement de l'O., c'està-dire en sens contraire des vents alisés du Grand Océan. Ils deviennent N.-E. et S.-O. près de la zône glaciale; mais ils ofrrent beaucoup d'irrégularités.

Si notre globe était entièrement recouvert d'eau, le soleil, agissant sur un corps parfaitement homogène, produirait partoul, cutro les tropiques, des vents alisés; mais 
l'Océan est in errompu par de grandes masses de terre qui, susceptibles, par leur nature, de s'échauffer plus que l'eau, et par leurs formes montagneuses d'interrompre les courants d'air et de les transformer, modifient singulièrement la direction principale de ces derniers, le long des côtes et sur la terre ferme. Tout ce que nous avons dit ne se rapporte donc qu'aux résultats de l'action du soleil sur l'Océan, à une assez grande distance des côtes. C'est ainsi que, sur la côte d'Afrique, le vent souffle toujours vers la terre, à cause de la raréfaction considérable qu'y subit l'air atmosphérique de ce continent, tandis qu'au contraire dans le Grand Océan, qui offre la plus immense nappe d'eau du globe, les vents alisés sont réguliers, et présentent les effets dont nous avons parlé plus haut.

Les vents alisés sont trés favorables ả la navigation, lorsqu'il s'agit d'aller de l'E. à l'O.; mais les navires qui doivent se rendre de l'O. à l'E. sont obligés de sortir de la zòne où régnent ces vents.

La plus ancienne explication de la tendance générale qu'ont les vents alisés à se porter de l'E. à l'O. est la suivante : l'air froid des régions polaires va remplacer á l'équateur l'air chaud, qui s'élève et se déverse de droite et de gauche, vers les pôles de la terre. L'air froid arrive donc en des lieux oú la vitesse de rotation du globe est de plus en plus grande; et alors, il paraît marcher en sens contraire, e'est-à-dire d'Orient en Occident, la terre le heurtant par l'efret de son mouvement d'Occident en Orient.

Ce raisonnement, s’il était juste, s'appliquerait à merveille, dit M. Saigey, ả l'air de nos régions tempérées, oú la chaleur et le mouvement de rotation croissent beaucoup plus rapidement que vers l'équateur; en sorte que nous devrions éprouver un ouragan perpétuel, dirigé de l'E. á l'O. ; mais au contraire le vent dominant, marche de l'O. à l'E.

Pour résoudre cette difficulté, on a prétendu que l'air qui, dans la zône torride, s'éléve et se déverse vers les pôles, produit, dans les hautes régions de l'atmosphère, un vent contraire à celui qui règne dans les couches inférieures; et que ce vent s'abaissant de proche en proche, finit par atteindre la surface de la terre, a peu près vers le quarantième degré de latitude. Mais á égalité de chaleur du sol, le décroissement de température des couches d'air à l'équateur est six fois trop lent pour que les couches inférieures puissent monter vers le ciel; d'ailleurs si ces couches montaient, elles se refroidiraient par leur expansion, et il n'y aurait pas de motif pour qu'elles se déversassent sur des couches demeurées plus chaudes. On donnait donc une très fausse idée de ces mouvements, lorsqu'on les assimilait à ceux de l'air dans une cheminée. Enfin, les molécules placées à l'équateur tournent plus vite que celles de nos régions, mais elles ne peurent échanger leur place, sans échanger en même temps leur vitesse. Les vents ne varieraient ni en direction ni en intensité, si, toutes les autres circonstances demeurant invariables, la terre ne tournait pas sur son axe, ou bien changeait la rapidité et le sens de son mouvement diurne.

L'astronome Halley avait déjà rejeté l'explication précédente des vents alisés. II croyait que le soleil, échauffantl'atmosphère d'Orient en Occident, produisait un vent dans cette direction; mais il oubliait que les actions qui se passent entre les molécules d'air sont nécessairement réciproques, en sorte qu'une molécule qui en repousse une autre vers l'o., doit être repoussée par celleci vers l'E. avec une égale force.

L'explication ordinaire des vents alisés, des moussons et des brises, repose sur ce fait général, que l'air froid coule par le bas vers l'air chaud, et que celui-ci se déverse par le haut sur le premier. A l'appui de cette théorie, on cite l'exemple suivant: deux chambres contigıës étant inégalement échauffées, si l'on vient à ouvrir une porte de communication, il s'y établit aussitôt deux courants d'air, l'un, inférieur, qui va de la chambre froide à la chambre chaude, l'autre, supérieur, qui marche en sens contraire, et tous deux pouvant être rendus sensibles par les directions que prennent les flammes de deux bougies placées dans ces courants.

Il résulterait de lả que, dans tous les lieux peu ćlevés au-dessus du niveau des mers, on ne devrait ressentir que des vents froids se dirigeant des pôles vers l'équateur, et, sur les hautes montagnes ou dans les cou- 
ches supérieures de l'atmosphère, des vents chauds marchant en sens contraire. Or, dans tous les pays, on éprouve indistinctement des vents chauds et des vents froids, non seulement d'une saison à l'autre, mais encore à des époques très rapprochées; et ces vents peuvent être excessivement chauds, aussi bien qu'excessivement froids.

Les vents alisés ont assurément pour cause principale, les températures si variées de la surface du globe; mais jusqu'á présent, on n'a pu faire un pas dans le développement de cetle théorie, sans heurter quelques lois de la mécanique.

ALISIER ou Alizier. Cratxgus, L. Spach. вот. PII. - G. de la famille des Pomacées, offrant les caract. suivants (Spach, Monogre. Pom. Suiles à Buff. Plant. Phan. 2. p. 9s.): Cal. urcéolé, semi-infère, 5-denté ; dents marcescentes; pétales 5 , cuculliformes, barbus au-dessus de l'onglet. Étam. divergentes ou conniventes. Ovaire 2--loculaire; styles 2, laineux et cohérents inférieurement, divergents ou arqués en dehors; stigm. petits, tronqués. Péricarpe ombiliqué aux 2 bouts, 2-loculaire ; loges 1 ou 2-spermes; endocarpe membraneux. Feuilles penninervées, simples, églanduleuses, souvent incisées ou pennatifides. Stipules sétacées, très petites. Pamules florifères, allongés. Fleurs odorantes, blanches ou rarement rosées, disposées en cimes corymbifơrmes; anthères jaunes; mésocarpe farineux. Ce g. est propre au nord de l'ancien continent; dans les limiles que nous lui avons assignées, il renferme 8 ou 9 esp. qui se cuilivent comme arbres d'ornement; leurs fruits sont mangeables, mais insipides.

(Sp.)

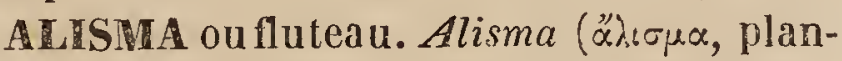
tain d'eau ). вот. PIr. - Ce g., type de la famille des Alismacées, se compose d'environ 8 espèces. Ce sont des plantes herbacées, vivaces, qui croissent dans les lieux marécageux, sur le bord des étangs et des rivières. Leurs fleurs forment ordinairement une esp. de grappe ou de panicule terminale, au sommet d'une hampe nue. Chacune d'elles présente un calice de 6 sépales; 3 extér. verts et de nature foliacée, et 3 intér. minces, roses et tout-à-fait semblables à des pétales. Lcs étam. sont au nombre de 6 ; les ovaires trés nombreux, réunis en une sorte de tête, au centre de la fleur, deviennent autant d'akénes indéhiscents. On a retiré de ce $\mathrm{g}$. les esp. peu nombreuses qui contiennent 12 étam. et plus, pour en former un g. que le prof. L. C. Richard a désigné sous le nom d'Echinodorus ( $V$. ce mot). Presque toutes les esp. de ce g. sont européennes. L'A. plantago L., vulgairement plantain d'ea l'esp. la plus commune et la plus généralement répandue. C'est une grande et belle plante, a feuilles ovales, aiguës, marquées de 3 à 9 nervures parallèles, portées sur de longs pétioles; sesfleurs assez petites forment une sorte de panicule allongée. La racine de cette plante a élé considérée dans quelques pays et particulièrement en Russie, comme un remède efficace contre l'hydrophobie. $3 \mathrm{esp}$. sont exotiques, 2 sont originaires d'Amérique, l'A.parviflorum Pursh, et l'A. tenellum Martius; 1 du Népaul, l'A. reniforme, Don.; l'A. damasonium L., forme un g. à part. V. Damasonium.

(A. R.)

ALIPEDS (ala, aile; pes, pedis, pied). maM. - Nom des Cinemoptères ( $V$. ce mot) dans la Zoologie analytique de M. Duméril.

$$
\text { (C. D’O.) }
$$

ALISTACEES. Alismacec. в0т. PH. Famille naturellè de Plantes monocotylédones, à élam. périgyniques, établie par L. C. Richard, pour les g. Alisma, Damasonium et Sagittaria, placés primitivement par A. L. de Jussieu dans la famille polymorphe des Joncs. Voici les caract. qui la distinguent : Cal. de 6 sépales, a peine unis par leur base, et dont 3 intér. minces, colorés et pétaloïdes, et 3 extér. verts. Étam. 6 ou davantage, insérées tout-á-fait à la base des sépales. Pistils en nombre très variable, distincts et quelquefois réunis en tête au centre de la fleur. Ovaire à une seule loge, contenant 1 ou 2 ovules dressés, attachés à une suture interne ou pariétale. Les fruits sont autant de carpelles distincts, uniloculaires, indéhiscents, dont la graine, dépourvue d'endosperme, contient un embryon ordinairement recourbé en forme de fer-à-cheval. - Les Alismacées sont des plantes herbacées, dépourvues de tige, c.-á-d. n'ayant que des hampes floriféres et rameuses. Elles croissent ordinairement sur le bord des eaux, ct appartiennent généralement à l'Europe; quelques unes néanmoins ne croissent que sous les Tropiques. 
Par leur port et l'aspect général de leurs fleurs, les Alismacées ont beaucoup de ressemblance avec les Renonculacées, qui appartiennent à la grande division des Dicotylédons polypétales, à insertion hypogyne. Les Alismacées se trouvent rapprochées des Butomées par leur structure. Elles en diffèrent par leur calice, dont 3 sépales seulement sont pétaloïdes, etsurtout par leur ovaire ne contenant qu'un ou deux ovules, tandis que, dans les Butomées, il en contient un grand nombre attachés ả la face interne de l'ovaire.

Rob. Brown (Prodr. Fl. Nov.-Holl.) placait dans la famille des Alismacées le g. Triglochin, qui fait partie des Juncaginées, et le g. Potamogeton, type des Naïadées. $V$. ces différents mots.

Les g. suivants constituent la famille des Alismacées : Alisma, L.; Sagillaria, L.; Damasonium, Juss.; Echinodorus, Rich.; Hydromystria, Meyer.

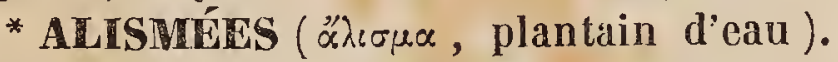
Boт. PII.-Ce nom a été donné par Bartling à une tribu de la famille des Alismacées, ayant pour type le g. Alisma. (C. D’O.)

ACISMOTDES. Aliswoidec. вот. PH.Ventenat (Tabl.du Règne Végét., 1i, p. 157), éclairé par les observations de Gærtner, avait séparé de la famille des Jones de Jussieu les g. dépourvus d'endosperme, pour en former une famille qu'il nommait Alismoïdes; mais ces g., mieux étudiés par L. C. Richard, ont constitué 3 familles distinctes : les Alismacées, les Butomées et les Juncaginées. $V$. ces mots.

(A. R.)

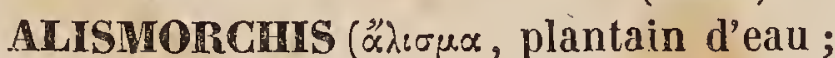

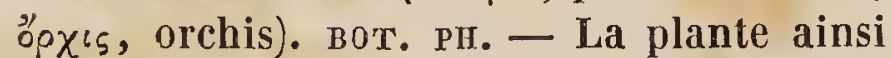
nommée par Du Petit-Thouars forme le type de notre g. Centrosia, dans la famille des Orchidées. $V$. Centrosie.

(A. R.)

*ALEX. вот. PH.-Commerson avait appliqué ce nom à des arbrisseaux de la famille des Composées, originaires des îles de l'Afrique australe et réunis aujourd'hui au g.Psiadia. P. ce mot.

ALEALI. CHIM. - I'. ALCALI. (C. D'O.)

* A I ANNA. - G. de la famille des Boraginacées, proposé par Tauscher (Flor., 1924), et réuni comme synon. à la div. ( $a$. baphorhiza, Link) du g. Anchusa. (V. Endl. Gen. Pl.).

(C. L.)

ALOCL (mot arabe qui signifie subtil). CIIM. $V$. ALCOOL。 (C. D'O.)
AlL

*ACKEKENGL (norit arabe), вот.PH.-G. établi par Tournefort (Inst.) et réuni au Physalis de Linné, qui en a fait la dénomination spécifique de l'espèce type. (C. L.)

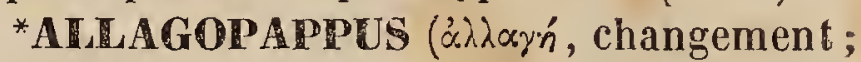
$\pi \dot{\alpha} \pi \pi \circ 5$, aigrette). вот. PI. -G. de la fumille des Composées, tribu des Astéroïdées, établi par Cassini, et réuni par M. De Candolle à son g. Jasione, où il constitue une section que caractérisent ses capitules discoïdes, homogames, ses fruits à angles velus, son aigrette dont la rangée intérieure est formée de 5-7 soies filiformes, scabres, et l'extérieure de soies également peu nombreuses et courtes. L'Allagopappus est originaire des Canaries; c'est un arbrisseau à feuilles glanduleuses.

$$
\text { (J. D.) }
$$

* Allagopterera ( $\alpha \lambda \lambda \alpha \gamma \dot{r}^{\prime}$, différence;

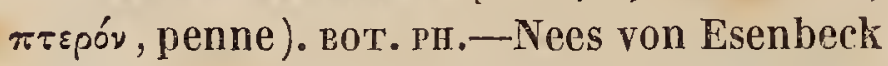
a désigné sous ce nom, dans le voyage au Brésil du prince de Neuwied, un g. de Palmier dont il n'a pas fait connaitre les caractères.

(AD. B.)

ALLAITEMENT. MAM. - Dépendante des organes qui caractérisent principalement les Mammifères, la fonction de l'Allaitement appartient exclusivement aux animaux de cette classe. Le lait, dont ces animaux ont seuls le privilége de nourrir leurs petits pendant les premiers temps de leur existence, est sécrété par des glandes désignées sous le nom de mamelles, dont le nombre et la position relative diffèrent suivant les espèces; mais qui, envisagées d'une manière générale, présentent constamment la même structure anatomique ( $V$. MAMELLES). Les modifications que subissent ces organes, durant la gestation et après l'accouchement, constituent un phénomène remarquable. Presque aussitôt que le travail de la conception a commencé à s'effectuer dans l'utérus, une excitation sympathique se fait sentir aux glandes mammaires, qui ne tardent pas à devenir le centre d'une fluxion évidente. Leur volume augmente rapidement; une sensibilité insolite se développe dans leur parenchyme; le tissu cellulaire qui les environne et la peau qui les recouvre semblent s'œématier un peu; enfin, ces glandes, sur la fin de la gestation, sont devenues le siége d'une sécrétion particulière. Cependant, le liquide sécrété alors ne s'écoule, le plus souvent encore, que sous l'influence de pres- 
sions assez fortes ou de succions réitérées. Ce n'est encore qu'une sorte de sérosité transparente, incolore et dénuée de consistance; mais, immédiatement après le part, cette sérosité s'opacifie rapidement, s'épaissit un peu, et se colore en blanc ou plutôt en blanc bleuâtre (colostrum). Plus tard enfin, ce nouveau produit se modifie à son tour, et acquiert définitivement les propriétés nutritives que réclame sa véritable destination (lail). - Une clıse digne de remarque, est l'art merveilleux avec lequel, dans ces diverses transformations, la nature se subvient à elle-même. Le premier liquide, en effet, prépare et lubrifie les voies d'écoulement; et, si le colostrum n'est point encore une véritable substance alimentaire, la légère action purgative dont il est doué a pour objet d'expulser de l'intestin du nouveau-né, le meconium, dont le lait proprement dit ne l'eût point débarrassé. Ajoutons enfin, que, pour s'approprier aux besoins croissants et à la puissance digestive du nouvel être dont il fait l'unique aliment, ce lait lui-mème, au fur et à mesure qu'on s'éloignera de l'époque du part, va devenir de plus en plus nourrissant, c'est-à-dire de plus en plus riche en matière butyreuse et en $c a-$ seum.-Ne pourrait-on pas déduire de ce fait d'observation vulgaire (puisque nos paysans le constatent journellement sur le lait de leurs chèvres et de leurs vaches), que nous faisons de véritables contre-sens en hygiène, lorsque nous confions nos enfants nouveaux-nés à des nourrices qui souvent allaitent déjả depuis un an et plus?

Très variable suivant les espéces, la durée de l'allaitement est ordinairement en rapport a vec celle de la gestation, de la croissance et de la vie totale de l'individu; mais, quel que soit le temps qu'elle se prolonge, cette fonction établit toujours dans l'organisme une sorte de dérivation, qui neutralise l'action physiologique de certains viscères, et s'oppose à l'accomplissement de plusieurs autres fonctions. C'est ainsi que le phénomène de la menstruation est suspendu chez les femmes qui allaitent, tandis que les femelles des animaux, placées dans la même conjoncture, échappent à la périodicité de ces sortes de congestions utérines, déterminant chez elles, en d'autre temps, la propension instinclive au coït, qu'on a déT. 1 . signée sous le nom de rut. - Si pourtant, en raison de quelque circonstance particulière : une conception intempestive survient chez la femelle qui allaite, ce nouveau travail de l'utérus trouble celui des marnelles, et le lait, en même temps qu'il s'appauvrit el s'altère dans sa composition chimique, diminue rapidement en quantité, si même il ne cesse complètement de se reproduire. I es moindres connaissances en physiologie suffisent pour expliquer comment, dans l'espèce humaine, des travaux forcés, une maladie accidentelle ou quelque aflection morale à la fois vive et prolongée, sont susceptibles de donner lieu au même résultat.

Suivant leur conformation et la position de leur's mamelles, les diverses esp. de mammifères ont une manière différente de procéder á l'allaitement de leurs petits; ainsi, les Singes, comme la femme, se servent de leurs membres antérieurs pour élever leurs petits à la hauteur de leurs mamelles, qui ont leur siége à la poitrine, tandis que d'autres animaux s'accroupissent simplement sur les leurs, pour leur donner à téter. Enfin, il est d'autres espèces (tous les g. de Ruminants, par exemple) chez lesquelles, le petit naît avec assez de forces pour se tenir tout d'abord sur ses membres, et vient de lui-même saisir le mainelon. - On trouvera à l'article Marsupiaux les particularités relatives à l'allaitement des Animaux à bourse. Quant à l'allaitement des Cétacés qui fut, pendant ces dernières années, un des points les plus controversés de l'histoire naturelle, nous nous abstenons d'émeitre notre opinion dans une question que nous ne regardons point comme jugée, et qui, pour recevoir une solution définitive, nous paraît exiger de nouvelles observations. Toul ce que l'on sait de positif là-dessus, c'est que ces animaux sont réellement pourvus d'une glande mammaire; que cette glande est située au devant de l'anus; que, de plus, enfin, elle est munie d'un muscle parliculier qui, en se contractant, aurait pour objet d'en déterminer la compression, et par suite, l'écoulement du lait : sorte de disposition que présentent d'ailleurs plusieurs autres animaux, chez lesquels l'absence de lévres rend la succion impossible. $V$. CÉTACÉs. (A. Teste.)

ALLAMANDA, Schreb., L.; Orelia, Aubl. (Allamand, professeur d'hist. nat. à Leyde). $18^{*}$ 
- G. de la famille des Apocynacées, sousordre des Carissées, fondé par Linné ( Mantiss. 214), et adopté par tous les botanistes postér. En voici les caract. essentiels : Cal. 5-fide. Cor. hypogyne, infundibuliforme, à tube cylindrique, à gorge pourvue de 5 squames ciliées, à limbe campanulé, ample, dont les 5 div. sont obtuses et inégales. Etam. 5, incluses, insérées à la gorge de la corolle; anth. sagittées, subsessiles, conniventes. Ovaire uniloculaire, comprimé. Ovules nombreux, enveloppés par le placenta marginal, auquel ils sont appendus par des funicules assez longs. Capsule coriace, subarrondie, elliptique, comprimée-lenticulaire, hérissée de pointes, uniloculaire et longitudinalement bivalve. Graines nombreuses, suspendues aux bords valvulaires par un funicule qui part d'un ombilic ven-tral, imbriquées inférieurement, un peu comprimées et ceintes d'une large aile membraneuse. Embryon dressé dans un albumen cartilagineux, peu abondant, à cotyl. foliacés, ovales-cordès, à radicule linéaire-acuminée, centrifuge.-Les Allamanda sont des arbrisseaux ou sous-arbrisseaux dressés ou grimpants, appartenant á l'Amérique tropicale; leurs feuilles sont verticillées ; leurs pédoncules multiflores, terminaux et interpétiolaires; leurs fleurs belles, jaunes. On en cultive plusieurs esp. dans les serres d'Europe. La plus commune et l'une des plus remarquables est l' $A$. Linnaei Don ( $A$. $c a$ thartica L., non A. cathartica Aubl.). (C. L.)

*ALLANIA, Benth. (Allan Cunningham, botaniste anglais ). вот. Pн. - G. de la famille des Légumineuses, sous-ordre des Swartziées. L'auteur de ce genre en expose ainsi les caractères (Hook. Journ. of Bot. 2, page .91; mars 1840) : Cal. cupuliforme, coriace, valvaire, irrégulièrement 4-on 5-lobé. Cor. de 5 pétales amples, irréguliẻrement imbriqués en préfloraison. Étamines très nombreuses, conformes, périgynes de même que la corolle. Anthères oblongues-linćaires. Ovaire stipité, pluri-ovulé. Style épaissi à la base, filiforme, pointu. Stigmate petit. Péricarpe inconnu. L'esp. sur laquelle est fondé ce g. est un grand arbre, trouvé récemment par Schomburg, en Guyane; les feuilles en sont impari-pennées, à pétiole aptère, long d'un $1 / 2$ pied et. plus; les folioles grandes, co- riaces, cotonneuses en dessous; les fleurs sont disposées en longues grappes; la corolle est grande, blanche, étalée.

ALLANITE, Cerin d'Hisinger. MiN. Esp. minérale dédiée par Thompson au minéralogiste anglais R. Allan. Ce minéral, encore rare dans les collections, a été découvert, par Giesecke, au Groënland, dans des roches micacées ; on l'a retrouvé, depuis, dans une roche feldspathique à Riddaryttan, en Westermanie. Il a d'abord été pris pour une variété de la Gadolinite, à laquelle i) ressemble beaucoup par son aspect; mais il en diffère en ce que sa poussière, mise dans l'acide nitrique légèrement chauffé, conserve sa couleur et ne s'y résout pas en gelée. L'Allanite est une substance noire et vitreuse qui fond difficilement au chalumeau, est assez dure pour rayer le verre, et pèse spécifiquement 3,4 . D'après l'anályse qu'en a faite 'Thompson, on doit la considérer comme un Silicate de Cerium, de chaux et de fer. L'Orthite et le Pyrorthite de Berzélius n'en sont probablement que de simples variétés, provenant du mélange de quelques principes accidentels. Beudant place l'Allanite dans un appendice, á la suite de l'esp. Cérine (ou Cérium silicaté noir). Ce minéral est cristallisé en prismes quadrangulaires, dont la coupe transversale paraît être un rhombe, très peu différent du carré.

(DEL.)

ALEANTITES (allusion synon. ả $\alpha \lambda \lambda \alpha \tilde{\alpha} \xi$, ävros, saucisson. $V$. Allantus ). INS. M. Newman (Ent. Mag.; Attempt. Dire of Brit. Ins. int. nat.ord.) forme sous ce nom un groupe appelé par lui natural order, et renfermant les g. Nematus, Cladius, Croesus, Empliytus, Dolerus, Dosythous, Fenusa, Selandria, Athalia, qui appartiennent à la famille des Tenthrédiniens (Porte-Scie, Lat.). $V$. ce mot.

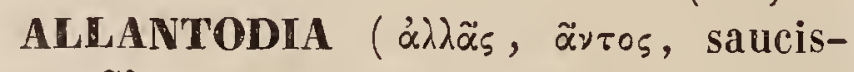
son; हiٔos, apparence; allusion à la forme des indusies). Bot. CR. - R. Brown a établi ce g. dans son Prodrome de la Flore de la Nouvelle-Hollande. II y comprenait alors deux esp. de ce pays et l'Aspidium umbrosum. Ce g., très voisin des Asplenium et surtout de l'Athyrium, en diffère, suivant cet illustre botaniste, par son tégument recourbé en forme de voûte (indusium fornicatum), adhérent d'abord par ses 2 bords à la 
nervure, le long de laquelle les capsules sont insérées en un groupe ou sore allongé, et s'ouvrant ensuite par son bord intér. L'esp. qui a servi de type à ce g., est l'A. australis. Kaulfuss y a plus tard ajouté les Aspidiım scandiciunm Willd. et axillare Sw.-Kunze et Wallich y en ont encore ajouté deux autres. Plus récemment, Presl a cru devoir supprimer ce g., en réunissant les esp. que $R$. Brown et Kaulfuss y avaient placées, au g. Alhyrium; celle de Kunze aux Diplazium, et plaçant l'Allantodia Brunonis de Wallich dans son nouveau g. Hemidyctium. Il est certain que les Allantodia sont très voisins des Athyrium, tant par leurs caract. que par leur port; mais leur identité ne paraît pas encore bien prouvée.

(AD. B.)

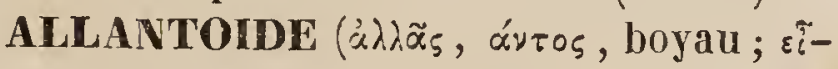
¿os, forme). Man. - Sorte de sac membraneux, faisant partie de l'arrière-faix des Mammifères, et ayant son siége entre le Chorion et l'Amnios. On croit généralement que cet organe, dont la cavité communique avec la vessie du fœtus, au moyen d'un canal nommé Ouraque, a pour objet de recevoir l'urine que sécrètent les reins, pendant la vie intra-utérine. Très évidente chez les animaux oú, suivant les esp., elle affecte des formes différentes, l'Allantoïde n'existe chez l'homme qu'à l'état rudimentaire. Cette membrane, en effet, est si peu apparente dans l'œuf humain, que, malgré les ingénieuses démonstrations de M. Velpeau et le savant mémoire présenté par ce médecin à l'Académie des sciences sur ce sujet (1835), plusieurs anatomistes doutent encore de son existence. Il n'est d'ailleurs pas de physiologiste qui n'ait constaté l'imperforation de l'ouraque sur des fœtus non à terme.

(A. TeSTE.)

ALLANTUS ( $\dot{\alpha} \lambda \lambda \tilde{\alpha} \varsigma, \tilde{\alpha} \nu \tau \circ \varsigma$, saucisson; forme de l'Insecte). Ins. - G. de la famille des Tenthrédiniens, de l'ordre des Hyménoptères, établi par Jurine (Nouv. Méthode de classer les Hym.), qui le distingue des Tenthrerlo, auxquelles l'ont réuni Latreille (Rèrgn. anim.) et Lepeletier de St-Fargeau (Monog.Tenth.), par des antennes composées d'au moins 9 articles, et par des ailes supér. présentant 4 cellules cubitales. Ce g. renferme un très grand nombre d'esp. généralement indigènes, dont les plus répandues en Europe sont les 1 . Scrophularice (Ten- thredo Scrophularia Fab.), lividus (Tenth. livida Fab'), nassatus (Tenth. nassata Lin., Fab.).

ALLASIA, Loureir. ( $\alpha \lambda \lambda \alpha_{\alpha}$, saucisson; forme $d u$ fruit). вот. PII. - G. incomplètement connu, et qui paraît appartenir à la famille des Cucurbitacées. Loureiro (Flor. cochinch.) en donne les caract. suivants: Fleurs hermaphrodites. Cal. 5-fide; lanières pointues, poilues. Pétales au nombre de 4 , poilus. Étam. 4. Style subulé. Baie grosse, charnue, oblongue, obtuse, pendante, 1-loculaire. Graines ovales, comprimées, nidulantes. - L'unique esp. sur laquelle se fonde ce g., est un arbre de la côte de Mozambique, dont les feuilles sont digitées, les pédoncules terminaux, multiflores. (Sp.)

ALLECULA. 1ns. - G. de Coléoptères hétéromères, famille des Hélopiens, établi par Fabricius et adopté par Iatreille dans son ouvrage intitulé : Familles naturelles, oú il le place dans sa tribu des Cistélides. Les caract. de ce g., suivant $\mathbf{M}$. Solier, sont : Pénultième art. du tarse ayant en dessous, au moins aux antérieurs, une pelote membraneuse plus ou moins prolongée sous le dernier. Yeux ne convergeant pas entièrement en dessous. Dernier art. des palpes maxillaires notablement transverse et tronqué carrément au bout. Premier art. des tarses antér. étroit, filiforme, notablement plus long que les 2 suivants réunis; $3^{\text {me }}$ art. des 4 tarses antér. subtronqué. M. Dejean, dans son dernier Catalogue, mentionne 35 esp. d'Allécules, dont 2 seulement sont d'Europe. Nous ne citerons que l'Allecula morio Fabr., qui a servi de type au g., et qui est de Suède.

*ALLENDEA. вот. рн. - G. de la famille des Composées, encore trés mal défini. Il a pour caract. : Des capitules multiflores, dont les fleurs du disque, en petit nombre, sont hermaphrodites, tubuleuses, à 5 dents révolutées; celles du rayon, femelles, filiformes, ligulées, et disposées sur plusieurs rangs; l'involucre est composé d'écailles aiguës, imbriquées; le réceptacle convexe porte des petites paillettes (fimbrilles) presque aristées au sommet; fruit...; aigrette par uniforme, poilue.-L'Allendea, décrit par Lallave et Lexarca, ost une herbe du Mexique, couverte d'un duvet tomenteux, soyeux, a rameaux droits, couverts de feuilles op- 
posées, connées, largement lancéolées , trinervées en dessous, et présentant 1-2 dents glanduleuses. Les capitules, disposés en corymbe, sont longuement pédicellés. (J. D.)

*ALCLAÉES. Alliace (allium, ail). вот. PIr. - Tribu indiquée par Link (Handb.) dans la famille des Liliacées, et qu'on réunit assez généralement à la tribu des Scillées, Bartl. (ou des Hyacinthées, selon d'autres), de la même famille. Elle ne contenait que le g. Allium, divisé en 5 sous-genres, Moly, Mœnch.; Ophioscordon, Wallr.; Codonoprasum, Reich.; Schenoprasum, Kunth, ou Porrum, Tourn. $V$. ces mots et allium. Peut-être mériterait-elle d'être distinguée. (C. L.)

ALLIAGE. MIN. CHIM. ET MÉTALL. - On nomme ainsi le résultat de la combinaison, opérée par la fusion, de 2 ou plusieurs métaux. Par exception cependant, les produits dont le mercure fait partie se nomment Amalgames.

Les alliages ne sont souvent que de simples mélanges, pouvant se faire en toutes proportions; mais, dans certains cas, ce sont des combinaisons en proportions déterminées, et susceptibles de crístalliser autrement que ne le feraient leurs composants. Tous les alliages sont solides, à l'exception de ceux dans lesquels le mercure prédomine. Ils sont opaques, ont l'éclat métallique, et une couleur qui leur est propre. Ils sont moins bons conducteurs de la chaleur et de l'électricité, que les métaux qui en font partie. Leur densité diffère en général, tantôt en plus, tantôt en moins, de la densité moyenne des métaux qui les constituent. Ils sont, la plupart du temps, plus durs et moins ductiles que leurs composants, somvent aussi plus oxydables, généralement plus fusibles.

Les métaux que l'on allie le plus fréquemment sont : $1^{\circ}$ le cuivre et le zinc, qui constituent le laiton, alliage dont on obtient plusieurs variétés distinctes par la couleur et la densité, suivant que l'on varie la proportion de ses éléments; $2^{\circ}$ l'étain et le cuivre, qui forment le bronze, employé si souvent pour les cloches, les statues, les médailles, et une multitude d'autres objets; $3^{\circ}$ le jlomb et l'antimoine ( 5 parties du premier et une du second) avcc lesquels on fond les caractères d'imprimerie. L'antimoine sert dans ce cas a donner au plomb assez de du- reté pour résister à une forte pression. On emploie aussi dans les arts plusieurs autres alliages, tels que ceux de mercure et d'étain, de mercure et d'or, d'étain et de plomb, d'étain et de cuivre, de fer, de cuivre et d'or, de plomb et d'antimoine, et l'alliage fusible de d'Arcet, composé de bismuth, de plomb et d'étain.

ALLIAIRE. Ailiaria, Adans. (Allium, ail, à cause de l'odeur de cette plante). вот. PH. - G. de la famille des Crucipères, tribu des Siliqueuses, offrant les caractères suivants (Spach, Suites à Buff., Plant, ph., 6, p. 413) : Sépales 4, très caducs, subnaviculaires; les 2 latéraux plus larges. Pétales 4, onguiculés; glandules 4 (opposées aux 4 sépales), inégales; les 2 latérales plus grosses, en forme de fer-á-cheval, entourant la base des filets impairs; les 2 autres petites, dentiformes, obtuses, insérées une à une derrière chaque paire de filets. Élam. 6 ; filets filiformes, rectilignes, un $\mu c u$ divergents ; anth. sagittiformes-oblongues. Ovaire grêle, 4-gone, 2-loculaire, multi-ovulé; style très court, columnaire ; stigm. pelté, orbiculaire. Silique columnaire, apiculée, tétràdre, 2-loculaire, 2-valve, polysperme; valves tantôt 1-nervées, tantôt sub-3-nervées, émarginées; nervures placentairiennes subcarénées, très saillantes. Graines suspendues, 1-sériées dans chaque loge, cylindriques, gibbeuses antérieurement, striées longitudinalement, immarginées ; cotylédons rectilignes ou pliés transversalement en carène, semi-cylindriques ou concaves; radicule flexueuse ou géniculée, obliquement dorsale. - Herbe bisannuelle ; pubescence nulle ou simple; feuilles crénelées ou dentées, pétiolées; grappes terminales, feuillées à la base, nues supérieurement, multiflores, lâches après la floraison; pédicelles fructifères horizontaux ou divergents, courts, très gros; fleurs blanches.

L'Erysimum alliaria L. constitue à lui seul le g.; toutes les parties de cette plante ont une forte odeur d'ail et des propriétés dépuratives; les graines peuvent servir en guise de moutarde.

ALLIGATOR. REPT.-V. CÄ̈LN. (G. B.) ALIONIE. Allionia (Ch. Allioni, botaniste piémontais). вот. PII. - G. de la famille des Nyctaginées, fondé par Linné d'après Loffling et auquel on a réuni , comme 
s. g., le Wedelia du second de ces auteurs. Ce g. a été adopté ainsi par tous les botanistes postérieurs. En voici les caract. : Invol. caliciforme, campanulé, 5-denté ou 3-phylle, 3flore, persistant. Périgone corolloüde, infundibuliforme, à tube court, dont la base est ventrue, persistante, a limbe 4-lobé, fendu d'un côté. Étam.4, incluses, libres, hypogynes. Ovaire uni-loculaire; ovulc unique, dressé, à micropyle infẻre. Style simple; stigm. capité. Le fruit est un akène libre, entrc les bases périgoniales épaissies, un peu épineuses par derrière, comme planes par devant, jointes entre elles et contenues dans l'invol.immu té.Semence dressée, à test conné avec l'endocarpe. Embryon condupliqué; cotyl. entourant un albumen amylacé ; radicule extraire, infère. Ce g., particulier à l'Amérique tropicale, ne renferme guère que 2 esp., séparées en 2 s.-g., dont l'un, l'Allionia, Lœfr. (A. violacea L.), est caractérisé par un invol. 5-denté, campanulé; l'autre, Wedelia, Lœfll. (A. incarnata L.), par un invol. triphylle.

(C. L.)

ALLIUM (Allium, ail, chez les Latins). вот. Рн. - Synon. latin d'AiL. (C. L.)

*ALLMANNiA, R. Br. (nom d'homme). вот. рн. - G. de la famille des Amarantacées, indiqué par Wallich dans son Catal. des Plantes de l'Herbier de l'Inde. Les caract. n'ont pas été publiés.

*ALlobrogiA, Tratt. (Allobroga, habitant du Dauphiné, de la Savoie). вот. рн. G. de la famille des Liliacées, synon. du g. Czarkia, andrz. $V$. ce mot.

(C. L.)

ALLOGARPUS ( $\propto \lambda \lambda \lambda_{0}$, autre; xaprós, fruit). вот. Pाr. - Ce nom a été donné par M. Kunth à une plante originaire de l'Amérique équinoxiale, appartenant à la famille des Composées, tribu des Sénécionidées, et dont les caract. sont : Capitule multiflore, radié; les fleurs du rayon, au nombre de 5 environ, sont ligulées et femelles; celles du disque, hermaphrodites, tubuleuses, 5-dentées. Involucre hémisphérique, formé pàr environ 10 squames faiblement-imbriquées, scarioso-membraneuses ; réceptacle presque plan, couvert de paillettes lancéoiées, persistantes, scarieuses; les rameaux des styles appartenant aux fleurs hermaphrodites, dépourvus d'appendices. Les fruits du rayon sont cunéiformes, comprimés, et manquent d'aigrette, tandis que ceux qui appartiennent aux fleurs du disque sont cunéiformes-cylindracés, couronnés d'une aigrette 1-sériée, et composés de plusieurs paillettes subulées, de la longueur de la corolle, comprimées inférieurement, barbellulées ou pectinées, comme j'ai pu m'en assurer par une analyse faite sur l'échantillon décrit par M. Kunth et conservé dans l'Herbier du Muséum.

On connait aujourd'hui 3' esp. d'Allocarpus; ce sont des herbes rameuses, à feuilles opposées, 3-7-nervées, entières, velues; les capitules sont jaunes, et peut-être blancs, d'après M. De Candolle.

(J. D.)

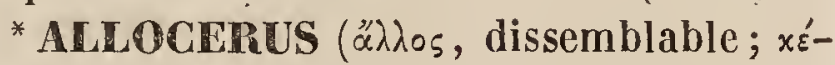
pas, corne). INs. - G. de Coléoptères tétramères, famille des Longicornes, établi par M. Serville, qui le place dans sa tribu des Prioniens, et lui assigne pour principaux caract.: Ant. de 12 articles cylindriques et allongés dans les mâles, courts et en dent de scie dans les femelles. Cors. mutique; corps étroit et très allongé. - Ce g., adopté par M. Dejean dans son Catalogue, ne renferme qu'une esp., A. Spencii, ou Prionus, id., de Kirby, rapporté du Brésil par M. Lacordaire.

ALLOCHROTTE ( $\propto \alpha^{\prime} \lambda \lambda_{0}$, différent ; $\chi \rho \circ \alpha$, couleur). Min.-Variété de Grenat compacte, d'un gris verdâtre, découverte par d'Andrada dans une mine de fer, près de Drammen, en Norwège. Sa composition est à peu près la même que celle du Grenat mélanite.

(DEL.)

*ALLODAPE ( $\alpha \lambda \lambda_{0} \delta \alpha \pi o_{\zeta}, n^{n}$, étranger, ère). INs. - G. de la famille des Mellifères, de l'ordre des Hyménoptères, établi par MM.Lepeletier de St.-Fargeau et Serville (Encyclop. méth.) sur 3 esp. du Cap de Bonne-Espérance, qui se rapprochent extrêmement des g. Stelis et Ammobates, Lat. L'esip. citée par les auteurs comme type de leur g., est l'A. rufogastra, Lep. et Serv.

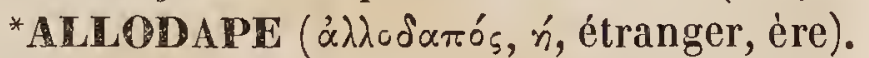
вот. PI. - G. de la famille des Épacridées, tribu des Épacrées, créé par Endlicher (Gen. $p l$.), d'après une plante figurée (Azalea bullata, Forst.) par Labillardière, rapportée par Hooker au g. Prionotes. L'auteur en établit ainsi les caract. : Cal. 5-parti, bractéolé. Cor. hypogyne, campanulée; limbe 5-parti, à segments un peu étalés, imberbes. Étam. 5 , hypogynes, incluses; filaments subclaviformes, dilatés au sommet postérieur des 
anthères adnées. Disque hypogyne, cyathiforme, 5-sinué. Ovaire 5-loculaire, ả loges multi-ovulées. Style simple; stigm. renflé-conique. Capsule 5-loculaire; placentas adnés à une colonne centrale? Graines nombreuses. - C'est un petit arbrisseau de l'Amérique-antarctique, à feuilles éparses, sessiles, ovales-aiguës, dentées ; à pédoncules axillaires, solitaires, uniflores, multibractéolés, penchés; à fleurs petites.

(C. L.)

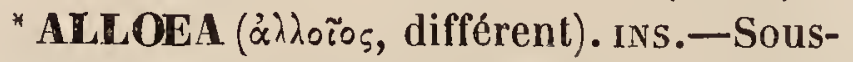
g. de la famille des Ichneumoniens, groupe des Braconites, ordre des Hyménoptères, établi par Haliday (Ent. Mag.), dans son tableau générique des Ichneumones adsciti. Il lui donne pour caract. : Mandibules écartées, avec leur dent intermédiaire allongée et aiguë; 3 cellules cubitales aux ailes antérieures.-Haliday regarde comme le type de son g. l'Alysia contracta Curt., trouvée en Angleterre.

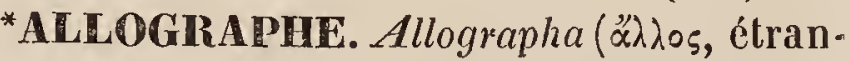

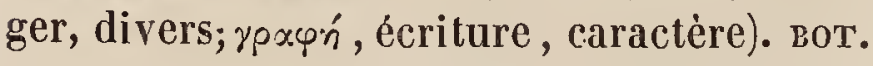
св. - M. Chevalier, dans son Histoire des Hypoxylons, ouvrage qui n'a pas été achevé, a réuni, sous ce nom générique, toutes les esp. du g. Graphis à lirelles recouvertes dans leur jeunesse d'une croûte farineuse, souvent colorée, dont leur bord se dégage à peine, même après leur complète évolution. Le Graphis Afzelii est le type de ce g., dont le nom n'a pas été adopté.

Plus tard, Persoon (Bot. du Voy. de l'Uranie, publiée par $M$. Gaudichaud) a tenté de ressusciter ce g., en lui imposant le nom de Ctesium, et M. Fée (Suppl. Ess. sur les Crypt. des écorc. offic.) a lui-même donné le nom générique d'Helminthocarpon, à une esp. de Graphidée qu'on peut encore y rapporter; mais ces 3 genres ne différant que fort peu des vrais Graphis tels que Fries les a définis, nous renvoyons à ce dernier g., où l'on en trouvera les caract. diagnostiques. (C. M.)

* ALLOIATHEROS ( $\alpha \lambda \lambda_{0}{ }^{\circ} \circ$, différent; $\alpha \theta$ ón $\rho$, źpos, épi). вот. pII. - (Famille des Graminées.) L'Andropogon ambiguus de Michaux, qui appartient au g. Gymnopogon de Beauvois, a vait élé désigné par Elliot sous le nom d'Alloiatheros ambiguus. V. Gymnopogon.

(A. R.)

ALLOISPERMUM ( $\alpha \lambda \lambda_{\circ} \tilde{\circ} \circ 5$, différent;

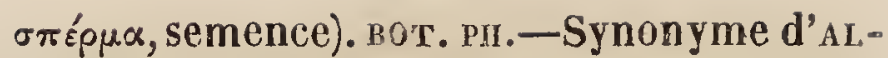
LOCARPUS.

*ALLOMORPHIA, Blume ( $\alpha^{\prime} \wedge \lambda \circ \varsigma$, différent ;

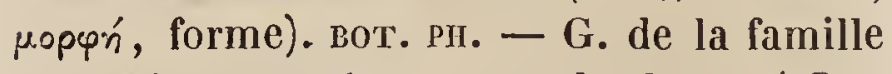
des Mélastomacées, auquel Blıme ( $B$ ot. $Z$ eit., 1831, p. 522) assigne les caract. suivants : Cal. oblong-tubuleux, courtement 4-denté; pétales 4. Étam. 8, toutes fertiles, alternativement plus longues et plus courtes; anth. linéaires, droites, pointues, inappendiculées, échancrées à la base, s'ouvrant par un seul pore apicilaire. Style filiforme; stigm. simple. Péricarpe sec, ovale-oblong, 4-loculaire. -- Arbrisseau à feuilles 5-nervées, glabres , très entières; fleurs en panicules terminales. - Le g. n'est fondé que sur une seule esp., indigène dans lesîles du détroit de Malacca.

* ALLONGÉS. Elongati. arachn. -- Ce nom est employé par M. Walckenaër (Hist. des Ins. aptères ) pour désigner certains petits groupes de divers g. d'Aranéides. (H. L.)

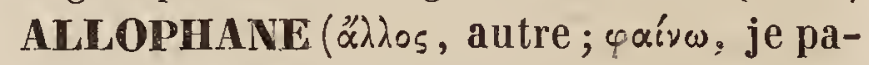
rais ; parce que ce minéral terreux ressemble souvent à un minerai de cuivre). MIN.-Nommée aussi Riemannite et Alumine hydratée silicifère, et érigée en esp. par Stromeyer sous le nom d'Allophane, cette substance a été découverte par Riemann à Grafenthal, près de Saalfeld, en Thuringe. Elle est opaline, demi-transparente, à cassure conchoïdale, d'un éclat vitreux passant à l'éclat de la cire tendre, et pesant spécifiquement de 1,8 à 1,9 ; sa couleur est d'un bleu céladon passant au vert et au brunâtre. Cette coloration est due á un peu de carbonate de cuivre dont elle est accidentellement mélangée. L'Allophane est infusible; elle donne de l'eau par la calcination, et se dissout en gelée dans les acides. Elle est composée sur 100 parties, de 22 de silice, 32 d'alumine, 41 d'eau, 3 de carbonate de cuivre, et de quelques traces de chaux et d'oxyde de fer. On la trouve en petites concrétions ou en nids irréguliers, dans une roche argilo-ferrugineuse à Grafenthal, à Schneeberg en Saxe, à Tanne, au Harz, à Friesdorf près de Bonn, et dans les houillères de Firmi (Aveyron). Ce minéral a de grands rapports avec celui que l'on nomme Collyrite. $V$. ce mot.

(DeL.)

ALLOPHYLLE. Allophyllus, L. ( $\propto 2 \lambda \lambda_{0} s$,

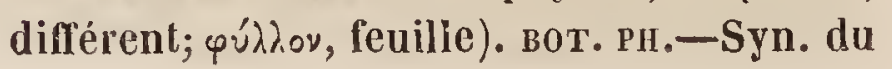


g. Schmidelia L., de la famille des Sapindacées.

${ }^{*}$ ALLOPLECTUS ( $(\not \lambda \lambda \omega \varsigma$, autrement ; $\pi \lambda \varepsilon x$ -

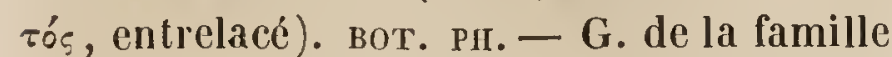
des Gésuéracées, tribu des Épisciées, établi par Martius (Nov. Gen. e $\boldsymbol{\imath} \boldsymbol{S}$.) , qui lui assigne les caract. suivants : Cal. libre, coloré, 5-phylle, à div. inégales, imbriquéesconniventes. Cor. hypogyne, tubuleuse, infundibuliforme ou claviforme, à tubegibbeux a la partie postérieure de la base, souvent ventru supérieurement à la partie antérieure, ả limbe 5-denté ou courtement 5-fide. Étam. 4, insérées à la base du tube, didynames, incluses ; une $5^{\text {me }}$ rudimentaire ; filaments embrassants. Anth. rapprochées par paires, biloculaires, ovales - oblongues. Ovaire libre, uniloculaire, ceint d'un disque annulaire et muni en arrière d'une glandule; placentas 2 , pariétaux, bilobés. Ovules nombreux, anatropes; funicules assez allongés. Style simple; stigm. hémisphérique, indivisé, concave au milieu. Caps. coriace, subpulpeuse, uniloculaire, bivalve, à valves placentifères au milieu. Graines nombreuses, oblongues ou fusiformes; embryon cylindrique, orthotrape, dans l'axe d'un albumen charnu; cotylédons trés courts, obtus; radic. centrifuge, dirigée vers l'ombilic. - Le g. Alloplectus comprend un petit nombre d'esp. propres à l'Amér. tropicale oú elles grimpent sur les arbres; ce sont des arbrisseaux à rameaux subquadrangulaires, un peu renflés aux articulations; remplis d'une moelle abondante, á épiderme brillant, caduc (secedens), garnis de feuilles opposées, souvent inégales, pétiolées, quelquefois rouges en dessous, subcharnues, coriaces; à fleurs axillaires, jaunes, tantôt solitaires et pédonculées, tantôt agrégées, sessiles ou en grappes, munies de bractées séparées, cramoisies ou couleur de sang, ainsi que les calices. Il a pour synon. : Crantzia, Scop.; Dalbergia ou Dalbergaria, Tuss.; Tussacia, Reich.; et comprend quelques esp. des g. Besleria et (Jrobanchia. (C. L.)

* AlLOPORE. Allopora (ähìos, différent; ropós, pore, conduit). zoopi.-G. de Polypes anthozoaires, considéré comme douteux par M. Ehrenberg lui-même, qui l'a établi et pris pour type de la famille des Alloporines, également douteuse ; laquelle serait caractérisée par la structure du poly- pier rameux, raide, fixé, composé d'une malière calcaire sécrétée à la manière des Oculines et sans axe central; ce qui le distingue des Gorgones et des Isis, composant la famille des Isidées. Les Polypes des Allopores auraient, suivant M. Ehrenberg, les rayons du corps en nombre variable, mais peu nombreux, d'oú vient le nom de Phytocoraux oligactiniés, par lequel cet auteur désigne la tribu qui comprend la seule famille des Alloporines.

(Dus.)

ALLOPTÈRES ( $\propto 2 \lambda \omega_{5}$, tantôt d'une façon, tantôt d'une autre; $\pi \tau$ ŕpov, nageoire). polss. - Nom donné par M. Duméril aux nageoires paires inférieures des Poissons, pour exprimer la variation de leur position, tantôt jugulaires, tantôt thoraciques, tantôt abdominales et quelquefois manquant tout-à-fait.

(VAL.)

ALLOSORUS ( $\left(\lambda \lambda_{05}\right.$, différent; $\sigma \omega \rho^{\prime} \sigma_{5}$, tas). BOT. CR.-Bernhardi avait séparé sous ce nom en un g.distinct, la plante européenne si commune dans les montagnes de l'Europe et désignée sous le nom de Pteris crispa Smith, d'Osmunda crispa L. - Kaulfuss, en le conservant dans les mêmes limites, forma auprès de ce g., sous le nom d'Onychium, un autre g. comprenant quelques esp. très voisines de celle-ci par leur port. Depuis lors, Presl a considéré le g. Allosorus d'une manière très différente, et y a réuni une infinité de plantes que tous les auteurs précédents avaient laissées parmi les vrais Pleris, et en particulier notre Pleris aquilina. Le caract. qui distingue ces plantes des vrais Pteris, c'est que les groupes de capsules ou sores, au lieu de former une ligne continue sous le tégument marginal, y forment, dans leur jeunesse du moins, des groupes arrondis, distincts, qui deviennent plus tard confluents, et sont recouverts par le bord enroulé de la fronde et par un tégument marginal scarieux, continu. Presl divise les Allosorus en 3 sections fort naturelles, qui deviendront peut-être autant de g. distincts, plus naturels encore que ne l'est le g. tout entier, tel qu'il est maintenant limité. La $1^{\mathrm{re}}$, ou les vrais Allosorus, correspond au g. établi par Bernhardi, et comprend, en outre, l'Onychium de Kaulfuss et quelques esp. de Cheilanthes. La $2^{\text {me }}$ section comprend un grand nombre d'esp.rapportées précédemm nt aux Pteris et aux Cheilanthes, tels que les Pteris argentea, 
sulfurea, hastata, cordata, esp. à stipe dressé, corné, à folioles distinctes, souvent cordiformes, et qui diffèrent beaucoup par leur aspect des vrais $P$ teris. Enfin, la $3^{\text {me }}$ section comprend le Pteris aquilina et les esp. voisines, assez nombreuses, qui représentent, pour ainsi dire, cette plante dans les autres parties du monde. On voit que le g. Allosorus, ainsi défini, est devenu très considérable mais il sera probablement subdivisé de nouveau.

(AD. B.)

*ALLOTERRHOPSIS et non Alloterropsis

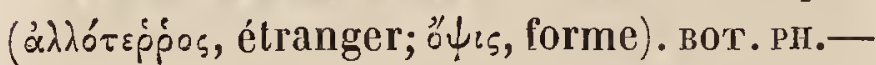
G. de la fam. des Graminées, établi par Presl (Rel. Haenk. 1, 344, t. 47), pour une plante originaire de la Californie, ayant un chaume simple, à nœuds velus, portant à sa base des feuilles linéaires et planes, et terminé par 2 épis courts. Ceux-ci se composent de 4 épillets, 2 hermaphrodites et sessiles, 2 neutres et pédicellés, enveloppés par 4 bractées en forme de glumes. Ces bractées sont inégales, concaves, distiques et imbriquées ; l'infér. est aristée à son sommet et trinervée; les intermédiaires sont plus grandes et à 5 nervures. - Ce g., qui ne se compose que d'une seule esp. ( $A$. distachya Presi, l. c.), paraît avoir des rapports avec les g: Apluda et Anthistiria.

(A. R.)

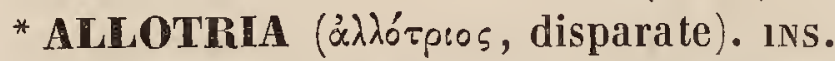
-G. de notre famille des Cyniphiens (Gallicoles, Lat.), de l'ordre des Hyménoptères, section des Térébrans, établi par Westwood (Synop.of Brit. Genera), qui le dístingue de ses congénères : $1^{\circ}$ par des ant. filiformes, plus longues que le corps, et composées de 13 articles au moins dans les femelles; $2^{\circ}$ par un écusson déprimé transversalement à la base; $3^{\circ}$ par la $2^{\text {me }}$ cellule cubitale des ailes supér., oblitérée ; $4^{\circ}$ par un abd. presque sessile. - Il ne rapporte à son g. qu'une seule esp., trouvée en Angleterre et à laquelle il donne le nom d'A. victrix.

(Bc.)

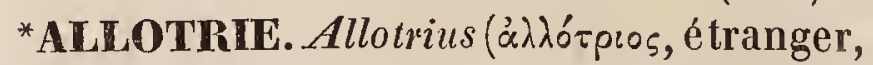
différent). ols. - G. récemment formé par M. Temminck sur 2 esp. indiennes de l'ordre des passereaux, et dont les caract. sont : Bec court, glabre, plus haut que large, trigone partout; mandib. supér. légèrement fléchic, sans arête vive; pointe faiblement carénée; mandib. infér. d'égale force à la supér., et faisant à peu près contre-épreuve.
Narines basales, latérales, nues, couvertes d'une membrane percée vers son extrémité antér., qui est totalement nue. Pieds à tarse assez long; le doigt externe soudé jusqu'à la $2^{\text {me }}$ articulation; l'interne soudé à sa base; doỉgts postér. et externes égaux. A iles courtes, arrondies; la $1^{\text {re }}$ penne très courte; la $2^{\text {me }}$ moins longue que les 3 suivantes, qui sont égales; queue courte. - Ce sont, d'åprès M. Temminck, des oiseaux insectivores, faisant à peu près le passage des Pies-grièches, proprement dites, aux Fourmiliers, et dont le bec, court, large, ressemble plus ou moins à celui des Pardalotes. Ils diffèrent des Piesgrièches par leur bec déprimé, peu crochu et seulement très faiblement échancré; par leurs narines ouvertes et glabres, non cachées par des poils raides, par leurs tarses longs et leur queue courte, arrondie. Des 2 esp. nouvelles composant ce petit groupe, et envoyées de l'Inde au Musée de Leyde par les naturalistes voyageurs de cet établissement, l'une est l'Allotrie à aile janne (A. flaviscapis Tem.Col., 589), et l'autre l'Allotrie oenobarbe (A. onobarbus id., ibid. 2) de Java et de Sumatra.

(LAFr.)

ALLOUGHIER. в0T. PH. - Nom vulgaire de l'Alisier commun (Cratagus Aria L.) (Sp.) *ALLUAUDTTE, Bernhardi. MıN.-S.-phosphate de fer manganésifère, qui accompagne l'Hureaulite, et qui a été trouvé par Alluaud, avec cette dernière esp., à Anglar et dans les carrières du Hureau, près de Limoges. Il est fibreux, de couleur verdâtre et bleuâtre, très facilement fusible, même à la flamme d'une bougie, et se compose, d'après Vauquelin, de 28 d'acide phosphorique, 56 de protoxyde de fer, 6 d'oxyde de manganèse et 9 d'eau.

(DEL.)

*ALLUVIAL et ALLUVIEN. Alluvius (alluo, baigner, couler sur). GÉoL. - Expressions adjectives désignant l'action qui produit les Alluvions ou l'Alluvium. $V$.ces mots. On dit une formation alluviale ou alluvienne, pour indiquer l'effet matériel de l'action ainsi dénommée. $V$. Formation. (C. P.)

ALLUVIONS. Alluvies, alluvio (alluo, baigner, couler sur). GÉoL. - Accumulation successive de particules tenues d'abord en suspension ou entrainées par les eaux des rivières et des fleuves, et rejetées par elles sur les rivages ou à l'embouchure de ces cours d'eau. Les Alluvions sont les dépôts 


\section{ALM}

meubles de vase, de sable, de graviers et de blocs plus ou moins volumineux, qui, en élevant peu à peu les portions du sol inondé jusqu'au niveau des eaux et même au-dessus, contribueut à angmenter l'étendue du sol exondé, à changer la forme des rivages, à modifier le cours des eaux et à déplacer les embouchures. Oı confond assez généralement les Alluvions avec les Auérissements, qui pourraient cependant en être distingués si l'on voulait indiquer par ceux-ci les accumulations produites sur' les rivages marins par l'action des eaux marines, tandis que l'on réserverait le noun d'Alluvions aux effets analogues produits par les eaux douces courantes.

On a long-temps nommé les terrains tertiaires, terrains d'Alluvion ; mais il s'est formé des Alluvions à toutes les époques; il ne peut donc pas y avoir des terrains, mais des formations d'Alluvion. $V$. Fonuation, TenRAIN, Attérissenent.

(C. P.)

${ }^{*}$ ALLUVIUM (alluo, couler sur). GÉOL. Terme général employé, pour ainsi dire, comme personnification de l'ensemble des effets alluviens, en opposition à celui de Diluvium, créé pour représenter les résultats matériels du Déluge. Cette distinction entre l'Allıviım et le Dilıvium étant fondée sur une hypothèse plutôt que sur les faits, il est impossible de donner des caracl. différents à chacun d'eux. On a bien dit que l'Alluvium étantle résultat de causes lentes et successives, les dépôts formés par celles-ci devaient ètrestratifiés, tandis que le Dilnvium ne pouvait se présenter que comme une accumulation de débris irrégulièrement disposés; mais il a été bien difficile de faire l'application de ces principes élablis à priori. ( $V$. D1Luvium el Déluge.)

(C. P.)

*ALLUX (Allux, orteil). ıss.-Nom donné par Kirby à l'avant-dernier art. du tarse des Insectes, quand il offre quelque chose de remarquable. Ex. : g. Curculio.

ALMAgRA ou ALMAGro. min. - Sorte d'argile ocreuse-rougeâtre, que l'on réduit en poudre fine, et dont on se sert dans l'Inde en guise de fard, et en Espagne pour colorer le tabac. On l'emploie aussi sous le nom de Rouge indien pour polir les glaces et nettoyer l'argenterie.

(DEL.)

* ALMANDIN. min.-Les anciens ont donné ce nom à une pierre rouge, que l'on croit T. 1 . être le grenat oriental ou le rubis-spinelle. M. Beudant s'est servi de la dénomination d'Almandine pour désigner une des esp. du g. Grenat, savoir : celle qui est à hase d'alumine et d'oxyde de fer, et dont les principales varićtés sont d'un rouge violet. (DEL.)

ALMANDINE. nin. - $V$. Alabandine. (C. i'O.)

* ALMEDDEA. вот. PII. - G. appartenant aux Diosmées d'A mérique, dédić par M. Augg. de St.Hilaire, à Don J. R. Pereira de Almeida, noble portugais dont le crédit et l'amitié favorisèrent ses recherches scientifiques au Brésil. Il a les caract. suivants : Cal. courl, 5 parti-fide ou denté. Pétales 5 , beaucoup plus longs, libres dans toute leur étendue, égaux, spatulès. Filets 5, plus courts que les pétales, libres, aplatis, hérissés antérieurement, au-dessus de leur milieu, d'une tonfre de poils; portant chacun une anthère en forme de cœur étroit et allongé. Ovaires 5, entourès à lrur base d'un disque cupuliforme, soudés inféricurement entre eux, glabres; autant de styles partant de leurs sommets, se rapprochant aussitôt et se soudant en un seul, que termine un stigmate en tête à 5 lobes. Le fruit est réduit à 2 coques, ordinairement 1 -spermes. L'embryon offre de grands cotylédons incombants, pliés dans leur longueur, sans compter de nombrenses et profondes rides transversales, et cachant la radicule qui naît d'une échancrure de leur sommet et se dirige obliquement vers le point d'attache. - On connaît de ce g. 5 esp., toutes brésiliennes. Ce sont des arbres ou des arbrisseaux, à feuilles alternes, quelquefois opposées vers lesommct des rameaux, simples, très entières, portées sur un pétiole noueux supérieurement.Les inflorescences terminent les rameaux quisont simples et nus au-dessous d'elles, puis divisés en panicules ou en thyrses avec des bractées à la naissance des pédoncules el deux bractéoles sur chaque pédicelle. I.es fleurs sont blanches, rouges, lilas ou bleues.

(AD. J.)

*ALNITES (Alnus, nom latin de l'Aune). вот. Foss.-M. Gœppert a décrit, sous le nom d'Alnites Kefersteinii, un des fossiles les plus intéressants des terrains tertiaires, par la conservation des parties de la fructification. En effet, dans les lignites bruns de Salzhausen, près Nidda en Wettéravie, on a tronvé plusienrs rameaux, les uns avec des 
rhatons garnis d'élamines avec leur pollen encore bien conservé; d'autres portant des chatons femelles avec leurs écailles et les fruits qui sont entre ces écailles. La comparaison de ces organes avec ceux de l'Aune commun, prouve évidemment que cette plante appartient au même g., et à une esp. voisine de notre Almus glutinosa, quoiqu'il soit impossible de décider si l'esp. fossile diffère spécifiquement des esp. vivantes en Europe ; car on n'a pas trouvé jusqu'à ce jour, dans la même localité, de feuilles analogues à celles de ce g., surtout à celles de l'Alnus glutinosa.

La forme des anthères et celle du pollen qu'elles renferment, est parfaitement identique avec celle de ces organes dans les $A l$ nus; et c'est sans doute un des faits les plus curieux de la botanique fossile, que la parfaite conservation de parties aussi délicates que les grains du pollen. M. Gœppert, auquel cette observation est due, l'a publiée en 1837, dans une dissertation spéciale sur les fleurs fossiles, avec tous les détails convenables et d'excellentes figures. ( $N$ ov. Act. Nat. Cur.). Cette plante confirme du reste ce qu'on savait déjả de la présence fréquente, dans les terrains tertiaires, de plusieurs plantes appartenant aux mèmes g. que nos arbres forestiers actuels; ainsi, parmi les Amentacées, outre le g. Alnus, M. Goppert cite une esp. de Betula, et nousmême nous en avons décrit une des environs de Narbonne. La même localité a présenté une esp. du g. Carpinus. D'après les feuilles, les peupliers et les saules paraissent fréquents; l'Orme et le Comptonia y existent certainement, et les Érables et les Noyers sont les plus abondants.

(AD. B.)

ALNUS (nom de l'aune chez les Latins). воT. PI. - Synon. latin de l'aune. (C. L.)

* ALOCASIa (altération synonymique de Colocasia. $V$. ce mot). вот. рн. - Sous-g. ou div. du g. Colocasia, Ray, de la fam. des Arö̈dées, Juss. (Aracées, Sch.), tribu des Caladiées, Sch. (Meleth), s.-tribu des Colocasiées, Sch., et aỉnsi caractérisée: Spathe cucullée, repliée sur elle-même (incurvaı́a). Organes génitaux rudimentaires situés audessus et au-dessous des étamines. Appendice du spadice renflé, plissé, veiné, obtus. Connectifs sessiles. Ovaires uni-loculaires; ovules au nombre de 6 environ. - Cette division comprend des plantes indiennes, à rhizôme caulescent, garni de feuilles peltées, simultanées, dont les nervures saillantes sur les 2 faces; à pédoncules courts, vaginés, presque solitaires; a spathe glaucescente. Elle a pour type l'Arum macrohizum L., qui, joint au Caladium cucullatum Pers. sont les 2 seules espèces qu'elle renferme jusqu'ici. (C. L.)

ALOES. Aloë ( $\dot{x} \lambda o ́ n$, probablement l'Aloès des modernes ). вот. PI. - G. de la famille des Liliacées, tribu des Aloïnées, fondé par Tournefort (Inst. t. 190 ) et adopté ensuite par tous les botanistes. En voici les caract. essentiels, tels que nous croyons devoir les établir aujouráhui : Périgone corollacé, régulier, tubulé, ou irrégulier, bilabié, droit on courbé, charnu, cylindrique ou subtriangulaire, sexfide, sécrétant à sa base interne une liqueur sucrée très abondante; formé de 6 divisions dont 3 externes, charnues, soudées en tube, et 3 internes ténues, soudées avec les premières par lí dos, dans pres. que toute leur longueur; ou toutes entièrement libres, réunies en forme de tube, ou distinctes et révolutées; segments du limbe ovales, à peu près égaux, imbriqués, alternes, un peu réfléchis en dehors, ou linéaires révolutés, canaliculés (Haworthia), ou arrondis, ténus (Apicra). Étam. 6, hypogynes, oppositives; filaments filiformes, légèrement courbes, libres; ou 3 seulement libres (ceux qui répondent aux divisions corollaires externes) et 3 enveloppés, dans presque toute leur longueur, par les bords enroulés des 3 pétales adhérents (Gasteria); tous inclus ou exserts; anth. biloculaires, fixées par la base au moyen d'une fossette où s'insère le sommet du filament. Ovaire trigone, triloculaire, charnu; ovules nombreux, ovales, bisériés, anatropes, presque horizontaux, alternes, insérés sur la paroi interne. Style obscurément trigone, allongé, courbe, moins long ou aussi long que les étamines. Stigm. peu apparent, triparti, papilleux. Caps. trigone, scarieuse-membranacée, triloculaire, loculicide-bivalve. Graines comprimées, planes ou anguleuses, à test membraneux, lâche, ailé sur les bords. Embryon axile, un peu plus court que l'endosperme à radicule très rapprochée du hile.

Les nombreuses espèces qui forment ce beau g., appartiennent presque exclusivement à l'Afrique et surtout à la partie aus- 
trale de ce continent. Les exceptions à cette règle, citées par quelques auteurs sont en fort petit nombre; et plusieurs espéces qu'on réunissait à ce g., en ont été retirées, par les botanistes modernes, pour devenir le type de g. nouveaux, ou pour être réuniesà des g. voisins. (V.Tritoma, Veltheimia, Lomatophyllum, Aletris, Sanseviera, Kniphofia, etc. Doués de formes à la fois belles et étranges, les Aloès arborescents se plaisent dans les sables les plus chauds des déserts, el les espèces naines recherchent l'ombre des taillis, oú elles croissent en touffes. Les Aloès prospèrent dans tous les terrains secs et pierreux. Ce sont, comme on le voit, des Sous-arbrisseaux, ou des Herbes caulescentes ou acaules persistantes, munies de feuilles charnues, distantes, sessiles, amplicaules, planes ou anguleuses, ou disposées cn rosace alterne-imbriquée, scrrée, ou en angles définis; souvent dentées - épineuses et toujours membranacées sur les bords, ou souvent encore couvertes, sur et sous les 2 faces, de papilles verruqueuses, transparentes, très rarement d'épines; à fleurs souvent grandes et belles, disposées en grappes ou en épis ombelloïdes, terminaux ou axillaires, simples ou rameux. On en cultive un grand nombre d'espèces dans les jardins oú la multiplicité des variétés menace d'en effacer les types. Le plus bel ouvrage iconographique dont les Aloès aient été l'objet, est une monographie du g. en cours de publication, et due à M. le prince de Salm-Dyck, qui depuis long-temps s'occupe de cette matière avec succès. Ce botaniste y réurit comme sous-genres, les genres que quelques auteurs précédents avaient cherché à en distraire comme distincts, et dont quelques uns, selon nous, mériteraient en efiet d'ĉtre reconnus comme tels. Ces g. sont: Apicra, Haw.; Haworthia, Duv.; Bouiea, Haw.; Aloë, Haw. (proprement dit); Pachydendron, Haw.; Rhipidodendron, Willd.; et Gasteria, Duv.; auxquels nous joindrons le g. Lomatophyllım séparé ả tort, selon nous, des vrais Aloès. L'autcur les subdivise en 29 sections, basces sur l'habitus des diverses plantes qu'elles renferment. Nous examinerons la caractérislique de chacun de ces s.-g., à son ordre alphabétique.

Lc suc gommo-résineux qu'on retire de plusieurs espèces, a été préconisé en mé- decine, et ne sert guère plus aujourd'hui que dans la pharmacie vétérinaire; mais nous devons signalcr ici les vertus que possède en particulier l' $A$. soccotrina, vertus qu'on ne connaissait peut-ètre pas sous le rapport que nous allons indiquer, et que nous avons expérimentées nous-même. La pulpe des feuilles de cette espèce, appliquée sur les brûlures les plus graves, en neutralise la douleur presque sur-le-champ, et, renouvelée 2 ou 3 fois en 24 h., prévient les accidents morbides qu'clles entrainent ordinairement. Il cst probable que d'autres esp. congénères doivent partager avec cellc-ci cettc précieuse qualité. (C. L.)

ALOEXYLON, Loureir. (áión, Aloès;

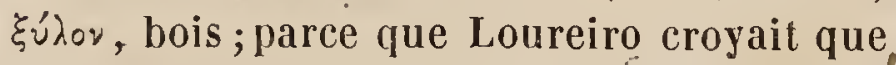
ce végétal fournit lc bois d'Alciès ou agalloche). вот. Рп. - G. de la famille des Légumineuses, sous-ordre des Césalpiniées, tribu des Cassiées, DC. (Césalpiniées vraies, Bartl.). Loureiro (Flor. Cochin.) attribue à ce g. les caract. suivants : Cal. à 4 sépales pointus, caducs : le sépale infér. falciforme, 2 fois plus court quc lcs autres sépales. Pétáles 5, inégaux. Étam.10, libres. Style filiforme. Légume falciforme, ligneux, monosperme; graine oblongue, courbée, arillée. -Arbre; feuilles simples; pédoncules terminaux, multiflores. Ce g. n'est fondé que sur une seule esp., indigène en Cochinchine.

(SP.)

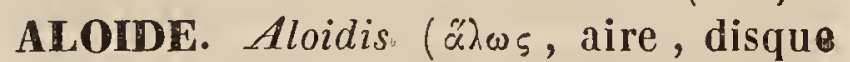
d'un bouclier ; हiंdos, forme; lisez Haloïde ). moLL. - Ce g. a été institué par M. Megerle de Mühlfeld, pour une coquille bivalve, figurée depuis long-temps dans Chemnitz (Conch. cab. t. 10. pl. 172. f. 1670, 1671). Nous comprenons difficilement le motif qui a pu porter M. Megerle à la création de ce g., puisque la coquille dont il s'agit est une véritable Corbule, et probablement la Corbula rugosa Lam. C'est dans le Magasin de Berlin pour l'année 1811, que l'on trouve pour la 1 re fois le g. Aloidis. ( $V$. CORBule.)

$$
\text { (IESH.) }
$$

* ALOINÉES. Aloinece (àón, aloès). вot. PH. - Tribu établic par lc professeur Link, dans la famille des Asphodélées (Liliacées), et qui a pour type le g. Aloë. (A. R.)

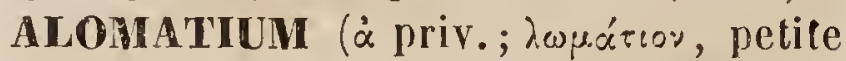
bordure). вот. PIr. - M. De Candolle donne ce nom à une section (artificielle) de ses 
Arabis, caractérisée par des graines immarginées. Les esp., comprises dans cette section, appartiennent pour la plupart au g. ou s.-g. Abasicarpon, Andrz.

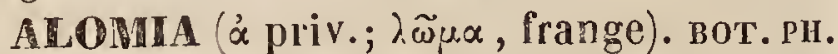
- G. de la famille des Synanthérées, établi par M. Kunth (Humb. et Bonap. Nov. Gen. Iv.) qui le définit ainsi : Capitule multiflore, homogame. Involucre campanulé, à squames imbriquées, étroitcs, aiguës. Réceptacle nu, convexe. Tube de la corolle grêle, glabrc, à limbe 5-denté. Anthères se terminant en appendices obtus, ovalesoblongs. Akèncs glabres, 5-angulaires; aigrette nulle. - Ce g. ne renferme qu'une esp., l'A. ageratoides, H. B. et K. (Ethulia - ageratoides Spr.) trouvée près de Mescala au Mexique. C'est une plante hcrbacée, glabriuscule, très rameuse, à fleurs blanchcs, très semblable pour le port aux Piqueria.

* ALOMHÉES. Alomiea, Less. (à priv.;

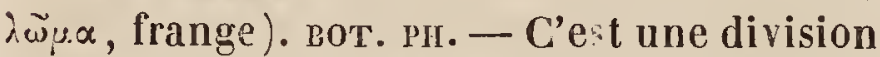
de la sous-tribu des Eupatoriées, famille des Synanthérées, caractérisée par l'absence de l'aigrettc, et renfermant les g. Orsinia, Berth.; Piqueria, Cav.; Alomia, H. B. et K., type; Phalacrcea, DC.; Gymnocoronis, DC., et Isocarpha, R. B.; etc. - M. De Candollc regardc cette division comme trop arificielle, en raison de la grande analogie des g. qu'elle renferme avec ceux de certaines autres tribus. $V$. Eupatoníes.

ALOMYA. INs.-G. de la famille des ichneumoniens, de l'ordre des Hyménoptères, élabli par Panzer ( ann. germ.) et adopté par Latreílle, Gravenhorst, et tous les entomologistes moderncs. Les caract. qu'il présente le rapprochent du g. Trogus; mais il en diffëre notablcment par une tête plus étroite et ylobuleuse; des ant. plus épaisses; des ailes ayant leur $2^{\text {me }}$ cellule cubitale, triangulaire ; un abd.comprimé et plus élargi vers son extrémité. - On nc connaît que quelques esp. indigènes de cc g., et celle que l'on en considère comme le type, est l'Alomya ovatrix Panz. Grav. (Jchneumon ovator Fab., et Ichneumon debellator ejusd). Elle est noirc avec les $1^{\text {ers }}$ segments de l'abd. roux. On la trouve lans la plus grande partie de l'Europe. (BL.)

ALONSOA, R. et P.; Hemimeris, Kunth; Hemitomus, Lherit.(ZanoniAlonso, espagnol). Bot. er. - G. de la famille des Scrophula- rinées, tribu des Verbascées, fondé par Ruiz et Pavon (Syst. Fl. Per.), et dont voici les caract. distinctifs : Cal. 5-parti, presque égal. Cor. hypogyne, inclinée, à tube très court, à limbe subrotacé, 5-fide, dont le lobe supér. plus grand, dirigé en avant; tous arrondis. Étam. 4, didyrames, exsertes, déclinées, ascendantes, insérées sur le tube de la corolle; anth. biloculaires, à logettes divariquées. Ovaire biloculaire, à placentas multi-ovulés, soudés des 2 côtés à la cloison. Style simple, filiforme; stigm. capité. Caps. ovale-oblongue, aiguë, biloculaire, septicide-bivalve au sornmct; valves indivises; graines nombreuses, ridécsverruqueuses.-Ce sont des plantes herbacées ou frutiqueuses, indigènes au Chili et dans les Andes péruviennes, à feuilles opposées ou ternées, dentées en scie, quelquefois très entières; à fleurs axillaires, disposées en une sorte d'épis, d'un rouge très éclatant, et penchées en raisen de la torsion des pédicelles. On n'en connaît qu'un très petit nombre d'esp. ( 5 ou 6 ) parmi lesquelles on cullive assez souvent dans les scrres d'Europe, les $A$. incisifolia, acutifolia, linearis, etc

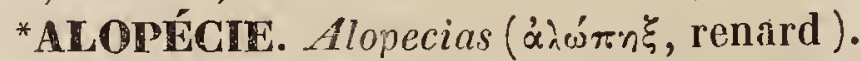
porss. - Nom générique, selon MM. Muller et Henle, d'un g. de la famille des Squales, comprenant le Squalus vulpes I. Ce nom, plus conforme an génie de la langue dont il est tiré, a été contracté par Rafinesque en celui d'Alopias, adopté par lc princc Ch. Bonaparte, pour désigner le même g. et le même poisson. Ce Cartilagineux , commun sur nos côtes et principalement dans la Méditerranée, est remarquable par le prolongement considérable du lobe supér. de la caudale; la forme de cette nageoire a souvent fait donner á ce poisson lc nom de Faulx; dénomination qui en exprime très bien le caract. le plus saillant. Il est d'ailleurs voisin des Carcharias, par l'absence des évents, la forme générale des dents, et la position des nageoires.

Le nom de Vulpes ou de Vulpecula, que les naturalistes modernes ont appliqué á cette espèce, vicnt de ce que les auteurs de la Renaissance, Rondelet et Salviani, ont

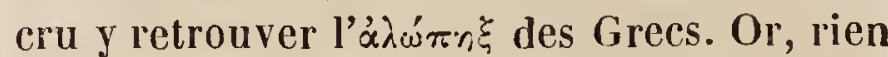
n'est moins certain que ce rapprochement; car en comparant les différents passages 
des Anciens, on arrive a conclure que l' $\alpha \lambda \omega ́ \pi n \xi$ était un poisson voisin des $\Gamma \alpha \lambda \varepsilon^{\prime} \circ \varsigma$; c'est-a-dire de nos Squales, et que, dans un seul passage d'Athénée, il est dit que

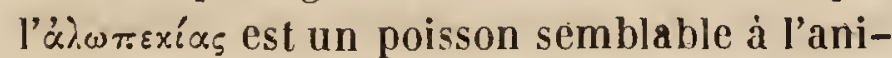
mal terrestre dont il a reçu le nom. Il faut avouer que cette phrase laisse encore bien à désirer, pour établir une synonymie avec quelque certitude. Toutefois, comme il est

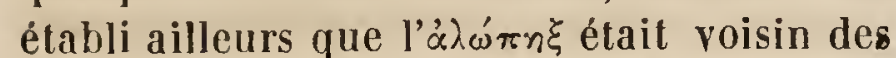
ràźos, il est certain que ces noms étaient donnés à un poisson de la famille des Squales.

(VAL.)

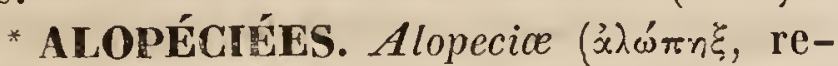
nard). P01ss.-Nom donné, par MM. Muller et Henle, $p .74$, à la $3^{\text {e }}$ famille dc la section des squales. (Hist.nat. des Cartilagineux.)(VAL.)

* ALOPECUROIDES ( $\alpha \lambda \omega \pi n \xi, n \times 0 \xi$, re-

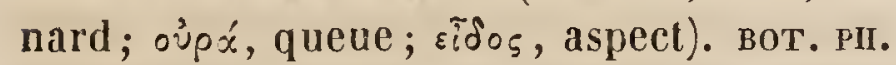
-On a donné ce nom à l'une des sect. du g. S'toxbe, tel qu'il a été circonscrit par M. Lessing. La seule esp. qui caractérise cette section est le Stobe (Seriphium) alopecuroides, originaire du Cap.

(J. D.)

*ALOPECURUS ( $\alpha \lambda \omega \dot{\pi} \pi \xi$, nxos, renard; o v $\rho \alpha$, queue). вот. Рн. - Ce g., de la famille des Graminécs, est souvent désigné en français sous le nom de Vulpin. Il se compose d'un assez grand nombre d'esp. (environ 20), pour la plupart originaires des diverses contrées de l'Europe ou de l'Amérique septentrionale. Les caract. de ce genre sont assez tranchés : Fleurs en épi dense, composé d'épillets nombreux, sessiles et uniflores; glumes au nombre de 2, allongées et carénées, mutiques, égales, et un peu soudées ensemble par leur partie infér., tantôt plus longues, tantòt plus courtes que la fleur qu'elles contiennent. Paillette infér. membraneusc, comprimée, carénée, portant une arête qui nait ordinairement un peu audessous de sa partie moyenne. Paillette supér. manquant. Étam. 3 ; styles quelquefois soudés entre eux par la base et portant chacun un stigm. très long, plumeux et velu. Écailles hypogynes (glumelles) nulles. Fruit ordinairement glabre et lenticulaire, nu ou recouvert par les glumes endurcies. - Les esp. de ce g. sont assez insignifiantes; ce sont des plantes annuelles ou vivaces, qui croissent dans les champs ou dans les lieux humides : tcls sont les $A$. aqrestis, geniculatus, bulbosus, pratensis, clc. (A. R.)
*ALOPHE. Alophus (a’loyos, sans crête). Ins. - G. dc l'ordre des Coléoptères tétramères, famille des Curculionites, division des Cléonides, établi par Schœnherr, qui lui donne les caract. suivants : Ant. médiocres, minces; les deux $1^{\text {ers }}$ art. du funicule peu longs, obconiques; les autres plus courts, lenticulaires, s'élargissant graduellement jusqu'au dernier; massue en ovale-oblong. Rostre allongé, s'épaississant vers le sommet, canaliculé en dessus. Yeux sub-ovales, déprimés. Prothorax presque oblong, tronqué à la base, s'arrondissant un peu latéralement avant le milieu, un pen plus étroit postérieurement, lobé derriẻre les yeux. Écusson distinct, arrondi au sommet. Élytres subovales, convexes ; les épaules arrondies. - Ce g. figure dans le dernier Catal. de M. Dejean, qui y rapporte 3 esp., dont 2 de la Sibérie, et une qui se trouve en Autriche, en lllyrie et dans les environs de Paris. Nous ne citerons que cette dernière, qui est le type du g. : c'est le Curculio triguttatus $\mathrm{Fab}$.

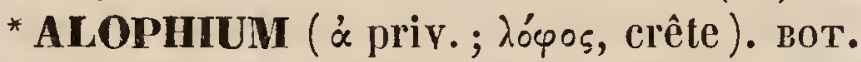
PII.-Cassini a donné ce nom à une plante que M. De Candolle réunit au g. Centaurea, pour en former la $31^{\text {me }}$ sect., qu'il considère même comme devant faire partie de celle qu'il désigne sous le nom de Séridées. Les caract. de l'Alophium sont : Invol. composé de squames ovales, imbriquées; les extér. terminées par une pointe simple; lcs moyennes par 3 petites épines; enfin les intér. oblongues, obtuses, mutiques et scarieuses au sommet. Les ovaires du disque glabres, couronnées par une aigrette courte, à 3 rangées de paillettes dont les extér. oblongues, les moyennes linéaires, denticulées, et les intér. filiformes et plus courtes que les autres. Les cor. du rayon, à peu près de même forme que celles du disque, sont stériles.

(J. D.)

*ALOPHOCHLOA ( $\varkappa_{\lambda} \circ \varphi_{\circ} \circ$, non"aigretté; $\chi$ גón, herbe). вот. PII.-G. de la famille des Graminées, proposé par Reichenbach (Flor. excurs. 12) et réuni comme synon. au genre Koleria, Pers. $V$. ce mot.

(C. L.)

*ALOPHORA ( $\ddot{\alpha} \lambda \omega \zeta$, aire, enfoncement en forme de disque; yópos, porteur; il faudrait écrire Halophora). Ins. - Genre de l'ordre des Diptères, division des Brachocères, subdivision des Dichœtes, famille des Athéricères, tribu des Muscides, sec- 
tion des Créophiles, sous-tribu des Phasiennes. Ce g., établi par M. Robineau-Desvoidy aux dépens des g. Conops de Linné, Thereva de Fabricius, Phasia de Latreille et de Meigen, a été adopté par M. Macquart, et offre les caractères suivants : Corps large, déprimé; jambes postérieures arquées ; première cellule postérieure des ailes fermée, terminée presque en pointe; pétiole assez long. - Parmi les espèces qu'il renferme, nous n'en citerons que deux, qui se trouvent dans toute l'Europe, savoir : les $A$. subcoleoptrata et hemiptera Rob. Desv., qui sont des Thereva pour Fabricius.

*ALOPHUS. ins. - Syn. latin d'Alopue. (C. D'O.)

AlOPIAS. poiss. - Synon. d'A lopécie.

(VAL.)

*ALOPONOTE. rept. - $V$. Analoponote. (G. B.)

ALOSE. Alosa (Alosa, l'Alose). polss. - Poisson que Linné et Lacépède ont classé dans le genre des Clupées, sous le nom de Clupea Alosa. L'Alose véritable a la bouche sans dents; la tête large et veinée, le dos large, épais et arrondi; le ventre mince et tranchant; une petite dorsale; une assez longue anale; la caudale fourchue; les nageoires paires petites;les ventrales sont abdominales.-C'est un excellent poisson qui remonte dans nos fleuves pour y frayer vers la fin d'avril et pendant le mois de mai (ce qui l'a fait nommer sur quelques points du littoral de l'Allemagne may fisch; les Anglais le nomment shad). A cette époque les poissons ont les laitances ou les ovaires remplis, et le ventre est tellement distendu que la hauteur du corps fait près du quart de la longueur totale. Elles remontent assez haut dans les fleuves; car, dans la Seine, on en prend jusqu'à Provins. Elles entrent aussi, mais plus rarement, dans les affluents de ces fleuves. Quand elles ont frayé, les Aloses deviennent comme malades; elles maigrissent considérablement, et ont si peu de force, qu'elles se laissent aller au fil de l'eau qui les rapporte vers la mer. Un petit nombre peuvent y arriver, la plupart mourant en route. Les petites Aloses nées dans les eaux douces, y croissent jusqu'à la taille d'un décimètre. Parvenues à cette force, on les voit toutes descendre le fleuve et gagner la mer, vers le mois d'août. Les petits y restent, pour s'y développer, jusqu'à ce qu'ils aient atteint la taille de 3 décimètres environ; alors les Aloses deviennent aptes à reproduire leur espèce; et, dès le printemps, les deux sexes remontent les fleuves.

L'Alose se pêche au tramail, sorte de grande nappe de filet, tendue verticalement contre le courant de l'eau; une petite ficelle que tient le pêcheur, l'avertit de la secousse donnée parle poisson au filet. L'Alose meurt aussitôt qu'on l'a tiréo de l'eau.

Il ne faut pas confondre l'Alose avec la Finte $(\boldsymbol{V}$. ce mot), qui est moins délicate, et qui se reconnaît aux petites dents dont sa bouche est garnie.

(VAL.)

ALOSE. Alosa (Alosa, Alose des modernes). polss. - M. Cuvier a établi, sous ce nom, un genre de la famille des Clupéides, dont l'Alose ordinaire est l'espèce autour de laquelle il a groupé toutes les esp. rangées dans le g. Clupea, et qui ont, comme elle, une échancrure entre les deux branches de la mâchoire supérieure. Ce g. est naturel, quoiqu'il repose sur un caractère qui en apparence est peu important. On trouve des esp. d'Aloses dans les eaux de l'Amérique septentrionale ( $A$. menhaden, oestivalis, vernalis, etc. de Mitchill), et dans celles de l'Inde. Rupel en figure plusieurs esp. Il ne paraît pas que toutes aient, comme notre Alose, l'habitude de remonter les fleuves pour frayer.

(VAL.)

ALOUATE. MAm. - Synon. du g. Hurleur, dans plusieurs méthodes. C'est aussi le nom de l'esp. type de ce g. (Hurleur Alouate).

(I. G.-S.-H.)

ALOUF. 015: - Nom vulg. de l'Alouette des champs.

(C. D'O.)

ALOUETTE. Alauda. 01s. - G.de l'ordre des Passereaux, de la famille des Dentirostres de Cuvier, faisant partie de notre famille Alaudidées et de notre sous-famille Alaudinées. Quoique, à l'article de cette sous-famille, nous ayons annoncé que, des différents g. et s.-g. établis aujourd'hui par les auteurs anglais aux dépens du g. Alau$d a$, nous croyions ne devoir adopter que les. 3 qui répondent aux 3 div. établies par MM. Cuvier, Vieillot et Temminck, nous devons avouer ici que tous nos efforts pour trouver des caract. distinctifs et de quelque imporlance à ces trois groupes, basés uni-m. 
quement sur la forme du bec, ont été infructueux, et nous ont convaincu que, dans ce g. plus encore que dans tout autre, cet organe donnait lieu à des rapprochements d'esp. dont l'analogie en tre elles disparaissait complètement sous d'autres points de vue. Fffectivement, si quelques unes offreut, dans la conformité du bec, un motif de réunion, la différence dans la forme de leurs ailes et de leurs paltes porte, au contraire, à les séparer. C'est ainsi qu'en prenant pour un des types ou g., l'Alouette des champs (A. arvensis $\mathrm{L}_{\text {.) }}$, au bec cylindrico-conique, aux rémiges primaires fort allongées, avec les trois $1^{\text {res }}$ seulement d'égale longueur et sans penne bâtarde, l'Alouette lulu, l'Alouette cochevis, qui, d'après leur bec, devraient lui être réunies, nous présenteront, au contraire, une coupe d'ailes fort différente, à pennes primaires de longueur moyenne, avec les 4 et non les trois $1^{\text {res }}$ égales et une penne bâtarde; tandis que la Calandre, la Calandrelle, dont les ailes ont entièrement la forme de celles de l'Alouette des champs, en diffèrent par leur bec remarquablement fort, arqué supérieurement et comprimé chez l'une, brévicône et obtus chez l'autre. Quant aux pattes, on les verra également subir, chez des espèces conformes dans leurs autres parties, de fortes modifications dans la longueur des doigts et des ongles, tandis qu'on les trouvera semblables chez d'autres qui diffèreront entre elles sous d'autres rapports.

Ces 3 divisions, adoptées par les auteurs précités et indiquées par M. Swainson, dans sa dernière classification, comme g., sous les noms d'Alauda, Calendula et Certhilauda, sont, ainsi que leurs s.-g., caractérisées par cet auteur, de telle sorte qu'une parlie de nos esp. européennes n'y peuvent trouver place; ce sont les Alouettes Calandre, Calandrelle, Cochevis et Lulu.

Persuadé depuis long-temps, d'après nos propres observations, du grand nombie de modifications qu'éprouve la forme du bec dans la plupart des g. un peu nombreux en esp., et, par suite, du peu d'importance de cet organe comme caract. générique, et, ayant reconnu, après une comparaison minutieuse des 28 esp. que nous possédons, que, chez les Alouettes, oú l'on voit la forme du bec passer par gradations insensibles de la forme particulière aux Gros-becs jusqu'à celle des Ténuirostres, les ailes ètaient conformées en général d'après deux types bien prononcés et distincts, c'est-à-dire ailes aiguës ou sul-aiguës, à primaires allongées, sans penne bâtarde dans l'un, sub-obtuses ou sub-aiguës, à primaires courtes ou médiocres avec une penne bâtarde dans l'autre, nous avons cru devoir renoncer à la division en 3 principaux groupes d'après le bec, admise généralement par les auteurs, parce qu'elle rapprochait un grand nombre d'esp. différant totalement entre elles par les ailes et les pattes. Convaincu que les modifications dans l'appareil du vol sont, en général, beaucoup plus importantes que celles du bec, comme divisions naturelles chez les esp. d'un même g., et chez les Alouettes en particulier (où elles coïncident d'une manière sensible avec des habitudes différentes), nous avons cru qu'il était plus naturel de sectionner le g. Alouette en deux groupes principaux, basés sur la forme des ailes. Un de ces groupes, d'ailleurs, est particulier à l'Europe, et son type alaire ne se rencontre chez aucune esp. exotique; c'est le type aigu ou sur-aigu; tandis que l'autre, qui ne se rencontre à son maximum que sous les zônes chaudes de l'Afrique et de l'Asie, renferme cependant quelques esp. européennes, à type moins prononcè et faisant transition entre les deux groupes.

Nous allons indiquer, dans le tableau suivant, les caract. de ces deux groupes et une série d'esp. qui se rappor tent à chacun d'eux, en commençant par celles chez lesquelles le type aigu et sur-aigu est à son maximum, et finissant par celies qui présentent le caract. opposé.

Genre Alouetre. Alauda. ( $V$. pour les caract. ceux indiqués pour la sous-famille Alaudinées.)

$1^{\text {re }}$ SECTION.— "Ailes aiguës ou sur-aiguës, sans penne bâtarde, à rémiges primaires longues ou très longues; les trois $1^{\text {res }}$ pennes seulement à peu près de la même longueur ; la $4^{\mathrm{m} t}$ et les suivantes décroissant brusquement ; les tertiaires n'atteignant jamais l'extrémité des primaires; queue légèrement fourchue; bec et pattes variant de forme suivant les esp.

Toutes les esp. de cette $1^{\text {re }}$ section sont exclusivement européennes; une seule se retrouve aussi dans l'Amérique du nord. Elles 
se font remarquer par leur vol facile et soutenu, s'élevant au plus haut des airs, et y faisant entendre leur chant sonore à des hauteurs où l'œil peut à peine les distinguer. Elles ne se posent jamais qu'à terre dans les plaines et nichent à la surface du sol; ce sont:

Alouettes grandes voilières et non percheuses (type européen).

A. Bec très fort, élevé, très arqué supérieurement, comprimé ; ailes sur-aiguës, atteignant l'extrémité de la queue;pieds grands et robustes; ongle postérieur fort, plus long que le pouce d'un tiers environ, et légèrement arqué; ex. : I'A. calandre, $A$. calandra L., type du g. Londra, Sykes. (Proceed. 1838, p. 112.)

$B$. Bec assez grêle, cylindrico-conique; ailes aiguës, n'atteignant que les $2 / 3$ de la queue; doigts allongés, mais moins robustes que chez l'espéce précédente; l'ongle postérieur moins gros, mais plus long et presque droit; ex. : l'A. des champs, Al. arvensis, type du g. Alauda, Swainson.

$C$. Bec et ailes comme chez l'esp. précédente; pattes noires à doigts courts, avec les angles antérieur et postérieur allongés, conformés comme dans le g. Plectrophane de Meyer (le Bruant de neige de Tem.), queue carrée à son extrémité; ex. : l'A. hausse-col noir, $A$.alpestris, type du s.-g. Phileremos, Bonap.

$D$. Bec plus gros, plus court, plus obtus que chez les deux esp. précédentes; ailes semblables; doigts et ongles faibles et très courts; ex. : l'A. calandrelle, A. brachydactyla.

$2^{\text {mr }}$ SEction. - " Ailes sub-aiguës ou subobtuses, à penne bâtarde, à rémiges primaires courtes ou moyenries; les 4 ou les 5 premières d'égale longueur à peu près; la $5^{\text {me }}$ ou seulement la $6^{\text {me }}$, décroissant d'une manière sensible; les tertiaires aussi longues ou presque aussi longues que les primaires; queue le plus souvent terminée carrément; bec et pattes variant suivant les espèces. "

Les espèces qui appartiennent à cette $2^{\mathrm{m}}$ • section sont beaucoup plus nombreuses que dans la $1^{\text {re }}$, dont nous ne connaissons que les 4 précitées ; 3 ou 4 esp. européennes en font partié ; mais la presque totalité appartiennent à l'Afrique ou aux Indes. Elles s'élèvent beaucoup moins dans les airs que celles de la $1^{\text {re }}$ section; ieur chant est moins étendu et moins prolongé, et elles le font souvent entendre étant posées. Elles se perchent souvent sur les tertres élevés, sur les murs, les maisons des villages, et mème les arbres et les buissons, et placent queiquefois leurs nids au pied ou au centre de ces buissons.

Alonettes petites voilières et percheuses (type indien, africain et européen).

1re s.-section. - - " Point de penne bâtarde; les 4 premières rémiges à peu près égales ; les tertiaires aussi longues qu'elles; bec nıédiocre, semblable à celı̇ de l'A. hausse-col noir; doigts et ongles courts et faibles comme chez la Calandrelle. "Une seule esp. africaine, et qui semble, par l'absence de penne bâtarde, faire exception à toutes les esp. étrangères à l'Europe, compose cette s.-section: c'est l'A. cendrille de Buffon, ou petite Alouette à tête rousse de Levaillant $(p l .199)$.

$2^{\text {me }}$ s.-Section.- ‘ Penne bâtarde fort petite, n'ayant guère que le quart de la longueur de la penne suivante."

$A$. Bec et pattes semblables à ceux de l'A. des champs, mais plus faibles et plus grèles; rémiges tertiaires n'atteignant pas l'extrémité des primaires; ex. : l'A. lulu, $A$. arborea.

$B$. Bec plus long et plus grêle que chez l'A. des champs; pattes semblables, mais l'ongle du pouce n'étant pas plus long que ce doigt ; tertiaires n'atteignant pas l'extrémité des primaires ; ex. : l'A. huppée, A. cristata.

$C$. Bec fort, dans le genre de celui de la Calandre, mais plus allongé et moins haut; primaires courtes, les tertiaires en atteignant presque la pointe; queue échancrée; pattes robustes, à peu près semblables aussi, mais l'ongle du pouce fort, allongé et presque droit ; ex. : l'Alouette à gros bec Vaill., pl. 193, type du g. Calendula de Swainson.

$D$. Bec gros, court, très arqué en dessus, approchant de celui des Fringilles ; tertiaires atteignant presque les primaires; doigts et ongles fort courts, comme chez la Calandrelle ; ex. : les Gros-bees croisés et Oreillon blanc Tem. (Col. 269). Type du g., PyrriuLAUDA,Smith., ou Megalotis, Swain. de l'Inde et d'Afrique. Ces esp., que tous les auteurs, excepté Lichtenstein, mettent dans les Fringilles, ont tous les caract. extér. et les habi- 
tudes des vraies $\Lambda$ loueltes. D'après Sylies (Proceerl., 1832, p.94), elles se tiennent toujours à terre et ne se perchent jamais. Elles se rapprochent de la Calandrelle par les pattes et même par le bec.

$3^{\text {me }}$ s.-SECTION. - " Penne bâtarde, atteignant la moilié en plus du tiers de la Iongueur de la penne suivante. »

$E$. Bec fort, intermédiaire á ceux de la Calandre et de la Calandrelle; ailes à primaires assez allongées, à tertiaires courtes ; doigts et ongles courts, comme chez la Calandrelle; ex. : l'A. Isabelline (Tem.Col.2442), l'A. à dos rollx (Vaill., pl. 197).

$F$. Bec et pattes à peu près semblables, mais ongle postér. plus court que le pouce; primaires courtes; tertiaires s'éteudant jusque près de leur extrémité; cx. : l'A. ferrugincuse, 4 . ferruginea de Lafr. (in Mus. nostro), Afr. austr.

$G$. Bec, pattes et huppe conformés comme chez l'A. huppée, mais l'ongle postér. plus arqué; primaires courtes, les lertiaires en atteignant l'extrémité; cx. : Mirafra africana Smith., la Calotte rousse, Vaill.(pl.198).

$H$. Bec de la Calandre, mais moins haut; doigts et ongles de l'A. des champs; penne bâtarde alteignant la moitié de la longucur de la suivante; primaires courtes, les terliaires en atteignant l'extrémilé; cx.: l'A. mirafre (Tem. Col. 305-2), type du g. Mirafra, Horsf. de l'Inde.

$J$. Bec médiocre, un peu plus fort et plus long que chez l'A. des champs; doigts et ongles très courts, comme chez la Calandrelle; les primaires très courtes; les 5 premières ả peu près de même longueur, entièrement recouvertes par les lertiaires; cx. : l'A. bateleuse (Vaill., pl. 194), type du g. Braco$n y x$, Swains.

$4^{\text {me }}$ S.-SECtion. - " Ailes conformées comme dans la s.-section précédente; mais bec grêle, allongé, arqué dans loute sa longueur; la mandibule inlér. recourbéc en dessous parallèlement à la supér. (g. Certhilauda, Swains., ou Sirly, Lesson, Traité d'Orn.).

$K$. Doigts assez allongés ; l'ongle du pouce fort, allongé, subulé et parfaitement rectiligne; ex. : l'A. Sirly, Buff., pl. 712; Vaill., pl. 192 (toute l'Afrique).

L. Doigts courts et robustes; l'ongle du pouce semblable à l'esp. précédente, mais T. I. légèrement recourbé vers le haut; ailes et queue beaucoup plus courtes que chez elle; ex. : le Sirly à queue barrée de blanc, Lesson (Tr. d'Orn.), Certhilauda albo-rasciata de Lafr. (May. Zool. 1836 , pl. 58); c'est le Certhilauda garrula de Spix (Afr. austr.).

$M$. Doigts semblables à ceux de l'esp.précédente, mais l'ongle du poucc eourt et courbé légèrement dans le sens ordinaire; primaires allongées, atteignant les $3 / 4$ de la longucur de la queue; ex. : l'A. bifasciéc, $A$. bifasciata Tem., Col. 393 (Égypte, Nubic)

$N$. Doigts robustes et beaucoup plus longs que chez l'esp. précédente; l'ongle du pouce à peu près semblable au sien; ailes à primaires moins longues, médiocres, n’atteignant que la moitié de la queue; cx. : l'A. à manteau roux, $A$. rufo-palliata de Lafr. (Mag. Zool., 1836, pl. 59). (Afr. austr.).

$O$. Point de penne bâtarde; doigts de longueur moyenne, mais faibles et minces ; tarses médiocres ou courts ; ongle du pouce court el légèrement arqué (type américain); ex.: l'A. mineuse Azara, n 148, Alauda cunicularia Vieill. (Dict., vol. I, p. 369); Certhilauda cunicularia de Lafr. et d'Orb. ( $\$ y-$ nopsis, p. 71); le Sirly à bec grêle, Certh. tenuirostris, d'Orb. et Laf. (Syn. p. 72); le Sirly maritime, Certh. maritima, iid., ibid.p. 72; d'Orb., Voy. en Amér., pl. 44, 1. La 1re est du Paraguay el de la République Bolivienne; les 2 suivantes sont de cette dernière contréc.

En indiquant cette nombreuse suite de petites subdivisions, nous sommes loin de prétendre les donner comme sections à suivre dans la classification. Notre but élait de prouver ce que nous avons avancé d'abord: que, chez les Alouettes, la forme du bec et des pattes varic, chez presque toutes les espèces, à tel point, qu'il est impossible de les subdiviser d'après eux, tandis qu'elles peuvent se fractionner naturellement en 2 groupes basés sur la forme de leurs ailes autant que sur la différence de leur's habitudes.

Le seul s.-g. Sirly nous paraît avoir quelque importance d'après ce que nous a communiqué, sur les mœurs des esp. africaines qui en font parlic, M. J. Verreaux, qui les a observées en Afrique. Sclon lui, ces esp. se tiennent habituellement sur les terrains élevés et arides, courent rapidement et grattent la terre de leurs pattes et de leur 
bec à la manière des Gallinacées. (LAFR.)

ALOUETTES DE MER. Pelidna, Cuv. oIs. - C'est, dans le Règne animal de $\mathrm{Cu}$ vier, une petile subdiv. de ses Échassiers longirostres, répondant en partie, au g. Bécasseau ou Tringa de Temminck. $V$. BÉcasSEAU.

(LAFr.)

ALOUETTINE. ors.-Synon. vulgaire du Pipit Farlouse dans quelques cantons de la France.

(C. D'O.)

${ }^{*}$ ALOUNERES, ou jahuquère. вот. CR. On nomme ainsi, dans les environs de Dax, l'Agaric paillet de Thore ( $A$. albo-rufus Pers.). C'est une esp. très recherchée. Son chapeau, large de trois pouces ou plus, est mameIonné, lisse, d'un blanc roux; ses feuillets sont décurrents, blancs dans le jeune âge et roussissent ensuite; le pédicule est nu, grêle, blanc et cylindrique.-Il croît au printemps et en automne, par groupes nombreux, aux pieds des sureaux. Sor odeur est très agréable et sa saveur douceâtre.

(LÉv.)

ALOYSIA, Ortega (Maria-Louisa, mère de Ferdinand VII, roi d'Espagne). вот. Pll. G. de la famille desVerbénacées, réuni comme synon. au g. Lippia, dont il forme une des 2 divisions. $V$. Lippla.

(C. L. )

ALPACA. mam. - Espéce du g. Lama. $V$. ce mot.

(I. G.-S.-H.)

ALPEE. Alpous. Ins. - G. de Coléoptères pentamères, famille des Carabiques, établi par Bonelli et non adopté par M. Dejean, qui en place les esp. dans le g. Nébrie. (D.)

ALPES. Alpes. géol. - Ensemble des hautes montagnes de l'Europe qui, des bords de la Méditerranéc en France, śétendent jusqu'en Hongrie, séparant l'Italie des autres contrées. Les limites des chaînes, que l'on peut considérer comme des rameaux des $\mathrm{Al}$ pes, sont difficiles à tracer d'une manière précise. Le radical alp ou alb paraît être d'origine celtique, et avoir été emprunté par les Latins au langage des Gaulois, ou, selon les lexicographes, ce serait un mot sabin (Alpus) ayant la signification d'Albus.

On désigne souvent aussi, sous le nom d'Alpes, les chaînes de montagnes de toules les parties du monde, qui sontassez élevées pour que leurs sommets restent constamment couverts de neige; et quelques étymologistes font mème venir alp ou alb d'albus, blanc.

Le point le plus eleve des Alpes d'Europe est le Mont-Blane, qui atteint 4,810 métres au-dessus du niveau de l'Océan. $V$. MontaGNES.

ALPESTRES (Alpes, Alpes). вот. - On donne ce nom à toutes les esp. de plantes qui croissent sur les montagnes peu élevées; celles, par exemple, sur lesquelles la neige ne séjourne pas, comme les Cévennes, les montagnes de l'Auvergne, etc., etc. Tandis qu'on appelle Plantes alpines, celles qui viennent à des hauteurs plus considérables, et qưi appartiennent à la végétation carac. téristique des hautes chaînes de montagnes.

* ALPHAA, DC. (ảìós, blane). вот. PH.G. ou s.-g. de la famille des Malvacées, différant des Althoca par un involucelle 5-fide et par des coques rugueuses. Les 2 esp. qui le constituent croissent, l'une à Bourbon, l'autre au Cap de B.-E. (Sp.)

* ALPHÉE. Alphoeus (nom myth.). CRUST. - G. de l'ordre des Décâpodes, famille des Macroures, établi par Fabricius, et ainsĩ caractérisé : Carapace s'avançant au-dessus des yeux, et formant un petit bouclier voûté. Rostre très petil, quelquefois nul. Ant. supér. petites, ayant leur $1^{\text {er }}$ art. court et armé en dehors d'une lame ordinairemene spiniforme, les suivants cylindriques. Ant. intér. placées en dessous des précédentes, pourvues d'un palpe lamelleux.Mandib. munies d'un appendice palpiforme, court. Pattes-mâchoires quelquefois grêles et allongées, d'autres fois de longueur médiocre, et pourvues d'un article élargi et presque foliacé. Pattes des deux $1^{\text {res }}$ paires didactyles; les antér. fortes, armées d'une grosse main renftée; les suivantes monodactyles et de longueur médiocre. Abd. grand, pourvu de fausses pattes allongées. - Ce g. renferme $12 \mathrm{esp}$. , dont quelques unes habitent la Méditerranée; mais la plupart les mers des Antilles et de l'Océan Indien. (H. L.)

*ALPHÉENS. Alphoi (Alphée, Aiphoeus, nom myth!。 cRusT. - Tribu de l'ordre des Décapodes, famille des Macroures, créée par M. Milne-Edwards, et ainsi caractérisée : Rostre très court, n'ayant jamais la forme d'une grande lame placée de champ, comme chez les Palémoniens. Ant. internes, placées au-dessus des externes, ordinairement très courtes. Une des paires de pattes très grosse, et en général terminéc par une forte main 
didactyle. Les deux paires de pattes antér. presque toujours didactyles; celles de la $2^{e}$ paire ne l'étant jamais ; enfin celles des 3 dernières assez robustes et servant pour la marche aussi bien que pour la natation. Cette tribu renferme les g. suivants: Alphous, Athanos, Pontonia, Autumnoe, Nika, Alya, Caridina, Hymenocera. (H. L.)

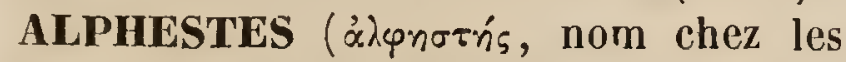
Grecs d'un poisson aujourd'hui inconnu). PoIss. - Nom grec tiré d'Athénée, attribué tantôt à une esp. de labre, et tantôt employé par Bloch, dans son édition posthume, pour un g. qui n'a pu être conservé, car les deux esp. que cet auteur y rapportait sont évidemment des Serrans.

(VAL.)

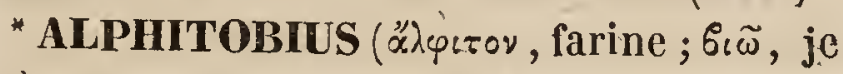
vis). Ins. - G. de Coléoptères hétéromères, famille des Mélasomes, établi par Stephens dans son Catal. des Ins. d'Angleterre, mais sans indication de caractères. Il le place dans. sa tribu des Ténébrionides, à côlé du g. Phaleria de Latreille. Ce g. ne renferme qu'une seule esp. qu'il nomme $A$. picipes, et qu'il rapporte avec doute au Tenebrio fagi de Panzer. Westwood (Syn. of Gen.) caractérise ainsi le g. dont il s'agit : Corps oblong, ovale; ant. terminées en massue; $3^{\mathrm{e}}$ art. aussi long que le $4^{\mathrm{e}}$.

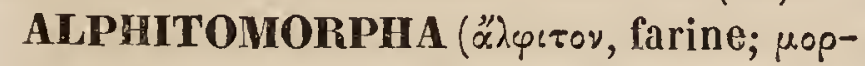
$\varphi$ '́, forme). вот.cr.-Wallroth (Verhand.naturf.Berl.1819), désigne sous ce nom le g. Erysiphe ( $V$.ce mot), parce que les Champignons qui le composent ressemblent à de la farine répandue sur des feuilles.

\section{(LÉV.)}

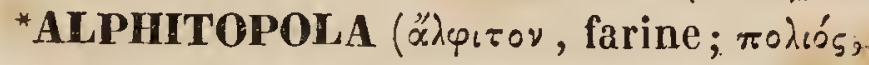
á, blanc, che). Ins. - G. de Coléoptères tétramères, famille des Longicornes, établi par M. Dejean (Catal., $3^{\text {e }}$ édit.), et dont les caract. n'ont pas été publiés.D'après la place qu'il lui donne, à còté du g. Gerania de M. Serville, il appartiendrait à la tribu des Lamiaires de ce dernier. Il n'y rapporie qu'une seule esp. fnommée par lui, A. lactea; elle est du Sénégal.

(D.)

*ALPHUS ('̊xyós, blanc). Ivs.-G. de Coléoptères tétramères, famille des Longicornes, établi par M. Dejean (Calal., $3^{\mathrm{e}}$ édit.), qui n'en a pas publié les caractères. Il y rapporte 7 esp. toutes nommées par lui, dont 5 du Brésil et 2 de Cayenne. Ce g., jar la place qu'il occupe dans le Catal., paraît appartenir à la tribu des Lamiaires de M. Serville.

ALPINES (Plantes). во т. $-V$. Alpestres. (A. R.)

ALPINIA, L.; Gethyra et Ethanium, Salish.; Zerumbet, Wendl., etc. (Prosper Alpin, ancien botaniste). вот. PII.-G. de la famille des Amomées de Jussieu, formé par Linné (Gen.Pl.), et dont les caract. sont ainsi circonscrits: Cal. tubuleux, lâche, se déchirant au sommet. Cor. à tube court; div. extér. du limbe égales, un peu dressées; les intér. latérales, denticulées ou nulles; labelle ample, étalé, entier ou 2-3-lobé. Filament linéaire non prolongé au-delá des loges de l'anth., qui est mutique et échancrée. Ovaire infère, triloculaire. Ovules nombreux, horizontaux, anatropes, fixés dans l'angle central des loges. Style filiforme, passant entre les loges des anth.; stigm. capité-trigone. Caps. bacciforme, 3-loculaire, indéhiscente. Graines arillées, très ou peu nombreuses par avortement. - Le g. Alpinia, tel qu'il a été limité, renferme encore une vingtaine d'espèces qui, presque toutes, sont cultivées pour l'ornement des serres chaudes; ce sont de magnifiques herbes vivaces, appartenant toutes à l'Asie tropicale. Les racines (rhizômes) en sont épaisses, tubéreuses, aromatiques, horizontales; il en sort plusieurs tiges à feuilles bifariées, lancéolées; à gaîne fendue, ligulée. L'inflorescence en est terminale, paniculée, ou en épi ou en grappe lâche.

(C. L.)

*ALPINIÉES. Alpiniece. вот. PH. - Troisième tribu établie par M. Blume (Enum. Plant. Javoe) dans la famille des Amomées, et qui comprend les g. Alpinia, Hellenia et Cenolophon. $V$. Amomées.

(A. R.)

ALPISTE. вот. PII. - Nom vulgaire du g. Phalaris, de la famille des Graminées. $V$. Рнhalais.

(A. R.)

ALQUE. 0Is. - Nom donné par Linné á un g. renfermant les Pingouins et les Macareux, et qui n'a pas été adopté. M. Lesson a rétabli ce nom pour une petite famille comprenant les g. Cérorhynque, Macareux et Pingouin. (C. D'O.)

ALQUIFOUX. Min. - Nom sous lequel on désigne, dans le commerce et dans plusieurs ateliers, la galène réduite en poudre, qu'on emploie pour la couverte de la poterie grossière. En Orient, elle entre, avec le noir de 
fumée, dans la composition de la poudre a vec laquelle les femmes se teignent les cils et les sourcils.

(DEL.)

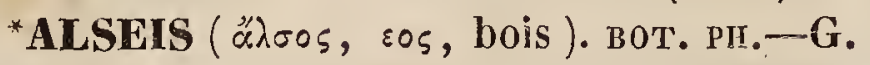
de la famille des Rubiacées, établi par M. Schott (in Sprengel Cur. Post., p. 404), et classé par M. Endlicher (Gen. Plant. 1, p. 555) dans la tribu des Cinchonées, entre les g. Danaïs et Exostemma. Les auteurs cités lui assignent les caract. suivants : Fleurs monoïques par avortement. Tube calicinal obconique, adhérent ; limbe supère, 5-parti ; lanières lancéolées. Corolle courte, subcampanulée, 5-dentée. Étam. 5, insérées à la base du tube de la corolle, saillantes dans les fleurs hermaphrodites, incluses dans les femelles; filets subulés, poilus à la base. Anth. ovales, dressées. Ovaire 2-loculaire; placentaires multi-ovulés, adnés ả la cloison; ovules suspendus, imbriqués, marginés. Style indivisé, saillant, poilu à la base. Stigmate bifide; lanières linéaires, étalées. (Péricarpe inconnu).-L'A. floribunda Schott (Endl.Atakt.l.c.tab.38), constitue seul le g. -C'est un arbrisseau du Brésil, à feuilles opposées, à stipules triangulaires, très courtes, à épis terminaux et alaires. Les fleurs sont petites, jaunâtres, très rapprochées.

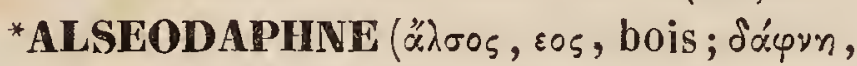
laurier). вот. rIr. - G. de la famille des Laurinées, tribu des Persées, Nees, formé par Nees ron Esenbeck ( in Wall. Pl. asiat. rar. 11-61), a vec la diagnostique suivante: Fleurs hermaphrodites. Périgone 6-fide, chartacé, a limbe décidu. Étam. 12, quadrisériées, dont 9 extér. fertiles, 3 intér. stériles; celles du 3 e rang interne des fertiles, munies à la base de glandules binées, stipitées, comprimées; leurs filaments le plus souvent dilatés. Anth. des $1^{\text {er }}$ et 2 rang introrses; celles du $3^{\mathrm{e}}$ extrorses; toutes oblongnes, 4-locellées, déhiscentes par autant de valvules ascendantes. Étam. stériles, stipitées, églandulées dorsalement, à sommet introrse, sagitté-lancéolé. Ovaire uniloculaire, uniovulé. Stigm. discoïde. Baie monosperme, placée sur la base périgoniale, entière, orbiculaire et étalée.-Ce g. renferme queìques arbres de l'Inde, à feuilles alternes, penninervées, dont les nervures primaires, costées; il gemmes compactes et couvertes d'un pelit nombre d'écailles entrebaillées; à fleurs disposées en panicules subcorymbiformes, naissant dans les aisselles d'une gemme terminale.

(C. L.)

*ALSEUOSUIA, Cunningh. ("̋

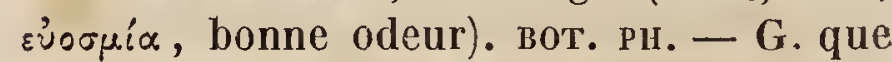
Cunningham rapporte avec doute à la famille des Cornées ou à celle des Caprifoliacées, et dont il expose ainsi les caract. ( $\vec{F}$ lor. Nov.-Zeeland. in Hook. Ann. of Nat. Hist., II, p. 209 ; 1839): Tube calicinal adhérent; limbe supère, 4-ou 5-fide, non persistant, à estivation valvaire. Cor. infundibuliforme; tube beaucoup plus long que le calice; gorge imberbe; limbe 5-parti, à lanières ovales, égales, pointues, sinuées-dentées, valvaires en préfloraison. Étąm. 5, courtes, égales, insérées à la gorge de la corolle, entre les segments du limbe; anth. saillantes, dithèques, longitudinalement déhiscentes. Disque épigyne. Ovaire 2-loculaire, adbérent; loges 2-5-ou pluri-ovulées; style fỉiforme, glabre; stigmate disciforme, indivisé. Baie turbinée, obovée, infère, 1-loculaire, polysperme ou, par avortement, oligosperme. Graines obovales, courbées, obtuses, convexes au dos, anguleuses du côté antér., médifixes; test épais, réticulé; embryon petit, rectiligne, niché à l'extrémité infér. du périsperme; cotyl. subfoliacés, contigus ; radicule courte, obtuse, éloignée du hile.Arbrisseaux dressés, hauts de 2 à 3 pieds; feuilles coriaces, persistantes, ${ }^{\prime}$ alternes, non stipulées, péliolées, très entières ou lobées; pétiole dilaté à la base; fleurs latérales ou terminales, pédicellées, bractéolées, trẻs odorantes, solitaires ou fasciculées ou en grappe. - Ce g. est propre à la Nouv.-Zélande; Cunningham en a décril $8 \mathrm{esp}$. (Sp.)

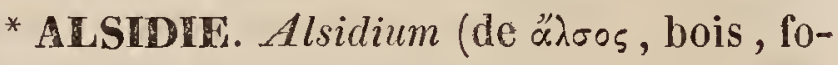
rêt; la plante ressemble i un arbre). вот. Cr. (Phycées). - Ce g. monotype, appartenant à la sous-famille des Floridées, a été établi par Agardh (Icon. Alg.europ., t. 9) sul une algue trouvée dans l'Adriatique. Elle est ainsi caractérisée : Fronde cartilagineuse, raide, cylindrique, filiforme, atténnée, dressée, irréguliẻrement rameuse. Plusieurs tiges naissent d'une même base crustacée, convexe, plate en dessous. C'est par là qu'elles se fixent aux rochers sous-marins. Cette Thalassiophyte n'est pas particulière à l'Adriatique; M. de Notaris l'a retrouvée dans la Méditerranée, à l'ìle de Capraja, et 
M. Roussel à Alger. On n'err connaît pas la fruetification.

(C. M.)

*ALSINACÉES. Alsinace , Lindl. вот. PH. - $V$. A LSINÉES.

*ALSINE ( $\alpha \lambda \sigma i v n$, nom chez les Grecs d'une plante indéterminée). L. Wahlenb., Koch.; Spergularia, Pers., Halianthus, Mœnch; Honrkenya, Ehrh.; Lepigonum, Fries; Alsine et $\$$ abulina, Reichb. вот. PI. - G. ou s.-g. pris pour type de la famille des Alsinées; tontefois il mérite à peine d'être séparé des Arenaria, dont il ne différe absolument que par une capsule 3-valve. Linné fondait le caract. distinctif des Alsine sur le nombre des étaruines; caract. moins valable encore que l'autre, parce que, dans les Alsine conme dans les Arenaria, le nombre des étamines varie de 3 à 10 . Dans les limites que lui assignent aujourd'hui la plupart des auteurs, le g. Alsine renferme environ $20 \mathrm{esp}$, dont la plupart appartiennent à la flore européenne. L'Alsine media L., nommé vulgaireinent Morgeline, Mouron des oiseanx, est in Stellaria.

ALSINÉE. Alsineo. вот. рII.-Une des 2 grandes tribus dans lesquelles se séparent naturellement les Caryophyllées. $V$. ce mol.

(AD. J.)

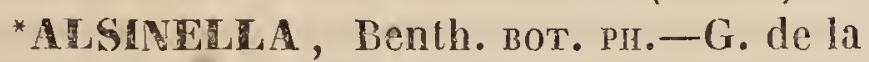
fimille des Aisinacées, dont le nom est indiqué dans le Catal. de Wallich, et reproduit depuis par Reichenbach et Lindley; les caractères n'en ont pas été publiés. (Sp.)

ALSODEEE. Alsodeic, Petit-Thou. (àró$\delta$ in, qui aime l'ombre des bois). вот.'Рі. G. de la famille des Violariées, tribu des Alsodinées. Aubert Du Pelit-Thouars (Hist. des Végét. des îles de l'Afr. austr., 11, p. 55 ; Nov. Gen. madag., no 65 ) en donne les caracl.suivants : Cal. de 5 sépales pointus, imbriqués; 3 extér., 2 intér. Cor. régulière, à 5 pétales plus longs que le calice, contourués en estivation. Etam. 5, monadelphes; androphore urcéolaire, souvent appendiculé; anth. contiguës, mais libres, sessiles, liguliformes, barbues au sommet. Style claviforme. Capsule subturbinée, obscurément Irigone, oligosperme, recouverte par le calice et la corolle. Cotyl. orbiculaires. - Arhres ou arbrisseaux. Feuilles en général éparses. Sípules petites, caduques. Fleurs vetites, disposćes en grappes axillaires et terminales; pédicelles articulés, bractéolés.
On en connaît 6 esp., dont 5 de Madagascar et 1 de Timor. M. A. de Saint-Hilaire (Hist. (les Plantes rem. du Brés.) réunit ce g. aux Conoria.

* ALSODINÉES. вот. ph. - $V$. ViolaRIÉES.

*ALSONITRA, Blume ( $\alpha_{\lambda \sigma} \sigma \varsigma$, bois ; $\mu$ í$\tau p \alpha$, ceinture). вот. Рн. - G. de la famille des Cucurbitacées, tribu des Nandhirobées, Aug. St-Hil. Ce g. paraît ne diffórer du Zanonia (auquel M. De Candolle le réunit) que par son ovaire à loges mulli-ovulées, et par son fruit hémisphérique, tronqué au sommet. Il est fondé sur une seule esp., qui croît a Java.

(Sp.)

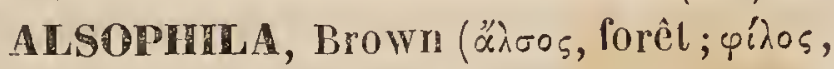
ami). вот. Cr. - R. Brown a donné ce nom a un des g. (qu’il a formés aux dépens des Cyathea de Smith, et qui comprend, comme les vrais Cyathea et les Hemitelia, des fougères arborescentes, la plupart américaines et quelques unes de l'ancien continent. Une scule esp. est herbacée : c'est l'A. pruinata du Chili. Comme toutes les fougères de la tribu des Cyathéacées, ces plantes présentent des groupes arrondis de capsules sessiles, portées sur un tubercule saillant. Ce tubercule, dans les Alsophila, tels que R. Brown les avait définis, correspond a la bifurcation des nervures secondaires, et les groupes de capsules, au lieu d'être enveloppés dans un tégument clos, sont enviromés à leur base par des écailles lacérées formant un tégument incomplet qui manque quelquefnis. Suivant Presl, ce tégument incomplet manque même généralement, et son absence distingue ces plantes des vrais Cyathea, des Hemitelia et de quelques autres g. voisins. Il est certain, du moins, qu'il n'enveloppe jamais complètement les groupes decapsules, et qu'on doit plutôt le considérer comme formé par des écailles analogues à celles qui naissent sur les nervures de la plupart de ces plantes, que comme un vrai tégument membraneus, continu. - Les g. Clnoophora de Kaulfuss, Trichopieris et Metaxya de Presl, en diffèrent á peine, si ce n'est par la transformation de ce tégument membraneux, scarieux et lacinié en poils nombreux, plus ou moins allongés, insérés à la base du lubercule qui porte les capsules, et les entourant de toutes parts. - Presl divise les Alsophila en 2 sections : les unes ont les ner- 
vures secondaires bifurquées, et portent les capsules à leur bifurcation; les autres ont des nervures secondaires simples qui portent les groupes de capsules vers leur milieu. On connaît maintenant prés de 40 esp. de ce g., toutes arborescentes, à l'exception d'une seule, et dont peu s'étendent au-delà des régions intertropicales.

(AD. B.)

ALSTONIA (Alston, professeur de bot. à Édimbourg). вот. PH. - G. de la famille des Ebénacées (Symplocées), fondé par Mutis, et regardé comme synon. du g. Symplocos, L. V. ce mot. (C. L.).

*ALSTONIA (Alston, professeur de bot. à Édimbourg). вот. PH. - G. de la famille des Apocynacées, tribu des Alstoniées, fondé par R. Brown (Mem. Wern. Soc. 1 ; Labill., Nov. Cal., t. 12), qui en circonscrit ainsi les caractères: Cal. 5-fide. Cor. hypogyne, hypocratérimorphe, à gorge et à tube non squameux; limbe 5-fide; segments obliques. Étam. 5, incluses, insérées au tube médian de la corolle; anth. subsessiles, lancéolées, libres; ovailes 2 ; ovules nombreux, fixés à la suture ventrale. Style unique, filiforme, dilaté au sommet; stigm. subconique. Squamules hypogynes nulles. Follicules cylindriques, allongés. Graines nombreuses, peltées, linéaires-comprimées, ciliées (cils de chaque extrémité chevelusallongés). Embryon non décrit? - Ce g., encore peu connu, renferme un petit nombre d'espèces, dont quelques unes sont cultivées dans nos serres. Ce sont des arbres ordinairement élevés, lactescents, à feuilles opposées ou verticillées, glabres, costées ; a fleurs le plus souvent blanches, disposées eu cymes terminales paniculćes. On les trouve dans l'Asie tropicale et dans les îles de l'Océanie.

(C. L.)

"ALSTONHÉES, Alstoniece ( $\boldsymbol{V}$.ci-dessus). воT. PH. - Tribu de la famille des Apocynacées, qui ne contient que le g. Alstonia.

(C. L.).

ALSTROEMERIA (Alstromer, naturaliste suédois). воT. PH.—Linné a donné ce nom à un g. de la famille des Amaryllidées, qui aujourd'hui se compose d'une cinquantaine d'esp., toutes originaires de l'Amérique méridionale. Ce sont des plantes à racine fibreùse et fasciculée, ayant leur tige tantôt dressée, tantòt volubile et grimpante, et des feuilles alternes, ovales ou lancéolées. Les flours, quelquefois très grandes, sont souvent disposées en sertule ou ombelle simple. Leur calice, pétaloïde et adhérent par sa base a l'ovaire infère, est presque campanulé , à 6 divisions inégales; 2 intér. étant tubuleuses et roulées à leur base. Les étam., aú nombre de 6 , insérées aux div. calicinales, sont déclinées. Le style, triangulaire, se termine par un stigm. trifurqué. Le fruit est une capsule triloculaire, trivalve, à loges polyspermes. - Plusieurs des esp. de ce g. sont cultivées dans les jardins. La plus commune est celle qu'on désigne vulgairement sous le nom de $L i s$ des Incas. C'est l'A. pelegrina L., originaire du Pérou, et qu'on doit soigneusement garantir du froid en l'abritant pendant l'hiver dans la serre tempérée.(A.R.) *ALSTR EMÉRIÉES. Alstrœmerice. вот. PH. - Nom d'une des tribus de la famille des Amaryllidées.

ALTEInia. bot. ph. $V$. Althenia. (C. L.) ALTENSTEINIA (Altenstein, nom propre). вот. Pн. - G. de la famille des Orchidées, tribu des Ophrydées, établi par Kunth (in Humb. Nov. Gen., et Sp. 1, p. 322). Il se compose de 3 ou 4 esp., toutes originaires de l'Amér. mérid., ayant pour caract. : Cal. à 5 div. lancéolées et réfléchies; les 3 extér. un peu plas larges. Labelle plus grand que les autres, dressé. Gynostème court, dressé; anth. à 2 loges écartées, attachées sur les côtés du gynostème. Masses polliniques au nombre de 2, portées sur un pédicule court, altaché á l'opercule de chacune des loges. Sligm. opposé à l'anthère, tourné du côté du labelle. - Les esp. de ce g. ont la racine formée de tubercules allongés, la tige simple, les fleurs sessiles, disposées en épis denses, et munies de bractées. (A.R.)

* ALTERNANCE ( loi d'). вот. - On a donné ce nom à un principe admis dans ces derniers temps par plusieurs botanistes et qui leur a servi de guide dans les recherches auxquelles ils se sont livrés relativement à la structure des fleurs en général, ou au plan normal d'aprés lequel les fleurs de certaines familles paraissent être disposées. Cette loi, sans avoir encore été formulée complètement dans aucun ouvrage général, est néanmoins fréquemment invoquée dans une foule de mémoires particuliers ; ce qui nous met dans la nécessité d'examiner successivement, son origine, sa va- 
leur et l'application qu'on peut en faire.

En vertu de la loi d'Alternance, on admet que toute fleur est formée d'un certain nombre de verticilles ou anneaux, d'organes appendiculaires, et que les pièces qui composent chaque verticille sont insérées entre celles du verticille qui précéde ou succède immédiatement, et par conséquent alternent avec elles. On aurait mieux fait d'employer le mot interposé; l'adjectif alterne ayant reçu dans la science une acception un peu différente, lorsqu'on s'en sert pour caractériser un certain mode de disposition des feuilles sur la tige. La position alternative des pièces dans les verticilles qui se succèdent immériatement entraîne comme conséquence que, lorsque 2 verticilles sont séparés par un intermédiaire, ils ont leurs parties superposées; dans ce cas on a dit souvent et d'une manière abusive qu'elles sont opposées; ce qui ne doit être dit que des organes dont les faces de même nom se regardent mutuellement. Quoi qu'il en soit, il résulte de ces conditions que tous les verticilles de même nombre (pairs ou impairs) ont leurs parties superposées.

C'est par l'observation et par l'analogie qu'on est arrivé à ces principes. On en trouve déjà des traces dans la philosophie botanique de Linné, lorsqu'il donne pour caractère distinclif à la corolle d'avoir ses pièces placées entre les étamines, tandis que celles du calice sont placées au-dessous de celles-ci. Plus récemment M. De Candolle entrevit réellement cette loi, en énumérant, dans sa Théorie élémentaire, les diverses combinaisons qu'on peut trouver dans l'arrangement des organes de la fleur. Cet habile botaniste remarqua que la disposition la plus fréquente est celle oú les pièces de chaque verticille sont placées entre celles du verticille précédent; mais il se contenta de cet aperçu, sans paraître avoir prévu qu'un jour il acquerrait la valeur d'une loi générale; ce qu'il eût été bien difficile en effet d'imaginer, dans l'état où se trouvait alors la Botanique.

En 1825, M. Raspail, dans ses Mémoires relatifs aux Graminées, formula positivement la loi d'Alternance, qu'il regarda comme une règle fixe pour toute cette famille. Il pensa même qu'elle devait être appliquée à toutes les Monocotylédones. Cependant nous devons" dire que, par suite de son opinion sur l'origine des verticilles floraux, il n'a pas compris celte loi tout-à -fait de la même manière que nous. Peu après, M. Rœper (Observ. sur la nat. des Fleurs et des Inflor.; Seringe Mel. Bot., et en latin dans le tom. $1^{\text {er }} \mathrm{du}$ Linncea) l'affirma également pour les verticilles extérieur's de la fleur, savoil : le calice, la corolle et l'androcée. Environ 3 ans plus tard, parut la thése de M. Dunal (Consid. sur la $\mathbf{N}$ at. et les Rapp. de quelques organes de la fleur, Montpellier 1829). La science de l'Anthogénie avait fait de grands progrès. L'auteur, après avoir démontré que l'androcẻe renferme souvent ainsi que le nectaire, plusieurs verticilles, fit connaître le nombre et la position relative des parties qui, suivant lui, doivent constituer la fleur la plus complète. Dans la description qu'il donne de cette fleur idéale, on voit qu'il adopte complétement le précepte de l'Alternance, et peut-être doit-il être considéré comme en étant le véritable fondateur, ou au moins comme le premier qui lui ait donné tout à la fois une grande extension et une forme régulière. Depuis ce temps, M. Aug. de St-Hilaire a, dans ses mémoires sur différentes familles, constaté fréquemment la rigueur du précepte, en en faisant de lumineuses applications. Nous citerons principalement à cet égard son second mémoire sur les Résédacées et son mémoire sur les Myrsinées et les Sapotées. Cependant on rencontre de sérieuses exceptions toutes les fois qu'on essaie de vérifier cette loi par l'observation; exceptions qui peuvent être expliquées, il est vrai, par des considérations particulières. Néanmoins, il se présente plusieurs questions à résoudre préalablement ; car ces exceptions résultent d'observations qui paraissent être en contradiction avec celles sur lesquelles la loi est basée. On se demande si les unes plutôt que les autres doivent être prises comme point de départ? si les divergences qu'elles présentent n'indiquent pas que la loi générale est tout autre? s'il existe réellement une loi générale ou des lois partielles, de sorte que celle qu'on a proposée convienne seulement à un certain nombre de végétaux?

Si , pour répondre ả ces questions, on s'en rapporte à l'observation pure et simple, on 
remarquera que la loi d'Alternance s'applique constamment au calice et à la corolle, c'est-à-dire aux verlicilles les plus exlérieurs de la fleur, et dans lesquels la situation des parties est le plus facile à constater; en outre qu'elle fournit la formule de position relative qui se réalise généralement, ainsi que l'avait déjá remarqué M. De Candolle. On verra, en outre, que, dans beaucoup de cas, l'analogie réclame l'existence de parlies avortées, et qu'en les rétablissant par la pensée, on fait rentrer dans la loi générale plusieurs faits qui semblaient la contredire. Cependant de nombreuses exceptions existent encore, et l'observation seule ne peut jamais suffire contre l'observation. Il y a donc au fond de cela une question plus générale à déballre; il s'agit de savoir sur quels fondements on s'appuie pour considérer comme universelle une loi qui n'est admissible qu'en expliquant, par des phénomènes secondaires, des épiphénomènes, si l'on peut s'exprimer ainsi, toutes les contradictions que la nature présente à chaque pas.

Les fondements de cette loi sont les théorèmes dont nous allons faire mention. Ils sont plus ou moins généralement admis, quoique quelques uns soient encore un objet de contestation dans la science. Ce n'est pas ici le lieu d'en démontrer l'exactitude; nous croyons devoir les rapporter, parce que sans eux la loi d'Alternance ne serait encore long-temps peut-être qu'une hypothèse un peu arbitraire ; el cependant personne, que nous sachions, n'a essayé de faire voir qu'elle n'est qu'une conséquence directe de ces théorèmes :

" $1^{\circ}$ Toute plante phanérogame n'est for" mée que par l'addition d'un nombre indé"fini d'individus ayant lous la même valeur "primitive; mais elle peut se trouver modifiée " par l'époque relative du développement.

" $2^{0}$ Chaque individu est formé d'un mé"rithalle qui se prolonge inférieurement, et "se termine à son extrémité supérieure par " un nombre quelconque d'appendices symé" triques constiluant un VERTICILle.

" $3^{\circ}$ Les pièces qui font parlie d'un verti" cille sont placées entre celles du verticille "précédent, sur un plan plus élevé.

" $4^{\circ}$ Cetle disposition, qui est générale, b) résulte de la manière dont les faisceaux li- "gneux se combinent pour se rendre dans "les appendices.

„5 $5^{\circ}$ Sur la tige ou les rameaux, les indi"vidus se développent successivement et à "l'infini, jusqu'à ce que des causes acciden" telles arrêtent ce développement. ils sont " exposés à un grand nombre de déviations " provenant de l'influence des agents exté"rieurs ou de celle qu'exercent les uns sur "les autres les organes qui se développent. - $6^{\circ}$ La fleur, dont les organes ne sont "que des feuilles modifiées d'une manière " spéciale, naît à un moment donné, lors"que la plante s'y est préparée par des dé" veloppements antérieurs. Elle naîl, deplus, " à une place déterminée; et, comme les par" ties qui la composent se développent dans "un espace de temps très court, elles n'ont " pas le temps d'être modifiées diversement " par les agents extérieurs, ou par le déve„loppement ultérieur de la plante; il en ré" sulte que chaque fleur, dans une espéce, est " toujours formée du même nombre de ver"ticilles, que ces verticilles ont toujours le " même nombre de parties el présentent "toujours les mêmes déviacions du type sy" métrique, lorsqu'il en existe de celle sorte. "7० Les déviations sont dues à des sou"dures, à des avortements, à des inégalités " de développements et à des dédoublements, "qui peuvent avoir lieu dans les deux sens "de l'épaisseur et de la largeur.

" $8^{\circ}$ L'avortement n'est que le non-déve"loppement d'un organe ; celui-ci doil done " toujours exister virtuellement; c'est pour" quoi l'arortement d'un verticille est sans " influence sur la position de ceux qui vien"nent ensuite."

Il est donc évident que le nombre des verticilles pourra bien varier suivant les familles; que le nombre des parties qui les composent jeut varier également, ainsi que leur régularilé, mais que toujours les fleurs d'une même espéce sont construites sur le même plan; que toujours, surtout, la loi d'Altemance devra trouver son application; et que, par conséquent, elle peut devenir un Criterium à l'aide duquel nous remonterons de l'état habituel d'une fleur à son état normal. Elle pourra donc nous servir à déterminer les rapports qui existent entre les végélaux au point de vue du plan normal de leurs fleurs; elle nous apprendra si réel- 
lement ce plan est constant dans chaque famille, et si vraiment, comme quelques uns le supposent, il est le même pour toutes les fleurs. Quoi qu'il en soit à cet égard, le plan se trouvant déterminé, soit unique et général, soit particulier pour chaque division $d u$ règne végétal (divisions qui prendraient rang très probablement entre les grandes scetions et les classes proprement dites, ou entre celles-ci et les familles); le précepte nous aidera encore à reconnaître quelles sont les modifications que le type a subics dans telle ou tclle famille, ou dans tel groupe de g. moins étendu. Il a déjà conduit plusieurs botanistes à reconnaître que, dans un grand nombre de plantes, le disque ou phycostème est formé par 2 verticilles d'étamines avortées, et non pas par un seul, comme on l'avait cru d'abord; M. Aug. de St-Hilaire a pu faire voir que l'écaille irrégulière des Résédacées représente les étamines ordinaires des plantes, tandis que leurs étamines sont formées par le développement du phycostème.

Dans tous les cas, le calice, dans lequel la position des parties est facile à apprécier, peut servir de point de départ, et l'argumentation se réduit aux 2 formules suivantes:

Les pièces de tel verticille sont superposées aux divisions du calice; donc elles en sont séparées par un nombre impair de verticilles; ou bien, elles sont placées entre les divisions du calice; donc elles en sont séparées par un nombre pair de verticilles, ou elles lui succèdent immédiatement.

On doit bien se rappeler que les superfétations et l'avortement complet d'un ou de plusieurs verticilles ne modifient point la position de ceux qui persistent, mais que les organes de la fleur sont susceptibles de se transformer les uns dans les autres.

Il est logique d'admettre que, si par ce procédé on arrive à des résultats satisfaisants, l'hypothèse de la loi d'Alternance, que l'on doit à cette sorte de sagacité qui résulte de la comparaison d'un grand nombre de faits, et à laquelle nous avons essayé de donner ci-dessus un fondement plus rationnel se trouvera vérifiéc par l'observation; car la meilleure démonstration d'une théorie se trouve dans les conséquences que l'on en peut déduire.

Il n'est malheureusement pas toujours faT. 1 . cile d'opérer comme nous venons de l'indiquer, parce que tous les verticilles de la fleur ne présentent pas le même nombre de parties. Dans ce cas, la science ne nous a fourni encore aucun précepte général qui puisse servir de guide; et e'est à la sagacité particulière des botanistes de résoudre ces difficultés, paraissant résulter, lc plus souvent, de ce qu'il existe des avortements ou des dédoublements d'organes. Nous avons dit qu'on rencontre dans les fleurs de fréquentes $\mathrm{ex}-$ ceptions à la loi d'Alternance : c'est ici le lieu de les indiquer succinctement, en montrant comment elles peuvent être interprétées. Quelquefois ces exceptions ne sont que partielles; ainsi, dans les Labiées à corolle quadrilobée, la division supérieure de cet organe est placée devant une dent du calice, tandis que les trois divisions inférieures sont situées entre les quatre autres dents calicinales; l'analogie nous fait voir que, dans ce cas, la division supérieure de la corolle résulte de la soudure de deux divisions primitives; mais, dans un grand nombre de plantes, l'exception est générale. On trouve, par exemple, qu'il n'y a pas de corolle, et que les étamines sont superposées aux divisions du calice : il faut admettre que la corolle est avortée. D'autres fois, ce sont les étamines qui sộ superposées aux divisions de la corolle; alors on peut admettre que, dans certaines plantes, il y a une rangée d'étamines avortées. Des explications différentes sont encore susceptibles d'être présentées dans des cas particuliers : ainsi, dans la fleur des Berberis, on trouve six sépales, six pétales et six étamines ; toutes pièces superposées les unes aux autres sur six rangées longitudinales; mais à l'aide d'une observation attentive, on reconnaît qu'il y a deux verticilles de sépales, deux verticilles de pétales, et natırellement deux verticilles d'étamines. Ces fleurs présentent donc six rangées horizontales de trois pièces chacune, pièces toujours placées entre celles de la rangéc qui précède et celles de la rangée qui suit.

Dans ces deux genres d'explication, on, suppose que toutes les pièces existant sur l'axe raccourci de la fleur sont du même ordre de développement, ainsi que les feuilles qui se trouvent sur un scion non ramifié; mais il peut arriver que, sur le 
même scion, existent des branches latérales garnies de feuilles; celles-lá naissent à l'aisselle des feuilles même et se développent plus tard. De même, on a vu, quoique très rarement, et seulement dans quelques monstruosités, un bourgeon se développer à l'aisselle d'une partie de la neur; cependant il arrive très souvent qu'on trouve des pièces superposées aux parties d'un verticille floral, sans qu'il soit possible de supposer un verticille avorté, entre ces deux rangées d'organes; fait maniPeste chez les Crassulées décandres, où les stamines les plus extérieures sont précisément celles qui sont placées devant les pétales; et chez les Résédacées, où chaque pétale porte un appendice sur sa face interne, etc., etc.

Ces productions nous paraissent être des formations de second ordre comme les branches latérales sur un scion, de véritables productions axillaires; ce sont elles que M. Dunal semble avoir cherché à reconnaître, peut-être un peu trop souvent, sous le nom de Lépales. Plusieurs botanistes ont exprimé à leur égard une opinion qui nous paraît ne pas différer essentiellement de la nòtre, en disant qu'elles sont le produit d'un dédoublement dans le sens de l'épaisseur. Lorsqu'elles arrivent à un développement complet, c'est-á-dire lorsqu'elles constituent un organe aussi parfait que les productions de premier ordre qui entrent dans la composition de la fleur, il est souvent très difficile d'en déterminer l'origine; cependant nous pénsons que l'on peut y parvenir assez souvent, à l'aide des considérations suivantes, lorsque ce sont des étamines, ce qui paraît être le cas le plus fréquent.

$1{ }^{\circ}$ Quoique superposées aux pétales, elles sont plus extérieures que les étamines de premier ordre; néanmoins, elles sont plus petites dans le bouton, et l'explosion de leurs anthères a lieu un peu plus tard.

$2 \circ$ Elles avortent plus fréquemment que les autres, par la même raison que, sur une branche, les feuilles du bourgeon axillaire se développent plus tard que les autres ou jamais.

$3^{\circ}$ Lorsque les fleurs viennent à se doubler, on trouve souvent que les étamines intérieures et même les carpelles se changent en pétales, tandis que les étamines exté- rieures, qui sont axillaires, gardent leur forme primitive. D'autres fois il y a entre tous les pétales de la fleur double des étamines situćes devant eux (sur leur côté intérieur). Toutes les fois que ces faits se présentent, nous regardons comme extrêmement probable qu'une portion des étamines de la fleur normale est une production axillaire des pétales; et, sous ce rapport, l'étude des fleurs doublées n'est pas à négliger dans la recherche de la structure primitive des fleurs.

Ainsi qu'on vient de le dire, les exceptions à la loi d'Alternance peuvent être expliquées par difiérentes suppositions.Comme celles-ci ne présentent rien qui soit en contradiction avec ce que l'on sait sur l'organogénie des plantes, les faits sont loin de nous conduire à abandonner cette loi. Cependant; la facilité qu'on trouve à les expliquer, à l'aide des suppositions, doit mettre en garde contre les résultats; et, de leur multiplicité, il résulte que l'état habituel d'une fleur peut encore fournir à l'imagination des interprétations très différentes. Il faut donc, dans ce genre de recherches, tout en se laissant guider par le précepte de l'alternance, vérifier encore les résultats auxquels on arrive par l'analogie, dont la valeur comme moyen'de démonstration est généralement reconnue et repose sur deux bypothèses fondamentales en histoire naturelle, savoir : une parenté réellè entre les genres voisins, et l'existence de lois générales qui ne peuvent subir que des exceptions apparentes. (Ad. Steinheil.)

Le morceau posthume qn'on vient de lire devait servir d'introduction à une série d'articles ( sur la disposition des organes de la fleur.), distincts à ce recueil, mais seulement ébauchés par Steinheil. Celui qui précède, le seul qui sera publié et qui ne l'eût peut-être pas été si son auteur eût vécu, est propre à bien peindre, à mettre en saillie, mieux que tout ce que j'essaierais d'en dire. la direction des études et l'importance attachée par notre ami, dans les recherches et le perfectionnement de la méthode naturelle. En lisant les divers mémoires publiés par Steinheil, mémoires si abondants en pensées ingénieuses et enchaînées par cet esprit logique qui le caractérisait si éminemment, on comprendra que la science aurait eu d s'enorgueillir d'une vie qui lui était consa- 
crée, mais qui malheureusement a été tranchée à son début.

(J. D.)

* ALTERNANCE (allerno, poser l'un après l'autre). GŕoL. - Disposition que présentent les dépôts stratifiés, lorsqu'ils sont composés de plusieurs sortes de roches qui se succedent plusieurs fois entre elles sur une certaine épaisseur. L'Alternance annonce des causes périodiques, successives, alternes, ou une cause continue, interrompue momentanément par des circonstances particulières. La composition des terrains houillers est un exemple remarquable de l'Alternance de grès, de schistes et de clıarbon, dont on yoit les diverses couches se présenter un grand nombre de fois dans le même ordre. (C. P.)

ALTERNANTHERA Forsk (alternus, alterne; anthera, anthère, parce que les filets sont alternativement anthérifères et ananthères). вот. Рн. - G. de la famille des Amarantacées, tribu des Gomphrénées, Endl. - Endlicher (Gen. Plant., 1, p. 301 ) en donne les caract. suivants : Fleurs liermaphrodites, 3-bractéolées. Périgone pentaphylle. Étamines 5 ; androphore cupuliforme; filets filiformes, alternes; chacun avec un staminode dentiforme, soit entier, soit trifide; anthères monothèques. Ovaire 1-loculaire, 1-ovulé. Style court ; stigm. capitellé. Utricule évalve, 1sperme; graine réniforme-lenticulaire; test crustacé; embryon arqué ou annulaire, périphérique; radicule supère. - Herbes décombantes; tiges subgéniculées, radicantes; fenilles opposées, subsessiles; fleurs en capitules axillaires. Ce g. renferme environ 20 esp., la plupart indigénes dans la zòne équatoriale.

ALTERNARIA (Alternus, alterne). вот. Cr. - Nees (Syst. der Pilze. 2. pag. 19. tab. 5. fig. 63) a décrit sous ce nom un petit g. de Champignons, appartenant aux Hypomycetes, et qui est caractérisé par des filaments (flocci) droits, simples, qui présentent alternativement dans leur longueur des renflements transparents en forme de nœuds et des rétrécissements opaques et filiformes. On ne connaît pas encore les organes de la fructification des 2 esp. que,renferme ce g.; dont l'une, $A$. tenuis, se développe sur les tiges des plantes seches et les couvre de petits coussins noirs, qui ressemblent à un léger duvet; l'autre, A.rudis, que M. Ehrenherg a trouvée en Allemagne sur l'écorce des pins, a les filaments plus courts et plus fermes. Je n'ai pas eu occasion d'étudier ce g.; mais j'ai rencontré bien souvent sur les tiges des plantes sèches, des petits coussins qui présentaient les caract. que je viens d'énoncer. En cherchant d'oú ils pouvaient provenir, j'ai constaté qu'ils étaient formés par des filaments de Botrytis en partie détruits, et: dont les cellules sont alternativement renflées et filiformes. Je ne serais pas étonné que le g. Alternaria dút son origine à ce singulier mode de dessiccation.

(LÉv.)

ALTERNE. Alternus (alterno, je pose l'un après l'autre). вот. - Cette épithète s'emploie dans des sens un peu différents; ainsi. elle exprime la superposition alternative des mêmes oryanes sur un axe commun. C'est dans ce sens qu'on dit des feuilles qu'elles sont alternes, par opposition aux feuilles opposées ou verticilles; mais on l'emploie aussi pour désigner la position alternante de deux organes de nature différente, par exemple: les pétales sont alternes aux sépales, dans le plus grand nombre des cas; les étamines, quand elles sont en même nombre que les pétales ou que les divisions de la corolle gamopétale, alternenı avec ces mêmes pétales, c'est-à -dire qu'elles correspon dent aux intervalles qui les séparent. Un cas très rare, au contraire, est celui où les étamines correspondent exactement au milieu de chaque pétale ou de chaque division de la corolle gamopétale, comme dans les familles des Berbéridées, des Vinifères, des Primulacées. On dit alors que les étamines sont opposées aux pétales. $V$. au mot Fevilde, la théorie de l'arrangement des feuilles et des autres organes foliacés.

(A. R.)

ALTHEA, L. ( $\dot{\alpha} \lambda \alpha^{\prime} \dot{\prime} \alpha$, guimauve). вот: PH. - Nom grec des Guimauves. (C. L.)

*ALTHEASTRE.Althceastrum, D.C. (augmentatif d'Allhcea. $V$. ce mol). вот. Рн.M. De Candolle donne ce nom à la $1^{\text {re }}$ sect. de son g. Allhcea : section ou s.-g. qui comprend les véritables Guimauves ou Althoea L.

(Sp.)

* Althenia, F. P., Bellevalia, Delil. (B. Althen, $1^{\mathrm{er}}$ cultivateur de la Garance en France). вот. Рі. - G. créé par F. Petit (Ann.Sc.obs. p. 451) pour une petite plante de la famille des Naïadées, que $M$. Delile avait rapportée au g. Zamnichellia, L. sous 
le nom de $Z$. setacea. On la reconnaît à des tiges articulées, noueuses, rampantes, garnies, à chaque noud, de feuilles alternes, embrassantes et réunies en glomérules. Elle croît dans les lacs salés du midi de la France, et principalement aux environs de Montpellicr, dans les étangs de Grammont. En voici les principaux caractères distinctifs : Plante d'une grande ténuité, à fleurs monoïques, terminales dans l'aisselle des fcuilles. Les mâles rares, solitaires au-dessous des feuilles; cupule calicinale, cyathiforme, tridentée; anthère unique, sessile, uniloculaire, longitudinalement déhiscente. Les femelles pédicellées-ternées, chacune munie à la base d'une bractée roliacée; périgone nul.Ovaire subfusiforme, uniloculaire, ovalc unique, appendu, orthotrope. Style filiforme, continu avec l'ovaire; stigm. pelté. Capsule comprimée, ailée sur les bords, à 2 valves inégales, réunies par un épicarpe rnembranacć; graine oblongue, comprimće, a test membraneux. Embryon exalbumineux, antitrope, à radicule infère, épaisse.

* ALTHERIA Thouars ( allusion synonymique à l'affinité du g. avcc les Waltheria). вот. PIr. - G. de la famille des Sterculiacées, tribu des Byttnériées, Endl.-Du PelitThouars (IVov. Gen. Madag., n0 64) lui attribue les caract. suivants : Cal. 5-fide, accompagnè d'un involucclle triphylle. Pétales 5. Étam. 5; filets complètement soudés en androphore tubuleux ; anth. adnées, extrorses. Ovaire 5 -gone. Styles 5 , soudés. Caps. à 5 coques monospermes; graines médifixes. Le g. nc se fonde que sur une seule esp., indigène à Madagascar.

(J D.)

ALTICA. Ins. - $V$. Altise.

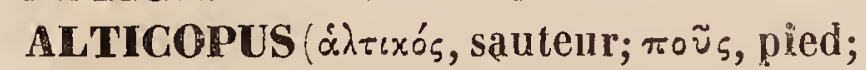
il faudrait écrire Halticopus). Ins. - G. de Coléoptères tétramères, famille des Curculionites, établi par Villa, et qui rentre dans celui des Choragus de Kirby. $V$. ce mot. M. Schonherr, qui l'a adopté (Monog. des Curcul.), le place dans sa división des Anthribides et lui assigne lcs caract. suivants : Ant. de 11 articles, posées sous lcs yeux; les deux $1^{\text {ers }}$ plus grands, coniques; les 6 suivants, minces, allongés, subconiques; lès 3 derniers plus épais, ovales, un pèu aplatis. Fiostre courbe, plan, court, ćlargi au sommet, subtronqué. Yeux grands, laté- raux, subovales. Corselet convexe, large, beaucoup plus étroit antérieurement, légèrenıent sinué postérieurement. Écusson extrêmement petit. Élytres de la largcur du corselet à leur base, presquc cylindriques, courbées à l'extrémité et couvrant presque l'anus. Corps oblong, convexe. Pieds courts ; les postér. propres au saut; cuisses en massue; tibias à peine courbes ; tarses allongés. - Ce g. a pour type l' $A$. Galeazii Villa, qui se trouve en Lombardie et dans d'autres. parties de l'Europe.

AltiaUS. ins. - $V$. Altigue.

ALTINGIA (nom d'homme). вот. PH.G. créé par Noronha (Batav. Verh. $V$.1.) non adopté par les auteurs, et qui reste réuni au g. Liquidambar de la famille des Balsamacées. $V$. Liquidambar, $L$.

(C. L.)

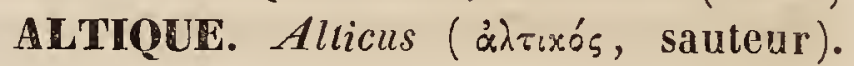
polss. - Nom tiré des manuscrits de Com'mcrson, et que ce savant voyageur se proposait de donner à l'un des poissons que M. Cuvier a nommé S'alarias. (V́́l.)

* ALTIPOSTRES. Altirostres (allus, élevé; rostrum, bec). ors. - M. de Blainville a donné ce nom à une section de la famille des Hétérodactyles, comprenant des Oiseaux grimpeurs a bec plus haut que large.

(C. D'O.)

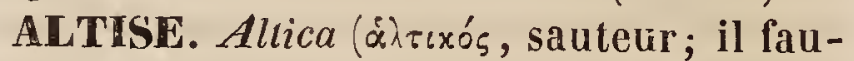
drait écrirc Haltica). Ins. - G. de Coléoptères tétramères, établi par Geoffroy aux dépens du grand g. Chrysomèle de Linné, et adoplé par presque tous les auteurs. M. Duméril le place dans sa famille des Herbivores ou Phytophages, et Latreille dans celle des Cycliques, tribu des Galérucites. M. Dejean, aprés l'avoir adopté dans ses deux $1^{\text {ers }} \mathrm{Ca}$ talogues, où il le faisait figurer parmi les Chrysomélincs, l'a rayé du $3^{\text {me }}$, sans faire connaitre dans qucls autres g. il en a réparti les nombreuses espèces. Voici les caractères que lui assigne Latreille : Ant. insérćes entre les yeux, très rapprochées ả leur base. Cuisses postér. très renflées, propres au saut. Le renflement des cuisses suffit pour les distinguer des Lupères, des Criocères et des Galéruques, avec lesquels clies ont beaucoup de rapports. Leurs ant. sont filiformes, plus longues que le prothorax. Lcur tête est petile. Les mandibules sont bi-dentées, ct les palpes maxillaires apparentes. La forme généralc de leur corps 
est hémisphérique ou ovale. Ces Insectes sont, en général, très petits. Les plus grandes esp. d'Europe n'excèdent pas 2 lignes de long, et celles des pays les plus chauds en atteignent à peine 3. Leurs ély tres sont lisses, luisantes, et souvent ornées de couleurs métalliques très brillantes. On les rencontre plus communément au printemps dans les lieux frais et humides, et répandues souvént en grande quantité sur les plantes potagères, dont elles rongent et criblent les feuilles. Leurs larves, qui se nourrissent de la même manière, et font encore plus de dégâts, ont beaucoup d'analogie arec celles des Chrysomèles et des Criocères; quelques unes sécrètent, du sommet de plusieurs petits tubercules, placés sur leur dos, une liqueur odorante et acide. Leurs nymphes ressemblent beaucoup à celles des Coccinelles, et restent 15 à 20 jours avant d'arriver à l'état d'insecte parfait. On désigne vulgairement les Allises sous le nom de Puces de jardin ou Sauteurs de terre. On en connaît un grand nombre; M. Dejean en mentionnait 149 dans son Catalogue de 1821. Parmi ce grand nombre, nous citerons seulement : l'Altise potagère ou bleue de Geofiroy, $A$. oleracea L., qui sert de type au genre; l'Altise rubis, $A$. helxines Fabr.; et l'Altise a pattes fauves, $A$. fulvipes Fabr.; trois esp. très cornmunes aux environs de Paris.

AITORA. вот. Pн. - Adanson nomme ainsi le g. d'Euphorbiacées, qui est reçu sous le nom de Clutia ou mieux Cluytia. $V$. ce mot.

(Ad. J.)

* ALUCITADES. ins. - Nom donné par Léach à une famille de Lépidoptères, ayant pour type le g. Alucite, Alucita. $V$. ce mot.

ALUCITE. Alucita (Allucita ou Alucita, sorte de moucheron). 1ns.-C'est le nom que Linné donne à la dernière div. de son grand g. Phalcena, div. qui comprend ces petits Lépidoptères à ailes étroites et divisées en plusieurs phalanges, garnies de poils ou de barbules des deux côtés, de manière à les faire paraître comme un assemblage de plumes; mais Geoffroy ayant appelé ces mêmes Lépidoptères Ptérophores, ce dernier nom a prévalu, et a été adopté par tous les entomologistes qui sont venus ensuite; de sorte que le nom d'Alucite de Linmé serait resté sans application, si Fabricius ne l'avait employé d'abord à désigner génériquement une réunion assez hétérogène de Tinéites, qu'il restreignit ensuite aux seuls Adèles de Latreille, en formant avec les autres son $\mathrm{g}$. Ypsolophe. Latreille, toutefois, ayant la priorité dans cette occasion, conserva le nom d'Alucite à ces dernières, auxquelles il assigne les caract. suivarits : Ailes supér. longues, étroites, très inclinées, relevées en queue de coq à leur extrémité postérieure langue distincte; palpes inférieursou labiaux avancés, avec un faiscéau d'écailles allongées sur le second arlicle; d'autres écailles sur le dessus de la tête, formant une sorte de toupet. - Nous avons adopté ce g. avec quelques modifications dans notre Continuation de l'Histoire naturelle des Lépidoptères de France, commencée par Godart, et nous l'avons réuni, comme Latreille, dans son dernier ouvrage, à la tribu des Tinéites. Nous y comprenons 6 espèces, dont les plus remarquables sont : $1^{0}$ l' 1 . xylostella L. Sa chenille vit à la fois sur différents arbrisseaux et sur un grand nombre de plantes potagères, parmi lesquelles elle attaque de préférence les choux et les navets; $2^{\circ}$ l'A. de la Julienne (Tin. porrectella L., I psolophus vittatus Fabr.), dont la chenille vit principalement sur la julienne (Hesperis matronalis). Elle se tient ordinairement dans les feuilles du centre, qu'elle réunit ensemble par des fils, et s'y transforme en chrysalide vers la fin d'avril, après s'être fabriqué une jolie coque ovoïde á claire-voie, dont les mailles en losange sont aussi régulières que celles d'un filet, et à travers lesquelles il est aisé de voir la chrysalide se former. Ces 2 esp. sont très communes dans les jardins potagers.

L'Alucite des grains, qui fit tant de ravages dans l'Angoumois en 1770, appartient, suivant Latreille, à son g. Ecophore. $V$. ce mot. (D.).

ALUINE ou ALUYNE. вот. вн. - Vieux nom de l'Absinthe. (C. D'O.)

* ALUMINATES (Alumen, inis, alun). MiN. - G. minéralogique composé des esp. dans lesquelles l'Alumine joue le rôle d'acide à l'égard de certaines bases, telles que la Magnésie, l'Oxydule de fer, et les oxydes de plomb. Ce g. ne comprend encore que 4 esp., qui sont le Spinelle, le Pléonaste, la 
Gahnite, et le Plomb-gomme ( $V$. ces mots). Tous ces corps sont solides. Leur caract. commun est de n'ètre attaquables par les acides qu'après avoir été fondus avec un alcali, et de donner alors une solution qui, traitée par l'ammoniaque, abandonne l'Alumine sous forme d'un précipité gélatineux, que dissoudrait la Soude ou la Potasse caustique.

(DEL.)

ALUMINE. (Alumen, inis, Alun). chin. - Cette substance signalée pour la première fois en 1754 , par Margraff, comme un corps particulier, est un véritable oxyde métallique dont le radical, l'Aluminium, n'a pu être isolé que depuis un petit nombre d'années. Son nom lui vient du mot latin Alumen qui signifie Alun, sel dont on l'extrait souvent. L'Alumine est blanche, légère, sans saveur ou d'une odeur terreuse à peine sensible, douce au toucher, happant à la langue, mais insipide, infusible au plus violent feu de forge, sans action sur l'oxygène et sur l'air, et sur la plupart des corps combustibles; elle est insoluble dans l'eau, très soluble au contraire dans la potasse et dans la soude caustiques. Elle joue le rôle de base relativement aux acides sulfurique, nitrique, hydroshlorique, elc., et le rôle d'acide avec certains oxydes métalliques, tels que l'oxyde de zinc, l'oxyde de cobalt et avec les alcalis eux-mêmes. Il a été impossible jusqu'ici de la combiner avec l'acide carbonique. Verse-t-on un carbonate alcalin dans la dissolution d'un sel d'alumine, on remarque aussitôt un dégagement d'acide carbonique et une précipitation d'alumine.

On prépare l'alumine anhydre en calcinant au rouge l'alun ammoniacal, sulfate double d'alumine et d'ammoniaque. L'alumine pure reste dans le vase opératoire sous la forme d'une masse blanche, spongieuse, peu cohérente. Pourl'obtenir en gelée, à l'état d'hydrate, on la précipite d'un de ses sels par un grand excès d'ammoniaque caustique. On choisit encore pour cela l'alun, qui est de tous les sels d'alumine celui que la cristallisation dépouille le plus facilement des malières étrangères qui peuvent accompagner cet oxyde.

La plupart des chimistes considèrent l'alumine comme formée de 2 équivalents d' $A$ luminium et de 3 équivalents d'oxygène, ou en poids de 100 d'Aluminium et de 87,7 d'oxy gène. L'alumine est très répandue dans la nature; c'est la base des argiles. A l'état de pureté, elle est au contraire très rare. Elle constitue le saphir et le rubis ou corindon des minéralogistes. La Gibsite est une combinaison naturelle d'alumine et d'eau.

L'alumine pure n'est employée que dans les laboratoires des chimistes pour la préparation des sels alumineux. Son mélange avec la silice, tel que la nature le présente dans l'argile, sert pour faire toutes les poteries, pour le foulage des draps, pour la fabrication de l'alun et des poteries. Ajoutons que l'alumine se rencontre dans la gangue de certains minerais, dans les scories des forges, etc., et que la plupart des terrains propres à la culture contiennent de l'alumine mêlée avec d'autres matières et particulièrement avec la silice, l'oxyde de fer et le carbonate calcaire. Enfin le véritable Émeri a pour base l'alumine á l'état de corindon.

(Pel.)

ALUMINE (Alumen, inis, alun ). Min.Oxyde d'Aluminium, composé, d'après les chimistes, de 2 atômes de ce métal et de 3 atômes d'oxygène. Son nom est dérivé de celui de l'alun, sel dont on extrait communément cet oxyde. On l'appelait anciennement terre argileuse, parce qu'il est une des bases des argiles et de la plupart des terres arables. L'Alumine préparée artificiellement est en poudre blanche, douce et onctueuse au toucher, infusible et insoluble dans l'eau. Elle est principalement caractérisée par la proprièté d'être éminemment réfractaire, et de former avec l'eau une pâte liante, qui sert de base aux poteries. Elle est facilement attaquable par la potasse et par la soude caustiques, et donne par la calcination, après avoir été humectée de nitrate de cobalt, une masse non fondue d'un beau bleu. L'Alumine est isomorphe avec le peroxyde de fer, l'oxyde chromique et le sesquioxyde de manganèse.

L'alumine joue différents rôles dans la nature. $1^{\circ}$ A l'état libre ou sans combinaison définie avec d'autres éléments, elle constitue une esp. minérale très remarquable par ses propriétés physiques, le Corindon ( $V$. ce mot).2० A l'état d'hydrate et mélangée avec la Silice, elle forme les Argiles, substances d'un haut intérêt pour les arts, 
et qui lui doivent la propriété de faire pâte avec l'eau ( $V$. Argiles ). $3^{\circ}$ Combinée avec certaines bases, à l'égard desquelles elle se comporte comme un acide, elle constitue un genre particulier de composés salins, auquel on donne le nom d'Aluminates. $4^{\circ}$ Dans le plus grand nombre des cas, l'Alumine joue le rôle de base relativement à différents acides et à la silice; c'est ainsi qu'elle se comporte à l'égard de l'acide sulfurique, dans l'alun, l'alunite, la webstérite, et par rapport à la Silice dans un grand nombre de composés, tels que les Feldspaths, les Micas, les Grenats, les Tourmalines, l'Émeraude, la Topaze, elc. ( $V$. Silicates aluMINEUX.)

(DEL.)

*ALUMINIDES (Alumen, inis). min. Nom donné par M. Beudant à l'une des familles de sa méthode minéralogique, celle qui comprend toutes les esp. formées d'Alumine, soit seule, soit combinée avec différentes bases, à l'égard desquelles elle joue le rôle d'acide. Cette famille se subdivise en 2 g. : le g. Alumine, et le g. Aluminate.

(DEL.)

AlUMINITE (Alumen, inis, alun). MiN. -Nom sous lequel on a confondu différents minéraux alumineux, qui se rapportent aux esp. de l'Alunite, de la Collyrite, et de la Webstérite $(V$. ces mots).

(DEL.)

*ALUMINIUM (Alumen, inis, alun). снім. -L'alumine n'est pas décomposée par la pile voltaïque la plus énergique. Il est impossible d'extraire le métal qu'elle renferme par le procédé que Davy a appliqué ả la préparation du potassium et des autres métaux alcalins. Il faut recourir à la méthode décrite par Wohler, qui consiste à décomposer le Chlorure d'Aluminium par le Sodium ou par le Potassium.

Le chlore seul ne chasse pas l'oxygène de l'alumine, mais lorsque celle-ci est mêlée avec du charbon, elle est attaquée à une température élevée et il se produit du Chlorure d'Aluminium anhydre. On introduit ce Chlorure dans un creuset de platine avec du Potassium divisé en petits fragments; on maintient le couvercle à l'aide d'un fil métallique et on élève graduellement la température du creuset. La décomposition se décide tout-á-coup avec dégagement de chaleur et de lumière. On lessive la masse refroidie, qui se compose de Chlorure de
Potassium soluble et d'Aluminium qui ne se dissout pas. Il ne reste plus qu'à faire dessécher ce métal à une douce température.

C'est une poudre grise qui prend un aspect métallique par la compression, qui conduit mal l'électricité et la chalcur, qui est sans saveur, sans odeur, plus réfractaire que le fer, et fixe. L'Aluminium chauffé jusqu'au rouge, s'oxyde rapidement au contact de l'air, et se transforme en alumine, seul degré d'oxydation de ce métal. Lorsqu'au lieu d'air, on chauffe l'Aluminium dans l'oxygène, sa combustion développe une lumière telle que l'œil n'en peut supporter l'éclat. L'alumine qui en résulte entre en fusion, ce qui annonce une température énorme, et elle devient aussi dure que le corindon.

L'Aluminium est sans action sur l'eau froide; il ne commence à la décomposer qu'alors qu'elle est bouillante, et encore l'action en est-elle très lente. Il en résulte un dégagement d'hydrogène et un précipité d'alumine. La potasse et la soude hydratée attaquent rapidement l'Aluminium. Il y a dégagement d'hydrogène et formation d'Aluminate de potasse ou de soude. (DeL.)

* ALUMO-CALGITE (Alumen, alun ; calx, cis, chaux). mis. - Substance compacte, d'un blanc de lait, et d'un éclat vitreux faible, ayant la cassure écailleuse, happant à la langue; acquérant, par un séjour prolongé dans l'eau, un assez haut degré de transparence, avec des reflets nuancés de bleu et de jaune. Elle est facile à briser, donne de l'eau quand on la chauffe dans un tube de verre; et se dissout en gelée dans l'acide chlorhydrique concentré. Cetle substance a beaucoup de rapport avec l'Opale, dorit elle ne diffère que par quelques centièmes de Chaux et d'Alumine; c'est pour cette unique raison que Breithaupt l'a séparée des Silex aquifères, en lui donnant le nom sous lequel elle est ici désignée. L'analyse que Kersten en a faite a donné pour résultat : silice, 86,60 ; chaux , 6,25 ; alumine , 2,23 ; eau, 4,00 ; total 99,08. Elle se trouve dans les cavités d'un filon ferrugineux à Eibenstock, dans l'Erzgebirge. (Dru.)

ALUN. - L'Alun, dans le sens que l'on attribue le plus souvent à ce mot, est un sel double hydraté, formé par la combinaison du sulfate d'alumine avec le sulfate 
de potasse ou avec le sulfate d'ammoniaque. L'alun à base de potasse a pour formule : $\mathrm{Al}^{2} \mathrm{O}^{3}\left(\mathrm{So}^{3}\right)^{3}, \mathrm{Ko} \mathrm{So}^{3}+24 \mathrm{H}^{2} \mathrm{O}$.

L'Alun à base d'ammoniaque $=\mathrm{Al}^{2} \mathrm{O}^{3}$ $\left(\mathrm{So}^{3}\right)^{3}, \mathrm{H}^{6} \mathrm{az}^{2} \mathrm{So}^{3}, \mathrm{H}^{2} \mathrm{O}+24 \mathrm{HO}$. Dans la théorie de l'Ammonium, on lui donne pour formule: $\mathrm{Al}^{2} \mathrm{O}^{3}\left(\mathrm{So}^{3}\right)^{3}, \mathrm{H}^{8} \mathrm{az}^{2} \mathrm{OS}^{3}+24 \mathrm{H}^{2} \mathrm{O}$. Ces deux espèces d'Aluns présentent la même forme, qui est l'octaèdre; la même saveur, la même solubilité dans l'eau, et un ensemble de propriétés générales, pour ainsi dire identiques. On a fait l'observation qu'en remplaçant l'Alumine par des oxydes isomorphes avec elle, par le peroxyde de fer, le protoxyde de chrôme, le sesqui-oxyde de manganèse, on obtient des sels doubles qui présentent la même forme cristalline, et contiennent la même quantité d'eau que les deux aluns précédents. A son tour le sulfate de Potasse ou celui d'Ammoniaque, peut être remplacé, sans changement de forme, par quelques sulfates, tels que ceux de soude et de magnésic. On a donné à tous ces sels doubles octaédriques le nom d'Alunis, de sorte qu'aujourd'hui ce nom ne désigne plus une substance unique, mais une classe assez nombreuse de sels isomorphes.Voici les formules de ces principaux Aluns :

Alun de potasse ordinaire $=\mathbf{A l}^{2} \mathbf{O}^{3}\left(\mathrm{So}^{3}\right)^{3}$ $+\mathrm{K}_{0} \mathrm{So}^{3}$ of. $24 \mathrm{H}^{2} \mathrm{O}$.

Alun d'ammoniaque ordinaire $=i d .+$ $\mathrm{H}^{8} \mathrm{az}^{2} \mathrm{O} \mathrm{S}_{0}{ }^{3}+24 \mathrm{H}^{2} \mathrm{O}$.

Alun de chrôme et de potasse $=\mathrm{Cr}^{2} \mathrm{O}^{3}$ $\left(\mathrm{So}^{3}\right)^{3}, \mathrm{Ko} \mathrm{So}^{3}+24 \mathrm{H}^{2} \mathrm{O}$.

Alun de fer et de potasse $=\mathrm{Fe}^{2} \mathrm{O}^{3}\left(\mathrm{So}^{3}\right)^{3}$, $\mathrm{Ko} \mathrm{So}{ }^{3}+24 \mathrm{H}_{2} \mathrm{O}$.

Alun à base de soude $=\mathrm{Al}^{2} \mathrm{O}^{3}\left(\mathrm{So}^{3}\right)^{3}$, No O $\mathrm{So}^{3}+24 \mathrm{H}^{2} \mathrm{O}$.

La formule générale d'un alun est donc: $\mathrm{M}^{2} \mathrm{O}^{3}\left(\mathrm{So}^{3}\right)^{3}, \mathrm{mo} \mathrm{So}{ }^{3}, 24 \mathrm{H}^{2} \mathrm{O}$,

dans laquelle $M$ représente un métal isomorphe avec l'aluminium, et $m$ un métal isomorphe avec le potassium.

Étant donné un petit cristal d'un de ces Aluns quelconque, on peut, en le portant successivement dans une dissolution de chacun des autres Aluns, augmenter son volume sans que sa forme change. C'est une observation fortintéressante que l'on doit à M. GayLussac. Nous ne parlerons ici que des Aluns du commerce, c'est-à-dire du sulfate double d'alumine et de potasse ou d'ammoniaque.

\section{$A L U$}

Propriétés de l'alun à base de potasse. C'est un sel transparent, incolore, inodore, d'une saveur fortement astringente, soluble dans environ 15 fois son poids d'eau froide, et dans un peu moins de son poids d'eau bouillante, circonstance qui est cause qu'une dissolution d'Alun saturée à chaud se prend presque entièrement en masse par le refroidissement.

Soumis à une douce chaleur, il fond dans son eau de cristallisation (Alun de roche). Si on élève graduellement la température, il perd peu à peu cette eau, augmente considérablement de volume, devieñt opaque (Alun calciné). A une température voisine du rouge, il laisse dégager de l'oxygène et de l'acide sulfureux mêlés d'un peu d'acide sulfurique anhydre, et laisse pour résidu de l'alumine et du sulfate de potasse. Une chaleur plus élevée encore décompose ce dernier sel, et il reste finalement, comme corps fixe, de l'aluminate de potasse.

Calciné avec du charbon ou avec des matières organiques, telles que du sucre, de l'amidon, il donne naissance á un pyrophore.

Propriétés de l'Alun à base d'ammoniuque. Les Alcalis en dégagent, soit à froid, soit à chaud, de l'ammoniaque, facile à reconnaître à son odeur piquante, à la propriété qu'elle possède de ramener au bleu !e papier de tournesol, et de répandre des fumées blanches, épaisses, par l'approche d'un tube imprégné d'acide muriatique faible. Sa calcination laisse pour résidu de l'alumine parfaitement pure. Au reste les propriétés principales de l'alun ammoniacal, sa solubilité, ses usages dans l'industrie, sont les mêmes que celles de l'alun potassique. Ces deux Aluns se trouvent souvent mêlés dans le commerce, non seulement dans des cristaux différents, mais encore dans les mêmes échantillons.

L'Alun naturel est très rare : on ne l'a rencontré jusqu'ici qu'en dissolution dans quelques eaux voisines de certains lignites, dans les fissures de quelques schistes alumineux et dans les produits des solfatares. Mais il existe dans la nature une grande quantité de sous-sulfate d'alumine combiné avec du sulfate de potasse. On en rencontre au Mont-d'Or, en Auvergne, et il constitue des collines entières à Piombino et à Tolfa. Il est là sous forme de roche ou de pierre 
très dure, rarement cristallisée, presque toujours mèlée de silice et d'oxyde de fer. D’après M. Cordier, ce minéral a une composition telle, qu'on peut le considérer comme formé d'Alun et d'alumine hydratée. Une chaleur ménagée détruit ce composé, en chasse l'eau; l'alumine anhydre ne peut plus rester unie à l'alun, de telle sorte que, lorsqu'on vient à lessiver la masse calcinée, l'eau laisse l'alumine et dissout l'alun, qu'on fait ensuite facilement cristalliser. Pendant long-lemps les marchés de l'Europe ont été presque exclusivement approvisionnés avec cet Alun, qui portait le nom d'Alun de Rome. On le considérait comme le plus pur et le plus propre aux opérations délicates de la teinture. Depuis un quart de siécle, on prépare en France des Aluns qui ne laissent rien à désirer; et, loin de les faire venir de l'Italie, on pourrait en exporter au besoin des masses considérables.

C'est presque toujours avec les schistes alumineux qu'on fabrique l'Alun. On les expose à l'air, soit dans leur état naturel, soit après les avoir calcinés. Le sulfure de fer, renfermé en grande quantité dans le schiste, se sulfatise; et, comme il se produit plus d'acide sulfurique que n'en peut prendre l'oxyde dẹ fer, l'alumine, de son côté, se change en sulfate. Quand le schiste est bien effleuri, on le lessive, on sépare, par des différences de solubilité, le sulfate de fer du sulfate d'alumine, et l'on verse dans la dissolution de ce dernier une lessive concentrée et chaude de sulfate de potasse ou de sulfate d'ammoniaque. Le nouveau sel double se dépose par le refroidissement; une seconde cristallisation le purge du sulfate de fer qu'il aurait pu conserver. On reconnaît l'absence de ce dernier, et par conséquent la bonne qualité d'un Alun, quand, dissous dans l'eau, ce sel ne produit pas de teinte verdâtre avec le cyanoferrure de potassium.

Les usages de l'Alun sont fort nombreux. Il sert à fixer sur les tissus la plupart des couleurs solubles dans l'eau, à rendre le suif plus ferme, à empêcher le papier de boire, ả passer les peaux et à les préserver des vers. En médecine, on l'emploie comme astringent à l'intérieur, et comme escharotique à l'extérieur lorsqu'il a été calciné. (PeLouze).

ALUN (Alumen, Alun). mon. - Alumine sulfatée alcaline, Haüy. On donne ce nom T. 1 . à un sel double composé de sulfate d'alumine, d'eau et d'un sulfate alcalin, dont la base peut être la potasse, la soude, l'ammoniaque ou la magnésie. Il existe donc au moins 4 esp. d'Alun, qui toutes peuvent être rapportées à la même formule atomique, et cristallisent dans le même système, c. à. d., le système régulier. L'Alun à base de potasse est celui qui se forme le plus communément dans la nature. On le troure en efllorescences ou en petites masses fibreuses á la surface ou dans les fissures de certains schistes argileux, et principalement des Ampélites ou Schistes alumineux, qui en sont plus ou moins imprégnés. Il se produít aussi journellement dans les houillères embrasées, dans les solfatares et dans les cratères d'anciens volcans encore fumants. Enfin on assure qu'on le rencontre tout formé, et en assez grande quantité, au milieu des déserts de l'Égypte, oú il se présente en petites couches recouvertes de sable. On sait que la couleur de l'Alun est blanche, sa saveur douce et astringente, sa réaction acide, et qu'il est beaucoup plus soluble à chaud qu'à froid. Ses usages sont nombreux et généralement corınus. Le principal est de servir de mordant, pour fixer les couleurs sur les tissus. On ne peut obtenir de cristaux d'Alun que par les opérations de la chimie. Les formes qu'il prend le plus habituellement sont l'octaèdre régulier, le cube, le cubo-octaédre et l'octaèdre-émarginé. Il est composé d'un atôme de sulfate d'Alumine ( Al Su ${ }^{3}$ ), d'un atôme de sulfate de potasse (K Su) et de 24 atômes d'eau ( $24 \mathrm{Aq}$ ); ou en poids : de 33,77 d'acide sulfurique; 10,502 d'alumine; 09,94 de potasse; et 45,47 d'eau.-La $2^{\mathrm{e}} \mathrm{esp}$. d'Alun naturel est l'Ammonalun, ou Alun ammoniacal. Elle diffère de la précédente, en ce que sa solution dégage, par l'addition d'un alcali caustique, une odeur ammoniacale. Elle ne s'est encore présentée qu'en petites masses fibreuses formant des veinules dans les dépôts de lignites de rschermig en Bohême. La $3^{\text {me }}$ esp. d'Alun, est le $\mathbb{N a -}$ tron-alun, ou l'Alun de soude, trouvée comme le précédent, en fibres éclatantes dans des solfatares ou des terrains provenant de la décomposition des roches trachytiques. Enfin la $4^{\text {me }}$ espéce d'Alun est l'Alun de magnésie, rapportée de l'Afrique méridio$20^{*}$ 
nale, en masses fibro-soyeuses. On a donné le nom d'Alun de plume à des substances salines en fibres blanches soyeuses, trouvées dans l'île de Milo, et qui ne paraissent être que des esp. d'Alun à bases de magnésie et de protoxycie de fer. On pourrait peut-être aussi rapporter aux Aluns à base de fer et de magnésie, une substance connue sous le nom de Beurre de Montagne, et qui s'est offerte sous la forme de petiles concrétions translucides, d'un aspect gras ou résineux, parmi les roches alunifères de l'île de Bornholm, dans la Baltique, et près de Saalfeld en Allemagne.

(DEL.)

ALUNTE (l'Alaunstcin des Allemands). Mun.-Vulgairement nommée pierre d'Alun, et pierre alımineuse de la Tolfa, cette espèce minérale, du g. des sous-sulfates alumineux, est composée d'Acide sulfurique, d'Alumine, de Potasse et d'eau, dans des proportions qu'on n'est point encore parvenu à déterminer d'une manière rigoureuse. C'est une substance picrreuse, se présentant accidentellement dans la nature, en masses cristallines, fibreuses, de couleur grise ou rougeâtre, et le plus souvent en masses compactes, blanches ou rosées, dans les cavités ou à la surface desquelles s'observent quelquefois de petits cristaux, dont la forme dominante est un rhomboc̀dre aigu, de $87^{\circ} 101$. Ces cristaux se clivent, d'une manière assez distincte, perpendiculairement à leur axe. Par une calcination modérée, l'Alunite donne d'abord une odeur sulfureuse, et ensuite une saveur alumineuse. Celte substance, très préciense pour la fabrication de l'Alun, se trouve dans beaucoup de lieux où l'action des volcans a laissé des traces, et particulicrement dans les terrains trachytiques, en Hongrie, au mont d'Or en France, à Montione en Toscane, à la Tolfa près de Civita-Vecchia, dans les États - Romains, à la Solfatare de Pouzzole, à Vuleano, etc. Le gîte d'Alunite le plus connu est celui de la Tolfa. La pierre que l'on en extrait fournit un Alun très pur, connu dans le commerce sous le nom d'Alun de Rome; il suffit, pour en obtenir ce sel, de calciner l'Alunite, puis de la lessiver a chaud, et de faire évaporer la lessive, qui donne de l'alun cristallisé par le refroidissement.

(DEL.) ment; c'est-à-dire qui peut servir ả la fabrication de l'alun; mot hybride). MIN. Sulfate d'alumine hydratée, en petites masses blanches, fibreuses ou écailleuses; soluble, mais non cristallisable, d'une saveur acerbe. On le trouve dans les solfatares, où il provient de l'action des vapeurs sulfureuses sur les silicates alumineux. M. Boussingault en a fait connaître une variété, observée par lui dans les schistes argileux qui bordent le Rio - Saldana, en Colombie. D'après son analyse, l'Alunogène serait formé d'un atôme de sulfate d'alumine et de $\$ 8$ atômes d'eau; mais, suivant une autre analyse que l'on doit à M. Beudant, elle ne contiendrait que 9 atômes d'eau. Cette matière serait très utile, si elle se trouvait en plus grande abondance, paisqu'il n'y ararait qu'à la dissoudre et à y ajouter du sulfate de potasse, pour avoir de l'Alun. (Del.)

ALURNE. Alurnus. Ins. - G. de Coléoptéres tétraméres, établi nar Fabricius et adoplé par M. Duméril, qui le place dans sa famille des Herbivores ou Phytophages, ef par M. Dejean, qui le mct dans celle des Chrysomélines. Latreille, dans ses premiers ouvrages, l'avait réuni au g. Hispe, comme Olivier; mais, dans ses familles naturelles, ill'en sépare et le range dans. sa famille des Cycliques, tribu des Cassidaires, sans toutefois en donner les caractères. Voici ceux que lui assigne M. Duméril : Cors. court, inégal. Élytres d'un tiers plus longs que l'abdomen, à grand écusson. Articles des tarses très développés, veloutés en dessous.-Les Alurnes sont des Coléoptères de moyenne taille, assez remarquables par leur forme et par leur couleur. Ils appartiennent exclusivement aux contrées intertropicales del'Amérique.M.Dejean (Calal., $3^{\text {me }}$ édil.)en mentionne 7 espèces, dont 2 de Cayenne, 4 du Brésil et 1 du Paraguay. Nous ne citerons que l'A. grossus Fabr., décrit et figuré par Olivier. (D.)

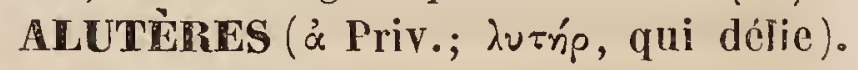
PoIss. - Nom générique de poissons de la famille des Sclérodermes, de l'ordre des Plectognathes, rangés autrefois dans le $g$. Baliste. M. Cuvier a réuni sous ce nom, les esp. dont l'os du bassin reste constamment sous la peau de l'abdomen, quoiqu'il soit mobile sous cette peau, comme l'os épineux des Balistes ou des Monacanthes l'est à

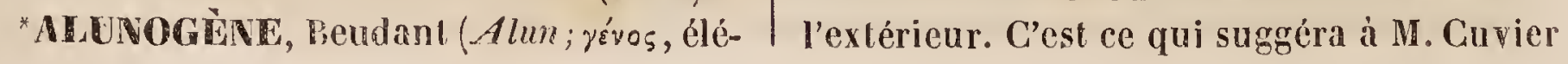


l'idée de les appeler Balistes non déliés. Quelquefoisla peau de l'abdomen forme un large fanon, en suivant le mouvement de l'os du bassin, quand il se redresse. Cependant le corps des Alutères est plus allongé que celui des autres Balistes. La peau est couverte de petits grains serrés, la dorsale antérieure réduite à une seule esp. comme dans les Monacanthes. Ce g. est un des moins nombreux du genre Baliste. On en connaît à peine 10 à 12 esp. Elles sont originaires des mers équatoriales, des deux continents, et aucune esp. n'existe dans les mers d'Europe. (VAL.)

*ALVANIE. Alvania. noll. - Dans son Histoire naturelle des productions de l'Europe méridionale, M. Risso a proposé ce g. pour les espèces turbiniformes du g. Rissoa. L'auteur n'alléguant, pour la formation de ce groupe, aucun caract. zoologique, et les esp. qu'il contiendrait se liant d'une manière insensible aux Rissoa proprement dites, ce g. ne peut ètre accepté. ( $V$. Risson.)

\section{( Desh.)}

ALVÉOLE. Alveolus (alveolus d'Alvus, ventre; par extension toute sorte de cavité). MOLL. - On a souvent employé ce mot pour désigner les loges composant l'intervalle compris entre les cloisons qui séparent l'intérieur des coquilles polythalames ou multiloculaires des Céphalopodes. (A. D'O.)

ALVÉOLE. Alveolus (alveolus, cavité). On a donné ce nom aux cavités qui existent sur les os des mâchoires, et dans lesquelles sont implantées les racines des dents. La grandeur et la forme de ces alvéoles varient suivant les différentes esp. de dents qu'ils doivent loger. Ces cavités sont percées, au fond, de trous par lesquels passent les vaisseaux et les nerfs dentaires. - On nomme aussi alvéoles : $1^{\circ}$ les petites cellules ou loges que les abeilles et guêpes se construisent pour y élever leurs larves et déposer leurs provisions; $2^{\circ}$ de petites fossettes ou cavités qu'on observe dans certaines parties des plantes, etc.

$$
\text { (C. D'O.) }
$$

*ALVÉOLÉ. Alveolatus (alveolus, alvéole). ANAT. DESCRIPT. - Qui est creusé de petites fossettes ou loges placées symétriquement les unes à côté des autres, êt se rapprochant, par leur forme, des alvéoles d'abeilles.

$$
\text { (C. D'O.) }
$$

\footnotetext{
*ALVÉOLINE. Alveolina, A. d’Orb. ( Di-
}

min. d'alvus, ventre). Foram. - G. de l'ordre des Hélicostègues, famille des Nautilö̈dées, établi par Bosc (Buf. de Délerv.) sous le nom d'Alerotites, auquel nous avons substitué celui d'Alveolina, après en avoir découvert des esp. vivantes. Nous le caractérisons ainsi : Coquille libre, régulière, équilatérale, orbiculaire ou oblongue dans le sens de l'axe spiral, à spire embrassante. Loges nombreuses, divisées, dans le sens de l'enroulement spiral, en une multitude de cavités capillaires. Ouvertures en lignes longitudinales à l'axe. - Voisin des Orbiculines par les divisions de ses loges, ce g. leur est directement opposé par la division des loges, et la direction de la ligne d'ouverture; les locules étant séparées longitudinalement dans les Orbiculines. Nous connaissons aujourd'hui 10 esp. d'Alvéolines, dont 2 vivantes, et les autres fossiles. Celles-ci appartiennent aux terrains tertiaires de l'Autriche et du bassin de Paris, et a de la formation crétacée. Comme nous l'avoñs fait remarquer (Tabl. des Céph. 1825), les g. Melonites, Lamarck; Melonia, Blainville; Clausulus et Borelis, Montfort; Oryzaria, Defrance; ne sont que des doubles emplois des Alvéolines. (A. D'O.)

ALVÉOLITE (Dimin. d'Alvus. $V$. ALvéole). furam. - $V$. Alveoline. (A. d’O.)

ALVEOLITE. Alveolites (alveolus, niche). zoop. - G. de. Polypiers pierreux établi par Lamarck, qui le place dans la section des Polypiers à réseau, et y comprend, avec une seule esp. vivante (Alveolites incrustans), plusieurs esp. fossiles dont M. Goldfuss a fait son g. Calamopora. Les Polypes en sont inconnus, et l'on peut seulement supposer que, pour certaines esp. du moins, ils se rapprochent de ceux des Tubulipores. Cependant M. Ehrenberg a placé le g. Calamopora ( $V$. ce mot) dans la famille des Milléporines, parmi des Phytocoraux dodécactiniés (où à douze rayons). C'est aussi dans la famille des Millépores que $M$. de Blainville (Man. d'Actin.) place les Alvéolites ou Calamopores ; mais cet auteur a composé tout différemment cette famille.Toutefois, à part l'esp. vivante $(A$. incrustans), qui ne se compose que d'un seul rang de cellules en forme de tubes courts, prismatiques, serrés, enroulant la surface des corps marins, on peut dire que toutes 
les Alvéolites sont des masses pierreuses, arrondies ou rameuses, formées de couches nombreuses, concentriques, superposées; ces couches étant composées d'une réunion de cellules courtes, alvéolaires ou prismatiques, et offrant à l'extérieur l'apparence d'un réseau. - On doil citer comme type dug. l'Alvéolite madréporaire, fossile des terrains tertiaires de Dax; elle a l'aspect d'un madrépore allongé, à rameaux courts, épais, arrondis, composés de cellules tubuleuses, pentagones et hexagones par couches superposées. Nous reviendrons sur les esp. fossiles du terrain de transition au mot Calamopore.

(Duj.)

AL VIN. - Nom donné aux jeunes poissons employés pour peupler les étangs, et que l'on affecte plus spécialement aux jeunes carpes longues d'un à deux décimètres. Les petits étangs où on les éléve se nomment Alviniers.

(VAL.)

ALVINAGE. Polss. - L'Alvinage consiste à se procurer et à conserver l'alvin ou les jeunes poissons dont on se sert pour peupler les étangs. Cette opération a ses régles et ses époques, dont en dépend la réussite.

(C. D'O.)

ALYDUS. Ins. - G. de la famille des Co. réens, groupe des Anisoscélites, de l'ordre des Hémiptères,section des Hétéroptères, établi par Fabricius ( $\$$ yst. Rhyng.), et restreint par Latreille aux esp. dont le corps est étroit et linéaire, les antennes filiformes, le prothorax un peu rétréci en avant, avec ses angles postér. relevés en poinie aiguë, et les paltes à cuisses renflées et munies d'épines. - On connaît aujourd'hui vingt et quelques esp. de ce g., dont le plus grand nombre habite l'A mérique. Le type est l' $A$. calcaratus Fabr. (Cimex calcaratus L.), que l'on trouve dans la plus grande partie de l'Europe. L'A. Geranii L. Duf., se rencontre aussi dans les départements méridionaux de la France.

(Bi..)

*ACYlerira (allusion'synon. à Polymnia. $V$. ce mot). вот. Pr. - Necker a appliqué ce nom à quelques plantes de la famille des Composées, réunies par M. De Candolle au g. Polymnia, dans lequel elles forment une petite sect. caractérisée par des ligules obovales ou linéaires, mais plus courtes que l'involucre.

(J. D.)

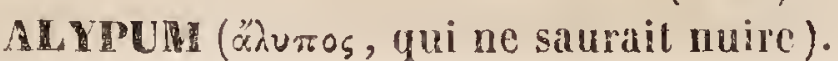

вот. Pn.-G. de la famille des Globulariées, mal défini par Tournefort (Inst.) qui l'avait créé d'après Matthiole, et dont Linné a fait le g. Globularia, aujourd'hui généralement adopté. $V$. ce mot.

ALYSE. BOT. FH.- $V$. ALISE. (C. D'O.)

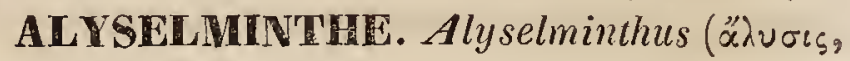
chaîne; $\tilde{\varepsilon}^{\prime} \lambda_{\text {r. }}$,,$\iota \nu 0_{0}$, ver; allusion à la forme annulaire de ces animaux). HeL MıNT.-Zéder avait substitué ce nom à celui de Tania, dans son suppl. à l'ouvrage de Goetze. M. de Blainville l'a adopté, en le restreignant à une div. générique qui comprend les Tonia sans trompe ni couronne de crocliets, comme le Tonia plicala Rud. (App. à la trad. franc. de Bremser). Leur renflement céphalique, très distinct, est pourvu de 4 suçoirs profonds; ce qui les distingue des Botryocéphales, des Botrydium, etc. ( $V$. art. vers du Dict. des $S_{c}$. nat., t. Lvi, p. 606 ; ToEnis, du même.

(L. D. Y. R.)

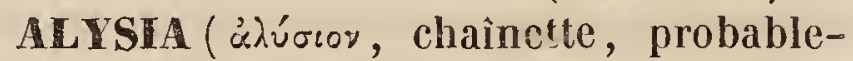
ment parce que ces insectes ont paru établir un passage entre 2 familles différentes). INs - Genre de la famille des Ichneumoniens, groupe des Braconites, de l'ordre des $\mathbf{H y -}$ ménoptères, sect. des Térébrans, établi par Latreille et adopté par tous les autres entomologistes. Ce g. est pour M. Wesmael (Mon. des Br. de Belg.) le principal de son groupe des Exodontes, dont le caract. le plus essentiel est de présenter des mandib. dépourvues de dents au côté interne. Les Alysia ont un corps grêle, des ant. Iongues, composées d'un fort grand nombre d'articles, des ailes pourvues de 3 cellules cubitales, des pattes grêles dont les cuisses un peu renflées, et un abd. légèrement pédiculé, avec son $2^{\text {me }}$ segment très grand, formant au moins le tiers de sa longueur. Les esp. connues de ce g. sont nombreuses, toutes indigènes et de fort petite taille. Celle que l'on doit en considérer comme le type est l' $A$. manducatrix ( $A$. manducator, Latr. Gen. Cr.et Ins._Cryptus manducator, Fab.). (BL.)

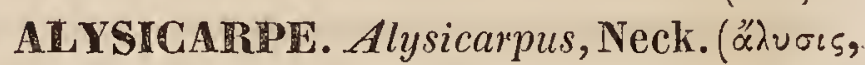
chaîne; xaptós, fruit : allusion à la forme du légume). - Hallia, Jaume Saint-Hil. (non Thunb.); Fabricia, Scopol. (non Gærtn.). вот. Pf. - G. de la famille des Légumineuses, sous-ordre des Papilionacées, tribu des Médysarées, s.-tribu des Alhagées, DC. - 
M. Desvaux (Journ. de Bol., 111, p. 120) en a donné les caract. suivants : Cal. caınpanulé, persistant, 5-fide; lanières inégales, pointues. Cor. papilionacée. Étam. diadelphes (9 et 1 ). Légume comprimé ou subcylindrique, moniliforme, se désunissant finalement en quantité d'articles monospermes, indéhiscents. - Herbes. Stipules et bractées scarieuses; feuilles simples, indivisées ; grappes oppositifoliées ou terminales, lâches; fleurs géminées ou solitaires; corolle blanche ou rougeâtre, à peine plus longue que le calice. - Ce g., propre aux régions intertropicales de l'ancien continent, renferme 19 espèces.

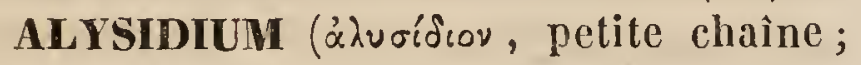
forme des filaments). BoT. Cr.-G. de Champignons créé par Kunze (Mycol. Heft., 1, p. 11, t. 1, f. 6), caractérisé par des filaments rapprochés, droits, simples, transparents et articulés ; les articles en sont ovales et se séparent les uns des autres sous la forme de spores. On n'en connaît encore que l' $A$. fulvum, trouvé sur le bois pourri des saules, dans la Lusace. Persoon (Myc.Europ.) réunit ce g. à l'Acrosporium, et M. Fries au g. Uidium.

(LÉv.)

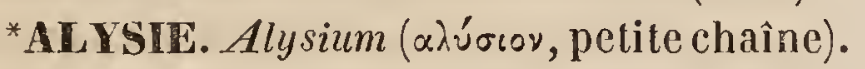
вот. Ск. - G. monotype de la famille des Phycées, créé par Agardh sur une Algue brésilienne que Mertens plaçait parmi les UIves. Comme on n'en a pas encore vu la fructification, sa véritable place est incertaine daus le systéme. Son organisation remarquable nous fait penser qu'elle pourrait bien se rapprocher des Corallines, et n'être qu'une esp. non encroûtée de ce g. ou d'un g. voisin. La plupart des zoologistes qui ont fait une étude spéciale des Polypiers, sont maintenant convaincus que les Corallines sont de vraies Phycées. Nous-mème, nous avons observé chez une espéce de Cuba, non encore recouverte de calcaire, que la structure était évidemment cellulaire, et se rapprochait beaucoup, la forme des mailles du réseau exceptée, de celle qu'Agardh attribue au genre dont il s'agit.Pour revenir au g. Alysium, en voici les caract. diagnostiques essentiels : Fronde articulée (comme dans le Chondria articulata), tubuleuse, dichotome, a articles ovales, longs de 2 à 3 lignes, séparés par un rétrécissement en forme de col. Les rameaux partent du sommet des articles. La couleur de cette plante est verte, et sa consistance membraneuse. A la loupe, on la trouve composée de fibres hyalines formant des aréoles pentagones réunies par une membrane. Nous avons déjá dit qu’elle croît sur les côles du Brésil. Nous ne pensons pas qu'elle ait été trouvée ailleurs. (C. M.)

ALYSON. ins. - G. de la famille des Crabroniens, de l'ordre des Hyménoptères , sect. des Porte-aiguillon, établi par Jurine, adopté par Latreille et tous les autres entomologistes, et confondu d'abord arec les Pompilus par Fabricius. Il se distingue facilement des Crabro et des g. voisins par des ant. filiformes; des mandib. tridentées; un métathorax muni d'une épine à son extrémité postéricure, et surtout par des ailes pourvues de 3 cellules cubitales (les 2 premières recevant chacune une nervure récurrente), et des pattes grêles avec le $1^{\mathrm{er}}$ art. des tarses fort long, et les cuisses postér. armées d'une pointe vers leur extrémité. On ne connaît que quelques esp. de ce g. dont le type est l'A. lunicornis Latr. (Pompilus lunicornis Fab.), répandu dans une grande partie de l'Europe.

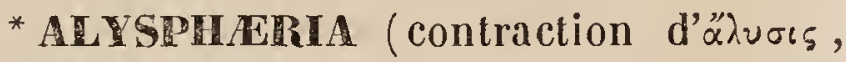

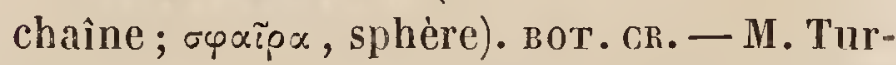
pin, dans un travail sur l'Organographie végétale (Mém. du Muséum. 1827), a donné ce nom à un groupe de plantes qui ont été classées par la plupart des auteurs, parmi les Lichens, dans le g. Lepra ou Lepraria, et que l'on peut regarder comme des états primordiaux de Lichens qui n'ont pas encore été trouvés pourvus d'apothéces permettant de savoir exactement quelle place ils doivent occuper. Le g. Alysphoeria présente des globules entremêlés de fibres ou filaments. Il a été rapproché des Nostocinées par M. Kutzing, et M. Meneghini le rapporte, avec doute, aux Leptomitées. Les globules de ces végétaux peuvent, d'après M. Turpin, être considérés comme les apothèces d'un thalle fibreux, légèrement aplati, ou coralloïde, dont ils émanent directement. Ce micrographe a figuré 6 esp. de ce g., qu'il désigne comme le $2^{\text {me }}$ degré de l'organisation végétale dont le g. Globuline forme le $x^{\mathrm{er}}$.

$$
\text { (BRÉB.) }
$$

AL YSSINÉES. вот. PH. - Tribu établie par M. De Candolle dans la famille des Crucifieres. $V$. ce mot. (AD.Jo) 


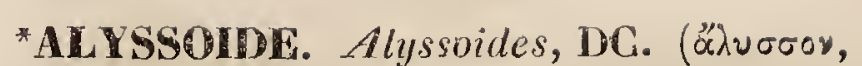
alysson ; عidos, forme). Bo'T. PII.-M. De Candolle donne ce nom à un s.-g. de ses $V$ esicaria; mais les 2 esp. sur lesquelles il le fonde sont de vrais Alysson.

ALYSSON. Alyssum, L. (ex parte).; Adyseton, Scopol.; Meniocus, Desv.; Aurinia et Odontarrhena, C. A. Meyer.; Alys-

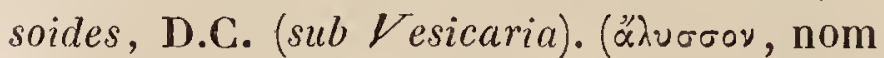
grec d'une plante que l'on rapporte á la Passerage; $\alpha$ priv.; iú $\sigma \sigma \alpha$, rage). вот. Pн. - G. de la famille des Crucifères, tribu des Siliculeuses. Nous lui avons assigné les caract. suivants (Suites à Buff., Plant.phan., 6, p. 476): Sépales ascendants ou dressés, naviculaires, égaux. Pétales indivisés ou bifides, onguiculés. Glandules 4, dentiformes ou sétiformes, opposées aux sépales latéraux. Étam. 6 ; filets anisomètres, ascendants, arqués, appendiculés (du moins les impairs; par exception tous inappendiculés, mais marginés) ou 1-dentés à leur base; anth. prolondément cordiformes à la base. Ovaire comprimé, 2-loculaire; loges 1-2-4-ou 6ovulées. Style filiforme ou subulé. Stigm. pelté, subhémisphérique. Silicule comprimée ou aplatie (parallèlement au diaphragme), courte, 2-loculaire, 2-valve, apiculée ou cuspidée; loges 1-6-spermes; valves planes ou convexes, écarénées, immarginées, innervées; nervures placentairiennes, filiformes, incluses. Graines ailées ou marginées, lenticulaires, suspendues, lisses, solitaires, ou collatérales, ou bisériées. Cotyl. rectilignes, presque planes, accombants. Herbes quelquefois sufirutescentes, en général colonneuses (pubescence étoilée); feuilles très entières ou rarement sinuées-dentées; grappes terminales (soit solitaires, soit en cyme), ou terminales et oppositifoliées, nues, multiflores; pédicelles filiformes : cenx des fleurs épanouies en général subfastigiés; fleurs petites, jaunes. - Ce g. est propre aux régions extra-tropicales du nord de l'ancien continent. Le nombre des esp. (en excluant les doubles emplois et les esp. qui constituent le g. Koniga, Adans.) est d'environ 12 ; plusieurs se cultivent comme plantes d'ornement.

*ALITES ('ávins, au propre, licteur, et signifiant, ici, quilie, qui attache, pour faire allusion á la manière dont le mâle, chez la seule esp. qui constitue ce g., dispose au- tour de ses cuisses les wufs de sa femelle, au fur eta mesure qu'ils sortentdu cloaque). REPT.-G. de Batraciens anoures, de la famille des Raniformes, dont la mâchoire supérieure est garnie de dents, et dont l'extrémité des doigts n'est point dilatée en disque, comme cela s'observe chez les Raineltes. Ses caract. sont les suivants : Langue circulaire, épaisse, entière, adhérente, creusée de quelques sillons longitudinaux; dents vornériennes, formant, en arrière des narines internes, une longue rangée transversale, à peine interrompue au milieu ; tympan distinct; trompes d'Eustachi trés petites; 4 doigts libres; 5 orteils réunis en partie par une membrane épaisse; saillie du premier os cunéiforme, peu développée, non tranchante. - C'est à Wagler qu'on doit l'établissement du g. Alytes; jusqu'à lui, l'esp. qui en est le type avait été rangée avec les Crapauds, quoiqu'elle a i t des dents à la mâchoire supér. et au palais, et que ceux-ci en soient complètement dépourvus. L'A. accoucheur ( $A$. obstetricans), car c'est ainsi qu'on le nomme, se trouve assez communément en France, en Suisse, en Allemagne. Sa voix, qu'il fait souvent entendre dans les belles soirées d'été, ressemble au son d'une clochette de verre. Les deux sexes se recherchent et s'accouplent sur la fin de mars et vers le commencement d'avril; la femelle pond 50 à 60 œufs d'un jaune pâle, gros comme des grains de chènevis; elle est aidée dans ce travail par le mâle qui, ả leur sortie, saisit ces œufs disposés en chapelet, et les tourne autour de ses cuisses; puis, ainsi chargé, il se retire dans des trous souterrains, à deux ou trois pieds de profondeur, oú il demeure complètement enfermé jusqu’à la parfaite mațurité des œufs, qu'il transporte alors dans l'eau, oú s'opère l'éclosion.

(G. B.)

ALYTOSPORIUM (ä̀นเ๐, indissoluble; бropó, emence). вот. CR.- G. de Champignons créé par le professeur Link pour placer quelques esp. de Sporotrichum dont les filaments sont colorés. Il est caractérisé par des filaments rameux, cloisonnés, auxquels adhèrent des spores simples, rondes ou ovales, très petites. M. Fries considère les esp. qu'il renferme comme le Mycelium de quelques Champignons. L' $A$. croceum, Link, que l'on trouve sous un grand nombre de noms dans les auteurs, est le Thelephora sulfurea 
Fr., et l'A. roseum Ehrenb., est le Cladobotryon varium Nees. Ce g. doit ètre effacé de la Mycologie, quoiqu'il ait été conservé dans la $2^{\text {me }}$ édition du Systema der Pilze.

(LÉv.)

ALYXIA , Banks et Scl., Gynopogon, Forst. ( $\alpha \lambda \nu \xi_{\iota \zeta}$, tristesse; allusion au sombre feuillage de ces plantes). вот. Рн. - G. de la famille des Apocynacées, tribu des Ophioxylées, créé par Banks et Solander (Ex R. Bro. Prod.) et dont les caract. distinctifs sont: Cal. 5-fide. Cor. hypogyne, hypocratérimorphe, à gorge nue ou barbue, à 5 lobes obliques. Étam: 5 , incluses, insérées á la gorge de la corolle; anth. ovales, subsessiles.Ovaires 2; ovules superposés, peu nombreux, insérés sur la suture ventrale introfléchie. Styles presque coudés; stigm. obtus, nu ou rarement barbu. Drupes 2, (l'un avortant quelquefois), pédiculés, simples, monospermes ou composés-lomentiformes; cloison coquillée,semi-bi-loculaire, naissant d'une suture un peu saillante. Graines biparties,insérées dans un sillon ventral, à la commissure de la cloison.Embryon dressé ou courbe, dans l'axe solide d'un albumen corné, replié-lobulé; cotyl. oblongs, obtus, à radicule infère. Les Alyxia sont des arbrisseaux glabres, lactescents, à feuilles verticillées ou rarement opposées, coriaces, toujours vertes, à fleurs axillaires ou terminales, quelquefois disposées en épis, blanches, d'une odeur agréable. Ils habitent les parties chaudes de l'Australasie et de l'Asietropicale. On en connaît une quinzaine, dont l' $A$. daphnoides est souvent cultivée dans les jardins.

(C. L.)

ALZATEA (nom d'homme). вот. Рн. G. de la famille des Célastrinées, tribu des Évonymées, créé par Ruiz et Pavon $(\boldsymbol{F} l$. per. Prod.) qui lui donnent pour caract. : Cal. 5fide, 5-gone, persistant.Pétales nuls. Étam.5, hypogynes? Style 1. Caps. obcordiforme, biloculaire, loculicide-bivalye. Graines nombreuses, superposées, ceintes d'une membrane.-Ceg., encore incomplètement connu, ne contientqu'une esp., l' $A$. verticillata; c'est un arbre à feuilles obovées, échancrées, à fleurs disposées en corymbe, et qui a été trouvé dans les forêts du Pérou, près du lieu appelé le Messapata. Ce g. rentrerait probablement dans le g. Maytenus, si ses fleurs n’étaient point apétales.
* AMACarUS (á priv.; $\mu \alpha x \alpha p$, ápos, humeur). INs. - G. de Coléoptères tétramères, famille des Hélopiens, tribu des Cistélides, établi par M. Dejean dans son dernier Catalogue, où il le place entre les g. Mycetocharis de Latreille, et Omophlus de Mégerle. Ce g., dont il n'a pas publié les caract., est fondé sur une seule esp. du Brésil nommée par lui, $A$. strigosus.

AMADEA, Adans. вот. PII. - Synon. d'Androsace. $V$. ce mot.

*AMADINA (ä $\mu \alpha$, ensemble; jivós, ń, tournoyant; lisez Hamadina). o1s. - G. de l'ordre des Passereaux et des Conirostres de $\mathrm{Cu}$ vier, formé par Swainson, et faisant partie de sa s.-famille des Coccothraustince, dans sa famille des Fringillidec. Les caract. en sont, d'après cet auteur (Class. of Birds.) : Taille très petite; bec très court, conique; ailes pointues, à penne bâtarde, petite; pattes médiocres ou petites. Ce groupe répond a celui des Bengalis des auteurs français.

Toutes les esp. de ce g. habitent les régions tropicales de l'ancien monde. L'auteur les subdivise en 5 s.-g., qui sont :

$1^{\circ}$ Estrelda, Sw. : Bec petit, médiocre ; queue allongée, étagée ou arrondie; pieds médiocres; tarse plus long que le pouce.-Espèce-type, Fringilla Bengalus L., Vieill.; Bengali mariposa Buff.; Enl., 115-1; Estrelda Phcenicotis Swains. (Birds of West. Alr., I, 192, pl. 14.).

$2^{\circ}$ Amadina, Sw. : Taille plus forte; bec court, très épais et large à sa base; queue courte, arrondie ou carrée ; tarse plus long que le pouce. Esp.-types, Loxia fasciala, Fringilla nitens (ou Cambasou).

$3^{\circ}$ Spermestes, Sw. : Béc court, épais; pieds à doigts très allongés, le médian surtout; ongles également fort longs et grêles, l'intermédiaire et le postér. surtout; queue courte, carrée ou étagée (chez les esp. de l'Inde, particulièrement). Esp.-types : Loxia Malacca, ou Gros-Bec-Jacobin;Loxia punctularia,ou GrosBec des Moluques; Enl., 139-1.-M. Swainson leur réunit une esp. a fricaine, son Spermestes cucullata (West.Afr. 1, 201), comme esp. de transition entre les esp. a doigts courts du groupe précédent et les esp. à longs doigts du groupe actuel, lesquelles appartiennent à l'Inde.Nous croyons reconnaître cet oiseau dans le Loxia prasipteron (Lesson, Revue zool., 1839, p. 104). 
Celte petite div., remarquable par la grosseur du bec, la longueur des doigts et des ongles, nous paraît assez naturelle, en ce qu'elle renferme des espéces qui, d'après M. Swainson, se nourriraient principalement des graines de grandes graminées ou de certaines espéces de roseaux. La force de leur bec, ainsi que la longueur de leurs doigts et de leurs ongles, leur serviraient admirablement pour concasser les graines et se tenir cramponnées sur les tiges glissantes deces grandes plantes exotiques. On retrouve ces mêmes caract. joints aux mêmes mœurs chez le Pinson de riz d'Amérique.

$4^{\circ}$ Erythura, Sw. : Bec gros, conique, allongé; queue fort longue, étagée et finissant en pointe.-Esp.-type, Fringilla quadricolor Gmel. (Enl., 101-2), ou Fringilla sphœnura, Gros-Bec longicône, Tem. (Col., 96-1,2,3) ou Erythura viridis Sw. (Class. of Birds., Il, p. 280.) Nous ne concevons pas pourquoi M, Swainson a donné ce $3^{\text {me }}$ nom spécifique à un oiseau qui en avait déjà deux. Il eût été plus conséquent de lui rendre son nom primitif de quadricolor Gmel., que Temmink avait déjà eu tort de changer en celui de sphoenuta.

$5^{\circ}$ Pytelia, Sw. : Bec mince, conique, allongé ; ailes à rémiges courtes, dont la $1^{\text {re }}$ est rétrécie ou échancrée au côté interne près de la pointe; queue arrondie ou étagée; pieds très petits, à doigts latéraux, égaux et fort courts.

Esp.-types : Fringilla elegans Gmel., ou le Beau-Marquet (Enl., 203-1); Pytelia Phonicoptera Sw. (West. Afr., 1, 203, pl. 16); toutes deux du Sénégal.

Il est facile de reconnaître que, sous le nom générique d'Amadina, g. subdivisé en 5 s.-g. ou petites sections, M. Swainson a réuni la plupart de nos anciens Sénégalis et Bengalis (n'y ajoutant toutefois aucune esp. analogue du nouveau Monde) qui diffèrent de toutes celles de l'ancien, en ce qu'elles n'ontjamais de penne bâtarde courte, et que leur $1^{\text {re }}$ penne, au contraire, n'est qu'un peu moins longue que la seconde. C'esí ce caractère, tiré de la forme des ailes, et établissant une distinction géographique entre tous ces petits Fringilles de l'ancien et du nouveau Monde, qui nous a paru donner le plus de valeur à l'établissement du g. Amadina de Swainson, et de ses subdivisions, que nous adoptons. (LAFr.)

AMADIS OU AMIRAL-AMADIS inom d'homme). MoLl. - Nom d'une belle esp. de Cône, Conus Amadis ( $V$. cône). ' (Desh.)

AVADOU. Igniarium, Pline. - Ce mot, qui appartient $\dot{a}$ la langue française, sert à désigner une substance préparée pour prendre et conserver le feu. Parmi les substances qui jouissent de celte propriété, on distingue un grand nombre de végétaux dont les tiges et les fenilles sont couvertes de poils longs, épais el soyeux, comme les Armoises, les Morines, elc. L’Amadou de Panama est formé avec le duvet de la face infér. des feuilles du Melastoma sericea L., des fleurs de beaucoup de composées : en raison des poils de l'involucre, des aigrettes, des graines et des soies du réceptacle, darıs le Gnaphalium italicum W., l'Echinops strigosus L. , l'Atractylis gummifera L., l'Andromachia igniaria Humb. etc. A l'ile-de-Trance on en obtient une esp. particulière du liber de l'Afoulh ou Ficus terebrata W, et dans beaucoup d'endroits, on se sert de chiffons à moitié brûlés.Le vérilable Amadou provient de quelques Champignons qui appartiennent au genre Polyporus. Le Polyporus igniarius et le $\boldsymbol{P}$. fomentarius sont les deux esp. les plus avantageuses pour cette fabrication, à cause de leur fréquence et de leur volume. On pourrait en retirer du Polyporus Ribis Fries, torulosus Pers., pinicola Fries, laccatus Pers., etc., mais ils n'ont pas assez d'épaisseur. Pour préparer l'Amadou, on enléve la partie supér. du chapeau, qui est dure, comme ligneuse, et la couche de pores qui garnit la face infér.; on coupe le tissu par tranches que l'on fait macérer dans l'eau pour les ramollir, et on les bat ensuite avec un marteau de bois sur un billot, pour les étendre. Cette opération renouvelée trois ou quatre fois, on obtient de chaque tranche une lame d'Amadou, qu'il suffit de tremper dans une solution de nitrate de potasse. Quelques personnes se contentent de le frotter avec de la poudre à canon; mais cette préparation le rend noir. C'est ainsi que nous le recevions autrefois d'Allemagne, sous forme de mèches. Persoon (Champ. com. p. 92) dit que les bûcherons des Vosges enterrent le Bolet coupé par tranches, et l'arrosent ensuite avec de l'urine. L'Amadou préparé avec le maillet ne 
diffère de l'Agaric des chirurgiens ( $V$. ce inot) qu'en ce qu'il r'est pas salpétré. On en obtient quelquefois des lames d'une très grande étendue, et qui, molles, souples, ties légères, ressemblent à un feutre. Grleditsch (Méth. Fung.) dit avoir vu en Franconie des paysans vêtus d'lıabits confectionnés arec cette singulière étoffe.

Les Polypores ne sont pas les seuls Champignons avec lesquels on puisse préparer de l'Amadou. L'Agaric labyrin'hiforme, Dádalea quercina Pers., préparé comme je viens de le dire, en donne de très bon. La base des grandes espéces de Lycoperdon, comme les $L$. colatum Bull., gigrnteum Batsch, trempée dans une solution de nitrate de potasse, remplace très bien l'Amadou ordinaire.Dans quelques contrées de France, en Hongrie, en Moldavie, j'ai vu employer le bois pourri; mais, en examinant attentivement, on s'apercoit facilement que la substance ligneuse a été détruite et remplacée à mesure par le mycelium de quelques Champignons. On appelle Amadou blanc, celui que l'on retire des Xylostroma et des Racodium qui ont cette couleur. J'ai reçu de feu Simonnet un morceau de Xylostroma giganteum Tode, qui prenait feu avec la plus grande facilité, et qui dégageait, en brûlant, une odeur d'encens très agréable.

(LÉv.)

AMADOUVIER; Bolet, Agaric amadouvier; Boletus igniarius L.; Polyporus igniariıs Fr. вот. CR - Espèce de Champignons d'oú l'on tire l'Amadou ( $V$. Amadou). On pourrait donner ce nom à toutes les espèces de Polypores, tels que les $P$. fomentarins $F r$., Ribis Fr., dryadeas P., pinicola Fr., laccans Pers.; mais il désigne particulièrement le $P$. igniarius, quoiqu'il fournisse un Amadou infér. en qualité à celui qu'on retire du $P$. romentarizs. Paulet a fait le g. Pyreium de ces Champignons et de quelques autres, qui, comme les Himantia et les Xylostroma, ont la propriété de prendre feu facilement.

(LÉv.)

AMAEBA. INF. - $V$. Amoeba. (Duj.)

AMABÉES. INF. $V$. AMoebées. (Duj.)

* AMAGRIS. bo'r. pIr. - L'Arundo arenaria de Linné a été placé successivement dans un grand nombre de g., tels que Calamagrostis, Psamma, Ammophila et Amagris. Celui qui a prévalu est l' Ammophila de Host, T. 1. dont l'Amagris de Presl n'est qu'un synonyme. $V$. АиморніL.

(A. R.)

AMAIOUA, AMAIOA OU AMAJOVA, Aubl.; Hexactina, Willd. - Ehrenbergia, Spr. (Nom de ces arbres chez les Indiens ). вот. PH. - G. de la famille des Rubiacées, tribu des Gardéniées, fondẻ par Aublet (Guyan. Suppl. 13, t. 375), et dont voici les caract. : Cal. ovale-tubulé, conné avec. l'ovaire, à limbe supère, cylindrique, 6 -denté, tardivement décidu. Cor. supère, hypocratérimorphe, à tube cylindrique, dépassani le limbe calicinal, partagée en 6 lobes oblongs, étalés. Anth. 6, linéaires, fossiles entre la gorge de la corolle. Ovaire infér., bitri-loculaire. Ovules nombreux, bisériés, horizontaux, anatropes. Style simple; stigm. indivis, en massue. Baie obovale-oblongue, 2-3-loculaire, aréolée au sommet, munie d'une écorce. Graines déprimées - planes, suborbiculaires, distinctes des cluisons membranacées et horizontales. Embryon... - Ce g., imparfaitement connu, renferme des arbres ou des arbrisseaux indigènes dans l' $\mathrm{A}$ mérique tropicale, a fenilles opposées ou ternées, courtement pétiolées, nervées, glabres, munies de stipules oblongues, décidues. Les fleurs sont subsessiles et disposées en corymbes au sommet des rameaux.

(C. L.)

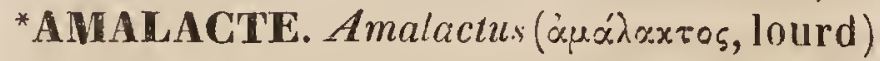
ins. - G. de l'ordre des Coléoptères tétramères, famille des Curculionites, div. des Érirhinides, établi par Schœenherr, qui Ini donne les caract. suivants : Ant. médiocres, peu fortes, insérées vers le sommet du rostre; funicule de 7 articles; le $1^{\mathrm{er}}$ court, obconique, le $2^{\mathrm{me}}$ presque en massue; les au-. tres plus courts, tronqués au sommet, s'épaississant graduellement; massue ovale, dont les articles ne peuvent être distingués. Rostre allongé, robuste, cylindrique, grossissant un peu vers l'extrémité, à peine courbé. Yeux oblongs, déprimés. Thorax presque carré, tronqué antérieurement, légèrement bi-sinué à la base, un peu convexe en-dessus. Écusson petit, triangulaire. Élytres allongées, presque linéaires, non calleuses à l'extrémité, avec les angles terminaux obtus. - Ce g. figure dans le dernier Catalogue de $M$. Dejean, qui y rapporte 3 esp., dont 1 de Cayeune et 2 du Sénégal. Nous ne citerons que là $1^{\text {re }}$, nommée par lui $A$. 
nigrints, et que, dans son précédent Catalo¿ue, il avait placée dans le g. Rhynchcenus.

* AMALE. Amalus (áuàiós, mou). ins. - G. de Coléoptères tétramères, famille des Curculionites, div. des Erirhinides, établi par Schonherr, qui lui donne les caract. suivants : Ant. peu longues, minces; funicule de 6 articles, les trois $1^{\text {ers }}$ assez longs, coniques; le $1^{\text {er }}$ épais, les autres courts, noueux; massue oblongue, ovale. Rostre allongé, presque mince, cylindrique, défléchi , arqué. Yeux latéraux, arrondis, peu saillants. Prothorax légèrement bi-sinué à sa base, un peu arrondi sur les côtés, plus étroit antérieurement, tronqué au sommet. Écusson très petit, à peine visible. Élytres brièvement subovales, légèrement convexes en-dessus, arrondies à l'extrémité, plus courtes que l'abdomen. Épaules obtusément anguleuses. Pattes médiocres, entièrement mutiques. Le corps, de grandeur Inédiocre, est brièvement ovale, sculpté, ailé, parsemé de quelques poils de grandeur médiocre. - Ce g., adopté par M. Dejean ( $\mathrm{Ca}$ tal., $\left.3^{\text {me }} \dot{e} d i t.\right)$, ne renferme qu'une seule esp., qui se trouve en France : c'est le C'urculio scortillum de Herbst (Col. vı, p. 418 , n० 402, t. 92, fig. 13). Cette esp. appartenait auparavantau g. Falciger de Mégerle, qui a été supprimé.

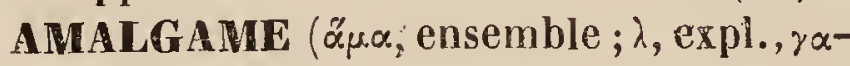
uш, je marie). min. - Syn. de Mercure aryental. ( $V$.Mercure.)

AMALGAMES ( $\ddot{\alpha} \mu \alpha$, ensemble ; $\lambda$, explé-

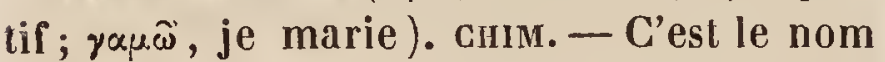
qu'on donne aux combinaisons du mercure avec les autres métaux. Ces sortes d'alliages sont en général blancs, quelquefois susceptibles de cristalliser, presque tous décomposables à une température rouge.

Les principaux amalgames sont : $1^{\circ}$ celui d'Étain, qui sert á étamer les glaces et à les méttre au tain; $2^{\circ}$ celui de Bismuth, qu'on emploie pour étamer intérieurement les globes de verre ; $3^{\circ}$ ceux d'Argent et d'Or, dont on se sert pour argenter ou dorer quelques métaux ou alliages, particulièrement le cuivre rouge, le laiton et le bronze. L'amalgame des argenteurs est formé de: mercure, 85 parties, argent, 15 p. ; celui des doreurs de: mercure, 90 et or, 10.-L'amalgame destiné a frotter les coussins des ma- chines électriques est formé de $50 \mathrm{p}$. de mercure, 25 p. d'étain el 25 p. de zinc. (PEL.)

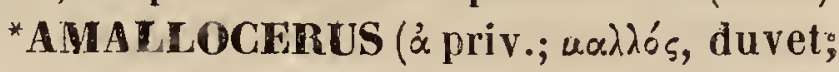
xદ́pas, corne). Ixs. - G. de Coléoptères tétramères, famille des Longicornes, établi par M. Dejean (Catal, $3^{\text {me }}$ édit.), qui le place immédiatement avant le g. Lophonocerus, Latr., appartenant à la tribu des Cérambycins de M. Serville. Ce g., dont il n'a pas publié les caract, est fondé sur une seule esp. du Brésil, qu'il nomme $A$. aculeatus. (D.)

* AMALLOPODE. Amallopodus (á priv.;

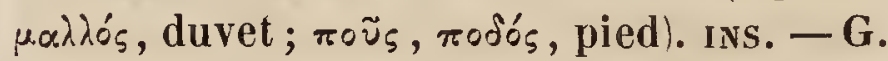
de Coléoptères tétramères, famillê des Longicornes, tribu des Prioniens, établi par M. Lequien, dans le Magasin zoologique de M. Guérin, $18: 33,3^{\text {me }}$ annèe. Ce g. , qui ne figure pas dans le Catalogue de M. Dejean , appartient à la $1^{\text {re }}$ subdiv. des Prioniens, et vient se placer entre les g. Titanus et Ctenoscelis de $M$. Serville, dont il se distingue principalement par la forme de son corselet, armé latéralement d'une seule épine, par ses tarses sans brosses en-dessous, dont les articles sont cylindriques, ef le $4^{\mathrm{me}}$ nullement bilobé. Il est fondé sur une seule esp., figurée, dans l'ouvrage précité, sous le nom d'A. scabrosus, qui lui a été donné par M. Dupont.

AMALOUASSE. 01s. - Nom vulgaire de la Pie-Grièche. (C. D'O.)

AMALOUASSE-GARE. oIs. - Syn. vulgaire du Gros-Bec dans quelques cantons de la France.

(C. D'O.)

AMALTHÉ. Amaltheus (ááa $\lambda \theta \varepsilon \imath$, chèvre, nourrice de Jupiter; par extension, ici, corne d'abondance). MoLL. - G. de Céphalopodes établi par Montfort (Conchyl. Syst. p. 90) sur une esp. d'Ammonite dont il place mal a propos le siphon contre le retour de la spire.

(A. D'O.)

AMA LTHÉE. Amalthea $\left(\alpha^{\prime} \mu \alpha^{\prime} \lambda \theta \varepsilon<\alpha\right.$, la chèvre Amalthée, nourrice de Jupiter). вот. PIr. - Dénomination proposée par M. Desvaux pour désigner une forme particulière de fruits dans plusieurs Rosacées, dont le cal. ne devient point charnu après la floraison. L'auteur cite le fruit de l'Aigremoine comme type de cette esp. de fruits, dont la distinction n'a pas été adoptée. Lindley le confond a vec l'Étairion de M. Mirbel. $V$. Érairion. (C. L.)

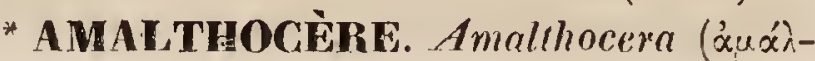




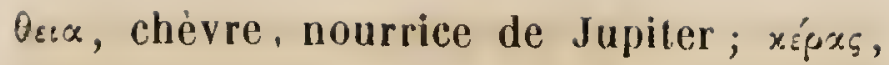
corne). ıxs. - G. de Lépidoptères, famille des Crépusculaires, créé par M. Boisduval, qui n'en a pas encore publié les caractères. Ce g., qu'il place dans sa tribu des Ágocérides, est fondé sur une seule esp. (du Sénégal), nommée par lui $A$. tiphys, et représentée pl. 14, fig. 8 , de son S'pecies général des Lépidoptères, faisant suite au Buffon de Roret.

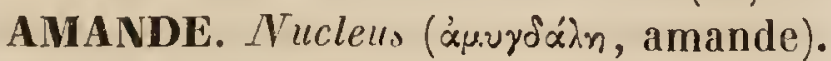
вот. PH. - C'est tonte la partie de la graine mûre placée sous l'épisperme ou tégument propre. Elle peut offrir, dans sa composition, deux modifications différentes. Tantôt, en effet, l'amande est formée par l'embryon tout seul, c'est-á-dire par la partie de la graine qui, à l'époque de la germination, se développe en un nouveau végétal, comme dans le prunier, le haricot, le marronnier d'Inde, etc.; tantôt, outre l'embryon, elle contient un autre corps de nature variée, qu'on nomme endosperme, et qui, a l'époque de la germination, diminue, se détruit insensiblement, et finit même par disparaître presque complètement ( $V$. GRAINE).

(A. R.)

AMANDE. вот. PH. - Fruit de l'Amandier. $V$. ce mot.

(A. R.)

AMANDE (amandala, basse lat.; corruption d'amygdala, áuvyd́'àn). MoLl. - Norn vulgaire de plusieurs coquilles. Ce nom s'applique : $1^{\circ}$ à la Venus pectinata Lin. (Cytherea pectinata Lamk.); $2^{\circ}$ ả l'Arca barbata ou à l'Arca lacerata de Linné, Amande à cils ; $3^{\circ}$ à l'Arca fuscata de Bruguière, Amande rôtie; $4^{\circ}$ Enfin Plancus donne le nom d'Amande de mer à l'animal du Bullce a aperta.

(DEsh.)

*AMANDE amère. вот. Cr. - Nom sous lequel Paulet (Traité des Champ., tom. II, p. 299, pl. CXLiII, fig. 1) a décrit une esp. d'Agaric dont la saveur et l'odeur rappellent exactement celles de l'Amande amère. Il croît en automne dans les environs de Paris. Il ne paraît pas vénéneux, puisque les expériences faites sur les animaux ne les ont point incommodés.

(LÉv.)

AMANDIER. Amygdalıs, Tourn. (áu.uy$\delta \alpha \lambda \tilde{n}$, amandier). вот. PII. - G. ou s.-g. de la famille des Amygdalacées ou Drupacées. Ce g., tout-à-fait conventionnel, ne diffẻre essentiellement des Prunus, auxquels l'avait réuni Linné, que par son drupe à mésocarpe non succulent, finalement presque coriace et irrégulièrement bivalve. La conformation du noyau, très variée suivant les espéces, ou même variable dans plusieurs, ne peut offrir aucun caractère générique: Le caract. distinctif que quelques auteurs ont cru trouver dans la vernation des feuilles est tout-à-fait imaginaire. On en connaît ' 5 ou 6 esp:l'une croìt au Mexique; les autres croissent dans les régions extra-iropicales de l'ancien continent. Tout le monde sait que l'Amandier commun ( $A$. cornmunis, L.), se cultive comme arbre fruitier. Plusieurs autres esp. se plantent dans les bosquets d'ornements.

(Sp.)

AMANITE. Amanita (áuayítns, sorte de

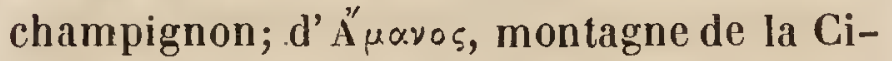
licie, sur laquelle on trouvait beaucoup de ces Champignons). вот. Cr. - Galien, Paul d'Égine et quelques auteurs des $15^{\text {me }}$ et $16^{\mathrm{m}}$ siècles, comme 'Tragus, Sterbeeck, ont désigné sous ce nom les Cèpes ou Bolets proprement dits, tandis que Dillen, Haller, Adanson et d'autres, l'ont donné aux Champignons garnis de lames dont Linné a fait le g. Agaricus. Persoon et les auteurs modernes, pour faciliter l'étude de ce genre, le plus nombreux de tous en esp., l'ont divisé en plusieurs s.-genres. Les Amanites, qui composent le $1^{\mathrm{er}}$, penvent ètre considérées comme des Champignons dont l'organisation est portée au plus haut degré. Ce sont des Agarics dont le pédicule est nu ou muni d'un anneau, et qui, dans leur jeune âge, sont renfermées dans une volve, ce qui les a fait appeler Agarics à bourse. M. Fries, en établissant les principales divisions du g. Agaric, sur la couleur des spores, s'est vu dans la nécessité de former 2 s.-genres des Amanites: Le ler, qui conserve le nom d'Amanita, a les spores blanches; le $2^{\mathrm{me}}$, qui les a rouges ou rosées, prend celui de Volvaria. C'est avec regret qu'on voit, dans le S'ystema mycologicum et dans l'Epicrisis systematis mycologici du célébre professeur de Lund. un groupe (dont les caractères naturels sont parfaitement distincts) partagé en deux sections si éloignées l'une de l'autre, qu'elles paraissent n'avoir aucun rapport entre elles. Les Amanites renferment à la fois les Champignons les plus recherchés pour la table et les plus vénéneux. $V$. Agaric.
(LÉV.) 
AMANOA, вот. PH. - G. établi par Aublet et ainsi appelé du nom d'Arnanoua que les indigènes de la Guyane donnent à l'arbre qui lui a servi de type. Il appartient à la famille des Euphorbiaeées, et présente les caract. suivants : Fleurs monoïques ou dioïques, à eal. 4-5-parti, avee les divisions duquel alternent queiquefois autant d'appendiees pétaloïdes. Dans les mâles: 5 étam. alternant avee autant de glandes ou avec les lobes d'un disque glanduleux, et insérées sous un rudiment de pistil simple ou trilobé. Dans les femelles : 3 stigm. tout-àfait ou presque sessiles el légèrement bilobés, surmontant un ovaire porté sur un disque glanduleux, et ereusé de 3 loges bi-ovulées. Le fruit est une caps. à péricarpe épais, s'ouvrant en 33 loges bivalves. Ce g., dans lequel vient se confondre le Richeria de Vahl, comprend 3 esp. originaires de la Guyane ou des Antilles. Ce sont des arbres ou des arbrisseaux à feuilles alternes, enlières, glabres, épaisses; à fleurs réunies, sur des épis axillaires et terminaux, en petits pelotons mêlés de bractées éeailleuses, et dans lesquels une seule est femelle, lorsque toutes ne sont pas mâles.

(AD. J.)

AMANSIE. Arnansia (nom d'homme).вот. cr. - Genre de la sous-famille des Floridées (Phycées), fondé par Lamouroux, qui le dédia à son eompatriote St-Amans, auteur de la Flore agénaise. Lamouroux n'envisageait que la seule strueture des espèees de ee genre, quand il lui assignait une plaee parmi ses Dielyotées; ear, de son aveı même, il en connaissait a peine la fruetifieation. Il avait aussi eomplètement négligé de mentionner la couleur; ee qui a droit d'étonner d'autant plus, qu'il estl'auteur' d'une elassification des Thalassiophy tes, où ce caraet. joue le $1^{\text {er }}$ rôle. Au reste, comme il le dil encore lui-même, il n'avait vu que des éehantillon's desséchés, et ne pouvait juger de leur eouleur à l'état de vie. Quoi qu'il en soit, voiei dans quels termes il le définit : Mailles du réseau formant un hexagone régulier et allongé, avec les sommets aigus. Cette définition nous montre que cet habile phycologue savait mieux deviner les genres naturels que les bien définir.

M. Agardh, qui admet ee g., en expose ainsi les earactères naturels : Raeine scutiforme. Fronde plane, munie d'une côte qui se prolonge en se ramifiant quelque?ois en dessous, striée transversalement, pinnatifide ou prolifère, à segments linéaires, dont les sommets sont souvent roulés en volute. Fructifieation eonsistant en sporophylles agrégés, dans lesquels se voieni des séminules réunies 4 par 4 ; eouleur pourpre ou rose. Substanee membraneuse. Structure aréolée, e'est-à-dire eomposée de mailles régulières, hexagones, étroites, parallèlement et transversalement disposées, formant, par leurs sommets, des lignes plus obscures que le reste de la fronde, et, par leur condensation au milieu de celle-ei, donnant naissanee à la eôte qui la traverse.

Réeernment, le genre qui nous oecupe a été eneore autrement eirconscrit par M. Gréville, lequel y réunit des esp. qui ne nous semblent y tenir que par un rapprochement foreé. Selon ee phyeologue, le Rhytiphloea obtusiloba Ag., et les Tharnnophora Seaforthii et triangularis Ag., doivent rontrer dans le g. Amansie, qu'il caractérise ainsi : Fronde plane ou eomprimée, membraneuse, obscurément parcourue par une eôte ou nervure, et souvent enroulée au sommet. Fruetifieation : $1^{\circ}$ eapsules ; $2^{\circ}$ granules ternés. D'un autre eôté, et sans plus de raisons de le faire, on, pour mieux dire, eontre toutes les lois de l'analogie, le même savant a distrait du genre qui nous occupe, pour la porter dans les Délesseries, l'Amansia fraxinifolia, que la structure aréolée de sa fronde et sa fruetification sporophyllaire auraient dù mettre á l'abri d'une semblable réunion. Nous ne pouvons donner ici les motifs qui nous font avoir une opinion différente $d u$ célèbre cryptogamiste écossais. Nous les a vons exposés dans notre travail sur les plantes eellulaires de Cuba, et nous y reviendrons au mot thamophora.Le genre Amansia est fort voisin du Claudea , si remarquable par l'éléganee et par l'originalité de ses formes. Les Amansies vivent, en général, plus d'une année. Elles ne sont pas nombreuses en espéces. On en connaît sept, pour la plupart originaires des mers australes ov de l'Inde. Une seule, l'Amansia jungermannioides, a été trouvée dernièrement dans la mer Rouge. Depuis l'impression de eet artiele, M. Decaisne a séparé cette dernière esp. de ses congénères, pour en former le nouveau g. Leveillea, dont nous donnerons en sor 
lieu les caract., en même tempsque les motifs sur lesquels se fonde notre savant ami pour une telle séparation.

(C. M.)

Amara (ácúp $\alpha$, sillon). ins. - G. de Coléoptères pentamères, famille des Carabiques, tribu des Féroniens, établi par Bonelli et adopté par tous les entomologistes. M. Dejean, dans son Species général, le caractérise ainsi : Les trois premiers art. des tar'ses antérieurs dilatés dans les mâles, moins longs que larges, et fortement cordiformes. Dernier article des palpes allongé, légèrement ovalaire et tronqué à l'extrémité. Antennes filiformes et peu allongées. Lèvre supérieure en carré moins long que large, coupée carrément ou légèrement échancrée antérieurement. Mandibules peu avancées, plus ou moins arquées et peu aiguës. Une dent bifide au milieu de l'échancrure du menton. Corselet transversal, le plus souvent trapézoïde, quelquefois earré oll rétréci postérieurement et presque cordiforme. Elytres légèrement convexes, ordinairement peu allongées, presque parallèles* ou très légèrement ovalaires et arrondies ả l'extrémité.

I.es Amara sont des Carabiques de taille moyenne pour la plupart, presque tous ailés, de couleur métallique ou brune, rarement noire, souvent très agiles, quelquefois assez lourds. Ils se liennent ordinairement sous les pierres, dans les champs, et de préférence dans les endroits secs et arides. M. Dejean, dans son dernier Cataiogue, en mentionne 84 espèces, dont 30 seulement n'appartiennent pas à l'Europe et sont de la Sibérie ou du nord de l'Amérique. Nous citerons comme type du g. l'Amara eurynota de Kugellann, qui se trouve partout en France.

*AMARACARPUS (áuáp $\alpha$, sillon; $x \alpha \rho \pi o ́ s$, fruit). BOT. PI. - G. de la famille des Rubiacées, tribu des Cofféacées-Psychotriées, formé par Blume (Bijdr.954), et ainsi défini : Cal. ovale-tubulé, eonné avec l'ovaire, à limbe supère 4-fide, inégal. Cor. supère, inlundibuliforme, à gorge velue, à limbe profondément 4-fide. Étam. 4, insérées à la gorge de la eorolle? Ovaire infère... Style simple; stigm. bilobé. Drupe bacciforme, bi-nuculé, eouronné par le limbe du calice; nucules osseux, monospermes, sillonnés. Graines... - Ce g. peu connu et incomplète- ment établi ne renferme qu'une espéce. C'est un arbrisseau japonnais, petit, à rameaux nombreux, pubescents, garnis de feuilles opposées, courtement pétiolées, lancéolées, glabres en dessus, plus pâles en dessous et pubescentes le long des nervures; à stipules décidues, bifides au sommet, connées à la base. Les fleurs en sont petites, sessiles, solitaires dans l'aisselle des feuilles, rarement terminales, et braetéées à la base.

$$
\text { (C. L.) }
$$

*AMARAGUS, Monch ('́ux́puxos, marjolaine).вот. PH.-G.de la famille des Labiées, tribu des Saturéinées de Bentham (Labiat., p. $3 \dot{3} 3)$, qui lui assigne les caract. suivants : Cal. ovale-campanulé, 13-nervé à la base, bi-labié ; lèvre supér. allongée, entière, dressée; lèvre inlér. tronquée ou presque nulle, ou très eonrtement bidentée; gorge nue. Cor. à tube saillant; limbe bi-labié; lèvre supér. dressée, échancrée, presque plane; lèvre infér. fendue en 3 lanières entières, presque égales. Étam. 4, dressées, ascendantes; les inférieures un peu plus longues; filets glabres; antennes à 2 bourses distinctes, divergentes ou divariquées. Style terminé en 2 branches, dont la supér. plus eourte; stigmates terminaux, petits. Fruit ineonnu. - Sous -arbrisseaux glabres ou laineux. Feuilles très entières; fleurs agrégées en épillets oblongs; bractées orbiculaires, membrariacées, colorées, lâchement imbriquées, beaucoup plus longues que le caliee.

Bentham signale 2 esp. de ce g. L'une et l'autre croissent dans l'île de Candie. (Sp.)

AMARANTACÉES. Amarantacec. вот. rH. - Famille de plantes dicotylédones apétales, à étamines hypogynes, offrant les caract. suiv.: Cal. scarieux, persistant, ordinairement à 5 (rarement à 3 ) folioles. Étam. égales en nombre, opposées, à filets membraneux, le plus souvent élargis et monadelphes, tantôt simples, tantôt partagés chacun à leur sommet, en plusieurs lanières, dont la moyenne porte l'anthère, et dont les latérales se soudent quelquefois avec celles du filet voisin, d'oú résulte un tube à 10 dents alternativement anthérifères et stériles; anthères à 1 ou à 2 loges; sur les cinq, 2 manquent dans quelques g. Ovaire simple, libre, contenant, dans une loge unique, plusieurs ovules, ou plus souvent un seul, sus- 
pendus a autant de funicules qui se dressent du bas et du milieu de la loge. Stigm. simple ou composé, tantôt sessile, tantôt terminant un style. Le fruit est un utricule membraneux; les graines lenticulaires renferment, sous un test crustacé, un embryon contourné autour d'un périsperme farineux el dirigeant sa radicule vers le hile. - Les plantes de cette famille sont des herbes ou des arbrisseaux à feuilles simples, opposées ou alternes, dépourvues de stipules; à fleurs disposées en têtes ou en épis, ordinairement hermaphrodites, quoique dans quelques cas rares les sexes soient séparés. Ces fleurs, vertes quelquefois, mais plus souvent colorées, sont fréquemment environnées et comme enveloppées de bractées scarieuses, colorées également, et erı général accompagnées à leur base de 2 bractéoles, que M. Martius a considérées comme un cal. tandis que notre calice est pour lui une corolle.- On doit à ce savant botaniste une monographie de cette famille, qu'il a aussi illustrée par un beau travail inséré dans le $2^{\text {me }}$ volume de ses $N_{0}$. Gen Pl. Brasil., et c'est à lui que nous emprunterons la classification suivante des g., ainsi que les considérations sur la distribution géographique des Amarantacées. Des esp. connues, qui sont au nombre de 230 à peu près, les $3 / 4$ se liennent sous les tropiques, $1 / 4$ seulement dans les climats tempérés. L’A mérique en fournit plus de la moitié, l'Asie plus d'1/3, la Nouvelle-Hollande y est pour.1/8, l'Afrique pour $\frac{1}{46}$, et l'Europe pour $\frac{1}{46}$ seulement. Quoique l'économie domestique emploie quelques esp., à cause du mucilage abondan sil des vertus extraordinaires soient attribuées à quelques Cromphrena, en général celte famille n'offre pas de propriétés bien remarquables.

\section{GENRES.}

\section{Toutes les fleurs développées.}

A. Stigmate composé.

Digera, Forsk. - Deeringia, R. Br. Chamissoa, Kunth. - Charpentiera, Gaud. - Allmannia, R. Br. - Amarantus, L. Erna,Forsk.-Berzelia, Mart. (non Brongn.) -PPolychroa, Lour. - Celosia, L. - Cladostachys, Don.-Lestibudesia, Du Petit-Th. - Oplotheca, Nutt. - Gomphrena, L. -
Hebanthe, Mart. - Philoxerus, R. Br. - Rosea, Mart. - Iresine, W. - Trommsdorffia, Mart.

B. Stigmate indivis.

Sertunera, Mart. - Pfaffia, Mart. - Mogiphanes, Mart. - Brandesia, Mari. - Bucholzia, Mart. (non Lhérit.) - Altemanthera, Forsk. - Trichinium, R. Br. - Psilothricum, Blum. - Ptilotus, R. Br.Nyssanthes, R. Br. - Achyranthes, L.Leiospermum, Wall. - Centrostachys, Wall.

II. Quelques fleurs avorlées dans chaque glomérule.

Desmochoela, D. C.-PPolyscalis, Wall.Pupalia, Mart. - Cyalhula, Lour. (paraît le même que le précédent.) (AD.J.)

AMARANTE. Amarantus, L.-Polychroa, Loureir. (áux́pavтos, qui ne se flétrit pas). вот. РіI. - G. de la famille des Amarantacées, tribu des Achyranthées, s.-tribu des Amarantées, Endl. Ses caract. sont les suivants (Martius, Amar. - Endl.Gen.Plant.) : - Fleurs polygames-monoïques, tribractéolées. Périgone 3-ou 5-phylle. Étam. 3 ou 5 , ou rarement soit 2 , soit 4 , toutes fertiles; filets libres, subulés; anth. dithéques. Ovaire 1loculaire, 1-ovulé; style court, terminé en 2 ou 3 stigm. filiformes. Pyxide membranacé , monosperme. Graine réniforme-orbiculaire, subverticale ; test crustacé ; hile nu; embryon périphérique, semi-circulaire ; radicule infére. - Herbes annuelles; feuilles alternes, décurrentes sur leur pétiole; fleurs petites, agrégées en épis ou en glomérules.

Martius énumère près de 50 esp. de ce g., la plupart indigènes dans la zône équator.; plusieurs se cultivent comme plantes de parterre. Les jeunes feuilles peuvent être mangées en guise d'épinards.

(Sp.)

* AMARANTE DE MER. Poly . - Ancien nom d'une esp. de Méandrine (Madrepora areolata L.), Meandrina aerolata Lam.

(DuJ.)

AMARANTÉES. Amarantece (áuápavzos, qui ne se flétrit pas). вот. Pн. - S.-tribu de la famille des Amarantacées, indiquée par Endlicher ( $G \in n$. pl. 303), pour renfermer les g. : Amaranlus, L., et Chamissoa, H.B.K.

$$
\text { (C. L.) }
$$

AMARANTINE. Gomphrena, Linn.; Schultesia, Schrad.; Bragantia, Vandelli

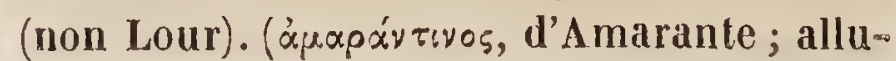


sion à la ressemblance de ces plantes avec certaines Amarantes). вот. Pu. - - G. de la famille des Amarantacées, tribu des Gomphrénécs, Endl. - Martius lui assigne les caract. suivants ( Nov. Gen el Spec., v. 2. - Monogr. Amar.): Périgone 5-phylle. Etamines 5; androphore tubuleux, cylindracé, 5-fide au sommet, à lanières soit 2ou 3-fides, soit 2-ou 3-dentées. Anth. monothèques, linéaires, sessiles entre les divisions des lanières. Ovaire 1-loculaire, 1ovulé; style court, indivisé. Stigm.2, subulés. Péricarpe vésiculeux, indéhiscent, 1-sperme: Graine réniforme-lenticulaire. Tégument crustacé; embryon annulaire, périphérique; radicule supère. - Herbes souvent velues ou cotonneuses, rameuses; feuilles opposées, subsessiles; fleurs (souvent laineuses) hermaphrodites, tribractéolées, disposées en capitules axillaires ou terminaux, aphylles ou feuillés. Bractées el Calice jaunes, ou rouges, ou blanchâtres. - On connaît environ 40 esp. de ce g., toutes indigènes dans la zòne équat.; plusieurs se cultivent comme plantes de parterre; quelques esp. brésiliennes sont réputées très toniques.

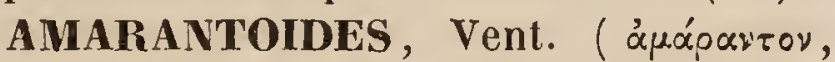
immortelle ; sidos, forme). вот. Pн. - Synon. d'Amarantacées, Juss. $V$. се мот. (C. L.)

AMAREL. вот. PH. - Nom vulgaire du Prunus mahaleb dans le midi de la Francc.

$$
\text { (C. L.) }
$$

*amarìne. Amarenus, Presl. (’́ priv.;

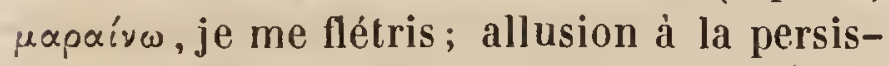
tance des pétales). вот. Pн.-G. ou s.-g. de la famille des Légumineuses, fondé aux dépens des Trèfles. Suivant Presl (Symb.Bot.), il offre les caract. suivants: Cal. scarieux ; tube court, à gorge ouverte; limbe à 5 dents, dont 2 supér. plus courtes et 3 infér. subulées. Pétales libres, persistants, longitudinalement plissés. Style oblique, court, courbé au sommet. Légume stipité, obovale, comprimé, monosperme. - L'auteur cité range dans ce g. le Trifolium agrarium L., et autres esp. voisines.

*AMARIA, Mutis (á $\mu$ apía, sillon). RO'T. PH. - G. de la famille des Légumineuses, sousordre des Césalpiniées, "tribu des Cassiées D.C. - Mutis ( ex DC., Prodr. 2, p. 519) en donne les caract. suivants : Cal. cylindrique, arrondi à la base, persistant, 5-fide, latéralement déhiscent; lobes linéaires, cohé- rents au sommet. Pétales 5, obovales, égaux, étalés, carénés de la base jusqu'au sommet. Étam. 10; filets subulés, dressés, soudés inférieurement en androphore tubuleux. Ovaire oblong, stipité ; stipe adné au calice; style filiforme; stigmate capitellé. Légume trẻs long, stipité, comprimé, toruleux , 1-loculaire, 2-valve, polysperme. Graines suborbiculaires, comprimées. - Arbrisseau; feuilles simples, cordiformes. - Ce g. n'est fondé que sur 2 esp., indigènes de la Nouvelle-Grenade.

(Sp.)

*AMARIDES. Amaridoe (allusion à Amara, $V$.ce mot).ıns.-Sous-tribu des Coléoptères pentamères, famille des Carabiques, établie par M. Delaporte dans la tribu des Féroniens de M. Dejean, et qu'il compose des g. Amara, Antarclia et Lophidius. Il la caractérise ainsi : Les trois $1^{\text {ers }}$ articles des tarses antérieurs dilatés dans les mâles; crochets des tarses sans dentelure; dernier article des palpes labiaux allongé, légèrement ovalaire et tronqué. - Les A marides sont des insectes de moyenne taille, presque toujours ailés, de couleur brune ou métallique. Ils vivent sous les pierres et dans les endroits sablonneux; on en trouve aussi sur les bords des eaux. C'est peut-être dans ce groupe, dit M. Delaporte, qu'on doit placer les g. Colostomus, Aphidius, Anaulacus, Hypharpax et Dioryche de Mac-Leay, qui sont inconnus en France. $V$. pour les caractères de ce genre les Annulosa javanica du savant entomologiste anglais.

(D.)

AMARINE ou AMARINO. BOT. PII.-On donne ce nom, dans quelques parties du midi de la France, au Saule-osier. $V$. Saule.

$$
\text { (C. D’O.) }
$$

* AMAROIDES. Amaroidoe (amara, sorte d'insecte; $V$. ci-dessus, eidos, forme). Ins. - Tribu des Coléoptères pentamères, établie par M. Zimmermann dans la famille des $\mathrm{Ca}$ rabiques avec les esp. du g. Amara de Bonelli, qu'il subdivise en $8 \mathrm{~g}$. sous les noms de Percosia, Celia, Amara, Bradyıus, Leirus, Leiocnemis, Amathites et Acrodon ( $V$. ces différents noms). Les caract. généraux des Amaroïdes sont : Tête courte, arrondie postérieurement, non rétrécie en forme de cou; lèvre presque carrée, dont le bord n'est jamais découpé droit, mais toujours plus ou moins évasé ; mandibules fortes; all milieu de l'échanirure du menton, 
une dent apparente, simple ou bifide, languelte coriacée avec des paraglosses membraneux ; palpes filiformes, dont le dernier article forme un ovale allongé; élytres striées, sans pointe, acuminées postérieurement ou légèrement arrondies, non tronquées; $a b$ domen composé de six segments; pattes plus souvent courtes que longues; toutes les jambes armées de deux épines à leur extrémité; jambes antérieures fortement échancrées entre ces deux épines; crochets des tarses lisses, sans épines; les trois premiers articles des tarses dilatés dans le mâle; triangulaires ou cordiformes, revêtus en dessous d'un duvet.

Les Amaroïdes sont des Coléoptẻres de petite taille, qui ne se trouvent guère que dans les parties froides et tempérées de l'hémisphère septentrional. Si l'on en rencontre quelques uns à une latitude plus méridio\#lale, c'est sur des plateaux très élevés, dont e climat se rapproche de celui de la zòne tempérée, comme, par exemple, ceux du Mexique. Les larves de ces Insectes vivent dans la terre, et atteignent ordinairement, avant leur métamorphose, une longueur double de celle de l'insecte parfait. Toutes se ressemblent tellement entre elles, qu'il est difficile d'en distinguer les espéces; leur forme générale est la même que celle des Zabrus et des Poecilus. Le développement de la plupart de ces larves, depuis l'état d'œuf jusqu'á celui de nymphe, ne dure guère que six à huit semaines; elles ne restent que la moitié de ce temps à l'état de nymphe. L'apparition des Amaroïdes, à l'état parfait, coïncidant en général avec le retour de la belle saison, a lieu, par conséquent, d'autant plus tôt que le climat est plus tempéré. Cependant, Zettersteit (Faun. Lapp., I, pag. 211) assure en avoir vu courir gaiment sur la neige, avant les chaleurs de l'été. Ordinairement ils se tiennent cachés pendant le jour sous terre, sous la mousse, sous l'herbe ou sous des pierres, et ce n'est qu'à l'entrée de la nuit qu'ils quittent leur retraite pour chercher leur nourriture et s'accoupler. Si donc on en rencontre courant au soleil, c'est qu'ils ont été forcés, par une circonstance quelconque, de déserter leur retraite. La moelle des graminées et les racines succulentes forment leur principale nourriture; cependant ils mangent aussi les larves et les nymphes des autres Insectes, lorsqu'ils sont assez forts pour s'en emparer. Les espèces qui ont des ailes ne s'en servent pour voler que pendant le crépuscule, par un temps très calme. En général, ils sont très agiles et couren très vite.

(D.)

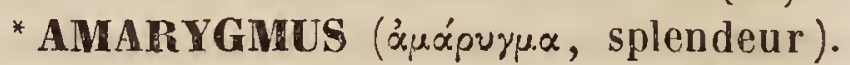
ıns. - G. de Coléoptères hétéromères, famille des Hélopiens, établi par Dalman et adopté par M. Dejean dans son dernier Catalogue. Il y rapporte 10 esp., dont une de la Nouv.-Hollande, 2 de Java, 3 des Indes orientales, 2 du cap de Bonne-Espérance, 1 dont la patrie est inconnue, et enfin 2 des Philippines. Nous citerons parmi ces dernières l' $A$. cereus Dalm. comme type du g.

* AMARYLUIDACÉES (Amaryllis, cidessous). вот. рн. - M. Herbert appelle ainsi un groupe de végétaux qui comprend, avec les genres qui forment la vraie famille des Amaryllidées, plusieurs g. appartenant à d'autres familles naturelles. M. Lindley adopte le même nom pour la famille des Amaryllidées de Rob. Brown ( $V$. AmarylLIDÉES ). (A. R.)

AMARYLLIDEEES. Amaryllidece (Amaryllis, nom myth.). вот. Pн.--Fam. naturélle de végétaux monocotylédonés, à ovaire infère, qu'on peut caractériser de la manière suivante: La racine, fibreuse, est ordinairement surmontée d'un bulbe à tuniques concentriques.Les feuilles sont radicales, rarement caulinaires, de figure très variée. Les fleurs, souvent très grandes et peintes de couleurs extrêmement brillantes, sont tantôt solitaires, tantôt diversement groupées, mais le plus souvent en sertule ou en ombelle simple. Elles sont accompagnées, à leur base, de spathes scarieuses plus ou moins colurées. Le calice, formé de six sépales, dont trois un peu plus intérieurs, est soudé par sa base avec l'ovaire infẻre; il forme, en général, un tube plus ou moins allongé. Les étamines, au nombre de six, sont opposées aux sépales, tantôt incluses dans le tube auquel elles sont insérées, tantôt saillantes. Dans un certain nombre de genres, on voit, en dehors des étamines et adhérente à la gorge du calice, une couronne pétaloïde formant quelquefois une sorle de godet à six lobes, que quelques botanistes considèrent comme une seconde 
rangéed'étamin es transforınées, rapprochant par ce caractire les Amaryllidées des genres de Monocolylédonées polyandres. Le style est simple, terminé par un stigmate très petit et à peine trilobé. L'ovaire infẻre est à trois loges qui contiennent chacune un nombre plus ou moins considérable d'ovules bisériés. Le fruit est une capsule à trois loges polyspermes, s'ouvrant en trois valves septifères sur le milieu de leur face interne. Rarement c'est une espèce de baie contenant seulement, et par avortement, une á trois graines. Les graines sont tan tòt globuleuses, tantòt, mais plus rarement, minces et planes. Leur embryon, souvent très petit, est cylindrique, placé dans un endosperme charnu.

Cette famille, telle que nous venons d'en Iracer les caractéres, est un démembrement des Narcissées de Jussieu. Elle comprend les genres réunis par cet illustre botaniste dans sa deuxième section, ceux à ovaire infère. R. Brown a partagé la famille des $\boldsymbol{N}$ arcissées de Jussicu en deux familles distinctes: $1^{\circ}$ les Amaryllidées et les Hypoxydées, qui ont l'ovaire infère; $2^{\circ}$ les Hémérocallidées, comprenant les genres à ovaire libre et supére. Nous pensons que cette dernière fainille peut être réunie à celle des Liliacées, dans laquelle elle forme une simple tribu. I.e même bolaniste a également retiré de la famille des Narcissées le genre Hypoxis, qui, avecle Curculigo, constituent un petit groupe qui ne me paraît pas différent des vraies Narcissces ou Amaryllidées. Enfin, le genre Pontedera est devenu le type d'une famille nouvelle sous le nom de Pontédérées. $V$. ce mot.

Le travail le plus étendu et le plus récent sur celte famille est celui de M. William Herbert. Sous le nom d'Amaryllidacées, il réunit un grand nombre de genres, dont quelques uns ne nous paraissent avoir aucun rapport a vec les véritables Amaryllidées; tels sont, par exemple, les genres Tamus et Dioscorce, appartenant à la famille des Dioscorées ou Asparaginées à ovaire infẻre. Il divise cette grande classe en cinq familles ou sous-ordres, sous les noms de : $1^{\circ}$ Xérophytées : Xeropluyta, Barbacenia, Vellozia; 2o Hypoxynées : Curculigo, Hypoxis, etc.; 3० Aønvél:s : Agave,Fourcroya, ct les genres

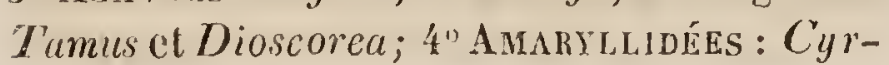
T. 1. lanlhus, Gethyllis, Pancratium, Crinum, Amaryllis, etc.; $5^{\circ}$ Narcissées : Narcissus; $6^{\circ}$ Galnntilés : Galanthus et Leucoium; 7o Taccacées : Tacca et Alaccia. Nous n'illsisterons pas sur celle classification trés peu naturelle, dans laquelle se trouvent rapprochés des genres qui ont entre eux peu d'analogie, comme l'Agave et le T'urnus, ou éloigués, pour former des familles distinctes des genres qu'on ne saurait séparer, sans rompre les rapports les plus naturels, par exemple: les genres $N$ arcisisus et Leucoium, formant cliacun le type d'une famille difićrente des vraies Amaryllidées. Quant à la première des familles établies par M. Herbert sous le nom de Xérophytées, elle fait partie des Broméliacées.

M. Lindley nous paraît, tout en suivant en partie le travail de son savant compatriote, avoir mieux limité la fumille des Amaryllidées, en y disposant de la manière suivante les genres qu'il y rapporte :

$\$$ I. HYioxídéEs :

Curculigo, Gaertu.; Hypoxis, L.; Colanthus, Schlecht.; Molinanthus, Herbert; 1 lstroemeria, L. ; Collania, Herb.; Sphacrine, Herb. ; Bornarea, Mirbel.

SII. Agavées :

Fourcroya, Vent.; Agave L.; Doryanthes, Correa; Bravoa, La Llave; 1xiolirion, Fisch.; Tecophilca, Poppig.

\$ III. Amaryllidées :

Cyrtanthus, Ait.; Gastronema, Herb.; Vallota, Herb.; Sprekelia, Herb.; Hippeastrum , Herb.; Phycella, Lind.; Habranthus, Herb.; Zephyranthes, Herb.; Haylockia, Herb.; Cooperia, Herb.; Sphoerotele, Presl; Pyrolivion, Herb.; Gethyllis, L.; Sternbergia, Waldst., et Kit.; Oporanthus, Herb.; Lapiedra, Lag.; Corbularia, Harv.; Ajax, Salisb.; Oueltia, Salisb.; Narcissus, L.; Liriope, Herb.; Clinanthus, Herb.; Leperiza, Herb.; Carpodetus, Herb.; Coburgia, Herb.; Stenomesson, Herb.; Tapeinanthus, Herb.; Pancratium, Herb.; Hymenocallis, Herb.; Ismene, Herb.; Callilhauma, Herb.; Calosternma, R. Brown ; Eurycles, Salisb.; Eucrosia, Ker.; Grifjinia, Ker.; Lycoris, Herb.; Clivia, Lindl.; Hcemanthus, L.; Buphane, Herb.; Armocharis, Herb.; Amaryllis, L.; Crinum, L.; Brunsvigia, Ker.; Nerine, Herb.; Strumaria, Jacq.; Inhofia, Hern.; Hcssea, Herb.; Carpoliza, Salisb.

\$IV. GALANTHÉES : 
Galanthus L.; Acis Salisb.; Lencoium L. Nous sommes loin d'adopter tous les genres dont nous venons de présenter l'énumération. Plusieurs sont établis sur des modifications de trop peu d'importance pour pouvoir être adoptés définitivement. Nous examinerons chacun de ces genres à sa place dans le courant de ce Dictionnaire. (A. R.)

AMARYLLIS (Nymphe chantée par les anciens). BOT. PH. - G. formant le type de la famille des Amaryllidées, composé d'environ une soixantaine d'espèces, presque toutes originaires de l'Amérique méridionale, quelques unes du Cap de B.-Espérance ou de la Chine. Ce sont, en général, de belles plantes bulbeuses, remarquables par la grandeur de leurs fleurs et l'éclat des couleurs dont elles sont peintes ; aussi un grand nombre de ces esp. font-elles l'ornement de nos serres et de nos jardins. Le g. Amaryllis peut être caractérisé de la manière suivante :

Fleurs renfermées, avant leur épanouissement, dans une spa the composée d'une ou de 2 pièces et contenant un nombre variable de fleurs entremêlées de bractées généralement très petites. Cal. adhérent par sa base à l'ovaire infère, à 6 divisions, un peu inégales, disposées sur 2 rangs et formant ainsi un calice plus ou moins infundibuliforme et irrégulier, très rarement régulier. Plus rarement les divisions sont étalées et le calice est presque rotacé, à gorge tantôt nue, tantòt garnic d'écailles. Étam. 6 , attachées au tube du calice ; filets libres et ordinairement déclinés vers la partie inférieure de la fleur; anth. allongées et à 2 loges, attachées au filet par leur partie postérieure. Ovaire infère, à 3 loges, contenant chacune un grand nombre d'ovules disposés sur. 2 rangées longitudinales, à l'angle interne de chaque loge. Style simple, ordinairement de la longueur des étamines, au milieu desquelles il est placé; il est cylindrique ou triangulaire et se termine par un stigmate trilobé ou à 3 divisions plus ou moins profondes. Capsule couronnée par le limbe du calice souvent persistant, à 3 angles obtus, a 3 loges s'ouvrant, sur le milieu de leur face inierne, en 3 valves septifères. Les graines sont excessivement variables dans leur forme, tantôt presque globuleuses ou eomprimées, planes et quelquefois minces et comme papyracées. Dans quelques espéces les loges sont monospermes par avortement et les graines quelquefois enveloppées d'une espèce de pulpe charnue. Les Amaryllis ont des bulbes simples, tuniqués, quelquefois très volumineux; des feuilles radicales quelquefois étroites et rubannées, d'autres fois plus ou moins larges; une hampe simple, nue, naissant du milieu de l'assemblage des feuilles. - Quoique ce g. soit assez naturel et que les esp. nombreuses qui le composent soient liées entr'elles par un ensemble de caract. assez tranchés, quelques auteurs ont profité des différences qu'elles offrent, dans quelques uns de leurs organes, pour en former un très grand nombre de g., composés chacun d'un certain nombre d'espèces. Le travail le plus complet, sous ce rapport, est celui d'Herbert (Bot. mag. $\mathrm{n}^{\circ} 2606$ et Amaryllideve). Ce botaniste a disposé les esp. d'Amaryllis en 10 genres, sous les noms de $Z$ ephyrarthes, $P y$ rolirion, Habranthus, Sprekelia, Hippeastrum, Leopoldia, Coburgia, Vallota, Lycoris, et Nerine; mais cette division n'a point été généralement adoptée, et ces g. sont considérés comme de simples sections dans le g. Amaryllis ( $V$. pour leurs caract. chacun de ces mots). Le nombre des espéces d'Amaryllis qu'on cultive dans les jardins est très considérable, nous nous contenterons d'en citer ici quelques unes des plus remarquables.

$1^{\circ} \mathrm{L}$ ' $A$. latea $\mathrm{L}_{\text {; }}$, seule esp. quilsoit originaire d'Europe; 20 l'A. de Guernesey, (A. sarniensis L.); elle est originaire du Japon; mais un bâtiment qui en contenait une grande quantité, ayant fait naufrage sur les côtes sablonneuses de l'île de Guernesey, elle s'y est neutralisée, au point d'y être devenue une plante presque indigène; $3^{\circ} A$. Lis St-.Jacques ( $A$. formosissima $\mathrm{L}_{\text {. }}$ ), très belle esp. de l'Amérique méridionale, que l'on cultive très facilement et très abondamment à Paris, remarquable par sa grande fleur étalée, très irrégulière et d'un rouge foncé ; $4^{\circ} A$. regina $L_{\text {. }}$, originaire du Mexique, portant 4 à 5 grandes fleurs d'un rouge ponceau; $5^{\circ} A$. Josephince Vent., du cap de Bonne-Espérance. C'est l'esp. la plus grande et la plus multiflore du genre. Sa hampe, longue de deux pieds et grosse en proportion, se termine par une ombelle simple, composée 
souvent de 50 à 60 fleurs roses, de 3 pouces de longueur. On peut encore citer, parmi les esp. les plus belles de ce g., les $A$. vittatr, belladona, rulgida, moluccana, etc. (A. R.)

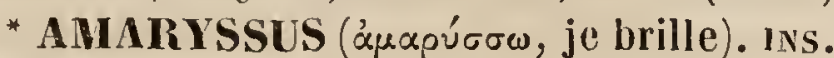
- G. de l'ordre des Lépidoptères diurnes, créé par Dalman et qui a pour type le papillon Machaon ( $\boldsymbol{V}$. PApILLON).

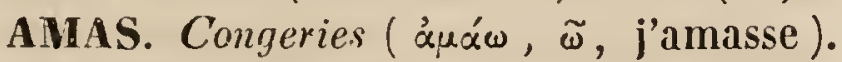
- Sorte de gisement des substances minérales. On dit qu'un minéral ou une roche est en anas, lorsqu'il constitue une masse irrégulière qui semble comme enveloppée par d'autres substances. $V$. DÉpôt et GiseMENT.

(C. P.)

*AMASIA (amasius, $a$, galtant, e). INS.-G. de Coléoptères tétramères, famille des Chrysomélines, établi par M. Dejean (Catal., $3^{\text {me }}$ ¿dit.), qui n'en a pas publié les caractères. Il y rapporte une seule esp. de Java, nommée par lui spinipes, varians par de Haan et volutina par M. Buquet.

AMASIS (Nom propre). ins. - G. de la fam. des Tenthrédiniens (Porte-scie, Lat.), de l'ordre des Hyménoptères, section des Térébrans, établi par Leach, sur quelques esp. confondues par Fabricius, Latreille, etc., avec le g. Cimbex, et qui s'en distingue, surtout, par des ant. multi-articulées, renflées en massue, et n'ayant que leurs $41^{\text {ers }}$ art. distincts, les autres étant réunis par des mandib. bidentées et par des ailes dont les $21^{\text {res }}$ cellules cubitales reçoivent chacune une nervure récurrente. On connaît une dizaine d'esp. de ce g., dont la plupart sont indigènes. Les plus répandues en Europe sont l'A. Jurince (Cimbex Jurince Lep.) et l'A. locta (Cimbex locta Fab. etc). (BL.)

AMASONIA (Th. Amason, voyageur en Amér.). вот. рн. - G. de la famille des Verbénacées, tribu des Egiphilées (Verbénées, Bartl.) proposé par Linné fils (Suppl., 294) pour remplacer le g. Taligalea d'Aublet.Cette substitution n'est pas généralement adoptée. Lindley (Introd.) les regarde tous 2 comme distincts, mais probablement par erreur. $V$. Taligalea.

AMASPERME. Amasperma (ö $\mu \alpha$, ensemble; $\sigma \pi \varepsilon \varepsilon^{\prime} \mu \alpha$, graine ). вот. Cr.-G. de la famille des Algues, formé par Rafinesque, et si incomplètement décrit par cet auteur, que tous les écrivains systématiques l'ont passé sous silence.

(C. L.)
AMASTOZOAIRES. Amastozoaria (á

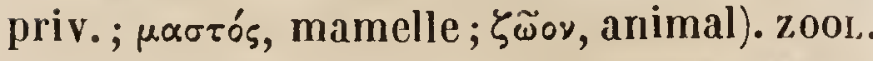
- Dans sa classification zoologique, M. de Blainville a donné ce nom à un groupe du règne animal, comprenant les animaux vertébrés qui sont dépourvus de mamelles.

$$
\text { (C. D'O.) }
$$

AMATA (nom myth.). ins.-G. de l'ordre des Lépidoptères, famille des Crépusculaires, établi par Fabricius, et qui répond à celui qu'Illiger avait nommé antérieurement Syntomis. ( $V$. ce mot.)

* AMATHIE. Amathia (nom d'une Néréide). Crust.-G. de l'ordre des Décapodes, famille des Oxyrhinques, établi par Roux, qui l'a ainsi caractérisé : Carapace ayant la forme d'un triangle allongé et à base arrondie; rostre terminé par deux grandes pointes en cornes divergentes. Yeux petits, non rétractiles, toujours saillants. Épistome grand, presque aussi long que large. Troisième article des pattes-mâchoires externes dilaté en dehors et tronqué à ses deux angles internes. Pattes de la première paire plus courtes que les suivantes, filiformes chez les femelles, renflées chez les mâles; pattes suivantes longues et filiformes, avec leur article terminal long et aigu. Abdomen composé de sept segments dans les deux sexes. - La seule esp. connue est l'Amathia rissoana Roux, qui se trouve dans la rade de Toulon.

* AMATHIE. Amathia (nom d'une Néréide). ıns. - G. de l'ordre des Lépidoptères, famille des Nocturnes, tribu des Phalénites, établi par nous (Hist. nat. Lépidopı. de France), aux dépens du g. Acidalis de Treitschke, et dont les caract. sont : Ant. simples dans les 2 sexes. Bord terminal des ailes simple ou entier. Ailes supér. seules, traversées par un grand nombre de lignes parallèles, ondulées ou séparées par bandes. Palpes très courts. Trompe longue. Ailes infér. des mâles ayant vers leur naissance et du côté interne, 2 petits appendices formant comme une $3^{\text {me }}$ paire d'ailes. Chenilles lisses, ả tête plate, échancrée ou bifide dans sa partie supérieure, et avec deux pointes au-dessus de l'anus. Chrysalide nue dans la terre. - Ce g. ne renferme que 4 esp. , qui se distinguent de toutes les autres Phalénites par les 2 appendices alaires dont nous avons parlé plus haut. Ces appendices ne sont qu'un 
prolongement du bord supér. et interne des secondes ailes, replié sur lui-même, et quị ne se développe que dans le vol. Il est petit, de forme ovale, et bordé d'une frange de poils comme le reste des ailes, dont il fait partie. Nous cilerons pour type de ce g. la Phalène à 6 ailes de Degeer (tom. II, Mém. vi, prg. 419, pl. 9, fig. 6-9).

AM ATIIE. Amathia (une des 50 Néréides). POLYP. - Nom donné par Lamouroux aux Polypiers sertulariens, dont Lamarck a fait son g. Sérialaire ( $V$. ce mot). (Dus.)

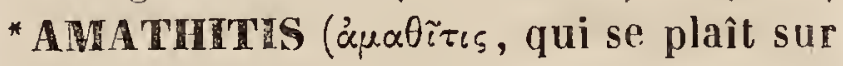
le sable). Ins. - G. de l'ordre des Coléoptères pentamères, famille des Carabiques, tribu des Amaroïdes, élabli par Zimmermann aux dépens du g. Amara de Bonelli, et auquel il donne pour caract. essentiels: Dent simple au milieu du menton; thorax en ccur.-Ce g., non adopté par M. Dejean, est fondé sur une seule esp., l'A. aegypiza de Klug. Elle estailée et habite l'Égypte. (D.)

* AMTHUUS (äuatos, ponssière). ins. G. de la famille des Phryganiens, établi par Stephens, pour quelques esp. indigènes, voisines des Hydropsyche, Pictet, dont Curtis avait déjá formé son g. Polycentropus. ( $V$. ce mot.)

AMATIUSTE. Amathusia (surnom de Vénus). ins. - G. de l'ordre des Lépidoptères, famille des Diurnes, établi par Fabricius, qui lui donne pour caract.: Deux palpes longs, velus, à 3 articles, le $2^{\text {me }}$ plus long que les autres, courbé ; le $3^{\text {ine }}$ court et comprimé. Ant. filiformes. Pattes antér. en palatine. Type : Papilio phidippus de Java. (D.)

* AMATODES. Amatodes. ins. - G. de l'ordre des Coléoptères hétéromères, famille des Mélasomes, tribu des Molurites, fondé

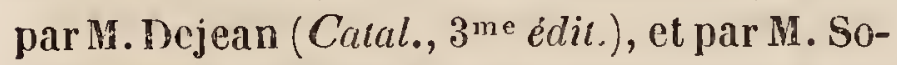
lier, qui le caractérise ainsi, dans son $E_{\text {ssai }}$ sur les Collaptérides: Menton très petit, fortement évasé antéricurement en trapèze;bord antér. avec une échancrure profonde. Palpes maxillaires courts, épais, terminés par un article transverse, comprimé et notablement sécuriforme. Labre saillant, transverse, élargi et tronqué antérieurement. Ant. filiformes ou grossissant légèrement de la base á l'extrémité; $3^{\text {m้e }}$ article presque aussi long que les 2 suivants réunis; les 3 derniers moniliformes. Prothorax transverse, à tergum subdéprimé, anguleux sur les côtés, et for- mant un hexagone pius on moins marqué. Base tronquée carrément ou à peu près, et s'appliquant exactement contre celle des ély. tres. Corps court, peu ou point convexe, et couvert d'un duvet serré ou d'un enduit pulvérulent. - Ce g. a pour type la Pimelia gemmata de Fabricius, qui se Irouve en Guinée, et à laquelle M. Dejean réunit 2 autres esp. du Sénégal, normmées par lui, l’une A. Petitii et l'autre A. hirsutula.

* AMLURONIA (árxupós, obscir). Ins. G. de l'ordre des Coléoptères pentamères, famille des Serricornes, tribu des Mélyrides, fondé par M. Westwood sur une seule esp. nommée par lui $A$. subcenea, et trouvée dans l'ile de Corfou par M. Templeton. Ce g. se rapproche, à plusieurs égards, des Dasyte. et des Melyris, mais plus particulièrement du g. Pelecophora Dej. Les caract. en sont figurés et décrits dans le $2^{\mathrm{me}}$ vol. des Trans. de la Soc. entom. de Londres, p. 175, pl. xıv, fig. 10 .

* AMAURUS (àuaupós, sombre). ins. G. de la famille dss Scutellériens, de l'ordre des Hémiptères, section des Hétéroptères; établi par le docteur Burmeister (Hand. der Entom). Ce g. s'éloigne sensiblement de ses congénères par l'aspect général et par les formes des parties des esp. qu'il renferme. Le corps est assez aplati. La tête presque carrée est divisée au milieu, en 2 parties. Les Ant. ont 4 articles, dont les 3 derniers offrent de chaque côté une expansion linéaire. Le sternum est sans carène; l'abd. est dépourvu d'épines à la base, les pattes sont courtes et robustes. Nous ne connaissons. qu'une dizaine d'esp. de ce g., propres à l'Afrique et à l'Ásie australe; les plus répandues sont I'A. dentatus Burm. (Megymenum dentatum Guér.) de la Nouvelle-Hollande, et l'A. spinosus Burm., assez connus aux Indes Orientales.

(BL.)

*ANAUSTTE. Min.-Gerhard a décrit sous ce nom un minéral composé ou une roche qui paraît n'être qu'une variété de Leptinite, et qui, d'après Breithaupt, serait formée par l'esp. de Feldspath qu'il nomme Oligoclase. On la trouve aux environs de $\mathrm{Na}-$ miest en Moravie, dans l'Erzgebirge en Silésie, etr. (Der.)

AMAZONE. ors. - Nom donné par Linné á une esp. de Bruant (Emberiza amazona L.), et par Buifon, aux esp. de Perroquets du nou- 
veau contlnent, dont le fouet de l'aile est garni de plumes rouges ou jaunes. (C. D’O.)

AMBAIBA. Adans. вот. PH. - Synon., selon Marcgraff et Pison, du Cecropia palmata.

(C. L, )

AMBASSE. Arnbassis.-G. de Poissons de la famille des Percoides, à 2 dorsales distinctes, mais rapprochées, avec une pointe couchéc en avant du $1^{\text {er }}$ rayon épineux de la $1^{\text {re }}$ nageoire $d u$ dos, des dents en velours aux 2 mâchoires et au palais ; le bord infér. du préopercule a une double dentelure, le sousorbitaire est dentelé. - Commerson avait désigné sous ce nom un poisson de peu de valeur, à cause de son abondance dans l'étang salé de l'ìle Bourbon, nommé Lugol. On y prépare ce poisson comme nous le faisons des Anchois sur les bords de la Méditerranée, et on l'y emploie aux mêmes usages. Les autres esp. du g. sont également recherchées sur les côtes de l'Inde qu'elles habitent. Ainsi M. Leschenault nous a appris que l'on pêche avec profit l'esp. que nourrit la rivière d'Ariancoupang qui se jette dans la mer près de Pondichéry. M. de Lacépède a reproduit trois fois la $1^{\text {re }}$ esp., que nous avons nommée Ambassis Commersoni:

- une $1^{\text {re }}$ fois sous le nom de Centropome ambasse, d'après la description de Commerson; une $2^{\text {me }}$ fois d'aprés le dessin tiré des manuscrits de cet infatigable observatenr, sous le nom de Lutjan gymnocéphale, et unc $3^{\text {ne }}$ fois d'après Forskal ; car on ne peut pas douter que le Scicnu sufgha du naturaliste danois ne soit encore le même. Hamilton Buchanan, dans son histoire des Poissons du Gange, a réuni plusieurs esp. d'Ambasses sous le nom de Clıanda; mais comme il avait joint sous cette dénomination des esp. do Scombéroïdes, et que d'ailleurs il n'avait point désigné les véritables caract. du g. dont nous parlons ici, nous avons cru devoir, dans l'Histoire naturelle des Poissons ( $1.11, p .175)$, établir ce g. sous le nom d'Ambasse, afin d'éviter toute confusion.

Nous ne connaissons encore que 11 à 12 esp. de ce g., toutes des Indes, el se tenant dans les eaux saumâtres, soil de l'embouchure des rivières, soit des étangs salés. Ce sont des petits Poissons qui ne dépassent pas un décimètre de long, et qui le plus souvent restent dans des dimensions plus pelites.

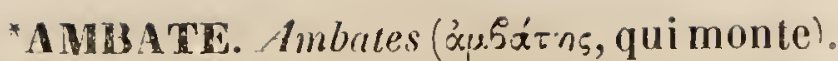
Ins.-G. de l'ordre des Coléoptères tétramères, fam. des Curculionites, div. des Erirhinides, établi par M. Schœnherr, qui lui donne les caract. suivants : Ant. médiocres, minces; les 4 premiers articles du funicule graduellement plus courts, les 3 suivants onduleux; la massue oblongue, ovale. Rostre allongé, un peu mince, linéaire, arqué. Prothorax oblong, subconique, beaucoup plus étroit par devant, resserré au-dessous du sommet, bi-sinué à la base. Écusson large; arrondi au sommet. Élytres subconiques, se rétrécissant sensiblement des épaules à l'extrémité, arrondies à la base, un peu planes en dessus, calleuses à l'extrémité. Pieds assez longs, surtout les antérieurs; cuisses dentées. M. Dejcan (Catal., $3^{\text {me }}$ édit.) adopte ce g. et y rapporte 12 esp., toutes des parties intertropicales de l'Amérique. Nous ne citerons que celle qu'il nomme $A$. pictus, et qui appartenait au $g$. Baris, avant que M. Schœnherr eût établi celui dont il est question dans cet article.

AMPBELANIA. Willughbeia, Schreb. non Roxb. (nom de cet arbre chez les Galibis). вот. PII.-G. de la famille des Apocynacées, tribu des Cárissées, fondé par Aublet (Guyan. 1,297, l. 105), adopté par Jussieu (Gen., Pl., 148), et dont voici les caract.: Cal. 5-fide. Cor. hypogyne, hypocratérimorphe, à tube cylindrique, rétréci supéricurement; ả gorge nue; à limbe 5-parti, dont les segments sont obliques et ondulés. Étam. 5 , incluses, insérées à la base du tube; anth. sagittées, subsessiles. Ovaire biloculaire. Ovules nombreux, fixés de chaque côté à la cloison... Style tétragone, dont le sommet arrondi porte un stigm. ové, bi-cuspidé au sommet. Le fruit est une baie coriace, ovoïde, biloculaire, renfermant des semences nombreuses, élargies-comprimées, rudes. - Ce g. ne se compose que d'un très petit arbre (s'élevant au plus à 2,65) encore peu connu, tronvé par Aublet à la Guyane. Les feuilles en sont opposées, le plus souvent inégales ; les pédoncules axillaires ou terminaux, 3-4-flores, el uni-bractées.

(C. L.)

AMBERBOA (Amberboi ou Emberboi, nom persan). вот. PII. - Isnard a donné ce nom à un g. de plantes que Linné a réuni aux Centaurées, et qui, depuis, a été rétabli de nouveau, en premant pour caract. 
son aigrette paléacée. Ce g. porte en francais le nom d'Ambrette, á cause de la légère odeur d'ambre qu'exhalent ses fleurs. Ses caract. sont : Invol. composé d'écailles de formes diverses, très rarement spinescentes; cor. du rayon dilatées, stériles. Étam. à filets pubescents ou papilleux. Fruit comprimé ou turbiné-tétragone, muni d'une aréole latérale ou basilaire. Aigrette formée d'écailles oblongues ou obovales rétrécies à la base, semblables entre elles, trés rarement petite ou nulle. - Le g. Amberboa dans le prodrome de M. De Candolle, se compose de 17 esp. qui se divisent en plusieurs sections de.valeur égale à celles des Centaurées.

(J. D.)

AMBETTI. BоT. PH.-Nom indou de diverses plantes dont certaines parties se mangent ; ce sont les : Begonia malabarica, Lmk., Hibiscus suratensis L., Sonneratia acida L. (C. D'O.)

AMBIGÉ⿴囗A Ambigenus (ambigenus, de deux natures). вот. PH. - Dénomination employée par M. Mirbel pour caractériser le cal., lorsqu'il tient, à l'extérieur, de sa propre nature, quant à la coloration, et de celle de la cor.ả l'intérieur. Ex. : les g. Grewia, Otnithoyalum, Passiflora, etc. (C. L.)

*AMBIGU. Ambiguzs. вот. PH.-Épithète employée pour désigner les organes d'une forme indéterminable, d'une insertion douteuse, etc. C'est ainsi que M. Mirbel dit: les cloisons ambiguës, quand, tenant au centre et à la paroi d'un péricarpe qui ne s'ouvre pas, elles n'ont point d'origine certaine ( $C_{i}$ urus); - le hile ambigu, quand cet organe correspond à la fois aux deux bouts réunis d'une graine recourbée ou repliée. - Cassini a dit: les coralles ambiguës dans les Synanthérées, quand elles sont intermédiaires entre deux formes déterminées; etc. (C. L.)

* AMB IGUES. Ambiguce. arachn. - Nom employé par M. Walckenaer pour désigner une petite division dans le g. Ctenus. $V$. ce mot.

(H. L.)

AMBsINUX (Anboe, deux; nux, noix). BoT. PI. - G. ainsi nommé par Commerson á cause des 2 gros noyaux qui se trouvent dans l'intér. de son fruit. Il est synonyme d'Aleurites. $I J$. ce mot.

(AD. J.)

AMBBIR. Porss. - Nom de l'esp. de Poissons, suivant Forskal, qu'il a décrite sous le nom de Mullus autiflammá, qui est une esp. du g. Upoeneus, de la 4me subdiv. générique de ce groupe; celles dont les esp. ont les mâchoires armées de dents distinctes sur un seul rang et le palais lisse. Il faut faire attention que le Mullus auviflamma de Forskal est d'une esp. distincte du Mullus auriflamma de Lacépède. Nous signalons ici ce mot, parce qu'il a été appliqué mal à propos dans le dictionnaire classique d'histoire naturelle au Mullus vittatus.

(VAL.)

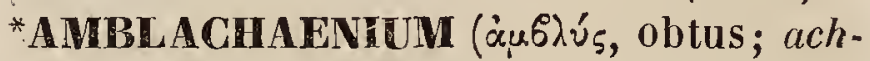

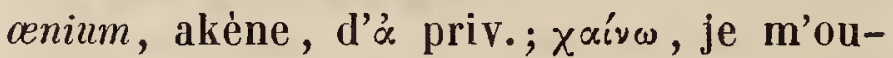
vre). вот. Рн. - C'est le nom d'une section du g. Achyrophorus, caractérisée par ses fruits obtus ou très brièvement rostrés. Les plantes qui composent cette sect. sont toutes originaires de l'Amérique, à l'exception d'une esp. de la Dahourie à laquelle le nom d'Amblachoenium a été spécialement appliqué.

AMBLÊEL. Amblema (plutôt Emblema,

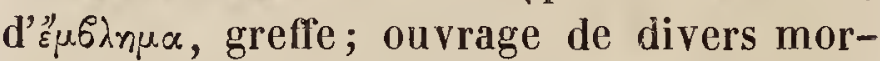
ceaux). MoLl. - C'est ainsi que M. Rafinesque nomme un nouveau g. formé aux dépens des Unio de Bruguière. Ce g. , dont les caract. sont insuffisants, a été inséré pour la $1^{\text {re }}$ fois dans le Mémoire publié par l'auteur dans les Amuales des Sciences physiques de Bruxelles (1820). Il n'a point été adopté. $V$.. MULETTE.

(Desh.)

AMBRÉRIDES ( $V$. AMBLEMA). MOLL. M. Rafinesque (Mém. sur les Unio, Ann. Sc. phys., Brux., 1820) a établi cette famille aux dépens du g. Unio de Bruguiẻre. Comme elle n'a pas de caract. suffisants, elle rentre parfaitement dans le g. Unio. ( $\boldsymbol{I}^{\prime}$. ce mot.)

(DESH.)

- AMBLESTIS (áu์iv́c, obtus). ins. - G. de Coléoptères tétramères, famille des Longicornes, établi par M. Dejean (Catal., $3^{\text {me }}$ édit.), qui n'en a pas publié les caract. Ce g. qui, d'après la place qu'il occupe, paraît appartenir ả la tribu des Lamiaires de M. Serville, est fondé sur une seule esp. du Cap de Bonne-Espérance, nommée par l'auteur A. alutaceus.

AMBLIPION (Contraction pour Amblyli-

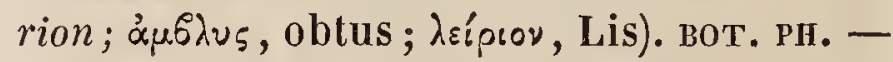
G. de la famille des Liliacées, tribu des Tulipacées, DC., proposé par Rafinesque (Journ. de Phys. 89), non adopté et réuni en synonymie au g. Lilium, L., comme une de ses divisions, caractérisée principalement par les 
folioles du périgone, sessiles, conniventes, par un sillon nectarifère obsolète. (C. L.)

AMBLODON ('ábiús, émoussé ; ỏdoús, dent). polss. - M. Rafinesque a désigné, sous ce nom générique, un Poisson de l'Ohio qu'il a malheureusement fait connaître si imparfaitement que MM. Cuvier et Valenciennes n'ont pu en déterminer l'espèce dans leur Histoire naturelle des Poissons.

L'auteur donne à ce g. la caractéristique suivante : " Corps elliptique, com"primé, écaillenx, ainsi que la tête et les " opercules ; mâchoires pourvues de petites " dents en cardes; gorge avec un os triangu"laire en bas (le pharyngien infér.) couvert "de dents larges, arrondies, creuses et ob" tuses; opercule de deux pièces; l'oper" cule sans épines ni dentelures; le préo" percule finement dentelé à la base ; mem" brane branchiale à six rayons; 2 dorsales; " $1^{\text {re }}$ épineuse $; 2^{\mathrm{c}}$ partiellement épineuse et "écailleuse le long de la base; les ventrales "reculées." - On voit que le poisson qui réunit ces caract. est èvidemment du g. des Sciènes. Les différences signalées par M. Rafinesque prouvent qu'il ne connaissait pas, en écrivant son Mémoire sur les Poissons de l'Ohio, les caract. de ce g. de Poissons. Il ne connaît, dit-il, qu'une seule esp. de ce g. qu'il nomme A. grognant ( $A$.grunniens). Il la donne comme argentée, brunâtre sur le dos, olivâtre sur les côtés de la tête; à lèvre supér. plus longue ; à museau arrondi et écailleux ; à ligne latérale convexe à sa naissance, concave au milieu, et droite jusqu'à sa terminaison; à caudale échancrée; à 9 rayons à la $1^{\text {re }}$ dorsale, et à 35 à la $2^{\mathrm{e}}$; le $1^{\mathrm{er}}$ étant court et épineux. Ces nombres, en ajoutant ceux des autres nageoires, donnent la formule suivante que nous écrivons de celte manière: $D 9-1 / 34, A 3 / 6, C 22 P 18$. Ils montrent que la siciène dont il sagit ici est voisine du Sciona oscula de Lesueur, que nous croyons toutefois en différer; mais les caract. indiqués par M. Rafinesque sont encore trop incertains pour établir, d'après eux, une espèce définitive. Les naturalistes des Etats-Unis nous feront un jour mieux connaìtre ce poisson qui mord bien à l'hameçon, donne aux pêcheurs un véritable plaisir de pêche, fraie au printemps et pond une grande quanlité d'œufs. M. Rafinesque en a indiqué la plupart des noms triviaux, et qui sont White-perch, White-pearch, Buffaloe-perch, Gruming-perch, Bubblingperch, Bubbler et Musch-eater. Les premiers noms rappellent la couleur argentée du poisson, les autres se rapportent au bruit ou sorte de grognement ou de bouillonnement que les Sciénoüdes font entendre. Le dernier prouve que cette Sciène se nourrit de mulettes (unio) dont elle peut briser la coquille avec ses dents pharyngiennes. Elle les trouve dans le sable ou la vase. Le nom de Buffaloe-perch (Perche Bison), qui lui a été aussi donnépour rappeler les sortes de mugissements qu'elle pousse, l'a fait confondre quelquefois avec les Catostomes qui s'appellent Buffaloe-fish (Poisson Bison), erreur signalée par M. Rafi nesque, et qui a donné lieu cependant à l'article très singulier que le rédacteur du Dictionnaire classique d'Histoire naturelle a inséré dans cet ouvrage, pour faire connaître aux lecteurs le mot que nous traitons ici.

$$
(\mathrm{V} \Lambda \mathrm{L} .)
$$

*AMBLYA( $\alpha^{\alpha} \mu \beta \lambda_{u_{s}}$, obtus). вот. CR.-Presi désigne sous ce nom, un des nombreux g. qu'il a formés aux dépens des Polypodes de Swartz et qui se distingue surtout par le mode de distribution des nervures. Dans celui-ci, qui ne renferme que le Polypodiım juglandifolium Humb. et Bonpl., les nervures latérales, pinnées, obliques, s'anastomosent en arcs arrondis et sont accompagnées d'autres nervures qui s'en séparent latéralement et portent les groupes de capsules, vers le milieu de leur étendue. - Ce g., dont les caract. sont peu tranchés, se distingue cependant des autres g. séparés des Polypodes et qui ont leurs nervures anastomosées, tels que les Campyloneurum et les Marginaria, par la disposition moins régulière des nervures et par la position des capsules sur le milieu et non à l'extrémité des dernières nervures. La seule esp. rapportée à ce g. a la fronde pinnée, à pinnules pétiolées, ovales-lancéolées, dentelées, mais non lobées. Elle croît dans l'Amér.-équatoriale. (Av. B.)

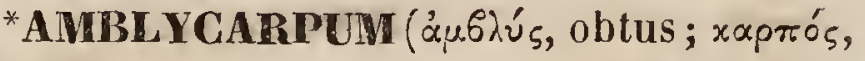
fruit). इот. Pn. - G. de la famille des Synanthérées-Sénécionidées, div. des Relhaniées, Less., formé par Fischer et Meyen (Ind. S'em. Hort. Petrop. 111, 1837), qui le caractérisent ainsi : Capitule multiflore, hétérogame. Fleurs du rayon unisérićes, ligulées, femel- 
les; celles du disque tubuleuses, hermaphrodites. Inv. imbriquées; squames 2-3-sériées; les extér. foliacées. Récept. hémisphérique, nu, ponctué. Cor. du rayon ligulées; ligule linćaire. Cor. du disque tubulées, 5-dentées. Anth. caudées stigm. Akènes subfusiformes, 5-angulaires, érostrés, obtus. Aigrette nulle. - Ce g. ne renferme qu'une esp. : c'est une herbe annuelle on bisannuelle, glabre, trouvée sur les bords de la mer Caspienne, rappelant le port du Pulicaria vulgaris. Les feuilles en sont éparses; les capitules solitaires et terminaux; les fleurs jaunes.

(C. L.)

*AMBLYCÉPHALE.Amblycephalus. REPT.

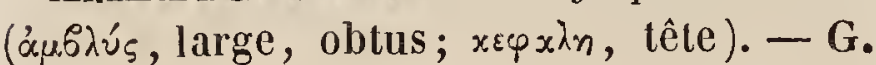
d'Ophidiens nommé ainsi par Boié, et que Wagler a appèlé Pareas. $V$. ce mot. (G. B.)

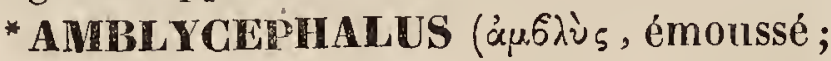

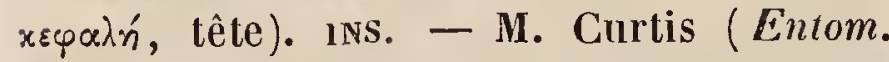
Magaz. 1.) applique cette dénomination à un g. ayant pour type la Cicada viridis $\mathbf{L}$. , qui est le g. Teltigonia pour Latreille, Germar, et la plupart des autres entomologistes. $V$. Tettigonia.

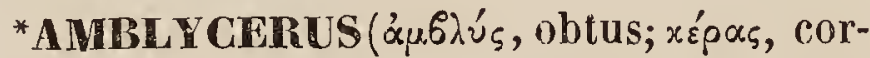
ne). ins. - G. de l'ordre des Coléoptères tétramères, famille des Curculionites, division des Anthribides , établi par Thunberg, mais non adopté par M. Schoenherr, qui en place les esp. dans le g. Anthribe. $V$. ce mot. (D.)

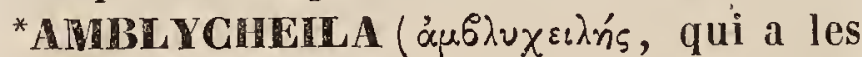
bords [lèvres] obtus). Ins. - G. de Coléotères pentamères, famille des Carabiques; tribu des Cicindélètes, établi par NI. Say, et voisin du g. Omas d'Eschschoitz, dont il se distingue, $1^{\circ}$ par la brièveté des 2 premiers art. du palpe labial et la longueur du $4^{\mathrm{mc}}$; $2^{\circ}$ par la courbure antér. de la marge du labre, qui est droit dans les Omus; $3^{\circ}$ par les dentelures médianes du labre; 40 par l'acuité du lobe intermédiaire du menton; $5^{\circ}$ par la plus grande longueur des pattes; $6^{\circ}$ enfin par la largeur des épipleures. Ce g. a pour type l' $A$. cylindriformis, Say. M. Reiche (Ann. Soc. ent. de France, t. 8, p. 560, pl. 19), en décrit et figure une seconde esp. de la Nouvelle-Californie, qu'il nomme d'après M. Dupont, A. Picolominii. (D.)

* AMBLICIIUS (áubiús, obtus). ins. G. de l'ordre des Coléoptères pentamères, famille des Carabiques, établi par Gillenhal el uon adoplé yar M.Dejean, qui en place les esp. dans le g. Barlister. $V$. ce mot. (D.)

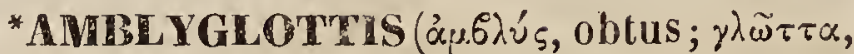
langue). вот. PH. - Le g. d'Orchidées, ainsi nommé par Blıme (Bijdr., 370), est le même que le Calanthe de Rob. Brown (in Bot. $R e g ., 578) . V$. Calantal.

* AMBR YGRATIHUS (áubì̀s, émoussé ; zuá(0)s, mâchoire). ins. - G. de Coléoptères pentamères, famille des Carabiques, tribu des Harpaliens, établi par M. Dejean, qui (Species général) lui assigne les caractères suivants : Les quatre $1^{\text {ers }}$ art. des 4 tarses antér. très légèrement dilatés et triangulaires ou cordiformes. Dernier art. des palpes assez allongé, légèrement ovalaire, presque terminé en pointe, mais cependant trouqué à l'exirémité. Ant. filiformes. Chaperon légèrement échancré en arc de cercle. Lèvre supér. en carré moins long que large. Mandib. assez fortes, arquées, obtuses, et presque entièrement cachées par la lèvre supér. Menton échancré en arc de cercle; point de dent au milieu de son échancrure. Corps oblong et peu convexe. Tête assez grande, arrondie, coupée presque carrément par devant, et rétrécie postérieurement. Yeux nullement saillants. Corselet plus ou moins carré ou rétréci postérieurement. Elytres légèrement ovales et presque parallèles. - Les insectes, en petit nombre, qui composent ce g., sont tous de Cayenne. Ils sont de moyenne taille, de couleur noire ou mıétallique, et, par leur facies, se rapprochent beaucoup des Harpales. Dans son dernier Catalogue, M. Dejean en mentionne 5 esp,, toutes nommées par lui, et dont nous ne citerons que l' $A$. cephalotes, qui forme le type du genre.

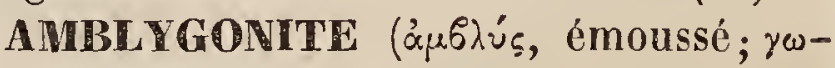
$v^{\prime} \alpha$, angle). Mns. - Substance vitreuse, yerte ou blanc-verdâtre, transparente, en petites masses cristallines ou en petits cristaux disséminés, qui sont des prismes rhombiques droits, de $106^{\circ} 10^{\prime}$, clivables parallèlement à leurs pans. Sa dureté est comparable à celle de l'Orthose; sa pesanteur spécifique est de 3,04. Elle est fusible sur le charbon en un verre clair, qui devient opaque par le refroidissement. Elle donne la réaction de la lithine, lorsqu'on la traite avec la soude sur la fenille de platine. D'après l'analyse de Berzélius, elle est composée d'acide phosphorique (4. $\left.\mathrm{P}^{2} \mathrm{O}^{5}\right)$, d'alu- 
mine (4. $\left.\mathrm{AL}^{2} \mathrm{O}^{5}\right)$ et de lithine (2. LO), avec quelques traces d'Acide fluoriquc; c'est par conséquent un Phosphate d'Alumine et de Lithine. Elle a été trouvẻe par M. Breithaupt dans le granite de Chusdorf, prés de Pessig, en Saxe, oú elle est associce á la topaze verte, à la tourmaline, au grenat et au Pyroxène. On la cite encore à Arendal en Norwége.

(DEL.)

*AMBLYGONUB, Mcisn. (sub Polygono); Fieichb., Lagunea, Lour. ('ap.6iv́s, obtus ; $\gamma \tilde{\omega}-$ yos, angle). вот. PH. - G. de la famille des Polygonées, fondé sur plusieurs esp. confondues par les auteurs avec les Polygonum. Meisner (Monogr. Polygon.) lui assigne lcs caract. suivants : Périgone coloré, profondément 5fide. Étam. 5 à 7 . Style plus court que les étamines, divisé, à partir du milieu, en 2 branches divariquées; stigmates capitellés. Akènc lenticulaire, comprimé, obtus aux bords, acuminé, recouvert par le périgone. Embryon unilatéral. Cotyl. incombants, linéaires. Périspermc farineux. - Herbes annuelles; racine fibreuse; feuilles trís entières, munies de gaìnes stipulaires-foliacées ; épis linéaires, cylindriques, denses; bractées turbinées, foliacées.

* AMBLYLEPIS (áucivís, obtus; $\lambda \varepsilon \pi i s$, écaille). вот. Рн. - Ce g. a été établi par M. De Candolle sur une plante du Mexique appartenant à la famille des Composées, tribu des Sénćcionidées. Elle a pour caract.: Invol. 2-sérié ; écailles extér. au nombre de 6-7, ovales aiguës, foliacées, égales au disque; celles du rang interne obovales-arrondies, très obtuscs et dépourvues de nervures. Capitules multiflores radiés; fleurs du rayon femelles, 1 -sériées, ligulées, trifides au sommet; celles du disque hermaphrodites, à tube court, à gorge large et diviséc en 5 lobes lancéolés, épaissis et apiculés à l'extrémité ; anth. terminées par de larges appendices aigus. Ramcaux des styles dépourvus d'appendices. Fruits turbinés velus; aigrette forméc par 5 paillettes unisériées, très obtuses, sans ncrvures et de même longucur que le tube de la cor. La seule esp. d'Amblylepis que l'on connaisse est une plante annucllé á tigc simple, couverte çà et là, ainsi que lcs feuilles et les écailles de l'involucre, de quelques longs poils déliés; les feuilles sont alternes, semiamplexicaules, non décurrentes, ovalesT. 1. lancéolées, très entières; les capitules terminaux solitaires, á fleurs jaunes, sont comparables, par leur grandeur et leur aspect, à ceux du Pyrethrum Myconis. (J. D.)

*AMBLYMERUS ('á.6่ús, émoussé ; unpóç, cuisse ). Ins. - G. de la famille des Chalcidiens ('Tribu des Chalciditcs, Lat.), de l'ordre des Hyménoptères, section des Térébrans, établi par Walker ( Monog. Chalc. in Ent. Mag.) qui le distingue des g. voisins, principalement par la forme du corps large et courte, par un thorax convexc, et par des ant. composées de 13 articles, dont les $3^{\mathrm{me}}, 4^{\mathrm{me}}$ et $5^{\text {me }}$ extrêmement petits. Walker décrit 27 espèces de ce g., trouvées en Anglelerre; cclle que l'on en considère comme le type est l'.A. amcenus Walk.

(BL.)

AMBLYOCARPUN. BOT. PII. - $V$. AMBLYCARPUM.

(C. L.)

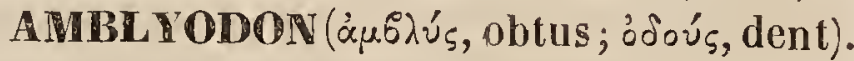
вот. Cr. - Palissot de Beauvois avait créé ce nom pour un g. de Mousses qui n'est autre que le Meesia d'Hedwig, avec la seule différence que le bryologiste français y avait fait entrer le g. Cinclidium de Swartz, devenu tout récemment un Mnium. $V$. MeESIA.

(C. M.)

AMBLYOLEPIS. вот. PH. $V$. AMBLYLPIS.

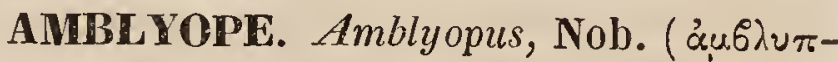
ós, qui a la vue faible). Porss. - G. de Poissons de la famille des Gobiö̈des, à corps allongé, à ventrales jointes en une seule sous la gorge, dont les 3 nageoircs verticales sont réunies. La bouche est fendue verticalement, armée de dents en crochets et découvertes; les yeux ne peuvent se voir que par la dissection, tant ils sont pețits et recouverts par la peau. Ce dernier caractère nous a suggéré le nom imposé à ce genre. M. de. Lacépède avait indiqué un poisson de ce g., d'après une copie d'une figurc chinoise gravée dans son ouvrage (tom. Iv, pl, 14, fig. 1). La copie est inexacte; aussi les caract. de M. de Lacépède sont-ils beaucoup plus fautifs que l'examen d'une bonne figure ne devrait en fournir; et ce qui est fautif dans la rédaction de M. de Lacépède, c'est que pour la parer des charmes de son style, il paraît donner une description d'après nature; ce qui n'est pas exact. Il s'était fait une idée fausse du poisson en lecomparant à une Cépole; aussi avait-il fondé ce 
genre d'après cette copie mensongère et sur des caractéres inexacts sous le nom de 'Trniö̈de. Voilá pourquoinous n'avons pas cru levoir le conserver. Shaw et Bloch ont suivi les erreurs de Lacépède, et donnent ce poisson sous le nom de Cépole aveugle (Copola ccecula, ou Cop. hermanniana). Linné avait connu une esp. de ce g., et l'avail placée, suivant ses affinités naturelles, dans le $g$. des Gobies, sous le nom de Gobius anguillaris. Nous ne connaissons que 5 espèces de ces Gobioïdes, toutes originaires de l'Inde, et se tenant enfermées dans la vase des étangs salés; on les mange à Pondichéry. (VAL.)

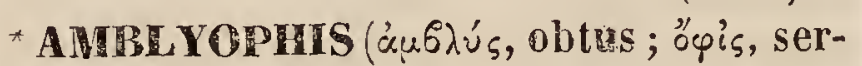
pent). INF. - G. élabli par M. Ehrenberg pour un infusoire vert, très voisin de ses Euglena, dont il ne se distingue que par l'extrémité postérieure obtuse de son corps. Il a été placé par cet auteur dans la fami.le des Astasiées, comprenant, suivant lui, des animaux polygastriques, sans intestin, nus, changeant incessamment de forrnes, et paraissant tantôt avec, tantòt sans queue; enfin, pourvus d'une seule ouverture. L'Amblyophis présente en avant, comme la plupart des g. voisins, un ou plusieurs points rouges qu'on a pris mal a propos pour des yeux. Il n'a d'autre organe locomoteur, pour la natation, qu'un filament flagelliforme très fin, partant d'uric échancrure antéricure etfaussement nommée trompe. On n'a pu observer encore chez cet animalcule, non plus que chez les g. voisins, aucune intromission d'aliments ou de substances colorées dans l'intérieur; de sorte qu'on n'a absolument aucun motif pour nommer estomac lelle ou telle partie de son corps. La seule esp. connue (A. viridis Ehr.) est longue de $\frac{\gamma}{4}$ mill. environ. Elle vit isolément au fond des marais ou dans les infusions d'herbes aquatiques conservées long-temps. (Dus.)

AMBL YOPOGON. вот. Рн. - $V$. AMBLYPOGON.

(C. L.)

AMBLYOPUS. INS. $-V$. AMBLyPUS. (D.) *AMBLYPOGON (áusiús, obtus; $\pi \dot{o} j \omega \nu$, arbe). вот. PH. - Ce genre, considéré par M. De Candolle comme section de l'Amberboa, se caractérise par son involucre a squames ovales, courtes, imbriquées, terminées au sommet en un appendice large, scaricux, ovale-lancéolé, cilié-pectiné sur les bords; cor. rlu rayon ne dépassant pas celles du disque. Anth. presque mutiques à la base. Aigrette simple, formée de paillettes ćlargies et dentículées au sommet. - Cette plante, qui a le port d'un Psephellum ou d'un Heterolophus, est originaire de ia Perse.

$$
\text { (J. D.) }
$$

AMBL YPTERE. Amblypterus, Ag. ( $\alpha_{1}^{\prime s-}$

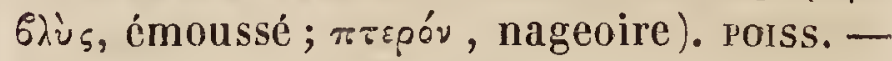
G. de Poissons fossiles de la famille des Léṕidoïdes, de l'ordre des Ganoïdes. Ils ont par conséquent des dents en brosse, des écailles plates et rhomboïdales, le corps allongé et fusiforme.Les nageoires sont larges et composées de nombreux rayons; les pectorales très grandes; la dorsale opposée à l'intervalle qui sépare les ventrales et l'anale; point de pelits rayons sur le bord des nageoires; le lobe supér. de la queue est plus long que l'inférieur, et soutenu par des vertèbres. Comme tous les Hétérocerques de cette famille, les Amblyptéres n'ont aucun représentant dans la nature vivante, et ils appartiennent tous aux formations inférieures des dépôts jurassiques. Des 5 esp. citées par M. Agassiz, quatre, les A. macropterus, eupterygius, lateralis, tatus, viennent des houilles de Saarbrük, de Lebach ou de Borscheweiler. La $5^{\text {e }}$ que M. Agassiz a nommée $A$. Olfersii, est une esp. de Ceara, au Brésil, sur laquelle M.Agassiz conserve encore quelques doutes, mais dont les écailles sont cependant plus étroites que dans celles d'Europe.

\section{(VAL.)}

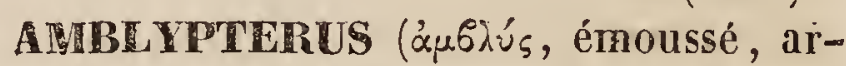
rondi ; $\pi \tau \varepsilon$ póv, aile). ols. - G. formé par M. Gould (Proceed. Zool. Soc., 1837,p. 105) dans la famille des Caprimulgidécs, et ayant pour caract. : Bec faible et allongé, muni d son ouverture de poils rigides qui le dépassent en longueur; narines élevées et arrondies. Ailes tronquées; les six $1^{\text {res }}$ rérniges égales entre elles et falciformes; les $2^{\text {me }}$, $3^{\mathrm{me}}$ et $4^{\mathrm{me}}$ échancrées sur leur côté externe; les $7^{\text {me }}, 8^{\text {me }}$ et $9^{\text {me }}$ allongées el rétrécies vers leur extrémité ; la $10^{\text {me }}$ brusquement raccourcie; les secondaires très courtes, arrondies et recouvertes par les tertiaires, qui sont trés longues. Queue très courte et terminéc carrément. Pieds propres à la marche; tarses allongés, grêles, couverts devant cl derrière de rangées d'écailles à peine distinctes; doigt médian très long et grêle; les 
latéraux courts et égaux; le postér. pelit, faible et libre; ongles allongés, le médian pectiné. - L'autcur décrit, à la suite, sous le nom d' $A$. anomalıs, un individu de celte espéce, de la collection du Musée britannique, qu'il croit être unique, et qui, d'après M. J.-E. Gray, serait originaire de Démérary ou du Brésil.

M. Gould s'occupe, depuis quelque temps, d'une Monographie des Caprimulgidés. Avant son départ pour la terre de Van-Diemen, ce travail comprenait déjả un grand nombre de g., et près de 150 esp., parmi lesquelles on remarque les formes les plus hétéroclites. Son voyage à Van-Diemen et à la NouvelleHollande lui-fournira sans doute de nouveaux matériaux, etlui permettra de les déterminer plus sùrement dans l'intérêt de la science.

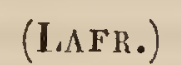

* Ambe ypteriy (áu.brús , émoussé; $\pi \tau \hat{\varepsilon} \rho\} \xi$, aile). ıns. - M. Stephens (Catal.), nomme ainsi un g. de la famille des Phrygeniens, ordre des Névroptères, établi précédemment par M. Curtis, sous le nom de Molanna. ( $V$.ce mot.) (BL.)

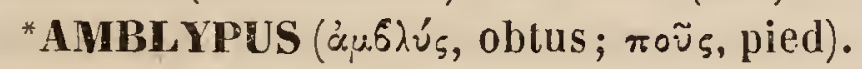
Ixs. - G. de Coléoptères tétramères, famille des Chrysomélines, établi, par M. Chevrolat, aux dépens du g. Triplax d'Olivier, et adopté par M. Dejean, qui y rapporte 2 esp. des Indes orientales, l'une qu'il nomme $A$. cinclipennis, et l'autre qui est le Triplax vitlutus d'Olivier. Les caract. de ce g. n'ont pas été publiés.

AMBL YR AMPHE. Amblyramphus (å. émoussé; ṕn.qos, bec). 01s.-G. que Leach a formé (Miscellan., t. 1, p. 82) sur un oiseau de la famille des Troupiales, décrit depuis long-temps par Azara, sous le nom de Troupiale noir à tête rouge, et en dernier lieu sous celui d' $\Lambda$. bicolor (pl. 36 des Miscell.) par l'auteur anglais. Ce g. est-il ou non basé sur des caract. assez importants pour être conservé? Celte question, ainsi que beaucoup d'autres du même g., ne pourra être résolue d'une manière satisfaisante que lorsqu'on aura obtenu des notions précises et détaillées sur les mocurs de l'esp. dont il est formé. Nous allons faire connaître, à ce sujet, les opinions de plusieurs auteurs, ainsi que la nôtre, basée sur quelques détails de mocurs puisés dans Azara, et sur quelques parlicularités de formes que nous arons re- marquées. Vieillot, croyant, comme Leach, cette especce nouvelle, adopta son g. sous la même dénomination génériquee t spécifique, dans le nouv. Dict. d'Hist.nat. (t. 1, p. 411). Plus tard, dans le vol. 34, p. 553, du même ouvrage, il décrit, sous le nom de Troupiale rouge (Agelaius ruber, Oriolus ruber Lath.

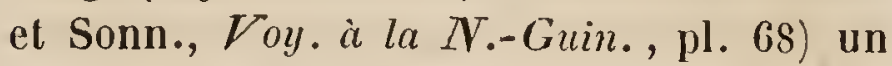
oiseau qui ne paraît autre que celui-ci. Enfin, dans l'Encyclop. méth., il le décrit encore et le place dans son g. Sturnella sous le nom de S. rubra (p. 635). Cuvier (Règ. anim.) en fait un Étourneau. Lichtenstein, dans ses Doubles du Mus. de Berlin, suit la même opinion, et le décrit sous le nom de $\mathbf{S}$ turnus pyrrhocephalus. Wagler (Syst. Avium) adopte ce dernier nom, en faisant toutefois observer qu'il le regarde comme une espéce de transition des Étourneaux aux Cassiques, et que ses pattes, garnies en-dessous de rugosités verruqueuses, indiquent, sans nul doute, un g. de vie différent de celui des autres esp. Swainson, dans sa Classification. citant toutefois la pl. 36 des Zool. miscel., oú il porte le nom spécifique de bicolor, le met dans son g. Teistes, sous le nom nouveau de L. erythrocephalus. Azara, le décrivant sous le nom de Troupiale noir à tête rouge, dit que, malgréses rappòrts avec les Troupiales, il en différe cependant par la forme de son bec, des plumes de sa tête, et en ce qu'au lieu de vivre en troupes, il ne vit que par paires. Il augure de la forme de son bec et de sa langue, qu'il doit se nourrir non de graines, mais d'insectes, d'œufs de poissons et de limaçons; considérations qui l'ont engagé à le présenter comme une esp. parliculière.

De ces divers sentiments, et de nos propres observations, nous avons cru pouvoir inférer : $1^{\circ}$ Que cet oiseau américain, d'après ses caractères, ne peut être réuni aux Étourneaux qui, habitant l'ancien monde, vivent en troupes, sont remarquables par des ailes sur-aiguës, à longues rémiges, par une queue courte, et par des narines recouverles d'une membrane voûtée; $2^{0}$ qu'il ne peut être réuni aux Stournelles de Vieillot, qui vivent en troupes et oni les narines des Étourneaux, et dont il diffère encore par le pouce beaucoup plus court et les ongles plus arqués; ce qui iudique qu'il est moins marcheur; $3^{\circ}$ enfin, que c'est avec les Leistes de Swain- 
son (Troupiale dragon, le Guirahuro d'Azara, etc.) que cet oiseau ofre le plus de rapports extérieurs, quoiqu'il en diffère par ses ailes plus obtuses, son bec plus déprimé et plus arrondi à son extrémité, et par ses ongles, lesquels, bien que longs et grêles comme chez la plupart des Troupiales graminicoles et vivant en troupes, sont néanmoins plus arqués, celui dupouce surtout, comme chez les Fauvettes de roseaux, les Donacobius ou Merles de roseaux.

En rapprochant ce dernier caract. de ceux de la plante des pieds verruqueuse, observée par Wagler, d'ailes très obtuses, à rémiges courtes, du bec singulièrement déprimé et arrondi à la pointe (qui indique une nourriture molle et facile a saisir, probablement sur le bord de l'eau ou dans les marécages), nous serions porté à croire que cet oisean, beaucoup moins marcheur et moins bon voilier que les Étourneaux, les Stournelles et mème les Leistes, est peutêtre un habitant des roseaux, qu'il escalade à la manière des Calamoherpes et des Donacobius, et qu'il se nourrit d'insectes et de larves aquatiques. Dans cette supposition, nous pensons que le g. doit être conservé, soit comme g. propre, soit comme s. - g. du g. Leistes, et nous en établissons ainsi les caract. :

Bec parfaitement droit, en cône allongé; mandib. supér. prolongée à sa base en forme d'angle aigu entre les plumes frontales, déprimée, surtout vers la pointe qui est arrondie, spatuliforme; mandib. infér. terminée de même. Ailes obtuses, à rémiges fort courtes, atteignant à peine le tiers de la queue; la $1^{\text {re }}$ un peu moins longue que la $2^{\text {me }}$ qui est presque égale à la $3^{\text {me }}$; celle-ci , ainsi que la $4^{\text {me }}$ etla $5^{\text {me }}$, d'égale longueur et les plus longues de l'aile. Queue assez longue, arrondie. Tarses et doigts robustes, mais de longueur médiocre. Dessous des doigts verruqueux; ongles longs, grêles et arqués, surtout ceux du pouce et du doigt médian. Comme nous l'avons déjà dit, la seule esp. de ce g. est l'A. bicolor de Leach (Loc. cit. et Synon.).

(LAFR.)

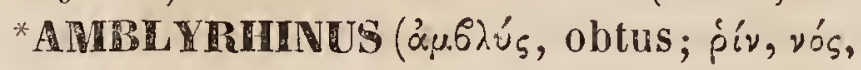
nez). ıNs. - G. de Coléoptères tétramères, famille des Curculionites, division des Phyllobides, établi par Schœnherr, qui lui donne les caract. suivants : Ant. peu longues, min- ces; scape atteignant le milieu du thorax, peu fort, légèrement arqué, s'épaississant un pêu vers l'extrémité; $1^{\mathrm{er}}$ art. du funicule peu long, obconique; les autres plus courts, presque égaux, très brièvement oljconiques; massue ovale, petite. Rostre trés court, plan en-dessus, rétréci vers le sommet; fossette oblongue, peu large, profonde. Yeux latéraux, ronds, un peu déprimés, assez grands. Thorax presque transverse, profondément bi-sinué à la base, droit sur les côtés, sensiblement plus étroit dans sa partie antérieure, obconique. Élytres oblongues, presque ovales, ayant leur base arrondie vers l'écusson et les angles huméraux obtus, réunies en pointe á leur extrémité, légèrement convexes en dessus. Le corpsest oblong, peu convexe, squamuleux, de grandeur moyenne. - Ce g., qui figure dans le Catalogue de M. Dejean (3 $\left.{ }^{\text {me }} e ́ d i \iota.\right)$, ne renferme que 2 esp., l'une nommée par lui $A$. brevirostris, et l'autre par Schœnherr. A. poricollis; toutes deux des Indes orientales.

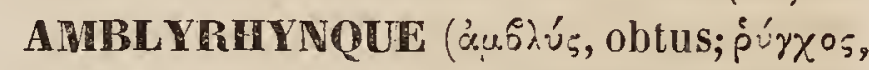
museau, groin). REPT. - Bell a désigné par ce nom un g. d'Iguaniens pleurodontes don voici les caract. : Des dents palatines; celles des mâchoires trilobées; gorge dilatable, mais sans fanon; une rangée de pores sous chaque cuisse; une crête dentelée sur le dos et sur la queue: celle-ci comprimée vers son extrémité'et revêtue de grandes écailles disposées en verticilles; museau court, arrondi ; tête couverte de tubercules inégaux, à base polygonale. A ce g. se rapportent 3 esp., originaires de la Californie.

(G. B.)

* AMBLYS (aubiús, obtus). ins. - G. de l'ordre des Coléoptères pentamères, famille des Sternoxes, tribu des Buprestides, établi par Gistl, et qui répond au g. Chrysobothris d'Eschscholtz. $V$. ce mot.

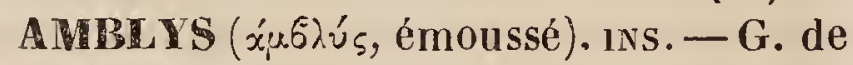
la famille des Mellifères, de l'ordre des Hyménoptères, établi par le docteur Klug, et réuni par Latreille au g. Osmia ( $V$.ce mot).

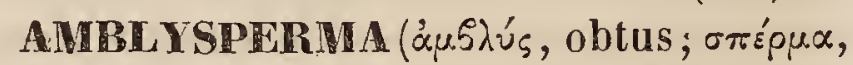
graine). вот. Рн. - G. de la famille des Synanthérées-Labiatiflores, s. tribu des Mutisiées, Less., div. des Eumutisiées, DC., formé par Bentham (Enum. Pl.Hug.) sur une seule plante trouvée dans la partie S.-O. de la 
Nouvelle-Hollande, a feuilles toutes radicales, pétiolées, oblongues, sinuées-dentées, scapigère, d'environ 50 cent. de haut., laineuse au sommet, á capitule ample, unique, terminal. Voici les caract. que lui assigne l'antéur: Capit. multiflore, hétérogame. Fleurs du rayon femelles; celles dù disque hermaphrodites. Invol. campanulé, à squames plurisériées, imbriquées, lancéolées; les intér. plus longues. Récept. plan, subalvéolé. Cor. glabres; celles du disque tubuleuses, à limbe 5-fide; les 2 segments intér. connés presque jusqu'au sommet. Cor. du disque ligulées-bilabiées'; lèvre extér. ample, oblongue-linéaire, courtement 3-fide au sommet; l'intér. courte, subulée, profondément bifide. Filaments des étam. distincts; lisses, plans; appendices des anth. glabres; ailes courtes. Style pubérule supérieurement. Akènes turbinés, papilleux, très obtıs. $\Lambda \mathrm{i}$ grette multisériée, paléacée-soyeuse, un peu scabre, longue, presque égale, ctc. (C. L.)

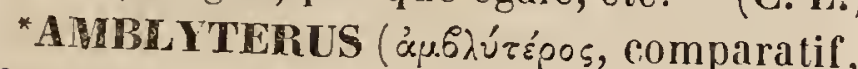
d'áp.5̀ús, obtus). Ins. - G. de l'ordre des Coléoptères pentamères, famille des Lamellicornes, tribu des Scarabéides-Phyllophages, établi par Mac-Leay et adopté par M. Dejean (Catal., $\left.3^{\mathrm{e}} e ́ d i l.\right)$. Le premier lui assigne les caract. suiv. : Ant. de 10 articles; $1^{\text {er }}$ article garni de poils raides; les $2^{\text {me }}, 3^{\text {me }}, 4^{\text {me }}$ et $5^{\text {me }}$ globuleux; les $6^{\mathrm{me}}$ et $7^{\mathrm{me}}$ courts et patériformes. Labre coriace, velu, saillant. Mandib. cornées, courtes, fortes, presque triangulaires, planes en dessus, arquées en dehors, velues, à peine échancrées, avec le bord interne presque bidenté. Mâchoires coriaces, presque cylindriques, obtuses au sommet, poilues et garnies de dents extrêmement petites. Palpes maxillaires grèles, avec le $2^{\mathrm{me}}$ et le $3^{\mathrm{me}}$ ar icles coniques; le dernier lancéolé, plus long que tous les autres réunis, et terminé en pointe obtuse. Dernier article des palpes labiaux épais et ovalaire. Mentor presque carré, fortement hérissé de poils, convexe, avec sa partie médianc avancée, déprimée et tronquée. Tète presque carréc, traversée par une suture; chaperon arrondi antérieurement, avec le bord un peu relevé. Corps ovale, non couvert postérienrement par les élytres ; écusson grand et triangulaire. Sternum non prolongé. Palles peu fortes; tibias antérieurs tridentés cxtéricurement. - Ce g. est fondé sur une séule esp. de Ia Nouvelle-Hollande, nommée par Mac-Leay et par M. Dejean $A$. geminatus.

AMBRYURES. Anablyurus, Ag. (à $\mu 6 \lambda^{2} \varepsilon_{\zeta}$, obtus; oúpá, queue). poiss. - G. de Poissons fossiles de la famille des Lépidoïdes, de l'ordre des Ganoïdes, et qui, suivant M. Agasiez, a pour diagnose les caract. suivants : Une longue dorsale, commençant vis-a-vis des ventrales; une petite anale étroite; une large caudale tronquée; corps large et aplati; gueule très fendue; os maxillaires étroits et très allongés; $1^{\text {er }}$ rayon branchiostège large, plat ct avancé horizontalement entre les dcux branches de la mâchoire infér.; les suivants courts et très étroits; os du crâne et pièces operculaires finement striés'en lignes ondulées et sculptés par une grosse granulation; rayons peu profondément fourchus, et articulations plus larges que hautes; écailles assez grandes ; celles des flancs et du ventre plus que celles des autres parties du corps. - Les onglets et les fossettes articulaires de ces écailles n'ont pu être vues par M. Agasiez. Ce savant ichthyologiste regarde ce $\mathrm{g}$. comme intermédiaire entre les Tetragonolepis et les Sémionotées. Il n'en connaît qu'une seule esp., l' $A$. $m a-$ crostomus, qui provient des Lias dı Lyma Piegis, et qu'il a observée dans la collection de miss Philpot.

(VAL.)

AMBORA, Juss.; Tambourissa, Sonn.; Mithridatea, Comm. (nom d'un de ces arbres chez les Madécasses). вот. PII. - G. de la famille des Monimiacées, Lindl, tr. des Monimiées, R. B., fondé par de Jussicu (Gen., pl. 41, et Ann. Mus., xiv), et dont voici la diagnostique: Fleurs monoïques. Dans les mâles, un périgone ovale-subglobuleux, puis fendu et étalé en 4 parlies. Étam. nombreuses, insérées sur le périgone de manière à l'en revêtir entièrement; filaments très courts, nus; anth. biloculaires, basifixes, d loges subopposées, Iongitudinalement déhiscentes. Dans les femelles, un périgone tubulé-subglobuleux, ombiliqué ouvert au sommet, à gorge nue. Ovaires nombreux, uniloculaires, fixés de toutes parts à la paroi interne du périgone. Ovule unique, pendant, anatrope. Style terminal, court, filiforme; stigm. simple. Drupes nombreux, monospermes, enveloppés par le périgone devenu bacciforme. Graine inverse. En- 
bryon droit dans l'axe d'un albumen charnuoléagineux. Cotyl. plans, elliptiques; radic. supère. - Les Ambora sont des arbres indigènes dans les Iles de France el de Madagascar, à feuilles subopposées, très entières, persistantes, revêtues, en dessous d'une pubescence étoilée, à inflorescence en grappes, à fleurs rarement solitaires, et naissant sur le tronc et a la base des branches; les femelles plus rares, et entremêlées avec les màles.

(C. L.)

AMBRARIA, Crus.; non Heist. (ambar, ris, ambre gris). вот. PI. - G. ou s -g. de la famille des Rubiacées. D'après M. A. Richard (Mém. de la Soc. d'Hist. nat. de Paris, t. v, p. 139), il ne diffẻre des Anthospermum que par la conformation de la commissure des méricarpes, laquelle est concave de mànière à former une loge vide au centre du fruit.

(Sp.)

AMBRE AUNE. Min.- $\mathscr{V}$. SuCGiN. (Del.) AMBRE GRIS (Ambar ou Ambarum cheZ les Latins). zooL. - Cette substance, qu'on trouve flottante à la surface de la mer, ou rejetée sur les côtes de Madagascar, des MoIıques, du Japon, etc., se présente en masses opaqnes et légères, plus ou moins volumineuses, irrégulières, arrondies, formées par conches et entremêlées quelquefois (découverte assez récente) de débris de poissons et de becs de Seiche; d'un gris nuancé de noir et de jaune, se ramollissant facilement à la chaleur de là main, se liquéfiant dans l'eau bouillante et à l'humidité prolongée; d'une cassure écailleuse; brûlant avec uné vive clarté, en répandant une odeur pénétrante qui rappelle celle du musc.

Il est peu de substances dont la nature et l'origine aient donné lieu à plus d'hypothèses différentes. On l'a considérée comme formée d'excréments d'oiseaux, ou comme des masses de résine végétale, modifiée par l'acđion combinée de l'eau salée, de l'air et du soleil; puis on l'a regardée comme un produit bitumineux élaboré au fond des mers. Ensuite on a généralement adopté l'opinion de Swediaur, qui en faisait des excréments résultant d'aliments mal'digérés de l'espèce de Cachalot, nommée Physeter macrocephalus. Plus tard, MM. Pelletier et Caventou, qui ont publié un travail intéressant sur l'Ambre gris, pensent qu'il poùrrait bien être un produit de la matière biliaire, qui en constituerait des calculs chez certains cétacés. Enfin, M. de Blainville considère aujourd'hui cette substance comme le résultat d'une sécrétion analogue au musc et au castoréum.

L'Ambre gris est fréquemment employé en parfumerie comme cosmétique, et très rarement comme remède; mais la propriété excitante trés prononcée dont il paraît jouir, le faisait entrer autrefois dans une foule de préparations pharmaceutiques. (C. I)'O.)

AMBREE ou AMPHBIE ( ambar, ris, ambre gris). MoLl. - Geoffroy, le premier, dans son excellent petit Traité des Coquilles des environs de Paris, a désigné sous ce nom un mollusque qui vit au bord de nos rivières, et qui est devenu pour Draparnaud le type de son $g$. Ambrette (Succinea). $V$. ce mot.

(Desir.)

AMBRETTE. Succinea (ambar, ris, ambre gris). MoLL. - G. de Gastéropodes pulmobranches, institué par Draparnaud pour un mollusque terrestre signalé pour la première fois par Lister dans son Traité des Animaux d'Angleterre. Gualtieri, Swammerdam et Geofroy ont également mentionné l'Ambrette, avant que Linné l'eût placée dans son g. Helix. C'est principalement à Geoffroy qu'on doit la connaissance plus exacte de l'Ambrette. Il en donne une fort bonne description dans son excellent petit trailé des Coquilles des environs de Paris. Linné, comme le savent les naturalistes, n'a établi aucune distinction entre les Mollusques terrestres; il les comprenait tous dans son grand g. Hélice, dans lequel on trouve aussi des coquilles d'eau douce et mème quelques coquilles marines. Les auteurs qui, les premiers, voulurent porter la réforme dans la classification linnéenne ne la firent pas contplète ; mais ils eurent le mérite de la préparer. C'est ainsi que Bruguière transporta les Ambrettes des Hélices dans son g. Bulime; g. qui n'est guère préférable à celui de Linné; mais qui a l'avantage de mettre les espéces dans d'autres rapports. Draparnaud, naturaliste judicieux, fut un des premiers qui sentirent l'importance des changements que Bruguiere, Cuvier et Lamarck proposaient dans la classification de Linné. Il s'associa à ces réformateurs en ce qui concerne les Mollusques terrestres et fluviatiles de France, et créa pour eux plusieurs genres utiles, 


\section{AM B}

parmi lesquels nous comptons celui qui nous occupe. M. de Roissy, dans le Bufron de Sonnini, fut l'un des premiers qui adoptèrent le g. de Draparnaud. Lamarck sentit aussi la nécessité de séparer les Ambrettes des Bulimes; et ayant vu une grande espéce des Antilles fort singulière par la grandeur et la forme de l'ouverture de la coquille, il proposa pour elle, dans le tome vi des $\mathbf{A n -}$ nales du Muséum, un genre particulier, auquel il domma, jusqu'à la publication de son dern:er ouvrage, le nom d'Amphibulime. Lamarck maintint dans ses divers travaux son g. Amphibulime; mais il reconnut enfin qu'il faisait un double emploi avec celui de Draparnaud, et finit par admettre le g. Ambrette dans son histoirc des Animaux sans vertèbres. On trouve ce g. dans la famille des Colimacées, à la fin des Colimacées à 4 tubercules. M. de Férussac, en cherchant à rendre au g. Hélice toute l'étendue que lui avait donnée Linné, se trouva dans l'obligation de sous-diviser le g. unique qu'il admettait pour les coquilles terrestres, en un grand nombre de s.-g. auxquels il impose des noms particuliers, ayant tous deux des racines communes. Pour lui le g. Ambrette devient son sous-genre Cochlohydre, placé comme groupe transitoire entre la section des Hélicoïdes et celle des Cochloïdes; mais au commencement de ces dernières. Cet arrangement de $M$. de Férussac ne pouvait être admis ; il entraînait de trop grands changements dans la classification; et M. de Blainville, dans son Traité de Malacologie, aussi bien que M. Cuvier, dans la $2^{\text {me }}$ édit. du Règne animal, ont colsservé le g. Ambrette de Draparnaud.

M. de Férussac avait un motif assez légitime en apparence pour justifier l'adjonction des Ambrettes aux Hélices. L'animal des Ambrettes a les mêmes caractères extéricurs que les Hélices; il respire l'air en nature; il a une coquille spirale allongée; il porte sur sa tête 4 tentacules dont les 2 plus grands sont oculés au sommet. Il fallait savoir si, à l'intérieur, l'organisation entière était conforme à celle des Hélices ; c'était le seul moyen de décider enfin si le g. qui nous occupe devait être maintenu dans une bonne méthode, ou s’il devait rentrer, soil dans les Hélices, soit dans les Bulimes. Pour arriver il la solution de la question, nous avons fait
ANB

343

l'anatomic de l'espèce qui vit sur les bords de la Seine, et voici ce que nous ayons observé :

Les organes de la digestion, sont constitués comıne dans Ies IIélices. Lorsque nous traiterons de ce dernier g., nous donnerons des détails étendus sur sa struclure organique; ici nous voulons seulement signaler les différences. Dans la bouche de l'Ambrette, on trouve une plaque dentaire qui n'est point pectinéc comme celle des Hélices. Son bord libre, coupé en croissant, estsimple et tranchant. Un œsophage assez long pénètre dans un estomac fusiforme, ridé, ne se terrninant pas comme dans les Hélices, en un cul-de-sac considérable, mais se terminant, au contraire, d'une manière insensible en un intes!in grêle dont les circonvolutions peu nombreuses se développent dans le foic et dans l'ovaire. Cet intestin remonte ensuite, et se dirige le long du bord supérieur de la cavité respiratrice, pour se terminer à droite dans l'angle supérieur du manteau. Dans la bouche aboutissent les canaux salivaires. Les glandes qui donnent naissance à ces canaux ne sont point aplaties et, en quelque sorte, disséminées à la partie de l'estomac, comme cela a lieu dans les Hélices. Elles constituent chez l'animal qui nous occupe, de petites glandes allongées ct situées de chaque còté de l'estomac. Le foie est con:idérable; il se partage en 2 lobes principaux de chacun desquels naît un vaisseau biliaire principal qui vient pénétrer dans l'estomac avant la naissance de l'intestin.-Si l'on compare ce qui précède avec ce qui est connu des Hélices, on verra que, sous le rapport des organes de la digestion, les Ambrettes en diffẻrent très peu; il cn est de même á l'égard des organes de la circulation et de la respiration. Il en est de mème cncore de l'appareil nerveux, quant à sa distribution. Le's principales différences entre les Anbrettes et les Hélices se manifestent principalement dans les organes de la génération. On sait, depuis le travail de $\mathrm{Cu}-$ vier, combien ces organes sont compliqués dans les Hélices. Dans les Ambrettes, ils son: beaucoup plus simples; leurs diverses parties sont aussi très nettement distinguées, de sorte que l'on reconnaît facilement celles qui appartiennent à l'un et l'autre sexe. I es organes mâles consistent en un testicule 
complètement détaché de la masse commune. Ce testicule est une glande oblongue, du sommet de laquelle naît un canal déférent, très grêle, qui descend jusque vers la base de la gaîne de la verge, remonte jusqu'à son sommet, pour pénétrer dans cette gaìne; il est fortement tortillé sur lui-même, et va directement aboutir au sommet de la verge qui est courte, conique, et diffère entièrement de ce long appendice que l'on observe dans les Hélices et dans les Bulimes.

Les organes femelies consistent en un ovaire situé dans les derniers tours de la sphère de la coquille. De cet ovaire part un premier oviducte mince et fortement contourné sur lui-mème. Cet oviducte se rend à l'extrémité inférieure d'une matrice irrégulièrement boursouflée, et remplie d'une abondante mucosité. Cette matrice se termine en un col étroit, recourbé sur luimême et qui vient s'implanter sur la partie latérale et supérieure d'un canal auquel les anatomistes donnent le nom de vagin. Ce vagin est allongé, cylindrique; ses parois sont assez épaisses et son extrémité postérieure se prolonge en un long col qui se termine par une petite vésicule arrondie. La gaîne de la verge et l'extrémité du vagin se réunissent à leur extrémité inférieure, et se terminent, au-dessous du tentacule droit, en une ouverture divisée en deux par un éperon. Comme on le voit, les organes de la génération dans les Ambrettes sont réduits à une grande simplicite qui permet une explication facile de l'usage de chacune de leurs parties. Dans un Mémoire que nous avons publić en 1831, dans les Annales des $\boldsymbol{S}_{c}$. INat., nous avons insisté sur l'usage présumé de cette vésicule singulière, à laquelle nous avons proposé de donner le nom de vésicule copulatrice. Il est èvident que cette vésicule appartient aux organes femelles; et, trouvant la longueur de son col en proportion avec celle de la verge, nous avons pensé qu'elle avait pour usage de recevoir la liqueur fécondante, et de la conserver jusqu'au moment oú les œufs, passant devant son entrée, recevaient leur fécondation. Cette explication nous paraît aujourd'hui plus spécieuse que juste; car les oufs des mollusques, lorsqu'ils arrivent à ce point de l'ovaire oú s'insère le col de cette vésicule, sont revètus d'une enveloppe tes- tacée, quelquefois très dure, et probablement imperméable. Ce mode de fécondation ne pourrail d'ailleurs s'appliquer á ceux des Mollusques terrestres et fluviatiles qui sont vivipares, et dans l'ovaire. desquels les petits ont déjả un assez grand développement.Ils étaient donc fécondés avant de passer devant l'ouverture de la vésicule. On ne peut mettre en dorte, actuellement, l'usage de la glande à laquelle Cuvier a donné, dans les Mélices, le nom de testicule; car, dans les Ambrettes, le canal qui en sort, au lieu de se lier intimement á la matrice, en reste constamment séparé, et va se rendre directetement au sommet de la verge.

Il résulte des faits anatomiques que nous venons d'exposer, que le g. Ambrette se distingue nettement de celui des Hélices par la disposition des organes de la génération. Nous verrons plus tard qu'il différe aussi sous ce rapport des Bulimes et des Maillots.

C'est ainsi que se trouve justifié, par nos recherches anatomiques, un genre créé depuis long-temps par Draparnaud, et dont on avait plus d'une fois contesté la valeur zoologique.

Caractères génériques : - Animal gastéropode pulmobranche, ovale allongé, paucispiré, portant sur la tête deux paires de tentacules; les infér. très courts; les supérieurs oculés a u sommel; pied large, à bords minces; organes de la génération sans vésicule multifide, èt le canal déférent aboutissant au sommet de la verge. Dent linguale simple, taillée en croissant. (Les autres caractères organiques comme dans les Hélices.)

Coquille ovale, oblongue, très mince, transparente, à spire courte, ayant l'ouverture très grande, entière et ovalaire. Columelle simple, très mince, arquée dans sa longueur; bord droit, mince et tranchant, non réfléchi en dehors.

On ne connaît jusqu'ả présent qu'un petit nombre d'espéces de ce genre. Toutes vivent dans les lieux humides, au bord des ruisseaux ou des rivières, sur les plantes aquatiques dont elles se nourrissent; elles ne peuvent, comme les Hélices, vivre dansles lieux secs. L'animal ressemble beaucoup à celui des Hélices, et il a des mœurs analogues. Comme on le trouve toujours au bord de l'eau,on a pensé qu'il pouvait vivre aussi dans 
l'eau, d'où le nom d'Amphibie, sous lequel il a d'abord été connu. L'animal contracté remplit ordinairement sa coquille, mais il ne peut s'y enfoncer profondément comme le font la plupart des Hélices. Les espéces se distribuent aussibien dans les climats chauds que dans ceux qui sont tempérés. Parmi celles des pays chauds, on remarque particulierement la plus grande du genre, dont la forme singulière a déterminé Lamarck à proposer pour elle le g. Amphibulime, qu'il a depuis abandonné. M. de Férussac, dans son Histoire des Mollusques terrestres, croit que notre esp., commune dans presque toute l'Europe, se trouve de même en Afrique et dans presque toutes les îles de la Polynésie ; mais nous pensons que cette opinion a besoin d'un nouvel examen.

Les Ambrettes, connues aujourd'hui à l'état fossile, ne se rencontrent que dans les terrains les plus modernes, connus des géologues sous le nom de travertins. On en rencontre aussi dans les dépôts sableıx des bords du Rhin, auxquels les géoloğues allemands ont donné le nom de Loës. Ces espèces fossiles sont analogues à celles qui vivent encore en Europe.

(DESII.)

*AMBRINA, Spach.; Roubieva, Moq. (ambar, ris, ambre gris; allusion à l'odeur de ces végéta ux). вот. Pn. - G. de la famille des Chénopodées, voisin des Blitum, et offrant les caract. suivants (Spach, Suites à Buffor, Plant. phan., t. v, p. 295): Fleurs polygames-monoïques, non bractéolées. Cal. 5-parti; segments carénés, non appendiculés après la floraison. Étam. 5 , insérées au réceptacle; anth. didymes. Style nul ou trés court; stigmates 3 ou 4. Péricarpe membranacé, indéhiscent, un peu comprimé, obovale, recouvert par le calice devenu pentagone et crustacé; graine inadhérente, verticale, subréniforme, périspermée ; test crustacé ; embryon périphérique, à radicule descendante. - Herbes annuelles ou vivaces, pubescentes, parsemées de points résineux; feuilles sessiles ou subsessiles, alternes, pennatifides ou sinuées; fleurs glomérulées; glomérules sessiles aux aisselles, ou agrégés en épis soit aphylles, soit feuillés. - Ce g. est fondé sur le Cheropodium ambrosioides L. (vulgairement Thé ou Ambrosie du Mexique) et quelques esp. voisines, toutes indigènes d'Amérique. Ces T. 1 . plantes sont aromatiques, toniques et stimulantes.

ambirosia (áubpóocos, immortel; qui donne l'immortalité). Bот. PH. - Tournefort a appliqué ce nom à des plantes dont les feuilles réplandent, quand on les froisse, une odeur forte et agréable. Elles ont pour caract. de porter, sur le même individu, des capitules femelles placés à la base des épis composés de fleurs mâles; ceux-ci sont plurillores, à involucre formé d'une seule série d'écailles presque toutes réunies en une sorte de cupule; le réceptacle manque de paillettes; le tube de la corolle, qui est court, porte des étamines qui ne lui adhèrent point. Les capitules femelles sont 1-flores, agrégés, entourés par un involucre commun et munis de bractéoles; la corolle est nulle ; les rameaux du style allongés dépassent le col de l'involucelle. Le fruit ovale s'accroît dans cet involucelle qui persiste, s'enroule en dedans et se termine souvent par des sortes de dents ou de cornes résistantes. Les Ambrosia, herbes ou sous-arbrisseaux que l'on rencontre dans les 2 continents, sont munis de feuilles constamment opposćes à la base et alternes vers le sommet, pinnatifides, lobées ou entières. (J. D.)

AMBROSIACÉES. вот. P!. - Petite famille, proposée par Richard père, pour renfermer les g. Ambrosia, Xanthium, Franseria et Iva, qu'il regardait comme devant être séparés des Synanthérées. Mais Cassini, sous le mème nom, et M. De Candolle, sous celui d'Ambrosices, en font une tribu de cette grande famille, en en séparant toutefois le g. Iva, devenu le type d'une autre tribu. $V$. IvÉES.

(C. L.)

AMBROSIE DU MEXIQUE. BOT. PH.Nom vulgaire de l'Ambrina ambrosioides ou Chenopodium ambrosioides.

AVBROSIÉES (áu. вот. PH. - Les Ambrosiées sont des plantes appartenant à la famille des Composées; elles ont le caract. remarquable, pour la classe à laquelle elles appartiennent, d'offrir des fleurs constamment uni-sexuces ; les mâles ou les femelles portées sur des individus distincts (dioïques), ou, sur un mêrne pied, des capitules renfermant des fleurs de sexes différents (Ilétérocéphales), ou bien encore des capitules composés seulement de fleurs des 2 sexes. L'aigrette que surmonte le $22^{*}$ 
fruit n’est jamais formée de soies. L. C. Richard, en élablissant sa famille des Ambrosiacées, y comprenait les g. Ambrosia, Xanthium, Fronseria et Iva, qu'il avait cru devoir séparer des Corymbifères pour en former une famille distincte, réunie depuis par la généralité des botanistes et seulement comme tribu, à la famille d'oú Richard l'avait retirée.

(J. D.)

AMBRosines. Ambrosinia (Ambrosinus, frères, botanistes bolonais du xvıl me siècle). Bот. PII. - G. très singulier de la famille des Aroïdées, établi en 1763 par Bassi, directeur du jardin botanique de Bologne, et adopté par tous les autres botanistes. Ce g. forme, avec le Cryptocoryne de Fischer, une petite tribu, celle des Ambrosiniées. En voici les caract. : Fleurs unisexuées et nues, réunies dans une petite spathe roulè, presque close, terminée par une longue pointe à son sommet. Cettespathe est comme partagée en deux loges par le spadice, qui est plane et sous la forme d'une cloison membraneuse, adhérente des deux côtés avec la face interne de la spathe. L'une de ces loges, plus grande, contient, à sa base, une seule fleur femelle, qui est sessile, composée d'un ovaire globuleux et déprimé, à une seule loge contenant un très grand nombre d'ovules dressés, appliqués sur un large trophosperme saillant, occupant tout le fond de la loge. Le style est court, terminé par un stigmate discoïde, épais, un peu déprimé à son centre. Les étamines ou fleurs mâles sont placées dans l'autre compartiment. Elles sont au nombre de huit, disposées sur deux rangées longitudinales, appliquées sur un renflement particulier de la cloison. Chacune d'elles se compose d'une anthère à deux loges placées transversalement. Ces deux loges, qui souvrent par un sillon transversal, a cause de la position des anthères, mais réellement longitudinales, sont un peu écartées à leur base, mais confluentes et confondues à leur sommet. Le fruit est sec, et contient un grand nombre de graines striées.

Ce g. se compose d'une seule esp., l'Ambrosinia Bassii, qui croît en Calabre et en Sicile, oú j'ai eu occasion de l'observer vivante. C'est une petite plante vivace, à racine tubéreuse et charnue, de laquelle s'élèvent ordinairement deux feuilles longuement pétiolées, ovales et ondulées, entre lesquelles naît la hampe, qui se termine par la spathe.

(A. R.)

*ANBROSINHÉES. вот. Рн. - L'une des tribus établies par M. Schott (Melethemata, 19) dans la famille des Aroïdées, et qui se compose des deux g. Ambrosinia et Cryptocoryne. $V$. AROÏDÉES.

(A. R.)

*AITBULACRES. Ambulacra (Ambulacrum, allée d'arbres, galerie). zooL. - Dénomination imposée aux mamelons multisériés, d'où sortent, chez les oursins, les tentacules ou piquants qui leur servent d'organes préhenseurs ou locomoteurs. $V$. OurSIN.

(C. D’O.)

*AMBBULATORIA (Ambulatorius, ambulatoire). INs. - Nom donné par M. Westwood à une section de l'ordre des Orthoptères, en considération des pattes qui sont toutes ambulatoires. Cette section ne renferme que la famille des Phasmiens ou Phasmides de Latreille. $V$. ce mot.

(BL.)

AMBULIA. вот. PH. - G. fermé par Lamarck (Encyc.méthod.) sur une plante aquatique que les Indiens nomment Manganari, caractérisé par l'auteur seulement d'après un dessin et une description incomplète de Pheede (Malab. 10, p. 11, t. 6). Ce g. qu'il plaçait dans la Tétrádrie monogynie de Linné, a été passé sous silence par tous les auteurs systématiques.

*AMÉDÉE. Amedea (nom d'homme). Ins. - G. de l'ordre des Diptères, établi par M. Robineau-Desvoidy dans sa tribu des Entomobies, famille des Myodaires, et qu'il caractérise ainsi : $2^{\text {me }}$ art. antennaire presque de la longueur du $3^{\text {me }}$; chète tomentenx à la loupe; tous les caract. dı g. Macquartie, mais épistome saillant. - Ce g. n'est fondé que sur une seule esp. nommée par l'auteur $A$. scutellaris, et trouvée à La Rochelle par M. Amédée de St-Fargeau fils.

AMEIVA (Nom vulg. brésilien). REPT. G. de la famille des Lézards lacertiens ou autosaures, établi par Cuvier, et auquel MM. Duméril et Bibron 'Erpétologie ou Hist. nat. des Reptiles) assignent les caractères suivants : Langue à base engaînante, longue, divisée à son extrémité en deux filets grêles, lisses; à papilles squamiformes, rhomboïdales, imbriquées. Palais denté ou non denté. Dents intermaxillaires petites, coniques, simples. Dents maxillaires comprimées; 
les antérieures pointues, les suivantes tricuspides. Narines ovales, obliques, percées dans la seule naso-rostrale, ou dans celte plaque et la naso-frénale. Des paupières. Une membrane tympanale distincte, tendue un peu en dedans du trou de l'oreille. Sous le cou 2 ou 3 plis transversaux, non scutellés sur leurs bords. Plaques ventrales quadrangulaires, lisses, en quinconce. Des pores fémoraux; de grandes plaques élargies sous les jambes. Pattes terminées chacune par 5 doigts légèrement comprimés, non carénés en dessus; ceux de derrière ayant leur bord interne tuberculeux. Queue cyclo-tétragone.-Ces caractères distinguent suffisamment les Ameivas des Aporomères, des Saure-gardes, des Cęntropyx, des Cnémidophores, des Dicrodontes et des Acrantes. Comme un assez grand nombre de Mammiféres et d'Oiseaux, les Ameivas présentent, pendant leur jeune âge, une livrée consistant en un nombre variable de raies ou de bandes longitudinales qui s'oblitérent et disparaissent sur les individus adultes. Les esp. de ce g. de Reptiles, au nombre de 6 , recherchent pour la plupart les lieux arides, de préférence au voisinage des eaux. Elles vivent de vers, d'insectes, de petits mollusques terrestres et même d'herbes, et habitent les Antilles, le Brésil et la Guyane. (C. D’O.)

AMÉLANCHER, Médik.; Petromeles, Jacq. fils. вот. PI.-G. de la famille des Pomacées, ofrrant les caract. suivants (Spach, Suites à Buff., Plant. phan., II, p. 82): Tube calicinal semi-supère, turbiné; limbe à 5 lanières persistantes, redressées aprés la floraison. Pétales 5, dressés ou étalés, allongés. Ovaire adhérent, cotonneux au sommet, 5-loculaire ; loges 2-ovulées, incomplètement 2-loculaires par le renflement de la suture postérieure; styles 5 , libres ou plus ou moins soudés par la base. Piridion subquinquéloculaire, ombiliqué a u sommet; endocarpe cartilagineux. - Arbres ou arbrisseaux ; feuilles non persistantes, dentelées; fleurs blanches, disposées en grappes simples; pédicelles allongés; bractées lancéolées-subulées, scarieuses, laineuses, caduques de même que les stipules. - Ce g. appartient aux régions soit froides, soit tempérées de l'hémisphère septentrional; on en connaît cinq ou six espèces; elles se cultivent comme arbrisseaux d'orne- ment, et leurs fruits sont mangeables. (Sp.)

* AMELES (áusińs, négligent). Ins. Le docteur Burmeister applique ce nom a une div. du grand g. Mantis, dans laquelle il comprend 4 esp. dont le prothorax est court, n'ayant que la longueur du mésothorax et du métathorax réunis.

* AMELETIA, DC. (áuź̀ño;, négligé). вот. PH.-G. de la famille des Lythracées ou Lythrariées, tribu des Salicariées, Da., voisin des Peplis el des Ammannia. M. De Candolle (Prodr., 111, p. 76 ) en expose ainsi les caractères : Cal. campanulé-tubuleux, terminé en 4 lobes dressés, ovales, pointus, connivents, alternes, chacun avec une denticule. Cor. nulle. Étam. 4, insérèes au tube calicinal. Ovaire ovoïde; style filiforme; stigm. capitellé. Caps. finalement 1 loculaire, polysperme, 2-valve. - Herbe à feuilles opposées, très entières; épis axillaires, sessiles, bractéolés; fleurs petiies, 3-bractéolées à la base; l'une des braclées plus grande, inférieure. - Ce g. est fondé sur le Peplis indica Willd.; on ne connait que cette seule espece.

AMELT AOU. BоT. PI. - Nom vulgaire d'une variété d'Olivier dans le midi de la France. (C. D'O.)

* AMELLES. Amellece (Amellns, fleur chantée par Virgile). вот. PH. - Division de la s.-tribu des Astérinées, famille des Composées : établie pour quelques g. de plantes appartenant à ce groupe, et caractérisée par des capitules rayonnés hétérogames ou rarement dioïques, dont le réceptacle e:t dépourvu de paillettes.

AMLLLIÉ. вот. PH. - Nom vulgaire de l'Amandier dans le ci-devant Languedoc.

$$
\text { (C. D'O.) }
$$

* AMELLOTDES. Amelloida (Amellus [ $V$. ce mot]; घidos, forme). вот. Рн. - Subdivision des Amellées, établic par M. Lessing et à laquelle M. De Candolle a substitué le nom de Euamellées.

(J. D.)

AME⿺辶US (Nom employé par Virgile pour désigner une plante, qu'on croit appartenir á la famille des Composées). bo'T. Pr.-Cassini a réservé ce nom pour des plantes de la tribu des Astérées, qui ont pour caractères : Capitules multiflores, souvent hétérogames; fleurs du rayon ligulées, uni-sériées; femelles fertiles; celles du disque hermaphrodites, tubuleuses, 5- 
dentées, rarement homogames, discoïdes. Récept. subconique, couvert de paillettes réunies entre les fleurs. Invol. formé de plusieurs rangées d'écailles imbriquées, raides, acuminées, et dont les internes se changent peu à peu en paillettes. Fruits cunéiformes, comprimés; ceux du rayon subtétragones et scabres, ceux du disque lisses, denticulés au sommet; les $1^{\text {ers }}$ terminés par une aigrette 1-sériée, à pailletles courtes; les seconds, par une aigrette double, dont la série externe est semblable à celle des fruits du rayon, tandis que l'interne se compose de 4 soies raides. - Les Amellus sont des arbrisseaux ou des herbes originaires du Cap. Les feuilles infér. sont opposées, les supér. alternes, oblongues, très entières ou denticulées, blanchâtres ou couvertes de petits poils raides. Les pédoncules terminaux, mu-nis de squamules, portent un seul capitule, a rayon bleu et a disque jaune. On connaît aujourd'hui une douzaine d'esp. de ce g.; toutes originaires de l'Afrique australe.

*AMÉNIE. Amenia (9amcenus, charmant). ıss. - G. de l'ordre des Diptères, établi par M. Robineau-Desvoidy dans la tribu des Muscides, et auquel il donne pour caract. : Ant. distantes, ne descendant pas jusqu'a l'épistome. Front et face larges, bombés ; faciaux à peine ciliés; épistome un peu saillant; trompe en grande partiesolide; corps épais, subarrondi, à teintes d'un vert métallique, orné de points argentés; cellule ouverte avant le sommet de l'aile et ayant sa nervure transverse droite. - Ce g., très voisin des Chrysomyes du même auleur, ne renferme que 2 esp. qui sont, suivant lui, les plus belles muscides connues : ce sont les Musca leonina Fab., imperialis R.D., toutes deux de la Nouvelle-Hollande.

AMENTACEES. вот. Рн. - Un grand groupe de plantes ligneuses, à fieurs apétales et diclines, dont les mâles sonı réunies en chatons (Amenta), avait formé la famille ainsi nommée par Jussieu; mais, malgré leurs rapports évidents, elles ne présentaient en commun que les caract. précédents, et, du reste, beaucoup de. différences qu'on est accoutumé à considérer comme d'une valeur ordinale. Une $1^{\text {re }}$ section même s'en séparait par ses fleurs hermaphrodites et non amentacées; elle a dû en ètre éloignée et a formé la famille des Celtidées ou Ulmacées. ( $V$. ce mot.) Les autres $g$. ont été distribués en plusieurs familles distinctes et généralemen ladmises a ujourd'hui, d'après la considération de leur fruil libre ou adhérent, indéhiscent ou bivalve, 1-loculaire ou multiloculaire, à loges 1-spermes ou polyspermes; de leurs graines pendantes ou dressées; de leu: embryon muni ou plus rạrement dépourvu de périsperme, homotrope ou antitrope. D'une autre part, on a dû rapprocher de ces familles celle du noyer, dont l'inflorescence et les autres caract. indiquaient sa place plutôt là que parmi les Térébinthacées, ou il avail été primitivement classé. $V$. BALsamfluées, Bétulinées, Cupulifères, Juglandacées, Myricagées, Platanées, Salicinées.

(AD. J.)

*AMENTALES. BoT. PH. - Groupe ou alliance créée par M. Lindley pour les Amentacées à pistil formé par la réunion de 2 ou plusieurs carpelles. I! comprend les familles des Cupulifères ou Corylacées, des Bétulacées avec une nouvelle qu'il élablit sous le nom de SCÉPACÉEs.

(AD. J.)

* AMERHINUS ("̋uń, faucille; ṕiv, vós, nez; $V$.Amerhis ). ins.-G. de Coléoptères tétramères, famille des Curculionites, div. des Cholides, établi par Sahlberg et adopté par Schœnherr, qui le caractérise ainsi : Ant. médiocres, presque minces; funicule de 7 articles; les deux $1^{\text {ers }}$ presque obconiques; le $1^{\mathrm{er}}$ plus long, les autres courls, tronqués au sommet, s'élargissant peu ả peu jusqu'au dernier, qui est séparé de la massue; celle-ci oblongue, ovale, pointue. Rostre de longueur moyenne, infléchi, robuste, cylindrique, médiocrement arqué. Yeux ovales, pen saillants. Prothorax transverse, légèrement bisinué à la base, arrondi sur les côtés, très rétréci antérieurement, convexe en dessus. Écusson oblong, un peu saillant. Élytres allongées, subcylindriques, très convexes, un peu étroites postéricurement, impressionnées transversalement à la base, avec leur extrémité obtuse el arrondie. Pattes fortes; cuisses renflées, dentées; jambes comprimées, un peu arquées; tarses élargis, spongieux en dessous. - Ce g. a pour type une esp. du Brésil, décrite et figurée par Kirby sous le nom de Rhynchcenus Durresnii (Trans. Soc. Linn. de Londres, tom. xı, p. 433 , no 73 , tab. 12, fig. 10). Il répond à celui 
d'Amerhis de Germar, adopté par M. Dejean (Catal., $3^{\text {me }} e ́ d i l$. ), qui en mentionne 6 esp., toutes dı Brésil.

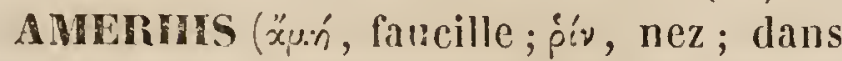
ce g. le rostre a la forme d'une aucille). uxs. -G. de l'ordre des Coléoptères tétramères, famille des Curculionitcs, établi par Germar, dont le nom avait été d'abord adopté par Schœnherr, qui, dans sa Monographie de celte famille, l'a remplacé par celui d' $A$ merlinus de Sahlberg, comme étant sans doute plus ancien. rependant M. Dcjean n'a pas adopté ce changement (Catal., $3^{\text {me }} e ́ d i t$.); il a conservé le nom d'Amerhis, et cité celui d'Anerhinus comme synonyme. $V$. ce dernier mot.

*AMÉRIGAINES. Americano. arachn.Ce nom est employé par M. Walckenaer pour désigner plusieurs petites divisions dans le g. Aluıs. $V$. ce mot.

AMERIMNUM, P. Brown (ávepusys, qui ne cause pas de souci; c'est-à-dire innocent). вот. PI. - Genre de la famille des Légumineuses; sous-ordre des Papilionacées, tribı des Dalbergiées, Brown. M. Kunth (Humb. et Bonpl. Nov. Cen. et Spec., vol. 6, p. 399) lui assigne les caract. suivants : Cal. campanulé, bilabié ; lèvre supér. bilobée; lèvre infér. trilobée. ả lobe moyen plus long et concave. Cor. papilionacée. Etendard trés étalé. Étam. 10, monarlelphes; gaîne fendue en dessus; anthères suborbiculaires, didymes, continnes an filet. Oraire stipité, subquadri-ovulé. Stigm. obtus. Légume stipité, lancéolé, oblong, comprimé, acuminé aux 2 bouts, uni-loculaire, 1-4-sperme, bivalve. Graines apérispermées; radicule courbée. - Arbrisseaux. Feuilles simples; pétiole articulé. Grappes solitaires ou fasciculées, axillaires ou latérales. Pédicelles uni-bractéolés à la base, bi-bractéolés au sommet. Fleurs blanches, uni-latérales.' Ce g., dont on connaît 2 esp., appartient à l'Amérique équatoriale. A l'exemple de Swartz, plusieurs auteurs y réanissent le g. Brya.

AMERIS. INs. $V$. AMERHS.

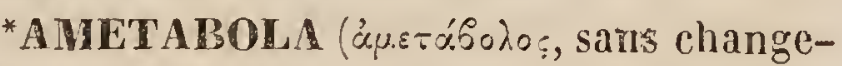
ment; sans métamorphose). Ixs. - Dénomination donnée par Leach et adoplée par quelques entomol., entr'au tres par le docteur Burmeister, qui tous comprennent par là les Insectes qui ne subissent pas de métamorphose complète, mais seulement des changements de peau successifs; tels sont les Hémiptères, a uxquels Burmeister réunit encore une partie des insectes parasites; les Orthoptères, auxquels le même aıteur joint l'autre partie de ces mèmes Insectes; et, enfin, les Névroptères; ces derniers, ont, depuis, reçu le nom d'HEMMETABOLA. (BL.)

AWETANORPHOSES ( $\%$ priv.; $\mu \varepsilon \tau \alpha-$

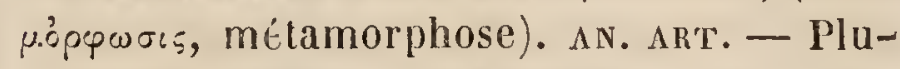
sieurs zoologistes comprennent sous cette dénomination les animaux articulés qui ne subissent point de métamorphoses, tels que les Crustacés, les Arachnides, etc. (Br.)

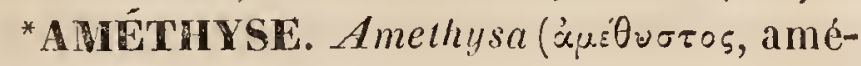
thyste; allusion a la couleur de l'insecte). INS. - G. de l'ordre des Diptères, div. des Brachocères, subdiv. des Dichœtes, famille des Athéricères, tribu des Muscides, section des Acalyptères, sous-tribu des Ortalidées, établi par M. Macquart et ayant pour caract. : Face plane; épistome saillant ; $3^{\mathrm{e}}$ article des antennes oblong, peu allongé; yeux arrondis; fre cellule postér. des ailes un peu rétrécie à l'extrémité. Ce g. ne contient qu'une seule esp., l' $A$. fasciata, qui se trouve au Cap de Bonne-Espérance. (D.)

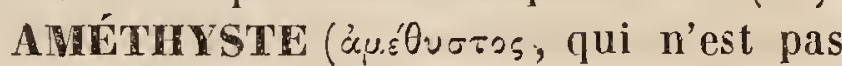
ivre). Mr. - Les anciens donnaient ce nom à certaines pierres, dans lesquelles le rouge du vin ne se montrait que faiblement, étant tempéré par un mélange de violet. Dans le langage vulgaire, il désigne aujourd'hui la variété violelle de Quartz Ityalin, quand il est employé seul, et le Corindon violet, quand on y joint l'épithète d'orientale. L'Améthyste ordinaire est assez estimée dans le commerce, lorsqu'elle est d'une belle couleur; mais il est rare que la teinte violette s'étende uniformément dans la pierre. Elle se distingue aisément de l'A méthyste orientale, qui est une variété de Corindon, par sa dureté el sa densité qui sont beaucoup plus faibles.

(DEL.)

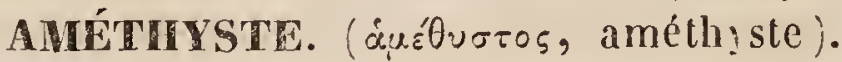
zooL. - Esp. du genre Oiseau-mouche. On a également donné ce nom à un Serpent dug. Python. $V$.ce mot. (C. n'O.)

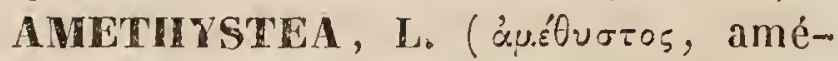
thysle; allusion a la coulcur). вот. рн. - G. de la famille des Labićes, tribu des Ajugoïdées de Bentham. Cet auteur (Monogr. Labiat. p. 657 ) en donne les caract. suivants: 
Cal. subglobuleux, campanulé, dressé, à 5 dents égales. Cor. à tube plus court que le calice; limbe décliné, à 4 lobes supér. courts, presque égaux, et à un $5^{\text {me }}$ plus grand, infér. Étam. 4 : les 2 supér. rudimentaires, filiformes; les 2 infér. ascendantes, saillantes entre les 2 lobes supér. de la corolle; anth. à 2 bourses presque confluentes et fimalement divariquées. Style divisé au sommet en 2 courtes branches presque isomètres. Nucules réticulées. - Herbe annuelle, rameuse, glabre; feuilles pétiolées, $3-$ ou 5 -parties : les florales plus petites ; les dernières minimes; cymes pédonculées, lâches, paniculées, garnies de bractées minimes; cal. bleuâtre; cor. bleue. $-\mathrm{L} \mathcal{A}$. corrulea L., est la seule esp. connue; cette plante, commune dans toute l'Asie moyenne, se cultive dans les parterres.

(Sp.)

* AMUILISTIL. Amherstia, Wall. (Lord Amherst, ambassadeur en Chine). вот. PH. -G. de la famille des Légumineuses, s.-ordre des Césalpiniées, tribu des Geofrroyées, DC. - Wallich (Plant. Asiat. vol. 1, p. 1) expose ainsi les caractères de ce genre : Cal. dibractéolé, coloré; tube long, cylindrique; limbe 4-parti, á lobes étalés. Pétales 5 , inćgaux : les 2 infér. petits, subulés; les 2 latéraux cunéiformes, divariqués; le supér. très grand, redressé, obcordiforme, onguiculé. Étam. 10, toutes fertiles, insérées à la gorge du calice : l'un des filets libre; les 9 autres soudés inférieurement en gaine, alternativement très longs et très courts. Ovaire stipité, falciforme, 4-6-ovulé; stipe adné au tube calicinal; style filiforme; stigm. petit, convexe. Légume stipité, plan, oblong, oligosperme, acuminé. - L'unique esp. de ce g. est l'une des plus magnifiques productions végétales que l'on connaisse; c'est un arbre trouvé par Wallich dans le pays des Birmans. L'inflorescence forme des grappes axillaires, pyramidales, pendantes, et atteignant jusqu'à 3 pieds de longueur, sur 1 pied $1 / 2$ de diamétre a la base. Chaque fleur est de la longuedr de la main, sur 2 poures de large; les pédoncules, les bractées, les calices et les pétales, sont colorés de l'écarlate le plus brillant. Le nom birman de cet arbre est Thoka.

AMIA. polss. - $V$. AnIE.

AMIANTE (ápíavos, qui n'est pas altéré par le feu; Amiante). mIN. - Variété, en filaments flexibles, des minéraux fibreux qu'on désigne plus généralement sous le nom d'Asbestes, et qui peut servir à fabriquer des tissus incombustibles. $V$. Asbeste. (Del.)

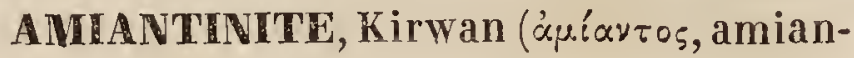
te). Mrn. - Variété de l'Actinote fibreuse. $V$. АмpHibole.

(DEL.)

AMMANTOIDE (áíavros, Amiante). MIN. -Nommée aussi Byssolite, Asbestoüde. Substance minérale, en filaments déliés, bruns ou verdâtres, qui ne diffère de l'Asbeste flexible que par la raideur et l'élasticité de ses fibres, et qui n'est, d'après l'analyse que Vauquelin en a faite, qu'une variété capillaire d'Actinote ferro-manganésifére. On la trouve au Mont-Blanc et dans les Alpes du Dauphiné, sur le Jiorite qui sert de gangue à l'Épidote, à l'Asbeste, à la Prehnite, elc.

(DEL.)

AHIATTE, Santi. mun.-Variélé de Silex résinite concrétionné, d'un blanc opaque, qu'on trouve au mont Amiata en Toscane. $V$. Quartz.

(Der.)

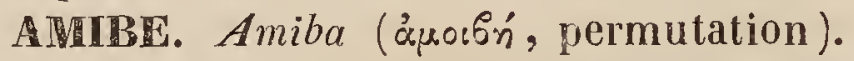
INF. - G. établi par M. Bory de St-Vincent pour le Proteus diffluens de Muller et pour d'auires esp. qu'il est fort difficile de caractériser; car la forme, qui, pour les autres animaux, fournit le caract. le plus essentiel, est ici d'une instabilité qu'exprime parfaitement le nom de Protée; et comme d'ailleurs il n'est pas possible d'y distinguer des organes quelconques de nutrition ou de reproduction, on est réduit à dire que les Amibes sont des infusoires, consistant en une masse de substance charnue, glutineuse, vivante, changeant de forme à chaque instant par la protension et la rétraction d'une partie plus ou moins considérable d'elle-même. Les Amibes sont transparentes; mais elles sont souvent colorées en rougeâtre ou en vert par des particules qu'elles ont enveloppées dans leur masse, de même qu'elles enveloppent aussi des Navicules et des Bacillaires, sans qu'on puisse dire que ces objets aient été véritablement avalés. Les prolongements qu'elles émettent dans diverses directions sont plus ou moins longs, plus ou moins effilés et souvent rameux. Les unes sont arrondies et semblent glisser comme une groutte d'huile sur le porie-objet du microscope; les autres présentent un contour 
irrégulièrement déchiré, ou bien la fórme d'un globule hérissé de pointes effilées, et roulent dans le liquide comme des chattaignes. Losana de Turin, se fondant sur ces différences de forme, en a décrit un grand nombre comme esp. différentes, suivant que leur contour se rapprochait de celui d'une fleur, d'une étoile, etc.

Les Amibes se produisent dans les eaux stagnantes, au milieu des détritus formant une couche vaseuse à la surface des herbes et des pierres. Elles se forment aussi dans les sédiments des vieilles infusions végétales, et dans les pellicules qui recouvrent au bout de quelques jours les infusions animales ou végétales.

On ne peut assurément regarder toutes ces Amibes comme une seule esp.; mais tant qu'on n'aura pas constaté leur mode de production, on ne pourra même pas les distinguer par leur habitation ou par la nature des infusions oú elles se développent. (DUJ.)

*AMICIE. Amicia, Kunth; Turpinia, Pers. nec alior. (Dédié à M. Amici, célébre physicien italien). вот. PII. - G. de la famille des Légumineuses, sous-ordre des Papilionacées, tribu des Hédysarées, DC. - Ce g. est trés voisin des Poiretia, dont il paraît ne différer que par un calice bilabié. On en connaît 2 esp., qui sont indigènes dans l'Amérique équatoriale.

* AMICTE. Amictus ( äuixros, pur). Ins. - G. de l'ordre des Diptères, div. des Brachocères, subdiv. des Tétrachotes, famille des Tanystomes, tribu des Bombyliers, établi par Wiedemann aux dépens du g. Bombylius de Fabricius et adopté par Latreille et par M. Macquart. Il a pour caract. : Tête de la largeur du thorax; trompe plus ou moins allongée; $1^{\mathrm{er}}$ article des ant. long, cylindrique; le $3^{\text {me }}$ subulé, à peine de la longueur du premier. Abdomen oblong. Des 2 esp. rapportées à ce g. par M. Macquart, l'une, A. oblongus, se tronve dans le nord de l'Afrique; l'autre, $A$. heteropterus, habite le Cap de Bonne-Espérance.

AMIDON (Corrupt. d'äpur sans meule). вот. - $V$. FÉcule amy acéE.

$$
\text { (A. R.) }
$$

AMIDON, Amylum (corruption d'čp. guidon, farine naturelle). cin . - On appelle Amidon une substance grenue, blanche et brillante qu'on rencontre dans un grand nombre de végétaux, par exemple dans les tubercules de la pomme de terre, les graines des céréales, la moelle du Sagouier et les liges de diverses plantes, etc.

La forme des grains d'Amidon est le plus souvent arrondie; elle est polyédrique quand ces grains sont très serrés dans leurs cellules végétales. Leur grosseur varie beaucoup : ainsi les grains de l'amidon de la pomme de terre dite de Pohan sont une fois et demie plus considérables que ceux de la fève, el dix fois plus que ceux du Chenopodium quinoa. L'amidon, vu au microscope, paraît formé de couches concentriques d'une substance homogéne dans sa composition et ses proprićtés; sauf de légères différences dans la cohésion. Tel qu'on le rencontre dans le commerce, il contient une proportion d'eau assez considérable qu'on peut lui enlever par la dessiccation. D'un autre côté, il est susceptible d'en absorber une quantité beaucoup plus grande et qui s'élève jusqu'à la moitié de son poids. Enfin, l'amidon chanffé dans l'eau subit un gonflement si considérable, qu'il prend l'aspect d'une masse gélatineuse, connue sous le nom d'empois. L'amidon converti en empois occupe plus de 30 fois son volume ordinaire. M. Payen a démontré d'une maniẻre très ingénieuse, en faisant plonger dans de l'empois délayé les radicelles d'une plante (de la jacinthe par exemple), que, dans ce cas, l'amidon n'est pas en dissolution, et que l'eau est absorbée et l'amidon se précipite. L'addition d'une faible proportion de soude $(0,02$ du poids de la liqueur) produit le même effet que l'augmentation de la température. C'est une condition de succès dans la préparation de l'empois que l'élévation brusque de la température. Ainsi 10 grammes d'amidon, chauffés rapidement à 100 degrés dans 200 gr. d'eau, ont donné un empois identique à celui que fournissaient $14 \mathrm{gr}$. d'amidon portés lentement à la même température dans la même quantité d'eau. Le froid produit un effet inverse de celui de la chaleur; ainsi l'empois exposé à une forte gelée laisse déposer, lors du dégel, la plus grande partie de l'amidon. Une des propriétés les plus intéressantes de l'amidon est sa coloration en bleu par l'iode. Ce caractère découvert par MM. Colin et Gaultier de Claubry est encore aujourd'hui le meilleur pour reconnaître l'a- 
midon. Le produit bleu qui se forme dans ce cas est connu sous le nom d'iodure d'amidon. Cette couleur bleue est très fugace et n'est pas employée ; ce n'est pas elle qui colore l'empois du commerce: la teinte blene qu'il présente souvent est dıe à une petite quantité d'azur. L'amidon, lorsqu'il a subi l'action d'une température convenable, n'est plus bleui, mais rougi par une dissoiution d'iode. L'amidon, dans ce cas, ne perd que de l'eau et devient trés facilement soluble : il peut dans uı très grand nombre de cas remplacer la gomme.

La réaction de l'acide sulfurique sur l'amidon est des plus remarquables. Elle a été découverte par Kirchofr. Il résulte des expériences de ce chimiste, que l'acide sulfurique trèsétendu convertit l'amidon, d'abord en une matière gommeuse soluble dans l'eau, et finalementen un sucre identique, pour les propriétés et la composition, avec le sucre de raisin. Celte propriété de l'acide sulfurique paraît, du reste, partagée par les autres acides. Ce sucre se prépare maintenant en quantité considérable ( $V$. Sucre).

L'Orge germée possède, comme les autres acides, la propriété de convertir la fécule en matière gommeuse et en sucre de raisin. La matière gommeuse qui se forme est la $d r x-$ trine. Cette propriélé de l'orge germée est due à une substance blanche, amorphe, soluble dans l'eau, insoluble dans l'alcool, isolée par MM. Payen et Persoz. Cette matière contient d'autant moins d'azole, qu'elle est mieux purifiée. Elle a reçu le nom de Diastase. La Diastase peut mettre en dissolution 2,000 fois son poids de fécule dans 4 fois le poids de celle-ci, la température étant maintenue entre 65 et $75^{\circ}$. M. Dubrunfaut emploie la liqueur sucrée provenant de l'action de l'Orge germée sur l'amidon, pour faire de la bière économique.

L'acide nitrique concentré, qu'on prépare en distillant 500 parties de salpêtre avec 460 d'acide sulfurique concentré, agit sur l'amidon d'une manière très remarquable. A la température ordinaire, il le dissout en quelques heures. La dissolution limpide est précipitée par l'eau, et le précipité, entièrement insoluble, peut être considéré comme formé des éléments de l'acide nitrique unis à ceux de l'amidon. M. Braconnot, qui a obtenu cette substance, l'a appelée Xyloüdine; c'est à M. Pelouze qu'est due la connaissance de ses propriétés principales et de sa composition. La xyloîdine est soluble dans l'alcool, incristallisable. Chauffée á l'air, elle prend feu à la température de $180^{\circ}$, et brûle sans résidu. Elle est soluble dans iacide nitrique concentré; l'eau peut la précipiter de sa dissolution, pourvu toutefois qu'on ne tarde pas trop, car elle cesse au bout d'un certain temps d'être précipitable. En effet, elle se décompose peu à peu, et se convertit en une substance acide incristallisable, qui se transforme par la chaleur en un acide noir susceptible de se régénérer par l'acide nitrique ou l'acide primitif. Cet acide déliquescent, qu'on obtient par la réaction de l'acide nitrique sur l'amidon, paraît être identique avec l'acide oxalhydriqué ou saccharique.

Le papier, le coton, le chanvre qu'on trempe dans l'acide nitrique concentré et qu'on lave en grande eau après un contact suffisamment prolongé, présentent toutes les propriétés de la xyloïdine. Le papier sans colle, le plus faible, acquiert la force du par'hemin et devient éminemment combustible.

Extraction de l'amidon. - On extrail l'amidon du blé, de la pomme de terre, etc. Pour cela, on ígruge le blé, on le met dans de grandes cuves avec de l'eau à laquelle on ajoute une certaine quantité d'eau sure provenant d'une opération précédente; la masse entre en fermentation, et le gluten est en partie dissous, en partie déromposé. Au bout de 12 a 15 jours, on décante la liqueur acide; on verse de l'eau fraîche sur le précipité; on décante de nouveau, dès que la masse s'est déposée; on jette ensuite celleci sur un tamis qui en retient les parties les plus grossières. Lorsque l'amidon s'est de nouveau déposé, que l'eau s'est écuulée, le son fin qui a passé à travers le tamis reste á la surface de l'amidon dont on le sépare. On délaie le résidu dans l'eau, on le passe au tamis de soie fin, qui retient le restant du son et ne laisse passer que l'amidon. Ordinairement on le moule quand il est encore humide.-Pour extraire l'amidon des pommes de terre, on râpe les tubercules, on les place sur un tamis, on verse de l'eau dessus; celle-ci devient laiteuse et laisse déposer de l'amidon. On décante; on lave 
plusieurs fois le dépôt et on le síche. De toutes les pommes de terre, la plus riche en amidon est celle dite grosse jumne, puis vient le sehaw d'écorce.

En séchant l'amidon encore humide à une température qui s'élève à $60^{\circ}$, il forme avec l'eau qu'il retient, une gelée demi-transparente qui reste translucide lorsqu'on la dessèche. C'est ainsi qu'on prépare le sagou, avec l'amidon qu'on extrail de la moelle d'une espèce de palmier.

On pensait que les pommes de terre gelées contenaient quelques centièmes de moins d'amidon qu'avant leur altération, et qu'elles en perdaient les $3 / 4$ par le dégel; mais M. Payen a reconnu dans ces derniers temps, que ces pommes de terre contenaient tout aulant de fécule aprés le dégel qu'avant la gelée; seulement les cellules désagrégées par la gelée échappent à la râpe et se séparent saus être déchirées.

Les usages de l'amidon sont trìs nombreux et très variés; c'est une des substances alimentaires les plus importantes; il sert á la préparation de l'empois et de la colle de pâte.

L'amidon gelé peut donner un excellent papier. La dextrine remplace la gomme dans une foule d'usages, et souvent lui est préférée $(V$. ce mot). Le sucre d'amidon sert à préparer des sirops, à faire la bière, à corriger les vins, etc. $V$. Sucre. (Barreswil.)

AMIE. Amia ( A' $\mu^{\prime}{ }^{\prime} \alpha$, nom de la Pélamide chez les Grecs). Polss. - Le G. de Poissons que les anciens ont désigné sous ce nom est du petit nombre de ceux que les Ichthyologistes modernes peuvent reconnaître, et cependant Pondelel seul l'a appliqué exactement à l'esp. qu'Aristote, entre autres, avait caractérisée par plusieurs traits zoologiques et anatomiques tels qu'on ne pouvait s'y tromper. Cetảuía est le S'comber Pelamys des auteurs modernes, ou Pelamys sarda de notre grande ichthyologie.

Salviani a mal appliqué le nom d'Ápía à un poisson a petites dents en velours, et bien différent, sous tous les rapports, de la vraie Pélamide. Cependant, son erreur perpétuée a donné lieu à une confusior presque inconcevable de synonymie, que nous avons débrouillée dans l'Histoire générale des Poissons (t. vin, p. 340 et fig.).

Il est assez difficile de concevoir par quelle absence de recherches el de criliques, Linné T. 1 . a ensuite appliqué le nom d'Amia à un poisson des eaux douces de l'Amérique seplentrionale, que Garden lui faisail connaitre. Le g. une fois élabli sous celle délermination, a dû conserver ce nom. Il renferme des Poissons à tête bombée, couverte d'os durs, granulés el comme nus ; les écailles du corps sont grandes; la bonche est peu fendue; les mâchoires sont armées de dents en pelits pavés et de quelques dents coniques el pointues; la dorsale est longue et commence entre l'insertion des ventrales et des peclorales; l'anale est très courte, la caudale arrọndie; la membrane branchiostège a douze rayons; les $1^{\text {res }}$ pièces de l'hyoüde for.ment, sous la gorge, entre les branches de la mâchoire, 2 grandes plaques que Linné désignail sous le nom de petits boucliers.

L'ouverture de la narine porte un pelit appendice charnu et simulant une sorte de barbillon. L'estomac est grand et charnu ; l'intestin large et fort, sans cœcums; la vessie natatoire grande et celluleuse comme le poumon d'un reptile; disposition anatomique propre à plusieurs Poissons de celle famille, sans que son organisation donne la moindre preuve que cet organe serve à sa respiration.

Linné n'en connaissail qu'une esp., des eaux douces de la Caroline, dont Garden lui envoya la description sous le nom de $M u d$ fish (poisson de vase), nom qui est appliqué, dans les États-Unis, à plusieurs autres esp. c'est l'Amia calva. Le g. AnrA, établi dans la $x_{11}{ }^{\mathrm{e}}$ édition du S'ystema naura, a été conservé par les auteurs; seulement Bloch, en l'adoptant, d'après Linné, l'a gâté en y introduisant une $2^{\mathrm{e}}$ esp. (A.immaculata), prise de Parra, el qui est un poisson d'un tout autre g., voisin des Butyrins. Bloch aurail dû cependant éviter cette erreur; car il avait étudié l'Amia calva sur l'individu conservé dans le cabinet du roi, qui a servi d'original à sa figure, ainsi qu'à celle publiée en 1788 par Bonnaterre dans l'Encyclopédie. M.Lesueur a vu l'Amia calva en grande abondance dans les aflluerits de l'Ohio, el surtou? à New-Harmony. Avec cetle esp., il en a observé deux ou trois autres qu'il n'a pas décrites, el qui sont nouvelles en ichthyologie.

M. Gédéon Mantell a donné, dans la géologie du comté de Sussex, un poisson fossile 
de la craie, comme appartenant avec doute au g. Amia, et il a nommé l'esp. A. lewicensis.

(VAL.)

AMIMONa. Amimonus. Molc. - Montfort (Conchyl.Syst.p. 326) a placé sous ce nom, parmi les Céphalopodes, un corps fossile, copié dans Knorr. (Supp.pl. Iv. $f .2)$ et dont il a formé un $g$. Nous n'avons pas la certitude que ce soit un mollusque. Cette coupe ne doit pas être conservée. (A. D’O.)

* AMINA. Ins. - G. de Diptères, famille des Myodaires, tribu des Scatophagines, établi par M. Robineau-Desvoidy pour y placer une seule esp. trouvée par lui dans les environs de Paris, et qu'il nomme $A$. parisiensis. Ce g. ne différe des Scatophages que par le chète absolument nu, le $3^{\text {me }}$ art. antennaire un peu plus long et les pattes plus allongées.

* AMINTE. Aminta. ins. - G. de l'ordre des Diptères, établi par M. Robineau-Desvoidy dans sa famille des Myodaires, tribu ales Anthomydes, et auquel il assigne pour caract. distinctifs des Fannies, dont il se rapproche d'ailleurs : Le chète tomenteux à la loupe; son $2^{\text {me }}$ article courtdans les mâles et plus long dans les femelles; les tibias intermédiaires des mâles ni échancrés ni dilatés; le corps un peu moins allongé. - Il y rapporte 5 esp., dont nous ne citerons qu'une seule, celle qu'il nomme A. floralis, et qui n'est pas rare sur les fleurs des Ombelliféres. Les larves de ces insectes vivent dans les débris des végétaux. (D.)

AIIRAL (en arabe, Amir ou Emir, chef.) BoLL. - On donne vulgairement ce nom à une belle esp. du g. Cône, à laquelle Linné a consacré le nom de Conus amiralis. Cette esp., recherchéc par sa beauté et le grand nombre de ses variẻtés, n'est pas la seule à laquelle les amateurs de coquilles donnent le nom d'Amiral. C'est ainsi que le Conus acuminatus a été nommé l'Amiral-Rumphius; le Conus aurantiacus, l'Amiral d'Orange; le Conus dux, l'Amiral de Hollande; le Conus yenuanus, l'A miral de Guinée; le Conus granulatus, l'Amiral d'Angleterre; le Comus malacanus, l'Amiral portugais; le Conus Maldivus, l'Amiral espagnol; le Conus miles, le faux Amiral; le Comus omaïcus, l'Amiral l'Oma; le Conus siannensis, l'Amiral chinois. Le Cône cedo-nulli recoit quelquefois des marchands le nom d'Amiral de
Curaçao, d'Amiral de la Trinité. (Desir.) AMIROLA, Pers. bot. Pif. - Syn. du g. Llagunoa, R. et Pav., de la famille des Sapindacées (Cambessèdes, Monogr.Sapind.).

* AMISALLUS. ins. - G. de Coléoptères tétramẻres, famille des Curculionites, div. des Brachycérides, établi par Schœnherr, qui lui donne les caract. suivants : Ant. médiocres, peu fortes, ayant leur scapus très épais au sommet; les deux $1^{\text {ers }}$ articles de leur funicule allongés, obconiques; les autres courts, subturbinés, égaux, avec la massue ovale. Rostre à peine plus court que le thorax, fortement épaissi vers le sommet, arqué en dessus, anguleux. Yeux oblongs, ovales, un peu déprimés. Thorax subtransverse, largement échancré antérieurement, lobé derrière les yeux. Écusson nul. Élytres en ovale allongé, avec les épaules arrondies, convexes en-dessus, déclivées postérieurement; leurs pointes réunies et obtuses. Ce g. a pour type l' $A$. tuberosus de la Nouvelle-Hollande, communiqué à l'auteur par M. Hope.

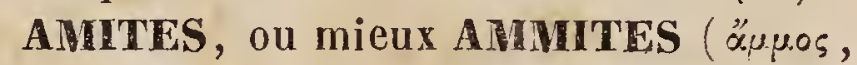
sable). Min.- On a donné ce nom à de petits corps ronảs, de nature calcaire, semblables à des graines de Millet, et qui ne sont probablement que des Oolithes ou concrétions globuleuses a couches concentriques. $V$. Oolitires. - M. De France croit que l'on a aussi confondu sous ce nom les Miliolithes, qui sont des corps organisés fossiles. (DEL.)

* AMITRUS ("丷u:троs, sans bandeau). INS. - G. de Coléoptères tétramères, famille des Curculionites, div. des Brachydérides, établi par M. Schœnherr, qui lui donne les caract. suivants : Ant. médiocres, peu fortes, légèrement poilues; leur scapus atteignant les yeux et s'épaississant peu à peu extérieurement; les deux $1^{\text {ers }}$ articles de leur funicule assez longs, obconiques; les autres courts, turbinés, avec la massue ovalaire et terminée en pointe. Tête large, convexe postérieurement. Rostre court, large, plan en dessus. Yeux ronds, peu convexes. Thorax tronqué à la base et au sommet, s'élargissant en rond des deux côtés. Métathorax distinct, nu. Écusson petit, triangulaire. Élytres en ovale allongé, ayant leurs pointes réunies et obtuses, et leurs épaules arrondies. L'auteur ne rapporte à ce g. qu'une 
seule esp., l' $A$. alutaceus d'Erichson, quí est du Pérou.

AMMANNIA, (J. L. Ammann, auteur d'un Traité sur les Plantes de la Russie). вот. PII. - G. de la famille des Lythrariées, tribu des Salicariẻes. M. De Candolle (Prodr., v. ill, n. 77) en donne les caract. suivants : Cal. campanulé, persistant, 4-7-denté; dents dressées, planes, alternant chacune avec un appendice corniculé, étalé. Pétales tantôt nuls, tantòt en même nombre que les dents calicinales. Étam. en nombre soit moindre, soit égal à celui des dents calicinales. Caps. ovale-globuleuse, membranacée, 4-loculaire; graines nombreuses, attachées à un réceptacle central 4-angulaire. - Herbes aquatiques, glabres; tige souvent tétragone, feuilles opposées, très entiẻres; fleurs axillaires, sessiles ou courtement pédicellées, petites. Ce g. appartient à la zồne équatoriale. On en énumère environ 40 espèces.

* AMMANNIOIDES, DG. (J. Ammann. $V$. ci-dessus). вот. pII. - G. ou s.-g. de la famille des Ly thrariées, réuni, par la plupart des auteurs, aux Lythrum, dont il differe par des fleurs 4-6-andres, et par un calice semblable à celui des Ammannia.

AMMAPTENODYTES. OIS. - $V$. AMMOPTÉNODYTES. (C. D'O.)

* AMMATOCERA (l'auteur aurait dù

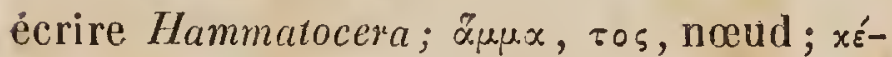
pxs, corne). ixs. - G. de Coléoptères tétramères, famille des Longicornes, établi par M. Chevrolat, et correspondant au Platyarthron de M. Dejean. $V^{*}$. ce mot.

AMMI, Tourn. ("̋us, nom grec d'une plante indéterminée; peut-être le Cumin?). BoT. PII. - G. de la famille des Ombelliféres, tribu des Amminées, DC.-Koch (Umbell., p. 122) lui assigne les caract. suivants : Limbe calicinal inapparent. Pétales obovales, bilobés au sommet et terminés en appendice infléchi ; lobes inégaux. Péricarpe ovale-oblong, comprimé des còtés. Méricarpes à 5 còtes filiformes, égales; les latérales marginales; vallécules à 1 bandelette ; carpophore libre, bi-parti; graine semi-cylindrique; commissure plane. - Herbes ayant le port des Daucus; racine fusiforme; feuilles pennées ou multi-parties; ombelles composées, multiradiées; collerettes polyphylles; la collerette générale à folioles.trifides ou pennatifides.
Fleurs blanches : celles des rayons marginaux souvent plus grandes que les autres. - M. De Candolle (Prodr., v. Iv, p. 112) énumère 12 esp. de ce g.; la plupart habitent la région méditerranéenne.

(SP.)

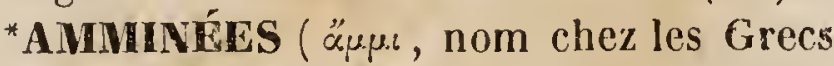
d'une plante arjourd'hui incertaine). вот. PH. - M. Koch donne ce nom à une tribu des Ombellifères, à laquelle il assigne pous: caract. : Péricarpe comprimé bi-latėalement, en général didyme. Méricarpes à 5 còtes filiformes, égales : les latérales marginales. Graine cylindrique, ou plane-convexe; périsperme non involuté. Inflorescence en ombelles composées.-M.Tausch ne considère les Amminées que comme une sect. de sa tribu des Pleurospermées.

AMMITES. MiN. - $V$. AMites.

(Sr.)

AMMOB̉ATE. Ammobates (áruocórns, qui marche sur le sable). Ins. - G. de la famille des Mellifẻres, de l'ordre des Hyménoptères, section des Porte-Aiguillon, établi par Latreille (Gen. Crust. et Ins.) qui en a tiré les principaux caractères : $1^{\circ}$ de l'ensemble du corps, généralement glabre ; $2^{\circ} \mathrm{du}$ labre, en forme de triangle allongé et tronqué à l'extrémité; $3^{\circ}$ des palpes maxillaires, composés de six articles; et 40 des ailes, ne présentant que deux cellules cubitales. Le type de ce g. est l'A. rufiventris Lat., du midi de l'Europe.

(BL.)

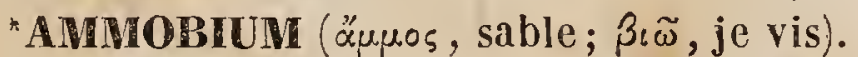
вот. рн. - G. de la famille des Composées, établi par M. R. Brown; il a pour caract.:Capitules multiflores, hornogames.Récept. convexe, couvert de paillettes oblongues, concaves, denticulées et acuminées au sommet. Invol. hémisphérique, formé d'écailles imbriquées, coriaces, blanchâtres, membraneuses sur les bords et terminces par un large appendice scarieux. Cor. tubuleuses, 5-lobées, à tube charnu. Anth. bi-aristées à la base. Styles à rameaux arqués, tronqués et velus à l'extrémité. Fruits comprimés. tétragones, terminés par 4 dents, dont 2 plus grandes.-L' Ammobium croît dans quelques parties arides et sablonneuses de ld Nouv.Hollande. Cette plante, qui a le port de certaines Immortelles, est vivace, à tiges dressées, tomenteuses; à feuilles entières; les radicales lancéolées - spatulées; les caulinaires décurrentes sur la tige où elles constituent des ailes très prononcées; les fleurs 


\section{6}

AMIM

sont jaunes et entourées par les écailles membraneuses et blanches de l'involucre. On ne connaît encore qu'une seule esp. de ce g., l'A. alalım, cultivée fréquemment dans les jardins de botanique.

(J. D.)

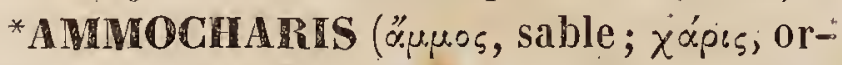
nement). вот. Рі.-Un des nombreux g. que Herbert a cru devoir séparer du g. Amaryllis, L. On le réunit généralement, comme s.-genre, au g. Brunsvigia, Ker, de la famille des Amaryllidacées. Les principaux caract. en sont, suivant l'auteur : Tube du périgone subinfundibuliforme; subtrigone ; segments du limbe non ondulés, presque étalés, réfléchis au sommet; les alternes plus petits. Filaments déclinés, recourbés en dessus au somimet. Style décliné, recourbé comme les filaments; stigm. très brièvement trilobé.

(C. L.)

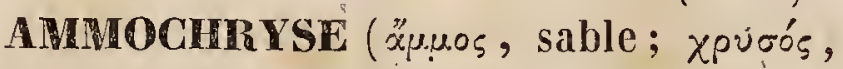
or). min.-Nom dónné, par quelques minéralogistes anciens, au Mica pulvérulent, de couleur d'or, qui sert de poudre pour l'écrilure.

(DEL.)

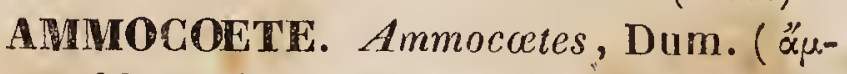
p.os, sable; xoírn, gîte). MıN. - Un des noms que Gesner donnait à l'Ammodyles tobianus, et qui a été affecté à un g. de Poissons établi par M. Duméril, dans le travail qu'ila publié sur la famille des Cyclostomes bu des Suceurs, et qui comprend nos Lamproies et les g: voisins. Celui-ci diffêre des Lamproies en ce que la bouché, sans áucunes dents, est garnie d'une lévre charnue qui n'est que demi-circulaire; aussi ne peuventils se fixer comme les Lamproies. La bouche est entource de petits barbillons, et l'eau arrive aux branchies par l'œsophage. Les 2 dorsales sont réunies entre elles et à la caudale. Leur squelette est en tout temps plus mou que celui des Lamproies. Les yeux ne se voient que pàr la dissection; ils semblent aveugles.

On n'en connait qu'une esp., longue de 1 à 2 décim., qui vit enfoncée sous le sảble, où les pêcheurs la prennent pour s'en servir comme d'appât. On lui a supposé l'habitude de sucer les branchies des Poissons, parce qu'on l'a confondue avec une autre esp. de Lamproie nommée le Pelromyzon Planeri. Le poisson que Lacépède a désigné sous le nom de Petromyzon rouge n'est autre que l'Ammocète ordinaire: On le nomme Lam-

\section{AMḾ}

pirillon, Lamproyon, C'hatouille, et quelquefois aussi Civelle, dénomination qui est plus souvent employée sur les bords de la Loire pour désigner les jeunes anguilles. Je n'en connais pas d'esp. étrangère. (VAL.)

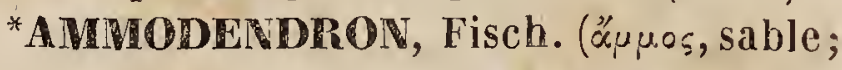

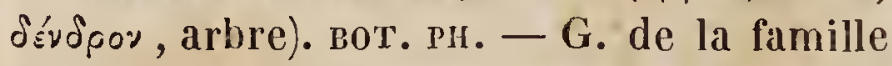
des Légumineuses, sous-ordre des Papilionacées, tribu des Sophorées, DC. - Ledebour (Flor. Alt. I1, p. 110) en donne les caract. suivants : Cai. 5-fide, subbilabié, persistant, finalement réfléchi. Cor. papilionacée , 5-pétale ; carène 2-pétale, aussi longué que les ailes. Étam. 10, libres; légume membranacế, plane, marginé, 1-spermè par avortemen $t$; graine réniforme, comprimée. - Arbuste. Pétioles diphylles, persistarits, spinescents; folioles spinescentes a sommet; grappes multiflores, nutantes; fleurs violettes. - L'unique esp. qui constitue ce g. habite les steppes de la Sibérie méridionale.

(Sp.)

AMMODRAMUS. ols. - $V$. AmmodroMUS.

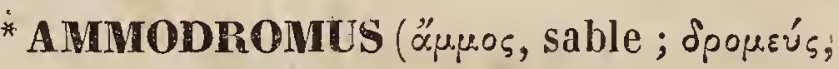
coureur; courant sur les sables). ols.-G. de l'ordre des Passereaux conirostres, Cuv., formé par Swainson pour deux ou 3 esp. de Fringilles marcheurs de l'Amérique du nord, et dont les caract. sont : Bec conique, formant à sa base une peti te arête anguleuse, intrantè dans les plumes du front, à commissure sinueusé, à pointe légèrement fléchie. Ailes obtuses, à rémiges très courtes, n'atteignant què le quart ou le tiers au plus de la queue; les cìnq $1^{\text {res }}$ rémiges à peu près d'égale longueur: Queue de longueur médiocre, grêle et étagée, ả rectrices étroites, lancéolées et un pen rigides à la pointe. Pieds grểles; tarses longs; doigts latéraux égaux; le médian allongé; pouce allongé, presque aussi long, avec son ongle, que le tarse; ongles très minces et pen courbés; les antérieurs très courts et très déliés; le postér. allongé. - Quoique M. Swainson n'ait fait des esp. de ce petit groupe qu'un s.-g. de son g. Fringilla, elles devraient, selon nous, former un g. distinct, d'après leurs formes, et surtout d'après leurs mœurs tout-à-fait anomales dans la famille des Fringillidées. En effet, on trouve chez elles un pouce allongé, une queue étagée à pennes pointues et un peu rigides, comme chez la plupart de nos oi: 
seaux arundinicoles (tels que les Fauvettes des roseaux, les Thriothores, Troglodytes, Synallaxes, etc.); et en même temps les doigts et les ongles antér. courts des oiseaux marcheurs, comme dans nos Alouettes et nos Traquets. Aussi, Wilson, en décrivant son Fringilla maritima, type du g., nous apprendil que ces oiseaux se tiennent liabituellement dans les ìlots bas el couverts de roseaux, qui bordent les côtes de là mer Allantique, et que, lorsqu'un ouragan du nord-est les a poussés au rivage, ils se tiennent sur la grève, courant avec la légèreté et la rapidité des petits Bécasseaux ou Chevaliers les plus ingambes. Dans ces circonstances, ils restent la nuit sur le sol sans se percher; et parcourent la plage en courant, même après le crépuscule. Leur nourriture est toute marine; car Wilson assure qu'aprés en avoir ouvert un grand nombre d'individus, il n'a jamais trouvé dans leur gésier que des débris de chevrettes ou thalitres, de petits mollusques et de petits crabes; et que leur chair, comme on doit s'y atlendre, a un goût prononcé de poisson et de marécage. Au milieu de leurs retraites marécageuses, habituellement arrosées par les eaux de la mer, ils choisissent, dit cet auteur, les endroits lesplus fourrés des joncs et des plantes marines, et grimpent le long de leurs tiges avec autant d'agilité qu'ils courent sur le sol. Cette circonstance est tout-à-fait remarquable; car presque tous nos oiseaux grimpeurs ne marchent que peu ou assez maladroitement:

Audubon, qui a figuré cel oiseau et son nid (Ois. de l'Am. du norll), nous apprend que ce nid est placé si près du sol, qu'il sem² ble y être creusé ; que les jeunes s'établissent près des fossés et des écluses qui séparent les marais d'eau salée, où ils trouvent une nourriture abondante, en visitant les trous des crabes, et en s'introduisant dans les crevasses de la vase sèche, à la manière des Troglodytes.-Nous ne sommes entré dans cées détails que pour prouver à quel point ces oiseaux méritaient, d'après leur mode de nourriture et leurs mœurs, si étranges chez des Fringillidées, de constituer un g. disinct. Il est certain que des Fringilles cou reurs et ingambes comme nos Alouettes de mer, grimpeurs comme nos Calamoherpes les plus agiles; fixés habituellement sur les rivages maritimes, et, par suite, uniquement crustacivores et molluscivores, sont des oiseaux tout-à-fait anoma ux dans leur famille.Swainson, après avoỉr décrit et figuré le Fringilla maritima (Americ. Ornit.,pl.34, fig.2), donne la description et la figure d'une $2^{\text {me }}$ espèce ( pl. 34; fig. 3 ) sous le nom de $F$. caudacula Lath., qui habite les mêmes lieux que la précédente; s'y nourrit de la même manière, et offré enfin les mèmes caract. dé formes et de mœurs. Elle n'en diffère, selon lui, que par une course moins rapide; nous ajouterons: un peu par les couleurs du plumage, et surtout par un bec plus allongé et plus grểle.-Audubon a figuré, sous le nom d'Ammoảromus Henslowi, une $3^{\mathrm{e}}$ esp., très voisine, par les couleurs, de l' $A$. maritimus, mais plus petite et a rectrices plus étroites et plus aiguës. Ces 3 esp., les seules du g. connues jusqu'ici, ont un plumage assez sombrè, mais remarquable par une bande longitudinale plus claire sur la tête et par la couleur pâle de léurs pattes et de leurs ongles. Nous les possédons toutes les trois. Vieillot décrit les deux $1^{\text {res }}$ (Nouv Dict. d'Hist. nat.) sous les noms de Passerine maritime et à queue pointue. Ne faisant que traduire les descriptions de Wilson, il est élonnant qu'il ait omis tout ce que cet auteur a dit d'intéressant sur les mœurs de ces deux espèces.

(LAFR.)

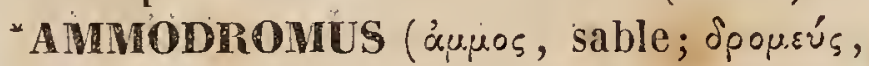
coureur). ixs. - G. de la famille des Mutilliens (Hétérogynes, Lat.), établì par M. Guérin (V oyage de la Coquille), suri 4 esp. dont les femelles seules sont connues; si toutefois elles n'appartiennent pas à quelques mâles formant d'autres g. Il en a tiré leurs principaux caractères génériques $: 1^{\circ} \mathrm{d} u$ corps allongé et aptère; $2^{\circ}$ des mandibules grandes, àrquées et terminées en pointe aiguë; $3^{\circ}$ des antennes courtes, contournées, composées de 12 articles; $4^{\circ}$ des palpes maxillaires de 6 arlicles et des labiaux de 4 ; $5^{\circ}$ du thorax divisé en 3 segments nodiformes; et $6^{\circ}$ des pattes courtes, épaisses et épineuses. -Les 4 esp. connues sont les $A$. frontalis, ruficeps, scolioformis, varius Guér: (Mymecoda varia, Perty); loutes sont de l'Amér. méridionale.

AMMODYTE (ápuodvins, qui se tient dans le sable). REPT.-Nom spécifique d'un Ophidien du g. Vipere. $V$. ce mut: (G. B.) 
AMMOD ITE. Ammodyces (ăuros, sable; dútns, plongeur). rolss. - Nom que les anciens donnaient à un Ophidien s'enfonçant dans le sable en Lybie.

Concolor exustis atque indiscretus arenis; Ammodyles, etc. Lucanus, lib. 9. Gesner l'employa pour désigner le poisson commun sur nos côles sablonneuses, que les Anglais nomment Sandliz, les Allemands Sandeel, expressions qui se rapportent à la manière de vivre de cet apode. Artedi en a fait le nom générique que tous les ichthyologistes postérieurs ont adopté. Son caractère consiste en ce que le corps est allongé, cylindrique, à nageoire dorsale simple et longue, à anale également assez étendue; la caudale est distincle et fourchue ; ils ont de petites pectorales, mais ils manquent de ventrales.

Ces Poissons, sans vessie natatoire, vivent, pendant l'hiver, presque constamment sous le sable; mais quand la mer est haute, et a certaines époques, ils se tiennent à la mer et y vivent en troupes, de manière qu'on en fail la pêche aux filets, et qu'on en prend en assez grande abondance pour rendre cette pêche profitable, à cause de la délicatesse du poisson. En tout temps, à marée basse, ils se tiennent cachés sous le sable où les riverains vont les prendre en soulevant le sable avec une sorte de bêche ou de hoyau. Il faut avoir une grande prestesse pour retourner le sable et saisir le poisson dès qu'on l'apercoit, car il s'y enfonce avec une facilité et une promptitude vraiment surprenantes. Il me parait probable, toutefois, qu'il s'y enfonce quand les grains sont encore soulevés et remués par l'eau de la mer, et avant que le sable ne soit foulé et tassé par le mouvement des vagues. J'ai laissé souvent sur la plage unie des Ammodytes qui ne cherchaient pas mème á se cacher ou à s'enfoncer sur cette surface unie qui leur paraissait vraisemblablement trop dure; mais dès qu'on les mettait sur du sable remué et par conséquent plus meuz ble, ils y pénétraient presque avec la rapidité d'un dard; aussi sur quelques unes de nos côtes on l'appelait Lançon. Le premier mouvement cache près de la moitié du corps, et le reste est enfoncé après 2 ou 3 ondulations de la queue. Je ne connais pas encore bien le mécanisme que le poisson emploie pour cheminer si vite sous le sable; il s'y tient souvent enroulé sur lui-même, et quoiqu'oll dise qu'il y cherche les vers dont il fait sa nourriture, je n'ai jamais rien observé qui justifiât cette assertion. Que devient la respiration de ce poisson, quelle modification éprouve-l-elle dans cette période régulière, où; pendant 3 ou 4 heures au moins, à chaque marée, les Ammodytes restent enfoncées sous un sable souvent peu humide?

Linné, qui avait observé un grand nombre de ces Poissons, jugea qu'il pouvait en exister 2 esp. sur nos côtes; toutefois il n'en caractérisa qu'une seule, celle que, suivant lui, les pêcheurs des côtes septentrionales de l'Europe nomment Tobis, ou Tobicen selon. Schonevelde, nom que cet auteur avait latinisé en celui de Tobianus; voilà comment l'esp. a été nommée par Linné, Ammodytes tobianıs. M. Le Sauvage, médecin distingué de Caen, a désigné la $2^{\text {e }}$ espèce sous le nom d'Amm. lancea, mais en transposant la citation des figures des auteurs anciens, et notamment celle de Ray.

La chair de ce poisson est très estimée; quand ils sont trop petits, les pêcheurs s'en servent pour amorcer les lignes, surtout pour la pêche des maquereaux qui en sont très friands.

(VAL.)

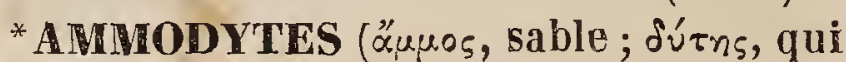
plonge). вот. рг.-É Eithète peu usitée, désignant les plantes qui croissent dans le sable. (C. L.)

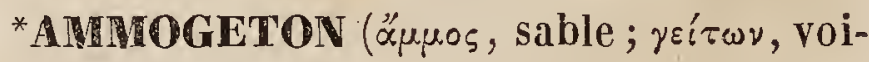
sin; qui croît dans les sables). вот. Pн. G. de la famille des Composées, tribu des Chicoracées, ayant pour caract. : Capitule multiflore. Involucre formé de 3-4 séries d'écailles imbriquées. Réceptacle chargé de paillettes linéaires-lancéolées, acuminées, placées entre les fleurs. Fruits obcomprimés, glabres, lisses; ceux du disque, seulement, pourvus d'un bec court et épais. Aigrette composée de plusieurs rangées de soies blanches et légèrement scabres. L'Ammogeton scorzonerafolium, seule esp. du g: , est une plante vivace de l'Amér. boréale; elle manque de tige et porte des feuilles radicales, linéaires, lancéolées, atténuées aux 2 extrémités, très entières, parcourues par une nervure moyenne, comprimée, présentant 3 veines plus saillantes; les hampes nues égalent les feuilles en lon- 
gueur ; linvoluere, couvert principalement a la base d'un duvet lanugineux et blanc, renferme des fleurs jaunes.

AMMOIDES ( «щu , plante ombellifére?

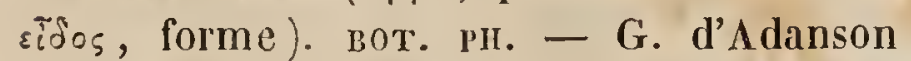
(Fam. 11.96.), rapporté comme synon. au g. Ptychotis de Koch, de la famille des Ombellifères.

AMIION. Mam. $-V$. Mlouton.

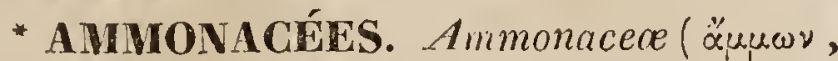
w) CÉPII.-Sous ce nom de famille, M. de Blainville (Traité de Malacologie) a placé, parmi les Céphalopodes multiloculaires, les g. Discorbite, Scaphite, Ammonite, Simplegade, Ammonie, Planulite, Ellipsolite. Le $1^{\mathrm{er}}$ de ces g. est un Foraminifère; les autres appartiennent à la famille des Ammonées de Lamarck, moins l'Ammonie, qui est un Nautile.

(A. D’O.)

*AMMONALUN, Beudant. Miv.-Synon. d'Alun ammoniacal. $V$. Alun. (Det.)

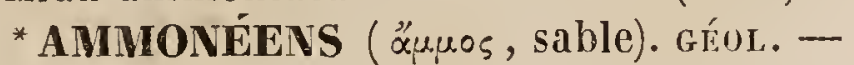
Nom donné quelquefois aux terrains secondaires, et particulièrement à ceux qui sont compris entre la craie et le lias inclusivement, parce qu'ils renferment un très grand nombre d'esp. d'Ammonites. $V$. ce mot et TERRAINS.

AMMONÉES et mieux AMMONIDÉES,

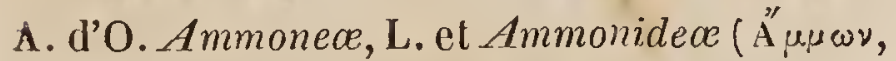
wros, Jupiter-Ammon; d'öpuos, sable; ici, sorte de coquille). NoLL. CÉPH, - Lamarck (Ext. de son cours, 1811) proposa ce nom ( $\mathrm{Am}$ monées), pour une famille de Coquilles multiloculaires, à cloisons découpées sur leurs bords, et dans laquelle il plaça les g. Ammonite, Orbulite, Turrilite, Ammonocératite et Baculite. M. de Blainvilie place dans ses Ammonacées qui correspondent aux Ammonées de Lamarck, les Discorbites et les sous-genres de Montfort, dont quelques unes appartiennent aux Nautilidées. M. de Haan divise la famille en 2 coupes, suivant que les sinuosités des cloisons sont ondulées ou anguleuses, et n'y réunit pas tous les g. que Lamarck y avait placés. Dans notre tableau méthodique des Céphalopodes (en 1825), nous avons ainsi caractérisé la famille : "Test simple, spiral ou droit ; cloisons découpées; cavité supér. à la dernière cloison, grande et engainante ; siphon marginal ( dnrsal sur la carène)." Nous y avons placé les g. Baculite, Hamite, Scaphite, Ammonite, et Turrilite, auxquels on peut ajouter aujourd'hui les Criocératites et les Gonialites.

Les Ammonidées (dénomination que nous préférons, pour suivre une terminaison identique dans toutes les familles du Règne animal) ne se trouvent qu'à l'état fossile, et leurs g. et leurs esp. très nombreux peuvent servir à caractériser les terrains. Les Baculites, les Scaphites et les Turrilites appartiennent aux couches crétacées; les $\mathrm{Ha}$ mites se rencontrent dans la formation crayeuse et dans les terrains oolithiques. Les Ammonites appartiennent exclusivement aux formations jurassiques et crétacées, et les Criocératites se trouvent dans les étages infér. de la craie et des premières couches de la formation jurassique. Pour les Goniatites, elles forment plutôt un groupe géologique que zoologique; ce sont des Ammonites à cloisons moins découpées, appartenant tou-

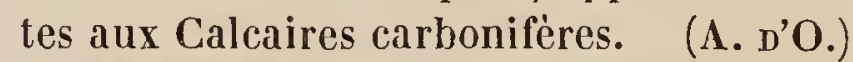

AMMONIA. MOLL. $-V$. AMMonie.

AMMONIAQUE ('́xusvraxóv, ammonia. que, chez les Grecs). cum. - C'est un gaz incolore, d'une odeur piquante, caractéristique, provoyuant la mort, quand on le respire, en amollissant et détruisant la muqueuse des poumons; il possède une réaction fortement alcaline qui permet de le distinguer de tous les autres fluides élastiques. Les alcalis le chassent de toutes ses combinaisons, de sorte qu'il est toujours facile de le reconnaître. Ce gaz n'est pas permanent; un froid de $-52^{\circ}$ le liquéfie, sous la pression ordinaire.

L'eau absorbe 670 fois son volume ou environ la moitié de son poids à la température ordinaire. Cette dissolution, connne sous le nom d'Ammoniaque liquide (Alcali volatil fluor), est très employée en médecine et dans les laboratoires, soit comme réactif, soit pour la préparation d'un grand nombre de substances. Le gaz ammoniac est formé d'azote et d'hydrogéne, dans le rapport de 1 vol. du $1^{\text {er }}$ gaz à :3 vol. du second. Quatre vol. de ce gaz résultent de la combinaison de 2 vol. d'azote et de 6 vol. d'hydrogène. On le démontre en $\mathrm{y}$ faisant passer une longue suite d'étincelles électriques. Après l'expérience, le gaz a doublé de volume et on le trouve formé d'azote et d'hy- 
drogène dans les proportions indiquées. Sa densité est de 0,5912 , somme des densités de $1 / 2$ vol. d'azote et de un vol. et $1 / 2$ d'hydrogène.

Le fer et quelques autres métaux décomposent le gaz ammoniac, à une température élevée. Il en résulte des combinaisons encore mal connues qu'une température blanche détruit complétement, en laissant pour résidu le métal à l'état de pureté, il est vrai, mais modifié dans ses propriétés physiques. Le gaz ammoniac, en passant sur du charbon rouge, donne naissance à une quantité considérable d'acide hydrocyanique. L'expérience présente toutefois des difficultés qui tiennent à ce qu'à une certaine température l'acide hydrocyanique luimême se décompose. Le chlore exerce une aclion décomposante très énergique sur l'ammoniaque, surtout quand on agit sur des gaz. Il y a production d'hydrochlorate d'ammoniaque et élimination d'azote.

L'ammoniaque liquide donne avec l'iode de l'hy driodate d'a mmoniaque qui se dissout, et un précipilé brun excessivement fulminant d'iodure d'azote.

Ull grand nombre d'oxydes métalliques possédent la propriélé de se dissoudre dans l'armmoniaque liquide, et de former avec elle des combinaisons qui ne sont pas toujours d'une nature semblable.

Les oxydes de cuivre, de zinc, de nikel, paraissent pouvoir s'unir à l'ammoniaque sans éprouver de décomposition. Ceux de mercure, d'argent, d'or, de platine, se distinguent par la grande facilité avec laquelle ils se décomposent en fulminant, par le choc, le frottement ou la chaleur.

Le gaz ammoniac s'unit aux deux chlorures de phosphore, au chlorure d'argent et à plusieurs autres chlorures métalloïdiques ou métalliques. Avec le protochlorure de platine, il produit une combinaison remarquable, d'un vert olive foncé, sur laquelle les alcalis sont sans action, ainsi que les acides, a l'exception de l'acide nitrique qui la convertit en une matière des plus singulières, èn ce qu'étant formée de chlore de platine, d'azote et d'luydrogène, elle possède toutes les propriétés principales des alcalis végétaux. L'ammoniaque se produit dans une multitude de circonstances parmi lesquelles nous citerons $: 1^{\circ}$ la calcination des matières azotées; $2^{\circ}$ l'action de l'acide nitrique sur beaucoup de métaux el particulièrement sur l'étain; $3^{\circ}$ l'oxydation du fer à l'air libre ; $4^{\circ}$ la putréfaction spontanée des matières animales; $5^{\circ}$ la décomposition de toutes les matières azotées, gazeuses ou volatiles par l'hydrogène en excès, sous l'influence de la mousse ou du noir de platine; $6^{\circ}$ la décomposition des cyanures alcalins par l'eau; $7^{\circ}$ celle de l'acide hydrocyanique et des cyanures par les acides hydratés etc. on prépare le gaz ammoniac en calcinant un mélange de chaux et d'un sel ammoniacal, sulfate, nitrate el surlout hydrochlorate. Comme ce gaz est très soluble, il faut le laver dans une très petite quantité d'eau, afin d'en perdre le moins possible; et, comme il est absorbé en quantité assez considérable par le chlorure de calcium, au lieu de ce sel, il faut employer la chaux pour le dessécher. Quant à sa dissolution (Ammoniaque liquide), on l'opère dans un appareil de Wolf, à la manière ordinaire des gaz très solubles dans l'eau. Comme elle a une densité plus légère que celle de l'eau $(0,850$ à $\left.+10^{\circ}\right)$, il faut avoir soin de faire plonger jusqu'au fond des flacons les tubes qui conduisent le gaz dans l'appareil. (PEL.)

AMMONAQUE MURIATÉE. MIN.Synon. de Salmiac et de Chlorure ammoniac. $V$. Chlorures. (Del.)

AMMONIAQUE SULFATÉE. MIN. - Synon. de Mascagnine. $\gamma^{\top}$. Sulfates. (DEL.)

* AMMONIDÉES. Moll. - $V$. Ammonées.

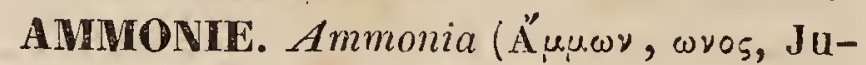
piter-Ammon; $V$. AMMONÉES). MOLL.-MONtfort (Conchyl. Syst.p. 74) a établi, sous ce nom, un g. dans lequel il place comme type le Nautile ombiliqué ; c'est un g. à supprimer ( $V$. NAUtile); car c'est à tort que Montfort regarde cette esp. comme l'analogue vivant des Ammonites. (A. D'O.)

AMMONITE. Inmonites (Ä $\mu \mu \omega \nu$, Jupiter-Ammon; $V$. AMmonéEs). MoLL. CÉPII. Bruguière (Encyclop. méth.) a formé sous ce nom un g. de Coquilles fossiles enroulées sur le même plan, et á cloisons découpées, que leur ressemblance avec des cornes de bélier faisait nommer, par les anciens auteurs: Comes d'Ammon (Comua Hammonis).

Ce g., bien circonscrit, a été subdivisé par Montfort (Conchyl. systém.) en plusieurs autres, qui n'ont pas été adoptés. De ce nom- 
bre sont les Planulites, les Ellipsolites, les Amalthées, les Pélaguses, les Simplegades. Lamarck en a fait 2 div. : les Ammonites et les Orbulites, suivant que les tours sont ou non embrassants; mais ces g. équivalant aux Planites et aux Globiles de M. de Haan ( Monogr.Ammon. etc.), et, de même que ceux de Montfort, n'étant pas basés sur des caract. zoologiques, n'ont pas été conservés. M. de Buch, après de savantes recherches, a proposé de distinguer les Ammonites en groupes, en prenant pour caract. les découpures des loges; mais jusqu'à présent, il manque un travail complet sur ces coquilles si nombreuses el si importantes pour les recherches géologiques.

Les caract. des Ammonites sont les suivants : Coquille enroulée sur le même plan, symétrique, à tours contigus plus ou moins embrassants; loges nombreuses, dont les cloisons sont lobées ou découpées sur leurs bords; siphon dorsal sur le bord. Dernière loge occupant le dernier tour de la spire. Bouche plus ou moins rétrécie, bordée ou lobée.-On a décrit, figuré ou indiqué plus de 300 esp. d'Ammonites; mais nous ne doutons pas qu'on n'en puisse réduire le nombre aux 2 tiers, lorsqu'on aura fait la part des changements apportés par l'âge, dans les divers individus. En effet, certaines esp., lisses dans lejeune âge, se couvrent, dans un âge plus avancé, de còtes ou de tubercules qui disparaissent dans la vieillesse; de là les noms différents donnés à une même esp. On trouve des Ammonites dans les terrains oolithiques et crétacés. Elles abondent surtout dans tous les étages des premiers, depuis le Lias, jusqu'aux couches les plus supérieures. Dans la formation crétacée, elles manquent dans les parties supérieures. Plusieurs esp. peuvent être regardées comme caractéristiques des terrains; par exemple l'A. Walcotii Sow. (Min. Conchyl.pl. 106 ) appartient aux couches infér. de la formation oolithique, du Lias; l' $A$. Gentoni vef., appartient seulement aux couches crétacèes, etc., etc. (A. D’O.)

AMMONITES. Ammonilo. вот. CR. L'origine de ce mot paraît être une corruption de celui d'Amanite ( $V$. ce mot). J.-B. Porta, dans l'ouvrage qu'il a publié sous le titre de Villa, s'en est servi pour désigner les Cépes ou Bolets ( $V$. ces mots), que T. I. les habitants de Naples appellent encore de nos jours Ammoniti.

AMMONIUM (Abréviation d'á $\mu \mu \omega \nu$ saxóv, ammoniaque). снім. - L'ammoniaque $\mathrm{H}^{\prime \prime}$ $\mathrm{N}^{2}$ ne peut s'unir aux oxacides pour produire des oxy-sels ammoniacaux, qu'autant qu'on fait intervenir la présence d'une certaine quantité d'eau dont il en entre constamment un atòme $\mathrm{H}^{2} \mathrm{O}$ dans le sel. Avec les hydracides, au contraire, la présence de l'eau est inutile. Plusieurs chimistes expliquent ces circonstances, en disant que l'ammoniaque n'est pas une base, qu'elle ne le devient qu'en décomposant un atòme d'eau, de manière à former l'oxyde d'un radical composé $=\mathrm{H}^{8} \mathrm{~N}^{2}$, qui est aux métaux alcalins ce que le cyanogène est au chlore et ả l'iode. Représente-t-on par $\mathbf{A}$ un oxacide, et le met-on en contact avec de l'eau et de l'ammoniaque, on a la réaction: $\mathbf{A}+\mathrm{H}^{6}$ $\mathrm{N}^{2}+\mathrm{H}^{2} \mathrm{O}=\mathrm{H}^{8} \mathrm{~N}^{2}, \mathrm{O}, \Lambda$, analogue à ammonium

K $O, A$, avec cette seule différence que l'ammonium $\mathrm{H}^{8} \mathrm{~N}_{2}$ est un radical composé, tandis que le potassium est un élément.

Met-on un hydracide, de l'acide hydrochlorique par exemple, avec de l'ammoniaque, l'hydrogéne de l'hydracide passe sur l'ammoniaque, la change en ammonium qui s'unit avec le radical de l'hydracide pour former un sel, le chlorure d'ammonium = $\mathrm{H}^{8} \mathrm{~N}^{2}$, $\mathrm{cl}^{2}$, analogue au chlorure de potassium $=\mathbf{K}$ cl $^{2}$. Les bornes de ce Dictionnaire ne nous permettent pas de développer ce point de vue.

(PeL.)

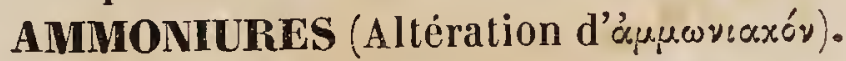
CHim. - $V$. AMmoniag巳e. (Pel.)

*AMMONOCÉRATE. Annonocera (Äu$\mu \omega \nu$, Jupiter-Ammon; xépcis, corne). MoLL. CÉPH. - Nom que Lamarck, dans son Histoire naturelle des animaux sans vertẻbres, a substitué à celui d'Ammonocératite qu'il avait proposé, dès 1811 (Extrait du Cours), pour la dénomination générique de certaines coquilles fossiles, polythalames, de la fam. des Ammonées. On voit que, dans son esprit, les 2 noms sont restés identiques, car les 2 esp. qu'il connaissait sont nommées à la suite de la caractéristique du g. Ammonocćrate, Ammonocérutile glossoüle, et Amm. aplatie. L'examen que j'ai fait de ces 2 esp. prouve que ce g. de Lamarck ne peut être conservé. $23^{*}$ 
La $1^{\text {ro }}$ est, sans aucun doute, l'Ammonites fimbriatus : le Cabinet du Roi possède les 3 fagments du même échantillon qui existxient dans le cabinet de Lamarck, et sur lesquels ce savant a établi le g. et l'espèce. Il dit qu'on l'avait trouvé dans les grandes Indes; et, en effet, il m'a souvent répété que ce fossile dont i] faisait grand cas, avait été rapporté par le secrétaire de la colonie de Pondichéry qui l'avait donné au fils de M. le comte de Bufion, de qui il le tenait. Je ne sais pas pourquoi Lamarck a oublié de citer cette petite anecdote, qui donne plus de valeur à ce morceau, non pas à cause de sa nature spécifique, mais parce qu'elle prouve que le lias des Indes contient la même esp. d'Ammonites que celui de notre continent. Je suis d'autant plus satisfait de l'identité fournie par l'examen de l'Ammonite possédée par Lamarck, que, parmi les Ammonites rapportées par Jacquemont, il s'y trouve aussi un fragment de I'Ammonites fimbriatus. Quant à la seconde esp., l' $A m$ monoceratites compressa, Lamarck l'a étabłie d'après un échantillon de la collection de M. De France, que j'ai sous les yeux, grâce à l'amitié dont m'honore ce célèbre paléontologiste. Ce corps n'offre pas de caract. suflisants pour le classer avec certitude, parce que ce n'est que le remplissage du moule creux de la coquille qui avait été détruite dans la roche. C'est un corps courbé en croissant, comprimé, atténué et mousse à une extrémité, plus gros, mais rompu à l'autre. Il est arrondi sur le côté interne comme sur le côté externe ; des côtes transversales s'élévent du bord concave pour se joindre à celles du côté opposé sur le bord convexe. D'ailleurs on ne voit aucun indice de cloison, et cela résulte nécessairement de ce que nous examinons au moule.

La courbure du corps, la nature des côtes, et même encore l'aplatissement, donnent à ce fragment la plus grande ressemblance avec celui que l'on pourrait tirer de l' $A m$ monites planulites; mais comme les còtes s'étendent sur le còté concave, on doit en conclure que ce fragment n'appartenait pas à une coquille enroulée sur elle-même et à bords contigus, comme dans les Ammonites. Je ne crois pas aussi qu'on puisse supposer qu'il provienne d'un Crioceras dont les tours ne se touchent pas, parce qu'il est Jui-même conpé carrément à l'intérieur, et que les còtes ne s'avancent pas jusqu'au milieu du côté interne et aplati. Il est plus probable que la coquille qui a donné naissance à ce moule était vraisemblablement une Hamitc d'une esp. particulière, mais qui, je le répète, ne peut pas être suffisamment caractérisée par l'examen du seul échantillon que possède M. De France. Ce que l'on doit conclure de cette discussion, c'est que le g. Ammonocérate ou Anımonocératite, comme on voudra le nommer, ne doit pas être conservé. (VAL.)

AMUONOCÉRATITE. NOLL. $-V$. AMMONOCÉRATE.

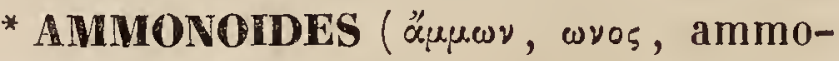

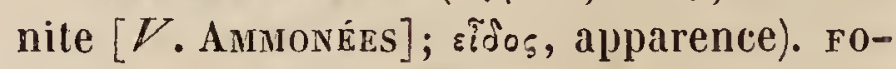
RAM. - Nous avons donné ce nom ( Tabl. méth. des Céphal.) à notre $3^{\text {me }}$ section de la famille des Hélicostègues, pour les g. dont la spire est apparente des 2 còtés. Aujourd'hui nous supprimons cette coupe; les esp. qui la composent étant fondues dans nos familles des Turbinidées et des Nautilidées. ( $V$.ces mots.) (A. D’O.)

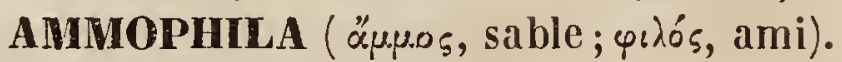
Ins. - G. de notre famille des Sphégiens ou de la grande famille des Fouisseurs de Latreille, et de sa tribu des Sphégides, ordre des Hyménoptères, établi par Kirby et adopté par tous les entomologistes. Les caract. essentiels de ce g. sont tirés: de la forme linéaire du corps ; des mandib. longues, arquées et tridentées; des mâchoires et de la languette fort longues; et des ailes dont la $2^{\text {me }}$ cellule cubitale reçoit les 2 nervures récurrentes.-Du reste les $A m m o p h i l a$ se rapprochent beaucoup du g. Sphex; leurs esp. sont assez nombreuses et répandues dans 'les diverses parties du monde. Celle que l'on en considère comme le type est l' $A$. sabulosa (S'phex sabulosa, L.), commune dans la plus grande partie de l'Europe. La femelle creuse dans le sable un trou assez profond, dans lequel elle apporte une chenille qu'elle blesse au moyen de son aiguillon; elle dépose ensuite un œuf dans le trou et le ferme avec des grains de sable.

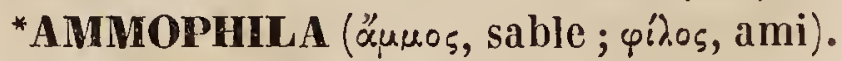
вот. PI. - G. de la famille des Graminées, tribu des Arundinacées, établi par Host et adopté par un grand nombre d'agrostographes. Voisin du g. Deyeuxia, il offre les ca- 
ract. suivants : Épillets biflores; fleur infér. pédicellée, barbue à sa base; la supér. avortée et réduite à un pédicelle plumeux à son sommet. Valves de la glume membraneuses, presque coriaces, lancéolées, carénées, plus longues que la fleur; l'infér. un peu plus courte, présentant une seule nervure, tandis que la supér. en offre trois; paillettes également membraneuses et un peu coriaces; l'extér. ovale, lancéoléc, carénée, à 5 nervures, bifide a son sommet qui offre, audessous de sa bifurcation, soit une simple petite pointe, soit une arête courte; paillette interne a peine plus courte, offrant 2 nervures très saillantes. Étam. 3. Ovairc glabre, pyriforme, surmonté de 2 stigmates terminaux, sessiles et plumeux. Paléoles lancéolées, acuminées, glabres, plus Iongues que l'ovaire. Caryopse glabre et non recouverte par les écailles. - Comme nous l'avons dit précédemment, ce g. est très voisin du Deyeuxia, dont il diffẻre surtout par sa paillette infér. mucronée au-dessous de son sommet bifide, et non aristée sur le milieu du dos. Il a pour type l'Arundo arenaria L., sous le nom d' $A$. arundinacea Host (Gram., 4, p.217,t.41), esp. excessivement communesur les dunes ou les bords sablonneux de la mer, oú ses rhizômes rampants s'étendent souvent à une très grande distance. C'est sous ce rapport une plante intéressante, et qu'on sème avec avantage dans les terrains sablonneux pour en fixer la mobilité. Ce g., que Palissot de Beauvois nommait Psamma, renferme une seconde esp. peu différente de la première, et qui croìt sur les bords de la mer Baltique.

(A. R.)

* AMMOPHORE. Ammophorus (äunos, sable; $\varphi$ ópos, qui porte). Ins. - G. de l'ordre des Coléoptères Hétéromères, fam. des Mé lasomes, établi par M. Guérin (Mag. zool., 6 vol., 1834) et adopté par M. Solier, qui le place dans sa tribu des Tagénites, en Iui donnant pour caract. distinctifs : Dernier art. des ant. tronqué brusquement et carrément. Tibias antérieurs notablement triangulaires. Prothorax peu sensiblement dilaté sur les côtés.-M. Solier comprend dans ce g. 4 esp., indiquées comme étant toutes du Pérou. Nous n'en citerons qu'une, l' $A$. peruvianus, ainsi nommée par M. Guérin, mais qui paraîtrait avoir été appelée antérieurement tagenioidcs par M. Petit. Eile serait aussi originaire du Chili, suivant $M$. Dejean (Catal. $3^{\text {me }}$ édit.) $)^{\text {qui }}$ la rapporte au g. S'Selenomma, Sol.)

* AMMOPTENODYTES. Ammoptenody-

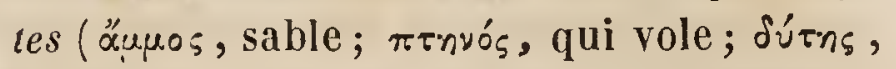
plongeur). oıs.-Ce nom, qu'on a écrit à tort dans les auteurs Ammaptenodytes, a été donné par Ritgen à une famille d'Oiseaux compreñant les Oiseaux non voiliers, et courant dans les sables comme l'Autruche.

(C. D'O.)

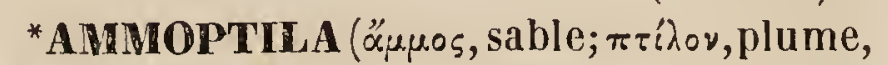
aile).ors.-G. établi par M. Swainson (Class. of Birds), répondant au Pluvianus, Vieill., et au Cursor, Wagl. L'auteur en fait un s.-g. du g. Tachydromus, lui réunissant encore comme s.-g. le Glareola et le T'achydromus. L'esp. type et la seule connue, ce nous semble, est le Pluvian du Sénégal, Plıvianus melanocephal'ss Vieill. (Nouv. Dicl., 27-130, et Gall., pl. 233), Charadrius melanocephalus Lath., Gmel.

Il est singulier qu'un ornithologiste aussi distingué que M. Swainson, tout en adoptant un g. déjá lormé par un auteur français, semble prendre à tâche d'en changer le nom, sans molif apparent. C'est à nos yeux une faute grave, laquelle ne peut qu'angmenter la confusion qui règne déjà dans la nomenclature; faute qui, d'ailleurs , se rencontre trop souvent dans ses ouvrages, ou il dénature à chaque instant les noms génériques ou spécifiques donnés par d'autres auteurs.

(LAFr.)

AMMOTHÉE. Ammothea (nom myth.). Arachn.-G. dela famille des Pycnogonides, de l'ordre des Trachéennes, établi par Leach (Znol. Miscell. xix 1, 2.), sur une seule esp. de la Caroline, qu'il a nommée $A$. carolinensis. Ce g., trés voisin des Nymphons, en diffère par les antennes-pinces bcaucoup plus courtes que la bouche, ayant leur article basilaire fort petit, et par les palpes composés de 9 articles, tandis que ceux des Nymphons n'en ont que cinq.

$$
\text { (BL.) }
$$

AMMOTuLE. Ammothea (nom mythol.) POLYP. - G. de la famille des Alcyoniens, établi par M. Saviigny pour des Polypiers formés d'une masse commune, charnue, divisée en plusieurs tiges courtes, rameuses, dont les derniers rameaux ramassés, ovales, conoïdes en forme de chatons, sont partout couverts de polypes; ceux-ci sont pourvus 
de huit tentacules pinnés, comme ceux des autres Alcyoniens et sont rétractiles dans des verrues inermes. Ce dernier caract. les distingue des Nephtées, dont les verrues sont au contraire armées de spicules. M. Savigny avait décrit et figuré une seule esp., de la mer rouge ( $A$. virescens), que M. Audouin, dans l'explication des planches de la Descripion de l'Égypte, nomme Nephiea Cordierii. M. Ehrenberg en a décrit une $2^{\text {me }}$ espèce, du même lieu, l'A. thyrsoides. M. MilneEdwarrls rapporte au même g. les Alcyonium imbricatum, ramosum, et, avec doute, l' $A$. annicorum de MM. Quoy et Gaimard. (Dus.)

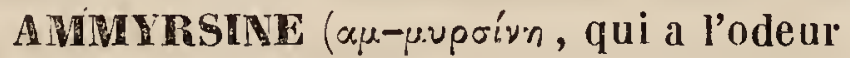
de la myrrhe). вот. рн. - G. de la famille des Éricacées, formé par Pursh $(F l$. bor. Am. 1. 301), et réuni, comme synon. au g. Leiophyllum, Pers.

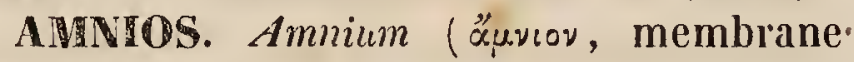
qui enveloppe le fotus ). $\Lambda$ NAT.-On a donné ce nom a une membrane particulière, formant une sorte de poche dans laquelle sont contenus le fotus et le liquide qu'on appelle l'eau ou les eaux de l'Amnios. Tout récemment on a avancé que le foetus ne se trouve pas en contact immédiat avec le liquide amniotique, mais bien dans une autre cavité formée également par la membrane Amnios réfléchie sur elle-même à la manière des séreuses en général. Comme il est plus facile de bien déterminer et de mieux faire comprendre la véritable disposition, la nature, et les rapports de l'Amnios à l'article OEUF, nous y renvoyons pour plus de détails.

(M. S. A.)

*AMNIOS (äuveov, membrane qui enveloppe le foetus). вот. PII.-Malpighi nomma ainsi, par analogie, la liqueur gélatineuse ou émulsive, dans laquelle nage et se nourrit l'embryon, et qui n'est visible qu'après la fícondation. La liqueur ou lait de l'amande du cocotier en offre un exemple re-marquable. Cette liqueur, en se concrétant, donne naissance au périsperme.-On appelle aussi Amnios, la membrane (la $3^{\mathrm{e}}$ ) interne qui contient immédiatement l'ovule; selon d'autres encore, cette membrane est le sac de l'Amnios $V$. Chorion.

(C. L.)

*AMNISGUS (dimin. d'áuvis, petitagneau). 1xs. - G. de Coléoptères tétramères, famille des Longicornes, établi par M. Dejean, mais dent il n'a pas püblić les caractères. D'après la place qu'il occupe dans son Catalogue (3ne édit.), il appartiendrait à la tribu des Lamiaires de M. Serville. Il y rapporte 31 esp., toutes de l' $\Lambda$ mérique, à l'exception de 3 dont la patrie n'est pas connue. La plupart de ces esp. ont été nommées par M. Dejean lui-même. Nous n'en citerons qu'une, comme type du g., l'A. perplexus, de l'Amérique septentrionale.

AMNIUM. ANAT. $-V$. AMnios.

*AMOEBA (ánot6ń , changement). INF. Dénomination substituée par.M. Ehrenberg a celle d'Amibe. ( $V$. ce mot.) (Duj.)

* AMOEBÉES ou AMOEBIENS. Amoebcece ('auor6́n', changement). Infus. - Famille d'Infusoires élablie par M. Ehrenberg pour le seul g. Amibe ou Amoeba. Elle est caractérisée par des prolongements variables, rameux, et par l'absence d'un test; elle fait partic de l'ordre des Polygastriques anentérés.

(Dus.)

AMOMÉES. Amomeoe (äuwrov, amomum, plante odoriférante de l'Inde, qu'on croit être l'Amomon des modernes). вот. PH. - La famille de plantes monocotylédonées à ovaire infẻre, qu'on appelle ainsi, a porté beaucoup d'autres noms. On l'a nommée successivemen! Cannées, Drymyrrhizées, Scilaminées, Zingibéracées, Alpiniacées, etc. C'est un groupe excessivement anomal et dont nous allons donner une description assez délaillée pour en faire bien comprendre la structure. Cal. adhérent par sa base avec l'ovaire infère, à limbe double; l'extér. plus court et à 3 lobes, à div. égales et régulières, rarement fendu d'un seul còté et irrégulier (Globba); l'intér. plus ou moins tubuleux, à 3 divisions de forme variée, mais ordinairement semblables entre elles. Ln dedans de ce calice intér. sont des appendices pétaloïdes en nombre variable : ordinairement 3 , dont 1 , plus souvent d'une forme irrégulière assez semblable au labelle des Orchidées, simple ou plus ou moins profondément bi- ou tri-parti. Comme nous venons de le dire, le nombre de ces appendices est variable; ils se soudent plus ou moins intimement avec Je cal. intér. et forment un seul et même tube avec lui. Une seule étamine; filet allaché au tube du cal. intér., ordinairement très irrégulier; le plus souvent plus ou moins dilaté surtout vers sa partie supér. qui est péta- 
loïde. Anth. a 2 loges quelquefois séparées l'une de l'autre et comme appliquées sur le milieu de la face interne du filet pétaloïde, quise prolonge au-dessus d'elles, en formant un appendice ordinairement bifide. Plus rarement, filet de l'étamine cylindrique et semblable à celui de toutes les autres plantes. Anth. à 2 loges, non surmontée d'un appendice pétaloïde, uniloculaire dans le g. Canna ( $V$. Balisier et l'Allas de ce Dict. Sub. Canna lutea, fig. $b, 2 ; c, 1)$. Ovaire infère, à 3 loges contenant chacune un grand nombre d'ovules attachés sur 2 rangs, à l'angle interne de chaque loge. Style ordinairement grêle, parfaitement distinct des autres parties de la fleur, naissant du sommet de l'ovaire et d'une longueur proportionnée à celle du tube calicinal. A sa partie supér. il passe en général au devant de l'anthère et se place souvent entre ses 2 loges, qui offrent presque toujours une sorte de gouttic̀re dans laquelle il est reçu. Il porte à son sommet un stigmate dilaté, concave, en forme de coupe dont l'irtér. est glanduleux, et le contour garni de poils. Sur le sommet de l'ovaire, en avant du point d'insertion du style, on voit un petit corps glandulaire, śimple ou bilobé; une sorte de disque épigyne, dont nous expliquerons plus tard l'origine et la nature physiologique. Ce petit corps manque fréquemment. Le fruit est communément une capsule à 3 loges polyspermes, s'ouvrant à sa maturité en 3 valves. Plus rarement, le péricarpe est légèrement charnu ou même presque bacciforme, pouvant, paravortement, ne plus être qu'ả une seule loge et contenir un très petit nombre de graines ou même une seule. Celles-ci ordinairement arrondies et presque globuleuses; quelquefois accompagnées à leur base d'un arille charnu et cupuliforme, contenant un endosperme farineux dans le centre duquel est un embryon presque cylindrique, nu ou plus souvent contenu dans une sorte de poche charnue nommée vitellus par Gærtner. Radicule tournée vers le hile avec lequel elle est en contact.

Nous nous sommes borné jusqu'à présent à décrire la structure florale des Amomées, sans nous expliquer sur les nombreuses anomalies qu'elle présente, quand on la compare a celles des autres familles de plantes monocotylédonées. En efret, nous trou- vons ici des fleurs qui, au premier abord, s'éloignent beaucoup du type propre au plus grand nombre des végétaux pourvus d'un seul cotylédon. Ainsi, iudépendamment du calice formé de 6 sépales plus ou moins soudés ensemble et disposés sur 2 rangs, nous observons 3 ou 4 autres div. pétaloïdes placées en dedans de la rangée la plus intér. des sćpales, et que quelques auteurs ont désignées sous les noms de $c n-$ rolles et de nectaires. De plus, au lieu de trouver 3 ou 6 étamines, comme dans la plupart des autres Monocotylédonées, nous n'en voyons qu'une seule, rarement portée sur un filet cylindrique, plus souvent appliquée sur une lanière pétaloïde, qui se prolonge et se bifurque au-dessus de l'anthère. Il y a donc évidemment ici, déviation $d u$ type régulier des Monocotylédonées ; aussi rien n'est-il plus étrange et plus disparate que les noms donnés aux diverses parties de ces fleurs par les différents botanistes qui en ont parlé, et la manière dont ils ont tracé les caract. des g. de cette famille.

Le premier botaniste qui ait cherché à reconnaître la nature physiologique des diverses parties constituantes de la fleur de cette singulière famille, est $\mathbf{M}$. Lestiboudois, professeur de botanique à Lille. Dans 3 mémoires successifs ayant pour objet: le $1^{\mathrm{er}}$ le Canna indica; le $2^{\mathrm{me}}$ l'Hedychium angusifolium; et le $3^{\text {me }}$ le Globba nutans, cet ingénieux botaniste s'est efforcé de ramener l'organisation des Amomées au type général propre à la plupart des familles des plantes Monocotylédonées. Pour lui tous les g. de cette famille doivent être considérés comme ayant un calice double à 6 sépales et 6 étamines. De ces 6 étamines une seule est fertile et développée, les autres sont transformées en appendices pétaloüdes. Nous adoptons complétement cette manière d'envisager l'organisation florale des Amomées, et nous la croyons conforme à la nature. Seulement nous nous éloignons de notre savant ami, dans l'explication qu'il donne de cette organisation et dans la dénomination des parties constituantes de la fleur; ainsi par exemple, dans le g. Canna ( $V$. l'Atlas de ce Dict.), on trouve, en dedans ducal. intér. : 103 div. pétaloüdes, dont 2 dressées et semblables, et une infér. réfléchie, disposée 
peu près de la même manière que le labelle des Orchidées. En dedans de ces 3 div. on en voit 2 autres, l'une, portant sur l'un de ses côtés l'anthère, dont le filet se manifeste aussi par un certain épaississement linéaire du côté de l'appendice auquel elle est attachée; et une autre, confondue à sa base avec la précédente, quỉ se termine latéralement par l'aréole stigmatique. Selon M. Lestiboudois, la division anthérifère doit compter comme 2 étamines, l'une fertile, l'autre stérile, dont l'anthère a complétement avorté et s'est prolongée en languette au-dessus de l'étamine fertile; la $3^{\text {me }}$ étamine est représentée par la division pétaloïde révolutée; de plus, l'auteur admet encore 3 div. pétaloïdes dressées, tandis qu'il n'en existe réellement que 2, ainsi qu'il le montre dans sa figure $2, d . d$. Ces 3 divisions représenteraient les 3 autres étamines. Ce n'est pas ici le lieu de réfuter ce que cette opinion a d'inexact sur ce point. Nous aurons occasion d'y revenir en traitant successivement des différents g. de la famille, et en particulier des g. Canna ( $V$. Balisier ), Hedychium et Globba ou Renealmia, sur lesquels M. Lestiboudois s'est particulièrement appuyé pour établir son opinion sur la structure florale des Amomécs. Pour le moment nous nous bornerons à énoncer ici en peu de mots notre manière d'envisager la structure primitive des Amomées, et d'en expliquer l'état anormal.

Les Amomées ont : $1^{\circ}$ Un calice double, formé de 3 divisions extérieures plus courtes; de 3 div. intér. plus longues et soudées en 1 tube ; $2 \circ 6$ étam. dont 2 ordinairement à anthère uniloculaire, développées, fertiles, et soudées ensemble, de manière à imiter une anthère biloculaire, dont les loges seraient plus ou moins écartées l'une de l'autre. Rarement une seule est développée et anthérifère (Canna). Les étamines stériles sont, sous la forme d'appendices pétaloïdes, souvent confondues et soudées 2 ou 3 ensemble, et plus rarement l'une d'elles sous la forme d'un petit mamelon glanduleux (disque épigyne) est placée sur le sommet de l'0vaire infère.

Ce qui distingue notre manière d'envisager la structure florale des Amomées, de celle des autres botanistes, c'est de considérer l'ètanine fertile : $1^{\circ}$ comme composée de 2 étamines uniloculaíres; $2 \circ$ comme une étamine avortée, le petit mamelon glanduleux que, dans un certain nombre de g., on observe sur le sommet de l'ovaire.

La nature même des parties constituantes de la fleur nous paraît confirmer pleinement notre opinion; ainsi, l'anthère est bien certainement uniloculaire dans le g. Canna, quoique quelques botanistes l'aient $\dot{a}$ tort décrite comme à 2 loges. Les 2 loges de l'anthère des autres g., sont plus ou moins écartées l'une de l'autre, et l'espace qu'elles laissent entre elles forme une gouttière souvent très profonde dans laquelle la partie supér. du style est reçue. Il nous semble donc rationnel, l'anthère étant bien réellement uniloculaire dans le g. Canna, de considérer les 2 anthères uniloculaires et plus ou moins écartées des autres g., comme représentant 2 étamines soudées en une seule; ce qui nous paraît encore appuyer cette opinion, c'est que l'appendice pétalö̈de qui surmonte ces 2 anthères uniloculaires, est toujours plus ou moins profondément partagé en 2 lobes à son sommet.

Quant aù mamelon surmontant l'ovaire et que nous croyons représenter une des étamines avortées, nous dirons qu'il manque, toutes les fois que les div. pétaloïdes placées en dedans du calice, sont en nombre suffisant pour représenter les étamines avortées et compléter ainsi le système staminal hexandrique; et qu'il existe, toutes les fois au contraire qu'il manque une div. pétaloïde pour parfaire le nombre normal des étamines. Appuyons ce fait de quelques exemples : $1^{\circ}$ Dans le g. Kampferia, les div. pétaloïdes, au nombre de 4 , sont soudées ensemble et forment un tube; 2 de ces div. sont dressées et 2 sont réfléchies. Avec les 2 étamines fertiles (soudées en une seule) voilà le nombre 6 complété, et il n'y a aucune trace de mamelon sur l'ovaire. $2^{\circ}$ Dans le g. Hedychium, en dedans du calice intér., on n'observe que 3 div. pétaloïdes distinctes; et le mamelon glanduleux , qu'on aperçoit sur le sommet de l'ovaire, complète les 4 étamines stériles. $3^{\circ}$ Dans le Globba nutans, qui doil être transporté dans le g. Alpinia, en dedans du calice intér., on trouve 3 div. pétaloïdes, dont 2 latérales excessivement petites confondues en une seule; ici encore, un mamelon, s'élevant de l'o- 
vaire, porte à 4 les étamines avortées et complémentaires.

Nous venons de décrire le groupe des Amomées ou Cannées tel qu'il a été admis par Jussieu, qui considérait les g. assez peu nombreux qui le forment, comme ne constituant qu'une seule famille. M. Robert Brown, le premier, a proposé de subdiviser ces g. en 2 familles: $1^{\circ}$ les Cannées ou Cannacées, comprenant les g. Canna, Maranta, Thalia, Plurynium et Myrosma; $2^{\circ}$ les Scitaminées, dans lesquelles viennent se ranger les autres g. non mentionnés ici. Cette div. a été adoptée par la plupart des botanistes. Seulement quelques uns, M. Lindley entre autres, ont cru devoir changer le nom de Cannées en celui de Marantacées. Les caractères qui distinguent essentiellement le groupe des Marantacées consistent : $1^{\circ}$ dans la position de l'étamine fertile toujours opposée à la div. pétaloïde révolutée; tandis que, dans les Amomées ou Scitaminées, l'étamine fertile (qui pour nous se compose rle 2 étamines soudées en une seule) correspond à une des div. latérales; $2^{\circ}$ et surtout dans l'absence du vitellus, qui recouvre complétement l'embryon dans tous les g. des vraies Amomées.

Malgré l'importance des caract. donnés pour séparer ces 2 groupes, comme 2 familles distinctes, l'affinité qui existe entre les g. qui les composent, est si grande que nous avons cru pouvoir les considérer seulement comme 2 tribus d'un même ordre naturel.

M. Lestiboudois est encore allé beaucoup plus loin que nous, dans la concentration des g. de celte famille, puisqu'il pense qu'on devrait les réunir avec ceux qui constituent la famille des Musacées, pour en former une famille unique. Suivant ce botaniste, les Musacées l'eprésentent le type normal et régulier des Amomées, dont la différence ne provient que de la transformation de 5 étamines en appendices pétaloïdes. Sans doute il existe une très grande affinité entre ces 2 familles, et c'est pour cela que dans toutes les classifications possibles on les place l'une à côté de l'autre; mais les caract. qui leur appartiennent sont trop constants pour qu'on puisse les réunir el les confondre; autrement il faudrait presque ne faire qu'une seule famille de tous les.g. monocotylédonés à ovaire infẻre, dont le type primitif est en effet à peu près le même; ce que personne ne proposera sans doute.

Voici les div. que nous admettons dans la famille des Amomées avec l'indication des g. qui leur appartiennent :

$$
\text { AMOMEES. }
$$

$1^{\text {re }}$ tribu.-CANNACÉES ou MARANTACÉES.

Canna, L.; Myrosma, L. fil.; Phrynium, IVilld.; Thalia, L.; Maranıa, L.; Calathea, Meyer.

$2^{\text {me }}$ tribu. - ZINGIBÉR ACÉES.

I. KOEMPFÉRIÉES.

Zingiber, Gœrtn.; Curcuma, L.; Kompferia, L.; Hilchenia, Wallich.

SII. amonézs, Blume.

Amomum, L. ; Elettaria, Rheede; Hedychium, Konig.

§ III. ALPINIÉES, Bl.

Alpinia, L.; Hellenia, Willd.; Cenolophor, Bl.; Gastrochilus, Wallich ; Monolopluss, Wallich ; Cassumunar, Colla ; Galanga, Roxb.; Monocystis, Lindl.; Phoomeria, Lindl.; Peperidium, L.

SIV. costées.

Costus, L.

$\$$ V. GLOBBÉES.

Le seul g. Globba L., auquel on doit réunir comme synonymes les g. Colebrookia, Don.; Ceranthera, Hornem. ; Mantisia, Sims.; Renealmia, L. fil.; Catimbium, Juss. (A. RichaRd.)

* AMOMOCARPUM ( $\ddot{\mu} \mu \omega \sigma^{\circ}$, Amomum; xхрто́s, fruit). вот. Foss. - J'ai désignẻ sous ce nom (dans mon Prodrome de l'Hist. des Végétaux fossiles), un fruit trouvé dans les argiles tertiaires de l'ile de Sheppey, et qui, par sa forme générale, a beaucoup d'analogie avec celui de quelques esp. du g. Amomum. C'est en effet un fruit triangulaire, déprimé, dont les angles sont saillants et arrondis, marqués de 3 sillons longitudinaux qui indiquent autant desutures; caract. qui se retrouvent bien dans les fruits d' $A m o-$ uurm, mais qui se présentent dans un trop grand nombre de plantes pour qu'on puisse en conclure, avec certitude, l'analogie de ces fossiles avec les Amomum. Il faudrait pour cèla connaître la structure intérieure de ces fruits fossiles, et jusqu'à présent elle nous est inconnue. Il me paraît cependant très 
probable que ces fruits appartiennent à une plante monocotylédone.

(AD. B.)

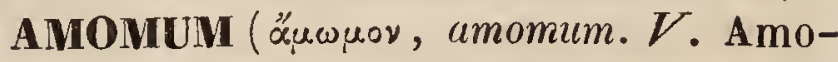
mées). вот. Рн. - G. de la famille des Amomées, qui se compose d'un petit nombre d'esp., toutes originaires des contrées chaudes de l'ancien continent, plus rarement d'Amérique, et dont les caract. peuvent être exprimés de la manière suivante : Cal. à 6 div. disposẻes sur 2 rangs. Appendices pétaloïdes formant une seule lèvre bilobée. Filament prolongé au-delà des deux anth. en un appendice ordinairement simple, quelquefois bifide. Filet pétaloïde, portant à sa base 2 autres petits appendices. Capsule quelquefois légèrement pulpeuse intérieurement, à 3 loges s'ouvrant en 3 valves, contenant chacune un grand nombre de graines arillées. - Les espèces de ce genre sont vivaces. Leur racine ou souche est charnue, rampante; leurs feuilles sont distiques, membraneuses, à gaînes fendues. La hampe est radicale, porte des fleurs disposées en épis et accompagnées de larges bractées.

On a retiré du g. Amomum, tel qu'il avait été établi par Linné, un certain nombre d'esp., telles que les Amomum zingiber, zerumbet, pour en former un g. à part sous le nom de Zingiber. Ce dernier g. se distingue surtout par l'appendice surmontant les deux étamines, et allongé en forme de corne recourbée en avant. Parmi les esp. d'Amo-

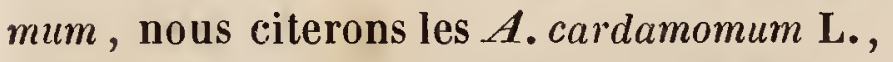
Grana paradisi, etc.

(A. R.)

AMONIA, Nestl. (contraction d'Aremonia) вoт. Pr.-Syn. du g. Aremonia, Neck., de la famille des Rosacées. (Sp.)

* AMONIE. Amonia. arachn. - M. Koch désigne sous ce nom (Deutschlands Crust. Myriap., etc.) une nouvelle coupe générique à laquelle il n'a pas donné de caractères.

(H. L.)

*AMOORA. вот. PH.-Ce g. de Roxburgh est le même que l'Aphanamixis de Blume, et ses esp. ont encore reçu les noms d'autres g., tels que Aglaia, Andersonia, Buchanania, Sphcerosacme. Il appartient á la famille des Méliacées et offre les caract. suivants : Cal. à 3 folioles, accompagnées de 2 bractées tout-à-fait semblables, qui semblent composer un calice quinconcié. Pétales 3, larges, concaves, ouverts; 6 filets larges et complé- tement réunis en un tube globuleux ou plus tard campanulé, d'abord soudé avec les pétales dont il se détache ensuite, découpé à son bord libre en 6 lobes peu marqués, et portant sur sa face interne 6 anthẻres tout-à-fait cachées dans son intérieur, opposées à ses lobes, oblongues, 3-gones, attachées par leur dos. Ovaire déprimé, surmonté d'un stigm. sessile, en forme d'une pyramide à 3 angles mousses, à 3 loges contenant chacune 2 ovules pendants et superposés. Fruit capsulaire, coriace, à 3 loges monospermes, se séparant en 3 valves dont chacune emporte avec elle la cloison opposée. Graines adnées à la paroi par la plus grande partie de leur face interne, enveloppées plus ou moins complétement d'un arille charnu , offrant une radicule courte et supér., et 2 gros cotylédons collatéraux, souvent soudés. - Les esp. sont de grands arbres à feuilles alternes, composées d'un grand nombre de paires de folioles inéquilatérales avec une impaire terminale, à fleurs disposées en panicules, ou plus souvent en longs épis axillaires. On en compte 5 , croissant dans les Indes orientales ou dans les grandes îles qui font suite à l'Asie, dans les Philippines, à Java, à Timor.

(AD. J.)

*AMORDHCA, Neck. (altération de $\mathrm{MO}_{\mathrm{O}}$ mordica, faisant allusion à la ressemblance des deux genres). вот. Pн. - Synon. du g. Momordica, L., de la famille des Cucurbitacées.

${ }^{*}$ AMORES. zool. $-V$. Amours. (Sp.)

*AMOREUXIA, Moç. et Sess. Flor. Mex. ined. ex DC. Prodr. 2, p. 638 (Amoreux, botaniste de Montpellier). вот. Pн. - G. incomplétement connu, que M. De Candolle place à la suite des Rosacées, en lui attribuant les caract. suivants : Cal. 5-parti; tube très court; segments oblongs, pointus. Pétales 5, plus grands que le calice. Étam. environ 2, 1-sériées, plus courtes que les pétales, obtuses ou échancrées au sommet. Ovaire ovoïde, inadhérent, 3-loculaire, multi-ovulé. Style filiforme, pointu. Caps. ovoïde.-Herbe, semblable par le port à une Dryadée, ou à un $N$ eurada. Feuilles Ionguement pétiolées, 2-stipulées, alternes, palmatifides; lobes dentelés au sommet. Pédoncules solitaires, oppositifoliés, subterminaux, dressés, infléchis au sommet, 1flores. Fleurs grandes, rougeâtres. On n'a 
signalé qu'une esp., qui croìt aux environs de Nexico.

(Sp.)

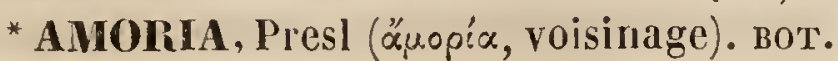
PIr.-G. ou s.-g. fondé sur 15 esp. de Trèfles, et dont le Trifolium hybridum L. peut être envisagé comme le type. Ses caract. dîfférentiels, selon l'auteur cité (Symbol. bot.), sont les suivants : Cal. campanulé; dents subulées. Cor. marcescente; étendard libre; ailes et caréne adnées á l'androphore. Ovaire oblong, 3-ou 4-ovulé. Slyle filiforme, oblique. Légume saillant, linéaire ou oblong, comprimé, toruleux, 2-ı) u 3-sperme, subdéhiscent.

(Sp.)

* AMORPHA (äropyos, informe). Ins. Sous cette dénomination, M. Newmann ( $\boldsymbol{E} n$ tom. Magaz., tom. Iı, p. 379) réunit les larves d'une grande partie des Insectes hexapodes et télraptères, qu'il divise en deux sections, Adermata et Dermata. La $1^{\text {re }}$ renferme les larves des Lépidoptères et d'une grande partie des Diptères; la $2^{\text {me }}$ celles du reste des Diptères. Chacune de ces sections se subdivise en un grand nombre d'ordres qu'il serait trop long de mentionmer ici. (D.)

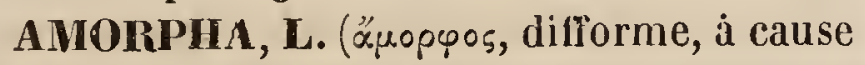
de l'irrégularité de la corolle). вот. рн. G. de la famille des Légumineuses, sous-ordre des Papilionacées, tribu des Galégées, Brown. Les caract. en sont les suivants : Cal. obconique, 5-denté. Cor. sans autre pétale que l'étendard, lequel est obconique et convoluté. Étam. 10, monadelphes par la base, saillantes. Légume comprimé, tuberculeux, subfalciforıne, très court, 1 ou 2-sperme. - Arbrisseaux; feuilles inultifoliolées; folioles ponctuées, ordinairement stipellées. Grappes terminales, denses, spiciformes; fleurs d'un violet foncé. - Ce g., qui se compose d'environ 10 esp., appartient à l'Amér. sept.; plusieurs se cultivent comme arbustes d'orriement.

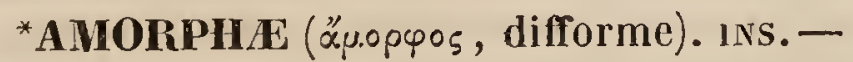
Nom donné par Hubner à une div. des Sphingides, qui correspond au g. S'mérinthe de Latreille. $V$. ce mot.

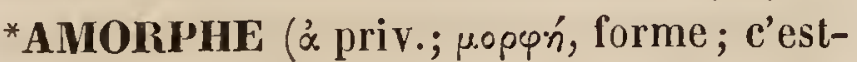
à-dire sans forme déterminable). mis. Nom spécifique, par lequel on désigne les minéraux qui se présentent en masses irrégulières.

(DEL.)

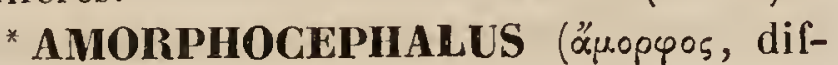
forme ; $x \varepsilon \varphi \alpha \lambda n_{n}$, tête). INs. - G. de ColéopT. 1 . tères tétramères, fanille des Curculionites, div. des Brenthides, établi par Schœnherr aux dépens du g. Arrlenodes de Latreille, et auquel il assigne les caract. suivants : Ant. assez courtes, moniliformes, ayant leur dernier article presque pyriforme, pointu. Tête profondément rayée dans les deux sexes. Rostre du mâle large, inégal, avec les mandib. découvertes, fortes, arquées; celui de la femelle allongé, cylindrique, avec les mandib. petites. Thorax oblong, également arrondi de chaque còté, convexe en dessus, entier. Élytres allongées, linéaires, un peu déprimées sur le dos. - Ce g. a pour type l'ancien Brentus italicus des auteurs, qui se trouve a la fois en Illyrie, en Italie (Toscane) et en Nubie. Cette esp. est figurée dans l'Icon. du Règne anim. de Cuvier, par M. Guérin, Iv, tab. 36, fig. 7, $a, b$.

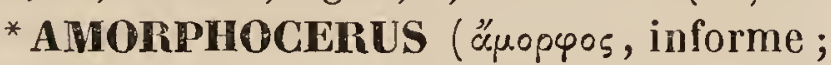
xśpas, corne). INs. - G. de l'ordre des Coléoptères tétramères, famille des Curculionites, div. des Cossonides, établi par Schœnherr, qui lui donne les caract. suivants : Ant. courtes, épaisses, insérées au milieu du rostre; leur funicule de 7 articles : le 1 er turbiné, les autres perfoliés, resserrés presque égaux; le dernier pressé contre la massue; massue petite, brièvement ovale, bi-articulée; le $1^{\text {er }}$ article corné, le dernier spongieux. Rostre peu long, peu épais, linéaire, presque cylindrique, légèrement plan, médiocrement arqué. Prothorax oblong, tronqué à la base et au sommet, arrondi sur les côtés, plus étroit antérieurement, resserré vers le sommet, un peu convexe en dessus. Ély tres allongées, linéa res, convexes, tronquées à la base, arrondies à l'extrémité, couvrant l'anus. Pattes courtes, presque comprimées; cuisses très élargies au inilieu ; tibias minces à leur base, beaucoup plus larges vers leur sommet, où ils sont denticulés et armés, en outre, d'un grand crochet mobile; pénuliième article des tarses plus long, bilobé. - Ce g. ne figure pas dans le Catalogue de M. Dejean (3me édit.). Schœnherr y rapporte $4 \mathrm{esp}$., dont une du Cap de Bonne-Espérance, et les trois autres de la Cafrerie. Parmi ces dernières, il en décrit une, $A$. setosus, que M. Chevrolat lui a mandé avoir prise vivante dans les environs de Paris.

* AMORPIOPE. Amorphopus (' $\alpha$ priv.; 243 


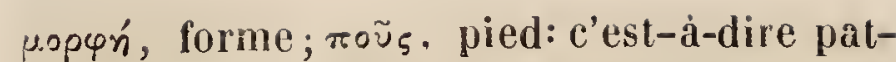
tes informes).ıNs. - G. de la fam. des Acridiens (Acridites, Lat.), de l'ordre des Orthoptères, établi par M. Serville (Hist. des ins. Orth. Suites à Buffon). Ce g. est très voisin des Tetrix, dont il ne diffère essentiellement que par les pattes, dont les cuisses antér. et intermédiaires sont grêles à leur base, et ensuite' brusquement dilatées en forme de folioles denticulées sur les bords, et les jambes très comprimées et légèrement dilatées. La seule esp. connue de ce g. est l'A. notabilis Serv. (Ins. Orth.), trouvée à Cayenne.

* AMORPHOPHALLUS ( ónop os, difforme; $\varphi \alpha \lambda \lambda_{o}{ }_{s}$, phallus). Candarum, Reichb. Consp. 44. - Schott. Meleth. - Pythion, Mart. Flor. 1831. - Arum campanulantm Poxb. Arum Rhumphii Gaud.id. Freyc., etc. - вот. рн. - G. de la famille des Arö̈dées, tribu des Thomsoniées, établi par M. Blume (in Balav. Diario, 1825 ; Decaisne in Fl. Timor, 1834, et in Rumphia, p. 138) qui en donne les caract. suivants: Spathe roulée à sa base. Spadice nu supérieurement, lisse ou verruqueux, florifère et androgyne à sa base; pas d'organes sexuels rudimentaires. Anth. sessiles, biloculaires, s'ouvrant par deux pores à leur sommet. Ovaires libres à 2, rarement à 3 ou a 4 loges. Orules solitaires et dressés. Style distinct ou nul. Stigm. capitulé, entier, émarginé ou comme bilobé. Baies distinctes, monospermes ou oligospermes. Graines dépourvues d'endosperme. - Ce g. se compose d'environ 9 à 10 esp., toutes originaires de l'Inde, et qui ont été parfaitement illustrées par M. Blume, dans sa magnifique Rumphia. Ce sont des plantes vivaces, à racine tubéreuse et charnue, ayant les feuilles et les spadices solitaires, environnés inférieurement d'écailles imbriquées. Elles diffẻrent des esp. du g. Arum, dans lequel quelques unes étaient placées auparavant, par la structure des anthères, et surtout celle des ovaires. $V$. ARum.

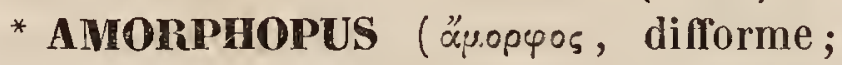
$\pi \circ \tilde{v}_{s}$, pied). INs. - Schœnherr avait d'abord donné ce nom à un g. de Coléoptères de la famille des Curculionites, div. des Brenthides, qu'il a remplacé par celui de Calodromus, imposé au même g. par M. Guérin. $V$. ce mot.
* AMORPHOSOME. Amorphosoma (änooyos, informe; $\sigma \tilde{\omega} \mu \alpha$, corps). Ins. - G. de l'ordre des Coléoptères pentamères, famille des Sternoxes, tribu des Buprestides, établi par MM. Gory et Delaporte aux dépens du g. Agrilus de Mégerle, et auquel ils assignent les caract. suivants : Palpes maxillaires de 3 articles visibles; le $1^{\text {er }}$ plus long, un peu arqué; le $2^{\text {me }}$ conique; le $3^{\text {me }}$ ovalaire ; palpes labiaux de 3 articles un peu allongés; les deux $1^{\text {ers }}$ en cône; le dernier en ovale long. Labre arrondi en avant; menton assez grand, arrondi en avant, un peu sinueux. Languette un peu arrondie. Màchoires a lobe externe grand et ovalaire; l'interne un peu arqué et pointu à l'extrémité. Mandibules fortes, aiguës, un peu échancrées au côté interne. Ant. courtes de 11 articles; le $1^{\text {er }}$ gros; les 3 suivants à peu près égaux; tous les autres dilatés extérieurement en dents de peigne. Tarses aux quatre $1^{\mathrm{ers}}$ articles à peu près égaux; le $1^{\text {er }}$ mutique; le $2^{\text {me }}$ muni d'une pelote à peine visible; les 2 suivants portant des membranes assez fortes; le dernier allongé; crochets très petits et unidentés. Corps un peu déprimé, tuberculeux. - Ce g., qui ne figure pas dans le dernier Calalogue de M. Dejean (3 $\left.3^{\text {me }} e ́ d i t.\right)$, a pour type l'A. exasperatun ou Agrilus exasperatus de Schœnherr, esp. du Cap de Bonne-Espérance.

(D.)

*AMORPHOzOAIRES. Amorphozoa (ärop-

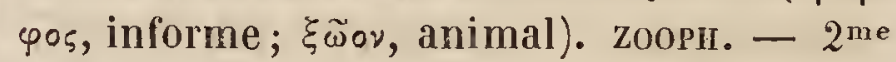
type des Actinozoaires vrais de M. de Blainville. Ce groupe, renfermant les Éponges et les Téthyes, est caractérisé ainsi par cet auteur (Man. d'Actin., y. 527) : "Corps organisés; animaux informes ou sans forme déterminée; percés d'oscules et de pores nombreux, mais sans bouches ; ou animaux particuliers, distincts, constamment adhérents et composés d'une substance fibrosogélatineuse, entremêlée ou non d'acicules calcaires ou siliceux avec des gemmules intérieurs non localisés. (Du.s.)

* AMOSA, Neck. (Amosa, par allusion à l'affinitéque présentent ces végétaux avec les Mimosa). вот. Pн. - Synon. du g. Inga, Plum., de la famille des Légumineuses-Mimosées. (Sp.)

AMOURETTE. вот. PH. - Nom vulgaire de diverses plantes des champs qui se font remarquer par un port gracieux. Ainsi on 
appelle Amourette trenblante, le Briza media, L.; grande Amourette, le Briza maxima, L.; petite Amourette, le Poa Eragrosti, L.; Amourette des prés, le Lichnis flos cuculi, L., etc., etc.

(C. D'O.)

AMOURIE. вот. PIr. - Nom vulgaire que les habitants de quelques cantons de la France méridionale donnent au mûrier et aux ronces des haies qui portent les mûres suuvages.

(C. D'O.)

AMOUROCHE. вот. P'I.-Nom vulgaire, dans quelques cantons français, du Maruta (Authemis) cotula Cass.

(C. I.)

AMOULS. Amores. zooL. - $V$. Ru'r, ACCOUPLEMENT et GÉNÉRATION. (C. D’O.)

AMPAC. Ampacıs. вот. pII. - Rumphius avait donné ce nom générique, tiré de la langne malaise, à 2 arbres des Moluques qui doivent rentrer dans le g. Zanthoxylon. $V$. ce mot.

(AD. J.)

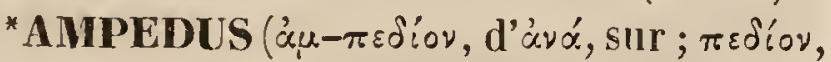
tarse). rvs. - G. de Coléoptères pentamères, famille des Sternoxes, établi par Mégerle, et correspondant à celui d'Élater, tel qu'il a été restreint par Eschscholtz, dans sa Classif. des Elatérides. $V$. le mol Taupin, synon. français du mot latin Elater.

* AMPELID E (Ampelis, nom latin du g. Cotinga). ors.- C'est, dans Swainson (Class. of Birds), le nom d'une famille de son $2^{\text {me }}$ ordre Insessores et de sa tribu des Dentirostres.

(LAFR.)

*AMPÉLIDÉES. Ampelidece. вот. PII.La famille fondée par A. L. Jussieu, sous le nom de Vignes (Viles), nommée plus tard par lui Vinifères, et récemment par M. Lindley Vitacées, avait aussi reçu de Ventenat celui de Sarmentacées, à cause de ses tiges, ordinairement sarmenteuses, et, enfin, de Kunth celui d'Ampélidées, emprunté

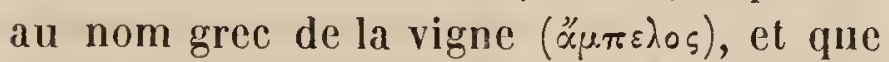
nous adopterons ici, pour éviter la confusion qui pourrait résulter de la ressemblance des premiers avec les Viticées ou Gatiliers. Elle appartient aux plantes dicotylédones polypétales-hypogynes. Voici ses caract. : Cal. petit, entier ou muni de 4-5 petites dents à son hord. Pétales en nombre égal, alternant avec ces dents, à préfloraison valvaire, et se séparant, soit de haut en bas, soit de bas en haut, de maniere à rester unis i leur sommet. Autant d'itam. opposées anx pétales, à filets libres ou monadelphes; anth. biloculaires, oscillantes, avortant quelquefois. Ovaire libre, entouré à sa base ou à une plus grande hauteur, d'un disque qui porte les pétales et les étamines insérés sur son contour; surmonté d'un stigmate simple, tantôt sessile, tantòt porté sur un style court; à deux loges, dont chacune renferme 2 ovules dressés; plus rarement 5-1-ovulées. Il devient une baie dans laquelle les graines se trouvent quelquefois en même nombre que les ovules, mais avortant souvent en partie, de sorte qu'on trouve un fruit uniloculaire et 1 -sperme. Ces graines sont osseuses et présentent, à la base d'un périsperme dur et presque corné qui Corme presque toute leur masse, un petit embryon plus court de moitié, dont la radicule cylindrique se dirige en bas, c'est-àdire vers le hile. - Les plantes de cette famille sont des arbrisseaux sarmenteux et grimpants, dont les feuilles, composées ou simples, mais alors ordinairement lobées, accompagnées de stipules, sont opposées entre elles dans le bas; dans le haut, aux inflorescences, qui avortent souvent, et se changent alors en vrilles. Ces inflorescences sont connues vulgairement sous le nom de grappes, mais ne répondent pas le plus souvent à la définition botanique de ce nom; ce sont des thyrses, ou fréquemment des cymes chargées de fleurs verdâtres ou plus rarement colorées. Ces fleurs, généralement hermaphrodites, sont, dans un g., polygames et accompagnées d'involucres foliacés, à lobes en forme d'ailes. - Les esp. sont disséminées dans les régions tempérées, el surtout tropicales des 2 hémisphères, au nombre de plus de 120 . Ce n'est pas ici le lieu de s'étendre sur les propriétés du suc de leur fruit, qui donnent au g. Vitis une si grande importance. C'est en effet à.ce seul g. de la famille, et de plus dans une partie fort limitée de notre zône tempérée, que paraît être réservée la culture avantageuse de la vigne et la fabrication de ses produits.

GENRES.

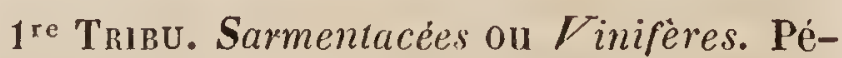
tales distincts à la base; filets ordinairement libres; ovaire à 2 loges bi-ovulées. Plantes grimpantes, ì pédoncules souvent changés en vrilles. - Cissus, L. (Woelanthus, Forsk.); 
-Pterisanthes, Blum.;-Ampelopsis, Mich.; -Vitis, L.

$2^{\text {me }}$ Tribu. Aquiliciées ou Lééacées. Pétales soudés à la base. Tube staminal à 5 lobes stériles, alternant avec les 5 filets anthériféres (qui sont opposés aux divisions de la cor.). Ovaire à 5 loges 1-ovulées. Pas de tiges sarmenteuses ni de vrilles. - Leea, L. (Aquilicia, L.; Ottilis, Gærtn.).

On en a rapproché encore le Geruma, Forsk., mais avec beaucoup de doute; car, si beancoup de ses caractéres indiquent des rapports avec les Ampélidées, on ignore la situation de ses étamines relativement aux pétales, et le fruit est une capsule à 4 loges et à 4 valves. Il est vrai qu'une monstruosité curieuse, observée par M. de Schlechtendal, a reproduit précisément cette structure du fruit dans la vigne commune.

(AD. J.)

*AMPÉLLÉES (Ampelis, nom d'un des genres de cette sous-famille). - C'est pour nous le nom d'une sous-famille de notre famille des Baccivores (Baccivorce), dans nos Dentirostres à bec déprimé, et dont les caract. sont: Bec court, déprimé, large à sa base, et très fendu jusqu'au-dessous des yeux; narines rapprochées de la pointe du bec, souvent à demi cachées par de petites plumes serrées. Ailes à rémiges assez longues, dont quelques unes des $1^{\text {res }}$ sont souven $ı$ rétrécies, ensiformes. Tarses et doigts courts; le doigt externe notablement plus long que l'interne, et soudé assez loin avec le médian; ongles élevés, courts et très arqués. Queue courte (carrée dans un seul cas), longue et fourchue. - Tous les g. qui appartiennent à cette famille, sont essentiellement percheurs et frugivores, comme l'indique la conformation de leurs pattes et de leur bec; ce sont les g. Cotinga, Averano, Piauhau, Tersine, Phibalure et Jaseur. ( $F$. ces mots.) Ils sont tous des contrées tropicales du Nouveau Monde, excepté le g. Jaseur, commun à l'Amérique septentrionale et à l'ancien continent.

(LAfr.)

AMPELIS ('ar $\varepsilon_{\varepsilon} \lambda_{i} i_{5}$ nom grec d'un oiseau indéterminé). ols. - Nom latin du g. Cotinga. $V$. ce mot.

(LAFR.)

AMPÉLTTE ( $\alpha \mu \pi \varepsilon \lambda_{\circ \sigma}$, vigne). MIN. el GÉOL. - Les anciens donnaient le nom d'Ampélite j̀ un schiste argileux, noir, qu'ils croyaient propre à servir d'amendement pour les terres à vigne, el a détruire les Insectes qui rongent cet arbuste. im. Cordier a conservé le nom spécifique d'Ampélite pour cette même roche qu'il classe dans la famille des Roches anthraciteuses. C'est un mélange d'anthracite et de matières phylladiennes schisteuses, fortement chargé de pyrites blanches. Cies pyrites, se décomposant, pénètrent les masses de sulfate de fer. Lorsqu'il abonde et que la présence de l'air favorise la réaction de ce sulfate de fer sur le charbon, il en résulte souvent une combustion spontanée. A Poligny, près Rennes, des combustions de ce g. ont formé des Tripolis résultant de la combustion superîcielle des ampelites. On a trouvé dans les Ampélites, divers corps organisés marins, tels que des Spirifères, des Fucus, etc. M. Cordier forme une espèce distincte du Graphite ( $V$. ce mot) que M. Brongniart a décrit comme une simple variété d'Ampélite (Ampélite grophique ). (C. is'O.)

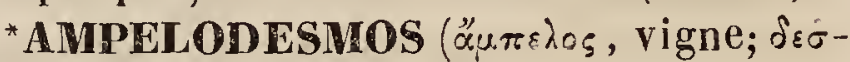
$\mu o ́ s$, lien). вот. Pн. - Le professeur Link a nommé ainsi un g. de la famille des Graminées, tribu des Arundinacées, qui comprend 2 esp. prìmi tivement placées dans le g. Arun$d o$, sous les noms d' $A$. tenax Wahl, et d' $A$. bicolor Desf. Ce g. a été adopté par le professeur Kunth, dans son excellente Agrostographie, et peut être caractérisé de la manière suivante: Fipillets contenant de 2 à 4 fleurs disposées sur un axe articulé et tout couvert de poils. Valves de la glume ou de la lépicène ovales, lancéolées, subulées, en gouttière, membraneuses. et plus courtes que les fleurs. Paillettes au nombre de 2, membraneuses ; l'infér. aiguë, toute couverte de poils à sa base, canaliculée et enveloppant la paillette supér., qui est un peu plus courte et bicarénée. Étam. au nombre de 3. Ovaire pyriforme, velu au sommet, portant 2 styles trés courts, terminés chacun par un stigm. plumeux. Les 2 paléoles lancéolées, plus longues que l'ovaire, et ciliées supérieurement. Fruit presque linéaire, cylindrique, marqué d'un sillon longitudinal et non recouvert par les écailles. - Les 2 esp. que nous avons citées précédemment composent à elles seules ce g. Ce sont des graminées très élevées, ayant le port des Arundo, et croissant dans les régions méditerranéennes de l'Europe el de l'A frique. Le g. Ampelodesmos différe surtout de l'Arundo par ses 
écailles entières au sommet et dépourvues d'arête.

(A. R.)

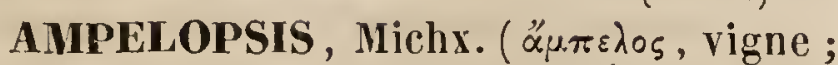
ő $\iota_{\llcorner 5}$, ressemblance). вот. Рі. - G. de la famille des Sarmentacées (Vitacées, Lindl., Ampélidées, DC.), ofrrant les caract. suiv.: Cal. non denté, subcupuliforme. Pétales 5 , caducs, libres, réfléchis. Étam. 5. Ovaire non enfoncé dans le disque, 2-4-ovulé; style court; stigm. capitellé. Baie 2-4-sperme. Feuilles simples ou composėes; fleurs rougeàtres ou jaunâtres ou verdâtres, paniculées ou en cymes.- On connaît 10 esp. de ce g.; la plupart habitent la zône équatoriale. L' $A$.hederacea, nommée vulgairement Vigne-vierge, se cultive comme arbuste d'ornement, pour couvrir les murs et les tonnelles.

(Sp.)

AMPEREA. вот. рн. - G. de la famille des Euphorbiacées, dédié à l'illustre et savant Ampère, et caractérisé de la manière suivante : Fleurs monoïques ou dioïques : MaLes : Cal. campanulé, 4-5-fide, à préfloraison valvaire. Étamin. $\delta$, saillantes, à filets à peu près libres, alternativement 4 extér., et plus courtes; anth. à loges distinctes et ovoïdes, pendant des 2 côtés d'un connectif graniforme, jaunes avec une ligne brune longitudinale, suivant laquelle elles s'ouvrent. Fenelles : Cal. persistant, à 5 divisions profondes et rondes. Ovaire à 3 loges 1-ovulées, surmonté de 3 stigm. sessiles, bifides. Cap. ovoïde, à péricarpe mince, se séparant en 3 corjues bivalves. - Les esp., au nombre de 3 , sont de petits arbrisseaux de la Nouvelle-Hollande, d'un port particulier et comparable á celui de notre genêt commun. Leurs rameaux, comprimés et dressés, sont chargés de petites feuilles rares, éloignées, linéaires et aiguës. Les fleurs axillaires sont solitaires ou groupées au nombre de 2 ou de plus, en petits fascicules, qui réunissent quelquefois les 2 sexes, accompagnées de bractées raides et aiguës. On peut en voir une esp. ( $A$. spartioides) figurée dans l'atlas du voy. de l'Astrolabe (Sertum Astrolabii, tab. 20), et dans celui du voy. de la Coquille (Bol., pl.49.)

(AD. J.)

AMPHAGANTHE. Amphacanthus (ám.ṕ, des 2 côtés; «ُxav $\theta \alpha$, épine). porss. - G. de Poissons de la famille des Teuthies, très voisin des Scomberoüdes, établi par Bloch, dans son système posthume, sous ce nom qui exprime bien le caract. singulier et unique, que présentent ces poissons dans le groupe des Acanthoptérygiens et qui consiste en ce que le rayon interne de la ventrale est épineux comme l'externe. Cette nageoire est donc épineuse des 2 côtés; d'ailleurs les A mphacanthes ont une seule dorsale à plusieurs rayons épineux, et une épine horizontale dont la pointe est dirigée en avant au pied $d u 1^{\text {er }}$ rayon. L'anale est longue et aussi armée en avant de 7 épines; tandis que ce nombre n'est généralement que de 3 dans le plus grand nombre des poissons à rayons osseux. La bouche est trés peu fendue; les 2 mâchoires forment un arc demi-circulaire, garni de petites dents serrées et èchancrées sur le bord.

Les ouïes sont peu fendues, la membrane branchiostège porte 5 rayons. Les écailles sont très petites, très minces, sans dentelures, et comme perdues dans la peau. La ligne latérale est tracée parallèlement au dos. L'anus est caché entre les ventrales. Il est ainsi avancé, parce que le canal intestinal est roulé en spirale sur lui-même et fait 5 a 6 tours dans la cavité abdominale qui est haute, mais peu étendue en arrière. Le pylore est entouré de 4 ou 6 cœecums, selon les espéces. Le foie est large et aplati, et subdivisé en plusieurs lobules; la vésicule du fiel est globuleuse et suspendue à un long canal cholédoque.Les Amphacanthes ont une vessie natatoire assez grande. La particularité la plus notable de leur squelette consiste dans l'allongement des 2 os styloïdes de l'épaule, qui sont arqués et arrondis, viennent se toucher sous le ventre, et former une sorte de bassin avancé et entourant les viscères abdominaux. Ils se nourrissent presque tous de matières végétales.

La singularité des ventrales à double épine a fait remarquer ces poissons par tous les naturalistes; mais comme plusieurs ont essayé de placer les esp.observées par eux dans les g. déjà établis par Linné ou par ses élèves, il en est résulté que leur synonymie a été pendant long-temps des plus confuses. Linné lui-même en avait placé une dans son g. Teuthis, et l'autre dans ses Spares. Bloch, qui a cependant établi le g. Amphacanthus, en a placé parmi les Chotodons. rorskal en avait donné la description sous le 
nom de Scarus Siganus, et cependant on voit qu'il avait eu l'idée d'en faire un $g$. distinct sous le nom de Siganus. Houttuyn avait créé pour eux le g. Centrogaster, auquel M. Gmelin a ajouté tant d'esp. disparates, qu'il a fallu laisser de côté, jusqu'au nom du voyageur Hollandais.

Commerson, en les décrivant sur les marchés de l'île de France et de Madagascar, a laissé pour eux, dans ses manuscrits, la dénomination générique de Buro qui a été reprise et publiée par Lacépède; ce qui n'a pas empêché cet excellent homme de reproduire dans son Ichthyologie toutes les esp. nominales, le Buro brun, le Centrogaster brunâtre, le Scare sidjan, le Scare étoilé, le Chétodon cannelé, le Chétodon tacheté, le Spare éperonné, et qui toutes ou presque toutes désignent le même poisson.

I.es esp. de ce g. abondent dans la MerRouge et dans le grand Océan indien. On n'en connaît aucune dans l'Atlantique ni dans nos mers d'Europe. Avant la monographie que nous en avons donnée, les auteurs n'en avaient indiqué que 2 ou 3 ; nous en avons décrit 27 dans l'Histoire naturelle des poissons. (VAL.)

* AMPHANTE. Amphantium (àp.pi; autour; $\ddot{\varkappa} \theta_{\circ \varsigma}$, fleur). вот. Рн.-Link (Handb. der Bot.) applique ce nom aux réceptacles dilatés qui contiennent ou enveloppent les fleurs. Ex. : Ficus, Dorstenia, etr.

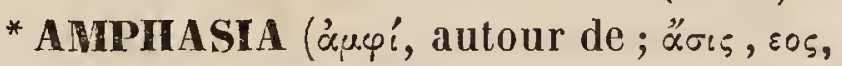
limon; par extension, marais). INs. - G. de l'ordre des Coléoptères pentamères, famille des Carabiques, tribu des Féroniens, établi par M. Newmann, et qu'il place près du g. Masoreus. Il a pour type une esp. de l'Amérique du nord, qu'il nomme $A$, fulvicollis. Ce g. ne figure pas dans le dernier Catalogue de M. Dejean ( $3^{\text {me }} \dot{e} d i t$.).

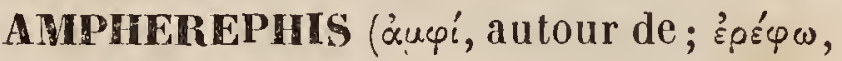
je couronne). вот. PI. - G. de la famille des Composées, synon. du g. Centratherum.

(J. D.)

* AMPHiachyris ('́u, í, autour, voi-

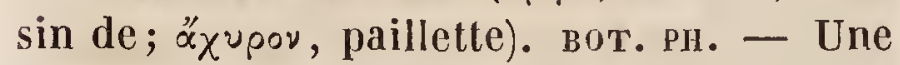
des 2 sections, ou sous-g., donnée par M. De Candolle, dans le g. Brachyris de Nuttal, de la famille des Synanthérées-Astéroïdées, et qu'il caractérise ainsi : Akènes du rayon presque nus ou munis d'une couronne très courte; fleurs du disque plus nombreuses que les ligules.

(C. L.)

* AMPIIBICORISES ou mieux AMPHIBIOCORISES (ámpícios, qui vit dans deux éléments; xópıs, punaise). 1Ns. - Nom créé par M. Léon Dufour et adopté par M. Spinola (Essai sur les Ins. Hémipt.), pour désigner une tribu de la section des Hétéroptères, de l'ordre des Hémiptères, correspondant ả la famille des Véliens de Brullé, ou Hydrodromici de Burmeister. Les principaux caract. que présente cette tribu ou plutòt cette famille, sont tirés : $1^{\circ}$ de la conformation des antennes, assez longues et composées de 4 articles cylindriques; $2^{\circ}$ des pattes antér. grêles, plus courtes que les autres et dépourvues d'épines propres ả retenir leur proie; $3^{\circ}$ de l'écusson presque entièrement caché; et $4^{\circ}$ des tarses pourvus de crochets situés en dehors et insérés dans une échancrure du dernier article.

Les Insectes qui composent cette petite famille vivent de proie vivante; ils sont tous aquatiques et cependant ils ne s'enfoncent jamais dans l'eau, á moins que ce ne soit accidentellement; mais ils courent à sa surface ávec beaucoup d'agilité et aussi facilement que les Insectes vivant à terre. Tout le dessous de leur corps est garni de petits poils très courts et excessivement serrés, qui leur permettent de glisser sur l'eau sans se mouiller.

Cette famille, confondue d'abord par Latreille avec tous les Hémiptères Géocorises, renferme aujourd'hui, telle qu'elle a été restreinte par les entomologistes modernes, les 6 g. suivants : Velia, Microvelia, Hebrus, Halobates, Gerris, Hydrometra. (BL.)

AMPHIBIE (árétios, qui vit dans deux éléments). MoLl. - Nom sous lequel Geoffroy (Conchyl. des environs de Paris) décrit le Mollusque dont Draparnaud a fait depuis son g. Ambrette. $V$. ce mot. (Desir.)

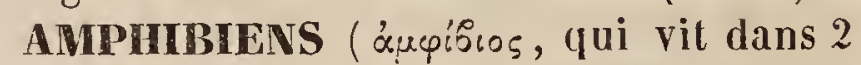
éléments). REPT.-C'est ainsi que M. de Blainville désigne les reptiles batraciens, dont il fait la $4^{\text {me }}$ classe de ses Ostéozoaires, première grande divis. ol, comme il l'appelle, le type 1 du Régne animal. $V$. Batriciens. (G. B.)

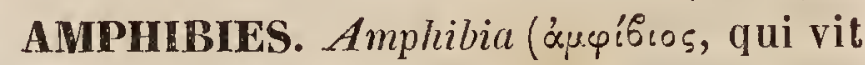
dans 2 éléments). zool.-Les Allemands réservent encore assez généralement ce nom 
aux animaux vertébrés de la catégorie des reptiles uus et écailleux, adoptant ainsi, dans la signification que lui avait donnée Linné, le mot Amphibia. I.es différences qui distinguent les esp. à peau écailleuse ou scutifére de celles à peau nue, tendent néanmoins à faire de ces 2 sortes d'animaux, 2 classes bien distincles. Aussi, dans la méthode de M. de Blainville, les reptiles écailleux conservent-ils seuls le nom de Reptilia, dont se servail aussi Brisson ( $V$. Reptiless), et les Batraciens ou Reptiles nus prennent-ils celui d'Amphibia ( $V$. Batraciens) : ces derniers étant en effel les seuls que l'on puisse dire Amphibies, c'est-à-dire jouissant successivement de 2 manières différentes de vivre, puisque, sauf les Cécilies, tous sont d'abord branclıifères, respirent l'air dissous dans l'eau, et n'ont les poumons développés que dans un âge plus avancé et après l'accomplissement de leur mélamorphose. On sail, cependant, que plusieurs (les Pérennibranches) n'arrivent pas à la respiration pulmonaire; mais si ces animaux sont, parmi les Vertébrés, les seuls auxquels l'épithète d'Amphibies convienne réellement, ils ne sont pas les seuls que dansle langage vulgaire on appelle ainsi, et dans toutes les autres classes de leur type, on signale des esp. amphibies; certaines de celles-ci pouvant sortir de l'eau, leur séjour habituel, pour s'exposer quelques instants à l'air, et vice versâ. On cile surtout au nombre de ces prétendus Amphibies : les Phoques et les Lamantins parmi les Mammifères, parce que, vivant habiluellement dans l'eau, ils peuvent venir sur le rivage; ou bien encore les Loutres, le Cynogale ou Potamophile, le Castor, l'Hippopotame et plusieurs autres qui, terrestres, dans quelques circonstances, vont souvent à l'eau et s'y meuvent même avec plus de facilité que sur le sul. Les Cétacés zoophages, au contraire, sont regardés comme exclusivement aquatiques, parce qu'ils ne quittent jamais l'eau. Ces particularités bien remarquables, sans aucun doute, ne sauraient cependant, comme celles qui caractérisent principalement les Amphibiens proprement dits, être prises en considération, quand il s'agit de classer méthodiquement les êtres chez lesquels on les a constatées et, si Blumenbach a cru devoir s'en servir pour admettre, parmi les Mammifères, un ordre réservé aux esp. aquatiques, c'est qu'il avaít plutôt en vue l'établissement d'un système que celui de la véritable méthıde naturelle. Celle sorte d'étal amphibie se retrouve en effel daus des g. d'ordres différents, et la disposition particulière des organes locomoteurs qui le caraclérisent, est une simple conséquence ou plutôt une condition harmonique, tout-à-fait dépendante des circonstances au milieu desquelles certaines esp., appartenantả des degrés divers de la série animale, doivent fonctionner. Aussi Blumenbach, que nous citons plutôt pour nous faire comprendre que pour le critiquer, admettait-il parmi les Mammifères palmipèdes ou aquatiques, des Rongeurs, des Carnassiers et des Edentés, comme il en admeltail dans son groupe des Fissipèdes ou digités. L'appréciation de la valeur réelle des caraclères fait aujourd'hui rapporter au même ordre ou degré de la série, des animaux aquatiques, terrestres et volatiles, quand, à part les différences, nécessitées par le séjour, la somme de complication de leur organisme se trouve être au fond la même.

Il n'est pas nécessaire d'ajouter que tous les Nammifères amphibies que nous citions plus haut, respirent, comme les autres g. de leur classe, l'air en nature, et, bien entendu, au moyen de poumons. Beaucoup d'entre eux doivent la faculté de plonger, à la forme de leurs narines, et surtout a un développement spécial de certaines parties du système veineux qui, retardant une portion du sang dans des plexus considérables, permet une respiration moins fréquente. Les Oiseaux qui vivent dans l'eau el qui s'y plongent fréquemment, les reptiles écailleux (Emides, Chélonées, Crocodiles, etc.) qui ont les mêmes habitudes, n'ont pas non plus, et à aucun âge, de branchies; mais chez les espéces de la classe des Reptiles, la circulation profondément modifiée dans quelques uns de ses organes, rend, pour ainsi dire, arbitraire leur acte respiratoire.

Quelques poissons, appelés pour cela même Amphibies, jouissent, comme les Phoques et les Lamantins, de la faculté de sortir de l'eau en quelques occasions, mais rien dans leur système respiratoire et circulatoire, ne rappelle ce qui a lieu dans les vertébrés pulmonés; l'orifice extérieur des branchies de certains d'entre eux (les anguilles) ayant un 
diamétre moins considérable que chez les autres, leur permet de conserver l'eau dans leur cavité branchiale, plus long-temps que ne peuvent le faire les carpes, par exemple, dont les ouies sont si largement ouvertes. Chez quelques groupes, l'appareil branchial est lui-même modifié à cette intention, et G. Cuvier a nommé Pharyngiens-labyrinthiformes, une famille d'Acanthopterygiens chez lesquels "les os pharyngiens supér. étant divisés en petits feuillets plus ou moins nombreux, interceptant des cellules oú il peut y demeurer de l'eau qui découle sur les branchies et les humecte pendant que le poisson est à sec; ce qui permet à ces poissons (Anabas, etc.) de se rendre á terre et d'y ramper à une distance souvent assez grande des ruisseaux et des étangs, oú ils font leur séjour ordinaire. :

Aimphibies s'emploie donc dans 2 acceptions physiologiquement différentes : $1^{\circ}$ pour des animaux qui vivent d'abord dans l'eau et respirent au moyen de l'air qu'elle renferme, et qui plus tard respirent l'air en nature; $2^{\circ}$ pour des esp. à respiration aérienne ou aquatique, et qui peuvent échapper pendant un temps plus ou moins loug à leur milieu habituel, mais sans varier dans leur mode de respiralion. Les Amphibies de la $1^{\text {re }}$ catégorie, lorsqu'ils ont quittẻ leur état aquatique pour la respiration à l'air libre, peuvent aussi être de la seconde, et vivre pour ainsi dire à volonté, dans l'air ou dans l'eau, mais en suspendant leur respiration, tant qu'ils restent plongés dans ce dernier milieu. Un fait curieux constaté par M. Milne-Edwards, est celui de la respiration cutanée accidentelle, par laquelle quelques uns de ces derniers (ex.: les grenouilles adultes) entièrement séparés de l'atmosphère, peuvent suppléer à son défaut.

Chez les animaux invertébrés, il y a aussi des Amphibies, les uns vrais ou de la première sorte; les autres apparents, c'est-àdire de la seconde. Certaines larves d'insectes hexapodes sont d'abord branchifères; elles vivent dans l'eau, et, plus tard, leur respiration devient aérienne, et alors elle s'opère au moyen de trachées. Ex. : beaucoup de Névroptères, des Diptères, des Coléoptères hydrocanthares et palpicornes, et l'Hydrocampa stratiotalis de l'ordre des Lèpidoptères. Les esp. de la même classe et à respiration aérienne qui vivent dans l'eau, soit à l'état de larve, soit à l'état adulte, sont fort nombreuses et de presque tous les ordres; mais ce ne sont plus lá que des pseudoamphibies. Quelques arachnides aussi sont dans ce dernier cas, et, parmi les Crustacés, plusieurs, bien que pourvus de branchies, se tiennent à la surface du sol; et c'est au moyen de l'air très humide qu'ils respirent.

Le type des animaux mollusques, n'a pas de véritables Amphibies; mais toute une famille de Pulmonés (les Limnées, Planorbes, Physes, etc.) vit dans l'eau à la manière des Insectes et des Arachnides.

Plus l'organisation des animaux est infér. et plus ceux-ci sont nécessairement aquatiques; aussi ne doit-on pas s'étouner de ne trouver d'espèces aériennes, ni même amphibiennes chez les véritables animaux rayonnés.

La respiration, cutanée chez quelques formes extrêmes (ex. : les Entozoaires) inséparables de la série des animaux articulés, permet aussi un g. de vie qui pourrait faire considérer comme Amphibies, quoique d'une autre manière, certains des êtres qui la présentent, puisqu'il en est qui peuvent également vivre dans l'eau ou dans l'intér. des autres animaux, soit dans leur canal digestif, soit dans divers autres points de leur organisme. C'est au moyen d'une respiration également cutanée que s'entretient la vie aquatique ou aérienne dans les lieux humides, signalée chez quelques esp. de Planaires, animaux fort voisins par leur organisation des précédents, et Amphibies par parasitisme. (P. G.)

AMPHIBIOCORISES. INS. - $V$. AMPHBICORISES.

AMPHIBIOLITHES ( $\alpha \mu \varphi i \epsilon_{10 \varsigma}$, amphibie; $\lambda\left(\theta_{\circ} 5\right.$, pierre ). AnIm. Foss. - Quelques auteurs ont désigné sous ce nom des fossiles qu'ils supposaient être les restes d'animaux amphibies.

(L.RD.)

* AMPHIBLESTRIA ( $\alpha \mu \varphi$ íßin ou réseau). вот. Cr. - Presl, dans sa Pteridographia, a formé, sous ce nom, un g. du Pteris latifolia Humb. et Bonpl., qui diffère des autres Piteris par ses nervures réticulées ou plutôt formant des aréoles à peu près quadrilatères, dans lesquelles quelques rameaux des petites nervures se terminent li- 
brement, comme dans les vrais Aspidium et les Phymatodes. Les capsules forment une ligne étroite, continue ou interrompue, recouverte par un tégument marginal étroit, scarieux, s'ouviant au dedans. - La seule esp. bien reconnue est celle citée ci-dessus, dont la fronde herbacée est trifoliée, à folioles profondément pinnatitides. Elle croìt dans la Colombie. Presl rapporte avec doute au même g., une plante du Chili qu'il n'a vue que dépourvue de fructification. (AD, B.)

* AMPHIBOLE. Amphibola (áupibòń, enveloppe, filet). MoLL. - M. Schumacher (Nouv. Syst. des Vers testacés) propose sous ce nom ung. particulier pour la T Verita mux avellana de Chnitz. Ce g. a été reproduit un peu plus tard par MM. Quoy et Gaimard sous le nom d'Ampullacère, qui a été plus généralement adopté. $V$. ampuldacère.

(DESH.)

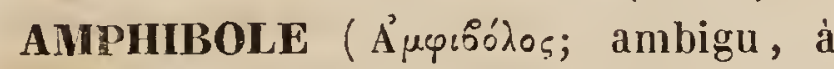
cause des analogies que les substances ainsi nommées ont avec d'autres minéraux, et notamment avec les Pyroxènes, les Épidotes et les Tourmalines ). mıN.-Haüy a donné le nom d'Amphibole à une esp. qu'il avait établie en réunissant les minéraux appelés précédemment Trémolite ou Grammatite, Strahlstein ou Actinote, et Hornblende. C'est un fait fort remarquable, que les fluctuations d'opinions auxquelles ces substances ont donné lieu parmi les minéralogistes. Rapprochées d'abord dans un même groupe avec beaucoup d'autres minéraux, sous le nom commun de Sichorl, d'après quelques rapports assez insignifiants, elles avaient été ensui te séparées par Werner, sur la foi de certains caract. extérieurs et fort peu décisifs. L'examen de leurs formes et de leur structure conduisit Haüy à les identifier sous le nom d'Amphibole. Plus tard, la découverte de l'isomorphisme est venue établir clairement la nécessité de considérer ce groupe non comme une véritable esp., mais comme un g. d'esp. isomorphes, c'est-à-dire d'esp. analogues et très rapprochées les unes des autres, tant par leurs formes que par leur composition atomique. On se trouvait ainsi ramené, en quelque sorte, au point de vue de l'École allemande, lorsque, peu de temps après, un cristallographe allemand, G. Rose, essaya de nous reporter encore à une manière de voir plus ancienne, en cherchant à démontrer l'identité des Amphiboles avec les Schorls volcaniques ou les Pyroxènes. \॥jourd'hui, la plupart des minéralogistes maintiennent la séparation des deux groupes, en considérant leurs esp. respectives, non comme isomorphes, dans l'acception rigoureuse du mot, mais simplement comme Plésiomorphes entre elles ( $V$. PlésiomonPHISME). Nous nous conformerons à cette opinion, en ayant soin de faire remarquer les analogies nombreuses et les rapports intimes qui existent entre toutes ces substances, et en insistant sur la valeur des 2 seuls caract. qui militent encore en faveur de la spécification généralement adoptée.

Nous allons indiquer d'abord les caract. qui distinguent le groupe des Amphiboles, considéré comme g. minéralogique; après quoi nous ferons connaître les différences qui nécessitent le partage de ce groupe en plusieurs espéces. - Les Amphiboles sont composés généralement d'un atôme de trisilicate calcaire ( $\mathrm{C} a \mathrm{Si}^{3}$ ) et de 3 atômes de bisilicate de magnésie ( $3 \mathbf{M} g \mathrm{Si}^{2}$ ), la chaux et surtout la magnésie pouvant être, en tout ou en partie, remplacées, équivalent pour èquivalent, par le protoxyde de fer ou le protoxyde de manganèse. Un atôme d'Amphibole est donc formé de 4 atômes de base monoxyde, et de 9 atômes de silice; si l'on admet avec M. Dumas, que la silice soit composée d'un atôme d'oxygène et d'un atòme de silicium. Nous adoptons cette dernière supposition, qui nous paraît plus probable que celle qui est généralement reçue parmi les minéralogistes, nous réservant de donner les raisons qui la justifient, dans l'article oủ nous trailerons des Silicates en général. Les Pyroxènes sont composés des mêmes principes dans des proportions peu différentes : ils résultent de la combinaison de 4 atômes de base monoxyde, et de 8 atòmes de silice, au lieu de 9 ; d'oú il suit que par la perte d'un atôme de silice, une molécule d'Amphibole se changerait en une molécule pyroxénique. Les Amphiboles fondent assez facilement au chalumeau en un émail diversement coloré ; si l'on expose une masse d'Amphibole cristallisée au feu des hauts-fourneaux, de manière à la fondre complétement, et si on la fait cristalliser de nouveau par refroidissement, les cristaux que l'on obtient ne ressemblent plus aux cristaux primitifs, mais $24^{*}$ 
ils offrent tous les caract. des cristaux de $\mathrm{Py}$ roxènes.

Les Amphiboles, comme les Pyroxènes, cristallisent dans le système Klino-rhombique : leur forme fondamentale est un prisme oblique, à base rhomboïdale, inclinée sur l'axe de 105 à $106^{\circ}$; mais les pans du prisme, tels que le clivage les donne, font sur l'arête antérieure $\mathrm{H}$ un angle obtus d'environ $124^{\circ} \frac{1}{2}$ dans les Amphiboles, et un angle aigu de $87^{\circ}$ à peu près dans les Pyroxènes. En admettant que la base ait la même inclinaison dans les 2 prismes, si l'on cherche à faire dériver l'un de ces prismes de l'autre, savoir le prisme de l'Amphibole de celui du Pyroxène, on trouve que l'angle du premier s'accorde à très peu près avec celui que donne le calcul, dans l'hypothèse où le prisme de l'Amphibole proviendrait de la modification ${ }^{3} \mathrm{H}^{3}$. Il faut, pour mettre les 2 prismes en rapport de position, supposer la coïncidence des bases et des sections diagonales respectives, en sorte que l'angle de 87० dans le Pyroxène corresponde à l'angle de $124^{\circ}$ dans l'Amphibole. De ce rapprochement, on peut conclure qu'il existe entre ces minéraux, sinon une identité complète de formes, du moins une analogie très grande et tout-à-fait comparable à celle qui s'observe ordinairement entre les substances dites isomorphes.

La pesanteur spécifique des Amphiboles varie de 2,9 à 3,5. Celle des Pyroxènes ne descend pas tout-à-fait aussi bas, mais elle s'élève jusqu'à 3,6 .

Les Amphiboles fondent plus facilement que les Pyroxènes; ils passent en conséquence moins vite, ou par un refroidissement beaucoup plus lent, de l'état de fusion à l'état eristallin. On trouve souvent la Hornblende et le Pyroxène augite composant ensemble des macles ou réunions régulières de cristaux, dans lesquelles les parties composantes d'espèces différentes sont entre elles dans le rapport de position indiquée plus haut; dans ce cas, c'est toujours le Pyroxène qui constitue le noyau ou le centre de la macle, et la Hornblende lui forme comme une sorte d'enveloppe extérieure. De tels groupements s'observent non seulement dans les cristaux disséminés (Diorites des monts Ourals), mais aussi dans les cristaux implantés (Sahlites d'Arendal). Les Amphiboles et les Pyroxé- nes ne se distinguent pas seulement par leurs faces de clivage; mais leurs formes extérieures, quoique susceptibles d'être ramenées les unes aux autres, sont le plus souvent différentes. Ainsi l'on n'a point encore observé les Pyroxènes sous les formes ordinaires de l'Amphibole; mais il existe dans les diorites de l'Oural des cristaux d'A mphibole qui se montrent sous l'une des formes les plus communes du Pyroxène; ce sont ces cristaux que G. Rose a décrits sous le nom d'Ouralite; ils renferment souvent un noyau de véritable Pyroxène. Cette observation semble indiquer que la différence des formes extérieures pourra disparaìtre un jour d'une manière plus complète. Il ne restera donc plus d'autre caract. distinctif, que la diversité des clivages, laquelle paraît dépendre d'une légère dilférence dans la composition chimique, savoir d'une petite quantité de silice en excès dans les Amphiboles. Si l'on regarde, avec la plupart des minéralogistes, cet excès de silice comme essentiel, par la raison qu'il est toujours en proportion simple et définie, il y a nécessité de maintenir la séparation des 2 groupes d'espèces. Il faudrait, au contraire, les réunir en un seul et même genre, si l'on considérait, avec G. Rose, cette différence de composition comme accidentelle, et comme provenant uniquement de celle des circonstances qui ont accompagné la formation des cristaux d'Amphibole et de Pyroxéne. Selon cet habile cristallographe, les Py roxènes auraient cristallisé par un refroidissement très rapide d'une certaine masse en fusion, et les Amphiboles par un refroidissement beauroup plus lent de la même masse fondue. $V$. Pyboxìne.

Nous rapporterons toutes les variélés d'Amphiboles à 3 esp., dont une, la Trémolite, comprendra les variétés à bases terreuses, qui sont généralement sans couleur; une autre, l'Amphibole proprement dit, se composera de toutes les variétés à bases terreuses et métalliques, dans lesquelles le protoxyde de fer ou de manganése entrera en quantité notable avec la chanx et la magnésie, et qui par suite présenteront une couleur verle plus ou moins foncée. Cette dernière se subdivisera en 2 s.-espéces : l'Áctinote et la Hornblende. La $3^{\text {me }}$ esp. comprendra les variétés à bases de fer et de magnésie, 
sans chaux, que l'on désigne sous le nom d'Anthophyllite.

fre Espèce.-TREMOLITE. Synon. Grammatite; composée d'ull atôme de trisilicate de chaıx ( $\mathrm{C} \mathrm{Si}^{3}$ ), et d'un atôme de bisilicate de magnésie ( $\mathrm{M} g \mathrm{Si}^{2}$ ). Cristaux blancs, blanc-jaunâtres ou gris-cendrés, ayant quelquefois une teinte verdâtre, et souvent un éclat qni tire sur le nacré; clivables parallèlement aux pans d'un prisme rhomboïdal oblique, dont le grand angle latéral est de $124^{\circ}, 37^{\prime}$, et dont la base est inclinée à l'axe de $103^{\circ}$ environ. Ces cristaux sont généralement vitreux et translucides; ils fondent avec assez de facilité en un verre blanc et bulleux.Densité, 2,9; Dureté, 5,6.Analyse: Silice 60,50 ; chaux 12,43 ; magnésie 27,07 . - La forme la plus ordinaire des cristaux de Trémolite est le prisme fondamental de $124^{\circ}$, dont la base est remplacée par un sommet dièdre de $148^{\circ}$; l'arête du biseau terminal est inclinée à l'axe, comme la base qu'elle remplace, et qui en serait la troncature tangente. Quelquefois cette troncature existe en même temps que celle des a rêtes longitudinales obtuses. La Trémolite se rencontre rarement en cristaux complets; elle est le plus souvent en longues baguettes prismatiques, terminćes irrégulièrement, comme si elles avaient été fracturées. Dans cette esp. de cassure transversale, on apercoit souvent une ligne colorée dans la direction de la grande diagonale; c'est ce caractère qui avait fait donner d'abord à l'esp. le nom de Grammatite. Elle se présente aussi en aiguilles divergentes, ou en masses composées de fibres délicees d'un aspect soyeux. Parfois elle offre des teintes d'un blanc rougeâtre, d'un vert d'asperge, ou d'un bleu-violet pâle. Elle est le plus ordinairement disséminée dans les Dolomies ou les calcaires saccharoïdes des terrains micaschisteux, et c'est ainsi qu'on la trouve à Campo-Longo au Saint-Gothard, à Pfitsch en Tyrol, à Gullsjo et Acker en Suède, à Jognatzka dans le Bannat, et dans une multitude de localités en Saxe, en Bohême, en Écosse, en Amérique.

On rapporte à la Trémolite une partie de ces substances filamenteuses, connues vulgairement sous les noms d'Amiante ou d' $A$ sheste. $V$. ces mots.

IIme Espèce. - MPHIBOLE. Composée d'un atòme de trisilicate de chaux ( $\mathrm{C} \mathrm{Si}^{3}$ ), et d'un atòme de bisilicate de fer ( $\mathrm{F} \mathrm{Si}^{2}$ ), cette esp. est souvent mélangée avec la précédente, surtout dans les variétés dites actinotes. Ses couleurs sont le vert tendre, le vert plus ou moins foncé, et le noir brunátre. Elle cristallise en longs prismes, ou en cristaux courts et bien terminés, clivables parallèlement aux pans d'un prisme klinorhombique de $124^{\circ} 30^{\prime}$. La base de ce prisme est inclinée sur les pans de $103^{\circ} 1^{\prime}$. Indépendamment des 2 clivages, que nous venons d'indiquer et qui sont les plus nets, l'Amphibole en offre d'autres qui sont beaucoup moins sensibles dans la direction des diagonales. La fusion au chalumeau donne un verre brunâtre ou noir. Densité, 3 à 3,4 ; Dureté, 5,5 .

jre Sous-Espèce. - actinotre. Synonyme Strahlstein; mélange de Trémolite et de Hornblende. Cristaux translucides, en longs prismes, ou en longues aiguilles rayonnées, d'un vert clair ou d'un vert foncé, disséminés dans des roches talqueuses; formant aussi des masses à structure lamellaire. Analyse de l'Actinote du Zillerthal : Silice 53,1; chaux 11,4 ; magnésie 7,8 ; protoxyde de fer 25,8.-Ori peut rapporter à l'actinote la substance appelée Kalamite, de Brattforsgrufva, en Wermelande; la Byssolite du Dauphiné. On pourrait aussi placer ici, d'aprés le résultat de leurs analyses, la plus grande partie des variétés d'Amphibole, dites Pargasites; mais leurs caract. extér. les rapprochent davantage de la Hornblende. On trouve l'Actinote disséminée dans des roches talquenses, au St-Gothard et dans le pays des Grisons en Suisse, et à Greiner dans le Zillerthal en Tyrol. Elle se rencontre aussi dans les lits de minerais ferrugineux des terrains schisteux cristallins, a Ehrenfriedersdorf en Saxe, à Arendal en Norwège, etc.

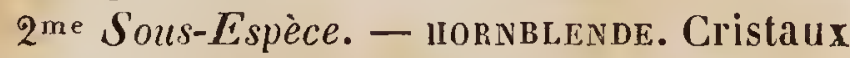
verts, vert-noirâtre ou d'un noir-brunâtre, ordinairement courts et complets, ayant souvent leurs arêtes et leurs angles arrondis, comme s'ils avaient été fondus; présentant des clivages latéraux très nets, et un éclat vitreux très prononcé. Leur forme la plus ordinaire est celle de la Var. Dodécaèdre, H., qui offre l'aspect d'un prisme hexaèdre terminé par des sommets trièdres á faces 
rhombes. Cette variétés est soumise à un groupement par hémitropie, qui lui donne souvent l'apparence de ces cristaux simples à sommets différents, qui sont si fréquents dans le groupe des Tourmalines. L'axe de révolution est horizontal, et perpendiculaire au plan des grandes diagonales. On voit quelquefois, à la jonction des 2 cristaux, une esp. de sillon qui annonce l'hémitropie; mais par l'extension que prennent cerlaines faces aux dépens de celles qui composent l'angle rentrant, celui-ci disparait d'ordinaire, et l'un des sommets présente 4 faces, tandis que l'autre en a 2 seulement. Ce qui distingue ces cristaux de ceux des Tourmalines, c'est qu'aucune des faces qui existent sur un sommet ne se retrouvent sur l'autre. Les Hornblendes sont composées comme les Actinotes, de silice, de chaux, demagnésie et de protoxyde de fer; mais les variètés d'un noir foncé renferment plus de fer ; et elles présentent, en outre, des traces d'acide fluorique, et une quantité d'alumine, qui va quelquefois jusqu'i 13 p. $0 / 0$, et dont la présence est encore tout-à-fait inexplicable.

La Hornblende se rencontre en masses laminaires ou lamellaires, formant des roches auxquelles on donne le nom d'Amphibolites. A l'état de grains cristallins ou de lamelles, elle entre dans la composition de beaucoup de roches mélangées (Syénitc, Diorite, Aphanite, etc.); elle y est ordinairement disséminée, soit en lamelles ou aiguilles reconnaissables a leurs clivages éclatants, faisant entre eux un angle très ouvert, soit en cristaux nets et courts, d'un vert ou d'un noir foncé. On doit rapporter à cette esp. : la Pargasite, Amphibole granuliforme, dissémincee dans un calcaire lamellaire à Pargas, en Finlande; la Karinthine, du Sau-Alpe en Carinthie; l'Arfwedsonite, ou Hornblende noire du Groënland; la Hornblende basalique, des terrains de basalte et de laves de la Bohême, de l'Auvergne, du Vésure, de l'Etna, du cap de Gates en Espagne, etc. Cette dernière variété est d'un noir foncé et à poussière brune; elle est susceptible d'une altération qui l'a fait passer à l'état terreux, et les écailles qu'on en détache, vues par transparence, paraissent souvent d'un beau rouge.

On peut aussi rapporter à la Hornblende:
l'Ouralite de G. Rose, variété d'Amphibole qui se présente sous la forme ordinaire du Pyroxéne, ẹt qui est abondamment répandue dans les diorites de l'Oural; et la S'maragdite (anciennement Diallage verte), qui, selon M. Heidinger, est un mélange ou groupement régulier de lamelles d'Ampihibole et de Pyroxène, offrant des faces de composition parallèles à la grande diagonale du prisme de $124^{\circ}$. La Smaragdite d'un vert foncé de Norwège r'est presque que de l'A mphibole pur. Elle fait, avec le Labrador ou la Saussurite, partie de la roche nommée Euphotide.

III ${ }^{\text {me }}$ Espèce. - ANTHOPHYLLITE. Subsance lamellaire, brunâtre, d'un éclat métalloïde, divisible en prismes rhomboïdaux de $121^{\circ} 31^{\prime}$, et aussi dans la direction de la petite diagonale. Sa couleur est le gris jaunâtre et le brun de girofle, quelquefois avec des reflets bleus. Son éclat est vitreux, ou perlé, et se rapproche un peu de l'éclat métalloïde.

Pesant. spécif $=3,5 ;$ Dur. $=5,5$. L'Anthophyllite est aux autres esp. d'Amphibole ce que l'Hypersthène est aux Pyroxènes ordinaires. Flle est composée d'un atôme de trisilicate de fer et de 3 atômes de bisilicate de magnésie; c'est donc une Trémolite dont la chaux a été remplacée entiẻrement par le fer. L'analyse de l'A. de Kongsberg par Vopelius a fourni : Silice, 56,74; magnésie, 24,35, oxydule de fer , 13,94; oxydule de manganèse, 2,$39 ;$ eau, 1,67 . Elle se trouve en couches dans le Micaschiste, à Kongsberg en Norwège, à Helsingfors en Finlande, et à Ikertoak en Groënland.

(DEL.)

AMPHIBOLES. Amphiboli ('supí, autour;

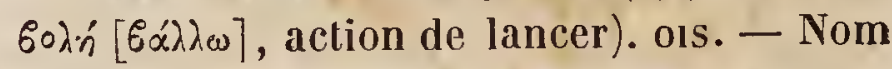
donné par Goldfuss et Illiger à une famille, et par Savi à une tríbu, de l'ordre des Passereaux, renfermant des oiseaux munis de 2 doigts en avant, de 2 en arrière, et dont le postérieur interne est versatile. (C. D'O.)

*AMPHIBOLINS. Amplibolini ( $\alpha \mu \varphi^{\prime}$, au-

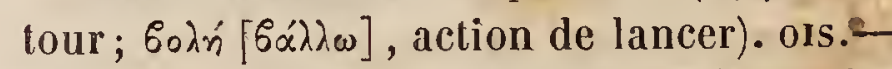
Ce nom, donné par C. Bonaparte à une famille d'oiseaux de l'ordre des Passereaux, est synonyme d'Amplitiboles. ( $\boldsymbol{V}$. ce mot.)

(C. D'O.)

AMPIIBOLIOUE. Amphibolicus ( $V$. AmPHIBOLE). GÉOL.-Les géologues donnent cette épithète aux roches dans lesquelles l'Am- 


\section{AMP}

Ilibole entre comme partie constituante essenticlle (ex.: Amphibolite, Diorite). Les Roches amphiboliques forment un groupe distinct dans les classifications de MM. Cordier, Brongniart , d'Omalius d'Halloy et de Bonnard. (C. D'O.)

AMPHIBOLIQUES [Roches] 'd'Amphibole; $V$.ce mot). GÉoL. - Les géologues donnent cette épithètc aux roches dans lesquelles l'Amphibole entre comme partie constituante essentielle. Les Roches amphiboliques forment un groupe dans les classifications de MM. de Bonnard, d'Omalius et Brongniart. M. Cordier en forme une famille comprenant les esp. Amphibolite Kersanton, Diorite, Porphyre dioritique et Grès dioritique. Les Roches amphiboliques sont généralement cristallines; les couleurs dominantes sont le noir et le vert plus ou moins foncé. Ces roches se présentent, soit en couches subordonnées, dans les terrains primordiaux, soit en filons ou en amas transversaux, résultant d'épanchement dans les terrains anciens.

(C. D'O.)

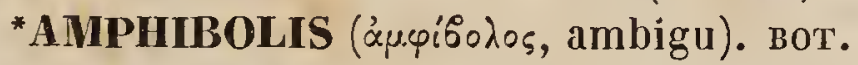
CR. - Il faut rayer ce $g$. du catalogue des Thalassiophytes. Le type sur lequel il a été fondé est le Ruppia antarctica Labill, qui est conséquemment une plante vasculaire. (C. M.)

AMPHIBOLITE (dimin. d'Amphibole; $V$. ce mot). GÉOL. - On. donne ce nom aux roches composées essentiellement et presque exclusivement d'Amphibole à l'état cristallin. Plusieurs éléments accessoires se trouvent quelquefois dans cette esp. de roche; ce sont, suivant M. Cordier, du Feldspath en petite quantité; du Quartz disséminé dans la masse en grains isolés ou en veines qui y forment de petits lits; du Grenat qui se présente en abondance sur certains points isolés; du Pyroxène; du Mica; de la Diallage; de l’Épidote; du Fer oxydulé; de la Pyrite ordinaire et de la Pyrite cuivreuse. L'Amphibolite présente unc texture grenue ou lamellaire; elle a beaucoup de ténacité, ce qui la rend difficile à casser. Sa couleur est le noir ou le vert foncé. Cette roche appartient aux terrains primordiaux ; elle se trouve dans les gneiss en couches subordonnées qui se répètent sollvent dans le même massif. Ia variété quartzilẻre appartient aux terrains micacés.

(C. D'O)
AMP

* AMPHIBOLOGARPÉES. Amphibolocarpce (áupíbòos, équivoque; xaprós, fruit). воT. PH.-Dénomination appliquée par Reichenbach (Handb. naturl. Pflanz.) à l'un des 3 groupes qu'il forme dans la famille des Fougères, dont il change le nom en celui de Ptéroïdées.

(C. L.)

* AMPHIBOLONARZON ( aucísolos, douteux ; narzon....? ). INs. - Nom donné par Porro à un g. de Coléoptères tétramères, famille des Xylophages, que Villa a nommé, de son côté, Calyptobium. $V$. ce dernier nom, qui a prévalu.

* AMPHIBOLURE. Amphibolurus ('u.

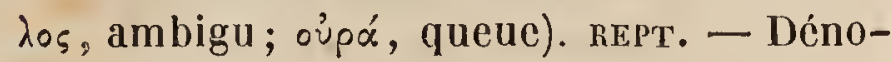
mination donnée par Wiegmann à un g. d'Iguaniens acrodontes que Kaup avait déjả fait connaître sous un autre nom. $V$. GraMMATOPHORE.

(G. B.)

- AMPHIBOLUS (áuḉco -G. de Colćoptères pentamères, famille des Hélophorides, Mac-Leay, établi par Waterhouse et adopté par Westwood (Syn. Gen. Ins. Angl.) qui en formule ainsi les caract.: Palpes maxillaires plus courts que le corselet; dernier article court. Élytres aussi larges que l'abdomen. - Il est fondé sur une seule esp., nommée $A$. atricapillus par Waierhouse.

AMPHIBULIME. Amphibulima (áupí, auprès de; bulima, sorte de coquille; mot hybride). MoLL. - Lamarck (Ann.du Mus.) a établi ce g. pour une coquille terrestre singulière qu'il a rangée depuis dans le g. Ambrette de Draparnaud. $V$. AM вRETTE. (DESH.)

AMPHICARPA, Elliot.-Amphicarpoa, DC. - Savia, Rafin.-Falcata, Gmel. S'yst. (áupé, autour de; ххрто́s, fruit). вот. Рн.-G. de la famille des Légumineuses, sous-ordre des Papilionacées, tribu des Phaséolécs, Brown. M. de Candolle ( $P$ rodr., v. 11, p. 583) en donne les caract. suivants : Cal. campanulé, 4-denté, ébractéolé; dents égales, subobtuses. Cor. papilionacée; pétales oblongs; étendard large, incombant, à peine onguiculé. Étarn. diadelphes. Style filiforme; stigm. capitellé. Ovaire à stipe engaîné par un petit disque tubuleux. Légume comprimé, stipité, 1-4-sperme. - Tiges herbacées, volıbiles; feuilles pennées-trifoliolées; grappes axillaires; fleurs souvent apétales : les caulinaires stériles ou produisant des fruits non conformes aux fruits inférieurs ; les ra- 
dicales le plus souvent fertiles.-Ce g., propre à l'Amér. septentrionale, ne renferme que 2 esp.

(Sp.)

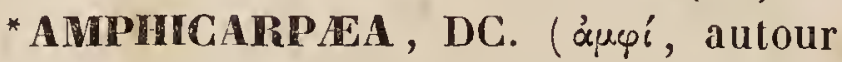

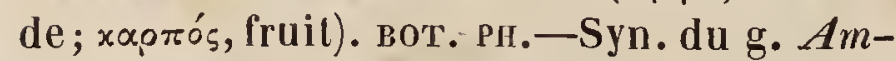
phicarpa, Ell., de la famille des Légumineuses.

*AMPHICARPUM (áp $\pi o ́ s$, fruil). вот. рг. - G. de la famille des Graminées, établi par le professeur Kunth (Enum.plant. 1, p. 57) pour une esp. de Millet décrite et figurée par $\operatorname{Pursh}(\mathrm{Fl}$. $\mathrm{Am}$. 1. p. $62,1.2)$, sous le nom de Milium amphicarpum.Voici les caract. de ce g. : Epillets biflores comme ceux du g. Milium; mais les uns composés de fleurs mâles, les autres de fleurs femelles sur le même pied. Dans les fleurs mâles : Lépicène unipaléacée, membraneúse, concave et mutique; écailles de la glume à peu près égales, minces et concaves sans arête. Étam. au nombre de 3 , et les 2 paléoles charnues, glabres, tronquées et presque bilobées. Dans les fleurs femelles : Lépicène également unipaléacée, membraneuse, concave et multinervée ; écailles de la glume coriaces, aiguës, l'infér. embrassant la supér. Les 2 stigm. presque sessiles, plumeux. Fruit allongé, cylindrique, glabre, $\mathrm{nu}$, seulement recouvert par les écailles de la glume. - L'Amphicarpum Purshii Kunth (Gram.1, p. 28;Enum. 1, p. 67) est une plante originaịre de l'Amér. Septent.; ses feuilles sont planes et velues; sa panicule à rameaux simples; ses épillets monoïques et pédicellés. Ce g. difière surtout du Milium par ses fleurs unisexuées et monoïques; par ses stigm. simples et les 2 palénles de sa glumelle qui sont simples et non bilobées.

* AMPHICÉNIANTHÉES. Amphicenian-

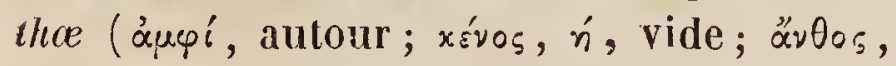
fleur). вот. Рн. - L. Reichenbach (Handb. Nat. Pflanz.), partageant en 3 grandes divisions la famille des Synanthérées, divise chacune d'elles en divers groupes, à l'un desquels il applique cette dénomination.

(C. L.)

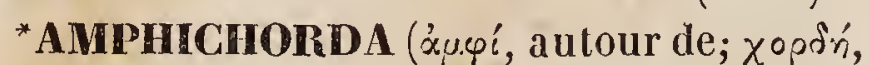
corde). вот. PI. - G. formé par M. Fries (Syst. Orb.veget. p 170). pour placer l'Isaria felina Chev. Ce champignon croìt dans les caves, dans les lieux humides,sur les excréments du chat. Il est caractérisé par des réceptacles allongés, filiformes, simpies, rarement rameux et blancs, dont toute la surface est recouverte de spores transparentes, rondes, d'une ténuité extrême. Le réceptacle est formé de cellules allongées, transparentes, sans cloisons, placées parallèlement les unes à côté des autres. Je ne connais pas de Champignons qui renferment un plus grand nombre de spores. Petiver paraîl être le premier auteur qui l'ait observé. M. De Candolle l'a rangé dans les Clavaires, Persoon dans le g. Fibrillaria, etM. Chevalier (.Jour. de Phys. fév.1822) le rapporte au g. Isaria dans lequel on aurait dû le maintenir, car il ne diffère pas, sous le rapport de l'organisalion, de quelques esp. qu'on rencontre sur les Insectes, les larves d'Insectes et les Araignées.

$$
\text { (LÉv.) }
$$

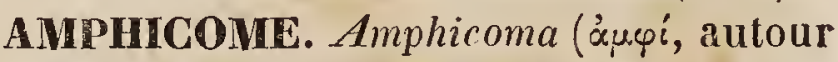
de ; xópin, chevelure). ins. - G. de Coléoptères pentamères, famille des Lamellicornes, tribu des Scarabéides, étabii par Latreille aux dépens du g. Melolontha, Fabr., et auquel il assigne les caract. suivants : Palpes filiformes, terminés par un article cylindrique; languette bifide, prolongée en avant du menton ; extrémité des mâchoires membraneuse, allongée, presque linéaire; labre saillant; mandib. coriaces, sans dents, arrondies à leur extrémité. - Indépendamment des caract. ci-dessus, les Amphicomes se distinguent au* premier coup d'œil des Hannetons, Anoplies, Hoplies et des autres g. voisins, d'abord par les poils plus ou moins longs dont leur prothorax et les côtés de leur abdomen sont hérissés (ce qui leur a valu leur nom générique); ensuite par l'écartement de leur's élytres, qui sont comme béantes à l'extrémité de la suture. Sous ce double rapport, elles ressemblent beaucoup aux Glaphyres etaux Anisonyx; mais elles s'éloignent des premiers par l'absence de dents à leur's mandibules, et des seconds par leur labre découvert et leur mandibule de consistance cornée dans toute leur étendue.-Ces Insectes vivent sur les fleurs et sont propres aux pays à la fois méridionaux et orientaux de l'Europe, ainsi qu'à l'Égypte, à la Syrie, a la Perse occidentale et à la Barbarie. On n'en a pas encore trouvé ni en Espagne ni dans le midi de la France. M. Dejean (Catal., $3^{\text {me }}$ édit.) en mentionne 13 esp., parmi lesquelles nous citerons l' $A$. vulpes Fabr., l'A. psilotri- 


\section{AMP}

AMP

chius Parreis, et l' $A$. Lasserei idem. Ces deux dernières sont très communes en Morée, oú elles se montrent dés la fin de mars.

* AMPIICOME (áucíxouos, entouré d'un épais feuillage). вот. Pl. - M. Rob. Brown, dans les Illustrations de la botanique de l'Inde d!̣ D. Royle, avait donné ce nom à une subdivision du g. Incarvillea; mais il avait expressément insisté pour qu'ou n'en constituât point un g. distinct. Néanmoins la plante a été figurée par le docteur Royle (L. c.tabl.72, fig.1.), sous le nom d'A. arguta, et M. Lindley, dans le Botanical register pour 1838 (Tab. 19), en a publié une $2^{\text {me }}$ esp., considérant le g. Amphicome, comme suffisamment établi. Celte opinion a été réfutée par M. R. Brown, dans son Mémoire sur les Cyrtandrées, oú ce botaniste a prouvé qu'excepté quclques différences dans les graines et le calice, il n'y a pas de caractères qui puissent justificr cette séparation. $V$. InCARVILLEA.

(Gr.)

*AMPHICONIUMI (áupí, autour de ; xóvis, poussiére). BOT. CR. - M. Nees d'Esenbeck (Syst. der Pilze p. 69, en note), avait établi ce g. dans la famille des Phycées. Les caract. en sont : Filaments simples ou rameux, articulés, dont les extrémités se renflent en conceptacles ou en sporidies qui se détachent et sont susceptibles de reproduire l'espèce. C'est là, comme on voit, une reproduction tomipare, analogue à celle du g. Oidium, parmi les Champignons; aussi, l'une des esp. du g. de M. Nees a-t-elle été inscrite parmi ce dernier genre. Adopté par Sprengel qui y réunissait deux autres plantes, l'Amphiconium, dans l'origine, ne se composait que de 2 esp. confervoïdes, dont l'unc appartient au g. Chroolepus et l'autre au g. Trentepohlia, Ag. Le g. Amphiconium n'ayant pas été adopté, ces 2 esp. ont été réunies, avec plusieurs autres plantes analogues, aux Chroolepus d'Agardh, par MM. Hooker et Harvey dans le t. v. P. 1. p. 380 de l' $\boldsymbol{E}_{n-}$ glish Flora (Lond. 1833). $V$. Chroolizus.

$$
\text { (C. M.) }
$$

* AMPHICORE. Amphicora (áupíxopos, qui semble tenir le milieu). annés.-G. établi par M. Ehrenberg pour une petite Annélide très voisine des A mphitrites, mais qui s'en distingue par la présence, aux 2 extrémités, de certains points noirs pris pour des yeux par cet auteur qui en conclut une duplicité de tous les organes essenticls chez ces animaux. (Dus.)

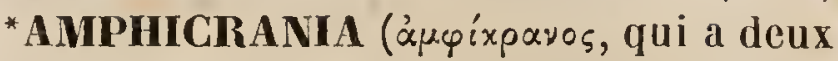
têtes ; crâne bifurqué, selon l'auteur du g.). INS. - G. de Coléoptẻres pentamères, famille des Lamellicornes, établi par M. Dejean, qui n'en a pas publié les caractères. D'après la place qu'il occupe dans son Catalogue (3me édit.), il appartiendrait à la tribu des Scarabćides-Phyllophages de Latreille. Il ne renferme qu'une esp., nommée par M. Dejean $A$. bidentata, ct $A$. paipalis par Eschscholtz; elle est du Chili. (D.)

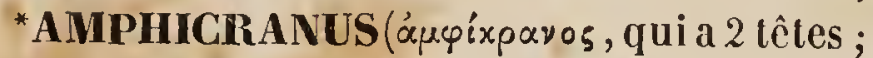
tête bifurquée). INs. - G. de Còléoptères tétramères, famille des Xylophages, tribu des Scolytites, établi par Erichson, qui lui donne les caract. suivants : Corps presque cylindrique. Ant. a funicule bi-articulé; le $1^{\mathrm{er}}$ article assez épais; le $2^{\text {me }}$ petit. Labre triangulaire. Palpes maxillaires ayant leurs 2 $1^{\text {ers }}$ articles très courts; le $3^{\text {me }}$ cylindrique, épais; le $4^{\text {me }}$ petit, pointu ; les palpes labiaux ayant.leurs deux $1^{\mathrm{ers}}$ articles grands, et le $3^{\text {me }}$ allongé et pointu. Jambes étroites, peu denticulées. Tarses ayant leur $1^{\mathrm{er}}$ article plus long que les suivants. Ce g., non adopté par M. Dejean, a pour type l'A. thoracicus Erichs., du Brésil; il est décrit dans les Archives de Wiegmann (1836, pag. 64).

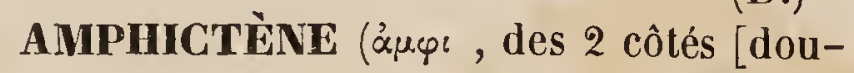

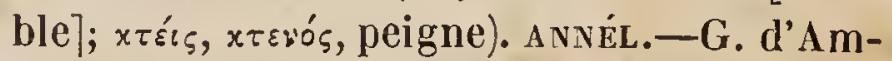
phitrites ou de Sabulaires, proposé par M.Savigny ; il est synon. du g. Pectinaria, Lamk. $V$. ce mot. (P. G.)

* AMPHICYON ( ápqí, près de [voisin]; $x i \omega \nu$, chien). mam. Foss. - Dénomination générique attribuée par M. Lartet à un Carnassier fossile de la taille du Lion, trouvé dans les terrains tertiaires lacustres du département du Gers, et dont le système dentaire ressemble beaucoup à celui du Chien, tandis que le reste de son ostéologie accuse une tendance manifeste vers les Carnassiers plantigrades. C'est à une esp. de ce g. que doivent être rapportées les dents recucillies à Avaray, près de Beaugency, et que Cuvier a décrites comme appartenant á un animal du g. Canis, mais d'une taille gigantesque. M. de Blainville pense que ces animaux doivent être placés entre les Ours et les Chiens.

$$
\text { (L. D.) }
$$

* AMPIICYRTA (áu. 
2 còtés). ıns. - G. de Coléoptères tétramères, famille des Chrysomélines, établi par Eschscholtz et adopté par M. Dejean, qui le place dans son Catal. (3me édit.), entre les g. Helodes et Colaspis de Fabricius. Ce g., dont les caract. n'ont pas été publiés, est fondé sur une seule esp. de la Californie, nommée par Eschscholtz $A$. dentipes. (D.)

* AMPHIDASIS et mieux AMPIIYDA-

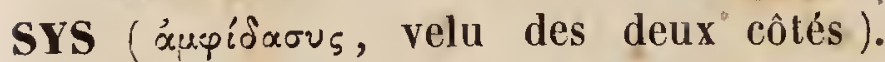
ıNs. - G. de l'ordre des Lépidoptères, famille des Nocturnes, tribu des Phalénites, établi par Treitschke aux dépens du g. Geometra de Linné, ou du g. Phalcena de Fabricius, Latreille, etc., et que nous avons adopté (Cortin. de l'Hist. nat. des Lépid. de France, par Godart), en le fondant sur les caract. suivants: Ant. pectinées dans les mâles, simples dans les femelles. Bord terminal des ailes simple ou entier. Cors. large et laineux. Ailes épaisses et petites relativement au corps. Tête enfoncée sous le corselet. Abd. gros et conique. Palpes velus et ne dépassant pas le chaperon. Trompe nulle ou presque nulle. Femelles ailées. Chenilles longues, cylindriques, garnies de tubercules en forme de bourgeons, et ayant la tête plate el plus ou moins échancrée dans sa partie supér. Chrysalide nue dans la terre. Ce g., qui renferme 8 esp. selon $M$. Treitschke, a été restreint par nous à 3 , qui sont les $A$. betularia, prodromaria et hirtaria; et nous avons réparti les autres dans deux nouveaux g. que nous avons créés sous les norns de Nyssia et de Phigalia. Les 3 esp. précitées ont la plus grande ressemblance avec les Bombyx, et se montrent à l'état parfait depuis le commencement de mars jusqu'à la fin d'avril. Leurs chenilles ne vivent que sur les arbres, au pied desquels elles s'enterrent pour se chrysalider sans former de coques.

AMPHIDASYS. INS. $-\boldsymbol{V}$. AMPHIDASIS.

*AMPHIDERRHIS, R. Br. ('auṕ̧, autour

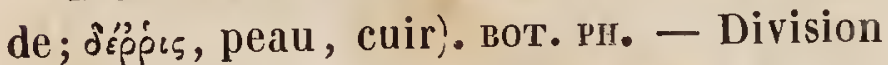
ou s.-g. du g. Orites, R. Br. (S'uppl. 32. Oritina, id.in Linn. Trans. x, 224.-A. Rich. S'ert. Astrol. 1. 25, 2.), caractérisée par des Anthẻres enveloppées entre les lamelles des folioles périgoniales; par des semences ailées des 2 côtés; par des feuilles cylindriques, sillonnées supérieurement et glandulifẻres sur les 2 faces.

(C. L.)
AMPHIDERRIS. BOT. $-V$. AMPHDERRHIS.

(C. L.)

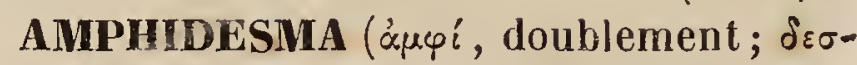
$\mu o ́ s$, lien). Moll. - G. de Mollusques acéphales, de la famille des Mactracés de Lamarck. Avant que cet auteur eùt proposé ce g. (Hist. Nat. des Anim. sans vertèbres), le petit nombre d'esp. connues ả cette époque était compris dans les Tellines de Linné. La création du g. Amphidesma était cependant nécessaire, fondé qu'il était sur des caract. très différents de ceux des Tellines et des Mactres. Cependant Cuvier, dans la $1^{\text {re }}$ édit. du Règne animal, soit à dessein, soit par oubli, n’a pas mentionné ce g., tandis que Férussac, Latreille, et M. de Blainville le comprennent dans leurs méthodes. Latreille, exagérant peut-être la valeur des caract., fait du g. Amphidesma, le type d'une famille à laquelle il donne le nom d'Amphidesmites. M. de Blainville au contraire amoindrit beaucoup trop la valeur des caract. de ce g. et le réduit à une simple section des Lucines. Cuvier ( 2 édit. du Règne anim.) parle des Amphidesmes dans une note, d'après laquelle il semblerait croire que le g. n'est pas suffisamment connu pour être admis dans une bonne méthode. Nous pensons que Cuvier a été dans l'erreur, et que ce grand zoologiste, détourné par d'autres travaux, n'aura pas minulieusement examiné le g. de Lamarck et n'aura pas senti la valeur de ses caract. Depuis les ouvrages que nous venons de mentionner, M. Sowerby a proposé sous le nom de Cumingia un petit g. qui ne nous paraît pas suffisamment distingué des Amphidesmes de Lamarck. Nous proposons, en conséquence, la réunion de ces 2 g. Il nous suffira de discuter les caractères de ce dernier pour en démontrer le peu d'importance.

L'animal des Amphidesmes n'est point encore connu; mais on a dejà rassemblé un assez grand nombre d'esp. de coquilles, d'après lesquelles les caract. du g. peuvent être exposés de la manière suivante :

Coquille bivalve régulière, équivalve, le plus souvent inéquilatérale, aplatie latéralement, tantòt transverse, tantôt obronde, ayant les crochets petits, rapprochés, et les bords simples; le postérieur un peu baîllant. Charnière offrant, dans le milieu, un petit cuilleron plus ou moins oblique, pour l'in- 
serlion du ligament, accompagné d'une ou de 2 dents cardinales. Une dent latérale comprimée de chaque côté de la charnière ; impression palléale profondément sinueuse du còté postérieur.

Il est à présumer que l'animal des Amphidesmes a une très grande ressemblance avec celui des Tellines; mais, comme dans un mollusque, l'animal n'est pas la seule chose à considérer, la coquille doil entrer aussi pour quelque chose dans les caract. génériques. Dans les Amphidesmes, ces caract. sont faciles à reconnaître; ce sont des coquilles généralement aplaties, minces, arrondies ou transverses, ayant le port des Tellines et offrant quelquefois, dans un développement assez considérable, le pli postér. que l'on a pendant long-temps considéré comme tout-à-fait particulier aux Tellines. Dans ce g., le ligament est toujours intér.; mais, dans quelques esp., surtout dans celles dont le cuilleron est le plus oblique, une portion de ce ligament paraît au dehors; ce qui a fait croire à Lumarck qu'il y a 2 ligaments dans ces Amphidesmes; d'oú le nom qu'il a donné à son g. A côté de ce cuilleron, on remarque, selon les esp., une ou 2 petites dents cardinales généralement peu saillantes, mais assez constantes dans certaines espèces; dans d'autres, elles ont une tendance à avorter et à disparaître. Dans ces esp., le cuilleron est moins oblique; c'est avec elles que M. Sowerby a fait son genre Cumingia. Nous pensons qu'il y a bien peu de valeur zoologique dans le caract. allégué par l'auteur anglais, pour le g. que nous venons de mentionner; mais pour le reste des caract., il présente une ressemblance parfaite. Outre le cuilleron et les dents cardinales, les Amphidesmes offrent constamment 2 dents latérales, également écartées du centre de la charnière, et assez semblables, par leur position et par leur forme, à celles des Tellines. Ce qui distingue cncore les Amphidesmes des autres g. voisins et surtout des Lucines dont M. de Blainville les a rapprochées, c'est le profond sinus postéricur de leur impression palléale. Ce sinus, comme on le verra en consultant l'article Lucine, n'existe jamais dans ce dernier g., tandis qu'on le remarque toujours dans tous ceux des Mollusques acéphales, terminés postéricurement par des siphons grêles et séparés dans une grande

$$
\text { T. } 1 \text {. }
$$

partie de leur longueur. Quclques personnes ont pensé qu'on devait attribuer aux Amphidesmes la Columelle d'A danson; mais nous pensons que cette coquille ne peut pas itre trćs ćloignée des Liłraea de Lamarck, parce que sa charnière est toujours pourvue de dents latérales.

On connaitt actuellement un assez grand nombre d'esp. d'Amphidesmes; elles sont distribuées dans presque toutes les mers; mais surtout dans celles des climats chauds. Nous n'en connaissons jusqu'à présent que 4 esp. fossiles, répandues dans l'étage supér. des terrains tertiaires.

(Desir.)

* AMPHIDESMITES ( $\alpha \mu \varphi i$, autour de ; $\delta \varepsilon \sigma \mu o ́ s$, lien). MoLL.-Famille de Mollusques acéphales, proposée par Latreille pour le g. Amphidesme de Lamarck. Cette famille ne peut être adoptée, parce que le g. qui la constitue se lie, par ses caract. les plus in!portants, soit aux Mactracés, soit aux Tellinides. Si l'on admet, comme nous l'avons proposé, des embranchements latéraux dans la classification des Mollusques, le g. Amphidesme devra servir de liaison entre les familles des Mactres et des Tellines, au moyen des Mésodermes, des Crassatelles et des Ericines. $V$. Anphidesme.

(Desir.)

*AMPHIDESHIUM (áréi, autour de;

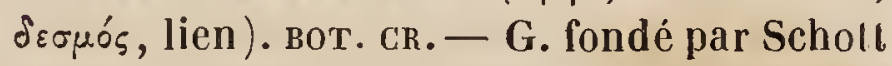
pour le Polypodium Parkeri d'Hooker et Gréville (Filie. 1. 232), ne différant peutêtre pas suffisamment dug. Metaxia de Presl, qui lui-même mérite à peine d'être distingué du Trichopteris du même auteur. La plante sur laquelle il a été établi aurait besoin d'être examinée de nouveau pour fixcr ses rapports avec les g. que nous venons de nommer.

(AD. B.)

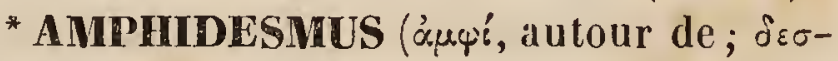
$\mu o ́ s$, lien). INs. - G. de Coléoptères tétramères, famille des Longicornes, établi par Eschscholtz et adopté par M. Dejean, ainsi que par M. Serville, qui le place dans sa tribu des Cérambycins, et !ui assigne les raract.suivants : Cors.arrondi latéralement, court, déprimé et inégal en dessus, muni de chaque côté de 2 tubercules; le postér. plus gros que l'autre. Ant. simples, glabres, plus longues que le corps dans lcs mâles, plus courtes que lui dans les femelles; de 11 articles cylindriques; le $2^{\text {me }}$ court, les $3^{m e} \mathrm{et}$ $4^{\text {me }}$ à peu près égaux ; le lerminal allongé, 
pointu. Palpes courts, presque égaux. Manlib. petites, courles. Tête courte, petite. Élytres allongées, allant un peu en s'élargissant vers l'extrémité; celle-ci arrondie; angle terminal un peu saillant. Écusson petit, triangulaire, pointu. Pattes de longueur moyenne; cuisses allongées. Facies d'une Callidie. - Ce g., d'après M. Dejean (Catal., $\left.3^{\text {me }} e d i \iota_{.}\right)$, ne renferme que 2 esp., l'une nommée par lui $A$. Hopfneri; l'autre qui est le Cerambyx quadridens de Fabricius, oll analis d'Olivier. Celle-ci est du Cap de Bonne-Espérance, et la $1^{\text {re }}$ des environs de Mexico.

AMPHIDETE. Amphidetus (áupíderos, lié des 2 côtés). EcHinod. - G. établi par M. Agassiz aux dépens du g. Spatangue, dont il comprend 2 esp. vivantes ( $A$. Seboe et $A$. pusillus), et une esp. fossile, l'A. Goldfussi. (Spatangus avenarius Marcel de Serres). Il correspond à la section A des Spatangues de M. de Blainville, caractérisée par des ambulacres non pétalö̈des, formant presque 2 lignes simples, et par un sillon antérieur assez profond. M. Agassiz y ajoute un caract. fort remarquable fourni par les piquants : les plus grands étant arqués et spathuliformes à leur extrémité, les autres étant petits et ras.

(D)

AMPHIDIUM ( $\alpha \mu \varphi เ \delta \tilde{\varepsilon} \iota \nu$, lier au tour ). вот. CR. - M. Nees d'Esenbeck a établi sous ce nom (Sturm. Fl. Germ. Abth. 11, Hift. 17) un g. de Mousses auquel il attribue les caract. suivants : Fleur terminale, diöque. Péristome double: l'extér. composé de huit dents réflexibles; l'intér. de huit cils. Coiffe conique, glabre, fendue de còté.

Le nom de Zygodon donné par M. Hooker au même g., étant non seulement généralement adopté, mais méritant encore la préférence à cause de sa priorité, nous y renvoyons le lecteur.

(C. M.)

* AMPHIDONAX ( $\dot{\alpha}_{\mu} \varphi^{\prime}$, autour de [voisin]; dóva, roseau ; g. Donax). вот. Pll. G. de la famille des Graminées, tribu des Arundinacées, Kunth, formé par Nees ab Esenbeck (in Lindl. Nat. Syst. of Bot.ed.11.) pour une Graminée indigène au Bengale, qui se distingue par des feuilles d'abord étroites, puis repliées sur elles-mêmes et subulées; par une panicule rameuse, diffuse. Endliclıer (Gen.Pl. 825) en résume ainsi les caract. donnés fort au long par l'auteur dans l'ouvrage cité : Épillets bi-tri-flores, géminés, polygames - monoüques par avortement; fleurs subsessiles. Glumes 2 , carénées, aiguës; la supér. plus grande. Paillettes 2, velues à la base; l'infér. acuminéesubulée ; la supér. obtuse. Squamules 2, bilobées. Étam. 3. Ovaire sessile. Styles 2, terminaux, allongés; stigm. aspergilliforme. Caryopse libre. (C. L.)

*AMPHIDONTA (áupí, autour de; ódoús, óvชos, dent). MoLL. - G. proposé par M. Fischer pour des coquilles qui ne diffèrent en rien des Gryphées de Lamarck. Nous regardons ce g. comme un double emploi des huîtres. Depuis long-temps nous avons proposé de le supprimer de la méthode, pensant que ses caractères ne peuvent supporter un examen sérieux. Nous nous proposons, en traitant le g. Huître, d'examiner la valeur des différents g. qu'on a voulu récemment en séparer.

(Desh.)

*AMPHIDORE. Amphidora (áupídopos, écorché tout autour). ıNs.-G. de Coléoptères Hétéromères, famille des Mélasomes, établi par Fschscholtz et adopté par M. Dejean, (Catal. $3^{\text {me }}$ édit.) ainsi que par M. Solier qui le place dans sa tribu des Blapsites. Eschscholtz le caractérise ainsi : Ant. de 11 alticles; le dernier comprimé et plus grand que les précédents. Palpes sécuriformes. Lèvre petite, presque ronde. Tarses garnis en dessous de poils très serrès. Thorax étroitement uni par sa base aux élytres. Ce g. es fondé sur une seule esp., du Chili, nommée par l'auteur $A$. littoralis.

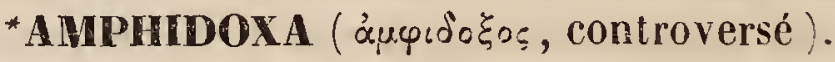
во'т. Pн. - Ce nom fait allusion aux affinités douteuses et multiples de ce g. avec quelques autres qui l'entourent et auxquels il emprunte pour ainsi dire ses caract.; ainsi l'Amphidoxa a le port d'un Helichrysum, mais ses fleurs femelles sont multisériées et dépourvues d'aigrette; il ressemble à un Gnaphalium, mais les fruits du rayon sont nus ; enfin il présente également quelques uns des caract. des Ifloga, mais son réceptacle est plan et dépourvu de paillettes. M. De Candolle qui a créé ce g. lui assigne pour caract. : Capitules multiflores hétérogames, à fleurs tubuleuses; celles du rayon femelles, plurisériées, très ténues; celles du disque b-dentées, hermaphrodites (peut-être stériles par avortement). Récept. plan, nu. In- 
vol. imbriqué, campannlé, à squammes extér. roussâtres-hyaliıes; les intér. terminées en un appendice blanc, ovale, obtus, presque rayonnant. Fruits oblongs; celux du rayon dépourvus d'aigrette; tandis que ceux du disque en possèdent une, formée par 5-6 soies, très caduques, barbellulées et renflées au sommet.-I'Amphidoxa, originaire du Cap, appartient à la famille des Composées, tribu des Sćnécionidées.

* AMIPHigameS ('áḉ, préposition de doute; $\gamma \dot{\alpha} \mu \circ s$, mariage). вот. Cr.-Quelques auteurs appliquent ce nom à la $4^{\text {me }}$ classe du régne végétal, comprenant les Lichens, les Champignons et les Phycées (Algues). C'est le synonyme de Cellulaires ( $V$. ce mot.).

(C. L.)

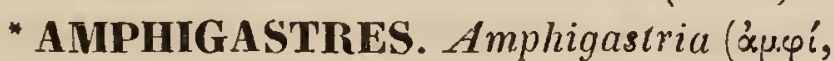

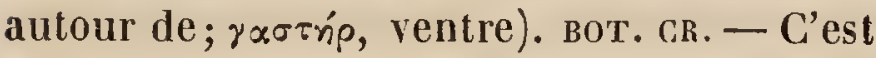
ainsi qu'on nomme aujourd'hui le $3^{\text {me }}$ rang de feuilles, qui, dans un grand nombre de Jongermanniées, recouvre la partie infér. ou le ventre de la tige. On leur donnait autrefois le nom de stipules (stipulce). Ces feuilles, ordinairement plus petites que les feuilles latérales, ont aussi une tout autre forme. Quand elles sont les unes et les autres divisées, leur mode de division n'est pas le mème. Souvent les feuilles sont entières et les Amphigastres bifides. La position de ceux-ci les rapproche davantage de la tige; et, lorsqu'ils s'en écartent, ce n'est jamais d'une manière aussi marquée. Leur texture est aussi plus délicate que celle des autres feuilles.

Les Amphigastres sont entiers ou bi-multifides à leur sommet, libres ou adhérents avec les 2 feuilles latérales, immédiatement au-dessus et au-dessous d'eux. Dans ce dernier cas, on les dit connés. Selon qu'ils sont placés à des distances plus ou moins grandes l'un de l'autre, ils sont dits espacés, rapprochés, imbriqués, etc. Dans les esp. ramipantes, c'est quelquefois de leur centre que part le faisceau de radicelles qui sert d fixer la plante.

Enfin les Amphigastres, dont la forme et la position varient infiniment dans les diverses esp. de Jongermanniées, fournissent d'assez bons caract. diagnostiques pour la distinction spécifique de ces plantes.

(C. M.)

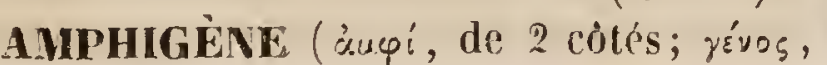

origine; qui a une double origine, a cause de ses 2 formes de clivage). min. - Synon. Leucite; Leucolithe; grenat blanc. Silicale d'alumine et de potasse, de la formule $\mathbf{A l}^{\prime}$ $\mathrm{K}^{\prime} \mathbf{S i}^{8}$, dans laquelle $\Lambda \mathrm{l}, \mathrm{K}, \mathrm{Si}$, représentent les atômes de l'alumine, de la potasse et de la silice, et oú l'on suppose cette dernière composée d'un atôme de silicium et d'un atòme d'oxygène. Dans la même hypothèse, le feldspath orthose, qui résulte de la combinaison des mêmes éléments, aurait pour formule $\mathrm{Al}^{\prime} \mathrm{K}^{\prime} \mathrm{Si}^{\prime}{ }^{\prime}$. L'A mphigène est une substance vitreuse, translucide, le plus souvent incolore, qui cristallise dans le système cubique, et presque uniquement sous la forme du trapézoèdre ordinaire, celui que produit la troncature tangente des arêtes du rhombododécaèdre, et dont les angles sont de $131^{\circ} 49^{\prime}$ et $146^{\circ} 27^{\prime}$. Ces cristaux sont susceptibles de se cliver parallèlement aux faces d'un cube, et à celles d'un rhombododécaèdre ; mais ces modes de clivage ne sont sensibles qu'à une vive lumière. Leur surface est rude, leur intérieur comme crevassé. Leur pesanteur spécifique est de 2,5 ; leur dureté de 5,5 . Ils sont infusibles et ne donnent point d'eau par calcination; ce qui les distingue des cristaux de Grenat et d'Analcime, avec lesquels on pourrait les confondre. Les cristaux d'Amphigène se réduisent souvent à la forme de grains arrondis, qui restent isolés, ou se réunissent pour constituer de petites masses granulaires. Ils sont sujets, tout en conservant leur forme extérieure, á une altération qui rappelle tout-à-fait celle qu'éprouve le feldspath orthose; ils deviennent blancs et friables, et passent à une sorte de Kaolin. lls sont quelquefois colorés de teintes grises, jaunes, ou rougeâtres. Sur 100 parties, ils conliennent 56,4 de silice; 22,5 d'alumine, el 21,1 de polasse.

L'Amphigène ne se trouve qu'en cristaux ou en grains disséminés dans les laves an-ciennes, savoir à la Somma et à Pompéi prés de Naples, dans presque tous les volcans éteints des États romains (Borghetto, Albano, Frascati, Tivoli, Capo di Bove, Acquapendente, etc.), et non seulement dans les laves, mais aussi dans les pouzzolanes et les tufs volcaniques; sur les bords du Rhin à Rieten près du lac de Laach; dans les Dolériles du Kayserstahl en Ririsgau, etc. Dans 
les laves qui composent le cône actuel du Vésuve, et celles du Stromboli et de l'Etna, l'Amphigène n'existe pas ; il paraît avoir été remplacé par du feldspath à base de soude et de chaux. Les cristaux de forme trapézoïdale, que l'on trouve sur l'Etna, appartiennent à l'Analcime.

(DEL.)

* AMPHIGÉnITE (dimin. d'Ampluigène; $V$. ce mot). GÉOL. - Ce nom a été établi par M. Cordier pour désigner les Basaltes et Basanites, dans lesquels le Feldspath est, en grande partie, remplacé par de l'Amphigène. L'Amphigénite se trouve principalement à la Somma.

(C. D'O.)

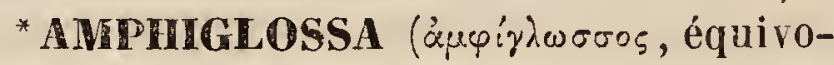
quе ). вот. Pн. - G. de la famille des Composées, tribu des Sénécionidées; il a pour saractères : Capitule multiflore 3-12 homo-ou hétérogame; fleurs ligulées en petit nombre; femelles très ténues, ne dépassant pas souvent celles du disque, qui sont hermaphrodites, tubuleuses, 5dentées. Récept. nu. Invol. cylindrique, imbriqué. Fruit glabre, sans rostre ni pédicule. Aigrette du rayon et du disque 1-sériée, caduque, composée de soies qui, de la base au sommet, deviennent graduellement et longuement plumeuses, et se trouvent entourées inférieurement d'un rebord a peine visible. - I es Amphiglossa sont des s.-arbrisseaux très rameux, droits ou décombants, quelquefois spinescents, ayant l'aspect des Seriphium et originaires cornme eux du Cap de Bonne-Espér. Leurs feuilles sont éparses, coriaces, très giabres et lisses en dessus; presque concaves et convertes d'un duvet blanc-tomenteux en dessous; les capitules sont solitaires et terminent les rameaux sessiles.

* AMPHIGLTTIS (áuṕ, doublement ;

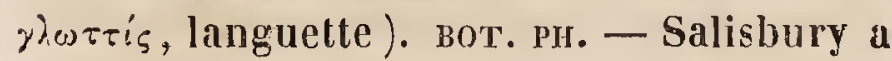
proposé d'établir sous ce nom un g. pour l'Epidendrum elongatum Jacq., l'une des Orchidées américaines les plus communes dans nos serres; mais cette esp. appartient bien réellement au genre Épidendre. $V$. ce not.

(A. R.)

* AMPHGONUS (árệ́, des 2 côtés [double]; yōvos, angle). mam.-Synon. d'Amphitherium, Blairuv., proposé par M. Agassiz, et comprenant les g. Thylacotherium, Val. et Phascolotherium, Owen.

(P. G.)

* AMPIIGYNANTHÉES. Amphigynan-

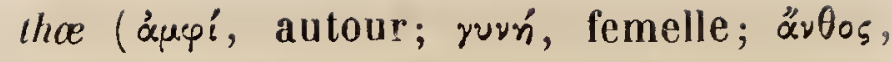
fleur). вот. Рн. - Dénomination appliquée par L. Reichenbach, à l'un des groupes qu'il a formés dans la famille des Synanthérées.

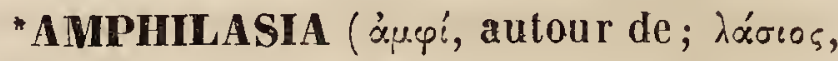
velu ). вот. pн. - Section du g. Petalacta, de la familie des Composées, caractérisée par les squames extér. de l'invol. élargies à la base, et les soies de l'aigrette, renflées en massue à l'extrémité libre. (J. D.)

*AMPHLEPTUS (áụ́, de 2 côtés ; $\lambda \varepsilon \pi-$ тós, grêle, mince), infus.-G. d'Infusoires, établi par M. Ehrenberg pour les Vibrio arser et cygnus de Müller, le Kolpoda meleagris du nuême, et quelques autres esp. voisines. Il fail partie de la farnille des Kolpodées du même auteur, renfermant les Infusoires poIygastriques, nus, pourvus d'un intestin, arec 2 orifices distincts qui ne sont point terminaux. Il se distingue des autres g. de cette famille, parce qu'il n'a point d'yeux, ni de langue ou valvule mobile à la bouche, et que son front se prolonge en manière de trompe, en même temps que son corps se termine par une queue courte et conique. Nous dirons à l'article Kolpodées ce qu'il faut penser de l'organisation de ces Infusoires; pour le moment, nous nous bornerons à dire que l'esp. la plus commune d'Amphileptus ( $A$. anser) est quelquefois si abondante dans l'eau des fossés et des ornières, qu'elle en colore le limon en brun. Sa longueur de $1 / 4$ à $1 / 3$ mill. permet de'la distinguer à l'œil nu, comme un point blanc qui se meut lentement dans l'eau; sa forme en fuseau très allongé en avant, la mobilité de sa partie antér. qui ressemble à une trompe, sa contractilité extrême, qui la fait continuellement changer de forme, et enfin la position dè sa bouche à la base du prolongenent en forme de trompe, la feront aisément reconmaître.

(Dus.)

* AMPIILOCHIA, Martius; Agardhia, Spreng. non Cabr. ('uupé, des 2 còtés ; $\lambda_{0-}$ $\chi^{\prime} a$, enfantement). вот. Рн.--G. de la famille desVochysiacées. Martius ( $N$ ov.Gen.el Spec.) en donne les caract. suivants : Cal. inadhérent, 5-parti ; segment supér. très grand, courtement éperonné; pour cor. un seul pétale obcordiforme; une seule étam. fertile, insérée á côté du pétale. Étam. rudimenlaires en général nulles. Ovaire à loges pauci- 
ovulées. Style indivisé; stigm. capitellé. Capsule ligneuse, 3-loculaire, septicide-3valve; loges 1 ou 2-spermes. - Arbres; feuilles opposées, pétiolées, coriaces ; fleurs en épis terminaux. Ce g., propre au Brésil, ne renferme que 2 esp.

* AMPHilochus (nom mythologique). Ixs. - G. de Coléoptères tétramères, fannille des Chrysomélines, établi par M. Dejean (Catal., 3me édit.), mais dont il n'a pas publié les caractères. Ce g. est fondé sur une seule esp. du Brésil, nommée par lui $A$. Klingii, et $A$. laticollis par M. Chevrolat.

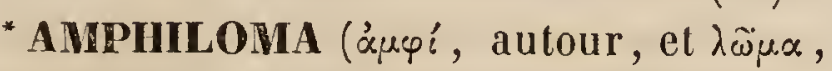
bord). вот. ріг. - C'est le nom qu'Acharius avait imposé, dans sa Lichenographia u'viversalis, à une section de son g. Urceolaria, caractérisée par des apothécies munies d'un double bord, l'un fourni par le thalle et l'autre par le disque ou la lame proligère. Il n'est fait nulle mention de cette div. dans le Synopsis Lichenum, qu'a publié plus tard cet auteur. La plupart des Urcéolaires ellesmêmes forment maintenant une tribu dug. Parmélie. Toutefois, le nom d'Amphiloma a été, dès 1825, employé par Fries pour désigner une section tout entière du g. Parmélie, de la famille des Lichens. Dans sa $L i-$ chenographia europoca, il s'en sert pour caractériser la $3^{\text {me }}$ tribu de ce nombreux genre. Cette tribu se compose des esp. dont le thalle est foliacé, presque monophylle par confluence et soudure, arrondi, formant le plus souvent, avec le temps, une croûte compacte vers le centre, appliquée sur un hypothalle laineux, très épais. Les apothécies sortent de l'intèr. du thalle, et sont accompagnées d'un rebord accessoire; quelquefois aussi ce rebord thallodique manque tout-àfait. Le disque, de consistance de cire, est assez épais et nu, c'est-á-dire qu'il n'est jamais recouvert de poussière blanche (pruina).

$$
\text { (C. M.) }
$$

* AMPHILOPIIIUM (áp.çi, autour de; hóøos, crète). вот. PII. - G. de la famille des Bignoniacées, tribu des Eubignoniées, Endl. forme par Kunth (in Humb. et Bonp. $\boldsymbol{N}_{o v}$. Gen.11. 149, 1.219), sur le Bignonia paniculata de Linné, et dont voici les caract. essentiels : Cal. campanulé, à limbe double ; l'extér. ample, membranacé, ondulé-crispé, étalé; l'intér. bilabié, à lobes entiers ou in- cisés. Cor. hypogyne, à tube court; à gorge ample, ventrue; à limbe bilabié; lévre supér. plus grande, galéiforme, bidentée ; l’infér. dressée, tridentée. Ėtam. insérées au tube de la corolle, incluses, 4 didynames, a vec le rudiment d'une $5^{\text {me }}$; anthères biloculaires, d logettes mutiques, divariquées-étalées.Ovaire biloculaire; ovules horizontaux, anatropes, nombreux, attachés aux 2 bords de la cloison. Style simple; stigm. bilamellé. Caps. ovale, comprimée, ligneuse, biloculaire , bivalve; valves paralléles à la cloison séminifère de chaque côté sur ses bords. Graines nombreuses, transverses, comprimées, ceintes d'une aile membraneuse. Embryon exalbumineux, orthotrope; radicule centrifuge. -Ce g. ne renferme qu'un très petit nombre d'especes, grimpantes au moyen de cirrhes, et propres à l'Amérique tropicale. On les distingue à leurs feuilles opposées, conjuguées, à leurs panicules, très roses, ou légèrement pourprées.

(C. L.)

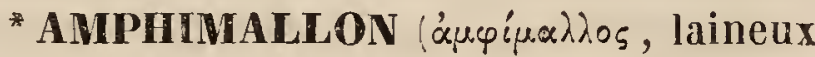
des deux còtés ). 1ns. - G. de Coléoptères pentamères, famille des Lamellicornes, tribu des Scarabéides phyllophages, désigné par Latreille dans ses familles naturelles, mais sans indication de caract. D'après MM. Serville et Le Peletier de St-Fargean dans l'Encyclopédie, ce g. ne diffẻre essentiellement des autres g. du même groupe, savoir : $P_{0}$ pilia, Euchlora, Dasyus el Plectris, que parce qu'il a les crochets de tous les tarses égaux et unidentés á leur base. Ces auteurs y rapportent les Melolontha solstitialis, pagana, pini el atra Fabr., que M. Dejean comprend dans le g. Rhizothrogus. Ces quatre esp. se trouvent en France.

AMPHINOME. Amphinoma ( $\alpha_{\mu} \varphi \varphi v \omega \mu \tilde{\omega}$, j'agite en rond). AnNÉL. - G. établi par Bruguière, et qui est devenu le type de la famille des Amphinomes. M. Savigny en a d'abord séparé quelques esp. sous le nom générique de C'hloeia (ex.: l' $A$. capillata Brug.), et il a donné aux esp. restées de vraies Amphinomes, celui de Pleiore adopté par Cuvier. MM. Audouin et Milne-Edwards, à l'exemple de M. de Blainville, lui préfẻrent celui d'Amphinome. Les caract. sont: Antennes all nombre de 5 ; une caroncule à l'extrémité antérieure du corps; pieds biramés, et portanl seulement 2 cirrhes; branchies en forme de houppes touffues qui recouvrent la base des 
rames supér.-La pl upart des Amphinomées connues habitent les régions tropicales, ou les mers voisines; une seule l' $A$. exrante, Pleione vagans, Sav., est donnée comme des mers d'Europe et provient des côtes d'Angleterre.

(P. G.)

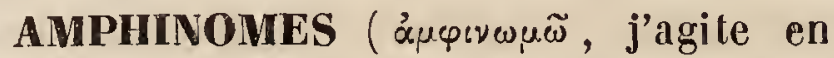
rond). ANNÉl.-M. Savigny appelle Amphinomes (Amphinomo), M. de Blainville Amphinomées (Amphinomece), et MM. Audouin et Milne-Edwards nomment Amphinomiens, Ia famille d'Aunélides setigères ou vers chétopodes, qui a peur type le g. Amphenoma ou Pleione, et quil comprend en outre ceux de Chloeia, Euphrosine, Aristenia et Hipponoa. Leurs caract. sont: Branchies en forme de feuilles très compliquées, de houppes ou d'arbuscules très rameux, toujours grandes et très apparentes, existant ainsi que les cirrhes supér., sans interruptions à tous les pieds ; point d'acicules; point de mâchoires ; point d'élytres.

*AMPHINOMIA (árú, adverbe de doute; ropós, allusion à l'incertitude de la classification du g.) вот. PH. - G. que M. De Candolle rapporte avec doute a la famille des Légumineuses (Incertce sedis, Prodrom. 2, p. 522) et auquel il assigne les caract. suivants: Cal. ovoïde, ventru, persistant, 5fide, à lanières étalées. Pétales 5 , onguicılés, spatulés. Étamines 10 , monade!phes. Ovaire ovoïde. Style latéral, filiforme, simple, obtus. Légume subglobuleux, muriqué, 1-loculaire, 2-valve, par avortement 1-sperme; graine réniforme-orbiculaire. - Herbe ; feuilles 3-foliolèes; pédoncules axillaires et terminaux, 3-5-flores. Ce g. ne se fonde que sur une seule esp., indigène du cap de B.Espérance.

AMPHIODON (áupi, autour de; ódov́s, óvтos, dent). poiss. - G. de poissons établi par Rafinesque, sur une des esp. de l'Olio, que les pêcheurs américaius y confondent avec d'autres, sous le nom de Shad, dénomination anglaise et vulgaire de l'Alose d'Europe; et que, dans l'origine de leurs établissements, les Anglo-A méricains ont transporté aux poissons de leur pays qui ressemblent á notre Alose. M. Rafinesque caractérise ce g. de Clupéoïdes par la diagnose suivante: Corps lancéolé; mâchoires infér. plus longues; dorsale commençant à l'opposé de la base de l'anale. Le nom indique qu'il y a des dents partout; et il ajoute que les mâchoires ont de grandes dents coniques et pointues, semblables à celles de la langue.

Il n'en cile qu'une esp. $A$. alosoides; poisson long de 14 à 18 pouces, dont la hauteur fait le $1 / 4$ de la longueur, à corps argenté, a dos bleu; il est bon à manger. (VAL.)

${ }^{*}$ AMPHION ( äu. mythol.). CRUST.-G. de l'ordre des Stomapodes, famille des Bicuirassés, établi par M. Milne-Edwards qui lui assigne pour caractère : Bouclier céphalique très développé, entièrement lamelleux, s'étendant jusqu'à l'origine de l'abdomen et cachant la base des pattes. Rostre nul. Yeux gros, ayant la tige qui les supporte extrêmement courte. Antennes au nombre de 4 , s'insérant sur la même ligne, immédiatement au-dessous et en arrière des pédoncules oculaires. Premier article des antennes externes peu distinct, donnant insertion à une tige cylindrique, et en dehors à un grand appendice lamelleux, ovalaire, et dépassant de beaucoup le niveau de la portion basilaire des antennes internes. Bouche très éloignée des antennes et formant vers le tiers antér. du bouclier céphalique , un petit tubercule arrondi, de la partie postérieure de laquelle nait le thorax. Thorax aplati, étroit, complètement caché sous la carapace. Pattes au nombre de 6 paires, grêles, cylindriques, présentant à l'extrémité de leur $2^{\text {me }}$ article un appendice palpiforme, composé d'un article cylindrique, terminé par une soie multi-articulée et ciliée. Pattes de la $1^{\text {re }}$ et de la $6^{\text {me }}$ paire beaucoup plus courtes que les autres. Abdomen presque aussi long que la portion céphalique du corps, composé de 7 segments, se terminant par une nageoire en éventail dont la pièce médiane lancéolée et les latérales ovalaires. La seule esp. connue est l' $A$. Reynaudii, Milne-Edw. , qui a été recueillie en haute mer dans l'Océan indien. (H. L.)

* AMPHION (nom mythologique). Ins.G. de Coléopt. tétramères, famille des Longicornes, tribu des Lamiaires, proposé par M. Reiche et dont il a donné les caract. (t. 8 , des Ann. de la \$oc. Entom. de France, p. 564). Ce g., fondé sur une seule esp. qu'il nomme $A$. vittatum, et qui a pour patrie Santa-Fé de Bogota eil Colombie, participe à la fois des g. Hippopsis, Serville, et Gnoma, 
Fabricius; il tient de celui-ci par la forme des mandibules et les stries transversales du corselet; mais il en diffère essentiellement par la forme du dernier article des palpes, la longueur relative du $1^{\mathrm{cr}}$ article des antennes, l'absence de protubérance sternale, et les pattes antérieures du mâle. Il se rapproche du $1^{\mathrm{er}}$ par l'inclinaison de la face antér. de la tête, la forme des palpes et des antennes, et s'en éloigne par les rides transversales du corselet, et l'extrémité tronquée et mulique des élytres. L'auteur pense que, dans l'ordre naturel, son g. Amphion doit être placé entre les g. Colobothea et Hippopxis de M. Serville.

* Amphonycha (áupí, des 2 côtés [double]; öv Coléoptères tétramères, famille des Longicornes, tribu des Lamiaires, établi par M. Dejean (Catal. $3^{\text {me }}$ édit.) qui n'en a pas douné les caract.; on voit seulement par sa synonymie que ce g se compose des g. Pyrobolus et Dadoychus de M. Chevrolat, et Hemilophus de M. Serville. L'auteur y rapporte 41 esp. toutes exotiques, don 126 du Brésil, 3 du Mexique, 5 de Cayenne, 1 des environs de Carthagène, 2 de Cuba, 2 de St-Domingue, une dont la patrie est inconnue, et une de l'A mérique du Nord. Nous citerons seulement ces 2 dernières, dont l'une est la Saperda marginata de Fabr., et l'autre la $S$. melanura de Latreille.

*AMPHIPÉPLÉE. Amphipeplea (ár.pi, autour ; $\pi \dot{\varepsilon} \pi \lambda_{0}$, manteau). MoLı. - M. Van Beneden a proposé $(S c$. Nat.) de former sous ce nom un g. particulier pour le Limncea glutinosa. Il s'est attaché à démontrer l'utilité de son g. en donnant sur l'animal des détails anatomiques du plus grand intérêt; mais nous pensons qu'avant de l'admettre, il serait utile de le comparer avec les différentes esp. de Limnées.

(DEsh.)

AMPHIPODES. Amphipoda (àupí, des 2

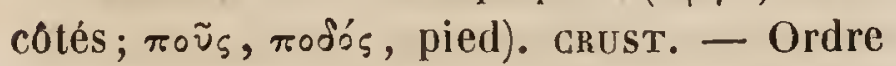
de la classe des Crustacés. ( $V$. ce mot.)

(DuJ.)

AMPHIPOGON. вот. ph. - C'est un g. de la famille des Graminées, tribu des Pappophorées, Kunth, qui a été établi par R. Brown (Prodr. Nov. Holl. 1 p. 175) et que Palissot de Beauvois a désigné plus tard sous le nom d'Egopogon; mais le premier de ces 2 noms doit être préféré comme plus ancien.
Les esp. d'Amphipogon, au nombre de 5 , sont toutes originaires de la N.-Hollande. Ce sont des plantes ordinairement vivaces, à souche rampante et à tiges fasciculées, ayant les fleurs disposées en épis denses et quelquefois presque globuleux. Les épillets sont uniflores; la fleur est sessile ou pédonculée, plus longue que la lépicéne. Celle-ci se compose de 2 valves membraneuses, concaves et mutiques. Les 2 paillettes de la glume, également membraneuses, sont : l'infér. trifide et la supér. bifide au sommet; chaque division étant lancéolée et terminée en arête à son sommet. Les paléoles de la glumelle sont entières et glabres.-Ce g. est très voisin du Pappophorum, dont il diffère surtout par ses épillets uniflores et par les valves de la glume terminées seulement par 2 ou 3 arêtes.

(A. R.)

*AMPHIPORINA ('aụí, des 2 côtés [double]; тópos, ouverture). IELm. - Section des Turbellaria rhabdocola (Ehrenb. Symb. Phys. Polyp.) où les 2 orifices du canal intestinal sont terminaux. Ex. Prostoma, Gyratrix, Amphiporus.

(P. G.)

*AMPHIPORUS (áupéi, des 2 côtés [double]; rópos, ouver(ure). ANNÉL.-G. de la famille des Gyratriciens, section des Tmbellaria amphiporina, proposé par M. Ehrenberg ( Symb. phys.) et caractérisé par la présence, sur la partie antér. ou frontale, de 4 bandes longitudinales convergentes d'0celles. Le corps est filiforme, grêle, molasse, visiblement annelé, sans cils. Ex. : A. albicans Ehr. (Pl. Iv. f. 2.) de la Mer Rouge, près Tor.

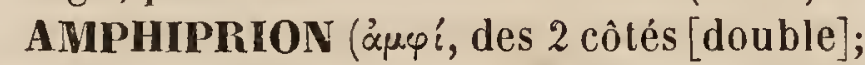
$\pi$ pećr, scie). Polss. - Nom générique de poissons imaginé par Bloch, sous lequel il comprenait, dans sa méthode artificielle, des Percoïdes et des Sciénoïdes très différents les uns des autres. M. Cuvier a réduit le $\mathrm{g}$. Amphiprion de Bloch, en retirant les Holocentrum, les Anabas, les Polyprions, les Trachychthes; et, après ces retranchements, il en a formé un g. naturel, qui comprend de pelites esp. á corps ovale, à une seule dorsale, à tête obtuse, à mâchoires garnies de dents sur une seule rangée; à palais lisse et sans dents; à 5 rayons aux viscères, armés de dentelures aux 4 pièces de l'appareil operculaire ; et enfin à ligne latérale finissant sous le dernier rayon de la dorsale. 
Leur canal intestinal est en cul-de-sac arrondi, avec 2 appendices cœcales au pylore. Il ne fait ensuite que 2 replis avant de se rendre à l'anus. Il y a une vessie natatoire, à parois minces, assez grande, et remplissant tonte la partie supér. de la cavité abdominale. Les Amphiprions se nourrissent d'herbes marines. Ils viennent tous des Indes et surtout de son Archipel. Ils ne dépassent guère un décimètre de longueur. Nous en connaissons aujourd'hui 12 ou 15 espéces. M. Cuvier les a laissées dans la grande famille des Sciénoïdes; mais je crois qu'il vaudrait mieux en faire le type d'une petite famille particulière dont il conviendrait de rapprocher les Chromis, qui ne sont pas des Labroïdes, et qui ne doivent pas être considérés comme des Sciénoïdes, pas plus que les Amphiprions dont la tête ne présente pas cet ethmoïde saillant et plus ou moins caverneux qui donne à tous les Sciénoïdes un caract. si particulier et si facile à saisir.

(VAL.)

* AMPHIPYRE. Amphipyra ('aụítipos, entouré de feu; pour l'auteur du g. : aulour du feu ). ins. - G. de l'ordre des Lépidoptères, famille des Nocturnes, tribu des Noctuélites, établi par Ochsenheimer aux dépens du g. Nocıua de Fabricius et adopté par M. Treitschke, son continuateur, qui le caractérise de la manière suivante: Antennes longues, crénelées, sétacées. Corselet presque uni. Abd. aplati avec des petites touffes de poils sur les côtes, chez le mâle senlement. Ailes supérieures obtuses se croisant à moitié l'une sur l'autre dans l'état de repos, peu inclinées, à rellets métalliques sans taches bien distinctes. Les chenilles sont glabres ou n'ont que quelques poils très fins; quelques unes ont une bosse pyramidale sur le $11^{\text {me }}$ anneau; elles se transforment dans des coques de diverses matières agglutinées. M. Treitschke, dans son supplément, rapporte à ce g. 18 esp. qui sont toutes assez disparates entre elles; aussi M. Guénée (Essai sur une nouv. class. des Noc(uél.) réduit-il ce même g. à la seule Nocura spectrum de Fabricius, en répartissant les autres dans ses g. Syntomopus et Philopyra dont il forme, avec ceux d'Amphipyra et de Mania, sa tribu des Amphipyrides; mais nous pensons qu'il faut joindre à l'A. spectrum la Noctua cataphanes de
Hubner qui n'en diffère guère que par sa taille beaucoup plus petite. Ces 2 esp. ne se tronvent que daus les parties méridionales de l'Europe; la $1^{\text {re }}$ est très commune en Italie et dans le midi de la France; sa chenille très belle, comme on peut le voir dans notre Iconographie des Chenilles, vit sur le genêt d'Espagne (Genisıa Junıcea), et se métamorphose, entre les branches de cet arbuste, dans une coque soyeuse d'un grisjaunâtre. L'autre esp., dont les premiers états ne sont pas connus, n'a encore été trouvée qu'en Dalmatie.

La réduction que M. Guénée a fait subir au g. Amplitipyra a dû nécessairement en modifier les caract. Voici ceux qu'il lui assigne : Chenilles à 16 pattes, rases, cylindriques, atténuées aux extrémités, sans éminences, de couleurs vives, avec les lignes bien marquées. Elles viveni complètement à découvert sur les sous-arbrisseaux, et se tiennent à l'extrémité de leurs branches. Chrysalides renfermées dans des coques de soie ovoïdes; filées entre les branches ou les feuilles. Insecte parfait: Antennes longues, subciliées dans les mâles. Palpes dépassant de beaucoup la tête, très ascendants, recourbés, comprimés laléralement; le $2^{\mathrm{me}}$ article large et arrondi; le $3^{\text {me }}$ long et uniforme. Thorax velu, sub-carré, lisse. Abdomen atteignant les ailes infér., aplati. Pattes et ergots trés longs. Ailes larges, luisantes, sub-dentées; les supér. épaisses, nébuleuses, ayant les lignes très distinctes et les 2 taches supér. assez visibles; les infér. bien développées, très velues à la base et au bord abdominal. Depuis le travail de M. Guénée, M. Boisduval a fait paraìtre un ouvrage intitulé : Genera et Ind. method. Europceorum Lepidopterorum, dans lequel il nomma Spintherops le g. Amphipyra dont il est question dans cet article, et range sous cette dernière dénomination générique les Noct. effusa, cinnamomea, pyramidea et perflua qui sont des Syntomopus pour M. Guénée. Nous ne voyons pas l'utilité de ces changements continuels dans sa nomenclature.

(D.)

* AMPIIIPYRIDES (d'Ampitipyra. $V$. ce mot. ). ıns.-Tribu de Lépidoptères nocturnes, établie par M. Guénée aux dépens de celle des Noctuélites de Latreille, et qu'il compose des g. Mania, Amphipyra, S'yntomopus et Philopyra ( $V$. ces mots). Les caract. 
qu'il assigne à cette tribu soht les suivants : Chenilles à 16 pattes, rases, cliarnues, non luisantes, ayant souvent le $11^{\text {me }}$ anneau relevé pyramidalement comme les $N$ otodonta; d'autres fois, les points trapézoïdaux verluqueux, ou une arête saillante sur le même anneau. Elles vivent sur les arbres ou les plantes basses, tantòt à découvert, tantôt abritées sous les feuilles. Chrysalides cylindrico-coniques, presque toujours renfermées dans des coques filées, assez solides, placées entre les feuilles ou les mousses, parfois enterrées comme celles du g. Noctua. Insecte paifaiı. Ant. simples et subciliées. Palpes bien développés. Spiritrompe de longueur moyenne. Thorax convexe, velı, lisse. Abd. plus ou moins déprinıé en dessus. Ailes ayant un reflet luisant et comme mélallique; les inférieures assez développées; au repos les supér. couvrent les infér., s'avancent mème parfois l'une sur l'autre et sont disposées en toît écrasé. Dans soll ouvrage intitulé: Genera et ind. method. Europceorum Lepidopterorum, qui a paru récemment; M. Boisduval adopte également la tribu des Amphipyrides qu'il compose des g. Gonoptera, Spintherops, Amphipyra, Scotophila, Mania et Rusina. De ces $6 \mathrm{~g}$., le $1^{\mathrm{er}}$ et le dernier ne nous paraissent pas heureusement rattachés à cette tribu : il n'en est pas de même des quatre autres; mais pourquoi M. Boisduval a-t-il substitué le nom de $S_{c o-}$ Łophila à celui de Pliilopyra donné au même g. par M. Guénée? Pourquoi également appelle-l-il Spintherops le g. Amphipyra du même auteur, et transporte-t-il ce dernier nom aux esp. de son g. Syrtomopus? Il nous paraît difficile de justifier tous ces changements qui ne font qu'embrouiller la synonymie.

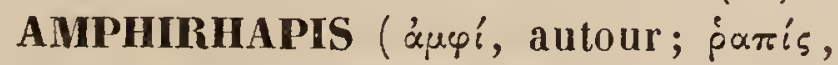
verge, baguette; à cause de son affinité a vec les verges d'or ). вот. Рн.-Ce g., élabli par M. De Candolle, se compose de quelques plantes de l'Inde, qui ont une très grande ressemblance avec nos Solidago, ou verges d'or. Elles ont pour caractères: Capitules multiflores, munis de 10-20 rayons étroits, les fleurs du disque tubuleuses, 5-dentées, hermaphrodites. L'involucre se compose d'un petit nombre d'écailles dépourvues d'ap. pendices; le réceptacle est alvéolé. Les ánthères et les styles semblables à ceux des AsT. I térées. Les fruits linéaires oblongs, légèrement comprimés, velus ou pubescents, présentent souvent, à la base de l'aigrette, des poils qui simulent un calicule poilu. Les Amplirhapis, originaires de l'Inde, sont des plantes vivaces, intermédiaires entre les g. Aster et Solidago; elles diffèrent du premier par la couleur uniforme des fleurons du rayon et du disque, du second par la forme allongée des fruits au lieu d'être comprimés.

(J. D.)

AMPHIROÉ. Amphiroa (nymphe de l'Océan). POLYP. ALG.-G. établi par Lamouroux dans l'ordre des Corallinées, qu'il regardait comme des Polypiers; mais aujourd'hui on est généralement d'accord pour reporter dans le règne végétal ces productions marines. Les Amphiroés ne diffèrent des Corallines que par la présence de petits disques nus, cornés, séparant les articulations encroûtées de calcaire, dont se composent les tiges et les rameaux nombreux, dichotomes ou verticillés de ces végétaux. Il faut remarquer pourtant que ce caract. n'a élé vérifié que sur des échantillons desséchés provenant des mers intertropicales, et que, dans nos Corallines mêmes, dont la croissance est moins rapide, on aperçoit souvent des intervalles également nus et cornés entre les articles. Lamouroux a décrit $13 \mathrm{esp}$. de ce genre encore imparfaitement connu.

(DuJ.)

"AMPHIRRHOGE. Reichb. Amphirrhox,

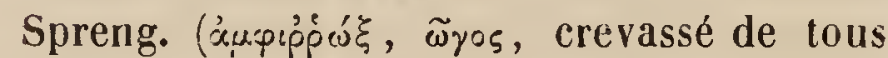
côtés). вот. Рн. - Synoll. du g. Spathularia, Aug. Saint-Hil., de la famiile des Violacées.

(Sp.)

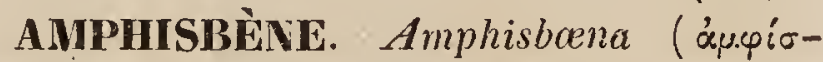

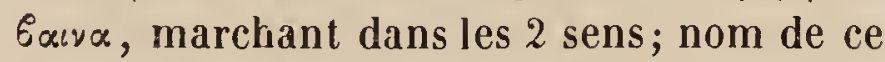
serpent chez les Grecs ). REPT. - G. de la s.-famille des Amphisbéniens pleurodontes, ou à dents appliquées contre le bord interne des mâchoires. Ces dents sont coniques, un peu courbées, simples, pointues, inégales, distinctes les unes des autres, en nombre impair dans l'os intermaxillaire. Les narines sont latérạles, petites, percées chacune dans une plaque unique, la naso-rostrale. Pas de mernbres du tout, mais des pores sur la marge antér. du cloaque. A ces caract. essentiels du g. Amphisbène, on peut ajouter que la tête est protégée par un plus on moins grand nombre de plaques de forme 
variable, et que les compartiments de la peau se ressemblent presque partout. La queue, ordinairement arrondie et aussi grosse que la tête, prend quelquefois une forme allongce et conique. Ce g., établi par Linné, faisait partie des Amphibii serpentes de cet auteur; nous y avons réuni les g. Blanus, Wagl. et Anops, Bell., qu'on en avait séparés, parce que l'un a la queue conique, et l'autre la tête comprimée. La plupart des Amphisbènes sont d'Amérique, car une seule paraìt propre à l'Afrique et une seconde est commune à cette partie du monde et à l'Europe. Celles dont on connaît les mours se tiennent dans les nids de Termites, des larves desquelles elles se nourrissent presque exclusivement. L'Amphisbène blanche, et l'A mphisbène enfumée, toutes deux du Brésil el de Cayenne, sont les plus communes; l'Amphisbène de King, fort remarquable par la forme comprimée et fortement arquée de la partie antér. de sa tête, se trouve à Buenos-Ayres; l'Amphisbène à queue blanche vient de la côte de Guinée, et celle appelée cendrée, la seule dont la quene soit conique, habite l'Espagne, le Portugal et les còtes barbaresques.

(G. B.)

* AMPHISBÉNIENS.REPT.-Il existe parmi les Reptiles proprement dits, ou ceux de la $1^{\text {re }}$ s.-classe, des esp. complètement dépourvues d'écailles et dont la peau est divisée à sa surface, par petits compartiments quadrilatères plus ou moins réguliers, disposés en anneaux aulour du corps, depuis une extrémité jusqu'à l'au tre : ces esp. sont les Amphisbènes, et quelques g. analogues qu'on a classés, tantôt avec les Sauriens, tantòt avec les Ophidiens, parce qu'en effet ils tiennent des uns et des autres sous certains rapports; mais ils en diffèrent tellement à plusieurs égards, que nous croyons plus convenable de les isoler tout-à-fait, ou d'en former un ordre particulier que nous proposons d'appeler Ámphisbéniens, du nom du g. le plus connu de ceux qui en font partie. Cetordre, réellement intermédiaire aux lézards et aux serpents, lie naturellement ceux-ci à ceux-lá, au moyen des derniers Chalcidiens, tels que les Ophisaures et les Pseudopes, et des premiers Ophidiens; si toutefois on doit considérer comme de vrais serpents, les Typhlops dont la structure de la lête conserve encore quelque chose de celle des Sauriens. Les Amphisbéniens ont dans la nudité de leur peau, et les lignes enfoncées qui la divisent circulairement par petits carrés assez semblables à des tubercules aplatis, ou mieux aux petites pièces qui composent une mosaïque, un caract. qui leur est propre entre tous les Reptiles non Batraciens. Leur tête seule est enveloppée de plaques pareilles à celles des lézards et des serpents. On n'y distingue, pas plus que chez ces derniers, de trous auditifs externes. Leur corps allongé, cylindrique, et presque de même diamèlre dans toute son élendue, se termine par une queue très courte, obtuse ou conique; il est dépourvu de pattes, excepté chez les Chirotes, qui, a reste, n'en offrent qu'une seule paire en devant. Leurs yeux, comme ceux des Typhlops, sont excessivement petits, et recouverts par la peau, au travers de laquelle on les aperçoit assez généralement comme de simples points noirs autour desquels on ne distingue pas d'iris. La plupart ont une série de pores en travers du bord antérieur de la fente anale, un sillon longitudinal de chaque còté du corps, et quelquefois un troisieme sur la ligne médiane du dos.

Leur squelette n'a d'au tre ressemblance avec celui des serpents, que par le grand nombre de pièces qui constituent la colonne vertébrale; tandis qu'il tient de celui des lézards en ce qu'on y retrouve un sternum, même chez les esp. A podes; en ce que les os de la face sont solidement articulés entre eux et avec ceux de la boite cérébrale; et aussi en ce que les branches sous-maxillaires qui, en arrière, sont plus courtes que le crâne, sc trouvent intimement soudées l'une à l'autre en avant. Il résulte de lá que la bouche de ces Reptiles n'est nullement dilatable, ce qui les rapproche des Sauriens et les éloigne au contraire des Ophidiens; mais, de même que ces derniers, ils ont un de leurs deux poumons excessivement court, tandis que l'autre est très étendu en longueur. La langue est plate, élargie, ovalaire, échancrée en $\mathrm{V}$ en arrière, et assez brusquement rétrécie à son extrémité antér.en 2 petits filets minces et lisses. Le reste de sa surface est revêtue de papilles squammiformes, unies, imbriquées et arrondies à leur bold libre, qui est celui qui regarde le fond de la gorge. Cet organe, qui est médiocre- 
ment exsertile et entièrement dépourvu de gaîne a sa base, emplit presque toute la concavité que laissent entre elles les 2 branches de la mâchoire inférienre.

Les dents présentent 2 modes d'implantation; ainsi, ou elles sont fixées sur le sommet même des os, auxquuels elles adhérent si fortement qu'elles ne semblent faire qu'un avec eux, ou bien elles sont appliquées contre la face interne des maxillaires dans une sorte de rainure qui y est pratiquée. On peut, en se fondant sur ces différences, partager les Amphisbéniens en esp. Acrodontes et en esp. Pleurodontes, ou en 2 familles qui comprennent ensemble les $g$. Trogonophidle, Chirote, Amphisbène et Lépidosterne. G. Cuvier avait rangé les deux derniers parmi les serpents dont ils composaient, avec les Typhlops, sa seconde famille ou celle des Double-Marcheurs, tandis qu'il avait placé le second à la fin des Sauriens, près des Seps et des Chalcides. M. Müller fait des Amphisbéniens la $1^{\text {re }}$ famille de l'ordre des Ophidiens. Nous-mème, avant de les avoir isolés comme nous le faisous maintenant, les rangions parmi les Sauriens, à la suite de la famille des Chalcidiens. Réunis aux Chalcides, ils sont pour Wagler l'orrle des Angues et pour le P. Ch. Bonaparte, celui des Saurophidiens (G. B.)

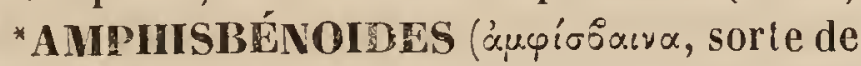
serpent; Eidos, forme). REPT. - Nom employé par plusieurs naturalistes, et notamment par M. Müller, pour désigner le groupe des Reptiles que nous appelons Amphisbéniens.

(G. B.)

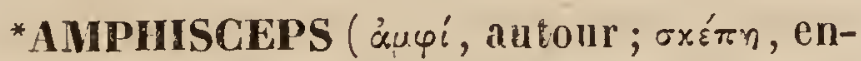
veloppe). Ins. - G. de la famille des Stridulantia, Burm. ou Cicadaires, Latr. de l'ordre des Hémiptères, seclion des Homoptères, indiqué par M. Germar, dans son tableau des g. de la lamille des Cigales ( Rev. Ent. de Silberm. t. 1, p. 174), comme devant se placer près du g. Issus, dont il réunit la plupart des caract., et dont il diffèe surtout, par les élytres non voûtés, mais infléchis perpendiculairement. L'auteur rapporte à ce g. 2 espèces qu'il ne décrit pas; ce sont les $A$. nodipennis et malina Germ.

(BL.)

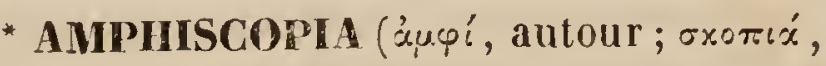
action d'observer). Bor. Pr. - G. de la famille des Acanthacées, tribu des Diclipté- rées, Nees, formé par Nees (in Wall. Pl. As. var. 111, 112), pour un petít arbuste du Brésil, encore peu connu, se redressant tout-à-coup dès la base, muni de feuilles opposées, oblongues, acuninées aux 2 extrémités; à fleurs unilatérales, bractéées, disposées en épis terminaux composés; a bractées florales simples, cornées, avec un pédicelle très court; les opposées très courtes, à bractéoles petites. Voici les caract.que donne l'auteur à ce g. : Cal. 5-parti, égal. Cor. hypogyne, ringente, à lèvre supér. bifide; l'infér. trifide. Étam. 2, insérées au tube de la corolle; anth. biloculaires, à logettes mutiques, et terminant les rameaux d'un connectif allongé, dont l'un regarde l'autre en dessus. Ovaire biloculaire, a loges bi-ovulées. Style simple; stigm. indivis. Capsule onguicúlée, biloculaire, tétrasperme... Graines sous-tendues par des rétinacles larges, tronqués.

* AMPHISE. Amphisa. ins. - G. de l'ordre des Lépidoptères, famille des Nocturnes, établi par Curtis, et adopté par Stephens qui le place dans sa tribu des Tortricides. Il n'est fondé que sur une seule esp., la Pyrala gerinugana de Fabricius, figurée par Hubner (Tab. 17, fig. 108), sous le nom de pectinana. Cette esp., pour nous, fait partie du g. Tortrix. $V$. ce mot.

AMPHISILE. Poiss. - G. de Poissons voisins des Centrisques, qui en diffèrent par leur dos cuirassé de larges pièces écailleuses et par l'épine antérieure de la dorsale qui, au lieu d'être relevée sur la ligne dorsale, est couchée horizontalement, et semble être une continuation des boucliers dorsaux. On n'en connaît que 2 esp. : l'une tellement cuirassée, età épine dorsale téllement grande, que la seconde dorsale et la queue ont l'air d'être rejetées en dessous et confondues avec l'anale. C'est le Centriscus scutalus de Linné ( $A$. scutatus Nob.). L'autre esp. A. velitaris (Cent. velitaris Pall.) n'a de boucliers que sur la moitié du corps. M. Dussumier a vu une fois, en traversant le détroit de Malacca, la mer couverte de poissons de cette espèce, morts et surnageant à la surface, sur un espace de plus d'une lieue de Iongueur.? Quelle action sous-marine avail pu agir sur une masse aussi considérable de Poissons de celte seule espèce? (VAL.) 
AMPHisorex. mam. $-V$. MusaraiGUE.

*AMPHISPORIUM ( $\varkappa_{\mu \varphi \omega}$, deux; $\sigma \pi \circ p \dot{x}$, spores ). вот. Св. - G. de Champignons appartenant à la famille des Gasteromycetes de Nees, et caractérisé par un sporange globuleux, déprimé, renfermant, sans aucun mélange de filaments, des spores de 2 sortes dont les unes sont fusiformes et les autres globuleuses. Ce g., adopté par des auteurs et rejeté par d'autres, demande à être étudié de nouveau, quoique les caractẻres énoncés soient suffisants pour le faire reconnaître.

(LÉv.)

*AMPHISTAURUS ins. $-V$. AmpIIIST0Ros.

*AMPHISTÉGINE, Amphistegina, d'O.

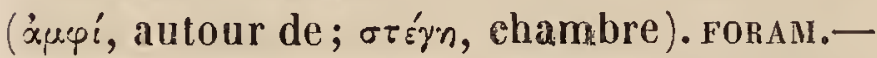
G. de l'ordre des Entomostégues, famille des Astérigérinidées, que nous avons établie en 1825 (Tab. méth. des Céphal.) pour des coquilles discoïdales, libres, spirales, inéquilatérales, plus bombées d'un côté que de l'autre; ayant la spire embrassante, composée en dessus de loges uniques, formée en dessous, sur la moitié de sa largeur, par la continuité des loges supér. et par d'autres loges constituant une rosace. Leurs loges sont de 2 sortes : les loges ordinaires, embrassantes, supér. ; les loges infér., médianes, servant à former une rosace centrale; les 2 se succeddent par alternance, dans l'accroissement de l'ensemble. Ouverture infér.

Ce g., distingué des Asterigerina, par les tours de spire embrassants de chaque còté, comprend 8 esp. que nous avons rencontrées dans les sables des mers, et dans les couches terrestres. Six sont vivantes des îles des diverses parties diı monde, des Antilles, des Iles Sandwich, de l'Ile-de-France, de Madagascar, etc. Les esp. fossiles appartiennent au bassin tertiaire de la Gironde, et à la craie sup. des environs de Maëstricht. (А. D’O.)

AMPHISTEPHIUM (ámpí, des 2 côtés;

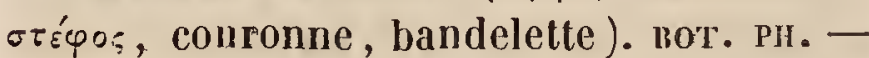
- Section dı g. Diplostaphiunn, Cass. $V$. ce mot.

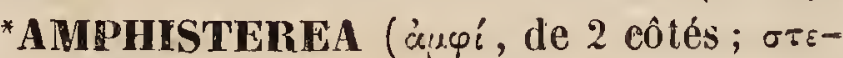
pros, á, solide). пrrm. - M. Ehrenberg (Symb. Phys. Polyp.) appelle ainsi une section de son ordre des Rhabdecolu dont le principal g. est celui de Derostoma, Dugès. Le tanal intestinal de ces animaux est complet, mais ses ouvertures ne sont terminales ni l'une ni l'autre.

AMPHSTOMES. Amphistoma, Rud. Amphistomum, des aut. (ápoírouss, qui a 2 bouches). HeLM. - Rudolphi fonda ce $\mathrm{g}$. (Étozoorum. Hist. Nal. 1809) pour les Trématorles à double ventouse terminale. I a caractéristique qu'il en donne est celleci : Corpus molle, teretiusculum; porus anıicus et posticus terminales, solitarii (t.2, p. 340). Il y comprenait 9 esp. ceriaines et 2 douteuses, et partageait le g. en 2 groupes; l'un pour les esp. dont le renflement céphaloïde est séparé du reste du corps par un étranglement; l'antre pour celles oú ces 2 parties sont continues entre elles. Jans le Synopsis (1819), le nombre total des esp. se trouve porté à 21. M. Nitzch en 1819 (Encyc'np. de Ersch et Gruber; 1 . 3) a proposé le nom de Holostomum, pour la $1^{\text {re }}$ de ces 2 div. ei pour plusieurs Distomes caractérisés, parce que la partie antér. du corps, très concave, sert, plus ou moins tout entière, de ventouse. Cette div. est, en outre, partagée par lui en 2 sous-g., Holostomım, proprement dit, et Cryptostomum. Nous citerons. comme appartenant aux Holostomum, en général, les $A$. macrocephalum, striatum, cormu, etc. Rud.et les Distoma alatum, spathaceum, etc., Rud.

M. Diesîng, en 1835 (Ann. du Muséum de Vienne, t. 1, p. 237) a donné une belle monographie du g. Amphistome, proprement dit, dont il a décrit et figuré 14 esp. nouvelles. Il en détache, sous le nom de Diplodiscus, les $A$. subclavaturr et unguiculatum, Rud., caractérisés par la perforation de la ventouse postér., par le centre de laquelle sort le pore génital. Acetabulum suctorium, terminale aut laterale, vaginans uperturain genitalem disciformem, protractilem. Ce caract. nous paraît excellent.

Jusqu'à ces 10 dernières années l'anatomie des Amphistomes n'était pas connue; mais depuis le beau travail de M. Laurer (Disquisit. anat. de Amph. conico, Gryphiæ 1830) et l'anatomie de l'A.giganteum, par M. Diesing (loc. cit.), ces animaux sont peut-être les mieux connus des vers intestinaux. Nous entrerons, à leur égard, dans tous les détaîls nécessaires, lors de l'étude générale que nous ferons do tous les Fasciolaires ( $V$. ce mot.).

$M$. Leblond, que la science a eu le malheur 
de perdre il y a 2 ans, a décrit, sous le nom d'A. rhopaloides, l'esp. d'enveloppe muqueuse dans laquelle est enfermé un petit Floriceps, très commun chez les poissons. Les mouvements de cetle enveloppe qu'il avait observés le premier, l'avaient conduit à la regarder comme un animal distinct de celui que la compression en fait sortir, et qui, d'après sa manière de voir, était un parasite du premier. Nous avons parfaitement vu, après lui, les mouvements dont il s'agit; mais ils nous ont conduit à penser que l'enveloppe muqueuse n'est que la partie postérieure du corps de l'animal, qui a la faculté d'y rentrer tout entier. $V$. FLORICEPS.

(L. D.Y.R.)

* AMPHISTOROS et.mieux AMPHIS-

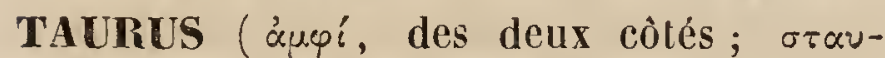
pós, pieu; fourchu! selon les anteurs dı g.). Ins.-G. de Coléoptères pentamères, famille des Lamellicornes, tribu des Scarabéides mélitophiles, établi par MM. Percheron et Gory, aux dépens du g. Cétoine des anleurs, et auquel ils donnent pour caract. essentiels : Sternum aigu, avancé; tête cunéiforme; mâchoire terminée par un onglet corné. Palpes grêles ; lèvre 2 fois plus haute que large. Ce g., adopté par M. Dejean ( Cat. $3^{\text {e }}$ édit.), ne renferme jusqu'à présent que 3 esp., dont nous citerons seulement celle qui lui a servi de type, et qui est l'A. trivittatum de Swederus, ou la Cetonia elata de Fabricius. Cette esp. est du Sénégal. (D.).

AMPHITANE, Pline. mon. - Pierre que les anciens disaient se trouver dans les mines d'or de l'Inde, et être de couleur jaune comme ce métal. Ils lui attribuaient en outre les propriétés de l'aimant, ce qui porte à croire que c'était une Pyrite magnétique.

(DEL.)

${ }^{*}$ AMPHITHALEA. Eckl. et Zeyh.-C $t^{2} y$ phiantha, id. - Ingenhoussia, E. Meyer. -

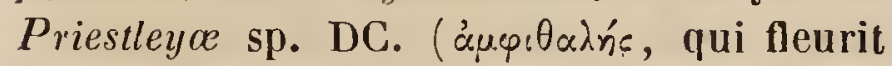
tout autour). вот. Рн. - G. de la famille des légumineuses, sous-ordre des Papilionacées, tribu des Lotées, sous-tribu des Génistées. Ecklon et Zeyher (Plant. Cap.1, p. 167) lui assignent les caract. suiv. : Cal. 5-lobé, subbilabié, rétréci à la base; étendard onguiculé, obovale, réfléchi aux bords, profondément échancré ; ailes subfalciformes, obtuses; caréne dicéphale, subrectiligne. Etam. diadelphes $(9$ et 1$)$. Style filiforme; stigm. simple ou capitellé. Légume ventru, obliquement ovoïde, 1-2-sperme.-Arbuscules; feuilles simples, très entières, non stipulées; fleırs nombrenses, terminales, disposées en épis ou fasciculées, 1-bractéolées.-Ce g., voisin des Priestleya, et dont les auteurs ont fait connaître 10 esp. (Walpers, Lequm. Cap.; Linnoea, 13, p. 470), est propre à l'Afrique australe.

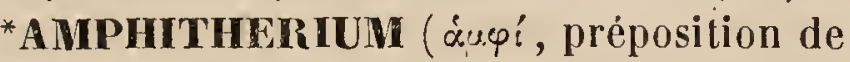
doute; $\theta$ npíov, animal). мnм.-M. de Blainville (Comptes rendus, Acad. Sc., 1838 , $2^{\text {me }}$ série) nomme ainsi le g. qui devra renfermer le fossile de Stonefield, regardé par quelques auteurs comme une esp. de didelphe, par quelques autres, comme un mammifére monadelphe, et par plusieurs enfin, comme un ovipare voisin des Sauriens ou de certains poissons. Les opinions sont donc, comme on le voit, bien loin d'être arrêtées à l'égard de l'esp. de ce fossile, et c'est ce que M. de Blainville a voulu indiquer par le nom ci-dessus. Il est probable d'ailleurs que les diverses pièces étiquetées dans les collections comme Didelphes du calcaire oolithique, ne sont pas d'animaux de même esp., et probablement. pas davantage de même g. Le morceau le mieux caractérisé paraît être celui qu'á décrit $M$. Broderip (Didelphis Bucklandi), et, d'après M. de Blainville, il ne serait pas sans analogie avec les Phoques par ses molaires; quoique le mode d'implantation des dents qu'on peut considérer comme incisives et canines, rappelle en même temps ce qui a lieu chez cer. taines esp. de la famille des Kerissons. Le Didelphis Prevostii, Cuvier, n'a plus les mêmes caract.; aussi M. Owen a-t-il accepté un g. pour chacun des animaux représentés par ces débris. Il emploie les noms de Phascolotherium et Thylacotherium dont le second est de M. Vaienciennes. M. Agassiz, dans la traduction allemande de la Géologie de M. Buckland, avait de son còté proposé celui d'Amphigonus, synon. d'Amphitherium ou If eterotherium, Blainv. $V$. DideLpHes.

$$
\text { (P. G.) }
$$

AMPHITHOE, Amphithoa (nom mythol.). crust. - G. de Crustacés amphipodes, établi par Leach pour de petites esp. de crevettes, différant seulement des crevettes proprement dites, par les antennes supérieures

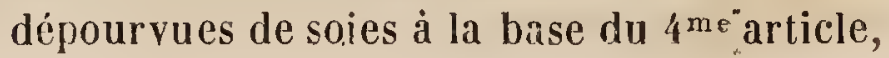


et par l'abdomen sans faisceau d'épines en dessous.

(DuJ.)

*AMPHITHOITES (áa.ción, nymphe marine). polyp. вот. Foss. - G. de Polypiers, faussement établi sur un fossile des environs de Paris, que Desmarest rapprocha des Sertulaires ; mais Léman a prouvé que c'est une souche de Zostera ou Caulinia. De là les noms de Zostérites et de Caulinites, qui lui ont été donnés depuis lors, et dont le dernier seul doit être couservé.

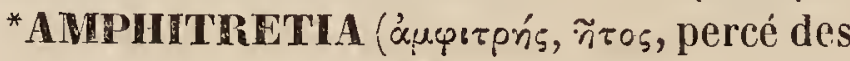
2 côtés). вот. Cr.-Hill. (Kist. of plants p. 31) donne ce nom à un g. de Champignons dont les 2 surfaces sont poreuses, et qu'il aurait pu réunir à son g. Poria.

(LÉv.)

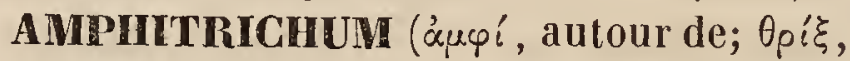

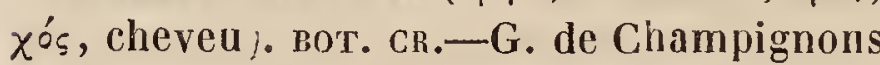
établi par Nees (Nov. Act. Cur. 9, Łab.6, fig. 17), et qui appartient aux Hyponycetes. Il est caractérisé par des filaments couchés, rameux et cloisonnés, qui se réunissent ensuite pour former des corps arrondis, hérissés de poils droits, raides et non cloisonnés. Ce g., malgré les observations assez étendues de l'auteur, est encore mal connu. Il serait très possible qu'il ne fût que le premier état de quelque autre champignon; car on n'y a pas encore reconnu d'organes reproducteurs. L'A. effusum Nees, seule esp. que l'on ait décrite, se trouve sur le bois des pins exposés á l'air, et dont elle rend, d'espace en espace, la surface noire comme du charbon.

(ÍÉv.)

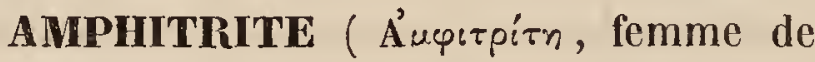
Neptune). ann. - Lamarck el M. de Blainville conservent ce nom aux Annélides tubicoles que G. Cuvier et M. Savigny désignent par celui de Sabelles; le second les caractérise ainsi : Corps en général assez allongé, déprimé et atténué en arrière ; tête peu distincte; thorax sans écusson sternal; abdomen fortlong, aplati et composé d'un très grand nombre de segments; bouche verticale, entourée d'un grand nombre de barbillons; tentacules au nombre de 2, fort courts, égaux, coniques et obtus; branchies très grandes, formées par un grand nombre de cirrhes, pourvues à leur côté interne de 2 rangs de barbes, et portées sur un pédoncule lamelleux ; tube vertical membraneux ou gélatineux, enduit d'une simple couche de limon a sa surface externe.
Les 3 s.-genres admis par MM. Savigny êे de Blainville sont :

$A$. Cirrhes branchiaux à un seul rang de barbes : Ies $A$. sabellce, simplices, Sav. $-A$. penicillus, flabellata, etc.

$B$. Cirrhes branchiaux à 2 rangs de barbes et dont la lame pédonculaire se roule en cornet: les $S$. astartce, Sav.- $A$. indica et magnifica.

$C$. Branchies inégales, pectinées d'un seul côté et contournées en spirales, l'une enveloppant l'autre. - (g. S'pirographis de Viviani). (P. G.)

AMPHITRITES. Amphitritoc (Áuętrítn, femme de Neptune). AnN. - Müller et Bruguière l'ont employé pour désigner un g. de vers marins tubicoles, et de la classe des Chétopodes, Blainv. C'est pour Cuvier (Dict. $s c$. n.1I) et Savigny (système des Annélides p.71), celui d'une famille dans laquelle rentrent, outre les Amphitrites, Blainv. ou Sabella, Cuv., les Amphitrites, Cuv. (Hermella, Sav. Sabellaria, Lamk.), les Pecinaria, Lamk. (Amphictène, Sav. Chrysodon, Oken, Cistena, Leach), les Terebella, Linn. et quelques autres auxquels nous renvoyons également. Pour M. de Blainville cette famille prend le nom de Sabulaires. $V$. ce mot. Tous ces genres sont facilement reconnaissables aux appendices de couleur brillante rangés en peigne ou en couronne d'un ou de plusieurs rangs à la partie antér. de leur tête, de manière à imiter en grand l'appareil tentaculaire des polypes. Les esp. en sont très nombreuses, et de toutes les mers. (P. G.)

* AMPHIUME. Amphiuma. RePT.-G. type de la famille des Amphiumoïdes, caractérisé par une langue triangulaire, adhérente de toutes parts; par des dents aux 2 mâchoires et une double rangée au palais; par un corps excessivement allongé, cylindrique; par 4 pattes très courtes. Il renferme 2 esp. nommées, l'une tridactyle, l'autre didactyle, du nombre des doigts qui terminent chacun de leurs 4 membres. Ces 2 esp. sont originaires de l'Amérique du nord.

(G. B.)

* AMPHIUMOIDE. Amphiumoidoe. Bept.C'est une famille du groupe des Trématodères, appartenant au sous-ordre des $\mathrm{Ba}-$ traciens urodèles.

(GB.)

* AMPHODE. Amphodus, Lindl. (ápyó- 


\section{AMP}

Sovs, qui a des dents de 2 côtés). BoT. PII.G. ou s.-genre de la famille des Légumineuses, s.-ordre des Papilionacées, tribu des Pbaséolées, DC. - Lindley (Bol. Reg. Sub. $n^{\circ} 1101$ et 1108 ) en donne les caract. suivants : Cal. non bractéolé, campanulé, bilabié; lèrre supér. bidentée; lẻvre infér. tridentée. Élendard réfléchi, bidenté à la base ; dents infléchies, embrassant la base du filet libre. Ailes et carène linéaires. Étamines diadelphes. Style filiforme, glabre. Stigm. capiłcllé. Légume linéaire-oblong , immarginé, polysperme, septulé intéricurement. Graines oblongues, comprimées; hile linéaire, petit, bordé d'une strophiole blanche. - Arbuste volubile. Feuilles 3-foliolées; folioles stipellées. Grappes' axillaires, multiflores. Fleurs grandes, d'un pourpre violet. L'unique esp. sur laquelle se fonde ce g. croîl aux Antilles.

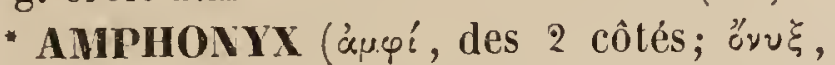
ongle). 1xs. - G. de l'ordre des Lépidoptères, famille des Crépusculaires, tribu des Sphingides, établi par M. Poey (centurie de Lépidopt. de Cuba). Ce g. ne diffère du g. Sphinx, que par le dernier article des Palpes plus long, nu, corné, fortement implanté sur l'article précédent, et saillant au devant de la tête; ce qui fait paraître celle-ci armée d'une double corne. Il est fondé sur une esp. inédite que l'auteur a bien voulu me dédier. L'A. Duponchelii, se trouve abondamment autour des habitations dont elle ne craint pas de s'approcher, notamment dans le jardin botanique de la Havane. Elle vole le soir au coucher du soleil, sur les fleurs d'une esp. de N'yclane appelée dans le pays Maravilla, ainsi que sur celles de l'Ahouai des Antilles (Cerbera Thevetia Lin.). Quand l'insecte est vivant, il exhale une orleur de musc. Cette esp., très bien figurée par l'auteur, est voisine du Sphinx Anceus de Druri 2, 25, 1, qui est le même que le S. Iatrophece de Fabricius.

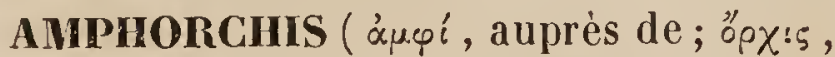
orchis ). вот. PH.-Dupetit-Thouars a décrit et figuré, sous ce nom, une Orchidée originaire de l'lle de France, dont nous avons fait le type de notre g. Arnottia. $V$. ce mot.

$$
\text { (A. R.) }
$$

AMPHRADENIUM ( $\alpha$ 'vappos [ contract.

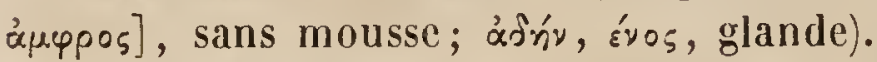
noT. Cr.-M. I)esvaux a désigné par ce nom un g. séparé des Polypodes, par M. Gaudichaud, sous le nom d'Adenopiorus. $V$. ce mot.

(AD. B.)

*AMPHYMENIUM. Kunth. (áa

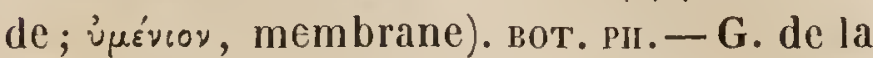
famille des Légumineuses; tribu des Papilionacées; section des Dalbergiées, Brown.M. Kunth (Nov. Gen.el S'pec. vol. 6, p. 380) en donne les caract. suiv. : Cal. campanulé, subbilabié, à 5 deuts pointues. Corolle papilionacée ; étendard à peine plus long que les ailes et la carène. Étam. monadelphes; androphore fendu. Ovaire non stipité, pauci-ovulé. Stigm. obtus. Légume non stipité, orbiculaire, comprimé, membranacé, boufli et monosperme au milieu, indéhiscent. Graine subréniforme, apérispermée; radicule infléchie en forme de crochet. Arbres. Feuilles imparipennées ; folioles alternes. Grappes axillaires, solitaires, simples; pédicelles uni-bractéolés i la base, dibractéolés au sommet. Fleurs jaunâtres. Ce g., confondu par beaucoup d'auteurs avec les Pterocarpus, appartient à l'Amérique équatoriale. On ne peut y rapporter avec certitude que 3 espéces.

*AMIPHYSUS (áu [ává], prépos. qui marque l'augment.; $\varphi v \sigma \tilde{\omega}$, je gonfle). Ins. G. de Coléoptères hétéromères, famille des Mélasomes, établi par M. Dejean (Catal. $3^{\text {me }}$ édit.) qui le place entre les g. $N y c t e-$ rinus d'Eschscholtz, et Misolumpus de Latreille; de sorte qu'il appartiendrait à la tribu des Blapsides de ce dernier auteur; ce que nous ne pouvons dire avec une entière certitude, les caract. de ce g. n'ayant pas été publiés. M. Dejean y rapporte 2 esp. nommées par lui, l'une sulcipemis et l'autre perforalls; la $1^{\text {re }}$ du Brésil méridional, et la $2^{\text {me }}$ du Chili.

* AMPLECTIF. Amplectivus (amplector, j'embrasse). вот. - Se dit de tout organe qui en embrasse un autre complètement; mais particulièrement de la préfoliation. Dans les Iridées, par exemple, la feuille laissante est complétement renfermée dans la feuille qui l'a précédée, comme si elles étaient emboitées les unes dans les autres : Iris, Marica, etc. Dans les Arö̈dées, les Cannacées, les Musacées, etc., la feuille naissante est roulée dans celle qui a précédé immédiatement. Cette sorte de préfoliation est dite Amplective, et ré ond à peu 
près à celle dite équitante. $V$. Préfoliation.

(C. L.)

*AMPLEXATILE. Amplexatilis (amplector, j'embrassel. вот. - Épithète employée par C. Richard pour qualifier la radicule, quand elle s'élargit et enveloppe l'embryon.

(C. L.)

AMPLEXE. Amplexus (amplector, j'embrasse). POLYP. MOLL. Foss. - G. établi par Sowerby, pour des fossiles qu'on supposait devoir être très voisins des Orthocères; mais qui, mieux étudiés, s’en éloignent au contraire beaucoup. Ainsi l'Amplexus coralloiieus est le Cyathophyllum flexuosum, Goldf., un des fossiles caractéristiques du terrain de transition infér. ; d'un autre côté, l' $A m$ plexus flexuosus de Sowerby et de Ciatullo, parait être une Hippurite du terrain crétacé.

(Duj.)

AMPLEXE. Amplexus (amplector, j'embrasse). MOLL. - Une étude plus approfondie de ce g. créé par M. Sowerby, dans son Minéral conchology, a fait reconnaître sa véritable place dans la série des êtres. Rapporlé d'abord parmi les Mollusques multiloculaires, il est certain que ce g. est voisin des Cyathophiles, et doit entrer dans la classe des Polypiers.

(DEsir.)

AMPLEXICAULE. Amplexicaulis (amplector', j'embrasse; caulis [xaviós], tige). вот. - Quand les pétioles, les pédoncules, les feuilles, les bractées, s'élargissant à leur base, embrassent la tige sans l'entourer complètement, on dit ces organes Amplexicaules. Ce cas est très fréquent; on en voit des exemples dans les Carduius marianus, Inula disenterica, Papaver somniferum, etc. Quand ils l'entourent complètement, comme d'une sorte de gaîne, on les dit engaînants; comme cela se voit dans les Liliacées : $A l$ lö̈, Crinum, Agave, etc. ( $V$. Engaînant.)

*AMPLEXIFLORE. Amplexiflorus (amplector, j'embrasse; flos, oris, fleur). вот. -. Épithète donnée par Cassini aux squamelles du clinanthe des Composées, ou Synanthérées.

*AMPLIATIFLORE. Ampliatiflorus (amplialus, agrandi ; flos, oris, fleur). вот. Qualification donnée par Cassini à la couronne des Composées, quand elle se compose de fleurs plus développées que celles du disque.

(C. L.)
* AMPLIATIFORME. Ampliatiformis (ampliatus, agrandi ; forma, forme). Boт.-Cassini donne cette épithète aux corolles des Composées, quand elles ressemblent à celles qu'il a nommées Ampliatiflores ou $A m$ plifiées. $V$. ces mots.

* AMPLIÉ. Ampliatus (amplio, j'agrandis ). ıNs. - Kirby appelle Ampliés les Élytres, quand ils sont disproportionnellement larges à leur extrémité, comme, par exemple, dans les Tycus fusciatus. (D.)

* AMPLIFIÉs. Amplificatu: (amplifico, j'augmente, j'agrandis ). вот. - Pour Cassini, quand les corolles du rayon d'un grand nombre de Composées (Centaurées), sont plus amples que celles du disque, ce sont des corolles amplifiées. Ce mot est synon. de celui d'Ampliatiflore, qn'il a également èiabli. $V$. Ampliatiflore.

(r. L.)

AMPONDRE (altération d'un nom malgache). вот.-Ce nom est donné, par queiques yoyageurs, aux gaînes des feuilles et aux spathes florales de certains Palmiers (Areca) qui croissent dans ìes îles de Madagascar et de Mascareigne. M. Bory (Dict. cl. I , 300), raconte que ces sortes de gaînes, dures et même ligneuses, en forme de cuvettes, glabres, polies, munies de spinules, ou convertes d'une sorte de bourre, tombent des arbres, sur le sol des forêts, comme pour recevoir les eaux pluviales qui s'y conservent pures. Un Ampondre, selon ce voyageur, peut contenir jusqu'à 2 bouteilles de celte eau précieuse; et il en a trouvé qui en contenaient jusqu'á six. "On peut, dit-il, faire chauffer cette eau dans l'Ampondre même, au moyen de cailloux rougis qu'on y éteint. Nous avons souvent employé cet artifice dans nos voyages; à défaut de poterie de terre, nous faisions cuire notre riz et bouillir le café dans cette vaisselle végétale dont on peut façonner la plus fraîche en assiettes, ou en petites tasses; il suffit, pour imprimer à ces ustensiles rustiques une forme durable, de les faire sécher sur la braise, après les avoir ployés et modifiés. i - On en couvre des cases, dit encore cet auteur, en guise de tuiles, et lui-mème s'est servi de cet abri. Les colons en transportent au bord de la mer et obtiennent ainsi du sel, par l'évaporation de l'eau dont ils les remplissent.

(C. L.)

AMPOULAOU. вот. PII. - Nom, dans le 
midi de la France, d'une variété de l'Oli- | plus blâmable, conserva, comme deux esp. vier.

(C. L.)

AMPOULE (ampulla, sorte de vase). MoLL. - Nom vulgaire d'une grande esp. de Bulle, la Bulla ampulla de Linné, à laquelle on donne aussi quelquefois le nom de Vanneau ou de Muscade. $V$. BuLte.

(DESH.)

AMPOULES. Ampulla (ampulla, sorte de vase). Bor. GR. - G'est le nom vulgaire de certains renflements pleins d'air qui se voient sur plusieurs espèces de Fucacées. $\boldsymbol{V}$. VÉSIGULES AÉRIENNES.

(C. M.)

AMPOULETA. BoT. PH. - Nom languedocien de la Mâche, Valerianella olitoria Mœnch.

(C. L.)

AMPULEX (am, signifiant en composition l'affinité; pulex, puceron). INS. - G. de la famille des Fouisseurs Latr., de l'ordre des Hyménoptères, sect. des Porte-aiguillon, établi par Jurine (Ne méth.p.cl.les Hymén. et les Dipt.), principalement sur une esp. européenne qu'il désigne sous le nom d'A. fasciata, et sur le Chlorion compressum Fab. Les caract. génériques qu'il leur assigne sont ceux-ci : Ailes présentant une seule cellule radicale allongée et quatre cellules cubitales : la première, grande, recevant la $1^{\text {re }}$ nervure récurrente; la deuxième, petite; la troisième, plus grande, recevant la 2 e nervure récurrente; la quatrième, atteignant l'extrémité de l'aile. Mandibules grandes, bidentées dans les mâles, et unidentées dans les iemelles.

(Bu.)

* AMPULLACERE.Ampullacera (ampulla, sorte de vase allongé; xśp $x_{5}$, corne, mot hybride, défectueux). MoLx. - Quoique nouvellement établi, le g. Ampullacère n'est cependant pas absolument nouveau dans la science. Il a été créé par M. Quoy pour un Mollusque dont la coquille a été figurée par Chemnitz (Conchyliol., t.5), sous la dénomination de Nerita nux avellana. Cette coquille n'est certainement point une Nérite; aussi Gmelin (System. Nat., 13 édit.) la mitil au nombre des Hélices, suivant en cela l'exemple de Martyns, qui, dans son magnifique ouvrage, a donné de nouveau une figure de cette esp., et l'a désignée, dans sa table, sous le nom d'Helix crenata. Gmelin, qui ajouta à l'ouvrage de Linné les produits d'une compilation faite avec la légèreté la

T. I. distinctes, l'Helix avellana pour la coquille de Chemnitz, et une Helix crenala pour celle de Martyns. Bruguière sentit bien que cette coquille n'avait aucun caract. des Nérites ou des Hélices. Il la transporta dans son g. Bulime, g. que l'on pourrait considérer. comme une esp. de Caput mortuum dans lequel l'auteur dont nous venons de parler plaçait toutes les coquilles à ouverture entière dont il ne savait que faire; mais Bruguière eut le mérite du moins de rectifier le double emploi de Gmelin, et en cela il fut imité par Dilwin et les autres conchyliologistes. L'auteur anglais dont nous venons de rappeler le nom, imitateur trop servile de Gme. lin, a inscrit parmi ses Hélices la coquille qui nous occupe. Enfin Lamarck, guidé par ce coup d'œil que lui donnaient une longue pratique de la science, un profond savoir, une sagacité peu commune, rangea parmi les Ampullaires le Nerita nux avellana de Chemnitz. A considérer la coquille seule, c'était dans ce g. qu'elle devait se trouver, jusqu'au moment où la connaissance de l'animal qui l'habite vint déterminer définitivement ses rapports. MY. Quoy et Gaimard, pendant leur dernier voyage de circumnavigation, eurent occasion d'observer a la Nouvelle-Zélande l'animal de cette espèce. Il se trouve en très grande abondance dans les eaux saumâtres, recouvrant, de quelques pouces seulement, des plages formées d'un mélange de sable et de vase. Ce qui a surtout étonné les observateurs cités plus haut, c'est que l'animal ne porte point de tentacules sur la tête, et qu'il vient respirer l'air à la manière des Planorbes et des Limnées. Ainsi on trouve dans ce mollusque très curieux une combinaison organique toute nouvelle et très inattendue. Jusqu'à présent tous les Mollusques pulmonés aquatiques avaient pour caractère de manquer constamment d'un opercule ; l'animal dont-nous parlons en présente un corné, paucispiré, et assez semblable à celui des Natices. Tous les Pulmonés aquatiques connus jusqu'alors étaient caractérisés par une paire de tentacules oculifères; ici il y a absence complète de ces appendices, et les yeux ne font aucune saillie à la surface de la tête. D'après des caractères d'une telle importance, il était nécessaire, comme on le voit, d'établir pour 
l'A mpullaria avellana de Lamarck ung. particulier, auquel M. Quoy a jugé convenable d'appliquer le nom qui est en tête de cet article. D'après ce que nous venons de dire, il nous paraît nécessaire non seulement d'accepter le g. de MM. Quoy et Gaimard, mais encore de créer pour lui une famille distincte, qui viendra se placer, dans la Méthode, à côté de celle des Pulmonés aquatiques sans opercule. Cette famille serait pour les Pulmonés aquatiques de la même valeur que celle des pulmonés operculés terrestres, par rapport à ceux de ces animaux dépourvus d'opercule. Outre les caractères zoologiques que l'on doit à MM. Quoy et Gaimard, ces naturalistes ont ajouté des détails anatomiques dont l'exactitude nous paraît incontestable, mais que nous n'avons pas eu jusqu'à présent l'occasion de vérifier. Caract. génér. Ampullacera, Quoy : Animal spiral, globuleux, à pied court, quadrilatère, avec un sillon marginal antérieur. Tête large, aplatie, échancrée en deux lobes arrondis, portant 2 yeux sessiles, sans apparence de tentacules. Cavité pulmonaire assez grande, cervicale, limitée en avant par un collier ayant son ouverture au bord droit. Bouche membraneuse; les deux sexes réunis. Coquille assez épaisse, globuleuse, ventrue, profondément ombiliquée. Ouverture ovale, obronde; peu oblique vers l'axe longitudinal, ayant les bords réunis et fermés par un opercule corné, mince, flexible, paucispiré, et quelquefois terminé par un petit talon. - L'animal, d'après MM. Qnoy et Gaimard, est très timide; il rentre dans sa coquille au moindre attouchement, et n'en sort ensuite qu'avec une extrême lenteur. Pour compléter ce qui a rapport à un g. aussi curieux, nous empruntons à l'ouvrage de MM. Quoy et Gaimard les détails anatomiques qu'ils donnent sur l'une des espèces, l'A mpullacera avellana.

"Le pied est grand, transverse, jaunâtre, séparé de la tête par un sillon. Celle - ci a la forme d'un chaperon divisé en deux lobes arrondis, dépourvus de tentacules; et portant deux très petits yeux sessiles sur un fond d'un assez beau jaune. En arrière est un collier assez bien formé par le bord du manteau, qui ne laisse au côté droit qu'un trou rond pour l'entrée de l'air, et oflre, un peu plus en dehors, l'ouverture de l'anus sur un pédicule saillant, bifurqué comme dans l'Au- ricule Midas. Ces parties, ainsi que celles que cache la coquille, sont d'un brun foncé. ")

"La cavité pulmonaire est grande, et porte sur son plancher un large organe dépurateur, folliculeux, dont on voit très bien l'ouverture sur un très court pédicule antérieur. Le cour lui est accolé en arrière, et l'on distingue au travers du pigmentum noir, dont le plancher est recouvert, une grosse veine qui vient du collier, et côtoie le rectum. Après avoir enlevé la.cloison qui sépare l'abdomen, on trouve l'œsophage recouvert de deux glandes salivaires linéaires et fixées par leurs extrémités. L'estomac ne se distingue point, de sorte qu'il donne dans un gésier globuleux, musculeux, nacré comme celui d'un oiseau, et contenant dans son intérieur quatre petites dépressions ou fossettes. L'intestin qui sort de ce gésier, après avoir reçu les canaux du foie qui l'enveloppe, se termine par le rectum, sans circonvolutions apparentes."

"La bouche est petite et membraneuse. Plus en dehors, on voit l'organe excitateur s'ouvrant près de l'œil droit, an lieu où serait le tentacule du même côté. Il y a en arrière un muscle protracteur et un long canal tortillé. Nous n'avons pu nous assurer, tant ces parties sont délicates, si ce canal fait suite et se continue avec un semblable, beaucoup plus long, qui enveloppe le testicule placé près du gésier. A la droite du pénis, est l'utérus, très renflé en arrière, où il reçoit l'oviducte qui vient en serpentant de l'ovaire, lequel coupe la partie postérieure du tórtillon $\%$. - Les coquilles de ce g. sont globuleuses ; leur spire est courte et pointue. L'ouverture est ovale, oblongue; elle-est peu inclinée sur l'axe longitudinal. La columelle est percée par un ombilic profond, et le bord est élargi et aplati à la base. Dans l'une des esp., l'ouverture ressemble assez à celles de certaines Paludines. Dans la plus grande, le bord droit oflre une échancrure large et peu profonde, qui correspond à l'angle supérieur des tours. On ne connaît jusqu'à présent que deux esp. dans ce g. : l'Ampullacera avellana, Quoy et Gaim.; Ampullaria avellana, Lamk.; la seconde est l'A mpullacera fragilis, Quoy; Ampullaria fragilis Lamk. ， (Desh.)

AMPULLAIRE. Ampullaria (ampulla, sorte de vase allongé). MouL. - Ie g. Ampullaire a cété créé par Lamark, qui en a 
trouvé le type parmi les Hélices de Linné. notre grand anatomiste, combien les JanthiMais, avant Linné, plusieurs esp. de ce g. avaient été très bien figurées : les unes, fossiles, sont représentées dans le IIfuseum metallicum d'Aldrovand; les autres, vivantes, sont figurées dans les ouvrages de Lister, de Rumphius, de Gualtieri et de Dargenville. Linué le premier comprit ces coquilles dans le g. Hclix, et rassembla presque toutes celles qu'il connut sous le seul nom spécifique d'Helix ampullaria. Linné trouva dans ses successeurs des imitateurs fidèles, et ce fut Lamarck qui, le premier, dès ses premiers travaux, proposa le g. Ampullaire pour y rassembler des esp. fluviatiles que Linné confondait avec ses Iélices, comme nous venons de le voir, et Bruguière avec ses Bulimes. Peu d'années après, M. de Roissy adopta le g. Ampullaire, lorsqu'il acheva, dans le Buffon de Sonnini, la Conchyliologie commencée par Montfort. M. de Koissy jugea, comme Lamarck, que ce g. ne devait pas $\hat{\text { é- }}$ tre éloigné des Paludines et des Valvées. C'est en effet près de ces g. que Lamarck, avec sa perspicacité habituelle, avait placé celui des Ampullaires. Lorsqu'en 1809, notre célèbre zoologiste essaya pour la première fois d'établir des familles naturelles dans le règne animal (Philosophie zoologique), il proposa une famille des Orbacées, composée de quatre g.: Cyclostome, Paludine, Planorbe et Ampullaire. Quelques années plus tard, Lamarck modifia cette famille d'une manière fort convenable, en utilisant les observations anatomiques faites par Guvier sur les Pulmonés aquatiques. La famille des Limnées fut créće, et le g. Planorbe y fut transporté. La famille des Péristomiens fut également proposée, et elle ne renferma plus que des Pectinibranches d'eau douce, dont la coquille a l'ouverture entière fermée par un opercule corné, à élément concentrique. Cuvier ne comprit pas aussi bien que Lamarck les rapports du g. Ampullaire; il l'introduisit en effet, à titre de s.-g. de ses Conchylies, avec les. Mélanies, les Phasianelles et les Janthines. Nous ne pensons pas qu'il soit nécessaire de discuter sérieusement les rapports des quatre g. que Cuvier a ainsi rassemblés. Il suffirait, pour réfuter cette opinion d'une manière victorieuse, de renvoyer le lecteur aux ouvrages de Cuvier luimême; il verrait, par les obscrvations de nes et les Phasianelles diffèrent entre elles, et il suffirait de rapprocher les coquilles et les opercules de ces différents g., pour se convaincre qu'ils n'ont entre eux que des rapports fort éloignés. En publiant son dernier ouvrage, Lamarck conserva sa famille des Péristomiens, et rassembla dans le g. Ampullaire un assez grand nombre d'esp. vivantes et fossiles. Parmi ces dernières espèces, il y en a un certain nombre qui n'ont pas exactement les caractères des Ampullaires véritables. Plusieurs personnes sentirent bien que ces esp. fossiles devaient être éliminées du g. Ampullaire. Lamarck avait établi pour elles un g. Ampulline, qui ne sortit point des galeries du Muséum. Il y renonça plus tard, et les coquilles fossiles dont il s'agit restèrent au nombre des Ampullaires. M. de Férussac, à l'article Ampullaire du Dictionnaire classique, dit, avec raison, que les coquilles fossiles rapportées aux Ampullaires sont très probablement des Natices. Des observations plus nombreuses, faites sur un plus grand nombre d'esp., une appréciation plus rigoureuse des caractères des Natices et des Ampullaires, nous ont déterminé, dans notre ouvrage sur les Fossiles des environs de Paris, à porter définitivement parmi les Natices les Ampullaires fossiles de Lamarck qui ont l'ouverture oblique à l'axe longitudinal, et dont l'ombilic est simple ou circonscrit par une callosité très plate. Dans l'arti. cle cité de H. de Férussac, ce naturaliste cherche en vain à justifier l'arrangement de Cuvier : car, en rapportant ce qu'il connaissait de l'animal des Ampullaires, il fait voir que ce g. se rapproche beaucoup de celui des Paludines.

L'animal des Ampullaires resta très longtemps inconnu. Le père Feuillée, dans ses voyages, avait eu occasion de voir en abondance une esp. de ce g. Il en parle dans la relation de son voyage; mais ce qu'il en dit prouve qu'il n'était guère versé dans l'observation des animaux. Aussi l'on peut dire que c'est à M. Caillaud d'abord, et ensuite à MM. Quoy et Gaimard, que l'on doit la connaissance exacte des formes extérieures de ces animaux. Pendant le premier voyage qu'il fit dans la Haute-Egypte, M. Caillaud rencontra, dans les eaux douces d'un oasis, l'Ampullaria ovala. Il en mit quelques exemplaires 
dans l'alcool, et les envoya à M. de Férussac; mais ce naturaliste n'utilisa guère, pour le moment, ces utiles matériaux anatomiques, car-il prétend, dans un article que nous avons déjà cité, que les animaux des Ampullaires se rapprochent de ceux des Nérites. M. Caillaud, ayant conservé des relations avec le pays qu'il avait si utilement parcouru, pria, lorsqu'il fut définitivement de retour en France, qu'on lui envoyât les divers mollusques d'une île; et la personne qui se chargea de ce soin, après une pêche assez abondante, mit sans précaution tous les animaux qu'elle avait recueillis dans une caisse qui fut remplie de sciure de bois. Cette caisse, confiée à un bâtiment de commerce, resta plus de quatre mois en route; et lorsque II. Caillaud la reçut, il la trouva infectée par la pourriture de la plupart des animaux, qu'on n'avait pas eu la précaution de retirer de leurs coquilles. Aussi M. Gaillaud s'empressi-t-il de jeter dans un baquet d'eau tous les objets que renfermait cette caisse, afin de pouvoir les nettoyer; mais il ne fut pas peu surpris, lorsque, en examinant le lendemain matin le contenu du baquet, il y vit presque toutes les Ampullaires marchant et ayant l'apparence de la force et de la santé. Ce naturaliste, plein de zèle, s'empressa de nous apporter plusieurs Ampullaires vivantes, et nous pûmes les observer pendant long-temps. Ces animaux sont loin de ressembler aux Nérites, comme l'a supposé M. de Férussac; ils ne ressemblent pas non plus aux Phasianelles, comme l'a supposé Cuvier; ils ont, au contraire, la plus grande analogie avec les Paludines, et cependant ils en diffèrent d'une manière assez notable pour constituer avec elles un bon g. dans la même famille. Ce que nous venons de rapporter sur ces Ampullaires, qui ont vécu si long-temps hors de l'élément qui leur est nécessaire, devait exciter l'attention des naturalistes et leur faire rechercher l'explication naturelle d'un phénomène, en apparence si extraordinaire. On sait que tous les Pectinibranches aquatiques périssent très vite lorsqu'ils sont hors de l'eau, et l'exception à cette règle générale, que présentent les Ampullaires, devait faire supposer dans leur organisation quelque particularité qui n'existe pas dans les autres mollusques du même ordre. Quelques personnes se hâtèrent de supposer que très probablement les Ampullaires avaient à la fois deux organes de la respiration, l'un aérien et l'autre aquatique. Nous apprîmes par plusieurs voyageur's que les Ampullaires habitent quelquefois en très grande quantité des étangs ou des marais, produits chaque année par les pluies abondantes qui tombent en automne dans les pays chauds. Pendant l'été, ces marais sont desséchés, et à peine y trouve-t-on quelques traces d'humidité. Les Ampullaires, ainsi que d'autres Mollusques acéphalés, s'enfoncent assez profondément dans la vase, et passent ainsi, sans périr, toute la saison de la chaleur. Il est évident que la nature a préparé ces animaux à vivre sans eau pendant un temps assez considérable. Nous cherchâmes, sur les individus mis en notre possession par M. Caillaud, s'il existait dans les organes de la respiration une modification quelconque qui rendît compte du phénomène dont nous parlons. Nos soins furent inutiles à cet égard, car nous trouvâmes dans la cavité cervicale un peigne branchial ássez considérable, la glande muqueuse qui l'accompagne, et rien qui annonçất, dans la distribution des vaisseaux, que les parois de cette cavité dussent remplacer la branchie et en remplir les fonctions. Ainsi les Ampullaires sont de véritables Pectinibranches, dont l'organisation ne diffère pas sensiblement, ă l'égard des organes de la respiration, des Paludines et autres g. yoisins. Mais, en examinant la paroi supérieure de la cavité branchiale, nous avons vu qu'elle est formée de deux parois réunies en avant, et formant un grand sac ouvert tout à fait en arrière, immédiatement au dessus de la base de la bran. chie. Nous nous aperçûmes que cette poche était toujours remplie d'eau, lorsque l'animal s'enfermait dans sa coquille au moyen de son opercule; nous nous aperçûmes également que cet opercule ferme l'ouverture dans une telle perfection, que rien ne peut s'échapper de l'intérieur sans que l'animal le veuille. Toutes ces observations nous ont permis d'expliquer d'une manière naturelle cette propriété dont jouissent les Ampullaires de vivre long-temps sans eau. Il leur suffit en effet de conserver pleine de liquide ambiant leur poche cervicale pour en verser le contenu sur la branchie, à mesure du besoin, et l'on conçoit que cette eau préserve aussi l'a- 
nimal du desséchement, son évaporation étant empêchée par une coquille dure et compacte, et par un opercule qui la ferme avec une rare perfection.

Dans un Mémoire publié dans le tome 5 du Zoological Journal, M. Guilding a fait connaître les animaux de deux espèces curieuses d'Ampullaires. Déjà, avant lui, s'était répandu dans les collections le Planorbis cornu-arietis des auteurs, mais pourvu d'un opercule; ce qui était resté inconnu aux anciens conchyliologistes. L'examen de cet opercule nous donna la preuve irrécusable que cette esp. est une véritable Ampullaire, comme le prouvent d'ailleurs la description et les figures du savant Anglais dont nous venons de parler. Nous connaissons actuellement les animaux de quatre esp. d'Ampullaires. Tous rampent sur un pied subquadrangulaire fort large, très aminci sur les bords, et portant en arrière un opercule corné ou calcaire, presque entièrement caché par la coquille lorsque l'animal marche. La tête est petite et fort singulière; elle est terminée antérieurement par deux tentacules coniques et très pointus, qui donnent à cette tête la forme d'un croissant à cornes très allongées. En arrière de ces appendices naissent les tentacules véritables; ils sont extrêmement allongés, pointus au sommet et au côté externe de la base. Ils portent de très courts pédicules, dont le sommet tronqué est occupé par l'organe de la vue. L'opercule est semblable, pour sa constitution, à celui des Paludines, étant composé d'éléments concentriques, et présentant au centre, du côté interne, une sur ${ }^{-}$ face rugueuse par laquelle il adhère au pied de l'animal. Les coquilles du g. Ampullaire sont presque toutes globuleuses, à spire presque toujours courte et obtuse au sommet. Cependant, à prendre le genre dans son ensemble, on voit les formes changer par nuances insensibles, depuis la discoïde du cornu-ariotis jusqu'à la forme acuminée de l'Ampullaria guineica. Toutes les esp. ont le test mince, d'une structure compacte et solide, toujours revêtu d'une épiderme verdâtre ou brunâtre. La coloration est peu variée; elle consiste toujours en zônes transverses, ordinairement d'un brun rougeâtre sur un fond d'une même nuance moins foncée ou sur un fond jaunâtre. Le plus grand nombre des espèces est ombiliqué; mais toutes sont caractérisées par une ouverture ovale-oblongue, toujours plus haute que large, droite, c'est-à-dire coïncidant avec l'axe longitudinal. Cette position de l'ouverture est très propre à faire distinguer les coquilles de ce g. de celles des Natices, qui peuvent quelquefois s'en rapprocher beaucoup. $\mathrm{Ca}$ ract. génér. - Animal discoïde, globuleux, ayant un pied mince et subquadrangulaire ; une tête petite, portant deux paires de tentacules inćgaux, dont les plus grands sont pédiculés à la base, et oculés au sommet de ces pédicules. Cavité cervicale très grande, ayant la paroi supérieure dédoublée en forme de sac. Opercule corné ou calcaire, non spiré, à sommet subcentral et formé d'éléments concentriques. Coquille discoïde ou globuleuse, mince, à ouverture entière, longitudinale, et ayant son plan parallèle à l'axe longitudinal. Surface extérieure lisse, toujours revêtue d'un épiderme tenace.

Les Ampullaires habitent les eaux douces des pays chauds. Olivier, néanmoins, dans son voyage au Levant, prétend en avoir trouvé une esp. vivante dans le lac Maréotis, dont les eaux saumâtres sont également peuplées de coquilles marines. Elles vivent à la manière de nos Paludines, et paraissent avoir les mêmes mœurs. Il y en a quelques unes de fossiles; mais presque toutes celles que l'on a citées doivent actuellement faire partie du g. Natice.

(DESH.)

AMPULLINE. Ampullina (diminut. d'ampulla, sorte de vase allongé ). MoLu. - Dans ses premiers travaux sur les Fossi-. les des environs de Paris, Lamarck avait pensé qu'il serait utile de séparer, en un g. particulier, certaines coquilles qui avoisinent les Natices et les Ampullaires. Il proposa pour elles le g. Ampullina, auquel il renonça plus tard, en mettant la plupart de ces esp. parmi les Ampullaires. Elles n'ont pas les caract. de ce g., et présentent ceux des Natices ( $\boldsymbol{V}$. ce mot.). M. de Blainville (Allas du Dict. des Sc. nal.) a repris le nom du g. de Lamarck, pour l'appliquer à un démembrement inutile des Hélicines. L'auteur sentit lui-même l'inutilité de son $\mathrm{g}$. Ampulline, et, dans son Traité de Malacologie, il le réunit aur Hélicines comme sect. du g. $V$. HÉLICINE.

(Desh.)

* AMPUSA. IVS. - V. EMPUSA. (BL.) 
* AMSINIRIA (nom propre?). Bot. PI. Nom employé par M. Walckenaer pour dé- G. de la famille des Aspérifoliées, L. (Borraginacées, Juss.), établi par Lehmann (Catal.Sem.Hort.Hamb.1831), et distingué principalement par ses 4 cotylédons; mais dont l'auteur ne paraît pas avoir encore publié les caractères.

(C. L.)

AMSONIA (nom propre). Вот. PH. G. de la famille des Apocynacées, s.-ordre des Euapocynées, tribu des Plumiériées, formé par Walther (Flor. Carol. 98), et adopté par les botanistes modernes. En voici les caract. essentiels : Cal. 5-fide. Cor. hypogine, infundibuliforme, à tube cylindrique, à gorge très barbue; les 5 lobes du limbe subobliques. Étam. 5, incluses, insérées sur le milieu du tube de la corolle. Anth. ovales, obtuses. Ovaires 2 ; ovules nombreux le long d'une sutare, ventrale. Style simple; stigm. pelté. Follicules cylindriques, dressés. Graines nombreuses, subcylindriques, tronquées aux deux extrémités, à ombilic ventral. Embryon..... - Ce g. ne contient qu'une esp. encore peu connue, retirée par l'auteur du g. Tabernamontana, et indigène dans l'Amérique boréale : c'est l'A. angustifolia, plante herbacée, vivace, à feuilles opposées, ovales-lancéolées ou linéaires, veinées, glabres ou pubescentes; à fleurs disposées en corymbes terminaux. Quelques auteurs rapportent encore à ce g. deux autres esp. : les A. salicifolia Pursh, et latifolia Michx. Ces trois plantes ont besoin d'être étudiées de nouveau.

(C. L.)

AMUSIUM (Amusium, girouette; basse lat.). MoLL. - G. proposé par M. Megerle (Mag. des Cur. de la Nat., Berlin, 1811), et adopté par M. Schumacker dans.son Essai d'un système de Conchyliologie. Ce g. ne peut être admis dans une méthode, où les coupes sont fondées sur des caractères zoologiques d'une égale valeur. En effet, il est destiné à rassembler ceux des Peignes qui sont lisses en dehors, comme les Pecten pleuronec. tes et japonicus, etc. Déjà des auteurs anciens tels que Petiver, Rumphius et Klein, avaient employé ce mot latin soit pour, désigner des esp., soit comme titre de groupes, pour réunir ces espèces. Linné a rapporté tout cela à la section de ses Ostrece acerince dont Lamarck a fait depuis le g. Peigne. $V$. ce. mot.

(DESH.) signer une petite division dans le g. Clichiona.

(H. L.)

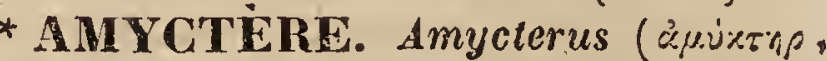
sans nez; ici sans trompe). INs. - G. de Coléoptères tétramères, famille des Curculionides, divis. des Cyclomides, établi par Dalman, et adopté par Schoenherr qui lui donne les caract. suivants : Antennes médiocres, minces, dont le scape, sensiblement épais, est presque de la longueur du prothorax. Les deux $1^{\text {ers }}$ articles du funicule subobconiques, les 4 suivants courts, lenticulaires; le $7^{\mathrm{e}}$ long, cyathiforme, embrassant la massue ; celle-ci turbinée, acuminée. Rostre très court, très épais, défléchi, inégal, ayant l'ouverture de la bouche très grande; mandibules très larges, fortement convexes, droites au bord interne. Yeux placés sur les côtés, ronds, petits, enfoncés. Prothorax presque rond, tronqué à la base, sublobé derrière les yeux, largement échancré en dessous après la bouche. Écusson petit, triangulaire, enfoncé, peu visible. Élytres grandes, oblongues, presque elliptiques, largement échancrées à la base et arrondies à leur extrémité, ayant les angles huméraux saillants par devant, et chacune d'elles étant surchargée souvent'd'un petit tubercule. - Ce g. figure dans le Catal. de M. Dejean ( $\bar{\zeta}^{\mathrm{e} e ́ d i t .),}$ qui y rapporte 12 esp., toutes de la NouvelleHollande. Nous ne citerons que celle qui lui sert de type, le Curculio mirabilis, décrit et figuré par Kirby dans les Trạnsactions de la Société Linnéenne de Londres (Tom. XII, p. 469, no 21, t. 23, fig. 9).

AMYDA (nom emprunté de Galien). REPT. - C'est ainsi que Schweiger, chélonographe distingué, avait d'abord désigné un genre de Tortues fluviales, dans un travail manuscrit qu'il présenta à l'Institut, en 1809; mais il substitua ensuite à cette dénomination celle de Trionyx, proposée par M. E. Geoffroy pour le même genre, dont celui-ci fit paraître une monographie avant l'impression du Mémoire de Schweiger, intitulé : Prodromus Monographia Cheloniorum. V. TRIONYX.

(G. B.)

* AMYDETES. INs.-G. de Coléoptères pentamères, famille des Sternoxes, établi par IIollmansegg, et adopté par M. Dejean, qui y rapporte 5 esp., toutes du Brésil, dont

* AMUSSES. Amussa. ARAchN. - Q nommées par lui A. pusilla et prousta, et 
la 3 e, plumicornis par Latreille. Ce dernier auteur, dans ses familles naturelles, place le g. dont il s'agit dans la tribu des Lampyrides, entre les Phengodes et les Lampyres. $V$. ces mots.

(D.)

* AMYGDALAIRE. Amygdalarius

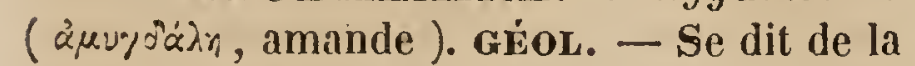
structure des roches qui présentent dans leur intérieur des parties minérales, en forme d'amandes plus ou moins grosses. Ces sortes d'amandes se sont quelquefois formées postérieurement à la masse, par suite d'infiltrations dans des cavités.

(C. D'O.)

AMYGDALE. Amygdalum (amygdala, amande). MoLL. - Megerle, dans le Magasin des Curieux de la nature (Berlin, 1811), a proposé ce g. pour une coquille curieuse, que Lamarck range parmi ses Modioles. Comme le g. Modiole a été institué long-temps avant celui de Megerle, il en résulte que le g. Amygdalum est un double emploi qui doit être supprimé. $V$. MODIOLE.

(DESH.)

* AMYGDALEES. вот. PH. - L. de Jussieu, en établissant la famille des Rosacées, l'avait subdivisée en plusieurs groupes naturels, dont l'un, contenant la plupart de nos arbres fruitiers à fruit libre; simple, êt à noyau monosperme, avait reçu le nom d'Amygraalées. Ces divers groupes ont été élevés au rang de familles distinctes par les auteurs qui ont suivi. Tout en les admettant avec eux, nous exposerons les caract. de ces familles diverses à l'article général Rosacées ( $r$. ce mot), pour mieux faire comprendre leurs rapports intimes, et la valeur de certains caract., dont on peut suivre là toutes lesmodifications graduelles, et en déterminer ainsi l'importance pour la classification des végétaux.

(AD. J.)

* AMYGDALINE. Amygdalinus ( $\dot{\alpha}-$

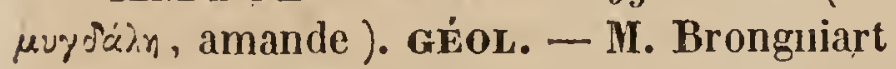
donne cette épithète aux roches composées de parties ovoïdes serrées les unes contre les autres, et comme liées par un réseau. (Ex. : le marbre de Campun.) (G. D'O.)

AMYGDALOIDE. Amygdaloides (a-

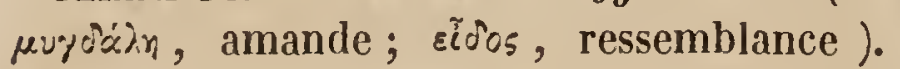
GÉOL. - Syn. d'Amygdalaire. Autrefois , on donnait aussi ce nom spécifique à certaines roches dans lesquelles on voit des sortes de noyaux plus ou moins arrondis, telle que la Variolite de la Durance; et mê- me à certains Poudingues. F. ces mots. (G. D'O.)

* AMYGDALOPIIORA, Neck. (å $\mu$ iydoxiov; amande; popós, porteur ). вот. PH. -Syn. du g. Amygdalus, Tourn., de la famille des Rosacées.

(SP.)

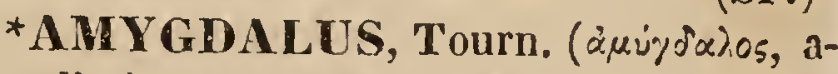
mandier). вот. PH. - Nom latin du g. Amandier, de la famille des Rosacées. (SP.)

AMYMONE. Amymona (nom myth. d'à $\mu^{\dot{y}} \mu \omega \nu$, parfait ). CRUST. - $V$. GXGLOPE.

(H. L.)

* AMYNTHIA (nom mythologique). INs. - G. de Lépidoptères diurnes, tr. des Piérides, établi par M. Swainson (Entomological Illustration, etc.) pour y placer une esp. nouvelle de Coliade, nommée par M. Leach Swainsonia. - Ce g. correspond au g. Rhodocère de .M. Boisduval. $V$. ce mot.

(D.)

* AMYRIDACÉES ou AMYRIDEES.

Bot. PH. - Plusieurs g., rapportés d'abord aux Térébinthacées, en ont été séparés plus tard, pour former cette famille, qui semble se rapprocher plutôt des Hespéridées. M. Rob. Brown, qui le premier en établit une sous ce nom, lui assignait des limites assez étendues, puisqu'il y confondait les groupes des Spondiacées et des Burséracées, qu'on distingue généralement aujourd'hui. M. Kunth, à qui l'on doit cette distinction, restreignit sa famille des Amyridées presqu'au seul g. Amyris, et la caractérisa de la manière suivante : Cal. petit, régulier, à quatre divisions, persistant. Pétales à nombre égal, à préfloraison imbriquée. Étamines en nombre double, libres, à insertion hypogynique. Ovaire libre, porté sur un réceptacle renflé en disque, surmonté d'un stigmate sessile en tête, renfermant, dans une loge unique, deux ovules suspendus. Fruit charriu, indéhiscent, 1-sperme. Graine dépourvue de périsperme, à tégument membraneux, à cotylédons épais et charnus, à radicule courte et supère. - Les plantes de cette famille se trouvent dans l'Amérique inter-tropicale. Ce sont des arbres ou arbrisseaux, à suc résineux, à feuilles opposées, ternées ou pennées avec impaire, à panicules axillaires ou terminales. Des utricules gonflés d'une huile aromatique abondent dans le tissu du fruit et des feuilles, qui se trouvent ainsi couvertes d'une foule de points transparents. Tels sont les caract. et 
la patrie des Amyridées réduites au g. $A m y-$ ris, plus rigoureusement circonscrit lui-même qu'il ne l'était dans le principe. Plus récemment, M. Lindley a proposé d'en rapprocher plusicurs g., les uns encore avec doute, comme le Tapiria Aubl., et le Spathelia L. (qui semblent plutôt devoir être mis à la suite des Zanthoxylées); les autres, comme le Myrospermum Jaca:, et le Copaïfera L., placés jusqu'ici parmi les Légumineuses, dont ils ont le fruit; enfin le Sabia, Coolebr., qui, d'après sa description, ne s'accorde pas avec les caract. généraux de la famille.

(AD. J.)

AMYRIS, Linn. ("̋̈upos, non parfumé; ici, par trope, non sans parfums). BoT. PH. - G. considéré comme type de la famille des Amyridées. Linné et les botanistes de son école le caractérisaient d'une manic̀re très vague, et y comprenaient beaucoup d'esp. appartenant à d'autres $g$. Dans les limites que lui assigne M. Kunth (Tereb., p. 21), ce g. offre pour caract. distinctifs : Fleurs hermaphrodites. Cal. 4-denté, persistant.Pétales 4, hypogynes, onguiculés, imbriqués en préfloraison. Étam. 8, plus courtes que les pétales. Ovaire 1-10culaire, porté sur un disque plane. Stigm. sessile. Drupe à noyau chartacé, 1-sperme. - Arbres ou arbrisseaux résinifères. Feuilles imparipennées, ponctuées. Inflorescences paniculées. Fleurs blanches. Drupes abondant en huile essentielle. - Ce g. appartient à l'Amérique inter-tropicale et sub-tropicale. Suivant M. de Candolle (Prodr. 2, p. 81), on n'y peut rapporter avec certitude que 7 esp. Au témoignage de MM. Wight et Arnott (Prodr.Flor. Penins. Ind. 1, p. 167), toutes les esp. décrites par Roxburgh ( Flor. Ind.) comme des Amyris doivent être exclues de la famille des Amyridées.

(SP.)

* AMYTIS. A mytis (nom mythologique). ors. - G. formé par Lesson ( $T r$. d'Ornith., pl. 453) sur deux oiseaux de la NouvelleHollande, décrits et figurés comme Mérions, dans le royage de l'Uranie. Ses caract. sont, d'après cet auteur : Bec moyen (relativement au corps de l'oiseau), peu élevé, comprimé sur les côtés; à arête convexe peu marquée; à pointe de la mandibule supérieure aiguë, recourbée, dépassant légèrement l'inférieure; commissure ample; bords légèrement recourbés. Narines nues, per- cées en fente dans une membrane recouvrant les fosses nasales, qui sont larges et profondes. Ailes courtes. Queue très longue, à pennes étagées. Tarses longs, robustes, scutellés. - Ce g. nous paraît avoir des rapports avec le Sphenosloma de Gould (Proceed. 1837, p. 149; et Synopsis of the Birds of Aus(ralia, part. 4). L'auteur ajoute que ces oiseaux représentent dans l'Australie les Colious d'Afrique, et que leurs plumes sont rigides, étroites, barbulées. Il en décrit deux esp. : l'Amytis natté, Amylis textilis (Mérion natté, Malurus texlilis Quoy et Gaim., Zool. de l'Uranie, pl. 25, f. 1, et pl. 107), à plumage gris-roux; chaque plume striée de blanc dans le sens de sa longueur; de la Baie des chiens marins; et l'Amytis bleu et blanc, Am. leucopterus (Malurus leucopterus Quoy et Gairn., Zool. de l'Uranie, pl. 25, f. 2, p. 108), de la même localité.

(LARR.)

AMYTIS (nom mythol.). ANNÉLW. G. de la famille des Néréides, établi avec doute par M. Savigny pour une annélide imparfaitement étudiée par Fabricius, et qui n'a point été observée depuis. (DUa.)

* ANAB ANNA ( $\alpha^{2} \alpha 6 \alpha i \nu \omega$, monter). BoT. PI. - G. de la famille des Euphorbiacées, ainsi nommé à cause de sa tige grimpante. Ses fleurs, monoïques, présentent dans les deux sexes un calice quinquéparti; dans les mâles, dix filets accompagnés à leur origine par quatre écailles, soudés entre eux inférieurement, portant chacun une anthère quadrilobée, et entourant un filet central stérile, qui se termine par une petite tête hérissée, et peut être considéré comme un rudiment de style et de stigmate; dans les femelles, un ovaire à trois loges 5-ovulées, surmonté d'un style oblong, épais, que termine un stigmate à trois lobes, sur l'extérieur de chacun desquels est imprimé un petit écusson glanduleux. Le fruit est composé de trois coques unies entre elles par leurs faces internes, renfermées dans un sarcocarpe mince qui se sépare à la maturité en six valves, contenant chacune une graine osseuse. - On ne connaît encore de ce genre qu'une espèce unique : c'est un arbrisseau du Brésil, à feuilles alternes longuement pétiolées, à grappes axillaires, portant inférieurement une seule fleur femelle longuement pédonculée; supérieurement, plusieurs males 
articulées sur de courts pédoncules qu'accom. pagnent autant de bractées. $\boldsymbol{V}$. Ad. Juss., Euphorb., p. 46 , tab. 15, no 48. (AD. I.)

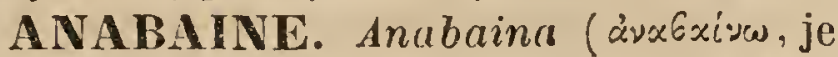
monte). BоT. GR. - G. de la tribu des Nostocinées, famille des Phycées, établi par M. Bory de St. - Vincent, et dont nous croyons pouvoir exprimer ainsi les caract. : Filaments simples, muqueux, moniliformcs, formés d'articles plus ou moins globulcux, dont quelques uns, et, le plus souvent, les terminaux, sont plus gros, oblongs-cylindriques, remplis de granules propagateurs; accroissement par duplication des articles. Ce g. est très voisin des Nostocs, qui ont également des filaments moniliformes; mais, dans ceux - ci on ne retrouve pas d'articles cylindriques. Ils sont, en outre, toujours contournés, comme crispés, et complètement plongés dans un mucus plus déterminé. Les filaments des Anabaines sont droits ou simplement flexueux; quelquefois ils sont libres dans leur partie supérieure, et seulement engagés par leur base dans la masse muqueuse qui les réunit. Leur accroissement est conforme à celui de la plupart des autres Nostocinées. Ises articles des filaments s'allongent d'abord; puis, s'étranglant de plus en plus vers leur milieu, ils finissent par former deux globules distincts. On remarque çà et là, dans la longueur des filaments adultes, et principalement à leur sommet, des articles plus gros, allongés, cylindriques, remplis de granules ou propagules de couleur foncée. Quand plusieurs articles de cette nature se suivent, ils sont presque toujours séparés par un globule assez gros, et plus diaphane que ceux qui constituent les articles ordinaires. Si les articles cylindriques et renflés sont au sommet des filaments, ils précèdent toujours un globule qui forme l'article terminal. M. Bory de St.-Vincent, considérant les filaments moniliformes comme renfermés dans un tube muqueux coniinu, avait rapproché ce 'g. des Oscillaires. Plusieurs auteurs ont partagé cette manière de voir ; mais nous croyons, avec M. Desmazières, qui a fait une étude toute particulière de ce g., que la couche de mucus qui entou-. re les articles ou segments des filaments, comme cela arrive dans les Nostocinées et dans d'autres tribus voisines, ne peut être regardée comme un tube. Jamais, dans un

T. 1 . cas de solution, nous r'avons aperçu d'extrémités de tubes vides, et des portions de filaments séparées, même récemment, nous ont toujours présenté, à de très forts grossissements du microscope, un mucus arrondi autour des segments terminaux, et non une partie tronquée et tubulée comme dans les Oscillaires. On ne reconnaît pas de mouvement oscillatoire dans les Anabaines, mais un mouvement de progression naturel à tous. ces végétaux, et qui tend à les faire rayonner autour de leur centre d'agglomération.

Le g. Sphorozyga, ayant été institué exactement pour les mêmes productions par Agardh, postérieurement au g. Anabaina de M. Bory de St.-Vincent, ne doit donc point être adopté.

On connaît à peu près une vingtaine d'esp. d'Anabaines, qui, presque toutes, habitent les eaux douces et thermales de l'Europe. Une esp., l'A. licheniformis Bory, croît sur la terre humide, et a l'aspect d'un Nostoc en dissolution. Nous en avons aussi découvert une autre, l'A. marina Bréb., à Granville, sur les sables marins un peu vaseux, qui ne restent à sec que peu de temps à chaque marée. Les esp. qui croissent au fond des eaux tendent à s'élever à la surface le long des végétaux submergés : de là l'étymologie (àvác<ives). Quelques unes sont nageantes, et forment des masses muqueuses ou gélatineuses qui constituent presque entièrement les substances prétendues nouvelles, auxquelles on s'est empressé de donner les noms de Barégine, de Plombiérine, etc. Leur couleur est, en général, d'un vert plus ou moins bleuâtre, ainsi que celle de beaucoup d'Oscillaires.

(DE BRÉB.)

* ANABAINELLA (dimin. d'Anabai$n a$; ¿́vx6xives, je monte). BOT. GR. - G. de la famille des Algues ou Phycées, proposé par M. Gaillon pour remplacer le mot Anabaina, afin de donner une terminaison uniforme aux noms des genres de ce groupe d'Algues. Ces changements n'ont pas été adoptés.

(DE BRÉB.)

ANABAS ( ¿่vaEsive, je monte). PoIss. - Nom imaginé par M. Cuvier pour désigner le g. créé par lui, et destiné à recevoir la seule esp. connue d'un poisson de l'Inde qui, selon le rapport de Daldorff, monte aux arbres pour trouver dans l'aisselle des feuilles l'eau nécessaire à sa respi- 
ration pendant les sécheresses, ou s'accroche aux branches qui pendent sur l'eau, pour éviter d'être emporté lors des grandes inondations. Quelque peu prouvées, et j'ajouterai même, quelque peu probables que soient ces deux assertions, le poisson auquel on les a rapportées n'en constitue pas moins un g. fort remarquable, et tout à fait particulier. Son caractère consiste dans la forme courte et arrondie du corps à la région des pectorales. Vers la queue il est un peu comprimé. La tête est arrondie, et couverte partout d'écailles fortes, dentelées, semblables à celles du corps, laissant à peine voir les pièces operculaires. Le sous-orbitaire antérieur est fortement dentelé; les bords de l'opercule, du sous-opercule et de l'interopercule, sont également dentelés; mais celui du préopercule est lisse et sans dentelures. Des dents en velours garnissent les mâchoires, le devant du chevron du vomer, et la base de cet os sous l'arrière du crâne. C'est une disposition unique dans les poissons. La membrane branchiostège a 6 rayons. La ligne latérale, d'abord voisine du dos, s'interrompt pour recommencer sous le milieu du tronçon de la queue, et venir sc terminer à la caudale.

A ces caract. extérieurs il faut ajouter que les 2e et $\mathbf{3}^{\mathrm{e}}$ pharyngiens supérieurs s'étalent en une lame très mince, plus ou moins contournée, et forment ainsi une sorte de fraise cachée sous les os élargis du crâne, qui constitue de chaque côté de la tête, un peu au dessus des branchies ordinaires, cet appareil appelé autrefois branchies supplémentaires, que M. Guvier a nommé pharyngines labyrinthiformes, et qui est devenu le caract. et la dénomination de la famille dans laquelle M. Cuvier classe ce poisson, avec l'Osphromène, le Colisa, et autres espèces voisines. Il faut encore ajouter que les Anabas ont une seule dorsale et une longue anale, armée chacune d'un très grand nombre de rayons épineux; les ventrales petites et thoraciques. Le foie est petit, l'estomac médiocre; le nombre des appendices coecaux n'est pas considérable. La vessie natatoire a ses parois très minces; elle est bifurquée en arrière, et chaque corne pénètre le long des apophyses inférieures des vertèbres caudales, dans les muscles de la queue. Ce que ces poissons

présentent de plus extraordinaire dans leur organisation est leur appareil labyrinthiforme. On l'a généralement regardé comme devant aider ou même suppléer l'appareil respiratoire; mais il me reste encore bien des doutes sur les fonctions de cet organe. M. Cuvier se demandait si les vaisseaux qui rampent sur la surface des lames pharyngiennes viennent d'une branche de l'artère branchiale ou de l'artère dorsale, c'est-à-dire de l'aorte des poissons; mais, dans ce cas, ces lames recevraient du sang artériel venant d'être hématosé dans la branchie ordinaire, laquelle ne doit plus avoir besoin de respirer de nouveau. Mais, dira-t-on, quand le poisson n'est plus dans l'eau, sa branchie ne sert plus à la respiration. Cette objection serait contraire à ce que nous savons de la respiration des poissons, et, si l'eau est retenue entre les lames de l'appareil pharyngien, il est impossible qu'elle ne donne pas assez d'humidité à la branchie pour que celle-ci puisse respirer. D'ail. leurs, combien de poissons restent des jours entiers hors de l'eau sans continuer de respirer! et l'anguille de nos eaux douces, ef les doras d'Amérique, qui vont, par terre, chercher une autre flaque d'eau, quand cellé où ils se tenaient vient à se dessécher!

J'ignore l'usage de ces organes; mais je crois qu'ils ont une toute autre fonction que celle qu'on leur attribue.

Les Anabas vivent très long - temps hors de l'eau; aussi les jongleurs indiens ont-ils toujours de ces poissons avec eux pour en amuser le peuple.

On ne connaît qu'unè seule esp. d'Anabas, répandue dans toute l'Inde, et dans les îles de son archipel. C'est un petit poisson, qui ne dépasse guère $0^{\mathrm{m}}, 160$. Sa couleur est verte, sombre, quelquefois rayée, en travers par des bandes plus foncées. On le mange à cause des vertus médicinales qu'on lui attribue, car sa chair est fade, sent la vase, et est remplie d'arêtes. Daldorff, lieutenant au service de la Compagnie des Indes, l'a publié en 1797, et l'a nommé Perca scandens, affirmant avoir pris un de ces poissons, en novembre 1791, dans la fente de l'écorce d'un palmier de l'espèce du Borassus flabelliformis; que le poisson, déjà à $1 \mathrm{~m}, 70$ au dessus de l'eau, s'efforçait de monter encore, en s'attachant à l'écorce par les épines de 
lopercule, et en fléchissant sa queue pour se cramponner par les épines de son anale ; qu'alors il détachait sa tête, allongeaitle corps, et parvenait, par ces divers mouvements, à cheminer le long de l'arbre. Le missionnaire .Iohn fit un récit scmblable à Bloch; mais j'ai tout lieu de penser que c'est la même histoire racontée par deux auteurs à la fois. En effet, John était Danois comme Daldorf, tous deux à Trinquebar, et s'y occupant des sciences naturelles. Cependant M. Reinwardt, qui a vu ces poissons à Java, m'a assuré n'avoir rien entendu dire qui puisse confirmer ce fait. Kuhl et Van Hafelt, Boić et Mucklot, n'en ont jamais parlé, et M. Leschenault, qui savait l'histoire de Dáldorff, nie cette habitude de l'Anabas, et regarde le fail observé par le naturaliste danois comme un fait isolć. M. Dussumier, qui a vu des myriades de ces poissons à Bombay, où tous les enfants vont les chercher dans les mares, n'a rien observé ni rien entendu raconter de semblable. Il serait bien étonnant qu'une habitude aussi merveilleuse eût échappé à tant d'observateurs habiles et actifs, si elle était constante chez ce poisson. V. l'Atlas, pl. 12 des Poissons. (VAL.)

ANABASIS Linn. Brachylepis, C. A.

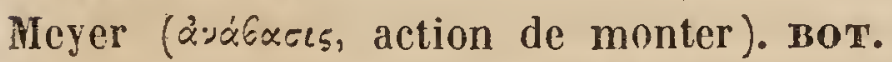
PII. - G. de la famille des Chénopodécs, tribu des Salsolées, Moq., auquel M. Moquin-Tandon (Nouv. Annales des Sc. nat., t. IV, p. 210,) assigne pour caract. : Fleurs hermaphrodites, 2-bractéolées. Calice à 5 sépales garnis (après la floraison) d'un appendice dorsal transverse (ou quelquefois les 2 sépales opposés aux bractéoles sont dépourvus d'appendice ). Etamines ॐ, insérées au réceptacle (devant les sépales). Anthères mutiques. Cinq squamules hypogynes, alternes avcc les étamines. Ovaire comprimé. Styles très courts, divariqués. Péricarpe succulent ou subchartacé, recouvert par le calice devenu plus ou moins charnu. Graine apérispermée, verticale, suborbiculaire; test membranacé. Embryon roulé en forme d'écuclle. Radicule dorsale. - Arbrisseaux ou sous-arbrisseaux. Tiges et rameaux articulés, aphylles ou à feuilles squamuliformes, connées par la base, sessiles, opposées ou ternées. Squamules hypogynes, velues ou ciliées, n'adhérant point aux étamines. Calice à appendices presque dressés. On en connaît
5 espèces. Ces plantes habitent les steppes salines de la Russie et de la Sibérie méridionales.

(SP.)

* ANABASITTA (d'Anabates et de silla). oIs. - G. formé par M. d'Orbigny et nous ( $V_{0 y}$. en $A m$.), pour 2 esp. d'oiseaux. de ce pays, et que nous avons changé en Anabazenops, comme exprimant mieux sa double affinité. $V$. Anabazenops. (Lafr.) * ANABASITTINE. Anabazenops (Anabates, Anabate; Zenops, Sittine). oIs. - G. que nous avons cru devoir former pour un oiscau décrit par Tem. minck ( $P l_{\text {. col. }}$ ), sous le nom de Sitline anabatoïde, quoiqu'il n'ait point les pieds conformés comme Ies vraies Sittines, mais plutôt comme ceux des Sittelles et des Ana $\rightarrow$ bates, n'ayant des Sittines que le bec retroussé en dessous. Ce g. fait partie de notre s.-famille des Anabatinées. Ses caract. sont: Bec droit, très comprimé, à mandibule supérieure presque rectiligne en dessus, l'inférieure retroussée en dessous. Ailes obtuses et surobtuses, à rémiges courtes, Queue longue, très étagée, à rectrices terminées en pointe obtuse et un peu rigides. Pieds robustes, à tarses courts; doigts longs, le médian et le pouce surtout, réunis seulement à leur base; ongles forts, allongés; celui du pouce aussi long que lui, comme dans les Sittelles. Esp. types : Sittelle brune, Sitta fusca Vicill. ( N. D., 51-531); Sittine anabatoïde Tem. (Col. 150-2); Anabazenops fuscus Nob.; Zenops rufo-superciliatus Nob. (Mag. de Guérin, pl. 7); Anabazenops superciliatus Nob. Il est évident que ces deux esp., à pattes de Passereaux grimpeurs très prononcées, et à bec retroussé en dessous, forment le passage des Sittines aux Anabates. Elles sont de l'Amérique méridionale, comme tous les g. qui composent notre s.-famille des Anabatinées.

(LAFR.)

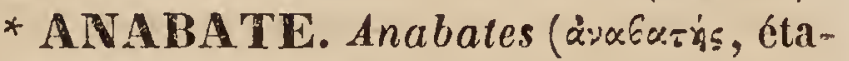
lon). ors. - G. de l'ordre des Passereaux et des Ténuirostres de Guvier, de notre famille des Certhidées, et de notre s.-famille des Anabatinées. Ce g., formé par Temminck, mais auquel nous croyons devoir faire quelques modifications, offre les caract. suivants : Bec de forme un peu variable, mais toujours assez allongé, entier, très comprimé, tantôt presque droit et fort, tantôt un peu courbé et plus grêle. Ailes obtu- 
ses ou sur-obtuses, à rémiges courtes ou médiocres, indiquant un vol plus ou moins faible. Queue ou médiocre ct arrondie, ou longue et très étagée, à rectrices larges, lui donnant une forme ample et étoflée. Pieds forts; doigts robustes, peu allongés, avec les ongles larges et arqués, ou allongés avec les ongles peu arqués. - En réunissant les détails de mœurs donnés par Azara à ceux que nous a fournis M. d'Orbigny, et comparant un très grand nombre d'esp. que nous sommes parvenu à rassembler, nous avons cru pouvoir établir dans le g. Anabate les sections ou s.-g. suivants :

S.-Gre ANABATE. Anabales. - Bec allongé, presque droit ou très peu arqué. Queue allongée, à rectrices rigides et terminées en pointes. Ailes à rémiges de longueur médiocre. Tarses et doigts peu allongés, mais forts et robustes; les latéraux presque égaux. Ongles élevés, très arqués. - Fsp. types : l’A. huppé (Spix., Pl. 84); les Sphanura sulphurascens, superciliaris, polycephala (Licht. Catal.); les A. moucheté et Oreillon brun ( Tem., Col. 238; 1, et 2 ); les A. guituralis, unirufus, d'Orb. et de Lafr. (Synops. Mag. de Gućrin). Toutes les esp. de ce groupe doivent, d'après la rigidité de leur queue et la forme de leurs ongles, se tenir cramponnées sur l'écorce des arbres; néanmoins elles se tiennent souvent sur les buissons, selon M. d'Orbigny.

S.-G. ANABAGERTHE. Anabacerthia, Nob. - Bec un peu plus grêle et plus arqué. Tarses plus longs, ainsi que les doigts, soudés, qui sont plus allongés à leur base, et les ongles moins arqués, surtout celui du pouce. Ailes à rémiges plus courtes, et queue plus rigide. Une esp. inédite de notre collection compose.ce s.-g. Un peu moins forte que le Mauvis, elle est d'un brun-roux un peu olivâtre en dcssus, avec le dessus de la tête et la queue d'un brun-cannelle, le dessous et unc bande derrière l'œil cendrés; la gorge et le haut du cou blanes, striés en travers, sur les côtés et en dessous, de petites bandes irrégulières, noirâtres. C'est notre Anabacerthie à cou strié, A. striaticollis Lafr. Cet oiseau, dans la forme de ses pieds àtarses assez élevés, à doigts très longs et grêles, soudés à leur base, à ongle du pouce allongé et peu arqué, a les plus grands rapports avec le g. Oxypyga de Ménétriés dans la famille des Fourmiliers, établi sur le Fourmilier à long bec de Cuvier. Wais, avant de l'y réunir, il faudrait avoir quelques notions sur ses mœurs. Il mène également aux Dendrocolaptes et aux Grimpereaux.

S.-G. Anvumbr. Annumbius Nob.-Bec à peu près de même forme que celui de certains Anabates, médiocre, légèrement arqué, très comprimé. Queue allongée, extrêmement étagée, à rectrices souvent élargies et très étoffées, rarement rigides et lancéolées à leurs pointes. Pieds semblables à ceux des Anabates, mais à ongles moins arqués. Ailes à rémiges très courtes; plumes frontales acu* minées, rigides. Esp. ítypes : l'A. Azara (No 222), Furnarius annumbi Vieillot (N.D.12117), 1'A. anthoïdes Nob. (Synopsis, Mag. de Guérin), l'A. rouge Azara (No 220), Furnarius ruber Vieill. (N.D. 12-118), l'A. rouge Nob. (Synops, id.ibid.), Anabates ruffrons Spix (Pl.83̃-1), Sphenura fronlalis Licht., 42; Malurus garrulus Swains. ( Zool.ill., pl. 158), où son nid en fagot est représenté placé obliquement sur un arbuste; les A. striaticeps, striaticollis Nob. (Synops. id.ibid.). Le g. tout particulier de nidification propre à ces esp., et qui consiste en un énorme nid composé de rameaux épineux à l'extérieur et en forme de fagot, à plusieurs entrées et galeries intérieures des. tinćes à être parcourues par les jeunes, avant leur sortie de ce nid, nous a fourni un caract. de mours qui, joint aux différences dans les formes, nous a paru suffisant pour établir ce s.-g., que nous avons encore indiqué comme des Anabates fagotteurs, Anabates fasci-nidificatorii, dans notre Essai de classification. S.-G. FOURnier. Furnarius. - Bec grêle, allongé, légèrement courbé et très comprimé. Ailes à rémiges primaires de longueur médiocre; les tertiaires aussi longues ou presque aussi longues qu'elles. Queue médiocre, simplement arrondie à son extré mité, à rectrices molles et rondes à la pointe. Tarses élevés, à doigts robustes, à ongles courts et peu arqués. Esp. types : le Fournier Azara (No 221), Merops rufus, Gmel.; le Fournier Buff. (Enl. 739 ; Vieill., Gal., pl. 182), le F. à sourcils, Furnarius superciliaris Lcsson (Tr., p. 307).

Outre les caract. de forme et surtout de plumage qui rapprochent les Fourniers des Anabates en général, on retrouve dans leurs 
moeur's, semblables à celles des Anabates, seIon Azara et M. d'Orbigny, et dans la forme de leur nid qui, quoique en terre, est énorme, avec une galerie circulaire comme dans le leur, une véritable analogie entre ces oiseaux. Les Fourniers ne sont que des Anabates marcheurs; or quelques Annumbis ont été décrits comme des Anabates, et ils sont tels effectivement, sauf la non-rigidité de la queue. Les Annumbis sont donc le chaînon entre les Fourniers et les Anabates, de même que ceux-ci se lient aux Sittines par nos Anabasittines, et aux Dendrocolaptes par nos Anabacerthies.

(LAFR.)

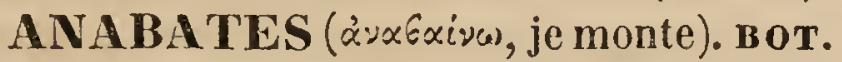
PH. - Sous cè nom, M. De Candolle formait une section du g. Aconite (Syst. Vegetal., t. , p. 177), comprenant 5̃ esp. volubiles, à fleurs bleues ou blanches, à sépale supérieur convexe, propres à l'hémisphère boréal. Il n'est plus question de cette division générique dans son Prodrome, dans lequel le $\mathrm{g}$. Aconit a été rédigé par MI. Seringe. V. AcoNIT.

(G. L.)

* ANA BA TINÉES. Anabatina (Anabates, un des principaux g. de cette s.-famille). oIs. - S.-famille de notre famille des Certhidées, de l'ordre des Passereaux et de la famille des Ténuirostres de Cuvier.

Les explorations récentes du continent américain, et principalement celles de la partie méridionale, y ont fait découvrir une infinité d'espèces d'oiseaux à plumage obscur, qu'on avait négligées ou ignorées jusqu'alors. On trouve parmi elles une nombreuse série tout à fait remarquable par la conformité de leur plumage, toujours roux ou roux-olive, souvent parsemé de mèches noirâtres, avec la queue d'un brun-roux ou brun-cannelle vif et uniforme. Tous ces oiseaux, qui font partie de notre famille des Certhidées, possèdent plus ou moins la faculté de grimper aux trones d'arbres comme nos Grimpereaux et nos Sittelles, ou de s'y cramponner comme nos Mésanges, ou d'escalader les tiges de roseaux comme nos Fauvettes de roseaux. Ce sont d'abord les Picucules de Buffon, les Sittines d'Illiger, les Queues-aiguës de Azara, nommées depuis Synallaxes par Vieillot; les Anabates de Temminck, les Anumbis et les Fourniers de Azara, puis nos Anabasittines et nos Anabacerthies, et, en dernier lieu, les Limnor- nis et les Dendrodromus de Gould (Beagle's Voyage). Parmi tous ces genres, les Picucules, d'après la forme toute particulière de leurs pattes et celle de leur queue épineuse, offrent un double caractère générique bien tranché, qui les place naturellement près du g. Grimpereau, dans la s.-famille des Certhinées, tandis que les Sittines, également bien caractérisées par des pieds syndactyles et un bec rectiligne en dessus, retroussé en dessous, et qui semble un bec de Sittelle porté à son maximum de forme typique, s'éloignent de ces dernières par leurs pattes et leur coloration, qui les rapprochent, au contraire, des Anabates, avec lesquels elles se lient évidemment par des espèces de transition. Telle est l'espèce appelée par Temminck Sittine anabatoïde, qui n'a des Sittines que le bec, et qui n'en a nullement les pieds; ce qui nous a engagé à en former un s.-g. de transition des Sittines aux Anabates, sous le nom d:Anabasittine. Sous celui d'Anabacerthie, et comme s.-g. d'Anabate, nous avons désigné une esp. de notre collection, à queue rigide, à bec un peu arqué, et à pieds de Passereaux-Grimpeurs. Notre s.-famille renfermera des genres et des s.-genres, différant quelquefois un peu de forme et de mœurs, mais offrant toujours le même genre de coloration, des pattes de Passereaux anisodactyles grimpeurs, et se liant presque tous par des espèces de transition. Ainsi les Synnallaxes, qui, d'après leur bec ordinairement grêle, droit et pointu, et leurs habitudes marécageuses, avaient paru à Temminck comme à nous les représentants, en Amérique, de nos fauvettes de roseaux, se lient aux Anabates d'une manière incontestable par quelques unes de leurs espèces, ayant, outre l'entière conformité du plumage, un bec un peu plus épais, comprimé, et légèrement arqué en dessus comme ces derniers. De plus, les uns et les autres renferment des esp. marcheuses et buissonnières, et d'autres grimpeusesarundinicoles ou sylvaines. Si les Anabates se lient aux Sittines par nos Anabasittines; les Sittines se lient aux Picucules par une esp. tout à fait anomale et mixte, le g. Dendrodromus de Gould (Beagle's Voy.), qui à un bec de Sittine réunit une queue épineuse de Picucule et des pattes de Sittelle. Les Anabates enfin se lient aux Synnallaxes de roseaux 
par les Limnornis de Gould (même Voy.), comme eux habitants exclusifs des roseaux.

Les caract. de cette s.-famille, très difficiles, d'après cela, à déterminer d'une manière précise, sont : Bec de forme très variable, mais toujours comprimé; tantôt de longueur médiocre, droit, pointu et grêle, tantôt assez épais, et légèrement arqué en dessus, quelquefois très comprimé, rectiligne en dessus, retroussé en dessous, ou allongé et arqué. Pattes le plus souvent conformées pour grimper ou se cramponner aux branches ou aux tiges des roseaux, et plus ou moins syndactyles ou propres à la station sur les branches, quelquefois à la marche. Ailes toujours obtuses ou surobtuses et à rémiges courtes. Queue moyenne ou allongée, ou très longue, plus ou moins étagée, à rectrices souvent rétrécies et acuminées à l'extrémité, quelquefois rigides et même épineuses dans cette partie. Fond du plumage toujours roussâtre, plus ou moins teinté d'olive, souvent parsemé de mèches plus foncées, et toujours d'un brun-roux ou brun-cannelle uniforme sur la queue.

Les genres qui font partie de cette nombreuse s.-famille sont: Geobate (Sw.),-Synallaxe,-Limnornis, - Anabate, avec ses s.g. Fournier,-Annumbi et Anabacerthie,Anabasittine, - Sittine èt Dendrodromus (Gould). Ces trois derniers genres forment le passage à la famille des Sittinées et à celle des Certhinées. $\boldsymbol{V}$. ces différents noms de genres, qui comprendront leurs divers s.-genres.

(LAFR.)

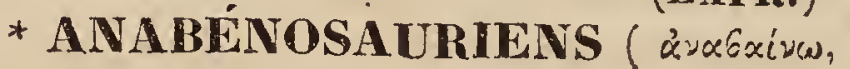
je monte; бxupós, lézard). REPT. - Ritgen désigne ainsi les Sauriens de la famille des Caméléoniens de Cuvier.

(G. B)

ANABICE. Anabix ( $\alpha \dot{\alpha} \dot{\alpha}-\beta \imath \tilde{\omega}$, revivre). BOT. CR. - Necker donnait ce nom, et Willdenow celui de Cormus, à la partie épigée des cryptogames, en en exceptant la fructification. Necker appliquait encore la même dénomination, dans son sens étymologique, aux Cryptogames privées d'or'ganes reproducteurs, et $s \mathfrak{e}$ propageant, selon lui, au moyen de parties qui se détacheraient de la plante-mère, et qu'il nommait bésimence.

(G. L.)

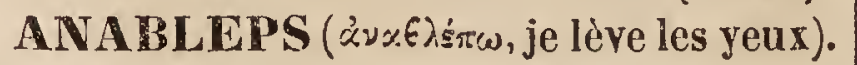
rorss. - Artedi a composé ce nom spécifique pour un poisson fort singulier des eaux de la Guyane, ou'il rangeait parmi les Loches sous le nom de Cobitis anableps. Bloch prit ce nom spécifique pour faire celui du genre distinct dans lequel il classait ce curieux poisson; g. qui a été, depuis lui, adopté par tous les Ichthyologistes. Ces Anableps sont des Malacoptérygiens à corps couvert d'écailles solides, dont le tronc est cylindrique, et la queue peu comprimée; la tête aplatie ou comme creusée, à cause de la saillie des yeux. Le museau est tronqué, aminci; la bouche est fendue en travers et au bout du museau; ses dents sont en velours. Les rayons de la membrane branchiostège sont au nombre de cinq. La vessie aérienne est très grande; la dorsale est petite et reculée sur le dos de la queue, beaucoup au delà de l'anale. A tous ces caractères ichthyologiques, qui n'offrent que dẻs particularités peu notables, ces poissons joignent une conformation d'yeux unique parmi les vertébrés, et qui les rend tout à fait dignes d'intérêt. Ces yeux sont très saillants, et enchâssés dans une orbite dont la voûte osseuse est formée par le redressement du frontal. La cornée, très bombée, est partagce en deux par une bande transversale, de façon que la portion supérieure de la cornée est dans un plan différent de celui de la portion inféricure, et que ces deux courbes n'appartiennent pas à une même portion d'une même sphère. L'iris est de même partagé en deux par une bande transverse analogue, en sorte qu'ils ont deux pupilles; d'où il résulte que ces poissons ont deux chambres antérieures de l'œil, quoiqu'ils n'aient qu'une seule chambre postérieure, un seul cristallin, une seule vitrée, une seule rétine. Il paraît donc que la ñature a organisé leur wil de manière à ce qu'ils puissent voir dans l'air en même temps qu'ils voient bien dans l'eau.

Ces poissons sont vivipares, et il y a lieu de croire à une sorte d'accouplement chez eux : car les organes de la génération du mâle et sa vessie urinaire donnent dans une sorte de verge écailleuse, attachée le long des rayons de l'anale, qui paraît n'avoir que trois rayons dans le mâle, tandis que celle de la femelle en a neuf. On ne connaît de ce g. qu'une seule esp., que Bloch a nommée Anableps tetrophthalmus.-Ces poissons sont longs de $0^{\mathrm{m}}, 20$ à $0^{\mathrm{m}}, 24$.
(VAL.) 
ANABOLIA (à $2 x 60 \lambda \dot{n}$, action de creuser et de fouiller la terre, à cause des habitudes de la larve). Ins. - G. de la famille des Phryganiens (Plicipennes Lat.), établi par M. Stephens, aux dépens du g. Limnephilus de Lea, en lui assignant comme caract. principaux ceux tirés $1^{\circ}$ des ailes, qui sont allongées, avec leur extrémité arrondie; 20 du corps, un peu déprimé, et $\mathbf{3}^{\circ}$ du dernier article des palpes maxillaires, épais et subelliptique. L'auteur donne comme type de son g. l'A. nervosa (Limnephilus nervosus Lea) d'Europe.

(Bน.)

ANACALYPTA ('ंvoxudiris, je me dévoile ). Вот. GR. - Rœhling, ayant remarqué qu'une Mousse, rapportée par Hedwig au g. Eucalypta (É. lanceolala), avait sa coiffe fendue sur le côté au lieu d'être entière, la sépara, et en fit le type d'un nouveau g. qu'il publia sous le nom en question, dańs son Histoire des Mousses d'Allemagne. Ce g., adopté depuis et modifié légèrement par $\mathbf{M}$. Bruch dans la Bryologia yermanica, a été formé aux dépens de plusieurs autres, et se compose, en conséquence, d'esp. de port un peu différent, quoique toutes remarquables par un péristome identique ou semblable, consistant en seize dents percées de trous, nées de la couche interne de la capsule, et réunies à leur base par une membrane. Nous ignorons si M. Bruch persiste à conserver ce g. ; Inais, dans tous les cas, le nom de Coscinodon (V. ce mot), qui lui a été donné antérieurement par Bridel, devra être adopté de préférence.

(G. M.)

ANACAMPSEROS Tourn. ( $\alpha 2 x x \dot{\alpha} \mu-$ $\psi \varepsilon_{\text {poss }}$ Sedum ). Bот. PH. - Synon. du g. Sedum Linn. (famille des Crassulacées).

(SP.)

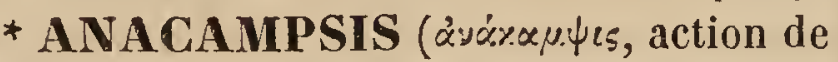
recourber). INs. - G. de l'ordre des Lépidoptères, famille des Nocturnes, établi par Curtis, et placé par Stephens dans sa tribu des Yponomeutides. En l'adoptant, nous l'avons rangé dans notre tribu des Tinéites, et Iui avons assigné les caract. suivants : Palpes inférieurs arqués et relevés au dessus de la tête; les 2 premiers articles velus et aplatis latéralement; le $3^{\mathrm{e}}$, nu et subuliforme. Trompe nulle. Antennes longues et filiformes dans les deux sexes. Tête courte et sessile. Corselet presque carré. Abdomen plat, terminé par un bouquet de poils dans les $m \hat{a}-$ les, et en pointe dans les femelles. Pattes, postérieures longues et velues. Ailes supérieures étroites, presque d'égale largeur dans toute leur longueur, avec le bord terminal presque droit ou légèrement arrondi, et brièvement frangé; ailes inférieures presque aussi longues, et largement frangées. Chenilles munies d'un écusson corné sur le $1^{\mathrm{er}}$ anneau, vivant entre des feuilles roulées ou réunies par des fils, et s'y métamorphosant dans un tissu soyeux, à la manière des Tordeuses. Chrysalide allongée et cylindrico-conique.-Les esp. que nous rapportons à ce g. ont été retranchées par nous du g. Lita de Treitschke, dont elles different principalement par la forme aplatie de leur abdomen, et la brièveté des franges de leurs. ailes supérieures. A l'état de, repos, les Anacampsis portent leurs ailes en toit plat, et croisées l'une sur l'autre, comme certaines Noctuelles. Elles sont généralement d'un gris brun qui se confond avec la couleur des écorces, dans les fentes desquelles elles se tiennent cachées. Elles s'éloignent peu de l'arbre quiles a vues naître, et font autant usage de leurs jambes que de leurs ailes pour échapper à leurs ennemis. Nous ne citerons qu'une esp., la $T i$ nea populella Linn., figurée par Hubner sous le nom de Blattariella. Elle varie beaucoup.

ANACAMPTIDE. Anacamptís ( $\dot{2} v x-$ rák. famille des Orchidées, tr. des Ophrydées, établi par le professeur L. C. Richard, dans son travail sur les Orchidées d'Europe, et qui a pour type l'Orchis pyramidalis de Linné. Ce g., très voisin du g. Orchis, en diffère surtout par ses deux masses polliniques attachées sur un rétinacle ou glande unique. Par ce dernier caract., il se rapproche du g. Aceras de R. Brown, mais en diffère par son labelle longuement "éperonné. L'Anacamp is pyramidalis Rich. est une plante qui croît dans les pelouses de la forêt de Fontainebleau et ailleurs. M. Lindley place dans ce g. deux autres esp., savoir : l'Orchis quadripunclata de Tenore, et l'Orchis Brancifor $\ddot{i i}$ de Bivona. Le g. Anacamptis est donc composé de trois esp., toutes trois originaires d'Europe. (A.R.)

ANACAMPTODON ( $\dot{\nu} \times \alpha \dot{\alpha} \beta \pi \tau \omega$, je courbe; joous, ovrcs, dent). BOT. CR. Le caractère sur lequel Bridel a établi 
ce g. de Mousses nous semble d'une faible importance. Il consiste en effet dans la courbure opposée des deux péristomes, dont l'externe se réfléchit en dehors, tandis que les dents de l'interne se recourbent en dedans, de manière à fermer presque complètement l'orifice de la capsule. Par leur organisation, leur forme, et la place qu'elles occupent, ces dents ne différant pas de celles du péristome du g. Neckera, le genre Anacamptodon peut-il en être séparé sur ce seul caract.? M. Arnott penche pour cette séparation, qu'il croit suffisamment autorisée par le port.

Nous devons toutefois convenir que ce port, très remarquable, pourrait bien être lié à des caract. inaperçus, propres à justifier l'opinion de Bridel et de M. Arnott.

En tout, ce g. est fort distinct du Cryphoa de Bridel (Daltonia Hook.) par sa coiffe en capuchon ou fendue sur les côtés, et c'est à tort qu'on les a réunis dans le Dictionnaire classique. $V$. NEGKERA.

(C. M.)

ANACAMPYL $\left(\dot{\alpha} \nu \dot{\alpha}\right.$, sur; $x \alpha \mu \pi \dot{\lambda} \lambda{ }^{\circ}$, courbe; d' $\dot{\alpha} \vee \alpha \times \dot{\alpha} \mu \pi \tau \omega$, je courbe). BoT. CR.Hedwig donnait ce nom aux écailles étalées et recourbécs au sommet, qui se trouvent sur quelques plantes agames, Agaricus croceus, Labaria squammosa, etc.

(G. L.)

ANACANDEF. REPT. - C'est, suivant Flacourt, le nom qu'on donne, dans l'île de Madagascar, à un petit serpent qui aurait la faculté de s'introduire dans le corps des animaux pour leur percer les entrailles.

(G. B.)

ANA CANTHE. Anacanthus (à priv.; $\nu$ euph.; $\ddot{\alpha} \times \alpha \nu \theta 05$, épine; $\alpha \dot{\alpha} \alpha \times \nu \theta 05$ ). Porss. - G. de Poissons de la famille des Raies, et de la tribu que le prince Charles Bonaparte nomme Anacanthini. Cette troisième sous-famille comprend les Raies à tête entourée de. larges pectorales, et à queue grêle, sans aiguillons ni nageoires dorsales. Les dents sont en petites mosaïques, disposées en quinconce. M. Ehrenberg a distingué dans cette famille le g. Anacanthe, dont les esp. manquent, en outre, de nageoire caudale. Le prince Charles Bonapartc rapporte avec doute à ce g. le Raia orbicularis de Schnceider. M. Fhrenberg en a une belle esp. nouvelle de la mer Rouge, que l'on trouve aussi aux Séchelles.

(VAL.)

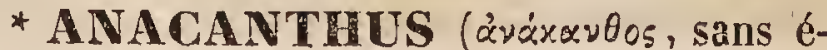

pine). INs. - G. de Coléoptères tétramères, famille des Longicornes, tribu des Prionicns, établi par M. Serville, et adopté par M. De-

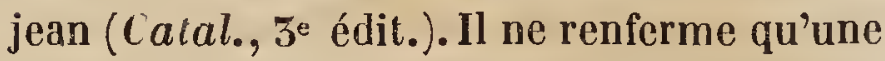
seule esp., l'A. costatus, ainsi nommée par ce dernier auteur; elle est du Brésil. Mr. Serville range le g. dont il s'agit dans sa subdiv. des Prioniens qui ont le corselet mutique latéralement. Ce qui le distingue des autres g. de la même subdiv., c'est d'avoir le corselet aussi long que large, presque orbiculaire, ou en carré à angles très arrondis.

ANACARDE DES BOUTHQUES. - Nom vulgaire du fruit du Semecarpus Anacarilium. (SP.)

* NACARDIACEES, ANACARDIÉES, Anacardiacee, Anacardieœ. вот. PH. La famille des Térébinthacées de Jussieu a été partagée en plusieurs autres : les unes portées à une autre place dans la série naturclle; les autres continuant à rester rapprochées en un groupe qui a continué à porter le nom de Térébinthacées. C'est à ce mot que ces diverses familles (dont l'une a reçu le nom d'Anacardiées) seront exposées pour mieux faire sentir leurs rapports et leurs différences.

(AD. I.)

ANACARDIER. Bot. PH. - Nom vulgaire de l'Anacardium occidentale L., et du Semecarpus Anucardium L. (SP.)

ANACHARIS ( $\dot{\alpha} \nu \dot{x}$, en comp. marque

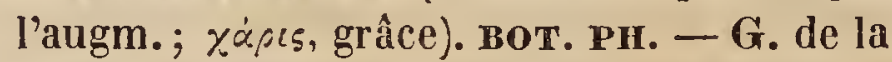
famille des Hydrocharidées, établi par L. C. Richard dans son travail sur cette famille (Mém. Institut, 1811), et offrant pour caract. essentiels des fleurs unisexuées; les mâles, les scules qu'on connaisse jusqu'à présent, sont solitaires dans une spathe sessile, tubuleuse, élargie et bifide à son sommet. Chaque spathe ne contient qu'une fleur pédonculée, ayant un calice à six divisions réfléchies; les extérieures plus larges et plus courtes que les intérieures. Neuf étamines dont les anthères sont sessiles, oblongues; attachées à une sorte d'axe ou de columelle centrale. Quoiqu'on ne connaisse ni les fleurs femelles ni le fruit de ceîte plante (Anacharis callitrichoides, Rich. l. c., t.2), cependant elle constitue, par la forme et la disposition de ses étamines, un g. différent de tous les autres g. de la même famille. L'esp. unique qu'il renferme a été trouvée 
par Commerson aux environs de Montevideo.

(A. R.)

ANACHARIS ( $\alpha \dot{\alpha} \dot{\alpha}$, prép. augm.; $\gamma \dot{\alpha} p \iota s$, grâce; très gracieux). rvs. - G. de notre famille des Cyniphiens ou Gallicoles, Lat., de l'ordre des Hyménoptères, établi par Dalman (Analect. entom.), et adopté par nous (Hist. des An.art., t. 4). Les Anacharis ont de grands rapports avec les Cynips, et de plus grands encore avec les Figites; ils s'en distinguent principalement par leurs antennes amincies à l'extrémité; par la seconde cellule cubitale des ailes antérieures oblitérée; et par le pédicule de l'abdomen plus long. On ne connaît que cinq ou six esp. européennes de ce g. ; la plupart sont encore inédites. La plus connue, et celle qui doit servir de type, est I'A. eucharidioides d'Europe Dalm. (An. ent., 9ỹ) et Blanch. (Hist. des An. art., t. 4, p. 249).

* ANACIS. Bot. PH. - Synon. du g. Chrysostemma. V. ce mot.

(J. D.)

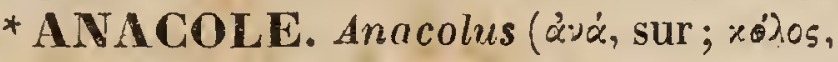
estropié; allusion à un des caractères du g.). INs. - G. de Coléoptères tétramères, famille des Longicornes, établi par Latreille, et adopté par M. Dejean, ainsi que par M.Serville, qui le place dans la tribu des Prioniens, et lui donne les principaux caract. suivants : Antennes de 11 articles. Corselet uni-épineux latéralement. Dernier article des antennes dépourvu de dent latérale. Élytres plus courtes que l'abdomen, béantes à leur suture, et laissant une partie des ailes à découvert.

Ce g. a été formé par Latreille pour y placer les Prioniens du Brésil, à élytres triangulaires, rétrécies en pointe. M. Dejean, dans son dernier catalogue, en mentionne 5 esp., toutes de cette partie de l'Amérique et nommées par lui. Nous citerons l'A. niger comme type du genre.

ANACOLUPPA (nom malabare). BoT. PH. - Rheede a figuré sous ce nom une plante rampante que l'on rapporte au $Z a$ pania nodiflora Lamk. (Verbena L.). Il raconte que le suc de cette plante mêlé au poivre réduit en poudre guérit l'épilepsie, et est le seul remede connu contre la morsure d'un serpent du g. Naja (Cobra di capello des Portugais).

(G. L.)

ANACONDO (nom vernaculaire).REPT. - Nom par lequel plusieurs erpétologistes T. I. ont désigné une espèce d'ophidien du g. Eunecte. $V$. ce mot.

(G. B.)

* ANACTIDEA (dimin. d'Anactis. F. ce mot ). Bот. PH. - Une des divisions du g. Matricaria, formée par M. De Candolle, et qui ne renferme jusqu'ici que la seule $\boldsymbol{M}$. discoidea. Elle est ainsi caractérisée : Capitules discoïdes. Corolles 4-dentées. Aigrette nulle ou à peine entière, marginiforme.

(G. L.)

ANACTILANA ( $\alpha$ priv.; v euph.; 2xxis, rayon; ixiyx, enveloppe ). BOT. PI. - Sect. du g. Cassinia, caractérisée par un involucre connivent, formé de squammes coriaces-scarieases, et par une aigrette caduque.

(J. D.)

ANACTIS ( $\alpha$ priv.; ข euph.; $\alpha x z i s$, rayon). Bot. PH. - Cassini avait établi ce g. pour deux plantes faisant partie du g. Acarna, auquel M. De Candolle les réunit de nouveau comme section, en conservant le nom proposé par Cassini.

(J. D.)

ANACYCLUS ( $\alpha$ priv. ; v euph. ; $x$ ix ${ }^{\circ}$, cercle, rayon; capitule bordé de plusieurs rangs d'ovaires sans fleurons ). Вот. PH. - Vaillant institua ce g. ( $\mathbf{M} \mathrm{cm}$. Acad. Sc.,1719) sous le nom d'Ananthocyclus, dont le mot Anacyclus est l'abrégé. Persoon d'abord, et M. De Candolle ensuite, lui ont donné pour caract. : Capitules multiflores, hétérogames. Fleurs du rayon femelles, stériles, ligulées ou subligulées, très rarement tubule uses ; celles du disque hermaphrodites, 5 den tées. Récept. conique ou convexe, paléacé. Invol. campanulé, plus court que le disque, et formé par un petit nombre de folioles. Cor. à tube obcomprimé, bi-ailé, dép ourvu d'appendices, ainsi que les rameaux. des styles. Fruit plano-obcomprimé, bordé d'ailes larges et entières, couronné au côté interne par une aigrette courte, irrégulière, denticulée, et presque continue avec les ailes du fruit. - Les Anacyclus, qui font partie de la tribu des Sénécionidées, dans la famille des Composées, appartiennent toutes à la région méditerranéenne. Ce sont, pour la plupart, de petites herbes annuelles, à feuilles pinnatilobées, à pédoncules terminés en général par un seul capitule, presque toujours dépourvu de rayons.

(J. D.)

* ANACYSTIS ( $\ddot{\nu} \nu \varepsilon v$, sans; sie, vésicule. Il aurait fallu écrire Aneucystis ). Bot. CR. - G. de la tribu des Nosto- 
cinées, famille des Phycées. M. Meneghini, qui l'a institué, lui assigne les caract. suivants: Fronde muqueuse remplie de granules devenant libres plus tard, et constituant alors de nouvelles frondes. - Ce g., établi aux dépens des Palmella de Lyngby et d'Agardh, se distingue du g. Microcystis de M. Kutzing, qui en est très voisin, par l'absence de vésicules au milieu desquelles naissent les granules reproducteurs. Le g. Anacystis renferme trois ou quatre espèces présentant une croûte ordinairement verte, se développant dans les lieux humides et ombragés, sur les pierres, le vieux bois, et même dans l'eau. Le Palmella botryoides Ag., que M. Meneghini place au nombre de ses Anacystis, nous a semblé s'en distinguer par des caract. assez tranchés pour nous déterminer à le considérer comme le type d'un nouveau g., auquel nous avons donné le nom de Botrydina. $V$. ce mot.

(DE BRÉB.)

ANADA BA. Molz. - Nom donné par Adanson à une espèce d'arche que les auteurs, depuis Linné, rapportent à l'Arca antiquata. $Y$. ARGIE.

(DESH.)

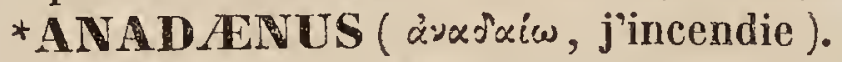
oIs. - G. formé par M. Swainson (Class. of Birds), dans sa famille des Cuculida, et répondant à celui de Boubou, établi antérieurement par Lesson dans son Traité. $V$. BoUBOU.

(LAFI.)

ANADENIA ( $\alpha$ priv.; v euph.; $\dot{\alpha}^{\prime} \hat{s}^{\prime} \nu$, Évos, glande ). вот. PH. - G. de la famille des Protéacées, tr. des Hakéées, Endl., formé par R. Brown (Linn., Trans. X, 165; Prodr.) pour quelques plantes propres à la Nouv.-Hollande australe. En voici les caract. essentiels : Périgone tétraphylle, à segments subspatulés, peu étalés. Anth. 4, cachées au sommet des segments concaves du périgone. Point de glandes hypogynes. Ovaire stipité, uniloculaire, bi-ovulé. Style décliné; stigm. conique. Follicule coriace, monosperme par avortement. Graine aptère. Arbrisseaux glabres ou pubescents vers leur partie moyenne, à feuilles pennatifides ou lobées, cunéiformes dans leur contour, munies en dessous de glandules cutanées, à épis terminaux ou latéraux, garnis de fleurs petites, géminées1-bractéces; celles du sommet s'épanouissant

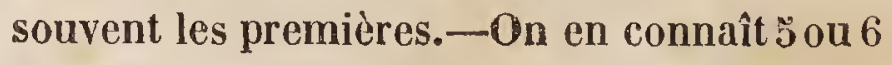
esp., dont les deux plus communes, et qu'on cultive dans les serres d'Europe, sont les A. pulchella et Manglesii. (C.L.)

ANADYOMENE. Anadyomena (surnom de Vénus; àvodjouxr, je sors de l'eau ). Pourp. вот. - G. de Polypiers flexibles, établi par Lamouroux dans l'ordre des Gorgoniées, sur une algue qu'il ne put étudier que très imparfaitement parmi les diverses productions qu'on trouve desséchées dans les pharmacies, sous le nom de Mousse de Corse. Ce sont des expansions vertes, flabelliformes, sillonnées de nervures symétriques et articulées, semblables à une broderie élégante et très régulière. La seule esp. décrite, l'A. flabellata, vit dans la Méditerranće.

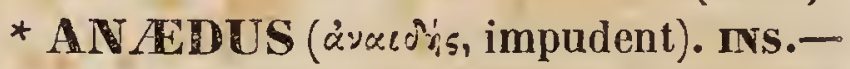
G. de Coléoptères hétéromères, famille des Ténébrionites, établi par M. Dejean (Catal., $\bar{\partial}^{2}$ édit.), mais dont il n'a pas publié les caractères. Ce g. a pour type l'Helops punctatissimus de son précédent catalogue, esp.du Brésil, à laquelle il en réunit 5 nouvelles, nommées par lui $\boldsymbol{A}$. aquinoctialis, de Carthagène; corvinus, du Brésil, et minutus, de l'Amérique septentrionale.

* ANZEMERUS ( $\alpha$ vispepos, d'un aspect farouche). Ins. - Genre de l'ordre des Coléoptères tétramères, famille des Curculionites, division des Brachydérides, établi par Schoenherr, qui lui donne les caract. suivants : Antennes courtes, assez robustes, dont le scapus claviforme atteint à peine les yeux; 1 er article du funicule un peu plus long que les suivants; le dernier serré contre la massue; tous un peu turbinés ; massue en ovale oblong, acuminé. Rostre court, large, plat en dessus, canaliculé. Front assez large, avancé en forme de paupière au dessus des yeux. Yeux presque.oblongs, placés longitudinalement, très proéminents. Thorax oblong, presque linéaire, légèrement bisinué à la base, anguleux, presque tronqué au sommet, déprimé en dessus. Élytres allongées, armées d'une petite pointe à l'extrémité. Tarses allongés, étroits, non spongieux en dessous.-Observ. Corps allongé, dur; ailé, de grandeur moyenne. - M. Dejean, qui a adopté ce genre (Catal., $\tilde{5}^{\mathrm{e}} \dot{e d i t .)}$, y rapporte $4 \mathrm{esp}$. dont nous ne citerons que celle qui a servi de type à Schoenherr pour l'établir : c'est le Curculio fuscus d'Olivier (Ent. V, 83, p. 
322, no $360 ;$ tab. 8, fig. 95). Cette espèce est / de la corolle; filaments inégaux à la base. du Sénégal.

(D.)

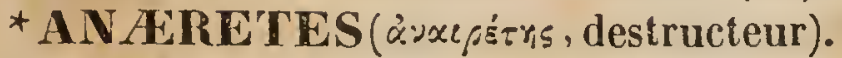
INs. - G. de Coléoptères pentamères, famille des Lamellicornes, établi par M. Dejean, qui n'en a pas publié les carart. Il le place dans son dernier catal. (ze édit.) immédiatement avant le g. Macrodactylus de Latreille, de sorte qu'il appartiendrait à la tribu des Scarabéides phyllophages de ce dernier. Il n'y rapporte que 2 esp. : l'une nomméc par lui A. litigiosa, et l'autre, par Say, A. elongata. Toutes deux sont de l'Amérique septentrionale.

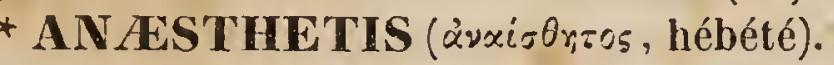
INs.-G. de Coléoptères tétramères, famille des Longicornes, établi par M. Dejean, qui n'en a pas publié les caract. D'après la place qu'il occupe dans le dernier catal. de cet auteur ( $\left.\bar{z}^{e} \dot{e} d i t.\right)$, il appartiendrait à la tribu des Lamiaires de M. Serville. Il n'y rapporte qu'une seule espèce, l'A. testacea ou Saperda $i d$. Fabr., qui se trouve en France. (D.)

* ANATIA (àvectio, innocence). INs. - G. de Coléoptères tétramères, famille des Longicornes, établi par M. Dejean, qui n'en a pas publié les caract. Il lui donne pour type la Saperda prausta Fabr., qui se trouve aux environs de Paris, et à laquelle il associe 2 autres esp. : l'une d'Autriche, qu'il nomme A. Muhlfedii; et l'autre de la Russie méridionale, nommée $\boldsymbol{A}$. gilvipes par Steven.

(D.)

* ANA gALLIDÉES. BOT. PH. $-V$. PRIMULACÉEs.

(C. L.)

ANAGALLIDIASTRUN (anagallis, idis, mouron des champs; astrum, astre; plante qui s'étale en étoile?). вот. Рн. Ge g., de Micheli,- est synon. du Centunculus de Linné. $V$. ce mot.

(C. L.)

* ANA GALLIDIUM (dimin. d'ana gallis, idis; ávxyailis, mouron rouge ou bleu. V. Anagallis ). вот. PH. - G. de la famille des Gentianacées Lindl., tr. des Gentianées, s.-tr. des Chironiées, formé par Griesebach (Observ. 52) sur le Swertia dichotoma de Pallas (Fl. Ross. II, t. 91 ). L'auteur en circonscrit ainsi les caract. Cal. 4-partite. Cor. hypogyne, rotacéc, 4-fide; anneau coronal de la gorge très ténu, frangé; segments munis à la base de fossettes géminées-glanduleuses, couvertes d'écailles non frangées. Étam. 4, insérées à la gorge
Anthères immutées. Ovaire uniloculaire. Ovules nombreux le long des sutures. Style terminal, court; stigm. échancré, bilobé. Capsule uniloculaire, bivalve. Graines nombreuses, comprimées, marginées.-Ce g. ne renferme que l'esp. précitée, propre à l'Asie médiane; c'est une herbe vivace, à tige dichotome, très rameuse, garnie de feuilles opposées, ovales, obtuses; les radicales longuement pétiolées, les caulinaires subsessiles, les pédoncules uniflores. (C. L.)

ANAGALLIS (Anagallis, Pline; $\alpha \nu x \% \alpha \lambda \lambda-$ $\lambda i s, d^{\prime} \alpha \nu x y \varepsilon \lambda \dot{\alpha} \omega$, j'éclate de rire. Les anciens prétendaient que cette plante excitait la gaîté, et l'employaient contre les obstructions du foie. Les lexicographes dérivent à tort ce

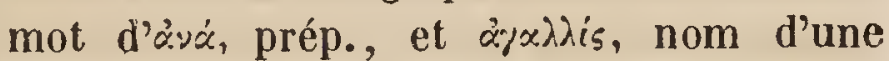
plante bulbeuse, aujourd'hui indéterminée.). вот. PH. - G. de la familie des primulacées, type de la tribu des Anagallidées, Endl., formé par Linné, et adopté par tous les botanistes postéricurs. En voici les caract. essenticls : Cal. 5-partite. Cor. hypogyne, 5-partite, subinfundibuliforme ou rotacée. Étam. 5 , insérées à la base du tube de la corolle, opposées aux segments de celle-ci, et exsertes ou incluses; filaments filiformes, velus, libres ou connés à l'extrême base. Anth. ovales, biloculaires, longitudinalement déhiscentes. Ovaire uniloculaire; placenta basilaire, globuleux. Ovules nombreux, peltés - amphitropes. Style simple; stigm. obtus. Capsule globuleuse, uniloculaire, s'ouvrant par la valve supérieure, en forme d'opercule. Graines nombreuses, planes dorsalement, ombiliquées à la partie ventrale conico-convexe. Embryon parallele à l'ombilic, dressé dans l'axe d'un albumen charnu.-Ce g. renferme une vingtaine d'esp. environ, indigènes dans l'Europe et l'Asie médianes; quelques unes dans l'Afrique méditerranéenne. Ce sont des herbes vivaces, dressées ou étalées, à feuilles opposées, très entières; à pédoncules axillaires opposés, uniflores, ébractéés ; à corolles rouges ou bleues, quelquefois blanches. La plus commune est l'A. arvensis, connue sous le nom vulgaire de Mouron des champs (et non Mouron des oiseaux, plante fort différente. $\boldsymbol{V} . \mathbf{A} \mathbf{L}_{-}$ SINF ). Elle croît partout, dans les champs, les moissons, etc., et varie sous le rapport de la couleur des fleurs, qui sont tantôt 
d'un rouge-pourpre, tantôt d'un bleu d'azur. Cette plante a été long-temps préconisée contre la rage; malheureusement l'expérience n'a pas constaté cette propriété. (G. L.)

ANAGENITE ( $2 \cdot \dot{\alpha}$, ici prépos. duplicative; زร์vos, naissance; c'est-à-dire régénération). GÉoL. - Ce nom, établi par Haüy, et adopté depuis par M. Brongniart (Class. des Roches), désigne, dans la classification de M. Cordier, une espèce de la famille des Roches talqueuses. Suivant ce dernier géologue, l'Anagénite est composée d'une pâte phylladienne, avec fragments plus ou moins gros de Feldspath, de Quartz et de Protogyne, réunis par un ciment mêlé de quelques parties de Feldspath et de Quartz. Cette association présente souvent l'aspect et la contexture de la Protogyne, et il est quelquefois diflicile d'en distinguer l'Anagénite. Les fragments sont ou anguleux ou arrondis; en sorte que l'Anagénite est tantôt à l'état de brèche, tantôt à l'état de poudingue. Les teintes les plus ordinaires sont le verdâtre plus ou moins foncé, le rougeâtre ou le noirâtre. Elle est assez dure, et généralement susceptible d'être polie; ce qui lui donne le plus souvent un aspect bigarré, résultant des diverses couleurs et du mélange des fragments. L'Anagénite à gros fragments n'est schistoïde qu'en grand, tandis que celle à petits grains l'est en feuillets assez minces, comme les Phyllades. Cette dernière variété est quelquefois calcarifère, et alors -il peut arriver qu'elle contienne quelques rares débris organiques marins, tels que des Spirifères, des Térébratules, des Productus et des Entroques. On trouve, en outre, des débris de végétaux terrestres peu conservés dans une variété d'Anagénite noirâtre, à petits grains, et chargée de parties charbonneuses, qu'on rencontre près des couches d'Anthracite renfermant les Anagénites.

L'Anagénite appartient généralement aux terrains de transition; cependant on en trouve aussi dans certains terrains problématiques des Alpes, qu'une partie des géologues rapportent soit aux terrains houillers, soit à l'étage des grès bigarrés, et que d'autres regardent comme étant contemporains de l'étage du Lias.

(G. D'O.)

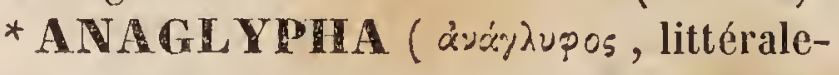
ment : ciselé en relief; ici, ¿̀ó, de nouveau; y่upow, je ciselle, je polis; c'est-à-dire g. à étudier de nouveau ? ). Bor. PH. - H. De Candolle a fondé ce genre sur un sous-arbrisseau originaire du Cap, dont les rameaux, couverts surtout au sommet d'un duvet court, glanduleux-velouté , portent des feuilles linéaires, striées-sillonnées sur les deux faces, et rendues très âpres par la présence des cils raides qu'elles portent sur leurs bords et vers l'extrémité des nervures. Les capitules terminaux, solitaires, sont garnis de fleurs jaunes, 1-sériées, ligulées, femelles à la circonférence; celles du disque tubuleuses, 5-dentées, hermaphrodites, légèrement velues. Involucre 2 -sérié, composé d'écailles de longueur égale, un peu plus longues que le disque et très acuminées. Réceptacle plan, alvéolé. Fruit obové, subpubescent, dépourvu d'aigrette. Les anthères ainsi que les styles de l'Anaglypha n'étant pas connus, ce n'est que par sa ressemblance avec d'autres Composées du même pays que M. De Candolle l'aura classé dans la tribu des Astéroïdées, de la famille des Composées.

(J. D.)

* A AGL Y PUTS (ávíyiurros, relevé en bosse). Irs. - G. de Coléoptèrès tétramères, famille des Longicornes, établi par M. Hulsant, dans son histoire naturelle des Coléoptères de France, aux dépens du g. Clytus de Fabricius, et auquel il rapporte deux espèces seulement, qui sont le $C$. gibbosus et.le $C$. mysticus de cet auteur. Les caract. qu'il assigne à ce $\mathrm{g}$. sont les suivants : Antennes subsétacées, presque aussi longues que le corps dans les mâles. Palpes à dernier article en triangle renversé. Yeux médiocrement échancrés. Prothorax oblong, un peu plus étroit postérieurement. Élytres chargées d'une bosse à la base, le long de la suture, soit tronquées au sommet, soit arrondies à l'angle sutural. Cuisses postérieures rétrécies à la base, et renflées en massue vers l'extrémité. Premier article des tarses postérieurs moins long, ou à peine aussi long que les suivants pris ensemble. (D.)

ANAGRUS. INs. - G. de la famille des Oxyuriens (Oxyuri Lat., Proctotrupidce Steph.), de l'ordre des Hyménoptères, établi par M. Haliday (Ent.Mag.). Il ne diffère essentiellement du g. Mymar de cet auteur que par'l'abdomen sessile et de forme conique; les antennes sont de même composées de 13 articles dans les mâles, et de 9 seule 
ment dans les femelles. - On connait quelques esp. indigènes de ce g., toutes d'une taille des plus exiguës; celle que l'on doit en considérer comme le type est l'A. atomus (Ichneumon atomus $\mathbf{L}$.).

ANAGYRIS Tourn., L. (àváyupos, nom, chez les Grecs, d'une plante indéterminée). вот. PH. - G. de la famille des Légumineuses, s.-ordre des Papilionacées, tribu des Sophorées. Ses caract. distinctifs sont : Calice campanulé, 5̌-denté, 2-labié. Carène à pétales distincts, plus longs que les ailes ; étendard plus court que les ailes. Légume courtement stipité, comprimé, bosselé, irrégulièrement septulé, 2-valve, pléiosperme. Arbrisseaux à feuilles 3-foliolées; folioles très entières. Stipules solitaires, oppositifoliées. Fleurs en courtes grappes axillaires. Corolle jaunâtre. Ce g. paraît être limité à une seule esp. (plusieurs auteurs en ont établi 2 autres sur des variétés de l'ancienne); c'est l'A. fotida, commun dans toute la région méditerranéenne, et qui se retrouve à Ténériffe. Cet arbuste fleurit en février ou dès la fin de janvier. Toutes ses parties ont une odeur désagréable. Suivant les expériences du docteur Loiseleur-Deslongchamps, les feuilles sont purgatives et émétiques.

(SP.)

* ANAITE. Anaitis (nom myth.). INs.G. de l'ordre des Lépidoptères, famille des Nocturnes, tribu des Phalénites, établi par nous (Hist. nat. des Lépid. de France) aux dépens des Larentics et des Aspilates de M. Treistchke, et auquel nous assignons les caract. suivants: Ant. simples dans les deux sexes. Bord terminal des ailes simple et uni ; ailes supérieures seules, traversées par un grand nombre de lignes parallèles, anguleuses ou ondées, et séparées trois par trois. Chaperon très proéminent et dépassé néanmoins par les palpes. Trompe longue. Chenilles lisses, sans tubercules, et de forme un peu aplatie. Chrysalide avec le fourreau de la trompe très allongé. - Ce g. ne se compose que de quatre esp., dont une, qui peut en être considérée comme le type, est très commune aux environs de Paris. C'est l'Anaïte triple raie, Phalcena plaginla de Linné, ou duplicala de Fabr., ou la Rayure à trois lignes de Geoffroy. Les trois autres, proformata, coarctata el boisduvaliata, ne se trouvent que dans les montagnes d'une certaine élévation. Toutes quatre sont figurées dans l'ouvrage précité, $t$. VIII, $p l$. 195, fig. 1-4, et pl. 210, fig. 6 .

(D.)

* ANAITE (nom myth.). вот. PH.-M. De Candolle a établi ce g. sur un sous-arbrisseau du Mexique à rameaux divariqués, couverts inférieurement de feuilles opposées, oblongues, entières, atténuées à la base. Ces rameaux, terminés par des sortes de pédoncules dépourvus de feuilles, portent chacun un capitule multiflore, ligulé, à ligules femelles, multisériées, presque persistantes; les fleurs du rayon hermaphrodites, tubuleuses. Invol. campanulé, composé de 2-3 séries d'écailles imbriquées, obtuses. Récept. convexe, couvert de paillettes caduques, terminées par une sorte d'appendice calleux. Styles du rayon à peine saillants; ceux du disque..... Fruits du disque trigones, glabres, couverts çà et là de très petits tubercules, et dépourvus d'aigrette; ceux du rayon planocomprimés, presque ailés, échancrés ou bidentés au sommet. - Ce g. fait partie de la famille des Composées, tribu des Sénécionidées.

* ANALAMPIS. INS. - Genre d'Insectes de l'ordre des Coléoptères pentamères, famille des Sternoxes, établi par $\boldsymbol{M}$. Dejean aux dépens du genre Elater Fabr., converti depuis en tribu sous le nom d'Elatérides. Ce genre, dont il n'a pas publié les caractères, ne renferme que trois espèces, toutes du Brésil, et nommées par lui $\boldsymbol{A}$. concolor, meticulosa et inornata.

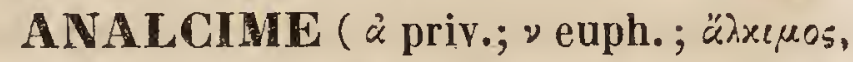
fort; corps sans vigueur, à cause de sa faible vertu électrique). Miv. - Synon. : Cubicite, Sarcolithe, Zéolithe dure. Silicate d'alumine et de soude hydraté, de la formule $\mathbf{A} l \mathbf{N} a \mathbf{S} i^{3} \mathbf{A} q^{2}$; la silice étant représentée par SiO. On voit que cette substance peut être considérée comme un Amphigène hydraté, dans lequel la potasse serait remplacée par la soude ( $V$. AMPHIGive.). L'Analcime a les plus grands rapports avec l'Amphigène par sa cristallisation, qui se rapporte au système cubique. Comme ce dernier minéral, il affecte plus particulièrement la forme trapézoïdale; mais il se clive en cube, et se présente aussi sous cette dernière forme avec. de petites facettes sur les angles, qui établissent le passage à l'octaedre et au 
trapézoèdre. De plus, il est fusible sans boursouflement, en un verre transparent.Sa pesanteur spécifique est de 2,2; sa dureté 5,5 . Il est soluble dans les acides; sa solution, traitée par le carbonate d'ammoniaque et filtrée, laisse, après l'évaporation et la calcination, un résidu alcalin qui ne précipite pas par l'hydrochlorate de platine. C'est une substance vitreuse, transparente, souvent incolore, mais offrant quelquefois des teintes de grisâtre, de rosâtre pâle, de blanc mat ou de rouge plus ou moins foncé. Dans ces derniers cas, il devient tout à fait opaque. L'Analcime est composé, sur 100 parties : de 55,9 de silice; 22,5 d'alumine; 14 de soude, et 7,8 d'eau. - M. Brewster a observé dans les cristaux trapézoïdaux d'Analcime des propriétés optiques fort curieuses, qui semblent annoncer que ces cristaux peuvent varier de structure ou de composition dans leurs diverses parties. En effet, toutes les lignes contenues dans les trois sections rectangulaires qui passent par les axes principaux du trapézoèdre sont dépourvues du pouvoir bi-réfringent et polarisant, tandis que ce pouvoir se manifeste avec plus ou moins d'intensité dans les directions qui ne sont pas comprises dans ces trois plans.

Les cristaux d'Analcime remplissent les fentes et les boursouflures des roches basaltiques et amygdalaires dans un grand nombre de lieux, à l'Etna, dans les îles Cyclopes, au mont Somma, à Montecchio-Maggiore dans le Vicentin, dans la vallée de Fassa en Tyrol, à Dumbarton en Ecosse, à Aussig en Bohême, aux îles Fébrides et aux Feroë. On a cité aussi la même substance dans les gîtes métallifères de Laurvig et d'Arendal en Norwége.

(DEL.)

* ANALCIPUS ( $\ddot{\alpha} / x x_{x} \times t_{5}$, impuissant;

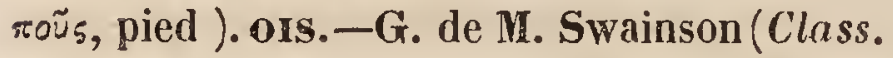
of Birds), répondant à celui d'Artamia d'Isidore Geoff. S.-Hilaire, et démembré des Langrayens (Oxypterus) de Cuvier. V.ARTAMIE.

(LAFR.)

* ANALGIS ( $\alpha 2 \nu x \lambda \times(\varsigma$, impotent). INS. G. de l'ordre des Coléoptères tétramères, famille des Curculionites, div. des Cryptorynchides, établi par Schoenherr, qui Iui donne les caract. suivants : Ant. courtes, un peu minces; leur funicule composé de six articles : les deux premiers allongés, obconiques; les autres presque lenticulaires; massue ovale, acuminée. Rostre un pea court, cylindrique, arqué , épais. Corselet oblong, un peu plus étroit antérieurement, présentant une saillie arrondie au milieu du sommet, légèrement lobé derrière les yeux; canal inférieur terminé disíinctement avant les parties antérieures. Élytres en ovale allongé, convexes, un peu acuminées à leur extrémité. Tibias médiocres, presque droits; tarses un peu larges. Ce g., adopté par M. Dejean ( Cat., כैe édit.), a été créé aux dépens du g. Bagous de Germar. II renferme douze esp., toutes exotiques, et a pour type l'A. areus du premier de ces deux auteurs, esp. de l'Amérique septentrionale.

ANALE (anus, fondement, rectum). PoIss. - On donne ce nom à la nageoire que les poissons portent ordinairement sous le tronçon de la queue, immédiatement après l'ouverture de l'anus. Elle varie beaucoup dans sa forme, dans le nombre, dans la composition des rayons qui la soutiennent; elle est quelquefois étendue sous tout le corps du poisson, et aussi longue que le poisson lui-même, ainsi que cela a lieu dans les Turbots, les Barbues, les Limandes, les Soles, et autres Pleuronectes. Quelquefois elle est réduite à un ou deux rayons, ou même elle disparaît tout à fait. On compte aussi quelquefois plusieurs anales sous la queue $d u$ poisson. Il y en a trois dans quelques Gades. En général, elle est plus courte que la dorsale; mais aussi le contraire a lieu. Sa forme varie trop pour prétendre ici en signaler les variations. Quant à la nature de ses rayons, ils sont généralement composés d'épines et de rayons articulés chez les Acanthoptérygiens, et seulement de ces derniers dans les Malacoptérygiens. Il est à remarquer que presque tous les Acanthoptérygiens, je dirai plus de 1,500 espèces, n'ont que trois rayons épineux à l'anale; un petit nombre n'en a qu'un seul; d'autres en ont deux, surtout parmi les Sciénoïdes ; puis on en connaît à quatre, à cinq, à six, à sept, et même à quatorze ou à quinze rayons épineux, et souvent dans ce cas le nombre des épines dorsales diminue. L'étude de cette nageoire est donc importante en ichthyologie, sans que cependant elle fournisse des caractères de haute valeur.

( VAL.) 
ANALOGUE ou ANALOGUES.

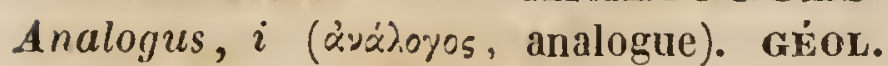
- Les géologues ont consacré ce terme pour désigner les corps organisés fossiles, qui, n'étant point identiques aux êtres qui vivent actuellement, ont cependant avec eux plus ou moins de ressemblance. On reconnaît plusieurs sortes d'analogies : des analogies d'espèce, des analogies de genre, des analogies d'ordre et des analogies de classe. Certaines especes perdues, qui appartiennent à des genres actuellement existants, sont des Analogues d'espèce : tel est l'éléphant fossile. D'un autre côté, l'Anoplotherium, qui vient se placer entre le sanglier, l'hippopotame, etc., sans pouvoir entrer dans aucun de ces genres, est un Analogue de genre dans l'ordre des Pachydermes. On n'a jusqu'à présent trouvé qu'un très petit nombre d'espèces fossiles identiques aux êtres vivants, et le nombre des Analogues d'espèce est d'autant moins grand quẹ l'on étudie des couches plus anciennes. $\boldsymbol{V}$. les mots FOSSILES et TERRAIN.

(C.P.)

* ANALOPONOTE. Analoponotus (à

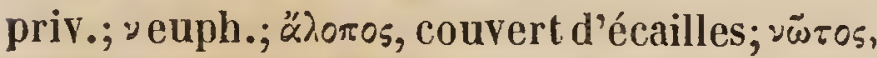
dos). REPT. - Nous avons désigné ainsi, dans notre Erpétologie générale, un g. d'Iguaniens pleurodontes, dont la peau du dessus du corps est effectivement tout à fait dépourvue d'écailles; particularité, encore unique dans l'ordre entier des Sauriens. Les autres marques distinctives de ce g. sont d'avoir le palais denté, les dents des mâchoires trilobées au sommet, un double rang de pores fémoraux, un petit fanon sans dentelure, une crête dorsale et une caudale fort basses, la queue comprimée et entourée de verticilles de grandes écailles carénées. La tête est revêtue de très petites plaques polygones, aplaties, égales entre elles; le dessous du cou ofire de petites écailles ovales, enchâssées dans la peau, et entourées de granules comme chez les Varans. La face supérieure des membres est protégée par de grandes squammes, enchâssées aussi, rhomboïdales et carénées, tandis que leur face inférieure en présente de lisses et un peu imbriquées. La squammure du ventre se compose de petites pièces carrées, unies. Des scutelles hexagonès, très élargies, entuilées, défendent le dessus des doigts; de grandes squammes tricarénées et dilatées transversalement en garnissent la face inférieure. La paume des mains et la plante des pieds sont comme hérissées d'épines produites par les carènes très prononcées des squammes qui les garnissent. - La seule esp. qui appartienne encore à ce g. est l'Analoponote de Ricord, grand Saurien originaire de Saint-Domingue, ayant le port et la taille d'un Iguane. Il est décrit et représenté dans notre Erpét. gén. (t. 4, p. 19, pl. 37 ).

(G. B.)

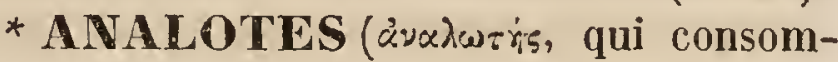
me). INs. - G. de Coléoptères tétramères , famille des Curculionites, div. des Anthribides, établi par M. Schoenherr, qui le caractérise ainsi : Ant. longues, grêles; les deux $1^{\text {ers }}$ articles courts, épais au sommet, $\mathbf{3}-8$, fort allongés, presque filiformes, 9-11, à peine plus épais, peu distants, formant une massue allongée. Rostre peu long, peu large, courbé, déprimé en dessus, légèrement échancré au sommet. Prothorax subconique, offrant de chaque côté, bien avant la base, un sillon élevé, subtransverse, fléchi par devant. Elytres presque linéaires, aplaties sur le milieu du dos. Pygiảium courbe, presque carré, échancré des deux côtés, tronqué au sommet. - Ce g., qui se rapproche du g. Gymnognathus, a pour type et unique espèce l'A. discoideus Klug., du Brésil.

ANAMENIA, Vent. (nom arabe d'une espèce de renoncule.) Bot. PH. - Syn. du g. Inowltonia, Salisb., famille des Renonculacées.

(SP.)

* ANA MIR T A, Colebrooke. Bot. PH.G. de la famille des Ménispermacées, auquel MM. Wight et Arnott (Prodr. Flor. Penins. Ind. I, p. 446) assignent les caract. suivants : Fleurs dioïques. Cal. 6-sépale, 2.bractéolé; sépales 2-sériés. Cor. nulle. — Fleurs mâles : Étamines soudées en colonne centrale dilatée au sommet. Anthères nombreuses, adnées, couvrant tout le sommet globuleux de l'androphore. - Fleurs femelles, inconnues. Péricarpe de 1 à 5 drupes distincts, 1 loculaires, 1-spermes. Graine subglobuleuse, profondément échancrée au hile. Périsperme charnu, comme 2-loculaire, à cotylédons très minces, linéaires-oblongs, distants, occupant chacun l'une des loges du périsperme. Arbuste volubile, à écorce subéreuse. Feuilles plus ou moins profondément cordi- 
formies à la base; panicules racémiformes, latérales. Les auteurs de ce genre n'y rapportent que le Benispermum cocculus, L. (Gærtn. Fruct., tab. 70, fig.1), esp. à laquelle ils rapportent comme syn. les Cocculus suberosus, orbiculatus, flavescens et lacunosus DG. (Prodr. )', ainsi que l'Anamirla paniculata Colebr. (Trans. of the Linn. Soc., XIII, p. 52 et 66), le Menispermum heteroclitum et le Menispermum monadelphum Roxb. (Flor. Ind.). C'est de cette plante que provient le fruit connu sous. le nom de Coque du Levant, et qui, comme tout le monde le sait, exerce une action si délétère sur les.poissons. D'après les expériences de M. Goupil, le principe vénéneux de ce fruit réside essentiellement dans l'amande de la graine, tandis que la partie charnue du drupe est seulement émétique.

(SP.)

* ANAMORPHOSE. Anamorphosis (àvxpópowsts, nouvelle forme). BOT. GR. On entend par ce mot., tout récemment introduit dans la science, la dégénérescence morbide ou. atypique qui fait qu'un Lichen ou toute autre Agame devient méconnaissable. Les changements qu'il éprouve sont en effet tels, que la même esp. a pu être et a été placée dans trois ou quatre genres différents, selon que le thalle et les apothécies ont subi séparément ou simultanément les altérations singulières qui en ont causé l'état anomal. Nous en parlerons plus au long au mot LIGHEN. $V$, ce mot.

(C. M.)

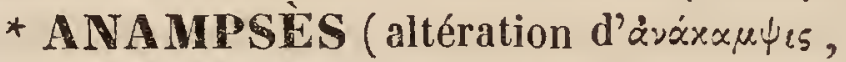
courbure à rebours). Poiss. - Genre de Labroïdes, voisin des Girelles, auxquelles ils ressemblent par leur tête nue et sans écailles, leur ligne latérale non interrompue, mais qui s'en distinguent, ainsi que de tous les autres poissons, par la singularité de leurs dents. Elles sont au nombre de quatre, deux à chaque mâchoire; ces dents sont licomprimées, tranchantes, couchées en avant, et recourbées comme les cils qui bordent nos paupières, de façon que quand la bouche est fermée elles se touchent par le dos de leur convexité. Il est difficile de concevoir l'usage que des poissons peuvent faire de pareils organes ; d'ailleurs, ils ont des dents pharyngiennes de Labroïdes ordinaires, avec lesquelles ils peuvent très bien broyer la caracace dure des Crustacés qu'ils avaleraient, et même briser le test des Mollusques s'ils les attaquaient. Les Anampsès sont de fort jolis poissons de la mer des Indes; on n'en connaît encore qu'un petit nombre d'espèces. La découverte en est due à Péron; mais, depuis lui, presque tous les navigateurs ou collecteurs dans la mer Rouge et l'Océan Indien en ont rapporté.

(VAL.)

ANANAS. Ananassa Lindl., Ananas Tourn. (nom vernaculaire). Бот. PH. - G. de la famille des Broméliacées, type de la tr. des Ananassées (Nob. in msc.), formé par Lindley (Bot. Reg., 1068 t. 1081 ), et dont les caract. sont ainsi exposés (in Endl. Gen. $p l$.): Périgone supère, sexpartite. Segments extérieurs calicinanx; dressés ; les intérieurs pétaloïdes, dressés, ligulés, munis intérieurement à la base de deux squammes tubulées. Étam. 6, épigynes, opposées aux divis. internes du périgone. Filaments enserrés parmi les squammes. Anth. linéaires, dressées. Ovaire infère, triloculaire; ovules renfermés dans un placenta palmatifide, et pendants du sommet en saillie de l'angle central de chaque loge. Style filiforme. Stigmates 3 , un peu charnus, dressés, frangés. Baies soudées entre elles et avec les bractées en une sorte de syncarpe, dont les loges, très rarement bi-tri-loculaires, sont le plus souvent aspermes par avortement. Graines solitaires dans les loges, au sommet desquelles elles sont appendues, ovoïdes, un peu comprimées, à test membranacé, roux, strié. Raphé rubaniforme, blanc, réunissant l'ombilic basilaire au sommet d'une chalaze tuberculiforme. Embryon très petit, dressé à la base d'un albumen farinacé, à extrémité radiculaire supère, atteignant l'ombilic.-Ce g., séparé avec raison par le savant auteur anglais (loc. cit.) du g. Bromelia, dont il diffère notamment par la présence de glandes nectarifères (squammes) à la base des divisions du périgone, renferme environ 丂 à 6 esp., dont la patrie originaire n'est pas connue, et qu'on présume généralement être l'Amérique. Quoi qu'il en soit, l'espèce type est, de nos jours, répandue dans les parties intertropicales des decix continents (Asie et Amér.), où on la trouve soit cultivée, soit même à l'état sauvage. Ce sont toutes des herbes à feuilles longues, rigides, linéaires, dentées-épineuses en hameçon sur les bords, ou très entières, toutes radi- 
cales, poudrées, glauques, et disposées en rosette. L'inflorescence consiste en un épi dense, puis charnu, conné, et souvent terminé par une couronne de feuilles. En Europe, I'Ananassa sativa, quoique d'une culture difficile et dispendieuse, est l'objet d'un commerce très étendu et très productif, en raison de l'excellence de son fruit, à tort ou à raison réputé le meilleur des fruits connus. Cette plante, grâce aux soins des horticulteurs, et sous les diverses influences climatériques, a produit un grand nombre de variétés, toutes cultivées avec soin, et dont les meilleures sont l'Ananas commun, le Violet de la Jamaïque, le Cayenne sans épines, le Cayenne épineux, le d'Envile, la Providence, etc. Les fruits de quelques unes de ces variétés diffèrent, pour le poids, de 1 et demi à 2 , et même à kilog., et valent, selon la qualité et le poids, de $6 \mathrm{fr}$. à 50 et au delà. Faute de graines, qu'il ne produit que très rarement, l'Ananas se multiplie soit par les æilletons qu'il produit à sa base, soit par la couronne de feuilles qui surmonte son fruit. Il demande de grands soins, une vive lumière, une chaleur très intense ( 25 à $40^{\circ}$ R.), surtout au moment de la production du fruit, pour en assurer la parfaite maturation. On le tient, à cet effet, dans des serres basses, où ses longues feuilles doivent être à quelques centimètres seulement du verre. Là, élevé en pleine terre et chauffé à l'eau bouillante, ou mieux en pot plongé dans une tannée tenue constamment très chaude, un æilleton soigné convenablement parcourra toute sa période de végétation, et.jusqu’à la maturité du fruit, en 2 ou 3 ans au plus. On distingue, outre $\mathbf{l}^{\prime} \boldsymbol{A}$. sativa, type de tant de variétés, les A. lucicia, debilis, bracteala, semiserrata, Lindl., etc. $\boldsymbol{V}$. BROMELIA.

(C. L.)

ANANAS DE MER. - Nom vulgaid'une sorte d'Astrée, Astrea cinanas.

MNANAS DES BOIS. BOT. PH. Synon. vulgaire, dans les Antilles françaises, de diverses esp. de Tillandsia, de Bromelia, etc.

(G. L.)

ANANAS FOSSILE. - Nom donné par Davila à un fossile très remarquable que Desmarest a supposé devoir être une tête d'Encrine.

(Dur.)
* ANANCUITES. Ananchites (ảpriv.; - euph.; äjкw, j’étrangle, je serre ). ECHINoD. - G. d'Echinodermes fossiles voisin des Spatangues, établi par Lamarck?, qui lui assigna les caract. suivants : Corps irrégulier, ovale ou conoïde, garni de tubercules spinifères. Ambulacres partant d'un sommet simple ou double, et s'étendant sans interruption, soit jusqu'au bord, soit jusqu'à la bouche, qui est labiée, subtransverse, située près du bord, à l'opposite de l'anus. C'est surtout cette continuité des ambulacres qui distingue les Ananchites des Spatangues. Mais ce g. a été encore réduit par MM. de Blainville, Desmoulins et Agassiz, qui en ont séparé les Collyrites ou Disaster, et l'ont. caractérisé plus rigoureusement, en tenant compte de l'absence du sillon dorsal qu'on observe chez les Spatangues, et de l'égalité des aires. Les Ananchites se trouvent presque exclusivement foșsiles dans les terrains crétacés, et l'une d'elles, Ananchites ovata, est regardée avec raison comme tout à fait caractéristique de ces terrains.

(DUJ.)

* MNCYLU (à priv.; àjxùios, crochet ). INs. - G. de Coléoptères tétramères, famille des Longicornes, établi par M. Dejean, qui n'en a pas publié les caract. D'après la place qu'il occupe dans son Catalogue $\left(\overline{3}^{\mathrm{e}}\right.$ édit.), il appartiendrait à la tribu des Lamiaires de M. Serville. L'auteur y rapporte seulement deux esp. de Java, nommées, l'une A. umbrifer par M. Bruguière, et l'autre A. calceatus par M. de Haan.

* ANARTRRE. Anandrarius ( $a$ priv.; $\nu$ euph.; àvip, opos, homme ; étam. en bot. ). Boт. PH. - Dénomination appliquée aux fleurs dont les étamines manquent complètement ou se sont transformées en péta les. Tel est le cas des fleurs dites vulgaire. ment fleurs doubles ou fleurs pleines.

(C. L.)

* ANANDPE. Anandrius. BOT. PH. V. ANANDR AIRE.

(G. L.)

ANANDRIA ( $\alpha$ priv.; v euph.; $\alpha \dot{\nu} \dot{\beta} \beta, \alpha \dot{\alpha}$, ơe's, mâle; fleur dépourvue d'organe mâle). вот. PH. - G. de la famille des Composées, tr. des Mutisiacées. Ses caract. sont : Capitules multiflores, hétérogames, presque constamment dépourvus de rayons. Involucre composé d'écailles plurisériées, allongées, lancéolées, appliquées les unes contre les antres, couvertes d'un duvet blanc plus ou $27^{*}$ 
moins fugace, colorées au sommet, et dépassant souvent les fleurs. Réceptacle nu, légèrement concave, fovéolé. Fleurs du disque hermaphroditer; celles du rayon femelles, sans indices d'étamines. Corolles glabres, bilabiées, cylindracées, courtes, à lèvre extérieure 3-et l'intérieure 2-dentée; celles du rayon à tube long, à lèvre extér. en forme de languette, l'intér. bipartite et très petite. Anth. des fleurs du disque terminées inférieurement par des appendices glabres, aigus. Style bilobé au sommet, à rameaux obtus et rapprochés. Le fruit, oblong, atténué aux deux extrémités, se termine au sommei en une sorte de petit cône hispide, qui supporte une aigrette multisériée, à soies très ténues, filiformes, presque lisses.-L'Anandria (Tussilago Anandria L.) ) est une herbe vivace, originaire de la Sibérie. Cette plante, cultivée depuis long-temps au $\mathrm{HLu}$ séum, ne m'a jamais offert de rayons comme elle semble en avoir quelquefois à l'état sauvage.

(匹. D.)

* AVANDREE. Anandrinus. BOT. PI. - Synon. d'Anandraire. V. ce mot.

(C.L.)

* ANANDRIQUE. Anandricus. BOT. PH. - V. ANANDRAIRE.

(C. L.)

ANANTHETRX (ả priv.; v euph.; Q: $\theta \varepsilon_{\rho} \rho \iota_{\text {, }}$ épi ). Bor. PH. - G. de la famille des Asclépiadacées, tribu des Euasclépiadées, formé par Nuttal, et si incomplètement déterminé, que, parmi les auteurs systématiques, les uns le réunissent au Gomjhocarpus de R. Brown, les autres au POdostigma, Elliot, etc. Le type de ce g. était 1'Asclepias viridis Vult., qui fait partie du premier des g. cités.

(G. L.)

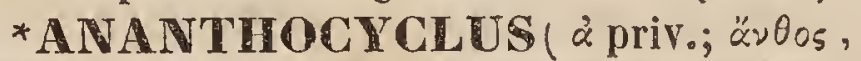
fleur; xuxzos, rayon, cercle; fleur dépourvue de rayon ). BOT. PH. - Ce g., établi par Vaillant (Act. Acad. Par. 1719), est réuni aujourd'hui au g. Cotula. (J.D.)

* ANANTHOPUS (à priv.; v euph.;

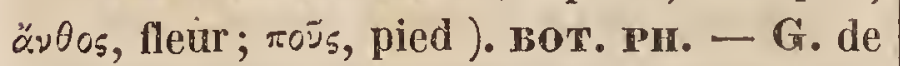
la famille des Commélinacées, formé par Rafinesque ( $\boldsymbol{F l}$. ludo. 21 ), et synon. du g. Commelina Dillen.

(G. L.)

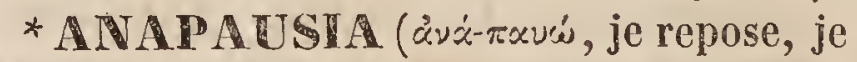
délasse). вот. GR. - Nom d'une sect. du g. Gymnopteris, de la famille des Fougères, établi par Presl, et dans laquelle il range l'Acrostichum nicotianifolium et quelquas autres espèces. V. G YMvopteris. (AD. B.)

* ANAPETE. Anapera (úvénipes; mutilé). INs. - $G$. de l'ordre des Diptères, div. des Brachocères, subdiv. des Dichætes, famille des Pupipares, tr. des Coriacés, dont le nom, substitué par Meigen à celui d'oxypterum employé par Leach, a été adopté par M. Macquart, qui assigne à ce g. les caract. suivants : Tête inséréc dans une échancrure du thorax, munie, de chaque côté, d'une touffe de poils. Palpes velus, presque cylindriques. Ant. valviformes, ciliées; point d'oreilles. Pieds velus; cuisses antérieures et intermédiaires fort épaisses; ongles des tarses tridentés. Ailes assez étroites, courtes, en pointe obtuse. Côte ciliéc. Nervure médiastine simple, marginale et sous-marginale soudées ensemble; básilaires de longueur inégale; anale distincte. - Ce g. se compose de deux esp., l'A. pallida et l'A. kirbyana. Ces Insectes vivent sur les hirondelles, auxquelles ils se cramponnent au moyen de leurs ongles tridentés. Le nom générique fait allusion à leurs ailes, qui sont pour ainsi dire mutiléss.

MNARIS (nom métonymique par lequel on désigne une herbe voisine des Gnaphalium ou Immortelles). Bot. PH. - Les Anaphalis sont des herbes vivaces, originaires des montagnes les plus élevées de l'Inde; elles ont le port des Antennaria ou Leontcpodium des Alpes d'Europe. Les tiges simples ne portent souvent qu'un seul capitule contenant un nombre considérable de fleurs tubuleuses, hétérogames. Celles $d u$ rayon, pluri- ou pauci-sériées, femelles et très ténues, sont pourvues d'un long style bifide; celles du disque, hermaphrodites et stériles, portent des anthères qui dépassent un peu la gorge de la corolle. Le style est indivis et obtus. L'involucre est formé par des écailles lancéolées, rayonnantes, blanches, scarieuses; les extérieures sessiles; les moyennes plus longues, presque stipitées, et marquées d'un onglet brun à la base. Les intérieures, étroites, très courtes, paléacées, reposent sur un réceptacle légèrement convexe, alvéolé. Les fruits, glabres, comprimés, sessiles, tronqués au sommet, sont couronnés par une aigrette 1-sériée, à soies filiformes, scabres de la base au sommet. (J.D.)

* ANAPHES (àxp's, impalpable, d'une petitesse extrême). rss. - G. de la famille 
des Oxyuriens (Oxyuri Lat.), de l'ordre des Hyménoptères, établi par M. Haliday ( Ent. Mag. ), qui le place dans la sous-famille des Abymarides, et près de son g. Abymar, dont il diffère surtout par l'abdomen ovoïde et presque sessile; il se distingue aussi du g. Anugrus par les antennes, n'ayant que 12 articles dans les mâles. On ne connaît que quelques esp. indigènes de ce g., toutes d'une extrême ténuité : l'une d'elles est l'A. fuscipennis Halid. (BL.)

ANAPHIA ( $\alpha$ priv.; $\dot{\alpha} \varphi \dot{y}$, tact, à cause de l'absence de palpes; il eût fallu écrire anhaphia). ARAGir. - G. de la famille des Pycnogonides, Latr., de l'ordre des Arachnides trachéennes, établi par Say (Journ. of Scienc. of Acad. of Phil., t. 2, p. 59), qui en énonce ainsi les caract. : Corps très grêle, composé de quatre segments (les quatre segments thoraciques) supportant les pattes, et un petit prolongement caudal, subovalaire (l'abdomen). Tète proéminente, presque imperceptible, formée par un petit prolongement du premier segment thoracique. Yeux au nombre de quatre, insérés sur un tubercule commun à la partie antérieure de la tête. Mandibules robustes, didactyles, insérées à l'extrémité de la tête, avancées, parallèles, et composées de deux articles. Rostre avancé, cylindrique, tronqué à l'extrémité, et plus court que le corps. Palpes nuls. Pattes au nombre de huit, filiformes, longues et grêles. Les hanches de trois articles; les jambes de deux; les tarses également de deux articles, dont le premier très court; les crochets simples et arqués. Ce g. ressemble aux Phoxichilus, dont il paraît voisin par l'absence des palpes; mais il s'en distingue par les mandibules didactyles et les crochets des tarses simples. Il se rapproche aussi des Nymphon et des Ammothea, dont il diffère essentiellement par l'absence des palpes. Le type de ce g. est l'Anaphia pallida Say (Journ. of Sciene. of the Acad. of Ph., t. 2, pl. s, fig. 7), dont l'auteur dit avoir trouvé deux individus sur les branches d'une Gorgonia virgulata, dans la baie de Charlestown (Caroline du Sud).

(BL.)

* ANAPLECTA ( $\dot{\alpha} \cdot \dot{x}$, en arrière; $\pi \lambda \varepsilon \times r o ́ s$, plié; à cause d'un repli des ailes). rvs. - Genre de' la famille des Blattiens, de l'ordre des Orthoptères, établi par le docteur Burmeister (Handb. der Entom.) sur quelques petites esp. américaines, dont le caractère générique le plus important est la grande longueur des secondes ailes, qui dépassent d'environ un tiers la longueur des premières, ou élytres, et se replient sous celles-ci, dans le sens transversal, de manière à être entièrement abritées. Les Anaplecıa ont des élytres semblables à celles des Blattes proprement dites, des antennes un peu plus courtes que le corps, et une pelote entre les crochets des tarses. M. Burmeister décrit quatre espèces de ce g. : ce sont les $A$. minutissima (Blatta minutissima de Geer.), de Surinam; lateralis, unicolor, de Colombie, et dorsalis de Porto-Rico. (BL.)

ANA PODOPHYLLUM ( $\alpha \dot{\alpha} \nu$, sur;

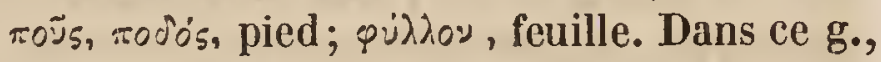
la feuille unique, d'une forme peltée, est portée par un long pétiole). Bot. PH. - Dénomination d'un g. établi par Tournefort, que Linné a contractée en celle de Podophyllum, généralement adoptée. $V$. ce mot.

(C. L.)

* ANAPORÉES. Anaporece ( $\alpha^{2} \cdot \dot{\alpha}$, à travers; rópos, pore; allusion au mode de déhiscence des anthères). BoT. PH. - Tribu formée par Schott (Meleth.) dans sa famille des Aracées (Aroïdées, Juss.), et qu’il subdivise en deux s.-tr. : les Spathicarpées : g. Spathicarpa Hook, Dieffenbachia Sch., Atherurus Bl.; les Richardiées :g. Aglaonema Sch., Homalonema Sch., Richardia Kunth. ( $\boldsymbol{V}$. ces mots.) Voici les caract. que l'auteur assigne à cette tr.: Spadice libre ou adné à la spathe, androgyne, ou organes génitaux rudimentaires le plus souvent mêlés aux fleurs femelles, rarement terminés par un appendice stérile. Anth. libres, ou le plus souvent connées, cachées par un connectif épais, déhiscentes par des pores. Ovaires nombreux, libres, uni- ou pauciloculaires. Ovules nombreux ou solitaires, orthotropes. Graines albumineuses. Embryon antitrope. - Cette section renferme des plantes à rhizômes articulés, acaules ou caulescentes; à gaînes pétiolaires allongées, à gaînes stipulaires nulles.

(C. L.)

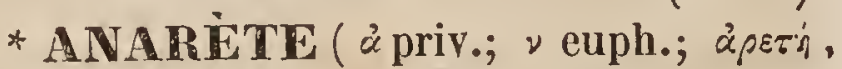
force, vertu?). INs. - G. de l'ordre des Diptères, div. des Némocères, famille des Tipulaires, tr. des Tipulaires-Gallicoles, éta- 
bli par Haliday, et adopté par M. Macquart, qui lui assigne les caract. suivants : Ant. courtes, de 9 articles; les deux 1 ers plus grands que les autres. Yeux échancrés. Trois ocelles. Pieds fort allongés chez le mâle; jambes sans pointes. Ailes couchées ; une cellule marginale divisée par une nervure transversale, quatre postérieures, deuxième non pétiolée, élargie à sa base.-Ge g. est voisin des Lectrémies, dont il ne diffère que par les antennes, et ne renferme jusqu'à présent qu'une seule esp. qui vit sur les pins, et n'est peut-être, d'après M. Macquart, que la Cecidomyia Pini de Meigen (Tipula Pini de De Geer.

* INARG IRUM, DG. ( $\alpha$ priv.; ข euph.; äprupos, argent ). BOT. PH. - S.-g. ainsi nommé par opposition à Panargyrum, dont il est regardé comme une section. $V$. ce mot.

(J. D.)

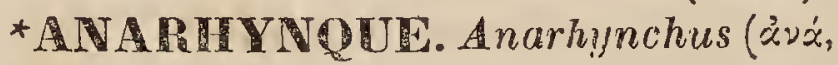
en dessus ; ṕvíreos, bec). oIs. - G. formé par MI. Quoy et Gaimard, dans la Zoologie de l'Astrolabe, vol. 1er, p. 252, sur une espèce de petit ichassier, voisin, selon ces auteurs, des Sanderlings, par le port, la longueur des pieds et la couleur, mais en différant par la forme retroussée du bec et la demipalmure de la base des doigts. Ils lui assignent pour caract. : Bec assez long, recouvert de plumes à sa base jusque près des narines, qui sont petites, linéaires, et : ouvertes dans une gouttière prolongée de chaque côté jusqu'au delà de la première moitié du bec. Mandibules très aiguës, dirigées en haut, déviées d'un côté à leur pointe. Jambes et tarses médiocres; pouce nul; doigts assez longs; les premières phalanges unies par une membrane se prolongeant en forme de rebord jusqu'à leur extrémité. Ailes dépassant la queue et très aignës; la première rémige la plus longue de toutes.

Une seule esp. compose ce g. Elle fut recueillie à la Nouvelle-Zélande lors de I'expédition de l'Astrolabe; elle y hábite les bords vaseux de la mer, et vit en troupes dans les canaux d'eau salée qui entourent la baie Chouraki. G'est l'Anarhynque à front blanc (Anarhynchus frontalis), Quoy et Gaim., Astrol., pl. 31, fig. 2. Plusieurs individus furent tués; tous avaient le bec recourbé en haut et dévié à droite, les pieds noirs, tout le dessus d'un cendré clair, avec. une bande blanche sur le front; les rémiges primaires brunes, ê le dessous d'un blanc assez pur; le cendré des épaules s'avançanê un peu vers la poitrine ; ce qui semblait indiquer que cette partie peut prendre une teinte différente, selon l'âge et les saisons. Leur longueur totale étaic de 6 ponces 2 lignes. D'après la fig. de la planche citée, le bec de cet oiseau, vu de profil, ne forme pas, en se recourbant, un arc comme chez l'Avocette, mais un angle ouvert à peu près comme chez l'AEdicnemus recurvirostris (Cuv.), et ses pieds, plus robustes et moins grêles que ceux des Sanderlings et des Bécasseaux, demi-palmés comme ceux des Avocettes, nous semblent le rapprocher davantage de ces derniers, et surtout des Pluviers.

(LAFR.)

ANARAR. Anarnacus. MAM. $-V$. DAUPHIN. (Is. G. ST-H.)

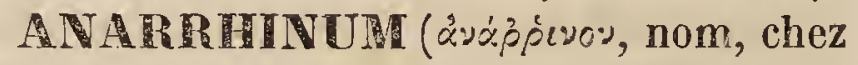
les Grecs, d'une plante aujourd'hui indéterminée. Ce mot fait opposition à celui d' $A n$ tirrhinum). Bors. PH. - G. de la famille des Scrophularinées, tr. des Antirrbinées, Chav., formé par Desfontaines ( $F l . A t l ., 11,51$, t. $141,142)$, et dont les caract. sont ainsi déterminés : Cal. profondément 5้-fide. Cor. hypogyne; tube un peu recourbé, uni à la base ou courtement éperonné; gorge ouverte ( principal caract. qui distinguè ce $\mathrm{g}$. de l'Antirrhinum), libre; limbebilabié; lobes de la lèvre supérieure dressés, puis réfléchis; ceux de l'inférieure étalés; tous presque égaux, plus ou moins échancrés. Étamines insérées sur le tube de la corolle, incluses, dont 4 fertiles, presque égales; une $3^{\mathrm{e}}$ stérile, très courte;"anth. réniformes, uniloculaires. Ovaire biloculaire; placentas adnés à la cloison, multi-ovulés. Style simple, renflé au sommet; stigm. obtus. Capsule chartacée, sphérique-comprimée, biloculaire ; logettes égales, déhiscentes près du sommet par un pore oblong, univalvulé. Graines nómbreuses, ovales, très petites, à test tuberculé ou submuriqué. - Ce g. renferme 5 ou 6 esp. environ, appartenant au bassin méditerranéen, et qui sont des herbes bisannuelles ou vivaces, à feuilles radicales souvent disposées en rosace; les caulinaires opposées, palmatiparties ou dentées au sommet; les supérieures très entieres; à fleurs petites, nutantes, disposées 
en grappe spiciforme, allongée et penchée. L'espèce la plus commune du g. est l'A. bellidifolium, qui croît dans Je midi de la Trance. Il a pour synonymes le Cardiothe$c a$, Ehrenb., Msc., et le Simbuleta de Forskal, qu'on lui rapporte avec doute. (C. L.)

ANARRHIQUE. Anarrhicas ( $\dot{\alpha} \nu x p \hat{p}^{2}-$ \%wsex, grimper). Porss.-Cenom fut imaginé par Gessner pour désigner un poisson, dont il recevait la description de l'un de ses correspondants, riverain de l'océan germanique, sous la dénomination de Klippfisch, ainsi nommé, disait-il, soit parce que ce poisson monte sur les rochers, soit parce qu'il se cache parmi les rochers sous-marins. Quoique cette habitude soit plus vraisemblable que la première, dont aucun auteur moderne ne parle, Gessner a préféré la première version, et a composé dans cet esprit le nom d'Anarrhicas, resté depuis à notre poisson. - Il est jusqu’à présent unique dans son genre, caractérisé par un corps long et comprimé, une tête grosse, à joues saillantes, à cause de l'énormité des muscles masseters. La gueule est armée de fortes dents coniques et pointues sur le devant des mâchoires; celles des côtés, ainsi que celles du palais, sont de gros tubercules hémisphériques portés sur des espèces d'épiphyses osseuses, coniques, qui tiennent aux os par une sorte de suture. La mâchoire supérieure a une rangée de quatre grosses dents coniques avec de plus petites au milieu, et une rangée intérieure de douze petites. A la mâchoire inférieure, il y en a une rangée extérieure de six grosses, puis une rangée intérieure de quatre plus petites. Ensuite viennent de chaque côté deux rangs de gros tubercules ronds portant des petites dents plates, au nombre de cinq à six sur chaque rang; et plus en arrière, trois ou quatre de ces tubercules, mais sur un seul rang. A ces dernières rangées de la mâchoire inférieure répondent les deux rangées adhérentes aux palatins. Le vomer est aussi garni de gros tubercules, et les pharyngiens portent aussi des dents coniques, mais beaucoup plus petites. A ce caractère de la dentition si forte et si remarquable de l'Anarrhique il faut ajouter encore qu'il n'y a pas de ventrales; que la dorsale et l'anale sont très étendues, et vont toucher, sans se confondre avec elle, à une petite nageoire caudale. Tous les rayons sont moux et flexibles. Ce poisson manque de vessie natatoire. Sa coulcur est d'un brun foncé tirant plus ou moins à l'olivâtre, quelquefois moucheté de noir ou rayé en travers de larges bandes noires plus ou moins nuageuses. L'Anarrhique habite l'Océan du Nord, et se porte très haut vers le pôle, car on le trouve jusque sur les côtes du Groënland. Il est très abondant sur les côtes d'Angleterre, mais il devient rare sur nos côtes de la Manche, et nous ne croyons pas qu'il dépasse cette mer vers le sud, car nous n'en avons jamais vu venir du golfe de Gascogne. Il se trouve aussi sur les côtes $d^{2} A$ mérique; nous en avons reç qui avaient été pêchés sur le banc de Terre-Neuve. Il nage avec lenteur par des mouvements d'ondulation, et comme en se traînant sur le sable. Il vit long-temps hors de l'eau, mord avec force les corps qu'on lui présente quand il est sur le pont d'un navire. Steller rapporte qu'il a vu un de ces Anarrhiques briser entre ses dents la lame d'un fort couteau. II ne dépasse guère $1^{\mathrm{m}}$ à $1^{\mathrm{m}}, \mathbf{3 3}$. On en fait dans le Nord des pêches assez abondantes pour donner lieu à des salaisons de ce poisson, estimé par les uns et tout à fait méprisé par les autres. Les auteurs s'accordent tous à dire que sa chair est bonne quand elle a été bouillie. Dans le Nord on emploie sa peau à divers usages, soit pour en faire de la colle-forte, soit pour en faire des lanières assez solides, soit enfin comme d'une sorte de chagrin.

(VAL.)

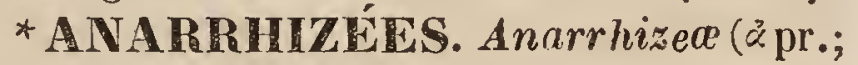

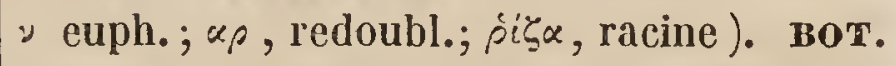
PH. - Dénomination appliquée par $\mathbf{L}$. C. Richard aux plantes acotylédones qui, suivant cet auteur, étant privées de graines, manquent de radicules, et, conséquemment, de racines.

(C. I.)

* ANARA (nom d'une coquille de mer suivant Pline). INs.--G. de l'ordre des Lépidoptères, famille des Nocturnes, établi par Ochsenheimer aux dépens du g. Noctua de Tabricius, et adopté par $\mathbf{M}$. Boisduval, qui le place dans sa tribu des Héliothides (Inciex method., p. 94). Treischke, continuateur de l'ouvrage d'Ochsenheimer, lui donne les caract. suivants, qui sont extrêmement vagues : Papillons très petits, dont le corps est gros et laineux; avec les antennes crénelées, les ailes supérieures marbrées, et les infé- 
rieures terminées par une large bordure noire. Il les divise en trois petites familles : Famille A, Pap. ayant les ailes supérieures étroites et arrondies; famille B, Pap. ayant les ailes mêlées de blanc et de noir, et les supérieures larges et arrondies; famille $\mathrm{C}$, Pap. ayant les ailes supérieures colorées en bandes, avec l'angle apical aigu. Les chenilles de ces Lépidoptères ont été très peu observées; on ne connaît encore que celles de deux espèces. Elles sont chargées de petits points verruqueux sur un fond barriolé; elles ont 16 pattes, et vivent sur les plantes basses. Leur métamorphose a lieu dans un tissu léger, revêtu des débris de leur nourriture.Le g. Anarla renferme 9 esp., toutes d'Europe. Ce sont des Noctuélites de moyenne taille, d'un vol très rapide, et qui a lieu en plein jour, par un soleil ardent, bien qu'elles appartiennent à la famille des Nocturnes. Quelques unes sont ornées de couleurs vives et variées. Nous citerons comme la plus remarquable sous ce rapport l'A. Myrtilli Linn., qui paraît deux fois, en juin et en àoût; elle est très commune dans les clairières des bois où abonde la bruyère commune (Erica vulgaris), sur laquelle vit sa chenille. Toutes les Anarta connues sont figurées dans Hubner et dans notre Hist. nat. des Lépid. de France.

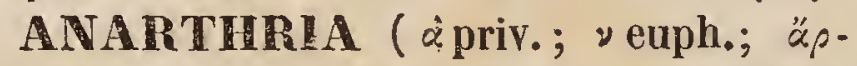
spov, articulation ). BOT. PH. - G. de la famille des Restiacées, formé par $\mathbf{R}$. Brown (Prodr.), qui lui assigne les caract. suivants : Fleurs dioïques, à périgone 6-glumé, presque égal. Dans les mâles : 丂 étam. à filaments libres, à anthères biloculaires, bifides aux deux extrémités. Dans les femelles : Ovaire triloculaire; $\tilde{3}$ styles, à stigm. simples; capsule 5-loculaire, trilobée, trisperme.-Les Anarthria sont des herbes vivaces, indigènes sur les côtes méridionales de la Nouv.-Hollande. Leur chaume est comprimé, simple ou rarement ramifié-prolifère, inarticulé, évaginé, garni de feuilles distiques, verticales, équitantes, et terminé par des épis composés, bractéés (bractée spathacée, caduque) ou simples, à fleurs solitaires. On en connaît 5 ou 6 espèces, dont la capsule, chez quelques unes, est nucamentacée et à peine déhiscente.

(G. L.)

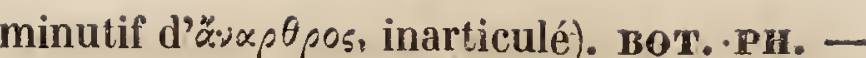
G. de la famille des Légumineuses, voisin des Desmodium, dont il ne diffère que par un fruit moniliforme, mais non septulé ni ruptile. Meyer (Comm., p. 124) n'en signale qu'une esp., laquelle croît au cap de BonneEspérance.

ANAS. oIs. - Syn. latin de Canard.

$$
\text { (C. D'O. ) }
$$

ANASPE. Anaspis ( ฉ’ priv.; euph.; $\dot{\alpha} \dot{j} \pi i_{5}$, bouclier; ici écusson ). INS. -G. de Coléoptères hétéromères, créé par Geoffroy, et adopté par MM. Duméril et Latreille, qui le placent, le premier dans la famille des Angustipennes ou Sténoptères, et le second dans celle des Trachélides, tribu des Mordellones. Les caract. de ce g., suivant Geoffroy, sont : Ant. filiformes, qui vont en grossissant vers le bout. Écusson imperceptible. Corselet plat, uni et sans rebords. - Fabricius et Olivier ont réuni les Anaspes aux Mordelles, parce qu'ils n'en diffèrent, selon eux, que par l'organisation de la bouche; mais ils s'en distinguent encore par le pénultième article de leurs quatre tarses antérieurs, qui est bilobé; leurs ant. simples, et non en scie; et enfin par la presque nullité de leur écusson, qui est à peine visible. Ce sont des Insectes très petits et très agiles, qu'on rencontre ordinairement sur les fleurs, et quelquefois sur les arbres. Ils glissent facilement entre les doigts de celui qui veut les prendre. M. Dejean, dans son Catal. ( $\boldsymbol{\zeta}^{\mathrm{e}}$ édit.), en mentionne 24 esp., dont 5 d'Amérique, 1 du cap de Bonne-Espérance, et les autres d'Europe. Nous citerons parmi ces dernières les $\boldsymbol{A}$. frontalis, flava, lateralis, thoracica et ruficollis, qui se trouvent toutes aux environs de Paris. Ce sont des Mordelles pour Fabricius et Olivier, qui les ont décrites les premiers.

(D.)

ANASSER ou ANASSERA (nom vulgaire à Timor ). Bot. PH. - Rumphius (Herb. Amboin., vol. 7, t. 7) a décrit et figuré sous le nom d'Anasser une plante que M. R. Brown a reconnue comme congénère du Pitlosporum. Ce dernier auteur a, en outre, signalé l'identilé du g. Anasser, fondé par A. L. de Jussieu, avec le Geniostonia de Forster. Le nom d'Anasser ou d'Anassera, que Lamarck a ainsi modifié, doit donc être rayé de la botanique. $V$. GE-

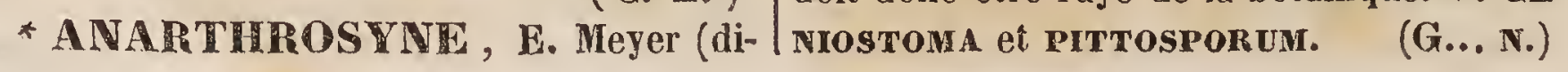




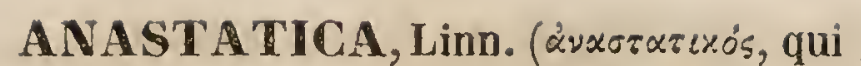
excite). вот. PH. - G. de la famille des Crucifères (Siliculeuses), ofirant pour caract. : Cal. de 4 sépales égaux, ascendants, divergents. Cor. de 4 pétales courtement onguiculés. Glandules 4 (opposées 2 à 2 aux 2 sépales latéraux), dentiformes, trigones, alternes avec les 2 étamines impaires. Étam. 6, subisomètres. Filets filiformes, trigones, ascendants, arqués. Anthères sagittiformeselliptiques, rétuses. Ovaaire 2-loculaire; loges 2-ovulées. Style filiforme, accrescent. Stigmate pelté, disciforme. Silicule rostrée (par le style), subglobuleuse, comprimée en sens contraire du diaphragme, diptère au-sommet, 2-loculaire, 2-valve, 2-4-sperme; valves cymbiformes, innervées, marginées, appendiculées postérieurement au dessous du sommet; diaphragme suborbiculaire, épais , subcoriace; nervures placentairiennes planes, très larges, superficielles; bec coniquesubulé, persistant. Graines tantôt solitaires et suspendues, tantôt géminées et subhorizontales, suborbiculaires, comprimées, immarginées. Cotylédons rectilignes, plans, tantôt accombants, tantôt obliquement incombants. (Spach, Hist. des Plantes Phan. VI, p. 527.) - Ce g., très caractérisé, mais d'ailleurs assez voisin des Vella, ne renferme qu'une seule esp. ( $\boldsymbol{A}$. hierochuntica L.), plante connue sous le nom vulgaire de Rose de Jéricho, et qui habite les déserts de l'Égypte, ainsi que ceux de l'Arabie et de la Syrie. C'est une herbe annuelle très rameuse, couverte d'une pubescence étoilée. Les rameaux sont dichotomes; les feuilles spatulées, pétiolées, peu ou point dentées. Les fleurs, subsessiles, très petites et de couleur blanche, forment des grappes dichotoméaires et terminales, sessiles, ébractéolées, pauciflores. Lorsque la plante est morte sur pied et desséchée, ses branches et ses rameaux se contractent, et forment une sorte de pelote presque globuleuse, tandis qu'elles s'écartent dès que ce squelette végétal est humecté. C'est probablement, à cette propricté hygrométrique, qui paraissait jadis une merveille, qu'est dû le nom vulgaire de l'Anastatica.

(SP.)

* ANASTATICÉS. Anastaticer. вот. PH.-Tribu établie par M. De Candolle dans les Grucifères ( $V$. ce mot), et ayant pour type le g. Anastalica.

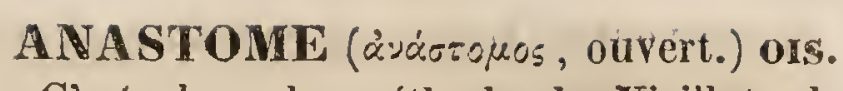
- C'est, dans la méthode de Vieillot, le synonyme du g. Bec-ouvert de Cuvier. V. ce mot.

(LAFI.)

* ANASTOME, et non ANOSTOML.

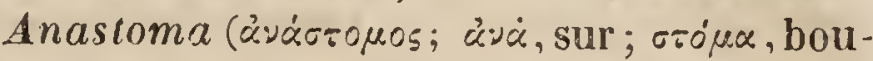
che). woux. - Une coquille très singulièro a été figurée autrefois par Lister ế plusieurs autres auteurs, et rapportée par linné it son g. Helix, sous le nom d'Helix ringens. Cette coquille présente un caract. des plus singuliers. La spire, après s'être enroulée do la manière habituelle, parvenue au dernier moment de son accroissement, se renverse subitement à la base, parcourt cette base transversalement, et l'ouverture vient se placer sur le bord extérieur, se dirigeant vers la spire, qui se trouve renversée dans une position diamétralement opposée à celle qui existe dans toutes les autres esp. d'Hélices. C'est avec cet Helix ringens que Lamarck a fait son g. Anastome. Depuis Linné, une $2^{e}$ esp. plus petite et plus globuleuse a été découverte, et Lamarck les a comprises toutes deux dans son genre. Si ce caract. se trouve confirmé plus tard par des modifications notables dans l'organisation des animaux, il sera nécessaire de conserver le g. Anastome; mais si, au contraire, comme cela est très probable, l'animal ne diffère pas des autres Hélices, il suffira dès lors, comme l'a d'ailleurs proposé M. de Férussac, de former dans les Hélices un petit groupe à part pour les deux esp. dont nous venons de parler. $V$. HÉLICES.

(DESH.)

ANASTOMOSE. Anastomoses (2ंyor: $\mu \omega \sigma \iota_{5}$, embranchement des vaisseaux [abouchement, communication qui existe naturellement entre deux vaisseaux ]). ANat. - On a donné ce nom aux communications nerveuses, bien qu'il soit difficile d'y constater les conduits du fiuide nerveux. Le nombre des Anastomoses est d'autant plus grand que les vaisseaur sont plus petits. Leur but principal semble être de multiplier les voies de communication, et de suppléer ainsi aux obstacles que les liquides peurent éprouver dans leur cours. En efiê, si on lie l'artère principale d'un membre, la circulation se rétablit bientôt entre la partie supérieure et la partie inférieure de la ligature. Dans ce cas, les petits vaisseaux de communication se développent d'une manière extraordinaire, 
et prennent un volume en rapport avec leurs nouvelles fonctions.

L'importance physiologique des Anastomoses est bien plus grande encore si l'on observe ce qui se passe du côté de la circulation du sang chez les têtards de certains batraciens à métamorphoses. Chez ces êtres remarquables sous plusieurs rapports, la respiration aquifère ne peut se changer en respiration aérienne qu'autant que des Anasto. moses vasculaires, d'abord imperceptibles, finissent, en se développant, par détourner le sang d'un appareil respiratoile au bénéfice de l'autre.

La circulation du sang chez les Crocodiles se trouve également modifiée d'une manière toute particulière par une Anastomose qui fait communiquer le sang artériel avec le sang veineux. $V$., pour plus de détails, l'article GIRGULA TION.

(M. S. A.)

ANASTOMOSE. Anastomosis (de ¿่vxorópow, je resserre). Bo' - Se dit, en botanique, de la réunion de diverses parties rameuses les unes avec les autres. (G. $\mathbb{D}^{\prime} \mathbf{O}_{\text {. }}$ )

* ANASTPRPIIA, et mieux ANA-

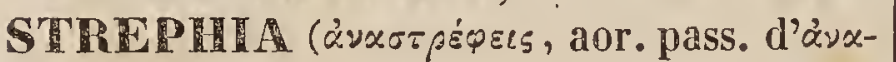

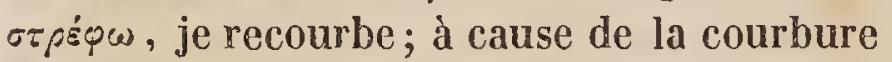
du limbe des fleurons). вот. PH.-M. Don a donné ce nom à une plante de la famille des Composées, tr. des Mutisiacées. Ses caract. sont : Involucre ovale, campanulé, composé d'écailles lancéolées, acuminées, multisériées; les extéricures plus courtes. Réceptacle nu. Fleurs hermaphrodites. Cor. glabres, pourpres, régul., 5-nervées. Tube coriace, divisé en 5 lobes linéaires, révolutés. à filets capillaires glabres, dépassant la gorge de la corolle. Anth. blanchâtres, longues, dures, munies de deux soies à la base. Style cylindrique, glabre, échancré au sommet, et légèrement papilleux. Fruit tronqué, comprimé, linéaire, couvert de poils soyeux, couronné par une aigrette persistante, formée de soies capillaires, denticulées, presque égales entre elles. - L'Anastraphia est un arbrisseau couvert de feuilles alternes, épineuses en leurs bords, et assez semblables, par leurs formes, à celles du chêne yeuse. Il est originaire de l'île de Cuba.

(J. D.)

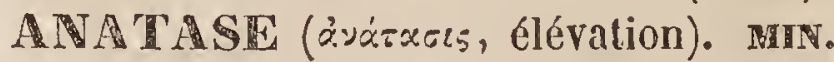
- Espece du g. Tutrane. $V$. ce mot.
ANATÉES. - V. ANATIDÉES.

ANATHERE. Anatherum (á priv,; $\vartheta$ euph.; $\dot{\alpha} \theta \dot{\beta}, \dot{\varepsilon}, 0 s$, barbe d'épi). BOT. PH.Le g. ainsi nommé par Palissot de Beauvois, dans la famille des Graminées, pour quelques esp. d'Andropogon, a été réuni de nowreau à ce dernier g. par le profeseur Kunth. $V$. ANDROPOGON.

(A. R.)

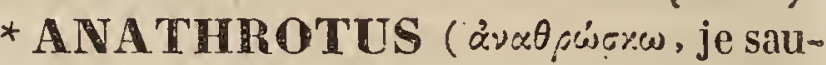
te).INs.-G. de l'ordre des Goléoptères pentanıères, famille des Sternoxes, tr. des Élatérides, établi par Stéphens, qui lui donne pour caract. : Tarses dilatés; 4 article menu. Ongles simples.-Ce g. correspond à ceIui d'Athous d'Eschscholtz. V. ce mot. (D.)

* AN TIDEES. Anatida (du mot latin anas, tis, canard). oIs. - Famille de l'ordre des Palmipèdes de Cuvier, répondant à celle des Lamellirostres de cet auteur. Ses caract. sont : Bec large, le plus souvent déprimé et arrondi à son extrémité, quelquefois conique et rétréci vers cette partie, revêtu d'une peau molle plutôt que d'une véritable corne, souvent renflé en dessus de sa base, terminé par une plaque ou onglet arrondi, plus ou moins incliné et saillant; ses bords garnis de lamelles transversales en forme de petites dents, souvent apparentes sur les côtés. Langue épaisse, charnue, dentelée sur ses bords. Fosses nasales amples et ovalaires; narines en fente et médianes. Tarses en général courts; robustes, comprimés, déjetés en arrière chez la plupart; bas de la jambe nu; doigts antérieurs palmés; pouce petit, souvent pinné. Ailes en général de longueur médiocre, de forme étroite, et souvent munies d'un ou deux tubercules osseux au poignet. Queue courte, souvent conique ou simplement arrondie. Sternum très grand, prolongé en arrière en forme de bateau.

Cette famille se compose de toutes les espèces que Linné comprenait dans son grand genre Anas, groupe des plus naturels, et que la seule inspection du bec fait reconnaître au premier abord. Ce bec, cependant, présente dans sa structure plusicurs modifications qui, jointes à celles d'autres parties extérieures, ont fait diviser ces nombreuses esp. en Cygnes, Oies, Céréopsis et Canards. Swainson, dans sa classification, n'admettant pour caract. génér.

(DEu.). de sa famille Anatidce que celui tiré de la 
forme du bec, y fait entrer, comme sousfamille, sous le nom de Phœnicoptince, le g. Phcenicoptère. Nous avouons qu'en n'ayant égard qu'au bec déprimé et lamelleux et aux doigts palmés du Phœnicoptère, ce serait effectivement dans cette famille qu'il devrait être rangé; mais, si l'on considère l'énorme longueur de ses pattes, la brièveté de son tronc, et ses habitudes riveraines et non nageuses, c'est évidemment à l'ordre des Échassiers qu'il appartient. Nous soupconnons fortement aussi que la forme de son sternum et de tout son squelette l'y place également. Du reste, il n'est pas doutenx que ce soit un oiseau de transition, faisant le passage des ichassiers aux Nageurs ou Palmipèdes, comme il s'en rencontre d'intermédiaires entre presque tous les ordres.

La tâche que rous nous sommes imposée de rechercher soigneusement et de reconnaître, autant que possible, dans toutes les familles, les difiérences de mœurs presque toujours jointes à celles des formes, comme base de nos divisions, nous a fait reconnaître, dans les nombreuses esp. qui composent celle-ci, trois ou quatre types de forme bien distincte, et en rapport avec diverses facultés prédominantes qui en sont la conséquence. Telles sont la marche et même la course chez les uns, la natation et l'immersion chez d'autres, un mélange de ces deux facultés chez ceur-ci, et enfin un vol plus facile, joint à la faculté de se percher, chez ceux-là.

Parmi les esp. marcheuses et même coureuses, et peu nageuses par conséquent, qui se font remarquer par des jambes et des tarses élevés, placés sur le trone, à l'équilibre du corps, nous avons cru devoir établir deux sous-familles. L'une, que nous nommons Ansérinées, renferme les Oies et les Bernaches, reconnaissables à leur bec conique, rétréci vers la pointe, et qui, par leur palmure entière, la forme allongée du tronc et la forme étroite'des ailes, leur queue courte et conique, rappellent entièrement les Canards proprement dits; l'autre, que nous appellerons Anatigrallinées, à cause de ses rapports avec les Échassiers, se compose d'esp. à jambes et à tarses encore plus élevés, à palmure échancrée, quelquefois rudimentaire, dont les ailes plus développées en T. I. largeur, et la queue plus longue et tombante, rendent le vol moins précipité et plus facile, en laissant même à quelques unes la faculté de se percher, et même de nicher sur les arbres. Leur bec non conique, large et déprimé vers le bout, comme chez les $\mathrm{Ca}$ nards, les distingue encore des Ansérinées.

Nous nommerons Cygnidées la $5^{\text {e }}$ sous-famille, renfermant les Gygnes, qui, quoique les représentants des vrais Canards sur une plus grande échelle, par l'ensemble de leurs formes et par leurs habitudes, en difèrent néanmoins par une taille beaucoup plus forte, par un cou fort allongé, et quelquefois par un caractère anatomique des plus saillants, et qui consiste dans un repli de la trachée-artère, pénétrant dans une cavité de la quille du sternum. Cette sous - famille ne renfermera que le g. Gygne.

Vous avons laissé le nom d'Anatinées à la $4^{\mathrm{e}}$ sous-famille, renfermant les Canards proprement dits, c'est-à-dire les esp. qui, beaucoup moins élevées sur pattes que celles des deux premières sous-familles, moins marcheuses par conséquent, et plus nageuses, font cependant quelquefois usage de la marche sans éprouver de difficulté réelle.

Notre 5้e sous-famille, celle des Fuligulinées ou Milouins, se compose pour nous, comme pour Cuvier et la plupart des auteurs, de ces Canards tout à fait pélagiens, nageurs et plongeurs par excellence, ne se servant qu'avec difficulté de leurs pattes pour la marche, tant elles sont déjetées en arrière, en dehors de l'équilibre du corps, et se rapprochant singulièrement par là, comme par tout leur ensemble; de la famille des Alcadées ou Pingouins.

Enfin, sous le nom de Merginées, nous désignerons la $6^{\mathrm{e}}$ sous-famille, se composant des esp. du g. Harle (Mergus), remarquable par une forme de bec toute particulière, et différente de celle des esp. des quatre sousfamilles précédentes. $V$. les mots ANSÉRI-

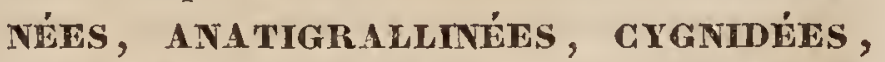

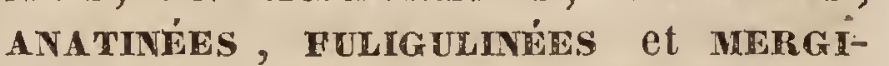
NÉES.

(LAFr.)

ANA TIFE. Anatifa (anas, tis, canard; fero, je porte, je produis. Dans le nord de l'surope, on croit que ces animaux donnent naissance aux canards sauvages). CIRRU. On désigne sous ce nom une famille de l'or- 
dre des Cirrhopodes, ayant pour type le g. Anatifa. Ce g. présente les caract. suivants: Coquille composée de s valves, deux de chaque côté; la cinquième sur le bord dorsal. Ces valves, rapprochées en forme de cône aplati par une membrane qui les borde et les maintient, sont soutenues sur un pédicule tubuleux, à parois musculaires et membraneuses, susceptible de s'allonger et de se contracter. Le pédicule des Anatifes est toujours fixé sur des corps marins, spécialement sur la cale des navires; ce qui fait présumer qu'on peut rencontrer dáns toutes les mers les diverses esp. qui constituent le g. Anatife. Ces esp. sont, d'après Lamarck, au nombre de 5 , dont voici les noms : Anatife lisse, velue, dentelée, strièe et vitrée.

Quant à ce qui regarde l'organisation des Anatifes, et la place que ces animaux doivent occuper dams les divisions zoologiques, il en sera question à l'article CHRBHIPEDS.

(M. S.-A.)

ANA TIVIE. Anatiferus (anas, canard; fero, je porte. $V$. ANATIE). GIREI. - La conque anatifere, Lepas anatifera, doit cette épithète à une croyance absurde de quelques habitants du nord de l'Europe, qui pensent encore que les Anatifes, en général, donnent naissance aux Canards sauvages quelques jours après qu'on les a retirés de l'eau. Leur crédulité à cet égard n'est point démentie par l'expérience; bien au contraire, ils pensent que, s'ils ne voient pas les Canards sortir de la coquille, c'est que ceux-ci se sont envolés pendant la nuit. La preuve en est, disent-ils, qu'on ne retrouve plus l'Anatife dans son enveloppe. Le fait est que ces animaux, une fois retirés de l'eau, se dessèchent promptement, et à tel point qu'il faut $y$ regarder avec attention pour découvrir au fond de la coquille les restes de l'animal racorni au dessus de toute expression.

(M. S.-A.)

* ANATIFERTDES. Anatiferida ( $V$. AVATIFE) ) CIRrer. - Nom donné par Giray à une famille de la classe des Cirrhipèdes, qui a pour type le g. Anatife.

(M.S.-A.)

ANATEES. Anatifo (V. ANITHE). GIRRH. - Férussac désigne sous ce nom une famille de l'ordre des Cirrhipèdes, ayant pour type le g. Anatife. (M. S.-A.)

* ANTIGILLE. Anatigralla (a-

nas, tis, canard; gralla, échassier). oIs. G. de l'ordre des Palmipèdes, de notre famille des Anatidées et de notre s.famille des Anatigrallinées. En août 1834, nous publiâmes ce g. dans le Mag. de Zool., et nous le formâmes alors sur l'Oie de Gambie (Anas gambensis), dont nous possédions une paire vivante, et dont le port', la démarche, et les mours enfin, nous parurent différer entièrement non seulement de ceux des Gygnes, avec lesquels Cuvier les rangeait, mais aussi de ceux des Canards et des Oies. Ses caract. sont : Corps peu allongé. Jambes et tarses robustes et élevés, placés sur le tronc, à l'équilibre du corps; doigts allongés, surtout le médian, et dépassant les membranes interdigitales; le pouce assez long, grêle, lisse et sans pinnule, pouvant s'appliquer sur le sol à son extrémité; ongles comprimés, allongés, pointus, légèrement arqués. Membranes interdigitales plus ou moins échancrées, quelquefois seulement rudimentaires. Bec semblabie à celui des Canards, allongé, à peu près d'égale largeur dans son étendue, déprimé, ayant sa base souvent tuberculeuse et charnue. Ailes amples, larges, atteignant souvent l'extrémité de la queue; à rémiges tertiairès prolongées jusqu'à la pointe des primaires, armées souvent au poignet de deuz forts tubercules, ou même de deux longs éperons osseux. Quene assez longue, presque carrée ou arrondie et tombante; ce qui, joint à l'élévation de la partie antérieure du dos, donne à quelques esp. un port de Cigogne. D'après le développement de leurs ailes et même de leur queue, ces oiseaux ont un vol plus facile, plus léger, à battements moins précipités que les Canards, et plusieurs d'entre eux se perchent et nichent dans les arbres. La plupart ont dans leur plumage et sur le miroir de l'aile une nuance d'un beau vert à reflets. - Ce g. a pour synonymes en partie les Canaroies (Anseranas) de Lesson, et le g. Plectropterus de Leach.

A notre Oie de Gambie nous réunissons, comme type du genre, le Canard-pie semipalmé de la Nouvelle-Hollande, Anas semipalmata, type du g. Canaroie de Lesson; - L'Anser jubatus (Spix) d'Amérique; L'Anas jubata (Latham) de la NouvelleHollande; - L'Oie bronzée de Coroman- 
fiel; celle d'Egypte, et même les Tadornes, qui marchent et courent arec facilité. Le Canard musqué, malgré la briècté de ses pattes, nous paraît devoir leur être réuni, vu la conformité de toutes ses autres parties, son vol facile et ses mœurs percheuses. Nous le présentons seulement comme s.-g. de notre g. Anatigralla, sous le nom de Moschatus, Less. Nous agirons de même pour le g. Dendrocygna de Sivainson, renfermant les plus petites esp. de nos Anatigralles, celles qui se perchent et nichent dans les arbres, telles que les Anas arborea, autumnalis, viduata, d'Amérique; arcuala, de l'Inde, ct autres. Notre g. Anatigralla a done pour s.-g. les g. Moschatus, Less.; Dendro. cygna, Sw.; et Tadorna, Leach. Le s.-g. Moschatus, Less. ne diffère réellement du g. Anatigralla que par des tarses et des jambes beaucoup plus courts. Ses pieds, ses ailes et son bec, ont absolument la même conformation. La seule esp. qui le compose est le Canard musqué d'Amérique (Anas moschata), qui se perche et niche dans les arbres; on pourrait peut-être lui associer l'Oie bronzée (Anas melanotos), remarquable par sa crête charnue et frontale.

Le s.-g. Dendrocygna, $\mathbf{S w}$. retrace en petit les formes du g. Anatigralla; les caract. tirés de la longueur des doigts et des ongles y sont seulement plus développés. Quoique le nom de Dendrocygna de M. Swainson ne convienne guère pour des esp. à peine plus fortes que nos Sarcelles, nous aimons mieux l'employer que d'augmenter encore la nombreuse synonymie des noms génériques déjà existants.

Le s.-g. Tadorna fait la transition des Anatigralles aux Canards proprement dits. Les esp. qui le composent tiennent aux premiers par leurs pattes élevées et leur marche facile; par leur bec retroussé, surmonté d'un tubercule au front; ils s'en éloignent par leur palmure entière et leurs doigts de longueur médiocre, comme chez les Canards. Les esp. qui le composent sont: l'Anas Tadorna ou Canard Tadorne; L'An. rutila ou Canard Kasarka;-L'Anas Radjah, Less. et Garnot (Coquille, pl. 49), - et l'Anas tadornoïdes des auteurs anglais.

(LATR.)

* ANATIgRALLINÉES. Anatigralline (anas, tis, canard; grallina, (diminutif de gralla, échassier ). ors. Sous-famille de notre famille Anatidécs, ayant pour caract. : Corps peu allongé. Jambes et tarses robustes et élevés, placés sur le tronc, à l'équilibre du corps; doigts allongés, surtout le médian et le pouce; ce dernier lisse, sans pinnule, et touchant à terre par son extrémité; ongles comprimés, allongés, arqués et pointus. Membranes interdigitales plus ou moins échancrées, ou même rudimentaires. Bec semblable à celui des Canards proprement dits, c'est-à-dire élargi, allongé, à extrémité de même largeur et arrondie, déprimé, et parfois légèrement concave, avec sa base souvent tuberculeuse et charnue, conique et rétréci vers sa pointe dans un seul cas. Ailes amples, larges, atteignant souvent l'extrémité de la queue; les tertiaires étant aussi longues ou presque aussi longues que les primaires; ces ailes souvent munies au poignet de deux tubercules, quelquefois même de deux forts éperons osseux. Queue médiocre, arrondie et tombante. De cette forme d'ailes et de pattes il résuite chez ces oiseaux un vol facile et léger, à battements lents, et souvent la faculté de se percher et de nicher dans les arbres. La plupart des esp. se font remarquer par une belle nuance verte à reflets dans l'ensemble de leur plumage et sur le miroir de leurs ailes. Leurs habitudes sont marcheuses et marécageuses, et la longueur de leurs jambes leur rend la natation moins facile. Cette s.-famille renferme d'abord le g. Anatigralle (Anatigralla, Nob.), avec ses s. -g. , et le g. Cereopsis de Latham. $V$. ces deux mots.

(LAFr.)

ANATHE. Anatina (anatinus [anas, canard], qui a la forme du bec d'un canard). MoL. -On doit la création du g. Anatine a Lamarck. Il l'a proposé dès 1809 dans les tableaux de classification de la philosophie zoologique. C'est dans cet ouvrage, remarquable à plus d'un titree, que notre grand naturaliste a institué des familles naturelles dans le règne animal. Celle des Myaires, outre le g. Anatine, contient encore les Myes et les Panopées. Reproduits nominalement à la même place dans l'extrait du cours, les caract. du g. Anatine n’ont été réellement bien connus que du moment où Lamarck en a démontré la composition dans son Hist. nat. des animaux sans verlébres. En 
1\$11, N. Megerle publia, dans le Magasin de Berlin, une classification des coquilles bivalves, dans laquelle se trouve un g. Auriscalpium, qui correspond exactement à celui des Anatines de Lamarck; mais ce genre de l'auteur allemand, quoique adopté par M. Schmach, ne peut l'être cependant, puisque celui de Lamarck est de beaucoup antéricur. Cuvier, dans la première édition du Règne animal, comprit le g. Anatine parmi les s.-g. des Myes, et il le place entre les Iryes proprement dites et les Glycimères. Il est évident que les rapports de ce g. n'ont pas été suffisamment compris par le savant auteur du Règne animal. M. de Férussac, dans ses tableaux systématiques, adopta la famille des Myaires de Lamarck en la modifiant, et plaça les Anatines entre les Lutraires et les Myes, en introduisant le g. dont nous nous occupons dans sa famille des Pyloridées. BH: de Blainville désigna des rapports beaucoup plus naturels. On le trouve entre les Pandores et les Thracies. II nous a semblé qu'avant de décider de la place que le g. Anatine doit occuper dans la méthode, il était convenable d'en étudier toutes les esp., et de juger d'après l'ensemble de leurs caractères, et non pas seulement d'après ceux de la charnière, comme l'ont fait Lamarck, et, après Iui, la plupart des conchyliologistes. Cet examen des espèces du g. Anatine de Lamarck nous conduisit à plusieurs déconvertes. Nous observâmes d'abord dans l'Anatina truncala, sur l'individu de la propre collection de Lamarck, que la chamière était consolidée par un osselet tricuspidé, entièrement détaché du reste du test, et fixé au moyen d'une portion du ligament. Bientôt après, nous reconnûmes que d'autres csp. avaient à la charnière un osselet courbé en demi-cercle, et nous nous aperçumes en même temps que ces esp. appartenaient à un g. oublié de M. Leach, g. qu n'était connu que par la correspondance de ce naturaliste. Dans d'autres esp., la charnière, offrant sur chaque valve une rigole décurrente, contient dans l'épaisseur du ligament une plaque osseuse quadrangulaire.

Le Mya solenialis de Lamarck et quelques unes de ses Anatines présentent dans leur charnière cctte dernière modification. En continuart ì examiner les esp., nous en trouvâmes plusieurs qui devaient passer à d'autres g.; ainsi lo Tugon d'Adanson est une vraie Myc; l'Anatine rupicole est une corbule perforante; et l'Anatine traphoïde devient le type du g. Périploon de M. Schumacher. Ce g. avoisine les Anatines proprement dites par les cuillerons de sa charnière et l'osselet cunéiforme qui s'y trouve attaché. On comprendra facilement qu'après toutes ces observations, une réforme devait paraitre nécessaire dans le g. Auatine de Lamarck. Tous avons proposé de créer une famille des Ostéodermes ( $V$. ce mot), dans laquelle nous avons rassemblé ce g. Anatine, considérablement réduit, le g. Thracie de M. Leach, le g. nommé Periploon par $\mathbb{M}$. Schumacher, et, enfin, un quatrième g. auquel nous avons donné le nom d'Osteoderma. Pour nous, le g. Anatine dut se réduire aux trois premières esp. de Lamarck, dans lesquelles la charnic̀re porte un osselet tricuspidé. Les animaux du g. ainsi réduit ne sont point connus. Les coquilles sont excessivement minces et des plus fragiles; leur test est subnacré. Ces coquilles sont transverses, ovalaires, bâillantes aux deux extrémités, mais surtout à la postérieure, par laquelle l'animal peut faire sortir des siphons assez volumineux, à en juger par l'écartement des valves. La charnière est presque centrale; ce qui rend la coquille presque ćquilatérale. Cette charnière consiste sur chaque valve en un cuilleron qui s'avance horizontalement, et qui est soutenu en dessous par un véritable arc-boutant oblique et fort mince, divisant en deux la cavité du crochet. Le bord postéricur de ce cuilleron est subtronqué, et, lorsque la ja charnière est complète, on voit s'appuyer sur cette troncature une branche horizontale d'un osselet à trois pointes, fortement retenu en place par une portion du ligament qui s’insère sur sa tige horizontale. Les deux autres tiges de cet osselet s'enfoncent dans la cavité des crochets, et viennent s'appuyer sur le test lui-même; mais, par une singularité dont nous ne trouvons aucun autre exemple, l'insertion de ces extrémités de l'osselet sur le test occasionne dans celui-ci une véritable solution de continuité et une fente naturelle, longitudinale, ferméc pendant la vie de l'animal au moyen d'une petite expansion epidermique. Cette fente continue jusqu'au 
bord cardinal, dont la solution est complète, de sorte que l'on peut faire jouer les deux parties du test en profitant avec précaution de l'élasticité de celui-ci. Il est toujours difficile, dans des coquilles aussi minces que celles du g. Anatine, d'apercevoir les impressions intérieures; néanmoins, dans les individus un peu ternes, et surtout en faisant miroiter la lumière, nous sommes parvenu à apercevoir les deux impressions musculaires ainsi que l'impression palléale. L'impression musculaire antérieure est très allongée; elle est très voisine du bord, et descend dans presque toute sa longueur en suivant son contour. L'impression musculaire postérieure, vers l'autre extrémité de la coquille, est arrondie, subsémilunaire. L'impression palléale offre, du côté postérịeur, une sinuosité large et assez profonde, dont l'extrémité remonte presque au niveau de la charnière. Les Anatines ne sont pas parfaitement équivalves; la valve gauche est ordinairement un peu plus grande que la droite.

Caract. génér. : Animal inconnu. Coquille transverse, subéquivalve, subéquilatérale, bâillante aux deux extrémités. Ligament intérieur inséré sur des cuillerons horizontaux, et complétés par un osselet tricuspidé dont les deux branches supéricures s'enferment dans la cavité du crochet. Une fente longitudinale, divisant le test depuis les sommets jusque vers le tiers supérieur de la longueur totale. Les cuillerons soutenus par des arcs-boutants obliques et fort minces.

Nous ne connaissons encore qu'un très petit nombre d'esp. appartenant aux véritables Anatines; nous en avons vu dans les collections quatre, parmi lesquelles nous comptons le Solen anatinus de Linné. Il y a dans les terrains jurassiques supérieurs des moules de coquilles qui ont tout à fait l'apparence des Anatines. M. Agassiz, dans son ouvrage intitulé : Eludes critiques sur les coquilles fossiles, a proposé d'établir pour ces esp. un g. particulier sous le nom de Sercomia. Plus nous examinons ces coquilles, et plus nous nous persuadons que le g. de M. Agassiz est inutile; cependant nous ne le rejetons pas encore absolument, parce que le texte de l'ouvrage du savant zoologiste de Neufchâtel n'a pas encore paru, et qu'il serait possible que les caract. d'après lesquels il sépare son g. nous eussent échappé pour la plupart.

(DESH).

* ANA TINES. Anatina (de anas, tis, canard). ors.-Sous-famille de notre famille Anatidées, ayant pour caract. : Jambes et tarses courts, insérés en arrière hors de l'équilibre du corps, et, par conséquent, peu propres à une marche facile; doigts de longueur médiocre, garnis de membranes entières; le pouce petit et court, sans pinnule développée ou n'ayant qu'un rudiment de membrane peu apparent; bec large et allongé, déprimé dans la plus grande partic de sa longueur; corps allongé en bateau; ailes de médiocre longueur, étroites et pointues; queue conique.-Cette sous-famille renferme toutes les espèces de Canards qui fréquentent les eaux douces plutôt que l'Océan, y cherchent leur nourriture en nageant au milieu des herbes et des plantes aquatiques des rivages, et non en marchant sur le sol et y paissant comme les Ansérinées. Leur démarche, vu la brièveté de leuis tarses reculés en arrière, est peu aisée. Après quelque hésitation, nous nous sommes décidé à placer ici le genre Dendronessa de Swainson, formé des Anas sponsa et galericulala, parce que ces petits Canards, quoique marcheurs, percheurs et nicheurs sur les arbres, comme nos Anatigralles, ont les pieds courts, les membranes entières, comme les Canards proprement dits; leur queue seule est plus développée. Nous adopterons donc ce genre Dendronessa comme basé sur une particularité de mours assez remarquable, mais seulement comme s.-g. du g. Anas, et nos Anatinées ne renfermeront alors que le genre Canard (Anas), subdivisé en plusieurs sous - genres, dont le Dendronessa. V. Canard. ( LAFR.)

* ANATOLICA (àvxròrexós, oriental). INs. - G. de Coléoptères hétéromères, famille des Mélasomes, établi par Eschscholtz, et adopté par M. Dejean ainsi que par M. Solier, qui, dans son essai sur les Collapté.rides, le range dans la tribu des Tentyrites, et le caractérise ainsi : Menton mitriforme, à échancrure anguleuse et très profonde. Palpes allant en grossissant vers l'extrémité; dernier art. des maxillaires et des labiaux sécuriforme. Labre transverse, toujours saillant, arrondi sur les côtés et très légèrement échancré à l'extrémité. Nandi- 
bules courtes, découvertes latéralement dans l'inaction, bifides à l'extrémité, et sans dents à la partie supérieure. Antennes grêles, filiformes, à articles coniques. Tête un peu dilatée au dessus des antennes; épistome formant une saillie largement tronquée, subrectangulaire ou légèrement trapéziforme. Yeux transverses, grands, bien ouverts, un peu convexes. Prothorax à angles postérieurs bien marqués, subrectangulaire ou légèrement rétréci dans les mâles. Écusson saillant entre les élytres en une pointe triangulaire, émoussée au bout. Base des élytres rarement marginée entièrement. Tibias antérieurs des mâles sinueux au côté interne ou fortement courbés; les mêmes, dans les femelles, plus droits et plus épais; postérieurs légèrement comprimés, sinueux et allant en grossissant insensiblement vers l'extrémité, ou courbés et brusquement épaissis au bout. Tarses grêles et filiformes. M. Dejean ( Catal., 3e édit.) rapporte à ce. genre 20 esp., dont aucune n'est d'Europe; elles appartiennent toutes, soit à la Russie méridionale-orientale, soit à la Sibérie, soit à la Bucharie, soit à la Daourie, soit enfin à la Mongolie. Les principaux caract. du g. Anatolica ont été représentés grossis par M. Solier, dans le $4^{e}$ vol. des $\mathbb{1} n n$. de la Soc. ent. de france, pl. vIII, fig. 12-20.

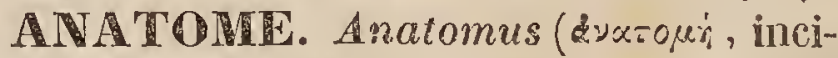
sion). MoLH. - Montfort, dans le premier volume de sa Conchyliologie systématique, a proposé ce g., que, dit-il, il a observé dans les mers de l'Inde, fixé en très grande abondance sur le Fucus natans. L'un des premiers, nous nous sommes singulièrement défié des travaux très légers de ce naturaliste. Ayant trouvé dans son ouvrage des preuves évidentes de fréquents mensonges, ce n'a été qu'avec une extrême réserve que nous avons parlé des travaux d'un naturaliste aussi suspect. Nous pensons que son g. Anatome aété formé pour des Spirorbes accidentellement fendues sur le bord; par conséquent, il appartient aux Annélides tubicoles. $T$. SPIRORTES.

(DESUI.)

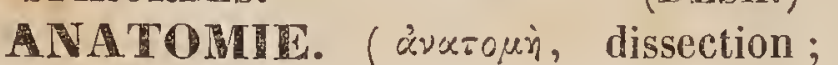
$d^{\prime} \alpha \nu x-\tau \varepsilon \mu \nu$, je coupe à travers.) $\mathbf{z} 00 \mathrm{~L}$.

$$
\text { S1. - De l'Anatomie en général. }
$$

L'Anatomie est à la fois un art et une science. C'est l'art de sćparer arec le scalpe], et de rendre évidentes, par ce moyen ou par d'autres procédés, les formes et les structures intérieures les plus intimes dont se compose l'organisme animal.

C'est aussi la science de l'organisation, ayant pour tâche de réunir les notions particulières ou générales acquises sur toutes les parties de cette organisation, extérieure ou intérieure, au moyen des instruments et des procédés de l'art de l'anatomiste.

L'organisation étant la première condition de la vie, on concevra facilement que son étude, objet de l'Anatomie considérée comme science, est la clef de toutes celles qu'il est possible d'entreprendre sur les êtres doués de la vie.

Dans l'état actuel des connaissances humaines, cette partie des sciences naturelles, qui expose avec ordre tous les détails de forme, de structure et de composition des machines organiques, doit comprendre, non seulement les tissus plus ou moins solides qui donnent à ces machines une forme déterminée; mais encore les liquides, et même les fluides aériformes, contenus dans les vides de ces solides, et dont la présence est plus ou moins essentielle pour l'accomplissement des diverses fonctions de la vie.

L'Anatomie est-elle une science par ellemême? Peut-on étudier uniquement dans le simple ordre des rapports de connexion, de forme ou de structure, indépendamment de leur emploi dans le grand phénomène de la vie, les diverses parties dont se compose lorganisme animal? G'est ce que nous examinerons dans ce paragraphe et dans les suivants.

L'usage des parties est le point de vue qui domine les descriptions anatomiques dès la plus haute antiquité. C'est ce point de vue qui transforme en notions plus ou moins générales ces simples impressions que produisent sur nos sens les formes et les structures des animaux, telles que nous les découvre l'art de l'anatomiste. C'est seulement en saisissant les rapports de ces formes et de ces structures, si nombreuses et si variées, avec les phénomènes multiples de la vie, que l'Anatomie peut s'élever du simple rang qu'elle occupe, comme art, à celui d'une science dont les abstractions, devenues graduellement et lentement de plus 
en plus générales, ont fini par aspirer à l'interprétation des lois les plus universelles touchant la composition, la formation, les transformations, et même les déformations des organismes.

L'Anatomie, considérée sous le point de vue de l'usage des parties, et conséquemment comme science, n'est donc qu'une section de la physiologie; c'est l'étude de l'organisation en repos, sorte d'introduction nécessaire, indispensable pour comprendre l'étude de l'organisation en action, qui constitue la physiologie ou la science de la vie.

L'exposé des faits, dans tous les ouvrages d'Anatomie concernant l'homme ou les animaux, a toujours lieu dans un ordre, soit exclusivement, soit plus ou moins physiologique. Les titres des divisions principales, ou tout au moins des divisions secondaires d'un traité quelconque d'Anatomie, expriment généralement soit les propriétés vitales ou les usages fonctionnels qui caractérisent les organes simples ou concrets, soit les systèmes d'organes dont les descriptions sont comprises dans le cadre de ces divisions.

\section{Q2. - De l'Anatomie descriptive el} générale, et particulièrement de l'Analomie humaine, considérée sous le point de vue physiologique.

L'Anatomie, ainsi que nous venons de le dire, est premièrement et essentiellement physiologique. Considérée sous ce premier point de vue, elle se compose de notions particulieres, ou de déductions générales, qui permettent de la sous-diviser en descriptive et générale.

L'Anatomie physiologique est dite simplement descriptive lorsqu'elle se borne à donner la description des parties de l'homme ou d'un animal, avec la simple indication de leurs usages ou de leurs propriétés vitales, mais sans insister sur ces usages, et sans établir de comparaison avec les parties semblables ou analogues entrant dans la composition des autres animaux.

Dans cette analyse de l'organisme de l'homme ou d'un animal, on a d'abord étudié les organes concrets servant à telle ou telle fonction : l'oil, par exemple, comme organe de la vue; le poumon, comme organe de la respiration; le cour et les vaisseaux sanguins, comme servant à la circulation du sang; l'estomac et les intestins, comme chargés de cette élaboration des aliments nécessaire pour la composition du chyle, etc., etc.

En comparant plus tard ces organes concrets entre eux, sous le rapport des organes plus simples dont ils se composent, on est arrivé à des notions générales sur la composition de chaque organisme, et en premier lieu sur celle de l'organisme de l'homme.

L'estomac, ainsi décomposé par lo scalpel et d'autres procédés, a montré, dans son agrégation organique, une membrane extérieure, qui a reçu le nom de péritonéale, recouvrant une couche de fibres contractiles qui forment sa membrane musculaire. On a vu que celle-ci était intimement lice à la précédente"par une couche de lames blanches interceptant des vides, et formant le tissu cellulaire.

Une autre couche de ce même tissu fait adhérer, mais plus lâchement, la membrane musculaire à la membrane interne qui tapisse les parois de cette poche si merveilleuse dans sa fonction qu'on appelle digestion .

Destinée à supporter le contact immédiat des aliments et des boissons, enduite de mucosités, ayant dans sa structure des cryptes ou de petites cavités glanduleuses, dont les parois sont les organes sécréteurs de ces mucosités, cette dernière membrane se distingue des deux membranes précédentes par des propriétés vitales, organiques et physiơues spéciales.

Des vaisseaux sanguins, artériels et veineux, des vaisseaux lymphatiques, des nerfs enfin, dont l'origine, les rapports et la distribution dans l'estomac ont des caractères particuliers, completent et vivifient cet ensemble compliqué dont nous venons d'énumérer les différentes parties.

Une membrane très analogue à celle qui tapisse l'intérieur de l'estomac se retrouve, avec de légères modifications, dans toute l'étendue du canal intestinal. Une membrane ayant des caractères semblables tapisse l'intérieur de la vessie urinaire, et l'urètre, son canal excréteur. On en rencontre encore une autre très analogue dans l'intérieur des narines, de la cavité buccale, du conduit aérien pour la respiration, ou de la trachéc-artère. Partout cette membrane 
a des caractères communs : ceux, entre autres, de tapisser des cavités qui ont une issue à la surface du corps; d'être plus ou moins enduites de mucosités, qui les préservent de l'action nuisible des corps éirangers qui traversent ces cavités, etc., etc. Ces caractères généraux lui ont fait donner la dénomination générique de membrane muqueuse, quel que soit l'organe concret où on la rencontre.

La membrane qui revêt l'estomac extérieurement se prolonge sur les intestins pour les envelopper d'une semblable manière. En l'étudiant avec soin dans toute sa continuité, on a remarqué que dans son ensemble elle forme, du moins dans le sexe, masculin, un sac fermé de toutes parts, dont les parois extérieures adhèrent à celles de la cavité abdominale, et les tapissent; se replient de différents points de ces parois sur les viscères contenus dans cette cavité, les suspend à ses replis, et les fixe; dirige vers ces organes les branches et les rameaux vasculaires, ou les protége à leur retour de ces mêmes organes vers leurs troncs; en fait de même à l'égard des nerfs qui vont des centres nerveux aux viscères. Cette membrane, fine, blanche, d'un tissu serré, et ayant sa surface libre très lisse, et constamment humectée, dans l'état de vie, d'une vapeur séreuse, prévient les inflammations qu'auraient excitées les frottements des surfaces viscérales entre elles ou contre les parois mobiles de la cavité abdominale.

Une membrane entièrement semblable et par son tissu, et par sa continuité, formant un sac fermé de toutes parts, ayant sa surface interne libre et constamment humectée d'une humeur séreuse, et sa surface externe adhérente aux parois de la poitrine, ou à la surface des poumons, autour desquels elle se replie, porte le nom spécifique de plèvre, de même que la première est appelée péritoine.

Mais ces caractères, communs dans la structure intime, les dispositions, et les fonctions, d'exhaler une humeur séreuse, qu'on retrouve encore dans le péricarde, ce sac membraneux qui revêt le cour; dans l'arachnoïde, membrane qui est, pour l'encéphale et la moelle vertébrale, ce que le péritoine est pour les viscères abdominaux, la plère pour les poumons; dans la tunique vaginale des testicules, ou pérididyme, etc., ont fait donner à ces membranes le nom générique de séreuses.'

Une membrane ou couche musculeuse semblable à celle de l'estomac se voit encore autour des intestins, de la vessie urinaire, dans la même position relative.

Des faisceaux de même nature, plus ou moins nombreux, et prenant toutes sortes de formes dans leurs agrégations, entrent dans la composition de tous les muscles volontaires, c'est-à-dire de tous les organes irritables ou contractiles que la volonté fait agir pour transporter l'animal d'un lieu dans un autre.

Dans tous ces organes concrets, les faisceaux musculeux les plus considérables sont composés de faisceaux plus petits, liés par du tissu cellulaire, et ceux-ci de fibres musculaires, cet organe élémentaire essentiellement contractile. ( $\boldsymbol{V}$. l'article Animal.)

En analysant l'estomac, en le décomposant dans ses organes élémentaires, nous l'avons vu composé de vaisseaux sanguins artériels et veineux, et de vaisseaux lymphatiques.

On retrouve les uns et les autres dans tous les organes concrets de l'organisme, liés les uns aux autres, communiquant les uns avec les autres, et formant un ensemble qu'on appelle Système des vaisseaux san. guins, Systeme des vaisseaux lymphatiques.

L'estomac n'est pas le seul organe concret pourvu de nerfs. Des filets nerveux ou des faisceaux de filets viennent, d'une manière évidente, animer de leur vie propre presque toutes les parties de l'organisme. Ils forment les nerfs de tous les organes qui vont abouir, de ces différentes parties, soit au cordon principal des nerís, lequel est renfermé dans le canal des vertèbres, soit aux différents centres de l'encéphale, que contient et protége le crâne, cette boîte osseuse de la tête. Voilà donc encore un des organes élémentaires de l'estomac lié par sa structure et sa construction, ainsi que par ses propriétés vitales, à des éléments organiques semblables, appartenant à d'autres organes concrets, et formant un ensemble, au moyen des parties auxquelles ils aboutissent. G'est le sysième nerveux. ( $V$. l'article Animal.)

La forme du corps humain est surtout déterminée, fixée par les parties osseuses; 
dont l'ensemble constitue le squelette. Les parties dures, oules os, entrent dans la composition de beaucoup d'organes chạgés de fonctions particulieres. Elles renferment et protégent essentiellement, ainsi que nous venons de le dire, les principaux centres ncrveux. Les organes de la vision, de l'audition, de l'odoration, de la gustation, sont plus ou moins à l'abri des lésions extérieures, sous des voûtes, ou dans des anfractuosités osseuses.

La cage osseuse de la poitrine renferme le cœur et les poumons, et conserve dans les parois solides une certaine mobilité pour le mécanisme de la respiration; mais c'est plus généralement pour la station et la progression sur deux pieds, et pour la préhension, que sont arrangés les leviers osseux de la colonne épinière et des membres, et admirablement adaptés les uns aux autres pour l'usage auquel chacun d'eux est particulièrement destiné. Toutes ces parties dures, osseuses, dont l'emploi est très varié dans les différentes parties de l'organisme, ont cependant des caractères communs de composition chimique, de composition élémentaire, de tissu, d'accroissement, qui distinguent cet ensemble qu'on peut appeler Système osseux.

Le corps est limité et protégé tout à la fois par la peau et les poils ou les cheveux qui s'élèvent à sa surface, et même par les ongles qui terminent les extrémités. Ces différentes parties, qui mettent tout l'organisme en rapport avec le milieu ambiant ou les agents physiques, et en général avec le monde extérieur, forment le système tégumentaire, dont l'étude se lie à celle de toutes les autres parties de l'organisme.

Enfin, tous les organes concrets, remplissant telle ou telle fonction particulière, sont composés, dans une proportion plus ou moins considérable, de ce lissu cellulaire que nous avons dit lier la membrane musculeuse de l'estomac, soit à sa membrane péritonéale, soit à sa membrane muqueuse. Ce tissu cellulaire est l'organe élémentairc le plus général et le plus simple.

Son étude dans toutes les parties de l'organisme, et les modifications qu'il y subit; celle de l'organe élémentaire nerveux et de son agrégation en système; celle de l'organe élémentaire musculeux, et des propriéT. I. tés de la fibre musculaire dans tous les organes concrets où elle se rencontre; l'étude du système osseux, celle de la peau et des autres parties tégumentaires; l'étude des membranes séreuses, muqueuses, etc., etc.; celle des systèmes vasculaires sanguins, lymphatiques, considérés dans leur structure intime, dans leur disposition la plus générale, dans leurs propriétés chimiques, physiques, organiques, vitales, composent cette partie de la science de l'organisation qu'on appelle, depuis Bichat; Anatomie générale.

\section{\$3.-De l'Analomie comparée.}

C'est à la science de l'organisation des animaux qu'on a réservé le nom d'Anatomie comparée, parce que son étude, dans le principe, avait pour point de départ, pour sujet de comparaison, l'organisation de l'homme.

Sans doute l'Anatomie générale telle que Bichat l'a conçue est aussi une Anatomie comparée, mais bornée à l'étude de l'homme. Dans cette limite étroite, la science est loin d'atteindre l'exactitude, la vérité et les généralités qu’elle doit, qu'elle peut embrasser, lorsqu'elle s'étend à l'étude des animaux. Pour n'en citer qu'un exemple, les membranes séreuses étudiées dans les animaux vertébrés ne sont pas, sans exception, des sacs fermés de toutes parts, comme l'avait cru Bichat. La cavité du péritoine s'ouvre chez plusieurs poissons, soit immédiatement au dehors, derrière l'anus (les Saumons, les Lamproies), soit dans le cloaque (les Sélaciens).

Chez ces derniers, la cavité même du péricarde a une sorte d'embouchure dans celle du péritoine, et peut aussi, par cet intermédiaire, communiquer avec le milieu ambiant.

Chez les Oiseaux, les sacs des plèvres et du péritoine sont sous-divisés en cellules aériennes, dans lesquelles l'air de la respiration pénètre, et dont les parois intérieures se continuent largement arec la muqueuse des bronches. On ne voit donc plus dans toute cette classe cette séparation tranchée entre les séreuses et les muqueuses qui semble les caractériser lorsqu'on ne les étudie que chez l'homme. Il est vrai que leur communication chez la femme par le 
pavillon de la trompe était déjà une exception bicn connue des anthropotomistes.

Qui aurait imaginé, avec les idées restreintes que donne l'Anatomic humaine, que le péritoine peut se prolonger en deux canaux étroits jusqu'à l'extrêmité de la verge, ainsi que nous l'avons découvert dans les mâles des Tortues, et publié dès 1805 (Lecons d'Anat. comp., t. V, p. 114 et 115 ,

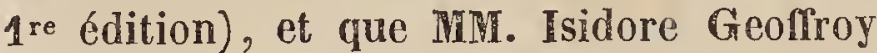
et Martin Saint - Ange l'ont vu dans la verge des Crocodiles en 1826.

L'Anatomie des animaux peut être plus ou moins analytique, plus ou moins judicieusement comparative.

C'est en analysant successivement les organismes dont les formes extéricures se rapprochent, et ceux qui s'éloignent les uns des autres par ces caractères extérieurs, qu'clle parvient à reconnaître tous les rouages de ces machines plus ou moins compliquées, et le rôle qu'ils jouent dans la vic.

G'est seulement après cette analyse, souvent répétée, multipliée sur urn grand nombre d'animaux, que l'Anatomie comparée parvient à déterminer les circonstances organiques qui peuvent faire l'objet de ses comparaisons. Cette science montre d'ailleurs, nous ne cesserons de le dire, bien des degrés de perfection dans ses analyses, dans l'étendue et la justesse de ses comparaisons, et dans les jugements qu'elie en tire.

Lorsqu'clle restrcint à une seule classe, comme l'a fait Vicq-d'Azyr, dans sor Système analomique, l'étude des organes appartenant à une même fonction, elle est loin de pouvoir atteindre aux généralités scientifiques qu'elle doit embrasser.

Il était réservé au génie de Guvier d'élever l'Anatomie comparée, en suivant les traces d'Aristote, au point de vuc élevé et essentiellement physiologique des comparaisons à la fois les plus détaillées, les plus analytiques et les plus étendues.

Dans son discours d'ouverture du premier cours d'Anatomie comparée qu'il a fait au Jardin des Plantes, en décembre 1795, M. Guvier annonce vouloir donner la préférence à la méthode physiologique sur la méthode zoologique, qui étudic classe par classe l'organisme animal. Il prévoit qu'en prenant chaque organe séparément, qu'en étudiant successivemeni les diverses modifications que cet organe éprouve dans toutes les classes, il sera conduit à toutes les comparaisons, à toutes les inductions qui pourront avancer la physiologie, le vrai but, ajoute-t-il, de la Roologie.

Ce n'est pas que cette méthode physiologique soit exempte de dificultés. Il faut à la fois un esprit juste, exercé et pénétrant, pour reconnaître et déterminer un même organe à travers toutes les diférences de structure, de forme, de développement, de position, et même de connexion, qu'il peut subir dans toute la série animale. Gítons-en quelques exemples, afin de rendre nos idées plus claires, plus élémentaires.

Les anatomistes ne sont pas unanimes sur la détcrmination des différentes parties de l'encéphale des poissons, ou sur leur analogie avec celles de l'encéphale des trois classes supérieures des Vertébrés. Plusieur's nomment tubercules optiques ce que les autres considèrent comme des lobes cérébraux, etc., etc. (Tist. nalur. des Poissons, par MI. Guvier et Valenciennes, . I, p. 420.) Ils ont reconnu un équiralent du Pancreas, organe qui existe indubitablement dans les trois classes supérieures des Vertébrés, dans de petits tubes aveugles qu'on rencontre, chez beancoup de poissons osscux, autour de l'origine du canal intestinal; ils ont mème compris qu'en l'absence de ces boyaux pyloriques, certaine modification glanduleuse de la muqueuse intestinale, telle qu'on l'observe chez les Cyprins, pouvait remplacer les cœcums pyloriques. Pour arriver à cette détermination de deux organes ainsi fondus l'un dans l'autre, dans ce dernier exemplc, il fallait avoir observé le pancréas, l'avoir comparé dans l'Es. turgeon, où il continue à se lier avec l'intestin, et tend à se diviser en tubes; dans le Polyodon, où cette division est déjà plus apparente; dans le Xiphios gladius, chez lequel elle est évidente, quoique encore très compliquée, jusqu'aux poissons où l'on ne compte plus que quelques cœcums pyloriques, qu'un seul même (Mugil alluta).

Meckel avait méconnu l'existence de la rate chez la plupart des Ophidiens, parce qu'elle y est soudée avec le pancréas et confondue en apparence en un seal organe. Un examen attentif, une analogie de la structu- 
re différente des deux organes ainsi réunis, ont conduit sûrement à leur détermination. (Fragments d'anatomie sur l'organisation des Serpents. - Annales des Sciences naturelles, s. XXX.),

Les difficultés augmentent si l'on étend ces comparaisons du type des Vertébrés, si évidemment organisés d'après un même plan, aux trois types inférieurs.

L'existence du foie dans ce type supérieur des Vertébrés est encore facilement démontrable, ainsi que les modifications de forme et de volume qu'il y subit.

Une étude approfondie, plus généralement comparée, de ses différentes formes dans les Mammifères, a fait découvrir une forme-type, qui caractérise le foie de cette classe; elle a démontré que ce qu'on regardait comme des divisions sont, au contraire, des additions à la partie constante et conséquemment principale de cet organe; que chez certains Mammifères le foie a son plus haut degré de composition; que chez d'autres il est, au contraire, réduit, ou à peu près, à la partie essentielle : tel est, entre autres, celui de l'homme. (Etudes sur le foic. - Annales des Scicnces naturelles, nov. 1835.)

Dans le type des Articulés, la détermination de cet organe, telle que la donne la science actuelle, est encore contestable pour un assez grand nombre de cas.

Ainsi, si je ne me trompe, on aurait pris de grands sinus veineux pour le foie chez - les Squilles, qui appartiennent à la classe des Crustacés. (Mémoire sur quelques points d'organisation des Squilles. - Annales des Sciences nalurelles, juillet 1837.)

Dans celle des Insectes, on a bien déterminé comme leur tenant lieu de foie, et probablement aussi de pancréas, de petits tubes aveugles, rappelant les cocums pyloriques des poissons. Ces tubes ont leur embouchure dans différents points de l'intestin, assez généralement cependant près de l'estomac duodénal. Mais leur insertion, très rapprochée de la fin de cet intestin chez quelques uns, et surtout la nature des substances qu'ils renferment, composées d'acide urique, ont démontré qu'on avait confondu l'organe remplaçant les reins, dans cette classe, avec l'organe biliaire. $(\boldsymbol{V}$. à ce sujet l'observation de M. Aubé, rapportée par
M. Audomin, Annales des Sciences naurelles, $2^{\circ}$ série, t. $\mathrm{V}$, et les Legons d'Anaiomie comparée de G. Cuvier, 2 édit., t. VII, p: 616-619.)

Les auteurs qui ont nommé et déterminé les différentes parties du canal alimentaire dans cette même classe des insectes sont loin de distinguer toujours la même partie par une même dénomination, et de lui recounaître la même fonction. ( $V$. à ce sujet la note que nous avons imprimée $\mathrm{t} . \mathrm{V}$, p. 601 , de la deuxième édition des Lecons d'Anatomie comparéc.)

Le type des Mollusques ofrait de même de grandes difficultés pour la juste détermination des organes semblables ou du moins analogues à ceux des Vertébrés ou des animaux inférieurs.

On doit dire qu'à cet égard la grande sagacité de $\mathbb{N}$. Cuvier ne lui a pas fait défaut. Si quelques unes de ses déterminations, qui se trouyent dans la série des beaux mémoires qu'il a publiés sur les MIollusques, ont été contestées, des observations plus justes et moins partiales n'ont pas tardé à les confirmer.

Quand on descend au type des $200 p h y t e s$, où les organes se simplifient et tendent à se confondre, ainsi que les fonctions; où même les organes élémentaires (les nerfs, les muscles) finissent par disparaître ou par se fondre les uns dans les autres en une substance organisée d'une singulière homogénéité, comme dans les Hydres, les ressemblances ou les analogies deviennent encore plus difficiles à reconnaître.

On s'est servi, dans ces derniers temps, d'un procédé ingénieux pour y parvenir. Il s'agissait de l'organe mâle de la génération ou de l'organe sécréteur du sperme. On a pu s'assurer de son existence dans plusieurs animaux inférieurs (les Actinies, M. Wagner; les Ascidies composées, M. Milne-Edwards; les Oursins, M. Peters), en découvrant des Zoospermes dans le produit de la sécrétion et les réservoirs de cet organe.

Nous venons de voir qu'on avait suivi la même marche pour reconnaitre dans les insectes l'organe sécréteur de l'urine.

Malgré ces difficultés, l'Anatomie comparée, telle que le génie de Guvier l'a constituée, dans laquelle on observe, compare et juge, les différentes modifications organi- 
ques d'un même organe remplissant une fonction analogue ou semblable dans la série animale; dans laquelle on parvient à démêler le plan fondamental de cet organe à travers toutes les transformations, les additions, les extensions, qui le perfectionnent, ou les soustractions quile dégradent; différences organiques qui font varier quelquefois à l'infini les phénomènes de la vie; cette Anatomie, disons-nous, ainsi comprise, est la source à la fois la plus solide et la plus féconde, nous en sommes convaincu, à laquelle la physiologie puise ses propositions les plus évidentes.

L'étude comparée des organes concrets de tous les animaux conduisait à une description générale des systèmes d'organes, des organes élémentaires, et même des éléments organiques essentiels de j'organisation animale. (V. l'article Animal.)

Aussi trouvera-t-on déjà dans les généralités écrites par M. Cuvier, et mises en tête des Lecons d'Anatomie comparée (1re édit.), les traits principaux de cette Anatomie générale, dans laquelle la considération des fuides généraux, yqui font essentiellement partic de l'organisation animale, occupe une place proportionnée à son importance et à l'étendue de la science.

Nous ne pouvons donc pas regarder l'Anatomie générale de Béclar comme le premier essai fait en France d'une introduction à cette étude des plus grandes génélités de l'organisation; d'autant moins que les propositions concernant les animaux $\mathrm{y}$ sont restreintes, et qu'elles n'y sont pas fondées sur les propres observations de l'auteur. Ajoutons que, dans cef ouvrage, d'ailleurs si recommandable pour tout ce qui concerne l'Anatomie de l'homme, la description des fiuides organiques a été entierement omise.

\section{\$4. - Analomie comparée dics sexes el des} âges, ou élude des mélamorphoses que subissent les organismes aux différenles époques de la vie; Embryolomie.

La science de l'organisation ne s'arrête pas à l'étude des organismes développés. Elle recherche les différences ou les ressemblances que les individus d'une même espèce, de même sexe ou de sexes différents, présentent aux différents âges, aux différentes époques de leur vie; elle parvient ainsi à saisir les re- lations de ces changements physiques avec ceux observés dans les mours et dans toutes les fonctions, même les plus spéciales.

Cette même science a étudié successivement dans le règne animal, comme elle l'avait fait dans le règne végétal, la première apparition de l'ovule et de l'œuf, origine primitive de tout corps organisé; les premiers linéaments du germe; les enveloppes de celuici; leurs rapports, leur liaison avec les orgạnes de la mère, même avant l'imprégnation, et surtout après le concours des sexes, quand ce concours est nécessaire.

Elle suit les changements de forme de toutes les parties extérieures de l'embry on ou du foetus, jusqu'à l'époque de sa vie indépendante. Elle pénètre dans son intérieur pour étudier l'apparition successive ou simultanée, transitoire ou permanente, de certains organes; afin de reconnaître leur développement proportionnel ou inégal; pour déterminer les métamorphoses successives qui s'opèrent dans la forme extérieure, dans celle des parties intérieures et dans leur structure, en un mot dans la composition organique du fœtus, aux différents âges de sa vie.

Cette embryotomie, qu'on appelle ernbryogénic, ou germination, lorsqu' on l'étudie avee la pensée physiologique, c'est-à-dire avec la considération de l'organisation en action, dans le but de comprendre la nutrition du germe et son développement, est une étude du plus haut intérêt.

C'est avec les matériaux fournis par cette partie importante de l'Anatomic comparée que l'esprit méditatif s'élève au point culminant de I'Anatomie spéculative, si dangereux pour la certitude du raisonnement.

\$5. - Anatomic des monstres, ou des déformations des organismes, on Wératolomie.

La base de l'Anatomie spéculative s'élargit encore lorsque l'on étudie les formations anormales des organismes. Cette dernière étude, ou l'Anatomic des diverses monstruosites, est une des parties les plus importantes de l'Anatomie comparée; soit que l'on ait pour but de reconnaître les organes ou les systèmes d'organes qui sont les plus susceptibles de ces déformations; soit que l'on cherche à déterminer les espèces de déformations et 
leurs limites; soit que l'on ait en vue la viabilité des organismes ainsi déformés, et que I'on veuille en tirer la conséquence du rôle que joue, relativement à la durée de l'existence normale, tel ou tel rouage qui a changé de rapports, qui est en excès, ou qui a disparu dans l'organisme déformé (1).

L'ensemble de ces déductions de l'Anatomie des monstruosités constitue cette partie de la science de l'organisation qu'on appelle Tératologie, des mots grecs -ípos, prodige, monstre, et iónos, discours.

\section{Q6. - Anatomie philosophique, transcendante et spéculative.}

L'Anatomic devient philosophique, ou transcendante et spéculative, lorsqu'elle étudie l'organisation en elle-même pour en expliquer les lois; pour révéler celles que suivent les organismes dans leurs différents degrés de composition, dans leur développement; pour en tirer les conséquences les plus générales sur l'origine, la durée et les limites de la variabilité des espèces; pour apprécier enfin les conditions de l'existence.

On concevra facilement que cette partie de la science de l'organisation aura des degrés de certitude très différents, suivant qu'elle revêtira le caractère des sciences de raisonnement, qu'elle conservera celui des sciences d'observation, ou qu'elle prendra un caractère mixte entre les unes et les autres.

Dans le premier cas, elle aura le droii d'aspirer à la certitude mathématique, et elle en approchera beaucoup.

Dans le second, ses propositions conserveront le degré de certitude des sciences d'observation, lorsqu'elles seront logiquement déduites de faits bien observés, incontestables.

Dans le troisième, elle pourra devenir de plus en plus spéculative, lorsque, s'élançant dans l'espace au dessus des faits qui ont été son point de départ, elle ne les contem-

(1) Voir le t. II de la Philosophie anatomique. qui traite des monstruosités humaines, par M. le cheválier Geoffroy Saint-IIilaire, Paris, 1822, pour les principes de classification des monstruosités et les limites des déformations. Voir encore le Traité de Téralologie, par M. Isidore Geoffroy SaintHilaire. plera plus que de loin, qu'clle étendra son horizon au delà du cercle où ils sont renfermés, qu'elle les perdra même entièrement de vue, et qu'elle finira par ne plus s'appuyer sur la base solide de l'observation.

L'Anatomie philosophique est une création du siècle actuel. Dès 1800, Cuvier en publiait les bases dans ses Considérations sur l'économic animale, qu'il a mises en tête de l'ouvrage des Lecons ( $\$ \mathrm{I}$, p. 45-60. Paris, an VIII, 1800). On y trouve surtout (art. IV) les principes les plus incontestables, l'exposé le plus clair de la loi des conditions d'existence, qui domine, à notre avis, et à laquelle sont subordonnées toutes les autres lois de l'économie animale.

Nous croyons devoir transcrire ici une grande partie de cet exposé, comme exemple propre à donner une idée juste de l'Anatomie philosophique, de cette science de l'organisation dont nous cherchons à faire comprendre la nature ou l'essence et toute la valeur par l'appréciation impartiale de ses différents degrés de certitude.

Après avoir esquissé les principales différences dont les organes affectés à chaque fonction animale sont susceptibles, M. Cu vier fait sentir qu'on pourrait supposer celles d'un organe unies successivernent avec celles de tous les autres, et qu'on produirait ainsi un nombre très considérable de combinaisons organiques, qui répondraient à autant de classes d'animaux.

"Mais, ajoute le fondateur de l'Anatomie comparée, ces combinaisons, qui paraissent possibles lorsqu'on les considère d'une manière abstraite, n'existent pas toutes dans la nature, parce que, dans l'état de vic, les organes ne sont pas simplement rapprochés, mais qu'ils agissent les uns sur les autres, et concourent tous ensemble à un but commun. D'après cela, les modifications de l'un d'eux exercent une influence sur celles de tous les autres. Celles de ces modifications qui ne peuvent pas exister ensemble s'excluent réciproquement, tandis que d'autres s'appellent pour ainsi dire..... G'est sur cette dépendance mutuelle des fonctions, ef ce secours qu'elles se prêtent réciproquement, que sont fondées les lois qui déterminent les rapports de leurs organes, et qui sont d'une nécessité égale à celles des 
) lois métaphysiques ou mathématiques : " car il est évident que l'harmonic conve"nable entre les organes qui agissent les 3) uns sur les autres est une cordition né") cessaire de l'cxistence. ")

Il y a dans cette grande et première lo $i$ des conditions d'existence la cause finale de la durée de la vie, pendant un temps déterminé, pour chaque individu, pour chaque espèce.

Toutes les causes finales, ces nombreuses modifications organiques qui font varier à l'infini les rapports des êtres animés et les fonctions particulières dont se compose leur existence, sont subordonnées à cette première nécessité.

L'observation certaine montre qu'entre les limites assez étendues des conditions d'existence il y a de grandes variations dans la composition des organismes.

“ Tel organe est à son plus haut degré de "perfection dans une espèce, et tel autre "l'est dans une espèce toute difórente." (Tbid.)

D'un autre côté, la vie ne saurait être élevée à un certain degré dans un organe ou dans un système d'organes, qu'elle ne soit diminuée dans les autres parties (1).

Après avoir reconnu les limites assez étendues que la loi des conditions d'existence a posées pour les différentes combinaisons organiques; après avoir établi que le nombre de ces combinaisons diminue avec l'importance des organes ou des systèmes d'organes, qu'il augmente au contraire et se multiplie à l'infini dans toutes les parties accessoires; après avoir signalé ces dégradations successives que suit un même organe, jusqu'à ce qu'il n'en existe plus qu'un vestige (2) et comme pour témoigner du plan général d'organisation d'après lequel l'organisme dont il fait partie a été conçu;

Après cette loi du balancement des forces destinée à devenir l'un des fondements les plus solides de la philosophie médicale; il restait à reconnaître et à démontrer la loi du balancement des organes, ou de l'accroissement, du développement inverse de cer-

(1) Réflexions sur les corps organisés,-Magasin encyclopédique, par G. L. Millin, p. 470. Paris, $1^{\circ \mathrm{x}}$ brum. an 8 (1799).

(2) Mr. Guvier, ibid. taines parties corrélatives, dans un seul et même organisme. Cette loi achève de donner l'intelligence des modifications si nombreuses d'un même plan de composition des organismes appartenant à une seule classe ou à un seul type; elle explique surtout los limites des déformations organiques, et c'est particulièrement l'étude de ces déformations et l'aperçu profond de ces limites qui paraissent avoir révélé cette loi à son illustre auteur, M. Geofroy Saint-Hilaire (1).

L'Anatomie philosophique étudie l'ensemble des organismes ou leurs différentes par.. ties, indépendamment de leurs usages. Elle cherche à découvrir les similitudes ou les analogies que présentent ces organismes dans leur composition; elle s'applique à déterminer les parties qui sont identiques, malgré les différences de leur emploi.

Son degré de certitude, dans cette voie, dépend du rapport des faits observés avec les conclusions qu'elle en tire.

Lorsque ses propositions sont́ rigoureusement déduites de l'exacte observation, nous ne cessons de la considérer comme vraiment philosophique.

Ainsi l'unité de plan de certains groupes du règne animal, des Vertébrés par exemple, est une vérité bien démontrée, formant un des principes les plus incontestables de l'Anatomie philosophique. Mais cette partie fondamentale de l'Anatomie n'est plus que spéculative; elle devient plus ou moins conjecturale lorsqu'elle s'efforce de rattacher les innombrables différences de l'organisation à une unité idéale de formation ou même de composition.

Cette unité semblerait, au premier aperç, devoir être pour l'anatomiste ce qu'est pour le peintre ou le sculpteur l'idéal de la beauté. Mais il y a cependant cette grande diflérence, que le génie de l'artiste peut réaliser, peut matérialiser sa création sur la toile ou le marbre; tandis que l'Anatomie spéculative n'a pas la puissance d'individualiser la sienne, et qu'elle est destinée à rester dans le vague de l'idéologie.

Si la détermination d'un même organe, remplissant une même fonction, devient quelquefois très difficile, ainsi que nous l'a-

(1) Philosophie anatomique des difformités humaines, p. 52 et 240 . Paris, 1822. 
vons démontré en parlant de l'Anatomie physiologique, surtout quand on s'avance au delà des Vertébrés, on concevra que les difficultés doivent augmenter lorsqu'il s'agit de déterminer l'identité des partięs dans des classes ou même dans des types différents, lors mème qu'il n'y a plus de ressemblance dans les fonctions. Il en résulte que les aperçus peuvent perdre peu à peu cette évidence de I'Anatomie positive, plus rapprochće des faits, et que ces aperçus doivent être plus ou moins contestables.

On a dû chercher une boussole pour se guider dans cette nouvelle roie. On a cru l'avoir trouvée dans le principe des connexions, c'est-à-dire de la dépendance mutuelle, nécessaire, et par conséquent invariable, des parties (1).

Dans beaucoup de circonstances, ce principe est incontestable, dans son application comme en théorie.

Ainsi, les organes des sens spéciaux se rattachant, par les nerís qui les constituent, au centre principal du système nerveux, on arrive, avec ceritude, de l'œil, par le nerf op-' tique, à la détermination du cerveau.

Mais ce principe des connexions, remarquons-le bien, ne donne que certaines positions relatives, dont les unes sont fonctionnelles ou physiologiques, dont les autres sont encore pour la science absolument irrationnelles. TYous rangerons parmi ces dernières la situation du principal cordon des nerís, qu'il faudra chercher, dans toute eśpèce d'animal articulé, à la face abdominale du cơrps, et sous le canal alimentaire, et non à sa face dorsale, comme dans les animaux vertébrés.

Le foie, au contraire, étant un annexe physiologique du canal alimentaire, c'est autour de ce canal, en union, en fusion même avec ses parois, qu'on dęra tenter d'en constater la présence et d'en découvrir les modifications.

Un organe de respiration circonserit, unique ou multiple, sera toujours en connexion physiologique, en rapport intime, avec les principaux troncs ou les principales branches du systeme vasculaire sanguin, et celles-ci serviront à faire reconnaître cet organe de respiration, quelle que soit sa position

(1) M. Geoffroy Saint-Hilaire, ibid., p. 32 et 447.1 I. I, p. 506 et suir si variable, soit à l'intérieur, soit à l'extérieur du corps.

Les Mollusques ont très généralement la dernière partie du canal intestinal en rapport avec la cavité des organes de la respiration. J'ai compris la raison physiologique de cette connexion, utile dans ce type pour la défécation, de même que celle qui existe entre cet intestin et certaines parties du mécanisme de la respiration (le diaphragme, les muscles abdominaux), dans le type des Vertébrés.

Mais le principe des connexions abandonne souvent l'anatomiste, surtout lorsqu'il cherche à le reconnaître dans le dédale de l'organisation des animaux sans vertèbres.

Les Mollusques, les Zoophytes, montrent dans leurs organes de génération les connexions les plus variées, les plus bizarres. Chez plusieurs Polypes à polypiers, l'ovaire devient même extérieur, comme dans les plantes. Relativement à ces organes, le principe des connexions me paraît absolument insaisissable chez les animaux inférieurs.

Le squelette des animaux vertébrés présente, dans l'ensemble de sa composition, une unité de plan, et conséquemment de pensée créătrice, qui se fait jour à travers les différences qui semblaient devoir la voiler à nom tre intelligence. C'est à l'Anatomie comparée, à peine constituée comme science, qu'on doit cette importante déconverte, qui date des premières années du siècle actuel.

Hlle devient indubitable, même dans les détails, pour la composition de la tête osseuse, lorsqu'on se sert du principe des connexions, ainsi que l'a fait $M$. Geofroy Saint-Hilaire, et qu'on a soin de comparer le jeune âge ou l'état fétal (1) des Mammifères et des Oiseaux avec celui des Reptiles or des oissons, ou même avec lcur état adulte.

Cependant, si l'on veut tenter de porter plus loin ces aperçus des ressemblances; si l'on essaie la démonstration de l'identité,

(1) Voir, pour l'bistoire de la science sur ce sujet important, l'opinion de M. Cuvier, rapportée par M. Geoftroy (Philosoplie analomique, t. II , p. 32 et suiv.), et les premières pages du t. $\mathbf{V}$, deuxième partie, édit. in $-4^{\circ}$, des Recherches sur les ossements fossiles; enfin l'Histoire naturelle des poissons, par MM. Cuvier et Valenciennes, 
ou seulement de lanalogie de composition de toutes les parties de ce squelette, on est forcé d'admettre de simples conjectures pour des vérités; et, dans ce vaste champ, la manière de voir de l'Anatomie spéculative varie presque autant que le nombre des savants qui s'escriment dans cette lice : car c'est ici une véritable lutte d'opinions contradictoires.

Pour n'en citer qu'un exemple, rappelons que l'opercule des Poissons, ou ses différentes pièces, a été successivement considéré comme l'analogue du cartilage thyroïde divisé, comme les pariétaux détachés du crâne, comme l'os jugal et les pièces de la mâchoire inférieure des reptiles, qui s'y trouvent de plus que dans les poissons; comme les analogues des osselets de l'ouie, enfin cornme n'ayant pas d'analogues dans les autres classes des Vertébrés (1).

L'idée ingénieuse et profonde qu'avait eue M. Geofroy Saint-Hilaire, pour comparer la composition osseuse des quatre classes des Vertébrés, de prendre celle des Oiseaux et des Mammifères dans le jeune âge, ou même dans leur foetus, avant la soudure de certains $0 s$, et lorsque cette tête est encore divisée en un grand nombre de parties; cette heureuse idée, remaniée par l'Anatomie spéculative, est devenue la source de tout un système sur le développement successif et graduel des animaux supérieurs.

Sans doute, le spectacle surprenant des métamorphoses que subissent les Reptiles batraciens et les Insectes a pu conduire à l'idée de ce système. On adrnet comme un principe fondamental de l'embryogénie que les embryons ou les foetus des animaux supérieurs passent par tous les degrés inférieurs de l'organisation, à partir de celle du Polype, avant d'atteindre la perfection organique de l'Oiseau ou du Nammifère. Cette hypothèse đe l'Anatomie spéculátive a fait déterminer comme des branchies les fentes cervicales découvertes chez les très jeunes foetus de ces denx dernières classes, et des reptiles non sujets aux métamorphoses.

On n'avait cependant démontré que l'existence de plusieurs branches artérielles paraissant répondre à ces solutions de conti-

(1) Voir à ce sujet la note 1 de la page 6 des Recherches sur les ossements fossiles de G. Cuvier, t. $\mathrm{V}$, premiere partie. Paris, 1824. nuité de la peau, mais sans aucun appareil capillaire pouvant caractériser un organe de respiration.

J'ai toujours considéré ces fentes apparentes comme un développement inégal des parois du pharynx, etc.

M. Serres, qui a publié une opinion analogue, vient de démontrer surabondamment que ces fissures cervicales, comme toutes les audres ouvertures de la surface du corps dans les foctus, sont bouchées par la membrane réfléchie de l'amnios, et que l'eau renfermée dans ce sac membraneux ne peut y pénétrer, sinon, faut-il ajouter, par imbibition (1).

On sait que les premiers linéaments des embryons des Vertébrés se composent de l'encéphale et de la moelle épinière, qui s'y montrent avant les autres systèmes, et dans un développement proportionnel extraordinaire.

Comment concilier cette première apparition des centres nerveux, cette composition primitive, nerveuse, incontestable, de l'embryon d'un Vertébré, avec l'idée très hypothétique qui roudrait en faire un Polype, c'est-à-dire un animal inférieur, dans lequel on n'a pu découvrir jusqu'à présent de nerfs distincts?

Ces exemples suffiront, j'espère, pour faire comprendre les différents degrés de certitude qui caractérisent l'Anatomie philosophique et l'Anatomie spéculative, et combien celle-ci devient conjecturale lorsqu'elle abandonne presque entièrement la voie de l'observation pour s'élever dans l'espace sans bornes des idées de pur raisonnement."

Sans doute de grands noms se rattachentà cette manière de philosopher sur l'organisation et la vie; mais la jeunesse, à laquelle cet article est destiné, devait être prémunie contre l'entraînement de ces exemples d'une aussi puissante autorité. Cet entraînement la conduirait presque toujours hors de la ligne étroite, mais sûre, de l'observation et de l'expérience, telle qu'Aristote et $\mathrm{Cu}$ vier l'ont tracée pour l'histoire naturelle; telle que Bacon en a posé les bornes infranchissables, du moins pour tous ceuk qui auront a cour de contribuer aux progrès réels des sciences d'observation.

(1) Comples rendus des séances de l'Académie des sciences. 1859 , t. IX, p. 383 ; 1840 , premier semestre, p. 273. 
Après ces différentes manières d'envisager I'Anatomie ou la science de l'organisation considérée en elle-même, nous avons à l'étudier dans deux de ses applications les plus importantes, je veux dire dans ses rapports avec la Classification des animaux, et avec cette partie de la Géologie qu'on appelle la palæontologie.

\section{ऽ7. - Anatomie systemalique ou classique.}

L'Anatomie systématique est l'application de la connaissance de l'organisation à la classification des animaux; on pourrait, conséquemment, l'appeler Anatomie classique.

Si la connaissance de l'organisation est la clef de la Physiologie ou de la Biologie, si elle est éminemment utile pour arriver à l'intelligence de la nature des animaux, on concerra que cette ètude, conduisant à la juste appréciation des différences ou des ressemblances organiques qu'ils présentent aux yeux de l'observateur qui les compare, devient la base solide, la base unique, sur laquelle doit s'ćlever la méthode naturelle de leur classification.

Cette méthode, qui divise le règne animal en un certain nombre de groupes, successivement sous-divisés eux-mêmes d'après des différences organiques, graduellement moins importantes; qui réunit dans un même groupe les animaux qui ont entre eux le plus grand nombre de ressemblances; cette méthode, disons-nous, considère tout l'ensemble de l'organisation, toutes les différences ou toutes les ressemblances qu'elle peut présenter, pour en tirer des conclusions sur la distribution du règne animal en types ou embranchements, en classes, en ordres, en familles, en genres ou en espèces. (Voyez Méthode naturelle.)

Ainsi le principe de la méthode naturelle de classification des animaux est fondé sur certaines différences et sur certaines ressemblances dans leur composition organique, que l'Anatomie comparée fait connaitre. Nous verrons, au mot Composition organique, que ces différences ou ces ressemblances peuvent être très importantes, fortement tranchées, et qu'elles indiquent, dans ce cas, des plans d'organisation très distincts, qui constituent les types ou les

T. $\mathrm{r}$. premiers groupes de la méthode. Ces différences sont une conséquence nécessaire de la loi des conditions d'existence. Cette loi, que nous avons exposée dans le paragraphe précédent, démontre qu'il y a certaines combinaisons organiques qui se repoussent, parce qu'elles seraient incompatibles avec la durée de l'existence. Il en résulte nécessairement des rapports ou des différences très variés entre les êtres vivants, et entre les animaux en particulier, et l'impossibilité de les ranger sur une même ligne ou sur une même échelle, qui ferait monter ou descendre de l'un à l'autre par des degrés très faibles, presque insensibles, indiquant de simples nuances de perfection ou de dégradation dans toute leur organisation (1).

G'est un principe reconinu par tous les vrais naturalistes classificateurs, établi déjà par Linné, que les caractères distinctifs des êtres, que ceux des animaux en particulier, doivent être pris de leur conformation et non de leurs mœurs, ou de propriétés et de phénomènes qui ne se manifesteraient pas en tout temps.

Mais la méthode naturelle de classification, appliquée par Guvier à tout le règne animal, a donné singulièrement d'extension à ce précepte. Dans l'état actuel de la science, tous les cadres de la méthode naturelle ont chacun leur étiquette, exprimant des caractères d'organișation ou des caractères anatomiques.

On concevra facilement d'après cela toute l'importance, toute l'utilité de l'Anatomie comparée, dans ses nombreuses applications, dans ses applications journalières à la méthode naturelle.

C'est une pierre de touche indispensable pour juger tous les essais de classification, faits avec la prétention d'être les plus conformes à la nature.

\section{S 8. - Anatomie géologique ou palcontologique.}

J'appelle ainși l'application des connaissances anatomiques les plus détaillées, les plus spéciales, comme les plus générales, pour distinguer et rapporter à leur espèce,

(1) Leçons d'Analomie comparée de G. Cuvier, t. I, p. 41 à 60. Paris, 1800. 
à leur genre, à leur famille, à leur classe, les débris des corps organisés, ceux des animaux en particulicr, qui ont été enfouis par les révolutions du globe, dans les difiérentes couches de son écorce.

Ces débris sont toutes les parties dures qui ont pu résister aux agents physiques, au poids des masses terreuses qui les ont recouvertes. Ce sont des squelettes, des portions de squelettes, des os, des dents, leurs fragments, des écailles, et d'autres parties dures tégumentaires des animaux vertébrés. Ce sont des coquilles ou des débris de coquilles des Mollusques, ou des parties calcaires ayant appartenu à quelque portion de leur canal alimentaire. Ce sont encore les parties dures des Crustacés; ce sont ces polypiers calcaires, rarement siliceux, dont les nombreux restes caractérisent les terrains littoraux.

Rarement a-t-on lieu d'examiner 'des animaux entiers, comme les Insectes assez nombreux qui ont été enveloppés par la matière encore liquide de l'ambre jaune ou du succin; ou comme le Rhinocéros et l'Éléphant, découverts en Sibérie, non loin des plages de la mer Glaciale, et conservés, selon toute apparence, pendant des milliers d'années, dans les glaces formées par un refroidissement subit de ces latitudes hyperboréennes.

Les différents sujets d'observation de cette Anatomie, souvent plus ou moins mutilés, incomplets, exigent donc une grande habitude, une connaissance approfondie de l'organisation actuellement existante à la surface du globe, pour établir des comparaisons certaines avec cette organisation des temps passés.

Une étude raisonnée de celle-ci a bientôt démontré que les mèmes lois règlent l'une et l'autre.

Leur exacte appréciation et les justes applications qu'on peut en faire ont été pour la première fois mises en pratique, d'une manière générale, par $G$. Cuvier, dans ses nombreuses et persévérantes recherches sur les ossements fossiles ( 1 ).

La méthode que sa science, nous devrions

(1) Elles ont été consignées dans les Recherches sur les ossements fossiles, vol. I-V, in-4. Paris, 1821-1824. dire son génie, lui a suggérée pour parvenir à restituer les squelcttes et les formes principales des Mammifères, des Oiseaux, des Poissons ou des Reptiles fossiles, avec leurs débris dispersés çà et là ; cette méthode, disons-nous, restera toujours comme un modèle de l'application à la Palæontologie des connaissances de détail les plus minutieuses, et, à la fois, les plus générales de l'organisation (2).

\section{\$9. - Des procédés que l'Analomie em-} ploie pour meltre en évidence les différents points de l'organisaion, ou de l'art de l'analomiste.

Nous l'avons dit en commençant cet article, l'Anatomie n'est pas seulement une science, c'est également un art, au moyen duquel celui qui le possède complétement peut mettre en évidence les parties les plus cachées, les plus déliées de l'organisation.

Ses procédés sont nombreux et variés; nous nous bornerons à passer en revue les principaux.

Dissection. - Le premier, le plus fréquent, celui qui a valu à l'Anatomie son nom, consiste dans la dissection, c'est-àdire à séparer avec le scalpel les organes réunis, confondus; à découvrir ceux qui sont cachés dans la profondeur des autres, en coupant la substance de ceux-ci ; à rompre les fils qui lient la trame, ou ceux qui unissent la chaîne des tissus organiques, afin de rendre visibles et distinctes les parties élémentaires qui entrent dans la composition de ces tissus.

Un procédé de dissection trop négligé peut-être par les anatomistes, qui s'attachent surtout au précédent, c'est-à-dire à délier, à dégager les organes concrets ou les organes élémentaires du tissu cellulaire qui les enveloppe, est celui de faire certaines coupes de ces organes, qui peuvent donner facilement et promptement une idée de leur composition, et de la position relative des parties élémentaires ou autres qui y sont agrégées.

(1) Rapport historique sur les progrès des sciences naturelles de 1788 à 1807 , rédigé par G. Guvier, p. 177 et 302. Paris, Verdière et Lagrange, 1828 , in- 8 . 
Dissection dans l'eau. - Lorsque l'organe que l'on veut analyser par la dissection est petit, le procédé qui consiste à le placer dans une assiette ou dans un petit bassin rempli d'eau; à le fixer avec des épingles sur un plateau de cire, qui est lui-même adhérent à une lame de plomb, est extrêmement utile pour distinguer les parties les plus délicates de la structure des organes ou les tissus qui ont peu de consistance.

Le poids de l'eau, la moindre légèreté spécifique de ces organes ou de ces tissus, détermine dans ce liquide, sans efforts, sans déchirure, le déploiement des filaments les plus déliés des membranes les plus minces. Les épingles et la cire donnent des moyens faciles de les étaler à volonté, et de les montrer sous l'aspect le plus favorable aux recherches et aux observations. C'est par l'emploi de ce procédé que M. Cuvier est parvenu à faire ces belles, et cependant si difficiles Anatomies des mollusques, et ensuite ces admirables dessins qui représentent, avec tant de vérité et de clarté, l'organisation compliquée de ces animaux. Ce procédé a été pour le maître de la science l'occasion d'une grande partie de ses découvertes en Anatomie. Il est devenu, entre les mains des nombreux anatomistes que M. Cuvier a rendus témoins de sa grande utilité, un moyen de succès nombreux dans les recherches qu'ils ont entreprises pour l'avancement de la science de l'organisation. Ce simple procédé doit donc être mis au rang des plus utiles qu'emploie l'art de l'anatomiste.

Procédé des injections. - Les vaisseaux, les canaux, les sinus plus ou moins anfractueux, dont peuvent se composer les différents organismes, les communications de ces diverses capacités entre elles ou avec d'autres parties du même organisme, leurs directions différentes, leur "étendue, leurs diversions, leurs rapports, sont mis en évidence par les divers procédés des injections.

Ils consistent, le plus souvent, à introduire dans ces capacités vasculaires ou autres des substances colorées, liquides au moment de leur introduction, mais susceptibles de se solidifier, et de prendre plus ou moins de consistance par le refroidissement.

C'est par ce moyen ingénieux des injections que l'anatomiste met en évidence les réseaux vasculaires les plus déliés à la surface des organes, et qu'il parvient à les découvrir, avec le scalpel, dans leur profondeur. C'est par ce procédé des injections colorées que Ruisch avait acquis une réputation extraordinaire; réputation qui était relative à son époque, et que ses préparations ne pourraient plus lui mériter, à en juger du moins par le petit nombre de celles qui existent dans les collections de l'université de Leide.

Injections au mercure. - Le procédé des injections consiste souvent à se servir du mercure, dont le poids, mesuré à volonté par la colonne de ce métal qui s'élève dans le tube ou siphon employé pour cette espèce d'injection, suffit pour pénétrer dans les vaisseaux les plus fins, les plus capillaires, et pour vaincre la résistance de leurs parois à sa pénétration. C'est par ce procédé des injections au mercure que le système lymphatique a été successivement découvert dans l'homme et dans les animaux vertébrés.

Alimentation colorée ou colorante. - Je ne puis m'empêcher d'indiquer ici le procédé des injections naturelles, ou l'introduction, dans l'état de vie, de l'eau colorée par le carmin ou l'indigo, pour dessiner et rendre évidentes les formes du sac ou du canal alimentaire des animalcules homogènes. On sait que M. Ehrenberg, qui s'est servi de ce procédé avec plus de succès que ses prédécesseurs, appelle ces animaux polygastres, parce qu'il a rendu évident par cette nutrition colorée un grand nombre de poches accessoires, en apparence, du sac ou du canal alimentaire, qui se sont remplies de cette eau rouge ou bleue, et qu'il regarde comme autant d'estomacs.

C'est encore le cas de parler de la garance, de cette substance colorante, qui, mêlée aux aliments des jeunes animaux, dans les expériences animales de Duhamel, rougit leurs os en se combinant aux sels calcaires que la nutrition y dépose, et donne la marche, montre les traces de leur accroissement successip.

M. Flourens, qui a eu l'heureuse idée de reprendre les expériences de Duhamel, vient de montrer qu'au point de vue actuel de l'anatomie et de la physiologie, c'est, pour ainsi dire, un procédé nouveau, au moyen duquel on peut espérer d'importan- 
tes découvertes sur la structure des os et des dents, et sur leur accroissement (1).

Procédés chimiques soit pour augmenter la consistance des organes, soit pour ramollir et même dissoudre quelques parties élémentaires des orgares concrets. - L'art de l'anatomiste met souvent en usage la macération, c'est-à-dire le séjour dans l'eau des parties organisées, afin de ramollir, de fondre, de dissoudre les filets, les lames du tissu cellulaire, qui lient, qui unissent certaines membranes entre elles, et qu'on parvient ainsi à détacher, à isoler les unes des autres, pour les observer et les décrire séparément.

G'est un moyen d'analyser les organes concrets, afin de prendre une idée plus nette, de leur composition, en facilitant les procédés de dissection employés pour les décomposer.

Dans une vue tout opposée, celle de donner plus de consistance aux organes, toujours afin de faciliter leur dissection, on peut faire macérer les substances animales dans l'alcool, ce qui les durcit, rend les filets nerveux et les fibres musculaires plus apparentes, et facilite les procédés de dissection au moyen desquels on cherche à isoler les nerfs ou les muscles. Plusicurs autres procédés chimiques peuvent servir à durcir, à ramollir, ou même à fondre, à dissoudre, à enlever ainsi certains éléments organiques, afin de mettre à découvert d'autres parties des organes concrets. Tel est celui au moyen duquel on enlève des os ou des dents, sans les déformer, tous les sels calcaires dont ils sont pénétrés, en plaçant ces organes dans un acide minéral plus ou moins étendu d'eau.

Microscope. - La vue simple est loin de pouvoir nous révéler tous les détails de l'organisation; tous les attributs physiques de forme, de couleur, de densité, qui distinguent les tissus des animaux; tous les caractères physiques et même organiques que présentent leurs fluides.

Heureusement que la découverte du microscope a mis les anatomistes à même de pénétrer plus avant dans l'intimité de l'organisation, de distinguer desformes qui n'ont qu'un

(1) Comples rendus de l'Académie des sciences de 1840, premier semestre, p. 143, 30s et 429 . millième de ligne de diamètre; de voir distinctement celles qui ne s'élèvent qu'à un centième, à un deux-centième, ou même à un trois-centième de millimètre.

Ce moyen, qui n'est pas exempt de beaucoup d'illusions, avait merveilleusement servi à Leuwenhoeck, à la fin du $17^{\mathrm{e}}$ siècle, malgré les imperfections de l'instrument dont il pouvait disposer, à faire ses belles et étonnantes découvertes sur les animalcules, les zoospermes, les globules du sang, la circulation de ce fluide dans les vaisseaux capillaires de plusieurs animaux, etc., etc.

Beaucoup trop négligé par les anątomistes du $18^{e}$ siècle, il a été repris par les anatomistes de l'époque actuelle comme un moyen d'investigation indispensable, auquel on peut avoir recours avec beaucoup moins de dangers d'erreurs, par suite des perfectionnements que la physique a apportés à cet instrument précieux, et de l'expérience acquise de ses avantages et de ses inconvénients par l'usage journalier qu'en font un grand nombre d'anatomistes. Le microscope dévoile à nos yeux l'organisation intime jusque dans les éléments les plus simples, ceux où se passe le mystère de la vie.

Non pas que cette révélation soit toujours tellement concordante dans les observations des micrographes les plus exercés, qu'on puisse, qu'on doive y ajouter une foi absolue, et sans la réserve de quelques doutes.

Il suffira, pour en juger, de jeter un coupd'œil sur l'utile recueil d'Anatomie microscopique publié par M. L. Mandl. (Paris, Baillière, 1858-1859.) On y apprendra, entre autres, combien il y a eu jusqu'à présent de manières de voir au sujet de la fibre musculaire élémentaire, dans les descriptions écrites et figurées qu'en ont données les observateurs micrographes.

Dessins, gravures. - Les dessins et les gravures, qui multiplient l'image des formes que l'anatomiste aurait souvent beaucoup de peine à faire connaitre avec le simple langage, sont des moyens très utiles de donner l'intelligence des faits dont l'Anatomie se compose, et d'en conserver la mémoire; ils servent conséquemment à répandre les connaissances anatomiques. L'art du dessin et celui de la gravure doivent donc être comptés parmi les procédés de l'art de l'anatomiste. La connaissance des formes organiques 
étant, en définitive, l'objet de l'Anatomie, li | tin Saint-Ange, entre autres, pour son beau est facile de concevoir l'immense utilité du dessin pour en conserver soi-même le souvenir, pour en transmettre aux autres une idée exacte. Le jeune anatomiste qui voudra faire de rapides progrès dans la connaissance de ces formes si nombreuses et si variées devra dessiner toutes les préparations qu'il aura l'occasion d'en faire. L'art du dessin lui sera surtout indispensable s'il se destine à l'enseignement. M. Cuvier n'a pas dû seulement à la grande lucidité de ses idées et de son langage le succès soutenu de son enseignement; les figures qu'il traçait à la craie avec une facilité et une justesse admirables, en donnant rapidement un corps à ses pensées, servaient merveilleusement à les faire comprendre.

Nous ne saurions donc trop recommander l'art du dessin à la jeunesse studieuse qui aura à cour de se distinguer par des connaissances solides en anatomie, et qui aspirera à contribuer aux progrès de cette science.

Nous lui citerons comme des modèles à imiter, autant que possible, pour la clarté et la bonne exposition des objets, les gravures sur H'Anatomie des Mollusques publiées dans le recueil des Mémoires de M. Cuvier sur ces animaux, d'après ses propres dessins.

Les planches de Lyonnet, dans son ouvrage sur l'Anatomie de la chenille qui ronge le bois de saule; celles de M. Strauss Düreckheim sur celle du hanneton, ont une perfection qu'il sera toujours bien difficile d'atteindre.

Celles annexées aux nombreux mémoires de M. Léon Dufour sur tous les ordres de la classe nombreuse des insectes, et qui ont été gravées d'après les beaux dessins de cet Anatomiste distingué, donnent un grand prix à ses très utiles travaux. Parmi les anatomistes actuels qui dessinent avec une grande perfection, je dois encore citer M. Milne-Edwards, et plus particulierement ses beaux dessins sur l'organisation des Z00phytes et des Grustacés, ou sur la circulation des Annélides, publiés dans la nouvelle édition du Règne animal de G. Cuvier; feu Dugès, pour ses dessins d'Anatomie zoologique ou physiologique des Arachnides, insérés dans le même ouvrage; et M. L. Doyère, pour ceux concernant les Insectes; M. MarTableau de la circulation du sang dans le foetus, sujet d'un prix décerné à cet anatomiste par l'Académie des sciences; et M. Guérin-Ménéville, pour ses dessins d'anatomie zoologique de la bouche des Insectes, que ce savant entomologiste a publiés dans son Jconograplie du règne animal de G. Cuvier.

Il y a dans les dessins d'Anatomie zoologique ou physiologique un art particulier de montrer les formes et les rapports les plus caractéristiques, les détails les plus essentiels, que l'anatomiste seul, qui connait la valeur de ces détails, peut faire saisir en disposant sa préparation dans le but de les mettre en évidence. La vérité, l'exactitude , la clarté, la manifestation nette et distincte des formes et des rapports, donneront beaucoup plus de valeur, pour la science, à un dessin d'anatomie fait par un anatomiste qui sera cependant un dessinateur médiocre, que les effets pittoresques qu'aurait cherchés en premier lieu un peintre distingué n'ayant aucune intelligence de la science.

Parmi les moyens que peut employer encore l'art de l'anatomiste pour conserver le souvenir des formes organiques, on doit citer les modèles en cire et en carton - pierre ou même en plâtre (1), dont les cabinets anatomiques d'Italie, de France et d'autres lieux, possèdent des exemplaires plus ou moins utiles. Cette Anatomie modelée vient d'être surpassée par un nouveau procédé, inventé par M. le docteur Félix Thibert (2). Au moyen du carton-pate, ce jeune anatomiste parvient à représenter avec la plus grande exactitude les formes et les tissus les plus déliés, auxquels son art, comme peintre, sert à communiquer les couleurs naturelles. L'invention du carton-pâte et son application à l'Anatomie pathologique, dont il est souvent difficile de conserver, dont il est heureusement impossible de multiplier les exemples instructifs, feront épo-

(1) Analomie humaine el comparée, moulée en platre sur nature, el peinté d'après les préparations, publiée par Aimé Robert et Émile Küss. Strasbourg , 18 0.

(2) Nouveau système d'analomie humaine et comparée, par F. Thibert, D., pour le carton. páte. Paris, 1839. 
que dans l'histoire de l'art de l'anatomiste(1). Tels sont les différents points de vue sous lesquels on peut envisager l'Anatomie de l'homme et des animaux dans son état actuel.

Cette science importante, cette science immense, si on l'étend à tout ce qui a vie, cette science infinie comme la nature organisée, sinon dans sa réalité actuelle, du moins dans son sujet et dans son but, a pris place de nos jours (2) parmi les sciences naturelles , comme une apparition gigantesque , comme un nouveau monde, offrant à l'investigateur de la nature un vaste champ sans limites de découvertes incessantes.

(G. L. DUvernoy.)

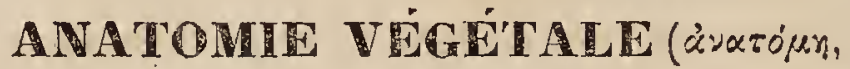
dissection). Bot. - L'Anatomie végétale a pour objet la connaissance de la structure intime des végétaux. Cette dénomination, appliquée au règne végétal, est moins étendue que quarnd elle a pour objet l'organisation des animaux. Ainsi, l'Anatomie animale comprend non seulement la connaissance des tissus élémentaires qui entrent dans la formation de tous les organes, et qu'on désigne aussi sous le nom d'éléments anatomiques, comme le tissu cellulaire, le tissu nerveux, le tissu musculaire, etc.; mais elle a également pour objet la description spéciale de chacun des organes constituant le corps, étudié dans sa position, sa structure, sa composition, son étendue, etc. De là la division de l'Anatomie animale en deux parties bien distinctes : $1^{\circ}$ l'Anatomie générale ou des tissus; $2^{\circ}$ l'Anatomie descriptive, ou topographie des organes. Il n'en est pas de même en botanique. L'Anatomie végétale ne s'occupe que de l'étude des tissus élémentaires qui composent les organes; elle correspond, par conséquent, à l'Anatomie générale des animaux. Quant à l'Anatomie deseriptive des parties constituantes ou des organes des végétaux, elle constitue une branche à part de

(1) Voir. G. Duméril : Essai sur les moyens de perfectionner et d'étudier l'art de l'Anatomiste. Paris, 1803. - Et le Nouveau Manuel de l'Anatomiste, par E.-A. Lants, $2^{e}$ édit. Paris, 1836.

(2) Nous faisons tous nos efforts pour donner une esquisse de ses progrès récents et de son état actuel dans la nouvelle édition des Leçons d'Anatomie comparée de G. Cuvier, dont le t. VII parait en ce moment. Paris, Fortin, Masson et Compagnie, 18 姑。 la botanique, que l'on désigne sous le nom d'organographie. ( $r$. le mot Botanique, où nous donnerons l'indication des diverses divisions qui ont été établies dans cette science.)

La structure des végétaux est généralement plus simple que celle des animaux considérés dans leur ensemble, et cette simplicité d'organisation est en rapport avec le nombre moins considérable des fonctions dont leur vie se compose. Ainsi, tandis que dans le règne animal la vie est le résultat de deux ordres différènts de fonctions, les fonctions vitales ou végétatives, qui servent à entretenir la vie de l'individu, et à propager les espèces, et les fonctions de relation, destinćes à mettre l'être en rapport avec tous les corps qui l'environnent, et par lesquels il peut être influencé, la vie des plantes se réduit aux seules fonctions vitales, que, pour cette raison, on a également désignées sous le nom de végétatives, tandis que les autres sont appelées fonclions animales, parce qu'en effet on ne les observe que dans les animaux. Il résulte de là nécessairement que les plantes manquent des organes servant aux fonctions de relation, et, par conséquent, des éléments anatomiques qui les composent. Aussi, chez elles, n'y a-t-il ni muscles, ni nerfs, c'est-à-dire ni organes de la locomotion, ni organes de la sensibilité, qui sont les deux grandes fonctions de relation des animaux; et, par suite, ni tissu musculaire, ni fibre nerveuse. Il n'y a donc dans les plantes que des organes de nutrition et des organes de reproduction.

De ce qui précède il résulte que l'Anatomie végétale ne comprend que la connaissance des tissus élémentaires ou éléments anatomiques qui constituent les organes des végétaux. Quoiqu'au premier abord ces tissus élémentaires se montrent sous des formes assez variées, et qu'ils semblent souvent fort différents les uns des autres, par exemple des utricules ou des tubes creux ou vaisseaux ; cependant on peut admettre, et l'observation confirme cette vérité, qu'il n'existe dans les végétaux qu'un seul élément anatomique primitif, l'utricule ou les utricules, dont le groupement constitue le tissu utriculaire. Nous verrons en effet par la suite, quand nous traiterons spécialement du tissu utriculaire, qu'originairement il constitue à 
lui seul tous les organes du végétal, et que seulement plus tard quelques unes de ses parties se modifient et se transforment soit en tubes courts ou utricules allongées, soit en véritables vaisseaux. Ainsi nous n'admettons dańs les plantes qu'un seul tissu élémentaire, qui, en se modifiant, constitue tous leurs organes; mais ce tissu élémentaire peut se présenter sous trois formes principales, susceptibles chacune de plusieurs modifications. Ce sont : $1^{\circ}$ le tissu utriculaire simple ou primitif, composé d'utricules de forme variée, rapprochées et plus ou moins intimement soudées ensemble, de manière à former une masse ou un tissu continu. Ces utricules, primitivement globuleuses, prennent, en se pressant et se soudant mutuellement les unes contre les autres, une forme plus ou moins régulièrement dodécaédrique, de telle sorte que leur coupe transversale offre une figure hexagonale, dont les côtés peuvent être égaux ou inégaux; $2^{\circ}$ le tissu vasculaire, composé de tubes très grêles, généralement simples, cylindriques ou anguleux, destinés à contenir soit des liquides, soit des gaz, et qui, au premier abord, paraissent si différents des utricules, bien qu'ils en procèdent constamment; $5^{\circ}$ enfin, une forme intermédiaire entre les utricules et les yaisseaux, c'est-à-dire participant à la fois des uns et des autres, et qu'on a désignée sous les noms de tissu ligneux, de tissu fibreux, de tissu fibro-uiriculaire, de tissu cellulaire allongé, etc. G'est, en effet, ce tissu qui constitue uniquement les fibres ligneuses soit dans les Monocotylédonés, soit dans les Dicotylédonés. Il se distingue des utricules proprement dites par sa forme plus allongée, par ses deux extrémités amincies en pointe ou taillées obliquement en bizeau; et, enfin, par ses parois généralement très épaisses, et dans l'épaisseur desquelles on apercoit souvent des couches distinctes les unes des autres. Par ces différents caractères, et surtout par leur longueur moins considérable, ils se distinguent des vaisseaux.

La forme d'un dictionnaire ne se prête pas à ce que nous traitions ici avec détails de toute l'Anatomie végétale; un semblable travail aurait trop d'étendue. Néanmoins, nous croyons utile de domner une idée générale et succincte de l'Anatomie des végétaux, parce que, dans le cours de cet ou- vrage, nous aurons à faire connaître successivement les particularités d'organisation de chacun des principaux organes des plantes, et qu'il est, par conséquent, indispensable d'avoir une connaissance exacte de la structure anatomique des plantes, considérée dans sa généralité. En effet, en traitant spécialement de chacun des organes, nous ferons connaître sa structure intime, et nous passerons ainsi successivement en revue toutes les modifications que le tissu élémentaire subit dans chacune des parties constituantes du végétal. Ainsi, par exemple, aux mots lige, racine, feuilles, etc., nous exposerons avec détails l'organisation anatomique de chacun de ces organes dans toutes leurs particularités.

Nous croyons utile de donner ici, en faveur des personnes qui, sans en avoir encore l'habitude, voudraient se livrer à des recherches d'Anatomie végétale, quelques considérations générales sur la manière de faire des observations.

Les éléments anatomiques des végétaux sont tellement fins et délicats, que leur structure échappe à notre vue. Pour l'apprécier et la bien connaître, nous avons besoin du secours du microscope; aussi l'Anatomie végétale est-elle une science toute moderne, et dont les anciens n'ont eu aucune connaissance. Malpighi et Grew, à peu près à la même époque, c'est-à-dire vers la fin du $16^{6}$ siècle, doivent être considérés comme les pères de cette branche de la botanique. Toutes les observations faites avant eux sont it peu près nulles pour la science, et ne nous font en aucune manière connaître la vraie structure des végétaux. Mais, depuis cette époque, des travaux importants ont été faits dans presque toutes les parties de l'Europe, et spécialement en Allemagne, en France et en Angleterre. Une louable émulation s'est établie entre les savants de ces pays, et a donné naissance à des découvertes qui ont singulièrement perfectionné la structure anatomique des végétaux ; aussi aurons-nous à citer bien souvent dans cet ouvrage, parmi les botanistes allemands, les noms de MM. Treviranus, Link, Bernhardi, Rudolphi, Schultz, Mohl, Moldenhaver, Meyer, Unger, etc.; en France, ceux de MM. de Mirbel, Turpin, du Trochet, Adolphe Brongniart, Decaisne; etc., et enfin MM. Robert Brown 
et Slack en Angleterre, MM. Viviani et Amici en Italic, dont les travaux ont contribué à amener l'Anatomie végétale au point où elle est parvenue aujourd'hui.

Yous venons de dire tout à l'heure que le microscope est indispensable pour faire connaître la vraie structure anatomique des végétaux. En effet, observé à la vue seule, le tissu des plantes représente une masse celluleuse et continue, dans laquelle, suivant la partic ou le végétal que l'on observe, se voient des fibres excessivement grêles. Pour prendre une idée exacte et complète de la structure de ces tissus élémentaires, il faut les soumettre au microscope. Nous n'avons pas à discuter ici les avantages de chacun de ces instruments, qui ont été modifiés ou perfectionnés dans ces derniers temps. Celui dont nous faisons habituellement usage, èt qui nous a toujours suffi pour les recherches les plus minutieuses et les plus délicates de l'Anatomie des plantes, est un microscope de MM. Charles Oberhauser et Trécourt. Lorsqu'on veut avoir une idée générale de la structure des tissus élémentaires des végétaux, il [faut enlever à la partie qu'on veut étudier des fragments aussi minces que possible, les uns enlevés suivant la longueur de l'organe, les autres faits transversalement. Cette partie mécanique de l'opération, qui paraît bien simple au premier abord, ofre cependant quelque difficulté, et exige non seulement de l'habitude, mais une certaine dextérité de la main. A cet efiet, il faut nécessairement se servir d'un instrument bien tranchant. Bien souvent on emploie un rasoir; mais il est préférable de se servir d'un instrument dont la lame soit plus mince, et que son poids et son étendue moindres rendent plus facile à manier. Ainsi, un petit couteau à peu près semblable à celui dont on se sert pour l'opération de la cataracte, dans la méthode par extraction, ou enfin un petit bistouri à lame étroite et mince, seront substitués avec avantage à un rasoir. Quand on est parvenu souvent, après plusieurs essais infructueux, à se procurer un fragment aussi mince que possible, il faut le soumettre à l'observation microscopique. Pour cela on le place sur une plaque de verre blanc, et l'on a soin de le recouvrir d'une petite goutte d'eau très claire. Cette dernière précaution est indispensable : en effet, l'eau donne une transparence presque complète au fragment, surtout s'il est très mince. On recouvre alors la première plaque de verre d'une autre plaque aussi mince que possible, surtout si les lentilles dont on se sert sont très fortes, et, paŕ conséquent, à très court foyer. Les choses disposées de la şorte, on place l'objet sur le porte-objet du microscope. Il faut d'abord employer des lentilles d'un grossissement moyen, par exemple un grossissement de 80 à 100 diamètres. On sait par expérience que, moins la lentille est forte, mieux l'objet est éclairé. Un grossissement tel que ceIui que nous venons d'indiquer permettra de voir les objets assez distinctement, et comme le champ embrassé par la lentille est assez large, on verra une portion plus grande de l'objet soumis à l'observation, et, par conséquent, on prendra ainsi une idée plus complète des rapports de position qui existent entre les différents éléments anatomiques de l'organe que l'on étudic. Mais on devra employer des lentilles plus fortes pour bien apprécier toutes les particularités de l'organisation. En général, avec une lentille grossissant environ 200 fois, on peut tout voir en Anatomie végétale, parce qu'avec ce grossissement, si les objets ne sont pas extraordinairenent amplifiés, ils sont encore assez bien éclairés pour qu'on puisse en bien saisir tous les détails. Aussi, pour les observations ordinaires sur les tissus, n'est-il guère nécessaire de recourir à de plus grandes amplifications. Néanmoins, il est un certain nombre de points encóre obscurs de l'Anatomie générale des plantes que leur extrême petitesse ne permet que de voir difficilement, et qui exigent des grossissements plus considérables, cinq ou six cents diamètres, par exemple, quand on peut les obtenir avec assez de lumière et de netteté. Telles sont les ponctuations ou pores, les lignes ou fentes du tissu utriculaire et des vaisseaux, la nature de la matière verte ou de la chlorophylle des tissus herbacés, et plusieurs autres points encore en litige parmi les phytotomistes. Mais, à part ce petit nombre de sujets difficiles, il n'est jamais nécessaire d'employer des lentilles aussi fortes. Il ne faut pas, du reste, perdre de vue que le plus souvent, en se servant de verres très grossissants, on perd en netteté et en 
Iumière ce que l'on gagne en amplification.

Il est une substance dont l'emploi est bien avantageux, et qui souvent sert merveilleusement pour bien distinguer les diverses parties constituantes des tissus végétaux : c'est la teinture d'iode. En effet, non seulement elle colore instantanément les grains de fécule en une belle couleur bleue violacée, ce qui, sur-le-champ, fait reconnaitre ceux-ci, et les distingue des autres corps que les tissus pourraient contenir; mais, en donnant aux membranes végétales une teinte jaune ou brun-clair, elle fait distinguer la disposition de parties que leur extrême ténuité et leưr transparence ne permettaient pas d'apercevoir.

Il faut quelquefois avoir recours à la macération dans l'eau, pendant un laps de temps plus ou moins long, pour bien reconnaitre la disposition des éléments anatomiques, et spécialement celle des faisceaux vasculaires. En effet, par ce moyen, on sépare et détruit en grande partie le tissa utriculaire, et les vaisseaux plus résistanis montrent plus clairement leur disposition et leurs anastomoses. On obtient plus rapidement le même effet en faisant bouillir pendant une minute ou deux dans de l'acide azotique pur ou légèrement affuibli la partie dont on veut reconnaître la structure. L'acide azotique jouit de la propriété de dessouder et d'isoler toutes les parties constituantes du tissu végétal, que l'on peut alors étudier bien plus facilement. Fous bornerons là ces observations préliminaires, et nous allons donner, en abrégé, une idée générale de la structure anatomiqque des végètaux.

Coup d'œil général sur la structure des étéments anatoniques des végétaux.

Ainsi que nous l'arons dit précédemment, en commençant cet article, il n'existe qu'un seul élément anatomique primitif dans les végétaux : c'est l'utricule. Wlle est pour le règne végétal ce que la forme primitive est pour les espèces minérales; toutes les autres formes n'en sont que des modifications, et, par conséquent, peuvent y ếre rapportées. L'utricule ou plutôt les utricules, en se réunissant et se soudant, forment une masse continue ou un tissu spécial, que l'on a dé- signé sous les noms de tissu utriculaire, tissu cellulaire, parenchyme, etc. Le tissu utriculaire est donc l'élément fondamental de toute l'organisation des végétaux; mais il se modifie de différentes manières, et peut prendre des formes extrêmement diverses , à tel point que ces formes ont été regardées par plusieurs phytotomistes comme constituant autant de tissus primitifs. Ainsi, lorsqu'on examine avec les moyens amplifiants convenables l'organisation intérieure d'un végétal phanérogame, on voit qu'il se compose : $1^{0}$ de cellules à parois minces et diaphanes d'une extrême petitesse, d'une formę variable, régulière ou irrégulière, toujours polyédrique; $2^{\circ}$ de tubes courts, terminés cn pointe à leurs deux extrémités, a parois épaisses et à diamètre intérieur très petit, disposées bout à bout, de manière à constituer des fibres souvent très résistantes; $z^{\circ}$ enfin de vaisseaux cylindriques ou anguleux, simples ou ramifiés, isolés ou réunis en faisceaux. Telles sont les trois formes principales sous lesquelles se présentent les parties élémentaires qui entrent dans la composition des végétaux, et auxquelles on a donné les noms de issu utriculaire, de lissu fibrenx ou ligneux, et de tissu vasculaire. Quoique ces trois tissus ne soient que des modifications d'un seul et même élément anatomique, l'utricule végétale, nous traiterons pourtant de chacun d'eux en particulier, afin d'en mieux faire connaitre la nature.

\section{Q1. Du tissu utriculaire.}

Ce tissu est le principe de l'organisation végétale parce qu'en êret il fait partie de tous les organes constituants des plantes qui, à une certaine époque de leur développement, en sont uniquement formés. On l'a encore désigné sous les noms de tissu cellu-: laire, tissu vésiculaire, et parenchyme.

Le tissu utriculaire se compose d'utricules' ou de vésicules d'une extrême ténuité, à parois minces et transparerites, très variées dạns leur forme, et soudées intimement les unes aux autres, de manière à former un tissu continu. C'est par suite de cette soudure des viricules entre elles que pendant longtemps on a considéré le tissu cellulaire comme formé de eavités ou de cellules creum 
sćes dans une masse continue, que l'on a comparée tour à tour soit à une épongée, soit à la mousse logère qui s'élève à la surface de l'eau de savon agitée, ou des liqueurs alcooliques en fermentation. Irais aujourd'hui il est généralement reconnu que le tissu utriculaire se compose de petits corps vésiculaires, qu'on pent considérer comme ayant été primitivement distincts, et qui ont fini par se souder cntre eux. Cette structure avait déjà été parfaitement indiquée par Malpighi, dans son Anatonie des planies, il y a plus d'rn siècle et demi. Et, en eflet, ce grand anatomiste se sert déjà du mot utricules pour distinguer les parties constituantes du tissu cellulaire. Sprengel en 1802, et MIN. Linck, du Trochet, ct un grand nombre d'autres phytotomistes, ont mis ce fait dans tout son jour. D'abord, cette séparation des utricules se fait quelquerois naturellement, par exemple dans l'intérieur de certaines tiges herbacées, ou de péiioles, on enfin d'autres organes parenchymateux, dont l'accroissement a été très rapide; mais on peut l'obtenir avec la plus grande facilité en faisant bouillir pendant quelques instants un fragment de tissu utriculaire soit dans l'acide azotique, soit dans l'eau simple. On voit alors, comme nous l'avons déjà dit, les diverses parties constituantes du tissu végétal s'isoler les unes des antres, et se montrer avec les caractères qui leur sont propres.

A. Formes des uiricules. (Consultez les planches de l'Allas consacrées à l'Anatomie végétale, et l'explication des figures.) Lorsque, dans une partie d'un végétal, on cherche à déterminer la forme des utricules, en soumettant à l'examen microscopique une coupe transversale de ce tissa on recomant que celles qui ie composent présentent une aire polyédrique, et le plus soivent hexagonale. Cependant cette forme de la coupe transversale des utricules n'est pas tellement générale qu'on ne la trouve fréquemment modifiée, soit dans le nombre de ses angles et de ses faces, soit dans leur proportion et leur régularicé. La forme vament primitive des utricules, c’est-à-dire celle 'qu'on observe dans les végétaux ou les organes végéçaux, à la première période de lenr développement, approche plus oumoins de la forme globuleuse; mais il est rare qu'clle se conserve long - temps dans cer état. Thos utri- cules, par suite de leur multiplication et des pressions diverses aurqualles elles sont soum: ses, se prósentent sous des aspects extrêmement variés. Généralcment, elles deviennent polyédriques, et leur forme est à peu près celle d'un dodécaèdre; de là la forme hexagonale que montrent les utricules d'une masse celluicuse coupée transversalement. Mais il arrive bien souvent aussi cue, dans leur agcrcement général, les utricules prennent la forme de prismes anguleux, juxtaposés les uns sur les autres, de manière à ressembler, s'il est permis de faire une semblable comparaison, à des masses de basalte prismatique : c'est ce que l'on observe fréguemment dans des coupes faites suivant la longueur de l'organe, dans le parenchyme des tiges par exemple.

La forme hexagonale a quelquefois une régularité presque parfaite, c'est-à-dire que ses six còtés sont égaux entre eux; mais néammoins il arrive plus souvent que chaque utricule, bien que conservant encore dans sa coupe transversale une aire à six pans, est cependant plus ou moins irréguiière, parce qu'une ou piusieurs de ses faces ont pris aux dépens des autres un développement ṕlus considérable. Il peut même se faire que les utricules perdent ainsi une on même deux de leurs faces, et qu'elles se trouvent réduites à une forme pentagonale ou carréc.

Les utricules sont quelquefois disposécs sans ordre dans la masse qu'elles constituent; mais, très souvent aussi, elles sont superposées régulièrement les unes au dessus des autres, de manière à constituer des séries longitudinales. Cette disposition s'observe fréguemment dans les plantes monocotylédonées, particulièrement dans la masse do la tige.

Telles que nous venons de les décrire, les utricules sont, en quelque sorte, à leur état normal; mais il y en a quelquefois qui ont une forme extrêmement irréguhìre ct tellement anomale, qu'il est fort difficile de la comprendre, ì moins qu'on ne les considere non plus comme des utricules simples, mais comme des groupes d'utricules soudées irrégulicrement. Nous aurons occasion de revenir sur ces cellules irrégulières et anomales, quand nous iraiterons spécialement de la structure des feuilles, qui sont les or- 
gaues oì elles existent principalement. ( $\mathrm{V}$. facilement entrevoir les parties contenues

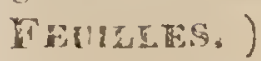

Il existe encore une modification très remarquable du tissu utriculaire : c'est celle qui existe dans ces lignes divergentes du rentre à la circonférence qui font communiquer le canal médullaire avec le parenchyme de l'écorce, et qu'on nomme los rayons méchllaires. Ici, en efret, le tissu utriculaire est dispesé en séries transversales et parallèles, et se compose d'utricules allongées dans le sens transversal. ( $\boldsymbol{V}$. Rayons me DULLARES. )

Lorsque l'on examine avec soin une masse celluleuse, on voî fréquemment que les utricules ne se touchent pas exactoment entre elles dans tous les points de leur circonférence. De cette disposition résultent de petits espaces ordinairement triangulaires, auxquels on a donné les noms d'espaces ou de méats intercellulaires. Pour bien se rendre compte de la formation de ces méats intercellulaires, il faut se représenter que les utricules ont d'abord été à peu près globuleuses. Bans cet état, elles ne pouvaient se toucher que par un certain nombre de points; mais, comme elles étaient compressibles, en s'appliquant et se pressant de plus en plus les unes contre les autres, ces points sont devenus des surfaces planes plus ou moins étendues. Mais les parties extérieures die leur surface externe, par lesquelles les vésicules n'étaiert pas en contact, ont formé des espaces libres et vides, qui représentent autant de canaux très courts ci très irréguliers, gẹ́nćralement triangulaires, communiquant entre eux, ef formant ainsi une sorte de réseau qui doit nécessairement, guand il existe, jouer un rôle important dans les phénomènes de la nutrition. On les appelle alors conduits intraceliulaires (duclus in(racellulıres). ( $\boldsymbol{V}$. ce mot.) Les méats infercellulaires sont quelquefois très àpparents et très développés, surtout dans les parties gui ne sont pas soumises a une trop forte pression de la part de celles avec lesquelles elles sont en contact. (Voyez, dans l'atlas de ce Dictionnaire, la planche $1^{\text {re }}$ de l'Anatomic végétale.)

B. Nature de la membrane qui forme les utricules. - La membrane qui constitue les utricules esî excessivement mince, parfaitement incolore et transparente; elle laisse

dans les utrirules, qui font que ces dernieres paraissent colorées, bien qu'elles soient toujours incolores. Le plus souvent, les utricules semblent avoir une coloration verte, ce qui cst dû à la présence d'une matière organique spéciale, contenue dans leur interieur, et qu'on a désignée sous le nom de Chloropltyile. Quand on cxamine une masse de tissu cellulaire en employant des grossissements mùme assez considérables, comme 120 à 150 diamètres, par exemple, les parois qui séparent les utricules paraissent tout à fait simples. Pendant long-temps, en efiet, un grand nombre de phytotomistes ont eu cette opinion sur la composition de la membrane constitrant les diverses parties du tissu cellulaire; mais ce que nous avons dit dans le paragraphe précédent sur la composition du tissu utricalaire doit déjà faire voir que cette opinion n'est pas généralement conforme à la nature. En effet, la membrane qui sépare deux utricules contiguës, quelque mince qu'elle paraisse, est formée de deux feuillets intimement unis, puisqu'il est constant qu'une masse de tissu utriculaire résulte en général de l'agglomération et da la soudure de petits corps vésiculeux qu'on peut considérer comme ayant été primitivement distincts et séparés les uns des autres. Cette duplicature de la membrane du tissu cellulaire peut néanmoins être apercrue dans certaines circonsiances, Guand on emploie des lentilles assez fortes. C'est surtout lorsqu'on examine des portions de tissu utriculaire dans lesquelles les espaces intercellulaires sont trìs marqués, qu'on peut suivre facilement chacun des deux feuillets, qui, après avoir été distincts et écartés dans les espaces intercellulaires, se rapprechent et se soudent pour former la membrane qui sépare les deux utricules. C'est ce que montrent très bien plusicurs des figures de la planche $1^{\text {to }}$ de ceî atlas, consacrée à l'anatomie végétale, et, entre autres, la fig. 5 , représentant le tissu utriculaire du carna indica.

Quclle que soit la puissance amplifiante des lentilles dont je me suis servi dans les nombreuses observations microscopiques aux\{quelles j'ai soumis les diverses parties du tissu cellulaire, j’ai toujours trouvé la membrane des ntricules parfaitement homogodne. 
et ressemblant en quelque sorte, pour l'aspect, à une lâme excessivement mince et diaphane d'un verre incolore, sans y pouvoir distinguer la moindre trace d'une structure organique quelconque. Cependant, pour quelques physiologistes, cette membrane aurait une organisation plus ou moins compliquée : ainsi, les uns la disent formée de fibres intimement soudées; les autres, de molécules excessivement petites, disposées en spirales. Nous n'avons à examiner ni à discuter ces opinions, qui nous paraissent d'ailleurs peu importantes, et qui sont fondées sur des faits vrais, mais formant plutôt une exception. Ainsi, pour nous, la membrane utriculaire est mince, transparente, parfaitement incolore et sans organisation appréciable.

Dans le plus grand nombre des cas, c'est en effot avec ces caracteres que se montrent les utricules; mais, dans certains végétaux, leurs parois semblent présenter, soit des ouvertures ponctiformes ou pores, soit des fentes transversales. Les vaisseaux ofrent aussi de semblables dispositions. L'exislence d'ouvertures sous la forme de pores ou de fentes dans les parois des utricules ou des vaisseaux est un des points de l'Anatomie végétale qui a été le plus débattu parmi les phytotomistes, surtout au commencement de ce siècle. M. de Mirbel, et, plus récemment, M. Amici, sont les observateurs qui ont le plus fortement soutenu l'existence de ces pores et de ces fentes dans le tissu cella laire et dans les vaisseaux; cependant cette opinion ne paraît pas conforme à l'observation rigoureuse des faits. Il est.vrai que, dans un assez grand nombre de végétark, et particulièrement parmi les Monocotylédonés, les parois du tissu cellulaire paraissent percées d'ouvertures ponctiformes, tantôt disposées symétriquement par lignes parallèles, tantôt dispersées sans ordre. Plusicurs causes ont pu souvent en imposer aux observatenrs, et leur faire croirc à l'existence de véritables perforations dans les parois des utricules là où il n'en existe que l'apparence. Ainsi, par exemple, les grains de fécule fins ê tout à fait transparents qui sont fréquemment attachés a leur face interne ont pu être pris quelquefois pour des pores. Et, en efiet, ces petits corps, à cause de lour transparence et de lear forme plus ou moins sphérique, agis- sent a la manière de lentilles, et, concentrant les rayons lumineux dans leur centre, y montreni un point beaucoup plus éclairé, entouré d'une partie circulaire un peu obscure. Le point lumineux a été pris pour un trou, et la partie moins éclairée pour un bourrelet circulaire; mais ce cas n'est pas celui où l'erreur a été le plus souvent commise. Il existe, comme nous l'avons dit précédemment, des utricules dont les parois ofrent soit des points transparents, soit des lignes transversales, qui ont entièrement l'apparence de pertes de substance. G'est dans ces cas que beaucoup de phytotomisies croient à l'existence de pores ou de fenies. Mais IN. Mohl a prouvé dans ses diférents mémoires, et, entre autres, dans ses belles anatomies des Palmiers et des Fougères recueillis au Brésil par MM. Spix et Martius, que ces prétendus pores et que ces fentés étaien non pas de véritables ouvertures faisant communiquer ensemble les deux cellules contiguës, mais de simples amincissements d'une partie de l'épaisseur de la paroi des cellales. Il en résulte que la coupe transversale d'un de ces points se présento sous l'apparence d'un enfoncement ou d'une sorte de petite niche, dont le fond est toujours bouché par une membrane, qui empêche qu’elle ne soit complètement perforée.

Ce qui est remarquable, c'est que, dans ine coupe longitudinale des vaisseaux ou des utricules où l'on observe ces pertes de substances ponctiformes, celles des deux utricules contiguës se correspondent ordinairement avec exactitude, de manière à ce gu'on voie un grand nombre de petits canaux transversaux, présentant, dans leur partic moyenne, c'est-à-dire dans le point où les deux utricules sont soudées, une petite membrane en forme de diaphragme, qui empêche les deux utricules de communiquer ensemble. Il est quelquefois très difificile d'apercevoir la petite membrane dont nous venons de parler, parce qu'en eflet elle cst excessivement mince; il arrive même que dans certaines circonstances, surtont par les progrès de la végétation, elle ne finisse par disparaître complètement. C'est dans ce cas là seulement qu'on peut admettre l'existence de pores, e'est-à-dire de perforations traversant complètement l'épaisseur des parois des utricules. Mais ces ou. 
veriures sont purement accidentelles, et le résultat de la destruction d'une partie du tissu, et non de l'organisation.

C. Matières contenues dans les utricules. - Les utricules conticanent des matières de nature diverse. Tantôt ces matières sont liquides, tantôt elles sont solides, tantôt enfin elles sont gazeuses.

10 Dutieres liquides. - Une branche trds jeune ou tout autre organe végétal examiné daris la première période de son développement offre un tissu cellulaire dont les utrirules ont non seulement les parois plus épaisses, mais encore la cavité remplic par un liquide aqueux, qui n'est autre chose que (ie la sève. Par les progrìs de la végétation, et à mesure que les organes foliacés se développent, ces sucs aqueux disparaissent: les parois des utricules s'amincissent, se sechent; et souvent le tissu utriculaire finit par former une masse spongicuse, sèche et légère, qui ne contient plus que de l'air dans ses carités.

La sève n'es: pas le seul liquide qu'on trouve dans les utricules du tissa cellulaire; il peut y exister encore des huiles de difrérente nature, volatiles ou grasses. Ainsi, l'huile grasse est abondante dans le parenchyme du péricarpe de l'olivier, dans l'endosperme charnue des Kuphorbiaccés, dans l'mmbryon des Cruciferes, de beaucoup de rosacées, etc.

2o Matieres gaznuses. - La présence de I'air atmosphérique est incontestable dans le tissu cellulaire des végétaux. L'air, en eflet, est absorbé dans une foule de circonstances, et sert à la nutrition de la plante; on y trouve de plus de l'acide carbonique, quelquefois de l'azote, etc. Rien n'est plus facile que de constater la présence des gaz dans le tissu des végétaux. Il suffit de recouvrir d'eau et de placer sur le porte-objet du microscope un fragment très mince du tissu à examiner; on voit alors un grand nombre de petites bulles opaques, adhérant chacune aux utricules ouvertes. Ces petites bulles sont formées par l'air ou par les autres gaz renfermés dans les cavités, ef rui se roient comme autant de points onarues. C'est mème cette opacité qui constate la présence de l'air dans les organes élémentaires des végétaux.

$\overline{3}^{\circ}$ Matieres solides. - Les matiores solides renfermées dans l'intélieur des utricules sont $1^{\circ}$ la fécule, $2^{\circ}$ la matière colorante ou chromule, $5^{\circ}$ les jeunes utricules, au moment où elles s'organisent ou le cambium solidifié, $4^{\circ}$ enfin les matières cristallisées ou les raphides et autres cristaux.

A. La fécule ou amidon. - Rien de plus commun dans le tissu utriculaire que les grains de fécule, qui quelquefois en remplissent presque complètement les cavités; d'antres fois ysont peu abondants et en quelque sorte clairsemés. La fécule existe dans le tissu cellulaire de presque toutes les parties des végétaux, dans les racines, les tiges, les feuilles, le péricarpe, les divers organes de la graine, etc. Elle se montre sous la forme de petiis corps plus ou moins sphéroïdaux, mais souvent d'une forme allongée ou irrégulière, parfaitement transparents et incolores, primitivement adhérents à la paroi interne de l'utricule, mais qui en sont souvent détachés, et, par conséquent, libres dans la cavité. On s'est particulièrement occupé, depuis un certain nombre d'années, non seulement des propriétés chimiques de la fécule, mais encore de sa constitution physique, ou, pour mieux dire, de son organisation. (V. Amidon et Fécule amilacée.)

B. La chromule ou matiere colorante.Le tissu utriculaire, comme nous l'avons dójà exposé précédemment, est formé d'utricules à parois minces et tout à fait incolores. Cependant, quand on examine ce tissu dans un grand nombre d'organes, dans les feuilles par exemple, ou l'enveloppe herbacée des jeunes tiges, il se montre sons l'apparence d'une masse colorée en vert. Cette coloration n'est pas propre au tissu lui-mê-me, mais provient d'une matière colorée qu'il contient; c'est cette matière qu'on désigne sous les noms de chromule, de matière colorante ou de chlorophylle. Mais le nom de chromule doit être préféré, parce qu'il exprime que c'est.ce corps qui colore, sans indiquer la teinte. En effet, toutes les autres colorations, et souvent si brillantes, que présentent les diverses parties du végétal, sont dues à la présence d'une matière tonjours la mîme dans sa siruchure, et dont la teinte seule varic. Cette matière ofire une véritable organisation. Ce sont encore des globules, ou plutôt des esmeces d'utricules contenant dans leur intopa 
rieur des corps plus petits, eux-memes composés; en un mot, il y a, pour plusieurs whytotomistes, une sorte d'emboitements indénnis d'utricules de plus en plus peities. Nous ferons connaître avec plus de déiails, au mot Chromule, cette organisation, et surtout les observations curienses que M. Mohl a récemment publiées sur la chlorophylle. F. GMPOMUUT.

C. Raphides. - Le tissu cellulaire de la tige et de la racine d'un grand nombre de végétaux contient, dans l'intérieur même des utricules, des amas réguliers de petits corps aciculaires, raides ef pointus aux deux extrémités, que Ir. De Candolle a désignés sous le nom de Raphides. Les Maphides avaient été parfaitement observées et décrites par plusieurs anatomistes. Ce sont, ainsi que II ieser l'avaid reconnu depuis long-temps, des eristaux excessivement grêles et allongés, le plus souvent d'oxalate, quelquefois de phosphate de chanx. Ces raphides sont toutes réunies parallèment entre elles, et quelquefois remplissent complètement l'utricule.

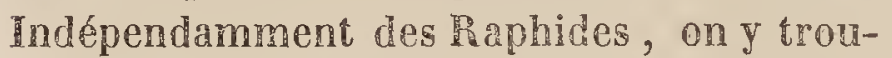
ve encore quelquefois d'autres cristaux de forme variće : ce sont tantôt des cristaux prismatiques et diversement groupés, tantôt des cristanx isolés. Ainsi, par exemple, dans plusieurs plantes de la famille des Amomées, j’ai observé des cristaux rhomboédriques, rappelane tout à fait la forme du carbonate de chaur.

D. Cambium. - Enfin les utricules contiennent fréquemment une matière qui, après avoir été liquide, se solidifie petic à petit, s'organise, passe par tous les états intermédiaires, depuis la forme mamelonnée jusqu'à celle d'utricules parfaites, et servant ainsi à la multiplication et à l'accroissement de toutes les parties de la plante. Cette matiòre est le cambium, dont 1 F. de Mirbel a si bien étudié dans ces derniers temps les développements successifs, avec cette sagaciće, cette persévérance et ce génie d'observation, qui caractérisent les travaux de ce savant physiologiste. (V. Cambium.)

Lacunes. - A mesure que les organes de la plante se dévelopnen el s'accroissent, lo tissu uiriculaire qui entre dans leur composition s'étend et se multiplie; mais, lorsque cet accroissement est tres rapide et très con- sidérable, comme dans les végétaux herbacés, le tissu atrieulaire se déchire, et il se forme dans l'intéricur des organes des cavités accidentelles, qu'on désigne sous le nom de lacunes. Ces lacunes sont ordinairement le résultat de la déchirure et de la destruction partielles du tissu intriculaire. Elles sont communes dans l'intérieur des tiges et des feuilles d'un grand nombre de végétaux qui vivent au voisinage des eaux, comme les joncs, les sagiutaires, etc. La cavité très grande qu'on observe dans la tige d'un grand nombre de Graminées, d'Ombellifères, et de plusieurs autres plantes herabacées dont la croissance a ćté très rapide, est une véritable lacune. La moelle contenue dans l'intérieur des hranches du noyer présente un grand nombre de cavités superposées, séparées les unes des autres par des cloisons minces, et qui sont aussi des lacunes. Leur cavité n'est pas tapissée par une membrane propre, mais seulement par une membrane accidentelle, résultant de la condensation du tissu utriculaire, un dépens duquel elle a été formée. Leur forme est extrêmement yariable, le plus souvent elle es très irrégniiere; d'autres fois, au contraire, elles ofrent une certaine régularité. Les réservoirs connus sous les noms de vaisseaux propres dans les Coniferes, les Térébinthacées, etc., et qui sont remplis de térébenthine ou de sucs gommo-résineux, sont une forme particulière de lacunes.

Tissu fioroso-utriculaire. - Le tissu cellulaire que nous avons décrit jusqu’à présent est, en quelque sorte, cet élément anatomique à son état de pureté primitive, et c'est ainsi, en effet, qu'on l'observe dans le plus grand nombre des cas; mais il présente que?quefois une modification toute spéciale, et qui a été très bien étudiéc dans ces derniers icmps. Les parois des utricules, au lieu d'être simples, présentent une ligne spirale ou spiricule contonrnée sur elle-même, et dont la disposition varie beaucoup. C'est à celte modification qu'on a domé les noms de $c e l-$ lules foreuses, tissu fibroso-ulriculaire.

Le tissu fibroso-utriculaire existe dans plusieurs parties des végélaur, les feuilles, les racines, la moelle, les anthères, le tégument des graines. $\mathbb{L}$ premier auteur qui ait sórieusement appclé l'attention des phytotomistes sur ce point est le docteur purkinje, 
ษans sa dissertation sur ces cellules fibreuses des anthères. Depuis celte époque, un grand nombre d'antres auteurs ont fait connaitre ce tissu dans presque toutes les parties des végétaux. Il nous suffira de citer ici les noms de Mril. de Mirbel, R. Brown, Lindley, Slack, Meyen, Schleiden, etc.

Lorsque les tours de la spiricule sont contigus, l'existence d'une membrane extérieure est bien moins évidente, et elle a même été niće par quelques auteurs, parce qu'au premier abord la spiricule se déroule sans apparence de déchirure, comme nous l'observerons bientôt dans les vaisseauz aériens, désignés sous le nom de trachées. Mais cette membrane n'en existe pas moins, comme nous le montrerons plus tard, quand nous parlerons en son lieu du mode de formation de ces utricules. D'autres fois, la spiricule forme des tours plus ou moins écartés, ou bien elle est interrompue en certains endroits; ou enfin une même utricule peut offrir deux spiricules enroulées en sens contraire, et formant une sorte de réseau à mailles quelquefois très régulières.

\section{GII.-Du tissu fibreux ou ligneux.}

Si l'on examine la structure du bois dans un chêne, un peuplier ou tout autre arbre dicotylédoné, on voit qu'il se compose de fibres immódiatement juxtaposées les unes à côté des autres. Ces fibres se composent de cellules très aliongées ou de vaisseaux fori courts, toujours terminés en pointe à leurs deux extrémités, et présentant une épaisseur considérable, eu égard à la petitesse de lcur diamètre intérieur. Le mûme tissu s'observe dans les couches de l'écorce, les nervures des feuilles, aussi bien dans les végétaux monocotylédonés que dans les végétaux dicotylédonés, soit herbacés soit ligneux. Ce tissu tient en quelque sorte le milieu entre le tissu utriculaire proprement dit et les véritables vaisseaux. On l'a tour à tour désigné sous les noms de tissu allongé, prosenchyme, tubilles, tubes ouvaisseaux fibreux, olosires, tissu ligneux.

On peut distinguer trois modifications principales dans ce tissu : 10 les uiricules 仿breuses ou cellules allongees, qui, par leur forme et leurs dimensions, ressemblent fout à fait aux utricules da tissu celinhirc, dont elles dinèrent par l'épaisseur de leurs parois, et leurs extrémités coupées obliquement en pointe; 20 les clostres ou tubes fusiformes, très distincts par leurs extrémités amincies en pointe aux dépens de chacun de leurs côtés, ct lenr forme de fuseau très allongé; $7^{\circ}$ enfin les ubes fibreax proprement dits, égaux en diamètre dans toute leur longueur, et ayant leurs extrémités coupées en pointe oblique et unilatérale. Mais cependant ces trois formes ne soni pas si disfinctes quo l'on ne puisse trowver facilement des interméciaires de l'une à l'autre dans un même végétal, et souvent dans un même organe. Tloutes les fibres textiles extraites des végétaux, et qui servent à la fabrication des cordes et des fils, et, en particulier, celles du lin et du chanvre, sont formées par ce tissu, qui ofire une force de résistance extrêmement considérable.

L'organisation de ce tissu est tris remarquable, et le distingue des utricules et des vaisseaux. Leurs parois sont iransparentes, diaphanes, mais d'une épaisseur extrêmement considérable; elles sont formées de plusieurs couches superposées et intimement soudées entre elles. Les vaisseaux fibreux paraissent à leurs deux extrémités pointues; cependant M. Slack assure leur avoir vu présenter quelquefois une très petite ouverture de communication.

\section{SIII. - Du lissu vasculaire.}

Les vaisseaux ne sont qu'une modification des utricules; c'est ce qu'il nous sera facile de prouver quand plus tard nous traiterons de l'organogénie végétale, ou de l'origine et du mode de formation primitive des éléments anatomiques des plantes. Ce sont des tubes tantôt cylindriques, tantôt angưleux, isolés ou réunis en faisceaux simples ou ramifiés, et qui varient beaucoup quant à leur structure et aux fluides qu'ils contiennení. Sous ce dernier point de vue, on peut admettre deux sortes principales de vaisseaux : 10 les vaisseaux séveux, destinés à contenir la sève; $2 \circ$ les vaisseaux aériens, qui contiennent de lair ou tout autre gaz. Sans doute cette distinction n'est pas à l'abri de tout reproche, en ce qu'elle tranche une question encore en lifige pour quelques phytolomistes, pour qui les trachées et leurs 
modifications sont les principaux conduits de la sève. En effet, dans quelques circonstances, Ies vaisseaux pneumatophores peuvent contenir les sucs séveux; mais c'est par exception, et leur principale fonction est de servir à la respiration du végétal, comme nous le démontrerons plus tard.

I. Vaisseaux séveux. - La nature, la disposition, la structure é la position des vaisseaux séveux, ne sont bien connues que depuis un petit nombre d'années. MI. le professeur Schultz de Berlin est le premier qui les ait décrits avec exactitude, et qui ait étudié leur disposition générale dans toute la série des végétaux qui les contiennent. Il leur a donné le nom de vaisseaux laticifères, parce qu'ils ne contiennent que la sève élaborée, c'est-à-dire déjà propre à se convertir en cambium ou matrice de l'organisation, et qu'en latin on désigne sous le nom de latex.

Ce sont des tubes simples ou ramifiés, complètement clos, à parois transparentes, sans apparence de ponctuations ou de lignes transversales; cylindriques quand ils sont isolés, prismatiques et anguleux quand ils sont réunis en faisceaux. Selon II. Schultz, ils peuvent se présenter sous trois élats différents, qui ne sont probablement dus qu'a des différences d'âge : 10 en état de contraction; 2o en état d'expansion; 5̃o en état d'articulation. Le latex ou sève élaborée est un suc ordinairement coloré, rarement incolore, et contenant des granules organiques, qui permettent d'én suivre le mouvement dans les différentes parties des vaisseaux.

Les vaisseaux du latex n'occupent pas la mème place dans les végétaux dicotylédonés et dans les végétaux monocotylédonés; en général, ils ne sont pas très abondants. Dans la tige des premiers on ne les observe guère que dans le parenchyme cortical, tantôt isolés, tantôt en faisceaux, tantôt enfin constituant une couche continue ou à peu près continue. Bans la tige des Monocotylédonés, ils font partie des fâisceaux ligneux épars au milieu du parenchyme qui constitue sa masse. On les trouve encore dans toutes les parties herbacées de la plante accompagnant les vaisseaux aériens.

Sous le nom de vaisseaux propres, on a, selon nous, confondu des organes fort différents. Ainsi on a donné ce nom: 1 o tantôt aux réservoirs qui, dans l'écorce des Coniferes et
des'Térébinthacées, contiennent les sucs résineux, et qui ne soní que des lacunes vasiformes; 20 tantòt aux espaces intercellulaires qui, à une certaine époque, se dilatent. pour recevoir la sève; 3o tantôt aux fibres du liber; $4^{\circ}$ enfin aux véritables vaisseaux laticifères. De tout ceci il résulte qu'on ne peut aujourd'hui admettre de vrais vaisseaux propres, tels qu'on les entendait autrefois; mais que les sucs propres peuvent être contenus soit dans des lacunes vasiformes, soit dans un systeme de vaisseaux particuliers, ramifiés et anastomosés entre eur, et qu'on nomme vaisseaux laticiferes.

II. Vaisseaux aériens. - Tous réunissons ici sous le nom de vaisseaux aériens $1^{\circ}$ les trachées, 20 les fausses trachées, $5^{\circ}$ les vaisseaux réticulés, $4^{\circ}$ les vaisseaux ponctués.

10 Des trachées ou vaisseaux en spirale. Ce sont des tubes communément cylindriques, ayant une analogie frappante avec les vaisseaux aériens des Insectes, auxquels ils ont emprunté leur nom. Ce qui distingue essentiellement ces vaisseaux, $c^{7}$ est qu'ils se composent d'un corps filiforme ou d'une lame mince et très étroite, que j'ai désignée sous le nom de spiricule, et qui est contournée sur cllc-même en hélice. Tantôt les tours de la spiricule sont contigus, et ne laissent aucun intervalle entre eux; tantôt, au contraire, ils sont plus ou moins éloignés. Dans le premier cas, il est à peu près impossible de constater l'existence d'un tube extérieur, à l'intérieur duquel la spiricule est appliquée; mais ce tube est évident quand les tours de la spiricule sont écartés. Ce tube est excessivement mince, diaphane, sans stries ni pores, et son existence, incontestable dans cette dernière circonstance, peut porter à l'admettre, même dans le cas où l'on ne peut la constater directement.

La nature de la spiricule n'est pas encore bien déterminée. Quelques phytotomistes admettent qu'elle est̂ creuse, c'est-à-dire que c'est un tube cylindrique ou comprimé; d'autres, au contraire, pensent que c'est un corps plein et solide. Nous reviendrons plus en détail sur ce sujet quand nous traiterons spécialement des trachées.

La spiricule ofre ordinairement une assez. grande régularité dans tous les points de son étendue; et quand les tours sont écartés, ils sont généralement espacés d'une manière à 
peu près égale; d'autres fois, au contraire, on remarque une certaine irrégularité dans la disposition des tours. Une de ces formes les plus remarquables, c'est quand la spiricule, après plusicurs tours continus, est interrompue, constitue plusieurs anneaux complets, et plus loin forme encore des spires continues. Nous avons observé cette modification des trachées dans les faisceaux ligneux de la canne de Provence (arundo donax L.), et nous lui avons donné le nom de vaissenux spiro-annulaires.

Les trachées ont une position bien déterminće, et qui varie dans les deux grandes classes de végétaux cmbryonés, les scules où elles existent. Ainsi, la tige des Dicotylédonés ne les présente que dans la partie de la couche ligneuse la plus intérieure qui environne la moelle, en un mot dans les parois de l'étui médullaire; nulle part ailleurs de la tige on n'observe ces vaisseaux. Dans les tiges des Monocotylédonés, ils font partic des faisceaux vasculaires et ligneux épars dans toute leur épaisseur, et généralement ils occupent la partie centrale de ces faisceaux. On les y retrouve encore dans les pétioles, les nervures des feuilles, et les diverses parties de la fleur qui ne sont que des modifications des feuilles. On a cru pendant long-temps que les racines en étaient dépourvues; mais nous en avons constaté l'existence dans les racines des plantes dicotylédonées où il existe un canal médullaire, et dans celles de plusieurs Monocotylédonés.

$2 \circ$ Des vaisseaux réliculés. - Ges vaisseaux ne sont probablement qu'une simple modification des trachées, dans laquelle la. spiricule, au licu d'être enroulée régulièrement et d'une manière continue, est irrégulièrement ramifiée et anastomosée, de manière à former un réseau à mailles très irrégulières. Je les ai souvent observés dans les racines; mais ils existent aussi dans la tige, celle de la Balsamine par exemple.

$5^{\circ}$ Vaisseaux rayés. - On a nommé ainsi des vaisseaux qu'on trouve abondamment répandus dans un grand nombre des organes de la plante. Ils sont simples, cylindriques ou anguleux, quand ils sont réunis en faisceaux, et ofrent, pour caracteres distincts, des lignes transversales qui n'occupent qu'une portion de la circonférence des vaisseaux. On a émis sur la nature de ces lignes des opinions

T. 1 . très diverses. Ciertains auteurs les ont regardées comme des fentes entourées d'un bourrelet : de là la dénomination de vaisseaux, fendus; d'autres, comme de simples lignes (vaisseaux rayés); quelques uns, comme des trachées incomplètes, dont la spiricule est irrégulière et interrompue (fausses trachées). Nous reviendrons sur ces diverses opinions quand nous ćtudierons avec plus de détails la structure intime de ces vaisseaux. Nous avons dit tout à l'heure que les raies transversales qui caractérisent cette sorte de vaisseaux étaient quelquefois irrégulières et inégales; c'est ainsi qu'on les observe dans le plus grand nombre des cas, et, en particulier, dans les faisceaux ligneux de la tige des plantes monocotylédonées. Mais il arrive aussi que parfois ces vaisseaux, surtout quand ils sont réunis en faisceaux, présentent ces lignes bien égales et symétriquement disposées les ines au dessus des autres. C'est à cette forme particulière qu'on a donné le nom de vaisseaux scalariformes. On les trouve très abondamment répandus dans les divers organes des plantes de la famille des Fougères.

Fous avons quelquefois observé que Ies vaisseaux rayés ou scalariformes se séparaient en lanières roulées en hélices, à la manière des vraies trachées. Nous en figurerons un exemple dans les planches de cet ouvrage consacrées à l'Anatomie végétale, que nous avons dessiné d'après une tige ligneuse d'une espèce de fougère.

4o Vaisseaux ponctués.-Ils sont aussi extrêmement communs dans l'organisation végétale, et, en particulier, épars au milieu du tissu ligneux de la tige des plantes dicotylédonćes. On leur a donné les noms de vaisserux ponclués ou vaisseaux poreux, suivant l'opinion qu'on s'était forméc de la nature de ces ponctuations. Ce sont, comme les précédents, des tubes ordinairement cylindriques, plus rarement anguleux, présentant des ponctuations très fines, rangées symétriquement en lignes transversales. Ces lignes transversales sont souvent interrompues par des espèces de bandes longitudinales qui ne présentent pas de ponctuations.

Telles sont les principales formes sous lesquelles se montre le tissu vasculaire des végétaux. Quant à l'origine et au mode de formation primitive des vaisseaux, nous en trai- 
terons spécialement au mot $V$ aisseaux des plantes, et au mot Organogénie.

Nous résumerons ici en forme d'aphorismes les principaux points de l'organisation végétale, dont nous venons de donner une ỹdée succincte.

\section{Aphorismes sur l'organisation des végétaux.}

1. Les végétaux sont composés originairement d'un scul élément anatomique, l'utricule, vésicule membraneuse, dont la forme et la structure, en se modifiant, produisent trois sortes de tissus élémentaires : 10 le tissu cellulaire ou utriculaire; 2 o le tissu fibreux ou ligncux; $5^{\circ}$ le tissu vasculaire ou les vaisseaux.

\section{\$. Tissu utriculaire.}

II. Le tissu utriculaire est la base de l'organisation végétale.

III. Il est composé d'utricules ou vésicules closes de toutes parts, primitivement globuleuses, se soudant ensemble, ê qui, par la pression égale qu'clies exercent les unes sur les autres, prennent communément une forme polyédrique, le plus souvent dodécaédrique.

IV. Dans une masse tissulaire, les lames membraneuses qui séparent les utricules les unes des autres sont formées de deux feuillets appartenant chacun à l'une des deux utricules contiguès.

V. La forme des utricules varie beaucoup; elles sont ou polyédriques ou prismatiques, quelquefois très irrégulières.

VI. Il Y a des utricules de forme irrégulière et anomale, et qui semblent résulter de plasicurs utricules soudées.

VII. Les utricules soudées d'une masse de tissu cellulaire laissent, dans les points où elles ne se tonchent pas, des espaces vides, ordinairement triangulaires, qu'on nomme méats ou conduits intercellulaires.

VII. La membrane des utricules est en général diaphane, et ne présente aucune ouverture appréciable.

IX. Les prétendus pores ou fentes qu'on observe quelquefois ne sont que des amincissements ponctiformes ou linéaires des parois; cependant, par les progrès de la végéta- tion, ces amincissements deviennent quelquefois de véritables ouvertures; mais ces ouvertures sont accidentelles.

$\mathbf{X}$. Les utricules ne communiquent entre elles que par des pores intermoléculaires e tout à fait invisibles.

XI. Il y a des utricules qui contiennent intérieurement une lame plane ou filiforme, roulce en spirale de différentes manières. Cette modification porte le nom de tissu fibroso-utriculaire ou cellules fibreuses.

XII. Les utricules contiennent des matieres gazeuses, liquides ou solides.

a. Zues matieres gazeuses sont principalement de l'air, souvent plus ou moins altéré.

$b$. Les liquides sont la sève, les huiles grasses ou volatiles, etc.

$c$. Les solides sont :

10 Le cambium, s'organisant insensiblement, ct prenant petit à petit toutes les formes du tissu utriculaire;

2o La chromule, chlorophylle ou globuline, matière colorante, de teinte très variée, composée de petites vésicules contenant des granulations colorées. C'est elle qui donne leur coloration spéciale à toutes les parties. du tissu végétal;

$3^{\circ}$ La fécule ou amidon, sous forme de grains plus ou moins globuleux ou cylindriques, incolores, d'une grosscur variable, suivant les espèces, se colorant en bleu par la tcinture d'iode;

$4^{\circ}$ Les raphides, petits cristaux sous forme d'aiguilles, terminées en pyramides pointues à leurs deux extrémités, et réunies en faisceaux;

5o Des cristaux ou tables rhomboédriques;

$6^{\circ}$ Les biforines, utricules allongées en forme d'hexagone, ouvertes ì leurs deux extrémités, contenant une seconde utricule intéricure plus étroite, remplie de cristaus aciculaires.

XIII. Les lacunes sont des cavités plus ou moins grandes qui se forment au miliev du tissu cellulaire, ordinairement par suite de la destruction d'une partic des uiricules quis le composent.

XIV. Le tissu utriculaire pent se multiplier de trois manières différentes :

1o Par addition de nouvelles utricules it l'extéricur des anciennes, accroissement extra-utriculaire; 
2. Par développement de nouvelles utricules entre les anciennes, accroissement inter-utriculaire;

$\tilde{\jmath}^{\circ}$ Par formation de nouvelles utricules dans l'intérieur des anciennes, accroissement intra-ulriculaire.

\section{@ II. Tissu fibreux.}

XV. Le tissu fibreux a reçu les noms de tissu allongé, tissu ligneux, prosenchyme, vaisseaux fibreux, lubilles, clostres, etc.

$\mathbf{X V I}$. Il est composé de cellules très allongées ou de tubes très courts, terminés en pointe à leurs deux extrémités, toujours simples.

XVII. En se pressant les uns contre les autres, les tubes fibreux prennent des formes très variées.

XVIII. Leurs parois sont généralement très épaisses, et leur cavité intérieure assez petite. Elles sont souvent composées de plusieurs couches superposées, qui apparaissent sur la coupe transversale comme autant de zones concentriques, emboîtées les unes dans les autres.

XIX. Les tubes fibreux peuvent offrir des enfoncements ponctiformes (pores) ou linéaires (fentes); ils présentent aussi, mais plus rarement, un fil intérieur roulé en spirale.

XX. En s'ajustant bout à bout, ils constituent les parties fibreuses, non vasculaires, de la plante, et, en particulier, le tissu du bois et celui du liber.

\section{QIII. Tissu vasculaire.}

XXI. On distingue deux espèces principales de vaisseaux, suivant la nature du fluide qu'ils contiennent : $1^{\circ}$ les vaisseaux séveux; yo les vaisseaux aériens.

\section{Vaisseaux séveux.}

XXI. Les vaisseaux désignés sous le nom de vaisseaux moniliformes ne sont que des séries d'utricules superposées, et dont la paroi horizontale finit quelquefois par se détruire.

XXIII. Les vaisseaux latexiferes ou laticiféres, ainsi appelés parce qu'ils contiennent le suc élaboré ou lalex, sont les conduits spéciaux de la sève descendante.

XXIV. Ce sont des \&ubes complètement clos, à parois ordinairement minces et transparentes, quelquefois d'une épaisseur considérable, cylindriques ou angulenx, simples ou rameux, et fréquemment anastomosés.

XXV. Ces vaisseaux existent au milieu des faisceaux vasculaires, épars dans la masse de la tige des plantes monocotylédonées.

XXVI. Dans les plantes dicotylédonées, ils sont épars dans le tissu cortical, ou forment des faisceâux ou une enveloppe continue autour du corps ligneux. On les trouve aussi quelquefois épars dans la moelle.

XXVII. Sous le nom de vaisseaux propres on a confondu: $1^{\circ}$ des lacunes ou cavités accidentelles dans lesquelles s'accumulent les sucs résineux; $2^{\circ}$ les méats intercellulaires; $3^{\circ}$ les vaisseaux du latex. Il n'y a donc pas de vaisseaux spéciaux qui puissent conserver le nom de vaisseaux propres.

\section{$2^{\circ}$ Vaisseaux aériens.}

XXVIII. Tous les vaisseaux pourvus d'une spiricule ou lame spirale, ou ceux qui présentent des enfoncements soit linéaires, soit ponctiformes, constituent les vaisseaux aériens. Les trachées, les vaisseaux rayés, ponctués ou réticulaires, en sont les principales formes.

XXIX. Les trachées sont des tubes cylindriques contenant un corps mince et filiforme nommé spiricule, roulé en hélice dans leur intérieur.

XXX. L'existence du tube n'est pas toujours très évidente. Il est presque impossible de la constater quand les tours de la spiricule sont très rapprochés et presque contigus; quand, au contraire, ils sont écartés, son existence ne saurait être niée.

XXXI. La spiricule est tantôt plane, présentant la figure d'une lame très étroite, tantôt filiforme et cylindrique.

XXXII. Malgré les assertions contraires de plusieurs observateurs, la spiricule m'a toujours paru pleine et non creuse intérieurement.

XXXII. La spiricule peut ètre simple 0 bifurquée.

XXIY. Assez souvent, deux, trois, ou un plus grand nombre de spiricules, se soudent ensemble, et se déroulent en formant un ruban strié.

XXXV. Les trachées sont ordinairement simples; très rarement elles se ramilient. 
XXXVI. La spiricule, au lieu d'ètre continue, forme quelquefois des anneaux complets et parfaitement distincts, placés au milieu de tours en spirale interrompus. Ces vaisseaux pourraient être appelés vaisseaux spiro-annulaires.

XXXVII. Les trachées, dans les tiges dicotylédonées, n'existent qu'aux parois de l'étui médullaire; on les trouve aussi dans les pétioles, les nervures "des feuilles, les filets des étamines, les enveloppes florales.

XXXVIH. Dans la tige des Monocotylédons, elles sont placées dans les faisceaux ligneux qui y sont épars.

XXXIX. On trouve des trachées dans les fibres radicales, particulièrement dans les plantes monocotylédonées.

XL. Les vaisseaux réliculés sont une modification des trachées dans laquelle la spiricule est irrégulière, ramifiée, anastomosée, et non déroulable.

$\mathrm{X}$ I. Les vaisseaux rayés, improprement appelés vaišeaux fondus, sont des tubes cylindriques ou anguleux, qui présentent des parties amincies sous la forme de lignes.

XLII. Ces lignes amincies peuvent être très étroites, ou avoir une certaine largeur. Elles sont ordinairement disposées régulièrement les unes au dessus des autres.

XLIII. Les vaisseaux scalariformes ne sont qu'une modification des vaisseaux rayés, dans laquelle les lignes transversales ont plus de longueur et de régularité.

XLIV. Les vaisseaux ponclués ou poreux sont des tubes cylindriques présentànt des enfoncements ponctiformes, disposés régulièrement.

XLV. Dans les vaisseaux ponctués et rayés, les prétendus pores et les prétendues fentes sont toujours bouchés extérieurement par une membrane mince et transparente, dont il est cependant facile de reconnaître l'existence.

XLVI. Ces deux sortes de vaisseaux se trouvent dans l'épaisseur des couches ligneuses des végétaux dicotylédonés, ou dans les faisceaux vasculaires des Honocotylédons, dans les racines, les feuilles, etc.; mais jamais dans l'écorce.

XLVH. Il existe un passage insensible des vaisseaux ponctués aux vaisseaux rayés, des vaisseaux rayés anx vaisseaux réliculés, des vaisseaux réticulśs an trachées: donc les vaisseaux ponctués, rayés et réticulés, ne sont probablement que des modifications des trachées.

XLVIII. Les vaisseaux n'existent pas dans la plante excessivement jeune ou dans les organes, dès le premier moment de leur apparition. A cette première période, la plante tout entic̀re n'est encore composée que du tissu utriculaire.

XLIX. Les vaisseaux, de quelque nature qu'ils soient, tirent leur origine du tiss utriculaire.

(A. RICHARD.)

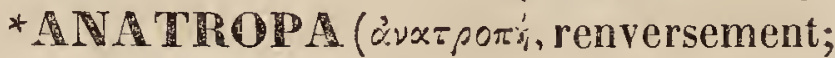
parce que l'ordre semble interverti dans quelques caract. de ce $\mathrm{g}_{\text {。 }}$ ). вот. P耳. - M. Ehrenberg a établi ce g. d'après une petite plante berbacée d'égypte, et il le caractérise ainsi : Calice à 4 dents, dont la préfloraison est valvaire; 4 pétales alternes; 4 étamines hypogynes attenant aux pétales, libres, persistantes; un ovaire simple à 4 lobes obtus; un style simple et court, s'élargissant en massue et se terminant en un stigmate également simple; une capsule à péricarpe un peu charnu, à 4 lobes, auxquels correspondent autant de loges, et qui se séparent, à la maturité, en autant de valves. Un faisceau placentaire central envoie dans chaque loge une branche horizontale épaissie en massue, à l'extrémité de laquelle viemnent s'attacher $4-5$ graines menues. Feuilles alternes, pinnatifides, munies de 2 stipules en forme d'oreillette à leur origine; les premières sont cependant opposées et cntières. - L'auteur rapporte ce g. à la fam. des Zygophyllées, desquelles pourtant semblent l'écarter ses feuilles alternes et ses fleurs isostémones. Si, comme on peat le soupsonner, c'est le même que le Tetradyclis de Marschall, sa place serait en efiet fort différente, et quelques uns de ses caráctères devraient être modifiés, en ajoutant ceux de l'embryon, qui est dépourvu de périsperme, et tout à fait analogue à celui des Elatinées.

(AD. I.)

* ANA TROPF. Anatropus ( $\dot{\alpha} \cdot \dot{\alpha}$, sur;

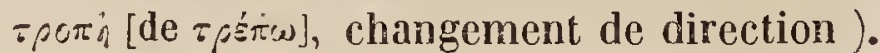
вот. PIr. - Dénomination appliquée par M. de Mirbel aux ovules chez lesquels l'exosiome et la chalaze sont diamétralement opposés, comme cela a lieu dans les Orthotropes; ou, en d'autres termes, lorsque la secondine et le nucelle, inclinés sur leur axe, 
se renversent complètement; mais alors le hile se trouve rapproché de l'exostome, et séparé de la chalaze par un raphé qui se prolonge sur l'ovule. Tel est le cas des Liliacées, des Rusacées, des Cucurbitacées, des Composées, des Rutacées, etc.

(C. L.)

ANAULACE. Anaulax ( $\alpha$ priv.; v euphon.; ajixร, sillon ou suture). moLL. M. de Roissy, craignant qu'il ne s'introduisît quelque confusion entre les g. Ancyle de Müller et Ancyle de Lamarck, proposa de substituer à ce dernier nom celui d'Anaulace; mais ce changement n'a pas été adopté. Voy. ArGuLAIRE.

(DESH.)

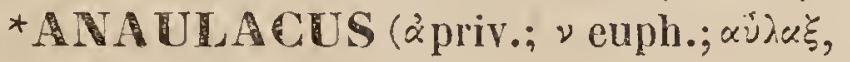
sillon). Ixs. - G. de l'ordre des Colćoptères pentamères, famille des Carabiques, tribu des Harpaliens, établi par Mac-Leay dans son ouvrage intitulé : Annulosa javanica, et auquel il assigne les caract. suivants : Ant. moniliformes, épaisses, à peine de la longueur de la tête; les $2^{\mathrm{e}}$ et $5^{\mathrm{e}}$ articles presque égaux. Labre court, large, carré transversalement, à angles obtus, à peine échancré antérieurement. Mandibules larges, triangulaires, courbées du côté externe. Dernier article des palpes maxillaires court, cylindrique, à peine plus mince à son extrémité. Paraglosses distinctes, minces, cylindriques, membraneuses. Menton trilobé. Tête triangulaire, très petite, bi-sillonnée entre les ycux. Prothorax deux fois plus large que long, échancré antérieurement, à peine convexe postéricurement, très légèrement canaliculé. Corps cntier, un peu déprimé, large, avec l'abdomen sessile. Ecusson non visible. Silytres à peine bordées. Les quatre pattes postérieures spinuleuses. - Ce g. est fondé sur une scule esp., nommée par l'auteur A. sericipennis, et figurée dans son ouvrage, $p l$. . $;$, fig. 1. Elle a été rapportée de Java par le docteur Horsfield.

ANAULAX. MOLL. - Voyez ANAUACE.

ANAUNGR, Lamk. (nom d'un arbusie au Malabar). БoT. MR. - Syn. du g. Casearia, Jacq. (famille des Samydées).

(SR.)

* ANAX (nom mythol. d'丷̋, 2 , roi, prince). INs. - G. de la famille des Libelluliens, de l'ordre des Névroptères, établi par Leach (Edinb. Encycl.), adopté par MM. Curtis, Stephens, Westwood, réuni au g. Zeshna ou Aschna par M. Burmeister (Handb. der Ent.), et regardé de nouveau comme genre distinct par M. de Selys-Longchamps (Monog. des Libellul.). Le g. Arax ne diffère récllement des Fshria que par les ailes postérieures, dont le bord anal est arrondi dans les deux sexes, tandis qu'il est anguleux chez les mâles des Eshra, qui ont encore, de chaque côté du deuxième segment de l'abdomen, un petit tubercule manģuant chez les Arax. On connaît 8 ì 10 esp. de ce genre ou plutôt de cette division de genre, dont trois seulement sont européennes. Le type est l'A. formosa (Ashria formosa Vand. Linden., - azurea Charp., et Anax irreperalor Leach), répandue dans une grande partic de l'Europe.

(BL.)

* A A MOPE (Anaxagoras, philosophe grec). BOT. PH. - G. de la famille des Anonacées, établi par M. Aug. de SaintHilaire (Bull. de la Soc. philom., 1825, p. 91), qui lui assigne les caract. suivants : Cal. 5parti. Gor. de 6 pétales 2 -sériés, connivents; les 5 intéricurs plus petits. Réceptacle convexe, hypogyne, tronqué au sommet. Etam. très nombreuses, claviformes. Anthères subsessiles, appendiculées au sommet. Ovaires 8 à 15 , distincts, 2-ovulés; ovules attachés au fond-des loges, renversés. Styles très courts, continus. Stigm. terminaux, soudés en disque. Follicules coriaces, stipités, obovés, 1-loculaires, subclaviformes, 2spermes, s'ouvrant incomplètement par la suture ventrale. Graines basifixes, inarillées, collatérales, obovées, planes et 1-sulquées d'un côté, convexes de l'autre. Test crustacé, fragile. Nmbryon minime; radicule infère.-Arbrisseaux à rameaux subdichotomes. Teuilles éparses, très cntières, ponctuées; pétiole court, inarticulé. Pédoncules axillaires et oppositifoliés, 1-flores, solitaires. Flears petites, d'un blanc verâtatre. - Ce g. appartient à l'Amérique mérioionale; il comprend plusicurs esp. autrefois renfermées dans le g. Tylopia.

(SP.)

ANAKETON, Cass. Bor. PiI. - G. de la famille des Composées, tr. des Sénécionidées. On lui donne les caract. suivants : $\mathrm{Ca}-$ pit. pauciflore, hétérogame; toutes les fleurs tubuleuses, j-dentées; l'une ou l'autre femelle, le reste mâle. Réceptacle plan, couvert d'un duvet tomenteux. Invol. formé d'écailles sèches, multisériécs, faiblement 
imbriquées; les intérieures onguiculées, spathulées, terminées par une sorte de lame très blanche. Style des fleurs mâles très simple. Fruits enveloppés dans le duvet tomenteux du réceptacle, et couronnés par une aigrette à soies peu nombreuses, capillaires, scabres ou plumeuses, plus courtes que la corolle. - Ce sont des s.-arbrisseaux du Cap, à feuilles alternes, coriaces, très entières, sessiles, mucronulées, parcourues par une nervure moyenne, creusée en forme de sillon à la face supérieure; capitules cylindracés, réunis en corymbe. - Ce g. est voisin de l'Antennaria (Gnaphalium dioicum et maryaritaceum).

* ce nom à un g. de Polypodiacées, qu'il a fondé sur le Polypodium crassifolium $\mathbb{L}_{\text {. }}$, et que Presl considere avec raison comme une esp. de son g. Phymatodes.

(AD. B.)

ANBL TUM. BOT. PH. - G. de la famille des Orobanchées, formé par Tournefort (Cor. 48), et dont Endlich. (Gen., Pl. 4189), forma une division de son g. Anoplanthus, en la caractérisant ainsi : Cor. à tube court, ventru, à limbe bilabié. Scape engainée par des squammes assez grandes, et se terminant en un pédoncule uniflore. Une seule esp. du Caucase.

(G. L.)

* MUCATH (nom grec, appliqué jadis à quelque espèce de Chardon). BaT. PH. M. De Gandolle a fondé ce g. sur une plante des monts Altaï (Cirsium igniarium Pall.), qui difière des Cirsis par les appendices de ses anthères, la cicatrice latérale et basilaire de son fruit. Elle a pour caract.: Capitule homogame multiflore. Involucre ovale-globuleux, à écailles imbriquées; les extérieures et les moyennes épineuses; les plus intérieures scarieuses, colorées. Réceptacle paléacé-fimbrillifère. Corolles égales, obliquement 5 -fides. Ftamines à filets glabres. Anthères terminées inférieurement par des appendices velus. Fruits très glabres, oblongs, anguleux, striés longitudinalement, pourvus à la base d'une aréole latérale, terminés au'sommet par une sorte de membrane crénelée, à l'intérieur de laquelle se trouve l'aigreite formée de deux rangées de soies plumeuses égales, rapprochées par Jeur base de manière à former une sorte d'anneau. - Ce g. ne renferme qu'une seule espèce.

(J.D.)
ACEE. Anceus (nom myth., un des Argonautes). GRUST. - G. de l'ordre des Isopodes, famille des Décempèdes, établi par M. Risso, qui lui assigne les caract. suivants : Tête des mâles pourvue de deux grandes mandibules, arquées, épaisses en dehors, concaves, tranchantes et dentelées en dedans. Deux yeux composés. Ant. au nombre de quatre, médiocrement longues, les extérieures l'étant plus que les intérieures, et terminées par des articles déliés et en soies; les intérieures grosses et poilues. Corps oblong, déprimé, formé de cinq segments, dont les deux premiers sont très larges, sillonnés et coudés ensemble. Dix pieds monodactyles; les six 1 ers assez courts et dirigés en avant, et les quatre derniers plus longs, se portant en arrière. Abdomen formé de quatre segments, terminé par une lame natatoire de chaque côté, et une intermédiaire, plus aiguë que celle-ci. - Ge g., vraiment singulier, se compose d'une seule esp., l'A. forficularius Risso. On la trouve près de Nice, dans les profondeurs de la mer. Elle se plaît au milieu de la région des Coraux, ou elle se cache dans les interstices des Madrépores. Sa natation est vive, et lorsqu'on cherche à la prendre, elle ne se roule pás en boule.

A.CLES. BOT. - Voyez ANGIPITÉ.

* AVCII d'un missionnaire jésuite). - Noisetlia Martius et Ruccar. Bor. Pr. - G. de la famille des Violariées, ofrant pour caract. : Gal. de 5 sépales inégaux, inappendiculés. Pétales 5̋, non persistants : les 2 supérieurs minimes; les 2 latéraux moins petits; l'inférieur très grand, onguiculé, éperonné. ctam. š; les 2 inférieures appendiculées. Anthères subsessiles. Style court, claviforme. Stigmate oblique. Capsule très grosse, vésiculeuse, polysperme, déhiscente long-temps avant la maturité des graines. Graines bi-sériées, bordées d'une large aile membraneuse, échancrée vers le hile (A. S.-Hil., Pl.us. des Prasil., t. 19). - Arbrisscaux. Feuilles pétiolées, penninervées. Stipules petites, caduques. Pédoncules courts, fasciculés. Corolle blanche. On n'en connait que deux esp., qui habitent le Brésil. Les racines de I'A. suiularis A. S.-II. sont employées par les cultivateurs des environs de Rio comme remide dépuratif et comme purgatif. (\$x.) 
AMCTIOIS. porss.-C'est un petit poisson qui ne dépasse guère 10 à 11 cent. , très abondant dans toutes les mers des régions tempérées de l'Europe, surtout dans la Méditerranée et sur les côtes d'Espagne, où l'on en fait des pêches nombreuses et productives pour le commerce d'exportation. Sa tête est assez grosse; son museau, prolongé par le développement de l'ethmoïde, est saillant, et dépasse de beaucoup la mâchoire inférieure. La gueule est très fendue; les ouïes Je sont aussi beaucoup. Le dos est arrondi; le ventre est comprimé et un peu tranchant. La couleur est verdâtre-clair sur le dos et argentée sur le ventre, quand le poisson est vivant; le vert du dos passe au bleu anssitôt après sa mort, et cette teinte fonce de plus en plus, jusqu'à devenir presque noire.

Comme tous les Clupéoïdes, ces petits poissons vivent en troupes nombreuses. Les Provençaux les pêchent avec des filets nommés rissoles, ế qui ont au moins 40 brasses de longueur sur 8 à 10 mètres de hauteur on de chute. Les mailles sont plus serrées que pour les Sardines. La pêche se fait ordinairement avec quatre bateaux dont un porte la rissole, et les autres, nommés fastiers, portent des réchauds à feu. Ils sortent pendant les nuits obscures, sans lune, depuis le mois d'avril jusqu'à la fin de juillet. $\mathrm{A}$ une ou deux lieues de la côte, les fastiers allument des feux de pins gras et très secs. Les Anchois, attirés par la lumière, se dirigent vers eux. Quand le pêcheur se voit entouré d'un assez bon nombre de poissons, il fait signe au bateau qui porte le filet de s'approcher, et de mettre ses engins à l'eau. Ensuite, sans trop serrer d'abord les bateaux fastiers, ils jettent les filets à l'eau, et les traînent de manière à entourer le bateau qui porte le feu. Ils resserrent alors leur cercle, et, quand ils voient tout bien disposé, le fastier éteint le feu. Les Anchois, effarouchés, abandonnent ce bateau, mais pour aller s'encolleter ou se mailler dans le filet. Quand une bande d'Anchois veut s'approcher du rivage pour frayer, on les prend aussi arec de grandes seines, que l'on tire sur les rives sablonneuses. L'Anchois frais se mange frit; mais c'est plutôt pour le conserver en salaison que l'on se livre à sa pêche. Aussitôt que les pêcheurs ramènent les filets, femmes et enfants accourent sur la plage, se hâtent de couper la tête et d'enlever avec elle les viscères de ces poissons : c'est pour cela qu'ils arrivent toujours sur nos tables ainsi décapités. Quand la tête est enlevée, on lave le tronçon du corps et de la queue restant, et, ensuite, on alile le poisson, c'està-dire qu'on le place dans de petits tonneaux confectionnés pour cet usage, en mettant un lit de sel et un lit de poissons. Le sel est écrasé en poudre assez fine, et rougie avec de l'ocre. On fait jusqu'à trois saumures avant de pouvoir livrer le poisson au commerce. Quand il a été convenablement préparé, il peut se conserver plus d'un an; cependant les meilleurs Anchois à employes pour la cuisine doivent êfre nouveaux, pe. tits, blancs dessus, vermeils en dedans, et avoir le dos rond. Cette chair, devenue piquante, est un assaisonnement agréable pour beaucoup de nos aliments. Sa préparation est des plus anciennes. Les Grecs et les Romains faisaient grand usage de l'Anchois. Toutes sortes de proverbes, de dictons, avaient lieu sur ce poisson, ainsi qu'on peut en juger par la lecture des comédies d'Aristophane. Ce poisson entrait dans leur garum, et, préparé avec le vinaigre, donmait leur acefogarum.

Linné classait l'Anchois dans le genre des Glupées, sous le nom de Clupea enchrasicholus; mais, depuis que les méthodes ichthyologiques se soni perfectionnées par les travaux de M. Guvier, l'Anchois est devenu le type d'ung. de la famille des Clupéoïdes, caractérisé par la saillie de son ethmoïle; ce qui donne à sa physionomie un aspect facile à saisir. - Ce g. comprend un assez grand nombre d'esp. soit des côtes d'Amérique, soit du Malabar et de Coromandel. Wlles sont, par conséquent, assez répandues sur la surface du globe.

( $\mathrm{VAL}$.)

ANCIOLL置. BOT. PIr.-Voyez AraoLIE.

(G. D'O.)

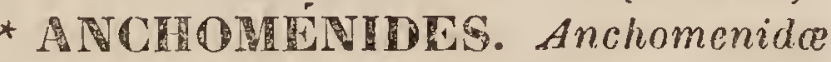

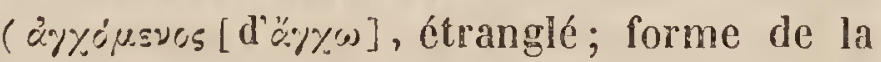
tête ). INs. - S.-tr. de Coléoptères pentamères, famille des Carabiques, établie par M. Delaporte dans la tribu des Féroniens de M. Dejean, et à laquelle il donne pour caract. : Tête rétrécie insensiblement à sa base. Mandib. pointues. Palette des tarses antérieurs étroite, allongée, et formée de 5 articles offrant, en dessous, deux séries longi- 
tudinales de papilles ou de poils, avec un vide intermédiaire. Une dent simple au milicu de l'échancrure du menton; labre entier ou sans échancrure notable. Cette s.-tr. se compose des g. Platynus, Agonum, Oli. sthopus et Anchomenus. Les Anchoménides sont de jolis petits insectes très agiles. Quelques esp. sont ornées de couleurs brillantes et métalliques.

(D.)

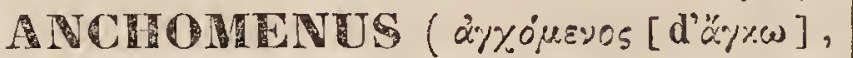
étranglé; forme de la tête ). INS. - G.'de Coléoptères pentamères, famille des Carabiquues, tr. des Féroniens, établi par Bonelli, et adopté depuis par presque tous les entomologistes. M. Dejean, dans son Species général, le caractérise ainsi : Les trois 1 ers articles des tarses antérieurs dilatés dans les màles, plus longs que larges, et légèrement triangulaires ou cordiformes; dernier article des palpes allongé, cylindrique, légèrement ovalaire et tronqué à l'extrémité. Antennes filiformes et assez allongées. Levre supérieure plane, en carré moins long que large. Mandib. légèrement arquées et assez aiguës; une dent simple au milicu de l'échancrure du menton. Corselet plus ou moins cordiforme; angles postérieurs toujours marqués. Élytrôs légèrement convexes, en ovale plus ou moins allongé; angles antérieurs arrondis, mais toujours marqués; le plus souvent des ailes propres au vol.-Les Anchomenus sont des Carabiques généralement au dessous de la taille moyenne, rarement parés de couleurs brillantes, et presque toujours ailés. On trouve ordinairement ces insectes dans les licux humides, aux bords des eaux, sous les pierres et les débris de végétaux; quelques uns se rencontrent aussi sous les écorces et dans les trones d'arbres. B. De-

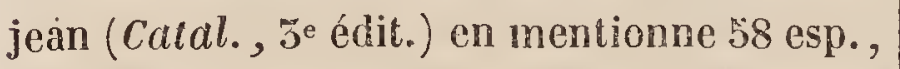
dont 13 seulement se trouvent en Europe; les autres appartiennent aux autres parties du globe, particulièrement aux deux $\mathbb{A m e ́ -}$ riques. Nous citerons comme type du g. l'Anch. pallipes Fabr., très commun sur les bords de la Şeine.

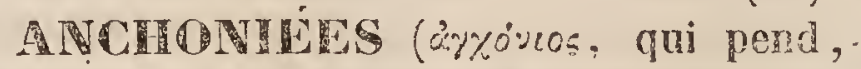
étrangle). מotr. Ply. - M. De Gandolle a donné ce nom à l'une des tribus dans lesquelles il sous-divise la famille des Crucifères.

(SP.)

A ICTONDUM (àyórsos, qui étrangle; forme de la silique). Bot. Pr. - G. de la famille des Cruciferes (Lomenteuses), établi par H. Candolle (Syst., t. 2, p. 578), qui lui assigne pour caract. distinctifs : Etam. majeures connées 2 à 2. Silique 2-articulée, rostrée par un style comprimé; articles 2spermes, indéhiscents, se séparant à la maturité. Graines suspendues, oblongues, collatérales dans chaque article. Cotylédons planes, incombants. - Ce g. ne comprend qu'une seule esp. qui croît au Liban. (SP.)

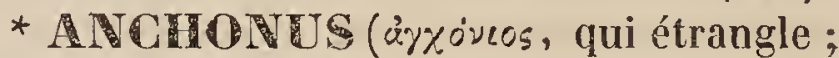
forme du rostre). INS. - G. de l'ordre des Colćoptères tétramères, famille des Curculionides, div. des Erirhinides, établi par Schoenherr, qui lui donne pour caract. : Antennes médiocres, peu fortes. Funicule composé de huit articles : le 1er très court, le 2 e long, obconique; les autres courts, presque perfoliés, successivement un peu plus épais extérieurement. Massue brièvement ovale. Rostre long, robuste, cylindrique, arqué, profondément attaché. Yeux très écartés, enfoncés et presque cachés sous le lobe inférieur du thorax. Thorax oblong, tronqué à la base, arrondi sur les côtés, rétréci au sommet, lobé derrière les yeux, profondément échancré en dessous. gues, subovales, convexes. Le corps est subovale, rigide, scabre', aptère, de moyenne grandeur. - Ce g., suivant M. Dejean ( $\mathrm{C} a$ tal., $3^{\text {e }}$ édit.), renferme dix esp., toutes de l'Amérique. Fous ne citerons que celle qui a servi de type à Schoenherr, le Rhynchanus suillus de Fabricius, figuré dans l'lcorographie du régne animal de Guvier par $\mathbb{N}$. Guérin Héneville, pl. 59 bis, fig. 1. (D.)

* ATCIORZLLE. Anchorella (dimin. d'anchora, ancre). CRUST. - G. de la famille des Lernées, proposé par G. Cuvier (liegn. anim., 2e édit., III, 257) pour une esp. qui " ne se fixe aux ouies (des poissons) que par une seule production qui part du dessous du corps, et se dirige en arrière ». C'est le Lernoa adunca Stroem. (Sondmoer, pl. 1 , fig. 7 et 8 ), commun sur plusicurs Gares. D'après M. Burmeister, ce g. est synonyme de ceux de Clavella, Oken; adopté par Guvier, et de Lerncermyzon, Blainv.; antérieurement établis. (P.G.)

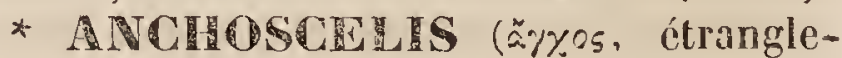
ment; $x_{n} i_{\varsigma}$, tache; forme des taches sur les ailes. Il faudrait écrire Anchocelis ). INS. G. de Lépidoptères, de la famille des Yoc- 
turnes et de la tr. des Orthosides, établi par M. Guénée (Ann. de la Soc. ent. de France, t. 8, p. 485), aux dépens du g. Orthosia de Treistchke, et qui a pour type la $N o \mathrm{ct}$. nitida de Fabr. Les caract. de ce g. sont formulés par l'auteur avec trop d'étendue pour trouver place ici; d'ailleurs ils nous ont paru ne reposer que sur, des différences extrêmement légères. Une des plus apparentes, c'est que la tache réniforme des ailes supéricures est toujours étranglée. Voy. le mot ORTHOSIE.

A NCHOYO. Un des noms vulgaires provençaux de l'Anchois.

(VAL.)

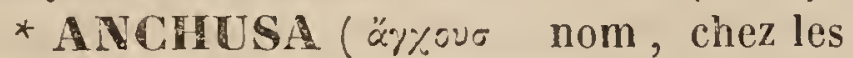
Grecs, d'une plante que les modernes rapportent à notre Orcanette ). BoT. PU. - G. de la famille des Aspérifoliées, L. (Borraginées, Juss. ), type de la tr. des Anchusées, formé par Linné, et dont les caract. sont ainsi circonscrits : Gal. כ̌-fide. Cor. hypogyne, infundibuliforme ou hypocratérimorphe, à gorge fermée par cinq appendices voûtés, à limbe ö-parti. Étam. כ̃, incluses, insérées sur le tube de la corolle. Ovaire quadrilobé. Style simple; stigmate indivis. Yoix 4, distinctes, rugueuses, creusées à la base, ceintes d'un bord renflé, insćrées sur le réceptacle. - Les Anchusa sont des plantes herbacécs, annuelles, bisannuelles ou vivaces, répandues sur toute la terre, à fleurs axillaires, solitaires, ou en grappes bractéées. Bien qu'on ait retiré bon nombre d'esp. de ce g., soit pour en faire le type de g. nou veaux, soit pour les réunir à d'autres, elles sont encore au nombre de 40 environ, qu'on partage en 4 s.-g. : Baphorhiza, Link.; Anchusa, Tausch; Buglossum, Gaert.; Buglossoïdes, Tausch (Voy. ces mots). L'espèce la plus commune, l'Anchusa italica Retz (Anchusa paniculata Ait) ou l'Anchusa officinalis Lamk., croît aux environs de Paris, partout, Je long des chemins, dans tous les endroits cultivés, et participe aux bonnes qualités de la bourrache, c'est-à-dire qu'elle est mucilagincuse, diaphorétique et diurétique. L'Anchusa tinctoria Lamk. ou l'Orcanette est le Lithospermum tinctorium. Voy. ce mot.

(G. L.)

* ANCIYLOMLPRE. CRUST. - Voyez ANCYLOMERE.

(M. E.)

* ANCIIYLOPERA. INs. - Voyez ANCYLOPERA.

(D.)

T. I.
* ANCHYLORHITCUS. Ins. Voyez ANCYLOR HYaUS.

(D.)

ANCILIE. Ancilia (ancile, bouclier). MoLL. - On trouve à la page $248 \mathrm{du}$ Musurum geversianum cette dénomination générique pour une espèce de Calyptrée qui est le Calyptroa trochiformis, dont Lamarck a fait son Trochus calyptraformis dans son ouvrage sur les Animaux sans vertébres. Voy. CALYPTREE.

(DESII.)

ANCLLL. MoLL. - Voy. ANGILLE. ANCILL IIE. Ancillaria (ancillaria, domestique; étymologie obscure). MoLL. G. de Gastéropodes pectinibranches, proposé par Lamarck dans ses premiers travaux conchyliologiques. Avant Lamarck, quelques espèces de ce genre étaient connues des naturalistes; Martini et Chemnitz en figurent quelques unes, qu'ils confondent avec les Olives. Forskal, dans son voyage en Egypte, laissa un dessin d'une espèce assez commune dans la mer houge, et ce dessin représente assez bien l'animal. Ce savant naturaliste mourut malheureusement avant d'avoir achevé son ouvrage, et son continuateur, en parlant de cette figure, la donne comme celle d'une espèce de Volute. Gmelin, Dilwin, ont suivi l'opinion de Linné et de Ghemnitz. Lamarck, le premier, reconnut les caractères de ces coquilles, et il en forma un genre auquel il appliqua le nom d'Ancillaire. H. de Roissy, dans le Buffon de Sonnini, adopta le genre de Lamarck; mais, craignant qu'à la faveur de deux noms aussi semblables qu'Ancyle et Ancillaire, il ne s'introduisît de la confusion dans la nomenclature, il proposa le nom d'Anaulax pour le genre de Lamarck. Ce changement ne fut point adopté, et presque tous les auteurs conservèrent le genre de Lamarck et le nom sous lequel il a été premièrement proposé par cet auteur. Le genre Ancillaire a la plus grande analogic avec celui des Olives; aussi Lamarck était-il sûr d'être compris et de voir son opinion généralement adoptée, en comprenant son genre dans sa famille des Enroulés, entre les Porcelaines et les Olives. Guvier ne mentionna pas le genre qui nous occupe dans. la première édition du Règne cinimal. M. de Férussac adopte entièrement l'opinion de Lamarck; ce que fait également M. de Blainville, dans son Traite de Malacologie. Malgré cette unifor- 
mité dans l'opinion des naturalistes, Cuvier, dans la seconde édition du Règne animal, mentionne les Ancillaires comme sousgenre des Buccins, et il les place entre les Eburnes et les Tonnes. Lorsque, quelques années après, dans leur grand ouvrage, MHI. Quoy et Gaimard eurent fait connaître l'animal des Anciliaires d'une manière beaucoup plus complète que Forskal, on put voir combien Lamarck avait eu raison de mettre son genre ì côté des Olives.

M. Quoy eat occasion d'observer deux especes d'Ancillaires. Les animaux de ce genre sont véritablement fort singuliers: dans l'un, l'animal développe un énorme pied dont il enveloppe la plus grande partie de sa coquille; une sorte de lobe conique, séparé da pied par un sillon circulaire, constitue une tête singulière, ou plutôt une sorte de voile labial qui cache une petite trompe et de courts tentacules. L'extrémité extérieure du mantean se prolonge en un canal charnu, très allongé, passant par l'échancrure de la coquille; ce canal est destiné à porter l'ean sur les branchies. Dans l'autre espèce, beaucoup plus voisine des Olives, le pied de l'animal est beaucoup plus court, n'enveloppe qu'une petite portion de la coquille; et le lobe céphalique, plus petit, permet à de grands tentacules cylindriques de se montrer au dehors. La tête est fort petite; elle se prolonge en avant en une trompe grêle, et l'on n'y trouve aucune trace des organes do la vue. L'œsophage se continue insensiblement en un estomac allongé, cylindrique, dont le diamètre diffère à peine de celui de l'intestin qui le suit. Cet intestin, très court et fort grêle, fait une seule circonvolution dans le foie, et revient ensuite au côté droit de la cavité branchiale, où il se termine en avant par l'anus. De chaque côté de l'estomac se montre une petite glande salivaire, dont le canal filiforme s'introduit dans la partie latérale et postérieure de la bouche. Les organes de la génération sont fort simples, comme dans tous les Mollusques dioiques. On trouve dans la cavité branchiale une grande branchie pectinéc, à filaments détachés jessqu'à la base, d'après les dessins de MM. Quoy et Gaimard. D'après los metmes observateurs, celle des Ancillaires caui a le pied le plus court porte, sur l'exlérmité de ce pied, un très petit opercule court assez semblable, pour la forme ef les caractères, à celui des Buccins. La coquille est allongée, ovalaire, lisse, brillante, et ayant constamment la suture des tours recouverte d'une callosité peu épaisse et comme vernissée; aussi, dans la plunant des espèces, est-il fort difficile de distinguer les tours les uns des autres. Un autre caractère qui se montre encore dans ce genre, c'est que toute la partie antérieure de la c0quille est également enveloppée d'une couche vernissée plus ou moins large, de sorte que du test primitif il ne reste réellement à découvert que le milieu du dernier tour. L'ou verture est généralement étroite, toujours longitudinale, parallèle à l'axe de la columelle, terminée, à son extrémité postérieure, par une échancrure fort étroite qui détach de l'avant-dernier tour l'extrémité supérieure du bord droit. L'extrémité antérieure de l'ouyerture se termine en une large échancrure comparable à celle qui existe dans les Olives. La columelle est concave dans le milieu,'tandis que, dans les Olives, elle est presque toujours droite, et son extrémité antérieurc porte un hourrelet cylindracé sur lequel se montrent quelques plis obsolètes plus ou moins nombreux selon les espèces. On a cru pendant long-temps que, sans exception, toutes les Ancillaires ont la columelle pleine et sans ombilic; mais, en étudiant avec plus de soin les espèces de ce genre, on s'aperçut qu'il devait venir se placer parmi elles une coquille fort commune dans les collections et que Lamarck avait comprise parmi ses Éburnes. M. Sowerby, I'un des premiers, indiqua cette utile réforme, à laquelle il fut conduit par la connaissance d'un grand nombre d'espèces d'Ancillaires que Lamarck ne connut pas. Parmi ces espèces nouvelles, il y en a trois ou quatre chez lesquelles on voit l'ombilic apparaitre d'abord sous la forme d'une fente très étroite, et prendre successivement plus d'étendue jusqu'à la grandeur de celui de l'Éburna glabrata de Lanarck. Dans le premier fascicule de son Species Cunchyliorum, N. Sowerby décrit et figure huit espèces vivantes dans le genre Ancillaire; nous en avons vu plusieurs dont $\mathbb{R}$. Sowerby n'ent point alors connaissunce. Şi à ces espèces vivantes nous joignons celles qui sont fossiles, nous en compterons au moins 15 espèces répan- 
dues dans les terrains tertiaires de l'Furope et de l'Amérique septentrionale; ce qui porterait au moins à 40 les espèces actuellement connues.-Caract.génér. : Animal allongé, cylindracé, ayant un pied très grand, dont les bords recouvrent la coquille en partie ou en totalité. In grand voile céphalique se contimuant $\mathrm{a} u$ pied, et cachant quelquefois une $\hat{\imath} \hat{c}-$ te petite, prolongée en une trompe étroite, et portant une paire de tentacules sans yeux, tantôt cylindracés et allongés, tantôt courts et coniques. Coquille allongée, lisse, polie, ayant constamment les sutures cachées par un dépôt calleux. Ouverture longitudinale largement échancrée à la base; columelle concave, terminée par un bourrelet tordu, lisse ou strié.

(DESII.)

ANCELLE. Ancilla (ancilla, servante). MOLL. - G'est sous ce nom que Lamarck avait d'abord proposé un g. auquel, quelque temps après, il a donné celui d'Ancillaire, qui a été généralement adopté. Foy. ArGLLLAIRE.

(DESH.)

* NCINE. CRUST. - Genre nouveau de l'ordre des Isopodes et de la famille des Sphéromiens, établi par M. MilneEdwards, et caractérisé par la conformation des pattes des deux 1 res paires, qui sont ¿erminées par une grande main subchéliforme, et par l'aplatissement extrême du corps, qui est presque foliacé. Le Crustacé qui a servi à l'établissement de cette petite division générique est conservé dans la collection du Musée britannique de Londres sous le nom de Nosea depressa Leach, et paraît être la même esp. que celle décrite sous le même nom par Say dans le journal de l'Académie des Sciences de Philadelphie, t. I, p. 485. (Voy. Milne-Edwards, Hist. des Crust., 1. III, p. 226, pl. 32, fig. 17.)

(M. E.)

ARCHDrFi Anceps (anceps, à 2 côtés, à 2 têtes). Bor. - Se dit de tout support comprimé, dont les deux bords sont, par conséquent, plus ou moins tranchants; ainsi les péíioles, les hampes, les pédoncules, les tiges, etc., peuvent être dits ancipités.

(C. H.)

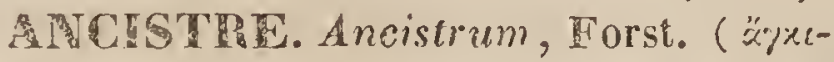
otfo\%, crochel). BоT. Pr. - G. de la famille des Rosacées, voisin de l'Acara (auquel le réunissent plusieurs auteurs), dont il diflère par le calice, qui, au lieu d'être hérissé de spinelles à toute sa surface, se ter- mine soit par 4 ou 5 dents spinescentes, soit par 4 ou 5 bosses; et, en outre, par une corolle de 4 ou 5 pétales distincts. - On en connaît environ 15 esp., la plupart indigènes dans l'hémisphère austral, surtout en Amérique.

(SP.)

ACCISTROCARPUS, Kunth. (äp-

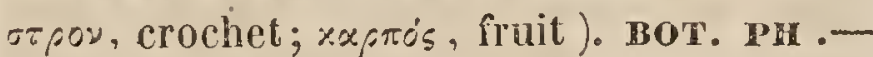
Syn. du g. Hicrotea, Swartz.

(SP.)

* ANCESTROCRRUS (öyre\%,0\%, hameçon, crochet; $x \dot{\varepsilon}, x_{5}$, corne, antenne ). INS. - M. Wesmael (Monog. des Odynères de la Belg. ) a établi sous ce nom une division dans le g. Odynerus de Latreille, et l'a caractérisée ainsi : Abdomen ayant la face dorsale de son premier segment formée de deux pièces réunies par une suture transversale. Antennes des mâles ayant leurs deux derniers articles en forme de crochet. Ea face postéricure du métathorax préseniant de chaque côté un angle saillant. - L'esp. type de cette division est l'Odynerus pariefum (Tespa parietum Lin.), commune dans la plus grande partie de l'Europe. (BI.)

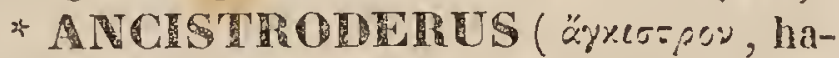
meçon; J'śr, cou ). INS. - G. de Coléoptères tétramères, famille des Longicomes, établi par M. Bejean, et que nous ne mentionnons que pour mémoire, les caract. n'en ayant pas été publiés. D'après la place qu'il occupe dans son Catalogue (3e édit.), il appartiendrait à la tr. des Lamiaires de Pr. Serville. Il est fondé sur une seule esp. trouvée dans les environs de Rexico, et que l'auteur nomme $\boldsymbol{A}$. hamaticollis.

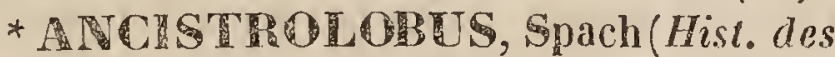
Plant. Phan., i. 5, p. 361). ("üytorpov, crochet; $\lambda 060^{\circ}$, cosse, fruit). BOT. IH. - G. de la famille des Hypéricacées, tr. des Desmostémonées. Il ofire les caract. suivants : Sépales 5 , subcartilagineux, persistants; les 5 ex térieurs convexes, opaques; les 2 intérieurs plans, semi-diaphanes, plus courts. Pétales 5, marcescents, spatulés, inappendicules. Eramines triadelphes, persistantes; androphores liguliformes, polyandres, staminifères presque dès la base, alternes chacun avec une écaille obovale, assez grande, recourbée au sommet; filets courts, capillaires, anisomètres; anthères subréniformes. Ovaire 5-loculaire, 3-sulqué ; loges 5- ou 6ovulées ; ovules ailés, imbriqués, renversés, attachés vers la base de l'angle central. Styles 
5 , courts, divergents, filiformes, épaissis au sommet. Srigmates subcapitellés, papilleux. Capsule coriace, oblongue, subcylindrique, apiculée par les styles, 5-loculaire, loculicidetrivalve; loges oligospermes; cloisons séminifères au bord antérieur; axe central nul. Graines imbriquées, à peine scrobiculées, ailées; aile membranacée, beaucoup plus grande que l'amande. Embryon cylindracé ; radicule courte, infère; cotylédons subfoliacés, linéaires, oncinés au sommet. - Arbres ou arbrisseaux ; rameanx cylindriques; ramules anguleux ou ancipités. Fevilles subcoriaces, très entières, ponctuées de vésicules noires. Pédoncules axillaires et terminaux, courts, 1-ö-llores; pédicelles courts, ordinairement en cymules. Sépales et pétales striés de bandelettes résineuses, claviformes. Corolle d'un jaune orange.-Ce g. renferme 2 ou 5 especes, de l'Asie équatoriale. (Sp.)

* ANCTSTROSOME. Ancistrosoma

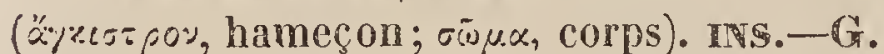
de. Coléoptìres pentamères, de la famille des

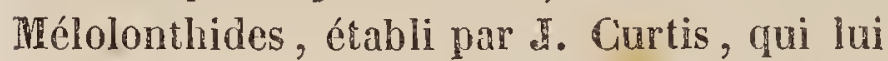
assigne pour caract. : $\mathbf{N}$ t. plus courtes que la tête; chaperon échancré, principalement chez les mâles. Corselet hexagone, à bords aigus, armé d'une petite dent vers le milieu de sa base. Pieds très longs et robustes. E'auteur n'y rapporte qu'une esp., l'A. K'lugii, qui a été trouvée au Pérou, dans les environs de Lima, sur les fleurs d'un Mimosa, et décrite et figurée par MI. Curtis (1er vol. des Trans. de la Suc. zool. de Londres, p: 3\$0, pl. 40). Son nom générique fait allusion à la pointe recourbée dont l'abdomen du mâle est armé à sa base. Ce genre correspond an genre Sciuropus, Latr. - Voy. ce mot.

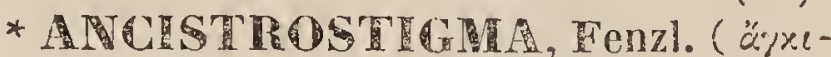

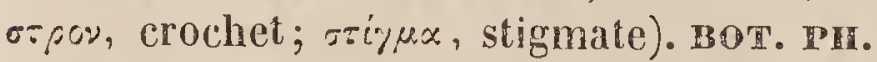
- G. de la famille des Portulacacées, voisin du Cypselea; l'auteur (in Endlicher, Novar. Stirp. Decad., 1, p. 83 ) en a exposé ainsi les caract. : Calice campanulé, 5 -fide jusqu'au dela du milieu; segments obtus, les 2 intérienrs plus larges, semi-scarienx, légèrement concaves. Corolie nulle. Ftam. 7 ou 8 , ou très rarement 9 , subisonitres; 5 externes, opposées au sinus du calice, les autres opposées aux segments calicinaux intérieurs. Anth. à bourses oblongues, cohérentes au sommet, libres inférieuremestt. Ovaire re- couvert par le calice, inadhérent, 1-loculaire, pluri-ovulé; ovales attachés (moyennant. des funicules ascendants) à un placenta central columnaire. Style indivisé, central, sigmoïde. Stigmate terminal, recourbé en forme de crochet, papilleux au dos. Pyxide subglobuleux, membranacé, s'ouvrant au milieu, క̌-8-sperme; graines réniformes, luisantes, noires. - On n'en connaît qu'une seale esp.; c'est une herbe (de la Nouv.Hollande extra-tropicale et orientale) vivace, diffuse, semblable, par le port, à un Herniaria. Les feuilles sont petites, tantôt alternes, tantôt opposées, à nétiole engaînant; les fleurs axillaires, solitaires, courtement pédicellées, minimes. (\$F.)

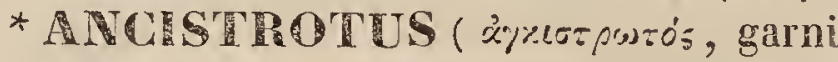
de crochets). HNs. - G. de Colćopières tétramères, famille des Longicornes, tr. des Prioniens, établi par M. Serville, et adopté par M. Dejean; il a pour type l'A. hareaticollis de ce dernier, rapporté du Brésil par M. Lacordaire. M. Serville lc place dans la subdivision des Prioniens proprement dits, qui ont les jambes munies intérieurement de deux rangées d'épines nombreuses; les antennes de 11 articles; le corselet épineux ou crénelé latéralement. Ce qui le distingue des autres genres de la même tribu et de la même subdivision, c'est d'avoir les angles antérieurs du corselet avancés, sensiblement dilatés, et armés chacun de deux fortes épines.

ANCISTRUM. BOT. PH. -Voyez ANCISTRE. (G. L.)

ANOLIE. Aquilegia, Linn. (corruption d'Aquilina, anc. Bot.; d'aquila, aigle). BOr. Pr. - G. de la famille des Helléboracées, tr. des Helléborées, sous-tr. des Isopyrinées, Spach. Ses caract. essentiels sont les suivants : Sépales 5, pétaloïdes, non persistants, planes, onguiculés. Pétales "j, alternes avec les sépales, comme médifixes, subonguiculés, à lame presque plane, dressée, prolongée postéricurement en un long éperon descendant, tubuleux, calieux et nectarifcre à l'extrémité. Étamines nombreuses, plurisériées : les 2 séries intérieures stériles; Glets anthérifères filiformes, élargis à la base, ayant l'anthère réfiéchie au sommet; filets stériles, larges, scarieux, ondulés, connivents, apprimés. Anthères elliptiques ou suborbiculaires, latéralement dćhiscentes. 
Ovaires 5 (accidentellement 5 ou 4, ou jusqu'à 9), multi-ovulés; ovules alternes-bisériés, horizontaux, immédiatement, superposés. Styles longs, filiformes, finement papilleux au bord antérieur. Péricarpe composć de $\breve{5}$ follicules verticillés (quelquefois moins de 5, ou jusqu’à 9), persistants, chartacés, subtrigones, aristés, dressés, cohérents ì la base, plus ou moins divergents au sommet, polyspermes, tantôt bivalves ou subbivalves, tantôt déhiscents seulement par la suture antérieure.Graines anatropes, horizontales, bisérićes, ovoüdes, lisses, unicarénées par le raphé. Embryon minime, obcordiforme; radicule centripète. - Les Ancolies sont des herbes vivaces, touffues, a tiges feuillées et ordinairement paniculées.' Les feuilles radicales sont longuement pétiolées, tantôt trifoliolées, tantôt biternées; les feuilles caulinaires, conformes aux radicales (surtout les inféricures), ou pédalées ou palmatiparties. Les pédoncules, tantôt uniflores, tantôt paucifiores, sont terminaux et solitaires, d'abord inclinés au sommet de manière à renverser la fleur, mais dressés après la floraison. Les fleurs, en gẹnéral grandes et légèrement odorantes, sont de cuuleur bleue, ou blanche, ou rouge, ou livide, ou panachée.

Personne n'ignore que les Ancolies se cultivent communément comme plantes de parterre. Ces végétaux sont un peu âcres et narcotiques; cependant, leurs propriétés vénéneuses paraissent avoir beaucoup moins d'intensité que celles des Aconits et de plusieurs autres Helléboracées. L'Ancolie commune (connue sous, le nom vulgaire de Gart de Notre-Dame) passait, dans l'ancienne Thérapeutique, pour apéritive, diurétique, sudorifique et emménagogue.

Nous ne pouvons reconnaitre dans ce $\mathrm{g}$. que trois esp., quoiqu'a force de doubles emplois, et en élevant des variations individuelles au rang d'esp., on en ait porté le nombre à près de trente.

fue nom d'A quilegia, déjà employé par les botanographes de l'antiquité, lérive, à ce qu'on dit, d'uquila, et fait allusion a ce que les éperons des pétales ofrrent quelque ressemblance avec les ergots de l'aigle.

(SP.)

* ANCUEOTLS (Anculi, orum, Dieux des domestiques). MOIL. - MI. Say, dans sa Conchyliologie américaine, a proposé ce genre pour quelques Mélanies de l'A mérique. septentrionale, qui ne difyèrent pas assez des autres espèces connues pour qu'il y ait lieu d'en faire un genre particulier. Voy. NEI.ANIE.

(DESII.)

ACYLANHE. Ancylanthus, Des-

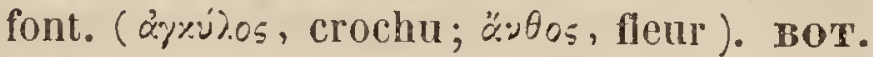
Pur. - G. de la famille des Rubiacées, tr. des Guettardées, auquel son auteur (Mém. du Muséum, vol. 4, p. 5, tab. 2) assigne les caract. suivants : 'Tube calicinal adhérent, ovoïde; limbe 5-parti; segments lancéolés, pointus. Cor. tubuleuse, courbée; tube évasé au sommet, garni en dedans, vers sa base, d'un anneau de poils; gorge nue; limbe à 5 lobes anisomètres, dressés, calleux et subulés au sommet; les deux supérieurs plus longs. Anth. 5, ovales, insérées immédiatement à la gorge de la corolle. Ovaire infère, 5-loculaire; loges 1 -ovulées; ovules attachés vers le milieu de l'angle interne des loges. Style indivisé. Stigmate gros, cylindracé, tronqué aux 2 bouts, obscurément 5̈-lobé au sommet, concave à la base. Péricarpe inconnu. - Ce g. n'est fondé que sur une seule esp., indigène d'Angola. C'est un arbrisseau à feuilles opposées, courtement pétiolées, réticulées; à stipules coriaces, pointues, engaînantes par leur base. Les fleurs sont solitaires ou ternées aux aisselles des feuilles, et courtcment pédicellées. (SP.)

AVCWLE. Ancylus (òjyijos, crochu). MoLl. - Gréé par Geofroy, dans son excellent Traité des Coquilles des environs de Paris, le g. Ancyle a été adopté par Müller, ế ainsi justement tiré des Patelles, parmi lesquelles il était confondu par Linné et ses imitateurs. Lister le premier, dans ses Animaux d'Angleterre, a figuré wne esp. sous le nom de Patella fuviatilis. La même espèce a été également représentée par Gualtieri et d'Argenville. La plupart des zoologistes ne suivirent pas l'excmple que Niiller leur avait donné; ils s'attachèrent beaucoup plus à l'opinion de Linné, et l'on doit particulièrement à Draparnaud d'avoir défnitivement introduit ce g. dans les méthodes actuellement en usage. Lamarck, pendant long-temps, parut ayoir oublić ce g.; il ne le mentionne ni dans sa première classification, que l'on tronve dans les $M i$ moires de la sociélé d'histoire naturelle, ni 
dans la seconde, faisant partie de son Système des Animaux sans vortèbres, ni dans tous ceux de ses ourrages qui précèdent son IHistoire naturelle des Animaux sans vertèbres. Noins oublieux que Lamarck, M. de Roissy mentionna le g. Ancyle dans le tome 3 des Mollus de Sonnini. Se conformant un peu à l'opinion de Linné, il place le g. de Geofroy entre les Patelles et les Fissurelles. Lamarck, n'ayant aucune bonne observation sur ce g., le place provisoirement dans sa famille des Galyptraciens, recomaissant bien lui-même qu'il n'est point dans les rapports naturels. Cuvier, dans la première édition du Règne animal, mentionna ce g. dans ses additions et le classa en tête des Pulmonés aquatiques. Nous ne sávons sur quoi se fonde le savant zoologiste pour se faire une telle opinion sur ce g. Quoique sans preuves, M. de Térussac préféra cependant l'opinion de Guvier à celle de M. de Roissy; mais M. de Blainville, plus scrupuleux, s'est natureliement demandé si l'on connaissait assez l'organisation des Ancyles pour les placer soit à côté des Patelles, soit parmi les scutibranches, soit enfin parmi les Pulmonés. Bientôt M. de Blainville s’aper cut que les observations manquaient com plètement pour éclairer la question; aussi, loin d'adopter aucune des opinions de ses devanciers, il en présenta une nouvelle à laquelle on n'était guère préparé. On trouve en efret dans le Traite de Halacologie une famille des otidés, dans laquelle se rencontrent les g. Ancyle et Haliotide. M. de Blainville suppose que, comme dans ce dernier g., l'animal des Ancyles a une branchie pectince placée dans une cavité particulière sur le côté gauche. Malheureusement M. de Blainville n'apporte aucune preuve à l'appui de ce que nous regardons comme une conjecture; il n'apporte en sa faveur aucun fait anatomique, ancune observation propre à Gémontrer que les Ancyles sont platôt Pectinibranches que Pulmonés. Ainsi ce nouveau rapprochement, fait par ce naturaliste, du g. qui nous occupe et des Haliolides, n'a servi à rien en ce qui concerne les rapports naturels des Ancyles. M. de Férussac, après avoir fait des observations sur les mours des Ancyles, prétendit que ces animanx sont Puimonés de la même maniè. re que les Limnées; mais nous n'y apercevoris rien qui justifie cette opinion. Il blâme quelques naturalistes de n'avoir pas placé les Ancyles parmi les Pulmonés; et, comme preuve de leurs torts, il apporte sa propre classification, dans laquelle on trouve, en effet, ce g. dans le groupe de Mollusques. On voit par ce qui précède que chacun des naturalistes qui ont eu occasion de mentionner les Ancyles ont émis à leur sujet une opinion différente. Rien, sans doute, ne paraîtrait plus simple que de donner, par de bonnes observations, la solution de cette difficulté ; les Ancyles se trouvant assez abondamment dans nos ruisseaux, dans nos rivières, dans nos étangs. La difficulté vient de ce que les espèces actuellement connues sont extrêmement petites; l'animal est presque transparent, gélatineux, et très difficile à soumettre à une dissection propre à éclairer sur sa structure intime. A moins de trouver un nouveau moyen d'observation sur des animaux aussi fugaces, les naturalistes resteront peut - être encore long - temps dans la même incertitude qu'aujourd'hui. On pouvait espérer que l'on rencontrerait dans les pays chauds des esp. plus grandes et susceptibles d'être soumises au scalpel de l'anatomiste; mais jusqu'à présent rien ne prouve que cette espérance doive se réaliser. II. Guiding en a observé dans les eaux douces de l'île Saint-Vincent quelques espèces, qui ne sont pas plus grandes que celles qui rivent en Furope.

Au petit nombre d'espèces virantes connues actuellement, il en faut joindre quelques unes fossiles mentionnées par Desmarets, dans une note qu'il publia dans le Bulletin de la Société philomatique; Hous en découvrîmes une autre esp. dans les marnes blanches qui font partie des terrains à lignite des environs d'Epernay.

L'animal des Ancyles est ovale, en cône surbaissé; il est enveloppé d'un manteau qui revêt l'intérieur de sa coquille et s'avance jusqu'à son bord. Le pied esí grand, ovalaire; il occupe presque toute la base de la coquille lorsque l'animal marche. La tête est à peine séparée du pied; elle est assez grosse, subquadrilatère, un per aplatie, et porte de chaque côté un tentacule court, subtronqué an sommet, et ayant l'organe de la vision sur le côté interne de sa base. MI. 
Guiding, dans les observations qu'il a faites sur ce g., a découvert, sur le côté droit de l'animal, une petite ouverture garnie d'une petite lèvre découpće. Cette disposition rappelle beaucoup ce que MM. Quoy et Gaimạard ont trouvé dans l'animal des Siphonaires. Il resterait à savoir maintenant si, dans les Ancyles, il y a, comme dans les Siphonaires, une branchie transverse au milieu du dos, daus un canal transversal communiquant avec cette ouverture latérale. Il est déji certain que chez les animaux qui nous occupent il n'y'a point de branchie autour du pied, comme dans les Patelles; que la branchie n'est point cervicale, comme dans les Calyptraciens; mais il reste à savoil si l'ouverture latérale communique avec une carité aérienne ou avec une branchie aquatique. Toute la question est la actuellement, et il nous semble qu'il ne faudrait qu'un petit nombre d'observations bien faites et suivies avec patience pour décider la question. Iusqu'au moment où ces observations seront faites, la place du g. Ancyle restera incertaine dans les méthodes.

Les caract. de ce g. peuvent être exprimés de la manière suivante : Animal gastéropode, conique, marchant sur un pied très large, profondément séparé de l'enveloppe paléale. Tête grosse, subquadrangulaire, portant latéralement une paire de tentacules courts, tronqués, ayant des yeux sessiles au côté interne de leur base, et, sur le côté droit, une ouverture garnie d'une petite valvule. Coquille patelloïde, ayant le sommet incliné postérieurement, ordinairement à droite, rarement à gauche, et plus rarement encore symétrique; test très mince, dans lequel on ne peut apercevoir aucune trace d'impression musculaire.

Les coquilles du g. Ancyle sont toutes patelloïdes; quelques unes sont coniques, ont le sommet subcentral, et sont plus symétriques que les autres. Dans d'autres esp., le sommet s'incline fortement à droite, et M. de Férussac en cite quelques esp. qui sont sénestres. Ces coquilles, minces et transparentes, ne paraissent recevoir aucune impression des muscles qui les attachent à l'animal; aussi, quelques soins que nous ayons pris pour découvrir la forme et la position de ces impressions musculaires, nous n'avons pu y parvenir. Dans un roya- ge qu'il a fait en Crimée, M. Rousseau, aide-naturaliste au Muséum d'histoir naturelle, a découvert, dans les terrains tertiaires des environs de Tasmann, une grande coquille patelloïde, de 5 à 6 pouces de longueur, et qui a les plus grands rapports avec une Ancyle gigantesque. Cependant nous pensons que cette coquille devra constituer un genre particulier, que N. Rousseau établira probablement lorsqu'il donnera la description de cette intéressante coquille.

(DESER.)

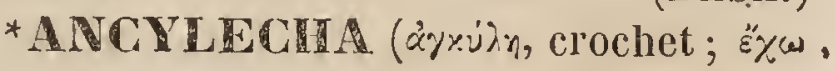
j'ai). Ivs. - G. de la famille des Locustiens, de l'ordre des Orthoptères, établi par M. Serville (Ins. Orth., suites à Bufon', qui le distingue des Phylloptères ef des Phanéroptères, avec lesquels il a la plus grande analogie par le prothorax, convexe, et surtout par les pattes, dont toutes les cuisses sont armées en dessous de crochets el de fortes épines; les jambes antérieures dilatées a leur base, et munies, ainsi que les intermédiaires, d'épines en dessus et de crochets irréguliers en dessous, et enfin les jambes postérieures ayant leurs carènes hérissées de petites épines et de dilatations crochues. M. Serville ne rapporte ì son g. qu'une seule espèce de l'ìle de Java, qu'il désigne sous le nom d'A. lunuligera, et qui n'est vraisemblablement que la Locusta fenestrata $\mathbf{F a b .}$, placée par M. Burmeister dans le g. Phyllopterus.

* ANCYLÉS. Ancyláa (áyxýios, crochu). MozL. - M. Menké, dans son Synopsis methodica Molluscorum, divise les Inférobranches de Cuvier en trois familles; la troisième, sous le nom d'Ancylœa, est consacrée au seul g. Ancylus de Geoffroy. Nous avons vu, dans la courte histoire de ce g., combien il est encore difficile à placer aujourd'hui; et l'opinion de M. Menké n'a pas plus de preuves en sa faveur que celle des autres naturalistes. Voy. AvGYLE.

(DESH.;

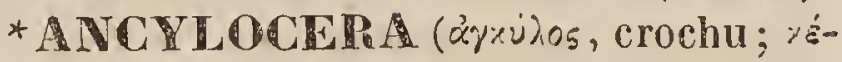

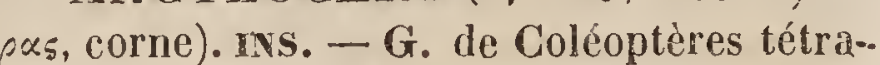
mères, famille des Longicornes, établi par ir. Serville, qui le place dans la tribu des Cérambycins, section des Longipennes, et lut donne pour caract. essentiels : Corsblet tres a llongé, cylindrique. $1^{\mathrm{e}}$ art. des ant. ( dans les mâles ) bombé en dedans, échancré antérieurement; le 2 dilaté intérieurement, eo 
forme de dent obtuse; les $\tilde{\jmath}^{\text {e }}$ et $4^{\text {e dilatés en }}$ biseau à leur partie intérieure; les autres cylindrico-coniques; le terminal trois fois plus court que le précédent, et formant un petit crochet. 2 art. des ant. (dans les femelles) peu prononcé, en dent de scie; le terminal court, mais point crochu. Élytres étroites, linéaires, un peu déprimées, tronquées carrément à leur extrémité. M. Dejean (Catal.,

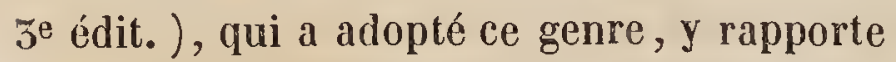
deux espèces; l'une est le Gnoma ruyicollis Fabr., et l'autre le Cerambyx cardinalis de Dalman ( $A$. sarguinea Dej.) Celle-ci se trouve au Brésil, où elle se tient sur les feuilles, et vole pendant le jour, d'après M. Lacordaire, qui ajoute qu'elle produit un son aigu avec son corselet. $L^{\prime} A$.rugicollis est de l'Amériqùe septentrionale; elle a été décrite et figurée par Olivier sous le nom de $\boldsymbol{S} a$ perda bicolor (tom. 4, p. 52, no 41, pl. 3, fig. 20$)$.

* NCILOCILIRA (áyrìos, crochu; yzip, ós, main ). INs. - G. de Coléoptères pentamères, famille des Sternoxes, tu ibu des Buprestides, établi par Eschscholtz, et dont, suivant Westwood, voici les caract. (Syr. of the Gen. of bril. Ins.) : Eusson distiuct. Menton transverse, tronqué antérieurement. Dernier article des palpes maxillaires aussi long que les précédents, légèrement dilaté au sommet. Tarses minces, tibias antérieurs des mâles inclinés et courbés. - Ce g. a été adopté par M. Dejean (Calal., $3^{\text {e }}$ éd.), qui y rapporte 18 esp., dont 13 d'Amérique et les autres d'Europe. Nous citerons, parmi ces dernières, les $\mathbb{A}$. rustica, punctata, octoguttata et flavo-maculata, qui sont des Buprestes pour Fabricius ainsi que pour MM. Solier et Gory-Delaporte, et qui toutes se trouvent en France.

(D.)

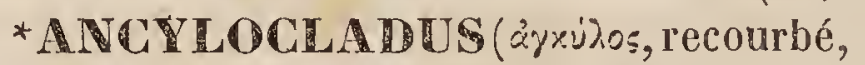

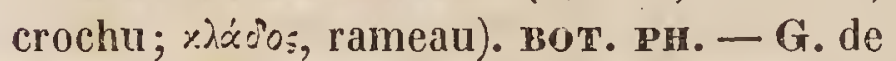
la famille des Apocynacées, tr. des Carissées, formé par Wallich ( Pl. As. rar., t. III, p. $45, \mathrm{t} .272$ ), et synonyme dug. Willughbeia de Roxburgh. Voy. ce mot.

(G. L.)

ANCYLODON (xyxuisos, crochu; dòis, oros, dent). rosss. - G. de la famille des Sciénoïdes, et qui ne se distingue des Otolithes que par le caract. suivant : $\mathbb{L} a$ mâchoire inférieure armée sur les côtés de dents longues et pointues. Dans les Otolithes, les dents latérales de la mâchoire sont en cardes très fines ou en velours, comme a la mâchoire supérieure. Les Ancylodons ont d'ailleurs le palais lisse et sans dents; la tête caverneuse; quatre appendices au pylore; et une vessie aérienne prolongée en deux cornes. Bloch, qui n'avait fait attention qu'à. la longueur de la caudale, en avait nommé une esp. de Surinam Lonchurus ancylodon; mais il a associé à son g. Lonchurus un autre poisson à dents égales et à deux barbillons sous le nom de Lonchurus barbalus. Ce g. établi par Bloch, devenait ainsi composé de deux esp. disparates; voilà pourquoi nous avons réformé dans notre Ichthyologie le nom de Lonchurus, et créé le g. dont il est question dåns cet article.

Yous connaissons encore une seconde esp. de ce petit groupe, originaire de Cayenne. Ce sont jusqu'à présent les deux seules réunies dans ce genre. (VAL.)

* ANCYLOEA. MOLL. - V. ANCYLÉS.

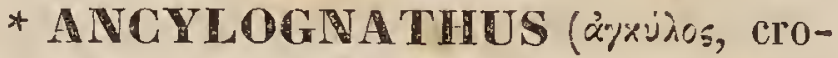
chu; yу'́x0s, mâchoire). INs. - G. de Col. hétéromères, famille des Mélasomes, établi par M. Dejean, qui n'en a pas publié les caractères. Il le place ( Catal., ze édit. ) immédiatement après le g. Cyrloderes de M. Solier, et n'y rapporte qu'une esp., du cap de Bonne-Espérance, qu'il nomme A. Dregei. Cette même esp. a été décrite par M. Guérin sous le nom de Calognatus Chevrolatii (Mag. zool. 1857, clas. 9, p. 172). Voy. ce mot pour les caract. du g.

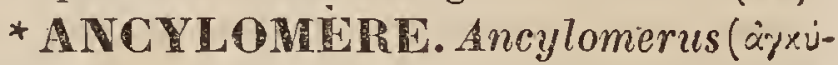
205 , crochu; $\mu$ śpıs, partie, article). CRust. - G. de l'ordre des Amphipodes et de la famille des Hypérines, établi par M. MilneEdwards, et caractérisé principalement par la conformation des pattes de la cinquième paire, qui sont très courtes, lamelleuses, clypéiformes, et terminées par une grosse main subchéliforme. ( $\boldsymbol{V}$. Ann. des Sc. nat., t. XX, et Hist. nat. des Crust., t. III, p. 85, pl. 30, fig. 4.) Le g. Hieraconyx de M. Guérin (Mag. zool.) ne paraît pas différer notablement des Ancylomères, et a été probablement établi d'après unindividu dont la croissance n'était pas achevée. (M. L.)

* ANCYLONOLUS (àyxìos, crochu;

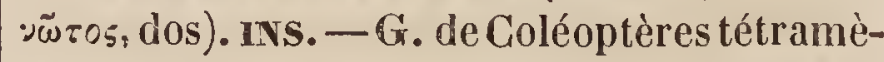
res, famille des Longicornes, établi par M. Dejean, qui le place ( Catal., $5^{\mathrm{e}}$ édit.) non loin du g. Megabasis de M. Serville, de 
sorte qu'il appartiendrait à la tribu des Lamiaires de ce dernier auteur. M. Delaporte (llist. naturelle des Coléopt., Bufion-Duménil) en formule les caractères ainsi qu'il suit : Corps assez allongé et convexe. Tête aplatie et verticale. Mandibules courtes, terminées en pointe aiguë. Palpes dépassant un peu les mandibules. Antennes grêles, beaticoup plus longues que le corps, très rapprochées à leur base. Corselet ayant son disque épineux let ses côtés armés chacun d'une pointe aiguè. F́cusson arrondi postérieurement et armé également de deux épines. Élytres presque parallèles, un peu conrexes, ayant leurs angles huméraux saillants et épineux, avec leur extrémité tronquée. Pattes assez longues; cuisses un peu comprimées. Jambes intermédiaires ayant en dessus, près de l'extrémité, un petit tubercule. - Ge g. est fondé sur une seule esp., originaire du Sénégal : Lamia tribulus de - Fabricius, Cerambyx id. Oliv. (Ent., t. IV, ins. 67, p. 65 , no 83 , pl. 14, fig. 100.) (D.)

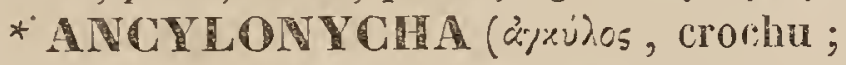
öขนรั, \%os, ongle). INs. - G. de Coléoptères pentamères, famille des Lamellicornes, établi par M. Dejean, qui n’en a pas publié les caractères. D'après la place qu'il occupe dans son Catal. (5 édit.), il appartiendrait à la tribu des Scarabéides phyllophages de Latreille. Il y rapporte 54 esp., toutes exotiques, dont 450 de diverses contrées de l'Amérique, 4 de Java, 1 de la Perse occidentale, 1 de la Mongolie, 1 de la Chine, 1 des îles Philippines, et 1 dont la patrie est inconnue. Cette dernière est le Relolontha serrata Fabr., que nous citons comme type du genre.

* MCILOPER ( $\pi \hat{s} \rho \alpha$, excessivement; allusion à la forme du sommet des ailes, qui est très recourbé).riss. - G. de l'ordre des Lépidoptères, famille des Nocturnes, établi par Stepheus dans sa tr. des Tortricides, et dont nous avons réparti les esp. dans les g. Tortrix et Phoxopleryx. Voy. ces deux mots.

* AVCYORHINUS. ois. - Voyez A GRILORHINUS.

(LARR.)

* ANCLORH VICUS (áarizos, recourbé; ṕur\%os, bec ). 1ss. - G. de l’ordre des Coléoptères têtramères, famille des Curculionides, div. des Érirhinides, établi par Klug et adopté par Schoenherl, qui le

T. I. caractérise ainsi : Antennes de longueur moyenne, ininces. Funicule composé de six articles, les trois 1 ers assez longs, subobconiques, les autres presque turbinés; massue allongée, ovale, acuminée. Rostre long, robuste, presque plan, élargi vers le sommet. Veux grands, latéraux, subovales. Prothorax transverse, beaucoup plus étroit antérieurement, avec les angles postérieurs subacuminés, légèrement convexes en dessus. Fiytres larges, subovales, un peu convexes, arrondies à leur extrémité, débordant l'abdomen. Pattes médiocrement longues, robustes; cuisses très épaisses, unidentées en dessous; tibias un peu comprimés. - Ce g., adopté par M. Dejean (C'atal., $3^{e}$ édit.), a, suivant Schoenherr, un peu le faciès du g. Myctère d'Olivier; il ne renferme qu'une seule esp., 1'A. variabilis de Klug, originaire du Brésil.

* AICYLOSCRLIS (áyxìos, crochu; oxśros, jambe ). INs. - G. de la famille des Melliềres, de l'ordre des Hyménopières, établi par Latreille (Règn. anim.) sur quelques esp. de l'Amérique méridionale, ayant de grands rapports avec Ies Antophora et les Saropoda, mais qui s'en distinguent surtout par les mandibules, munies de plusieurs dentelures. Leurs palpes maxillaires n'ont que quatre articles, comme chez les Saropoda.

(BL.)

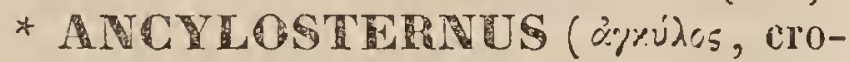
chu; rrépro\%, poitrine. INs. - G. de $\mathrm{Co}-$ léoptères tétramères, famille des Longicornes, tribu des Cérambycins, établi par N. Dupont dans sa monographie des Trachydérides, et adopté par M. Serville dans son travail sur les Longicornes, mais non par

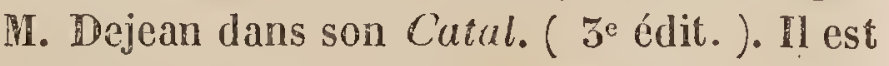
fondé sur une seule espèce d'Amérique, Trachyderes scuteliaris de Schoenherr, ou Cerambyx sculeilaris d'olivier (inlom., t. 4, capr., p. 16, no 13, pl. 21, fig. 160), et a pour caract. : Présternum transversale-ment et profondément échancré, tuberculeux entre les pattes antérieures. Mésosternum peu avancé, plan, semi-circulaire intérieurement. Tête grande, rugueuse, marquée de deux impressions longitudinales; menton large, canaliculé transversalement. Antennes longues; $1^{\text {er }}$ article robuste, 2 plus long que de coutume. Corselet aussi lolig que large, armé latéralement d'une épine cour- 
te. Feusson grand, triangulaire. Filytres longues, s'atténuant peu à peu, tronquées à l'extrémité, et terminées extérieurement par une épine courte. Pattes médiocres; tarses antéricurs dilatés; extrémité des cuisses intermédiaires et postérieures munie d'une petite épine.

* IICLLUS (àyxìos, crochet). INS. M. Haliday a employé cette dénomination pour désigner un g. dWyménoptères correspondant à celui de Leiophron de Trees von Esenbeck, tel qu'il a été adopté par MI. Westwood (Gen. Synop.) et nous (Fist.des An.art., t. IV). Foy. ce mot.

(BiL.)

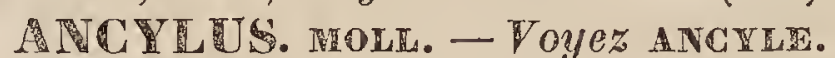

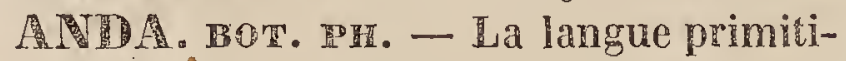
ve des. Brésiliens nommait ainsi un arbre qui, dans le pays, recoit encore vulgairement le nom d'Andaaçu, et qui, décrit d'abord dans l'ouvrage de Marcgraff et de Pison, réuni long-temps à l'Aleurites, a plus tard paru devoir former dans la famille des Euphorbiacées un genre distinct, auquel on a dû conserver son premier nom. Il avait été établi par Bern. Gomez sous celui de Joannesia (Tém. Acad. Lisb. III). Ses fleurs, monoïques, présentent, dans les deux sexes, un calice campanulé à cinq dents, et cinq pétales distincts, plus longs que le calice, avec les divisions duquel ils alternent, et aternaint eux-mêmes avec autant de glandes. Dans les mâles, huit étamines, dont trois intérieures plus longues, dont les filets se soudent ensemble inférieurement en une colonne centrale, et dont les anthères, allongées, sont vacillantes; dans les femelles, un ovaire à deux loges uni-ovulées, surmonté de deux styles courts, que terminent des stigmates déchiquetés en plusieurs lobes réfléchis. Il devient un fruit sphéroïde de la grosseur d'une petite pomme, dont le sarcocarpe charnu se sépare, à la maturité, de la base au sommet en quatre valves, et dont l'endocarpe forme un noyau ligneux relevé de quatre angles longitudinaux disposés en croix, percé de chaque côté, vers le haut de deux des angles opposés, de deax ouvertures communiquant chacune avec une loge intérieure, dans laquelle est une graine ovoïde, revêtue d’un double tégument, couronnée d'une caroncule dans sa jeunesse; l'extérieur crustacé, ế l'intérieur membraneux, épais.$\mathbb{L}^{2}$ Anda, auquel on a donné le nom spécilique de Gomez ou de Pison, est un grand arbre à suc laiteux, à feuilles alternes et dépourvues de stipules, qui portent à l'extrémité d'un long pétiole deux glandes, ế cinq folioles articulées, entières, portées elles-mêmes sur des pétioles partiels plus courtś. Les fleurs sont disposées, à l'extrémité des rameaux, en une sorte de panicule par une dichotomie assez régulière et plusieurs fos̀s répétée, dans laquelle les femelles sont ordinairement sessiles dans la fourche des dichotomies, les mâles courtement pédicellées sur les côtés. (Voy. Ad. Juss. Euph., p. 39, tab. 12, no 37, et Pl. usuelles des Bras.) - L'amande des graines offre les propriétés communes à la famille et était employée autrefois comme purgatif. Leur usage paraît abandonné aujourd'hui, quoique l'arbre ait con tinué à être cultivé communément à cause de sa beauté.

(AD. I. )

* IVTAGU. BOT. - Vnyez ANDA.

(AD. J.)

1P LOUSETL (Andalousie, province d'Espagne). Min. - Voyez MAGLE.

(DEL。)

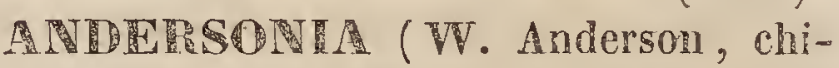
rurgien, compagnon de Cook). BOT. PR. G. de la famille des Loganiacées, formé par Willdenow (Msc.), et synon. du g. Gartnera de Lamark. - G. de la famille des Méliacées, formé par Roxburgh, et synon. de son g. Amoora. - G. de la famille des Stylidiées, formé par Koenig (Nlsc.), ê synon. du g. Stylidium (Nitrangium). - Cette dénomination générique, après bien des vicissitudes, comme on le voit, est enfin resté à un g. de la famille des Épacridacées, type de la tr. des Épacrées, établi par 奋. Brown (Prodr., p. 554), qui lui assigne les caract. suivants: Cal. coloré, 5-parti, accompagné de bractéoles foliacées, géminées, ou en nombre double. Cor. hypogyne, subcampanulée ou hypocratérimorphe, égalant le calice, à limbe 5parti, dont les segments étales et barbus à la base. Extam. 5 , hypogynes, ne dépassant pas la gorge du tube floral; filaments comprimés, plans, subulés. Anth. insérées par le dos au dessous de leur partie moyenne. Gquammules hypogynes $b$, distinctes ou con nées. Ovaire quinqué-loculaire, à loges multi-ovulées. Capsule 5-loculaire, à placentas dressés du fond des loges, ê adnés à une colonne centrale. Graines rares par a- 
vortement, dressées. - Les Andersonia sont des sous-arbrisseaux squarreux, indigènes de la Nouvelle-Hollande méridionale, à rameaux marqués de cicatrices par la chute des feuilles; celles-ci alternes, à base cucullée et semi-engainantes. Fleurs dressées, terminales, solitaires ou en épis. - Ce g. est fort borné dans le nombre de ses esp. Òn cultive dans les serres d'Furope l'A. sprengelioides R. B.

(C. L.)

ANDIR A Pison, Lamk.;-Vouacapoua, Aubl. (Andira est le nom brésilien d'une esp. du genre ). вot. PH. - G. de la famille des Légumineuses, tr. des Césalpiniées, $\mathbf{R}$. Br., s.-tr. des Géofîroyées, De Cand. - M. Kunth (in Humb. et Bonpl. Nov. Gen. et Spec., v. VI , p. 585 ) en trace ainsi les caract. : Gal. urcéolé ou turbiné-campanulé , quinquécenté; dents presque égales, pointues, dressées. Cor. papilionacée; étendard arrondi, échancré, horizontal, plus long que la carène. Extam. diadelphes (9 et 1). Ovaire stipité, tri-ovulé. Stigm. pointu. Légume stipité, suborbiculaire, drupacé, uniloculaire, monosperme, séparable en deux valves. - Arbres inermes. Feuilles imparipennées; folioles opposées, stipellées. Panicules simples ou rameuses, terminales, composées de grappes multiflores. Fleurs courtement pédicellées, pourpres. - Ce g. appartient à la zone équatoriale. On en connaît 6 esp. (dont 5 de l'Amérique et 1 du Sénégal). Ces végétaux sont remarquables par la beauté de leur inflorescence, ainsi que par l'extrûme amertume de leur écorce et de leur fruit. En Amérique, on leur attribue des propriétés anthelmintiques très efficaces; mais leur emploi exige beaucoup de circonspection, car, à trop forte dose, il peut devenir mortel.

(SP.)

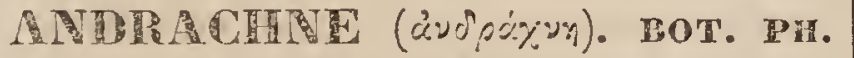
- C'est le nom gree du Pourpier, que les botanistes on transporté à un g. entièrement difrérent, mais qui, par le port et les feuilles épaisses et charnues de quelques unes de ses esp., présentait avec lui quelque ressemblance extérieure. Ce g. , appartenant à la famille des Euphorbiacées, ofre les caract. suivanis : Fleurs monoïques, à calice quinquéparti. Dans les mû́les : 5 pétales membraneux, avec lesquels alternent autant d'écailles biparties, qui manquent quelquefois; ¿ étamines dont les filets se sourlent en une colonne soutenant un rudiment de pistil. Dans les femelles : pas de cololle; ovaire entouré à sa base de 5 écailles biffdes, alternes avec les divisions du calice, et qui manquent, d'autres fois; surmonté de $\mathbf{3}$ styles courts et divariqués, chacun à 2 branches stigmatiques, renfermant 3 loges bi-ovulées, et donnant une capsule à 5 coques 2-spermes et bivalves. - On ne connaît d'Andrachne que 2 esp., dont plusieurs auteurs ont fait deux g. distincts : l'une herbacée, répandue dans le midi de l'Europe et l'Orient, qui est le Tolephioides de Tournefort, l'Eraclissa et le Limeam de Forskal (c'est elle dont la fleur mâle est munie de squammules alternant avec les pétales); l'autre frutescente, répandue dans le midi de l'Asie, depuis l'Indostan jusqu'à Timor', et dans laquelle manquent ces mêmes squammules : c'est l'Arachne de Necker.

(AD.J.)

AIIRANE. Androna. INS. - G. de l'ordre des Wlyménoptères, famille des Mellifères, tr. des Andrénides ou Andrenètes,

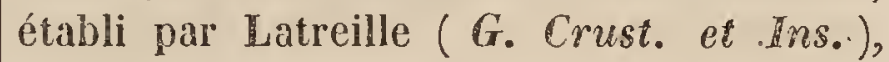
et adopté par tous les entomologistes. Les Andrænes ont le corps velu; le labre trigone; les palpes maxillaires beaucoup plus longs que le prolongement de la mâchoire; la langueíte repliée sur le côté supérieur de la gaîne, et les ailes antérieures pourvues de trois cellules cubitales, avec le commencement d'une quatrième.

Ce genre renferme un assez grand nombre d'espèces; la plupart sont indigènes. Leurs femelles creusent des trous ordinairement dans un sol exposé au midi, et enlèvent la terre à l'aide de leurs paites; elles déposent. ensuite un ouf dans ces trous, et l'approvisionnent d'une pâtée formée de pollen et d'un peu de miel. Les Andræenes les plus répandues dans notre pays sont les A. pilipes Fab., Nigro-cenea ejusd., etc.

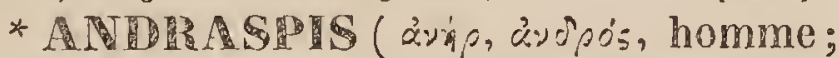

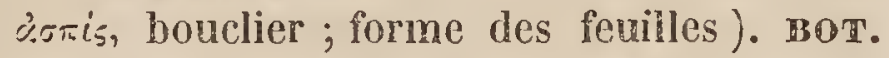
Pr. - G. de la famille des Primulacées, formé par Duby (Bot. Gall. 1851), et syn. du g. Androsace, dont il est une division, avec ces caractères : Feuilles en rosette à la base de la scape. Pédoncules ombellés, involucrés. Ovaire 5-multi-ovulé. (G. L.)

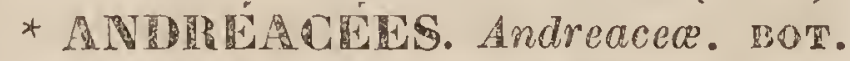
Ga. - M. Lindiley, dans son Nixus planta- 
rum, p. 24, a formé du g. Andraea un ordre distinct, se fondant sur ce que, par sa structure, il n'appartient pas plus aux Mousses qu'aux Tépatiques, dans lesquelles il a été tour à tour placé. S'il se rapproche des premières, en effet, par une coiffe et un opercule, il s'en écarte par la division valvaire de sa capsulc; d'un autre côté, s'il a des rapports avec les Jongermannes par ce dernier caractère, il s'en éloigne beaucoup plus encore par la présence d'une columelle et l'absence d'élatères, ainsi que l'a fort bien remarqué $\mathbb{M}$. Hooker. $M$. Lindley en conclut qu'il doî̀ être regaraé comme le type d'une famille naturelle très distincte. Le fait est que le g. Andrcea, si l'on ne prend le parti de le séparer complètement, devient un des plus rebelles à nos méthodes de classification.

(C. M.)

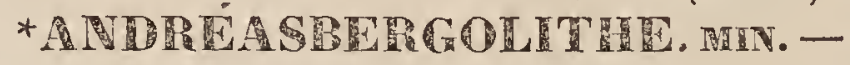
Nom donné à l'Harmotome d'Andréasberg, au Hartz. Voy. HAROTOHE.

(DER.)

ANDIENCWES. Andreneta. INS. 'Tr. de la famille des Mellifères, de l'ordre des Hymónoptères, sect. des Porte-aiguillon, circonscrite par Latreille et caractérisée principalement $1^{\circ}$ par la languette irifide, ayant son lobe intermédiaire lancéolé et plus court que la gâne; qo par les mandibules, simples ou terminées en une ou deux dentelures; $5^{\circ}$ par les palpes labiaux, de quatre articles, ayant la même forme que les maxillaires; cenx-ci toujours composés de six articles. Les Andrenètes ne se composent que de deur sortes d'individus; il n'existe pas de neutres ou d'ouvrièes chez elles, comme parmi les Abeilles, les Bourdons, etc.; elles vivent solitaires, et les femelles creusent dans la terre des trous assez profonds où elles déposent leurs oufs; elles ferment ensuite l'ouveriure de ces trous avec aes grains de terre après avoir approvisionné leurs oufs d'une pâtée formée d'une certaine quantité de miel ef de pollen qu'elles recueillent sur les étamines à l'aide de leurs pattes.

Cetce tribu était confondue par Linné dars son g. Abeille (Apis); elle en fut distinguée par Réaumur, qui désigna les espèces qui la composent sous le nom de Pro-Abeitles. Fabricius en forma le g. Andrana et le g. Rlylous, auxquels Latreille adjoignit, les g. Platichus, Sphecodes, Nomia, Dasypoda et Colletes. MM. Lepelletier de St.-Fargeau êt
Serville (Encycl. méth.) y ont ajouté le g. Scrapter, et, tout récemment, MI. Léon Dufour a repris pour une Andrenèie de la France méridionale le g. Megilla de $\mathbf{F a -}$ bricius, dont les espèces ont été disséminées dans d'autres genres. Voy., pour plus de détails sur l'organisation, l'art. MELLIFERES.

(BL.)

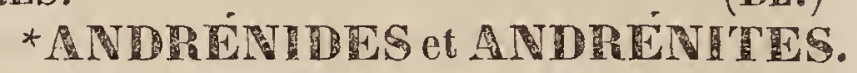
- Syn. d'ANDRENETES.

* IVIRTOE (nom d'homme). Bot. Cr. - Nom imposé par Ehrhardt et consacré par Hedwig à un genre de la famille des Monsses, ainsi caractérisé par Bridel (Bryologia universa, t. II, p. 7230 ) : Point de péristome. Capsule renflée en forme d'apophyse à la base, entière au sommet, où un opercule adné, persistant, maintient rérnies les quatre valves, dans lesquielles elle est fendue au milieu. Calyptre courrant primitivement la capsule, puis hémisphérique et susceptible de se fendre latéralement après sa rupture irrégulière. Séminules nombreuses, petites, exactement sphériques, lisses êt brunes. Ges Mousses sont monöques ou dioïques; les fleurs mâles axillaires au sommet, la fleur femelle terminale. Anthères 5 à 7, légèrement pédicellées, accompagnées de paraphyses nombreuses, plus longues, filiformes, un peu plus grosses au sommet, munies d'articles à segments égaux. Bistils 3 à 20 , nus, dont un seul devient fécond.-Les Andréées ont le port des Jongermannes. Flles sont dressées, ramęuses, fragiles, ef forment des petites toufes d'un rouge brun qui passe au noir. Leurs feuilles sont éparses, imbriquées, assez épaisses en raison de la petitesse de la plante, munies ou privées de nervure, et ont leur réseau composé de mailles ou aréoles circulaires, disposées par lignes paralleles. La capsule est petite, droite, courtement pédonculée, dépassant à peine le niveau des feuilles, et reposant sur une apophyse d'une consistance molle, oblongue ou turbinée. Le pédoncule, un peu renflé à sa naissance, est̂ inséré dans une gaine très courte. L'opercule est conique ei petit. Les Housses qui forment ce genre habitent les deux continents de l'hémisphère boréal. Elles choisissent de préférence, pour s'y établir, les rochers et les pierres. Peu communes dans les plaines, elles s’élèvent juscu'à la région 
des neiges éternclles. Elles sont vivaces.

Limné avait placé parmi les Jongermannes les deux seules esp. connues de son temps. Ehrhardt, qui créa le genre, le laissa aussi dans la famille des Hépatiques. Hedwig et tous les bryologistes qui l'ont suivi l'ont définitivement classé parmi les Mousses. Il faut convenir que, par son organisation, il tient le milieu entre l'une et l'autre famille. MII. Endlicher et Lindley ont peut-être eu raison d'en former un ordre distinct des Mousses et des Hépatiques, sous le nom d'Andréacées. (Voy. ce mot.) On n'en connaît que 5 esp. bien distinctes, dont l'une ( $A$. subulata) est originaire du Cap; les sutres appartiemnent à l'Europe. Comparé à d'autres Mousses, ce g. a quelque analogie avec les Sphagnum par son pédoncule charnu et blanc, non primitivement renfermé dans la coiffe, et avec les Phascum par un opercule yersistant; mais il diffère de l'an ê de l'autre par le mode de déhiscence de sa capsule.

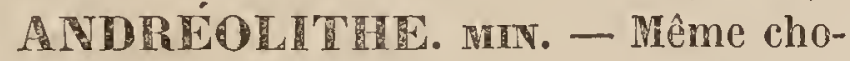
se qu'Andréasbergolithe.

(DEL.)

* NDPEOSTR , DG. (Andrzeioski, botaniste polonais ). Bor. Pr. - Syn. du g. Dontostemon, Andrz., de la famille des Crucifères.

(SP.)

* NDPEUSTA (nom d'homme). BOT. P1. - G. de la famille des Vacciniées, établi par M. Dunal, et synon. du g. Symphysia de Presl. (in Litt. ad Jacq. 1827). Voy. ce mot. - G. de la famille des Hyoporacées, fondé par Ventenat, non adopté, et qui reste réuni au g. Myoporum. Voy. ce mot. (G. L。)

A NDIE WVSR (nom d'homme). BOT. 1H. - G. de la famille des Gentianacées, proposé par Sprengel (Linn. Syst., pl.419), et qui reste réuni au G. Centaurella de Michaux. Voy. ce mot.

(G. I.)

ANDRALA (Linné [Phil. Bot.] fait dériver ce nom de àvis, àvípós, homme, et de "ूin, erreur, égarement; il n'est pas facile de saisir les rapports qu'il trouve entre ces-mots et les caractères ou propriétés de ces plantes). BOT. PII. - Les plantes de ce genre font partie des Sémiflosculeuses ou Chicoracées, famille des Composées. Elles ont pour caract. : Capit. multiflore. Invol. campanulé, formé d'écailles linéaires, nombreuses, unisériées, accompagnées quelquefois à la base de quelques petites folioles accessoires. Récept. couvert d'alvéoles fimbrillifères se décomposant en espìces de soies, ou quelquefois paléacées sur leur contour. Fruits obovés-oblongs, parcourus par 10 stries, couronnés par une aigrette raide, scabre, unisériée et caduque.Les Andriala habitent l'Europe australe. Ce sont des herbes bisannuelles ou vivaces, couvertes d'un duvet serré, blanchûtre, drapé, ei entremêlé de poils glanduleux, principalement vers la partie supérieure. Les capitules sont à fleurs jaunes, et disposés en corymbe. (J. D.)

ANDPRALODES. Andriala (Voy.ce mot; zioos, forme, aspect; qui a l'aspect de l'Andriala). - M. De Candolle a donné ce nom à la première section du g. Conyza, et la caractérise de la manière suivante : Réceptacle muni d'alvéoles à bords entiers. Aigrette à soies scabres, à peu près de même longueur que le fruit. Cette section ne renferme qu'une seule esp., originaire des montagnes de l'Inde. C'est une plante vivace, à feuilles couvertes d'un duvet blanc, et a capitules solitaires au sommet des rameaux.

(J. D.)

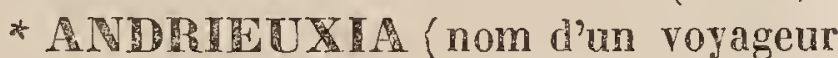
qui a parcouru le Mexique dans ces derniers temps ). $\mathrm{BDT}_{\mathrm{T}}$. P政. - Ce g. appartient à la famille des Composées, tr. des Sénécionidées. M. De Candolle le caractérise à peu près de la manière suivante : Gapitule multiflore hétérogame; fleurs du rayon au nombre de 20 environ, unisériées, ligulées, femelles, stériles; celles du disque hermaphrodites, tubuleuses, 5̌-dentées. Invol.composé de deux rangées d'écailles oblongues, foliacées, étalées à leur paríc supérieure; récept. convexe, couvert de paillettes membraneuses, aiguës, concaves, ê embrassant les fleurons. Les fleurons ligulés sont coriaces et munis de 5 étamines avortées, réduites à de petits filaments; le style, glabre, se divise en deux rameaux cylindracés. Les fleurs du disque, infundibuliformes, sont pourvues d'étamines linéaires et d'un style dont les branches se terminent par un petit cône velu. Les fruits des tleurons sont stériles, petits, obovales, comprimés, trigones et velus au sommet; ceux du disque oblongs, trigones, glabres, dépourvus d'aigrette.-Le g. Andricuxia ne renferme qu'une esp., originaire du Mexique; c'est une herbe vivace 
à fcuilles opposées, à rameaux parcourus dans leur longueur par des séries de poils alternant avec les insertions des feuilles. Les fleurs sont jaunes. (Voy. Delessert, Ic. Select., vol. 4.)

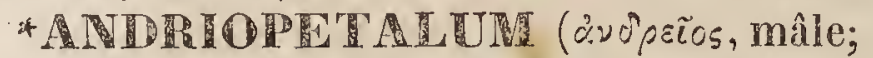
$\pi \varepsilon ́ \tau \alpha \lambda$, p pétale; allusion à l'insertion staminale). Bot. Int. - G. de la famille des Protéacées, tr. des Nakéées, formé par $\$ \operatorname{chott}(M s c$.$) ,$ adopté et décrit ensuite par Pohl ( Pl.bras., t. 91-92), et dont voici les caractères : Périgone tétraphylle, régulier, à folioles révolutées au sommet. Etam. base du périgone; les filaments linćairesplans, égalant les folioles périgoniales. Glandules 4 , hypogynes, connées entre elles. Ovaire uniloculaire, bi-ovulé. Style filiforme. Stigm. vertical, en massue. Follicule... Quelques arbres (Rhopalo Sp. Kunth:, t. 121 ) indigènes au Brésil, peu connus, à feuilles alternes, très entières, à épis axillaires en grappes, à fleurs unibractéées par deux.

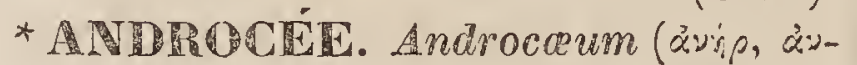

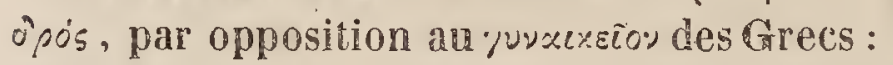
donc réunion d'hommes; ici, réunion d'étamines). BoT. P蕰. - on a proposé d'appliquer cette dénomination à l'ensemble staminal, comme on applique celle de corolle à l'ensemble des pétales; celle de calice à l'ensemble des sépales; celle de pistil à l'ensemble du stigmate, du style et de l'ovaire. Elle est peu connue, et son emploi pourrait cependant parfois t̂tre utile dans certaines descriptions.

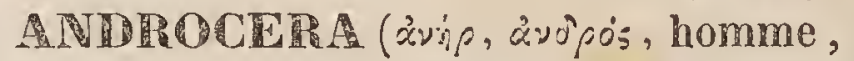
étamine; $x \varepsilon \rho \dot{s}$, corne; l'une des ćtam. est allongée en forme de corne). BOT. PII. - G. de la famille des Solanacées, établi par Nuttal (Gen., t. 129) aux dépens du g. Solanum, L., et qui n'a pas été adopté.

(C. 更.)

* AMPOCROPE. Androctonus ( $\alpha$ opo:óvos, meurtrier). ARAGRN. - G. de la famille des Scorpions (Voy. ce mot), dans les Arachnides pulmonaires, établi par $\mathbb{P}$. Ehrenberg, et caracténisé surtout, à l'égard des autres grompes de Scorpions, par le nombre de ses yeux, qui est de douze, dont cing de chaque côté et deux plus gros à la partie médio-antérieure du céphalothorax. - Ce g. renferme quelques espèces de l'ancien monde et principalement d'Afrique; mais il n’a pas encore de représentants en Amérique. Plusieurs d'entre elles causent des blessures assez dangereuses. "A Thèbes, dit M. Ehrenberg, et dans le Dongola, où les hommes redoutent tellement les Scorpions, que la vue de ces animaux leur fait horreur, et où ils disent que leur piqûre est mortelle, nous avons surfout trouvé les Androctonus quinque striatus et funestus ( Memprich et Ehr.); c'est donc à ces espèces qu'il faut surtout attribuer la propriété de donner la mort, du moins dans cette partie de l'A frique septentrionale. Nous avons vu des bateleurs égyptiens qui avaient l'And. quinque-striatus mêlé à d'autres scorpions, mais ils lui avaient enlevé le plus souvent son aiguillon. Comme je prenais souvent des Scorpions, cinq fois j’ai été piqué par ces animaux. A Dongola, la piqû̀re de l'A nd. funestus m'a causé pendant trois jours de douleurs très aiguës, et j'ai aussi observé que des femmes et des enfants pouvaient bien succomber à cette blessure, mais qu'elle est incapable de donner la mort à un homme robuste. Aucun des hommes de tempérament et d’âge aassez divers, qui, à ma connaissance, ont été piqués, n’ạ péri. ")

Ni. Ehrenberg partage les Androctonus en deux sous-genres, les Iiurus et les Prionuris.

Les espèces de ce g. qu'il a étudiées sont surtout celles d'orient, et il en porte le nombre à treize. (B. G.)

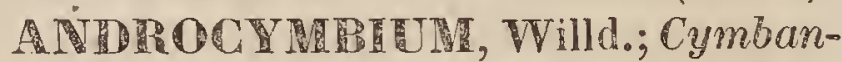
thes, Salisb. (avip, àvoo's, homme, étamine; xurfico, petite barque : mode d'insertion des étamines). Bor. Pr. - G. de la famille des Mélanthacées, tribu des Vératrées, établi par Willdenow (Berl. Mag., II, 21), et dont les caractères sont ainsi limités : Périgone corollacé, hexaphylle; folioles onguiculées, roulées en cornet au dessus de l'onglet, décidues; cornet nectarifère. Stam. 6 , insérécs sur le cornet des folioles; anth. extrorses. Ovaire 3-loculaire, multiovulé. Styles 5, coniques, continus par les loges. Caps. 3 -loculaire, 3-partible, déhiscente intérieurement par le sommet. Graines nombreuses bisérićes dans l'angle des loges... - Ce genre, encore peu connu, renferme un petit nombre de plantes du Cap, à racines bulbeuses, à fouilies ovales-lancéolées ou linéaires, cucullées à la base. I'inflorescence est en épis 
courts, cachés entre des bractées foliacées. Sert, dans son acception ordinaire, à dési-

(G. L.)

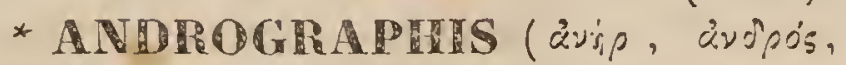
homme; yexpis, pinceau; étamines en forme de pinceau ). Bот. PH. - G. de la famille des Acanthacées, type de la tribu des Andrographidées, formé par Nees (in Wall. Pl. as. rar., t. III, p. 116), qui lui assigne les caractères suivants : Cal. 5-parti, égal, à segmenis étroits. Cor. hypogyne, bilabiée; lèvre supérieure entière ou bifide; linférieure trifide. Etam. 2, insérées au tube de la corolle. Anth. biloculaires, à logettes parallèIes, barbues à la base. Ovaire biloculaire, à loges bi-multi-ovulées. Style simple. Stigm. aigu. Capsule ovale ou lancéolée, déprimée, biloculaire, tétra-poly-sperme, loculicidebivalve; valves septifères au milieu. Graines ovales, obtuses, subcylindriques, tronquées obliquement à la base, alvéolées-scrobiculées, retenues par des rétinacles décidus. Ce g., formé aux dépens de quelques espèces de Justicia, renferme des plantes herbacées, annuelles, vivaces ou même suffrutescentes, indigènes dans l'Asie tropicale; à feuilles opposées; à grappes axillaires, grêles, simples ou di-tri-chotomes, unilatérales, munies de deux bractées opposées, plús courtes que le calice; bractéoles nulles. On en cultive quelques unes dans nos serres d'Europe.

(C. L.)

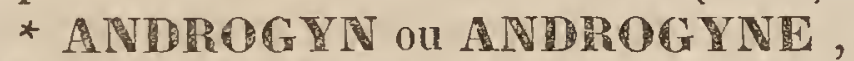
ANDROG OUDO. Androgynus, An-

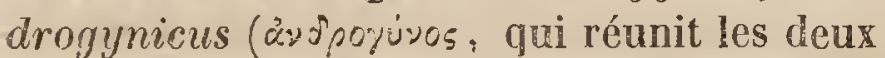
sexes). Bor. Pr. - Cette épichète s'emploie pour exprimer qu'une plante réunit à la fois des fleurs mâles et des fleurs femelles, ou qu'une fleur contient en même temps des organes mâles et des organes femelles, c'est-à-dire des étamines et des pistìls.

(A. $\mathbb{R}$.)

* DPOG YITRES (fleurs). Androgynarii flores (àvspoyivos, qui réunit les deux sexes). Bor. Pr. - Le prof. De Candolle a donné ce nom aux fleurs doubles dont les pétales surnuméraires sont dus à la transformation des deux organes sexuels. en pétales, sans que les enveloppes florales aient éprouvé aucune modification.

(A. R.)

AVDPOG YNT. Androgynus ( $\dot{\alpha} \dot{s}_{i}, \dot{\alpha} y-$ oposs, homme; yuri, fernme). zoOL. et BOT. - Ge terme, synonyme d'hermaphrodite, gner les individus qui paraissent réunir les organes des deux sexes; mais, en zoologie, on a proposé de nommer Androgynes les animaux qui, tout en possédant les deux sexes, ne peuvent se reproduire qu'en s'accouplant deux à deux, comme les Limaces; et de réserver le nom d'hermaphrodites à ceux de ces animaux qui semblent se féconder euxmêmes, comme les Huitres et les Moules. En botanique, on peut établir une division analogue, en nommant androgynes les plantes qui ont les deux sexes mâle et femelle dans des fleurs séparées sur le même individu; tels sont le Noyer et le Noisetier; et her. maphrodites celles dont les sexes sont réunis dans une même enveloppe florale. Telles sont la plupart des plantes. (C. D O.)

ANDPCCYNETTE.BOT. PR. - Synon. de Stachygynandrum. Voy. ce mot.

(G. L.)

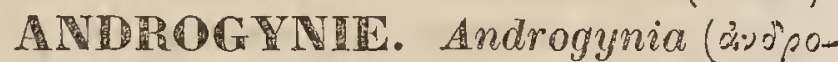
yن́vos, qui réunit les deux sexes). BoT. P1. - On appelle ainsi la réunion des deux organes sexuels soit sur un même individu, soit dans un même périanthe. Dans le premier cas, ce mot est synonyme de Thonacie; dans le second, d'Hermaphroditisme. Voy. ces mots. (1. R.)

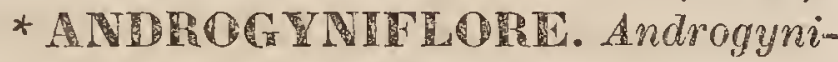
florus (ávópoyúvos, androgyne; flos, fleur ; mot hybride). Cassini, dans ses Mémoires sur les Synanthérées, disait que le capitule ou la calathide était androgyniflore, quand il se composait uniquement de fleurs hermaphrodites ou androgynes, par opposition. aux expressions de masculifore ou féminifore employées pour la calathide portant uniquement des fleurs mâles ou des fleurs femelles.

(A. R.)

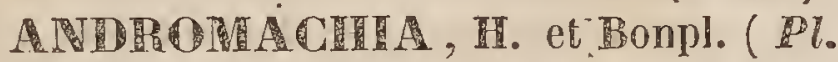
aquin., 2, 104, t. GXIl, non Cass.) (Nom mythologique.) BoT. PH. - Ge g. faic partie des Composées, tr. des Vernoniées. II a pour caract. : Capit. radié, muni d'une seule rangée de ligules femelles; les fleurs du disque nombreuses et régulières. Invol. form mé d'écailles imbriquées, sèches, acuminces. Récept. couvért de courtes fimbrilles ou de paillettes. Cor. glabres : celles du disque 5Gdes, à lobes acuminés, révolutés, légèrement plus courts que le tube; cclles do 
rayon ligulées, à tube allongé et à limbe oblong. Les filaments des étamines lisses. Styles à base bulbeuse et rameaux semi-cylindracés. Fruit cylindracé, muni de cannelures dont les angles rentrants sont velus, couronné par une aigrette composée de deux rangées de paillettes dentées; les extérieures beaucoup plus courtes et légèrement plus larges que les intérieures. - Les $\boldsymbol{A} n$ aromachia, au nombre de huit ou dix, appartiennent toutes au nouveau Continent. Ce sont des herbes ou des sous-arbrisseaux munis de feuilles opposées, tomenteuses et blanches en dessous, et de capitules disposés en corymbes.

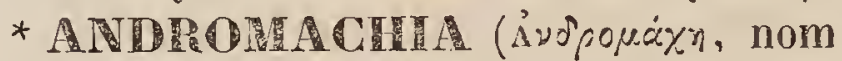
mythol.). BOT. TH. - G. de la famille des Synanthérées, proposé par Cassini (Bull. plitom., 1817), et réuni comme synonyme au g. Liabum d'Adanson.

(C. L.)

ANDONEDE. Andromeda (nom myth. d'une constellation voisine du pôle arctique; allusion à l'habitation de la plupart des plantes de ce $g_{0}$ ). BOr. la famille des Ericacées, type de la tr. des Andromédées, établi par Linné, et dont yojci les caract. essentiels : Cal. 5-fide ou 5parti. Cor. hypogyne, campanulée ou globuleuse, à limbe quinquéfide, réfléchi. Étam. 10, hypogynes, incluses, insérées à la base de la corolle; filaments subulés; anthères obtuses ąu sommet ou bicornes, à dos mutique ou rarement aristé. Ovaire š-loculaire, à loges multi-ovulées. Style simple; stigmate obtus, quelquefois dilaté. Capsule subglobuleuse, 5-loculaire, loculicide-5-valve; valves septiféres au milieu, indivises ou ensuite bifides; colonne centrale placentifere au sommet. Graines nombreuses, lisses ou scrobiculées. - Arbres ou arbrisseaux assez nombreux en espèces, dont l'habitation est variée. On les trouve principalement dans l'Amérique boréale, dans l'Asie tropicale, et dans les contrées situées sous les pôles ou qui les environnent. On en cultive quelques unes dans les jardins. Endlicher (Gen., $\mathbb{P} l$. 4318 ), à qui nous empruntons ces caractères, fait observer qu'on devra, un jour, diviser ce g. en plusieurs autres, en raison de divers caractères importants, dont on a négligé l'étude dans les Ericées, comme la forme des anthères, la déhiscence du fruit, la situation du placenta, la nature des grai- etc. nes qưil. a observées lui-même dans quel ques espèces; et que, s'il laisse dans son ceuvre le g. Andromeda intact, en y ajoutant toutefois les sections qu'on en a formées, c'est de peur d'accumuler erreur's sur erreurs. Ces sections sont : Cassiope, Don.; Polifolia, Buxb.; Cassandra, Don.; Zenobia Don.; Leucothoë, Don.; Pieris, Don.; Agonista, Don.(Yoy. ces divers mots.). Quant au dernier, comme il a été omis à son ordre alphabétique, nous en citerons ici les caract. : Cal. 5-parti. Cor. ovale. Anth. mutiques sur le dos, tubulćes-bicornes au sommet. Style cylindrique; stigm. capité. Graines anguleuses. - Arbrisseaux toujours verts, indigènes de l'Amérique tropicale et de l'île de Bourbon (insulis Borbonicis? ), à feuilles coriaces, souvent très entières, réticuléesveinées, à fleurs terminales, en grappes. (Don., Syst. III, 837; A. salicifolia Commers; A. buxifolia Lamk., etc.) (G. L.) ANDOMEDE. Andromedes (nom mythol.). FORAMIr. - G. établi par Montfort (Conchyl. Syst., p. 38) sur une fgure copiée et dénaturée de Fichtel et Moll. (Test. Microsc., p. 49, f. 5, f. c. d.). Nous croyons que c'est une esp. du g. Polystomelle. (Voy. ce mot.) Lamarck en a fait une Vorticiale. Voy. ce mot.

(A.sD'O.)

* ANDOMÉRERES. Andromedece (Voy. ANDRONEDA). EOT. PH.-Tribu de la famille des Ericacées, dont le type est le g. Andromeda, formée par Endlicher (Gen., $P l$ p. 754), et caractérisée par une corolle décidue.

(C. I.)

* ANDPOP DUS. ors. - S.-g. établi par Swainson (Class of Birds), dans sa famille Merulidae, sur un oiseau d'Afrique (le Merle importun, de Levaillant), et synonyme de notre g., Polyodon, que nous avons proposé dès 1852 dans le Mag. de Zool., de Guérin. Voy. le g. Brachypus, dont le g. Poliodon est un s.-g.

(LAFR.)

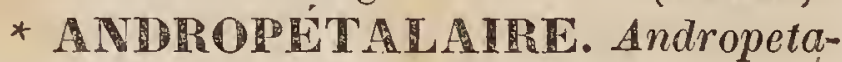

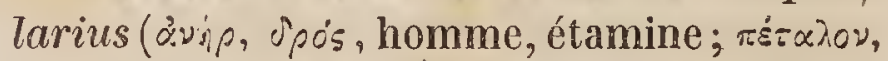
pétale ). \#OT. BY. - M. De Candolle applique cette dénomination aux plantes à fieurs doubles ou pleines; monstruosité due à la métamorphose des étamines en pétales, et dans laquelle le pistil reste intact, comme cela se voit journellement en horticulture, dans les Pivoines, les Roses, les Camellias,

(G. L.) 


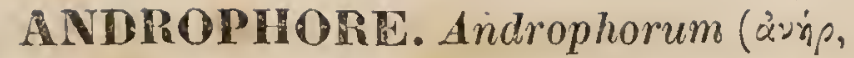

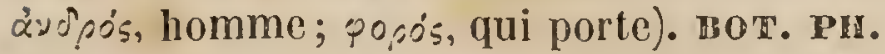
- Quelques botanistes, et spécialement M. De Mirbel, ont proposé d'appeler ainsi le faisceau ou les faisceaux formés par la soudure des filets staminaux, quand les étamines sont monadelphes, diadelphes ou polyadelphes, ou même chacun des filets des étamines en particulier. Dans ce dernier cas, le mot Androphore est, comme on voit, synonyme de flet staminal. Voy. ÉTAMNE.

(A. R.)

ANDROPIVLAX, Wendl. (ávip, àvopós, homme; quंx乡, gardien, protecteur). пот. PIr. - Syn. du g. Cocculus, DG., de la famille des Ménispermacées.

(SP.)

ANDROPOGON (ávip, àvosos, homme; $\pi \dot{i} \gamma(\omega \nu$, barbe ). Вот. PH. - L'un des plus grands g. de la famille des Graminées, type de la tr. des Andropogonées, qui se compose de plus de 150 esp., la plupart exotiques, quelques unes cependant croissant dans les contrées méridionales de l'Europe. Le prof. Kunth, dans son Agrostographie, a réuni à ce genre les genres Sorghum, Holcus et Centrophorum, et lui assigne les caractères suivants : Fleurs disposées en épis solitaires, géminées, fasciculées ou en panicules. Épillets géminés ou ternés au sommet : l'un complet et muni d'arête; l'autre stérile, rudimentaire, et ordinairement dépourvu d'arête. Le premier a denx fleurs : l'une inférieure, neutre et unipaléacée; l'autre supérieure, hermaphrodite, très rarement femelle, composée de deux écailles qui deviennent dures et coriaces, et sont mutiques. Les paillettes de la glume sont plus petites, minces et presque transparentes; l'inférieure est longuement aristée. Les étamines au nombre de trois; l'ovaire glabre; les styles terminés par deux stigmates plumeux; les paléoles tronquées et ordinairement glabres; le fruit glabre, environné par les écailles.

En rétablissant le g. Andropogon à peu près dans les limites qui lui avaient été assignées par Linné, M. Kunth y a, par conséquent, réuni plusieurs des g, qui n'en étaient que des démembrements, et, entre autres, l'Anatherum de Palissot de Beauvois, l'Heteropogon de Persoon, le Colladoa de Cavanilles, etc. Ainsi constituć, c'est, sans contredit, un deg g. les plus nombreux

T. 1. en esp. dans toute la famille des Graminées. On en compte 174 dans l'Enumeratio plantarum de M. Kunth, qui a paru il y a déja sept ans, c'est-à-dire en 1855.

Quelques esp. du g. méritent d'être citées à cause de leurs propriétés : $1^{0}$ l'Andropogon muricatus (Retz, t. III, p. 45), ou $A$. squarrosus (L., Suppl., p. 453), originairo de l'Inde, fournit cette racine odorante, aujourd'hui si connue sous le nom de vétiver, et qui sert à aromatiser le linge et les habits. C'est à tort qu'on a voulu en faire un g. distinct sous le nom de Vetiveria.

2. La racine de l'And. narảus $\mathbf{L}$. esî une des esp. que les anciens désignaient sous le nom de Nard indien. Elle est aromatique et excitante; mais on ne l'emploie plus aujourd'hui.

$5^{\circ}$ L'Androp. schoenanthus L. ofire également une racine, mais surtout une tige et des feuilles très aromatiques, qu'on emploie encore aujourd'hui dans quelques préparations pharmaceutiques très compliquées, comme la Thériaque et le Diascordium.

(A. R.)

* ANDROPOGONELE. (Voy. ANDHOPogov.) BoT. PH. - L'une des tribus établies par le prof. Iunth dans la famille des Graminées. Elle contient entre autres les g. Andropogon, Erianthus, Saccharum, etc., etc. Voy. GRAMUWES.

(A. R.)

ANDIOSACE (nom d'une plante dans Dioscoride ). POLYP. - Nom donné, par les anciens botanistes, à l'Acétabulaire de la Méditerranée.

(DUJ.)

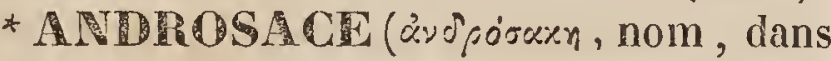
Dioscoride, d'une plante aujourd'hui indé-

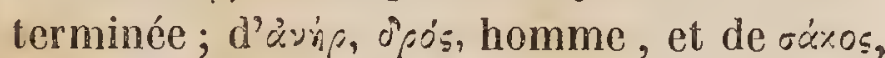
bouclier; allusion à la forme peltée des feuilles). BOT. GR. - Boccone (MLuseo di piante rare, p.143) appelle ainsi une petite espèce d'Agaric, à cause de sa ressemblance avec la fleur qui porte ce nom. L'Agaricus androsaceus Linn. crô̂t très abondamment en automne sur les feuilles et les rameaux de plusicurs arbres, et particulièrement du chêne. Son chapeau est mince, membraneux, convexe ou légèrement déprimé au centre, plissé, et d'un roux très pâle. Les lames sont simples, blanches, adhérentes au pédicule, qui est filiforme, plus ou moins allongé, fistuleux, lisse, sillonné suivant sa longueur, et d'un brun noir brillant. Il ar- 
rive souvent dans les temps secs que le chapeau avorte; s'il survient ensuite de l'humidicé, il s'allonge, se ramifie, et ressemble parfaitement à des crins. Dans cet état, Persoon et Acharius l'ont décrit sous le nom de Rhizomorpha setiformis. Persoon même (Mycologia europ., sect. 1re, p. 49) en a fait le Ceratonema hippotrichodes, en raison de son habitus. Il est probable que plusieurs petits Agarics, qui ont beaucoup d'analogie avec celui-ci, éprouvent les mêmes modifications quand ils sont soumis aux mêmes circonstances.

(LE.)

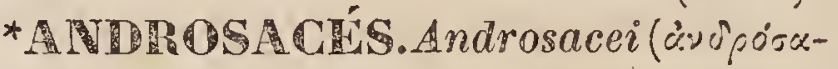
$x$, nom d'une plante aujourd'hui indéter-

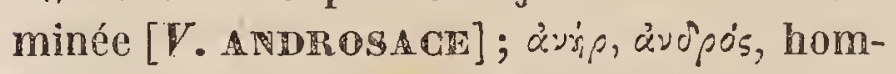
me, et óx<0s, bouclier). BOT. CR. - Panlet (Traité des Champ., t. I, p. 559) a formé, sous ce nom, un petit groupe de Champignons qui ont quelque ressemblance entre eux, et qui comprend l'Ag. Vaillanti $\mathrm{T}$. 1'A. androsaceus Linn., l'A. saceharinus Batsch, ef l'A. squammula Batsch.

(LE.)

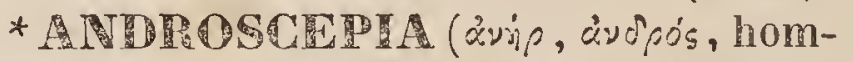

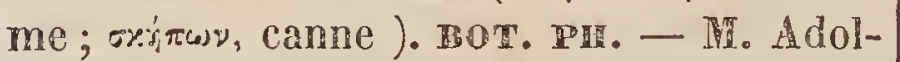
phe Brongniart (in Duperrey $I . B$ Bo 0,78 ) a établi sous ce nom un g. dans la famille des Graminées, tr. des Andropogonées, pour une esp. déjà connue, qui a été tour à tour désignée sous les noms d'Antisthiria gigantea Gavan. (Ic.5, p. 36, t. 458 ), Apluda gigantea Spreng (Syst., t. $\mathbf{1}$, p. 290), Calamina gigantea Romer et Schult. - Cette Graminée est originaire des Moluques. Ce g. diflere surtout da g. Anthistiria par ses épillets, au nombre de cinq à sept, et non de trois seulement, accompagnés à leur base par quatre autres épillets mâles, formant une sorte d'involucre à quatre valves; par ses épillets hermaphrodites et mâles biflores; par la paillette inférieure de la fleur hermaphrodite, qui est membraneuse, mutique, trinervée, et non changée en arête coriace, seulement comprimée et clargie à sa base, comme dans le g. Anthisíria. Voy. ce mot.

(A. R.)

ANDIOSGE. Anarosamum, Allioni;

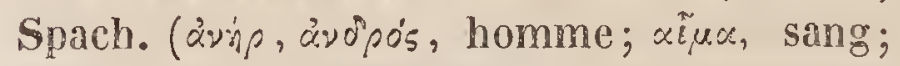
allusion à la coulcur du suc : il aurait fallu écrire Androshomum). BOT. $P$ D. - G. de la famille des Hypéricacées, tr. des Hypéricécs. Ses caract. sont : Cal. š-parti; seg- ments très inégaux, trìs entiers. Pétales $\xi_{7}$ étalés, inéquilatéraux, inonguiculés, non persistants. Eum. pentadelphes, caduques; androphores larges, très courts, polyandres, insérés devant les pétales. Anthères cordiformes-orbiculaires, couronnés d'une glandule diaphane. Ovaire 3 -loculaire ou 1-loculaire, globuleux; ovules horizontaux, multisériés dans chaque loge. Styles $\mathbf{3}$, divergents, libres dès la base. Stigmates petits, subcapitellés. Capsule coriace ou subchartacée (ordinairement charnue et colorée avant. la maturité), 1-loculaire ou incomplètement 3-loculaire, septicide-trivalve (indéhiscente dans 1'A. offeinale), à 3 placentaires lamelliformes, oblongs, biapiculés au sommet, séminifères aux bords, attachés aux borrs infléchis des valves, libres après la déhiscence; valves cymbiformes, persistantes, de nckme que les placentaires. Graines petites, plurisériées sur chaque placentaire, ellipsoïdes, apiculées aux deux bouts, criblées de fossettes ponctiformes. - Arbrisseaux ou sous-arbrisseaux très glabres, exhalant une odeur forte et fétide. Rameaux et ramules subtétragones. Feuilles sessiles ou subsessiles, opposées-croisées, très entières, ponctuées de vésicules transparentes, en général grandes. Tleurs en cimes trichotomes ou paniculées, ou en ombelles. Pédoncules terminaux ou subterminaux couris, dressés, anguleux, articulés et 2-bractéolés au sommet. Cor. jaunes, en général grandes. - Ce g. comprend environ 6 esp., dont la plupart habitent la région méditerranćenne. Outre I'A. officinale All., il faut y rapporter l'Hypericum hireinum L., et plusieurs autres esp. voisines de cette dernière. (SE.)

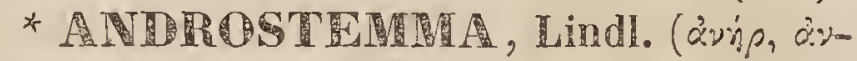

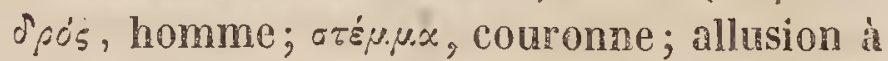
la disposition staminale). Вот. PH. - G. de la famille des Hémodoracées, très voisin des Conostylis. II. Lindley (Bot. Reg. Append., p. 46) lui attribue les caract. suivants : Périanthe semi-supère, cylindracé, cotonneux à la surface externe; limbe régulier, 6-fide, réféchi. Etam. 6 , isomètres, longuement saillantes, insérées à la gorge du périanthe. Anth. linéaires, dressées. Siyle subulé, tripartible a la base. Stigm. indivisé. (Péricar-

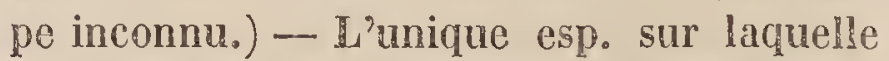
se fonde ce g. a été observíe dans la Fouvelle-Hollande occidentale (colonie du Swan- 
niver'). C'est une herbe acaule, à racine poIycéphale, à feuilles dressées, comprimées, très glabres; à pédoncules radicaux, courts, uniflores, dressés, garnis, vers leur sommet, de bractées membranacées; à fleurs grandes, verdâtres.

(SP.)

ANBOTORES. Androtomce (ámp, ḋuòpós, homme, étamine; rousi, coupe, section ). Бот. Pu.-Cassini proposait de donner ce nom aux plantes de la famille des Synanthérées, parce que les filaments staminaux semblent coupés vers le milieu en une sorte d'articulation produite isoit par un étranglement, soit par une mutation de forme, soit par une coloration différente; caractère qui lui semblait préférable à celui de la connexion des anthères, pour imposer la dénomination qui exprime liftéralement son opinion à la vaste famille dont la première appellation a prévalu. (C. L.)

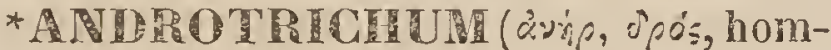

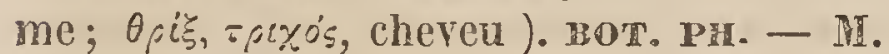
Ad. Brongniart (Voyage de la Coguille, part. bot., p. 176) a donné le nom d'Androtrichum à une division du g. Abildgaardia, qu'il a reconnue ensuite comme devant constituer un genre distinct. Ce genre serait essentiellement caractérisé par l'allongement considérable des filets des étamines, qui, par leur nombre considérable, leur longueur et leui blancheur, ressemblent à des poils sortant des écailles des épillets, et accompagnent les fruits lorsqu'ils tombent à leur maturité. L'Anäroirichum polycephalum, ou Abildgaardia polycephala Brongn., a été décrit par Nees et par Sprengel sous les noms de Cyperus prolifer et irigynus, et par Iink sous celui d'Eiophorum montevidense. Cette plante a en effet un port qui la fait ressembler à certains Eriophorum. Elle croît à l'île Sainte-Catherine et sur le littoral du Brésil méridional. (G...N.)

* ANDPREZOVISKIA, Reichenb. (Andrzejowshi, botaniste polonais). BoT. PeET. - G. de la famille des Crucifères (Siliqueuses), dont les caract., suivant l'auteur (Iconogr. exot., I, tab. 13), sont les suivants: Sépales 4 presque dressés; les 2 latéraux subsacciformes à la base. Pétales 1 , oblongs, obtus. Etam. 6 , non dentées, tétradynames. Stigm. obtus. Silique indéhiscente, subtétragone; valies carénćes au dos, prolongées au sommet en cornes coniques, comprimées, aussi longues que le style ; nervures placentairiennes convexes; diaphragme, innervé. Graines au nombre d'environ 4 dans chaque loge, suspendues, ovales-oblongues, immarginées; funicules filiformes, libres. Cotylédons elliptiques, plans, contraires au diaphragme, accombants. - Merbe annuelle, glabre; feuilles pennatiparties, alternes; pétiole amplexatile, auriculé à la base; grappes oppositifoliées et terminales; fieurs blanches. - Ce g., voisin des Notoceras, n’est fondé que sur une esp., indigène d'orieni : c'est le Lepidium cornutum Smith, et le Notoceras cardaminefolium $\mathbf{D G}$. (SP.)

ANE, ou mieux. TERE DARE. Porss. - Dénomination qui vient du nom vulgaire que les Languedociens, sous la forme de Téte d'aze, donnent au Chabot de nos rivieres (Cottus gobio), et qui parait tenir à la grosseur de cette partie du corps. C'est ainsi qu'en anglais on l'appelle Bullhead (tête de taurean), en allemand Faullopf (tête en boule), ou Firale quappe (lote en boule), en italien Capo grosso, etc., etc.

(VAL.)

ANE. Asinus. MOLL. - Les marchands d'histoire naturelle désignent sous ce nom vulgaire plasieurs esp. de coquilles. Ils nomment Petit ûne le Cyprcea asellus, Peau d'âne le Cyproe a caurica. (Voy. PORCELAIN⿴囗大 L'âne rayé ou le zèbre, pour eux, est I'Achatina zebra Lamarck. ( $F o y$. AGA THINE.) Enfin, dans quelques cantons, les pêcheurs donnent aux Poulpes le nom d'Anes marins. (Voy. PoULP.) Ces dénominations commencent à tomber en désuétude.

(DESH.)

ANE. Asinus. MA. - Esp. du g. Cheval. Voyez ce mot.

(C. $\mathbb{D}^{\top} \mathrm{O}$.)

AND P YÁ. MAM. - \$yn. de Zebre, autre esp. du g. Gheval. Voyez ce mot.

(G. D'O.)

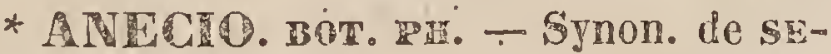
NEGEO.

(I. D.)

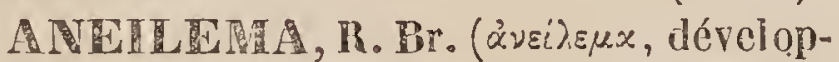
pement ?). BOT. PR. - Division du g. Commelina, Dill., caractérisée par un involucre nul, une inflorescence paniculée-divariquée (R. B. Prodr. 270). Voy. ComMELINA.

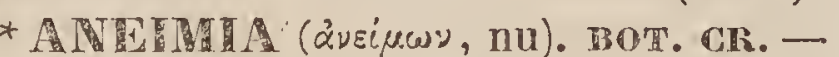
Genre de Fougères de la tribu des Osmundacées, établi par Swartz ( Synopsis 
Filic., pag. 155), sous le nom d'Anemia, dont l'orthographe a été modifiée par Kaulfuss et Sprengel. II est ainsi caractérisé : Capsules presque turbinćes, disposées en épis composés ou panicules rameuses, sessiles, nues (sans aucun induse), terminées supérieurement par une calotte à stries rayonnantes, s'ouvrant par ine fente latérale. Plusieurs espèces de ce genre avaient été placées par Linné parmi les Osmunda; mais ce dernier genre diffère des Aneimia par ses capsules lisses ou irrégulièrement veinées sur toutes les surfaces, au lieu d'être striées concentriquement au sommet. Par ce caractère, les Aneimia se rapprochent beaucoup plus des Schizœa, auprès desquels les auteurs modernes les ont placées. Les panicules sont plus ou moins rameuses, fréquemmend géminiées à la base de la feuille; quelquefois elles sont portées sur de longs pédoncules qui partent des racines. C'est cette disposition des capsules sur de longs épis ordinairement géminés qui détermine le port de ces Fongères et en fait un genre facile à reconnaître. Les feuilles ou frondes stériles sont ternées, pinnées, bipinnées on décomposées. Il est très facile de voir sur ces Fougires la transformation des feuilles en frondes fertiles qui sont alors devenues plus longues et plus divisées, portant les sores sur leurs pinnules latérales.

Le nombre des Aneimia, primitivement de 17, s'est accru, par les voyages de Raddi et de Martius dans le Brésil, de plusieurs espèces très remarquables. Ce sont des plantes d'un aspect élégant, et dont plusieurs sont cultivées dans les serres des jardins d'Europe. Elles croissent toutes dans les contrées chaudes de l'Amérique, principalement de la partie méridionale.

Le g. Ornithopteris de Bernhardi est synonyme d'Aneimia.

(G...N.)

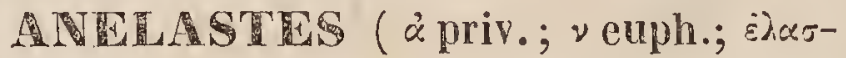
sis, qui saute). INs. - G. de Coléoptères pentamères, famille des Sternoxes de M. Dejean, ou des Serricornes de Latreille, établi par Iirby, qui lui donne les caract. suivants : Labre couvert, petit, arrondi au sommet. Lèvre presque carrée, bifide. Mandibules exsertes, édentées, courbes, aiguës. Palpes très courts, filiformes; dernier article des maxillaires plus grand, tronqué obliquement. Antennes moniliformes; dernicr arti- cle presque en croissant. Corps linćaire, presque cylindrique. Poitrine inerme. - Ce g. lie la tribu des Cébrionites à celle des Élatérides. Il diffère de tous les g. de la première par ses antennes moniliformes, par ses palpes courts, et plus spécialement encore par le labre entièrement caché sous le chaperon. Il a beaucoup du faciès des Elater; mais, outre qu'il en est séparé par les caractères précités, il en diffère encore par ses mandibules avancées et son sternum déprimé. Il est fondé sur une seule espèce, Anelast. Drurii, décrite et figurée dans un ouvrage de Kirby intitulé : Centurie d'Ins., contenant plusieurs genres nouveaux décrits dans sa collection, p. 10, pl. 1, fig. 2.

D'après cette figure, M. Dejean avait pensé que l'insecte fqu'elle représente appartenait au même genre que son Perothops cervinus; aussi n'a-t-il pas adopté le genre Anelastes; mais $\mathbb{R}$. Guérin, ayant reçu depuis cet insecte en nature, s'est assuré qu'il est le même que le Silenus brunneus de Latreille (Ann. de la Soc. ent. de France, tom. 5, p. 128), et que l'Agriotes tardus Dej. ( $3^{\mathrm{e}}$ édit. de son Catalogue, 1857 ). Ainsi voilà un Goléoptère qui a reçu trois noms génériques et spécifiques différents; mais celui a'Anelastes Drurii $\mathbf{L}$ irby doit prévaloir comme étant le plus ancien. Cet insecte, dont Kirby n'avait pas indiqué la patrie, est de l'Amérique du Nord et appartient à la tribu des Cébrionites, Latr.

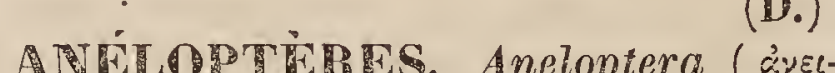

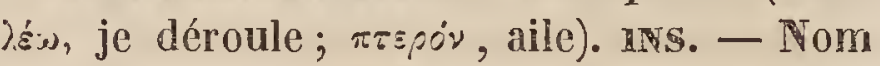
donné par hay aux Insectes à quatre ailes, dont les supérieures n'ont pas la consistance d'élytres.

AININAGROSTTS ( ypostcs, sorte de Graminée ). Bot. P玨. II. Trinius a établi sous ce nom un g. de Graminées fondé sur les Agrostis Spicaventi $\mathbf{L}$. et interrapta $\mathbf{L}$. Palissot de Beauvois avait. distingué ce g. sous le nom d'Apera. Voy. AGROSTIDE et APTRA. (G...N.)

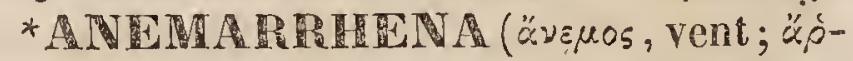
ṕr, mâle; étamine qu'agite le vent). Bo'T. Pr. - G. de la famille des Liliacées, tribụ des Anthéricées, formé par Bunge (Enum. Pl. Chin. bor. 66), qui en circonscrit ainsi les caractères : Périgone corollacé, 6-phylle; segments oblongs-linéaires, canaliculés; les 
intérieurs un peu plus courts et plus larges. Étam. 5; filaments nuls. Anthères fixées par le milieu sur les folioles périgoniales internes. Ovaire 3-loculaire..... Style filiforme. Stigmate simple. Capsule hexagone, 3-loculaire, loculicide - trivalve. Graines 1-2 dans chaque loge, oblongues, subailées, 5-4-quètres, noires... - Ce g. ne renferme qu'une plante encore peu connue, ayant le port d'un Asphodèle, et trouvée sur les hautes montagnes de la Chine boréale. Le rhizôme en est horizontal, rampant; les feuilles radicales linéaires - lancéolées, très acuminées; la scape est munie à la base de feuilles larges et subulées, et de bractées hyalines. L'inflorescence est en grappe terminale, simple, allongée. Les fleurs sont agglomérées-éparses, subsessiles, bractéées, petites, de couleur lilas.

* ANEMIA ( $2 \nu \varepsilon \mu i x$ vent). ING. - G. de Coléoptères hétéromères, famille des Taxicornes, tribu des Diapériales, établi par M. Delaporte (Hist. des Anim. arficulés, Buffon-Duménil, t. 2, p. 218). Les Insectes de ce g. ont le corps épais, cylindrique, et le faciès des Aphodius. Ils ont la tête fortement échancrée en avant, et diffèrent du g. Coelus par les jambes antérieures, élargies, comprimées, et offrant deux très fortes dents au côté interne. M. Delaporte décrit comme type une espèce du Sénégal qu'il nomme $A$. granulata; elle est très granuleuse, d'un brun noir assez luisant; elle a le corps garni sur les côtés de cils jaunes; la tête et le corselet couverts d'une ponctuation serrée, mais égale; celle des élytres plus forte et irrégulière; les pattes et le dessus du corps rougeâtres; les antennes et les pattes d'un brun rouge-

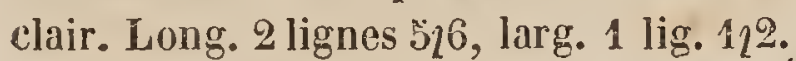

ANEMIA. BOT. CR.-VOy. ANEIMIA.

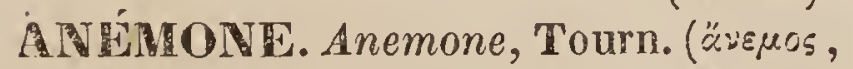
vent). Bot. - G. de la famille des Renonculacées, tr. des Renonculées, Spach, s.-tr. des Anémoninées, Spach. Ce g., que beaucoup d'auteurs ont confona fort mal à propos arec les Pulsatilles et avec l'Anémonelle, se compose d'environ 30 esp. , lesquelles se groupent en plusieurs s.-g. très naturels. Les caract. les plus essentiels du g. sont les suivants : Sépales en nombre indéfini (de ¿à 20 , et quelquefois plus ), bi ou pluri sé- liés, pétaloïdes, submarcescents. Détales nuls. Étamines en nombre indéfni; filets capillaires ou filiformes, épaissis au sommet. Antheres elliptiques ou suborbiculaires, comprimées, latéralement déhiscentes (jamais extrorses), non arquées après l'anthese. Ovaires aplatis ou comprimés bilatéralement, nombreux, agrégés, contenant chacun un ovule suspendu un peu au dessous de l'angle interne de la loge. Styles ascendants ou dressés, subulés (souvent oncinés), papillifères au bord antérieur. Gynophore cylindracé, ou conique, ou ovoïde, ou subglobuieux, en général très développé. Péricarpe composé d'un nombre plus ou moins considérable de nucules comprimées ou aplaties, subcoriaces, agrégées en capitule, apiculées, ou rostrées, ou oncinées au sommet. Graine inadhérente.

Les Anémones sont des herbes vivaces à tiges soit scapiformes et très simples (garnies seulement d'un verticille de 5 feuilles), soit dichotomes. Les feuilles sont ternati-décomposées ou digitées, ou palmati-parties, ou pédati-parties, ou rarement indivisées; les inférieures longuement pétiolées; les supérieures en général sessiles ou subsessiles. Les fleurs, le plus souvent grandes et élégantes, sont terminales ou dichotoméaires et terminales, longuement pédonculées, blanches ou rouges, ou jaunes, ou bleues, ou panachées. Dans plusieurs esp., les nucules du péricarpe sont enveloppées d'une laine épaisse, d’abord entrelacée et apprimée, mais qui se déroule a l'époque de la maturité.

Les s.-g. suivants sont peut-être à considérer comme autant de genres: Sylvia, Spach; Oriba, Adans.; Anemonidium, Sp.; Homalocarpus, DG.; Phacandra, Sp. Voy. ces mots.

La plupart des Anémones habiteni les contrées extra-fropicales de l'hémisphère septentrional. Quelqques esp. ont été trouvées dans les régions tempérées de l'Amérique méridionale. Plusieurs se cultivent comme planies de parterre.

(ST.)

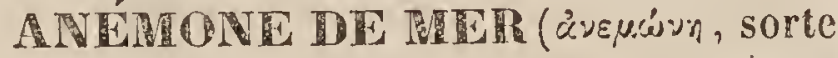
de fleur). Dénomination donnée anciennement aux Actinies, qui ressemblent souvent, en effet, à une fleur épanouie sous les caux.

AJEROR:ES. Bot. Pu. - Tribu ou 
s.-tribu de la famille des Renonculacées. (Sp.)

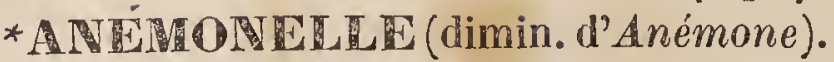
Anemonella, Spach. BoT. PH.-G. de la famille des Renonculacées, fondé sur l'Anemone thalictroides Linn., et très voisin tant des Anémones que des Pigamons (Thalictrum). Il difmère des Anémones par son péricarpe à nucules trièdres et submuticques , portées sur un réceptacle fort petit, non prolongé en gynophore. D'un autre côté, l'on ne saurait le confondre avec les Pigamons (dont il se rapproche par le port et par la conformation des fruits), à cause de son calice de 6 à 9 sépales persistant plusieurs jours après l'épanouissement.

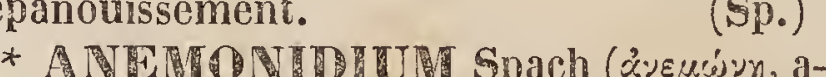
némone; zĩsós, forme).-\$.-g. ou sect. des Anémones, dont les caract. sont : Rhizôme subvertical, irrégulier, pluricaule. Tiges dichotomes. Pédoncules solitaires, dressés. Fenilles palmatifides : les canlinaires ternées ou opposées, sessiles. Anthères jaunes. Gynophore petit, subglobuleux. Nucules non laineuses, peu nombreuses, aplaties, terminées en bec rectiligne, agrégées en capitule globuleux.

(SP.)

ANETONOSTERTIR, De Candolle

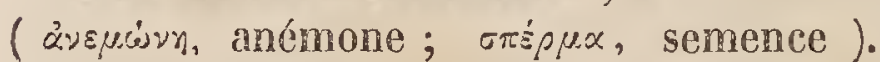
Bow. $\mathbb{P}^{\text {捝. }}$ - Syn. du s.-g. Oriba, Adans.; de la famille des Renonculacées. (SP.)

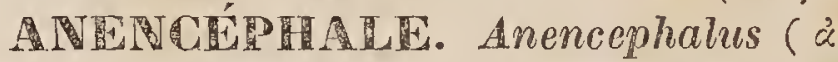

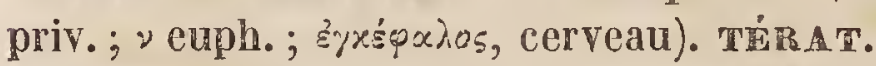
- Tom introduit dans la science par Malacarne en Italie, et par Chaussier en France, pour distinguer les monstres privés de cerveau de ceux chez lesquels la tête manque entièrement. Il appartient aujourd'hui en propre à un genre de Monstres unitaires, type de la famille des Anencéphaliens. Voy. ce mot.

(1. G. S. H.)

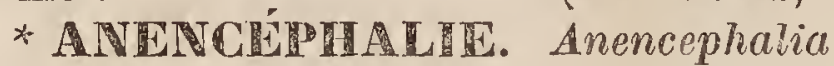

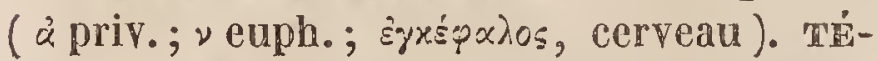
RAT. - Mr Breschet a donné ce nom à un g. de déviation organique, caractérisé par l'absence du cerveau.

(G. D'O.)

* ANEMCERTILITIS. Anencepha-

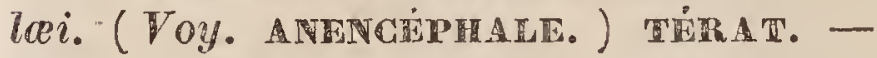
Famille de Monstres unitaires, appartenant à l'ordre des Autosites, et dont le caractère général, exprimé par le nom même d'Anencéphaliens, consiste dans l'absence de l'encéphale, et aussi de la totalité ou d'une portion de la moelle épinière. Le crâne est largement ouvert en dessus, et présente à l'extérieur sa base, la voûte n'existant que rudimentaire et seulement dans sa portion périphérique. Le canal vertébral, dans sa totalité si la moelle épinière manque tout entière, ou, dans le cas contraire, dans la portion qui correspond au segment manquant de la moelle épinière, présente des déformations analogues du crâne; clle est largement ouverte en arriere, et offre l'aspect d'une gouttière presque plate, faisant suite à la base du crâne. Cette gouttière, avant la naissance, est recouverte de membranes fines et transparentes, sous lesquelles existe un amas plus ou moins considérable de sérosité, et qui d'ordinaire se déchirent pendant le travail de l'accouchement. Elles laissent échapper la sérosité, et ne se présenten plus ensuite à l'observation que sous la forme de lambeaux ou débris irréguliers que l'on aperçoit des deux côtés de la gouttière vertébrale. La région dorsale se trouve ainsi déformée diversement, mais toujours d'une manière très remarquable, après comme avant la naissance. Au contraire, le reste du trone ct les membres ofîrent la conformation normale, à moins que des vices de conformation étrangers à la monstruosité principale ne viennent s'y ajouter et la compliquer par des anomalies accessoires.

Les monstruosités anencéphaliques sont pour le moins extrêmement rares chez les animaux : nous ne saurions en citer, même parmi les espèces domestiques les plus répandues autour de nous, un seul exemple vraiment authentique. Chez l'hoinme, au contraire, les Anencéphaliens, surtout ceux du sexe féminin, ne sont pas très rares. Leur naissance a généralement lieu avant terme, et même le plus souvent dans le cours du huitième mois. Elle est constamment précédée de l'écoulement d'eaux très abondantes, parce qu'aux eaux de l'amnios s'ajoute ici la sérosité de la poche hydrorachique existanê dans la région veréébralc. Au moment de leur naissance, les Anencéphaliens ont un embonpoint remarquable, et présentent̂ toutes les apparences de la force et de la santé.

Des Monstres qui naissent avant terme, sans encéphale et sans crâne, avec une moelle epinic̀re incomplète ou nulle, dont. 
le système nerveux est, en un mot, comparable à celui d'ún'Insecte ou d'un Crustacé, peuvent sembler, au premier aspect, condamnés à une mort immédiate. L'impossibilité qu'ils prolongent leur vie, même pendant quelques instants, a paru évidente à la plupart des anciens physiologistes; mais, à leur grand étonnement; ils ont dû reconnaître que les Anencéphaliens peuvent vivre des minutes, des heures, des jours même. Sans nous arrêter à quelques autres exemples moins remarquables, Fauvel a vu la vie se prolonger 2 heures; Jean-Jacques Sue, 7 ; Malacrane, 12; Méry; 21 ; et ce n'est pas encore le cas le plus remarquable : un Anencéphalien né en 1812 à l'Hôtel-Dieu de Paris, et auquel les soins les plus éclairés furent donnés sous la direction de MI. Serres, vécut trois jours, et fut nourri avec du lait et de l'eau sucrée, aucune nourrice n'ayant voulu lui donner le sein. Il est à remarquer que ce dernier Anencéphalien appartient au genre qui offre au plus haut degré et le plus complètement les déformations qui caractérisent cette famille : la moelle épinière n'était pas seulement incomplete, mais nulle. Ce n'est pas ici le lieu d'insister sur l'intérêt que ces faits peuvent ofirir pour la physiologie : nous devons nous borner à les rapporter; leurs conséquences trouvent place ailleurs.

Les monstruosités anencéphaliques sont du très petit nombre de celles sur les causes desquelles, grâce aux travaux de M. Geofiroy Saint-Hilaire, quelque lumière commence ¿ se répandre. Elles paraissent dépendre, au moins le plus souvent, de vives impressions morales éprouvées par la mère durant les premiers mois de sa grossesse. Ainsi un Anencéphalien dont l'observation a été recueillie par les docteurs Arlaud et Roux était né d'une jeune femme à laquelle son beau-père avait causé plusieurs fois de vives frayeurs en lançant d̀ l'improviste sur elle ou sur son lit d'énormes crapauds, afin, disait-il, de la guérir de l'aversion et du dégoût instinctif que lui inspiraient ces animaux. La mère d'un autre Anencéphalien plus anciennement décrit par les illustres Valsalva et Morgagni avait eu, pendant sa grossesse, des chagrins dont la cause n'est pas indiquée, mais quilui faisaient fréquemment verser d'abondantes larmes. Celle d'un Anencéphalien né en 1824 à la Maternité avait été eflrayée par deux de ses compagnes, qui s'étaient précipitées sur elle brusquement et avec bruit, au moment où elle passait sans lumière d'une chambre dans une autre. Enfin un autre Anencéphalien, décrit ainsi que le précédent par 1H. Geoffroy Saint-Hilaire, était né d'une pauvre femme qui, devenue enceinte par suite de relations secrètes avec un juif, était sans cesse obsédée de terrears religieuses; des fantômes, des démons, des êtres fantastiques et hideux, s'agitaient chaque nuit devant elle, et la privaient de tout repos.

Les diverses remarques que nous venons de présenter sont également applicables aux deux genres, très intimement unis, mais très distincts, qui composent cette famille. Dars l'état présent de la science, et selon les vues de M. Geoffroy Saint-Hilaire, confirmées et développées par les travaux de divers auteurs, ces deux genres sont nommés et caractérisés de la manière suivante :

1. - DERENGFHALE. Derencephalus,

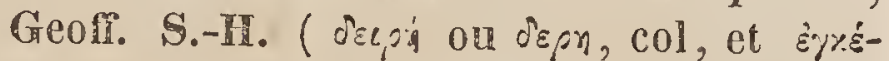
qxios, cerveau). - Dans ce g., le canal rachidien n'est ouvert et la moelle épinière ne manque que dans la région supérieure, par exemple dans la région cervicale et le commencement de la région dorsale, ou bien dans la région cervicale seulement. G'est ce que rappelle le nom de ce genre, nom qui doit être considéré comme une contraction de Déranencéphale. Ge genre ne renferme qu'un petit nombre de cas, dont les mieux connus ont été recueillis et publiés par le docteur Vincent Portal.

2. - AVETGEPHALE. Anencephalus,

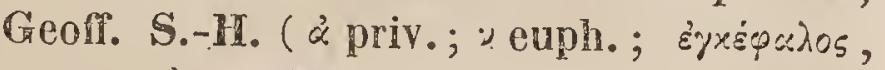
cerveau ). - Dans ce genre, ce n'est plus seulement en haut, mais sur toute la longueur du trone que le canal vértébral est ouvert et que la moelle épinière manque. Les Anencéphales ofrent done des conditions beaucoup plus remarquables encore que celles des Dérencéphales, et sont en même temps beaucoup moins rares qu'eux. Par cette double raison, ils ont ćté souvent le sujet de travaux plus ou mons dignes d'intérêt, au premier rang desquels se placent ceux de M. Geoffroy Saint-Hilaire, qui a publié plusieurs mémoires sur l'Anencéphalien, 
et en a fait connaitre jusqu'à neuf exemples, d'après ses propres observations.

Parmi ces derniers, il en est un trop remarquable par les circonstances où il a été trouvé pour que nous puissions nous dispenser de nous arrêter quelques instants sur lui. Parmi les précieux objets rapportés d'í:gypte, il y a quelques années, par M. Passalacqua, se trouvait une petite momie venant des Catacombes d'Hermopolis, sépulture ordinaire des Singes et des Ibis. Une amulette de terre cuite, 'représentation grossière, mais assez fidèle d'un Singe, le Gynocéphale des anciens, avait été trouvée près d'elle; et la pose de cefte figure était exactement celle de la momie. Soumise à l'examen de M.Geofi. St-Hilaire (Voy. Ann. des Sc.nat., t. VII, p. 357 ), cette momie se trouva être, non un Singe, comme on devait s'y attendre, mais un Anencéphale humain, bien reconnaissable à sa large gouttière vertébrale, à sa face étendue et oblique, à son crâne sans voûte, que bordaient, à son pourtour quelques cheveux bien conservés. Gette détérioration, qui, pour la Tératologie, n'est que curicuse, offre un intérêt réel sous le point de vue historique. Get Anencéphale, sujet humain rejeté des sépultures humaines, et cependant embaumé avec soin dans une attitude de singe, et avec une figure de singe près de lui, a été évidemment considéré par les Egyptiens comme un singe né d'une femme. Ainsi se trouve confirmée par un fait remarquable une opinion existant bien antérieurement dans la science sur ces prétendus animaux, nés dans l'espèce humaine, dont la crédulité des Tite-Live et des Valère-Maxime nous a conservé le souvenir, et dont l'apparition répandait l'épouvante parmi les populations d'une province, et souvent d'un Etat tout entier.

(I. G. S. H:)

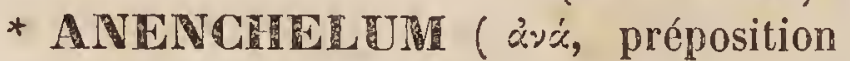

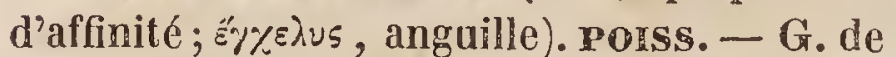
poisson fossile, établi par. Y. Agassiz dans la famille des Scombéroïdes. Les espèces connues viennent de Glaris : tels sont les Anenchelum dorsale, glarisianum, heteroplenron, isopleuron, et latum.

* ANENTERÉS. Anentera (à pr.; v eu-

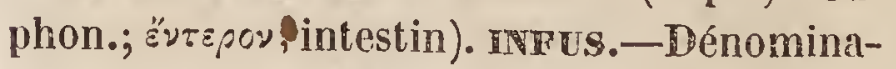
tion donnée par M. Ehrenberg à la $1^{\text {re légion }}$ des Infusoires, qu'il nomme $\mathbb{P}^{\circ}$ lygastriques, pour exprimer la mulkiplicité des estomacs supposés chez ces animaux. Les Anentérés sont censés avoir les estomacs appendus autour de l'ouverture buccale ou du pharynx; ils doivent done avoir une bouche, mais ils n'ont point d'intestins ni d'anus, comme les Entérodélis du même auteur. (DUJ.) ANESORHIZA. вот. PH. - Уоуеz ANVESORHZA.

(SP).

ANETII. Anethum, Tourn. ( " nom grec d'une plante que l'on croit être notre fenouil). Bor. PM. - G. de la famille des Ombellifères (sect. des Peucédanées). Ce g., dans les limites que lui a assignées M. Koch (Umbell., p. 91), offre les caract. suivants : Limbe calicinal 5̆-denticulé, minime. Pétales égaux, très entiers, enroulés, terminés en pointe tronquée. Disque presque plan, à bord sinuolé. Styles courts, finalement recourbés. Péricarpe ovale ou elliptique, solide, lenticulaire ( comprimé dorsalement ), marginé; méricarpes 5-costés; côtes filiformes, carénées : les latérales moins saillantes, confluentes avec le rebord; vallécules égales, à 1 seule bandelette; commissure plane. Carpophore finalement libre, 2parti. Graines adhérentes, piano-convexes. - L'Aneth graveolens, connu sous les noms vulgaires d'Anet, Aneth, ou Fenouil puant, et auquel il faut rapporter plusieurs variétés considérées à tort comme espèces, constitue à lui seul ce genre. Cette plante, qui croît spontanément dans toute la région méditerranéenne, se cultive fréquemment en raison de ses graines, qui sont très aromatiques.

(SP.)

* AMEUंGMENUS. Irs. - Div. établie parM. Haliday dans le g. Emphytus, de la famille des T'enthrédiniens, de l'ordre des $\mathbf{H y}$ ménoptères, sur une seule espèce européenne (Emphytus coronatus Klug.) remarquable par ses ailes postérieures, présentant deux cellules médianes.

* NEURA (övevpos, sans nervure).BOT. GR. - G. de la famille des Hépatiques, établi par M. Dumortier dans son Comm. Bot. p. 115, et son Sylloge Jungermannidearum Europá; p. 85, et adopté par M. Nees (Europ. Leberm., t. III, p. 419 ), qui le caractérise comme il suit : Fructification femelle marginale ou sous-marginale ascendante. Involucre court, lacéré, très mince. Périanthe nul. Pistils peu nombreux, courts, épais, cylindriques. Calyptre très saillante, 
eylindrique, charnue, puis papyracée, pubescente ou tuberculeuse, privée de style. Capsule oblongue, à quatre valves. Élatères la plupart dispersés avec les séminules; quelques uns persistant pourtant au sommet contracté des valves. Ces organes, atténués aux deux bouts, sont clos, monospermes ou composés d'une seule lame (fibra), dont les tours sont plus amples que le tube. Anthères globuleuses, supportées par un filament très court, et immergées dans des lobules marginaux sur une fronde distincte. Frondes sans nervure, uniformes, charnues, composées de cellules petites et semblables entre elles.

Les huit ou dix esp. connues de ce g., qui a pour type le Jungermannia pinguis L., vivent sur la terre (les racines sont à fleur de terre), et les troncs pourris dans les licux humides, près des sources, sur le bord des ruisseaux, entre les Mousses, etc. Leurs radicules sont éparses dans toute l'étendue de la face inférieure de la fronde, et n'en occupent pas seulement la ligne moyenne. Elles sont communes aux lieux tempérés et chauds des deux hémisphères; mais on les rencontre plus fréquemment sous la zone tempérée.

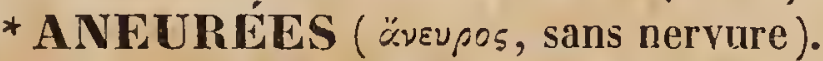
BOT. CR. - M. Nees (Europ. Leberm., t. III, p. 419) établit sous ce nom une tribu qui se compose du g. Aneura, et d'un autre encore douteux qui a été fondé par M. Corda sous celui de Trichostylium. (Voy. ce mot.) Les caract. en sont à peu près les mèmes que ceux du premier de ces g. Comme le second n'a pas été retrouvé depuis qu'il a été publić par l'inventeur, il reste encore enveloppé d'une grande obscurité. Nous dirons pourtant en son lieu à quels signes on peut le reconnaître.

Parmi les Jongermanniées frondiformes, les Aneurées se distinguent des Haplolénées par leur fructification ventrale, et des Metzgériées par l'absence de toute trace de nervure.

(C. M.)

* ANEURISCUS, Presl. (Symb. Bot.) (àveupíræs, je découvre). вот. PH. - Double emploi du g. Moronobea, Aubl., de la famille des Guttifères.

(SP.)

* ANEURUS ( «̌vupos, sans nervure ). ivs. - Genre de la famille des Aradiens, de l'ordre des IIémiptères, sec- naître en lui le poisson de Forskal. ils le T. 1 . tion des Hétéroptères, établi par Curlis (Brit. Ent.), adopté par MM. Laporte et Burmeister, et confondu précédemment par Fabricius, Latreille, etc., dans lo g. Aradus. Les Aneurus se distinguent surtout de ce dernier et du g. Brachyrhynchus, dont il est beaucoup plus voisin, par des élytres presque entièrement transparentes et n'ayant pas de nervures distinctes. La plupart des autres caractères leur sont communs avec les Brachyrhynchus. Nous ne connaissons que deux espèces de ce $\mathrm{g}$. , dont une seule indigène : c'est l'A. lavis Fabr. Fa!l.

* ANEURHYNCHUS ( ávev, sans ; ṕryðos, bec). INs. - Dénomination employéc par M. Westwood (Gener. Syn.), el nous (Hist. des Anim. art.), pour désigner un $\mathrm{g}$. de la famille des Oxyuriens (Oxyuri, Lat.), de l'ordre des Hyménoptères, établi par $\mathbb{M}$. Haliday (Ent. Mag.) sous le nom de $M$ ythras. Ce g., très voisin des Diapria, en diffère par la tête, munie d'un petit tubercule, et surtout par les ailes, dont la nervure subcostale s'éloigne du bord et forme, à l'extrémité, une cellule marginale allongée; les antennes sont composées de quatorze articles. M. Westwood rapporte six esp. européennes à ce g., dont le type est l'A. galesiformis Westw.

(BL.)

ANGE ou ANGELOT (Angelus, an-

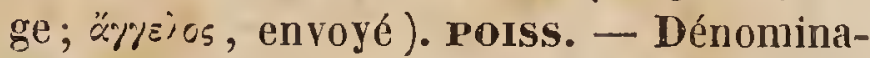
tion vulgaire du poisson, commun dans la Méditerranée et un peu moins dans la Manche, qui sert de type au g. Squatine. Voy. ce mot.

(VAL.)

ANGED. PoIss. - Dénomination vulgaire, selon Forskal, du poisson de la mer Rouge qu'il a décrit sous le nom de Mugil charos. Ce poisson se retrouve aussi dans les mers du détroit de la Sonde, et aussi de l'île de France. M. de Lacépède, ne le connaissant que d'après la description du voyageur danois, en a fait un $g_{c}$, et a introduit l'espèce dans son Ichthyologie sous le nom de Chanos arabique. Croyant toutefois que le Chanos devait ressembler à un Mugil, puisque Forskal l'avait placé parmi les esp. de ce g., il intercaia ce g. entre les Mugiloïdes et les Mugilomores. Kuhl et van Hasselt ont les premiers envoyé ce poisson dans les cabinets de l'Europe, mais sans recon39 la 
donnèrent comme un poisson d'un g. nouveau sous le nom de Lutodeira orientalis. M. Ehrenberg, ayant micux étudié qu'aucun autre zoologiste les animaux de Forskal, retrouva le Mugil chanos dans la mer Rouge, et le déposa sous ce nom dans le cabinet de Berlin. Ce poisson, qui n'a aucune affinité avec le Mugil, est un Malacoptérygien intermédiaire entre les Ciyprinoïdes et les Clupéoïdes. Nous en parlerons avec détail à l'article Gramos. Voy. ce mot.

(VAL.)

* ANGELA ( $\ddot{\alpha} y \gamma \varepsilon \lambda \circ$, qui annonce). INs. - N. Serville (Ins. orth. , Suites à Buffon) applique ce nom à une division qu'il a établic dans son $\mathrm{g}$. Thespis (famille des Mantitiens, ordre des Orthoptères) sur des femelles qu'il a considérées comme des mâles, d'apress la forme des appendices abdominaux, qui diffèrent récllement de ceux des véritables mâles, mais ne constituent qu'une difPérence sexuelle. Cette division, que M. Scrville pensait pouvoir être regardée comme un g. distinct, doî donc être supprimée.

* ANGELLICEES. Bot. PH. - Tribu établie par M. De Candolle dans la famille des Ombellifères ( Voy. ce mot), et ayant pour type le genre Angélique.

(AD. J.)

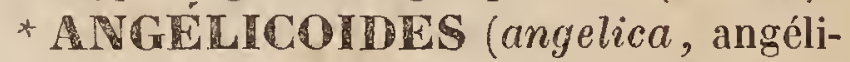
\{ue; ziơs, forme). BOT. PH. - M. De Can(lolle (Prodr., t. IV, p. 181) donne ce nom à une section du g. Peucedanum, caractérisée par des méricarpes à large rebord ct à côtes équidistantes; des ombelles dépourvues de collerette générale, mais munies d'involucelles polyphylles; des fleurs d'un jaune verdâtre. Cette section ne comprend que lc Peucedanum verticillare Koch, et peut-être est-elle plus voisine des Imperatoric que des Peucedanum.

(SP.)

ANGELEUE. Bot. PH. - Nom vulgaire de l'Archangelica officinalis.

(SP.)

ANGELIQUE. Angelica Hoflm. (ange-

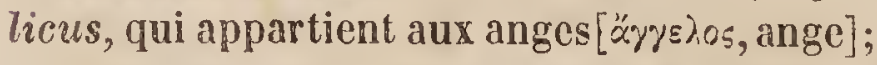
allusion aux vertus médicales qu'on prêtait à l'une des esp.). BOT. P1. - G. de la famille des Ombellifères (tr. des Angélicées); auquel M. Koch (Umbell., 99) a assigné les caract. suivants : Limbe calicinal inapparent. Pétales jancéolés, entiers, terminés en pointe soit dressée, soit infléchie. Péricarpe comprimé dorsalement, 2-ptère de chaque côté; méri- carpes ailés au bord, à 5 côtes dorsales filiformes; vallécules à une seule bandelette; carpophore finalement libre, 2-parti. Graine adhérente, subsemi-cylindrique. - Herbes vivaces ou annuelles. Feuilles 2-pennatiparties ou surdécomposées. Ombelles terminales, à collerette-générale oligophylie ou nulle; collercttes partielles polyphylles. Fleurs blanches ou verdâtres. - M. De Candolle (Prodr. IV) énumère 11 esp. de ce g., dont 5 incomplètement connues. La plupart habitent l'Europe et la Sibérie. La plante appelée vulgaircment Angélique ou Angélique officinale constitue le g. Archangelica.

(SP.)

INGELONIA, Kunth ( in Humb. ct Bonpl., Nov. Gen. et Spec., t. II, p. 92).Physidium, Schrad.-Schelveria, Nees et Martius. (Nom vernaculaire.) BOT. PH.-G. de la famille des Scrophularinćes ( $\mathrm{tr}$. des Hémiméridées, Benth.), offrant pour caract. : Cal. 气ै-fide ou 5̆-parti. Cor. à tube court, à gorge voûtéc, d̀ limbe subbilabié, plan. Lèvre supéricure très obtuse, 2-lobée; lèvre inféricure 3-lobée, à lobe moyen plus long, arrondi, sacciforme à la base. Étamines au nombre de 4, incluses, didynames, insérées au tube de la corolle. Anthères 2-thèques; bourses divergentes. Ovaire 2-loculaire, à 2 placentaires multi-ovulés, adnés à la cloison. Style indivisé, à stigmate capitellé. Capsule subglobuleuse, 2-loculaire, loculicide-bivalve; valves septifères au milieu, indivisécs, non placentifères; placentaires soudés. Graines très nombreuses, à test làchc. - Herbes dressées ou procombantes. Feuilles opposées (du moins les inférieures). Pédoncules 1-fiores, solitaires, axillaires ou en grappes terminales. - Ge g. appartient à l'Amérique; on en connaît 丂̆ esp. Ces végétaux, remarquables par des fleurs très élégantes, sc cultivent comme plantes d'ornement de serre.

(SP.)

* ANGERONE. Angerona (nom mythol.). Ivs. - G. de l'ordre des Lépidoptères, famille des Foeturnes, tribu des Phalćnites, que nous avons ćtabli dans notre Histoire naturelle des Lepidoptères de France, et auquel nous assignons les caractères suivants : Corselet étroit et peu velu. Ailes inféricures seules légèrement dentelées, avec une échancrure au milicu de leur bord terminal. Palpes très minces et n'attcignant pas jus- 
qu'au chaperon. Trompo longue. Antennes très pectinées chez le mâle et simples chez la femelle. Chenille tuberculée sur le $4^{\mathrm{e}}$ et le $8^{\mathrm{e}}$ anneau, s'amincissant sur la partie antérieure, avec la tête petite et dirigée en avant; sa transformation a lieu dans un léger tissu entre des feuilles. - Ce g. ne comprend qu'une seule espèce, que nous avons retranchée des Ennomos de M. Treistchke. Elle est décrite dans plusieurs ouvrages, et entre autres dans l'Encyclopédic Méth. sous deux noms différents : Phal. prunaria et Phal. corylaria, paree qu'elle offre une variété constante et tranchée, à large bande marginale brune, dont les auteurs ont fait une espèce distincte, dans l'ignorance où ils étaient qu'elle provenait de la même chenille, qui donne l'espèce ordinaire, ainsi qu'on en a eu la preuve en élevant cette chenille. L'Angérone du prunier se trouve dans une grande partie de l'Europe; elle est figurée avec sa variété dans l'Hist. nat. des Lépid. de France, t. VII, pl. 147, fig. 1-4.

(D.)

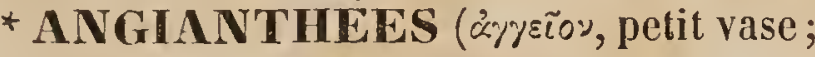
¿ँvos, fleur ). - M. De Candolle a donné ce nom à une division de la tribu des Gnaphaliées. Cette division renferme les genres où les capitules, uni-ou pauciflores, sont réunis en un glomérule entouré lui-même d'un involucre général.

(I. D.)

ANGIANTHUS $(\dot{\alpha} \gamma \gamma \varepsilon \tilde{\varepsilon} 0 \nu$, sorte de vase; ¿2005, fleur). вот. PH. - G. de la famille des Composées, s.-tr. des Gnaphaliées. Il a pour caract. : Capitules biflores, hétérogames. Réceptacle très étroit, tomenteux. Involucre de \& écailles scarieuses, dorées, ovales, dont deux planes et 2 convolutées enveloppant chacune une fleur. Corolles hermaphrodites, tubuleuses, à 5 dents. Branches du style plus longues que la corolle et velues à leur extrémité. Fruit oblong, glabre, couronné d'une aigrette bisériée, à soies membraneuses, dilatées et denticulées à la base, plumeuses au sommet. - L'Angianthus est une herbe originaire de l'île SaintFrançois, sur la côte australe dc la Nouvelle-Hollande, et munie de feuilles alternes, oblongues, spatulées, obtuses, blanchâtres , tomenteuses, ainsi que toute la plante. Les fleurs sont réunies, à l'extrémité des rameaux, en une sorte d'épi dense, accompagné inférieurement de \& bractées. (J. D.) vase, capsule). Bот. PH. - Division du g. Cymbidium de Swartz, famille des Orchidacées. Voy. Gymbidium.

(G. L.)

* ANGIOCARPE. Angiocarpum (ày-

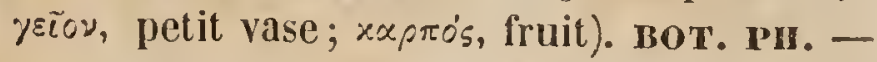
C'est le fruit des ANGiocarriens. Voy. ce mot.

(G. L.)

ANGIOCARPES. Angiocarpi $\left(\alpha^{2} \gamma \eta \varepsilon \bar{l}{ }^{\circ}\right.$, sorte de vase; xxpлós, fruit). BOT. GR. Schrader et Fries ont consacré ce nom pour désigner un ordre tout entier de la famille des Lichens, caractérisé par des apothécies closes, renfermant un nucléus. Les g. Spharophoron, Endocarpon, Verrucaria, Trypethelium et Limboria, sont les types des diverses tribus qui composent cette grande subdivision. Les caract. essentiels en sont : Apothécies closes, percées d'un ostiole, ou s'ouvrant, irrégulièrement au sommet, renfermant un nucléus ordinairement globuleux ou ovoïde, ascigère. Fries, qui, dans sa Lichenographia, a adopté le nom créé par Schrader, avait d'abor'd nommé ce groupe (Syst. Orb. veget., p. 258 ) Gasterothalami. Ce sont les Cenothalami phymatoidei d'Acharius (Lich. Univ.), et les Verrucarince d'Eschweiler (Lich. Bras.).

Plusieurs Lichens gymnocarpiens peuvent subir dans leurs apothécies une dégénérescence ou anamorphose, qui rende difficile leur diagnose, et les fasse rapporter à des lichens de la subdivision qui nous occupe ici. Ainsi, l'on voit tous les jours des Parmélies dans lesquelles, l'évolution normale des apothécies ayant été arrêtée, celles - ci peuvent simuler une Verrucaire ou une Pertusaire. Il faut avoir observé ces plantes in loco natali, et en avoir acquis une grande expérience, pour ne pas s'en laisser imposer quelquefois par ces états tout à fait atypiques. Meyer et Wallroth sont les deux lichénographes qui ont jeté 'le plus grand jour sur ces transformations, dont on n'avait pas tenu assez de compte avant eux. (C. M.)

* ANGIOCARPR (áy $y \varepsilon \tilde{\imath} o \nu$, sorte de va-

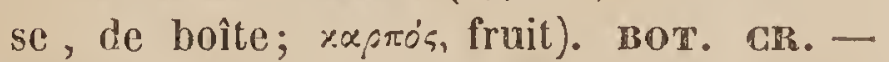
Persoon donne ce nom a tous les Champignons dont les organes de la fructification sont renfermés dans une enveloppe générale. Les Angiocarpes forment la première classe du Synopsis Fungorum, qui comprend les Sclérocarpes, les Sarcocarpes et les Dermatocarpes, Yoy. ces mots. 
ANGIOCARPIENS. Angiocarpii ( $\alpha y-$ yร̃ov, petit vase; хxрлоंs, fruit). BOT. PH. M. de Mirbel donne ce nom aux végétaux dont les fruits, contrairement à ceux des Gymnocarpiens, sont couverts en tout ou en partie d'un organe qui trompe sur leur forme réelle. Tels sont les fruits dî́s : Carybror, STrobile, Sycône, etc. Voy. ces mots.

(C. L.)

* ANGIORIDIUM (àyzĩo, sorte de vase ; sicos, forme. L'auteur a probablement voulu écrire A TGIONIDIUM. ). BOT. CR. Gréville, l'auteur de ce genre, dans le Scot. Crypt. t. 310, Flora, t. 310, a pris pour type le Physarum bivalve Persoon, à qui il assigne les caractères suivants : Péridium sessile, membraneux, papyracé , comprimé sur les côtés, sinueux, et s'ouvrant par une rupture longitudinale à son bord supérieur. Les spores sont renfermées dans les mailles d'un réseau adhérant aux parois de la cavité. L'A. sinuosum Grév. croît sur les mousses, les feuilles et les stipules, etc., tombées à terre. Son péridium est d'un blanc gris, long de 2 à 5 lignes et haut de 1 à 2, comprimé, ondulé, légèrement veiné sur les côtés. Le réseau, comme dans les autres Physarum, n'est pas formé par un capillitium, mais par une matière blanche, granuleuse et irrégulière. Les spores sont noires et globuleuses. Il arrive quelquefois que la rupture du péridium a lieu sur un des côtés, ce qui dépend de modifications produites par les circonstances locales et atmosphériques. Comme ce Champignon est mucilagineux dans son jeune âge, on explique facilement les différentes formes qu'il peut prendre sous l'influence des causes les plus légères.

(LÉv.)

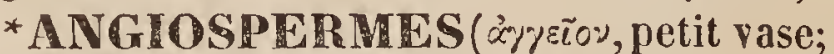
$\sigma \pi \dot{p} \rho \mu x$, graine). BOT. PH. - Dénomination appliquée aux graines couvertes d'un péricarpe distinct, et par opposition à celle de Gymnospermes. Voy. ce mot.

(C. L.)

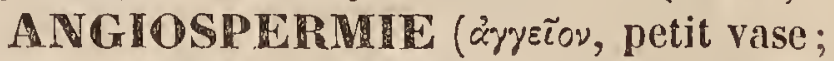

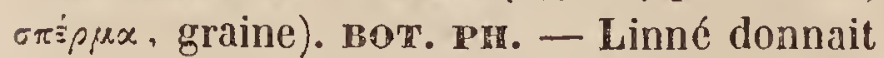
ce nom au second ordre de sa quatorzième classe, caractérisée par étam. didynames, et par des graines renfermées dans une capsule. Ce mot fait opposition à Gymnospermie, nom du premier ordre de cette mime classe. Voy. ce mot et writrodr.

(C. L.)
* ANGIOSPORES. Angiospori (áyzeiov,

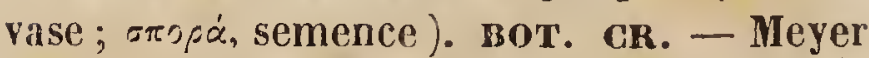
divise la famille des Lichens en deux parties fort inégales. La première, à laquelle il donne le nom de Lichens angiospores, comprend tous les g. dans lesquels les sporidies sont contenues dans des thèques; la seconde n'en renferme qu'un petit nombre, et se compose des esp. chez lesquelles les sporidies sont à nu sur la lame proligère. Mais j'ai démontré pour l'un de ces g., le Sphoerophoron, que cclles-ci, primitivement incluses dans des thèques, n'étaient libres de toute enveloppe qu'à une époque avancée de leur existence. Comme il est probable qu'il en est ainsi pour les deux autres (Coniocybe et Calycium), cette division du lichénographe allemand reste donc sans fondement ou ne s'appuie que sur une base bien chancelante. (C. M.)

* ANGIOSTOMES. Angiostoma (an-

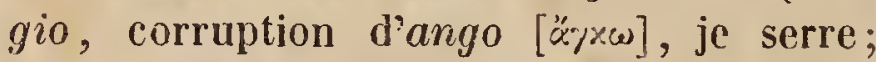
$\sigma \tau \sigma^{\prime} s \alpha$, bouche ). MoLL. - M. de Blainville a donné ce nom à une famille de l'ordre de ses Paracéphalophores siphonobranches, comprenant ceux de ces mollusques dont la coquille a une ouverture généralement fort étroite.

(C. D'O.)

* ANGIOTHEQUES. Angiotheci ( $\alpha \cdot y-$ yeion, sorte de vase; $2 \xi \% n$, tout objet dans lequel on en serre d'autres; ici, thèque). Bot. GR. - Nom d. Ia première classe des Champignons de Persoon (Dispos. Meth. Fung.), et qu'il remplaça plus tard par celui d'Angiocarpes. (Voy. ce mot.) (LÉv.)

* ANGLARITE (Anglar, nom de localité ). mu. - Nom donné par Berthier an phosphate de fer hydraté en petites masses rayomantes, vertes, qui se trouve à Anglar, près de Limoges. Voy. PHospuates.

(IELL.)

ANGLE, angulus (corruption d'angulus, angle ).MOLL. - Sous ce nom, M. Mégerle (nouvelle classification des Coquilles bivalves, publiée en 1811 dans le Magasin de Berlin) a proposé ce genre; il le subdivise en plusieurs groupes de Coquilles, que Lamarck rapporte plus naturellement à ses genres Telline et Psammobic. Voy. ces mots.

(DEsir.)

* ANGLESITE (Anglesea, île de la mer d'Irlande). Mrx. - Yom donné par Beudant au sulfate de plomb naturel, dont les 
mines d'Anglesea fournissent de beaux (périeures parfois alternes), non ponctuées. échantillons. Voy. PLONB et SULPA TES.

(DFL.)

* ANGLEURIA ( d'Angleur, nom de l'habitation d'été de l'auteurr du g.). INs. G. de l'ordre des Diptìres, établi par M. A. Carlier, conservateur du Cabinet de Zoologie de l'université de Liége. Ses caract. sont : $\tilde{\jmath}^{e}$ article des antennes très comprimé et pointu, terminé par un style bi-articulé, un peu plus long que les antennes. Yeux velus; face très étroite dans les mâles. Organes copulateurs ayant leurs appendices intérieurs terminés par un renflement en forme de bouton, et les extérieurs filiformes. - Ce g., dont l'auteur n'a encore trouvé que deux individus mâles, diffère de tous ceux qui l'avoisinent par la conformation des organes copulateurs et par le style des antennes. II se rapproche des Porphyrops de IIeigen ( $2^{\mathrm{e}}$ div.) par la forme des antennes, dont lestyle est inséré à l'extrémité, el par les appendices extérieurs des organes copulateurs, filiformes et rejetés en arrière; des Raphium et des Dolichopes en général par le devant de la tête, dont la face est très étroite dans les màles; et enfin des Dolichopes et un peu des Raphium, par la direction des nervures des ailes. L'unique espèce sur laquelle ce g. est fondé est nomméc par l'auteur $A$. anterinata; clle est figurée et décrite dans les Ann. de la Soc. ent. de France, tom. IV, p. 65\%, pl. 20 , fig. c.

(D.)

ANGOLAM, Adans. (nom idéal). воT. PH. - Syn. du g. Alangium (famille des Alangiées ).

(SP.)

ANGOLAMIA, Scopol. ( nom idéal). вот. PH. - Syn. du g. Alangium (famille des Alangiées ).

(SP.)

ANGOLAN. BоT. PH. - Nom français du g. Alangium.

(SP.)

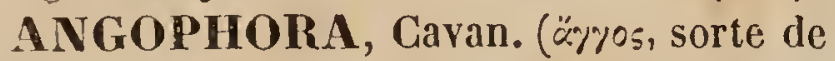
vase; pópos, porteur). вот. PH. - G. de la famille des Myrtacées ( $\mathrm{tr}$. des Leptosperinées, DG. ), offrant pour caract. : Cal. turbiné, כ̌-denté, 5-ou 10-costé. Dents persistantes. Pétales 5, libres. Étam. en nombre indéfini. Anthères ovales. Style filiforme. Stigmate capitellé. Capsule adhérente, coriace, turbinée, tronquée, 5-loculaire, 5-valve, oligosperme, ou par avortement 1-sperme. Graines aptères, quelquefois marginées. - Arbres. Feuilles grandes, opposées (les su-
Fleurs en corymbe. Cor. blanche. - Ce g. , propre à la Nouvelle-Hollande, renferme 5 esp. L'A. cordifolia Cavan. se cultive comme arbrisseau d'ornement dans les collections de serre.

(SP.)

ANGORA, et non Angola. MAM. - Variétés de Chats, de Lapins et de Chèvres (Voy. ces mots.) originaires d'Angora, dans l'Anatolie. (C. D'O.)

ANGOSTURA. воT. PH. - L'arbre à écorce fébrifuge, connu dans le commerce sous ce nom, emprunté à celui de la ville où on l'avait connu pour la première fois, est devenu pour Romer et Scheltes le type d'un g. qu'ils ont appelé de même, mais qui rentre dans d'autres plus anciens, notamment dans le Galipea d'Aublet. Voy. ce mot.

(AD. J.)

ANGOURIE. Anguria Linn. ( nec Tourn.).-Psiguria, Neck. (Q̀yyoúpcov, sorte de melon d'eau). Бот. PH.-G. de la famille des Cucurbitacées (tr. des Cucurbitées), auquel on attribue pour caract. : Fleurs monoïques.-Fleurs mâles : Cal. campanulé, 5-denté. Cor. (de couleur rouge) ventrue, 5-fide, cohérente inférieurement au calice; limbe étalé. Étam. 2, opposées, libres. - Fleurs femelles : Calice et corolle comme ceux des fleurs mâles. Étam. 2, stériles. Style semibifide. Stigmates 2-fides. Baie 2-4-loculaire, subtétragone, polysperme. (Graines incomplètement connues.) - Herbes à racine charnue, verruqueuse. Feuilles anguleuses ou lobées. Pódoncules axillaires. Fleurs mâles en grappes; fleurs femelles solitaires. Fruit mangeable dans quelques esp. - Ce g. est propre à l'Amérique équatoriale. On en connaît 7 esp. (la plupart très superficiellement signalées).

(Sp.)

ANGREC. Angracum (altération du nom malais Angurek, appliqué aux plantes de ce g.). вот. PH. - G. de la famille des Orchidées et de la tribu des Vandées, établi par Du Petit-Thouars (Orch. Afr., tab. 65), et caractérisé de la manière suivante par M. Lindley : Périanthe étalé. Sépales et pétales à peu près égaux, libres. Labelle sessile, continu avec la base de la colonne, charnu, indivis, beaucoup plus large que les pétales. Éperon droit, cornu, souvent presque cylindracé, beaucoup plus long que le périanthe, rarement obconique. Colonne courte, pres-- 
que cylindrique, rarement allongée, semicylindrique. Anthère biloculaire, tronquée. Masses polliniques au nombre de deux, bipartibles, à caudicule courte, étroite; à glande triangulaire.-L'esp. type du g. $A n$ gracum est I'A. eburneum Du Petit-Th., (loc. cit.), figuré par M. Bory de SaintVincent (Voyage aux îles d'Afrique, t. 19) sous le nom de Limodorum eburneum. Cette plante est assez commune dans les iles de France, de Bourbon et de Madagascar. Elle croît sur les arbres, est munie d'une tige et de feuilles coriaces, ligulées, striées. Les fleurs en sont grandes, verdâtres, avec le labelle d'un blanc d'ivoire. Dans son Genera and Species of Orchidaceous Plants, M. Lindley a porté le nombre des esp̉. d'Angroecum à 19, déjà signalées par Du PetitThouars, et par M. Ach. Richard dans sa Monographie des Orchidées des iles Maurice. Il leur a joint 2 autres esp., l'une du Cap de Bonne-Espérance, l'autre de l'île d'Haïti ; mais, plus tard, dans le Botanical Register, no 1522, il a proposé de séparer des Angracum quelques espèces décrites par Du Petit-Thouars, et il en a formé le $g$. OEceoclades. Le g. Aerobion de Sprengel a été fondé sur l'Angrcecum fragrans, qui ne doit pas être séparé du genre primitif. G'est cette plante dont les feuilles aromatiques sont connues et livrées dans le commerce sous les noms de Faham et de Thé de l'île Bourbon. Enfin le g. Aeranthus a pour type l'Angracum sesquipedale Du Petit-Th. Voy. AEranthe.

(G.......)

ANGUIFORMES. Anguiformes ( $A n-$ guis, serpent ; forma, forme ). REPT. Voyez Batrachophidiens.

ANGUILLARD. REPT. - Dénomination spécifique d'un Batracien du g. Protée. Voy. ce nom.

(G. B.)

ANGUILLARIA ( anguilla, anguille; peut-être en raison de l'ondulation du bord des feuilles ). вот. PH. - G. de la famille des Myrsinacées, formé par Gaertner, et synon. du g. Ardisia de Swartz. Voy. ce mot.

(G. L.)

ANGUILLE. Anguilla (anguilla, nom du même poisson chez les Latins). Porss. - Poisson connu de tout le monde, abordant presque à l'excès dans les rivières, les lacs et les étangs de toute l'Europe, quoiqu'il paraisse moins commun vers le Nord; ce qui doit faire penser que l'Anguille craint le froid. Quelques unes de ses habitudes s'expliquent aussi par la crainte du froid. Ce poisson a le corps allongé, arrondi vers la poitrine et comprimé vers la queue. Cette partie du corps est entourée par les trois nageoires verticales, réunies entre elles; la dorsale n'avance pas sur le dos jusqu'à la région des pectorales, qui sont les seules nageoires paires du poisson; car il n'a pas de ventrales. Les nageoires de la poitrine sont petites, et insérées au dessus de la fente verticale des ouïes. L'ouverture des branchies est réduite à leur simple fente, parce que la membrane branchiostège, soutenue par rayons, est attachée tout autour du cou. L'appareil operculaire est composé des quatre pièces qui se retrouvent dans le plus grand nombre des poissons osseux, savoir : l'opercule, le sous-opercule, le préopercule et l'interopercule. Il y a des dents sur les mâchoires, sur les palatins et sur le vomer. La peau est enduite d'une mucosité abondante, secrétée par des glandes ouvertes le long de la ligne latérale. Cette mucosité recouvre les écailles petites, oblongues, très nombreuses, et très fortement attachées au derme. La peau a, d'ailleurs, une forte ténacité qui la fait employer dans plusieurs arts. Elle est très adhérente aux muscles qui ont des fibres courtes, retenues par un tissu cellulaire très dense, et dont les mailles sont remplies d'une graisse huileuse abondante. L'estomac est un long culde-sac, et est suivi d'un intestin qui n'est pas très long. Le foie est épais, de couleur fauve ou jaunatre, et n'a qu'un seul lobe situé en travers sous l'œsophage. La vésicule du fiel est grande; la rate est noirâtre. Il y a une grande vessie natatoire, pourvue de corps rouges glanduleux très gros; elie communique avec l'intestin. Les reins sont longs et gras, et versent l'urine dans une vessie urinaire allongée, qui s'ouvre derrière l'anus par un trou rond, facile à trouver. Entre le canal intestinal et la vessie aérienne flottent, dans l'abdomen, deux rubans oblongs, plissés comme une fraise, qui ne paraissent, au premier aspect, être qu'un épiploon très gras, ce qui les a fait souvent nommer les corps graisseux. Ce sont les annexee des organes génitaux.

On trouve l'albumine des oufs attachée à 
ces membranes; car j'ai fait bouillir dans l'éther des portions de ces corps graisseux, et j'ai trouvé au fond du tube et du verre des globules durcis, non dissous dans l'éther à chaud; ces globules n'étaient donc pas formés de graisse seule, mais d'albumine. D'ailleurs, les organes représentés par Richard Owen, et indiqués par plusicurs auteurs comme les organes génitaux de l'anguille, ont encore besoin d'être étudiés avec soin, et l'on est loin d'en avoir une connaissance anatomique parfaite.

Le cocur lympbatique, organe curieux dont on doit la découverte au célèbre professeur Müller de Berlin, a été observé pour la première fois sur l'Anguille par M. Marshall Hall, et on en trouve une figure dans l'ouvrage de M. Yarell. Le docteur Marshall Hall, en poursuivant ses recherches sur la circulation dans les heptiles et les Poissons, a vu, en 1851, ce sac douć de pulsations près de la queue de l'Anguille. Il est situé à la fin de la veine caudale du poisson. M. Müller n'a pu voir de pareils organes chez les Mammifères et les Oiseaux, et M. Richard Owen pense même que les cœurs lymphatiques remplacent, dans les dernières classes, les valvules qui n'existent en grand nombre que dans les deux premières classes de Vertébrés. Il était donc nécessaire qu'il y eût dans les Reptiles et les Poissons un agent pour diriger et exciter le mouvement de la lymphe chez ces animaux, tandis que les valvules des vaisseaux lymphatiques des Mammifères et des Oiseaux impriment à la lymphe un courant intermittent et une direction bien déterminée.

Les eaux douces de l'Europe nourrissent plusieurs esp. d'Anguilles, désignées depuis très long-temps sous leurs difrérents noms vulgaires, soit dans Lacépède, soit déjà dans Pennant. I'ai fait à leur sujet de nombreuses recherches, et les observations que j'ai communiquées à M. Cuvier lui ont fourni des matériaux pour établir les distinctions dont il a exprimé les caract. dans la seconde édition du Règne animal. Depuis, M. Yarell a donné, dans son ouvrage sur les Poissons d'Angleterre, d'excellentes figures de trois de nos espèces. Cependant j'ai lieu de penser que quielques unes des différences appréciées entre les nombreux individus d'Anguilles soumis à nos observations, et que l'on a considérées comme des caract. spécifiques, tiennent à la différence des sexes. Ie présume, par exemple, que l'Anguille nomméc le Pimperneau est le mâle de l'Anguille plat-bec; toutefois, je n'ose encore l'affirmer. Ces diverses Anguilles ont à peu près les mêmes mours, et, par conséquent, le même genre de vie.

L'Anguille vit dans les eaux courantes ou dormantes indifféremment. Elle aime le mouvement de la vanne d'un moulin, de même qu'elle croît dans l'eau d'un fossé. C'est un poisson vorace, qui se nourrit de petits animaux de sa classe, et surtout de Goujons, dont il est très friand; mais qui attaque aussi les petits quadrupèdes et les oiseaux aquatiques, les vers, et même les débris des corps des animaux que l'on jette à l'eau. Il chasse particulièrement pendant la nuit; le jour, il se tient blotti dans les touffes de plantes aquatiques, ou même se retire dans des trous le long des berges, et l'on en prend jusqu'à trente dans un même trou. On les force à en sortir en les enfumant comme on le fait pour les Renards.

L'Anguille s'enfonce aussi sous la vase des étangs, pendant le froid, mais c'est surtout quand on met ces amas d'eau à sec pour en faire la pêche; on est même oblige de faire marcher sur cette vase et de la piétiner pour en faire sortir les Anguilles. Dans les chalcurs de l'été, et quand le temps est orageux, les Anguilles aiment aussi à sortir de l'eau, et vont quelquefois très loin au travers des herbes. Elles chassent à terre, mangent les petits reptiles, les colimaçons, et même, quand elles sont dans les champs cultivés, certaines plantes dont elles sont très friandes, entre autres les pois. Si elles sont surprises par le jour et les chaleurs, elles se blottissent dans une touffe d'herbes, et, roulées sur elles-mêmes, y attendent la nuit suivante. Il n'est pas très rare qu'en fauchant les prairies le fer des travailleurs coupe une Anguille. J'en ai vu de très grosses qui avaient été ainsi blessées.

Dans les eaux courantes, elles nagent avec force et rapidite contre les courants; mais en descendant, elles se laissent, le plus souvent, entraîner au fil de l'eau sans faire d'efforts; aussi prend-on beaucoup d'Anguilles dans de grandes nasses tendues en travers 
des rivières, et bordées, de chaque côté, d'une muraille faite avec de grandes perches entrelacées de branchages, et dont les trous sont bouchés avec de la vase. C'est ce que les pêcheurs appellent des gords. On en prend surtout en grande quantité dans ces filets, à l'époque où l'Anguille descend le courant des rivières pour se rendre à la mer, vers l'eau salée ou saumâtre, afin d'y frayer.

II y a lieu de s'étonner que l'on ait perpétué et que l'on perpétue encore les contes les plus ridicules sur la reproduction des Anguilles; car, au milieu de toutes ces fables, on trouve consignés, dans presque tous les ouvrages qui traitent de l'histoire naturelle de l'Anguille, des faits vrais, et plus ou moins déguisés dans des rapports basés sur les erreurs populaires.

L'observation que les Anguilles se rendent à la mer pour y frayer est, je dirai, aussi ancienne que l'Histoire naturelle. Elle est déjà consignée dans les Halieutiques d'Oppien. Depuis, de très bons observateurs ont affirmé ces faits, et Spallanzani l'a très bien établi dans ses ouvrages, si remplis de faits curieux et bien observés. Ces observations ont été reproduites de nouveau par M. Yarell dans son excellent ouvrage.

Nos pêcheurs de la basse Seine croient que l'Anguille est ovipare. Suivant eux, elle fraie une première fois vers la fin de février ou le commencement de mars, et une seconde fois au mois de septembre. Cependant un fait avancé par M. de Joannis (Revue zoologique, 1859, no 2) pourrait faire croire à la viviparité, ou mieux, à l'ovo-viviparité de l'Anguille. Un paysan lui a dit qu'ayant mis une grosse Anguille entre deux plats, et l'ayant ensuite découverte à son retour à la maison, après le travail aux champs, il la trouva entourée de plus de deux cents petites Anguilles longues d'un pouce et demi à deux pouces, grosses comme des fils et presque blanches. M. de Joannis n'a d'ailleurs pas vu cette ponte; il ne la rapporte que sur l'assertion d'un homme qui n'était pas en état de bien observer. La longeur, la couleur et la grosseur indiquées pour les petits nouveaux-nés, me portent à croire que l'Anguille en question s'était débarassée d'une grande quanité d'Ascarides ou de filaires, sortes d'intes- tinaux dont ces poissons nourrissent quelquefois des masses surprenantes. L'innombrable quantité de petits produite par l'Anguille me ferait croire au mode de reproduction ovipare. Elle fraie dans la vase, après une sorte d'accouplement; c'est-àdire que le mâle se place près de la femelle, et, le plus souvent, les individus sont tête bêche. Ils exécutent tous deux des mouvements qui font dire aux pêcheurs qu'ils se frottent le ventre l'un contre l'autre; le mâle arrose de sa laitance les cufs que pond la femelle, de sorte que l'accouplement est analogue et comparable à celui des grenouilles et des crapauds, dont le mâle arrose les oufs de sa laitance, et les féconde au fur et à mesure que le chapelet qui les contient est expulsé par la femelle. Il paraît même que quelquefois plusieurs Anguilles de sexe différent se tiennent entrelacées. Je ne pense pas que les œufs de l'Anguille soient isolés; je les crois réunis ensernble par une viscosité analogue à celle qui réunit les œufs de nos Perches d'eau douce. Ces œufs forment de petits pelotons en forme de boules arrondies. Je ne sais pas si chaque boule contient tout ce qu'a pondu une même Anguille, ou si une femelle produit plusieurs de ces pelotes. Les petits éclosent bientôt, et restent, pendant les premiers jours de leur naissance, réunis dans ces pelotes, que les pêcheurs des rives de la Loire, au dessous de Nantes, vont ramasser et jeter dans des étangs qu'ilis veulent peupler d'Anguilles. Quand les petits ont atteint 4 à 5 centim. de longueur, ils se débarrassent des liens qui les retenaient ainsi pelotonnés, et ils semblent alors adhérer à la plage qu'ils paraissent encore sucer. Ceci explique pourquoi l'on dit que les Anguilles naissent du limon ou de la vase de la mer. Quand ces poissons ont acquis quelques forces, ils remontent tous en bandes serrées le fleuve principal ou ses affluens : ils reçoivent alors le nom de Montée. Ils se répandent ainsi dans toutes les caux avoisinantes. La quantité de ces poissons est si grande dans certaines rivières, qu'on ne saurait s'en faire d'idée sans l'avoir vue. On en prend la charge de chevaux sur les bords de la Loire. Quand les petites Anguilles ont atteint 10 à 12 centimètres, elles sont grosses comme un tuyau de plume, le plus 
souvent d'un beau jaunc soufre, et prennent dans quelques localités le nom de $\mathrm{Ci}$ velles; mais, parvenues à cet âge, il y a dans leur croissance, dans leur manière de vivre et dans leur mode de dispersion dans les différentes eaux, plusieurs points encore obscurs, et, par conséquent, il y a encore plusieurs questions auxquelles il est difficile de répondre d'une manière très précise.

Ceux qui étudient et observent les Poissons ont dû être étonnés que ce ne soit que dans les ports de mer, ou très près d'eux, que l'on voit arriver sur les marchés de petites Anguilles; j'entends des Anguilles ayant déjà la couleur et la forme des Anguilles adultes, et longues seulcment de $0^{\mathrm{m}}, 20$ a $0^{\mathrm{m}}, 50$ environ. La montée se cache-t-clle dans les premiers étangs voisins de la mer, et les Anguilles y prennent-elles leur seconde croissance? Et, cependant, les Civelles montent dans la Loire jusqu'à Angers, et en troupes très nombreuses; mais j'ignore ce que deviennent les Anguilles dans nos rivières et nos lacs jusqu'à ce qu'clles aient atteint la taille de $0^{\mathrm{m}}, 43$ à $0^{\mathrm{m}}, 50$, qui est celle où l'on commence à les trouver dans nos eaux douces.

Elles prennent ordinairement une taille d'un mètre et même davantage. Le Cabinet du Roi en possède me qui a $\mathbf{i}^{\mathrm{m}}, 70$ de longueur, et dont la circonférence est de $0^{\mathrm{m}} \mathbf{3} 2$. M. Yarell en cite du poids de vingt-sept livres.

Une seconde question, dont la solution est Ioin d'être complète, est celle de savoir comment les Anguilles se rendent dans les lacs intéricurs, et les peuplent, surtout quand ces lacs sont à de grandes hauteurs au dessus du niveau de la mer. Sennebier a déjà fait remarquer qu'il n'y a pas d'Anguilles lans le lac de Genève, parce que, dit-il, il ne communique pas avec la mer, à cause re la perte du Rhône; tandis que l'on trouve ce poisson dans le lac de Morat; mais il est toujours difficile de donner une explication bien satisfaisante de la quantité d'Allguilles qui se trouvent dans certains lacs, du développement qu'elles y prennent, de la convenance qu'elles y trouvent et dont on peut juger, par la grosseur à laquelle elles parviennent, lorsqu'on a la certitude que la nature $n$ 'a pas mis les organes génitaux en état de reproduire l'espèce. T. 1 .
On ne voit pas, dı moins dans nos eaux douces, d'Anguilles arec des laitances ou des ovaires pleins. C'est à cette circonsiance qu'il faut attribuer l'origine de toutes les fables reproduites sur les générations des Anguilles. Pourquoi, si les Anguilles peuvent entrer dans ces lacs, r'en sortent-elles pas quand clles sont adultes et assez grandes pour frayer? L'action continue de l'eau douce de ces étangs empêche-t-elle le développement des organes génitaux? produit-elle une sorte de castration naturelle? et alors n'estce pas à cette circonstance que tient la quantité de graisse et d'huile dont le corps de ce poisson abonde? Les Anguilles sont, dans certains pays, d'un très grand rapport. Le marché de Londres en est fourni par deux compagnies hollandaises, qui ont chacune cinq vaisseaux disposés pour contenir une cargaison de 15 à 20,000 livres d'Anguilles vivantes. L'un est stationnaire près de Londres quand les autres retournent en Hollande pour se fournir de nouvelles Anguilles. Chaque marchand paic un droit de treize livres sterling par chaque cargaison pour avoir la permission de vendre. Les lagunes salées de Commachio, qui reçoivent les crues du $\mathbf{P o}$, du Reno et du Ronco, et de tous leurs affluents, sont célèbres aussi depuis longues annćes par la quantité de Niuges et surtout d'Anguilles qu'elles produisent. On estime que la pêche des Anguilles, qui se fait de septembre à décembre, produit cent dix mille pesi d'Anguilles ( un peso vaut 25 livres romaines ou $8^{k}, 49$, et dans le printemps on en tire 8 à 10,000 pesi. Ces Anguilles, préparées de diverses manières, sont envoyées dans toute l'Allemagne, et celles qu'on mange fraîches sont distribuées dans les états pontificaux, le royaume Lombardo-Vénitien, le Piémont, les états de Modene, de Parme, de Toscane et de Naples.

Après ces généralités sur les Anguilles, j'ajouterai que nous distinguons sur nos côtes :

$1^{\circ}$ L'Anguille au long bec (Anguilla acutirostris Yarell), qui a la tête étroite, le museau pointu, la màchoire inféricure plus longue, et cependant le crâne plus large, et cent trente vertèbres au squelette.

20 L'Anguille pimperneau (Glut-eels des Anglais), à tête plus large, à cause de la 52 " 
grosseur des crotaphytes; à yeux plus grands, à crâne plus étroit, et qui n'a que cent quinze vertèbres.

$5^{\circ}$ L'Anguille plat bec (ou Grig-eel des Anglais), qui a l'œil plus petit, le museau plus aplati, le crâne encore plus étroit.

M. Yarell croit qu'il faut encore distinguer comme espèce le Snig-eel des Anglais.

Je crois aussi qu'il faudrait encore en distinguer d'autres en Europe. M. Savigny m'a entre autres donné une Anguille distincte par ses formes, et qu'il m'a assuré être tout à fait marine; il l'a prise à Naples; elle ne sortirait, selon lui, jamais de l'eau salée.

On volt d'après cela que l'Anguille devait être considérée comme type de genre dans la famille des Anguilliformes; et c'est effectivement ce qu'a fait M. Guvier. Les Anguilles sont pour lui des Apodes qui ont les trois nageoires réunies, les pectorales et les ouïes ouvertes sous les nageoires. Il divise le groupe en deux : celui des Anguilles dont la dorsale naît sur le dos, loin en arrière des pectorales, et celui des Congres (Voy. ce mot), dont la dorsale naît presque sur la nuque. Celles-ci sont marines, tandis que les Anguilles sont généralement d'eau douce. Le g. des Anguilles est nombreux en espèces étrangères. On en connaît des États-Unis, des eaux douces de l'Inde. Les îles les plus isolées en nourrissent aussi dans leurs eaux douces. Nous en possédons des Canaries, de l'île de France, où elles atteignent une taille aussi grande qu'en Europe.

Celles des Canaries offrent une habitude plus extraordinaire encore que celles de l'Europe, car elles vivent dans des torrents qui se dessèchent, et restent trois ou quatre mois à sec cachées sous les pierres. Toutes les espèces de ce g. étaient confondues sous le rom de Murœna anguilla.

( $\left.\mathbf{A L}_{\mathbf{L}}\right)$

ANGUILLE DE HAIE. REPT. Nom vulgaire de l'Orvet.

(G.B.)

ANGUILLE DU VINAIGPE, DE 1A COLLE, etc. - Voyez ANGULLULE.

(Dบ..)

* ANGUILLIFORME. Anguilliformis (anguilla, anguille; forma, forme). zuour. - Se dit des Poissons et Reptiles qui ont la forme d'une Anguille.

(C. I'O.)

MNGULLIFOMIES. Anawilifor- mis (anguilla, anguille; forma, forme). PoIss. - Nom du quatrième ordre des Nalacoptérygiens dans le Règne animal de M. Cuvier. Il correspond au g. Murona de Linné, et à quelques g. déjà établis par Bloch et Lacépède. Il réunit tous les Poissons sans ventrales, le plus souvent sans pectorales, et quelquefois sans aucune nageoire. Leur forme est allongée, leur peau visqueuse , avec ou sans écailles, et dont l'anatomic varie assez.

(VAL.)

* ANGULLOIDES (anguilla, anguille; civos, forme : mot hybride). PoIss. - Nom imaginé par quelques auteurs pour désigner comme famille ce dont M. Guvier faisait un ordre.

(VAL.)

* ANGUILLULE. Anguillula (anguilia, anguille). vers. - G. créé par M. Ehrenberg pour plusieurs Vers nématoüdes, anciennement confondus avec les divers Infusoires, auxquels on donnait le nom de Vi. brions, réservé aujourd'hui pour les seuls Infusoires filiformes, sans oiganisation appréciable, et sans organes locomoteurs visibles.

Les Anguillules, par leur structure, se rapprochent beaucoup des Ascaridiens et des Oxyures. Comme ces Vers, elles ont un tégument résistant, élastique, strié en travers; un long nesophage musculeux, renflé à sa base, séparé par un étranglement de l'intestin, qui est large, droit, et se terminant par un anus latéral, en avant de la queue. Elles ont des sexes séparés : les femelies ont un ovaire contenant des oufs qui, chez la plupart, éclosent à l'intérieur du corps de la mère; les mâles ont un long vaisseau séminal ou testicule aboutissant, près de l'anus, à un pénis en forme de tige courbée en arc et résistante. La bouche est armée à à l'intérieur de trois tiges courtes, articulées à l'extrémité de l'œesophage.

Les Anguillules les plus connues sont celles qui se développent dans le vinaigre et dans la colle de farine. Elles ont été observées par tous les micrographes depuis Leeuwenhoek, et nommées par Müller Vibrio anguillula aceti et Vibrio anguillula glutinis; mais elles forment deux esp. bien distinctes par leur taille. Une troisicme esp., non moins célèbre, est celle qui se trouve dans le blé niellé, et qui a été étudiée complètement par bauer en Angleterre, sous le nom 
de Vibrio tritici. Cette esp). est surtout remarquable par la proprićté qu'elle a de se dessécher entièrement sans perdre la vie, et te pouvoï même, à plnsieurs reprises, passer alternativenent de l'état de vie à l'état de dessiccation complète et de mort appareule. Des Anguillules de cette esp., sous la forme de fibrilles sèches, cassantes, jaunàtres, forment des amas considérables dans l'intérieur des grains de blé niellé, oì elles remplacent la fécule. Ces fibrilles, humectées avec de l'eau, se gonflent peu à peu, et finissent par repreindre la vie au bout de quelques heures. Elles sont vivipares, et généralement plus grosses que celles du vinaigre et de la colle.

D'autres Anguillules se trouvent, soit dans les eaux stagnantes, soit dans la terre hamile, dans les touffes de brumiet, dans les croûtes vertes d'oscillaires qui se forment ì la surface du sol, enfin dans l'intérieur du corps des Lombrics, et dans l'intestin des Limaces, des Chenilles et de divers Insectes. Il est bien probable qu'on pourra distinguer entre elles non sculement des esp., mais aussi des g. différents. Plusicurs de ces Anguillules ou Vibrions terrestres sont susceptibles de se dessécher sans périr ; d'autres peuvent offrir diverses particularités d'organisation en se développant plus completement.

(DU.r.)

ANGUINIRE. Anguinaria (anguis, serpent). MoLL. - Dans son Essai d'un nouveau système de Conchyliologie, M. Schumacher propose de donner ce nom à un g. créé depuis long-temps par Lamarck sous le nom de Siliquaire. Ce changement proposé par l'auteur danois ne peut être adopté. VOY. SHULUAIRE.

(DESET.)

ANGUINE (anguis, serpent). Bot. mi. - Nom français donné par quelques auteurs au g. Trichosanthes, de la famille des Cucurbitacées.

(Sp.)

ANGUIS. IRPT. - Nom d'un serpent chez les Latins : latet Anguis in herbâ. Virg., Egl. III. C'est Linné qui l'a introduit dans la science, en l'applicuant à un genre de Reptiles composé de toutes les espèces écailleuses, sans pieds ou à pieds très courts, dont les écailles du dessous du tronc et de la queuc étaient semblables ou à peu près semhlabies à celles du dessus : tels que les Hryx, les Ophisaures, les Séflotes, les houlenmx. les Typhlops et les Orvets. Aujourd'lumi il sert seulement à désigner ces derniers. Voy. ORVET.

(G. B.)

* ANGUIVIPRES (anguis, vipera, sorte de Serpents). REPT. - Ce nom a été donué par Carus, Ficinus et Latreille, ì une famille de Reptiles comprenant les Serpents venimicux dont le corps est anguilliforme.

(C. D'O.)

* ANGULEUSES. Angulosce (angulus, angle ). ARACurs. - Ce nom est employé par M. Walckenaer pour désigner une petite division dansle g. Thomisus. (H. L.)

* ANGUENERUE. Angulinervis (angulus, angle; nervus, nerf, nervure).BoT.-M. De Candolie s'est servi de ce mot pour désigner les feuilles qui ont une nervure primaire centrale ou plusieurs nervures primaires divergeant en droite ligne de la base du limbe, et dont les diverses subdivisions partent aussi en droite ligne de manière à fuurnir des angles à leur originc. Telles sont les feuilles de la plupart des Monocotylédones. Toy. CuRviNER VES.

(G. L.)

ANGULEROSTRES (angulus, angle; rostrum, bec). oIs. - Nom donné par Illiger, Goldruss et $\mathbf{c}$. Bonaparte à une famille de l'ordre des Passercaux comprenant ceux de ces oiseaux qui ont le bec pointu et anguleux.

(C. D'O.)

ANGULITIE. Angutithes ("丷yos, sorte de vase; $\lambda \dot{\theta} 0 s$, pierre). MoLL. - Montfort a, dans sa Conchyliologie systématique, formé un g. particulier d'une esp. de Nautile carénéc (Voy. NaUTLE), ou peutêtre d'unc Ammonite. Dans tous les cas, c'est un g. à supprimer. (A. D'O.)

ABGULOA (Dédié à D. Fr. Angulo, directeur des mines du Pérou). вот. PH. Ruiz et Pavon (Brodrom. Fl.peruv., 1).118, tab. 26) ont ćtabli sous ce nom un geure qui fait partic de la famille des Orchidées et de la tribu des Vandées de M. Lindley. II est ainsi caractérisé : Périanthe fermé, globiforme. Sépales et pétales libres, concaves, presque égaux. Labelle longuement onguiculé, en capuchon, bilobé, avec une petite languette intermédiaire, réfléchie. Colonne semi-cylindrique, en nassue, bicorne an sommet. Anthère rostréc. Masses polliniques au nombre de deux, a candicule lancéoice (bifirle?), it petile glande oyale. 
L'Anguloa uniflora $\mathrm{R}$. et Pav. est une plante herbacée, pseudo-bulbeuse; à fenilles lancéolées, plissées; à fleurs solitaires, très grandes. Elle croît au Pérou, dans les bois. M. Kunth en a décrit et figuré dans les Nova Genera et Species Pl. amer., t. I, p. 345, tab. 95, une seconde esp. sous le nom d'Anguloa superba, qui est également du Pérou, et que les habitants nomment Periqueto, à cause de la ressemblance de sa nleur avec la tête d'un Perroquet. (G....v.)

ANGULOSAE. ARACHN. - Voyez ANGULEUSES.

(II. L.)

ANGURIA, Tourn. (nec Linn.) ( $\dot{\alpha}_{y}$ \%ojplov, sorte de petit vase ). BoT. PH.-Tournefort et quelques auteurs plus anciens donnaient ce nom à la Pastèque ou Melon d'eau (Citrullus), et à quelques esp. du g. Cucumis. VOy. ANGOURIE.

(SP.)

* ANGUSTIFOLIL.Angustifoliatus (angustus, étroit ; folium, feuille). Se dit de toute plante dont les feuilles sont étroites et plus ou moins linéaires. Cette expression ne s’emploie que comme nom spécifique.

(C. I.)

ANGUSTIPENNES ou STENOPTERES (angustus, étroit ; penna, plume, aile). rrs. - Nom donné par Mr. Duméril à sa $12^{\mathrm{e}}$ famille de l'ordre des Coléoptères, sous-ordre des Hétéromères, qu'il caractérise ainsi : Élytres dures, rétrécies. Antennes en fil, souvent dentées. - Elle se compose de 6 genres qu'on distingue entre eux par la suture des élytres, la forme des antennes et la présence ou l'absence de l'écusson. - Ces g. sont les Sitarides, les OEdémères, les Nécydales, les Ripiphores, les Mordelles et les Anaspes, Voy. ces mots.

(D).

ANGUSTURA. Bot. PH. - Voyez ANGOSTURA.

(C. L.)

ANGYSTOME. Angystoma (angy, corruption d': $2 \% \varepsilon \varepsilon \nu$, étreindre, serrer; $\sigma \tau \sigma^{-}$ $\mu \propto x$, bouche ). MoLL. - Mauvais g. proposé par Klein, dans son Tentamen Methodi Ostracologice, pour rassembler toutes les $\mathrm{Co}^{-}$ quilles à ouverture "etroite qui ont celte partie obstruée par des dentelures plus ou moins saillantes. Quoique ce caract. soit très superficiel, et qu'il réunisse des coquilles extrêmement différentes, on conçoit jusqu'à un certain point qu'il ait pu être proposé; mais il aurait fallu, du moins, que l'auteur i laine très abondante, persistante. Inflores- se conformât aux caract. que lui-même avait trouvés; tandis que, loin de là, on trouve aussi, dans ce g. oublié de Klein, des Coquilles dont l'ouverture est grande et sans dents.

(DEsh.)

* ANG YSTOMES (les). Angystomata (angy, corruption d'čy $y \varepsilon l \nu$, étreindre, serrer; $\sigma \tau^{\prime} \mu \alpha$, bouche). MoLL. - M. de Blainville a proposé cette famille dans son Traité de Malacologie. Il y rassemble un grand nombre de g. sous un caract. qui nous semble de peu d'importance, celui de l'étroitesse de l'ouverture. On conçoit, en effet, que des animaux très différents peuvent habiter des Coquilles dont l'ouverture longitudinale est proportionnellement étroite. C'est ce qu'on a reconnu lorsqu'on a examiné avec toute l'attention convenable les différents g. compris dans la famille de M. de Blainville. On y trouve les Cônes à côté des Strombes, quoique les animaux de ces deux g. n'aient pas la moindre ressemblance. L'on y remarque, à côté des deux g. que nous venons de nommer, tous ceux de la famille des Enroulés de Lamarck; on y rencontre mêmé les Volutes et les Mitres. Une personne qui aurait été plus exercée que M. de Blainville à juger de l'importance des caract. des Coquilles aurait évité certainement la confusion qui règne dans sa famille des Angystomes. Les premières observations de MII. Quoy et Gaimard, quelques unes de M. Lesson, plusicurs de R. Delle Chaje, auraient pu guider M. de Blainville dans l'appréciation des caract. zoologiques de plusicurs de ces genres. Aujourd'hui qu'ils sont parfaitement connus, depuis les beaux travaux de MM. Quoy et Gaimard, il faut revenir, sans beaucoup de changements, aux familles de Lamarck, et abandonner cette famille des Angystomes de M. de Blainville. (Desh.) *ANIIALONIUM.Ariocarpus, Scheidw.

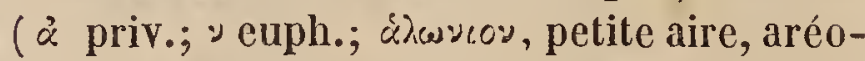
le). вот. PH. - G. de la famille des Cactées, de notre tr. des Phymatocotylédonées, que nous avons établi (Cact. Gen. nov. Spec.q. nov. 1859. - Herb. de l'Am. 1840 ) en hii assignant pour caract. : Rhizôme perpendiculaire, bétiforme. Aréoles nulles. Mamelons prismatico-triangulaires, plans en dessus, foliiformes à la base, disposés en rosace spirale. Aiguillons nuls. Aisselles garnies d'une 
cence axillaire. Fleur's amples, à divisions périgoniales biséricées, connées à la base en un tube court, lisse, charnu. Étam. nombreuses, inégales, incluses, insérées sur le tube en séries spirales, à filaments très ténus. Style égalant presque les divisions, dilaté au sommet, charnu, infundibuliforme, creux dans toute sa longueur, et peu à peu atténué vers la base; rayons stigmatiques 8 , grands, révolutés, papilleux, charnus, arrondis en dessus. Baie subanguleuse, lisse, d'un blanc-rosé pâle, comme les fleurs. Graines nidulantes, digitaliformes. Pulpe rare. - Ge g. ne se compose encore que d'une seule espèce, l'A. prismaticum Nob., plante rare et l'une des plus singulières de cette singulière famille. Elle rappeile complètement par son faciès l'Alö̈ retusa, dit vulgairement le pouce écrasé. Elle a été découverte au Mexique, croissant dans les fissures d'une roche porphyrique, près de San Luis de Potosi, à $2,111^{\mathrm{m}}, 454$ ou $2,275^{\mathrm{m}}, 875$ de hauteur au dessus du niveau de la mer. Le rhizôme de cette plante, d'environ $0^{\mathrm{m}}, 217$ à $0^{m}, 271$ de long, sur une grosseur proportionnée, est semblable à celui de notre betterave cultivée, et rempli, comme dans celleci, d'une pulpe épaisse et violacée, très fibreu. se, caverneuse, laissant couler, quand on la coupe, un suc lactescent pour ainsi dire intarissable. Le caudex est formé de mamelons prismatiques, triangulaires, très glauques, obtus et membranacés sur les bords ainsi qu'au sommet, sur le côté plan duquel, et à peu de distance de son extrémité, se voit quelquefois, dans la jeunesse du mameIon, un véritable nectaire (ou fausse aréole) garni d'un court duvet fauve et caduque. Dans les très jeunes individus (naissants), les mamelons sont cylindriques-déprimés, et portent au sommet un faisceau de soies caduques, barbelées, qui rappellent les aiguillons ordinaires des Cactées, et ne prennent que peu à peu la forme angulaire des individus adultes. Toute la surface cuticulaire des mamelons est membraneuse et parsemée de petits points blancs (stomates). Les fleurs naissent en grand nombre au sommet de la plante. Elles sont d'une excessive délicatesse, et ont près de $0^{\mathrm{m}}, 054$ d'ouverture. Les pétales en sont légèrement frangés au sommet, et munis, en dehors, d'une nervure médiane pourprée. Les anthères sont d'un beau jaune orange; le stigmate est blanc. Les graines sont noires, multiforaminées, en forme de dé à coudre. - Ce g. est très voisin des Mammillaria, en raison de son inflorescence axillaire, et d'autres caract. qui leur sont communs. Toutefois son faciès, l'absence de véritables aiguillons, le mode d'insertion des étamines, etc., l'en élnignent suffisamment. Ce g. parait devoir être adopté. Voy. aniocaripus.

(C. L.)

ANHALTIA (nom d'homme). BOT. CR. - (Phycées.) M. Schwabe (Linnaa, 1854; Heft.tome I, p. 127, cum icon.) a tenté d'élever sous ce nom, au rang de genre, une esp. que tous ses caractères rejettent dans le g. Chotospora. (Voy. ce mot.) Ine seule espèce, que l'auteur nomme $\boldsymbol{A}$. Friderica, composait le g. Anhaltia, qui n'a pas été adopté.

(C. M.)

* NILAMMUS. INs. - G. de Coléoptères tétram., famille des Longicornes, établi par M. Dupont, et adopté par M. Dejean, qui, dans son dernier Catalogue, le place ì côté du g. Monohammus de Megerle, qui appartient à la tribu des Lamiaires de MI. Serville. - Ce g., dont les caract. n'ont pas été publiés, ne renferme qu'une seule esp., de Java, nommée par M. Dejean $\boldsymbol{A}$. conspersus. D'après l'examen que nous avons fait de cette esp., les caract. principaux qui la séparent du g. Monohammus sont : Point d'épines latérales au corselet. Présternum très avancé. Yeux oblongs. Angles huméraux très aigus.

* ANHEBECARPEA ( $\dot{a}$ priv.; $v$ euph.;

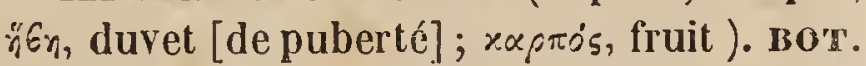
PH. - Division du g. Felicia, Cass. de la famille des Synanthérées-Astéroïdées, foimée par M. De Candolle (Prodr., v. 221), et caractérisée par des akènes très glabres.

(C. L.)

* ANHINGA. Plotus (Anhinga, nom brésilien de ces oiseaux, selon Marcgrave; Plotus ou Plautus, en latin pied plat, employé primitivement par Klein pour une famille de Palmipèdes, et appliqué par Linnó aux Anhingas ). ors. - Ce g., de l'ordre des Palmipèdes de Cuvier et de sa famille des Totipalmes, fait partie de notre famille des Pélécanidées, syn. de ces derniers, et de notre s.-famille des Plotinées. Les caract. en sont. Bec plus long que la lête, trìs droit, grêle, très fendu el très aigu, à bords rentrants ef 
finement denticulés vers la pointe; narines peu visibles, situées, au bord du front, dans une rainure linéaire. Tête petite et grêle, cou extrêmement long et mince. Tarses très courts, mais robustes; doigts intermédiaires et externes égaux; tous, ainsi que le pouce, engagés dans une membrane; ongles robustes, recourbés et acérés, l'intermédiaire pectiné à son bord interne. Ailes allongées. Queue très longue, arrondie, formée de 12 pennes singulièrement raides, les médianes surtout, qui, ainsi que leurs tiges, sont traversées de stries profondes en forme de cannelures.

Ces Oiseaux sent piscivores et excellents nageurs et plongeurs, quoiqu'en même temps percheurs. Leur conformation particulière concourt parfaitement à leur rendre plus faciles ces deux genres de locomotion. Leurs tarses courts, mais très robustes et déjetés en arrière; leurs larges pieds totipalmés, et leur queue à pennes longues et raides faisant l'office de gouvernail, leur servent merveilleusement non seulement à plonger, mais à nager et à se diriger rapidement sous l'eau, lorsqu'ils y poursuivent leur proie. La longueur de leur cou semblerait seule un obstacle à cette marche rapiảe et sous-riveraine; mais, dans cette circonstance, ils le tiennent raide et tendu; de plus, leur bec et leur tête effilée, qui le précèdent, en font une sorte de flèche susceptible de fendre l'eau avec la plus grande facilité.

Nous ne doutons pas que ce cou ne soit doué d'une grande énergie musculaire et que ses vertèbres n'offrent de fortes apophyses pour l'attache des muscles, comme on peut le remarquer chez les Plongeons, les Grèbes, excellents plongeurs et nageurs conme eux, et possédant la même faculté de natation sous-marine et sous-riveraine.

D'après cette organisation particulière, les Anhingas, naturellement méfiants, plongrent dès qu'ils éprouvent la moindre frayeur et ne reparaissent le plus souvent qu'à une grande distance; encore ne mettent-ils que leur tête hors de l'eau pour respirer un instant et nagent souvent dans cette position.

Quoique Palmipèdes, ils se perchent, comme tous les Totipalmes, sur les arbres qui bordent les rivages, y passent la nuit et y nichent. C'est sur les caux douces ef les sa- vanes noyées des régions les plus méridionales des deux mondes que les Anhingas vivent habituellement. Ils y poursuivent les poissons qui font leur nourriture. Quand ils en ont saisi quelqu'un, ils l'avalent tout entier s'il est petit, et sans sortir de l'eau; mais s'il est trop gros, ils l'emportent sur un rocher ou sur un tronc d'arbre, où ils le dépècent à l'aide de leur bec et de leurs ongles crochus. Jusqu'ici l'on n'a encore bien constaté que deux espèces d'Anhingas: l'une africaine, c'est l'Anhinga, Levaillant (Platus Levaillantii, Enl.107; Tem. Col. 587), noir depuis la poitrine jusqu'à la queue, avec la tête, le cou et les couvertures alaires, d'un roux doré, et une bande blancne descendant de chaque côté depuis l'œil jusqu'à moitié du cou; l'autre américaine, c'est l'Anhinga à ventre noir (Plotus melanogaster, Enl. 959 et 960 ; Vieillot, Gal., pl. 278; et Wilson, pl. 74, 1, 2). Le mâle, dont nous nous sommes procuré un individu adulte et en livrée de ncces, est alors tout noir, à reflets vert-bouteille, et ports sur la tête une huppe de plumes effilées retombant en arrière, et qui, réunies à celles du dessus du cou, également allongées, lui forment une sorte de crinière très remarquable. Les variations assez nombreuses qu'éprouve le plumage de ces oiseaux suivant les mues et la différence des sexes en ont fait multiplier à tort le nombre des espèces.

(LAR.)

* ANHISTE. Anhistus. (ảpriv.; isos, toile, tissu). BOT。CR。 - Quelques auteurs se servent de cet adjectif pour caractériser certains organes des végétaux, dans lesquels on n'observe, au plus fort grossissement cu microscope composé, aucune structure cellulaire. De ce nombre sont les tubes extérieurs des Conferves, et, en général, des Algues filamenteuses articulées. (C. M.)

* ANHYDPE. Anhydrus ( $\alpha 2 \nu$ Do pos, qui manque d'eau). Épithète donnće à tout corps qu'on soupconne d'être privé d'eau.

(G. D’O.)

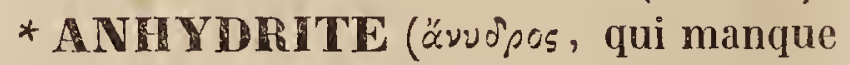
d'eau). GíoL. - M. Cordier (Classification des Roches) a donné ce nom à une esp. de sa famille des Roches à base de sulfate de chaux. - L'Anhydrite est formée de chaux et d'acide sulfurique, et ne conticnt par coneco 
quent pas d'eau de composition. Wile se présente tantôt à l'état gremu, tantôt à l'état compacte, et quelquefois avec ces deux sortes de contexture. Elle est ordinairement blanche, bleuâtre, ou même rougeâtre, et, dans ce dernier cas, elle doit sa conleur au protoxyde de fer; quelquefois elle est noirâtre ou grise par suite de la présence de quelques maticres bitumineuses. on trouve aussi, mais très rarement, le soufre, disséminé en parties très ténues dans l'Anhydrite. Il peut arriver alors que la roche prenne une teinte citrinc, et donne une odeur sulfureuse par la calcination.

Indépendamment des minéraux que nous venous de citer comme se trouvant dissémiués accidentellement en parties impalpables dans cette roche, on peut y rencontrer des grains plus ou moins distincts, savoir : $1^{\circ}$ de Carbonate de fer, $2^{\circ}$ de Pyrite ordinaire, $5^{\circ}$ de Boracite (borate de magnésie) toujours cristallisé, $4^{\circ}$ de Chlorure de sodium (sel commun), quelquefois assez abondant pour y être exploité, par dissolution, comme à Bex, en Suisse. L'Anhydrite, considérée en grandes masses, contient presque toujours quelques parties sédimentaires, même celle des terrains les plus anciens. Dans les terrains primordiaux, elle ne renferme guère que les minéraux accessoires de la doIomie, tels que le Mica, le Talc, l'Amphibole grammatite, et des cristaux de carbonate de chaux magnésifère. Dans les terrains subséquents, elle peut contenir du Quartz et du Hica.

Cette roche, qu'on croyait jadis restreinte à l'étage des grès bigarrés, figure, ainsi que nous venons de le dire, dans quelques terrains primordiaux, dans tous les étages de la période salino-magnésienne, et dans ceux de la période craycuse. Il est probable que, dans beaucoup de cas, elle doit sa formation à une épigénie qui s'est exercée plus ou moins profondément sur des masses calcaires par l'action de vapeurs sulfureuses, qui ont transformé le carbonate de chaux en sulfate anhydre. Cette opinion est justifice par la présence des fragments de la roche originaire qu'on trouve dans les amas d'Anhydrite de diverses localités; dans les autres cas, elle paraît s'être formée de toutes pièces à la manière des roches de sel gemme.

L'Inhydrite est suscentible de s'hydrater à la longue; alors elle se désagrège, devient spongieuse, augmente de volume, et finit par se convertir en gypse proprement dit.

(C. D'O.)

ANHYDRITE ("ّ̋ufos, sans eau). MIN. - Nom domé par Verner au sulfate de chaux anhydre ou sans eau, autrement dit Karsténite. Voy. sulatims. (DEL.)

ANI. Crotophaga (ani, nom ver-

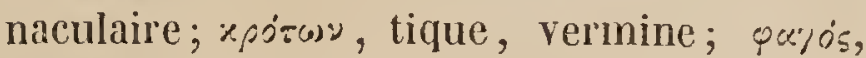
mangeur ). oIs. - G. de l'ordre des Grimpeurs de Cuvier, et des Zygodactyles de Vieillot et de Temminck, faisant partie de notre famille des Cuculidées et de notre s.-famille des Crotophaginées. Les caract. en sont : Bec très élevé et très arqué supérieurement, très comprimé, et formant une carène arquée et très mince, souvent ridée sur ses côtés, et s'avançant par derrière entre les plumes du front. Narines de forme ovalaire, placées près de la base du bec, vers le milieu de la mandibule. Ailes faibles, à rémiges courtes, sub-obtuses. Tarses médiocres, à larges scutelles; doigts minces, terminés par des ongles faibles. Queue longue, étagéc.

Ces Oiseaux, particuliers au nouveau monde, sont d'un naturel très familier et éminemment sociable. Ils vivent en troupes plus ou moins nombreuses, et se tiennent ordinairement hors des grands bois, dans les savanes plantées de buissons, ou au milicu des palétuviers des marécages. Ce qu'ils offrent de plus remarquable dans leurs mours est leur nidification. Ils travaillent en commun à la construction d'un nid assez grand pour que plusieurs femelles puissent y pondre et y couver ensemble; à peine une très légère cloison les sépare-t-elle l'une de l'autre, et souvent les oufs se trouvent mêlés et couvés par une scule, lorsque les autres sont à chercher leur nourriture. Toutes les esp. ont la même coloration de plumage, un noir intense, arec la plupart des plumes bordées de vert ou de bleu luisant. On n'en a connu long-temps que deux espèces, l'Ami des palétuviers (Crotophaga major, Lin., Enl., 102-1), et l'Ani des savanes (Crotophaga Ani Enl., 102-2, et Vieillot, Gal., pl. 45). Depuis, MI. Lesson en a publié une troisième esp., dans son Traité et dans sa Cent. zool., pl. 9, sous le nom d'Ani $d_{s}$ Lascasas (Crot. Casasii), que M. Swainson a préten!lu ctre le même que son Crotopho 
ga sulcirostra, publié antérieurement daus sun Synopsis of Mexican Birds. Ce dernier auteur en a encore décrit deux autres dans la $5^{*}$ partie de sa Classification, sous le nom de Crot. rugirostra et de Crot. semisulcata, toutes deux de l'Amérique méridionale.

Vieillot a rangé parmi les Anis, sous le nom d'Ani Guira cantara (Crot. Piririgua, Gal., pl. 44), un Oiseau du Paraguay et du Brésil qui, d'après les couleurs de son plumage et la forme de son bec, semblerait mieux placé avec les Coucous, mais qui réunit les habitudes toutes exceptionnelles de nidification et d'incubation en commun des Anis, et qui, d'après Azara, s'associe même à eux pour nicher et couver sur le même arbre. M. Lesson, dans son Traité, a fait de cet oiseau une division de ses Coucous, sous le nom de Guira.

Ces habitudes toutes particulières, et qui ne se retrouvent chez aucune autre esp. de Coucou, nous engagent à adopter cette dénomination de Guira donnée par M. Lesson; mais nous en formerons un s.-g. du g. Ani; la conformité de leurs mœurs nous paraissant, dans cette circonstance, assez déterminante pour un tel rapprochement.

Ainsi notre g. Ani (Crotophaga) renfermera le s.-g. Guira Less., formé d'une seule esp., le Guira piririgua Nob. (Piririgua Azara, Crotophaga piririgua Vieill., Gal., pl. 44), à bec rougeâtre, ayant un plumage mélangé de roux, de flammettes brunes sur un fond blanc, une huppe de plumes étroites, pointues, rousses au sommet, blanchàtres ḋ la base; des ailes brunes, variées de brun et de blanc; la queue blanche en dessous, traversće au milieu d'une très large barre noil'e, et les tarses jaunes; du Brésil et du Paraguay.

(LAFR.)

ANIA ( $\alpha$ vi $\alpha$, chagrin?). Bot. PH. - G. de la famille des Orchidacées, tribu des Épidendrées, créé par Lindley (Orchid. 129), qui lui assigne les caractères suivants : Lacinies du périgone linéaires-lancéolées, égales, conniventes; les extérieures semblables. Labelle trilobé, plan, lamellé au milieu, cunné avec la base du gynostème, qui se prolonge quelquefois en éperon ou en capuchon. Gynostème dressé, allongé, ailé. Anthère 6-8-loculaire. Pollinies 8 , égales, ou les alternes plas petites. - Les espèces peu nombreuses de ce g. appartiennent à l'Inde, et sont épiphytes, à rhizôme rainpant; à feuilles plissées, membranacées, solitaires; à scapes multiflores.

* ANIARA (ávexpós, triste). INs. - G. de Coléoptères hétéromères, famille des Taxicornes, établi par M. Dejean, mais dont il n’a pas publié les caract. D'après la place qu'il occupe dans son dernier Catalogue, il appartiendrait à la tribu des Diapériales de Latreille. Il y rapporte 7 esp., toutes exotiques, et chacune d'une contrée différente. Nous citerons comme type celle que $\mathbf{M}$. Buquet a nommée $\boldsymbol{A}$. dorsalis, et que nous avons vue dans sa collection. Elle sê rapproche beaucoup, pour la forme, de l'Uloma culinaris Fabr. La tête et le corselet sont noirs; les élytres rougeâtres, avec une grande tache noire elliptique sur la suture; les antennes et les pattes rougeâtres. Cette espèce est de Java.

ANIBA. Cedrota, Schreb. (nom vernaculaire ). BOT. PH. - G. formé par Aublet (Guyan., t. 126) sur un arbre de la Guyane, et ainsi incomplètement caractérisé : Cal. sex-parti, à segments obtus, concaves. Étam. 8, hypogynes, à filaments courts, à anth. ovales. Un seul style. Oraire ceint d'une glandule. Un style court, à stigm. obtus. Fruit.... ? Feuilles opposées ou verticillées. Fleurs petites, en grappes. Bois citrin, aromatique, appelé, dans le pays, bois de cèdre. - Les botanistes sont d'accord pour regarder cet arbre comme une espèce indéterminée du g. Laurus. Voy. ce mot. (G. L.)

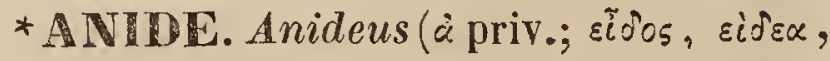
¿ $\delta \dot{\alpha}$, forme, espèce). TÉrat. - Genre de Monstres unitaires, type de la famille des Anidiens. Voy. ce mot.

(I. G. S. H.)

* ANDIENS. Anidai.(Voy. ANIDE.) TÉrA - Cette famille, que nous ayons nous-même récemment établie (Voy. Hist. gén. des Anomalies, t. II, 528), ne comprend qu'un seul g., composé d'un très petit nombre de cas ; et elle est jusqu'à présent fort imparfaitement connue. L'excessive simplicité de l'organisation des Anidiens les place tout à fait au bas de la série des Monstres unitaires omphalosites; c'est non seulement le dernier terme connu parmi les Monstres de cet ordre, mais presque le delnier terme que l'on puisse concevoir comme possible. Qu'on se figure un sac de forme ovoïde ou globu- 
leux, mais toujours mal symétrique, tantôt nu et tantôt velu, ne renfermant aucun viscère distinct, pas même de canal intestinal, mais seulement du tissu cellulaire, de la graisse, quelques branches vasculaires, et tout au plus quelques osselets informes : tel est le corps d'un Anidien, réduit ainsi à une sorte de bourse cutanée dont on aurait peine à déterminer la nature, sans ses connexions avec le cordon ombilical, à l'extréGmité duquel on la trouve suspendue. De là, un caractère très remarquable et exclusivement propre à ce groupe, au moins par rapport à tous ceux qui le précèdent : c'est l'absence de toute forme spécifique. Chez tous les Monstres unitaires autosites sans exception, chez tous les autres Omphalosites, c'est-à-dire chez les Paracéphaliens et les Acéphaliens, il est toujours facile de déterminer à quelle espèce zoologique appartient l'être anomal que l'on examine. Parmi les Anidiens, cette détermination est impossible, au moins sans une analyse anatomique très délicate, puisque le corps n'est plus qu'un sac ovoïde ou globuleux, sans appendices comme sans caractères spéciaux de forme.

Le genre Anide, type de cette famille, a été établi seulement en 1832 par Gurlt (Voyez Lehrbuth der path. Anat. der Haus-Sceugeth. , partie II, page 13) sous le nom inadmissible d'Amorphus; mais on connaissait déjà depuis long-temps deux exemples de la même monstruosité. L'illustre Ruysch avait figuré, il y a un siècle, dans ses Trésors anatomiques, un Anide né d'une vache, et un cas analogue chez l'homme avait été décrit il y a cinquante ans en Angleterre par le docteur Bland. Mais ce type organique, qui caractérise le singulier genre des Anides, et dont ni Ruysch ni Bland n'avaient saisi les conditions, avait été laissé dans un oubli complet, et c'est à Gurlt que l'on doit d'avoir reconnu dans les Anides de véritables monstres, plus simples seulement que les autres, et notamment que les Acéphaliens, dont, comme nous l'avons montré, ils sont d'ailleurs voisins à quelques égards. Aux deux cas déjà connus, Gurlt a eu en outre le mérite d'en ajouter deux autres, fournis, comme celui de Ruysch, par l'espèce bovine. Nous ne doutons pas que, l'attention se trouvant T. T. ainsi fixée sur ce groupe physiologique si remarquable, son histoire ne s'enrichisse promptement de nouveaux faits, et que bientôt la famille des Anidiens ne comprenne un plus grand nombre de cas, dont quelques uns pourront devenir les types de nouveaux genres.

(1. G. S. H.)

* ANIDIUM, Neck. (corruption et dimin. d'anisum, anis ). вот. PH. - Syn. du g. Bifora, Hoffm.; de la famille des Ombellifères.

(Sip.)

* ANIDRUM, DG.Prodr. est une erreur typogr. pour Anidium.Voyez ce mot. (SP.) ANIGOSANTHUS, Labill.; Anigozia, Salisb.; Anærgosanthus, Reich.; Schwce-

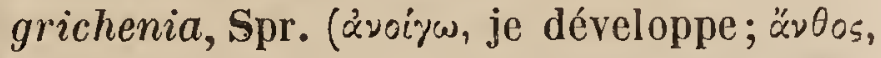
fleur). вот. Рн. - G. de la famille des Hémodoracées, créé par Labillardière (Voyag., t. I, 441, t. 22, Nov. Holl., II, 119) et dont voici les caractères essentiels : Périgone corollacé, laineux en dehors; tube allongé, conné avec l'ovaire à la base, puis décidu. Limbe sexfide. Lacinies presque égales, unilatérales supérieurement. Étam.6, ascendantes, insérées à la gorge du périgone. Filaments filiformes. Loges des anthères adnées à un connectif en avant. Ovaire 5-loculaire; ovules nombreux insérés sur des placentas saillants, dans l'angle central des loges... Style filiforme. Stigmate simple. Caps. infère, 3-loculaire, subglobuleuse, loculicide-trivalve au sommet; graines nombreuses. - Ce genre, qui a besoin d'être encore étudié, renferme cinq ou six espèces, presque toutes cultivées, pour la singularité de leur inflorescence, dans les serres d'Europe. Elles sont indigènes dans la partic australe de la Nouvelle-Hollande; ce sont des plantes herbacées, vivaces, persistantes, à racines fibreuses, fasciculées, épaisses; à tige simple ou ramifiée au sommet, laineusevelue, garnie de feuilles ensiformes, à lame inverse, semi-vaginantes à la base; fleurs grandes, remarquables, disposées en une sorte de corymbe formé d'épis courts et garnis de bractées oppositiflores. Périgone laineux en dehors. Poils colorés, ramifiés. - L'esp. la plus remarquable du g. est l'A. coccincus de Paxion.

(C. L.)

ANIL ou ANIR. вот. PI. - Synon., dans les Antilles, de l'Indigofera tinctoria $\mathbf{L}$. (C. L.)

ANILOCRE. Anilocra. CRUST. - 
Leach désigne sous ce nom un g. de l'ordre moyen de ses organes du mouvement. des Isopodes, famille des Cymothoadés, On a cru pouvoir ajouter encore à ces cadont les caractères peuvent être exprimés ractères facultatifs un caractère d'organisaainsi : Yeux granulés, convexes, écartés. Cô- tion et de fonction, celui d'être pourvu d'utés des derniers articles de l'abdomen presque ne poche intéıieure, ayant son entrée (la involutés; le dernier article plus étroit à son extrémité. Pattes d'égale grosseur. Lames des appendices ventraux postérieurs inégales, allongées; les extérieures plus longues que les internes.- Ce g. renferme trois espèces, dont une a été dédiée à Cuvier, et se trouve dans la mer de l'île d'Iviça ; les autres habitent la Méditerranée et les mers du cap de Bonne-Espérance.

(II. L.)

ANIML. - Le mot animal exprime, dans la langue française comme dans la langue latine, un être doué d'un principe de sentiment et de mouvement, que les Latins

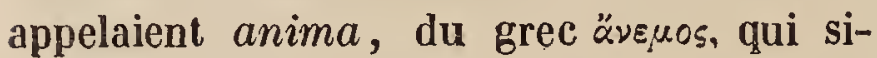
gnifie air, vent, souffle de l'air. C'est que respirer, pour les peuples qui ont créé le mot animal, était le premier caractère de la vie. Cesser de vivre était rendre, par la dernière expiration, le principe de la vie, animam efflare. La distinction nominale latine et française des animaux a donc été prise d'abord du phénomène de la respiration aérienne; aussi l'adjectif animalis, dérivé d'animal, voulait-il dire, chez les Romains, non seulement qui respire, mais encore qui a vie, et, ce qui était pour eux la même chose, qui est animé.

Ces idées sur la vie étaient d'ailleurs conformes à celles des Grees, chez lesquels les mots $\zeta \tilde{\omega} 0 \nu$, animal, et $\zeta \omega \dot{y}$, vie, ne differaient que par la terminaison et par le gerre.

Ainsi l'idée la plus simple qu'on s'est faite d'abord d'un animal était celle d'un être qui respire. Plus tard, cette idée s'est complétée par celle d'un être ayant en lui un principe d'activité qui le rend susceptible de recevoir les impressions du monde extérieur, d'en être excité ou affaibli; puis un autre principe d'activité qui lui donne la faculté de se mouvoir ou d'agir sur ce même monde. Enfin on s'est élevé à un principe supérieur d'activité, auquel les deux autres sont subordonnés, au moi, qui a la faculté de percevoir ces impressions, auquel elles deviennent sensibles, et qui produisent en lui un sentiment de plaisir ou de peine, des désirs ou des aversions; et, par suite, la volonté d'agir, dont il a la puissance au

bouche ) à la surface du corps, pour recevoir du dehors les substances alimentaires et les digérer; mais nous verrons bientôt que ce caractère n'est pas absolu, et qu'il manque à quelques uns des animaux les plus simples.

La science n'a réuni que depuis peu d'années tous les êtres vivants, les végétaux et les animaux, en un seul groupe, celui des êtres organisés, pour les opposer, dans une étude commune, aux êtres privés de la vie, aux êtres inorganiques.

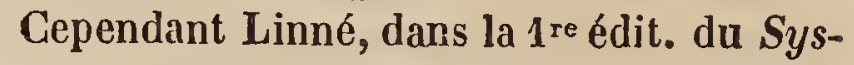
tema Natura, qui date de plus d'un siècle ( 23 juillet 1725 ), définissait déjà les végétaux des êtres naturels qui croissent ei vivent, et il les distinguait des minéraux par ce dernier caractère, qu'il retrouvait dans les animaux, jouissant, de plus que les végétaux, de la sensibilité : LApides crescunt. VEGETABILIA crescunt et vivunt. ANImalia crescunt, vivunt et sentiunt.

Après plus d'un demi-siècle, Gmelin, dans une édition du même ouvrage, ajoutait au caractère d'être vivant, donné par Linné aux végétaux et aux animaux, celui d'être organisé, et à celui de sentir, par lequel les animaux se distinguent, suivant Linné, des végétaux, celui de se mouvoir spontanément : LAPIOES, corpora congesta. VEGETABLIA, corpora organisata et viva, non sentientia. ANimalia, corpora organisata et viva, sentientia, sponteque se moventia.

Mais il y avait encore, dans ces trois divisions des êtres de la nature, dont les principaux caractères distinctifs étaient sans doute bien indiqués, le défaut capital, à notre avis du moins, de ne pas les grouper d'après le degré d'importance de leurs principaux caractères différentiels et de ressemblances.

Il fallait opposer d'abord tous les êtres organisés, ou doués de vie, aux êtres inorganiques.

C'est surtout au célèbre Bonnet que l'on doit de s'être arrêté à cette importante considération de l'organisation, et d'avoir étu dié tous les êtres qui en jouissent, du moins sous le point de vue de leur propagation. 


\section{S1. - Caractères généraux de l'organisation.}

Les corps organisés ont principalement, et en premier lieu, le caractère de l'individualité. Il résulte d'une forme propre, bien circonscrite, qui distingue l'ĉtre individuel de tout ce qui l'entoure, qui le limite dans l'espace, qui le sépare des autres êtres organisés et de l'être compliqué dont se compose le monde inorganique. Elle suppose des forces indépendantes qui agissent en lui, pour lui conserver cette forme particulière, ou pour la modifier, toujours d'une manière caractéristique, aux différentes phases de son existence.

Cet être individuel est un petit monde, qui ne se distingue pas seulement par sa forme et par son volume; Inais encore par sa composition chimique et par sa composition organique, c'est-à-dire par la nature et par les différents arrangements de ses molécules constituantes. C'est un centre d'attraction et de répulsion, qui prend et rejette autour de lui les matériaux quil doivent entrer et s'user dans la composition de ses organes. G'est un tout, dont les parties sont d'autant plus dépendantes de l'ensemble, qu'elles sont plus nombreuses et plus compliquées. C'est une machine (l'organisme) dont les rouages (les organes) sont admirablement arrangés pour produire la succession des phénomènes qui constituent et caractérisent la vie individuelle.

Tous ces caractères d'individualité distinguent le corps organisé et vivant du corps brut ou inorganique, dont l'individualité est beaucoup plus difficile à saisir.

Pour les uns, l'individualité minérale existe dans la molécule intégrante, composée d'un groupe d'atornes de même nature (les corps simples) ou de nature différente (les corps composés ), affectant une forme déterminée. Pour les autres, l'individualité minérale ne se montre que dans les agrégats réguliers de ces mêmes molécules intégrantes dont se composent les cristaux.

Le repos, la permanence de la forme, de l'agrégation des atomes, qui constituent la molécule intégrante, ou de l'agrégation des molécules intégrantes qui constituent le cristal, caractérisent, dans l'une et l'autre sup-- positton, l'individualité minćrale, dont la durée est indéfinie, une fois qu'elle a été constituéo; elle ne peut être détruite quo par une force extérieure étrangèro, dont l'énergie viendrait surmonter celle qui maintient réunis, dans l'état de repos, les atomes de la molécule intégranto ou les molécules intégrantes du cristal.

Les vicissitudes successives de forme, de rolume, de compositions chimique et organique, de phénomènes, qui manifestent et distinguent le mouvement vital dans chaque individualité organique; qui limitent son existence, comme elles la caractérisent ; tous ces changements, et leur succession régulière, établissent, au contraire, de la manière la plus évidente une séparation tranchée entre le monde organique et le monde inorganique.

Nous n'avons pas besoin de pousser plus loin notre comparaison pour en conclure qu'il n'y a pas de passage gradué et insensible de l'un à l'autre; que l'échelle des êtres est uno hypothèse insoutenable, et que les êtres naturels, étudiés sous ce premier et grand point de vue, se séparent et se classent en deux grandes séries bien caractérisées, celle des corps inorganiques et celle des corps organisés.

Les corps organisés (Voy. ces mots) composent le règne organique, le règne de la vie individuelle, et l'autre le règne inorganique, le règne de la vie générale.

\section{S 2. - Les corps organisés se divisent en végétaux et animaux.}

Ce dernier peut se subdiviser de même, mais d'une manière beaucoup moins tranchée, en deux autres séries, celle des végétaux et celle des animaux, formant ensemble deux règnes subordonnés au grand règne organique.

Nous venons de faire connaître les animaux par leurs caractères les plus généraux, ceux qu'ils partagent avec les végétaux, comme corps organisés et doués de la vie, et qui se distinguentles uns et les autres des corps bruts ou inorganiques.

Pour compléter l'idée que nous devons nous faire d'un animal quelconque, il nous reste à exposer, avec quelques détails, les caractères qui le distinguent plus ou moins 
d'un individu végétal. Ces caractères sont | nique solide, une substance nourricière en matériels et dynamiques ou phénoméniques. réserve, que le mouvement vital dissoudra

\section{S5. - Composition chimique.}

La composition chimique différentielle entre l'organisme végétal et l'organisme animal tient sans doute à la prédominance du carbone dans le premier, et à la grande proportion relalive de l'azote dans ce dernier.

Le tissu cellulaire végétal a généralement une composition chimique isomère avec l'amidon, et le ligneux qui se dépose dans ce tissu et le durcit se compose d'un dixième en sus de charbon, ou de 0,54 , au lieu de 0,44 . (D'après M. Payen. Voy. les comptesrendus de l'Académie des sciences pour 1839, no 2, p. 51.)

Mais ce tissu n'est pas dépourvu d'azote, surtout dans les graines (ibid. p. 60) ou dans les organes naissants. Le cambium même en renfermerait. (Ibid. - Premier sémestre de 1838 , p. 132.)

Cependant l'organisme animal est généralement plus azoté. Remarquons d'ailleurs que, quand il se durcit, c'est surtout en se pénétrant de matières salines (de sels calcaires) étrangères à sa constitution primitive; tandis que le ligneux qui solidifie le tissu végétal appartient essentiellement à son organisme, et le caractérise tellement, qu'il semble que le dernier but de la végétation est d'en surcharger cet organisme, et de lui donner la rigidité qui finit toujours par le caractériser.

\section{$\mathbb{S}$ 4. - Eiléments organiques.}

Les éléments organiques des végétaux sont les différents sucs celluleux ou les différentes sèves qui se meuvent dans ce tissu végétal, pour leur propre élaboration, ou pour la nutrition et pour les sécrétions. Ces sucs, ou ces sèves en mouvement, composent les liquides nourriciers en usage. Il faut y comprendre le cambium, liquide ou demi-fluide nourricier en mouvement d'assimilation, ou s'organisant.

La fécule ou les grains d'amidon, soit purs, soit enveloppés de chlorophylle, si généralement répandus dans les tissus végétaux ; la fécule, dis-je, est un élément orga- tôt ou tard dans la sève, pour donner à celle-ci les qualités nutritives nécessaires.

Les animaux ont de même des liquides nourriciers, montrant différents degrés d'élaboration, de dépuration, d'organisation; se mouvant dans l'organisme animal, pour y subir la triple action dépuratrice, organisatrice et assimilatrice, de cet organisme. La lymphe, le chyle, le sang veineux, le sang artériel, ce dernier comparable au suc vital des végétaux, composent dans les animaux ce que j'appelle le fluide nourricier en usage.

Ils ont, en réserve, les substances huileuses ou graisseuses renfermées dans les vésicules du tissu cellulaire, et dont les principaux réservoirs sont dans la cavité viscérale ou sous les téguments. La graisse est donc, pour les animaux, ce que la fécule est pour les végétaux.

Le fluide nourricier fait partie essentielle de l'organisme en action : sans lui, point d'activité vitale. Cette activité, suspendue dans la graisse, ne commence que lorsqu'elle a été mélangée à une certaine proportion de liquide, qui transforme la substance nourricière en réserve en un fluide nourricier en mouvement, et, par suite, en usage.

Il est bien remarquable qu'à l'origine du végétal et de l'animal, la substance nourricière en réserve, qui doit s'organiser dans le germe pour son premier développement, est à la fois de nature huileuse et albumineuse (l'endosperme des graines, le vitellus de l'œuf).

Je ne fais qu'indiquer les différents sujets de ce chapitre, qui pourront être développés aux articles SUc CELLULEUX, Sève, LATEX, FÉCule (BOT.), GRAISSE, hULLE (zoor.).

I'ajouterai seulement que les liquides nourriciers des végétaux, complètement élaborés, charrient des globules comme ceux des animaux supérieurs; et que la chlorophylle me parait avoir une certaine analogie physiologique avec l'hœmatosine, cette matière colorante du sang rouge.

\section{S5. - Organes élémentaires et systèmes généraux qu'ils composent.}

L'organisme animal ne se compose, dans 
les animaux inférieurs, comme dans les végétaux, que du seul organe élémentaire appelé celluleux, tissu cellulaire, parce qu'il se montre souvent sous la forme de lames, interceptant des cellules dans leurs divers entrecroisements. Dans d'autres cas, il ne se compose que de fils plus ou moins résistants; dans d'autres cas enfin, ces lames ou ces fils sont à peine solidifiés, et semblent etre le cambium des animaux.

C'est le tissu cellulaire qui sépare et qui individualise, pour ainsi dire, dans les organismes les plus compliqués, les deux autres organes élémentaires dont nous parlerons tout à l'heure, l'élément nerveux et l'élément musculeux.

C'est lui qui forme la trame de tous les organes composés ou concrets; c'est lui qui les sépare et qui les unit.

Counme dans les végétaux, l'élément celluleux est l'organe générateur de toutes les capacités du fluide nourricier. C'est donc aussi à cet organe élémentaire, et aux parois de ces capacilés qui en sont essentiellement formées, qu'il faut rapporter toutes les sécrétions, et, en général, la grande fonction de nutrition.

Dans les animaux inférieurs, ces capacités ne sont que des cellules, dont les parois sont tellement molles et transparentes, qu'à peine les distingue-t-on, dans beaucoup de cas, du fluide qu'elles renferment. On dirai même que l'une et l'autre ne forment qu'une seule substance homogène, ressemblant à du verre fondu, laquelle, dans ces derniers temps, a été désignée, par M. Dujardin, sous le nom de Sarcode.

Dans cet état de simplicité, l'organisme animal se distingue déjà de celui de la plante, du moins de la plante dont la végétation est avancée, par le caractère physique d'une moindre consistance, et par le caractère phénoménique de l'expansibilité, sans nouvelle addition d'eau ou de toute autre substance du dehors; en troisième lieu, par sa contractilité.

Dans les animaux plus compliqués, le tissu cellulaire est l'organe élémentaire principal, et l'élément producteur $1^{\circ}$ Des vaisseaux de toute espèce;

$2^{\circ}$ Des organes de sécrétions, arrangés en follicules, en capsules, en canaux de toute forme et de toute étenduc: $\tilde{5}^{\circ}$ Des membranes dermoïdes, muqueu. ses, séreuses, fibreuses, élastiques ;

40 Des parties dures, de la nature du cartilage ou des os.

Ghacune de ces parties, comme l'organe élémentaire qui les forme, a, dans l'économie animale, un caractère propre qui la distingue de l'économie végétale.

Le plus général est la souplesse pour celles qui ne doivent pas prendre la consistance osseuse et la contractilité modérée, ou cette faculté de se resserrer qui caractérise cette propriété vitale qu'on appelle tonicité, et qui se manifeste par une plus grande activité vitale de la partie où elle se manifeste.

Les vaisseaux des animaux, en particulier, ont un caractère qui les distingue nettement de ceux des plantes. Is sont disposés en arbre, ayant une partie centrale composée d'un tronc et d'une souche. Les racines amènent et concentrent dans celleci, des différentes parties de l'organisme, le fluide nourricier dont elles sont remplies. Il passe ainsi de la souche dans le tronc, et se répand de celui-ci dans les branches et les rameaux.

Tous les vaisseaux de cet arbre communiquent donc les uns dans les autres, et ces communications sont d'autant plus nombreuses que les divisions sont plus éloignées du tronc. Il en résulte que toutes les parties d'un même arbre vasculairé sont, jusqu'à un certain point, dépendantes, et qu'elles unissent de même tous les organes où elles se distribuent. C'est pourquoi on donne le nom de système à l'ensemble des vaisseaux du fluide nourricier, dans l'organisme animal. Ce système, lorsqu'il est complet, se compose au moins de deux arbres, arrangés de manière que les derniers ramuscules de l'un se continuent avec les premières radicules de l'autre, et réciproquement.

Les communications deviennent si fréquentes dans les vaisseaux intermédiaires des deux arbres, qu'elles forment les mailles nombreuses d'un double réseau de vaisseaux capillaires, origine et aboutissant des racines et des ramuscules de chaque arbre, et complétant, dans les animaux supérieurs, le cercle dans lequel le fluide nourricier doit circuler.

D'autres arbres vasculaires peuvent être 
annexés ou subordonnés a ces deux arbres principaux.

Je ne dois pas traiter ici des différences que présente, à cet égard, la série animale; il me suffit d'indiquer en ce moment ce grand caractère des vaisseaux de l'économie animale, de communiquer tous les uns dans les autres, et de former un ensemble, un organe général excitateur de tout l'organisme, par le fluide nourricier qu'il en reçoit et qu'il lui envoie, et qui lie, par là même, toutes les parties de cet organisme.

Il centralise et généralise tout à la fois la grande fonction de nutrition à laquelle il préside, et toutes celles qui lui sont subordonnées. Il en rend les efiets plus ou moins dépendants dans toutes les parties de l'organisme. (Voy. notre Appendice aux Lecons d'Anatomie comparée de G. Cuvier , t. VI, $2^{*}$ édit.)

L'autre organe général qui forme un lien puissant entre toutes les parties de l'organisme animal est le système nerveux, lequel préside à toute espece d'activité vitalể, et plus spécialement à la sensibilité, attribut exclusif de l'animalité.

La présence du système nerveux distingue essentiellement de l'organisme végétal l'organisme animal qui en est pourvu. $\mathbf{A}$ la vérité , on n'a pu le reconnaître jusqu'ici que dans très peu d'animaux du type des Zoophytes. Le genre Linguatule, parmi les Intestinaux, les Astéries et les Oursins, parmi les Echinodermes, sont les seuls animaux de ce type chez lesquels on soit parvenu à en découvrir des traces incontestables. On croit, à la vérité, pouvoir l'admettre par le raisonnement, et conclure sa présence de celle des yeux dans un grand nombre d'animalcules; mais les points colorés que l'on suppose être les organes de la vision en remplissent-ils réellement les fonctions ? C'est ce qu'il faudrait démontrer en premier lieu.

Au reste, il est à présumer que, chez beaucoup de Zoophytes, sa structure et sa transparence l'empêchent de se dessiner dans lereste de la substance, en apparence homogène, qui constitue leur corps.

Tout système nerveux a ses parties ou sa partie centrale; ses parties périphériques ou terminales; et ses parties intermédiaires conductrices, chargées de transmettre son activité de la périphérie à un centre, et re. ciproquement.

Il se compose, en général, de deux organes élémentaires distincts :

Les globules, ayant une enveloppe celluleuse, renfermant un parenchyme granuleux, et un noyau, lequel montre toujours dans un point de sa surface une apparence de noyau plus petit.

Ces globules paraissent être l'organe producteur de l'animation vitale.

L'autre organe élémentaire nerveux sert de conducteur à cette même animation. Il consiste en filets extrêmement ténus, dont les faisceaux composent les nerfs. Ces filets ont une gaîne celluleuse contenant une pulpe molle, demi-fluide, limpide, transparente, non granuleuse comme le parenchyme des globules. (Voy. le Mémoire de M. Valentin, sur la composition du système nerveux, inséré dans les Mémoires de l'Académie $\boldsymbol{L}$. C. des Curieux de la Nature, t. XVIII.) Ces deux organes élémentaires nerveux se trouvent inégalement répartis at agrégés dans les différentes parties de l'organisme, pour en constituer le système nerveux.

Dans sa partie périphérique, ou terminale des organes, ce système ne montre que des filets élémentaires ou restés réunis en faisceaux peu nombreux, se détachant des uns pour se rapprocher des autres, et former des apparences de réseaux irréguliers ; mais ayant pour caractère de se replier toujours sur euxmêmes, en figurant des anses plus ou moins fermées.

Ce même système montre un mélange, une agrégation de globules et de filets, dans ses parties centrales (les ganglions, les principaux cordons nerveux). Ces filets paraissent repliés sur eux-mêmes à leur origine centrale, comme à leur terminaison périphérique; de manière que chaque filet, dans toute son étendue, dessine une longue ellipse. Dans sa partie la plus initiale, si je puis m'exprimer ainsi, ou la plus centrale, le système nerveux ne se compose que d'une agglomération de globules producteurs : telle est la substance grise qui se trouve au centre de la moelle épinière, et à l'extérieur du cerveau et du cervelet, dans les animaux vertébrés.

La disposition générale du système nerveux est en rapport évident avec le plan général 
d'organisation qui constitue chaque type du règne animal; avec l'arrangement des parties qui composent l'organisme de chacun de ces types; et surtout avec la forme générale qui les caractérise. Cela devait être : ce système, ayant pour fonction de faire irradier de ses centres, ou d'un centre unique, sur chacune des parties de l'organisme, toutes les activités vitales résultant de l'influx nerveux; ou de faire aboutir à ces mêmes centres et d'y faire retentir toutes les impressions du dehors ou du dedans que peuvent recevoir ces mêmes parties ; il devait être arrangé pour cette communication générale et réciproque d'impulsions motrices, ou d'excitations sensitives ou non sensitives et de simple innervation.

L'organisme animal se distingue encore de l'organisme végétal par l'organe élémentaire moteur, qui entre dans la composition de tous les muscles, de tous les faisceaux musculeux, de toutes les fibres de même nature, qui jouissent de la contractilité, que j'appellerais volontiers nerveuse, parce qu'elle agit généralement sous l'influence évidente de l'innervation; mais qui est plus connue sous le nom d'irritabilité.

La fibre musculaire se compose de filets élémentaires cylindriques, creux ou tubuleux, renfermant une série de globules selon les uns, une pulpe homogène selon les autres. La gaîne de ce tube paraît avoir des stries transversales ou obliques, également distinctes, qui manquent dans certains muscles et dans certains animaux. Cette gaîne est formée de l'élément celluleux. Plusieurs filets élémentaires sont réunis dans une gaîne commune de même nature, pour composer une fibre musculaire. Des fibres musculaires plus ou moins nombreuses sont réunies de mûme dans une gaîne commune, pour former des faisceaux graduellement plus compliqués.

L'organe élémentaire musculeux est, comme on voit, composé d'un élément contractile qui le caractérise essentiellement; élément contenu dans la gaîne celluleuse du filet ou du tube élémentaire. Cet organe élementaire avait besoin d'être complété dans son organisation par les deux organes élémentaires précédents. Cela est incontestable pour l'élément celluleux.

On peut le démontrer encore pour l'élément nerveux chez les animaux qui ont des nerfs, la communication libre des filets qui se rendent aux muscles avec les parties centrales du système nerveux étant indispensable pour l'exercice de l'action musculaire. Doit-on supposer que, chez les animaux où les muscles sont évidents et qui nous paraissent privés de nerfs (les Actinies), cette privation apparente tienne plutôt à nos moyens imparfaits d'investigation qu'à la réalité ?

Si les systèmes nerveux et muscu!eux distinguent et séparent de tout le règne végétal la plupart des animaux, nous ne pruvons pas ajouter qu'ils caractérisent essentiellement l'organisme animal.

Dans les organismes inférieurs, on ne découvre plus de traces de ganglions médullaires ni de nerfs; on n'y trouve même plus de fibres musculaires bien évidentes. Cependant les phénomènes caractéristiques de la vie animale y sont plus ou moins manifestes.

A présent que nous connaissons l'organisme animal, comparé à l'organisme végétal, dans sa composition élémentaire, au delà de laquelle nos sens ne peuvent pénétrer, étudions-le dans l'agrégation de ses éléments, composant des individualités, dont la forme générale est la première circonstance qui frappe notre vue, qui doit attirer notre attention.

\section{$\$$ 6. - De la forme extérieure générale des organismes.}

Le caractère le plus général de l'organisation ou de l'arrangement moléculaire des êtres vivants, est d'abord dans la forme $e x$ térieure, dont l'élément générateur est toujours, ainsi que nous l'avons dit, en totalité ou en grande partie, une ligne courbe.

Mais déjà, sous ce premier point de vue, l'organisme animal s'éloigne rapidement de l'organisme végétal.

Les détails dans lesquels nous allons entrer à cet égard se résument dans la proposition générale suivante, et n'en seront qu'un commentaire: Que la forme, dans les êtres qui jouissent de la vie, est l'expression figurative de l'organisme, mis en rapport avec le monde extérieur. En effet, si nous comparons sous ce point de vue un animal à un végétal, nous aurons la certitude que, dans les deux règnes, la forme n'est que l'expression de ces rapports. 
Dans les animaux, au lieu d'être épanouie, comme dans les végétaux, elle est ramassée. Au lieu d'être amincie et étalée, afin de multiplier la surface que la quantité de matière organisée attribuée à chaque individuaalité végétale peut occuper, cette surface est le plus souvent restreinte dans les animaux par la forme, qui lui donne le moins d'étendue possible.

$\mathrm{Au}$ lieu de se diviser pour embrasser le plus d'espace, comme le végétal, l'animal montre dans sa forme une tendance à l'unité, à la concentration.

Au lieu de porter au dehors, comme la plante, tous ses organes d'alimentation et de respiration, de fécondation, de fructification ou de propagation par germe libre, l'animal les voile sous ses téguments protecteurs, sans que ceux-ci en suivent toujours les contours, sans qu'ils soient astreints à en revêtir la forme; ou mieux, il les recèle dans des cavités plus ou moins profondes, creusées en dedans de lui. Les substances alimentaires et le fluide respirable y sont introduits à sa volonté. Les germes y reçoivent leur premier développement, et souvent leur développement subséquent à la fécondation, dont le principe d'activité pénètre jusque dans le réduit des ovaires.

Ces caractères de la forme animale sont essentiellement en rapport avec les deux attributs de l'animalité : la locomotilité et la sensibilité.

Toute l'économie animale en est d'autant plus modifiée, et sa forme en particulier, que ces facultés y sont plus parfaites, c'està-dire plus développées, à la fois, et plus actives.

La forme animale ne devait avoir rien d'embarrassant pour le transport d'un lieu dans un autre; elle devait, au contraire, être disposée pour vaincre les résistances de la pesanteur et du frottement que l'animal éprouve nécessairement et doit surmonter dans ses mouvements variés à la surface du sol ou dans sa profondeur, dans les airs ou dans les eaux.

Cette forme, si bien disposée pour toute espèce de progression, devait l'être encore pour recevoir les impressions du monde extérieur. Elle devait montrer au dehors ces organes des sens extérieurs, faits pour avertir l'animal de ce qui se passe autour de lui.
Cette impressionnabilité, cette excitabilité extéricure, peut çire départie dans tous les téguments, sur toute la surface de l'animal, dont elle ne modifie pas autrement la forme.

Mais lorsqu'elle devient sensibilité spéciale pour la lumière, dans l'appareil de l'œil ; pour les vibrations des corps sonores, dans l'appareil de l'ouie; pour les effux odorants, pour les corps sapides, dans ceux de l'odorat et du goût; pour les résistances des surfaces et leur température, dans l'appareil du toucher actif ; il en résulte des modifications de forme très remarquables par la position à la surface du corps, ou plus ou moins rapprochée de cette surface, de ces organes spéciaux des sens externes. La forme même de l'organe du sens interne, ờ réside le moi, où viennent retentir les impressions des sens externes, ou du moins la forme de la boîte osseuse qui le renferme dans les animaux les plus parfaits, influe sur cette forme générale, dont nous cherchons à apprécier, à analyser les causes et les rapports avec tout l'organisme.

Cet organisme manifeste donc, dans toutes les individualités animales, simples et non agrégées, qui jouissent de la locomotilité, des caractères de forme qui le distinguent d'une manière bien tranchée de l'organisme végétal.

Mais il existe des animaux composés ou agrégés, privés d'organes des sens spéciaux, chez lesquels on ne peut plus assigner de place déterminée et circonscrite à un orgàne du sens interne; qui ne sont plus revêtus d'organes particuliers de locomotion; mais dont tout le corps est une substance molle, impressionnable et contractile. Ici la forme se rapproche de celle de la plante, et plus particulièrement de cette partie do la plante où la vie se manifeste par des mouvements, par un reste de motilité plus évident: je veux parler de la fleur, et de l'hydre d'eau douce, pour l'animal que je lui compare.

La forme de la plante tout entière, avec -ses racines, sa tige, ses rameaux, et même des apparences de fleurs et de fruits (les feuilles seules sont exceptées), reparaît dans les animaux de la même classe, les Polypes à polypier, qui sont entièrement privés du mouvement progressif. Ils ont des organes 
de fixité, des racines, mais qui ne paraissent avoir que cette seule fonction de fixer l'animal au sol ou aux corps submergés. La des organes du mouvement, ne s'étend et ne se divise, comme celle de la plante, que pour la nutrition. Les parties de cette agrégation, qui ressemblent à une fleur composée, jouissent seules d'une grande mobilité. Ce sont des organes de préhension, disposés en rayons autour d'un axe, dans lequel est l'entrée de l'estomac.

Chez quelques uns même (les polypiers flexibles), les ovaires apparaissent au dehors, comme les capsules, comme les fruits des végétaux. Cette tige bourgeonne, pousse des germes adhérents, qui prennent la forme de l'espèce, dans leur développement ultérieur.

On voit combien encore, dans ce cas exceptionnel de la forme animale, les modifications de la forme générale se lient à tout l'organisme, et par suite à tout le genre de vie; elles sont toujours l'expression de cet organisme, mis en rapport avec le monde extérieur.

Remarquons que, pour les animaux, cette forme phytoïde, qui devient incompatible avec le mouvement progressif, entraîne la nécessité de vivre dans l'eau; soit que l'organisme animal, privé de moyens de rechercher sa nourriture, n'en eût pas trouvé suffisamment dans l'air qui l'entoure, et que l'eau, et plus généralement l'eau de la mer, ait pu seule charrier autour de cet être immobile toutes les molécules nutritives qui lui sont indispensables; soit que l'air eût promptement desséché cette substance animale, si souple, si molle, si aqueuse, dans laquelle sont probablement fondues et méélémentaires de nutrition, de motilité et d'excitabilité, sinon de sensibilité(1). tige est un organe central qui, dépouillé langées les parties essentielles des organes

\section{S 7. - Des téguments.}

Après la forme, la circonstance matérieilk qui nous frappe le plus, dans l'observation des organismes végétaux ou animaux, ce sont les parties qui les terminent, qui les recouvrent, qui les enveloppent et qui les protégent; je veux parler des téguments.

Si nous avons défini la forme l'expression figurative de l'organisme mis en rapport avec le monde extérieur, nous pouvons appliquer cette même définition aux téguments, avec cette seule différence, qu'ils sont l'expression matérielle de ce même organisme, dans tous ses rapports avec ce qui est hors de lui, ou dans toutes les dispositions qui l'en séparent.

En effet, les téguments sont les parties superficielles de l'organisme, qui limitent chaque corps organisé; qui le séparent du monde extérieur ; qui l'individualisent; qui le protégent contre les effets nuisibles de tout ce qui l'entoure, et particulièrement du milieu dans lequel il est plongé; mais qui le mettent aussi en rapport avec ce milieu, pour en recevoir l'influence nécessaire à l'entretien de la vie.

Ainsi les téguments ont à remplir deux fonctions générales opposées dans leur but. L'une doit séparer l'individu organisé de tout ce qui l'entoure, et le protéger particulièrement contre l'action désorganisatrice des agents physiques.

L'autre a pour effet de le lier, de le mettre plus ou moins en rapport avec ces agents, ou avec les autres corps de la nature, étrangers à l'individualité organique.

Ces deux buts fonctionnels, communs à tous les corps organisés, sont subordonnés à des nécessités bien différentes dans les végétaux et dans les animaux.

Les végétaux puisent leur nourriture, à l'état moléculaire, dans le sol, dans l'air ou

(1) Nous avons donné, depuis plusieurs années, dans nos cours, la définition de la forme des corps organisés, qui vient d'être expliquéc dans le présent paragraphe, et nous avons l'habitude de la développer dans une ou plusieurs leçons, afin d'en faire sentir toute la portée, principalement dans ses applications à l'Histoire natur elle classique.

L'intérêt du sujet a frappé plusieurs de nos au.

diteurs les plus assidus. L'un deux l'a choisi, d'après notre conseil, pour sa Thèse de zoologie, soutenue devant la Faculté des sciences de Paris, le 5 juin 1840. Il y traite, d'après un plan et plusieurs vues remarquables, de la forme animale considérée dans ses rapporls avec l'organisme intérieur.

T. I. 
dans l'eau, par toute la surface de leur corps ou par quelques parties de leurs téguments, suivant la simplicité ou l'homogénéité, l'hétérogénéité ou la complication des types organiques auxquels ils appartiennent.

Ils respirent de même par toute l'étendue de leurs téguments plongés dans l'air ou dans l'eau, ou par des organes particuliers qui sont dans l'une ou dans l'autre de ces conditions physiques, suivant les mêmes différences de simplicité ou de complication organique.

Ils produisent au dehors leurs organes de fécondation, ef le plus souvent ceux de fructification.

Cette double série de rapports fonctionnels avec les agents physiques modifie partiellement ou universellement la partie superficielle de leur organisme, pour les deux grandes fonctions de la vie végétale, la nutrition et la propagation.

Les animaux, pour l'immense majorité, ont leurs principaux organes d'alimentation et de propagation, et même souvent ceux de respiration, retirés dans des cavités intérieures; ce qui diminue chez eux, sans les faire disparattre entièrement, le nombre des arrangements superficiels de leur organisme, c'est-à-dire de leurs téguments, pour les fonctions de mutrition ou de propagation.

Hiais celles de la sensibilité, dont ils sont exclusivement doués, ont nécessité de grandes modifications dans la peau, qui en est le siége général.

D'autres nécessités, qui tiennent à la locomotilité, ont fait que leurs téguments sont pourvus d'organes moteurs (les muscles sous-cutanés) qui les doublent; ou qu'ils sont attachés à des leviers durs et raides (les écailles abdominales des serpents, le test des animaux articulés); ou bien enfin qu'ils sont munis d'armes ofrensives (les ongles, les cornes) plus ou moins puissantes.

Mais cette peau sensible et mobile, qui peut encore être en rapport d'absorption et de respiration avec le milieu dans lequel l'animal esi plongé, est revêtue de parties insensibles qui modèrent cette sensibilité (les couches d'épiderme, les écailles épidermiques des Serpents; ies plaques cornées ou osseuses des Crocodiles, des Tortues, des Taious, etc.); ou bien elle est implantée de poils (les Mammiferes), ou de plumes (les
Oiseaux), ou d'écailles (les Poissons). Elle peut être encore pénétrée ou doublée, ou bien enduite de substances muqueuses, huileuses ou graisseuses, qui la protégent contre l'action dissolvante ou desséchante des agents physiques, et tout l'organisme contre l'action refroidissante ou échaufiante de ces mêmes agents.

Les différents appareils qui produisent ces parties ou ces substances insensibles qui entrent dans la composition des téguments sont enfouis, pour ainsi dire, dans le derme ou dans le tissu cellulaire sous-jacent, et font de la peau, en général, un organe très important de sécrétion; dont l'activité plus ou moins forte, surexcitée dans les moments de la mue, ébranle et modifie, à cette époque, celle de tout l'organisme.

Toutes ces considérations feront comprendre la justesse de la définition que nous avons donnée des téguments.

Elle est applicable, à la lettre, aux végétaux cellulaires comme aux animanx les plus simples. Chez les uns et les autres, les téguments ne sont ni de l'écorce proprement dite, ni de la peau, dans l'acception ordinaire de ce mot; c'est-à-dire un appareil organique plus ou moins compliqué, qui serait très distinct de l'organisme intérieur, qu'il recouvre et qu'il protége, et dont on pourrait le séparer facilement. Dans ce double type des organismes inférieurs appartenant aux deux règnes, l'organisme intérieur paraît se continuer, sans interruption, jusqu'à la surface du corps, et s'y montrer arec de simples modifications; celles qui étaient les plus indispensables pour terminer le corps, pour résister à la fois aux agents physiques et pour en recevoir l'influence vitale.

Ici les ressemblances, ou plutôt les analogies entre les végétaux et les animaux, sont dans la disposition la plus générale des parties tégumentaires; mais les différences sont dans la nature même de chaque organisme, qui se montre au dehors, à peu près comme il est constitué dans toute sa profondeur.

Les $\dot{E}$ chinodermes et les Intestinaux cavitaires ont presque seuls, parmi les animaux de ce type, une peau bien distincte du reste de l'organisme.

Cependant, cette partie superficielle et terminale qui constitue les téguments des ani- 
maux inférieurs a sans doute plus de cohésion, plus de consistance, que les parties sous-jacentes. Elle se garnit d'ailleurs de parties dures de nature cornée ou calcaire. Tel est le bouclier des animalcules ou la coquille polythalame des Rhizopodes. Remarquons, d'ailleurs, que, dans les éponges, toute la substance animale n'est qu'une peau très mince et de la plus faible consistance; que, dans l'hydre d'eau douce, ce n'est de même qu'une peau disposée en sac, et coupée en lanières sur les bords de l'ouverture de ce sac, qui est la bouche de ce singulier animal.

Les Polypes à polypier, qui s'agrègent de tant de manières, ont une peau commune, sécrétant de sa couche superficielle, interne ou externe, la matière cornée ou calcaire, qui forme l'écorce (les sertulaires), ou l'axe ( le corail) du polype. Les petits Polypes sont comme des bouches entourées d'appendices préhensiles, conduisant dans le sac ou le canal alimentaire partiel de cette partie centrale. Ils forment une extension tégumentaire de cette peau commune, laquelle reste molle par ses deux faces, et ne se charge jamais de matières calcaires.

Dans les trois autres types du règne animal, les Mollusques, les Articulés et les Vertébrés, les téguments forment toujours une peau distincte, organe compliqué, dont les parties peuvent aroir une forme, une nature et un développement très variés. Ces difiérences sont cependant, du moins pour les principales, en rapport avec le reste de l'organisme, et caractérisent les types et les classes.

Pour compléter l'idée générale que nous cherchons à donner de la nature des animaux, il nous reste à esquisser les trois grindes fonctions de la vie animale, et les caractères principaux des instruments ou des appareils d'organes qui les mettent en jeu.

Voyons d'abord comment les animaux se nourrissent.

\section{8. - Fonctions et organes de nutrition.}

Tous les corps organisés ont deux degrés de nutrition : le premier est celui du fluide nourricier, qu'on appelle plus particulierement alimentation quand les substances nutritives sont prises hors de l'atmosphère, ou respiration quand elles sout puisees dans le lluide respirable, et absorbées par l'organe respirant.

Le second degré de nutrition est celui qua assimile les molécules du fluide nourricier aux parties solides de l'organisme, et qui les organise de mème; c'est à cette seconde opération qu'on réserve plus particulièrement le nom de nutrition.

L'alimentation des plantes est une simple intussusception, et les voies capillaires de cette introduction des molécules alimentaires sont toujours quelques parties de leurs téguments, ceux des radicelles, modifiés pour cet usage seulement. Ces parties absorbent les molécules de toute nature mises en contact avec leurs bouches absorbantes, pourva qu'elles soient suffsamment dissoutes dans l'eau; mais elles ne paraissent avoir aucur moyen organique ou chimique d'agir sur ces substances alimentaires, en les atténuant ou en les dissolvant par des sucs digesiifs, et d'en préparer l'introduction dans l’organisme végétal. C'cst le sol qui est chargé de cette opération préliminaire, et c'est la permanence de son contact avec les racines qui le pénètrent, et qui y restent fixées, qui permet l'action lente, mais plus ou moins continue, de l'absorption alimentaire.

Dans les animaux, au contraire, dont les mouvements de progression d'un lieu vers un autre auraient été incompatibles avec ce mode de nutrition, qui suppose la fixité, la peau extérieure se replie en elle-même pour former une capacité intérieure, qui reçoit et tient en réserve une provision d'aliments, et les parois de cette cavité exercent sur la masse alimentaire des actions multiples de décomposition; jusqu'àce qu'étant sufrisamment préparées, ces molécules, ainsi désagrégées, puissent servir à composer le fuide nutritif réparateur; opération dont est chargée la partie absorbante de ces mêmes parois.

Cette action digestive des parois du sac ou du canal alimentaire est tellement caractéristique de l'organisme animal, que, dans quelques animaux inférieurs qui n'ont ui sac ni canal alimentaire, elle semble s'exercer par leur peau extérieure ou par leurs tégiments. 
Les Rhizostomes et les Eudores, parmi les Méduses; les Physales, parmi les Aoalèphes hydrostatiques, n'ont ni estomac ni canal alimentaire. Ces animaux composent et absorbent leur fluide nourricier répararateur par les bouches absorbantes de leurs téguments; mais la surtace de leur corps exhale un liquide caustîque, qui produit sur la main qui le touche un sentiment de brûlure. On vient même de constater que, dans les Physales, ce suc est de nature acide. Analogue à celle des sucs digestifs des animaux supérieurs, cette composition chimique fait comprendre comment ces animaux dissolvent ou digèrent une proie qu'ils ont embrassée ou enveloppée par quelques parties de leurs téguments. Ceux-ci agissent sur cette proie, comme la peau de l'estomac ou celle du premier intestin des animaux supérieurs. Ainsi que nous l'avons signalé, depuis plus de dix années, dans nos Cours de la Faculté des sciences (Lecons d'Anat. compar., t. $V$, p. 454 et 456 ), c'est une digestion extérieure, démontrant une nouvelle analogie entre les deux peaux. On peut en conclure que la digestion est un caractère fonctionnel plus général de l'animalité que l'existence d'un sac ou d'un canal alimentaire, c'esi-à-dire d'un organe destiné spécialement à l'exercice de la digestion, ou de cette fonction préliminaire de la nutrition dans les animaux.

Leur nutrition atmosphérique ou leur respiration est plutôt une dépuration qu'une alimentation. Il existe entre le fluide nourricier et le fluide respirable un tel échange de principes, que ceux que l'organisme animal verse dans l'atmosphère ne le cèdent pas de beaucoup, en poids, à ceux que l'atmosphère lui abandonne. I'air expiré a été trouvé moindre d'un quatorzième au plus, et d'un cent vingt-deuxième au moins, de l'air inspiré, dans les animaux des classes supérieures (Mammifères et Poissons).

On ne pourrait pas en dire autant de la respiration des végétaux, dont la substance prend généralement plus à l'atmosphère qu'elle rte lai rend. Ici la respiration est plus essentiellement une alimentation (1).

L'action moléculaire de l'air sur le fluide

(1) Voir, entre autres, les belles recherches de M. Boussingault (Comptes rendus des séan- et 585 ). nourricier, et celle du fluide nourricier sur l'air atmosphérique, qui constitue la respiration, doit agir à travers les parois des capacités qui renferment ce fluide, et les téguments gui recouvrent et protègent tout l'organisme.

Les téguments, qui sont en contact immédiat avec le fluide ambiant respirable, sont les organes de respiration les plus naturels, les plus simples. Quelle que soit la quantité de sang qu'ils reçoivent, elle y est soumise à l'action du fluide respirable, toutes les fois que leur structure ne les empêche pas de la ressentir. Les belles expériences de M. Edwards (Influence des agents physiques ) l'ont prouvé.

Cependant ce contact de la peau avec le fluide ambiant ne suffit pas pour en faire un organe spécial de respiration. Les téguments remplissant essentiellement les fonctions d'organes protecteurs, devaient être composés de parties dures, insensibles, qui diminuent leur aptitude à recevoir l'action atmosphérique. Il a donc fallu des modifications organiques particulières, qui font de certaines parties de la peau des animaux, ou de ses dépendances extérieures ou intérieures, des organes spéciaux de respiration.

Les plantes elles-mèmes respirent plus particulièrement par les cavités pneumatiques des feuilles.

Les arrangements spéciaux des téguments ou de leurs appendices, pour la respiration, consistent essentiellement dans l'extrême diminution de leur partie protectrice, et dans le nombre et la grande division des capacités qui dirigent successivement une portion plus ou moins considérable du fluide nourricier à la rencontre du fluide respirable.

Toutes Ies fois que c'est à la surface du corps qu'ont lieu ces dispositions, s'il n'y a pas de couvercle ni de capsule pour contenir les parties de la peau ainsi modifiées, afin de les préserver contre l'action desséchante de l'air atmosphérique, la respiration est aquatique, l'animal vit plongé dans l'eau. G'est par la même raison que les feuilles des plantes submergées n'ont pas de cavités pneamatiques, ainsi que l'a très bien obser-

ces de l'Acalimie des sciences, 1. VI, p. 102, 122 
vé M. Ad. Rrongniart. (Mémoire sur la structure des feuilles; Annales des sc. natur., t. XX.)

La quantité de respiration, et son influence vivifiante sur la température des animaux, sur leur activité, sur leur vivacité de sentiment, se mesurent assez exactement, en premier lieu, par les modifications organiques qui déterminent une respiration aérienne atmosphérique, ou qui réduisent l'animal à ne respirer que la petite quantité d'air contenue dans l'eau. Elles se calculent ensuite par celles qui amènent, dans un temps donné, la plus grande quantité de fluide nourricier dans l'organe de respiration, à la rencontre du fluide respirable (les Manmifères et les Oiseaux); ou la plus grande quantité de ce dernier fluide à la rencontre du fluide respirant (les Insectes).

Nous n'insisterons pas ici sur les différences que présentent les organes de respiration dans la série animale. Comparés à ceux des plantes, ils sont généralement plus distincts, mieux séparés, ainsi que leur fonction, des organes d'alimentation proprement dits.

Disons encore que les organes de respiration aquatique sont généralement, et à très peu d'exceptions près, des corps saillants de forme arborescente, tubuleuse ou en lames; tandis que ceux de respiration aérienne sont des poches ou des canaux, prolongements intérieurs des téguments, devenus tellement minces et déliés, qu'ils devaient s'enfoncer dans des cavités spécialement destinées à les protéger contre l'action nuisible des corps extérieurs. Cette disposition rappelle les cavités pneumatiques des feuilles.

Relativement à la nutrition proprement dite, ou au fluide nourricier que les organes s'assimilent, on peut dire qu'en général l'organisme reçoit pour cela, dans ses interstices, certaine quantité de ce fluide qui sort de ses réservoirs, comme on voit le cambium des végétaux supéricurs se placer entre l'écorce ei le bois; comme on voit de même les sucs nutritifs s'épancher, chez les animaux, entre les bouts d'os fracturés. Ceux qui transsudent de la surface d'une plaie, en préparent la réunion organique. Dans ces trois cxemples, les parties organisées, essentiellement vasculeuses ou celluleuses, que le fluide touche, ont sur lui une ac. tion plastique gavi l'organise à leur manic̀re.
C'est alnsi que l'organisation ancienne devient le moule et la puissance d'une organisation nouvelle.

Quant aux organes des sécrétions, l'anatomie ne découvre, dans les animaux qui ont des vaisseaux, que des divisions particulières de ceux-ci; que des enlacements plus ou moins différents, avec les capacités qui renferment le fluide sécrété et le portent hors de l'organe, soit dans des réservoirs particuliers, soit dans les parties où il est mis immédiatement en usage.

Le mystère des sécrétions semble se passer en partie dans la structure des membranes formant les canaux ou les capsules du đluide sécrété, et séparant leur capacité du sang contenu dans les ramifications vasculaires qui enlacent ces parois. Il y a là, sans doute, une cause qui modifie plus ou moins les affinités chimiques mises en jeu sous l'empire de la vie, et qu'afin d'exprimer ces modifications, nous avons distinguées sous le nom d'affinités vitales. (Réflexions sur les corps organisés, etc., publ. en 1799, Magasin encyclopédique de A. L. Millin.)

\$9. - Organes et fonctions de propagation.

Les innombrables individus qui composent le liègne organique, n'ayant qu'une existence passagère, auraient bientôt dispa$\mathrm{ru}$, du moins pour la plupart, sans laisser aucune trace de cette existence, s'ils n'étaient remplacés par d'autres individus qui leur succèdent. C'est la fonction des corps organisés, produisant cette suite d'individus de la même espèce, provenant successivement les uns des autres, que nous appelon $\mathrm{s}$ propagation.

La propagation est la condition essenticlle de la vie de l'espèce; de même que la nutrition est la condition essentielle de la vie des individus.

G'est une faculté inhérente aux organismes, qui paraît d'autant plus étendue que les individus, soit en germe, soit développés, sont exposés à plus de causes de destruction. Les végétaux la possèdent au plus haut degré, sans doute à cause des conditions désavantageuses sous le rapport de leur durée auxquelles ils sont soumis par suite de leur immobilité.

Les animaux inférieurs, gui virent immo. 
biles, fourssent de la même compensation; et, comme nous royons encore cette puissance de propagation chez ceux qui possedent la locomotilité, tels que les Hydres, etc., après avoir apprécié sa cause finale dans les premiers, il faut en faire remonter la faculté, chez les uns et les autres, à la simplicité de leur organisation.

Plus, en eflet, l'organisation est simple, plus elle a de moyens de se reproduire.

La multiplication des individus peut se faire par une division spontanée ou accidentelle. Les parties ainsi mutilées ont la faculté de se compléter, en reproduisant celles qui leur manquent.

Les Paramécies, les Vorticelles, les $\boldsymbol{H y}$ ares, les Actinies? les Planaires, etc., etc., parmi les Zoophytes; les Naïdes, parmi les Articulés, pouvant ainsi se reproduire par scissure, sont doués de cette propagation fissipare.

La propagation gemmipare, ou par germe adhérent, consiste dans l'apparition, sur quelques points de la surface du parent, d'un bouton, dont le développement ultérieur le fait paraître tôt ou tard sous la même forme, avec la même organisation que ce parent.

Cette propagation gemmipare est commune à tous les Zoophytes, susceptibles, comme beaucoup de plantes, de former des agrégations d'individus.

J'appelle encore cette sorte de multiplication propagation par germe adhérent, parce qu'en effet le germe, qui porte le nom de bourgeon, reçoit son développement durant sa continuité avec son parent, en se nourrissant par le concours de tous les moyens de nutrition départis à celui-ci. Seulement il semble que ce germe soit le centre d'une activité nutritive particulière, subordonnée à l'activité gémérale de cette grande fonction.

Le troisième mode de propagation départi aux animaux comme aux végétaux est la propagation par germe libre ou par ouf.

I'appelle ainsi le germe avec ses enveloppes protectrices, et les matériaux nuiritifs nécessaires pour son développement ultérieur.

Dans les plantes, ce germe libre porte les noms de gongyle, de sporule et de yraine, suivant les classes auxquelles il ap- partient, et la nécessité du concours des sexes pour le produire.

Dans les animaux, tout germe libre, de quelque animal qu'il provienne, sera pour nous un ouf.

L'œuf d'un animal n'atteint jamais son développement définitif, qui complète son individualité, et lui donne les facultés de vivre indépendant dans la partie de son parent où il a reçu son premier développement ou'sa première organisation apparente.

Quelques animaux, parmi ceux dont l'organisation est la plus homogène, n'ont point d'organe spécial pour cette première évolution des germes libres. Les $\mathbb{H}$ ydrés paraissent être dans ce cas. Ici, la propagation par germe libre est unisexuelle et diffuse.

Mais, le plus souvent, l'ouf est produit dans un organe spécial qu'on appelle ovaire. Dans ce cas, la propagation unisexuelle par germe libre est élective, c'est-à-dire qu'il y a un lieu d'élection, dans l'organisme, pour remplir cette fonction.

Le mode de propagation par wuf a toujours ce dernier caractère quand la génération est bisexuelle.

Celle-ci présente encore des différences très importantes. Tantôt le même individu possède au moins un organe femelle ou un ovaire, et un organe mâle, sécréteur de la liqueur fécondante nécessaire pour produire le développement ultérieur de l'ovule, préparé dans l'ovaire.

C'est la génération bisexuelle monoïque. Tantôt la génération bisexuelle est en même temps diö̈que, c'est-à-dire que les organes sexuels appartiennent à des individus différ ents.

L'une et l'autre générations bisexue lle: présentent des difrérences remarquables.

Dans la génération bisexuelle monoïque, les individus ainsi pourvus des organes sexuels des deux sexes peuvent se suffire à eux-mêmes, et manquent des organes de copulation : tels sont, entre autres, les Actinies, les Bivalves, les Cirrhipèdes, chez lesquels on a récemment découvert des Spermazoïdes (1).

(1) Nous désignons ainsi, dans nos Cours, les prétendus animalcules spermatiques appelés encore mal à propos, à notre avis, Zoospermes, parce que nous les regardons comme des machines mobiles, ayant pour fonction de uranspor- 
D'autres fois, il y a des organes de copulation qui montrent que la fécondation doit être réciproque. C'est le cas, entre autres, de la Limace et du Colimacon.

La génération bisexuelle dioïque présente de mûme de grandes différences. Elle suppose toujours le concours des sexes pour la première apparition du germe dans l'œuf; mais cet ouf peut ne recevoir l'influence vivifiante de la liqueur fécondante du mâle qu'après la ponte et sans rapprochement préalable des sexes. C'est le cas de la plupart des Poissons, dont le mâle vient répandre sa laite sur les œufs de la femelle, plus ou moins long-temps après qu'elle les a déposés sur les rivages. D'autres fois, c'est à l'instant de la ponte, lorsque le mâle est rapproché de la femelle, que celui-ci féconde les æufs; ce qui a lieu pour les Crapauds et les Grenouilles.

Enfin la fécondation peut s'effectuer avant. la ponte. C'est le cas de quelques Poissons vivipares, de la plupart des Reptiles, de tous les Oiseaux et des Mammiferes. Ce paraît ètre encore celui des Animaux articules, à pieds articules, des Mollusques Céphalopodes, el de beaucoup de Gastéropodes.

$L$ 'œuf n'acquiert jamais que son premier développement dans l'ovaire; il y est à l'état l'ovule. C'est dans l'utérus des Mammifères, ou dans l'oviducte des Oripares ou des Ovorivipares, qu'il prend son second degré de développement, qu'il complète les enveloppes protectrices ou nutritives, et les substances alimentaires qu'elles doivent contenir pour composer un ouf achevé, sauf la fécondation si elle n'a pas encore eu lieu.

ter dans l'ovule la part du germe fournie par le màle. Cette doctrine est en partie, celle adoptée relativement aux filaments-machines déeouverts par Needham, et dont l'histoire vient d'être reprise par MM. Philippi, Carus, Péters et MilneEdwards, qui les appellent spermatophores. (Voy. Annales des sciences natur., avril 1840, p. 195.)

L'usage, qui parait indubitable dans les Céphalopodes, de ees porte-semence, qui ne contiennent cependant que des prétendus animaleules spermatiques, détrut, il me semble, de fond en eomble, le système de Burdach, qui en fait des animalcules parasites, existant aceidentellement dans le sperme. Les Spermazoïdes ordinaires sont des spermalophores moins compliqués que eeux des Mollusques Céphalopodes.
C'est une différence très caractéristique avec l'ovule des plantes, qui ne se déplace pas pour se changer en graine, cet ouf complet des végétaux.

Dans ce cas, le germe ou l'embryon a tous les moyens de prendre autour de lui la nourriture nécessaire pour terminer sa vie foctale. Ghez les Mammilères ordinaires, il absorbe cette nouriture dans les parois de l'utérus; chez les Didelphes, après avoir pris un premier développement dans l'utérus intérieur, il achève cette première période de son existence, et commence, sans transition précise et apparente, la vie mammairc dans une sorte d'utérus extéricur.

Dans les plantes comme chez les animaux, l'orule préexiste dans l'ovaire avant la fécondation; mais chez les uns et les autres, du moins chez ceux à génération bisexuelle, cet orule ne paraît contenir de germe qu'après la fécondation.

Celle-ci commence une seconde période de l'existence de l'ovule; clle détermine chez les animaux à la fois l'apparition du germe, et le déplacement de l'ovule, qui passe dans l'oviducte, ou dans la matrice. Là, il se complète et devient œuf.

Une troisième période est celle de la vie utérine du germe, de la vie embryonaire pour les Vivipares, de l'incubation pour les Ovipares, pendant laçuelle l'embryon acquiert le développement nécessaire pour vivre librement dans l'air ou dans l'cau, c'està-dire sous l'infiuence directe d'un milieu respirable.

La période d'incubation suit immédiatement l'époque de la fécondation dans les Vivipares, dans les Ovovivipares et dans les Ovipares chez lesquels la fécondation n'a lieu qu'après la ponte.

Mais, dans les Ovipares ordinaires, chez lesquels la fécondation a licu avant la ponte (les Oiseaux), l'incubation ou la germination de l'cuf, qui dépend de la mère ou des agents physiques, peut n'avoir lieu qu'après un intervalle assez marqué, qui la sépare du moment de la fécondation.

Dans ce cas, l'activité vitale de l'œuf est suspendue, comme dans la graine, et elle a besoin des agents physiques, surtout d'un certain degré de chaleur et d'air, pour être mise en mouvement.

Il n'y a que l'humidité, nécessaire pour la 
germination de la graine, mais dont l'œuf animal n'a pas besoin, parce qu'il en contient suffisamment, qui établisse une différence importante entre la germination de la plante, et celle de l'œuf, ou l'incubation.

Il résulte de tout ce que nous venons de dire sur la fonction destincé à multiplier les individualités qu'elle n'est qu'une sorte de nutrition ou d'assimilation qui reproduit les parties manquant à un individu mutilé par la propagation fissipare; qui développe par continuité des germes adhérents à la surface du corps, dans la propagation gemmipare; qui détermine l'évolution successive d'un germe libre dans l'ovaire ou l'oviducte, ou dans l'utérus, lors de la propagation sexuelle, à laquelle nous réservons le nom de génération.

Jans tous ces cas, la propagation n'est qu'une nutrition partielle, subordonnée à la nutrition générale; un foyer simple ou multiple d'assimilation, sur lè modèle de tout. l'organisme dans lequel est mise en jeu cette activité vitale, cette force organisatrice, dont la première impulsion, la direction première, remonte, de génération en génération, jusqu'à la Puissance créatrice.

S 10. - Fonctions de relations ou de motilité, d'excitabilité et de sensibilité.

Nous avons déjà dit, en parlant des organes élémentaires, que l'organisme animal se distingue, dans la plupart des cas, de l'organisme végétal, par la présence de la fibre nerveuse ou sensible, et par celle de la fibre musculaire ou motrice.

Ces deux organes élémentaires s'agrègent de mille manières avec l'élément celluleux, pour former les instruments si variés de l'excitabilité, de la contractilité, de la sensibilité et de la motilité. Ils caractérisent la plupart des animaux, et distinguent ceux-ci des végétaux, d'une manière tranchée, toutes les fois qu'ils y sont évidents; mais il y a des organismes inférieurs où ces deux éléments sont confondus, avec l'élément celluleux, en un tissu homogène, dans lequel il est impossible de les distinguer (le corps des Hydres, des Cristatelles, etc., etc.'. Il en est d'autres chez lesquels la fibre musculaire se dessine très distinctement sans la fibre nerveuse, ou même sans la pulpe mé- dullaire, qui en est la partie esscntielle (les Actinies).

Nous avons vu la faculté génératrice se manifester dans tout l'organisme (l'Hydre) avant d'avoir des organes ou des instruments particuliers chargés de cette fonction. Nous ayons vu, de mème, la peau extérieure ajouter à ses fonctions multipliées la faculté digestive (certaines Méduses, les Physales) avant qu'une peau intérieure en soit spécialement chargée.

Il en est de même des fonctions de relations, réduites, à la vérité, dans les animaux inférieurs, à l'excitabilité et à la contractilité, ou à la facuité excito-motrice, d'autant plus répandue dans les organismes animaux, que ces organismes sont plus simples. Cette faculté distingue essentiellement, à notre avis, le tissu animal du tissu végétal, dont la rigidité et l'immobilité contrastent, d'une manière frappante, avec la mollesse et la mobilité du premier.

A la vérité, beaucoup de végétaux supérieurs manifestent, dans leurs feuilles ou dans leurs fleurs, des mouvements partiels très remarquables, qui ne peuvent s'expliquer que par une faculté excito-motrice analogue à celle des animaux, susceptible, dans quelques cas ( celui de la Sensitive), de se montrer dans un point éloigné de la partie immédiatement sollicitée, par la trans mission de cette excitation; mais cette faculté est toujours localisée; elle n'est jamais répandue dans tout le végétal; ensuite elle y montre des caractères particuliers.

Les parties mobiles de la plante se rapprochent toujours de l'axe de leur mouvement par une simple inflexion vers cet axe, et s'en éloignent par une inflexion semblable dans un sens opposé. Le tissu végétal, en un mot, se courbe en arc dans ses mouvements, qui ne sont jamais que des mourements de rétraction, ainsi que l'a démontré M. Dutrochet.

$\mathrm{Au}$ contraire, la fibre musculaire animale paraît se plier en zigzags quand elle se contracte; et, en général, les tissus contractiles animaux peuvent s'infléchir dans tous les sens, et produire des mouvements de répulsion ou de protraction tout aussi bien que des mouvements de rétraction.

Le tissu animal contractile et la fibre musculaire changent à la fois, plus ou 
moins manifestement, de forme et de di- $\mid$ "plushasardée, que la philosophie ne peut mension, dans leurs mouvements de coniraction.

La fleur qui s'épanouit ou qui se ferme ne fait que changer sa forme en plissant ou déplissant ses pétales ou sa corolle, sans changer de dimension, sans se resserrer sur elle-même dans toute l'étendue de son tissu.

Voila pour les différences ou les ressemblances organiques ou mécaniques que nous pouvons apercevoir dans les fonctions de relation entre les végétaux et les animaux.

Quant aux phénomènes généraux de ces fonctions dans les animaux les plus simples, ot à cette facultě excito-motrice qui en est le principe, ils semblent ne différer que par le degré d'énergie, que du plus au moins, entre les animaux inférieurs du type des Roophytes, qui passent leur vie fixés aux rochers sous-marins, et les végétaux supérieurs, chez lesquels ils se manifestent partiellement, ainsi que nous venons de le dire.

Mais, dès qu'on peut supposer de la spontanéité dans les mouvements des animaux, ces mouvements distinguent évidemment l'animal de la plante.

Les actions spontanées des animaux ont pour principe la sensibilité, fonction qui leur est propre, et dont la fibre nerveuse ou Ia pulpe médullaire, qu'ils possèdent exclusivement, est l'organe spécial.

Les animaux sont avertis, par son moyen, de certains changements qui se passent en eux, ou autour d'eux, à la suite desquels ils éprouvent un sentiment de plaisir ou de peine, et qui excitent leur volonté à rechercher l'un, à repousser l'autre.

Cette faculté suppose un sens interne, auquel les nerfs transmettent ces impressions; elle suppose un moi, qui en a la conscience; une volonté qui commande aux organes du mouvement pour réagir sur le monde extéricur.

On voit que nous distinguons les mouvements des animaux, produits par leur faculté excito-motrice, des actions, qui supposent la conscience des impressions et la spontanéité des mouvements.

"Quant à l'impression des objets extérieurs

"sur le moi, dit M. Cuvier, à la production

"d'une sensation, d'une image, c'est un

1) mystère impénétrable pour notre esprit,

" et le matérialisme une hypothèse d'autant

T. $\mathrm{x}$.

" donner aucune preuve directe de l'existen" ce effective de la matière. "(Règne animal, t. I, p. 40.)

Dans cette courte esquisse de l'organisation et de la vie animale, nous ne saurions avoir pour but d'en caractériser tous les phénomènes. Nous cherchons simplement à donner une idée générale des principaux, et à montrer leur liaison avec l'organisation.

Si nous analysons les actions des animaux supérieurs, nous verrons que les unes supposent un certain raisonnement, ou l'intelligence et même la prévoyance de leur suite ou de leurs effets : ce sont les actions intellectuelles;

Que les autres ont pour principe l'instinct, celte faculté départie aux animaux pour la conservation des individus ế des espèces; qui les pousse invinciblement à exécuter, dans ce double but, des actions quelquefois très compliquées, et leur en donne l'intelligence, sans que l'expérience puisse en être la source, ou vienne la modifier.

Cette analyse nous montrera, en troisième lieu, des actions involontaires, dont l'animal n'a pas la conscience, ciui peuvent, du moins, se passer chez lui sans la participation de son moi. Tels sont les mouvements du cœur, ceux des intestins; et même les mouvements des membres, qui peuvent avoir lieu involontairement, que l'animal dorme ou qu'il soit éveillé.

$L^{2}$ existence et l'énergie, ou l'étendue, en un mot, des fonctions intellectuelles, lesquelles sont loin de se manifester toujours par des actions produites au dehors, mais par l'activité intérieure du moi, est dans un rapport marqué avec les masses centrales du système nerveux; particulièrement des hémisphères du cerveau, qui en sont les instruments matéricls nécessaires.

L'instinct, au contraire, et ses différents degrés, n'ont aucun rapport connu, évident, avec le développement ou la forme des parties centrales du système nerveux.

La série animale, étudiée sous ce point de vue le plus relevé, nous offrira trois grandes catégories.

La plupart des Zoophytes, ceux qui n'ont pas de système nerveux démontrable, pourraient bien n'avoir, pour principe de leurs mourements, que la facultć excilo-motrice. 
Chez les autres animaux dont l'organisation est plus compliquée, il y aurait, outre ces mouvements involontaires, des actions instinctives ou intellectuelles, qui seraient du domaine de la conscience.

Mais les animaux les plus bas dans l'échelle, qu'on nous passe cette expression, n'auraient que l'instinct pour principe déterminant de leurs actions spontanées.

Quelques Zoophytes, qui paraissent avoir des actions volontaires, les types des Mollusques et des Articulés, les Poissons et les Reptiles parmi les Vertébrés, seraient dans ce cas. Du moins les actions intellectuelles sont-elles encore, dans ces deux dernières classes, plus ou moins bornées et peu manifestes.

Enfin les deux classes les plus élevées, celles des Oiseaux et des Mammifères, réuniraient à la faculté excito-motrice des organismes inférieurs, à l'instinct des classes qui ont une organisation plus compliquée, une partie de cette intelligence qui distingue si éminemment le Genre Humain; mais ils ne la posséderaient qu'à un degré plus ou moins limité.

L'homme lui-même, outre les mouvements qui s'exercent à son insu dans son organisme, outre les actions instinctives qui ne se manifestent chez lui que dans la première enfance, se distingue $d u$ reste de la création terrestre, non seulement par l'étendue de son intelligence, mais encore par ses actions libres, pour le choix desquelles il peut se déterminer avec réflexion, indépendamment des impressions des sens.

Ce libre arbitre, ce choix libre dans ses déterminations; cette prévoyance possible de leur suite, que lui donne la faculté de réfléchir sur les impressions reçues actuellement ou sur les souvenirs, sur les idées abstraites que lui fournit la langue parlée ou écrite, sur la mémoire ainsi conservée de l'expérience et des idées des générations qui se succèdent, imprime aux actions de l'homme un caractère de moralité, qui les classe dans une catégorie supérieure.

Ce caractère s'élève encore lorsque cet être privilégié médite sur l'univers et ses lois, transporte ses pensées jusqu'à la contemplation de la Cause première, et déveoppe ainsi en lui - même lc sentiment reli-

fini.

Nous terminerons ici ces considérations, toutes positives, sur l'organisation des animaux et les facultés qui les distinguent.

La longueur de cet article, et les limites qui nous sont prescrites, et que nous craignons déjà d'avoir dépassées, nous forcent de remettre à d'autres plusieurs considérations importantes qui pourraient se rapporter au mot animal. Nous traiterons, au mot COMPOSITION ORGANIQU , des principaux plans qu'elle présente dans le Règne animal; au mot ESPÈcE, des carací. indélébiles et des caractères variables de l'espèce; de la GÉNÉRATION SPONTANĖE, à ces mots ;

Au mot GÉographe zOOLOGIQUe, de la distribution des animaux à la surface de la terre, et de leur nombre;

Au mot MéTHODE (zool.), de la méthode naturelle de classification du Règne animal.

Enfin nous examinerons, au mot RèGNE INTERMÉDIA IRE, s'il existe des corps organisés qui n'ont que les caractères généraux de l'organisation sans montrer les caractères distinctifs et particuliers de l'animal ou de la plante (1).

(DUVERNoY.)

ANIMALCULES. Animalculi (petits animaux ). - Expression à employer au sens figuré, dans le langage zoologique, pour indiquer des animaux très petits dont l'organisation et souvent même l'individualité ne sont pas bien distinctes, mais dont cependant l'animalité est aussi réelle que pour les animaux plus parfaits.

(Dud.)

ANIMAUX DOMESTIOUES.zooL.

- L'homme a réussi à dompter et à soumettre à sa volonté un certain nombre de Mammifères, d'Oiseaux, etc., qui habitent avec lui, et que, par cette raison, on appelle domestiques.

(1) Voir, sur le sujet de cet article : 18 la $\mathrm{Com}$ paraison des Animaux et des Végélaux, formant le sujet du chapitre Ier de l'Histoire des Animaux, par Buffon; $2^{\circ}$ les pages 10-46 du t. $1^{\text {er }}$ du Règne animal de G. Cuvier, Paris, 1829 ; $3^{\circ}$ et surtout, pour l'histoire de Ia science, le Traité complet de la physiologie de i'homme, par $\mathbf{M}$. F. Tiedemann, traduit de l'allemand (t. 1, Paris, 1831), comprenant la Physiologie génírale et comparée. 
L'Histoire naturelle des Animaux domesriques est intimement liée à celle de l'espèce humaine; elle comprend plusieurs questions importantes sur le nombre et la détermination des espèces dornestiques; sur les espèces sauvages auxquelles elles se rapportent; sur les différences dans la taille, les téguments, les habitudes, etc., etc., que l'influence de l'homme a produites sur les espèces sauvages en les rendant domestiques; sur les dispositions instinctives que les premic̀res doivent avoir pour devenir domestiques, ou comme condition essentielle de leur Domestration. Nous en traiterons à ce dernier mot. Foy. encore powsstictT⿱宀⿻三丨口.

(DUv.)

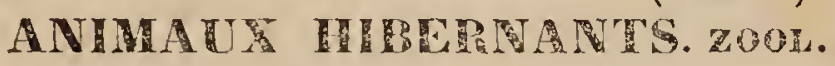
- On nomme ainsi les animaux qui passent l'hiver engourdis et dars un sommeil plus ou moins profond, qui s'appelle léthargique lorsqu'il cst porté au degré le plus fort. Tels sont, entre autres, parmi les Mammifères, les Ours, qui ne paraissent s'engourdir qu'a un faible degré; les Chauves-souris de nos climats, les Marmottes, les Loirs, ete.

Les animaux ainsi engourdis durant la saison froide présentent, dans leur circulation, dans leur respiration, dans leur chalcur propre, etc., des modifications très remarquables, que nous ferons connaître à l'article sonMEIL D'LIVER. Voy. ce mot.

(DUv.)

ANIMAUN A SANG BLANG, RNMLUX A SAG ROUGE.zoor. - M. Cuvier s'est servi de ces deux dénominations dans ses premicrs Mćmoires de Classification, qui datent de 1795 , et dans son Tableau élementaire de l'histoire naiurelle des Animaux, imprimé à Paris en 1797. Elles répondent aux deux grandes divisions du Règne animal désignées plus tard sous les noms d'Animaux sans vertèbres et d'Animaux vertébrés.

Ces deux dernières dénominations prévalurent, surtout après la découverte que fit M. Guvier en 1801, et qu'il communiqua à l'Institut en décembre de cette même année (Bulletin des sciences, messidor an 10 , $n^{\circ} 64$ ), que le sang de la plupart des Vers articulés a aussi la coulcur rougc.

Cette découverte détermina M. Cuvier à faire une classe à part des Vers à sang rou- ge, et a les séparer des Yers intestins ou intestinaux.

Dix annécs plus tard, Lamarck désigna cette même classe sous le nom d'Annélides (Voy. ce mot). La faible coloration en rouge, ou même la limpidité séreuse du sang des Aphrodites, la coloration en vert de ce même liquide dans d'autres g. découverts récemment, ont confirmé la nécessité de cette réforme dans la nomenclature de cette classe, dont le groupe avait d'ailleurs été bien limité par M. Cuvier. Les exceptions reconnues successivement, et qui ont fait réformer l'une après l'autre la dénomination d'Animaux à sang rouge opposée à cclle d'Animaux à sang blanc, ct celle beaucoup plus restreinte de Vers à sang rouge, par laquelle on distinguait d'abord les Annélides des Vers à sang blanc ou des intestinaux, ont montré que la couleur du sang n'est pas un caractère assez important pour servir à distinguer les divisions principales du Règne animal. Voy. aux mots SANG et MÉTHODE VATURELE (zool.), et le vol. VI des Lecons d'Anatomie comparée de G. Cuvier, 2e éd., Paris, 1859, p. 392-596.

(Duv.

ANIMAUX A SANG CIIAUD, ANMAUX A SANG FROHD. zoou. - Tous les Animaux peuvent se diviser, sous le rapport de leur température, dans les deux grandes catégories d'Animaux à sang chaud, ou à haute température, et d'Animaux à sang froid, ou à basse température.

Deux classes seulement appartieninent à la première : ce sont les Oiseaux et les Mammifères; le reste du Règne animal ne comprend que des êtres à basse température.

Dans le premier cas, la chaleur propre à chaque animal se maintient généralement à une élćvation de $30^{\circ}-40^{\circ}$ centigrades, quelle que soit la température du milieu dans lequel il vit. Des téguments, mauvais conducteurs du calorique, les plumes pour les Oiseaux, les poils pour les Mammifères, contribuent puissamment à conserver ce foyer de chaleur intérieure que les Animaux à haute température développent en eux, et conséquemment à entretenir leur chaleur propre et indépendante.

Les Animaux à sang froid n'ont qu'une température très peu différente du milicu dans lequel ils vivent, qu'une faible chaleur 
propre, qui ne s'élève au plus que de quelques degrés au dessus de ce milieu.

MM. Newport, en Angleterre; Berthold, en Allemagne; Breschet et Becquerel, d'un cóté, Dutrochet de l'autre, en France, ont soumis beaucoup d'A nimaux à haute ou à basse température à de nouvelles et récentes expériences, afin de constater leur chaleur intérieure.

Les physiciens et les physiologistes francais que nous venons de citer ont mis en usage, dans ce but, un appareil thermo-électrique, comme moyen plus sensible et plus sûr que les thermomètres ordinaires. Nous en parlerons plus en détail au mot GHATEUR ANIVALE.

(Duv.)

ANT IUX SANS VERTLBRES, ANMAUX VERTÉBRÉS. zoou.Duchesne, professeur d'histoire naturelle à lécole centrale de Versailles, vers la fin du siecle dernier, dans un Mémoire sur les rapports des êtres naturels (Magasin encyclop. de A. L. Millin, Paris, 1798̈), se sert du mot invertébroses pour désigner les Animaux appelés plus tard sans vertèbres. M. Cuvier, dans les considérations préliminaires de ses Leçons d'Anatomie comparée (t. I, p. 63 , Paris, 1800 ), dit «que lc Hègne animal entier se divise d'abord en deux grandes familles, celle des Animaux a vertèbres et à sang rougc, et celle des Animaux sans vertebres, qui ont presque tous le sang blanc.

Les mots d'Animaux vertébrés et d'Animaux sans vertèbres sont adoptés, pour ces deux grandes divisions du Règne animal, dans le premicr des tableaux de classification de ce régne que M. Cuvier avait dressés conjointement avec M. Duméril, et qui ont paru à la fin de ce premier volume des Lecons d'Anatomie comparée.

Dès cette même annéc 1800, Lamarck s'était servi de ces deux dénominations d' 1 nimaux vertébrés et d'Animaux sans vertèbres dans un discours qu'il prononça à l'ouverture du cours qu'il fit au MIuséum d'histoire naturelle de Paris. Ce discours fut imprimé l'année suivante en tête de son Système des animaux sans vertèbres. Paris, 1801.

Cependant M. Cuvier, déjà en 1797, faisait connaître, dans son Tableau élémentaire, "que les Animaux dont le sang est rouge comme celui de lhomme lui ressemblent tellement par toutes leurs parties, qu'ils ne paraissent d'abord être que des dégradations d'une forme commune. Ainsi ils ont toujours une tête osseuse contenant le cerveau et les principaux organes des sens, placée à une extrémité d'une colonne vertébrale, qui contient le faisceau commun des nerfs, etc."

Il me paraît indubitable, d'après ce passage, que M. Cuvier a publié, avant Lamarck, ce grand rapport des Animaux à sang rouge, rapprochés de l'homme, d'avoir comme lui une colonne vertébralé; mais la dénomination de vertébrés a été employée pour la première fois par le dernier. M. Cuvier le reconnât (Annales du Muséum, t. XIX, p. 75 \%. Voy. à l'article míthodF NATURELEE (zool.). (DUE.)

ANIMAUN FOSGELES. GEOL. Voyez FOSSILES. (C. DOO.) ANIMAU PEDDUS, ou ANTEDILUVIEIS. GEOL. - Voyez FOSSILES. (C. D'O.)

ANIMAUN PA TONNANTS. GEOL. - Toyez zoophytes et RaYonNés.

ARS. Anisum (anisum, nom de l'anis dans Pline; d'óvtro:, même chose chez les Grecs). EoT. PH. - Nom vulgaire d'une esp. de Pimpinella (famille des Ombelliferes ).

(SP.)

MNISACANTHA, R. Br. (ävtros, inégal; $\ddot{\alpha} \kappa \alpha \nu \theta x$, épine). вот. PH. - Genre de la famille des Chénopodées (tribu des Chénopodiées, G. A. Meyer). M. R. Brown (Prodr., p. 410) lui assigne pour caract. : Fleurs hermaphrodites. Calice \&-fide; segments finalement garnis de spinelles dorsales anisomètres. Étamines 5 ou 4 , insérées au fond du calice (opposées aux segments calicinaux). Point de squammules hypogynes. Ovaire comprimé. Style biparti. Péricarpe mewbranacé, comprimé, recouvert par le calice durci, et garni (au dessous du sommet) de 4 spinelles anisometres. Graine verticale, compriméc. 'T'est membranacé. Périsperme copieux. Embryon périphérique, annulaire; radicule supère. - Ce g. est fondé sur un sous-arbrisseau de la Nouvelle-Hollande méridionale. Les feuilles sont alternes, subcylindriques; les fleurs axillaires, sessiles, ébractéolées. 
* ANISACTIS ( zutros, inégal ; àsis, rayon ). вот. PIf. - Troisième division du g. Daucus (Ombellifères), proposée par MI. De Candolle (Prod. IV, 214), ct qu'il caractérise ainsi : Carpophore indivis ou à pcine échancré-bifide à l'extrême sommet. Rayons de l'ombelle très inégaux. - Cette division ou s.-g. renferme 4 esp., dont 1 de la Youvelle-Hollande, et 5 de l'Amérique méridionale.

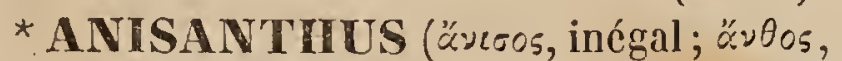
fleur). вот. Pн. - Genre de la famille des Caprifoliacées, formé par Willdenow, et synon. du g. Symphoria. - Genre de la famille des Iridacées, formé par Swect, et synon. du g. Gladiolus.

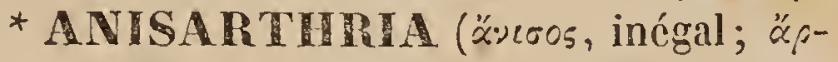
$\theta_{\rho \circ \nu}$, article). rNs. - Genre de Golćoptères pentamères, famille des Mycétophagides de Westwood, établi par Waterhousc, et adopté par Westwood, qui le caractérise ainsi : Corps large, subovale, subconvexe. Massuc des antennes composée de trois articles; leur dixième article mince. - Ce g., qui comprend 9 esp., a pour type le Dermestes melas de Marsham.

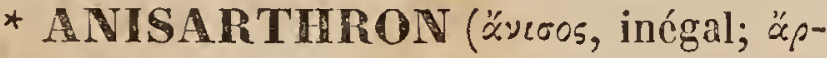
$\theta_{\text {pov }}$, article). INs. - Genre de Colćoptères tétramères, famille des Longicornes, établi par M. Dejean dans son dernier Catalogue, mais dont il n'a pas publié les caract. -.- Ce g., qui fait partic de la tribu des Cérambycins de M. Scrville, est fondé sur une seule esp. qui se trouve en Autriche, et qui a été nommée par Dahl A. barbipes. Elle appartenait auparavant au g. Callidium de Fabr. (D.)

* ANISEIA ("̈veros, inégal). вот. PH.Genre de la famille des Convolvulacées, tribu des Convolvulées, formé par M. Choisy (Mem. Soc. Gen. VI et VIII, t. 4) sur plusicurs esp. des g. Convolvulus, L., ct Ipomcea, et ainsi caractérisé : Calice כ̌-phylle; les deux folioles extér. insérées plus en arric̀re et subdécurrentes sur le pédorcule. Cor. hypogyne, campanulée; limbe plissé, quinquélobé. Étam. 5, incluses, insérées à la base du tube de la corolle. Ovaire biloculaire ; loges bi-ovulées. Style simple; stigm. capitć-bilobć. Caps. biloculaire. Graines 4, dressées. Embryon courbe, mucilagineuxalbumineux; cotylédons ridés; radiculc infère. - Ge g. renferme un petit nombre l'espèces suffrutcscentes ou herbacées, pro- pres à l'Asie et à l'Amérique tropicales; les feuilles en sont alternes, oblongues-linéaires, entières à la base ou sagittées; les pédoncules axillaires, uniflores, bractées. On cultive dans les serres d'Europe les Aniseia calycina et salicifolia, dont les fleurs sont blanches. (G. L.)

ANRSOBRIEES. BOT. PH. - Voyez A NISOBRYEES.

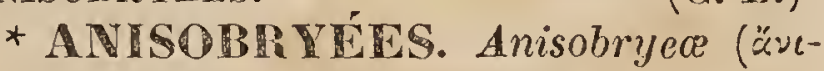
oos, inégal ; 6piw, je végète ). пот. PH. Gette épithète, ainsi que celle d'Anisodynames, avait été proposéc par Cassini pour remplacer la dénomination de Nonocotylédones.

(C. L.)

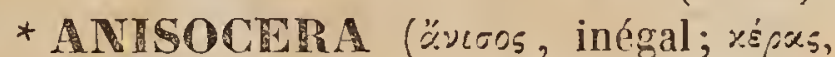
corne). rvs.-Genre de Colcoptères pentamères, famille des Malacodermes, établi par M. Dcjean, mais dont il n'a pas publić les caract. Il le place, dans son dernier Catalogue, dans le voisinage du g. Cantharis de Linn. ou Telephorus d'Olivicr. Il appartiendrait, par conséquent, à la tribu des Lampyrides de Latreille. Il cst fondé sur une scule esp. doa cap de Bonne-Espérance, que l'auteur nomme A. dilaticornis.

* ATISOCTRUS (̌́veos, inégal; xépus. corne). Irs. - Genre de Coléoptères pentamères, famille des Nitidulides de Nac-Leay, établi par Howitt, et adopté par M. Westwood, qui en formule ainsi les caract. : Corps ovalc, subconvexe. Elytres tronquées. La basc des deux premiers articles des antennes très large, surtout chez le mâle. Il ne renferme qu'une esp., que l'auteur nomme Spirea.

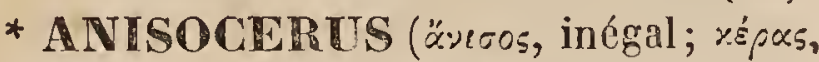
corne). Irs. - Genre de Coléoptères tétramères, famille des Longicornes, tribu des Lamiaires, établi par M. Serville aux dépens du g. Lamia de Fabr., et qu'il caractérise ainsi : Corps court, ramassé, ailé, un peu convexe en dessus, duvetcux. Antennes glabres, très distantes à leur base, sétacées, de onze articles dans les mâles, de dix dans les femclles : le premier allongé en massuc; le second court; Je troisième extrêmement long, cylindrique, portant au bout une touffe de poils; les suivants (dans les mâles) ont aussi une touffe, mais beaucoup plus pelite. Article terminal sans touffe, très court dans les deux sexes. Corselet unituberculé latéralement; son disque inégal. Tête assez forte: 
face un peu bombée. Yeux petits. Mandibules très courtes, point saillantes à l'extérieur dans le repos. Palpes courts; pénultième article des maxillaires en cône renversé; le dernier pointu. Eiytres courtes, peu convexes en dessus, arrondies et mutiques à l'extrémité. Angles huméraux saillants. Écusson très petit, arrondi au bout. Pattes fortes, égales. Guisses en massue. Tarses antérieurs houppeux dans les mâles. - Ce g., qui a pour type la Lamia scopifera de Germar, esp. du Brésil, a été adopté par M. Dejean dans son dernier Gatal.; mais il en a remplacé le nom par celui de Tragomorphus, probablement à cause de la trop grande ressemblance du mot Anisocerus avec celui d'Anisocera, précédemment employé par lui pour désigner un autre g. dans la famille des Malacodermes. Mais comme son dernier Catalogue, où il emploie pour la première fois le mot d'Anisocera, n'a paru que trois ans après la Monographie de M. Serville, il est clair que le nom d'Anisocerus de ce dernier doit prévaloir sur celui de rragomorphus.

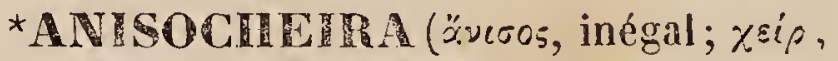
ós, main). INS. - Genre de Coléoptères hétéromères, famille des Taxicornes, étabii par M. Dejean, mais dont il n'a pas publié les caract. Il le place immédiatement après le g. Diapère de Fabricius dans son dernier Catalogue, et le fonde sur une seule esp. du Brésil, qu'il nomme A. picta. Cette esp. nous étant inconnue, le g. qu'elle a servi à établir ne figure ici que pour mémoire.

* ANGOG

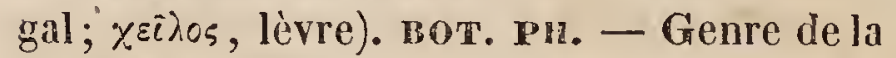
famille des Labices (tribu des Ocymoïdées, s.-tribu des Plectranthées Benth.), dont M. Bentham (Labiat., p. 59) expose les caract. comme il suit : Cal. ovoïde, presque dressé, Q-labié, fermé après la floraison. Lèvre supérieure entière; lèvre inférieure tronquée, et soit très entière, soit très courtement 4dentée. Corolle à tube saillant, défléchi ; gorge un peu renflée; lèvre supérieure courte , à 5 ou lobes obtus; lèvre inférieure allongée, concave, entière. Ṫtam. 4, déclinées; les deux inférieures plus longues. Filets libres, non dentés. Anthères ovales-réniformes, à bourses confluentes. Stigmates subulés, isomètres. Akènes lisses. - Herbes aninuelles ou vivaces. Faux verticilles bractéo- lés, très rapprochés, imbriqués de manière à former des épis oblongs-cylindracés. Braclées imbriqucées. - Ce g. appartient à l'Asie équatoriale. M. Bentham en a énuméré 4 esp.

(SP.)

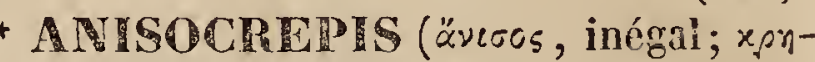
$\pi i s$, sorte de chaussure). INs. - Genre de Coléoptères hétéromères, famille des Taxicornes, établi par M. Dejean, mais dont il n'a pas publié les caract. Il le place dans son dernier Catalogue près du g. Cnodalon de Latreille, que celui-ci range dans sa tribu des Grassicornes. Il est fondé sur une seule espèce dont la patrie est inconnue et que II. Dejean nomme $\boldsymbol{A}$. hilaris. Dans l'impossibilité où nous sommes de rien dire de plus satisfaisant sur ce g., nous ne le mentionnons ici que pour mémoire.

ANISODACTYLES. Anisodactyli(áve-

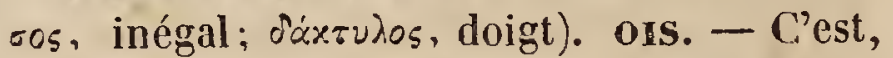
dans la méthode de Vieillot, la deuxième tribu de son ordre des Oiseaux sylvains, et dont le principal caractère est d'avoir trois doigts dirigés en avant et un par derrière, par opposition à ses Zygodactyles ou Grimpeurs, qui en ont deux dirigés en avant et deux en arrière. C'est encore, dans la méthode de Temminck, son sixième ordre, répondant aux Ténuirostres de Cuvier, et composé d'espèces à bec presque toujour's grêle et effilé, souvent arqué, quelquefois droit, et qui, quoique pourvu de trois doigts en avant et d'un en arrière comme les Oiseaux percheurs, n'en ont pas moins, pour la plupart, la faculté de grimper aux arbres comme les espèces de l'ordre des Grimpeurs, ou de se tenir cramponnés verticalement sur les troncs, les branches ou les rochers. Enfin c'est, dans notre méthode, notre second sous-ordre de l'ordre des Passercaux, que nous subdivisons en trois sous-ordres : les Zygodactyles, les Anisodactyles et les Déodactyles. Ce second sousordre comprendra toutes les esp. qui, sans avoir les doigts disposés par paires, comme celles que l'on a classées dans l'ordre des Grimpeurs, ont néanmoins la faculté de grimper le long des troncs et des branches d'arbres, et sur les plans verticaux des rochers, ou de se cramponner et de se suspendre aux ramuscules et aux tiges des fleurs pour en extraire le pollen.

Si, d'une part, on ne peut raisonnable- 
ment désigner par le nom de Grimpeurs une réunion de genres d'Oiseaux dont le plus grand nombre ne grimpent pas, quoiqu'ils aient tous la même conformation zygodactyle, il n'est pas moins indispensable de former, dans l'ordre des Passereaux, une section ou sous-ordre de tous ceux qui, sans être Zygodactyles, possèdent au plus haut degré cette faculté de grimper, ou, au moins, celle de se cramponner et de se suspendre verticalement aux branches.

Nous avons cru devoir désigner ces esp. par le nom d'Anisodactyles, comme l'a fait Temminck, mais en en formant un sousordre de nos Passereaux. Les principaux caract. en sont : Pieds robustes, disposés trois doigts en avant et un en arrière, organisés pour grimper ou se cramponner au moyen de doigts ou d'ongles puissants, le pouce principalement. Bec de forme très variable, mais toujours comprimé, et plus ou moins allongé, souvent grêle et arqué ou droit, quelquefois de longueur médiocre et assez épais; langue ou simple et membraneuse à la pointe, ou bifide et tubuleuse, ou terminée en pinceau fibreux. Ailes très variables, depuis la forme arrondie et sur-obtuse, jusqu'à la forme sur-aiguë et très longue, comme chez les Martinets. Queue souvent de longueur médiocre ou simple, ou rigide , ou épineuse.

Ce sous-ordre, tel que nous l'envisageons, comprendra les familles suivantes au nombre de onze : Paridée, Oxyrhynchidée, Orthonyxidé, Colidee, Buphagidee, Certhidée, Melliphagidée, Cymiridée, Proméropidée, Paradisidée et Trochilidée. Notre famille des Upupidées, que nous considérons comme une transition de ce s.-ordre à celui des Déodactyles, sera effectivement placée immédiatement à la suite du premier et en tête du second.

(LAFR.)

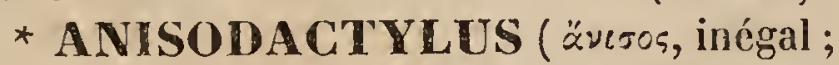
$\delta \dot{x} \times \tau$ น pentamères, famille des Carabiques, tribu des Harpaliens, établi par M. Dejean dans son Species général, et auquel il assigne les caractères suivants : Les $2^{\mathrm{e}}, \mathbf{3}^{\mathrm{e}}$ et $4^{\mathrm{e}}$ articles des quatre tarses antérieurs très fortement dilatés dans les mâles; les 2 e et $5^{\text {e }}$ des tarses antérieurs moins longs que larges et très légèrement cordiformes; le $4^{\mathrm{e}}$ très fortement cordiforme et presque bilobé. Dernier arti- cle des palpes assez allongé, très légèrement ovalaire, presque cylindrique et tronqué a l'extrémité. Antennes filiformes et assez courtes. Lère supérieure en carré moins long que large. Mandibules peu avancées, assez arquées et peu aiguës; point de dent au milieu de l'échancrure du menton. Corps 0blong, plus ou moins allongé. Tête plus ou moins arrondie, un peu rétrécie postérieurement. Corselet plus ou moins carré ou trapézoïde. Élytres plus ou moins allongées, souvent presque parallèles, quelquefois en demi-ovale.

Les Anisodactylus sont des Carabiques de taille moyenne et au dessous, peu agiles, épigés, vivant surtout dans le voisinage des eaux. M. Dejean, dans son dernier Catalogue, en mentionne 24 esp., dont 8 d'Europe , 4 d'Afrique, 1 de Java et 11 d'Amérique. Parmi celles d'Europe, 4 se trouvent aux environs de Paris; ce sont : l'A. signatus IIlig., l'A. binotatus Fabr., l'A. spurcaticornis Ziegler, et l'A. gilvipes Dejean. Nous citerons encore comme type du g. l'A. heros Fabr., qui se trouve en Espagne et dans le midi de la France.

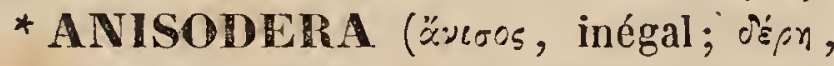
cou). INs.-Genre de Coléoptères tétramères, famille des Chrysomélines, tribu des Hispoïdes, établi par M. Chevrolat aux dépens du g. Alurnus de Fabricius, et adopté par M. Dejean (Cat., $5^{\mathrm{e}}$ édit.), qui y rapporte deux esp. de Java, savoir : l'A. lucidiventris Buquet, et l'A. ferruginea, qui est l'Alurnus ferrugineus de Fabr. - Les caract. de ce g., d'après M. Chevrolat, sont : Tête avancée, arrondie, entaillée circulairement sur la face. Palpes assez développés; le dernier article des maxillaires long, un peu renflé au milieu. Antennes presque réunies par la base sur le front, épaisses, cylindroïdes, de 11 articles : les cinq $1^{\text {ers }}$ lisses; les $\mathbf{3}^{\text {e }}$ et $\mathbf{4}^{\circ}$ du double plus longs que le 2 ; les suivants presque égaux, un peu plus allongés; le dernier terminé en pointe mousse. Corselet plus long que large, inégal, coupé obliquement en avant, droit à la base, conné et abaissé sur les côtés. Élytres modérément convexes, à stries ponctuées, arrondies à l'extrémité et non armées. Pattes simples, trapues; les $2^{e}$ et $3^{e}$ articles des tarses profondément bilobés.

* ANISODERIS ( $\alpha$ priv.; ข euph.; ¿̌oミ, 
semblable; ১épn, col). вот. ти. - Section du g. Barkhausia, comprenant les esp. doni les fruits de la circonférence du capitule ne sont point ou sont très peu atténués au sommet, tandis que ceux du centre le sont, au contraire, très longuement. (J. D.)

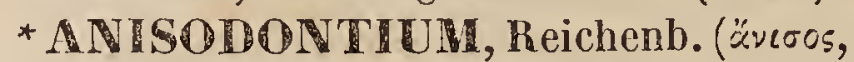
inégal; ơovs, ovros, dent). BOT. PH.-Genre ou s.-g. de la famille des Labiées, voisin des Marrubium, dont la plupart des auteurs ne l'ont pas séparé. Il n'en diffère en effet que par un calice à ら̌ dents anisomètres, non réfléchies après la floraison. Son type est le Marrubium creticum $\mathbf{L}$.

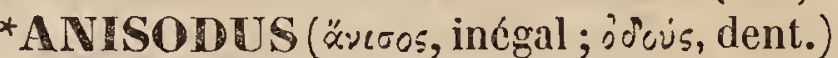
Bot. Pr. - Genre de la famille des Solanacées, tribu des Hyoscyámées, formé par Link (Icon. select., 77), et dont les caract. essentiels sont : Cal. campanulé, inégalement šfide. Cor. hypogyne, campanulée, à limbe plissé, 5-lobé, dont les lobes obtus, inégaux. Etam. 5, incluses, droites, insérées à la base du tube de la corolle. Anth. déhiscentes longitudinalement. Ovaire biloculaire; placentas adnés à la cloison, multi-ovulés. Style simple; stigmate capité. Caps. biloculaire, subglobuleuse, un peu charnue, coriace, enveloppce par le calice persistant, renflé, costé, connivent, s'ouvrant par moitié au dessus de son milieu; la partie supérieure devenant un opercule mucroné, quadrivalve. Graines nombreuses, réniformes. Embryon périphérique, semi - circulaire, renfermé dans un albumen charuu. - Une seule esp., l'A. luridus, Lk. (Nicandra anomala ejusd.; Whitleya stramonifolia Swt., etc.) originaire du Népaul, compose ce g.; elle est cultivée dans les jardins de l'Europe. G'est une plante herbacée, vivace; à racine fusiforme, épaisse; à feuilles alternes, pétiolées, ovales, un peu rélléchies, subtomenteuses en dessous; les florales géminées; à pédoncules axillaires, solitaires, uniflores, nutants, portant des fleurs d'un vert jaunâtre passant au pourpre.

(C. L.)

* ANISODVNAME. Anisodynamo

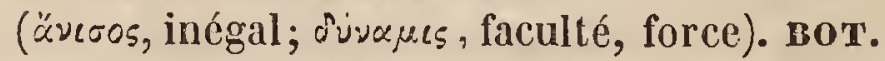
PH. - Voyez ANISOBR Ý́Es.

(C. L.)

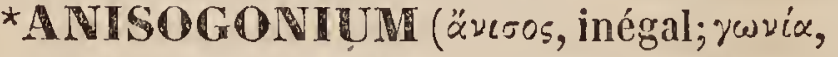
angle). BOT. GR. - Presl (Tentam. Pteridograph., p. 115) a ćtabli, sous ce nom, un g. de Fougères de la tribu des Aspléniacées, et de la sect. des Diplaziées, qui diffère essentiel- lement du Diplazium par ses veines internes, dont les inféricures sont opposées, réunies en un arc aigu, vénulifère au sommet ; les supérieures libres avant d'atteindre le bord de la fronde,terminćes obtusément ou rarement réunies en arcs vénulifères au sommet. Le reste de l'organisation rapproche infiniment les Anisogonium des Diplazium; quoique M. Presl pense qu'ils doivent en être séparés au même titre que, dans les Aspidiacées, le Nephrodium et le Cyclodium l'ont été de l'Aspidium.

Environ 10 esp. indigènes de l'Asie intertropicale composent ce g.; la plupart d'entre elles ont été décrites par Swartz, Blume, Sprengel, Kunze, Kaulfuss, et par d'autres auteurs, sous les $110 \mathrm{~ms}$ génériques de $\boldsymbol{\nabla i}$ plazium et d'Asplenium. Ainsi l'Asplenium decussatum $\mathbf{S w}$. peut être cité comme un des types du g. Anisogonium. (G...N.)

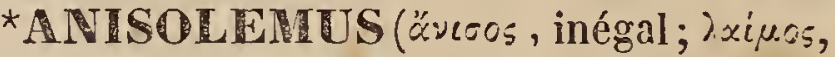
cou, gouleau). ANNÉL. - Genre d'Annélides, de la famille des Sabulaires, établi par M. Templeton pour une espèce de l'île de France : An. luteus Rempl. (Trans. zool., Soc. Lond. , II , 27, pl. 5, f. 9-14). II a pour caract. : Bouche entourée de huit tentacules disposés par paires, filiformes et préhensiles; branchies simples, tentaculiformes, existant aux quatre segments antérieur's du corps. Un tube cylindrique, calcaire, enfoncé par sa base dans les pierres, loge l'animal.

(P. G.)

ANISOMELES, R. Br. (Prodr., p。

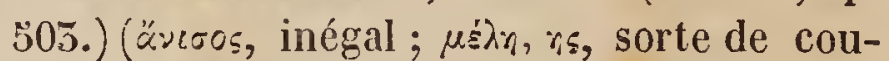
pe). вот. Pн. - Genre de la famille des Labiées, tribu des Népétées, s.-tribu des Lamiées, Benth., auquel son auteur assigne pour caract. : Calice ovoïde-allongé, presque dressé, régulier, 5̋-denté. Corolle à tube aussi long que le calice, garni en dedans d'un anneau de poils; lèvre supérieure oblongue, dressée; lèvre inférieure plus grande, 5-lobée, lıorizontale; lobes latéraux ovales, obtus; lobe moyen, échancré ou 2-lobé. Étamines 4, ascendantes, saillantes : les 2 inférieures plus longues. Filets non dentés. Anthères rapprochées deux à deux : celles des deux longues étamines 1-thèques; les deux autres 2-thèues, à bourses transverses, parallèles. Stigmates subulés, subisomètres. Akènes secs, lisses. - Herbes ou s.arbrisscaux. Fleurs en cymes ou en grappes. 
Corolle rougeâtre. On connaît $8 \mathrm{esp}$. de ce g. Ces plantes habitent l'Asie équat. et la Nouvelle-Hollande.

(Sip.)

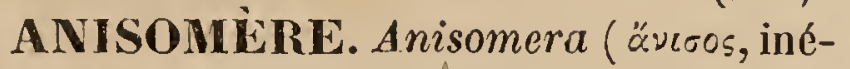

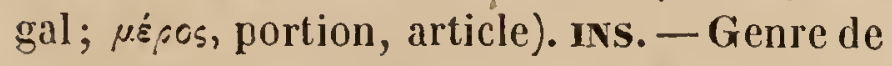
l'ordre des Diptères, division des Némocères, famille des Tipulaires, tribu des Tipulaires terricoles, fondé par Hofrmansegg, et adopté par Meigen, qui y a réuni, depuis, son g. $\mathbf{N e}$ matocera. M. Macquart, en l'adoptant de son côté arec cette réunion, lui assigne les caractères suivants : Antennes sétacées, à peu près de la Iongueur du corps chez le mâle, plus courtes chez la femelle; de six articles velus, dont le troisième est plus ou moins long, et les autres sont courts. Jambes terminées par deux pointes courtes. Ailes couchées; point de cellules discoïdales, trois postéricures. - Ce g. renferme quatre esp. européennes, dont l'une, A. nigra, est nommée par Latreille, dans son Genera, Hexatoma nigra; le nom d'Anisomera indique l'inégalité des articles des antennes.

(D.)

* ANGOMERIA, Don. - Pircunia,

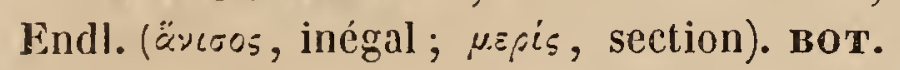
Pii. - Sous-genre ou section du g. Phytolacca. Ses caract. différentiels sont un péricarpe à coques presque sèches, non cohérentes.

* ANISOMERIS, Presl (炎:øos, inégal;

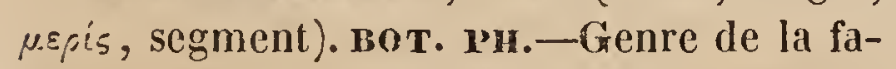
mille des Rubiacées(tribu incertaine), auquel son auteur ( Yymb. II, p. 5, tab. \$4) attribue les caract. suivants : Tube calicinal obové, adné à l'ovaire; limbe supère, «-parti, étalé, irrégulier. Corolle hypocratériforme; tube grêle; limbe 4-fide, à lobes ovales, pointus, valvaires en préloraison. Anthères 4, linćaires, sessiles, subsaillantes, insérées à la gorge de la corolle. Ovaire infère, 2-10culaire. Style filiforme, saillant; stigmate à 2 lobes obtus, étalés. Drupe 2-loculaire, couronné du limbe calicinal; loges 1-spermes; l'une d'elles plus petite, souvent asperme. - Arbrisseau (du birésil) à rameaux opposés, divariqués; un de chaque paire spinescent, de même que les ramules; feuilles opposées, courtement pétiolées, coriaces; stipules interpétiolaires, entières, ovales. Fleurs en capitules pédonculés, axillaires, solitaires, accompagnés d'un petit involucre 2-phylle; corolle blanche. (SP.)

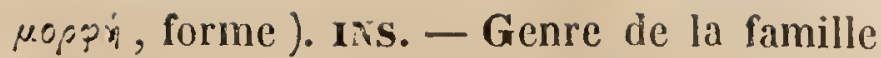
des Phasmiens, de l'ordre des Orthoptères, établi par Gray (Syn. of the sp. belong. to the fam. of Phasmida), réuni au g. Bacteria par Brullé (Hist. des Ins.), et adopté par Burmeister (Hand. der Ent.). Ce g. se distingue des Bacteria et de quelques autres Phasmiens privés d'ailes 10 par un corps glabre, lisse et brillant; $2^{\circ}$ par des antennes longues, filiformes, ayant leur second article aussi long que le troisième; $\breve{5}^{\circ}$ par des tarses dont le premier article est plus court que les deux suivants. - On ne connait encore que 2 esp. d'Anisomorpha, provenant de l'Amé-. rique du nord: ce sont les A ferruginea Gray, Burm. (Phasma ferruginea Dal.Beauv.), et buprestoides Gray, Burm. (Spectrum buprestoides Stoll, Say).

(BL.)

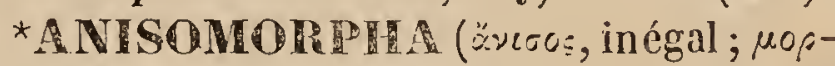
pi, forme). INs. - M. Newman, dans sa classification des Insectes de l'Angleterre l'après les larves, désigne ainsi celles des Névroptères, qu'il divise en 8 ordres naturels nommés par lui : Termites, Perlites, Raphidites, Hemerobiites, Phryganites, Ephemerites, Libellulites et Panorpites.

(D.)

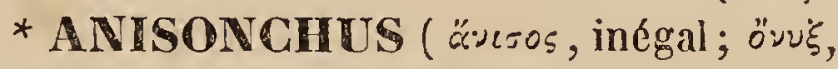

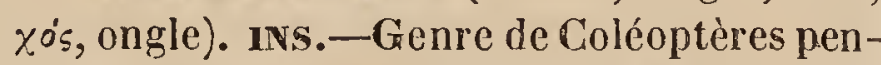
tamères, famille des Lamellicornes, tribu des Scarabéïles phyllophages, établi par M. Dejean sur une seule espèce de Barbarie nommée par Fabr. Melolontha atriplicis; mais, long-temps auparavant, M. Delaporte avait fondé sur cette même esp. son g. Oplopus, publié dans le Magas. zool. de M. Guérin, 1852, clas.9, pl. 20. Voy. ce mot pour les caract. du genre.

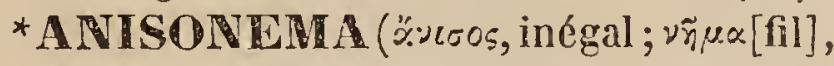
filet). Bot. PH. - Genre de la famille des Euphorbiacées, à fleurs monoïques. Dans les mâles, on trouve un calice à 4 on 5 divisions, avec lesquelles alternent autant de glandes qui manquent rarement. Élam. ¿ै, dont les filets, assez épais, et terminés chacun par une anthère biloculaire, sont inégaux; trois plus longs au centre et soudés en partie entre eux; deux latéraux, presque libres. Dans les femelles, calice à $4-6$ divisions el autant de glandes alternes. Ovaire surmonté de 610 stigmates sessiles et simples, creusé d'autant de loges dont chacune contient deux ovules superposés, quoique insérés à pex 
près à la mème hauteur. Le fruít est une capsule deprimée, ombiliquée au sommet, creusée extérieurement d'autant de sillons qu'il y a de loges, et renfermant dans chacun deux graines anguleuses, où les avortements ne sont pas rares.- - Les esp., au nombre de cinq, sont répandues dans l'Inde et dans les îles, depuis Java jusqu'à Timor. Ce sont des arbrisseaux rameux, à feuilles alternes, enlières, stipulćes, disposées comme les folioles d'une feuille pennée sur des rameaux souvent fasciculés. Les fleurs sont à l'aisselle de ces petites feuilles, accompagnées de bractées et pédonculées; les mâles en faisceaux, les femelles ordinairement solitaires. Ces plantes noircissent souvent en se desséchant. Voy. Ad. Juss. (Euph., p. 19, tab. 4, n. 11).

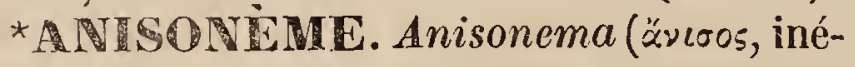
gal; ข M. Dujardin pour des Infusoires de la famille des Thécamonadiens, c'est-à-dire revêtus d'une enveloppe résistante non contractile, et sans autres organes visibles que deux filaments partant du même point à la partie antérieure, mais difrérant beaucoup l'un de l'autre. En eflet, l'un est flagelliforme, analogue à celui des Monades, toujours agitè d'un mouvement ondulatoire très vif, et déterminant la progression de l'animal en avant; l'auîre, plus épais et traînant, sert, comme un gouvernail, à rendre le mouvement plus uniforme; ou bien il s'agglutine çà et là à quelque corps solide, et, comme un câble, retient l'animal qui s'agite en se balançant autour du point d'appui; ou enfin, en se contractant tout a coup, il. retire brusquement l'animal en arriere. D'autres Infusoires sans tégument, ou munis d'un tégument contractile, ont deux filaments com me les Anisonèmes; mais ils doivent faire partie de familles et de g. différents. Une esp. d'Anisonème ( A. acinus) se rencontre fréquemment dans l'eau des marais, autour des débris de végétaux, et particulièrement dans la couche floconneuse et vaseuse qui recouvre les feuilles mortes de Typha et de Sparganium, à la fin de l'automne. Sa coque membraneuse, en forme de pépin, est longue de 0,02 a 0,04 de millimètre, et moitić moins large que longue; les filaments égalent au moins trois fois la longueur de la cogue.

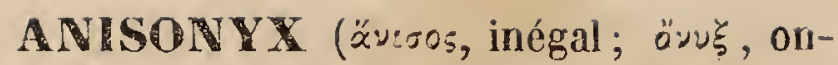
gle). INs. - Genre de Coléoptères pentamères, famille des Lamellicornes, établi par Latreille aux dépens du g. Melolontha de Fabricius, et placé par lui dåns sa tribu des Anthobies. Ses caractères sont : Palpes filiformes. Mandibules très minces, en partie membraneuses. Languette bifide, avancée au delà du menton. Mâchoires terminées par une pièce membraneuse et allongée. Le bec recouvert par un chaperon avancé, rétréci, et allant en pointe vers son extrémité antérieure. Grochets des quatre tarses antérieurs bifides, ceux des deux postérieurs simples ou terminés par une seule pointe. Ce dernier caractère suffit pour les distinguer des genres voisins, principalement du g. Amphicoma, avec lequel ils ont beaucoup de rapports. Ces Insectes ont le corps court, velu, et plus étroit en avant, avec les antennes de dix articles, dont les trois derniers forment une massue ovoïde et lamellée. Ils sont tous propres au cap de Bonne-Espérance. M. Dejean, dans son dernier Catalogue, en mentionne sept esp., parmi lesquelles nous citerons le Crinitum et l'Ursus de Fabr., qui sont pour lui des hannefons, ainsi que pour Olivier, qui les a figurés.

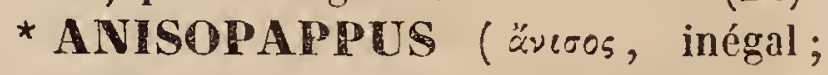
$\pi \dot{\alpha} \pi \pi 0 s$, aigrette; aigrettes inégales ). Вот. pry. - Genre de la famille des Composées, sur lequel on ne possède pas de données suffisantes. M. De Candolle croit pouvoir le rapporter au Verbesina chinensis L. MM. Hooker et Arnott lui donnent les caract. suivants : Gapitule radié, hétérogame. Fleurs femelles 1-sériées, ligulées; celles du disque tubuleuses. Involucre formé d'écailles nombreuses, imbriquées, linéaires et tomenteuses. Réceptacle paléacé. Anthères munies d'appendices basilaires. Style des fleurs du disque à rameaux obtus, inappendiculés. Fruits de même forme dans les deax sortes de fleurs, linèaires - tétragones, dépourvus d'ailes et de rostre, couronnés de plusieurs paillettes courtes, inégales, avec lesquelles se remarquent 4 soies beaucoup plus longues. - Là seule espèce connue est une plante herbacée droite, couverte de poils, munie de funilles alternes, oblongues-linéaires, obscurément dentées en leur contour. Les rameaux forifèes, terminés chacun par un capitule, forment, 
par lęur disposition, des sortes de corymbes.

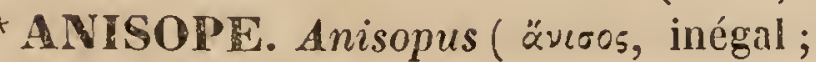
roũs, pied). CRUST. - Nouveau genre de l'ordre des Amphipodes et de la famille des Grevettines, établi par M. Templeton pour un petit Crustacé qui ressemble aux Amphitoés par la conformation des antennes, et aux Isoes par la structure des pattes, lesquelles sont toutes élargies vers le bout, et plus ou moins subchéliformes. (Voy. Trans. of the Entomological Soc. of London, vol. I, p. 185 pl. 20, fig. 1.)

* ANISOPLLNA ("丷̌ plante des pieds, tarse). Irs. - Genre de la tribu des Braconides, famille des Ichneumoniens, de l'ordre des Ilyménoptères, section des Térébrans, établi par H. Wesmael (Monogr. des Bracon. de Belg.), et adopté par nous (Hist. des anim. art., t. IV).

Les principaux caract. que présente ce g. sont tirés : $1^{\circ}$ des antennes, longues et filiformes; $2^{\circ}$ de la tête, aussi longue que large; $5^{\circ}$ des ailes, ne présentant que deux cellules cubitales; et $4^{\circ}$ des tarses intermédiaires, beaucoup plus courts que les autres, et composés d'articles égaux. Nous ne eonnaissons que 2 esp. indigènes de ce g., dont le type est l'A. belgicum Wesm. (Mon. des Br. de Belg.) et Blanch. (Hist. des an. art., t. IV, p. 345), trouvé aux environs de Liége. Nous avons rapporté (An. art.) aux Anisopelma, à l'exemple de M. Westwood, le g. Hecabolus de Curtis. Voy. ce mot. (BL.)

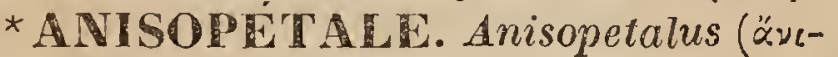
๘os, inégal; $\pi \dot{\tau}-\alpha i o \nu$, pétale). Вот. - Se dit d'une corolle dont un ou plusieurs pétales sont plus courts que les autres. (C. L.)

*ANISOPRTLLUM, De Cand. (Prod.,

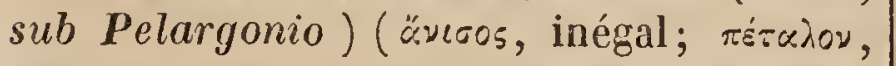
petite feuille, pétale ). Boт. PH. - Section du g. Pelargonium, caractérisée par la corolle, dont les 2 pétales supérieurs sont notablement plus longs et plus larges que les 5 inférieurs.

(Sp.)

ANISOPETAEUS. BuT. - Voyez ANISOPYTALE.

(C. L.)

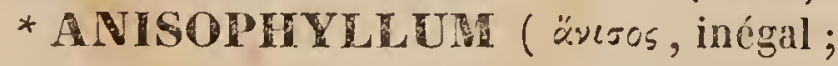
quirò, feuille ). Bux. Pu. - L'un des nombreux g. établis par Haworth aux dépens de l'Euphorbe (Voy. ce mot), nommé d'après l'inégalité des deux bords de la feuille, qui se trouve ainsi oblique. Il est subdivisé en deux sections, dont la première, bien maturelle, est composée des Euphorbia peplis et Chamasyce.

(AD. J.)

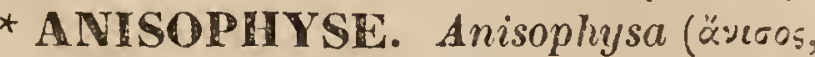
inégal ; püıь, sexe). INs. - Genre de l'ordro des Diptères, division des Brachocères, subdivision des Dichotes, famille des Athéricères, tribu des Muscides, sect. des Acalyptères, s.-tribu des Piophilides, formé par $\mathbf{M}$. Macquart aux dépens du g. Pioplizla de Fallen, et nommé par lui Anisophysa, en raison des différences que présentent les deux seres. Il a pour caractères : Trompe assez épaisse. Palpes très petits, terminés par une soie. Face carénée. Épistome saillant, d̀ deux soies courtes. Antennes couchées; troisième article large, allongé; siyle nu. Front convexe. Thorax mat. Écusson allongé chez la femelle et arrondi postérieurement. Abolomen allongé. Pieds presque nus. Cuisses antérieures munies, chez le mâle, d'une tourfe de petites soies vers le milieu et en dessous. Jambes antérieurement munies de petits poils. Pieds antérieurs simples chez la femelle. Guisses intermédiaires munies dans toute leur longueur, et chez les deux sexes, de petites soies distantes. Jambes intermédiaires garnies, vers leur extrémité, de quelques petites soies. Tarses allongés chez le mânle et chez la femelle. Ailes à cellule médiastine double, ne s'étendant que jusqu'au milieu du bord extérieur, et marginale n'atteignant pas le bord postérieur. Première cellale postérieure un peu rétrécie à l'extrémité. Nervures transversales rapprochées. Mi. Nacquart ne rapporte à ce g. que deux espèces communes dans le nord de la France, et se trouvant ordinairement sur les fleurs des baucus; ce sont l'A. scutellaris de Fallen, et l'A. albipennis de l'auteur.

ANISOPLIE. Anisoplia (“̌veos, inégal, ó $\lambda \dot{n}$, ongle; anishoplia). INs. - Genre de Coléoptères pentamères, famille des Lamellicornes, tribu des Scarabéïdes-phyllephages, établi par Mégerle aux dépens du g. Melolontha de Fabr., et dont voici les caractères d'après l'Encyclopédie : Antennes de neuf articles : le $1^{\mathrm{er}}$, conique; le $2 \mathrm{e}$, globuleux; les deux suivants, ovales-allongés; les 5e et $6^{\mathrm{e}}$, cupulaires; les trois derniers formant une massue assez grosse, ovale, presque glabre. Mandibules ayant leur portion interne moins solide que l'externe. Muchoires multi- 
lentées; leurs dents très fortes, surtout la terminale. Palpes maxillaires de quatre artiles : le 1er, très petit; le 2 , conique, assez long; le $3 \%$, court, conique ; le dernier aussi long que les deux précédents pris ensemble, ovale-allongé . Palpes labiaux de trois articles : le $\mathbb{1}^{\mathrm{er}}$, peu distinct; le 2 , conique; le terminal, ovale, aussi long que les deux autres réunis. Chaperon souvent avancé et relevé; dans ce cas, séparé de la tête par une ligne transverse peu prononcée. Corps ovale, un peu déprimé en dessus. Corselet ayant ses angles antérieurs saillants, échancrés en rondeur à sa partie antérieure. Ses côtés arrondis antérieurement, son bord postérieur sinué, saillant vis-à-vis de l'écusson. Écusson large, arrondi postéricurement. Élytres déprimées en dessous, élargies sur leur bord au dessous des angles huméraux en une sorte de bourrelet, et laissant à découvert l'extrémité de l'abdomen. Pattes assez fortes; jambes courtes, les antérieures bidentées à leur partie externe. Tarses longs, leü dernier article presque aussi long que les quatre précédents réunis; les dix tarses terminés par deux crochets. Grochets antérieurs et intermédiaires très inégaux; le plus mince entier, l'autre bifide (l'une des divisions des crochets bifides plus large et plus longue dans les mâles que dans les femelles). Crochets postérieurs un peu inégaux, entiers, l'intérieur guère plus petit que l'extérieur. - Ce genre a été adopté par Latreille dans ses Familles naturelles, ainsi que par $\mathbf{M}$. Dejean dans son dernier Catalogue, où il en mentionne 2 ss espèces, dont 13 d'Hurope, 1 de Syrie, 1 du Sénégal, 1 d’s. Grece ou d'Orient, et 6 de l'Amérique. Parmi celles d'Europe, nous en citerons deux, qui se trouvent aux environs de Paris. Ce sont les Melolontha agricola et horticola de Fabricius. Ces Insectes, dont les larves doivent être conformées comme celles des hannetons et vivre de la même maniere, mangent avidement, à l'étá parfait, les feuilles des arbres et les pétales de certaines fleurs.

(D.)

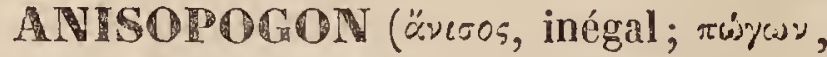
barbe). Graminées, tribu des Avénacées (Tristéginées, selon Trinius), formé par Robert Brown, et ainsi caractérisé : Épillets billo- res; fleur inférieure hermaphrodite, pédicellée; la supérieure neutre, sétiforme. Glumes 2, presque égales, mutiques, plus grandes que les fleurs. Paléoles 2 : l'inférieure roulée en cylindre, bifide au sommet, à lobes aristés, séparés par une troisième arête allongée, torse à la base; la supérieure plus longue, bifide au sommet, sillonnée dorsalement. Squammules 3 : les latérales cultriformes, renflées à la base; la $\breve{3}^{\mathrm{e}}$, concave, oblongue. Étam. 5. Ovaire stipité, comprimé, velu au sommet. Stigm. 2, plumeux, terminaux. Caryopse... - Ce g. ne se compose encore que d'une esp. (Danthonia anisopogon Trin., Ic., t. LXI), ayant le port d'une Avoine, et indigène dans la Nouvelle-Hollande orientale. C'est une Graminée, haute de $0^{\mathrm{m}}, 963$ environ, à feuilles roulées, à panicule diffuse. (C. L.)

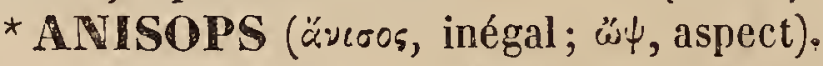
INS. - Genre établi par M. Spinola (Essai sur les Hémipt. hétér.) dans la famille des Notonectiens (tribu des Hydrocorizes Spin.), de l'ordre des Fémiptères, sur le Notonecta nivea de Fabricius, prenant en considération la forme du front dans les mâles, qui est plus acuminé que dans les femelles, et canaliculé en dessous, tandis que, dans les espèces que cet auteur conserve au genre Notonecta, le front est conformé de la même manière dans les deux sexes. Le g. Anisops n'étant fondé que sur ce seul caract., dont les femelles sont privées, nous avons cru devoị (Hist. des anim. articul., IV) le rejeter ou au moins ne le regarder que comme une simple division du g. Notonecta. Voy ce mot.

(BL.).

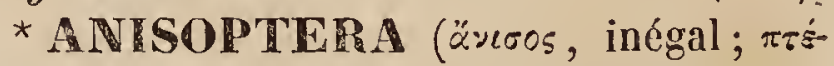
pov, aile). Ins. - Genre établi par Latreille (Règn. anim.) sur 2 esp. de la famille des Locustiens, dont les élytres et les ailes sont fort courtes, mais dont tous les autres caract., étant analogues au moins pour une esp. (Locusta brachyptera Lin., Fabr., etc.) au g. Decticus, ont déterminé MM. Serviile (Ins. orth., suites à Buffon) et Burmeister (Handb. der Ent.) à la placer dans ce dernier genre. Voy. DECTICus.

(B⿺.)

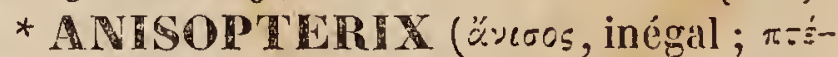

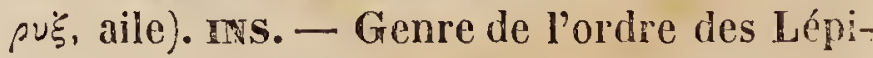
doptères, famille des Nocturnes, établi par Stephens dans sa iribu des Géométrides, et dont les espèces ont été placćes par nons 
dans le g. Hibernie Latr., tribu des Phalé- presque disposées sur deux rangées, ainsi nites. Voy. ce mot.

(D.) que les intérieures, qui sont plus longues.

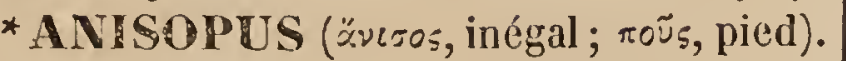
rss. - Genre de Coléoptères tétramères, famille des Longicornes, établi par M. Serville (An. Soc. ent. de Fr., 18555, p. 50), qui le place dans sa tribu des Lamiaires et lui assigne les caract. suivants : Corps très déprimé. Corselet arrondi latéralement, muni, sur ses côtćs, d'une épine placée près de l'angle postérieur. Antennes glabres, sétacées, plus longues que le corps dans les femelles, le dépassant notablement dans les mâles; distantes à leur base; de onze articles : le premier, grand, en massue allongée; le second, très petit, cyathiforme; les suivants cylindriques; le troisième à peine plus long que le quatrième. Pattes postéricures très longues dans les mâles; cuisses en massue, les postérieures très allongées, ainsi que leurs jambes et leurs tarses dans les mâles; jambes antérieures un peu arquées dans ce sexe; leurs cuisses un peu plus courtes que les intermédiaires. Taric̀re des femelles toujours saillante et dépassant l'abdomen. Palpes courts. Mandibules courtes. Tête ayant sa face antérieure assez courte; front peu aplati. Élytres très déprimées, allant en se retrécissant vers l'extrémité, qui est tronquée; chaque angle de la troncature uni-épineux. Écusson petit, semi-circulaire. Tarses glabres, les postérieurs ayant leur premier art. beaucoup plus grand que les trois autres réunis; les second et troisième très courts.

M. Dejean a adopté ce g. dans son dernier Catalogue; mais il en a remplacé le nom par celui de Leptoscelis, sans en dire le motif. Les espèces qu'il y rapporte sont au nombre de six, dont deux du Brésil et deux de Cayenne. L'esp. type, qui appartient au premier de ces pays, a été décrite par M. Serville sous le nom d'A. arachnoides. (D.)

ANIGOPUS. CRUst. - Voyez AN soPE.

(iI. E.)

* ANISORAMPIIUS (övers, dissemblable; $\dot{\rho} \dot{\alpha} \mu \rho \sigma_{\text {, }}$, aigrette; $\dot{a}$ aigrette dissemblable). вот. Pir. - M. De Candolle a formé ce g. pour une plante du Cap, appartenant à la famille des Composées, tribu des Chicoracécs. Les caract. en sont : Capitule inultiflore. Inyolucre caliculé à folioles imbriquées, linéaires; les extérieures courtes, 1 corc été signalées et ne sont conves tau

Réceptacle dépourvu de paillettes. Fruits oblongs, comprimés, striés; les extérieurs terminés par un rostre plus court que ceux de l'intérieur; l'aigrette poilue, multisériée, de couleur jaunâtre. - Cette plante a le port d'un Hieracium ou d'un Hippocharis. La tige, presque nue, porte au sommet environ 3 capitules, dont les folioles sont couvertes de poils noirs et raides; les fleurons sont jaunes.

(J. D.)

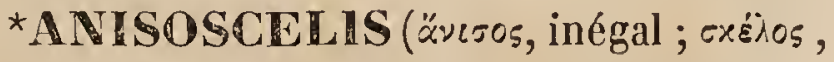
jambe). 1ss. - Genre de la famille des Coréens, de l'ordre des Hćmiptères, section des Hétćroptères, établi par Latreille, confondu d'abord avec les Lygaus par Fabricius, et adopté maintenant avec de plus ou moins grandes modifications par tous les entomologistes. Tel que nous l'avons considéré (Hist. des anim. articul.), les caract. essentiels de ce g. peuvent être résumés ainsi : Corps élancé. Antennes très longues, fort grêles, filiformes dans tonte lcur étendue, n'ayant aucun article plus élargi que les autres, et le dernier plus long que les précédents et terminé en pointe. Prothorax ayant ses angles postérieurs aigus. Pattes longues, avec les jambes postéricures ordinairement munies d'expansions membraneuses plus ou moins considérables.

Le $\mathbb{D r}^{\mathrm{B}}$ Burmeister (Handb. der Entom.) a restreint le g. Anisoscelis aux esp. qui, présentant les caract. que nous ayons énoncés, ont une tête un peu triangulaire et légèrement avancée entre les antennes, tandis qu'il forme un g. Diactor avec celles qui ont une tête plus arrondic. Enfin M. Spinola (Essai sur les Hémipt. hétéropt.), poussant plus loin la restriction, ne comprend parmi les Anisoscelis que les esp. dont les cuisses postérieures sont renflées, et les jambes pourvues d'une expansion foliacée, plane.

Toutes les esp. d'Anisoscelis sont propres aux pays chauds, et, à peu d'exceptions près, à l'Amérique méridionale. Elles ont généralement une taille assez grande, et plusieurs des coulcurs très vives. Leur nombre peut être porté maintenant à une soixantaine, en énumérant tant les espèces décrites par les auteurs que celles qui n'ont pas en- 
dans les collections; mais, si l'on adopte ic g. Diactor, ce nombre sera réduit de près de moitié. Les esp. types pour tous les auteurs sont les A. phyllopus Linn., A. gonagra Fabr., du Brésil; A. membranacea Fabr., d'Afrique, etc.

(BL.)

* ANSOSCLZTTES (ávercs, inégal; oxغ̇os, jambe ). INS. - M. Laporte employa le premier cette dénomination (Essai d'une cl. syst. des Hém.) pour désigner sa septième famille des Hémiptères hétéroptères, ayant pour type le g. Anisoscelis, et renfermant en outre douze autres g. M. Burmeister (Handb. der Entom.) réunit les Anisoscélites avec les Coréites de M. Laporte, et n'en forma qu'une seule sous-famille sous le nom de Coréodes. Cet exemple fut suivi par N. Brullé ( Hist. des Ins.), qui modifia seulement la dénomination de Coréodes en celle de Coréens, que nous avons adoptée (Hist. des anim. art.), en divisant la famille en deux groupes, les Coréites et les Anisoscélites. II. Spinola (Essai sur les IIémipt. héter.) regarde les Anisoscélites comme une famille distincte, et leur adjoint plusieurs g. que la plupart des auteurs placent parmi les Coréites.Voy. Gorersws. (BL.)

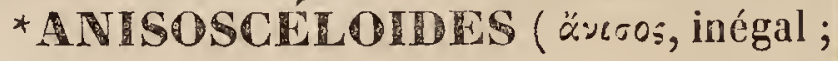

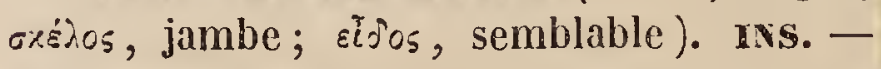
M. Spinola forme sous ce nom une sousfamille comprenant le g. Astemma et quelques autres g. de la famille des Jygéens, dont les esp. sont privées d'ocelles. Toy. ASTRMMITES et LYGEENS.

(BL.)

* ATSOSCL DIVM, DG. ("̌visos, iné-

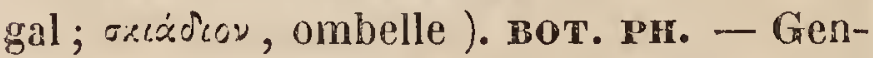
re de la famille des Ombelliferes, que son auteur place entre l'oliveria et l'Echinophora, et auquel il assigne pour caract. : Calice des fleurs marginales à lobes extéricurs très grands, ovales, foliacés; calice des fleurs centrales à lobes extérieurs raides, mucroniformes; lobes intérieurs (des calices de toutes ies fleurs) nuls ou dentiformes. Corolle très irrégulière; les pétales extérieurs très grands, obcordiformes-bifdes; les pétales intérieurs minimes. Styles coniques, raides, presque dressés, accrescents. Fruit pubérulé, oblong, cylindracé, couronné du limbe calicinal ê des styles. Néricarpes scmi-cylindriques (l'un d'eux souvent abortif), à 5 côtes très obtuses; bandelettes (nulles sur la commissure) brunes, solitaires dans cliaque vallécule. Périsperme involuté. (DC. Mém. V, p. 63, tab. 15.) - Ilerbe à racine simple; tiges diffuses, raides, dichotomes; feuilles pétiolées, pennées; folioles pennatifides; involucre 4 - ou 亏-phylle, à folioles oblongues, anisomètres, finalement subspinescentes; involucelles de 4 ou 5 folioles elliptiques, persistantes, anisomètres; fleurs blanches, sessiles, au nombre de 7 à 10 par ombellule. - Ce genre est fondé sur une seule espèce, trouvée par Olivier entre Bagdad et Alep.

* ANISOSTERTEN. Anisostemones

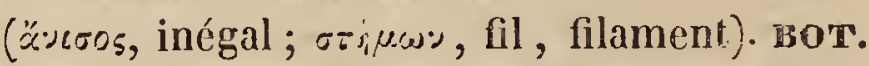
Pr. - On applique cette épithète aux fleurs dont les étamines ne sont pas en nombre égal à celui des pétales libres ou soudés. C'est le cas de beaucoup de Dipsacées.

* ANISOSTICL ("丷vısos, inégal; tix-

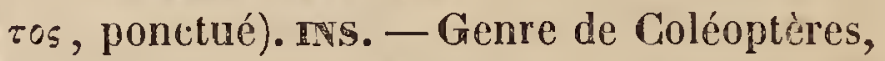
de la section des Trimères, établi par MI. Chevrolat aux dépens du g. Coccinella de Fabricius, dont il diffère par un corps ovale et étroit, au lieu d'être hémisphérique; par le dernier article des tarses, plus long, et par les crochets, qui sont simples, plus grands, et recourbés en dessous. M. Dejean, qui a adopté ce genre dans son dernier Catalogue, y rapporte six espèces, dont quatre d'Amérique et deux d'Europe. Nous citerons parmi les premières la Cocc. 10-maculata de Fabr., qu'on rencontre dans toutes les contrées de l'Amérique, et parmi les secondes la Cocc.19-punctata du même auteur : celle-ci se trouve aux environs de Paris.

* ANSOSTRCTR, Bartl. (äveros, inégal, riros, ponctué ). вот. H. - Synon. (suivant M. Endlicher) du g. Marila, Swartz, de la famille des Ternstrémiacées. (\$Fr.)

ANISOSTOME. вот. PH. - Voyez A NISOTOME.

(G. L.)

* ANSOTARSES (ävoos, inégal; тxpoós, tarse ). INs. - Genre de Coléoptères pentamères, famille des Carabiques, établi par M. le baron Haximilien de Chaudoir pour y placer 2 espèces nouvelles du Nexique qu'il nomme l'une $\boldsymbol{A}$.brevicollis, et l'autre A. lceviusculus. Les caract. qu'il assigne à ce g. sont formulés trop longuement pour être rapportés ici dans leur entier. (Foy. son Mém. intit.: G. nouveaux et esp. nouvelles de $\mathrm{Ca}$ - 
rabiques, p. 41.) En résumé, le g. dont il s'agit ne differe, suivant M. Chevrolat, de eclui que H. Dejean a créé sous la dénomi'nation d'Anisodactylus que par la dent de l'échancrure du menton; et des autres Harpaliens par la forme des tarses, qui le rapproche de ce même genre.

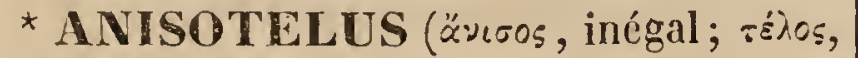
extrémité). ins. - Genre de Coléoptères pentamères, famille des Malacodermes, tribu des Lampyrides, établi par M. Hope aux dépens du g. Téléphore des auteurs (Coleopterist's Manual, part. III , p. 141), mais sans indication de caractères. Il lai donne pour type une esp. inćdite du Népaul, qu'il nomme $A$. lividus.

ANISOTOME. Anisotoma (äuroos, inégal ; roun, section). rws. - Genre de Colćo-

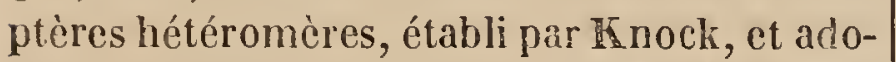
pté par Illiger, Fabricius et M. Duméril. Ce dernier le range dans sa famille des $\mathbb{F}$ ongivores ou Mycétobies et le caractérise ainsi : Corps aplati en dessous, convexe et ovale en dessus; masse des antennes de cinq articles perfoliés, qui peuvent s'écarter et se rapprocher. M. Dejean, qui l'a également adopté, y rapporte, dans son dernier Catalogue, 25 espèces, dont 21 d'Europe et 4 de l'Amérique septentrionale. Nous citerons seulement, comme type du genre, l'Anisotoma ferrugineum de Fabr., qui se trouve principalement en Allemagne. Gyllenhal (Fauna suecica, app. ad syn., 511-515) décrit 21 esp. d'Anisotomes, dont il faut déduire les esp. rapportées aux Agathidies. Sturm en décrit 15 , et en figure 8 , propres à l'Allemagne.

Les Anisotomes avaient d'abord été confondus avec les Sphéridies, bien qu'ils en difièrent par le nombre des articles des tarses; par les antennes; par les parties de la bouche et par les habitudes. Latreille est le premier qui en ait formé un genre, auquel il a donné le nom de Léiodes; mais celui d'Anisotoma a prévalu, quoique postérieur. Voy. néanmoins le mot LÉrodes pour les caract. génériques de Latreille.

* ANISOTOME. Anisotomus (äveos, inégal; :oros, section).BoT.-Dénomination appliquće au périanthe soit interne, soit externe, lorsque les divisions en sont alternativement inégales.

(G. L.) o0s, inégal; ropri, section). Ns. - Nom d'une famille de Coléoptères établic par Stephens, dans laquelle il réunit les Diapériales et les Érotylénes de Latr, ainsi que les Sphæridiides de Mac-Leay. Elle se compose des genres Tritoma, Phalacrus, Ephistemus, Leiodes, Agathidium, Clambus, Clypeaster, et deux autres genres innommés.

ANGOTOMUS. BOT. - Voyez ANISOTOME. (C. L.

ANISOTRTCHLA ( Opí, poil; poils inégaux ). вот. Рн. - Section du g. Albertinia (Voy. ce mot), caractérisće par les fruits, dont la rangée externe de l'aigrette est de moitié plus courte que l'interne.

(J. D.)

* ANISTOPHORES. Anistiophori

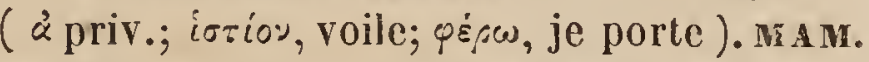
- Ce nom été donné par Spix et Gray à une famille de Chauves-souris qui ne présentent aucun appendice sur le nez.

(C. D'O.)

* ANISUM, Adans. (anisum, nom de l'anis dans Pline. Voy. AvIs ). BoT. PH. Double emploi du g. Pimpinella L., ou, si l'on veut, section de ce g. , caractérisće par des fruits pubérules.

(SP.)

ANISUS (๕̌vıros, inégal). INS. - M. Dejean, dans son avant-dernier Catalogue, avait désigné sous ce nom un g. de Coléoptères tétramères, famille des Curculionites, fondé sur une seule espèce du cap de Bonne-Espérance nommée par lui Auriculatus; mais, dans son dernier Catalogue, il place cette espèce dans le g. Hipporhinus de Schoenherr. Voy. ce mot.

* ANXI (ävolsıs, ouverture).BoT. CR. - Ce genre appartient à la tribu des Champignons rhizogonés de l'ordre des Périsporés de Fries. Il est caractérisé par un peridium d'abord charnu entièrement, puis creux el s'ouvrant au sommet ; sa substance intérieure est d'une consistance molle, presque gélatineuse et parsemée de spores simples. L'A. villosa, seule espèce connue jusqu'à ce jour, a été trouvée, en septembre, sur la terre recouverte de feuilles. Ses peridium, qui atteignent jusqu'à un demi-pouce de haut, sont plus ou moins rapprochés les uns des autres, difformes, oblongs, sessiles, ou presque pédicules, recouverts d'un duvet blanc,

* ANISOTOMIDES. Anisotomidce (üve- et fixés à la terre par des fibrilles qui res- 
semblent à de petites racines. Le Sclerotium radicatum de Tode (Fung. Meck. Fasc., 1, tab. 1, fig. 8 ), que M. Fries a cru devoir rapporter à ce genre, mais avec doute, sous le nom d'A. glabrata, en donne une idée assez juste.

(LÉv.)

ANIEENDA (nom vernaculaire), IIermann. BoT. PH. - Synon. du g. Acronychia, Forst. (famille des Zanthoxylées).

(SP.)

* ANRÉRTTE. Miv. - Nom donné par Eaidinger, en l'honneur du prof. Anker de Gratz, à un minéral de Styrie, nommé aussi Rohwand, et Fer spathique blanc, et qui est un mélange cristallisé de carbonate de chaux et de carbonate de fer. Voy. CaRBONA TES.

(DEL.)

ANIR YLOSE. Ankylosis (àyxìitwrts; de ¿́yxìos, courbé ). ANAT. - On désigne, par ce mot, l'état qui résulte de la diminution ou de l'impossibilité absolue des mouvements d'une articulation naturellement mobile. Cette maladie est ainsi appelée, parce que le membre qui en est atteint reste ordinairement fléchi.

(G. D'O.)

ANNEAU (annulus, anneau). MoLL. - Nom vulgaire d'une petite esp. très commune de Porcelaine, Cyprce a annulus. Voy. PORCELAINE.

(DESH.)

ANNEAU. Annulus. [вот. - Dans les plantes cryptogames, ce mot sert à distinguer trois organes très différents, suivant les familles auxquelles on l'applique. Dans les Mousses, il désigne un rebord saillant et quelquefois crénelé, qui garnit l'orifice de l'urne. Dans les Fougères, on a nommé ainsi un anneau ou bourrelet qui entoure le plus souvent leurs capsules, et qui, jouissant d'une grande élạsticité, facilite leur rupture et la dispersion des graines. Enfin, dans les Champignons, on nomme anneau, collier ou collet, la collerette membraneuse qui entoure le pédicule de beaucoup d'Agarics et de certains Bolets.

(C. D'O.)

ANNEAUX. Annuli. ANIM. ARTICUL. - Cette dénomination est employée en Entomologie pour désigner l'assemblage de plusieurs pièces constituant les parties qui composent, par leur réunion, l'enveloppe extérieure des Animaux articulés. Dans l'origine, ce nom s'étendait aux pièces qui entrent dans la composition des antennes et des pattes; mais, depuis, le nom d'Articles (Voy. ce mot) a été adopté pour ces pièces, et celui d'Anneaux a été réservé pour les parties du corps, parties non pas simples, mais toujours composées de plusieurs pièces constituant deux arceaux, l'un supérieur, l'autre inférieur, entièrement joints entre eux ou quelquefois même complètement soudés, de manière à former des cercles plus ou moins parfaits. Ainsi défini, l'Anneau ne peut plus être confondu sous les noms de Segments, d'Arceaux, d'Articulations, qui ont une acception différente et plus restreinte. Voy. ces mots.

On peut étudier les Anneaux dans leur composition, leur forme, leur consistance. Dans les Annélides, les Myriapodes, tels que les Jules, les Scolopendres, etc., les Anneaux sont semblables entre eux ou à très peu de chose près, quant à la forme et à la consistance, dans toute la longueur du corps, et ils représentent alors des cercles plus parfaits. Il en est de même dans lâ plupart des Larves. Mais, dans les Insectes parfaits, les Anneaux sont nettement séparés en trois groupes constituant une tete, un thorax et un abdomen (Voy. chacun de ces mots). Alors chez ceux-ci le développement de plusieurs Anneaux est plus grand en raison du plus grand nombre d'appendices qu'ils supportent. C'est ainsi que le mésothorax ou second anneau du thorax, qui supporte la première paire d'ailes et une paire de pattes, offre une plus grande quantité de pièces distinctes et bien développées que les Anneaux plus simples, où elles sont soudées. entre elles, comme dans le prothorax, qui ne supporte pas d'ailes, et surtout dans les Anneaux de l'abdomen, qui ne supportent ni ailes ni pattes. Dans les Crustacés et les Arachnides, aucun Anneau ne supportant d'ailes, il en résulte une plus grande simplicité que dans ceux du thorax des Insectes ailés, et, chez la plupart, on ne distingue que deux groupes d'Anneaux, car la tête et le thorax se confondent ensemble. Les points de jonction entre les Anneaux reçoivent le nom d'Articulations. Voy. ce mot.

(BL.)

ANNELĹS. Annulata (annulus, anneau). zoor. - Mac-Leay a donné ce nom à une division du Règne aninal, comprenait les Animaux articulés, dont le corps 
est composé d'Anneaux unis les ưu aux autres.

(c.. D'O.)

ANNELIDAIRES. Annelidaria (Annélides, classe d'animaux). ANNÉL. - M. de Blainville a quelquefois nommé ainsi, ou mieux Subannélidaires, c'est-à-dire ressemblant aux Annélides, une partie des Vers apodes comprenant les Borlases, Planaires, Douves et Tonoïdes.

(P. G.)

ANNÉLIDES. Annulosa, Annelides (annellus, petit anneau). ANNÉL.-(Zool.) Lamarck, auquel on doit la création du mot dont il est ici question, s'exprime ainsi sur la classe d'animaux auxquels il l'applique:

“M. Cuvier, nous ayant fait connaître les faits d'organisation qui concernent la Sangsue, les Néréides, l'animal des Serpules, etc., assigna à ces animaux le nom de Vers à sang rouge; mais, reconnaissânt la nécessité de les écarter considérablement des Vers, et de leur assigner un rang plus élevé qu'aux Insectes, j'en formai de suite une classe particulière que je présentai dans mes cours, à laquelle je donnai le nom d'Annélides, que je plaçai à la suite des Crustacés, et dont je n'eus occasion de consigner les déterminations, par l'impression, que dans l'Extrait de mon cours, qui parut en 1812."

"Pour les mettre en ligne dans la série, nous avons trouvé, dit encore Lamarck dans un autre passage de son Hist. des animaux sans verièbres, des motifs qui nous autorisent à les placer après les Crustacés, quoiqu'ils interrompent les rapports que ces derniers ont avec les CIRRHIPÈDES, parce qu'il eût été très inconvenable de les ranger ailleurs. "

D'après le même naturaliste, la classe des Annélides a pour caractères distinctifs :

Animaux mollasses, allongés, vermiformes, nus ou habitant dans des tubes; ayant le corps muni, soit de segments, soit de rides transverses; souvent sans tête, sans yeux et sans antennes; dépourvus de pattes articulées; mais la plupart ayant, à leur place, des maemlons sétifères rétractiles, disposés par rangées latérales. Bouche subterminale, soit simple, orbiculaire ou labiée, soit en trompe souvent maxillifère. Une moelle longitudinale noueuse et des nerfs pour le sentiment et le mouvement; le sang rouge, circulant par des artères et des veines. Respiration par des branchies,

T, I. soit internes, soit externes, quelquefois inconnues.

Ces animaux sont ainsi partagés en trois ordres : $1^{\circ}$ Annélides apodes, les Hirudinées et les Échiuridées; 2o Annélides antennées, les Aphrodites, Néréides, Euniles et Amphinomes; $3^{\circ}$ Annélides sédentaires, les Dorsalées et Maldanies, Amphitritées et Serpulées.

G. Cuvier accepte, dans son ouvrage sur le Règne animal, le nom d'Annélides donné par Lamarck à ses Vers à sang rouge, et il fait remarquer que c'est lui qui, en 1802, a établi " cette classe, en la distinguant par la " couleur de son sang et d'autres attributs. "

Pour Cuvier, les Annélides formant la première classe des animaux articulés, entre eux et les Vers intestinaux, qu'on leur associait en tout ou en partie dans la Classification de Linné, de Bruguière, etc., sont : les Grustacés, les Arachnides, les Insectes et les Échinodermes; mais cette séparation des Annélides et des Vers inférieurs n'a pas ici le même inconvénient que dans le système de Lamarck, Cuvier ne pensant pas, comme celui-ci, que le règne animal puisse être classé sérialement.

Plusieurs naturalistes ont adopté cette distinction tranchée entre les Annélides et les Vers, et parmi eux nous citerons M. Savigny (Syst.des Annélides), dont les beaur travaux n'avancèrent pas moins la connaissance des organes extérieurs des Annélides que ceux de Pallas et de Cuvier l'appréciation de leurśs organes intérieurs. Toutefois de nouvelles recherches ont dû ramener les naturalistes aux idées bien des fois critiquées de Linné et de Bruguière, et elles leur ont d'ailleurs donné la précision et la régularité qui leur manquaient à cette époque de la science helmintologique. Quelques espèces qu'on plaçait à tort parmi les Annélides en ont été distraites.

Les Vers intestinaux ou extérieurs ont été mieux connus, et de nouveaux liens sont venus les unir aux Annćlides et former des uns et des autres une véritable série partielle dont la place est certainement au dernier rang de la catégorie des Animaux articulés. Il nous serait donc impossible, en parlant isolément des Annélides, de faire comprendre leurs affinités avec les Entozoaires et les autres animaux réunis par $\mathbf{L}$ a - 
marck et Cuvier sous le nom de Ver ; aussi n'avons-nous rapporté au sujet des Annélides qu'un abrégé de ce qu'en ont dit les auteurs de cette classe. Les Annélides, qu'on a voulu séparer des Vers, ne paraissent en effet que les premiers termes d'une séric que les Borlases, les Planaires, les Intestinaux, etc., continuent par degrés à peine distincts les uns des autres, et il paraît préférable de traiter de tous ces animaux en même temps. Cette seconde manière de voir est celle à laquelle M. de Blainville s'était depuis longtemps arrêté dans ses ouvrages; et, comme nous le verrons en détail à l'article vERs de ce Dictionnaire, plusieurs naturalistes qui avaient eu, comme les deux hommes célèbres que nous avons cités antérieurement, une autre opinion, professent actuellement celle-ci, et ils l'ont même renforcée par de nouvelles preuves que nous aurons soin de rappeler.

Alors on conserve assez souvent encore le nom d'Annélides, et la classe d'animaux à laquelle il se trouve appliqué reste avec la même circonscription que pour Lamarck et Cuvier ; mais ses rapports naturels sont appréciés d'une manière plus convenable. C'est ce que fait M. Milne-Edwards. M. de Blainville donne au contraire au groupe des Annélides sétigères la valeur classique : ce sont ses Entomozoaires chétopodes; et les Sangsues ou Annélides apodes des auteurs sont dans la même classe que les Vers intestinaux sous le nom d'Apodes; celui d'Annélides n'a pas d'cmploi dans cette classification.

(P. G.)

* ANNESLEIA, Wallich (Plant. asiat. rar., t. I, p. 5, tab. 5 (lord G. Annesly). Bot. PH. - Genre de la famille des Ternstrémiacées, auquel son auteur assigne pour caractères : Calice 2-bractéolé, à tube très court, adhérent à la base de l'ovaire; limbe 5-parti, à segments inégaux, imbriqués. Corolle : 5 fide, à lobes pointus, imbriquess, connivents, opposés aux segments calicinaux. Étamines très nombreuses, 2-sériées, incluses, insérées sur un disque périgyne; filets très courts; anthères basifixes, introrses, innées, 2-thèques, linéaires, cuspidées, longitudinalement déhiscentes. Ovaire semi-infère, 3-loculaire; ovules très nombreux, campylotro. pes, suspendus au sommet de l'angle interne des Inges. Style indivisé, terminé par 3 stig- mates subulés. Baie presque sèche, subglo buleuse, 5-loculaire, couronnée du limbe calicinal. Graines par avortement solitaires ou géminées dans chaque loge, suspendues, ployées en forme de fer à cheval, apérispermées, recouvertes d'un arille charnu; test chartacé, luisant. Embryon cylindracé, courbé conformément à la graine; radicule et sommet des cotylédons supères. - Ce g. n'est fondé que sur une seule esp. (A. fragrans, Wall., $l$. c.). G'est un arbre indigène du Martaban; ses feuilles sont alternes, courtement pétiolées, lancéolées, subcoriaces, très entières, non stipulées: les fleurs sont axillaires, solitaires, très longuement pédonculées, odorantes, blanchâtres.

(SP.)

* ANNESLEIA, Salisb. (lord G. Annesly). вот. PH. - Syn. du g. Inga, Plum., de la famille des Légumineuses (Mimosées).

ANNESLIA, Andr. (lord G. Annesly). вот. Рн. - Syn. du g. Euryale, Salisb., de la famille des Nymphéacées.

(SP.)

* ANNESORHIZA, Cham. et Schlecht.

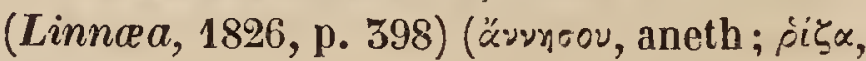
racine). вот. Вн. - Genre de la famille des Ombellifères, auquel ses auteurs assignent les caract. suivants : Limbe calicinal marginiforme, 5ै-denté, persistant. Pétales elliptiques, acuminés, à pointe infléchie. Styles réfléchis après la floraison. Péricarpe prismatique-5-gone, couronné par les styles et par le limbe calicinal. Méricarpes convexes au dos, dissemblables : l'un 3-ptère (la côte carénale et les côtes marginales ailées; les côtes intermédiaires filiformes ); l'autre 4-ptère ( la côte carénale filiforme ; les 4 autres côtes ailées ). Bandelettes solitaires dans chaque vallécule, géminées sur la commissure, qui est plane. Carpophore 2-parti. - Ce g. , voisin des OEnanthes, n'est fondé que sur une seule espèce, laquelle croît au Cap de Bonne-Espérance. C'est une herbe à racine fusiforme ( ayant une odeur d'anis ); à tige dressée, garnie de feuilles squammiformes; à ombelles 12-15-radiées, munies d'involucre et d'involucelles polyphylles.

(SP.)

ANNUEL, LE. Annuus, a (annus, année). Boт. - Se dit des plantes qui parcourent toute leur période végétative dans le cours d'un an, depuis leur germination 
jusqu'à leur fructification, après laquelle elles périssent. C'est l'opposé de vivace. (C. L.)

ANNULAIRE (annulus, anmeau). INS. - Mouffet nomme ainsi la chenille du Bombyx neustria, vulgairement appelée Livrée.

* ANNULAIRE. Annularia (annulus, anneau). MoLL. - M. Schumacher, dans son Essai d'une classification des Coquilles, confondant le Turbo elatius de Linné avec les Cyclostomes, fait pour le Cyclostoma volvutus et quelques autres espèces un g. Annulaire que l'on ne saurait adopter, mais qui donne la preuve que l'auteur dont nous parlons avait mal compris plusieurs parties importantes de la classification de Lamarck. Voy. cy CLOSTOME.

(DESH.)

* ANNULINE ( annulus, anneau ). BоT. CR. - Quelques espèces de Conferves avaient été désignées sous ce nom par MM. Link et Léon Leclerc.

(C. M.)

ANNULOSA. ANvéL. - Synon. latin d'ANNÉLIDES.

(C. D'O.)

ANNULUS, BоT. - Synon. latin d'aNNFAU.

(C. L.)

ANNUMBI. Annumbius. oIs. - Nom donné par Azara à deux espèces d'Oiseaux du Paraguay, remarquables par la grandeur de leur nid, et dont nous avons fait un sous-genre de notre genre Anabate. Voy. ce mot.

(LAFR.)

ANNUUS, A. вот. - Voyez ANNUEL.

(C. L.)

ANOA. mah. - Genre d'anthope. -Voyez ce mot.

(C. D'O.)

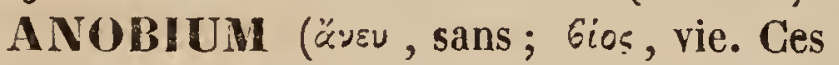
Insectes contrefont les morts quand on les surprend). INs. - Voyez VRILlette.

(D.)

ANOCARPUM, De Cand. (Syst., t. II, p. 222, sub Diplotaxi) ( «ँ хxлто's, fruit). вот. Pн. - Section du g. Diplotaxis, famille des Crucifères. Suivant M. De Candolle, elle offre pour caract. différentiels : Style conique, comprimé, asperme, ou 1-2-sperme à la base; stigmate bilobé. Silique (le plus souvent non-stipitée ) dressée.

(SP.)

ANODA , Cayan. (à priv.; v euph.; ójós, route; sans suture apparente). Bот. Pн. - Genre de la famille des Malvacées, dont W. Kunth (in Humb. et Bonpl., Nov. Gen. et Spec., t. V, p. 260̃) a limité les caractères comme il suad : Calice écaliculé, B-fide. Pétales 5, obovales, étalés lors de l'épanouissement ; onglets adnés à la base de l'androphore. Androphore à partie inférieure ventrue, recouvrant l'ovaire, et à partie supérieure columnaire, couronnéo al'une touffe de filets très nombreux, filiformes; anthères réniformes, bivalves. Ovaire non stipité, multiloculaire. Ovules solitaires dans chaque loge, appendants, attachés à l'angle interne. Styles en même nombre que les loges, filiformes, soudés par la base, terminés chacuı par un stigmate capitellé. Péricarpe orbiculaire, déprimé, composé d'un nombre indéfini de coques cohérentes, 1-spermes, radiantes, mutiques, ou cuspidées au sommet, irrégulièrement ruptiles, sans se désunir entre elles. Graines subréniformes, appendantes, à hile situé dans l'échancrure; tégument crustacé. Périsperme très mince, mucilagineux étant humecté. Embryon courbé conformément à la graine; cotylédons foliacés, plissés ; radicule supère. - Herbes annuelles (indigènes du Mexique). Feuilles hastiformestrilobées ou anguleuses, alternes, longuement pétiolées; stipules latérales, géminées. Pédoncules axillaires, solitaires, 1-flores. Corolle jaune, ou pourpre, ou violette. L'A. hastata, Gavan., est cultivée comme plante de parterre. On connaît 5 ou 6 autres esp., dont plusieurs se font aussi remarquer par des fleurs élégantes.

(Sp.)

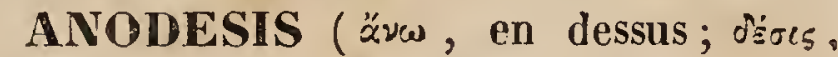
ligament ). INs. - Genre de Coléoptères hétéromères, famille des Mélasomes, établi par M. Solier (An. Soc. ent. de Fr., 183 ś. t. III, p. 594) aux dépens du g. Erodius de Fabr., dont il se distingue, suivant lui, par les caract. ci-après : Menton convexe en dehor's, comme gibbeux, et sans strie ni sillon longitudinal. Yeux très courts, très larges et fortement transverses, filiformes, et point saillants; ils se prolongent d'une manière très notable en dessous du bord latéral de la tête. Cuisses minces, cylindriques à leur base, fortement renflées en massue à leur extrémité et non comprimées, et subfiliformes comme dans les Erodius; les cils des antérieures sont plus courts et plus épineux. Dessus du tergum du prothorax presque tronqué à sa base; les angles postérieurs non prolongés en arrière. Corps peu convexe en dessus, moins ovalaire, presque filifor 
me, brusquement arrondi à l'extrémité postérieure.

M. Dejean n'a pas trouvé ce g. assez caractérisé pour l'adopter, et il en a réuni la seule espèce sur laquelle il est fondé (Anod: Cleryi, originaire du Sénégal ) au g. Erodius de Fabricius. Voy. ce mot.

* ANODOCHEILUS ( $\alpha$ priv.; $\nu$ euph.; ¿̀ojs, dent; $\chi \varepsilon \bar{\imath} \lambda o s$, lèvre ). Ins. - Genre de Coléoptères pentamères, famille des Hydrocanthares, tribu des Haliplides, établi par M. Babington, d'après une esp. de Rio-Janeiro, qu'ii nomme A. maculatus. - Ce genre ne nous est connu que par l'indication qu'en donne M. Hope dans son ouvrage intitulé : Hope's Coleopterist's Manual, part. II, p. 132.

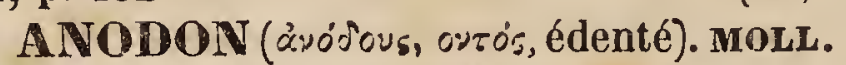
- Dans son Traité de Zoologie, M. Oken préfère ce nom grec à celui d'Anodonta consacré depuis long-temps au g. Anodonte de Bruguière et de Lamarck. Voy. AroDONTE et MULETTE.

(DESH.)

ANODONTE. Anodonta (àvóơus, oyธơs, édenté). MoLL. - Ce genre a été créé par Bruguière dans l'Encyclopédie Méthodique lorsqu'il coordonna les planches de cet ouvrage. Ge savant conchyliologue étant mort sans avoir achevé le texte de ce grand ouvrage, ce fut Lamarck qui, le premier, détermina rigoureusement les limites di g., et le caractérisa dans le premier tableau systématique de conchyliologie qu'il publia en 1799 dans les Mémoires de la Société d'Histoir enaturelle de Paris. A l'époque où le genre Anodonte fut créé, il pouvait être maintenu sans difficulté dans la méthode; mais depuis que de nombreuses observations sont venues successivement enrichir la science; depuis que le nombre des espèces s'est accru dans ce g., aussi bien que dans les Mulettes, de la manière la plus inattendue, toutes les personnes qui se sont occupées de conchyliologie se sont aperçues que les Anodontes et les Mulettes se liaient par les nuances les plus insensibles, et que, par l'étude seule des coquilles, il était impossible de déterminer d'une manière rationnelle la limite des deux genres. Mais il fut bien plus impossible encore de déterminer cette limite lorsque l'on sut enfin que les animaux des $\Lambda$ nodontes ne diffèrent en rien de ceux des Mulettes; et, dès lors, il fallut convenir que, pour les deux g. que nous venons de mentionner, les caractères de la charnière ne sont de nulle valeur. Les espèces qui ont cette partie le plus fortement articulée ne diffèrent en rien, quant à l'animal, des espèces qui ont la charnière simple et sans dents. On conçoit, d'après cela, qu'il est nécessaire de rassembler en un seul genre les Anodontês et les Mulettes, et nous verrons, en traitant de ce dernier, qu'il faudra y réunir aussi les Hyris et les Castallies de Lamarck. Voy. MuLETTE.

(DESH.)

ANODONTEA, DG. (Syst. II, p. 517,

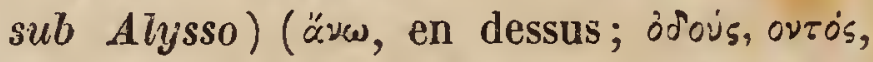
dent ). вот. PH. - Syn. du s.-g. Aurinia, C. - A. Meyer, de la famille des Crucifères.

(SP.)

* ANODONTIDES, et non ANODONTHIDES. Anodontidia (àvóơvs, ov-

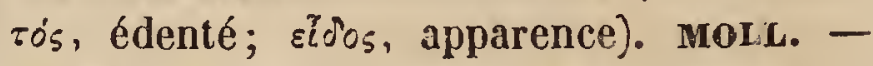
M. Rafinesque, dans une monographie des coquilles de l'Ohio, publiée dans le Journal général des Sciences naturelles de Bruxelles, a divisé en un grand nombre de genres et de familles les Anodontes et les Mulettes. Il a proposé une famille des Anodontines, qui, correspondant exactement au g. Anodonte des auteurs, est aujourd'hui absolument inutile, lorsque surtout le genre Anodonte lui-même ne peut subsister. V.oy. ANoDonte et MUletTe. (DESH.)

ANODONTTE (dimin. d'àvóơus, oyros, édenté). Moss.-Nom sous lequel Bruguière a d'abord séparé les Anodontes. Ce nom a été changé depuis contre celui qui est encore en usage.

(DESH.)

* ANODONTIUM (àvojous, ovrós, édenté ). BOT. CR. - Ce, genre acrocarpe, uniquement fondé sur un caractère très variable comme la présence ou l'absence de fleurs mâles axillaires, a été abandonné par Bridel lui-même, qui l'avait établi aux dépens du g. Gymnostome, et sur une seule espèce d'Hedwig, le G. prorepens, propre à l'Amérique septentrionale. Ce g. n'a point été adopté et ne devait pas l'être.

(C. M.)

*ANODONTYRA (ávódovs, ovtos, sans dents ; oup $\dot{\alpha}$, queue ; extrémité abdominale). INs. - Genre établi par M. Westwood (proceedings of the Zool. Soc. of Lond.), qui le place dans la famille des Scoliens, et lui as- 
signe les caracières suivants : Corps allongé. Antennes grêles, de treize articles. Mandibules armées d'une forte dent au côté interne, avant l'extrémité; palpes maxillaires, longs, composés de six articles; les labiaux de quatre. Abdomen oblong, sans pointes à l'extrémité. D'après M. Westwood, les Anodontyra sont voisins des Tengyra. Leurs ailes présentent la même disposition dans les nervures, mais le coips est plus court que dans les Tengyra et les Myzine nâles. -L'auteur ne rapporte à son g. ru'une seule espèce du Ghili, qu'il désigne sous le nom d'A. tricolor.

(Bu.)

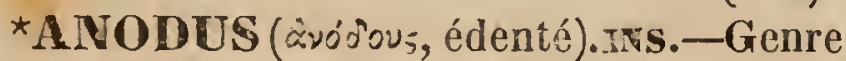
de Coléoptères pentamères, famille des Brachélytres, triba des Fissilabres, établi par M. Nordmann (Symbola ad monographiam Staphylinorum), et auquel il assigne les caract. suiv. : Palpes courts ; les maxillaires comme dans les Staphylins; les labiaux ayant les deux premiers art. courts, le deuxième épais, tronqué au bout. Mandibules peu allongées, non fortes, falquées, minces, édentées, légèrement rétrécies à la base, ce qui leur donne une forme singulière. Chaperon très court. Labre court, échancré. Antennes allongées, filiformes, plus minces extérieurement; 1 er article plus long que les autres, épais à la base; le second très court; le troisième une fois plus long. Les autres, cylindriques, presque linćaires et graduellement plus courts; le dernier échancré obliquement au sommet. Tête grande, transverse, arec les yeux petits et non saillants. Cou distinct. Corselet peu allongé, carré, un peu aiténué postérieurement. Corps et pattes comme dans les Staphylins. L'auteur rapporte à ce $g$. trois espèces d'Europe, dont deux nouvelles nommées par lui $\boldsymbol{A}$. messor et $\boldsymbol{A}$. falcifer, et la $\boldsymbol{Z}^{\text {e }}$ qui esi le Staphylinus morio des auteurs.

ANOECTANGIUM. Anictangium

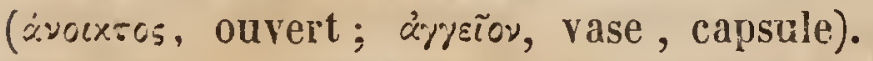
вот. Cr. - Ces deux noms ont été indifiéremment employés pour désigner un genre de Mousses, mais il s'en faut bien que chacun des bryologistes qui s'en sont servi lui ait attribué les mêmes caractères. On trouve, en effet, sous ce nom, dans les auteurs, des Mousses acrocarpes et pleurocarpes, munies ou dépourvues de péristome. Un grand nombre de Gymnostomes, pres- que toutes les apeces du genre Schistidium Brid., une Necière et un Macromitrium, s'y trouvaient réunis, sans rien avoir de cominun que le nom.

Aujourd'hui, on réserve le nom qui fait le sujet de cet article à des Mousses pleurocarpes de la tribu des Hypnées et dont voici les caract. : Péristome nul. Calyptre cuculliforme ou en capuchon. Capsule égale, sans anneau, latérale, munie d'un opercule conique, recourbé en bec. Fleurs dioïques, latérales. Fleur's mâles gemmiformes. Anthères nombreases, accompagnées de beaucoup de paraphyses filiformes, articulées. Pistils aussi très nombreux, dont un seul est fécond. Ce g., étant purement artificiel et se composant de deux tribus distinctes, offre peu de caract. qui soient communs à toutes deux. Dans l'une, à laquelle Bridel conserve le nom d'Anictange, les espèces sont dressées ; dans l'autre, qu'il nomme Erpodium, elles sont rampantes. Les premières sont rapprochées des Hypnées par le port, les secondes des Cryphées par leur capsule presque sessile et leurs feuilles à réseau lâche. Les cinq ou six espèces connues vivent entre les tropiques, soit sur les troncs d'arbres, soit sur la terre. Le g. Hedwigia, établi par Hooker (Musc. exot., t. 46, et 159), est absolument le même que celui-ci. Il ne pouvait être conservé à cause d'un g. homonyme de la Phanérogamie, fondé par Swartz et universellement adopté ; aussi voyons-nous dans l'énumération des g. de cette famille, jointe à l'exposition qu'en fait M. Lindley (A nat. Syst. of Bot.), M. Hooker lui-même y renoncer et adopter le g. Ancectangium. Anyctangie, qu'on trouve dans le Dict. class., est un mot que condamne l'étymologie. (G. M.)

* ANOECTOCHILUS. Chrysobaphus, Wall.; Orchipedum, Kuhl et Hass. ( $\dot{\text { voox }}$ тós, ouvert ; $\gamma \varepsilon \hat{\imath} \lambda{ }^{\circ}$, lèvre ). вот. Pir. - Genre de la famille des Orchidacées, tribu des Néottiées, formé par Blume (Flor. Jav., Prof. VI), avec ces caract. : Périgone ringent; segments extérieurs plus larges, supposés au labelle, et légèrement connés à la base; le supérieur soudé en casque, avec les segments internes, qui sont plus petits et inégaux. Labelle conné avec le gynostème, renflé-ventru à sa base, canaliculé-onguiculé au sommet, à limbe dilaté, semilobé, étalé. Gynosteme court, courbé en 
dessus, atténué-échancré, calleux des deux côtés, bilamellé en avant. Anth. terminale, biloculaire. Pollinies 2 , subbilobées, à caudicules très courtes; glandule commune, oblongue. - Ce g. renferme quelques plantes javanaises caulescentes, radicifères à la base; à feuilles membranacées, nervées; à inflorescence en épis bractéés. $\quad($ C. L. $)$

ANOEGOSANTHUS. Bot. - Voyez ANIGOSANTHUS.

(G. L.)

ANOEMA. MAM. - Nom scientifique donné par Fréd. Cuvier au Cochon d'Inde. VOY. COBAYE.

(G. D'O.)

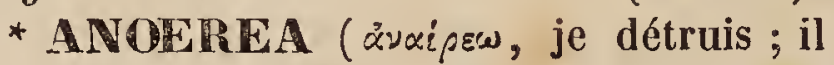
eût fallu écrire Ancerea). Iss. - Genre de Coléoptères tétramères, famille des Longicornes, établi par M. Mulsant, dans son Hist. nat. des Coléopt. de France, p. 184, aux dépens du g. Saperda de Fabricius, pour y placer une seule esp., la $S$. carcharias de ce dernier. Après avoir comparé attentivement les caract. assignés à ce g. par M. Mulsant avec ceux du g. Saperde, nous n'y avons aperçu d'autre différence que celles qui résultent de ce que les élytres de la $S$. carcharias sont terminées par une petite pointe, tandis que celles des autres Saperdes sont obtuses. Ce caract. nous parait bien minime pour constituer un genre. Voy. le g. SAPERDE.

(D.)

* NOGCODES (à priv.; v euph.; $\dot{\gamma} \gamma-$ xádìs, enflé ). Ins. - Genre de Coléoptères hétéromères, famille des Sténélytres, établi par M. Dejean, dans son dernier Catalogue, aux dépens des g. OEdemera d'Olivier, et Dryops de Fabricius. Il y rapporte 11 esp., dont 8 d'Europe, 1 de Sibérie, 1 de Guinée, et 1 de la Perse occidentale. Nous citerons seulement comme type du g. l'Anog. melanura, ou OEdem. $i d$. d'Olivier, qui se trouve en Allemagne, et quelquefois aux environs de Paris. - Ge g., dont M. Dejean n'a pas publié les caract., se distingue principalement des OEdémères par les cuisses postérieures non renflées, et des Dryops et des 4 sclera, genres voisins, par un écusson arrondi et non triangulaire, comme chez ces derniers. Du reste, les Anogcodes ont les élytres assez larges, molles, légèrement convexes, faiblement amincies vers l'extrémité, avec trois côtes longitudinales à peine marquées sur chacune d'elles.

(D.)

*ANOGEISSUS, Wallich, Cat. - Co- nocarpi sect. Leiocarpus et Anogeissus, YG. (Prodr. III, p. 16; Mém. Soc. d'hist.

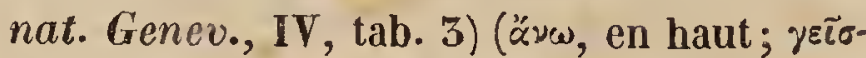

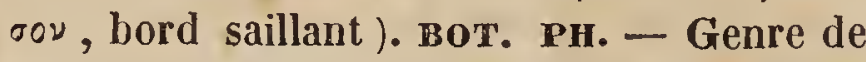
la famille des Combrétacées (tribu des Terminaliées, DC.). M. Guillemin (Flor. Seneg., t. I, p. 279) en a donné les caract. suivants : Tube calicinal à partie adhérente comprimée, diptère ; partie inadhérente prolongée beaucoup au delà de l'ovaire, filiforme, persistante; limbe cyathiforme, 5-denté, non persistant. Corolle nulle. Étamines 10, 2-sériées, saillantes, insérées au limbe calicinal; filets subulés; anthères 2-thèques, cordiformes, longitudinalement déhiscentes. Ovaire infere, 1-loculaire, 2-ovulé ; ovules anatropes, suspendus au sommet de la loge. Style filiforme; stigmate pointu. Fruits comprimés, coriaces, 2-ptères, 1-spermes, mucronés (par la portion persistante du tube calicinal), lâchement imbriqués. Graine ovoïde, suspendue. Embryon rectiligne : cotylédons charnus, convolutés en spirale; radicule supère. - Arbres à feuilles alternes, très entières, non glanduleuses ; fleurs jaunes, 1-bractéolées, agrégées en capitules pédonculés, axillaires. - On en connait 4 esp., dont 1 de la Sénégambie et 5 de l'Inde.

* ANOGLOCHIS ( $\alpha \omega \omega$, en haut; $; \gamma \omega-$ $\chi i_{5}$, pointe). - Mot formé par l'abbé Groizet pour désigner son s.-g. de Cerfs fossiles de l'Amérique, dont le premier andouiller est éloigné de la couronne.

*ANOGRA, Spach (Nouv. Ann. des Sc. nat., t. IV, p. $\mathbf{3 5 9}$ [Anagramme d'Onagra]). - Baumannia, Spach (Hist. des Plantes phan., t. IV, p. 551 , non DG). вот. РH. Genre de la famille des Onagraires (tribu des Onagrées, sect. des F́nothérinées ), établi sur quelques esp. d'AEnothera des auteurs. Il differe des vrais Anothera par des fleurs diurnes, pendantes en préfloraison, à corolle rose; des ovules 1 -sériés dans chaque loge, non imbriqués ; des capsules linéairestétragones; des graines lisses, anguleuses.

(SP.)

* ANOLENES. Anolena ( $\dot{\alpha}$ priv.; o $\lambda \dot{\varepsilon} \sim n$, bras ). TÉRAT. - Ranzani a donné cette épithète aux animaux de la classe des Acéphales qui n'ont pas de bras. (G. D'O.)

* ANOLEPTUS ( $\ddot{\alpha} \nu \omega$, en haut; $\lambda \varepsilon \pi \tau 0^{\circ} s$, étroit; sommet aminci ). BoT. PII. - Ce mot a été appliqué par M. De Candolle à la 
premiere section du g. Sonchus, dans laquelle il comprend deux plantes vivaces, originaires du Cap, dont les capitules sont multiflores, les fruits striés longitudinalement et presque atténués au sommet en une sorte de bec.

ANOLIS. REPT. - Genre de Reptiles, formé par Daudin, et que MM. Duméril et Bibron placent dans leur famille des Lézards iguaniens ou Sauriens cunotes. Cocteau assigne à ce genre les caractères suivants : Tête pyramidale, allongée. Corps épais, légèrement comprimé latéralement. Queue longue, renflée par intervalles, surmontée à sa naissance d'une crête plus ou moins prononcée ; les membres, et les postérieurs surtout, très développés, grêles, ainsi que les doigts, qui sont terminés par des ongles forts et crochus. Bouche grande; langue molle, spongieuse, entière, un peu extensible; dents nombreuses, peu inégales, serrées et aplaties de dehors en dedans : les antérieures simples; les postérieures bicuspides, ou tricuspides, ou dentelées en scie. Plusieurs auteurs prétendent que les Anolis ont des dents simples, coniques, au palais ; d'autres disent qu'ils n'en ont pas ; le fait est que ces dents ne sont pas constantes chez tous les Anolis, preuve que ces Phanères ne peuvent pas avoir, dans l'Histoire des Reptiles, toute l'importance caractéristique que l'on a voulu leur attribuer. Les branches postérieures de l'os hyoïde se prolongent chez ces animaux, fort en arrière, sous le thorax, et le rapprochement de leurs extrémités détermine, dans certaines circonstances physiologiques, une saillie plus ou moins considérable de la peau du gosier, élargie en une sorte de fanon que l'on a appelé improprement goître, et qui a fait donner aux Anolis les noms vulgaires de Goitreux, de Papa-Vento, etc. I.es côtes se réunissent entre elles à la partie inférieure du thorax, à peu près comme chez les Caméléons, avec lesquels les Anolis ont encore d'autres points de ressemblance; les yeux sont saillants, munis de deux paupières à peu près égales; le tympan forme une ouverture ovalaire-libre. La tête est couverte de petites plaques égales, polygones, irrégulières; le corps est revêtu d'écailles petites, égales, uniformes, quadrilatères, lisses, subverticillées, réunies sous le ventre en forme de suture; sur les membres elles prennent une forme rhomboïdale, et deviennent carénées; mais le caractère propre des Anolis est celui qui leur a valu les noms de Lézards larges-doigts ou Dactyloa; la dernière phalange de tous les doigts est grêle, arrondie, tandis que l'avant-dernière est renfléc, élargie en une plaque discoïdale aux quatre doigts extérieurs de chaque pied, garnie au dessous de petites lamelles transversales qui aident ces Sauriens dans l'action de grimper : car les Anolis chassent ordinairement sur les arbres et les buissons, et se nourrissent non seulement d'Insectes, mais encore de fruits et de baies; leur coloration, en général verdâtre, se perd facilement dans la teinte du feuillage sous lequel ils se cachent; cette couleur est aussi, comme celle du Caméléon, sujette à varier brusquement, selon les sensations de l'animal. Les Anolis sont vifs et lestes; ils courent avec promptitude, et sautent avec légè reté d'une branche à l'autre; ils mordent fortement et avec assez d'acharnement la main qui les saisit; mais leur morsure est innocente. Ils s'accouplent et se reproduisent comme la plupart des autres Sauriens. NM. Duméril et Bibron indiquent 25 esp. d'Anolis, qui appartiennent presque toutes à l'Amérique et aux Antilles. (C. D'O.)

ANOMA, Lour. (Flor. Coch. ed.Willd.,

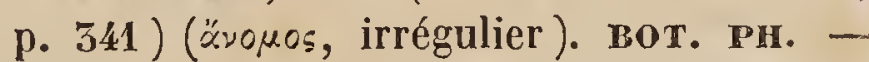
Genre de la famille des Légumineuses (s.ordre des Césalpiniées, tribu des Cassiées, DC.). Établi par Loureiro sur des esp. très hétérogènes, ce g. a été limité à une seule esp., fort incomplètement connue, et à laquelle on assigne pour caract. génériques : Cal. de 5 sépales presque égaux, oblongs, soudés par la base.Pét. 5, presque égaux, oblongs. Étamines 10 , ascendantes, alternativement fertiles et stériles. Légume épais, oblong, 1loculaire, 2-valve, polysperme. - Arbrisseau (indigène de Cochinchine) à feuilles opposées, bipennées; folioles subovales, cotonneuses; fleurs blanches, disposées en panicules.

(Sp.)

ANOMAL. Anomalus ( $\alpha^{2} \nu \omega \mu \times \lambda 0^{\circ} s$, irrégulier ). - Cet adjectif s'emploie, en Histoire naturelle, pour désigner un être qui, par son facies, l'absence ou la présence de certaines parties, s'éloigne des êtres que leurs caractères généraux placent à cô- 
té de lui, et auquel il doit être compars. l ces, principalement l'homme, et les animaux

(C. D'O.) domestiques réparúus comme lui dans des

ANOMAL. Anomalus (áviósuscios, irrégulier ). Bot. - Se dit de tout organe dont. la forme s'éloigne de celle du type général. On dit en général qu'une fleur est anomale quand sa forme n'est pas celle des fleurs qu'on voit le plus ordinairement : par exemple les fleurs des Linaires, des Ancolies, des Aconits, etc.

(G. L.)

* ANOMAL. Anomalis (àv'́usxios, irrégulier). MAM. - Qui est irrégulier ou contraire à l'ordre naturel.

(G. D'O.)

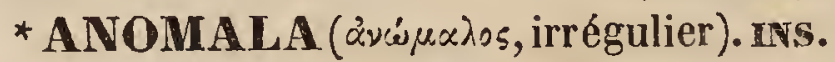
- Genre de Coléoptères pentamères, famille des Lamellicornes, tribu des Scarabéides phyllophages, établi par Mégerle aux dépens du g. Melolontha de Fabricius, et adopté par presque tous les entomologistes. Ses caract., suivant VWestwood, le seul auteur, à ma connaissance, qui les ait publiés (Synopsis of the genera of British Insects ), sont : Antennes de 9 articles. Ongles inégaux. Chaperon non avancé. Corselet large postérieurement. - Ce genre a pour type le Melolontha vitis de Fabricius, auquel sont venues se réunir une foule d'espèces analogues, tant d'Europe que des autres parties du globe. M. Dejean, dans son dernier Catalogue, en mentionne 71. Ce sont des Insectes de moyenne taille pour la plupart; d'un vert métallique très brillant, qui se change en bleu ou couleur de bronze doré dans quelques espèces. Ils se distinguent, à la première vue, des Hannetons par leur forme presque ovoïde, et par leurs pattes, plus courtes et plus trapues. On en trouve une esp. aux environs de Paris : c'est le Melolontha Julii de Fabricius, qui varie tellement, suivant les contrées qu'ii habite, qu'il a reçu neuf noms différents.

(D.)

ANOMALES. Anomalce ( $\alpha \dot{\alpha}, j \mu \alpha \lambda 0_{5}$, irrégulier). BOT. - Tournefort donnait ce nom aux plantes de sa $11^{\mathrm{C}}$ classe, à corolle polypétale, irrégulière : Balsamines, Fumeterres, Delphinelles, etc. (C. L.)

* ANOMALIE. Anomalia ( $x^{2} \nu \omega \mu \alpha \lambda i \alpha$, irrégularité ). вот. - Dénomination qui, en Botanique, s'applique en général à toute déviation des formes ordinaires. (G. L.)

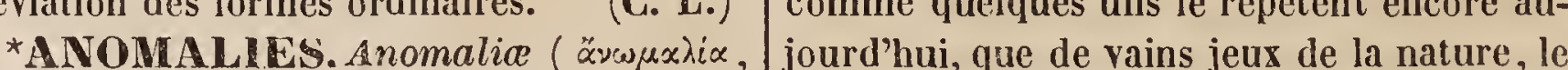
disparité). zooL., TÉR AT.-Toutes les espè- sentiment qu'elles doivent inspirer serait 
celui qu'exprime cette phrase célebre de Pline : Ludibria sibi, miracula nobis ingeniosa fecit natura. L'étude d'un être anomal, son examen anatomique lui-même, ne saurait conduire à d'autres résultats qu'à la constatation des formes plus ou moins bizarres, à la mesure de la distance plus ou moins grande qui les sépare des formes normales et, par suite, à un étonnement stérile et irrationnel. Si, au contraire, les Anomalies, seIon la belle expression de Montaigne, sont contre la coustume seulement, et non contre la nature; si elles ont leurs règles et leurs lois; si même ces règles et ces lois ne diffèrent pas essentiellement des règles et des lois qui régissent les êtres normaux, un lien intime se trouve établi, non seulement entre tous les faits de la Tératologie, mais aussi entre les faits tératologiques et les faits relatifs aux êtres normaux. La Tératologie devient dès lors une science, à l'étude de laquelle s'attache un double intérèt et une double utilité, puisque l'observateur peut s'y proposer un double but : la coordination des faits tératologiques considérés en eux-mêmes; puis l'application de ces faits et des conséquences qui en résultent aux diverses branches des sciences de l'organisation. Tel est le caractère, telle est la portée de la Tératologie, telle que l'ont faite les travaux récents. Et comme la Tératologie, dans les mille et mille faits qui lui appartiennent, embrasse toutes les conditions de l'organisation chez tous les êtres, nous ne craignons pas d'aller trop loin en disant qu'il n'est pas une des lois de l'organisation qui ne puisse si elle est vraie, recevoir de cette branche nouvelle de la science une utile confirmation, et dont la fausseté, dans le cas contraire, ne puisse être par elle mise en lumière.

Dans cet article placé presque au début de ce Dictionnaire, et alors que l'ordre alphabétique nous a permis à peine l'exposition de quelques faits particuliers, nous ne saurions suivre la Tératologie ni dans ses hautes généralités, ni dans les brillantes applications qui déjà en ont été faites ou peuvent l'être à la Physiologie, à l'Anatomie comparée, à la Zoologie. Leur exposition trouvera naturellement sa place dans un article général sur la Tris Tologie (Voy. ce mot), tandis qu'il est indispensable, même pour l'intelligence des articles spéciaux qui

$$
\text { T. } . \text {. }
$$

vont suivre, de placer ici quelques notions préliminaires sur la nomenclature et la classification tératologiques.

En remontant à la définition que nous avons donnée au commencement de cet article, il est évident que les Anomalies, bien qu'elles soient, sous un point de vue général, intimement liées entre elles, doivent être infiniment nombreuses et variées. Elles le sont en efret. Tout écart du type spécifique est une Anomalie, depuis la variété la plus simple, la moins apparente, la plus dénuée d'influence sur l'ensemble des fonctions, jusqu'à la déformation la plus bizarre et la plus hideuse de l'être tout entier, à l'altération qui entraîne comme conséquence la non-viabilité ou la nécessité de vivre dans les conditions les plus exceptionnelles; depuis, par exemple, la plus légère modification dans la couleur, dans la forme, dans la grandeur du corps ou de l'une de ses parties, jusqu'à l'existence de deux, de trois têtes pour. un seul corps, jusqu'à la suppression simultanée de tous les organes réputés les plus essentiels à la vie.

Tous ces états de l'organisation, s'ils ont quelque chose de commun, en tant que con. stituant des faits de déviation du type spécifique, sont manifestement très différents entre eux; et la nécessité de leur division et de leur subdivision en groupes de divers ordres régulièrement subordonnés les uns aux autres n'est pas moins évidente que le lien par lequel les Anomalies sont unies sous le point de vue le plus général. Cette nécessité a cependant plus ou moins complètement échappé à un grand nombre d'auteurs, et tellement, que le mot Monstruosité, malgré ses données étymologiques et l'acception qu'il tient de l'usage, avait fini par devenir, dans la nomenclature tératologique, un synonyme exact du mot Anomalie. On trouve, en effet, jusque dans les ouvrages les plus récents, ces deux termes pris indifféremment l'un pour l'autre, et appliqués également aux déviations les plus légères comme aux plus graves et aux plus complexes.

Frappé des inconvénients d'une telle confusion, et persuadé que, si les mots ne font pas la science, ils aident puissamment à la faire, nous n'avons pas craint de consacrer des recherches assez longues à la réforme de la nomenclature tératologique, en même 
temps qu'à l'établissement d'une classification régulière pour l'ensemble des Anomalies.

Ces recherches nous ont conduit à distinguer les Aumalies en quatre groupes principaux, qu'à l'exemple des zoologistes nous avons appelés embranchements.

Le tableau synoptique suivant les présente dans l'ordre et avec les noms que nous avons adoptés, et donne une première idée de leurs rapports.

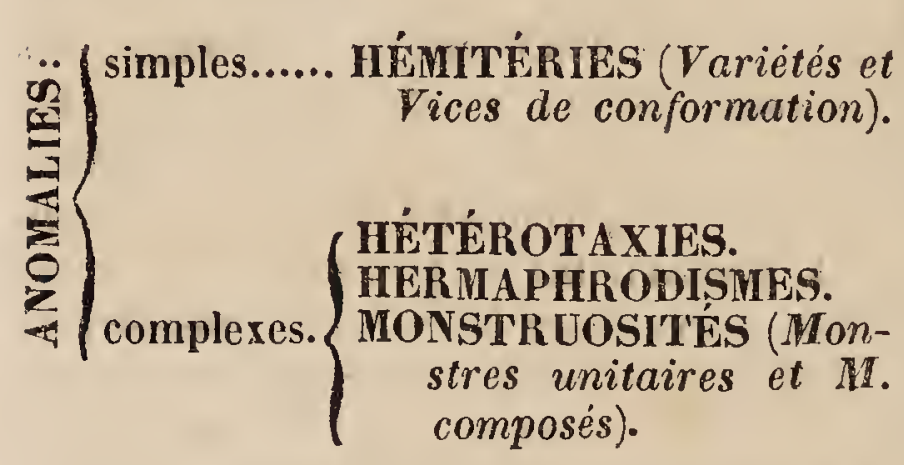

Les HÉMITÉRIES, qui, ainsi qu'on le voit par ce tableau, constituent le premier embranchement, peuvent être définies par leur simplicité même. Toute Anomalie simple, c'est-à-dire portant sur un seul organe, sur un seul système, sur une seule condition organique, est une Hémitérie. Aussi la plupart des Anomalies de ce premier embranchement ne mettent-elles obstacle à l'accomplissement d'aucune des fonctions vitales, et constituent-elles ce qu'on nomme habituellement de simples variétés. S'il en est autrement de quelques autres généralement comprises sous le nom de vices de conformation, c'est par des obstacles apportés en quelque sorte mécaniquement, et sur un point seulement, a l'accomplissement d'une fonction dont l'appareil est d'ailleurs bien développé. Entre ces dernières Hémitéries, plus ou moins nuisibles à l'individu qui les présenté, et les simples variétés, il n'existe d'ailleurs aucune différence organique de quelque importance; les unes et les autres sont également simples, et souvent même ce qui est vice de conformation dans une espèce constitue seulement une variété dans une autre.

Les Hémitéries sont, entre les quatre embranchements tératologiques, le plus vaste, sans nulle comparaison. Il n'est peut-être pas un seul sujet, surtout parmi les esp. placées hors des conditions uniformes de la vie sauvage, qui, examiné attentivement dans tou- tes ses partles, se trouvât exempt de toute Hémitérie. Cet cmbranchement est aussi celui de tous dont l'étude offre le plus d'importance, soit à cause des nombreuses applications pratiques auxquelles elle peut conduire, soit parce que, les autres Anomalies pouvant toutes être considérées comme résultant de l'association de deux ou de plusieurs Hémitéries, la connaissance de celles-ci est en quelque sorte la base sur laquelle repose la Tératologie tout sntière.

Le second embranchement, celui des $\mathbf{H E}$ TÉROTAXIES, est aussi peu nombreux et aussi peu étendu que le précédent est vaste. Il résulte, en effet, de conditions dont la coexistence est nécessairement fort rare, et pourrait même, au premier aspect, être jugée impossible. Les Hétérotaxies diffèrent essentiellement des Hémiléries en ce qu'elles sont complexes; en d'autres termes, en ce qu'elles affectent à la fois un grand nombre d'organes; et cependant, comme les variétés les plus simples, elles ne mettent obstacle à l'accomplissement d'aucune fonction. - Ce sont donc des Anomalies fort remarquables sous le rapport anatomique, et dont cependant l'influence physiologique est presque nulle; ce qui, au premier aspect, semble contradictoire. Le plus souvent même, chez les animaux, et toujours chez l'homme, en raison de la symétrie de ses organes extéricurs, les Hétérotaxies ne modisent pas d'une manière appréciable la forme générale; en sorte que, quelque complexes que soient ces Anomalies, il est parfois bien difficile de les découvrir sans l'aide du scalpel. Sans entrer, sur la nature des Hétérotaxies, dans des détails qui auront naturellement leur place dans un autre article (Voy. hétírotaxiss), il est nécessaire d'indiquer dès à présent par une courte remarque, comment se produit un résultat en apparence si paradoxal. Les Hétérotaxies résultent de la coexistence et de la coordination régulière de plusieurs modifications qui seraient, chacune prise à part, des causes de trouble ou même de mort, mais qui, combinées ensemble, se compensent mutucllement, annulent réciproquement leurs effets fâcheux, ế finissent par reproduire, sous une autre forme el daus un autre sens, toutes les conditions de la vie normale. 
Les deux enibranchements précédents n'avaient encore été ni distingués et déterminés, ni dénommés. Le troisième, celui des HERMAPHRODISMES, était, au contraire, établi à l'avance sous ce nom par les tératologues allemands, qui ont ainsi beaucoup étendu et généralisé le sens du mot Hermaphrodisme. Un Hermaphrodite, dans l'acception usuelle de ce mot, est un être possédant les deux sexes, et pouvant, soit se féconder luimême, soit alternativement féconder et être fecondé. Tel est le sens dans lequel le mot Hermaphrodite, et, de mùme, le mot Hermaphrodisme ou Hermaphroditisme, ont d'abord été cmployés en Tératologie. Les anciens auteurs réservaient le nom d'Hermaphrodite aux individus auxquels ils attribuaient la faculté de remplir tout à la fois les fonctions dévolues aux dcux sexes dans l'actc de la reproduction, ou du moins dans lesquels ils admettaient l'existence simultauée d'organes mâles et d'organes femelles. Mais le sens tératologique des mots $\boldsymbol{H e r -}$ maphrodite et Hermaphrodisme a pris peu à peu plus d'extension; et nous n'avons véritablement fait que donner une expression nouvelle, plus nette et plus concise peut-être, d'un système d'idées et de nomenclature déjà consacré par l'usage, lorsque nous avons défini l'Hermaphrodisme anormal la réunion chez le même individu des deux sexes ou de quelques uns de leurs caractères. Ainsi, tandis que pour les anciens auteurs il n'existait et ne pouvait exister qu'un seul genre d'Hermaphrodisme, l'Hermaphrodisme absolu, nos définitions nouvelles nous font concevoir la possibilité, et prévoir l'existence d'une multitude de genres d'Hermaphrodisme. Entre les deux termes extrêmes des déviations qui existent dans ce groupe; entre la réunion de touies les conditions normales d'un sexe avec un seul des caractères de l'autre, premier degré possible de l'Hermaphrodisme, et la duplicité complexe des sexes, qui en forme le dernier, il peut se trouver, et il se trouve, en effet, une longue série de cas remarquables et variés.

Le rang que nous assignons aux Hermaphrodismes, après les Hémitéries et les Hétérotaxies, et avant les Monstruosités, n'est mullement arbitraire, mais résulte nécessairement de leur degré d'influcnce sur l'orga- nisation et les fonctions des êtres qui en sont affectés. Ainsi, lors de la naissance, l'influence des Hermaphrodismes n'est pas sensible, et son importance physiologique, en particulier, est nulle ou presque nulle, comme celle d'une Variété ou d'une Hétérotaxie. Au contraire, à partir de l'époque de la puberté, les Hermaphrodismes deviennent causes de modifications très notables dans l'ensemble de l'organisation, exercent une infuence manifeste sur plusicurs fonctions, et par là se montrent comparables aux Anomalies les plus graves, c'est-à-dire aut MONSTR UOSITÉS.

Les Hermaphrodismes conduisent ainsi, sous quelques points de vue, à ces dernières, essenticllement caractérisées par leur complication et leur gravité; mot dans lequel se résument tout à la fois l'importance des modifications subies par un plus ou moins grand nombre d'organes chez les Monstres, et l'influence exercée sur leurs fonctions; influence qui est telle, que la vic devient, ou impossible hors du sein maternel, ou possible seulement dans des circonstances et avec des conditions tout exceptionnelles. Telles sont, pour eiter dès à présent quelques excmples, celles que l'on a observées plusieurs fois, et toujours avec un si vifintérêt, chez les êtres doubles, résultant de l'association, de l'union plus ou moins intime de deux sujets ( Voy. Monstres doubles MONOMPUALIENS, SYSOMENS, MONOSO

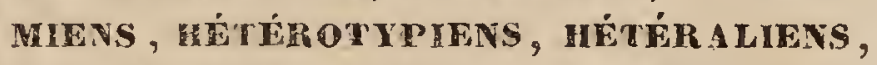
etc.). Telles sont, et plus remarquables encore, celles dont plusieurs exemples ont été ofierts par ces êtres imparfaitement développés, et parfois tout à fait informes, qui, inclus et cachés dans l'abdomen d'un frère jumeau, ont pu y traîner, durant un grand nombre d'années, une existence ignoréc de tous, sans excepter celui qui les portait (Voy. Monstres doubles ENDoCYMIENS).

Telles sont les quatre divisions primaires ou embranchements que nous avons cru devoir admettre parmi les Anomalies. Nous en avons donné en peu de mots la caractéristique, nous réservant de consacrer à chacun d'eux, dans la suite de cet ouvrage, un article spécial, et de résumer, au mot TérA TOLOGLE, les généralités qui sont applicables à l'ensemble des Anomalies.

(Is. G. S. If.) 
* ANOMALIFLORE. Anomalifforus

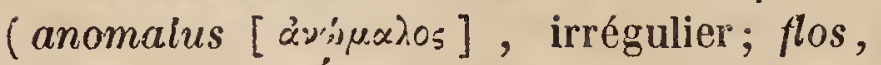
fleur). вor. - Épithète appliquée par Cassini à la calathide, au disque et à la couronne des Synanthérées, quand les corolles de leurs fleurs sont anomales.

(G. L.)

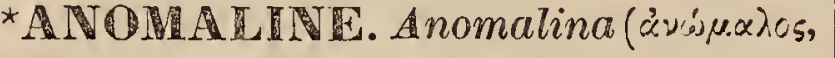
irrégulier, anomal). ForAm. - Genre de Foraminifères, de l'ordre des Hélicostègues, famille des Turbinoïdées, que nous avons créé en 1825, et que nous caractérisons ainsi : Coquille libre, déprimée, rugueuse ou perforée; spire non apparente, entièrement embrassante du côté opposé à l'ouverture. Loges bombées, allongées; ouverture en fente située à la région ombilicale, souvent continue d'une loge à l'autre.

Les Anomalines se distinguent des Rosalines, dont elles ont l'ouverture, par la spire, qui, au lieu d'être trochoïde, élevée, toujours apparente en dessus, est, au contraire, embrassante comme celle des Nautiles.

Nous avons découvert cinq espèces de ce genre, dont trois vivantes, deux de l'Adriatique et une de l'sle de France. Des deux fossiles, l'une est des terrains tertiaires de l'étang de Thau; l'autre, des environs de Bordeaux, où elle est caractéristique.

(A. D'O.)

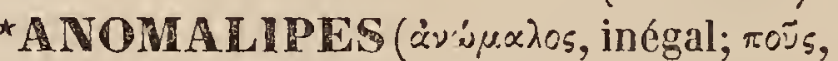
pied). Ivs. - M. Guérin, dans son Iconographie du règne animal de Cuvier, pl. 29, fig. 7 , a représenté sous ce nom, d'après l'indication verbale de Latreille, un $\mathrm{g}$. de Coléoptères hétéromères, famille des Mélasomes, tribu des Blapsides, que ce célébre entomologiste a nommé depuis Heteroscelis. Voy. ce mot pour les caract. du genre.

* ANOMALIPEDES.Anomalipedes ( anomalus, anomal ; pes, pied ). ors. Nom donné par Schœffer, dans sa Méthode ornithologique, à un ordre d'Oiseaux, carac térisés par un doigt postérieur et trois antérieurs, dont l'intermédiaire est uni à l'externe par trois phalanges, et à l'interne par une scule.

(G. B'O.)

ANOMALOCARDE. Anomalocardia.

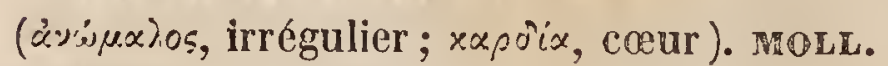
- Klein a proposé ce nom dans son médiocre ouvrage intitulé : Tentamen Methodi Ostracologia. Ce g. rassemble, sans discernement, toutes les Coquilles bivalves qui sont cordiformes. On y trouve des Arches, des Pétoncles, des Bucardes, etc.

M. Schumacher, dans son Essai d'une classification des Coquilles, a emprunté à Klein sa dénomination générique, pour l'appliquer à un genre dont la Venus rugosa est pour lui le type. Cette Venus rugosa ne peut se séparer des autres espèces du même genre; par conséquent, le g. Anomalocardia de $\mathbb{M}$. Schumacher ne peut être conservé. Voy. venus. (DESH.)

ANOMALOECIE. Anomalacia (a.xis$\mu x$.os, irrégulier; oixix, habitation ). ВоT. Dénomination imposée par L.-G. Richard à la 24 e classe (Polygamie) du système linnéen.

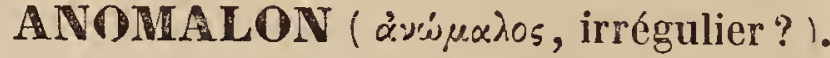
Genre de la famille des Ichneumoniens, de l'ordre des Hyménoptères, établi par Jurine (Nouv. méthode de cl. les Irym.), et adopté par Gravenhorst (Ichneumonol.) comme une simple div. du g. Ophion. Les Anomalon diferent seulement des esp. de la div. des Ophion proprement dits par la seconde cellule cubitale des ailes antérieures, nulle; par les tarses postérieurs, plus épais, et par l'abdomen, comprimé, caréné en dessus, avec un pédicule long et grêle. Cette division générique comprend un certain nombre d'espèces indigènes, dont les plus répandues sont les Ophion (Anomalon) circumflexum Lin., Amictum Fabr., etc.

* ANOMALOPEDES. Anomalopedes (anomalus, anomal; pes, pied). MAM. Klein a désigné sous ce nom une famille comprenant les Mammifères qui ont les cinq doigts réunis par une membrane.

(C. D'O.)

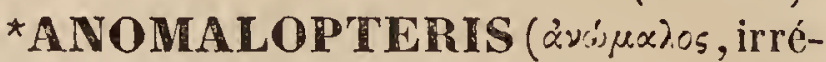
gulier; $\pi \tau \varepsilon \rho 0^{\circ}$, , aile). Bot. PH. — Synonyme d'Acridocarpus, de la famille des Malpighiacées.

(J. D.)

*ANOMALOPTERIS ( $\dot{x} \nu \cdot \dot{j} \mu x \lambda \circ$, ano-

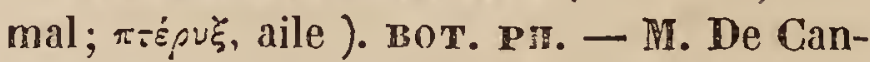
dolle avait, sous ce nom, proposé dans le g. HEeteropteris une section qui lui paraissait pouvoir être elle-même un jour élevée au rang de genre. MH. G. Don l'a établi plus tard en lui conservant le nom proposé; mais il l'étair déjà dans la Flore de Sénégambie sous celui d'Acridocarpus. Voy. ce mot.

(AD. JUGS.) 
ANOMALUS. вот. - Voyez ANoMAL.

(C. L.)

ANOMATHECA. вот. - Voyez AnoMOTHECA.

(C. L.)

ANOMAUX.Anomala ( $\dot{\alpha}$ priv.; $\nu$ euph.; ouxhós, égal ). CRust. - Section de la grande famille des Décapodes macroures établie par Latreille et comprenant les Hippides et les Paguriens, c'est-à-dire les Macroures, dont les deux ou les quatre derniers pieds sont beaucoup plus petits que les précédents, dout l'abdomen n'offre jamais en dessous plus de quatre paires de fausses pattes; et dont les pièces latérales de la nageoire caudale sont rejetées de côté et ne forment pas avec le dernier segment une nageoire en éventail. (Voy. Règne animal de Cuvier, t. IV, p. 73.)

(II. E.)

ANOMAZA, Laws. (? º opos, irrégulier; $\propto$ ¿ $\alpha$, couleur de brûlé ). вот. PH. Genre de la famille des Iridacées, synon. du g. ANovathega.

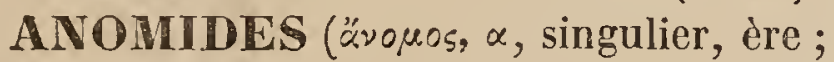
iờ $\alpha$, forme ). INs. - MI. Duméril ( Consid. génér. sur les Ins.) emploie cette dénomination comme nom de famille pour désigner les Mantes et les Phasmes ou Spectres. Voy. mantiens et Phasmuens.

(BL.)

ANOMIE. Anomia (contraction d'ày-

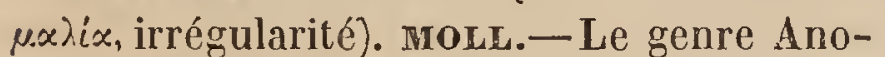
mie a été créé par Linné dans la $10^{\circ}$ édition du Systema Naturae : il y rapporta non seulement les Coquilles qui conservent encore ce nom, mais aussi des Térébratules et une espèce $\mathrm{d} \boldsymbol{\jmath} \mathrm{g}$. IIyale appartenant aux Ptéropodes. Cette conclusion se maintint dans la douzième édition du même ouvrage, et fut conservée par tous les imitateurs de Linné. Müller nous semble être le premier qui, dans son Prodromus Zoologice danicce, détacha des Anomies le g. Térébratu$l e$, que Bruguière adopta plus tard dans l'Encyclopédie, et que presque tous les historiens lui attribuent. Ce g. n'était pas le seul qui méritât d'être séparé. Cheinnitz, dans son grand ouvrage de Conchyliologie, avait indiqué nettement un g. fort naturel, auquel Bruguière imposa Ie nom de Crania pour conserver le souvenir de l'Anomia craniolaris de Linné, présentée comme type de ce nouveau g. Forskal, dans sa Fauna arabica, avait, par de très bonnes observations, préparé les moyens de détacher en- core des Anomíes de Linné l'Anomia tridentata, qui est devenue pour Lamarck le type de son g. Hyale. Ces démembrements successifs réduisirent sans doute de beaucoup le g. Linnéen; mais ils eurent l'avantage de le rendre parfaitement naturel, en le laissant en contact avec des espèces qui ont entre elles la plus grande analogie. Vivant en abondance sur nos côtes et dans la Méditerranée, les animaux ne furent cependant connus que depuis le grand ouvrage de Poli sur les Testacés des Deux-Siciles. Malgré les soins que prit cet habile anatomiste, il lui échappa plusieurs faits intéressants sur l'organisation du genre Anomie. Cuvier, entre autres, découvrit un pied rudimentaire qui avait échnappé aux investigations du naturaliste napolitain; mais il restait encore plusieurs découvertes à faire dans l'organisation de ce genre, et nous-même y avons ajouté plusieurs observations tendant à en assurer les rapports d'une manière définitive.

Tous les auteurs systématiques, sans exception, ont rangé les Anomies dans la famille des Ostracées; cependant, si l'on eût fait attention à ce caractère si singulier du nombre des muscles dans les Anomies, on aurait peut-être balancé à les comprendre dans la famille des Huitres. En effet, les Huîtres sont monomyaires, tandis qu'on trouve constamment trois muscles dans les Anomies. Si l'on eût également comparé avec soin l'organisation des animaux telle qu'elle a été donnée par Poli, on se serait bientôt aperçu que les deux g. dont nous parlons sont extrêmement différents ; aussi Poli a-t-il eu le soin de ne pas les réunir. L'animal des Anomies est irrégulier, enveloppé dans les lobes inégaux d'un manteau très mince, dont les bords, entièrement séparés, sont garnis, dans tout leur pourtour, d'une branche tentaculaire; la bouche, placée à la partie supérieure et vers le bord dorsal, est dégarnie de palpes labiales; au dessus d'elle se trouve un pied rudimentaire, et la masse viscérale, assez considérable, est principalement formée des organes de la digestion, enveloppés dans un foie assez considérable et pénétrant dans une petite étendue d'un ovaire peu volumineux; sur les parties latérales et inférieures de cette masse viscérale, sont attachés les feuillets bran- 
chiaux inégaux, qui, par leur organisation, ont quelque ressemblance avec les bras ciliés des Mollusques brachiopodes. - Le nanteau, dans ce genre, offre une particularité assez remarquable qui ne se présente dans aucun autre Mollusque lamellibranche : c'est que l'ovaire se décharge entre les deux membranes dont le manteau est formé, et les oufs finissent par s'y accumuler en quantité considérable avant d'être rejetés au dehors. Cette disposition de l'ovaire ressemble beaucoup à ce que l'on observe dans les Térébratules. On trouve constamment trois muscles dans les Anomies; deux de ces muscles viennent s'insérer sur l'osselet qui sert de point d'appui à l'animal et qui passe à travers la valve perfo rée; l'autre représente le muscle adducteur central des Mollusques monomyaires. Les coquilles du g. Anomie sont fort irrégulières; elles sont très inéquivalves, presque toujours orbiculaires et aplaties. Se fixant aux corps sous-marins, elles en prennent, pour ainsi dire, l'empreinte et en conservent la forme et les accidents. La valve inférieure, qui est en contact immédiat avec les corps servant de point d'appui, est presque toujours la plus petite; elle est toujours concave en dehors, et convexe en dedans; son sommet est toujours percé, et son bord supérieur se détache au dessus de la perforation sous la forme d'une apophyse plus ou moins grosse, à sommet tronqué, et sur laquelle le ligament vient s'insérer. La valve supérieure est convexe; son lord supérieur est presque toujours rentré en dedans, de manière à dominer la cavité du crochet; c'est immédiatement au dessous de ce bord que se remarque une cavité transyerse peu profonde à laquelle correspond l'apophyse articulaire de la valve opposcee, et qui est destinée à recevoir le ligament. Si l'on examine l'intérieur de cette valve, on aperçoit au centre un espace ovalaire circonscrit par une légère impression. C'est sur cette portion centrale que l'on distingue très nettement trois impressions musculaires inégales, et dont la position varie selon les espèces. Si l'on examine le même espace dans la valve opposée, on y trouve la perforation dont nous avons parlé, et, au dessous d'elle, une seule impression musculaire. Lnfin, si l'on examine l'animal encore attaché au corps sur lequel il a vécu, on voit qu'il a fixé sur ce corps un osselet fort saillant, qui passe au travers de l'ouverture de la valve inférieure, pénètre dans l'épaisseur de l'animal, et donne insertion aux fibres de deux muscles, qui viennent l'embrasser dans toutes ses parties. Jusqu'à présent ce mode d'adhérence est sans autre exemple chez les Mollusques. D'après ce que nous venons de dire, les caract. génériques du g. Anomie doivent être exposés de la manière suivante : Animal aplati, orbiculaire, irrégulier; les lobes $d u$ manteau frangés et désunis dans toute leur circonférence. Une paire de feuillets branchiaux de chaque côté; une bouche dégarnie de palpes latéraux. Un pied rudimentaire. Trois muscles, dont un adducteur, les deux autres s'insérant sur un osselet suspenseur. L'ovaire se déchargeant entre les feuillets du lobe droit du manteau. Coquille irrégulière, inéquivalve, orbiculaire, ayant la petite valye percée au sommet. Charnière simple; ligament placé dans une cavité de la valve supérieure à laquelle correspond une apophyse de la valve opposée.

Si nous prenons maintenant chacun des caractères essentiels des Anomies pour les comparer arec ceux des genres qui paraissent les plas voisins, nous verrons que : $1^{\circ}$ les Huîtres n'ont aucune trace de pied; les Anomies en ont un rudiment; $2^{\circ}$ dans les Huîtres, la bouche est toujours garnie de quatre palpes labiaux; dans les Anomies, ces appendices $n^{\prime}$ existent jamais; $\mathbf{z}^{\circ}$ il est sans exemple jusqu'à présent, dans les Lamellibranches, que l'ovaire se décharge dans l'épaisseur du manteau; dans les Anomies, au contraire, les œufs s'accumulent en quantité innombrable entre les parois de cet organe.

Enfin, nous ajouterons que les branchies des Anomies n'ont pas une organisation semblable à celles des autres Lamellibranches. Cette comparaison, plus complète qu'on ne l'avait faite jusqu'à présent entre les Anomies et les g. circonvoisins, nous fait sentir la nécessité de séparer ce g. de la famille des Ostracées pour le rapprocher du groupe des Brachiopodes. On verra, en effet, à l'article qui concerne ces animaux, que leur organisation a beaucoup de rapport avec celle des Anomies, et que le g. dont 
nous traitons ici est réellement intermédiaire entre les Lamellibranches et les Brachiopodes. Une analogie à laquelle on n'a pas fait assez attention, c'est que, selon nous, la petite valve des Anomies représente la valve perforée des 'Térébratules, et que l'ossclet qui passe à travers représente le ligament suspenseur de ceux des Brachiopodes qui en ont un.

On connaît actuellement un assez grand nombre d'espèces dans le genre Anomie, et il est à présumer que, dans la nature, il y en a bien davantage; ce g. offrant généralement peu d'intérêt aux voyageurs, qui pensent retrouver partout les espèces qu'ils voient sur nos côtes. M. Sowerby, dans son Genera of shells, a établi sous le nom de Placunanomia un g. très voisin de celui-ci, et qui démontre les rapports qui existent entre les Anomies et les Placunes. On a rapporté aux Placunes fossiles une grande Goquille qui ne s'est rencontrée jusqu'à présent qu'en Égypte. Cette Coquille, pour la forme extérieure, a en efiet les plus grands rapports avec les Placunes; mais elle a la charnière des Anomies; elle appartient au g. Placunanomia de M. Sowerby. On connaît un assez grand nombre d'espèces fossiles appartenant au g. Anomie; presque toutes se distribuent dans les terrains tertiaires; on en rencontre cependant quelques unes dans les terrains crétacés inférieurs, et nous en avons trouvé une très intéressante dans le Corall-Rag des environs de CommercY.

(DESH.)

ANOMIOPSIS ( 2 vópocos, dissemblable; ¿ł (s, figure). Irs. - Genre de Coléoptères pentamères, famille des Lamellicornes, tribu des Coprophages, établi par M. Westwood, qui lui donne pour caract. : Pattes Inngues; tibias intermédiaires courbés et armés de deux éperons mobiles : l'interne long et aigu, l'externe court et spatuliforme. Tarses des pattes antérieures obsolètes ; ceux des quatre autres déprimés, poilus et dépourvus d'ongles. Palpes maxillaires fliformes; lcurs trois derniers articles presque d'égale longueur. Palpes labiaux difformes; leur second article très grand, transverse, ovale ; le dernier très petit, inséré obliquement sur le précédent, du côté interne. Ce g. est voisin des Pachysoma, et vient après les Scéliag ss. M. Westwood y rapporte deux espèces nommées par lui, l'une A. dioscorides, et l'autre A. sterquilinus, sans indication de patrie, et comme faisant partic du cabinet de M. Walker. Toutes deux sont décrites dans le $2^{\text {e }}$ vol. des Transactions de la Société zoologigue de Londres, p. 159162 , et la seconde y est figurée pl. 29, fig. 5 .

ANOMITES (augmentat. d'Anomia,

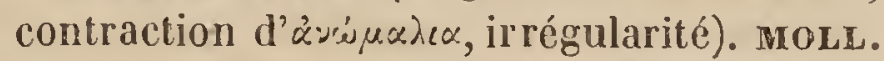
- On donnait autrefois le nom d'Anomites aux esp. fossiles du g. Anomie, et ce nom s'appliquait particulièrement aux 'Térébratules. Les zoologistes, qui séparaient presque toujours leurs travaux de ceux des oryctographes, avaient laissé introduire dans la nomenclature la terminaison en ite pour les esp. fossiles de genres connus vivants. Cette habitude est tombée en désuétude, et on a presque oublié ces g. Anomite, Bucardite, etc., qui surchargeaient, inutilement les classifications. Voy. ANOMIE.

(DESH.)

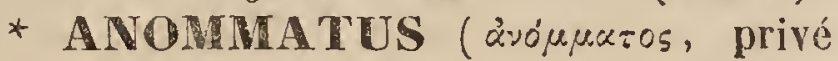
d'yeux ). INs. - Genre de Coléoptères pentamères, famille des Engides de Mac-Leay, établi par Wesmael et adopté par Westwood (Synops. of the gen. of British Insects), qui lui assigne pour seuls caract. : Côtés du corselet quelque peu dilatés. Yeux entièrement oblitérés. - Ce g. ne renferme qu'une esp., le Zyctus obsoletus de Spence, ou An. terricola de Wesmael, qui se tronve en Angleterre.

* ANOMOCEPHALE. Anomocepha-

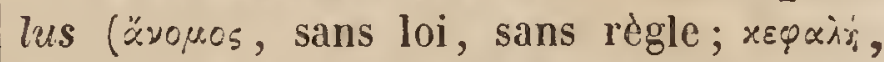
tête). TrRAT. - M. Geoffroy-Saint-Hilaire désigne sous ce nom générique tous les Animaux dont la tête ofre accidentellement quelque difformité. (G. D’O.)

ANOMODON ("丷opos, contraire aux règles, anomal ; òovs, dent). (Mousses.) Bot. GR. - MIN. Hooker et Taylor ont établi ce g. (Muscol. Brit., 1re éd. 1818) sur deux esp. qu'ils ont retirées des Neckères, parmi lesquelles elles étaient confondues. Bridel, ayant cru remarquer que l'une de ces Mousses n'offrait pas le caractère essentiel sur lcquel les bryologistes anglais avaient fondé leur nouveau genre, en changea le nom par ce seul motif, et imposa à l'espèce unique qui restait alors, celui d'Antitrichia curtipendula; mais, s'il était permis de changer ainsi à volonté la nomenclature sur d'aussì 
légères considérations, on ne pourrait jamais compter sur rien de stable. Le nom donné à ce genre par MM. Hooker et Taylor, ayant la priorité, doit être conservé. Voici les caractères qui lui sont assignés : Péristome double : l'extérieur composé de 16 dents linéaires, lancéolées; l'intérieur d'autant de cils fugaces, nés au côté interne et à la base des dents. Ces deux péristomes, naissant de la même membrane, sont sur le même plan et ont bien plus d'analogie avec le péristome interne des Hypnées. Coiffe cuculliforme ou en capuchon. Capsule droite, égale, sans anneau.

Les deux esp. qui composaient d'abord ce g. se sont successivement accrues de plusieurs autres, prises parmi les Neckera ou les Pterigynandrum. MM. Balsamo et De Notaris (Prodr. Bryol. mediol., p. 52) y ont réuni le Neckera cladorrhizans Hedw., et M. Hübener (Musc. germ., p. 557-559) les Pterigynandrum repens Brid., et striatum Savi. Nous voyons que M. Hooker y rattache encore des esp. d'Isothecium Brid.

Toutes ces Mousses font partie de la tribu des Hypnées, et ont conséquemment le pédoncule latéral. Quelques espèces sont propres à nos climats; plusieurs communes à l'Europe et à l'Amérique septentrionale. Elles vivent sur les arbres et les rochers.

(C. M.)

* ANOMOEUS (ávóuocos, dissemblable). Irs. - Genre de Coléoptères pentamères, famille des Carabiques, tribu des Troncatipennes, établi par M. Fischer de Waldheim Entomographie de la Russie, vol. I, p. 127, 128 ), et qui tient le milieu, suivant lui, entre les genres Cymindis et Zuphium de Latr. Voici les caract. qu'il lui assigne : Lèvre supérieure prolongée, subcarrée, ciliée, séparée du chaperon par un sillon. Mandibules arquées, très aiguës, tridentées à la base. Mâchoires à crochet pointu, ciliées intérieurement; tous les articles des palpes libres. Lève inférieure débordant les lobes latéraux du menton, soutenant le premier article des palpes dans toute sa longueur. Nenton très échancré, à dent intermédiaire courte, et lobes latéraux arrondis. M. Fischer rapporte à ce g. trois espèces que M. Dejean place dans le g. Cymindis : ce sont les $\boldsymbol{A}$. cruciatus, lateralis et dorsalis, toutes trois de la Russie méridionale. Les deux premic̀- res sont figurées dans l'onvrage précité ( pl. 12, fig. 1 et 2 ).

* ANOMOIA (ávónocos, dissemblablé). INS. - Genre de Coléoptères tétramères, famille des Chrysomélines, établi par M. Chevrolat, qui l'a nommé ainsi à cause de la dissemblance que présentent les deux sexes. Non seulement ils diffèrent par la couleur, qui est ordinairement d'un jaune pâle dans les mâles, tandis qu'elle est noire ou rougeâtre dans les femelles; majs encore par les pattes antérieures, beaucoup plus longues chez les premiers que chez les secondes. Du reste, les caractères de ce $\mathrm{g}$. sont : Chaperon à $\mathbf{z}$ échancrures anguleuses (c'est le plus saillant). Tête rugueuse, à front lisse et convexe. Palpes maxillaires, modérément allongés et épais; dernier article aminci et pointu. Antennes de 12 articles, 2-3 noduleux, 4-10 fortement dentés et anguleux du côté externe; le dernier excessivement petit. Tarses longs; leurs 3 articles étroitement bilobés. M. Dejean, qui a adopté le genre Anomoia dans son dernier Catalogue, y rapporte trois esp., dont une de l'Amérique du nord, une du Mexique, et la troisième de la Colombie. - Nous citerons pour type la Clythra obsita de Fabricius, Ephippium, Germ.

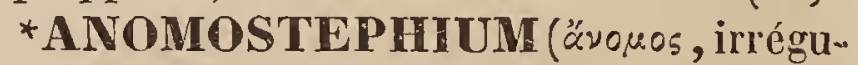
lier; rs乏́pos, couronne). BoT. PH. - Genre de la famille des Composées-Sénécionidées, division des Rudbeckiées, formé par M. De Candolle (Prod., t. V, p. 560 ), et ainsi caractérisé : Capitule multiflore, hétérogame; fleurs du rayon uni-sériées, ligulées, neutres; celles du disque tubuleuses, hermaphrodites. Squammes extérieures de l'involucre campanulé, ovales, foliacées; les intérieures oblongues, membraneuses, plus étroites, égales. Réceptacle plan, à paléoles membranacées, arrondies, enveloppant les akènes. Tube des corolles radiaires grêle, allongé, à ligule ovale; tube de celles du disque à gorge étroite, longue et campanulée. Anthères exsertes; stigmates pubérulés, obtus au rayon, surmontés d'un cône très aigu au disque. Akènes du rayon subtétragones-allongés, glabres; ceux du disque courtement bicornes, couverts de poils couchés, et couronnés d'une aigrette irrégulière. - Les Anomostephium sont des herbes brésiliennes et caraibes, sufiruti- 
queuses à la base; à tiges presque simples, dressées, hispides; à feuilles opposées, sessiles, couvertes de poils rudes; à inflorescence en capitules terminaux, dont les corolles sont jaunes et les anthères noirâtres.

(C. L.)

*ANOMOTHECA. Anomaza, Lows.

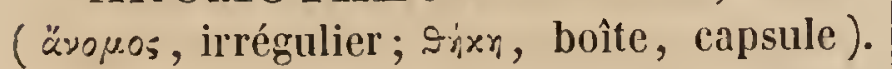
вот. Pн. - Genre de la famille des Iridacées, formé par Kier (Gen. Irid. in Ann. of Bot., t. 1, p. 217), et ainsi caractérisé : Périgone corollacé supère, hypocratériforme; tube filiforme, triquètre, resserré à la gorge; lacinies du limbe sexpartites, oblongues, cunéiformes, étalées; les 3 postérieures rapprochées. Étam. 5, insérées à la gorge du périgone et presque unilatérales; filaments courts, filiformes; anth. oblongues, basifixes. Ovaire infère, ovale-subglobuleux, $\tilde{z}$-loculaire. Ovules nombreux, horizontaux, anatropes, bisériés dans l'angle central des loges. Style filiforme; stigm. $\tilde{\mathbf{s}}$, étroitement linéaires, bifides, repliés. Capsule ovalesubglobuleuse, hérissée de papilles, triloculaire, loculicide-trivalve au sommet. Graines nombreuses, subglobuleuses.... - Ce genre, dont le Gladiolus junceus est le type, renferme quelques plantes herbacées du Cap, à rhizôme bulbeux-tubéreux; à feuilles ı éniformes, bifariées; à scape cylindrique, subjunciforme, portant des fleurs nombreuses, disposées en un épi paniculé, subunilatéral, garni d'une spathe herbacée, courte, diphylle.

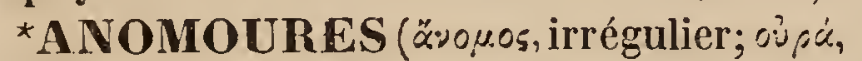
queue). CRUST. - S.-ordre de Crustacés décapodes, proposé par Milne-Edwards, et intermédiaire entre la section des Brachyures et celle des Macroures. Ce groupe nouveau n'est pas aussi naturel que ceux des Brachyares et des Macroures; mais son établissement permet de retirer de ces derniers les espèces hétérogènes qui jusque alors y étaient rangées, et rend de la sorte ces deux grandes divisions parfaitement naturelles. De même que cela arrive dans tous les points de transition par lesquels la nature passe d'un type principal à un autre, on remarque dans l'organisation des Décapodes, réunis sous le nom d'Anomoures, des anomalies nombreuses et importantes; les uns se rapprochent beaucoup des véritables Brachyures, tandis que d'autres ne diffèrent que peu T. 1. des Macroures proprement dits; et tous les caractères les plus importants qui les distinguent des uns et des autres peuvent manquer tour à tour; mais néanmoins l'ensemble des particularités de structure qui s'y remarque toujours ne peut laisser de doute sur les limites de cette division.

La portion céphalo-thoracique du corps des Anomoures est toujours beaucoup plus développée que la portion abdominale, et celle-ci n'est jamais conformée de manière à remplir, dans la locomotion, le rôle important qui lui est dévolu chez les Macroures. La forme générale de la carapace se rapproche presque toujours de la forme propre aux Brachyu. res, mais quelquefois cette partie s'allonge davantage. Le front ne donne que rarement naissance à un prolongement dont l'union avec la portion inférieure de l'anneau antennulaire masque l'anneau ophthalmique comme chez les Brachyures, et il n'existe presque jamais de fossettes antennaires et d'orbites distinctes, mode d'organisation qui se retrouve dans toutes les divisions des $\mathrm{Ma}$ croures. En général, les antennes internes sont grandes et ne peuvent se reployer sous le front; les pattes-mâchoires externes sont ordinairement allongées et subpédiformes. La disposition du thorax mérite aussi d'être signalée; en général, le dernier segment de cette portion du corps ne se soude pas aux segments précédents et en est séparé par une membrane articulaire ; quelquefois même il n'est pas recouvert par la carapace, et constitue un anneau complet. Quanc au plastron sternal, sa conformation varie beaucoup : tantôt il est linéaire dans toute sa longueur, comme chez la plupart des Macroures; tantôt linéaire entre les pattes des trois dernières paires ou entre celles de la première paire, et élargi dans le reste de son étendue; tantôt enfin élargi dans toute sa longueur, comme chez les Brachyures; mais alors on n'y voit pas de suture longitudinale indiquant la présence d'un apodème médian; et, en effet, cette lame verticale manque alors complètement, tandis que chez les Brachyures elle existe toujours. Les pattes des trois ou quatre premières paires sont grandes et conformées d'ordinaire à peu près comme chez les Brachyures; mais presque toujours celles de la cinquième paire ou même celles des deux dernières paires ne ser- 
vent plus à la locomotion, et sont rudimentaires et transformées en organes de préhension, ou du moins se trouvent refoulées, en quelque sorte, au dessus des précédentes. La disposition de l'abdomen varie aussi ; presque toujours il est mince et lamelleux, à peu près comme chez les Brachyures, et il ne porte jamais au dessous une double série de fausses pattes réellement natatoires; mais ordinairement on trouve fixée à son pénultième segment une paire d'appendices plus ou moins développés. Quelquefois ces appendices disparaissent presque complètement par les progrès de l'âge, et d'autres fois ils forment avec le septième segment une espèce de nageoire caudale; mais il est bien rare que cette nageoire soit disposée en évertail comme chez les Macroures. Enfin, chez plusieurs Anomoures, l'abdomen reste toujours membraneux dans une grande partie de son étendue.

A ces caractères, tirés de la conformation extérieure des Anomoures, se joignent d'autres particularités de structure encore plus importantes, qui nous sont offertes par la plupart des grands appareils de l'économie.

Ainsi chez ces Crustâcés l'appareil femelle manque de la poche copulatrice qui existe chez tous les Brachyures, et les vulves, au lieu d'occuper le plastron sternal, sont percées dans l'article basilaire des pattes de la troisième paire. Les branchies sont toujours lamelleuses comme chez les Brachyures; mais en général ces organes sont plus nombreux et se fixent sur le pénultième anneau thoracique, aussi bien que sur les segments précédents, dispositions qui ne se rencontrent pas chez les Brachyures; il est aussi à noter que souvent ils sont fixés sur plusieurs rangs et par faisceaux, comme chez Ies Macroures. Enfin la disposition du système nerveux paraît tenir, en quelque sorte, le milieu entre ce qui se voit chez les Brachyures et les Macroures.

Cette section de l'ordre des Décapodes se divise naturellement en deux familles, savoir :

10 Les Aptérures, Edw., comprenant les Dromiens, Ies Homolien's, les Raniniens et les Pactoles;

20 Les Ptérygures, comprenant les Porcellaniens, les Hippiens et les Paguriens.

(M. E.)
ANON. Ma. - Petit de l'Ane. Voy. ce mot.

(C.D'O.)

ANONACEES, ou ANONÉES. Anones, Anonacex, Anonece. ROT. Pr. - Famille de plantes dicotylédones, polypétales, à insertion hypogynique. Les caractères en solt : Calice à quatre ou plus souvent trois parties, ordinairement soudées ensemble ; six pétales sur deux rangs, coriaces, à préfloraison valvaire, très rarement soudés entre eux. Étamines en nombre indéfini, à peu d'exceptions près, insérées sur un large disque hypogynique, serrées les unes contre les autres, mais libres, terminées par un grand connectif quadrangulaire, qui porte en dehors les deux loges de l'anthère adnée. Ovaires nombreux, en nombre défini ou le plus ordinairement indéfini, soudés entre eux ou libres et serrés, chacun avec un síyle court et un stigmate simple, et renfermant des ovules solitaires ou en très petit nombre, dressés ou ascendants. Le fruit esî composé d'autant de carpelles charnus ou secs, sessiles ou pédonculés, libres ou soudés, contenant une graine unique ou plisieurs sùr un ou deux rangs. Ces graines, quelquefois munies d'un arille, sont remarquables par leur périsperme dur, charnu et runciné, revêtu d'un test lisse, et contenant un très petit embryon dans une petite cavité correspondant au point d'attache.

Les Anonacées sont des arbres ou arbrisseaux des parties tropicales de l'ancien et du nouveau monde, et qui ne s'en éloignent que peu et rarement. Leurs feuilles sont alternes, simples, presque toujours entières, dépourvues de stipules. Leurs fleurs, de couleur ordinairement verte ou brunâtre, sont solitaires ou groupées en très petit nombre à l'aisselle des feuilles plus longues qu'elles; quelques unes avortent quelquefois, et leurs pédoncules s'endurcissent, s'agrandissent et se courbent. En général, toutes les parlies sont fortement aromatiques au goût et à l'odorat.

Genres : Anona, L. - Rollinia, SaintHilaire. - Lobocarpus, Wight et Arn. Monodora, Dunal. - Uvaria, L. - Mitraphora, Blum.-Unona, L. - Artabotrys, R. Br. - Habzelia, Alph. DG. - Calocline, Alph. DG. - Xylopia, L. - Anaxagorea, St.-Hil.-Hexalobus, Alph. DC.Miliusa, Alph. DC. - Orophea, Blum. - 
Bocagea, St.-Hil. - Trigyncea, Sihlecht. d'Anonica. - Ce g. du zoologiste allemand, - Polyalthia, Blum. - Duguetia, St.- étant évidemment un double emploi de Iiil. - Guatteria, Ruiz Pav. - Hentschelia, Presl. - Hyalostemma, Wall.

Outre ces g., M. R. Brown en a fait connaìtre un anomal, originaire de la Nouvellc-Hollande, et qu'il a nommé Eupomatia. Ses ovaires adhérents et ses étamines périgynes semblent l'exclure de la classe, quoi¿u'il se rapporte à la famille. (AD.J.)

ANONE ou COROSOL. Anona, L., Alans. (nom vernaculaire), вот. PI.-Genre type de la famille des Anonacées, et dont les caract. distinctifs sont : Calice 5-parti ou $\mathbf{5}$ lobé, non persistant. Pétales 6 , coriaces, distincts : les externes plus grands que les internes. Étamines nombreuses, linéaires-claviformes, à appendice-apicilaire large, tronqué, anguleux. Gynophore conique. Ovaires nombreux, soudés, renfermant chacun un ovule solitaire, renversé, attaché au fond de la loge. Styles (quelquefois nuls) distincts ou soudés. Stigmates (quelquefois sessiles ) capitellés ou continus avec les styles. Syncarpe écailleux, ou muriqué, ou tuberculcux, ou lisse, subcoriace à la surface, pulpeux en dedans, pluriloculaire, polysperme. Graines ovoïdes ou elliptiques; radicule infère. - Arbres, ou arbrisseaux, ou sousarbrisscaux. Pubescence simple ou étoilée, en général roussâtre ou ferrugineuse. Pédoncules axillaires, ou extra-axillaires, ou oppositifoliés, 1- ou pauci-flores, ordinairement solitaires, en général bractéolés à la base. - Ce g., propre à la zone équatoriale, comprend environ $40 \mathrm{csp}$., dont plusieurs sont renommées pour la bonté de leurs fruits, et, par cette raison, fréquemment cultivées dans les climats intertropicaux ou subtropicaux. De ce nombre sont notamment:I'A. squamosa L. (vulgairement Cœur de bœuf, Pommier de cannelle, Attier ou Atocire), l'A.Cherimolia Lamk. (vulgairement Chérimolier), I'A. reticulata L., connue sous le nom vulgaire de Cachiman; enfin l'A. muricata L., ou Cachiman épineux. G'est le fruit de cette espèce qui est le plus estimé parmi ceux du genre.

(SP.)

ANONEES. вот. - Voyez A voviCrEs.

ANONICA. mous. - Ignorant sans doute l'existence du g. Avicule de Lamarck, H. Oken l'a de nouveau créé sous le nom celui de Lamarck, a ćté depuis long-temps abandonné. Voy. A vicule.

(DESH.)

ANONYMOS ( $\alpha$ priv.; v euph.; övoux, nom ; sans nom). Bor. Pr. - Walter avait désigné sous ce nom des plantes de la Caroline, qui font aujourd'hui partie des Liatris. La plupart d'entre elles appartiennent à la seconde section établie dans ce g. par M. De Candolle sous le nom de Suprago. Ce sont des herbes vivaces, à racines tubéreuses, à tiges simples, et dont les capitules sont disposés en épis ou en grappes. L'aigrette qui surmonte les fruits est formée de 1-3 sćries de soies munies de barbellules courtes et scrrées.

(J. D.)

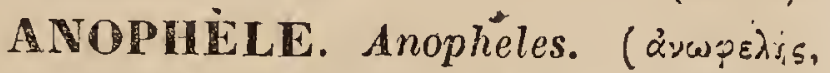
inutile, nuisible). INs. - Genre de l'ordre des Diptères, div. des Némocères, famille des Culicides, établi par Meigen, et adopté par Latreille, ainsi que par M. Macquart, qui lui assigne pour tous caract. d'ạoir les palpes de la longueur de la trompe dans les deux sexes. Son nom générique signifie, dit-on, importun, mais plus exactement inutile. Ce g. renferme trois esp., dont une du Sénégal, An. minuta Macquart, et deux d'Europe, l'An. maculipennis d'Hofimansegg, et I'An. bifurcatus de Meigen. La larve de cette dernière a été particulièrement observée par Meigen. Elle est transparente; elle a quelqnes poils à la bouche; deux tumeurs grises, ovales, derrière la tête, et deux autres plus minces avant la queue. Sous la:queue, se trouvent un grand nombre de longs poils qui servent probablement à la natation. Elle se métamorphose en nymphe contournée, dont la partie antéricure est plus épaisse que la postérieure, et dont la tête est munie de deux cornes. (Meig., Suppl. 242.) (D.)

* ANDPHYT (àv'sẹvos, né en haut). BOT. CR. - C'est ainsi que M. Endlicher (Gener. Plant., p. 42) nomme la première cohorte de ses Acrobrya (Voy. ce mot). Elle comprend deux familles, les Mousses et les Hépatiques. Pour les caract. généraux, Voy. MUSCIVÉES.

(G. M.)

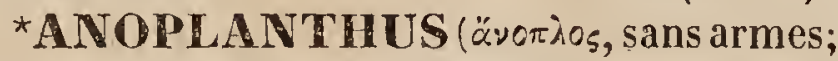
$\ddot{\alpha} \nu$ Aos, fleur). Bot. PH. - Genre de la famille des Orobanchées, formé par Endlicher (Gen. Pl., t. IV, p. 189), et ainsi caractérisé : Fleurs hermaphrodites, ébractéo- 
lées. Cal. subcampanulé, quinquéfide. Cor. hypogyne, tubuleuse, à tube court, ventru ou allongé, subcourbé à la base, à limbe subbilabié, également quinquéfide. Étamines 4 , incluses, didynames, insérées au tube de la corolle; anth. biloculaires, mucronées, à loges libres à la base. Ovaire uniloculaire, à 4 placentas pariétaux, distants. Ovules nombreux, anatropes. Style simple; stigm. capité , obscurément trilobé. Capsule uniloculaire, bivalve; valves placentifères de chaque côté, en dedans du bord; placentas convergents. Graines nombreuses, très petites..... Plantes herbacées, parasites, observées dans l'Amérique boréale et la région Taurico-caucasique, à scape uniflore, nue au sommei, munie à la base de squammes vaginantes.-Ce g., qui paraît ne renfermer que deux espèces, est divisé en deux sections : Euanoplon (Orobanche unifora); Anblatum (Phelippaa foliata, Lamb.).

(C. L.)

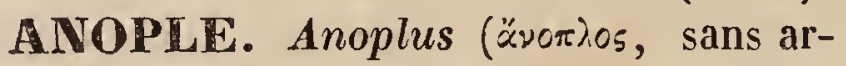
mes). Ins.-Genre de l'ord. des Coléoptères tétramères, famille des Curculionides, dir. des Frirhinides,établi par Schuppel, et adopté par Schoenherr, qui lui donne les caract. suivants : Antennes médiocres, minces; leur funicule de sept articles : le premier médiocrement long, peu épais, sub-obconique; les autres courts, presque perfoliés, serrés, s'épaississant successivement un peu du côté externe; massue ovale. Rostre assez long, robuste, cylindrique, un peu arqué. Yeux presque latéraux, arrondis, peu convexes. Thorax presque transverse, bi-sinué à la base, légèrement arrondi sur les côtés, très étroit antérieurement, tronqué au sommet, convexe en dessus. Élytres ovales, avec les angles huméraux obtus, convexes en dessus. Tarses mutiques, entièrement dépourvus d'ongles.

observ. - Corps petit, brièvement ovale, convexe, ailé. Schoenherr a fondé ce g. sur une seule esp., le Rhynchœnus Plantaris de Gyilenhal, qui habite le nord et le centre de l'Europe; mais M. Ghevrolat en possède une seconde, qui n'a pas encore été décrite. M. Dejean, qui, dans son dernier Catalogue, a adopté le g. Anoplus, n'y rapporte également que l'esp. précitée de Gyllenhal. gle). INs. - Sous-genre de Coléoptères pentamères, famille des Sternoxes, tribu des Buprestides, établi par Kirby, sans indication de caract. (Fauna borealis americana, p. 151), et auquel il donne pour type une esp. qu'il appelle $\boldsymbol{A}$. rusticorum. Il y comprend deux Buprestes de Fabricius (B. lineata et fasciata) qui appartiennent au g. Ancylocheira d'Eschscholtz, suivant le dernier Catalogue de M. Dejean.

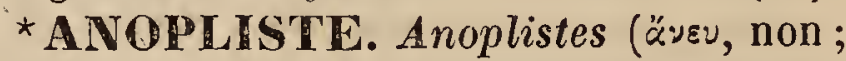
ónìeoris, qui arme; ici, par extension, armé ). Ins. - Genre de Coléoptères tétramères, famille des Longicornes, tribu des Cérambycins, établi par M. Serville dans sa Monographie de cette famille, et adopté par M. Dejean dans son dernier Catalogue. Les esp. de ce $g$. se distinguent principalement de celui des Purpuricenus (Voy. ce mot) par leur corselet, qui est mutique et plus long que la tête. - Il renferme 4 esp., dont nous ne citerons qu'une seule, le Cerambyx ephippium de Schoenherr, figuré par Olivier, t. IV, Capr., pl. 19, fig. 141. Il habite la Russie méridionale.

*ANOPLOCHEILUS (ầerios, non ar-

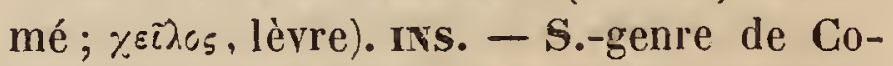
léoptères pentamères, famille des Lamellicornes, tribu des Mélitophiles de Latreille, établi par Mac-Leay (Illustrations of the Zoology of south Africa, etc., 1858, p. 21) dans son g. Macrominus, pour y placer 2 nouvelles esp. de Cétoine, de l'intérieur du sud de l'Afrique, qu'il nomme l'une $A$. spinitarsis, et l'autre $A$. setosus. La premiere est figurée pl. 5 dudit ouvrage. Il rapporte à ce même s.-g., mais avec doute, la Cetonia tomentosa de l'Iconographie de MM. Gory et Percheron, pl. 51, fig. 5. Voy. le g. MAGROMINUS.

ANOPLOCHEYLUS. INS. - Voyez ANOPLOCHEILUS.

* ANOPLODERA ( «ँvorios, non armé ; Jiśn, cou ). Ins. - Genre de Coléoptères tétramères, famille des Longicornes, établi par M. Mulsant, aux dépens du genre Leptura de Fabricius, dont il ne diffère essentiellement que par ce que les élytres, au lieu d'être rétrécies de la base à l'extrémitć, comme dans ce dernier, sont sub-parallèles, rétrécies dans leur partie moyenne, ou presque aussi larges à l'extrémité qu'à la base.

* ANOPLIS ( $\dot{\alpha}$ priv.; v euph.; $\dot{\pi} \lambda \dot{i}$, on- L'auteur y rapporte les Lept. 6-guttata, 
rufipes et lurida, de Fabricius. Toutes trois sont figurées dans Olivier, et se trouvent en France.

* ANOPLODERME. Anoploderma (à

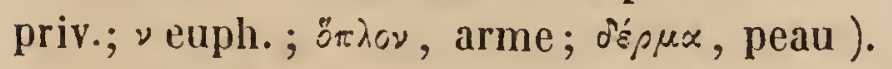
INs. - Genre de Coléoptères de la famille des Longicornes, tribu des Prioniens, établi par M. Guérin Méneville (Revue zoologi$q u e)$, et ayant pour caractères essentiels : Corps cylindrique; mandibules aussi longues que la tête, arquées, simples. Palpes inégaux, longs, composés d'articles allongés, avec le dernier ovoïde-oblong. Corselet de la largeur des élytres, arrondi. Élytres parallèles, arrondies. Pattes fortes, à tarses simples et assez allongés. La seule espèce connue est l'A. bicolor, Guér. M., long de 20 mill., noir, chagriné, avec les côtés du corselet et les élytres d'un rouge ferrugineux. Elle hahite les Andes du Pérou.

* ANOPLODERMILNS.Anoplodermii

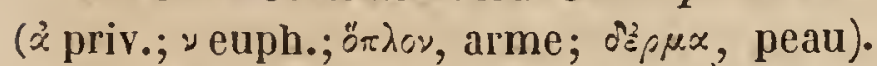
Ixs. - M. Guérin-Méneville a établi sous ce nom (Rev. zool. par la Soc. Cuv., 1840, p. 276) une s.-tribu des Prioniens, voisine de celle que M. Serville a fondée sous le nom de Spondyliens (An. Soc. Ent.), mais qui s'en distingue parce que les Insectes qui la composent ont les antennes allongées, serriformes, et les tarses simples et non élargis. Cette division comprend deux g. : le premier (Anoplodermus) est distingué par des antennes dont le troisième article est plus long que le premier et les suivants; le second (Sipylus) a ce même article beaucoup plus petit que le premier et les suivants. L'esp. qui lui sert de type est le S.Orbignyi, de Patagonie.

ANOPLOGNATHE. Anoplognathus.

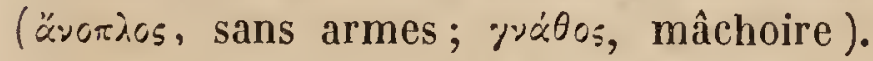
INS. - Genre de Coléoptères pentamères, famille des Lamellicornes, tribu des Scarabéides, établi par Leach et adopté par MacLeay et Kirby (Horce Ent., p. 76, ed. leg.). Voici les caractères que ce dernier lui assigne : Labre transverse, aigu antérieurement au milieu. Lèvre carrée, pointue au milieu, palpigère presque à son extrémité. Mandibules courtes, très fortes, cornées, édentées au sommet, très entières, extérieurement arrondies, intérieurement aiguës, courbées en dedans. Mâchoires mandibuliformes, arquées, courtes, fortes, cornées, avec un lobe voûté et sans dent, sub-échancré à l'extrémité. Palpes presque en massue. Ant. de dix articles; massue trifoliée, semi-ovale, garnie de poils. Prosternum se prolongeant en pointe conique vers la tête. Tous les ongles simples.

Ce g. figure dans le dernier Catalogue de M. Dejean, qui y rapporte huit esp., toutes de la Nouvelle-Hollande. Nous n'en citerons qu'une, l'Anop. Latreillei (rutela) de Schoenherr (App. ad syn.), figurée par Donovan sous le nom de Viridi aneus. (D.)

ANOPLOGNA THIDES. Anoplogna-

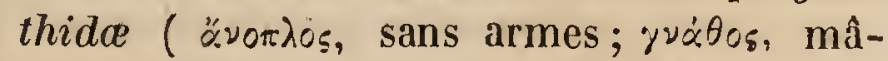
choire ). Ivs. - Nom d'une division établie par Mac-Leay dans la grande tribu des Scarabéides, famille des Coléoptères lamellicornes de Latreille, ou pétalocères de Duméril. Elle se compose des g. Amblyterus, Anoplognathus et Leucothyreus. Les caract. des Anoplognathides sont d'avoir le chaperon divisé transversalement par une suture ; les mâchoires cornées, tantôt dentées, tantôt inermes; et le labre triangulaire. Cette division ne renferme que des Insectes exotiques dont les mœurs ne sont pas connues. D'après l'organisation de leur bouche, on les présume Phyllophages. Tous sont revêtus de couleurs brillantes et métalliques, et les plus remarquables sous ce rapport viennent de la Nouvelle-Hollande.' M. Delaporte (Hist. nat. des animaux articulés, Buffon-Duménil, Coléopt., t. II, p. 125) désigne sous le nom d'Anoplognatites une sous-tribu, à laquelle il donne pour caract. : Mâchoires ayant au plus deux dents à l'extrémité. Mandibules entièrement cornées. Elle se compose des g. Anoplognathus, Brachysternus, Dasygnatus, Areoda, Amblyterus et Pachycerus. Voy. ces différents mots.

(D.)

ANOPLOGNATHUS. INS. - Voyez ANOPLOGNATHE.

* ANOPLOMERUS (๕้̋

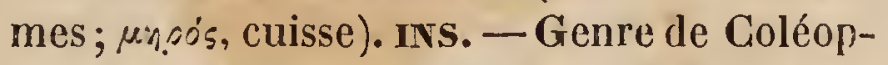
tères tétramères, famille des Longicornes, établi par M. Dejean, mais dont il n'a pas publié les caract. Il le place, dans son dernier Catalogue, cntre les g. Eburia et $\mathbf{C e}$ rasphores de $M$. Serville, et, par conséquent, dans la tribu des Cérambycins de ce dernier auteur. M. Dejean n'y rapporte que deux esp. nommées par lui $\boldsymbol{A}$. rotundicol- 
lis et A. Jacquieri, l'une du Brésil, et l'autre de Cayenne.

(D.)

* ANOPLON (ävorios, sans armes). BoT. PH. - Section du g. Orobanche, formée par Wallroth, et synonyme du g. Anoplanthus. Voy. ce mot.

(C. L.)

* A NOPLONYCHIA. Bot. PH.-Genre ou sous-genre de la famille des Paronychiées, tribu des Illécébrées, sous-tribu des Euparonychiées, Fenzl, établi par M. Fenzl comme sous-division du g. Paronychia, et caractérisé comme il suit (in Endl. gen. $\boldsymbol{P l}$., p. 958) : Segments calicinaux ovales-oblongs ou lancéolés, herbacés, à peine scarieux aux bords, pointus, concaves, mutiques, pubescents. Pétales 5; style très court, 2-fide. Fruit indéhiscent à la base, recouvert par le calice. - Herbes (la plupart habitant les contrées voisines de la Méditerranée) touffues, quelquefois suffrutescentes. Fleurs agrégées en glomérales très denses, et enveloppées de grandes bractées scarieuses. M. Fenzl fonde ce groupe sur le Paronychia capitata et quelques autres esp. voisines. (SP.)

ANOPLOPHORE. Anoplophora ( $\alpha$ priv. $\nu$ euph.; $\delta \pi$ ropopos, qui porte des armes). Ins. - Genre de Coléoptères tétramères, de la famille des Longicornes, tribu des Lamiaires, établi par Hope (Trans. Lin.-Soc., vol. 18 , p. 439 , pl. 30 , fig. 1) d'après un admirable insecte récemment découvert dans l'Assame, aux Indes orientales. Voici les caract. de ce g. : Tete de forme carrée. Antennes deux fois plus longues que le corps, avec le dernier article très allongé. Ellytres aussi larges en arrière qu'en avant, arrondies au bout. Corps écailleux en dessous, avec la poitrine inerme. Pieds difformes et robustes. La seule esp. connue est l'Anoplophorus Stanleyarus Hope. Il est long de 20 lignes, d'un beau vert foncé, luisant, tournant au noir, avec la tête, le corselet et les élytres couverts de grandes taches d'un beau vert pâle. Les antennes sont noires, avec la base des articles bleue. Les pattes sont couvertes d'écailles d'un beau bleu verdâtre.

(D.)

* ANOPLOSTERNUS ( $\dot{\alpha}$ priv.; $v$ eu-

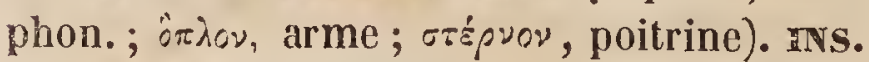
- Genre de Coléoptères pentamères, famille des Lamellicornes, tribu des Scarabćides, ctabli par M. Guérin-Méneville ( Mag. de Zool. 1858, ins., Voyage de la Favorite).
Ce g., volsin des Aroplognathes de Leach en diffère surtout par le sternum du mésothorax, parfaitement inerme entre les pattes intermédiaires, et par sa lèvre inférieure, garnie en dessous de soies courtes et serrées en forme de brosse, comme dans les Geniates. L'auteur n'y rapporte qu'une seule espèce trouvée près de la rivière des Gygnes, dans la Nouvelle-Holiande, et qu'il nomme An. opalinus.

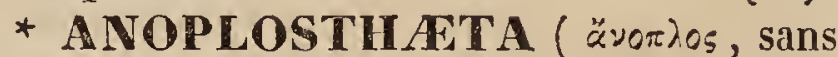
armes; $\sigma \tau \tilde{\gamma} \theta 05$, poitrine ). Ivs. - Genre de Coléoptères tétramères, famille des Longicornes, établi par M. Dejean, qui n'en 'a pas publié les caract., mais qui l'a nommé ainsi, sans doute à cause des épines du corselet qui sont courtes et obtuses. D'après la place qu'il occupe dans son dernier Catalogue, il appartiendrait à la tribu des Lamiaires de II. Serville, et a pour type le Lamia lactator de Fabricius (radiata Gory); esp. de Guinée et du Sénégal. (D.)

ANOPLOTHERIUM ( $\ddot{\alpha} \nu 0 \pi \lambda^{\prime} s$, sans armes; Orpiov, animal ). MAM. Foss. - Genre de l'ordre des Pachydermes ayant quelques rapports avec les Chameaux, découvert par Cuvier dans les plâtres des environs de Paris. Ces animaux, dont la race est éteinte, avaient quarante-quatre dents en séries continues ainsi que l'homme, savoir : 6 incisives, deux canines et quator ze molaires à chaque mâchoire. Les canines étaient peu différentesd es incisives et ne saillissaient pas plus qu'elles, ce qui a donné lieu au nom d'animal sans armes ou sans défenses. Les trois molaires postérieures, de chaque côté, carrées et à deux collines transverses en haut, à double et à triple croissant en bas dont l'antérieure termince par une pointe, séparće par un sillon, étaient fort semblables à celles des Rhinocéros, des Damans et des Palæotherium ; les trois molaires antérieures étaient comprimées. La quatrième molaire ressemble en haut à la moitié postérieure d'une des dents carrées, et, en bas, aux molaires antérieures. Les pieds, terminés par deux grands doigts, ne différaient de ceux des Ruminants que par la séparation des os du métacarpe et du métatarse, qui ne se soudaient point en canon. Leur tarse était composé comme celui du Chameau; leur carpe, à peu près comme celui du Cochon. 
Les Anoplotherium, d'après ces caractères, établissaient un point de contact entre les Pachydermes et les Ruminants, de la même manière que les Damans en établissent un entre ces mêmes Pachydermes et les Rongeurs.

Guvicr en a reconnu six esp. dont il a foriné trois s.-genres.

I. - Les Anoplotherium, proprement dits, qui comprennent deux espèces :

L'Anop. commune, animal de la grandeur d'un petit âne, mais plus bas sur jambes; à queue très fortc et de la longueur lu corps; à pieds de devant munis, du côté interne, d'un rudiment de doigt. Cet animal siait herbivore et probablement nageur comme la loutre, dont il avait l'allure. Il se nourrissait sans doute des tiges et des racines des plantes aquatiques, et avait, sclon toute apparence, le poil lisse et les orcilles pelites comme l'Hippopotamc.

L'Anop. secundarium, semblable au précédent, mais de la taille du Cochon.

11. - Les Xiphodontes, de క̇i̧os, épée, et d'ơờs, dent; dénomination tirée de la forme tranchante d'une partie des dents de la seule espèce de ce s.-g., savoir :

L'Anop. gracile, animal de la grandeur et de la forme élégante d'unc Gazelle, à membres allongés; sans doigts accessoires aux. pieds de devant, et probablement sans longue queue; à dents antćricures tranchantes comme celles des Chevrotains.

III. - Les Dichobunes, de oiyx, divisés,

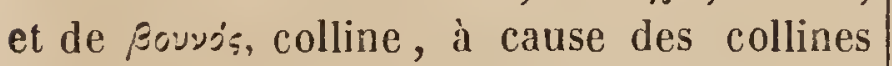
disposées par paires sur ses quatre dernières molaires de la mâchoire inférieure; s.-g. qui comprend trois espèces:

L'Anop. leporinum, de la taille du Lièvre, à pieds tétradactyles, mais dont les doigts latéraux ne touchaient pas à terre;

L'Anopl. murinum, de la taille du Cochon d'Inde;

L'Anopl. obliquum, même taille que le précédent; à branche montante de la mâchoire inférieure oblique.

Ces deux dernières espèces ne sont encore connues que par des mâchoires.

Les plâtres des environs de Paris qui font partie de l'étage inféricur des terrains tertiaires (dits de la période Éocène) ont seuls fourni jusqu'à ce jour des os complets et des parties de squelettes d'Anoplotherium. On en a trouvé quelques dents détachées en Bavière, dans l'fle de Sheppey, dans les sables des environs d'Eppelshcim, et dans ceux des environs d'Orléans, mêlés avec des os de Mastodontes, de Rhinocéros et de Dinotherium, dans l'étage moyen de ces mêmes terrains (dits de la période Miocène), et qui proviennent vrassemblablement de remaniements des terrains de la période précédente. G'est par les Anoplotherium que Cuvicr a commencé ì démontrer, pour ainsi dire mathématiquement, que parmi les ossements fossiles il y avait des débris de races d'animaux inconnues aujourd'hui dans la nature vivante, qui attestent les variations que ces races ont éprouvées; variations amenées, selon ce grand naturaliste, par les révolutions du globe, qui détruisaient les races existantes, au moment et dans le lieu de ces révolutions. Aussi pensait-il que ces débris des êtres organiques doivent être étudiés avec soin, comme nous fournissant l'un des plus puissants moyens de parvenir à la connaissance de l'histoirc ancienne du globe, ct comme pouvant même servir au perfectionnement de la science de l'organisation.

(LAURILARD.)

* ANORLUREG. Anoplure (á priv.; ,

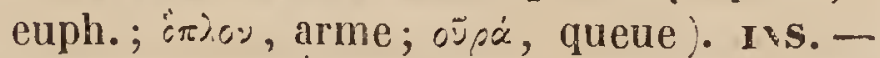
Nom donné par Licach à un ordre de la classe des Insectes, sans métamorphoses, comprenant ceux qui ont la queuc dépourvue de filaments.

(D.)

* ANOPLURIFORMES. Anopluriformes (anopluriformis, qui ressemble aux Anoplures ). INs. - Mac-Leay et Kirby donnent celte épithète aux larves de Colćoptères qui sont carnivores, antennifères, à corps oblong et dćprimé. Ex. : Coccinella.

(D.)

ANOPLUS. INS. - Voyez ANOPLE.

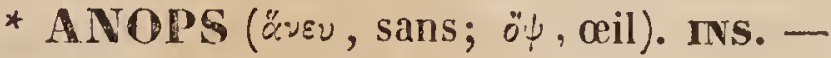
Genre de l'ordre des Lépidoptères, famille des Diurnes, sect. des Hexapodes, tribu des Lycénides, créé par M. Boiscluval, mais dont il n'a pas publić les caract. Il a pour type le Polyom. Phodrus de l'Encyclopédic, Pap. id. de Gramer. Une autre esp. décrite par Horsficld sous le nom de A. terrestris apparticnt aussi à ce g. ; toutes deux sont des Indes orientales.

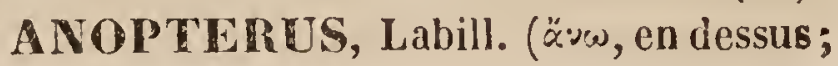


$\pi \tau \varepsilon \rho o ́ v$, aile). вoт. PH.-Genre de la famille des Escalloniées, offrant pour caract.: Calice à tube turbiné, adné par sa base à l'ovaire; limbe à 6 lobes courts, pointus, persistants. Pétales 6 , insérés au calice, alternes avec les lobes de celui-ci. Étamines 6 , ayant même insertion que les pétales, opposées aux lobes calicinaux. Style court. Stigmate 2-fide. Capsule oblongue, 1-loculaire, polysperme, 2valve de haut en bas; placentaires marginaux. Graines ovales, comprimées, ailées au sommet. - Ce genre est fondé sur un arbrisseau habitant la terre de Van Diémen; les feuilles sont alternes ou subopposées, subsessiles, coriaces, à dents calleuses; les fleurs naissent en grappes simples, terminales, subfasciculées.

(SP.)

* ANORGANIQUE. Anorganique (à priv.; öpyavov, organe; qui n'a pas d'organe).-Synonyme peu usité d'Inorgarnique.

(C. 'D'O.)

* ANORGANOGNOSIE. Anorgano-

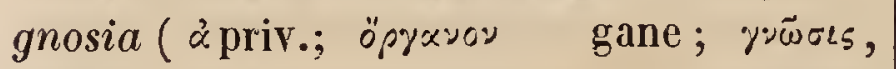
connaissance). Gravenhorst et J. Reisinger se sont servis de cette épithète comme synonyme de Minéralogie.

(C. D'O).

* ANORgANOGRAPIIE. Anorga-

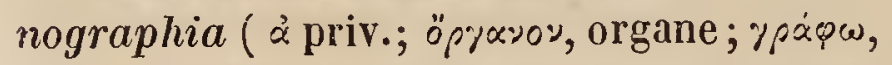
j'écris). - Description des corps inorganisés.

(C. D'O.)

* ANORGANOLOGIE. Anorganolo-

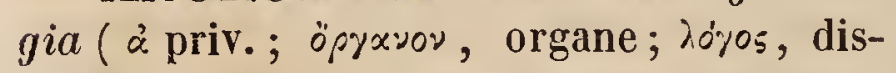
cours). - Discours sur les corps inorganiques.

(C. D'O.)

* ANORIIYNQUES. Anorhyncha ( $\alpha$ priv.; ṕvyos, bec; appendice de la tête ). HeLM. - Nom de la troisième famille des Vers Bothrocéphalés dans M. de Blainville (Dict. des Sc.nat., t. LVII, p. 606). Le renflement céphalique n'a ni tentacule ni mamelons proboscidiformes garnis de crochets. Ex. : Massette, Tétrabothrie, Bothriocéphale, etc. (P. G.)

* ANORMAL ( à priv. ; norma, règle ; c'est-à-dire irrégulier, exception à la rc̀gle). вот. - Se dit en Bot. des parties de plantes ou des organes présentant des altérations produites par des maladies, des dégénéreseences, etc.

(C. D'O.)

* ANOROPS ( $\alpha$ priv.; v'społ, brillant). rvs. - Genre de Coléoptères hétéromères, famille des Hélopiens, établi par M. Dejean, aux dépens du genre Helops de Fabricius, dans son dernier Catalngue. Il le met avant les Stenochia de Kirby; mais sa place naturelle serait près des Eustrophus d'Illiger, qui appartiennent à la tribu des Ténébrionites. Les caract. en sont : Tête moyenne, aplatie; palpes maxillaires grands; 2e et $\mathbf{5}^{e}$ articles coniques; 4 e ovoïde. Antennes velues

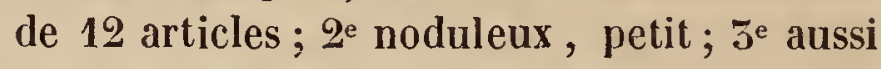
long que les trois suivants réunis; le dernier turbiné. Yeux latéraux, rétrécis sur le milieu antérieur, plus larges en dessous qu'en dessus. Corselet arrondi latéralement, cintré antérieurement, tri-sinué à la base, avec deux fortes impressions longitudinales. Écusson grand, arrondi postérieurement. Elytres plus larges que le corselet, arrondies conjointement à l'extrémité, à nombreuses stries ponctuées, et dont les points sont carrés. Corps ovalaire, aplati. M. Dejean rapporte à ce g. 3 esp., dont 1 do Java, et les 2 autres de l'Amérique septentrionale. Nous citerons parmi ces dernières l'Helops obliquatus Fabr. comme type du genre.

(D.)

*ANORTHITE ( $\dot{\alpha}$ priv.; $v$ euph.; op $\theta \dot{o} s$. droit ; qui n'est pas rectangle). MIN. - Nom donné par G. Rose à un minéral appelé Christianite par Monticelli, et qui, par sa composition et sa forme cristalline, a de grands rapports avec les esp. du groupe des Feldspaths. On le trouve en petites masses à structure grenue dans les blocs de dolomie du mont Somma, au Vésuve. Voy. Feldspatr.

(DEL.)

* ANOSMIA , Bernh. ( $\alpha$ priv.; v euph.; órin, odeur). вот. Pн. - Genre de la fa. mille des Ombellifères (tribu des Smyrnées, Koch.), fondé sur le Smyrnium apiifolium, Willd. Son auteur (Linncea, t. VII, p. 608) lui assigne pour caract. : Limbe calicinal ondulé, non denté. Pétales subradiants, obcordiformes, surmontés d'une pointe infléchie. Fruit subdidyme, contracté bilatéralement ; méricarpes ovoïdes, 5-costés ; côtes équidistantes, 1-nervées au milieu; vallécules déprimées, munies d'une seule bandelette; carpophore finalement 2-parti. Périsperme involuté (de manière à former une demi-lune sur une coupe transversale). - Herbe (indi gène de Candie) bisannuelle, dressée, glabre; feuilles pétiolées : les inférieures surdécomposées ; les supérieures pennées; pétiole commun membranacé; ombelles oppositifo- 
liées et terminales, sans involucre; involucelles oligophylles; fleurs blanches, hermaphrodites.

(SP.)

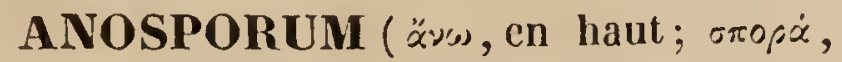
semence). BoT. PH. - Genre de la famille des Cypéracées, tribu des Fuirénées, Fenzl, formé par Nees von Esenbeck aux dépens du genre Monocephalus de Roxburgh. Il est principalement caractérisé par un ovaire surmonté d'un style simple, décidu, très entier au sommet, devenant une caryopse cartilagineuse, stipitée au moyen d'un disque spongieux; indè nomen. L'unique esp. qui constitue ce genre est une herbe indienne, à chaume triquètre, folié à la base, et dont les épillets, ovales, courbes, sont disposés en épis imbriqués-bractéés, formant une sorte de capitule.

(C. L.)

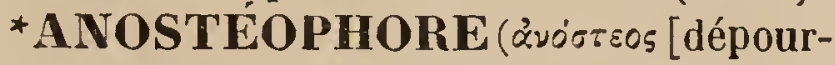
vu d'os], polype; yopós, porteur). MoLL.II. Gray, dans sa nouvelle classification des Mollusques, divise en $\mathbf{z}$ ordres la classe des Céphalopodes, et il donne le nom d'Anostéophore à celui qui comprend le seul g. Poulpe. Voy. ce mot, et CÉPHALOPODE.

(DESH.)

* ANOSTÉozoAires. Anosteozoa-

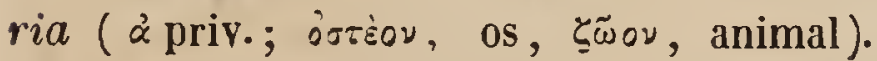
zOoL -M. de Blainville donne ce nom à un type du Règne animal, comprenant les Animaux dépourvus d'os proprement dits.

(G. D'O.)

ANOSTOME. MoLL. - Voyez aNaSTOME. (DESH.)

* ANOSTOSTOMA (爻orros, qui n'est pas agréable; бró $\mu$, bouche). INs. - Genre de la famille des Locustiens, de l'ordre des Orthoptères, établi par M. Gray (Lond. mag.) et adopté par M. Serville (Ins. orthopt., suites à Buffon). Ce genre est l'un des plus extraordinaires que l'on connaisse, par une tête d'une grosseur disproportionnée avec le corps, ayant ses bords latéraux notablement dilatés; une bouche fort large, très avancée, avec le chaperon prolongé en museau; des mandibules très robustes, dentelées et dilatées à l'extrémité; des palpes grêles et cylindriques d'une extrême longueur, surtout les maxillaires, trois fois aussi longs que les labiaux, et à peu près de la longueur de la tête, et un thorax plus étroit que Ia tête, en forme de selle arrondie avec le prosternum, muni de deux épines rappro-

$$
\text { T. } \mathbf{I} \text {. }
$$

chées à la base.-Le type du g. est l'A. Auw stralasia, espèce de la Nouvelle-Hollande, et connue seulement sans ailes, n'ayant pas très probablement atteint son état parfait. $M$. Gray rapporte encore à ce genre l'A. Locusta monstrosa, Herbst. (Nat. Fr. Berlin, t. IV), également aptère, et indiquée comme de Surinam. Enfin M. Serville croit devoir encore y rapporter le Gryllus vorax, Stoll. (Sau.pl. 4, fig. 19 et 20), que nous connaissons seulement par cette figure, qui le représente pourvu d'ailes, et ayant une tête qui, bien que très forte, est moins grosse que celle de l'A. Australasia.

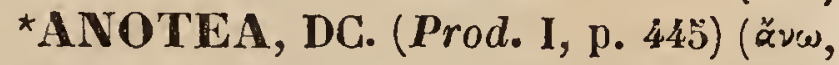
en dessus). вот. PH. - Section du genre Pavonia, Cavan. (famille des Malvacées), caractérisée comme il suit : Ċorolle comme tubuleuse par la convolution des pétales. Organes sexuels longuement saillants. Péricarpe à coques mutiques.

(SP.)

*ANOT A. INs.-Genre de la famille des Fulgoriens, de l'ordre des Hémiptères, sect. des Homoptères, établi par Kirby (Trans. of the Lin. Soc., t. XIII), et adopté par Latreille et tous les autres entomologistes. Ce genre est principalement caractérisé : $1^{\circ}$ par les antennes, insérées en arrière des yeux, ayant leur premier article fort court, ne formant guère que la sixième partie du suivant : celui-ci comprimé, élargi et tronqué à l'extrémité, avec une soie terminale implantée dans une échancrure ; 2o par l'absence d'0celles ; par les pattes grêles, avec les jambes mutiques. La seule espèce encore connue de ce genre est l'A. Bonnetii, Kirby, Burm., Bl., de l'Amérique du Nord.

(BL.)

ANOTIDE. Anotis, DC. (ápriv.; v euphon.; cists, oreillette). вот. PH. - Genre de la famille des Rubiacées (tribu des Hédyotées, DC). Ce genre, que MM. Wight et $\mathbf{A r}$ nott ne considèrent que comme s.-genre des Hedyotis, est caractérisé par M. De Candolle (Prodr., t. IV, p. 431) comme il suit : Tube calicinal obové, à 4 dents jointues, per* sistantes, séparées par des sinus pointus. Corolle hypocratériforme ; limbe 4-lobé, presque aussi long que le tube; gorge presque glabre. Anthères incluses ou peu saillantes. Stigmate subbilobé. Capsule ovoïde, 2-loculaire, couronnée du limbe calicinal, loculicide-2-valve au sommet; loges 4-8-spermes. Graines ovoïdes, légerement anguleuses. - 
Herbes ou sous-arbrisseaux; feuilles opposées ; stipules très entières ou dentées; fleurs solitaires ou en corymbe, terminales. M. De Candolle rapporte à ce g. 14 esp. (toutes indigènes de l'Amérique équatoriale, et la plupart énumérées comme des Hédyotes par d'autres auteurs), qu'il groupe sous 5 s.-g. ou sect., savoir : Ereicotis, DC., Amphiotis, DC., et Panetos, Rafin. (Voy. ces mots.)

* ANOURELLE. Anourella ( $\alpha$ priv.; ojpx, queue). systou.-Genre établi par M. Bory aux dépens des Brachions de Müller pour les esp. sans appendice postérieur ou sans queue, mais pourvues, comme les vrais Brachions, d'une enveloppe membraneuse ou d'un têt, et portant en avant des organes ciliés; rotatoires. M. Bory place ce g. avec les Plœsconies, qui sont de vrais Infusoires, dans sa famille des Citharoïdes. M. Ehrenberg, le premier, a distingué convenablement des Infusoires les Systolides, qu'il nomme Rotatoria; il nomme Anuræa le g. Anourelle, et le place dans la famille des Brachions, en le caractérisant par l'absence de l'appendice postérieur, et par la présence d'un point rouge supérieur qu'il nomme un æil. Müller a décrit cinq espèces qui doivent appartenir à ce genre; ce sont les Brachionus squamula, B. striatus, B. bipalium, B. pala et B. quadratus. Ce dernier a été placé par M. Bory dans son $\mathrm{g}$. Kératelle, et M. Ehrenberg range le B. pala parmi les Brachions; mais ce même ąuteur a fait connaître plusieurs autres espèces d'Anourelles, les unes tout à fait nouvelles, les autres déjà reconnues ou décrites par divers naturalistes. Les Anourelles se trouvent presque toutes dans les eaux douces marécageuses; cependant l'A. striata vit également dans les eaux de la mer Baltique, et l'A. biremis a été trouvée exclusivement dans cette mer. Leur grandeur varie entre 0,05 et 0,22 de mill.

(DU..)

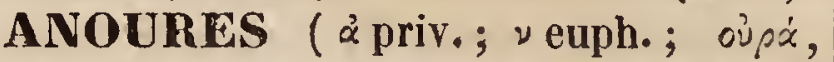
queue; sans queue). Ecaudati. REPT.-Nom donné par Duméril et plusieurs autres auteurs à une famille de la classe des Reptiles, comprenant les Batraciens, qui, aquatiques dans leur jeunesse, perdent leur queue à l'époque où ils deviennent terrestres. Ils se distinguent des Batraciens à queue permanente par la brièveté des pattes antérieures et le développement extraordinaire des extrémités abdominales, ce qui les rend impropres à la marche ordinaire, et ne leur permet d'autre mode de progression que la natation et le saut. Les Batraciens Anoures sont les Crapauds, les Grenouilles, les Rainettes et les Pipas.

(C. D'O.)

ANOXIE. INS. -Voyez ANOXYA. (D.)

* NOXYA (à priv,; v euph.; ó่̧s, pointu). INS.-Genre de Coléoptères pentamères, famille des Lamellicornes, établi par M. Delaporte aux dépens du g. Melolontha des auteurs, dont il diffère par les caract. suivants : Massue des antennes composée seulement de 5 feuillets dans les mâles et de 4 dans les femelles; le $2^{e}$ article très court ; le $5^{\mathrm{e}}$ très allongé; le corselet plus long, quoique sa dimension en ce sens n'égale pas celle de sa largeur. Les articles des tarses plus renflés, et garnis d'épines plus fortes à leur extrémité ; crochets du dernier article arnøés en dessous d'une forte dent. Jambes antérieures simples, ou à peine tuberculées. Segment anal plus grand, échancré à son extrémité, non prolongé en pointe.

Ce g. est le même que celui auquel $M$. Dejean donne le nom de Catalasis dans son dernier Catalogue. II renferme 5 esp., dont le Melolontha villosa de Fabricius peut être considéré comme le type. Il se trouve aux environs de Paris.

ANREDERA, Juss. вот. PH. - Genre de la famille des Chénopodées (tribu des Chénopodiées), offrant pour caractères : Périanthe membranacé, 5-parti : les $2 \mathrm{seg}$ ments extérieurs carénés, munis d'une aile dorsale longitudinale; les 5 intérieurs un peu plus courts, concaves. Etam. 5 , antéposées, insérées au fond du périanthe; filets subulés; anthères sagittiformes - oblongues. Point de squamules hypogynes. Ovaire ovo:de, 1-loculaire, 1-ovulé, 5-style. Stigmates simples. Péricarpe coriace, indéhiscent, 1sperme, reconvert par le périanthe, qui est sec et diptère. Graine verticale, à test membranacé. Embryon annulaire, périphérique : radicule infère. - Herbe grimpante; feuilles alternes; fleurs hermaphrodites, 2-bractéolées (bractéoles petites, coneaves), disposées en épis axillaires. On n'en connaît qu'une seule esp., qui croît aux Antilles. (SP.)

ANSER. ors. - Synon. latin d'ore. Voyez ce mot. 
*ANSERANAS (anser, Oie ; anas, Canard ). ors. - Section formée par M. Lesson (Tr. d'Orn.) dans son genre Anas, pour recevoir le Canard à pieds demi-palmés (Anas melanoleuca Lat.), que nous plaçons dans notre g. anatigralle. Voy. ce mot.

(LARR.)

ANSERES ( anser, Oie ). oIs. C'est, dans la méthode de Linné, le nom par lequel il désigne l'ordre des Palmipèdes de Cuvier ou des Nageurs de Vieillot. (LAFR.)

ANSÉRINE. Bot. PIr. - Voyez GHeNOPODIUM.

(G. D'O.)

*ANSÉRIVÉES. Anserince anserinus, qui concerne les Oies). ors.-Sous-famille de l'ordre des Palmipèdes de Guvier et de notre fam. des Anatidées, ayant pour car. : Bec de Iongueur médiocre ou court, conique, élevé à sa base, où il est plus haut que large, rétréci en avant, garni latéralement de lamelles en forme de dents souvent apparentes sur ses bords. Pattes assez élevées, et placées, sur le tronc, presqu'à l'équilibre du corps; loigts de Iongueur médiocre, terminés par des ongles courts et assez obtus, réunis par une membrane entière ou presque entière. Habitudes marcheuses et paissantes.

Malgré les grands rapports de forme qui existent entre les Oies et les Canards proprement dits, ou Anatinées, nous avons cru indispensable d'en former une sous-famille particulière : car, outre une plus grande élévation des tarses placés plus en avant, et une forme de bec moins déprimée et plus conique que chez les Canards, nous leur avons reconnu des habitudes bien différentes et dépendantes de ces deux causes. Ainsi elles sont beaucoup plus marcheuses et plus nageuses; et, tandis que le bec déprimé et spatuliforme des premiers leur sert à recueillir sur l'eau une nourriture moitié animale et moitié végétale, le leur, de forme conique, plus court, et, par conséquent, plus fort, indique un autre genre d'alimentation, qui consiste effectivement ì arracher ou à paitre I'herbe, qui fait le fond de ieur nourriture. Cette différence bien marquée dans l'alimentation se reconnaît dès que les petits sont éclos. Les jeunes Canards sauvages, au sortir de l'œuf, se jettent à l'eau; et, loin de chercher à en gagner les bords, ils y restent constamment avec leurs mères pour y chercher leur nourriture, consistant en insectes et moucherons de toute esp). qui voltigent § sa surface, et qu'ils poursuivent et attrapent en nageant avec une promptitude incroyable. Ils y joignent encore Ies insectes aquatiques et tout ce qu'ils peuvent saisir en barbottant sur Ies rives. Les jeunes Oies sauvages, au contraire, à peine écloses, s'acheminent avec leur mère vers des terrains herbus, et leur première nourriture se compose des pointes des feuilles de graminées, que leur mère arrache et dépose devant elles tout en parcourant le sol; mais bientôt elles s'exercent et parviennent elles-mêmes à arracher ces pointes d'herbes, qu'elles paissent réellement et qui leur suffisent. Cette nourriture est donc toute végétale, tandis que celle des jeunes Canards est presque exclusivement animale.

D'après les caractères de forme que nous avons assignés à nos Ansérinées, les Bernaches, à bec plus court et plus conique, à tarses plus élevés, à corps plus court, doivent être considérées comme les espèces-types de cette sous-famille; elles ont aussi la marche beaucoup plus facile et plus rapide que les Oies proprement dites.

Notre sous-famille des Ansérinées comprendra donc le seul genre oIE, Anser, et les deux sous-genres Bernache et Oie. Voy. oII.

(LARR.)

* NTACANTIIUS, L. G. Rich., Mss.

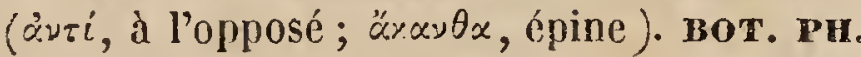
- Synon. du g. Scolosanthus, Vahl, de Ia famille des Rubiacées.

(SP.)

ANTALE. MoLk.-(Un des synonymes de Dentale.) Nom d'une famille d'animaux mollusques que, jusqu'aux recherches de MM. Deshayes et de Blainville, on classait parmi les Annélides.

(P. G.)

* ANTARCT (àroport*ós, antarctique, austral ). INs. - Genre de Coléoptères pentamères, famille des Carabiques, tribu des Féroniens, établi par M. Dejean dans son Species général, et auquel il assigne les car. suivants : Les trois premiers articles des tarses antérieurs dilatés dans les mâles, aussi longs que larges, et fortement cordiformes; dernier article des palpes allongé, presque cylindrique, et tronqué à l'extrémité. Antennes filiformes et assez allongées. Lèvre supéricure en carré moins long que large, légèrement échancrée antérieurement. Mandibules peu avancées, assez fortement 
arquées et assez aiguẻs; point de dent au milieu de l'échancrure du menton. Corselet presque carré ou légèrement cordiforme. F́lytres assez allongées, presque parallèles et légèrement sinuées à l'extrémité. M. Dejean a établi ce nouveau genre sur plusieurs esp. de l'extrémité de l'Amérique méridionale, et c'est pour désigner le pays qu'elles paraissent habiter exclusivement qu'il leur a donné le nom générique d'Antarctia.

Ces Carabiques sont de moyenne taille, toujours ailés, de couleur métallique, et ont les plus grands rapports de forme avec quelques Amara et quelques Harpales.

M. Dejean, dans son dernier Catalogue, en mentionne 13 esp., dont 6 du Chili, 1 des iles Malouines, ế 6 de Buénos-Ayres. Nous citerons parmi ces dernières l'Ant. carnifex Fabr. comme type du genre.

(D.)

ANTEDILUVIEN ( Ante, avant ; $d i$ luvium, déluge). GÉoL. - Cette dénomination, introduite en France par les géologues anglais, s'applique aux formations alluviales qu'on suppose avoir précédé la grande catastrophe dont parle la Genèse. On reconriaît aujourd'hui que l'on a abusé de ce mot en confondant sous un même nom des dépôts terrestres d'époques différentes; et M. Brongniart en a restreint l'emploi à la désignation des terrains de trass et d'alluvion qui ont précédé la période animale.

On donne le nom d'Antédiluviens aux Animaux qui se trouvent dans les terrains de transport appelés Diluviens : tels sont les Mastodontes, les Éléphants, les Tapirs, etc., quelques uns appartenant à des genres perdus, d'autres ayant disparu du continent européen. Ce terme s'emploie en général pour désigner tout ce qui paraît remonter à une haute antiquité.

(C. D'O.)

ANTENNAIRE.Antennarius, Commerson. Poiss.-L'habile naturaliste, compagnon de Bougainville, que je cite ici, Commerson, avait eu l'idée d'établir sous cette dénomination le g. de Poissons dont M. Cuvier a donné la monographio dans les Mémoires du Muséum, sous le nom de Chironectes. (Voy. ce mot.) M. de Lacépède et M. Cuvier, en se servant des manuscrits de Commerson, ont cité la dénomination de ce voyageur dans leur Synonymie. (VAL.)

+ ANTENNAIRES. Antennaria (an- voldy nomme ainsi deux petites pieces soudées ensemble qu'on remarque sur la tête des Diptères de la famille des Muscides ou Myodaires, et sur lesquelles sont implantées les antennes. Ces deux pièces sont quelquefois susceptibles de mobilité, et font saillir, au côté interne du premier article, deux petites crêtes ou squamules qui portent le nom de pièces inter-antennaires (inter-antennaria).

ANTENNARIA, Link (Nouv. Journ. de Bot. de Schrader, t. III) (antenna, antenne). BOT. CR.-Genre de Champignons appartenant aux Hypomycetes de Link et aux Périsporiacées de Fries, caractérisé par des filaments en forme de thallus, couchés, rameux, articulés, entrelacés, et supportant, principalement vers leur base, des sporanges globuleux remplis de matière gélatineuse et de spores moniliformes. Pendant longtemps on a ignoré la fructification de ce g., dont on ne connaissait qu'ane espèce, le Torula fuliginosa, de Persoon, qui croît sur les pins, et en recouvre les rameaux et les feuilles d'une couche filamenteuse, noire, souvent très épaisse. Comme l'auteur du Synops. fungorum ne l'avait jamais observé qu'à l'état stérile, il l'avait placé dans le g. Torula, dont les filaments présentent les mêmes caract.; mais le professeur Link ayant observé les organes de la fructification sur l' $A$. ericophila, qui croît en Portugal sur l'Erica arborea, les caractères génériques ont dû être modifiés. Dans la France méridionale, on en rencontre une troisième espèce sur les Cistes ligneux. M. Fries a cru devoir réunir à ce genre le Racodium cellare de Persoon, espèce de feutre noir composé de filaments extrêmement ténus que l'on trouve sur les tonneaux, dans les caves; les filaments sont bien rameux, articulés ou cloisonnés, et les petits globules noirs que l'on observe ne sont pas des sporanges, mais bien des excréments d'Insectes, ainsi quo je l'ai constaté un grand nombre de fois.

(Ĺ丶龴.)

ANTENNARIA (Antenna, antenne). вот. PH. - Les Antennaria sont des herbes vivaces, quelquefois sous-frutescentes, garnies de feuilles entières, blanchâtres et tomenteuses à leur face inférieure, portant des capitules disposés en corymbe, et dont
les folioles de l'involucre sont blanches ou 
lavées de rose ou de brun, mais jamais jaunes comme celles de la plupart des Gnaphaliées. Les plantes de ce genre, employées en médecine, sont connues sous le nom de Pied-de-chat. M. R. Brown, qui les a, le premier, nettement circonscrites, leur assigne les caractères botaniques suivants : Involucre imbriqué, scarieux, coloré. Réceptacle dépourvu de paillettes, scrobiculé. Fleurs dioïques : les mâles à anthères garnies d'appendices basilaires. Stigmates tronqués; poils de l'aigrette en forme de pinceaux, ou épaissis au sommet; les femelles à limbe court, dépourvues d'étamines rudimentaires, et munies d'une aigrette à soies capillaires.

ANTENNARIEES (antenna, antenne). вот. pr. - Une des divisions de la sous-tribu des Gnaphaliées, qui renferme les genres dont les capitules sont indépendants les uns des autres, multiflores, dioïques, subdiö̈ques ou monoïques; les fleurs mâles pourvues d'un style très simple, en forme de massue, et tronqué au sommet; le réceptacle dépourvu de paillettes, ou en ayant seulement vers sa circonférence.

(J. D.)

ANTENNARIUS. PoIss. - Voyez ANTENNAIRE.

(VAL.)

ANTENNES. Antenna. zoou. - On nomme ainsi des organes appendiculaires, mobiles, composés d'un plus ou moins grand nombre d'articles, de formes très variées, plus ou moins développés, et situés sur la tête de la plupart des animaux articulés, à savoir : au nombre de deux, de quatre et quelquefois de cinq, dont un impair, chez les Néréides, dans la classe des Annélides; de deux et le plus souvent de quatre chez les Crustacés, à l'exception des Limules, qui en sont privés (à moins qu'on ne prenne pour des antennes les deux corps articulés qu'ils présentent à leur partie antérieure, et que Savigny assimile, avec plus de raison, à la seconde paire de pieds-mâchoires des Crustacés, ou aux mandibules des Arachnides); et enfin de deux seulement chez les Myriapodes et les Hexapodes ou les Insectes proprement dits, c'est-à-dire non compris les Arachnides, qui sont également dépourvues de ces organes, comme les Limules.

Considérées anatomiquement, les Antennes se composent d'une quantité variable de grosses et plus courtes chez le mâle que chez petits articles cornés ou coriaces a l'extérieur, tubulaires et perforés dans toute la longueur de leur axe, et renfermant une substance molle et membraneuse, qui reçoit les derniers rameaux des nerfs et des trachées de l'extrémité antérieure du corps.

Savigny a le premier constaté l'existence des antennes dans les Nérćides. Avant lui, ces parties étaient considérées comme des Tentacules ou des Cirrhes. Elles sont peu rétractiles, de forme variable, en nombre pair ou impair, courtes, et de deux articles seulement dans le premier cas, comme dans les g. Lycoris, Nephtys, Aricie, Glycère, Ophélie, Hésione, Myriane, Phyllodocé; longues et composées de beaucoup d'articles, dans le second cas, comme dans le g. Syllis.

La plupart des Crustacés ont 4 antennes. Ghez les Décapodes, elles sont tantôt petites et tantôt très longues; dans le premier cas, les intermédiaires sont ordinairement cachées dans un creux, où elles sont repliées, et, dans le second, elles sont à découvert, et presque aussi longues que les latérales. Dans l'ordre des Stomapodes, les antennes internes se terminent par trois filets, tandis que les externes n'en offrent qu'un seul; la base de celles-ci est composée d'un grand nombre d'articles groupés entre eux et placés sur des plans differents. D'autres Crustacés offrent une disposition semblable; et, sous ce rapport, leur base diffère beaucoup de celle des mêmes parties dans les autres animaux articulés. Dans l'ordre des Amphipodes, les antennes sont presque toujours en forme de soies, et placées par paire, les unes au dessus des autres, sur une tête distincte; dans celui des Isopodes, elles ont une disposition à peu près semblable : les latérales sont toujours sétiformes et composées de 8 articles; les intermédiaires sont quelquefois si petites, qu'on les aperçoit à peine. - Dans le dernier ordre, celui des Branchiopodes, les antennessont au nombre de 4 ou de 2 seulement, et de formes très variées. Elles sont ou simples, ou velues, ou en pinceaux, dans le g. Lyncée; rameuses dans le g. Daphnis; en pinceaux dans le g. Cypris; velues dans le g. Cythérée; capillaires dans le g. Branchipe; celles du g. $\mathbf{C y}$ clope sont divisées en trois articles, et plus 
la femelle; les antérieures sont petites et composées de $\mathbf{3}$ articles, et les postérieures plus longues et composées de 4 articles dans le g. Argule; enfin dans le g. Zoé, les quatre antennes sont placées à peu près sur la même ligne; les internes sont assez grosses, à articles peu distincts, avec un petit appendice cylindrique près de leur extrémité, et au devant est un article conique, garni de poils du côté intérieur; les externes sont très courtes, grêles et styliformes.

Les Myriapodes n'ont que deux antennes, comme les Hexapodes; elles sont courtes, un peu plus grosses vers le bout ou filiformes, et composées de 7 articles dans les Chilognathes; longues, sétacées et composées d'un grand nombre d'articles dans les Chilopodes.

De tous les animaux articulés munis d'antennes, les Insectes ou Hexapodes sont ceux chez qui ces organes ofirent la plus grande variété de formes. Chez eux, l'articulation des antennes avec la tête rentre dans celles que M. Strauss nomme cotyloïdiennes. La base du premier article se renfle, surtout chez les Coléoptères et les Hyménoptères, et est reçue dans une cavité de la tête (torulus, Mirby), ordinairement arrondie, très lisse également, et tapissée, excepté à la partie centrale, d'une membrane épaisse. Le bulbe est percé à son extrémité pour donner passage aux muscles et aux nerfs que contient l'antenne; les bords de l'ouverture ont de chaque côté une légère échancrure, et sont garnis d'un ligament membraneux qui s'unit à la membrane de la cavité, au centre de celle-ci. Cette sorte d'articulation imprime à l'antenne un mouvement de rotation dans tous les sens. Dans les deux ordres que nous venons de nommer, la rotule est quelquefois très grande, comme séparée du reste de l'article par un étranglement bien marqué, et fait une saillie hors du torulus. On pourrait alors la prendre pour un article distinct; mais en l'examinant avec attention, on apercoit promptement qu'elle n'a pas de mouvement propre, et qu'elle n'est qu'un simple renflement du premier article. Le torulus, de son côté, pourrait également quelquefois donner lieu à une semblable méprise, lorsque ses bords sont relevés et qu'ils prennent la forme d'un tubercule plus ou moins sail- lant, évasé et à bords inćgaux; mais son union intime avec la tête ne peut laisser aucun doute à cet égard.

La partie de la tête où cette articulation a lieu, en d'autres termes, l'insertion des antennes, présente d'assez nombreuses variations, dont les principales s'expriment par les termes suivants, d'un usage fréquent dans l'entomologie descriptive.

Les antennes sont dites : Préoculaires (prǫoculares), lorsqu'elles sont insérées devant les yeux; ex. : Chrysis, Carabus, etc.;

Interoculaires (interoculares), quand elles sont placées sur un point quelconque entre les yeux; ex. : Leptura, Haliplus, Reduvius, etc.;

Inoculaires (inoculares), si elles sont insérées dans une échancrure des yeux, qui sont alors plus ou moins réniformes et les entourent partiellement à leur base; ex. : un grand nombre de Longicornes;

Suboculaires (suboculares), lorsqu'elles sont placées au dessous des yeux; ex. : Fulgora, Nepa;

Rostrales (rostrales), si elles sont portées sur un prolongement de la tête ou bec: c'est le cas où leur éloignement des yeux est le plus considérable; ces derniers restant toujours à la base du bec; ex. : la majeure partie des Curculionites;

Supérieures (superiores), quand elles sont situées sur le vertex; ex. : quelques Longicornes;

Inférieures (inferiores), lorsqu'elles sont insérées sous la tête; ce qui a lieu quand l'épistome et les joues sont dilatées et recouvrent les parties de la bouche et celles qui sont adjacentes. Les antennes sont alors situées à l'angle intérieur de la jonction des joues et de l'épistome sur le front; ex. : $\mathrm{Co}$ pris, Ateuchus.

Quant à leur situation relative, c'est-àdire la distance qui les sépare l'une de l'autre, les antennes sont dites : Écartées (distantes, remoía), lorsqu'elles sont éloignées l'une de l'autre à leur base; ex. : Buprestis rustica, et la majeure partie des Golcoptères ;

Rapprochées (approximatce), quand elles sont séparées à leur base par une distance peu considérable; ex. : Donacia, Galeruca; Contiguës (contiguce), si elles se touchent presqu'à leur base; ex. : Imatidium; 
Connées (connatre, coadunata, coharentes', lorsqu'elles sont réunies à leur base; ex. : Conops, Ceria.

De leur proportion. - Pour exprimer les différences de longueur des antennes, on les compare, sous ce rapport, aux autres parties du corps. On dit qu'elles sont très courtés (brevissima), lorsqu'elles sont plus courtes que la tête; ex. : Coccinella;

Courtes (breves), quand leur longueur égale celle de la tête; ex. : Hister;

Médiocres (mediocres), si elles sont aussi longues que le corps; ex. : Callidium violaceum;

Longues (longar), quand elles dépassent le corps en longueur, mais de peu; ex. : Monohammus sutor;

Très longues (longissima), lorsqu'elles sont considérablement plus longues que le corps ; ex. : un grand nombre de Longicornes parmi les Coléoptères, et le genre Adèle dans les Lépidoptères.

De leur structure. - Les Antennes sont composées d'un plus ou moins grand nombre d'articles, qui, en général, ont chacun leur mouvement propre, ce qui permet à l'animal de les fléchir dans tous les sens. Chaque article se joint au précédent, tantôt par articulation cotyloïdienne, tantôt au inoyen d'un ligament, sans qu'il y ait enchâssement d'un condyle dans une cavité. En général, ces articles sont placés bout à bout; mais, dans beaucoup de cas, leur disposition est telle, que le premier, qu'on nomme basilaire ou scapus, forme un angle plus ou moins aigu avec le reste de l'antenne; ce qui a fait appeler coudées, brisées ou géniculées (geniculatce), les antennes ainsi conformées. Telles sont celles des Lamellicornes, des Curculionites-Gonatocères, et d'un grand nombre de femelles et de neutres chez les Hyménoptères. Dans les antennes coudées, le scapus forme à lui seul la moitić de leur longueur; dans celles qui sont droites (recte) , cet article se distingue toujours des autres, soit parce qu'il est plus gros ou plus long, soit parce qu'il affecte une forme particulicre. Quant au reste de l'antenne, on le divise eñ tige (caulis), et en massue (clava) lorsqu'elle s'épaissit vers son extrémité : c'est ce qu'on remarque dans toutes les antennes coudées, et dans beaucoup de celles qui sont droites, telles que celles des Coléoptères clavicornes et des Lépidoptères diurnes ou Rhopalocères. Le second article des antennes, qui forme le premier de la tige (pedicellus, Kirby), ne mérite pas moins d'attention que le scapus sur lequel il s'insère. Tantôt il est très grand et forme à lui seul le tiers ou la moitié de la longueur de l'antenne, comme dans les Mélasomes, et tantôt il est à peine visible et soudé avec le troisième, comme dans les Longicornes. Quant aux autres articles, leur dimension varie autant que leur forme, ainsi que nous le verrons plus bas.

Maintenant, si nous considérons les antennes sous le rapport du nombre des articles dont elles se composent, nous verrons que ce nombre est extrêmement variable, et que, si la nature a suivi un plan à cet égard, il est encore à deviner. Cependant, comme on a remarqué que les antennes des Coléoptères sont presque toujours composées de onze articles, on s'est accordé à regarder ce nombre de onze comme la règle dans cet ordre d'Insectes, et tout ce qui s'en écarte comme une exception. On a d'ailleurs supposé que, si l'on ne les aperçoit pas tous dans certains genres, ceux qui paraissent manquer n'en existent pas moins, et seraient visibles comme les autres, s'ils n'étaient soudés entre eux ou avec ceux qui les avoisinent. Aussi il en serait des antennes comme des tarses, qu'on prétend être toujours composés de cinq articles, bien que, dans plusieurs familles, il soit impossible d'en distinguer plus de quatre, trois ou même deux, avec la loupe la plus forte. Quoi qu'il en soit de cette théorie, qui repose sur une idée philosophique (l'unité de composition), toujours est-il qu'au dela de onze, le nombre des articles des antennes ne paraît plus assujetti à aucune règle. Ainsi on en compte douze chez le Cebrio gigas et certaines Chrysomèles et Saperdes; vingt chez le mâle du Prionus imbrioornis, dont la femelle n'en a que neuf; trentedeux chez la Rhipicera marginata, et jusqu'à trente-huit chez d'autres esp. du même g. Les Orthoptères offrent surtout les plus grandes anomalies sous ce rapport. Quelques Sauterelles ont quatorze articles, d'autres seize, et quelques unes vingt-cinq. Ils sont au dela de trente chez les Mantes; mais 
nulle part, dans cet ordre, ils ne sont plus nombreux que chez les Blattes, chez qui l'on en compte jusqu'à près de cent cinquante. On a remarqué, en outre, que, chez ces Insectes, le nombre des articles varie non seulement d'une espèce à l'autre, mais dans une même esp. Dans les Hémiptères, ils suivent la même progression que chez les Coléoptères, c'est-à-dire qu'on en compte depuis deux (g. Flata) jusqu'à onze (g. Coccus).

Tous les Lépidoptères, à l'exception du genre Hépiale, ont les antennes composées d'un nombre considérable d'articles, souvent si minces et si peu distincts, qu'il est presque impossible de les compter même avec l'aide d'une forte loupe. Il en est de même de la tribu des Ichneumonides parmi les Hyménoptères; mais d'autres tribus du même ordre se rapprochent à cet égard de la loi générale. Ainsi, les esp. pourvues d'un aiguillon ne possèdent que douze articles chez les femelles, et treize chez les mâles. Les Tenthrédines et le reste de l'ordre présentent sous ce rapport des variations si nombreuses, qu'il serait impossible de les énumérer brièvement. Enfin, chez les Diptères, il paraît y avoir deux types généraux : l'un composé des antennes des Tipulaires, qui ont de quatorze à seize articles, et le second qui embrasse tout le reste de l'ordre, où elles ne dépassent jamais trois articles; mais il est à observer que le premier, qui a reçu dans cet ordre le nom de palette, paraît assez souvent formé de plusieurs articles soudés ensemble.

Les antennes qui ont beaucoup d'articles se disent multi-articulatc; celles qui en ont peu, pauci-articulata. Lorsque le nombre de leurs articles est susceptible d'être compté, on les appelle bi-articulés, triarticulés, quadri-articulés.

Les articles dont se composent les antennes offrent dans leur forme d'innombrables modifications, qui influent sur celle de l'antenne en général. Toutefois, ces modifications peuvent être ramenées à un certain nombre de types, dont nous allons faire connaître les principaux, en divisant les Antennes en Régulières et en Irrégulières.

Parmi les premières, on nomme : Sétacées ( setacece), celles qui diminuent quelconque de leur longueur; comme pour de grosseur de la base au sommet; ex. : les Sauterelles; etc.;

Sétiformes (setiformes), celles qui sont courtes et rigides, et vont en diminuant de la base au sommet, où elles se terminent en pointe allongée et très aiguë; $e x_{\text {. }}$ : les Libellules;

Filiformes (fliformes), celles qui gardent le même diamètre dans toute leur longueur; ex. : les Carabes;

Fusiformes (fusiformes, celles qui sont renflées dans le milieu, en forme de fuseau; ex. : les Zygènes, les Sésies;

Prismatiques (prismatica), celles qui offrent trois côtés presque égaux; ex. : les Sphynx;

Ensiformes (ensiformes), celles qui sont en forme de lame d'épée; ex. : les Truxales;

Moniliformes (moniliformes), celles qui sont composées d'articles globuleux, arrondis et disposés comme les grains d'un chapelet; ex. : les Ténébrions;

Perfoliées (perfoliatce), celles dont les articles sont discoïdaux, et portés par un pédoncule qui semble les traverser; ex. : les Lagries;

Imbriquées (imbricata), lorsque les articles sont concaves d'un côté, convexes de l'autre, et s'emboîtent l'un dans l'autre ; ex. : leś Diapères ;

Feuilletées (foliatce) ou lamellées (lame?latce), celles dont les articles terminaux se dilatent en lames plus ou moins minces et larges, lesquelles s'épanouissent ou se ferment à la manière des branches d'un éventail ou des feuillets d'un livre; ex. : le Hanneton foulon;

Épaissies (incrassatœ). Ce mot, employé seul, indique un grossissement dans une partie quelconque de l'antenne. Si ce grossissement est subit, on dit que les antennes sont subitement épaissies (subito incrassa$t(e)$; s'il a lieu graduellement de la base au sommet, elles sont dites sensim incrassa$t a$;

Noueuses (nodosa), celles qui ont un on plusieurs articles disproportionnément plus gros que ceux qui les avoisinent; ex. : $M e^{-}$ lö̈;

Atténuéés (attenuatce), celles qui sont disproportionnément grêles dans une partie 
les antennes épaissies, on dit qu'elles sont subitement ou graduellement atténuées (subito vel sensim attenuate);

En scie (serrata), celles dont chaque article se prolonge du côté interne en une dent de scie ; ex. : les Buprestes;

Pectiuées (pectinata), celles dont la tige est munie de chaque côté d'une rangée de petites branches paralleles imitant les dents d'un peigne ; ex. : un grand nombre de Bombyx;

Plumeuses ou penniformes (penniformes), celles qui resseinblent aux grandes plumes des Oiseaux ; ex. : mâles d'un grand nombre de Phalenides;

Rameuses (ramosa), celles qui sont garnies d'un côté de deux ou trois longues branches irrégulières; ex. : le g. Phengodes;

Flabellées (flabellatce), celles dont Ies articles, excepté ccux de la base, envoient intérieurement de longs rameaux flexibles et aplatis; ex. : Tetralobus flabellicornis;

Palmées (palmatce), celles qui sont très courtes, et qui envoient extérieurement quelques longues branches ressemblant à des doigts; ce qui leur donne quelque rapport avec une main;

Subulées ( $s u b u l a t a)$, celles qui sont cylindracées inférieurement, et se terminent en une pointe roide et aiguë comme une alène ;

Capillacées (capillacece), celles qui se terminent par un filet capillaire, articulé;

Mucronées (mucronatce), celles qui se terminent par une pointe courte et mousse; ex. : le g. Scotobius;

A aigrettes (aristatce), celles qui se terminent par un article en forme de palette, et portant une soie latérale nue ou garnie de yoils; ex : les Muscides;

Fn massue ( clavatce), celles dont les articles terminaux deviennent graducllement plus gros;

Capitées (capitata), celles dont les articles se renflent subitement pour former la massuc. Cette dernière offre dans sa composition des différences très remarquables.

Cile est fissile (fissilis), lorsque les articles ont la forme de feuillets, et peuvent s'ouvrir et se fermer comme ceux d'un livre; ex. : le g. Melolontha;

Tuniquée ou enveloppante (tunicuta), lorsque l'un des articles de sa base est creu- l'un appendice en forme d'oreillette, qui les

$$
\text { r. I. }
$$

sé en entonnoir, et recouvre plus ou moins les suivants ; ex. : le g. Lethrus;

Solide (solida), lorsqu'elle ne consiste qu'en un seul article, ou que, s'il y en a plusicurs, ils sont à peine distincts, et comme soudés ensemble; ex.: les g. Rhina, Hister;

Renflée (inflata), lorsqu'elle est d'une grosseur disproportionnéc avec le reste de l'antenne, et paraît comme gonflée.

Quant aux antennes irrégulières, elles affectent, en général, des formes si bizarres, qu'il n'existe pas de terme de comparaison pour les exprimer. Du reste, elles lentrent plus ou moins dans l'un des types que nous venons de désigner, et ne se rencontrent que dans un petil nombre d'espèces, parmi lesquelles nous citerons pour exemple les mâles du g. Cerocoma, et le g. Paussus.

Les antennes sont rarement glabres; le scapus, la tige, la massue, ou tous les trois in la fois, sont plus ou moins tomenteux ou velus. Souvent aussi, comme dans les Prioniens, elles sont rugueuses ou hérissées de tubercules, de piquants, d'épines, etc. On leur applique alors les termes que nous avons indiqués plus haut en parlant de ces excroissances.

Après avoir fait connaître les formes extrêmement variées des antennes, il nous reste à parler de leur position lorsque les Insectes sont en repos ou en mouvement. Dans le premier cas, la plupart se contentent de les ramener sur le dos en les y appliquant plus ou moins exactement (Longicornes), ou sur les bords latéraux de la tête du thorax et du corps (Carabiques, Mélasomes, Noctuélites, etc.); mais d'autres sont pourvus de cavités spéciales dans lesquelles elles sont reçues totalement ou en partic. Tantôt ces cavités sont creusées sur les côtés inférieurs du prothorax, comme dans quelques Élatérides(Pterotarsus Galba), les Anthrènes, les Gribouris, les Chlamys, etc.; tantôt sur les parties latérales de la tête, comme dans les Curculionites; mais, dans ce dernier cas, le scapus seul est reçu dans cette rainure. Chez les Gyrins et les Parnes, qui font partie du même ordre, la cavité antennaire est également situéc dans la tête; mais, ces Insectes étant aquatiques, la nature, pour protéger leurs alltennes contre l'action de l'eau, 'les a pourvues à leur base 
recourre complètement Iorsqu'elles sont ainsi cacbées. Chez les Nèpes, principalement celles dn g. Belostoma, on observe également entre les yeux et les pièces inférieures de la tête une rainure profonde et réniforme dans Iaquelle les antennes se replient de manière à ce que les premiers articles soient visibles et protègent les autres. Les Cryptocères (g. remarquable de Fourmi) portent sur la tête une sorte de pièce carrée dont les bords forment une profonde cavité longitudinale, dans laquelle les antennes sont complètement cachées au repos. Enfin, chez un grand nombre de Muscides, elles sont reçues dans une fossette verticale du front, qu'elles remplissent entièrement. Avant de se replier pour entrer en repos, les antennes, flabellées. et feuilletées, ferment leurs feuillets ou leurs branches, et les appliquent exactement l'une contre l'autre. Celies qui sont coudées plient leur tige, et l'appliquent contre le scapus. Lorsque les Insectes qui sont pourvus de ces deux sortes d'antennes se mettent en mouvement, on les voit écarter les lames qui composent la massue, comme pour percevoir les impressions relatives au sens dont elles sont te siége, ou, si elles sont brisées, séparer la tige du scapus, et la porter en avant. En général, tous agitent plus ou moins ces organes pendant le mouvement, les uns alternativement, avec lenteur et une sorte de régularité; d'autres dans tous les sens, et quelques uns, tels que les Ichneumonides chez les Hyménoptères, leur impriment un mouvement de vibration très rapide et continuel; pendant le vol, elles sont dirigées en avant ou perpendiculairement à l'axe du corps, ou enfin ramenées sur le dos.

De l'usage des antennes. - Les naturalistes sont loin d'être d'accord sur ce point. Les uns, et c'est le plus grand nombre, ont vu dans ces appendices l'organe principal du toucher; d'autres celui de l'odorat; quelques uns celui de l'ouie; il en est enfin qui en ont fait le siége d'un sixième sens, destiné à apprécier l'état de l'atmosphère. Cette diversité d'opinions n'étonnera pas si l'on considère que les antennes, indépendamment de leur fonction principale, qui est nécessairement la même dans tous les animaux qui en sont pourvus, servent en même temps à des usages secondaires, qui varient avec leur forme, ainsi que nous le verrons plus bas. De là deux ordres de faits bien distincis, que les expérimentateurs auront confondus dans leurs observations. Mais quelle est cette fonction principale? Des expériences plus judicieusement faites que celles qu'on a recueillies jusqu'd présent pourront seules décider la question. En attendant, l'opinion qui nous paraît la plus vraisemblable est que les antennes ont pour fonctions essentielles celles du tact. En effet, la majeure partie des animaux qui en sont pourvus sont couverts d'un tégument calcaire ou corné, qui les rend peu sensibles au contact des corps environnants. Des organes spéciaux devaient donc suppléer chez eux à ce défaut de sensibilité. On peut objecter, il est vrai, qu'une famille nombreuse d'Articulés, les Arachnides, parmi lesquels on remarque plusieurs g. à gaîne tégumentaire solide, sont privés des appendices antennaires; mais, chez les Aranéides ( Araignées proprement dites) et chez les Phalargiens (Faucheurs), les pattes semblent disposées pour exercer les fonctions tactiles; chez les Pédipalpes (Scorpions, etc.), les pinces sont destinées à remplir les mêmes fonctions; enfin, chez les Acariens, la bouche, conformée en suçoir, est armée de palpes, de pinces et de soies douées d'une grande sensibilité. L'opinion qui place le siége du toucher dans les antennes, chez les Articulés, nous semble confirmée par l'observation de dispositions analogues chez un grand nombre d'autres animaux de classes toutes differentes, et qui présentent à la tête et aux environs des organes masticatoires, des appareils tactiles très développés : tels sont les bras des Mollusques céphalopodes; les tentacules et les yeux pédonculés des Gastéropodes; les barbillons de certains Poissons; le bec revêtu d'une membrane riche en filets nerveux chez quelques Oiseaux; les moustaches des Chats, et surtout des Phoques; enfin le museau de la Taupe, de la Musaraigne; le boutoir du Cochon, du Tapir, et, par dessus tout, la trompe de l'Éléphant.

C'est ici le lieu de discuter si les antennes sont réellement le siége d'un toucher tout particulier qui constituerait comme un sixième sens. Cette opinion nous paraît logiquement inadmissible, quelque exquise qu'on suppose la sensibilité des appendices 
qui nous occupent, puisque nous ne pou- l d sur quoi ils la fondent. Si l'on regarde, vols nous rendre compte que des sensations que nous éprouvons nous-mêmes. Nous royous en efret tous les jours chez les aveugles la surface tégumentaire devenir tellement sensible, qu'elle perçoit le moindre ébranlement atmosphérique, et certes personne n'a jamais songé à admettre chez eux le développement d'un nouveau sens. Le toucher est tellement parfait dans les ailes membraneuses des Chéiroptères, que ces animaux, au milieu d'une obscurité complète et dans de profondes cavernes, se dirigent avec la plus grande précision sans le secours de la vue, et par conséquent par la seule impression de l'air sur leurs ailes. Ce fait est constaté par de nombreuses observations.

11 est donc raisonnable d'admettre que les antennes des Articulés sont le siége d'un toucher analogue à celui qui réside dans les ailes des Chéiroptères. Cette opinion acquerra un nouveau poids si l'on considère que ce sont les antennes des Insectes crépusculaires et nocturnes qui offrent la plus grande surface (antennes feuilletées des Scarabées, pectinées des $\mathbf{L u}$ canes, plumeuses du Bombyx, des Phalères, etc.), et, de plus, que dans certaines familles, dans certains genres où les femelles sont sédentaires, celles-ci ont les antennes à peines ciliées et même filiformes, tandis que chez les mâles, qui voltigent sans cesse, ces appendices sont très développées.

Les antennes, organes du tact, semblent, chez certains Hyménoptères qui vivent en société, devenir organes de relation. Le der. nier article des antennes chez ces Insectes, dit M. Robineau-Desvoidy, est à lui seul un organe à part, essentiellement pulpeux; il recèle des facultés bien supérieures à celles du tact, comme on peut l'observer chez les Fourmis et les Abeilles, qui ont l'air de se comprendre et de se communiquer leurs idées en se touchant réciproquement avec la massue de leurs antennes. Devenus organes de relation, ces appendices seraient alors comparables aux membres thoraciques de l'homme, membres qui, siége du toucher par excellence, sont également orgaues d'expression.

Quant à l'opinion de ceux qui placent dans les antennes le siége de l'odorat, voidisent-1ls, comme identiques les nerfs qui, dans lo cerveau des Vertébrés et dans la masse ganglionnaire analogue des Invertébrés, naissent en avant des nerfs optiques, on sera amené à regarder les nerfs des antennes comme cenx de l'olfaction : tel est, en effet, le raisonnement de MM. de Blainville et Robineau - Desvoidy. Réaumur et Roesel, avant ces deux savants, avaient déjà pensé que l'odorat des Articulés résidait dans les antennes. Le dernier avait appuyé son opinion sur les dispositions anatomiques qu'il avait reconnues chez l'Écrevisse et chez les Mouches; et, de nos jours, l'anatomiste allemand Carus avoue que, dans l'embarras où sont les naturalistes d'assigner avec quelque certitude le siége du sens olfactif chez les Articulés, l'opinion de Réaumur, combinée avec celle de Roesel, lui paraît réunir toutes les probabilités, tant à cause de la forme de lames ou de branchies qu'affectent souvent les antennes qu'en raison de Jeur voisinage du ganglion cérébral. Dugès admet aussi que les antennes sont le siége de l'odorat; il a fait à ce sujet une série d'expériences sur des Grillons, des Bombyx, des Mouches (Vomitoria et Carnaria), et il a cru remarquer que la perception des odeurs était abolie par l'amputation des antennes. M. Alex. Lefebvre a fait la même opération sur une Guêpe, et il a obtenu un semblable résultat ( $A$ nn. de la Soc. ent. de France, t. YII, 1838, p. 398 ). En comparant ces faits avec ce qui s'observe chez les animaux d'un ordre supérieur, tels que l'Éléphant et le Cochon, chez lesquels la trompe et le grouin touchent et flairent, l'analogie nous conduirait également à admettre que le sens de l'odorat chez les Articulés peut se trouver dans le voisinage de celui du toucher.

Les inductions qui ont été tirées de la distribution des nerfs, et qui ont porté à placer l'organe olfactif dans les antennes, donneraient les mêmes résultats pour le sens de l'ouie. Chez les Grustacés, ou du moins chez les Crustacés macroures, l'antenne externe (grande antenne ou antenne postérieare) pré sente à sa base une petite saillie cylindrique, percée d'un trou arrondi et fermé par une membrane ; cette membrane est elle-mème perforee d'une fente ou ouverture oblongue 
d laquelle fait suite un cul-de-sac. M. Dugès, auquel nous empruntons ces détails anatomiques, admet que ce cul-de-sac recoit un nerf dont le tronc représente à la fois les deux parties de la septieme paire chez les vertébrés (nerf auditif et nerf facial). Une portion de ce nerf est destinée à l'organe auditif, et l'autre va se distribuer à l'antenne même. La cavité dont nous venons de parler serait donc un sac vestibulaire, avec sa fenêtre ovale; sac qu'on pourrait comparer aux vestibules des Poissons cartilagineux; et les antennes, qui, par leur vibration, faciliteraient la perception des sons, offriraient ainsi une sorte de ressemblance avec le pavillon de l'oreille, souvent si développé chez quelques Mammifères. Si la disposition observéc par M. Dugès était démontrée, il faudrait signaler chez les Crustacés la similitude qui existe entre les appareils de l'audition et de l'olfaction, qui tous deux ont la forme d'antennes dont la base renferme l'organe sensitif, tandis que le prolongement ne sert qu'à des fonctions tactiles. Le siége de l'audition n'est pas aussi visible dans les antennes des Insectes. Carus prétend que la membrane qui unit ces appendices à la tête est peut-être chargée de percevoir les sons; mais rien ne le prouve. Treviranus croit que la massue antennaire des Papillons diurnes renferme un appareil guditif. M. Strauss place le siége de l'ouie dans les antennes feuilletées des Hannetons; enfin M. Lacordaire, qui, dans son introduction à l'entomologie, adopte l'opinion des auteurs qui font des antennes le siége de l'audition, développe cette opinion avec beaucoup de clarté, et l'appuie de raisons spécieuses, qu'il serait trop long de rapporter ici. Au reste, si l'on ne consultait que l'analogie, on ne pourrait se dispenser d'admettre que les antennes sont effectivement le siége de l'ouie chez les Articulés, car elles occupent chez eux la même place que les oreilles chez les Vertébrés, et l'on voit certains Insectes les dresser ou les baisser au moindre bruit ; mais cette analogie peut être trompeuse.

Nous terminerons cet exposé sur l'usage présumé des antennes en rapportant quelques faits qui ne permettent pas de douter que ces appendices ne servent à des emplois secondaires, indépendamment de leurs fonc- tions principales, comme nous l'avons dit plus haut. Dans certaines familles de Coléoptères dont le corps est très allongé, et chez lesquels l'attache des ailes est placée très haut, à cause de la brièveté du corselet, les antennes, par leur longueur et leur grosseur, servent évidemment à faire équilibre avec le corps, et à le maintenir pendant le vol dans une position horizontale, ainsi qu'on le voit dans un grand nombre de Longicornes. Dans les Lépidoptères à vol puissant et rapide tels que les Sphyngides, les Vanesses, les Nymphales, les antennes sont en rapport avec le corselet, qui est très robuste; elles sont longues, raides, épaisses, filiformes, ou se prolongent insensiblement en massue; tandis qu'elles sont courtes, à tige grêle, et terminées par un bouton court et piriforme, chez les Lépidoptères, dont le vol est faible et sautillant, comme dans la plupart des piéries et des Satyres. Dans les g. Lyncée, Daphné et Cypris, parmi les Crustacés, les antennes serviraient secondairement à la natation, tandis que, dans le g. Cyclope, suivant les observations de M. Jurine fils, elles serviraient à maintenir l'animal en équilibre au milieu du liquide ambiant, et que, de plus, celles du mâle seraient des organes d'excitation et de préhension dans l'accouplement. Les antennes sembleraient être également des organes excitateurs chez certains Lépidoptères; l'un des auteurs de cet article a vu un mâle du Satyre Megera préluder à l'accouplement en frappant de coups répétés avec le bouton terminal de ses antennes la tête et le corselet de sa femelle, jusqu'à ce qu'elle se fût rendue à ses désirs, et ce manége a duré plusieurs minutes. Enfin M. Audouin (Annal. de la Soc. entom. de France, t. I, p. 5) assure avoir observé que c'est par les antennes que les Hydrophiles se procurent l'air nécessaire à leur respiration, en remontant à cet effet à la surface de l'eau. Ainsi, soit que les antennes aient pour fonctions principales le toucher, l'odorat ou l'ouïe, elles serviraient en même temps, dans certains cas, d'organes locomoteurs, respiratoires et excitateurs.

Do l'emploi des antennes dans ia classification. - Cet emploi n'est pas aussi important qu'on pourrait le croire au premier abord. Leurs formes éminemment variables , 
qui s'accordent rarement avec celles d'organes plus essentiels, ne les rendent propres qu’à fournir des caractères tout au plus du troisième ordre dans les coupes génériques; mais il n'en est pas de même pour les rrandes divisions. Ainsi M. Duméril, dans sa Zoologie analytique, s'en est servi pour diviser l'ordre des Lépidoptères en quatre familles, qu'il nomme Rhopalocères ou Globulicornes, Clostérocères ou Fusicornes, Nématocères ou Filicornes, Chétocères ou Séticornes. M. Boisduval s'en est également servi, mais sculement pour établir deux grandes divisions dans ce même ordre, à savoir : les Rhopalocères et les Hétérocères. Dans les Coléoptères, on compte quatre familles, qui tirent leurs noms de la forme des antennes, à savoir : les Clavicornes, les Lrmellicornes, les Taxicornes et les Longicornes. Au reste, si les antennes ne peuvent fournir de bons caractères génériques, elles sont très utiles pour servir à distinguer un sexe de l'autre. C'est une règle constante que celles des mâles sont toujours plus développées que celles des femelles, et souvent très différentes non seulement pour la forme, mais pour le nombre des articles. Nous citerons ici quelques exemples des plus saillants à l'appui de cette assertion. Dans certains Longicornes (Lamia, Astynomus, Acanthocinus), et quelques Curculionites ( $A n$ thribides), celles des mâles sont deux et trois fois plus longues que celles des femelles. Le mâle de la Rhipicera marginata a 32 articles aux siennes, tandis que la femelle n'en a que 11. Ghez le Hanneton Foulon, la massue feuilletée des antennes a dix fois plus d'étendue dans le mâle que dans l'autre sexe. Mais c'est surtout sous le rapport de la forme que ces organes offrent les différences les plus frappantes entre les deux sexes. Dans les Bombyx, les Rhipicères, les Lampyres, certaines Tenthrédines, certaines Tipules, on reconnaît au premier coup d'œil les mâles aux rameaux plus ou moins nombreux dont est garnie la tige des antennes, tandis que cette tige est simplement en scie, ciliée, sétacée ou moniliforme, dans les femelles. Il en est de même du g. Cérocome, dont les antennes, presque filiformes dans les femelles, sont très épaisses et d'une forme très compliquéc dans les mâles.
Telles sont les considérations les plus es sentielles auxquelles donne lieu l'examen des antennes dans ceux des animaux articulés qui en sont pourvus.

\section{(D. et A. Dupovanel.)}

ANTENNES. Antennce. porss. - Dénomination très peu usitée en Ichthyologie pour désigner les appendices filiformes que portent certaines Scorpènes, la plupart des Blennies, et les espèces démembrées de ces g. L'expression la plus employée pour nommer ces organes est celle de tentacules.

(VAL.)

ANTENNULAIRE. Antennularia (antenna, antenne). PoLYP. - Le genre Antennulaire de Lamarck ou Nemertesie de Lamouroux se compose de Polypiers flexibles de la famille des Sertulariens, dont la tige est articulée, et garnie tout autour de branches courtes et grêles, sur lesquelles sont placées sur un seul rang de petites cellules sessiles et campanuliformes. (M. E.)

ANTENNULAIRE. Antennularius (antenna, antenne). CRUST. - Anneau antennulaire ou second segment céphalique du squelette tégumentaire des Crustacés.

(M. E.)

ANTENNULES. Antennule (dimin. d'anterna, antenne). rvs. - Synon. de palpes chez les anciens entomologistes, principalement pour désigner les palpes maxillaires, qui, dans beaucoup d'Insectes, ressemblent à de petites antennes; mais cette expression vicieuse n'est plus employée depuis long-temps. Voy. PALPES.

ANTENOR. Antenor ( nom mythol.) FORAMiv. - Genre établi par Montfort (Conchyl. syst., p. 70) pour une des nombreuses variétés de la Robulina calcar. Voy. ROBULINE. (A. d'O.)

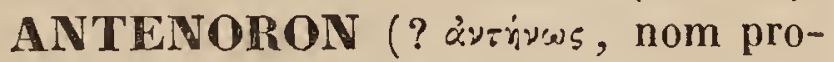
pre). вот. PH. - Genre de la famille des Polygonacées, tribu des Polygonées vraies, formé par Rafinesque (Flor.Ludov.t. VIII), et rapporté en synonymic au g. Persicaria, Tourn., qui n'est lui-même qu'une section du grand genre Polygonum. Voy. ces mots.

(G. L.)

ANTEON. INS. - Genre de la famille des Oxyuriens, de l'ordre des Hyménoptères, section des Térćbrans, établi par Jurine (Nouv. Méth. de cl. les Hym.), adopté I par Latreille, Necs von Esenbeck, elc., 
et réuni au g. Dryinus par Walker (Ent. mag.) et par nous (Hist. des Anim.art., ใ. IV). Les Antéons diffèrent des Dryinus proprement dits, d'après Latreille, par le thorax, continu, ne formant pas de nœuds, et par les tarses, terminés par des crochets simples et droits. Le type de ce g., dont on ne connaît que quelques espèces indigènes, est I'A. Jurineanum, Latr. Voy. DRYIrus.

(BL.)

ANTHACTINIA, Bory. - Granadilla, DG. , sub Passiflora ( $\alpha \alpha_{\nu} \theta \eta$, fleur ; axris, ìos, rayon ). вот. PH. - Sous-genre ou section du g. Passiflora. Ses caract. estiels sont : Involucre de $\mathbf{5}$ bractées très entières ou dentées, non découpées, distinctes. Segments du périanthe au nombre de 10. Étamines au nombre de 5. Pédoncules 1-flores, accompagnés d'une vrille. (SP.)

ANTHALMUM ( $\ddot{\alpha} \nu \theta 0 s$, fleur, et $\dot{\partial} \varphi-$

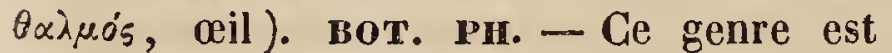
synonyme de Pallenis, Cast.

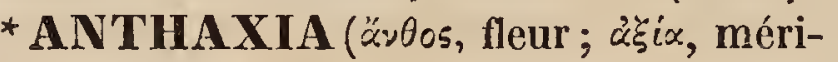
te). Lvs. - Genre de l'ordre des Coléoptères pentamères, famille des Sternoxes, tribu des Buprestides, établi par Eschscholtz, et adopté par la plupart des autres entomologistes. Voici les caract. assignés à ce g. par HI. Delaporte et Gory, dans leur belle iconographie de cette tribu : Palpes maxillaires à $\mathbf{3}$ articles visibles: le $1^{\text {er }}$ long, un peu arqué; le $2^{\text {e }}$ conique, le $\tilde{5}^{\text {e }}$ ovalaire. Palpes labiaux de 3 articles serrés, courts; le dernier un peu pointu. Labre un peu transversal, bilobé en avant. Menton en pentagone régulier. Languette transversale, velue en avant. Mâchoires à lobe externe, grand, arrondi ; l'interne petit, aigu, arqué. Mandibules fortes, arquées, offrant une forte dent interne. Antennes de 11 articles : le $1^{\text {er }}$ grand; le $2^{\text {e }}$ petit, globuleux; le $\mathbf{z}^{\mathrm{e}}$ presque de la grandeur du $1^{\mathrm{er}}$, conique; tous les autres courts, égaux, transversaux, formant une forte dent au côté externe. Tarses à deux $1^{\text {ers }}$ articles coniques, les deux suivants cordiformes, le dernier allongé ; crochets moyens.

MM. Delaporte et Gory décrivent et figurent 38 esp. d'Anthaxia dans leur ouvrage précité. M. Dejean en désigne 44 dans son dernier Catalogue, dont 25 d'Europe, $9 \mathrm{du}$ Cap de Bonne-Espérance, 1 du Sénégal, et 8 de l'Amprique. La plupart de ces esp. sont de petite talle, de forme assez large et a platie, et de couleurs métalliques très brillantes. Flles se tiennent ordinairement sur le tronc des arbres exposés au soleil, et s'envolent facilement lorsqu'on veut les saisir. Nous n'en citerons que quelques unes :

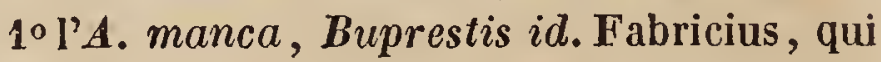
peut être considérée commo le type du g., c'est le Richard rubis de Geoffroy. Il est commun aux environs de Paris, où on le trouve, en mai, sur le tronc des ormeaux, réuni quelquefois en assez grand nombre; 2o l'A. salicis, Buprest. id. Fabricius, qui se trouve également en mai sur le saule; mais plus rarement; et $3^{\circ} l^{\prime} A$. umbellatarum, Buprest. id. Fabricius, qui est très commun sur les Ombellifères, dans le midi de la France.

ANTHELE. Anthela ( $\dot{\alpha} \nu \theta \dot{y} \lambda 0^{\prime} \nu$, petite fleur). вот. - Dénomination imposée par Meyer, dans son travail monographique du g. Juncus, à l'inflorescence spéciale de ces sortes de plantes.

(C. L.)

* ANTHELEPHILE. Anthelephila

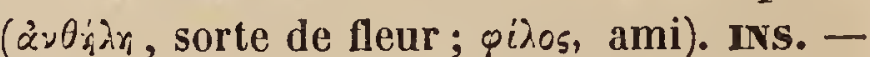
Genre de Coléoptères hétéromères, famille des Trachélides, établi par M. Hope, sans indication de caract., dans la tribu des Anthicides, et auquel il rapporte deux esp. qui vivent dans le sable, sur les bords du fleuve Hoogly, dans les Indes orientales, et qu'il nomme, l'une $\boldsymbol{A}$. ruficollis, et l'autre $\boldsymbol{A}$. mutillaria. Ces deux esp., figurées dans les Transactions de la Soc. entom. de Londres, Ier vol., 1834, pl. 7, fig. 8 et 9, ressemblent à des Mutilles.

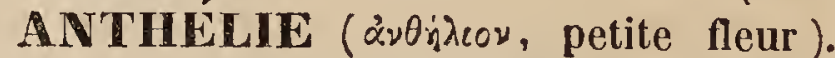
POLYP. - Genre établi par M. Savigny, et se composant de Polypes dont la structure in. dividuelle ne diffère guère de celle des Lo bulaires ou Alcyons proprement dits, mais dont le tissu tégumentaire commun, au lieu de s'élever en une masse arrondie ou lobée, s'étend en plaque mince. L'espèce qui a servi de type pour l'établissement de ce genre est figurée dans le grand ouvrage sur l' gypte ( Hist. nat., t. 2, Polypes, pl. 1, Gg. 7 ). (M. E.)

* ANTHELMINTHIQUE $(\dot{z} \nu \div \iota$, contre; $\varepsilon^{\prime \prime} \lambda_{\mu \iota \nu s,} \theta_{05}$, ver ). - Syn. de VERMuruge. Voyez ce mot.

(C. D'O.)

ANTHEMA, Medicus (Malv., p.42).- 
Anthema, DG. (Prodr. I, p. «3̄9) (avtnux, fleur). Bot. Pr. - Genre ou sous-genre de la famille des Malvacées, fondé sur le Lavatera arborea, Limn., et quelques autres esp. de Lavatères. Toutefois, il est beaucoup moins voisin des Lavatera que des Malva, car il ne diflère absolument de ces dernières qu'en ce que les 5 bractées caliculaires, au lieu d'être parfaitement libres, sont soudées par la base.

(SP.)

ANTHEMIDÉES ( $\dot{\nu} \otimes \varepsilon \mu i \varsigma$, fleur). Bot. PH. - Tribu du groupe des Composées-Sénécionidées, portant des capitules presque constamment hétérogames, et munis de fleurons femelles ou neutres; les anthères dépourvues d'appendices basilaires; les rameaux des styles tronqués, barbus, fort rarement terminés par un cône; les fruits, cylindriques, anguleux ou comprimés dans les fleurs du rayon, sont ordinairement terminés par une aigrette en forme de couronne ou plus rarement formée de squammelles capillaires.

(J. D.)

ANTHEMIOPSIS ( $\dot{\alpha} \nu \varepsilon \mu \dot{s} \varsigma_{s}$, Anthemis ; ö $\downarrow$, aspect; quiressemble à I'Anthemis). вот. Рн. - Nom donné par M. Bojer à une plante qui fait partie du g. Wollastonia.

(J. D.)

ANTHEMIS ( $\dot{\alpha} \nu \theta \varepsilon \mu i s$, petite fleur; fleuron). вот. PII. - Ce genre fait partie de la tribu des Sénécionidées parmi les Composées. Il a pour caractère des capitules multiflores hétérogames; les fleurs du rayon ligulées, femelles; celles du disque tubuleuses, 5-dentées, hermaphrodites; le réceptacle, convexe, conique ou oblong, est couvert de paillettes membraneuses, placées entre les fleurons. L'involucre est composé d'écailles peu nombreuses, imbriquées. Les rameaux des styles sónt dépourvus d'appendices. Les fruits, cylindracés ou obscurément tétragones, striés ou lisses, sont, en général, terminés par une aigrette membraneuse, très courte, entière ou dimidiée, munie parfois d'une oreillette au côté interne. - Les Anthemis, connues sous le nom de Camomilles, sont des plantes herbacées, originaires en grande partie de la région méditerranéenne; leurs feuilles sont très finement découpées; les capitules, ordinairement pourvus de rayons blancs, les ont cependant d'une belle couleur jaune dans une seule esp., l'A. tinctoria. En médecine, on emplote les capitules de plusieurs esp. de ce g.; tout le monde conıaît la Camomille romaine, dont la plupart des fleurons du centre se sont convertis, par la culture, en demi-fleurons de couleur blanche. (J.D.)

ANTHEMOIDES ( $\alpha \dot{\alpha} \theta \varepsilon \mu i$, petite fleur;

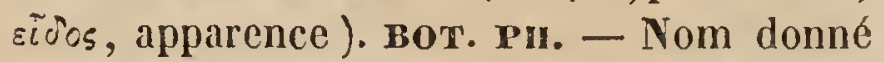
par M. Lessing à une division du g. Sphénogyne.

(J. D.)

ANTHENANTHIA, $P$. de B. BoT. PII. - Genre de la famille des Graminées, syn. du g. Tricholana de Schrader.

(C. L.)

ANTHEPHORA ( $\dot{\alpha} \nu \theta_{\dot{q}}$, fleur; popós, porteur ). BoT. PH. - Genre de la famille des Graminées, tribu des Panicées, formé par Schuber (Gram., t. 54), et caractérisé ainsi : Épillets biflores (dont la fleur inférieure neutre, les supérieures hermaphrodites), quaternés - connés à la base. Glumes 2 , inégales. Paléole unique de la fleur neutre unissant la fleur hermaphrodite; dans celle-ci, 2 paléoles chartacées, concaves; squammules nulles. Étamines 5 ; styles 2. Ovaire sessile. Caryopse elliptique. - Ce g. ne se compose que d'une esp., qui est annuelle, le Tripsacum hermaphroditum L., indigène dans l'Amérique tropicale. Le chaume en est rameux, les feuilles planes; l'épi floral est simple, terminal. Il a pour synon. le Colladoa de Persoon. (G. L.)

ANTHERE. Anthera ( $\dot{\alpha} \nu \theta_{i} \rho \dot{s} s, \dot{\alpha}$, fleuri ). BOT. PH. - Voyez ÉtaMINE et sysTÈME STA MINAL.

(C. L.)

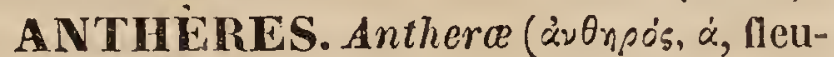
ri) Bot. GR. - Dans l'ordre des Muscinées, qui, comine nous l'avons dit au mot Anophyta, comprend les Mousses et les Hépatiques, on donne généralement le nom d'Anthère à l'organe que l'on suppose remplir dans ces plantes la fonction de féconder les pistils ou archégones. M. Bischoff, considérant que sa structure, si différente de celle du même organe dans les plantes supérieures, l'assimile davantage à un grain de pollen, a proposé, pour l'en distinguer, de le désigner sous le nom d'Anthéridie. Ce nom serait sans doute fort bon; et peut-être faudrait il l'adopter si nous n'avions à redouter de voir se multiplier, sans utilité réelle pour la science, les noms des organes qui servent à une fonction identique, pour peu qu'une orgánisation quelque peu 
diverse vînt favoriser le déplorable néologisme qui menace de nous envahir de toutes parts. Quel que soit le terme qu'on emploie pour le désigner, l'organe en question, réduit à sa forme la plus simple, consiste en une petite bourse sphérique ou ellipsoïde, courtement pédicellée, composée d'une membrane celluleuse fort mince, transparente, et renfermant dans sa cavité un fluide mucilagineux plus ou moins coloré, souvent lactescent, assimilable à la foville du pollen. La couleur de ces corps, qui dépend de celle du fluide contenu, varie du blanc nuancé de vert au jaune pur. Ils sont portés par un pédicelle plus ou moins long, formé d'une ou plusieurs rangées de cellules cloisonnées. A une certaine époque, la bourse s'ouvre ou se déchire au sommet, et le fluide qui s'en échappe, et qui contient des animalcules spermatiques, va, sans que l'on puisse dire par quelle voie, dans les espèces diö̈ques surtout, féconder le pistil ou l'organe femelle. Aux articles généraux MoUSSES et IÉPATIQUES, nous entrerons dans plus de détails touchant la place qu'occupent ces organes dans les différents genres, et les fonctions qu'ils sont appelés à remplir.

(C. M.)

ANTHERIC. Anthericum ( $\dot{\alpha} \nu \theta \dot{\varepsilon} \rho(x \circ)$, nom grec d'une plante que l'on croit être l'Asphodèle ). вот. PH. - Genre de la famille des Liliacées, type de la tribu des Anthéricées, formé par Linné, et ainsi caractérisé : Périgone corollacé, hexaphylle; à folioles égales, étalées ou campanuléesconniventes. Etam. 6, hypogynes; filaments filiformes, glabres ou barbus. Ovaire triloculaire; ovules nombreux, bisériés, amphitropes. Style filiforme, décliné, ascendant; stigmate capité, obtus. Capsule membranacée, subglobuleuse, loculicide - trivalve. Graines peu nombreuses, anguleuses, convexes dorsalement, à test crustacé, noir, ponctué-rugueux. Embryon axile, presque courbe, aussi long que l'albumen; à extrémité radiculaire infère, renflée. - Ce g. renferme un assez grand nombre d'especes herbacées ou à peine suffrutescentes, indigènes dans les parties chaudes d'Europe, d'Asie, de la Nouvelle-IIollande et du Cap; à racines fasciculées-fibreuses; à feuilles radicales, plus rarement caulinaires, filiformes ou linéaires-lancéolées, souvent char- I res, notre sarant confrère et collaborateur

nues ou velues; à fleurs disposćes en grappes ou en panicules sur une scape radicale, et à pédicelles articulés. On en compte plus de 60 , dont la plupart sont cultivées dans les serres d'Europe. On subdivise le g. $A n$ thericum en 3 sous-genres : Euanthericum, Schult., Czackia, Andr., et Bulbine, que nous examinerons chacun à leur ordre al. phabétique.

(C. L.)

ANTHERICIS. Apularia, Nutt.

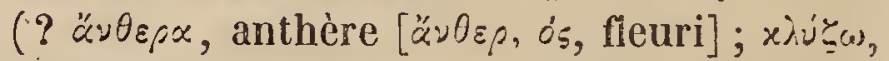
je baigne ). вот. PH. - Genre de la famille des Orchidacées, formé par Rafinesque, et ainsi caractérisé : Périgone étalé ; folioles externes, obovées; les internes conformes, moins grandes. Labelle libre, petit, trilobé, pourvu d'nn long éperon. Gynostème dressé, marginé, de la longueur du labelle. Pollinies 2 , biparties, à caudicule linéaire; glandule petite, transverse. - Ce g. ne renferme qu'une espèce (Orchis discolor Pursh), indigène dans l'Amérique septentrionale. C'est une esp. terrestre, dont les pseudobulbes, formant gazons, sont monophylles; la feuille en est plissée; les fleurs verdâtres-pourprées, et disposées en grappes.

ANTHLRIDIE. Antheridium $\left(\dot{\alpha} \nu \theta_{4}, 00^{\circ}\right.$, $\dot{\alpha}$, fleuri, e [d'où anthère]; zĩoos, forme). Bot. GR. - (Anthera.) M. Agardh désigne sous ce nom des organes propres aux Thalassiophytes articulées, et qui consistent en de petits corps ovalaires, celluleux, anthériformes, portés par un long pédicelle articulé, et placés, souvent en grand nombre, à l'extrémité des rameaux de plusieurs esp. du g. Polysiphonia. On les observe surtout dans les $P$. amentacea et fibrillosa. Lyngbye a figuré les Anthéridies de cette dernière espèce à la $t$. $35, \mathbf{f}$. a, de son $\boldsymbol{H} y$ dirophytologia danica.

Ainsi que nous l'avons déjà dit au mot antuíres, le même mot a été employé par M. Bischoff pour indiquer l'organe mâle des Mousses et des Hépatiques.

Enfin M. Corda (llcon. Fung., t. III, p. 40) nomme encore Anthéridies des organes propres aux Champignons, mais qu'on ne rencontre que dans la famille des $\mathbf{H y}-$ ménomycètes, et surtout dans les Agaricinées. Ges organes, que MI. Corda considère comme remplissant les fonctions d'Anthè- 
M. Léveillé leur donne le nom de crstiDEs. Voy. ce mot.

(C. M.)

ANTHERILIUM. вот. - ${ }^{-V_{0 y} z}$ ANTIERYLIUM.

(C. L.)

ANTHEROGENE ( $\dot{\alpha} \nu \theta_{\eta} \rho \circ$, fleuri ;

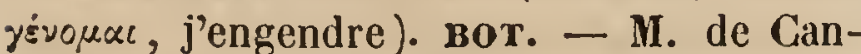
dolle a donné le nom de fleurs anthérogènes à celles dont les anthères sont transformées en pétales roulés en cornet. On les appelle aussi fleurs corniculécs. Nous citerons comme un exemple de cette transformation l'Aquilegia vulgaris corniculata.

(C. D'O.)

ANTHEROPHAGE. Antherophagus à Orpós,fleuri; póxos, mangeur ). INs. Genre de Coléoptères pentamères, famille es Clavicornes, étab li par Knoch, et adopté par M. Dejean, qui, dans son dernier Catalogue, le place entre le g. Cryptophagus de Herbst et le g. Engis de Fabricius, ou Dacne de Latreille. Il appartient, par conséquent, à la tribu des Peltoïdes de ce dernier. Ce genre diffère des Cryptophagus par ses antennes, proportionnellement plus grosses ; par leurs articles, plus transversaux, presque égaux depuis le $2^{\mathrm{e}}$ jusqu'au $8^{\mathrm{e}}$, et par la massue, formée presque insensiblement. - M. Dejean y rapporte 2 esp. seulement, qui sont le Mycetophagus nigricornis de Fabr., et le Tenebrio pallens du même auteur. Toutes deux se trouvent en France, et la première mème aux environs de Paris. Elles vivent sur les tleurs.

ANTHERURA, Loureiro, Flor. Cochinch., ed. Willd., t. 1, p. 144 ( $\alpha_{\nu} \theta \dot{r}_{1} \rho \dot{\alpha}$ [d'ávonpós, fleuri], anthère ; ò $\rho x$, queue). вот. Рн. - Genre ou sous-genre de la famille des Rubiacées (tribu des Cofféacées DC.). D'après la description de Loureiro, il diffère des Psychotria par une corolle rotacée , 5-partie; par des anthères sagittiformes, surmontées d'un long appendice réfléchi; par un style subulé, plus long que la corolle, à stigmate simple. - On n'en connaît qu'une seule esp., rapportée aux Psychotria par plusieurs auteurs. (SP.)

ANTHERYLIUM, Rohr, Act. Soc. Hist. nat. Hafn., t. II , part. 1, p. 211.

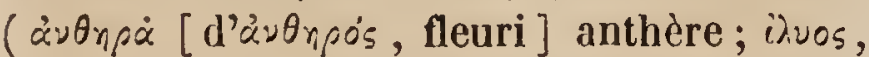
cavité, fond). Bot. PIr. - Genre de la famille des Lythracées ou Lythrariées, tribu des Salicariées de M. de Candolle, qui lui assigne (Prodr. III , p. 91) pour caract.: CaT. I. lice 4-parti, régulier, à sinus inappendiculés. Pétales que les segments calicinaux. Étamines 12 à 16, insérées au fond du calice. Ovaire (peutêtre 3- ou 4-loculaire) ovoïde, non stipité. Style filiforme; stigmate tronqué. Capsule ovoïde, $\mathbf{3}$ - ou 4 -gone, $\mathbf{3}$ - ou $\mathbf{4}$-valve ; placentaire épais, $\mathbf{3}$-ou 4-gone, polysperme. - On ne connaît qu'une seule espèce : c'est un arbre indigène des Antilles, très glabre, à feuilles opposées ou alternes, ovales, très entières, accompagnées chacune de 2 épines basilaires; pédoncules axillaires, 1-flores, fasciculés.

(SP.)

ANTHESE ( $\dot{\alpha} \nu \theta ; \sigma c \varsigma$, floraison ). вот. - On désigne sous ce nom l'ensemble des phénomènes qui accompagnent l'épanouissement des fleurs; c'est l'époque à laquelle leurs organes sont arrivés à leur état complet de perfection. On peut regarder l'Anthèse comme le moment de la puberté des plantes. Elles se parent alors de leurs couleurs les plus belles et exhalent les parfums les plus suaves pour procéder au grand acte de la reproduction.

Ce phénomène est dû à la chaleur, à la lumière et aux influences météoriques ambiantes; ce qui fait qu'il est modifié de mille sortes, suivant la diversité des milieux où se trouve le végétal. Ainsi, nous voyons des plantes dont l'Anthèse a lieu à époque fixe, et dure quelques instants; chez d'autres, les fleurs s'ouvrent chaque jour pendant un petit nombre d'heures et se ferment dès qu'est passé l'instant favorable à leur épanouissement. Quelques unes sont diurnes; d'autres nocturnes. Certaines fleurs, inodores pendant le jour, répandent une odeur fort agréable à l'entrée de la nuit. C'est sur le phénomène de l'Anthèse que Linné a établi son horloge de Flore.

(G. D'O.)

ANTHIA. INS. - Voy. ANTHIE.

ANTHIAS $\left(\alpha \nu \theta i \alpha_{s}\right)$. PoIss. - Nom grec d'un poisson de l'Archipel, et, par conséquent, de la Méditerranée, que Rondelet a appliqué à un petit poisson abondant sur nos côtes, et habitant les profondeurs rocailleuses. Les naturalistes de la fin du dixhuitième siècle ou du commencement de celui-ci ont adopté sans examen les idées du savant ichthyologiste de Montpellier, et out attribué au poisson de Rondelet, que nous 
désignons aussi sous le nom de Barbier, les faits racontés par les anciens de leur Anthias, et ont fait croire que le poisson ainsi nommé par les Grecs est aussi connu que le sont aujourd'hui ceux qu'ils appelaient Narke ou Trygon.

Il s'ell faut de beaucoup cependant qu'il en soit ainsi, et M. Cuvier l'a suffisamment prouvé en écrivant l'histoire de ce poisson (Cuv. et Val., Poiss., t. II , p. 255 et suiv.).

L:Anthias des anciens est un poisson vivant en troupes, sacrẻ pour les pêcheurs d'éponges, qui ne trouvaient jamais de poissons voraces dans les lieux fréquentés par l'Anthias. Ils plongeaient alors en sûreté. Toutefois, Pline attribuait ce nom de Poisson sacré à d'autres espèces, et surtout aux poissons plats; mais cet élégant écrivain rapporte d'autres traits de l'Anthias. Suivant lui, les pêcheurs des îles Ghélidonies se donnaient beaucoup de peine pour apprivoiser un Anthias; et, quand il prenait le pain avec confiance et presque à la main, ils cachaient un hameçon dans un morceau, et sitôt qu'ils réussissaient à prendre l'Anthias sans défiance, on faisait une pêche abondante, parce que tous les autres Anthias accouraient pour délivrer le poisson accroché à la ligne. A ces traits peu caractéristiques, tirés en partie des Halieutiques d'Ovide, on en peut ajouter d'autres qui précisent un peu mieux ce que devait être l'Anthias des anciens.

Elien en fait un poisson de haute mer, très gros, puisqu'il lui donne l'épithète de xnscesons, que l'on perce àe traits quand il veut s'élancer hors du filet. S'il ne surpasse pas le Thon pour la taille, il est cependant plus robuste que lui. Il dit que l'Anthias a de fortes mâchoires, un œil grand, le dos bleu, et le ventre blanc. Une ligne dorée s'étend, le long des flancs, de la tête à la queue.

Oppien ne lui attribue pas de dents, mais il en fait un très grand poisson, dont il reconnaît quatre espèces ou variétés : l'Ellope ou l'Aulope, dont l'œil est entouré de noir, est une de ces variétés; les autres, distinguées par les couleurs, sont jaunes, blanches, ou d'un rouge rembruni. Ce qui prouve la force et la grandeur du poisson, c'est qu'il lui donne un Labrax (Labrax lupus Nob.) pour appât. On emploie aussi des
Perches et des Corbs, ioujours des poissons assez forts pour donner une idée de la grande taille de l'Anthias. Enfin il ajoute que, comme pour le Callichthe, l'Orcine, et les autres grands poissons qu'il appelle Cétacés, le pêcheur est obligé de livrer un combat à l'Anthias, quand il a réussi à l'attirer dans son bateau. Comment a-t-on pu appliquer tous ces passages à notre Barbier, qui ne dépasse jamais 20 à 24 centimètres?

Mais si l'on peut, par exclusion, dire que l'Anthias des anciens n'est pas le petit poisson de la Méditerranée auquel Rondelet a appliqué cette dénomination, il est presque impossible de déterminer à laquelle des espèces désignées dans nos Catalogues zoologiques nous devons rapporter l'Anthias. M. Guvier a émis l'idée que ce pouvait être le Germon, grande espèce de Thons ou de Scombéroïdes, l'Ala longa des pècheurs de Sardaigne; mais les couleurs attribuées par Oppien à l'Anthias ne se voient pas sur le corps du Germon. Aussi M. Cuvier cherchat-il de suite un autre poisson tel que le Merou (Serranus gigas), qui est noir; le Cernier (Polyprion cernium), également noirâtre, ou , dit-il, tel autre grand Acanthoptérygien. C'est presque toujours à un résultat aussi incertain que conduit une saine critique de la synonymie des anciens.

On ne peut pas même s'aider par les dénominations des Grecs modernes, car, selon Belon, l'Anthias serait un Gyminètre, poisson qui n'a jamais pu avaler un Labrax ou un Corb, et avec lesquels les pêcheurs n'ont aucun combat à livrer, puisque ces poissons, longs de deux à trois mètres, et minces comme des rubans, sont si faibles, qu'ils se rompent d'eux-mêmes dès qu'ils sont hors de l'eau.

Cependant la confiance avec laquelle l'opinion de Rondelet a été adoptée a introduit la dénomination d'Anthias dans nos nomenclatures zoologiques, en l'appliquant tantôt comme nom spécifique, tantôt comme nom générique, à des poissons aujourd'hui bien connus.

Dans la première acception, le mot $\boldsymbol{A}$ nthias est appliqué à une espèce de Serran (Serranus anthias), un des petits poissons les plus communs de la Méditerranée. Il est remarquable par son corps ramassé, couvert partout de petites écailles âpres; 
par le prolongement en filet du second ou lu troisième rayon de la dorsale, et des lobes de la caudale; par celui des trois premiers rayons branchus de la ventrale, qui lui donne une forme particulière que l'on ne rencontre que dans deux ou trois autres espèces très étrangères, voisines de celle-ci. Sa couleur, d'un beau rose avec trois raies lilas sur les joues, en fait un des plus beaux poissons. Cette espèce s'avance dans l'Atlantique jusqu'aux Canaries, et peut-être traverse-t-elle cette grande mer; du moins il y en a une espèce très voisine sur les côtes du Brésil (Serranus tonsor, Nob.).

On trouve plusieurs autres esp. de Serran qui ont, comme celle que je viens de signaler, le maxillaire supérieur et les branches de la mâchoire inférieure écailleux, ce qui a permis d'en faire un petit groupe, dans ce genre si nombreux, sous le nom de Barbiers. Ces espèces viennent de la mer des Antilles ou de la côte de l'Amérique équinoxiale; on en connaît aussi des mers de l'Inde; mais, comme l'un de ces Barbiers a des intermaxillaires et une mâchoire inférieure sans écailles, avec le maxillaire seul écailleux, on voit que cette espèce devrait, en se servant de caractères aussi fugaces, former une nouvelle coupe distincte, ou bien, comme nous l'avons adopté, il faut réunir les petits Serrans à mâchoires entièrement nues avec ceux qui ont le tout ou une partie de la mâchoire garni d'écailles plus ou moins petites.

Bloch avait aussi formé, sous la dénomination d'Anthias, un g. d'Acanthoptérygiens voisin des Serrans, et caracterisé par la présence de petites écailles sur le maxillaire; mais les raisons que nous venons de donner ont dû faire supprimer cette coupe comme les coupes établies dans ce grand g., dont Bloch n'avait eu aucun sentimert.

(V AL.)

* AN'THICIDES. Anthicides (anthicus [Voy. ce mot]; ciojos, forme). INs. - Nom donné par Latr., dans ses familles naturelles, à une tribu de Colćoptères hétéromères, famille des Trachélides, qu'il caractérise ainsi : Pénultième art. des tarses bilobé. Corps oblong. Corselet en forme de cœur ou divisé en deux nœuds. Dernier art. des palpes maxillaires plus grand que les précédents, en forme de hache. Antennes simples ou un peu en scle, filiformes, ou grossissant in sensiblement vers le bout. Cette tribu se compose des genres Steropes, Notoxus et Xylophilus (Voy. ces mots). M. le comte de Castelnau, dans son Hist. nat. des Coléoptères faisant suite au Buffon-Duménil, designe sous le nom d'Anthicites un groupe de Coléopt. de la tribu des Trachélides, qui renferme les g. Anthicus (Notoxus Latr.), Psammcecius, Scraptia et Steropes. Ses caract. sont : Antennes simples, ayant la plupart des art. coniques. Palpes maxillaires à dernier article sécuriforme. Yeux peu on à peine échancrés. Les Anthicides ou les Anthicites sont de petits Insectes que l'on trouve à terre, sur les plantes basses.

ANTHICUS ( $\dot{\alpha} \cdot \theta<x 0^{\circ} s$, quil concerne les fleurs ). Ivs. - Paykull, dans sa Faune suédoise, a donné ce nom à des Insectes appelés Notoxes par Geoffroy, et qui sont des $M \dot{M}$ loès et des Attélabes pour Linné. Fabricius, en adoptant le nom et le g. de Paykull, y a réuni lès Psélaphes d'Herbst, tout en collservant cependant le g. Notoxe de Geoffroy. D'après cet emploi très différent du même nom, Latreille avait cru devoir le rayer du Vocabulaire entomologique; mais M. Dejean, dans son dernier Catalogue, l'a conservé; et, sous la dénomination générique d'A $\boldsymbol{A}$ thicus, il mentionne 60 espèces, parmi lesquelles $\mathbf{b}$ seulement appartiennent au $\mathbf{g}$. de Fabricius. Il y a lieu de croire d'après. cela que le g. Anthicus de M. Dejean n'a que le nom de commun avec celui de l'entomologiste danois. Voici, au reste, les caractères que lui attribue $\mathbf{M}$. le comte de Castelnau, dans son Histoire naturelle des Coléoptères faisant suite au Buffon-Duménil : Antennes filiformes de $\mathbf{1 1}$ art. presque coniques, le dernier ovale. Palpes maxillaires longs, de 4 art.; le dernier grand, sćcuriforme; labiaux de $\mathbf{3}$, le terminal épais et tronqué.- Labre carré et membraneux. Mandibules fortes, arrondies, pointues. Mâchoires velues, bilobées : le lobe externe grand, obtus; l'interne petit, aigu. Lèvre allongée en carré, à angles un peu arrondis. Menton petit. Corps oblong, ovalaire. Tête assez grande, arrondie, dégagée. Corselet globuleux, élargi en avant, quelquefois prolongé en corne au dessus de la tête. Écusson très petit. Élytres allongées, presque cylindriques; pattes longues. M. le comte do 
Castelnau partage ensuite les espèces qu'il rapporte à ce genre en deux divisions. La première comprend celles dont le corselet se prolonge en forme de cornes au dessus de la tête, ex. : Anthicus monoceros Fabr. Cette division répond au g. Monocerus de Mégerle. La seconde division se compose de celles qui ne présentent pas ce prolongement; ex. : Anthicus antherinus Fabr. Ces deux espèces se trouvent dans les environs de Paris.

(D.)

ANTHIDIUM. INs. - Genre de la famille des Mellifères, de l'ordre des Hyménoptères, sect. des Porte-Aiguillon, établi par Fabricius, et adopté par Latreille et tous les autres entomologistes. Ce genre se distingue facilement de ses congénères, et surtout des Osmia , avec lesquels il a de grands rapports, par le corps plus large, les antennes fliformes moins épaisses, les palpes maxillaires d'un seul article, l'abdomen plus large et voûté, denté dans les mâles et arrondi dans les femelles. - Les esp. connues de ce genre sont indigènes et peu nombreuses. Le type est l'A. manicatum, Fab. (Apis manicata, Lin.). Les femelles creusent leur nid dans la terre, et le tapissent de duvet, qu'elles arrachent à diverses plantes.

(BL.)

- ANTHIDULÉES (Anthidule) ). INs. -Nom donné par M. Robineau-Desvoidy à une tribu de sa famille des Myodaires $m i$ cromydes.

ANTHIE. Anthia. nss. - Genre de Coléoptères pentamères, famille des Carabiques, tr. des Troncatipennes, établi par Weber, et adopté par tous les entomologistes. M. Dejean, dans son Spec.gén., le caractérise ainsi : Premier article des palpes presque cylindrique, ou grossissant un peu vers l'extrémité. Antennes filiformes. Lèvre supérieure arrondie, avancée el recouvrant presque entièrement les mandibules. Point de dent au.milieu de l'échancrure du menton. Tarses antérieurs légèrement dilatés dans les mâles. Corps épais et' plus ou moins allongé. Corselet plus ou moins cordiforme. Élytres convexes, en ovale plus ou moins allongé, sinuées, ou même presque arrondies à l'extrémité.

Les Anthies sont de grands Garabiques noirs, ornés pour la plupart de taches blanches formées par une espèce de duvet. Ces
Coléoptères, à l'exception d'une seule espèce ( $A$. 6-guttata) qui se trouve au Bengale, paraissent exclusivement propres aux contrées sablonneuses de l'Afrique et de l'Arabie.

Leurs mœurs sont peu connues; on les trouve dans le sable, ordinairement non loin des étangs salés ou des rivières, près des monuments en ruine, sous les pierres. Quand on les inquiète, ils répandent par l'anus, d'après l'observation de Leschenault de la Tour, une liqueur caustique ; ils ont, d'ailleurs, cela de commun avec plusieurs autres Carabiques. M. Guérin, dans sa monographie du g. Anthia, donne la description et la figure de la larve de l'A. 6-guttata envoyée du Bengale à Latreille par Leschenault. Cette larve est très grosse relativement à l'insecte parfait. Elle est d'un brun noir luisant, avec les segments bordés de rouge inférieurement, et munie de deux fortes mandibules. Elle diffère beaucoup, suivant M. Guérin, de celle des Cicindelles, découverte par M. Desmarest; ce qui doit faire présumer que ses mœurs sont différentes, et qu'elle ne s'enfonce pas comme celle-ci dans la terre. M. Dejean, dans son dernier Catalogue, en mentionne 19 espèces, dont 12 du cap de Bonne-Espérance, 1 de la Nubie, 1 de l'Arabie, 1 des Indes orientales, 2 du Sénégal et 2 de Barbarie. Nous ne citerons que ces deux dernières comme ayant été connues les premières : $\boldsymbol{A}$. venator de Fabr., et A. 6-maculata du même auteur. Toutes deux de Barbarie.

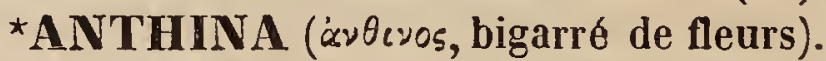
BOT. CR. - M. Fries (Syst. myc., t. III, p. 281) a réuni dans ce genre, qui appartient aux Hypomycètes, plusieurs petits Champignons byssoïdes que les auteurs avaient rangés dans les genres Ceratomema, Claveria, Isaria, Imanlia, etc. Il est caractérisé par un pédicule mince, plus ou moins allongé, terminé à sa partie supérieure par un réceptacle dilaté, comprimé, plumeux, composé de fibres parallèles faiblement unies entre elles, et parsemées d'un petit nombre de spores globuleuses. - Toutes les espèces croissent dans les lieux humides, sur les feuilles et sur les bois; elles sont remarquables par leur élégance et la vivacité de leurs couleurs. Quoique ce genre paraisse établi sur de bons caractères, on peut le considérer, ainsi que 
plusieurs espèces d'Himantia et d'Ozonium, etc., comme une des nombreuses modifications que les circonstances locales font éprouver au mycetium des Champignons.

(LÉv.)

* ANTHIPNA ( $\ddot{\alpha} \nu \theta_{0 s}$, fleur; $i \pi \nu \bar{\omega}$, je dors ). Ivs. - Genre de Coléoptères pentamères, famille des Lamellicornes, établi par Eschscholtz aux dépens du genre $\boldsymbol{A} m$ phicoma de Latreille, dont il s'éloigne par la massue de ses antennes, à feuillets libres ; le chaperon, non rebordé antérieurement, et les quatre premiers articles des tarses, lobés dans les mâles. Ce genre a pour type le Melolontha abdominalis de Fabricius, figuré dans I'Iconographie du Règne animal de Cuvier, par M. Guérin. Une seconde espèce a été trouvée par l'auteur de cet article, en 1822, près du lac d'Albano, dans les environs de Rome, et retrouvée, depuis, près de Tivoli par feu Carcel, à qui M. Delaporte l'a dédiée, en la décrivant le premier dans les Annales de la Société entomologique de France, sous le nom d'Anthipna Carcelii. Néanmoins M. Dejean, dans son Cata-

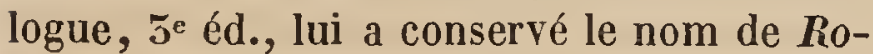
mana, sous lequel je la lui avais offerte à mon retour d'Italie. Elle est figurée et décrite dans le t. II des Annales précitées, p. 251, pl. 9, B, fig. 1-5.

Les Anthipna se tiennent comme endormies dans la corolle des fleurs, ainsi que l'indique leur nom générique.

ANTHISTIRIA, L.; Thomeda, Forsk.

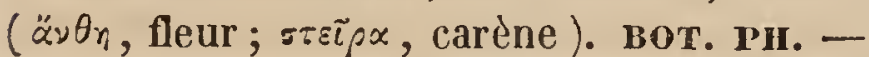
Genre de la famille des Graminées, tribu des Andropogonées, formé par Linné (Gen., 135̃9), et dont les caract. sont ainsi déterminés par les agrostographes plus modernes : Épillets septénés; les quatre inférieurs verticillés, le plus souvent sessiles, neutres et enveloppant les autres; trois centraux, dont les deux latéraux pédicellés, mâles ou neutres ; l'intermédiaire ordinairement sessile, billore; la fleur inférieure neutre, unipaléacée ; la supérieure hermaphrodite. Glumes 2, mutiques, persistantes ; l'inférieure enveloppant la supérieure. Paléoles 2, plus courtes que les glumes; l'inféricure prolongée, chez la fleur hermaphrodite, en arête très allongée et tortue. Squammules 2, érodées, tronquées, glabres. Étamines 3. Ovaire sessile, glabre.
Styles 2, terminaux; stigmates plumeux. Garyopse libre. - Le g. Anthistiria renferme environ une douzaine d'espèces croissant dans les parties tropicales et subtropicales du globe, surtout en Asie, et sur les plages de la Nouvelle-Hollande. Les feuilles en sont planes, les supérieures en forme de spathe. L'inflorescence en est en panicule très ramifiée.

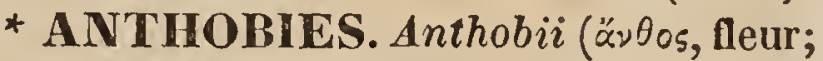
6ios, vie ). Ivs. - Latreille, dans son ouvrage intitulé : Familles naturelles, donne ce nom à une tribu de Coléoptères pentamères, famille des Lamellicornes, qu'il caractérise ainsi : Languette saillante au delà du menton (bilobée); mandibules cornées. Mâchoires terminées par un lobe membraneux et soyeux. Corps souvent allongé, avec le chaperon avancé, le corselet oblong ou presque orbiculaire; les élytres écartées ou béantes à leur extrémité postérieure interne ou suturale. Antennes de 9 à 10 articles, dont les trois derniers forment la massue.

Cette tribu se divise en deux sections : un seul crochet aux tarses postérieurs : Pachycnemus, Anisonyx; deux crochets aux tarses postérieurs : Amphicoma, Anthipna, Glaphyrus, Chasmatopterus, et Chasme. Voy. ces différents mots.

Les Anthobies vivent sur les fleurs, ainsi que l'indique leur nom, et sont parées de couleurs brillantes.

* ANTHOBIUM ( $\alpha 2005$, fleur; Gios, vie). INs. - Genre de Coléoptères pentamères, famille des Brachélytres, établi par Leach, et adopté par M. Dejean dans son dernier Catalogue, ainsi que par plusieurs entomologistes. M. Lacordaire (Faune entomologique des environs de Paris, vol. I, p. 468) place ce g. dans la tribu des Oxytélides, tandis que M. de Mannerheim ( Mém. de l'Acad. imp. de Saint-Pétersbourg, t. I, p. 431 ) et M. Delaporte (Hist. nat. des Coléopt. faisant suite au Buffon-Duménil, t. I, p. 191) le mettent dans celle des Omalides. Ses caract. distinctifs des autres g., d'après M. de Mannerheim, sont : Tarses simples; leur dernier article aussi long que les autres réunis. Palpes maxillaires, à dernier article conique. Antennes plus épaisses antérieurement. Abdomen ordinairement plus long que les élytres.

Les Anthobies sont de très petits Braché- 
lytres, dont le plus grand nombre vit sur les fleurs, ainsi que l'indique leur nom générique. Cependant plusieurs espèces vivent en même temps dans les bolets et les plaies des arbres, et quelques unes se tiennent sous les écorces. M. Dejean en mentionne 20 esp., dont une du cap de Bonne-Espérance; toutes les autres sont d'Europe. Nous citerons parmi ces dernières l'Anth. Viburni, de Gravenhorst, qui se trouve communément sur les fleurs de la Viorne.

(D. et GiI.)

* ANTHOBIUS ( $\ddot{\nu} \nu 0$ os, fleur; Gios, vie ). I.s. - Genre de l'ordre des Coléoptères, section des Tétramères, famille des Curculionides, tribu des Érirhinides, établi par Schoenherr aux dépens du g. Rynchanus de Fabricius, et qu'il caractérise ainsi : Antennes médiocres, grêles; leur funicule composé de sept articles: les deux premiers un peu longs, obconiques; le basilaire plus épais; les autres plus courts, presque perfoliés, serrés, s'élargissant successivement; massue ovale. Rostre long, un peu mince, cylindrique, très arqué. Tête allongée postérieurement. Yeux ronds, très saillants. Prothorax oblong, bisinué à sa base, avec un rebord arrondi sur les côtés, plus étroit antérieurement. Élytres en ovale long, avec les angles huméraux obtus.

Ce genre, qui ne figure pas dans le dernier Catalogue de M. Dejean, a pour type et unique espèce le Rynchanus testaceus de Fabricius, espèce de l'Amérique méridionale.

(D.)

ANTHOBOLEEES. Anthobolece ( $\alpha$ 'y-

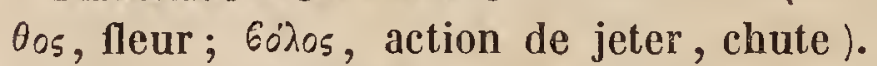
вот. PH. - Famille de plantes dicotylédones, formée par Martins (Consp.), et rapportée en synonymie à celle des Thymélacées, dont elle est une des divisions.

(G. L.)

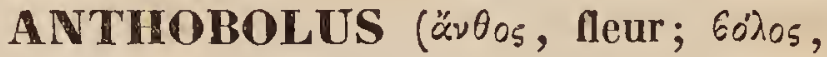
action de jeter, chute). Bor. Pr. - Genre de la famille des Thymélacées, type de la tribu des Anthoboléées, formé par R. Brown (Prod. 357), et dont voici les caract. : Fleurs diö̈ques. Dans les mâles, périgone triphylle. Étamines 3, insérées à la base des lacinies du périgone; filaments très courts. Anthères biloculaires. Rudiment d'ovaire nul. Dans les femelles, périgone semblable, décidu (undè nomen). Ovaire libre, uniloculaire; ovules inconnus. Stigmate trilobé, sessile. Drupe monosperme. Graine inverse. Embryon cylindrique, orthotrope, dans l'axe d'un albumen charnu. - Arbrisseaux indigènes dans la partie tropicale de la Nouvelle-Hollande, ayant le port d'un Genêt. Ils sont glabres, très rameux ; rameaux articulés; feuilles éparses, exstipulées, sessiles, étroites; pédoncules axillaires ; les mâles $\mathbf{5}$-4.flores, ombellés; les femelles, $1-\tilde{\jmath}-$ flores; fleurs petites, jaunâtres. (C. L.)

ANTHOBRANCHE. Anthobranchia

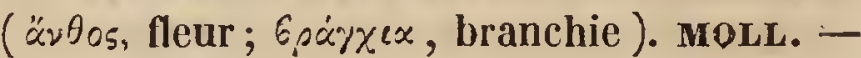
Ce nom d'Anthobranche a été proposé par M. Goldfuss pour réparer le double emploi fait par M. de Blainville; en effet, ce savant anatomiste, dans le Bulletin des Sciences de 1816 , avait établi, sous le nom de Cyclobranches, un ordre de Mollusques nus; et déjà, antérieurement, M. Cuvier avait lui-même proposé, sous le même nom de Cyclobranches, un ordre de Mollusques également nus, mais appartenant à d'autres genres que ceux de M. de Blainville. M. Goldfuss proposa le nom d'Anthobranche pour les Cyclobranches de M. de Blainville. M. de Férussac, dans ses $T a-$ bleaux systématiques, a adopté les Anthobranches de M. Goldfuss pour les g. Doris et Polycères.

(DESH.)

* ANTHOCÉPHALE. Anthocephalus ( $\alpha 200 s$, fleur ; $x \varepsilon \varphi \alpha \dot{\lambda} \cdot$, tête ). HELM. - M. Drummond, dans ses notes helminthologiques insérées dans le Magazine of nat. hist., réserve encore ce nom comme générique, et en l'appliquant à quelques animaux de la famille des Tétrarhynques, parmi lesquels il décrit l'A. rudicornis, esp. nouvelle. Ce groupe, dénommé ainsi par Rudolphi, répond à celui de Floriceps, Cuv., auquel nous renvoyons. (P. G.)

ANTHOCEPHALUS, A. Richard

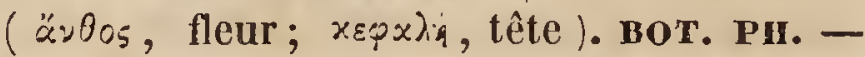
Genre de la famille des Rubiacées (tribu des Isertiées, Rich.), fondé sur le Cephalanthus chinensis Lamk. Son auteur ( Mém. de la Soc. d'hist. nat. de Paris, t. V, p. 237) en donne les caract. suivants : Tube calicinal adhérent ; limbe supère, persistant, 5ै-parti. Corolle longuement tubuleuse, à limbe 5parti. Etamines 5, incluses. Ovaire 4-loculaire. Style longuement saillant. Fruit couronné du limbe calicinal; à 4 coques ovoïdes, coriaces; un peu charnues, tronquées à la 
base, indéliscentes, 4-ou 5-spermes. - Arbrisseau à feuilles opposées; stipules interpétiolaires, solitaires; fleurs subpédicellées, agrégées (sur un réceptacle globuleux) en capitules très denses, terminaux.

(Sr.)

ANTHOCERCIS, Labill. (爻光os, fleur; xepxis, pilon; forme des segments de la corolle). вот. PH. - Genre de la famille des Scrophularinées, tribu des Salpiglossidées Benth., offrant pour caract. : Cal. campanulé, 5-fide. Cor. subcampanulée, 丂̆-fide (parfois 6-8-fide), rétrécic vers la base; segments égaux, acuminés, arqués en dehors. Étam. 4, insérées au fond de la corolle, incluses, didynames, accompagnées du rudiment d'une cinquième étamine; filets élargis vers leur base; anthères ovales, 2-thèques. Ovaire 2loculaire; placentaires multi-ovulés, adnés à la cloison. Ovules anatropes. Style indivisé, terminé par un stigmate capitellé, échancré. Capsule oblongue , 2-loculaire, septifrage-bivalve; valves indivisées; colonne placentifère-libre après la déhiscence. Graines très nombreuses, réticulées, à base courbée en dedans. Embryon axile dans un périsperme charnu; cotylédons très courts, obtus; radicule cylindracée, courbée conformément à la graine. - Arbrisseaux (habitant la Nouvelle-Hollande extra-tropicale) à feuilles alternes, épaisses, coriaces, très entières, courtement pétiolées, quelquefois ponctuées; pétiole articulé par sa base; pédoncules axillaires, subsolitaires, 1-flores; corolle jaune ou blanche, grande. On en connaît 5 esp. L'A. littorea et l'A. viscosa se cultivent pour l'ornement des serres.

(SP.)

* ANTHOCERE. Anthoceros (๕̈2005, fleur; xśpas, corne; fleur cornue). Box. CR. - Genre de la famille des Hépatiques, établi par Micheli (Nov. Pl. Gen., p. 10), et adopté par Linné et par tous les botanistes modernes. La structure de ce g. est si remarquable, qu'il a dû former à lưi seul une tribu dont nous allons donner les caract., d'après notre illustre ami M. Nees d'Esenbeck. Ces caract. étant communs au g. et à la tribu que celui-ci représente, nous 1'y reviendrons pas dans l'article suivant.

Les Anthocères ont une capsule étroite, linéaire, subulée, ou en forme de silique, s'ourrant en deuz valves, à partir du somnel jusque vers son milieu, et naissant de la face supérieure ou du dos de la fronde. Cette capsule est entourée à sa base par un involucre tubuleux, tronqué ou lobé en son bord, et formé par une élévation ou une sorte de dédoublement de la fronde. Il n'y a point de périanthe. Le réceptacle des séminules, linéaire, sétiforme, occupe le centre de la capsule. On lui donne aussi le nom de columelle, à cause de son analogie avec un organe semblable observé dans la capsule des Mousses. A la place des élatères qui manquent dans ce g., on trouve des funicules fixés à la columelle, articulés, géniculés, tubuleux, tortillés par affaissement, simples ou rameux, et variables quant à leur forme. Des séminules globuleuses ou presque létraèdres, très finement muriquées, sont attaclées aux funicules. Dans sa jeunesse, la capsule est renfermée dans une coiffe ou calyptre conique, surmontée d'un style sessile, laquelle se rompt à la base et tombe de bonne heure. Les anthères, monoïques, sessiles, sont entourées d'un involucre cyathiforme, denté, formé, comme celui de la capsule, par un léger rehaussement de la fronde. Outre les organes de la reproduction dont nous venons de parler, il existe encore, dans une espèce, des propagules naissant probablement des radicelles de la plante. Lies Anthocères ont une fronde tantôt orbiculaire et lobée, tantôt dichotome ou multifide, privée d'épiderme véritable, et dont la texture, -molle et vésiculeuse, est surtout remarquable par la laxité des cellules de la couche dorsale et l'absence complète des pores.

Ces plantes cosmopolites croissent sur la terre humide, dans les champs cultivés et les bois. Sur dix esp. aujourd'hui connues, deux, les plus anciennes, sont communes à l'ancien et au nouveau monde; deux sont particulières à la Nouvelle-Hollande, une à la Nouvelle-Zélande, une autre à l'île de Java, et une enfin, l'A. dichotomus, n'a encore, que nous sachions, été trouvée qu'en Europe. Les autres espèces sont exclusivement intertropicales. (C. M.)

* ANTIIOCEROTÉES. BOT. GR. Troisième tribu de la famille des Hépatiques, établie par M. Nees (Europ. Leberm. 4, p. 519), et qui se compose du seul genre Anthocères, dont nous avons donné plus haut les caract. Voy. AnTuocènes. (C. M.) 
*ANTHOCH $A$ ERA $(\ddot{\alpha}, v 0$ os, fleur; $\chi \alpha i p \omega$, je me plais ). ors. - Genre formé par Vigors et Horsfield sur la Pie à pendeloques de Daudin(Merops carunculatus Lath.), et adopté par tous les auteurs anglais modernes. Ce genre étant synonyme de celui de Créadion, de Vieillot, qui lui est antérieur, nous adoptons de préférence ce dernier, comme l'a fait M. Lesson dans son $T r$. d'ornith.; et, comme lui aussi, nous en retirons les esp. désignées depuis par le nom générique de Tropidorhynque, et celle dont M. Is. Geoff. a fait le g. Philestourne.Voy. CRÉadron.

(LAFR.)

*ANTHOCHARIS ( $\ddot{x}: 0 \circ$ os, fleur; $\chi \dot{\alpha} \rho\llcorner s$, ornement ). Ivs. - Genre de Lépidoptères, famille des Diurnes, tribu des Piérides, établi par M. Boisduval aux dépens du g. Pie$r i s$ de Latreille, et que j'ai adopté dans mon Supplément à l'Histoire naturelle des Lépidoptères de France. Les Anthocharis se distinguent des Pieris $1^{\circ}$ par leurs antennes, beaucoup plus courtes et terminées par un bouton presque globuleux; $2^{\circ}$ par leurs palpes, beaucoup plus velus, et dont les poils se confondent avec ceux du chaperon; $3^{\circ}$ par leurs ailes, plus arrondies, plus minces et plus délicates; $4^{\circ}$ enfin par leurs chrysalides, courbées en forme de nacelle, pointues aux deux bouts, et inflexibles dans toutes leurs parties. Leurs chenilles ressemblent à celles des Piérides.

Le g. Anthocharis renferme un grand nombre d'espèces, dont nous ne citerons que les plus connues : l'Anth. aurore (Anth. Gardamines), qui se trouve dans toute l'Europe; l'Anth. eupheno, ou l'Aurore de Provence, qui habite principalement le littoral de la Méditerranée; les Anth. belia et auzonia, qu'on rencontre dans les endroits arides du centre comme du midi de la France; et enfin les Anth. glauce et belemia, qui habitent l'Espagne, le Portugal, l'Algérie et l'Égypte. Presque toutes ces espèces paraissent au commencement du printemps. Elles sont figurées dans une foule d'ouvrages, dont le plus récent est l'Histoire naturelle des Lépidoptères de France, avec son supplément.

(D.)

*ANTHOCHLAMYS. Anthochlamys, Fenzl. ( $\alpha 2 \theta_{0 s}$, fleur ; $\chi \lambda \alpha \mu \dot{\nu}_{s}$, sorte de tunique). вот. PH. - Genre de la famille des Chénopodées, voisin des Corispermum. M.
Fenzl (in Endlicher, Gen. Plant., 1, pag. э00 ) en donne les caractères suivants: Fleurs hermaphrodites. Périgone quinquéfide, campanulé, coloré, subdiaphane; segments bilobés au sommet, un peu dentelés. Étamines au nombre de 4 à 6 , hypogynes, opposées aux segments du périgone. Filets subulés, légèrement monadelphes par la base. Anthères dithèques, oblongues-linéaires , bifides aux deux bouts. Ovaire lenticulaire, uni-loculaire, uni-ovulé. Style biparti : chaque branche terminée en stigmate filiforme. Caryopse comprimé, monosperme, bordé d'une aile étroite.-Herbe annuelle, diffuse, glabre. Feuilles uni-nervées, mucronulées: les florales raccourcies, rapprochées en épi dense. Fleurs petites, axillaires, roses, non bractéolées. L'unique espèce sur laquuelle se fonde ce g. (Corispermum polygaloides, Fischer et C. A. Meyer) a été récemment découverte en Perse.

ANTHOCHLOA ( $\not 2005$, tleur; $\chi \lambda$ ón, herbe). вот. PH. - Genre de la famille des Graminées, tribu des Festucacées, s.tribu des Broméées, formé par Nees von Esenbeck et Meyen (In litt. ad Lindl., cit. Introd. Edit. II), et ainsi caractérisé : Epillets 3-4-flores; florules inférieures hermaphrodites, celles du sommet abortives. Glumes 2, mutiques; l'inférieure un peu plus petite. Paléoles 2; l'inférieure très grande, subarrondie; la supérieure plus petite, bifide, à lacinies biparties. Squam. mules 2, aiguës. Styles 2, terminaux ; stigmates très grands, plumeux. Étamines, ovaire et caryopse, inconnus. Une seule espèce (A. lepidula $\mathbf{N}$. et M.) compose ce g., incomplètement connu. C'est une Graminée trouvée dans, les Andes du Pérou, à $48.72^{\mathrm{m}}, 585$ de hauteur; à inflorescence en grappe paniculée, dont les divisions sont fasciculées, pauciflores. (G. L.)

ANTHOCHORTUS ( $\left(2, \nu 0 \%\right.$, fleur ; $\chi_{0}$, zós, enceinte). вот. PII. - Genre de la famille des Restiacées, formé par Nees von Esenbeck (In litt. ad Lind., cit. in Introd. Edit. II), et dont voici les caract. sommaires : Fleurs dioïques. Dans les mâles ( femelles inconnues), périgone infundibuliforme, sexparti ; à lacinies égales, dont les extérieures plus étroites. Étamines 3. Anthères uniloculaires, peltées. - Ce g. parait ne renfermer encore qu'une esp. ( $A$ 
Eckloniz). C'est une plante du Cap, à chaumes aphylles, filiformes; à rameaux fasciculés, portant des fleurs mâles disposées en forme de grappes.

(C. E.)

* ANTHOCLEISTA, Afzel. ined. ex R. Br., in Tuck. Congo, p: 449 ( $\ddot{\alpha} \nu \theta_{0}$, fleur;

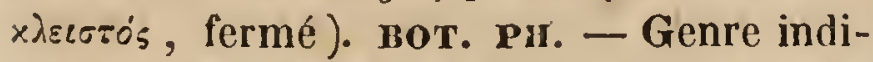
qué par M: R. Brown comme voisin des Logania, dont il différerait notamment par un fruit 4-loculaire. - Ce genre, dont les caract. n'ont pas été exposés avec plus de détails, est fondé sur un arbre indigène de Guinée.

(SP.)

* NNTHOCONUM ( $\ddot{x} \nu 005$, fleur; $x$ wैyos, cône ). вот. CR. - Palissot de Beauvois avait créé ce nom pour un démembrement, déjà fait avant lui, du genre Marchantia. C'est le Marchantia conica L., qui servait de type à ce genre établi par Raddi sous le nom de Fegatelia (Voy. ce mot), et adopté par M. Nees.

(C. II.)

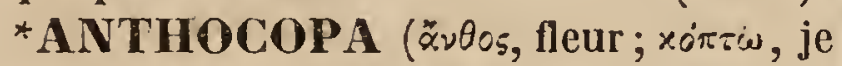
coupe). Ns. - Genre de la famille des Mellifères, Lat., de l'ordre des Hyménoptères, sect. des Porte-Aiguillon, établi par MIM. Lepelletier-Saint-Fargeau et Serville (Encycl. méth.), aux dépens du g. Osmia de Latreille, sur plusieurs espèces dont les mandibules sont pourvues de trois dents, et dont les femelles coupent les pétales des fleurs pour en construire leurs cellules, tandis que les vrais Osmia n'ont que deux dents aux mandibules, et construisent leurs nids avec une sorte de mortier qu'elles préparent avec de la terre et d'autres substances. Voy. osmia.

(BL.)

*ANTHOCORIS ( $\ddot{\alpha} \nu \theta_{0}$ s, fleur; $\times o_{i}^{\prime}, \iota s$, punaise). INs. - Genre de la famille des Lygéens, de l'ordre des Hémiptères, section des Hétéroptères, établi par Fallen (Hemipt. suecica), et adopté par Burmeister (Handb. der ent.) et nous (Hist. des Anim. art.). Ce g. se distingue surtout des autres Lygéens par une tête étroite, très avancée en museau, de la longueur du premier article des antennes, un thorax conique et des élytres presque transparentes dans toute leur étendue. Les Anthocoris étaient confondus par Fabricius dans les g. Lygaus et Salda. Ce sont des insectes de très petite taille, de forme élégante, et parés de couleurs assez vives; on en connait une douzaine d'espèces européennes dont le type est

$$
\text { I. I. }
$$

l'A. nemorum, Burm:, Blanch. (Cimex nemorum, Lin.), qui offre un grand nombre de variétés de coulcurs, que Fabricius a considérées comme des espèces distinctes.

(Bu.)

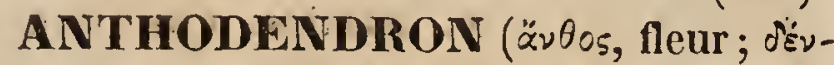
spov, arbre). Bot. PH. - Genre de la famille des Éricacées, tribu des Rhododendrées, formé par Reichenbach (Flor.Germ.), et réuni, comme synonyme, au g. Rhododendrum, dont on en fait une des divisions.

(C. L.)

ANTHODISCUS, Meyer (Flor. Esse-

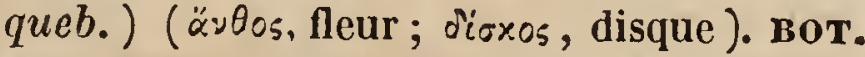
PH.-Genre incomplètement connu, rapporté àla famille des Rhizobolées, et dont l'auteur (l. c., p. 193) donne pour caract. : Calice plan, légèrement 5-lobé. Pétales 5 , hypogynes, oblongs, concaves. Étamines très nombreuses, insérées sur un disque annulaire qui engaîne la base de l'ovaire. Filets capillaires, tortueux, libres. Anthères petites, dressées, didymes. Ovaire petit, inadbérent, déprimé, strié. Styles au nombre de 14 à 20 , subulés, courbés en dedans au sommet. Stigmates pointus. Baie cortiquée, disciforme, suborbiculaire, déprimée, ombiliquée, marquée de stries rayounantes. - L'esp. sur laquelle est fondé ce g. est un arbre de la Guyane, à ramules cylindriques, glabres; à feuilles éparses, 3-foliolées, pétiolées; à folioles oblongues, acuminées, subsessiles, crénelées, veineuses ; les fleurs sont disposées en grappo terminale, à pédicelles 2-bractéolés.

(SP.)

*ANTHODISCUS, Martius, in Schult. Mant., t. I, p. 253 ( $\ddot{\alpha} \nu 05$, fleur; Jíxos, disque ). вот. Рн. - Syn. du g. Anthodon, R. et Pav., de la famille des Hippocratéacées.

(Si.)

ANTHODON, Ruiz et Pavon (Flor. Peruv., t. I, p. 45.) - Anthodus et Antho-

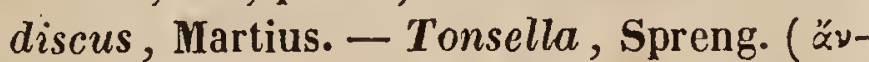
Oos, fleur ; jovy, dent'). Bот. PH. - Genre de la famille des Hippocratéacées, auquel on assigne pour caract. : Calice à 5 lobes arrondis. Pétales 5 , inéquilatéraux, dentés. Étam. 5, insérées entre le disque et l'ovaire; filets élargis vers leur base. Anthères 1-thèques, déhiscentes au sommet par une fente transversale. Ovaire 3-loculaire; loges pluri-ovulées; ovules attachés à l'angle interne des loges. Style très court. Baie sub- 
globuleuse, 2 ou 3-loculaire; loges 1-spermes par arortement. Graines ovoïdes, a tégument muqueux. - Ce genre est propre à l'Amérique équatoriale. On en connaît environ 12 espèces.

(SP.)

* ANTHIODUS, Martius, (in Schult. Mant., t. I, p. 253 ) ( $\alpha 2 \theta 05$, neur ; ojovs, dent ). Bor. PH. - Syn. du g. Anthodon, R. et $\mathbf{P}$., de la famille des Hippocratéacées.

(SP.)

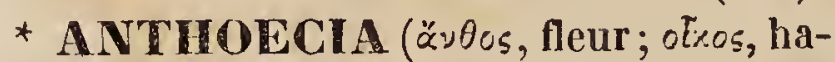
bitation). INs. - Grenre de Lépidoptères, famille des Nocturnes, tribu des Héliothides, établi par K. Boisduval (Genera et Index methodicus europaorum Lepidopterorum) aux dépens du g. Heliothis d'Ochsenheimer, et auquel il assigne les caract. suivants : Chenilles allongées, ponctuées, avec la tête petite, globuleuse; se nourrissant des fleurs et des graines des plantes de la Syngénésie, et se métamorphosant dans leurs calices. Insecte parfait: Antennes simples: Palpes courts; dernier article avorté. Taille petite, robuste. Gorselet arrondi, abdomen conique, annelé, terminé, dans les femelles, par un oviducte pointu. - L'auteur n'y rapporte que deux esp., la Noctua cognata de Hubner, et la Noct. Cardui d'Esper. La première se trouve en Hongrie, et la seconde en Autriche.

(D.)

ANTHOGONIUM ( $\hat{\alpha} \nu \theta_{0}$, fleur ; ? y'svix, angle). Bot. PH. - Genre de la famille des Orchidacées, dont Lindley ( Introd. Edit. II, p. 341 ) attribue la formation à Wallich, et qu'il place à côté du g. Limodorum, dans sa tribu des Aréthusées; toutefois, les caract. ne paraissent pas en avoir encore été publiés.

(C. L.)

ANTHOLISE ou ANTHOLIZE. RoT. - Voyez ANTHOLYze. (G. L.)

ANTIIOLOMA, Labill. ( $\alpha 2905$, fleur ; $\lambda \omega \mu \alpha$, frange). вот. PI. - Genre de la famille des Marcgraviacées, et auquel son auteur (Nov. Holl., t. II, p. 121 ; Voyage, tab. 4) assigne pour caract. : Calice 2- ou 4-sépale, ovoïde, caduc. Corolle ovale-cylindracée, crénelée. Etamines très nombreuses, insérées sur un disque fongueux, alvéolé; filets très courts; anthères oblongues, introrses, déhiscentes au sommet. Ovaire obscurément 4-gone, 4-loculaire. Style long, terminé par un stigmate pointu. - Arbre à feuilles pétiolées, coriaces, elliptiques-oblongues, agré- gées vers l'extrémité des ramules; grappes axillaires, réfléchies; pédoncules nus. L'unique esp. sur laquelle est fondé ce genre croît dans la Nouvelle-Calédonie. (SP.)

ANTHOL YZE. Antholyza ( $\ddot{\alpha} \nu 005$, fleur; $\lambda \dot{\sigma \sigma \kappa}$, rage. Linné, comparant à des gueules entr'ouvertes les fleurs de ces plantes, a, par métaphore, appliqué à tout le genre ce nom, qu'il aurait dû écrire Antholyssa). вот. PH. - Genre de la famille des Iridacées, formé par Linné.

Ce genre ayant été tour à tour annulé ou adopté par les auteurs systématiques, et demandant des recherches ultérieures pour le faire bien connaitre, nous nous en occuperons de nouveau spécialement au mot GLADIOLUS. (C. L.)

* ANTIOMETRA ( $\alpha \dot{*}, \theta_{0}$, fleur ; $\mu$ śт $0^{\circ}$, mesure ). Irs. - Genre de Lépidoptères, famille des Nocturnes, tribu des Phalénides, établi par M. Rambur, et adopté par M. Boisduval (Genera et Index europaorum Lepidopterorim), qui lui assigne les caractères suivants : Métamorphoses inconnues. Antennes du mâle courles, plumeuses ou largement pectinées. Spiritrompe courte. Ailes très entières, rousses, sans taches; taille très petite. Vol du mâle en plein soleil. - Ce genre est fondé sur une seule espèce, trouvée en Andalousie par M. le docteur Rambur et nommée par lui $A$. plumaria.

* ANTIOMYIDES. Anthomyide (äv Oos, fleur; $\mu \tilde{v} \iota \alpha$, mouche [Anthomyia]; घĩos, forme ). Ins. - Nom d'une tribu de l'ordre des Diptères établie par M. Robineau-Desvoidy dans sa famille des Myodaires, et qu'il caractérise ainsi : Antennes descendant ordinairement jusqu'à l'épistome; le premier article toujours très court; le socond quelquefois aussi long que le troisième, qui est prismatique ou cylindrique; chète quelquefois plumeux, souvent villeux, plus souvent tomenteux, et presque nu, à premiers articles indistincts. Front nul chez les mâles, tout à fait carré ou allongé chez les femelles, arec les frontaux ordinairement rougeâtres à leur base; face verticale, triangulaire chez les mâles et carrée chez les femelles; péristome souvent en carré long, plus souvent carré, avec l'épistome quelquefois saillant. Abdomen cylindriforme, souvent atténué chez les mâles; anus des mâles re- 
plié en dessous et souvent muni en dessus de $\_$appendices latéraux; cuillerons beaucoup plus petits que dans les tribus précédentes. Ailes moins triangulaires, déjà plus allongées, et à cellule sans nervure transverse; taille moyenne et ordinairement petite. Teintes noirâtres brunes, d'un brun gris, d'un bruil cendré.

Cette tribu renferme 15 genres, dont celui des Anthomyes forme le type. Les larves colnues vivent dans les excréments, dans les débris des animaux et végétaux en décomposition. Les insectes parfaits se rencontrent en toute saison dans les bois, parmi les herbes des champs, sur les excréments, sur l'écorce des arbres, sur les fleurs, et même sur la terre. Les mâles de plusieurs espèces forment des danses dans l'air. (D.)

ANTHOMYIE. Anthomyia ( $\ddot{\alpha} \nu 0 s$,

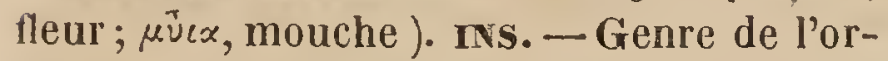
dre des Diptères, division des Brachocères, subdivision des Dichœetes, tribu des Muscides, section des Anthomyzides, dont il est le type et le groupe le plus considérable. Ce genre, détaché par Meigen du g. Musca de Linné, Fabricius, Latreille et Fallen, comprend plus de quarante espèces, se trouvant toutes en France et en Allemagne, et pullulant à l'infini sur les fleurs, et particulièrement sur les Synanthérćes et les Ombellifères. On les voit souvent réunies dans les airs en troupes nombreuses, comme les Tipulaires. Les caract. du g. Anthomyia, d'après M. Macquart, sont les suivants : Antennes n'atteignant pas l'épistome ; style ordinairement tomenteux, quelquefois nu; abdomen étroit, atténué à l'extrémité; cuillerons petits; valve inférieure ne dépassant pas ordinairement la supérieure. Ailes sans pointe au bord antérieur. M. Robineau-Desvoidy a formé de ce genre une section sous le nom d'Anthomyda chorella, et l'a divisée en six genres ainsi désignés : Anthomyia, Fannia, Philinta, Amenta, Delia, Eglé.

Les femelles des Anthomyies déposent leurs cufs dans la terre, où leurs larves se développent rapidement. Celles-ci, du moins dans les A. municata et scalaria, se fixent à un corps pour subir leur métamorphose, et leurs nymphes demeurent suspendues comme les chrysalides de quelques Lépidoptères, suivant la remarque de $\mathbf{M}$. Robi-
neau-Desioldy. La Musca phuvialis de Linné é de Fabricius peut être considérée comme le type du g. Anthomyia.

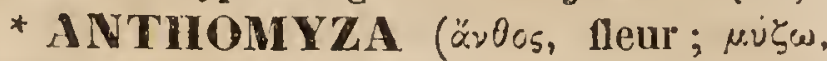
je suce ). Ins. - Genre de Lépidoptères établi par M. Swainson (Zoological illustration, etc., pl. 124); qui le place dans la tribu des Sphingides, et lui donne des caractères tellement vagues, que nous croyons devoir les passer sous silence. Ce g. a pour type le Pap. Tiresias de Cramer, qui appartient au g. Hazis de M. Bolsduval. Voy. ce mot.

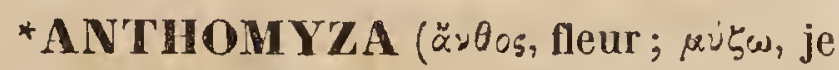
suce). ors. - C'est, dans la classification de Swainson, un g. de sa famille des Melliphagidce, que M. G. R. Gray vient de changer en Anthornis, le premier mot étant employé en Entomologie. Voy. AnThokis.

(LAFR.)

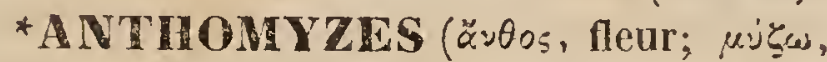
je suce). ors. - C'est, dans la méthode de Vieillot, la 22 e famille de son ordre des Oiseaux sylvains, composée des g. Guitguit, Souimanga, Colibri et Héorotaire.

(LAFR.)

* ANTHOMYZIDES. Anthomyzida

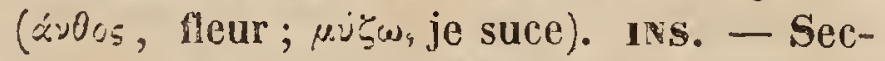
tion de la tribu des Muscides (Diptères). Ces insectes, outre les caractères généraux des Muscides, présentent les caract. particuliers suivants : Antennes couchées, troisicme article allongé. Style de deux articles distincts. Yeux ordinairement contigus chez le mâle. Pelotes destarses allongées dans ce même sexe. Cuillerons médiocres ou petits. Ailes à premidre cellule postérieure ouverte. Cette section, ne formant d'abord que le genre Anthomyia, détaché du genre Musca de Linné, par Meigen, s'est trouvée si nombreuse, que Latreille, en lui donnant le nom d'Anthomyzides, l'a subdivisée en plusieurs genres; elle en renferme maintenant 14. M. Robineau-Desvoidy a adopté la. dénomination de Mesomyace pour désigner ces Dipteres, et de la plupart des genres il a. formé des sections, subdivisées elles-mêmes. en nouveaux genres. Voici les noms de ces. s.-tribus : Aricince terresires, correspondant au g. Aricia, Macq.; Aricince littorales, g. Hydrophoria, Macq.; Helemyda, g. Helemyia, Macq.; Anthomyde herbicola, g. Chortophyla, Maca.; Azelidee, 8. Alomo- 
gaster, Macq.; Anthomyda chorello, g. Anthomyia, Macq.; Limosella, g. Canosia, Macq.; Pegomyda, g. Pegomyia, Macq.

Les Anthomyzides ont, par leur organisa tón et par leurs mours, une grande analogie avec les Muscies; elles en diffèrent cependant par un vol moins rapide et moins soutenu, par moins de véhémence dans leurs appétits. Presque toujours cachées sous les feuilles, elles ne se montrent sur les feurs que lorsque l'atmosphère est échauffée par le soleil. On conçoit, du reste, que leurs habitudes varient selon les genres.

Les Hylémies habitent particulièrement les bois; les Leucophores préfèrent les prairies; les Hydrotées, les Aricies, les Limnophores, vivent exclusivement dans les lieux aquatiques; les Anthomyies se trouvent partout. Outre les sucs des fleurs, qui sont leur nourriture ordinaire, quelques unes, telles que les Hylémies, recherchent les matières stercorales; les femelles des $\mathbf{H y -}$ drophories et de quelques Aricies se jettent sur les bestiaux; et, quoique leur trompe ne pụisse pas pénétrer jusqu'aux vaisseaux sanguins, et ne leur permette que de humer les fuides répandus sur la surface des corps, elles les harcellent et les tourmentent cependant par leur poursuite opiniâtre. Les larves du plus grand nombre se développent dans les débris des plantes, soit terrestres, soit aquatiques. Les Conosies paraissent vivre dans les racines. M. Robineau a observé une femelle de Lispe qui déposaî une grande quantité d'œufs sur les pétales d'un $\mathbf{N y m}$ phaa. Les Hylémyies naissent souvent dans les bouses ; les Pégomyies rongent le parenchyme des feuilles, et vivent entre les deux surfaces, solitaires ou en sociétés nombreuses : ce sont les larves mineuses de la Jusquiame, de l'Oseille, des Chardons, si bien observées par Réaumur et de Géer. Dans le premier âge, les Anthomyzides ont, comme les Muscies, la bouche munie de deux crochets écailleux qui leur servent à prendre leur nourriture et à se trainer en avant Cependant, dans les larves mineuses, ces crochets se convertissent en un instrument corné en forme d'S, qui se meut autour d'une petite tige fixe et qui ronge ainsi le parenchyme des feuilles. Les nymphes ne paraissent pas différer de celles des Muscies. Peu de jours leur suffisent pour passer à l'état adulte. Dans quelques espèces, on observe plusieurs générations dans la même année; ce qui augmente encore la grande fécondité de ces Diptères.

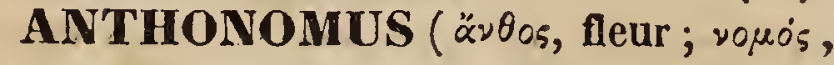
qui paît). Ins. - Genre de l'oràre des Coléoptères tétramères, famille des Curcuculionites, établi par Germar aux dépens du g. Rhynchanus de Fabricius, et adopté par Latreille, ainsi que par tous les autres entomologistes qui sont venus depuis. Schoenherr le place dans sa division des Érirhinides et lui donne les caract. suivants : Antennes longues, grêles; leur funicule de 7 articles : les deux premiers allongés, presque obconiques; les autres courts, lenticulaires, presque égaux. Massue allongée, ovale. Rostre long, mince, filiforme, un peu arqué. Yeux ronds, convexes. Corselet presque conique, bisinué à la base, légèrement arrondí sur les côtés, très étroit antérieurement, tronqué au sommet. Éeusson allongé, distinct. Élytres en ovale allongé, convexes, sourent amples; angles huméraux obtus. Pattes de longueur moyenne; les antérieures plus longues; cuisses épaisses, dentées.

observ. - Corps presque ovale, convexe, pubescent, ailé ; de taille petite ou moyenne.

Le dernier Catalogue de M. Dejean désigne, comme se rapportant à ce genre, 43 espèces, parmi lesquelles on en compte 19 d'Europe ; les autres appartiennent à l'Amérique et à la Nouvelle-Hollande. Nous ne citerons que celle qui a servi de type à Germar, le Rhynchanus druparum, Fabricius, qui se trouve aux environs de Paris. (D.)

ANTHONOTA, Beauv. ( $\ddot{\alpha} \nu 0 \circ$, fleur ;

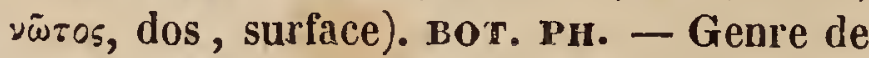
la famille des Légumineuses (s.-ordre des Césalpiniées, tribu des Cassiées), auquel son auteur (Flore d'Oware, t. I, p. 70, tab. 42) attribue les caract. suivants : Galice pétaloïde, 4-fide; 5 des segments lancéolés, pointus; le $4^{\mathrm{e}}$ plus large échancré. Corolle réduite à un seul pétale, à onglet très long, et à limbe cochléariforme, échancré. Étamines 10 , libres, anisomètres : 3 très longues; les 7 autres plus courtes que le calice. Ovaire comprimé, ovale, non stipité. Style filiforme, terminé par un stigmate 2-fide. Légume aplati, subréticulé, presque indéhiscent, 1-loculaire, polysperme. Graines orbiculaires, planes. - Ce genre est fondé sur 
un arbrisseau du pays d'Oware; ses Peuilles sont pari-pennées, 2- ou 3-juguées, non stipulées; à pétiole cylindrique; à folioles coriaces; les neurs sont disposées en grappes axillaires très courtes.

(SP.)

ANTHOPHAGE. Anthophagus ( $\ddot{\alpha} \nu$ 0os, fleur; p'́yos, mangeur ). INs.-Nom sous lequel Gravenhorst désigne un g. de Coléoptères pentamères, famille des Brachélytres, établi antérieurement par Latreille sous le nom de Lesteva. Depuis, M. Erichson, dans un nouvel ouvrage intitulé : Genera et species Staphylinorum (pars prior, p. 51), divise le g. dont il s'agit en deux; il applique à l'une le nom d'Anthophagus, et à l'autre celui de Lesteva; mais, au moment où nous écrivons ceci, nous n'avons pu encore nons procurer la seconde partie de son ouvrage où se trouvent exposés les caract. qui distinguent ces deux g., avec la description des espèces qui se rapportent à chacun d'eux. Dans cet état de choses, le nom d'Anthophagus est pour nous synonyme de celui de Lesteva, auquel nous renvoyons pour les caractères génériques.

* ANTHOPHILE. Anthophila ( $\alpha_{\alpha} \nu-$

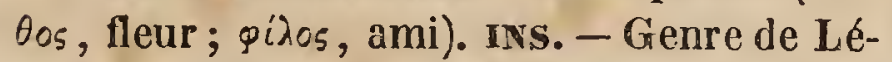
pidoptères, famille des Nocturnes, tribu des Noctuo-Phalénides, établi par Ochsenheimer, et adopté par M. Treistchke, son continuateur, qui lui attribue les caract. suivants : Tête lisse. Corps étroit. Pattes de derrière très longues. Ailes supérieures presque triangulaires, manquant des taches ordinaires, et ayant l'angle apical très aigu; ailes inférieures garnies de larges franges. Antennes légèrement crénelées, presque filiformes.

Ces Lépidoptères, dont les chenilles ne sont pas encore connues, sont propres aux contrées méridionales de l'Europe, à l'exception d'une seule esp., l'Ant. anea, qui se trouve au nord comme au midi de la France. Toutes volent sur les fleurs à l'ardeur du soleil, et leur apparition a lieu depuis la fin de mai jusqu'en avût, selon les espèces. Nous citerons comme une des plus intéressantes du genre l'Anthophila purpurina (Noct., id. Fabr.), qui n'est pas très rare dans le Languedoc. Elle est figurée dans l'Hist. natur. des Lépid. de France, t. 4 , des Noct., pl. 123, fig. 7.

(D.)

ANTHOPLILES. Anthophila (艾005, neur; pìos, ami ). INs. (Diptères ). - M.
Hobineau-Desvoidy nomme ainsi la 2 section de sa tribu des Entomobies. Elle se compose des g. Lynnœmya, Bonnelia, et Marshamia, et répond au g. Micropalpus de M. Macquart. Les Anthophiles diffèrent essentiellement des Macromydes par la proportion des derniers articles antennaires et par la forme toujours prismatique du dernier. Leur corps, cylindriforme, plus allongé, plus gris et moins noir, les fait distinguer à la première vue. On ignore les habitudes de leurs larves; mais les insectes parfaits se trouvent plus particulièrement en automne sur les Ombellifères. Leur vol n'est pas bourdonnant.

ANTHOPHORA ( $\alpha_{\nu} \theta 0 s$, fleur; yopós, qui a du goût pour). INs. - Genre de la famille des Mellifères, de l'ordre des Hyménoptères, établi par Latreille, adopté par tous les entomologistes modernes, et confondu par Fabricius dans les g. Megilla et Centris. Les Anthophora présentent des caractères qui les séparent très nettement des g. voisins. On peut les résumer ainsi : Antennes courtes et filiformes. Mandibules unidentées au côté interne. Palpes maxillaires composés de six articles, et les labiaux de quatre; ailes ayant trois cellules cubitales complètes. Ce genre renferme une quinzaine d'esp. européennes dont les plus répandues sont les $\boldsymbol{A}$. pilipes', Latr., etc. (Megilla pilipes, Fabr.), Retusa (Apis retusa, Lin.), Acervorum et Parietina (Megilla $i d$., Fabr.). Les habitudes de cette dernière ont été pour Latreille l'objet d'un mémoire plein d'intérêt, inséré dans le tome III des Annales du Muséum. D'après lui, la femelle construit son nid dans les murs, et élève à l'entrée un tuyau perpendiculaire légèrement courbé, composé de grains de terre; après sa ponte, elle le détruit ou peut-être l'emploie pour fermer l'entrée du nid.

(BL.)

* ANTHOPHORIDES. Ivs. - Nom d'une des sous-familles de M. Westwood pour la famille des Mellifères, correspondant à notre groupe des Anthophorites. Voy. ce mot.

(BL.)

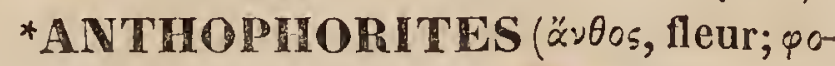
pós, qui a une tendance vers). INs. - Nous avons employé cette dénomination (Hist. des Anim. art., t. IV) pour désigner un groupe de la famille des Mellifères ou Mel- 
lificiens, répondant à la division des Scopulipèdes de Latreille. Il est caractérisé par les tarses postérieurs, dont le premier article est dilaté inférieurement au côté externe, et couvert, ainsi que le côté externe des jambes, de poils épais et serrés, formant une sorte de houppe ou de brosse. Ce groupe a pour type le g. Anthophora, et renferme en outre les g. Euglossa (placé ici avec doute. Voy. ce mot.), Acanthopus, Epicharis, Centris, Ancyloscelis , Saropoda, Melliturga, Eucera, Macrocera, Melissodes, et quelques autres qui se rattachent à ceux-ci comme synonymes. Les Anthopho. rites ne se composent que de deux sortes d'individus : des mâles et des femelles, chez lesquels il existe des différences notables, non seulement dans la couleur, mais aussi dans la structure des antennes et des pattes. Les femelles construisent leurs nids dans les crevasses des vieux murs ou dans les terrains ordinairement exposés au soleil ; leurs cellules sont formées de terre et très unies intérieurement. (Voy., pour de plus longs détails, MELUIFìnES.)

(BL.)

*ANTHOPHYLLE.Anthophyllum (žx-

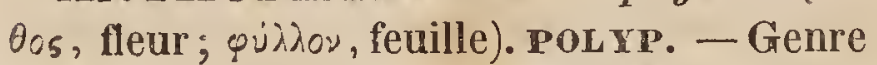
de Polypiers fossiles, établi par M. Goldfuss aux dépens des Caryophyllies, et renfermant surtout les espèces dont les étoiles terminales sont plus élargies et comme pédicellées. Le plus grand nombre des Anthophylles appartient aux terrains anciens. (Dux.)

ANTHOPHYLLTIE. (Anthophyllum, clou de girofle; à cause de sa couleur brune ). MIN. - Nom donné par Schumacher et Werner à un minéral brun rayonné, découvert pour la première fois à $\mathbf{K}$ ongsberg, en Norwège, et retrouvé depuis au Groënland. Werner y avait réuni la Bronzite, sous le nom d'Anthoph. lamelleux. La Bronzite n'est qu'une variété de la Diallage (Voy. ce mot); et l'Anthophyllite aciculaire, dont Haüy avait fait une esp. à part, n'est luimême qu'une variété d'Amphibole actinote. Voy. Avrhibole.

(DEL.)

ANTHOPHYSE. Anthophysa ( $\alpha \theta_{0}$, neur; $\varphi$ y la famille des Monadiens, créé par M. Bory pour Ie Volvox vegetans de Müller, que M. Whreuberg a rangé parmi ses Vorticellines dans son g. Epistylis. Les Anthophyses sont bion des Monadiens, c'est-à-dire des Infu- soires nus, formés d'une substance glutineuse, en apparence homogène, susceptibles de s'agglutiner et de s'étirer plus ou moins, et pourvus d'un seul filament flageliiforme sans cesse agité; mais ils se distinguent de tous les autres Monadiens en ce qu'ils vivent agrégés en masses globuleuses, à l'extrémité des rameaux d'une sorte de petit Polypier rameux, sécrêté par eux-mêmes. Ces petits rameaux, d'abord diaphanes et comme gélatineux, se colorent peu à peu et deviennent solides et cornés. Les groupes d'Anthophyses, venant à se détacher de leur support, se meuvent en tournoyant dans le liquide, et ne pourraient alors être distingués des Uvelles, qui sont des Monadiens agrégés, mais toujours libres. Enfin, quand, spontanément ou par accident, les Anthophyses sont désagrégées, elles ressembient entièrement à des Monades propremeut dites. L'espèce décrite par Müller (A. vegetans) se trouve abondamment dans l'eau de la Seine, à la fin de l'été; il suffit de mettre dans un flacon, avec de l'eau, des herbes recueillies au fond du fleuve, ou des cailloux couverts de petites Conferves, pour voir, au bout de quelques jours, les Anthophyses fixées aux parois. La longueur des Animacules isolés est d'un centième de millim., et le diamètre des groupes est de 0,024 à 0,052 millimètres.

(DUd.)

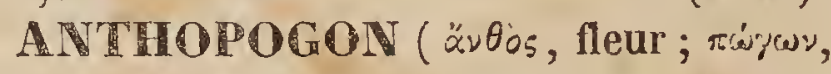
barbe). BOT. RH. - Genre de la famille des Graminées, tribu des Chloridées, formé par Nuttal (Gen., t. I, p. 82), et synonyme du g. Gymnopogon de Palissot de Beauvois.

(C. L.)

ANTHOPORA. zoOPH. Foss.- Voyez ANTHOPORITI.

(M. E.)

ANTHOPORITA ( $\ddot{\alpha}, \theta 0 s$, fleur; rópos, filament).zoopr. Foss. -Nom employé par Hofer pour désigner l'Encrinites liliiformis (Acta Helv., t. IV , p. 204).

(M. E.)

ANTHORA, DC. (Syst. I, p. 564)( $\ddot{\alpha} v-$ Oos, fleur; öpos, butte; forme du sépale supérieur). Bot. PH. - Section du genre Aconit, constituée par l'A. Anthora, L., et ofrant pour caract., distinctifs : Calice persistant; le sépale supérieur (ou casque) plus ou moins rétréci vers la base, à embouchure arquée ou tronquée (soit verticalement, soit très obliquement), plus ou moins longuement rostrée. Pétales à capuchon très court 
et termine en labelle obcordiforme ou suborbiculaire, longuement stipité; onglet brusquement géniculé au sommet. Graines ailées à l'un ou deux des angles, tantôt très lisses, tantôt très légèrement rugueuses. - Feuilles pédatiparties, peu ou point luisantes. Fleurs d'un jaune pâle, ou d'un bleu livide, ou panachées de bleu et de jaune. Racine tubéreuse. (Spach, Hist. des Plant. phan., t. VII, p. 380.)

(SP.)

* ANThORNIS ( $\ddot{\alpha} \nu 0$ os, fleur; öpves, oiseau). ors.-C'est, dans la liste of the Genera of Birds de Robert Gray (1810), un g. de sa famille des Melliphagida ou Philédons, s.famille des Melliphagina, substitué, par cet auteur, à celui d'Anthomyza de Swainson, ce dernier étant employé en Entomologie, et dont les caractères sont : Bec assez court; langue.....? Ailes très arrondies; toutes les pennes plus ou moins terminées en pointe. Queue échancrée; doigts latéraux égaux. - L'esp. type citée par ces deux auteurs est l'A. melanura (Sparr. Mus. Carls., t. I, pl. 5 , et Gray), A. caruleocephala Swainson.

(LAFR.)

ANTHOSOME. Anthosoma ( $\alpha^{\prime}: 005$, fleur ; $\tau \tilde{\omega} \mu x$, corps). CRUST. - Genre de l'ordre des Siphonostomes, famille des Caligites, tribu des Hyménopodes, établi par Leach, qui le caractérise ainsi : Test arrondi en avant et en arrière. Antennes formées de six articles. Abdomen beaucoup plus étroit que ce test, muni de deux lames foliacées sur le dos, et de six autres sous le ventre; celles-ci tenant lieu des trois dernières paires de pattes. Pattes de la paire antérieure étendues en avant ; leur ongle étant crochu, et rencontrant une petite dent située vers le sommet de l'article qui précède. Pattes de la seconde paire ayant l'ongle comprimé. Le dernier article de la troisième paire très épais, denté antérieurement, terminé par un ongle très fort ou inséré derrière les pattes de devant, et muni, à son extrémité, de deux appendices droits et cornés. - L'espèce-type de ce genre Anthosoma Smithii, Leach, a été trouvée fixée à un Squale (Squalus cornubiensis) sur la côte du Devonshire.

(II. L.)

ANTHOSPEDME. Anthospermum, Linn. - Tournefortia, Pontedera, non $\mathbf{L}$.

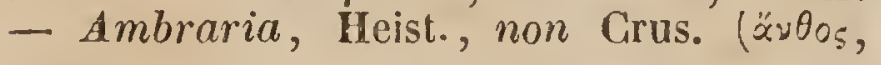
fleur; $\sigma \pi \dot{\varepsilon}, p \alpha \alpha$, graine ). BoT. DI. - Genre de la famille des Rubiacées (tribu des Anthospermées, Cham. et Schl.). Il offre pour caract. : Fleurs dioïques, ou polygames, ou hermaphrodites. Tube calicinal obové, adhérent; limbe 4-ou s-đenté, minime, non persistant. Corolle des fleurs mâles ou hermaphrodites rotacée, profondément 3-à 5-fide; à lobes ovales-oblongs, révolutés lors de l'anthèse. Corolle des fleurs femelles minime, subcampanulée, courtement 4-fide, à lobes dressés. Étamines 3 à 5, saillantes, insérées à la base du tube de la corolle; filets filiformes; anthères oblongues, dressées. Ovaire infère, 2-loculaire, couronné d'un disque mince; loges 1-ovulées; ovules anatropes, renversés, attachés au fond des loges. Style très court, terminé en 2 stigmates fliformes, plumeux. Péricarpe ovoïde, denticulé au sommet, crustacé, 2-coque, 2-10culaire; coques indéhiscentes, 1-spermes, convexes au dos, planes antérieurement. Embryon rectiligne, subdorsal dans un périsperme cartilagineux; cotylédons foliacés; radicule allongée, infère (Endlicher, Gen. Plant., p. 324). - Herbes on sous-arbrisseaux habitant l'Afrique australe; tiges rameuses; feuilles opposées ou verticillées, connées par la base (moyennant une stipule interposée, prolongée en forme de dent au delà du plan de soudure). Fleurs axillaires, sessiles, opposées, ou verticillées, ou rarement paniculées; ovaire 2 - ou 3-bractéolé à la base. Ce g. comprend environ 14 esp. (SP.)

* ANTHOSPERMÉES. BoT. PH. Tribu de la famille des Rubiacées, ayant pour type le g. Anthospermum. (AD. J.)

* ANTUOSRERMUMT. Bot. PH. Voyez ANTHOSPERME.

* ANTHOSTEMA. вот. Ph. - Nom donné à un g. d'Euphorbiacées, dont chaque fleur ( $\left.\ddot{\alpha} \theta_{0}\right)$ mâle est réduite à une étamine ( $\left.\sigma \operatorname{rin}_{\mu}\right)$. Les fleurs des deux sexes sont réunies dans un involucre commun, formé par le rapprochement de deux lobes on bractées, à chacune desquelles est opposéc intérieurement une petite glande. Les mâles sont nombreuses, et réunies dans un involucre particulier découpé en lobes moins profonds, inégaux, au nombre de 8 environ; elles consistent chacune en un filet terminé à son sommet par une anthère biloculaire, entouréc à sa base par un petit calice 5-4-fide et articulé au dessous de lui avec un pédi- 
celle plus long que lui ; des écailles ou bractées, plus larges, sont entremêlées à ces pédicelles. La fleur fernelle est unique, située sur le côté de l'involucre qui porte les mâles, portée sur un pédoncule épais et non articulé, et présente, dans un calice campanulé, à 5-4 dents, un ovaire aminci supérieurement en un style court, divisé supérieurement en trois branches stigmatiques légèrement bilobées, creusé à l'intérieur de trois loges 1-ovulées, et qui devient une capsule à 3 coques, à sarcocarpe un peu charnu. La seule esp. connue est un arbre de la Sénégambie et du Congo, dont les diverses parties sont gonflées d'un suc blanc et laiteux comme celui des Euphorbes, dont les feuilles alternes, entières et glabres, portent à leur aisselle, sur des pédoncules rameux et articulés à leurs divisions, plusieurs de ces amas de fleurs que nous avons décrits. M. Robert Brown avait éclairci la structure du g. Euphorbe par la comparaison d'un autre g. inédit qu'il n'avait pas nommé (Voy. Gen. Remarks, p. 24), et qui n'est autre que notre Anthostema. Voy. Ad. Juss., Euphorb., p. 56, tab. 48, n. 60 .

(AD. I.)

ANTHOSTOMES. Anthostoma $(\dot{\alpha}, 20 \circ$,

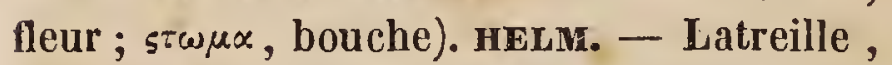
dans sa Famille naturelle du règne animal, p. 520 , nomme ainsi une famille de Vers intestinaux comprenant les Tétrarhynques, les Floriceps ou Anthocéphales, etc.

* ANTHOTHELGES $(\ddot{\alpha} \nu \theta 0 s$, fleur; $\ddot{\alpha} \theta \varepsilon \lambda-$ $\gamma \omega$, je suce). Ivs.-M. Laporte (Essai d'une class. syst. des Hémipt.) a employé cette dénomination pour une des deux grandes coupes qu'il a établies dans les Hémiptères hétéroptères, et désignées comme tribus. Il caractérise áinsi celle des Anthothelges, en l'opposant à l'autre, nommée Hæmathelges : "Insectes ne vivant pas de rapine, se nourrissant ordinairement de liquides végétaux. Pattes antérieures non ravisseuses. Rostre souvent long. " Ces deux tribus n’ont été adoptées par aucun entomologiste, non seulement parce que les caractères présentés par M. Laporte n'ont pas d'importance réelle, mais encore parce que dans sa tribu des Anthothelges (suceurs de fleurs) on trouve les Hydrometra, Velia, Gerris, etc., insectes aquatiques, essentiellement carnassiers, et même la Punaise des lits. (Bu.)
ANTHOTIUM , R. Br. ( $\alpha_{\nu} \theta 0 s$, fleur; wsioy, oreillette ). מot. PH. - Genre de la famille des Goodéniacées, auquel son auteur (Prodr., p. 582) assigne pour caract. : Limbe ealicinal supère, 5-parti, presque régulier. Corolle 2-labiée, 5-partible, fendue antérieurement; onglets infléchis aux bords ; segments aptères, valvaires en préfloraison: les deux supérieurs auriculés au bord intérieur. Étam. 5 , épigynes ; filets libres ; anthèrés cohérentes pendant l'anthèse. Ovaire 2-loculaire. Style indivisé; stigmate à enveloppe verticalement 2-labiée, imberbe. Fruit inconnu. - Herbe basse, acavle; glabre; feuilles subcylindriques, un peu dilatées vers la base; hampes nombreuses, diffuses, simples; fleurs fasciculées, accompagnées de bractées foliacées; corolle violette; pollen simple. - L'A. humile, R. Br. (Lechenaultia humilis, Spreng.) constitue à lui seul ce genre. Cette plante habite la Nouvelle-Hollande.

(SP.).

* ANTHOTROCHE, indl. ( $\alpha_{2} \theta 0 s$, fleur; тpoxós, roue). вот. Pн.-Genre de la famille des Scrophularinées, tribu des Salpiglossidées, Benth., établi très récemment par M. Endlicher (Novar. Stirp. Decad., fasc. 1, p. 6), qui lui assigne les caract. suivants : Calice 5 -fìde. Corolle infundibuliforme, à tube évasé vers le sommet; limbe rotacé, 5-lobé. Étamines 5, toutes fertiles, saillantes, insérées à la gorge de la corolle. Filets subulés, flexueux. Anthères à deux bourses confluentes, s'ouvrant par une seule fente transversale. Ovaire 2 -loculaire. Placentaires multi-ovulés, adnés à la base de la cloison. Ovules ascendants, anatropes. Style indivisé; stigmate capitellé, échancré. Capsule globuleuse, 2-loculaire, 4-valve; cloison membranacée, septifère à la base, finalement libre. Graines très nombreuses, ascendantes, réticulées, incourbées à la base. Périsperme charnu. Embryon axile. Cotylédons très courts, obtus. Radicule cylindrique, infère. - Ce g., que son auteur classe entre les Anthocercis et les Browallia, n'est fondé que sur une seule esp. C'est un arbrisseau indigène de la Nouvelle-Hollande austro-occidentale, laineux sur toutes ses parties; à feuilles alternes ; à fleurs axillaires, solitaires, subsessiles, petites, violettes.

(SP.)

ANTHOXANTHUM $(\ddot{\alpha} \theta 0 s$. fleur; 
Gxข $0^{\circ} ;$, jaune ). Bor. PH. - Genre de la famille des Graninées, tribu des Phalaridées, formé par Linné, et ainsi caractérisé : Épillets triflores; les deux fleurs inférieures neutres; la supérieure hermaphrodite. Glumes 2, carénées; l'inférieure plus courte, uninerve; la supéricure trinerve. Dans les fleurs neutres, une paléole canaliculée, échancrée au sommet, aristée dorsalement. Dans la fleur hermaphrodite, 2 paléoles naviculaires, mutiques; la supérieure uninerve, enveloppée par l'inférieure. Squammules nulles. Etamines 2. Ovaire sessile. Styles 2; stigmates distiques-plumeux. Cariopse subcylindrique, libre entre les paléoles, étroitement fermées. - Les espèces de ce genre, au nombre de douze environ, sont perannuelles, aromatiques; elles croissent dans toute l'Europe, à l'exception du nord, et paraissent avoir été transportées dans l'Amérique boréale; les feuilles en sont planes, en ligule allongée; l'inflorescence est en panicule spiciforme, simple, sinuée. On en cultive quelques espèces dans les jardins.

(C. L.)

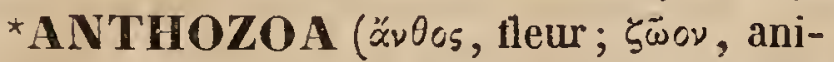
mal ). PolyP. - Nom employé par M. Ehrenberg pour désigner la grande division des Polypes à une seule ouverture digestive ; groupe que M. Milne-Edwards a proposé d'appeler sous-classe des Polypes parenchymateux.

(M. E.)

* ANTHRACIAS ( $\alpha^{2} \nu \theta_{i}$ oxicixs, noir comme du charbon ). INs. - Genre de Coléoptères hétéromères, famille des Ténébrionites, établi par Steven, et adopté par M. Dejean, qui, dans son dernier Catalogue, le place immédiatement avant le g. Toxicum de Latreille. Il a pour type l'Anth. bicornis de Steven, le même insecte que l'Uloma cornuta de Fischer, ou le Tenebrio fusca de Frivaldsyky.

* ANTHRACIDES ( $2 \nu \theta_{\rho} * \xi$, charbon;

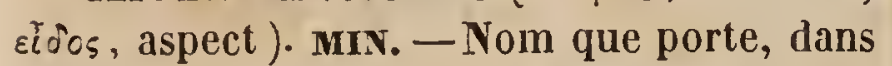
la méthode de Beudant, une famille de minéraux dont le Carbone constitue le type fondamental. L'auteur l'a changé, depuis, en celui de Garbonioss. (DEL.)

ANTHRACIENS. Anthracii ( $\ddot{\alpha} \nu \theta \rho \dot{\alpha}-$ x $\mathrm{L}_{5}$, noir comme du charbon). INs. - Tribu de l'ordre des Diptères, division des Brachocères, subdivision des Tétrachoètes, famille des Tanystomes. Elle présente les r. I. caract. suiv. : Tête ordinairement arrondie antérieurement; trompe courte et dirigée en avant ; lèvres terminales distinctes ; palpes insérés sur la base de la trompe, le plus souvent d'un seul article distinct; antennes presque toujours distantes ; yeur séparés dans les deux sexes. Thorax plan; pieds menus; pelotes des tarses très petites, quelquefois nulles. Ailes grandes, écartées, ayant ordinairement quatre cellules postérieures. Les Anthraciens, compris dans le g. Mouche de Linné, en furent détachés par Scopoli, qui en fit le g. Anthrax. Plus tard, Latreille et Fallen en firent une tribu que Meigen, Wildemann, et M. Macquart, à leur exemple, réunirent depuis à la tribu des Bombyliens; cependant ce dernier les en a de nouveau séparés. Ils diffèrent, en efret, des précédents par leur tête presque sphérique, placée à la hauteur du thorax; par leur trompe, courte et cachée dans la bouche; par leur corps, moins velu; par leurs grandes ailes, dont la livrée de deuil est remarquable. Ces caractères extérieurs donnen aux Anthraciens une physionomie toute particulière, et ils présentent, en outre, dans la plupart de leurs organes, d'autres différences qui établissent une ligne de démarcation bien tranchée entre eux et les tribus voisines. Cette tribu, telle qu'elle existe maintenant, renferme sept g., dont voici les noms : Mulion, Corsomyze, Enice, Anthrax, Tomomyze, Lomatie et Hirmonèvre (Voy. ces différents noms). Dans cette nomenclature on ne voit pas figurer le g. Némestrine de Latreille, qu'il comprenait dans cette même tribu; mais, d'après la méthode de M. Macquart, que nous suivons ici comme la plus récente et la plus complète, il fait partie de la tribu des Némestrinides.

Les Anthraciens se trouvent partout, mais bien plus fréquemment dans les contrées méridionales. Leurs larves ne sont pas encore connues. Suivant Latreille, leurs nymphes sont nues, incomplètes, avec les segments du corps munis de petites pointes.

(D.)

ANTHRACITE ( $\alpha \theta_{\rho}$ pxirys, qui ressemble à du charbon). Mrr. et GÉoL. Glanzkohle, W. ; vulgairement Houille éclatante, Houille et Charbon incombustible. Substance minérale de la classe des Combus. 
tibles non métalliques, opaque, d'un noir métalloìde, composée de carbone presque pur, sans bitume, avec 3 ou 4 p. 100 de matiere terreuse, et quelques traces d'hydrogène. On l'a regardée comme une variété de la Houille, en la distinguant cependant des Houilles communes par les épithètes de sèche, d'éclatante et d'incombustible. Elle diffère de la véritable Houille par sa composition, et par les caract. suivants, qui en sont la conséquence : Elle brûle difficilement, avec une flamme très courte, sans aucune fumée ni odeur, s'éteignant à l'instant même où on la retire du foyer, et se couvrant alors d'un enduit de cendres blanches. I'Anthracite peut être employé comme combustible; mais on ne l'enflamme que difficilement lorsqu'il est en petite quantité; il faut, pour y parvenir, le mêler avec du bois ou de la Houille, et disposer surtout les fourneaux de manière à ce qu'il y ait un fort tirage ; mais, une fois qu'il est embrase, la combustion se continue d'elle-même, en produisant une chaleur intense. On ne peut en faire usage ni dans les foyers d'appartement, ni dans la forge du maréchal; mais on l'emploie avec avantage dans une multitude d'usines où l'on a besoin d'une haute température. On s'en sert principalement pour la cuisson de la chaux, des briques, des poteries, pour le chauffage des fours de verrerie, et des chaudières de machines à vapeur. Ce combustible a été beaucoup trop négligé en France et dans d'autres pays d'Europe, quoiqu'il y soit assez abondant; mais, depuis un certain nombre d'années, il joue un très grand rôle aux États-Unis d Amérique, où il est répandu avec une profusion extraordinaire. La Pensylvanie, le Connecticut et la Virginie, lui doivent une grande partie de leur prospérité.

Le principal gisement de l'Anthracite est dans les terrains de transition, au dessous du terrain houiller; on le trouve là en couches ou en amas, an milieu de dépôts arénacés, et dans le voisinage des roches porphyriques et amygdalaires, anxquelles on attribue généralement une origine ignée; il est accompagné quelquefois d'empreintes végétales. Cette analogie dans les caractères géologiques de I'Anthracite et de la Houille donne à penser que l'Anthracite n'est que de la Houlle calcinée, une sorte de Coke naturel, qui s'est formé dans le sein de la terre, à l'époque des grandes éruptions de Porphyres. On voit, en effet, dans les dépôts de Houille proprement dite, des portions de ce combustible qui sont changées en véritable Anthracite dans les points où elles touchent les filons de Porphyre ou de Basalte qui souvent les traversent. L'Anthracite ne se trouve pas seulement au dessous de la Houille et au milieu d'elle; on le rencontre encore dans les terrains beaucoup plus élevés, au milieu du Lias des AIpes, et c'est à cette position que l'on rapporte les dépôts anthraciteux du Dauphiné, de la Tarentaise, du Faucigny, du Valais, etc. Les principaux gîtes de ce combustible en France sont dans les départements de l'Isère, des Hautes-AIpes, de la Mayenne et de la Sarthe.

Dans la classification de M. Brongriart et dans celle de M. Cordier, I'Anthracite forme une esp. de Roche.

(DEL.)

ANTHRACOLITHE $\left(\ddot{\alpha} \nu 0 \rho \alpha \xi\right.$, $\alpha x 0^{\prime} s$,

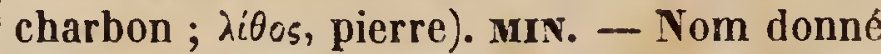
par de Born à une variété d'Anthracite trouvée à Schemnitz, en Hongrie. (Dez.)

* ANTHRACOTHERIUM ( $\ddot{\alpha} \nu \theta \rho \alpha \xi$, xos, charbon; Onpiov, animal ). MAM. Foss. - Nom donné par Cuvier à un genre de Mammifères fossiles de l'ordre des Pachydermes, qui tient des Anoplotheriums et des Ghéropotames, et dont les premiers débris ont été trouvés dans les lignites ou charbons de Cadibona. Ces animaux paraissent avoir eu quatorze molaires en haut, et en bas deux canines, et, du moins la grande espèce, quatre incisives en bas. Le nombre de celles de Ia mâchoire supérieure n'est point encore connu. Les trois arrière-molaires supérieures des Anthracotheriums sont à couronne carrée, composée de quatre grandes pyramides, presque quadrangulaires. L'angle interne de ces pyramides étant mousse, ces dents sont plus ou moins convexes du côté du palais. En outre, une pyramide moyenne, triangulaire, est située entre l'interne et l'externe de devant ; et, de plus, le bord externe de la base de la dent s: relève et forme trois pointes obtuses, unc plus grande à l'angle antérieur, une moyenne au milieu, et une plus petite à l'angle postérieur. A demi usées ces dents ont un 
grande ressemblance arec celles des Anoplotheriums, et n'en diffèrent guère que par la face externe, qui est creusée de sillons pour former les pointes dont nous venons de parler. La quatrième molaire est à deux pyramides, avec un bourrelet circulaire relevé en pointe aux deux angles de la face externe; les trois premières sont composées d'une pyramide, et d'un bourrelet qui forme une pointe basse et mousse à la partie interne, et qui se relève aux angles en une crête qui va se réunir à la pointe.

Les arrière-molaires inférieures, plus étroites, sont également formées de quatre pointes, à l'exception de la dernière, qui en a cinq, avec de légères collines de réunion; les antérieures sont à une et à deux pointes comprimées latéralement. Les canines sont épaisses, et les incisives inférieures sont projetées en avant comme dans les Cochons.

Cuvier en a décrit cinq esp. : une grande de Cadibona (Anthr. magnum); une petite du même lieu, de moitié moins grande (Anthr. minus); une encore plus petite des environs d'Agen (Anthr. minimum); une du Puy, en Velay (Anthr. velonum); et enfin une découverte en Alsace (Anthr. alsaticum).

La grande esp. paraît avoir eu deux races de taille un peu différente, et qui, sous ce point de vue, si les variations de grandeur ne tiennent pas aux sexes des individus, sont dans les mêmes rapports que les deux races de Khinocéros bicorne, aujourd'hui vivantes à côté l'une de l'autre à Sumatra. L'abbé Croizet en a découvert, dans les terrains lacustres de l'Auvergne, plusieurs espèces qui n'ont point encore été confrontées avec celles de Cuvier, mais qui donnent aussi, pour la plus grande, deux races de taille différente. M. de Saint-Léger a trouvé dans les environs de Digoin, sur les bords de la Loire, des dents d'Anthracotherium non encore décrites, qui paraissent être semblables à celles de la grande esp. de Gadibona, et qui indiquent aussi deux races, l'une un peu plus grande que l'autre. Une màchoire inférieure de la grande esp. trouvée par M. l'abbé Croizet a montré que le bord inférieur de cette mâchoire est pourvu d'une forte saillis apophysaire qui se projette en dehors vis-à-vis des troisiène et quatrième mőlaires. Cette proéminence donnait sans doute attache à un fort muscle digastrique, ot portait peut-etre, en outre, un tubercule analogue d̀ celui que le Sanglier á masque offre à sa mâchoire supérieure. (L. D.) ^ANTHRAKONITE $\left(\ddot{\alpha} \nu \theta \rho x \xi, x \theta_{\varepsilon}\right.$, charbon). Miv. - Simple variété de calcaire, mélangée de charbon. Yoy. MA DRÉPOR ITE.

(DEL.)

- ANTHRASOMUS ( $\alpha 2 \theta \rho \alpha \xi, \alpha \times o^{\circ} s$, noir; $\sigma \bar{\omega} \mu x$, corps ). Irs. - Genre de l'ordre des Coléoptères hétéromères, famille des Mélasomes, tribu des Blapsides, fondé par M. Guérin sur une espèce unique rapportée du Chili par M. Gaudichaud, et à laquelle il a donné le nom spécifique de Chevrolaiii. Ce g., que M. Guérìn regarde comme volsin du g. Platynotus de Fabricius, est ainsi caractérisé : Chaperon échancré; labre trés saillant, de la largeur du bord antéricur du chaperon, un peu moins long que large, échancré au bord antérieur. Ldvre inféricure beaucoup moins large que le dessous de la tête, avec une languette saillante échancrée; palpes maxillaires allongées, avec le dernier article plus long que large, coupé obliquement au bout; corps ovalaire, assez bombé; pattes robustes, courtes, avec les jambes antérieures un peu plus larges et un peu aplaties. Corselet plus large que les élytres dans le mâle.

M. Dejean comprend l'Anthr. Chevrolatii de M. Guérin dans le g. Praocis d'Eschscholtz. Suivant M. Blanchard, cette espèce est répandue dans les collections de Paris, sous le nom de Pr. sylphoüdes.

ANTHRAX ( $\ddot{*} \vee \theta_{\beta} \propto \xi$, charbon; couleur des insectes ). Irs. - Genre de l'ordre des Diptères, division des Brachocères, subdivision des Tétrachoètes, famille des Tanyistomes, tribu des Anthraciens, dont il est le type. Ce g., créé par Scopoli aux dép̣ens des Mouches de Linné et de Geoflroy, aété adopté par Fabricius, Duméril, etc., et divisé ensuite en trois g. par Latreille, savoir : Les Némestrines, les Mulions et les $\boldsymbol{A} n$ thrax proprement dits. C'est de ce dernier g., ainsi réduit, qu'il est íci question. Voici les caract. que lui assigne M. Macquart : Face ordinairement unie. Troisieme article des antennes court, ordinairement à base. sphériquẹ. Yeux réniformes, séparés dans les deux sexes. Quatre, trois ou deux cellu- 
les sous-marginales aux ailes. M. Macquart décrit $\mathbf{3 5}$ espèces d'Anthrax, qu'il divise en quatre sections d'après la couleur des ailes, le nombre de leurs cellules sous-marginales, et la forme de l'épistome, plus ou moins avancé. Sur ce nombre, 7 sont exotiques; les autres appartiennent à l'Europe, et la plupart à sa partie méridionale. Ces Diptères, dont le vol est rapide, se font remarquer par leur corps velouté, quelquefois orné de bandes d'argent, et par leurs ailes larges, moitié opaques et moitié transparentes. La partie opaque est souvent noire, et, dans tous les cas, de la couleur du corps. Nous ne citerons que trois espèces: l'A. entouré, Anthrax circumdata de Hofmansegg, ou hottentota de Fabricius, qui peut être considérée comme le type du g. ; l'A. agréable, venusta, de Meigen, qui se trouve aux environs de Paris; et l'A. sinuata de Fallen ou Morio de Fabricius, commun dans toute l'Europe.

* ANTHRAXIFERE ( $\ddot{\alpha} \nu \rho \rho x \xi$, charbon; pśpo, je porte ). GÉoL. - Nom donné par quelques géologues à une famille de Roches souvent colorées par l'Anthracite. M. Cordier se sert aussi du mot Anthraxiferes pour désigner un groupe de terrains caractérisés par la présence de l'Anthracite.

(C. v'O.)

ANTIRENE. Anthrenus ( $\dot{\alpha} \nu \theta_{p} \dot{\gamma} \nu$, guêpe, frelon. On ne conçoit pas pourquoi Geofrroy a donné ce nom à un g. de Coléoptères qui n'a rien de commun avec les Guêpes). INs.-Genre de Coléoptères pentamères établi par Geoffroy et adopté par tous les entomologistes. M. Duméril le range dans sa famille des Solidicornes ou Stéréocères, et le caractérise ainsi : Élytres couvertes de poils ou d'écailles colorées. Tête engagée dans le corselet. Antennes très courtes, en masse solide. Latreille le place dans sa famille des Clavicornes, et lui assigne pour caractères : Pattes contractiles, dont les jambes se replient sur le côté postérieur des cuisses, auxquelles elles sont annexées, et dont les tarses sont libres. Antennes en masse solide, se logeant dans une cavité pratiquée aux angles antérieurs du corselet. Mandibules petites ou point saillantes. Avant-sternum dilaté à son extrémité antérieure pour recevoir la bouche. Corps ovoïde.

Les Anthrènes sont de très petits Coléopt. à corps ovale et presque globuleux, et dont les élytres et le corselet sont agréablement colorés par une poussière écailleuse analogue à celle qui couvre les ailes des Lépidoptères; aussi suffit-il du moindre frottement pour enlever cette poussière, et alors l'insecte paraît lisse et tout noir. On rencontre souvent les Anthrènes en quantité sur les fleurs, dont elles sucent la liqueur mielleuse. Quelques espèces se tiennent de préférence dans l'intérieur de nos habitations. Si ces Insectes sont très innocents à l'état parfait, il n'en est pas de même de leurs larves, qui ne sont que trop connues par les ravages qu'elles causent dans les collections d'animaux desséchés, aux dépens desquelles elles vivent. Ces larves ont une tête écailleuse, arrondie, garnie de deux espèces d'antennes corriques, très courtes, et munie de deux mandibules très fortes, à l'aide desquelles elles détruisent promptement tout ce qu'elles attaquent. Leur corps est composé de $12 \mathrm{ou}$ 15 anneaux, dont les trois premiers sont supportés chacun par une paire de pattes écailleuses terminées par un crochet recourbé. Tous ces anneaux sont couverts de poils disposés en faisceaux ou en aigrettes, principalement sur les côtés et à la partie postérieure du corps. Ces poils, qui sont érectiles, sont habituellement couchés en arrière; mais la larve les redresse dès l'instant qu'elle se sent toucher, comme fait le Porc-épic avec ses piquants lorsqu'on l'irrite ou qu'on s'en approche. Ces houppes de poils érectiles suffisent pour distinguer les larves des Anthrènes de celles des Dermestes, avec lesquelles elles ont d'ailleurs beaucoup de rapports. Ces larves changert plusieurs fois de peau, et mettent près d'un an à parvenir à toute leur taille avant de passer à l'état de nymphe. Cette métamorphose présente cela de singulier qu'elle s’opère sans que la larve se dépouille de sa dernière peau, qui se fend seulement le long du dos, et sert de coque à la chrysalide. L'insecte parfait éclot au printemps suivant.

On rencontre des larves d'Anthrènes dans presque toutes les saisons ; mais c'est principalement à la fin de l'été, lorsqu'elles ont acquis presque toute leur grosseur, qu'elles font le plus de dégâts. Le moyen le plus eflicace pour en débarrasser les collections qui en sont attaquées, c'est de recourir au $N i$ - 
crentome (Voy. ce mot). Quant aux préservatifs, nous n'en connaissons pas de plus sùrs que beaucoup de soin, de propreté, et surtout l'attention de tenir hermétiquement fcrmés les armoires, cadres, tiroirs, etc., qui contiennent les collections, afin d'empêcher les Anthrènes d'y pénétrer pour y déposer leurs œufs.

II. Dejean, dans son dernier Catalogue, mentionne 24 espèces de ces petits Coléoptères, dont 15 exotiques et 9 d'Europe. Nous l'en citerons qu'une, l'Anthrenus museorum Fabr., qui est le plus grand fléau des collections. Elle est figurée dans Olivier, $t$. II , n. 14, pl. 1, fig. 1 .

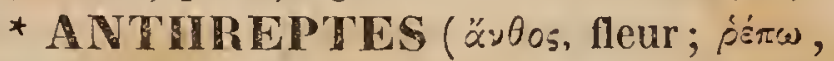
j'ai du penchant pour). o1s. - Genre établi par Swainson, faisant partie, dans sa clas-sification, de sa famille Cinnyride (les Souimangas), et ayant pour caract. : Bec médiocre, assez fort, légèrement courbé, s’élargissant vers la base, où il est beaucoup plus large que haut. Base de la mandibule inférieure épaisse et non couverte en partie par la supérieure. Ailes, queue et pattes, comme dans le g. Cinnyris (Souimanga). L'esp. type est l'Ant. javanica (Zool. ill., t. I, pl. 121).

(LARR.)

ANTHRIBE. Anthribus ( $\ddot{x}, \theta_{\nu s}$, fleur ; -pifw, je broie). Ixs. - Genre de l'ordre des Coléoptères tétramères, famille des Curculionides, fondé par Geoffroy, et adopté par la plupart des entomologistes qui sont venus ensuite, mais avec de grandes modifications : car, des 7 esp. que l'auteur y rapporte, les trois premières seules sont des Anthribes pour Fabricius, ainsi que pour Latreille, qui range la quatrième dans les Nitidules, et les trois dernières parmi les Phalacres de Paykull ; tandis qu'Olivier forme son g. $\mathbf{M a}$ crocéphale avec les trois premières, et conserve aux autres le nom générique d'Anthribes, bien, comme le fait observer Latreille, que ce soient des insectes très différents de ceux que Geoffroy avait particulièrement en vue en créant son g. Anthribe. En définitive, le g. dont il s'agit, tel qu'il est consacré aujourd'hui par l'ouvrage de Schœnherr sur la famille des Curculionides, et par le dernier ratalogue de M. Dejean, n'a plus de rapports que nominativement avec celui de reofroy : car aucune des esp. qu'il renferme maintenant n'a été connue de cet auteur.
Ces espèces sont au nombre de 10, dont 9 exotiques, et 1 d'Europe. Cette derniere est l'Anthribus albinus de Fabricius, et le Macrocephalus albinus d'Olivier, t. IV, n. 80 , pl. 1 , fig. 4.

Dans sa famille des Curculionides, Schoenherr comprend le g. Anthribe dans l'ordre des Orthocères et la division des Anthribides, et lui donne les caractères suivants : Antennes assez minces, insérées dans une cavité profonde au dessous des yeux; celles du mâle souvent plus longues que le corps, avec la massue étroite ou peu épaisse, le dernier article allongé, aigu; celles de la femelle plus courtes, avec la massue très épaisse, le dernier article très court, aigu; dans quelques unes, la massue s'élargit un peu ; elle est comprimée avec les articles, peu serrés. Rostre court, large, réfléchi, profondément échancré au sommet. Mandibules arquées, aiguës à l'extrémité, munies en dedans d'une seule dent obtuse. Yeux latéraux, proéminents , échancrés antéricurement. Corselet plus étroit dans sa partie antérieure, un peu tronqué postérieurement, à angles très aigus, convexe en dessus, avec un rebord latéral avant la base. ÉIytres ob- longues, subcylinäriques, très convexes en dessus.

De Géer a établi sous le nom d'Anthribe un g. d'insectes ayant pour type le Sylpha rustica de Linné et de Fabricius; ce g. n'a rien de commun avec celui dont il est question dans cet article.

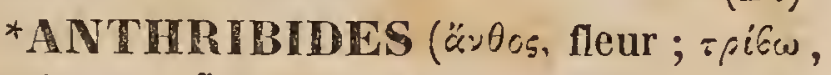
je détruis ; عĩo'os, forme ; c'est-à-dire forme des Anthribes). INs. - Nom donné par Latreille à une tribu de sa famille des Rhynchophores, ei par Schoenherr à la seconde division de l'ordre des Orthocères dans sa famille des Curculionides. Ses caractères sont : Rostre ordinairement large, recourbé, rarement allongé, peu avancé. Antennes droites, très souvent en massue, composées de 11 articles. Tarses dont les 4 articles sont peu distincts, le deuxième absorbant presque toujours le troisième. Cette division se compose de $\mathbf{3 7}$ g.; dont les noms suivent : Sintor, Tophoderes, Ptychoderes, Phloepemon, Dendropemon, Ecelonerus, Brachytarsus, Eucorynus, Eugonus, Phloeotragus, Mecocerus, Litocerus, Recotarsus, Lagopezus, 
Ischnocerus, Acorynus, Phlooophilus, Stenocerus, Analotes, Gymnognathus, Uterosomus, Tropideres, Enedreytes, Cratoparis, Platyrhinus, Xylinades, Xenocerus, Anthribus, Blaberus, Piezocorynus, Parablops, Corrhecerus, Phonithon, Polycorynus, Caranistes, Arcecerus et Alticopus. La plupart de ces nouveaux g. ont été formés aux dépens de l'ancien g. Anthribus, devenu insuffisant pour y rapporter le grand nombre d'esp. découvertes depuis sa fondation. La majeure partie des Anthribides sont exotiques. Parmi celles d'Europe, les unes se tiennent sur le tronc carié des arbres ou sous les écorces; les autres vivent sur les fleurs. Leurs larves il'ont pas encore été observées.

ANTHRISCUS, Haffm. ( $\not 2 \nu \theta \rho c o \times 05$, esp. d'Ombellifère?). - Cerefolium, Hall. BOT. PH. - Genre de la famille des Ombellifères, tribu des Scandicinées DC., offrant les caract. suivants : Limbe calicinal inapparent. Pétales tronqués ou échancrés, inégaux, terminés en languette infléchie. Disque (stylopode ) conique. Styles courts, dressés. Péricarpe linéaire, comprimé bilatéralement, courtement rostré, privé de côtes; bec 8sulqué; méricarpes lisses ou tuberculeux, contractés aux bords, canaliculés antérieurement. Carpophore foliiforme, après la déhiscence, libre,'2-fide au sommet. Graine adhérente, semi-lunée sur la coupe transversale. - Herbes annuelles, ou bisannuelles, ou vivaces ; feuilles décomposées ; folioles ou lanières souvent très étroites; ombelles oppositifoliées ou terminales, dépourvues d'involucre; involucelles polyphylles ou oligophylles et incomplets; fleurs blanches. Ce genre, dans les limites que lui assigne M. Koch, comprend environ 8 esp. (Charophyllum, Scandix, et Myrrhis, des auteurs plus anciens), la plupart indigènes d'Europe. La plus notable est l'A. cerefolium, Hoffm. (Scandix cerefolium, L.), plante potagère connue sous le nom vulgaire de Cerfeuil.

(SP.)

ANTIROCERA ( $\ddot{*} \nu \theta_{\rho} x_{\xi}$, charbon [noir]; $x \dot{\varepsilon} \rho x_{5}$, corne ). INs.-Genre de l'ordre des Lépidoptères, famille des Crépusculaires, établi par Scopoli, et adopté par Stéphens, qui le place dans sa tribu des Zygénides. Ce g. est le même que celui des $Z y$ gènes de Fabricius. Voy. ce mot.
* ANTHRODACTYLA ( $\ddot{\nu} \nu \theta \rho \alpha \xi$,

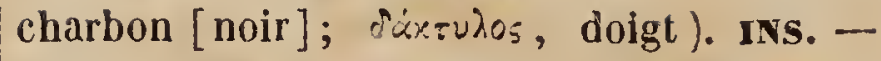
Genre de l'ordre des Coléoptères hétéromères, famille des Mélasomes, tribu des Ténébrionites, établi par M. Klug d'après deux espèces rapportées de Madagascar par M. Goudot. Ce g. est voisin des Calcar; mais il en diffère par les articles des tarses, qui sont très courts, larges et aplatis, profondément incisés, serrés, se recouvrant l'un l'autre, et garnis en dessous d'un épais duvet. Du reste, le corps est allongé, presque filiforme, aplati ; la tête est rétrécie postérieurement, visiblement distincte du corselet; le chaperon visiblement échancré; la lèvre librement proéminente, presque carrée, ayant le bord antérieur droit; les articles des palpes labiaux égaux entre eux en longueur, cylindriquement arrondis, un peu resserrés à la base ; les deux articles basilaires plus courts que les autres; les quatre derniers, au contraire, un peu plus larges et plus longs, non pas lisses ei luisants comme les autres, mais ponctués et pnbescents; le dernier se terminant en pointe.

Les deux esp. rapportées à ce g. sont appeiées par M. Klug, l'une $\boldsymbol{A}$. elongata, et l'autre $A$. aiternata, et toutes deux sont de Madagascar, comme nous l'avons dit plus haut.

ANTHROLOMUS. INs. - Genre de Coléoptères tétramères, famille des Curculionites, cité par M. Dejean, dans son dernier Catalogue, comme ayant été créé par M. Hope, mais dont nous n'avons pu trouver de trace dans aucun auteur. M. Dejean place l'espèce sur laquelle il est fondé ( $\boldsymbol{A}$. Guildinii Hope) dans le g. Trypetes de Schoenherr. Voy. ce mot.

ANTHROPOIDE. Anthropoides ( $\alpha \dot{\nu}$

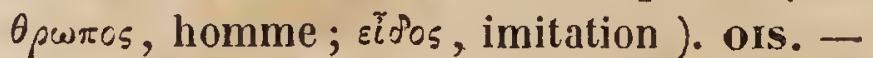
Genre formé par Vieillot de celui de Grue. Nous croyons devoir en retirer, comme la fait MI. Lesson, la Grue couronnée ou Oiseau royal (Ardea pavonina), type du genre Baléarique (Balearica, Brisson), que nous adoptons également. Les caractères sont alors: Bec un peu plus long que la tête, conique, un peu renflé, comprimé sur les côtés, épais, entier; narines basales. Tête et cou complètement emplumés ; deux touffes de longues plumes sur la région auriculaire. Couvertures des ailes excessive- 
ment allongées; ailes longues, pointues; les terrains tertiaires de tous les étages.

les première, deuxième, troisième et quatrième rémiges, les plus longues; de longues pluınes étroites sur le bas du cou.

Deux espèces font partic de ce genre. 10 l'Ant. demoiselle de Numidie (Ant. virgo; Ardea virgo, L., Enl. 245; Vieillot, Cal, planche sans numéro), d'un joli gris bleuâtre, avec la tête et le haut du cou noirs, et derrière chaque æil un faisceau de plumes blanches, longues, flexibles, et pendantes en arric̀re; un troisième faisceau noir au bas du cou, avec les tertiaires très prolongées, et formant des touffes flexibles et pendantes. - Cette esp. a été remarquée de tout temps à cause de sa démarche cadencée, de ses mourements mimiques et de ses sauts, par lesquels elle semble vouloir fixer l'attention, et qui lui avaient fait donner par les anciens le nom de Comédien. Flle ofre dans son anatomie une particularité remarquable, et qui ne s'est retrouvée jusqu'ici que chez quelques espèces de $\mathbf{C y}$ gnes. Sa trachée - artère vient s'engager par une double circonvolution dans la crête du sternum, creusée à cet effet ( $\boldsymbol{T r}$. d'Anat. comp., par Carus, atlas, pl. 16, f. 11 ). Vieillot pensait qu'il ne scrait pas impossible de naturaliser ces oiseaux en France, puisque ceux de la ménagerie royale y avaient produit, et que celle qui y avait vécu 24 ans y était néc. Elle se rencontre dans les partics de l'Asie voisines de l'Europe, et en Afrique, dans la Guinée et la Numidie.

La seconde esp. est l'Ant. de paradis (Ant. paradisea); Grus paradisea, Bechst. (Trad. de l'Ind. de Lath.); Tem. (Pl. col., texte); Ant. stanleyanus, Vig. (Zool. Journ., t. II, p. 234, pl. 8), de l'Afriquc méridionale, et aussi de l'Inde.

(LAFR.)

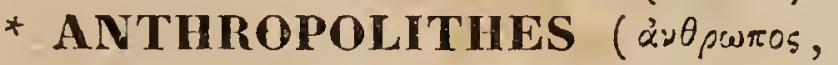
homme; $\lambda i \theta 0$, pierre). GÉOL. etPAL EONT.Nom donné aux pétrifications d'os humains, c'est-à-dire aux ossements fossiles que l'on a cru être des ossements humains ou des portions du corps de l'homme. Nous disons que l'on a cru, parce que la plupart des prétendus Anthropolithes ont été reconnus, après un examen sérieux des géologues et des anatomistes, pour des restes de Mammifères ou de Reptiles; et l'on peut affirmer que jusqu'à présent on n'a point trouvé d'ossements humains dans les terrains anciens, ni même dans
Il a été annoucé par Lamanon et confirmé par Cuvier que les soi-disant têtes humaines tirées des plàtrières des environs d'Aix devaient être regardées comme des carapaces de Tortues terrestres. Cuvier a démontré également que le fameux homo diluvii testis de Scheuchzer, trouvé dans les schistes calcaires d'OEningen, était un Reptile batracien, voisin des Salamandres aquatiques, et que les os considérés de tout temps comme des os de géants, ne pouvaient être, d'après les descriptions qui en ont été données, que des os d'Eléphants ou de quelques autres grands Mammifères.

C'est ainsi que la croyance générale à l'existence de races des géants repose sur un fait positif, sur la découverte d'ossements fossiles de grands animaux, que le vulgaire et même les anatomistes ont pris pour des os humains d'une très grande taille. C'est ainsi que s'expliquent ce prétendu corps d'Orion ou d'Otus, de quarante-six coudécs de long, trouvé, sclon Pline, dans une montagne de Grète, après un tremblement de terre; cclui d'Oreste, qui avait sept coudées, exhumé par ordre d'un oracle, et tous ces récits qui, jusqu'à nos jours, ont amusé les gens crédules.

Les véritables ossements humains n'ont été découverts que dans des roches de formation récente, comme celles que l'on remarque sur plusicurs points de la côte des Antilles et plus particulièrement de lạ Guadeloupe, ou bien dans ces brèches osseuses qui remplissent les fentes ou failles des rochers, en plusieurs lieux des côtes de la Méditerranée et des îles de l'Archipel, comme à Gibraltar, à Cette, à Nice, à Pise, en Dalmatie; dans les îles de Corfou, de Cérigo, de Candie, etc. Les cavernes renferment aussi quelquefois (par exemple la carerne de Bize, département de l'Aude) des os humains recouverts de stalactites; mais comme ils sont séparés des ossements d'animaux, lorsqu'elles cn renferment, par une couche plus ou moins épaisse de dépôts calcaires, et que l'on trouve parmi eux de petits ouvrages fabriqués probablement avec les os de la caverne, on doit croire que ce sont les restes des premiers habitants de ces contrées, de ceux qui ne s'étaient point encore construit de demeures; on ceux d'individus 
qui ont fui dans ces grottes, soit pour se soustraire à l'action de la justice, soit pour éviter les persécutions; ou bien enfin que ce sont des squelettes d'hommes tués dans une bataille et inhumés dans ces lieux, comme la tradition le rapporte de ceux de la caverne de Durfort, départ. du Gard. Les brèches osseuses, géologiquement parlant, sont d'une origine assez récente; mais il est probable qu'elles datent historiquement de la même époque que le diluvium. Ainsi les os humains qu'elles renferment viennent vraisemblablement d'hommes qui ont vécu avant le déluge et qui ont été témoins et victimes de la dernière révolution du globe, que tout annonce avoir été une grande inondation. A ce titre, ils méritent d'être examinés avec soin et d'être confrontés avec les squelettes des races actuelles. Spallanzani, qui avait visité les brèches de l'île de Cérigo, annonce que la plupart des os qu'elles renferment sont des os humains; mais cette assertion d'un voyageur qui n'était point anatomiste parut, avec raison, insuffisante à Cuvier pour admettre ce fait comme prouvé, quoiqu'il eût lui-même, en parlant des brèches osseuses de Nice, annoncé qu'il avait reconnu parmi elles un maxillaire supérieur d'homme, en faisant remarquer toutefois que cet os n'était enduit que d'une légère couche de stalactite.

On voit aujourd'hui, au cabinet de géologie du Muséum d'histoire naturelle de Paris, une portion de squelette humain, de taille au dessous de la moyenne, mêlé avec des coquilles marines, trouvé en 1837 dans les brèches osseuses de l'île de Candie, au milieu de la partie concrétionnée de cette espèce de roche : ainsi c'est un fait acquis maintenant à la science que les brèches osseuses du littoral de la Méditerranée renferment un certain nombre d'ossements humains. Il reste à savoir quelle position ils $\mathbf{y}$ occupent et quels caractères ils présentent; deux points qui ne peuvent être décidés que par un grand nombre d'observations.

On voit dans les mênres galeries une portion de squelette d'homme, que Cuvier a décrite à la fin de son Discours sur les révolutions du globe, incrustée dans la Roche de formation récente de la Guadeloupe, Roche composée, comme l'on sait, de petits grains de Calcaire compacte et de débris de Coquil- les, de Madrépores et antres Zoophytes, réunis par un ciment calcaire. Les os d'un autre squelette du même lieu, que l'on voit à Londres, ayant été analysés par Davy, ont donné tout le Phosphate calcaire et presque toute la gélatine qu'ils devaient contenir, en sorte que l'on peut conclure que ces ossements ne sont pas fossiles, dans l'acception actuelle de ce mot, mais que ce sont des portions de squelettes de naufragés, enveloppées par l'espèce de Travertin qui se forme journellement dans les lieux où on les trouve.

(L. D.)

* ANTHROPOMORPHES. Fungus

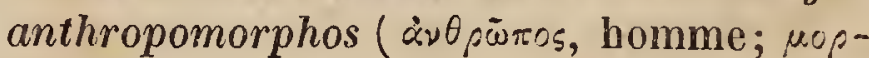
$\varphi \dot{x}$, forme ). BoT. CR. - Léger a décrit et figuré, sous ce nom, dans les Miscellanea curiosa (Decur. I, ann. vI, obs. 55), un champignon monstrueux qu'il avait trouvé dans la forêt d'Alt dorf. L'imagination de l'auteur a créé des têtes, des bras et des pieds, dans un groupe de Champignons qui avaient été gênés dans leur développement. Tous les jours on rencontre de semblables monstruosités; mais, l'amour du merveilleux étant passé, on n'y fait plus attention.

(Lív.)

* ANTHROPOMOR PIES. Anthro-

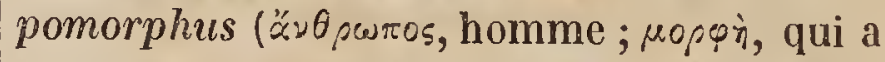
la forme d'un homme). MaM. - Nom donné par Linné, dans ses premiers essais de classification, à un ordre de la classe des Mammifères. (G. D'O.)
(G.

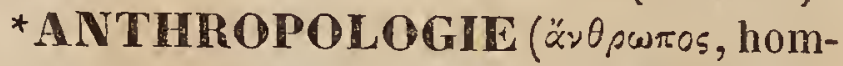

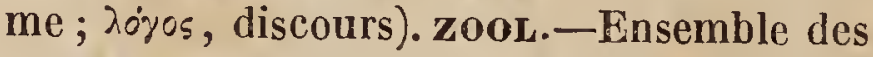
connaissances relatives à l'homme considéré sous ses rapports physiques et moraux.

(C. D'O.)

ANTHURE. Anthura ( $\ddot{\nu} \nu \theta_{\circ}$, fleur ; oupó, queue). GRUst. - C'est un genre de l'ordre des Isopodes, famille des Sphéromides, qui a été créé par Leach, et dont les caractères peurent être ainsi exprimés : Antennes courtes; les intermédiaires étant un peu plus longues que les latérales. Pieds antérieurs pourvus d'un ongle mobile ou d'un pouce. Corps linéaire. Lames latérales de la queue foliacées. L'esp. type de ce g. est l'Anthura gracilis Leach, dont la patrie nous est inconnue.

(H. L.)

ANTHURIUM ( $\ddot{\alpha} \nu \theta 0 s$, fleur; ov $\rho \dot{\alpha}$, queue ). вот. Рн. - Genre fort remarquable de la famille des Aracées (Aroïdées?, 
tribu des Orontiacées - Pothoinnées, formé par Schott (In Wien. Zeitschr., 1829, et Meleth., 22), qui le caractérise ainsi : Spathe assez courte, réfléchie et persistante. Spadice cylindrique, subsessile, garni de fleurs hermaphrodites. Périgone tétraphylle. Étamines 4, opposées aux folioles périgoniales; filaments linéaires, plans. Anthères biloculaires. Ovules géminés dans les loges, collatéraux, anatropes, pendants du sommet de l'axe. Stigmate sessile, oblong. Baie biloculaire, 2-4-sperme. Graines inverses, exalbumineuses. Embryon or thotrope, dans un albumen à peine charnu; extrémité de la radicule supère. - Ce g., créé aux dépens de toutes les esp. du g. Pothos de Linné, à l'exception d'une seule ( $\boldsymbol{P}$. scandens), renferme ( $e x$ nost. investig.) des plantes américaines tropicales, perannuelles, subacaules, dressées, très rarement grimpantes ou subligneuses, coriaces, glabres; à feuilles palmées, digitées, ou simples et entières, alors très amples, fortement nervées; à pé-

- tioles renflés au sommet, et comme articulés avec la feuille; pourvus à la base d'une écaille vaginante ou stipule. - Ces plantes sont épiphytes plutôt que terrestres. Elles croissent dans les enfourchures des grosses branches des arbres, qu'elles enlacent de leurs longues racines fibreuses. On en connaît un assez grand nombre d'esp., dont on cultive au delà de 20 dans nos serres chaudes d'Europe, où elles se font remarquer par leur bel et ample feuillage et la singularité de leur inflorescence. Une des plus remarquables est l'A. glaucescens, dont les feuilles ont plus d'un mètre de longueur sur une largeur proportionnée (ex specim. in caldario nostro $).$

(C. L.)

ANTHUS. oIs. - Nom latin du g. Piji. Voyez ce dernier mot.

(LAFR.)

* ANTHUSINEES (Anthrs, Pipi). oIs. -S.-famille de notre famille des Alaudidées. Les caract. en sont : Bec grêle, droit, pointu, et légèrement échancré; tarses allongés et pieds propres à la marche, le pouce et surtout son ongle allongés; ce dernier quelquefois fort Iong, très grêle, et presque droit ou peu courbé; rémiges tertiaires obtuses et prolongées; queue plus ou moins développée en longueur, les rectrices latérales toujours bordées de blanc ou de roussâtre, pâle comme chez les Alouettes. Mœurs mar-

T. 1. cheuses, et chant souvent en volant, comme chez ces dernières. Nidification sur le sol ou entre les pierres des carrières, et æufs à coloration à peu près semblable à ceux des Alouettes.

Si les Pipis ou Alouettes de pré ont avec les vraies Alouettes des rapports de formes et de mours tels, qu'il nous a paru indispensable de les réunir dans une même famille, les Bergeronnettes en offrent avec les premières de non moins frappants dans la forme des pattes, des ailes et du bec, et dans leurs mours marcheuses. Les Énicures de Temminck ne peuvent non plus être séparés de celles-ci, et les Grallines de Vieillot, qui paraissent être les représentants de ceux-ci à la Nouvelle-Hollande, nous semblent également devoir être groupées ici.

Cette sous-famille renfermera donc le g. Pipi, avec ses sous - genres Agrodroma, Macronyx et Lessonia; celui de Bergeronnette avec son sous-genre Lavandière, et ceux d'Enicure et de Gralline. Voy. ces divers noms génériques.

(LAFR.)

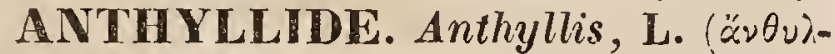
$\lambda i s$, nom grec d'une plante aujourd'hui indéterminée). - Barba Jovis, Erinacea et Vulneraria, Adans. вот. PH. - Genre de la famille des Légumineuses, sous-ordre des Papilionacées, tribu des Lotées, sous-tribu des Génistées, DG., offrant pour caract. essentiels : Calice persistant, 5-denté, plus ou moins bouffi. Carène, ailes et étendard subisomètres. Étamines monadelphes; gaîne entière. Légume en général ovoïde et $\mathbf{1 -}$ ou 2-sperme (chez quelques espèces allongé, polysperme), recouvert par le calice. - Arbrisseaux, ou sous-arbrisseaux, ou herbes. Feuilles 1-foliolées, ou 3-foliolées, ou imparipennées. Fleurs solitaires $\partial x$ en capitules, jaunes ou rougeâtres, ou rarement bleuâtres.

Ce genre renferme une vingtaine d'esp., indigenes la plupart dáns les régions yoisines de la Méditerranée; les plus notables sont . l'A. vulneraria L. (vulgairement Vulnéraire, nom dû à ses prétendues propriétés vulnéraires), excellente plante fourragère, commune dans les prés secs; l'A. barba $J_{0-}$ vis, L., et l'A. erinacea, L., cultivées comme arbustes d'ornement.

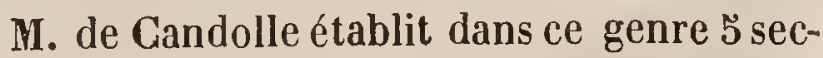
tions ou sous-genres, savoir : Dorycnoides, 
Aspalathoides, Erinacea, Vulneraria, et Cornicina.

* ANTHXLLIS, Adans. (nec aliorum) ( $\alpha_{\nu} \theta \nu \lambda \lambda i s$, nom grec de cette plante ). вот. PH.-Synon. du genre Polycarpon, Læfl., de la famille des Paronychiées.

(SP).

* ANTHYPNA. INs. - Voyez ANTHIPNA.

ANTIARIS (Antjar ou Antsjiar, chez les Japonais ). - Genre de la famille des Urticées, tribu des Chlorophorées, formé par Leschenault (Ann. Mus. hist. nat. XVI, t. 22), et ainsi caractérisé : Fleurs monoïques. Dans les mâles : Cananthe (réceptacle ou involucre des auteurs) discoïde, multiflore, écailleux en dessus. Périanthe 4rarement $\tilde{5}$-phylle, à préfloraison imbriquée. Anthères 4, rarement 3, subsessiles. Dans les femelles : Cœnanthe turbiné, uniflore, couvert d'écailles, et croissant avec le fruit. Point de périanthe. Ovaire attaché au conanthe; ovule anatrope, inverse. Style biparti. Drupe charnu, monosperme. Embryon exalbumineux, inverse. - Ce genre renferme quelques arbres laiteux de l'Inde, a feuilles alternes, courtement pétiolées, stipulées, subcordiformes, sinueuses ou dentées, à nervures saillantes. Le plus généralement connu est un grand arbre de l'Inde, décrit sous le nom d'Antiaris toxicaria par l'auteur cité. Le poison qu'il fournit, et qui porte dans son pays natal le nom d'Upas antiar, est une gomme-résine qui découle du tronc et des branches, au moyen d'entailles qu'on y pratique. "La préparation de ce poison, dit Leschenault, se fait à froid, dans un vase de terre; on mêle à la gomme-résine les graines du Capsicum fruticosum, du poivre, de l'ail, les racines du Kempferia galanga, du Maranta malaccensis (Bauglé en malais), du Costus arabicus; on mélange lentement chacune de ces substances écrasées, à l'exception des graines du Capsicum fruticosum, que l'on enfonce précipitamment une à une au fond du vase au moyen d'une petite broche de bois. Chaque graine occasionne une légère fermentation et remonte à la surface, d'où on la retire pour en mettre une autre, jusqu'au nombre de 8 à 10 ; alors la préparation est terminée. "L'Upas antiar introduit dans l'économie animale agit comme vomitif et comme purgatif. "Son action, dit M.
Delille, se porte ensuite sur le cerveau, en trouble les fonctions et cause la mort avec des convulsions tétaniques. "C'est dans ce poison, qui ressemble à une mélasse épaisse et très brune, que les Javanais et les habitants de Bornéo trempent leurs flèches. Les premiers le conservent dans de petits tuyaux de Bambou; et il paraît que son action délétère a bien moins de puissance quand on l'emploie à l'état liquide que lorsqu'il a séché sur l'instrument. Il existe encore une autre sorte d'Upas. Voy. ce mot.

$$
\text { (C. L.) }
$$

ANTI-BARILLET. MoLx. - Geoffroy donne ce nom à une petite coquille qu'on trouve aux environs de Paris, et qui appartient au genre Pupa de Draparnaud; c'est son Pupa quadridens. Voy. MAILLOT. (DESH.)

*ANTICHARIS, Endl. (ávזi, à l'opposé; $\chi \dot{\alpha} \rho c_{s}$, ornement). вот. PH. - Genr" de la famille des Scrophularinées (tribu des Gratiolées Benth.), auquel M. Endlicher (Gen. Pl., p. 682 ; Novar. Stirp. decas II , p. 23 ; Iconogr., tab. 93) assigne pour caract. : Calice ébractéolé, régulier, J̀-parti. Corolle subbilabiée, 5-lobée; lobes presque égaux, obtus. Étamines 2, incluses, insérées à la partie antérieure du tube de la corolle ; filets très courts; anthères 2-thèques : bourses divariquées, finalement confluentes. Ovaire 2-loculaire; placentaires multi-ovulés, ađ̃nés à la cloison. Style indivisé ; stigmate obtus, échancré. Capsule pyramidale, 2-loculaire, loculicide, 2-valve; valves finalement 2-fides, septicides; placentaires restant soudés l'un à l'autre, mais séparés de la cloison après la déhiscence. - Herbe presque simple, parsemée d'une pubescence glandulifère. Feuilles alternes, pétiolées, très entières; pédoncules axillaires, solitaires, 1-flores, courts, 1bractéolés au dessous du milieu. L'esp. sur laquelle est fondé ce genre habite l'Égypte.

ANTICHEIRA ( $\dot{\alpha} \tau \iota \chi \varepsilon \varepsilon \rho$, pouce). INS. - Genre de Coléoptères pentamères, famille des Lamellicornes, tribu des Xylophiles, sous-tribu des Rutélites, établi par Eschscholtz (Mém. de l'Acad. imp. de Saint-Pétersbourg, t. VI, p. 451, an.1818), et auquel il assigne pour caract. : Mâchoires cornées, tridentées ; ${ }^{\text {re }}$ dent entière, $2^{\text {e bj- }}$ 
fide, $亏^{e}$ trifide. Labre corné, tridenté, caché par le chaperon. Antennes en massue feuilletée. D'après les espèces rapportées à ce genre par l'auteur, il scrait le même que le g. fondé depuis (Hora Entomol., pars 2e , 1828) par Macleay sous le nom de $\boldsymbol{M} \boldsymbol{I}$ craspis; et cependant ce dernier nom seul est connu dans les collections. Nous cite. rons comme type du genre d'Eschscholtz l'A. tetradactyla (Cetoina id. Fabr.) (D.)

ANTICHORUS, Linn. fils. - Caricteria, Scopol.-Jussicea, Forsk., non Linn. (contraction d'àvii, à l'opposé, et de Corchorus. Voy. ce mot). вот. PH. - Genre de la famille des Tiliacées, et très voisin des Corchorus. Les caractères qui l'ont fait séparer de ces derniers sont les suivants : Calice \&-sépale; corolle \&-pétale; étamines en nombre défini (8); capsule subulée, 4-loculaire.-On n'en comnaît qu'un seule esp., qui habite l'Arabie.

(Sp.)

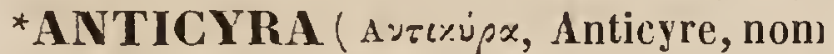
de ville). INs. - Genre de la famille des Polygoniens, de l'ordre des Névroptères, établi par Curtis (Descript. of some non desc. Br. sp. of May-flies of Angl.), et adopté par M. Westwood (Generic synopsis). D'après les auteurs, les caractères de ce genre sont tirés : $1^{\circ}$ des antennes, dont le premier article est grêle; $2^{\circ}$ des ailes, longues et étroites, sans cellule discoïdale, et $\mathbf{3}^{\circ}$ des jambes antérieures, bi-mucronées. Ce genre ne nous paraît pas devoir être séparé des Rhyacophila de M. Pictet, dont il ne diffère que par de très légères modifications dans la forme des ailes, etc. M. Curtis y rapporte deux espèces d'Angleterre, l'A. gracilipes et latipes Curt., et M. Westwood en signale deux autres.

(BL.)

* ANTIDA PHNE, Pæpp. (Nov.Gen. el

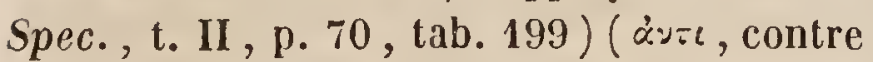
[sur]; dóàn, laurier; cette plante croît en général sur les Laurinées ). BOT. PH. Genre de la famille des Loranthacées, auquel son auteur assigne pour caract. : Épis strobiliformes, monoïques, à bractées imbriquées, caduques ; les épis mâles géminés ; les épis femelles ternés. - Fleurs mâles : Périanthe simple, à tube filiforme, et à limbe court, 3-lobé. Étamines 3 , insérées à la gorge du périanthe, alternes avec les lobes; filets pétaloïdes, linéaires, un peu dilatés au sommet. Anthères 2-thèques; bourses ad- nées, pointues, disjointes à la base, longitudinalement déhiscentes. - Fleurs femelles : Périanthe simple, urcéolé, adhérent. à limbe narginiforme, très entier. Ovaire 1-loculaire, 1-ovulé; ovule suspendu. Stigmate subsessile, capitellé, concave. Baie 1sperme, à endocarpe plissé. - Oll rie connaît qu'une esp. de ce g. : c'est un arbuste parasite, indigène du Pérou. Les feuilles sont alternes, obovales, très entières; les épis axillaires, courts, agrégés.

(Sp.)

ANTIDESMA ( $\alpha \dot{\alpha} \tau i$, en guise de;

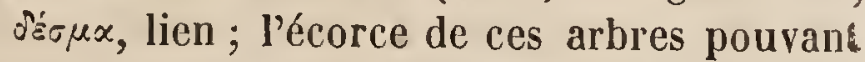
servir à lier). Bot. Py. - Genre de la famille des Antidesmées de Sweet, fondé par Linné (Gen.pl., 1110), et dont les caract. sont: Fleurs dioïques. Dans les mâles : un périgone 5-5-partite. Étamines 2, 3, 5, insérées sur un disque annulaire; filaments filiformes. Anthères biloculaires, à loges divariquées - étalées. Ovaire rudimentaire. Dans les femelles : Périgone identique. Ovaire ceint à la base d'un disque annulaire, puis ovale, libre, 1-loculaire; ovules 2 , appendus au sommet de la loge, collatéraux, anatropes. Stigmate sessile, 3-5̌-radié. Drupe monosperme, couronnée par le stigmate. Endocarpe ( putamen) subépineux intérieurement ; albumen épais, scrobiculé par les pointes saillantes de l'endocarpe. Embryon orthotrope, axile; cotylédons amples, foliacés ; radicule courte, supère.Ce g. renferme un petit nombre d'esp. Ce sont des arbres ou des arbrisseaux des Indes et de Madagascar, non laiteux; à feuilles alternes, presque sessiles, coriaces, très entières ou dentées-anguleuses; à stipules caduques; à inflorescence axillaire, à chatons spiculés. On réunit à l'Antidesma le g. Stilago, L., dont on en fait une division. Plusieurs esp. sont cultivées dans les serres: ce sont principalement les $\boldsymbol{A}$. zeylanica et A. pubescens.

(G. L.)

ANTIDESMEES ( $\alpha \tau \tau \iota$, contre ; $\delta \sigma \mu o ́ s$, lien; qui ne se lie à rien; pour faire allusion aux affinités multipliées de cette plante). вот. PH. - Les Antidesmées ont encore reçu le nom de Stilaginées, et plusieurs auteurs ont cru pouvoir la constituer uniquement sur deux genres assez mal connus euxmêmes. Ces genres sont : l'Antidesma et Stilago, que A. L. de Jussieu laissait dans les incertce sedis. Depuis, M. Reichenbach 
les a rapprochées des Euphorbiacées; M. Sweet des Empétrées et des Urticées; rapprochement également admis par M. Lindley, qui, dans son groupe des Urticales, les classe entre les Ulmacées et les Myricées, en faisant observer, toutefois, qu'elles en diffèrent par la présence d'un disque annulaire et des anthères supportées par des filets élastiques. Caractères semblables, suivant M. Lindley, à ceux des Hensloviacées, qui cependant me paraissent se rapprocher davantage du groupe des Saxifragées par ses fruits bicarpellés et polyspermes. Enfin, A. L. de Jussieu leur trouvait de l'affinité avec certains genres voisins des Rosacées, tels que les Grangeria et Hirtella. Quoi qu'il en soit, les Antidesmées ont pour caractères : Fleurs unisexuées. Calice 3-5๊-parti. Corolle 0: étamines 2 ou plus, insérées sur un disque renflé adhérent au calice; les filets, filiformes, supportent des anthères à deux loges réunies par un connectif charnu. Un ovaire libre, terminé par un stigmate sessile, $\mathbf{3}-\mathbf{4}$ lobes. Pour fruit, une sorte de petite drupe, à endocarpe rugueux, 1-loculaire, à une seule graine pendante, contenant un embryon vert, à cotylédon foliacé, entouré par un périsperme charnu, assez épais. - Les Antidesmées appartiennent à l'ancien continent ; ce sont des arbrisseaux à feuilles alternes, simples, munies de stipules cadnques. (AD. Juss.)

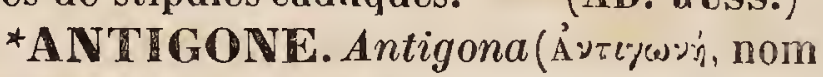
myth.). MoLs. - M. Schumacher, dans son Essai d'une classification des Coquilles, propose ce g., qui nous paraît complètement inutile, pour la Venus cancellata de Linné. L'auteur en trouve les caractères dans les dents cardinales, légèrement courbées sur leur longueur. Cette coquille, d'après ses caractères, appartient au g. Cythérée de Lamarck. Il est évident que le g. Antigone est un double emploi qu'il faut supprimer de la méthode. Voy. CYTuristit.

(DESH.)

${ }^{*}$ ANTIgONON, Endl. (allusion à $P_{0}-$ lygonum). Вот. PH. - Genre de la famille des Polygonées, tribu des Polygonées-spuriées Endl.; son auteur (Gen. Pl., p. 510) le place à côté du Brunnichia, et lui assigne pour caract. : Périanthe coloré, accrescent, à 5 segments inégaux, dont 2 extérieurs, larges, cordiformes, 1 demi-intérieur, obli- | nus. Ces caract. assez fugitifs, et qui ne se que, et 2 intérieurs, oblongs. Fitamines 5 ; en forme de cupule; anthères oblongues, versatiles. Ovaire 1-loculaire, trièdre; ovule d'abord renversé, puis redressé, attaché à un funicule libre, inséré au fond de la lom ge. Styles 3, libres, recourbés, terminés chacun par un stigmate subréniforme. Akène ovoïde, 5-èdre, recouvert par le périanthe. Graine basilaire, dressée, pyramidale; embryon probablement axile dans un périsperme charnu ; radicule supère. - Arbrisseau grimpant, indigène du Mexique; rameaux anguleux; feuilles alternes, cordiformes, penninervées, à pétiole semi-amplexatile, et à gaîne stipulaire rudimentaire. squammiforme, opposée, adnée au rameau par toute sa surface intérieure; fleurs en grappes cirrhifères au sommet; pédicelles fasciculés à l'aisselle des bractées. M. Endlicher ne signale qu'une seule espèce.

(SP.)

* ANTIGRAMMA ( $\nu^{2} \iota$, à l'opposé ; үрхикі, ligne ). Bот. GR. - Genre de Fougères, établi par Presl (Tentam. Pteridograph., p. 120), qui ne diffère du Scolopendrium que par le réseau de ses veinules, qui sont parallèles, s'étendant du milieu vers le bord de la fronde, ct formant, par leurs anastomoses, des taches hexagonales, du bord externe desquelles partent des veinules très courtes et libres.

Par la même raison qu'il a formé le genre Hemidyctium aux dépens de l'Asplenium, M. Presl a cru devoir séparer du Scolopendrium les Antigramma, qui offrent la même différence. On en connaît 5 š espèces ; toutes du Brésil intertropical, parmi lesquelles on remarque l'Antigramma repanda (Scolopendrium ambiguum, Raddi). (G......v.)

* NTILAMANES. Antilambari ( $\alpha \dot{v}<\lambda \times \mu 6 \dot{\alpha} \nu \omega$, saisir). oIs. - Ranzani a donné ce nom à une famille de l'ordre des Grimpeurs, comprenant des oiseaux qui se servent de leurs doigts pour saisir leur nourriture et la porter à leur bec. (G. D'O.)

ANTILOPE.zooL. - Genre de Mammifères de l'ordre des Ruminants, caractérisé par des cornes creuses, généralement rondes, marquées au moins à leur base d'anneaux saillants ou d'arêtes longitudinales, dont le noyau osseux est totalement ou ì peu près solide, c'est-à-dire sans pores ni sifilets subulés, isonètres, soudés par la base 
rencontrent pas tous dans chaque espèce, sont cependant les seuls que l'on ait pu trouver jusqu'à présent pour distinguer ce genre : car l'ordre des Ruminants, l'un des mieux déterminés et des plus naturels de la classe des Hammifères, est en même temps l'un des plus difficiles à diviser génériquement, tant ces animaux, à l'exception des Chameaux proprement dits, ont l'air d'être formés sur le même modèle. C'est donc plutôt par intuition ou par sentiment, plutôt par des caractères négatifs que par des caractères positifs, que l'on reconnaît le genre d'un animal de cet ordre. Les Antilopes sont, en général, des animaux faits pour la course. A taille élancée et légère, elles ont le plus souvent des larmiers comme les Cerfs, des brosses ou touffes de poils plus longs aux genoux, des pores inguinaux ou digitaux, c'est-à-dire des enfoncements de la peau aux aines et entre les doigts; la queue courte, garnie de longs poils; les oreilles droites et assez longues; mais ces circonstances manquent quelquefois, et si le plus grand nombre ont la légèreté des Cerfs, quelques unes ont l'allure grave des Chèvres, et d'autres, pres(que la démarche pesante des Bœufs. Les unes ont le museau effilé, mais d'autres ont un mufle assez proéminent. Les AntiIopes appartiennent presque toutes à l'ancien monde; la plupart des espèces vivent en troupes, mais quelques unes sont solitaires et monogames. Elles sont confinées, comme, au reste, presque toutes les espèces d'animaux, dans certaines limites plus ou moins étendues, qu'elles franchissent rarement. Quelques unes hạbitent les plaines arides, sablonneuses et rocailleuses, et ne se nourrissent que de plantes aromatiques ou salées; d'autres se tiennent de préférence sur les bords des fleuves, et ne vivent que d'herbes douces. Ce sont, en général, des animaux doux et sociables, qui ont les yeux grands et vifs, l'ouie très fine, et qui sont doués d'une grande légèreté. Malgré sa tournure grecque, le nom d'AntiIope n'a pas été employé par les anciens; c'est une corruption du mot Antholops, employé par. Eustathius, qui vivait sous Constantin, pour désigner un animal à longues cornes dentelées en scie; et c'est Pallas qui, séparant ce genre de celui des
Chères, lui appliqua le nom d'Antilope, connu depuis long-temps dans l'art héraldique, et employé par Ray pour désigner l'esp. connue sous le nom d'Antilope des Indes. Ce mot Antholops vient lui-même, selon Bochart, du copte Panthalops, qui signifie Licorne.

Les espèces de ce genre étant en fort grand nombre, et leurs formes étant très variées, plusieurs naturalistes ont tenté de les séparer en groupes particuliers ou en sous - genres.

En 1804, Guvier, dans le Dictionnaire des Sciences naturelles, en annonçant que Daubenton a cherché à les diviser en plusieurs genres, en fit six groupes, à l'exemple de Pennant et d'Erxleben, d'après la forme de leurs cornes. M. Lichtenstein, en 1812, dans le Magazin der gesellschaft naturforschender freunde, $6^{\mathrm{e}}$ année, les divisa en quatre tribus, qu'il nomma Bubalides, Conn chætes, Antilopa et Gazelloe.

M. de Blainville, en 1816, dans le Nouveau bulletin de la Société philomathique, réunit tous les Ruminants à cornes creuses en un seul genre, sous le nom de Cérophore, et le partagea en douze sousgenres, dont huit se rapportent au g. Antilope : ce sont les s.-g. Antilope, Gazella, Cervicapra, Alcelaphus, Tragelaphus, Boselaphus, Oryx, et Rupicapra.

Dans la 1 re édition du Règne animal, $\mathrm{Cu}$ vier en forma sept groupes.

M. Desmarest, en 1820, dans sa Mammalogie, ajouta deux sous-genres à ceux de M. de Blainville, les Oreas et les Égocères et adopta celui d'Antilocapra de M. Ord.

En 1822, Antoine Desmoulins, dans ie Dict. class. d'hist. nat., les subdivisa en Gazelles, Bubales, Oryx, Acuticornes, Tseiran, Strepsicères, Léiocères et Ramicères.

Hamilton Smith, dans sa traduction de la 1 re édition du Règne animal de Cuvier, divisa les Antilopes en trois genres et vingtdeux groupes : le g. Antilope, comprenant dix-sept groupes, à savoir : Dicranocerus, Aigocerus, Oryx, Gazella, Antilope, Redunca, Oreotragus, Tragulus, Raphicerus, Tetracerus, Cephalophus, Neotragus, Tragelaphus, Namorhedus, Rupicapra, Aplocerus, Anoa; le g. Damalis, comprenant quatre groupes, à savoir : Acronotus, 
Boselaphus, Strepsiceros et Portax; enfin le g. Catoblepas, qui ne comprend qu'un seul groupe.

Dans la 2 édition du Règne animal, Cuvier, ne trouvant sans doute pas que ces tentatives pour établir des divisions naturelles dans ce trop grand genre eussent complètement réussi, continua à les réunir en un certain nombre de groupes, d'après la forme des cormes. Ces groupes, auxquels il n'imposa pas de noms, sont au nombre de onze. Depuis, M. Ogilby a divisé les Ruminants en cinq familles, et les Antilopes se trouvent réparties dans deux de ces familles, celles des Capridées et des Bovidæ, et forment douze genres, à savoir : Mazama, Madoqna, Antilope, Gazella, Tragulus, Sylvicapra, Tragelaphus, Calliope, Kemas, Capricornis, Bubalus et Oryx, dont les types sont, en suivant le même ordre: Ant. mazama, Ant. saltiana, Ant. cervicapra, Ant. dorcas, Ant. pymmca, Ant. mergens, Ant. picta, Ant. strepsiceros, Ant. goral, Ant. Thar, Ant. bubalus, Ant. $\operatorname{ory} x$.

Tout ell prétendant que la forme des cornes, adoptée par Cuvier pour caractériser ses groupes, est un moyen artificiel, c'est cependant sur cette forme que la plupart des auteurs dont nous venons de parler fondent principalement leurs divisions. Et, en eflet, quoique l'on ignore les rapports qui existent entre les cornes et le reste de l'organisation, il n'en est pas moins certain qu'elles donnent une physionomie particulière à la tête, et que, la tête fournissant les caractères les plus essentiels, ceux que l'on tire de sa forme sont peut-être les plus sûrs qu'on puisse employer pour subdiviser les familles à esp. nombreuses comme celle-ci.

Il est également vrai de dire que, malgré la variété de formes des diverses espèces d'Antilopes, il y a entre elles un air de fainille qui les fait distinguer par tout le monde, et qui a déterminé Pallas à les réunir en un seul g., quoique quelques unes se rapprochent évidemment ou des Chevrotains ou des Chères, ou des Bœufs, ou enfin des Cerfs. Acceptant donc cet air de famille des Antilopes comme un fait, et trouvant également nécessaire d'établir des coupes dans ce genre, mais moins multipliées qu'on ne l'a fail dans ces derniers temps, nous proposerons dans cet article de le subdiviser en huit sous-genres, d'après la forme et la position relative des cornes, en avertissant toutefois le lecteur qu'ici, comme dans tout le règne animal, faute de caractères absolus, les esp. qui se trouvent sur la limite d'un sous-genre sont fort voisines de celles d'un second ou même de plusieurs autres.

Cette absence de caractères absolus nous a engagé à n'employer pour nos sous-genres que des noms sans signification, comme se prêtant davantage aux modifications de chaque type que ceux qui signifient une chose ou une propriété que ne possède pas l'être que l'on est cependaut forcé d'y comprendre par un ensemble d'autres caractères.

Quelques uns de ces noms, tels que ceux d'Oryx et de Bubale, ont été employés par tout le monde, mais pas toujours dans le même sens et avec les mêmes limites. Outre les ouvrages que nous citons, nous avons consulté avec fruit les procès-verbaux de la Société zoologique de Londres, dans lesquels on trouve des descriptions de plusieurs Antilopes, faites principalement par M. Bennett. Nous avons aussi mis ì profit des notes qui nous ont été fournies par M. Jules Verreaux, qui a résidé plusieurs années au Cap.

$1^{\circ}$ Le sous - genre DORGAS. - Gornes à double courbure, soit de face, soit de profil, plus ou moins lyrées, presque toujours de la longueur de la tête, implantées au dessus des orbites ou au moins à leur angle postérieur, à tête et flancs presque toujours marqués de bandes longitudinales de couleurs foncées. Deux mamelles. Comprenant le premier et le second groupe de Guvier, les Gazelles et les Antilopes de Blainville, de Hamilton Smith et d'Ogilby. La GAZELLE, Antilope dorcas (Buff:, t. XII , p. 23). - Animal de la grandeur, de l'élégance et de la légèreté du Ghevreuil. Ses cornes sont noirâtres, assez grosses, et marquées de 12 à 14 anneaux saillants. Le cou, le dos et la face externe des membres, sont de couleur fauve-clair; la face interne de ces derniers, le ventre et les fesses, sont d'un beau blanc. Une bande brune règne le long de chaque flanc. La tête est fauve, à 
l'exception du sommet, qui est gris-clair, et d'une bande blanchàtre de chaque côté, qui embrasse le tour de l'œil; quelques individus ont la tête marquée de trois bandes brunes, séparées par deux blanches. Cette espèce porte des larmiers, des brosses aux genoux, ét, à chaque aine, une poche profonde, remplie d'une matière fétide. Sa chair est d'un goût fort semblable à celle du Ghevreuil. Les Gazelles vivent dans tout le nord de l'Afrique en troupes nombreuses. Quoique timides, elles forment un cercle quand on les attaque, et présentent à l'ennemi leurs cornes de tous côtés; cependant, elles ne peuvent résister aux Lions et aux Panthères, qui en font leur proie ordinaire. On les chasse avec le Chien, l'Once ou le Faucon; on en prend aussi en lâchant des individus apprivoisés, dont les cornes sont garnies de nceuds coulants, auxquels les Gazelles sauvages viennent se prendre. La chasse au Faucon est le principal amusement des riches en Syrie. L'oiseau saisit la Gazelle à la gorge, et la lui déchire avec son bec et ses ongles. La beauté de leurs yeux, la douceur de leurs regards, l'élégance de leur taille, la grâce de leurs mouvements, leur légèreté, ont fourni de tout temps des comparaisons et des images à la poésie arabe. Les beaux yeux se nomment en Orient des yeux de Gazelle. Élien a fort bien décrit ces animaux sous le nom de Dorcas, donné antérieurement au Chevreuil. Leur nom de Gazelle est arabe.

La CORINNE, A. Corinna, Gm. (Buff., t. XII, pl. 27); le KEVEL, A.'Kevella, Gm. (Buff., t. XII, pl. 27); l'Ant. arabica, Hemp. et Ehreniberg (Symb. physic., sect. I, pl. 5), ne diffèrent de la Gazelle que par des cornes plus grêles dans la première, plus comprimées à leur base et à anneaux plus nombreux dans la seconde, et par une taille un peu plus forte et des teintes un peu plus foncées dans la troisième.

Le KEVEL GRIS, Fréd. Cuv. (Mam.), s'il n'est pas une variété de la Gazelle, est une esp. très voisine. Enfin, l'Ant. subgutturosa (Schreb., 170 B.) paraît également en être ou une variété on une esp. encore très rapprochée.

Le DSEREN, ou Ant. goîtreuse; Chèvre jaune des Chinois (Ant. gutturosa, Pall.; Schreb., 275), offre à peu près les mêmes cornes et la même distribution de couleurs que la Gazelle; mais il est plus trapu, et de la taille du Daim. Le larynx du mâle, très volumineux, fait une saillie en dehors, qui a valu à cette esp. le nom qu'elle porte. Les larmiers sont petits, les brosses courtes, et les poches inguinales grandes. Le mâle porte en outre, sous le ventre, un sac, au même endroit que le Musc, et dont le cérumen a l'odeur du Bouc; la femelle ne porte point de cornes. Cette esp. habite les déserts de la Mongolie, entre la Chine et le Thibet, et dans quelques contrées de la Sibérie orientale; elle est surtout abondante dans le désert sablonneux de Cobi. Elle évite les forêts et le voisinage de l'eau, et préfère les lieux découverts et arides. Sa nourriture se compose de végétaux doux. Des troupes nombreuses de Dseren s'approchent quelquefois en hiver des habitations, et se mêlent avec le bétail domestique. Lorsque ces animaux sont poursuivis, ils font, diton, des sauts énormes. Leur horreur pour les bois est telle, qu'ils se heurtent la tête contre les arbres plutôt que d'y pénétrer. Ils ne craignent pas moins l'eau, et se laissent prendre ou tuer sur place plutôt que de se résoudre à s'y jeter; cependant, ils nagent très bien s'ils viennent à y être précipités par hasard. Les femelles mettent bas à la mi-juin, et les petits s'apprivoisent parfaitement.

L'ANTILOPE A BOURSE, Ant. eucho$r e$, un peu plus trapue, et d'un tiers plus grande que la Gazelle. Ses cornes sont aussi un peu plus lyrées, et celles des mâles plus grosses; mais elle présente presque la même distribution de couleurs. Elle s'en distingue par une raie blanche à la partie postérieure du dos, dont les longs poils s'écartent quand elle saute, et qui sont logés dans un repli de la peau, que le panicule charnu développe en se contractant par l'effort du saut. La queue, plus grande que dans la Gazelle, est blanche, et terminée par un flocon noir; la tête est presque toute blanche, avec une ligne latérale noire. Elle a des larmiers, et point de brosses aux genoux. Cette belle espèce vit par troupes nombreuses dans les environs du Cap. Au temps de la sécheresse, ces animaux voyagent, et, les premiers rangs ayant tout brouté, les derniers sont obligés d'arracher 
les racines pour vivre. Ces immenses troupeaux sont escortés de Lions, de Panthères et de Hyènes, qui en dévorent un grand nombre, quoiqu'elles se défendent en faisant cercle, et en présentant les cornes. On assure qu'elles présagent les mauvais temps par des sauts et des bonds plus fréquents. Elles s'apprivoisent aisément en captivité.

Le SAIGA, Antilope saïga (Pall.; Schr., 276), a les cornes comme la Gazelle, mais jaunâtres et transparentes. Il est grand comme un Daim. Sa couleur, pendant l'été, est fauve sur le dos et les flancs, et blanche sous le ventre; pendant l'hiver, il est grisblanchâtre. Son museau cartilagineux est tellement saillant, que l'animal ne peut paître qu'en reculant ou en saisissant l'herbe par le côté. Il habite les landes de la Pologne et de la Russie jusqu'à l'Irtich, et les monts Altaï en Sibérie, et se nourrit d'Absinthes, d'Armoises, d'Arroches, et autres plantes âcres qui abondent dans ce pays sablonneux et salé. Les Saïgas ont la vue courte; mais leur odorat est si fin, qu'ils éventent l'ennemi de très loin. Ils se rassemblent pour voyager en troupeaux de plusicurs milliers. Pendant que la troupe dort, quelques uns des mâles font la garde; ce sont aussi les mâles qui défendent leurs petits contre les attaques des Loups et des Kenards. Les femelles mettent bas un seul petit au printemps. Dans la saison du rut, au mois de novembre, les mâles sentent fortement le musc. La chair du Säga se mange en hiver; mais elle est rejetée en été , parce qu'alors on trouve sous ia peau de cet anima! une quantité considérable de larves d'une esp. d'Oëstres. Pour boire, le Saïga plonge entièrement son museau dans l'eau, et c'est par les narines qu'il aspire la plus grande partic du liquide, comme l'a dit Strabon, mais sans pouvoir y en garder, comme l'a cru cet auteur. On élève assez aisément les Saïgas en domesticité lorsqu'on les prend jeunes. Ceux qui ont été ainsi apprivoisés courent librement au dehors sans se joindre aux sauvages, et viennent à la voix de leur maître, auquel iis ne manquent pas de faire quelques caresses. Les anciens ont conna le Saïga sous le nom de Colus.

Le NAYGUER, Ant. dama, Pall. (Acad. de Berlin, 1824, pl. 3 et 4); Ehrenb. (Symb. phys., t. I, pl. 6). - Cornes dans les deux sexes, à cinq ou six anneaux peu marqués à la base, dont la pointe se courbe fortement en avant. Cette belle esp., de la grandeur et de la légèreté du Daim, est d'un brunfauve en dessus. Sa face est blanche, avec trois bandes grises; les fesses, la queue, le ventre et les membres, sont blancs; dans le jeune âge, la face externe de ces derniers est fauve. Une tache blanche se remarque à la région moyenne du cou. On trouve cet animal, qui est d'un caract. doux, et dont la chair est très bonne à manger, en Nubie et au Sénégal.

Les jeunes Nanguers n'ayant encore que la partie supérieure de leurs cornes, celle qui est simplement courbée en avant, Buffon, qui n'en avait connu que de tels, appliqua à cette esp. le nom de Dama de Pline, qui ne convient pas aux individus adultes.

L'Ant. ruficollis Ham. Smith, et I'Ant. mohrr Bennet (Trans. de la Soc. zool. de Londres, t. I, pl. 1), ne sont, selon nous, que des variétés du Nanguer.

II. Bennet croit que l'Ant. addra est également une variété de ce même Nanguer, qui n'en diffère pas plus que le Kevel ou la Corinne ne diffèrent de la Gazelle.

L'ANT. DE SOEMMERING, Ant. Soemmeringii, Gretzschmar ( Atl. de Rupp., pl. pl. 19 ). - Cornes noires, à pointes fortement courbées en dedans, de la grandeur du Nanguer. La tête, le dos et la partie extér. des extrémités, de couleur isabclle, avec de nombreuses taches plus foncées; la poitrine, le ventre, la croupe et la partie intér. des extrémités, blancs. La tête marquée de trois bandes noires, dont celle du milieu très large. De l'Abyssinie.

I'AN'T. A PIEDS NOIRS, ou PALLAH, Ant. melampus, Licht. (Schr., 274); Licht. ( Mag. de Berlin, v. 167 ). - Animal presque de la grandeur du Cerf. Cornes rondes, longues dans le mâle seulement. Pelage brun-fauve en dessus, blanc à la croupe et en dessous; une ligne noire longitudinale sur le dos, traversée par une bande de même couleur, qui sépare le blanc du fauve sur la croupe. En arrière des pieds de derrière, au dessus des ongles, une touffe de poils plus longs, formant tache noire. Cet élégant et vigoureux animal habite la $\mathrm{Ca}$ - 
frerie, où on le rencontre par petites troupes de six a huit individus. Il se laisse facilement apprivoiser.

L'ANTILOPE POURPRE, Ant. pygarga (Schr., 275). — Très bel animal de la taille d'un très grand Cerf commun, à cornes lyrées, portant douze demi-anneaux saillants dans le mâle seulement. Le col et la tète d'un beau bai-brun, presque couleur de sang; le dos brun-bai, glacé de blanchâtre. Une large bande brune sur chaque flanc. Fesses, ventre et face intér. des cuisses, d'un beau blanc. Une large bande blanche sur le chanfrein, qui se rétrécit entre les cornes. Brosses et larmiers nuls. Des environs du Cap de Bonne - Espérance.

L'ANT. A NEZ TACHÉ, Ant. naso maculata, Bl.; Ant. mytilopes, Ham. Sm.; ayant la mème distribution de couleurs et les mêmes cornes que l'Ant; pourpre, et ne s'en distinguant que par une taille moindre d'un quart environ. Il nous paraît que celleci doit être considérée comme une variété de celle-là.

L'ANTILOPE DE BENNETT, Ant.Bennetii, Sykes. - Queue noire des Mahrattes. Cornes lyrées, marquées de 8 à 9 anneaux. Face marquée de bandes noires. Corps brun - rougeâtre en dessus, blanc en dessous.

Le KOB, Ant. Kob. (Buff., t. XII, pl. 52, fig. 1). - Cornes peu lyrées, à première courbure peu marquée, formant par devant une figure elliptique, marquée, dans leur premier tiers, de 7 à 8 anneaux.

De la taille du Daim.

Le KOBA, Ant. Senegalensis, Penn. (Buffon, t. XII , pl. 52, fig. 2), à cornes longues, un peu aplaties, latéralement lyrées, marquées de 15 à 17 anneaux. De la taille du Cerf.

Ces deux espèces, imparfaitement connues, paraissent devoir entrer dans ce sousgenre.

Le TGHIRU, Ant. Hodgsonii, Abel; Ant. kemas d'Elien, selon Ham. Smith.Cornes deux fois de la longueur de la tète, comprimées en bas, arrondies en haut, à vingt anneaux; première courbure en arrière peu sensible; seconde en avant assez forte. Presque de la grandeur du Cerf, gris-bleu. Épaules de couleurs plus c'aires; les canons marqués d'une ligne noi-

$$
\text { T. : }
$$

re en avant. Front noir, un mufle, une touffe de poils sur le nez. De chaque cóté du museau, près de la marge externe des narines, une tumeur de la grandeur d'une moitié d'œuf de Poule; la bouche et le nez entourés de nombreux poils raides. Vit par troupes de plusieurs centaines dans les plaines élevées du Thibet, sans jamais approcher des montagnes. Au moment du repos, des sentinelles sont placées dans toutes les directions; et si l'une d'elles vient donner l'alarme au camp, toute la troupe fuit avec la plus extrême vitesse. Est très sauvage; et, comme tous les animaux de cette contrée, il a deux sortes de poils.

go Le s. -genre ORYX. - Cornes plus ou moins arquées en arrière comme celles des Chèvres, ordinairement très longues, implantées à l'angle postérieur des orbites, à tête presque toujours marquée de bandes de couleur foncée.

Le PASAN DE BUFFON. Ant. Oryx, Pall. (Bufion, Suppl., t. VI, pI. 17). - Cornes rondes, de deux fois la longueur de la tête, plus petite dans les femelles, presque droites, annelées au tiers inférieur. Queue moyenne, couverte de longs poils. Plus grand que le Cerf. Pelage gris-bleuâtre en dessus, et blanc en dessous; une ligne brune sur les flancs; sur l'épine, une bande noire formée de poils dirigés vers la nuque. Tête blanche, avec une ligne d'un brun noir allant de chaque côté de la corne à la bouche et passant sur l'œil. Le haut du front et une bande traversant le chanfrein.

On trouve cette Antilope au nord du Cap et dans l'intéricur de l'Afrique, où elle vit par paires. Ses longs sabots lui permettent de grimper sur les rochers; aussi on assure qu'elle fréquente de préférence les contrées montagneuses. Elle est très courageuse et combat souvent avec succès contre les Carnassiers qui l'attaquent. Ses cornes, très dures, servent d'armes aux habitants des contrées qu'elle habite. Comme nourriture, elle passe pour la meilleure des Antilopes. Cet animal, comme on voit, se rapproche du Tchiru et pourrait être placé presque aussi bien dans le sous-genre précédent que rlans celui-ci; ses cornes, quoique dites droites, ayant une très légère double inflexion. L'ANTILOPE BEISA, Ruppel (Faune de l'Abyssinic, Mamm., nl. "3, semblable, 
par la taille et par les cornes, à l'Oryx. Le col et la partie supérieure du corps de couleur isabelle. Le front et le chanfrein marqués d'une bande brun-roux, plus étroite entre les yeux. De chaque côté de la tête, deux bandes de la même couleur : l'une sur l'œil et la joue, l'autre formant collier à la naissance du col. Une bande sur les flancs, des bracelets au dessus des genoux; une ligne brun-foncé sur les canons antérieurs, le bout de la queue de même couleur. De la province de Dongola.

L'AlGAZEL, Ant. leucoryx, Licht. (Acad. de Berlin, 1824, pl. 1). - Cornes grêles, annelées dans leur moitié inférieure, légèrement courbées en arc de cercle, de deux fois la longueur de la tête. De la taille d'un petit Ane. Pelage blanchàtre, teinté de fauve clair sur le dos et les flancs. Le col et le poitrail fauve plus foncé. Des taches sur la tête, distribuées comme dans l'Oryx, mais de couleur moins intense. Point de mufle. De petits larmiers; des poches aux aines; des brosses aux genoux. Deux mamelles. De l'Afrique septentrionale, depuis la Nubie jusqu'au Sénégal. D'après M. Lichtenstein, cette esp. est probablement l'Oryx des anciens : car celui-ci, ue vivant que dans le midi de l'Afrique, n'a vraisemblablement pas été connu dans l'antiquité. Quoi qu'il en soit, comme 'l'Algazel est souvent représenté sur les monuments d'Éygte, de profil et avec une seule corne, la seconde étant comprise dans le même plan, on pense que ce sont ces figures mal interprétćes qui ont donné lieu à la fable de la Licorne.

L'ANTILOPE BLEUE, Ant. leucopha, Gm. : vulgairement Chèvre bleue (Buff., Suppl. VI, pl. 20, sous le nom de Tseïran), de la taille d'un grand Cerf, à cornes grosses, recourbées uniformément, portant une trentaine d'anneaux qui vont en grossissant, et en s'écartant davantage de la base au sommet, d'une fois et demie la longueur de la tête. Pelage d'un gris cendré, bleuâtre, excepté le ventre, la face interne des membres et le bout de la queue, qui sont blancs. Une mèche de poils blanes plus longs que les autres en avant de l'œil, à la place des larmiers. Le devant des canons presque noir. Poils de la ligne dorsale récurrents. Du Cap, où elle vit par paires ou par pe- I n'en ont point. tites troupes de cinq a six individus, au pied des montagnes. La femelle a les cornes plus petites, et en manque même quelquefois (1).

L'ANTILOPE CHEVALINE OU OSANNE, Ant. equina, Geoff. and Smith (Illusir. of the zool. of south Africa, pl. 27), de la grandeur d'un petit Cheval. Cornes arquées en arrière, ridées à leur base, marquées de vingt-cinq à trente anneaux, d'une fois et demie la longueur de la tête. Une crinière sur le cou; poils plus longs sous le cou. Pelage gris-blanchâtre. Les épaules, le dos, la croupe et la face extérieure des membres, nuagés d'orange. Tête brune, avec le chanfrein blanchâtre. Une mèche de grands poils blancs au devant de chaque oil. De l'Afrique méridionale, et peut-être même du Sénégal.

L'ANTILOPE NOIRE, Aigocerus niger, Harris (Trans. de la Soc. zool. de Londres, t. II, pl. 59). - Cornes de deux fois la longueur de la tête, annelées dans les deur tiers inférieurs. Animal de la grandeur du Cerf. Une crinière depuis la tête jusqu'd la croupe, récurrente sur le col; une autre sous le cou. Couleur générale d'un beau noir. Une bande blanche s'étendant depuis les sourcils jusqu'aux naseaux. Le dessous de la mâchoire inférieure, le ventre et l'indérieur des cuisses, blancs; l'intérieur des jambes brun-fauve. Des hautes montagnes de l'intérieur du Cap. Vit par petites troupes. Les cornes de la femelle plus grêles que celles du mâle.

Fous pensons que cet animal pourrait bien être l'Antilope chevaline en pelage d'été.

Le CAMBING OUTANG ou GAMBTAN, Ant. Sumatrensis, Desm. (Fr. Cuv., Mam., et Marsden, 2e éd., pl. 10), de la taille d'unie grande Chèvre. Cornes moins longues que la tête, annclées dans les deux tiers de leur longueur. Pelage noir. Une crinière blanche, couchée sur le col et le garrot. Oreilles et queue de longueur moyenne.

(1) A cette occasion, nous remarquerons qu il est impossible de prendre pour caractères de sous-genres la présence ou l'absence des cornes dans les femelles; quelques unes en étant privées dans les espèces où celles-ci en portent, et d'autres en étant pourvues dans les espèces où clles 
Des larmfers, un mufle. - Cette esp., qui a les allures des Chèvres, habite les montagnes boisées de Sumatra. Marsden assure qu'elle est d'un caractère sauvage, extrêmement agile; qu'elle a le pied d'une grande sûreté, et que ses habitudes ressemblent tout à fait à celles du Bouquetin.

Le GORAL, Ant. goral, Hardwick (Trans. Lin., t. XIV, pl. 110), et Fréd. Cuv., sous le nom de Bouquetin du Népaul. - Cornes courtes, noires, amnelées à leur tiers inférieur. De la taille de la Corinne. Brun - marron, teinté de noir sur le chanfrein, sur le col et sur le dos, jusqu'à l'extrémité de la queue, et en avant de l'épaule. Le ventre et la face interne des menbres fauve-clair ; le dessous de la mâchoire inférieure, la gorge et l'intérieur des oreilles, sont blancs.

L'ANT. THAR, Hodgs. - Espece intermédiaire entre le Cambtan et le Goral, et qui vient aussi du Népaul. Est un peu plus grande.

Nous plaçons à la fin de ce sous-genre un animal qui pourrait, aussi bien que le Tchiru, entrer dans le sous-genre précédent, ou même faire un sous-genre à part, les cornes étant implantées tout à fait sur l'orbitc, et la distribution des couleurs étant à peu près celle des Gazelles; c'est :

Le CHAMOIS ou ISARD, Ant. rupicapra (Buffon, t. XII, pl. 16 ; Schr., 269 ; Fréd. Cuv., Mamm., in-fol., t. IV), à cornes de 12 à 13 centimètres de long, ct de 2 à 3 d'épaisseur à leur base, marquées de stries longitudinales et d'anneaux transversaux peu apparents, dirigées d'abord verticalement, puis subitement recourbées en arrière en forme de crochets; à pelage fauve dans la belle saison et d'un brun vineux en hiver, est le seul animal de l'Europe occidentale qu'offre le genre Antilope; encore, par l'absence des larmiers, par des jam bes plus courtes, et par un corps plus gros que dans les vraies Gazelles, se rapproclıct-il tellement des Chères et des Bouquetins, que Buffon n'a considéré ces trois espèces que comme des variétés constantes. Son poil est plus court en été qu'en hiver, et, dans cette dernière saison, sous les longs poils ordinaires se trouve un poil laineux très abondant; cn tout temps une bande brune ou noire naît de chaque côté au coin de la bouche, et vient finir en embrassant l'ail à la base des cornes. La queue est noire, le tour de l'anus, les fesses et l'intérieur des oreilles sont blancs. Derrière chaque oreille existe une petite poche contournée en spirale, que l'on trouve toujours vide, circonstance qui, mal indiquée, paraît avoir fait croire aux anciens que les Chèvres respirent par les oreilles. Cet animal est d'une grande agilitê et se tient en petites troupes dans les régions. moyennes des montagnes. On le voit fran-chir les précipices, bondir de rocher en rocher et s'arrêter tout court sur la pointe d'un roc offrant à peine l'espace suffisani pour y placer ses pieds rapprochés les uns des autres. Ses sens sont très délicats; il entend et voit de très loin. Sa voix ordinaire est un bêlement sourd ; Inais lorsqu'il est effrayé par quelque danger, surtout. lorsqu'il est averti par son odorat ou par son ouie de la présence d'un homme qu'il ne. voit point, il fait retentir les montagnes d'un sifflement aigu rendu par les narines. II se nourrit de fleurs, de bourgeons tendres et des herbes les plus aromatiques, ce qui sans doute a fait croire à la vertu curative de son sang dans quelques maladies, et surtout dans la pleurésie. Il s'accouple en automnc; le temps de la gestation est de six mois, et les petits naissent couverts de poils et les yeux ouverts. La chasse du Chamois est l'une des plus pénibles et des plus dangereuses, le chasseur étant obligé de le suivre sur les bords des précipices, au risque d'y tomber, comme il arrive quelquefois, lorsque, ne trouvant plus de moyen d'échapper, cet animal se jette sur lui avec violence. Sa chair est bonnc à manger, et son suif est d'une qualité supérieure à celui de la Chèvre; sa peau est ferme et souple, et on l'employait beaucoup autrefois pour les vêtements. Le Chamois se trouve daris les Pyrénées, les Alpes, les montagnes de la Grèce et les îles de l'Archipel; mais partout il devient de plus en plus rare.

$3^{\circ}$ Le sous-genre ADDAX. - Cornes contournées en spirale, implantées à l'angle postéricur ou même tout à fait en arrière de l'orbite.

Ce sous-genre doit suivre immédiatement. lc précédent, et pourrait même lui être réuni, les cornes des Chèvres ayant une tenw 
dance manifeste à prendre une courbure pareille dans quelques espèces.

Le COUdous, Ant. strepsiceros, Pall. (Condoma de Buff., Suppl., t. IV, pl. 15; Schreb., 267). - Cornes de deux fois la longueur de la tête, demi-transparentes; a triple courbure spirale, avec une arête longitudinale; lisses à leur moitié supérieure, portant environ vingt demi-anneaux peu saillants à leur moitié inférieure. Une crinière brune sur et sous le cou. Un mufle. Les oreilles larges et pendantes. De la taille du Cerf commun. Gris-brun, avec plusieurs raies transversales blanches sur le corps. Une raie blanche allant de l'un à l'autre ceil, en décrivant une courbe, dont le sommet est presque au milieu du chanfrein. Vit par familles de cinq ou six individus dans les parties boisées de la Cafrerie et sur les bords des rivières, qu'il traverse à la nage lorsqu'il est poursuivi. On ne le trouve jamais dans les plaines découvertes ni dans les montagnes. Il est extrêmement rapide à la course, et saute avec tant d'agilité, qu'on l'a vu franchir un obstacle de 3 mètres de hauteur. Les mâles montrent beaưcoup de courage lorsqu'ils sont poussés à bout. Pris jeunes, ils s'apprivoisent aisćment, et ne cherchent jamais à recouvrer leur liberté.

L'ADDAX, Licht. (Sangeth., pl. 2); Ehr. (Symb. phys., t. I, pl. 4); Gretzsch. (Atlas de Rupp., pl. I); Fr. Cuvier (Mamm.); Ant. suturosa, Otto. - Cornes noires dans les deux sexes, plus petites que celles du Coudous, aplaties, sans arête sensible, à anneaux complets jusqu'aux trois quarts de leur longueur, à triple courbure spirale. De la taille du Daim. Tête et cou brunclair; dos jaunâtre; le reste blanc. Le front brun-chocolat ou noir, entouré de blanc, qui descend sur la joue, au devant de l'œil. Une petite crinière sur et sous le cou, de conleur brunâtre. Le bout de la quene brun. En hiver, le dos et le cou sont de couleur plus foncée. La peau du cou, surtout dans le mâle, formant une sorte de fanon. Des déserts de la Nubie.

L'ANTILOPE EUR YCERUS, Ogilby. Cornes à double spirale, avec une arête saillante à leur face postérieure; à extrémilés couleur d'ivoire.

Dc la grandeur du Cowlous.
Le CANNA ou MPOOKO, Ant. oreas, Pall. (Elan du Cap des Hollandais, Bufí., Supp., t. VI, pl. 12 ; Schr., pl. 256).-Cornes longues, coniques, dirigées en arrière, divergentes dans leurs deux tiers inférieurs, et parallèles dans leur tiers supérieur, ayant une forte arête spirale vers leur base. Point de larmiers. Un garrot saillant. Une crinière depuis le chanfrein jusqu'au sommet de la tête. Un fanon garni de longs poils, semblable à celui du bœuf. Une loupe sous la gorge. Queue médiocre, terminée par un flocon de crins noirs. Couleur générale fauve-grisâtre, avec une raie noire sur le dos. Habite, en troupes assez nombreuses, une grande partie du centre de la colonie du Cap. Il fréquente de préférence les plaines où croissent des mimosas. Les habitants en estiment la graisse. C'est la plus grande esp. d'Antilope, quoiqu'elle soit basse sur jambes. Flle atteint à la hauteur des plus forts Chevaux.

L'ANTILOPE DES IVDES, Ant. cervicapra, Pall. (Buff., t. XII, pl. 55 et 56; Schr., 268). - Cornes noires, à triples courbures, tordues en spirale, à anneaux nombreux. Dessus du corps brun-fauve, dessous blanchâtre. $\mathrm{Nez}$, lèvres, tour des yeux et dessous de la queue, blancs. Museau un peu renflé. De grands larmiers; des brosses aux genoux. De la taille d'un petit Daim. La femelle ne porte point de cornes, et acquiert, à l'âge de six ans, une bande blanche de chaque côté de l'épine; elle porte neuf mois, et ne fait qu'un petit. Les Fakirs indiens font avec leurs cornes, en les joignant par leurs bases, une arme qu'ils portent à leur ceinture en gaise d'épée ou de poignard.

Ces animaux sont si rapides à la course, que les Chiens ne peuvent les atteindre, à moins qu'ils ne soient surpris dans une embuscade. On assure qu'ils peuvent sauter à la hauteur de 4 mèt., et qu'ils franchissent d'un bond un espace de 12. Ils habitent les plaines ouvertes de l'Inde, évitant les forêts, et se tenant toujours dans les lieux d'où l'on peut voir au loin dans toutes les directions. Ils vivent en familles composées de dix jusqu'à soixante femelles pour un mâle adulte. Lorsqu'ils paissent ou qu'ils ruminent, ils détachent de tous côtés les I jeunes mâles à une distance de 2 à 500 mè 
tres, et les chargent de veiller à la sûreté commune. Ceux - ci examinent attentivemeut les buissons et les touffes d'herbes qui leur paraissent suspects, et, à la première alarme, tout le troupeau prend la fuite, en suivant pas à pas le vieux inâle.

Le GUIB, Ant. scripta (Buff., t. XII, pl. 40). - Cornes triangulaires, contournées par des, arêtes spirales, dans le mâle seulement. Pelage fauve-marron, marqué de lignes sur les flancs, et, sur les cuisses, de taches de couleur blanche. Le front et le chanfrein noirâtres. Faces antérieure de la cuisse et interne des canons blanches. Un petit mulle. Point de larmiers. - Cette belle espèce vit par troupes dans les plaines et les bois de la côte ouest de l'Afrique; elle a été rapportée pour la premid̀re fois du Sénégal en Europe par Adanson.

Le BOSH-BOCK, Ant. sylvatica, Sparmann et Gm. (Buff., Suppl., t. VI, pl. 23 ; Schr., pl. 2507 B), qui se trouve au cap de Bonne-Espérance, pourrait bien n'être qu'une variété du Guib, à couleur plus foncée, et à taches et raies blanches moins nombreuses, la distribution des couleurs et la forme des cornes étant les mèmes dans les deux esp. Quoi qu'il en soit, le BoshBock habite les forêts, dont il ne sort que pendant les beaux clairs de lune et le matin pour paître sur ses bords, ou pour faire quelques incursions dans les jardins ou les champs cultivés du voisinage. Sa voix ressemble tellement à celle du Chien, que, trompés par elle, les voyageurs s'enfoncent quelquefois dans les endroits les plus reculés, croyant toujours, en suivant cette voix, arriver à quelque habitation.

L'ANTILOPE OGILBY, Waterh., n'est probablement aussi qu'un Bosh-Bock.

Le Canna, que nous avons placé dans ce sous-genre, à l'exemple de Cuvier, se rapproche beaucoup des Bubales par son port, et presque par l'implantation de ses cornes, et l'Antilope des Indes est si voisine des Gazelles, que plusieurs naturalistes ont fait un sous-genre de cette espèce, et de quelques unes de celles de notre sous-genre Dorcas.

40 Le sous-genre NAGOR. - Cornes divergentes, plus ou moins recourbées ell avaut, implantées à l'angle postérieur des orbites.
Le NAGOR, Ant. redunca (Bufi., 1. Xlt, pl. 46 ; Schr., pl. 265). - Cornes du mille rondes, de la longueur de la tête, courbécs en are, la pointe en avant. Oreilles longues. Pelage gris-brun, plus clair en dessous. Intérieur des canons brun. Bout du nez noir. Queue moyenne, touffue. De la grandeur du Daim.

Le RITBOCK, Ant. eleotragus (Schreb., Tab. 266). - Cornes du mâle assez petites, noires, légèrement courbées en avant, avec dix anneaux obliques sur leur première moitié. Dessus du corps gris-cendré; gorge, ventre et fesses, blancs. Oreilles très longues. Des pores inguinaux. Quatre mamelles. De la taille du Daim. De la Cafrerie, à une assez grande distance du Cap. Ils se tiennent en petites troupes parmi les roseaux et les joncs au bord des fontaines, et dans les bois voisins des rivières.

L'ANT. LALANDII, Desm. - Cornes de la moitié de la longueur de la tête, annelées à leur base, et fortement strićes en long, peu divergentes. Oreilles plus longues que les cornes. Poils recurrents depuis le milieu du dos. Dessus du corps gris-verdâtre; tête jaunâtre ; dessous de la mâchoire, du ventre, et intérieur des cuisses blanc-roussâtre; bout de la queue blanc. De la grandeur du Ghevreuil. Des environs du Cap, où elle vit par paires dans les grands buissons et sur les flancs des montagnes. Elle est difficile à atteindre, étant d'un caract. très farouche.

L'ANT. DE FASSA, Rüppel (Faune de l'Abyssinie, pl. 5). - Cornes un peu plus longues que la tête, penchées d'abord en arrière dans la direction du front, et recourbées en avant vers le tiers supérieur. Dessus du corps brun - rouge pâle, plus foncé sur le chanfrein, le front, le dessus du col et du dos. Noirâtre sous le ventre. Les quatre membres brun-noir. Le bout du museau blanc, et une tache de même couleur sur et autour de l'ail ; l'intérieur des oreilles, un collier qui naît de la base des oreilles, les fesses, une tache aux onglons, et une bordure au dessus des sabots, également blancs. La queue descend presque jusqu'au jarret, et se termine par une touffe de poils noirs. De la grandeur du Cerf. Vit dans les pâturages gras de l'ouest de l'Abyssinie.

L'ANT. ELLIPSIPRYMINUS, Ogilby et I Smith (Illustr. of the zool. of south Afri- 
$c a$, pl. 28 et 29 ). - Cornes une fois et demie de la longueur de la tête, à vingt anneaux environ, courbées en arc, la pointe en avant; les pointes se rapprochant un peu par les extrémités. Tête courte. Poils longs, raides, séparés en mèches : ceux du dos dirigés en avant; ceux du cou plus longs et plus hérissés. Couleur générale gris-brun; ce dernier prédominant sur le dos, la croupe et les canons. Dessus de la tête brune. Bout du museau blanc, sauf l'extrémité du nez, qui est noire. Une tache blanche sur chaque oil. Vers le milieu des fesses, une bande blanche, qui va se rejoindre sur la croupe à celle du côté opposé, de manière à décrire une ellipse régulière, dont la racine de la queue occupe l'un des foyers, circonstance qui lui a valu le nom d'Ellipsiprymnus.

De l'Afrique méridionale, à vingt - cinq journées, au nord, de la rivière Orange.

L'ANTILOPE UNC'TUOSA, Nob.-Il existe aujourd'hui à la ménagerie du Muséum d'histoire naturelle de Paris une Antilope rapportée du Sénégal par M. Malassis, qui ressemble fort à l'espèce précédente; seulement, ses cornes sont presque droites, très légèrement infléchies en avant. Du reste, la tête est également courte, le poil long, de couleur brun-jaunâtre ; le bout du muscau blanc, et les narines noires. Une tache blanche sous la gorge; point de bande blanche aux fesses. Pendant l'hiver, cet animal suinte une humeur grasse d'une odeur très désagréable, qui tombe en gouttelettes de chacull de ses poils. Il se roule alors par terre, et, cette huile s'épaississant, son poil s'agglomère en mèches, qui prennent toutes les directions.

Il existe aussi au Cabinet d'anatomie comparée le squelette d'une Antilope envoyée du Sénégal, en 1828, par M. le général Jubelin, sous le nom de Mbill, qui est de la grandeur de la Gazelle, dont les cornes, épaisses à la base, sont d'abord dirigées en arrière, dans la direction du front, puis recourbées fortement en avant et en dedans, de manière à ne laisser qu'un intervalle de quatre centimètres entre leurs pointes. Elles ont huit anneaux à leurs deux tiers inférieurs, et sont fortement striées longitudinalement. La structure du crâne montre que celle espece est pourrue de larmicrs. $5^{\circ}$ Le sous-genre OUREBIA. - Cornes courtes, parallèles, droites ou légèrement courbées en avant, implantées à l'angle postérieur des orbites. Quatre mamelles.

Le SAUTEUR DES ROGHERS, Klipspringer des Hollandais, Ant. oreotragus, Forst. - Cornes du mâle minces, coniques, presque droites, écartées l'une de l'autre. Pelage formé de poils raides, cassants, de couleur gris-verdâtre. Queue très courte. Tour des yeux noirâtre. Cet animal vit par petites troupes de quatre à cinq individus; il habite les hautes montagnes voisines du Cap, et saute, comme notre Chamois, de rochers en rochers, avec une vigueur et une précision remarquables. Sa pose sur les rochers, suivant M. Jules Verreaux, est des plus curieuses : ses quatre pieds, rapprochés les uns des autres, ne portent que sur l'extrémité des sabots. Il court mal en plaine. Sa chair est très délicate, et sa peau estimée par les colons pour en faire des garnitures de selles. Sa hauteur à l'épaule est de $\mathbf{3 4}$ à $\mathbf{5} 3$ centimètres. La femelle est sans cornes.

ANTILOPE DE SALT, Ant. saltiana, Blainv. (Ehr., Symb. phys., t. I, pl. 7). Cornes triangulaires, couchées dans la direction du front, portant des anneaux saillants sur leur moitié inférieure. Les poils du front redressés, formant toupet. Tête rousse. Cou, flancs et cuisses, gris-bleuâtre, résultant de poils annelés de blancjaunâtre et de gris-ardoisé. Dos brunâtre. Ventre, fesses et intérieur des cuisses, blanc.roussâtre. Des larmiers. Queue courte.

Très petite esp. de l'Abyssinie, où on la nomme Madoka.

Le STEEY-BOGK, Ant. tragulus, Lichst. - Cornes du mâle de la longueur des deux tiers de la tête, écartées légèrement, courbées en avant, annelées à leur base. Animal léger, haut sur jambes. Corps roux, brun en dessus, blanc en dessous. De grandes oreilles grises, bordées de noir. Sourcils blancs. Du noir au museau, aux aisselles et aux aines. De petits larmiers. Point de brosses. Taille d'une petite Chèvre. Cette espèce fréquente les plaines garnies de buissons élevés, et vit presque toujours seule. Pendant la chaleur du jour, elle se cache derrière un buisson isolé sur une 
hauteur, afin de pouvoir observer de loin. Lorsqu'on la chasse, elle part à une grande distance. Elle aime beaueoup les jeunes pousses d'herbes, qu'elle va brouter le soir et le matin.

Le GRIS-BOGK , Ant.melanotis. - Cornes du mâle noires, rondes, courbées légèrement en avant. Pelage roux, entremêlé de longs poils blancs sur le dos et les cuisses. Ventre jaunâtre. Queue presque nulle. Oreilles presque de la longueur de la tête, grises, bordées de noir. De petits larmiers. Point de brosses. Taille d'une petite Chèvre. Est peut-être la plus répandue des Antilopes dans toutes les directions de la colonie du Cap. Vit isolée sur le penchant et dans les gorges des montagnes. Elle aime les lieux humides. Lorsqu'elle a adopté une place, elle y revient toujours, de sorte que, pour l'atteindre plus sûrement, il faut se poster à l'endroit d'où elle est partie. Sa chair est assez délicate; aussi les Panthères en font-elles leur principale nourriture.

L'OUREBI, Ant. scoparia (Shreb., pl. 261 ). - Cornes du mâle à 5 ou 6 anneaux ; espèce plus grande que les deux précédentes. La tête et le dessus du corps jaune l'ocre tirant sur le fauve. Ventre et intérieur des cuisses blancs. Oreilles grises, bordées de brun en dehors, blanches en dedans. Du blanc aux sourcils, au museau et sous la gorge. Queue très courte, brune; des larmiers, des brosses. Vit dans les plaines couvertes de quelques petits buissons. Quoique ne vivant pas en familles, on en voit assez souvent plusieurs à peu de distance les uns des autres.

L'ANTILOPE MONTANA que Rüppel a trouvée en Abyssinie est très voisine de la précédente, si elle en diffère. Une particularité que l'on rencontrera peut-être dans d'autres espèces de cette division est que le jeune mâle porte des canines à sa mâchoire supérieure, comme plusieurs Cerfs et les Muscs.

L'ANTILOPE LAINEUSE, Ant. lanata , Desm.; Ant. capreolus, Lichst. - Cornes du mâle rondes, minces, de la longueur de la tête, légèrement courbées en avant, annelées à leur moitié inférieure.Poil laineux, frisé, gris-roussâtre en dessus, blanc en dessous. Bout des lèvres blanc. Du noir après le blanc à la mâchoire inférieure et au bout du nez. Queue moyenne, velue, grise en dessus, blanche en dessous. Point de larmiers ni de brosses. De la grandeur du Daim. Du Cap.

60 Le sous-genre GRIMMIA, Cephalophus de Ham. Smith.-Petites cornes droites ou peu courbées, naissant loin des orbites au milieu du front.

La GRIMME, Ant. grimmia, Pall. (Spec. zool., fas. I, pl. כ) ; Fréd. Cuv. (Mamm.). Cornes très courtes, coniques, droites, à anneaux gris-fauve. Chanfrein et ligne dorsale noirâtres. Queue noire au bout. Membres gris. Un mufle assez grand; une tache noire, sans poils, entre les yeux et le mufle, sécrétant ủne humeur inodore. Petite espèce de la côte de Guinée, dont le train de devant a environ 450 centimètres de hauteur. Les poils du front au devant des cornes se relevant en toupet. Quatre mamelles.

Le GUEVEI, Ant. pigmaea, Pall. (Sch., pl. 260, B ). - Cornes petites, coniques, dirigées en arrière. Brun-clair cendré en dessus, blanchâtre en dessous ; une ligne pâle de chaque côté du front, qui est noirâtre. Queue blanche en dessous. Une ligne muqueuse sous-orbitaire. Poils du front en toupet. Cette espèce n'a que 26 à 27 centimètres de hauteur au train de devant. On la trouve dans les environs du Cap. Malgré sa petite taille, on assure qu'elle peut faire des sauts de 4 mètres de haut.

L'ANTILOPE DE FRÉDÉRIC, Ant. Frederici, Nob. (Fréd. Cuv., Mamm., sous le nom de Gucvei. - Animal de la grandeur du précédent, à cornes d'un tiers de la longueur de la tête, grosses en bas, coniques, recourbées en avant. Une ligne nuuqueuse sous-orbitaire. Couleur générale brun-fauve; à la partie supérieure de la tète et le long du museau, la teinte est brun foncé, et elle est séparée des côtés de la tête par une ligne blanche qui en suit les contours. La face interne des oreilles est blanche. Quatre mamelles. Du Sénégal.

Une jeune femelle de ce joli petit animal a été décrite et figurée par M. Fréd. Cuvier, dans son ouvrage sur les Mammifères, sous le nom de Gucvei, en observant qu'elle différait notablement du Guevei du Cap. Deux individus adultes, mâle et femelle, envoyés depuis au Muséum, ont montré qu'en effet c'était une espèce autre que le Guevei. 
Nous lui donnons le prénom de M. Frédéric Cuvier, afin que l'on sache bien que c'est à lui, et non à son frère, que cette espèce est dédiée.

L'AYTILOPE DES BUISSOHS, Ant. sylvicultrix, Afzel. (Ham. Schm., Reg. anim., t. IV, p. 258 , avec figurès ). - Cornes courtes, petites, couchées dans la direction du front, striées en travers près de la base. Deux mamelles. Un peu plus grande que le Chevreuil; de couleur brun foncé; plus pâle sur le cou et les flancs; grisàtre sur la croupe ef les cuisses; jaunâtre à la gorge. Une ligne isabclle le long de l'épine, s'élargissant sur les rcins, où les poils sont plus longs. Habite les penchants couverts de buissons des montagnes de Sierra-Leone. Sa chair est estimée.

L'ANTILOPE PLOYGEANTE, DuikerBock des Hollandais (Ant. mergens, Al.). - Cornes de moitié de la longueur de la tête, assez grosses, annelées à leur base dans le mâle seulement. Brun-fauve clair. Une ligne noire à la face antérieure des membres. Un petit mufle. Un sillon sousorbitaire sans poils, sécrétant une humeur visqueuse qui noircit en se durcissant. Cette espèce habite presque tous les cantons de la colonic du Cap, et fréquente les plaines couvertes de buissons. Il n'est pas rare de rencontrer des femelles avec des cornes; celles-ci sont plus minces que dans le mâle. Son nom lui vient de la manière dont elle se précipite dans les buissons quand on la poursuit. De la taille d'une petite Chèvre.

Nous mettons à la fin de ce sous-genre une espèce qui a deux paires de cornes placées au devant l'une de l'autre, les postéricures étant situées, presque comme dans les espèces précédentes, vers le milieu du front.

Le TGHIGARA, Ant. quadricornis, Blainv.; Ant. chicarra, Hardw. (Transact. de Linn., t. XIV, pl. 25 ), et Fréd. Cuvier (Mamm.). - Animal de la taille d'une petite Chèvre. Les cornes postérieures, plus longues que les antérieures, sont annelées à leur base, légèrement courbées en avant. Les antérieures, plus rapprochées l'une de l'autre, naissent entre les yeux, et n'ont pas au delà de 2 centimètres de hauteur. Les oreilles sont grandes, les larmicrs mé- | divergentes, dirigées tout à fait en arrière diocres, la queue courte. Le pelage, formé de poils assez épais et assez longs, est entièrement d'un fauve uniforme. Du Népaul.

70 Le sous-genre BUBALUS. - Cornes grandes, implantées loin des yeux, vers le milieu du front, comme chez les Buffles.

Le BUBALE, Ant. bubalis, Linn., vulgairement Vache de Barbarie (Buffon, Supp., t. VI, pl. 14; Schr., 277, B).-Cornes grosses, dont la racine est dans le prolongement du front, se touchant presque a la base, s'écartant plus haut latéralement, puis se rapprochant pour se courber ensuite de manière à porter la pointe en arrière. De la taille d'un petit bœuf. Tête longue et étroite, terminée par un demi-mufle. Pelage fauve, excepté le bout de la queue, qui est terminé par un flocon noir. Cet animal, bien connu des anciens, est représenté sur les monuments égyptiens. Il vit par troupes nombreuses dans tout le nord de l'Afrique, entre les terres cultivées et les déserts, et combat à la manière du Taureau, en baissant la tête. Shaw assure que, fréquemment, les jeunes Bubales se mêlent aux troupeaux domestiques, et ne les abandonnent plus; ce qui prouve que cette espèce d'Antilope, comme plusieurs autres, pourrait être rendue domestique.

Le CAAMA, Ant. caama, Cuv., vulgairement Cerf du Cap (Buffon, Supp., t. VI, pl. 13 ; Schr., 277). - Semblable à l'espèce précédente; mais à courbures des cornes plus anguleuses. Pelage fauve-brun, plus foncé sur le dos; le tour de la base des cornes, une bande sur le chanfrein, sur le col et sur la face antérieure des jambes, noirs ou bruns. Bout de la queue noir. Fesse blanchâtre; le ventre et la face interne des quatre membres blancs. Vit en grandes troupes au Gap, et court avec une si grande rapidité, qu'un Cheval ne peut l'atteindre. chair est très bonne à manger.

L'ANTILOPE A CORNES APLATIES, Ant. depressicornis, Quoy et Gaimard ( $A n$. des sc., no XVII, pl. 20 ; Astrol. zool., t. I, pl. 26) ; Anoa depressicornis, Ham. Smith (loc. cit., pl. 24). - Animal de la grandeur d'une Chèvre, à port lourd, à cornes droites, un peu plus longues que la tête, peu Son cri est une sorte d'ćternument. Sa 
dans la direction du front, aplaties intérieurement à leurs deux tiers inférieurs, de manière à former un bord interne, comme chez les Buffles ; la partie aplatie annelée irrégulièrement; le reste de la corne rond et lisse. Dessus du corps brun-cannelle; le dessous plus clair. De l'île Célèbes, où elle est appelée Vache des bois.

Le GNOU, Ant. gnu, Gm. (Buff., Supp., t. VI , pl. 8 et 9 ) ; Schr., 280 ; Fréd. Cuv. (Mamm.). - A cornes élargies et rapprochées à leur base comme celles du Buflle du Cap, descendant d'abord obliquement en devant et se redressant ensuite brusquement; à mufle large, aplati, entouré d'un cercle de poils. Sur le chanfrein, une touffe de poils longs, raides, dirigés vers le front. Une crinière redressée sur le cou, blanche à sa base, et non au bout. Une barbe, un fanon, avec crinière; le reste du corps semblable à celui d'un petit cheval à jambes fines. La queue garnie de longs poils blancs. Pelage brun. Les deux seres ont des cornes. Les Gnous vivent dans les montagnes, au nord du Cap, en troupes nombreuses. Ils sont sauvages, et se laissent difficilement approcher. Lorsqu'ils sont blessés, ils se retournent contre le chasseur, et le poursuivent tant qu'il leur reste assez de force pour se soutenir. Au commencement de leur frayeur, ils frappent du pied comme un Cheval rétif, et vont heurter lcur tête contre les taupinieres ou antres petites saillies du terrain; mais, bientôt après, ils prennent la fuite avec une si grande vitesse, qu'en un instant ils sont hors de danger. Ils ne courent pas confusément comme les Moutons ou les Bœufs, mais sur une seule file, en suivant un conducteur. C'est un beau spectacle que d'en voir ainsi un grand nombre voler, pour ainsi dire, à la suite l'un de l'autre à travers les plaines. On dit qu'à certaines saisons de l'année, ils sont sujets à une éruption cutanće, qui est toujours mortelle.

Le Gnou paraît avoir été connu des anciens, qui le nommaient Catoblepas, animal, dit Pline, qui tient toujours sa tête penchée vers la terre, afin de ne point détruire la race humaine, car tous ceux qui voient ses yeux expirent aussitôt. Le fait de la tête penchée vers la terre est vrai jusqu'à un certain point : car le Gnou,

$$
\text { T. } 1 \text {. }
$$

comme tous les ruminants dont les cornes sont dirigées en arrière, met, pour combattre, la tête cutre les jambes, afin de présenter à l'ennemi la pointe de ses cornes.

Le GORGON, Ant. gorgon, Ham. Smitl. - Cornes semblables, par la courbure, à celles du Gnou, mais dirigées latéralement, en sorte que les pointes se rapprochent l'une de l'autre, presque comme dans le Buffle du Cap. Un large mufle. De longs poils sur le nez, non redressés. Une barbe noire, qui s'étend jusqu'au milieu du cou. Une crinière de la même couleur jusqu'au milieu du dos. Queue longue, descendant jusqu'aux onglons; garnie, à sa moitié inférieure, de longs poils qui l'entourent complètement, et, à sa moitié supérieure, de chaque côté seulement. De couleur grisbrun, avec des taches transversales noires, dans le genre de celles du Zèbre, mais moins régulières. Un peu plus grand que le Gnou.

Le KOKOON, Ant. taurina, Burchell, est une esp. fort voisine de la précédente, et peut être l'une n'est - elle qu'une variété de l'autre.

De la grandeur du Gnou, et du même pays.

Après ce sous-genre, qui se rapproche des Bœufs, nous terminons par un autre, qui a , par ses cornes bifurquées, beancoup d'analogie avec les Cerfs, et auquel nous appliquons le nom que notrc première espèce porte dans la langue sanscrite, selon M. Hamilton Smith. Outre ses cornes, qui font évidemment passage aux cornes bifurquées, cette même espèce a tellement le port d'un Cerf, que le mâle vivant aujourd'hui à la Ménagerie est pris par tout le monde pour un grand Cerf dont les cornes commencent à pousser. C'est :

$8^{\circ}$ Le sous-genre RISIA. - Cornes plus ou moins bifurquées, implantées à l'angle postérieur des orbites.

Le NYLGAU, Ant. picta et Trago-camelus, Gm. (Buffon, Supp., t. VI, pl. 10 et 11 ; Schr. 262 ). - Cornes du mâle très courtes, un peu recourbées en avant, ayant un prolongement triangulaire et tuberculeux à leur base, que l'on peut considérer comme un rudiment d'andouiller. De la taille du Cerf. Des larmiers. Quatre mamelles. Un flocon de poils sous le milieu du 
cou. Une crinière sur le cou et le milieu du dos. Le pelage gris-cendré dans le mâle; gris-fauve dans la femelle. De doubles anneaux noirs et blancs aux pieds, au dessus des sabots. Bords de la lèvre supérieure, mâchoire inférieure, gorge, bas - ventre, fesses et dessous de la queue, blancs. Queue longue, terminée par de grands poils. Le Nylgau habite le bassin de l'Indus et les montagnes du Cachemire, et se tient dans les forêts les plus épaisses, d'où il fait des excursions le matin, et même pendant la nuit, sur les champs du voisinage. G'est un animal d'un caractère indomptable et d'un grand courage. Lorsqu'il veut attaquer son ennemi, il se jette sur ses genoux, et s'avance, dans cette position, jusqu'à une certaine distance; puis, se redressant, il s'élance en avant avec la rapidité d'une flèche, et avec une force irrésistible pour l'homme et pour les animaux qui cherchent à en faire leur proie.

L'ANTILOPE A FOURCHE, Ant. furcifer et bifurcata, Ham. Smith (t. IV, pl. 1 des Ant.). - Cornes de la longueur de la tête, rugueuses, recourbées en arrière comme celles $\mathrm{du}$ Chamois, mais portant, au commepcement de cette courbure, un andouiller comprimé, projeté en avant. Animal de l'aspect du Chamois, quoiqu'un peu plus grand et plus élégant. Oreilles moyennes. Pelage brun-rouge en dessus, plus pâle sur les flancs, les lèvres, le menton. Deux taches sous la gorge; une sur le somm te la tête et une au bas de chaque oreille. La poitrine et le ventre blanc-jaunâtre; la croupe et la queue d'un blanc pur. Une touffe de poils rougeâtres au chignon. Cette esp. habite les plaines des bords du Missouri, aux États-Unis.

L'ANTILOPE PALMÉE, Ant. palmata, Ham. Smith ( t. IV). - Cornes de la longueur de la tête, à pointes recourbées en arrière, et portant tout auprès de la base un andouiller plat, triangulaire, dirigé en dedans. Cette espèce, que l'on ne connaît que par les cornes, habite le Mexique.

On a voulu considérer, mais à tort, ces animaux comme les Mazames d'Hernandez.

(LAURILEARD.)

ANTILOPE. MAMm. Foss. - Les brèches osseuses ont offert à Guvier, les Aluns de la Touraine à M. Desnoyers, et les cavernes du département de l'Aude d M. Marcel de Serres, des ossements de Ruminants qui peuvent avoir appartenu d quelques esp. d'Antilopes. M. l'abbé Groizet, dans les terrains tertiaires de l'Auvergne, et M. Lartet, dans ceux du département du Gers, en ont signalé chacun deux espèces. Tout nouvellement, M. Lund annonce en avoir trouvé une dans les cavernes du Brésil. Mais, jusqu'ici, tous ces ossements n'ont point été décrits avec assez de détails pour qu'il soit possible de les rapporter d'une manière certaine au g. Antilope, et moins encore pour que l'on puisse les rapprocher ou les éloigner des espèces vivantes. On peut en dire autant du Sivatherium giganteum (Voy. ce mot), découvert dans la chaîne basse de l'Himalaya par M. Hugh Falconer et le capitaine Cautley, animal d'une taille voisine de celle de l'Éléphant, qui portait quatre cornes comme l'Antilope quadricornis, et que M. de Blainville regarde comme une Antilope, tandis que M. Geoffroy Saint-Hilaire le considère comme une esp. de Girafe.

Nous terminons ici ce que nous avions à dire sur les Antilopes vivantes et fossiles, non pas que nous ayions enregistré toutes les espèces des premières mentionnées dans les auteurs. Il nous aurait fallu pour cela un temps plus long que celui qui nous a été accordé; d'ailleurs, la plupart de celles que nous avons négligées ne nous paraissent point encore assez caractérisées.

(LA URILLARD.)

* ANTIMAQUE.Antimachus(nom d'un poëte grec). 1xs. - Genre de Coléoptères hétéromères, de la famille des Mélasomes, tribu des Ténébrionites, établi par M. Gistl (Isis, 1829, cah. 10, p. 105ั5े). Ce g., suivant l'auteur, est voisin des Upis, et a pour caract. : Tête oblongue, arrondie; front surmonté d'une corne droite, un peu recourbée vers le bout. Antennes presque filiformes à art. coniques : le 1er le plus long, le dernier ovale. Corselet transverse, sinué et échancré antérieurement, avec deux épines de chaque côté. Élytres allongées, courbées à l'extrémité.-L'auteur n'y rapporte qu'une seule espèce, recueillie au Brésil, et qu'il nomme $\boldsymbol{A}$. furcifer. Elle est figurée dans le journal précité.

(D.)

ANTIMOINE (contraire aux moines. 
parce que les premiers essais de l'Antimoine, comme médicament, eurent lieu sur des moines, qu'ils firent périr). mis. - Ce métal s'offie dans la nature sous divers états : 10 à l'état libre (Antimoine natif); $2^{\circ}$ à l'état de mélange avec l'arsenic, un de ses isomorphes (Antimoine arsénifère); $3^{\circ}$ à l'état d'Antimoine métallique (Antimoniures d'argent, de Nickel); ‘º̀̀ l'état de sulfure simple ou multiple (Stibine, Federerz, Zinkénite, Plagionite, Jamesonite, lierthiérite, Bournonite, Fahlerz, Argyrythrose, Psathurose, Miargyrite, Polybasite, Schilfglaserz, etc.); 5้o à l'état d'oxyde (acide antimonieux, oxyde antimonique); $6^{\circ}$ à l'état d'oxysulfure (Kermès). Nous renvoyons au mot SULFURE la description des nombreuses combinaisons sulfurées dont nous venons de faire l'énumération, nous contentant de parler ici des trois genres Antimoine, Antimoniure et Antimonoxide, auxquels on restreint d'ordinaire le groupe des Antimonides, dans les méthodes minéralogiques les plus récentes.

Premier genre. Antimoine. - Il comprend deux espèces : l'Antimoine natif et l'Antimoine arsénical.

L'Antimoine natif est facile à reconnaître à son blanc d'étain, à sa grande fragilité et sa faible dureté, à son tỉssu éminemment lamelleux, aux vapeurs blanches qu'il répand lorsqu'on le brûle, et au dépôt blanchâtre qu'il produit lorsqu'on le dissout dans l'acide nitrique. Sa forme cristalline, telle que le donne le clivage, n'est pas l'octaèdre régulier, comme on le croit communément, mais bien un rhomboèdre obtus, tronqué sur ses sommets, et passant par là à une forme octaédrique, dont les angles diffèrent de ceux de l'octaèdre régulier. Il a cela de commun avec l'arsenic, dont il est un des isomorphes. L'angle de deux faces culminantes du rhomboèdre de clivage est de $117^{\circ}, 15^{\prime}$. Cette espèce est rare dans la nature : on ne l'a encore rencontrée qu'en petites masses lamellaires dans les filons, notamment à Allemont, en Dauphiné.

L'Antimoine arsenical n'est qu'un Antimoine arsénifère, c'est-à-dire mêlé d'arsenic dans des proportions variables. On le trouve aussi à Allemont, sous la forme de croûtes ou de petites masses testacées, accompagnées souwent d'arsenic natif.
Deuxième genre. Antimoniure. - Il comprend trois espèces : la Discrase, I'Antimonnickel de Hausmann et l'Antimonnickel de Beudant.

La Discrase est un Antimoniure d'argent : on le nomme aussi Argent antimonial. C'est un minéral cassant, d'un blanc d'argent, qui se trouve assez rarement dans quelques filons argentifères, et qui, par la quantité d'argent qu'il renferme, peut être considéré comme minerai de ce métal. Nous renverrons pour cette raison ce que nous avons à en dire au mot ARGENT.

L'Antimonnickel de Hausmann et de Stromeyer est un Ántimoniure de Nickel, sans arsenic, mêlé de quelques centièmes de sulfure de plomb. Il paraît appartenir au système di-hexaédrique, et cristallise en petites tables hexagonales, d'un rouge de cuivre clair, avec une nuance de violet. Il est composé, d'après l'analyse de Stromeyer, de 68,79 d'Antimoine, et de $\mathbf{5 1 , 2 1}$ de Nickel, ce que l'on peut exprimer par la formule : SbNi. On le trouve à Andreasberg, dans le Hartz, où il est accompagné de calcaire, de galène et de cobalt arsenical.

L'Antimonnickel de Beudant (Nickel antimonglanz) est un sulfo-antimoniure de Nickel, à éclat métallique, d'un gris de plomb ou d'acier passant au noir de fer, et cristallisant dans le système hexa-diédrique, c'està-dire dans le système dont les formes dérivent d'un dodécaèdre pentagonal. Dureté 5 ; pes. spéc. 6,5. Il fond au chalumeau, en dégageant des vapeurs abondantes d'Antimoine; il est attaquable par l'acide nitrique, en donnant un précipité immédiat. Sa solution verdâtre devient violette par un excès d'ammoniaque, et précipite en vert par les alcalis fixes. - Formule de comp. : NiSbSo, ou en poids : Antimoine, 55,76; Soufre, 15๊,98; Nickel , 27,36. - Cette substance est isomorphe avec la disomose (Nickelglanz), qui est un sulfo-arseniure de Nickel. Les deux espèces sont susceptibles de se mélanger, et le Nickelspiessglanzerz d'Ullmann ne paraît être qu'une variété mixte de ce genre. On trouve l'Antimonnickel en petites masses à structure lamellaire, rarement en cristaux, dans quelques filons cobaltifères du pays de Siegen, et à Ebersdorf, dans la principauté de Reuss.

Troisième genre. Antimonoxyde. - Ce 
genre renferme deux especes : l'Exitèle ou Oryde antimonique, et la Stibiconise ou l'Acide antimonieux. Ces substances, non métalloïdes, sont attaquables par l'acide chlorhydrique; la solution précipite en blanc par l'eau, en jaune par les hydrosulfates.

$I_{\perp}$ 'Exitèle, ainsi nommée parce qu'elle est complètement volatile, est un oxyde formé de 2 atomes d'antim. et de $\mathbf{5}$ atomes d'oxygène; on ne l'a encore trouvée qu'en petites lames rectangulaires et groupées, ou en aiguilles rhomboïdales divergentes. C'est une substance blanche, nacrée, cristallisant dans le système rhombique, et isomorphe avec l'arsenic blanc ou acide arsénieux. L'angle obtus du prisme de l'Exitèle (Weissantimonerz des All.) est de $136^{\circ}, 58^{\prime}$. Cette substance est excessivement tendre, et fond à la simple flamme d'une bougie. Elle contient 84 parties sur 100 d'Antimoine. On la trouve en petite quantité dans quelques dépôts d'argent arsénifère (aux Chalanches en Dauphiné, à Braunsdorf en Saxe, etc.)

La Stibiconise est une substance terreuse, d'un blaıc ou gris jaunâtre, très tendre, et qu'on trouve en petites couches à la surface de la Stibine ou Sulfure d'antimoine, dont elle est une épigénie. Il arrive souvent qu'elle conserve la forme des cristaux de ce Sulfure.

(D)L.

* ANTIMONIURE. Mis. - Petit genre minéralogique, composé des esp. dans lesquelles l'Antimoine fait fonction d'élément électro-négatif. Voy. AnTrmorne. (DEL.)

ANTIMONNICKEL. MIN. - Voyez ANTIMOINE.

(DEL.)

ANTIMONOXYDE. MN. - Voyez ANTIMOINE.

(Di:L.)

AN'TI - NOMPAREILLE. MOLL. Nom donné par Geoffroy, dans son Traité des Coquilles des environs de Paris, à une coquille qui appartient au g. Maillot de Draparnaud, et qui est son Pupa cirenea. Voy. MAILLOT.

(DESH.)

* ANTINORON, Rafin. Bot. PH. Synon. du g. Atraphaxis, L., famille des Polygonées.

(SP.)

* ANTIOCHALINS. Anthiochalina

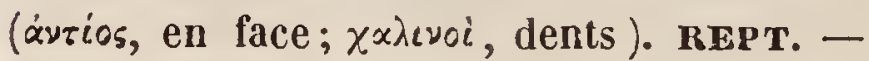
Muller a donné ce nom à une famille de Reptiles ophidiens comprenant ceux qui ont les dents antérieures venimeuses.

(C. D'O.)
ANTIPATE. POLYP. - Voyez ANT!PATHE. (M. E.)

ANTIPATHE ( $\alpha^{2} \tau t \pi x \theta i s$, contraire). PoL XP. - Genre très voisin des Gorgones, mais dont l'axe solide ou tige se dépouille. par la dessiccation, de la partie corticale formée par le tissu tégumentaire commun et par le corps des Polypes. D'après les observations de M. Gray, il paraîtrait que ces animaux auraient la même conformation que les Polypes des g. Gorgone, Corail, Alcyon, etc., si ce n'est que leurs tentacules ne seraient qu'au nombre de six. M. Ehrenberg place ce g. dans sa division des Bryozoaires, mais à tort, car il doit évidemment prendre place dans l'ordre des Polypes parenchymateux, à côté des Gorgones.

M. E.)

AN'TIPE. Antipus ( $\dot{\alpha} \nu \tau \iota$, en avant;

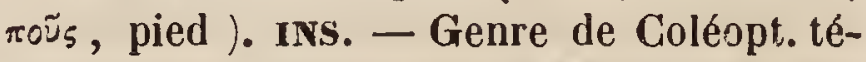
tramères, établi par de Géer (Mem., t. VII, p. 659-661) sur un insecte rapporté du cap de Bonne-Espérance, et figuré par lui, pl. 49, fig. 10 et 11. Cette espèce, qu'il nomme Antipe roux, doit, suivant Olivier, former un genre distinct, voisin de celui des Gribouris (Cryptocephalus). M. Duméril la rapporte au g. Clytre, probablement d'après la description qu'en donne l'auteur : car la figure, d'ailleurs très grossière, n'a nullement le faciès d'un Clytre. Voici, au reste, les caract. génériques indiqués par de Géer : Antennes de 11 articles : le premier cylindrique; les deux suivants grenus; les autres triangulaires et en dents de scie. Tête forte, aplatic, avec des mâchoires (mandibules) grandes et avancées. Corselet large et peu convexe, avec un petit rebord. Corps allongé, presque cylindrique. Pattes antérieures plus longues que les autres. 4 articles à pelotes à tous les tarses. Fabricius et Latreille ne paraissent pas avoir connu cet insecte.

* AN'TIPHYLLA, Haw. (Saxifr., p. 45)

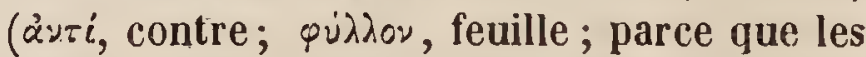
feuilles sont opposées ). Bor. PH. - Synon. du genre ou sous-genre Porphyrion, Tausch: ( de la famille des Saxifragées ).

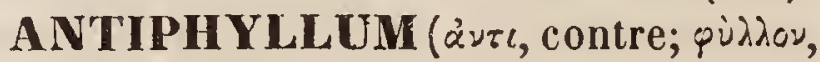
feuille). вот. PH. -Quelques auteurs écrivent Antiphylla. Genre de la famille des Saxifragacées formé par Haworth (Saxifr.), 
non adopté, et réuni au g. Saxifraga.

(C. L.)

ANTIRHOEA, Commers. ( $e x$ Juss. Gen., p. 204). - Genre de la famille des Rubiacées (tribu des Guettardées, Kunth), auquel M. Endlicher (Gen. Plant., p. 541) attribue les caract. suivants : Tube calicinal ovoïde ou oblong, adhérent ; limbe supère, court, persistant, campanulé, 4-denté. Corolle subinfundibuliforme; tube cylindracé; gorge nue; limbe 4-fide, à lobes pointus, plus courts que le tube. Etamines incluses, insérées à la gorge de la corolle; anthères cordiformes-oblongues, subsessiles. Ovaire infère, 2-loculaire; loges 1-ovulées; ovules appendants, anatropes, attachés au sommet des loges. Style indivisé, terminé par un stigmate 2-fide. Drupe ovoïde ou oblong, charnu, couronné, à noyau 2loculaire. Graines oblongues-cylindracées, solitaires dans chaque loge. - Arbrisseaux. Feuilles opposées ou verticillées-ternées, pétiolées, souvent glandulifères aux aisselles des veines; stipules interpétiolaires, pointues, caduques. Pédoncules axillaires, bifurqués, plus courts que les feuilles; fleurs petites, blanchâtres, quelquefois dioïques par avortement, disposées en épis unilatéraux. Ce genre, que M. A. Richard réunit au Malanea, Aubl., appartient aux îles de France et de Bourbon. On en connaît 3 esp., dont la plus notable est l'A. verticillata, DC. (Malanea verticillata, Lamk.), connue à Bourbon sous le nom de Bois de Losteau.

(SP.)

* ANTIRRHINASTRUM (allusion à anturrhinum). Bot. PH. - M. Ghavannes, dans sa Monographie des Antirrhinées, donne ce nom à l'une des 2 sections qu'il établit dans son g. Antirrhinum; cette section correspond exactement au g. Antirrhinum de Tournefort, et ses caract. distinctifs, relativement à l'Asarina (que M. Chavannes réunit aussi aux Antirrhinum) sont fondés sur la structure de la capsule; toutefois, ces caract. nous semblent assez tranchés pour motiver la distinction générique de ce dernier genre. Voy. ANTIRRHINUM et ASARINE.

(SP.)

* ANTIRRHINÉES. Bot. PH. - La famille établie par Jussieu sous le nom de Scrophulaires, changé plus tard en celui de Scrophularinées, a aussi reçu de quelques auteurs, dans son ensemble, le nom d'Antirrhinées; mais, pour d'autres, ce nom sert à désigner seulement une tribu de cette famille ayant pour type le g. Antirrhinum ou Muflier; c'est dans ces limites que l'a particulièrement adopté M. Chavannes, à qui l'on en doit une bonne monographie. YOy. SCROPHULARINÉES. (AD. J.)

ANTIRRHINUM, Tournef. - Orontium, Pers. - Antirrhinastrum, Chavannes (sub Antirrhino) (ávtiṕócvov, nom grec du Muflier). вот. PH. - Genre de la famille des Scrophularinées, tribu des Antirrhinées Bartl., offrant les caract. suivants : Calice oblique, 5-parti; segments inégaux : le supérieur plus grand, presque dressé ; les autres subhorizontanx. Corolle personée ; tube large, évasé, un peu comprimé, caréné au dos, convexe en dessous et muni à la base d'une bosse plus ou moins saillante (placée entre les deux sépales inférieurs); lèvres conniventes : la supérieure plus longue, redressée, voûtée vers la base, à deux lobes réfléchis, arrondis; l'inférieure horizontale, inégalement trilobée (à lobe moyen redressé, concave, beaucoup plus petit que les lobes latéraux), fortement bouffie vers sa base (de manière à former une bosse très saillante en dessus, appliquée contre la voûte de la lèvre supérieure et fermant Ia gorge); 2-dentée au sommet, creusée en dessus d'un profond sillon longitudinal, lequel est bordé de 2 barbes qui se prolongent sur la partie correspondante de la surface interne du tube. Etamines 4 (parfois accompagnées du rudiment d'une $5^{e}$ ), didynames, insérées à la base du tube de la corolle, plus longues que celui-ci, mais recouvertes par la bosse de la lèvre inférieure; filets charnus, comprimés, linéaires, ascendants, élargis et fortement géniculés à la base; anthères cordiformes-orbiculaires , échancrées, supra-médifixes, 2-thèques, obliquement horizontales, conniventes 2 à 2 ; bourses inégalement 2 -valves, disjointes jusqu'au delà du milieu, divariquées après la floraison. Ovaire 2-loculaire, ovoïde; placentaires gros, multi-ovulés, adnés à la cloison. Style filiforme, érigé, élargi à la base, infléchi au sommet; stigmate petit arrondi, inégalement 2-lobé. Capsule crus . tacée, fragile, très inéquilatérale, obovoï de, 2-loculaire, déhiscente nu sommet par 
5 trous 3-angulaires ; loges polyspermes, inégales : la postérieure beaucoup plus petite, s'ouvrant par un seul trou qui est à quatre valvules; l'aritérieure s'ouvrant par deux trous collatéraux, dont chacun est bivalvulé; valvules dentiformes-triangulaires, caduques. Graines petites, irrégulièrement anguleuses, profondément fovéolées et rugueuses. - Herbes ou sous-arbrisseaux. Feuilles très entières : les inférieures opposées ou verticillées-ternées; les supérieures éparses. Fleurs solitaires aux aisselles des feuilles, ou disposées en grappes bractéolées terminales. - Dans ses limites actuelles, ce genre ne renferme que 6 espèces bien reconnues; la plupart des Antirrhinum de Linné et de beaucoup d'autres auteurs appartiennent au genre Linaire (Linaria, Tourn.); suivant notre manière de voir, l'Asarina, Tourn., que l'on réunit en général aux Antirrhinum, mérite également d'être séparé de ce genre (Voy. ASAMIE).

La plupart des Antirrhinum se font remarquer par l'élégance de leurs fleurs; de ce nombre est surtout l'A. majus L. plante de parterre connue de tout le monde sous le nom de Muflier, Mufle de veau, ou Gueule de loup. Cette espèce est indigène de l'Europe méridionale. L'A. angustifolium, Poir., se cultive comme arbuste d'orangerie. L'A. Orontium L., ou Muflier des champs, passe, à tort ou à raison, pour être vénéneux.

(SP.)

- ANTITHESIA ( $\dot{\alpha} \nu \tau i \theta \varepsilon \tau_{\varsigma}$, contraste). INS. - Genre de l'ordre des Lépidoptères, famille des Nocturnes, établi par Stéphens dans sa tribu des Tortricides, et qui correspond en partie au genre Penthina de Treistchke, que nous avons adopté, et qui fait partie de notre tribu des Platyomides. Voy. ces deux mots.

ANTTTRAGUS ( $\dot{\alpha} \nu \tau i$, comme; $\tau$ p $\dot{\alpha} y 0^{\circ} s$, sorte de Graminées chez les Grecs). вот. PII. - Genre de la famille des Graminées, formé par Gaertner, et synonyme du genre Crypsis, dont il constitue une division, avec ces caract. : Fleur très courtement pédicellée dans la glume. Paléole supérieure uninerve. Etam. 2.

(C. L.)

ANTITRICHIA ( $\dot{\alpha} \nu \tau i$, vis-à-vis; $\theta \rho i \xi$, xós, poil, cil). Bot. IP. - Genre de la famille des Mousses, créé par Bridel, et qui a pour synonyme inomodos. Voy. ce mot. (C. M.)

* ANTITRIXIA ( $\alpha$ ve, contre; Atrixia, près de l'Atrixia). вот. PH. - M. de Candolle a donné ce nom à un genre de Composées très voisin de l'Atrixia par la forme de son aigrette, mais dont il diffère par ses feuilles opposées. Ses capitules sont multiflores, radiés; les ligules femelles. Involucre composé d'écảilles linéaires-oblongues, scarieuses et obtuses au sommet. Réceptacle dépourvu de paillettes. Corolles du disque tubuleuses, 5-dentées. Anthères munies d'appendices basilaires ; rameaux des styles tronqués. Fruits cylindracés, rétrécis au sommet, glabres, portés sur un stipe court, calleux et pubescent; aigrette formée d'une seule rangée de soies raides, scabres, très nombreuses, et légèrement soudées entre elles à la base. - La seule espèce du genre est un sous-arbrisseau originaire du Cap, muni de feuilles opposées, tomenteuses à la face supérieure, et de capitules solitaires à rayons jaunes.

* ANTLIARHINIDES. Antliarhinides (Antliarhis [Voy. ce mot] ; عĩosos, forme). INs. - Nom donné par Schoenherr à une division ou tribu de sa famille des Curculionides, ordre des Gonatocères, et qu'il caractérise ainsi : Rostre avancé. Antennes presque droites, de 12 articles; scapus assez long, claviforme; massue étroite, composée de 4 articles. Écusson distinct. Corps aplati, ailé. - Cette division ne se compose que de 2 g. : Antliarhinus et Platymerus. Voy. ces deux mots.

*ANTLIARHINUS $\left(\alpha^{2} \nu \tau \lambda i x\right.$, sentine [canal] ; pós, nez). Irs. - Genre de Coléoptères tétramères, famille des Curculionides, division des Antliarhinides, établi par Schoenherr aux dépens du g. Rhynchanus de Fabricius, et auquel il assigne les caract. suivants : Antennes médiocres, un peu grêles, presque droites. Scapus assez long, claviforme; funicule de sept articles, tous presque subconiques; massue allongée, acuminée, composée de quatre articles. Rostre avancé, court, droit, large à la base, s'atténuant peu à peu vers le sommet chez le mâle; très long et presque capillaire dans la femelle. Yeux latéraux, ronds, très proéminents. Corselet presque orbiculaire, arrondi en s'élargissant sur les côtés, aplati en des- 
sous, avee un bord élevé a la base. Élytres oblongues, presque linéaires, avec les épaules rectangulaires; elles sont aplaties en dessus, et chacune d'elles est arrondie à son extrémité. Pattes médiocres, robustes, très rapprochés à leur origine; cuisses comprimées, très dilatées en dessous, et dont le milieu forme un angle. - M. Dejean, qui a adopté ce g. dans son dernier Catalogue, n'y rapporte qu'une seule esp., l'A. Zamia de Thunberg, originaire du cap de BonneEspérance; mais Schoenherr en décrit deux autres de la Cafrerie, d'après Schuppel, qui nomme l'une $\boldsymbol{A}$. rectirostris, et l'autre A. signatus.

(D.)

*ANTLIARHIS ( $\dot{\alpha} \nu \tau \lambda i \alpha$, canal; $\mathfrak{p} i s$, nez). INs. - Genre de l'ordre des Coléoptères tétramères, famille des Curculionides, établi par Billberg, le même que le genre Antliarhinus de Schoenherr. Voy. ce mot.

(D.)

ANTLIATES. Antliata ( $\alpha \dot{\nu} \tau \dot{\lambda} i \alpha$, canal ). rvs. - Onzième ordre de l'Entomologie systématique de Fabricius, qui répond en grande partie à celui des Diptères des autres auteurs, et qui comprend, de plus, celui des Parasites et la tribu des Acarides de Latreille. Foy. ces mots. (D.)

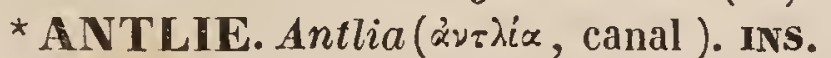
- Kirby donne ce nom à la spiritrompe des Lépidoptères.

* ANTLIO-BRANCHIOPHORES.

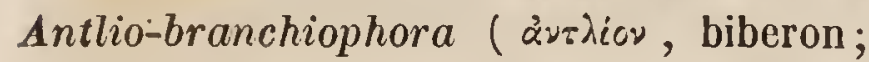
Epáyrex, branchie; popós, porteur). MoLL.En proposant un nom aussi long que celuici pour remplacer celui de Céphalopode, universellement admis, M. Gray devait s'attendre à ce qu'il ne serait point accepté; et c'est, en effet, ce qui est arrivé. C'est dans sa classification générale des Mollusques, publiée en 1821, que se trouve cette classe des Mollusques antlio-branchiophores, divisés en 5 ordres : les Anasteophora, les Sepiaiphora et les Nautilophora. (Voy. ces mots, ainsi qUe CÉPHALOPODE.)

(DESH.)

ANTODON ( $\alpha$ priv. ; ójous ovros, dent ; sans dents ). вот. Рн. - Syn. de Leontodon. Voy. ce mot.

(J. D.)

ANTOIRIA. Bot. CR. - Genre de la tribu des Jongermanniées, de la famille des Hépatiques, établi par Raddi (Jungermannia gr. Etr.), et qui avait pour type le Jungormannia platyphylla L. Le nom de
Raddi n'a pu être conservé, paree que sur le même type il avait formé deux genres. $M$. Nees lui a substitué celui de Madatheca, que nous avons adopté.

(C. M.)

* ANTOMARCHIA. Bor. PH. - Ce genre, dédié au docteur Antomarchi par M. Colla, est synonyme de Correı. Voy. ce mot.

(Av, J.)

*ANTONIA, R. Br. Mus. (nom d'bomme). вот. Рн. - Synon. du g. Loxotis, R. Br., de la famille des Gesnériées. (SP.)

* ANTONia (nom d'homme), Pohl, Plant. Bras., II, p. 14, tab. 109; Hook, Ic., tab. 64. вот. PH. - Genre de la famille des Loganiacées, auquel son auteur attribue pour caract. : Calice 5̈-sépale, recouvert d'un grand nombre de squammules plurisériées, imbriquées, conformes. Corolle infundibuliforme; gorge poilue; limbe 5-fide, à lobes révolutés, valvaires en préfloraison. Étamines 5ै, saillantes, insérées à la gorge de la corolle. Ovaire 2-loculaire; loges 1ovulées ; ovules peltés, amphitropes, insérés chacun au milieu d'un placentaire basilaire, stipité, pelté, orbiculaire, libre. Style filiforme, saillant; stigmate très courtement 2-lobé. Capsule coriace, oblongue, 2-loculaire, septicide-2-partible. Graines solitaires dans chaque loge, peltées, oblongues, aplaties, ailées aux deux bouts; ailes membraneuses. Embryon rectiligne, axile dans un périsperme charnu; cotylédons suborbiculaires, foliacés ; radicule cylindrique, infère. - Arbrisseaux à feuilles opposées, très entières, subsessiles; pétioles dilatés à la base, cohérents moyennant une courte membrane stipulaire; fleurs blanchâtres, disposées en cymes trichotomes, terminales. Ce genre appartient à l'Amérique méridionale; on n'en connaît que 2 esp.

ANTONIANA (nom propre). вот. PH. (famille des Rubiacées). - Tussac, dans sa Flore des Antilles, a établi ce genre aux dépens du g. Coffáa. Suivant ce botaniste, il s'en distingue par le nombre quaternaire de ses parties fiorales, et par ses étamines, qui ne dépassent pas la corolle.

(C. D'O.)

* ANTONIÉES. вот. PH. - Tribu ou section de la famille des Loganiaciées, proposée par M. Endlicher (Gen. Pl., p. 575), qui lui assigne pour caract. distinctifs : Cap- 
sule 2-loculaire, 2-partie, 2-sperme . Graines peltées, ailées.

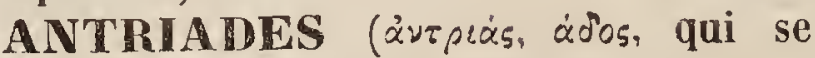
plaît dans les cavernes ). ois. - C'est, dans la méthode de Vieillot, la $26^{\text {e famille de son }}$ ordre des Oiseaux sylvains, ne renfermant que le g. Rupicole ou Coq de Roche. Voy. RUPICOLE et PIPRADEES. (LAFR.)

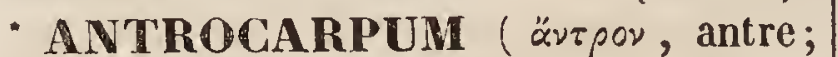

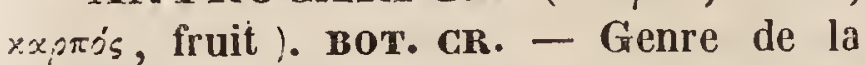
famille des Lichens et de la tribu des Endocarpées, établi par M. Meger (Entwikl. der Flecht.), et adopté par Sprengel (Syst. veget., t. IV, p. 240). Ce genre, formé sur le Thelotrema lepadinum, Ach., n'a pas remplacé définitivement celui de Thelotrema, auquel nous renvoyons le lecteur.

(G.: M.)

*ANTROCEPHALUS (àvזpov, antre; xęoxì, tête). BoT. GR. - Genre de la famille des Hépatiques, tribu des Marchantiées, récemment créé par M. Lehmann ( Act. Nat. Curios., t. XVIII, p. 2), et qui est très voisin du g. Plagiochasma. Les caract. essentiels en sont : Capitule fructifère privé de rachis. Involucre simple, sphérique, s'ouvrant horizontalement ou transversalement en deux valves, ef contenant un seul fruit. Sporange ou capsule sessile, tournée en dehors, et s'ouvrant au sommet en lanières inégales. Coiffe ou calyptre" persistante, se rompant inégalement et environnant le fond de la capsule. Disque des anthères à moitié immergé à la superficie de la fronde. - Une seule espèce, originaire de l'Inde, compose ce g., qu'il est fort difficile de distinguer de certaines variétés monocarpes du genre Plagiochasma. La plante unique dont nous avons dit que se composait le g. en question est formée de frondes linéaires, d'environ un pouce de long, simples ou bifides, planes ou légèrement concaves par le relèvement des bords et du sillon moyen desquels s'élèvent les pédoncules qui portent les réceptacles. Elle habite l'Inde.

(C. M.)

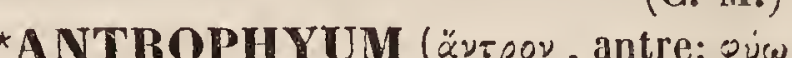
je nais). Bot. CR. - Kaulfuss (Enum. filic., p. 197) a établi sous ce nom un genre de Fougères aux dépens de diverses espèces placées dans le g. Hemionitis par les auteurs. II l'a caractérisé par ses sores linéaires, continus. immergés dans les veines réticulcés de la fronde; par un induse géminé, déhiscent par le milieu. M. Blume, qui a adopté ce genre, et qui l'a enrichi de plusieurs especes (Flor. Java, t. I), a nié l'existence de l'induse. Il a formé deux sections dans ce genre : l'une composée des vrais Antrophyum, parmi lesquels figure l'Antrophyum plantagineum; l'autre, sous le nom de Loxogramme, dans laquelle entre le Grammitis lanceolata de Swartz. M. Presl n'a pas admis le genre Antrophyum, et l'a réduit au rang de simple section des Hemionitis. Quoi qu'il en soit, ce groupe se compose d'environ 15 esp. qui croissent pour la plupart dans les îles de l'Inde orientale et dans celles de France et de Bourbolı. On en a également trouvé à Cayenne.

(G........)

ANTURA. вот. PH. - Genre de la famille des Apocynacères, tribu des Carissées, formé par Forskal (Descript., 63), et synonyme du genre Carissa de Linné.

(G. L)

ANTUSE. Antusa. вот. PH. - Genre de la famille des Légumineuses, établi par Smith. Il ne diffère du Pultenea que par son calice, simple et sans appendice.

(C. 1'O.)

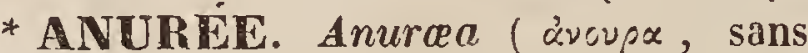
queue ). systol. - Nom donné par M. Ehrenbergaug. Arourelite. Voy. ce mot.

(Dux.)

ANUBIA. Bot. PH. - Synonyme brésilien de Laurus sassafras Linn. Voyez LA URIER. (C. D'O).

ANURUS, Presl. - Nissolia, Tourn. ; Mœnch., non L. ( $\dot{\alpha}$ vovp $\dot{\alpha}$, sans queue). BOT. PH. - Genre ou sous-genre fondé sur les Lathyrus Nissolia, L. (famille des Légumineuses ). Ses caract. distinctifs ne consistent qu'en ce que les feuilles sont simples (ou, si l'on préfère, remplacées par des phyllodes dépourvus de folioles), et dépourvues de vrilles. On peut considérer comme caract. accessoires que la dent calicinale inférieure est notablement plus longue que les autres dents, et que le style est exactement linéaire.

(SP.)

ANUS. zooL. - Mot latin conservé dans notre langue pour désigner chez l'homme et chez les animaux l'ouverture naturelle de l'intestin par laquelle sortent les excré ments. Cet orifice extensible se trouve ordinairement placé à la région postérieure ou 
Inféricure du tronc. Son pourtour, appelé marge de l'anus, présente le plus souvent des plis ou rides formés par la contraction d'un muscle circulaire nownmé sphincter de l'anus, qui fronce l'orifice anal, et le ferme de manière à empêcher la sortie des matières contenues dans l'intestin. Entre les plis radiés dont il vient d'être question, il se forme quelquefois de petites ulcérations allongées et superficielles qui, chez l'homme, constituent la fissure à l'anus, différente de la fistule, ulcère en forme de canal étroit, profond, plus ou moins sinueux, et ouvert communément à la marge de l'anus.

L'anus est dit contre nature lorsqu'au lieu de se trouver à l'endroit où il est ordinairement, il s'ouvre dans une toute autre région, à l'ombilic par exemple, dans la vessie, le vagin, etc., ou enfin dans le canal de l'urètre, ainsi que j'ai pu le constater une fois chez un jeune cnfant de quinze jours, qui succomba à une affection de poitrine. L'anus artificiel est celui que les chirurgiens établissent, dans certains cas, sur diverses régions du tronc, pour permettre la sortie des excréments. Enfin on nomme anus accidentel celui qui se forme quelquefois à la suite des plaies pénétrantes de l'abdomen, lorsque, l'intestin ayant été percé, son bout supérieur a contracté adhérence avec les lèvres de la plaie des parois abdominales.

(II. S. A.)

* ANVILLEA. вот. PH. - M. de Candolle, qui a dédié ce genre à la mémoire du célèbre voyageur J.-B. Bourguignon d'Anville, lui donne les caractères suivants : Capit. multiflore, homogame, composé de fleurons tubuleux, hermaphrodites, à 5 dents. Le réccptacle porte des paiilettes dont les extérieures se terminent au sommet en une pointe, et les intérieures en une soic assez longue. L'involucre, de forme campanulée, est formé d'écailles ou de bractées foliacées; les extérieures sont étalées et spatulées; les intérieures, disposées sur deux rangs, sont imbriquées. Le fruit, tétragone, dur, est terminć par une aigrette courte, entière, en forme de couronne. - Ce genre, qui fait partie des Composées, est très voisin des Cerruana et Buphthalmum; on n'en connaît encore qu'une espèce, l'A. Garcini, rapportée de l'Asie-Mineure et de la Perse par Olivier.

(J. D.)

ANYCHIA, Rich. (in Mich. Flor. T. I.
Bor. Amer., t. I , p. 115). - Iuss. ( Iém. du Mus., t. II , p. 389 ). вот. PII. - Genre ou sous-g. de la famille des Paronychices (famille des Caryophyllées, sous-ordre des Paronychićes, tribu des Illécébrées, section des Euparonychiées, Fenzl). M. Fenzl (in Endl.Gen.pl., p. 957) ne l'admet que comme sous-division du g. Paronychia, Juss., et lui assigne pour caractères distinctifs : Segments calicinaux elliptiques-oblongs, herbacés, à peine scarieux aux bords, subcuculliformes au sommet, légèrement mucronulés. Corolle nulle. Étamines 3 , ou moins souvent 5. Fruit indéhiscent, aussi long ou plus long que le calice.-Herbes (de l'A mérique septentrionale) annuelles, dichotomes, très rameuses, ayant le port du Linum catharticum. Feuilles elliptiques ou lancéolées, minces, opposćes. Fleurs solitaires ou fasciculées, dichotoméaires et terminales, accompagnées de bractées subulées. - Le type de ce g. est le Queria canadensis, $\mathbf{L}$. (A. dichotoma, Michx.); on ne connaî! jusque aujourd'hui qu'une seule autre esp. congénère.

$(\mathbf{S P}$,

ANYCTANGIE. BOT. CR. - Voyez ANOEGTANGIUM.

*ANYPH ANES. Anyphance. AR ACHr. - Ce nom est employé par M. Walckenaër pour désigner un petit groupe du g. Clu. biona.

(H. L.)

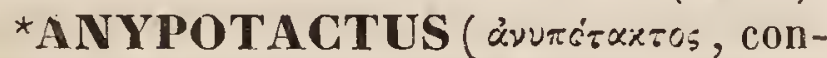
fus, troublé). INs. - Genre de Coléoptères tétramères, famille des Curculionides, division des Brachydérides, établi par Schoenherr, qui le caractérise ainsi : Ant. peu longues , minces ; les deux premiers articles du funicule assez longs et coniques, les autres plus courts, arrondis au sommet, séparés; massue ovale. Rostre court, épais, ayant une impression angulaire à la base, profondément échancré en rond au sommet, élevé sur les bords. Yeux petits, arrondis, peu convexes. Corselet oblong, presque cylindrique. Élytres en ovale oblong, légèrement convexes, avec les angles huméraux obtus. Pattes assez faibles; cuisses dentées en dessous. - Ce g. est voisin, suivant l'auteur, de cclui qu'il nomme Pandeleteius. Il a pour type une espèce de la Colombie, nommée $\boldsymbol{A}$. exilis par Klug, qui la met dans le genre Polydacrus. Voy. ce mot.

* ANYGTIS. ARAcir. - Genre de la $40^{*}$ 
famille des Acariens trombidiés, proposé par M. Heyden (Isis, 1826, p. 609 ) et dont le type est le Trombidium cornigerum Hermann. Voy. TROMBIDIE.

(P. G.)

AODON (á priv.; jo'ous, ovros, dent). porss. - Forskal avait laissé dans ses manuscrits l'indication de deux Squales, dont il avait fait mention par une diagnose latine de quelques mots écrits à la suite du nom arabe sous lequel des pêcheurs du marché de Djedda ou de Lohaje les lui donnèrent. L'éditeur de ses manuscrits, en imprimant ces notes, a donc cité un Squalus Massasa (à Djedda ), - Mafreka (à Lohaje), dont Forskal disait: - Dentibus nullis, primis pectoralibus. longis a carcharia diversus; et un autre Squalus Kumal, dont Forskal disait aussi : Dentibus nullis, pinnis pectoralibus, brevibus cirrhis oris quatuor.

On voit que rien n'est plus vague que ces deux indications, qui n'ont pas manqué cependant d'entrer dans la compilation dé Gmelin, comme une subdivision des Squales. M. de Lacépède, en les y retrouvant, a cru devoir en rapprocher une indication assez singulière que lui fournissait Brunnich dans son Squalus edentulus.

Il a formé alors à la suite des Squales, sous le nom d'Aodon, un genre de Cartilagineux à mâchoires dépourvues de dents. Ce genre n'a pas dû être conservé par les raisons suivantes : Les indications de Forskal ne peuvent aider à reconnaître les êtres qu'il a vus. Müller place la première dans les synonymies douteuses des Carcharias, la seconde dans ceux de toute la famille des Squales, où il aurait dû, selon moi, y laisser la première, car je ne vois pas pourquoi cet illustre savant rapproche des Requins un Squale sans dents. M. Müller sait d'ailleurs que je professe pour lui et ses travaux une si haute estime, qu'il ne prendra pas cette légère observation pour une critique. Quant à la troisième espèce, que Lacépède a nommée Aodon cornu, la lecture tant soit peu attentive de l'article de Brunnich y fait bientôt reconnaître la description de la tête d'un Céphaloptère (Raja giorna, Lacép.). Ainsi, non seulement le genre, mais encore les espèces que l'auteur y rapporte, ne peuvent être conservés, et prendre rang dans le catalogue raisonné des êtres de la nature.
* ODORHYNCHUS ( à priv.; ovous, dent; óvyðos, bec). ors.-C'est, d'après Wagler, dans sa Monographie des Perroquets, le nom générique donné par Spix à l'Ara hyacynthe de Vieillot. Voy. ARA.

(LAFR.)

* AOME. Aomus ( à priv.; w «ros, épaule; il eût fallu écrire : Anomus ). INs. - Genre de l'ordre des Coléoptères tétramères, famille des Curculionides, division des Cyclomides, établi par Schoenherr, qui lui donne les caractères suivants : Antennes longues, un peu grêles, dont le scapus, en forme de massue, est de la longueur du corselet; les deux premiers articles du funicuic un peu longs, obconiques; les autres plus courts, turbinés; massue oblongue, ovale; rostre à peine de la 'longueur de la tête et plus étroil qu'elle, linéaire, un peu enfoncé à la base, légèrement et triangulairement échancré au sommet; fosse oblongue, assez large, un peu courbe. Yeux ronds, faiblement convexes. Corselet tronqué à la base et au sommet, arrondi latéralement, un peu plus étroit antérieurement. Écusson triangulaire.

Ce genre, qui ne figure pas dans le dernier Catalogue de M. Dejean, a pour type et unique esp. l'Aom. pubescens de Schuppel, originaire de la Perse.

AONE. Aonia (Aon, ou Aonius, fils de Neptune ). ANvéL. - M. Savigny a établi sous ce nom un genre comprenant le $\boldsymbol{N}$ ereis coea d'Othon Fabricius, et M. de Blainville, qui le conserve provisoirement (Dict. sc. n., t. $\mathbf{L V}$, p. 479 ), le rapporte à ses Néréides microcères, avec la caractéristique suivante : Corps linéaire, épais, robuste, atténué aux deux extrémités et subpolyméré; tête petite et triangulaire en avant, sans traces d'yeux; bouche pourvue d'une trompe subglobuleuse avec un cercle de barbillons et un grand nombre de papilles à son orifice; un seul tentacule, court et mou, à chaque angle de la tête ; pieds biramés, celui du premier anneau beaucoup plus court que les autres; un cirrhe inférieur fort court; point de cirrhe supérieur; des cirrhes caudaux ou styles fort longs.

MM. Audouin et Milne Edwards placent dans ce genre un animal de nos côtes appelé par eux Aonia foliosa (Littor. de la France, II , p. 263), et provenant de La Rochelle. Yoici comment ils résument les caractères 
des Aonies, qu'ils moditient d'ailleurs en quelques points : 'Tête très petite, mais distincte; antennes rudimentaires; pieds similaires, pourvus d'un seul cirrhe, et divisés en deux rames garnies chacune d'un lobe lamelleux; point de branchies.

Pour MM. Audouin et Edwards, les Aonies appartiennent à une famille diffé. rente de celle des Néréides, celle qu'ils ont dístinguće sous le nom d'Ariciens.

(P. G.)

*AOPL (ăotios, sans armes). BOT. PH. - Genre de la fanille des Orchidacées, tribu des Ophrydées, fondé par Lindley (Bot. Reg., 1701), qui lui attribue pour caract. : Périgone bilabié; segments extérieurs latéraux, défléchis; le supérieur dressé, et formant casque avec les inférieurs, agglutinés. Labelle linéaire, sans éperon. Anthère dressée, à lobes courts, ascendants. Une sorte de bec courbé, allongé. Glandule nue. - Une seule esp. de l'Inde : c'est une herbe à racines testiculées. Une seule feuille radicale, de laquelle sor un épi lâche, unilatéral, à fleurs verâatres.

(C. L.)

* AORE. Aorus (äwpos, sans ornement). INs. - Genre de l'ordre des Coléoptères tétramères, famille des Curculionides, division des Erirhinịdes, établi par Schoenherr, qui lui donne pour caractères : Antennes médiocres, assez grêles; leur funicule composé de sept articles : le premier court, obconique; le second allongé, presque en massue; les autres courts, tronqués au sommet, un peu serrés, et s'élargissant graduellement du côté extérieur; massue ovale, dont les articles ne sont pas distincts. Rostre long, assez robuste, cylindrique, arqué. Yeux oblongs, déprimés. Corselę oblong, tronqué à la base et au sommet, également arrondi et élargi sur les côtés, convexes en dessus; écusson médiocre, triangulaire. Élytres allongées, cylindriques, légèrement échancrées à la base, avec les angles huméraux obtus. Tibias un peu flexueux, muriqués et armés d'un crochet robuste du côté interne.

Ce genre, qui ne flgure pas dans le dernier Catalogue de M. Dejean, ne renferme qu'une seule espèce, qui se trouve darıs le Galam, en Afrique : I'Aor. spadiceus de Schuppel.
AORTE. Aorla, arteria magna (úopts, aorte). zoor.-On donne ce noun à la principale artere du corps des animaux qui out un véritable cœur (Voy. ce mot), et l'on désigne plus particulièrement sous le nom de vaisseau dorsal l'Aorte, irréguliìrement renftée, des animaux dépourvus de cour. Voyez VAISSEAU DORSAL.

L'Aorte naît le plus souvent du cour, parcourt les régions thoracique et abdominale, fournit de nombreuses branches aux organes, et présente de très remarquables modifications qui sont relatives à l'âge et surtout aux diverses classes d'animaux chez lesquels on l'étudie. Dans la plupart des vertébrés, l'Aorte se recourbe peu après son origine du coeur, et c'est à celte portion, plus ou moins courbée en forme de crosse, que les anatomistes ont donné le nom de Crosse aortique ou de Ćrosse de l'Aorte. Celle-ci varie de disposition, de volume, d'étendue, de rapports, de nombre, et même d'usages, suivant qu'on l'étudie comparativement chez l'Homme, les Mammiferes, les Oiseaux, les Reptiles, les Poissons et les Invertébrés, aux diférents âges. Dans l'Iomme et quelques Mammifères, la crosse naît du ventricule gauche du ccur, se recourbe bientôt et se dirige ordinairement de droite à gauche pour aller gagner le rachis. Elle fournit : $1^{\circ}$ les artères cardiaques, qui vivifient le cœur ; 20 l'artère brachio-céphalique ou innominée; $\tilde{3}^{\circ}$ la carotide primitive gauche; $4^{\circ}$ outre ces deux troncs, chez le fotus, l'artère thymique, qui quelquefois naît du trone brachiocéphalique; 5० enfin la sous-clavière gauche, qui conduit le sang à la tête, au cou, et dans les membres supérieurs. Après cela, l'Aorte se continue le long des vertèbres, et donne, dans la poitrine, plusieurs petites branches qui vont se rendre, les antéricures aux bronches, à l'œsophage et dans le médiastin postérieur; les latérales ou inter-costales, qui fournissent aux muscles, aux cartilages et aux os du thorax. Arrivée dans l'abdomen, l'Aorte donne successivement les artères diaphragmatiques, le tronc coliaque, qui envoie une branche à l'estomac, une au foie et la troisième à la rate; la mésentérique supérieure et la mésentérique inférieure, qui se distribuent. aux intestins et au pancréas ; les capsulaires 
et les rénales; les spermatiques; les lombaires, et enfin l'artère sacrée, moyenne ou caudale, et les iliaques, qui envoient des branches dans tous les organes du bassin et aux membres inférieurs. - Chez le fœetus, les iliaques donnent deux artères importantes : ce sont les ombilicales. Voy. GIRGuLaTION DU SANG GHEZ LE FOETUS.

Dans les Oiseaux, la crosse de l'Aorte naît aussi du ventricule gauche, et est plutôt dirigée de gauche à droite que de droite à gauche, comme cela a lieu pour les Mammifères. Elle se continue avec l'Aorte thoracique et ventrale, fournit des branches aux organes de ces deux grandes régions du corps, et ne présente de différence réelle avec l'Aorte des Mammiféres que par la subdivision plus ou moins grande ou le manque de quelques unes des branches.

Dans les Reptiles, au contraire, chaque ordre, chaque groupe, pour ainsi dire, présente une remarquable différence, sous le rapport surtout de l'origine et de la distribution de l'Aorte. G'est ainsi que chez le Grocodile on trouve deux crosses; mais elles ne proviennent point de la même cavité du cœur, comme on le croyait avant nos recherches sur la circulation du sang chez les vertébrés : la gauche naît du ventricule droit; la droite, du ventricule gauche. Ces deux crosses se réunissent, après un trajet assez long, pour former un seul tronc, qui est l'Aorte proprement dite. Il résulte de cette double origine des crosses, de leur anastomose et de l'existence de deux ventricules bien séparés pour le cœur des Grocodiles, un fait physiologique important que nous ferons connaître à l'article CIR CuL ATron.

Les Serpents ont aussi deux crosses qui se réunissent pour constituer l'Aorte; mais ici l'une et l'autre proviennent d'une source commune : c'est parce que les deux ventricules du cœur, chez ces animaux, communiquent ensemble au moyen de plusieurs petits trous pratiqués dans l'épaisseur de la cloison qui les sépare, et par une large ouverture inter-ventriculaire. Toutefois, des valvules situées à l'orifice de celle-ci peuvent modifier le cours du sang, d'après les savantes recherches de M. le professeur Retzius.

Dans les Tortues, la crosse gauche naît immédiatement d'un ventricule unique du cour; la droite, d'un tronc commun, avec la branche qui porte le sang à la tête. Ce tronc lui-même provient du ventricule commun; les deux crosses ne se réunissent pas par leurs troncs, mais seulement par une grosse branche qui se détache de l'une d'elles.

Chez les Lézards, la structure intérieure du cœur ressemble à celle du cœur des Tortues; mais la disposition des crosses est différente. Deux troncs s'élèvent du ventricule commun et se bifurquent en quatre branches, qui se réunissent deux à deux bientôt après leur divis., de sorte que chaque tronc résultant de cette union se trouve être for. mé d'une branche de chaque tronc primitif.

Après cette singulière disposition, les deux crosses se réunissent sur la ligne médiano, et constituent l'Aorte descendante.

Dans les Poissons, ainsi que chez les Reptiles, au moment de leur métamorphose, le tronc artériel qui s'élève du ventricule unique du cœur va se distribuer aux branchies, et ne se continue pas d'une manière immédiate avec l'Aorte proprement dite, qui, dans ce cas, se trouve être la résultante des divers troncs provenant des branchies.

Dans les Mollusques gastéropodes, au contraire, le vaisseau qui s'élève du cœur distribue le sang dans tout le corps.

Ce sont là les principaies variétés qu'on observe relativement à l'origine, à la disposition et aux rapports de l'Aorte. - Le résultat de ces différences anatomiques sera mieux apprécié à l'article GIRGULATror.

(M. S. A.)

AORUS. INs. - Voyez AORE.

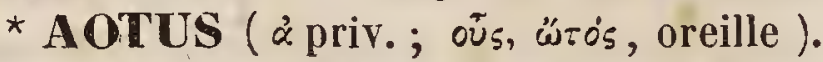
MAMM. - M. de Humboldt, dans son travail sur les Primates américains, donnait ce nom à un petit genre de la famille des Sapajous, dont l'esp. type, A. trivirgatus (Douroucouli de F. Cuvier), était supposée privée d'oreilles externes, ou n'en avoir que de fort petites. De nouvelles observations ont fait voir à $\mathbf{F}$. Guvier et Spix que l'Aotus avait les oreilles aussi distinctes que les autres Sapajous. Le premier a dès lors donné aux Aotus le nom de Nocthora, et le second, celui de Nyctipithecus. Le Douroucouli est, en effet, un animal nocturne ou crépusculaire. Ses dents sont au nombre de 36 , comme celles des Sapajous; sa queue est entièrement velue et non prenan- 
te; son crane a quelques rapports avec celui des Saïmiris, et son squelette, figuré par M. de Blainville dans son Ostéographie, est remarquable, parce que les vertèbres lombaires sont plus nombreuses que chez les Sapajous (huit au lieu de cinq). (P. G.)

AOTUS, Smith (Ann. of Bot., t. I, p. 450 ; Trans. Linn. Soc., vol. IX , p. 249)

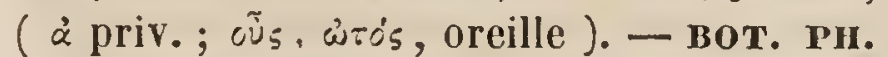
- Genre de la famille des Légumineuses, s.-ordre des Papilionacées, tribu des Sophorées, auquel M. R. Brown (in Hort. Kew., 2c éd., vol. III, p. 14) a assigné les caract. suivants : Calice $\mathbf{5}$-fide, 2-labié, ébractéolé. Pétales et étamines caducs. Ailes plus courtes que la carène. Style filiforme. Légume 2-valve, 2-sperme. Graines non strophiolées. Arbustes (de la Nouvelle-Hollande) à feuilles simples, linéaires, subulées, révolutées aux bords, éparses, ou subopposées, ou verticillées-ternées. Fleurs jaunes, axillaires, solitaires. On connaît 5 ou 6 esp.: l'A. villosa Smith (Bot. Mag. , tab. 949). - Pultencea villosa Andr. (Bot. Rep., tab. 509). - Pultencea ericoides (Vent. Malm., tab. 557 ) est un arbuste très élégant, qu'on cultive dans les collections de serre.

(SP.)

AOURADE ou AURADE. POISS. Nom de la Daurade (Chrysophrys aurata, Cuv., Val.) sur presque tout le littoral de la Méditerranée. Voy. DAURADE. (VAL.)

* APACHYA (à priv.; $\pi \approx \chi u \dot{s}$, épais). ros. - Genre de la famille des Forficuliens, de l'ordre des Orthoptères, établi par M. Serville (Revue méth. de l'ordre des Orthopt.), et regardé par tous les autres entomologistes comme une simple division du g. Forficula. Les Apachya sont caractérisées par un corps d'une minceur extrême, et surtout par l'abdomen, dont le dernier segment est très grand et distinctement échancré de chaque côté, et l'arceau supérieur de l'avant-dernier prolongé en manière de fer de lance. La seule esp. connue est l'A. depressa (Forficula depressa. Pall. de Beauv.), du royaume d'Oware en Afrique.

(BL.)

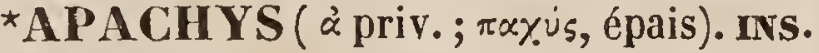
- M. Burmeister (Handb. der Entom.), ayant adopté le g. Apachyus de M. Serville comme une division du g. Forficula, en a, avec raison, ainsi rectifié l'orthographe.

(BL.)
Ixs. - M. Serville avait d'abord employé ce nom dans sa Revue méthodique; il l'a changé en Apachyia dans I'Ilist. des Orthopt. (suites à Buffon).

APACTIS ( ? à priv.; $\pi \times x \tau o \dot{s}\left[\pi n \times \tau c_{s}\right]$ ajusté, fixé ; genre incertain ). вот. PII. Genre formé par Thunberg, qui lui attribuait un calice corollacé, formé de 4 sépales obronds, crénelés ; les opposés plus larges. 16 à 20 étamines. Un ovaire libre, surmonté d'un style simple. - Ce genre est trop incomplétement décrit pour pouvoir être rapporté à une des familles naturelles, et entre naturellement dans la Dodécandrie (ou Icosandric) monogynie de Linné. L'auteur y rapportait un arbre du Japon, aujourd'hui indéterminé.

(C. L.)

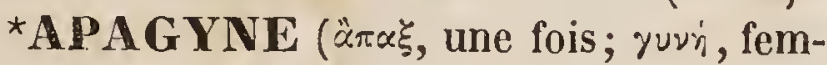
me). вот. - Nom proposé par M. Desvaux pour remplacer celui de Monocarpique, et désigner les plantes qui ne fructifient qu'une seule fois; le nom de Monocarpique ou de Monocarpien, ambigu dans ce sens, devant être donné seulement à celles qui ne portent qu'un seul fruit. (C. D'O.)

APALACHINE (monts Apalaches). вот. PH. - Synonyme vulgaire de l'Ilex vomitoria $\mathbf{L}$.

(C. L.)

APALAT, APALATOU (noms caraïbes ). вот. PH. - Noms vulgaires de quelques espèces du genre Crudia. (SP.)

APALA TOA, Aubl. Guian. (nom caraïbe ). Bот. PH. - Synon. da genre Crudia, de la famille des Légumineuses. (SP.)

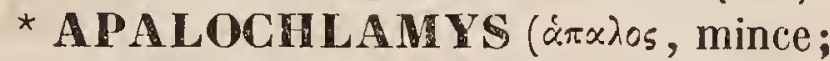
$\chi$ хxмus, tunique ). вот. PH. - Ce genre, qui fait partie des Composées, correspond à la troisième section des Cassinia de M. Brown. Il a pour caract. : Capitules multiflores (10-16) homogames; fleurons tubuleux, hermaphrodites. Réceptacle étroit, paléolé. Involucre oblong, formé d'ćcailles épaissies à la base, scarieuses, diaphanes, membranacées, conniventes au sommet. Anthères dépourvues d'appendices basilaires. Fruit obové, court, couronné par une aigrette caduque, uni-sériéc, à soies filiformes, finement barbellulées de la base au sommet. - Ce genre, intermédiaire entre les Cassinia et l'Humea, se compose de trois espèces particulières à la Nouvelle-Hollande. Les feuilles, décurrentes, couvertes d'un *APACHY US ( $\alpha$ priv.; $\pi \times x \dot{v}_{s}$, épais ). I duvet blanc, exhalent une odeur particulic- 
re assez forte; les fleurs, disposées en panicules rameuses à ramuscules pendants, partent de nombreux capitules, petits, jaunâtres ou fauves. On cultive dans les jardins de Botanique 1'A. Ferrii, Cassinia spectabilis K er.

* APAODERMA ( $\dot{\pi} \pi \lambda 0^{\circ} s, \mathrm{mou}$, molle;

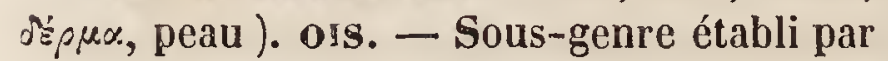
Swainson dans sa famille des Trogonidae ou Couroucous sur le Couroucou narina de Levaillant, et que nous n'admettons, ainsi que cet auteur, que comme sous-genre du genre courovcou. Voy. ce mot. (LAFr.)

* APALUS ( $\dot{\pi} \pi\rangle_{\circ}^{\circ} 5$, mou). Ivs. - Genre de Coléoptères hétéromères, famille des Cantharidées de Latreille, qui répond à celle des Vésicants de MM. Duméril et Dejean. Ce genre, établi par Fabricius et adopté par tous les entomologistes, est caractérisé ainsi par cet auteur : Palpes filiformes, égaux; mâchoires cornées, unidentées ; languette membraneuse, tronquée et entic̀re. Il a pour type une espèce fort rare de la Suède, le Meloë bimaculé de Linné (Apalus bimaculatus Fabr., Pyrochroa bimaculata Degéer), auquel sont venues se réunir depuis d'autres espèces que Fabricius n'a pas connues. M. Dejean en mentionne cinq dans son dernier Catalogue, y compris celle que nous venons de nommer. Nous n'en citerons qu'une, qu'il nomme A. dimidiatus, et qui est du Sénégal. Quant à l'A. 4-maculatus de Fabricius, il appartient au g. Tetraonyx Latr. Voy. ce mot.

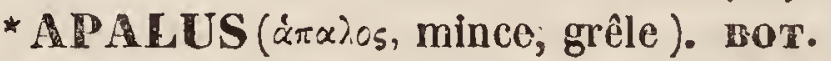
PI. - Syn. de Blennosperma, Less. Voy. ce mot.

(J. D.)

APALYTRES ou MOLLIPENNES

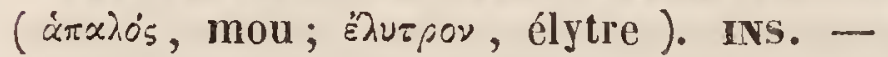
Nom donné par M. Duméril à la dixième famille des Coléoptères pentamères, qu'il caractérise ainsi : Élytres molles; corselet aplati; antennes en fil variable. Cette famille, qui correspond à celle des Malacodermes de Latreille, se compose, suivant M. Duméril, des g. Drilus, Lycus, Lampyris, Malachus, Téléphorus, Omalisus, Melyris et Cyphon. Voy. ces mots.

* APAMEA (nom d'une ancienne ville de Syrio ). Ins. - Genre de l'ordre des Lépidoptères, famille des Nocturnes, tribu des Noctuélites, établi par Ochsenheimer et
Treistchke, et adopté, avec quelques modifications, par M. Boisduval, dans son Index methodicus Lepidopt. Europ., et par N. Guénée dans son Essai sur une nouvelle classification de Noctuélites. Voici les caract. que ce dernier lui assigne : Chenilles lisses, cylindriques, rases, à tête assez grosse, un peu rétractile. Elles vivent de plantes basses ou de graminées, et se retirent parfois dans leurs tiges. Chrysalides cylindrico-coniques, luisantes, à peau mince, renfermées dans des coques légères à la surface de la terre ou entre les mousses et les feuilles sèches.-Insectes parfaits : Antennes filiformes ou subcrénelées dans les mâles. 'Palpes dépassant peu la tête, droits ou peu remontants; leur dernier article assez court, nu. Thorax velu, peu carré, ayant une petite crête bifide derrière le collier, et une autre à sa jonction avec l'abdomen; celui-ci dépassant les ailes inférieures, souvent crêté, mème dans les mâles. Ailes supérieures arrondies au bord terminal, subdentées, n'ayant des taches ordinaires que la réniforme de bien distincte; les lignes assez bien marquées, surtout l'anté-terminale, qui circonscrit, entre elle et la frange, un espace toujours plus fon. cé que la couleur du fond.

Ce genre renferme 15 esp. suivant Treist chke, et 15 seulement suivant M. Guénée, qui les divise en trois groupes, de chacun desquels nous en citerons une, savoir : l'A. nictitans Linn., l'A. latruncula Var., strigilis Linn., et l'A. didyma Borkhausen. - Cette dernière est une des plus communes et ofre plusieurs variétés telle. ment tranchées, que Hubner en a fait autant d'espèces différentes. Consultez cet auteur, ainsi que l'Hist. natur. des Lépidopt. de France, ou toutes les Apamea connues sont figurées.

APARGIA (àrapjix, nom grec d'une plante qui nous est inconnue). BOT. PH. Genre des Composées, tribu des Chicoracées, qui a pour caract. : Gapitules multiflores. Involucre composé d'écailles 1-sériées, à la base desquelles on en remarque d'accessoires beaucoup plus courtes. Réceptacle nu. Fruits semblables entre eux, cylindracés et légèrement atténués au sommet; l'aigrette, bisériée, très blanche, se compose de soies plumeases, loutes de même naturc. - Le 
genre Apargia, autrefols fort nombrous on espèces, se trouve réduit aujourd'hui au seul $A$. Taraxaci, qui croît dans les prairies des plus hautes Alpes du Dauphiné et de l'Autriche.

(J. D.)

APARINE, Tourn. - Nonch. - Neck. ( $\dot{\pi}$ xpion, caille-lait). вот. ru. - Double emploi du genre Galizm, de la famille des Rubiacées. - H. Reichenbach et M. de Candolle groupent sous ce nom tous les $G a$ lizum annuels.

(SP.)

* APARINÉES. Aparinece, Link. вот. PH. - Syn. de la tribu des Stellatex, de la famille des Rubiacées.

(SP.)

*APARISTHMIUM ( $\alpha$ priv.; $\pi \alpha \rho i \sigma \theta \mu \iota \alpha$, glandes). вот. PH. - L'Herbier de Richard rapprochait, sous le nom de Conceveibum, le Conceveiba d'Aublet, connu seulement par ses fleurs femelles, et une autre Euphorbiacée voisine, dont les femelles difléraient cependant par leur calice dépourvu de glandes, et dont les mâles présentes permettaient de compléter le caract. générique. Nous avions donc cru devoir les réunir provisoirement en un seul genre, tout en exprimant des doutes qui ont paru suffisants à M. Endlicher pour distinguer du Conceveiba Aubl. notre Conceveibum sous le nouveau nom d'Aparisthmium. Ses caract. sont : Des fleurs dioïques; dans les mâles, un calice triparti, hors duquel font saillie 5-4 étamines soudées inféricurement par leurs filets, à anthères introrses et adncées; dans les femelles, un calice dépourvu de glandes, quinquéfide ; un ovaire surmonté de trois styles, dont la face interne est toute hérissée de papilles stigmatiques, et comme plumeuse, à trois loges chacune 1ovulće, et devenant, à la maturité, une capsule à trois coques. La seule espèce connue est un arbre de la Guyane, à feuilles alternes, simples, dentées, portées sur un long pétiole qu'accompagnent à sa base deux stipules; à fleurs, les mâles pelotonnées, les femelles situécs une à une sur des épis axillaires ou terminaux, solitaires ou fasciculés. Voy. Ad. Jussieu, Euphorb., p. 42 , tab. 14, fig. $42 A$. (AD. Juss.)

*APARTIUM, Neck. Bot. PII. - Syn. du g. Spartium, de la famille des Légumineuses.

(SP.)

* APATANTIIUS (ảrx־áco, je trompe; $\ddot{x} \nu 0 \circ$, leur; fleur qui induit en erreur). Prencontre souvent sur les bois morts, sur fleurs ni sur les arbres sains; mais on les

вот. Ри. - Ce genre a été décrit par Viviani dans sa $\boldsymbol{F l}$. Libyca, mais d'une manic̀re tellement incomplète, que Cassini et I. de Candolle l'ont laissé dans les genres non classés, tout en croyant cependant pouvoir le considérer comme une espèce d'Hieracium. Cette plante, qui a le port de l'H. pilosella, est originaire des montagnes de la Gyrénaïque.

(J. D.)

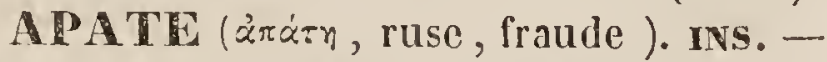
Nom dolné par Fabricius à un genre de Coléoptères tétramères, famille des Xylophages, que Geoffroy avait créc avant lui sous la dénomination de Bostriche. Bien que ce dernier nom eût dû prévaloir à raison de son antériorité , cependant tous les entomologistes, a l'exception d'Olivier et de Latreille, ont adopté celui d'Apate, en transportant, comme Fabricius, le nom de Bostriche à des Insectes d'un autre genre. Geofroy caractérise ainsi le genre dont il s'agit : Antennes en masse composées de trois articles ; rostre nul ; corselet cubique, dans lequel la tête est cachéc, tarses nuls ef épineux. Latreille le place dans sa tribu des Bostrichins et lui assigne pour caract. distinctifs : Palpes filiformes; mâchoires à deux lobes; massuc des antennes perfoliée ou en scie, quelquefois pectinéc; corps allongé, convexe; corselct élevé, globuleux ou cubique.

Ce genre diffère des Scolytes par les antennes et les tarses, et des Psoas par la forme du corps et le nombre des lobes des mâchoires.

Les larves des Apates ont le corps mou, un peu renflé, courbé en arc; il est muni de six pattes et d'une tête écailleuse; celleci est armée de deux mâchoires, très solides et tranchantes. Ces larves, comine celles des Vrillettes, vivent dans le bois mort, où clles tracent des chemins tortueux, qu'elles remplissent de leurs excréments, qui ressemblent à de la sciure de bois. Ce n'est qu'après avoir vécu ainsi deux ans environ, que, parvenues à toute leur taille, elles se changent en nymphe dans une coque composéc de poussière de bois et d'un peu de matière soycuse, d'où l'insecte parfait sor't au printemps suivant.

Les Apates ne se trouvent jamais sur les 
les écorces à demi pourries et sur les bois anciennement coupés.

Ce genre est aujourd'hui très nombreux en espèces; M. Dejean, dans son dernier.Catalogue, en mentionne 62 , dont 45 sont exotiques. Parmi celles d'Europe, nous citerons l'A. capucina Fabr., Bostrich. capucinus Oliv., ou Dermestes id. de Linné, qui peut être considéré comme type du g. Cette espèce est très commune aux environs de Paris, et a été figurée par Geoffroy et Schœffer.

* APATELE. Apatela ( $\left.\alpha \pi_{\varepsilon} y\right) o_{\circ}^{\circ}$, trompeur). INs.-G. de l'ordre des Lépid optères, famille des Nocturnes, établi par Stéphens aux dépens du g. Acronycta d'Ochsenheimer, et qu'il place dans sa tribu des Noctuides. Ce g., qu'il n'a fait qu'indiquer dans son Catalogue des insectes de l'Angleterre, ne comprend que $\mathbf{3}$ esp., les $\boldsymbol{A}$. leporina, bradyporina el aceris. Voy. le g. Acronycta.

(D.)

^APATELIA, de Cand. (Prodr., t. I, p. 526 ) ( $\alpha \pi \alpha$ rndós, trompeur ). Bor. PH. Synon. (suivant M. Cambessèdes, Mém. sur Ternstrémiacées ) du g. Saurauja, Willd.

(SP.)

* APATEUM ( $\alpha \pi \alpha \tau \dot{\alpha} \alpha$, je trompe). INS. - G. de Coléoptères pentamères, famille des Sternoxes, tribu des Buprestides, établi par M. Maximilien Spinola, qui lui donne pour caract. (Ann. de la soc. ent., t. VI, p. 120): Prosternum sans dépression; bord antérieur fortement échancré, comme dans les Polybothris; appendice presternal rebordé dans toute sa longueur, légèrement atténué près de son extrémité; extrémité arrondie, recouvrant le milieu du mésosternum et atteignant le métasternum ; celui-ci largement évasé pour recevoir l'extrémité du prosternum. Épimères sinueux, notamment élargis après l'insertion des hanches postérieures, un peu échancrés au dessus d'elles. L'auteur a donné à ce genre le nom d'Apateum, parce que l'espèce unique sur lequel il le fonde simule l'habitus d'un Psiloptère. Cette esp. est le Buprestis calceata (Klug, Ins. $\operatorname{mad} .$, no $^{4} 7$, tab. 11, fig. 5).

APATHIQUES (Animaux). zooL. Lamarck a donné ce nom aux Zoophythes ou Animaux rayonnés de Cuvier, qu'il considérait comme dépourvus d'organes de sensation, et n'ayant même pas le sentiment de leur existence. Ce nom n'a pas été adopté.

(C. D'O.)

* APATHUS (ăr $\alpha \theta \dot{n} s$, qui ne se donne aucune peine). Irs. - Genre de la famille des Mellifères, groupe des Bombites, de l'ordre des Hyménoptères, établi par M. Newmann, et adopté par M. Westwood (Gener. synops. of all the Brit. gen.) pour quelques esp. indigènes, très voisines des Bourdons proprement dits (Bombus), dont elles ne different essentiellement que par les jambes postérienres, privées d'organes propres à la récolte du pollen. Le type de ce genre, qui correspond à celui de Psythirus Lep. S. Farg. (Voy. ce mot), est l'A. rupestris (Apis rupestris Fab.), espèce commune en Europe. (BL.)

APATTE ( $\dot{\alpha} \pi x \tau \dot{\alpha} \omega$, je trompe ; à cause des erreurs nombreuses auxquelles cette substance a donné lieu). MrN. - Nom donné par Werner à une partie des variétés de la Phosphorite ou du Phosphate de chaux naturel, et que M. Beudant a étenduà toute l'espèce. Voy. Phosphates eí PhosphoRITE.

(DEL.)

*APA TITL, Hamilt. (Prod. Flor. Ind. occid. 42) ( $\dot{\alpha} \pi \dot{\alpha} i n$, tromperie). BoT. PH. - Sous-genre de la famille des Mélastomacées, fondé sur le Blakea quinquenervis Aubl. Il ne paraît différer essentiellement des autres Blakea qu'en ce que les fleurs sont à 8 ou 9 pétales.

(SP.)

* APATOMYZE. Apatomyza ( árárn, ruse ; $\mu \nu \tau \tilde{i} \alpha$, mouche). INs. - Genre de l'ordre des Diptères, division des Brachocères, subdivision des Tétrachœtes, famille de Tanystomes, tribu des Bombyliens, établi par Wiedmann et adopté par Latreille ( Fam. natur.), ainsi que par M. Macquart, qui lui assigne les caract. suivants : Trompe une fois plus longue que la tête; palpes saillants de deux articles distincts; premier article des antennes allongé; troisième subulé, comprimé; style peu distinct; abdomen allongé, cylindracé ; pieds longs, ailes couchées. Deux espèces exotiques, l'une du Cap, et l'autre de l'Amérique du Nord (Géorgie), composent ce genre, dont le nom (Apatomiza, mouche trompeuse) indique la ressemblance apparente de ces diptères avec les Therèves, genre de la famille des Brachystomes.

* APA TURA (àró, sans; ojpá, queue). 
INs. - Genre de l'ordre des Cioléoptères pentamères, famille des Sternoxes, tribu des Buprestides, établi par MI. Delaporte et Gory, qui lui donnent les caract. suivants : Palpes maxillaires de trois articles visibles: le premier aliongé, presque cylindrique, conique; le deuxième un peu arqué; le troisième en ovale allongé. Palpes labiaux de deux articles visibles : le premier cylindrique; le deuxième ovalaire, un peu renflé. Labre en demi-cercle, un peu cilié en avant. Menton large, transversal. Lèvre pointue en avant, un peu ciliée. Mâchoires à lobe externe allongé, ovalaire, droit; l'interne petit et pointu. Antennes à premier article gros, renflé; le deuxième court ; le suivant allongé, conique; les autres triangulaires. Tarses antérieurs un peu élargis, à 5 premiers articles égaux, triangulaires; le pénultième très court, prolongé de chaque côté en une pointe aiguë; les postérieurs semblables, mais plus allongés; le premier article très long.

Ce genre a pour type l'Apat. appendiculata, Fabr., que M. Dejean rapporte au genre Phcenops, Mégerle, dans son dernier Catalogue. Voy. ce mot.

Nota. Si le genre dont il est ici question est conservé, il faudra en changer le nom : car celui d'Apatura, que les auteurs lui ont donné, a été appliqué depuis long-temps par Fabricius à un genre de Lépidoptères diurnes, et forme d'ailleurs contresens avec le nom de l'espèce qui lui sert de type.

(D. et Ch.)

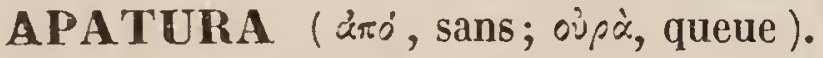
INS. - Genre de l'ordre des Lépidoptères, famille des Diurnes, tribu des Nymphalides, créé par Fabricius, et réuni au genre Nymphale par Latreille, mais qui nous paraît devoir en être séparé, et auquel nous assignons les caractères suivants, dans notre Catalogue méthodique des Lépidoptères d'Europe : Antennes de la longueur du corps, se formant insensiblement en une massue fusiforme, plus renflée que dans les g. $\mathbf{L i}$ menitis et Nymphale. Palpes plus Iongs que la tête, connivents vers leur extrémité, avec leur dernier article nu et très aigu; les deux premiers articles plutôt squammeux que velus. Tête un peu plus étroite que le corselet. Corselet robuste, et presque aussi long que l'abdomen. Ailes sinuées et denti-

T. I. culées; les inférieures dépourvues de queue. Chenilles limaciformes, ayant la tête surmontée de deux cornes divergentes, et deux petites pointes anales conniventes. Chrysalides comprimées latéralement, avec le dos renflé, caréné, et la tête bifide. Ce genre ne renferme en Europe que deux espèces vulgairement connues sous le nom de grand et de petit Mars, Apat. iris et Apat. ilia, Fabr. Ce sont deux de nos plus beaux $\mathbf{P a}$ pillons, dont le fond de la couleur en dessus, chez les mâles, paraît ou d'un noir brun ou d'un bleu très vif, suivant l'aspect de la lumière, avec des taches blanches qui sont souvent lavées d'orangé dans la seconde espèce. L'A $\boldsymbol{p}$. iris n'habite que les grands bois un peu humides; l'Ap. ilia se trouve à la fois dans les bois et les prairies bordées de saules.

(D.)

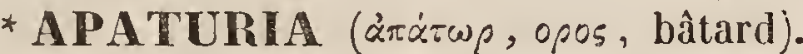
вот. РH. - Genre de la famille des Orchidacées, tribu des Épidendrées, formé par Lindley (Orchid. 150), et ainsi caractérisé : Divisions externes du périgone pubescentes, étalées; les latérales quelquefois plus grandes, obliques à la base ; les internes plus étroites. Labelle onguiculé, articulé avec la base plus ou moins allongée du gynostème, ventru à son point d'insertion, charnu, trilobé au sommet, relevé de crêtes au disque. Gynostème cylindrique, claviforme, arqué, à clinandre ailé. Anthère 48-loculaire. Pollinies. - Les Apaturia sont des plantes herbacées de l'Inde, épigées, aphylles, à scapes embrassées par des squammes scarieuses, filamenteuses; à bractées membranacées, à inflorescence en grappes penchées, pubescentes. (G. L.)

APEIBA, Aubl. (Guian., t. I, p. 538, tab. 215-216) (nom caraïbe). - Oxytandrum, Neck. - Sloanea, Loeffl. - Aubletia, Schreb. вот. PH. - Genre de la famille des Tiliacées. M. Kunth (in Humb. et Bonpl., Nov. Gen. et Spec. V, p. 547) lui assigne pour caract. : Calice de 4 ou 5 sépales lancéolés, colorés. Pétales \& ou 5, obovales; ou lancéolés, aussi longs que le calice, ou plus longs, convolutés en préfloraison. Etamines très nombreuses; filets filiformes, libres; anthères lancéolées-tétragones, basifixes, 2-thèques, longitudinalement déhiscentes, surmontées d'un appendice membraneux. Ovaire 8-ou pluri-10* 
calaire, non stipité; loges multi-ovulées. Ovules anatropes, multi-sériés, subhorizontaux, attachés à l'angle interne des loges. Style indivisé, épaissi vers le sommet, terminé en stigmate infondibuliforme, denticulé. Caps. tuberculeuse ou spinelleuse, coriace, orbiculaire, déprimée, ombiliquée, 8- ou pluri-loculaire; loges polyspermes, remplies d'une substance pulpeuse. Graines nidulantes, petites, ovoïdes ; test crustacé; raphé inapparent; chalaze epaisse, terminale. Embryon rectiligne, axile dans un périsperme charnu. Cotylédons plans, foliacés; radicule cylindracée, centripète. - Arbres ou arbrisseaux ( habitant l'Amérique équatoriale); feuilles très entières ou dentelées, alternes, courtement pétiolées, discolores, couvertes d'une pubescence étoilée; stipules latérales, géminées, caduques; pédoncules terminaux et oppositifoliés, dichotomes ou trichotomes, multifiores, bractéolés; fleurs jaunes ou verdâtres. On en connaît 9 espèces.

(SP.)

* PENULA (Legonzia, Dur., fl. Bury). BOT. PH. - Genre de la famille des Campanulacées - campanulées, formé par Necker, et réuni en synonymie et comme sousgenre au g. Specularia de Heister, avec ces caract. distinctifs : Tube calicinal allongé, prismatique, anguleux. Capsule déhiscente près du sommet, vers le limbe du calice. Graines ovoïdes. - Quelques esp. propres à l'ancien Continent.

(C. L.)

APER. MAM. - Nom latin du SANGLIER. Yoy. ce mot.

(C. D'O.)

APERA (à priv.; $\pi \dot{s} \rho \alpha$, sac). вот. PIr. - Genre de la famille des Graminées, formé par Palissot de Beauvois, et réuni, comme synonyme, au genre Agrostis de Linné.

(C. L.)

APEREA. Mam. - Nom donné au Cochon d'Inde. Voy. GoBAYE.

(G. D'O.)

APEIRIA NTHA CEES ( $a$ priv .; repi, autour; $\ddot{\alpha} \nu 005$, fleur). BOT.-M. de Mirbel a ronné ce nom à la famille des Gycadées, formée des Cycas et des Zamia, parce que les fleurs des plantes qui la composent sont dépourvues d'enveloppes florales ou de périanthe.

(G. D'O.)

APERISPERME ( $\alpha$ priv ; $\pi \dot{e} p$, au-

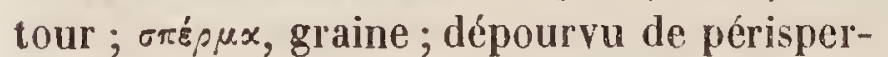
me). вот. - Se dit d'une graine ou d'un embryon qui manque de périsperme, com- me cela se roit dans la Sabsola trajus. (C. D'O.)

* APERISTOMEES ( $\alpha$ priv.; $\pi \varepsilon$ pirtcMos, péristome ). BOT. CR. - On donne cette épithète aux Mousses dont la capsule a son orifice nu ou privé de péristome.

APETALES ( $\alpha$ priv.; $\pi \dot{\varepsilon} \approx \lambda_{0} \%$, pétale). Boт. - Tournefort a désigné sous ce nom la dix-huitième classe de sa méthode, qui renferme les arbres dont les fleurs sont dépourvues de corolle. M. de Iussieu en a fait une des trois grandes sections des Dicotylédones.

(C. D'O.)

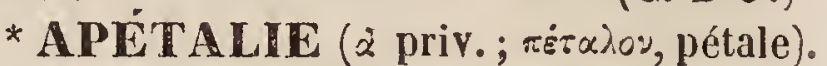
вот. - Nom d'une des grandes divisions de la Méthode botanique de M. de Jussieu, qui comprend toutes les plantes dicotylédones apétales.

(C. D'O.)

* MPE TLIFLORES (apetalus, opétale; flos, fleur ). Boт. - Eithète donnéc par M. H. Cassini à la calathide et à la couronne des plantes de la classe des Synanthérées quand elles sont composées de fleurs apétales. Ex. : les calathides féminiflores des Xanthium, la couronne des Gymnostyles. (C. D'O.)

APHACA, Tourn. ( $\dot{\alpha}_{\rho} \dot{\alpha} x \eta$, sorte de gesse; en latin aphceca; nom employé par les Botanographes anciens pour désigner certaines Légumineuses). BoT. PH. - Section du g. Lathyrus, L., de la famille des Légumineuses, constituée par le Lathyrus Aphaca, L., et caractérisée par des feuilles réduites la plupart à des vrilles filiformées, mais accompagnées de grandes stipules foliacées, hastiformes-ovales.

APH ENA ( à priv.; $\varphi x^{\gamma} \nu^{\prime} \dot{\omega}$, je brille). Iss. - Syn. d'Aphana. M. Guérin avait établi ce g. sous le nom d'Aphana, et c'est d'après la rectification grammaticale faite par M. Burmeister qu'il a été changé en celui d'Aphana. M. Spinola (Essai sur les Fulgorelles ) a adopté l'orthographe de M. Guérin.

(BL.)

* APHAENA GEMINAE. INs. - Le savant II. Spinola (Essai sur les Fulg.) emploie cette dénomination pour désigner une petite division établie dans le g. Aphana ou Aphena, sur les espèces qui n'ont point du tout de protubérance céphalique.

(BL.)

APHANA ( ipxyis, sombre, obscur). 
ixs. - Genre de la famille des Fulgoriens, de l'ordre des Hémiptêres, section des IIétéroptères, ćtabli par M. Guérin (Voyage aux Indes orient. de Bellanger), et adopté maintenant par tous les entomologistes. Ce genre est principalement caractérisé $1^{\circ}$ par une tête sans protubéranco ou n'en ayant qu'une très peu sensible, forméc par la face frontale; $2^{\circ}$ par le front, plus long que large, presque carré, ct fortement échancré à sa base; et, $3^{\circ}$, par les antennes, de quatre articles, dont le premier très petit, le second fort grand, ovalaire; le troisième petit, rentrant dans la cavité située à l'extrémité du précédent, et le dernier sétiforme. Les ailes et les pattes sont analogues à celles des Fulgora.

On connait une dizaine d'esp. exotiques de ce genre, presque toutes propres aux Indes orientales. Les plus répandues sont les A. farinosa (Lystra farinosa Fab.), variegata Guér., etc.

(BL.)

* APHANAMIXIS. вот. PH.-Voyez A Moora.

(AD. J.)

* APHANANTUE, Link. (àp xvớs, obs-

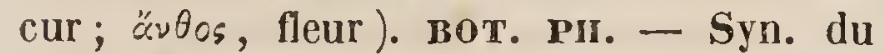
genre Microtea, Swartz, de la famille des Phytolaccacées.

(SP.)

* APHANANTHEMUM, Spach (Hist. des Plant. phan., t. VI, p. 17, sub Melianthemo) (àpry's, peu apparent; $\ddot{\alpha} \nu \theta \varepsilon \mu \circ \nu$, fleur). Boт. Pr. - S.-genre ou section du g. Hélianthème, constitué par le Melianthemum ledifolium et quelques esp. voisines. Ses caract. distinctifs sont les suivants: Style court, rectiligne, épaissi au sommet. Ltamines 7 à 15,1 -sériées, insérées au bord du disque; anthères obréniformes. Herbes annuelles. Grappes terminales, très làches, souvent feuillées, et distiques ou subdistiques. Pétales petits, étroits, souvent abortifs. Ovaire quelquefois parfaitement 1loculaire.

(SP.)

* APHANASIUM (ápxvis, obscur). INs. - Genre de Coléoptères tétramères, famille des Longicornes, établi par M. Dejean, mais dont il n'a pas publić les caractères. Il est fondé sur une seule espèce de la Nouvelle-Hollande, nommée par lui Australe, et qu'il avait mise dans son précédent Catalogue parmi les Callidies. N'ayant pu nous procurer la vue de cette espèce, qui n'a pas cncore été décrite, nous men- tionnons ici seulement pour mémoire le nouveau g. auquel M. Dejean la rapporte. (D.)

APHANE. INs. - Voyez APHANes.

MPIANE. Aphanes, L. ( a pevis, obscur ). Bot. PH. - Genre ou sous-genre de la famille des Rosacées (tribu des Sanguisorbées, DC.). Beaucoup d'auteurs le réunissent au genre Alchimilla, dont il ne diffère que par des fleurs 1- ou 2 -andres, à calice 4 - ou 5- lobé, chaque lobe alternant avec une tris petite dent. L'A. arvensis, L., plante annuclle, commune dans les champs, est la scule esp. qu'on puisse rapporter avec certitude à ce genre.

(SF.)

APIINA, Blum. (Bijdr., p. 250) ( $\dot{p} \dot{\alpha} \nu \varepsilon \varepsilon \alpha$, incertitude). вот. Pн. - Geure incomplètement connu, qu'on rapporte à la famille des Sapindacées. Son auteur en donne les caract. suivants : Calice inégalement 4-parti. Pétales 4, ciliés, 2-squammellés à leur base. Disque hypogyne, engaînant les organes sexucls. Étamines $\check{y}$, apprimées au pistil. Ovaire ovale, comprimé, 2-locuiaire; loges 1 -ovulées. Stigmate subsessile, échancré. (Fruit ineonnu.) - Arbre à feuilles pari-pennées; folioles subopposées; grappes terminales, rameuses. L'A. montana , Bl., indigène de Java, est la seule espèce connuc.

(SP.)

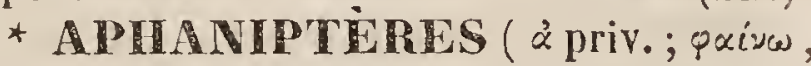
je parais; $\pi \tau \varepsilon_{\rho} 0 \%$, aile ). INs. - Dénomination employée par M. Kirby, synonyme de celle de Siphonaptères, Lat. Voy. ce mot.

(B⿺辶)

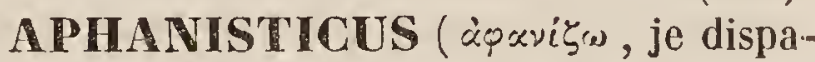
rais ). HNs. - Genre de Coléoptères pentamères, famille des Sternoxes ou des Serricornes, tribu des Buprestides, établi par Latreille et adopté par tous les entomologistes. Voici comment il est caractérisé par II. Lacordaire, dans la Faune entom. des environs de Paris : Bouche située entièrement au dessous de la tête et n'ofirant d'autres parties distinctes que le labre, qui est presque carré et entier à sa partic antéricure; ycux grands, oblougs, rapprochés à leur partie inférieure; antennes très rapprochées, et reçues, chacune à leur base et Ieur partic moyenne, dans une rainure parallèle aux yeux, et à leur extrémité dans une échancrure des flancs du prothorax; beaucoup plus courtes que ce dernier; leur 
premier article renflé en massue; le deuxième gros, ovalaire; les 5 suivants courts, presque grenus; les 4 derniers dilatés, formant une massue en scie. Tête très grosse, subcylindrique, canaliculée sur le vertex, avec le front très étroit, réduit à un mince filet entre les yeux, et l'épistome légèrement échancré. Prothorax presque carré, légèrement rétréci et bilobé à sa base en dessus, échancré antérieurement sur les côtés pour recevoir les antennes; prosternum large, légèrement convexe, spatuliforme à son extrémité postérieure ; élytres sinués latéralement ; pattes grêles, courtes et contractiles, les intermédiaires très écartées à leur naissance; cuisses larges, comprimées et tranchantes à leur côté interne; articles des tarses très courts; les 4 premiers munis de pelotes en dessous; crochets des tarses unidentés à leur base; corps allongé, très étroit, presque linéaire.

Les Aphanistiques se tiennent sur les plantes basses, où ils échappent à la vue par leur petitesse, ainsi que l'indique leur nom générique. M. Dejean en mentionne dans son dernier Catalogue 3 espèces, dont une de Madagascar, et deux qui se trouvent en France, et même aux environs de Paris, savoir : l'Emarginatus Fabr., qui forme le type du g., et le Pusillus d'Olivier. (D.)

APHANITE ( $\alpha$ 'pxv's, qui disparaît; par allusion à l'état imperceptible des éléments minéralogiques composants ). GÉoL. - Ce nom , proposé par M. Haüy, employé par MM. Léonhard et Brongniart, a été adopté par M. Cordier pour désigner l'une des espèces de sa famille des Roches pyroxéniques.

L'Aphanite, que Dolomieu appelait Cornéenne, était autrefois rangée parmi les anciennes Roches trappéennes. Suivant M. Cordier, elle ne diffère de l'Ophitone ( ce mot) que par l'extrême ténuité des parties pyroxéniques et feldspathiques qui la composent. C'est l'Ophitone à l'état compacte, et offrant une apparence parfaitement homogène.

Malgré le résultat déjà ancien des recherches de M. Cordier, on a pris pendant longtemps, et quelques géologues prennent encore la matière pyroxénique de l'Aphanite pour de l'Amphibole; mais c'est à tort : car cette roche fond en émail verdâtre, tan- dis que l'Amphibole cornmunique une teinte d'un brun - noirâtre aux roches compactes qui en contiennent lorsqu'on la vitrifie. Les autres caract. fournis par l'analyse mécanique, aidée du microscope, ne laissent d'ailleurs aucun doute.

Les variétés de cette espèce offrent des teintes verdâtres plus ou moins foncées; elles sont quelquefois cellulaires, ou plutôt amygdalaires ; ce qui, joint à son état compacte, indique qu'elles se sont consolidées avec plus de rapidité que l'Ophitone. On y trouve assez fréquemment de la Pyrite ordinaire, ainsi que des veines ou taches d'Épidote d'un vert pistache.

L'Aphanite est une Roche d'épanchement, et peut-être aussi, dans quelques cas, une Roche d'éruption. Son gisement est dans les terrains secondaires très anciens, tels que ceux de la période phylladienne. On la trouve dans les Vosges, en Corse, et dans la presqu'île du Sinaï.

Cette Roche est rare. La matière qui la compose fait, d'ailleurs, la base de l'esp. de Porphyre pyroxénique qui est si connue sous le nom d'Ophite antique.

(C. D'O.)

* A PHANIUS. poiss. - Genre de Poissons abdominaux, placé par H. Nardo, auteur du genre, entre les Saumons et les Cyprins. Il le caractérise ainsi : Corps couvert d'écailles très fortes, une très grande arrondie sur la nuque. La tête comprimée entre les yeux; le museau obtus ; l'ouverture de la bouche oblique, presque verticale; les mâchoires pourvues de petites dents égales ; les lèvres minces; la mâchoire inférieure plus longue que la supérieure, et dirigée vers le haut. Point de ligne latérale. Quatre ou cinq rayons à la membrane branchiostège. Les nageoires simples; les ventrales sous l'abdomen; la dorsale reculée sous les courbes, opposée à l'anale. M. Nardo fait observer que les os sont remarquablement durs, en comparaison de la petite taille du poisson. Il en cite deux esp. abondantes dans les lagunes de Venise, d'un goût amer, et qui ne se mangent point. - Ce g. me paraît être celui déjà établi sous celui de Fundellus, et l'une des espèces être le Pacilia calaritana de Bonelli.

(VAL.)

*APHANIZOMENE. Aphanizomenon 


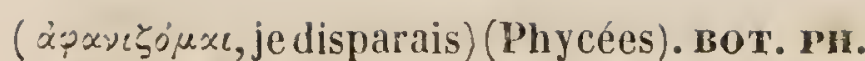
- H. Ch. Morren a imposé ce nom à un nouveau genre de la tribu des Confervées, qu'il a observé le premier, et qu'il a caractérisé de la manière suivante : Filaments simples, cylindriques, flexueux, membraneux, hyalins, formant, par leur réunion, à certaine époque de leur existence éphémère, des espèces de lamelles planes, semi-lunaires ou fusiformes, lacérées ou comme déchiquetées à leurs extrémités opposées. Chacun de ces filaments est composé d'articles droits, cylindriques ou renflés çà et là, contenant de la matière verte, jouissant d'un mouvement de reptation remarquable, et se séparant enfin spontanément les uns des autres. Une espèce unique constitue ce genre. On la trouve de mai à juillet dans les fossés et les étangs de la Flandre.

Voici, d'après l'auteur, les rapports de ce singulier végétal, sur lequel il a publié un mémoire fort intéressant. "Les Aphanizomènes lient les Conjuguées vraies aux Zygnémées par un accouplement bien prononcé chez ces dernières, accouplement qui devient une simple soudure dans les premiers. Ce genre met en rapport les Conjuguées avec les Laminaires des eaux marines, par la forme de la lamelle qui résulte de la soudure des filets. Il établit une analogie entre les Oscillariées et les Confervées, en démontrant qu'un mouvement de reptation, de natation, d'oscillation, peut appartenir aussi bien à l'organisation des Conferves qu'à celle des Oscillaires, dans lesquelles on croit reconnaître les caractères de l'animalité. Les vésicules renflées ramènent l'Aphanizomène à la Conferva vesicata, Ag.; et les articles, comme l'organisation des filets ellemême, lui conservent avec les Confervées vraies des rapports si clairs, qu'il serait hors de propos de placer ailleurs que parmi elles ce genre nouveau.

(C. M.)

* APHANOBIUS (ápxyis, obscur; Fios, vie). INs. - Genre de Coléoptères pentamères, famille des Sternoxes, tribu des Élatérides, établi par Escholtz, qui lui donne pour caract. : Tarses dépourvus de pelote; ongles simples. Front défléchi, et, le plus souvent, plan ou concave. Bouche avancée ou infléchie. Carène du front très fine. Lames de la poitrine subitement dilatées intérieurement. Quatrième article du tarse entier; écusson ovale; dessous des tarses garni d'un duvet épais. M. Dejean qui a adopté ce g. dans son dernier Catalogue, y rapporte 9 esp., dont 7 de l'Amérique, 1 de l'île Bourbon, et 1 de Java. Nous ne citerons que cette dernière, nommée Aph. flabellatus Dejean.

(D.)

* APHANOCHILUS, Benth. ( ápxvis, obscur ; $\gamma \varepsilon \bar{i} \lambda o s$, lèvre ). Вот. PH. - Genre ou sous-genre de la famille des Labiées, que M. Bentham (In Wallich, Plant. As. rar.) avait d'abord considéré comme un g. distinct, mais qu'il a réuni depuis (Labiat., p. 161) au g. Escholtzia, Willd., dans lequel il figure comme section caractériscé par des anthères à bourses divariquées ou divergentes, confluentes après l'anthèse.

(SP.)

* APHANOPE (Aphanopus, Lowe). Poiss. - Genre de Poissons de la famille des Scombéroïdes, de la forme du Lépidope, à corps allongé, comprimé comme une lame d'épée, avec une courte carène de chaque côté de la queue. Le museau et les dents sont semblables à ceux du Lépidope; mais le palais n'a point d'armure. On voit deux dorsales presque égales. Il n'y a pas de traces de ventrales. M. Lowe, auteur de ce genre, n'en cite qu'une seule espèce, qu'il nomme Aphanopus carbo, poisson fort rare à Madère, où il est appelé Espada prete. Il est d'une couleur café foncée, presque noire. M. Lowe n'en a vu qu'un seul individu.

(VAL.)

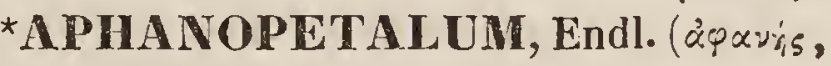
obscur ; $\pi \dot{\varepsilon} \tau \alpha \lambda_{10 \%}$, pétale). Bor. PH. — Genre de la famille des Cunoniacées. Son auteur (Annal. Wien. Mus., t. II ; Gen. Plant., p. 818 ; Nov. Stirp. decas, t. V, p. 54; Iconogr., tab. 96) lui assigne pour caract. : Calice inadhérent, 4-parti, à segments ètalés, membranacés, veineux, un peu inćgaux. Pétales 4 (souvent nuls), linéaires lancéolés, minimes. Étam. 8, insérées au fond du calice; filets subulés. Anthères 2thèques, basifixes, subsagittiformes, privées d'appendices basilaires. Ovaire inadhérent, 4-loculaire; ovules solitaires dans chaque loge, suspendus au sommet de l'angle interne. Styles 4, cohérents. Stigmates 4, courts, pointus, terminaux, étalés en forme d'étoile. Fruit inconnu. - Arbres habitant la côte orientale de la Nouvelle-Hollande ; 
ramules ponctués; feuilles opposées, courtement pétiolées, simples, coriaces, dentelées, glabres; stipules interpétiolaires, caduques; panicules axillaires et latérales; pédicelles 2-bractéolés au milieu; bractéoles sétacées. On ne connaît qu'une espèce.

(Sp.)

* APIIANOSTEMMA , Aug. S.-Hil. (ápxirs, peu apparent; oтruce, étamine). вот. PH. - Genre de la famille des Renonculacées (tribu des Anémonées DG.). Son auteur (Flor. Brasil. merid., t. I, p. 9) lui assigne les caract. suivants : Calice pétaloïde, ち-sépale, non persistant. Pétales 5, glanduliformes, suborbiculaires, minimes, munis d'une fovéole nectarifère 2-labiée. Ltamines en nombre indéfini, à anthères introrses. Ovaires très nombreux, libres, 1 -ovulés. Ovule suspendu au sommet de la loge. Stigmates sessiles. Akènes disposés en épi ; réceptacle conique. Graines à radicule supère. Le Ranunculus apiifolius, L., constitue à lui seul ce genre; cette plante croît dans l'Amérique méridionale. (SP.)

* APHANOSTEPIIUS ( $\dot{\alpha} \varphi x v_{i j}$, invisible; $\leftarrow \tau \varepsilon \varphi \dot{\alpha} \nu$, couronne; couronne invisible ). вот. PH. - M. de Candolle a fondé ce genre sur une plante originaire du Mexique, laquelle fait partie des Composées, tribu des Astéroïdées. Elle a pour caract. : Capitules multiflores, hétérogames; fleurs du rayon ligulées, 1-sériées, femelles; celles du disque hermaphrodites, כ̌-dentées. Réceptacle très convexe, nu. Involucre composé de deux rangées d'écailles acuminées, membraneuses sur les bords. Fruit cylindrique, parcouru de légères stries, et terminé par une membrane entière, courte, en forme de couronne. - La seule espèce connue habite le Mexique; c'est une herbe dressée, rameuse, pubescente, à feuilles sessiles, alternes, incisées ou légèrement lobées; les rameaux, dépourvus de feuilles au sommet, portent un capitule à ligules blanches plus Iongues que l'involucre.

(J. D.)

* APIIANUS (ápxvis, obscur). ivs. - M. de Laporte (Essai d'une classific. syst. de l'ord. des Hémipt.) a appliqué cette dénomination à un g. de la famille des Lygéens, de l'ordre des Hémiptères, déjà désigné par MM. Lepelletier de Saint-Fargeau et Serville (Encycl. méth., t. X) sous le nom de Packamerus. Ce dernier nom, étant le plus ancien, doit être conservé de préférence à l'autre. Quoi qu'il en soit, ce g. est adopté dans plusieurs ouvrages d'entomologie sous le nom d'Aphanus ou Aphana. Voy. PAGHYMERUS.

(BL.)

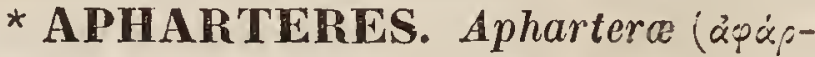
твpos, agile). ARAGHN. - M. Walckenaër désigne sous ce nom une petite division d'Aranéides appartenant au genre Selenops.

(H. L.)

* APHEDRODERE (Aphedroderus, Lesueur ) (àprofís, cloaque; ১ìn, cou ). PoIss. - Genre de Poissons établi, par l'auteur que nous citons, pour un petit poisson des eaux douces de l'Amérique septentrionale. C'est un Percoïde à six rayons branchiostèges et à dents en velours, à dorsale reculée, à ventrales avancées, n'ayant aucune épine au côté de leurs sept rayons articulés. L'anus est avancé 'sous la gorge, presque entre l'isthme de la mâchoire inférieure. Ce Poisson a les deux bords du sous-orbitaire dentelés, des épines sur leurs crêtes mitoyennes, des dentelures au bord du préopercule, et une épine à l'angle de l'opercule. M. Lesueur a observé la seule espèce encore connue de ce genre dans le lac de Pontchartrain, où il se tient sur un fond vaseux, et près des rives ombragées. On l'y appelle Tétard de Saint-Domingue. Le docteur Gillians a fait le premier mention de ce Poisson, trouvé près d'Harrowgate, lieu de plaisance peu éloigné de Philadelphie, où l'on va prendre des bains. Cet auteur avait nommé l'espèce Scolopsis sayanus, genre des Sciénoïdes, avec lequel notre Poisson n'a aucun rapport.

(VAL.)

APHELANDRA，R. B.; Sinandra, Schred.; Hemitome, Nees (ápsiǹs, simple; ג'sip, àvópós, homme, étamine). вот. Рн. - Genre de la famille des Acanthacées, tribu des Aphélandrées, Nees, formé par R. Brown (Prod., 475 , etc.), et ainsi caractérisé : Calice 5-partite, inégal. Corolle hypogyne, ringente. Lèvre supér. comme voûtée, bidentée; lacinies latérales de l'infér. beaucoup plus courtes. Etamines 4 , insérées au tube de la corolle, incluses, didynames. Anthères mutiques, uniloculaires. Ovaire biloculaire; loges biovulées. Style simple; stigmate bifide. Capsule subcylindrique, biloculaire, tétrasperme, loculicide, bivalve. Valves septifères au milieu. Graines 
comprimeses, sous-tendues par des rétinacles. - Ce g. comprend plusicurs espèces retirées du g. Justicia de Linné. Ce sont des sous - arbrisscaux propres à l'Amérique tropicale, à feuilles opposées, à inflorescence en épis axillaires et terminaux, tétragones; garuis de bractées opposées, submembranacées; de bractéoles étroites. Fleurs belles, rougeâtres.

* APHELEXIS (àp $\varepsilon \lambda \dot{y}_{s}$, simple, sans ornenients). BoT. PII, - Ce genre a ćté établi par M. Bojer aux dépens de certains $\boldsymbol{H} e-$ lichrysum de Madagascar. Ses caractères sont les suivants : Réceptacle à peine alvéolé. Involucre composé d'écailles plus longues que les fleurs du disque, verdâtres on brunes à leur base, et terminées en un appendice linćaire, lancéolé. Les soies de l'aigrette, filiformes à la base, préscntent au sommet quelques barbellules. Toutes les fleurs sont hermaphrodites; ce qui distingue ces plantes"des genres voisins.

APHELIA ( $\alpha \dot{\varphi} s\rangle \xi \dot{\varepsilon} \alpha$, simplicité ). BOT. Pн. - Genre de la famille des Centrolépidées, formé par R. Brown ( Prod., 251), adopté par Desvaux (Centrol. in Annal. scienc. nat., t. XIII, p. 36 ), ct ainsi caractérisé : Épillets distincts, uniflores. Glume antérieure mucronéc, enserrant la postérieure et une palćole mutique. Étamine unique, placée cn avant. Ovaire unique, sessile. Style filiforme; stigmate simple. Utriculc déhiscent longitudinalement d'un côté. Graine comprimée. - Ce g. ne contient qu'une plante herbacée (A. cyperoïdes) de la Nouvelle - Hollande australe. Elle forme une touffe composéc de feuilles radicales, filiformes, vaginantes à la base; à scapes nues, indivises; à ćpis terminaux, dont les glumes sont hispides, acuminées ; les inférieures souvent stériles, plus longues.

(C. L.)

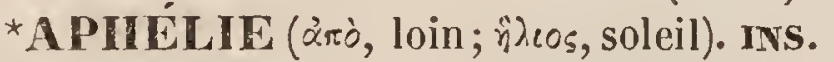
- Genre de l'ordre des Lépidoptères, famille des Yocturnes, établi par Stéphens, et placé par lui dans sa tribu des Tortricides. Il y comprend 5 esp. dont aucune ne nous est connue, de sorte que nous ignorons à quel genre des autres Auteurs celuici correspond.

* APHELINUS (ápeirs, simple). INs. -Genre de la famille des Chalcïdiens, de l'ordre des Hyménoptères, section des Té- rébrans, établi par Dalman (Acta Holm.), et adopté par H. Walker (Ent. Mag.), qui y rapporte un certain nombre d'esp. indigènes. - Ce genre est principalement caractérisé $1^{\circ}$ par les antennes, ne présentant que six articles distincts, dont le sixicme fusiforme et allongé; et $2^{\circ}$ par les tarses, de cinq articles. Le type du g. est l'A. $b a$ salis, Walk. (Agonioneurus id., Westw.). M. Westwood a donné à ce même genre lc nom d'Agonioneurus, ne croyant pas sans doute asscz reconnaitre son identitć avec le g. Aphelinus de Dalman, et il a crée en outre les g. Pteropterix, Coccophagus et Trichogramma, que M. Walker regarde comme de simples divisions du g. Aphelinus. Voy. chacun de ces mots.

(Bc.)

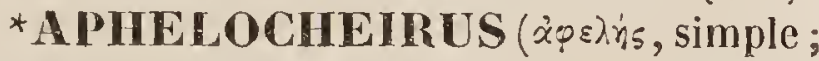
$\chi \varepsilon \tilde{i} \rho$, main, tarse). INs. - Genre de la famille des Leptopodicns, Brul. (Riparii, Burm.), de l'ordre des Hémiptères, sect. des Hétéroptères, établi par M. Westwood (Int. mod. class. of Ins.), qui se distingue des Salda de Fab., ou Acanthia Lat. par les antennes, très épaisses, et les jambes postćrieures, propres à la natation. La seule esp. que l'auteur rapporte à son g. est l'A. astivalis (Naucoris cestivalis Fab.).

(BL.)

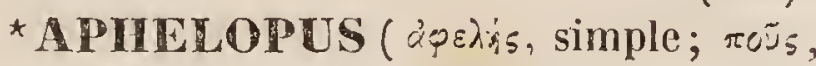
pied ). INs. - Genre de la famille des Oxyuriens, de l'ordre des Hyménoptères, section des Térébrans, établi par Dalınan (Analecta entom.), et adopté par la plupart des cntomologistes. - Ce g., très voisin des Dryinus et Gonatopus, s'en distinguc par plusieurs caract. importants : $1^{\circ}$ par un corps assez large; 20 un thorax fort large en avant, et rétréci considérablement en arrière; $3^{\circ}$ des pattes grêles et simples, sans dilatation et sans renflement, avec les crochets des tarses très petits, et $4^{\circ}$ par un abdomen ovalaire comprimé, bcaucoup plus court et plus étroit que le thorax. Le type de ce g., dont on ne connalt que quelques esp. indigènes, est l'A. melaleucus Dalm., etc., répandu dans le nord de l'Europe.

* PIIENE. - Voyez APHATA. (BL.)

* APHERESE (ápxipross, soustraction). MIv. - Nom donné par M. Beudant à une nouvcllc esp. appcléc Libéthénite par les minéralogistes allemands, et formée aux dé- 
pens de l'ancienne espece Cuivre phosphaté d'Haüy. Flle se compose des variétés de phosphate de cuivre hydraté, que l'on trouve principalement dans les mines de Libethen en Hongrie. Voy. Phosphates.

(DEL.)

* DHIDIAD AE. INs. - MM. Stéphens et Haliday ont appliqué ce nom à un petit groupe de la tribu des Braconides, de la famille des Ichneumoniens, ayant pour type générique le g. Aphidius, et renfermant en outre quelques autres petits genres voisins de celui-ci. M. Westwood emploie le nom de Flexiliventres, et M. Wesmael celui de Polymorphi, pour désigner le même groupe. Voy. ces mots.

(BL.)

APIIDIENS. Aphidii (aphis, puceron). Ixs. - Famille de l'ordre des Hémiptères, section des Homoptères, établie par Latreille, et adoptée par les entomologistes modernes, avec de grandes restrictions. Telle qu'on la considère maintenant, elle se distingue des familles voisines par les caract. suivants : Corps ovalaire. Tête large. Antennes sétacées, et composées de cinq à sept articles. Rostre infléchi ou presque perpendiculaire, ayant trois articles distincts. Yeux très saillants, généralement globuleux. Ailes infléchies. Pattes longues, avec le dernier article des tarses muni de deux crochets. Cette famille a pour type générique le g. Puceron (aphis), et renferme en outre, d'après les caract. que nous avons énoncés, les g. Chermes, Auct.; Lachnus, Illig.; Rhizobius, Burm. Latreille y comprenait aussi les g. Psylla et Livia, qui constituent maintenant une autre famille, ainsi que les Thrips, avec les g. qui en ont été détachés, et encore les Aleyrodes, que l'on place généralement aujourd'hui près des Cochenilles. Voy. l'art. PUCERon pour les détails sur les mœurs et l'organisation.

(BL.)

* APHIDLNA. Ivs. - Dénomination employée par le Dr Burmeister, exactement synonyme de APunless, Aphidii. (BL.)

APIIDIPHAGES. Aphidiphagi (aphis, puceron; $\varphi \dot{x} \gamma(\omega$, je mange). INs. - Latreille désigne ainsi la $1^{\text {re }}$ famille des Coléoptères trimères, laquelle se compose des g. Coccinelle, Scymine et Cacicule. Ses caract. sont : Antennes plus courtes que le corselet, et terminées en une massue compri- mée, ayant la forme d'un triangle renversé; dernier article des palpes maxillaires très grand, en forme de hache. Corps hémisphérique, avec le corselet très court, presque lunulé. Les Insectes de cette famille, principalement à l'état de larves, sont de grands destructeurs de Pucerons. (D.)

* APIIIDIUS (diminut. de aphis, puceron). INs. - Genre de la famille des Ichneumoniens, tribu des Braconides, de l'ordre des Hyménoptères, établi par M. Nees von Esenbeck (Berl. Mag.), et adopté par M. Westwood (Generic. synopsis) et nous (Histoire des anim. artic., t. IV). $-\mathrm{Ce}$ g. est principalement caractérisé $1^{\circ}$ par des antennes composées d'environ 24 articles, 20 des palpes courts, $3^{\circ}$ des mandibules faiblement bidentées à leur extrémité, et $4^{\circ}$ des ailes pourvues d'une cellule radiale incomplète, et de deux cubitales, dont la seconde complète, et la première confondue avec la cellule discoïdale externe. Ce g. se compose d'un assez grand nombre de très petites espèces indigènes. Les femelles déposent leurs œufs dans le corps des Pucerons, et leurs petites larves vivent parasites de ces Insectes jusqu'au moment de leur métamorphose en nymphes. Le type du g. est l'A. aphidum (Ichneumon aphidum Lin.), espèce à peine longue d'une ligne, répandue dans une grande partie de l'Europe, vivant parasite à l'état de larve du Puceron du rosier (Aphis rosa).

(BL.)

APIIDVORES (Aphis, puceron; voro, je dévore). Ins. - Nom donné dans le Dictionnaire de Déterville aux larves de plusieurs Insectes de genres et d'ordres différents qui dévorent les Pucerons. Elles appartiennent soit à des Coccinelles, soit à des Hémérobes, et quelquefois à des $S y r-$ phes. Voy. APHIDIPHAGES.

APMIE. Poiss. - Voyez aphye.

*APHIES. INs. - Genre de Coléoptères tétramères, famille des Longicornes, établi par M. Dejean, mais dont il n'a pas publié les caract. D'après la place qu'il occupe dans son dernier Catalogue, il appartiendrait à la famille des Lamiaires de M. Serville. Il y rapporte 5 esp., nommées par lui Erythrodera, Lebasii et Peruviana, les deux premières de Cárthagène, et la troisième du Pérou. Ce genre se rapproche du genre Erenica par 
son corselet cylindrique, et en diffère par des yeux plus saillants et presque globuleux. Nous citerons, comme type, l'A. erythrodera, Dej., dont les antennes et les pattes sont noires, la tête et le corselet d'un rouge-brun; les élytres noires et légèrement pubescentes, ef l'abdomen arec un reflet soyeux. Longueur, 5 lignes ; largeur, 1 ligne $1 / 5$.

(D. et C.)

APHIS. INS. - Voyez PUGERON.

(Bu.)

* APIILOIA, DG (Prodr., t. I, p. 261. - Lightfootia, Swartz, non L'Hérit.) ( ״phocos, dénué d'écorce ). вот. PH. - Sousgenre de la famille des Bixacées, fondé sur les Prockia serrata, integrifolia, et theaformis Willd. Son caractère différentiel consiste en ce que le stigmate est sessile ou subsessile, large, suborbiculaire, presque plan.

(SP.) bascum). Bот. GR.-Gaillon séparait en deux familles les Algues filamenteuses cloisonnées. Dans la première, à laquelle il donnait le nom de Phlomidées, étaient rangés les genres dont les filaments, composés de cellules uni-ou multisériées, sont revêtus d'une sorte d'épiderme formé soit par un tube anhiste, homogène, transparent, continu, soit par une réunion de cellules très petites, plus ou moins serrées et rapprochées entre elles. Par opposition, sa seconde famille, ou les Aphlomidées, était constituée par des Algues dont les filaments, cloisonnés aussi, sont dépourvus de cette seconde enveloppe. Le nom est, du reste, mal choisi : car

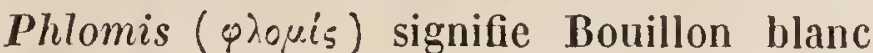
(Verbascum). En suivant l'étymologie présumée de Gaillon, il eût fallu nommer ces deux familles Phlaodées et Aphlaodées, ou, ce qui eût été encore plus convenable, Chlamydées et Achlamydées.

(C. M.)

IIN DU PREMIER TONF 

Page 35, $1^{\text {re }}$ col., ligne 4 (Mantis fuscifolia) Oviv.), lisez Mantis fuscifolia, Oliv.).

Page 37,2 col., ligne 5 4 , Scutellaires, lisez Scutellériens.

Page 96,2 e col., ligne 16, pl. 6 , lise z pl. 4 .

Page 119 , 2e col., ligne 34 , cellule radicale, lisez cellule radiale.

Page $189,1^{\text {re }}$ col., ligne 44 , cellule cubitale, lisez cellule radiale.

Page $189,1^{\text {re }}$ col., ligne 45 , cellules radiales, lisez cellules cubitales.

Page 200, 1re col., ligne 55, Aflavo-lineatum, lisez A. flavo-lineatum.

Page 353, 1re col., ligne 4 , sehaw d'Écorce, lisez Shaw d'Écosse.

Page 401, 1re col., ligne 18, AMPULEX, supprimez l'étymologie de ce mot.

Page $401,1^{\text {re }}$ col., ligne 28 , radicale, lisez radiale.

Page $427,1^{\text {re }}$ col., ligne 4, Abymarides, lisez Amymarides.

$$
\text { - - - Abymar, lisez Amymar. }
$$

Page $442,2^{\mathrm{e}}$ col., dernière ligne, analogie, lisez analyse.

Page $451,1^{\text {re }}$ col., ligne 44 , diversions, lisez divisions.

Page $451,2^{e}$ col., ligne 43 , animales, lisez anciennes.

Page 453, $1^{\text {re }}$ col., ligne 34, Düreckheim, lisez Dürckheim.

Page 43ั4, note 1, ligne 4, Lants, lisez Lanth.

Page 571, fre col., ligne 58, plus marcheuses et plus nageuses, lisez plus marcheuses et moins nageuses.

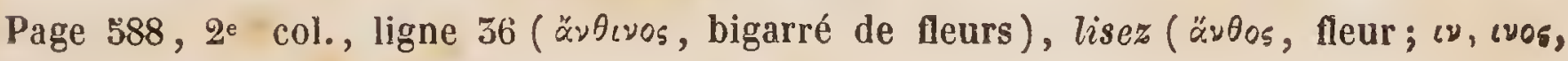
fibre).

Page 588, 2e col., ligne 39, Hypomycètes, lisez Hyménomycètes.

Page 588, 2e col., ligne 41 , Claveria, lisez Clavaria.

Page 588, 2e col., ligne 42, Imanlia, lisez Himantia.

Page 589, $1^{\text {re }}$ col., ligne 4 , mycetium, lisez mycelium.

Page 608, 2e col., ligne 16, Léger, lisez Séger.

Page 626, 1re col., ligne 53, aluns, lisez Faluns. 




DICTH, UVIY, IDPIIST. NAT.

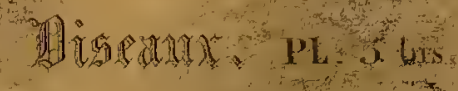

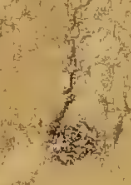


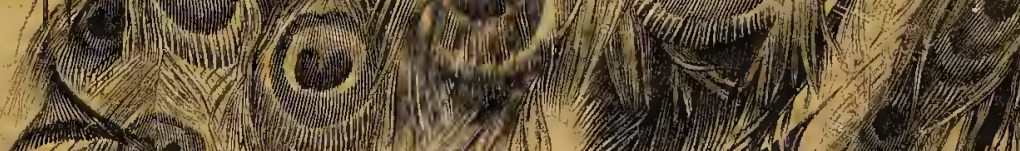

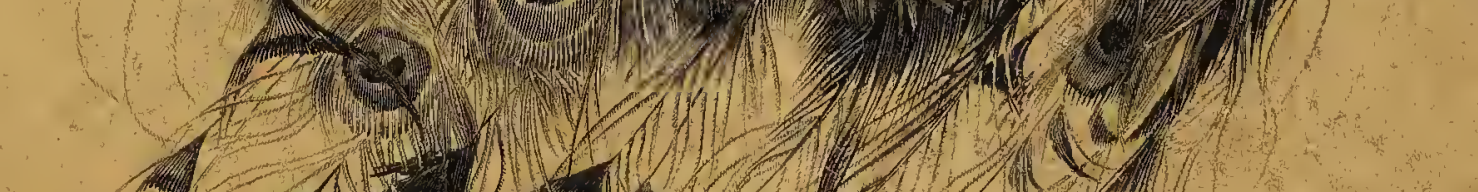

(1)

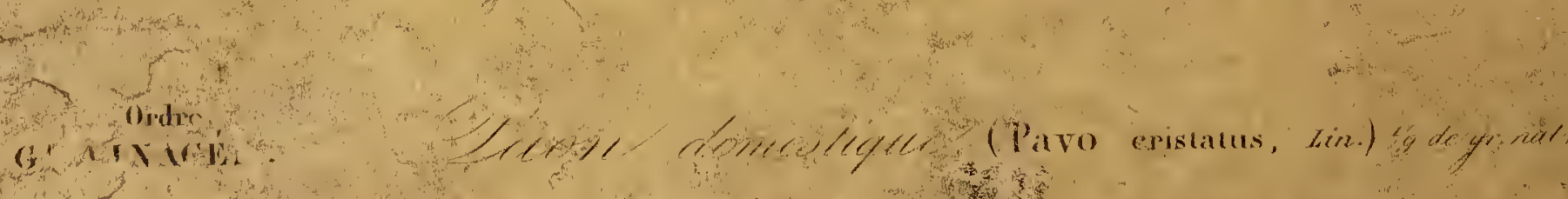

